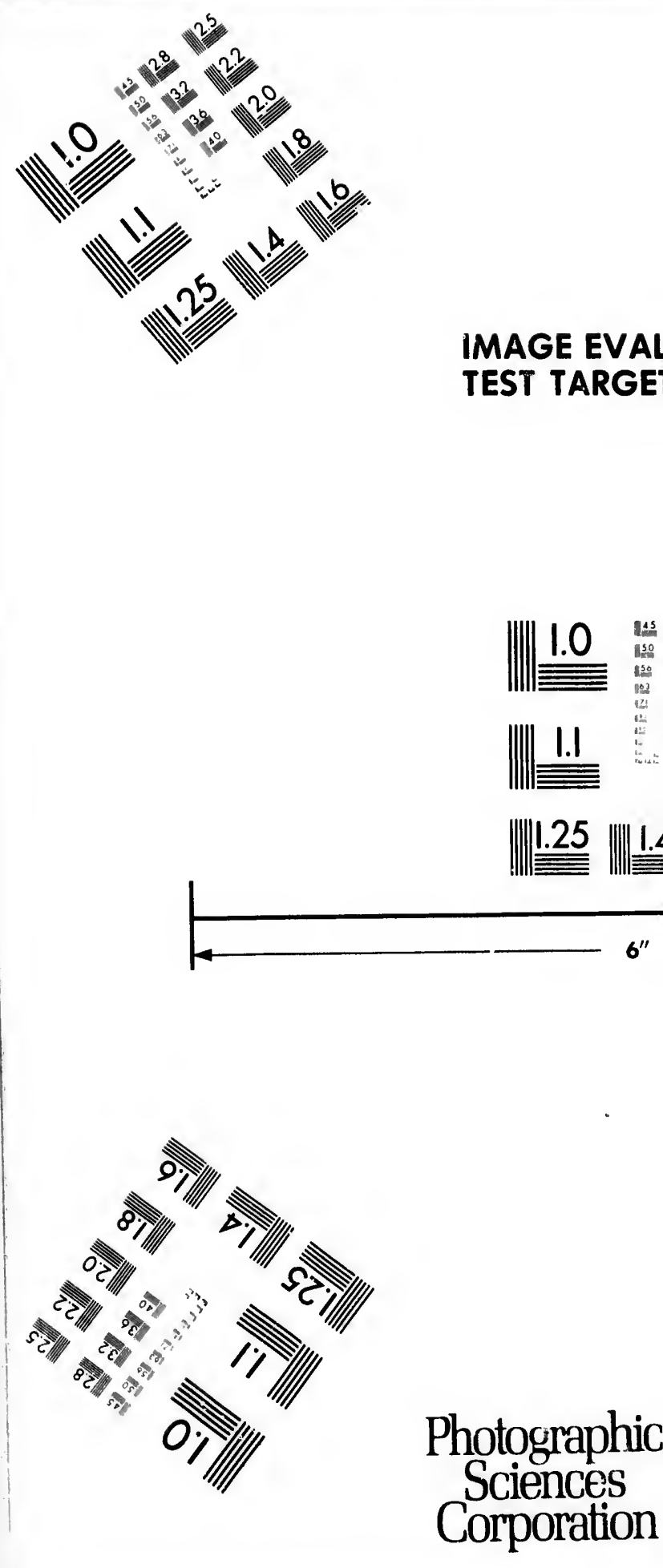




\section{IMAGE EVALUATION}

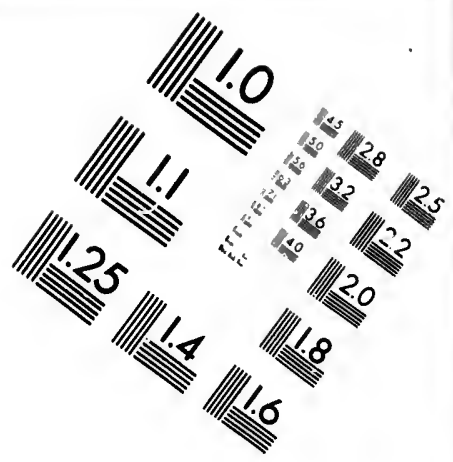

TEST TARGET (MT-3)

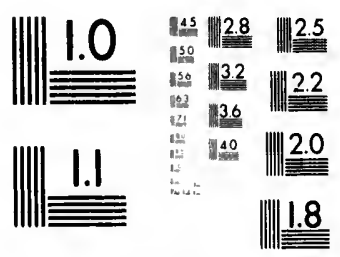

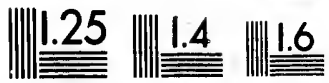

6"

Photographic Sciences

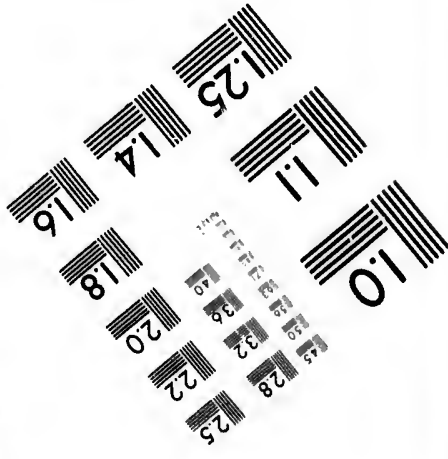
Corporation 


\section{CIHM/ICMH Microfiche Series.}
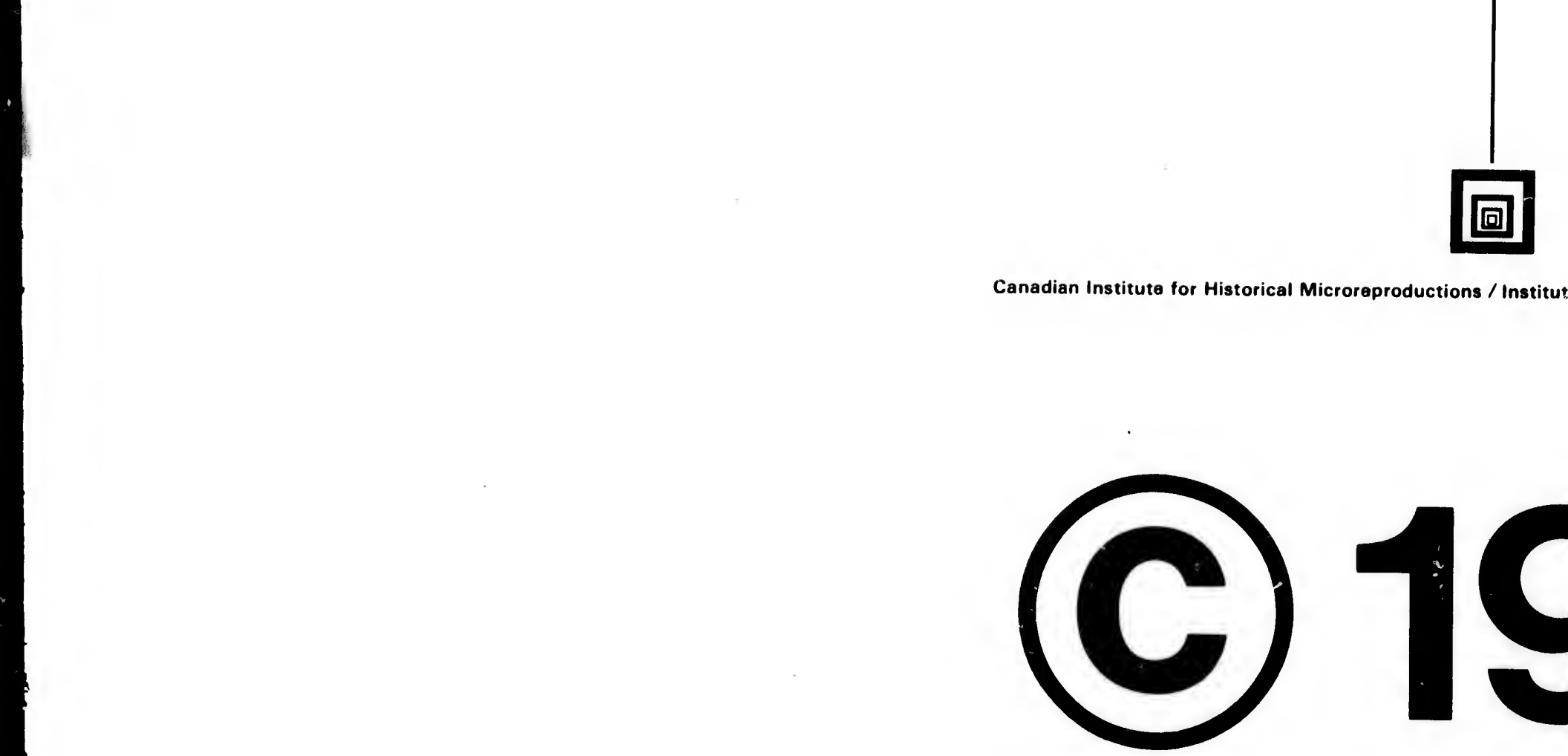


\section{CIHM/ICMH Collection de microfiches.}
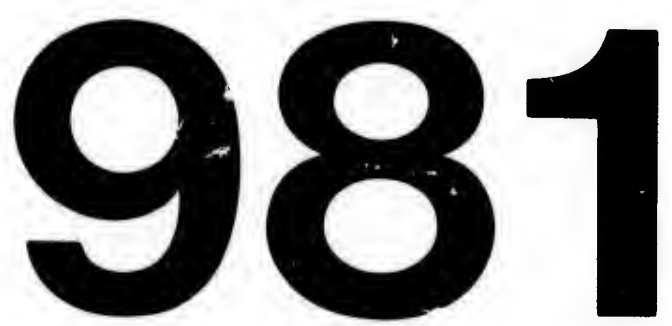
The Institute has attempted to obtain the best original copy available for filming. Features of this copy which may be bibliographically unique. which may alter any of the images in the reproduction, or which may significantly change the usual method of filming, are checked below.

7 Coloured covers/

Couverture de couleur

Covers dameged/

Couverture endommagée

Covers restored and/or laminated/

Couverture restaurée et/ou pelliculée

Cover title missing/

Le titre de couverture manque

Coloured maps/

Cartes géographiques en couleur

Coloured ink (i.e. other than blue or black)/ Encre de couleur (i.e. autre que bleue ou noire)

Coloured plates and/or illustrations/

Planches et/ou illustrations en couleu

Bound with other material/

Relié avec d'autres documents

Tight binding may cause shadows or distortion along interior margin/

La reliure serrée peut causer de l'ombre ou de la distortion le long de la marge intérieure

Blank leaves added during restoration may appear within the text. Whenever possible, these have been omitted from filming/

II se peut que certaines pages blanches ajoutées lors d'une restauration apparaissent dens le texte, mais, lorsque cela était possible, ces pages n'ont pas été filmées.

Additional comments:/

Commentaires supplémentaires:

This iten is filmed at the reduction ratio checked below/ Ce document est filmé au taux de réduction indiqué ci-dessous

$10 \mathrm{X}$

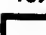

$14 \mathrm{X}$
$18 \mathrm{X}$ 
the best

atures of this unique,

the

itly change

ked below.

e or blackl/

bleue ou noire)

ons/

ouleur

culée

IS or distortion

l'ombre ou de la érieure

ration may

possible, these

anches ajoutées

ont dans le texte. ces pages n'ont
L'Institut a microfilmé le meilleur exemplaire qu'il lui a été possible de se procurer. Les détails de cet exemplaire qui sont peut-être uniques du point de vue bibliographique, qui peuvent modifier une image reproduite, ou qui pelvent exiger une modificetion dans la méthode normale de filmage sont indiqués ci-dessous.

Coloured pages/

Pages de couleur

Pages damaged/

Pages endommagées

Pages restored and/or laminated/

Pages restaurées et/ou pelliculées

Pages discoloured, stained or foxed/

Pages décolorées, tachetées ou piquées

Pages detached/

Pages détachées

Showthrough/

Transparence

Quality of print varies/

Qualité inégale de l'impression

Includes supplementary material/

Comprend du matériel supplámentaire

Only edition available/

Seule édition disponible

Pages wholly or partially obscured by errata slips, tissues, etc., heve been refilmed to ensure the best possible image/ Les pages totalement ou partiellement obscurcies par un feuillet d'errata, une pelure. etc., ont été filmées à nouveau de façon à obtenir la meilleure image possible.

io checked below/

uction indiqué ci-dessous.

$18 \mathrm{x}$

$22 x$

26x 27x 30x

$20 x$

$24 X$

$28 x$

$32 x$ 
The copy filmed here hes been reproduced thenks to the generosity of:

Library of Congress

Photoduplication Service

The imeges appearing here ere the best quality possible considering the condition and leglbility of the original copy end in keeping with the filming contract specifications.

Original copies in printed paper covers ere filmed beginning with the front cover and ending on the last page with a printed or illustreted Impres. sion, or the back cover when appropriate. All other originel copies are filmed beginning on the first page with a printed or illustrated impression, end ending on the last pege with a printed or illustrated impression.

The lest recorded frame on eech microfiche shall contain the symbol $\rightarrow(1$ reening "CON TINUED"), or the symbol $\nabla$ (m taning "END"), whichever applies.

Maps, pletes, cherts, etc., may be filmed at different reduction ratios. Those too large to be entirely included in one exposure are filmed beginning in the upper left hend corner, left to right and top to bottom, as many frames as required. The following diagrams illustrete the method:

\begin{tabular}{|l|l|l|}
\hline 1 & 2 & 3 \\
\hline
\end{tabular}

\begin{tabular}{|l|l|}
\hline 1 & 2 \\
\hline 4 & 5 \\
\hline
\end{tabular}


L'exemplaire filmé fut reproduit grêce à la générosité de:

Library of Congress

Phofoduplication Service

Les images suivantes ont été reproduites avec le plus grand soin, compte tenu de la condition et

de la netteté de l'exemplaire filmé, et en

conformité evec les conditions du sontrat de filmage.

Les examplaires originaux dont la couverture en papler est imprimée sont filmés en commençant par le premier plat et en terminant soit par la derniere page qui comporto une empreinte d'impression ou d'illustration, soit par le second plat, selon le cas. Tous les autres exemplaires originaux sont filmb́s en commençant par la première page qui comporte une empreinte d'impression ou d'illustration et en terminant per la derniere page qui comporte une teile empreinte.

Un des symboles suivants apparaîtra sur la dernière image de chaque microfiche, selon le ces: le symbole $\rightarrow$ signifie "A SUIVRE", lo symbole $\nabla$ signifie "FIN".

Les cartes, planches, tableaux, etc., peuvent être filmés à des taux de réduction différents. Lorsque le document est trop grand pour être reproduit on un seul cliche, il est filmé a partir de l'engle supérieur gauche, de gauche à droite. ot de haut en bas, en prenant le nombre d'ímages nócessaire. Les diagrammes suivants illustrent la méthode.

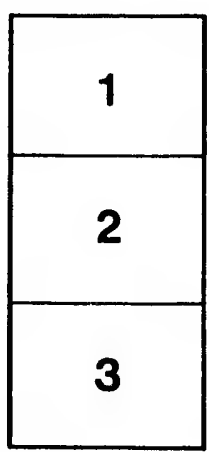

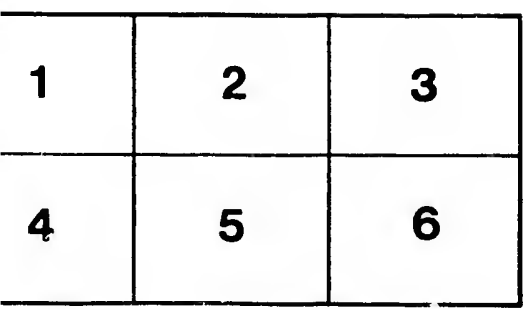




VIAJE POLÍTICO-CIENTIFICO

\title{
ALREDEDOR DEL MUNDO
}

POR I.AS CORBETAS

\section{DESCUBIERTA y ATREVIDA}

\author{
AL MANDO DE LOS CAPITANES DE NAVio \\ D. ALEJANDRO MALASPINA \\ Y \\ DON JOSÉ DE BUSTAMANTE Y GUERRA \\ DESDE $\quad 1789 \wedge \quad 1794$ \\ PUBLICADO CON UNA INTRODUCCIÓN \\ POR \\ DON PENRO DE NOVO Y COLSON \\ TENIENTE DE NAVIO
}

ACADEMICO CORRESPONDIENTE DE LA REAL DE LA HISTORIA

MADRID

IMPRENTA DE LA VIUDA É HIJกS DE ABIENZO ISABEL LA CATÓLICA, \& PAZ, 6

$$
\overline{188}
$$




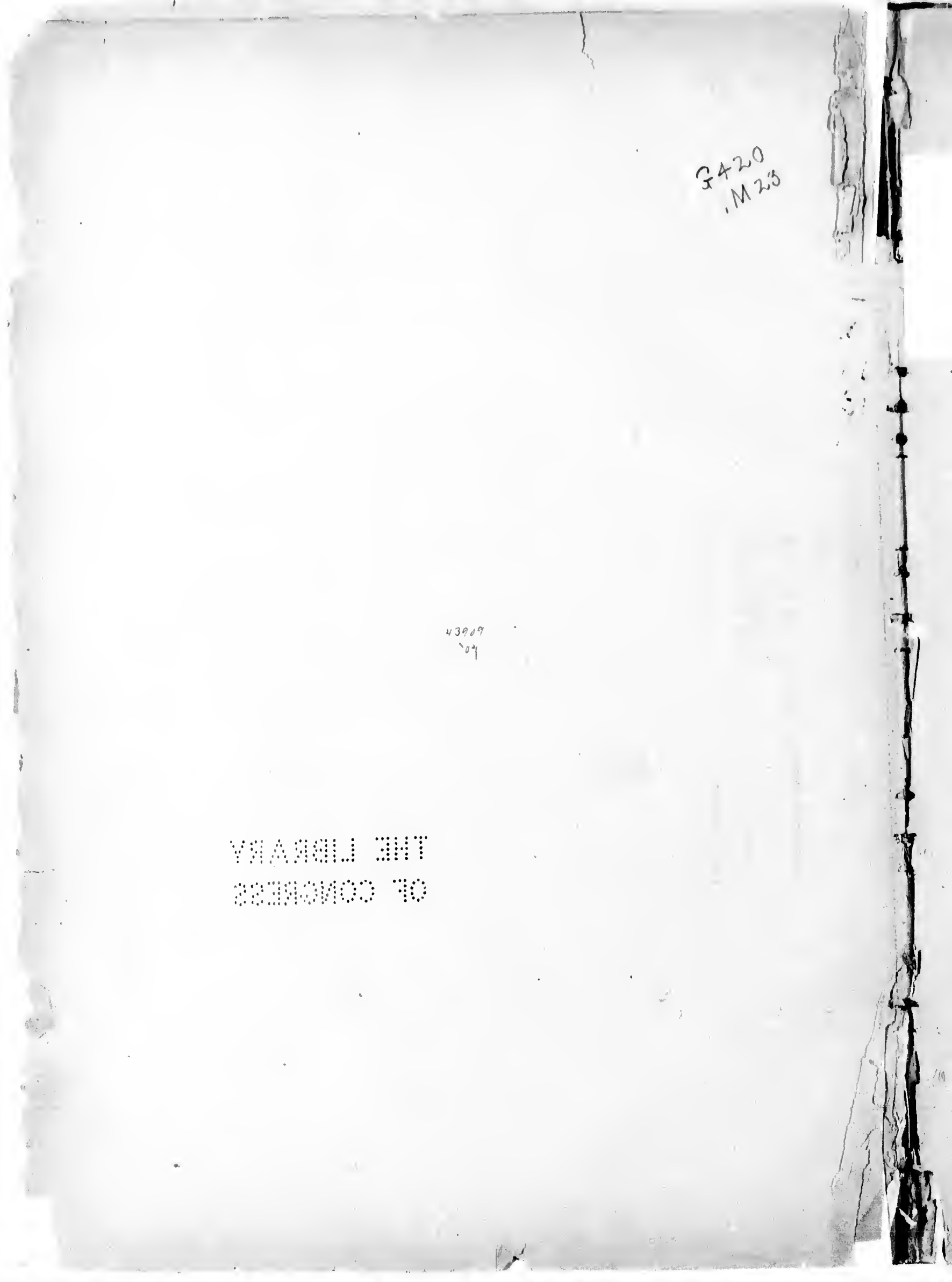




\section{Excmo. SR. D. JUAN B. ANTEQUERA Y BOBADIL.LA}

MINISTRO DE MARINA

EXCMO, SBÑOR:

Animado por mi entrañable amor á nuestra Armada, me atrevo hoy á dar á luz la inapriciable joya que durante cien años estuvo encerrada en el polvo de los archivos; y al buscar el nombre de un navegante contemporáneo á quien dignamente pudiera dedicársela, he hallado que á $V$. E. asiste el mejor derecho, nó por la alta posición yue ahora ocupa (cualquiera que sea la gloria que en ella logre,, sino por los grandes méritos que contrajo como Fefc de la fragata Numancia en su asombroso viaje de circunnavegación.

No es dudoso que V. E. verá con simo agrado enaltecidos al fin, por sus propias obras, á esos marinos eminentes que dirigieron la famosa expedición de las corbelus Descubierta y Atrevida. Yo me felicito de que este verdadero desagravio se cfectíe en momentos de encontrarse al frentè de la Marina el antiguo Comandante dcl primer acorazado que dió la -vielta al mundo, con sorpresa de Europa, y' en momentos de hallarse á punto de emprender un viaje igual la fragata Blanca, á cuyos Oficiales reportara esta obra grande instrucción $y$ noble estimulo.

Con la mayor consideración y respeto saludo a $V$. E. y B.S. M.,

Pedro de Novo $\times$ Colson.

Madrid, Mayo de 388 


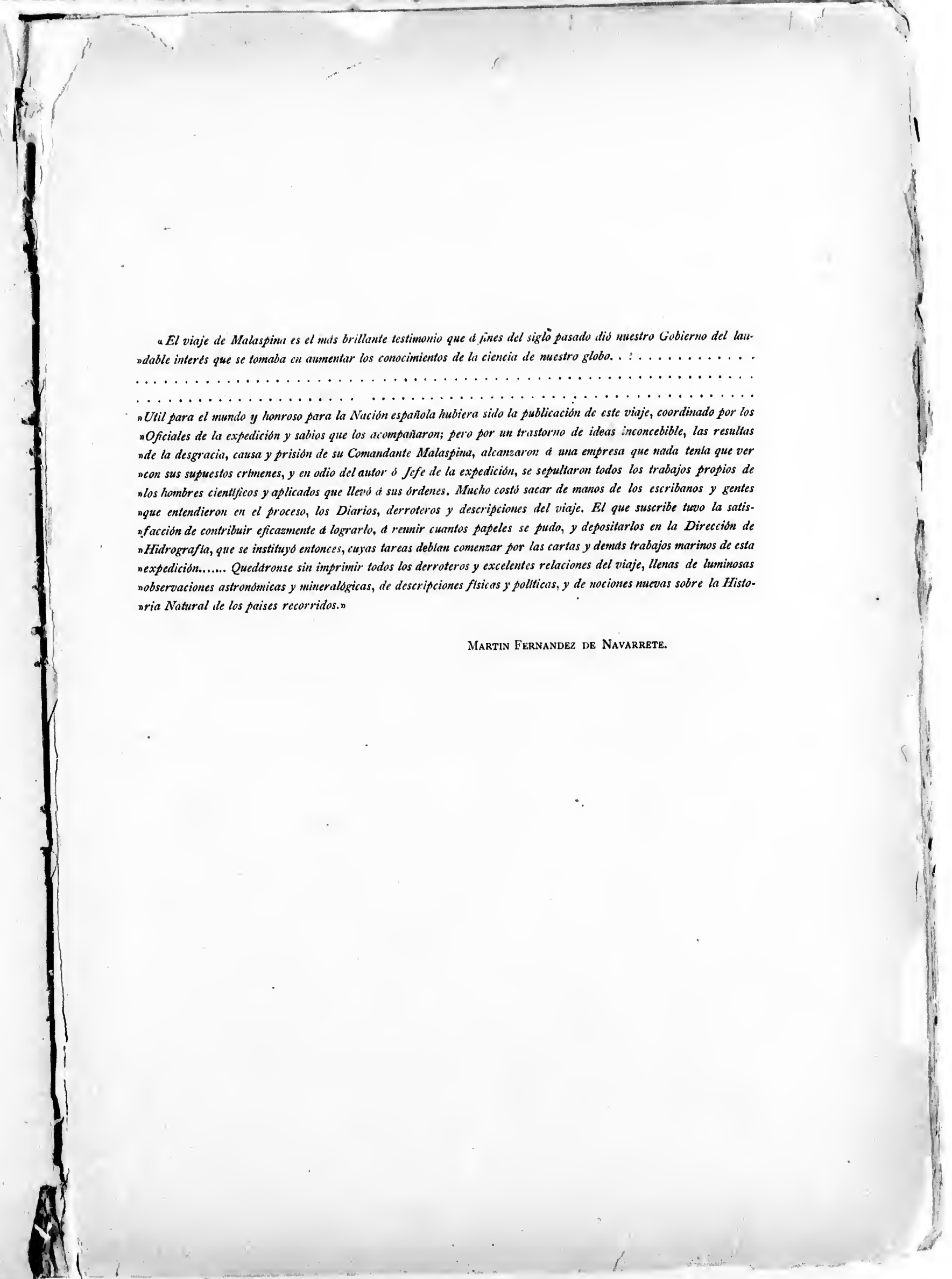




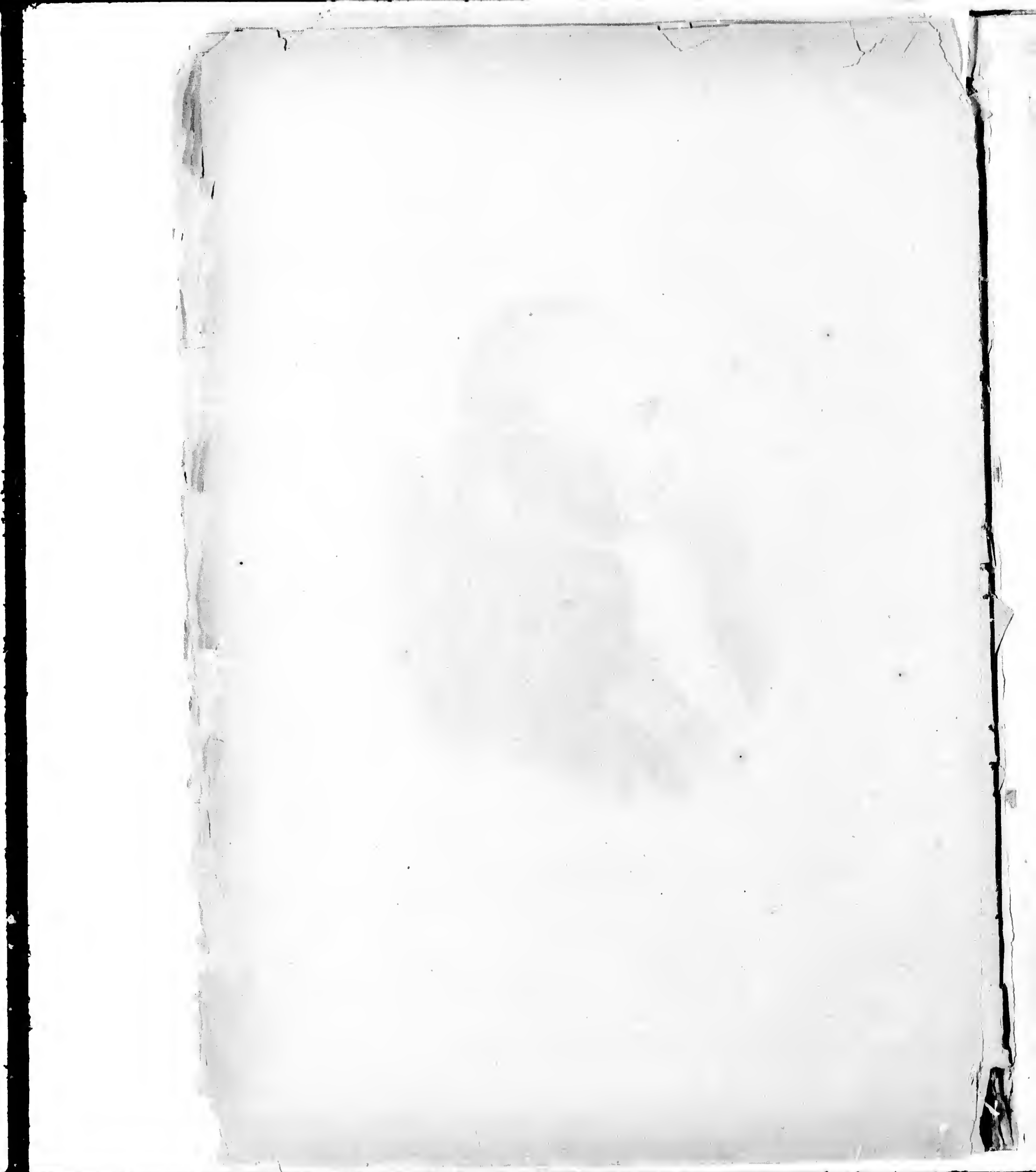




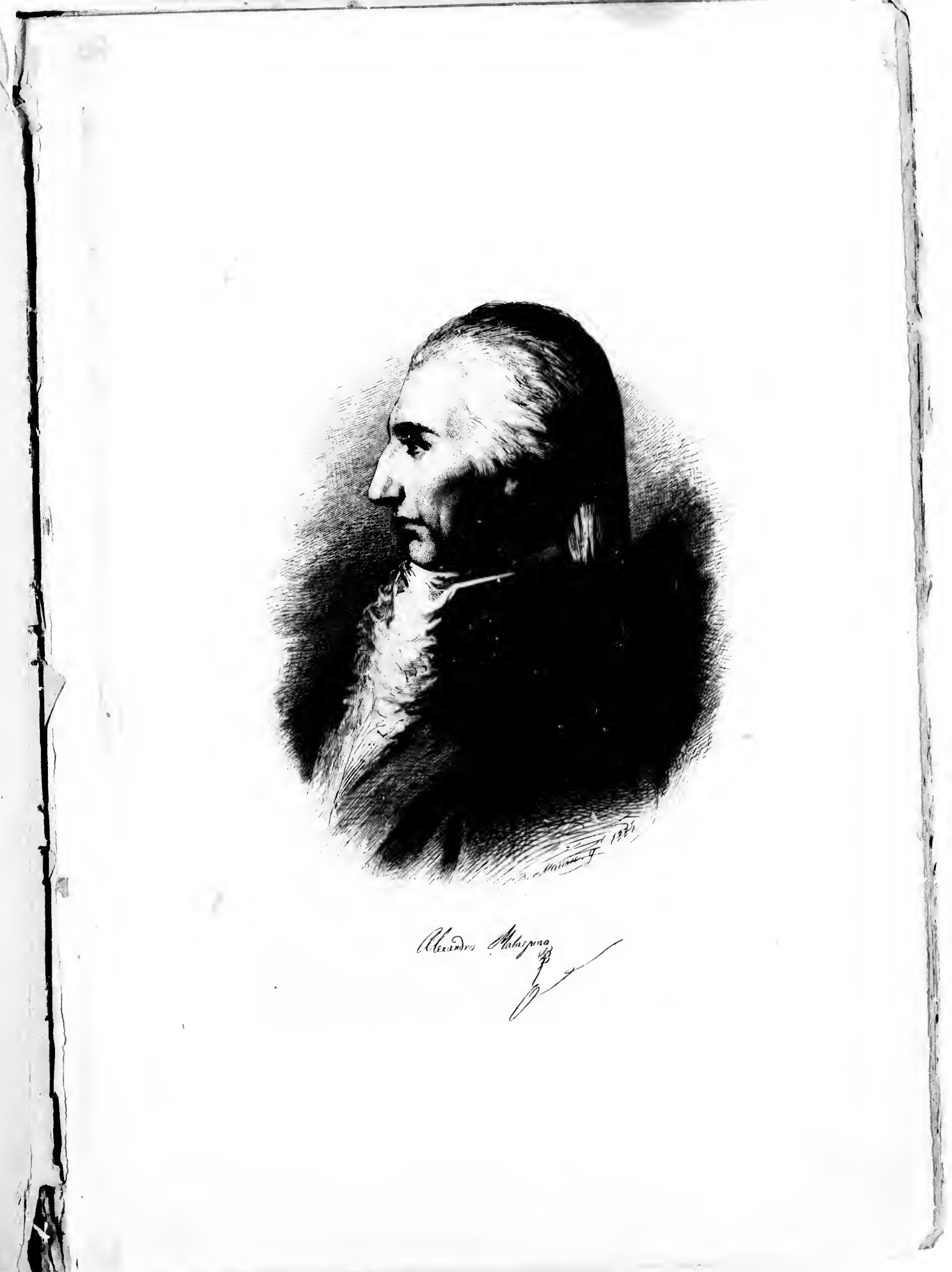




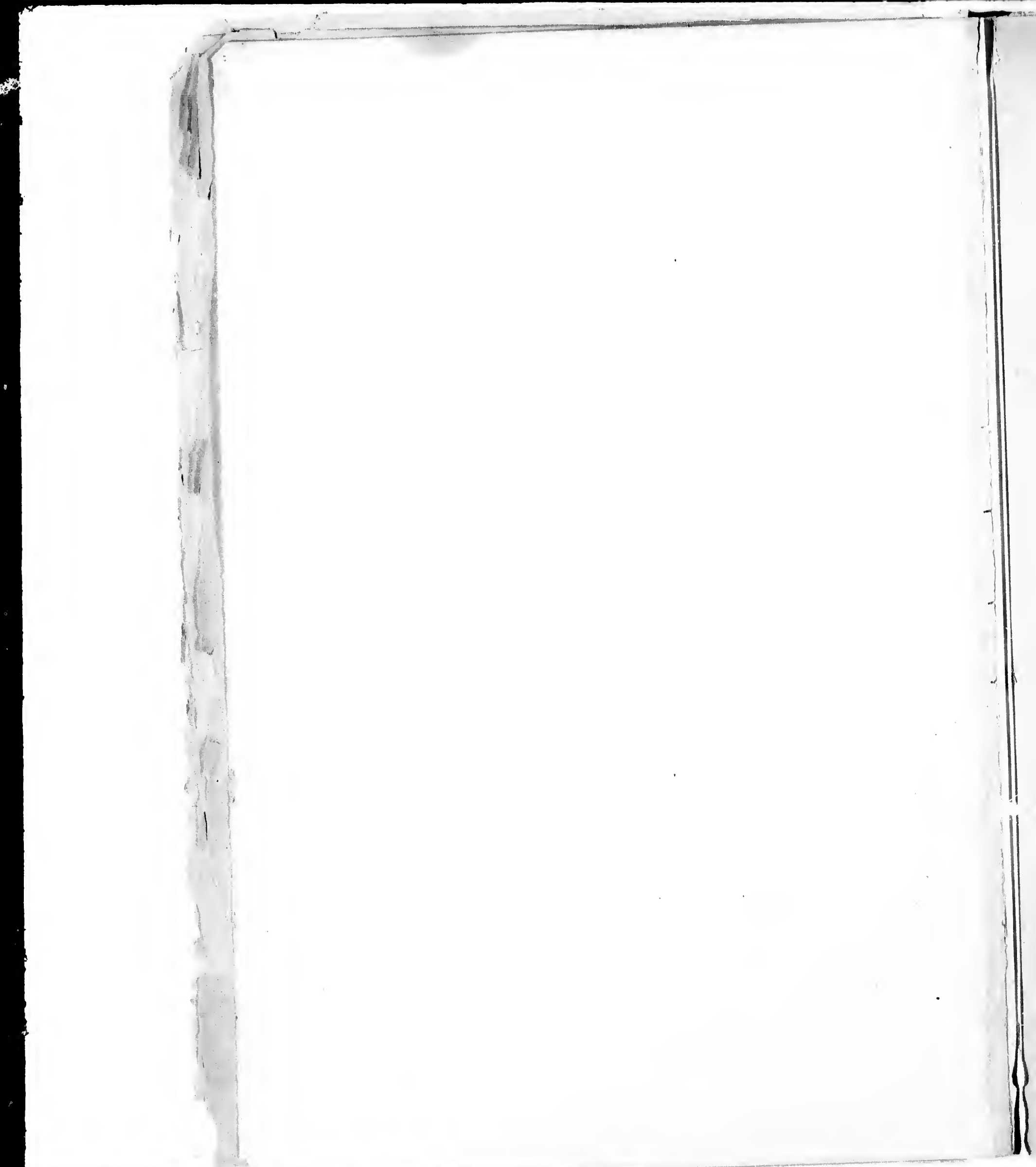




\title{
INTRODUCGIÓN HISTÓRICA
}

\author{
I \\ Algunas Reflexiones sobre la conveniencia de publicik esta obra
}

Pocos días hace que, entregado á mi lectura iavorita, fijé la atención en una página de In Historia general de los Descubrimientos Maritimos, famosa obra de W. Desborough Cooley. Con más disgusto que sorpresa, encontré en ella las apreciaciones que transcribo -literalmente:

«En 1775, dos buques españoles, bajo las órdenes de D. Juan de Ayala y de D. Anstonio Maurell, contribuyeron en algo á los progresos de la Geografia, examinando su"perficialmente la costa N. O. de América entre los 47 y $57^{\circ}$ de latitud. Esta expedición * había recibido orden de llegar hasta el paralelo de $65^{\circ}$; pero los navegantes cspañoles no "habian estudiado tanto como los de otras naciones la ciencia de levantamientos de planos "y su examen de la costa no pasó de los $57^{\circ}$. Una gran bahía ó estrecho en $57^{\circ}, 17^{\prime}$ de »latitud, fué nombrado por ellos Puerto Bucarelli, en honor del Virey de Méjico..... El re» sultado de este viaje pareció satisfactorio al Virey, pues en 1779 envió una segunda ex»pedición para que continuara el examen de la costa desde los 58 á los $70^{\circ}$. Como la signorancia de los españoles igualaba en esta época á su RESERVA y su sILENCio, es posible "que el Virey no supiese la existencia de un navegante inglés llamado Fames Cook, el ^ cual había hecho este estudio el año anterior, con el firme propósito de comunicar sus * resultados á todo el universo. Aquella nueva expedición no añadió nada á los conoci`mientos gcográficos..... Maurelle, á su vuelta, quiso levantar una carta exacta de la costa; "poro se sube que en 1779 los españoles calculaban todazia su longitud sigún le cstima, smientras que los franceses y los ingleses se servian ya, desde algunos años, de cronóme"tros Y de OBSERYACIONES LUNARES."

Si no fuera tan ilustre y respetado el nombre de Desborough Cooley, habría yo leido impasible una vez más ese cúmulo de inexactitudes é injusticias, cosecha añeja y frecuentc que recibimos del extranjero; pero el notable historiador británico, es, desde mediados del siglo, el oráculo de mucluos eruditos y escritores, así como su obra nasto casi universal de los estudiosos; y esto ya merece que contesie España vindicándose, no por conducto 
de sus sabios, que fuera inoportuna cortesía, sino por uno de los más humildes oficiales de su Armada, lo que toma carácter de severo castigo.

Tantos nombres y tantos hechos acuden á mi memoria; tan grande es el número de nuestros marinos ilustres, que necesito concretarme á los que lo fueron solamente por su sabicluría, $y$ de ellos citaré nada más, como aludidos, á los que durante esos años de 1770 á 1780 suıcaban el Océano sin otra ayuda que la brújula y la corredera, según afirnación del historiador inglés.

¿Será cierto que D. Francisco Maurelle, ignorase en su segundo viaje al N. O. de América, que Cook existía y navegaba y que se proponía comunicar al mundo sus trabajos? Quizás. Pero, en cambio, no admite duda que este famoso marino tuvo perfecto conociniento de la primera expedición de Maurelle y que su Diarıo sirvió de guía y consulta á Cook, quien aprovechóse de las noticias y descubrimientos consignados en sus páginas. Más adelante fuć impreso el Diario de Maurelle por Sir Barrington en su libro las Misce. láncas (1) Maurelle efectuó muchas exploraciones y una notabilísima en la fragata Princesa, en 1780 , desde Manila á Nuča España al través del Pacífico, tardando 10 meses. Formó una tabla de la s'tuación de los bajos é islas vistos durante el viaje.

Según Desborough Cooley, los españoles eran incapaces de lcvantar planos con exactitud en 1779 y desconocían el uso de los cronómetros y de las observacioncs lunares..... Con efecto, prueba todo lo contrario el hecho sabidísimo que siete años antes de aquella fecha (navegando en la fragata Venus, por cercanías del Cabs de Buena Esperanza), un Oficial español, D. José de Mazarredo, fué inventor (que así puede llamarse), del procedimiento para hallar la longitud valiéndose de las distancias lunares.

Era la noche despejada; cerca de la luna brillaba Aldevarán, y contemplándolas el sabio joven, imaginó obtener la situación de su nave, tomando simultáneamente las alturas de ambos astros y su distancia, y resolviendo los triángulos esféricos precisos para lograr la longitud de la luna como base de partida. Consultó Mazarredo á su Comandante, que lo era el insigne Lángara, y éste, lleno de fé, se dispuso á ayudarle en unión de otro inteligente Oficial, Ruiz de Apodaca. Los trabajos duraron dos días y fueron ímprobos, porque aún no se habían generalizado los almanaques náuticos ingleses, donde se daban las tablas de distancias de luna á estrellas, publicación que casi conenzaba. El éxito más feliz coronó la idea de Mazarredo, y pudo enorgullecerse de haber invertado un método importantísimo, que si bien ya había sido indicado por Lecaille, era aún totalmente desconocido para el marino español y para la inmensa mayoría de los navegantes (2). Seis años después, en 1779 , usábanse mucho estos cálculos en nuestra Marina y apenas se halla un Diario de aquella época en que no se vean reunidos los adelantos todos de la Astronomía náutica.

Ninguna nación pudo jactarse de enseñar mejor á su juiventud que nuestro país, desde que en 1751 el ilustre Jorge Juan fué nombrado Capitán de Guardias Marinas. No existía por entonces en Europa obra más perfecta que su Compendio de Navegación. Quien dude de la superioridad de este sabio, recuerde el curioso fruto de su viaje á Inglaterra

(1) Véase en la Biblioteca del Depósito Hidrográfico de Madrid. Obra titulada Establecimientos Ultrama. rinos, tomo IV, paig. $53^{8}$.

(2) Para mayores detalles consuiltense, entre otras obras, la Biblioteca Maritima de D. Martín Fernández de Navarrete y la Galeria Biografica de Generales de Marina, por el Vicealmirante Pavfa. 
en 1 749. Fué comisionado por el Gobierno para estudiar y aprender los métodos de construcción naval en aquella Monarquía, y á poco de hallarse allí, inventó un nuevo sistema, tan ventajoso y ad irable, que los ingleses, abandonando todos los suyos, adoptaron inmediatamente el ideado por Jorge Juan; y este método fué el único que presidió desde entonces y aún hoy preside para las construcciones de los buques de velá.

Discípulo del autor de la inmortal obra Examen Maritimo, fué D. Juan de Lángara, hidrógrafo excelente, quien á su vez difundió los últimos descubrimientos de la ciencia entre la pléyade de Oficiales que navegaron con él; y desde 1772 á 1776 efectuó trabajos que llenaron de asombro á los marinos ingleses y franceses, capaces de comprenderlos (1).

Bajo las ordenes de Lángara sirvieron: D. Diego Alvear y Ponce, quien de Alférez de fragata fué nombrado Conisario de la demarcación de límites de España y Portugal en América, y de cuyo curiosísimo Diario (cinco tomos folio) se conserva una copia con gran estimación en el Musco Británico de Londres; D. Bruno de Hecela, que en 1773 hizo importantes descubrimientos en la Alta California y construyó cartas y planos excelentes de sus puertos; D. Francisco Millau, que en 1776 determinó los límites entre Buenos Aires y Paraguay; levantó los planos de Rio Grande, en la América del Sur, de su costa y también de las Malvinas; D. Juan Varela, que en 1774 ayudó eficazmente á marcar la situación verdaclera de la Isla Trinidad y poco más tarde la de las islas del Golfo de Guinea, las de Santa Catalina en el Brasil y de los puertos del Rio de la Plata, mereciendo el título de Correspondiente de la Real Academia de París; y por último, el ilustre Mazarredo, que ya se ha citado, así como otros muchos brillantes Oficiales que sería prolijo enumerar.

Es por cierto sorprendente que desde époc a bastante anterior á 1779 se dicran tan buena traza para sacar partido del atraso de la cosmografía tantos marinos españoles rezagados en el estudio ó enemagos de la ciencia. Así lo prueban D. Vicente de Doz, Alférez de fragata, que en 1760 levantó el plano del Rio Orinoco y en 1769 obscrvó en California el paso de Vénus por el disco solar, y determinó la longitud exacta de la misión de San Jorge; D. Gabriel de Aristizábal, de quien por sus profundos conocimientos dijo Mazarredo dirigiéndose al Ministro: "Suponiendo que cada Oficial de Marina valiera un ciento por ciento más que yo, no valdrían, sin embargo, todos juntos la mitad que Aristizábal.» Sus trabajos hidrográficos en Turquía y sus apuntes para la obra Viaje á Constantinopla, dieron más tarde disculpa al apasionado elogio. D. Santiago de Zuloaga, autor de las Maniobras Navales y de la demarcación de límites en Cumaná de Venezuela, en 1751 ; D. Domingo Boenechea, descubridor de varias islas del Pacífico y constructor del plano de la de Otahiti; D. Juan Herrera Dávila, que levantó planos de casi todos los puertos de la Costa Firme septentrional; D. Gonzalo López de Haro, que reconoció é hizo cartas del Estrecho de Fuan de Fuca; que antes labia recorrido la costa N. O. de América hasta los $60^{\circ}$, levantando su plano, y después señalado los límites del puerto de Nutka y reconocido y formado los planos de la California, la Sonora é islas inmediatas; D. Joaquín Fidalgo, que en los bergantines Empresa y Alerta realizó un amplísimo é importante trabajo hidrográfico en las costas de Tierra Firme, desde la provincia de Cumaná á Darien del Norte y Portobello, nereciendo ser en su ancianidad nombrado Director del

(I) La mayor parte de sus trabajos y de sus obras se conservan en el Depósito Hidrográfico. Su simple inspección da idea del mérito de este marino. 
Depósito Hidrográfico y luégo Director también del Observatorio Astronómico..... Pero ¿qué manifestación más elocuente é irrefutable de la altura que habia alcanzado España en las ciencias positivas que la ofrecida a .iundo en 1735, con motivo de la medición del grado de Meridiano en la América Central? Recuérdese que entonces nombró Francia para el objeto á tres sabiós ilustres, mienbros de su Acadenia, y España, por su parte, envió, llena de confianza, á dos imberbes Guardias Marinas, que hubo necesidad de ascender á Tenientes de navio á fin de que pareciera ménos escandalosa la desproporción de categorías, ya que lo eran tanto las edades. Aquellos sabios franceses, los Sres. Bouguer, Godin y la Condomine, aceptaron por compañeros á los dos españoles con despecho y desdén profundo en un principio; despecho y desdén que más tarde se trocaron en admiración sin limitos. ¿Cómo no, si aquellos jóvenes se llamaban D. Jorge Juan y D. Antonio de Ulloa?

De! priniero he hablado lo indispensable; del segundo, squé puedo decir de nuevo á la Europa culta?

A más respeto y justicia cran acreedores nuestros antepasados en el ilustre cuerpo de la Armada. Hariase interminable la relación de los que le dieron honra con su ciencia; pero no he querido mencionar sino aquellos que por haber gozado larga vida y alcanzado altos puestos, consolidaron sus reputaciones envidiables, $y$ en todo tiempo se prestan fácilmente al análisis del historiador. No cito, pues, á los que por su corta existencia sólo recogieron primeros laureles, si bien éstos son inmarcesibles y constituyen una gran parte del tesoro de nuestros Archivos.

Atento á dicho propósito, evocaré á algunos más de universal renombre, como D. Vicente Tofiño, constructor del grandioso Atlas nuarítimo de España, celebrado por propios y extraños; astrónomo eminente, en concepto de Bordá, Lalande y otros de igual fuste. D. Julián Sánchez Bort, verdadero genio en el arte de construir, á quien se deben las mejores obras de muestros arsenales, el que (desde 1748 á i 785 , que falleció siendo Capitán de navío), logró innumerables triunfos, citándose por lo difícil el gran muelle que cierra la dársena de Ferrol, levantado en 24 metros de agua. D. José de Mendoza y Rios, geómetra excelente al par que hábil maniobrista, autor de la $\mathrm{Na}$. vegación Astronómica, libro que le conquistó el empleo de Capitán de fragata cuando aún era menor de edad; el que compuso y publicó las voluminosas Tablis que llevan su nombre, prinera y única obra de su género que se hacía en Europa, y que adquirieron con avidez todos los marinos del mundo civilizado como objeto indispensable para las navegaciones prolongadas; sin las Tablas de isendoza era largo y dificilísimo el cálculo de la longitud por las distancias lunares: con ellas cualquier pilotín mal instrúdo puede utilizar este método de situación. D. Gabriel de Ciscar, comparable al marino que antecede por su ciencia profunda, y el primer hombre de la Naciön considerado por su saber matemático, según escribía al Rey el Ministro Lángara al proponerle que el Capitán de navío Ciscar representara á España en un Congreso de sabios convocado por el Instituto de Francia. Y por último, D. Martín Fernández de Navarrete, miembro de todas las Academias importantes, y tan alabado como erudito, que apenas se recuerdan los diez y siete años que navegó y que combatió, ya con los franceses, ya con los ingleses, así como tampoco es del vulgar dominio que en las ciencias sobresalía hasta el punto de admirar á hombres de la talla del Barón de Zach, de Hunıbolt, de Washington Irving, de Prescott, de Berthelot y de Miguet. 
Con lo expuesto, basta para contestar á las apreciaciones del historiador britinico. Ahora debo añadir que no era suya la culpa de la ignorancia que demuestra respecto á los méritos contrá́dos por navegantes españoles: debíase en gran parte á la rescria y el siIencio que guardábamos, como acertadamente dice Desborough Cooley. Reserva y silencio que inspiraron al ilustre Vargas Ponce estas reflexiones amargas (1). "Aquellas circuns. tancias (las razones políticas que aconsejaron el sigilo) perdiercii su valor, y la calidad de tales negocios y navegaciones no sufría un absoluto secreto; y con todo ocultaba nuestro Gobierno papeles tan instructivos. Empezaron otras naciones á hacer gala de sus trabajos marineros y á publicar, así las cartas nuestras, de que se apoderaban, según aconteció al Almirante Anson, como las que corregían con superiores auxilios; y todavía continuaba nuestro ya insensato misterio. De aquí que busquemos con ansia en viajes y derroteros extraños el conociniento de nuestros estrechos y mares, de que fuimos los más escrupulosos investigadores; de aquí que atormentemos nuestros oídos y forcemos nuestra pronun. ciación con nombres peregrinos y rudos para entrambos, trascordados los primitivos españoles con que se bautizaron; y de aquí que recibamos con admiración y como recien. tes noticias y objetos que supimos y con que nos familiarizamos los primeros de Europa. Si en las Islas de Salomón y tantas del Pacífico no fuera esto tan patente, bastaría citar el aparato con que se nos vendió como descubrimiento ageno la proyección de la California, que el Piloto Castillo, su primer descubridor, ya le señaló como península. A pesar de tıın bochornosas lecciones, no há veinte años que los documentos maritimos que perclonó la polilla y el polvo yacían dispersos en distintos depósitos, tan oćultos como cuando se so. terraban á principios de la dinastía austriaca, para que no se divulgaran los nuevos runbos á las Molucas. "

Es verdaderamente sensible la indiferencia cuanclo nó la oposición demostrada por nuestros Gobiernos hacia las tentativas de dar á luz tantas brillantes demostraciones de lo que ha valido siempre la Armada española. Crecríase, quizás, que el abandono ó falta de propósito de nuestros marinos, hicieran difícil la compaginación y arreglo de sus apuntes para ser publicados, mas por el contrario, suspenden y arroban cl espíritu las metódicas é interesantes narraciones que manuscritas yacen condeuadas á perpétuo encierro. Por suerte, en ocasiones (raras) una mano audaz ó gencrosa arranca del estante algún legajo y lo arroja á la prensa. Esto hago yo ahora, no audaz ó generoso, sino verdaderamente subyugado, aturdido, lleno de emoción gratísima y de patrio orgullo, ante la lectura del asombroso al par que desconocido viaje de circunnavegación efectuado por los españoles desde 1789 á i 794 , á bordo de las corbetas Descubierta y Atrevida.

¡Es triste considerar que el inapreciable tesoro de gloria y ciencia cosechado en esta expedición ha permanecido oculto cerca de cien años, á causa de la venenosa política que asomó su cabeza de Medusa; recordar que aquel tesoro estuvo condenado á desaparccer, á ser destruído por odio ó envidia á un hombre eminente, y tocar como resultado de este anatema, que no sólo los extranjeros, sino los españoles, poseen una muy vaga idea de la notabilísima expedición, y tambiéu ideas vagas de su importancia, sólo por preseııimiento ó por lo que han escuchado á algún erudito!

(1) Importancia de la Historia de la Marina Española, pág. 98.-Discurso por D. José de Vargas y lonce. Madrid, 1807. 
Para disponer el ánimo á seguir los rumbos de las corbetas Descubierta y Atrevida, necesito valerme de un término de comparación exacto y oportuno. Los viajes (publicados) de D. Antonio de Córdoba en 1785 á bordo de la fragata Niestra Señora de la Cabeza y en 1788 mandando los paquebots Santa Casilda y Santa Eulalia, rindieron un hermoso estudio descriptivo é hidrográfico del Estrecho de Magallancs; pues bien: con no menor amplitud los Jefes de las corbetas estudiaron, levantaron planos y recorrieron cuanto solicitaba entonces la curiusidad científica, desde las cercanlas de Bcering á Nueva Holanda, desic la Alta California al Cabo de Hornos, desde el Círculo Boreal hasta las barreras del Polo Sur. Y si en las expediciones de Córduba brillaron Oficiales tan entendidos como D. José cie Gardoqui, D. Alejandro Belmonte, D. Miguel de Zapiain; de tan sobresaliente mérito como D. Francisco Javier de Uriarte, que por espacio de un mes reconoció en un débil bote el proceloso Estrecho descubrienclo islas y puertos, de los cuales uno lleva su nombre; D. Dionisio Alcalá Galiano, que efectuó trabajos admirables; D. Ciriaco Cevallos y D. Cosme Churruca, que unidos soportaron, con valor inaudito, la inclemencia de aquellas regiones, tripulantes de otra lancha, mientras levantaban planos de la Tierra del Fuego en la totalidad de su costa, desde Cabo Dunes hasta el Pacifico....., es lo cierto que también á las órdenes de Malaspina y Bustamante, Jefes de las corbetas, sirvieron (escogidos por el primero) además de los mismos señores Cevallos y Alcalá Galiano, infatigables y entusiastas, el famoso sabio D. Felipe Bauzá, cuyos servicios fueron solicitados más tarde, aunque sin fruto, por los ingleses; el inimitable en la construcción de cartas, de las que legó un sinnúmero de portentosa exactitud, D. José de Espinosa y Tello, cuyo saber pregonan el reconocimiento que hizo de los canales de Nutbea y de los mares de la India, y años después las extensas Memorias que dió á luz siendo primer Director del Depósito Hidrográfico; D. Juan Gutierrez de la Concha, digno compañero de los anteriores y á quien estaba reservado alcanzar en América la palma de la gloria y la palma del martirio; D. Cayetano Valdés, cl más jóven de esta Oficialidad, pero no el menos inteligente, según lo prucba su exploración difícil del Estrecho de Fuan de Fuca, hecha con rapidez y maestría. Y por último, los hermanos D. Arcadio y D. Antonio Pineda, notabilísimo naturalista éste, que á su muerte, acaecida durante el viaje, legó al primero el arreglo y continuación de sus observaciones $y$ escritos.

Con tan valiosos auxiliares no sorprenderá que transcurridos los cuatro años de navegación hubiera presentado al Gobicrno de España el ilustre Malaspina, para que vieran la luz pública, además de la Relación ceneral del viaje, verdaderos tratados de cada una de las ciencias que fueron objeto de sus estudios, á saber: Astronomia, Hidrografía, Física, Historia Política é Historia Natural ( 1 ).

Antes de dar más amplias noticias de Malaspina, de su viaje y de su proceso, debo repetir las palabras del epigrafe: que es conveniente publicar esta obra:

Primero: á fuer de vindicación cumplida, y dato irrefutable que hará impresión en el pucblo inglés, marítimo por excelencia y gran maestro en las empresas navales.

(1) Para formar juicio de la extensión con que se hicieron estos estudios, basta decir que el Tratado de Historia Natural ocupa cinco tomos de 500 páginas con cerca de 40 mapas y dibujos. Para pensarlos y escribirlos su principal autor, D. Antonio Pineda, tuvo por gufa valiosa un plan o instrucciones que el célebre naturalista de Módena, Jázaro Spallanzani, habła remitido á Malaspina. 
Segundo: porque España debe á aquellos nobles hijos suyos un desagravio, aunque tardío, mostrando al mundo sus prendas eminentes y abriéndoles paso á la inmortalidad ganada por su ciencia, ya que no todos, afortunados como Galiano y Valdés, la merecic. ron por las armas.

Tercero: porque tanto se adelantaron á su tiempo aquellos sabios Ofieiales y tan pro. funda y discretamente meditaba Malaspina, que, comenzando por los preparativos de los buques y concluyendo por el desarme de los mismos á su regreso, son hoy (ipasado un siglo!) enseñanzas provechosísimas todas sus páginas para la marina actual, y más directamente para los que se disponen á emprender el viaje de circunnavegación en la fragata Blanca.

A tan buenas razones fáltanos añadir la más poderosa; evitar que España reciba una lección que le avergience, pues vergonzoso sería que otro país, anticipándose, diera á luz esta misma obra. No era remoto el peligro. Me consta que un hombre de ciencia $y$ alto funcionario de Chile ha sacado copia (por orden de su gobierno y con autorización del nuestro), de todos los manuscritos, cartas y hasta dibujos pertenecientes al viaje de las corbetas. Trabajo ímprobo y costoso que honra á aquella República modelo y que una vez más confirma su cultura y amor al estudio. Ignoro si śu propósito es publicarlos ó enriquecer sus bibliotecas con las copias; pero en tal caso á nadie perjudica, el que impreso, facilite yo á todos una lectura selecta. Si era éste también su móvil, entonces perdóneme la patriótica Chile, considerando que desde los tiempos bíblicos es divino mardamiento el dar al. César lo que es del César.

Don Alejandro Malaspina.-Su viaje.-Su proceso.

Este ilustre marino nació el 5 de Noviembre de 1754, descendiente de la casa soberana de Lunagiana y de Mulazzo (famosa entre los giielfos y defensora de Italia contra Federico Barbaroja). Era su padre el Marqués Cárlos Morello y su madre Catalina Melilupi, de la familia de los Príncipes de Soragna, circunstancia que facilitó á Malaspina cruzarse de Caballero de Justicia en la Orden de San Juan de Malta apenas hubo sentado plaza de Guardia Marina, en Cádiz, en 1774, entrando al servicio de España. Dos años después, con el empleo de Alférez de fragata, navegó por el Atlántico, Océano Indico y mar de China. En 1778 ascendió á Teniente y en 1779 tomó parte en el glorioso combate del Cabo de Santa María, á las órdenes de Lángara. Su navio (el San Fulian) fué uno de los cuatro que con aquel ilustre caudillo mantuvieron el choque de las triples fuerzas inglesas ( 14 buques españoles contra 31 ) para salvar á los restantes. En I 788 , ya de Teniente de navio, asistió al terrible bombardeo de aquella plaza inespugnable y fué de los que tripularon las famosas baterias flotantes (imaginadas por el francés d'Arson) que tan 
en cuidado pusieron al General Eliot por los extragos que hacian en las murallas. Como recurso supremo, aunque opuesto al derecho de gentes, Eliot empleó contra ellas balas rojas de grueso calibre, que las incendiaron muy pronto merced al huracán deshecho que á la sazón reinaba. Más de 1.000 hombres perecieron ahogados 6 carbonizados. Malaspina logró salvarse, y poco después embarcaba en la escuadra de D. Luis de Córcloba, que atacó en la boca del Estrecho á la del Almirante Scrope (Conde de Howe), el cual se batió en retirada.

En 1782 ascendió Malaspina al inmediato empleo, $y$ obtuvo el nando de la fragata Astenciön, con la que efectuó un largo viaje por Asia y Oceanía, hasta 1784 que, de re. greso á Cádiz, fué nombrado Teniente de la companía de Guardias Marinas, cuyo destino abandonó pronto para mandar la Astrea, magnífica fragata de condiciones excepcionales, y citada con frecuencia por Malaspina en la presente obra. En ella dió la vuelta al mundo, recorriendo primeramente varios puertos de la costa occidental de América, y, doblado el Cabo de Hornos, otros impórtantes de la occidental; luégo muchas islas del Pacifico, las lïlipinas, regresando al fín por el Cabo de Buena Esperanza á Cádiz. Este largo y penoso viaje habiale rendido mucha enseñanza y había templado su espíritu para emprender el que hoy se publica, y para llevarlo á término tan feliz como de resultados asombrosos, ya se consideren estos resultados bajo el punto de vista científico, ó político, 6 histórico 6 marinero. No quiero anticipar á los lectores lo que han de hallar escrito por el ilustre navegante en estilo poco correcto sí, pero lleno de frescura, de espontaneidad y de sencillez, condiciones preferibles á todas las otras. Me concretaré, por tanto, á decir lo que no pudo ni áun sospechar que le ocurricra cuando volvió á España ceñido de laureles.

Publícansc una serie de documentos que, á más de lo curiosos, encierran útil enseñanza. La solicitud de Malaspina y Bustamante pidiendo dirigir la expedición; la respuesta y observaciones del gran Ministro D. Antonio Valdés; las cartas de Malaspina al insigne Ulloa y al Proto-Médico Salvaresa; las que el mismo escribió al Subinspector de Arsenales y al sabio Ingeniero Muñoz, son bucnos testimonios del profundo conocimiento, sentido práctico y escrupulosidad con que atendía y lo preparaba todo hasta en sus menores detalles; asf como las Instruccioncs que comunicaba á su inmediato subalterno, el Comandante de la ATREvida son un modelo de previsión, sagacidad, cordura y sabiduría. Sólo estas Instrucciones revelan que Malaspina era un hombre superior: el Discurso preliminar convence de que sus ideas políticas eran liberales (quizá con cxceso para aquella época), sobre todo en lo referente á las colonias; y la Relación de su viajc persuade de la justicia con que de él decía cl Ministro Valdés: «Que por sus conocimientos, cuna, nobleza y elegancia de la persona y maneras, arrogante presencia, afabilidad, firmeza de carácter y talento de sociedad, era Malaspina el primero de la Armada española y el único para aquel cargo, alma de la culta y distinguida sociedad que nuestros marinos debian representar en los paises americanos, para influir favorablemente en el ánimo de los criollos y ayudar á la politica y demás fines ciue la expedición llevaba.»

Poquísimos antecedentes se conocían de tan insigne navegante, hasta que, por fortuna, el Académico de la Historia y cruditísimo escritor Sr. Jimenez de la Espada publicó (I) un amplio estudio con el título de Una causa de Estudo lleno de revelaciones interesantes sobre

(1) Rerista Contemporanea, ano de $188 \mathrm{r}$.-Carta dirigida al Sr. D. Gaspar Muros 
el proceso de Malaspina. $Y$ como dicho estudio es originario de las únicas fuentes que existen, á él necesito concretarme y referirme casi en absoluto, para lo que me doy por concedida la venia del distingurido Académico y buen anigo nío.

Dice el Sr. Jimenez de la Espada eque resulta de varios papeles, unos reservados y " confidenciales, otros probablemente destinados al público, aunque no me consta que sa- licran á luz, que la causa del insigne navegante se relacionaba con un grave suces. politici- amoro:o, que estuvo á punto de dar al traste con la más larga y felicisima prizanza de "las que: influyeron en los destinos 6 fueron Destino de nuestra patria en el pasado siglo."

Ello es que Malaspina, á su regı eso, fué cariñosamente recibido en la córte y con toda bonclad por María Luisa; sábese que en aquellos días algunas sombras nublaban la estrella de Godoy; pero que este favorito posela medios para sobreponerse á las veleidades de la Reina.

Véase la luz que accrca de estos puntos nos da D. Joaquín. Lorenzo Villanueva, contemporáneo de Malaspina:

- A todos nos causó sorpresa su arresto cuando estábamos aguarclando la publicación de su viaje. Por largo tiempo se estuvieron haciendo castillos en el aire sobre este incidente; atribufanle unos á escritos suyos; otros a haber comentado la vida de la Reina Maria Luisa, que poco tiempo antes había aparecido en Francia. Para nul lo más verosínil, y pudiera decir cierto, es que aquel célebre marino fué víctima de una intriga entre la Reina y dos damas suyas, que fueron la Matallana y la Pizarro, y el Principe de la Paz. En un intervalo de desafecto y resentimiento en que audaba la Reina á caza de medios para cortar la privanza del valido, fué buscado Malaspina por estas damas para que á la vuelta de la Lombardía, su patria, á donde iba con l: :encian, trajesc realizado el plan de cierta carta que había de influir con el Rey para tan santa obra. Este plan, escrito incautamente por $M a$ laspina y guardado por la Reina en una gaveta, fué revelado á Godoy por la Pizarro, estrechada de él por sospechas que le inspiró una indeliberada expresión de la Reina. La $M a$ tallana, de quien exigió primero la revelación del secreto, se negó á ello constantemente. El plan, descubierto y pintado por Godoy á Carlos IV con los colores que le convenían, sirvió de instrumento de su venganza. La Malallana fué presa y desterrada de la corte. A Malaspina, después de haber sido preso en el cuartel de Guardias de Corps y confinado en ẹ castillo de San Antón de la Coruña, se le permitió restituirse á su país, previniéndole, so pena de muerte, que no volviese á territorio ninguno de la Monarquia española. Los achaques contrafdos en sus viajes y en el encierro deterióraron su robusta salud en términos que, á poco tiempo de haber llegado á la Lombardía falleció con el desconsuelo de no haber podido volver á España, la cual llamaba patria suya en las cartas de sus anigos. *

- Lo que nunca pude atinar fué qué pecados cometió para el Príncipe de la Paz, en aquella ucasión, el docto Padre Manuel Gil, Clérigo menor de Sevilla, para que fuese lle. vado de Madrid á aquelia ciudad á la casa de corrección llamada Los Toribios, de que habia sido Director. Habíasele dado la comisión de poner en buen lenguaje español la relación del viaje de Malaspina; en su infriga nadie creyó que hubicse tenido parte ninguna, y por lo mismo fué mayor la sorpresa de los que le conocimos al ver tratado á un eclesiástico tan digno con aquella especie de escarnio. Estos frutos amargos de la desmedida deferencia de los Reyes á las pasiones de sus validos, no se cogen sino en las Monarqquías despóticas. En ellos he visto yo envueltos aún á algunos de los que las aman., 
* Hé aquí por qué perdió la causa literaria de la Marina europea la publicación de aquel viaje y de las observaciones de los sabios matemáticos que lo desempeñaron á costa de grandes trabajos y de largas expensas de la nación. Por fortuna pudieron salvarse la relación del derrotero, las observaciones hechas durante la expedición en las cost.us de Antérica, Nueva Holanda, Macao y Manila; las de Espinosa y Bauzá, en el interior de la América Meridional, con los demás documentos que se acopiaron en aquella enpresa. Mas esto se debió á la suma reserva con que se depositaron tan preciosos tesoros en la Secretaría de Marina, de donde, formado ya el Depósito Hidrográfico, vencicndo dificultades, pudieron trasladarse á este Estableciniento. En las Memorias sobre las Observaciones astronómicas que publicó el año 1809 , se imprinió una noticia de 'os descubrimientos y observaciones de Malaspina, única muestra de sus viajes que ha visto la luz pública.."

Este Padre Manuel Gil, era hombre de erudición y perspicacia, y aunque tal vez ageno á los planes del marino, no dejaba de agitarse en la política, pues á ello debió más tarde haber sido Embajador en Sicilia y andar en candiclatura el año 1812, para Regente del Reino. Este cura escribió en la casa de los Toribios un gran tomo con la historia prolija de su proceso y su defensa, que apenas terminado en r 797, envió al Príncipe de la Paz, sin resultado favorable por el pronto. La lectura de algunos párrafos de esta Defensa impondrá al lector cumplidamente de cuanto importa saber.

\section{DEFENSA DEL PADRE GIL, HECHA POR EL MISMO}

E. Marqués de Matallana había servido los Ministerios del Rey en Parma y Nápoles con acep. tación, y la Marquesa lo había accinpañado en ellos y había participado y ám contribuído á aqué1la. Acababan de darse al Marqués los honores del Consejo de Estado y la embajada de Venecia y la Secretaría de éste á su cuñado, hermino de la Marquesa, el Teniente de navío D. José Conock; y finalmente, aquellos dos meses antes de su prisión, había recibido de la Reina nuestra Señora la prueba más señalada de su real agrado en el nombramiento y aámisión á la Real orden de Damas Nobles de María Luisa.

Malaspina gozaba igual y áun quizá mayor aprecio. Al lucimiento y brevedad con que había hecho su carrera, se había juntado la felicidad de la expedición gravísima que se le encomendó, de la cual y de ios conocimientos adquiridos en ella, se había dado noticia en la Gaceta con muchos elogios de qquél, y anunciando la historia que se haría y publicaría de este viaje. A pesar de los apuros del Erario con motivo de la guerra, se habían franqueado á Malaspina por el Ministerio las considerables cantidades que había juzgado necesarias y pedido, para que nada faltase á la histo. ria y su impresion, ni de utilidad, ni de adorno, ni áun de magnificencia. Se habían, á propuesta suya, premiado los Oficiales de la expedición; no se habían olvidado los Capellanes, Cirujanos y demás empleados de ella; el mismo Malaspina había sido, sin consultar la antigüedẹr promovido al grado de Brigadier, y acababa de solicitar y obtener liceicia para pasar á Italia con circunstancias que manifestaban la gracia en que se hallaba.

Considerado mi estado, carácter y genio, podría acaso decirse que eran aún mayores las hoiras que se me habían hecho. Sin que precediese pretensión mía, deseo, ni áun pensamiento de tal destino, se me propuso por el Ministerio de Marina y nombró por el Rey, para escribir la historia del viaje de Malaspina; empresa literaria sumamente difícil por la wultitud de materias que había de abrazar, todas gravísimas y algunas bien distintas de mi profesión, y la más importante también y de extraordinario honor, así por estas razones como por la espectación y ansia con que la aguardaba la Luropa sabia. La expresión verdaderamente sirgular de la Real orden de 26 de Julio de 1795 , en que se me encomendó la comisión, el sueldo y facultades que por ella se me conceden, y sobre todo, la honrosa aprobación que en 28 de Setiembre se sirvió el Rey dar al plan de la his. torii. que había presentado, autorizándome para que, como yo proponía, pudiese escribir y e.tre- 
gar al Ministerio las Memorias secretas que estimase necesarias para el buen gobierno de las Américas, son y serán perpétuamente el testimonio más alto, no sólo de la confianza que se tenía en mi literatura, sino áun todavía de mi prudencia, de mi amor á la Nación y al Rey, de mis conocimientos políticos, y de la rectitud, extensión, solidez y profundidad que con fundamento ó sin él, se les atribuía. Podían añadirse las públicas y no comunes señales de estimación con que me distin. guían los Excmos. Sres. Príncipe de la Paz y D. Antonio Valdés, Ministros de Estado y de Marina.

¿Cué ansiedad, pues, qué pasmo y áun qué temor no debieron mover la repentina prisión de tres personas de esta clase, el impenetrable secreto de la sumaria después, y finalmente, las gravísimas penas que se les han impuesto? Si hemos de creer á la voz pública, la Matallana, desterrada del Reino con la terrible condición de no poder unirse á su marido en Venecia; Malaspina, privado de sus grados y honores y encerrado en el castillo de San Antonio de la Coruña; yo, sin duda, destinado á la casa de los Toribios de Sevilla hasta nueva orden.

XXXIV.-Yo trataba á Malaspina, y este trato, y el haberme propuesto para escribir la Historia de su viaje, denotaban confianza de aquél conmigo. Se ha querido decir también que mi tal cual erudición se extendía á la política....

XXXV.-Se me hizo desde luego la pregunta de qué papeles suyos me había tado á leer Malaspina. Respondí señalándolos: r. Algunas memorias sueltas de su viaje, el diario de éste, y los planes de su historia. $2 .^{\circ}$ Una memoria sobre el establecimiento inglés de Bahía Botánica. $3 .^{\circ}$ Un tomo de disertaciones sobre varios ramos de Marina, que me ofreció y no llegó el caso de darme. $4 .^{\circ}$ Un plan de tratado de paz con Francia. Y habiendo yo declarado que Malaspina me había ma. nifestado tantos papeles suyos de materias físicas, económicas, políticas y de tan varia literatura, ¿no recaía, como por necesidad y legalmente, la pregunta de si me había comunicado también algunos sobre el Gobiernn 6 para mudar el sistema del actual?

XXXVI.-Porque acaso no habrá ocasión de hablar otra vez de los expresados papeles de Malaspina, es muy importante añadir, que ninguno de los que me confió era reservado, sino el tratado de paz con Francia, pues los demás los tenía frecuentemente encima de la mesa y podía leerlos cualquiera de los que entraban en sı̣ cıarto. Además, á excepción del tomo de disertaciones, los otros papeles los había presentado al Ministerio mucho tiempo había, y la memoria sobre Bahía Botánica creo le oí decir que la había remitido estando en Lima.

XXXVII.-Merece especial memoria el plan del $\uparrow$ atado de paz con Francia. Malaspina lo había trabajado y entregado al Ministerir en Diciembre de 1794 , cuando ni me trataba, ni yo había veniło á Aranjuez, que no lo hice hasta Marzo del año siguiente, que es decir que no pude concurrir á él. Por entonces, parece que ocultó enteramente el plan y su presentación, áun de aquellos de quienes tenía más confianza; y en efecto, yo no oí habłar á nadie de sus amigos jamás del tal plan.

Hecha la paz, tuve la primera noticia de él por una insinuación del serior Príncipe de ia Paz, que me hizo conocer el plan de aquella que había presentado Malaspina y los principios falsos $y$ contrarios á los intereses y gloria de la Nación, sobre que giraba. Sorprendióme esta noticia, á que contesté por palabras onerales, pues no podía de otra manera, porque nada sabía del tal plan; pero inmediatamente, sin revelar el conducto por donde la tenía, la comuniqué al Capitản de fragata D. Luis María Salazar, Oficial de la Secretaría de Marina, y á D. Juan Jacobo Ganh, Cónsul general de Suecia en Cádiz, que estaban en San Ildefonso y trataban mucho á Malaspina. Admiramos todos la poca reflexión de éste en haberse, sin ninguna orden y por sí mismo, introducido á escribir en materia tan grave, secreca y delicada de Estado; pero nada le dijimos aunque poco después pasó á aquel sitio.

Vine yo en principios de Octubre á Madrid, y espontáneamente me dió Malaspina á leer cl expresado plan y contó su presentación. Preguntóme después su dictámen sobre él, y le respondí con palabras de püra atención y cortesanía. Procuré con todo, con arte, saber de él cómo había recibido el pian el Ministerio, y me contestó que muy bien, fundándose en lo que dije en mi declaración, y no hace mucho honor á sus conocimientos de córte. Inmediatamente después de esta conversación ví á Ganh, á quien había ya también confiado el plan de Malaspina, y renovamos la censura de él, pasmándonos de la osadía de haberlo presentado.

\section{S $30^{\circ}$-Los indicios que hubo de mi complicidad con Malaspina, futron lcvisimos, etc., ctc.}

VII.-TRaro. Las preguntas que se me hicieron sobre el origen y tiempo del mío con Malaspina, y sobre tantas particularidadeș muy menudas y secretas de la vida privada é interior de éste, manifiestan que las personas que las extendieron suponían habia entre los dos un trato antiguo, 
intimo, familiarísimo, al cual nada se escondía recíprocamente. Se engañaron $\sin$ ducla en este juicio, y por mi declaración y por notoriedad, resultó la siguiente historia de mi trato con Malaspina, su origen, progresos y estado al tiempo de la prisión.

Nalaspina llegó á Cádiz de vuelta de su famosa expedición en Julio de r794, á cuya sazón me hallaba yo en aquella ciudad. No le conocía antes ni entonces lo ví, hasta un día en que comí en la casa en donde yo estaba hospedado, y segunda vez en la del Conde de Prasca, á donde también comimos juntos casualmente. Hícele en una y otra ocasión muchas preguntas de curiosidad, y no sé en cuál de cllas me previno que me enseñaría, como así lo hizo, una colección de monedas de Asia para D. Francisco de Bruna, Oidor decano de la Real Audiencia de Sevilla, con honores ahora del Consejo y Cámara. No le visité, no supe dónde vivía, ni le volví á ver ni saber de él, hasta que en Marzo del año siguiente de I795, habiendo yo venido á Aranjuez, lo hallé en este sitio y lo traté otra vez en las casas del Sr. Valdés, Ministro entonices de Marina, y de D. Juan Jacobo Ganh.

En la de éste se juntaban varias gentes por las mañanas á conversación, y entre ellas Malaspina y yo, y las mismas y otras nos uníamos por la tarde para el paseo, y las más noches en la tertulia del Sr. Valdés. Dudo si me visitó Malaspina en esta jornada; yo lo visité uíounas veces, y aunque, porque debe hacerse justicia á todos, y más al desgraciado, los modales de Malaspina, la variedad y unnenidad de su erudición, sus costumbres y otras circunstancias, hacían su trato muy âpreciable, yo no me distinguí en él, ni el mio llegó jamás á la frecuencia é intimidad que tenía y era público, con muchas personas de las más altas de la córte.

Víneme á Madrid, y no obstante que estaba ya hecha por Malaspina la propuesta y admitida por mí la comisión de escribir la historia de su viaje, me visitó sólo una vez, y yo á él cuatro ó cinco con motivo del paseo del Retiro, á donde íbamos por la tarde varios amigos, y para el cual era camino la casa en que estaba hospedado Malaspina, á saber, li del Príncipe de Monforte, al fin de la calle de Alcalá.

En fines de Julio marché yo á San Ildefonso, á donde pasó también Malaspina para el dia de San Luis. No me visitó; nos vimos algunas tardes en el paseo, y por la noche en la tertulia del ড̀r. Valdés.

Volvióse en principios de Setiembre á Madrid, y yo lo hice en 24 del mismo. No me visitó tampoco, y yo le visité dos veces para hablar de los documentos de la historia y de la colección célebre de los pertenecientes á Indias, que ha juntado y posee D. Manuel Pérez, del Consejo de éstas.

Partí en 6 de Octubre á Andalucía, y ni él me escribió ni yo le escribí, aunque lo hice á casi todos los amigos de la córte. Volví en 7 de Noviembre al Escorial, en donde estaba Malaspina, y no me hizo visita, y yo le hice sola una citado por él, en la cual tratamú $I .^{\circ}$ De la Memoria de su viaje, sobre el plan de cuya historia me entı egó una larguísima carta, con fecha de 3 de Octu. bre. $2 .^{\circ}$ Del modo de recoger y aprovechar la colección de Pérez. $3 .^{\circ}$ De una pretensión á favor de los Cirujanos de la expedición que seguía, y de la cual me habian hablado los interesados en Cádiz.

Las más tardes nos paseábamos juntos con otros amigos, dándonos frecuentemente Malaspina quejas de que, aunque su posada estaba al paso, jamás le avisábamos ni áun por una seña para que bajase, $y$ tenía siempre que buscarnos en otra parte; y si cuando llegaba habíamos salido, como sucedió algunas veces, se quedaba sin compañía para el paseo. Comimos dos veces juntos con otras gentes y una de éstas fué en el día I8 de Noviembre, en que tomamos en su posada el coche y nos vinimos á Madrid, en donde el 22 del mismo, á presencia de sus criados y otros, me entregó los documentos para la historia, y el 23 fuimos presos.

LVIII.-Téngase presente, que desde Nayo me habló Malaspina para la Comisión; que en Junio se hizo la propuesta formal; que en Julio se expidió la Real orden de mi nombramiento; que aquél se marchaba á Italia; que era preciso que antes me entregase los muchos y varios documentos originales de la historia y que me instruyese de palabra de una multitud de hechos y circunstan. cias, que por los papeles, ó no podía entender $b$ entendería con mucho trabajo é imperfectamente; en suma, que la comisión de escribir un viaje que abrazaba tantos y tan diversos ramos y conocimientos, y del cual había sido Comandante Malaspina, pedía, por necesidad, para desempeñarse, muchas conferencias privadas con aquél y un trato grande, contínuo, íntimo y reservado. La Real orden, atendiendo á estas consideraciones, me lo encomendó expresamente con las palabras encarecidas que siguen: "Con esta fecha (la de 26 de Julio de 95) doy el correspondiente aviso á Don "Alejandro Malaspina, y le prevengo que acordándose V. R. con él, le entregue lo que sobre la " materia ticne ya trabajado, y le enterc de ello para su gobierno, y en acielante irá suministrando -á V. R. los materiales que haya juntado, según las órdencs, agregando á ellos lo que le dicton sus distin"guidos conocimientos, al mís completo logro del objeto." 
No hubo con todo nada de esto. (Las conferencias íntimas y privadas que pudo y debió haber para cumplir su órden). Dios, por su admirable providencia, dispuso que, haciendo yoo violencia á rni carácter, no tuviese ninguna junta secruta coì Lialaspina, faltando en cierto modo al desempeño de la 'somisión. No estuvimos, pues, encerrados una sola vez; no escribinos; no hicimos apıntaciones; no hablamos jamás reservadamente.

LX.-Y que se ha pensado así (que la propuesta de Malaspina para la comisión es indicio de delito), lo dicen manifiestamente las dos rarísimas preguntas que se me hicieron, de "quién me había propuesto al Rey para escribir la historia del viaje y por qué me había S. M. nombrado para esta comisión." Se vé que nadie como S. M. puede estar instruído de estos dos hechos; yo, sin embargo, contesté sencillamente las preguntas con las palabras de la Real orden, que dice: "que á propuesta de Malaspina, y por la confianza que el Rey tiene en mi literatura......"

Había Malaspina escogido varios Oficiales de la Real Armada y otros profesores para que trabajasen en los muchos y dificultosísimos ramos á que había de extenderse la historia; velaba incesantemente sobre todos, y áun dos Oficiales le escribían dentro de su casa desde la primavera anterior; últimamente había ya propuesto al Rey para que durante el viaje que iba á hacer á Italia, quedase en su lugar el Capitán de Fragata D. Ciriaco Cevallos, muy digno de este cargo por sus talentos.....

LXI.-Las mismas circunstancias particulares que sobrevinieron en mi propuesta y cuanto ha seguido á ella, muestra mi inocencia aún sobre los temás. Yo vine á Aranjuez. Malaspina había leído algunos papelejos míos impre. os y oído á personas que me eran apasionadas; preocupóse y no se desengañó con mi trato: ocurriósele el extrañísimo pensamiento de que revisase y corrigiese las Memorias que había escrito de su viaje: manifestólo antes q’e á mí á varios; se lo aprobaron y celebraron; me lo declaró á mí y me quedé atónito; mi agradecimiento, - ıgen de cuanto he padecido en mi vida, me representó como una obligación no negarr le á propuesta tan honrosa en sí misma y en el modo con que se hacía: algunos amigos me disuacían su admisión por razones harto graves, que acaso hubieran hecho impresión en otro, pero que no la hicieron en mí; y dí al fin, el funesto y trisle si que me ha traído tantos y tan horribles males. Nada hubo en todo esto de misterioso ni reservado entre mí y Malaspina. Están vivos los Oficiales de la Secretaría de Marina y otras personas que concurrieron á ello, lo supieron y pueden deponer de su verdad y publicidad.

A las primeras conversaciones penetró Malaspina que no conveniamos en algunas ideas políticas; y csto le iispiró desconfianza de mí, que se descubre con claridad en esçuela suya que está en autos y la cual se confirmó cuando supo de oficio que yo había presentado, y el Rey se había dignado aprobar, plan para la Historia que en muchos puntos era derechamente opuesto á los formados y entregados al Ministerio por él.....

LXII.-Supo Malaspina lo anterior que yo había obrado en la comisión, pero ignoru acaso otras cosas que hice también y que, á haber tenido noticia de ellas, hubieran sido mayores y mảs fun. dadas sus desconfianzas conmigo. Cuando se me hizo la propuesta, había ya obligación gravísima en mí de mostrar todo respeto y deferencia al Excmo. Sr. Príncipe de la Paz y no podía con honor admitirla sin su expreso beneplácito. Se la manifesté, pues; la celebró mucho; insinuó no lí agradaba el modo de pensar de Malaspina, que le hacía estar cuidadoso sobre esta historia por el interés general que en ella tenía el Estado: me honró diciéndome que mi nombramiento lo libraba enteramente de aquel cuidado y me mandó admitirla y que avisase lo que ocurriese.

En cumplimiento de este encargo, previne que se habían facilitado á Malaspina, por la Secretaria de Gracia y Justicia y de Hacienda sus archivos y se tomó providencia. Remití después copias de mi plan de 20 de Setiembre y de la Real aprobación de 28, y el señor Príncipe de la Paz me contestó alabando mi celo. Finalmente, al despedirme de S. E. en el Escorial en I'y de Noviembre, le renové mis protestas de respeto y volví á reclamar su alta protección para el feliz éxito del trabajo que iba á emprender, lo que repetí en carta de 20 del mismo, esto es, tres días antes de mi prisión.

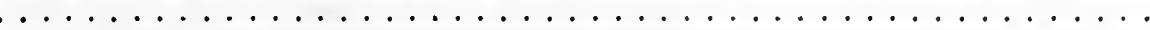

LXV. - La hora escogida para la visita al confesor del Rey era la de beber y conversación, nó la más á propósito para tratar asuntos reservados.

LXVI.-La tarde en cuya noche hizo Malaspina su segunda visita al confesor del Rey, me preguntó en el paseo delante de todos si iría cu aquella noche á despedirme de la tal persona. Le respondí con incertidumbre.

En la primera visita, acabado el paseo, nos esperamos unidos en la Lonja del Escorial para hacer hora de aquélla; nos separamos después del paseo en esta segunda, testimonio evidente de que no estábamos conformes en hacerla aquella noche juntos.

LXVIII. - Pero lo que deja todo en suma claridad es lo que me sucedió á mí con la tal persona (el confesor del Rey) en el martes $\mathrm{I} 7$ de Noviembre, en que lo visité para tomar sus órdenes. 


\section{sุ $4 .^{\circ}$-Prućbase que no ha habido cn mi ningnna complicidad criminal con Malaspina.}

LXXI. - La naturaleza de los mismos proyectos of rece la primera reflexión. A mí no se me han mostrado ni áun dado idea clara de ellos; pero por las preguntas que se me han he; ho, conjeturo y casi no me queda duda en que el desiguio de Malaspina era que se mudase todo el Ministerio, y que había escogido como medio para conseguir esta mudanza, persuadir al Rey, que de permanecer aquél, corrían peligro las preciosísimas vidas de S. M. y de la Reina Nuestra Señora, y con ellas la Monarquía, á fin de que asustada su religiosa conciencia impidiese estos horribles males en la des. gracia y cutcra separación del Ministerio actual. Extremece sólo el decir que hayan podido concebirse ideas tan abominables, etc., etc.

LXXII.-Pero aún hay tod.cvía más: lejos de tener esta (confianza) Malaspina conmigo, ni de haber contraido en aquel poco trato alguna amistad, desde el principio de él me miró con declarada desconfianza, que creció en vez de acabarșe, y se fué haciendo cada día mayor hasta el de la prisión. Veámoslo por el orden de los tiempos.

Marzo y Abril de I 795. Había precedido habernos visto casualmente dos de las veces en Cádiz, y en Aranjuez no había más que la concurrencia general y común al paseo y casas del Sr. Valdés $y^{\prime}$ de Ganh.

Mayo, Funio y fulio. Un suceso de cste tiempo descubre la confianza que podría haber entre mí y Malaspina, mi carácter, y la resistencia y estorbos que ofrecía éste á la comunicación de los proyectos.

Malaspina me dió á leer algunas Mcmorias sueltas de su viaje para que ingénuamente le dijese $s i$, como cstaban, podrían imprimirse. No faltó alguno de sus amigos que me aconsejó disimulase ó templase mi dictamen, y no hiriese el amor propio de aquél. Ni mi carácter, ni el honor de la Nación, ni áun del R-y, que yo creía interesados en la publicación de aquellas Memorias, permitieron que siguiese este consejo. Dijele abiertımente que yo podía engañarme; pero que mi juicio del mérito de sus Menorias er $ı$ que, como tales ó documentos para la Historia, lo tenían no común, mas que no eran verdaderimentc listoria, ni convenía que se imprimiese sin darles otro orden, claridad y estilo.

Algo sorprendió á Malaspina la franqueza ó sea dureza de este parecer.....

IXXIII.-Malaspina me había propuesto para censor de su obra solamente, ó como un subalterno que trabajase bajo su dirección. El Rey no tuvo á bien conformarse con su propuesta y me nombró ridactor principal y sin dependencia. Conocí, desde luego, cuán temible había de serle esta mudanza y que acaso la atribuiría á manejo mío, que ciertamente no hubo, y así me esforcé á templar su queja, escribiéndole que ja tenía otro subalterno de quien disponer. En respuesta, me dice abiertamente que el subalterno lo es él, y que yo he quedado jefe. Entre mis papeles se hallará esta esquela, que manifiesta con toda cortesía, pero con no menos claridad su resentimiento.

LXXIV.-Creció éste y su desconfianza en Agosto, Setiembre, Octubre y Noviembrc. Una esquela suya de este tiempo, que se puso en autos, descubre aquéllos con suma evidencia. Me dice en ella que me habia eścrito otra con cosas harto graves (no recibí ésta); que acabe de manifestarle mis ideas, porque si no me he de conformar y seguir las suyas, más bien que concurrir á la historia, se echará á escritor del Diario, $y$ usa otras expresiones que indican evidentemente que no se aseguraba de mi modo de pensar, que temía que era opuesto al suyo, y que este temor lo tenía en cuidado y desconfianza.

LXXV.-.Confirmóse ésta y llegó al más alto grado, cuando en fin de Setiembre se le pasó de oficio copia de la Real orden de 28 del mismo, en que le aprobaba el plan de la historia que yo había presentado con fecha de 20 . Veía en efecto un plan contrario á los dos que él había dispuesto y entregado al Ministerio mucho tiempo antes; que lo había yo formado y presentado sin acuerdo ni la menor noticia suya; que se había aprobado sin que él informase; que se me mandaba escribir la historia con arreglo á lo que proponía, y que de él no se hablaba ni se le comunicaba sino para su inteligencia y gobierno. ¡Cuántos y cuán graves motivos de dolor y queja!

Agregóse á esto, el que cuando recibió esta Real orden trabajaba una larga carta para que me sirviese de plan; que el día autes de recibir aquélla, me había leído grandes retazos de esta carta y yo ni áun le hab' in insinuado el plan que había propuesto en la Secretaría, y cuya aprobación presumiria, y no se engañaba, que yo sabía, pues acababa de llegar del Sitio. Lo ví, é hice, pues, el mayor empeño en satisfacerlo; le mostré el borrador de mi plan, las razones sólidas en que lo fundaba y los elogios que en el mismo hacía de su trabajo y celo; le pedí continuase y acabase su carta, cuyas advertencias me serían muy provechosas y leería siempre con agradecimiento y con respeto; pero por más que doré la píldora, no pude quitarle la amargura que tenía verdade- 
ramente y cuyos efectos fueron: $r{ }^{\circ}$ Cortar la carta en el estado en que se hallaba, expresando sin disimulo lo hacía porque juzgaba inútil continuarla, pues mi plan aprobado ya, manifestaba no es. tábamos conformes en la ideas. $2 .^{\circ}$ No entregármela, sino dirigiıla á la Secretaría de Marina y solicitar que se me comunicase de oficio para obligarme por esta manera indirecta á adoptar y seguir sus principios y máximas.

Trabajó en esto todo el mes de Octubre que estuve yo en Andalucía; pero como nada hubiese conseguido, me entregó al fin dicha carta con fecha 23 Octubre, á mi vuelta del Escorial en el día

de Noviembre, que estará de mi letra al fin de ella. Advierto que esta nota, que acaso parecerá inútil, y la conservación de las cartas y áun de las esquelitas de Malaspina, tenía por fin de parte mia, el que constase cn todo tiempo, no sólo de mi correspondencia literaria con aquél, sino áun de las más pequeñas circunstancias de la privada nuestra; prevención que creí merecería muy bien la importancia de la obra de que estábamos encargados, y el temor de que podría interrumpirse nuestra buena harmonía.

LXXVII.-Pero busquemos ya pruebas de mi inocencia en hechos más públicos, dando, en efecto, muchas y muy eficaces el trato y conversaciones de las demís personas que nos acompañaban.

Cualquiera que haya observado con atención la Italia moderna, ó en el trato con sus nacionales ó en sus historiadores, habrá de converir en que uno de los vestigios más claros que conservan del antiguo dominio del mundo que gozaron, es la violentísima propensión que los arrastra al estudio de la política y del gobierno que conviene á los demás pueblos, y áun á tomar parte en sus acaecimientos y revoluciones. Admira el ardor con que, áun en su situación actual (escribíase esto en Diciembre de 1796 ) hablan de los intereses de las naciones grandes, de sus leyes y medios de aumentar su poder; los partic'os que forman y áun el furor cun que disputan á pesar de su aparente y estudiada flema. Observindolos yo con pasmo, me pareció, más de una vez, que no discurrían con más empeño y calor de aquellos puntos de política, en el Augusto Senado de Roma, los mismos Silas, Antonios, Marcelos, Flavios, Pompeyos y Césares cuando verdaderamente gobernaban desde allí el Universo y eran sus señores y quizás su azote.

Malaspina estaba dominado sumamente de este prurito político de su país; su literatura le han:dado gran aumento; el viaje y la facilidad y áun orden que tuvo para rann-y visteiná ae gobierno

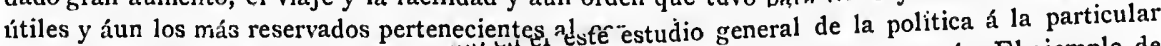
de nuestras Indias, convirt:? . .........u c. que convenía á aquèllas, y crecíb después hasta parecer como un comisión y áun contra la voluntad las otras naciones; la lección de tantos como modernamente, sin comision y aun contra; el sunerficial de Minerva, se han tomado el alto y dificultosísimo oficio de muchas de sus conocimiento de la historia de nuestras Indias, del orígen, motivo y ocultos fines de á la buena 6 leyes, y quizá también el deseo de adquirir una gloria, 6 sea celebridad, semejanté án como él, mala de que ciertas gentes han encubierto al Abate Raynal y á otros eternos habladoricas, que él inspiraron á Malaspina algunas ideas sobre la legislación oportuna para nuestras Américas, que creía, sin duda, sólidas y provechosas, como lo convencen la misma publicidad con que utilidad muy y la confianza con que las ha dirigido al Ministerio; pero que en la verdad erá de utilian aquellas pose. dudosa, y áun sin temeridad se puede pronosticar que, establecidas, $\delta$ destruir sobre ellas.

siones, ó turbarían, si no acababan del todo, el justo imperio de España sobs podía moverse en su

Esta, pues, insanable comezón política de Malaspina hacia que apenas comercio, industria, relapresencia, conversación que, 6 derechamente ó con arte, no la trajón la aplicación de todo esto á las ciones de los pueblos entre sí, y demás ramos de la legislacion, con la apliones con que las manifestaba, Américas. Ln exótico de algunas de sus ideas, y áun de las expresiones con que háa persuadido, le porque á la verdad, no poseía el idioma español con la perfeccion que é se híábamoslo áun á su hicieron un lenguaje propio suyo, y muy extraordinario por no decir más. Imitábariales y colonialcs; de presencia los denís burlonamente y con el uso de las sonoras palabras ittcreses socie mostrábamos, cstablecinicutos, ora mineros, ora agricultores, ora comerciantcs, y otras de esta especie, mos y política y yo acaso más que todos, nuestra desaprobación, y qué sé yo qué más de aquellas ideastera, segundo extravagantes. Pueden deponer en esta verdad el Brigadier D. José Bustamante Comandante del viaje; los Capitanes de navío D. Alberto Sisma y D. Dionisio D. Juan Jacobo pitán de fragata D. Luis María Salazar, el Teniente de navio D. Jos Concisco Saavedra, del Ganh, y cuantos concurrían á nuestros paseos y tertulia, y además D. I y Consejo de Guerra, á

dije deseaba que se conservase y recogiese una carta priónedaba este estilo meque habia yo escrito á Salazar tres días antes de mi prision, en la cual rem sistema político...... dio arabesco de Malaspina, y descubría entre las burlas mi ningún aprecio por su sistema politico.... 
Imposibilidad moral de que Malaspina me comunicase sus proyectos; necesidad moral de que, comunicados, yo los reprobase y, solicitase que no tuviesen cjecución.

LXXXV.-Malaspina tenía toda la reserva, cautela, disimulación, por no decir doblez, propias del país en que nació. Los talentos, la educación, la lección, el conocimiento y experiencia del mundo y de las córtes, habían perfeccionado y llevado en el más alto punto aquellas calidades. Basta ver Ios progresos que ha hecho en su carrera y la rapidez de ellos; el arte con que ha aprovechado ó buscado, como dirian sus émulos, las ocasiones de adelantarse; y finalmente, la buena harmonía y subordinación que mantuvo en los buques de su mando en su largo y penoso viaje, para persuadirse á que Malaspina sobresalía en prudencia política, en esta ciencia dificultosísima que alcanzan tan pocos, y que pide tanto tino y discernimiento de conocer los hombres, su carácter, virtudes, pasiones, inclinaciones y áun vicios, aplicarlos á los destinos más análogos á aquéllas, manejarlos, moverlos y áun doblarlos al fin que se desea y sacar de ellos todo el parido posible.

(El Padre Gil hace la pintura de su carácter, enteramente opuesto al de Malaspina).

Malaspina había conocido tan perfectamente este carácter mío, que hizo la descripción más cabal de él en una sola palabra. Es el caso que él y los demás quisieron sospechar que yo tendría prontamente destino, y temieron que no me encargaría de la comisión, 6 que, áun cuando la ad. mitiese, no concluiria la obra. Malaspina detuvo algún tiempo la propuesta por estos temores, y me estrechó muchas veces á que lo desengañase con ingenuidad. Díjele que las sospechas suyas y de los demás carecian de todo fundamento; pero que lo tuviesen 6 no, y aunque se verificase lo que sospechaban, dada mi palabra, como la daba, de encomendarme de la historia del viaje, ningún interés, ningún honor, ningán destino que se me propusiese podría hacer que no lo acabase.

Sin embargo, aún hizo la propuesta con duda ó miedo de si la admitiría; la admití y en respuesta, entre otras clianzas, me da este título, que no había usado antes ni usó jamás despues: Citoyer: noir, cuyo espíritu y motivo de él no habrá quien no penetre.

Spừ Ni olvidaré tampoco, la singular con que continuó honrándome su muy digno sucesor

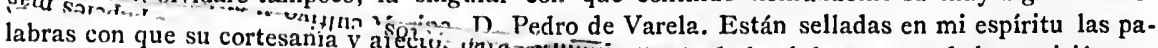
habló al despedirme en el de comisión, me Iŕ á drá agradecer bien el obsequio que $V$. le ha hecho en taberse encargado de la historia del viaje. Cuente $V$. conmigo y con cuanto yo pueda." ¿Y por qué jurar yo la férdida de personas que mos-
traban apreciarme tanto?

CCXrli Concluía CCXII.-Concluirá tan fastidiosa relación lo que ha puesto la Corona á mis tales 6 cuales méritos, hasta casi envanecerme, á saber: Comisión que el Rey sin pretensión y apenas notivia mía se sirvió encargarme. Honremo. esta defensa copiando á la letra la Real orden que decía así: "A propuesta del Brigadier D. Alejandro Malaspina y por la confianza que el Rey tiene en la literatura dc $V$. R., se ha dignado confiarle la redacción y arreglo de los resultados del viaje, que al mando de aquel Oficial han ejecutado las corbetas Descuiserta y ATrEvida, y para cuya empresa se ha prcstado el celo de V. R. que ha movido el Real aprecio.

"Deja S. M. al arbitrio de V. R. la ordenación de este trabajo en los términos que le dicten sus conocimientos; pero sin apartarse de los hechos, como debe suponerse, y empleando en su narra. ción la sencillez conveniente para cabal instrucción de todos y principalmente del Cuerpo de arra. mada.

"Con esta fecha doy el correspondiente aviso á D. Alejandro Malaspina y le prevengo, que acordándose V. R. con él, le entregue lo que sobre la materia tiene ya trabajado y le entere de ello para su gobierno; y en adelante irá suministrando á V. R. los materiales que haya juntado según las órdenes, agregando á ellos los que le dicten sus distinguidos conocimientos y sean conducentes al más completc objeto.

"Para los gastos que ha de producir á V. R. este encargo, le ha señalădo S. M. mil y quinientos reales vellón al mes; pero esto se entiende sin perjuicio de mayor asignación si le fuere quinienó lo exigiesen las urgencias para la adquisición de libros, manuscritos ó pago de escribientes; pues así como S. M. se persuade que el estado religioso de V. R. ni su voluntad y desinterés que la pues festado, le permiten fijar el valor de su trabajo, tampoco quiere dejarlo sin recompensa.

"Comunícolo á V. R. de Real orden para su inte'igencia, en la de que S. M. no duda que co. rresponderá á esta confianza con todo el esmero que exige su importancia. Dios, etc.=Sán Ilde. fonso, 26 de Julio de I 795.=Valdés.=R. P. Manuel Gil de los Clérigos menores." 
CCXIV.-Aunque sean tantas y tan distinguidas las expresiones de honor hacia mí con que se extendió esta Real orden, como que se descubre algo mís grande y extraordinario en la que se me comunic 6 aprobando el plan que presente, decia así: "El Rey se ha enterado de las reflexio. nes que comprende la representación de $V$. $R$. de 20 del que acaba, sobre el método conveniente en la publicación del viaje de las corbetas Descubierta y ATrevida, y S. M. las la hallado muy opcrtunas y conforme á las ideas que deben sızuirse en la obra. A este fin, arreglará V. R. sus pensamientos, omitiendo todo lo que no deba saber el público en cuanto al gobierno interior de las provincias de América y las variaciones que convenga hacer en él, y tratándolo por Memorias separadas y secretas en la forma que propone V. R., para hacer en los Ministerios á que competan el uso que fuere conveniente."

"Bajo este principio y el de que establecen juiciosamente las mismas reflexiones, de que deben indicarse por separado, y con la extensión científica que se requiere, los diversos ramos que ha de abrazar esta obra, de Historia Natural, Botánica, Medicina, etc., se arreglará V. R. á los tratados que con distinción escriban los profesores de aquellos ramos, para que, dando noticia en la historia general del viaje de lo que sea preciso en aquellas clases, se eviten las repeticiones de to que abracen y traten con toda la prolijidad que se requiere los profesores de las mismas ciencias.

"Y para resolver con toda su extensión esta obra, se facilitarán á V. R. los libros, manuscritos y documentos que conceptúe precisos de los archivos donde se hallaren, y además pedirá V. R. el escribiente 6 escribientes que necesitase.

"Por Secretaría se abonará á V. R. el goce de los 1,500 reales vellón al mes que el Rey le ha señalado $y$ ha de percibir desde la fecha de su concesion.

"Todo lo que prevengo á V. R. para su inteligencia y gobierno. Dios, etc. $=$ San Ildefonso, $\approx 8$ de Setiembre de $1795 .=$ Valdés. $=$ Al Padre Manuel Gil, de la Congregación de los Clérigos menores."

Además de las anteriores amplísimas noticias que nos da el astuto é hipócrita Padre Gil (pues nr obstante extremecerse ante la idea de un cambio de ministerio más tarde presidió una Junta revolucionaria), copio otras muy interesantes debidas al señor Conde de Greppi, Embajador que fué de Italia en España (1) y cuyo abuelo tuvo relaciones íntimas de amistad con Malaspina.

Dice el Conde de Greppi respecto al ilustre marino:

"En su ánimo apasionado, este viaje (la vuelta al mundo) le hizo impresionarse por la felicidad de sus semejantes, pensando en la absoluta precisión de un cambio radical en el sistema de gobierno y de la legislación de las colonias. No expresa en sus cartas la manera de conseguirlo, pero bastante' se comprende, porque insistía en la necesidad de quitar todo cuanto estorbase al libre desarrollo, tratando de hermanar aquel imperio con más amplias y recíprocas relaciones, para que no se consideren tan lejanos dominios como depósitos de ricas minas, sino como una inmensa región capaz de todas clases de productos y apta para formar la felicidad de millones de individuos. Entre las cosas que decía, hay un concepto de singular belleza, que pronto fué el grito del siglo:

"La harmonia de la naturaleza, no obstante el torcido rumbo de tantos años que ha procurado sofocar los clamores, se oye aún gritar pidicndo que no la opriman, y atiendan sólo a encarrilarla en los lindes de su verdadero camino.

„En medio de estos argumentos, confesaba él mismo que tenía la cabeza algo caliente, y conservaba, sin embargo, bastante prudencia para comprender que era temible el acreditarse de proyectista en tal ocasión. Ei olvido de esta máxima fué causa de su ruina......

(I) De un legajo que existe en la Academia de la Historia, y que contione muchos datos biograficos de Malaspina y multitud de cartas dirigidas por éste a D. Paolo Greppi. El señor Conde de Greppi hizo á la Academia el donativo de este legajo. 
"En cl abandono de sus confidencias epistolares con Greppi, se revclan sus intenciones, no ya sediento de poder y de gloria, sino dulcemente melancólico y démasiado delicado para sostener mucho tiempo los combates de la vida real, como nucvo Fausto, ó como decía un escritor francés, "un hombre ocupado en los negocios de la vida, pero anhelante del reposo de una contemplación filosófica."

"En la persuasión que tenía de poder servir á España, y por lo que deseaba partici. pación en el Gobierno, le daban ciertas esperanzas que pronto se convirtieron en desengaños. Decia Malaspina (en 24 de Diciembre de 1 794): He escrito cuanto mis ideas me sujerian para poder sor uitil a este pais en momentos tan tempestuosos: un solo dia me hubiera bastado para explicar mi sistema: todo to he visto, todo lo he visitado; con un piqueño paso quiza se hubicra podido entrar in buen camino y en la sana filosofia; todo parecia pres. turse à cllo; me cncontraba ligado con cuanto habia de más virtuoso y mejor en cl pais; se mo concedia grandisima atención, rectitud cn mi corazón y una devoción absoluta al biencstar gencral sin cgoismo y sin preocnpaciones; pero ol súbito advenimiento dol Sultín (esto is, dcl primir Ministro Godoy) to hacen todo dificil: cuanto le rodca cae cn la confusiön y en la inacción.

"No se desanimaba por eso, pues el 27 de Febrero escribía: En este momento pende te una nada al que yo sea destinado á cosas de la mayor entidad respecto á la prosperidad del Rino in todas sus partes, y que yo vuclua á mi antiguo oficio de marinero.

"No se sabe si por maquiavélicas artes ó para perderlo, continuaba el Gobierno tratándole con mucha consideración. Así, en Marzo de 1794 el Rey le nombraba Brigadicr; en Mayo pedia licencia y le era lisonjeramente rehusada; en Agosto, los íntimos de Godoy decían que podía ser Ministro en lugar de Valdés; en Octubre, Godoy mismo, en pública corte y en su presencia, habia hecho un gran elogio de sus méritos; las numerosas relaciones que él envió al Ministerio (convertidas luégo en otros tantos capítulos de cargos), le habian sido agradecidas gencrosamente. Esto no obstante, los presagios de los más expertos le eran siempre desfavorables, $y$ en informes de un Ministro de Malta, Jacinto Malaspina, se expresaba el temor de que á su hermano le tocase la suerte de Colón, así como Greppi se esforzaba en inculcarle prudencia.

"Lo verdadero es que él se créa con la misión de iluminar al Rey y al país, de haberlo hecho con honradez, siendo precisa consccuencia de ello ó la ruina ó el triunfo. En cuanto á mi ánimo (decia desde la carcel), jürote que no puede estar más tranquilo, no abrigando cl temor de que me desvie de mi camino ni una despreciable apatia ni nna baja precipitación. La causa que aqui me ha conducido me hace repetir que, en iguales circunstancias, MII, VECES VOLVERía Á I.ACER LO MISMO.

Malaspina permaneció encerrado en el castillo de San Anionio, de la Coruña, hasta 1803 . Debióse su libertad á influencias del Conde de Melzi cerca de Napoleón; este gran guerrero solicitó y obtuvo del Gobierno de España la libertad cle Malaspina; que fué desterrado á Milán. Apenas llegado le ofrecieron el cargo de Ministro de la Repúblicä italiana; pero el insigne marino lo rehusó y prefirió retirarse á su casa de Lnnigiana, donde nurió á 9 de Abril de ı 809 , á los cincuenta y cinco años de su edacl.

Ya hemos visto que para este hombre superior eran contrariedades de fácil consuèlo su prisión y su ruina; pero acaso no fuere exagerado señalar como causa de su nuerte prematura, el estúpido decreto que sepultaba en el olvido más injusto todo el caudal de sus 
trabajos; esto cs, su nombre, su gloria, su eterna fama, tan costosa y honradamente aclquirida hora por hora, en cuatro afios consecutivos de estudios y penalidades.

Como testimonio de las últimas huellas que el pié de Malaspina dejó en España, publicamos á continuacion varios documentos que llenan el alma de melancolía. Tambien insertamos, á fin de que pueda apreciarse en toda su excelencia, el plan oue PARA EsCRIBIR su VisJE entregó el ilustre marino al clérigo Gil, cuyo plan no quiso terninar cuando supo que áun antes de conocido, estaba desaprobado.

Tanto este notabiísimo trabajo, como las cartas escritas á varios prohombres de su época, y las Instrucciones que dió á Bustamante, han sido copiadas de borradores originales de puño y letra de Malaspina y se han impreso con todas sus incorrecciones de cstilo, por respeto al autor $y$ culto á la verdad.

El Sr. Conde de Greppi, tan alıante de la memoria de su ilustre compatriota, terninaba los datos biográficos con estas palabras: "Un voto me queda que espresar; y es que desenterradas las nuchas revelaciones y memorias, goce el público del fruto de tantas meditaciones sobre España y sobre América y saboree el estilo del viajero generoso».

Ya está, pues, complacido.

$\mathrm{Y}$ ahora, hablen solamente Malaspina y sus dignos compañeros; sean sus relatos brillantes manifestaciones de saber, timbres gloriosos que hoy surgen y se estampan en el li. bro de la Historia, dejándome como gratísimo premio el honor y la ventura de haber enriquecido con tan hermosas páginas nuestra CRÓNICA NAVAL.

Pedro de Novo y Colson.

Madrid, 8 de Mayo de 1835. 


\title{
APÉNDICE
}

\author{
A LA INTRODUCCIÓN HISTÓRICA
}

SOBRE EL DESTIERRO DE MALASPINA ( $($ )

«Fxcro. SR.: Por el adjunto parte original que en a del corriente me dío ol Capitán do este puerto, so enterará V. E. de lo ocurrido con el trasbordo que intentó y verificó en el Cabo de las Salinas, do esta isla, Don Alexandro Malaspina y su criado, procedente do Cádiz, con destino á Génova, en la fragata mercanto española, su Capitán Santiago Mantica.

Inmediatamente que reconoc! en los términos que iba extendido el pasaporte, donde so advertia la circunstancia de no poder dicho Malaspina saltar en tierra de España, dispuse, no tan solamento el quo se mantuviese en cuarentena el patrón Antonio Roca con su laud, á cuyo bordo se hallaba Malaspina, sino que mandé diese la vela sin pérdida do tiompo para restituirlo á la fragata, con la estrecha prevención y precepto de no saltar á tierra en la costa, caso de no hallarla, y de regresar á este puerto como lo verificó.

nLuego de restituĺdo y manteniéndoso en la cuarentena con centinelas de vista, mandé so lo proveyese al Patrón Roca do los viveros que necesit sse y despacharlo para las costas do Francia, con los dos pasajeros, sin convenirme con li proposición que me hizo Malaspina de permitirle su embarco para Barcelona, desde donde per tierra, pasarfa á Francia. Todo lo cual pongo en noticia de V. E., por si creyeso conveniento elevarlo á la de S. M.

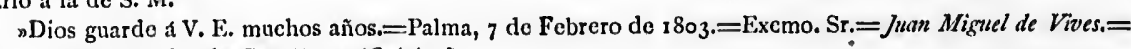
Excmo. Sr. D. Pedro de Cevallos.n (Original).

Al margen de esta comunicación va el siguiente decreto: «A Vives, que arreste à Malaspina si desembarca en la extensión de su mando y que avise. Igual orden al Capitín General de Barcelona para que arreste al mismo Nalaspina si desembarca en Bo . 'ona o en otro puerto de su departamento.»

Debajo de esto decreto y de otra letra: «Contestado así, ménos lo de Barcelona, que se puso en orden aparte, somo también á Valencia, en 5 de Marzo, segun minuta.”

El parte original del Capitån del puerto de Palma, dice asi:

«El Patrón Antonio Roca, mallorquín, del laud la Virgen del Carmen, con tres marineros, venido de Alcudia, de donde salió el dí $3^{1}$ del pasado, dice que en el día de ayer por la mañana, á las 1 I, halló fondeada en el Cabo de las Salinas una fragata española, su Capitán Santiago Mantequi (sic), que habia salido do Cádliz el día 21 del próximo pasado, con cargo de azúcar y cacao para Génova. Que de dicha fragata se llamó al declarante y se le embarcó un pasajero llamado D. Alejandro Malaspina, con su criado, cuyo pasaporte y boleta acompaño. Dicha fragata, desde que salió de Cádiz, no ha tenilo roce ni comunicación con embarcación alguna; por lo que me parece, siendo de la aprobación de V. E., se le puede admitir á libre plática. Dicho pasajero quería escribir a V. E. y le he dicho tuviese paciencia.=Lucas Orell.o

La Real orden causada del decreto marginal de la comunicación de Vives, dice:

axcmo. SR.: Habiendo sabido el Rey que D. Alexandro Malaspina á quien se embareó para llevarlo fuera de los dominios de S. M. con prevención de que no pudiese saltar en tierra de España, ha intentado desembarcar en la Isla de Mallorca, hallándoso á bordo de un buque mercante, quiere el Rey que si efectuare su desembarco en algún puerto ó costa de la Península se le arreste inmediatamente y se dé parte á S. M. De Real orden lo comunico á V. F. por lo que pertenece á ese Principado de su mando (el de Cataluña.)= Dios, etc.n-Al de.Valencia se le dijo además: Previniéndole lo participe cuanto antes al Gobcrnador de Cartagena.n=Aranjuez, 5 de Narzo de 1803.0

(1) A ta amabilidad de D. Gaspar Muro debo estos documentos, que fueron hallados y copialos en el archivo de Alcalá de Henares (legajo 3.013 ) por el Sr. Jimcisez de la Espada. 
Junto con la anterior minuta y los demas papeles copiados, hay estos otros:

- lixcmo. Sr.: Referente á lo que dije á V. E.. con fecha de 7 del pasado Febrero, le incluyo el certificado original del Vicecomisario de comercio do S. M. en el puerto de Portvendre que me ha entregado el l'atrón Antonio Roca, que regreso el $26 \mathrm{del}$ mes último, acreditando el desembarco de la jersona do D. Alexandro Malaspina.

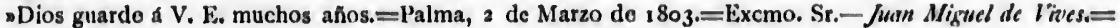
Excmo. Sr. D. Pedro Covallos, " (Original.)

El certificado es como sigue:

«Don Josef Miguel Burria, Vicecomisario do Comercio do S. M. C. en el puerto de Portvendre:

"Certifico: Como el Patrón Antonio Roque (sic), de la matrícula de Mallorca, embarcó el dia seis Febrero en el puerto de Palma, on la dicha isla como consta de su pasaporte, al Sr. D. Alexanclro Malaspina, italiano, y quo hoy diez y ocho mismo Febrero lo desembarcó on este puerto; llegando el dicho Patrón con su barco la Virgen del Carmen. $=\mathrm{Y}$ porque conste a donde convenga, doy el presente certificado, que firmo y sello con cl P. S. de este Vicecomisariado.=Portvendre, a i 8 Febrero de $1803 .=$ Por el seňor Vicecomisario de España, L.uis Bronsoni,

Sello en lacre rojo.

Esto, no obstante, el Capitán General de Cataluña dirigła al ministro de Estado este oficio:

«Excmo. Sr.: La justicia del puerto de Palamós mo avisa, que segun noticia dada por aquel Comandante militar do Marina, D. Alexandro Malaspina desembarcó on Marsella, adonde lo condujo un barco mercante de Mallorca, según constaba en ol rol de equipaje de su Patrón. Lo noticio a V. E. consecuente á lo que se sirvió prevenirme de orden do S. M. en 5 de este mes.

Dios guarde a V. E. muchos affos.=Barcelona, 22 de Marzo de $1803 .=E x c m o$, Sr. $=E l$ Conde de Simht C'sra. $=$ Sr. D. Pedro Cevallos. (Original.)

(Archivo general central de Alcalá de Henares, legajo 3013.)

\author{
PLAN PARA ESCRIBIR SU VIAJE, DADO POR MALASPINA AL P. GIL.
}

Cumpliendo con una orden de S. M. la cual me prescribe el que entregue a V. P. Rma. todo lo que sea relativo á la parto histórica y política del viaje de las corbetas Descubierta y Atrevida para que de este modo llegue á sor público con mayor brevedad y perfección, antes manifestaré la debida complacencia por una terminación que ciertamente refluirá toda á beneficio de la instrucción pública y luégo procuraré en los siguientes párrafos dar una idea tan exacta cuanto lo permita la extensión de un oficio, del método que me habfa prefijado para ia dicha publicación y del estado en el cual se halla hoy en dia la misma obra.

La introducción general, la cual precede á la narración del viaje, bastaria á la verdad por sí sola para el objeto propuesto: la he entregado con el mismn diario á V. P. Rma. y si bien no haya aủn merecido la Real aprobación la parte que en ella se comprende y es relativa á las materias politicas, debe tranquilizarme en mucho el que, aún no aprobada, en nada trastorna las demás partes del plan propuesto.

Pucliera hacerse, sin embargo, digno de reparo el estilo algo enfitico del cual va vestida. Lo he preferido con el solo intento de couvidar á la Nación á reunirse hacia un Gobierno prudente, que sacrificará cualquiera preocupación $\delta$ descanso al deseo del bien público. Y a la verdad, en el estado deplorable en el cual se hallan nuestra Hacienda, el crédito público y áun la seguridad individual, o es preciso que las materias pollticas so traten con aquel objeto, ó que no presenten sino el infeliz espectículo de un hoinbre entregado á la adulación y al cuidado de sí mismo..... Pero hablaré más difusamente de esta materia en su lugar; básteme por ahora el repetir, que el descubrir la América, sea en cuanto á sus orillas, ó en cuanto a su estado interior, como por precisión lo hará la narración aún mas superficial del viaje, sería un acelerar ó las invasiones más temibles de las naciones rivales, 0 el desmembramiento do sus partes por aquella misma reacción que agita en el dia a las sociedades reunidas en los siglos pasados.

Anexo á la introducción puede considerarse el legajo nümero 1 de los papeles originales: en él se comprende esencialmente todo lo que se refiere al objeto del viaje y a las medidas tomadas para su ejecución en los diferentes ramos, sean cienteficos $\delta$ de policia, orden, seguridad y conservación. Las correspondencias originales de algunos sabios de Europa y de varios oficiales de los más expertos de la Armada, hállanse encerradas en el mismo legajo. Pudiera por la misma razón darse la extensión que se quisiera á la nuisma introducción, detallando a la par de las historias de los viajes extranjeros, cuanto hubiésemos tenido presento en los aprestos. Pero lo he omitido as! por ser estas materias ya harto repetidas entre las diferentes naciones martimas, como por hallarse la nayor parte recordados ó en la misma narración y en la obra médica, si se refieren a la policía, obien en cl diario astronómico y materiales de las cartas, si se refieren á las ciencias, que más de cerca procurábamos abrazar.

La narración del viaje debła reunir precisamente tres objetos: $10^{\circ}$ La responsabilidad mfa inseparable 
del honor nacional, 2. La mayor amenidad ó descripción ménos molesta de las cosas acaecidas. 3." La ins. trucción general de la Armada, para la conducta más propia en los mares y colonias distantes de los domi. nios do S. M. Con igual atención he procurado no perder de vista los tres objetos indicados, y si bien halle que la demasiada repetición de las tareas hidrográficas, sea algo cansada en el total, he debido sin embargo decidirme a no hacerla inis superficial porque era indispensable el dar una idea clara de la prolijidad con la cual habiamos trabajado en la parte principal del viaje que se reducia a la construcción do las cartas del Mar lacffico. Opinaria por consiguiente que ni el orden ni la extensión del dicho diario pueden variar considerablemente; sólo sí debo advertir que faltan on śl dos capitulos correspondientes al libro terceto y deben tratar: el priinero, del viaje de la corbeta Atrevibs á Macao desde la bahía de Manila, y el se. gundo, del viaje de la misma corbeta en $x 793$ y 94 desde la Concepción de Chile hasta el puerto de Montevideo: su Comaudante, el llrigadier D. José liustamante y Guerra, ha tomado a su cargo el poner en ordon aquellos dos capitulos y remitirlos despues al Kxcmo. Sr. Ministro de Marina. Incluyo, no obstante, para cualquier evento las copias de su diario original, de las cuales seria fácil doducir los misınos capitulos y debo nñadir como prevenciones sobre esta materia, para $\mathrm{ml}$ larto delicada, on primer lugar, que D. José Bustamante desoaba cxtender en un capitulo aparto cl viajo do la A TREvina separada de la Descumerta en los mares de Nicaragua, el cual yo he reasumido con otras materias para el mayor orden y brevedad: segundo, que el mismo orden de la narración me ha conducido $\{$ considerar en fines del año de 1793 soparadas las corbotas $\tan$ sólo desde la Concepción de Chile, cuando en la realidad debian considerarse como tales desdo lima: tercero, finalmente, que era el ánimo de Bustamante (Inanifestado así al Excmo. Sr. Ministro de Marina), de comprender en el capitulo del viajo á Macao una disertación ó memoria sobro el comercio do los europeos en la China, obra que serfa sin duda utitsima para la instrucción pública, porque según el plan adoptado, no scria fácil embober en la narración histórica del viajo.

Estas tres prevenciones exigirán ciertamente que V. P. Rma. se corresponda con ol mismo Bustamante, quien se halla actualmente en Cídiz. Por mi parte no desco sino el quo quede complacido, cuando sus ideas parezcan plausibles, y de todos modos crecré acertado ol que se consulten á la supcrioridad cuando ya estén a la vista los materiales remitidos, accediendo yo do muy buena voluntad á cualquier partido que parezca preferente, visto el todo de la obra por jueces imparciales é intcligentes: van también anoxos a csta parte en el legajo número 2 los diarios originales cuales se remittan al Excmo. Sr. Ministro de Marina desde los diferentes puertos dondo llegaban las corbetas. Pueden scrvir á las veces para aclaración de algunos párrafos oscuros, a veces de fehacientes de la verdad más escrupulosa en la narración respecto a haberso escrito puntualmente en el viaje y habcrse presentado a la oficialidad de gucra para su confrontación con la verdad más exacta.

Ya la composición del segundo tomo aún no bien ordenada, pide una aplicación difusa la cual sirvaso V. P. Rma. $d$ - mirar con la mayor reflexión, pues envuelve on st no sólo cl trabajo complicado de muchos, sino también el fin principal de la obra; esto es, la utilidad pública.

Un estudio no superficial de la América me habfa convencido años antes, que cuanto sobre clla se habia escrito, más bien scrvfa para confundir que no para ilustrar á la nación posecdora. Gemlan los archivos, $o$ püblicos ó particulares, bajo el fúrrago inmenso de las acusaciones reciprocas de los Gobernadores, ó militares 0 oclesiásticos, do los proyectos soñados de la fuerza y riqueza nacionales; de las descripciones pomposas de los patses invadidos y do las lcyes incautas y no obedecidas do un Gobierno acosado do la necesidad é imposibilitado de examinar con cordura lo que deb/a juzgar. Qufsose ordenar un pals inmenso de rnodo que sobrepujase en pocos años á las riquezas, al poderio y á la población de la España; y la miseria, la debilidad y la despoblación, fueron las consecuencias inmediatas de aquel sistema funesto; pero sobro todo el malogro de unos proyectos tan plausibles no pudo ménos de acarrear con la justificación de cada uno, las descrip. ciones más equivocadas de los paises de los cuales se hablaba. La América se halló á poco tiempo á la disposición absoluta do sus Gobernadores, los cuales invadian ó abandonaban centenares de leguas, ya en una, ya cn otra dirccción. El suclo, los productos, los habitantes indigenas, los mismos proyectos de nuevas colonias, ya en las orillas del mar, ya eu las cumbres de los munisa los más olevados del orbe, fucron descritos $\delta$ con parcialidad $\delta$ con ignorancia. La misma imposilitidad de descifrar la verdad entre tantas contradicciones hizo abandonar el estudio de un pais tan inmenso y fivé nuestra única felicidad el que, ocultadas por naturaleza descripciones tan equivocas y contradictorias, los extranjeros se viesen arrastrados en pos de nosotros á las mismas idcas erradas sobre la cualidad de nuestras Américas, y finalmente, tantas causas reunidas á la supernicialidad con la cual se escribe hoy en dfa, diesen de aquellos paises una idea aún más errada de la que tenfamos en los principios de la conquista.

A la verdad, los límites do nuestros destinos á las orillas del-mar; las operaciones hidrograficas y astronómicas que debfan ocuparnos incesantemente; la misma celeridad con la cual deblamos correr de uno $\mathfrak{a}$ otro extremo de la América, parecian destinarnos á contribuir más bien al aumento que á la disminución de aquucllos errores, cuando hubiesemos querido mezclarnos en materias tan oscuras y complicadas; pero como quiera que visitásemos de camino á las diferentes capitales de los vireinatos, que en ellas se agolpasen alrededor de nosotros los hombres más ilustrados, creyendo hacer un buen servicio a la patria y al Gobierno, que los Vireyes y Gobernadores nos franqucaran las noticias más exactas y reservadas, que nosotros mismos, 6 ya con la imparcialidad de unos meros caminantes, $\delta$ ya con entromcternos entre los campos y entre los naturales de las clases aún más abyectas, como lo exiglan nuestras excursiones, tuviésemos lugar á confrontarlas; finalmente, como quiera que los mismos progresos de las ciencias diesen lugar ahora a que se examinasen 
aquellos paises por los colonos con mayor cinpeño y utilidad, juede, por último, conocer que ni careciamos do los materiales necesarios para dar á la Nación una idea cabal do sus colonias, ni esta empresa iebia nmi. tirse cuanilo se pretendiese examinar polfticamente la defensa de la América de las iwvasiones externas o de las revoluciones interiores.

Anadlase á estas consideraciones otro reparo de no menot extensión, y era el semlılante que del,amos rlar á los objetor c historia del viaje: casi el todo de el habia tenirlo lugar en las colonias nacionales, do las cuales lubiera sillo absurdo, clespués do tres siglos corridos desde su clesculurimiento, el dar una idea superficial, yuo suele darse do un pais visitado por la primera vez, en donde las nociones áun más imperfectas y frivolas, sisven o do instrucción ó de entretenimiento para los lectores. l'or consiguieste, la descripción sen. cilla do pocas minas, algunas piedras, etc., de nada servia sino es de un nuevo aumento para la misma confu. sión sobre el estudio de la Ainérica, que procurábamos evitar. Mayor empeneno, ideas más extendidas nos pres. cribla'auestra situación iuıperiosamente, y se diriglan a dar una idea cabal de toda la América espanola, por manera que se reasumiesen en nna sola masa torlas las noticias útiles y veridicas, separíndolas do las tialas e impertinentes, $y$ el legislador $y$ el vasallo pudiesen leer sus deberes respectivos on un espejo fiel, en donde la naturaleza grabaso con los colores de la realiclad lo que fue la América, lo que es y lo que será, siguiendo por una parte el orden suyo inalterable y por la otra los obstáculos quo intenta poncrle la débil mano del hombre, conspirando tan sólo á su propia infelicielad y clestrucción.

Con este solo intento tuvo á bien S. M. prescribir a los hermanos del difunto D. Antonio Pinerla, que reuniesen á nuestra obra los apuntes ó notas de aquel hábil observador, sin escribir otro viajo separado, cl cual ciertamente ó dobla coñirse á pocas icleas inconexas y nada uitiles para los progresos de la ciencia, $\delta$ adop. tar como suyos aquellos conocimientos que pertenccian a la sola expedición: con este intento los hábiles bo. túnicos D. Luis Nee y D. Tadeo Heenke, tributaron siempre al mismo plan aquella parte do sus diarins que tuviese relación con el examen de la naturaleza cual nos la hablamos prefijado, sin descender con particularidad a una ú otra ciencia. Este intento, finalmente, fué el que manifestó como esencial la ordenación de la obra en Mfadrid, en donde únicamente podian hallarse, ó los manuscritos precisos para formarla, ó los hom. bres ilustrados y testigos do vista que pudiesen ratificar aquellas idens. Cúl sea la principal división do la obra, y cuales lon motivos que asl lo han dictado, lo demuestra la Iutroducción con la mayor claridad. Era preciso dividir la América Moridional de la Septentrional y do las Filipinas. La utilidad, las relaciones entro sí y con la matriz de cada una de estas partes, eran tan diferentes, que no alcanzarfa a rcunirlas la imaginación más viva y arrobatada. Siguiendo, pues, el mismo orden, hablar é ahora con distinción do cada uno do los libros premeditados.

\section{TOMO PRIMERO}

Descripción física de la América Meridional comprendida entre los Cabos de Valdés y Hornos y el Istmo de Panamá.

Capirulo 1.: Trataré del mar que cerca aquel pais inmenso, de los golfos, do las islas, de las sondas, de los vientos dominantes. Grandes harmonias de la naturaleza entre los vari os elementos que la componen.

2.0 Tratare de los temperamentos y de las diferentes zonas correspondientes. De Sur a Norte, pais montuoso y pass llano. Término de las estaciones variables y de las constantes y conformes a la acción del sol, etc.

3. Población general de la América meridional. Indios primitivos. Invasión de los peruleros. Invasioncs de los curopeos. Estado actual de las colonias. Idea natural de desterrar todos los nombres do tribu y familias para un examen semejante: no se individualizan castas y números. .

4." Trátase del Rio de la Plata y de las Fampas hasta el Paraguay y Tucuman. Naturalcza de este terreno. Ios ganados, sus utilidades, su multiplicación, su retiro.

5." Descripciones individuales del país reconocido por nosotros alrededor de Montevideo y Bucnos Aires. 6. Descripciones del Puerto Deseado y Puerto Fgmont.

7. Reúnense estas noticias á las de los demás navegantes españoles y se forma una idea cabal de las tierras Patagónicas y del Fuego.

8." Descripción de la isla de Chiloé y de la parte meridional del continente no sujeta á la dominación española.

9. Recopilación de las diferentes naciones quo habitan el pals inmenso desde la latitud de $36^{\circ} \mathrm{y}$ medic hasta el Cabo de Hornos. Sns costumbres, sus enlaces, su número. Historia de los Césares y de los proyectos de Fol-Kaner.

10. Descripción de Chile: sus naturales de todas especies, su suelo, sus manufacturas, su temperamento, minas, comunicaciones interiores con el Perú y las provincias del Vireinato de Buenos Aires, Mendoza, San Luis de la Punta y las Pampas. 
11. Del Tncuman; del Paraguay, de las misiones de Noxas y Chiquitos, clase: bien distantes de los peruleros.

12. Descripción de las costas desde Coquimbo hasta Lima; minerales y volcanes. Uvas y aceites. Calidades lel mar y de los vientos reinantes. Trínsitos de comunicación de los pasajeros, acarreo de mulas. Varias comunicaciones con la capital de Lima. Temblores, ingenios de azucar.

13. La Sierra del Perú, su naturaleza y minas. Peruleros que la habitaban al tiemno de la conquista. Im. perio del Cuzco. hagunas de Chucuito, País de las Yangas. Elevación de los montes. Temperamento y estaciones quo la dimanan; vicuña y llama. Ninerales de azogue de Guancavelica.

14. Descripción de Lima, sus costumbres; los colonos, los negros, los indios; mezcla de castas, influjo de las costumbres de la capital sobre toda la costa. Agricultura del valle de Rimac. Industria de los paises inmediatos de la Sierra. Costumbres antiguas de los peruleros conservadas en la sierra; su naturaleza; viaje de los Sres. Pineda, Ieenke y Nee. Conchas altas, calidad de los montes; causas del caracter actual de los limeños, vicios, e!c.

15. Pais comprendido entre Lima y Guayaquil. Navegación, pescas. Limite singular de las estaciones en Payta.

16. Reino de Quito. La quina, el cacao y los demás productos. Misiones y curs, del rio de las Amazonas ó Marañón.

1. Moutes de Chimborizo Pichincha y Juriguragua. Observaciones de los Académicos franceses y Oficiales españoles. Caminos de Popayan y minerales de oro.

r. Descripción del Brasil en cuanto se combina con las medidas nuestras. Navegación del Marañón. Productos útiles para el comercio. Límites naturales para la conveniencia recfproca. Desembocadero de nuestros frutos por e? Orinoco.

19. Bocas del Orinoco y gobernación de Caracus. Costas de Maracaibo, etc.

20. Curso del rio de la Magdalena hasta Santafé y Popayán. Naturales indómitos que los habitan. Negros y mulatos que atienden á la agricultura. Estado de las minas.

21. El Choco y el Tinon.

22. Istmo de Panamá.

23. Resumer de la población y productos de la América meridional. Beneficio de sus minas; sus industrias rurales y azogues; costumbres de sus liabitantes y causas físicas que se oponen por largo tiempo á su prosperidad.

Los materiales para estos caṕtulos se hallan todos reunidos, ei mi entender, con una más que medianir claridad:

I. En las obras de los Excmos. Sres. Juan y Ulloa, y particularmente en las noticias americanae.

2. En las memorias manuscritas de los mismos Oficiales, presentadas al Gobierno á su regreso.

3." En los viajes y reflexiones físicas do' 'us 'rres. Bouguer y Condamine.

4." lin la excelente colección de los mercurios peruanos.

5." En la historia de Chile del Abate Molina.

6." En las dos obras de los Sres. Alcudo, padre é hijo.

7." Lin algunos apuntes del Médice de Lima, D. Cosme Bueno, conocidos bajo el nombre de Lazarillos de los Ciegos.

8. En los pajeles inanuscritos la D. Antonio Pineda, de los cuales va una parte ordenada.

9. En las descripciones fisicas ordenadas desde Buenos Aircs hasta Coquimbo inclusivr, que remitimos durantc el viaje.

10. En las Guías de forasteros de Lima y Buenos $\Lambda$ ires de estos tiltimos años, que se hallarán en los archivos de Hacienda y Gracia y Justicia.

II. En la colección nuestra de papeles manuscritos relativos á las Costas Patagónicas, Malvinas: Chile, etc.

r2. En los manuscritos y diarios de los Sres. Heenke $\%$ Nee, los cuales han atravesado filosóficamente la América meridional.

13. Finalmente, en los archivos de Hacienda y Gracia y Justicia, por lo que toca á la población y mejoras interiores, y en la excelente colección de manuscritos del Sr. D. Manuel de Ayala.

Pero aun cuando supusiésemos que los escritos nacionales no adoleciesen del doble mal inevitable de haberse siempre ordenado con el interés natural de los empleados que los remitfan y del respeto, ó mejor dicho. esclavitud á las leyes y costumbres patrias, siempre el semblante tan vario que toma á cada paso la América y el pormenor do los pasajes de los cuales se intenta tratar en la obra, exigirfạ irremediablemente ." $_{\mathbf{i}}$ le consultasen á viva voz los muchos hombres instruidos y de autoridad que desde el Ministerio del Marqués de la Sonora han recorrido y organizado la América cual se halla hoy en día. Los escelentisimos Sres. Ex-7ireyes Vertiz y Loreto, por lo que toca al Rio de la Plata y provincias interiores de aquel Vireinato; D. N. Marien y los Directores de la Compaña marítima de Pescas por lo que corresponde al Puerto Deseado; el Sr. D. Tomís de Acevedo, Visitador de Chile; D. Jorge Escobedo, Intenciente del Potosí y Visitador del l'eru, y D. José 'jarcia de León y Pizarro, Visitador del Reino de Quito; el Coror al de Ingenieros D. N. Requena, viltimo Gobernador de la provincia de Naynas; D. Francisco Saavedra y e! Marqués del Socorro, exGobernadores de Caracas; D. Vicente de Rivas, ex-Director de la Compañía de aquellas provincias; Don N. Gal:ra, ex-Presidente de Chanas, y D. Vicente $\mathcal{U}_{2}$, Corrsgidor en la Sierra del 1 rú, son otros tantos sugetos qne cieben consultarse prudentemente, por manera que ni se malogren las exce ontes noticias que han 
acopiado, ni la obra decline insensiblemente al plan de icforiua que procuraron introducir y tantos inconvenientes ha producido en la América. Fu cuanto a Misiones, podrán también suministrar noticias importantes los Procuradores de los diferentes Colegios que residen en esta Cortc, y en particular el de Santa Cruz de Ocopa; asl como serán utilísimas la Historia fisica del Paraguay, escrita por el Capitán de navio D. Félix Azara, destinado en la linea divisoria del Brasil, y la de la provincia de Buenos Aires del Oidor de aquella Audiencia D. Rafacl de Videsigue; pero estos dos tratados no han siou aún remitidos á Madrid; el primero so ha pedido á Roma al Excmo. Sr. D. Nicolás do Azara, su hermano, quien lo recibió en el año pasado, y el segundo debe haberse presentado ahora al nuevo Vircy D. Pedro Mclo. Algo queda por decir soture la iateresantísima colección de manuscritos de D. Manuel de A;ala; este celcso individuo ha empleado, no sólo una gran parte de su vida, si también la mayor parte de sus ca'ndales. en acopiar la dic'ıa colección, la cual, ofrecida reiteradamente á S. M. para que se custudiase con la debida reserva y sirvies, al mismo tiempo do norma para los varios asuntos que se ofrecen tratar en su Consej ) de Fistado, debía producir á su autor, no sólo los debidos aplausos de todo el quo se interesa $\mathrm{en}$ cl bien público, si también algún premio que resarciese en parte los sacrificios hechos del tiempo y del dinero. Sería tan imprudente de su parto como de la nuestra el que la obra ahora proyectada aprovechaso de todas las noticias all comprendidas, dejando despues un caput mirtorum inutil absolutamente para todo lo que fuese relativo á la América. Esto parece dictar, y asl lo haré pr usento a S. M. (dentro de pocos días), que finalmente se adquiera con regulares condiciones la colección indicada y que la ap*oveche en primer lugar nuestra obra, extractandó libremente todo lo que parezca convenir para su mayor utilidad y hermosura.

La descripción del Brasil no necesitará en nuestro plan tanta extensión como la exiren las posesiones nacionales; basta que el lector estudioso sepa la calidad de su suelo, la clase de sus moradores, scan indigenas 0 colonos, sus industrias minerales y comercio, para que pueda valuar después ó la fuerza real del enemigo doméstico, ó los principios de discordia é inquietud que puede rausarle su inmediación; se ha consultado en esta parte con la mayor escrupulosidad todo lo que ha escrito el Abate Rainal, y merece, según los mismos portugueses, muy poca ó ninguna fé: mucho mejores datos podrán derivarse ó de las noticias verbales del Coronel Requena, ya nombrado, ó de las que ya ha enviado y seguirá enviando el Excmo. Sr. Marqués de Oyra, Embrjador de S. M. en la Corte de Lisboa.

Como lo hice ver en la Introducción, la descripción física de la América, dirigida al bien sólido nacional, debe tener siempre ála vista los tres puntos esenciales: $x^{\circ}$ La prosperidad y multiplicación de la especie humana, cualesquiera sean las castas de que se compone ó los climas que habita. $2 .^{\circ}$ La reunión do la socicdad, esto es, de las colonias y de la matriz, de modo que sus labores é industria conspiren unánimes a la felicidad común, siempre ligada con los sugerimientos de la naturaleza, madre y maestra común, cuyos preceptos, mal atendidosp se convierten inmediatamente en otros tantos rigores imposibles de contrarcstarse. $3 .{ }^{\circ}$ Finalmente, en la defensa de toda la sociedad, la ménos molesta y más segura que dicten às conveniencias locales y los progresos de la opulencia. Fácilmente, con estos principios á la vista, se podrá conducir al filosofo desapasionado, á considerar en la América meridional las cuatro especies diferentes de habitadores que han contribuído con tanto vigor al choque contínuo de sus leyes y sistema. Los salvajes indígenas; los sermberos invasores; los españoles introducidos después, y últimamente la continua conducción de los aegros, bastarían por sí solos para constituir la necesidad de un cxamen scparado de nuestra cspecie; agréguese á esto el afán nariñn a] para bnscar las minas colocadas por lo común en los terrenos más áridos, elevados y desiertos; corasidérese el efecto que esa misma claso de industria, semejante a la del jugador, debia producir en la robıstez del hombre, en la colocación de los pueblos, en la ingratitud de los cultivos y en la suavidad de las costumbres. La historia civil de la América descubrira inmediatamente á los ojos del observador desapasıonado las causas clirectas de su cstado actuzl; le hará remontar poco después po: un orden sencilln al estado en el cual se ha'laba al iiempo de la conquista, y le conducirá entre el caos de las cosas venideras, á $\lambda$. acifrar la suerte de aquella grand; porción del globo y de los individuos que la haibitan. Ya no cs tan dificil, al ménos tan complicado, el tratar con utilidad y amenidad cl segundo libro que abraza ia América septentrional desde el Istmo de Panamá hasta los límites más elevados de la California y provincias intcrnas; sus capítulos pudieran dividirse de tal modo que la provincia de Costa Rica y Veragua, abracen el primero; el segundo el reino de Guatemala; los Giros seis siguientes el reino de Méjico libre de invasiones; el sétimo las provincias internas del Oriente; $\cdots$ uctavo las del Occidentc; el noveno las Californias antigua y moderna; el décimo las costumbres mejir _nas en tndas sus partes comprensivas del reino de Guatemala: el undécimo las costumbres de los salvajes Liabitadores de la Costa Rica y Veragua al Sur y de las Californias al Norte; el duodécimo nuestras indagaciones fisicas hechas sobre las orillas del mar Pacffeo; el trece la costa y provincia do Campeche; cl catorce la Nueva Orleans y Florida, con algunas nociones de Kentuki y de la Georgia; el quince los establecimientos ingleses de la costa de Honduras; el dieciseis, finalmente, el estado de la indusiria y población de todos los dominios nacionales, y como ya lo hemos manifestado en el capitulo primero, las trazas evidentes de la historia de a conquista y los indicios de lo que deben producir en una época determinada mancomunados como lo están en el dia la naturaleza, la legislación y el sistema nacional, si puede l'u.umarse ast.

No se extienden las reflexiones de este libro á los paises más septentrionales del Nuevo Méjico, inclusas las costas do Fuca, Nutka y los paises inmediatos á la Siberia, porque los individualizarán con más propiedad y extensión los Oficiales encargacios de la redacción del viaje de las goletas Mexicama y Sutil al Estrecho de Fuca; y por lo que toca a uma ideá de la Isla de Habana y de las utras Antillas, el mismo orden de las ideas irá dictando si debo considerarse como titil ó como supérflua. 
Las materias para este libro a.ben sacarse principalmente de las Cartas de Cortés, de la Historia de Cla. vijero y de los muchos manuscritos ítiles del Archivo de Ayala. Los jesuitas y el Oidor honorario D. José Velazquez han descrito tambien con $n$ :ucha ciencia y elegancia diferentes provincias de eso gran Imperio; y como desde la visita del Excıno. Sr. L José de Gálvez, y sus dişosiciones sucesivas cuando fué Ministro, se hallan perfectainente sistenıadas sus dife ontes provincias, sca en cuanto á numeración de pueblos, vigor do las leyes, beneficio de las minas y cultura de los campos, como por lo que mira a 1 ,s desembocaderos al mar y comunicación con la matriz de los produ tos uitiles y necesarios; result: que no es tan necesaria una confrontación nimia de estos elementos con las personas que la han administrado estos viltimos años, tanto más que cl voto íntegro y perspicaz de todos ellos pu vdo considerarso reunido en una sola persona, y este es el Vixcıno. Sr. Conde de Revillagijedo. A estos docume ntos agréganse todos los que hemos adquirido y van comprendidos en el paquete número 3 . Su mismo índice 'tenota su importancia, y por lo que toca á las pro. vincias internas y costas de California, pueden consideraıse extractados los mejores documentos en la Memoria que formé en aquel entonces $y$ ahora acompaño iguaimente con los papeles indicados. En nuestro plan todo el continente de la América, del cual se ha hecho wención hasta aquí, debra manifestarse po: meclio de cartas geogrificas, las cuales separasen en primer lugar lis posesiones nuestras de las extranjeras y entre aquéllas dividiesen áun á la vista del ménos reflexivo, los paizes de misiones $y$ los que habitan los pueblos salvajes, de los que siguen radicalmente y sin violencia nuestras costumbres, tiuestra religión y nuestras leyes. F.sta separación, libre de tedos aquellos nombres de pueblos y nacıones errantes que sólo sirven para cansar la vista y la memoria del que quiere ocuparse en estas materias, y ceñida á la misma razón tan sólo por los puntos fortificados y residencia do Jefes, Gobernadores y Obispos, facilitaría el estudio cabal do nuestros dominios; y uiltimamente dictaria por sí solo cuáles son las Misiones que deben promoverse, cut́les los terrenos que pueden polblarse, dónde el colono podrá estar seguro sin más reunión quo la de su familia, dónde necesitaría formar una seciedad numerosa para resistir a las hostilidades traidoras de los salvajes, cuáles son, ea fin, los derechos territoriales de cada nación de las que han tomado parte en la posesión de la América: semejante empresa no está fuera del alcance de nuestras fuerzas. Háse adquirido y se van adquiriendo materiales importantísimos, pero de ninguna manera pudiéramos prometernos el llevarla á debido cfénto, mientras D. Fclipe Bauza, particularmente encargado de este ramo, no acabe el $\Lambda$ tlas Hidrográfico, wn " $\mathrm{C}$. se lialla hoy din tutalmente ocupado.

Fiste segundo libro será, por su naturaleza, mucho más entretenido y metódico que el primero. La u. iciau de slćjico y varias otras de las principales del Reinö, llevan consigo el semblante de la opulencia, del orden y de las antiguas costumbres espanolas. En a.s minas situadas aquí on terrenos ménos altos y estériles que on el Perú, combinan para su labor y beneficio los brazos necesarios, la subsistencia fícil y los fondos inagotables; ábrense cada día nuevos objetos itỉes en la agricultura, sea para el propio consumo ó para $\cdot$ la exportación extranjera; y si bien á la inversa del Perú faltan aquí rios navegables que faciliten la comunicación de uno á otro exiremo del Reino, pueden considerarse como ventajas casi equivalentes la no mucha distancia de los dos mares, la igualdad de los productos en todas sus partes, y el inmenso nimero de mulas, cuya destrucción no es tan comun por la mayor suavidad del suelo. Los majicanos, bien sea por una agricultura mejor ordenada, $\delta$ por otras mil causas que ahora es importumo el indagar, se han prestado mucho inás para mancomunarse con los conquistadores de lo que se hayan prestado los peruloros, de lo cual ha dimanado, como era natural, el que las leyes tengan más vigor; que la mano de obra sea más barata y periódica; finaimente, que en todas las empresas relativas a las industrias del suelo, pucda calcularse con la misma probabilidad con la cual se calcula en Europa. Saldrán, por consiguiente, muy luégo a la vista del observador racional, los acopios inmeısos de algodoues quo de las provincias meridionales pasan á tcjerso a Puebla: las granas de Oaxaca, los añiles y azúcares que ahora se multiplican con tanta rapidez y prosperidad. Las provincias de Yucatán y Campeche ofrecerín al paso tinte: la Nueva Orleans las maderas, y las mismas provincias septentrionales, aunque no bien sistemadas, contribuirán sin embargo, a la prosperidad y reunión de la Mlonarciúa con aquellos productos, de los cuales no es capaz un país situado en la Zona Tórrida y en particular con la variedad y crecido numero que únicamente pueden equilibrar en cicrto modo nuestro comercio úcl Asia.

Las Lisiones en la América septentrional que ahora tencruos a la vista, no son tampoco por su misma posición, tan desordenadas cono en la América meridional. 'uas hay tan sólo on los dos extremos del Sur y del Norte, poco útiles á la verdad, tanto hac a el Istmo de '’anamá como hacia los pueblos rayanos de nues. tras provincias internas; pero que no sería, sin embargo, prudente el abandonar, así por prometer muchos y inejores efectos en ainbas Californias, como poriue son por naturaleza otras tantas guardias vigilantes sobre la mayor extensión de nuestros línites relativanente á las potencias rivale. de la Europa, y la menor aproximación de los salvajes a nuestras colonias ordenadas. Pero para los razonamientos mas fundados del sistema político nacional, importa mucho el examinar filosóficamente aquellos países, y ver hasta dóndo la naturaleza y la legislación han influido para ilevarlas al estado en el cual se hallan hoy en día. Una atención particular no puede omitirse relativamente al examen, del cual ahora tratamos, y es el verdadero estadn do las provir cias de Sonora y Pinceria, del cual, si bien he precurado dar una idea cabal en la Memoria indicada de las provincias internas, la creo, sin embargo, más bien concisa cuando se trate do cestru: th fisitivamento los conceptos errados que años há se habían formado de aquellos paises, y que al xa pudior cotiducirnos á consecuencias muy funestas cuando se tratase de establecer los línites del Imp. rio sobre I a sscripriones cmprendidas. 
Pero ya es ticmpo de pasar al tercero y último libro, el cual hablará de las posesiones españolas en Asia, esto es, de las Marianas y Filipinas. En esta parte, para el fiiósofo observador, la naturaleza no es iméros entretenida que la segunda, y la sola Isla de Luzón, examinada por nosctros con bastante exactitud, es capaz. de suministmar materlales fecundisimos para la instrucción nacional. Con la diferencia de pocas horas, pue de conducirse al lector, atónito de la suma fertilidad de un suelo cultivado con todo cl arte que pucda desearse, á unos bosques impenetrables y húmedos, donde cl inismo sol no tiene cabida alguna. De unos pueblos civilizados, tranquilos y el retrato de la docilidad del malayo y de su feliz multiplicación, á unas tribus errantes, montaraces y parecidas más bien á las fieras que á los hombres. Y de la suma sequedad á la lluvia casi continua de seis meses.

La salubridad del clima de las Filipinas; su posición esencialmente útil para el comercio combinado do Asia con la Furopa y la América; la misma facilidad con la cual all se multiplica la especie humana por manera que puedan surtirse fácilmente la navegación y las emigraciones periódicas en una Monarquía tan extendida como la nuestra, han merecido ya en este siglo la atención y la envidia de las uaciones comerciantes y europeas, y exigen ahora de nuestra parte un examen reflexivo y dirigido del solo bien nacional. Ia nación malaya merece por sl el examen del filósofo. Propensa con extremo a la navegación, ha emigrado ella sola con más tino y facilidad que nuestros curopeos, en cualquiera siglo se observe; propensa a la multiplicación, ha adoptado los alimentos, los trajes y la legislación que más le convenían para este intento; tan apacible en las sementeras y en las chozas, como feroz en la gucrra, se ha amoldado, sl, á nuestro sistema; pero al mismo tiempo ha modificado, para hacerlos llevaderos, los varios arbitrios que habiamos introducido en ambas Américas. Finalmente, del sumo grado de civilización con el cual se presentar en nuestras Filipinas, han podido pasar al sumo grado de rusticidad y libertad politica, con el cunl se presentan en las varias islas del Mar Pacifico, sin abandonar, sin embargo, su instinto primitivo: el de vivir subordinados, multiplicarse, trabajar para su sustento unicamente y llevar una vida alcgre y divertida.

No debe inferirse de las hostilio ades y rencor que contra nuestros isleños esplayan los más meridionales de Borneo, Macasar, etc., que la esjecic no sea la misma de unos y otros. Las invasiones europeas; la tirania codiciosa de los holandeses; nuestras guerras poco advertidas del siglo pasado en aquella parte del mundo; el mismo afán imprudente de introducir la religión y a su sombra la violación de los derechos, son las verda. deras causas que han atizado y conservan aún esta guerra fatal, la cual nos despoja anualmente de seiscientos á ochocicstus vasallos y nos hace malograr los inmensos productos de un crecido numero de islas fertilisimas. No es arrojo el asegurar que hallado un arbitrio para que cesase esta guerra continua, la población de las Filipinas pudiera crecer inmensamente y subsanar, siquiera en parte, la destrucción petiódica de hombres que la posesión de la América, y mucho más el beneficio de las minas. causan constantemente á nuestra Peninsula.

De lo dicho se infierc que la descripción ffsica do las Islas Filipinas debia tratar con distinción en primer lugar del clima, posición y feracidad del suelo, y despues de sus moradores y de las costumbres que los dis. tinguen, sea en cuanto a agricultura, industria y a!tes, como al idioma, música, vida doméstica y geniu, militar.

No merecen menor atención las dos clases difercutes de pueblos que habitan los montes interiores de la Isla de Luzón, y son los igorrotes y los negrillos. Ocúpanse continuamente los misioneros en retraerlos de la vida brutal a la cual estín entregados entre los bosques; pero la legislación, 0 por mejor decir, aquella seric de ordenes que se lleva á debido efecto, se le opone directamente; y asl en este momento más bien hemos perdido que adclantado en esta parte esencial de nuestros pasos, ni es fícil conocer si disminuyendo el mimero de aquellos sai:ajes en raźńn del método con el cual viven, podemos esperar para las épocas venideras in día en el cen: $\delta$ se destruyan enteramente 0 se agreguen a nuestra sociedad los pueblos indicados.

Las Islas Marianas, cuales son en el dia, no suministran materiales para un examen tan detallado. Sun ciertamente falsas las ponderadas descripciones de su numcrosa población al tiempo en que las conquistamos. Al contrario, no es en nada ponderada la descripción do su fertilida d; pueden considerarse como el línite de las Monzones que causan la ferti': 'ad en los mares del Asia; hay, sin embargo, bastante humedad para que los frutos de la agricultura, inclusc el beneficio de la azucar, pudiesen sustentar un núnero grandísimo de habitadores, y su division en varias islas, fáciles ‘. comunicarse una con otra, daria tal vez lugar á que la repartición do los ramos de industria fuese más retódica, como también la segregación de los díscolos, la introducción de los colonos emigrados de las $\mathrm{r}^{\circ}$ as Carolinas, etc. Es á la verdad bien sensible que carezcan absolutament? de puertos para un crecido numero de buques. El pequeño puerto de Apra $\delta$ San I uis, apenas pudiera contener tres $\delta$ cuatro embarcaciones de no mucho porte; pero en desnuite las radas de Humata y Finian, son accesibles y seguras en casi todo el año.

Después de las ideas indicadas de las Islas Marianas y Filipinas, era mi ánimo el presentar al lector un extracto juicioso de los productos y climas de las demás islas que ciñen el mar Pacífico por el Oeste. Son generalmente habitadas, 6 por los malayos $\delta$ por los aegros. Tal vez exigen alguna atención los habitadorez de la Nueva Caledonia, Nneva Holanda y Nucva Zelanda, los cuales parecen derivar en su origen primitivo de otras castas distintas.

Conclufilo aqui lo que se refiere al segundo tomo, es tiempo ya de pasar al tercero; esto es, al examera político do la América. Obra delicadísima, la cual exige tal vez mayor pulso y cautela de las que caben en mi método de tratar estas matcrias. Vo habia comprendido que después de la inmensidad de proyectos que desdo la conquista se habian proruesto al Gobierno en diferentes ticmpos, el proponer nuevas especies que 
no variasen de aquel método hubiera sido cansado, inútil y tal vez ofensivo para los depositarios del orden público, los cuales en el dá vigilan más de cerca y con mayores conocinientos sobre la buena administra. ción de toda la Monarqufa. Adverti en las diferentes épocas y en los diferentes paises de la América que iba recorriendo, que el mal primitivo y la causa sola de nuestros desórdencs estribaba en la Constitución. Me convencia de esto mismo asl al recorrer las historias políticas nacionales como al tener a la vista todos los asuntos relativos á la América que ocupaban loy en dia al Gobierno; ni a la verdad nuestro método de administrar aquellos dominios, podfa llamarse rectamente una Constitución cuando atendiésemos las diferentes causas quo desde los Reyes D. Fernando y Doña lsabel hasta nuestros días, ya hicieron de la América el teatro de mil hazañas de parte de nuestros conquistadores aventureros, ya separándola del Continente casi en el mismo modo en el cual estaba antes de descubrirse, la hicieron fácil presa o de los piratas saltcadores que por uno y otro mar la bloqueaban exteriormente, $o$ de los que gobernaban en el pais interior los indios y los colonos, ó ya, finalmente, en las ilttimas épocas variaron tantas veces cl método de gobernarla y lefenderla cuantos dieron cabida a los muchos proyectos que se presentaban para este intento. Confundiéronso indistintamente con el nombro de América los paises desiertos de la parte meridional, las poblaciones colocadas sobre las cumbres más altas de los inontes y las que gozaban del convenio y navegación de la orilla. Confundiéronse los paises sugetos á nuestras leyes con los que habitaban los salvajes aủn no domesticados; nuestros enlaces territoriales con las potencias rivales europeas se hicieron cada día más oscuros y complicados; pretendiose aplicar al Reino de Méjico y a las Filipinas lo que tal vez júda ser oportuno para las provincias de la Plata ó del Peru; finalmente, los pedriscos áridos y desicrtos de las Malvinas y costa Patagónica y los miserables anfibios de la costa de Nutka, causaron a la nación conquistadora mayores gastos y riesgos que los que tal vez le causaron las ticrras fertilisimas y las ciudades populosas del Rcino de Méjico y las Filipinas.

Este pequeño extracto de la historia nacional pedia mayor atención cuando lo refiriésemos al estado actual de las cosas; ain ignorábamos los límites del Imperio. Un Virey proponia invadir lo que otro habia abandonado; la utilidad det sistem $\iota^{\cdot},{ }^{*}$, , en las Misiones se confundía con su vida e. andalosa en los pueblos grandes; ya se equivocaban $1 . \quad$. 's con las causas y las causas con los efectos; finalmente, no había cálculos ni medidas que alcanzasc: definir rectamente cual era la influcncia de las colonias sobro la matriz; cuáles los derechos legales de entrambas, cuál su utilidad recíproca, y cuál, finalmente, el efecto de una tan grande extensión de dominios sobre la felicidad individual y sobre la verdadera fuerza racional.

Un desorden tamaño de idcas, remontaba naturalmente hasta las épocas de la conquista. Era menester decidir cstas grandes cuestiones: si el descubrimiento de la América y los accidentes que de él han dimanado hasta el día, pueden considerarse como una felicidad para la España actual; y si atendidas todas las circuustancias de la Monarquia, y combinadas con el estado politico de todo el globo, debc prometerse una grande prosperidad de la administración ó sistema nuevamente propuesto. Porque, Rmo. Padre, jamás podrá parecer plausible una reforma si no se demuestran evidentemente los males que dimanaran del sistema anterior; iamás podrá haber harmonia en las leyes y amor de toda la socicdad hacia ellas, si no comprenden los hombres reflexivos, ó su nccesidad ó su utilidad.

Esto supuesto, me parece que el tratado politico proyectado debfa tomar su origen a imitación del señor Roberston, del estado de España al tiempo del descubrimiento de la América. No se cxigen aquf aquellas particularidades, prołjias tan sólo del historiador, que desme turan las épocas, los trances, el carácter do los sujetos, y cuanto conduce al conocimiento de las cosas pasadas. El político, parte donde acaba el historiador; el uno describe lo que ha acaccido en otras épocas; el otro, combinando lo pasado y lo presente, pasa a investigar y á dirigir con acierto lo venidero. Pro al mismo tiempo ocurrfase una dificultad considerable, y era la de fijar con certeza el estado de opulencia en el cual so hallaba la Monarqua al tiempo de sus conquistas ultramarinas. La famosa feria do Medina, tomada por nuestros escritores políticos como la piedra de toque de la antigua opulencia nacisnal, citándola toda por la sola autoridad de Sancho de Moncada, parecía después de un examen moderno sumanente equivocada, o bien se consultasen los armamentos de Colón y Cortés en sus cartas al Empcrador Carlos V, 0 examinásemos las notas a las Ordenanzas de Marina del Reino de Aragón, copiadas y publicadas por D. Antonio Capmany ó recorriésemos, finalmentc, con el escritor perspicaz do la historia del Potosi, aquelios tiompos en los cuales Jacobo I, Rey de Aragón, ordenaba que ninguno pudiese comer más do dos viandas, sin exceptuarse él mismo de esta ley. Fernando el Catolico decía a su tío el Almirante de Castilla: «Quedáos a comer con Nos, que tenemos pollas.» $\mathrm{Y}$ el mismo, pidiéndole las Cortes de Castilla dejase entrar pimienta y canela quo habla empezado a venir de Portugal por la India, decia: a Excusemos esto, que buenz especia es el ajo.»

Sin atreverme a penetra ahora en lo más sagrado de nuestras historias nacionales y en la presento crítica con !a cual deben interpreturse, diré, sin cmbargo, que merece suma atención esta materia para deducir con cordura del influjo del descubrimicuto y gobcrnación de la América, subre la prosperidad nacional. Ni nos alucinen o las abuliadas fábricas de Segovia, o los muchos telares de Sevilla y Granada. Tal vez no existieron, tal vez nu alcanzaran en el estado de los telares do entonces, a vestir m edianamente la sola Nación, cuando por otra parte los franceses, ingleses y moriscos, hallábanse aún en mayor pobrcza que nosotros, y los italianos se abastecian por sí mismos de las rerias más opulentas de Alejandría. Demostrado que la Nación era pobre al tiempo de la conquista; que, sus csfuerzos militares en la América no pudieron causar su despoblacićn y debilidad; que después de la expulsión de los moriscos, ni siquiera las guerras de Flandes é Italia pueden compararse en cuanto á destrucción a las gucrras civiles de Inglaterra, Francia é Italia; es preciso, 
finalmente, indagar una causa de la cual dimane rectamente la despoblación, la pobreza y el desorden natural do España; y esta causa nn es otra, en mi entender, que la poscsión ilimitada y la gobernación desordenada de América.

Pero scría cl dar una extensión cnfadosa a cstos apuntes, si quisicse analizar uno por uno los diferentes razonamientos que me han guiado en esta senda oscura, para descnvolver los inconvenientes políticos de la posesión de nuestras colonias y los remedios que presentan sus circunstancias. En un momento en el cual todos los lazos del órden social se han cxaminado separadamente y unidos entre s; en un momento en cl cual so han traído á la práctica todos los abusos dictados por el demasiado abandono de los mctafísicos á sus imaginaciones cxaltadas, no scrá tal vez diffcil el demostrar que cl sistema de las colonias, de quien dimana el sistema mercantil, ha sido y scra el origen de muchos males que agobian a la Europa en cl día. Con estu atención, me ha parecido, pues, más oportuno el ordenar también esta parte de la obra en los capitulos siguien. tes, los cuales abrazan $\delta$ el todo $\delta$ el mayor número de los objetos que deben tencrse á la vista el cl tratado propuesto. Sirvase V.S. recorrerlos con alguna atención y seguirme después en las reflexiones importantes que de alli mismo deben dimanar.

\section{TOMO III}

Examen politico de los dominios ultramarinos de España.

\section{INTRODUCCIÓN}

Capitulo 1. Se analiza el verdadero estado de la opulencia nacional al ticmpo de la conquista de América.

2. Se hace un resumen de las emigraciones que ha causado á la matriz su poscsión. Inconvenientes del sistema militar; esto es decir, pocas mujercs y muchos célibes.

3. Se examinan las costumbres políticamente y su influjo natural, sobre el no regresar los emplcados ó emigrados nucvamente á España. Util efecto en csta parte del comercio libre.

4. Correspondencia de los diferentes periodos de la historia nacional en América y en Europa, y órdenes Reales para que procuren beneficiar en la nievn. España la seda y el cáñamo, y en los reinos de Murcia y Valencia el añil y grana.

5. Análisis del sistema nacional de las minas. Historia del valor de los metales ricos en América, en Europa y en el Asia, desde la conquista hasta ahora. Por qué á medicia de haber crecido el producto de las minas, ha crecido la introducción del papel moneda. Discusión sobre la libertad de la introducción del azogue é historia de los contratos y abastos de este metal desde Europa, América y Asia.

6. Análi. is del sistema de emigración y agricultura americana.

$7 .^{\circ}$ Influjo $1^{i e}$ entrambos sistemas en la legislación y administración de las rentas de América.

8. Idem en la administración religiosa.

9.9 Idem en el sistema militar de mar y tierra para su custodia y defensa.

ro. Retroacción de estas causas en el sistema nacional del Continente y amalgama viciosísima de los in. tereses recíprocos de éste y de las colonias.

II. Estado politico de la Europa en la época actual y principios sociales á que propende.

\section{LIBRO PRIMERO}

Examen político del continente meridional de la América, desde el Istmo de Panami hasta el üabo cle Hornos.

Capitulo t.o Por qué toda esta parte extensisima do la América, debe, como en las primeras épocas de la. conquista, formar una sola gobernación. Distinción en ella de los paises agrícolas y de las minas.

2. Enlaces y reunión recíproca de los diferentes paises que componen esta región, sus productos y sus necesidades. Sus relaciones son el Continente antiguo y sus enemigos internos y externos.

3. ${ }^{-}$Sisicma de legislación que rige en el día; sus contradicciones y su debilidad.

$4 .^{\circ}$ Método para su sistema militar, relativo a las invasiones externas.

5. Método para su sistema de agricultura, comercio y población.

6. Colocación de las diferentes autoridades y medios para evitar los choques entrc unas y otras.

$7 .^{\circ}$ En qué puede contribuir al bien general de la Monarquáa y cuáles son sus derechos para que ésta sea garante de su conservación territorial.

9. Sistema relativo a las colonias del Brasil.

10. Idem á las colonias de Orinoco y Guayana.

1x. Sistcma de las Misiones y reforma del estado eclesiástico.

12. Subsistencia de la parte correspondiente de la Armada

13. Determinación de nuestros límites y su ratificación con las potencias de la Europa. 


\section{I.IBRO SEGUNDO}

Examsn de la América scptentrional deste el Istmo de Panama hasta las fronteras del Norte..

Captrulo $10^{\circ}$ Estado de las minas en el reino de Méjico, en las provincias internas y en el reino de Guatemala y Tierra Firmo en el Sur.

2." Estado de su agricultura y productos do industria.

3. - En qué necesita la América septentrional española el auxilio de las demás partes constituyentes de la Monarquia para su prosperidad interna.

4. ${ }^{0}$ Utilidad de las reformas del señor Marqués de Senora.

$50^{\circ}$ Su sistema do comercio.

6." Su sistema de misiones.

$7^{\circ}$ Enemigos externos é internos con los cuales dobe lidiar.

8." Se examina particularmente la invasión inglesa del reino de Nicaragua.

9.0 Limites con los Estados-Unidos de la América, determinación de nuestrá frontera del Norto y su ratificación con las potencias de Europa

xo. Subsistencias de la parte correspondiente de América.

I I. Sistema económico y militar de esta parte de la Monarquía.

12. Hasta dónde puede contribuir á la prosperidad nacional y cú́les sun los enlaces suyos con la matriz.

13. Sistema de legislación que rige en el día y sus inconvenientes y debilidad.

14. Nueva colocación de las diferentes autoridades y medios do evitar sus choques.

r 5. Jinlaces de esta parte del mundo con el Asia.

16. Emigración de la China sustituida á la de los negros.

\section{LIBRO TERCERO}

Sobro los cstablecimientos nacionales de las Filipinas y Marianas.

Captrulo t. Cuál es la utilidad de las Marianas y bajo de qué sistema deben conservarse. Emigración de la China y de las Carolinas á su favor. Emigración, causa y gubernativa de los europeos y filipinos. 2. Proyectos actuales de agricultura en la Isla de Luzón.

3. Despoblación y poca seguridad de las demás Islas Filipinas.

4. Causas de esta despoblación y método do atajar estas jrrupciones de los solvanos y mindanaos.

5.- Sobre la civilización de los igorrotes y negrillos de la Isla de Luzón.

6. Sobre la conservación de los presidios de Batanes y Mindanao.

$70^{\circ}$ Estado de las naciones europeas su el Asia y sus conexiones con las Filipinas.

8. Sistema nuestro de defensa en el Asia.

9. Sistema nuestro militar para hostilizar.

10. Comercio de la Europa con la China y utilidad de hacerlo discreto con la América.

11. Manutención en las Filipinas de la parto correspondiente a la Armada.

12. Sistema religioso en las Islas Filipinas.

13. Utilidad que pueden rendir dichas Islas al total de la Monarquia y sus derechos para ser defendidas.

14. Sistema de gobierno y residencias de los diferentes depositarios de la autoridad pública.

\section{CoNcLusión}

Capitulo 7.0 Resulta de la naturaleza de los principios sentados, que el Código antiguo de ia legislación de América no puede subsistir, y que en el nuevo deben atenderse las circunstancias de cada una de las tres partes indicadas, por manera que la legislación de la una no se aplique á las otrás.

2.0 Unidad del sistema religioso y del militar con la matriz.

3..$^{-}$Grandes franquicias de navegación, industria, comercio y agricultura.

4." Indiferencia á favor de las minas.

5. Influencia de la posesión de la América en la población y costumbres de la España. Emigración, educación, holgazanerfa; ninguin amor á la patria, inconstancia y debilidad de las leyes. Idea errada de las riquezas. Efecto de la circulación violenta de la plata.

6. ${ }^{-}$Se propone un sistema de comercio para la América, que sea útil, mas nunca pueda ser pernicioso a nuestro continente.

$7 .^{\circ}$ Idea de un puerto franco en España para el comercio extranjero con la América. 
8. Reflexiones sobre el impuesto de nuestro continente.

9.0 Derechos reciprocos de la matriz y do las colonias.

ro. Emancipación moderada de las colonias y prosperidad y fuerza respectiva de !a matriz.

rx. Unión legal de toda la Monarquía.

Dos reflexiones de la maycr entidad son las que nos vienen al encuentro después de la difusa enumeración que preccde; la primera, si efectivamente el tratar de la emancipación do las colonias divididas en los tres grandes trozos ó confederaciones que se han indicado, es una proposición en realidaci tan odiosa y temible cual lo parece á primera vista; la segunda, si el tratado propuesto puedo ó debe sin riesgo alguno ser publico para toda la Nación y áun para las demás naciones, ó émulas ó superiores á nosotros en fuerzas.

En cuanto á lo primero, dice lisa y llanamente que en todos tiempos, desde la conquista, y mucho más en el dfa, tanto los empleados en América por parte de S. M., como las mismas colonias, han sido árbitras de eludir cualesquiera órdenes que se opusiesen directamente á sus intereses. Pocas veces con la violencia, de la cual, sin embargo, hay ejemplos impunes en ambas Américas y en las Filipinas, y por lo común con el soborno han triunfado siempre de las rabas r!e la legislación, y bastarfa alegar á favor de lo que aqui se asienta, casi todos los artículos de nuestras leyes, casi todos los asuntos ocurridos ó pendientes en el Consejo de las Indias y en la via reservada para demostrar que en el mismo choque de las autoridades y de la misma idea equivo. cada que acá se recibe de todos los negr, -'os de allende, dimanan por una reacción na 'ral la inutilidad de las órdenes, la ninguna responsabilidad en quien manda y en quien obedece, y últimamente todos los sintomas, aunque solapados, de una anarquia incurable.

Lejos do $\mathrm{mi}$ aquellas ideas te libertad y de independencia que, sacrificando el bien p'iblico permanente al egoismo momentáneo y por lo común engañoso, sólo conspiran á subvertir el orden de la sociedad y á hacer de los hombres mansos y apacibles unas fieras capaces de rlevorarse unos á otros. Pero tampoco se conciba la menor esperanza de que paises sumamente distantes y que no tienen entre sf la menor conexión, pueden sacrificarse uno por otro, ó bien en el libre albedrío de sus conveniencias ó en cl abandono generoso de sus hogares y de su vida doméstica.

Hay, empero, una grande conveniencia en la reunión política de las sociedades numerosas y es la mayor facilidad para resistir a los enemigos externos; con tal que el suelo que se defiende sca proporcionado al número de defensores; con tal que la ofensa de un solo individuo de la sociedad sea trascendental á los demás; con tal, finalmente, que las fuerzas de todo sean proporcionadas á las dei ćéensor, estos reparos demues. tran con evidencia que si bien no sea justo ni útil el desmembrar la Monarquia, es sin embargo preciso $\mathrm{cl}$ templarla de tal modo, que dividida en cuanto á sus intereses y gobernación interiores, sólo se halle reunida en un solo centro, cuando se trate ó de los grandes esfuerzos nacionales, ó de aquella equidad intrinsic: que excluyendo los monopolios y trabas, sólo se dirige á la mayor comodidad, tranquilidad y seguridad a sus individuos.

Este es el sistema de la Inglaterra, la cual, después de las lecciones recibidas en la América septentrional ha emancipado la Irlanda, y apenas conquistada la Circega, la ha mirado como parte integrante del Estado y no como una colonia ó unz conquista. Ası en la antigua dominación de la España, la Flandes, el Portugal y la Italia, no dependían de ella sinö en la parte militar; asf, finalmente, hoy en día la nueva Constitucion francesa ha acomunado los derechos de la sociedad í todas las partes del mundo $\mathrm{y}$ á todas las castas que quisieren agregarse. Nosotros mismos (si recorriésemos con alguna atención nuestras leyes), no verfamos acaso los derechos concedidos de comunidad á todas las ciudáes populosas de la América, los fueros de ciudadanos ratificados mil veces á los perulcros, mejicanos y filipinos; los tratados solemnes que nos reunen á todos en una sola masa, la misma inmunidad y derecho de radicarse, concedidos con tanta justicia como necesidad á los negros. $Y$, en fin, si después de reconocido el suelo tan feraz do nuestras Américas y comparada su despoblación actual, tanto con el Africa como con las islas fertilisimas del Asia que.bajo de un mismo clima alimentan . . : nn , grandisimo de hombres, puede aún creerse que tengar, remedio los

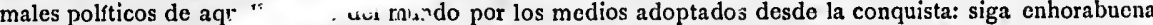
nuestra Constitución; $y$ la despoblacion, la debilidad y la independencia solapada do nuestras colonias, scan los únicos ġarantes de aquelle paz interior que con tanta razón anhelamos.

Sobre la necesidad de hacer públicos estos razonamientos cuando hubiesen merceido la sanción de S. M. y de sus Ministros, ya no es preciso insistir mucho. Cuando el sistema de gobierno no es público y cons tante, cada uno, alegando ó la ignorancia ó el no acceder á ello, es inocente si conspira á violarlo en aquella sola parte que se refiere á sí mismo. No asf cuando todos son sabedores de lo que por su parte deben hacer cuando cuentan con la estabilidad de las medidas tomadas con las razones que las apoyaron al tiempo de adoptarlas y con las circunstancias que pueden en un tiempo hacer tan útil una reforma como antes hubiera sido perniciosa... Pero me os preciso dejar la pluma. Recibo en este momanto una orden de S. M. que aprueba el plan propuesto últimamente por V. P., y se reduce á tratar estas materias con reserva y separadamente las unas de las otras. Por mi parte coadyuvaré en cuanto pueda á este mismo plan, y ojalá deriven do él todos bienes y felicidades que he deseado constantemente a la Monarquia y á la Nación que me adoptó por suyo.

Concluyo, pues, ofreciéndome de nucvo á las órdenes de V. P. Rma., cuya vida ruego á Dios guarde por muchos años.=Madrid, á 3 de Octubre de 1795 . 


\title{
De como tuvo origen el viaje de las corbetas
}

\section{Descubierta $y$ Atrevida.}

\author{
PLAN de un viaje cicntifico y politico alrededor del mundo, romitido al Excmo. Señor \\ Bailio D. Antonio Valdés, Ministro de Marina, por los Capitanes de fragaita \\ D. Alejandro Malaspina y' D. José Bustumante.
}

Excmo. Sr.: Desde veinte años á esta parte, las dos naciones inglesa y francesa, con una noble emulación, han emprendido estos viajes, en los cuales la navegación, la Geografía y la humanidad misma han hecho muy rápidos progresos: la historia de la sociedad se ha cimentado sobre investigaciones más generales; se ha enriquecido la Historia Natural con un número casi infinito de descu. brimientos; finalmente, la conservación del hombre en diferentes climas, en travesías dilatadas y entre unas tareas y riesgos casi increibles, ha sido la requisición más interésante que ha hecho la navegación.

Al cumplimiento de estos objetos se dirige particularmente el viaje que se propone; y esta parte, que puede llamarse la parte científica, se hará con mucho acierto, siguiendo las trazas de los Sres. Cook y la Pérouse.

Pero un viaje hecho por navegantes españoles debe precisamente implicar otros dos objetos: el uno es la construcción de cartas hidrográficas para las regiones más remotas de la América, y de derroteros que puedan guiar con acierto la poca experta navegación mercantil; y la otra la investigación del estado político de la América, así relativamente á España como á las naciones extranjeras.

E] estado del comercio de cada provincia 6 reino por sus productos naturales ó artefactos; su facilidad, dificultad para resistir u^a invasión enemiga 6 suministrar fuerzas para intentarla contra los mismos enemigos; la situación de los puertos más conducentes á facilitar el comercio recíproco; finalmente, los interesantes ramos de construcción 6 productos navales, serán otros tantos puntos cuya investigación, causa y secreto no será inútil al Estado; tanto más que procurará nivelarse á diferentes axiomas políticos sobre la prosperidad nacional, cuya admisión 6 repulsa dependerá de antemano de jueces respetables que hayan de examinar estas tareas; deberán por consiguiente quedar divididas en dos partes: la una pública, que comprenderá además del posible acopio de curiosidades para el Real Gabinete y Jardín Botánico, toda la parte geográfica é histórica; la otra reservada, que se dirigirá á las especulaciones políticas ya indicadas, y en las cuales, si el GoLicinu lo hallase conveniente, podrá comprenderse el establecimiento ruso de California y los In. gleses de Bahía Botánica y Liqueyos; puntos todos interesantes, así para las combinaciones de comercio como de hostilidad.

La Real Armada podrá suministrar todos los sugetos para esta Comisión, menos los dos botá. nicos 6 naturalistas y los dos dibujantes de perspectiva, que será posible y áun fácil hallar en Madrid voluntarios. En cuanto á la clase de buques y calidad de armamento, podrán fácilmente combinarse los tres principales objetos de seguridad, comodidad y economía; el armamento de cada uno de los dos buques necesarios se reducirá próximamente á unos cien hombres. El detall, así de cada clase como de los aparejos, repartición interior, calidad y número de embarcaciones menores y pertrechos, y finalmente, cantidad y calidad de víveres, es demasiado prolijo para exponerse en esta ocasión; además, que no puede determinarse con precisión hasta que S. M. no tuviese á bien prefijar los límites de la expedición propuesta. 
E1 plan siguiente pudiera ocupar prósimamente el espacio de tres años y medio, á empezarse desde $x .^{\circ}$ de Julio de 1789 , época en la cual puclieran salir las dos embarcaciones, si S. M., dig. níndose aprobar desde ahora lo propuestó, 6 en un todo 6 modificado, diese unos ocho meses de tiempo á los que han de ejecutarla, asi para el acopio de todos los materiales precisos, como para los estudios preliminares, $y$ principalmente el ejereicio de la astronomía práctica.

Las dos corbetas saldrán de Cádiz en $\mathrm{I}^{\circ}$ de Julio de ${ }^{2} 7^{8} \mathrm{q}$ y se dirigirán á Montevideo, en londe sc hará nucvo arreglo de relojes, las posibles observaciones astronómicas y todas las inda. gaciones de Historia Natural. Se adquirirín allí también variäs clases de víveres para la manuten. ción sucesiva de las tripulaciones, como para las experiencias que han de hacerse: desde este puerto se reconocerán las Malvinas, y si el Gobierno lo liallase prudente, la bahía del Buen Suceso, en el I:strecho Le Maire; pues que parece ya evidente que este pasaje será la escala más cómoda y má: barata para la navegación del Cabo de Hornos. Desde la bahía del l3uen Suceso se harí derrota á montar el Cabo de Ilornos: se procurarí reconocer el Cabo Victoria y alguna Ticrra del Archipiélago de Chonos; finalmente, se fondeará en Chiloé, lo que podrá verificarse hacia fines del año de 8\%. Todo el año de $179^{\circ}$ se empleará en las costas oceidentales de América, desde Chiloé hasta San Blas. Procurará simplificarse la navegación desde Guayaquil, Acapulco, etc., hasta Lima. Se buscarán las Islas del Gallego, y desde Acapulco se hará una excursión á Méjico.

El reconocimicnto de las Islas Sandwich ocupará los primcros tres meses del año I $79 \mathrm{r}$. Luégo se costeará la California, se seguirí al Norte, entre el Asia y la América, hasta donde lo permitan las nieves, y hecha escala en el Kamsckatka (si el Gobierno lo tuviese á bien), se seguirá al Can. tón para vender las pieles de nutria en favor de las marinerías.

La salida de este puerto tendrá, pues, lugar hacia Octubre 6 Noviembre de 1791 . Se aprovecha. rá esta Estación para reconocer los Cabos Bogeador y Engaño, en la contra-costa de Luzón; luégo sc pasarí á Marianas, y desde alli se trabajará prolijamente la carta de la navegación por el Estrecho de San Bernardino hasta Manila.

Desde esta capital se hará derrota al reconocimiento de Mindanao, y después á pasar entre Celebes y Molucas, y pasando al $\mathrm{N}$. de la Nueva Holanda, descmbocar en el Océano Indico.

Costeada toda la parte occidental de la Nueva Holanda, se has i derrota (hacia Marzo de 92) á la Bahía Botánica; se visitarán lućgo las Islas de los Amigos y de la Sociedad, y hacia Octubre 6 Noviembre la Nueva Zelanda, de donde tinalmente se hará rumbo al Sur, para después navegar al Noroeste, y ya montada la Nueva Holanda, entrar en derrota para el Cabo de Buena Esperanza, y de allí regresar á Europa en $\mathrm{Abril}$ ó Mayo de 1793 .

Los Capitanes de fragata D. Alejandro Malaspina y D. José Bustamante y Guerra, deseosos de emplear todas sus facnas en el servicio del listado, si ofrecen á la ejecución de este plan, lisonjeándosc que concurriran á dirigirlos para el mayor aciesto, no sólo la ilustración y penetración del Golbierno, sino también cuantas noticias puedan facilitar los particulares, así del Continente nuestrn como de todas las Américas. İn cuanto á los subalternos, la especie de Comisión exige que scin todos voluntarios y que se conozcan recíprocamente, así por lo que toca á robustez como á capacidad. = Isla de León, Io de Setiembre de 1788.

\title{
Dc la pronta y catcgórica contestación de un gran Ministro á un brillante Oficial, accptando su of recimicnto de dar la íuclta al mundo con dos buques: oficio modelo de sobricdad, previsión, scncillez y sentido práctico.
}

\begin{abstract}
"Ha merecido la aceptación del Rey el proyecto de dar la vuelta al mundo en los términos que propone Vm. en carta de Io de Setiembre último; y queriendo $S$. M. que se lleve á efecto y que para ello quede $\mathrm{Vm}$. relevado de la tenencia de la compañia de Guardias Marinas de ese Departainento de Cádiz, como así lo prevengo al Capitán Comandante de este cuerpo para que pueda $\mathrm{Vm}$. desde ahora dedicarse como desee á las ilustraciones y preparaciones que necesita para desempenar con el fruto que of ạce esta Comisión, lo prevengo á Vm. para su gobierno; y también, que en el concepto de que ası en buques (los qu: Vm. clija), sus aparejos, respetos y víveres, como en oficialidad, pilotos, tropa y marinería ha de aprontarse esta expedición $a$ entera satisfacción de $V m$., medite y proponga sobrc estos puntos y demás quc comprende el proyecto cuanto necesite, á fin de que dándose las correspondientes órdenes se apronte todo como Vm. lo considcre más
\end{abstract}


conventintu á su mejor descmpeño. Dios guarde á Vm. muchos años. =San Lorenzo, $x_{4}$ de Octu bre de $1788 .=$ Valdís. $=$ Sr. D. Alejandro Malaspina, Isla de León.*

\section{Recomianda at Ministro que los Oficiales cligitos para la expedición gnarden resiria hasta - il momento oportuno.}

"Conformándose el Rey con lo que Vm. propone en su carta del 2 I del corriente como consecuente á la aprobación de $\mathrm{S}$. M. que merceió su proyecto, me manda decir á $\mathrm{Vm}$. que encargue á todos los Oficiales con quien trate, solamente de los puntos que cita, la reserva, pues el que á faltare ella no irá al destino y merecerá el desagrado de S. M. Particípolo á Vm. cee su Real orden para su intc. ligencia y cumplimiento. Dios guarde á Vm. muchos años. = San Lorenzo, 28 de Octubre de $\mathbf{7} 788 .=$ l'aldis. $=$ Sr. D. Alejandro Malaspina."

I'ide Malaspina que se construyan dos corbetas cxpresamente para cl inaje, y al Ministro se dificude del gasto, mandando hacer una y reformar otra de bucnas condiciones.

"Conformándose el Rey sobre la elección de buques y pertrechos que Vm. ha hecho en vista del reconocimiento que ha practicado en la Marina Real y mercante, ha resuelto S. M. que de la bombarda Santa Rosa de Lima se saque partido para corbeta, y se construya ahí otra según acuerdo del Ingeniero Comandante D. Tomás Munoz, con los que hayan de navegarla; lo que participo á $\mathrm{Vm}$. de orden de S. M. a fin de que trate con Muñoz sobre el expresado asunto para que se verifique en términos que se consigan las ventajas que Vm. manifiesta. Dios guarde á Vm. muchos años. =San Lorenzo, I 7 de Noviembre de $1788 .=$ Valdís. $=$ Sr. D. Alejandro Malaspina.»

\section{El Ministro se ratifica cu la misma decisión.}

"Los asuntos de la comisión de que está Vm. encargado, así relativos á Marina como al Ministerio de Indias, ha de tratarlos Vm. por aquél, pues yo les daré el giro que á cada uno corresponda; pero ha de procurar dividir con claridad las materias, por ser método conforme á la más facil expedición. Lo que advierto á Vm. para su gobierno en respuesta de su carta de 2I del que sigue; previniéndole al mismo tiempo no haber convenido el Rey en la construcción de otra corbeta á más de la mandada fabricar, respecto de sir la Santa Rosa un buque apropósito para la expedición proyectada y como tal elegido por Vm:; cuya vida guarde Dios muchos años. $=$ San Lorenzo, $28 \mathrm{de}$ Noviembre de $1788 .=V$ aldís. $=$ Sr. D. Alejandro Malaspina, Isla de León."

Pero Malaspina no se conforma con buque vicjo é insiste en que se deben construir las dos - corbetas. El sabio Almirante comprende, sin duda, que ál solicitaria lo mismo en caso equivalente y vuclve sobre su acucrdo de buena voluntad.

"Sin embargo de tener el Rey resuelta la habilitación de la bombarda Santa Rosa para la expedición á que está $\mathrm{Vm}$. destinado, mediante á haberla considerado apropósito para el objeto; no queriendo S. M. escasear á $\mathrm{Vm}$. ninguno de los medios q'e puedan conducir al completo logro de los fines á que ha de dirigirse el viaje; se ha servido condescender á la solicitud de $\mathrm{Vm}$. de que se 
construya otra nueva corbeta, en virtud de lo cual comunico con esta fecha la correspondiente Real orden al Capitan General de la Armada para que disponga su fábrica con exacta igualdad á la mandada construir con acuerdo de Vm., cuya vida guarde Dios muchos años.=.Madrid, 9 de 1)iciembre de $1788 .=$ Valless. $=$ Sr. D. Alejandro Malaspina."

\section{Concede el Ministro à Maluspina que clija á su gusto hasta el zultimo marinero de lus iripulacioncs.}

"Lìn efecto, la tripulación de los buques que han de hacer el viaje confiado á Vm. deberá com. ponerse de marineros de entera satisfacción, así por su conducta como por su robustez, habilidad, etc., según expresa Vm. en su carta de 7 del pasado; y para que pueda juntarse con la con. veniente anticipación la gente necesaria, me dirá Vm. el número de la que haya de destinarse de las provincias de Galicia, Asturias y Montaña, indicando al mismo tiempo las circunstancias que han de concurrir en ella, á fin de expedir en consectuencia las órdenes que correspondan. Dios guarde á Vm. muchos años.=Madrid, 9 de Diciembre de $1788 .=$ Valdés. $=$ Sr. D. Alejandro Malaspina."

Donde se vé que el Ministro, con exquisito tacto, rechaza ciertas innovaciones y acepta otras que sobre la policia de a bordo propone Malaspina, llevado del mejor deseo (1).

"Sc ha enterado el Rey de cuanto Vm. tiene expuesto en cartas de 9 y 16 del que rige, y á con. secuencia se ha servido S. M. resolver lo siguiente:

La dotación de cada corbeta se compondrá del número de individuos que $\mathrm{Vm}$. ha propuesto con aumento de Contador y Despensero; pues ni á los Oficiales conviene distraerlos de su primor. dial objeto recargándolos con las funciones de aquél, ni puede suprimirse éste, tan necesari ra el arreglo, cuidado y distribución de los víveres; y como el primero puede contribuir tan $\mathrm{l}$ desempeño de los objetos de la comisión, prevengo á ese Intendente clija en dicho. clase .. us sugetos que le parezcan más apropósito, así por su robustez y aplicación como por su instrucción y buenos modales, procediendo en esto de acuerdo con $V m$., quien indicará al mismı Intendente los dos individuos que le acomodase llevar por despenseros.

Los sueldos han de graduarse desde el día de la salida de la expedición de ese puerto, hasta el de su regreso, por el Reglamento deterninado para la mar de! Sur: además se abonará á la tripu. lación el importe de vino; y queda á la consideración de S. M. el premiar 'á cada uno con gratifi. caciones correspondientes al mérito que contraiga.

La reducción del número de criados, aunque será muy conveniente, ha de hacerse por convenio entre Vm. y el Comandante de la otra corbeta con sus respectivos Oficiales, pues como interesados todos en la mayor comodidad, acordarán lo conveniente; bien entendido, que cualquiera que sea el número que se determinase, se librarán los salarios por completo.

En cuanto á las funciones de cada uno á bordo, nada hay que prevenir respecto á las que determina la Ordenanza; así como declara las facultades de los Comandantes para el establecimiento del mejor servicio, orden y policía á bordo de los bageles: bajo este supuesto, podrá Vm. arreglar sus disposiciones según le pareciere conducente, empleando á cada uno sin sujeción á antiguedad ni escala en los encargos que mejor pueda desempeñar; pero caminando en el concepto de que el Detall ha de llevarlo el primer Teniente del navio, y del de que si bien el Guiardia Marina deberá instruirse como marinero y Piloto, no ha de alternar con ellos en el servicio; pues ha de hacerlo con la distinción que la misma Ordenanza le concede, alojándose después del Contador y abonándose á Vm. por él la gratificación de mesa por entero.

Tampoco al Capellán y Cirujano puede precisárseles á más trabajo que el de sus obligaciones respectivas; pero como quiera que la de ser de clección de $V m$., no le será difícil encontrar sugetos que

(1) Los argumentos de Malaspina sobre este punto véanso en las Instrucciones que da a Bustamante. 
puedan contribuir á los fines del viaje prestándose á la ejecución de los encargos que Vm. les co. metiese; cuyo mérito les será recomendable. El segundo, como igualmente el primer Piloto, se alojarán después del primero y tendrán gratificación de mesa.

Respecto de que los Oficiales de mar han de ser de la confianza y elección de $\mathrm{Vm}$. adquiriendo informes de los Departamentos, me indicarí los que lo parccicse apropósito para providenciar su destino.

Mediante á que no hay razón de utilidad en la sustitución del título de Oticiales de mar con el de Oficiales de segundo orden, ni en el de mozos de carpintero y calafate con el de ayudantes de los mismos, no deberá introducirse esta novedad en la actual práctica.

Como podrá ser muy necesario en el discurso de la campaña el servicio de los buzos y no será muy fácil hallar artilleros de mar que lo sean, podrá Vm. elegir dos de los de ese Arsenal que tam. bién puedan desempeñar las funciones de Cabos de guardia en el servicio ordinario: por esto, además del sueldo, se les dará en cada faena extraordinaria una gratificación proporcionada á lo que en ella hayan trabajado, llevando $\mathrm{Vm}$. una cuenta exacta y circunstanciada para rendirla á su regreso.

Aunque los individuos de Maestranza no deben, según está mandado, percibir estipendio alguno por los trabajos de su oficio que ejecuten en el buque de su destino, y solo el medio j:rnal cuando vayan destinados á otros, les determinará Vm. las gratificaciones que le pareciere en las ocasio. nes extraordinarias que se of rezcan, ejecutando lo propio con las demás clases siempre que laagan algún distinguido mérito é individualizando el motivo en la indicada cuenta.

Conforme Vm. lo solicita, comunico al Capitán General de Ferrol la conveniente Real orden para que el Teniente de navío D. Antonio Toba Arredondo elija dc. la marineria de aquel Arsenal la que considere apropósito para el viaje, y que si aquélla no la contemplase apropósito, lo manifieste al General para que, oficiando con el Intendente, se traiga de los provincias con las circunstancias que Vm. insinuia.

Desde que quede elcgida esta marinería, cuya conducción á ese puerto se encargará al mismo Oficial, disfrutará su sueldo de Europa, y antes de salir para el viaje será socorrida, como el resto de la dotación de los buques, con cuatro pagas de anticipación; y durante la campaña podrá todo el que la ejecutase dejar la mitad de su suelclo por asignación de su familia.

Todo lo cual advierto á Vm. para su inteligencia y gobierno. Dios guarde á Vm. muchos años.=Madrid, 30 de Diciembre de $\mathrm{I} 788 .=V$ aldés. $=$ Sr. D. Alejandro Malaspina."

í con.

opuesto primor. ri ra -

De cómo los documentos del Archivo de Indias y de otros Archivos saldrán al cncucntro de Malaspina merced á una órden del ilustre General, para quien todo lo que is provechosa le parece convenicute.

"Se franquearán los documentos que Vm. pide del Archivo de Indias al Teniente de navío Don José Espinosa, y coinunicaré al Virey de Lima la correspondiente Real orden para que remita á Chiloé los que desea Vm. encontrar á su llegada; pero no podrá hallarlos en Buenos Aires por falta de tiempo para su oportuno envío. Adviértolo á Vm. para su gobierno, en contestación á sus dos cartas de 23 del pasado. Dios guarde á Vm. muchos años.=Madrid, 6 de Enero de $1789 .=$ Valdós. $=$ Sr. D. Alejandro Malaspina.".

El gran Ministro aprueba en absoluto el plan de operaciones propuesto por su subalterno. De éste será, pues, toda la gloria y toda la responsabilidad. Obtuvo cuanto quiso, para asegurar el éxito. Valdés y Malaspina cran dignos uno del otro.

"Ha visto el Rey, y se ha servido aprobar, el plan de operaciones que Vm., según indica en carta de 23 del pasado, se ha propuesto para el primer año de su campaña, y lo aviso á $\mathrm{Vm}$. para su inteligencia y gobierno. Dios guarde á Vm. muchos años.=Madrid, 6 de Enero dr: $1789 .=$ Valdés.=Sr. D. Alejandro Malaspina." 


\title{
CARTAS que escribio el Capitán de fragata D. Alcjandro Malaspina al Teniente General de la Armada D. Antonio Ulioa, solicitando de su sabiduría algunos conscjos.
}

\author{
"Excmo. Sr. D. Antonio Ullou:
}

Al momento de haber recibido la orden de S. M. para encargarme de un viajc marítimo y científico alrededor del mundo, conocí evidenteme.ate que la parte más difícil de esta comisión, á V. E. más bien que á mí se había confiado. Sus vastos conocimientos, su verdadero amor a' progreso sólido de las ciencias, $y$ finalmente su bondad constante y casi paternal hacia mí, son otros tantos títulos que afianzan aquel concepto. Y así estoy scguro que V. E. no ússdeñará el satisfacer á mis preguntas, yue para mayor orden y menos molestia sujetaré en algunas cartas.

Esta tratará particularmente de las costas espanolas de la América Meridional, hacia donde se dirigirún mis primeros pasos. Su cxacta investigación, así por la parte hidrográfica como por la de Historia Natural importan sumamente al Estado, y 110 ha de ser indiferente á las demás nacinnes europeas si S. M. tuviese á bien mandarla publicar.

I." La parte hidrográfica se dividirá por mí en dos ramos. Abrazará el uno la configuración y situación astronómica de las costas: el otro tratará de los vientos, mareas, corrientes, variaciones, objetos extraños visibles, y finalmente, de todo lo que pueda ilustra. al navegante que trille aquellos inares con el único objero de transitar de una á otra paite.

2." Desde Buenos Aires hasta el Cabo de Hornss, debe considerarse sin duda la costa como un punto muy interssante de la navegación española, y por consiguiente tenga $\mathrm{V}$. E. á bien acompa narme en el examen de lo que hay hecho y de lo que hay por haces en aquella parte.

3." Si las operaciones del Câjitán de navío D. José Varela no se hubiesen extendido hasta determinar astronómicamente los límites de la boca del Rio de la .Plata en los Cabos de San Antonio y Santa Mrría, la extensión de los bancos salientes por una y otra parte y la verdadera posición de la Isla de Lobos y Banco Inglés, me parece indispensable el verificarlo.

4." Pueden considerarse como guías desde este paraje, los viajes de Anson, Biror., Wallis y Conk; los reconocimientos hechos por los chambequines Andalız y Aventurcro; los planos que se inayan sacado de la bahía de San Julián y sus inmediaciones al tiempo de establecer allí la desgraciada colonia que luégo se retiró; finalmente, todas las noticias imrortantes que se hallarán comprendidas en el viaje hecho últimamente al Estrecho de Magallanes por la fragata de S. M. Nucstra Señora de la Cabraa. En cuanto á las Malvinas, habri sin duda muchas noticias por nuestra parte que podrár combine se con las de ingleses y franceses. Pero lo dicho hasta aquí corresponde sólo á la configuración de costes, sobre la cial, por consiguiente, podremos referimos en mucha parte á los documentos anteriores.

5." No es tan fácil estrechar ía parte stronómica y fiarse de lo hecho hasta aquí. Los relojes marinos y las distancias lunares serán desde luego nuestros principales medios para fijar longitudes, así como los sextantes determinarán por lo común jas latitudes. Parece que en cuanto á la costa patagónica (que se procurará no perder de vista), será bastante colocar por este método todcs aquellos puntos que proporcione una navegación nó interrumnida, dando sólo por precisos el cabo Blanco, el puerto Deseado, la bahía de San Julián y las inmediaciones del Estrecho de Mayre por una y otra parte.

6." Pö lo que toca á Malvinas, no’ será posible visitar sino la parte occidental, por no perder la estación uportına. Si pareciese preciso avistar el extremo orienta! para determinar astronómica. mente sus límites, se procurará combinar más bien en el último año de unestras tareas, atrave. sando desde el Cabo de Buena Esperanza. 
7. El segundo ramo de la parte hidrográfica, no podrá reducirse á la verdad, sino á conjeturas, bien que el prolijo reconociniento de muchos diarios, combinado con la experiencia, concurrirá sin duda á hacerlas más probables. En est: parte, deseara que V. E. esplajase en toda su extensićn sus pensamientos limitando nuestras pesquisas á lo útil, para que ni los derroteros carezcan de aquellos avisos que pueda aprovechar el navegante, ni sean por otra parte un confuso acopio de incertidumbres, más bien para distraerle de la verdad que para dirigirle. En el importante punto de corrientes, se hará uso contínuo del método común de examinarlas por medio de un botecito referido á la embarcación; pero creo que los puntos diarios de observación comparados con esta exacta estima, son el método más seguro y desde luego sirven de comprobación al primero. Indíqueme V. E. si halla útiles niz̧unas pruebas en la corredera de $\mathrm{Mr}$. Bouguer que en algunos días de navegación N. S. sin atención á las costas pudiẻramos exuminar con prolijidad, á initación de Lord Mulgrave en su viaje hacia el polo Norte.

8." Uno de los obstáculos más terribles en la navegación mercante al Sur, ha sido laasta aqui el encuentro de los bancos de nieve. Fallándome en las altas latitudes meridionales ¿cree V. E. que sería de alguna utilidad el seguir al Sur hasta encontrar los hielos en una estación como la de los meses de Diciembre y Enero?

$9 .^{\circ} \quad$ Pasemos ya á los objetos de Historia Natural; y antes de tratar de los que presenta en su seno la tierra, no desagradará á V. E. un pequeño examen de los que encierra el mar y pueden ser útiles, $o ́$ en general á los conocimientos físicos, $o$ en particular al aumento de la prosperidad nacional. Entre estos ocupa seguramente el primer lugar la abundancia de cetáceos en la costa patágonica, cuya pesca y sucesivo beneficio pudieran ser de mu ha utilidad á la Monarquía. ¿Cuáles serán, pues, en este caso nuestras investigaciones para decidir este punto que ya tantas veces se ha sujetado 6 al discurso 6 á la experiencia, y que no obstante queda aún sin decidirse? Su tamaño, calidad y cantidad referidas luego á los demás ramos que componen esta pesca y particularmente (por 1) que á nosotros corresponde) á los tiempos y parajes en que haya de hacerse, ¿seráll datos suficientes para un juicio fundado?

Io. El renovar la experiencia del aceite en los mares sumamente agitados, el comparar el calor de este agua con el grado de la que está en calma y el examinar los diferentes grados de calor á las diferentes alturas de la misma agua, ¿serán experiencias que puedan ser de alguna utilidad? Y en tal caso, ceuáles serán los instrumentos más oportunos y el modo más exacto para ejecutarlas?

Ir. No creo que en esta parte de mar nos sea posible ni áun alcanzar lo que han examiuado en cuanto á las producciones terrestres los Sres. Banks, Solander y Torster por lo que toca á la Tierra del Fuego. El tiempo algo escaso para las operaciones sucesivas en las costas desde Cabo Victoria hasta Chiloé, no zie dejazá árbitro en esta parte de completar las indagı́ciones de un ramo tan in. teresante. '̌ así suría muy bueno para el completo aprovecham:onto del tiempr que V. E. me in. dicase aquellas cosas hacia donde más útil fuera dirigir nuestros esfuerzos en los intervalos, aunque breves, que pasemos fondeados.

r2. Scbre las costumbres de los patagones y de los indios Pecharis, tan robustos y sociables aquéllos como éstos endebles y, digámoslo así, los más infelices de la especie humana, no omitiremos tampoco todas aquellas indagaciones que las ocasiones, los encuentros y nuestro alcance nos digan. Pero como quicira que la penetración en aquellos países, particularmente de los patagones, " un objeto de mucia entidad para ia listoria de la propagación de la especie humana, tal vez la perspicacia de V. IE. en estas materias pudiera dictarnos 6 algunas confrontaciones de costumbres ó voces, ó algunos exámenes que sirviesen ó de parcial ó de completa aclaración á este punto.

13. Antes de abandonar el Cabo de Hornos me es preciso hablar de la bahía de San Francisco, de que V. E. hace memoria al fin de su viaje para la Meridiana. ¿ No pudiera ser ésta la misma que Cook en su segundo viaje denominó $t$ ! Cristmas Sound por haber pasado en ella el día de Navidad de 1774 ? O bien, aunque no lo sea, ¿i1o podrá cualquier navegante que piense liacer escala en aquellos parajes, contentarse cın la segunda, en donde una entrada no difícil, una grande abundancia de agua, de pájaros y antiescorbúticos, y, en fin, la agradable vista de la especie humana, aunque en el semblante ménos lisonjero, convidan unánimes á darle la preferencia?

14. La falta de tiempo será quien nos obliguc á abandonar aquel reconocimiento y áun á sepa. rarnos de la vista de la Tierra del. Fuego para tener más franca y más espedita nuestra entrada en el inar Pacífico.

5. De ningún modo me desentenderé de reconocer las inmediaciones de los Calos Pilares y Victoria y terminar así con buenas observaciones las penosas tareas del Estrecho de Magallanes. Será preciso omitir la parte de la Tierra del Fuego entre Cabo Negro y Cabo Pilares, no sólo porque se nos haría muy difícil el navegar contra viento y corriente, sino también porque es este parajc el que ménos ha de ser frecuentado en la navegación común. 
16. Desde Cabo Victoria, ó por mejor decir, desde jos Evangelistas, empezarán nuestros cuidadosos conocimientos; y aunque desde liego las navegaciones de los Nodales de Natborosegh, Sarmientos y de los dos buques de la escuadra de $A$ nson, como también las noticias que V. E. especifica en la aclaración $o$ ilustración de su carta, puedan suministrar muy buenas conjeturas sobre estas costas, mucho nos queda aún por investigar. No nos empeñaremos en el Archipiélago de Clonos sino cuanto dicte la prudencia. Para la navegación común fuera bastante el conocer sus extremos más occidentales; pero como quiera que el reconocimiento de esta parte no puede verilicarse sin algún riesgo, y que es ya casi la única que en la superficie del globo navegable queda por reconocer, parcce que al honor nacional exige este tributo de nuestra empresa, $y$ así me serán muy agradables cualesquiera indagaciones útiles que V. E. me insinúe relativamente á la parte de costa comprendida entre el Cabo Victoria y Chiloé. No creo que la especie humana, ni la ve. getación en general, sean muy brillantes en aquellas regiones. No obstante, los productos y cos. tumbres de Chiloé, y áun las noticias comunicadas por aquellos indios, darán márgen tal vez á que nuestras pesquisas sean más útiles $\mathrm{y}$ acertadas.

17. De orden del Gobierno, en estos últimos años D. José Moraleda, Piloto de la Real Armada, ha reconocido y bajado la costa desde Lima hasta Chiloé; pero creo que lo interior del golfo de este nombre no está aún bien reconocido. En tal caso, no fuera inútil el intentar el paso entre la Isla y lit 'Tierra Firne, y abrir así mayor abrigo y navegación más segura en esta colonia aún algo arriesgadi.

18. Hasta fines de Abril no considero que sea temeridad el permanecer en latitudes altas meri. dionales. Bastará por consiguiente que á esta época las dos corbetas puedan fondear en Chiloé.

I9. Franqueadas las inmediaciones de Chiloé, ya puede considerarse la costa sin el menor riesyo, y así es mi ánimo el separar las dos corbetas para que el sucesivo reconocimiento y colo. cación astronónica de las costas, sin perder nada de su exactitud, duple en celeridad y no se malogre un tiempo precioso.

20. Si el tránsito por tierra ó desde Valdivia, Concepción 6 Valparaíso hasta Lima es fácil, será muy útil y de sumo adorno para la comisión el hacer pequeñas cuadrillas que en las tierras inme. diatas adquieran los posibles conocimientos, $y$ con vistas dibujadas, con producciones naturales, con descripciones, ya naturales, ya geográticas, den á la obra aquel útil resalte que el curioso ó el público no navegante suelen buscar en tales comisiones. Estas euadrillas dirigidas por instrucciones claras y ceñidas á un número determinado de objetos útiles, pudieran irse desembarcando en diferentes puntos por la corbeta delantera (llamémosla así), recogerse después por la postrera, proporcionando de este modo la necesaria ventaja de tiempo á las tareas de tierra sobre las de mar.

2r. Dígame, pues, V. E. cuál es el modo mejor y más expedito de verificar estos tránsitos, y cuáles son las indagaciones más oportunas que han de hacerse relativamente á las ciencias. Deben existir en los pueblos de la Ensenada de Arica diferentes rastros muy apreciables de antigüedad. El representarlos á la zuriosidad europea con dimensiones y colores exactos fuera desde luego agradable, y tal vez no dejaría de ser útil.

Acabo ya esta carta, cuya molestia no tuviera disculpa en mi si sus resultas no se refiriesen al bien público y al lionor nacional: dos objetos que desde tanto tiempo ocupan las útiles é incesantes tareas de V. E., cuyaa vida ruego á Dios guarde por muchos años."

\section{Carta II}

"Extmo. Sr. D. Antowio Ullur.

Continuaudo en solieıtar nuevas é interesantes neticias sobre los parajes á dónde haya de digirse la expedición puesta á mi cargo, no parezca á V. E. molesto que añada á mi primera carta algunas otras preguntas que para mayor orden seguirán aquellos números á los cuales V. E. con tanta bondad suya é ilustración mia se ha servido responder.

22. Además de los cascabeles y algún galón falso de oro y piata, ¿cuáles serán los objetos más oportunos para cambios con los indios de los países más meridionales que Chiloé? 
23. Reinando sobre las costas de Chile y Chiloé haria principios del invierno los vientos Nortes tan temibles como tempestuosos, suelen saltar de contraste y con igual fuerza al Oeste y Oesudoeste; V. E. indicó ya en su viaje que liabía algunas señales que anunciaban esa alteración temible y áun la entrada del Norte, según la práctica de aquellos mares. ¿Considera, pues, V. E., que scría temeridad aventurarse sobre las costas en aquel tiempo?

24. La navegación desde Acapulco, Panamá y Guayaquil á Lima, al paso que es un objeto nada indiferente para la comunicación recíproca de aquellos puertos, es tan duradera, que inciertos hasta aquí los navegantes si preferir la derrota que llaman de altura á la costanera, suministran anualmente ejemplos de unos riesgos verdaderamente considerables, y á veces de un singular malogro del viaje. En el año de 1757 no hubo en Lima navío procedente de Guayaquil que no tardase en su travesía cerca de cien días. V. E. hace memoria en la narración de sus viajes de otro bien singular que tardó cerca de siete años. ¿No podrá combinarse una derrota que, sin depender del acaso y estribando más bièn sobre las estaciones, dicte medios de acortar mucho aquel plazo? En el tiempo de mi demora en Lima no dejaré de inquirir en aquellos diarios todo cuanto sea conducente á este punto importante; pero V. E. atravesó uquellas costas con todas las luces de un físico, y en aqutllos mares poco trillados, de dicha ciencia, mís bien q $:$ e de la mera práctica, han de esperarse los principios sólidos que afiancen el bienestar y la felicidad de los que habitan sus orillas. \demás, que descuidado al mayor punte el pilotaje en tan indolentes costas, ni en cuanto á vientos ni á corrientes podrán deducirse allá noticias seguras y claras para formar buenos razonamientos.

25. Sobre las Islas de los Galápagos y del Gallego, éstas más ocviuentales que aquéllas, creo que no tendré otras nociones que las que V. E. se sirva comunicarme. A la verdad, su ituación no las hará jamás interesantes ni á la geografía ni á la navegación. Pero como quiera que es importante el que se examinen siquiera su latitud y longitud, sus principales productos y sus moradores (si los hay), nos será sumamente útil el tener de antemano algunas nociones que al mismo tiempo dirijan nuestros pasos y nuestras pesquisas.

26. L aman vulgarmente en aquellos mares engorgonarse (como V. E. In indica) el ensenarse hacia la Gorgona en unas calmas tan duraderas, que han causado siempre, " con justa razón, mucho terror á los navegantes. El tiempo infructuosamente perdido, la escasez de víveres, los frecuentes riesgos del rayo no tienen comparación con el peligro extremo de la conservación de los hombres en un paraje en donde el ánimo y el cuerpo han de ser igualmente atormentados. No obstante, hemos de trazar sus costas y iun trabajaremos con mucho lesón en esta parte de mar, para cuyo fin sírvase V. E. indicarnos cuanto le parezca útil en ellas, no sólo por lo que toca á G̀eografía, sino también á la Física.

27. Es tiempo ya de hablar de dos cuestiones físicas que por mucho tiempo han ocupado la curiosidad de los sabios ' asto es, el nivel de los dos mares, Atlántico y Pacífico, suponiéndose más alto el Pacífico, y querien on con esto explicar la corriente contínua que por el Cabo de Hornos se dirige al Este y la unión de los mismos $r \quad$ s. Sobre esta última parte, á la verdad, ya se sirvió V. E. manifestarme zuánto la creia fuera d lcance de la posibilidad, no sólo por lo que mira á los celos del arte, sino tambièn á los de la naturaleza; pues que las cordilleras en el Istmo de Panamá pa. recíán hechas para aterrar á la primera mirada. lquiera idea de esta especie. Mas por lo que toca al nivel indicado, que desde luego (si lo hay) supongo de una dif crencia muy leve, fuera útil el intentar averiguarlo, aunque dé por supuesto que ni las operaciones greodésicas ni las del barómetro, áun corregida la escala de Mr. de Lanc, puedan determinarla. Creo, obstante, que el primer método es el que déue preferirse, si se ha de adoptar alguno; y como nu conozco lo local de aquellos contornos, quisiera que V. E. me manifestase el modo y el derrotero que más acertado fuera elegir para intentar esta curiosa averiguación.

28. No creo que sea ya prudente, después de lo hecho hasta aquí por los navegantes españoles, ingleses y franceses, el invertir un tiempo precioso en busca del pa n al Atlántico por los Estre. chos de Fonte ó Juan de Fuca. Todas las noticias relativas á est uportante descubrimiento parecen infundadas, á ménos que no haya una ú otra no pública, $v$ alguna tradición probable que dé iuairgen aún á nuevas investigaciones.

29. Si en las costas desde Guayaquil hasta San Blas (ya harto conocidas) hubiese, al parecer de V. E., algo que examinar con particularidad, además de lo que dicta cl orden común de exploración, fuera muy útil que se nos indicase, singularmente en lo que toca á drogas medicinales, de que parece abundan aquellos contornos.

Acabo ya con renovar á V. E. la utilidad que nos ha de producir su dictamen, sus preceptos, y el agradecimiento y el respeto que así por este n:sevo favor como por los que antes he recibido, profesa á V. E. S. S. S. Q. S. M. B.=Cádiz, á $3 \mathbf{r}$ de Enero de 1789 . 


\section{CARTAS que el Sr. D. Alejandro Malaspina escribió al señor D. Fosé Salvaresa, Proto-Médico de la Real Armada, sobre varios puntos dictéticos, y del régimen profiláctico que deberan observarse en el acopio de viveres para cl viruje de la wuelta al mundo.}

Con mucha satisfacción mía aprobó S. II. (que Dios haya) el que consultase con V'm. sobre los anticscorbúticos más opoittinos para usarse en el dilatado viaje que se me ha confiado: no moleste á Vm. cl que yo me cxtienda sobre un punto de tanta importancia. La conservación del hombre es el objeto más digno de sus semejantes.

Para proceder con el orden posible cn esta materia, la dividiré en ties partes, que scrán objeto de otras tantas cartas: indagaremos en la primer parte el mejor método para conservar sano al marinero, y se comprenderán por consiguiente en esta carta los comestibles de ración y la policía, así en cl pucrto, ccmo en la mar. La segunda carta tratará del navegante, ó como ya próximo á enfeımar ó como ya enfeımo; finalmente, la tercera, se dirigirá particuiarmente sobre aquellas cosas que componen más bien la comida del Oficial que del marinerc.

Algunas advertencias han de apuntarse, que servirán como base á nuestros razonamientos sucesivos, y scrán: $\mathrm{I} .{ }^{\mathrm{n}}$ Que se da por supuesta la suministración de toda el agua recesaria y su renovación en bodega todas cuantas reces sea posible. $2 .{ }^{n}$ Que la marinería y parte de los Oficiales de mas, será de las provincias septentrionales de España, esto es, asturianos, montañeses y galiegos. 3." Que ha de ser, así esta gente, como los Oficiales mayores, libres de toda enfermedad habitual, y dotados por consiguiente de aquella robustez y resistencia, que tanto sobresalen en el navegante español.

El mútodo que yo considero más útil para la conservación del marinero español es, no tanto aquella estúpida disciplina que fácil es de guardar para los del Norte, como un freno racional, y vario, según las ocasiones, adaptado principalmente á las pasiones vivas de aquéllos y á los razonamientos que de ellas dimanan. El adjunto extracto de mis reflexiones en el último viaje de la Astrea por la Real Compañía de Filipinas, manifestará á Vm. con la mayor individualidad el ca. rácter del marinero español; $y$ aunque en la preferencia á las provincias septentrionales haya procurado precaver, cuanto cs posible, esta sensibilidad excesiva, creo que convendremos en ser ésta característica propia también de aquéllos, bien que no en tanto grado como de los andaluces.

El entrepuentes será desde luego espacicso, y cada marincro tendrá su coi, para que los mias. mas del que acaba de lcvantarse, y particularmente de su ropa, no traspasen al que le sucede inmediatamente en el descanso. El fogón estará igualmente en la misma eubierta en donde duerme la marinería; cl humo y el fuego espelerán así naturalmente mucha parte del aire infecto, tanto más que de ticmpo en ticmpo y con acción mayor del mismo fuego, puesto oportunamente en cual quier paraje, se frotarán las maderas de las cubicrtas. En cuanto al aseo de ropa, al abrigo oportuno de los soles y de las aguas, á unas chaquetas con capucha adecuada al frío, al estar comun. mente en guardias de tres cuartos en lugar de dos; al lavar su ropa con agua dulce más bien que con salada, y finalmente, á cuidar el aseo del buque y de todo cuanto contenga, puede Vm. estar scguro, que más bien sobresaldrá nuestra prolijidad, á todo cuanto han usadu nasta aquí los Oficiales de la Real Armada.

Dos cosas únicamente prewuntaré á V'm. ántes de pasar al segundo objeto y son: I. ${ }^{\mathrm{a}}$ Si considera $\mathrm{V} m$. preferente al uso del fuego el del vinagre, 6 ya rociado ó por vapores, para conseguir en las cubiertas el aire menos infecto. 2." Si cn los rávidos tránsitos del mucho frío al mucho calor, debe ser preferente á exponer la marinería á unos resfriados siempre temibles, el molestarlos (contra su genio siempre abando1 : ${ }^{\circ}$ ) con una carga rxcesiva de ropa te abrigo.

Pasemos ya á los comestibles; éstos pucden muy bien referirse á cuatro cosas principales: pan, mencstras, carnes saladas y tocino, á los cuales luégo jor vía de condimento, deben considerarse agregados el accite, el vinagre y el vino.

En cuanto al pan, uno de nuestros principales alimentos, yo creo que conviene mucho que to teng amos de un trigo fuerte, más bien que de otro de menos sustancia, en cuyo caso, cl de Anda- 
lucía y Castilla serán desde luego preferentes al de Sicilia, Cerdeña y Berbería; conviene también, que no sea el pan muy abizcochado, pues me parece que cuanta menos cochura tenga, tanto mónos habrá exhalado de aquellas partículas, que hacen á éste y á los demás vegetales tan sanos. A la verdad adquiere entonces un cierto sabor correoso, que desde luego no es agradable al paladar, y que puede áun ser de una digestión algo mús dificil. Quisiera que puestas en una balanza estas dos ventajas contradictorias de la mucha ó poca coclaura del pan y los inconvenientes que las acompañan, Vm. me indicase su parecer para dirigir, acorde á él, la fábrica de este importante ramo. Fuera oportuno al inisıno tiempo, indagar si conviene alternar con el pan de trirro, los de maíz y centeno, pues embarcadas harinas de una y otra semilla, pudieran hacerse á bordo unas tortas qü sirviendo de variedad, fuesen al mismo tiempo más saludables. A lo meros será útil que Vm. nos dicte algunas experiencias que podrán servir de cimiento á las que hayan de hacerse en lo venidero sobre un punto tan interesante.

Las menestras son dotadas por sí de cualidades antiescorbúticas; y como quiera que así cn este Continente como en el de América abundan ó ya una ú otra especie, pueden desde lucgo considerarse como el alimento más útil para la navegación. En el viaje que acabo de hacer, no he podido waminar sino la segunda de las dos propiedades que han de investigarse en sus clases, esto es, la major ó menor bondad relativa y la $\mathrm{m}$ is ó ménos fácil conservación relativa en campañas dilatadas, y particularmente en los climas temibles de entre Trópicos. No desagrade á Vm. que analice a!gún tanto estos comestibles: el arroz es el vegetas que yo he hallado de menor evaporación á borclo y áun en tierra, á lo ménos entre Trópicos; sígueseá éste el garbanzo, con preferenciá á la garbanza, y finalmente la lenteja: el frijol, así blanco como cocacho, el chícharo $y$ las habas, aquí conocidas bajo el nombre de Tarragona, son otras tantas especies que, con igual ó mayor cuidado que las demás, no han absolutamente resistido al calor y liumedad, que con tanto daño se hallan mezclados en tan sumo grado entre 'Trópicos.

Pero como la conservación no es ni el único ni digámoslo así el punto principal en este ramo de víveres, es justo investigar si la bondad respectiva hace mís bien preferentes otras semiłas, tanto más que no siempre en nuestra navegación habrá de requerirse la duración, y que una gran parte de nuisıras tareas serán mís bien en climas fríos que en calientes. Esta parte, que más corresponde á un análisis químico que á las experiencias marítimas, será peculia.: de Vm., y cualquiera advertencia que Vm. nos especifique será de una utilidad real para el mejor acierto en la delicada elección de víveres.

Sobre la carne salada y tocino, diré lisa y llanamente que es ya casi un axioma cn la Armada que el segundo ha de preferirse á la primera, y que, en mi entender, la razón misma afianza este concepto, mucho más si en el salado del tocino (particularmeite cntre 'Trópiços) se usan todas aquellas precauciones que con tanto provecho han imaginado los Sres. Cook y la Pérouse, y por cuyos métodos hice yo últimamente mis salados en Manila. Desde luego á causa de la abundancia de vasos sanguíneos $y$ de otras sustancias nutritivas imposibles de extraerse, ha de ser más propensa á la putrefacción la carne que el tocino, y aunque la calidad más porosa de éste le haga naturalmente más propenso á la mayor penetración de la sal, también le hace luégo más fácil de expelerla con las dos aguas en que se infunde por largo tiempo antes de cocerse. Síguese, pues, de esto que el tocino es seguramente de mayor duración y probablemente de menor daño que la carne salada, á menos que en la direrencia de calidades entre las carnes de puerco y vaca no haya tal vez (lo que ignoro) una suficiente compensación de lo 3 inconvenientes ya indicados. Mr. la Pérouse usó del vinagre para sus salados, teniendo el tocıno tres días en una moderada infusión, y después embarrićńndolo sin salmuera, con solo una capa superior de sal marina. Este método es bien costoso, tanto más que he e : arimentado que los vinagres de nuestras Américas no tienen las propiedades necesarias para esta operación; no obstante, es métods que mercéce ser preferido á todos los conocidos hasta el presente.

Por lo que toca al aceite, temo mucho que no pueda generalizarse su uso tanto como verá Vm. que he hecho en la Astrea. Ya no se triıa de nutrir una marinería andaluza, sino una de las costas septentrionales, en donde el aceite apenas se conoce y ya no es una producción natural. Quisiera que Vm. me determinase los prudentes límites de su uso, particularmente por lo que toca á sopas, ó como almuerzo ó como cena, y que me indicase algunas señales por donde pueda venir en conocimiento cuando los efectos no sanos de su crasitud y dificultad de digerirse, prevalecen á los buenos de su verdadero alimento y de un gusto agradable.

Fuera omisión el no tratar aquí del gazpacho; ¿serán tan útiles sus efectos como en las maririnerias de estas provincias? ¿Y deberemos insistir en su uso casi contínuo, aunque la marinería lo repugnase algún tanto?

Finalmente: en cuanto á vinos hallo preciso su uso casi continuo; y por repetidas experiencias 
estoy convencido que la espirituosidad del de Sanlúcar le hace preferente á cualesquiera otros de nuestra lispaina. Me quedan sólo dos dudas que Vm. podrá resolverme; es la primera si la cantidad de un medio cuartillo es suficiente para hacer un efecto saludable, particularmente despues que el vino con una larga navegación la adquirido nuevo vigor; la segunda si conviene que este excelente digestivo y antiescorbútico se suministre más bien por la mañana que al mcdio dia; más bien á esta hora que por la noche.

La total exclusión del aguardiente y del pescado salado (incluso el bacalao) son dos cosas en que creo no discrepemos: en cuanto al queso, que también suele usarse en nuestra ración de Armada, hallo difícil de combinar su utilidad, si no se refiere á las ocasiones de tempestad en que se halle expuesto el usar del fuego, y ústos serán los únicos casos en que lo usemos.

Acabo esta carta con renovar á la memoria de $\mathrm{Vm}$. cuánto interesa á la humanidad y al paternal amor de S. M. el que este punto de la conservación de los equipajes se examine con toda extensión y cuánto aprecio hará del parecer de Vm. sil más afecto y agradecido amigo Q. S. M. B.= Cádiz, á 23 de Diciembre de 1788.

\section{CARTA II}

Si la conservación del hombre en general, y en particular de la especie preciosa del marinero, me ha arrastrado una y otra vez á reflexiones médicas, en cuanto hayan de combinarse con los deberes de un Oticial de Marina, y si el próximo viaje mío me obliga ahora á exponerlas con el solo objeto de verlas ó aprobadas ó destruidas, sîrvase $\mathrm{Vm}$. mirarlas como procedentes únicamente de un verdadero celo y como dirigidas al solo alcance de la verdad.

Nada puede compararse al hombre enfermo en la mar: el alojamiento, la falta de quietud, la evaporación 6 fermentación de las medicinas, los alimentos, el aire que respira, todo concurre á hacerle el más infeliz de la especie humana, y á causar una sensación no indiferente hasta al marino más sordo á las voces de la naturaleza.

Sirvase Vm., pues, acompañarme en este examen del navegante 6 próximo á enfermar ó ya enfermo; unidas nuestras investigaciones ó más bien unidos los preceptos de Vm. á la exactitud mia en ejecutarlos, tendremos desde luego la satisfacción de ocuparnos con tesón de la conservación del marinero, y conseguiremos tal vez la de coadyuvar eficazmente á este punto importante de la prosperidad nacional.

Supuesto en nuestro caso al marinero de una naturaleza no viciada con enfermedades habituales ni acosado del trabajo, sus enfermedades pueden reducirse á tres únicas causas; la calidad del alimento, la calidad del aire que respira y un tránsito demasiado rápido del sumo calor al sumo Fio ó al contrario: las dos primeras inclinadas directamente á la putrefacción, y ésta última á una total falta de traspiración si el tránsito es al f́río, ó á un excesivo enardecimiento en la sangre si se pasa al calor. En las navegaciones muy pronto dejan verse al especulativo varios síntomas que denotan el efecto de aquellas causas cuando ya empiezan su acción: son estas principalmente una especie de letargo ó sea un sueño excesivo, una sed frecuente, una grande dejadez ó flojera en el trabajo, y finalmente, una náusea á la comida; señales todas que no pueden ocultarse cuando diariamente se asiste por mero entretenimiento á los ranchos y en toda cuncurrencia con el marinero se dirigen los reparos á su conservación ó estado de salud. Ni es de extrañar que se hagan visibles estos efectos, si se considera que alimentados, alojados y atareados todos de un mismo modo, por diferentes que sean las naturalezas, no han de ser muy diferentes los males de que se adolezcan. Este es el momento en que, á mi entender, deben obrar con vigor los métodos curativos; lo exigen así la naturaleza de la sangre aún no muy viciada, la utilidad saludable de un trabajo moderado que sabe considerarse como indispensable y los efectos aún muy limitados det aire respirado, que por consiguiente puede no causar enfermedad epidémica.

Ls, pues, mi ánimo, si Vm. lo aprueba, que luego que los más propensos á estas enfermedades declaren con los síntomas ya referidos, y otros semejantes, que empieza á viciarse la sangre, se adopte inmediatamente para su alımento el Sowrkroit y el Malt de cerveza: para su bebida, sudorificos con mucho az'icur, y áun el agua impregnada de aire fijo; finalmente, que por algún tiempo se les prive de todo sala to, para lo cual podrán sustituirle, con las menestras mejores, el caldo en pastillas, ó alguna carne eservada en aceite. 
No permite la manutención de muchas gentes á un tiempo, que con todos haya de usarse contínuamente un método seguro. El solo uso de carnes saladas bastaría para trastornar cualesquiera otr medidas, ni el caracter del marinero, áun considerándose éste sano, le permitiría el sobrellevar con paciencia y sin desorden un método largo de alimento no agradable por lo común á su paladar y ceñido á una cierta dieta. Esta reflexión es la que me ha inducido (con buen exito hasta aquí) á no molestar al marinero ni al Erario con una especie de perenne método curativo, sino más bien atender á si se declaran en uno á otro los primeros síntomas nada temibles del vicio é inme. diatamente sujetarlos á un régimen tan sano como inalterable, apoyado tan eficazmente por la dulzura como por la disciplina.

De este modo habrá en nuestros buques una clase media entre los verdaderamente sanos y los absolutamente enfermos; y así como es difícil el reponer á éstos sin aquellos auxilios, que rara vez en la mar pueden proporcionarse, fácil será recurrir á unos remotos principios de enfermedad si cl Comandante, con un régimen oportuno de aseo y trabajo, y el médico con remedios uniformes y activos, concurren unánimes á rebatirlos.

Sobre la mezcla del aire fijo con el agua potable según los preceptos de Prestley, creo también que fuera inoportuno el usarla para todos en todos tiempos, áun suponiendo que el aparato químico para impregnarla fuese más sencillo; pero también el omitir su uso con los que se inclinen ya á enfermar, creo que fuera culpable en un tiempo en que tantos sabios se ocupan de la felicidad de los navegantes y las repetidas experiencias confirman la utilidad de estos inventos. De los buenos efectos del Sowrkrout ó coles agrias no debe quedar ya duda alguna. Queda únicamente por examinar la utilidad del Malt ó cehada fermentada, aunque ciertamente convendremos que en el caso de excluirla se le haya de sustituir algún equivalente que contenga mucho aire fijo.

Una especie de crasitud inseparable de las pastillas de caldo, puede tal vez representarlas como perniciosas; pero no recayendo este uso sino sobre personas de un estómago aún fuerte, esto es, apenas propensas á la enfermedad; y por otra parte, debiendo únicamente sustituir al tocino, creo que en el indicado estado medio entre la salud y la enfermedad pueden considerarse como muy útiles.

Fuera mucha satisfacción para mí, que Vm. al justo examen de las reflexiones anteriores se sirviese también añadir su parecer en cuanto al método de servicio para esta clase media; esto es, si debemos inclinarlos al sudor con preferencia al respirar un aire libre, en cuyo caso podrán proporcionárseles faenas interiores en lugar de las que se hacen sobre cubierta; si el relente, el frío, el agua, le son muy nocivos; finalmente, si en las latitudes altas, en donde según muchas experiencias el aire está más saturado de sales, puede seguirse para esta clase de gentes el mismo método que en los climas templados de trópicos.

No entraré en el detall del hombre ya enferno; esta parte será totalmente del Cirujano: yo me ceñiré á desearle todo el acierto y á contribuir elı cuantos modos puedan combinarse al más fácil logro de lo que haya menester; no obstante, varias cosas que á mí me corresponden aún en este ramo, han de exponerse ahora a la perspicacia de Vm., para que ni en esto carezca de sus instrucciones.

Por muchas razones, así de disciplina como de "tilidad real á los enfermos, nuestra enfermería no será de firme: la sustituirá un repuesto de catres ingleses que colocados unos sobre otros, si la necesidad lo pidiese, $y$ rodeados el total de una lona pintada pero. vible, tendrán las ventajas de poderse aumentar cuanto se quiera, de estar cada enfermo separado del otro, así en cuanto á persona como á ropa, de sei la curación más fácil, y sobre todo, de no tener ni la madera embebid $\cdot$ de unas exhalaciones tan perniciosas, ni imposibilitados el contínuo aseo y ventilación de los parajes más recónditos. Fácil será remediar los pequeños inconvenientes que se ocurren á primera vista sobre la instabilidad de estas camas para las operaciones quirúrgicas, la dificultad de bajar y subir los enfermos de las camas altas, y la sujeción inmediata de todos los utensilios necesarios para un enfermo. Creo que esta distribución merecerá la aprobación de Vm., quien conoce cuantos inconvenientes dimanan de nuestro método actual de enfermería.

Una duda, nada indiferente, se servirá Vm. resolverme sobre esta especie de enfermos, pues que de ella dimana el mayor acopio de unos más bien que de otros efectos. Supuesta, como es natural, la falta de carnes frescas en las travesías largas que hagamos, thasta dónde podrá extenderse para los enfermos el uso de los caldos de repuesto, ó será más útil sustituirles en muchas ocasiones el aceite? El acopio de medicinas propuesto por nuestros cirujanos ha sido ya por Vm. aprobado; por consiguiente omitiré el hablar de él; su conservación me merecerá un cuidado particul $\_,$y áun para esto estimaré $\mathbf{a} \mathrm{Vm}$. me indique algunas precauciones, si lo hallase oportuno.

Al concluir esta carta, sólo repetiré á Vm. que he procurado que las mismas voces denoten no ser mi ánimo tratar de una facultad, cuyos umbrales conozco apenas. La existencia á bordo de un 
estado medio cntre la salud y la enfermedad, $y$ las útiles consecuencias que dimanan de esta distinción de clases, particularmente por lo que toca á las medidas del Comandante, han producido los párrafos que anteceden. Puedan éstos llevarme á obrar con acierto en un punto de tanta importancia y acreditar con repetidas pruebas cuánto aprecia el dictamen de V'm. su más afectísimo y seguro servidor, etc. $=$ Cádiz, $\mathrm{I}^{\circ}$ de Febrero de ${ }_{1} 789$.

\section{CARTA III}

Muchos Oliciales se han ocupado hasta el día de hoy de la conservación del marinero en cuanto á alinentos; ninguno la examinado aún la del Oficial, en quien, para los altos fines á que está destinado, debemos exigir, no sólo la material conservación del físico, sino una buena disposición en las potencias intelectuales, para que esté más agil en las fatigas y más dispuesto á la reflexión y al estudio. A la verdad, debe atribuirse este silencio, más bien que á descuido, á un natural pun. donor en los Capitanes, quienes, recelosos de que se confundiese el espíritu de orden con el de economía, han preferido á ctralquier otro partido el callar; muchas veees, áun con evidente daño propio y del servicio, el inclinarse más bieı á una mesa demasiado expléndida que á una frugal.

Por mi parte, deseoso únicamente del acierto, y unánime en esto con los Oficiales que han de acompañarme, sin mezclarme cn otros reparos que es fácil luégo destruir, tendré aún más cuidado en el método de mesa del Oficial que en la comida del marinero, con tanta más razón cuanto mayor y más progresiva es la utilidad de aquél sobre la de éste.

Tenga Vm., pues, á bien afianzar mis conceptos si los hallase justos, ó rechácelos, si pareciesen infundados. Ne alegraré mucho ver guiados mis pasos de la razón y de una autoridad tan res. petable.

Converuicmos desde luego que en unas campañas en donde cada uno ha de ejercitarse diaria.nente en tareas y cálculos complicados, es casi indispensable un trastorno de horas para las comidas; esto es, que servido á las ocho de la mañana un buen almuerzo de algunos fiambres, puede diferirso la comida hasta las seis de la tarde, $y$ á las diez de la noche usar de una merienda de chocolate 6 tó, con pan tostado y manteca; consíguese así, además de un espacio más largo para las excursiones científicas ó marítimas en los puertos, un trabajo más seguido y natural en el mar; un plazo mejor y más libre para la digestión; finalmente, un par de horas bien necesarias ó para el reposo ó para el sosiego después de comer.

Ocúrrense algunas dudas para adoptar unos ú otros comestibles, unas ú otras bebidas, y las voy á exponer á Vm. inmediatamente. La carne ahumada del Norte, según muchas experiencias hechas en los mares de Noruega, parece fácilmente expuesta al escorbuto; ignoro si prefiriendo para conservar las verduras el aceite á la salmuera, sc logra un beneficio en su bondad, desentendiéndome de su duración.

El uso del té y del café, éste algo flojo, creo que puede emplearse mucho, pues con el azúcar que se le agrega es un grande antiescorbútico, y también su calor coadyuva mucho á la digestión. Para condimentos deben, á mi entender, abandonarse las especias y cas: todo lo craso; de suerte que las salsas en general deben mirarse como nocivas, y repetir cuanto sta posible el asado. Considero también como muy danosa la manteca de puerco; ignoro hasta dónde puede ser útil la masa; y en cuanto á la manteca salada, creo su uso contínuo, si no saludable, á lo menos necesario, para gentes acostumbradas en Andalucía.

Omito otros muchos detalles que parecerían demasiado frivolos, y áun no carecen de este aspecto los que anteceden, si no se considera que, relativamente á la salud, no hay punto despreciable, y que por lo común en nuestro método de mesas se ha atendido más bien á la abundancia que a la calidad.

El bien de la humanidad, los progresos de la nación y del Real servicio, las recientes brdenes de S. MI., el ejemplo de las demás naciones, la amistad misma que á Vm. merezco, todo concurre á que yo no me acuse de haberle molestado; y Vm. se sirva guiar con sus respuestas al que es y será siempre su más afecto servidor y amigo, etc. $=$ Cádiz, á 5 de Febrero de I $_{789}$. 
Reflexiones sobre la conseración de la salud de los cyuipajes.

-Fuera digno de reprensión el prefeirir otro punto alguno al de la conservación de la salud en el mar, dictado al mismo tiempo por la humanidad y por el interés, y no obstante descuidado hasta aquí de tal modo en las navegaciones al Perú, que ha costado pérdidas considerables al éo. mercio, y á la Nación el sacrificio casi anual de excelente marineria, sin que por esto hayan aún escarmentado, 6 movídose á compasión los armadores de los buques que navegan á la mar del Sur.

Séame permitido no confundir en esta parte la Real Compañía con los demás, y lisonjearme que no le serán desagradables los apuntes, aunque algo extensos, sobre este interesantísimo punto, relativo á las ventajas nacionales y á la total seguridad de sus expediciones venideras.

Ojeando algún tanto los viajes modernos extranjeros, en particular los clel Capitán inglés Cook, y reparando aunque levemente, en la policía de los buques de las diferentes compañías europeas del Oriente, parecerá desde luego que pueda hallarse un manantial inagotable entre ellos de preservativos. Embarcaciones ventiladas $y$ sahumadas interiormente, mucho espacio interior libre para el acomodo de cada uno; comidas sanas y abundantes; finalmente, una disciplina vigorosísima para el aseo de las personas y del buque, son los puntos esenciales de la policía extranjera en este ramo, los que adoptados, deberían al parecer prometer tan buenos efectos en los buques españo. les. Ls de advertir en esta parte, que las navegaciones ordinarias de los buques españoles al Perú no pueden ser igualadas de ninguna de las que en cl día emprende el comercio europeo á las demás partes del globo, pues ninguna of rece más desigualdad de climas, menos abrigo contra las enfermedades y las averías, ni mares tan tempestuosos, á quienes arrostran después de tres y á veces de cuatro meses de navegación.

Pero en desquite, puede asegurarse que la marinería española está dotada de una robustez y de una resistencia muy aventajada á las demás naciones extranjeras; de sueṛte quuc, haciendo éstas contrapeso con los mayores ries rns de la navegación por el Cabo de Hornos, parece, finalmente, que pudiera deducirse la evidencia del buen éxito de todos los preservativos extranjeros.

Arraigado yo mismo en esta idea, desprecié en mi interior nuchas veces la que me of recía una meditación constante de una seric de campañas de diez ú once años, sobre la necésidad de otros bien diferentes preservativos para la salud del marinero español en la mar. Mil veces comprendi (estudiado á fondo el carácter nacional) que cl sosiego de ánimo era más interesante á nuestra marinería que todo lo que le rodeaba exteriormente, y mil veces creí infundada semejante idea, y la deseché, no obstante de poder sujetar esta lucha de ideas á la experiencia.

El viaje de la fragata Astrea acaba de cerciorarme de la verdad de aquella sospecha y de animarme en el día con tanto vigor á la necesidad de este preservativo con preferencia á todos los demás, cuanto había sido antes el que me hacía interponer á todo el seguir ciegamente en esta parte Ia policía de los buques del Norte; ni se podrá tachar de imperfecta mi experiencia (bajo el fundamento de que un Capitán no tiene conexión inmediata con la marinería) cuando se sepa que mis compañeros D. Luis de Concha y D. Francisco Viana, movidos de un corazón verdaderamente noble y caritativo, y á su imitación los Contramaestres, han coadyuvado diariamente á la demostración de esta verdad, áun con mayores pruebas de las que yo podía desear.

La tripulación de la Astrca se componía en muclia parte de excelente marinería de la carrera mercantil de Lima. Desde luego unos 60 entre ellos habían estado una, dos, tres y cuatro veces en las tempestuosas mares del Cabo de Hornos, se habían hailiado cn arribadas, en epidemias, etc., lo habían pasado en invierno y en verano' y habían experimentado, finalmente, la escasez como la suma abundancia. Se nos hacía, no obstante, repareh'e en las primeras conversaciones que cariñosamente trabábamos con ellos, el que en medio de la abundancia y en las mares sumamente benignas, todas sus reflexiones se parasen en los riesgos muy distantes del Cabo de Hornos, y que áun entre éstos despreciasen casi el hablar de la poca ó mucha comida, de la poca ó mucha ropa de abrigo, y fijasen más bien su atención en la contínua incertidumbre de su suerte, y especificasen, un io tocante á esa navegación, las más mínimas circunstancias con una puntualidad propia más bien de un político que de un marinero; ni cabía el pensar que esto pudiera rer de niedo, cuando al mismo tiempo se arrojaban con el mayor denuedo entre los peligros, y áun veíamos entre los polizones, alguno que nor seguir tan solamente uno ó dos amigos habían preferido, áun sin ropa y sin dinero, esta navegación á otras más cómodas y menos inciertas á que estaban contratados á la sazón. Inferíamos desde luego con estos datos que el marinero nuestro, bien diferente en esta parte del extranjero, era su- 
mamente sensible y capaz de reflexión, y nuestro natural hacia ellos nos hizo aumentar las pruehas casi sin conocerlo. Sabian el rumbo que debiamos 6 pensábamos seguir, y á cada paso se arrimaban á la aguja á ver cuínto distaba de aquél el que seguiamos por necesidad. Oían con el mayor agrado, y áun nos preguntaban á veces, nuestras observaciones diarias de latitud. El día del mal tiempo todo les era insufrible; un soplo de buen viento los volvía á su primera docilidad, y finalmente, á medida que descubri on en nuestra unánime conducta una mezcla de cariño, de amor al trabajo, de inteligencia, iba aumentando en ellos, áun en proporción adecuada, una mezcla de amor y respeto hacia nosotros. Ya en el largo tiempo que nos contrarestaron los vientos varia. bles de las inmediaciones de la Línea sa nos hizo patente el buen efecto de adoptar este prin. cipio. Yo prefería el dia de viento contrario al de mal tiempo para mejorar sus comidas con carne fresca y distraerlos con el saludable vino de Sanlúcar. Se toleraron en las maniobras y áun en su misma conducta, algunos defectos leves, que rios era luégo fácil remediar ó cortar enteramente en el día de buen tiempo; aumentaron nuestros halagos y premiábamos y fomentábamos á los que do. tados de un genio alegre podian excitarlo en los demás; no se hacía un zafarrancho ni otra ma. niobra de aseo que no concurriese un poco de vino y nuestros razonamientos á hacer ménos gravosa la disciplina, y esta conducta, seguida con constancia, nos proporcionó ya la agradable perspectiva de verlos después de veintiocho días de chubascos, turbonadas, calma y contrariedades, más ro. bustos aún de lo que habían salido de Cádiz. Concurrió á cimentar este anhelo nuestro de darles gusto, la derrota que nos proporcionó el reláj marino de la Equinoccial hasta la Ascensión. Navegamos á viento largo cuando los pilotos vociferaban el riesgo de no montar (áun ciñendo) el Cabo de San Agustín en la costa del Brasil, y les proporcionamos por rumbo oblícuo la vista de la Ascensión, que les convenció y les hizo confesar por sí mismos, que nuestras navegaciones al $O$., para salir de la costa de Africa en las inmediaciones de la Equinoccial y el no haber ceñido los S. E., habían desde luégo aventajado de quince á veinte días el viaje de la Astrea. Los temporales de la costa patagónica dieron nueva fuerza á nuestro amor recíproco; las maniobras se mandaron con método y con la posible seguridad. Ellos las ejecutaron con el mayor ardor; si fué preciso varias veces ó el exponer algún tanto las gavias ó el maniobrar á cada paso, ya sabían y entendian que nuestra situación lo requería, y sacaban de los mismos peligros el mayor buen humor, de suerte que finalmente todas las contrariedades de la costa patagónica, y los semblantes de un viaje al sumo largo y dilatado, se deshacían fácilmente en su imaginación con las razones, 6 ya aparentes 6 ya verdaderas, que les alegábamos. A la llegada al Cabo eran más bien nuestros amigos que nues. tros súbditos; sin faltarnos al respeto, nos manifestaban sus necesidades, 6 sus deseos, 6 sus ideas, 6 sus aventuras; mezclaban á esto algunas chanzas y veían en nuestros rostros cuánto gustábamos de ellas; llegamos aún á complacerles en sus caprichos moderados, ó ya relativamenté á comida ó bebida, ó bien en cuanto á algunos puntos de disciplina. Los veíamos así siempre alegres y aptos al trabajo, y aumentaba su robustez casi á medida que se aumentaba la campaña.

A pesar de estas bellas disposiciones, pero en prueba de su grande sensibilidad, les trastornó muy mucho en las inmediaciones del Cabo Pilares, el ver tomar de nuevo las muras estribor, y aunque no duraran estas nunca un día entero ni nosotros nos descuidásemos en hacer compren. der á fondo wiestra ventajusísima situación, y áun en reprimir los más tercos, se conocía luégo en los semblantes la mura que llevábamos.

No les faltaba cosa alguna; antes bien, crecía con el mal tiempo su ración y nuestra tolerancia, y no obstante menores que todos los trabajos que en el Cabo hacen consigo las muras estribor, desmajaban, y áun entre sí caracterizaban ya á cualquier leve achaque de escorbuto. Nuestra derrota al N. disipó todas aquellas ideas, y los buenos tiempos sucesivos nos han proporioionado de verlos ya en inmediaciones de Concepción en la mayor unanimidad, buen hunor y tranquilidad de ánimo, $y$ en un estado de robustez proporcionado á aquellos resortes.

No se crea, no obstante, que este preservativo, que por su novedad exigía toda la atención que se le ha dado, nos hiciese descuidar en el uso de otros muchos; hemos contribuído al aseo personal de todos (que en verdad no necesitaba de mucho estímulo) con nuestro ejemplo, y con algunos premios, muchas alabanzas y tal cual reprensión, y no les ha sido un anxilio indiferente la repartición de ropa embarcada por cuenta de la Real Compañía, y perteneciendo mís bien al ramo de aseo que al de abrigo. Daba ciertamente el n? yor gusto el verles peinarse y lavar su ropa casi diariamente en los dias de mayor frío; y como se tuvo la precaución de comprender en la repartición de camisas á los mismos polizones, aunque no turiesen con qué descontar su valor para con la Compañia, puede asergurarsc que el aseo personal en la fragata Astrea ha llegado al punto más alto.

Los zafarranchos, viceversa, no fueron tan frecuentes como parecía exigirlo nuestro anhelo por la conservación de la salud; pero se omitieron varias veces, ya porque no eran necesarios, ya porque hallábamos muy sensible al marinero la molestia de descolgar su coi cuando necesitaba más 
bien dormir en 6 l que limpiarlos. Los más tardos en esta parte, que fueron siempre muy pocos, sa aguijonaban con premio, arma que hemos hallado infinitamente más poderosa que el castigo.

La ventilación interior, el sahumar y rociar con vinagre los parajes ménos ventilados, fueron preservativos que empleamos con la posible frecuencia; y á este fin áun en las mares más tempes. tuosas, se aprovechaban los posibles instantes para abrir algunas portas del combés y de las escotillas, y desterrar así cualquiera enfermedad y malos hábitos.

Por lo que toca al frío, se procuraron remediar con la mayor igualdad las urgencias de todos, libertando finalmente del servicio sobre cubierta y empleando en otros menesteres de la fragata en lugar de pajes, aquellos polizones que ni habian alcanzado lo bastante en la repartición, ni traian por si prenda alguna. Fué también menester remediar las necesidades de los reclutas de trasporte; además se tuvo la precaución en los dias de agu: y frio, no sólo de hacer las maniobras con atención á estos dos fúớrtes obstáculos de conservación de la salud, sino también de proporcionarles el posible abrigo en las guardias, para cuyo fin se entregaron á cada una diferentes capotes, que sirviesen precisamente al marinero que se hallase en puesto desabrigado.

En el régimen importantisimo de comida, se procuró combinar del mismo modo que en las de. nıás cosas, el conocimiento del carácter y naturaleza española, con las luces que nos sugerían los extranjeros. Preferimos algunas veces lo más' vario á lo más sano; el vino de Sanlúcar fué el principal antiescorbútico que adoptamos, así para los calores como para los fríos; la carne fresca se dí de ración una 6 dos veces á la semana; hasta la altura de Buenos-Aires no se escasé 5 absolutamente el agua; las calabazas y el Sowrkro.t alternaron en hacer más saludables y más sazonadas las comidas; y el gazpacho por cena, solo se suspendio en las latitudes muy crecidas, para sustituirles sopa en aceite, que dimos también con el almuerzo durante el tiempo de los fríos. No titubeamos en este último partido, aunque generalmente la crasitud del aceite sea muy propensa al escorbuto, ya porque nuestros aceites eran de la mejor calidad, y ya porque esta especie de comida es muy homogénea á la naturaleza andaluza. No nos pareció conveniente distinguir en el trato unos más que otros; se suministró de un mismo caldero á los marineros, á los polizones, á los soldados de marina y á los reclutas, y todos igualmente tuvieron parie en la distribución del vino y aguardiente; finalmente, en esta nueva entrada de los calores, después de la recalada á Concepción, han crecido nuestros cuidados hacia ellos, tratíndolos aún con mucho más cariño y afabilidad, proporcionándoles el preciso descanso, y dándoles por almuerzo un abundantísimo plato de Sowrkrout, acompañado con medio cuart:llo de vino de Sanlúcar, y por cena un buen gazpacho: precauciones que no parecerán inútiles a! , ue advierta en los mayores estragos que ha causado en las navegaciones al Perú la entrada de lo calores más bien que la de los fríos.

Si después de un régimen como éste y de las razones que lo apoyan, puede creerse que la robustez de la tripulación de la Astrea sea uno de los muchos acasos favorables que suelen experimentarse en las navegaciones al Perú, hágasenos al ménos la justicia de no dudar, que este punto principal, así relativamente á la humanid ad como al buen éxito y concepto de las expediciones de la Compañia, ha ocupado incesantemente nuestros desvelos, nuestra conducta y nuestra aplicación, y que hemos sido bastante dichosos para lograrlo, hasta el punto de ver en uu estado, 6 nada peor, 6 algo mejor de los primeros dias de la salida hombres gravemente enfermos de mal venéreo que en todo el viaje no han podido salir de la enfermería y que parecian, por consiguiente, destinados á ser víctimas del escorbuto."

\section{RESPUESTA del Sr. D. Fose Salvaresa a las cartas que anteceden del Sr. D. Alejandro Malaspina.}

\section{RESPUESTA PRIMERA}

Con el debido reconocimiento al favorable concepto que á Vm. merezco; deseoso de corresponder á la superior confianza y del desempeño en puntos que tan de cerca se refieren al beneficio de la humanidad, expondré bajo la consideración de $\mathrm{Vm}$. algunos apuntamientos en contestación á su muy apreciable carta de 24 de Diciembre pasado, reduciéndome á solo aquellos artículos sobre que su anhelo por el acierto y su modestia no le permiten resolver con la seguridad y mano maestra que relucen en todas las providencias anticipadas por $\mathrm{Vm}$. que se sirve comunicarme y doy por 
supuestas. No puedo, sin embargo, desentenderme de las refles ines que, dimanadas de un estudio prof undo y experiencia aprovechada, extiende $\mathrm{Vm}$. sobre el carácter de nuestra marinería y medios de nanejarla con vetı́ija á la de cualquiera otra nacion. ;Ojalá prendan estas ideas en todos los que hayan de mandar, superando sin desaire de la gerarquia los obstáculos que susciten el amor propio y el destemple naturall

Concibo, pues, en orden al primer punto, que son preferentes en la eficacia las depuraciones del aire for el fuego en las cubiertas á las practicadas por medio del vinagre. Puede, no obstante, el estado de la atmósfera caliente y seco, exigir se rocien con dicho licor, cuyas exhalaciones of recen con la virtud artipútrida bastante recreo y atemperacion; y en este caso, es mejor el rocío que el vapor, por el que se disminuye la fuerza y pureza del ácido.

Por lo que respecta á graduar las resultas del desabrigo en los rápidos tránsitos del mucho frío al mucho calor y las dcl excesivo abrigo por la carga de ropa, hallo ser más temibles las primeras; pucs por poco que se radique un resfriado en $\mathrm{cl}$ marinero y haga tiro al pecho, lo consume insensiblemente hasta inhabilitarlo; y el exceso de iopa sólo ocasionará una molestia que se irá haciendo tolerable con el convencimiento del motivo y más á los del Norte de España, de genio ménos desali. ñado en sus personas y más acostumbrados á andar cubiertos. Dejo, no obstante, en su lugar, lo que exija la ocasión, en que á presencia de excesivo calor puede quizás ser de impedimento á las maniobras ejecutivas la mucha ropa.

En materia de comestibís, siendo de tanta consideración el objeto del pan, he reflexionado mucho sobre su cochura, pesundo y comparando entre si las ventajas y perjuicios de que esta operación sea diminuta; y me parece que toda la salubridad que quedaría en el pan poco cocido, se desvanece.ía jor las digestiones trabrjosas y proximidad á criar humores glutinosos, que resulta. rian obstruccinnes en las visceras del vientre, $y$ en esta situación el escorbuto hace fácilmente presa, siendo también del caso no despreciar la poca satisfacción del paladar en el uso de un alimento cuotidiano.

Considerando con igual prolijidad las resultas de la alteración del pan de maíz y centeno con cl de trigo, se presenta desde luego la bondad de aquéllas semillas y su sabor no ingrato; pero in. duce algún temor su mayor tenacidad y crudeza, especialmente en forma de tortas infermenta. das, $y$ mucho más en uso repetido. Reflexionando, no obstante, que es alimento de gente robusta y laboriosa, y á que están acostumbrados los habitantes de nuestras provincias septentrionales, no desapruebo la tentativa de otras tortas sin frecuentarla, hasta asegurarse en lo posible, de la resistencia de sus estómagos. No por eso ocultaré que propendo más á que se suministrén las harinas de estas semillas con parte de la de trigo, en forma de poleadas, y con suficiente azúcar, que además de su especial virtud antiséptica avivaría su digestión. En esta preparación es más domable la tenacidad de dichas subsistencias, que el fuego no penetra con tanta inmediación á causa del vehículo del agua. El día de este alimento podia ser menor la ración de pan.

lor lo que dice á las menestras, cuya virtud antiescorbútica es evidente, hecho cargo de que deben calificarse respectivamente á dicha calidad y á cualquiera otra saludable con preferencia á su conservación y duración bajo las circunstancias verificables en la dilatada navegación de que Vm. se halla encargado; y en el concepto que alcanzo á formar de que la análisis química en esta parte no sugiere fundamentos decisivos, se hace preciso recurrir á experiencias, que derivadas en lo ocurrente en el ejercicio de la práctica médica, adquieren alguna presunción de asentadas. Estas me han enseñado que en el arroz y los garbanzús se encuentra cuanto beneficio contienen las demás de uso sin la tenacidad y la aspereza de las otras.

Por tanto las contemplo más oportunas; y sólo para evitar el fastidio de la uniformidad, juzgo se dé lugar para alguna alternativa á los frijoles blancos.

Aunque el objeto de la conservación y de la duración sean distintos de virtud, estoy muy inclinado á creer, que en razón de ésta se verifiquen aquellos en muchas sustancias; entendiéndose por conservación la corta evaporación del espíritu rector especial que las caracteriza intrínsecamente, y cuya existencia y diuturnidad no se determina por las afecciones externas. Ocúrreseme apuntar que en $\mathrm{cl}$ arroz del Piamonte, y en el veronés, aunque de exterior ménos agradable y ménos blanco, se encuentra más proporción para el gusto de la nutrición.

Toda la ventaja que lleva en lo saludable la carne de vaca al tocino en estado fresco, se desvanece con palpable desmedro é inferioridad en el de salada, y por lo mismo se reputa como casi proscrita de la Armada. Conozco lo costoso del atocinado, y más en vista de la debilidad de los vinagres de América; pero el caso exige esforzar lo mejor conocido, esperando de las experiencias ulteriores todo lo que sin perderlo sea compatible con la prudente economía.

Sobre el artículo del aceite, á pesar de que no deben considerarse los marineros septentrionales de España como habituados á su uso, y que por lo mismo no extrañarían su falta; la bondad de 
este condimento alimenticio, la recomendable calidad del nuestro, y el que no les desagrada, persuade se le dé lugar entre las provisiones de boca.

En cuanto á determinar su uso prudente, me parece se destine a las sopas por almuerzo, $b$ cena en los climas fríos, y por sólo cena á los gazpachos en los calurosos; cuidando que su cantidad se tase á solo objeto de un moderado aderezo. En el segundo modo se doma algun tanto su acritud con el vinagre y tendencia á la rancidez, y en cl primero mucho más agregando azúcar. No es esta muy conforme á mi paladar, pero conozco la casi natural afición de nuestros nacionales, y que esencialmente se opone á la putrefaccion. Ni tampoco me atrevo á determinar si su coste excederá con. siderablemente los límites de una amplitud arreglada.

En los términos que van apuntados, concibo que el gazpacho será utilísimo; pero de ningún modo me parece se insista en su uso repetido si un fastidio verdadero lo hace ménos tolerable áun en amago á gente no acostumbrada á el: espcro, sin embargo, que se aficionen.

Un principio de pesadez, y menos seltura de los miembros con algún enronquecimiento, scrín á mi ver indicios de que se van espesardo los humores, y amonestarán se desista de tomar comidas con aceite hasta su disipación: cuidando no confundir estas señales con los efectos del frío ex. cedente, que son más pasajeras.

Sobre los puntos relativos al importantísimo renglón del vino, aunque no hallo escasa para un efecto saludable la cantidad to medio cuartillo por la medida mayor que equivale á ocho onzas, me inclinaba á que se agregasen dos onzas más; $y$ en este caso á que se compartiese en la comida de medio día y cena cuando ésta no fuera de gazpacho, pues entonces, siendolo, podría suministrarse en el almuerzo este eficaz digestivo. $Y$ de todos modos reputo por más oportuna ocasión la de la comida más fuerte del medio día.

La exclusión del aguardiente y del pescado salado, incluso el bacalao, me parece acertadisima, como sblida la determinación de circunstancias bajo que pueda darse lugar al uso del queso.

Es cuanto, ansioso por el acierto, he alcanzado á deducir de las más serias reflexiones; debiendo sinceramente confesar, que la precisión, solidez é inteligencia con que trata $\mathrm{Vm}$. el asunto en su carta, me han hecho la costa para satisfacerla. Espero los demás artículos referentes á materia tan importante, y órdenes del agrało de $\mathrm{Vm}$., en cuyo obsequio se empleará gustoso su más apasionado y afecto servidor y amigo $Q$. S. M. B. -Cádiz, 5 de Febrero de $\mathbf{r} 789^{\circ}(\mathrm{I})$.

\section{CARTA de Malaspina al Subinspector de Airsenales, por la que se inficre la inteligencia, celo é iniciativa del Fefe de la expedicion hasta en los más insignificantes pormenores.}

Sr. D. Fermin de Sesma, Capitán de Navio y Subinspector de Arsenales:

Expondré á V.S. con el posible detalle, las pocas ideas que tengo presentes sobre armamento de las dos corbetas para la próxima expedición, no tanto para que puedan ser de alguna utilidad en el sumo caudal de conocimientos relativos particularmente á este ramo que V. S. posee, como para cumplir una orden que nos impone S. M., y manifestar por escrito aquellos sentimientos de respeto y concepto que desde tanto tiempo en mí se hallan grabados.

El aparejo pendiente (para proceder según orden de inventario) estará por completo al arbitrio de V.S. Ambos Comandantes conformes en este particular, estamos seguros que nada nos quedará que desear, $y$ s 6 lo atentos al número de gente que tendremos para la maniobra y á los parajes que con más frecuencia habremos de trillar y á la duración del viaje, nos aventuraremos á hacer las siguientes insinuaciones, remitiéndolas no obstante todas á la absoluta determinación de V. S.

Conviene que las menas en general, así de cabos como de motones (comprendidas áun las jarcias mayores) sean más bien con algún exceso delgadas que gruesas; que la motonería del propao

(1) Suprimense las segunda y tercera cartas, por ser éstas ininteligibles, á causa de lo deteriorado que se halla el manuscrito. 
gire sobre pernos, como en la fragata Astrea, y que se eviten en general todos aquellos casos de refuerzo, que, propios tan solamente de mares tempestuosos, en los apacibles sólo sirven de atraso en el andar y de un grave deterioro en los pertrechos. Doy por supuesto que el aparejo, crucetas, guinda y cruzamen de los juanetes y sus velas, han de seguir aquella excelente proporción que admiraban hasta los extranjeros en la Astrea. Supongo que se facilitará con rolletes el manejo de los cables y que en el laboreo en general de la maniobra se preferirá, con prudente método, no tanto un excesivo aligeramiento y desembarazo, como una sólida compensación de fuerzas que no necesite alterarse á cada paso.

En cuanto á la arboladura de respeto, sólo añadiremos á la dotación general de los buques de S. M., una jimelga y dos masteleros de juanete en lugar de astas de hierro. La igualdad de ambos aparejos de popa y proa, excepto los palos y vergas mayores, es una de aquellas ventajas indecibles que ćsde luego V. S. nos ha dictado y llevará á debjdo efecto.

Las anclas podrán llegar al número de seis, dos de á 22 quintales y cuatro de á i $\delta$. Nos ceñiremos á cuatro anclotes, dos de nueve quintales, uno de siete y otro de cinco, los cuales, si tuviesen cepos de hierro para su nlás fácil manejo y acomodo interior, descle luego podrían no estorbar el fácil manejo de anclas. Los cabos y calabrotes correspondientes á estas anclas, pueden, á nuestro entender reducirse á los siguientes: tres cables de $\mathbf{I}_{5}$ pulgadas, cuatro ídem de $\mathbf{r}_{3}$, tres calabrotes de siete y tres de cinco y media. Podrán omitirse los viradores y simplificarse el número de orinques, refiriendo unos y otros á las guindalezas y veteria en piezas completas, en las cuales por consiguiente, se envolverán todas las piezas cortadas, especificadas en el inventario con el nombre de jarcia de respeto. La cantidad de guindalezas y veteria de repuesto será pues adecuada, no sólo á esas necesidades en atención á cuatro años de un trabajo contínuo de amarras, sino también á los climas ordinariamente destructivos de la zona tórrida bajo la cual serán mucha parte de nuestras tareas.

De la jarcia alquitranada de peso llevaremos toda la posible, y áun mucho mayor cantidad de jarcia trozada en cables, que nos servirá también para estiva, pues quc en cualquiera escala nos será tan fácil un acopio de leña como dificil, y áun imposible, uno de jarcia trozada, necesaria, por otra parte, para la conservación del aparejo.

En la motonería, herrajes y piezus sueltas, dependerán éstas enteramente del aparejo pendiente. Sólo sí llevaremos por duplicado, si pareciese oportuno, los cuadernales de tumbar que considero también suficiente para varar, si fuera preciso, una ó entrambas embarcaciones.

Los utensilios del Contramaestre y los betunes necesitarán por lo común de aumento. A estos últimos será preciso añadir una cantidad considerable de aceite de linaza y un buen acopio de pinturas en polvo.

En el velamen de lona podrá facilitar su manejo, sin disminuir de resistencia, el que sea todo do lona de gavias de fragatas, ó si fuera posible de otra más fina. Podremos llevar tres juegros completos y otras dos gavias sin relingas. El velamen de vitre pourá en general ceñirse á dos juegos; cuando más se le añadirá un juanete (según lo convenido) común á entrambos palos. En los tejidos de respeto pueden considerarse las mismas necesidades que en la jarcia. Si pareciese más conveniente para los consumos de ese Arsenal, pudieramos emprender la salida de aquí, y por consiguiente, el primer corte de la línea, siempre destri:stivo para el velamen, con un juego ya usado ó de media vida. Los utensilios para coser velas y el número de cois serán proporcionados al viaje. Treinta catres ingleses por embarcación reemplazarán los de madera para Oficiales de mar y la enfermería.

Nada diré por ahora sobre utensilios de piloto, si no es que nos serán precisas un par de agujas azimutales por corbeta, ó á lo ménos una.

Nuestra artillería será (si a V. S. parece lo mís conveniente) de 22 cañones de á seis, arreglada su carga á 50 tiros, 25 con bala, Io con palanqueta y I 5 con metralla. Sólo si, que cerradas para mayor comodidad de los alojamientos las primeras tres portas de popa, reservaremos en estiva ca. ñones y cureñas correspondientes, y para esto será sumamente útil, el que se entreguen desarmados y en pequeños atados los herrajes y maderas de dichas seis cureñas. Dos cañones de á cuatro y un disparador de cohetes, entrambos para señales, y finalmente, un repuesto, no grânde, de utensilios, uno muy abundante de balas para fusil y pistola, un excelente armamento, inciusas en él bayonetas, cinturones y vainas para sables, y cuatro ó seis pedreros sin recámara. El cargo de Armero, indispensable para nuestra comisión, se fiará á dos soldados elegidos oportunamente. Res ronderá de sus utensilios el Condestable.

Sobre los cargos de Carpintero y Calafate será preciso hacer algunas innovaciones en atención á las circunstancias del buque, á las faenas de una varada no muy extraordinaria, y á la existencia á bordo de un lierrèo. Cuanto más se disminuya el cargo de estos Oficiales de segundo orden, tanto 
más cómodo será el situar cada co a en su lugar sin franquear á cada una paraje seguro, que en un buque, nó demasiadamente espacioso, siempre ha de ser incómodo. El visitar algunas islas dcl Mar Pacífico hará preciso el no fiar á muchos, antes bien el no fiar sino al Contramaestre los utensilios sueltos de hierro y en particular la clavazón; y esta atención exigirá una alteración no indiferente en los cargos, único modo de que no sea luégo ofensiva una:precaución tan necesari i como al parecer inoportuna.

En cuanto al número, calidad y aparejos de embarcaciones menores, no parezca á V. S. im. propio el que suspenda el hablar de ellas hasta que sistemado todo lo relativo á los buques prin. cipales, y por otıa parte, enterado ya más al pormenor de loz diferentes destinos de la expedición, podamos con más acierto ocuparnos de este ramo secundario, tien que no ménos importante. Desde luego, constituídos en nuestro método de poca gente, á no nombrar patrones de las distintas embarcaciones menones, tendremos que fiar este nuevo cargo al Contramaestre, del mismo mocio que en los buques de S. M. se hace conelos sereníes.

Hasta aquí no nos hemos separado de los cargos comunes de las embarcaciones de la Real Armada; pero no se ocultará á V. S. que una expedición de esta especie há menester de otros mil utensilios, sin los cuales cada paso fuera un tropiezo y áun á veces temeridad el empeñarse en cosas de algún riesgo. Tales son particularmente los fogones con destilador y ventilador semejantes al que ha usado en la última campaña el Navío San Sebastitin; unas fraguas bien manejables y adaptadas á todas las necesidades que pueden of recerse de estas excelentes máquinas; los oportunos utensilios de pesca y caza, tomados entrambos objetos en toda su extensión; varias bagate. las interiores que, á pesar de referirse á principios de comodidad, son de perdonarse en unas personas constituídas á vivir tres 6 cuatro años en la mar, á encontrar no pocos riesgos, y particularmente á emplear en cálculos y detalles bien prolijos las horas libres del servicio marítimo ó del preciso descanso.

Acabo ya esta narración casi del todo inútil, si bien se considera la inteligencia y celo que guian á V. S. en cuanto mira al Real servicio ambas cualidades, de las cuales ya desde mucho tiempo así Bustamante como yo somos tan buenos testigos como elogiadores.

Nuestro Señor guarde á V. S. muchos años.=Cádiz, á 2 de Ẽnero de i 789 .

\section{CARTA de Malaspina al sabio Ingeniero Muñoz, haciéndole indicaciones sobre la colocación de pararayos.}

\section{“Sr. D. Tomás Muñoz:}

Combinado el espíritu de la última Real orden sobre el establecimiento de pararayos át bordo de los buques de S. M., con lo que han escrito y experimentado los físicos y con las últimas iecciones de Mr. Le Roi, oídas en París por los Sres. de Ureña y Betancourt, he podido deducir para ias corbetas Descubierta y ATrevida, la siguiente aplicación que expongo ahora al juicioso exarren de V. S., á fin de ponerla en práctica si mereciere su aprobación.

Desde luego, la acción del pararayo con la cadena eléctrica, no exige en el largo de nuestras corbetas que sea sino uno; y éste, en mi entender, podrá colocarse del siguiente modo:

La aguja será de hierro y del largo de cinco piés, formando figura cónica sobre una base de una pulgada próximamente. Esta base podrá enroscarse con bastante fuerza en un macho igualmente de hierro puesto en el tope y macizado con resina. Encajará en la aguja con el largo de una vara desde la cúspide, una vaina ó contera de latón que termine agudísima y tenga dorada como una pulgada en su extremo superior.

Estará igualmente firme en el macho del tope el principio de la cadena, que será del largo de siete piés, y de un alambre grueso. Esta pieza se abarbetará á la encapilladura de modo que pueda za: rrse cuando se quiera, ó unirse á la cadena larga cuando amenace el rayo.

La cadena para su mayor acomodo y áun colocación, será de eslubones de un pié de largo, fá. ciles á doblarse y áun á zafarse cuando se hayan de quitar algunos trozos según la diferente posición del mastelero de juanete. Desde el canto popel y exterior de cada mesa de guarnición mayor, 
bajará algo más grueso y hecho firme en el mismo canto otro trozo de la cadena con un peso inferior; y de este modo, firme un extremo de la cadena movible en el remate del trozo alto, y el otro en el principio del trozo bajo, se logrará la deseada comunicación desde la cúspide del para. rayo hasta el agua.

Las prevenciones oportunas para el mejor logro de esta conducción, serán principalmente las

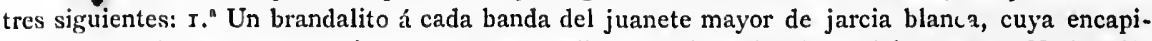
lladura superior á todo, aproxime cuanto sea posible con el macho firme del tope. 2." Un botalón de dos piés de quita y pon para desatracar el conductor de la cruceta, cuando el juanete esté calado, ó sustituirle el asta de hierro. $3 .{ }^{n}$ Un botalón en la borda del alcázar 6 en la mesa de guarnición de mesana que desatraque del costado y llame algo para popa el último trozo de cadena. Para la firmeza de estc botalón se le pondrán amantes al tercio y tendrá en su extremo un guardacabo embutido en la madera y macizado igualmente con resina, de suerte que la cadena sujeta de este modo, ni se aproxime á las cadenas de la mesa de guarnicłon, ni toque al forro de cobre en la cum. bre del agua.

Serán, por tanto, precisos para este efecto los materiales siguientes: Un suncho de hierro de cuatro pulgadas de largo, dos pulgadas de base y una leve disminución en la parte superior en figura de cono truncado. El pararayo en forma de cono truncado, cuyo largo sea de tres y medio piés y sus diámetros proporcionados á la base del suncho y á la parte que falta á la cúspide. La otra mitad de latón enroscará en el hicrro y sobre un largo de dos piés tendrá toda la agudeza posible, dorándose su extremo alto como el largo de dos á tres pulgadas. Finalmente, la cadena en tres trozos, el uno de diez pićs para hacer firme en el suncho; el otro de ciento diez parn venir desde éste á la mesa de guarnición, y el último de quince para pasar de la mesa de guarnición al agua. El modo de engancharlos uno con otro, se elegirá el más expedito y seguro. El grueso de los eslabones podrá ser algo mayor de una línea; su largo de un pié ó dos, y sólo los últimos eslabones tangentes al agua, serán de un grosor doblc 6 triple en proporción para gravitar con más facilidad y solidez.

En cuanto al cabo blanco y los botalones, probaré primeı usar una de las drizas de seña y de piezas sueltas de á bordo. Si fuesen necesarios, se pedirán luego los correspondientes efectos. de $r ; 99$.

Nuestro Señor guarde á V. S. muchos años. A bordo de la Descubierta, á 22 de Mayo

\section{CARTA del Fefe de Escuadra D. Gabriel de Aristizábal á D. Alejandro Malaspina, en la que tan insigne marino se excusa modestamente de aconsejarle sobre un plan hidrografico.}

Apruebo las sabias medidas que V. S. toma para desempeñar la Real confianza, tan dignamente depositada en V. S.: su importancia y objeto exigen el ímprobo trabajo $y$ las noticias fundadas que V. S. pretende acumular; como materiales náuticos y físicos para la obra que emprende, y cuya utilidad deseo se logre en lo futuro.

Yo estimo en mucho el concepto que á V. S. merczco, cuando ha creído que mis conocimientos podrían darle luces para ilustrar la parte hidrográfica de su plan en el Archipiélago Filipino; el interés con que justamente miro los progresos de la navegación, las glorias de nuestro Cuerpo (en sus empresas militares y científicas) y el mayor lustre y désempeño de un amigo como V. S., me estimularían siempre, áun sin la espuela de querer responder dignamente á sư consulta, á recordar cuantos conocimientos me proporcionó en aquellos mares la experiencia de cinco años, cuantos pude adquirir de los prácticos, cuantos me pudieron prestar archivos y papeles que ciertamente consulté con varios motivos en distintas representaciones al Rey nuestro Señor en aquel tiempo, y alanıbicando todo lo ménos inútil hiacer á V. S. un corto presente, para que conociese mi voluntad de contribuir á sus lucimientos, más que la profundidad ni extension de mis indagaciones; pero al cabo de catorce años que he regresado de aquellas regiones, y habiencio estado durante este tiempo cmpleado en tan varias comisiones como á V. S. consta, apenas conservo unas ideas remotas que 
comparadas con las vivas y nuevas que V. S. logró de resultas de repetidos últimos viajes, hacen desvanecerse la conjetura de su utilidad. Tampoco conservo documentos 6 copias de mis citadas representaciones al Rey desde allí como Comandante de aquella Marina, ni desde aquí como consultado; per.) se hallarán en la Secretaría del Despacho universal da Marina de Indias, si acaso merecieron ac-ptación al Soberano y sus Ministros en aquel tiempo; todo esio es cuanto puede reproducir á V. S. en respuesta á su favorecida del I7 de Marzo de este año, asegurándole mi eterna gratitud $\mathrm{y}$ deseos de su prosperidad y aciertos futuros, como la justa estimación que me merece V. S., á quíen Dios guarde muchos años. $=$ Ferrol, 8 de Abril de $I 789 .=S r$. D. Alejandro Malaspina=Gabriel Aristizábal.

\section{PRUEBA' de las Descubierta y Atrevida segín nota de Malaspina.}

Estas corbetas, construídas pcr el Ingeniero Comandante de este Departamento, D. Tomás Muñoz, se probaron el dia 5 de Julio á presencia de este Oficial y del Excmo. Sr. D. Antonio Ulloa, uno y otro embarcados en la Descubierta. Varios otros Oficiales d': la Armada asistieron á las mismas pruebas en la ATrevida.

Se examinaron cuidadosamente los calados y se hallaron:

\section{En la Desclbierta.}

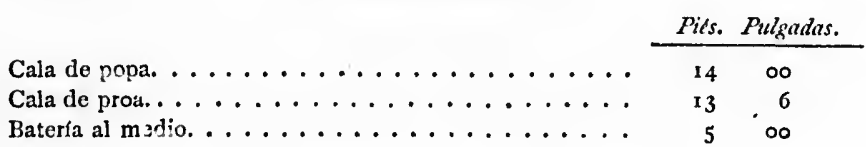

En la Atrevida.

\begin{tabular}{|c|c|c|}
\hline & Pits. & Pulgadas. \\
\hline ala de popa. . . . . . . . . . . . . . . & I3 & I I \\
\hline ala de proa. $\ldots \ldots \ldots \ldots \ldots \ldots \ldots$ & 13 & 5 \\
\hline
\end{tabular}

Los pesos en la Descubierta eran los siguientes sobre una aproximación de 150 quintales y deducidos del pormenor de cada una comprniéndose de muchas u.da partida de las que aquí se expresan:

\begin{tabular}{|c|c|c|}
\hline & Quinta & les. \\
\hline Lastre, pierlra y hicrro. . . . . . . . . . . . . . . . & 1,000 & $\infty$ \\
\hline Arboladura pendiente y do respeto. . . . . . . . . . & 398 & 50 \\
\hline Aparejo pendiente. $\ldots \ldots \ldots \ldots \ldots \ldots \ldots$ & 150 & $\infty$ \\
\hline Artillerfa, pollvora y municiones. . . . . . . . . . & 639 & 63 \\
\hline Amarras de todas especies.. . . . . . . . . . . . . & 509 & 25 \\
\hline Embarcaciones menores y sus utensilios. . . . . . . . . & 35 & $\infty$ \\
\hline 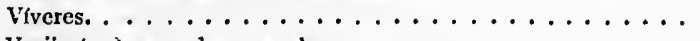 & 1,470 & 30 \\
\hline Vasijeria de aguada y rancho. . . . . . . . . . . . & 391 & Io \\
\hline Aguada. . . . . . . . . . . . . . & $x, 291$ & 70 \\
\hline 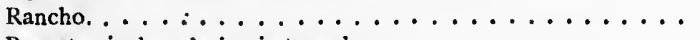 & 216 & 75 \\
\hline Respetos incluso la jarcia trozada. . . . . . . . . . . & 836 & 50 \\
\hline 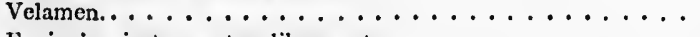 & 75 & oc \\
\hline Equipajes, instrumentos, libros, etc. . . . . . . . . . & 25 & $\infty$ \\
\hline Utensilios de cirujía y cajas. . . . . . . . . . . . . & 12 & $\infty$ \\
\hline 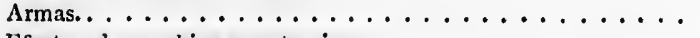 & 9 & $\infty$ \\
\hline Efectos de cambios y vestuario. . . . . . . . . . . & 102 & ০o \\
\hline Cien hombres y parte de sus equipajes $\ldots \ldots \ldots \ldots$ & I 50 & ০o \\
\hline
\end{tabular}


Los pesos de la ATrevida podian considerarse próximamente los mismos, pero su estiva estaba más bien proporcionada, aligerada la proa de cerca de 200 quintales de lastre, y hecha la repartición de efectos con atención á lo que se advertía en la DescubierTa, cuyos trabajos se anticiparon siempre unos quince dias, intervalo con el cual se botaron al agua.

La ariedad de efectos embarcados; la precisión de tenerlos casi todos á mano; los mismos plazos de su apresto, y finalmente, la ninguna práctica del mismo buque y de sus verdaderas capacidades difíciles de graduarse de un solo golpe de vista, nos aseguran que estamos muy lejos de haber acertado en esta ocasión con el mejor modo de estiva, bien que nos dan esperanzas de poderlo acertar en lo venidero cuando se haga nuevo arreglo.

Consideramos nuestros repuestos existentes hoy á bordo, en la rroporción que sigue. Toda especie de pertrechos para cuatro años supuestas unas regulares pérdidas y deterioros, así en las altas latitudes por los temporales, como en las inmediaciones de i. Equinoccial por los efectos del sol y de las lluvias. La aguada y víveres son para diez meses, menos el pan que compone súlos seis meses de ración completa. El vino de Sanlúcar, coles agrias, vinagre y aceite, pueden considerarse suficientes para un plazo de dos á tres años. Las medicinas, todos los libros, instrumentos simples y utensilios que corresponden á la Historiz Natural y á la Astronomía, todo lo necesario á dar de quilla y habilitar entre la tripulación varios obreros de Calafate, Carpintero y Herrero, y finalmente, un acopio, grande y áun excesivo de generos de cambios, regalos y de vestuarios para la gente, forman una cantidad de efectos difícil de combinarse con la apariencia exterior de las embarcaciones cuyo calado no excede de catorce piés, $y$ en cuyo buque se ha dejado sitio bastante para los acopios de Historia Natural.

Las corbetas dieron la vela á las siete y media de la mañana sobre las gavias, juanetes, foque y mesana. La marea era entrante con la velocidad correspondiente á las inmediaciones del plenilunio y el viento bonacible del $O$. Fué menester pairear un buen rato, para que la ATṘevida concluyese sus faenas de ancla; luégo, con el mismo aparejo y la mura babor, empezamos las pruebas al mismo tiempo de comparación de los buques entre sí y de sus cualidades aosolutas. Viramos á las diez á un tiempo por avante y se tieron las mayores y los estays; reviramos sobre los bajos de San Sebastián y dado nuevo bordo á lac nostas de Rota, nos hallamos bién franqueados y volvimos á virar al S. O., con viento del O. $1 / 4$ N. C.

A la una nos pusimos al pairo, y mareado nuevamente todo aparejo á las tres, se hicieron en diferentes bordos $y$ sin sujeción una á utra, varias pruebas hasta las seis y media de la tarde, á cuya hora arribamos, y con trinquete, gavias y juanetes logramos fondear de nuevo en bahía al ponerse el sol.

Deducción de ias pruebas.

lil andar, gobierno y aguante de ambas embarcaciones, puede considerarse igual según todas las pruebas de este día. La ATrevida en dos ocasiones ganó algún barlovento á la Descubierta, pero esto debe atribuirse tal vez al mejor estado de su estiva, que ya se ha manifestado.

Las corbetas han virado por avante en dos minutos con gavias, juanetes y foques, viento de cuatro millas y marea contraria. En un minuto, con todo aparejo de bolina, andar de cinco millas y marea contraria; en dos minutos y medio con el timón á la vía, todo aparejo de bolina, marea favorable y andar de seis millas; han virado en redondo en dos minutos, andar de seis millas, todo aparejo y marea contraria; bién que fué menester dilatar la virada por no poderse preparar el aparejo con la debida celeridad; finalmente la Descubierta ha virado en redondo, con el aparejo de proa en facha en dos min:itos y la ATREvida había casi alcanzado la virada por avante que intentaron ambas sobre las gavias, juanetes y estays, con la sobremesana en facha y la mesana cargada; siéndole sin duda obstáculo además de la marea, la ola bien picada de la virazón.

Hemos ceñido constantemente en die $z$ cuartas en las dos vueltas. Nuestro mayor andar ha sido de siete millas corredera larga, en cinco cuartas y todo aparejo largo; y al mismo tiempo la inclina. ción de la batería era en la ATrevida de tres piés y dos pulgadas y en la Descubierta de tres piés y una pulgada. En la una se determinaban las inclinaciones con un aplonic desde el batiporte exterior; en la otra servía un apiomo interior en el puntal proel de la escotilla mayor, comparados sus largos á la semimanga. El abatimiento no ha sido mayor de cuatro á cinco grados. Bien casado todo el aparejo de popa se necesitaban tres cabilias ó arribar para equilibrar el aparejo, y hasta esta circunstancia era igual en ambas corbetas. 
Como la colocación de las embarcaciọnes menores, que llegan á cinco y todas sobre cubierta, podía parecer difícil ó á lo menos peligrosa, se han metido las dos que deben contener las otras dos más chicas. El último bote, destinado particularmente para pescar y medir la corriente, tiene sólo once piés de quilla, igual á popa y proa. Su acomodo, por tanto, no debe dar el menor cuidado. Se ha conocido palpablemente que ni en los mares más tempestuosos correrán el menor riesgo estas cinco embarcaciones menores.

Debía hoy examinarse por medio de pesos conocidos una inclinación que resultase en la batería para deducir luégo las fuerzas comparativas necesarias á lograr la mayor inclinación. No lo han permitido las circunstancias, pero se hará á la primera ocasion oportuna.

Entre tanto, debemos asegurar que cuantas propiedades hemos examinado en ambas corbetas, al paso çue acreditan más y más la pericia de su autor, nos dan las esperanzas más lisonjeras de poder dese'mpeñar con' acierto el destino que S. M. se ha servido poner á nuestro cargo.

"Excmo. Sr. D. Luis de Córdova:

Excmo. SR.: La adjüıta noticia cerciorará á V. E. de las principales ocurrencias del día de ayer relativamente á las pruebas hechas á la vela en las corbetas de S. M. Descubierta y ATreVIDA, que han fondeado nuevamente en esta bahía en la misma tarde.

Nuest: $: 0$ Señor gäarde la vida de V. E. por muchos años.=Corbeta Descubierta, á 7 de Julio de $\mathrm{r} 789 .=$ Alejandro Malaspina."

\section{RESUMEN de los aprestos para un viaje alrededn: del mundo emprendido por las corbetas Descubierta y ATrevida.}

Interesados igualmente el paternal amor de S. M. en beneficio de sus vasallos y su constante anhelo de fomentar los conocimientos $m$ trítimos, ha determinado 'su Real ánimo destinar las corbetas de la Marina Real Descubierta y ATrevida á un viaje alrededor del mundo, con el doble objeto de continuar la grande obra de las cartas esféricas, en todas las costas de sus casi inmensos dominios y de contribuir á los progresos de la Geografía, de la navegación y de la Historia Natural en todos sus ramos.

Han sido proporcionados á unos fines tan humanos y tan grandes los aprestos de aquellos buques; y no debe parecer molesto el por menor, así del armamento como de las tareas que han de emprenderse.

\section{Buques y pertrechos.}

Confesando de antemano que la extensión de los dominios de S. M. en las diferentes partes del globo disminuyen mucho las necesidades del navegante español en un viaje de esta especie, y que por tanto los acopios, particularmente de comestibles, no han de ser tan crecidos; podemos aspirar en cualquiera otra relación en que se miren, al concepto de ser nuestras embarcaciones las más idóneas para el intento, de todas las que se han hecho hasta aquí. Un calado de catorce piés escasos, sobre una capacidad de 342 toneladas, y un aguante, gobierno, andar y barloventear, cual lo han acreditado las últimas pruebas, nos hacen creer que no habrá costa cuyo reconocimiento nos sea imposible y que no habrá cala sil donde no podamos ponerlas al abrigo.

Al mismo tiempo la casi total igualdad de propiedades que han manifestado entrambas y la ventilación y acomodo interior de todos, nos ponen casi á salvo de una separación involuntaria 6 de unas perniciosas enfermedades. El plano número $\mathrm{I}$ deja ver claramente que la decencia y comodidad de los Oficiales y demás individuos adictos á la parte científica, están combinados con un regular alojamiento en los Oficiales de mar y con el mejor que puedan desear la tropa y marinería, de los 
cuales ni uno deja de tener su coi colgado. La misma distribución de alojamientos que ha proporcionado el buque, ha dado lugar al establecimiento metódico de nuestra disciplina, de la cual, siendo bien arraigada, pende casi todo cl buen éxito de estas empresas.

Durante esta primera navegación, que ni da cuidados ni ocupaciones, correremos el tingladillo de la popa y abrigaremos algún tanto la proa para resistir con más seguridad á los temporales. De este modo, sin perder ninguna de sus buenas cualidades, las corbetas proporcionarán el mayor abrigo á la gente y áun á las plantas ó animales que se quisieran conservar en climas fríos. Las maderas con que se han construído estas corbetas son cir las más selectas y bien sazonadas. Además, se ha tenido la precaución de masijar las ligazones y calafatearlas. La tablazón del firme, el zulaque, el forro de madera con clavos de metal, y últimamente el de cobre, son otros tantos preservativos que nos ponen al abrigo de muchos peligros á que estuviera expuesta una embarcación de las comunes.

La colocación del cabrestante mayor en el combés y de las embarcaciones menores sobre cu. bierta, ha parecido á muchos imprudente, ó á lo menos aventurado. Hemos experimentado ya la fuerza del cabrestante y la facilidad de su manejo por medio de un retorno. El uso constante de las embarcaciones inglesas de la India Oriental; el poco peso de nuestras embarcaciones menores; su mismo número y necesidad de usarlas frecuentemente, deben justificarnos en cuantu al segundo partido.

El número de nuesiros botes, que llegan á cinco, nos suministra los mayores recursos para el objeto primitivo de las tareas hidrográficas, combinadas con las precisas atenciones á la Historia Natural, á la pesca, á la caza y á las urgencias naturales de aguada, leña, etc. La lancha resistirá á levar nuestras anclas de mencr peso. Con mares bonancibles pueden embarcarse á un tiempo 95 hombres. La aguada se hará con suma facilidad por medio de barricas que se han preparado para el intento. Los aparejos de estos botes aún no se han perfeccionado; pero la experiencia misma irá dictando diariamente, con la pericia de manejarlos, los que más convengan á cada especie.

Las capacidades del buque, á pesar de lo que hemos dicho al principio, son tales, que nos dan lugar á embarcar dos años de toda especie de provisiones de boca, menos el agua y la leña, que deben reducirse á seis meses, cantidad excesiva para unos buques destinados al reconocimiento constante de las costas. En el dia, en que los pertrechos navales están arreglados á cuatro años; el vinagre, el aceite y el vino, á tres; las menestras y tocino, á un año; el pan á seis meses, y el agua y la leña, á diez; se acomodan, no obstante, un grande repuesto de efectos de cambios y ves. tuario; muchos efectos para las operaciones de todas especies; muchos utensilios correspondientes á las ciencias con que intentamos abrazarnos, y por último, todos los equipajes correspondientes en la misma proporción.

Navegamos, no obstante, con cinco piés de batería, y el día en que hemos hecho las pruebas, un andar de siete millas, corredera larga en cinco cuartas, no nos precisó á cerrar las portas de Santa Bárbara. Esstos efectos, dimanados de la inteligencia y celo del Ingeniero D. Tomás Muñoz, han sido perfectamente correspondidos en cuanto al aparejo y repuestos por el Brigadier D. Fermín de Sesma. Brillan en todo nuestro aparejo pendiente el primor y la resistencia, y á pesar de la poca pericia de una tripulación no reunida ni conocedora aún sus Oficiales, la maniobra, ni las voces, en el dia de las pruebas la ATREvida ha virado pol avante con todo aparejo en un solo minuto desde las seis cuartas de una amura á las seis de la otra; lo ha verificado la Descubrerta en pocos segundos más y entrambas han ceñido siempre en cinco cuartas. Nuestras mayores son prc porcionadas á la manga, las gavias algo menores, los juanetes son grandes y en las mares apacibles nos dan un considerable aumento de vela, que en las tempestuosas no es incómodo, echados abajo mastelero y verga.

Seis anclas, cuatro anclotes, siete cables y seis calabrotes, forman todas nuestras amarras. Cerca de 200 quintales de jarcia trozada nos proporcionan conservar en buen estado el aparejo. Tres juegos de velas, un buen repuesto de arboladura y los cuadernales correspondientes á dar de quilla ó varar la corbeta para carenarla, todo nos pone al abrigo de los. muchos incidentes que suelen hacer fatal una varada 6 un viaje excesivamente largo.

A imitación de los Sres. Cook y la Pérouse, parecía natural la precaución de la lancha en piezas capáz de rucoger y llevar á grandes distancias toda la dotación con los víveres correspon. dientes. Nosotros hemos creído inútil esta precaución por dos razones: r. "En los dos extremos peligrosos de nuestros establecimientos del mar Pacífico, podrán las colonias inmediatas de Chiloe y Monterey, suministrarnos embarcaciones oportunas con las cuales puedan aún reconocerse más individualmente todas las calas y sinuosidades de las costas, y trabajar con más perfección sus cartas y descripciones. 2." Que ambos navegantes, áun trillando mares más peligrosos, no las han nccesitado. 
No es tan fácil como á primera vista aparece, la pérdida de una embarcación, aunque navegue en mares tempestuosas ó sobre costas muy peligrosas, ni fueran útiles las precauciones de la construcción misma del buque, de todos los utensilios para dar de quilla, varar, etc., si se tratase en una urgencia de abandonar el mismo buque.

No debe omitirse hablando de pertrechos, el hacer mención del fogón de hierro con destilador y ventilador, de que irán provistas ambas corbetas. Cuáles sean las ventajas de uno y otro, lo demuestran evidentemente, además de los razonamientos, las pruebas hechas en el navío de S. M. San Sebastián, en el pasado año de 1788 . A la verdad, no es tanta la economía de leña como en un número crecido de raciones á bordo de un navío de 74 cañones; pero si para cocer los tres calderos que usa nuestra marina en las navegaciones largas se necesitan próximamente diez horas de tiempo, nos aseguran repetidas pruebas que el mismo tiempo y la misma leña suministran en un solo alambique media ración de agua á cada individuo de los que componen la total dotación de una corbeta. Tenemos, no obstante, otro alambique que puede destilar por el caldero cuando unos balances excesivos ó una suma escasez hiciesen necesaria una destilación más dilatada, y al contrario cuando fuese necesario cocinar para las dos dotaciones, el caldero de destilar fuera más que suficiente á este doble aumento. Los hornos, la cocina de los Oficiales y las hornillas para dos ollas de Oficiales de mar, son otras tantas comodidades de esta excelente máquina, á la cual da la mayor perfección el ventilador. Aunque nadie en nuestros buques habite en los parajes poco ventilados, lo usaremos para la salubridad de la bodega y particularmente de la sentina; el hümo mismo en la cubierta habitada, será, aunque incómodo, un nuevo principio de conservación. Ambos fogones tienen un excelente acopio de repuestos; la duración por tanto no debe darnos ni el menor sobresalto.

A los utensilios de repuesto hemos añadido también una fragua y una cocinita portátil para s:xpediciones de Oficiales. Las herramientas de Calafates y Carpinteros, se han multiplicado pria que soldados y marineros hábiles puedan trabajar en cualquier apuro. Dos trozos de cadena ; rrar y utros dos para cables, nos aseguran también de no tener pérdidas en paraies de mal fondo.

\section{INSTRUCCIONES notables que D. Alejandro Malaspina comunicó a D. Fosé de Bustamante (segundo Fefe de la expedicion) sobre la policia de los buques.}

Fuera agravio recíproco el llamar instrucción á los siguientes apuntes, en los cuales expresaré únicamente el método que ha de segurise en la Descubierta para que $\mathrm{Vm}$., si gustase, lo adopte también en la corbeta de su mando.

El fin que entrambos nos hemos prefijado al abrazar esta comisión, "es uno mismo: de servir á la Nación con tareas particulares, acreditar el honor que nos anima y hacernos dignos de la confianza pública y del aprecio de los Oficiales que se han hrindado á encontrar bajo nuestras órdenes una serie bien dilatada de fatigas y de peligros. Pero p p nos variar en el concepto de lo que nos guíe más directamente á conseguir aquel fin; y como la uniformidad es, sin la menor duda, la base esencial del servicio, podemos aún, guiados de un mismo celo y de una misma inteligencia, acertando aún entrambos en la elección de los medios, destruir sus buenos efectos con el solo inconveniente cie haber tomado diferentes sendas.

Esta reflexión es la que me hace creer que no parecerá á $\mathrm{Vm}$. frívola la muchedumbre de cosas que he de exponerle; si le pareciese temprana, puede considerar que los cimientos son los que deciden de la solidez del edificio, y que han de influir mucho en el concepto general las primaras ideas que aquí se formen de la expedición puesta por S. M. á nuestro cargo.

Están $\tan$ estrechamente ligadas en un buque la disciplina y la conservación de la salud; depen. den tan inmediatamente una de otra la disciplina que llamaremos de policía y la militar; finalmente, dimana tan directamente de esos principios la poca 6 mucha utilidad científica que puede producir la expedición, que fuera imprudencia el no eslabonar entre sí estas materias, y contraerlas como á un mismo centro al más cabal cumplimiento de las ideas de S. M. Así la distinción de materias me ha parecido en este caso perniciosa, pues al paso de ser mís dilatada traía tam. 
bién consigo la idea de que pudiesen mirarse estos objetos desunidos y que el uno tuviese algún rigor si se descuidase el otro.

En un viaje de esta especie ha de prevalecer precisamente un método opuesto al de los buques ordinarios de la Armada. En éstos la disciplina militar es la que rige; en aquél debe apartarse cuanto sea posible; ni se ocultará la razón de semejante necesidad cuando se considere que la parte militar no há menester para su buena liarmonía de que concurra la voluntad gustosa del súbdito; pcro en la científica, que abraza un número infinito de combinaciones, sólo puede lograrse un buen resultado si cada uno, nó lo que le mandan, sino más bien lo que pueda, haya de practicar para el intento.

Multiplicados en un solo individuo los cargos á medida que se ha disminuído su número, y la misma comisión arrastrando consigo tales deberes que ya se hacen despreciabies los que parecen más graves en otro buque, ¿cómo puede el rigor militar por sí solo obligar á un soldado ó un marinero que sufra el insulto de un indio, que coma más bien una cosa que otra, que se transforme, según las ocasiones, en cazador, 6 cn pescador 6 en artesano á medida que lo exijan los infinitos acasos?

Dejando aparte la disparidad de carácter del español con el francés septentrional 6 el inglés, se deja ver que en esta clase de expediciones los que nos han precedido siempre han dado ld preferencia al cariño sobre el rigor, han tolerado más bien que la disciplina militar sufriese graves ultrajes, que no truncar aquella grata harmonía del súbdito con el Jefe, que hace suaves los mismos sufrimientos y suministra fuerzas y vigor para que una sociedad de pocos se alcance á sí misma y saque de los mismos peligros de que está rodeada nueva seguridad para su nejor conse' vación. Ei ejemplo de los Oficiales era la única arma en los buques del Capitán Cook para persuadir á los marineros á comer cosas, sanas sí, pero asquerosas. Resistióse la marinería en la bahia del Rey Jorge, que es la navegación desde el Norte á las islas de Sandwich, á beber el extracto de la caña de azú. car fermentada, y se usaron el ejemplo, las persuasiones, nunca la fuerza, para atraerlos á esta átil medida; $y$ finalmente, para conseguir la quietud en tierra y evitar un roce intempestivo vió el sabio Capitán lleno su buque de mujeres entregadas á la sed insaciable del marinero, y lo vió con indiferencia porque aquéllas eran voluntarias, $y$ la conducta de éste y su sufrimiento en los trabajos exigían un premio análogo á su carácter.

Así es mi ánimo en esta parte que la razón y la uniformidad sean las armas siempre preferidas al rigor militar y que éste sólo se emplee agotados ya todos los demás medios para el buen orden de la sociedad y el buen exito de la empresa.

Miro, no obstante, el rigor militar como cosa bien diferente de la disciplina militar, y seré tan exacto en dar á ésta cotidianamente el útil lugar que se merece, como resistente y áun opuesto á sentar el ejemplo aún más suave del primero.

\section{II}

Sentado ya que ha de constar, no sólo á los ojos de los súbditos, sino también á los del público, que la razón y el mejor desempeño de la empresa son casi la única base de nuestro sistema, ha de fijarse la consideración en otro punto igualmente importante, y que apoya el principio anterior; es á saber: que se mirará como supérfluo, y por consiguiente se apartará muy luégo todo lo que distante de aquellos dos agentes tenga sólo en su favor, 6 el ejemplo de otros, aunque para mí sumamente respetables, ó el deseo de alcanzar cierta áura popular que, como una ola impelida del vicnto á la playa, es tan fácil á entrar como á retrocedcr.

\section{III}

Supuesto que en esta comisión es la parte facultativa más bien que la militar la que ha de contribuir á la utilidad pública, he creído que deben variar también las reglas del buen orden á bordo, esto es, que el Comandante ha de aproximarse mucho al subalterno, y áun si es posible so. brepujarlo en el ejercicio de todo lo que corresponde á la parte facultativa, aunque distase mucho de la militar. Mil razones, y nuestra misma felicidad, exigen que seamos pocos para muchas cosas: esto envuelve en sí el que todos hayan de hacer lo que puedan, y si es honorífico para un militar, cualquiera sea su esfera, el correr el primero al encuentro del enemigo, creo no será ménos gloria para el facultativo humano el correr á tirar 6 arriar un cabo más bien que despertar uno 
que duerme libre de su guardia, 6 atrasar y á veces contrarestar los buenos efectos de una maniobra.

Las ideas son unas en todos los hombres: la comparación nos hace felices ó infelices: la falta de una pequeñez da á veces una idea perniciosa de debilidad que desalienta. El Comandante, dividiendo con prudente economia, y nunca sin recesidad, el trabajo de sus inferiores, ya to hace suave en lugar de ser molesto; y además, infundiendo en cada uno nuevo aliento, les inspira aquel vigor que tantas veces suple al número, y da la más alta idea del propio alcance y resistencia. Son muchos los que en un buque de S. M. están exentos de trabajo personal: nadie lo está cuando e: Comandante establece con su ejemplo un principio contrario, ni parecerá inútil el acomunar esta ided si se considera que los peligros, 6 por mejor decir, las ocasiones de practicarla, serán casi diarias, antes bien serían cortínuas, pues que el desempeñar más 6 ménos lo que espera de nosotros la Nación, pende precisamente de las mayores 6 menores fuerzas con que contemos.

\section{IV}

Como es natural me arrastrará lo que acabo de expresar, al principio de que la aproximación del Jefe con el súbdito en esta clase de destino, no sólo al trabajo, sino támbién debe extenclerse á la manutención. Mientras llega el hablar del reparto de ración, diré á $\mathrm{Vm}$. que estoy firmemente decidido á verificar esta aproximación cuanto sea posible. Nunca llegará el caso de que el enfermo carezca del alimento más saludable mientras lo haya para el hombre sano de cualquier clase que sea. La proporción de alimento desde el más alto hasta el ínfimo individuo, ha de ser siempre una misma así en la cantidad como en la calidad; antes bien, así como espero que el ejemplo mío sea para los Oficiales (si lo necesitasen) un nuevo estímulo para los sufrimientos, lo será la tranquilidad de éstos también para el marinero. En éste no prevalece otra razón que la necesidad; tal pudiera representársele por otra parte si condenado á nutrirse de alimentos igu almente escasos y malos, viese en la abundancia á los que deciden de su suerte y tal vez hasta el fruto han de coger de sus sufrimientos.

El buque además no admite en sí un gran número de cosas frescas; y en cuanto al uso de las saladas, queriendo S. M. que no se economice gasto á favor del marinero, y entregada á nosotros la dirección del apresto, no hay motivo para que sea mejor lo de unos que lo de otros ó para que

- las cantidades sean tan desproporcionadas, que el uno sufra escaseces mientras el otro se halla en la abundancia.

Empero esto no implica que la uniformidad sea rigurosamente la misma. Este partido sería pernicioso áun á los fines que me he prescripto, é injurioso al Oficial cuya cuna y sucesiva educación le hacen ya necesarias diferentes cosas, que al soldado 6 al marinero fueran más bien mo. lestas. El aseo de comida y el repuesto de varias cosas agradables que ni apetece el marinero ni ocupan demasiado buque, ni son emblemas de la abundancia, serán siempre un distintivo considerable que dividirá las clases una de otra y un alivio no indiferente para el Oficial.

La costumbre hace suaves, y áun bien agradables muchas cosas que llevaban en sí el sem. blante de sufrimientos. Hay quien aborrece los manjares más delicados. No pocos hacen depender su felicidad y su conservación del mismo método de vida que á otro fuera insufrible. La misma costumbre es la que á primera vista nos representa como insufrible la falta de variedad de las comidas, como imposible de sustituir al excelente sabor de vacas, carneros y aves domésticas y de las verduras de nuestros huertos, el de un guanaco, de un ave de mar, de una yerba silvestre. Pero también es positivo que en la clase de viajes como este á que nos hemos comprometido, hemos de ser felices 6 infelices según nuestra costumbre logre mirar con indiferencia unas ú otras privaciones.

\section{$\mathrm{V}$}

Es mi ánimo, pues, por lo que toca á esta necesaria aproximación de comida, el seguir el siguiente plan. Se procurará adaptar á la mesa de plana mayor todo el aseo posible, la abundancia necesaria y la indispensable buena calidad. El uso de las harinas, del té, café, chocolate y algunas especies más delicadas de vinos, serán la distinción constante de los demás; al paso que proporcionando las primeras una diversidad grande de manjares agradables, y suministrando los segundos 6 por sí 6 mezclados con el azúcar un entretenimiento saludable, nì con el tiempo pierden su buena calidad, ni el volúmen que ocupan es nocivo para otras cosas de mayor importancia. Nunca me sujetaré para el acopio de cosas frescas á la duración de la siguiente cam- 
paña; de suerte que suponiendo que en los correspondientes sitios destinados no quepan más de quince terneras y cien gallinas, la misma cantidad se embarcará para un viaje de dos meses, desde Cádiz á Buenos Aires, que para uno de veinte desde Manila al Cabo de Buena Esperanza por las islas del mar Pacifico y la Nueva Zelanda. Algunas veces será aún más sensible la privación, pues que siendo el ánimo de S. M. que los rastros de esta expedición en los paises no sujetos á la Monarquía derive más bien de efectos de humanidad que de medallas 6 instrumentos destrictivos, deheremos propagar en varios parajes ias castas de animales más útiles á la sociedad, y por consiguiente el pescado y las carnes silvestres serán á veces nuestro alimento, mientras tendremos á la vista animales de carnes sumamente apetitosas.

\section{VI}

Bien se deja ver que semejantes privaciones, aunque guiadas de la razbn, por lo común saludables y á veces necesarias, fueran, no obstante, muy sensibles si no las atemperase un método uniforme, en el cual se combinen con recto equilibrio las ocasiones de mucha escasez con las de mucha abundancia. Las diferencias y las privaciones resultan así ménos reparables; la necesidad misma dicta nuevos recursos, y finalmente, se establece como sictema la debida aproximación de todos los que naveguen en un mismo buque, como ya se ha indicado.

\section{VII}

İntiendo, pues, que el método proyectado debe empezar al mismo principio del armamento. Debe quedar convencido de la constancia de este sistema, no sólo el que haya de navegar con nos. otros, sino también el público, sean 6 no injustas las consecuencias que luego se deduzcan de aquéllos, dadas por gentes arrastradas de la ignorancia á veces de la emulación. A esta vista irán la seguridad de que no es el capricho el que dicta semejante medida; el navegante podrá deponer cualquiera idea de superfluidad, se irá familiarizando con una vida bien diferente de la que ha seguido hasta aquí, y podrá pesar sus fuerzas y su constancia con datos mucho más ciertos y desagradables. El público, por otra parte, verá grabadas en nuestro sistema la unidad, el buen orden, el ejemplo del sufrimiento, la independencia de todo lo que pudiera 6 atrasar 6 hacer más gravosas al erario nuestras operaciones; finalmente, aquel deseo natural de que emulen nuestros navegantes la constancia tan admirada de los que nos han precedido en semejantes empresas.

\section{VIII}

Admitida esta necesidad, y bajo la consideración de que el alimento es más bien un tributo á la naturaleza que un recreo para los que se han fijado satisfacer las potencias espirituales con prefe. rencia á las animales, se hace presente que en esta especie de comisiones, no sólo ha de privarse uno á sí mismo de lo supérfiuo, sino lo ha de extender á los demás, evitando, por consiguiente, toda clase de banquetes. Nuestro objeto en el día es conservarnos, no desperdiciar buque, ocuparnos enteramente de los altos fines á que se nos ha destinado y acreditar esta verdad, si es posible, á la vista de todos. Cuatro cosas se oponen al banquete. Es pernicioso á la salud, implica el embarco de mil superfluidades, distrae muchas horas útiles, y finalmente, borra la reminiscencia de aquellos mismos trabajos que se hacen sólo sufribles por el deseo de ser admirados de los demás hombres.

El que busque examinar de cerca nuestras tareas; el que quiera añadir á este favor el de disfrutar de la compañía de los Oficiales en la hora en que esté más reunida, más agradable y más chancera, será admitido con aquella confianza y agradecimiento que exige un lazo amistoso de csta naturaleza. Se le manifesiarán estos sentimientos de modo que no pueda dudar de ellos. Comerá con aseo y con abundancia, pero será muy luego que el deseo de merecer su aprobación se apoya más bien en el estado de nuestros buques, nuestra disciplina, nuestras tareas y nuestras máximas, que en un número ostentoso de platos útiles únicamente al paladar, muchas veces fatales al estómago. 
Consecuente á este sistema será el número de criados que se embarquen. Los he ceñido á un Mayordomo, un Repostero, un Cocinero y un Panadero, todos bien asalariados, pero constituídos á trabajar por sí cada uno en su ramo, y ayudarse recíprocamente siempre que el caso lo requiera. Seguirán á éstos otros cuatro criados, el uno como familiar del Comandante, dos para servir á los seis Oticiales y el Guardia Marina, y uno para los de las demás clases que alternen con los mismos Oficiales. Este arreglo se ha hecho de común acuerdo, según lo prescribía la Real orden correspon. diente. S. M. abona el número completo, aunque no se embarquen, habiéndolo así mandado al señor Intendente general de Marina.

\section{$\mathrm{X}$}

La ociosidad, temible en todas las clases embarcadas, lo es aún más en la de criados, por la facilidad con que pueden brindarse y cautivar otros regalando una ú otra cosa de rancho. Con pru. dente método han de intervenir los nuestros en los trabajos, particularmente en todo lance que necesite un mayor número de brazos. Pero como quiera que se les haria sumamente gravosa tal nove. dad, contraída á la comparación con los demas buques de S. M., han de atraerse á esta costumbre, nó con la violencia ni con demasiada prontitud, sino más bien con el tiempo, con el ejemplo y con el aprovechamiento de ocasiones oportunas; causas todas que sin el menor desagrado arrastrarán seguramente la realización del fin deseado.

\section{$\mathrm{XI}$}

Contribuirá mucho á hacer útil y áun más dócil esta clase de individuos, comunmente díscolos en todos los buques de S. M., el hacerles entender que no están depositados en ellos ni nuestra felicidad ni nuestro lucimiento, y que reduciéndose á pocas cosas el cabal desempeño de su oficio, pueden muy bien ocuparse del trabajo á que mejor se hallen dispuestos y diariamente en las muchas horas ociosas contribuir con sus mismos brazos al justo equilibrio de tareas cor todas las demás clases.

\section{XII}

Será su alojamiento parte en la repostería y parte en la Santa Bárbara: en entrambos parajes, muy próximos al escotillón de la escala. Tendrán catres ingleses 6 cois, según sea posible acomodarlos, y así estarán más separados del roce con las demas clases de á bordo, más próximos á la Oficialidad á quien han de servir, y más fácil la inspección de su conducta, lo que considero necesario.

\section{XIII}

En la bahía de Cádiz y áun al salir de la Carraca, se dividirán indistintamente las clases por alojamiento y comida según el método establecido; esto es, que el Piloto, Cirujano, Cortador y Guardia Marina, se tratarán en un todo con uniformidad al Oficial, atento no obstante á la diferencia de confianza del Comandante, que será proporcionada á unos y á otros; el Contramaestre, Pilotines, Condestable, Sargento y Sangrador, comerán y alojarán juntos en un rancho á estribor de la repostería, adaptado su tamaño al acomodo de los seis catres ingleses correspondientes al primer Carpintero, primer Calafate, dos Guardianes, Armero, Velero y Tonelero, tomarán igual sitio á babor.

\section{XIV}

La Real orden que acompaño con el número $\mathrm{x}$, enterará á Vm. del ánimo de S. M. sobre los diferentes puntos relativos á disciplina que había propuesto anteriormente. Era mi ánimo con el nombre de mozos, aproximar los segundos Carpinteros y Calafates al trato y servicio de marineros, 
disminuyendo así la clase de Oficial de mar y simplificando el régimen interior. Intentaré conse. guirlo aunque se miren como Oficiales de mar; pues su número haria muy gravoso el alojarlos y aumentar la comida de éstos.

\section{$\mathrm{XV}$}

He indicado ya cuanto considero necesario para el buen orden, toda la posible distancia en el roce entre las tres clases primordiales de á bordo: $x_{0}$ " Oficialidad de guerra. 2." Oficialidad de mar.

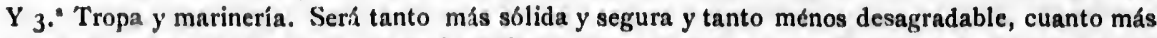
temprano sea su establecimiento. Se han dispuesto á este fin las comunicaciones de la cubierta con el aluzzar, las reparticiones de comida y alojamiento y el mismo esplritu de disciplina. Bastará por consiguiente una muy leve inclinación á la balanza, para que propenda hacia este partido tan saludable. Con avisar á cada uno cuando éntre á bordo con quiénes ha de familiarizarse y á quiée. nes ha de evitar, indicándole blandamente si anduviese errado en sus pasos, y procurando al principio promover la buena harmonia y amistad entre los que componen una misma clase, se hará el enlace tan sólido que será luégo superior á cualquier acaso que quisiese trastornarlo.

\section{XVI}

Conviene mucho que los buzos sean de la misma clase de marineros, 6 si la ciega obediencia á las Reales ordenes y la necesidad obligase á admitirlos de esta clase propietaria, sólo en el nombre se mirarán como Oficiales de mar; su agregación, por lo que toca á comida, coi y servicio, será exactamente á la clase marinera. Los que han scrvido mucho ticmpo en esta clase, sea en los arsenales 6 en los buques armados, tienen por lo común dañado el pecho y además son muy inclina. dos á la bebida. Espero que los marineros suplan muy bien esta plaza.

\section{XVII}

He extendido á dos el núm ro de cocineros del equipaje para que tengan á su cargo no menos el caldero del equipaje que las ollas de Oficiales de mar y de la enfermerla. De este modo, exclúda toda necesidad de ranchero, pues un Grumete de la guardia 6 el mismo Cocinero podrán llevar la comida al rancho; y por lo que toca al aseo del alojamiento, á una misma hora y con igual intervención del Oficial de guardia, se vigilará por medio de los grumetes sobre éste y sobre el que corresponde á la marinería.

\section{XVIII}

Al Oficial de mar se dará diariamente ración de vino y ración de carne fresca cuatro veces á la semana. El modo de recibir esto de la provisión es los domingos y miércoles; para extenderla á los jueves y lunes se determinará con la menor incomodidad de los buques menores, según el paraje en donde estén fondeadas las corbetas. Con este equivalente, con buenas menestras y tocino, y con una variedad agradable y proporcionada á las circunstancias, apoyaré el partido de que nadie embarque para su uso particular comestibles de cualquier especie que sean. Importa mucho borrar las ideas de ranchos, que al paso que ocupan un crecido número de brazos, son manantial inagotable de áiscordias, de desórdenes y de enfermedades. La ración que se suministrará será abundante; serán tres las comidas calientes. Habrá alguna distinción en favor del primer rancho de los dos que componen esta clase. Se determinará, aunque no invariable, la cantidad y calidad de comestibles por cada día de la semana, y con este antecedente se prohibirán toda clase de raciones, todo cambio de efectos comestibles que no sea en la misma despensa y con intervención y anuencia del Oficial del Detall; finalmente, toda venta particular de-cualquier clase que sea, y se singularizará entre éstas la de vino ó licores, que será grave delito, áun por la primera vez.

\section{XIX}

Apartándome nuevamente del método común de los buques de S. M., así como el Sargento y Condestable rozarán mucho con Oficiales de mar, rozará igualmente la tropa con la mari- 
neria, coadyuvando yo mismo y los Oficiales á que se familiaricen unos con otros y sea tan depositaria de la autoridad la marinería como ejecutiva la tropa de todo trabajo. He indicado ya que no es el rigor militar quien ha de mover las ruedas de nuestra disciplina, y que ha de brindarse cada uno voluntariamente al trabajo, no ignorando desde el principio que es de su obligación todo lo que esté en la esfera de sus alcances y de sus fuerzas.

\section{$\mathrm{xx}$}

De ningún modo opino que hayan de nombrarse patrones fijos de las embarcaciones menores. Muy luégo formarian una nueva clase que se consideraria superior á los demás, y los gavieros, timoneles y cabos de guardia absorberian inmediatamente casi todo el número de marineros. El contramaestre 6 guardián que esté de servicio, inspeccionará todos los días el estado de las embar. caciones menores y de sus pertrechos, y dimanando de él el .:umbrar de la gente existente aquellos que parezcan más oportunos, quedará con rapidez pronta la embarcación, y lo yue más importa, todos se irán adiestrando en su manejo, práctica sin la cual nos hallariamos envueltos en mil imposibles. Los botes chicos procurarán meterse dentro siempre que no hayan de enviarse á ninguna cnmision; y en general, las mareas y el viento se combinarán y aprovecharán cuanto sea posible para sus movimientos, debiendo por lo común preferirse la lentitud á un excesivo trahajo de remos y á la necesidad de emplear mucha gente en los botes.

\section{XXI}

Hallo muy importante el infundir desde el mismo principio en todos los individuos de las corbetas una idea harto útil en lo venidero; y es que no hemos de contar con otros auxilios que los de nosotros mismos. Será oportuno bajo este supuesto el valerse de nuestras gentes, de nuestros botes y de nuestros pertrechos para muchas cosas que con más facilidad conseguiriamos pidiendo auxilios extensos á los buques de S. M., á la Capitanía del puerto ó al Arsenal. Por ejemplo, cual. quiera faena de anclas, muchos transportes de efectos cuando los buques menores estén sin des. tino; el mismo amontonarse muchos efectos en los primeros y en los últimos días de nuestra estada en puerto, serán otras tantas lecciones útiles del alcance de las fuerzas al que ha de mandar y al que ha de obedecer. EI uno moderará algún tanto el natural principio de celeridad que se mira como único en los demás buques del Rey; el otro se irá insensiblemente amoldando á no graduar por el número de brazos el exito de las faenas por pesadas que parezcan, y sobresaldrá en este temple de tareas la inteligencia de los Oiciales de guardia y el buen ejemplo de los Oficiales de mar.

\section{XXII}

La debida atención á la comodidad respectiva, y el no hallarse aún reunidos todos los Oficiales destinados á la comision, ha hecho que indistintamente se ocupasen otros en aquellos objetos que ya desde algún tiempo requerían la presencia del Oticial. Al principio del armamento es muy pro. bable que ya no haya otra atencion extraña sino la Astronomía, en la cual se ocuparán únicos los dos Oficiales nombrados en cada corbeta, agregándoles un Piloto para copiar y confiar el diario. Alternarán, por consiguiente, los demas Oficiales y el Guardia Marina en el servicio de.á boido, y particularmente en la asistencia al armamento. Sin superfluidades, procuraré no obstante que nada se omita de lo que implica el acto formal é importante que á la sazón llena el OCicial. A éste, sin molestarlo al principio, se procurará atraerlo cuanto ántes á la asistencia á bordo áun de noche, y con esto será tan fácil ocurrir á cualquier urgencia que necesite la intervención de un Olicial, como agradable é instructivo el no ocuparse ya de otras cosas cuando los aprestos, los estudios y los mismos ejercicios exigen todo nuestro tiempo y toda nuestra atención. Es este justo sacrificio para los más jóvenes; al cabal desempeño de lo que S. M. ha fiado á nuestro honor, verá el público con mucho agrado que no serán vanas nuestras promesas, y la expedición, desde su misma cuna, adquirirá tal vez aquel patrocinio de los hombres sabios, sin cuyas luces y dictamen, particularmente en la parte científica, fueran muy arriesgadas nuestras empresas y muy dudoso el buen exito de ellas. 


\section{XXIII}

Sin urgente motivo ó de servicio, de salud ó de habilitación propi", el Guardia Marina y el Pi. lotín no empleado en la Astronomía, estarán contínuamente á bordo. Aquél se inclinará á la vida activa de aparejar, asistir personalmente á la estiva, transporte y colocación de pertrechos en las lanchas ó botes, 6 vigilar sobre la exacta observancia de las órdenes, 6 soltarse en su manejo al remo ó á la vela. Esoiro tendrá corrientes los libros de Detall, atenderá á las señales, será el ins. trumento de comunicaciói: $s n n$ el Observatorio, y se encargará, finalmente, de toda la práctica del Detall científico á que no fueda aissızar el Guardia Marina.

\section{XXIV}

Alternarán en la guardia de puerto, uno de los cuatro Oficiales restantes como Jefes, y el Sargento y Condestable como subalternos. El traje de uno y otros indicará el destino en que se hallan. La tropa estará dividida igualmente en babor y estribor. Bastarán para el buen orden dos centinelas; uno sobre cubierta, y otro en el combés hacia el paraje en donde esté el fogón. Los individuos de :rigada harán la guardia unidos á la tropa de marina; se dividirán, no obstante, en los dos cuartos para que no falte diariamente quien pueda manejar la artillería si fuese menester alguna maniobra ó saludo.

\section{XXV}

En la división de sollado he atendido á un paraje oportuno para encerrar las cajas de la oficialidad de mar y marinería, pues de ningún modo se permitirá á los primeros sobre cubierta más que un baul y una frasquerita, y á los otros más que la ropa que quisieren tener dentro del coi. Se guardará todo lo demás en el pañol indicado, abriéndose precisamente una hora antes de mudar la guardia, y accidentalmente siempre que el Oficial ó el Sargento de guardia lo hallen oportuno para que cada uno pueda tomar ó guardar la ropa que le pareciese. El Sargento 6 Condestable de guardia serán depositarios de esta llave. Las cajas y mochilas podrán dividirse por ranchos, y por ranchos bajar también al pañol los individuos, ó subir de tiempo en tiempo su ropa para orearla.

\section{XXVI}

Casi todas las operaciones periódicas de la embarcación, así por lo que mira á la parte cientí. tica como á la del Detall, se reducirán á un método uniforme con el auxilio de pliegos impresos en los cuales el plta y baja de víveres, agua y gente, ios accidentes relativos al cuadernillo de bitácora y todas las observacionts meteorológicas, lograrán su lugar sin confusión de materias ni de estilo. Pero fuera imprudente el coordinar estos pliegos con demasiada anticipación, faltando aún la mayor parte de los instrumentos meteorológicos, é ignorándose hasta dónde en la situación local de nuestross buques podrá extenderse su uso. Así, estos pliegos no se imprimirán sino poco antes de la salida. Con la precaución de anotar metódicamente los acontecimientos, será luégo fácil trasladarlos á aquellos impresos, logrando ya que rija un solo método desde el principio hasta el fin de la campaña y consiguiéndose de este modo una más fácil reducción de noticias en la muchedumbre de cosas que precisamente abrazará la comisión.

\section{XXVII}

Lil papel número 2 će los que acompaño, dará á Vm. una idea cabal del estado de dotación de cada corbeta. Eı la de Vm. podía suprimirse el velero. Basta uno para dirigir el obrador 6 recorrida del velamen de ambas corbetas, y por otra parte, el Contramaestre y guardianes, son siempre un equivalente á un Maestro de velas. 


\section{XXVIII}

Me ha parecido oportuno ( $y$ lo he verificado ya) enterar á los subalternos de la razón que dirige las innovaciones prefijadas. Debía combinarse con ellos, según la orden de S. M., el número oportuno de criados. Halle esta la mejor ocasión para indicarles al mismo tiempo que el ejemplo en los sufrimientos, $y$ un noble desprecio de toda superfuidad y distracción, serían lo característico de nuestra empresa; que se seguiría precisamente de aquellas máximas una reforma en la mesa, adaptada, no menos á la estrechez del buque y á la dilatada ausencia de todo paraje que proporcionase repuestos de aquella clase, sino á las reflexiones de aproximación nuestra con el Cficial de mar, el soldado y, el marinero, y que para combinar con este método inalterable el naatural exceso de las gratificacio'ıes asignadas por S. M. en este viaje, se haría un fondo sobrante reversible después así en aqueilos gastos extraordinarios relativos á la comisión, que comunmente suelen ser gravosos á cada uno en particular, como en un dividendo último igual entre todos los comprendidos en el abono de las mismas gratificaciones.

Este aviso me pareció tanto más necesario cuanto mayor sería mi tesón en llevar á debido efecto desde sus mismos principios el plan adoptado de evitar toda superfluidad, y cuánto más temible sería en mis jueces externos una siniestra interpretación de mis ideas. El primer cuidado del hombre debe ser el de evitar las acusaciones de su mismo corazón; pero el inmediato es no incurrir en la crítica de los demás. Siendo un mero administrador de esta parte, la más gravosa del mando, yo evito las acusaciones así de mi corazón como de los externos; puedo libremente entregarme á los reparos de buen orden, moderación, buen ejemplo, humanidad y disciplina; puedo, finalmente, no aventurar mi propiedad ni mi honor en una administración cuyas pérdidas nadie ha de participar, y las ganancias, si las hubiere, pueden, por lo: dictados de mi misma conciencia, pertenecer legítimamente á otros.

\section{XXIX}

Acompaño á $\mathrm{Vm}$. en el papel número 3 , las pocas señales que servirán en puerto para la inteligencia mejor de las corbetas. Embarcados los relojes marinos, podrá examinarse su marcha por una misma señal, desde tierra, referida á entrambas corbetas y áun referida al resultado de las alturas correspundientes observadas por distintos observadores, como sea en un mismo péndulo. Esto es lo que por ahora he creído preciso manifestar á Vm., no tanto, como dije al principio, por que me parezcan preferibles estos métodos á otros, como porque constituído cada uno en el día á satisfacer á muchos, ó superiores ó amigos, sobre las medidas áun más frívolas de la cxpedición, muy luégo incurriríamos en una discrepancia de pareceres trascendental á nuestro concepto, al buen orden interior y á la satisfacción de los que sirvan á nuestras órdenes, cuanđo es fácil después en el dilatado tiempo de nuestras navegaciones, practicar todas aquellas cosas que, apoyadas en la razon, merezcan sujetarse á la experiencia aunque de su utilidad ó necesidad no quedásemos entrambos convencidos. $=$ Cádiz, á $\mathrm{r} .{ }^{\circ}$ de Abril de $\mathrm{r} 789$. 


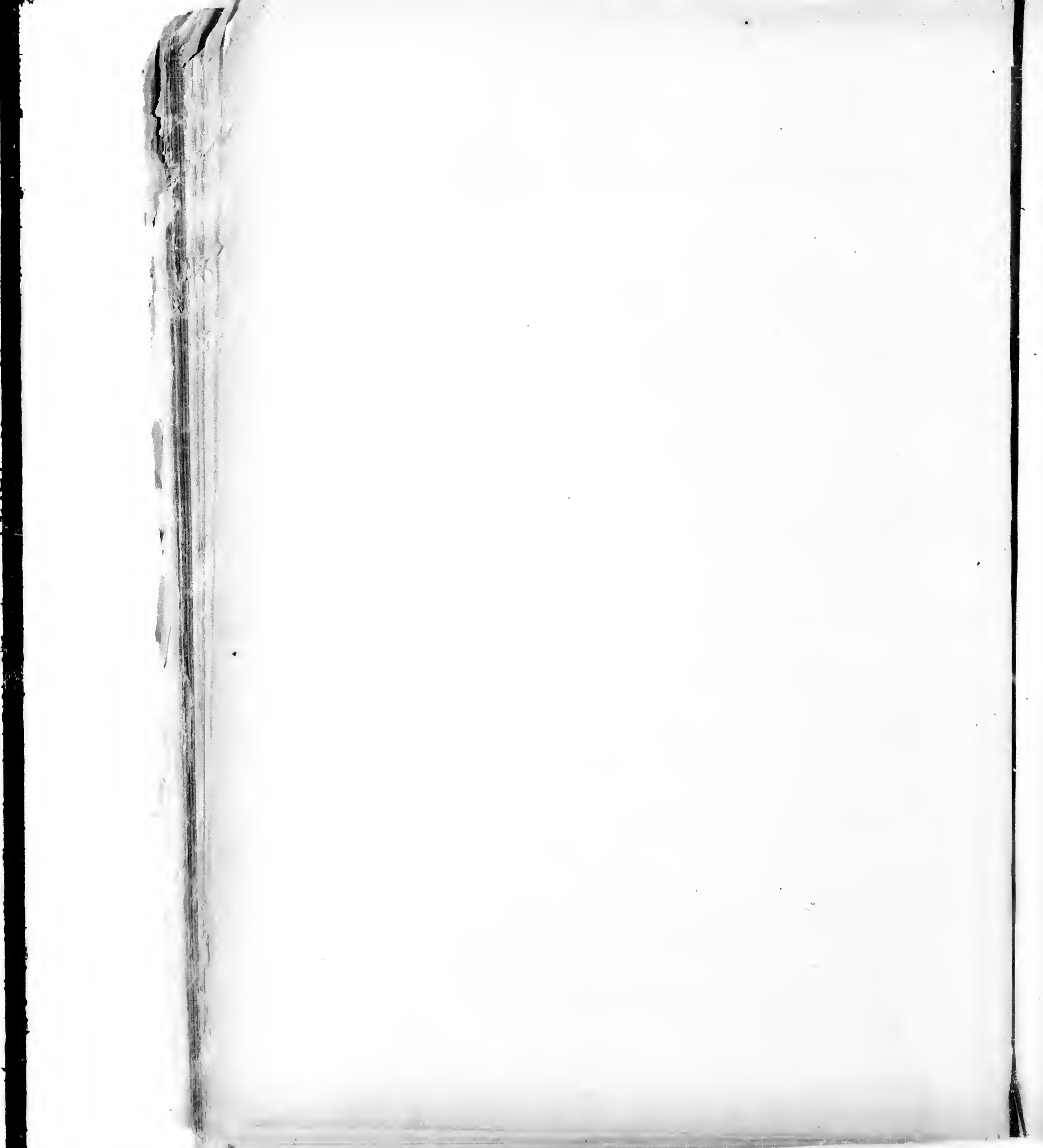




\title{
RELACIÓN GENERAL DEL VIAJE
}

\author{
DISCURSO PRELIMINAR
}

POR

\author{
D. ALEJANDRO MALASPINA
}

Quien comparase el viaje de ias corbetas De scubierta y Atrevida de la Marina Real, á los ingleses y franceses que le han precedido desde el año 1765 , erraría ciertamente sobremancra. Cualesquiera que sean los puntos de vista bajo los cuales se miren uno y otros, son otras tantas las dis. paridades que presentan, y bastará el enumerar aquí algunas para que sea fácil inferir las demás sin recelo de error.

En el año de $\mathrm{r}_{7} 89$, época en la cual se emprendió el viaje, cuyos resultados presentaremos ahora al público, ya el globo habitable podía considerarse enteramente conocido. Fijados en uno y otro polo los límites de la navegación por el hielo constante; detalladas las costumbres, el número y el orígen de los habitantes de las orillas del mar Pacífico; examinadas sus producciones y combinadas las derrotas más seguras y más breves que pudiesen comunicar entre sí los puntos más remotos de la tierra; el intentar un nuevo viaje de descubrimientos hubiera merecido el desprecio de los sabios y áun la mofa de aquellos pocos que buscan en esta especie de narraciones, 6 el entretenimiento de una ociosidad perpétua, ó el or óon úe nuevos sistemas, bien sean políticos ó referidos á las riencias.

Los progresos de la navegación habíanme llevado á un punto todavía más alto: ni los aparejos, ni las carenas, ni la calidad y cantidad de los viveres, ni los accios precisos de agua potable, ni finalmente, la mezcla á bordo de un trabajo contínuo y desordenzdo, con la rápida variación de climas y con la perpétua respiración de un aire infecto, podían mirarse comn obs úculos para no.vegar directamente hacia los puntcs más distantes del globo: todo lo venció la navegación mo. derna, $y$ variado el semblante de la ciestión, se halló tan fácil, tan sencilla y barata la conservación del hombre de mar ó en los paises tesiertos, 6 en aquél mismo Océano que parecía amenazar por todas partes, como era difícil en lo's parajes poblados y particularmente en las colonias europeas del Asia y de la América.

No eran, pues, los adelantamientos de la Hidrografía y de la navegación en general los que pudiesen mover el viaje actual con la esperanza de algún suceso; pero una mirada aunque leve al estado de los conocimientos y combinaciones europeas sobre la America y el Asia, debía descubrir luégo al punto otros objetos de igual ó mayor importancia que prestasen un justo motivo para emprenderle, y prometiesen á la Nación aquella utilidad, si no aquel lustre, al cual habían aspirado los últimos navegantes extranjeros.

Esta variedad del fin propuesto, no podía ménos de influir directamente en la suma discrepancia de los medios para ejecutarle. Debiamos visitar la mayor parte de nuestras colonias del mar Pacífico y franquear la navegación fácil de unas á otras: đebíamos, si fuese posible, apurar los conocimientos físicos y astronómicos para vencer, $b$ los riesgos, 6 la retina de las especulaciones mercantiles. ¿Cómo pudiéramos conseguirlo, sin detallar con una suma prolijidad las costas, sin hacer una larga demora en las colonias principales, sin buscar las estaciones favorables á una y otra parte de la Equinoccial, en fin, sin exvoner á cada momento, al influjo combinado de los vicios y 
del clina unas ti ipulaciones que hubiera sido más fácil preservar en el mar, 6 en las soledades de las Malvinas, de la Nueva Zelanda y de la costa Noroeste de la Amórica?

En una palabra, dirigía á los pasos ingleses el afan de hallar nuevas posesiunas y nuevas ra. mas de comercio en los paises aún no bien conocidos; y de allí la celebridad, la novedad, la economía, el feliz triunfo de mil obstículos en la navegación y la fácil conservación de lo: navegantes; nuestras miras, al contrario, se dirigian al conocimiento cabal de unas posesiones inmensas, al prudente desprendimiento de las que fuesen inútiles ó perniciosas, y á la reunión precisa de los diferentes puntos de una Monarquía tan extendida, de donde dimanaban por precisión la nimiedad hidrográfica y" política, la lentitud, los costos, los menores riesgros de la navegación, las ideas más trilladas, y sobre todo, la mayor dificultad de coiservar las tripulaciones en buen orden y buena salud.

Sin embargo, como la ocasión fuese oportuna, debian sujetarse á una experiencia constante y advertida las diferentes ideas para viajes largos $y$ distantes que sugerían las narraciones ya publicadas de ingleses y franceses. Hubiera sido tan reprensible el adoptarla sin reflexión y con una servıl admiración, hija á lo ménos de la desidia, cuando no lo fuese de la ignorancia, como poco cuerdo el graduar su utilidad por nuestra sola esperiencia sin sujetarlas antes y después á los razonamientos nacionales. Son bien distintas la educación, el carácter y la constitución de nuestras marinerías; es tan varia la disposición interior de nuestra disciplina y nuestros buques, $y$ son tantas las colonias españolas esparcidas sobre toda la superficie del globo, que la mayor parte de las precauciones dictadas por el Capitán Cook para esta especie de viajes, serán siempre en nuestra Marina ó perniciosas ó impracticables.

Indicados ya los objetos generales que dictaron como útil el viaje actual y como prudente el no prefijarse una imitación servil de los viajes ingleses, :s fácil descender á las ideas de donde dimanó el pormenor de su ejecución. La construcción de un Atlas Hidrográfico para las navegaciones distantes de los buques nacionales, ora atendiesen al abasto recíproco de las colonias con la matriz, ora á un comercio más extendido con los paises independientes de la Europa, era por sí un objeto suficiente rara mover hacia el mar Pacífico buques y sujetos que lo verificasen: $\sin$ mayores costos era fácil después combinar con este examen nimio de las costas algunos progresos en la Historia Natural, referidos esencialmente al hombre y luégo al suelo y á los diferentes animales que lo habitan. Pero sin publicar los resultados de aquellas indagaciones, se malograría su fruto más bien para los nacionales que los extranjeros, y publicándolos, caería finalmente el telón espeso y misterioso que había ocultado hasta ahora á unos y á otros el semblante real de la América á fuer de su misma extensión. Entonces sí que la confesión auténtica de nuestra misma debilidad convidaría á la codicia siempre voraz de los europeos á invadirnos por todas partes y con acierto; entonces nuestro entusiasmo para la defensa general sería tan inútil y desmayado, como los esfuerzos que debían incitarle.... ¡Triste situación que parecía dictarnos como más útil el caos y la falta de sistema y de conocimientos, que una mirada cabal, generosa y científica á los límites, á la calidad y á los inconvenientes de lo que componía la inmensa Monarquía española!

Pero en fin, eesta debilidad podía ocultarse? Y áun oculta, ¿debíamos mirarla como un vicio irremadiable? ¿O bien existía un choque directo de los principios sociales con la naturaleza capaz de trastornar los cimientos más juiciosos de la legislación? Semejante cuestión debió, en fin, convencer á un Ministerio cauto y reflexivo, que cualquiera fuesen los males inherentes á la constitución actual de la Monarquia, no lo habría ciertamente peor que el de no ar cipios sencillos y naturales. Decidióse la publicación del Atlas Hidrográfico y con ella se decidió por precisión un examen político de la América, el cual manifestase con una filosófica indiferencia nuestros males y nuestros remedios, nuestra debilidad y nuestros recursos, nuestros errores pasados y los principios más cabales de nuestra administración del dia.

¡Ojalá que semejante encargo, capaz por sí solo de reunir al mismo centro de las virtudes sociales al Monarca, á sus Ministros y á las diferentes clases constituídas á obedecer, ojalá que hubiese recaído en unas manos capaces de tratarle como se merece! Pocas verdades aisladas 6 independientes del fárrago de sistemas que nos abruma en el día, bastarían tal vez para variar el semblante de la Monarquía. El trabajo comán, ya no tuvicra otro objeto sino la común utilidad ccñicla en cada individuo á unos deseos aprobados y asequibles; suelos y climas tan fértiles y tan varios, tributarían un fruto abundante, ó al propietario ó al colono; no habría una lucha contínua entre los mismos micmbros de la sociedad; cesarían la esclavitud política y la mercantil; satisfechos de nuestia misma felicidad social, ya no mirariamos con envidia ó con temor los pasos agenos, y esta sola indiferencia política bastaría por una parte para hacernos respetables á las naciones extrañas, y por la otra, para enfrenar el abuso del sistema militar.

¡Oh! Si alcanzase para tamaño encargo la filantropía más enérgica, el estudio mís asíduo de la 
naturaleza, un examen desapasionado del instinto y del derecho del hombre, referidos á la sociedad; una reflexión lenta y razonada sobre los tristes desórdenes del día; los sugerimientos, en fin, de la gratitud más viva y más indeleble al Monarca que me ha distinguido y á la Nación que me ha adoptado por suyo, no cesarían, no, mis voces para el intento; los pasatiempos del día y las vigilias de la noche fueran en.tributo igualmente sencillo á la felicidad general; miraría como dicha más bien el guiar la opinión pública hacia la tranquila prospericlad social, que el conducir una falange militar contra un enemigo, quien ignora por lo común cuáles son sus motivos y los nuestros para pelear.... Pero no; es en valo el aspirar al cabal desempeño de tal empresa; otros más hábiles franquearán muy luégo los cortos límites que á mí han prescripto á la par la falta de estudios políticos y las distracciones del mar; seré feliz, sin embargo, si las pocas verdades que he de sentar y son el fruto de las taceas de muchos años, sirven siquiera de un primer escalón para el alto edificio del poderío y prospe idad nacionales.

Si dejásemos á ưn lado para los razonamientos políticos y económicos las ideas elementales que desde la conquista de la América y de ina parte del Asia han establecido su imperio en nuestra Europa, evitariamos, ciertamente, el ser cifusos y el luchar contra una serie de principios endurecida con el tiempo, con la costumbre y con las çonveniencias de cada uno. Pero al mismo tiempo, $o ́$ dejariamos en la misma oscuridad en que yace el origes: verdadero de nuestros males, 6 sin tocarlos, pretenderíamos infundadamente elevar un edificio sólito y permanente sobre unos cinientos dẻbiles y mal distribuídos. Un nuevo proyecto, parecido tal vez y ya más cansado que los escritos del Abate Raynal, entretendría por breve tiempo al lector ocioso y s'perficial, al paso que alentaría al Gobierno á mirar los súbditos, más bien como enemigos que conı una parte de sí mismo; y tal es la propensión de la opinión pública, que la misma insuficiencié de los remedios propuestos serviría para desalentar la práctica de los que pudiesen seguirle con mayor utilidad en lo venidero.

Es, por consiguiente, necesario en el examen propuesto de la América, abandonar el hilo de los razonamientos adoptados hasta ahora; $y$ después de una ojeada in structiva é imparcial á ese vasto continente y á la utilidad real de sus proçuctos y de su comunicazión con la Europa, es preciso descender particularmente á la naturaleza de las posesiones españolas; á las condiciones sociales que las unen entre sí; á los motivos que condujeron á su formación; al estado en que se hallan en el día, y finalmente, á los medios que suministran ellas mismas sin violencia para restablecerse y contribuir á la felicidad pública.

El objeto de las asociaciones humanas no es otro, sin duda, que la propia seguridad y defensa y una mayor facilidad de los canıbios recíprocos que conduzcan directa ó indirectamente á urıa vida tranquila y agradable. Pródigo el-Creador hacia el homire, al paso que su infancia penosa, su vejez inmóvil, sus armas débiles y su cutis delicado, le hacíaı tal vez al animal más expuesto 6 á la fiereza de los otros ó á la inconstancia de los elementos, dióle un instinto y una disposición á pensar, con las cuales pudiese, sí, señorearse con facilifad sobre toda la naturaleza; pero se viese in. clinado al mismo tiempo á ejercerlas contra su misma especie, movido de la envidia más bien que de la necesidad. De alli dimanan los diferentes periodos de la sociedad: triunfan al principio la edad y la fuerza para abatir los bosques y vencer las fieras que los habitan: los dictados del entendimiento se ejercen después para el abrigo de las intemperies y la fácil adquisición del alimento: síguese, en fin, muy de cerca la tercera época, la cual se dirige, ya no á triunfar de los obstáculos de la naturaleza, sino es á subyugar á sus semejantes y hacerles que trabajen á su favor: de aquí han derivado en diferentes tiempos según la varia constitución casual de las sociedades, las guerras externas para la adquisición de esclavos y la exiensión de dominios; y las internas ó civiles para la destrucción de las facciones ó de las opiniones; el aprowechamiento de la navegación para los cambios y transportes voluminosos, y el afinamiento del discurso para simplificar las artes y las labores; de aquí ha dimanado, por último, el sistema de las conquistas lejanas y de U1tramar, sistema que ha acarreado consigo la multiplicación del lujo $\mathrm{g}$ ba confundido todos los co. digos de gobierno en el solo código mercantil.

Este es el vicio social que triunfa hoy en día de las opiniones; el que elogian con tanto afan los escritores políticos, unos è pos de otros, y es este por la misma razón el que debe sujetanse á una discusión juiciosa antes que ecro alguno, semejantes al cultivador industrioso, que no pudiendo ciertamente evitar que Iegue a su tiumpo la estacsio $x$ zurosa del invierno, escoge, planta y abriga los di mentes árboles, por manera, que resistan á sus efectos; así nosocos, indagando el maí en su mismo origen y teniéndole á cada paso presente, ya no pretenderemos violentar la naturaleza, para que destruya las leyes que ella misna se ha prescripto, sino más bie sujetaremos las medidas sociales al recto equilibrio que debe siempre conservar con el instinto inconstante del hombre.

No parezca violento este orden de los razonamientos propuestos, cuando se presentan á un mismo instante á la vista del lionbre reflexivo, el estado de nuestra Earopa, el de las colonias en 
general, y el de los pueblos rudos en los primeros grados de la sociedad. Estos son ios elementos invariables que la naturalezat ha prescripto para nuestro estudio: sus costumbres, sus leyes, su situación física y sus ideas morales, demuestran con bastante evidencia que el antojo ha de luchar siempre con aquella maestra, que la imaginación no cesará de labrar allá en el caos de las cosas venideras, mil compensaciones de los males que nos agobian en la realidad, que el mismo antojo será cl que trastorne las mejores instituciones sociales, y haga, por consiguiente, necesaria su reforma periódica; finalmente, que si son 6 infructuosas 6 temibles por lo violento las reformas que no estriben sobre la opinión pública y uniforme del legislador y del que obedece, son, al contrario, precisas y agradables las que lleven por base el convencimiento unjversal.

Si preguntásemos sencillamente á la España, esto es, á toda la reunión que forma la Monarquía española: $r .^{\circ}$ cuáles son en el día sus necesidades reales; $2 .^{\circ}$ cuáles sus temores; $3 .^{\circ}$ cuáles los contratos legítimos de su constitución interior, ciertamente la hallaríamos bien confusa para responder; ni por otra parte, pudiera tacharse con razón á persona alguna que exigiese de antemano la clara y general respuesta de aquellas dudas para fundar sus razonamientos con arierto. Titubearía aún mucho más si persistiésemos en preguntarle cuáles son las necesidades reales para cuya adquisición 6 dominio puede y debe usarse la fuerza pública. Si son inalterables en cualquiera estado de la sociedad los deberes del individuo, ¿hasta que grado son útiles el comercio, la industria y las colonias? Finalmente, ¿qué es lo que entiende por el sumo grado de opulencia al cual pueda y desea llegar?

Ya una mirada, la más sencilla á esta clase de cuentos políticos, le demostraría que es preciso reconcentrarse en sí misma; que son por lo común engañosos, tanto los temores de una dema. siada robustez de las demás naciones, como el afán de imitarlas ó excederlas en la opulencia, y que la naturaleza de sus posesiones ultramarinas, el deseo ilimitado de nuevas conquistas, y el juicio no cabal de lo que ellas valen, no sólo han formado un todo débil y mal urdido, sino que han alucinado también sus pesquisas constantes sobre las causas de un mal tamaño.

Al plan de una reforma útil de la constitución nuestra colonial (si pareciese últimamente nece. saria), debian, pues, preceder en un orden claro é inconcuso, antes una idea cabal de lo que son hoy en día nuestras colonias, de lo que serán mediante el impulso lento y contradictorio de la legisla. ción actual, y del influjo verdadero que causaron á la España su conquista, su posesión y sus productes; luégo ur. examen sencillo de los derechos originales de cada una de las partes que compo. nen la Monarọía, y sobre todo un examen de sus conveniencias, sean internas 6 externas; débese procurar después el reunirlas en el nuevo plan de legislación hasta donde lo permitan los vicics inherentes al hombre en sí, al hombre nacido en un clima y en una situación determinadas, y á los inconvenientes inevitables de la demasiada extensión de dominios..... ¿A qué servirían 6 un espejo fiel de la legislación del día engendrada por la necesidad sostenida por las distracciones que ella misma causaba y robustecida por los órganos que debían impedir su acrecentamiento, 6 unos cla. mores vanos sobre la debilidad nuestra, sobre la fuerza imaginaria de las demás naciones, y sobre las miradas tímidas, sospechosas y traidoras con las cuales debiésemos acecharnos una á otra en cada individuo, en cada palmo de terreno, en cada vara de tegidos pertenecientes á todas? Sería este un nuevo fárrago de ıdeas mezquilias y cansadas, tan importunas y áun despreciables para el Go. bierno y para la Nación, como ignomininsas para quien se encargase de ordenarlas. Llevarían estampadas en su frente las marcas odiosas ó de la adulación, ó de la ignorancia, y sería digno de reprensión y castigo, el que intentase ó alucinar ó seducir al público.

Examinada de este modo la Monarquía, descubrirá sin duda al político nacional una nueva perspectiva agradable. La variedad de los productos en suelos y climas tan varios y tan extenditos, le presenta innumerables medios de ocurrir á sus necesidades y á sus deleites, sin auxilio de otra nación alguna. La inmensidad de sus territorios desvía de un golpe así las discordias internas en el choque contínuo de los poseedores oprimidos, como las externas en el interés mal entendido de los enlaces políticos de la Europa: conocidos los hábitos, la naturaleza, el instinto y el derecho de los indios sujetos, ya los mira como una parte preciosa de sí misma, los despierta, los hace felices con la alternativa del trabajo y del goce, y los multiplica sin temor de que le ofendan; ceden enteramente al blando lialago de la vida sociable y á los pasos lentos, sí, pero pacíficos de los misioneros, tondas las tribus errantes que habitan los bosques y los rios internos; ya no es el espíritu de doninio el que mueve nuestros pasos interiores. Nos basta verlos tranquilos é inclinados á la reunión y al trabajo, para que el legislador vea el fruto de sus medidas y el colono el de sus gastos. Avalúanse después en la balanza de la felicidad pública los metales ricos, los tintes, los simples medicinales, la industria, la agricultura, la de las pescas y todo cuanto tributa 6 puede tributar el contiuente americano á nuestra Europa y á las demás partes del globo. La prosperidad de las co. lonias es una misma con la nuestra. No hay estancos; crece la población, su reunion es sencilla y 


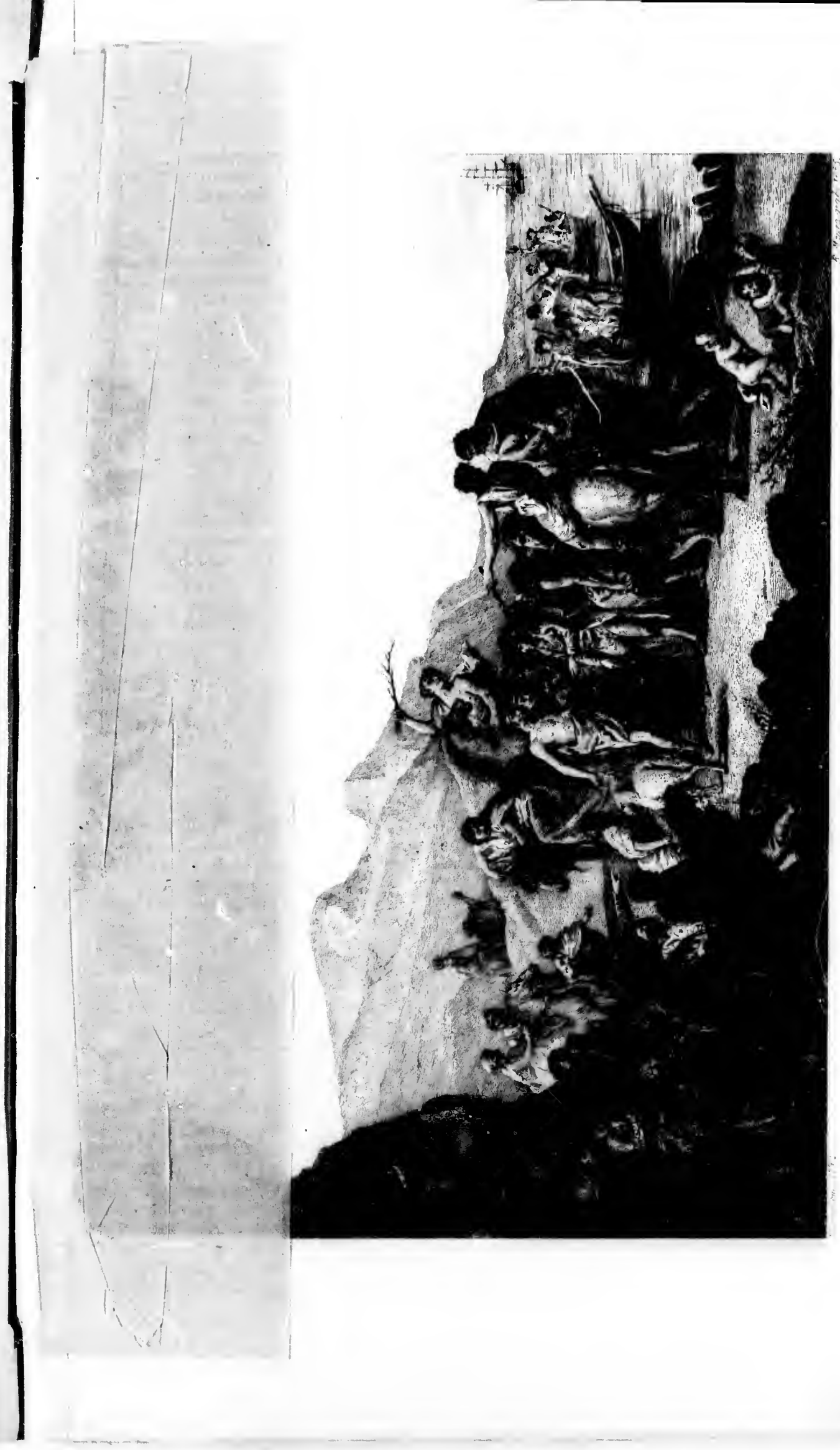


agradable; más fácil su defensa, más suave el impuesto, ménos intrincadas y quebradizas las leyes; más enérgico, sí, pero más coartado el sistema militar; y mirados, finalinente, con una igual predileccion el minero y el agricultor, el colono y el habitante de la matriz, el fabricante y el cosechero, la emigración y el radicarse tonde parezca. La sola idea de un semblante tan halagueño, bastaría para excitar el patriotismo; esto es, aquella persuasión firme, de que sean átiles y justos los sacrificios prescritos al individuo para el bien público; del patriotismo, en una sociedad que nada necesita y que convida á su seno á otros muchos con la abundancia de las tierras fértiles, con la dulzura de su legislacion y con la facilidad de su defensa, derivaría inmediatamente el crédito público; esto es, el concepto que adquiere una nacion consigo misma y con las demás, de ser poderosa en su defensa, justa en sus pretensiones y legal en sus contratos; del crédito público, finalmente, se veria dimanar aquella noble indiferencia, con la cual deben respetarse los derechos y las propiedades de cada nación sea más 6 ménos poderosa, más 6 ménos distante y con la cual ya no se da cabida al sistema político adoptado en Europa; esto es, un sistema en donde los pasos de las sociedades envuelven en sí ántes la lucha de ellas mismas con su gobierno, y luégo la lu. cha de unas con otras sin objeto y sin utilidad.

¡Ohl si por un acaso feliz entre las convulșiones terribles que agitan la especie humana y conspiran contra su propia multiplicación; si fuese destinada la España á contener una mayor efusion de sangre y á cicatrizar unas llagas cuyos efectos serán tal vez funestos por más de un siglo á la Europa desventurada; si descollando con un noble sosiego entre la colision general de principios y de intereses, descubriese al mismo tiempo una moral no violenta, una religión pura, una adhesión gustọsa á su constitución enérgica y cariñosa, un poder extenso brotado casi repentinamente del suelo que habita, y ceñidos los límites de su territorio; unos medios indecibles para aprovecharle y defenderle, porque no sería capaz ella sola de llamar otra vez la opinion pública hacia el orden; y al sosiego de fijar los límites de la autoridad y de la subordinación; de derivar el coloso de una soñada balanza política, la cual haría consistir el bien propio en la debilidad 6 en la ruina de los demás; en fin, de presentar un abrigo tranquilo y uniforme á los que quisiesen adoptar sus leyes, su gobierno y sus derechos nacionales.

Después de estos antecedentes, ya es preciso dar una idea del método seguido ahora para la publicacion, el cual no podrá parecer extraño ni será tal vea desagradable. Atento á la division necesaria para tratar las materias politicas, hemos considerado los dominios ultramarinos de la España divididos en tres grandes trozos: la América meridional desde el Cabo de Hornos hasta el Istmo de Panamá; la septentrional (comprensiva de las Antillas), desde el Istmo hasta sus limites inconcusos al Norte; y las Islas Marianas y Filpinas en los mares del Asia, agregándoles como era natural los intereses nacionales en aquella parte del mundo y en el mar Pacífico, ora se refieran á las colonias europeas, ora á los habitadores independientes de aquellas regiones: á esta división preliminar ha sucedido otra inmediatamente y ha sido la de separar las materias hidrograficas de las que más directamente se referían á la instrucción y entretenimiento comunes: aquellas no podian ser útiles ni exactas, si no las desmenuzásemos con una tal prolijidad y evidencia, que ia vida de los navegantes y las propiedades del comercio pudiesen considerarse seguras en las partes más remotas del globo; esotras, al contrario, debían unir lo útil á lo agradable y convidar á su lectura con la novedad del objeto, con la claridad del método y con la seducción de las materias. ¿Cuál no sería el placer del lector patríbtico, si despues de una corta suspensión de ánimo al ver la lucha del navegante con la tempestad, las escaseces, la variedad del clima y aquel afán constante que le deben causar la estrechez, la monotonía, la incertidumbre de su suerte y los vicios de su imaginacion, se hallase luego trasplantado en un solo instante entre los laboratorios más prodigiosos de la naturaleza, en donde se ven reunidas la fecundidad natural de la tierra, con la suma variedad de los climas, con la acción perpétua de un Océano inmenso que la rodea y con los efectos de un sol más directo y penetrante? Qué, jno se complacería aún más si viese inmediata. mente después el estado del hombre en medio de tantos agentes para multiplicarse y destruirse, para vivir errante y reunirse en sociedad, para trabajar con fruto y entregarse á una ociosidad perpétua? Y finalmente, ¿̨cuál no sería su satisfacción, si viese casi instantáneamente y por un orden natural referidos esos pasos y esas reflexiones à la prosperidad nacional?

Este ha sido, pues, el fin que nos hemos propuesto en la división de las materias; los asuntos hidrográficos se refieren s6lo al navegante, al legislador y á los que quieran por su propia aplica. ción penetrar en el pormenor de la una 6 la otra ciencia. La narración del viaje y la descripción física y política de los países visitados, comprenden á cualquiera clase de los hombres estudiosos; deben darle una idea justa, si no completa, de los establecimientos nuestr os de Ultramar, y conducirle al verdadero patriotismo, demostrándole las ventajas permanentes de la Monarquia, la debilidad de los males que la impiden medrar, y la actividad de los remedios que nos suministra la na- 
turaleza; el todo lleva en si además la división primordial de las diferentes partes de la Monarquía. Asl es fácil á cualquiera no sólo el adquiriry el estudiar la sola mitad de la obra que crea útil, sino también el estudiarla con un método uniforme, por manera que á la par de no poderse confundir en nuestra Europa el clima, el suelo, la navegación, los habitantes y las costumbres de la Rusia y de la España, no se confundan tampoco en adelante las nevadas montañas de Chile y de la costa Noroeste de la América, con los volcanes y las inundaciones del Reino de Guatemala y de las Filipinas ó con los llanos iumensos de las provincias de la Plata y de la costa Pata. gónica.

Entrando ya á detallar con una mayor individualidad el plan seguido en cada una de las dos partes indicadas y dejando por ahora las materias hidrográticas, hablaremos con alguna extensión de lo que comprende la primera parte, esto es, la narración del viaje.

Hállase ésta dividida en tres tomos y cada tomo en tres libros; aquéllos llevan en sí la division natural de la descripción del viaje; de la descripción del suelo y de sus habitantes, y de la descripción de la legislación actual, juntamente con la reforma que parece adecuada al todo de los objetos é intereses nacionales: los tres libros, como ya se indicó, comprenden la América meridional, la América septentrional y nuestros dominios del Asia.

La descripción del viaje, 6 sea el diario, es por su naturaleza más bien cansado; pero era indispensable el dar una idea aunque fuese mediana, del método seguido en nuestras tareas y particularmente de los objetos que han devorado el largo espacio de cinco años; era indispensable el tributar á cada uno de los hábiles individuos que han servido en la expedición la parte de trabajo y los elogios que le correspondiesen; debíamos, en fin, señalar con una especie de sinceridad marinera los inconvenientes relativos á la navegación que, ó fuesen hijos de la constitución general de la Monarquía ó pudiesen con mayor probabilidad atribuirse á defecto de nuestros armamentos y conducta: de la mejor voluntad confesaremos que en ningún modo pudiéramos aspirar á nivelar este viaje con los que ha hecho el Capitán Cook; nuestros sufrimientos y nuestros riesgos han sido en mucho menores á los de aquel navegante esclarecido; tal ve $z$ el ansia de imitarle más de cerca no auxiliándonos igual fortuna, nos hubiera conducido precipitadamente $y$ sin fruto alguno sobre las huellas, ó del desgraciado Conde de la Péyrouse en la costa Noroeste de la América, en las Islas de los Navegantes y en los bancos no distantes de la Nueva Caledonia, ó del Capitán Rion, casi sumergido con el Guardián por accrcarse á una banca de nieve, 6 del Capitán Hunter, náufrago con el Supply sobre la Isla de Norfolk, 6 de la Pandora, igualmente perdida sobre las tierras de Salo. món; repetirémoslo una vez más todavía; el nucstrn no ha sido un viaje de descubrimientos: lle. vaba por objeto el conocimiento de la América para navegar con seguridad y aprovechamiento sobre sus dilatadísimas costas, y para gobernarla con equilad, utilidad y métodos sencillos y uniformes.

Ya el segundo tomo abraza en sí materias mucho más amenas é instructivas. En él, atendida siempre la división de los tres libros, se examinan el suelo con sus producciones, los habitadores indígenas y los colonos. En cada uno de estos objetos, sin omitir particularidad alguna de las que hemos advertido en el viaje, reunimos luégo en un solo punto de vista todas las indagaciones nacionales, y de allí resultan por una parte las vicisitudes que han causado y deben causar en aquel continente, el tiempo, los trámites de la naturaleza y los trabajos lentos, débiles y á veces contradictorios del hombre; por la otra las dos especies de habitantes, que se hallan en.toda ella y en las Filipinas al tiempo de la conquista; esto es, unos hombres embrutecidos, errantes en corto número, entregados á la desnudez, al bosque y á la caza; sin principios sociales, sin leyes, sin gerarquía y sin religión; débiles en sus fuerzas, ilimitados en sus apetitos; y otros procedentes de una emigración antigua, civilizados, unidos, amantes del orden y del gobierno, baștantemente provectos en algunas artes, y sin otra inferioridad á las asociaciones europeas, más que la falta de conocer el usode la pólvora, del hierro, del caballo y de la navegación: á estas dos perspectivas que presenta la América relativamente á su población antigua, siguese luégo la tercera, y es la que deriva de las conquistas europeas, comprendiendo las castas y costumbres mixtas que ha producido y rigen en el día: cuanto más nos acercaremos en estas discusiones interesantes á los informes nacionales, 6 impresos ó manuscritos y al rastro incapaz de borrarse que dejan tras sí la conquista, la legislación y el abuso, tanto más fácilmente veremos derivarse y caer por su propio peso la mayor parte de las novelas y de los sistemas que se han forjado relativamente á la América: sistemas y novelas dignas á la verdad de disculpa, cuando miradas con tanto halago por las naciones extrañas cuanta era la indiferencia con la cual las escuchaban los españoles, tenían además á su favor ora las exa. geraciones militares, ora los clamores de un celo intempestivo, ora las maravillas y milagros de una credulidad por lo común maliciosa.

La mayor parte de este libro será por consiguiente una redacción de obras agenas, más bien que 
un trabajo original. En ella tendrán una parte esencialisima las observaciones locales del Coronel D. Antonio Pineda, las de los hábiles naturalistas D. Tadeo Heenke y D. Luis Nee, pero siempre desprendidas de aquellas descripciones nimias y ordenadas que corresponden mís bien al estu. dio científico de la Historia Natural y deben por la misma razon formar una obra separada. Las leyes unas veces, otras las historias auténticas, y por lo común manuscritos é informes fidedignos de nuestra misma época, serán los cimientos de la descripción de lo que no hemos visto. $\mathrm{Y}$ sin nom. brar á persona alguna cuando las materias pudiesen parecer odiosas, tendremos sin embargo un particular cuidado por medio de las notas, de tributar á cada uno lo que es suyo y autorizar nues. tra obra con sus mismos nombres; por la misma razón deberemos citar á cada paso al Sr. D. Antonio de Ulloa. Este observador filbsofo, que ha seguido la verdad con no seguir los sistemas, y ha estudiado los habitadores de la América con una asiduidad constante y por cl largo espacio de veinte años, merecerá tal vez un nuevo aprecio entre los sabios por la claridad y sencillez de sus descripciones; y las epocas, bastantemente distantes de sus escritos y los nuestros, serán un nuevo apoyo de los pasos ordenados de la naturaleza en aquella parte del mundo.

Pero ya es tiempo de dar una idea algo más difusa del tercer tomo, que trata de las materias po. líticas: la prosperidad y la defensa de la América, y sus enlaces directos y naturales con la matriz, son los puntos esenciales 6 más bien los únicos que debemos tener á la vista: la historia de la con. quista y de la conservación de nuestras posesiones, descenderá por consiguiente muy luégo á la descripción de las demás posesiones europeas; veremos cuáles fueron las causas que las arrancaron de nuestras manos, cuáles las ventajas directas 6 indirectas que de ellas sacan los poseedores, y cuáles los daños reales que á nosotros resultan de su inmediación; y demostrada la poca importan. cia de todos estos objetos, se procurarán establecer de tal modo nuestrcs derechos territoriales, que puedan evadirse de una vez en lo venidero las desavenencias que semejantes cuestiones, natural ó maliciosamente mal entendidas, han originado hasta ahora en tanto número. Fijados ya los limites del imperio relativamente á las demás potencias europeas en una parte, y á nuestra conveniencia en otras, es justo examinar en la inmensidad de paises que aún quedan, cuáles son los que forman una parte efectiva de la Monarqula gobernados ya por nuestras leyes y capaces de contribuir en algán modo á la defensa de la república, y cuáles son los que no debemos considerar como sujetos á la autoridad nuestra. ¿Convendría sujetarlos por las armas, 6 dejar al tiempo, á las misiones bien ordenadas y á un comercio ligado con la humanidad el que se opere paulatinamente esta crisis deseada?

Sea como fuere, ya cada parte de los que constituyen la Monarquía ultramarina así determinada, debe organizarse de tal modo, que suministre para su propia defensa y para una cierta moderada progresión de su opulencia, antes de contribuir á la matriz. Deben, por consiguiente, estable. cerse el pié militar de paz y guerra para los salvajes y para los invasoles antes de determinar el impuesto, examinando al paso qué es lo que contribuye neto en el día á la matriz, y disminuirle, continuar 6 aumentarle según sean sus fuerzas cabalmente reconocidas.

Con estos razonamientos será fácil ver, que la existencia de nuestra marina, aplicada directamente á las colonias, no sólo suministrará unos medios eficaces para la defensa y reunión recíproca de unas costas tan extendidas, sino que aumentándose rápidamente en razón de los mismos auxilios que le presta la naturaleza, vivificará la industria de las colonias, al paso que disminuirá en mucho los gastos de la Armada recargados al Erario de España.

Organizados de este modo los límites y la defensa asi externa como interna de cada parte ultramarina de la Monarquía y dejados á ella misma los medios de atender á su prosperidad local, y aquella administración sencilla de policía y de justicia, que jamás pudiera ligarse ó con una pauta uniforme para todas las provincias, 6 con una inmutabilidad perpétua, por cuanto varían las circunstancias y las necesidades; el orden mismo de las ideas nos guía directamente á desenvolver los derechos legítimos de las colonias y sus deberes sociales entre sí y con la matriz. ¿Cuáles son en el día los sacrificios recíprocos y cuáles las ventajas? Este solo examen, reducido á los objetos de necesidad, de utilidad y de superfluidad, y sujetado á la enorme diferencia del derecho que traen en sí el comercio interno 6 nacional y el externo 6 extranjero, descubrirá con un orden sencillo el verdadero valor de los metales ricos, su circulacion irresistible, su daño real en nuestro Continente, adoptadas las trabas del día y su mayor daño en la América por la persuasión errada d: que sea el símiolo de la riqueza. De allí la indiferencia de la legislación en pro de esta indus. tria; de alli la indiferencia del Continente para amontonarle con violencia; de alli, en fin, el estuJio de los errores políticos que nos han conservado por tres siglos en la misma debilidad y no nos han permitido enfrenar 6 hacer úl:les los pasos de nuestros conquistadores.

Luego hay un medio para que las colonias nuestras de la América sean felices, se fortalezcan, puedan defenderse, $y$ entrando en la asociación natural de la Monarqula como parte activa, tributen 




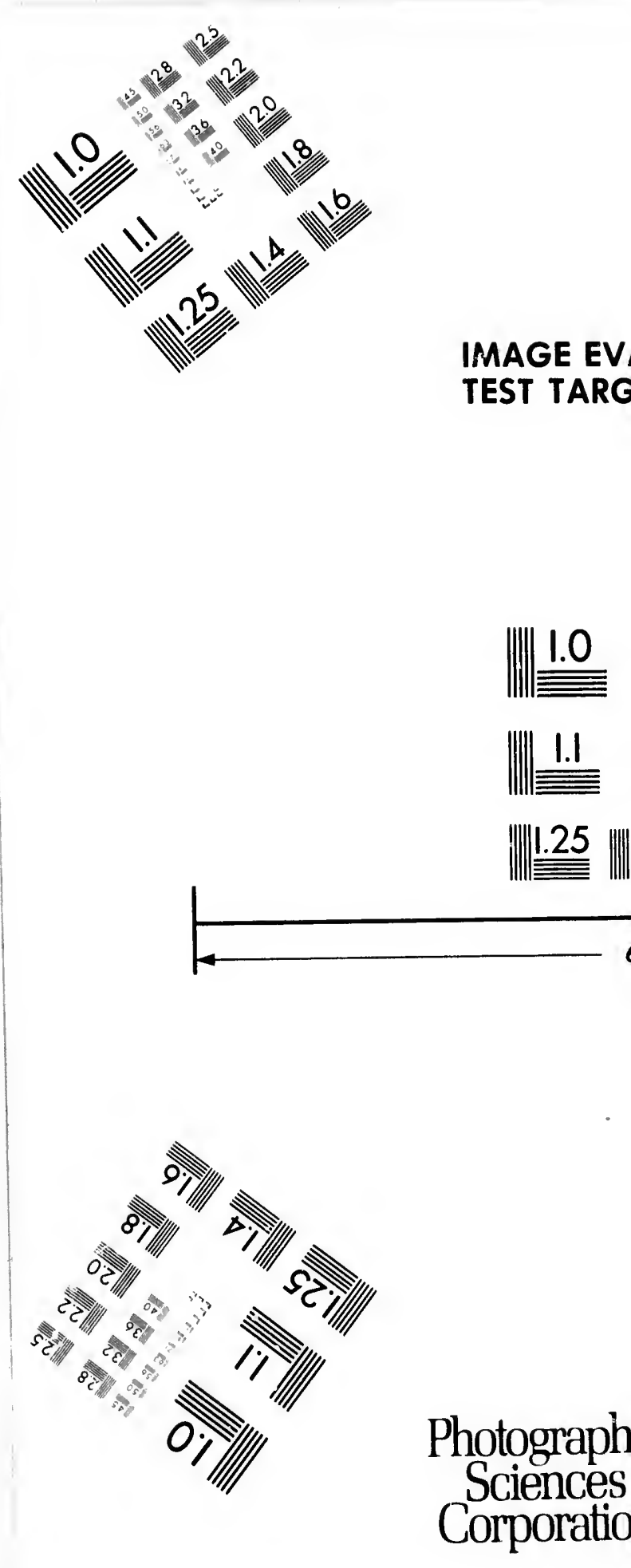


IMAGE EVALUATION

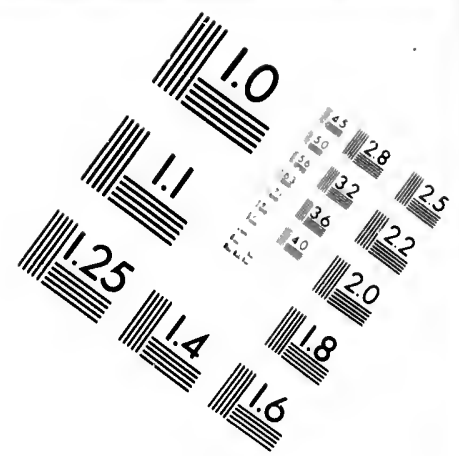

TEST TARGET (MT-3)
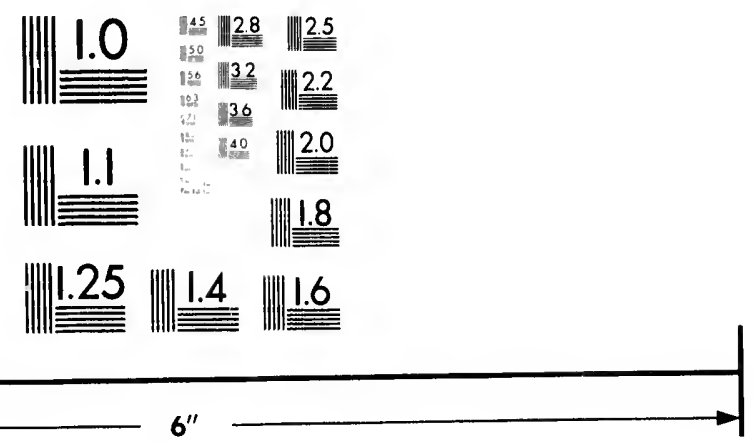

Photographic Sciences

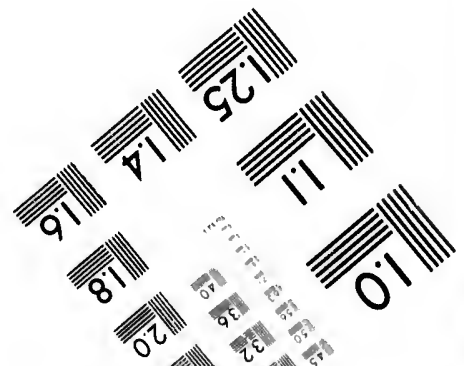

Corporation (716) 872.4503 


\section{CIHM/ICMH Microfiche Series.}


$\mathrm{CMH}$ che

CIHM/ICMH

Collection de microfiches.
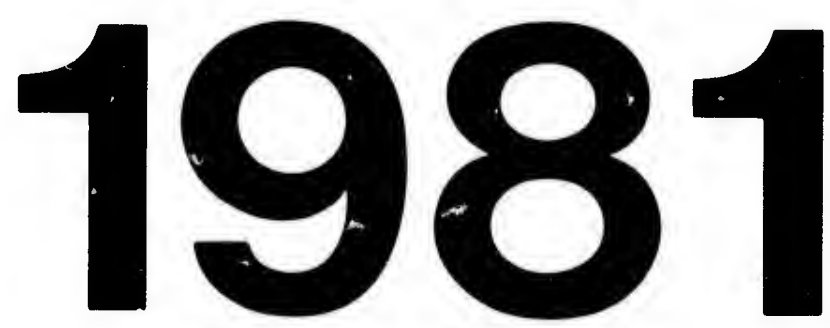
á la fuerza y prosperidad pública aquella cuota que les corresponda. ¿Cuáles son, pues, estos enlaces legítimos de la America con la Europa, enlaces que nos deben conducir á un? independencia absoluta de las potencias rivales, á un sistema de gobierno y de impuestos más moderado y más equitativo, á una población y una educación ınós adecuadas á nuestro estado actual, y á unos prin. cipios de legislación y de opulencia que tan impresos en el español de Ultramar como en el de Europa, un el legislador como en el súbdito, no presenten ya para una misma sociedad un choque contínuo de miras, de intereses y de la fuerza parcial de cada uno?

Semejantes reflexiones, sin las cuales fuera inútil, antes bien, sería pernicioso un examer politico de la América, nos conducen irresistiblemente á un examen de la administración pública de Esspaña. Emancipadas, digámoslo asi, las colonias por manera que deban considerarse una parte alícucta más bien que una parte secundaria de la Monarquía, y examinada su influcncia directa en la fuerza y opulencia del continente, el comercio natural de unas con otras debe inferirse por precisión, y deducir de alli el sistema del impuesto comerciante, distinguiendo lo que damos y consumimos de la Nación de lo que damos y consumimos del extranjero; aquí debemos inmediatamente probar cuán. tos son los vicios de la legi,slación actual de la Europa y en particular de la España, la cual, convirtiéndose de golpe en una nación colona industriosa y comerciante, ha hecho casi necesaria una emigración que prohibe $\mathrm{y}$ ha abandonado el cultivo de los mismos alimentos que necesita. Sin la infinidad de vicios políticos dimanados de la confusión de nuestros intereses con los de las colonias $y$ de los intereses de las colonias con las discordias parciales de la Europa, acaso el desnivel de nuestros precios sería tal que los trigos de Beauce y del Orleanois, distante ciento y tantas leguas del mar, pudiesen llegar á Cádiz más pronto y con una economía de cier.to por ciento en su trasporte cotejados con los de Palencia, que sólo distará 40 leguas de Santancier (I). ¿Acaso el soldado y el minero español, quie en su país no pueden lograr las más veces el pago moderado de un trabajo asíduo y enfadoso, se convertirian luego al punto en la América en otros tantos ministros de la autoridad pública, distinguiclos, ricos y sin necesidad de trabajar?

Pero sobre todo, desembarazada la España de los cálculos políticos en los cuales la envuelven ya la asociación, ya la defensa, ya la administración de sus colonias; sabidos los auxilios 6 periódicos ó extraordinarios, que la pueden tributar; conocidos á la par los esfuerzos militares á que se halla ligada por los mismos contratos, y desterradas lejos de sí misma aquellas semillas inagotables de discor 'ia, ora relativamente al territorio, ora al comercio, ora á los celos políticos con las demas naciones, ¿por qué no podrá ya reflexionar tranquilamente sobre sí misma y sin pensar en una mejor ó peor situación de la que permitan la naturaleza, sus brazos reunidos y los auxilios equilibrados de las demás partes de la Monarquía? ¿Por qué no podrá arreglar su impuesto, restablecer su erario, emplear directamente sus fondos para su propia opulencia y hacerse respetar sin necesidad de otro alguno por las demás potencias de la Europa?

De alli derivaría tal vez un nuevo plan del derecho público confundido en el día, como ya se ha dicho, con el derccho comerciante; derivarian la mútua dependencia de las colonias con la matriz, con medios tan directos, justificados y naturales, cuanto son torcidos, injustos y perniciosos los que rigen en el día; derivaría, finalmente, el método de captar en cada año la opinión pública y el amor al Gobierno, con hacer públicas la administración y la existencia de los caudales y fondos de la Nación. Pero esta empresa pertenece á un ramo particular que no está comprendido en nuestra esfera, y es la organización interior de la España. Para nosotros bastará el sacudirla de los pesadísimos grillos que la causan las posesiones de Ultramar, y presentarle un plan general de reunión, con el cual sean todas felices y no teman las invasiones externas, ni apetezcan las riquezas agenas.

El deseo de dar una idea algo clara del plan propuesto en la verificación y en la publicación del viaje, nos ha hecho difusos; pero era indispensable, tanto para iustifiçar el método adoptado, como para hacer ver desde el principio el último término que hemos llevado á la vista en nuestros pasos, y es la prosperidad śllida de la Monarquía. Aliora volveremos á reasumir el hilo de la publicación para dar idea de los demás ramos que abraza el total de la obra.

A los tres tomos inđicados se sigue otro relativo también á la narración, y trata del viaje oue verificaron en 1792 sobre la costa Noroeste de la América, las :;oletas Mejicana y Sutil, del Departamento de San Blas, á las órdenes de los Capitanes de navis D. Dionisio Galiano y D. Cayetano Valdés, sirviendo en clase de sus subalternos los Capitanes de fragata graduados D. Juan Vernaci y D. Secundino Salamanca. Galiano y Vernaci han sido los redactores. Comprende además de los descubrimientos interiores del decantado Estrecho de Juan de Fuca, los trabajos hechos de mancomún con la expedición ingla del Capitán Vancoover, una idea bien clara de las costumbres

(r) Menoria mos. de D. Gaspar Jovellanos sobre in Agricultura de España. 
y ritos de aquellas naciones, y cuanto conduzca á aclarar indubriahlemente las ventajas y alcances del comcrcio europeo en aquellos mares. Le han añadido después una narración extractada de todos los viajes nacionales hechos hasta el día sobre aquella costa, y últimamente han procurado dar una idea no ménos exacta de los establecimientos rusos de la Siberia, y de las utilidades que prometen comparados á los gastos y á las pérdidas que han causado hasta ahora.

Tal vez podrán comprenderse como apéndices á este mismo tomo, los extractos de otras tres expediciones que han dimanado de la de las corbetas; y son la del Capitán de fragata D. José Meléndez del Departamento de San Blas á las costas de Tecoantepeque y Soconusco, en los Reinos de Nueva España y Guatemala; la de los Pilotos D. Juan Maqueda y D. Jerónimo Delgado en las Islas Visayas 6 Filipinas meridionales y la del Capitán de fragata D. Juan de la Concha, con los Pilotós D. José de la Peña y D. Juan Inciarte, al Gulfo de San Jorge en la costa Patagónica orien. tal, entre los paralelos de 45 y $47^{\circ}$ de latitud meridional.

Corresponden á estos cuatro tomos en una masa común setenta diseños, cuyo objeto es el de dar una idea á las veces de las costumbres de algunos paises aún no bien conocidos de los europeos, á las veces de los pobladores, 6 indígenas 6 colonos de nuestros dominios ultramarinos, $y$ á las veces de la situación y hermosura de algunas capitales de América. Son todos sacados del natural por los hábiles sugetos que en diferentes épocas nos han acompañado, y de los cuales daremos una relación individual al tiempo de hablar de los armamentos de las corbetas.

A esta parte del viaje, la cual hemos mirado como preferente, sólo porque se refería á un mayor número de personas, síguense ya los trabajos hidrográficos que distinguimos con el nombre de Atlas de la América meridional, de las demás costas de la Monarquía en el Mar Pacífico, y de las Islas Marianas y Filipinas. Se le han añadido después por una parte las cartas necesarias para las navegaciones nacionales en el Océano Atlántico desde las Islas de Cabo Verde, término de las publicadas por los Jefes de escuadra D. Vicente Tofiño y D. José Varela, y por la otra tołas las que indiquen los descubrimientos modernos y las derrotas antiguas nacionales. Reunida esta colección á la de los mares de la India, trabajada por los navegantes ingleses y franceses; y á la del seno mejicano, actualmente entre manos de orden de S. M., el navegante nacional tendrá siempre á la vista datos individuales y bien claros para dirigir sus viajes con igual seguridad y presteza á do le llamen 6 el servicio del Estado 6 sus intereses particulares. Comprenderá nuestro Atlas unas setenta cartas, parte esféricas, parte de los planos de los puertos y parte con las vistas de las costas.

Aunque el diario 6 el primer tomo de la narración del viaje aclare en cierto modo la escrupulosidad con la cual hemos mirado esta parte esencialísima de nuestro destino, nos ha parecido, sin embargo, un deber anexo á la nimiedad que piden semejantes trabájos, el de individualizar antes los materiales de donde han dimanađo, y luégo los derroteros que hagan más fácil, ménos cansado y más general su aprovechamiento.

Todos los objetos indicados se comprenderán un dos tomos: el primero se formará con el voluminoso diario astronómico, las observaciones meteorológicas hechas en los puertos y en el mar, y los estados de la declinación de la aguja; lo hará luégo sumamente útil é instructivo un tratado de navegación y geodesia que le hará preceder D. Dionisio Galiano, aplicando á una práctica bien comprobada, varios métodos tan útiles como nuevos que le ha sugerido el estudio constante de la Astronomía y de los demás ramos que corresponden al pilotaje sublime; últimamente, en una Me. moria separada, el Capitán de fragata D. Ciriaco Cevallos, expone con mucha claridad el resumen de nuestras experiencias sobre la gravedad de los cuerpos, hechas con el péndulo simple constante en diferentes paralelos de entrambos hemisferios, y las refiere al mismo tiempo á la figura de la tierra, nó tan simétrica como se suponía, y luégo á una medida universal, cuya conprobación constante é invariable en diferentes parajes, dependa sencillamente de los resultados de las experiencias hechas hasta ahora, ó por nosotros ó por los viajeros que nos han precedido.

Corresponderán después al otro tomo, que será el sexto de la obra general, la recopilación de los elementos que han servido de base á nuestras cartas y los derroteros de las navegaciones ra "stas comprenden. Un tratadito sobre los vientos y las corrientes y otro sobre las derrotas más breves por alta mar de uno á otro paraje del globo, cualesquiera sean las estaciones del año, hará ver á continuación, cuántas son las vías, y cuánto son fáciles para comunicarse contínuamente entre sí la América, el Asia y la Europa.

Siguiendo por naturaleza en los trabajos indicados, por: una parte las noticias astronómicas que se nos han comunicado ó sabíamos de antemano, y por la otra la serie casi inmensa de los navegantes nacionales que nos han precedido para los reconocimientos parciales de la América, procuraremos no defraudar á persona alguna el fruto de sus fatigas, bien que dejando aparte aquellas cuestiones hidrográficas sobre la primacía y la legitimidad de los descubrimientos, que ya tantas veces han sido agitadas en la Europa y siempre decididas pór el público imparcial á favor 
de la navegación antigua española. El mejor modo de dispersar las acusaciones, con las cuales á su salvo varios escritores lian tachado la España hasta estos últimos años, scrá ciertamente el de no impugnarlos sino con los hechos cuando se hallasen infundadas, 6 el demostrarles, cuando fuesen fundadas, que ni eran absurdos nucstros misterios pasados, ni era otro, tal vez, el objeto de la publicación de sus viajes, sino el mismo que manifestaba la ocultación de los nuestros ó como prudente, 6 como necesaria.

Con los seis tomos ya indicados, concluiría la obra que ahora presentamos al público, si la habilidad y la aplicación constante de los Cirujanos de ambas corbetas, D. Francisco Flores Moreno y D. Pedro González, no diesen ocasión de añadirles otro tomo relativo á la conservación de la salud de los navegantes españoles. En balde intentaremos recomendar esta obra tanto como ella merece; se hallan aplicados á la práctica con igual felicidad los conocimientos más modernos sobre la digestión animal, los inventos más preciosos para la depuración del aire y del agua, los métodos más seguros para preparar y conservar los viveres, y finalmente, los muchos medios que para la conservación del navegante en los climas temibles de la Zona Tórrida suministra la naturaleza en las posesiones españolas: se comparan ahora con la reflexión y tino correspondientes, la calidad del marinero español y la de los navegantes ingleses; los vicios que produce el mar y los que dimanan de los países inmediatos á la Equinoccial. El escurbuto, las fiebres pútridas y las catarrales, juntamente con las causas que las producen, pasan por un examen igualmente científico, claro é inteligible; se enumeran las muchas bebidas fermentadas que es fácil aplicar á la navegación; tráense luégo á una comparación exacta con los principios prescritos, las varias enfermedades acaecidas últimamente en nuestras escuadras; y finalmente, se prescriben por una parte los temperamentos y métodos de vida que más bien correspondan á los muchos climas que presentan nuestras posc. siones dilatadísimas, y por otra el sistema de disciplina que parezca más propio para los buqu's de S. M., reunidos en un sólo punto de vista los objetos militares, los de policía y economía y lis de la conservación del individuo.

Estos son los límites actuales de la publicación del viaje. Se seguirán luégo, con un plazo pr )porcionado á la multiplicidad é importancia de los materiales, las diferentes obras científicas que se refieren más directamente á la Historia Natural. Los her manos y herederos del difunto D. Antonio Pineda, tributarán ciertamente de mancomún con la Nación entera este nuevo homenaje á las ciencias y á la memoria de aquel hábil filósofo.

Luégo que regrese D. Tadec Heenke, el cual ha recorrido por un año más la América meridional con indecible ventaja de los varios ramos de la Historia Natural, serán públicas ignalmente las colecciones botánicas y zoológicas que ha formado, y describirá á la par con el otro botánico, Don Luis Nee. Tal vez no sería aventurado el asegurar que las colecciones formadas en el viaje son las más sclectas que existan en el día, por sus rarezas, variedad y número. El de las plantas no es ciertamente menor de $\mathrm{r}_{4} .000$.

Describirá después el mismo Heenke, con la elegancia que le es propia, los importantes paises que ha recorrido últimamente en los Vireinatos del Perú y Buenos Aires, penetrando á Guamanga y Guancavelica, el Cuzco, Arequipa, la Paz, Potosí, los Yungas, Chucuito y el fértil país de los Moxos; las antigüedades peruleras, estudiadas ahora en el Cuzco, darán nuevo matirial para conocer la arquitectura de aquellos pueblos, que ya D. Fernando Brambila había estudiado y descrito con tanto acierto á la par de la arquitectura mejicana. En fin, cuantas ideas hayamos adquirido y cuantas podamos adquirir en lo venidero sobre los objetos que abraza el viaje, otras tantas se presentarán al público como un tributo que le es debido y como una prueba de nuestro deseo incesante de coadyuvar á las intenciones benéficas de $\mathrm{S}$. $\mathrm{M}$.

Aclarado con alguna individualidad el objeto del viaje y el método ahora adoptado para su publicación, debemos con igual claridad manifestar cuáles fueron los aprestos y las medidas tomadas para el intento; serán éstos una prueba bien evidente de la generosa protección del Rey ś favor de las ciencias y de la navegación, y harán ver las razones por las cuales nos hemos apartado á las veces $\mathrm{y}$ otras hemos imitado servilmente á los navegantes que nos han precedido en esta senda.

Las dos corbetas con las cuales se ha verificado el viaje eran absolutamente iguales, $y$ en ellas reunió el Brigadier D. Tomás Muñoz, Ingeniero Director y Comandante del Arsenal de la Carraca, todas las propiedades que parecieron más ventajosas, así para la resistencia como para la capacidad y comodidad del buque: sobre 120 piés de eslora, $3 \mathrm{I} \%$ de manga y ${ }_{5}$ de puntal, manifestaban un arqueo de 306 toneladas; macizadas las cuadernas y calafateadas sus juntas, presentaban un se. gundo costado inaccesible al agua del mar, aun cuando el fatal encuentro de algún escollo hubiese roto la tablazón extericr; eran los fondos forrados antes con madera sujeta con clavos de metal y luégo con planchas de cubre, por manera que se destruyesen los perniciosos efectos de éstas sobre la clavazón interior de hierro. El calado no excedía á popa de $13 \%$ piés, facilitando así el poder 
internar en cualquiera cala de poco fondo. $\mathrm{Y}$ proporcionadas luégo las dimensiones de la arbola. dura, para que no se opusiese un aguante extraordinario de vela á una regular velocidad, habíase logrado un excelente gobierno y una deriva más bien moderada, particularmente cuando se hiciese el debido uso de las mayores. Podían contener los buques en su bodega y sollado dos años de víveres para la dotación asignada, y seis meses de aguada y leña; los pertrechos de todas especies y particularmente de hierro, lona y jarcias, eran adaptados á la falta absoluta de estos efectos, que ha. llaríamos en los diferentes puertos de la America. Eran igualmente crecidos los repuestos para vestuario de la marinería y para efectos de cambios. Las embarcaciones menores llegaban á cinco para ocurrir á los diferentes objetos de la aguada, leña, caza, pesca, observatorio, Historia Natural y comunicación contínua de los buques con la playa; aumentadas las lanchas y aprestadas con cubierta de hierro, como lo verificamos después en Guayaquil y San 13las, podian las tres embarcaciones mayores contener tcila la dotación de los buques en el caso de un naufragio. Al mismo tiempo, los fogones de hierro para dulcificar el agua del mar, con dos alambiques, aplicado el segundo al caldero de la comida, suministraban el agua necesaria para la subsistencia de todos. Y lo que nos pareció lo más interesante; ni había persona alguna que no alojase en la cubierta principal, esto es, en un paraje bien ventilado y en donde el mismo fogón, con una acción contínua, debía renovar frecuentemente el aire, ni en los alojamientos dejaba de haber aquel método y diferencia que exigen, sí, la conservación de una buena disciplina por largo tiempo. Sería cansado, mas no totalmente inútil, el repetir uno á uno los diferentes reparos que se tuvieron presentes para esta distribución de alojamientos, la cual, luégo por lo que toca á la Oficialidad de guerra reunía, los objetos de una total independencia entre sí, de la debida quietud para las tareas científicas y de sitio cómodo y oportuno para reunirse y no olvidar los halagos de la vida sociable, sea con el auxilio de la música 6 con la lectura de libros igualmente amenos y entretenidos.

Ni en lo que mira á la buena calidad de los aparejos, velámenes y otros pertrechos, fué méno's eficaz el Brigadier D. Fermín de Sesma, Subinspector del Arsenal de la Carraca. Toł́o era de ia mejor calidad y proporciones, y para un facultativo será buena prueba de esta asє rción, el que la aseguremos haber sido una misma la driza de gavia que ha servido en la Descubierta durante el largo espacio de cinco años y dos meses.

A estas dos clases de aprestos, de las cuales dependia en mucha parte la seguridad del viaje, siguiéronse luégo las no ménos importantes que se referían á la conservación de las tripulaciones. No ignorábamos (como se ha hecho ver ya), que nuestras escalas repetidas en los varios puertos de las colonias nacionales, proporcionarían el renovar los víveres cuantas veces fuese necesario; pero teníamos también á la vista el que mil alimentos de los que suministran las últimas navegaciones, pudieran á veces presentar objetos de variedad y de economía aun cuando no ofreciesen (lo que parecía difícil), ventaja alguna para la conservación de la salud.

Adoptáronse con esta atención el Snarkrout y las salazones del tocino, éstas por ambos métodos usados por el Capitán Cook y por. el Conde de la. Péyrouse: hicimos grande uso del vino de Sanlúcar, al cual sustituyóse el de Chile, y finalmente, el Groog ó aguardiente aguada. Turnaban después la suministración de las comidas calientes y del gazpacho, el uso de las bebidas fermentadas y la diferente distribución de horas, según los climas y las estaciones en los cuales nos hallamos. A lavez se premió el baño, siempre se animó el ejercicio con tal que fuese moderado, ni nosotros, cuando no le hallásemos absolutamente neçesario, prescribimos el trabajo en las horas de la mayor fuerza del sol estando en los climas más temibles de la Zona Túrrida. Por la misma razón de promover un ejercicio frecuente en todas las clases de los armamentos, se procuró que la ma. rinería y tropa estuviesen siempre á dos guardias y que los demás individuos fuesen tambien com. prendidos por lo general en este útil servicio. Nunca se omitieron, cuando estuvimos fondeados, la pesca, la caza y el aprovechamiento en el caldero de aquellas yerbas saludables que ofrece la na. turaleza al navegante áun en los parajes más áridos y desiertos. La narración del viaje manifes * tará después que muchas veces, más bien debimos reponer en el mar los armamentos harto debilita. dos en los puertos, que no expresar en éstos el restablesimiento de los efectos harto comunes de la navegación.

Pero el resorte principal que adoptamos para la conservación de nuestro hombre de mar, fué sin duda alguna la tranquilidad del ánimo. En balde intentaremos suponer en el marinero espanool aquella misma insensibilidad, que tantas veces se advierte y parece incorregible en el marinero del Norte. Los nuestros raciocinan, preven, y en una larga enumeración, por lo común abultada según los mismos efectos de la imaginación, conservan la idea de todas las desgracias acaecidas en las navegaciones harto aventuradas del mar del Sur; de allí aquel entrometimiento impertinente en todas las providencias adoptadas y en los obstáculos que se encuentran casi diariamente; de allí aquel vuelo indecible de la suma valentía á la suma abyección, según los trances 
reales ó imaginarios que se le presenten; de allí, finalmente, un tránsito igualmente actelerado de la salud $r$ as robusta á una enfermedad epidémica; enfermedad que agravıı luégo más y más los mis. mos induios de su fatal existencia á bordo. Por ventura un verdadero espíritu de subordinación les hace tener las miradas siempre fijas en la Oficialidad de guerra que los gobierna. Basta que éstos sepan templar con tino el rigor y la dulzura, la fatiga y el descanso, la severidad y la persuasión, el acomunarse en cierto modo con ellos y el apartarse repentinamente á mucha distancia, para que la generosidad nacional se despierte luego al punto y obre con toda la energía debida para infundir. ántes la tranquilidad del ánimo y triunfar despues de los mayores obs'áculos. Pero de las ideas relati. vas á la conservación de la salud, se liablará con la debida extensión en el séptimo tomo ó tratado mé. dico. Nos ceñiremos aquí á ratificar lo que había demostrado con la mayor evidencia el Capitán Cook, y es que relativamente á los víveres y á la conservación económica del navegante, no hay plazo, no hay clima, no hay punto alguno de la tierra en donde no sea fácil conseguirlo, con tal que se mo. difiquen las reglas generales á los hábitos y calidades de cada nación. Por lo que toca á nuestres aprestos, e: Swrkrout se mantuvo por dos años largos de buena calidad, exceptuándose, sin embargo, aquellas barricas que por falta de sal ó por una introducción del aire atmosférico entre las tongas no bien comprimidas, pudrieronse muy luego y despedian una fetidez extraordinaria. Los tocinos salados por uno y otro método, han durado por el espacio de tres años, con tal que se les renovase de tiempo en tiempo la salmuera. No resistieron tanto las menestras sin ser invadidas por el gorgojo; lo mismo sucedió al pan. No así á las harinas, particularmente de Filadelfia, las cuales conservaron la misma excelente calidad después de dos años de haberse embarcado en Cádiz. Hízose también una prueba escrupulosa con las carnes saladas de Montevideo. Las tuvimos fabricadas en el año de 1786 , y después de haber navegado por cuatro años y medio, se conservaban aún de buena calidad en Marzo y Abril de r 794 .

A estos aprestos para la conservación del hombre, fueron después proporcionados los que exigía con justa razbn el hombre enfermo. Las pastillas de caldo se fabricaron por diferentes me. todos, los más introducidos en Europa. Dispúsose un abundante acopio de zumos de naranja y de limón. No descuidamos el embarcar algunas barricas con cebada fermentada y molida. Las cajas de medicina variaron mucho del método común de los buques de S. M., varió también el sistema de enfermería, evitando el embarcar dietas vivas y el destinar paraje fijo para los enfermos. Cuál haya sido el fruto de cada una de estas medidas, se manifestará después con verdad y método al tiempo de hablar, en el tratado médico, de éstos y de los aprestos que se indicáron en los párrafos anteriores. Aqui añadiremos, que en la dirección de nuestras medidas para este ramo, intervino de ordeı de S. M. el Proto-Médico de la Real Armada, D. José Salvaresa, cuyo dictamen sobre la conservación de la salud en el niar, se halla comprendido en tres cartas responsivás á otras tantas que manifestaban nuestras dudas 6 incertidumbre para apartarnos unas veces de los métodos nacionales y otras de los que nos prescribían casi invariablemente los extranjeros.

Ya es tiempo de decir algo también sobre los objetos científicos que se prefijaron en el viaje y sobre los medios empleados para conseguirlos. Han sido muchos; nos han ocupado incesantemente; los dirigian por la mayor parte homores bien conocidos en la república literaria, y el sabio Ministro que dí el primer impulso á la expedición y la ha protegido después con igual constancia y generosidad, condescendió desde luego á que se consultasen, con aquella docilidad que es siempre in. separable de la ciencia verdadera y del deseo de coadyuvar con la mayor extensión á la utilidad sólida de nuestros semejantes. Franqueáronse desde el mismo principio los archivos de las Secreta. rías de Indias y Marina, para extraciar los materiales hidrográficos que en ellas hubiese. Este primer examen manifestó de nuevo la necesidad del viaje próximo á emprenderse, pues confundidos en una sola masa, materiales á las veces excelentes y otras perniciosos 6 en una perpétua contradicción los unos con los otros, si descubrían por una parte los esfuerzos repetidos y costosos que habia hecho constantemente el Gobierno á favor de la navegación, convencían por la otra cuánto era fácil ó debilitarlos ó hacerlos inútiles con la sola insuficiencia de los medios adoptados para consegıirlo. Tuvimos, igualmente, una orden circular para que se nos franqueasen en las diferentes capitales de la América los archivos de los expulsos jesuitas, en donde con mucha probabilidad se hallarían rastros recientes de los reconocimientos y viajes interiores que aquellos religiosos habían verificado en el siglo pasado y en el actual, ó con el objeto de coadyuvar á la conversión de las naciones no conquistadas, ó para auxiliar al Gobierno on el estudio é investigaciones de un pais de tanta extensión; pero frustráronse también aquellas medidas, hallándose aquellos archivos en parte maltratados, y despojados en parte de lo que tuviesen de más precioso. Fue, finalmente, preciso recurrir á los autores impresos, bien que con la felicidad do poder comparar en las diferentes capitales de nuestros reinos ó provincias aquellas nociones qu sirviesen de base para la historia de la América con los manuscritos é ideas locales que de allí mismo pudiesemos derivar. 
Sin omitir de indicar lo más difusamente en los parajes de los tomos siguientes que por naturaleza lo exijan, no debemos en esta ocasión pasar en silencio que hemos hallado en todas las personas ilustradas de la América, á cualquier ramo á que correspondiesen, otros tantos socios de nuestra empresa, los cuales, por consiguiente, la han facilitado sobremanera y han ratificado asi, tanto la necesidad de una reforma, como las causas, harto complicadas, que han llevado la América al estado en el cual se halla hoy en dia.

A estos elementos esenciales para el acierto de nuestros pasos y á los encargos más estrechos del Gobierno á los Vircyes y Capitanes Generales de las provincias para que auxiliasen esta em. presa con cuantos medios les dictaizen su celo y los conocimientos locales, virnos añadirse después con indecible utilidad dèl servisio varios dictámenes bien importantes de los Excmos. Señores D. Antonio de Ulioa, D. Juan de Lángara y D. José Mazarredo, sobre la Hidrografía y la constitución física de la América meridional, sobre la adquisición y el uso de la mayor parte de los ins. trumentos astronómicos, y sobre algunas experiencias relativas al nivel de los dos mares, Atlántico y Pacífico, y sobre varias modificaciones en el casco, en las maniobras y en la disciplina de nues. tros buques. Consultóse también al Teniente General D. Gabriel de Aristizábal. El Marqués de Ureña dio varias nociones sobre la aplicación de los aires fijos á diferentes enfermedades y sobre el mejor uso de los eudiómetros, y D. José Armenteros, Secret ario en Manila por la Real Compañía de Filipinas, á instancia del Gobierno, agregó á las nuestras todas las reflexiones físicas y políticas sobre aquellos establecimientos que le había suministrado el estudio más asíduo de veintidos años. Tantos auxilios bastaban por sí solos para alentar á la empresa los hombres aún más tibios y des. confiados de sus propias fuerzas. ¿Pues qué, cuando concurrieron al mismo intento varios doctos ex-jesuitas residentes actualmente en Italia, los abates Cordoba de Castro, Jimenez y de Cesaris, el Marqués Gerardo Rangone y el abate Spallanzani de la misma Italia; el Sr. La Lande, de París, y los Sres. Banks y Dalrymple, de Lóndres? Debémosles, 6 unas direcciones oportunas sobre aquellos puntos á los cuales con más acierto pudiesen dirigirse nuestras investigaciones siguientes, 6 aquellas correspondencias sucesivas que aclarasen particularmente, por lo que toca á la As. tronomía, las dudas que debían dimanar por precisión de unas operaciones aisladas é independientes hechas á tamaña distancia de la Europa.

Intervino después el Sr. D. Alejandro Dalrymple en el acopio hecho en Londres de la mayor parte de los instrumentos astronómicos, de los cuales se dará una razón más extensa. en el diario de las observaciones. Empero no fuimos tan felices por lo que toca á una excelente cole cción de instrumentos hecha en París para los progresos de la física. No llegó á Cádiz á tiempo de poderla embarcar en la.s jorbetas, y equivocadas después las marcas con otras remesas correspondientes á la minería de Méjico, jamás pudimos recibirla por cuanto fuesen eficaces nuestras diligencias para el intento en los diferentes puertos en donde estuvimos.

No faltarnn, sin embargo, al genio sumamente laborioso del Teniente Coronel D. Antonio Pineua, oastantes medios para esplayar constantemente su amor indecible á los diferentes ramos de la Historia Natural y aquella actividad que finalmente le trajo al fin desgraciado de su vida. Tuvo á sus brdenes una excelente librería, acopiada en parte en Madrid y en parte en París. Los hábiles botánicos D. Luis Ne z y D. Tadeo Heenke, además de atender con la mayor asiduidad á su objeto principal, no descuidaron el auxiliarle con cuantas indagaciones útiles le viniesen á mano, especial mente en la Litología. Pintores y disecadores procuraron conservar cada cual en el modo que su profesión les permitía, los objetos más raros que la naturaleza iba desplegando á su vista en los varirs paises que recorríamos. Encargábanse otros al mismo tiempo de la caza y de la pesca. Pre. miábase altamente á los naturales que presentasen algo útil para las colecciones y el estudio. Así pudimos remitir en difereutes ocasiones al Real Gabinete de Madrid unas 70 cajas con esos mismos acopios..... ¡Oh! si la suerte nos hubiese concedido el reconducir sano á su patria al mismo Pineda, ¡cuánta utilidad no debía ésta prometerse de un examen científico, tan extcndido como él habia procurado abrazarle y de su carácter tan investigador como filántropo. No defraudaremos á lo ménos cosa alguna á su memoria en la actual recopilación del viaje, bien sea conservada en sus manuscritos ó deducida de sus conversaciones verbales; tiempo vendrá en que siendo públi bién con el detalle debido todas sus descripciones zoológicas y los muchos objetos particulares sobre los cuales se extendieron sus incesantes observaciones, la Nación conozca la pérdida que hà tenido.

Concluiremos ya esta introducción, bastantemente difusa, con recordar al lector la juiciosa advertencia de Mr. de Bouganville al tiempo de escribir la narración de su viaje, viendo cuánto debían por naturaleza apartarse uno del otro, el estilo bronco y árido del hombre de mar, del más ameno, elegante y entretenido, que por sí exigen las narraciones de un viaje. Felices nosotros si pueden compensarlas, á lo ménos en parte, la verdad, la sencillez y el amor del bien público que 
no hemos perdido un solo instante de vista. Felices, finalmente, si en la ejecución y en la publicación de esta obra hemos acertado á obedecer completamente las benéficas órdenes de S. M. y las sabias providencias de su Ministerio ( $\mathrm{x}$ ).

Las corbetas, arreglada la marcha de los relojes marinos en el Real Observatorio de Cádiz, provistas de cuanto les fué necesario y examinadas de antemano sus propiedades marineras, se hallaron prontas para dar la vela en los últimos días del mes de Julio; eran voluntarios todos los in. dividuos que en ellas navegaban. Los carpinteros, calafates, herreros y 45 marineros, procedian del Departamento de Ferrol; completáronse los demás en Cádiz. Los armamentos, al tiempo de dar la vela, se hallaban en el pié que á continuación se expresa:

\section{Corbeta Descubierta.}

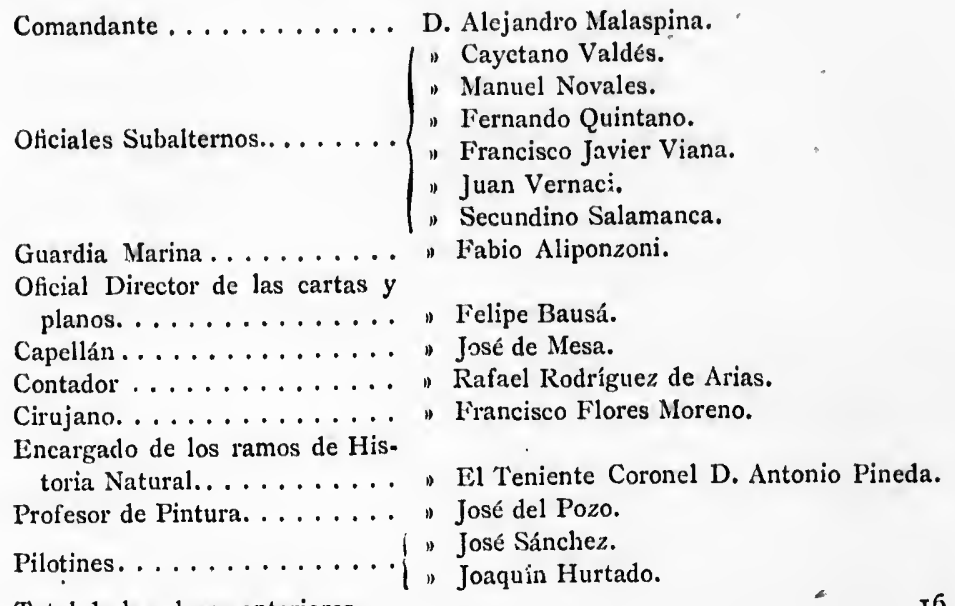

Total de las clases anteriores. ................. I6

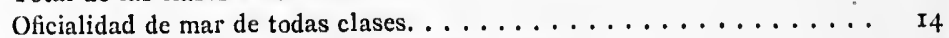

Tropa de marina con un Sargento y dos Cabos. ............. I5 $_{5}$

Tropa de brigadas con un Condestable. .............. 4

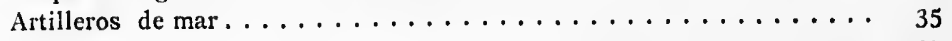

Grumetes........................ ro

Criados. ....................... 8

ToTAL. .......... 102

\section{Corbeta Atrevida.}

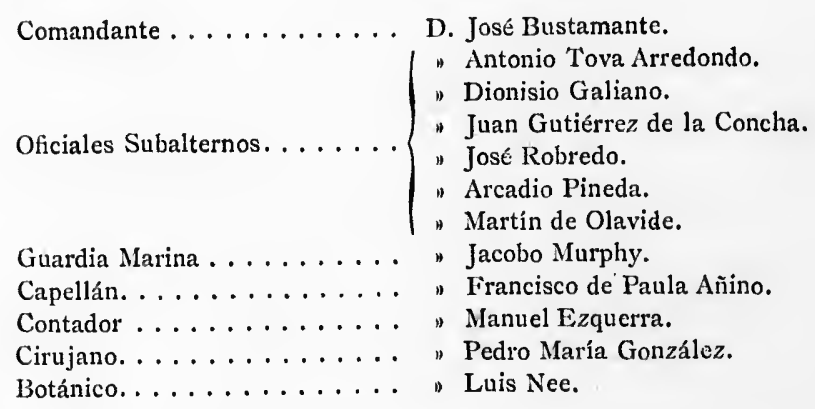


Piloto... . . . . . . . . D. Juan Maqueda.

Disecador y Pintor Botánico. . . "José Guio.

Pilotines. ........... "Jerónimo Delgado.

Total de las clases anteriores. ................... I6

Oficialidad de mar de todas clases. .................. I4

Tropa de marina con un Sargento y dos Cabos. .............. I5

Tropa de brigadas con un Condestable. ................ 4

Artilleros de mar. . . . . . . . . . . . . . . . . . . . . 35

Grumetes ..................................... ro

Criados................................ 8

TOT'L.............. 102

Agregáronse luégo á la expedición, como se verá en el diario, el Botánico D. Tadeo Heenke en Santiago de Chile; los Tenientes de navío D. José Espinosa y D. Ciriaco Cevallos, y los Profe. sores de pintura D. Fernando Brambila y D. Juan Ravenet, en Acapulco; y se separaron D. José del Pozo, en la primera escala en Lima; D. Dionisio Galiano, D. Cayetano Valdés, D. Juan Vernaci, D. Secundino Salamanca y el Pintor José Guío, en Acapulco; D. Martín de Olavide, D. Juan Maqueda, D. Jerónimo Delgado y D. José María Sánchez, en Manila; D. Tadeo Heenke en la segunda escala en Lima; y finalmente, D. Juan de la Concha y D. Juan Inciarte en la segunda escala en Montevideo; todos con diferentes destinos relativos á la misma comisión esencial de las corbetas, excepto los dos Pintores y el Piloto D. José Sánchez, á los cuales obligó á este partido el mal estado de su salud.

En los seis meses que estuvimos sobre la costa Noroeste de la América, nos acompañó tam. bién, en clase de Profesor de Pintura, el Académico de Méjico D. Tomás Suria. 


\title{
LIBRO PRIMERO
}

\author{
Navegación de las corbetas desde Cádiz a Montevideo, costa \\ Patagónica, Maluinas, Chile, Perú, Guayaquil y Panamá. \\ Acaecimientos y tareas en los puertos que visitaron.
}

\section{CAPITULO PRIMERO}

Navegación desde Cádiz á Montevideo.

${ }_{\text {Jul. }}^{379}$ Recibidas las últimas instrucciones para verificar la salida, dimos la vela en la mañana del 30 de Julio, y el viento, ya declarado al Nordes se desde el día anterior, nos fué tan favora. ble, que pudimos alcanzar la Punta de Naga, en Ag. 3 la Isla de Tenerife, al medio día del 3 de Agor to. I 2 longitud determinada á esta Punta nos di 6 lugar á comparar los relojes marinos, entre los cuales manifestaron mucha exactitud el cronónetro 6r de Arnold, y el número ro de Berthoud

En la corbeta ATrevida disiṕse de nuevo con marcaciones al Pico de Teide, la sospecha del Capitán Cook sobre el error de las longitudes determinadas por $D$. José Varela; sus resultados y comparaciones fueron las siguientes:

Longitud del Pico de Teide, por el nú-

mero to (occ' de Cádiz).. . . . . . r ro.2r.44

Por el réloj ro5. . . . . . . . 10.23.17

Por el cronometro 71. . . . . . . . . 23.49

Eran las deter- Berdun, Bordá y Pingre.. 21.30 minaciones de D. José Varela ...... 21.00 los señorcs. . . El Capitan Cook. . . . . 43.00

A este tiempo se habían ya manifestado en la Descubierta cuatro polizones ( $\mathrm{r}$ ), y otros dos en la Atrevida, los cuales habían podido frustrar nuestras pesquisas bien eficaces para evitar este desorden. La esperanza de una fácil subsistencia en América, y el no inclinarse con esta misma esperanza la educación plebeya á un trabajo asíduo y uniforme, son el verdadero principio de esta emigracion constante que hemos visto as: cender en muschos buques, particularmente mer-

(1) Se distinguen con este nombre 0 el de llovidos los que se esconden en las embarcaciones para emigrar á la América sin licencia. cantiles, á un número no menor de 50 y 60 indi- $\mathrm{Ag} \cdot 3$ viduos.

En la misma tarde desembocamos con viento favorable entre la Gran Canaria y Tenerife; eludiéronse después á la medir noche las apa. ricncias de huracán, que indicaban probable, así el plenilunio como el descenso excesivo del mercurio en el barometro marino; antes del amanecer navegábamos de nuevo con fuerza de vela para durigirnos á pasar entre la costa y las Islas de Cabo-Verde.

Muy luego nos abandonaron las brisas, tanto que en latitud de $19^{\circ}$ empezaron á experimen. tarse calmas, cerrazones y lluvias: las corrientes, según las observaciones diarias, parecían dirigidas al Este.

Ya próximos á las Islas de Cabo.Verde, al. canzamos algunas embarcaciones que seguían nuestros rumbos. Se reconocí la una, cuyo Contramaestre vino á bordo, y era la Philips-Stevens, de Liverpool, que con cinco semanas de navegación desde Inglaterra, se dirigía á Old-Calebar para cargar de negros. Se le avisó de su situación en longitud, pues traía errada la estima en grado y medio al Oeste.

No bien había llegado la lancha á su bordo y nosotros marcado todo aparejo, cuando nos sobrecogió una turbonada fuerte, la cual dí lugar á experimentar la resistencia de los buques y aparejos, ya que nos era contraria para la de. rrota. Con la noche calmó el viento y al medio día siguiente nos hallamos en latitud de $16^{\circ} 2^{\prime}, y$ en longitud de $14^{\circ} 6^{\prime}$. No distaba el centro del Sol de nuestro zénit, sino $40^{\prime}$.

Se aprovecharon los variables en los tres días siguientes; y áun en la mañana del $\mathrm{I} 2 \mathrm{se}$ logr6 observar algunas distancias del Sol á la Luna, de las cuales resultó la longitud de $12^{\circ} 3^{\prime}$ igual con los relojes 6 I y $x_{3}$.

Lọs vientos luégo se declararon del Sudoeste, tempestuosos y acompañados de una lluvia tan copiosa como constante; nos aproximaron hacia 
Ag. 3 la costa de Africa, haciendo mucho más arriesgada la conservación de la salud de la marinería.

En la mañana del I $_{5}$, nuestra estima, traída desde las últimas observaciones, había contraído un error de $4 t^{\prime}$ al Este, y $47^{\prime}$ al Norte, y este error, reunido á unos rumbos poco ventejosos, nos había llevado á las sondas de la costa inmediata y á solas I6 leguas de la Isla Poilón en latitud de $10^{\circ} I^{\prime}$, y longitud $9^{\circ}{ }_{4} 6^{\prime}$.

Tomamos las muras á babor y continuaron nuestros esfuerzos, ara aproximarnos á la línea, malogrados en mucha yarte, ó por las calmas ó por la contrariedad de las corrientes.

Toda la tarde y noche siguientes, conserva. ron los cielos y horizontes su acostumbrado velo de celajería nebiinosa. Velo que, si bien se consultase la inmediación del Sol á aquellos paralelos, debiera manifestársenos como un nuevo rasgo de la Providencia, pero que el navegante no aprecia, sólo con ser un símbolo de calmas y vientos contrarios para su viaje, cuyo término ocupa naturalmente todas sus ansias y pensamientos.

Las ventolinas varias y calmosas del tercer cuadrante, que habian hecho en la noche nuestra navegación tan molesta como poco prove2. chosa, nos compensaron en la siguiente mañana con proporcionarnos por la primera vez una visita recíproca de la Oficialidad y gente de am. bas corbetas.

Ya distábamos quinientas leguas del paraje en donde nos habíamos separado la última vez y además una estrecha amis ${ }^{\prime}{ }^{\prime} \mathrm{y}$ un verdadero aprecio ligaban intimamente ambas Oficialidades, á las cuales imitaba, como es natural, toda la demás gente.

No parezca, pues, extraño, que aquellas dos solas causas, sin aventuras 6 riesgos que contarsc, 6 sin haber pasado en nuestra separación más plazo que el de dieciocho días, infundiese en todos una alegría poco común.

Hasta el medio día, los botes transitaron constantemente, ya unos, ya otros, á bordo de las dos corbetas. Los marineros de la ATrevida regalaron á los nuestros un tiburón recien pes. cado; las agradables noticias de una constante buena salud, infundían en todos nuevo aliento, y las mismas ventolinas, ya del Oestenoroeste que al medio día nos obligaban á separarnos para seguir la derrota, nos daban esperanza de unas próximas singladuras más favorables.

Metidos los botes poco después del medio día, navegamos con fuerza de vela al Sur. Las observaciones de la altura meridiana del Sol, nos determinaban le: latitud de $9^{\circ} 4^{2}$. Casi acordes los números 6 r y I3 daban la longitud de II $^{\circ}$ $40^{\prime}$ de la cual discrepaban insensiblemente el ro de Bertloud, y el ros de faltriquera de Arnold de la Atrevida. Los dos cronómetros recien lle- Ag. ', gados de Londres, eran por consiguiente los únicos, cuyo movimiento parecía aún no bien sentado $y$ uniforme.

Un objeto nada agradable y del cual es pre. ciso hablar particillarmente, hubo, no obstante de ocupar muclia parte de nuestras conversaciones. En ambas corbetas, al abirir los pañoles del pan, concluído á los siete ú ocho días de 1 a salida el que nos había quedado de la diaria, habían hallado toda la galleta infestada con una oruga, que D. Antonio Pineda después de haberli maduramente examinado en todas sus transformaciones y procedimientos, describió del siguiente modo:

"Es una oruga que forma su crisálida, membranosa, transparente y amarillenta, de donde sale una palomita de las que llaman polillas, blanquecina y pequeña, la que pone unos huevos amarillentos, pegados entre sí como hilitos de araña.

"La oruga á simple vista tiene como cuatro ó cinco líncas de largo y algo más de media de ancho, tlancuzca, con tuberculitos y pintas coloradas, que la dan un elegante tinte de este colur; la cabeza de color castaño; de los tuberculillos nacen unos pelitos blancos.

"Al microscopio simple ó con una lente de aumento, en la cabeza se registran dos grandes ojos, que verosímilmente serán compuestos de otros muchos, pues se ven tuberculados: poco detrás hay dos chapetitas. La boca se compone de chapetitas y manecillas; el cuerpo de I9 020 anillos; se le registran seis piés en el pecho más distantes que los demás, terminados en pun. tas; luégo, á distancia de tres $\delta$ cuatro anillos, hay cuatro pares de piés y un par de éstos junto al ano, de figura cónico-truncada, cuyas plantas están bordadas alrededor, de puntos colorados. Sobre el lomo de esta oruga reinan cuatro li. neas de tuberculos puestos longitudinalmente $y$ colorados, de donde nacen unas cerdas ó pelos finísimos.

* Este insecto, cuando llega al estado de su mayor crecimiento, deja su piel ó camisa y se convierte en una crisálida membranosa amarillenta, tinturada de castaño; de ella sale una palomilla blanca, cuyas antenas van en disminución desde la basc hacia la punta, y son poco mayores que el tórax ó pecho. La lengua es es piral, $y$ las manecillas $o$ barbillones que tiene junto á la boca, son plumosas.

"Las alas superiores tienen su posición horizontal, son más cortsis que el cuerpo, blancuzcas con manchas algo negruzquillas. Las alas inferiores son la mitad ménos anchas y también blancuzcas. El cuerpo es grande y bastante abultado, más que las otras partes. El ano termina en punta aguda; se compone el abdómen de siete 
ecien 1le- Ag. 17

iente los

no bien

al es pre.

obstante,

conversa -

s pañoles

ías de la

iaria, ha-

con una

is de ha.

odas sus

cribi6 del

da, mem -

de donde

polillas,

nos hue-

no hilitos

no cuatro

media de

pintas co-

e este co-

tuberculi-

lente de

$s$ grandes

uestos de

dos: poeo

compone

le 19 ó 20

el pecho

ss en pun-

$o$ anillos,

stos junto

as plantas

solorados.

suatro lí-

almente $y$

s ó pelos

do de su

misa $y$ se

a amari-

le una pa-

disminu -

son poco

yua es es-

que tiene

ción hori-

blancuz-

Las alas

y también

ante abul.

termina

n de siete
Ag. 17 anillos. El tórax es de color más oscuro. Las patillas son de color negruzco. Esta polilla pone un grupo de huevos en la galleta, que se unen por filamentos como telas de araña. Estos huevos son amarillitos y algo cilíndricos, y se encuentran parduscos en toda la sustancia de la galleta.

"La oruga que sale primero se forma entre ellos como una tienda de tela de araña; y después entre la miga forma unos agujeritos de donde saca la cabeza, y que agranda al paso que come, hasta que, llegando á su estado de perfección, sigue las transformaciones á que la naturaleza los destina.

"Por lo visto, esta paloma es del género $T e c$ nes; Geofroi Tomia, de Linneo. Y. la especie se acerca más á la Io de Geofroi; pero ni su descripción ni las que trae Fabricio, cuadran á lo que se ha observado en ésta; y así debe tenerse por variedad ó especie diversa de la Tennia Granitella y de la Farmalis, pues esta oruga difiere de las que dan aquella polilla."

La introducción de este insecto que nos manifestaba como homogéneo al pan, el no haberse comunicado á muchos sacos de menestras depositados en los mismos pañoles, nos dió fundados recelos, de que desde su misma conducción á bordo, el pan tuviese consigo á lo menos los huevecillos del gusano que el mismo calor interior hizo luégo fermentar y multiplicar rápidamente.

Pero como quiera que ni las calidades del gusano eran nocivas á la salud, ni faltaba oportunamente nuestro ejemplo para vencer el asco natural en sus principios, muy luego se había conseguido en ambas corbetas el no extrañar este mal, y la concurrencia de este día, haciendo común á entrambas la misma suerte, sirvió desde luego á suavizarla.

Atento siempre D. Antonio Pineda á cuanto pudiese cooperar á los progresos de sus ciencias favoritas, había sacado de la calma de la misma mañana otras dos ventajas; la una, en conseruir que un botecillo nuestro le cogiese dos Galeras Holothu ia pínisalis, de Linneo, que inmediatamente sujetó al más prolijo examen: lą otra, en experircintar por primera vez un vaso de su invencióri para sacar el agua del mar á una pro. fundidad determinada. Aunque ésta no se sacase sino á diez brazas debajo de la superficie, dió no obstante me_do grado de diferencia de temperamento, sumergido inmediatamente en una y otra el termómetro de Farenheit.

Finalmente, en la mañana del $\mathbf{2 2}$, aicanzada la latitud de $6^{\circ} o^{\prime}$ vimos entab!ada la brísa del Sur, con la cual nos dirigimos á la Equinoccial; pero como se mantuviese escasa y áun las aguas tuviesen una dirección á el Oestenoroeste, el corte de la línea se retardó luasta el 29 en longi- tud $17^{\circ} 24^{\prime}$ por los relojes marinos y $17^{\circ} \mathrm{O}^{\prime}$ por $\mathrm{Ag}$. setenta series de distancias lunares.

Cortada la línea, las brisas refrescaron hasta Set. .." causar en la Descubierta la rendidura de dos masteleros, y se inclinaron de tal modo al Este, que nos fué fácil alcanzar los meridianos de la Isla Trinidad. Era importante la determinación en longitud de esta isla, pues discrepaban considerablemente los resultados de los últimos viajes nacionales deducidos de los relojes marinos y de las distancias lunares, con los que se habían inferido de las solas distancias en el viaje de la fragata Sanii Rosalia, de la Marina Real (año de 1774 ). Estos se inclinaban á prefijarle la longitud de $24^{\circ} \mathrm{r}^{\prime}$; aquéllos la limitaban próximamente á $23^{\circ} \mathrm{o}^{\prime}$.

En la tarde del 5 , se dió vista á la isla y navegamos en la noche siguiente de tal modo, que al amanecer fuese aún bien visible para deducir su posición del rumbo y distancia navegada, y de las dos marcaciones en los extremos, cuyas latitudes y longitudes mirábamos por otra parte como seguras, pues las unas derivaban del solo medio día próximo; las otras, estaban observa das en el mismo extremo. Resultó, agregados á los promedios de $6_{3}$ series de distancias á Antares y Alta del Aguila, que la longitud de la medianía de la isla era de $23^{\circ} 7^{\prime} 35^{\prime \prime}$; su latitud se supuso cual se había determinado en la fragata Santa Rosalía, de $20^{\circ} 32^{\prime} \mathrm{o}^{\prime \prime}$.

Al cortar el Trópico de Capricornio, empe. zaron á desmayar las brisas: el viento se inclinaba al Norte y eran los días sumamente placenteros y templados: siguiéronle vientos variables á veces aturbonados: luégo sobre contraste se decidieron del tercero al segundo cuadrante $y$ arreciando mucho por esta parte, con mares sumamente gruesas, lluvias contínuas y frios bien sensibles, nos dieron lugar á navegar en buena derrota, precavidos si en el aparejo, en cuanto lo exigiesen las corbetas, las cuales acreditaban su igualdad de andar y sus buenas propiedades con exceso uniformes.

Hasta el medio día del $\mathrm{r}_{3}$, no conseguimos nuevas observaciones, las cuales nos manifestaron hallarnos en latitud de $3 \mathrm{I}^{\circ}{ }_{4} 8^{\prime}$ y longitud de $40^{\circ} 2^{\prime}$. Después de una noche tempestuosa, los relámpagos y la cerrazón indicaban la proximidad del viento pampero ó Sudo ste. Pudimos á pesar de esto ver disipadas por la tarde aquellas apariencias y desde el día siguiente dirigirnos con tiempo claro á la entrada del Rio de la Plata.

No nos habían abandonado desde algunos días varias especies de pájaros bobos, tableros, pardelas y pamperos ó martín-placas y áun pocas horas antes habiamos visto una mata de sargazo, que en aquellos paralelos (según voz común), suelen verse de ciento cincuenta á doscientas 
Sct. 13 leguas de la embocadura del rio. Pudieron después observarse distancias del Sol á la Luna que ratificaron nuestros conceptos de que el cronómetro 72 había variado su movimiento; y al contrario, que le conservaba con una suma aproximación el cronómetro 6 I. $5^{6}$ series de distancias lunares indicaban la longitud de $4 \mathrm{I}^{\circ} 22^{\prime}$. Era la del número $6 \mathrm{I}$ al medio día, de $+\mathrm{I}^{\circ} 24^{\prime}$, latitud observada, $32^{n} 7^{\prime}$.

Al aproximarnos á la embocadura, empezamos á esperimentar una densa neblina, la cual por dos días nos precisó á valernos de los cañonazos para la conserva recíproca. Seguimos con fuerza de vela, $y$ al anochecer del is sondadas 32 brazas, arena y conchuela, arribamos á ponernos en el paralelo de la Isla de Lobos, en cuya demanda se navegó luégo desde la media nocle sin acostar de aparejo.

La neblina continuaba espesa en la mañana siguiente y áun el vicnto ya del Nornoroeste arrafagado, nos amenazaisa de una próxima alteración contraria; no obstante, pareció preferente el seguir en derrota y se avisó á la ATREvida que nos siguiese de cerca. Las sondas desde las ocho hasta las doce fueron entre $\mathrm{I}_{5}, \mathrm{I}_{3} \mathrm{y}$ I 4 brazas. Arena fina, negra $y$ blanca $y$ á rato alguna conchuela y caracolillo, y como este fondo y el de $12 \%$ brazas que cogimos un momento hacia las diez nos indicase que estábamos algo al Sur, orzamos al Noroeste, partido que acreditó la observación de la latitud al Mediodía, aunque los horizontes sumamente corios con la neblina, no le diesen toda la confianza necesaria.

Las sondas aumentaban paulatinamente hasta I8 y Ig brazas; luégo encontróse la lama, y finalmente, á las cuatro, despejada algún tanto la neblina, logramos avistar la Isla de Lobos por la serviola de babor. No tardóse en atracarla á distancia de uná legua escasa por fondo de $r ;$ á $x 7$ brazas: se tomaron horarios, y últimamente, con tiempo despejado se consiguió ver claras todas las sierras de Maldonado, hasta Solis-chico.

Los carices claros y apacibles nos anunciaban la contiıuación del Nordeste; así, nos que. damos con poca vela para proporcionar la distancia hasta la mañana siguiente y para sondar con mayor comodidad; nuestro andar con las gavias arriadas era de tres á cuatro millas. La corriente ó marea nos parecían favorables. A pesar de tan bellas apariencias, no bien había anochecido cuando empezó á cerrarse el tiempo por el Oeste y poco después turimos ventolinas del Norte y Noroeste con algunos truenos, muchos relímpagos y mal cariz. Pareció el mejor partido cl de dar fondo í un ancla, pues que el viento variaha en los cuatro cuadrantes y la corriente (según las sondas), nos aconchaba hacia tierra; al mismo tiempo se tomaron dos rizos á las ga- vias, y se prescribió con la bocina igual manio- Set. 19 bra á ia atrevida. Fué la noche excesivamente lóbrega hasta las doce. A esta hora roló rápidamente el viento al Sur y Sursudeste primeramente con lluvia y últimamente con no mucha cerrazón, y á las cuatro, habiendo ya arreciado y la mar engruesado mucho, nuestras anclas, que hasta entonces habían aguantado sobre medio cable, empezaron á garrear, de suerte que descaeciamos considerablemente sobre la costa. Toda tentativa para cobrar el ancla fué, pues, inútil; se procuró resistir á la mar con el estai de gavia, la mesana y los foques, y no pudimos cobrar jamás ni dos brazas de cable. Parecía im. prudente aventurar otra ancla. Así, fué preciso últimamente picar el cable y marear con las cuatro principales, las gavias en dos rizos, para montar las puntas inmediatas.

N.uy luégo lo conseguimos, y como después el viento aminorase su fuerza, nos dirigimos, guiados de la sonda, á la Isla de Flores, la cual, poco despuéz del medio día, nos demoraba al Norte distancia de una milla; últimamente, con fuerza de vela y un andar de nueve millas, nos dirigimos á Montevideo, y precaviéndonos de los arrecifes de las Puntas Brava y de las Carretas, logramos dar fondo en el puerto á las tres y media de la tarde y á los cincuenta y un días de navegación.

Hallamos en él la fragata Santa Sabina y la corbeta San Gil, entrambas de la Marina Real; la primera de armadilla y al mando del Capitán de navío D. José Orozco, y la segunda, próxima á salir para los puertos de la costa Patagónica y al mando del Teniente de navío D. Pedro de Messa; dos bergantines pertenecientes á la plaza y confiados á Pilotos de la Armada; las fragatas correos de S. M. el Colón y la Princesa; otras siete fragatas mercantes y reintidós embarcaciones de dos palos completaban el total de bu. ques surtos en el puerto, perteneciendo todos al comercio de Europa, si se exceptúa una que pertenecia al de Lima.

\section{CAPÍTULO II}

Estado ch Monteridco.-Excursiones desde el mismo puerto y aprestos para la campaña sucesina.

La noche apacible nos dió lugar á concluir casi de un todo la faena de amarrarnos según la costumbre del puerto, tendiendo por largo y por la proa dos cables, uno al Sudoeste y otro al Sudeste, y sujetando la popa con un calabrote al Norte. En esta posición demoraban, la cumbre del cerro al Oeste; su punta saliente con Restingas al Oestesudoeste; las piedras negras del fondeadero al Norte $3^{\circ} \mathrm{O}$; el fondo I6 piés, lama 
Set, $x$ suelta con vientos del Sur y I 3 con la: vaciantes del Norte. Distábamos como un cable y medio de la Sabina y dos y medio del muelle. La ATrLvinA se amarró del mismo modo y á corta distancia de nosotros.

No parecia á primera vista asequible el levantar el plano del rio. Debía ser objeto más bien de muclios meses que de pocos días. El emprenderlo sin esperanzas de concluirlo bastaba para retraernos dic toda idea de esta especie, ni por otra parte debíamos sacrificar á esta obra un día siquiera del próximo verano, destinado con preferencia á las costas Patagónicas y tierras del liuego.

Pero examinados con más madure $z$ estos obstículos y bien graduadas así nuestras fuerzas, como el tiempo indispensable de nuestra permanencia en el puerto, no sólo por la estación temprana, sino también por los muchos aprestos que necesitaban los buques, empezaron á disiparse las dificultades y á parecer fácil el que una Oficialidad activa é inteligente $y$ un acopio de instrumentos astronómicos y geodésicos, cual era el de las corbetas, combinasen en sus pasos esta nueva utilidad.

Establecido el observatorio en Montevideo, en el cual al mismo tiempo se comparasen cotidianamente los relojes marinos y se emprendiese una serie no interrumpida de tareas astronónicas, así para la determinación de la longitud como para coadyuvar á los progresos de la misma astronomía, podíamos mirar este punto como el centro ó reunión de nuestras excursiones, y convidaban á ello no ménos su posición casi equidistante de todos los parajes importantes que debía abrazar la carta, si también el paradero en él de las corbetas, el cual nos daba lu. gar á trabajar con más descanso y á no omitir el apresto más breve de ambos buques.

Desde el día siguiente quedó, pues, decidido que D. José Bustamante y los Oficiales subalternos Valdés, Quintano, Conclia y Vernaci pasasen en una sumaca (I) á Buenos Aires; y de allí, con los auxilios que el señor Virey les prestase, emprendiesen el reconocimiento de la costa meridional del rio desde aquella capital hasta el Cabo de San Antonio. 'Tomaron otros á su cargo el reconocimiento de la costa-liasta Maldonado. No quedaría después sino la parte comprendida entre Montevideo y la Colonia del Sacramento, la cual sería fácil explorar al regreso de Maldonado.

Los tiempos no permitieron navegar á Buenos Aires antes del 28. En el entretanto se aprovecharon todos los instantes para que D. Felipe l3ausá midiese una base en el fondo de la rada

(1) Sumaca es una especie de goleta con cubierta y sirv obremanera para la navegación del rio. y otra lacia la punta de las Carretas, y con mar- Set. 30 caciones correspondientes emprendiese el plano del l'uerto y la situación de los puntos adyacen. tes. Fué luégo en la maĩana del 26 á marcar con el teodolito desde lo más alto del monte Urdeo todos los puntos á la vista, entre los cuales el Pan de $\Lambda z$ úcar y la Isla Flores tomada en sus extremos, eran objetos de la mayor importancia para nuestro intento.

Le acompañaron también D. Antonio Pineda y D. Luis Nee. Habían ya herborizado y cazado en las inmediaciones del pueblo; encontraron, no obstante, ell qué pacer su curiosidad y confirmaron la primera idea de la suma abundancia en aquel suelo de plantas aún no bien conocidas en las descripciones botánicas.

Las primeras comparaciones de los relojes nos habían indicado que su movimiento era bied diferente del que le habiamos deterninado en Cádiz. El 6 r había disminuido de $3^{\prime \prime}$ diarios pró. ximamente. Había aumentado su retardo el nú mero 13 hasta $I^{\prime} I^{\prime \prime}$ diarios $y$ el número 72 aceleraba de $14^{\prime \prime}$ á $\mathrm{I} 6^{\prime \prime}$ por cadá día medio. Pero re ducidos sus resultados á la Isla de Lobos situada por las observaciones astronómicas hechas por el Brigadier D. José Varela en Montevideo, podía conjeturarse que sólo el 72 liabía padecido esta alteración en la época en que lo habíamos sos. pecliado. Los 13 y 6 r combinaban su marcha primitiva con una longitud tan aproximada, que el primero sólo daba $4^{\prime}$ ménos y el otro I 4 de la que inferimos después de nuestras operaciones (I), y así nos confirmaban en la seguridad que la situación determinada á la isla T'rinidad y sujetada particularmente al io, pocó nada se apartaba de la verdadera.

La diferencia de meridianos entre la Isla Lobos y Montevideo fué de $\mathrm{r}^{\circ} 24^{\prime} 42^{\prime \prime}$ por el número 6r. Resultó la de $I^{\circ} 24^{\prime} 8^{\prime \prime}$ por un prome. dio de los números ro y ro $_{5}$ de la ATrivina conformes con nuestras operaciones trigonométricas.

Ya el 27 D. José Bustamante y los Oficiales destinados á Buenos Aires habían determinado emprender el camino por tierra hasta la Colonia del Sacramento y de allí con la chasquera 6 embarcación del correo transitar inmediatamente á aquella capital. Quedó Vernaci con el cuidado de conducir por agua la colección de instrumentos de la ATREvida y el cronómetro $6 \mathrm{I}$ $y$ tuvieron orden de acompañarle un pilotín $y$ un soldado de Marina. IEl camino á la Colonia, que los naturales suponen de 42 á 44 leguas apartán. dose mucho de la orilla para vadear con más se.

(1) Como se verá más extensamente en el Diurio Astronśmico, las observaciones correspondientes í las mestras han aproximado mucho más aquellos resul. tados. 
Set, an guridad los arroyos, resulta, no obstante, mucho más corto en nuestros planos. Pasa por el Canelón, el Campamento, San José, Jufre, el Rosario y el Sauce, en donde hay puestos de dragones con caballos del Rey. Estos se franquean al pasajero, con un dragón que le acompaña mediante un pase ú orden de auxilios del Gobierno de Buenos Aires ó Montevideo. Los chasques ó extraordinarios, los correos periódicos y la comunicación liasta los puestos del rio Grande por Maldonado, llegan así á su destino con una bre. vedad de la cual fuera dificil dar una eabal idea sin temer de ser tachados de exageración. No faltan en el camino algunos pueblos $\mathrm{y}$ áun $\mathrm{mu}$ chas estancias (I) en donde el pasajero pueda encontrar un buen acogimiento. La carne y la leche allí, son frutos más bien de lá naturaleza que de la industria y pueden caracterizarse de ningtin valor.

1.os Oficiales llegaron á la Colonia en la noche del 28, y en la mañana siguiente á Buenos Aires, casi al mismo tiempo en que fondeaba la sumaca en la cual Vernaci conducía instrumentos y relojes. En una travesía de pocas horas y sujetado á comparaciones anteriores y posteriores, había determinado el número 6r la diferencia de meridianos entre nuestro observatorio de Montevideo, y la casa de cabildo de Buenos Aires de $2^{\circ}$ Io $^{\prime} 22^{\prime \prime}$, igual absolutamente á la que había deducido de sus observaciones el Brigagadier D. José Varela.

La actividad de nuestros Oficiales encontró la correspordiente protección en el señor Marqués de Loreto, Virey á la sazón de aquellas provincias. Establecieron un observatorio, en el cual diferentes distancias meridianas al zénit, tomadas al Norte y al Sur con el cuarto de círcu. lo, determinaron la latitud de $34^{\circ} 6 \mathrm{I}^{\prime} 39^{\prime \prime}$. Em prendieron una serie de triángulos sobre base medida, llevándola hasta la ensenada de Barragán, sin permitirles el terreno penetrar más al Este; y dispusieron la total habilitación del paquebot Bclén y una chalupa, pues era preciso preferir un reconocimiento por mar á los que pudieran intentarse por tierra, no ménos por las dificultades que of recian las distancias y cami-

Oct. nos, como por el riesgo funesto á que podia urrastrarlos la suna proximidad de los indios pampas álas orillas del Cabo San Antonio. Se encargaron de esta operación importante los Oficiales Concha y Vernaci, embarcándose en el Belén. E1 ro se perdieron de vista ambos buques, y el I2 regresaron á Montevideo D. José Bustamante, D. Cayetano Valdés y D. Fernando Quintano, con una travesía de vemticuatro horas.

(c) Llaman estancia en la provineia de $\mathrm{Bv}$ los Aires á un terreno determinado en donde haya $]$ cos y ganado vacuno.
Desde el 29 del pasado Setiembre, sistema- Oct. 22 das como ya se indicó todas las medidas para la prontitud de los aprestos, se labía emprendido por tierra también el reconocimiento de la costa desde Montevideo hasta el Cabo de Santa Maria. Iban el reloj ro5 del Comandante de la ATREVIDA, algunos sextantes, un teodolito $y$ todos los utensilios para medir bases y sondar, y se habían unido á D. Felipe Bausá y á entrambos naturalistas, el Capitán de fragata don Santiago Liniers, segundo Cornandante de la Sabina, y el Piloto D. José de la Peña, siendo de la mayor utilidad así la pericia del segundo en el conocimiento de las costas, como la les treza del primero en acopiar por medio de la caza mil objetos útiles á la Historia Natural.

El 3o, por la noche, estuvieron al pié de la montaña denominada el Pan de Azúcar. Con este motivo, á la siguiente mañana determinaron su. bir á su cúspide Bausá y Peña para hacer marcaciones con el teodolito á todos los puntos de la costa. Pineda, Nee $y$ Liniers, con el de examinar científicamente un suelo múntuoso que en aquellos paises debía dar otro semblante á la naturaleza, del que presentan las inmensas pampas ó llanuras que le componen por todas partes.

Era bién el tin del crepúsculo, cuando llega ron á Maldonaúo los instrumentos y poco después en dos trozos las diferentes personas que habían subicio al monte. La Litología y la Botánica, lograron en esta excursión de unas ventajas considerables: las marcaciones daban ya sujetos todos los puntos principales de la costa y á pesar de lo escarpado del monte, ni los instrumentos ni los viajeros habían padecido el más leve daño.

E1 día r. $^{\circ}$ de Octı re se les presentó con un semblante aún más favorable. Emprendieron inmediatamente el levantar el plano del puerto, el cual, con un trabajo constante hasta las cinco, quedó concluído en todas sus partes. Los naturalistas y Liniers, los cuales habían empleado la nañana en poner orden á las muclias adquisiciones bechas en el camino, fueron por la tarde al pueblo Chico, población distante de Maldonado como dos leguas y compuesta 6 de familias portuguesas expatriadas del Brasil ó de españolas traídas en los últimos años para pobladoras de la costa Patagóniça y' depositadas entonces en las inmediaciones de Maldonado.

L1 2, concluídas ya las operaciones y examinado el país inmediato en cuanto el tiempo lo permitiese, emprendióse el viaje de regreso, $y$ hechas marcaciones en diferentes puntos de la costa, cuales fueron Punta de Ballena, Punta Negra y la cmbocadura de Pando, lograron res* tituirse á bordo en la tarde del 4 , viendo con mucia complacencia que no se había alterado la marclia del ro5, y que sus resultados, confor- 
(ac. mes con las primeras determinaciones, no discrepaban sino pocos segundos de las operaciones trigonométricas traidas al Pan de Azúcar, desde Maldonado $y$ desde Montevideo. En el entretanto, D. Francisco Viana, á cuyo cargo había quedado la corbeta por enfermedad de D. Manuel Novales, adelantaba considerablemente los aprestos.

Todos los trabajos emprendidos procedían con igual actividad. No era menor en la ATREvid. la del Teniente de navío D. Antonio Tova; y D. Dionisio Galiano, siguiendo con tesón las operaciones astronómicas, había observado en la mañana del 27 la inmersión del segundo satélite de Júpiter; determinada después la marcha del péndulo y de los relojes marinos, observadas casi diariamente la inclinación y declinación de la aguja, y por diferentes alturas meridianas de estrellas bien determinadas en el catálogo de Mr. de Lambre, deducida la latitud del observatorio. El trazar diariamente la órbita de la Luna y calcu lar con operaciones gráficas la hora y paraje de las ocultaciones de las estrellas, había sido un trabajo, que si bien infructuoso hasta entonces, denotaba no ménos la exactitud de aquel Oficial astrónomo, que la utilidad que sacaríamos en lo venidero de este examen incesante de la rarcha de la Luna.

Los Guardias Marinas y los Pilotos destinados á sondar el puerto interior y exteriormente, no se habian tampoco descuidado en este examen preciso para la cxactitud de nuestros planos, bien que lo hacía siempre dudoso la diferencia del nivel del agua en el puerto, más baja por lo común de cuatro á cinco piés con los Nordestes y Noroestes, de lo que lo es con los vientos del Sudeste, Sur y Sudoeste.

Ya regresado Bustamante á Montevideo, em prendióse el I $_{3}$ de Octubre nueva excursión a Buenos Aires. El tiempo, algo indeciso, nos determinó á ir por tierra: los Sres. Pineda y Nee prefirieron la sumaca y tuvieron la felicidad de llegar al día siguiente por la tarde á la Colonia del Sacramento, pocás horas antes que los demás.

Era nuestro ánimo llevando un sextante, una aguja y el relój I05, el examinar desde los parujes más cómodos la continuación de la costa hacia el Oeste, de suerte que esta parte quedase bien ligada y sujeta á enfilaciones como las demás: pero como fuese que el camino se apartaba mucho de la orilla, hallamos difícil esta empresa $\sin$ el sacrificio de dos ó tres días, el cual parecía tanto más considerable cuanto mayor era el riesgo de que unos tiempos más oscuros no permitiesen luégo el observar en la $\mathrm{Co}$ lonia, cuya latitud y longitud debían sujetar oportunamente la direccíón y extensión de la costa intermedia. Con estas reflexiones seguimos el camino directo apartándonos sólo hacia el arroyo de la Caballería, desde donde por medio oct. ${ }_{3}$ de alguuas marcaciones se tomó la dirección de la costa al Estc en cuanto alcanzase la vista.

Los Sres. Pineda y Nee habían y'a lyerborizado en la misma tarde con mucha felicidad. La tuvieron aún mayor en la siguiente mañana, en la cual, habiendo pasado á la Isla de San Ga. briel, paraje oportuno para las observaciones de latitud y longitud, juntaron en poco tiempo tal variedad de arbustos, yerbas y flores, que parecía más bien fruto del examen de un país entero que de una isla pequeña.

Retirados así poco después del medio día a bordo de la sumaca, $y$ hechas nuevas marcaciociones, dimos la vela para Buenos Aires con vientos del Sur y Sudeste galenos. Nuestro rumbo fué, por largo rato al Oeste y Oeste cuarta al Sudoeste, con el cual, y á una distancia andada de cuatro y media á cinco leguas, avistamos las torres de Buenos Aires por el Sudoeste y logramos fondear al ponerse el Sol, en sus inmedia ciones. La corriente, á la sazón, era muy lenta para fuera.

Nuestra demora en Buenos Aires fué únicamente de cuatro días. Tuvimos, sin embargo, la satisfacción de ver regresar á los Sres. Concha y Vernaci, concluida completamente su comisión; y examinada á nuestra vuelta en Montevideo la marcha del ro5, después de una travesía de pocas horas en la sumaca, no sólo. se halló ésta conforme con las determinaciones anteriores, si también se halló conforme la diferencia en longitud que había asignado el número $6 \mathrm{I}$ entre Buenos Aires y Montevideo.

No ménos había sido favorable esta última época para el doble ubjeto de completar el plano del rio, sin causar la menor demora en los aprestos ni en la salida. Bustamante y Valdés habían concluído casi en un todo las obras interiores de los buques y el embarco de víveres y aguada. En ura pequeria balandra fletada para el intento, los Sres. Robredo, Bausá y Peña, llevando consigo el cronómetro 72 , habían observado la longitud y latitud en el paralelo y el meridiano del banco Inglés, sondando hasta las inmediaciones de la Isla Flores y por su banda del Norte. Con la misma balandra Don Antonio Tova y el Guardia Marina Aliponzoni, se hallaban ahora en el rio de Santa Lucía para examinar aquel fondeadero, buscar un bajo no distante de la punta del Espinillo, y seguir los triángulos lo más al Oeste que fuese posible; y entre tanto, no se olvidaba el sondar las inmediaciones del Puerto, y Galiano continuaba sus tareas astrónomicas en el observatorio.

El 26 regresaron de Buenos Aires los señore Pineda y Nee; el primero había hech z en una excursión á las Conchas, nuevas adqusiciones importantes para la Historia Natural. El segundo 
O.4. 26 habia examinado las inmediaciones de aquella capital, y entrambos, desembarcíndose en Martin García, dentro de la embocadura del $\mathrm{Pa}$ raná, habian después, en un viaje de cinco días, reconocido el terreno comprendido entre aquel puerto y Montevidico. Finalmente, el $3 \mathrm{r}$, con la reincorporación de los Sres. Concha y Verraci, logramos ver rcunida toda la Oficialidad.

Sc reemplazaron con este mismo motivo los marineros díscolos, los enfermos y los ciesertores, librada una paga á la Oficialidad de mar, tropa y marinería, $y$ se hizo señal de aprontarsc para dar la vela.

Con haber anticipado á la marinería el leve socorro que indicamos, era nuestro ánimo el de manifestarles un premio al trabajo, hacer una nueva experiencia de su conducta y desapego del desorden, $y$ finalmente, no enturbiar con sus vicios, si se inclinasen á ellos, las próximas fiestas que en Montevideo se preparaban para la. jura de S. M., felizmente reinante. Conclúsias las faends á bordo, se dió licencia á todos para que fuesen á tierra por tres d'as. Se detuvieron para el servicio de las emivarcaciones menores ó los que habían tomado nuevamente plaza en reemplazo de los enfermos y desertores ó los que enfermos desde la salida de Cádiz, sin haber aliviado á sus compañeros en el trabajo, se hallaban en el día perfectamente restablecidos.

Los primeros días del mes de Noviembre cran demasiado favorables para la Astronomía, para que no intentásemos aprovecharlos, tanto más, que no quedaba aún bien segura la longitud de Montevideo, ó por las circunstancias poco favorables de las observaciones del primer satélite de Júpiter, ó por la órbita de la Luna, que aún no había proporcionado ocultación alguna visible de las estrellas hasta de sexta magnitud. D. Dionisio Galiano había preparado los cálculos preliminares. El eclipse de la Luna y el paso de Mercurio por el disco del Sol, merecían toda la atención. Podía no proporcionarse esta observación en Europa, por la oscuridad bien natural en los principios del invierno; ni allá podía ser visible la emersión del planeta, la cual debía acaece: en Montevideo entre dos y tres de la tarde.

En la noche del 2, que fué sumamente clara, pudo observarse el eclipse parcial de Luna: $\mathrm{cm}$ pezó á las 7 h $4 \mathrm{I}^{\prime}$, tiempo verdadero, y feneció á las $9 \mathrm{~h}+\mathrm{S}^{\prime}$. Ya a esta hora habíamos observado la ocultación de la $90^{\text {a }}$ de Nayer por la Luna; tu. vimos luégo la de la 93 del mismo catálogo. Asistieron todos los Oficiales libres, y en los intervalos que dejaban las observaciones indicadas, se ocuparon en medir distancias de la Luna á las estrellas, cuyos resultados quedarou luégo agregados á los que se habian observado anteriormente.
El día 5 al amanecer, nucstro sobresalto era Nov. 5 por precisión muy grande. Una porción crecida de celajería oscura parecía querer inutilizar los aprestos. No podían conseguirse siquiera dos al. turas scguidas del Sol en el cuarto de círculo para las correspondientes de la tarde: se habian preparado los eliómetros, $y$, sin embargo, no bien disipada aún la celajería fué absolutamente imposible el ver el ingreso del planeta; pero luégo se observó su ruta por Galiano con el cuarto de círculo y por Vernaci en el eliómetro. La emersión pudo determinarse con entera satisfacción de entrambos.

En la misma nccle observóse la inmersión y la emersión de Tauro por la Luna; $y$ finalmen. te, en la siguiente del 6 fué también una obser. vación de mucha importancia la inmersión del primer satélite de Júpiter á las $3 \mathrm{~h} 3^{\prime}$ y $\mathrm{I}^{\prime \prime}$ de la mañana, observación que comparada á las horas de las Efemérides dió para el observatorio la longitud occidental de Cádiz de $50^{\circ}$ $5^{\prime}$ y $45^{\prime \prime}$.

Tomadas el día 7 las alturas correspondien. tes para la exacta determinación de la marcha del péndulo, se encajonaron todos los instrumentos y sólo atendióse á ordenar los planos y los acopios relativos á la Historia Natural. El señor Virey había agregado á las dos corbetas un bergantín de la plaza mandado por el Piloto Don José de la Peña. Debía seguirnos al andar de la costa Patagónica y rigresár desde allí ó desde las Malvinas con los pliegos y noticias que se lo diesen; con este motivo le comunicamos ahora las instrucciones oportunas y se le dieron los auxilios necesarios para que estuviese pronto.

Concluídos así todos los objetos que podía. mos abrazar en aquella parte de los dominios de S. M., metidas las embarcaciones menores y ya desamarrados, creímos poder dar la vela en la mañana del $\mathrm{r} 2$; pero ni el viento fué favora. ble ni dejaba de inquuietarnos la nueva deserción de algunos individuos en ambos buques. Lo avi . samos la noche antes al Mayor de la armadilla para que trajese algunos reemplazos voluntarios. Fúté preciso traerlos violentos y la mayor parte inútiles; apenas la ATREVIDA pudo completar su dotación; faltaban aún cuatro hombres en la Descubierta. Hizose con este motivo una leva de gente vaga; á las seis de la tarde tuvi mos á bordo los cinco hombres que nos faltaban, desechado uno inútil. La ATrevida com. pletó y mejoró su tripulación.

Amaneció con vientos del Nornordeste al Nordeste, frescos y algo arrafagados; emprendimos inmediatamente el dar la vela y lo hubiéramos verificado en el instante si el Capitán del bergantín no viniese personalmente á avisarnos que el agua extraordinariamente baja y los mis mos horizontes cargados por el Sudoeste, le ha- 
Nuv. 13 cían creer no tardaría el tiempo sino pocas horas para declararse contrario y tempestuoso. Desistimos inmediatamente de la primera idea, $y$ no bien habiamos echado ' njo las vergas de juanete y calado sus mastele us, cuando el viento se declaró al Norosste, Nordeste y Liste, tempestuosos. Ėl agua había bajado aún más que en el día anterior $y$ ambas corbetas estaban varadas con proa al Nordeste. A la fuerza del viento, que ya en la tarde podía llamarse un verdadero huracán, acompañaron una lluvia abundante y no pocos truenos y relámpagos. Sólo á las dos de la mañana cesó el temporal y amaneció con ventolinas del cuarto cuadrante, las cuales cedieron luégo al Sudoeste fresquito con semblantes apacibles.

La noche inmediata fué tranq̨uila; amaneció hermoso $y$ con viento bonancible del Nordeste y Norte, con el cual emprendimos inmediatamente el dar la vela.

\section{CAPÍTULO III}

Navegación desde Montevidco hasta el Puerto Deseado.-Larios reconocimientos de la cosia intermedia. Acaecinientos en aquel puerto y algunas concurrencias con los Patagones.

Nuestra derrota, como es natural, debía guiarnos á pasal al Oeste del banco Inglés; exa. minando al mismo tiempo aquellas sondas para que fuese en lo venidero más fácil y más segura la navegación del rio, y aproximándonos paulatinamente para la continuación de las ta. reas hidrográficas á los $37^{\circ}$ y $1 / 2$ de latitud, término de los reconocimientos de los señores Concha y Vernaci. Empero en las tareas indicadas, debiamos también tener á la vista no sólo el que no se repitiesen ahora inútilmente, reconocimientos hechos hasta entonces particularmente por los Pilotos 'Tafor, Peña y Villa. rino en sus navegaciones harto frecuentes sobre la costa patagónica y las Malvinas, si tam. bién el que se economizase de tal modo la estación favorable del verano, que no fuese difícil verificar igualmente los reconocimientos oportunos en las costas occidentales hasta Coquimbo, término verdadero de los efectos harto temibles de! invierno. Dejaremos para un lugar más oportuno el desplegar en un solo punto de vista las diferentes expediciones, que con muy varios objetos y suerte bien varia han precedido á la nuestra. Baste el decir por ahora, que el no baberlas reunido y publicado, era su mayor, ó tal vez, su único defecto; que no desmentían ni la genero. sidad del Erario, ni la intrepidez de nuestros navegantes, ni el sistema hasta aquí temido $y$ aislado de nuestras medidas políticas; finalmente, que bastaba un verano para perfeccionarlas, xuv, s adaptando tan solo á las tareas anteriores los últimos progresos de la astronomía náutica y las útiles indagaciones de la Física, en cuanto lo permiticse la vida errante $y$ desalinada del hombre de mar.

En el entretanto, la navegación emprendida llevaba consigo el semblante más favorable y halaguieño. Puestas las corbetas y el bergantín en una línea de frente y á regular distancia unas de otras, seguían tres líneas bien simćtricas de sonda; repetíanse las marcaciones á Montevideo, así para la colocación de las mismas sondas, como para la rectihicación de los relojes mari. nos; habíamos alcanzado y propasado el veril del Banco, por un fondo de cinco brazas, cas. cajo $y$ piedra, y el v..nto, aunque flojo, conti. nuaba favorable del Norte y Nornordeste; sin embargo, no bien el Sol hubo pasado del meridiano, cuando empezaron á asomarse todas las apariencias de una revolución inmediata del tiempo, y por la misma razón fueron precisas de nuestra parte otras medidas bien diferentes de las que habíamos seguido hasta entonces. Hi. zose fuerza de vela, abandonando ya el bergan. tín, cuyas cualidades con extremo zorreras nos habían atrasado considerablemente y cuyo calado y maniobras hacian árbitro á su Capitán de cualesquiera partido más seguro. Navegamos al Sursudeste y Sudeste sin abandonar la sonda, la cual se conservaba de 12 brazas; se tomaron algunas precauciones en el aparejo; $y$ así cuando al anochecer el tiempo empezó á declararse vario y más bien tempestuoso, ya ha. bíamos conseguido una posición bastantemente aventajada para esperarle sin el menor recelo de la costa ni del Banco.

Efectivamente, las primeras horas de la no. che no podian ser más lóbregas ni más contrarias á nuestro intento. Después de algunos aguaceros acompañados con truenos y relámpagos por los cuatro cuadrantes, el viento fué ro. lando al Estesudeste y nos obligó á virar al Nor. deste; calmó. Declaróse al amanecer por el Sur y Sursudoeste fresco. Nuestra derrota pasada, el rumbo del Estesudeste, que seguimos inmediatamente con fuerza de vela, y el fondo de ro brazas, arena negra, en el cual nos hallábamos, nos persuadian unánimes que no tardaríanios en sondar las $x_{4}$ y $\mathrm{I}_{5}$ brazas, prueba segura de tener ya una navegación libre por una y otra parte. Jebió, pues, sorprendernos muy mucho el caer á las siete de la mañana en solas seis brazas arena, accidente tanto más desagradable, cuanto que no dictaba partido alguno conveniente para mejorar la derrota en el caso de ser peligrosa la que actualmente seguíamos. Por largo rato se conservó el fondo indicado; creció luégo paulatinamente hasta las ro y las $I_{4}$ brazas, y como 
Nov, 16 hubiese continuado en este intervalo el riento fresco, al medio día nos hallamos por las observaciones, en $35^{\circ} 5^{2}$ de latitud y unas 15 leguas al liste de Montevideo. Libres ya de este riesgo y con una navegación alierta, cualesquiera fue. sen los vientos que hubiéramos de experimentar, debimos mirar como un acaso bien feliz el ha. ber preferido la derrota del Sur á la que solía comunmente practicarse por el Norte del bance Ingles. La inconstancia y la contrariedad del viento nos lubbieran precisado á dar fondo hacia la Isla Flores; con el Sur fresco, probablemente hubiéramos garreado sobre la costa. Las anclas, cuando no los mismos buques, hubieran sido un nuevo tributo á las inmediaciones harto temibles del Rio de la Plata.

Hasta el día 20 , el viento se mantuvo al ()este Sudoeste tempestuoso, y nuestra navega. ción fué por la misma razón lenta y precavida. Habiamos alcanzado la latitud de $38^{\circ} 3 \mathrm{r}^{\prime}$, apartados ya de la sonda, y ahora procurábamos con los vientos del Norte el volvernos á aproximar á la costa y emprender su reconocimiento, el cual ya no tendría lugar sino desde las inmediaciones del rio Negro, atento á la mucha extensión de los bajos del Colorado y á la imposibilidad de retroceder al Norte $\sin$ un sacrificio demasiado considerable de tiempo.

A las seis de la tarde conservábamos todavía un andar de siete á ocho millas, cuando una densa calina por el Sudneste nos avisó que muy luego cesaría el viento favorable. Efectivamente fué así, y aturbonándose en un momento cielos y horizontes amenazaban una tempestad violenta. Ya los truenos y relámpagos fueron temibles y repetidos. El viento rolaba instantá. neamente del Sudoeste al Norte, y según variase la atmósfera, variaba sensiblemente el grado de calor; una media hora de lluvia terminó al parecer esta lucha, quedando un viento flojo del Norte, muchos relámpagos muy vivos y una cargazón fuerte desde el Oeste hasta el Sur; sin embargo, á las nueve el tiempo volvió á tomar un semblante lorrible, al cual sucedieron luego un fuerte granizo, muchos truenos y relámpagos, y algunas ráfagas lel Sudoeste; cedieron éstas, pero para que les sucediesen una hora después carices aún peores, una incesante variedad de vientos y una lluvia abundante, la cual no cesó sino á las cinco de la mañana, á cuya hora, habiendo entablado viento galeno del Norte, pudimos emprender de nuevo nuestra derrota y navegar con fuerza de vela.

No fuć difícil con el rumbo y viento indicados el alcanzar en poco tiempo la sonda. Al medio dia, por latitud de $39^{\circ}$ y un medio grado al Oeste de Montevideo, estábamos en $\mathbf{5 2}$ brazas arena fina negi $x$; variación magnética $15^{\circ}$ y $13^{\prime \prime}$ Nordestc, siguióse luégo una navegación más bien feliz, y á pesar de que en la noche del 23 nos sobreco. Nuv, giese de nuevo un contraste vivo de los vientos del tercero y primer cuadrante con los truenos y aguaccros acostumbrados, ya poco después del medio día del 24 estábamos á la vista de la costa por latitud de $f^{\prime \prime} 24^{\prime}$ y iongitud de $56^{n}$ r $5^{\prime}$. Corría del Norte al Oeste toda igual suavemente alomada en la orilla, $y$ no quedaba duda, si consultásemos el fondo de $25,2+y$ ig brazas cascajo y chinitos, por el cual á la sazón nave. gabámos, que sería la que conduce desde la em. bocadura del Rio Negro á la Punta de Belen y á las costas interiores del puerto de San José. Parecian formarla unas capas horizontales de tierra franca algo negra, otras blanquecinas, rojizas, y sobrepuestas una á otra en número de veinte próximamente, y se compondrían todas probableinente de arenas, margas, arcillas, etc., presentando un suelo más bien estéril y despe. jado en un todo, no sólo de árboles grandes, si que también de cualquiera especie de arbustos.

En éste $y$ en el día siguiente nuestra navegación debió ceñirse al examen del golfo indicado, que los navegantes antiguos solian distin. guir con el nombre de Bahía sin fondo, y á pesar de que los vientos coadyuvasen muy poco á nuestros deseos, siendo ya varios, ya calmosos, y á veces ocultándonos el sol con lina densa neblina y tal cual llovizna, pudimos, sin embargo, alcanzar la vista de la sierra San Antonio, colocada precisamente en el fonto, $y$ últimamente, torcer hacia el extremo septentrional de la Península San José. Corridas diferentes bases y repetidas las observaciones astronómicas hasta donde las circunstancias las permitiesen ó las hiciesen útiles. La sonda en este intervalo había aumentado hasta las 70 brazas lama. Volvió luégo á disminuir hasta las 45 y 50 brazas, así que nos aproxinamos á la Península. La mañanita del 26 , con un semblante apacible y hermoso, debió, pues, mirarse por nosotros como el principio de una época mucho más feliz en cuanto á tiempos de la que habíamos disfrutado hasta entonces. Soplaban vientos del Norte y Nornordeste fresquitos. La mar era apacible, y frecuentada ya por las ballenas, ya por los lobos, ya por mil especies de aves acuáticas, las cuales volateaban alrededor de las corbetas. 'na atmósfera pura descubría sobre la costa los objetos aún más pequeños; finalmente, el Sol, brillando constantemente sobre el horizonte, daba lugar á multiplicar las operaciones geodé. sicas $\mathrm{y}$ astronómicas con una exactitud, $\mathrm{y}$ sin embargo con un aprovechamiento de tiempo, que poco antes apénas hubiéramos alcanzado i desear. Usábamos frecuentemente de la medida de la altura del tope para deducir una base exacta; se repetían los horarios, los azimutes y la sonda. Con la claridad deî día cesaban luégo á un mis. 
Nov. mo tiempo (si bien por pocas horas) nuestras tareas y la continuación del-viaje. Asl era fácil al día siguiente coger por principio de los triángulos los mismos extremos de las tareas de la tarde anterior, y nuestros progresos eran por la misma razón igualmente útiles $\mathrm{y}$ acelerados. En la tarde del zo ya las corbetas se hallaban inmediatas al puerto de San Gregorio, por latitud de $45^{\circ} 9^{\prime}$, longitud $59^{\circ} 20^{\prime}$. Habían, por consiguiente, en los cuatro días anteriores reco. nocido un trozo bien considerable de costa, en el cual estaban comprendidas las inmediaciones del puerto nuevo de San Antonio, Santa Elena y la Bahía de los Camarones.

El clima, el abrigo y la seguridad de la na. vegación sobre aquellas costas. son otros tantos incentivos para que en lo venidero las frecuenten con ménos recelo, así los buques que navegan al Perú, como los que en las épocas felices, y no muy distantes de la Monarquía, abracen los varios objetos de la pesca con toda aquella extensión de la cual es capaz y puede refluir tan extraordinariamente hacia el bien público y la opulencia nacional.

- Al aproximarnos al Puerto de San Gregorio, habíamos experimentado unos remolinos bien vivos, los cuales á veces llegaban á alucinar á los vigias de nuestros topes hasta hacerles creer que serían restingas; otras veces nos hacían 6 difícil ó imposible el gobierno de los buques. Así atravesamos el canal entre las Islas de Leones y Arce por una parte y la Isla Rasa por la otra; así navegamos luego á reconocer otra islita exterior guarnecida con arrecifes, la cual no era fícil descubrir á los navegantes cuando se hallasen muy aterrados; asi, finalmente, se nos presentaba ésta como una nueva razón para que omitiésemos á la sazón como ageno de nuestros objetos esenciales el reconocimiento del Golfo inmediato de San Jorge.

Era, á la verdad, bien extraño que la extremada internación de este Golfo (á lo ménos según las noticias adquiridas por los Patagones) se hubiese totalmente ocultado á los hidrógrafos europeos, áun de las épocas más modernas. Había muy pocas nociones de ella entre nosotros; la derrota de Lord Anson en la carta que acompañaba á la narración de su viaje seguía en esos paralelos una tal inmediación á Ja costa, que nadie pudiese dudar que la llevaba contínuamente á la vista. El mismo Comodoro Biron, á pesar que aterrase sobre el Cabo Blanco y viese correr la costa hacia el Oeste, no indicaba siquiera sus sospechas sobre la existencia del Golfo. La natural actividad de nuestros navegantes fué la que en los últimos años aceleró é hizo evidente esta singular internación de la costa. Eil Piloto D. Bernardo Tafor, partiendo desde el Puerto San Gregorio con una lancha, reconoció hasta unas zo leguas de la orilla septentrional del Nor, 30 Golfo, bien que sin poder alcanzar su término; y esta única excursión fué la que dió nuevo realce á las aseguraciones de los Patagones sobre el extenderse aquel Golfo unas $7^{\circ}$ leguas proximamente al Oeste y no distar, por consiguiente, el mar Atlántico del Pacítico en esos paralelos sino unas 20 á $3^{\circ}$ leguas (I).

La naturaleza de las costas reconocidas por el Piloto Tafor, todas ellas pedregosas, rodeadas de arrecifes y extremadamente áridas, bastaba por sí sola para disuadirnos de este reconoci. miento, el cual, por otra parte, ni dejaria de absorber la mayor parte del verano, ni evitaría el hacer inútiles las corbetas, debiéndose emprender con lanchas y éstas permanecer separa. das por largo tiempo y sufrii por su debilidad $y$ tamaño unos riesgos $y$ fatigas que pudieran muy bien remediarse si se adoptasen con el regreso nuestro á esas costas unos auxilios más premeditados y más eficaces para el conseguimiento deseado.

Hizose con estas reflexiones derrota directa desde la caída de la tarde hacia el Cabo Blanco; se mantuvieron las sondas de 49 á 52 brazas, arena lamosa y fango; el viento fué constante. mente bonancible del Norte al Nornordeste, $y$ así no fué difícil el que poco después del medio dia siguiente avistásemos nuevamente la costa, observadas ya la latitud de $46^{\circ} 33^{\prime}$, la longitud de $59^{\circ} 18^{\prime}$ y la variación magnética de $19^{\circ} 15^{\prime}$. Había precedido á este aparecimiento, la ilusión harto frecuente en esos parajes, de una calima en el horizonte perfectamente parecida á la extructura común de las costas. Yor más de una hora no hubo en entrambas corbetas quien no asegurase su extensión verdadera desde el Sur por el Occidente hasta el Norte, ni bastaban á desengañarnos ó los avisos del Comodoro Biron, después de haber caído en una equivocación semejante, ó las noticias de nuestros navegantes, los cuales mil veces la habían visto correr desde el Cabo Blanco hacia el Oeste directamente.

Disipada finalmente esta ilusión, á las tres de la tarde pudimos dar nuevamente principio á nuestras tareas acostumbradas. La costa era la misma que había señalado al medio día la Atrevida y la que Anson llamaba el Cabo Blan. co, bien que fuese en realidad el Cabo de Tres Puntas. Desde el verdadero Cabo Blanco, fácil de conocerse por un islote que tiene inmediato y que teníamos á la vista, corre como al Esnordeste hacia el Cabo ya dicho de Tres Puntas, desde donde sigue luégo hacia el Este y forma la (1) Se verá después por el viaje del Capitán de
fragata $\mathrm{D}$. Juan de la Concha, verificado con un falucho y una lancha en Diciembre de 1794 , que esta internación no es tanta como debfamos suponerla. 
1 hic s. parte meridional del Golfo de San Jorge. Con. venía con bastante exactitud una vista de este trozo de costa inserto en el viaje de Lord Anson, y' no quedaba duda que el Comodoro Biron había Ilamatdo Cabo Blanco al mismo punto que el $\mathrm{Al}$. mirante distinguia con aquel nombre.

A la distancia de tres á cuatro leguas eran nuestras sondas de 50 brazas chinitos y fango; pero muy luégo con el rumbo del Sur, cuarta Sudoeste, aproximándonos como á dos leguas, caímos en 28 y 23 brazas piedra. Costeamos á esta distancia y próximamente con el mismo fondo por largo rato, consiguiendo ási, no sólo un cabal reconocimiento de aquellas orillas, sino también el observar por dos veces la longitud en el meridiano del islote del Cabo Blanco y últimamente el disponer la base de las corbetas en la clirección más oportuna para que las marcaciones en los extremos tuviasen la seguridad posible.

Hechas estas operaciones y observados azimutes magnéticos, como quedase aún poco más de una hora de día, pareció lo más oportuno el emplearla en el examen del bajo hallado por el Comodoro Biron, en cuyo arrumbamiento con el Cabo Blanco nos hallábamos próximamente á la sazón. Hecha, por consiguiente, señal í la ATR1:vIIJA de navegar por la popa, nos dirigimos á conservar la misma marcación alargando la distancia hasta las cinco leguas que señala el Comodoro. Navegábamos sobre las gavias y sin dejar el escandallo; la mar, excesivamente llana, debía hacernos más descontiados sobre cualquier peligro que no descubrirían en esta ocasión las rompientes.

No tardamos de las 20 brazas en caer en 16 , 14 y 13 chinitos de una á otra escandallada. El rumbo del Nordeste nos apartaba de la costa, y por consiguiente, todo contribuía á confirmar la existencia del bajo hacia aquella parte. Era demasiado tarde para destinar embarcación menor í un examen más prolijo y era temerario emprenderlo con la corbeta, tanto más que, según $\mathrm{Bi}$ ron, el peligro era oculto y la sonda no indicaba su proximidad. Así, persuadidos, no sin razón, de su existencia, siguióse nuevamente rumbo del Este y de Sudeste y muy largo caímos en is y 20 brazas.

Según nuestra costumbre, la navegación de la siguiente noclie debía proporcionarse para amanecer al Sur del Cabo Blanco y á no mucha distancia de él. Se conservaba el tiempo sumamente placentero y debíamos ya tener algunas esperanzas de su duración. Navegamos del Sud. este al Sur una distancia de ocho leguas y las sondas pasaron casi instantáneamente de las 20 á las 30,40 y 48 brazas piedra. Luégo fueron de 60 v 66 arena y lama; últimamente, aproximándonos á la costa con pairear de la vuelta del Sudoeste las vimos disminuir de nuevo a 55,50 y 45 bra. Dic, z, zas arena y lama.

No podiamos desear situación más agrada. ble de la en que nos hallamos á la siguiente mananita. li] tiempo sumamente claro, la costa y el mismo Cabo Blanco á la vista y á no mayor distancia de tres leguas, la mar agradablemente llana y muchos ballenatos que surcaban el arua con tanta tranquilidad como majestad, todo anunciaba que áun en estos climas desiertos al. canzaban los benignos efectos de la primavera.

Con las ventolinas del Sur que reinaban á las cinco de la mañana gobernamos á aproximar. nos aún más. Luçyo se midieron bases, y como nos hiallásemos aún con poco viento $\mathrm{y}$ distantes de la costa sólo una legua escasa, ceñimos al primer cuadrante el viento Hojo dei Sudeste, el cual últimamente, llamando al Este después de hábernos desatracado algún tanto de la costı, nos dió lugar á navegar zafos de ella con rumbo del Sursudeste. A las seis habíamos caído de las +3 á las zo brazas.

L1 fondo que tuvimos en las restantes horas hasta el medio día, fué de 19,20 y 21 brazas chinitos y conchuela. Era nuestra latitud de $47^{\circ} 29^{\prime}$ y la longitud $59^{\circ} \mathrm{o}^{\prime}$.

Pasado el Sol del meridiano el viento tomó algún leve incremento y se declaró favorable al Norte, con el cual navegábamos a distancia de una ó una y media leguas de la costa, conservando un fondo igual de $2 \bar{z}$, 20 y i 8 brazas chinitos. A las tres de la tarde se declaro virazón fresquita del Este y con ella pudimos ya navegar en demanda del pilerto Deseado, el cual no debía estar distante cuando veíamos clara la Isla de Reyes. Acechada por la misma razón la piedra en tigura de torre que sirve de marca para hallar la entrada algro difícil del puerto, logramos avistarla como á las cuatro y lucgo que la vimos demorar al Oeste arribamos sobre la costa, dando últimamente fondo á poca distancia de la boca del puerto en siete brazas cascajo.

La marea era aún vaciant $r$ con velocidad de una milla. La Atrevida lo veı " "ó poco después á poca distancia de nosotros. No tardamos en avistar una lancha que salía del puerto con remo $y$ vela, $y$ que conocimos inmediatamente ser la del bergantín Carmen con su Capitán D. José de la Peña. Vịno inmediatamente á bordo de la Descubierta y avisándonos que parada ia marea era entonces ocasión oportuna de entrar en el puerto, instó á que lo verificásemos sin perder tiempo, para lo cual se of recía á servir de práctico aunque ya no quedasen sino pocos minutos de crepúsculo.

La marca en el puerto y particularmente en su boca, corre con una velocidad difícil de imaginarse, á lo cual se agregan los muchos escollos $y$ el poco lugar que hay para fondear. Debe se- 
Diro, guramente considcrársele como uno de los puertos de más difícil ácceso ( $x$ ).

Pero en esos paralelos el tiempo favorable era un don con el cual no debía contarse por mucho ticmpo. No titubeamos, pues, en dar la vela, manifestándolo así á la Atrivins, la cual se dispuso luego á seguirnos, pero sin poderlo últimamente verificar por habersele corrido el cable ya suspendida el ancla.

Eran ya cerca de las nueve cuando la DEscubierta estuvo á la vela, con velacho sobre mesana y foques. El viento se conservaba bonancible del Estenordeste, la mar era llana y la marea entraba con alguna fuerza. Antes ceñimos al Norte para atracarnosá aquella costa y franquear la boca huyendo de los arrecifes que salen de la punta Sur del pucrto. Luego arribamos en busca de las piedras del medio, y avistadas éstas las dejamos por estribor, penetrando así muy luego en paraje oportuno para dar fondo. $A$ las nueve y media dejóse caer el ancla de estribor en seis lrazas y combinadas después las horas de la marea para las difcrentes faenas de amarrarnos, conseguimos que para el amanecer ya estuviese la corbeta bien segura sobre dos anclas.

Había, pues, la ATrevida debido desistir de la idea de entrar ell aquella misma noche, ya que no podía seguirnos de cerca. D. José de la Peña, con su acostumbrada actividad, volvió á salir del puerto para servirle de práctico; pcro como en toda la mañana soplase viento algo fresco del Sudoeste, que aún la hizo garrear considerablemente, no consiguió dar la vela sino á la caída de la tarde, y aún por largo ratn no podía contrarestar la marea. Declarada ésta favorable como á las ocho, le permitió finalmente entrar y dar fondo en las inmediaciones nuestras. El bergantín Carmen, para lograr una menor fuerza en las mareas, estaba fondeado como una milla más adentro. Su Capitán nos informó que en la noche de nuestra separación en el Rio de la Plata había arribado á la costa de Samborombon y permanecido cuatro días á su abrigo. De allí, abonanzado el tiempo, había hecho derrota directa al Cabo Blanco, y abierto el pliego de reunión que fijaba á este Cabo por primer punto de crucero, había creído preferente no exponer su débil embarcación á nuevos riesgos y entrar en el puerto. En la tarde anterior había tenido á su bordo un Cacique y algunas otras personas, la mayor parte conocidas suyas de una corta tribu de Patagones, la. cual en el día vagaba por aquellos contornos. La componían precisamente muchos, así hombres como mujeres, que al.tiempo de nuestro desgraciado establecimiento en el

(1) Con motivo de haberse establecido all la Compañia marítima de Pescas, se ha conseguido una práctica mucho mayor de la entrada y fondeaderos. puerto habían tomado alguna idea de nuestro nic. 3 idioma y nuestras costumbres.

Cambiada, pues, la marea de la mañana y disipada la esperanza, como ya se insinuó, de que la Atrevida fondease antes de la noche, pensamos aprovechar el día en el examen del pueito, á cuyo objeto se reunía naturalmente el deseo de trábar, si fucse posible, una correspondencia amistosa con los Patagones.

Iban en el bote D. Antonio Pineda, D. Cayetano Valdes y dos soldados armados: nos habíamos prevenido con algunas bagatelas de regalo, y mientras atendiamos a la caza en la costa del Sur, acechábamos con ansia el aparecimiento de los Patagones en la costa opuesta. Finalmen. te, al medio día se dejó ver uno de ellos á caballo en un altito no distante. luimos con cl bote hacia el, y dejada la escopeta al tiempo de saltar en ticrra, le ofrecimos algunas bagatelas, lo cual visto por los demás de la tríbu, que á muy corta distancia de nosotros estaban en cspera detrás de un montecito, fueron poco á poco aproximándose todos á caballo, y últimamente enviaron en busca de las mujeres, que no tardaron en reunirse y echar pié á tierra. Se componía entonces la tríbu de unas 40 personas, de las cuales eran yo las mujeres y 12 los ninos, entre ellos tres 6 cuatro aún de pecho; dos mujeres solas eran ancianas, y á pesar de esto sumamente ágiles. Entre el restante número de hombres, el Cacique y otro eran ancianos, y habría otros cinco cuyos años podían más bien corresponder á la pubertad que á la virilidad. En general eran todos (inclusas mujeres y niños) de una cuadratura agigantada. La talla era inferior á aquella proporción, pero natu. ralmente alta. El Cacique funchar, medido excrupulosamente-por D. Antonio Pineda, tenía de alto seis piés y ro pulgadas de Burgos. La anchura de hombro á hombro era de 22 pulgadas y Io líneas.

Sentados ... en cerco, $y$ desechada por una $y$ otra parte toda desconfianza, empezb á esplayar. se el deseo innato en el hombre de querer cono. cer más de cerca á su semejante.

En esta escena, compuesta naturalmente más bier de gestos que de palabras, las mujeres patagonas no.tardaron en abrogarse la principal parte, y 6 fuese curiosidad 6 una mayor propensión al discurso, muy luego se hicieron cargo de nuestras preguntas, y no faltó entre ellas quien esforzándose en usar palabras españolas con aquella volubilidad de lengua que siempre han admirado los viajeros, añadiese á este nuevo cebo de la conversación un cierto agrado que án entre un traje $y$ unas costumbres extrañas, dejaba traslucir esta característica principal del sexo.

Les regalamos varios adornos de vidrio, algunas cintas $y$ algunas gargantillas; nos dieron 
thic, 1 en desquite una piel y un bezoa de guanaco y un guanaco vivo peqqueno, al cual podía muy bien uplicasse la elegante pintura que el Comodoro biron habia hecho de otro animal seme. jante.

Se dirigian particularmente nuestras pregun. tas al conocimiento de su idioma y costumbres. Convinimos con 1). Antonio Pineda en cuanto al ilioma, que trabajariamos separados; que hecho un peq̨ueño acopio de palabras en un sesión, procurariamos confrontarlas todas en la sesión siguiente untes de aprender otras; finalmente, que siendo sumamente equivoco el enterarse de las costumbres mientras no se tuviese la menor idea del idioma, dejaríamos en mucha parto este objeto para las visitas sucesivas, en las cuales nos acompañase el l'iloto l'eña: asi lo bi. cimos, y como ya se la indicado, nos fueron principalmente útiles dos mujeres que sabían no pocas palabras castellanas, y conocían los pilo. tos 'T'afor y Peña.

Desde el principio, los naturales habian solicitudo que se apartasen los dos soldados armalos; se les complació inmediatamente, y esta confianza nos ligó al parecer de tal modo, que habiéndole preguntado D. Cayetano Valdés si extrañarian que tirase á un ave no distante, con. descendicron los hombres á ello, mas oponiéndose mujeres $\mathrm{y}$ niños que hacían ademán de asustarse $y$ áun de quererse ausentar, lo omitió prudentemente y con esto causó una satisfacción general.

Eran las dos y media de la tarde, cuando pensamos en separarnos después de reciprocas aseguraciones de la anjistad más estrecha y con la esperanza en nosotros de que viniesen al día siguiente á bordo, á donde los habíamos convidado y prometícloles crecidos regalos. Fuéronse todos á caballo. Nosotros con la marea ya favorable, no tardamos en regresar á bordo y no omitimos el buscar entre las muchas aves que nos pasaban á tiro aquellas que pudiesen suministrax nuevos objetos para la Historia $\mathrm{Na}$ tural.

Fondeada la ATrevios, debió ocuparnos esencialmente desde el día siguiente, ei aprovechar los instantes para hacer tan breve y útil cuanto pudiésemos nuestra demora en el puerto.

Desde la misma noche habíamos convenido con el Piloto Peña, en una señal que nos avisase cuando los Patagones estaban á la vista para ir á su encuentro, con cuya precaución economizábamos el tiempo que hubiéramos empleado en buscarlos infructuosamente y cn el entretanto la caza, la pesca, la aguada, las tareas hidrográficas y astronómicas y las investigaciones de los naturalistas, progresaban con un paso uniforme y bastantemente acelerado.

Muy luégo, la caza, que por su abundancia cebaba áun á los más inexpertos, fuć el entrete. pic. nimiento diario de toda la Oficialidad en . us lio. ras de recreo. Nuestra mesa no se cubrió sino con el fruto de nuestras excursiones y pudo lit marinería hallar en el marisco, el pescado y las muchas aves acuáticas de buen gusto, una va. riedad de comida tan ayrudable como abundante.

Destacados en la misma manana los 'Tenien. tes de fragata Quintano y Salamanca, para reconocer las aguadas de la costa inmediata del Sur, en donde se habin provisto el Comodoro Biron, las hallaron tan escasas y distantes de la playa, que les parecía bien incómodo el hacer una provisión mediana. Prefirióse con este motivo in aguada de la población antigua, la cual, aunque distante de las corbetas como tres leguas, debía parecernos más cómoda porque las lanchas po. dian ir directamente á ella con el auxilio de las mareas, sin atención á los vientos, pero siempre cran inconvenientes de alguna entidad el que á media marea no pudiese entrar ni salir lancha al. guna del estero y que la misma escasez del agua no permitiese llenar sino unas doce pipas en veinticuatro horas. El viaje, además, era peligroso por las revesas ó remolinos que en diferentes recodos formaba la marea, en contraposicion al impulso del viento. Así, para la seguridad de ambas lanchas, las cuales navegan juntas $y$ en nada sobrecargadas, se destinó un tercer bote con un Oficial para que las dirigiese. Con esta precaución, habíamos ya conseguido el día 6 dos viajes de cacla lancha dirigidos con mucha inteligrencia por los Tenientes de navio Valdés y 'lova, cuando en esa misna tarde nos obligó un nuevo acaso á dar otro destino á las embarcacio. nes menores. Con una ráfaga fuerte del Nor. noroeste y la marea vaciante había faltado á la ATrevida el cable del Oeste, y aunque sus ma. niobras fuesen sumamente vivas y acertadas, no había podido evitar el que su ancla de esperanza, en lugar del fondo, agarrase nuestro cable del Oeste y ella misma nos abordase por babor, sin causar, sin embargo, daño alguno considerable. No fuimos poco felices en suspender el ancla agarrada á nuestro cable antes que le rozase ó rompjese, y después por medio de calabrotes, en devolverla á su buque sin lancha; finalmente, cambiando la marea á las nueve, la ATrevida pudo volverse á amarrar, bien que con una demasicda inmediación á algunas piedras.

Como en un paraje de mareas tan vivas no fuese posible el uso de las boyas y de los orinques, el ancla carecía de este útil medio de recobrarse; fué, pues, preciso emplear las dos lanchas en rastrearla, maniobra difícil por los pocos instantes en que está la marea parada, únicos, por otra parte, para que un buzo pudiese pasar el orinque. Se trabajo inutilmente en la mañana del 8 , pero en la del 9 tuvimos la felicidad de 
Dic, o encontrarla, $y$ pasado un orinque por el liuzo de la ATrivins, se levb en la misma tarde y se res. tituyó á su bordo.

En el trahajo del plano del puerto, extendido por su parte exterior hasta las Islas Keyes, ha. bia explayado 1). leelipe lausá su acostumbrada actividad é inteligencia. En ln mañana del 7 , me. dida una base ea la costa del sur, halía despucis pasado á diferentes puntos de la misma costa en clonde pudiesen hacerse marcaciones útiles para ligar los parajes esenciales del puerto; luégo, en un bote, habia atravesado al cxtremo Norte de la boca; finalmènte, $b$ con enfilaciones $b$ con nuevas marcaciones del teodolito, habia extendido poco á poco los triángulos hacia dentro, navegando últimamente del io al 11 con el Teujente de fragata Quintano y el Piloto Peña, lasta donde pudiese internarse el botecillo que los llevaba. Marcaban alternativamente en una y otra orilla, prefiriendo tal cual paraje alto que sobresale $y$ domina á las muchas islas de que cstá sembiado cl canal. No omitían tampoco las sondas, guiados de las excelentes noticias del Piloto Peña; así, con la excursión actual podía considerarse también concluído otro ramo, tal vez el más esencial de nuestra comisión.

Iil examen de la marcha de los relojes marinos emprendido desde los primeros días por medio de las alturas absolutas del Sol, medidas con cl sextante, habia indicado en todos ellos una va. riación tan extraña del movimiento asignádoles en Montevideo, que nos fuese preciso el desconlar de estos resultados y echar mano de las observaciones astronómicas, aunque contra la primer idea nuestra arrastrasen consigo el estable. cimiento de un puesto en tierra y los repetidos viajes de las cmbarcaciones menores así de no. che como de día. En la mañana del 5 plantóse la tienda del observatorio en la costa del Sur, en. frente de las corbetas. Se llevaron á ellas el cuarto de círculo grande $\mathrm{y}$ el cronómetro $72 \mathrm{y}$ D. Dionisio Galiano debía intentar la deducción de la longitud por los pasos de la Luna al Meridiano, comparados á una estrella, ya que no se proporcionaban á la sazón obscrvaciones de los satélites de Júpiter, ni ocultaciones de las estrellas por la Luna.

Para seguridad del observatorio y áun para el buen orden de la gente que diriamente fuese á tierra, se plantó en sus inmediaciones una barraca, en la cual estaban constantemente un cabo y dos soldados. Se puso el asta para las señales de correspondencia con las corbetas, así de día como de noche, y siempre desde el ariochecer hasta la siguiente mañana se mantuvo uno de los dos Guardias Marinas encargado de la responsabilidad del puesto. Como ya se hubiese dejado conocer el genio pacífico de los Patagones y no desamparasen la costa del Norte, pareció que nada se aventuraba en establecerse hacia el bu. Sur, tanto mís que siempre dirigianse hacia el mismo lado todos los que deseasen ir á tierrı a con objetos de entretenimiento o de caza. liucron infructuosos en las primeras noches los es. fuerzos de D. Dionisio Galiano para las observaciones de la I.una. Dedujo, si, la latitud de 47 grados $45^{\prime} 33^{\prime \prime}$ por alturas meridianas de estre. llas al Norte y al Sur. La variación en la aguja del teodolito fué de $19^{\circ} 5^{\prime}{ }^{\prime}$ al Nordeste y reunidos los Oficiales de entrambas corbetas, observaron en la mañnna del 9 , I0 I series de distancias lunares, cuyo resultado fué de $9^{\circ} 29^{\prime}$ al Occidentc de Montevideo, longitud algo más oriental de la que determinaban los relojes.

Más felices cn sus tareas los Sres. Pineda y Nec, habian aprovechado todos los instantes para aumentar sus respectivas colecciones cientilicas; el primero, adicto particularment $`$ al examen de las piedras, de las conchas, de los cuadrúpedos y de las aves, encontró tan crecido número dc curiosidades, que podian muy bien suministrarle matcrial de estudio en la siguiente campaña algo dilatada alrededor del Cabo de Hornos. D. Luis Nee, con su acostumbrada perspicacia, constancia y asiduidad, logró á pesar del semblante árido que tenian aqucllos contnrnos, recoger muchas plantas de una rareza y méritos singulares.

Perci volvamos ya á los Patagones, cuya ausencia por el espacio de cinco días debía parecernos con exceso extraña, después de la amistad con la cual nos habíamos separado en la primera concurrencia.

Al medio dia del 8 , hizo señal el bergantín que estaban á la vista, y no tardamos en ir á su encuentro, acompañándonos el pintor $\mathrm{D}$. José del Pozo. A nuestra llegada al bergantín, hallamos al Cacique con otros subalternos y tres ó cuatro mujeres con alguros niños de pecho. Dormían éstos tranquilamente á poca distancia de la camarita; los demás, así hombres como mujeres, no habian cesado de comer galleta y menestras, ya crudas, ya cocidas, mezclándoles repetidas veces el uso del cigarro y del vino. Nosotros mismos los vimos fumar y beber otra vez y nn pudo que. darnos duda que el uso del aguardiente, ni les era nuevo, ni dejaba de serles agradable. La fuga de sus caballos liabía sido la causa de no volver en los días anteriores, viéndose precisados á destinar á los más jóvenes para buscarlos, los cuales no los habían encontrado sino al teicer día de su comisión.

No nos habiamos descuidado en llevar aquellas bagatelas para regalo, que pudiesen serles agradables; algunas t:jeras y cuchillitos regalados generalmente á todos, un cuchillo grande $y$ un espejo dados con preferencia al Cacique $y$ algunos adornos que presentamos á las mujeres, arraigaron de tal modo nuestra amistad recípro- 
11ic. s ca, que fué fácil sacar sus relratos y la conversación se trabó larga é interesante. Rectificamos las palabras aprendidas en la primera sesión, á éstas se agregaron muchas nuevas, pudieron adquirirse ideas claras de algunas de sus costumbres $y$ en particular de sus enlaces de parentesco $y$ del amor hacia los padres y los hijos; finalmente, como procurásemos aún con el auxilio de Peña adquirir algunas nociones de su religion, esto nos fué llevando poco á poco á hablarles de su morada actual, distante como tres leguas de la playa, la cual nos manifcstamos dispuestos á visitar al clía siguiente si trajesen algunos caballos para nuestro uso. En esto se aproximaba ya la hora en que debian retirarse. Peña les habia dado un buen repuesto de galletas y menestras secas; debían llevarlas al resto de la tríbu y cada cual, fuesen hombres ó mujeres, parecía igualmente afanado, ó con el cuidado de acrecentar sus repuestos, nombrando ya unos, ya otros de los ausentes, 6 con la dificultad de transportarlos no pudiendo hacer sino unos sacos pequeños con los extremos de las pieles que formaban sus trajes. Hízose en esta ocasión digna de reparo una joven patagona de edad de catorce años próximamente, cuyo regular parecer, mucho agrado y singular sagacidad, habia hecho que se le prefiriese á las demás para ser retratada. La piel que la cubría, por cuanto se adaptase al intento, no era capaz de dar cabida á los muchos dones que había re. cibido y que 'estinaba con mucho amor para sus padres: no quería abandonarlos; consultata á sí misma, consultaba á los suyos, todos le aconsejaban que usase del poncho que llevaisa en forma de camisa debajo de la piel del guanaco; pero era preciso desnudarse á presencia nuestra; y Iuchaban a porfía sobre el partido que debiese adoptar, la honestidad por la una parte y por la otra el consejo de los demás; venció, finalmente, no tanto éste cuanto el amor filial; se decidió á quitar el poncho para envolver los comestibles; mas lo verificó con tal arte y tal modestia, que dió un nuevo resalte no ménos á sí misma que al sexo en general, en quien es característica aquella calidad y sobresale hasta en los pueblos más incultos. Despidiéronse, finalmente, y nosotros regresamos á bordo.

Puntuales al día siguiente, concurrieron en mayor número á la orilla acostumbrada, y no tardó la mayor parte de la Oficialidad en ir á su encuentro: conducían un solo caballo para la vi sita proyectada en sus hogares; pero cnmo en este caso hubiese sido mucha imprudencia el aventurar uno solo de nosotros á tanta distancia de cualesquiera recursos que hiciesen temibles siquiera 'ds consecuencias de un insulto, les manifestamos, que desistíamos del viaje propuesto, y les convidános por la misma razón á que viniesen á bordo: fué imposible el persuadirlos ó bien dimanase de nuestro número algo crecido, Dic. 9 ó del cabello rubio $y$ de los trajes de la mayor parte de la Oficialidad, lo cual podía (según Peña) hacerles sospechar fuésemos de otra nación: debimos, por consiguiente, contentarnos con repetir sobre la orilla una larga sesión, animada como era natural con varios dones, particularmente de comestibles y dirigida ó bien á estrechar una amistad rećproca ó á progresar cuanto fuese posible en las nociones adquiridas sobre sus costumbres y principios sociales: advertimos er esta ocasión cuán macilentos eran sus caballos, débiles y pequeños los perros y cuál era el afan con el cual comian, todas pruebas nada duclosas de una subsistencia más bien mezquina é incierta en todos esos contornos.

Aproximándose ya el Sol al horizonte, fué finalmente preciso el separarnos: dió el Cacique la orden para que la tríbu montase á caballo, y obedecido con puntualidad, no tardó en empren der la marcha, bien que dejando atrás algunos que ó no habían sido tan expeditos en apretar sus toscos arneses ó esperaban con este pretexto algún otro regalo capaz de hacerles más felices que á los demás: en este número se hallaba casualmente la joven patagona, cuya modestia habíamos reparado en la tarde anterior. No se había desviado de su padre, y su mayor atención ó más bien cuidado, era en aquel momento el de montar á nuestra vista sin ofender en modo al. guno á su pudor: usan allí lás mujeres el montar á caballo en el modo siguiente: sorman con la brida una especie de estribo, en el cual hacen firme el pié derecho; asidas luégo con la rodilla izquierda sobre la coyuntura alta de la mano del caballo, tienen finalmente lugar para sentarse trepando sobre la albarda y después pasár la pierna derecha al otro lado; parecíanle, pues, arriesgados para su extremo pudor estos movimientos. Ya pedía á su padre que la ayudase, ya que se ocupase más bien en ocultarla de nuestra vista, y mientras tanto quedaba casi sola: deter. minóse por último á montar, pero fué esto con tal cuidado é incomodidad, que mal asegurada sobre el caballo, apenas se ausentó de nosotros unos doscientos pasos cuando volvió á apearst para montar con aquella libertad que ie era necesaria. Un grado tan sobresaliente de honestidad entre un.pueblo casi desnudo y bárbaro, no puede menos de producir en el filósofo moral y amante de nuestra especie, algunas reflexiones que la vistan tal vez á sus ojos con unos colores ménos viciosos y propensos naturalmente á la vida brutal.

Concluídas en el entretanto todas las opcraciones que nos hacían ó util ó necesario el puerto, y tocándose á cada paso con mano los muchos riesgos que en él sufrian amarras, embarcaciones menores y los mismos buques, pareció finai- 
Dic, g mente lo más acertado el abandonarle. Diéronse instrucciones al bergantín Carmen, atento á su corto andar y á la práctica de su Capitán sobre aquellas costas, para que navegase sólo y reconociese los rios de Santa Cruz y Gallegos, al Sur del Puerto San Julian. Debían las corbetas navegar en derechura al extremo occidental de las Maluinas, y alli, con una travesía directa al Cabo de las Vírgenes, ligar en uno y otro extremo con las tareas del año anterior, de los paquebotes Eulalia y Casilda, de la Marina Real; y como los Patagenes no se dejasen ver más en los contornos del puerto, se aceleraron de tal modo los aprestos, que en la noche del II pudimos considerarnos prontos para dar la vela, reincorporados ya en aquella hora los Sres. Pineda, Bausá y Quintano, los cuales, como ya se dijo, habían internado en la ria con un bote chico, y dado cada cual nuevo ensancine á las tareas útiles de su profesión.

El viento al Norte que había soplado con mucha vioiencia en toda la tarde, nos había per. suadido á meter dentro los botes; y pues que en el día siguiente la continuación del mismo viento no nos daba lugar á desamarrarnos, la emplea. mos en sistemar la marcha de los relojes, y trazar la carta de la costa que habíamos reconocido entre el rio Negro y Puerto Deseado.

Poco Áspués de salir el Sol al día siguiente, pareció entablar viento bonancible del Sur, la marea debía cambiar á la vaciante hacia las diez y como por la proximidad de la ATREvida á la piedra no era posible quedase sobre su ancla del Oeste, aprovechamos entrambas la marea entrante para levar aquella ancla. A las diez ya es tábamos á pique de la otra y enteramente prontas a car la vela: el bergantín que según las señales hechas de aniemano lo había reriicado ya, vió imposible poder rontar unas isletas que media han entre él y nosotros, y volvió á dar fondo. No fué otra tampoco la suerte de la Descubierr por haberse declarado en el mismo instante de dar la vela ventolinas flojas del Este. Así pasa. mos entrambas el restante día, en el cual el viento se mantuvo flojo; por la misma parte, la marea con velocidad de tres y media á cuatro millas, y el tiempo no sólo neblinoso, sino también por la tarde algo aturbonado con truenos distantes. Siguiéronse por la noche algunos chubasquillos, los cuales, finalmente, produciendo á las cuatro de la mañana siguiente algunos soplos del terral del Oeste, dieron lugar á que en pocos instantes, parada la marea, ambas corbetas estuviesen á la vela $\mathrm{y}$ franqueasen, aunque con algủn riesgo, la boca del puerto. El bergantín, fondeado más adentro, no pudo seguirnos y le perdimos inmediatamente de vista.

\section{CAPÍTULO IV}

Navegación de las corbetas á las Islas Maluinas y de alli alrededor del Cabo de Hornos hasta el puerto de San Carlos de Chiloi.--Reconocimicntos de las Tierras del Fuego y otros accidentes ocurridos $\mathrm{cn}$ aquel tienpo.

Nuestros conceptos no iban errados cuando Dic. ", al amanecer habíamos procurado dar la vela con la posible precipitación. Apenas propasada la boca del pueito, declaróse al mismo tiempo la marea contraria y calmó totalmente el terral. En diferentes ocasiones la ATrevinA se vió casi precisada á dar fondo. Ambas corbetas eran arrisstradas rápidamente hacia la costa del Norte; pero á las ocho empezó á entablar viento galeno del Sur y las muras á estribor con fuerza de vela nos franquearon á poco tiempo de aquellas inmediaciones, de suerte que pudiésemos considerar como libre la navegación siguiente, cualesquiera fuesen los vientos que debiésemos experimentar.

Un nuevo bordo hacia la costa antes del medio día, nos dió lugar á multiplicar en la restante tarde las tareas hidrográficas, las cuales debían ligar varios puntos externos con el extremo interior de nuestros triángulos; repitiéronse tamłıén las obseıvaciones astronómicas; diferentes azimutes manifestaron la variación de $20^{\circ} 4^{\prime}$ Noroeste. Al ponerse el sol ya demoraba la Isla Reyes al Sur $40^{\circ}$ Oeste, distancia de seis leguas; la mar era llana y los vientos empezaban á entablar por el Norte y Noroeste, favorables sobremanera para nuestra derrota.

Emprendimos, pues, el atravesar directamente al extremo occidental de las Islas Maluinas; crecieron las sondas hasta las 60 y $6_{5}$ brazas fango duro; creció también rápidamente la variación de la aguja hasta los $23^{\circ}$. Las ballenas, los lobos, las muchas aves acuáticas, solazándose frecuentemente alrededor de los buques, hacían nás divertida la navegación, al paso que atizaban nuestros deseos de ver cuanto antes abierto por medio de las pescas este nuevo ramo, tal vez inagotable de la industria nacional.

Los rumbos del Suisudeste y Sudeste que seguiamos constantemente, no podían ménos de conducirnos en breve tiempo al término prefijado. Fueron casi momentáneas las contrarieda. des que experimentamos de los vientos del Sur, los cuales, atnque al principio oscuros y tempes tuosos, no tardaban en rolar más claros y apacibles al Sudoeste y Oeste. Así no nos fué difícil para la tarde del I 7 el avistar á larga distancia los Salvajes, Islas Altas, las más occidentales de las Maluinas, y poco después, favorecicios extraordinariamente del viento, el emprender en ese 
1)ic. in mismo extremo las tareas hidrográficas acostumbradas. Importaba mucho en aquellos contornos su máxima exactitud, en cuanto debian compararse al mismo tiempo con las del Capitán inglés Mac-Bride y servir de norte en las navegaciones venideras de los buques nacionales al mar del Sur, para que ni se retardasen los viajes con unos bordos retrógrados, á veces infundados, ni con las oscuridades larto frecuentes en esos mares, peligrase algún buque en las inmediaciones de la Isla Rasa, difícil á ser vista á una mediana distancia.

Con este intento fué nuestro objeto en la res. tante tarde el de reconocer de cerca aquella isla y costear después entrambos Salvajes. En cada mcridiano se observaban longitudes con los relojes marinos, sondábamos frecuentemente, aunque sin encontra: loudo con rio brazas de son. daleza; Gisservábamos desde los topes con cuanta vigilancia fuese dable, los diferentes canales que alli forman un laberinto sumamente complicado de islas, pero ya veíamos imposible el alcanzar hasta la mañana siguiente el puerto Egmont, en donde era nuestro ánimo el dar fondo y combinar con un nuevo examen de la marcha de los relojes marinos, el reemplazo completo de la aguada $y$ un mediano reconocimiento físico de aquellos contornos.

l'ué, por consiguiente, preciso el procurar mantenernos hasta la mañanita siguiente en la misma posición. Se seguían los bordos más oportunos, ya con las solas gavias, ya agregándoles mayores y estais; y sin embargo, como tuviése. inos una corriente bastanteriente fuerte al Norte, nuestra distancia de los Salvajes al amane. cer no era menor de unas cinco leguas. Inmecliatamente, entablado viento fresco del Oeste volvió á atracarse al mismo extremo de la tarde anterior; costeamos varias islitas, á muy corta distancia, dejando las unas á estribor y á babor las otras y no tardó mucho cuando ya empezaron í descubrirse las inmediaciones del puerto y pudimos dirigirnos hacia él.

Estas inmediaciones, formadas por la mayor parte de islas, son por lo común altas $\mathrm{y}$ acantiladas; si hay una ú otra punta baja, despide al. gunas restingas, las cuales, viniendo del Oeste, se dejan á la izquierda; el mismo inconveniente y cl de un bajo al Sur de otra isla, indica, como preciso, el atracarse mucho á la derecha y muy luégo se hace notable el blanquizar de arena, del cual hizo memoria el Comodoro Biron, como un paraje oportuno para dar fondo, cuando el viento ó la noche impidan internar en el puerto I:gmont, pues sobre un braceaje de 12 á 20 brazas arena, puede un buque estar bien cerca de tierra, abrigado de todos los vientos que sean contrarios á la entrada, y con un riachuelo á la vista que le suministre en el entretanto el agua que recesite. No tardamos, continuando á un viento favorable del Oeste, en internar en el 10ic, 18 puerto: navegábamos con gavias, foques y vela de estai cle gavia; costeálbamos las orillas del Oeste á un tiro de fusil, por fondo de I 2 , I I y io brazas arena, y acechábamos cualquier riachuelo para dar fondo enfrente de el. Le vimos muy luégo y era fácil apercibir en sus inmediaciones muchos fragmentos de la colonia antigua ingle. sa; así no diferimos un instante en dar fondo $y$ á poco tiempo quedaron amarradas las dos corbetas á corta distancia la una de la otra y en una excelente disposición para los objétos que se habían prefijado. Algo más adertro cstaba fondeada una sumaca del Rey, procedente pocos días antes del establecimiento de la Sucuizic en el extremo oriental de las Maluinas.

En el entretanto, se habían destacado algu. nos Oficiales para reconocer con un bote los parajes inmediatos y dirigir con el mayor acierto la aguada. Nada liabía en aquellos contornos que no debiese recordar al navegante los dones pródigos de la neturaleza, siempre uniforme en sus hechos, siempre suporior á cuanto pudiesen suministrar el arte y el trabajo lento, mezquino y contradictorio del hombre. En el fondo de una ensenadita ó más bien dársena, descendía al mar un arroyuelo cuyas aguas cristalinas apenas á no mucha distancia de allí asomaban unidas, desplo. mándose de los altos inmediatos; cuando se agolpaban á aprovechar de sus derrámenes y á deberles una subsistencia lozana y saludable, varios gramenes, la coclearia y el apio silvestre: éstas dos plantas, destinadas espr ialmente á la conservación del navegante, retinen en sí la otra ventaja no ménos apreciable de su constante iumediación al agua. Tanto es hallar la una cuanto encontrar el otro. Queda casi suspenso á la primera vista, el que pisando apenas la tierra se ha aproximado por el solo instinto á una ú otra de estas cañaditas; unas veces extasiado contempla la inagotable abundancia de lo que poco antes le era imposible el conseguir; el suave murmullo con cl cual desciende, le recuerda un momento el rápido correr de la vida humana y de sus trances ó los más felices ó los más desgraciados; pero atónito y casi olvidado de sí mismo, tere perderla de nuevo. El apetito por una parte, el agradeci. miento por la otra, le arrastran hacia ella: no bien ha satisfecho sus ansias, no bien ha besado mil y mil veces en este símbolo de la vejetación la próvida mano de la naturaleza, cuando mira en torno y ve moverse por un vientecilio suave 6 por el mismo salpicar de las aguas, el apio y la coclearia: las coge, las masca, las bendice: el cansancio y la quietud le excitan un breve sueño; disipa en un momento aquella languidez que 10 oprimia poco ántes.

$\mathrm{E}$ intanto obblia

La nosa, é il mal de la passata via. 
inme-

nto en-

rimera

a apro-

e estas

upla la

s le era

con el

rápido

s 6 los

atónito

erla de

radeci-

1la: no

besado

etación

nira en

uave ó

io $y$ la

ice: el

sueño; que lo
Las aves acuáticas varían luégo esta escena, pero $\sin$ aminorar su semblante agradable: las liay de hermosa pluma; las hay de mil tamaños: sus voces allí no son los símbolos 6 de una constante emigración según las estaciones, 6 de la pérdida sufrida poeo antes de la compañera fiel $y$ de los tiernos hijuelos. Denotan tan solo aquel afán natural con el cual se hacen casi indivisibles entre sí, con el cual se llaman cuando mudan de morada ó de aposento y se convidan cuando ó el mar les presenta una subsistencia diaria y abundante $o$ las costas no trilladas del hombre les brindan con la facilidad de solazarse y cle volatear á su albedrío. Ni es ménos entretenida la vista del mar, en donde los peces, los anfibios y á veces las mismas bailenas, ignorantes de su propio poder y del genio destructivo del hombre, se presentan casi con emulación para saludarle y no imaginan jamás que esto baste para ser destruídas.

Con un semblante tan favorable cual acabamos de describir, y sin la interrupción de aquellas distracciones que en los paises habitados son inseparables del navegante, ó ya para precaverse de las tretas, ó para ultrajar los derechos, ó finalmente, para se $_{i}$ víctima de los halagos engañosos de sus semejantes, no parezca extraño que muy pocos días bastasen para cuanto nos liabíamos propuesto en aquella escala. En la misma tarde tuvo cada corbeta una lancha con agua; siguióse llenando el vacío durante la noche, y al día siguiente, no bien el Sol había disipado la calima, cuando estuvieron cada cual ocupados con ansia en las tareas de su destino. Los naturalistas, los hidrógrafos, les astrónomos, los cazadores y los que se habian destacado para la pesca, subieron los primeros al monte de la Vigía, en donde D. Felipe Bausá hizo marcaciones bien importantes con el teodolito, y D. Antonio Pineda reconoció el suelo, las plantas que le vestían y los animales que le habitaban; D. Dionisio Galiano y D. Juan Vernaci, establecieron el observatorio y empezaron con las alturas correspondientes del Sol, el examen de la marcha de los relojes marinos. Midićronse por ios demás Oficiales muchas series de distancias lunares; sondaban los Pilotos; oíanse frecuentes y siem. pre con buen éxito, los tiros de los cazadores; la aproximación de la noche debía por la misma razón presentar á bordo un espectáculo más bien agradable, cuando llegaban por todas partes y se veían uno sobre otro los barriles del agua, los atados del apio silvestre, los peces, las aves y los anfibios, presentando cada uno, ó en su pluma y en sus caracteres, si estuvicsen muertos, ben sus graznidos y movimientos si viviesen aún, aquella variedad contínua que hace el mayor adorno de la Naturaleza.

Referidos al medio día del 20 los resultados de las tareas astronómicas, dieron para el obser- vatorio la longitud siguiente occidental de Mon- Dic. 2 tevideo.

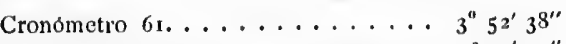
Cronometro 72............. $3^{\circ} 5^{\mathrm{r}^{\prime}} 25^{\prime \prime}$

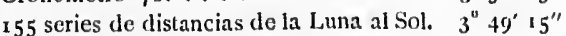
El promedio de los relojes de la $\Lambda$ TREVIDA,

bien conformes entre sl. . . . . . . 3 $3^{\circ} 52^{\prime} 30^{\prime \prime}$

Latitud, $5 \mathbf{1}^{\circ} 2 \mathrm{I}^{\prime} 3^{\prime \prime}$ por astros al Sur $y$

al Norte. Variación mégnética, $22^{\circ} 34^{\prime}$

al N. L.

Las observaciones de la latitud, habian á la verdad encontrado un obstácul s cual no era fácil imaginarle. La hermosura del día, la conclusión de las faenas de á bordo, y la misma litil necesidad de alejar á veces la marinería de aquel yugro constante y opresivo de la disciplina, el cual en una nación sumamente viva, si bien no cause frecuentemente la desesperación, debe causar á lo ménos la melancolía, nos habían dictado como prudente, el permitir á entrambas marinerías que pasasen en ticrra la mayor parte del día. Repartiéndoles jabón para que lavasen su ropa, tolerando er. otras y paxcicularmente en la tropa, el que ller asen el fusil para cazar, debían errar á su alb ¿drío por aquellos contornos y no reunirse en la orilla sino á la entrada de la noche: dispersados así en muy poco tiempo, no tardaron en dar muestras de su genio natura', inclinado al desorden y á la destrucción. Prendieron fuego á un montón de turba en donde esta planta se hallaba más espesa, y en un momento, no sblo vimos arder por diferentes partes el monte inmediato, sino que el humo que salía del incendio, ocultaba los objetos áun más cercanos. Fué, pues, preciso enviar utensilios de la DEscubierta para atajarle. Oficiales, Contramaestres y cuanta marinería estuviese á mano, trabajaban con igual vigor, pero inútilmente. Era imposible el asolar de un todo aquellos contornos, y era por otra parte imposible el extinguir el fuego como quedase una mata siquiera. Así, después de repetidos esfuerzos y de las esperanzas por tres veces frustradas de haberlo conseguido, debimos, finalmente, retirar la gente á las nueve de la tarde y dejar que á más del destrozo siempre nocivo, nos inundase una columna de humo, la cual á veces imposibilitaba el vernos de una á otra corbeta. Detiéronse con este motivo aprovechar todas las claras que los vientos quisiesen proporcionarmos. Apenas se pudieron observar en la noche inmediata dos alturas meridianas de astros al Sur del zénit, En la mañana siguiente, en la cual debíamos deducir de las alturas de los topes la distancia verdadera de una á otra corbeta para que nos sirviese de base, fué preciso acechar por largo rato una clara favorable antes de poderlo conseguir.

En esta última operación tuvimos tambiẻn la casualidad bien extraña de no poder jamás com- 
1hic. a binar una medida uniforme en las dos corbetas, si bien la mar estuviese en una completa calma y la elevación de Ios topes fuese positivamente irual. Parece difícil el adoptar para esta clase de operaciones una mayor prolijidad de la que solía usarse en las corbetas. Excelentes instrumentos, medidas exactas, cálculos rigurosos, muchos observadores bastantemente expertos, no podían, sin embargo, evitar el que incurriésemos frecuentemente en errores de mucha monta, los cuales últimamente nos han convencido que en la necesaria multiplicación de las tareas hidrográticas, sin descuidar est; método realn. ente exacto, deben, sin embargo, emplearse constantemente las bases por corredera.

Frustradas de este modo, ó ya por el humo de la quema indicada, ó á veces por las nubes que ofuscaban el cielo particularmente cuando reinasen vientos del Norte, varias observaciones astronómicas que debían acaecer en el corto intervalo de nuestra demora en el puerto, fué preciso acelerar la salida. Se habia y'a sustituído á la primera base otra medida con cadena en el corto terreno que permitian las orillas; se habían re. petido las marcaciones en diferentes parajes altos, los más oportunos para ligar interior y exteriormente los triángulos, y completada la aguada, hecho un cuantioso acopio de apio silvestre, $y$ dispuestos últimamente velamen $y$ aparejo para la próxima navegación alrededor del Cabo de Hornos pensábamos dar la vela en la mañana del 23 , para lo cual se habia ya levado un ancla y metidas las embarcaciones menores.

Debió, pues, parecernos bien inoportuno el viento al Norte, el cual, tomando en aquella mis ma mañana mucho incremento, nos hizo desistir de la idea de dar la vela. Calmó sin embargo por la tarde, roló poco después al Noroeste y declarado finalmente al Sursudoeste, después de una leve garua, nos dió lugar para que á las cuatro de la siguiente mañana entrambas corbetas estuviesen á la vela y franqueasen poco después la boca del puerto.

Empero, apenas distaríamos de él unas dos mills.s, cuando las ventolinas calmaron enteramente, se ocultaron con calima la mayor parte de las islas inmediatas $y$ un marullo grueso del Norte y Noroeste empezó á aconcharnos sobre la costa occidental del puerto. Sondamos Io brazas arena y á pesar que trabajásemos constantemente para hacer algo ménos arriesgada nuestra posición, veíamos á cada paso aminorar la distancia de los arrecifes del Este. Per manecimos cerca de una lora en esta posición poco agradable, en la cual además la suma variedad de las ventolinas nos exponían frecuentemente al riesgo de un abordaje con la ATREVidd; peróalas ocho, entablado finalmente viento fresquito del Sudoeste pudimos con fuerza de vela continuar la derrota y pasado el canal entre los Hermanos y las Pie- Dic. 2 dras blancas, islotes fronteros y distanter unas dos leguas de la boca del puerto, considerar ya libre la navegación siguiente hacia la costa patagónica. Al medio día era la latitud de $5 \mathrm{I}^{\circ} 2^{\prime}$, la longitud de $4^{\circ} 5^{\prime}$ de Montevideo y demoraba al Sur verdadero, el extremo occidental de los $\mathrm{Her}$. manos.

Calmosa, sí, pero despejada la tarde inme. diata, nos dió lugar á repetir á la vista del puerto las observaciones de longitud por las distan. cias lunares: r02 series observadas en la DEscuBIERTA sólo discreparon en tres minutos de id longitud asignada á aquel meridiano por los relojes marinos. Era esta una nueva evidencia del grado de exactitud que solía comunmente alcanzar esta especie de observaciones tan útil en cl mar y tan fácil á repetirse.

Hasta la media noche quedamos en la misma posición; pero entablado á aquella hora casi repentinamente viento fresco del Norte, pudimos inmediatamente aprovecharle con fuerza de vela $y$ propasar antes de las seis á distancia de cuatro leguas las Islas Salvajes y la Rasa. Con las cuatro principales y lus foques, llevábamos un andar de nueve á diez millas. El viento era muy fresco y arrafagado: la mar ya gruesa y los carices bastantemente aturbonados. Emprendido de este modo el atravesar de nuevo á la costa patagónica y el ligar sobre el Cabo de las Vírgenes nuestras tareas con las de los paquebotes Eulalia y Casil$d a$, la navegación debía ser naturalmente sencilla y expedita. Los vientos fueron sumamente va. riables, pero comunmente frescos y achubascados. Los ceñíamos ya de la una ya de la otra mura, rara vez decidiéndose por el Oeste nos apartaban de una derrota directa. Era común á pesar de las cerrazones el conseguir las observaciones de la latitud. Para la variacion magnética, después de muchas desigualdades que la hacían vacilar entre los 22 y $25^{\circ}$, habíamos adoptado en la tarde del 26 la de $22^{\circ} 30^{\prime}$ dimanada de muchos azımutes de bastante saćisfacción, y en la tarde del 28 de clarados nuevamente vientos favorables después de algunas turbonadas recias del Sudoeste es. perábamos de uno á otro instante la vista oportuna del Cabo de las Vírgenes.

Le avistamos efectivamente á las cinco $y$ media de la tarde. Demoraba al Oeste $\%$ Sud. oeste verdadero y su longitud, atracádole después á la sola distancia de tres leguas escasas, resultaba por nuestras observaciones, bien conformes entre sí los relojes marinos de entrambas corbe. tas, de $12^{\circ} 12^{\prime}$ al Occidente de Montevideo.

Conseguido este objeto, y siendo nuestro ánimo el atracar á la costa del Fuego desde el Cabo de Espíritu Santo, hízose señal á la ATRE. viDA para que pasase á nuestra voz, y se encargó í D. José Bustamante, que pues tenía á su bordo 
Dic. 28 los diarios de Sarmiento, navegase aquella noche de tal modo que pudiésemos pasar entre la costa y el bajo que indicaba aquel navegante, adquiriendo al paso aquellas señales sobre su existencia que las circunstancias dictasen por prudente. Se le prescribía después, que la distancia por navegar hasta la mañanita siguiente, no fuese mayor de diez leguas, lo cual logrado, estaríamos seguramente á la vista del Cabo de Espíritu Santo. El viento á la sazón era del Norte, los horizontes cerrados con garna y los rumbos adoptados por la $\Lambda$ TREviDA, variaban, según las sondas, del Sursudeste al Sudeste de la aguja.

Fueron éstos tan acertados, que á la hora indicada, nuestra posición era en efecto cual nos la habíamos propuesto. De la A rrevida nos di. jeron á la voz que en la noche le habia disminuído el fondo hasta las I $_{4}$ brazas y aumentado después á las 45. La tierra se conservaba aún fosca y el tiempo muy calimoso y vario.

Pero declarado poco después viento bonancible del Nordeste y despejada algún tanto la tierra, pudimos dirigirnos á reconocer su verdadera posición, precavido, sí, en los rumbos, pues que el viento parecía quererse mantener fresco y la dirección de la costa se inclinaba mucho más al Este de lo que la indicasen las cartas del Capitán Cook y del viaje al Magallanes. Desde luego, guiados del derrotero de los Nodales, aunque bien confuso, pudimos reconocer la costa inmediata al Cabo. Dejamos con Anson el nombre de Cabo de la Reina Catalina á la punta más Sur de la tierra medianamente alta que es contígua al primero, y ya nuestro principal deseo se dirigía á fijar lós términos del Canal de San Sebastián, con cuyo objeto costeábamos la tierra baja á distancia de dos á tres leguas. Pero como el tiempo volviese á ser bastantemente calimoso, y el vien. to ya fresco del Esnordeste hiciese más bien imprudente el descaecer demasiado sobre las costas, quedó finalmente alguna duda sobre el extremo Sur de dicho canal, nó á la verdad porque careciésemos de muchos datos bien probables para determinarle, sino porque no era posible combinar. su latitud con la que habían indicado los Nodales. Convenía en general su configuración, particularmente la señal de empezar las tierras altas y nevadas, desde el extremo Sur del Canal de San Sebastián y desde el Cabo de Penas. Era nuestra latitud de $53^{\circ} 23^{\prime}$ y la longitud de $\mathrm{II}^{\circ} \mathrm{I} 4^{\prime}$ $30^{\prime \prime}$, deducida ésta de un promedio de las observaciones de la mañana con la tarde, y traídas con la estima, en la cual no se hacía xisible efecto alguno de corrientes.

El viento, inclinado ya al Estenordeste, fue arreciando con la tarde y oscureciendo la tierra, de la cual no distaríamos á las cuatro sino dos á dos y media leguas, y era en nuestro entender la inmediata al Cabo de Penas. Las sondas se c. - 1 pic ay servabail de 39 y 35 brazas fango. Viramos al Norte, y poco después rolando el viento al Este, le ceñimos al primer cuadrante, aumentándolas á 44,42 y 40 brazas, chinitos y caracolillo. Ya no se descubría la costa y áun á ratos se nos hacía difícil la conserva con la ATrevida. Calmó luégo en un todo el Nordeste hacia las diez, y á la media noche ya se había declarado al Sur y Sursudeste bonancible. Amaneció con tiempo hermoso; distábamos de la costa unas cinco leguas y todo nos convidaba á dirigirnos inmediatamente á su reconocimiento y situación, tanto más que alcanzábamos en las tareas de este dia la vista del Cabo de Penas, en el cual habían concluído las bases del dia anterior.

En efecto, la costa desde este paraje empieza á ser alta y nevada, pero no con tal horror que no descubra en las inmediaciones del mar diferentes valles y llanuras, en donde la vegetación parece esplayar todo su verdor y hermosura. La nieve ó hielo sólo de ja verse en las cimas agudas de los montes hacia la parte del Sur, y sembrada, digámoslo asi, en pequeños montones en los cuales brilla el Sol, representa un contraste más bien agradable de las dos estaciones más opuestas entre sí. Esto nos dió lugar á congeturar que el verano estaba más bien ade. lantado sobre las costas, concurriendo unánimes á apoyar aquella idea, los tiempos apacibles que habíamos disfrutado á lo largo de la corta patagónica y la serenidad y temple agradable que experimentábamos en aquel día. A medida que íbamos entrando en meridiano, de diferentes puntos notables se observaban longitudes con el número $6 \mathrm{r}$. El todo se ligaba con pequeñas bases y áun para no alterarlas se habían puesto las sondas al cargo de la ATREvida, la cual nos senaló á las ocho y á las diez 40 y 37 brazas de fondo, distando entonces como dos leguas de la costa.

Las tareas astronómicas del Capitán Cook empezaban en el Cabo Santa Inés, desde cuyo punto hasta el Cabo San Juan de la Isla de los Estados y hasta la Isla de la Recalada al Oeste del Cabo Negro, nos aseguraba aquel navegante que todas las longitudes estaban ligadas entre si por medio de los relojes marinos y sujetas á la que había determinado al Cabo de Hornos, por muchas series de distancias lunares en $6 \mathrm{r}^{\circ} 30^{\prime}$ de Cádiz. Cualquiera fuese, por consiguiente, el error de esta detırminación que el mismo Capitán sospechaba pudiese llegar á un cuarto de grado, debía manifestarse en el Cabo Santa Inés, del mismo modo que en cualquiera otra parte de las determinadas.

Con esta atención, luégo que estuvimos en posición oportuna, hicimos señal á la ATREVida de observar longitudes y las observamos nosotros 
Wic. con el número $6 \mathbf{I}$, de cuyo movimiento casi uniforme y áun sujcto á una corrección en sus pequeñas alteraciones, no nos dejaban la menor duda las comparaciones diarias con los otros relojes; sus resultados fueron para el Cabo de Sianta Inés de $60^{\circ} 40^{\prime}$.

Pero no fueron tan uniformes con las suyas nuestıas ilaciones de las siguientes longitudes, que referidas al Cabo San Diego en la entrada del Estrecho de Maire y al Cabo San Juan en el extremo Oriental de la Isla de los Estados, denotaron unánimes que las longitudes del Capitán inglés determinadas en su segundo viaje, estaban afectadas de un error de $2 I^{\prime}$ próximamente en longitud que las inclinaba demasiado al Oeste.

11 medio día estábamos en latitud de $54^{\circ}$ I $0^{\prime}$ $y$ en longitud occidental de Montevideo $10^{\circ} 19^{\prime}$, variación magnética por diferentes azimutes 25 grados r $9^{\prime}$ Nordeste. Marcábamos el Cabo Santa Inés al Oesnoroeste distancia de cuatro leguas y e] Cabo San Vicente á la entrada del Istrecho de Maire nos demoraba al Sueste cuarta al Este distancia de zo leguas.

Navegamos con fuerza de vela hasta las tres de la tarde, que arreciando mucho el viento del Oesnoroeste y cerrándose con carices cargados los cielos y horizontes, aferramos las velas menores $y$ con gaviats y trinquete secruimos costeando de modo que no se ocultasen ni la configuración de la costa, ni las longitudes de sus puntas salientes, ni finalmente aquellas vistas que sirviesen de guia para las recaladas venideras. Entre las últimas merecen el primer lugar los Tres Hermanos y el Pan de Azúcar; la posición que les da Frezier, nos ha parecido equivocada, aunque merezca los elogios del Lord Ansón. Es sumamente exacta la que indica en su carta el Capitán Cook.

Hasta las seis de la tarde no pudimos alcanzar el Cabo San Vicente, del cual distaríamos á dicha hora una legua y media; las corrientes no habian influido en modo alguno en nuestra derrota, pues unánimes lo denotaban así las diferentes bases corridas, las muchas longitudes observadas y la misma exacta uniformidad de nuestras latitudes estimadas con las correspondientes de la costa, según la carta del Capitán inglés.

No siendo nuestro ánimo el fondear en la bahía del Buen Suceso, ya debía parecernos preente el costear la Isla de los Estados por la ida del Norte. Combinábanse así un reconoci. nto más prolijo de las inmediaciones del puerto ciel Año Nuevo, una determinación más segura de la longitud del Cabo San Juan, para que en lo venidero dirigiese con más acierto las recaladas de los buques nacionales y también un mayor aprovechamiento de tiempo ya que contraria á la sazón la marea y amenazando el viento de inclinarse rápidamente al Sur, era preciso que nos mantuviésemos paireando al abrigo de la costa. 1)ic. 30 El atravesar desde el Cabo San Dicgo á la Isla de los Estados, debió, pues, ocupar la poca claridad del dia que aún nos quedaba; de sucrte que eran bien las nueve cuando estuvimos Norte-Sur con el Cabo San Antonio, distancia de clos leguas. E] viento al mismo tiempo habia girado al Noroeste fresco y arrafagado y por un acaso difícil á precaverse, apenas habíamos atracado la isla, cuando nos sobrecogió una corriente tan fuerte al Sur que nos aconchaba sobre la costa, de la cual no distaríamos á las diez sino dos millas escasas.

I'ué, pues, preciso orzar al Nordeste y resistir una fuerza desproporcionada de $v$ sla, la cual, $\sin$ embargo, llevándonos á las once á propasar las islas del Año Nuevo á muy corta distancia, nos permitía finalmente á las doce navegar al Este corregido, con un aparejo regular. No podían ser más exactas la configuración y la dirección de aquellos contornos de lo que los habia descrito el Capitán Cook. Las islas que forman el fondeadero del Año Nuevo, se dejan ver á regular dis tancia y como sobresalen mucho al Norte, siendo al mismo tiempo bajas mientras toda la tierra de la Isla de los Estados es alta y escarpada, puede mirarse aquel fondeadero como el ménos equívoco para venir en busca suya.

$A$ las tres de la mañana ya nos era fácil tomar algunas vistas de la costa. Midiéronse después horarios en diferentes horas $\mathrm{y}$ marcaciones $\mathrm{y}$ dieron unánimes al Cabo San Juan la longitud de $7^{\circ} 25^{\prime}$ al Occidente de Montevideo, atendiendo sólo al número $6 \mathrm{I}$, pues cue los $\mathrm{I} 3$ y 72 se apartaban de aquél considerablemente, el uno al Oeste y el otro al Este, dando, no obstante, un promedio enteramente igual á los resuitados del primero.

Desde la mañanita, el viento, á veces claro á veces achubascado, había rolato al Oeste y Sursudoeste. Le ceñimos á ratos, otras veces navegamos algo arribados para contrarestar una corriente viva la cual nos arrastraba al Sur y hacia el Cabo San Juan; pero á las once, con una turbonađa del Sudoeste ya se declaró viento fresco por aquella parte, y engruesando luégo el mar, nos obligó á precavernos con dos rizos en las gavias y con éstas y el trinquete á seguir el bordo del Sursueste

Siguió en toda la tarde bicn fresco y arrafagado; al anochecer eran las mares excesivamente gruesas, y nuestro aparejo se había reducido al solo trinquete y á la gavia en tres rizos, arriada ó izada según lo exigiese la mejor conserva con la Atrevida.

Sólo en la mañana siguiente empezó el tiem- En. ${ }^{\text {I790 }}$ po á minorar su contrariedad. El viento luégo fué rolando hasta el Oeste y últimamente al Sursu. doeste. Tomáronse las muras á estribor con fuer- 
i costa. Dic. so la Isla ca clarirte que rte-Sur dos leirado al caso dircado la nte tan a costa, dos mi -

resistir ual, $\sin$ asar las cia, nos al Este dían ser ción de scrito el fondea dar dis. , siendo ierra de a, puede os equí -

il tomar después iones $y$ longitud tendien. y $72 \mathrm{se}$ 1 uno al inte, un ados del

es claro Jeste $\mathbf{y}$ ces natar una - y hacia ina turo fresco el mar, en las el bordo

arrafa. ramente ucido al arriada rrva con el tiem- $\begin{gathered}1790 \\ \text { En. }: 0\end{gathered}$ ıego fué Sursuon fuer-
E.n. a za de vela y esto nos condujo para el medio día del 2 á la latitud de $57^{\circ} 3^{8^{\prime}}$ y longitud $57^{\circ} 6^{\prime}$.

Desde esta época la navegación del Cabo de Hornos fué para nosotros más bien una de las más placenteras de entretrópicos, que de las penosas á que la embarcación y el ánimo del navegante están ya bien dispuestos. La mar fué constantemente llana, los vientos variables del Nornoroeste al Sur, por lo común bonancibles y $a ́$ veces acompañados ó de neblina ó de garua ó de alguna granizada casi momentánea; observamos siempre la altura meridiana del Sol y los ho. rarios para la longitud, En los días 4 y 5 se proporcionó observar azimutes, los cuales dieron unánimes la variación de $26^{\circ} 30^{\prime}$.

Las distancias lunares observadas en la mañana del 8 , en número de 56 séries, aproximándose mucho á los relnjes, dieron lugar á la esperanza de que su marcha se conservase uniforme.

El 6 había sido la mayor latitud observada de $60^{\circ}+3^{\prime}$. Las diferencias con la estima eran considerables, pero unas veces al Sur y otras al Norte. En la longitud no las hubo de entidad al principio; pero desde el 8 hasta el $\mathrm{r} 2$ se manifestaron corrientes bastartemente rápidas hacia el Este entre los par "los de $57^{\circ}$ y $59^{\circ}$.

Fué también muy ıeliz para nosotros en aquellos días el encuentro que tuvimos de la fragata del comercio de Cádiz, Santa María Magdalena, su Capitán, Piloto y Maestre D. Martín Antonio de Iturriaga, la cual, con Ir 2 días de navega. eión, se dirigía á los puertos de Valparaiso y Arica. La tripulación, en número de 44 personás, gozaba de la mejor salud, ni le hacia falta la menor cosa para concluir su navegación, según lo aseguraron al Teniente de navío $\mathrm{D}$. Cayetano Valdés, el cual había ido desde la mañana á reconocerla.

Metido el bote á las tres de la tarde, procuramos aprovechar para nuestra derrota las diferentes ventolinas que se nos presentaban y las cuales (si se exceptúa un chubasquillo del Este casi momentáneo) nos dejaron casi siempre sin gobierno. Sólo por la mañana entabló viento flojo del cuarto cuadrante, que ceñimos inmediatamente con todo aparejo al Sudoeste. Hablóse á la ATREVIDA para comunicarle las noticias adquiridas el día antes, y supimos en aquella ocasión, que la longitud de sus relojes, conformes entre sí, coincidía al medio día anterior en el minuto, con nuestras longitudes sujetadas al número $6 \mathrm{r}$. La latitud fué de $5^{\circ} 6^{\prime}$ y la longitud de $20^{\circ} 2 t^{\prime} 30^{\prime \prime}$ al Occidente de Montevideo. La fragata mercante distaba de nosotros unas tres leguas al Sudeste, y como no tardase el viento en pasar del cuarto cuadrante al tercero y aquélla le ciñese de la vuelta del Sur opuesta á la que seguían las corbetas, se perdió de vista hacia las seis de la tarde.
Restituídos poco despućs los vientos á su an- En 13 tiguo semblante apacible é inclinándose paulatinamente del Noroeste al Norte y Nornordeste volvieron nuestros progresos en longitud á ser más bien considerables; los rumbos que procurá. bamos seguir torcían al Norte, aprovechábase tal cual hora de calma para comunicarnos con la otra corbeta aquellas dudas 6 noticias las cuales pudiesen acelerar la ordenación de las pasadas tareas 'y hacer útil en cierto modo la inacción hidrográfica en la cual vivíamos en la actualidad. Repetíanse las observaciones y los exámenes sobre los relojes marinos, y considerándonos ya en el Mar Pacífico, vencida la longitud de $22^{\circ} 33^{\prime}$ de Montevideo, se avivaba la esperanza de poder cuanto antes emprender de nuevo y para mucho tiempo aquella serie de operaciones científicas á la cual nos habíamos contraído.

La situación del navegante en aquellos ma. res $\mathrm{y}$ en unas regiones tan distantes de las que le vieron nacer, es sin duda alguna de las más extraordinarias que puedan acontecerle.

La incertidumbre le rodea á cada instante; una sola mirada hacia las costas más cercanas lc recuerda en una complicada perspectiva el naufragio, el frío, el hambre y la soledad. Vuélvese al Polo, y una nueva clase de peligros, aún más temibles, se desplega instantáneamente á su imaginación; campos inmensos de escollos de hielo, amenazan la frágil nave. No basta procu. rarlos evadir con cuantos auxilios dicta un arte falible: ellos mismos son los perseguidores, y su posición, variable á cada instante y con tantas direcciones cuantas son las islas, aumenta el riesgo y la desconfianza. La tenacidad de los Oestes parece al mismo tiempo oponerse directamente á la continuación del viaje: su violencia no permite á veces sino poca vela, las olas mo. vidas con un impulso tan violento y tan cons. tante agitan la nave con balances extraordinarios y la exponen á cada paso á desarbolar. Las c $n$. rrientes le son al mismo tiempo contrarias, el retroceso ignominioso y mil veces fatal á su mis. ma conservación. Tales son las contrariedades que opone la navegación en aquellos parajes, y que, sin embargo, vencen cada día con más faci. lidad, reunidas á porfía la codicia y la ciencia del arte marinero.

Pero ya en la posición en la cual nos hallábamos, debíamos considerarnos libres de los peligros indicados, pues los vientos tempestuosos del Sudoeste podían ceñirse constantemente con las muras á babor, y este rumbo nos conducía á disminuir rápidamente la latitud. En efecto, para el medio día del 18 , aunque hubiésemos sufrido temporales recios, nuestra latitud era de $5^{\circ} 35^{\prime}$. El Cabo Victoria nos demoraba al Este $49^{\circ} 0^{\circ}$ leguas.

En esta disposición, y franqueado el paso al 
Eil. เo Mar Pacífico, debíamos tomar á la vista los objetos de la expedición para dirigir con más acierto la derrota siguiente. Eran éstos de fijar los límites en longitud de la costa occidental patagónica, sin exponer intempestivamente los buques, de reunir nuestras tareas á las que se hubiesen hecho anteriormente y mereciesen alguna confianza; finalmente, de llegar á Chiloé en estación oportuna para continuar el reconocituiento prolijo $y$ científico de la costa siguiente al Norte, el cual debía ocuparnos en todo el año de r 79o; no igno. rábamos al mismo tiempo que los vientos reinan. tes sobre la costa eran travesías tempestuosas con mares gruesas, $y$ que en los meses siguien. tes de Febrero y Marzo no sería tampoco extraño el aparecimiento de los vientos Nortes, los cuales por su fuerza, duración y cerrazones, han sido siempre temidos en aquellos mares. El Cabo Victoria y los livangelistas podían ya considerarse como situados con la mayor exactitud hidrográfica, dependiendo directamente de las observaciones de los Tenientes de fragata $\mathrm{D}$. Cosme Churruca y D. Ciriaco Cevallos (I). Por otra parte, la expedición del Piloto Machado desde San Carlos de Chiloé en $\mathbf{1}_{7} 65$, conducía las marcaciones por allí hasta el Cabo Corso en latitud de $49^{\circ} 30^{\prime}$. Así no quedaba realmente para reconocerse sino el trozo comprendido entre aquellos extremos ó entre los paralelos de $52^{\circ}$ y $49^{\circ}$, en donde podían mirarse como algo dudosas las de. terminaciones del Capitán Sarmiento, si bien hechas por un navegante tan experto é interpretadas luégo con exquisita crítica por los Tenientes de navío D. Dionisio Galiano y D. Alejandro Belmonte (2).

No tardó mucho, adoptado ya el plan que dimanaba de aquellas reflexiones, en manifestársenos tiempo al parecer oportuno para el intento. En la noche del I9, sobre algunos chu'ascos con granizo, se declaró viento fresco del Sirr y Sursudoeste, el cual, convidándonos á navóar hacia la costa y prometiendo la ocasión favorable para hacer al mismo tiempo algunas observaciones, ya para el medio día siguiente por latitud de $5 \mathrm{I}^{\circ} \mathbf{I} 7^{\prime}$, nos había aproximado á unas 20 leguas del Cabo Santa Lucia. No parecían, pues, infundadas nuestras esperanzas de empezar en aquella misma tarde los reconocimientos proyectados; pero muy luego debimos recordarnos del paraje en el cual nos hallábamos, siendo así que á las cuatro nos había alcanzado viento tempestuoso del Oeste con las acostumbradas cerrazones y mares gruesas, el

(1) En la expedición de los paquebotes Eulatia y Casilda (ano de 1789) mandada por el Brigadier Don Antonio de Córdoba.

(2) Fueron destinados en I 786 al Estrecho de Magallanes en la fragata Cabcza, mandada por el Brigadier D. Antonio de Córdoba. cual nos obligaba á precavernos con otros rum- En. so bos de los que habíamos seguido hasta entonces.

Empero como á este tiempo hubiésemos alcanzado una distancia de la costa no mayor de 17 leguas, $y$ por otra parte, antes de cerrarse los horizontes, pudiésemos con toda certeza fijar la extensión de nuestras visuales hasta unas ro le. guas, los límites en longitud para aquel cabo podian considerarse determinados con una certeza evidente, á lo ménos por lo que tocaba á una posición más occidental de la que le suponía la carta agregada á la narración del último viaje al Estrecho de Magallanes.

La noche fué lluviosa con viento arrafagado y mares gruesas; siguióse la vuelta del tercer cuadrante hasta la mitad de ella; viramos luégo con vientos del Ocste al Nornoroeste; así al me dio día siguiente, por latitud de $5 \mathrm{r}^{\circ} \mathrm{r} 7^{\prime}$, el Cabo Santiago demoraba al Este $2 \mathrm{I}^{\circ}$ Norte 22 leguas próximamente; $y$ pues el tiempo había tomado un semblante algo más favorable volvían á revivir nuestras csperanzas de avistar la costa.

El cogerla al Norte del Cabo Santiago y el cogerla temprano para que recorriéndola por todo un día nos condujese á la vista del Cabo Corso, debió ser por la misma razón el objeto esencial de la navegación siguiente; continuáronse en la tarde rumbos del Norte; arribamos al anochecer hacia el Este, $y$ hechas desde la media noche algunas horas de pairo, ya que la calima nos avisaba de hallarnos en muy buena posición, logramos efectivamente á las tres y media del 22 la vista de un trozo considerable de costa.

Las tierras avistadas se extendían desde el Nordeste hasta el Esueste, eran altas, entrecortadas y semejantes en un todo á las que había. mos visto en la parte oriental, y á pesar que no distásemos de ellaşsino unas cinco ó seis leguas, ni la sondaleza alcanzaba el fondo con 120 bra $z a s$, ni veíamos á nuestro alrededor aquel número de pájaros que suele comunmente solazarse en los días placenteros á la vista de la costa. Creímos desảe luego unánimes con los Oficiales de la ATREvida, que era este trozo el comprendido en las narraciones de Sarmiento entre los Cabos de Santiago y Tres Morros; veíase un canal el cual.debía ser el del Oesudoeste. Ambos extremos parecían sin tierra contígua; su direć ción era del Norte $1 / 4$ Noroeste y Sur $1 / 4$ Sueste verdaderos y se veían pospuestas á larga distancia otras sierras sumamente altas y nevadas, próximamente en la dirección del Norte-Sur, las cuales serían con mucha probabilidad una conti nuación de la Cordillera de los Andes. Todo presentaba á la vista un semblante árido y (por cuanto pudiese conjeturarse á tan larga distancia) parecía ser su masa de granito .. oscuro. 
Lin. 2 No tardamos un instante en emprender las tareas correspondicntes; se repetían las alturas del Sol, medidas con el sextante para deducir los horarics, se corrian bases ordenadas, aprove. chando toda vela; observáronse hacia el medio día unas ochenta series de distancias lunares, $y$ como se consiguiese también el observar la al. tura meridiana del Sol, justamente cuando marcábamos á larga distancia el cabo Corso, no de. bió parecernos enteramente malogrado nuestro intento, aunque el viento hubiese sido débil en toda la mañana, y muy luégo le sustituyese el Noroeste y Oesnoroeste tempestuoso con las ma. res y cerrazones que solían acompañarle. Nues. t:? latitud habia sido de $5^{\circ} 4^{\prime} 30^{\prime \prime}$; la longitud de $20^{\circ}$ II $\mathrm{I}^{\prime}$ al Occidente de Montevideo; la variación magnética por diferentes azimutes de $2 \mathrm{I}^{\circ} 2 \mathrm{O}^{\prime}$ y el resultado medio de las distancias lunares, diferentes de los relojes solamente en ocho minutos. Podía deducirse de los datos indicados, que la latitud del cabo Corso seria de $49^{\circ}$ $27^{\prime} 30^{\prime \prime}$ y su longitud al Occidente de Cádiz de $69^{\circ} 40^{\prime}$ algo más occidental de lo que manjfestaba la carta al Magallanes, pero mucho más al Este de lo que había sospechado el Sr. D. Antonio de Ulloa.

Cerrado casi enteramente el tiempo con llu. via, ráfagas y mares tempestuosas, fué preciso navegar al Oeswivieste de la aguja, con el solo trinquete y la gavia en dos rizos; á ratos se nos hacía difícil la conserva con la ATREvida, los ba. lances nos amenazaban á cada instante de algunas averías en la arboladura. Pocas aves y algunos lobos marinos eran los únicos compañeros que dividian con nosotros en estos climas desiertos la tenacidad de los elementos, constantes sólo en su dureza y contrariedad.

Al medio día del 24 fué cuando pudimos con. cebir de nuevo algunas esperanzas de lograr unos tiempos algo más favorables: con vientos del Oeste ménos recios y algo más despejados reviramos al Norte y fué nuestro intanto el resarcir las pérdidas adquiridas en la latitud, las cuales, más bien por efecto de las corrientes, que del rumbo seguido, no habían sido menores de 50 á $6 \mathrm{c}$ minutos. Nos fue fácil en esta ocasión el alcanzar la latitud de $49^{\circ} 32^{\prime}$ y el em. prender inmediatamente después rumbos directos hacia la costa, siendo nuestro ánimo el atra. carla por los $49^{\circ}$, de tal modo, que ligásemos con las tareas del día 22 sobre el cabo Corso, las que ah ra se nos pudiesen proporcionar; pero no bien ha biamos empezado en la tarde del 25 á aproximarı) de nuevo á la costa, cuando volvimos á vernos rodeados de las contrariedades acostumbradas.

Este tercer ensayo ya no dejaba duda de la constancia de los vientos contrarios, tanto más recios, cuanto mayor fuese la inmediación á la costa. Además, que siendo momentáneos los kn. vientos del Sur, igualmente cerrados y tempestuosos los del Noroeste y sicmpre inmediata á ellos la travesía del Oeste, ni rsría asequible recono. cimiento alguno, ni pudiera á veces evitarse el ser cogidos á poca distancia de la costa, con uı riesgo evidente de naufragar. En el entretanto nuestras circunstancias, sea en cuanto al tempo. ral 6 en cuanto al aparejo, eran en mucho peores de las que habíamos sufrido en los dias anteriores. Fué preciso ceñir de nuevo hacia el Sur y resistir una fuerza extraordinaria de vela; se nos hizo á ratos peligroso el solo aparejo del trinquete y la gavia en dos rizos arriada: pasá. ronse asi días enteros entre esta lucla contínua con los elementos, y era, sin embargo, uria perspectiva para nosotros bien desagradable, la que nos recordaba que en el espacio de seis días, apenas habíamos ganado un medio grado en latitud, si bien los masteleros y los mismos bu. ques se hubiesen comprometido más de una vez entre las ráfagas y contrastes que nos ocasiona. ban frecuentemente.

Pareció, pues, haber llegado el tiempo oportuno para que abandonásemos unas regiones tan directamente opuestas á la navegación y pensásemos en transferirnos á Chiloé. Alejados de la costa con los bordos que habíamos debido seguir en los días anteriores, pudimos conservar el del Norte, y éste, conduciéndonos muy luégo á latitudes más suaves, nos presentó ya por algunos momentos las ideas casi olvidadas de los climas apacibles de los trópicos. Nos hallamos el 28 en latitud de $47^{\circ} 4 I^{\prime}$ y longitud $22^{\circ} 50^{\prime}$ de Montevideo; la variación magnética por ambos métodos de los azimutes y de las amplitudes era de $19^{\circ} o^{\prime}$ al Nordeste.

Dcbía á la sazón complacernos mucho el es. tado bien robusto de una y otra tripulación. La ATrEvida nos dijo que no tenía enfermo alguno de entidad. En la Descubierta, tres ó cuatro marineros que habian tenido algunos principios de calenturas catarrales ó tal cual ardentía de sangre, se hallaban curados en pocos dias; y lo que debía parecer extraño, á pesar de los fríos y de las lluvias, apenas se hacían perceptibles en uno ú otro los sintomas terribles del mal venéreo. Atento á los principios adoptados para la conservación de la salud, y de los cuales dare. mos en otro lugar una idea más individual, cesó en estos paralelos la distribución del cuartillo diario de vino, se le sustituyb la ración de Sover. krout 6 coles agrias por tres veces á la semana. El gazpacho tomó el lugar de las sopas de aceite, y la ventilación, el aseo y la tranquilidad del ánimo, fueron nuevamente los resortes principales que se adoptaron por nuestra parte para la conservación sucesiva de la salud, la cual en es. tos tránsitos rapidísimos del calor y el frío, me- 
Fil a rece sin duda algruna la atención más prolija y reflexiva.

Abandonadas como se ha diclo las costas occidentales que acabábamos de visitar en parte y en parte debiamos mirar como inaccesibles, ya uuestra derrota debió acercarnos rápidamente á las costas de Chiloć.

In la tarde del 30 , rodeados de una neblina espesísima, sondamos go brazas piedra, lo cual nos hizo sospechar que estariamos inmediatos á la Isla de Guafos, no distante al Sur de la de Chiloé; y sobrecogidos en la noche siguiente de un fuerte contraste del Sudoeste, el cual nos precisó á navegar con dos rizos en las gavias, pro. curamos al principio seguir tales rumbos, que nos alejasen algo de la costa, avistada al parecer hacia la media noche; después volvimos de nuevo á dirigirnos hacia ella para atracarla y apro. ximarnos al puerto.

L a tierra á la vista era bastantemente eleva. da; bajaba luégo desde su medianía para el Norte y presentaba un semblante tan agradable por lo froncloso de sus bosques, como horrible por lo escarpado de sus eostas, cuyas desigualdades sin embargo no descubrían entrada ó puerto que las hiciese accesibles. liran las que corren desde los altos de Cucao hasta la punta septentrional de la isla y cuya vista si continuase el viento fresco del Sudoeste, hacía esperar que no sería difícil alcanzar para el dia siguiente el pucrto de $S$. Carlos.

Paireamos en la noche con el mismo intento hasta que siguió el viento fresco: abonanzado éste, arribamos hacia aquel extremo; así, al ama. necer no distábamos sino tres leguas de la costa y nuestra posición era tal que en pocas horas hu. bićramos podido internar en el puerto; pero nos estabadestinada una extraña equivocación la cus' debía en parte apoyar con la experiencia cuánta fuese la necesidad de unos planos exactos de aquellas costas; el que nosotros teníamos era evidentemente equivocado en la escala de las distancias y en la posición respectiva de las puntas que formaban la boca, lo cual nos persuadió á que la entrada estuviese en una ensenadita al Sur de la punta de Cocotuya, confundida ésta con la Punta Capitanes en el Continente. Es aquella ensenada no muy honda, con algunos islotes entresembrados $y$ unos altitos notables en la tierra alta, los cuales hacen de tal modo en-

r sh. .. gañosa la proyección real de la costa, que á la distancia de dos leguas no es fácil apercibir el error, tanto más que coincide la latitud con la del pueblo interior y como sucede frecuentemente no se distingue otra tierra al Norte.

Con estos antecedentes no parecerá extraño que continuase nuestro error áun después de observada la latitud, y que aprovechando los vientos variables á las veces del Norte, á las veces del Oeste, los cuales nos proporcionaban diferen. Feb. a. tes bordos, no alcanzásemos hasta las tres de la tarde á resolver enteramente las dudas contrai. das desde el principio de la mañana. Fchamos el bote al agua, paireose algún tiempo á media legua de la playa, en la cual, finalmente disipada también la neblina que la ofuscaba, se conoció claramente que en lugar de abra sólo habia una continuación peligrosa de arrecifes; el fondo era de 22 brazas conchuela y cascajo; al medic día le habiamos hallado de 30 brazas, misma ca. lidad.

liué, pues, preciso ceñir con todo aparejo para separarnos algo de la costa; hízose señal á la ATRLvibi, la cual estaba á barlovento nuestro, para que reconociese con mayor individualidad las inmediaciones del puerto, $y$ efectivamente, señaló poco después el que las distinguia clara. mente al Norte de la puntil de Cocotuya; nos. otros entonees ya nuevamente á media milla de la costa, debimos revirar al tercer cuadrante y na. vegar liacia el Oeste, tanto por la proximidad de la noche, como porque las apariencias del tiempo amenazaban próximo un temporal. Iin esta ocasión perdióse la $A$ TrRevida de vista, la cual no distinguiendo la señal de unión se habia conservado á barlovento. $Y$ pues la noche y el día si: guiente fueron con exceso cerrados y tempestuo. sos obligándonos sólo á cuiclar del aparejo y de los bordos que nos conservasen en buena disposición, no fué fácil el reincorporarnos hasta la tarcle del 3; en la noche anterior la IEscumierTA había atracado nuevamente la costa, y paireado á dos leguas de ella; pero reconociéndola con más claridad por la mañana de suerte que estu. viese aún distante al Nortc la boca del puerto, le fué preciso revirar y con este motivo encontrar la Atrevida, la cual navegaba de la mura opuesta.

No permitieron los vientos sumamente variables y lluviosos, el conseguir ventaja alguna en la restante tarde y en la noclse inmediata; pero tinalmente, en la mañana del + entablado viento fresco del Sur y Sudoeste nos fué fácil, hecha toda vela, el atracar la punta de Cocotuya, y á pesar de la contrariedad dè la marea el alcanzar para el anochecer las inmediaciones del puerto, en donde extinguidas casi al mismo tiempo las últimas ventolinas de fuera, dejóse caer un ancla en seis brazas fango: en esta posición la bateria de la punta de Yaqui, extremo occidental del puerto, nos demoraba al Sudoeste distancia unos cuatro cables; no tardamos en la mañana siguiente en aprovechar de la marea para internar en el puerto con el auxilio de los remolques. Al medio día entrambas corbetas estuvieron amarradas en buen paraje $y$ todo dispuesto para acelerar cuanto fuese posible las operaciones que debian detenernos en el puerto. 
diferen. Feb. un

es de la

contral.

cluamos

i media

lisipada

corroció

bía una

ndo era

edic día

ma ca.

zjo paria

ial á lá

huestro,

ualidad

imente,

clara.

a; nos-

la de la

e y na.

idad de

tiempo

ta oca-

iual no

conser.

día si.

pestuo.

jo $y$ de

dispo-

iasta la

IBIERTA

aireado

sla con

e estu.

erto, le

contral

mura

varia.

una en

a; pero

viento

hecha

ia, y á

canzar

puerto,

las úl-

ancla

batería

tal del

a unos

iguien-

$r$ en cl

medio

das en

cuan.

an de.
Feb. 5 lin efecto, desde las primeras horas de la manaina se habia remitido á la población la mayor parte i: los instrumentos astronomicos, y franqueada casa oportuna desde donde fuese fácil la comunicación por senales con las corbetas, se había armado el péndulo y dispuesto el cuarto de círculo. Así en la noche inmediata, los Oliciales astronomos pudieron olservar diferentes al. turas meridianas de estrellas al Sur $y$ al Norte del zénit, malograda por la intcrposición casi momentánea de algrunas nubes la observatción de una estrella ocultada por la Luna; y en la mañana del 6 ya las lanchas y botes se ocupaban con tesón de los reemplazos de agua y leña, mientras los restantes Oficiales atendian cada cual á multiplicar los objetos útiles de la expedición.

Lira á la sazón Gobernador de la Isla de Chiloé el Coronel D. Pedro Garoi; guarnecian á la plaza, además de una plana mayor, algunas compañias de infanteria, artillería y dragones. $Y$ pues que en las últimas combinaciones del Gobierno relativamcnte á la América Meridional, se liabía particularmente comprendido aquella parte hasta entónces olvidada de los dominios ultramarinos, las primeras medidas útiles para este intento eran las de atraer por una parte la amis. tad y confederación de los pueblos contiguos no bien sujetos á la Monarquía; por la otra, de reconocer y describir con la posible exactitud hidrográfica las costas y los muchos puertos útiles de toda la isla. Apenas habia concluído cste objeto el Pilotc de la Armada D. José Moraleda con algunas piraguas. Entendian con asiduidad en la pacificación indicada, así el Presidente y Gobernadores de la frontera del Chile, como los de Valdivia y Chiloé, haciendo respetar á las veces el nombre español cuando hubiese alguna traición que quebrantase la buena fé de los tra. tados, á las veces agasajando con regalos cuantiosos á aquellos caciques y soldados que más bien se inclinasen á la vida sociable y amistosa con nuestras colonias.

Debi6, pues, parecernos una verdadera felicidad, la que nos proporcionaba en los mismos días de nuestra llegada el conferenciar por la una parte con el mismo Moraleda sobre el éxito de su pasada comisión y por la otra el asistir á las concurrencias de algunos caciques y soldados viliches, los cuales por primera vez hacían una visita al Gobeınador. Tuvieron éstos su primera audiencia en la mañana del 6; eran unos cuarenta y cuatro, presididos del Cacique Catiguala; dos ó tres Capitanes de amigos procedentes de Valdivia y acostumbrados á vivir entre ellos desde. mucho tiempo les servían como intérpretes; y para dar una mayor solemnidad á la visita, habíase de nuestra parte reunido la Oficialidad, y por parte de ellos, se procuraba conservar en la comitiva un cierto orden; la acompañaba con el mismo in- tento una inúsica no muy grata y compuesta de Feh. ulgumas cañas largas y luceas, cerrudo casi del todo el un estrèmo con hojas de árboles; los más robustos soplaban con muclia fucrza por sun agujero lateral y cuando esturiesen cansados les recmplazaban algunos otros inmediatamente.

Puestos nosotios en torno, los viliches, a imitación del Cacique, fueron desfilando y dándonos la mano uno á uno, acompañada esta muestra de amistad con la voz de compá, la cual seguramente aludia al epíteto de compadre. Iimprendió después una arenga bien larga el Cacique Catiguala. Recordaba al Gobernador el largo plazn en el cual había sido interrumpida la co. municación recíproca; veía con mucha coniplacencia un suelo que liabían habitado sus antepasados, y debía mirarse como una prueba evi. dente de la sinceridad de sus proposiciones, el que ahora vinicse á visitarle y á estrechar con más solidez los vínculos ya entablados de una amistad duradera. Respondió el Gobernador asegurándole en nombre de S. M., que sería por su parte inviolabic la fé de los tratados; que vcrían en los dones repetidos una prueba nada equí. voca, así de la generosidad del Monarca, como de su deseo de atraerlos á una vida tranquila y sociable; y que en el entretanto podrían descansar de sus fatigas pasadas, pues se les darían cn nombre de S. M. habitación, alimento y cualquiera otra cosa que solicitasen. Con el mismo orden y una igual formalidad, hablaron después otros caciques inferiorcs; $y$ seguramente inclinados por naturaleza á esta especie de arengas solemnes, las hubieran continuado por mucho tiempo si no les interrumpiese oportunamente el ref resco compuesto casi en un todo de licores es pirituosos, á los cuales son por naturaleza cxtre. madamente propensos. Bebieron por largo rato, pasearon después las calles y en breve tiempo hicicron conocer què la música que los acompa. naba era más bien una instancia para que los convidasen de nuevo á beber, que un obsequio y una muestra de las ideas pacíficas que les animaban.

No había sido ménos oportuno (como ya se dijo) el encuentro del Piloto D. José Moraleda, el cual no sólo había trabajado y conservado las cartas más detalladas de las costas del Perú, si también habiendo navegado por muclos años en aquellos mares, conocía mejor los vientos, đas estaciones y los parajes más ó ménos trillados, los cuales debiésemos visitar. Por orden del Vi. rey del Perú nos entregó dichas cartas y los planos y derrotcros últimamente trabajados sobre toda la isla de Chiloe; el Gobernador de la plaza nos franqueó al mismo tiempo varias noticias relativas al conocimiento verdadero de aquellos contornos, y pudieron los Tenientes de navio 'Tova, Valdés y Quintano, hacer una breve 
Int. a excursión hast : la capital de Castro, situada en la costa oriental de la isla, con el objeto de indugar más de cerca el país interior y las costum. bies de los naturales.

I os días siguientes, por lo común serenos y templados, dieron lugar á yue no procediesen con lentitud los muchos ramos científicos que in tentábamos abrazar. D. Antonio Pineda, con un Guardia Marina, extendio sus excursiones unas veces hacia Chacao, otras hacia las orillas de Oeste. 1). lielipe Bausá, levantado el plano in. terior del puerto, seguía luégo los triángulos por medio del teodolito, hasta donde lo permitiese nuestra demora en aquellos contornos. Algunos soldados cazadores suministraban nuevos obje. tos de curiosidad y de instrucción para la Histo ria Natural; admiraba D. Luis Nee, vagando ya a una ya á otra parte con una actividad singular, la variedad indecible de las plantas y la fer. tilidad del suclo. linalmente, los Oficiales as trónomos, aunque á veces contrariados por las nubes, habían sin embargo llevado sus tareas con tal felicidad, que el examen de la marcha de los relojes y la determinación segura de la lon. gitud podian mirarse como bien conseguidas al poco tiempo de nuestra llegada.

La inmersión del primer satélite de Júpiter observada en la noche del 6, manifestó (corregidos los errores de las tablas) que el observatorio estaria $67^{\circ} 3^{6^{\prime}} 0^{\prime \prime}$ al Occidente de Cádiz. Los relojes uniformados con las ecuaciones correspondientes, determinaban $17^{\circ} 48^{\prime} 30^{\prime \prime}$ entre el mismo observatorio y el de Montevideo. Final. mente, 80 series de distancia del Sol á la Luna, indicaban la longitud de $67^{\circ} 2 \mathrm{I}^{\prime}$ menor en $15^{\prime}$, de la que se había deducido del primer satélite cxpresado; variación de la aguja por muchos azimutes, I $7^{\circ} 20^{\prime}$ Nordeste; latitud Sur, $4 \mathrm{I}^{\circ} 5 \mathrm{I}^{\prime} 5^{\prime \prime}$.

Solicitada por nosotros, tuvn lugar á bordo en la mañana del I I una visita de todos los vi liches, de los cuales se ha hecho memoria: co mieron abundantemente, manifestaron su cons tante propensión á las bebidas; hubo lugar para que el pintor D. José del Pozo retratase con mu cha propiedad á Catiguala y á su hijo; pudimos, finalmente, en una larga y bien ordenada conversación, enterarnos de muchas costumbres suyas y de su roce y comunicación con las tribus de los Patagones.

- Reconcentradas el mismo día a su destino las diferentes partidas que se habian destacado y completados los acopios de agua y leña, se de. terminó acelerar la salida, y en el observatorio tuvieron orden los Oficiales para que hacia el I 3 observadas, si era posible, algunas otras inmersiones de !ns satélites de Júpiter; se fijase por medio de las alturas correspondientes del Sol, la última época relativa al examen de la marcha de los relojes. Empero estas medidas no pudieron verificarse por alcunos dias, porque Fob. , las inmediaciones del novilunio inclinaron des. de aquella misma tarde los vientos al Norte $y$ al Noroeste, tempestuoso, con cerrazones $y$ lluvia; de sucrte que tuviésemos interrumpida á veces liasta la comunicación de los botes y se hiciese infructuosamente arriesgada la conduc. ción de los instrumentos. Así sólo en la noche del I5 pudimos ver concluidas aquellas medidas y restituido el tiempo á su antiguo scmblante apacible, disponernos sin perder tiempo para la salida. No se omitió en aquella misma noche la observación en la plaza inmediata de la emersion del primer satélite de Júpiter, la cual, compara do inmediatamente con señales de pistola, el reloj conducido á tierra con los demás de á bordo, confirmb con iguales resultados la longitud que liabíamos deducido en la noche del 6

Un solo rnmo en el entretanto habia tras. tornado en cierto modo la felicidad con la cual habíamos podido abrazar en pocos días los dife rentes objetos del viaje; y era éste la conserva. ción á bordo de una disciplina exacta, cual convenía, $\delta$ más bien era necesaria en los muchos trances en los cuales debíamos encontrarnos en lo venidero. El puerto á do nos hallábamos, no podia á la verdad ser más oportuno para que de jando algún tanto la rienda á la disciplina mili tar, intempestiva por otra parte en esta comision, fundásemos sobre la experiencia, más bien que sobre tradiciones 6 caprichos, el método más oportuno que habíamos de seguir en los demás. El vecindario de Chiloé (mediante su ninguna comunicación con la matriz) carecía enteramente de españoles, lo cual daba un nuevo realce á los que procediesen directamente de los pucrtos del Continente; y los representaba á las veces como poseídos del mismo valor, constancia y dominación de los conquistadores, á las veces como los únicos capaces de dirigir y fomentar una familia entre las labores del campo y la industria del comercio. Reuníase después á estos antecedentes, por si razonables, una suma mezquindad en las mujerek, haturalmente propensas al libertinaje, una ciertio indolencia incorregible en los hombres, $l_{2}$, wal les hacía como necesaria la bebida; in inente, un desmayo indispensable n el sistema gubernativo, para que unas veces mirase la presencia de nuevos colonos como un aumento feliz de su fuerza y autoridad, otras no hallase resortes oportunos para refrenar los pasos uniformes de la colonia al tiempo ó de viciarlos ó de seducirlos. Tantas razones reunidas no podian ménos de dar, finalmente, al hom. bre de mar, una errada idea de la felicidad. Por unia parte todo le convidaba al desorden y á la deserción; por la otra recordaba aún las fati. gas y peligros pasados en la navegación del Cabo de Hornos. Cómo resistiria á tamaña perspec. 
Fels. is tiva y no se decidiria, tinalinente, a variar de suerte abandonando el buque de su rlestino y ol. vidando en un solo instante su patria y su fa. miliu?

Asi, casi en los primeros momentos de nuestra comunicacion con el pueblo de San Carlos, pudo ulvertirse la faltu cusi constunte á la hora senalada para el regreso á bordo del mayor nú. mero de nuestros soldudos, marineros y criaclos; algunos permanecieron varios días en tierra á pesar de una expresa prohibición para verificar. lo; muchos se entregaron con abandono á la be bida; no tardó después un soldado de la $\Delta$ TrReviDA, el cual solía permanecer en ticrra para cus. todia de las fraguas y de la ropa lavada de los marineros, en ceder á las seducciones de un labrador no distante, quien le convidó á la deserción y al robo de muchos utensilios de la misma fragua $y$ de toda la ropa que tuviese á mano. 'l'amaños desórdenes exigicron por sí unos remedios bastantemente activos; y por la misma razón, al paso que se ofrecieron premios á cualquier paisano que entregase ó soldados 6 marineros, después de haberse separado los botes del embarcadero, se castigarou los delincuentes con algún rigor, según los métodos establecidos en la Armada. Aprehendióse tımbién por la actividad del Teniente de fragata D. Francisco Viana, el soldado de la AiTrevidi que había robado los utensilios de la fragua, y se le castigó con tres carreras de baquetas reunida la tropa de entrambas corbetas. Listo no bastó, sin embargo, para que pudiésemos cortar del todo la deserción y el desorden; y al tiempo de dar la vela echábamos aún de ménos ocho marinerns: los cinco, de la ATrevida, y tres de la Descubiekta. Quien considere con alguna atención cuánto se apartaba por necesidad en una comisión como la nuestra el método de disciplina del que siguen comunmente los buques de S. M., conocerá que era im. posible el no atandonar mil veces al marinero á sí mismo, siendo así que cinco embarcaciones menores estaban en un contínuo trabajo; que la sola caída maliciosa de un instrumento al tiem. po de embarcarlos 6 echarlos en tierra pudiera causarnos una pérdida irreparable; finalmente, que la quietud y una subordinación habitual $y$ voluntaria serian los medios seguros para aquella harmonía de nuestras fuerzas y ocupaciones, sin la cual no se hallarían á cada pizso, sino inconvenientes y lentitud.

Todo así dispuesto para dar la velia en la ma. ñanita del 16 , cuando aún fuese favorable la marea, estuvimos efectivamente á pique con las primeras claras del día, y la Descubierta, ayudada de los remolques, emprendió el aproximarse á la Punta de Yagui para estar algo más franqueada y aprovechar la otra marea. La ATrEvidA no varió de posición, y como no empezasen á asomar sino á las dos de la tarde las primeras Vol. í ventolinas del ()esudoeste al tiempo que rupuntuba la vaciante, sólo á esa lora pudimos entrambas dirigirnos con todo aparejo liacia la boca del puerto, y empezar una lucha con los ticmpos contrarios, la cual no imaginábamos jamás que dehiese durar por el espacio de cuatro dias. Em. pero era tanta la vuriedad y llojedad de los vien. tos y tal la facilidad de la marea en oponerse directamente á nuestro intento $\delta$ en aconcharnos sobre los muchos bajos é islotes del liste, que en balde en el intervalo indicado estuvimos maniobrando á lo ménos cuatro veces al dia para levarnos y dar fondo, pues siempre tenínmos que volver á nuestra untigua posición con el lin de no exponernos 6 al albedrío de las mareas 6 a ul golpe repentino de vientos contrarios y tempes. tuosos. Lil bosque espeso que cubre casj toda la isla, es sin cluda alguna la causa más activa para que reinen en aquellos contornos con tanta fre. cuencia los vientos del Norte, húmedos en sí y directamente opuestos á la salicla del puerto. Suelen durar en el invierno hasta treinta 6 cuarenta días seguidos. L̇n los veinte de la estación favorable del verano que habian corriclo después de nuestra venida a la costa, á lo ménos diez habían sido lluviosos y dominados del mismo viento.

Procurábamos, sí, de eludir esta especie de inaccion, con inquirir por medio de la caza y de la pesca algún nuevo tributo para los progresos de la Historia Natural; y como se nos proporeionase á veces el poder medir alturas absolutas del Sol con el sextante, no habíamos descuiclado un nuevo examen del movimiento de los relojes marinos, el cual era ahora tanto más necesario, cuanta mayor ptolijidad nos habíamos propues. to para las operaciones venideras: efectivamente, en los relojes de la Descubierta habían sucedido alteraciones de mucha consideración, lo cu.d, combinado con las ecuaciones dimanadas de la comparación diaria, daba el siguiente re. sultado:

\begin{tabular}{|c|c|c|c|c|c|c|c|}
\hline \multirow{2}{*}{ Dias } & \multirow{2}{*}{$\begin{array}{l}\text { Longitudes } \\
\text { por } \\
\text { marcación. }\end{array}$} & \multicolumn{2}{|c|}{ Longitudes del $6 \mathrm{r}$. } & \multicolumn{2}{|c|}{ Longitudes del 72.} & \multicolumn{2}{|c|}{ Long:tudes del $: 3$} \\
\hline & & Directa. & Correg. & Directh. & Corres. & Directis. & Correg. \\
\hline 18 & $\operatorname{oc}^{\prime} x^{\prime} 4^{\prime \prime}$ & $x^{\prime} 3 x^{\prime \prime}$ & $x^{\prime} 15^{\prime \prime}$ & $6^{\prime} 10^{\prime \prime}$ & $2^{\prime} 16^{\prime \prime}$ & $4^{\prime} 29^{\prime \prime}$ & $0^{\prime} 43^{\prime \prime}$ \\
\hline 19 & n I'? & $0^{\prime} 30^{\prime \prime}$ & $0^{\prime} \times 5^{\prime \prime}$ & $4^{\prime} 42^{\prime \prime}$ & $0^{\prime} 5 x^{\prime \prime}$ & $4^{\prime} 44^{\prime}$ & $0^{\prime} 5 x^{\prime \prime}$ \\
\hline
\end{tabular}

Finalmente, en la tarde del ro, declarado viento favorable $y$ llamados inmediatamente los botes, pudimos dar la vela ayudándonos la marea de tal modo en aquella ocasión que para el ano. checer, cuando calnó el vierís, ya marcásemos la Punta Capitana al Norte $7^{\circ}$ Oeste, la de Gue. chucucui al Sur $23^{\circ}$ Este y el Farallon Mayor de Carelmapú al Sur $62^{\circ}$ Este. 


\section{CAPÍTULO $\mathrm{V}$}

Navegaciones y tareas hidrogrificas desde Chiloé hasta Lima.-Escalas en los partos de Concepción, Valparaiso, Coquimbo, Arica y Lima.-Ixxcursión de algunos Oficiales á Santiago.-Varios acaeciinientos ocurridos cu aquel tiempo.

Las contrariedades sufridas por el espacio de ocho días en el puerto de San Carlos de Chiloé antes de verificar la salida, $y$ las noticias adqui. riclas sobre la constancia de los mismos vientos en el puerto de Valdivia, áebieron hacernos desistir de la iłea de visitarle, tanto más, que con motivo de las diferentes fortificaciones y de los alcances de sus baterías repetidas veces los ingenieros del ejército habian levantado su plano escrupulosamente y le habian examinado después el mismo Piloto Moraleda y algunos otres Oficiales de la Armada.

Nuestra derrota debía por la misma razón couiucirnos al andar de la costa liasta la bahía de Pcneo ó Talcahuano, dond. haríamos nueva escala, y al paso de repetir las acostumbradas tareas, reconoceríamus con alguna escrupulosidad aquel verdadero término ó frontera de nuestras posesiones en el hemisferio austral.

No debió sorprendernos en el entretanto el ver poco después de que hutiese anochecido entablar de nuevo vientos Hojos del Norte y Nornoroeste con la Hovizna y calima acostumbradas Los ceñimos con las muras á estribor y con poco aparejo. Su continuación en todo el dia siguiente nos desvió de lá costa; y una extraña ilusión $\in$ umbas corbetas en la mañana del 2 I (entablado ya vienio fresco y claro del Sur) hizo que no la pudiésemos atracar de mievo, sino en la tarde inmediata, siencio las tierras que ahora texíano a la vista, las que conduc en desde las inmediacio nes del rio Bueno hasta la entrada de Valdivia. $A$ las scis de la tarde ya nos hallamos $九$ tres le. guas del puerto: se determinó su longitud por los relojes marinos; tomáronse algunas vistas de las costas y puntas inmediatas; la ATrevida no en'ontıó fondo eon 120 brazas de sondaleza; 62 series de distancias del Sol á la Luna observadas en la Discubierta y bien conformes entre sí, sólo discrepaban en dos minutos al Oeste de la longitud determinada por los relojes. Se continuó luégo la navegación entrada la noche, ya que los vientos, sumamente favorables, nos convidaban à aprovechar en objetos de mayor importancia los pocos restos de la estacion beuigna del vera110. De este modo, en la iguiente mañana teníamos á la vista la Isla Mocha y una parte no mediana de las costas fronteras. Con el andar de día nuestra derrou fué después tan favorecida del viento, que si lien siguiésemos las diferentes direcciones de la costa, ya páa el anochecer Feb. zr marcábamos las puntas de Rumena y Lavapiés, y las primeras claras del día 23 nos descubrian á un mismo tiempo las Tetas de Viovio al Este, y al Sur la Isla de Santa María, á distancia de una legua. El viento abonanzó entoncés mucho, aso. mado ya el Sol sobre el liorizonte. El abrigo de la costa presentó una mar sumamente tranquila, en la cual se veían ballenas y lobos marinos en mucho número. Emprendiéronse al mismo tiempo la derrota para el puerto y los reconocimien. tos de la costa intermedia. Así, para las ocho y media ya habíamos atracado á muy en: ca ciītancia el cxtremo Sur de la Isla Quirig cina, y nuestros bordos sucesivos para internar en la bahía hasta el fondeadero de Talcahuano fueron tan felices, que á las dos y media pudimos dar fondo en siete brazas lama arenosa, como tres cables al Oeste de la batería de Gálvez, y quedar poco después amarrados con dos anclas en la direc. ción de Norte-Sur.

Era á la sazón Goberuador Intendente de la provincia el Brigadier D. Irancisco de la Mata Linares, el eual, si bien ocupado en 1 visita de Chillán, pueblo interior de unas zo leguas, había manifestado su ánimo de regresar á la ciudad luégo que llegásemos, y sin embargo, estaban tomadas las medidas más eficaces para que ni áun en ese corto intervalo careciésemos de cuan. tos auxilios nos iuesen necesarios. El Coronel D. Pedro Quijada, el cual mandaba interiramente, explayó entre tanto una atención y una generosidad que sería difícil describir. No había una persona, no había una choza en aquel suelo feliz, en donde no sobresaliesen á porfía la recti tud y la unanimidad de los Comandantes y la felieidad y subordinación de los súbdjtos. Desde el primer día de nuestra liegada, cuantos objetos nos rodeaban, otras tantas muestras teníamos á la vista de la sericille\% é inocenria de la vida campestre.

Apenas los habitantes de la provincia empezaban á ver:je 'il res de los estragos sumamente funestos de una epidemia de viruelas, la cual, en la sola ciudad de la Mocha y en sus inmediaciones, había arrebatado casi instantáneamente la vida á unas dos mil quinientas personas sin distinción de sexos, edades ni condiciones. La inoculación no se había introducido hasta entonces, porque jamás penetraba là epidemia hasta aquella latitud. Pero en el día ya se había adoptado aquel preservativo por medio de un mulato recién llegado de la capital de Santiago, y pu. dieron, finalmente, contenerse los progresos ul . teriores del mal; muy tarde, sin i nbargo, para que á más de las víctimas indicadá no quedase también en mucho despojada de su atractivos exteriores la mayor parte del scxo ، иjeril, el cual poco antes podía sin recelo alguno de pon. 
anochecer Feb. ฉr

- Lavapiés,

descubrian

ol Liste, y

neia de una

hucho, aso-

1 abrigo de

e tranquila,

marinos en

hisno tiem-

conocimiell-

las ocho $y$

cicia ciistan-

ina, $y$ nues-

en la bahía

fueron tan

is dar fondo

tres cables

quedar poco

un la direc.

tendente de

o de la Mata

i. visita de

guas, había

í la ciudad

go, estaban

para que ni

os de cuan-

- El Coro-

laba interi.

nción y una

r. No había

aquel suelo

fía la recti-

ites y la fe-

s. Desde el

itos objetos

teníamos á

de la vida

incia empe-

sumamente

la cual, en

s inmedia.

táneamente

ersonas $\sin$

iciones. La

asta enton-

emia hasta

iabía adop-

un mulato

ago, y pu.

ogresos ul.

sargo, para

to quedase

atractivos

'ujeril, el

to $\therefore$ e pon.
Feb. 23 deración caracterizarse cono uniformemente hermoso y digno de la admiración de los de afuera.

Era tambión un objeto nuevo para nuestras indagaciones en aquellos contornos, el seguir de cerca las huellas de la expedición francesa de las gabarras la Bríjula y el Astrolabio, mandadas por el Conde de la Peyrouse y el Vizconde de Langle. Sus pasos, sus nperaciones, el régimen interior de aquellos buques, nada debía parecer. nos indiferentes ó bien para que procurásemos imitarlos $\delta$ para que atizasen con nuevo vigor fquella especie de emulación que es el móvil principal de semejantes empresas. Habían permanecido unos veinte di is en la bahía, en la eual nos hallábamos, y abastecidos particularmente de un buen repuesto de vinos, al paso que no descuidasen muchos ramos científicos que prozuraban abrazar, habían después seguido en Marzo de $x$ 786 una breve derrota hacia las Islas Sandwich y la costa Noroeste de la América. Debían á la sola actividad del Mariscal de Campo D. Ambrosio O-Higgins, Gobernadur entonces de la provincia, el que se hubiese evitado la deserción de una patte no mediana de sus tropas y marinerías, las cuales, ó fuesen los atractivos del país ó la natural inconstancia del hombre de mar, ya no pensaban en seguirles. Los resul tados de sus tareas, sea en cuanto á las observaciones astronómicas ó á los trabajos geodésicos, habían sid envueltas en un profundo silencio. Finalmente, sus atenciones y miramientos hacia todos los indivíduos de la colonia, merecían ‘ún en el día quc se recordasen á cada paso sus nombres unidos con la idea de la afabilidad y de un amor constante al bien público.

Movidos pues nuestros pasos con igual actividad, del ejemplo indicado, de los auxilios de la colonia y del tiempo favorable, el cual después de algunos días del viento lluvioso del Norte pareeía haber n'revamente establecido un imperio duradcro, debieron por precisión corresponder en cuanto fuese posible al cúmulo de objetos que procurábamos abrazar. Se habian aprovechado du antemano varios intervalos de una mar tranquila para sondar soldos teodolitos, ?'sunos bajos peligrosos, los cuales intercerian la navegación libre de la bahía; empreıdióse ahora con tesón el levantar su plano; se estableció el observatorio en el mismo paraje donde le había tenido Mr. Dagelct: corrían luego á su albedrío por las campinas, bosques y habitaciones rô distantes 1). Antonio l'ineda, D. Luis Nee y la niayor parte de lcs Oficiales, admirando á veces la prodigalidad y otras la variedad hermosa de la naturaleza en ese clima feliz.

Ciertamente, quien rccorra aunque pur poco tiem. $\mathrm{c}$ cl país fértil que baña el Viovio; quien examine enn una mirada política las veces que $\mathrm{reb}, 28$ ha sido regado con la sangre de nuestros valerosos antepasados; quien vea finalmente ó en las maderas esquisitas y monstruosas de la corclille. ra inmediata ó en la fertilidad demasiada del suclo ó en la abuidancia de los lobos, ballenas, congrios, etc., de sus orillas, los muchos y ricos dones que debiera ofrecer con su propio acrecentamiento no sílo á la matriz sino también á las demas colonias y:e mmponen la casi innensa Monarquía española, no nuede á méno, de ensalzar mil y mil veces una voz patriótica hacia los depositarios de la legislación y del bien público, para que sacudan de una vez los grillos que allí puso á la misma naturaleza una época ménos advertida y más tímida, y vean finalmente prosperar un país al cual llamaba con mucha razón el docto Sr. Venegas, el Reino á porfía rico y pobre del Chile.

Asegurada en el entretanto la continuación de tiempos favorables conforme nos lo indicaban casi cotidianamente las apariencias y las noticias unánimes de los habitantes, ya el plan de nuestras operaciones en aquella parte del mar Pacífico pudo mirarse más bien como ligads al prog!eso súlido de las ciencias en general, que como sujeto á las estaciones y á la frecuencia de tiempos contrarios y lluviosos: cualquiera fuese el plazo de la llegada de las corbetas al Callao debían luégo esperar que cesase en las costas de Panamá y Guatemala la estación llu. viosa del vendabal y le sucediesen los Nortes y Nordestes, los cuales nunca suelen reinar con alguna fuerza, sino en la mitad ó fines del mes de Noviembre: así podíarnos contar con un plazo bastantemente largo para permanecer sobre las costas del Chile y Perú, las cuales favorecidas de la naturaleza coll unos tiempos constantemente apacibles y con unos vientos galenos siempre firmes entre el Sursudeste y Sursudoeste convidaban igualmente á la navegación y á las tareas científicas: debían éstas luego r ..ificarse hacia la Hidrografía, ia Astronomía, los muchos objetos de la Historia Natural y el conocimiento físico y político de aquellos dominios de S.M. Todo por consiguiente concurría á indicarnos el actual teatro, como el más oportuno para des. plegar cuanta actividad pudiesen alcanzar los as mamentos.

Con estas atenciones la separación de las corbetas pareció desde lucgo indispensable; diéronse á la ATREvinA los mejores instrumentos astronómicos y algunos Oficiales de la DiscuBIERTs, para que navegando al andar de la costa hasta Valparaiso, continuase los reconocimien. tos acostumbrados, hiciese luégo en aquel puerto una demora mis larga, y mientras que los Oficiales astrónomes trabajasen cotidianamentc en el catálogo de las estrellas meridionalcs, otros se 
Mar. ocupasen ó en el examen del país hasta !a capital de Santiago ó en conducir hacia ella, si las circunstancias lo dictasen prudente, una scrie te triángulos que afianzase con datos positivos su situación en latitud y longitud. Quedó al cargo de la Descubierta el reconocimiento prolijo de la bahía en la cual nos hallábamos y de otros dos puertos no distantes; el indagar las ventajas locales para la construcción de buques, ora fuesen mercantiles 6 de guerra; y después el atra. vesar á entrambas Islas de Juan Fernández para que ni su extensión ni su posición geográfica admitiesen ya la menor duda en lo venidero.

No tardó la ATREvióa en llevar á efecto por su parte el plan jropuesto: determinada de antemano la latitud del observatorio, $y$ atendido con las alturas correspondientes el movimiento actual de los relojes marinos, dió la vela en la mañana del 2 de Marzo, y favorecida con vientos ralenos del Sur, en pocas horas salió de la bahía, ocultándosenos cou la interposición de la Isla Quiriguina: aceieráronse al mismo tienıpo los diferentes objetos que debía desempeñar la Descubierta, tanto que en aquel día ya empezaban á recibirse á bordo reinte pipas de vino, correspondientes á los repuestos de las dos corbetas para las campañas venideras y la mayor parte de los Oficiales se destinaban á los varios reconocimientos de la costa.

Nos ocuparon aquéllos incesantemente liasta el 8: los puertos de Sar Vicente, del Tomé y del Coliumo, más ó menos abrigados del viento Norte, y por la misma razón preferentes en cierto modo al fondeadero de Taicaluuano, fueron nrolijamente reconocidos; sondáronse la bahia, el canal que formala Quiriguina con la Tierra Firme y los alrededores de la misma isla; D. Fernando Quintaro y D. Secundino Salamanca emprendieron el naverar con un botecito cl rio Andariel lasta donde fuese accesible, y combinásonse con tal felicidad las marcaciones, que últimamente las triángulos dimanados del teodolitn se extendiesen por la embocadura del Viovio hasta la

- Isla Sante María y la Nueva Mocha, mientras por el Norte llegaban desde los extremos de la Quiriguina hasta las inmediaciones del Coliumo: soliamos en estas excursiones pasar indistintamente las noches en la choza de un labrador o en las casas de los vecinos más acomodados: no nos afanaba el cuidado de la comida, pues la cucontrábamos en todas partes igualmente exquisita, barata y abundante. El marinero, el labrador, el hacendado, descubrían cada cual en sus conversaciones entretenidas cuáles fuesen sus circunstancias, cuáles sus deseos y la posibilidad ó rectitud de conseguirlo's. Así acomunados frecuentemente con ellos y llevando las conferencias más bien el objeto indiferente de un entretenimiento que el de unas indagaciones siempre temibles del legislador, debían, final- Mar. mente, nuestros resultados aproximarse tanto más á la verdad cuanto mayor era después nues tro empeño de compararlas con las noticias y observaciones de los que presidian con tanto ji: cio y patriotismo á la admiristración pública.

'encidos aquellos objetos muy á nuestro pla. cer, fus preciso abandonar sin mayor dilación los contcrnos de Talcaliuano y emprender la navegación royectada hacia las Islas de Juan Fernández. La latitud del observatorio se había deducido por las distancias meridianas al zénit de muchas estrells's, de $36^{\circ} 42^{\prime}$. La variación magnética observada con el teodolito fué de $15^{\circ}$ $20^{\prime}$ Nordeste y el estahlecimisnto de la marea en los días de la oposición resultó para las ro horas $40^{\prime}$ de la mañana, siendo su mayor elevacior de $5 \%$ á 6 piés de Burgos. Por lo que toca á los relojes, quedó bien comprobada la cons tancia del movimiento asignádoles en Chiloe $V$ su determinacion de la longitud, aplicadas las pequeñas ecuaciones por los desvios diarios, fué uniforme en diferentes días, de $3 \delta^{\prime} \mathbf{2 2}^{\prime \prime}$ al Oriente del último meridiano, esto es, de $66^{\circ} 5^{8}$ de Cádiz, menor tan solo en seis minutos de la que al principio del siglo había observado el pa're Feuille por medio de varia's inmersiones del primer satelite de Júpiter, correspondidas en $\mathrm{Pa}$ rís por los Sres. Cassini y Maraldi.

Sobre la deserción de la tropa y marinería, en lugar de que hallásemos alguna ventaja en las medidas eficaces que habíamos adoptado con los risados escarmientos, concurrieron más bien todas ellas á manifestarnos, que en balde lucharíamos con una infinidad de abusos tan añe jos como la conquista y tan arraigados como las costumbres de nuestras colonias; of reciéronse por' nuestra parte treinta pesos fuertes por cada desertor que se aprehendiese: el Gobernador-Intendente destacó por la suya varias partidas de tropa y nersonas activas y prácticas del país. Nada bastó para nuestro intento, y finalmente, al dar la vela 1a Descuniekta, los desertores de ambas corbetas no eran en menor número de oclio, tres soldados artillero's, uno de marina y cuatro artilleros de mar.

En la miñana del ro estuvimos ya prontos para dar la vela, reunido á su destino D. Antonio Pineda; el cual en los ocho días anteriores labía reconocido los cam, 0 s y fortificaciones no distantes de la frontera. Reinaron ventolinas de Norte liasta las cuatro de la tarde; pern entablado finalmente en aquella hora viento galenito del Sur, pudimos aprovecharle con toda vela $y$ hacia el anochecer hallarnos fuera de la bahía.

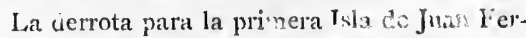
nández, no debía mirarse en mido alguno sino sujeta á errores de una medirna consıdsiación, pues labían 'sido determinados su distancia y 
Shar. to arrumbamiento con la Isla Santa María por una estima llevada con la mayor exactitud por cl señor D. Antonio Ulloa; $y$ siendo los vientos proporcionados para que la navegación fuese dire:ta, nada podía oponerse á que desempeñásemos con toda brevedad la excursión emprendida. Arreciaron mucho los Sures luégo que con el andar de la noche nos fuimos alejando de la cos. ta; $a$ las veces nos era preciso arriar las gavias á medio mastelero y eran bastantemente frecuentes los golpes de mar que se nos introducían á

- bordo. Esto, sin embargo, aceleró de tal modo 1. nuestro viaje, que al amanecer del i 2 ya estábamos á la vista de la Isla. Observáronse latitud y longitud en las mejores posiciones, reconocióse de cerca el extremo Sur y navegamos después con fuerza de velu para alcanzar en el día si. guiente las inmediaciones de la Isla Matafuero.

Sero en aquella ocasión, mucho más calmoc s los vientos de lo que debíamos esperirlo, causaron una tal lentitud en la navegación pro-

13 puesta, que al amanecer del $\mathrm{r}_{3}$ aún distábi.mos de ella unas nueve leguas, $\sin$ que pudiésemos contar sino con ventolinas variables del Oeste al Noroeste, las cuales no nos permitían una base ordenada siquiera; por ventura despejadas una y otra isla, $y$ bien determinados sus extremos, daban mustios para ligar en cierto modo con tal cual evidencia el total de nuestras operaciones; esto bastó para que conseguidas al medio día unas observaciones exactas de latitud y longitud, volviésemos nuevamente la proa al Este, y con la brisa, que entabló fresquita por la tarde, atra cásemos la isla de adentro por su cxtremo del Norte, del cual distaríamos al anochecer unas cinco leguas: Matafuero quedó situado por nues. tras operaciones en latitud de $33^{\circ} 4 \mathrm{r}^{\prime}$ Oeste $y$ en longitud de $6^{\circ} 44^{\prime} 30^{\prime \prime}$ al nccidente de Chiló́. El extremo Norte de la de adentio en $33^{\circ} 37^{\prime} 39^{\prime \prime}$ y longitud $5^{\circ} 6^{\prime} 30^{\prime \prime}$. La distancia de una á otra isla era por las mismas ilaciones de 79 millas.

A medida que nos apartábamos de ellas, andada en la noche una regular distancia, volvieron la mar y el viento á la misma fuerza que habíamos experimentado en la travesía anterior. Recibimos algunos golpes de mar, nos fué preciso navegar con ménos aparejo, los tiempos mantuviéronse claros lo más frecuentemente; nuestra derrota, interrumpida en la noche del I $_{5}$ por el arrumbamiento inexacto de las costas en las cartas trazadas hasta entonces, y en el día siguiente por varias ventolinas del Norte entre. mezcladas con algunas calmas, sólo nos permitió el avistar nuevamente la costa en la tardedel i6. y fondear en la bahía de Valparaiso al medio día del 17 .

Hallábase fondeada desde el II la corbeta ATrevina, cuya navegación desde Talcahuano había sido más dilatada de lo que debiésemos sospechar á primera vista. Molestáronle mucho Mar, 17 las neblinas, calmas y la mar gruesa del Sudoeste, unas veces separándole de la costa, otras haciéndole casi indispensable el dar fondo con un anclote: había, sin embargo, trazado con la mayor exactitud las costas desde la Quiriguina por las bocas del rio Itata, hasta la Ensenada del Sorre las inmediaciones del Morro de Topo. calma, los bajos de Rapel, las playas de Carta. gena, y finalmente, el trozo comprenciido entre las puntas dis Coronmilla y los Angeles. Ya el observatorio se hallaba establecido en el ángulo del Norte del Castillo del Rosario. Los Tenien. tes de navío Galiano, Concha y Vernaci, agregádoles un pilotín y un soldado, alojaban en sus inmediacioncs para que las tareas de la noche pudiesen seguirse sin la menor interrupción. Las solas cerrazones y neblinas habían podido es. torbar que no estuviese ya empezado el proyectado catálogo de las estrellas dei hemisferio aus. tral. No había tampoco diferido el Teniente de navío D. Cayetano Valdés en transferirse á la capital de Santiago, y ahora avisaba que el Mariscal de Campo D. Ambrosio O-Higgins, Capitán General y Presidente del Reino, volvería inmediatamente de los baños á do se hallaba, para coadyuvar con aquel celo y actividad que le eran naturales, al mayor aprovechamiento de la expedición. Vagaba á su albedrío D. Luis Nee por aquellos contornos; no diferiría tampoco D. Antonio Pineda en internar hacia Santiago, y la cordillera inmediata; finalmente, nuestra demora en la Tahía, debiendo ser algo más dilatada con atención á las observaciones indicadas, podía también un número competente de Oficiales transferirse á Santiago, y alli multiplicar en varios modos las tareas útiles de la expedición. No parecía á la verdad, asequible la conducción de los triángulos por el terreno intermedio, como nos le habíamos propuesto. Ese tránsito, aunque corto, es todo pedregoso y con muchas vueltas: atraviesa tres hileras de montes, los cuales au. mentan considerablenente su elevación á medida que se aproximan al pié de la cordillera; la primer. llanura es de hastante extensión, y algún :anto aprovechada, ó en pastos ó en siembrıs: el lugare jo de Casa Blanca liace más amena y útil la segunda; y si se exceptúan los valles dc la Viñilla y Puangni, entrambos de muy corta extensión, el tercer llano es el hermoso valle que baña el Mapocho, y en donde á las faldas de la cordillera de los Andes, está situada la ciudad de Santiago: algunas haciendas intermedias hacen á la verdad más fácil y más entretenido el ca:niuo, explayando los que lás poseen un tal grado de hospitalidad generosa, que á pesar de ser ésta una propiedad casi innata del carácter español, allí sobrusale con unos colores y adornos difíciles para describirse; pero como los 
var. $z$ montes scan por sí casi inaccesibles, y que á más del tiempo que debiera alssorber la colocación previa de las marcas en los parajes oportunos fuesen también temibles en aquella es. tacjón los rigores del Estio, debe finalmente inferirse, que la operación proyectada excedía los límites del tiempo y de las fuerzas, que podíamos á la sazón sacrificarle.

Apoyaron estos inconvenientes la mecesidad de que se transtiriese á Santiago la secrunda co. lección de los instrumentos astronómicos, y allí se repitiesen observaciones directas para fijar la posición geogrática de aquella capital: hizose así cn efecto, y si bien el mal estado del reloj ro5 no permitiese deducir por él la lonfitud, como lo habíamos intentado, pudieron suplirle dos observaciones del primer satélite de Júpiter, las cuaes determinaron (hechas las correcciones de las tablas) la de $64^{\circ} 26^{\prime} 30^{\prime \prime}$; latitud, $33^{\circ} 26^{\prime}$ I $6^{\prime \prime}$; variación de la aguja, $13^{\circ} 20^{\prime}$ al Nordestc. Dejaremos para otro lugar más oportuno el dar una idea adecuada de la feracidad de las t..r. $r$ 's y de la amabilidad de los moradores de los ، , nos de Santiago y Valparaiso. Obra es esta pide una mayor extension de la que permitei. los límites de un diario, y cuyo detall, si bien difuso, no podrá ménos de parecer importante á los que sigan de cerca la prosperidad de la Monarquía y el bienestar de sus conciudadanos. Por ahora baste el decir que los primeros dias de nuestra permanencia en la capital, nos descubrieron una tan feliz unión de los depositarios de la autoridad pública con la satisfacción su. bordinada de los pueblos y con los dones pródi. gos de la Naturaleza, que en balde prockirarían el tiempo ó la multiplicidad de objetos nuevos, e! borray jamás de nucstrá memoria un espec. táculo tan agradable.

D. Antonio Pineda hizo al mismo tiempo una excursión á lo alto de la cordillera en las minas de plata denominadas de San Pedro Nolas. co. Sirvió ésta á aumentar con algunos conoci. mientos de la mayor importancia la idea cabal que procuraríamos dar á la Nación de esos depósitos peligrosos de su opulencia y de su miseria.

Tal ve $z$ una mirada filosófica hacia cllas, guiada de la humanidad y de lo que realmente son en sí, volverá finalmente la fuestión á pocos principios sencillos, y nuestros cá :ulos económi. cos reducirán los diferentes produ _tos de la tierra $y$ del trabajo del hombre á su nivel verdadero: el de las necesidades recíprocas de cada uno.

Conforme á las medidas tomadas de antemano nos alcanzó también en la capital de Santiago el liábil Botánico D. Tadeo Heenke, el cual había sido agregado á la expedición por órdenes posteriores de S. M. Sus peregrinaciones hasta aquella época podían mirarse como sumamente penosas; pues si bien apenas determinada su admisión á instancias del Consejero Born y del señor Jacquín de Viena, emprendiese precipitada. mente su viaje desde Alemania, no había podido llegar á Cádiz sino en el mismo día en el cual las corbetas daban la vela; y después, á más de no alcanzamos en Montevideo, había padecido naufragio en las inmediaciones de aquel puerto, con la pérdida lastimosa de casi todos sus libros, papeles y equipaje. Con un verdadero amor á las ciencias y particularmente á la botánica, consideraba sin embargo resarcidos en mucha parte los sufrimientos pasados, pues le habían deparado la casualidad de atravesar las I'an:pas ó llanuras de Buenos Aires y las cordilleras del Chile, logrando acopiar hasta $\mathbf{I} .400$ plantas, la mayor parte nuevas ó no bien caracterizadas.

En Valparaiso no habían sido los pasos de la expedición ménos activos y felices. Una asiduidad indecible de los Oficiales astrónomos (agregádose ahora nuevamente D. Juan Vernaci) hacía que ni se malograse hora alguna en las no. ches claras, ni fuese por la misma razón ya nienor de 300 el número de las estrellas, cuya declinación y ascensión recta podían determinarse ó rectificarse con toda seguridad. Sc liabían repetido las observaciones de los satélites de Júpiter, levantado el plano de la bahía y sondada ésta con la mayor escrupulosidad, observadas 36 r series de distancias del Sol á la Luna, y finalmente dispuestos los buques y aparejos por mancra que, abastecidos de agua y leña, efectos bien escasos en la costa siguiente al Norte, pudiesen dar la vela al primer instante oportuno.

Ya no debíamos extrañar los nuevos desórdenes de la tro:a y marinería en un puerto donde todo estaba dispuesto para seducir y fomentar los vicios entre las marinerías harto díscolas de la carrera mercantil de Lima; ni por nuestra parte ó por la de la plaza cabía otro arbitrio, sinn el de sufrir más bien que comprometer el decoro de la autoridad descubriendo la debilidad de sus resortes. Así, contentándonos con que no desmayase la disciplina á bordo ni hubiese la menor demora en las tareas emprendidas, vimos casi con indiferencia la deserción de utros ${ }_{15}$ indivíduos, ya soldados, ya marineros de las dos corbetas. Repitiéronse sí los of recimientos de los treinta pesos fuertes por cada desertor que se nos presentase en Lima, y al señor Capitaı General se remitieron listas exactas que pudiesen coadyuvar en cierto modo á una pesquisa más exacta sobre este punto importante del servicio.

Aprovechada, finalmente, toda la noche del I 3 para las observaciones celestes, y embarcadas por la mañanita siguiente la tienda, el cuarto de círculo y el péndulo, únicos efectos que habíamos dejado, levamos la amarra de tierra, quedando sobre un solo calabrote, y nos dis- 
Ab. it pusimos á dar la vela a! primer soplo de viento favorable. La cuenta.de los relojes narinos se había cerrado para el medio dia del $\mathrm{i} 2$, y desde el 7 se había colocado sobre esferas el cronóme. tro 72 , para ver si aquella situación le era efec. tivamente $\tan$ ventajosa como lo habia sido para el número $7 \mathrm{I}$ de la Atrevidos.

En lugar de suceder el viento Sur á las horas de calma comunes al principio de la mañana, declaróse una neblina espesa procedente del Norte, que imposibilitaba la vista de los objetos aun más cercanos; y manteniéndose sin asomo de viento hasta las cuatro de la tarde, ya casi nos había precisado á desistir de la esperanza de dar la vela en el mismo dia. Pero en in, habiéndose disipado la neblina con algunas ventolinas del Sur, pareció que el buen andar de las corbetas, el auxilio de los remolques y de la corricnte, y la muy corta distancia que era preciso navegar para considerarnos libres de todo peligto, nos proporcionarían el verificar la salida en el plazo prefijado y sin exponernos á que las rentolinas del Norte, bastantemente comunes en el mes de $\Lambda$ bril, nos detuviesen algunos más días en el puerto. Así entrambos buques emprendimos luégo el cobrar el cable del Norte, recogiendo el calabrote de tierra.

A las cuatro y media levamos el ancla, y remolcados de la lancha, procuramos con las gavias, juanetes y estai, aprovechar las ventolinas favorables del Sur. Al principio fueron lentos nuestros progresos y estuvimos algo aconchados sobre las pir "ras de 'a entrada, luégo fué mejoranda nuestra situació. 1; al anochecer ya habíamos ganado dos millas al Norte de lia punta de la Batería, $y$ las ventolinas aún nos permitían el gobernar. La ATrevida nos siguió de cerca y con igual buen éxito. Netimos lat lancha y determinamos á las seis por Puerto Salido según las marcaciones, la latitud de $33^{\circ} \mathrm{o}^{\prime}$, y la longitud de $2^{\circ} 7^{\prime} 39^{\prime \prime}$ al Oriente de San Carlos de Chiloé. Era nuestro primer ánimo el fondear en el puerto del Papudo, distante ro ó I 2 leguas de Valparaiso, porque nos habían persuadido que tendría algún abrigo; indicándolo así por otra parte el que le frecuentasen mucho los buques franceses, cuando al principio del siglo concurrían en tanto número á las costas del Perú y Chile. Tuvieron alli muchas bodegas, de las cuales aún subsistían las ruinas, bien que siempre fué más bien el comercio ilícito que otra causa cualquiera, la que los guiaba hacia aquellos parajes ménos habitados. El señor Presidente previno de antemano á los Subdelegados del particlo para que concurriesen á auxiliarnos; pero en fin, debimos desistir de aquella idea, no sólo por la escasez del tiempo, por los nuevos riesgos de la deserción y el actual semblante calmoso y oscuro de los horizontes, si también porque en $\mathrm{cl}$ año anterior el Ingenicro D. Pedro Rico había Ab.s levantado el plano, así de aquella rada, como de la siguiente de ichichangue ó del Gobernador.

Pasamos la mayor parte de la noche en calma y rodeados de una densa neblina; al amanecer declaróse viento favorable del Sursueste con el cual, aunque llojo, gobernamos al Nornordeste y Nordeste pasa atracar la costa; ésta, á la sa. zón, se nos presentaba confusa y cargada de neblina aunque no distásemos de ella sino unas tres leguas. $A$ las ocho pudimos ya avistar distintamente como al Sudeste $1 / 4$ Liste el puertecito de Quintero, hasta donde habían llegado suestros reconocimientos desde Valparaiso. No distábamos, por consiguiente, ni del Papudo ni de la Ligua, y pues la costa se distinguía con bastante claridad con motivo de la poca distancia, empezamos á correr bases con todo aparejo en vuelta del Norte $1 / 4$ Noroeste, siendo el viento á la sazón muy llojo del Sursueste al Sur. A las nueve y media, á distancia de clos leguas escasas, la sonda dió 92 brazas arena gruesa blanca; ál las doce, la boca del Papudo nos demoraba al Este, y la costa avistada hasta entonces parecía bajar con algunos playazos, particularmente hacia la Ligua; habia tal cual islote entre el Papudo y el puerto de Quintero, y se veían algunos arrecific en las inmediaciones del segundo: al Norte del Papudo se presentaba un monte aislado, que podia servir de reconocimiento para buscarle.

En un paraje en el cual no debíamos dudar de un efecto considerable de las corrientes y en donde la dirección de la costa no variaba del Sur al Norte, la falta de la latitud observada era precisamente un mal que debía alarmarnos para la exactitud de las tareas emprendidas. Acechábames dos alturas del Sol en cualesquiera claras, aurique: momentáneas, que se nos presentasen. Pero no nos fué posible alcanzar sino la una ́́ las dos y cuarto de la ...rde, de la cual, $\sin$ la latitud, no deduciriamos sino una longitud sumamente dudosa. La ATrevida había ya sondado 85 brazas; y como el viento tomando algún vigor conservase su dirección del Sur, continuáronse las bases hasta el anochecer, yá esta hora nos pareció preferente el seguir también la derrota, siendo así que ya sabíamos por una tradición envejecida, que los tiempos sobre aquella costa, eran por lo común igualmente oscuros y calimosos.

La noche fué apacible, pero igualmente ce. rrada con calima; viéronse algunas candeladas; á la una de la mañana no se encontró fondo con todo el largo del cordel; le hallamos sí á las cinco en 80 brazas, lama y chinitos; y como se hubiesen heclio algunas horas de pairo, pudimos amanecer á corta distancia de la costa, por manera, que antes de salir el sol se empezasen á correr bascs, navegando con todo aparejo al Nor- 
noroeste. La costa que teníamos á la vista, era la r. te desde la silla del Gobernador pur la punta del Negro, corre hasta las inmediaciones de Cunclialí. Se veía aquel pueblo y la tierra parecía bastantemente alta, advirtiéndose en nuestra posición por cuanto pudiésemos combinarla con la de la tarde anterior, que no había sido excesivo el error contraído por las corrientes, limitándose á dos ó tres leguas solamente. La falta de las observaciones en el segundo aıa, debió inquietarnos ya mucho más que en el anterior, pues no solo iban multiplicándose los errores irremedia bles en la ne vegación y dimanados de las corrientes de la marejada y de otras causas, sino que ya nos queaaba á la espalda un trozo no mediano de la costa sin sujeción alguna en sus posiciones respectivas; pero acechando las claras, aunque repentinas, por ventura luimos algo más felices que en el día anterior; tuvimos varias. alturas del Sol con diferentes intervalos y algunas no distantes del medio día, cuyos resultados nos prometían una latitud bastantemente aproximada á la verdadera. Finalmente, despejado por la tarde el cielo, pudimos á las tres y á las cuatro observar dos series de alturas, las cuales, multiplicando las combinaciones con las de la na. ñana, afianzaban con mayor probabilidad nues. tras pesquisas sobre la latitud, al paso que daban la verdadera longitud según el útil método hallado por D. Dionisio Galiano.

Adoptáronse á este fin las últimas dos series de 1.1 tarde y una altura en la cual dos observa. dores habían convenido á las in horas $39^{\prime}$ de la mañana. Acordes entre sí entrambos resultados, dieron la latitud al medio día de $31^{\circ} 36^{\prime} 1^{\prime \prime}$ diferente en $19^{\prime}$ al Norte de nuestra estima. ".a longitud deducida fué de $12^{\prime}$ al Este de Valpa-aiso, la altura meridiana á las seis y cuarto dió la latitud de $31^{\circ} 30^{\prime} 3^{\prime \prime}$ la cual, confirmando la del medio día, servía al mismo tiempo de ratifi. cación á nuestras longitudes, de las cuales aquélla había dimanado.

Las irregularidades de los relojes 6 I y 13 y la uniformidad de la marcha del 72 , nos habían precisado á adoptar al último por magistral, aunque nos fuese fácil igualar los otros por medio de la ecuación diaria: sus resultados, comparados á las longitudes estimadas y á la que ba. bíamos observado en la tarde del $\mathrm{I}_{5}$, nos proporcionaron el corregir la latitud de aquel medio día y pudo deducirse, finalmente, de tan feliz combinación, que los errores habían sido proporcionales y que nuestra posición inferida en los dos medios días anteriores era muy aproximada á la verdadera.

Luégo que empezaron á entablar ventolinas del Sudoeste y Sur con hermoso semblante, hicimos proa del Nornoroeste siguiendo así la costa á regular distancia para ligarla con la exactitud posible. Los azimutes indicaban la variacion de $14^{\circ}$ al Nordeste. $\Lambda$ ponerse el sol nos liallá. bamos casi al Esteoeste con el extremo Sur de los altos de Chuapa y la última tierra al Norte distaba de nosotros unas seis leguas.

Lin las horas del pairo que debimos mantener. nos en la noche siguiente, se conoció clarament el electo de la corriente al Norte en la dificultad de orzar que tenía la corbeta. Conjeturamos desde luego, que debía atribuirse á aquellas 'ioras la mayor parte de los errores que encontrásemos en la latitud del día siguiente: amanecimos en efecto algo más al Norte de lo que debía supo. nerse. Li rio de Cliuapa y la Quebrada de Linarí, punto de tierra bien notable, eran los parajes que teníamos más inmediatos. No distariamos sino unas cuatro millas de la costa. Nuestros rumbos de bases fueron el Norte y después el Nornoroeste, con los euales, y un andar de tres millas con todo aparejo, se conservaba la costa á rérular distancia. Observáronse al medio día la latitud de $30^{\circ} 39^{\prime}$ y la longitud de $18^{\prime}$ al Oeste de Valparaiso. La Quebrada de Limarí demoraba al Sueste corregido de tres á cuatro leguas, y parecía la Lengua de Vaca la última tierra que se alcanzaba á la distancia de seis leguas. Con mucha propiedad en la navegación costanera se ha dado este nombre á la punta de tierra baja, muy saliente al nıar, desde donde empieza ha cia el Norte la grande ensenada, la cual conduce al puerto de Coquimbo y Frezier llama de Tongoy.

Fué luego más feliz y más acelerada nuestra navegación en aquella tarde, habiendo refrescado mucho la brisa sin que se acelajasen los cielos y horizontes. Así, para el anochecer ya habíamos propasado la punta indicada de la Lengua de Vaca, sobre la cual sondanos $7 \mathrm{I}$ brazas arena blanca, y veíamos como á unas seis leguas de distancia la entrada del puerto ie Coquimbo, de suerte que paireando en la, sche inmediata nc nos fuese difícil el alcanzarle al otro día con los primeros soplos de la brisa.

Descaecimos de tal modo en las horas del pairo, especialmente por el efecto de las corrientes al Norte, que al amanecer del 18 apenas distaríamos una legua de la entrada del puertecito de la Herradura. El viento del Sur, á la sazón flojo, parecía deber tomar algún incremento luégo que saliese el sol, lo cual, combinado con el natural deseo de reconocer de cerca las inmediaciones de un puerto importante, nos indujo á atracar la costa á distancia de una milla escasa. Así hízose rumbo del Este en vuelta de la Punta de : obo, de la cual ya no distaríamos á las ocho sino la milla prefijada.

Pero en aquel momento y en aquella situa. ción, contra todas nuestras espectativas, dieron alguuas ventolinas del Nordeste, las cuales y la 
Ab. s mareta gruesa del Sur, nos hicieron al mismo tiempo imposible el gobierno, por cuanto intentásemos auxiliarle con la maniobra y fueron causa para que entregados á la revesa, nos viésemos arrastrados con rapide $z$ lracia la costa in. mediata, de la cual ya á las nueve y media no distaríamos sino unos cuatro cables. $\mathrm{Ni}$ el bote que habiamos echado de antemano al agua, ni la lancha que echamos á la sazón, podían vencer el embate de la ola para ponernos en dirección de aprovechar las ventolinas de la virazón, que ya empezaban á dejarse sentir. Finalmente, atando al mismo tiempo la lancha por la proa y cl bote por la popa en sentido contrario, conse. guimos caer de la vuelta de tierra y poner la proa al Nornordeste, largando toda vela $y$ haciéndonos al mismo tiempo remolcar de las embarcaciones menores. La Atrevida, que había podido mantenerse algo distante del peligro y se había valido de los remos, aunque con la mortificación de romper el mayor número de ellos, envió in. mediatamente su lancha á auxiliarnos. Se mantuvo ésta corto rato por la proa, hasta que en. pezando á tomar vigor la virazón, la devolvimos á su bordo y metimos la nuestra, dejando sólo el bote en el agua al remolque y ayudado de sus velas.

A las doce ya habiamos pasado la boca de la Herradura, y pues el viento se mantenía llojo, pareció tan aventurado como inútil el entrar en el puerto por el canal que forma el islote de adentro con la tierra firme: se hizo rumbo á dejar por estribor el Pájaro Niño de fuera, y antes de la una pudimos atracarle y ccstearlo á tiro de pistola. Ciñóse luégo por estribor; y sobre el mismo bordo acercándonos mucho á las piedras sumamente acantiladas, conseguimos alcanzar el fondeadero: algunas espías nos internaron después en paraje oportuno, y la corbeta quedó amarrada á distancia de un cable de tierra en fondo de cinco brazas. Bajamos demorando la punta Sur de la boca del puerto Norte $8^{\circ}$ Oeste y la Torre de Santo Domingo de Coquimbo al Nordeste.

La ATREvida fondé como cable y medio al Norte, y quedo amarrada casi en la misma disposición que nosotros.

En la orilla inmediata á las corbetas, había unos almacenes bien acondicionados y pertene. cientes á un vecino de Coquimbo, los cuales se nos franquearon inmediatamente para que alli estableciésemos el observatorio. En la mañana siguiente, dos destacamentos de marinería los asearon y ordenaron en cuanto fuese neçesario, y armado inmediatamente el péndulo, se adoptó el cronómetro 7I para las alturas correspondientes mientras se sistemase en cierto modo su movimiento. Ya en la noche anterior se habían observado en la playa dos emersiones del se. rundo y primer satélite de Júpiter. L1 72 acre- $A$ b. ıs ditó en aquclla ocasión, que no habian sido in. fundados nuestros conceptos sobre su marcha uniforme: se había deducido y cerrado la cuenta de los relojes cl día 2 en Valparaiso, y las al. turas correspondientes del I 3 nos habían indicado que los tres habian tenido algina alteración en las veinte y cuatro horas anteriores; pero la del 72 mucho más corta que la de $\operatorname{los} 6$ I y 13 , $y$ en todos procedente tal vez del cañonazo de leva, que habíamos disparado en la mañana del 12.

La sucesiva deducción de su marcha en el observatorio de Coquimbo, ratificó esos mismos conceptos y pudimos determinar los siguientes resultados:

\begin{tabular}{|c|c|c|}
\hline & $\begin{array}{c}\text { Corrección } \\
\text { cn } \\
\text { tiempo. }\end{array}$ & $\begin{array}{l}\text { 1.ongitul que } \\
\text { reaultar } \\
\text { de Valparaiso. }\end{array}$ \\
\hline 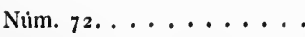 & $3^{\prime \prime} 7^{8}$ & E $15^{\prime} 17^{\prime \prime}$ \\
\hline im. $6 \mathrm{I}$ & $29^{\prime \prime} 40$ & I5 47 \\
\hline$\ldots \ldots$ & $18 \quad 22$ & $16 \quad 54$ \\
\hline
\end{tabular}

Las dos emersiones del pri-

mer satélite de Juipiter, ob-

servadas en la noche ante.

rior y en la siguiente del 20$\} \ldots . .733^{8} 30^{\prime \prime}$

y corregidas de los errores

de las Tablas. ........

Mientras así procedían con actividad las didiferentes tareas que debíamos abrazar en el puerto, emprendimos la mejor parte de los Oficiales una excursión á la ciudad no distante de Coquimbo 6 la Serena. El camino es en mucha parte por la playa, agradable al tiempo de la baja mar, si bien algo molesto cuando la marea está alta. Luégo interna para huir del terreno pantanoso que media entre el mar y el terreno algo más elevado en el cual está situada la ciudad. Segun los naturales, son tres leguas las que comprende; pero pueden andarse con comodidad en 45 ó 50 minutos.

La situación de la ciudad no puede ser más amena ni más cómoda. La vista de la marina, la abundancia de aguas cristalinas, las llanuras inmediatas todas capaces de riego, un rio cons. tantemente caudaloso aunque sin riesgo de inundaciones, el cual al mismo tiempo fecundiza los campos y da varias acequias para molinos $y$ trapiches; las minas no distantes y ricas; el puerto excelente; la mar abundante en peces; los ali. mentos sabrosos y baratos y el clima agradable. mente templado y uniforme en todo el año, forman uno de aquellos esicces maravillosos de la naturaleza, que parecerán más bien ficciones poéticas que realidad á los que ciñan sus combina. ciones al solo examen de una parte nó la más feliz del globo.

Contribuyen la labor de las minas y la fertilidad de los campos á que la ciudad parezca desierta. Ambas orillas del rio siguen pobladas 
14. $\&$ hasta la cordillera, hasta donde llegan también las pesquisas y el beneficio de las minas, aunque disten del mar unas to o 50 legruas. Así la poblacion $d \approx$ Coquimbo puede considerarse compuesta de unos $I_{5}$ ó 20 comerciantes mercaderes que labilitan á los mineros; de seis ú ocho familias de conquistadores bien acaudaladas; de algunos empleados por el Rey y de un número creeido de religioses de San l'rancisco, Santo 1)omingo, la Merced, San Agustin y San Juan de Dios; ocupan los Agustinos la casa de los expulsos jesuitas.

1) I Subdelcgado 1). José Antonio Corvera, nos labía prevenido una comida igualmente abundante y sabrosa; pero como $\mathrm{el}$ dia se mantuviese despejado, lo que no es frecuente en aquellos parajes, nos pareció preciso el restituirnos casi todos inmediatamente al observatorio para medir algunas distancias de la Luma al Sol. Entre dos y tres de la tarde 80 series observadas con muy buenas circunstancias, determinaron para el observatorio la longitud media al Oriente de Chiloé de $2^{\circ} 2 f^{\prime} 50^{\prime \prime}$. Igual número y con igua. les circunstancias nos indicó al medio día si. rruiente la de $2^{n} 15^{\prime}$ : asi el promedio de 160 se. ries manifestaba la longitud oceidental de París de $73^{\circ} 5^{6^{\prime}}$ mayor tan solamente en ${ }^{5}$ á la que senalaban las observaciones del primer satélite de Júpiter.

Una situación tan placentera como la que acabamos de descuibir, la tranquilidad del puerto $y$ el temple agradable del clima, debieron preci. samente acalorar tambicn las operaciones geo. désicas del mismo modo que lo habíamos conse. gruido con las observaciones astronómicas. En los dos días indicados, alternando los Guardias Marinas en el cuidado de las sondas y repitiéndore las bases y las marcaciones del teodolito en cuantos puntos fuesen necesarios para el plano exacto del Puerto Grande, del de la Herradura y para la configuración de la costa hasta donde aleanzasen las visuales, pudieron considerarse concluidos también aquellos objetos; por manera, que inferida en la noche anterior la latitud del observatorio por diferentes alturas meridianas cle estrellas al Norte y al Sur del zénit, á las cuarenta y ocho horas de nuestra llegada á Coquimbo ya hubiéramos podido emprender de nuevo la continuación del viaje, si la sola Hidrografía hubiese sido el objeto de nuestras tareas.

Pero el país en el cual nos hallábamos, además de contener en si una cantidad indecible de minas de oro, plata y cobre, habia sido tainbićn en estos últimos años un objeto de nuevas especulaciones importantes para la Monarquía, con deseubrir en las minas no distantes de Punitaqui la esperanza de una nueva suministra. ción abundante de ázogue, la cual, ó alcanzase á reemplazar los beneticios bien desmayados de
Guancavelica, ó tal vez úrese en lo reniciero las $\mathbf{A l}, 19$ crecidas cantidades que la Nación solía recibir de los minerales de Alemania. Reunianse á estos objetos, por sí de la mayor importancia, las observaciones del eclipse de Luna y de dos ocultaciones de estrellas que debían proporcionársenos de allí á pocos dias; $y$ en el entretanto no serían tampoco inútiles ó las excursiones contínuas de los botánicos, 6 un estudio algo más prolijo de las costumbres y riqueza intrínseca de aquellos contornos. Quedó pues deejdido, que la salida de las corbetas para la continuación de sus tareas no tendría lugar sino en el dia $30, y$ que mientras por la una parte atendiésemos al estudio de los contomos de la ciudad y á las disposiciones necesarias para las observaciones indicadas, por la otra D. Luis Nee no abandonaría sus excursiones botánicas, y los scñores Pineda y Hecnke, con el Teniente de navío D. lernando Quintano, internarian hacia las minas de Andacollo y Punitaqui para visitarlas y ensanchar sus conocimientos físicos en cualesquiera tros ramos que les viniesen á mano, Acompañábales el Administrador Superintendente de l'unitaqui Don Miguel José Lastarría. Ll l'eniente Coronel Don 'lomás Shee, Oficial cuyas prendas morales sc describirán con la individualidad correspondiente en las reflexiones siguientes, dirigría más de cerca el examen nuestro en las inmediaciones de la ciudad. La caza, la pesca, el cuidado de las tripulaciones, con una mezcla ordenada de trabajos y de entretenimientos, finalmente, la instrucción militar de la tropa con unos ejercicios diarios de fusil, repetidos despuiés con fuego $\mathrm{y}$ algunos tiros al blanco, eran otros tantos objetos, que reunidos á la suma hermosura del tiempo, debian hacer nuestra demora en el puerto con extremo agradable $y$ entretenida.

Cuantos objetos nos habíamos propuesto, otros tantos efectivamente se llevaron con la mayor felicidad á debido efecto. Reconcentráronse á bordo los naturalistas y botánicos; se lograron las observaciones de los eclipses con tanta mayor complacencia, cuanto mayor habia sido nuestro temor de malograrlas por el eielo siempre fosco después de los dos días primeros; y observadas el 29 las alturas correspondientes del Sol para el último arreglo del movimiento de los relojes, quedaron embarcados en aquella misma tarde los instrumentos, y todo dispuesto para dar la vela en la siguiente mañana.

No habían sido en el entretanto ménos escandalosas las deserciones en aquel puerto, de las que habíamos experimentado en los puertos visitados anteriormente. Y lo que debía causarnos una mayor extrañeza, era el que hubiesen incurrido ahora en ese delito, aquellos precisa. mente de los cuales debíamos tener mayor confianza y en un momento en que ni los desórde. 
ero las $\mathbf{A 1 . 3 9}$

recibir

a tus-

tancia,

de dos

porcio-

retanto

es con-

go más

seca de

lo, que

ción de

a $30, y$

mos al

las dis-

nes in-

clonaria

ineda $y^{\circ}$

trnando

Anda-

har sus

ros ra.

bales el

qui Don

iel Don

rales se

ndiente

de cer-

es de la

las tri-

traba-

instruc-

ios dia.

fuego $y$

bj jetos,

tiempo,

rto con

puesto,

ila ma-

ráronse

graron

ta ma-

a sido

siem.

s; y ob-

tes del

de los

misma

ara dar

ios es.

ito, de

unertos

zausar.

biesen

recisa -

r con-

sórde.
A1. an nes diarios de la población, ni una demasiada fatiga 6 un excesivo rigor en !as corbetas, podian convidarlos siquiera remotamente á abandonar su destino; pero 6 fuese aquella una ocasión de las que llevan á su albedrío el ánimo de la gente nuestra de mar, exactamente como una ola impelida del viento en una dirección cualquiera, 0 bien (lo que no parece imposible) precediesen sugestiones $y$ promesas de los vecinos para aumen. tar su número con personas bastantemente ro. bustas y trabajadoras, cllo es que en la misma no che del 28, viéronse faltar á la lista tres solảados, un artillero y un marinero de la Descubierta; y después se halló también abandonado el bote, el cual debía reconducirnos á bordo concluídas las observaciones astronómicas. En baldc desdc cl amanecer del día siguiente D. Fernando Quin. tano recorrió á caballo las chozas más distantes, por si alguno de los fugitivos hubiese que. dado en ellas durmiendo, acosado del vino ó del cansancio. Su regreso á las dos y media de la tarde, sólo sirvió para convencernos, mediante las noticias adquiridas, que la fuga era efectiva: los soldados procuraban hacerla más expedita con dos mulas que habían tomado violentamente: cuando los marineros fueron vistos, iban aún á pié, pero alcanzarían muy luégo el auxilio de los caljallos para alejarse con más rapidez.

Descrtaron casi al mismo tiempo otros dos marineros de la Atrevida. Un accidente apoplético arrebató en pocas horas al mejor gavicro de la Descubierta. Tantas pérdidas y tan repetidas, no podían á ménos de debilitar con extremo los armamentos, y no sólo hacer arriesgada en lo venidero nuestra navegación, si también indicar bien próximo el momento en el cual, si acacciesen nuevas deserciones, $y a$ las corbetas se halla. rían imposibilitadas para navegar hasta Lima. Esas reflexiones nos persuadieron finalmente como el mejor partido, el de cortar toda comunicación con la tierra. Se aceleró la salida para el día siguiente, y la precaución de hacer embarcar en cualquier bote un Oficial de guerra con dos soldados armados, debió tranquilizarnos sobre la conservación de los pocos restos de la marinería.

Finalmente, en la mañana del 30 , entablado viento bonancible del Oeste Noroeste, ambas corbetas pudieron dar la vela, y con todo aparejo emprender sobre bordos la salida del puerto. $\mathrm{Al}$ medio día el Pájaro Niño de fuera demoraba al Oeste Sudoeste. Al anochecer ya distábamos unas tres leguas de la boca del puerto, $y$ le marcábamos al Norte $43^{\circ}$ Este de la agujai varia. ción magnética por varios azimutes $\mathbf{x} 3$ grados al Nordeste.

En el último examen de la marcha de los re. lojes, el número 72 había manifestado la misma exactitud que se le había conocido en la travesía desde Valparaiso, acreditando así no súlo lats Ah. 30 determinaciones que sobre él se habían liecho antes, si tambien el partido tomado de colocarle sobre esferas: el $6 \mathrm{r}$, al contrario, continuaba con una ex+raña irregularidad en su movimiento, el cual determinado en Valparaiso de $55^{\prime \prime}$ I 6 llegraba en este puerto á $\mathrm{I}^{\prime} 3^{\prime \prime} 45$, promedio de todas las observaciones bien diferentes una de otra: $e:$ número s 3 ya no daba la menor esperanza de que llegase á ser ni medianamente exacto: variaba considerablemente de un día á otro, aunque en la mayor quietud, en el temperamento más uniforme y manejado con el posible cuidado; el cronómetro $7 \mathrm{I}$ y el reloj ro5 de la Arsividi, continuaban con una marcha regular; se había notado alguna alteración en el número so, reloj de una exactitud sobresaliente luasta aquella época.

No dejó de aprovechar D. Felipe l3ausá la situación de la tarde misma para lacer nuevas marcaciones al cerro del Guanaqutero y á la si punta de Lengua de Vaca, las cuales, ligadas actualmente con los puntos bien situados de las inmediaciones del puerto, ratificasen nucstras determinaciones traídas desde el Sur al tiempo de dirigirnos á Cocjuimbo: tuvimos la satisfacción de verlas confrontar con una exactitud que no podíamos esperar, mucho más cuando se lc agregaron las marcaciones de la mañana siguiente, pues teníamos aún á la vista los mismos puntos de la tarde anterior.

Hasta la mañana del 3 de Mayo nuestras ta. reas hidrográficas pudieron contínuar con el método y exactitud acostumbradas. Reconocié. ronse bien de cerca los fondeadcros del Guasco y del Totoral; las observaciones repetitlas de longitud dieron. un nuevo grado de exactitud á la: bases por corredera. Tomáronse varias precau. ciones para no propasar en la noche los extremos de los reconocimientos hechos en la tarde anterior. Así alcanzamos, finalmente, las inmediaciones del Morro de Copiapó, á cuya vista debían separarse de nuevo las dos corbetas, la una para atravesar al reconocimiento de las Islas de San Félix y describir á su regreso la costa del Perú desde la latitud de $15^{\circ} 30^{\prime}$ hasta Lima; la otra para continuar sus tareas al andar de la costa hasta aquella latitud, fondeando antes en Arica, y reincorporándose después en Lima. Se abrazó la Atrevida con el segundo destino, y por la misma razón se reforźo su armamento con ocho hombres de la Descubierta; hízose nueva comparación de los relojes marinos para su mayor exactitud, y á las tres de la tarde apenas se decidian las primeras ventolinas de la brisa, cuando ya recogidas las embarcaciones menores, navegaron las dos corbetas, cada cual al rumbo de su destino. Perdiéronse después de vista ape. nas entrada la noche. La Descubier'TA, al ama- 
May. 3 necer del día siguiente ya se hallaba engolfada y con vientos más variables de los que solian experimentarse sobre la costa.

Pero á medida que aprovechados aquellos

by 7 vientos la distancia andada aumentaba considerablemente, los tiempos iban tomando el más hermoso semblante, y los vientos, aunque cal. mosos, inclinándose más al Sur y Sueste, nos daban lugar á progresar en nuestra derrota. Se conoció por las observaciones diarias un efecto de corrientes al Oesnoroeste; y como ya en la tarde del 7 avistásemos un lobo marino y algunos pelícanos, hallándonos aún en latitudes de $26^{\circ} 25^{\prime}$ arribamos en aquella misma noche, logrando asi en la mañana siguiente observar la latitud de $26^{\circ}$ or y longitud al Oeste de Coquimbo de $5^{\circ} 5^{\prime}$. La variación magnética, por una serie no interrumpida de observaciones de azimutes $y$ amplitudes hechas con circunstancias las más favorables, se había conservado hasta esta época de $\mathrm{I}_{3}$ á $\mathrm{I}^{\circ}$ Nordeste.

Como es natural, habíamos aprovechado el cuarto menguante de la Luna para observar sus distancias al Sol. Las considerábamos como un nuevo apoyo de la posición que determinásemos á las Islas de San Félix con los relojes marinos, de cuya exactitud ya debíamos tener la más fundada seguridad, particularmente después de haber colocado ambos cronómetros sobre esferas: así las emprendimos desde la mañana del 5 , y en los siguientes días 6,7 y 8 , se procuró aplicarles toda la exactitud que estuviese á nuestro alcance, así en cuanto á las observaciones como á los cálculos. Debe pues imaginarse cuál sería con aquellos antecedontes nuestra sorpresa en ver sus resultados bien distantes de los relojes marinos: confirmábansc una á otra las observaciones anteriores con las posteriores. Con. currían el conocimiento de tiempos y el almanaque náutico en las mismas determinaciones de los lugares de la Luna; nuestras deducciones para el meridiano de Coquimbo no podían apoyar sobre datos de mayor confianza; finalmente, nuestra uniformidad en observar tan crecido número de distancias y la misma correspondencia entre las diferencias diarias en longitud deducidas de las distancias y las que indicaban los re. lojes, parecían exigir tanta confianza en lós unos como en los otros.

\begin{tabular}{|c|c|c|c|c|}
\hline $\begin{array}{c}\text { Dias en } \\
\text { que se } \\
\text { observó. }\end{array}$ & $\begin{array}{l}\text { Nümero } \\
\text { de series. }\end{array}$ & $\begin{array}{l}\text { Longituic medida } \\
\text { por las dis. } \\
\text { tancias de Paris. }\end{array}$ & $\begin{array}{c}\text { Los relojes } \\
\text { al } \\
\text { mismo tiempo. }\end{array}$ & $\begin{array}{l}\text { Biferencia de } \\
\text { las distancias } \\
\text { â los relojes }\end{array}$ \\
\hline $\begin{array}{l}5 \\
6 \\
7 \\
8\end{array}$ & $\begin{array}{r}49 \\
143 \\
88 \\
16\end{array}$ & $\begin{array}{llll}74^{\circ} & 53^{\prime} & 21^{\prime \prime} \\
76 & 47 & 57 \\
78 & 6 & 10 \\
78 & 48 & 22\end{array}$ & $\begin{array}{lll}75^{\circ} & 32 & 30 \\
77 & 26 & 00 \\
78 & -17 & 00 \\
79 & 21 . & 2\end{array}$ & $\begin{array}{ccc}E & 39^{\prime} & 30^{\prime \prime} \\
3^{8} & \circ \circ \\
40 & 50 \\
3^{8} & 40\end{array}$ \\
\hline
\end{tabular}

Así la diferencia andada en longitud des le el día 5 hasta el 8 era:

$$
\begin{array}{rlll}
\text { Por las distancias. . } & 3^{\prime \prime} & 55^{\prime} & 1^{\prime \prime} \\
\text { Por los relojes... . } & 3 & 53 & 3^{8} \\
\text { Difcrenciu. . . } & 1^{\prime} 23^{\prime \prime}
\end{array}
$$

El cielo, por lo regular calimoso ó nublado en las horas próximas al amanecer, no dió lugar á observar distancias con astros occidentales á la Luna como lo hubieramos deseado; tal vez nos daríun alguna luz sobre las causas verdaderas de una diferencia tan extraña, que de ningún modo podía atribuirse á los sextantes ratificados con la mayor prolijidad $y$ siendo casualmente de los inejores artífices ingleses Ramsdcm, Dollond, Nairne, Stancliff, Wright y Trougliton.

Lin la tarde del 9 se avistó al Oessudoeste y á larga distancia, la Isla bien alta de San Am. irosio, y con el objeto de descubrir las otras de San Félix en la mañana siguiente, continuó. ronse en la noche rumbos proporcionados con fuerza de vela; por manera, que al anochecer pudiésemos marcar la primera al Norte $17^{\circ}$ Oeste, distancia de tres leguas, y avistar las otras más occidentales que parecían merecer el nombre más bien de pedruscos que de islas.

Varios chubasquillos, con una extraordinaria variedad en cl viento hasta las dos de la tar. de, hicieron luégo algo más complicados, bien que no ménos exactos, los reconocimientos que intentábamos. Lográronse las observaciones de la latitud y longitud. Reconocimos bien de cerca las calidades de la masa ṕedregosa de la cual se componía la isla mayor, y á las cuatro, pare. ciéndonos ya supérflua cualquiera ulterior demo. ra en aquellos contornos los más áridos y mal. aventurados que puede presentar la Naturaleza, pusimos de nuevo la proa hacia el Continente con brisa galena del Sursudeste.

El Archipiélago reconocido se compone de una isla grande, tres medianas y un islote, ade. más de algunos pedruscos aislados que se hallan inmediatos al extremo oriental de la isla grande, y otro que está á igual distancia en el extremo occidental. 'Todos presentan un semblante igualmente horrible y escarpado. Las dos capas que componen su masa, parecen contener muchas partículas férreas; son algo inclinadas al horizonte, y las negras 6 ferruginosas son mucho más espesas que las coloradas, $\delta$ de una sustancia córnea. La isla grande de San Ambrosio es ciertamente inaccesible por todas partes, pudiéndose considerar como cortada á pico, si bien de una elevación no menor de 190 á 200 toesas. Sólo se advierte en una especie de meseta alta una vegetación bien mezquina, compuesta de pocos arbustos de dos á tres piés y de algunos gramenes; ningún rastro de agua, ningún semblante de abrigo que pueda convidar al navegante hacia ella. Las mismas aves y los lobos marinos que debían considerarse en crecido número en 
May. to este asilo, el más seguro y el más templado para la subsistencia, parecen ahuyentados de su sem. blante horrible. No debe quedar duda que sean igualmente francos para la navegación todos los canales que forman entre sl las islas y los is. lotes. La latitud del extremo Oeste de la misma isla grande, es de $26^{\circ} 20^{\prime} 15^{\prime \prime}$, su longitud de $8^{\circ} 28^{\prime}$ al Occidente del observatorio de Coquim. bo. La variación magnética lıa quedado algo dudosa, pues fuese casualidad 6 realmente un efecto de las muchas partículas ferruginosas de las cuales se ha heclio mención, no tuvimos sino $8^{\circ}$ al Nordeste en aquellas inmediaciones, cuan. do en la tarde anterior, á una distancia de $\mathbf{2}$ leguas, observábamos $11^{\circ} 30^{\prime}$, cantidad proporcional á las que habiamos observado en las tra. vesías desde la costa.

Nada ocurrió en la navegución siguiente que merezca ser referido. Los cielos fueron comun. mente foscos, los vientos galenos del segundo cuadrante, y nuestros rumbos por lo común los que permitiese una bolina descansada. Arribóse últimamente al Norte $y$ en la mañana del 16 por latitud de $16^{\circ} 29^{\prime}$ ya teníamos á la vista una par. te no mediana de costa, la cual, á distancia de unas cinco leguas, demoraba desde el Norte has. ta el Este corregido.

Componense alli las costas de unas andanas altas de arenales, prolongadas en su misma di. rección y terminadas hacia el Oeste con puntas uniformes desde las cuales empieza nuevamente y en forma de escalón la otra andana; se advierte igualmente en todas partes un semblante casi desierto; hay algunas calas, pero son de poco abrigo, particularmente en donde bate la mal constante y siempre temible del Sudoeste.

Nuestros reconocimientos desde el paraje indicado hasta Lima, si bien emprendidos con cuanta exactitud pudiesemos alcanzar, debieron sin embargo ceder á las veces á la mucha contrariedad que alli ponen las corrientes $y$ las calimas casi con emulación una de otra. No es fá. cil en algunas ocasiones el no dejarse arrastrar de las corrientes en las noches largas que hay en aquellas latitudes. Las nubes impiden otras veces 6 las observaciones 6 la vista de la usta más inmediata. Es preciso, que en la mucha repetición de operaciones se deslice algún error; empero, los que hayamos cometido jamás serán tales que arrastren el menor riesgo al navegante áun más descuidado, particularmente desde la Nasca y el Morro Quemado á donde suelen por lo común recalar los que vienen de las costas le Chile 6 de las inmediaciones del Cabo de Hornos. Nos ocuparon aquellos objetos hasta la ma20 ñana del 20 , en la cual, finalmente avistada la Isla de San Lorenzo y inontado su extremo septentrional á distancia de un tiro de fusil, logra. mos internar en la bahía del Callao y sobre el mismo bordo dar fondo en paraje oportuno, litl. May. so cia las once de la mañana.

En el entretanto la ATREvidA, la cual, como se dijo ya, debía seguir sus reconocimicntos y tareas al andar de la costa, no habia sido mérnos feliz que la Descumukra. Distínguese general. mente con el nombre de ensenada de Arica y puertos intermedios, toda la costa comprendida entre Coquimbo y la Nasca. Concurren di ella diferentes embarcaciones costaneras con el ob. jeto, 6 de cargar el guano para la mayor fecundi. dad de las tierras, 6 de extraer los diferentes fru. tos de la provincia de Arequipa, 6 finalmente, dc proveer la misma y las Intendencias inmediata: con los pocos efectos de Europa que pueda ne. cesitar el corto número de sus moradores. La ensenada ó puerto de Arica, con el mismo inten. to de hacer más fácil la internación de los efecto: europeos á las minas inmediatas, ha logrado ser comprendido entre el número de los puertos ha. bilitados, lo cual, reunido á lo mucho que liuc frecuentado por los navegantes franceses cuindo al principio del siglo se extendieron en tanto número sobre las costas del Perú, decidio ta preferencia á su favor para un reconocimiento más exacto de lo que pareciesen exigirle las demás ensenadas de Cobija, el General, Nuestra Seño. ra, Mejillones, Iquique, Ilo y Quilca, todas ménos frecuentadas y generalmente con la sola ventaja para llamarse fondeaderos, de que liaya un paraje abrigado de la mar del Sudoeste, no tanto para fondear, cuanto para atracar los botes y enibarcar ó alijar los efectos.

En aquella parte bien extendida de costas, corren siempre constantes los vientos del Sur al Este, caracterizándose luégo según el día ó la noche con el nombre de terrales y virazones. No son raras las calmas acompañadas por lo común de algunas ventolinas casi imperceptibles del Norte. La mar del Sudoeste es el único peligro del cual debe precaverse el navegante, $o$ fondeado ó á la vela. Jamás hay un temporal, jamás la lluvia y el trueno interrumpen el trabajo ó el descanso del marinero. Todo allí anuncia la naturaleza tranquila, feliz y reposada, y $\sin$ embargo, en cuanto se extienda algo más adelante una mirada filosófica se apercibe inmediatamente el contraste, $\dot{c}$ en la sequedad indecible de los desiertos de lí.cama y en los contornos de Co. piapó y Guantajaya, ó en los repetidos extragos del volcán harto temible de Arequipa. Rara es la ve $z$, por otra parte, en la cual el Sol vivifique con su brillo encantador las tierras, las plantas ó los pocos moradores de aquellos contornos. Tantos inconvenientes y tantas ventajas, componen, en fin, aquella compensación universal del mal y del bien, sin la cual, soberbio el hombre y entregado al albedíío de su propia imaginación, muy luego declararía la guerra al mismo 
May zo cielo $y$ apenas bastarla su propia ruina para re. tracrle otra rez del vuelo desmedido al cual se labia entregado.

1)espues de una enumeración como la que antecede, de las diferentes circunstancias que debia encontrar la ATREvida recorriendo las costas indicadas, parecerá más bien extraño, que sus tareas fuesen igunlmente cxactas y expeditas en la dilatada extensión que le labja tocado en suerte. Sustituíanse á la ultura meridiann del Sol para la deduccion de la latitud, otrus alturas medidas en ocasiones oportunas $y$ calculadas por los métodos más exactos. lil excelente reloj número ro del Sr. Ferdinando Berthoud, con un movimiento inalterable, suministraba nucvas combinaciones no violentas para el mismo intento, ó para la deducción de las longitudes, ó finalmente, para la sujeción de las bases de corredera. Los pairos durante la mayor parte de la noche y una suma aproximación á la costa durante el día, compensaban lućgo la estreclicz de los horizontes y la fosquedad de las ticrras. Así pudiéronse recorrer uno á uno los diferentes fondeaderos, de los cuales se ha hecho memoria: $y$ : linalmente, fondear en Arica en la noclic del r4.

Son una excelente marca para el fondeadero de Iquique, el cerro de Tarapací que está un poco más al Sur de la boci del puerto, unos méganos de arena que hay dentro de la misma en. senada y una punta al Norte formada de piedras blancas del guano (I): cl Morro de Arica no lo es ménos para buscar la entrada del puerto 0 bahia de ese nombre.

Atento á los objetos que alli debía desempeñar la $\Lambda$ Trevida, ý á la epidemia de tercianas que según costumbre acosaba en aquella estación a la mayor parte de los labitadores de los contor nos, fueron sólo cuatro dias los que permaneció fondeada. En ese intervalo, sin embargo, fueron repetidas las observaciones de latitud y longitud por medio del sextante, $y$ nó sin algún riesuro por la mucha mar al tiempo de desembarcarse, lograron el Comandante $y$ algunos Oficiales el levantar el plano cxacto del puerto, valiéndose de las bases de cadena y de las marcaciones del tcodolito bien multiplicadas, por manera, que no cupiese el menor error bien en los puntos interiores ó en la costa siguiente por una y otra parte hasta donde se le alcanzase á la vista. Al mismo tiempo se sondaron á las órdenes del Te. niente de navio $D$. José Robredo todos los parajes útiles para fondear: se olsservaron muchas series de distancias lunares, se examinó de nuevo con la posible escrupulosidad el movimiento de

(1) Guano es el estiércol del sinunumero de ga. viotas que habitan sobre aquel]as costas y' posan en al. gunos islotes desicrtos. Su cantidad y utilidad para el beneficio de la Agricultura, se detallarán después con Ja mayor claridarl. los relojes, y se adquirieron, finalmente, todas May. , aquellas noticias sobre los paises inmediatos, que pudiesen dar una idea mediana así de su opulencia interior como de sus relaciones politi. cas con la matriz.

Muy poco correspondian los vientos al ansia natural de abandonar el fondeadero con la ma. yor presteza; fué, pues, preciso valerse de los botes para remolque, ya que las ventolinas del terral no alcanzaban en la mananita del ig a apartar la corbeta á una mediana distancia de la costa, ni bastó todo aquel día para que granjea. sen una tal distancia cuanta era necesaria para perder el pucrto de vista.

I'a desde alli, con un mejor semblante del tiempo y vientos algo más frescos y favorables, pudieron acelerarse $y$ ser más cxactos los reconocimientos siguientes. La costa ménos fosca, las bases más arregladas y varios montes inter. nos que servían para cnlazar oportunamente lasi marcaciones más distantes, veianse, por otra parte, correspondidas con una mayor frecuencia en las observaciones, las cuales daban al todo un grado de seguridad hidrográfica cual no debía fícilmente esperarse en aquellos contornos. Al. canzados así los paralelos del Morro de Acarí, en donde habían empezado de nuevo los reconocimientos de la Descubirrta, omitióse sólo el pairear en una parte de la noche, pero se apro. vecharon de tal morlo los dos dias siguicntes para repetir las mismas operaciones favorecidas ahora con una presencia casi constante del Sol, que pudo darse á las primeras un nuevo grado de perfección, y sin embargo, alcanzar el fondeadero del Callao en la noche del 28 , quedando inmediatamente amarrada y desaparejada al lado de la corbeta compañera.

Ya en el plan propuesto $y$ aprobado por Su Majestad, se envolvía una demora en Lima que diese lugar á un nuevo acopio de víveres, á la recorrida de las embarcaciones $y$ de sus pertrechos, al examen prolijo de un pais de tanta importancia para la Monarquía, y sobre todo á la ordenación de los muchos materiales hidrográlicos que habíamos acopiado, y que ya nó sin mu. cha confusión se iban aglomerando $y$ en cierto modo destruyéndose en la imaginación, se agre. gaba que en la costa siguiente al Norte reinaría á la sazón.el vendaval lluvioso enteramente opuesto á nuestras tareas, y que, por consiguiente, á ninguna parte pudiéramos dirigirnos que no envolviese á lo ménos igual sacrificio de tiempo para retroceder á las costas desde Gua. yaquil á Acapulco, en donde sólo por Diciembre empiezan á entablarse las brisas.

Con estos objetos, desde Chile habiamos suplicado al señor Virey que tuviese á bien inter- Jun. poner su influjo con los religiosos de la Buena Murerte, para que nos dejasen establecer cl 
Jun. real en su casa del pueblo de la Magdalena, mientrus las corbetas perunaneciesen desurma. das en el Callao.

Iis la Magdalena, un pucblecito de indios, cono muchos que stmenizan el luermoso valle del Rinac, sito al de la ciudad y no distante de ella sino dos millas murítimas: la amenidad de su suclo, la salubridad de sus aires y aruas, la tal cual separación de la vida bulliciosa de Lima, te lacen concurrido de muclios enfermos y conva. lecientes, para los cuales el cielo de la ciudnd es conocidamente pernicioso y funesto.

Muclias razones habian demostrado la nece. sidad de que nuestro real se estableciese algo distante del Callao y de Lima, de modo que combinásemos la reunión necesaria de todos parn las nuchas tareas a que debíamos arrostrar, con aquella natural independencia que es solat el primer móvil del descanso y del recreo. Li Callao, además de ser conocidamente expuesto á unas tercianas constantes, nos arrimalsa demasiado á los armamentos para que ni dcjasen de incomo. darnos á cada paso con su método poco aure. glado de vida, ni á la inversa les incomodásemos con nuestra presencia demasiado frecuente, la cual no nos diera lugar á disimular uno ú otro desorden. Además, que si la Oficialidad estuviese distante de Lima y precisada á unas tareas casi diarias, mal pudiera dedicar las pocas horas que le quedaban á la vida sociable y no ménos instructiva con que le brindaba la capital inmediata.

No era tampoco oportuno el establecernos dentro de la ciudad misma, asi porque scrían las distracciones y la dificultad de reunirnos mucho más frecuente, como porque la misma curiosidad $y$ ociosidad natural arrastrarian continuamente hacia el centro de nuestras tareas un número crecido de personas, con un grave perjuicio de la mayor economía del tiempo que nos propo. níamos. En la Magdalena, además de evadir los inconvenientes indicados, disfrutaríamos de un cielo algo más despejado para nuestras observaciones, de un clima mucho más sano, y particularmente de una cierta libertad campestre inse parable del sosiego.

Así, desde el momento en el cual la Descubierta fondeó en el Callao, como pasase el Teniente de navío D. Cayetano Valdés á cumplimentar al Virey y por la tarde lo verificasen también los demáa Oficiales con los Sres. Pineda y Heenke, quedó a probado por su excelencia el plan propuesto y accediendo los religiosos de la Buenc. Muerte á la total cesión de la casa ya indicada, pudicron en la mañana siguiente.tomarse medidas bien activas para la verificación del establecimiento y particularmente del observatorio. Los instrumentos astronómicos y geodésicos, los acopios de Historia Natural, la mayor parte de los libros y planos, se transfirieron allí $\sin$ la menor deinora y acompañándole nuy lué go algunos de los Oficiales, al paso que vigila. lsan sobre el buen orden y acomodo de cada co. sa, acechaban cualesquicra momentos favornbles pura las observaciones astronómicas, tan difíciles de conseguirse en el ciclo contínuameste nu. blado de aquellas inmediaciones.

los días que á la sazon corrian, eran preci. suneute los que la ciudad de Lima había destinado para la entrada pública del nuevo Virey del Perú, el 'Teniente General D. I'rancisco de Gil y Lemus. Este General reunia á su alto carac. ter y a unos talentos y cualidades personales dignas de mucha admiración, aquel amor hatcia nosotros que debia dictarle el ser el mismo un individuo de la Keal Armada, lo cual, al paso que nos liacia participar de aquellos regocijos páblicos, excitaba también una natural curiosidad, hija de unos aprestos tan magníficos cua les eran los que por todas partes se nos presen. taban á la vista. Lil Sr. 1. Antonio de Ulloa, en la narración de sus viajes, ha descrito el porme. nor de esas funciones con tanta puntualidad $y$ clegancin, que fuera reprensible el describirlas nuevamente, tanto más, que restituídas aliora á su antiguo lustre todas las ceremonias propias de aujuella ocasión, en nada podía la nariacion tacharse de poco exacta, si no es en el número ya muclio mayor del pueblo y en las aclamaciones procedidas ahora de un afecto más vivo hacia el augusto Soberano noblemente represen. tado á tamaña distancia del trono.

Veriticada la incorporación de la corbeta ATIEvida, fueron las primeras atenciones en entrambos buques la de examinar el movimiento de los relojes con alturas absolutas del Sol, me. diclas con el-sextante. La buena posición de verticales en las primeras horas de la tarde, facilitaban mucho la exactitud de aquel método; así para los primeros días del mes de Junio, conseguido el examen indicado, pudimos proceder sin mayores dilaciones al arreglo de las cartas, las cuales debían abrizar las costas reconocidas hasta entonces. Tuvimos tambien sobre pocas claras, la casualidad de poder observar para el anochecel. del día 5 la emersión del primer satélite de Júpiter, la cual, según los métocios adoptados, debía ligar las deducciones de los relojes marinos con los resultados de las observaciones celestes.

El primer día de Junio había sido la época en la cual empezamos el método de disciplina últimamente adoptado. D. José Bustamante, con su Oficialidad, se había establecido en una her. mosa casa de campo del Conde de San Carlos, á muy poca distancia de la Magdalena. Cada Oficial tuvo muy luégo un caballo con el cual nuestras visitas al Callao, nuestra concurrencia casi diaria á Lima, y á veces nuestros paseos, eren tan fáciles y frecuentes como sanos y entreteni-

\section{Jun.}

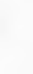

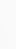


J11. dos. ira isma recopilación de los materiales acopiridos que se hacía de mancomún en ambas casas y que trabadas precisamente entre sí las diferentes materias exigía la solución continua de una ú otra duda, se hizo de este modo muy fácil, destacándose en el mismo traje de caza una ú otra persona á caballo que lás preguntase y resolviese. Empero muchos más objetos debieron tenerse presentes para adaptar á aquellas circunstancias un método general y oportuno, por manera que en lass clases subalternas tuviésemos a la vista la menor familiaridad entre si, una distracción no enfadosa de los vicios harto comunes en ('l Callan, una regular asistencia á sus cioberes, la nirguna deserción, y si fuese posible la ionservación de una salud robusta en medio de los muchos riesgos que la rodeaban. Con dichos objetos, en el mismo día primero pasó á acuartelarse en la Maydalena la tropa de batallones y brigadas de ambas corbetas, haciendo que los destacamentos á bordo fuesen de cuatro lombres á las órdenes del sargento, conde'cable ó primer cabo. Un solo Oficial de guerra, al ternando los de una y otra corbeta $y$ los mismos Guardias Marinas, quedó encargado de la guar dia de entrambos buques tondeados en una gralde inmediación uno de otro. l'asaron también á la Magdalena los pilotines y pintores y el sanrrador de la Discubirita, para encargarse de las disecaciones y aprestos correspondientes á la I listoria Natural. Se permitió á la Oficialidad de mar vivir indistintamente á bordo ó en tierra en el Calla, siempre que sri condueta no fuese escandalosa; sólo sí que el Contramaestre y dos guardianes, debían precisamente turnar en cormir ia bordo con la tercera parte de la tripulación, á cuyo aargo estarían la laneha, bote y chinchorro

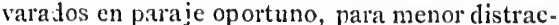
ción las otras dos embarcaciones menores. En el dia de trabajo ninguno estaría exento de él si no precediese liceneia, cuyo término se encargaba á los Oticiales de guardia no excediese de tres días, castigando por otra parte severamente los que interrumpiesen aquella distr:' :ción equitativa.

Pero aunque no hubiésemos conocido de antemano los desórdenes de la marinería en el Ca1lao, no hubiéramos podido ocultarno's que semejarites providencias en poco ó el nada se llevarian ń efecto, si no !igasen con agentes mucho más poderosos que los consejos ó el castigo; aquéllos poco eficaces, cuando el halago, los ejem. plos, el clima, la ociosidad y una fácil subsistencia, convidaban al vicio; éstos otros difíciles de realizarse cuando la fuga era tan fácil com ol delito. El interés ciebió, por consiguiente, parecer la única arma propia eis aquella ocasión, y la misma necesidad en que nos hallábamos de dar algunas pagas á las marinerías, así para que no echasen á mènos la gratificación del vi.o, cuya distribución sólo debía veriticarse en Manila, Jum. como porque eran acreedores á premios los pocos que en las costas de Chile no se habían abandonado á la deserción ó al desorden, dictó el medio más oportuno de reunir los objetos de interés á la conservación de una disciplina tan poco mo. lesta como lo permitiese el buen servicio del Rey.

Rajo de estos principios, se estableció que en los meses en que permaneciesen las corbetas en el Callao, además de la ración, se abonarian á cada marinero que asistiese al trabajo, cuatro reales diarios a cuenta de sus pagas; por manera qü, sujetado á las listas, no sóiv el ausente :o tri unfase de sus faltas ó vicios, sino que perdiese una parte correspondiente de su pagá favor de la Real Hacienda; debía también preferirse esta especie de castigo pecuniario, á los que deslizándose en alguna falta digna de castigo, quisiesen lavarla con el trabajo en lugar de vegetar ocio. samente en el cepo. A la tropa, pilotines y Oficialidard de mar, para mayor decoro, se ció la paga á principio de cada mes, reservándose, no s'sitante, el detenerla oportunamente á los que no siguiesen un método arreglado de vida. $\mathrm{Fi}$. nalmente, para los enfermos se adoptó, sí, el hospital muy bien asistido de Bellavista, pero en ¿na sala separada, bajo la inspección de nuestros ciruianos $y$ al cargo inmediato del sangrador de la Atrevida.

Entretanto, nuestras tareas científicas se habían emprendido y llevaban adelante con todo aquel vignr que debía exigir nuestro anhelo, de que correspondiesen á las intenciones de S. M. en pro de la navegación natcional. Se examinaron de liuevo y arreglaron sobre datos más probables las marchas de los relojes marinos, particularmente en las épocas comprendidas desde Buenoś Aires á Chiloé, resultando con esto alterada la posición en longitud del Puerto De. seado. Los diarios meteorológicos, los estados de variaciones y mareas, el diario astronómico, las tablas de las variaciones diarias en el novimiento de los relojes, todo recibió un nuevo orden delido á los diierentes Oficiales á cuyo cargo se puso; se repasaron y extractaron las $o^{\prime}$ servaciones de lat ‘ud ó de longitud que siriesen de base á las operaciones hidrográficas; se emprendieron los derroteros por los señores Quintano y Vernaci, y D. Dionisio Galiano en una bien hilada disertación que hizo preceder á las observaciones astronómicas, explicó por extenso los instrumentos relativos así á aquella ciencia, como á la Irísica, y los métodos con que hasta entonces se habían aplicado á la fidro. grafía los principios más sólidos de la Astronomía. No estaban tampoco ociosos los naturalistas; artes bien. encontrando por todas partes nuevos objetos de admiración en los diferentes ramos de Historia Naturil, aprovechaisn de aquel 
Nanila, Jun. is los pobían abanctó el mede interés poco mo. o del Rey. ció que en orbetas en onarían á jo, cuatro or manera usente :o e perdiese á favor de erirse esta e deslizán. - quisiesen setar ocioines y Ofise ció la índose, no á los que vida. Ii ptó, sí, el ta, pero en " de nues. del sangra-

ntíficas se te con todo anhelo, de de S. M. en examinaron nás probainos, part idas desde on esto al?uerto Deistados de nómico, las n el inoviun nuevo les á cuyo ictaron las dd que sirirográficas; los señores Galiano en preceder á licó por exi á aquella los con que la Hidrola Astrolos naturadas partes ferentes rasnde aquel
Jun clima uniforme para vagar á su albedrío los contornos del ameno valle de Rimac. D. Antonio Pineda, á cuyo cargo estaban los ramos de la Historia Natural, excepto la Botánica, no pudo á la verdad apartarse tan luego de la Magdalena; pero los Sres. Nee y Heenke, ya desde la mitad de Junio emprendieron excursiones dilatadas y de la mayor importancia, dirigiéndose el primero hacia las Quebradas de Canta, y ei segundo por Tarma al otro lado de la cordiliera hasta Guanuco, cuyo rio, vertiendo ya sus aguas hacia el Este, comunica con el Marañón y empieza á ser navegable. Se prescribieron á D. Luis Nee solos treinta días de ausencia; se amplió las $a$ cincuenta dias la de D. Tadeo Heenke; y les acompañaban los Sres. Tafallas y Pulgar, botánicos pensionados por S. M. en Lima y dos dragones milicianos medianamente prácticos del idioma indio.

Todas las medidas indicadas necesitaban á cada momento ó bien la autoridad ó el influjo del señor Virey. No ros faltaron uno ni otro, en cualquiera ocasión que los solicitásenıos; antes bien, franque: ndo S. L. á D. Cayetano Valdés, á cuyo cargo había puesto el examen del Archi. vo de temporalidades, cuantas noticias pudiesen conducir al mayor ensanche de nuestra obra, vimos que el plan propuestu podría llevarse á debido efecto en cuantos ramos nos permitiese extenderle ei tiempo de nuesira demora en aquellas inmediaciones.

Los armariciicos de entrambas corbetas, harto desmembrados así en cuanto á tropa como á marinería desde aue sitremos en el mar Pacífico, exigían también una atención tanto más seria por lo que toca á su reemplazo, cuanto que debíamos temer que las escalas siguientes de Gruayaquil, Panamá y Acapulco, nos arrastrasen nuevas deserciones y desórdenes. Para la tropa y brigadas suplicamos desde luégu al señor Virey que nos permitiese conpletarlas cun aquella sente vo-'ntaria que del resimiento Fijo de $\mathrm{Li}$ ma 6 de la Artillería, quisisse pasar á nuestras banderas. Exigíamos las cualidades de robustez, buena conducta y de que procediesen de los re

jul. gimientos veteranos de Soria y Extremadur?, los cuales, al tiempo de regresar á España, lin. bian comp, etado dicho regimicnto, y dejábamos al arbitrio de D. Cayetano Vaicies el decidir, después del examen más prolijo, ruáles entre los muchos que se brindaron voluntariamente, fuese. ó no oportunos para el intento. En cuantoá la marinería, conociendo el genio inconstante de esa clase infeliz, y pudiendo combinar-con el corto núm to que a la sazón nos liabía quedado así el desempeño de las faenas diarias como una prudente economía al Erario, dejamos para el último mies de nuestra estada en el $\mathrm{Ca}$ llan el completarla, ó bien con los muchos que en los navíos mercantes habian venido de Euro$F^{2}$ in aquel misno aino, 6 con los que 1 legroen en la fragata Licbre de la Marina Real, destinada según los últimos correos á la mar del Sur y particularmente al puerto del Callao.

La policía del puerto, harto abandonada desde que no $1 \approx$ frecuentaban los buques de la Ma. rina Real, fué otro objeto que debió precisamente ocuparnos mientras no hubiese otra em. barcación que le tomase á su cargo. Se prescribieron á este fin á los Capitanes de los buque: mercantes las precisas instrucciones sobre anclas, amarradero y número de gente á bordo, particularmente de noche, para su seguridad. Debía. rondar el Oficial de guardia para el exac. to cumplimiento de la instrucción in:icada; debía examinar el estado de los buques que saliesen, para que, poco advertidos, no careciesen de aquellas precauciones que son indispensables aun en 'a más extricta economía mercantil; finalmente, debían pcr sí cortar con igual dulzura, rectitud y prudencia, todas aquellas quejas diarias que ya el Capitán, ya el marinero, en los buques mercantes, encuentran en sus ideas harto contrarias y opuestas entre sí. Estas precauciones no alcanzaron sin embargo á evitar, que en la noche del 7 de Junio un buque mercante, incendiado por descuido del Oficial de mar y pocos marineros que le he.oían abandonado, pusiese cn evidente riesgo las mismas corbetas y particu. larmente la Descubierta, á cuyo orinque del ancla del Nor:e quedó ,or largo tiempo agarrado con el timón. El Guaria Marina D. Jacobo Murphi y los dos primeros contramaestres de las corbetas con ambas 'anchas, despuegaron en aquella ocasión una actividad é inteligencia dig. nas de elogio, logrando remolcar y varar en la playa del Ancon el buque incendiado, ya que se habían frustrado todos sus esfuerzos para apa. garle 6 aprovechar los palos y alguna otra parte de sus pertrechos.

En los buques mercantes recién llegados de Europa, el Intendente general de Marina en la Isla de León, nos había dirigido varios efectos que aún no estaban prontos al tiempo de nuestra salida. Entre ellos tuvimos la satisfac. ción de ver comprendida una ecuatorial de Do. llón, la colección de libros acopiados en París para los objetos de Historia ivatural, y dos cajas de cristales, casi todos utensilios pertenecientes á las experiencias de los aires, siendo entre ellos dos máquinas de muclıa importancia, los eudiometros de los Sres. Volta y Fontana; pero no pudimos ménos de extrañar y hallar sumamente perniciosa para los objetos que nos proponíamos seguir en el viaje, la falta no sólo de la excelente colección de instrumentos físicos que acopiada en París por disposición rlel Excelentísimo Señor Conde de Fernán-Núñez estaba ja cmbar- 
c ıda en Ruar al tiempo de muestra salidu de Cádiz, si tambićn los pararayos y algunos otros utensilios que debían remitirnos del Arsenal de lá Carracit en las primeras ocasiones. Nos entregamos entre tanto de todo lo que había llegado, y no tardó 1). Antonio lineda en examinar la salubridad de los diferentes aires atmosféricos que se respiraban en los contornos de Lima.

Casi al mismo tiempo habian llegado á Lima, remitidos por los correspondientes Gobernadores, casi todos los desertores de Chiioé, y entre los de Chile un marinero quedado en Coquimbo y otro y' un cabo de escuadra de la Descubierra desertados en Valparaiso; se les trató con mucha ménos severidad de la que debían esperar, obligríndolos sólo á que descontasen á borlo con un grillete ó cédena el premio de su aprehensión; no les quedí tampoco cortado todo medio de evadirse de nucvo, y sólo al cabo de escuadra se obligó á que sirviese en la Arrevidi en clase de soldado raso, hasta que manifestase en su conducta datos tales, que pudiesen borrar el error pasado harto escandaloso. En nuestro sistema dc armamentos, en los cuales por ningún motivo podíamos admitir gentes cuya custodia y conducla exigricsen la ocupación constante de otros muchos, esos rasgos de dulzura eran más bien necesarios que oportunos, ni dejaron de intluir mucho en ligar cl amor de la marinería al servicio, pues que además de que los marineros apresados eran buenos y generalmente amados de sus compañeros, no les quedó duda que la autoridad en nuestras manos era inseparable de la compasión y que al paso de perseguirles con el mayor tesón donde estuviesen, no era esto con ánimo ó de emplearlos violentamente y casi por necesidad en la misma comisión, ó desplegar sobre ellos un rigor militar intempestivo. Al mismo tiempo se examinó en Consejo de guerra junto á bordo de la AtrevioA, el delito cometido en Valparaiso por un soldado de marina de su guarnición, que había mal herido á un marincro, muerto después á bordo más bien por haber ocultado por largo tiempo la herida que por su gravedad al principio. D. Secundino Salamanca, en una defensa bien ordenada, recordó á los ji. ces las circunstancias del delito, la dificultad de resistir á unos ultrajes contra su misma clase y servicio en un soldado que voluntario se había alistado en el servicio de las corbctas cuando podía gozar quieto de una paz duradera; finalmente, la gallaruia con la cual solo y con armas inferiores se había defendido de dos marineros; y el Consejo, reflesionando en estas circunstancias, le sentenció á scis meses de prisión, contando la que ya laabía sufriclo, $y$ á un recargo de cinco años en el servicio militar, bien que debia tener lugar en la fragata Licbre más bien que en nuestros buques, para que ni los armamentos tuviesen á la vista casi impunc el autor de una muerte, ni quedase entre lat tropa y marinería un principio de rencor que después de largo tiempo pudiera acrecentar y ser funesto.

Aìadidas á estas muestras de escarmientos la ocupación diaria, el cebo del jornal y la naturaì disciplina militar, haciendo la marinería frecuentes ejercicios de cañón y los de fusil la tropa, juntamente con las revistas de armas y ropa, guardia de prevención, toques de retreta diaria, etc., lográbamos ver, nó sin mucha compla. cencia, que el buen orden, el amor recíproco de las diferentes clases y de los mismos individuus entre sí, finalmente, que la robustez misma, iban precisamente cimentándose en el paraje donde más bien debíamos recelar su última destrucción.

:... los primeros días de Julio vimos llegar la rata Liebre de la Marina Real, al mando del Capitán de navio D. 'Tomás Geraldino; siguieron luégo con mediana actividad nuestros aprestos para las próximas campañas; así, al concluir del mismo mes, las corbetas aparejadas de un todo, la tonelería y velamen recorridos con la mayor cscrupulosidad, reemplazados ó conpuestos los diferentes pertrechos, completadas aguada $y^{\prime}$ víveres, recibido el número de tropa que nos faltase áun excluído uno ú otro individuo de los antiguos, ó como enfermo ó como inútil, y la estación oportuna para seguir nuestras tareas ya muy próxima, todo nos avisaba que era tien. po de arrostrar de nuevo unas ocupaciones que por tanto tiempo debían tenernos á tamaña distancia de la patria. Incorporados ya por otra parte los Sres Nee y Heenke, después de unas excursiones tan útiles como penosas, y no debiendo ser sino de muy pocos días la ausencia de D. Antonio Pineda, que intentaba un nuevo reconocimiento de la cordillera en aquellas in. mediaciones, debímos poner un término á nuestro deseo de que nada faltase ni en la exactitud ni en la multiplicidad, ni en el orden ni en el aseo, en todo lo que había de componer nuestra remesa de las tareas pasadas y más bien inclinarnos á aquellos objetos cuyo cumplimiento exigiese in. dispensablemente nuestra demora eir el Callao.

Quedó por consiguiente deisrminado para el 20 de Agosto el principio de las tareas hiurográ ficas y del restab'ecimiento de la mavr: parte de 1 Oficialidad á bordo. Debía hacerse cargo del Real de la Magdalena D. José Bustamante, á quien dos meses de calentura casi contínua, hacían necesaria mucha guietud y una regular convalecencia. Sería el otro establecimiento á bordo de la Descubierta para acelerar las últimas ta. reas y disponernos á la salida, con cuyas precauciones, cada uno de los individuos de las corbetas lograría indistintamente del necesario descanso, comodidlad y acogimiento donde sus
Jul. 
Ag. ocupaciones principales le detuviesen, bien sea á bordo ó en la Magdalena. Aquí delían permanecer particularmente todos los encargados del ramo de la Historia Natural; D. Felipe Bausá, cl piloto Maqueda $y$ dos pilotines para continuar el trabajo de cartas; $y$ los Tenientes de navío Galiano y Concha que intentaban arreglar antes de la salida el catálogo de las estrellas observadas en Valparaiso. Al cargo de D. Juan Vernaci estaría el arreglo de la marcha de los relojes marinos, formado el observatorio muy oportunamente en una de las torres de la ciucladela del Callao, y el mismo Bausá, medida una base en las inmediaciones de la Magdalena, extendería poco á poco los triáng:los desde el observatorio hasta la catedral de Lima, Pachacamac, Lurin y el mismo puerto de donde le encontraríamos nosotros con otra serie de triángulos emprendidos sobre otra base para extender hacia las islas de Pachacamac.

La constante benignidad del tiempo, que hace cl mérito principal del hermoso clima de aque. llas costas y su menor fosquedad, pues ya con la caída del invie "no se iba poco á poco disipando, hicieron que li:s medidas indicadas pudiesen llevarse á debido efecto casi con la misma precisión con que las habíamos dispuesto, y así para los primeros dias de Setiembre estaban concluídas las operaciones hidrográficas, sondado prolijamente el puerto, usando de teodolito para la colocación de los bajos, bien encami. nado el arreglo de los relojes, $y$ hecha por el piloto Maqueda una excursión al Ancón y los Pes. cadores, para ligar aquella pa"te adonde no alcanzasen nuestras marcacic es, examinar sus sondas y hacer una ú otra observación de la d. Sói D. Manuel Novalss, quien con el Gu - Marma Alí debía en el falucho de las Rentas 1. conocer los islotes foranos de las Hormigas y determinar con buenas observaciones su latitud y longitud, tuvo la desgracia de no poderlo verificar completamente acosado de un viento extraordinariamente fresco del sisr, el cual, engruesando mucho el mar, ni le permitió permanecer fondeado entre aquellos pedruscos, ni dejó de exponerle á mucho riesgo é incomodidad para alcanzar nuevamente el puerto. Completamos al mismo tiempo, con marineros de la fragata Licbre ó de otros buques, todos los que falta-

Set. 15 ban, y así nara el I5 de Setiembre, época en la cual serróse la cuenta de los relojes, pudimos considerar ya todo dispuesto para dar la vela.

Dos cosas habían no obstante contribuído á la sazón á enturbiar considerablemente Ja natural complacencia que debía causarnos, no sólo la perspectiva de nuestras tareas del primer año, si también la aprobación de S. M. á nues tras operaciones del Rio de la Plata, que acababa de manifestarnos en carta de Marzo el señor
Bailío D. Antonio Váldés, y fueron éstas la se- Set. 2. paración del pintor D). José del Pozo del destino al cual se había contraído, no pudiendo sujetarse ni á aquella natural subordinación que sola es el principio y cimiento del buen orden, ni á aquel tesón y asiduidad en el trabajo que exigían así el ejemplo de los demás, como la harmonía de los objetos que teníamos entre manos. La segunda, fué el que no faltaron en los últimos días de muestra demora en el Callao algunos desórdenes en ambos 'urmamentos, inseparables á la verdad del marinero cuando abandonando un pás lleno en su entender de halagos y atractivos para arrostrar las fatigas del mar, ¿.stenta sepultar en un goce momentáneo la idea de los peligros que le esperan. Muchas veces la dulzura y muy pocas el rigor, se em. plearon para contenerlos: la Oficialidad, ya casi toda reconcentrada á bordc, alternó en este útil objeto; y finalmente, pudo conseguirse que se reuniesen á borấo en el día anterior á la salida todos los individuos de la Descumerta, si se exceptúa un soldado de Marina y otro de los recién pasados del regimiento Fijo. No fueron mayores las faltas de la $\Lambda$ Trevidis, según avisó su Comandante por medio de D. Francisco Javier Viana, y así, nada oponiér dose ya cn ia tarde del in para la verificación de la salida, esperamrs con ansia la mañanita siguiente, metidas ya dentro algunas de las embarcaciones menores y cortada cuanto fuese posible la comuni. cación con tierra.

\section{CAPÍTULO VI}

\section{Varegacion. desde el Callao al andar de la costa wa el l' who de Perico en al Cingo de Pamameí. O rencias on Guayaquil. on aquel puerto.}

Eran las diez de la mañana cuando pudimos dar la vela con la brisa ya entablada. Al medio día, el estremo Noneste de I Islit San Lorenzo, nos demoraba pri simamente al Norte distancia de media milla. y el rumbo emprendido del Oeste $1 /$ Noroeste debía conducirnos directamente á dar vista á los Islotes de las Hormigas, cuya posición intentábann - tificar, malograda en mucha parte por $\mathrm{cl}$ iporal del Sur la expedición del Teniente de Navío D. Manuel Novales, de la cual se hizo memoria. Los avistamos efectivamente á las tres y media de la tarde, cuando desde la cofa de mesana se alcanzaba todavía la vista de la Isla de San Lorenzo. Fué fácil después reconocerlos de cerca, y finalmente, á las cincu, sondadas 94 brazas arena y conchuela, y observados algunos horarios, arribar el Norte para continuar las tareas emprendidas. Los dos is lotillos indicados y ya bien reconocidos por Don 
Sec zo Manuel Novales, el cual había fondeado entre ellos, serían seguramente un peligro no mediano en aquellas navegaciones, así por su poca elevación, como por sus restingas salientes en varias direcciones; pero por ventura tienen buen fondo á una milla de distancia, y además es fácil evadirlos saliendo de la Isla de San Lorenzo para cl Oeste: viniendo á Lima siempre se costea la tierra firme á corta distancia, ni hay motivo alguno que pueda precisar á otro partido. Nues. tras observaciones combinadas con la estima; determinaron para el islote mayor la latitud de $\mathrm{II}^{\circ} 54^{\prime} 4 \mathrm{o}^{\prime \prime} \mathrm{y}$ la longitud de $34^{\prime} \mathrm{o}^{\prime \prime}$ al Occidente del Callao.

No hay tal vez en la dilatada extensión de las costas de la América sobre el Mar Pacífico, una parte más oportuna para las tareas hidro. gráficas, de la que se halla comprendida en ${ }^{*}$; Lima y Paita, debiêndose considerar este último puerto como el verdadero término por una parte de los vientos siempre constantes del Sur, por la otra del imperio de las dos monzones opuestas del Sudoeste y del Nordeste. Son allí los cielos algo ménos calimosos que sobre las costas de Coquimbo y Arica, en donde por la misma razón no pucden repetirse con tanta frecuencia las observaciones, los vientos son muy frescos $y$ largos, las costas ménos desjertas y por eso más frecuentes los fondeaderos ó abrigos, las sondas no se extienden á ménos de cinco leguas mar en fuera, finalmente, frecuentan á esas orillas felices un número tan crecido de aves acuáticas, de anfibios, de ballenas y de peces, que el navegante halla por todas partes nuevos objetos agradables para satisfacer á su codicia ó al entretenimiento de su imaginación. Córrense así unas tras de otras cerca de doscientas leguas de costa casi todas en la dirección Norte-Sur. Se ven en la orilla del mar los diferentes puebios que sirven como otros tantos albergues, para los que transitan por tierra desde Paita á Lima. La cordillera de los Andes, sumamente elevada, descúbrese pospuesta á poca distancia, siempre calimosa $y$ formadas al parecer sus cimas por materias areniscas y cenicientas; siguen después los arenales Ge Pascamayo, Cherrepe y Cechura. Las ciudades de Trujillo y Paita son las más considerables y las que por diferentes razones atraen á sí algún comercio, sea de los productos naturales ó de los artefactos.

Nuestra navegación hasta Paita ó más bien hasta el Cabo Blanco, debió con aquellos antecedentes ser igualmente sencilla $y$ ag vable. Las bases de corredera y las observacionts, sean de latitud 6 de longitud, se daban constan. temente la mano unas con otras. La ATrevida de hora en hoia examinaba las sondas, las cuales desde las 80 irazas á cinco leguas mar en fuera, solían últimamente alcanzar de I6 á 20 á una legua de la costa. Paireábamos la mayor set. 20 parte de la noche; solíamos medir una ú otra altura de los montes más elevados. La variación de la aguja disminuía paulatinamente desde el Nordeste y los derroteros antiguos, los nombres conocidos en nuestras historias de la conquista, $y$ sobre torlo, los rastros apreciables de la expedición de los Sres. D. Jorge Juan y D. Antonio Ulloa se seguían tan de cerca, cuanto lo permitiesen los límites de la exactitud que nos habíamos prefijado para la descripción hidrográfica de unas costas tan extendidas.

Para el amanecer del día 27 estuvimos efectivamente en las inmediaciones de Paita. Largas las insignias, atracóse el fondeadero por sondas de I $_{4}$ y I 5 brazas. Reconocimos con bastante exactitud 'ese teatro harto célebre de las hazañas militares del Almirante Anson; algunos buques mercantes fondeados, dos balsas grandes á la vela á pesar del mucho viento, muchas canoas varadas en aquellas inmediaciones, eran objetos que hacian más agradable la vista del puerto, y como no tardasen en ceder los últimos soplos del terral á la brisa nuevamente fresca del Sur, á las nueve nuestra derrota ya nos conducía directamente hacia el Cabo Blanco, y para el anochecer habíamos conseguido el montar aquel Cabo, orzando después inmediatamente para el golfo de Guayaquil.

Aquí anocheció con viento galeno y semblante algo calmosos. Nav́egamos dos ó tres le. guas con poca vela, y luégo nos atravesamos de la vuelta de tierra con ánimo de aprovechav cuanto fuese posible la mañanita siguiente, y si la virazón se declarase fresca, alcanzar el fondeadero de Punta de Arenas en la Isla de la Puná. La mar gruesa sorda que oíamos romper en las orillas y la vista de la costa, nos avisaban en las horas del pairo, que nos aproximábamos considcrablementc á la tierra; pero como cl fondo se mantuviese aún mayor de 80 brazas y el viento galenito de la brisa pareciese no querer cesar de un todo, continuamos el pairo hasta las cuatro de la mañana, en cuya hora marcamos sobre las gavias algro desviados de la dirección de la costa.

Al amanecer no distaba ésta efectivamente sino una legua escasa y parecía según las noticias, la comprendida entre las ventas de Mero y Mancova: el Cabo blanco y la costa reconocida en la tarde anterior aún estabain á la vista. lira el fondis de 60 y $6_{5}$ brazas arena lamosa. No tardamos un instante en emprender las bases con toda vela; pero e' desmayas considerablemente el viento hızo que adelantísemos poco hasta el medio día, tunto más, que la precisión de reco. rrer la costa ya algo baja, no nos permitía se. pararnos de ella $y$ hacer rumbos directos al is. lote el Amortajado. Observóse la latitud de $3^{\circ} 40^{\prime}$ y la longitud de $3^{\circ} 4 \mathrm{r}^{\prime} 25^{\prime \prime}$ al Occidentc 
Set. zo del Callao. Floja aún la virazón despues del medio día, quedó la atmósfera tan cargada de vápores, que se nos dilató la vista del Amortajado hasta ponerse el Sol. A la sazón veíamos también á distancia de dos leguas la Punta de Malpaso $y$ las rompientes inmediatas, y nos hallábamos en fondo de zo brazas lama. La noche fué lóbrega, la marcación al Amortajaco y la sonda no nos dejaban. sin embargo, el menor rewiu subre nuestra derrota; antes bien, navegábamos algo orzados con el objeto de avalizarnos de nuevo con aquel islote y evadir los bajos de Poyana que salen muy afuera del rio de Tumbes. Empero contra nuestras expectativas, cuando ya nos considerábamos próximos á dicho islote á las nueve y media de la noche y le acechábamos por entre la oscuridad, eaimos de las 20 brazas lama en 5 arena, y la Atrevida sondó nueve brazas piedra. No nos quedaba duda que habíamos eaído sobre bajos; orzamos por consiguiente, y hallamos de nuevo las 20 brazas lama que en un momento llegaron á 30. Por este fondo, ya puestos nuevamente en derrota, avistamns á las I I por nuestro babor el Amortajado, que supusimos distase una y media leguas, y considerándonos ya en buena derrota nos dirigimos hacia la Duná.

Era la voz común, que desde el Amortajado con el Nordeste cuarta al Este, se subía p:óximamente á la Punta de Arenas, aminorando el fondo hasta to brazas lama. Este fué, pues, el rumbo que seguimos con toda vela desde las once de la noche; pero como encontrásemos á las dos solas to brazas, inciertos del cantil hacia el cual nos habíamos aproximado, dimos fondo á un ancla, y precedida la señal correspondiente lo verificó á poco rato la ATrevidA. Este acaso en la mañanita siguiente, debió parecernos bien favorable, pues nos hallábamos en la posición más oportuna de hacer buenas marcaciones á las Puntas de la Salina y Arenas en la Puná, al Amortajado y á varios puntos de la costa de Tumbes, sobre la cual habíamos caído con rum. bos demasiado del Este.

En el entretanto, calmado enteramer : el viento, ó más bien, declarado el terral, fué nuestro primer paso el de enviar el bote con un sargento al pueblo de la Puná para que saliesen prácticos del rio á encontrarnos en Punta de Arenas. Algo elevado después el Sol sobre el horizonte, se observaron algunos horarios. Finalmente, no queriendo malograr el tiempo que la brisa algo tarda nos obligase á pasar fondeados, destacamos por cada corbeta un bote con un pilotín para que á diferentes rumbos empren. diesen dos líneas de sonda. A las diez y media empezó á declararse la virazón; llamamos luégo los botes y avisamos á la ATREvida que se mantuviese fondeada hasta el medio día para ob. servar la latitud, mientras nosotros álejíndonos set. a? algún tanto, proporcionaríamos una regular distancia y dirección para medir una base por altu. ras de topes sobre la cual los puntos principales a la vista, quedasen al mismo tiempo bien situados entre sí y sujetos á una cabal posición astronómica.

En efecto, al medio día la Descublekta había abierto una regular base sobre la cual se hicieron las operaciones indicadas, conviniendo una y otra corbeta en el ángulo medido. Nos di. rigimos luego con fuerza de vela á la Punta de Arenas, en cuyas inmediaciones fondeamos á las tres de la tarde en $\mathrm{I} 2$ brazas arena, habiendo navegado por 15 y 18 brazas igual fondo. La marea á la sazón entraba con fuerza de tres millas escasas.

"oda la noche permanecimos en la misma posición; y caída, según costumbre, la brisa antes del amanecer, le sucedió un terral flojo, eon el cual y con carices bastantemente neblinosos, salió el Sol, dejándose ver poco después el bote que regresaba de la Puná. Sólo á las diez de la noche había alcanzado aquel pueblo atracada por equivocación la Punta Salinas en lugar de la de Arenas, é inmediatamente embarcados los prácticos, habían emprendido el regresar á bordo. El pilotín que iba destinado para las sondas, las babía ejecutado muy oportunamente. Conso á las siete de la mañana se nos presentaron algunas claras que aprovechamos inmediatamente para observar distancias lunares, sus resultados indicaban una longitud $3^{8}$ más corta que la indicada por los relnjes. Las distancias observadas en la Atrevida fueron aún más cortas que las nuestras.

Hasta después de las dos de la tarde, ni aminoró la fuerza de la marea contraria, ni entabló la brisa regularmente fresca para que pudiésemos aproximarnos al foncieadero. Dimos pues la vela, $y$ antes con proa del Este para rebasar el bajo de Mala. luégo arribando paulatinamente por fondo de siete á ocho brazas lama, navegamos la restante tarde para aproximarnos á la Puná. El viento escaso en sus inmediaciones nos obligó á dar un repiquete hacia los buques fondeados, pern alargándose después dió lugar á que nos propasase la $A$ TREvida, y que entrambas favorecidas con extremo de la brisa y la marea, alcanzásemos la boca del rio, en cuya angostura nos dirigian unánimes la sonda, y ambas orillas que veíamos claras, aunque la noche fuese bastantemente lóbrega.

Se aprovechó hasta las once la marea favorable navegando dentro del rio; dimos luégo fondo cerca de la Punta de Piedras en cinco brazas lama, para esperar que se declarase de nuevo la otra entrante, la cual, aprovechada desde las seis de la manana siguiente con los remolques 
Oct. , $^{\text {y }}$ las ventolinas variables, nos condujo para el medio dia á fondear á solas dos leguas de la ciudad. Finalmente, en aquella misma tarde á favor de la virazón y cesada la fuerza de la marea vaciante, volvimos á emprender la navegación para adentro, y auxiliadas de la sonda fondearon á las siete de la noche entrambas corbetas en frente de la ciudad y distantes como un cable de la orilla. La faena de amarrarlas á son de marea ocupó después muy poco tiempo, y para evitar las vueltas procedentes de la alternativa de las marcas, se tomaron los dos cables á estribor, abøzándolos uno con otro.

No bien había amanecido, cuando se presentó á la vista de todos y particularmente de los que no habían frecuentado los paises amenos de la Zona Tórrida, un espectáculo tan nuevo como placentero. Las orillas agradablemente vestidas de varios verdes cuy'as graduaciones mismas con un nuevo contraste aumentaban el primor de la escena, muchas aves enteramente nuevas así por el canto como por los colores, las balsas, las canoas, la mezcla de casas, árboles, agua y embarcaciones casi en un sólo grupo; todo recordaba al espectador admirado, que la naturaleza tan varia como extendida, excede en sus primores maravillosos á las imaginaciones áun más vivas $\mathrm{y}$ arrebatadas.

Los Oficiales astrónomos no tardaron un solo instante en dar principio á sus tareas; y á pesar de la imposibilidad de valerse de casa alguna para la colocación del péndulo y del cuarto de círculo; aquél porque la cimbra de los tablones que forman el piso alto causaba un movimiento extracrdinario con el solo andar de las personas, el otro porque la inmediación del Sol al zénit hacía que los techos fuesen desde muy temprano un estorbo irremediable, combinaron la posición de un y otro instrumento en la plazuela inmediata con tanta actividad, que pudo deducirse en medio día en el péndulo por medio de alturas correspondientes y referirse por las comparaciones á los relojes de una y otra corbeta. Nuestras deducciones fueron las siguientes:

\begin{tabular}{|c|c|c|c|}
\hline & Nuim 13. & Núun. 16. & Núin. $7^{2}$. \\
\hline $\begin{array}{l}\text { Medio dia verda- } \\
\text { dero en Giuaya- } \\
\text { quil. . . . . . }\end{array}$ & 8. $17.5^{6.40}$ & $2.10 .3^{8.55}$ & $7 \cdot 36.48 .10$ \\
\hline I1. en el Callao. & 8. $7 \cdot 15.25$ & $1.59 \cdot 57.23$ & 7.26 .8 .14 \\
\hline $\begin{array}{l}\text { Diferencia de Me. } \\
\text { ridianos.. . . } \\
\text { Ecuaciones con- } \\
\text { frontadas con } \\
\text { el num. Io... }\end{array}$ & 10.41 .15 & 10.41 .32 & I 0.39 .56 \\
\hline $\begin{array}{l}\text { Resulta la dife- } \\
\text { rencia corregi- } \\
\text { da. . . . . . }\end{array}$ & $10.3^{8,23}$ & $0.3^{8.23}$ & 10.38 .2 \\
\hline $\begin{array}{l}\text { En graduaciones y } \\
\text { del Callao. . . . }\end{array}$ & Occidente & $2^{\circ} 39^{\prime} 36^{\prime \prime}$ & 10.30 .2 \\
\hline
\end{tabular}

Los relojes de la ATrevios daban al mismo oct. a tiempo los resultados que siguen:

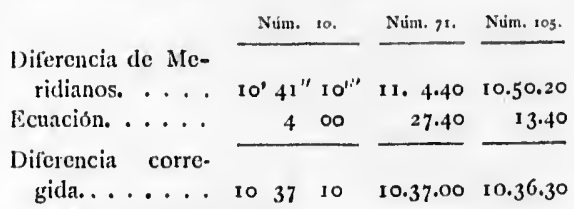
En graduaciones y Occidente

$$
\text { de] Callao. ......... } 2^{0} 39^{\prime} 13^{\prime \prime}
$$

Tanta uniformidad, ya no sólo debía tranquilizarnos sobre la diferencia considerable que hallábamos con la longitud deducida por la estima desde Quito por el Sr. D. Antonio Ulloa la cual era mucho más oriental que la nuestra, si también nos autorizaba á emprender la construcción de la carta de las costas reconocidas, sin esperar los resultados de las observacinnes astronómicas, ó en la Luna ó en los satélites de Júpiter, que ya no discreparian sino muy poco y de una cantidad, que sólo pudiéramos emplear al tiempo de dar la última mano á la obra. Fué al mismo tiempo muy buena precaución de los Oficiales astrónomos, la de deducir por la posición nuestra y la del Chimborazo en la carta de Don Antonio de Ulloa, el rumbo y elevación á que debía verse si el ticmipo claro fuese en esta parte favorable á nuestros deseos: debía demorar al Norte $59^{\circ} 40^{\prime}$, E. $\mathrm{I}^{\circ} 20^{\prime}$, ángulo apreciable sobre la horizontal de Guayaquil, y desde luego según los puntos hacia donde decían verle estos habitadores confrontara su posición en la aguja con la que sospechábamos. Los pasados incidentes en cuanto á los desórdenes ó extravío de la tropa y marinería, el riesgo de malograr otros con tanto mayor sentimiento cuanto mayores eran los objetos de que se habían libertado los pocos rezagos de los armamentos primitivos; finalmen. te, las noticias no favorables del país, en el cual nos hallábamos á la sazón, precisaban á imagi nar nuevos resortes, que sin violencia ni sujeción consiguiesen el fin deseado. A este intento unánimes entrambos Comandantes fijamos nuestro sistema para la conservación de la disciplina $y$ de la salud, en una ocupación constante mas no violenta, en una ración diaria algo crecida en dinero, que les franquease sí algún pequeño desahogo mas le sujetase á un pronto castigo y á la lista diaria; finalmente, en una frecuente suministra. ción del vino por vía de ración, que apagándoles algún tanto el deseo innato de la bebida los apartase insensiblemente del desórden, tan opuesto á la salud como á la disciplina. Una idea aunque remota de libertad, en dejarles elegir á su albedrío la clase de comida, debia concurrir á hacerles más agradable este rofresco; nuestra intervención sólo sería necesaria cuando el desórden 6 el abandono lo requiriesen, y entre tanto 
net. a cl uso constante de los refrescos sazonados según sus antoins, ahorraba para nuestros pasos venideros una igual cantidad de víveres de repuesto. No por esto se permitió la subdivisión del caldero: con igual método que en Lima, siempre se preparó una sola olla para la marinería y otra para la tropa; se repitieron las comidas calientes tres veces al día y á lais horas más regulares para la recta distribución del trabajo; finalmente, suministrada á cada uno después de la lista de la mañanita la ración igual á la de Lima, se les permitió que pactasen la cantidad diaria que había de invertirse en los comestibles, y la que sobrase se dividiese entre todos por igual porción diaria ó semanalmente. En cuanto al trabajo, se ciñó por ahor á los dos objetos del aseo y del servicio de embarcaciones menores. La segunda parte era bastantemente penosa así por las ocurrencias nuestras diarias de observatorio, Historia Natural y comunicación recíproce, como por las muchas excursiones que se requerían para el cabal reconocimiento del rio y para el reemplazo mismo de la aguada, que la mucha internación de las mareas precisaba buscar á una distancia considerable.

Tanta individualidad en nuestras medidas para el mejor régimen de la. marinería, parecerá tal vez tan afectada como importuna si no se tienen presentes el natural desaliño de todo marinero, las pasiones sumamente vivas de la marinería española y los extragos harto destructivos á que se ve sujeto en aquellos climas el europeo transeunte. Cuanto más sencilln ó bien desconocido fuese nuestro sistema para unas gentes naturalmente opuestas á toda monotonía, tanto mayor debía ser nuestro arrimo hacia él; y á la verdad no dejaba de alentarnos á la empr'ssa la vista agradable de una suma robustez y del semblante de una satisfacción natural en liss rostros de entrambos armamentos. En el mismo paraje en donde se habían observado las primeras alturas, se colocó después la tienda de Observatorio $y$ se le cercó con un recinto de caña, tomando la precaución, que un soldado de marina en las horas del día y uno de la plaza en las de la noche, vigilase sobre la seguridad del cuarto de círculo y el péndulo. D. José Elizalde, cuya casa estaba bien inmediata, nos franqueó al mismo tiempo los cuartos oportunos para que atendiésemos con la mayor comodidad al dibujo, á la pintura y á todos los demás ramos de la Historia Natural, y un balcón por nedio del cual los pistoletazos de comparación indicasen al medio día á ambos buques las horas del péndulo.

Las pequeñas excursiones que los naturalistas emprendieron en el primer día, muy luégo les dieron una idea grandiosa de la naturaleza. Todo les prometła un caudal grande de nuevas adquisiciones y excitaba su celo ardien- te para los progresos, particularmente de la Bo- Oct. s tánica.

Todo el día siguiente se empleó en clisponer nuestras excursiones principales, las que en efecto tıvieron lugar en las mañanas del 4 y 5 , según el plan que nos habíamos propuesto; muy poco pudo proseguirse la parte astronómica, porque las inmediaciones del novilunio, al paso que con una revolución natural en el tiempo tuvieron los cielos por lo común nublados y áun á ve. ces achubascados, imposibilitaban toda especie de observaciones por la Luna. No debían proporcionarse antes del I 7 las primeras observaciones de los satélites de Júpiter.

Nuestras excursiones científicas, según el 4 ys plan propuesto, debían pues, dirigirse á los objetos siguientes: los Tenientes de navío T'ova y Robredo de la ATRevida, con un piloto de la Descubierta se dirigieron en una balandra del rio, fletada para el intento, á desembocar por el naranjal y costear por Tenguel y Marhala hasta la embocadura de Tumbes; quedó al arbitrio de dichos Oficiales el internar ó no hasta Tumbes; pero se les recomendó estrechamente yue procurasen observar á la vista de los bajos de Po. yana. El cronimetro 6 r y los sextantes, suministrarían en esta navegación los datos principales; puès las mareas harían por lo común muy difícil é inexacto el método de las bases. La lancha de la Descubierts, provista con 15 días de ración y á las órdenes de D. Juan Ver. naci, con otro pilotín, fué destinada á internar por el rio hasta las bodegas de Babahoyo. Llevala el cuarto de círculo pequeño y el reloj ro5, con los cuales no sólo pudiese hacer las precisas observaciones astronómicas, si también renovar la medida geometrica del Chimborazo sobre bases exactas para aproximarnos con estos datos á las precisas observaciones de la meridiana de Quito. C $n$ buenas guías, D. Aritonio Pineda y D. Luis Nee debían nenetrar hasta el mismo Chimborazo; y el unocu. ubjetos físicos y el otro con los botánicos, aprovechar cuanto fucse posible el plazo de quince días que se les prefijaba.

Las dos expediciones dieron la vela en la mañanita del 4 con las dos mareas oportunas. En la del 5 lo verificó también la lancha de la Arrevida á cargo del Alférez de fragata Murphy y del piloto Maqueda. Debían recónocer la Isla de la Puná por las puntas de Arenas y Salinas, liacer las observaciones oportunas con el cronómetro 71 y los sextantes, y finalmente, determinar la extensión de los bancos de Mala. Un teodolito, una aguja y los escandallos, eran utensilios de que no carecían ninguna de las tres expediciones. Quedaba á D. Tadeo Heenke el examen físico y botánico de los contornos y una excursión á los montes de Taura, depósito de las mejores maderas; finalmente, los demás Oficia.

\section{3}


1k+1ys les se ocuparian ya en una, yá en otra parte del rio con los objetos reunidos de la Hidrografía, de la pẹsca, de la caza, de las mareas y del buen orden á bordo.

Ya no nos quedaba ctro cuidado que el de la aguada, cuyo corto reemplazo confiamos á un bote chico de cada corbeta, despachándole dia. riamente rio adentro hasta que entrase la marea, para llenar á la baja mar siguiente; estas precauciones, que son las acostumbradas en el país, suministran desde lućgo un agua enteramente dulce y de muchá duración para las $\mathrm{en}$ barcaciones, pero arrastran el sacrificio de tres mareas, el cual nos pareció excesivo para los usos á que debia destinarse; así, se determinó que nuestras embarcaciones penetrasen rin adentro en las últimas dos horas de la marea entran'e, esperasen dos horas de vaciante para empe$z$ ur á llenar, y con las últimas dos horas de la nıisma vaciante se restituyesen últimamente á burdo.

La obra intentada de agrandar y disponer las lanclias para expediciones dilatadas, era demasiado fácil y barata en el país donde nos hallábamos, para que omitiesemos el emprenderla; pero pareció más oportuno el trabajar antes la una que la otra, para que cualesquiera defectos que se advirticsen en su construcción ó en su apa. rejo, pudiesen iemeciarse con mayor facilidad en la secunda. Lograríanos así tambien el ocu. par con mucha economía de tiempo la maestranza de ambas corbetas en us solo buque; la cantidad y excelencia de los cedros del Realejo, Amapala y San Blas, nos darían lugar á innovar la de la ATrevida con igual facilidad en cualquiera de aquellos puertos á donde los objetos de Hidrografía é Historia Natural nos detuviesen por die $z$ quince dias. No diferimos un instante con este concepto para encargar el preciso acopio de maderas, disponer la fragua y emplear algunos aserradores. Al cargo del Teniente de navío D. Cayetano Valdés, las medidas correspondientes á ese ramo debían precisamente proceder con la mayor actividad $e$ inteligencia.

Tuvimos los días siguientes por lo común foscos y á veces achubascados, las marcas se manifestaban con una viveza $y$ elevación considerable; el calor fué á ratos bien sensible cuando el chariduí ó viento periódico del Oesudoeste y Sudoeste, cedia á la calma ó á los terrales, y un temblor repentino que pudo percibirse también á bordo á las tres de la tarde del 7, atemorizó algún tanto los ánimos de los poco acostumbrados á ese azote temible de la Naturaleza. İn la mañana del 8 los Sres. Valdés, Heenke y Arias, hecha con el auxilio de las mareas una excursión al rio Daule, regresaron no ménos complacidos de la amenidad de las orillas que habían recorrido, que de las nuevas adquisiciones, así de aves como de plantas, que traían para las colecciones oct. 8 de la Historia Natural. Tuvimos también á bordo un lagarto, caimán ó cocodrilo vivo, cuya descripción, extendida á algunos objetos ana. tómicos, ocupó la atención prolija del señor Heenke.

Hasta el día 2 I puede decirse que estuvie. ron en una acción contínua todos los individuos de la expedición. D. Juan Vernaci se lrabía incorporado el ir: el Alférez de fragata Murphy regresó al día siguiente: vimos llegar el is la balandra de los Sres. Tova y Rohredo: del iz al 19 otro destacamento de un Oficial y un piloto había penetrado hasta el Morro para extender desde allí las marcaciones á la Punta de Santa Elena y regresar por el canal que forma la Puná con las bocas del rio: estaban bien cerca los Sres. Pineda, Nee y Heenke; finalmente, logradas por los Oticiales astrónomos la vista del Chimborazo y varias otras observaciones importantes para la longitud, todo nos anun. ciaba no distante el plazo en el cual debiésemos verificar la salida y alcanzar el Golfo de $\mathrm{Pa}$. namá antes que allí cambiase la monzon del Nordeste.

D. Antonio Pineda había penetrado por Gua randa hasta el Chimborazo, y después hasta la cima del volcán del Tunguragua. Este monte, cuyas faldas con producir abundantes los dones de la naturaleza abrigan y mantienen un número considerable de familias indias y mestizas, arroja aún por diferentes bocas 6 cráteres un humo espeso compuesto en la mayor parte de vapor acuoso. Examinóse la boca inmediata á la línea de la nieve, hallándose que por unas grietas de un palmo de ancho y á veces de seis ú ocho va. ras de largo, era por donde el volcán arrojaba tlores de antimonio y otras sustancias metálicas que se veían pegadas á las piedras inmediatas. En el año de I772 la erupción había sido temible y á primera vista se dejaban ver tambien los rastros de otra mayor y más antigua; no quedaba tampoco duda que el Chimborazo era un volcán extinguido: tanto abundaban en él las piedras pome $z$, las lavas, las piedras alteradas por el fuego y las tierras puzolánicas, bien que fuesen éstas comunmente calificadas con un color de ceniza.

Los reșultados de las observaciones astronó micas y geodésicas no habían sido ménos favo. rables á nuestro intento, como ya se há indjcado. La elevación del monte se midió con ambos cuartos de círculo. Su posición verdadera relativamente al observatorio, se dedujo del ángulo medido entre la cúspide y un objeto no distante, referido éste en la mañana siguiente al Sol, cuyos azimutes se observaron y calcularon. No parecerá tal vez molesta una enumeración prolija de aquellos resultados. 
ecciones acs. 8

i á bor.

o, cuya

os ana.

1 señor

estuvie.

dividuos

abía in.

Murpliy

el I5 la

: del I7

y un pi-

a exten-

unta de

e forma

an bien

e; final.

omos la

ervacio-

os anun.

jiésemos

de $\mathrm{Pa}$.

hzon del

or Gua-

hasta la

monte,

os dones

número

as, arro-

in humo

le vapor

la línea

ictas de

cho va-

arrojaba

ietálicas

ediatas.

10 temi -

bien los

quedaba

1 volcán

piedras

a por el

fuesen

olor de

astronó-

is favo.

dicado.

ambos

a rela-

ángulo

istante,

Sol, cu-

on. No

in pro-
ELEVACIÓN DLL CHIMBORAZO

1'or los Fxcmos. Sres. Juan y

Ulloa. $\ldots \ldots \ldots \ldots \ldots 3.380 \quad 3.161 .7 \quad 218.3$

Por los Sres. Bouguer y La.

condamine. $\ldots \ldots \ldots .3 .217 \quad 3.161 .7 \quad 55.3$

En cuanto á la longitud de Guayaquil deducida por el medio indicado en ambos mapas español y francés, que manifestaban el rumbo y distancia del Chimborazo relativamente á Quito, podía mirarse bajo los aspectos siguientes:

\section{Segín los Excmos. Sres. Fnan y Ulloa.}

angitud occidenta
de Paris.

Por las observaciones de los satélites

de Júpiter hechas en Quito. . . . .

Por la observación del satélite de $\mathrm{Ca}$ -

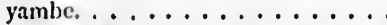

Promedio de cuatro determinaciones por un eclipse de Luna obscrvado en Yaruqui y correspondido en París por el Sr. Le Monnier. . . . . . . . . Promedio de siete determinaciones del mismo eclipse correspondido en $\mathrm{Pa}$ ris por el Sr. Grand Jean de Fouchi.

\section{Segin Mr. Bonguer.}

Promedio de varias determinaciones por un eclipse de Luna $y$ algunas inmersiones $y$ emersiones de satélites de Júpiter observadas en Quito.

\section{Segín nosotros.}

Por la observacion del primer satélite en Lima corregida de los errores de las tablas y con los relojes marinos.

Debía, á la verdad, sernos tanto más ayra. dable el logro de estos resultados, cuanto que le habiamos conseguido en poco tiempo y bajo un cielo no tan favorable á la Astronomía, que no se frustrasen dos observaciones en el primer satélite de Júpiter visibles en aquel meridiano; las distancias lunares no habían tampoco logrado una mejor suerte, aunque intentásemos obser. varlas en la tarde que pareció la más oportuna y despejada. Una espesa calima que solia oscurecer toda la atmósfera desde la media noche liasta el medio día siguiente, se aparecía también algunas veces al auochecer, aunque ménos es. pesa, y ya no se disipaba en toda la noche.

Era difícil, ó más bien imposible, el continuar nuestros triángulos desde Guayaquil á la Puná, por las diferentes puntas y ensenadas que forman así el brazo principal y navegable del rio, como los muchos esteros, que ó en plea mar ó á todas mareas, circundan una porción de islas de que se compone aquel terreno anega. dizo. Pero, por ventura, los altos de la Puná y ute at los de Taura, se descubrian casi desde todas partes, de modo que bien colocados f́stos con operaciones trigonométricas, sería fácil luégo por medio de marcaciones, determinar cuales. quiera puntos intermedios y á ellos referir el pormenor de las orillas, ligadas entre sí con en. filaciones. En cuanto á las sondas y posición de los diferentes bajos, nos parecía lo más oportuno el hacerlas depender principalmente de nuestras dos navegaciones de ida y vuelta, de los informes de los prácticos más acreditados y cxpcrtos, que constantemente le sondan para conducir las embarcaciones grandes, que vicnen á carenar ó salen construídas ó carenadas; final. mente, á los exámcnes parciales que con nues. tro bote se harian, siempre que la ocasión lo exi. giese al tiempo de bajar las corbetas á la Puná.

Con esas reflexiones, D. Felipc Bausá midió una base en una de las calles de Guayaquil, la cual, relerida después al terreno de la orilla, en donde fuera inascquible una medida igualmente exacta, se hicieron marcaciones á diferentes puntos, y particularmente al alto de Guayaquil y un cerrito opuesto. Continuáronse después las mismas tareas en los días siguientes, y como en los altos indicados se alcanzase la vista de los de la Puná y de varios otros hacia Babahoyo y cl Morro, pudimes, examinadas también prolijamente la dirección, extensión y posición de los edificios principales de la ciudad, considerar para el día 25 concluida aquella parte principal de la comisión nuestra.

Ya para que verificásemos la salida en la tar- 25 y 26 de del 28 , como lo deseábamos, fué preciso ace. lerar con exceso la construcción de la lancha, dejando para un mayor despacio la perfección de la arboladura, aparejo, velámen y varios utensiiios; se encargó á todos los que compo. nian el ramo de Historia Natural que pusiesen término á sus indagaciones científicas. Los objetos de Astronomía debían ceñirse ya á la sola conclusión de la marcha de los relojes; ni los cielos, por lo común nublados, hubieran permitido mayores progresos en aquel ramo.

A la sazón había fondeado en el rio un paquebot costanero procedente de Panamá, el cual en u'a travesía anterior, alucinado en mucha parte por las corrientes y en mucha por la impericia del Piloto, había recalado á las Islas de los $\mathrm{Ga}$ lápagos, y navegado entre ellas creyendo al principio estar sobre la costa firme. Varias razsnes habian precisado al Gobernador de Panamí á detener el Piloto, y su diario, reemplazándole para la seguridad del regreso con otro sumamente práctico de las costas del Choco, en las cuales había navegado desde su edad más tierna. La adquisición de este práctico parecio, pues, un objeto de mucha entidad para la mayor per- 
1ate af fección cie nuestru obra; $y$ asi, se le contrajo in. mediatamente á la dotación de la Discuinirera; en cuanto al diario é informe del Piloto sobre la navegación de la Copacavana, á los Galápagos; se dejó el encargo al Gobernador D. Jose Aguirre para que nos le remitiesc á Madrid como parte de los documentos relativos á nuestra comisión; según las noticias de algunos pa. sajeros, las islas eran muchas, $y$ algunas tan grandes, que formaban un estrecho de 20 leguas: earecian por la mayor parte de agua, según lo denotaba su sequedad, y el mismo suelo por la mayor parte de pomez (del cual dicron muestras i 1). Antonio Pineda) las manifestaba como un fragmento de varios volcanes, destinados por la Nituraleza a ser probablemente un desierto: unúuimes avisaban la duración constante de cal. mas y chubascos, en la inmediación de acquellas islats, $y$ su distancia de la costa en 160 leguas, siendo sul latitud próxirnamente entre $I^{\circ}$ al Sur $y \mathrm{I}^{0}$ al Norte de la Eiquinoccial.

listas noticias, y una voz envejecida entre las prácticos, de que los Galápagos se extendian mucho hacia el Este, debieron prccisamente hat cernos cáutos sobre el partido más oportuno, para que ni el ticmpo dejase de aprovecharse cuanto fuese posible, ni bien comprometiésemos por cosas de poca entidad los plazos y destinos que nos labíamos propucsto en los puntos importantes de la costa siguiente al Norte. De ningún modo podía determinarse una separación de las corbetas cuando nuestras tareas en $\mathrm{Pa}$ namá, extendidas tal vez hasta Puertovelo, serían muchas, penosas y delicadas; cuando sería aquel partido probablemente necesario en las costas de la Nueva Lispaña, cuyos productos y situación debían mirarse como muy interesantes para la Monarquía; finalmente, cuando toda anticipación en la llegada nuestra á San Blas arrastraria precisamente grandes utilidades para la próxima campaña sobre la costa Noroeste.

Finalmente, en la tarde del 27 , cleducido el medio día por las alturas correspondientes, y cerrada la cuenta de los relojes, se embarcaron los instrumentos astronómicos y geodésicos; se habían encajonado ya las aves y cuadrúpedos disecados, y los herbarios de los Sres. Heenke y Nee; $y$ votada al agua al anochecer la lancha, ya casi concluída, no faltaba cosa alguna para dar la vela.

La marea del 28 no debía declararse á la vaciante hasta el medio día; por consiguiente, sólo á las diez de la mañana, cedida un poco su fuer$z a$, suspendimos ambas corbetas la amarra del Norte y quedamos á pique de la otra; y últimamcnte, á la una de la tarde, con prácticos del rio en uno y otro buque, dimos la vela con las solas gavias.

Como el viento, por lo común, sea del Sud- oeste, y muy estrecha y áun sembrada de bajos la Ocl. a8 canal navegable, es costumbre y cesi siempre precisa el entregarse á la marea para bajar á la Puná; paireando siemipre que se esté á media canal, y valiéndose de las gavias únicamente para arrimarse á una ú otra orilla, según el caso lo requiera: á veces es oportuno el navegar á popa para que el plazo en que se pueda buscar la canal, sea algo más largo; y entonces la in. mediación de los árboles, reunida á la mayor actividad de la marea, presenta el espectáculo diveftido de una navegación de retroceso: la tranquilidad del agua, la amenidad de los contornos, y el vientecillo, contrario sí, pero templado; la seguridad misma de poder con un anclote evadir cualquier peligro, hacen aquel tránsito á lo ménos divertido, ya que debe ser muy lento: en algunas partes disminuye el fondo de tal modo en la bajamar que ya no son navegables; $y$ en aquel caso es preciso, áun sacrificando una parte de la marea favorable, dar fondo para esperar el paso con el agua alta al principio de la vaciante. El estar la Luna en el cuarto menguante hacía que la mareas á la sazón fuesen lentas y poco elevadas.

Las causas indicadas, y principalmente la del poco fondo entre la punta Sur de Santay y la Punta Gorda, nos obligaron á fondear como á las cuatro y media de la tarde, andadas sólo dos leguas; no obstante, no se malogró el tiempo enteramente, pues se dirigíeron algunos Oficiales á reconocer unos bajos no distantes y marcar en una punta de la costa del Oeste. Luégo que se declaró á las diez y media cle la noche la otra marea favorable, nos levamos de nuevo, $y$ algo favorecidos ćal viento, á veces con bordos cor. tos, á veces con otros más largos, alcanzamos á fondear entre la Punta Miel y la Punta Leon, no distantes de las bocas de Taura.

Yá á las once, declarada con alguna fuerza la vaciante, pudimos levar nuevamente el ancla, y continuar paulatinamente nuestra derrota, la cual nos condujo al Sur de la Punta de Piedras, proporcionándose también á D. Felipe Bausá el salir con el bote á reconocer la piedra sola, çue angosta mucho el canal en esta parte, bien que le compensa ventajosamente, el mucho fondo que hay así á pique de la misma piedra, como de los árboles de la costa. El chanduy no nos permitió en la tarde el aprovechar toda la vaciante, con la cual, siendo muy endeble, no era fánil contrarestar el impulso opuesto del viento: dimos fondo al ancla á las dos y media, y permanecimos en la misma disposición hasta la siguiente marea. Debía ésta conducirnos hacia la Isla Verde; pero como en la dificultad de conservar la media canal, se hiciesen temibles ló bajos inmediatos á la Isla Mondragón, á las rios de la mañana, y con solas dos horas cle vaciante 
the to volvimos a dar fondo entre la P'unta de Alcatraces y aquella isla. Iuégo que amaneció fué un bote de cadu corbeta á la orilla inmediata para cortar leña, y medida una base en la Punta de Alcatraces, se ligaron oportunamente con las marcaciones hechas en Guayaquil los diferentes puntos importantes á la vista, que ceñían aque. lla parte exterior del rio. Al medio dia pudimos ya dar nuevamente la vela, y antes buscando la medianía de la canal, y conservándola después, vernos finalmente como á las cuatro y media de la tarde, casi franqueados de la Isla Verde. Su. cesivamente con el auxilio de la virazón y con todo aparejo, pudimos dar un bordo con las muras á estribor, del cual revirando últimamente á las cinco, alcanzamos al ponerse el Sol el folldeadero de la Puná, en donde dejamos caer el ancla algo distante de la población, así por el efecto ya sensible de la marea contraria, como por la mejor disposición para continuar en la siguiente noche nuestra derrota. Hízose así efec. tivamente. Tuvimos la sonda de cinco á siete brazas lama; y como no diesemos fondo hasta las cinco de la mañana, precisados de la calma $y$ de la marea contraria, pudimos ya hallamos Esteoeste con los altos de las Salinas en la Isla de la Puná, demorando la Punta de Jambeli al Sur $5^{\circ}$ Este de la aguja (I).

Desde las nueve de la mañana siguiente em. pezaron á declararse ventolinas favorables del Noroeste, con las cuales, a casi parada la marea contraria, dimos la vela con ánimo de proporcionarnos mejores bordos al tiempo de entablar la virazón, con cuyo fin inclinamos también nuestros rumbos hacia la Punta de Salinas y el Amortajado: no pudimos á la sazón desentendernos de las distancias de Sol á Luna que por un corto intervalo se nos presentaban fáciles y seguras, para agregar aquel dato por medio de los relojes marinos, á los demás que nos habian suministrado la longitud de Guaya. quil. Treinta series observadas á bordo de la Descubierta poeo antes del medio día, y calculadas con la mayor exactitud por las fórmulas del caballero Bordá, dieron una longitud de $30^{\prime} 26^{\prime \prime}$ más oriental que la de los relojes; por consiguiente, muy aproximada á nuestras deducciones por las observaciones hechas en Guayaquil.

Entablada poco después la virazón y despe. didos los práctizos, continuaron nuestros bordos según lo exigían las circunstancias. No tardó el fondo en aumentar hasta 16 brazas, disminu yendo luégo paulatinamente á ro á medida que

(x) Parecerá demasiado difusa y cansada la descripción de la salida de las corbetas de la ria de Guayaquil, si no se atieude á que son importantes aqueyaquil, si no se atiende á que son importantes aque-
llas noticias para las ideas sucesivas de la navegallas noticias para las ideas sucesivas de la navega-
ción y defensa de aquellos contornos. nos aproximamos á la costa tirme. I a lama nos the st avisaba que conservábamos la canal, y las dife. rentes mareaciones á los muclios puntos en torno, entre los cuales ya conseguiamos también la vista del $\mathrm{Amolta}$ jado; nos daba lugar á reunir con las actuales, las tareas de los Sres. Tova, liobre. do y Murpliy y aun las que las mismas corbe. tas habian verificado a la venida: era el tiempo agradablemente placentero, $y$ la mar únicamente algo picada de la virazón. I a noche siguicnte fue algo más penosa por la necesidad continua de maniobrar, con el fin de conscrvar sobre bordos el eanal entre la costa de 'lumbes y la l'uná. Preferimos este partido al de dar fondo, como por lo común debe verificarse en aquel trínsito, porque no teniendo ya los efectos de la marea, deseábamos no perder momento á pesar de ser el viento algo flojo y vario. Nuestros bordos fueron, por consiguiente, repetidos, y siempre con atención á que nos encontrásemos sobre la costa de la Puná antes del amanecer para aprovechar con más ventaja los terrales del Noroes. te. Conservamos el fondo lama, y alcanzábamos por lo común las io brazas en uno $y$ otro extremo, no extendiéndose los bordos á más de dos leguas, $y$ viéndonos muchas veces precisados á virar rápidamente, porque pocos minutos nos hacían caer de las 15 á las nueve brazas.

Al amanecer vimos con mucho agrado que siv. in nuestros esfuerzos no habían sido infructuosos; por fondos de 17 brazas lama, nos hallábamos entre el Amortajado y los Islotes de Payana que lúego conducen á Tumbes; y la vista del alto de las Salinas, nos proporcionaba un nuevo en lace de marcaciones con nuestra pcsición de Guayaquil. Demoraba el Amortajado al Norte $70^{\circ}$ Oestè de la aguja, distancia tres á cuatro leguas; á la sazón calmó enteramente el viento y creimos vernos precisados á dejar caer un an. clote, pues la marea nos arrastraba considera. blemente sobre la punta de los Manglares; pero por ventura no bien habian llegado las ocho, cuando un viento galeno del Nornoroeste nos dió lıgar á ceñir al Oeste y apartarnos algo de la costa de Payana: las bases corridas en aquella ocasión debian destruir por medio de la latitud observada algunas dudas soibre la verdadera latitud del Amortajado originadas de la demasiada proximidad del Sol al zénit, al tiem. po de nuestras primeras observaciones con las corbetas. En efecto, observada al medio día la latitud de $3^{\circ} 20^{\prime} 30^{\prime \prime}$, y tomados de antemano diferentes horarios, nos cercioramos que la latitud del extremo Sur del Amortajado, era de $3^{\circ} 14^{\prime}, y$ su longitud de $0^{\circ} 32^{\prime} 40^{\prime \prime}$ al Oestc de Guayaquil.

Franqueada la navegación con el aprovechamiento de la virazón de la tarde, y evadidos al dia siguiente los efectos de algunas turbona. 
Suv t. das con mantenernos solyre poca vela casi en una posicion uniforme, ya en i? tarde del 3 de No. viembre pudieron empezar de nuevo las tareas acom:uiciviradas al andar de la costa. Lebiamos utravesar ahora los limites constantemente llu. viosos de las dos cstaciones opuestas en aquellos mares; debíamos lucluar al mismo tierapo con las calmas, las corrientes, las lluvias y las turbona. dlas que casi á porffa dominan allf en todo el año; la Isla del Gallo, la Gorgona, la bahla de San Buenaventura eran nombres hasta entonces temidos con muclsa razón en aquellas inmedia. ciones, $y$ sin embargo, delíamos reconocerlas y sujetarlas á observaciones exactas de latitud y longitud; finalmente, las costas á donde se diri. gian ahora nuestros pasos, si bien sujetus á la Monarquía, no podian á ménos de reunir á nues. tra vista en una sola perspectiva. los sufrimiell. tos de los primeros navegantes españoles, las invasiones d. los filibusteros y la despoblación natural de un qis aún no desmentado, y sujeto por la misma racín á unas lluvias y tempestades tan duraderas.

Atracada en el entretanto la costa para las dos de la tarde, yi que la calima no había per. mitide el distinguirla hasta entonces, conocimos que nuestra posicion, al paso de facilitarnos la reunion prolija de las tareas emprendidas, con las que se habian efectuado en las excursiones al Morro desde Guayaquil, exigia una no mediana precaución en los rumbos siguientes, los cuales, si nos descuidásemos en no hacerlos con. trarestar á la corriente, pudieran muy bien arrastrarnos sobre los muchos arrecifes de que están llenas aquellas costas: demoraba la punta Santa Elena al Norte $18^{\circ}$ Oeste, las costas de Chanduy y los altos del Tambo, se extendían hasta el lisnordeste.

Vencida en la noche aquella punta, y proporcionándose después de algunas lioras de pairo el marcarla de nuevo en la mañana siguiente, al tiempo que un vientecito favorable y galeno nos conducía con bastante velocidad hacia el Norte, ya la navegación emprendida dejó aproximarnos rápidamente lacia la linea Equinoccial. Pasá. ronse el pueblo de Colonche, la Isleta Salango, la Isla de la Plata y el Cabo San Lorenzo: atracamos luégo el fondeadero de Manta, paraje frecuentado ó bien por un pequeño comercio de comestibles y manufacturas, 6 bien por las muchas arribadas de las embarcaciones, que navegando desde las costas del Norte á Guayaquil ó al Perú, se ven al mismo tiempo contrariadas del viento de la marea y de la corriente, y como carezcan de agua y víveres, les es preciso el reemplazarlas en aquel paraje. La observación de un eclipse de Luna hecia por Mr. Bouguer en el pueblo de Monte-Christi, dió allí un nuevo dato importante para la comparación de nuestras longitudes. Fi. malmente, en la tarde del 5 , jur fondo de fll y siov. 45 brazas lama, ya marcábamos el Cabo l'asado al Este á distancia de tres leguas, y por consi. guiente se aproximaba muy mucho nuestro in. greso en el hemisferio del Norte.

lifectivamente, como siguiesen los vientos favorables del Sur y Sursudoeste y nosotros en la navegación de la noche continuásemos sjem. pre con las mismas precauciones de no propasar los limites de la tarde anterior en los extremos de la costa, ya al dia siguiente observamos la latitud de $0^{\circ} 49^{\prime}$ al Norte de la Equinoccial. La longitud era de solos $15^{\prime}$ al Oeste de Guayaquil. lil cabo San Francisco se veía al Sur $25^{\circ}$ Iisto y la Punta de la Galera al Este; en las proxi. midades del rio de las Ismeraldas, la sonda. leza en aquella misma tarde no alcanzaba el fondo con cien brazas, cuando á lasdos y á las tres habiamos navegado por io $y$ I 7 brazas arena, prueba evidente, que el placer que desde la Punta de la Galera se extiende hasta la Gorgona sale á veces con el poco fondo hasta dos leguas mar afuera, $y$ conforme con los derroteros hace aque. lla navegación bastantemente arriesgada.

Nunca la navegación nuestra fué más feliz que en los días siguientes, en los cuales, como ya se manifestó, debíamos luchar con unos obstáculos tan constantes como dificiles de vencerse. Las lluvias, lo más frecuente. mente, eran sólo copiosas durante la noche; $y$ los dias, al contrario, despejados, nos proporcionaban al mismo tiempo la vista individual de las costas y la repetición necesaria de las ob. servaciones: verificadas éstas oportunarnente y combinadas en una masa común las latitudes, las longitudes y las marcaciones, diescubrian una á otra los errores respectivos, por manera que fuese fácil en las bases de corredera hacer fren. te á las variaciones complici ias y oscuras de las corrientes, las cuales ya daban diariamente un error á lo ménos de $2 \mathrm{o}^{\prime}$ en latitud y otros tautos en la longitud estimada. Recorriéronse así y pudieron describirse con mucha exactitud, las cos. tas que desde el cabo San Francisco corren por las Puntas de Mangles y Salaonda, por las Islas del Gallo y la Gorgona y por la ensenada dc San Buenaventura, hasta la Punta de Chirami. ra y el Cabo Corrientes. En las inmediaciones del cabo ya las tierras son bien altas, cesando los Manglares que vienen $\sin$ interrupción desde el cabo San Francisco; no se encuentra fondo á tres leguas de la costa con cien brazas de sondaleza. Finalmente, siguen allí muchos rios de los que inundan el Choco, tributando al mar al mismo tiempo, los despojos de una vejetación siempre lozana y las arenas de oro, que con su brillo engañoso atraen hasta aquellos bosques al hombre codicioso.

Las inmediaciones del Cabo Corrientes fue. 
Nir. s ron para nosotros el verdadero término del mé. todo de trreas seguido hasta entonces con tanta felicidad. Ya las lluvias eran igualmente copio. sas y constantes; los estallidos de los rayos nos indicaban proxino otro peligro mayor. Las co. irientes sumamente rápidas, no podian corregirse por medio de las observaciones, ni era posible con aquellos tiempos el conservar siempre á la vista una costa á las veces baja, á las veces coronada de peligros. Navegábanos, ya con mucho, ya con poco aparejo, yu al Nordeste ya al Nor. neste según parecian dictarlo las circunstancias y carices, 6 lo pedian imperiosamente los vien. tos varios desde el Sudoeste al Oe $\$ 1$.roeste $y \mathrm{en}$. tremezclados con algunas calmas.

Aprovechábase, finalmente, cualquier clara para reconocer los trozos intermedios de la cos. ta, la cual seguiamos á distancia de cuatro le. guas, pero las inmediaciones del Golfo de Panamá pusieron finalmente un término á los obs. tácules indicados, y en la tarde del I I, restitulda la serenidad á los cielos y horizontes, fué fácil descubrir las costas que desde el Puerto de Pi. ñas conducen á la Punta de Garachine, extremo occidental del Golfo. En el día siguiente, á m?dida que atracábamos aquella punta, se perci. bían más eficaces los impulsos de la marea, y con este auxilio, más bien que con el del viento, la pudimos marcar al anochecer hacia el Este; veíanise al mismo tiempo una parte considerable de la costa del Darien, varias islas de las Perlas, la de la Galera y la de San Telmo.

La entrada del Golfo de Panamá se hace algo cuidadosa por una laja sumergida llamada el Bajo de San José, la cual media entre la Punta de Garachine y la Isla Galera. Las vaciantes lle. van hacia ella con bastante rapide $z$; las entrantes arrastran hacia el Darien también sembrado de bajos. Así, cuando el viento calma, parece el partido preferente el de fondear; y éste fué efectivamente el que tomamos á las ocho de la noche, ya que se reunía á la marea contraria un viento flojo y directamente opuesto á nuestra de rrota. Pero aquella situación no duró mucho, pue á las tres de la mañana ya estábamos nueva. mente á la vela para aprovechar las mareas y los vientos variables hasta alcanzar el puerto de $\mathrm{Pe}$. rico. Quien conozca la flojera inseparable de los navegantes de aquellos mares y la clase de sus buques, no extrañará que muchas veces la sola navegación desde la Punta Garachine á las Islas de Perico, les detenga después de repetidos ries yos, por un plazo de diez ó doce días. Nosotros, sin dar nuevamente fondo y contrarestados directamente del viento, el cual á veces calmaba, á većes desfogaba con algunas turbonadillas variables, no tardamos sino dos días; á las dos 6. de la mañana del 16 se dejó caer un ancla á poca distancia del fondeadero, $y$ apenas hubo amanecido, cuando entrambas corbetas mejora. Nov. in ron su posicion y quriaron amurradas. 1.os es. collos y el poco fondo que rodean las orillas de Punamá, y su desabrigo con los vientos del Su. doeste, han dado la preferencia para el fondea. dero a la parte Nordeste de las dos isletas de Perico y l'lamencos, faltas á la verdad de agua y leña, pero bien cultivadas, favorecidas con un buen fondo de arena, y sobre todo, no distantes de la ciudad sino una legua escasa.

lira el paraje donde nos hallábamos, el más importante tal vez de cuantos liabíamos visitado hasta entonces, bien le refiriésemos á los ob). jetos científicos de la Hidrografía y de la Histo. ria Natural, 6 á los objetos políticos de las conquistas nacionales y de lit prosperidad actual de la Monarquia; combinábanse alli, á muy poca distancia unas de otras y en una tan grande inmediación de la İquinoccial, unas playas fértiles y amenas, un pais áspero y montuoso, varios bosques apenas trillados, $y$ una variedad inmensa de maderas, gomas, aves, cuadrúpedos y conchas, dignas cada una por sí de la mayor atención del naturalista. Era precisa la determinación más escrupulosa de la longitud, en cuanto á la posición nuestra tan inmediata á los puertos de Chagres y Portovelo; podría arrastrar errores incompatibles en los arrumbamientos del Istmo por ambos mares, si las observaciones astroní. micas no fuesen conformes con las que debian repetir en las orillas del Atlántico los Oficiales destinados á las cartas de la América Occidental. Por otra parte, un golfo importante y las Islas renombradas de las Perlas, ne s recordaban al mismo tiempo, ó el tránsito de tantos millones de numerario ó el antiguo comercio de los galeones, $\delta$ finalmente, los extragos y proezas de los corsarios filibusteros. Era aquel el primer paso que había conducido nuestros antiguos con. quistadores al mar del Sur, y debíamos mirarle todavía como el centro de las expediciones ma* logradas de los Almirantes ingleses Vernon y Anson; su fortificación y sus fuerzas, suficientes apenas aunque con extremo costosas, para hacer frente á los indios inmediatos del Darien; sus calles desiertas, sus casas arruinadas y el puerto abandonado; todo hacía un contraste singular en nuestra imaginación, de las vicisitudes del tiempo, de los progresos actuales de la navegación $y$ de la diferente robuste $z$ de la Monarquía en este $y$ en los siglos anteriores.

Desde luego el Brigadier de la Real Armada D. José Domas y Valle, á la sazón Gobernador y Capitán General de la provincia, accedió gustoso á coadyuvar á nuestras medidas para que aquellas atenciones no dejasen de realizarse hasta donde lo permitiese el plazo prefijado dc nuestra demora; era entonces tanto más necesaria una cierta precipitación en nuestros pasos, 
cuanto que en los días inmediatos debían proporcionársenos algunas olsservaciones las más im. portantes para el objeto prefijaclo de la longitud; en efecto, en la misma tarde del 16 quedú establecido el observatorio en las inmediaciones de un bastión, desde el cual erá fácil comunicar a las corbetas, por medio de fusilazos, las horas del péndulo referidas á los relojes marinos, y el día r8, malogradas algunas observáciones por la interposición de las nubes, pudo á lo ménos deducirse la longitud por los relojes y compararla it algunos otros resultados.

La longitud deducida fué la siguiente:

\begin{tabular}{|c|c|c|c|}
\hline & Nủm, 61 , & Nủm, $7^{2}$ & Nim. 80. \\
\hline & Adelanto. & Atritso. & Atraso. \\
\hline $\begin{array}{c}\text { 'iempo medio de } \\
\text { Panamí. . . . }\end{array}$ & $3^{\circ} 55^{\prime} 6^{\prime \prime} 11^{\prime \prime \prime \prime} \mid$ & $3.18,28,4$ & $3.40,30.5$ \\
\hline Irl. de Givarquil. & 3.16 .28 .15$. & 3.46 .50 .55 & $\begin{array}{l}3 \cdot 49 \cdot 3 \cdot 9.36 \\
3 \cdot 48 \cdot 9.36\end{array}$ \\
\hline $\begin{array}{l}\text { Diferencia de me- } \\
\text { ridianos. . . }\end{array}$ & 1.22 .4 & 1.37 .9 & $1.20 .3^{8}$ \\
\hline Ecuación por jas & & & \\
\hline $\begin{array}{l}\text { comparacio- } \\
\text { nes. } A t^{\circ} . .\end{array}$ & 4.42 & 20. 6 & 4.12 \\
\hline $\begin{array}{l}\text { Diferencia co- } \\
\text { rregida.. . . }\end{array}$ & 1.17 .22 & $1.17 \cdot 3$ & 1.16.26 \\
\hline
\end{tabular}

Curo promedio daba la longitud Orien-

tal de Guayaquil en grados. ...... $\circ^{\circ} \mathrm{d} 9^{\prime}$ I $4^{\prime \prime}$ Que referidos â aquel Meridiano según

nuestras series. . . . . . . . 73.24.15

Daban finalmente á Panami la longitud occidental de Cádiz de. . . . . . .

Era la deducción por la observación de Mr. Bouguer en Manta traída con

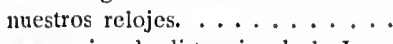

Y 243 series de distancias de la Luna al Sol observadas en los días I3, I4 y i5 y traidas con los relojes mari. nos, daban. . . . . . . . . .

Del in al 23 se dispusieron y emprendieron todas las excursiones cientificas de cuyo regreso dependería únicamente el plazo de nuestra demora en el puerto. Al cargo de D. Secundino Salamanca iba la lancha de la ATREVida con tun Pilotín, y sus operaciones debían limitarse á determinar con buenas sondas el fondo de tres brazas al andar de la costa desde Panamá la Vieja liastá las Islas de Majaguar y el l'clado: debía particularmente determinar la verdadera extensión del bajo de la Punta Manglares, hacer en los puntos más altos marcaciones con el tcodo. lito, que reuniesen el pormenor de toda aquella costa con las tareas que se emprenderían en el puerio, y sr ie encargaba que observase algunas latitudes, ligándolas, si fuese posible, con el extreme de una ú otra base.

D. Juan Vernaci con un Pilotín de la DEscUizierTA, el cuarto de círculo de Ramsden, el reloj ro5 de Arnold y un teodolito, tuvo orden de dirigirse á Cruces, $y$ de allí por el rio hastá Nov. 23 Chagres, con el objeto de referi: la longitud á lit orilla del otro mar.

La lancha de la Descubterta, con otro Pilotin, un práctico natural, el cronómetro $7 \mathrm{r}$, dos sextantes y un teodolito, sc puso en el cargo del T'eniente de navío Novales, para que recorriese y trazase cuidadosamente todas las islas, que bajo el nombre de las Perlas y del Rey, componen aquel Archipiélago. Debía examinar el bajo de San José, medio entre la Punta Garachine y la Isla de San Telmo; y debía procurar que todo estc trabajo ligase con los otros por medio de marcaciones hechas e: algunos altos con teodolito y aguja.

Quedaba luégo al cargo de D. l'elipe Bausá y del Piloto D. Juan Maqueda, el poner orden á los materiales hidrográficos acopiados. Los botánicos y D. Antonio Pineda debían correr á su albedrío, ó el país llano ó el montuoso, á do les llamase su activiciad indecible; ocupábanse al mismo tiempo algunos individuos en las diseca ciones, y u11 joven bastanteniente experto de la corbeta Descubierta había tomado á su cargo el representar con el dibujo los objetos más propios, ó bien fuesen de perspectiva ó relativos á la Historia Natural. La sondas, el corte periódico de la leña y el cuidado diario de los buques y sus pertrcchos, donde era tan temible, el efecto de la bruma, como el de las lluvias y def Sol con exceso ardiente, fueron últimamente otros tantos objctos más bien de entretenimiento que de fatiga para la demás gente de entrambas tripulaciones; se añadían á la ración algunos refrescos y vino, sc les permitía un esparcimiento útil en las playas inmediatas, en donde frecuentemente les convidábamos con cl ejemplo á ba. nalse rara vez iban al pueblo, y correspondiendo felizmente los efectos á las medidas indicadas, lográbamos combinar con $\mathrm{c}^{\frac{1}{2}}$ trabajo contínuo una robustez y alegría que no pueden ser comu. nes en aquellas it ryiones.

Fueron allí más frecuentes y nocivas que en otra parte alguna las inmediaciones y la sombra del árbol del manzanillo. Los botánicos, movidos seguramente de un cierto pundonor, y nuestras gentes destinatas al corte de la leña por un ef ecto á las veces de su antojo, á las veces de su ignorancia; en cuantas ocasiones se arrimaron á ese arbol extrano, en otras tantas sufrieron considerablemente. La hinchazón en difei entes partes del cuerpo, una grande propensión al vómito $y$ un dolor general en todo el cuerpo, eran efectos repentinos de su sombra, los cuales no se disi. paban sino después de muchas horas. Is aún más extraño el que siendo tan temible la sombra, 6 lo que es lo mismo, la emanación en las hojas causada por la acción del Sol, el tronco al mismo tiempo no sea en modo alguno nocivo, $y$ 
1 rio hasta Nov. 23

longitud á

otro Pilo-

I'o $7 \mathrm{I}$, dos

el cargo del

recorriese

islas, que

y, compo-

nar el bajo

iarachine $y$

rar que to.

por medio

os con teo-

elipe Bausá

er orden á

i. Los botá-

orrer á su

so, á do les

pábanse al

las diseca -

perto de la

á su cargo

os más pro-

relativos á

rte periódi-

os buques $y$

le, el efecto

y del Sol

mente otros

miento que

rambas tri-

algunos re.

parcimiento

ide frecuen.

:mpló á ba-

respondien-

idas indica-

jo contínuo

n ser comu.

ivas que en

y la sombra

os, movidos

y nuestras

eña por un

veces de su urrimaron á frieron conei entes par1) al vómito eran efectos no se disi. as. Es aún ole la somción en las el tronco al o nocivo, y
Nov. ${ }_{23}$ ó conviértase en leña para quemar, ó se aplique "á ci.ferentes usos de la vida sociable, nunca cause al tiempo de emplearle el menor daño ó molestia.

La actual mudanza de la estación lluviosa del Sudoeste con la otra seca y despejada del Nordeste, la cual, como ya se ha insinuado, debía proporcionarnos la continuación fácil de las tareas hidrográficas al andar de las costas de la Nueva España, no puclo ménos de acarrearnos en aquellos dias muclias lluvias mezcladas á veces con ráfagas violentas y con algunos rayos. Scguíase luégo naturalmente el correr los vientos calmosos con rapidez por toda la aguja. Entablado, finalmente, el Norte y el Norosste, volvía el tiempo á su antiguo semblante hermoso, y á medida que se aproximaban los primeros clías de Diciembre, iban esos vientos arraigando más su imperio. Estas alternativas del tiempo debieron precisamente causar alguna lentitud en las excursiones emprendidas; hicieron malograr varias observaciones astronómicas, $\mathrm{y}$ ocasionaron el naufragio de una lancha de la ATRlivida cargada de leña, la cual, rota la amarra por una resaca extraordinaria, se clesfondó sobre las piedras é hizo infructuosos los esfuerzos de la gente, que procuraba libertarla. En una playa desierta, mojada, sin ropa para mudarse $y$ sin comida, debió por naturaleza sufrir mucho en la noche sigurente. Los auxilios que le condujo al otro día D. Antonio Tova fueron por la misma razón recibidos con el gozo correspondiente; se comprendía también entre los náufragos una partida de cazadores dirigida por el Cirujano de la ATREvIDA, la cual debió malograr en aquella ocasión varias adquisiciones preciosas para ntestras colecciones naturales. Todos, finalmente, volvieron á bordo, y poco después el Teniente de navío Robredo, con maniobras bien entendidas, condujo también la lancha para vararla en las playas inmediatas y atender á su composición.

El día 4 de Diciembre, ya se hallaron reconcentrados á bordo, además de la lancha del Te. niente de fragata Salamanca, la cual lo había verificado mucho antes, tambien todos los naturalistas y D. Juan Vernaci. El primero, adenás de los reconocimientos que se le habian encargado, había hecho marcaciones bien importantes en los altos de las Islas Chapera y Pacheca, precisado a ir á ellas por falta de agua. El último había con la mayor felicidad repetido las observacio. nes en Chagres y conseguido al mismo tiempo el observar dos inmersiones del primer satélite de Júpiter y un nuevo examen en Cruces para la marcha más segura del reloj ro5. Tampoco fueron ménos felices los Oficiales astrónomos en el conseguimiento de unos datos exactos para la deducción te la longritud y á pesar que se hubiesen malogrado diferentes olsservaciones, pudie- ron, sin embargo, agregarse á los que ya se han bic. . expresado los resultados siguientes:

Por la ocultación de la 88 del catálogo de Nayer por la Luna, calculada por las tablas de Mr. Mlasón. . . . . . . . Por la 2.43 del mismo cat́ĺlogo (nu observada con igusi co stianza). ... . Por las diferencius ascensionales de la Luna deducidas por las comparacio. nes á Régulus, y al corazón de la Hidra con el cuarto de circulo. . . . .

Una inmersión del primer satélite de Júpiter corregida de los errores de las tablas. ............. 81.51 .00 Ocultación de ul Virgo. . . . . . . 8I.46.2 I

Estos resultados, euando alcanzásemos á corregirlos é igualarlos por medio de los errores de las tablas averiguados en algún observatorio de Europa, debian ya tranquilizarnos sobre el objeto primero de evitar una contradicción ó discre. pancia con las determinaciones hechas en la orilla del mar Atlántico; pues la diferencia cie $29^{\prime}$ II $^{\prime \prime}$ al Este, que indicaba el relcj ro5 para el observatorio de Pananú relativamente al de Chagres, bastaba para la exacta comparación de unos y otros elementos. Finalmente, en la tarde del 7 vimos también reincorporarse la lanclua de la Descubreríd á las órdenes del Teniente de ravío Novales. Como lo habíamos sospechado, desde el día 2 estaba detenido en la Pacheca acosándole los vientos contrarios, los cuales, una vez le habian renclido el palo maycr y otra hécliole peligrar en el mismo fondeadero. Eran frutos de esta excursión, el prolijo reconocimiento de todo el Archipiélago de las Perlas y del bajo de San José, una multiplicidad grande de nuarcaciones á los puntos más distantes de ambas costas, y una serie de observaciones de latitud y longitud que no podían ya dejar la menor duda sobre la posición verdidera de cada punto.

$\Lambda$ sí, concluídos los diferentes objetos que hacían ó útil ó necesaria nuestra estada en el puerto de Perico y auxiliados al mismo tiempo los almacenes de la plaza enteramente exliaustos con aquellos pocos efectos que pudiesen suministrar nuestros repuestos, ya no debió diferirse por más tiempo la salida de las corbetas.

El i2 la transferimos al fondeadero de la Isla de T'aboga, donde ciebíamos reemplazar la aguada, lo cual verificado en los dos días siguientes muy á nuestro placer por la amenidad del sitio, la abundancia, la comodidad y la pureza de las aguas; $y$ sobre todo por la facilidad de repsetir allí también varies tareas importantes relativas á los objetos esenciales de nuestra comisión; finalmente, en la mañanita del I $_{5}$ dimos la vela para la continuación de los recono. cimientos emprendidos. 
cuanto que en los días inmediatos debían proporcionársenos algunas observaciones las más importantes para el objeto prefijado de la longitud; en efecto, en la misma tarde del i 6 quedó establecido el observatorio en las inmediaciones de un bastión, desde el cual era fácil comunicar á las corlhetas, por medio de fusilazos, las horas del péndulo referidas á los relojes marinos, y el día 18 , malogradas algunas observaciones por la interposición de las nubes, pudo á lo ménos deducirse la longitud por los relojes y compararla a algunos otros resultados.

La longitud deducida fué lí siguiente:

\begin{tabular}{|c|c|c|c|}
\hline & Núm. $6 \mathrm{r}$, & Nưnu. $7^{2}$ & Nuin. 10. \\
\hline & Adelento. & Atrisso. & Atraso. \\
\hline Tiempo medio de & & & \\
\hline $\begin{array}{l}\text { Panamá. } \\
\text { I1. de Grayaquil. }\end{array}$ & $\mid \begin{array}{ll}3^{\circ} 15^{\prime} & 6^{\prime \prime} 11^{\prime \prime \prime} \\
3 . & 16.28 .15 .\end{array}$ & $\begin{array}{l}3 \cdot 48.28 .4 \\
3.46 .50 .55\end{array}$ & $\begin{array}{l}3 \cdot 49 \cdot 30.14 \\
3 \cdot 48 \cdot 9.36\end{array}$ \\
\hline $\begin{array}{l}\text { Diferencia de me- } \\
\text { ridianos. . . . }\end{array}$ & 1.22 .4 & 1.37 .9 & $1.20 .3^{8}$ \\
\hline $\begin{array}{l}\text { Ecuación por las } \\
\text { comparacio- }\end{array}$ & & & \\
\hline nes. $A t^{0} \ldots$ & $4 \cdot 4^{2}$ & 20.6 & 4.12 \\
\hline $\begin{array}{l}\text { Diferencia co- } \\
\text { rregida.. . . }\end{array}$ & 1.17 .22 & $1.17 \cdot 3$ & 1.16 .26 \\
\hline
\end{tabular}

Cuvo promedio daba la longitud Oriental de Guayaquil en grados. . . . . $\circ^{\circ} \$ 9^{\prime} 14^{\prime \prime}$ Que referidos á aquel Meridiano según nuestras series. . . . . . . . . .

73.24 .15

Maban finalmente á Panamá la longitud occidental de Cádiz de. .

Era la deducción por la obscrvación de Mr. Bouguer en Manta trafda con nuestros relojes. ..........

Y 243 series de distancias de la Luna al Sol observadas en los días 13,14 y 15 y traídas con los relojes mari-

Del I9 al 23 se dispusicron y emprendieron todas las excursiones científicas de cuyo regreso dependería únicamente el plazo de nuestra demora en el puerto. Al cargo de D. Secundino Salamanca iba la lancha de la ATREvida con $u 11$ Pilotin, y sus operaciones debian limitarse á de. terminar con buenas sondas el fondo de tres brazas al andir de la costa desde Panamá la Vieja hasta las Islas de Majaguar y el Pelado: debía particularmente determinar la verdadera extensión del bajo de la Punta Manglares, hacer en los puntos más altos marcaciones con el teodolito, que reuniesen el pormenor de toda aquella costa con las tareas que se emprenderian en el puerto, y sf ie encargaba que observase algunas latitudes, ligándolas, si fuese posible, con el extremc de una ú otra base.

D. Juan V'ernaci con un Pilotín de la DEs. cUBAERT, el cuarto de círculo de Ramsden, el reloj ro5 de Arnold y un teodolito, tuvo orden de dirigirse á Cruces, y de allí por el rio hasta Nov. 2 Chagres, con el objeto de referi: la longitud á la orilla del otro mar.

La lancha de la Descubierta, con otro Pilotin, un práctico natural, el cronómetro $7 \mathrm{I}$, dos sextantes y un teodolito, se puso en el cargo del T'eniente de navio Novales, para que recorriese y trazase cuidadosamente todas las islas, que bajo el nombre de las Perlas y del Rey, compo. nen aquel Archipiélago. Debía examinar el bajo de San José, medio entre la Punta Garachine y la Isla de San Telmo; y debía procurar que tro. do este trabajo ligase con los otros por medio de marcaciones hechas en algunos altos con teodolito y aguja.

Quedaba luégo al cargo de D. Felipe Bausá y del Piloto D. Juan Maqueda, el poner orden á los materiales hidrográficos acopiados. Los botánicos y D. Antonio Pineda debían correr á su albedrío, ó el país llano ó el montuoso, á do les llamase su actividad indecible; ocupábanse al mismo tiempo algunos individuos en las diseca ciones, y un joven bastanteniente experto de la corbeta DEscubierta había tomado á su cargo el representar con el dibujo los objetos más pro pios, ó bien fuesen de perspectiva ó reiativos á la Historia Natural. La sondas, el corte periódico de la leña y el cuidado diario de los buques y sus pertrechos, donde era tan temible, el efecto de la bruma, como el de las lluvias y del Sol con exceso ardiente, fueron últimamente otros tantos objetos más bien de entretenimiento que de fatiga para la demás gente de entrambas tripulaciones; se añadían á la ración algunos refrescos $y$ vino, sc les permitía un esparcimiento útil en las playas inmediatas, en donde frecuentemente les convidábamos con el ejemplo á banarsc; rara vez iban al pueblo, y correspondiendo felizmente los efectos á las medidas indicadas, lográbamos combinar con el traba jo contínuo una :obustez y alegría que no pueden ser comunes en aquellas regiones.

Fueron allí más frecuentes y nocivas que en otra parte alguna las inmediaciones y la sombra del árbol del manzanillo. Los botánicos, movidos seguramente de un cierto pundonor, y nuestras gentes destinadas al corte de la leña por un efecto á las veces de su antojo, á las veces de su ignorancia; en cuantas ocasiones se arrimaron á ese arbol extraĩo, en otras tantas sufrieron considerablemente. La hinchazón en diferentes partes del cuerpo, una grande propensión al vómito y un dolor general en todo el cuerpo, eran efectos repentinos de su sombra, los cuales no se disipaban sino después de muchas horas. Is aún más extraño el que siendo tan temible la sombra, ó lo que es lo mismo, la emanación en las hojas causada por la acción del Sol, el tronco al mísmo tiempo no sea en modo alguno nocivo, $\mathbf{y}$ 
rio hasta Nov. 23

ongitud á

otro Piloo $\mathrm{I}, \mathrm{dos}$ cargo del recorriese islas, que , compoar el bajo urachine $y$ ir que troor medio s con teo-

ipe Bausá er orden á Los botárrer á su b, á do les ábanse al as disecaerto de la su cargo s más pro. - elativos á te periódi$s$ buques y , el efecto y del Sol ente otros iento que ambas triIgunos rearcimiento le frecuennplo á baespondienlas indicao contínuo ser comu-

as que en la sombra s, movidos nuestras ia por un eces de su rimaron á ieron conentes paral vómito an efectos 10 se disi3. İs aún c la somión en las 1 tronco al nocivo, $y$
Nov, ${ }_{23}$ ó conviértase en leña para quemar, 6 se aplique "á ci.ferentes usos de la vida sociable, nunca cause al tiempo de emplearle el menor daño ó mo. lestia.

La actual mudanza de la estación lluviosa del Sudoeste con la otra seca y despejada del Nordeste, la cual, como ya se ha insinuado, debía proporcionarnos la continuación fácil de las tareas hidrográficas al andar de las costas de la Nueva Lispaña, no pudo ménos de acarrearnos en aquellos días muclias lluvias mezcladas á re. ces con ráfagras violentas y con algunos rayos. Suguíase luégo naturalmente el correr los vientos calmosos con rapidez por toda la aguja. Entablado, finalmente, el Norte y el Noro-ste, volvía el tiempo á su antiguo semblante hermoso, y á medida que se aproximaban los primeros clías de Diciembre, iban esos vientos arraigando más su imperio. Estas alternativas del tiempo debieron precisamente causar alguna lentitud en las excursiones emprendidas; hicieron malograr varias observaciones astronómicas, y ocasionaron $\mathrm{el}$ naufragio de una lancha de la ATrevind cargada de leña, la cual, rota la amarra por una resaca extraordinaria, se desfondó sobre las picdras é hizo infructuosos los esfuerzos de la gente, que procuraba libertarla. En una playa desierta, mojada, sin ropa para mudarse y sin comida, debió por naturaleza sufrir mucho en la noche sigurente. Los auxilios que le condujo al otro dia D. Antonio Tova fucron por la misma razón recibidos con el gozo correspondiente; se comprendía también entre los náufragos una partida de cazadores dirigidat por el Cirujano de la ATREvIDA, la cual debió malograr en aquella ocasión varias adquisiciones preciosas para ntestras colecciones naturales. Todos, finalmente, volvieron á bordo, y poco después el Teniente de na. vío Robredo, con maniobras bien entendidas, condujo también la lancha para vararla en las playas inmediatas y atender á su composición.

Lic. + El día 4 de Diciembre, ya se hallaron reconcentrados á bordo, además de la lancha del T’e. niente de fragata Salamanca, la cual lo había verificado mucho antes, tambien todos los naturalistas y D. Juan Vernaci. El primero, además de los reconocimientos que se le habían encargado, había hecho marcaciones bien importantes en los altos de las Islas Chapera y Pacheca, precisado á ir á ellas por falta de agua. El último había con la mayor felicidad repetido las observaciones en Chagres $y$ conseguido al mismo tiempo el observar dos inmcrsiones del primer satélite de Júpiter y un nuevo examen en Cruces para la marcha más segura del reloj ro5. Tampoco fue. ron ménos felices los Oficiales astrónomos en el conseguimiento de unos datos exactos para la deducción de la longitud y á pesar que se luubieson malogrado diferentes olsservaciones, pudie- ron, sin embargo, agregarse á los que ya se han Dic. " expresado los resultados siguientes:

Por la ocultación de la 88 del catálog

de Nayer por la Luna, calculada por

las tablas de Mr. Masón. . . . . . .

Por la 243 del mismo catálogo (nu observada con iguai co ulianza). . . . .

Por las diferencias ascensionales de la Luna deducidas por las comparaciones á Régulus, y al corazón de la $\mathrm{Hi}$. dra con cl cuarto de circulo. . . . . Una inmersión del primer satélite de Júpiter corregida do los errores de las tablas. ............ 81.51.00 Ocultación de ny Virgo. . . . . . . 8

Estos resultados, cuando alìanzásemos á corregirlos é igualarlos por medio de los errores de las tablas averiguados en algún observatorio de luropa, debían ya tranquilizarnos sobre el objeto primero de evitar una contradicción ó discre pancia con las determinaciones hechas en lat orilla del mar Atlántico; pues la diferencia die $29^{\prime}$ II $^{\prime \prime}$ al Este, que indicaba el relcj ro5 para el observatorio de Panamí relativamente al de Chagres, bastaba para la exacta comparación de unos y otros elementos. Finalmentc, en la tarde del '7 vimos tembién reincorporarse la lancha de la Descubieria á las órdenes del Teniente de navio Novales. Como lo habíamos sospechado, desde cl día 2 estaba detenido en la Pacheca acosándole los vientos contrarios, los cuales, una vez le habian rendido el palo maycr y otra hé. chole peligrar en el mismo fondeadero. Eran frutos de esta excursión, el prolijo reconocimiento de todo el Archipiélago de las Perlas y del bajo de San José, una multiplicidad grande de marca ciones á los puntos más distantes de ambas costas, y una serie de observaciones de latitud y longitud que no podían ya dejar la menor duda sobre la posición verdidera de cada punto.

Así, concluídos los diferentes objetos que hacían ó útil ó necesaria nuestra estada en el puerto de Perico y auxiliados al mismo tiempo los almacenes de la plaza enteramente exhaustos con aquellos pocos efectos que pudiesen sumi. nistrar nuestros repuestos, ya no debió diferirse por más tiempo la salida de las corbetas.

E1 I2 la transferimos al fondeadero de la Isla de 'Taboga, donde ciebíamos reemplazar lat aguada, lo cual verificado en los dos días siguientes muy á. nuestro placer por la amenidad del sitio, la abundancia, la comodidad y la pu. reza de las aguas; $y$ sobre todo por la facilidad de repetir allí también varies tareas importantes relativas á los objetos esenciales de nuestra comisión; finalmente, en la mañanita del I $_{5}$ dimos la vela para lạ continuación de los reconocimientos emprendidos. 
1.ic 17 Sobre las islas indicadas, era la latitud observada de $7^{\circ} 10^{\prime}$. La variación se conservaba de $7^{\circ}$ á $8^{\circ}$ al Nordeste y apenas habíamos perdido la sonda, la cual clesde las inmediaciones de Panamá hasta el Morro de Puercos, solía conservarse á distancia de una á dos leguas de la costa desde 18 á fo brazas, ar ena negra y lama.

Muy distantes estábamos á la sazón de imaginar que eran aquellas inmediaciones el término cle nuestra felicidad y del método seguido hasta entonees para las tareas hidrográficas. $\mathrm{Ni}$ las pocas personas que teníamos á bordo y habían navegado una ú otra vez en aquellos mares; ni los pasos antiguos de los filibusteros; ni finalmente, los derroteros oscuros de la mar del Sur, lubicran podido hacérnoslo sospechar siquiera; empero por las inmediaciones de la Isla Montuosa, aleanzándose aún á la vista hacia el Este los altos de Coiba y Quicava, y al Norte las costás del golfo del Montijo, cmpezáronse á combinar tal contrariedad de corrientes y tales calmas, que en balde nos csforzábamos con repetidas maniobras y bordos en aprovechar cualesquiera ventolinas que se nos presentasen ménos contrarias.

Esta lucha inf ructuosa por nuestra parte, wos turo casi inmóviles hasta el día 28, y aysinas podíamos mirar como una compensación adecuada al malogro de tanto tiempo, el que se hiciesen en el entretanto algunos progresas para la Historia Natural. Entre unas bandadas casi innumerables de peces que rodeaban las corbetas, y que á veces con un alboroto general y repentino presentaban con sus saltos $y$ con el hervidero del mar un espectáculo agradable, se cogieron, ó bien con la fizga ó con el anzuelo, diferentes dorados, atunes y bonitos, se logró la rista de una manta, á la cual estaban agarrados tres peces del largo de un codo; la lucha singular de un taurón con una tortuga, y el destrozo instantáneo de dos de aquéllos en una tonina herida por nuestras fizgas, of ecieron nuevos objetos entretenidos; y se logró cojer un atigrado que nuestros naturalistas hallaron sér de la clase anfibia de los balistas, y parecido á los guaperuas del Brasil, ya descritos en Linneo. Las mo. luscas ó aguas malas, en sus combinaciones dilerentes y multiplicadas, habían sido tamtién un objeto digno de un examen repetido y nuevo para I. Antenio Pineda, $y$ entre las aves consiguiéronse coger vivos dos pájaros bobos y una especie de esterna 5 golondrina de mar.

No nos habíamos tampoco descuidado en abrigar del Sol, harto pernicioso y directo, las tripulaciones de ambas corbetas, cubriendo desde su salir hasta el ponerse todas las partes de la cubierta con toldos, usando del vinagre para los zafarranclos, no permitiendo á nadie que estuviese al Sol á pié tirme ni áun con objetos de pesca; finalmente, añadiendo á la ración diaria Dic, 26 medio euartillo de vino. Con estas precauciones, y particularmente con la felicidad de que no acompañasen á las calmas (como es común) unos aguaceros frecuentes, pudimos conseguir que no se extendicran, antes bien, que se extinguiesen de un todo las calenturas, ya introducidas en ambas tripulaciones por los calores excesivos de Panamá; en una y otra corbeta llegó el número de los enfermos á i 3 y I 4 , y en lá ATrevida, complicándose en tino de sus marineros esta enfermedad con una rotura de vasos procedida de un violento culatazo de fusil en el pecho, ocultado al Cirujano hasta los últimos días, tuvieron la des rracia de que no alcanzasen los remedios á salvarle y pagase en la misma tarde del 28 el último tributo á la Naturaleza.

D. Francisco Flores conoció desde el principio, que las calenturas de las cuales adolecíun varios en la Descubierta (y entre ellos el $\mathrm{Al}$. férez de fragata D. Felipe Bausá), eran unas sinocales, ó simples ó pútridas, dominando en todas la plétora sanguínea y el humor bilioso, dimanadas sin duda, la primera de los efectos del Sol, y el segundo del exceso en la comida, particularmente los plátanos y otras frutas no bien maduras. En algunos se complicaron con malignidad; pero adaptando á éstos la quina y por lo conún las sangrías y los antimoniales y ácidos vegetales, 110 tardaron á desterrarse de un todo. bien que con una debilidad considerable en la onvalecencia, que sería difícil repar'xr en el mar. Merecen en est?. ocasión particuiar memoria la mixtura antinionial para exeitar el vómito y la secreción de las materias biliosas, así como el uso de la rosella para los, convalecientes, entrambas cosas propuestas por el doctor Masićval y usadas ahora con el mayor acierto. El termómetro de Farenheit puesto á la sazón al aire libre y á la sombra, solía no pocas veces llegar á los $90^{\circ}$.

El último día del año, fué finalmente la época en la cual debían terminar, á lo ménos en mucha parte, los enfados de una calma de quince días, que hubiera sin duda merecido una pintura del historiador elocuente del viaje de Lord Anson, pues que había descrito con tan vivos colores el malogro de un viaje felizá Acapulco, con la demora de sólos cinco días á la vista de la Isla de Cocos. Al anochecer empezaron á entablar ventolinas del Esueste y Esnordeste con mar algo gruesade la misma parte, $y$ como en esta ocasión las corrientes nos fuesen más bien favorables que adversas, pudimos, conservando la proa al Oesnoroeste, aprovechar la marea favorable, y por la mañana marcar la punta de Bu. ricas al Norte $20^{\circ}$ Este, logrando de la vista de un trozo nuevo de costa, que por tanto tiempo habíamos deseado. 
En. I." $\quad \Lambda$ estos objetos por sí sumamente agradables $y$ al brillo de un día con exceso sereno y risueño, se agregó un espectáculo nuevo con la pescá de un copioso número de dorados excelentes, atraídos de la carne de algunos atunes que habíamos cogido de antemano, y rodeando la popa con una constancia poco común en su especie, fácilmente caían en uno ó en otro anzuelo de los muchos que se les presentaban, y reuniéndose á esta facilidad é riesgo de que su mismo peso (como acaecía frecusntemente) en fin rompiese el anzuelo, $\sigma$ bien cor: sus debates violentos consiguiesen zafarse antes du tenerlos sobre cubier. ta, resultaba con aquel contraste, y á veces con la misma fuga, la pesca más interesante y más amena.

Continuaron nuestros progresos en: la tarde y noche siguiente, aunque muy lentos. $\Xi 1$ viento era calmoso del Sudoeste y nos prometimos luégo el aproximarnos al Golfo de Nicoya: sólo sí que á la una de la mañana, ya bastantemente inmediatos á la costa, y recelando el efecto de las corrientes contrarias, viramos al Sur co'a viento calmoso, acompañado de algunos cbibasquillos.

Desde la tierra baja, que siempre habíamos creido Isla del Caño, $v$ desde la tierra alta inmediata, que en todos los dias anteriores de calma marcábamos como extremo Oeste de la tie * rra firme, empieza ésta á bajar paulatinamente terminando luégo en una punta baja, extremo oriental del Golfo Dulce. Su extremo occidental es igualmente bajo; pero escarpado, se eleva muy luégo considerablemente y ccntinúa así la costa por espacio de cuatro ó cinco leguas al Oesnoroestẹ, retrocediendo después algo más al Norte y volviendo á bajar hasta la Punta Mala, que distará de la otra una distancia casi igual á la que acabamos de expresar. Se dejaban ver á larga distancia en la parte interior del Golfo Duice diferentes serranias algo confusas y toda la costa parecía igualmente frondosa y acantilada.

Hasta el dia 6 las calmas, las corrientes y los vientos contrarios, nos hicieron permanecer de nuevo en una inacción total, ó más bien nos costaron algunos sacrificios, particularmente en la latitud, pues en este último medio día apenas contábamos la de $6^{\circ} 29^{\prime}$, por longitud de $4^{\circ} 26^{\prime}$ al occidente de Panamá. Habíanse, no obstante, aturbonado ahora los cielos $y$ horizontes por los cuatro cuadrantes, había relámpagos al Sur y Sueste, y con esto reposábamos algún ta 'to del calor excesivo de tantos días dimanado de la acción no interrumpida del Sol, y nos prometíamos más próxima la revolución deseada del tiempo.

En el entretanto, las circunstancias que nos rodeaban no podían á ménos de trastornar casi enteramente el plan formado para nuestros pa. En, 6 sos del año empezado de I79I; pues ó bien llegásemos demasiado tarde á Acapuico y San Blas, para poder emprender el viaje oportunamente á la costa Noroeste, ó el omitir una parte de las costas de la Nueva Ėspana nos obligase á retroceder deşpués para reconocerlas, siempre el atraso de un año en la totalidad del viaje pa. recía indispensable, y por la misma razón debíamos precaverle con la anticipación posible. Una nueva separación de las corbetas debió por consiguiente presentársenos á la vista como el único medio para ocurrir al día á tamañas contrariedades, $y$ así sin perder momento quedó decidido que la $\Lambda$ TREVIDA, reconociendo la isla de $\operatorname{Cocos}$ y aproximándose á la derrota de Lord Anson para entrar en los límites de los vientos generales, navegase directamente hacia el puerto de Acapulco, allí se enterase de las últimas órdenes de S. M. y conforme á ellas (si exigian una campaña á la costa Noroeste), pasase á San Blas y completase lancha, víveres, pertrechos y cuanto fuese necesario antes que se le reuniese la Descubierta hacia los últimos días de Febreru. Esotra corbeta debia en el entretanto continuar las tareas hidroyráficas al andar de la costa, y reconocido principalmente el puerto del Realejo, arribar por últin o á Acapulco y San Blas, para reincorporarse con la compañera. Hízose inmediatamente una comparación de los relojes marinos, y en aquella mis. ma mañana, como reinasen vientos bonancibles del Oesnoroeste y los ciñéramos con las muras opuestas, perdiéronse de vista y la Descubierta procuró aproximarse nuevamente á la costa.

Fueron, sin embargo, nuestros esfuerzos infructuosos hasta la tarde del I $_{3}$, acosados unas veces por turbonadas y lluvias abundantísimas que movian los vientos bonancibles del Oeste, otras veces por las calmas y la contrariedad constante de las corrientes. Pero, en fin, avistados en aquel día el Cabo Blanco y los extremos del Golfo de Nicoya, devuelto el tiempo á su serenidad primitiva, cesadas por otra parte las corrientes contrarias, y entallados con aiguna fuerza y constancia los vientos del Nordeste, pudiéronse emprender de nuevo los reconocimientos interrun. pidos de la costa, $y$ aproximarnos paulatinamente al puerto del Realejo.

Acosados del tiempo, ya no podíamos á la sazón sujetarnos á la prolijidad adoptada hasta entonces, sacrificando la mayor parte de la noche y navegando de tal modo en el día, que la derrota siguiese siempre de cerca todas las ensenadas de la costa: es esta sin embargo y por ventura bien alta y escarpada, de modo que no cupiesen errores considerables en su descripción, y así pudiéronse recorrer brevemente las que conducen desde la Punta de Santa Catalina 
tin. 13 hacia el Golfo del Papagayo, golfo cuya comu. nicación con Nicaragua y de allí por el rio San Juan con el mar Atlántico, se ha mirado siempre como un punto de la mayor importancia, no ménos para la geografía general del globo que para los intereses nacionales.

Atravesamos aquel golfo $\mathrm{cn}$ la noche del $\mathbf{6} 6$, apercibiendo, pero sin ser muy violentas, aque. llas ráfagas del Nordeste que tanto amenazan los derroteros antiguos, aunque Dampierre sólo las llama rnedianamente fuertes; aprovecháronse también diferentes estrellas para deducir la latitud y la longitud en algunas horas de la noche y referirlas á algunos puntos altos que teníamos á la vista; y continuada la navegación en todo el día siguiente, pudimos al amanecer del IS hallarnos á la vista del puierto deseado del Realejo.

Se presentaba la costa con el semblante más noble y majestuoso. Desde el volcán de Iseón por el de Telica hasta el del Viejo, diferentes montes, ya más, ya ménos elevados, erguían sus cabezas volcánicas y puntiagudas. Seguían al Noroeste, después de un terreno bastantemente bajo, los Sierras de la Cosivina, la Mesa de Roldán y los Montes de Peltacartepe, ya próxi. mos á la Conchagua; una ilusión no extraña re. presentándonos como fuego 6 humo de los vol. canes las quemas alias de los rastrojos, hacía aún más entretenida la vista; y asomándose ya con la salida del Sol los primeros soplos de la virazón, todo parecía prometernos un nuevo teatro agradable para nuestras tareas. Observóse al medio día la latitud de $\mathrm{I} 2^{\circ}$ I $9^{\prime}$, la cual disipó cualesquiera dudas sobre el conocimiento del Volcán del Viejo, marca precisa paradescubrir laboca bien oculta del Puerto; y finalmente, aprovechada la virazón para disminuir conside. rablemente la distancia, distinguiéronse claramente al anocliecer la Isla del Cardón y las de. más inmediaciones del Puerto, á cuya vista nos obligó poco después á dar fondo la calma que sobrevino y duró toda la noche.

Aprovechado este intervalo para enviar el bote con un Piloto, el cual sondase y examinase la entrada, que sabíamos ser algo peligrosa, tuvimos la satisfacción de verle regresar al amanecer del dia siguiente, trayendo además un Práctico, el cual se hallaba casualmente en aquellas inmediaciones. No dió lugar la virazón á que nos levásemos antes de las diez; pero en el entretanto, para aprovechar todos los momentos favorables, destacáronse en el bote los Sres. Pineda, Heenke y Valdés, con ánimo de internar hasta el pueblo del Realejo y emprender desde allí sus excursiones científicas, las cuales, por parte de los primeros, debían tener por objeto un país $\tan$ poco conocido y tan lleno de riquezas naturales; por la del tercero una prudente investigación de cuanto fuese relativo á la cons- En, נ7 trucción y apresto de las naves en esas inmediaciones. No tard 6 después en seguirles la corbeta, declarados los primeros soplos de la virazón, fueron las sondas al principio de 54 , to y ocho brazas lama, dióse resguardo á un arrecife quo sale med:o cable al Norte del extremo de la Isla del Cardón, luégo orzamos al Este á atracar bien de cerca, y á ménos de medio cable la parte interior de la misma Isla, con el fin de huir de los bajos que salen de la tierra firme y que estrechan el canal á poco más de un cable, cayendo entonces casi repentinamente de las cuatro á las die $z$ brazas arena y lama, cuyo fonda se encuentra hasta tocar con los penoles en la punta; $y$ en fin, ya rebasado este paso $y$ favorecidos más y más del viento y de la marea, fuimos por medio canal dando resguardo á algunos peligros, $y$ comunmente por sondas de ocho, siete, seis $y$ cinco brazas, hasta que ya á las once en el fondeadero interior del Xaquei dimos fondo á un ancla y quedamos amarrados poco después. Demoraba la cima del volcán al Norte $25^{\circ}$ Este $y$ la punta de Icacos al Sur $10^{\circ}$ Oeste; una fragata pequeña del comercio de Lima estaba también surta á un cable de nosotros.

Era demasiado favorable la estación, $y$ nues tros pasos eran harto acelerados por la estrechez del tiempo, para que, ó sacrificásemos un mo mento siquiera á objetos ménos importantes, ó no aprovechásemos cualesquiera ocasiones que pudiesen hacernos más útil aquella escala. Por ventura la claridad constante de los días y las noches, la excelente disposición del fondeadero, la multiplicidad de nuestras embarcaciones menores, y á un mediano trecho varias poblaciones numerosas que coadyuvaban á los acopios y excursiones de los naturalistas, combinaban un tal conjunto de ventajas que difícilmente hubiéranse podido hallar en otra parte alguna. Así, á pesar que la falta de la corbeta ATrevida disminuyese de una buena mitad el número de personas ca. paces de dirigir las diferentes excursiones científicas, y que por m!nestra parte estuviesen enfermos D. Fernando Quintano y D. Felipe Bausá, fué tal cl empeño de los demás, que casi al mismo tiempo de haberlas emprendido, estaban con. cluídas la mayor parte de las tareas proyectadas, y por consiguiente podíamos pensar de nuevo en aproximarnos á Acapulco.

En el solo plazo de diez días fueron suma. mente importantes las observaciones que tuvimos para la latitud y longitud del observatorio; multiplicáronse de tal modo las tareas hidiográficas, que ni las sondas importantes de las dos bocas de la entrada, ni los canales internos, el puerto de los Aserradores, la elevación exacta del Volcán del Viejo y la deducción por ésta y el rumbo de demora de la posición respectiva de 
a cons- En, i

imedia.

corbeta,

virazón,

$y$ ocho

ife que

e la Isla

car bien

arte in.

ir de los

e estre-

cayendo

cuatro á

a se en-

a punta;

rorecidos

imos por

peligros,

e, seis $y$

$n$ el fon-

ndo á un

pués. De-

$25^{\circ}$ Este

una fra.

taba tam-

n, y nues-

estrechez

is un mo-

rtantes, $\dot{0}$

iones que

scala. Por

dias y las

ndeadero,

:iones me-

oblaciones

pios y ex-

ban un tal

hubiéranse

sí, á pesar sminuyese rsonas caones cienesen enferipe Bausá, zasi al mistaban conoyectadas, de nuevo

ron sumaque tuviservatorio; s hidiográde las dos internos, el ión exacta por ésta y espectiva de
* En, 7 algunos otros pueblos, careciesen de toda aque. lla prolijidad á la cual estábamos acostum. brados.

En la excursión que hicieron algunos Oficiales con dos botes al puierto de los Aserradores, $\because$ intentaba durante la noche una caza de tortugas, que solían comunmente venir á la playa, cuando se encontró, que una clase de rivales bien temibles les habían precediclo en una hora, $y$ eran éstos un número considerable de tigres, casi los únicos habitadores del terreno anegadizo y lleno de mangles y de icacos, que media entre los dos puertos y abriga el canal por donde se comunican entre sí, dando ingreso á los muchos esteros que conducen á los astilleros las precio. sas balsas de los cedros y de los pinos. Hubo una entre aquellas fieras, que si bien acosada de las voces de nuestra gente, no abandonó la presa, y con tanta constancia como maña, fué arrastran. do la tortuga desde la playa hasta el bosque. Otras, al amanecer, se veían aún en la playa, á poca distancia de nuestra barraca; puede considerarse que no fué largo ni tranquilo el sueño de los que allí se hallaban, resarcidos sí en parte con los frutos abundarites y exquisitos que les suministraban la pesca, la caza y los mariscos.

Mientras la Oficialidad y los botes se empleaban de esa manera en los diferentes objetos indicados, no dejaba la demás gente de atender diariamente á los reemplazos de agua y leña, los cuales pusimos al cargo de un sargento y un contramaestre; sólo sí, que los escarmientos de Panamá nos dictaron ahora como más pru. dente el que no se trabajase en aquellos objetos sino desde el ananecer hasta las diez de la mañana, abandonando las demás horas como exce. sivamente arriesgadas para las tercianes, de las cuales ahora adolecía de nuevo uno ú otro tina. rinero; la pesca y la pesquisa eficaz del infinito número de preciosas conchas muy varias entri si, que liermosean aquellas costas, era otro objeto que nos ocupaba diariamente. Fuimos en esta parte con exceso felices, y vimos en un momento enriquecerse considerablemente nues. tros acopios para el Real Gabinete de Madrid.

- Atentos como se ha indicado ya, D. Dionisio Galiano y D. Juan Vernaci á cuanto pudiese ser útil en el observatorio, habian deducido los re. sultados siguientes:

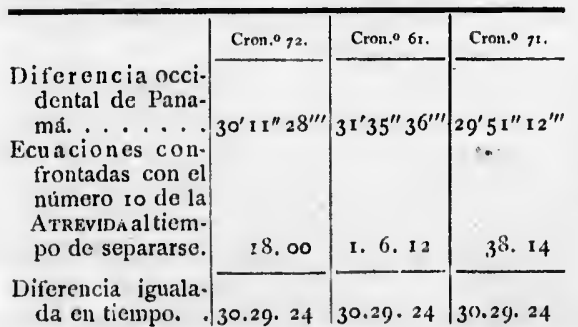

En grado y Occidental do Panamá. . . 70 $37^{\prime} 21^{\prime \prime}$ Vin. 17 Nuestras serics corregidas lo asiguaban. 81. 41. 30

Era por consiguiente la longitud del

observatorio.......... 89.18.51

Por las inmersiones del primer satélite de Jupiter observadas en $\operatorname{los}$ días 25 у $27 \ldots \ldots \ldots \ldots . \ldots . \ldots 89.21 .00$ Ochenta y cuatro series de distancias del Sol a la Luna, traídas con los re. lojes marinos. . . . . . . 89.16.00

Omitióse por entonces el hacer uso de otros muchos materiales que se habían acopiado para el intento; resultó la latitud del observatorio de $12^{\circ} 29^{\prime} 5^{\prime \prime}$ Norte y la variación magnética de $7^{\circ}{ }_{1} 5^{\prime}$ Nordeste; $y$ como se incorporasen ya para la noche del 28 los diferentes individuos que se habían destacado á una ú otra parte, se pudo prefijar para el día zo la salida. Conside. rábanse los naturalistas con extremo felices, bien sea poi las disecaciones y colecciones botánicas y de conchiología que se habian hecho, bien sea por el examen científico de los volcanes y terrenos adyacentes. La cresía del volcán del Viejo descubría un doble cráter, algunos depúsitos de azufre, varias otras piecras singulares. y sobre todo, una vista realmente majestuosa, la cual compensaba en mucha parte la fatiga de dos días para alcanzarla y el riesgo que había corrido D. Tadeo Heenke de ser mordido por una víbora de cascabel. Aunque no $\tan$ alto el volcán de Telica, presentó á D. Cayetano Valdés objetos aún más interesantes. Su caldera, desde luego, no le era inferior, no bajando una ni otra de 1.000 varas de diámetro próximamente, ni puede darse vista más hermosa de la que presentan las paredes de la caldera con un amarillo sumamente vivo é igual en todas partes, dimanado del azufre que las viste. El humo es casi general, no sólo en lo interior, si también en las inmediaciones externas. Cede el terreno bien fofo aproximándose á la cima; una piedra echada á la cavidad, por largo tiempo devuelve un mirmullo distante, prueba segura de la profunc. 1 á que penetra; se oyen á lo lejos hacia las partes ménos altas las conversaciones de los que están en el monte; la vejetación es bien mezquina; en fin, todo denota un hueco sumamente profundo, del cual emana en mucha abundancia un vapor acuoso, $y$ en donde parecc una obra periódica é incesante de la Naturaleza la liquidación de muchos materiales, y en particular de varios montoncitos de piedra, que con una prudente igualdad se advierten sembrados en lo interior. No era muy remota la época de los últimos extragos del volcán. En 1762 una lluvia de cenizas y arenas, cubrió las cam. piñas inferiores hasta el pueblo del Viejo, distante unas diez leguas. Los extremecimientos ó temblores duraron unos quince días. Los acom- 
E. s. pañaban á veces los bramidos del mismo monte, y la Naturaleza, grandiosa hasta en sus convulsiones, se explayaba al mismo tiempo aún con más vigor en el volcán del Rincón de la Vieja, inmediato al Istmo de Nicaragua. Se conservaban además bien vivos en la memoria de aquellos naturales los extragos dimanados de las lavas del Nomotambo y del Nindiri, habiendo la primera indicado como prudente la traslación del pueblo de León, y la otra por casualidad, dirigido cuatro lavas diferentes hacia unos parajes no bien habitados. En general, la dirección de esta dilatada cordillera de volcanes parece próximamente del Oesnoroeste al Esueste. A sus faldas se exticnde hacia el mar una porción de tierra baja, regada en parte de los rios y en parte de las mareas. Su mucha fertilidad es difícil de describirse, y las maderas excelentes que por todas partes crecen en sus orillas, convidan tanto más á una construcción activa, cuanto que el conducirlas y el labrarlas es obra de poco costo.

No oponiéndose dificultad alguna á la conti nuación de nuestro viaje, le pudimos efectivamente emprender para la mañana del 30 , como lo habíamos proyectado; al medio día ya estábamos fuera del puerto; y al anochecer, el terral fresco con el semblante más hermoso, nos hacía conti I yar con bastante velocidad nuestro viaje y uuestras tareas, si juzgásfmos, pues, por aquellas primeras apariencias; la travesía hasta el puerto de Acapulco no debía costarnos tanto tiempo ni tantas inquietudes como la anterior. Con solos dos días de navegación estábamos delante de Sonsonate, cuya rada fué fácil reconocer; apenas anochecía, cuando entablaba el Nordeste. La elevación de los montes y la claridad de las noches facilitaban aún más las tareas emprendidas; y era tal la útil posición de aquellos volcanes, que á la vista de Sonsonate se alcanzaban al mismo tiempo el de la Cosivina sobre el Realejo, y los de Guatemala á cuyas faldas se halla situada la capital del reino.

reb. A pesar de su fondeadero bien incómodo, es Sonsonate el paraje por donde se extraen casi todos los frutos del reino de Guatemala, destinados á los del Perú y Méjico. Los tintes para sus manufacturas, las breas y alquitranes, el algodón y una cantidad grande de maderas preciosas, forman los ramos principales de esta extracción; siendo los de introducción los vinos, aguardientes y algunos comestibles secos del Perú y Chile, alguna azúcar del reino de Méjico, y una proporcionada compensación en dinero efectivo. Hasta las inmediaciones de los volcanes de Guatemala nuestro viaje pudo todavía caracterizarse por feliz; pero desde aquel paraje, fueron tales las oposiciones que tuvimos por las calmas y por las corrientes contrarias, que el detallarlas por menor, fuera tan difícil como can- sado. Fil yg de Febrero aún estábamos á la vista de los mismos volcanes, aunque por unos ocho días luubiésemos procurado alejarnos á distancia de 40 leguas de la costa. Pocas horas del Nordeste fresco del Goifo de Tecoantepeque, nos separaron, hacia el 24 , de aquellas inme. diaciones; pero como atracásemos nuevamente la costa hacia los puertos de los Angeles y de Aguatulco, volvimos á hallarnos rodeados de las mismas calmas y ventolinas contrarias, con las cuales habíamos luchado deside tanto tiempo, y la desconfianza de poder realizar en el próximo verano la campaña proyectada, debió, por la misma razón, adquiril un nuevo vigor bien desagradable. Entre tanto, los calores cran excesivos, influyendo no sólo en la salud en general, si tambien en el mal trato de la arboladura, de las cubiertas y de las embarcaciones menores. No aparecía una nube, que al paso de modificar el ardor del Sol nos indicase algunos preludios de vientos más favorables; varias especies de aves y peces se presentaban á nuestra vista miıándo. nos casi como los habitadores de aquellas costas; finalmente, debiamos temer que la excesiva sensibilidad de nuestra marinería no trastornase en cierto modo la mucha tranquilidad, de la cual habíamos gozado hasta entonces, influyendo la calma lo que tal vez no lograrían influirle los mismos peligros de las latitudes altas septentrionales. Ya para compensar la falta casi total de carnes frescas, debimos tambien ocuparnos diariamente de la pesca de la tortuga, valiéndonos á las veces de la fizga, á las veces de un botecillo, según lo requiriese la posición de la corbeta; solía esta pesca ser más abundante á medida que nos apartábamos de la costa, y éste fué el par. tido que adoptamos de nuevo el 6 de Marzo, si bien tampoco le hallásemos útil hasta el 2 I. No debe pasarse en silencio el efecto que experimentamos en aquellos quince días por las corrientes contrarias, pues no fué menor de 92 leguas al Sur y 68 al Este, cantidad que de ningún modo pudiéramos contrarestar con las ventolinas contrarias, que por lo común nos rodeaban.

En el mismo día 2 I pudimos atracar de nuevo la costa á no mucha distancia de Acapulco, y gozando ya con una mayor fuerza y duración de los terrales y virazones, hacer diariamente algunos progresos hacia el puerto, por el cual anhelábamos con tanta eficacia. Se destacó la lancha á las órdenes del Teniente de navío D. Cayetano Valdés para que reconociese las costas fronteras; $y$ alcanzado después el puerto de Acapulco, nos saliese al encuentro con las órdenes y avisos que allí hubiese para la expedición. Nosotros continuamos luchando hasta el 27 con las contrariedades acostumbradas; pero en fin, como lográsemos en la mañana de aquel día el hallarnos algo á barlo.

reb. 19. 
M.r. 27 vento de la entrada y al mismo tiempo recibir por medio de la lancha diferentes ordenes y noticias que exigían medidas complicadas para la continuación del viaje, fué preciso determinarnos á entrar en el puerto y lo verificamos así, quedando fondeados y amarrados en muy buena posición antes del anochecer.

Como se verá después, la Atrevida había hecho la escala prescrita en el puerto y emprendida luégo su navegación hacia San Blas, bien que con la probabilidad de necesitar próximamente un mes de tiempo para aquella travesía. La estación estaba extraordinariamente adelantada para la campaña proyectada sobre la costa Noroeste de la América, ni sería prudente em. prenderla antes de reunir las dos corbetas abastecidas además con cuanto fuese necesario para unos reconocimientos útiles; por otra parte, atento á los vientos y corrientes que reinaban sobre la costa, parecía tan fácil este consceruimiento para la otra corbeta, como difícil para la DesCUBIERTA; así fué últimamente la medida adoptada con anticipación á todas las demás, la de encargar á la ATrevida que retrocediese con la posible brevedad á Acapulco, no descuidándonos en el entretanto en reponer aguada y víveres, y completar aquellas obras en el casco, arboladura y velamen, que el último viaje penoso dictase ya como necesarias.

Mientras cuidábamos así de la mayor economía del tiempo, y según costumbre, los Oficiales astrónomos, los naturalistas, los hidrógrafos, los cazadores y los disecadores, atendían cada cual á los muchos objetos que le suministraban los alrededores de Acapulco, no pareció intempestivo el que se destacase también un Oficial hasta la capital de Méjico, y allí, al paso de re. cibir verbalmente del señor Virey el Conde de Revillajigedo, las órdenes é instrucciones oportunas para las campañas siguientes, verificase algunas observaciones astronómicas, entre las cuales mcrecían sin duda un lugar preferente una emersión del primer satélite de Júpiter y la oci, tación por la Luna de (2) Cáncer, que debían acaecer en las noches del 7 y 12 de Abril, y eran visibles en Méjico, Acapulco y San Blas; contábamos con que no faltarían los instru. mentos oportunos aunque la precipitación del viaje y el camino largo y pedregoso imposibilitasen el transporte de los nuestros, pues además de los que pertenecían al Real Observa torio de Cádiz y habian sido entregados al Comandante de San Blas D. Bruno de Hezeta, sabíamos que existían aún allí los que habían scu vido en San José de California al $\mathrm{dbate}$ Chappe y eran ahora propios de D. Antonio Gama, persona sumamente instruída y habitualmente inclinada á los estudios y tareas astronómicas.

Malográronse en mucha parte las observacio. nes indicadas, por las turbonadas periódicas que desde el medio día hasta la media noche suelen comunmente en aquella estación oscurecer los cielos y horizontes. No asi con las combinacio. nes más favorables relativamente á nuestro via. je y con aquellas ideas políticas del estado general del reino que tanto anhelábamos; pues en cuanto á lo primero, dos extraordinarios de San Blas, participaron casi á un mismo tiempo al señor Virey la llegada de la corbeta ATrevida, las órdenes de S. M. que allí había para que ve. rificásemos la navegación á la costa Noroeste de la América y sus activas disposiciones para reunirsenos cuanto antes en Acapulco; por la otra, el mismo señor Virey y todas las personas más ilustradas de la capital, concurrieron eficazmente ya con libros, ya con instrucciones y noticias útiles, para que extendiésemos nuestras ideas $y$ llevasen los pasos venideros una dirección ménos incierta hecia el bien público y la prosperidad de la Monarquía.

\section{Viaje efectuado por la ATREviDA durante su separación de la otra corbeta, segin relación de Bustamante.}

Navegación de la AtRevida al reconocimicnto de la Isla de Cocos, y sucesiva á los puertos de Acapulco y San Blas.

La constante tenacidad de los tiempos se Er. , oponían tanto á los progresos de nuestra derrota, que su atraso daba ya algún cuidado para evacuar los objetos que debían ocuparnos el verano próximo. Esta justa reflexión produjo la necesidad en D. Alejandro Malaspina de dividir En. ? desde este punto las corbetas, y prevenirme que con la de mi mando me dirigiese á los puertos de Acapulco y San Blas, combinando, si era po. sible en este tránsito, la posición astronómica de la Isla de Cocos por ser preferente el desempeño de otros objetos comprendidos en su instrucción.

Dando cumplimiento á ella, se trasbordó in. 
Yin a mediatamente á la Descubierta el equipaje del liegente de Guatemala, solore cuyas costas debia dirigirse $y$ fondear en el puerto de Realejo. A esta diligencia siguió la comparacion de los relo. jes, $y$ ciñendo ambos el viento del ()este-Noroes te con muras encontradas, quedamos fuera de la vista á las diez y media de la mañana.

Al medio día observamos la latitud Norte de $6^{\circ} \times 5^{\prime}$ y la longitud de $77^{\circ} 0 z^{\prime}$ occidental de Cádiz, aunque estas observaciones no merecian toda confianza por carecer de ella la altura meridiana. I a inconstancia de los vientos entre el tereero y cuarto cuadrante alteraban con fre. cuencia las bordadas para seguir aquella más proxima al Oeste. La noche fué oscura y cerra da con chubascos repetidos que precisaban á guardar la debida precaución en el aparejo.

Del mismo modo permaneció el tiempo hasta el clia ro, en tćrminos de no permitir averiguar por cbservaciones nuestra posición verdadera. Todavía hoy no pudo conseguirse con exactitud por no estar bien determinados los limbos del Sol y' el horizonte also interrumpido. Sin embargo, siempre era muy preferente á la de estima, en la cual se habian reunido y multiplicado las causas que producen sus errores comunes. Listas observaciones señalaban la latitud de $5^{\circ}+6^{\prime}$ Norte, y la longitud de $80^{\circ} 00^{\prime}$ con una diferencia de $34^{\prime}$ al Sur de la estima en los tres días y $30^{\prime}$ al Iiste.

Si la abundaneia de pájaros fuese aquí señal cierta como lo es en otros parajes, de tierras in. mediatas, sin duda que la Isla de Cocos no debía estar muy distante. Los alcat “ues y pelíca. nos ell mayor número eran exactamente iguales a los que nuestros naturalistas describieron en Coquimbo; su frecuente ejercicio de los primeros en precipitarse desde grande altura para buscar el sustento, era indicio evidente de su abundancia por estos mares. En efecto, nuestros marineros le conseguian también con el anzuelo, llegando á veces á tal exceso, que para aumentar su agradable diversión en la pesca restituían á la presa su libertad. Pero esta misma abundancia de pescado produjo algunas indigestiones y re: caídas á los convalecientes, contra cuyos excesos, aunque por otra parte fuesen disculpables, no alcanzaba nuestro celo á precaverlos.

Desde el medio día nos favoreció el viento iresquito por el Nordeste hasta las euatro que abonanzó, á euya hora avistamos con sorpresa la Isla de Cocos al ángulo corregido de $48^{\circ}$ en el tercer cuadrante, distancia de seis á siete leguas, cuando á la sazón nos considerábamos como 60 de ellas; error á la verdad muy considerable, que excita tanto el deseo de corregirlo como el de justificar la admiración de hallarle.

Nos era sensible á este intento no tener la mayor confianza en las observaciones de hoy por si le frustrasen las calmas ú otros accidentes muy comunes en estos parajes; también el viento era flojo $y$ desigual, circunstancias que aumentaban el error de las operaciones que emprentié. semos. No obstante, se corrió una base cuyos re. resultados determinaban al centro de la isla la latitud de $5^{\circ} 34^{\prime}$ Norte, y la longitud de $80^{\circ} 36^{\prime}$ $29^{\prime \prime}$ occidental del Real Observatorio de Cádiz.

Durante la noche se procuró conservar la in. mediación de la isla á pesar de las ventolinas variables que lo dificultaban. Logramos, no obstante, amanecer á tres leguas escasas de ella, y dirigiéndonos á favor ánico de una ma. rejada del Norte, á buscar con proa del Sur su paralelo antes de la úbservación del medio dia, no pudimos alcanzarle, bien que la inexactitud dc la observación la hizo también desatendible para el efecto.

Al día siguiente otras apariencias más favo. rables nos lisonjeaban de satisfacer nuestros deseos. Toda la mañana tuvo el tiempo el mejor semblante, y sólo cerea del medio día se presentó un chubasco, que sin embargo de acortar el hori zonte, le dejaba bien determinado. A pesar de esto se doblaron todas las precauciones para asegurar la mayor exactitud, arreglando un reloj, y con cel á la vista se observó la latitud con mucha confian. $z a$, resultando ála isla la de $5^{\circ} 34^{\prime}$ por el prome. dio de siete observadores muy acordes entre sí, marcándose al mismo tiompo el centro de ella al Sur $73^{\circ}$ Oeste, corregido á distancia de cuatro millas. Nuestra longitud, observada por el nú mero ro, fué de $80^{\circ} 4^{8^{\prime}} 34^{\prime \prime}$, habiéndose hallado la variación Nordeste de $8^{\circ}$.

Hasta las tres de la tarde se había barajado la isla con una ventolina de Noroeste, á cuya hora, reconocida la parte del Sur, un chubasco fuerte nos obligó á separarnos de ella, siendo mi ánimo pasar por la del Norte. No se presen. taba la noche con las mejores apariencias, y aunque era correspondiente el celo y cuidado en el aparejo, no fué posible precaver un contraste fuerte por è Nordeste á las euatro de la mañana, que por fortuna no nos causó la menor avería, y el viento cedió con la mucha agua que llovía.

La cerrazón impidió verse la isla hasta las ocho, que demoraba lo más Oeste de ella al Sur $30^{\circ}$ Oeste, y lo más Este al Sur $23^{\circ}$ Oeste, distancia.como de seis leguas. Se midió luégo una base tomándose horarios. Las observaciones las mirábamos de tanta mayor importancia, cuanto que sus resultados decidirían la situación de la isla, por no estar conformes entre sí los de los cías anteriores. El viento no fué muy constante ni igual su fuerza, cuyo defecto para las bases se corregía midiendo frecuentemente la distancia de corredera. A pesar de todo, puede adoptarse $\sin$ grave escrúpulo de error una base medida 


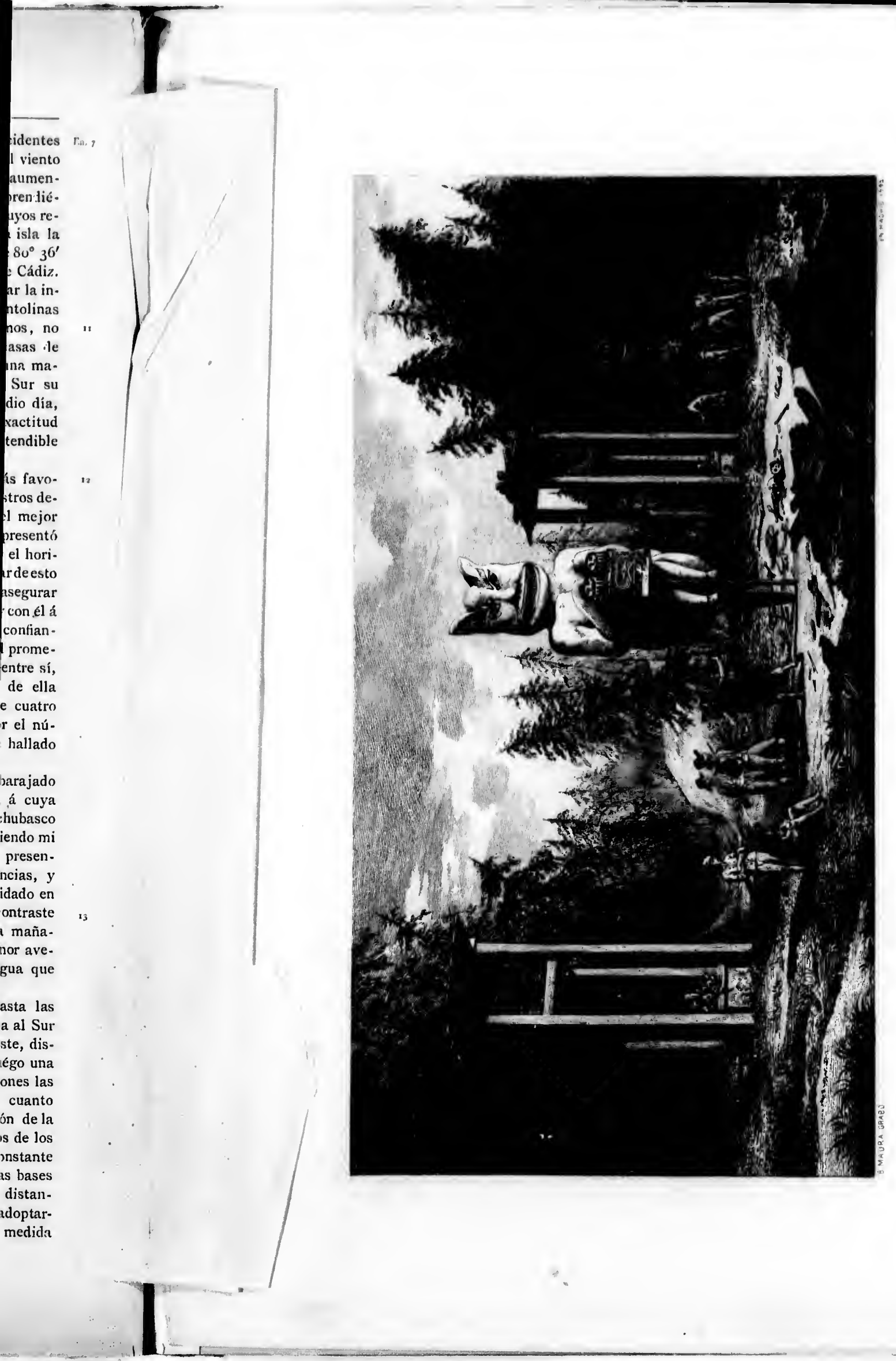


Fin se las dos á las cuatro de la tarde con horarios antes $y$ después de ella, y con igual confianza se ha adoptado la latitud del medio dia tomada por siete observadores.

De la relación que acaba de referirse para conocimiento de los navegantes, se puede con. cluir que las observaciones de los dias I $_{2}$ y 13 merecen absoluta preferencia para la situación astronómica de la Isla de Cocos; por consiguiente, la que he adoptado para su latitud fue obser. vando próximos á su paralelo, y es de $5^{\circ} 33^{\prime}$ I $0^{\prime \prime}$ y la longitud del día 13 también casi en su me. ridiano, de $80^{\circ} 47^{\prime} 3 x^{\prime \prime}$ occidental de Cádiz.

Esta Isla de Cocos corre del Estenordeste al Oestesudoeste y tiene de extensión algo más de una legua. Desde el centro hacia la parte del Oeste es su mayor altura, y en ésta se eleva un pico agudo de donde va descendiendo suavemente para el Este, en que remata con punta baja formada por dos islotillos inmediatos entre sí $y$ á la isla; al Noroeste hay también otro próximo; toda la superficie está cubierta de una frondosa y verde arboleda hasta sus orillas; en la parte del Nordeste tiene fondeadero al frente de unas palmas, según noticias que tenemos; y en la del Sur se vió una playa corta en donde infiero no le tenga por ser alli la isla tajada al mar.

Hay agua en ella, produce abundancia de cocos, y abriga multitud de pájaros, los cuales, en tiempos oscuros, podrán indicar sus cercanías.

Si se coloca la isla por el promedio de las observaciones antes referidas, estará su centro en latitud Norte $5^{\circ} 33^{\prime} 10^{\prime \prime}$ y en longitud $8^{\circ} 42^{\prime}$ Oeste de Cádiz.

İsta posición de la isla se aparta de la del Lord Anson desde $5^{\circ} 20^{\prime}$ de latitud en que la es. tablece á $5^{\circ} 34^{\prime}$ en que ahora queda, siendo aún más notable la diferencia con la que asignan los pilotos particulares de este tráfico con la del re. ferido Almirante.

Es de notar que en la relación elegante de su viaje, no exprese las circunstancias ó métodos para la situación de la citada isla, mucho más habiendo permanecido cinco días á su vista cuya circunstancia induce á creer algún error en sus operaciones, 6 días con observaciones de latitud muy inciertas.

No pudo perderse de vista la isla por las contínuas calmas hasta la tarde del $r 6$, y si aprove. chando ventolinas se granjeaba algo, las corrientes para el Sur lo volvían á perder. Las diferen. cias en este sentido eran constantes, lo mismo que aguaceros fuertes y el calor, para aumentar el número de nuestros enfermos y de nuestros cuidados. Sin embargo, no eran aquellos de tanta gravedad que no contásemos su alivio como seguro luégo que se entrase en la región de las brisas, y este era de mucho tiempo el término de nuestros deseos.
Habiamos podido rectificar con observaciones de distancias a Régulus y Aldebarán la longitud del número ro, con la cual estaban muy con. formes.

Esta seguridad de la exactitud de nuestra po. sición verdadera después de tantos días y tantas causas para alterarla, nos era ciertamente muy apreciable y disminuia el fastidio de una nave. gación desagradable por todas sus circunstan. cias.

Ėsta misma oposicion no nos abandonó sino después de treinta y cuatro dias, declarándose las brisas aunque todavia sin pasar del Norte en Ia mañana del 22, hallándonos al medio día en latitud de $5^{\circ} 37^{\prime}$ Norte $y$ en longitud de $83^{\circ} 19^{\prime}$, ob. servando la variación de $9^{\circ} 30^{\prime}$ Nordeste.

Al dia siguiente las brisas estaban en el primer cuadrante con todas las señales de su fir meza. Habian cesado las diferencias al Sur y nuestro objeto no era ya más que forzar constantemente de vela para llegar cuanto antes á Aca pulco; nuestra longitud del número ro pudimos comprobarla con 26 series de distancias luna. res el día 26, cuyo promedio correspondía exac. tamente á la misma longitud que señalaba el reloj; la variación por amplitud señalaba $8^{\circ} 27^{\prime}$ Nordeste, hallándonos en latitud de $10^{\circ} 24^{\prime}$ Norte $y$ en longitud de $90^{\circ} 28^{\prime}$.

Al día siguiente volvimos á observar distancias cuyo promedio de sesenta y cuatro stries nos indicaba con sorpresa una diferencia de $I^{\circ}$ $3^{8^{\prime}}$ al Este de la del número Io, cuya novedad tan repentina nos produjo la admiración que era consiguiente.

No podíamos acertar con la verdadera causa de esta notable diferencia, y aun cuando en esta clase de observııciones son fáciles de deslizarse algunos errores, no pudimos, sin embargo, ad vertirlos, ni tampoco conceder uno $\tan$ considerable ell esta ocasión, para no presumir alguna causa 6 alteración en el reloj, difícil de averiguarse aquí.

Se había observado desde ayer una mayor abundancia de pájaros, y un color en el agua que indicaba sonda; pero no se encontro con 90 brazas. Nuestros rumbos desde el medio día se dirigieron al Noroeste, siendo la distancia al continente como de go leguas. A las cuatro, después de calcularse los horarios, se orzb al Noroeste $\%$ Norte, rumbo que nos conducía á recalar al Nor te de Acapulco. Por la noche fué rolando el vien. to para el Este, aumentando también su fuerza desde que se puso la Luna; al amanecer era ya bastante recio por el Estesudeste, tanto que obligó á navegar con solo las principales. Estas se nales anunciaban la permanencia de las brisas y con esta seguridad fue ya mi ánimo buscar el puerto oirectamente.

Los grandes armamentos que sabíamos des. 
1n. 28 de Panamá había en Europa, daban justo recelo para que bubiese rompimiento con la Inglaterra.

Aun cuando éste se hubiese verilicado, podíamos mirar como remoto todo encuentro de ene. migos por estos mares; pero no obstante estos antccedentes, y de una debida consideración a nuestra escasa y fatigada tripulación, se procuró ejercitarla en el manejo de lás armas, montán. dose antes toda la artillería.

Las observaciones del medio cía, advritiendo rrandes diferencias, parece querían frustrar mis deseos sobre la recalada. Observamos la latitud de $13^{\circ} 43^{\prime}$ que diferenciaba al Sur de la estrma en $r 7^{\prime}$, y la longitud de $94^{\circ} \mathrm{oo}^{\prime}$ también se apartaba en $5^{2}$ al Oestr. Pareció muy considerable esta diferencia para atribuirse toda á error de la estima á pesar de que el viento recio y á fugadas y la mar muy elevada pudieran justiticarle. Pero observadas muevas longitudes por la tarde, con. lormaban con las del medio día, y por consi. guiente repetían la misma diferencia.

Desde las siete de la mañana se gobernó al Norte para atracar la costa por los meridianos de Acapulco en que á la sazón casi nos considerábamos. La brisa fué cediendo al principio cle la tarde, y siguiendo el propio rumbo se forzó al instante de vela.

Con sospeclia de haberse corrompido algunos barriles de coles agrias, se procedió á su reconocimiento, hallándose sólo en ertado consumiijic aquellas que por estar en vasijas bien accndicionadas habían conservado la salmuera, y por el contrario corrompidas cuantas carecían de ella, siento preciso echarlas al agua como in. útiles ó perjudiciales á la salud pública. Esta experiencia hace conocer cuánto cuidado exige el acondicionar este saludable alimento con toda la escrupulosidad que merece la conservación de tan poderoso antiescerbútico.

Alcinzamos al medio día siguiente la latitud observada de $14^{\circ} 56^{\prime}$ y la longitud de $93^{\circ} 34^{\prime}$, ćsta diferenciándose en $35^{\prime}$ al Este de la estima; esto es, en sentido contrario de ayer, pero no ¿así con la latitud, cuya diferencia de 12 ' fué hoy también para el Sur. Aunque estas diferencias hacia el segundo cuadrante venian conformes con las noticias que teníamos de ia dirección de las corrientes en estos parajes, no obstante, para confirmarlas, se repararon los horarios y otros nuevamente tomados á las tres de la tarde repitieron la misma diferencia. Con esta confirma. ción, mandé gobernar al Noroeste $\%$ Norte con el viento ya inclinándose para el Sudeste bonancible. A las nueve de la noche llamó al Sudoeste y esto indicaba el término de las brisas sustituídas por los variables del $30^{n}$ y $4 .^{\circ}$ cuadrante.

Avistóse la tierra al aménecer, reconociéndo. se luégo las Tetas elevadas de Coyuca, la del Jiste es algo más baja y redonda que la del Oes- te, demorándonos al Norte $1.4^{\circ}$ Oeste. Estas senales y la del cerro de la Brea que está sobre el mismo puerto de Acapulco, unidas á que todo el frontón de costa er' nucho más alto que las tierras al Este y al Oeste de su entrada, no dejó género de duda de haber recalado frente del referido puerto.

En efecto, por marcación hecha al medio día á las Tetas de Coyuca al Norte corregido, y la latitud observada de $16^{\circ} 10^{\prime}$, nos demoraba Acapulco al Nurce $13^{\circ}$ Este, distancia de I4 leguas. Una carta española que nos guiaba en esta derrota, se le corrigió la longitud en medio grado al Ceste que se advirtió de error á las Islas de Coiba, con cuya corrección resultaba por longitud de Acapulco $93^{\circ} 5^{6^{\prime}}$ casi la misma que señalaba el reloj estando hoy en su meridiano.

Las bonanzas hicieron inútiles nuestros es. Fub. 1 . fuerzos de atracar la costa hasta la mañanita del día I." que con ventolinas del primer cuadrante gobernando al Nornoroeste, se pudo distinguir la Isla Roqueta por la proa, entre la cual $y$ el continente hay paso estrecho pero hondable, por donde entran las naves de Filipinas cuando vienen con vientos bien entablados. Esta isla escarpada, tiene unas manchas blanquizcas, miy propias para distinguirla y conocer la boca del puerto en tiempos oscuros, ó cuando la niebla, frecuente en algunas estaciones del año, oculta las altas montañas de sus inmediaciones.

Estábamos al ponerse el Sol entre el puerto Marqués y la Isla Roqueta, á distancia de ésta como dos cables y en sonda de 35 brazas lama.

Rebasada la Punta del Grifo se ciñó el viento al Nornordeste y Norte, intentando con un repiquete alcanzar el fondeadero.

Se vió luégo la candelada que se enciende en el sitio del Vigía cuando se avistan embarcaciones, y las luces de la población; calmó el viento, y las ventolinas variables obligaron á dar fondo á un anclote en 23 brazas lama, demorando la Vigía al Oeste $5^{\circ}$ Norte, y lo más saliente de la Roqueta al Sudoeste $1 / 4$ Sur.

A media noche por garrar el anclote con unas rachas del Noroeste, se dió fondo á un ancla, permaneciendo así hasta por la mañana.

\section{Entrada en cl pucrto de Acapulco.-Obserwaciones ejecutadas $y$ otras ocurrencias.}

Al romper el día salí en el bote para tierra, con el fin de anticiparme las noticias sobre el es. tado político de la Europa y aprovechar los ins tantes para combinar con la estrechez del tiempo las providencias y aprestos necesurios. Pero antes previne al Teniente de navío $\mathrm{D}$. Antonio de Tova que echada la lancha al agua, dirigiese la corbeta á la vela 6 al remolque alparaje donde se amarra la Nao de Manila, la cual, no viéndola en el 
Estas se- En. 30

\section{tá sobre el} que todo to que las la, no dejó ite del re-

\section{nedio día á} lo, y la laba Acapul eguas. Una a derrota do al Ces. de Coiba, ongitud de señalaba el

lestros es - Fub. , mañanita rimer cua e pudo dis. tre la cual ro honda Filipinas ados. Esta anquizcas, er la boca 6 la niebla, ño, oculta aes. e el puerto sia de ésta azas lama. ió el viento con un renciende en nbarcacioel viento, a dar fonlemorando ís saliente
Feb, puerto, inferimos no hubiese venido este año, pues nunca sale para su destino hasta Marzo. Sólo había fondeada la fragata marchante la Pastora, que salió de Guayaquil después de las corbetas con carga de cacao, y á los treinta y cinco días avistó estas costas sin poder cojer el puerto hasta completar los cincuenta de su salida, á causa de las corrientes para el Este y su poca diligencia; defecto común de todas las em. barcaciones de este tráfico.

Por ausencia del castellano el Coronel Don José Manuel de Alava, ejercía las funciones de Subrelegado D. Diego Carrillo, quien me informó la subsistencia de la tranquilidad de Europa, pareciendo casi segura la transacción amistosa entre la España y la Inglaterra, á pesar de que existían los grandes armamentos de ambas coronas.

E1 referido Subdelegado me entregó las órdenes de S. M. dirigidas á D. Alejandro Malas. pina, advirtiéndome se hallaba con urias repetidas del Excmo. Sr. Conde de Revillajigedo, Virey de estos dominios, para franquear á los buques de esta expedición los caudales y auxilios nece. sarios para la continuación de su viaje, y además tenía especial encargo del Gobernador para obsequiarnos en su nombre mientras estuviésemos en la jurisdicción de su mando.

Inmediatamente regresé á bordo, encontrando la corbeta á la vela con ventolinas del Nornordeste y ayudala de remolques dirigiéndose al fondeadero prevenido. A las ocho y media de la mañana quedó ya amarradá con un ancla afuera y dos calabrotes de reguera dados al árbol más Este de los dos inmediatos al muelle; bajo las marcaciones del asta de bandera del castillo nuevo de San Carlos (antiguamente nombrado de San Diego) al Norte $59^{\circ}$ Este; el Islote del Obispo al Norte $69^{\circ}$ Este; y el convento de San Hipólito, que ahora sirve de Hospital, al Norte $46^{\circ}$ Oeste; rumbos de la aguja, en fondo de $5 \mathrm{y}^{\mathrm{1}} / \mathrm{2}$ brazas lama.

Por la tarde despaché extraordinario al Virey con aviso de mi llegada, las ocurnencias de la navegacion, y pidiéndole las órdenes de S. M. relativas $h$ la expedición que tal vez luubiesen llegado á su poder por el último correo, en inteligencia que daría la vela luégo de recibirlas y se me incorporasen los Tenientes de navío D. José de Espinosa y D. Ciriaco de Cevallos, que suponía en camino para este puerto, habiendo sabido su llegada al de Veracruz el ig del pasado.

Por informes que recibí sobre la comparación de precios en los víveres entre este pueblo y San Blas, hallé preferente hacer el acopio de ellos'en aquel departamento, así por ser allí mucho más fácil y equitativa su adquisıción, como por poder contar al mismo tiempo para su apresto con otros auxilios y recursos que no hay en este puer- to. Esta resolución nos facilitaba emplear el feb. tiempo en otras operaciones y observaciones combinables con nuestro objeto hasta el momento de la salida.

Desde luego se principió al día siguiente el córte de leña, y el reemplazo de la aguada. Se armó el cuarto de círculo en el patio de la propia casa del castellano, llevándose tambien el reloj I05 para las comparaciones diarias, y el uso de otras observaciones que of reciese la Astrono. mía. Por otra mano se emprendió levantar el pla. no del puerto, para cuya operación se midieron dos bases, la una de I .83o piés ingleses en la pla. ya grande al Este del Islote del Obispo, y la otra de 588 inmediata á la población y á la popa de la corbeta. Las sondas verificadas en el número posible, se prefirieron aquellàs más importantes, siéndolo la del canal formado por la Roqueta y la tierra firme, y la del bajo falsamente supuesto en nuestros planos cerca de la Punta del Grifo, en donde se hallaron nueve brazas de agua.

La ejecución completa de todas estas aten. ciones debía considerarse como segura y breve si u i suceso acaecido la noche del 8 no hubiese querido malograr mis deseos. A las oche de la noche, cuando con la Oficialidad me iba á embarcar en el muelle, hallamos que toda la esquifación del bote, excepto el patrón, le habían aban. donado. A pocas diligencias practicadas á bordo, averigüé haber desertado toda esta gente, á pe. sar de ser de la de más confianza. Comisioné al punto á los Oficiales D. Juan Concha y D. Francisco Viana con el sargento y cinco soldados para que imponiendo del hecho al Subdelegado, tomasen de acuerdo las medidas más prontas que dictasen su actividad $\mathrm{y}$ las circunstancias. Estc Jefe facilitó á dichos Oficiales tropa escogida de la guarnición muy práctica del pueblo y caminos, y registrando primero las casas sospechosas contestaron la fuga de dichos individuos al principio de la noche. Con estas noticias, se formaron dos divisiones, dirigiéndose á los caminos de Méjico y Coyuca, únicos por donde podían haber salido; siguieron sus respectivas direcciones toda la noche haciendo diligencias grandes á ca. ballo, pero con el sentimiento de haber sido infructuosas. Sin embargo, haciendo especial encargo á las Justicias para prenderlos, también á los pueblos de su jurisdicción hicieron saber la recompensa pecuniaria que obtendrían como los cogiesen, según yo lo había prometido. Nuestros Oticiales fundaban tanto sus esperanzas en este recurso por informe de las propias justicias, que cuando resesaron, ya vieron cuadrillas de indios lanceros apostadas cautelosamente, y no dudaban de su celo lograsen resultas tan felices como podían esperarse de medidas las más oportunas.

Eis la mañana del 9 recihí contestación del Virey, incluyéndome pliegos de la Corte llegados 
Yeb." últimamente á aquella capital, y manifestándome no ser tan fácil la pronta reunión de los Oficiales Espinosa y Cevallos como yo lo deseaba, si acaso no dilatase yo de algunos días la salida. Como al mismo tiempo me advertía el haber anticipado sus órdenes preventivas al Comandante de San Blas para el acopio de nuestros aprestos; $y$ por otra parte, miraba de tanta importancia la aprehensión de los desertores, no pude dudar en la resolución de detenerme ni de manifestársela para que también se sirviese estrechar sus providencias para conseguir el coger los desertores, cuya falta, así por el número como por su suficiencia marinera, me era de notable importancia para la campaña venidera.

Se conoció muy breve la falta que nos hacían tan buenos marineros, entre los cuales se hallaba el gaviero mayor, pues las faenas ocurridas por la noche la justificaron. A las dicz principió á relampaguear por el cuarto cuadrante con truenos bastante frecuentes. Apunt 6 después el viento al Este, y dando una fuerte fugada cambió con violencia al Noroeste aturbonado, ráfagas muy fuertes y mucha agua. No tomé hasta aquí precaución alguna atendiendo á la excelencia del puerto, y hallarnos justamente en el rigor de la estación más benigna del año. La noche se puso del peor semblante, haciéndola más horrorosa la repetición de truenos y relámpagos, que causaban un estrépito espantoso entre las montañas elevadas que circundan este puerto. Pero se tomaron luégo las precauciones debidas de reforzar las amarras de tierra, en donde faltaron luégo dos de los calabrotes. Al Este se tendió el ancla de ba. bor, y de este modo se pudo resistir la fuerza del viento hasta las ocho de la mañana, en que el tiempı serenó enteramente.

Para el i 6 se consideraban ya evacuados todos los objetos que me había propuesto, y en disposición de dar la vela en el instante que llegaran nuestros Oficiales de Mijjico. No era poca satisfacción el verlos verificados, y agregar á ella la de haber conducido hoy presos los nueve marineros desertores, por varios individuos de las justicias que los cogieron á zo leguas de esta población; á quienes como también á los indios Hecheros que los custodiaban, se satisfizo á presencia del Subdclegado los gastos de conducción y gratificaciones of recidas por este servicio, cargándoselos en sus asientos respectivos.

Se ha hecho relación prolija de este suceso para que en lo sucesivn pueda servir de gobierno á otros buques de $\mathrm{S}$. M. que frecuenten este puerto, por si acaso tomando iguales medidas corresponien con el mismo fruto.

La suma claridad de las rguas en este surgidero nos ha proporcionado hacer una observación importante, aunque contraria á la del Capitán Cook. Esste navegante supone que el forro de cobre en las embarcaciones impide que se arrime el pescado, fundándose en que el cardenillo sea un veneno activo que le mate, en cuya opinión se apoyó para proponer al Almirantazgo el forro de madera á los buques de su último viaje, como medio de facilitar la pesca, y un alivio $\tan$ considerable en semejantes expedicio. nes. Nosotros, aquí, después de repetidas experiencias, podemos con seguridad oponernos á la opinión de aquel ilustre navegante. Muchos días liemos notado, que acudiendo el pescado con abundancia á las conchuelillas pegadas á las planchas de cobre, se detenían en ellas para arrancar algun alimento que encontraban, probándose así que léjos de serle nocivo, le era muy sabroso y agradable.

Por el resultado de nuestras observaciones de esta ciudad nombrada de los Reyes, queda determinada su situación astronómica, referida á la casa del Gobernador en donde se colocó el observatorio, como se expresa.

Latitud observada por estrellas al Norte $\mathrm{y}$ al Sur del zénit. . . . . . . N Longitud observada de confianza por el primer satélite de Júpiter en la noche del $\mathrm{r} 8$ de Febrero por D. Juan

Concha, occidental de París.. . . . .

Longitud por el promedio de 48 séries de distancias lunares observadas el día r 2. . . . . . . . . . 102.22 .00

Deducción de la longitud por los relojes marinos.

Diferencia al tiem.

po medio por

las alturas co-

rrespondie ntes

el día 3 de lie.

brero. ...... $2^{\mathrm{h}} 42^{\prime} 43^{\prime \prime} 2 \mathrm{O}^{\prime \prime \prime}$ oh $32^{\prime} 3 \mathrm{I}^{\prime \prime} 4 \mathrm{O}^{\prime \prime \prime}$

Por sus diarios a

Panamá. ... .

Diferencia de me-

ridianoscon $\mathrm{Pa}$ -

namá .....

Longitud Oeste de

Panamá.. . .

Panamá al Oeste

de París.... $8 x^{0} 53^{\prime} 45^{\prime \prime}$

$81^{\circ} 53^{\prime} 45^{\prime \prime} \quad 81^{\circ} 53^{\prime} 45^{\prime \prime}$

Longitud de Aca.

pulco occiden-

pulco occider

I. a variación de la aguja por el teodolito resultó de $7^{\circ}$ I $2^{\prime}$ Nordeste.

Renunciando ya la esperanza de reunirnos aquí con la corbeta Descumierta, dejé en poder del Subdelegado un cajón con los pliegus de la Córte, planos y documentos relativos á nuestras operaciones desde la separación, rotulado á Don Alejandro Malaspina, para que á su arribo se le 
Feb, th entregase inmediatamente. También dejábamos otro cajón de aves disecadas y preparadas por la diligencia recomendable del Cirujano D. Pedro González, para que Malaspina, si lo hallase por conveniente, pudiese determinar su remesa por Veracruz á España.

Tuve yo noticia la tarde del 24 , que !os Oficiales Espinosa y Cevallos debían llegar ten.prano en la mañana siguiente, con cuyo antecedente me dispuse á dar la vela en aquel instante. En efecto, nos hallábamos con las gavias ensunchadas é izadas cuando llegaron, pero advirtiéndome que su equipaje no estaría aquí hasta la mañana siguiente por lo malo de los caminos, cuya propia causa había también dilatado su llegada, tuve que suspender la salida, cortando torla comunicación con la tierra á fin de evitar nue va deserción en los últimos momentos que tanto favorecen á los que la intentan sabiendo también la imposibilidad de perseguirlos.

\section{Salida de Acapulco y navegación hasta San 'slas.}

Apenas llegó el equipaje de dichos Oficiales por la mañana, y apuntó la brisa, dimos la vela con todo aparejo atracando la punta del Grifo, en donde escaseando el Sudoeste obligué á se. guir el bordo sobre la de la Bruja y á costa de otros dos repiquetes conseguimos estar fuera de puntas al medio día; á esta hora, por marcaciones á la punta de la Bruja al Norte $26^{\circ}$ Este, la del Grifo al Norte $4^{\circ}$ Oeste, y el farallón del Obispo al Norte $5^{\circ}$ Este, resul tó la latitud Norte de $16^{\circ} 48^{\prime}$ y longitud occidental de Cádiz de $93^{\circ}$ y $43^{\prime}$.

Siguióse la vuelta del Sur con viento fres. quito del Oesudoeste, conduciéndonos este rumbo al ponerse el Sol á 6 ó 7 leguas de la costa. No podíamos esperar mutación muy favorable en los vientos, pues por noticias adquiridas en Acapulco, nuestra ravegación á San Blas, debi’ndo hacerse con vientos constantes del $4 .^{\circ}$ cuadral: ${ }^{4} \mathrm{c}$ debía ser por precisión bien larga. Sobre esta causa se agregaba la de las grandes diferencias hacia el segundo cuadrante, causas que producen atrasos en este viaje aunque sea corto en razón á la distancia. Por esto la derrota ordina. ria que se hace, es separarse de la costa, buscando fuera de ella las variaciones favorables de vientos.

Habían conducido los Oficiales Espinosa y Cevallos dos relojes pequeños que dejamos en el Observatorio Real de Cádiz, pertenecientes á los dos cronómetros que traen las corbetas, los cuales se pusieron desde luego en movimiento. Estas máquinas, fabricadas igualmente por $\mathrm{Ar}$ nold, tienen los números 344 y $35 \mathrm{I}$.

Los vientos desde aquí entre el Oestenn: oeste y Oeste con poca fuerza, nos produjeron sacrificios considerables en la latitud y longitud: Fel. 26 á medida que fuimos saliendo para el Oeste fue. ron inclinándose paulatinamente hacia el Norte, pero con las diferencias al Sur constantes y no pequeñas, aumentaban el atraso de la derrota: nuestra situación el 4 de Marzo era bien desven. Mar. tajosa estando en latitud Norte de $13^{\circ} 5^{\prime}$ y en longitud de $95^{\circ}+6^{\prime}$, observando la variación Nordeste de $7^{\circ}$.

Todavía hasta el 7 tuimos perdiendo en latitud, pues sin embargo de que los vientos ha. bían tomado un giro algo más favorable llegando á veces hastit el Nornordeste, como las diferencias al Sur eran grandes, no pudimos excusarnos de bajar hoy hasta la latitud de $13^{\circ} 4 \mathrm{I}^{\prime}$ Norte, en longitud de $97^{\circ} 26^{\prime}$, desde cuyo punto ya empezamos á sentir menores diferencias y también á lograr otros progresos para el Norte. Los vientos tomaron asímismo más fuerza y esta circunstancia con la constante fuerza de vela dis-minuía el abatimicnto, y los efectos de las corrientes, ya en este paraje eran bien poco sensibles.

Las observaciones del día i I nos manifestaron la latitud Norte de $\mathrm{I}^{\circ} 4^{\circ} \mathrm{I}^{\prime}$, y longitud de $99^{\circ} \mathrm{I} 2^{\prime}$, por las cuales, y otros indicios como abundancia de pájaros, algunos chubascos y ramas de árboles, nos indicaban la cercanía de la Isla de Posesión. Esto nos hizo navegar con vigilancia todo el dia siguiente por si algún error presumible en su situación podía hacer que la avistásemos.

En los dias I 5 y I 6 notamos una constante 15 y 16 variedad eı los vientos, pero sin salir del primer cuadrante. Fsta alteración, ó nuestros deseos, nos daban csperanzas de que liegásemos breve á encontrar los vientos del Oeste $\mathrm{y}$ Noroeste, para tomar luégo la otra vielta. Nos considerábamos al medio día del hoy $\mathrm{I} i$, como soo leguas dis. tantes de la costa, y á esta causa atribuírmos el ningún efecto ya de las corrientes para el Sur y también tal vez á hallarnos al Oeste del meridiano del mar de Cortes, cuyo desagüe derramándose en su misma dirección, producirá alguna corriente, cuya conjetura podremos quizá comprobarla si experimentamos sus efectos sobre las Islas Marias.

Desde la media noche ¿î el viento alguias llamadas del Norte al Nornmoeste, pero con tan pora subsistencia, que no permitio seguir la otra vuelta. A la mañana se temó la del Nordeste un costo intervalo favorable, llegando al medio día á la latitud de $I 7^{\circ} 34^{\prime}$, y lnngitud de $105^{\circ} 46^{\prime}$ Oeste. Notóse en esta última una grande diferencia con la de estima en ' $\mathrm{I}^{\circ} 09^{\prime}$ para el Oeste. También bubo $12^{\prime}$ de diferencia al Sur: no olistante, como al día siguiente no encontramos alguna en la longitud, puede suponerse que aquella tan considerable dimanase de almin error en 
Mar. 8 las alturas, ó al contar en el reloj al tiempo de tomarlas.

Por las comparaciones de los relojes resultó haber alterado su movimiento el número so en $3^{\prime \prime}$ con el ro5, diferencia que no se atribuiría á defecto de aquella sobres aliente máquina, á no repetirla los otros dos relojes de Arnold, cuya uniformidad de movimiento entre sí desde España habían dado muy buenas longitudes. El temperamento había alterado muy sensiblemen. te, $y$ desde luego esta repentina mutación puede haber causado en el númcro io aquella novedad.

Sin embargo, en las comparaciones del día siguiente volvió á uniformar su movimiento con los relojes 105 y 344 .

Los días 21 y 22 estuvo el tiempo cubierto, y á veces achubascado ó garuando, lo cual ocasionaba variaciones de vientos con las que se tomaba la vutlta que granjease más para el Es. te. Estos aparatos parecían anunciarnos la próxima mutación de viento favorable, pero no tuvieron lugar estos deseos hasta pasada la media noche del 24 , en que aclarando, roló el viento al Nornoroeste y Norte bien fresco al amanecer, prometiéndonos por todas las bellas apariencias con que se entribló la seguridad de su constancia y el pronto arriio al puerto deseado. Estábamos al medio día por la latitud observada en $22^{\circ}$ or'; $y$ en longitud de $108^{\circ} 34^{\prime}$ Oeste hallando la variación por amplitud occídua de $7^{\circ}$ Nordeste.

La Carta española que nos guiaba difería en $\mathrm{I}^{\circ}$ en la longitud entre la bahía de San José y el puerto de San Blas de la que señalaba un planito remitido por D. Francisco Maurelle, 'Teniente de navío de la Real Armada, residente en Méjico. Pero la longitud que resulta de San Blas según la distancia estimada de 6o leguas entre ambos puntos, y la diferencia en latitud, es de I $00^{\circ} 3 \mathrm{O}^{\prime}$ occidental de Cádiz. Wl Abate monsieur Chappe, comisionado por la corte de Francia í observar el paso de Venus acaecido el 3 de Junio de 1769 , á cuya comisión le acompañaron los Oficiales de la Armada D. Vicente Doz y D. Salvador de Medina, establece la longitud de San José por la observación de Doz en I $2^{\circ} 2^{\prime} 30^{\prime \prime}$ occidental de París, ó en el mismo sentido de Cádiz de $103^{\circ} 26^{\prime} 30^{\prime \prime}$ y la latitud de $23^{\circ} 3^{\prime} 30^{\prime \prime}$ Norte. El citado Chappe es quien pone la distancia estimada de las 60 leguas, bien que las contrariedades que sufrió para navegarlas, por corrientes, calmas, etcétera, clan motivo suficiente para creer algún error en su cálculo y conceder la preferencia á la estima de Maurelle no habiendo tenido aquellos obstáculos.

No nos abandonó después el tieinpo favorable del Norte, y Nornoroeste ni sus bellas apa. riencias, de modo que al medio día del $27 \mathrm{con}$ tamos la longitud de $\mathrm{ro3}^{\circ}$ I $5^{\prime}$ Oeste, por latitud de $21^{\circ} 30^{\prime}$ Norte, considerándonos como 50 le- Mar. guas de las Islas Marias, demorando la del centro al Este correg:do, cuyo rumbo es el que seguimos desde haber liegado á su paralelo. Esta longitud, indicada por los relojes, tuvimos en esta mañana ocasión de comprobarla por 36 se. ries de distancias lunares, cuyos. resultados sblo diferenciaban en $8^{\prime}$ al Este del reloj.

La suma confianza que teníamos en estas observaciones nos persuadía la exactitud de nues. tra verdadera posición. Así, aunque el viento continuase fresco, seguimos toda la noche con fuerza de vela en vuelta de las islas, pudiendo distar de ellas al medio día siguiente como ocho leguas por una Carta reducida que teníamos; pero por el plano de Maurelle, ya estábamos al Este de ellas; sin embargo, no era de creer error considerable en su longitud considerando estuviese referida á las observaciones ejecutadas por Don Vicente Doz en el Cabo de San Lucas, y creo también en San Blas.

Efectivamente, ála una de la táde, estando en latitua al medio día de $2 \mathrm{I}^{\circ} 25^{\prime}$ y longitud de $100^{\circ} 25^{\prime}$ se avistaron desde los topes las islas demorando por la proa. Tardamos poco en atra carlas y barajándolas á distancia de dos leguas, nos dirigimos á pasar por el Sur de ellas. Estas islas corren Noroeste-Sueste, son muy limpias, la más Norte tiene dos puntas bajas y un islotillo en la del Noroeste, pero carecen de puertos. Por noticias que tenemos abundan de varias y excelentes maderas, con especialidad de guayacan que se conduce á San Blas para los usos del Departamento; se coge buen carei y se hace una bebida de la corteza de cierto árbol, cuyo uso está prohibido.

De las longitudes observadas á las diez horas y reinte minutos de la mañana por el número ro llevadas con la estima hasta la hora de avistarse la isla más Norte estimando la distancia de ella de seis leguas, se deduin la longitud de ella de $100^{\circ} 30^{\prime}$ occidental du Cádiz que diferenciaba en $\eta^{\prime}$ de la que indicaba la Carta es. pañola, y $\mathrm{I}^{\circ}$ al Este de la de Maurelle. No será esta la situación que establezcamos á estas islas porque sólo hago mención para indicar aquellos errores, respecto á que en San Blas deduciremos con toda exactitud la referida situación después de averiguar el movimiento del número Io, cuya marcha no fuera extraño haberse alterado después de cuarenta días que se cerró en Acapulco su diario.

Con rumbo del Estesueste íbamos á atracar la isla más Sur de la cual al anochecer por tres marcaciones hcchas á las dos del Norte, señalaban la distancia á ella de diez leguas. El poco viento 6 calmas desde la media noche no dió lugar á rebasarlas todavía a! amanecer, teniéndola á esta liora por el través á cuatro millas. Ciñose 
Mar. 29 luégo el viento fresquito del Nordeste en demanda del puerto, y cuando el Sol tuvo una competente altura, se convino estar próximos al meridiano de la isla, para correr bases en estas circunstancias y observar longitudes. Por las referidas al medio día por los relojes, llegamos á la de $99^{\circ}$ $32^{\prime}$ Oeste, y latitud observada de $21^{\circ}$ I $3^{\prime}$ Norte; teniendo de variación por amplitud ortiva $7^{\circ}$ Nordeste. A este tiempo demoraba lo más Norte de la isla, más Sur al Norte $75^{\circ}$ Oeste, y el islotillo que tiene á la parte del Sur, al Norte $87^{\prime} 30^{\prime}$ Oeste.

A la una de la tarde se descubrió la costa de San Blas y notablemente el monte de San Juan por la proa, cuya elevación y figura formando dos cerros redondos en la cúspide, puede servir de marca muy segura para buscar el puerto. Perdíamos las esperanzas de alcanzarle hoy por haber entrado tarde la brisa del Noroeste, y sólo al ponerse el Sol pudo verse poco á barlovento el islote de piedra blanca, el cual dista del puerto como seis leguas.

Seguimos en demanda de él hasta las diez de la noche que calmó la brisa, sondando entonces 26 brazas lama. Por la mañanita conocimos el efecto de las aguas para el Sur, y así declarándo. se la brisa á las ocho por el cuarto cuadrante (que sopla aquí desde Noviembre á Mayo) se orzó al Noreste. En este paraje suele fondearse con bonanzas por no caer á sotavento del puerto, y más siendo en la estación benigna en que estamos, cuya maniobra hubiera yo ejecutado al contar ménos en la diligencia del buque, y á querer evitar este trabajo á la gente, y á los cables que tanto padecen en esta faena.

A las diez y media marcábamos la segunda piedra blanca situada cerca de la entrada de San Blas, cuya figura representa una embarcación á la vela, al Nortc $72^{\circ}$ Este, por cuyo rumbo nos dirigíamos al fondeadero con todo aparejo. Después del medio día se divisaban ya las banderas del Rey en el fuerte de la entrada y en la altura de la población donde se halla la Contaduría del Departamento, cuyo edificio representa una fortaleza. Poco después llegó á bordo el Secretario del Comandante el Capitán de navío D. Juan Francisco de la Cuadra, quien me informó la llarse en el pueblo de Tepique, pero que llesuría Il día siguiente.

Cerca ya de la segunda piedra Hanca navegamos sobre las gavias por foncin de srete, seis y media $r$ seis brazas lama, y rebasula se dió fundo al ancte de babor en cines y media la mis ma calidad, y seguidamente se tendió la ntra al Este, quedando de este modo en las marcaciones del asta de bandera del fuerte de la entrada al Norte $7^{\circ}$ Este, la que está en la Contaduría al Norte 46 Este, y el Cerro de San Juan al Sur $8 I^{\circ}$ Este.
Estada en San Blas y aprestos para la ejecución de la campaña al Norte, consecuente a lis riltimas órdenes de $S . M$. recibidas en este puerto.

En la mañana siguiente llegó de Tepique el Al. ${ }^{\circ}$ Comandante Cuadra, y me manifestó el particular interés que tomaría en contribuir con sus providencias eficaces en que nos aprestásemos con todos los auxilios que exigiese el éxito feliz de nuestra comisión. Y á este efecto se halla ba con órdenes anticipadas y amplias del Virey, para que nada faltase al desempeño cabal de un ob. ieto tan importante $y$ recomendado muy espe. cialmente por S. M.

No bien se habían concluído las faemas marineras, cuando se $\epsilon$ mpezaron todos aquellos reparos para el aparejo y velamen en que podía ocuparse la marinería sin auxilio del arsenal. Con igual celeridad se dió principio por la maestran. za á la recorrida de costados y trancaniles, limi. tándose estas obras sólo á lo muy preciso para reducir los gastos grandes que aquí causan, y contando con que en la invernada en Manila se compietarian con notable economía. Las em. barcaciones menores fué también preciso enviarlas á carenar al Arsenal por los territles extragos que había hecho la brona en sus fondos, y una lancha nueva que estaba ya principiada, fué también necesario aıımentarle su capacidad y resistencia, sin cuyas circunstancias no podría desempeñar los objetos á que debía destinarse.

Por el correo del 5 recibí pliegos de Su Majestad para D. Alejândro Malaspina, previ. niéndole expresamente la verificación de la cam. paña al Norte con el fin de decerminar la falsa ó verdadera existencia del estreclro 6 paso de comunicación entre el mar Pacifico y el Atlántico. A este efecto sse acompañaba una Memoria pu. blicada en Francia por $\mathrm{M}_{2}$. Bauche, miembro de la Academia de Ciencias, leída en aquella sabia Asamblea el I $3_{3}$ de Noviembre del año próximo pasado, en la cual se trata de probar como cierto el referido estrecho, fundándose sobre la autoridad de un viaje por el naxegante español Lorenzo Ferrer de Maldonado

Ignoraba yo el paradere de Malaspina, y su retardo cn llegar á Acapulco siendo considerable, me hacía recelar algún colitratiempo en su navegación, pues según aviso del Virey con fecha de 27 le Marzo todavía no había entrado en Acapulco, siendo así que según me indicaba en su instruccion contaba para el zo de Febrero coger aquel puerto. Parreción indipensable, no obstante, dirigirle por excraordinarse á Néjico las últimas órdenes de S. M., suplicando al Virey las trasladase á sus manos en el instante de saber su arribada sobre cualewaiera puertn de la costa. 
Ab. 5 Yo consideraba ya muy contingente el reunimos, por lo tanto juzgué preciso avisar á Malaspina el plan de la derrota que me proponia ejecutar para cumplir las órdenes recientes de S. M., en el caso de que las suyas para el 24 del corriente no me previniesen el alterarle.

Era, pues, mi ánimo hacer navegación directa a la altura de $60^{\circ}$, atracar la costa y reconocerla al Norte y al Sur del monte de San lilias, en donde la citada Memoria supone el cuestionable paso, buscándole por las señas que advierte en la entrada de esta parte; si no le hallaba, como parecía lo más probable, pensaba dirigirme para el Sur á reconocer los trozos de costa sin trazar se hasta aquí por navegantes nacionales ó extranjeros. Después entraría en Nutka y Monterey, si la estación lo permitiese, y rectificando las Cartas del Continente de la América ó corrigiéndolas de los errores que incluyen los métodos cmpleados en semejantes operacic zes por la falta de relojes, regresaría luégo á Acapulco en Octubre 6 Noviembre de este año.

$\mathrm{Al}$ mismo tiempo que con fecha de hoy participaba al Excmo. Sr. Ministro de Marina todas estas medidas como cons zcuentes á haberme enterado de las últimas órdenes de S. M., le avisaba la llegada también del péndulo simple destinado por S. M. á esta expredición para que en el dis. curso de ella se repitiesen las observaciones con arreglo á la reducirón instrucción que acompañaba el Capitán de fragata D. José de Mendoza, que lo remite desde París. Se reducen éstas á comparar el movimiento del péndulo con el tiempo medio para determinar así las distintas relaciones de la gravedad, y deducir por ellas una medida universal y la verdadera figura de la tierra.

Habiase colocado el observatorjo en la plaza de la iglesiá para el arreglo de los relojes, y ejecutar las observaciones c'elestes que ocurriesen, en cuya inmediación se tomó una casa para alojar a los (Oriciales encargados de este ramo, pues la gran distancia á que se hallaba el buque de la población, hacía indispensable esta providencia para asegurar aquellos objetos. Con el propio empeño se principió á levantar el plano del puerto, $y$ este cúmulo de atenciones para evacuarlas con la brevedad á que estrechaba el tiempo, no dejaba de hacerme recelar en un país tan mal sano el que la gente enfermase.

Por la mañana del $\mathrm{r}$, recibí aviso de Don Alejandro Malaspina de haber llegado el 27 de Marzo á Acapulco, después de 57 días de una cansada naregación desde Realejo, en la que por calmas y corrientes no le había sido posible situar la costa intermedia desde que dejaron los rolcanes de Guatenala; $y$ atendiendo á las circunstancias que nos rodeaban y á las tareas de nuestros navegantes españoles, y de los señores Cook, La Perouse y llixon, sobre las costas sep- tentrionales de la California, determinaba dirin $\mathbf{A k}$, girse á las Islas de Sandwich, y recorriéndolas en lo restante del verano, regresar por Octubre á Acapulco, atravesando después á ias Filipinas. Como para la ejecución de este plan me recomendaba la mayor diligencia en trasferirme á aquel puerto, yo, descle el instante, estreché mis providencias para dar la vela pasado mañana, avisáncloselo así por extraordinario que salió inmediatamente. A la sazón teníamos la aguada y leña completa, habiendo hecho también I 60 quintales de lastre para reemplazar los pesos muy disminuídos desde la salida de Cádiz, cuya falta en latitudes altas perjudicaría á la resistencia y buenas propiedades del buque, justamente en oca. sión en que eran más precisas ambas circunstancias.

Habíamos concluido á la sazón así las observaciones que determinaban la situación exacta de San Blas, como el plano del puerto con tuna línea de sonda desde la rada ó para je donde se hallaba la corbeta hasta la entrada al rumbo del Sursudoeste por fondo de $36,35,26$ y 18 piés siem. pre fango. Esta calidad disminuye en parte la poca seguridad del fondeadero de la rada, con especialidad en los meses de Julio, Agosto y Setiembre por los vientos reinantes del Sur y Sudeste que soplan con fuerza y frecuentemente traen turbonadas. Son pocas las embarcaciones que pueden entrar en el puepto por el poco fondo de la entrada, y para evitar la detención de alijar, fondean como á cuatro ó cinco cables del islote pequeño que está á la entrada y á tres de la punta Sudoeste de la misma. Sobre ésta se halla una batería, y se extiende para el Este de ella un arrecife de piedra como de 80 toesas, en cuyo extremo empiezan las valizas indicando el paso estrecho que conduce al interior del Arsenal. El fondo en pleamar (que sucede en novilunio y plenilunio á las ocho y media de la mañana) entre las prime. ras es de 16, I $_{5}$ y 14 piés; continúa así hasta cerca de la chata gue bajá á nueve y ocho; en la bajamar disminuye de tres á cuatro piés el fondo, $y$ éste es variable á uno y otro lado de las valizas, á causa de los cantiles ó placeres formados por el rio de Santiago que desagua por esta parte.

Todo el día siguiente se empleó en recibir del arsenal los efectos para entrambas corbetas como eran clavazón, madera, brea, la pipería compuesta y nueva, 220 quintales de pan y i 50 arrobas de tocino. La lancha nueva, como también el observatorio, equipajes y los útiles de tonelero y herrero, quedaron también á bordo, de modo, que al anochecer nada faltaba para efectuar la salida desde que apuntase el terral.

Por nuestras observaciones, habiamos establevido la posición astronómica de San Blas referida al paraje del observatorio en la forma sigurente: 
ba diri- Ah. s

lolas en

tubre á

lipinas.

ecomen-

á aqquel

nis pro-

na, avi-

ió inme-

la y leña

uintales

dismi.

lta en la-

a y bue-

en oca-

circuns.

as obser-

n exacta

con una

de se ha-

o del Sur-

iés siem-

rte la po.

con espe-

S Setiem-

Sudeste

nte traen

ones que

fondo de

de alijar,

del islote

e la punta

la una ba-

un arre-

o extremo

estrecho

fondo en

nilunio á

as prime-

asta cerca

$n$ la baja-

fondo, $y$

s valizas,

nados por

$\imath$ parte.

ecibir del

tas como

ría com-

I5o arro-

ambién el

tonelero

de modo,

ectuar la

nos esta-

San Blas

la forma
Ab. " l.ongitud de San Blas deducida por la emersión del primer satélite de Júpiter en 7 de Abril de 3 I occidental do Parrs. ...

Cádiz al O. de París. . . . . . .

I,ongitud de San Blas occidental de Cádiz.. . . . . . . . . .

l.ongitud de San Blas por el número to occidental de Aca. pulco. . . . . . . . . . . Acapulco al O. de Cádiz. . . . . . longitud de San Blas por il 10 occidental de Cádiz. . . . . . .

I.atitud observada en San Blas por estrellas al Norte y al Sur de Zenit. . . . . . . . . . N.

Variación de la aguja por el pro. medio de seis azimutes obser. vados a bordo por dos observadores. . . . . . . . . . . N. E. $9^{\circ} 26^{\prime} 00^{\prime \prime}$

Descripeión del departamento de San Blas, origen de su establecimicnto, $y$ ventajas que of receria trasladado á Acapulco.

La villa de San Blas se halla situada á un cuarto de legua del Arsenal, á la falda de una eminencia que presenta su cara á la brisa, por lo general reinante desde las $\operatorname{die} z$ de la mañana hasta las seis de la tarde. El terral la sustituye á pocas horas, pero la situación local impide gozar de este beneficio tan saludable en estos climas calurosos. La población, reducida á muy pocos regulares edificios, se compone de chozas cubiertas de paja, presentando aquella vista po bre y miserable de un pueblo situado en un clima insano, habitado sólo por la necesidad ó por las ventajas que su conservación produce á los intereses del Estado. Algunas casas de particulares, y uno ú otro edificio del Rey, están hechos cor alguna solidez, pero en !a estrechez de las primeras no se ha combinado la capacidad que piden las habitacione, entre trópicos. El terreno de las calles desigual y pedregoso, hace su tránsito bastante incómodo. El temperamento de San Blas, por naturaleza enfermo, lo es excesivamente en la estación lluviosa de Mayo, Junio, Julio y Agosto. Por estas y otras causas locales que re. feriremos, los naturales tienen una languidez y tristeza en sus semblantes, que las justifican tanto como la necesidad de abandonar el pueblo por aquél tiempo en que tanto aflijen las enfermedades agudas. Así no puede fijarse el número de sus habitantes como tampoco la multiplicación de la especie humana puede tener aquí aquel aumento proporcionado á su número, ruando tantas circunstancias lo embarazan. Podrá as cender la población en tiempo ménos mal sanóa 4.500 almas, y á la mitad de este número cuando la abandonan trasladándose á Tepique.

Para que así este pueblo como el Arsenal sean poco sanos, concurren causas físicas que existirán Ah, , mientras existar ambos establecimientos, y por consiguiente habrá de sufrir sus perniciosas consecuencias. Hállanse uno y otro rodeados de esteros ó pantanos, cuyas aguas y las llovedizas que los forman, comunicándose con las marinas, producen la putrefacción destructora terrible de la humanidad. Unese á estas causas una plaga casi contínua de mosquitos conocidos aquí con el nombre de gegenes ó perjuicios. Divídense en dos clases, unos son pequeños, de tamaño poco mayor de una pulga, y otros mayores que se distinguen cen el nombre de zancudos. Una y otra espacie de insectos tienen una actividad singular ell la picada, y molestan especialmente en las conjunciones y oposiciones de un modo inexplicable. Si este es un motivo tan poco agradable para habitar en la población $y$ en el Arsenal, puede inferirse cuanto debe au. mentarse á los operarios de este sitio, en donde el terreno más bajo y ménos ventilado hace in. sufrible su residencia, causando atrasos muy grandes en las obras que allí se ejecutan.

Fué el objeto de formar aquí este Arsenal el de resguardar y de extender los reconocimientos de la costa Noroeste de este continente y facilitar el socorro de los presidios de Monterey, San Diego, Loreto, etc. Esta idea, protegida por el Excmo. señor Marqués de Sono:a, desde la visita general que hizo en este Reino el año de $\tau>69$, empezó á formalizarse en el inmediato, destinándose un constructor y alguna maestranza para la fábrica de las pequeñas embarcacio. nes con que se abrío este establecimiento. Lo enfermo del paraje y la mayor abundancia de mosquitos obligó á abandonarle cl año de .73 y fijar la residencia en donde hoy se halla la vi lla; en el de 74, se consideró precisa la forma. ción de un Departamento, destinando al efecto Oficiales de la Armada y Pilotos, los cuales, después de haber hecho algunos descubrimien. tos sobre estas costas septentrionales, se retira. ron los primeros en el de 83 . Por este tiempo, la Rusia habia emprendido sobre las mismas costas algunas expediciones, formando en las altas latitudes de ellas uno ú otro establecimiento para facilitar el comercio de la peletería. El examen de estos, ó el averiguar sus intenciones siendo un punto que llamaba la atención del Go. bierno, volvi6 á restablecerse el Departamento en 89 , nombrando S. M. por Comandante, al Capitán de navío D. Juan Francisco de la Cuadra, con sus Oficiales subalternos.

Las embarcaciones que actualmente pertenecen al Departamento, son tres fragatas como de 300 toneladas, un paquebot y una goleta. Estos buques se hallan en muy buenas condiciones, excepto Is fragata Concepción, por cuyo motivo se ha propuesto al Virey la construcción de 
A3. " otra del mismo tamaño, la cual podrá estar de. tenida por el excesivo costo de 120.000 pesos en que se ha presupuestado su valor. Yo creo sería preferente que así ésta como otras embarcaciones que hayan de emplearse en estos mares fueran construidas en España bajo otros principios ó conocimientos para desempeñal los objetos á que se destinen, y economizando sumas inmensas que aquuí se sacrifican. No en vano asciende á una tan considerable de 374.488 pesos fuertes los gastos del Departamento, debiéndose á su celo cl haberlos disminuido con árbitros que ha meditado hasta 50.000 pesos anuales el citado Comandante.

Se han hecho ver ya los inconvenientes que of rece el liallarse en este puerto cl Departamen. to, pero todavía resta otro mucho más grave. En la relación del diario se ve la imposibilidad de entrar dentro del puerto las embarcaciones que calen $\mathrm{I} 4$ piés, $\mathrm{y}$ áun éstas no pueden ejecutarlo sin la molesta y á veces arriesgada maniobra de alijar. La capacidad del puerto no ofrece tampoco toda la que necesita un Arsenal, por muy reducido que sea, y tan solo estas dos causas pudieran convencer de la necesidad de trasladarle á paraje más conveniente y seguro. Este punto de tanta importancia al servicio de S. M., ha sido muy disputable hasta ahora, en que el actual Virey, tan celoso en su acierto, ha propuesto el traspaso del Departamento á Acapulco, precediendo varios informes y á mí me lo pidió también cuando regresé á dicho puerto.

Es cierto que no cabe comparación entre el puerto de Acapulco y el de San Blas, sin que para decidir las superiores ventajas de aquél sobre éste, se necesiten más conocimientos que el cotejo de sus planos respectivos. Acapulco ofrece la may or comodidad para formar el Departamento con la precaución que exigen los grandes intereses que abraza, facilita para celarlos la residencia en él de todos los Jefes, su inmediación á la capital y á Veracruz disminuye mucho el costo de la conducción de efectos, las fortificaciones grandes que tiene, y las que provisionalmente pueden formarse en tiempo de guerra para defender su entrada con el auxilio de la Marina, daría á este punto de la $\Lambda$ mérica todo aquel grado de seguridad que necesita para no temer un ataque por ninguna potencia marí tima que lo intente.

En cuanto al temperamento, es también preferente el de Acapulco, porque además de no tener su disposición local los inconvenientes que San Blas, también es fácil corregir los que tiene. La necesidad haria muy luego conocer la precisión de cegar una pequena laguna que hay á la salida del pueblo, así como éste sería necesario irlo extendiendo hacia la cañada, por donde viene la brisa, cuya providencia, y la de desmontar los alrededores aumentando la ven- Ab. : tilación, se disminuirá la humedad que aquí tanto ofende la salud pública.

Si con estas saludables diligencias no se alcanzase el objeto á que se dirigian, siempre hay aquí el recurso de mejorar de clima á muy corta distancia de la población. Ni aquéllas son asequibles en San Blas por la localidad del terreno, ni Tepique dista ménos de 12 leguas 6 más de aquel Departamento, cuando á las doce de Acapulco se experimenta la influencia de un tempe. rainento sano en todas las estaciones del año. Se deja, pues, conocer la utilidad que resultaría al servicio del Rey en este caso, residiendo los Jefes constantemente 6 en el mismo Arsenal, para inspirar con su presencia todo el celo $y$ actividad necesaria, 6 más próximos á él, y sólo la corta estación que afligen ahora las enfermedades. A pesar de estas ventajas tan palpables, el Comandante Cuadra me informó, cómo no fal. taban opiniones para disminuirlas, ó informes á la superioridad dando la preferencia á San Blas para Departamento. No podía Cuadra suscribirse á un dictámen tan difícil de apoyarse, ó de superar las razones de la opinión contraria, y así estábamos conformes en la misma, de que algún día había de triunfar de todas las dificultades ú obstáculos que encontrase. No obstante, expondremos aquí los fundamentos que apoyan el sentir de los primeros para dejar al público la facultad de decidir con acierto en la opinión de que se trata.

A dos puntos reducen el apoyo de su opinión; el primero hallarse San Blas más al Norte que Acapulco, y por consiguiente, en disposición más fácil de socorrer los presidios, debiendo ser más corta la navegación, lo mismo que la que se verifica todos los años á las exploraciones en las latitudes crecidas; y segundo, en la abundancia de maderas que tiene San Blas de las cuales suponen que carece $\Lambda$ capulco. Para juzgar del primer punto bastará saber que la derrota para entrambos objetos es siempre una misma, por razón de los vientos constantes desde uno y otro paraje, y que debiendo separarse siempre de la costa para buscar los del Oeste y Noroeste, no hay en este caso más diferencia en distancia que la diferencia corta en latitud entre ambos puertos (I), y esta se gana justamente en donde los vientos son favorables.

Lin cuanto á las maderas, no creo pueda pasar de una suposición fácil de probarse. Por lo ménos yo me he informudo de haberlas muy buenas no lejos de Acapulco, y cuando faltasen

(r) La navegación de las corbetas descle Acapulco habiendo atracado la costa en cincuenta y tres dias por los $56^{\circ}$ de latitud, podrá compararse a la que ejecutan los buques de San Blas, que rara vez pueden conseguirlo en ménos de sesenta días. 
1. en sus inmediaciones, no es un inconveniente que no pueda fácilmente remediarse. Supongamos no haya otro paraje de donde cortarlas más que en San Blas, en este caso, cuando las em. barcaciones regresen del Norte por Setiembre ú Octubre, pueden al paso cargarlas en San Blas sin dispendio ni riesgo alguno por el tiempo, y conducirlas á Acapulco.

Yo quisiera saber si estas dos objeciones que se oponen, áun cuando no pudieran satisfacerse, son capaces de compensar las ventajas referidas, ni cómo cabe á los que tengan las menores nociones de la facultad, el dejar de conocer las excelentes cualidades del puerto de Acapulco para formar un completo Departamento, de las cuales carece absolutamente cl de San Blas. Nadie podrá negar que la seguridad y capacidad de un puerto son las primeras $\mathbf{y}$ esenciales circunstancias que deben consultarse para establecer un Arsenal, y si á ellas se agregan otras particulares del clima, de la localidad del terre. no, facilidad de defensa, $y$ de poderse hacer un Departamento respetable, nadie tampoco podrá resistirse á conceder á Acapulco unas ventajas tan considerables que unidas se encuentran en muy pocos puertos del Globo.

Salida de San Blas; navegación en busca de unos bajos al Noroeste de Cabo Corricntes, y reunión a la Descubierta en Acapulco.

Desde las primeras horas de la noche se principió á levar las anclaș, y teniéndose al Oeste un anclote conducido del Arsenal para dar la vela sobre él, quedamos á las diez prontos á verificarlo en el momento de apuntar el terral. Fal. tando á la común experiencia, no se declaró hasta las dos de la madrugada, á cuya hora, largando el chicote dimos la vela con todo aparejo gobernando al Sudoeste $5^{\circ}$ Sur por fondo de ro, II, I6 y $3^{8}$ brazas lama hasta el medio día, distando solo al salir el Sol de tres á cuatro le. guas del fondeadero.

Siendo mi objeto acelerar la llegada á Acapulco, no era posible detenernos en trazar la costa aunque las circunstancias lo facilitasen; pero no causaría atraso notable el averiguar la existencia de unos bajos nuevos de arena y piedra que había encontrado el Capitán y Piloto del paquebot San Fuan Neponuceno, D. Máximo Domingo de Zeleta, según me informó en San Blas antes de su salida para Acapulco, conforme á sus noticias estaban al Noroeste de Cabo Corrientes, distancia de siete leguas. No dejá de sorprenderme el ver que semejantes bajos no existían en ninguna carta, ni en el Departamento había la menor noticia de ellos, que á la verdad era bien extraño estando tan inmediatos á él. Esta reflexión me hacía mirar con suma descon- fianza su existencia, á pesar de que para lacér - Ab. " mela creer Zeleta me aseguró había pasado en. tre ellos sondando 64 brazas; no obstante to. do, pensé dirigirme á buscar los bajos, y por si a]gún accidente me impedía el poderlo verificar, recomendé su reconocimiento al Comandante Cuadra para que por su parte hiciese iguales di. ligencias en aclarar decisivamente un punto de tanta importancia á esta navegación.

Desde el medio día en que labiamos observado la latitud de $2 \mathrm{r}^{\circ} \mathrm{I}^{\prime}$ Norte, y la longitud de $99^{\circ} \mathrm{IO} \mathrm{O}^{\prime}$, seguimos el rumbo constantemente por la tarde del Sudoeste $\%$, Sur con viento fres co del Noroeste al Norte, y '́uerza de vela para alcanzar el Cabo Corrientes ó sus inmediaciones, donde se suponían los nuevos bajos que buscába. mos. A las seis logró marcarse el referido cabo al Sur $52^{\circ}$ Este á distancia de siete á ocho leguas, pero ni en esta posición ni en toda la gran dis. tancia que se descubría con un horizonte de los más hermosos, pudo advertirse la menor señal que indicase los referidos bajos. Después de este examen tan prolijo, puede muy bien concluirse su inexistencia y condenarse como ligereza re. prensible á quien forja semejantes noticias. Yo me inclino á creer que el Capitán Zeleta equivoci tal vez el paso que ejecutó entre las Islas Marias con el que se le figuró entre los supuestos bajos. La distancia que estimó de uno á otro, el fondo hallado en el canal y la calima que suele cubrir aquellas islas representándolas muy bajas, han sido las razones en que he fundado este concepto.

Convencidos á las seis de la tarde de no descubrirse nada, arribamos al Sur con intención de llevar la costa á la vista hasta Acapulco. El tiempo siguió hermoso y el viento también fresco toda la noche, arreciando más al ponerse la Luna.

Los dos días siguientes no tuvimos la brisa ni tan fresca ni tan constante; hubo vientos thojos del Este y Sursueste, circunstancias que nos habían hecho alejar de la costa, la cual pudimos tener inmediata por la tarde del día siguiente, 14 y 15 pero el poco viento ó ventolinas variables no permitían mediana exactitud en las operaciones que emprendiésemos para colocar uno ú otro punto notable de la costa.

Llegamos al medio día del r 7 á la latitud de $18^{\circ} 7^{\prime}$ Norte y á la longitud de $97^{\circ} 05^{\prime}$ desde cuya hora, tesando la virazón principiamos algunas bases que se siguieron con fuerza de vela en cuanto no atrasaban nuestro viaje. Entre otros puntos notables que teníamos á la vista, era uno el de las Tetas sin nombre que equivocó el $\mathrm{Al}$ mirante Anson con las de Coyuca por latitud de $77^{\circ} 5^{6^{\prime}}$ Norte, por cuya señal dirigió un bote sobre este paraje á reconocer la bo:a del puerto.

La tarde apacible, la mar muy llana, el viento igual y fresquito, con bảstante inmediación á la costa, eran circunstancias que favorecian mucho 
sa, con Ab. so Als a la Descubiskta en los mares de Nicaragua, hizo la Ro- derrota hacia la Isla de Cocos, cuvo reconociavién. pare jo roeste, $\tan$ in. al fon. Drsce. natural de una edando io dia. vino á ado de ando, $y$ le ama. es acer.

año la Pacílico mismo an Blas ndo ter. re nues. á pesar ro avan. Iemoria os docu. os de di. por apó. 1 conceduda no

de la de el r. ${ }^{\circ} \mathrm{de}$ las para aquellos saña larıpo para general del Nordeste con la celajerin stuelta acos. . Wh re tumbrada, y con ella hizo derrota directa hacia el puerto de Acapulco. Cesaron entonces las di. ferencias considerables al Sur que se habian ex. perimentado, mientras duraban !os variables; la variación de la aguja aumentó hasta $9^{\circ} 30^{\prime}$ y va. riado enteramente el semblante del tiempo, fucron tan aceleradas las singladuras siguientes, que en la tarde del 30 , se avistó la costa haci las inmediaciones del puerto, y el dia $I^{\circ}{ }^{\circ}$ de lee. brero dió fondo en él, mejorándose desplućs y quedando amarrada al día siguiente. Hallábasc igualmente fondeada ell el puerto una fragata mercante de Guayaquil, su Capitán y maestre D. Vicente López de Escudero, la cual, con car ga de cacao, había salido de aquel puerto pocos días después de las corbetas, $y$ atracadas las cos. tas algo á sotavento con sólos treinta y cinco días de navegacion, habia después debido emplcar otros quince para vencer la poca distancia que inadvertidamente le laltaba al tiempo de la reca. lada. No perdió un momento D. José Bustamante para acelerar la salida, $y$ al mismo tiempo aprove char la demora indispensable en el puerto con aquellos objetos que suministraba por sí la comisión nuestra. Las observaciones astronómicas se pusieron al cargo de D. Juan de la Concha; los pi lotos levantaron el plano del puerto con el teodolito, sondándole interior y exteriormente. D. Luis Nee emprendio sus excursiones botánicas, y mien. tras se esperaban las \}rdenes del señor Virey, los reparos del casco y los reemplazos de aguada, leña $y$ algunos víveres, no hicieron desmayar un solo instante la actividad de los aprestos.

Debió, pues, en aquellas circunstancias más bien favorables, causarle una mayor sorpresa y sentimiento la deserción de doce marineros de los mejores de su tripulación. Nada podía convidarlos á aquel delito, si no es un recelo infundado de los peligros de la campaña siguiente, y por la misma razón importaba con extremo el aprehenderlos, no tan sólo para que el escarmiento contuviese á los demás, sino también para que real. mente no se frustrasen los planes venideros con una excesiva debilidad de la marineria. Fueron, sin embargo, infructuosos los primeros pasos de las diferentes partidas destacadas para buscarlos á las órdenes de los Tenientes de navio Concha y Viana y del sargento; pues pasada toda una noche en los diferentes caminos que conducen á Méjico y Coyuca, debieron retroceder con la esperanza de hallarlos y con la sola ventaja de haber cundido la alarma entre los habitantes del país: por manera, que movidos del premio prometido, se obligasen á buscarlos y perseguirlos con rigor. Estas últimas medidas lograron el buen efecto que debia prometerse. Se les aprenendio, efectivamente, á distancia de unas treinta leguas de la orilla, y conducidos á bordo, se entregó á los na. 




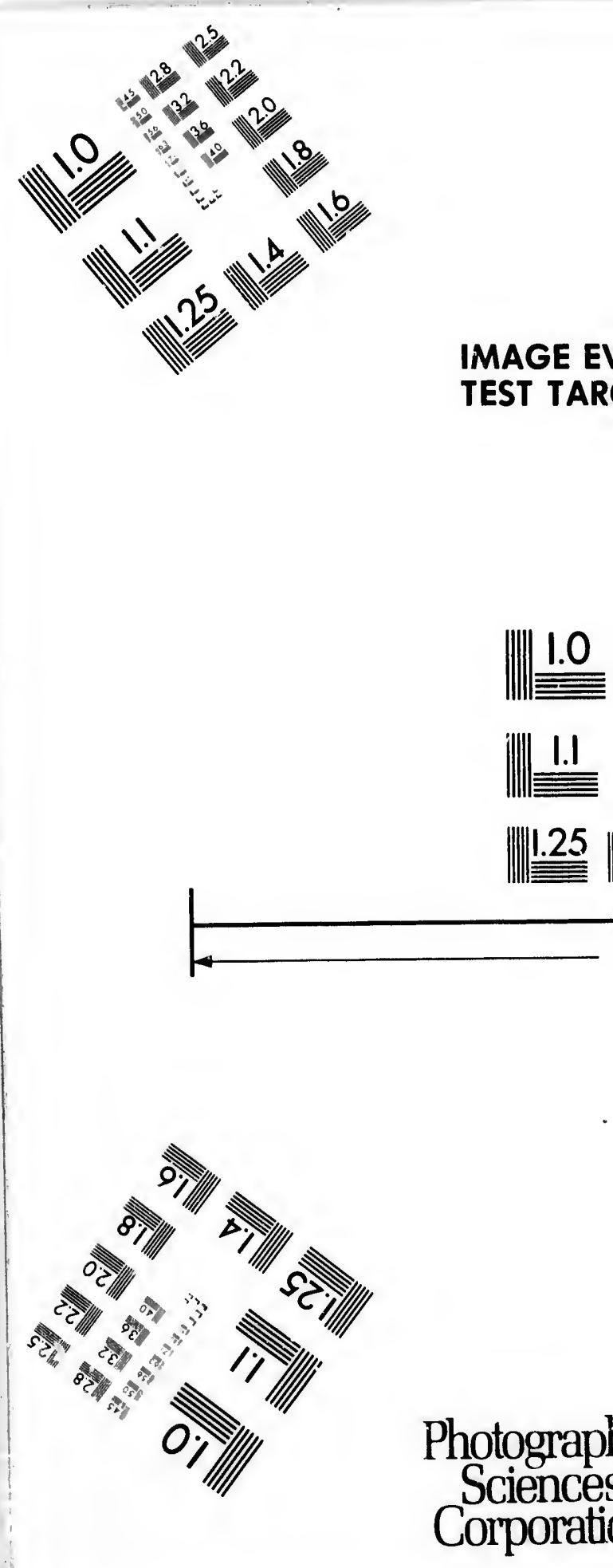


IMAGE EVALUATION

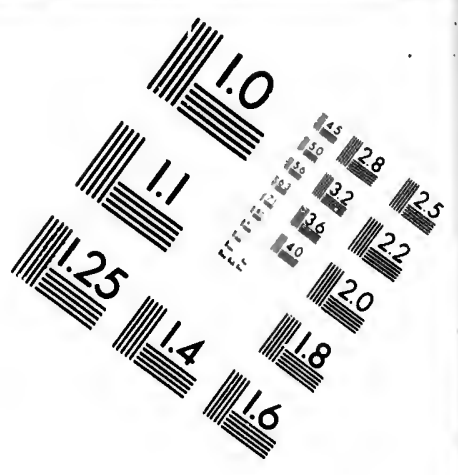

TEST TARGET (MT-3)

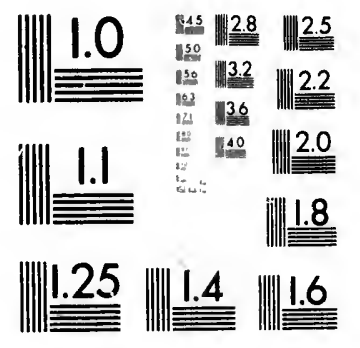

$6^{\prime \prime}$

Photographic Sciences Corporation

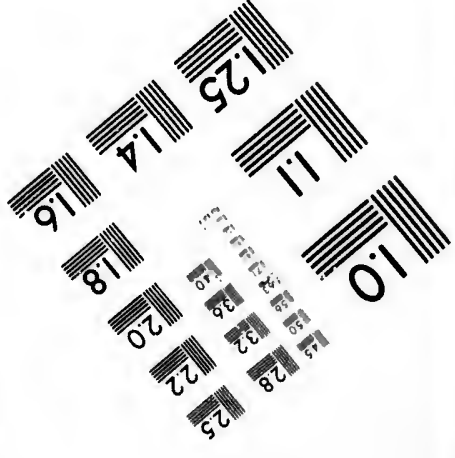




\section{CIHM/ICMH Microfiche Series.}


. del señor Conde de Rivillajigedo, recibidas al re. greso del extraordinario, no podían en el entretanto ser más favorables á los progresos sóiicos de la expedición. S. E. había dado ya las ordenes correspondientes en el Departamento de San I3las para la co.sstrucción de la lancha solicitada; ha. bía destinado á D. Tomás de Suria, Dibujante hábil de la Academia de Méjico, para que reem. plazase la falta de D. José del Pozo, quedado en Lima; avisaba, finalmente, á D. José Bustamante que sería oportuno se detuviese en el puerto liasta q'e lograsen incorporarse los Tenientes de navio D. José Espinosa y D. Ciriaco Cevallos, últimamente llegados de Europa al puerto de Veracruz, y destinados de orden de S. M. á servir en las corbetas. No tardaron, efectivamente, entrambos Oficiales en llegar á Acapulco, y al día siguiente 26 , la corbeta estuvóa la vela para emprender la navegación á San Blas.

No cabía duda sobre la preferencia de la derrota de altura 6 golfo á la que pudiese emprenderse por una navegación costanera, acosada igualmente de los vientos y corrientes contrarias. Efectivamente, fué aquella la que siguió la ATREVIDA, enmarándose inmediatamente con rumbos del Oeste y ciñendo con las muras á estribor los vientos del Norte, variables al principio y luégo más firmes á medida que se alejaban de la costa. Viéronse al paso todas las señales que indicaban inmediata la isla desierta de la Posesión; se aumentó despućs pa`ılatinamente la latitud hasta cojer los paralelos de San Blas, unos $15^{\circ}$ al occidente de Acapulco; y finalmente, cambiada la mura cuando ya los vientos se inclinaban del Norte más bien al Oeste que al Este, en pocas singladuras se halló la corbeta á la vista de las Islas Marias, y poco después en la rada de San Blas, por cuanto fuesen precipitados los aprestos en aquel puerto, los cuales exigían la perfección de la lancha grande empezada ya, una recorrida del casco, aparejo, velamen y alguna tonelería, y el natural repuesto crecido de víveres, aguada y leña; no por eso se omitieron las acostumbradas tareas de levantar el plano de la rada y del puerto, de seguir una serie no interrumpida de observaciones astronómicas y de estudiar el estado político y natural de aquellos contornos, estudio á la verdad tanto más importante en el paraje en donde se hallaban, cuanto que estaba aún por decidirse la cuestión importante, si convenía allí más bien que en Acapulco la permanencia de un Departamento ó depósito de las fuerzas de la Marina Real. La latitud del observatorio prefiriendo en esta ocasión las de terminaciones de los sextantes á las del cuarto de círculo, quedó de $2 \mathrm{I}^{\circ} 3 \mathrm{I}^{\prime} 0 \mathrm{o}^{\prime \prime}$, la longitud de $5^{\circ} \mathrm{I}^{\prime \prime}{ }^{\prime}$, al occidente de Acapulco, y la variación magnética de $9^{\circ} 26^{\prime}$ al Noreste. Son muchos los elogios y las expresiones de un justo agradeci- Ab. 20 miento que tributa D. José Bustamante al Co. mandante del Departamento el Capitán de navío D. Juan Francisco de la Cuadra, pues brillaban en él diariamente, y casi á porfía, la actividad para los aprestos y la generosidad para el regalo de todos los individuos de la corbeta. Recibidos, finalmente, en la mañana del II los pliegos relativos á la reunión de las corbetas, dieron la vela en la madrugada del $\mathrm{I}_{3}, \mathrm{y}$ aprovecharon de tal modo los vientos favorables del Oesnoroeste y Noroeste que, sin dejar de trazar con mucha exactitud trozos considerables de costas, llegaron á Acapulco, como se ha dicho ya, en la mañana del 20.

Reunidas en una sola masa las observaciones de ambas corbetas, $y$ adoptadas para la diferen. cia de longitudes entre Acapulco y San Blas, más bien que los primeros, los resultados de la áltima travesía de solos siete dias referidos además á un mayor número de relojes, pudieron, finalmente, adoptarse para la longitud del observatorio los datos siguientes:

\section{ATPEvida}

Determinación del núm. Io referido

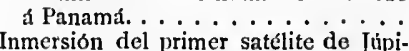
ter el 18 de Febrero. Cuarenta $y$ ocho series do distancias lunares. . . . . . . . . . . De San Blas traidas con los relojes. 102.20 .00 20.38 22.00 22.00
20.28

\section{Descubierta}

Determinación de los tres relojes del Realejo. . . . . . . . . . . . Inmersión del primer satélite observa do el 7 de Abril con la mayor confianza y corregido de los errores de fianza y corregido de los errores de

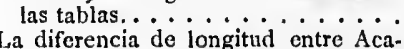
La diferencia de longitud entre Acapulco y San Blas quedó finalmente adoptada de ........... $55^{\circ} 20$ Latitud. . . . . . . . . . . . $16^{\circ} 50^{\prime} 30^{\prime \prime}$ Variación de la aguja. . . . . N. E.

El diario astronómico manifestará después cuántos son los resultados que además de las observaciones indicadas han concurrido á afianzar la posición verdadera de aquel meridiano, por manera que pueda ya considerarse, como uno de los que sobre las orillas del mar Pacífico se han determinado con mayor prolijidad.

Al día siguiente $2 \mathrm{I}$, los Tenientes de navío D. José Espinosa y D. Ciriaco Cevallos, entre. garon los instrumentos que traían á su cargo, y eran dos relojes chicos de faltriquera de Arnold nún cros 344 y $35 \mathrm{r}$, y un péndulo simple constante, construído en Lóndres por dirección del $\mathrm{Ca}$ pitán de navío D. José Mendoza Rios. Según 10 prevenia el Sr. Ministro de Marina en oficio particular, debían repetirse cuanto fuese posible por medio de dicho péndulo las experiencias de la gravedad de los cuerpos en diferentes paralelos de la tierra, no sólo para una medida uni- 
gradeci- Ab. 20

al Co.

de navío

brillaban

actividad

a el re-

a. Reci-

II los

corbetas,

$y$ aprove-

ables del

$r$ de tra-

rables de

ha dicho

rvaciones

a diferen-

Blas, más

e la silti-

idos ade.

pudieron,

del obser.

102.20 .00

$20.3^{8}$

do á afian. meridiano, como uno Pacífico se d.

s de navío los, entreu cargo, y de Arnold le constanón del Ca- Según lo en oficio ese posible riencias de ntes paraiedida uni-
Ab. a versal dimanada del mismo cotejo de las observaciones nuestras comparadas á las que verificasen los astrónomos de Europa cn el paralelo de $45^{\circ}$, si también para no perder de vista la: pesquisas sobre la verdadera figura de la tierra en la cual no sin mucha probabilidad se sospechaban algunas desigualdades de uno á otro hemisferio. Inmediatamente se emprendieron las observaciones indicadas, referido como era natural el número de oscilaciones del nuevo pén. dulo al número de segundos del tiempo medio contados en el péndulo del observatorio, y los primeros resultados bastaron para indicarnos que de ningún modo pudiera considerarse aquella máquina arregiada al tiempo medio del $\mathrm{Ob}$ servatorio de Greenwich ó de cualquier otro paralelo de la Europa.

Entretanto, procedían con toda la actividad posible los aprestos para la próxima campaña, pues que era nuestro ánimo el verificar la salida en la mañana del primer día de Mayo: la Descu. BIEkTA recibió la mitad del pan y tocino que la ATrevida había tomado en San Blas, y entregó á ésta 30 quintales del pan, mucho mejor que se había fabricado en Acapulco y Tiscla; se hizo una compensación de betunes y maderas; ambas dejaron en los almacenes del Rey una parte considerable de las arboladuras de respeto $y$ cure. ñaje. La Descúbierta dejó también unos diez fardos, parte de ropa de abrigo y parte de efectos de cambios. Se completaron los acopios de agua y leña y se asearon exteriormente los bu. ques, y como al mismo tiempo lográsemos ver ya casi prontas las cartas, manuscritos y acopios de Historia Natural, que debían remitirse á Madrid, parecía que ya no pudiera trastornarse el plan proyertado.

Este, sin embargo, no era ya tan sencillo como á primera vista lo habíamos imaginado; pues un examen maduro de todas las circunstancias, que en el día rodeaban á la expedición, nos había determinado á subdividir algunas comisiones, que al mismo tiempo acelerasen la perfección de la obra emprendida y combinasen las posibles ventajas cientificas á la nación: nuestras circunstancias (determinada ya la campaña al Norte), no podían dejar de recordarnos que las últimas contrariedades de los tiempos entre Realejo y Acapulco, y el regreso precipitado de la ATrevida desde San Blas, habían causado una gran imperfección en las cartas por lo que toca á aquellos parajes, la cual no pudiera corregirse 6 á lo ménos se conseguiría muy tarde y con mucho cxtravio, si cualquier evento, 6 muy feliz 6 muy desgraciado, impidiese para el próximo Octubre el regreso de las corbetas á Acapulco. Y bien mirada aún la naturaleza de los recono. cimientos indicados, y la importancia de que se trazasen con exactitud no sólo las costas, si tam. bién los put:tos importantes de Singuatanejo, $A b .29$ Aguatulco, Los Angeles y Tecoantepeque, una embarcación menor fácil á adquirirse en San Blas, verificaría aquel objeto con una mayor puntualidad y seguramente con una mayor economía de tiempo y de caudales. Semejantes re. flexiones nos conducían directamente á otras no minos útiles, y eran la de poder los mismos Oficiales que desempeñasen aquel objeto, ocuparse después en los reconocimientos de los golfos de Amapola y Nicoya, en los cuales no habian podido internar las corbetas y examinando con proligidad el Istmo que media entre el mar Pacífico y el golfo de Nicaragua, pasar después al mismo golfo, trazar sus orillas con exactitud y pene. trar por el río San Juan hasta el Atlántico. Ni nos guiaban los solos objetos hidrogiáficos, referidos á las cartas, si bien una nueva traslación de nuestras longitudes al otro mar por medio de los relojes marinos no debiese mirarse con in. diferencia. Las inmediaciones del río y golfo de Nicaragua, eran en el día un cebo harto eficaz para las naciones émulas, por consiguiente, su conocimierito cabal debía mirarse como muy importante para la defensa maritima nacional y además era aquel el único desembocadero cómodo para el tránsito á Europa de una porción considerable de frutos preciosos hasta aquí malogrados, que producía aquella fértil provincia, sin que nuestros navegantes intentasen aún el adquirirlos ó bien por las frecuentes hostilidades de los mosquitos ó por el poco conocimiento de la navegación del río.

Este deseo de ir así comunicando á la costa opuesta nuestras longitudes y examinando cualesquiera puntos interesantes para la navegación $y$ defensa nacionales en cuanto lo permitiesen los Oficiales, instrumentos y tiempo destinados á la expedición, debió también naturalmente inclinarnos hacia la parte del continente comprendida entre la desembocadura del Guazahualcos por el mar del Norte y el puerto de la Ventosa por el del Sur; pues no sólo la comodidad de la internación de los rios del corto terreno llano que mediaba, y de la barra transitable del Guazahualcos habían llamado hacia aquella parte la atención de los primeros conquistadores y luégo del Gobierno; si también debía mirarse como un punto de fácil invasión para el Reino de Méjico, y tal vez ' único que pudiese temerse por la comunicación abrigada con el mar; por el terreno muy entrecortado con canales, y bastante despoblado, y por la distancia de Méjico, desde donde debieran dimanar precisamente los socorros, no sólo para aquella parte, sino también para el Reino invadido de Guatemala.

Se agregaba á las retlexiones indicadas, la de ser de tal naturaleza la próxima campaña nuestra al Norte, ceñida á pocas saliclas de lanchas des. 
1h. ag tinadas á operar casi siempre dehajo del cañón de las corbetas, que quedaría, sin duda alguna, ociosa y casi oprimida de su misma habilidad, una parte considerable de los buenos Oficiales instrumentos que en el día se hallaban en andbas corbetas, y era más digno de atención este repa ro, si le refiriésemos á la Historia Natural, cuyas indagaciones serían tan cautas $y$ limitadas en lats orillas harto peligrosas que intentábamos visitar, como copiosas y útiles en la Nueva España, en donde I. Antonio Pineda, con su constante amor al trabajo, pudiera hacer una comparación sumamente util y nueva de todos sus productos con los de la América meridional, que tan recientemente $y$ en tantos parajes había visitado.

Así concluídos para el día prefijado todos los objetos que nos habiamos propuesto, completados los armamentos hasta un total de roo personas por cada uno, $y$ los víveres paı corbetas en el último dia de Abril pudieron considerarse enteramente prontas para dar la vela, y realizar en los siguientes meses el plan proyectado. Un examen de las bajas sufridas desde la salida de Cádiz que insertarémos á continuación, no parecerá tal vez molesto ó inoportuno, cuando se advierta que podiá servir de escarmiento á los buques de la Marina Real, que frecuentasen las costas del mar Pacífico con tripulaciones más numerosas y ménos escojidas que lats nuestras.

\begin{tabular}{|c|c|c|c|c|c|c|}
\hline \multicolumn{7}{|c|}{ DESĊUBIERTA } \\
\hline CLASES. & $\begin{array}{l}\dot{y} \\
\vdots \\
\bar{y} \\
\vdots \\
0\end{array}$ & $\begin{array}{l}\text { Muertos } \\
\text { a herdo } \\
\text { en los } \\
\text { hospitales }\end{array}$ & $\begin{array}{c}\text { Dejados } \\
\text { en los } \\
\text { hesplitites }\end{array}$ & 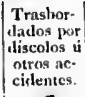 & \begin{tabular}{|} 
Despedi- \\
dos por \\
acciden- \\
tes hati- \\
tuites.
\end{tabular} & TOTH. \\
\hline $\begin{array}{c}\text { Oficiales de } \\
\text { mar. }\end{array}$ & & & n & $"$ & 1 & \\
\hline Mlarineros.. & 28 & 1 & I & 6 & 4 & \\
\hline Soldados de & & & & & & \\
\hline $\begin{array}{l}\text { marina. } \\
\text { Id. de briga- }\end{array}$ & 8 & 1 & $n$ & 2 & $n$ & \\
\hline das.... & 2 & I & n & $n$ & $n$ & \\
\hline Criados. . . . & $n$ & $"$ & $n$ & $n$ & 3 & \\
\hline Pintor.... & $\bowtie$ & $n$ & $n$ & $n$ & I & \\
\hline Totral. & 40 & 3 & 1 & 8 & 9 & $6 \mathrm{I}$ \\
\hline
\end{tabular}

ATrevidA

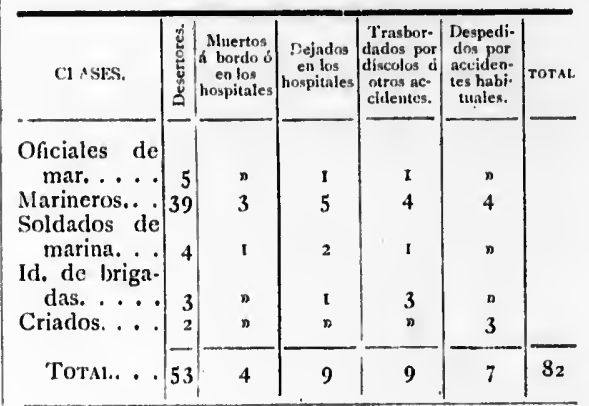

Haja total en ambas corbetas. . . 143

\section{CAPITULO I}

Objetos de la siguiente campaña sobre la costa Noroeste de la América.-Navegacioncs, escalas y reconocimientos en el paralelo de $60^{\circ}$.- Regreso al Archipielago de Nutka.-Refexiones sobre las dos Mcmorias que dieron lugar ia estos reconocinicutos.

Como se ha manifestado en el capítulo ante- May. 1.. cedente, las últimas órdenes de S. M. prescribían un examen prolijo sobre la lejitimidad del viaje de un Lorenzo Ferrer Maldonado, el cual decía, según una Memoria hallada en los archivos del Sr. Duque del Infantado, haber pasado en 1588 desde las costas de los Bacallaos ó Nueva Inglaterra, hasta el mar Pacífico, desenibocando en él próximamente por el paralelo de $60^{\circ}$. - Leída esta Memoria en la Real Academia de Ciencias por Mr. de Bauche, habianse hallado más bien probables todas las señas y parecía plausible un nuevo ensayo, el cual, por la misma razón, se nos encargaba estrechamente. No será importuna para el lector una copia literal de las dos Memorias indicadas. 


\section{RELACIÓN del descubrimiento dei Estrecho de Anian que hice yu el Capitan Lorenzo Ferrer Maldonado, el año 1588, en la cual esta el orden de la navegación y la disposición del sitio y modo. de fortalecerle, y asi mismo las utilidades de esta navegación, y los daños que de no hacerla se siguen.}

Señor: Ante todas cosas conviene saber cuáles son las comodidades que se pueden conseguir por la navegación del Estrecho de Anian al mar del Sur, y habiendo considerado la navega. ción que hasta ahora se ha tratado para las Filipinas, China y Japón, y las otras partes de aquel mar, parece por buena cosmografía, que navegando por este Estrecho se ahorra casi la mitad del camino. Donde esto se conoce bien es en un globo terrestre, 6 un mapa que tenga por centro el Polo, y no en las cartas planas, las cua les, $\tan$ grande y dilatado muestran el punto del Polo como es la línea equinoccial; y por esta ra $z$ on en ellas no puede parecer menor el un camino que el otro; y supuesto que esta doctrina quiere práctica visible, es escusado tratarla aquí; basta decir que por este Estrecho se ahorra la mitad del camino poco menos; fuera de que tiene otra comodidad mucho mejor, y es que de una embar cación se puede ir desde España á las Filipinas, y esto no puede ser por donde ahora se camina, por haber de desembarcar en la Nueva España, y caminar I 50 leguas por tierra, y esto es causa que la más de la gente que se envía á aquellas partes para los presidios y socorros, se quedan en la Nueva España, 6 cansados del mar, ó asidos las delicias de aquellas tierras. Fuera de esto tiene otra notabilísima utilidad, y es que puede V.M., navegando toda la especiería (del Maluco y todo el Archipiélago y otras partes), por este Estrecho hacerse total señor de ella con mucha facilidad; porque almacenándola en la ciudad de Sevilla, le importará más de $\mathbf{5} .000 .000$ por año, obligando á muchas naciones que vengan á Es paña por ella, y en su recompansa traigan abundantemente todas las cosas necesarias á estos reinos, con lo cual se escusará llevarse toda la plata que cada año viene de las Indias, poniendo al reino en tanta necesidad: así mismo se considera que haciendo este Estrecho navegable, se muda el trato y comercio que tiene la China con las indias, y se pasa á España; la cual comodi. dad alcanza á las Filipinas y á todas aquellas partes, porque el trato de la China con las Indias ha sido dañosísimo para España; tanto, que ha impedido la mayor parte del que solía tener, lo que está probado con que V. M. (por este respecto) tiene ahora estrechado el comercio que la China y Filipinas tienen con las Indias, tanto que es im posible sustentarse aquellas partes, como es razón, para resistir sus enemigos, que son muchos, $y$ de necesidad aquellos reinos han de venir a disminución $y^{*}$ no poderse sustentar, y por el contrario, podrian por este camino y navegación crecer y aumentarse en tanto número y posibilidad por sus riquezas, que traerian flotas en esta carrera, tan grandes como las que van á las In. dias, trayendo á España mucha abundancia de riquezas de la gran China y Tartaria y de otras partes, que serían muy baratas, porque de sólo oro se puede traer 2.000 .000 cada año, en que se puede conseguir muy grande interés, porque el oro vale en la China ménos de la mitad de lo que aquí vale, $y$ junto con esto se traerán otras $m u$. chas cosas, las cuales ahora estos reinos se proveen de ellas de manos de sus propios enemigos: con lo cual se enriquecen y cobran fuerzas para hacer guerra.

Es de mucha consideración, ásí mismo, proveer de gente de guerra aquellas partes para la defensa de aqueilos reinos, y hacerlo con tanta facilidad como por este camino se puede, con lo cual se impide que los enemigos se puedan hacer señores de ellos, como es posible hacerse, por falta de gente y socorro; y siendo Dios servido de que nosotros hagamos semejante navegación, se abre con ella una puerta por la cual se facilita la conversión de aquellos gentiles habitadores de aquellas partes, por cuyas almas quiso Dios padecer, que no es esta la menor, sino la mayor utilidad. Otras muchas puede of recer el discurso del tiempo; empero, la más esencial de todas conocidamente, es prevenir los grandes daños que podrían sobrevenir por no reconocer el Estrecho de Anian y fortalecerle, porque siendo verdad que lo hay, como yo testifico haberlo visto, sería 
notabilísimo el daño que podría suceder si fuese hallade y tortalecido de los enemigos, los cuales con mucho cuidado desean hallarle, pues sabemos cómo el año pasado de 1608 salieron unos navíos de Inglaterra á le buscar. Porque siendo tomado de enemigos pueden desde allí hacer muy grandes daños, que por la vecindad que tienen sus ticrras con aquel estrecho, les sería fáci cosa enviar por él una armada, la cual repartida de $3^{\circ}$ en 30 navíos, se enseñorearan de las tie rras de la Nueva Esspaña y Perú, á donde publicando ancha conciencia y libertad de indios podria ser que muchos y áun todos se les viniesen á las manos, y de tal suerte encastillarse en todo aquel mar, que no teniendo por donde enviar breve socorro quedasen por señores de él irremediablemente; $y$ tanto se puede temer este peligro, que cuando no supiéramos por cierta ciencia y vista de ojos tener esta entrada del mar del Sur, la habiamos de buscar para fortalecerla, para desengaño si no la hay, y quedar sosegados los corazones sin temer este peligro, y aquí se advierte, que si los enemigos no tienen hechos muy grandes daños en aquel mar, es por no tene en todo él un puerto que sea de consideración, como lo es el que tiene el Estrecho de Anian, según adelante se dirá, $y$ porque ahora parecc tratarse de semejante navegación por mandado de V. M. y su Consejo de Estado, y del modo de lortificar el estrecho, parece ser cosa al propósito racer relación de las derrotas de la navegación, el sitio y puerto de aquella parte con todos los discursos de mi viaje, y habicndo de comenzar por la navegación, se advierta á la doctrina siguiente, según la cual todo buen marinero la po. drá hacer.

Pártese de España y presupónese que es des. de Lisbna, desde donde conviene poner la proa al Noroeste por camino de $45^{\circ}$ leguas hasta llegar á $\operatorname{los} 60^{\circ}$ de altura de Polo ártico, á donde se dará vista á la Isla de Frislandia, antiguamente nombrada Tyle 6 'Tule. Es una isla poco menor que Irlanda, desde la cual se toma la vuelta del Oeste corriendo por los $60^{\circ}$ de altura por navegación de 180 leguas, hasta llegar á tierra del Labrador, que es á donde comienza el Estre. cho del Labrador ó Estrecho Davis, cuya entrada es bien ancha por más de 30 leguas, y la tierra que tiene á la parte del Labrador que es al Oeste es baja; mas la parte contraria que es aquella de la cual se forma aquella boca del Estrecho es de montes muy altos: allí se muestran dos bocas en medio de las cuales están aquellos montes altísimos y la una de ellas corre al Estenordeste y la otra al Noroeste, y así conviene dejar la que corre al Estenordeste que es la que estáá la mano derecha mirando al Norte, porque esta boca la lacen la Grutlandia y unas islas por donde últi. mamente se torna al mar de la Frislandia; y de otra suerte, tomando la otra boca se ha de poner la proa en el Noroeste entrando por aquel Estre. cho por camino de 80 leguas hasta llegar á los.0 $4^{\circ}$ escasos de altura. Allí hace el estrecho otra vuelta al Norte por 120 leguas hasta llegar á los $70^{\circ}$ de altura y allí torna aquel estrecho á hacer otra vuelta al Noroeste, por la cual se ha de navegar 90 leguas hasta llegar álos $75^{\circ}$ de altura algo escasos, con lo cual queda desembocado todo el Estrecho del Labrador, como que el dicho comienza en $60^{\circ}$ y acaba en $75^{\circ}$ y tiene de largo $29^{\circ}$ leguas, haciendo tres vueltas muy grandes: la primera y última se corren de Noroeste.Sudeste y la del medio Norte-Sur, y es por donde más angosto de 20 leguas, $y$ por donde más ancho 4o leguas, y hacen muchos puertos, calas y abrigos que pueden ser socorro de cualesquiera necesidad, y hasta los $73^{\circ}$ pareció ser habitado de algunas gentes, porque en muchas partes de aquellas costas se vieron humos, así en la una parte como en la otra. Paréceles á algunos inconsideradamente ser imposible navegar por tan grande altura de Polo. A esto se responde, que los anseáticos viven en $72^{\circ}$ de altura, en cuyo puerto, que es el de San Miguel y en toda aquella bahía de San Nicolás, entran todos los años casi r.00o naves de trato, las cuales por haber de pasar al mar de Flandes, de necesidad han de subir á $75^{\circ}$ de altura para dar vuelta á la Dinamarca.

Habiendo desembocado el Estrecho de La. brador, se comienza á bajar de aquella altura navegando al Oesudoeste y Sudoeste por $35^{\circ}$ leguas y se llega á los $71^{\circ}$ de altura, que es á donde nuestro viaje, al tiempo que volvimos, descubrimos una tierra altísima, sin que se pu. diese entender si era tierra firme 6 isla; - mas hácese consideración que si es tierra firme es contra costa de la Nueva España. Desde esta tierra vista á $7 \mathrm{I}^{\circ}$ de altura se ha de caminar la vuel. ta del Oesudoeste por 440 leguas hasta bajar á los $60^{\circ}$ á donde ha de ser hallado el Estrecho de Anian, con lo cual será observata la misma na. vegación que yo hice, á lo ménos desde la Fris. landia, pues es de saber que yo partí de los Bacallaos en demanda de esta isla por llevar necesidad de bastimentos, los cuales tomé en unas islas que están cerca de ella llamadas Gelandillas, que siendo tres solamente es habitada la una, y las otras dos son pastos para los ganados de aquella gente que es muy rústica, aunque parecían ser católicos ó cristianos. Tornando á nuestra navegación, digo, según mi parecer, que será más acertado cuando se haya desembocado el Estrecho del Labrador, costear toda la contracosta de la Nueva España por dos razones; la una por entender que aquel tiene población, $y$ la otra para buscar en ella escalas y refrescos para las Armadas que por este camino han de navegar. 
Según la relación hecha, parece haber de lis. paña á la Frislandia 450 leguas, y descle allí a! Labrador r 30 ; á desembocar el estrecho suyo; 290, que todas son 920 leguas, las cuales suma. das con 790 que hallamos desde la parte septentrional del estrecho del Labrador, hasta el Estrecho de Anian, hacen 17 ro leguas, que tanto es lo que hay desde España al Estrecho de Anian.

El tiempo en que desembocamos el Estre. cho del Labrador fué muy riguroso por ser en los principios de Marzo, porque por el estrecho se navegó parte de Febrero; así padecimos grandísimos trabajos de oscuridades, fríos y tormen. tas, porque el día era breve en todo aquel tiempo, y el frio tan grande, que el agua del mar que salpicaba en el costado del navio se helaba de tal suerte que parecía el navio hecho de cristal, y había necesidad de picar los hielos porque. se iban engrosando de tai suerte, que algunas veces los hallamos de más de un palmo de gruesos, y es grande yerro pensar que aquel mar se puede helar todo, porque como es grande, y aquel estrecho de grandes corrientes, estas y las grandes olas por su contínuo movimiento no le dejan helarse; mas en las orillas y partes donde el mar está quieto, creo que se puede helar, según pareció en tierra que el agua que salpicaba se helaba; solamente se sabe, y así nos fué dicho por aquellas gentes de las Gelandillas, que un estrecho de mar que hay entre la Frislandia y la Grutlandia, está helado la mayor parte del año, porque está en medio de grandes montes y cerros de la parte le la Frislandia y no da lugar á los rayos del Sol, y por estar abrigado de altísi. mos montes no tiene combate de vientos, que les inquieten sus aguas, $y$ así el contínuo sosiego le hace estar helado como dicho es, y no se puede navegar, y lo mismo es en la misma bahia.

Mas cuando tornamos por aquel Estrecho del Labrador, que fue por el mes de Junio ỳ parte de Julio, siempre gozamos de contínua claridad, y tanto, que cuando llegamos á cortar el círculo ártico, que se hacen $66^{\circ} \mathrm{y}^{1} / 2$, comenzamos á no perder el Sol de vista, ni jamás se cubrió por el horizonte hasta que otra vez le tornamos á cortar. En medio del Estrecho del Labrador, por la continuación del Sol sobre el horizonte estaba el aire tan caliente, que nos causo más calor que el que hace en la parte que mayor es en España, mas no que cuando nos poníamos al Sol, sus rayos ofendiesen mucho y siempre nos corrieron vientos largos dei Norte, con los cua. les se desembocó fácil y prestamente el Estrecho del Labrador. Verdad es que sus grandes corrientes del flujo y reflujo ayudan mucho á entrar y salir, aunque sean los vientos contrarios, porque así como son muy contínuos los del Norte, hay necesidad á la ida de España á Anian, de valerse de las mareas, con la cual relación se con- cluye con lo que es la derrota de esta navegación y sus accidentes.

El estrecho que descubrimos en $60^{\circ}$ de altura, que está y 7 ro leguas de España, parece, según tradición antigua, ser el que los cosmógrafo: nombran en sus mapas, de Anian, y si es verdad que lo es, de necesidad lia de ser estrecho de la una parte del Asia y de la otra de América, lo cual parece ser asi, según el discurso siguiente.

Despućs que hubimos desembocado por el mar Grande, fuímos costeando por la parte de la América por más de roo leguas la proa en el Sueste hasta llegar á los $55^{\circ}$ de altura, en la cual costa no se halló población ni boca del mar que fuese indicio de otro estrecho, por el cual, pasando el mar del Sur al inar del Norte, pu. diese aislar aquella parte; y de aquí se coligió ser toda aquelia parte de $\Lambda$ mérica, y que continuán. dola podría llegar brevemente á Quivira y cabo Mendocino; dejamos esta parte, la cual como dicho es, conocimos que se iba continuando, y puesta la proa al Oeste, caminamos cuatro días con un viento tal, que se pudiera contar á zo leguas por singladura, $y$ habiendo caminado 120 leguas según esta fantasía y punto de la carta estimado, descubrimos una grandísima tierra, y continuando la costa de la que nos apartamos por convenir así á nuestro intento; siempre enmarados, navegamos unas veces al Nordeste, otras al Nornordeste y otras al Norte, de donde nos pare. ció (por mayor) que se corria aquella costa Nordeste Sudoeste. No pudimos conocer las cosas particulares por ir (comn dicho es) tan enmara. dos, y así tan solamente puedo atirmar que tiene población hasta muy cerca del estrecho, porque en muchas partes se vieron salir muchos humos, y así, según buena cosmografía, nos pareció ser tierra de Tártaros 6 del Catai, y que á pocas leguas de aquella costa estaría la gran ciudad de Cambalu, metrópoli del Gran Tártaro; finalmen. te, siguiendo la dicha costa, nos hallamos en la boca del mismo Estrecho de Anian, por donde quince días antes habíamos desembocado al mar Grande, el que reconocimos ser el del Sur, donde son Japon, China, Molucas, India y Nueva Guinea, con el descuijrimiento del Capitán Qui. rós y toda la costa de la Nueva España y Perú.

En la boca que hace el estrecho por donde desemboca el mar del Sur, hay un puerto á la banda de la América, capaz de 500 navíos, aun. que en cierta parte de él es desapacible y de mal surgidero, á causa de las corrientes que en la marea que baja del Norte al Sur, entri por la boca de él, y bate fortísimamente en una punta que hace el puerto cerca de la boca, entrando en él en la mano derecha, porque se ha de enten. der que la boca del puerto está abierta al Norte y entra haciendo una espiral 6 caracol. Pareció no haber sido tocado aquel puerto de piés huma- 
nos, digo sus orillas, porque en cierta parte de el tiene un remanso, en cuya orilla se hallaron infinidad de cáscaras de huevos de las aves marítimas que á las orillas del mar suelen desho. var, y éstos pareció ser traídos de las corrientes del Norte, y eran en tan grande número, que hacían un muro de una vara de alto y ocho palmos de ancho; hallóse en este puerto un río de agua dulce muy grande, $y$ tan fondable, que se pudo entrar con nuestro navio á hacer agua en él, y me parece quc pudiera entrar una nave de 500 toneladas: la mayor parte de este puerto es arenisco, particularmente á donde se hace este río y á donde baten las corrientes; mas por la banda del Norte tiene un abrigo de perias corta. das de más de dos picas de alto en algunas partes, sobre las cuales se hace un sitio llano, largo $y$ angosto, al cual circunda el mar, dejándole un pico de tierra firme por la banda del Este, en el cual sitio se puede hacer una grandísima pobla. ción, y por ahora un fuerte que será de mucha consideración. La tierra, que es continente con este puerto, es muy apacible y tiene llanos grandísimos á la parte del Sueste, haciendo punto en el puerto, y éstos son poblados de un monte bajo que en algunas partes de él se hallaron romeros, los cuales llanos siendo desmontados pueden servir de lindas labranzas y huertas, porque según su disposición, se puede regar la mayor parte de ellos, porque es de saber que aunque esta tierra está en $59^{\circ}$ de altura de Polo, es de muy precioso temperamento, porque todo aquello que está á la banda del Sur, le abrigan y le defienden los montes que tiene á la banda del Norte. is muy templado á donde el frío del invierno no es con exceso, sino muy moderado, porque siempre está descubierto á los rayos del Sol y libre de los vientos del Norte, y solamente le soplan los del Sur cua.ido corren, que estos siempre son templados, y más allí que vienen por cima del mar, que es lo que suele hacer caliente el aire.

El efecto fué conocido por los géneros de fruta que alli se hallaron, $y$ es de considerar que aunque csta tierra está en tanta altura, no por eso dejará de ser muy buena de habitar, pues 10 son otras muchas que corren por este paralelo, como son Edimburgo de Escocia y los principios de la Suevia, Hapselia y Riga, ciudades de la Libonia, Dublín de Hibernia y Nidrosia, ciudad de Noruega y muchas partes de la Moscovia y otras tierras muy buenas que son habitadas, tra. tadas y conocidas, que aunque están apartadas del calor de la costa son de frío tolerable. El mayor día del verano en esta tierra es de diez y oclio horas y media y lo mismo la mayor noche de invierno, y por esta razón es ln noche del ve. rano de cinco horas y media y el día de invierno de otras tantas. En el río que entra en el puerto y en otro que está más abajo á la banda del Sud. este, hay muchos y grandísimus árboles, y los más de ellos frutales, de frutas buenas y algunas semejantes á las de Espana, como son manza. nas, peras y ciruelas silvestres, $y$ otras no cono. cidas de diversas formas; $y$ así por no caer en algún gran peligro (como fuera posible) ordené á mi gente no comiesen de la fruta que primero no so hallase picada y comida de las aves, $y$ con esto se conoció no haber fruta dañosa, $y$ todas las más de ellas eran pasadas en sus mismos árbo. les del año pasado, porque en aquella sazón no liabía frutas maduras por ser el tiempo que alli tuvimos parte de Abril, todo Mayo y parte de Junio; y así de conservarse las frutas de un año para otro pasadas en sus árboles se conoció no haber sido su invierno muy riguroso. Halláronse en un valle que el río de abajo hace (que era hondo y parecía muy templado), vides de uvas silvestres, y lechias, que es una fruta sabrosa de la India, que siempre se halla en tierras tem. pladas. Por cima del puerto, mirando entre el Norte y Este por toda aquella cuarta de aguja, hay unos montes no muy altos, sino muy tratables y abundantes de todo género de caza, á donde se hallaron perdices $y$ conejos algo diferentes á los de España, venados pintados de pintas blancas y negras sobre lo pardo, y por cuernos unas grandes palas, aunque algunos no las tenían: viéronse dos géneros de puercos; los unos como los que se crian en las Indias, que tienen en el espinazo el ombligo, aunque mayores, y los otros como jabalíes de España. Halláronse algunos búfalos y otros muchos animales; mas no se vió ninguno que fuese feroz. El mar es abundantísimo de pesca, y todo marisco nuy bueno y sabroso, aunque mayor que el que acá conocemos, porque se tomaron cangrejos de media vara de través, siendo los de nuestras costas no mayores que la palma de la mano.

La parte frontera que es á la banda de Asia o Tartaria, tiene montes altisimos, tanto que en algunas partes de su mayor altura se sustenta la nieve todo el año, particularmente aquellos que miran al Norte, y estos son tan montuosos, ásperos y fragosos, que parece imposible poderlos tratar, y la mayor parte de sus árboles son pinos muy altos, los cuales nacen hasta la orilla del mar. En la misma parte del Asia, enfrente de la boca del puerto, se hace un remanso de aguas del mar, adonde hay un cañaveral muy grande de carrizos que nacen dentro de la misma agua, cerca de la cual hallamós ser la mayor pesquera de todas aquellas partes. Alli se mataron muchos pescados y muy grandes, $y$ algunos conocidos como son corvinas, congrios, lenguados y otros semejantes, aunque mayores que los que por acá se hallan; viéronse pasar á veces grandes pescados los cuales iban del mar del Sur al mar del Norte y entre estos se conocieron 
ballenas y bufadores, y otros mónstruos muy grandes.

El Esstrecho de Anian es de 15 leguts de largo, porque fácili.ıente se desemboca $y$ pasa con una marea que dura seis horas, y estas ma reas son allí recisimas; tiene seis vueltas en todo este largo y las dos bocas que tiene de Norte á Sur, digo, que está la una con la otra Norte Sur La boca que tiene á la banda del Norte (que es por donde nosotros entramos), tiene ménos de medio cuarto de legua de anchura $y$ de la una $y$ otra parte tiene dos peñones cortados, aunque la peña que tiene á la parte del Asia, es más alta y más pendiente que la otra, de tal suerte, que hace debajo de sí un abrigo en tal modo que ninguna cosa que cayese de la parte alta, podrá dar en el pié de ella. Lá boca que sale al mar del Sur por junto al puerto, es de más de un cuarto de legua de anchura y desde allí se va siempre ensanchando y abriéndose aquellas dos costas. Tiene el Estrecho en medio de sí en el fin de la tercera vuelta, un gran peñón 6 isleta hecha de una peña tajada de tres estados de altura poco más 6 ménos, y porque es en forma râjunda, muéstrase su diámetro de 200 pasos; está dis tante de la tierra del Asia un muy breve es pacio, mas todo es de vagíos $y$ arrecifes y no se puede navegar sino con barcos; mas aquella que hay desde la isleta á la tierra firme de la América es su anchura menor de medio cuarto de legua, y aunque su canal es tan fondable que dos navios $\mathrm{y}$ aun tres pueden pasar juntos por él, es hacia las orillas de vagíos, y sobre los cuales con una fácil diligencia puede levantar y fundar dos baluartes en angostando la canal á tiro de mosquete; sobre esta isleta 6 sobre los vagíos que se podrían levantar, y sobre la contraria costa se pueden hacer (como dicho es) dos baluartes, los cuales con la artillería podrán muy seguramente guardar y defender el Estrecho, y si las corrientes no fueran tan grandes se le pudiera poner una cadena que fuera de gran importancia aunque ya se podría hacer con tal in. dustria gue pudiese sustentarse y resistir á las corrientes. La disposición del Estrecho es en tal forma, que con tres atalayas que se miraran la una á la otra se puede descubrir treinta leguas dentro del mar del Norte y con ahumadas dar aviso á los baluartes y al fuerte del puerto si descubriesen navíss, para que se les impida el paso si fueren de enemigos, y teniendo continuamente en el puerto dos navíos aprestados para seme jantes necesidades, podrán ésto 3 atravesarse entre los dos baluartes (que para todo tendrán tiempo), supuesto que el que quisiere entrar ha de esperar la marea, $y$ alli entretener $y$ emivarazar los navíos enemigos, en el ínterin que los baluartes los ciñonean y ponen á fondo, porque es de saber que aunque vengan muchos navíos ene- migos, no podrán pasar más de dos 6 tres por la canal y si conviniese desculurir el mar del Sur, alınque pienso no ser necesario por ahora, tiene el Estrecho dos montes altos, uno á la parte del Asia y otroá la de América, los cuales se miran uno al otro $y$ ambos juntos al fuerte $y$ á las ata. layas, y éstos descubren las dos costas en contra. rio puesto cada uno, los cuales podrán dar aviso de todos los bajeles que se descubriesen por el mar del Sur para que haga la prevención ya dicha con la que será este Estrecho defendido, y solos los españoles lo podrán navegar con gran libertad y ozarán de las grandes utilidades que promete, porque verdaderamente no sé yo, qué puerto hay en todo lo descubierto, que así tenga correspondencias con casi todas las tierras del munclo como éste, porque desde allí se puedc navegrar á todas ellas, $y$ asi se puede presumir que vendrá á hacerle el tiempo una grandísima y riquisima población.

La boca del Estrecho por la banda del Norte es dificilísima de conoccr, porque tiene una costa continuada de Este á Oeste, y las dos partes que hacen el Lstrecho se encubren una con la otra porque su entrada y vuelta se describe Nordeste Sudoeste y no se deja ver desde el mar afuera y por esta causa no es mucho que no se haya hallado de los que le han buscado, porque cuando nosc 'ros llegamos, no lo conocimos por algunos días que allí estuvimos barloventeando por aque. lla costa, con tener una muy buena relación de Juan Martínez mi Piloto, que era un portugués natural de Algarbe, hombre muy vie jo y de mu. cha experiencia, mas faltábanle las señales de aquellos montes, que son las que yo tomé y pinté para hacer otra segunda navegación si se me ofreciera, porque aunque sabíamos haberle de hallar en los $60^{\circ}$ de altura, por ser aquella costa muy larga de Este-Oeste, nos hizo estar en dudas, tanto, que al Piloto le pareció no haber llegado á él por más de roo leguas, según la fantasía de su derrota, y á mí me pareció que ya estábamos sobre èl, como sucedib, que saliendo en una chalupa á costear la orilla del mar, la mis ma corriente me embocó por el Estrecho, con que fué conocido. La razón por donde me pareció ha ber llegado al Estrecho y estar sobre él, fueron las grandes corrientes que allí halle, las cuales venían de tierra, $y$ tornaban á ella; tanto que algu. nas veces, estando con nuestro navío enmarado y mar en través, muy apartado de la costa, lo hallámos junto á ella, y otras veces, estando junto á la tierra, lo hallábamos muy enmarado.

Tienen aquellos montes junto al Estrecho una peña altísima sobre un alto monte á la banda de Asia, de color blanca, y siendo la peña tajada $y$ en forma inaccesible, tiene en su mayor altura tres muy grandes árboles, que mirados de Norte á Sur se ven bien distintos el uno del otro, y de la 
una y otra parte de esta altísina peña, muestran los montes una perspectiva á manera de dos silia res muy conocidos. Una legua de la boca del es. trecho, á la banda del Oeste, hay un peñón alto y pelado, al que circunda el mar, y que cuando está la marea más baja me parece que distará de la costa firme cuatro picas de largo; a la banda del liste de la boca del estrecho, hay un grande y hermoso río de linda agua y de muchos árboles, á donde licimos agua, porque alli tiene un media no abrigo con dos grandes peñones que se hacen en una punta: los montes que se descubren á la parte del Asia por esta banda del Norte, son al. tísimos mirados desde el mar dcl Norte y tienen grandes arboledas, y llegando cerca parece ser todo pinares; mas los montes de la América son más bajos y de árboles menores, mas no parecia haber frutales en ninguna de estas dos partes.

En el puerto donde nuestra nave surgió, que cs el que está dicho en la boca del estrecho en la banda del Sur, estuvimos desde los principios de Abril hasta mediado de Junio, y en este tiempo vino por alli una nave grande de 800 toneladas de la parte del mar del Sur á emboca por el estrecho, con la que tuvimos ocasión de ponernos en armas, $y$ habiéndonos apaciguado los unos con los otros, tuvo aquella gente gusto de darnos algunas cosas de las que traían por carga y mercancía, que era mucha y toda cono. cidamente, ó la mayor parte de ella eran cosas semejantes á las de la China, como son hroca. dos, sedas, porcelanas, plumas, cajones de piedras, perlas $y$ oro, y esta gente parecio ser anseáticos, que son los que habitan en la bahía de San Nicolás ó en el puerto de San Miguel, y para mejor entendernos con ellos nos fué forzoso ha blar latín, los que lo sabían hablar con los que lo sabían hablar; mas no parecían ser católicos, sino luteranos; decían venir de una ciudad muy grande que estaba poco más de roo leguas del estre. cho, que aunque no me acuerdo bien de su nom. bre, me parece que la nombraban Roba 6 un nombre á este modo, la cual decían ser un buen puerto, $y$ un río navegable, y que era sujeta al Gran Can, porque dijeron ser de Tartaria, y que en aquél puerto dejaban ellos otra nave de su misma patria. No pudimos informarnos más de esta gente, porque siempre procedian con re cato $y$ poca confianza, teıniéndose de nuestra gente; $y$ por esta causa nos dividimos los uno de los otros, y habiéndolos dejado cerca del es trecho dentro del mar del Norte, nos vinimos de la vuelta de España; y es cosa muy de creer que estos fueron anseáticos, porque como habitan en $72^{\circ}$ de altura, les es cosa fácil y muy á propósito tratar este estrecho y navegación, y pues queda bastante relación de todas las cosas particula. res de esta navegación, y los daños que de no hacerse se puede of recer, parece ser cosa puesta en razón tratar cuales sean las cosas que ha de prevenir la persona á quien le fuese encomenda. do este negocio y saber los gastos que en seme. jantes prevenciones se pueden ofreces para que con esto tenga efecto el inter to de $>$ M. y su Real servicio.

\section{Prevenciones $y$ gastos de este viaje.}

Primeramente conviene hacer tres navlos, la Capitana de I5o toneladas, y los otros dos cada uno de á roo, y éstes sean hechos con unos ca. jones debajo del agua, según la traza que para ello se dará á su tiempo, y con esto se excusa irse al fondo una nave aunque se abra por la parte de abajo, porque solamente se hinche de agua aquel cajón que rtsponde á la rotura y los demás no, por ir todos calafateados, y también que si recibiese el navío algít bombardazo entre dos aguas por donde el agua en rase, por allí tornará á salir sin echarle á fondo, como me consta por experiencias del mismo navío con que hice la navegacion y descubrimientos. Estos navios han de ser de contracostado y emplomados, hechos con muchos y muy gruesos corbatones y pernos muy largos, cuya forma ha de ser cerrados por la parte alta, digo metidos de bordo, y por la parte baja chatos y mu-, bien lastrados, y siendo fabricados en este modo, podrá cualesquiera de ellos salir orzando contra $\mathrm{el}$ viento si se hallare cerca de la tierra en alguna tormenta con viento en travesía, que es el mayor peligro en que una nave se puede hailar, pues que siempre estos navios son grandes bolineros y pueden meterse del Oeste cinco cuartas, y si por desgracia viniese á encallar en algún vagio, por ir por mares no conocidas, podrán salir mejor que otros mayores, porque como son chatos de abajo, no se trastornan y pueden esperar socorro de los suyos en la pleamar.

Asímismo, conviene llevar dos lanchas, una armada y otra desarmada en madera para armarla al tiempo de la necesidad si la que va armada se perdiese; $y$ éstas han de llevar remos para mejor llegar á sus navíos en todos tiempos, ó hacer otras cosas que se puedan of recer, porque esta lancha ha de ir cerca de la costa y á vista de los tres navios, los cuales, siempre han de ir apartados cuatro leguas metidos á la mar y les avise de todas las cosas particulares y señaladas que hallasen en la costa, y por esta razón con. viene que su Capitán sea hombre experto, hábil, animoso, prevenido y muy fiel, y esta lancha : a de ser tan grande, que pueda en una necesidad hacer 20 pipas de ugua, la cual y los tres navios y la lancha desarmada, todos envelados y puestos á punto de navegar, bien enjarciados, costarán. 8.000 ducados.

Es bien llevar en estos navíos seis piezas de 
ue ha de comenda. en seme. para que M. $y \mathrm{su}$ artillería reforzadas para la amura, porque siendo ellos muy fuertes, como dicho es, muy bien las podrán sustentar, $y$ mas otras doce menores, las cuales 18 piezas se repartan en los tres navios, que costarán r.500 ducados. Mas 200 mos quetes á tres ducados cada uno, costarán 600 ducados (1).

Mas 150 arcabuces para si se ofreciese saltar en tierra en alguna ocasión de muchas que se ofrecen en los descubrinientos, á dos ducados cada arcalsuz, valen 300 ducados.

Picas, pólvora, plomo, cuerda, bombas, artificios de fuego, balas de artillería y todas mu niciones, 700 ducados.

Hay necesidad de tres pilotos, hombres cuerdos, fieles, vigilantes $y$ españoles, y sus ayudantes, $y$ dos docenas de bonísimos marineros que vayan repartidos por los tres navios, los cuales quedan de este viaje diestros para ser pilotos de esta carrera, y finalmente, es bien llevar de toda suerte de gentes 200 hombres, y que éstos sean los más que se pudiese, hombres de mar, porque el marinero cuando es menester, sirve de soldado, mas el soldado no sabe en ninguna ocasión servir de marinero; todos los cuales se han de repartir en esta forma: que en la Capitana vayan 80 hombres y en cada navio á 50, y los 20 res. tantes en la lancha primera; que si se of reciese torner remo en las manos haya gente para ello, y toda esta gente vaya pagada $\mathrm{pc:}$ un año, dándoles á los pilotos r.00o ducados á cada uno; y todos los 200 hombres á 48 ducados cada uno, que es á razón de cuatro ducados cada mes, que montan 9.600 ducados por un año.

$Y$ porque entre estos 200 hombres hay aven. tajados Oficiales de guerra y mar, y acompañados de los pilotos, me parece que podrán montar las ventajas de un año 3.000 ducados.

Hánse de llevar respetos de jarcia, cables, áncoras, lona, brea, estopa y todo velamen, herramientas, clavazón y tiras de plomo para reparar algún daño de la artillería enemiga, que todo montará $\mathrm{x} .500$ ducados.

Mas 200 ducados de achotes de cera para el farol de la Capitana y Almiranta, que por ser en esta navegación los días muy largos y las noches breves, no pongo más, pues es sin duda que en muchos días no se verá cubrir el Sol.

Repártanse en todos los navíos 200 ducados de botica. $\mathrm{Y}$ porque las cosas del mar son dudosas, es bien llevar bastimentos para dos años, porque á lo ménos, lo que es el vino puede servir á la vuelta, y así guardando la orden de las raciones ordinarias, son necesarios para los tres navíos 2.200 quintales de bizcocho, que pagados á cuatro ducados, montan 8.800 ducados.

(1) La mayor utilidad de esta relación es esta nota pormenor de los precios de aquella época.
Y porque sucle dañarse el bizcocho y por esta falta venir la gente á padecer grandes tra. bajos, es bien llevar 400 quintales de harina, que pagados á dos ducados, montan 800 ducados.

Las raciones de vino en dos años suman 9.125 arrobas, que pagadas á razón de seis rea. les, hacen 4.977 ducados.

De toda carne, cecina, tocino y gallinas para los enfermos, 2.500 ducados.

Mas 400 ducados de todo pescado.

De aceite, vinagre y legumbres, 600 ducados. Mas 300 ducados de queso.

Itas 100 ducados de sal, porque es de mucha importancia llevar buena cantidad, pues que en las necesidades suele aprovechar, que 6 bien to. mada alguna cantidad grande de pescado (como suele acaecer), 6 llegando á donde se pueda ha. cer alguna carne, con la sal se sustenta para todo el viaje.

Todas las cuales dichas partidas y gastos su. man 47.077 ducados, y esto es lo más que puede costar el despacho de unos navíos, aunque dejo algunas cosas menudas que se pueden of recer $y$ no sc pueden excusar, y mirado bien se compra hart. barato un beneficio tan grande, que es uno de los may'ores que ahora se pueden ofrecer, $y$ se cxusuan grandisimos daños como de no hacerse ,e podrían ofrecer á los Reinos de V. M.; $y$ finalmente, es bien tomar todo lo que otro puede tomer y hacernos daño con ello; porque no sé yo por qué es bien hecho que la parte descubierta y conocida por hombres españoles la dejemos tomar á extranjeros y más si con ella nos puede dañar y hacer guerra, y no sólo esto, que si la toma es sin duda, que éste tal le dará a! demonio las mejores primicias de aquellos Reinos, que son las almas de sus naturales, sembrando entre ellos su mala y perversa secta, que todo eśte riesgo tiene desamparar esta navegación y dejarla á que la haga el enemigo, para que por ella se venga á apoderar de todos aquellos Rei. nos y más fácilmente de aquel nuevo descubrimiento de la tierra austral, que siendo tan grande y tan dilatado como nos informan, aquél quie se hiciese señor de él lo será de todo el mar del Sur, $y$ pues habiendo de caminar por tan largo y prolijo camino como es el del Calo de Buena Esperanza, han tenido medios los enemigos para tener en la India y en aquellas partes siete fac. torías (como se dice que las tienen hoy día) y ocho fuertes en la Isleta de Terrenate con tan. to perjuicio de la Hacienda Real de S. M., claro está de entender que si hallasen este camino tan breve y puerto tan acomodado, sería mucho ina. yor el daño que podrían hacer. Por lo cual, pare. ce ser cosa más justa atender al daño que puede suceder de no tomar y fortalecer este estrecho, que no. á los gastos que de hacerlo se pueden ofrecer, porque quien quisiera tener y gozar 
grandes haciendas, grandes y diversos son los gastos que lia de tener y grandísimos los cuida. dos que ha de padecer.

Finalmente, si V. M. se hicier señor del inar, lo será en lá tierra, $y$ si no con dificultad se podrá conservar lo que se posee; y esto lo digo como hombre que conozco mucho de las cosas del mary sé cuánto vale el imperio de $\hat{c}^{\prime}$ sin el cual es imposible gozar el imperio de la tierra, y estas últimas razones basten para los que saben entender materia de Estado, y para que si hay quien se descuide, despierte y se ponga en vela, que pienso que son muchos los enemigos públicos $y$ secretos, $y$ muchas las naciones que aborrecen á España, y no diga nadie (como pienso que se ha dicho), que no hay dinero para hacer semejantes prevenciones, porque $\mathrm{V}$. M. está necesitado, y si alguno lo dijere, y hallare estar á su Rey cou necesidad, ayúdele con par tes de su hacienda y advierta que le estará mejor gastarla en esto, que por no hacerse se la quite toda otro día el enemigo, que por muclio que él ponga, pondrá más el que se hiciere cargo de poner en ejecución un negocio tan árduo, que yo como márinero no ignoro cuán grande es y cuántos peligros tiene. Sólo puede conocer esto el que supiere cuán grande es la brave. za del mar del Norte $y$ su grande inquietud; en verdad que para la navegación del Golfo haciendo tan buenos navios como para este efecto se han de hacer, no hay que temer al mar por muy bravo que sea. Mas aquí se ha de costear por las razones atrás referidas y el costear en un mar $\tan$ inquieto, es sumo peligroso y tanto, que no habrá marinero á quien no naga temblar el co. razón solo el pensarlo, y así me parece que si se hallare quien lo acepte, no lo pierdan de vista, porque si hay uno, creo que no habrá dos; $y$ adviértase que semejante jornada no le puede ser de ningunos provechos al que la hiciere, sino de muchos trabajos; por lo que es aprovechamiente no sé yo que lo tenga por esta primera vez y no hay que contial en que los enemigos no la han de hallar esta entrada, ú otra, si la tiene el mar del Sur, pues sabemos, que son muy marineros y tan animosos como yo para arrojarse, como yo me arrojé; $y$ digo Señor, que es tanto el cuidado que tienen de hallar alguna entrada, que tergo entendido por relación que me hizo el Capitán Baitasar de la Just, residente en Fonte Rabia, estando tratando conmigo de este particular á siete días del mes de Julio de este año de I609, cómo los franceses tienen hecho un luerte en el ro de Canadá que está 300 leguas metido tierra adentro de los Bacallaos, confiados de hallar desde, alli entrada que pase al mar de Sur; digo esto, no porque entiendo que por alli puedan hallar entrada, porque es imposible que puedan atravesar aquel río más de 1.000 leguas que hay de travesía, y tambien porque yo $\cos$. teé casi todo lo que estaba por descubrir de la costa de América por el mar del Sur, y no halle ninguna entrada ui boca de río que fuese de consideración. Mas dígolo, Señor, porque se entien. dan las grandes diligencias que hacen los enemigos por entrar.

Asimismo se advierte que si V. M. mandare hacer este descubrimiento sea con secreto, y de tal suerte ordenado que los pliegos y la instrucción no los abra el cabio de los navíos hasta haber entrado 40 leguas á la mar; porque con esta disimulación se pueden desmentir los espías suponiendo que se arma para otro efecto, y queriendo Dios que no sea otra vez descubierto el Estrecho, conviene luégo el primer año siguiente enviarlo á fortificar, porque se ha de entender, ser cosa imposible que tanta gente como se da en este descubrimiento hayan de ca. liar tanto, y ser todos tan prudentes que no se publique esta navegación y sus derrotas, $y$ siendo entendidas de los enemigos por ellos mis mos lo buscarán y liallarán y fortificarán de tal suerte, que sea menester mucho, y muchos gastos y hombres para quitárselo, $\mathrm{y}$ así conviene llevar esta mira desde el dia que se dé el despacho para descubrirla.

\section{Nota}

Mandé sacar la copia que antecede del ejemplar $4 .^{n}$ Ms. acaso de letra del mismo autor, que posee el Excmo. Sr. Duque del Infantado. Del mismo ejemplar se han copiado la tabla y las figuras. Todo lo he corregido con atención. Madrid, á 24 de Marzo de 78r.= Fuan Bautista Yuñoz.

Mentoria sobre el descubrimiento antigno del paso del Norte do del mar Océano al del Sur por la parte scptentrional de la América, leida en la Real Acade. mia de Ciencias de París, por Mr. Bauche, Geógrafo mayor de S. M. Cristianisima (r).

"Há cerca de 300 años que se conoce la importancia del paso del Noroeste de la América, siendo este el objeto de las frecuentes indagaciones de las naciones ccmerciantes de la Europa y de un premio de 20.000 libras esterlinas of recido por el Parlamento de Inglaterra á los navegantes nacionales que lleguen á descubririo.

IEn vista de todas as tentativas que inútil. mente se han hechocon este objeto, y de los via. jes que en estos últimos tiempos emprendieron el célebre Cook con el $f_{\Omega}$ de reconocer las costas del Noroeste de la América, donde se sujo. nía una de las bocas del paso; Mr. Young, regis-

(1) Es traducción del original francés hecha por el Capitán de fragata D. Martín Fernández Navarrete. 
porque yo cos. descubrir de la sur, $y$ no halle e fuese de con. rque se entien hacen los ene.

i V. M. mana con secreto, $s$ pliegos y la de los navíos la mar; porque desmentir los ara otro efecto, vez descubier primer año si rque se ha de ue tanta gente o hayan de ca. ntes que no se us derrotas, $y$ $\mathrm{s}$ por ellos mis rtificarán de tal y muchos gas. y así conviene se dé el despa-

tecede del ejem. 1 mismo autor, del Infantado. piado la tabla y o con atención. $=$ fuan Bautista

itiguo del paso del Sur por la parte Bauche, Geógrafo sime (I).

se conoce la im de la América, cuentes indaga. ites de la Euro. libras esterlinas Inglaterra á los en á descubririo tivas que inútil. eto, y de los via. is emprendieron? :onocer las cos. donde se supoIr. Young, regis.

ancés hecha por e andez Navarrete. trando de nuevo la bahía de Hudson, donde se creía la otra, y Mres. Hearne y Pound, cruzando desde la bahía de Hudson hasta los confines de] mar Glacial, al traves de las tierras donde se imaginaba un estrecho, cualquiera podría inclinarse á dudar de la existencia de la comunicación de ambos mares; $y$ ésta tal ve $z$ es la opinión general en el día. A pesar de esto, asegurado de la confianza que inspira la verdad, paso á proponer á la Academia la relación de un navegante, que desde los principios en que empez 6 á cuestionarse, halló el paso del Noroeste. La relación de semejante descubrimiento es auténtica. Los hechos que se citan en ella de ningún modo se oponen á las circunstancias ciertas que hemos sabido de otros navegantes, $y$ además, nos informan de la verdad de otros muchos hechos que refieren diferentes autores, los cuales, como hasta ahora no se han podido comprender, se han mirado como fabulosos 6 como disputables.

"Un navegante español llamado Lorenzo Ferrer de Maldonado, es el que én el año de ${ }_{5} 58$ descubrib el paso del Noroeste que voy á describir, y la relación de semejante descubrimiento se halla en una Memoria manuscrita que él mismo presentó al Rey de España en r6o9, para estimularlo á que repitiese la navegación de este paso y se hiciese dueño de él. El Sr. Mendoza, Oficial de la Marina de España, conocido de la Academia por sus luces y celo y encargado de la córte de Madrid para formar un establecimiento semejante al que tenemos en Francia para la construcción de cartas marítimas, etc., es quien me comunicó una copia fiel de esta Memoria. Después de haberla leido y habiendo hecho conversación sobre ella, me la franqueó para que hiciese el uso que tuviese por conveniente. En tanto que el Sr. Mendoza se ocupa entre nosotros en juntar los objetos necesarios á su establecimiento, el Gobierno ha dispuesto que se re. conozcan todos los Archivos de España y se sa. quen de ellos las relaciones originales de antiguos viajeros y navegantes españoles, y yo me atrevo á decir desde ahora que la Geografía puede esoerar los mayores auxilios de sus conocimientos y de su celo.

"La Memoria del navegante español se intitula: Rulación del desubrimiento del Estrecho de Anian, que yo el Capitín Lorenzo Ferrer de Maldonadu hice el año de $\mathrm{I} 588$, en la cual se ve la derrota que es preciso :aguir, la disposición local y mndo de fortificarie, como también las utilidades que puede ocasionar é repetir una nueva expedición y los inconvenientes que pudiera haber en omitirla. En dicha Memoria se halla trazada por el autor la derrota y un plano particular del Estrecho de Anian, con dos vistas, una de la entrada y otra de la sa. lida, las cuales igualmente delineb en dichos lugares para facilitar su reconocimiento. Este plano y estas vistas, son las que tengo el honor de pre. sentar hoy con mayor extensión á la Asamblea. Pero como en el día sólo puedo ofrecer una idea de este descubrimiento, no haré más que mani. festar la derrota que siguió dicho navegante en ${ }_{5} 8^{8}$ y hacer constar por ella la existencia del paso del Noroeste.

Hé aquí la relación del navegante:

"Partiendo de España, v.g., del puerto de Lisboa, es preciso navegar al Noroeste la distancia de $45^{\circ}$ leguas y hasta los $60^{\circ}$ de latitud, desde donde se avistará la Isla de Frislandia. Desde allí se camina I8o leguas al Oeste bajo del paralelo de $60^{\circ}$, y se arriba á la costa del Labrador, donde comienza el Estrecho del Labrador ó de Davis. Aquí hay dos entradas 6 bocas, una que va ar Nordeste $y$ otra al Noroeste. Se dejará á la dereclia mirando al Norte la que va al Nordeste; esta boca está formada por la Groelandia y sus islas, y vuelve á tomar la mar de Frislandia. Tomando la otra entrada, se hace derrota al Nordeste en un estrecho, el espacio ó distancia de 80 leguas y hasta la altura de $64^{\circ}$; aquí el estrecho vuelve al Norte, y sigue esta dirección r 20 leguas hasta los $72^{\circ}$; desde este punto vuelve otra ve $z$ al Noroeste siguién. dolo $9^{\circ}$ leguas, y se llega á los $75^{\circ}$ de latitud, donde acaba el Estrecho del Labrador. Este tiene 290 leguas de longitud; su mayor anchura son 40 leguas y 20 la menor. Encuéntranse en él puertos, calas y abrigos que pueden servir en caso necesario, y parece ser habitado hasta los $73^{\circ}$, á juzgar por los fuegos que se vieron alli en muclios parajes, tanto de una costa como de la otra.

"Concluído el Estrecho del Labrador se nave. ga al Oeste un cuarto Sudoeste la distancia de $35^{\circ}$ leguas hasta los $7 \mathrm{r}^{\circ}$. A nuestro regreso descubrimos por esta latitud una tierra muy elevada, pero no pudimos averiguar si era tierra fir. me ó isla; sólo sí se pensó que en caso de ser tierra firme debiera ser la costa opuesta á la costa septentrional de Nueva España. Luégo que se ve esta tierra, y desde el $7 \mathrm{I}^{\circ}$ de latitud, es preciso correr al Oeste-Sudoeste la distancia ¿: 440 leguas y se arriba á la altura de $60^{\circ}$, donde se debe hallar el Estrecho de Anian. Con esta instruccion se logrará hacer la misma derrota que yo conseguí desde la Isla de Fr:slandia, que fué el punto de mi salida.

"Cuando llegamos á la salida del Estrecho del Labrador hacía un tiempo muy riguroso: esto era á principios de Marzo. La travesía del Estrecho fué en parte de Febrero, por cuya razón padecimos mucho por la oscuridad, por el frío y por las tempestades; el día fue muy corto todo este tiempo, y el frío tan intenso, que al agua de la mar que rechazaba con el bagel se helaba súbitamente, de manera que el navio parecía seı 
de cristal. También tuvimos precisión de aferrar las velas, las cuales en muchos parajes tenían más de uu palmo de espesor.

"El pensar que el mar de que voy hablando pueda helarse del todo es un error, porque como es un Esstrecho muy ancl:o y tiene corrientes inuy violentas, éstas y las gruesas olas no le permi ten el helarse por su movimiento contínuo, $y$ as me persuado, que sólo puede helarse en la orilla y en los parajes donde el agua está tranquila, á juzgar por lo que pasaba en torno de nuestro navío.

"Cuando regresamos por el Estrecho del Labrador, que fué en el mes de Junio y parte de Julio, disfrutábamos de una claridad contínua. Desde que llegamos al Círculo Polar por $66^{\circ}$ y $1 / 2$ de latitud, comenzamos á gozar del Sol, el cual no nos faltó hasta que volvimos á pasar segunda vez este círculo, que se halla hacia ia mitad del Estrecho. Con motivo de tener contí nuamente el Sol sobre el horizonte, era tan cálido el aire, que sentíamos mucho más calor que en España, pero de ningún modo nos incomodaba, á pesar de estar expuestos á los rayos del Sol, porque siempre logramos un viento fresco del Norte, que al mismo tiempo nos facilitó pasar con prontitud el Estrecho del Labrador.

"Según la tradición antigua, parece que el Es. trecho que hemos descubierto por latitud de $60^{\circ}$, es el mismo que llaman los geógrafos en sus cartas Estrecho de Anian; y si esto es verdad, debe ser formado de un lado por el Asia y del otro por la América. Esto es lo que igualmente nos ha parecido verosímil por la derrota que hemos hecho en la mar del Sur, que es la que voy á referir.

"Luego que entramos en la Mar Grande, seguimos la costa de la América, la proa del Sudeste por más de cien leguas y hasta la latitud de $55^{\circ}$. No se vió habitación alguna sobre esta costa, ni entrada ó embocadura que indicase algún otro paso de la mar del Sur á la mar del Norte; se creyó que esta costa era la de la América, y que continuando la derrota sc llegaría en poco tiempo á Quivira y al Cabo Mendocino, que sabemos se halla en esta misma costa prolongada. Desde este punto ó de la altura de $55^{\circ}$, navegamos al Oeste cuatro días con un viento fresco que podía hacernos caminar zo leguas por día. Después de haber andado r 20 leguas siguiendo la estima, descubrimos una gran tierra de altas montañas y una costa larga y contínua que $d$ jamos para volver al objeto principal de nuestro viaje.

"Nada pudimos averiguar en varticular de esta tierra, á causa de las contradicciones que experimentamos á nuestra vuelta, y sólo podemos asegurar que se halla poblada hasta las cercanias del Estrecho, mediante que se veía salir bastante humo de muchas partes. Siguiendo esta costa, nos volvímos á hallar en la entrada del Estrecho de Anian por donde habiamos embocado en el Mar Grarde quince días antes que estuviéseinos en el del Sur.

„El Est:"echo de Anian tiene ${ }_{5}$ leguas de largo. Así se le pasa fácilmente con seis horas de una marea, que son aquí violentas. La boca que mira al Norte y por la que entramos, no tiene un medio cuarto de legua de anchura. La que mira al mar del Sur, no llega á un cuarto de legua. En medio del estrecho hay un islote formado de rocas escarpadas que angosta más el canal. En este sitio apenas hay un medio cuarto de legua de inchura, por lo que no pueden pasar sino dos ó tres buques de frente.

"La Loca del estrecho del lado del Norte, es muy difícil de reconocer, porque la costa se extiende aquí Este-Oeste y las dos partes que forman esta boca se ocultan una con otra demorando lin entrada Nordestesudoeste. Por esto no es de admirar no la hayan encontrado los que la han buscado. Cuando nosotros llegamos, estuvimos bordeando algunos días cerca de ella sin reconoccrla, no cbstante de tener una relación exacta de Juan Ma.tinez, mi Piloto, que era un portugues nacido en Algarbe, hombre anciano y muy experimentado; pero le faltaba la vista de las montañas, que yo tomé y dibujé para guiarme en otro viaje que la ocasión me presentase. Así, aunque estuviésemos bien advertidos de que el Estrecho estaba situado por $60^{\circ}$ de latitud, como la costa corre Este-Oeste un tan largo espacio, quedamos algun tiempo en duda. El piloto, según la estimá de su derrota, creía hallarse á más de roo leguas, yá mí me parecía que estábamos muy cerca, como en efecto se verificó; porque liabiéndome embarcado en la chalupa para cos. tear la orilla del mar, la corriente me entró en el Estrecho y me lo hizo reconocer de este modo. Lo que me hizo ereer que habíamos llegado al Esstrecho ó que nos hallábamos muy cerca, fué efecto de lo que yo advertí en las corrientes de esta parte, las cuales venían de la costa, á donde volvían seguidamente; de modo, que nuestro bajel, aun estando muy en alta mar, se hallaba de repente arrastrado á la costa y clesde alli era de nuevo arrojado muy adentro de la mar.

-Desde principios de Abril hasta mediados de Junio, permanecimos en un puerto que hay en la boca del Estrecho por la parte del mar del Sur. A este tiempo llegó un bagel de 800 toneladas que venía del mar del Sur á pasar el estrecho, y cuyo equipaje nos parecíb ser de las naciones anseáticas que habitan la bahía de San Nicolás 6 el puerto de San Miguel. Con motivo de recelarse ó cautelarse ellos de nosotros, y al parecer temiéndonos mucho, no pudimos recibir instrucción alguna de ellos; por consiguiente, nos separamos, habiéndolos dejado en el mar del Sur, y nos aparejamos para regresar á España. 
do en el

viésemos

as de lar-

horas de

boca que

$b$ tiene un

que mira

de legua.

rmado de

canal. En

de legua

o sino dos

Norte, es

sta se ex-

s que for-

demoran-

to no es de

ue la han

estuvimos

sin reco-

ción exac-

an portu-

ano y muy

ista de las

guiarme en

ntase. Así,

de que el

itud, como

yo espacio,

piloto, se-

larse á más

estábamos

có; porque

para cos-

entró en el

este modo.

llegado al

cerca, fué

rrientes de

sta, á don.

que nuestro

se hallaba

sde alli era

mar.

nediados de

de hay en la

ar del Sur.

o toneladas

estrecho, $y$

as naciones

in Nicolás 6

de recelar

parecer te-

bir instruc-

e, nos sepa-

r del Sur, y

ña.
"Este es el resumen del viaje y del descubrimiento que dice haber hecho el navegante espa. ñol el año de 1588 . En las particularidades que he omitido y q'ie relacionare en nuestras sesiones $o$ juntas privadas, se hallarín suficientes pruebas de la existencia del paso y de los conocimientos del navegante. Por ahora es mi desig. nio examinar la derrota que nos ha ırazaris, y proponer algunas observaciones sobre las prir.cipales circunstancias de su descubrimients.

"Ia derrota del navegante desde Lisboa á la Isla de Frislandia y de Frislandia al Estrecho del Labrador, es la que nos dan los navegantes modernos desde Lisboa al Cabo Farewell en la entrada del Estrecho de Hudson, donde se encuentran las mismas latitudes y las mismas dis. tancias.

"El paso que después describe desde el Océano al mar del Sur, se compone, como hemos visto, de tres partes: r." La travesia del Estrecho del Labrador, que va desde el Océano al mar Glacial. 2." La navegación ó carr.no de 700 leguas en el mar Glacial. 3." La travesía del Estrecho de Anian, que va desde el mar Glacial al mar del Sur.

El Estrecho del Labrador donde el navegan. ie pone 290 leguas de longitud ó extensión, se divide en tres partes, como es fácil de comprender. La primera que dice ser de 8 o leguas al Nor. oeste, es efectivamente el Estrecho de Hudson, desde su entrada hasta la bahía de Hudson; esto es, las mismas demoras y la misma distancia.

"En el año de I $_{5} 88$ todavía no se conocía la bahía de Hudson, ni tampoco pudo verla el navegante, porque siguió la costa septentrional del estrecho, la cual siempre está más libre y ménos cmbarazada de hielo.

"La segunda parte, que navegó al Norte y cuya longitud se ha puesto de r 20 leguas, se advierte también en el Estrecho que avanza al Norte de la bahía de Hudson y que en las cartas inglesas se denomina Namcless Strait ó Straitundiscobered, esto es, Estrecho sin nombre ó Estre. cho no descubierto; donde todavía no se conoce más que una parte del lado del Sur que ha sido vista por Baffin en $16 r 6$, por Fox en 1631 , y por Tomás James en 1632 .

"Estos navegantes intentaron penetrarle es. perando encontrar allí el paso que buscaban; pero se retiraron asustados con los hielos que veían venir del Norte. Es de notar que Baffin, estando al Sur de la entrada, y viendo que las mareas se dirigían al Norte, infirió de aquí que había un paso, y á consecuencia dió el nombre de Cabo Confort á una punta de tierra cerca de la cual el hizo esta observación. Igualmente Fox ha inferido del crecido número de ballenas que se ven en la parte del Noroeste de la bahía de Hudson, que debía haber en esta parte 6 sitio un paso al mar del Sur, lo cual creyó hasta su muerte. Las cartas inglesas que se han publicado de cuarenta años á esta parte, hacen conmemoración de una comunicación entre el estrecho sin nombre y la bahía de Baftin, la cual, como se halla fundada solamente en conjeturas, es verosímil haya im. pedido hacer nuevas indagaciones, tanto más cuanto los navegantes que han ido en busca del paso á la bahía de Baffin, no han hallado más que hielos en su parte del Sudoeste, donde se su. ponía la salida del Estrecho sin nombre. Las cartas antiguas dan una anchura mucho menor á la bahía de Baftin, que todas las modernas; la colocan ménos al Oeste y la aproximan ménos á la bahía de Hudson; y yo pienso con Mres. de Lisle y Danville, quienes las habían adoptado, que merecen la preferencia.

"La tercera parte del Estrecho del Labrador, ó la que termina en el mar Glacial, se halla en un territorio que todavía no conocemos; por consiguiente, no contradice ninguna de las nociones que se nos han dado; antes bien, me parece confirma lo que se ha visto sin mucho interés en una carta inserta en L'Americain Traveller y en una carta grande japonesa, traída del Japón por Rempfler y depositada en el gabinete del difunto Mr. Hansloane. La carta del Americain Traveller manifiesta una comunicación ó un estrecho entre el mar Glacial y la bahía de Hudson, donde se ven las denominaciones de Spurle y Foulrc, dadas á los dos puntos que forman la entrada de este Estrecho del lado del mar Glacial. La carta japonesa, la cual nos manifiesta todavía desconocidas las costas de la América Septentrional, nos indica igualmente un estrecho por donde se comunica el mar G!acial con el Océano, y coloca este Estrecho en el mismo sitio á donde nos ha conducido el navegarate español. Por las indicaciones sabias de Mr. Guignes, sabemos que los chinos navegaban antiguamente á las costas del Noroeste de la América; tambien se sabe por Benjamín de Tudela, autor indio del siglo xil, que los chinos conocieron el mar Glacial, al cual llamaban Nikpha. Decían ellos, que los que en. tran en este mar no pueden salir y que mueren dcspués que se les acaban las provisiones. Seixas rehere en su Teatro nazal que en la bahía de Hudson se han hallado cascos de navios chines. cos; por esto podemos comprender de dónde tomaron los japoneses los conocimientos que po. nen en sus cartas. E1 Americain Traveller no hace la menor expresión de los conocimientos que nos manifiesta la carta inserta en esta obra. Monsieur de Bogoundi, quien en el año de 1774 hizo indagaciones sobre este objeto, nos dice que el autor era un Capitán inglés llamado Elmui, y que había recorrido una parte de las costas del mar Glacial al Norte de la América. Nadie ha usado de estos conocimientos desde esta época por no 
saber apreciarlos; pero hoy día se pucde creer que no carecen de fundamento. Permítaseme citar aquí un artículo de la Gaceta de Londres, que al presente parecerá más digno de atención. En el día 4 de Abril de $\mathbf{r} 769$, se dice en ella que un Oficial que había montado navíos de la Com pañía de Hudson, había hallado poco hacía, el paso deseado por el Noroeste para ir á las Indias Orientales; que había pasado felizmente desde el Estrecho de Lepulse-Bay á otro, por el cual había entrado en el Océano de Tartaria, y se añade que á instancias de la Compañía de Indias y de las de la bahía de Hudson se habian desaparecido repentinamente su diario y sus cartas en el momento que iba á publicarlas.

"En el diario de sabios del mes de Noviembre de 1773 , se halla igualmente una carta de Monsieur de la Lande, que dice que un navío danes, llamado la Corona del Norte y mandado por el Barón de Ulfeld, había pasado el año de 1769 del Océano al mar Glacial, de éste al del Sur, de donde volvió á Luropa por el Estrecho de Le Maire.

"Toda esta relación, unida al testimonio del navegante español, no de jan duda, á mi parecer, de la comunicación de la bahía de Hudson con el mar Glacial, y consiguientemente del paso del Noroeste, del cual esta comunicación hace la parte principal.

"La navegación del mar Glacial, desde el Estrecho ciel Labrador hasta la entrada del Estrecho de Anian, tal vez parecerá difícil, pero no imposible, como se hubiera podido inferir de los viajes de Phipps y Cook. Por la derrota del navegante español se ve que la costa declina hacia el Sur ála salida del Estrecho del Labrador, y que se halla á los $7 \mathrm{I}^{\circ}$ de latitud laacia la mitad de espacio que separa los dos Estrechos. Mr. Hearne ha hallado la. embocadura del río de la Mina de Cobre por cerca de $7 \mathrm{I}^{\circ} 4 \mathrm{o}^{\prime}$, y $\mathrm{Mr}$. Pound, en una carta de sus descubrimientos presentada á la Academia en 7786 por Mr. de la Rochefoucault, indica la embocadura del río Arabosca hacia los $65^{\circ}$. Este último no ha llegado hasta el mar Glacial; pero nos dice que parlamentó cerca del lago Arabosca con cuarenta de los naturales que vi. ven á corta distancia de la costa.

"Estos le confirmaron que en este mar había Hujo y reflujo; le aseguraron que no conocían ninguna tierra al Norte, y que habían visto muchas veces allí hielos flotantes; pero que la navegación de los ríos que allí embocan, se hallaba franca desde principios del estío. También pre. guntó Mr. Pound á muchos salvajes que hahían acompañado á Mr. Hearne en su viaje, y nos dice que le ocultaron las principales circunstan. cias de él, y que en el día es prohibido á todos ir hacia el Oeste: lo mismo sin duda sucedió en el viaje de Mr. Young, del cual jamás se lıa tenido conocimiento alguno y en el del Capitán Cluny; pero en lo poco que nos enseña Mr. Pound, nos anuncia bastantc que el mar Glacial no es impracticable por la parte de la América. Śblo me resta hablar del Estrecho por donde el navegante español pasó del mar Glacial al del Surr y que él llamó Estrecho de Anian, según las cartas de su tiempo. Se ve que este Estrecho, que él pone por $60^{\circ}$ de latitud y al cual no le da más que un cuarto de legua de anchura, no puede ser el Es. trecho de Bering que hallo Cook á los $66^{\circ} \mathrm{dc}$ latitud y de I $_{5}$ leguas de anchura: luego hay otro Estrecho que todavía no conocemos en esta parte del Noroeste de la América, y por consiguiente de las islas al lugar de las tierras que nosotros tenemos por una parte del continente.

"En efecto, esto es lo que nos indican muchas cartas de los rusos, y particularmente la que Mr. S. Thalin publicó de sus descubrimientos. Se ve en ella una gran isla á continuación de otras muchas pequeñas situadas al Este del Estrecho de Bering y separadas del continente de la América por otro Estrecho.

"La relación del navegante ofrece aquí una gran dificultad, que yo no puedo pasar en silencio. El cálculo de su derrota al salir del Estrecho del Labrador, coloca el Estrechode Anian al Oeste del de Bering y sobre la parte del Nordeste del Asia, donde sabemos por otro lado que allí no hay Estrecho, y así es menester suponer que hay un error considerable en la estima que ha hecho de su derrota. No me atrevo, por consiguiente, á confiar poder determinar de un modo satisfactorio la posición de este Estrecho, y solo propongo como verosímil lo que voy á decir sobre esta materia.

"La latitud del Estrecho de Anian, establecida ó fijada á los $60^{\circ}$, deb ser casi cierta, respecto que estaba así indicada en la relación del Piloto, que halló exacta el navegante, quien por otra parte permaneció allí mucho tiempo para poder asegurarse. Esto supuesto, debe estar el Estrecho hacia Shoal Ness al Oeste del rio de Cook, ó ha. cia el Monte de San Elías al Este del mismo río, porque estas son las únicas partes del lado de la América que se hallan en la latitud dicha. Los rusos han reconocido todas las inmediaciones de Shoal Ness, como se ve en la última carta de sus descubrimientos, y no han hallado ningún Estre. cho; por consiguiente estamos en la precisión de fijarnos en las cercanias del Monte de San Elías. Por ctra parte se adoptará esta posición considerando el camino que hizo el navegante á su salida del Estrecho ó á su entrada en el mar del Sur. Se advierte que él navego dirigiéndose al Sudeste, $y$ hasta los $55^{\circ}$ de latitud no puede estar sino la costa de la América situada al Sudeste del Monte de San Elías. Del mismo modo la costa que halló á las rzo leguas al Oeste de la Amé- 
rica y que siguió en la dirección del Nordeste y hasta el puerto, no puede ser representada sino por la costa de Alaska y las tierras vecinas al rio de Cook. El navegante ha supuesto que esta última costa era una parte de la Tartaria; pero por lo que él mismo dice bajo la fe de las cartas de su tiempo, y porque había supuesto que su Estrecho era el que significaban estas cartas con el nombre de Anian.

"Todavía me inclinaría á admitir esta posición del Estrecho, la consideración de las reclamaciones de la España y de sus pretensiones sobre esta parte de la cosía de la América. No cabe duda en que los españoles han tenido conocimiento del Estrecho, supuesto de que independientemente de la relación de nuestro navegante, se lee en Purchas que habiendo entrado Drake en el mar del Sur, quiso el Virey de Méjico construir un fuerte á la entrada del Estrecho por la parte del Mediodía; y que por casualidad pasó por allí el año I6og un bajel de Acapulco, el cual vino á Lisboa. Con este motivo se reconoce la data de la Memoria de nuestro navegante y su proyecto de fortificar el Estrecho. Las cartas antiguas indicaban una continuación de costas de r.70o leguas de extensión, que iban de la punta del Sur de la California hacia el Japón, y es ve. rosímil que esto fuese el resultado de los primeros descubrimientos que se hicieron y que después se ha suprimido, porque no se conocía con fundamento. Extendiendo los españoles su derecho hasta Williams Sound á la entrada del Príncipe Guillermo, sin duda que to han hecho con conocimiento de causa, $y$ es de presumir que han querido incluir el Estrecho en los límites que ellos han reclamado.

- En cuanto á los nuevos establecimientos que se forman en esta parte, tendremos en breve co. nocimientos ciertos. Se sabe que los rusos han avanzado más allá del río de Cook y tal v̀ez intentarán de nuevo su antigua navegación por el Estrecho donde fueron vistos por nuestro navegante en I588; también es verosímil que los in. gleses no esperen á publicar los conocimientos que hoy día tienen del paso del Noroeste, sino es en el momento en que se hallen asegurados de la posesión de esta parte de la América que dispu. tan á los españoles.

"Se ha visto en la Memoria del navegante es. pañol, que su Piloto tenía una relación exacta del paso del Noroeste; de donde se debe inferir que semejante paso era ya conocido, ó por lo ménos se había descubierto antes del año de 1588 , época de su viaje. El nos dice que su Piloto era portugués, viejo y muy experimentado; pero nosotros sabemos por Purchas, que un portugués llamado Martín Chaeke había descubierto en 1555 un paso desde las Indias al mar Septentrional, que había hecho una relación de su viaje, y que este paso se hallaba á los $59^{\circ}$ de latitud, que como se ve es la del Estrecho descubierto por nuestro navegante.

"Un piloto inglés llamado Tomás Cowles, testificó por escrito en 1579 que había leídc la relación impresa en 1567 , pero que después de este tiempo no la había podido volver á ver, á causa de haber sido prohibidos y recogidos los ejem. plares por orden del Rey de Portugal, temiendo que este descubrimiento acarrease algún perjuicio á su comercio.

"También se lee en Purchas, que este paso del mar del Sur al mar del Norte fué confirmado por un portugués que aprisionaron los ingleses en tiempo de la Reina Isaliel; que otro portugues de Guinea había hablado á Forbisher, como habiéndolo pasado; y en fin, que era comunmente reconocido por los pilotos de Lisboa.

"Después de todas estas consideraciones, me parece que se puede tener por un hecho constante el descubrimiento que acabo de exponer del paso del Noroeste, buscado ciespués de tan largo tiempo. Para conservar la memoria y asegurar la gloria á quien corresponde, he creído debía dar el nombre de Ferrer al estrecho descubierto por el navegante espariol, tanto más, cuanto es muy incierto que esté allí el verdadero Estrecho de Anian. De este modo llamaré al Estrecho que hace la comunicación de la bahía de Hudson con el mar Glacial, y que hasta ahora se ha llamado Estrecho $\sin$ nombre ó Namess Strait. Sacando á luz este descubrimiento, he da. do la solución de un gran número de dificultades, que siendo verdades interesantes, habían declinado á la clase de fabulosas, y en adelante harán leer con mayor interés la historia de las antiguas navegaciones. Acaso habré destruído también las preocupaciones que se opondrían todavía por mucho tiempo á los progresos de la navegación en los mares del Norte, y me atrevo á confiar que el fin del siglo xvul añadirá el conocimiento de las tierras próximas al Polo, y áun del Polo mismo, á todos aquellos con que este siglo ilustrado ha enriquecido la Geografía."

Ya, pues, con las medidas tomadas anteriormente, desde el amanecer del día $1 .^{\circ}$ de Mayo entrambas corbetas se hallaron enteramente dis. puestas para dar la vela; el correo de Méjico que llegó antes de las ocho de la mañana, en nada se oponía á nuestro intento, de suerte que á las nueve y media, con las primeras ventolinas del Noroeste, pudimos zarpar la última amarra y navegar con todo aparejo á franquear con la mayor brevedad la boca del puerto.

Por un acaso poco común, el viento se llamó y mantuvo después al Sursudoeste flojo; la marea no nos era favorable sino en la mucha roximi. dad de la costa del Sur, y así debimos continuar 
Miy, t,o nuestros bordos hasta las dos de la tarde, á cuya hora, inclinándose finalmente el viento al Oeste galeno, pudimos con la mura estribor pasar como á un cable y medio de la punta de la Bruja y media milla del Diamante, y últimamente, á las cuatro de la tarde, considerarnos libres de toda necesidad de dar fondo.

Si constiltásemos las derrotas de las Naos de Manila, lo acaecido al Comodoro Anson proximamente en principios del mes de Mryo y la misma voz común sobre aquellas costas, no era tan fácil el alcanzar las brisas, y aun para este intento debían hacerse sacrificios considerables al Sur; pero las navegaciones últimas de nues tras corbetas parecian oponerse mucho á la infalibilidad de estas reglas, pues la Descubierta, en $\operatorname{los} x 3^{\circ}$ de latitud y distante unas 70 leguas de la costa, no había hallado más que calmas y ventolinas variables, y la ATREvid. había tenido la fortuna, de quc las brisas en su primera travesía le alcanzasen hasta casi la vista del puerto, lográndolas también frescas en su navegación á San Blas luégo que distanto de Acapulco unos 6 ó $7^{\circ}$ al Oeste, purlo repo.serse en la latitud de 15 y $16^{\circ}$. En cuanto á la preferencia de una derrota de altura sobre las costaneras que al mis mo tiempo hacían difícil los vientos del Noroeste y las corrientes muy vivas, ninguna duda podía admitirse, tanto más, que cualesquiera derrotas, si hubiesen de conducirnos con brevedad á latitudes altas, siempre debian dirigirse á mucha dis tancia de la costa de California para evadir los Nortes y tener mejor bordada con los Noroestes.

Con estas reflexiones se prescribió descle lue go el rumbo del Oeste aprovechándole con mayor andar, siempre que los vientos, particularmente por la madrugada, se inclinasen al terral, y aproximándonos de él con preferencia á los rumbos del Sur, siempre que estuviesen á la virazón, del Oeste y Oeste-Sudoeste; demasiado descaeceríamos al Sur con el solo ef ecto de las corrientes $y$ de los vientos, sin coadyuvarles por nuesra parte con derrotas voluntarias que nos atrasasen.

No fueron sin embargo frecuentes al principio las ocasiones en que pudimos apartarnos de la derrota común. Después de cuatro singladuras, al medio día del $\mathbf{5}$ apénas habíamos adelantado $I^{\circ}$ al Oeste con el sacrificio de $2^{\circ}$ en la latitud, y los carices no manifestaban aún la proximidad de las brisas; pero al día siguiente ya los vientos se declararon algo más fresquitos y constantes del Nornoroeste y Norte, con los cuales nuestros progresos empezaron á ser considerables y los carices á indicar la brisa no dis tante. A la sazón, y aun al otro día de haber perdido la costa de vista, eran pocas las aves que alcánzábamos en el horizonte, y éstas por lo común se ceñían á las dos clases de los pelícanos y larus; un solo bonito de muy corto tamaño ha- Mny. o bia sido presa de nuestros anzuelos. La claridad de los cielos y horizontes, la mar y el viento sumamente apacibles nos recordaban casi con emulación nuestra existencia en el mar Pacífico.

Las variaciones de la aguja, que observába. mos diariamente, bien sea por los azimutes ó por las amplitudes, aún manifestaban casi constante la de $6^{\circ} 30^{\prime}$ al Nordeste, y la segunda compara ción de nuestros relojes con los de la ATrevid/ hecha al día siguiente, indicaba muy poca dife. rencia entre unos y otros, manifestandolas ecua. ciones diarias que aquéllas debían atribuirse más bien á atrasos del número 72 que á adelan. tcs del número ro.

Hasta entonces había sido el objeto esencia. de nuestro método de disciplina, el atender á los dos únicos inconvenientes de la deserción y de la falta de asistencia al trahajo; hubiera sido imprudente con una disciplina más molesta é intempestiva, ó representar á los armamentos la idea de un peligro próximo que pidiese el uso de las armas, 6 cuidarles con un tesón opresivo una salud que á cada paso podían aventurar en los diferentes puertos visitados hasta aquel momento; de este modo habíamos podido insensiblemente disponerlos para nuestro intento, infundiéndoles otras dos crilidades, de las cuales ya no podíamos prescindir, y eran la robustez y un cierto amor y confianza hacia nosotros, de suerte que nos mirasen más bien como amigos que como superiores, en todas las ocasiones que no tuviesen conexión directa con el servicio militar. Pero en el día no podíamos desentendernos de la necesidad de una disciplina militar, la cuai al mismo tiempo pusiese á cubierto de cualquier riesgo nuestras vidas $y$ las de los naturales cuyas costas visitásemos, y no distrajese un roce amistoso del cual dependían nuestros progresos en las indagaciones científicas que nos habiamos propucsto; tampoco debíamos omitir cuanto pudiese conducir á la conservación de la salud, en una mudanza tan rápida de clima como la que debíamos encontrar, y en la estrechez con la cual debíamos naturalmente vivir por largo tiempo. Con este objeto se aumentaron á bordo las precauciones para el buen orden $y$ aseo, se encargó estrechamente á la Oficialidad de guardia que vigilase cuotidianamente sobre ambos puntos; pero con tal pulso que ni un momento se perdiesen de vista el cariño y la confianza recíproca; se repartió alguna ropa de abrigo; finalmente, se formó un plan militar que trazado sobre los escarmientos de los que nos hai.an precedido en esta especie de viajes, pudiese al mismo tiempo combinarse con todos nuestros intentos y con cualesquiera otras costas que hubiésemos de visitar en lo'venidero.

Cualquiera que conozca el carácter de nues. 
Nay, 6 tras marinerias, insensibles á otro freno más que á la razón y al ejemplo de una Oticialidad que respete, $y$ por otra parte tan entregadas á unas pasiones excesivamente viva como resistentes á una sujeción directa, no extr aará que nuestras medidas en esta parte lleven siempre consigo un sistema casi diametralmente opuesto al que han seguido los ingleses bajo las órdenes del Capitán Cook; bien que en las memorias relativas á la conservación de la salud se anotarán estas razones con mayor extension, de suerte que manifiesten hasta dónde es preciso extender en el marinero español aquella sensibilidad, razonamiento y viveza de pasiones que tanto difieren del carácter de las marinerías del Norte.

Ya en la estación en la cual nos hallábamos, debimos desistir de toda idea de reconocer 6 algunas 6 todas las islas intermedias entre el continente y las de Sandwich. Los Comandantes Hezeta y Cuadra habían visto las del Socorro; el Piloto Maurelle la Roca Partida, y el Conde de la Peyrouse, corriendo el paralelo de las de Ulua y los Majos, había conocido ser estas mismas las de Sandwich, con el solo error en longitud, que por lo común encuentran las Naos en la travesía desie Acapulco á las Marianas: el rumbo del Oeste, fue por consiguientc, el que seguimos, y los vientos, aunque algo varios del Nornordeste al Esnordeste, nos fueron $\tan \mathrm{fa}$ vorables, que al medio día del $\mathrm{I}_{3}$ habíamos alcanzado la latitud de $16^{\circ} 25^{\prime}$ y la longitud al occidente de Acapulco de $14^{\circ} 22^{\prime}$, demo:sinidonos casi al Norte la Isla de Santa Rosa (ó tal vez la Nublada), según la disposición de las costas de San Blas.

La variación de la aguja había por ese tiempo disminuído hasta $2^{\circ}$ y $3^{\circ}$ al Nordeste, conformes en manifestarla así diferentes azimutes, pues que la mucha celajería imposibilitaba el observar las amplitudes occídua y ortiva. Volvió luégo

23 á aumentar con bastante celeridad y el 23 , por latitud de $27^{\circ} 22^{\prime}$ y longitud de $28^{\circ} 20^{\prime}$ al Oeste de Acapulco, ya la hallábamos de $8^{\circ} 40^{\prime}$.

Hasta ahora nos habían parecido, si no supérfluas, á lo ménos muy tempranas las experiencias de los eudiómetros, las cuales denotasen con certeza la salubridad del aire que respirábamos, y los progresos de las enfermedades sépticas á medida que la dilatación del viaje, los alimentos, el frío y cualesquiera otras causas cooperasen juntamente á producirlas; pero ya con veintidos días de viaje, con un temple bien diferente del que habíamos experimentado en Acapulco, y precisados, 6 bien por el frío 6 por la mar algo gruesa á cerrar la portería de barlovento en la:s noches, hubiera sido omisión reprensible el no darlas principio con toda aquella exactitud que requería la novedad y la importancia de esta materia: encargáronse, pues, de dicho examen D. Francisco Flores y D. Tadeo Heenke, May, 2, y los primeros resultados debieron parecernos bien agradables, pues veiamos reunida á una salubridad considerable en el aire atmosférico, una grande aproximacion de todos los demás que habíamos examinado, entre ellos los de la bodega y entrada de la sentina. Renovadas las mismas experiencias en la mañana del $3 \mathrm{I}$, dieron los mis. mos resultados, aunque sustituyésemos el uso del agua salada á la dulce para el traspaso de los aires. Todo conducía á convencernus que el sólo desaseo y la falta de ventilación eran las causas de respirarse un aire más infecto en el mar que. no en la tierra.

Todoel mes de Mayo no podía haber sido más feliz; por latitud de $3 \mathrm{I}^{\circ}$ nos hallábamos entre los vientos variables; la tistancia de la costa nos permitía indiferentemente aquellos bordos que con mayor brevedad nos elevasen hacia el Norte y jin. las tripulaciones más bien se habían robustecido; sólo sí, que en la corbeta Atrivida habian tenido la desazón de ver inutilizado por una extraña casualidad el reloj número to del Sr. Berthoud: olvidado accidentalmente el darle cuerda, no fué después posible el vol verle á poner en movimiento, por cuanto se adoptasen las sacudidas $y$ un calor violento artificial; el temor de romper una máquina tan preciosa, dictó como más prudente el dejarle así parado más bien que desarmarle; pues no debía quedar duda que lo espeso y crasoso de los aceites, combinados con algún frío que le condensase, era la verdadera causa de la inposibilidad para adquirir nuevamente el antiguo movimiento.

Ya desde los paralelos indicados nuestra na. vegación hacia el Norte debió por naturaleza ser más acelerada: experimentáronse algunos temporales por el Oeste y Oesnoroeste, los cuales no tenían para nosotros sino el sólo inconveniente de hacernos descaecer algo más sobre la costa; repetidas con mucha frecuencia las distancias lunares, nos indicaban un error al Oeste de medio grado próximamente para los relojes marinos; y como á medida que nos elevábamos hacia el polo, la costa inclinaba más y más su dirección al Oeste, finalmente, por latitud de $56^{\circ}$ I $7^{\prime}$ avistóse el día 23 la tierra bastantemente distante y elevada.

Era la comprendida entre el Cabo Engaño y las islas septentrionales al Cabo San Bartolomé, reconocida por el Capitán de fragata $D$. Juan de la Cuadra en 1775 , por el Capitán Cook en 1778 y por el capitán Dixon en 1786 : no tardamos en distinguir el monte Edgecumbre, llamado por Cuadra, de San Jacinto, la grande ensenada que él mismo llamó del Susto, y poco después el abra del Cabo Landers y puerto de Banks visitados por el Capitán Dixon; nos demoraban el Cabo Engaño al Norte $14^{\circ} 30^{\prime}$ Oeste de la aguja, la 
Jun. ss punta Sur de la ensenada del Susto, que llamamos Serena por la seienidad del día que lográ. bamos á la sazón, al Norte $5^{\circ} 30^{\prime}$ Este; y los extremos al Este, al parecer una punta roma, no distante de una isla algo grande, al Norte $77^{\circ} 30^{\prime}$ liste; la descripción de este trozo bien individua lizada por el Capitán Cook, nos pareció corres. ponder puntualmente á la exactitud de aquel navegante exclarecido: un número crecido de mogotes altos (probablemente islas) indicaba un número casi igual de buenos puertos; entre la isla y la punta roma, en el extremo del Este, se veía - claramente una abra 6 estrecho considerable; no se nos ocultaba tampoco que la tierra del monte lidgecumbre era otra isla; y el erguido descuello del mismo monte le hacía notable entre todos los demás, y por consiguiente, muy oportuno para guiar en este paraje al navegante incierto, que carezca, como frecuentemente sucede, de la latitud observada; las vistas que damos de estc monte lo manifiestan tal vez ménos alto de lo que pudiera inferirse del viaje del navegante inglés; logramos medir su altura con toda exacti. tud, y como la diferencia de latitudes determinase con mucha seguridad la distancia, podemos creer que nuestros resultados se aproximen á la verdad. D. Juan de la Cuadra había ya determinado á la Punta ó Cabo de Engaño la latitud de $57^{\circ} 2^{\prime}$; no le excede más que en un minuto la que supone el Capitán Cook, y así no debíamos tener la menor desconfianza de la distancia de leguas al monte, y tinalmente, de su altura sobre el nivel del mar.

Era muy poca, á la sazón, la nieve que notábamos sobre su cumbre; antes bien, nos pareció que la conservaban más baja y más copiosa va. rios otros cerros interiores á la ensenada del Susto y á la Punta Serena. No se halló fondo con 120 bra:as de sondaleza; la variación magnética, así por el azimute meridiano, como por varios otros azimutes, fué de $24^{\circ}$ á $25^{\circ}$ Nordeste.

La comparación de nuestras longitudes con las del navegante inglés era un punto importante para que le descuidásemos en esta ocasión, tanto más oportuna, cuanto que el Cabo Edgecumbre 6 del Engaño era un paraje de los que había determinado con mayor exactitud, y dependía de una travesía de pocos días desde Nutka, después de una conformidad grande entre las distancias $1_{u}$. nares y una observación del primer satélite de Júpiter, y después de un arreglo bien prolijo de sus relojes marinos. Se agregaba á estas razones en favor de la determinación indicada, el reparo de convenir exactamente en la carta inglesa la longitud del puerto de San Pedro y San Pablo en Kamshatka, con la que resultaba de las observaciones del primer satélite de Júpiter hechas en eì mismo puerto por el Sr. de Krissilinkof, y examinadas con tanta sagacidad por el Sr. Coxe; de suerte que sujetos ambos extremos, parecía Jun. is que las longitudes medias debían también considerarse como seguras.

Hé aquí nuestros resultados y los del Capitán inglés:

\begin{tabular}{|c|c|c|c|}
\hline & 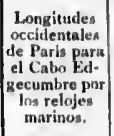 & $\begin{array}{c}\text { Idem por las } \\
\text { distancias } \\
\text { Junares. }\end{array}$ & Idem nor el Capitán Conk. \\
\hline Cronóm. 72 & 138.49 .13 & $\begin{array}{l}195 \text { series } \\
\text { en los dias } \\
6,7 \text { y }(10 \\
\text { de Junio. }\end{array}$ & $138.31 .38 \quad 138.15 .30$ \\
\hline $\begin{array}{l}\text { Cronom. } 71 \\
\text { Cronóm. } 61\end{array}$ & $\mid \begin{array}{l}13^{8.48 .30} \\
13^{8.38 .30}\end{array}$ & $\mid \begin{array}{r}97 \text { id. dia } \\
23 \ldots \ldots\end{array}$ & 137.31 \\
\hline Reloj 105. & $13^{8.42 .10}$ & | & $n$ \\
\hline Promedios. & $\mid 138.44 \cdot 37$ & $"$ & $138.1 .19 \times 38.15 .30$ \\
\hline
\end{tabular}

Pareció preferente el adoptar los resultados del Capitán Cook, á lo ménos hasta que tuviése. mos por nuestra parte observaciones celestes que determinasen más directamente su exactitud.

Algo más feliz que nosotros el Sr. Heenke en sus pesquisas para la Historia Natural, logró en el mismo dia examinar diferentes especies de moluscos, entre las cuales una enteramente nueva, que distinguío con el nombre de Speciosi, merecía particular atención, no ménos por su ta. maño y movimiento vivo ondulatorio, que por los colores mezclados de perla y púrpura que en diferentes partes presentaban el contraste más vivo y agradable: no debía sernos extraño que las demás especies, conocidas anteriormente con los nombres de Medusa eguorea cruciata aurita, fuesen en un todo semejantes á las que se hallaban en el mar Báltico: una grande harmonía en los productos de la naturaleza trasluce á cada paso cuando éstos se examinen y comparen, so. bre todo, la extensión del globo.

No era nuestro ánimo el sacrificar un día siquiera de la actual estación favorable al reconocimiento prolijo de las costas que teníamos ac. tualmente á la vista; antes bien, con el deseo de alcanzar cuanto antes los paralelos inmediatos al de $60^{\circ}$ hacia donde debían dirigirse nuestras pesquisas, no podíamos desentendernos que el recalar en paralelos tan bajos era sólo efecto de los últimos vientos escasos, y que la misma corta distancia á la costa sería un nuevo obstáculo. para gozar de vientos frescos y favorables. Así, luégo que pasadas algunas horas de calma, logramos en la mañanita del 24 ver entablado viento galeno del Este, hicimos rumbos más bien algo divergentes de la costa, la cual, sin embargo, lográbamos no perder de vista con el auxilio de un tiempo bien claro y placentero; á las tres de la mañana el Monte Edgecumbre nos demoraba al Norte de la aguja, y al medio día ya le mar. 
os, parecía Jun. is ubiên consique tuviése. celestes que xactitud.

Sr. Heenke tural, logro especies de amente nue. de Speciosin, os por su taio, que por pura que en ntraste más extraño que ormente con ciata aurita, que se hallaarmonía en luce á cada mparen, so-

ur un día si. te al recono. eníamos ac1 el deseo de inmediatos rse nuestras irnos que el Ho efecto de misma corta ro obstáculo orables. Así, de calma, er entablado bos más bien sin embar. on el auxilio ro; á las tres os demoraba a ya le mar.

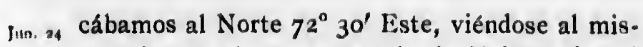
mo tiempo el monte nevado de Tairweather 6 Buen Tiempo al Norte $25^{\circ} 30^{\prime}$ Oeste; en este punto era nuestra latitud de $67^{\circ}$ ro $0^{\prime}$ y la longitud por el cronometro 72 de $37^{\circ} 23^{\prime} 30^{\prime \prime}$ al Oeste de Acapulco; la variación magnética, próximamente de $25^{\circ}$.

En balde, a la distancia á que navegábamos de la costa, intentábamos determinar la verdadera posición de los puertos de Guadalupe y de los Remedios, visitados en el ar̃o 75 por el Te. niente de navío Cuadra: varios mogotes que ya en una, ya en otra parte, se hacían visibles hacia el Noroeste del Cabo de Engaño, debían naturalmente confundirse unos con otros, abriendo á veces unas al parecer bocas, que á poco rato notábamos ser más bien efecto del terreno, en partes nevado y en parte no. Pero no podía ocultársenos el Monte de la Cruz, asíllamado por el Capitán Cook, descle donde sigue la cordillera que termina en el Montc Tairweather; medimos su altura y la de este último monte notable, el cual en aquella estacion tan benigna estaba aún cubierto de nieve hasta la falda.

Hasta las cuatro de la tarde habíamos gozado del viento favorable del primer cuadrante, bien que ya muy calmoso, pero poco después roló al Noroeste precisándonos á ceñir al Oestesudoeste con mar algo gruesa, que en nuestro mal estado de estiva nos causaba un abatimiento considerable. Continuamos el mismo bordo hasta Jas cuatro de la mañana, á cuya hora marcábamos el Cabo Tairweather al Norte $15^{\circ}$ Este de la aguja, y luégo tomamos las muras á babor, lisonjeándonos que con el día el viento que aún se mantenía del Noroeste rolaría algo más á la virazbn. No puede imaginarse un tiempo más sereno y placentero del que gozábamos á la sa. zón. D. Felipe Bausá había conseguido tomar á la una y media de la mañana una vista del Cabo Buen Tiempo, aunque bien distante, y al salir el Sol, una marcación segura á su centro nos manifestaba la variación de la aguja de $24^{\circ}$ I $5^{\prime}$ al Nordeste.

En la misma mañana, ro5 series de distancias lunares conformes entre sí y medidas con circunstancias bien favorables, manifestaban una longitud aún más oriental que la del día 23 , pues se apartaba en $I^{\circ}$ y $\mathbf{3 2}^{\prime}$ de la del cronómetro $\mathbf{7 2}$, cuyo movimiento, sin embargo, continuaba tan arreglado y uniforme como le habíamos advertido hasta entonces.

- Fué nuestra longitud al medio día, de $39^{\circ} 35^{\prime}$ y la latitud de $57^{\circ} 59^{\prime}$ demorándonos á este tiempo el Cabo Buen Tiempo al Norte $3^{\circ}$ Este de la aguja, y el monte, al Norte $I I^{\circ}$ Este, de suerte que ya podíamos sin el menor recelo continuar nuestro bordo hacia la bahía de Bering, tanto más que las estimas diarias nos manifestaran casi segura la dirección de una corriente favora- Jun. a ble hacia el Norte. En efecto, ya á las ocho de la tarde conseguimos marcar el Monte Buen T'iempo al Norte $33^{\circ}$ Este, distancia como siete leguas, viéndose al mismo tiempo una parte de la costa hacia el Oeste, en la cual nuestra imaginación y nuestros deseos nos representaban como existentes algunas abras grandes que á veces sospechábamos ser las de Bering y á ve. ces otras de una internación mayor y más favo. rable. A la verdad, por cuanto se ciñesen las conjeturas de Mr. de Bauche sobre la existencin del paso al paralelo de $60^{\circ}$, no podíamos desentendernos después de un examen maduro, ni de la poca exactitud de los instrumentos nátiticos por los años de ${ }_{5} 58$, que pudieran muy bien equivocar la latitud en $I^{n}$, ni de las advertencias del Capitán Cook, el que había notado hacia la bahía de Bering un trozo de tierra llana que por consiguiente debía reconocerse con toda exactitud; pero temiendo que las calimas 6 los vientos contrarios no permitiesen este examen con las corbetas, hallábamos preferente el verificarlo con las lanchas, mientius las corbetas en el puerto Mulgrave ( $I$ ) se abasteciesen de agua, leña y lastre.

Con estas reflexiones pareció prudente el dar una mirada siquiera á la calidad de aquellas costas, de suerte que las lanchas pudiesen aventurarse con mayor conocimiento 6 inclinarse hacia los parajes á donde más fácil fuese hallar un abrigo para los vientos contrarios. Con este solo intento se prolongó por la tarde el bordo hasta muy corta distancia de la tierra, y sblo á las once fué preciso tomar la vuelta de fuera, porque cerrado el tiempo con chubascos y ven. tolinas variables por lo común escasas y á veces calmosas, nos aconchaba demasiado sin darnos ventaja alguna ni en latitud ni en longitud: la sonda aún no había dado fondo con I20 brazas.

Ya á las dos de la mañana entablo viento fresquito del Sudoeste, que despejado medianamente el cielo nos dió lugar á navegar con ga. vias y mayores al Noroeste; pero la costa estaba aún muy cargada de arrumazón, de suerte que no pudimos verla hasta las tres, aunque á la sa. $z 6 n$ no excediese su distancia de cuatro 6 cinco leguas; nos hallábamos precisamente entre las dos bahías avistadas en la tarde anterior; se nos representaba una isla que creíamos la indicada en las cartas inglesas, y los montes distantes estaban todos cubiertos de nieve hasta la falda: á las cinco ya no distábamos más que cuatro millas de la costa y particularmente de unos pedruscos amogotados, que al principio creimos islotes,

(1) Ast llamado por el Capitán Dixon, que fué el primero á visitarlo. 
Jim. zo pero que vimos lućgo unidos á la ticrra firme por medio de un arenal: el viento era aún escaso y calmoso y la marejada algo gruesa, lo cual nos obligó á navegar hasta las siete del bordo de fuera.

Inmediata á la orilla y antepuesta á toda la cordillera nevada que desciende del Cabo Buen T'jempo, se extendía por largo trecho una faja de terreno bajo tan polslada de pinos hermosamente fronclosos, que si pudiesen por algún tiempo ocultarse las nieves que le dominan, sin duda darian una idea más bien de un paralelo inmediato á la Línea, que de uno no distante del círculo polar: se agregaban á aquella hermosa perspectiva di. ferentes manchas de nieve en los ángulos salientes, que 6 bien reflejaban con nucvo brillo los rayos bcnéticos del Sol ó representaban á la ima. ginación con diferentes sombras, ya un camino bien ancho 6 ya unos campos perfectamente nivelados: muchas bandadas de chorlitos voletea. ban en nuestras inmediaciones; el agua había tomado un color más verdoso y la hallábamos mucho ménos sulada de la común del mar; finalmente, á medida que se iban disipando la calima 6 las nubes, parecían extenderse mís y miás hacial el Oeste las arboledas que daban tan hermoso realce á aquella escena.

Se observaron algunas series de horarios; se corrieron constantemente bases, y al medio día se halló la latitud de $j 9^{\circ}$ Oeste, considerándonos en longitud de $38^{\circ} 46^{\prime}$ y manifestando el azimute meridiano una variación de $34^{\circ}$, que muy extraña si se comparase á las demás, debía sin duda atri. buirse $a$ un efecto extraordinario de la atracción de los montes inmediatos. Hacia las cuatro de la tarde, la ATrevina encontro fondo con 50 brazas, hallándonos á la sazón desviados de la orilla unas tres leguas.

En el actual reconocimiento ya disipadas cualesquiera dudas sobre la existencia de un paso 6 de un abra siquiera más bien nuestras pesquisas se dirigían á combinar lo que habia visto el Capitán Cook; pues no existiendo la isla que pone en la entrada de la bahía de Bering, deseábamos acertar con la parte de costa que le habia causado aquella equivocación nada extraña en la distancia de siete leguas á que navegaba. La que nos había parecido isla por la mañanita, distaba mucho al Oeste de la caída de la cordillera que desciende del monte Buen Tiempo, y desde ésta hasta el principio de la stra que sigue hacia el monte de San Elias, ningún monte chico aislado se dejaba ver entre la tierra llana que efectivamente veíamos extenderse más adentro de la primera cadena de montes. Si el Comandante Bering (como lo sospecha el Capitán Cook) tecaló á esa parte de costa que de ningún modo puede llamarse sino una costa brava, no debía ser ex. traño que no hubiese podido mantenerse fondea. do por largo tiempo, bien que el haber desem. Jid. $a 6 n$ barcado sus gentes precisamente en una isla y el hallarse ésta en latitud de $58^{\circ} 28^{\prime}$, hacen creer que deba más bien suponerse su recalada hacia la entrada de la Cruz.

Las observaciones de longitud hechas á las seis de la tarde, nos indicaron una corriente no muy rápida hacia el Este, y en efecto, por cuanto nos esforzásemos en aprovechar cualesquiera ventolinas, apenas habíamos ganado desde el medio día unos diez minutos en longitud $y$ nues. tra distancia á la costa no era mayor de siete á ocho millas: advertíamos á la sazón en la inme. diación de las arboledas una ú otra llamarada, señal segura de habitantes. El viento se conservaba aún calmoso del Sur, y los ciclos y horizontcs bien despejados $y$ apacibles, no tardaron, sin embargo, en llenarse de calima, cuando ya puesto el Sol empezo el viento á rolar hacia el Este: con él navegóse alguna distancia, y á la media noche ya por fondo de 70 brazas arena nos ha. bíamos alejado unas cinco leguas de la costa.

$\Lambda$ segurado á lo ménos por algunas horas el viento favorable, no nos descuidamos en empren. der de nuevo un reconocimiento bien prolijo, orzando antes al Noroeste y luégo al Norte sobre las gavias, por manera que á las tres de la ma. ñana sólo distásemos dos millas escasas de la playa, por fondo de 22 brazas arena negra fina: antes de llegar á esta posición, la casualidad de estar claros los horizontes del primer cuadrante, nos había proporcionado la vista de los montes traseros á la bahía de Bering, cargados de nieve y regularmen dillera que disipaba por consiguiente cualesquiera sospechas de la existencia de un mar hacia el Norte, como parecía indicarlo el Capitán Cook: al mismo tiempo veíamos sin la menor duda el montecito aislado que desde lejos pudiera equi. vocarse por isla; bien que si consultásemos la la. titud de $59^{\circ} \times 8^{\prime}$ determinada por el Capitán in. gles, debían más bien recaer nuestras sospechas en un trozo de ticrra llana que sigue al Oesno. roeste.

Continuábamos á distancia de una 6 dos leguas reconociendo la costa que conduce á la Punta Carrew ( $\mathrm{r}$ ) del Capitán Dixon, y áun favorecidos del viento, ya á las seis de la mañana habíamos atracado aquella misma purita, examinando prolijamente la entrada del puerto Mulgrave, cuando en la cordillera de montes cuyas faldas baña el mar en lo más hondo de la ba: hía del Almirantazgo, descubribse un abra cuya boca $e$ internación culebreada parecían asemejarse á las tierras de Ferrer Maldonado: muy

(1) Por la comodidad de la pronunciación y ortograffa española más bien que para tomar el derecho de descubridores, se ha variado el nombre de la Pun. ta Carrew y algunos otros parajes de aquella costa. 
per desem. Juh. as z

ha isla $y$ el lacen creer lada hacia

echas á las orriente no por cuanto ualesquiera desde el ud $y$ nues. de siete en la inme. llamarada, se conser. y horizon. rdaron, sin do ya puescia el Este: á la media na nos hala costa. as horas el en emprenprolijo, orNorte sobre de la macasas de la negra fina: sualidad de - cuadrante, los montes dos de nieve egunda corcualesquienar hacia el pitán Cook: nor duda el idiera equisemos la laCapitán in. s sospechas e al Oesno.

6 dos le. ce á la Pun. áun favorenañana haita, examiunerto Mulontes cuyas - de la ba. n abra cuya ían asemenado: muy

viación $y$ orur el derecho re de la Punella costa. 1ul. „ Juégo la imagrinación prestó mil razories aparentes al desso: contemplábamos todo lo que pare. cia poderse combinar con la descripción del paso; recliazábamos 6 procurábamos justiticar lo que de uingún modo concurria con el terreno descrito; finalmente, cada uno á su albedrio, 6 alarga . ba la extensión de la cañada hacia el Norte $\delta$ atribula á la distancia y á la vista la falta de aquellas circunstancias que aún no podian re. unirse para disipar las últimas dudas. Puede imaginarse que no tardamos un momento en orzar hacia el abra indicada, pues, sin embargo que no fuese auestro ánimo el aventurar las corbetas sobre la sola relación de Ferrer Maldonado, cra muy importante examinar de cerca la probabili. dad de su continuación hacia el Norte, y si ésta quedase enteramente destruida, continuar nues. tra derrota hacia la entrada del Príncipe Guillermo.

Toda la costa que desde la balía de Bering corre hacia la Punta Muñoz, es igualmente formada de la misma faja de arena, cascajo y tie. rra vegetal que en el día anterior habiamos no. tado hermosamente poblada de un monte majestuoso de pinos: puede creerse que á distancia de una ó dos millas conserva el mismo fondo de 20 a 22 brazas arena, pero no presenta el menor abrigo que convide al iavegante á frecuentarla: ya en las inmediaciones de la punta, el fondo crece rápidamente á 50 y á 60 brazas cascajo; ni se halla menor en parte alguna de la bahía ex. terna, luégo que se aparte una milla siquiera de las costas 6 de los arrecifes.

La playa desde la Punta de Muñoz y mucho más desde la que le sigue, tuerce rápidamente hacia el Norte inclinándose después al Oeste, y como le estén muy proximas y fronteras diferentes islas tendidas ya en una ya en otra dirección, forma naturalmente algunos puertos tan cómodos para su seguridad y abrigo como agradables por la lozanía de la vegetación: estas islas y tierra baja salen afuera como tres leguas desde la cordillera inmediata; la cual luégo vuelve á aproximarse al mar hacia el abra indicada y fondo de la bahía, y se retira de nuevo para dar lugar á otra faja igualmente lozana de tierra baja, que después de algunas barrancas corre hacia el Oeste hasta las faldas de la montaña de San Elías.

Ya navegando hacia la boca indicada, empe. zamos á precavernos con la sonda de cualquier peligro, tanto más, que atravesando como á una y media milla del extremo exterior de la isla más Sur, habiaruos encontrado II brazas cascajo y veíamos hacia la costa algo sospechosos los arrecifes salientes; pero muy luégo conocimos que los fondos de la bahía, áun comprendida la inmediación de las islitas internas, más bien tenian el inconveniente de un grande exceso que de una cortedad peligrosa; pues, ni nosotros con
40 y 50 brazas, ni á veces la ATrevids, podia Jd. alcanzarle con ménos de $80 ;$ y (lo que ya exigla alguna utención) ambas puntas del abra eran tan escarpadas y á pique, que no debian dejar ducla de un fondo probablemente excesiyo y pe. dregoso en sus mismas inmediaciones.

$A$ las nucve de la mañana ya con viento cal. moso del Este, horizontes achubascados y alguna garua, distábamos una y media legua de la boca sospechosa; y aunque la suma debilidad do las mareas concurriesen á la sazón á conlirmar la sospecha de conocersc á la vista la muy cort: internación del canal, como no pudiese csto real mente asegurarse sin recelo de equivocacion harto posible en la proyeccion de las quebradas, pareció debido el dirigirnos al puerto inmediato de Mulgrave para emprender luégo con las lan. chas un reconocimicnto prolijo, al paso que los buques se abasteciesen de agua y lcña. Reviramos, por consiguiente, para alcanzar sobre hor. dos el mismo canal que desde la punta lilipps conduce al puerto; el viento á la sazón se ha. bia declarado al Este y Esueste bonancible con tiempo cerrado de llovizna y algunas ráfagas no fuertes.

No ignorábamos por las relaciones del Capitán Dixon, que estas islas eran habitadas por un corto número de gentes; pero ya á las diez nos lo confirmaron dos canoas grandes y una peçueña, que poco distantes una de otra salían de un canal y parecían dirigirse á la ATREvida que navegaba por nuestra popa: resonaba á mucha distancia el himno harmonioso de paz, al cual acompañaron después la señal no dudosa de los brazos abjertos, para demostrar que venian inermes y que sólo ansiaban de nuestra parte unas ideas pacíficas y amistosas.

Como casi al mismo tiempo hubiésemos determinado virar y dirigirnos al fondeadero, muy luégo pudieron ambas canoas grandes hallarse al costado de las corbetas, y finalmente, atra. carle, nosir. . ccler algunas muestras de temor y seguir en todo las órdenes 6 avisos de un viejo venerable que en la canoa pequeña vogaba yá á una ya á otra parte $y$ daba todas las señales de ser el caudillo de la pequeña tríbu.

Precedidas por una y otra parte las primeras muestras harto equívocas del instinto sociable, é interpretado por cada uno cada expresión 6 gesto más bien por los dictados de la imaginación que del razonamiento, se dirigieron como era natural nuestros esfuerzos á convidarles á bordo, agasajándoles en primer lugar con galletas, tocino y sebo; y accediendo después á su instancia de que bajasen como rehenes á la canoa tantos hombres nuestros cuantos entre ellos subiesen á bordo, no tardaron de este modo en convencerse de la seguridad de nuestras ideas pacíficas; y como no nos déscuidásemos al mis. 
Iiil. "no tiempo en regalar algunas frioleras á los que subieron primero, ya media hora después ni necesitábamos dar rehenes para los que subie. sen, ni era precisa de nuestra parte la menor instancia para este intento, tanto más, que se de jaba ver en casi todos una propensión grande a deslizarse bajo cubierta, sin duda con ánimo de robar, ya una ya otra friolera de las que es. tuviesen á mano.

Se mantuvieron á bordo hasta después del medin dia; en todas sus acciones manifestaron un genio vivo y alegre y no tardando nuestra tropa y marinerla en desprenderse 6 bien de una parte de su ración ó de sus vestidos, fueron precisas muchas instancias para que se embarcasen y apartasen la canoa del costado, la cual podia correr algún riesgo por el viento á la sazón fresco del Essnordeste y los bordos algo largos y repetidos que debiamos correr.

Con la tarde se cerró mucho más el tiempo, de suerte que apenas veíamos las dos costas que ceñlan nuestros bordos, y nos era preciso virar con mayor precaución, pues que salían de la punta Muñoz hacia el Sudeste p.lguras restingas de bastante extensión: la marea nos fué constantemente contraria; el viento calmó casi de un todo; los bordos eran precisamente muy cortos, y asi, eran las siete de la tarde cuando montada la punta de 'Turner, pudimos dejar caer el ancla en 12 brazas lama delante de la ranchería de la islita y no distantes más de un cable de la playa.

Desde el momento que franqueada la punta habíamos empezado á coger el abrigo y aproximarnos al fondeadero, fueron muchas las canoas que salieron á encontrarnos, repitiendo unas veces el himno de paz, otras una voz general har. moniosa al parecer de convite ó admiración, y of reciéndonos por cambio, más bien algún salmón y artefactos de madera, que las pieles de nutria á las cuales procuraban dar un valor cuantioso. Admiraron con mucho silencio y tal vez no sin algún temor nuestra faena de echar las embarcaciones menores al agua y particularmente la lancha; y finalmente, siendo ya las nueve de la tarde $y$ tendido por ambas corbetas un anclote al Norte por segunda amarra, nos despedimos con recíprocas señales de amistad para lograr de un mediano descanso.

Cuál fuese nuestra posición en el puerto Mulgrave y cuál la amenidad de sus contornos, lo indicarán más bien las perspectivas que acom. pañan á esta relación que cualesquiera descripciones aunque prolijas y estudiadas para el in. tento: á pesar del tiempo lluvioso y cerrado todo anunciaba un clima apacible; el puerto podía más bien llamarse una dársena, los naturales estaban inmediatos $\mathrm{y}$ en bastante número para estudiar $\sin$ recelo y $\sin$ molestias sus costumbres; y el agua, leña, lastre, pescado y vegetales, todas co. Jut. of sas que necesitábamos, estaban tan á ıano, que ni áun podía llamarse molestia la que debiamos emplear para acarrearlos á bordo.

A la verdad, el agua y lastre debian buscarse en la isla 6 playa del Este del fondeadero, y aún no nos hubiera sido fácil el hallar tan luego el paraje oportuno de la primera, si un indio de los más dispuestos que habían concurrido á bordo desde la mañanita, no nos hubiese acompañado para buscarla; pero la tranquilidad constante del mar, la poca fuerza de la marea y la duración del día auxiliaban de tal modo á estas tareas, que desde luego podiamos mirarlas como agradables más bien que incómodas.

Ya desde la mañanita, los naturales habian concurrido en bastante número á bordo de una y otra corbcta, empezando á proponer algunas pie. les, muchos salmones frescos y uno ú otro uten. silio de madera en cambio de ropa y hierro, úni. cas cosas que manifestaban apetecer con ahinco, sin embargo que admitín toda éspecie de botones, varios clavos y una ú otra pieza de las mu. chas que comprende la voz de quincalleria.

Procuraron estrechar su familiaridad con las tripulaciones, y como en el carácter del navegan. te, el capricho 6 el antojo sustituyen á la necesidad con un exceso difícil de comprenderse, desde luego, en los primeros cambios, conocieron que esta especie de mercado les sería sumamente ventajosa; y si juzgásemos por el ansia de los contratantes, más bien deblamos inferir que nues tros marineros no pudieran vivir sin la adquisición de todo lo que veían, que los naturales sin la ropa y el hierro que con tanta razón anhelaban.

Las tretas de que usan estos naturales en sus cambios ó contratos han sido muy bien descritas por el Capitán Dixon: no sólo traen ocultos los efectos que intentan cambiar, sino que nunca se presentan con mayor indiferencia que en esas ocasiones. Después de un plazo á veces mayor de una hora en que se mantienen tranquilos á la vista de los muchos objetos que se les presentan, descubren finalmente 6 una tira de piel, 6 una muñeca, 6 una cuchara, 6 cualquiera otra ba. gatela, solicitando canibiarla por todo lo que ven. Apelan al tamaño y á la simetría, cuando ya no pueden apelar $\{$ la calidad; convenido el cambio lo vuelven á anular; y finalmente, si entre las cosas que traen hay alguna piel realmente buena, la enserian con tanto misterio, la retiran tan lue. go y vuelven después á manifestarla, que excitan en el ánimo más indiferente una mezcla singular de enfado y de antojo, difícil de sujetarse por las miras solas del interés.

No se advierte entre ellos la menor competencia 6 para la adquisición 6 para la alienación; antes bien, reunidos con admirable unanimidad todos los intereses, 6 consultan entre sí para la 
s, todas co- Jul.

irano, que

debiamos

an buscarse

dero, y aún

an luego el

indio de los

do á bordo

compañado

onstante del

la duracion

tareas, que

agradables

ales habian

do de una y

lgunas pie.

ú otro uten.

hierro, úni .

con ahinco,

cie de hoto.

de las mu.

allería.

idad con las

lel navegan.

á la necesi.

derse, desde

ocieron que

sumamente

ansia de los

rir que nues.

la adquisi.

turales sin la

1 anhelaban.

urales en sus

ien descritas

ocultos los

que nunca se

que en esas

veces mayor

anquilos á la

is presentan,

piel, ó una

era otra ba.

- lo que ven.

uando ya no

do el cambio

entre las co-

lente buena,

iran $\tan$ lue.

, que excitan

zcla singular

ttarse por las

or competen-

alienación; unanimidad tre sil para la verificación del cambio, 6 bien si llegasen á veri. licarlo, lo aplauden con una, dos ó tres aclama. ciones unánimes, según imaginan que el contra to les ha sido más 6 ménos ventajoso.

Desde las nueve de la mañana, ambos botes con el mayor número de la Oficialidad, se habian dirigido á reconocer el paraje más oportuno de la aguada; uno de los naturales, con la facilidad adnirable de qu: todos están dotados de comprender $b$ hacers: comprender por señas, los gui 6 antes $a$ un paraje no distante pero muy escaso de agua luégo los dirigio á la playa opuesta 6 del Sudeste en donde efectivamente se hallaban como á un tiro de fusil diferentes manantiales, capaces cuando se les formasen algunas pozas, de suministrar toda el agua necesaria: visitaron en esta ocasión una choza no distante de la aguadi, que el indio conductor parecía expresarles ser la de su familia, $y$ tributada la natural curiosidad y admiración al desabrigo, suciedad y estreche\% con que vivian dos mujeres y algunos niños, como también á los adornos, trajes, alimentos y utensilios que alli se hallaban, regresaron á bordo lacia el medio día, acompañados siempre de una lluvia bastantemente fuerte, que oculcaba la vista de cualesquiera otros objetos más distantes: no por esto se omitió en el entretanto el examinar la playa inmediata al fondeadero para la medida de una base, y particularmente el procurar estre char la amistad de los naturales, familiarizándo nos algún tanto con las voces de una necesidad más inmediata y enterándonos de sus costumbres $b$ inclinaciones. Desde luégo, por nuestra parte, se habian tomado muchas medidas para que nada pudiese enturbiar un roce amistoso: nuestra vi gilancia á todas horas usando aún la precaución de pasar la palabra de noche de una á otra corbeta, debía disiparles cualesquiera ideas de la posibilidad de una sorpresa: podían verse prontas á bordo diferentes armas de fuego, que debieran àtemorizarlos: se prohibió todo roce de las clases inferiores con las mujeres y niños en sus chozas; finalmente, al paso que deseábamos apartarlos con estas precauciones de la idea de hos. tilizarlos, eran constantes nuestros regalos y bien expléndidos particularmente por parte de la marineria: las repetidas señales que desde el día anterior nos habian hecho de facilitarnos el uso de las mujeres cuando nos hallábamos en el puerto, aunque bastantemente claras nos parecían aún equivocas $y$ tal ve $z$ mal interpretadas, si consultásemos la poca concurrencia en aquel paraje de buques europeos y la extrañeza de semejante of recimiento, cuando no le dirigiesen ni la vene. ración 6 el cariño hacia nosotros, ni unas costumbres transformadas del lujo, del interés y del ejemplo: hallándose, pues, á la sazón, no distante de las chozas uno de los Oficiales é importunado ya de esta especie de ofrecimientos, quiso cer- ciorarse de su verdadera significación, tanto más, Jul " que si realmente existiese aquella fucilidad como la suponiamos, era importante el precavernos para el buen orden de los primeros pasos de las tripulaciones, 6 si un fuese verdad, debíamos di. sipar esta idea siniestra de sul carácter y costum. bres: dirigido por consiguiente de dos jovenes naturales que con un aire misterioso le repetian la ya conocida voz de Shouit, se aproximb á unos árboles inmediatos $a$ las clivzas y entonces fué fácil disipar cualesquiera dudas, pues efectiva. mente se hallaban al pié del arbol cuatio 6 cinco mujeres medianamente cubiertis con pieles ce lobo n.urino y desde luego obedientes a la volun. tad de casi toda la tribu, que parecia unánime en la intención de prostituirlas: cuanto no alcanza. sen la moral ni el ejemplo á apartar toda idea de esa especie, lo hubieran conseguido ciertamente el semblante horrible y la mucha grasa y sucie. dad de que estaban cubiertas, despidiendo ua olor difícil de describirse por lo desagradable.

El vicjo caudillo que en la mañana anterior habia sido regalado á bordo de la Atrevida y á li sazón había pasado á la Dzscubierta á im. pulsos del Comandante de aquellat corbeta, con quien parecía haber cstrechado una amistad du. radera, logramos nuuy luégo el que D. Tomás Suria lis retratase con mucha exactitud; dejó á un hijo suyo el cuidado de atender á los cambios, en los cuales prefería los vestidos á cualesquiera cirras cosas; y últimamente trabó con nosotros usa conversacion seguida, cuyo objeto era en nuestro entender el de describirnos algunas reyertas tenidas no había mucho con sus vecinos: era su presencia realmente respetable, bien sea por la edad, por la estatura \& por el vigor que traslucía en todas sus acciones: cada parte dc la reyerta se nos representaba con los colores más vivos: entendimos que los enemigos traian hasta seis fusiles (I), que había habido algunos muertos de una y otra parte, y que habian pedido la paz y ésta muy luégo concedida; pero lo que debió causarnos la mayor confusión para la cabal inteligencia de esta narración, fué la representación que nos hizo de que de parte de los enemigos había un hombre á caballo, llegando sus deseos de que así lo enten diésemos, hasta hacer llamar á su hijo y ponerle en la postura te un cuadrúpedo, señalando luégo que el enemigo le montaba: á la sazón ya se había concluido su retrato á cuya vista se complació mucho, solicitando con ansia que no sblo se re-

(1) Por cuanto hayamos combinado las noticias posteriores, no pudiéramos apropiar esta narración sino es al combate harto sangriento que tuvieron las dos lanchas del Conde de la Péyrouse, o en aquellas inmediaciones on las de la entrada del Príncipe Guillermo Guillermo. La descripción del caballo pudiera interpretarse tal vez por el modo europe
botes la Oficialidad desde las playas. 
Jul. a7 tráase también el morrión (I) (que nos enseñaba) del caudillo enemigo, vencido en la reyerta, sino que se expresase individualmente que era el fruto $y$ la señal de la victoria; finalmente, ya bien adelantada la tarde $\mathrm{v}$ empleados de nuestra parte cuantos halagos pudiesen estrechar la confianza y la amistad, se despidió el Cacique de á bordo y pudimos comer trairquilamente.

Según amaneció al día siguiente, parecía que el tiempo continuaría aún constante del Sueste con cerrazón y llovizna, debimos, por consiguiente, desistir aún de toda idea de operaciones hidrográficas y astronómicas; no así de las tareas de proveernos de agua y lastre, que se emprendieron con las dos lanchas armadas á las órdenes del Teniente de navío Tova, de la Atrevida: en las inmediaciones del paraje en donde debían ha. cerse estos acopios, no había, á la verdad, sino muy pocas chozas y éstas muy distantes unas de otras; pero como nuestro ánimo fuese prevenir aun el orígen más remoto de una discordia, no sólo los botes fueron siempre con un Oficial y algunos soldados armados, sino que procuramos atraer hacia nosotros el respeto de los naturales y cualesquiera quejas contra nuestras tripulaciones, distinguiendo la Oficialidad con una banda encarnada en el sombrero y manifestándoles ser ésta entre nosotros la señal de los principales ó depositarios de la autoridad.

La inclinación al :obo que ya los naturales habían manifestado desde el principio, se esplayó aún más luégo que á la sombra ó de la va. riedad de los cambios ó de su mismo rúmero, creyeron poderlo verificar impunemente. En la ATREV1DA habían robado un candado de hierro en la mañana anterior, pero por ventura lo había advertido tan oportunamente el Alférez de fragata Murphy, que cetenido el reo, aunque le amenazase con el puñal, había logrado que el misno Cacique, á $1_{i}$ sazón presente, obligase luégo la restitución de la prenda robada; no fué así en la misma anrieta en la otra mañana con dos pasadores de hierro, cuya restitución no pudo cor:seguirse aunque procurásemos apremiar mu. cho al caudillo y éste rnanifestase grande empeño para complacernos; fué preciso creer á sus aseguraciones, que habían sido otros y de una familia distante los autores del robo; pero se tomaron nuevas precauciones para que no sucediera otra ve $z$ aquel inconveniente, no tan sólo evitando que los naturales subiesen á bordo, sino también asignando el paraje de los cambios en la orilla frontera á las corbetas: era esta dominada de nuestra artillería, algo distante de los ranchos habitados y enteramente libre de escondrijos, arboledas ó abrigos: así, pareció también

(x) Este morrión tenía tres cercos de plancha delgada de cob. e. la más oportuna para la colocación del observa - Jul, a torio.

Plantada, pues, inmediatamente ia tienda y no cesando aún la lluvia, se acogieron en bas. tante número en sus inmediaciones y contir.uaron los cambios con mayor actividad; se reducían estos más bien á la adquisición de los utensilios, armas y manufacturas que debíamos acopiar para el Real Gabinete de Madrid, que al cambio de las pieles de nutri'‘ que solían traer en poco número: fué tambiér: una nueva y esencial ventaja de este primer contisto el establecer un precio fijo por el salıón fresco, que deseabamos dar dia iamenıe á las tripulaciones; quedó éste fijado en un clavo de cres á tres y media pulgadas por cada salmór, cuyo peso medio podía considerarse próximamente de siete á ocho ymedia libras, y se logró después la felicidad de conservarle invariable hasta el último día, aun. que á veces por una ú otra parte, el natural desnivel de su número convidase á trastornarle.

Ya al medio día, el tiempo parecía querer mejorar mucho; y apenas cesada la lluvia, había tenido lugar D. Felipe Bausá de medir una base desde la tienda del obser atorio hasta la punta de Turner, haciendo en sus ex:-emos todas aquellas marcaciones que permitiese la poca claridacl de los objetos distantes: á las tres de la tarde empezó también á manifestarse el Sol en algu. gunas claras, $y$ finalmente, hacia las cinco logramos ver ya no infructuosas nuestras prevenciones de haber establecido la tienda y traido á ella el cuarto de círculo de Ramsden. Se tomaron alturas absolutas, y referidas por medio de señales á los relojes marinos, fijaron con mucha satis. facción nuestra la primera época de las compa. raciones de su movimiento.

La concurrencia de los naturales hacia nuestra tienda crecía á cada paso; ya deseaban mirar con los anteojos, ya aproximarse a las cajas y reconocer sus contenidos, y como la experiencia de dos días no nos dejase duda de su mucha in. clinación al robo, pareció más seguro el traer á bordo todos los instrumentos y la misma tienda, que ó cansar la tropa con una contínua vigilancia de noclıe 6 exponernos á las causas de una rotura que en la natural confusión puüics son mal interpretada é injusta: por lo cuse toca á nuestro roce con los naturales, no podía á la sa. zón llevar un semblante más halagúeño; nos habíamos familiarizado con las palabras más ne. cesarias del idioma, visitábamos francamente sus chozas; D. Tomás Suria pudo retratur algunas mujeres y representar la no crecida cantidad de utensilios domésticos; los cambios se habían aca. lorado mucho po: una y otra parte, y ya se nos había dado el permiso de proveernos de la leña necesaria en las mismas inmediaciones de las chozas sin contrato alguno, preliminar al cual, 
ión del observa- Jul. 2q

ente ia tienda $y$ ogieron en bas es y contir.uaron ad; se reducían de los utensilios ebíamos acopiar id, que al camsolían traer en nueva y esencial el establecer un que deseabamos ones; quedó éste y media pulgaeso medio podia siete á ocho s la felicidad de último día, aun. e, el natural destrastornarle.

arecía querer mela lluvia, habia e medir una base b liasta la punta emos todas aque. la poca claridad tres de la tarde el Sol en algua las cinco logra. stras prevencioda y traído á ella n. Se tomaron al. medio de señales on mucha satis. a de las compa-

rales hacia nuesa deseaban mirar se á las cajas y 1o la experiencia de su mucha in. seguro el traer á la misma tienda, :ontínua vigilans causas de una sión puciics í car rlo rue toca á no podía á la sa. halaguleño; nos palabras más ne. francamente sus retratur algunas cida cantidad de os se habían aca. rte, y ya se nos ernos de la leña tiaciones de las eliminar al cual,
Jul. 29 sin embargo, no hubiéramos dejado de acceder inmediatamente.

En las inmediaciones del observatorio se hallaba enterrado el cadáver de un indivíduo muerto en las últimas reyertas; lo indicaba un palito plantado entre las yerbas $y$ un tejido de juncos que con algunas piedras sobrepuestas le abrigaba: los naturales manif estaron bastante repugnancia para arrimarse hacia aquella parte, y aun insistían en que nosotros no lo ejecutásemos, acompañando las instancias con aquellas señales y aquel silencio que corresponden al temor de interrumpir un sueño tranquilo.

Entre las muchas cosas que á la sazón habían venido al mercado, se dejaban ver frecuentemente los rastros de la escala en aquel puerto del Capitán Dixon con el bergantin Reina Carlo$t a$ : vimos alguna hacha y cacerolas, una cuchara de plata, dos 6 tres libros y algunos vestidos: frecuentemente los más jóvenes repetían la $S a$ loma (I) de ias maniobras y una ú otra palabra inglesa; y por lo que toca á los pedazos de hierro, debiamos creer que prontamente los convirtiesen con el auxilio del fuego y d: las piedras, en el puñal 6 daga que llevaba siempre cada uno consigo suspenclido debajo del brazo izquierdo y escondida con la piel de lobo, nutria ú oso: no era un rastro ménos evidente de aquella misma escala la continuación de las instancias para que usásemos de las mujeres, siendo preciso en este día el reprender sériamente al viejo Cacique, quien trajo una mujer hacia la tienda del observatorio á donde nos hallábamos á la sazón, y repetir las órdenes para que no se aproximasen ha. cia las chozas, otros indivíduos que los Oficiales de una y otra corbeta: crecieron con este motivo los halagos, y hacia las seis de la tarde vimos próxima á la popa de la Descubierta, una canoa con tres mujures, dos de las cuales no excederían la edad de die $\mathbf{y}$ ocho á veinte años; repitieron algunas palabras inglesas, ejercitaron después por largo tiempo su natural locuacidad, y finalmente, entonaron un canto bastantemente melodioso que $\mathrm{D}$. Tadeo Heenke copí́ con su natural exactitud is inteligencia de la música.

Pero con la caída de la tarde, despejado enteramente el tiempo, cra ya igualmente nuevo y grandioso el espectáculo que se nos presentó á la vista: semejante al telón de un teatro, que corrido con la mayor prontitud descubre en un solo instante al espectador admirado un número crecido de objetos tan nuevos como varios y agradables, así disipadas las nubes y cerrazón que habían hasta entonces interceptado los objetos distantes, se de jo ver toda la cordillera majestuo

(r) Saloma en el vocabulario do Marina, significa la voz del que dirige los movimientos uniformes do una maniobril, para que repetida á un mismo tiempo por todos, sirva de señal para el esfuerzo unánime. sa que desde el monte Buen Tiempo sigue hasta Jul. 29 el de San Elías. El hielo de que estaban cubiertas desde su cima hasta la última falda, reflejaba con nuevo brillo los rayos del Sol: se dejaba ver antepuesto á la tierra alta por algunas leguas torlo el bosque de pinos con una lozanía y frondosidad difíciles á describirse; finalmente, la atmósfera sumamente pura con un vientecito suave del Noroeste, dilatando mucho la duración del día con la mayor claridad del crepúsculo, ni aún á la media noche nos hacía carecer de esta vista agradable y majestuosa. D. Felipe Bausá, con el teodolito, inmediatamente se dirigió á uno de los extremos de la base para extender las marcaciones y rec. tificar las que se habían hecho anteriormente, $y$ como ya fuesen las diez de la noche cuando regresó á bordo, debimos entregarnos por alguraus horas al descanso, para aprovechar con mayor constancia la esperada hermosura del dia siguiente.

En efecto, no eran aún las cuatro de la mañena cuando D. José Lspinosa, en quien recaía el turno de servicio, fué con las lanchas y bombos armados á continuar los acopios de agua. Don Felipe Bausá, con un bote igualmente armado, emprendió la continuación de sus tareas hacia el canal de la entrada hasta la punta Filipps; D. Juan Maqueda examinó con otro bote las sondas interiores del puerto, y los Oficiales astrónomns emperaron á disponerse para todas las obscrvaciones que estuviesen á nuestro al cance: ocupaba el primer lugar entre ellas el examen de las oscilaciones del péndulo simple constante, el cual se colocó bajo la tienda en el mismo paraje del día anterior, sustituyéndose para el examen del tiempo medio, el cronómetro 7 I al péndulo compuesto; pues hubiera sido im prudente entregarnos á sus resultados casi al mismo momento de ponerle en movimiento. Con el cuarto de círculo de Sissón, debían luégo tomarse las alturas correspondientes del Sol, determinar la latitud por la altura meridiana del mismo astro y medir en el extremo de la base la elevación del monte San Elías sobre el nivel del mar.

Entendiendo aún hacia las seis de la mañana en los aprestos para estas operaciones y no siendo sino muy corto el número de los naturales que se habian aproximado al observatorio, vimos venir repentinamente hacia nosotros el viejo Ankau (r), acompañado de otra persona cuyas preeminencias entre los demás eran bien grandes, sin poder, sin embargo, alcanzar jamás 6 sus derechos 6 sus funciones en la tríbu: uno y otro con mucho afán y no sin las muestras de un temor grande, nos anunciaron la aproximación de

(r) Es la voz fropia, con la cual distinguen al Cacique $\delta$ Jefe principal. 
Jul. zo dos canoas que acababan de descubrir y cuyas ideas ignoraban aún si serian hostiles ó pacíficas: solicitaron con ansia (no distando ya las dos canoas más que una ó dos millas del puerto) que fuésemos á la orilla frontera $y$ disparásemos un fusilazo para ohligarles á manifestar sus ideas, y entretanto, dispusieron que toda la tríbu tomase las armas, se retirasen las mujeres y se echasen al agua las dos canoas grandes que estaban varadas en la playa: desde luego determinamos complacerles en lo que solicitaban, y pasando á la playa opuesta, disparóse un fusil luego que nos hallamos en paraje oportuno para ser vistos de la gente de las canoas. Con esta señal prorrumpieron inmediatamente en el himno de paz todos los que las esquifaban, que serían próximamente cuarenta, continuaron luégo el mismo caricu á medida que se iban aproximando, y finalmente, se acercaron á la orilla interna, no sin nuevos recelos y precauciones de parte de nuestro Aniau, quien no cesaba de gritarles que mirasen bien lo que hacían, pues éramos sus aliados.

Ya disipados casi todos los recelos de una rotura pero no aún inermes los habitadores del puerto, se aproximaron á las piraguas y recibieron en sus brazos á los caudillus para co.nducirlos á la playa sin mojarse: fueron inmediatamente presentados por nuestro Ankan. Siguióse á esta ceremonia una pacíficación general; muy luégo, unos y otros entre abrazos, regocijos $y$ narraciones se dirigitron á las inmediaciones de las chozas; y si se exceptúa el paraje en donde enjugaban sus pieles y preparaban la comida parecían más bien todos de una misma tríbu que personas dispuestas una hora antes á des. truirse reciprocamente.

No es fácil acertu si los muchos naturales que se aproximaban al observatorio entenderían las ideas religiosas hacia el Sol con que procuramos colorear nuestras observaciones astronómicas, 6 si aun entendidas conducirían algún tanto á que lográsemos de toda la quietud que nos era precisa; pero es bien positivo que en esta parte debimos considerarnos sumamente felices, pues en nada nos molestaron en el espacio de do. ce horas próximamente, en que estuvieron á su vista los instrumentos astronómicus: se repitie. ron por tres veces las comparaciones del péndulo simple al cronómetro, y no siendo menor cada una de una hora, logramos sin embargo, veilas corresponder entre sí hasta el cuarto de segundo, precaviéndonos además para la determinación segura del tiempo medio, con sujetar por repetidas señales comparativas el número 7 I á los demás relojes marinos de una y otra corbeta: en cuanto á las demás circunstancias que concurrieron al tiempo de hacerse aquella observación desscada, podemos lisonjearnos, que parecerán satisfac. torias á los físicos, cuando les aseguremos, que gul. 30 el péndulo estaba con la mayor estabilidad; que el termómetro de Farenheit se mantuvo entre los 67 y $68^{\circ}$; el terreno se hallaba considerable. mente distante de toda montaña y por sí mismo despejado $\mathrm{y}$ formado por la mayor parte de las. tre; que las experiencias se hicieron inmediatas al medio día; y que la marcha del cronómetro de comparacion se hallo en el mismo segundo por las observaciones del dia anterior y del siguiente: examinada la salubridad del aire de la tienda en la cual se hicieron las experiencias, dió en el eudiómetro de Fontaiı la bondad de 0,92 . No se había descuidado D. José Espino. sa en observar también en las inmediaciones cle la aguada la altura meridianu ciel Sol con un excelente sextante de Stancliff, acompañado de un pié y de un horizonte artificial: sus resultados, referidos al observatorio en nuestro plano, confirmaron la latitud deducida por el cuarto de círculo en este y en el día siguiente: y con el medio día derivado de las alturas co. rrespondientes, pudimos ya también investigar cuál fuese la lon citud del observatorio asi por las distancias lunares como por los relojes marinos.

A las cuatro de la tarde volvieron á encajonarse todos los instrumentos y la tienda, y re. gresados al mismo tiempo los Sres. Espinosa, Bausá, Heenke y Maqueda, que como se ha di. cho habían sido comisionados á destinos de su profesión, pudimos comer tranquilamente y emplear las horas restantes de la tarde en el examen de los habitadores d aquellas regiones.

D. Tomás Suria rectificó en esta ocasión para representarlas al vivo, todas las jdeas adquiridas en los días anteriores; D. Cayetano Valdés y D. Fernando Quintano, examinando las armas y utensilios, hallaron muchos que merecían adquirirse para el Real Gabinete; se advertían por otra parte las mujeres muy ocupadas en hacer los canastillos de coser, así como los hombres en hacer muñecas, cucharas y otros utensilios de madera que la Oficialidad y aun la marinería habian adquirido con ansia; finalmente, unos en la adquisición de nuevas voces $\mathrm{y}$ otros en el estudio de sus costumbres do.nésticas, habian esplayado aquel constante amor á las ciencias y al trabajo que tantos frutos había producido a la expedición.

Fue también oportuna la ocupación de tirar al blanco, á la cual se entregaron por algún tiempo el Comandante y Oficiales de la corbeta ATREvida; pues esmerándose en el acierto y estando á la vista un crecido número de naturales, no podía á ménos este ejercicio de influir mucho en la continuación de un trato tan paci. fico como debíamos desearlo: ro faltó entre los expectadores uno bastantemente advertido, que 
remos, que !nl. 30 bilidad; que htuvo entre onsiderable. or sí mismo arte de las. inmediatas cronómetro mo segundo ior $y \mathrm{del}$ si. el aire de la xperiencias, bondad de osé Espinomediaciones ciel Sol con ff, acompa rtificial: sus o en nuestro ucida por el ía siguiente; $s$ alturas co. en investigar torio así pol relojes ma-

eron á enca. tienda, y res. Espinosa, mo se ha di. istinos de su imente y em. de en el exaregiones. ocasión para as adquiridas no Valdés y olas armas y recían adqui. dvertían por das en hacer los hombres os utensilios la marinería ente, unos en otros en el icas, habían as ciencias y producido á

ción de tirar n por algún de la corbe. an el acierto ero de natuio de influir ato tan paciltó entre los vertido, que ful. 3o con general aprobación ó mas bien admiracicn de los demás. creyó haber hallado un remedio en sus vestidos para que fuesen impenetrables á la bala del fusil: mojó muy bien la piel que le cubría, luego muy ufano la puso por blanco á la distancia prefijada, y estaba tan persuadido de la impenetrabiliciad, que cuando D. Ciriaco $\mathrm{Ce}$ vallos la hubo agujereado con la bala, se enfadó agriamente y se retiró de aquellas inmediaciones.

En la aguada todo había procedido con la mayor quietud, aunque se apareciesen algunos naturales más que en el čía anterior; antes bien, D. José Espinosa había tenido lugar de enterar'se entre una familia inmediata, de varias costum. bres domésticas y adquirir una ú otra cosa de los trajes y adornos mujeriles: debió criusarnos una admiración particular en cuanto al carácter de aquellos naturales, lo que acaeció en la ATrevi. DA con un criado natural de las Islas Filipinas: Desde el primer día que visitaron aquella corbeta le habian creído por uno de los suyos, examinándole prolijamente los cabellos, el cutis, las facciones de la cara y áun diferentes miembros: le pidieron ahora que quedase en la tribu, y pro. curaron enterarse cómo estaba entre nosotros, $y$ si había sido vendido ó aprehendido.

Los recien venidos traían, como es natural, algunas pieles buenas de nutria, las cuales, por la tarde, empezaron á aparecer en el mercado que se celebraba en las carıas, debajo del portalón de cada corbeta; pero ligados ya sus intereses con los de la tríbu antigua y aún acompañados siem. pre por uno de éstos, 110 sólo no disminuyeron sus pretensiones con la concurrencia, sino que fueron poco á poco aumentándolas á tal extre. mo, particularmente para la adquisición de ves. tidos, que uno ú otro marinero nuestro perdió considerablemente en los cambios aún si se refiriese el valor de las pieles al mercado de Cantón.

Era, sin embargo, un espectáculo bien singu. lar y curioso el ver á la sazón una buena mitad de la tríbu antigua y algunos de la nueva, vestidos tan extrañamente con uniformes vitjos de soldados, chaquetas de la marinería, gorros, pañuelos, camisas, calzones, etc., indistinta: mente de invierno y de verano, que sin duda hu. bieran causado la mayor novedad á una embar. cación á cuyo bordo fuesen, y probablemente héchole sospechar que la tripulación de un buque español hubjese sido asesinada en aquellas inmı:diaciones.

Según refirió D. Felipe Bausá, la parte de costa comprendida entre la aguada y la Punta Muñoz, era con exceso frondosa y los campos inmediatos tan abundantes de una especiè de fresa silvestre, que en vano hubiera intentado agotarlos toda su comitiva, en la cual se hallaban unos cinco marineros; además había internado algo en Ju. go el río contiguo y visitado no sin mucha admira. ción, e! paraje de los entierros ya indicados por el Capitán Dixon: las rircunstancias de todo lo que rodeaba aquel paraje eran demasiado curio. sas y podrian dar tanta luz sobre los principios religiosos de aquellos pueblos, que hubiéramos sido culpables en no visitarle.

Así en la mañana siguiente, D. Tomás Su- Jul. ı* ria, D. José Ispinosa y otros Oficiales, fueron con el bote directamente al río, $\mathrm{v}$ poco después de las nueve ya estaban en el paraje indicado; se aparecieron oportunamente cuatro 6 cinco natu. rales que erraban en los campos innediatos bus. cando fresas para su alimento; parecíail, á la verdad, de la última plebe, y por consiguiente, poco aptos á satisfacer la curiosidad; pero como fuese el principal objeto de aquella excursión el recojer para el Real Gabinete una ú otra cosa de los sepulcros, esta compañía era á la sazón más oportuna que cualesquiera otras de la po. blación del fondeadero; la cual, 6 por ideas de temor ó de veneración, no hubiera tal vez permitido la ejecución de las ideas inü:cadas: midié ronse al principio, y D. Tomás Suria representó en una vista de perspectiva, los postes y vigas que encerraban una habitación larga y dispuesta al parecer para el inviemo; luego, les ocupó por largo tiempo con los mismos objetos el sepulcro antiglio, y úitimamente el nuevo, que por su co. locación, adornos y buena conservación, no podía á ménos de causar extrañeza y adiniración: final. mente, no repugnándolo los naturales, pues se les había prevenido con algunos dones, se sacó y envió al bote una de las cajas que estaban en el sepulcro antiguo. Era ésta ligeramente adornada por fuera con los caracoles acoitumbradcs: encerraba otra caja menor, en la cl al halláronse en. vueltos en una especie de espo $: \vdots 11_{\mathrm{a}}$, sólo pocos huesos calcinados y en mucha parte pulverizados. Empero, la vista de dichos sepulcros que acompañan á esta narración, dará mejor idea de sus diferentes partes y de sus proporciones, de lo que pudiera alcanzar una descripción por sí di fícil y cansada; sólo especificaremos aquí, que ya comprendióse por los naturales ser éstos los se. pulcros únicamente de los Ankaus ó familia rei nante, y que no quedó duda de la combustión de los cadáveres alrededor del figurón; pues además de señalarlo así los naturales, vieron tres ó cua. tro pequeñas fosas del largo de un hombre, en las cuales estaban cubiertas con algunas tablas y piedras los rarbones 6 leña que habían servido para la pira: se hablará después con más extensión de esta parte interesante de las costumbres de aquellos pueblos y aventuraremos nuestras ccnjeturas sobre la interpretación de cuanto he. mos podido advertir.

Entretanto, á las órdenes del Teniente de 
I w. $x^{*}$ navio Concha, de la Atrevida, las lanchas $y$ bombos armados habían hecho un nuevo acopio abundante de agua, y D. Juan Vernaci, continuando la hermosura del dia con la misma cla. ridad del anterior, había logrado otra observación de latitud $y$ un medio día bien satisfactorio por las alturas correspondientes, el cual ratificó la marcha del cronómetro $7 \mathrm{I}$ determinada en Acapulco, $y$ manifest 6 una aceleración no indiferente en los cronómetros 61 y 72. Ya, pues, concluídos los acopios de agua y lastre, para los cuales eran precisas las lanchas, no diferimos un instante en emprender el reconocimier to del abra que nos había atraído al puerto en el cual nos hallábamos actualmente; y pues era nuestro ánimo si existiese el paso deseado conducir hacia él las corbetas, quisimos examinar aquellos parajes y decidir fuera de toda duda una parte tan importante de nuestra comisión. A este fin, las lanchas bien armadas $y$ esquifadas, se previnieron con quince días de víveres y una suficiente cantidad de agua y leña: iba D. Felipe Bausá en la lancha de la Descubierta, y mandaba la de la Atrevida el Teniente de navío D. Antonio Tova; se embarcaron también el relój de faltriquera $35 \mathrm{r}$, el cuarto de círculc de Ramsden, un calafate y un carpintero, con todos los utensilios necesarios.

Dejado, yor consiguiente, el cuidado de las corbetas á D. José Bustamante y destinados los bombos para el acarreo de la leña, bien temprano en la mañana siguiente dimos la vela, prefiriendo el transitar por entre las islas, así porque el viento á la sazón achubascado y del Sueste nos sería más favorable, como porque haríamos un nuevo examen de la verdadera posición de sus canales: al principio debimos na. vegar al remo por largo trecho, pero luégo ya próximos á salir fuera de las islas, empezamos á gozar de un vientecillo galeno del Sur, que en breve tiempo nos aproximó al abra. Flotaban hacia la costa del Oeste varias bancas sueltas de hielo, y por la del Este se dejaba ver, próximo al mar, un trozo de tierra llana que estando bien abrigado del Norte por los montes contiguos, manifestaba ser el asilo de algunos indios, por el humo que advertíamos en uno ú otro paraje; sólo se encontraba un fondo de 20 ó 30 brazas á un tiro de fusil de la costa; á una mayor distan. cia, ni aún con 60 brazas podíamos alcanzarle, $y$ íltimamente, pasado el terreno llano, y ya próxima la entrada, acrecentaba de tal modo el fondo, que la lancha de la ATrevida, á un solo cumplido de bote de la orilla, no le podía alcanzal con 120 brazas.

A la sazón nos había abandonado el viento del Sur, y á veces una total calma y otras un viento contrario y lluvioso del Nordeste, nos habian precisado á valemos nuevamente de los remos, aunque la gente estuviese cansada y las IuI. a $^{2}$ lanchas algo sobrecargadas.

No bien habiamos pasado en las inmediaciones de las chozas, cuando vimos venir hacia nosotros una canoa con un solo indio, cuyo traje no era fácil distinguir aun'̧ue le contemplásemos cuidadosamente: en efecto, no era posible acertarlo, y lo juzgamos así, cuando ya próxima la canoa á nuestra lancha, no sólo vimos que el traje se componía de un gorro, camisa, calzones y uniforme, sino que el recién llegado en la canoa era un hijo del Ankan del puerto, que nos había visitado á bordo repetidas veces: con el traje nuevo parecían haberse humanizado mucho sus costumbres, pues habiéndole en diferentes ocasiones debido caracterizar por el mas altanero $y$ provocativo de la tríbu, ahora advertíamos en su conducta una mansedumbre y subordina. ción, cuyas causas no fuera fácil el acertar; trasbordó á la lancha de la Descubierta; nos indicó que era el caudillo de la póviación inme. diata y que allí estaban sus mujeres é hijos los cuales nombraba con mucha ternura; se prestó á acompañarnos precedido el regalo de algunas frioleras y una regular comida, de la cual tenía, al parecer, una no mediana necesidad.

I. a poca fuerza de la narea y todas las res. puestas del nuevo $A n k a u$, ya nos convencían que no sólo no existía en estos parajes el paso de. seado, sino que era muy corta y ya casi terminada la internación de este canal: veíamos por otra parte guarnecida dis un perpétuo hielo toda la orilla interna del Oeste, lo que no pudiera tener lugar si las aguas en algún tiempo del año tuviesen una rapide $z$ proporcionada ó á la co. municación de otro mar, ó á los recodos que suponía Ferrer Maldonato; per: la cerrazón del tiempo y el viento contrario, dilataĩon aún por dos horas nuestra jlusión, á la cual coad’’ıvaba únicaniente, como hemos dicho, la excesiva cantidad del fondo por una y otra parte, y la tal cual semejanza en el ancho, escarpe y sinuosidad de la eritrada.

Como á la una de la tarde, guiados del indio pudimos alcanzar un fondeadero en la parte in. terna de la bahía: era una playa de bastante cascajo, frontera á una cañada de dos montes bastantemente altos, la cual, regada con un riachuelo y gozan do de un poco de tierra lla. na, presentaba á la vista el semblante más halagüeño de la vejetación: pero exceptuando estos trozos pequeños, que pudieran con propiedad llamarse manchas verdes, todo cuanto rodeaba la bahía era una masa de piedra cubierta de hielo, $y$ éste tan constante, que en las muchas bancas que nadaban en nuestras inmediaciones y oíamos desplomarse de tiempo en tiempo con notable es. truendo de los montes vecinos, se advertían sobre el hielo primitivo las nuevas capas recientes que 
ansada y las lul. a

inmediaciovenir hacia io, cuyo traje templásemos posible acera próxima la vimos que el hisa, calzones ado en la carto, que nos veces: con el hizado mucho en diferente 1 mas altane advertíamos y subordina il el acertar UBIERTA; nos viacion inme. es é hijos los ara; se prestó lo de algunas a cual tenía esidad.

odas las res onvencían que s el paso de a casi termi veíamos por tuo hielo toda e no pudiera iempo del año la 6 á la co codos que sucerrazón del aron aún po al coaàj"uvaba excesiva canrarte, y la tal rpe y sinuosi.

ados del indio la parte in de bastante de dos mon. regada con un de tierra lla. unte más halaptuando estos propiedad lla. to rodeaba la ierta de hielo. uuchas bancas ones y oíamos on notable es. dvertían sobre recientes que
Jul. a se le habían amontonado; y ni siquiera en los pocos parajes en donde se manifestaba ia vejetación dejaban de encontrarse masas enormes de hielo, tan sólida y tenazmente afianzadas que parecía imposible pudiesen disolverse en el corto espacio del restante verano.

A pesar de que continuasen aún la lluvia y el frío, mientras ambas esquifazones aprestaban su comida, nosotros no descuidamos el ocuparnos en adquirir una idea más cabal de aquellos contornos: D. Felipe Bausá midió una base é hizo marcaciones, aunque bien limitadas, así en los extremos como en otro altito inmediato al fondeadero; D. Antonio Tova se encargó de la caza, $y$ otros emprendieron el acopiar todo lo relativo á la Historia Natural, que sujetariamos luego al examen científico de D. Tadco Heenke: insistiendo el Ankau en querer regresar á su choza antes de la noche, lo despedimos con algunos regalos y nos prometió volver á la mañana siguiente con algunos salmones frescos.

El deseo de aprovechar el tiempo y el temor de que continuasen ó aún aumentasen la cerrazón, lluvia y frío, no permitieron dejar á las marine. rías más descanso del que exigían las mareas, que ya advertíamos periódicas y casi uniformes con las del puerto Mulgrave. Por consiguiente, hacia las nueve de la tarde emprendimos el in. ternar con los remos y examinar el término de las abras contiguas á la línea del hielo constante, y el canal, que parecía dividir del continente una islita que habíamos visto frontera al fondeadero: mil circustancias hacían esta pesquisa realmente molesta y cansada á la marinería, pero más que todas lo eran sin duda la dificultad de vogar en. tre las muchas bancas flotantes que nos rodeaban, la precisión de dar mil tornos para evadirlas, y la dificultad de encontrar fondo, que Don Antonio Tova, mucho más aterrado que noșotros hacia la derecha, no podía alcanzar con I 20 brazas.

Finalmente, á las once y media de la noche, aún antes de alcanzar la isla, encontramos la línea del hielo constante, y nos fué preciso retroceder al fondeadero antiguo, en el cual, dado fondo poco después de la media noche, pudo permitirse á la gente el rescanso necesario.

El tiempo, hasta entonces cerrado con lluvia, no nos había sin embargo permitido el for. mar una idea tan cabal de la cordillera sobre estante á la bahía, cuanto la deseábamos para la exactitud de nuestras operaciones: tampoco liabíamos podido determinar el verdadero extremo de una entrada que notábanıos al Noroeste, pues estaba comprendida en los límites del hielo constante; por último, quedaban inútiles los ins;rumentos astronomiros, y mal fijadala posición geográfica de aquel puerto, aunque á la verdad, sólo pudiera ser útil á los navegantes venideros más bien para evadirle que para buscarte. La sue. quiso favorecernos en aquella ocasión, y un vientecillo galeno del Noroeste dando lugar á que desapareciese toda la cerrazón y calima, ya nos permitía contijnuar nuestras operaciones. Se agregó á esta felicidad el aparecimiento de va. rias canoas de la ranchería contigua á la boca, que nos proveseron con abundancia de un excelente salmón fresco, y así pude la marinería lograr de un completo descanso, y nosotros finalizar poco después del medio día las observaciones emprendidas: logramos de una excelente vista de perspectiva que podrá mani.estar el liorror de aquellos contornos; se observó en el cuarto de círculo la latitud de $59^{\circ} 50^{\prime} 30^{\prime \prime}$; scis azimutes del Sol indicaron conformes la variación magnética bien extraña de $32^{\circ}+49^{\prime}$; se ratificaron $y$ aumentaron las marcaciones del día anterior, $y$ hubiéramos deducido dircctamente la longitud, si 6 la marcha irregular del reloj ó alguna equivocación en las observaciones, no nos hiciesen malograr en aquella parte nuestras tareas, imposibles de combinarse con las marcaciones ligadas hasta el fondeudero de las corbetas.

Ya en las primeras horas de la tarde, empezando á declararse la marea favorable, $y$ embarcados los instrumentos y utensilios, nos disponíamos á emprender el viaje de regreso, cuando entre los marineros de la ATREvidA, se advirtió la falta del artillero de mar Manuel Fernández, refiriendo sus compañeros que se había separado de los demás liacia las ocho sin decir á dónde iba, y que sólo habían extrañado su falta á la hora de comer.

Este marinero tratado en su corbeta con un rigor mode:ado desde que había sido aprehendido con los demás desertores en Acapulco, ahora había solicitado con mucho empeño el ser destinado en la lanclia, para acreditar con su conduc. ta el arrepentimiento de aquel desliz involunta. rio: se nos hacía, por consiguiente, tanto más dificil el combinar sus ideas, cuanto que creíamos que la puntualidad y asiduidad en el trabajo serían el único medio que alcanzase para acreditarse; por ventura, sabíamos que su ruta había sido por la orilla de la derecha hacia la isla y fondo de la ensenada, y con este antecedente no tardamos en destacar otro marinero, que siguiendo sus huellas le gritase y le trajese: puede, pues, imaginarse cuál sería nuestra confusión cuando hallamos también infructuosa esta medida, au11. que el marinero, va á mucha distancia de las lanchas y sobre unos riscos casi impenetrables, gritase á toda fuerza y casi alcanzase la vista del fondo de la bahía: ya fué preciso que D. Antonio Tova, con la lancha, emprendiese por sí mismo una nueva pesquisa. Se le encargo que internase cuanto fuera posible; que disparase de tiempo en tiempo algunos fusilazos y reconociese pro- 
Jul. 2 lijamente toda la orilla, por si alguna enfermedad ó caída le imposibilitasen al mismo tiempo el gritar y el regresar á bordo. $\Lambda$ medida que la lancha internaba y casi se aproximaba al 'ielo, crecían los recelos sobre la suegrte de aquel infeliz, pues no hallando el menor rastro, ni ce respondiendo señal alguna á los fusilazos, dc síase temer, ó que se hubiese dado una muerte voluntaria, ó que hubiese sido presa de algunos osos, que, según informes de los naturales, erraban en mucho número en aquellos contornos; pero tinalmente, lográronse disipar estas sospechas con verle aparecer á larga distancia; y áun habiéndole recogido después en la lancha, debió reprimirse el natural enfado y deseo de reprenderle cuando satisfizo con decir que era su ánimo el descubrir el Estrecho por el cual ansiábamos. En efecto, su deseo de contraer este mérito y el oir nuestras conversaciones sobre el no haber reconocido el término del abía de la derecha, le ha. bían persuadido á dirigirse hacia ella por tierra, $y$ temeroso de que otros quisiesen participar de esta gloria, no sólo había ocultado su pensamiento á todos, si que tambien llevado con un tesón correspondiente, caminando unas seis ho. ras por riscos $y$ hielos de una escabrosidad real mente difícil de imaginarse.

Ciertamente debió causarnos tanta risa el poco acierto en arruel plan, como admiración el pundonor que le dirigía; el marinero, no sólo fué perdonado de su mala entendida ausencia, si también devuelto por ?. José Bustamante á su destino antiguo de gaviı1o mayor. y no parecerá ni frívola ni ociosa la relación de este hecho, cuando se refiera, ó bien al objeto de reflejar el noble pundonor del carácter nacional, ó de con. vencer cuánto yerran los que piensan asemejar el marinero á un bruto destituído cası en un todo de las facultades de sentir y de pensar.

Antes de abandonar la bahía, dejamos enterrada una botella con la inscripción de nuestro reconocimiento, la fecha en que lo habíamos he. cho y la posesión tomada en nombre de Su Ma. jestad, que acreditaba una moneda enterrada al lado de la botella; el puerto tuvo el nombre del Desengaño, el abra externa la de Ferrer, por el navegante antiguo que actualmente dirigía nuestras pesquisas, y la isla interna el de Heenke, en obsequio del Botánico, que dividía con nos. tros en aquel viaje todos los peligros é incomo. idades de la navegación.

Con el auxilio de la marea $y$ del Noroeste que á la sazón soplaba galeno, creíamos que nuestros progresos en la próxima tarde serían considerables, pero muy luego, abandonándonos una y otra, debimos valernos de los remos y continuar constantemente con ellos, aunque molestasen mucho á la marinería de ambas lanchas. Los naturales nos habían precedido con sus canoas, y nos salieron al encuentro cuando inmediatos al Jul. o paraje de las chozas atracamos á él para que se hiciesen algunas marcaciones con el teodolito, comprendida en ellas la del Monte de San Elias que teniamos á la sazón á la vista: el jóven Aukau continuó con la misma afabilidad que había esplayado en el día anterior, y áun trajo á bordo en una canoa dos hijos suyos de edad muy tierna, hacia los cuales manifestaba un.cariño extremado, y que, por consiguiente, fueron bien regalados: el trozo pequeño de tierra llana en el cual estaban establecidas estas chozas, se hallaba á la verdad bien abrigado de los vientos sep. tentrionales, y su dirección bastantemente incli. nada hacia el Sur, para que pariciese preferente para habitarle; pero en desquite era la orilla en exuremo hondable y seguramente tan expuesta á la ola muy gruesa de la travesía, que muchas veces, particularmente en invierno, no sería asequible el intentar la pesca: ésta debía creerse muy abundante en aquellos contornos, si consul. tásemos los muchos salmones de que nos proveyeron en el primer día y en el siguiente.

Navegando en toda la restante tarde como á dos tiros de fusil de la costa por fondos de $25 y$ 30 brazas, unas veces piedra y otras cascajo, tu. vimos lugar al mismo tiempo de reconocerla prolijamente y de buscar un mediano abrigo para pasar la noche: eran las diez de ella cuando dejamos caer la amarra, y no obstante, se hicieron las marcaciones necesarias con el teodolito, sujetándolas nuevamente al Monte San Elías que aún teníamos á la vista.

El paraje donde se hallában á la sazón las lanchas, era un canal que forma la tierra firme con una isla de mediana altura y que sería un excelente fondeadero si el fondo en una $y$ otra orilla no subiese rápidamente á 40 y 50 brazas, y las mismas orillas no fuesen rodeadas de piedras, bien incómodas para la comunicación de embarcaciones menores: un enjambre de mos. quitos nos hizo luego acelern r la salida en la ma ñanita siguiente; pero antes se midio una base para trazar aquel puerto, $y$ luego, con viento bo nancible del Oeste, á veces achubascado y á ve. ces calmoso, emprendimos el continuar nuestras pesquisas sobre aquel corto Archipièlago, y últimamente alcanzar las corveias.

La isla que actualmente reconocíamos, es sumamente frondosa, $y$ por partes llena de mariscos; además se dejan ver en su costa del Sur otros sepulcros, iguales en un todo á los que habíamos visitado en las inmediaciones del puerto: se advierten sembradas, ó en la islas ó en la costa firme inmediata, muy pocas rancherías de naturales, y si juzgásemos por el crecido número de 30 ó to salmones que vendieron dos solas canoas á bordo de las lanchas, deben ser aque. llos canales bien abundantes en pescado, y por 
Jul. 4 consiguiente de una fácil subsistencia para sus moradores.

Ya el viento continuó favorable aunque acom. pañado con lluvia: le aprovechamos con todas las velas, y frustrado nuestro intento de internar ha. cia otro canal interno, pues le conocimos cerrado y que sólo formaba una bahía bastantemente ancha; á las cinco avistamos las corbetas y poco después estuvimos á bordo.

En los tres días anteriores, según informó D. José Bustamante, habían variado mucho las circunstancias de nuestro roce con los naturales; y á pesar que ni hubiese habido el menor dano por una ni por otra parte, los trances habían sido bien delicados y exigían otra circunspección en nuestros pasos.

En el mismo día en que salieron las lanchas para el puerto del Desengaño, fueron nuestras partidas al corte de leña en un paraje poco distante de las chozas; recayó el turno de servicio en D. Cayetano Valdés, quien tomó todas las disposiciones para la seguridad, el trabajo y la conducción; y en efecto, aunque concurriesen en aquel paraje muchos naturales, ni en la asiduidad ni en el roce amistoso se había notado la menor interrupción; pero como luego se descuidase un marinero de la $\mathrm{E}$,UBIERTA en poner su chaqueta en el paraje en donde estaban las demás, y que prudentemente se habia puesto al cuidado de un centinela, no faltó un natural que la quitase con lijereza, ni dejó el marinero de echarla de ménos y advertirlo así al Oficial Comandante; informado este muy luego por uno de los circunstantes de quién era el delincuente, lo avisó al Anka:l, estrechándole á que le obligase á la restitución y le castigase del mismo modo que nosotros lo ejecutaríamos con quien quisiese violar los derechos de su propiedad; sin embargo, 6 fuese mengua de autoridad, 6 (como es probable), no dejase el mismo jefe de ser cómplice èn esos atentados, aunque siempre bajo el semblante de la mayor amistad hacia nosotros, no volvió la chaqueta á nuestras manos, y J). Jose Busta. mante (aconsejándole əsí el mismo Ankiauá bordo de la Descubierta), prohibió para el día siguiente los cambios é insistió en la restitución de la prenda robada. Los naturales habianse irritado con esta medida, $y$ así, cuando al día siguiente D. José Robredo emprendió con las partidas acostumbradas el corte de leña, no sólo advirtió en ellos una conducta provocativa é insolente, sino que debí presentar el fusil contra uno, que insultada la centinela á quien estaba confiada la custodia de las chanquetas, á la menor reconvención se volvís con el puñal desenvainado hacia el mismo: insistían al mismo tiempo al costado de ambas corbetas, no sin mucha altanería, que nos fuésemos luego si no queríamos continuar los cambios; finalmente, en todos sus pasos ma- nifestaban que la sola falta de una ocasión opor- Jul. 1 tuna los detenía de una rotura sangrienta y destructiva.

Oportunamente, á la sazón los Oficiales de la ATRIVIDA emprendieron de nuevo, por diversión, el tirar al blanco en la playa, $y$ un acierto continuado con la internación de la bala en el tronco de un árbol, perforada de antemano la piel mojada, les convenció de nuevo que la superioridad de nuestras armas decidiría muy luego cualquier refriega á favor nuestro; con estos antecedentes, regresada la Oficialidad á bordo $y$ retiradas las partidas que se hallaban en el corte de la leña, continuaban sí una ú otra vez las instancias de los naturales para la verificación de los cambios, pero ni manifestaban un enojo inmediato, ni cabía el sospecharle después del escarmiento que se les había repetido á la vista, y después de las asegruraciones del Conıandante de la ATrevidA, que al día siguiente se renova. rían los cambios: era difícil, á la sazón, acertar con las intenciones verdaderas del Ankau: á bordo de las corbetas parecía querer coadyuvar á nuestras intenciones de recobrar la chaqueta; entre los suyos, 6 peroraba con debilidad, 6 ma. nif estaba con una conducta apacible que no des aprobaba cl robo; bien que como se entregase tan frecuentemente en nuestras manos y nos asesurase de la constancia de su amistad, jamás debian recelarse consecucncias funestas, tanto más, que cada uno de los nuestros se precavía con las armas oportunas para la seguridad propia.

A las cuatro de la tarde, D. José Bustamante con el ánimo de dar algunos pasos para la pacificación y continuar la diversión del blanco á la sazón ya casi necesaria, determinó bajar á tierra hacia la playa frontera á la Descubierta: estaban los naturales amontonados alrededor de sus chozas, y algunos entre ellos iban dirigiéndose hacia la misma playa en donde atracaba el bote. Dejado, pues, éste al cuidado de los mariner. que le mantuviesen á flote, los demás empezaron á aproximarse hacia las chozas, precediendo á alguna distancia el Comandante y mediando po. cos marineros entre el y los Tenientes de navío Cevallos, Concha y Viana. Pareció esta ocasión demasiado oportuna á uno de los naturales para la empresa que meditaba de hacerse dueño de uno de nuestros marineros, que advertia sin armas, y probablemente obligarnos para su recobro á la continuación de los cambios 6 á cualquiera otro partido que quisiesen prescribirnos; $y$ así no tardó en cogerle por la espalda, y corriendo con la posible velocidad se dirigió hacia los suyos: el marinero era un jóven americano, el cual, ó persuadido que fuese uno de sus compañeros el que le llevaba, 6 bien amedrentado con este liecho, ni aun se precavía con avisar á los Oficia- 
Jul. + les; pero por ventura, ni éstos podían dejar de advertirlo, ni omitieron el avisarlo inmediata. mente á D. José Bustamante, el cual no tardó en amenazar al natural para que soltase al marine. ro; logró, en efecto, verle suelto; pero al mismo tiempo vió dirigirse hacia ćl con el puñal desenvainado al mismo natural de la contienda, el cual, ya á muy corta distancia, se detuvo por un momento $y$ gritó á los sujos, qur, no tardaron en moverse, hallándose entre ellos el mismo Anka:t.

Ya el semblante de la contienda era bastantemente serio: el fusil de Bustamante no estaba cargado ni tenia la bayoneta; y ya el natural enfurecido le amenazaba muy de cerca: por una parte iba creciendo considerablemente el númcro de los naturales armados, y por la otra, los tres Oficiales ya nombrados, el Contador Ezquerra $y$ unos dos marineros que se habían armado con sables, se disponían á defender á su Comandante, tanto más, que advertían en su adversario algunos movimientos para cojerle diestramente por la espalda: en aquel trance no olvidó Bustamante ni los principios de liumanidad, ni los de la seguridad propia; presentó su fusil como si estuviese cargado, difirió el advertirle á los suyos para que aún suspendiesen las hostilidades, y llamó con denuedo al Ankat para que refre. nase la osadía en sus súbditos; éste, suspenso por algún tiempo, se decidió á hablar al más alentado, bien que no en el tono acostumbrado de mando; $y$ el otro tal ve $z$ persuadido ó ate. morizado, no tardó en abrir los brazos y cantar el himno de paz.

Este paso, sin embargo, no parecía merecer aún la aprobación de los demás, quienes perma. necían armados alrededor de sus chozas, y ale. jadas las mujeres llamaban con ansia las po. cas canoas que estaban al costado de las corbetas. Advirtieron los Oficiales estas circunstancias, pero no hallaban prudente embarcarse 'an luego, dando muestras de inferioridad, ni les parecía oportuno avisar á las corbetas, para que les auxiliasen con nuevas fuerzas, tal vez mal interpretadas y prevenidas por los natura. les: permanecieron, por consiguiente, aún por algún tiempo en la playa, dieron ruevas mues. tras del desprecio con que miraban á sus adversarios y de sus deseos de una pacificación, y finalmente, regresaron con el bote á bordo.

Una mezcla semejante de tesón y dulzura, no podía ménos de dar un nuevo aspecto á estas circunstancias desagradables, y convencer á los naturales, asi de nuestras fuerzas, como de nuestras ideas realmente pacíficas: no tardó el Ankau en manifestarlo así á los suyos en usa arenga bien larga y enfática, que se advertía desde las corbetas; y finalmente, en atraerlos á que pidiesen unánimemente la paz, entregada la chaqueta origen de la discordía. Con ella, pues, se dirigió á la ATREvidA, acompañándole las muestras más Jul, solemnes de una paz verdadera, y suplicó á Don José liustamante para que en una y otra corbeta cantasen nuestras gentes la paz, así como los suy'os la ejecutarían en la orilla opuesta; muy luego este agradable esiruendo repetido en ainbos buques y en tierra, no sin alguna harmonía, y con la expresiva acción de los brazos abiertos, presento á la vista de los nuestros un espectáculo bien diferente del que poco antes habían imaginado, y nuestras tripulaciones, olvidado el enojo que les había inspirado el oir el riesgo de sus Ofieiales, volvieron á recibir aquellas idcas de compasion y humanidad, que con tantas ansias deseábamos inspirarles á cada paso.

Bien establecida la paz, quisieron los naturales después de puesto el Sol ratificarla aún con mayor solenınidad, $y$ con este intento, encendidos algunos fuegos sobre la orilla inmediata á las corbetas, cmprendieron algunos bailes y fes. tejos, los acompañaron con cantos narınoniosos $y$ alegres (que cl Sr. de Heenke no omitio de copiar inmediatamente) y mezclaron con bastan. te frecuencia las voces de Atrevida y DesscuBIERTA, procurando dirigirse hacia los buques $e$ imitando nuestro modo de llamar una y otra.

En el día siguiente que fué lluvioso, parecio á D. Jcisé Bustamante tanto más oportuno el desistir de todo trabajo, cuanto que ya era crecido el acopio hecho de leña; la gente necesitaba de algún descansu; así pudieron examinarse con más despacio el carácter é intenciones de los naturales: los Oficiales de la Descubierta, acompañados del mismo Ankau, visitaron el paraje de los sepulcros y acrecentaron mucho en aquella ocasión sus conocimientos, así de las costumbres, como del idioma: se avivaron los cambios bajo el sistema primitivo de no subir los naturales á bordo, fué abundante la cantidad de salmones traídos al mercado sin alterar $: *$ precio, $y$ agregada ya á las antiguas una nueva tribu, que acababa de llegar y estaba regida por un hijo de nuestro Ankau; finalmente, al momento de la llegada de las lanchas, todo estaba en el mejor orden y tranquilidad, repitiendo el caudillo las aseguraciones de una sincera amistad y su satis. facción por nuestro regreso.

Concluídos todos los objetos que nos habian inducido á entrar en el puerto, era nuestro áni. mo el abandonarle con la mayor prontitud para aprovechar la estación favorable en el reconocimiento de la costa siguiente hacia el Oeste; pero como el tiemro estuviese cerrado con lluvia, y por otra parte fuese muy útil para nuestra estiva un nuevo acopio de agua, se determinó que en la mañanita siguiente, las lanchas y bombos bien armados y á las órdenes del Teniente de navío Cevallos, se ocupasen en este servicio, mientras á bordo se acelerarian los demás apres. 
Jul. $s$ tos para una pronta salida: luégo, tomando el dia mejor semblante, $y$ aún prometiendo uno ú otro aparecimiento del Sol, al mismo tiempo se destacó D. Juan Maqueda con un bote armado, para examinar algunos fondos que aún faltaban, $y$ el Teniente de fragata D. Juan Vernaci con el cuarto de círculo de Ramsden, el reloj de lon. gritud 35r, un pilotín y dos soldados armados, tuvo orden de acechar algunas claras en la pla. ya próxima por si lográsemos una nueva época distante para el examen de la marcha de nuestros relojes.

Bien temprat.o el Ankau se había transfe. rido á bordo de la ATREVIDA, atendiendo á los canıbios en los cuales lograba siempre de una grande ventaja sobre los demás, con la prefe. rencia de subir á bordo de la cual él solo disfru. taba; muchas canoas entendian igualmente en el mismo objeto; $y$ en el paraje en donde estaba el cuarto de círculo para esperar las alturas correspondientes de la tarde, sólo se advertía un corto número de naturales expectadores tranqui los de aquellas operaciones: pero poco antes del medio día, ó bien fuese un nuevo efecto de una curiosidad ociosa, 6 un nuevo prurito de abusar de nuestra paciencia, empezaron luégo á concurrir allí el mayor número, luégo á pretender tocar ya uno ya otro utensilio, y últimamente, en rodear los soldados que procuraban apartarlos, llegando hasta pedir los fusiles no sin algunas muestras de insolencia; no omitió D. Juan Vernaci de a visar muy luégo estas circunstancias al Coman. dante de la Atrevida, á cuya voz estaba, y éste les participó inmediatamente avisando que tenía á su bordo el Ankan y que para obrar de con. cierto, deseaba se le previniese lo que había de hacer: la debilidad de nuestras fuerzas actual. mente en tierra, el riesgo de la pérdida de una pieza cualquiera del cuarto de círculo difícil luégo de reemplazarle, y sobre todo el deseo de evitar una discordia que fuese tal vez funesta á unos y otros, no dejaba elección sobre e! partido más conveniente: se le previno que detuviese al Ankau, y que éste instase á los suyos para que se apartasen de las inmediaciones del cuarto de círculo, y que tuviese la artillería pronta para usarla si fuese necesario: al mismo tiempo fué el bote de la ATrevida con el Teniente de navío Concha, y ya nos precedía algún tanto D. Cayetano Valdés con cuatro soldados armados.

En esta ocasión ya hubiera sido imprudencia pretender mantenernos en aquel puesto hasta la hora c'e las observaciones de la tarde y hacer del cuaıin de círculo un paladio que fuese la causa de una reyerta sangrienta; así los primeros pasos de los Tenientes de navío Valdés, Vernaci y Concha, se dirigieron á cubrir con la tropa el cuarto de círculo, á apartar un poco los que estaban inmediatos, y aun á convencerles (encargándonos nosotros mismos de esta opera. Jul. s ción), á que era necesaria esta medida, y acom. pañada siempre de las ideas más pacíficas y sua. ves; diose después la orde:. al pilotín para que encajonase los utensilios, y á la marinería para que los llevase al bote: resistían los naturales el retirarse; manifestaban en sus posturas y ros. tros (ya bien conocidos) el deseo de usar de sus puñales si se les presentase una ocasión favo. rable; todas las canoas se hablan retirado de las corbetas, y al mismo tiempo veíamos aproximarse algunos por la parte de la laguna $y$ al abrigo de algunos árboles, mientras de la ATREvIDA nos avisaban, que ya toda la tribu armada se encaminaba hacia nosotros; procuramos enunces dirigirnos con algún imperio á los natura. les más adelantados y enseñándoles los fusiles les dijimos que se retirasen, pero el uno de ellos solo retrocedió dos $\dot{o}$ tres pasos, y sacando su puñal nos manifestó que él tampoco estaba sin armas y que no temía: en balde á la sazón el Ankau deterido contra su voluntad en la ATRL vIDA, gritaba á los suyos que se retirasen y les avisaba de estar la artillería pronta para ofenderlos: insistían en su primer ánimo y más bien redoblaba su furor ciego, llegando al punto de presentarse un natural pecho á pecho contra el Teniente de navío Valdés, quien tenía pronto su fusil y bayoneta: ya, pues, en este trance, pareció lo más oportuno acelerar el embarco del cuarto de círculo sin detenerse en encajonarlo, y avisar á la ATREvida que disparase un cañonazo sin bala, mientras nosotros nos aproximábamos en buen orden y paulatinamente á la orilla: al estruendo miraron todos en torno para ver el daño acaecido; el Aukau solicitó que no se dirigiese la puntería á las chozas, y algunos parecieron determinados á retroceder, pero muy luego volviendo á cobrar aliento, uno de ellos que nos seguía de cerca empuñó la daga con noble audacia y gritó al Ankaı que pusiese su persona en salvo y entonces no tardaría en ata. carnos.

Ya embarcado el cuarto de círculo, próxima á los botes toda nuestra gente cuyo número se había aumentado con la reunión de los que estaban sondando, nuestros cuidados no debían dirigirsc tanto á la seguridad nuestra como á evitar que uno ú otro natural no buscase por sí mismo la muerte entre nuestros fusiles y bayonetas; por consiguiente, se dispuso que se embarcasen al. gunos soldados, y después lo ejecutamos nosotros, considerándonos bien felices de haber po. dido evitar toda efusión de sangre humana en una ocasión tan próxima á derramarla.

Con la retirada de nuestros botes ya variaban mucho las circunstancias de la contienda; pues sin tener los naturales objeto alguno para sus tretas y venganza, veían su jefe y otro indio de- 
Jil. s tenidos á bordo de la Atrevios, y por consi. guiente, de nuestra parte aquellas mismas ventajas que hubicran deseado tener en los días an. teriores por medio del marinero: se agregaban á esto las repetidas voces del mismo Anka:k, y la cesación de los cambios, todos ugentes para que tuviese lugar muy luegro una nueva pacificación; y últimamente, nuestra conducta uniforme para atraerlos á un roce amistoso, sin que dependiese ó del recelo de la ofensa ó del cebo é interés del comercio: así, no pasó largo tiempo sin que muchos naturales se aproxinsaseu á la orilla y grita sen al Ankau que estaban dispuestos á la paz; pero como nuestras lanchas del agua no se hubiesen reunido aún á sus buques, pareció prudente á Don José Bustamantc el detener aquel jefe á bordo con diferentes pretestos, hasta que se reincorporasen.

Conseguímoslo muy luego, y á las tres de la tarde, repitiendo los naturales sus instancias para la devolución del jefe y áun ofreciendo la restitución de un par de calzones que habían quitado diestramente á un marinero en el segundo dia del corte de la leña; accedimos, á que se restituyese á tierra en una canoa que vino á buscarle, con las señales acostumbradas de paz; muy luego le vimos aparecer de nuevo $y$ entonando el himno, con llevar en alto y con la mayor solemnidad los calzones robados, ratificó la paz, solicitando de nuestra parte las vo'es y señales acostumbradas en el pasamano, as'، como los suyos las repetirían desde la playa; así cesó de nuevo toda desconfianza, y no pasó media hora, cuando se hallaban á nuestro costado proponiendo una piel ó cualquiera otra friolera, los mismos indivíduos que al medio día despreciaban su vida por el solo placer, ó de ultrajarnos ó de ofendernos.

$A$ las cinco de la tarde ya el viento se declaró bonancible por el Oeste despejando en un momento los cielos $y$ horizontes: la marea debía continuar favorable hasta las diez, y así, no diferimos un momento en emprender la faena de desamarrarnos, $y$ últimamente (metida la lancha) la de dar la vela.

No malograron los naturales estas últimas horas para la posible multiplicación de cambios, trayendo al mismo tiempo todos aquellos efectos que pudiesen agradarnos, y disminuyendo mucho sus pretensiones, que hasta entónces habían sido excesivas particularmente por lo que toca á las hachas y á los vestidos. Retiráronse al dar la vela casi todas las canoas, y sólo quedó una inmediata á la Descubrekta, y en ella una mujer, la cual, entónces, no solo quiso borrar de nuestra memoria con una acción buena el poco agrado que habíamos hallado entre los suyos, si también recordarnos, que ni aquellos climas ásperos pudieran destruír el carácter dul- ce y cariñoso que ha sido siempre la verdadera Jul. s senal caracteristica de su sexo: nuestro cirujano, advirtiendo que esta mujer trala consigo un niño casi de pecho, le tiró desde la popa algunos cas. cabeles y avalorios, diciéndole que se los pusiese como adornos: subió después al alcázar y aproximándose al portalón, halló ya al costado la canoa. La compasión le movió entonces á ha. cer un segundo regalo de la misma especie, pero la mujer no pudiendo ya refrenar su agradecimicnto, cortada con prontitud la mitad de una picl que traía, la puso en la cabeza del niño, y como si fuese en su nombre, la regaló; una acción semejante pedia de nuestra parte las mues. tras de una aprobación agradecida; así, no tardaron los que estaban presentes en regalarle una ú otra bagatela de las que entonces tuviesen á ma. no; pero la mujer léjos de ceder en aquella oca. sión á los dictados de su pobreza 6 de su natural inclinación á los adornos, prefirió el competir con nosotros en cuanto á la generosidad, devolviendo á medida que le alcanzaban nuestros regalos, ya una ya otra cosa en nombre del niño, y conti. nuando con igual tesón en este empeño, hasta que estuvo enteramente despojada de las pieles que la cubrían. Puede imaginarse, que última. mente quedó de nuestra parte la superioridad de esta contienda; bien que sin mengua de la justa admiración que debia producirnos aquella conducta.

Eran ya las nueve de la tarde cuando reba. sada la punta Turner, empezamos á ceñir el vien. to á la sazón muy flojo del Sudoeste, para sa: lir sobre bordos del canal que forma la Isla Dixon con la punta Muñoz: en uno de estos bordos, prolongado hacia la boca de un río, en cuya punta el actual bajamar había disminuído el fondo considerablemente la Descubierta, al tiempo de virar por avante quedó varada de proa, aun. que por ambos costados y por la popa no fuese el fondo menor de tres á cinco brazas: inmedia. tamente se hicieron las maniobras para caer con el solo aparejo; pero no siendo bastantes, tendimos con el bombo un anclote y halando por la popa, de los calabrotes, quedamos á las once á llote y en ro brazas de agua, sin haber experimentado otro daño alguno.

La corbeta ATREvida había ya destacado su bote á las órdenes del Teniente de fragata Viana para auxiliarnos y luego arribó para dar fondo en nuestras inmediaciones, cuando se aviś́ á su Comandante nuestro ánimo de esperar fondeados la otra vaciante que no empezaría hasta las cuatro de la mañana.

Efectivamente, no bien había salido el Sol con semblante hermoso y vientecito galeno del Oesnoroeste, cuando emprendimos el dar la vela. Fueron muchos nuestros bordos hacia una y otra costa, antes que pudiésemos considerarnos safos 
a verdadera jid.s ro cirujano, vigro un niño Ulgunos cas. e los pusie. 1 alcázar y al costado tonces a ha specie, pero su agrajeciitad de una del niño, y alo; una acte las mues. sí, no tardaralarle una ú viesen á ma. aquella ocale su natural competir con devolviendo s regalos, ya ño, y contipeño: hasta de las pieles que última. perioridad de a de la justa aquella con.

uando rebaceñir el viente, para sa: la Isla Dixon :stos bordos, n cuya punta ido el fondo , al tiempo e proa, aun. opa no fuese as: inmediaJara caer con antes, tendiLlando por la á las once á aber experi-

destacado su ragata Viana dar fondo en visó á su Coar fondeados rasta las cua.

salido el Sol - galeno del el dar la vela. ia una y otra erarnos safos
Jul. 6 de la punta Muñoz, cuyas restingas salen al mar unos cuatro ó cinco cables; pero á las nueve, inclinadc el viento al cuarto cuadrante, logramos rebasarlas á distancia de una media milla, y seguir al Sudoeste con todo aparejo, viento galeno del Oesnoroeste, mar bastantemente llana $y$ tiempo hermoso $y$ apacible.

La latitud de $59^{\circ} 24^{\prime}$ observada al medio dia y diferentes marcaciones liechas á todos los puntos que teníamos á la vista, dieron lugar á una prolija confrontación de nuestras tareas desde el puerto; que pudimos reunir de nuevo á las inme. diaciones del Cabo Buen 'Tiempo, al fondo de la ensenada 6 abra de Ierrer, y á la costa que desde este abra sigue laacia el Oestc á las faldas del Monte San Elías.

Era la navegación que ahora emprendíamos el verdadero objeto del viaje; pues como se diri. giese á la parte de costa comprendida bajo e paralelo de $60^{\circ}$, en ella debiera hallarse precisamente, según las reflexiones del Sr. de Bauche, el pretendido paso de Ferrer Maldonado: por nuestra parte, á la verdad, ya no podía subsisti ni la esperanza más remota de la legitimidad de aquella Memoria, pues á todas las reflexione ocurridas al tiempo de examinarla y que comprenderemos para mejor orden en un capítulo separado, se agregaba ahora la seguridad, no sblo de estar estrechamente unida toda la cordillera que desde el Cabo Buen Tiempo sigue hasta e Monte de San Ellías, si también de estarle antepuesta y saliente al mar una faja de tierra baja que de ningún modo indicaba el navegante Mal donado. Al Oeste del Monte San Elías no pudieran tampoco verificarse jamás sus narraciones cuando era una precisa circunstancia de las tierras inmediatas al canal, que toda la costa del Oeste fuese sumamente alta $€$ impenetrable, y muy lozana y capaz de toda siembra la del Este.

Sin embargo, aquel trozo de costa no habí sido hasta entonces prolijamente reconocido ni por nuestros navegantes, ni por el Capitán Cook, ni por los Capitanes Portlock y Dixon; y por consiguiente, resultaría de nuestras tareas una ventaja no mediana á la Hidrografía, aunque inalográsemos el intento primitivo del descubrimiento de un paso desde el mar Pacífico al At lántico: así, parecíb conveniente emprenderlo con la posible exactitud, cualesquiera fuesen los sacrificios del tiempo que hubiese de costar, en los meses restantes del verano.

Las navegaciones anteriores á la nuestra y las mismas observaciones que habian podido hacerse después de auestra recalada sobre la costa, debian convencernos unánimemente que ningún reconocimiento pudiera hacerse con los vientos del primero, segundo y á veces del tercer cuadrante, siendo solos los Noroestes y Oestes, los que despejando la atmósfera, facilitaban la vista clara de todos los puntos de la costa y las obser- Jul. vaciones correspondientes para la determinacion de la latitud y longitud; movidos de estas refle. xiones labiamos precipitado en la tarde anterior la salida del puerto Mulgrave luégo que asomaron las primeras ventolinas del Noroeste, $y$ atento á ellas, dispúsose ahora la navegación que de. blamos seguir.

Ninguna duda cabía ni en la calidad ni en la posición de la costa desde la entrada de Ferrer hasta la punta Barrientos: la hablamos visto en diferentes ocasiones, correr al principio algo estéril y escarpada $y$ luégo extenderse en una frondosa arboleda más allá de la punta indicada, no descubriendo otra boca que la de una ría 6 canalizo muy parecido á los muclıos que forman las islas últimamente reconocidas. Además, la costa de la orilla distaria en estos parajes unas cuatro leguas de las faldas de la cordillera, y presentaba el mismo aspecto lozano que habia. mos notado en el puerto Mulgrave: por consiguiente, no sólo no era preciso un nuevo arrimo a esos parajes, sino que malograríamos en el caso de repetirlo, el tiempo claro y bonancible de que gozábamos á la sazón.

Pretiribse con estos antecedentes un bordo largo al Sursudoeste, declarado ya el viento al Oeste; $\boldsymbol{a}$ las ocho de la tarde cambiamos la mu. ra, $y$ en la mañana siguiente debimos variar el bordo otras dos veces, así para adelantar cuanto fuese posible al Oeste con los vientos varia. bles y llojos, como para esperar ocasión más oportuna de reconocer la costa, pues que se ha. bía cerrado con calima y llovizna luego que el viento habia rolado al tercer cuadrante.

No nos habíamos descuidado, sin embargo, en aprovechar de todas las claras que el tiempo nos proporcionase y áun en mantenernos en tal posición, que la tierra no pudiese ocultársenos hacia el medio día ó las primeras horas de la tarde: así el Mor.te Buen Tiempo y las tierras contiguas al fondeadero antiguo se habían marcado á las seis de la mañana, se habian observado luégo dos series de horarios, y conseguida al me. dio día la altura meridiana del Sol, podiamos ya ver extendidos algún tanto $y$ cimentados con igual solidez nuestros reconocimientos: era la latitud de $59^{\circ} 30^{\prime}$ y la longitud de $55^{\prime}$ al Oeste del puerto Mulgrave, cuyo meridiano adoptamos para hacer independientes las cartas siguientes de cualesquiera dudas sobre la verdadera longitud de aquel puerto; y nos demoraban la Punta Barrientos al Nornordeste, $y$ el extremo occidental del abra de Ferrer al Nordeste corregido.

Pasado el Sol al meridiano, la tierra despejó sí suficientemente de la calima que le cubria, pero al mismo tiempo se escaseb el viento al cuarto cuadrante obligándonos á seguir rumbos del primero para atracarla; á las dos ya no dis- 
Jul., tábanos de ra costa más que dos leguas y la Arkevida nos señalaba el fondo de 68 brazas, pudiénciose al mismo tiempo reconocer con individualidad el trozo de costa hasta la Punta No vales, en la cual, si bien habían llegrado nuestras marcaciones desde el Cabo $\mathrm{Mluñoz}$ con el teodo lito, la dirección era demasiado oblícua para determinarse con propiadad todo lo que hubiese entre los varios recodos que formaba: no fue fácil marcas con seguidad las tierras altas inciuso el Monte de San Lłías; en cuanto á la baja que teníamos actualmente á la vista, no nos quelaba ducla de estar perfectamente unida, y veía mos que cesada la arboleda poco después de la Punta 13arrientos, se extendía luégo en una es. pecie de barrancas rojizas con el terreno inte riormente amogotado hasta la falda del mismo monte.

En esta posición viramos por avante, y casi al mismo tiempo, el viento que había estado por un corto intervalo calmoso del tercero y cuarto cuadrantes, se declaró de nuevo por el Oesudoeste, cerrando en muy poco tiempo toda la costa con calima.

Así se mantuvo también en todo el día si. guiente; $y$ como se dirigriese nuestro intento á ganar siquiera una regular diferencia al Oeste, antes de recalas nuevamente sobre la costa reconocida, nos ocuparon únicamente los bordos más ventajosos, desentendiéndonos de la costa que por la mañana veíamos confusa $y$ tomada del Nornoroeste al Noroeste.

Aunque no tuviésemos sino un conocimiento muy superficial de los anuncios del tiempo, ya los semblantes que se nos manifestaban, no nos dejaban duda de una próxima variación al Sueste, tanto más segura, cuanto que acrecentaba á cada paso la cerrazón, imposibilitándonos el medir siquiera una altura del Sol. En efecto, antes le la media noche, ya el viento había rola? fresquito al Sudoeste y Sur con agua menrda y mucha cerrazón, y podíamos, por consiguauce, navegar al Oeste, como lo ejecutamos muy luégo con todo aparejo.

Como era natural, del Sur paś el viento rápidamente al Sueste y Este bastante fresco, pero tan calimoso, que nos haría malograr cualesquiera reconocimientos. No cabía, por consiguiente, la menor duda sobre el partido que clebiese preferirse, y era el de navegar con fuerza de vela hasta la entrada del Príncipe Guillermo, y allí esperar la alteración favorable del viento para retroceder reconociendo prolijamente la costa. Para que, sin embargo, no se malograsen nuestros pasos por lo que toca á las tareas hidrográficiás, desde el medio día emprendimos el navegar en una misma línea Norte-Sur, distantes los dos buques una legua uno de otro, para indagar la existencia de un bajo, visto ha- cia aquellos parajes por nuestras corbetas la Jul., Princesa y la Favorita, en $\mathbf{1 7 7 9}$.

Estábamos entonces persuadidos por la esti. ma, de hallarnos en los paralclos proporcionados á aquel intento, combinando los diarios originales del Teniente de navio Arteaga y del Piloto Yaurelle, con la carta de aquella expedición, sa cada del $\Delta$ rchivo de Indias en la Corte, pero comn luégo en las inmediaciones del medio dia tuviésemos con el auxilio de algunas claras la altura meridiana del Sol con bastante exactitud, y por otra parte, inclinándose el viento hacia cl İsnordeste despejase regularmente la costa, nos pareció deberse omitir aquel empeño y navegar di rectamente hacia el Cabo Suckling del Capitán Cook, para extendernos luégo r.acia el Oeste ó al Este según los vientos lo exigiesen, en la mañanita siguiente.

Hasta las seis de la tarde se mantuvo el vien. to fresco sin disiparse la cerrazón y llovizna, aunque se de jaba ver confusa la tierra, pero des. pués abonanzó considerablemente, y despejando al mismo tiempo la costa, pudimos distinguir con certeza toda la Isla Kaye, el mismo CaboSuckling $y$ unas tres leguas de costa oriental contigua al mismo Cabo, la cual, no omitimos de reconocer.

Las sondas que en toda la tarde habian estado á cargo de la ATrevida, aunque examinadas con roo brazas de sondaleza aún no estaban á nues. tro alcance, y no obstante, á las nueve ya no dis tábamos más que tres á cuatro leguas de la costa y el agua tenía un color muy cargado y verdoso.

En la pasada corta travesía y áun en la re calada al Cabo Suckling, si la refiriésemos á la carta del Capitán Cook debía causarnos mucha extrañeza la variación de la aguja, la cual, bieı determinada en el puesto Mulgrave de $26^{\circ} 40^{\prime}$, la hallábamos luégo en el puerto del Desengaño $y$ por los azimutes meridianos de este día y del 6 , de $32^{\circ}$ al Nordeste; no adoptándola, hallálamos muy equívoca nuestra posición; y sin embargo, veíamos que era mucho menor la que había observade jusado el Capitán inglés para sus cartas.

Fueror inuy pocas las pardelas que vimos á alguma distancia de la costa: nos abandonaron luégo jor volvimos á atracarla y en su lugar ó de cualquiera otra especie de aves sólo aparecia de tiempo en tiempo uno ú otro lobo marino.

La tierra reconocida al Este del Cabo Suckling se componía en la orilla del mar de una ar boleda de pinos, tan unida, espesa y frondosa, como las que habíamos visto en las inmediacio. nes del puerto Mulgrave: sobresalían á la espalda, los montes medianamente altos y nevados entre los cuales se distinguía el que (según el $\mathrm{Ca}$ pitán inglés) se elevaba sobre el mismo Cabo: no se advertía la menor abra en este trozo de costa, y desde su extremo oriental que termina. ba en una punta no muy saliente, la costa pare- 
rbetas la Jul.9

r la esti. rcionados sorigina. lel Piloto ición, sapero comn dia tuvie. la altura ud, y por el Iisnor. , nos pa. svegar dil Capitán Oeste 6 en la ma.

ro el vien.

llovizna, pero des. espejando inguir con o Suckling ontigua al reconocer. ian estado nadas con un á nues. ya no dis. de la costa y verdoso. en la reemos á la os mucha cual, bien $26^{\circ} 40^{\prime}$, la sengaño $y$ ia $y$ del 6 , allábamos embargo, había ob. sus cartas. e vimos á andonaron su lugar 6 aparecía narino.

Zabo Sucde una ar frondosa, mediacio. 2 la espalevados en. ứn el $\mathrm{Ca}$. mo Cabo: e trozo de terininaosta pare-
Iul. a cla inclinarse de nuevo y suavemente máy bien al Norte que al Sur del Oeste del mundo.

A las diez y media de la tarde, por sondas de 35 y $\%$ brazas lama, ya no distábamos másque dos leguas del Cabo Suckling, el cual nos demoraba al Norte $28^{\circ}$ (leste de la aguja. Se veian dis tintamente el pedrusco intermedio y toda la Isla Kaye, cuyos extremos marcábamos del Oeste $26^{\circ}$ Norte, al Sur $67^{\circ}$ Oeste, y al mismo tiempo casi el viento galeno del Lste como la costa bastante mente clara, convidaban unánimes á pasar entre la Isla Kaye y el Cabo Suckling ( $y$ ) pary reco. nocer la bahia Comptroler, lo que habia intentado infructuosamente el Capitán inglés.

Con este ánimo y más bien con el objeto de examinar con mayor claridad este paso y' no entregarnos ciegamente al viento aunque favora. ble que amenazaba refrescar dernasiado, toma. mos el partido de pairear hasta las dos de la ma. nana siguiente, conservando pormedio de la soll. da la posición en que nos haliábamos, y después, según las circunstancias, i’łternar en el canal b́ pasar al Sur de la Isla Kaye. Empero á la media noche ya el viento sopló recio y arrafagado: la mar había engruesado, y qucdaba cerrada con 110 vizna y mucha celajeria toda la costa, ocultán. dose, aunque no distante, la mayor parte de la Isla Kaye. Con estas apariencias hubiera sido imprudente, as i internar en un paraje de difícil salida como esperar tranquilos que declinando el viento al Sur no nos permitiese montar la Isla liaye: hasta aquí, si consultásemos la sonda (pues las marcaciones ya no podian repetirse) el efecto de la marea habia sido muy corto, y clebíamos, por consiguiente, considerarnos casi en el mismo paraje en el cual nos habiamos atra. vesado.

Así, fueron nuestros rumbos primeramente del Sur y luego arribamos paulatinamente al tercer cuadraste á medida que disminuyendo la latitud, nos apartábamos de la isla, cuya direc. ción es próximamente del Sudoeste al Nordeste.

Las corbetas Princesa y Favorita del Departamento de San Blas, costeando en I779 la Isla Kaye, habian descubierto un bajo al Oeste del islote de la punta y saliente al mar unas dos millas: nos pareció preciso el reconocerle, incitán. donos á esto, además de la seguridad de las navegaciones venideras, la actual marejada algo gruesa que le hacía perceptible desde mayor distancia y nuestro deseo de pasar al regreso entre la Isla Kaye y el Cabo Suckling, ya que las cir. cunstancias no lo permitían en la actualidad: na vegamos, por consiguiente, con la vigilancia co. rrespondiente y á tal distancia en la marcación indicada, que de ningún modo pudiese ocultárse

(I) Este nombre, traducido literalmente en uuestras cartas, es el Cabo Chupador. nos acquel peliftro, y usi (no pervibićndolo), debi- ful. , nos creer que serian estos los mismos pedrus. cos salientes que habla visto el Capitín Cook. bien que ni en la dirección ni a la distancıa que expresaban nuestros navegantes.

l'rarqueadra á las tres y media de la mañana la punta meridional de la Islı liaye, y arreciundo mucho el viento ya declarado del Esnordeste, hi. cimos rumbos hacia la entrada del l'ríncipe Gui. llermo, bien que procurando reconocer In costa que corre desde lı isla ya nonbrada hasta el Cabo Inchinbrook (1). Navegamos algo precavidos en el aparejo: sondamos dos veces sin encontrar fondo, $y$ como aprovechásemus todas his claras para observar la longitud, á las cinco y media y á las diez y media conseguimos inedir algunos hotarios que ratificaron nuestras marcaciones $y$ bases corridas.

Con el Nordeste que reinabáa la snzón muy fresco con mar bastantemente gruesa, la costit habia despejado mucho y se hacía fácil un reco. nocimiento prolijo; pero consultando los carices, parecia que el tiempo más bien que inclinarse al Norte no tardaría en rolar al Sueste y Sur tempestuosos, haciéndonos malograr algunos días que ni empleariamos en los reconocimientos hidrográficos, ni en los físicos; y como los tiempos oscuros sólo permitiesen los ségundos, debimos inclinarnos á fondear en la entrada del Príncipe Guillermo, con ánimo de permanecer allí hasta que durasen vientos contrarios para nuestras ta. reas $y$ atender en el ínterin á la Botánica, Litologia y estudios de los naturales: con este ánimo navegamos llevando un andar de ocho á nueve millas, hacia el Cabo Arcadio. Habíamos atra. cado la costa unas cuatro ó cinco leguas al Este de la Ensenada de Menendez y no omitien. do el correr bases, hacíamos tales rumbos que no distásemos de la costa más que una ó dos millas cuando nos aproximamos al Cabo (Español) Arcadio.

Este trozo de costa, reconocido con no mu. cha prolijidad por el Capjtán Cook á causa de los malos tiempos que le acosaban, había sido luégo avistado por nuestras corbetas Princesa y Favorita, las cuales, aunque no se aproximasen á ménos de seis ó siete leguas (según los diarios del Comandante Arteaga y del Piloto Maurelle) haivian logrado de unos días bien despejados y largos, y trez.1zs algunas puntas salientes con la posible exactitud: mucho mayor debiamos su. ponerla en los trabajos hechos por D. Salvador Fidalgo en el año próximo anierior, pues pene. trando con lancha por el canal interior desde el puerto de la Magdalena hasta la Ensenada de Me. néndez, había observado con bien sextante la la-

(1) Es en nuestras cartas el Cabo Arcadio por la misma atención a la sencillez y ortografia. 
Int. so titud en un islote saliente, sondados todos sus contornos y determinada su extensión con bastante regularidad: con estos antecedentes, nuestro trabajo actual más bien se dirigía á la determinación de las longitudes, independiente de la pesquisa de un paso que parecía muy poco probable en aquellos contornos, y desle luego no comprendido en las combinaciones del que indi. caba Ferrer Maldonado. Las tierras al'as, quebradas y cubiertas de hielo, en el cual it!ejaba el Sol, ya nos habían representado otras abras hacia el Este como 'as que habíamos notado en las inmediaciones del puerto Mulgrave; pero con aquel escarmiento, algo cautos sí en no juzgarlas como tales, bien que no precipitados en excluirlas, dejamos para el regreso hacia el Este el destruir cualesquiera diıdas hidrogránicas en aquella parte.

A las diez, ya veíamos el Cabo Arcadio, y hacia las once también el extremo de la Isla Montagut, aunque confuso. Se anteponía á ésta una isleta rodeada de arrecifes, de la cual no distaríamos más que unas tres millas, y dejándose ver sobre la tierra del Cabo algunos mogotes que no especificaba el Capitán Cook, podía caber alguna leve duda en nuestra actual posición, tanto más, que cerrado nuevamente el tiempo con chubascos y ráfagas fuertes, exigía mayor cautela en la navegarión, y esta misma sería muy peligrosa, si la entrada á que nos dirigimos fuese ca sualmente la de la Enseneda de Menéndez.

Paireamos con este antecedente como un cuarto de hora de la vuelta del Sur y á distancia ie una milla larga del Cabo Arcadio; sondose ri mismo tiempo sin encontrar fondo con 80 bcazas, y luégo, contirmadas con disiparse algo la cerrazón nuestras ideas del paraje donde nos hallábamos, arribamos nuevamente para at:-acar la Lierra del Cabo y dirigirnos sobre as gevias al fondeadero.

No fué posible por las muchas nubes obser. var a' medio día la altura meridiana del Sol, que deseábamos con ansia, porque discrepaba mucho la latitud determinada por el Capitán Cook de la que determinaban nuestros navegantes: distábamos á dicha hora media milla de la costa, la cual orre sumamente acantilada desde el Cabo Arcadio hacia el Nordeste y Este, para alcanzar el fondeadero.

El viento á la sazón soplaba con ráfagas bien fuertes que venian por las cañadas de los cerros inmediatos, y además, á meảida que orzábamos, se escaseaba más y más y variaba su d:rección, segun la figura $\mathrm{da}$ los monies. Puede imaginarse, por consiguiente, que ni nos descuidábamos en atracar la costa cuanto fuese posi. ble. ni en buscar con el escandallo, ó el fondo de I7 hrazas que l.abia hallado el Capitán Cook delante del Cabo Inchinbrook, 6 los que habian proporcionado el dar fondo al C'omandante Ar- Jul. 10 teaga. Hubiéramos de jado caer inmediatamente un ancla, y esperado mejor ocasión para internar en el p:serto; pero aunque ya á distancia de unos dos cables de la orilla, fué inútil aquella precaución, y hubimos de emprerider algunos bordos entre unos pedruscos qui nuestros nave. gantes llamaron los negrillos, y la costa sobre la cual deseábamos fondear.

Las ráfagas, demasiado inconjtantes y recias, hacían estos bordos no tan sólo incómodos y arriesgados, sino también inútiles, tanto más, que la marea parecía á la sazón y debía ser más bien contraria que favorable; pe: c á tan cor ta distancia del fondeadcro, era desagradable e abandonarle, y el internar más hacia el Norte, 6 el buscar abrigo de la Isla Montagut, parecían partidos poco convenientes para aprovechar des. pués todas las horas del primer Noroeste que nos favoreciese en el prolijo reconocimiento de la costa que dejábamos al Este. Determinamos, por consiguiente, continuar en el mismo. intento, y desde luego el Piloto Sánchez fué en el bote á buscar en la costa más inmediara y á nuestro alcance, un paraje en donde pudicse capr el ancla con alguna seguridad: poco después, no distando en el bordo del Este más que un cable y medio de la orilla, fué picciso virar por avan. te, aunque las ráíagas continuasen muy fuertes $y$ varias $y_{0}$ con el as una misma posición del aparejo, fuese á ratos 6 contraria 6 favorable para el tin que deseábamos.

De este modo permanecía aún la DescubiekTA sin caer de la mura opuesta, cuando una ráfá ga excesivamente fuerte partió por la.cruz la verga łe velacho y nos obligó á variar de idea. Tomamos la mura de babor con trinquete $y$ gavia, y recogido el bote, metiéndole nuevamente, se sustituyó despuis á la rota otra verga nueva pero ya distábamos dos leguas del Cabo Arcadio y las rompientes al Este de la Isl. Triste nos demoraban proximamente al Sur distancia de dos millas.

A la sizón ul tiempo había abonanzado y despejado mucho, le sucrte que parecía prometer una próxina variación al Norte y Noroeste, afianzando este concepto la vista de todos los montes internos, que advertíamos sin la menor celajería ó calima: tomáronse en estas circunstancias las muras á estribor nuevamente; costeamos á poca distancia la parte de la Isla Montagut, que forma su extremo septentrional, y á las seis de la tarde nos hallamos bien internados en la entrada; de suerte, que no distando de la costa más que media legua, ya marcábamos al "iste y al Esueste el fondeadero de la mañam, no sin esperanzas de vernos dueño de alcan arle, según la mar: 2 nos sostenía hacia el Este. la vuelta del Sueste pareció ahora la más conve. iente, $y$ así 
C'omandante Ar-Jul. .o inmediatamente casión para inter. ya á distancia de fué inútil aquella mprender algunos uc nuestros nave. y la costa sobre

onstantes y recias, sólo incómodos y itiles, tanto más, sazón y debía ser ble; pe:s á tan cor. era desagradable el is hacia el Norte, 6 lontagut, parecian ra aprovechar des. imer Noroeste que econocimiento de la Determinamos, por 1 mismo. intento, $y$ ez fué en el bote á edirta y á nuestro le pudicse caer el poco después, no - más que un cable tiso virar por avanhuasen muy fuertes na posición del apa. a 6 fuvorable para el

a aún la Descubierta, cuando una ráfa ió por la.cruz la ver variar de idea. Totrinquete $y$ gavia, ole nuevamente, se otra verga nueva is del Cabo Arcadio. Isl. Triste nos deur distancia de dos

a abonanzado y des e parecía prometer e y Noroeste, afiande todos los montes la menor celajería circunstancias las ; costeamos á poca lontagut, que forma las seis de la tarde s en la entrada; de la costa más que al "iste y al Esuesian., no sin espelcan arle, según la Este. la vuelta del conve. iente, $y$ así
Int. to no tardamos en preferirla, aprovechando al mis. mo tiempo esta ocasión favorable, asi para unas observaciones exactas de la longitud y de la va. riación de la aguja, como para extender las mar. caciones hacia los puntos internos cuanto estu. viese en nuestro alcance.

No tardaron, sin embargo, la marea y el viento á oponernos nuevos obstáculos, desatra. cándonos la primera del paraje por el cual á la sazón anclábamos, y manitestándose el segundo con nuevas ráfagas y mal cariz que nos obliga. ron á precavernos en el aparejo; fueron inútiles por consiguiente nuestros esfuerzos en la restan. te tarde, no sólo para atracarnos al fondeadero, si también para pasar al Este de la Isla Triste; $y$ linalmente, á las once $\mathrm{d}$ la noche hubimos de decidirnos á pasar al $\mathrm{O}$ sste de ella para franquearnos algo de aquellas inmediaciones.

Unas tres canoas de naturales, de las cerradias con piel de lobo, ya se habian dejado ver á las seis de la tarde cuando tomamos las muras á babor: gritaron con sus acostumbradas señales y tono enfático á la Descubierta que navegaba algo distante, y luégo alcanzaron á la ATrevidA: fueron, $\sin$ embargo, inútiles cuantas instancias y of recimientos se hicieron para atraerles á bordo; usaban frecuentemente de la voz Capitin; parecían poco ó nada expertos en el idioma del puerto Mulgrave; sus señales se dirigían en un todo á convidarle fondease al abrigo de la Isla Montagut; $y$ en sus canoas se notaba una niayor perfección que en las del puerto Mulgrave: como por una y otra parte, ć no fuese fácil ó no pa. reciese nruciente el dar cur.splimiento á los deseos del otro, muy luego se separaron, dirigién. dose aquellas hacia el puerto de Santiago é in corporándosenos táciïmente la ATREvidA.

Eran próximamente las once de la noche cuando nos decidimos á pasar al Oeste de la Isla Triste, por cuya parte no advertiamos rèstinga alguna, mientras las que se tendían al Este $y$ no podíamos rebasar, no tenían ménos extensión de media milla escasa; á la media nocive la re. basamos, no encontrando fondo á dos millas de distancia con unas zo brazas de sondaleza á pique; orzamos luégo al Sueste, é hicimos alguna fuerza de vela para separarnos algo de la Isla Montagut

Por :entura, nuestros navegantes habían visto en aquellos contornos unas islitas (llama. das de Hijosa), que ni el Capitán Cook, ni el Capitán Dixon (I) habían comprendido en sus cartas; omisión de la cual no podía prescindir el primero fur inaijar salido al Oeste de la. Isla Montagut; pero que no debía disimularse en el segundo, así porque su derrota del primer año,

(i) Fn las cart is inglesas postcriores al vicje del Capitán Dixon, está señalada dicha isla. le llevaba en aquellas inmediaciones, como por Jul ro que táchaba impávido á nuestros navegantes an tiguos por uno ú otro error en la Hidrografía del sin número de costas que habían reconocido; los bordos sin este antecedente á que nos pre. cisaba nuestra situación actual, y el tiempo que ya se había declarado del Este al mismo tiempo cerrado y tempestucso, pudieran tal vez habernos acarreadi algún error que nos produjese las consecuencias más funestas, pues que :ra natural el ceñir al segundo cuadrante, “o sólo para separarnos de la Isla Montagut, si también para coger de nuevo los meridianos en que debían comenzar nuestros reconocimientos.

L̇n efecto, poco después de salir el Sol, el tiempo se había cerrado extraordinariamente, engruesando la mar y refrescando el viento, de modo que no podiamos resistir las gavias izadas: debíamos también aterıder á la composición del trinquete envergado, cuya relinga estaba tronchada desde la tarde anterior, y con este objeto, sustituímos otro trinquete mientras aquél se compusiese, pero volviendo á desenvergarle de nuevo, luego que el primero estuvo compuesto.

Nuestra derrota corregida fué próximamente al Sur. Con la cerrazón perdimos muy luego toda tierra de vista, y no cediendo la mar, el viento, ai la lluvia, continuamos de la misma vuelta hasta el medio día, á cuya hora viramos en re. dondo sobre las cuatro principales, un rizo en las gavias, considerándonos en latitud de $59^{\circ} 30^{\prime}$.

No tardó mucho en ceder el viento, y áun en convertirse en ventolinas flojas, bien que sin variar de dirección; se disipó algo la cerrazón. y á las dos de la tarcie pudimos descubrir por nuestro través de barlovento á distancia de tres leguas, una jsła rasa que desde luégo creimos las de Hijosa, aunque variase mucho su posición en latitud $y$ longitud, $y$ no pareciese sino wila sola isla.

La calma no fué tampoco muy duradera; á las siete de la tarde el viento estuio nuevamente fresco del primer cuadrante y acompa ddo con mucha lluvia; sin cesar ésta, quedamos luego en calma, habiende disfrutado por algún tiempo de los vientos del segundo cuadrante: últimamrnte. al amanecer disipada en mucha parte lä cerra. zón y caido el marullo considerablemente, pudimos creer que el tiempo tomase me.jor semblan. te $y$ nos permitiese continuar nuestras tareas. La navegación, desde la tarde anterior, habia tenido por único objeto el conservarnos al Sur de la isla avistada y de la de Montagut, mientras continuasen los vientos variables tan interpola. dus con las calmas y acomrañados de una lluvia y cerrazón constantes; pero como al amanecer del dia siguiente pareciese muy próxima una variación favorable, no tardamos en aprovechas con todo aparejo las ventolinas del primer cua- 
Jus. \& drante para emplear oportunamente el tiempo.

Ya á las ocho logramos nuevameite rer la isla rasa, de la cual distábamos unas nuatro leguas: el rumbo del Noroeste $4^{\circ}$ Norte nos fue luégo aproximando hacia ella, y al medio día sı's extremos Norte y Sur nos demoraban del Norte $82^{\circ}$ Este, al Sur $86^{\circ}$ Este distancia tres leguas escasas, viéndose al mismo tiempo la punta Sur de la Isla Montagut al Sur $86^{\circ} y^{1} / 2$ Oeste de la aguja, y señalando la ATREvidi un fondo de 67 brazas arena.

A esta hora, por dos series de azimutes habíamos deducido con mucha satisfacción lá va. riación Nordeste de $26^{\circ}$, y aunque careciésemos de la exacta altura meridiana del Sol, los elementos acopiados para la latitud eran tales, y tan conformes, que la nodiamos considerar sin equivocación de $59^{\circ} 30^{\prime}$ : siendo al mismo tiempo la longitud de $6^{\circ} 5^{8^{\prime}}$ al occidente de Mulgrave. E1 viento aunque apacible, no varió en toda la tarde del Nordeste; le ceñimos al cuarto cuadrante corriendo bases para la exacta determinación así de varios puntos de la Isla Montagut, cono de la rasa; según las señales de la Arrevid, navegamos por fondo de 40 á 50 brazas; $y$ finalmente, á las siete nos hallábamos otra vez una milla y media al Sur de la Isla Triste por fondo de $7+$ brazas, demorando al mismo tiempo la punta Norcleste de Montagut al Norte $+^{\circ}$ Oeste, y cl extremo interno del puerto de la Magdalena al Norte $36^{\circ}$ Oeste de la aguja.

En esta posición, nos fué preciso virar al Essueste; el viento fué rofrescando paulatinamente bien que sin impedirnos el aventajar con. siderablemente al Este con los bordos que variamos á la media noche y á las cuatro, así, á esta última hora navegando de nuevo al Essueste, marcábamos al Norte $15^{\circ}$ Oeste de la aguja á distancias de solas cuatro leguas las puntas inmediatas al Cabo Arcadio. Los dos rizos que í las diez habíamos tomado á las gavias, porque además del viento, la mar había engruesado mucis, hubieron de largarse de nuevo al medio día para montar la isla rasa, que descubrimos al Sur $5^{\circ}$ Oeste á distancia de tres leguas. Nuestra posición en latitud y longitud á este medio día, ratificaba enteramente los resultados del dia anterior para la situación de la isla, y como dependiesen de las mismas tareas los puntos de la cos. ta oriental de Montagut, parecía que podiamos sin temeridad asignarles un grado más que mediano de exactitud: así el extremo Sudoeste do la Isla Montagut quedó últimamente en latitud de $59^{\circ}+7^{\prime}$ y $8^{\circ} 16^{\prime}$ al occidente de Mulgave, diferiendo nuestra latitud de la del Capitán Cook en la cantidad de II' al Sur, lo cue había advertido también el Capitán Dixon, observando próximamente ell su paraiclo.

Monteda la isla rasa á distancia de una le- gua larga, y continuando el bordo del Sur, ya Jul. nuestra posición era nuevamente la misma que en los días anteriores; y pues que el viento en todo el día siguiente $y$ las primeras horas del I $_{5}$ se conservaba bien fresco y arrafagado con mar gruesa por el Nordeste, fué más hien nuestro an velo la conservación del an?.ejo, ya tomando, yi. 'argando los rizos, que el aventajar algo hacia el Este, lo que conseguiriamos con mucha diticultad. Sin embargo, el tiempo claro favorecía en esta oc.'sión algo más nuestros bordos, que pudimos sieinpre llevar hasta dos ó tres leguas al Sur de la is!a, y finalmente, en la mañana del I $_{5}$ (no sin preiecier algunas ráfagas, variedad de viento $y$ no poias horas de calma) se aparecieron algunas veninlinas del Sudoeste, que conıbinadas con muy buen cariz y el semblante bien risueño de la costa, parecían anunciarnos una próxima alteración análoga á nuestros de. seos; no distábamos más que dos leguas de la isla, cuyas rompientes hacia el Lste se percibían con la mayor claridad; se veían á larga dístancia la Isla Montagut y las inmediaciones de Cabo Arcadio, y la mar, agradablemente llana, nos presentaba un espectáculo que desde la sa. lida del puerto Mlulgrave no habíamos podido renovar á la memoria.

Para coadyuvar con la varjıdad á la hermosuta le este día, se nos apareció hacia las diez de la mañana, no distante del costado, una canoa cerrada, con dos naturales; hablaban, ó más bien, gritaban, repitiendo las mismas voces, cuya significación no pudimos alcanzar; mantenían alta sobre un palo una piel de nutria, que nos pareció de las más finas que habíamos visto hasta entonces, $y$ nos señalaban constantemente con el canalete, que nos dirigiésemos hacia la isla, á cuya parte del Oeste encontrariamos un buen abrigo y un regular comercio de pieles.

Fué imposible el atraerles á bordo, aunque usásemos, no solo de la señal acostumbrada de paz con los brazos abiertos, sino también de la precaución de manifestarles varios pedazos gruesos de hierro $y$ algunas otras bagatelas. Se des pidieron á las once y se encaminaron con mucha velocidad hacic. la isla.

İn cuanto á ésta, las observaciones del medio día y su prolijo reconocimiento por la parte del Este, conformes con las de los días 12 y I 3 ya afianzaban de tal modo su extensión y posición astronómica, que p.líamos considerarnos con algún derecho para asignarle otro nombie. Tuvo, por consiguiente, el de Galiano, por el Teniente de navío agregadoá esta comisión, que pol' su talento y amor al trabajo debía ccaservar ell nuestra memoria un lugar bien distinguido, y quedó determinada su latituó ray la riccianía de $59^{\circ} 26^{\prime}, y$ su longitud de (.' $37^{\prime}$ al $00^{\prime \prime}, \mathrm{H}^{\prime} \mathrm{c}$ puerto Mulgrave. Es casi redo ida, extecxiéndo. 
del Sur, ya Jul. 13 misma que 1 viento en horas del I 5 do con mar nuestro ana tomando, ar algo hacia mucha ditiro favorecía bordos, que tres leguas la mañana as, variedad ma) se apadoeste, que 1 semblante anunciarnos unestros deeguas de la te se perciá larga dis iaciones del nente llana desde la sa. is podido re.

á la hermocia las diez o, una canoa ban, ó más voces, cuya mantenían ia, que nos os visto has. temente con cia la isla, á os un buen es.

rdo, aunque umbrada de mbién de la edazos gruelas. Se des. 1 con mucha nes del mepor la parte lías I 2 y I 3 , sión y posionsiderarnos tro nombie. iano, por el misión, que bía ccaser. n distingui"ar lastia. al $\mathrm{Oe}^{2} \mathrm{del}$ xteráiéndo.
Iwl. is se algo más del Nordeste al Sudoeste; presenta por todas partes en la orilla una tierra abarran. cada, elevándose algo más la parte del Sur, y manifestando en el solo centro una buena arboleda; los arrecifes que la rodean de la parte del Este, deben hacer temible al navegante el atracarla por alli; no así por la del Oeste hacia donde nos convidaban los naturales, pues el verla enteramente libre de arrecifes y $\mathrm{\epsilon l}$ fondo de arena que hemos hallado á tres leguas de distancia, nos hacen creer que presente un abrigo cómodo para los vientos del primero y segundo cuadranre, aunque á la vista no se aperciba punta alguna saliente que suministre la idea de un puerto ó bahía. La canoa de que se ha heclo mención, venía seguramente de la isla, $y$ sin embargo, no nos aventuramos en asegurar que sea poblada constantemente, pues tal vez la pesca de las nutrias riede en ciertas estaciones atraer hacia allí los aturales. En los cuatro días que hemos $\epsilon s$ ta .o á su vista, jamás se notó la menor huma e. da, $y$ sin duda no se hubieran descuidado en esta señal, así por el desen de un comercio, que manifestaron después, como porque hemos notado esta práctica bastantemente puntual en toda la costa.

Hasta las tres de la tarde, el viento se mantuvo calmoso del Sudoeste, y ó bien fuese efecto de alguna corriente $\sigma$ de la maretita que aún permanecía del Este, nos fué preciso hacer rumbos del Esnordeste para desatracarnos de la Isla Galiano: finalmente, la perdimos de vista á las siete, y casi al mismo tiempo se retiró otra canoa grande, que con unos 20 hombres se nos había aproximado, no omitiendo el himno acostumbrado cie paz; la Arrevida que le est tba algo más próxima, orzó, le tiró un cabo para que atracase, y usó de todos los medios que pudiesen atraerla; pero no fué posible decidirlos á este paso, y así, como cl viento reirescase algo $\mathrm{m}$ 's, continuamos nuestra derrota, y ella nareció dirigirse hacia la isla.

Nos dirigirnos, como era natural, bacia la -osta oriented del Cabo Arcadio, desde donde en mañana lel ro habíamos empezado los ruro. nocimientos; el viento se conserví bonancibl:, la mar sumamente llana, y el tiempo, particu larmente desde las diez de la noche, bien calimoso.

Sin embargo, antes de las nueve de la maña. na del 16 ya podia distinguirse claramente el extremo meridional de la Isla Kaye, del cual no distaríamos al Oeste más que unas cuatro ó cinco leguas; y aunque la costa estuviese algo calimosa, no reinando tampoco á la sazón sino unas ventolir:ss variables; muy luégo conocimos que nuestra situación, relativamente á las tareas hidrográficas, era cual podíamos desearla: la sonda manifestaba yo brazas lama, y la variación de la aguja, deducida de algunos azimutes de la tarde anterior y de aquella mañana, parecía con bas- Jut. is tante probalsilidad ser de $2 S^{n}$ próximamente.

Hasta las nueve y media permanecimos de este modo en una casi total inacción; pero, finalmente disipada la calima con los primeros soplos de la virazón, no sólo pudimos navegar hacia la costa, sino también extender nuestra vista y mar. caciones hasta el mismo Cabo Arcadio é intentar el paso entre la Isla Kaye y la tierra firme.

En la mañana del so habíamo creíds ver alzunas abras considerables al Oeste de la Punta Sarmientos entre la cordillera no muy alta pero enteramente nevada que descle la Ensenada cia Menéndez corre hasta el Cabo Chupador. No nos costó alıora mucho tiempo el disipar aquella sos. pecha con el aparecimiento de una porción de ticrra baja antepuesta á la alta y poblada de alboleda, la cual presentaba una orilla igualmente cerrada y sin punta alguna saliente; pero sucedía lo contrario con otra abra que á la sazón nos de. moraba al Nornordeste, y cuya existencia, así por el término de la costa como por el abra de los montes internos, parecía tanto más probable, cuanto más nos aproximábamos.

Al medio día no distábamos de ella más que tres leguas; al mismo tiempo nos demoraban los extremos de la Isla Kaye del Sur $75^{\circ}$ Este, al Norte $66^{\circ}$ Este de la aguja, eran nuestras sondas de $6_{5}$ brazas lama y las observaciones nos indicaban la latitud de $6^{\prime \prime} 3^{\prime}$ y longitud de $5^{\circ} 20^{\prime}$ al Oeste de Mulgrave.

Como con el poco viesto del Sudoeste y Oesudoeste nuestros progresos hacia la costa fuesen bier ientos aun en las primeras looras de la tarde, eran ya las dos cuando conseguimos des. engañarnos de la primer idea de la existencia del abra hacia la Punta Sarmientos. Se le anteponía otro trozo considerable de tieria, por partes cas anegadiza y por partes algo frondosa, y si bien hacia. el Este, entre la misma tierra baja, proyectase una pequeña boca cuyo término no al canzábamos, no podía caber duda de ser ésta la boca de un río, así por las rompientes que se manifestaban de tiempo en tiempo en sus inme. diaciones, como porque en las serranias internas no aparría la meror cañada. Ya, pues, pudimos arriba: paulatinamente al Este, refrescando algo la irazón y contiuuando aún las sondas de $6_{5}$ á 6o brazas lama. El valle reconocido tuvo el nombre de Valle de Ruesga, y sc dió el de Cabo Nodales á la punta que le terminaba hacia el Este, inclinando luégo la costa para la bahía del Contralor.

Iis el Cabo de los Nodales una punta de tie. rra baja y arenisca, de la cual salen hacia el Este dos pedruscos notables y continúa luégo la costa interma toda de arena en la orilla, pero á m:y poca distarcia poblada de una hermosa arboleda; los montes en este paraje hurtan rápida. 
Jw. 2 mente al Norte; son de mediana elevación y van á unirse luégo con la cordillera, que postergada al Cabo Chupador, corre casi Esteoeste hasta el Monte de San Elías.

$\Lambda$ las seis de la tarde, continuando aún la virazón bonancible, pudimos rebasar este Cabo y emprender el paso meditado, pues que veíamos ya claramente el Cabo Chupador y los extremos del Norte de la Isla de Kaye: precavidos, como era natural, con el escandallo, debimos á la verdad extrañar poco después el fondo te 12 brazas arena; pero creyéndolo efecto de nuestra inme. diación á la costa firme, inclinamos muy luégo la derrota hacia la derecha: sin embargo, el fondo iba disminuyendo rápidamente; á las nue ve, ya le teníamos de solas cinco brazas, y la proporción con que había disminuído siendo arena, hacía creer que muy en breve no permitiría navegar, pero en esta posición nos era fácil ya examinar toda la parte interna de la bahía, y por consiguiente, disipar el concepto que hasta entonces nos había alucinado. L. que nos otros habíamos creído Isla Kaye, no er. . una península unida a la tierra firme lengua de tierra baja toda cubierta de arboi $y$ dispuesta en una forma casi semicircular: se le posponían el Cabo Chupador y el extremo Nor deste de la península; y si creyésemos la dispo. sicion interna de la bahía, el mismo islote alto y escarpado en cuy'a inmediación estábamos, debía hallarse unido á la península por otra lengua no muy extendida de tierra baja, que en la actualidad nos era difícil investigar. Le llamamos con atención á esto la Isla Dudosa : la península conservó el nombre de Kaye; á su extremo Sur se puso el nombre de Cabo Esjañol, y dejando á la bahía en que nos hallábar.ıos el de Contralor, que labía puesto el Capitán Cook, apellidamos bahía de Burgos, la que formaba hacia el Este el Cabo Chupador con la tierra escarpada y saliente de la peninsula.

No pareció habitador alguno en todos aquellos contornos, aunque la calidad del terreno, la fal cual distancia de los montes y el abrigo de la bahía, convidasen ciertamente á habitarlos: si hay ó no un buen puerto al Nordeste de la Isla Dudosa, fuera difícil decidirlo, atendiendo al poco fondo en que nos hallábamos no á menor distancia de dos millas; hubiéramos querido poderlo averiguar con el auxilio de los istes, pero la necesidad de aprovechar los poco, días claros en la continuación de nuestras tareas, nos hicieron creer como preferente, el salir cuanto antes sobre bordos de la ensenada, y por el Cabo Español reconocer la costa siguiente al Este.

Muy luego aumentamos el fondo hasta 17 brazas lama, ciñendo hacia la tierra alta de la península, pero los disminuíamos nuevamente aproximándonos al Cabo Nodales, del cual dis- tariamos dos millas largas, cuando la sonda ma- Jul, is nifestaba solamente seis 6 siete brazas arena.

Contrariados de la marea, aunque el vien. to se mantenía galeno y la mar sumamente llana, no hicimos muchos progresos para nues. tro intento hasta las cinco de la mañana, á cuya hora la costa de la península y en general los cielos y horizontes, se habían cargado con calima, y navegábamos por 15 y 17 brazas lama.

Algunas ventolinas del Oeste dieron despues lugar á ganar considerablemente al Sur; á las nueve y media, disipada algo la calima, vimos el islote que sale del Cabo Espanol, y á las once y. media ya no distando de el más que dos millas, viramos al Oeste con viento bonancible del Sursudoeste y tiempo despejado.

Con la tarde, el viento fué paulatinamente rolando por el Sur al Essueste galeno, que de. biamos precisamente ceñir con la mura á babor, apartándonos de la costa; no cambiamos la mura hasta las tres de la ruañana siguiente; aunque no teníamos otro objeto en estos bordos que el montar el Cabo Español, al medio día tis in ha. bíamos aún conseguido; antes bien, distábamos de él unas seis leguas, marcándole al Norte $33^{\circ}$ Este, cuando apenas era este el rumbo que podíamos seguir.

Pero, después, variando el viento al Sueste, este bordo nos fué más favorable de lo que imaginamos, y nos condujo á barlovento del islote, inmediatos á las piedras aisladas que en este nuevo reconocimiento conocimos, sin la menor duda ser las mismas que el Comandante Arteaga había creído en otro arrumbamiento y á mucha mayor distancia del Cabo Español.

En esta posición, y sin hallar fondo con 65 brazas, vi iamos á las seis al Sur $1 / 4$ Sueste y continuamos la misma vuelta hasta las nueve $y$ media en cuya hora declarado el viento al Sur navegamos algo al Este; y arribamos después al Norte para atracarnos al frontón del Cabo Chu. pador, y continuar nuestras tareas.

El Cabo Español, que en la navegación de estas costas será siempre un punto no indiferente, se halla en latitud de $59^{\circ} 50^{\prime}{ }^{\prime} 5^{\prime \prime}$ y en longitud de $138^{\circ} 34^{\prime} 15^{\prime \prime}$ occide-tal de Cádi $z$, y si atendemos á las diferentes observaciones que' se luan hecho á su vista y que concurren exactamente en las marcaciones, podemos lisongearnos que esta determinación no admita error alguno que pueda influir ni remotamente en la seguridad de la navegación.

Nuestros proyectos para el día siguiente se deshicieror con el Sur y Sueste, que como se ha dicho se había declarado en la tarde anterior, pues cerrándose inmediatamente con lluvia y neblina toda la costa, ya ni era posible su reco. nocimiento, ni careciendo de observaciones $\mathrm{pu}$ diéramos sujetarle como deseábamos. Al medio 
Jut. in día por fondo de $6_{5}$ brazas lama, marcábamos el Cabo Chupador al Norte ro $^{\circ}$ Oeste de la aguja á distancia de tres á cuatro leguas.

Aunque la precisión de suponer las tierras altas al Oeste para la verificación del paso de Ferrer Maldonado excluyese también de nuestro examen el trozo actual de costa comprendido entre el Cabo Chupador $y$ el Monte de San Elías, sin embargo, en el plan adoptado de nuestras tareas, de ningún modo podíamos descuidarle, pues que le habian trazado á mucha distancia, así el Capitán Cook como nuestros navegantes; en este supuesto no quedaba duda sobre el partido preferente en la actual situación y era el de conservarnos próximamente en aquellas inmediaciones, hasta que cedido el Sur tuviésemos nuevos soplos favorables del Noroeste, que su corta duración nos hacía más preciosos á cada paso; en el

so y a día 20 y hasta el medio día del 21 , fué éste por consiguiente el único intento de nuestras maniobras, bien que adelantándonos algo hacia el Este para aprovecliar con mayor extensión las primeras claras á una y otra parte; á este áltimo medio día por la altura meridiana del Sol, está. bamos en latitud de $59^{\circ} 36^{\prime}$ y nos consideramos como ocho leguas al Este del Cabo Chupador.

Como el tiempo se mantuviese aún cerrado con agua, y nuestra inacción, necesaria más bien, nos obligase á retroceder algo al Oeste, intentamos en la tarde inmediata navegar al Norte, precavidos con la sonda, y examinar luégo la costa del Oeste á tan poca distancia que pudiese ésta remediar la faltó de claridad y evidenciar. nos siquiera de su direc nion y calidad hasta el Cabo Chupador, ya que $n$ s sería posible por aho. ra determinar su posición astronómica.

La avistamos, en efecto, á distancia de dos ó tres leguas, como á las cinzo y media de la tarde, y poco después la ATrevida á cuyo cargo se había puesto la sonda, por medio de la señal correspondiente nos indic 6 haber hallado 87 brazas. La costa más inmediata al Norte y Noroeste era una arboleda enteramente igual á las que habíamos visto al Este y Oeste del puerto Mulgrave: la excesiva arrumazón no permitía distinguir claramente su continuación; pero no de. jaban de apercibirse algo más al Oeste otras puntas ai parecer escarpadas, y que no debían distar mucho del Cabo Chupador: esta idea im. perfecta de la costa (ni fuera posible á la sazón conseguirla más exacta áun á la distancia de dos leguas) no pudo, por consiguiente, evitar que retrocediésemos hasta las ocho hacia el Oeste y paireásemos luégo con la mura babor. El sem. Wlante del tiempo, aunque continuaba el viento bonancible al Sueste con muclia lluvia, prometía, sin embargo, no distante una revolución favora. ble, y esto nos animaba doblemente á sostenernos hacia el Oeste.
Aquellas apariencias no nos habian engañado: Jul. at en la mañana del 21 , después de algunas horas de una total calmn empezaron á apercibirse ven. tolinas del tercer cuadrante, las cuaies, despejados en poco tiempo los cielos $y$ horizonte, final. mente nos proporcionaban la vista de la costa, cual la habíamos deseado; y así, al medio día por latitud de $59^{\circ} 49^{\prime}$ marcamos el Cabo Español al Sur $59^{\circ}$ Oeste de la aguja, viendo al mismo tiem. po toda la costa desde el Cabo Chupador por el Sur $84^{\circ}$ Oeste hasta el Norte $21^{\circ}$ Este.

Desde el extremo oriental de nuestros reconocimientos del día ro (del que distaríamos ahora unas ocho leguas), la costa parecía continuar con muy poca entrada, toda compuesta de terreno bajo y frendoso en la orilla, y algo adentro, ce. nída de una cordillera de mediana altura, nevada hasta la falda, la cual, por una parte, estaba contígua á los montes postreros de la bahía del Contralor, marcados en la tarde del $17 . y$ por la otra venía á unirse, después de haber formado un valle considerable, á un monte bastantemente alto, que por el modo en que terminaban sus cimas, hemos !lamado el de las Coronas.

Ninguna abra considerable podía apercibirse en esta parte alta, y ni se conocía que en la baja antepuesta hubiese algún puerto 6 boca del río, bien que siempre de muy poca importarcia, según la dirección de la arboleda en uno y otro extremo.

Esta misma arboleda, cuya vista cogíamos de nuevo, como al Noroeste de nusstra posición actual, seguía luego sin interrupción hasta la Pun. ta Verde, no distante de las faldas del Monte San Elías, y en toda la costa, cuya extensión Este-Oeste no era menor de diez leguas, no se manifestaba ni la más remota apariencia de un abra: por lo cemún, á distancia de cuatro leguas hallamos fonclo de $\sigma_{5}$ \& $\% 0$ brazas lama.

Las pocas horas del crepúsculo (siendo el tiempo uumamente placentero) nos habían permitido el continuar nuestras bases y marcaciones sin interrupción, y habian sido frutos de esta tarea constante los reconocimientos expresados; aunque el viento en toda la tarde anterior, $y$ aun en la mañanita del 22 se mantuviese sumamente flojo; así, á las dos ya marcábamos el Monte de San Elías al Norte $29^{\circ}$ Este, y á las tres, por fondo de 55 brazas, no distábamos más que dos leguas de la costa, la cual, desde la Punta Verde, es pedregosa tajada al mar y dimanada de un frontón de tierra alta que se antepone á la cordillera majestuosa en la cual está compren. dido el Monte de San Elías.

Puede imaginarse, que no nos descuidamos en aprovechar la actual claridad de los cielos para todas las observaciones que estuviesen en nues. tro alcance: la longitud, por los relojes marinos y por distancias del Sol á la Luna; la variación 
Jul. a magnética, y la continuació- de las bases, fueron, por consiguiente, objetos que no: ocuparon i.cesantemente en las primeras hüus de la. lia. nana, en las cuales procurábamos al mismo tiem. po aprovechar cuanto fuese posible el viento, navegando á dos leguas escasas de la costa por sor. das de 35 á 40 brazas lama.

Contra nuestras expectativas, $y$ áun mucho más contra nuestros deseos, el viento á las nue ve de la mañana calmó enteramente, y desde este momento nuestros progresos fueron tan lentos y el tiempo tan calmoso, que hasta la mañana del 26 puede decirse que no variamos de posición.

Las pocas ventolinas que á veces nos alcan zaban, fran sumamente flojas y por lo común del segundo ó tercer cliadrante; nuestra distancia á la costa descle dos á cuatro leguas, las marcaciones al Monte San Llías, desde el Norte 1/ Nordeste hasta el Norte $1 / 4$ Noroeste, y esta altera ción, efecto más bien de las mareas las cuales en la tarde $y$ principios de la noche pare cían correr al Nordeste y en las restantes horas al Noroeste con velocidad de una 6 dos millas. La serranía, de mediana elevación, antepuesta como se ha dicho á la cordillera é inmediata al mar, termina en la Punta Olavide 6 más bien se une a la falda del Monte San Elías, cuyo picn (según nuestras operaciones trigonometricas), está por la perpendicular más interna de la orilla de siete legruas y media marinas, y elevado sobre el nivel del mar 2.792 toesas: desde aquél Cabo la costa forma una ensenada poco considerable, que en nuestras cartas tuvo el nombre de Extremadura, y en ella sólo se advierten dos abritas ó calas, la una al Oeste cerrada con hielo al parecer perpetuo; la otra al Este inmediata á la Punta del Indio y abrigo de una pequeñ : ranchería de naturales.

Entre estas dos puntas, la orilla aunque pe dregosa no carece de alguna arboleda, la cua cesa después dando lugar á las barrancas amo. gotadas que por la Punta Novales se dirigen hacia el Este hasta la de Barrientos y distan algo más de la cordillera, dirigida como es natural, hacia el Norte del puerto del Desengaño.

Como en todo este tiempo nuestras sondas no variasen desde 30 hasta 47 brazas, siendo su calidad lama suelta hacia la Punta Olavide arena fina hacia la del Indio, cansadas las tripulaciones de trabajar con los remolques para que las corbetas, aprovechando las ventolinas no cayesen excesivamente sobre la costa, hubimos de decidirnos en la noche del $24 \mathrm{y}$ en la mañana del 25, á dar fondo con un anclote grande, cuya maniobra, en este último día, nos produjo la feliz casualidad de la visita de un natural de los que habitaban las innediaciones de la Punta del Indio.

Aunque no distásemos á la sazón ménos de siete millas de la orilla, ese joven se aventuró á Jul. 26 reconocernos con su canoa; á una milla de distancia, parecía, sin embargo, arrepentido de su proyecto, y más bien se inclinaba á retroceder que no á aproximarse; pero como á la sazón se diri. giese hacia él con el bote el Teniente de navio Valdés y le repitiese las muestras ménos equívocas de paz y de cariño, finalmente se dejb alcanzar, y determinó venir con el bote á bordo; su poca extrañeza, sus ansias para convidarnos al fondeadero inmediato, finalmente, su prontitud á brindarnos con la misma facilidad para usar de las mujeres, que se nos habia of recido tantas veces en el puerto Mulgrave, no nos dejaron duda que no éramos los primeros europeos conocidos por aquellos naturales; i ien que examinando los viajes anteriores al nuestro, parece más probable que haya dcrivado aquel conocimiento del roci con los vecinos del puerto Mulgrave, que de al. guna visita directa á sus hogares. Las costumbres, las facciones y el idioma de aquel joven, parecieron totalmente iguales á las que habíamos advertido en aquel puerto; nos regaló algunas fresas, y cambió su manto de pieles de nutria, aunque no se le concediese el hacha que tanto apetecía: finalmente, hacia las nueve, regalado con varias frioleras, se despidí de nosotros $y$ regresó á la costa.

Tampoco habíamos omitido en la casi total inacción de estos dias, de aprovechar siquiera la uniformidad de nuestra posición para ratificación de las longitudes, no sólo repitiendo las observaciones de las distancias lunares, sino también examinando la marcha diaria de los cronómetros por nicdio de las longitudes comparadas á las marcaciones del Monte San Elías, y sujetas con la latitud observada. Las distancias lunares observadas en ambas corbetas volvían á ratificar con mucha admiración nuestra los resultados del mes anterior distantes al Este de los relojes marinos $\mathrm{I}^{\circ} \mathrm{I}^{\prime}{ }^{\prime}$ próximamente, " lo que no era ménos extraño, el movimienı, de esta máquina quedaba bien acreditado con no discrepar más que en dos minutos la determinación diaria ac. tual de la longitud del Monte San Elías, con la que habiamos deducido de las operaciones geo. désicas en el puerto Mulgrave; éstas, que hemos preferido por depender del teodolito, situan el pico alto en latitud de $60^{\circ}$ I $7^{\prime} 40^{\prime \prime}$ y en longitud occidental de Cádiz de $I 34^{\circ} 45^{\prime} 45^{\prime \prime}$. La determinación del Capitán Cook difiere de la nuestra.

Finalmente, en la mañanita del 26 , entablado viento galeno del primer cuadrante y dada en pocos instantes la vela, pudimos separarnos de la cosia : mo unas cuatro leguas 6 cinco y considerarnos libres de la necesidad de dar nuevamen. te fondo aunque el viento hacia el medio día fuese calmoso del Sur y los horizontes cerrados 
se aventuró á Jul. 26 lla de distan. ido de su protroceder que azón se dirinte de navio nénos equívose de jó alcan. á bordo; su onvidarnos al su prontitud lad para usar frecido tantas dejaron duda eos conocidos aminando los más probable ento del roce ve, que de al. Las costum. aquel joven, que habíamos egaló algunas les de nutria, cha que tanto leve, regalado de nosotros y

Ia casi total har siquiera la ara ratificacion Io las observasino también is cronómetros paradas á las y sujetas con as lunares ob. ian á ratificar resultados del os relojes mao que no era esta máquina discrepar más ión diaria acElías, con la eraciones geo. tas, que hemos lito, situan el " $\mathrm{y}$ en longi$45^{\prime} 45^{\prime \prime}$. La - difiere de la

126 , entablado y dada en po. jararnos de la cinco y considar nuevameli. el medio día ontes cerrados
Jul. 26 con arrumazón y alguna llovizna: á la sazón ya no liallábamos fondo con roo brazas de sondaie. $z a$; le habíamos, sí, alcanzado desde $5 t$ hasta 85 brazas lama al tiempo de no distar más que cinco leguas de la costa, la cual, cogidas de nuevo las puntas Novales y Barrientos que habíamos examinado y colocado con las marcaciones del puerto Mulgrave 6 de la tarde del 7 , ya no dejaba la menor duda, ó bien de su calidad ó dirección, 6 bien de su continuidad al Este y al Oeste contra las aseguraciones de Ferrer Maldonado.

A la verdad, cuanto más examinásemos aque. llos contornos, la tierra baja que los ciñe por todas partes á la orilla, y la alta, que tenazmente unida sin el abra siquiera de una cañada 6 de un río mediano termina con una noble y natural arquitectura, por una parte en el Monte de San Elías, y por la otra, en el de Buen Tiempo, tanto más debiamos extrañar, 6 bicn el origen de la Memoria de Ferrer Maldonado, ó la facilidad conn que se le había dado por el Sr. de Bauche un as. censo tan público y legitimado: si las tareas nuestras ya descritas (por ser posteriores á las del célebre navegante inglés) no nos dan siquiera la complacencia de poderlas considerar como importantes para los progresos de la Geografía, puedan á lo ménos, evitando en lo venidero nue. vos discursos sobre la existencia de un paso hacia esos paralelos, no aventurar más en semejantes pesquisas un número no mediano de vidas y de caudales.

El tiempo á la sazón, con una nueva altera. ción favorable, nos dirigió hacia el partido más conveniente para nuestras tareas siguientes. pues que podíamos considerar ya concluído el objeto principal del viaje á esos paralelos: navegamos en derechura hacia el Cabo Buen Tiempo, ratificando con nuevas marcaciones y observaciones la posición y encadenamiento de toda la cordillera que desde el Monte San Elías corre hasta el de Buen Tiempo; repetidas observaciones magnéticas nos indicaron la variación de 29 á 29 y $1 /{ }^{\circ}$ Nordeste, y á pesar que al principio mereciesen más bien el nombre de ventolinas que de viento las que á la sazón disfrutábamos del Noroeste, fueron éstas poco á poco acrecentando su imperio, de modo que al medio día del 28 nos hallábamos al Oeste del Cabo Buen Tiempo, á distancia de unas tres leguas.

Si sea aquélla 6 no la misma pinta que dis. tinguió con ese nombre el Capitán Cook, fuera difícil asegurarlo en la dirección real de la costa que veíamos casi seguida sin objeto alguno considerablemente saliente al mar; es, sin embargo, la que termina la bahía de.Bering, algo amogo. tada y escarpada al mar, llena de nieve hasta la orilla, y próximamente al Sudoeste del monte del mismo nombre; la cima de éste se interna desde la orilla unas 5 y $1 / 3$ leguas, está elevada sobre el nivel del mar $5 \cdot 3^{68^{\prime}} 3$ varas castellanas, Jul. 28 y resulta en latitud de $59^{\circ} \circ 0^{\prime} 42^{\prime \prime}$ y longitud de I $3^{1^{\circ}} 33^{\prime}$ I $5^{\prime \prime}$ occidental de Cádiz.

Aunque hast entonces hubiésemos navegado bien desatracados de la costa, habían sido considerables los efectos de una corriente hacia el Sur, la cual pareció cesar luégo que empezamos de nuevo á costear de cerca y sujetar con nuevas bases y observaciones la verdadera posición de las orillas. Eran bien las cuatro de la tarde, cuando perdimos de vista el Monte de San Elías, y á este ticmpo con vientos frescos del cuartn cuadrante, navegamos á distancia de dos á tres leguas de la costa.

Esta, pasado el Cabo Buen Tiempo, se deja - pr poblada de arboleda, pero sin la faja c: tierra llana que se nota desde la bahía de Bering: se disipan, al atracarla, las apariencias de $\mathrm{mu}$ clias abras, unidas luégo entre sí por medio de tierra baja, y no pudimos dudar que estuviese poblada, advirtiendo en una humareda que veíamos por la tarde, y en otra candelada, que al princi pio de la noche se apercibió hacia la entrada de la Cruz: la sonda es de 70 á 80 brazas como á dos leguas de la costa del Cabo; á la misma distancia no es posible hallarla después con go y Ioo brazas de sondaleza.

Eran próximamente las diez de la noche, cuando la oscuridad nos obligó á terminar nues tras tareas; aprovechamos las pocas horas hasta la mañana siguiente para atracar la ensenada de la Cruz, en cuyas inmediaciones advertimos por nuestro costado un trozo flotante de hielo, y á las tres, ya muy próximos á su extremo Sur, hubimos de variar de rumbo y pudimos emprender las bases.

Ya la costa que examinábamos era bien diferente de la que dejábamos al Oeste y correspon. día con las sospechas del Capitán Cook, de ser formada de un grupo numeroso de islitas con algunas abras y puertos bien útiles para la nave gación; se anteponen á no mucha distancia va. rios pedruscos también por la mayor parte poblados con árboles; el fondo á dos y tres millas de los pedruscos, se manifiesta de 50 á 60 brazas piedra.

La mucha calima que en toda la mañana nos habia imposibilitado el renovar como de. seábamos las observaciones de longitud é investigar las calidades de los montes internos, cedió al aproximarse el Sol al meridiano; de modo que D. Felipe Bausá pritn con su acostumbrada perspicacia, fijar casi sin recelo de la menor equivocación, el número y posición de este pequeño Archipiélago, y nosotros, observando para el medio día la latitud de $57^{\circ} 29^{\prime}$ y la longitud de $3^{\circ} 28^{\prime}$, confrontar la posición de los puertos de los Remedios y Guadalupe, delante de los cuales nos hallábamos. 
(ul. 2) La vista de aquellos puertos no podia me. nos de recordarnos con mucha complacencia, así la intrepidez del Comandante Cuadra que con una golcta los había visitado en Agosto de 1775 , como los derechos de primacía que habiamos adquirito sobre aquella costa, igualmente que en casi todas las demás de la América, antici. pándose dicho viaje unos tres años al del Capitán Cook: y si fuera posible hacer honrosa memoria de dicho viaje en pocos renglones, seguramente no ocultaríamos ahora muchas cir. cunstancias que le acompañaron; pero se referirán en otra parte más por extenso, y áun re. presentadas por el buril, lograrán tal vez de la Nación aquel justo tributo á que se han hecho acreedoras.

Aclarado por la tarde el tiempo y continuando viento fresco del Noroeste, nos fué fácil continuar nuestras tareas por el Cabo Engaño y Ensenada del Susto hasta las islas meridionales de aquella Ensenada: deseábamos con ansia un examen prolijo de la entrada del puerto de Banks, visitado por el Capitán Dixon, y aún paireamos algunas horas de la noche siguiente que fué lóbrega y lluviosa; pero una corriente algo fuerte al Este nos hizo malograr estas medidas, encontrándonos propasados á las seis de la mañana del 30 , hora en que pudo verse con alguna claridad la costa: nuestros rumbos fueron por con. siguiente dirigidos á atracar el extremo Sudoeste de la bahía del Príncipe, lo que conseguimos hacia las ocho de la mañana, y luégo á internarnos algún tantc en la Ensenada, bien que prefiriendo últimamente el pasar al Sur de las Islas Nubladas del Capitán Dixon, de las cuales distaríamos al medio día una milla larga por latitud de $55^{\circ} 57^{\prime}$ y longitud $5^{\circ} 14^{\prime}$ del puerto Mulgrave; ya á este tiempo no alcanzábamos fondo con go brazas; le habíamos sí cogido de unas 95 brazas chinos en la noche anterior; y en las primeras horas de la mañana, nos le había señalado la ATrevida de 76 y 82: la variación cic la aguja había bajado casi instantáneamente á $26^{\circ}$ Nordeste. La felicidad con que habíamos podido describir la costa con toda individualidad, era demasiado cebo para que no intentásemos seguirla estando la elección de nuestra parte: así, apenas rebasadas las Islas Nubladas, orza. mos de nuevo para atracar el principio del Archipiélago de Bucareli, reconocido tanibién por el Comandante Cuadra en 7775 y luégo examinado también prolijamente en $\mathbf{r} 779$ pnr el Piloto Maurelle á las órdenes de los Tenientes de navío Arteaga y Cuadra. A las cinco de la tarde ya estábamos inmediatos á algunas islas, pero como por la mucha cerrazón no nos fuese fácil extender nuestras marcaciones hacia dentro, mal pudiéra. mos ligarlas entre sí con la exactitud que deseábamos. El viento calmó al mismo tiempo casi de un todo, se cerró el tiempu más y más con llovizna Jul n, y neblina, y finalmente, debimos prefijarnos por único objeto separarnos algo de la costa, tanto más que la sonda constante de 55 y 60 brazas parecía confirmarnos las sospechas de una co. rriente $\delta$ marea hacia los canales internos.

A la suma inconstancia de ventolinas que continuó en la noche y mañana siguiente, se agregó una neblina tan espesa, que era preciso el uso de los cañonazos para conservarnos unidos con la Atrevida. La sonda era de 70 á 76 brazas arena lamosa, y al medio día era aún im. posible el acertar con nuestra actual posición, bien fuese respecto á las observaciones 6 bien á las marcaciones, pero no duraron mucho esta inacción y desconfianza. A las doce y media la neblina empezó á disiparse poco á poco, y á la una y media no solo teníamos lugar de repetir con seguridad nuestras observaciones, si también alcanzábamos á la vista la costa firme próximamente desde los puntos del medio día an. terior hasta las primeras Islas, extendiéndose luégo éstas en una cadena bien unida hasta la entrada grande y últimamente hasta la Isla de San Carlos: esta última demoraba al Sur $5^{\circ}$ Este de la aguja, y el Cabo San Bartolomé al Sur $87^{\circ}$ Este, distancia de tres leguas.

Con la tarde, aunque el viento nos abando. nase enteramente, nuestra posición debla parecernos bien agradable, pues reuníamos nuestras tareas astronómicas y algunas vistas exactas de las inmediaciones de aquellos fondeàderos á los trabajos harto útiles y penosos de los navegan. tes nacionales que nos hablan precedido sobre la costa; cuyo conocimiento y utilidades (si juz. gásemos por las noticias y cartas del Capitán Dixon), podían considerarse como enteramente ocultos á la navegación Europea.

El Cabo San Bartolomé está en latitud de $55^{\circ}$ I $7^{\prime}$ y longitud $6^{\circ} 5^{\prime}$ al Este de Mulgrave; es una punta de piedra que cae con poca loma de un monte bastantemente alto y frondoso, y tiene hacia el Este á poca distancia tres farallones ó más bien islotes, detrás de los cuales con una abra considerable se deja ver la costa también frondosa del otro lado de la entrada, que sale más al Oeste y va luégo á unirse con los extremos de la costa que forman el Canal de Dixon.

$O$ bien se considere el paralelo en que se halla este número crecido de buenos puertos, $\delta$ bien su inmediación por el Sueste con el Canal de la Reina Carlota, 6 por último, la muchedumbre de los naturales que lo habitan, debe sin duda mi. rarse como preferente á los demás parajes conocidos hasta ahora para emprender el comercio de las pieles sobre un establecimiento sólido y permanente, bien que parece harto dudoso que puedan jamás sostenerle las combinaciones de. masiado arriesgadas, precarias y limitadas de 
con llovizna Jul.", efijarnos por costa, tanto y 60 brazas s de una co. internos. ntolinas que siguiente, se era preciso ervarnos unira de 70 á 76 a era aún im. ual posición, ones 6 bien á mucho esta ce y media la poco, y á la gar de repetir ones, si tam. sta firme próhedio dia an. extendiéndose nida hasta la sta la Isla de ba al Sur $50^{\circ}$ rtolomé al Sur

nos abando. n debía pare. umos nuestras tas exactas de leàderos á los los navegan. ecedido sobre idades (si juz s del Capitán enteramente en latitud de Mulgrave; es poca loma de ndoso, y tiene farallones 6 ales con una costa también rada, que sale on los extreal de Dixon. n que se halla rtos, 6 bien su Canal de la chedumbre de sin duda miparajes conor el comercio ento sblido y dudoso que inaciones delimitadas de
Jul. 3 esta especie de comercio, particularmente en manos de una nación por necesidad poco económica; pero dejaremos para su lugar esta discusion política y volveremos ahora á la sola narración del viaje.

En las horas de calma la corriente nos había llevado algo al Su:, bien que sin separarnos de la boca del puerto, de la cual distariamos unas dos leguas á las seis de la tarde, por fondo de $7^{\circ}$ brazas, arena fina, parda y variación por varios azimutes de $23^{\circ} 30^{\prime}$ Nordeste: á esta hora se dejaron apercibir algunas ventolinas del Norte, las que declinando poco después al Nordeste, pareclan convidarnos tan solamente á navegar algo más desatracados, pero no á cesar de la empresa cic continuar el reconocimiento de la costa hasta Nutka, de modo que los navegantes venideros no nos tachasen de omisos en un punto tan inmediato á los objetos esenciales del viaje. A la verdad, supuesta de nuestra parte una necesidad de visitar el nuevo establecimiento de Nutka y uno ú otro puerto de nuestra California, y de no diferir de la mitad de Octubre la llegada á los puertos de San Blas y Acapulco, el reconocimiento de la parte interior del Estrecho de la Reina Carlota no pudiera ser tan prolijo que describiese toda la costa, particularmente, si como parecía probable, ésta fuese más bien formada de islas que de tierra fiıme 6 contigua; pero á lo ménos se ase. guraría la navegación y se dirigirían con más acierto las pesquisas venideras, si tuviesen por objeto el perfeccionar la hidrografía de aquella parte del Globo.

1. . Abandonada con este intento toda idea de una escala aunque breve en el Puerto de la Cruz del Archipiélago de Bucareli, nos dirigimos á pasar al Este de la Isla San Carios unas dus ó tres leguas y orzar después hacia lo interior de la canal. Pero muy luego vimos frustradas enteramente estas medidas, con los vientos, que después de la media noche se declararon frescos del segundo cuadrante, engruesando considerablemente el mar y cerrando cielos $y$ horizontes con calimas y lloviznas: el bordo del Sur que se guimos al principio, nos hizo perder toda tierra de vista desde las siete de la mañana, y al medio dia, por latitud de $54^{\circ} 3^{\prime}$, nos considerábamos en longitud de $4^{\circ} 44^{\prime}$ de Mulgrave, variación magrstizd $24^{\wedge} 23^{\prime}$ Nordeste.

No por esto era nuestro ánimo desistir ente. ramente del reconocimiento proyectado, el cual también si pareciese arriesgado ó largo intentarle por el canal interno, pudiera á lo ménos resarcirse en algún modo por la costa externa, en donde las atenciones bien diferentes del $\mathrm{Ca}$ pitán Dixon nos dieran lugar á explayar un mayor grado de exactitud, particularmente en los arrumbamientos referidos á uno y otro extremo de la costa firme; pero en estos conceptos está. bamos bien distantes de imaginar los tempora. AY, .," les que desde aquella época debíamos encontrar, pues ya poco después del medio día, rodeados de una lluvia y cerrazón constantes y con mar bien gruesa, nos fué preciso precavernos con dos rizos en as gavias y aun en el día siguiente navegar con las dos mayores y la gavia arriada.

Sin embargo, nuestros bordos habían sido tales, que para las siete de la mañana del 3 avistamos á distancia de cinco 6 seis leguas el extremo oriental de las Islas de la Reina Carlota pro. bablemente por el Cloak Bay del Capitán Dixon: era una costa medianamente alta, con algunas abras al Sur, generalmente vestida de una arbole. da hermosa, y para nosotros en la actualidad terminada en sus extremos, del Norte $72^{\circ}$ Este, al Sur $87^{\circ}$ Este de la aguja: aunque el tiempo continuaba muy oscuro y de mal cariz, navegamos hacia ella hasta las nueve de la mañana, y luego reviramos al Sudoeste frustradas nuestras esperanzas de conseguir á su vista las precisas observaciones de latitud y longitud, tanto más necesarias, cuanto que las observaciones inme. diatas no nos dejaban duda de un erior considerable en la estima, que influía en ambas determinaciones; si en este caso pudiésemos dejar correr nuestras conjeturas en cuanto á la lon. gitud (adoptada la latitud del Capitán Dixon) nos persuadiríamos, combinadas las estimas des. de el día $\mathrm{r}^{\circ} \mathrm{y}$ desde el 4 en que tuvimos ob. servaciones de regular confianza por los relojes marinos, que la longitud de este extremo está $7^{\circ} 5^{\prime}$ al Este del puerto Mulgrave y por consiguiente algo más interna, 6 al Este de la de. terminada por el Capitán Dixon, según el arrum. bamiento con la Isla San Carlos, que él llamó Isla de Forest.

No bien habíamos virado, cuando empez6 el viento á arreciar de nuevo y á precisarnos á navegar bien precavidos en el aparejo; desde esta época hasta la tarde del 7 , puede decirse que no experimentamos más que un temporal seguido del Sueste, en el cual, sin embargo, sobresalí mucho la noche del 5 , mereciendo el viento en aquella ocasión más bien el nombre de huracan: las olas con exceso gruesas, la lluvia contínua y el viento seguramente más tempestuoso y arra. fagado que todos los que habíamos experimen. tado desde la salida de España, dieron lugar á las corbetas de acreditar sus propiedades sobresalientes, no habiendo tenido la menor avería, sin embargo que resistiesen constantemente á la mura con trinquete y gavia en dos rizos arriada.

Al medio día del 7 , cedido este temporal, nos hallamos en latitud de $53^{\circ} 20^{\prime}$ y en longitud de $3^{\circ} I^{\prime}$, distantes por consiguiente mucho de la costa y al Sur de los extremos reconocidos. Esta posición nos persuadió de que sería el partido más conveniente el hacer derrota directa 
Af, hacia Nutka 6 á lo ménos hacia el extremo sep. tentrional de su costa, y asl pues que á las seis de la tarde se declaró viento bonancible del Sud. oeste y Oeste navegamos con todo aparejo al Es-Sueste.

Los ticmpos continuaron bonancibles y aún algo variables en los días 8 y 9 , en los cuales, aprovechando los ciclos bien despejados, se observaron en una y otra corbeta hasta 200 series de distancias lunares: su resultado debió causarnos nuevas confusiones, aproximándose de tal modo á la longitud de los relojes marinos, que no diferia ménos de $\mathrm{I}^{0}$ de la longitud deducida en Junio y Julio, y por las observaciones hechas á la vista del Monte Buen Tiempo y del de San Elías; pero nos lisonjeábamos de lograr en Nutka tales observaciones, que decidirian luego con seguridad esta cuestión harto desagradable y nueva enel mśtodo seguido para nuestras tareas.

A las diez de la mañana del día Ir, ya logra. mos ver la tierra, aunque confusa; $y$ la latitud de $5 \mathrm{I}^{\circ} \mathrm{I} 7^{\prime}$ observada al medio día, nos convenció que no distábamos de los extremos meridionales del Canal de la Reina Carlota, entre los Cabos Cox y Woody del Capitán Dixon: próximos á este último Cabo á las tres y media de la tarde arribamos con viento bien fresco al Sueste un cuarto Sur, y empezamos á reconocer con prolijidad la costa, pues el rumbo que traíamos de mar en fuera no nos había permitidı trazar más que los puntos altos al Norte del mismo Cabo.

Es sin duda aquel trozo de costa más tendido del Noroeste al Sudeste de lo que lo suponían las cartas publicadas hasta entonces; y el Cabo Woody, fácil de distinguirse no ménos por su hechura amogotada y frondosa que por el islote que tiene saliente al Oeste y taladrado, quedaba por nuestras observaciones en longitud de $\mathrm{II}^{\circ}{ }_{5 \mathrm{O}^{\prime}}$ al Este del puerto Mulgrave; de suerte, que los resultados de nuestros relojes debían acercarse mucho más en Nutka á las longitudes del Capitán Cook de lo que lo habíamos conseguido en el puerto Mulgrave y entrada del Príncipe Guillermo. Aproximándose la noche, calmó mucho el viento, $\mathrm{y}$ los cielos $\mathrm{y}$ horizontes acrecentando su claridad, hicieron que en las horas siguientes jamás careciésemos de la vista de la costa: distábamos de ésta á la sazón unas dos leguas por sonda de 50 brazas chinos; nos demoraba el islote del Cabo Woody al Oeste $20^{\circ}$ Norte unas seis ó siete leguas; y al Norte $88^{\circ}$ Este de la aguja la punta que suponíamos de la entrada de Nutka: en aquella posición pareció lo más prudente el pairear hasta las prineras claras del día próximo, siguiendo una á otra mura, según lo exigiesen, $\delta$ la sonda que alcanzamos de $35 \mathrm{t}$. $9 \cdots$ 's 6 ol viento que parecía calmar de un todo al abrigo de la tierra.

Antes de rayar el día empezamos de nuevo nuestra navegación, y aunque el viento fuese As., calmoso con exceso, para las ocho de la mañana estábamos delante del puerto de la Esperanza, marcando sus islotes internos á distancia de una legua y media, y desengañados de la que creíamos en la tarde anterior ser Punta de Nutka; ésta, que ya marcábamos con seguridad al Este de la aguja, distaba aún cuatro 6 cinco leguas, y sin embargo, se nos habian ya acercado algunas ca. noas, bien que al parecer más bien con objetos de pesca que de comercio: notamos del mismo modo que en la noche anterior varias hogueras ó fuegos en las playas contiguas.

No entabló la virazón hasta lao clos de la tarde; debimos al principio apartarnos algo de la costa para evadir algunos remolinos que nos aconchaban sobre los bajos de la Punta Macuina: últimamente arribamos no sin alcanzar por fondos de 17 y 20 brazas piedras los extremos del mismo bajo que había reconocido el Capitán Cook.

Dos ó tres canoas de naturales, á la sazb́n habían atracado á ambas corbetas anhelando por las conchas de Monterey y por algún pan ú otra especie de comida, manifestándonos, que ni le era extraña la bandera, el idioma y las costumbres nuestras, ni ignoraban los nom. bres de los comandantes Martínez y Elisa: nos hicieron comprender que había una sola em. barcación nuestra en el puerto, y después de al. gún tiempo, se separaron, para regresal á la orilla.

A las cinco de la tarde no distábamos más que unas dos leguas de la boca del puerto, cuyo extremo Sur nus demoraba al Nordes e; ceñimos hacia este rumbo las pocas ventolinas variables que aún dejaban apercibirse, y largamos las insignias con la esperanza de que en el 'establecimiento inmediato las viesen y supiesen nuestra proximidad. Puede imaginarse cuál sensación nos haría el ver poco después tremolar la bandera nacional en un altito inmediato á la punta Sur, y entre los árboles distinguirse los tres palos de una embarcación desaparejada: no ignorábamos de antemano la existencia de un establecimiento nuestro en estas costas; no ignorábamos cuántos caudales se habian derramado y cuánta sangre pudo haberse esparcicio para sostener su posesión legitima; y sin embargo, es tal el instinto del hombre hacia la sociedad; tal el anhelo de hallarse entre los suyos libre de las trabas que dictan, 6 bien la envidia, 6 la codicia, 6 un pundonor mal entendido, que en aquel momento nos parecía una felicidad lo que tal vez debieramos mirar como un objeto funesto y malaventurado.

Puesto el Sol debajo del horizonte, quedamos en una total calma, no distando á la sazón media legua de la boca del puerto y una milla escasa de la costa inmediata: sondadas al mismo tiem. 
iento fuese As."

e la mañana

Esperanza,

incia de una

ue creiamoss

Sutka; esta,

1 Este de la

eguas, $y$ sin

algunas ca.

con objetos

del mismo

as hogueras

os de la tar.

algo de la

os que nos

ta Macuina;

ar por fon-

os extremos

b el Capitán

á là sazón

anhelando

lgún pan ú

ndonos, que

dioma y las

h los nom.

- Elisa: nos

a sola em-

spués de al.

gresar á la

ábamos más

uerto, cuyo

s e; ceñimos

as variables

irgamos las

el estable-

sen nuestra

:nsación nos

la bandera

junta Sur, y

es palos de gnorábamos

blecimiento

nos cuántos

inta sangre

su posesión

nstinto del

elo de ha-

as que dic-

n pundonor

o nos pare-

amos mirar

rado.

quedamos

azbin media

illa escasa

ismo tiem.
Ag. if po 55 brazas fondo lama, dejamos caer un an. clote para esperar la virazón del día siguiente, nos alcanzó poco después la lancha de la fragata Concepción, de San Blas, que venia para auxiliar. nos, $y$ se mantuvo en la noche $a$ nuestro cos. tado.

El terral sopto fresquito en las primeras ho. ras de la mañana, cedió luégo al salir el Sol, y hacia las siete le sustituyeron las primeras ven. tolinas de la virazb́n con las cuales dimos iume. diatamente la vela: nos siguió de cerca la ATKE- vibs, y costeada á un cumplido de corbeta la $\wedge_{k}$. punta Oeste del puerto, logramos dar fondo en él á las nueve y media.

Evacuados de este modo los objetos esencia. les que nos liabian conducido en aquelios mares y particularmente al paralelo de $60^{\circ}$, ya pudimos examinar con una mayor individualidad las Memorias que liabian dado lugar á la campaña an. terior, $y$ ordenar nuestros razonamientos en la disertación siguiente, la cual no parccerá tal vez totalmente inútil 6 censada al lector:

DISERTACIÓN sobre la legitimidad de la navegación hecha en 1588 por Ferrer Maldonado deste las inmediaciones de Terranova al mar Pacifico, y al contrario. Se examinan en esta ocasión las reflexiones del Sr. de Bauche, presentadas a la Real Academia de Ciencias en 13 de Noviembre de 1790, los rastros engañosos de otras navegaciones semejantes y la utilidad verdadera para la navegación al Asia, de una comunicacion cualquera entre los dos mares.

Es realmente una suerte bien desgraciada para los progresos de la Geografía y para su utilidad hacia el bien público, el que le sea más bien nociva la subdivisión natural de las operaciones que le dan origen y la fomentan, cuan. do en la mayor parte de las demás ciencias, esta misma subdivisión ha coadyuvado extraordinariamente á sus progresos. La Física, la Mecánica, la Medicina, divididas actualmente en otros muchos ramos secundatios, han multiplicado al mismo tiempo la ocripación útil de los sabios y sus inventos para el bien de la sociedad; con iguales ventajas les ha seguido de cerca la nave. gación, y ciertamente, si hubiese tenido igual suerte la Geografía, no hubieran sido otros tan:poco los progresos del comercio, primitivo enla. ce de los hombres, juez verdadero del equilibrio de las naciones, y único móvil de la paz, de la civilización y de la opulencia, cuando se contenga en sus justos límites. Así, este fué el afán unánime de la Europa, y seguramente lo hubiera conseguido, si su sistema científico 6 su no cabal atención á las cualidades de esta cie... cia, no la hubiesen arrastrado á confundirla con las otras.

Esta equivocación no debe parecer extraña. Los progresos de la Geografía, dependen como en las demás ciencias de los razonamientos y de la experiencia, y la ruda educación del navegante $a$ quien debe fiarse necesariamente la segunda, le hace comparecer á los ojos del público como incapaz de no equivocar los primeros; de suerte, que en esta ciencia, más bien que en cualquiera otra, parece precisa una subdivisión natural del que raciocina y del que experimenta.

De aquí dimanan, sin embargo, todos los errores. El primero no interviene en las experiencias y el segundo no está autorizado á contradecir los razonamientos. Los navegantes, por consiguiente, abultan á su albedrío las narraciones. Los sabios, con igual libertad, adoptan ó desechan á veces la veracidad, á veces áun la exis iencia del navegante, y finalmente, este caos de ideas equivocadas, más bien trastorna que favorece los progresos deseados.

Por desgracia, con el recto conocimiento de la Geografía está enlazado estrechamente el sistema político de la Europa, y siendo este en el día la ocupacion? nredilecta del mayor número de los hombres citiosos, particularmente alrededor de las capitales, es más fácil la equivocación, ó más bien diré, la ninguna inteligencia entre el navegante y el geógrafo (r), si el magnetismo opere 6 no directamente sobre los nervios;

(I) Es preciso adoptar esta von para distinguir al que combina 6 amasa los materiales suministrados por el navegante; pero á la verdad en el día no debra aplicarse sino al que observa y raciocina sobre sus observaciones del mismo modo que el físico, el mé. dico, el fisiologo, ctc. 
si haya ó to existido una Atlántida; si la pobla. ción de la $A$ mérica haya dimanado del Norte, del Este $\sigma$ del Oeste, y si el estado de ia Luna sea efectivamente cual nos lo describe Herschel, tal vez con igual aceptación con la cual poco há leíamos en las épocas de la naturaleza su total enfriamiento; son verdades aisladas que intere san á pocos y cuya admisión 6 repulsa no influ. ye en el bienestar de la sociedad.

Pero la existencia de un Continente austral cuyos habitadores y productos á veces enriquez. can, á veces aniquilen toda la Europa; la legitimidad de los anuncios del Capitán Carver sobre sus montañas brillantes, la seguridad de que haya una fácil comunicación por agua entre el mar Pacífico y el Atlántico sin deber navegar al hemisferio Austral, son verdades en qu todas las naciones toman una parte directa, is bien para aumentar su propio poderío o para debilitar e ageno con el objeto de conservar un soñado equilibrio.

Aún es más desagradable en esta parte la constitución de la Geografia: las experiencias son costosas, arriesgadas para los que las emprenden, y de un éxito bien dudoso para aquella cvidencia fisica que depende de los sentidos de cada indivíduo; de suerte que finalmente debia ser una fatal consecuencia de tantos inconvenientes, el que 6 los principios fundamentales de esta ciencia se admitiesen con un respeto servil de la boca de pocos navegantes que los revelasen como oráculos, 6 continuase el mismo descarrío de ideas, tanto mayor ahora cuanto mayor era el número de las noticias que concurrian á producirlo.

La Inglaterra fué la primera en conocer la necesidad de decidirse por uno ú otro de estos dos partidos, y prefiriendo con mucho acierto el primero, depositó toda su confianza en el Capitán Jaime Cook ( $\mathrm{r}$ ). La util consecuencia de una determinación tan paudente, no tardó sino muy pocos años. Desaparecí el Continente Austral del Presidente de Brosse; se cerró la comunicación de los dos mares, $\tan$ sostenida por Mr. Dobbs, e confirmaron los límites del hielo constante hacia el polo del Norte, que el Capitan Phipps y los navegantes rusos habían explorado de antemano, y pudo la nación despachar sus buques á la bahía Botánica y á la costa Noroeste de la

(1) Por cuanto los ingleses so esfuercen particu. larmente en la introducción del tercer viaje del Ca. pitán Cook a reunir bajo un mismo punto de vista las expediciones de los Capitanes Biron, Wallis y Carte. expediciones de los Capitanes Biron, Wallis y Carteret y las del Capitán Cook, no deben absolutamente confundirse por quien las considere atentamente. Las primeras fueron una sola consecuencia de su sistema de aproximarse a los dominios españoles de la América meridional, y combinadas sobre principios pura. mente militares: las segundas han manifestado siquiera un noble arrimo a los progresos de la ciencis y en particular de la Geografia.
América con la misma seguridad, con la cual los despachaba 6 al Mediterráneo 6 á las Antillas.

La expedición del Conde de la Peyrouse, pa. reció confirmar la aceptación de este mismo sis. tema entre los franceses. Aquel viaje no tenia por objeto sino el completar las tareas del nave. gante inglés en las costas, que 6 no habia reco. nocido, 6 la necesidad le habia hecho dejar in. formes: $y$ tijados ya los conocimientos del globe habitable sobre estas dos expediciones, la Geografía podia considerarse concluida, y tanto más libre de todo razonamiento externo, cuanto que los navegantes por sí solos los habian hecho: además accedia ahora la España y áun coadyuvaba á este sistema con la expedicios de las corbetas Drs CUBIERTA Y ATREvidA, las cuales debian reconocer prolijamente todas sus costas de la América y del Asia. En efecto, tantas indagaciones 6 ya públicas, 6 próximas á jublicarse; con aquella exactitud que suministra la Astronomía; con aquella verdad que la filosofia debe dictar; con aquella claridad metódica que ya no debe considerarse opuesta á la educación del marino finalınente, con aquella excelencia que la perfec. ción del buril y la generosidad de los Monarcas of recen actual mente, debían ya hacer considerar la sana Geografla como regenerada; representar los derechos de las naciones sin la menor equi. vocación; y guiar con toda certidumbre á los depositarios del bien público en las diferentes com. binaciones de derrotas y de comercio: resultaba por consiguiente inutil la ocupación del geógrafo, y el ménos experto en esta clase de operacir nes, podía, con el solo auxilio de dos compase seguir de cerca á los navegantes venideros en los progresos útiles que hiciesen para la sociedad.

Sin embargo, no es así: han vuelto los razo. namientos á oponerse directamente á las nave. gaciones, y si la existencia del Continente Austral no ha podido en modo alguno revalidarse, á lo ménos el Sr. Lemonier (I) ha defendido, en cuatro Memorias la existencia del Cabo Circun. cisión del Capitán Bouvet; el Doctor Barrigton ha amontonado, tal vez con alguna predilección (2), diferentes noticias de viajes al Polo Norte, que han pasado del grado 32 de latitud; se ha autorizado y casi toda la nación inglesa ha suscrito álas combinaciones del Capitán Meares, quien no contento con denigrar la memoria del Capitán Cook sobre las indagaciones que hizo en la ria de su nombre, ha revivido las derrotas casi olvidadas del Almirante Fonte $y$ de Fuca (3);

(1) Véase la introducción y el apéndice al tercer viaje del Capitán Cook.

(2) Véanse las Memorias de la Real Sociedad de Londres, año de 1774 .

(3) Véanse la introducción al viaje del Capitán Meares y su Memoria sobre la posibilidad de que exista el deseado paso del Noroeste. 
on la cual los. las Antillas. syrouse, pa. e mismo sis. aje no tenia cas del nave. habia recoho dejar in. os del globo es, la Geoy tanto más ianto que los cho: además uvaba á este prbetas Des. bian recono. - la América aciones 6 ya con aquella onomía; con e dictar; con no debe condel marino; que la perfec. los Monarcas er considerar ; representar menor equi. abre á los de. erentes com. io: resultaba del geógra. de operacir os compase venideros en a la sociedad. Ito los razo. á las naveitinente Ausevalidarse, á efendido, en Jabo Circun. or Barrigton na predilecajes al Polo 2 de latitud; on inglesa ha itán Meares, memoria del $s$ que hizo en derrotas casi de Fuca (3);

idice al tercer 1 Sociedad de e del Capitán ilidad de que
- finalmente, se ha leído á la Real Academia de Ciencias de París una Memoria, en la cual, no sólo se expone como cierto el viaje liecho en 1588 por Ferrer Maldonado, hallando la comunicación de los dos mares, Atlántico y Pacifico, sino que de él se deduce la verdad de otros muchos he. chos que refieren diferentes autores, los cuales, como hasta ahora no se han podido compren. der, se han mirado como fabulosos 6 como dis. putables.

A la primera de estas aserciones respondió inmediatamente Mr. Wales; la segunda no debe haber hallado muchos partidarios cuando no se ha tratado de hacer nuevos ensayos hacia el Polo; resolvieron en parte las goletas Mejicana y Sutil, y en el todo la expedición inglesa del Capitán Vancoaver, los términos de la internación del Estrecho de Fuca descrito por el Capitán Meares; la cuarta, finalmente, cuyo examen, $\mathrm{dc} \mathrm{cl}$. den de S. M. fué puesto al cargo de las corbetas Descubierta y Atrevida en el año de 1791 , no, exigiria para satisfacerla otras pruebas que el diario de aquella navegación y las diferentes vistas y descripciones de las costas reconocidasentonces con el mismo objeto.

Seria por consiguiente inútil y seguramente nubiéramos omitido un examen detallado de las circunstancias del viaje de Ferrer Maldonado, si no se advirtiese al mismo tiempo una facilidad grande en los geógrafos de arrimarse aúr. á las opiniones antiguas, cualesquiera sean los cimientos sobre los cuales estriban, y si no tuviésemos fundada razón para creer que no es el solo papel de Ferrer Maldonado el que corrí enton. ces, para apropiarse uno ú otro individuo 6 bien el honor de un descubrimiento ya creído 6 bien las ventajas de una comisión árdua y distante, la cual, por otra parte, traía consigo la administración de una suma más que mediana de cauda. les (I). La utilidad verdadera de una comunicación de un mar á otro es también un objeto del cual no debe absolutamente desprenderse todo razonamiento sociable; pues es bien diferente la proposición aislada de que exista una comunica. ción 6 la hilación común, de que deba buscarse á cualquier costo y riesgo. Tal vez no será indife.

(z) Hallase en los archivos de Palacio y Santo Domingo de Manila, una copia de la Real Orden siguiente: «El Rey. D. Pedro de Acurta á quien he proveldo por mi Gobırnador y Capitán General de proveldo por mi Gobiernador y Capitán General de de ellas. Con esta os mando enviar copia de una carta que Fernando de los Rios, Coronel, me escribió de las diches islas, en que trata do un astrolabio que estaba haciendo para tomar la altura del Polo a todas horas; y del descubrimiento de dos Estrechos por donde so podia entrar en aquellas islas, uno que ila man do Anian que divide la tiorra do la China man do Anian que divido la tierra do la China y pana, y el otro Estrecho por el nuevo Méjico; y otras cosas sobre la navegacion de aquellas islas ála Nueva rente la utilidad que derive de un examen de esta especie; $y$ en lo venidero, 6 las relaciones antiguas se examinarán con mayor pulso ó áun sien. do auténticas se desecharán cuando sus heclos no intluyan en modo alguno hacia el bienestar de la sociedad:

Existia efectivamente en la corte á principios del siglo XVII un Iorenzo Ferrer Maldo. nado, Cosmógrafo mayor de Indias, pero nada en el Archivo de Simnncas acredita que fuese este mismo el autor del memorial presentado, ni el memorial se lialla en otra parte que en el Archivo del señor Duque del Infantado. Is tam. bién positivo, que en los años próximos anterio. res se trataba en el Consejo de S. M. del paso del Noroeste, no sólo porque asi consta en la urden citada en los párrafos anteriores, si tam. bién porque era aquella precisamente la época en la cual los esfuerzos de los navegantes ingle. ses Davis, Lancaster, Weymorth, Hudson, Buttons y Ciibons, más debian despertar la aten. ción del Gobierno español.

Sin embargo, estos datos no bastaban en Madrid para que se admitiese por veridica la navegacion de Maldonado: Malo de Luque (I) veía crecer á tal punto las dificultades entre la auten. ticidad de la Memoria y la evidencia de las prue. bas contrarias, que no pudo decidirse á admi. tirla; y en el plan del viaje que debían seguir las corbetas Descubierta y Atrevida, las or denes de S. M. sólo indicaban que se emprendiese esta uveriguación en el caso que las apo. yasen las noticias adquiridas en la continuación del mismo viaje.

In el entretanto, un examen de la relación hecho con tanta mayor atención cuanto más se acercaba el tiempo de deberle caracterizar á los ojos de la Nacion, 6 coino verídico y glorioso 6 como apbcrifo é infundado, descubría un número crecido de incompatibilidades que se ex. pondrán ahora con la mayor brevedad.

I. Era bien extraño que no se presentase á S. M. sino en r6og la noticia de un descubrimiento el más importante para la Monarquía, que había tenido lugar en ${ }_{5} 5^{88}$, habiéndose callado por consiguiente por el largo espacio de veintiun años y precisamente en una época en la

Espanfa y sobro la mucha gente que se consume y muere en estas islas, de la que se lleva de la Nueva España, y porque todas las cosas que apunta son de mucha consideración y particularmente lo que toca mucha consideración y particularmente lo que toca al descubrimiento de los dichos Estrcchos, os mando cho Fernando de los Rios, sobre lo que contiene su carta y también con las otras personas que tuviesen inteligencia de ello, si será conveniente tomar posesión de la Isla de Armiño para hacer cscala alli las Naos que salen do cstas islas para la Nueva Espata, Naos que salen de cstas islas para la Nueva España como lo advierte el dicho Fornando de los Rios.=
Fecho en Zamora á $166^{\prime}$ de Febrero de 1602 años. (r) Tit. IV, pág. $5^{8} \mathbf{7}$. 
cuai estạ’a más encendido el cleseo de semejante descubrimiento.

2. Reducidas las derrotas por rumbos y dis. tancias, no resultaba sino la latitud de $72^{\circ}$ al extremo del Estrecho del Labrador, que Maldonado hacía alcanzar al grado 75 .

3. Mal podían combinarse la situación del navegante buscando víveres en las Celandillas, después de haberse ocupado en la pesca de los bacalaos, $y$ su pronta determiıación 6 más bien inspiración de navegar para el mar Pacífico á costa de infinitos trabajos y en la dura estación del invierno; á lo cual tampoco accederían fá. cilmente sus marineros no presentándoles objtin alguno de utilidad.

4." No era tampoco fácil averiguar cual sería el puerto de San Miguel ó bahía de San Ni. colás, en donde según nuestro viajero entran todos los años casi mil naves de trato, las cuales para haber de pasar al mar de Flandes, precisamente han de subir á $75^{\circ}$ de altura para dar la vielta sobre la Dinamarca.

5. En un canal no ménos ancho de 40 á 20 leguas, se veian ahora fuegos, puertes, calas y abrigos á una y otra costa, y al mismo tiempo nuestro navegante ign rraba si se helaría el mar en las orillas, siendo así que se helaba el agua que salpicaba alrededor del buque y las veias tenían un paimo de espesor pror el efecto del r.:smo hielo.

6. Como á la ida para el mar Pacífico los vientos reinantes fuesen contrarios del Norte $y$ fuese preciso valerse de las mareas, debíamos cieer que seguiría la costumbre de fondear y le. varse al principio y al tin de cada marea contraria, lo cual no solo se hacía difícil por la manio. bra en sí, sino también por la precisión de navegar á medio caüsal con motivo de los hielos y de las vi:tas de ambas costas.

$7{ }^{\circ}$ Se r.percibió una contradicción bien clara entre la práctica del Piloto portugués y su ig. norancia en el solo paraje en donde la necesitaba; entre la casualidad del beneficio de las mareas para mantener el bajel for algunos días á la vista del Estrecho de Anian ensenando el bote luégo que se echó a $i$ agua, : la consecuen. cia de Ferrer Maldonado de que no hubicse otro Estrecho.

8. Admirábamos también la felicidad $\mathrm{con}$ ' cual este navegante había logrado siempre de unos vientos sumamente favorables; había en su navegación al Oeste, desde la costa de la América, eıcuntrado después de solos cinco días la del Asia, y sacrificada á unos ânes ocultos le evidente necesidad en la cual debía hallerse de comestibles, saliendo de un puerto que según él mismo dice, farecía to haber sido tocado de piés huntanos.

$9 .^{\circ}$ No era posible combinar esta misma na. vegación en el mar Pacífico con las costas reconocidas por el Capitán Cook, de cuya posición segura nadie podía dudar.

Io. No era fácil comprender la demasiado poca cordura de Maldonado en apropiar por suyo el descubrimiento de un Estrecho, por el cual no sólo navegaba ya descuidadamente una embarcación anseática de 800 tonelados cargada de brocados, sedas, porcelanas, plumas, cajones, piedras, perlas $y$ oro, $y$ cuyos navegantes eran luteranos $y$ hablaban latín, sino que había de seguirle otra muy luégo, y entrambas proceden. es de una ciudad muy grande al parecer llarada Roba, sujeta al gran Can de Tartaria.

I I. En estas circunstancias eza aún mucho más de extrañarse, que nuestro navegante encargase repetidamente el sigilo y la celeridad en el proyecto que proponía, y sobre todo, que ima. ginase la construcción tosca y el tamaño reducido is los buques exploradores, cuando ni eran ne. cesarios semejantes descubrimientos hahiéndolo ya todo reconocido, nii podía haber el menor ries̃os á donde él mismc hahía navegado en in. vierno y las embarcaciones anseáticas transita. ban ricamente cargadas.

12. Dejábamos aparte la improbabilidad del terreno, de las frutas, de los animales y de los pájaros que describía; el calor que experimentaba al regreso, mayor que el de verano en España; finalmente, la tenaz unión de las costas de la América y Asia en sodo lo que había reconocido, de suerte que no hubiese en las 300 leguas costezias en el espacio de once días, ya al Sues. te, ya al Norte, sino únicaniente la boca del Estrecho.

A tantas razones se agregaron luego el reconocimierto nuestro de la costa entre la entrada del Príncipe Guillermo y el Cabo Buen Tiempo, y las investigaciones en el año anterior del Te. niente de navío D. Salvador Fidalgo hacia el fondo de la Ensenada del Príncipe Guillermo; todo contribuía á manifestar la total inverosimilitud de semejante passo y debilitaba mucho los razonamientos de la rueva Memoria, de los cuales exa:ninaremos ahora solamente la parte que corresponde al mar Pacífico; no pudiéramos extendernos al otro mar sin envolvernos en otras hipótesis que probablemente nos apartarían de la verdad.

Omitiremos, por consiguiente, el indagar por qué el Sr, de Bauche ha dejado en el extracto de la derrota los nombres de la fabulosa Tule con los cuales distingue Ferrer la Frislandia; por qué varie al Nordeste la dirección del Es. nordeste que supone Maldonado á la boca falsa que se deja para ir ai Estrecho del Labrador; por qué en oposición á los hechos positivos que aleg la Comrañía de Hudson y á las últimas medidas del Cobierno Británico al cual segura. 
con las costas reco-

$k$, de cuya posición

ender la demasiado o en apropiar por in Estrecho, por el scuidadamente una o toneladas cargada as, plumas, cajones, os navegantes eran - sino que había de ntrambas procedeninde al parecer llaian de Tartaria. cias era aún mucho estro navegante enrilo y la celeridad en sobre todo, que ima. y el tamaño reducido , cuando ni eran nerimientos hahiéndolo día haber el meror thia navegado en inanseáticas transita-

la improbabilidad del os animales y de los alor que experimenta1 de verano en Espanión de las costas de lo que había reconoiese en las 300 leguas once días, ya al Sues. mente la boca del Es-

-egaron luego el recocosta entre la entrada 1 Cabo Buen Tiempo, año anterior del $\mathrm{Te}$ ador Fidalga hacia el Príncipe Guillermo; tar la total inverosimidebilitaba mucho los a Memoria, de los cuaolamente la parte que ico; no pudiéramos ex1 envolvernos en otras te nos apartarían de la

iguiente, el indagar por dejado en el extracto de la fabulosa Tule Ferrer la Frislandia; e la dirección del Es. Idonado á la boca falsa Estrecho del Labrador; os hechos positivos que Hudson y á las últimas ritánico al cual segura. mente no hubiera aquéllì ocultado todas sus noticias, sólo opone las noticias de Purchas y Seijas, las Gacetas inglesas de 1769 , el Diario de Sabios de I779, y una orden confusa del Conde de Monterey, el cual seguramente no tenía tales conocimientos, cuando por los $43^{\circ}$ de latitud uno de los buques del Gencral Vizcaino, creía alcanzar el Estrecio de Anian (I) por qué finalmente, puede suponerse que no hayan arredrado en invierno á nuestro navegaute los peli. gros y trabajos que en verano hicielon vetroceder á los navegantes ingleses, de los cuales hay memoria.

Sin embargo, áun sin entrometernos en iste pormenor de inconvenientes, y no apartánd -nos de las costas del mar Pacífico, en balde nos es. forzaríamos á suponer, que $\delta$ el paralelo de $60^{\circ}$ sea el que determine la posición de la boca Sur, ó haya un paraje en aquellas inmediaciones en el cual quede al Norte ioda la tierra alta y mon. tuosa y al Sur la que describe como apacibie y suavemente alomada. Ln primer lugar, es el extremo Norte del Estrecho el que debe suponerse en $\operatorname{los} 60^{\circ}$, y el extremo Sur, por consiguiente, debe quedar in $59^{\circ} 5^{\prime}$, lo cual confirman, no sólo las descripciones que da Ferrer del hermoso puerto del Sur, si también la narración del viaje, haciéndole llegar con rumbo del Sueste por mas de roo leguas á la latitud de $55^{n}$.

Ya entonces sería el Monte Buen Tiempo el que debía. quedá á la derecira ó al Norte del paso en lugar del Monte San Elías que supone el Sr. de Baucke; y á la verdad, sería esto algo más favorable á los defensores del viaje, porque las tierras, desde aquel monte son realmente algo más bajas, si bien se conserven nevadas aún en Agosto, y el Monte de la Cruz y el mismo Monte Edgecumbre no sean de ulià altura des. preciable.

Pero lo que envuelve las mayores nulidades geográficas, es sin duda alguna la dirección Este-Oesia que supone Ferrer á la costa del Norte; $i c i$ to es que no atraviesa el Monte San Elías, las inmediaciones del Sabo Suckling y de la entrada del Príncipe Guillermo, aún concediendo un error favorable de medio grado á las observaciones del Piloto Martínez? Es preciso confesar que si áun adoptada la veracidad de Memoria (2) "se consiguiese evidenciar la verdad de otros muchos herhos, los cuales, como hasta ahora no se han comprendido se han mirado como fabulosos 6 como disputables", siempre quełaría para los geógrafos una igual ó una mayor dificultad, debiendo mirar con aquel carácter todos los viajes modernos desde el $\mathbf{1} 774$.

(1) Venegas, tomo 111 , pág. I 16.

(2) Son palabras de Mr. de Bauche al fin de su Memoria.
Era bien favorable para conservar tal cual esperanza sobre el problema propuesto, la casua ex: : sión del Capitán Cook al tiemno de rccono cer la bahía de Bering que entre los extremos de las dos cordilleras que se dirigían al Monte Buen Tiempo y al de San Elías, veía un claro de al. gunas leguas al cual no podía acertar si se pos. tergaría tierra baja 6 agua (I); pero tuvimos la felicidad de disipar también esta duda y ver que el solo hielo había causado aquella ilusión es tando tenazmente unida toda la cordillera.

Pero aunque se hayan manifestado las razones que convencen para no admitir como legítimo el viaje de Ferrer Maldonado. faltr aún para la evidencia un dato esencial, y es el de hallai el origen de una Memoris, en la cual se advierte un estilo adecuado al tiempo en el clial se escribió, un desinterés que no hace enspechúso al autor, la cita del viaje de Quirós que acababa de rendirse en I606, por último, un sello bastantemente auténtico, que es el de hallarie en un archivo bien acreditadu. No es fácil dar una solu. ción juiciosa á estas dudas ni nosotros $10 \mathrm{em}$. prenderemos directamente, contentándonos por consiguiente con indicar sólo algunos puntos autorizados de la Historia Navional, los cuales pueden haber dado lugar, ó á este proyecto ó á otros semejantes, que eî actual prolijo exameı de los archivos manifestará seguramente (2).

Que por los años de 1524 arduviese ya muy válida en España la noticia del Paso del Noroeste, ó á lo ménos, que se hubiesè dado una no ex. traña interpretación á las expediciones misteriosis del Caboto, nadie put.te ponerlo en duda cuando atienda á la carta escríz en aquella fe. cha por el célebre Herná. Cortés al Señor Cárlos V. Aquel esclarecido caudillo no sélo no se había descuidado en esta parte guiado como el mismo dice udel contínuo cuidado y ocupación nen pensàr todas las maneras que se puedan te"ner para poner en ejecución y efectuar el deseo "que al Real servicio de S. M. tenía, sino que con "aquel cabal juicio que desplegó constantemen"te hasta el último término de su vída", había dispuesto dos expediciones para el mismo intento,

(I) Vol. 1I, del tercer viaje: The chain of moun. tains is interrvpted by aplain of a fejw leaques extent, beyond Wich the sight was vnlimited, so that theve is either a level coantry, or water be hind it.s

(2) Al mismo tiempo que se uscribla esta Memo(2) Al mismo tiempo que se scribia esta Memo-
ria en Manila con las solas noticias adquiridas en ria en Manila con las solas noticias adquiridas en
América, el Capitán de fragata D. Martín Fernández Navarrete desenvolvía en España el carácter y circunstancias de Lorenzo Ferrer Maldonado y aun de Fernando de los Rios: hallóse bien claro lo de Maldonado en ul libro $\mathrm{V}$ de los Comentarios de la einbajada que de parte del Rey de Esparía D. Felipe III hizo D. Garcfa de Silva y Figueroa al Rey Xaabas hizo D. Garcha de Silva y Figueroa al Rey Xaabas de Persta, el ano de $1618 \ldots .$. . Publicado por el señor D. Eugenio la Historia del Gran Tamorlan de Kersia y da la Crónica de D. Pedro Nino, en la imprenta de Sancha, afio de 1782 . 
I na que costease la Florida en el mar tel Norte y la otra que en el Pacífico ó hallase paso para el Este al Norte de la California, 6 precisada por la costa á navegar al Oeste encontrasc finalmente las Filipinas (I). Hé aquí su plan digno de emular al que ha formado el Gobierno británico en este siglo feliz para la navegación. Porque si le hay (son sus palabras), "no se pue"de esconder á éstos por la mar de! Sur, y á los "otros por la mar del Norte, porque éstos del "Sur llevarán la costa hasta hallar el dicho Esn trecho, ó juntar la tierra con la que descubrió "Nagallanes, y los otros del Norte, como he di"cho, hasta juntarla con los Bacallaos. Asi, por "una y por otra parte, no se deje de saber el se"creto. Porque (habla de la tierra de los Baca"llaos) se tiene cierto, que en aquella costa hay "Estrecho que pasa á la mar del Sur, y si se ha"llase, segúa cierta figura que yo tengo del pa"raje á donde está aquel archipiélago que des"cubrió Magallanes por mandado de V. M., pare"ce que saldría muy cerca de allí, y siendo Dios "Nuestro Señor servido que por allí se topase el "dicho Estrecho, sería ia navegación desde la es" pecería para esos reinos de V. M., muy buena y "muy breve, $y$ tanto, que sería las dos tercias par"tes ménos que por donde ahora se navega, y sin "ringún riesgo ni peligro de los navios que fueu sen y viniesen, porque irían siempre y vendrían "por reinos y señorios de V. M., que cada vez que " alguna necesidad tuviesen, se podrían reparar "sin ningún peligro, en cualquiera parte que qui"siesen tomar puerto de V. M."

No merece ménos fé la aserción de que antes de terminar' el siglo XVI ya estas mismas voces liabían tomado preciso incremento, tanto más natural entre nosotros, cuanto que suponíamos en los ingleses igual ansia de ocultar sus descubrimientos: y ya empezado el terrible período de la decadencia de la Monarquía, no faltaban proyectistas que aspirasen á devorarla. Por los años de I6I5, refiriendo el Padre F. Juan de Torquemada la jornada de Sebastián Vizcaino á la costa de Califurnia, y satisfaciendo á lo que había movido al Señor Felipe III para servirse mandar la ejecución de dicha jornada, añ de lo siguiente:

"Supo también S. M. cómo otros Vireyes "habialı intentado este mismo descubrimiento " por mandato de su padre, y cómo no habían sa"lido con él (como en adelante se dirá), halló

(1) Véanse las cartas do Cortés, páginas $3^{82}$ y 83 . En esta segunda navegación, discrepamos como so ve, de la interpretación del Excm's. Lorenzana, el cual cree que cl Estrecho buscado por Cortés en el mar del Sur estaba hacia Panamá, más bien que en paralelos más septentrionales de la Nueva Espana Todo depende de la intención de Cortess do hablar a la sazón, o de las Filipinas o Molucas, o mis bien de la Tierra del Fuego: cl Excmo. Loreizana cren de la Tierra del Fuego: el Excmo Lorenzana cree lo segundo; nosotros nos arrimamos a lo primern. "también S. M., entre otros papeles, una infor* mación que ciertos extranjeros habían dado á "su padre, en que se dicen algunas cosas nota. - bles que ellos en aquella tierra habían visto. "llevados allí con fuerza de tiempos en un navío "desde la costa de los Bacallaos, que es en Te "rranova, dando en ella razón de haber pasado "de la mar del Norte á la del Sur por el Estrecho "de Anian, que es más adelante del Cabo Men. "docino, y que habían visto una populosa y rica " ciudad bien fortalecida y cercada, y muy rica "de gente política y cortesana y bien tratada y " ctras cosas dignas de saberse y ser vistas.

"Confirmábase, por otra parte, esta noticia "ó sospecha por ei mismo Padre Torquemada, "cuando continuando esta narración y descri"biendo el viaje de Martín de Aguilar, volvía á " por vedar que ese sería probablemente el río que

ińa á dar á una gran ciudad que descubrieron "los holandeses viniendo derrotados, y que aquel " era el Estrecho de Anian, por donde el navío "que le descubrió atravesó y pasó de la mar del "Norte á la del Sur, y que sin falta era en esa " comarca ó recindad la dicha ciudad que sf. "llamó de Quivira, y de este sitio parece que es "de quien trata la relación que S. M. leyó, por lo "cual se movió y aficionó á mandar que con mu. "cho cuidado se hiciese este descubrimiento y se "le diera aviso cierto de todo."

Ya, pues, no debe dudarse que fueron muchos los proyectos presentados desde el tiempo de Fe. lipe II á la corte de España, que todos ó á lo ménos la mayor parte estribaban sobre la navegación de un buque holandés, y que nuestro $\mathrm{Fe}$. rrer Maldonado adolece de estas mismas ideas.

En tal caso, ¿por qué será absurdo el suponer una de estas tres cosas: 6 que Maldonado, movido de un justo celo nacional, en un tiempo en el cual los descubrimientos eran el objeto de los afanes europeos, intentase apropiarse lo que otros habían hecho, 6 que pensase en otras empresas á costa del Erario, diciendo no haber hallado la boca misteriosa, coino ya se había ocultado en su presencia al Piloto Martínez; 6 finalmente, que fuese éste un solo borrador, que los amigos le aconsejasen después á sepultar más bien que á producirle delante del Rey?

¿Pero á qué no's ocuparemos tanto en sta es. pecie de indagaci snes; 6 creeremos que pueda ser verídica la relación de Ferrer Malcionado. porque no se hallan rastros positivos de su origen, cuando á nuestros mismos ojos, en una época que llamamos filosófica é ilustrada no sólo se escriben, sino se publican relacionss parecidas á la de $\mathrm{Fe}$. srer Maldonado y del Coronel Ríos? Han revivido ya los viajes del Almirante Fonte y de Fuca, como si la esperanza de hallar un paso en los 48 y $55^{\circ}$ hubiese de combinarse precisamente col un absurdo, $y$ seguramente si cesasen en este 
momento las pesquisas, harto costosas para la resolución de esta cuestión hidrográfic̨, ¿cuál no sería la confusión de un lector del siglo XXI en leer antes los apéndices del docto Padre Vene. ras, y la introducción del tercer viaje del Capitán Cook y luégo las retlexiones del Capitán Meares; cuáles no serían, finalmente, sus descarríos si creyese verídico el viaje alli citado del bergantín americano Lady Washington desechando, por consiguiente, los reconocimientos de los Oficiales españoles Quimper, Elisa, Ga liano, Valdés y Caamaño, y del Capitán inglés Vancoaver, y entregándose para la diferencia de longitudes á un diario, en donde se nombra un relój marino, se citan á cada paso las distancias lunares, é intervienen en su publicación las personas más ilustradas de la nación británica?

Por ventura el Capitan Dixon, picado por diferentes acusaciones que le resultaban del mismo diario, emprendió responderle con aquellos colores que le suministraban su encono y el libro contra el cual se explayaba (r). Po: ventura las juiciosas reflexiones de la instrucción dada al Capitán Cook en su tercer viaje, podrán siempre poner la cuestión er unos términos claros y se. guros sin que alcancen á variarla, ó la existencia de unas islas en lugar de costa seguida ó la internación de algunos buques al Este; pero ello es que semejantes razonamientos pocóa poco nos habían condıcido á considerar el continente septentrional de la América como dividido en diferentes trozos que diesen otras tantas comunicaciones de un mar á otro, y á llamar, por consiguierie, bien desgraciada y tím , la navegación actual; pues no llevando otro : tento, no hahín podido, sin embargo, encontrar lo que $n$ tros a. iguos habían encontrado sin buscarlo, $\sin$ los auxilios, ó de los demás viajes 6 de nuestra exactitud en las determinaciones geográficas.

Aquí concluiría esta disertación bastantemente difusa, si el ansia general en Europa para descubrir el paso del Noroeste, habiendo por lo común hecho perder de vista la verdadera utilidad de semejante descubrimiento, no precisase á mirar este examen como bien importante para los intereses nacionales. Nuestros armamentos son con exceso costosos, nuestras miradas hacia lo que pasa en todo el continente de la América, aún tímidas, silenciosas y mal interpretadas; finalmerte, es aún fatal nuestra disposición para oir cualesquiera proyectos, como parezcan aspi-

(x) Es frase bien insultante la que usa al principio de sn carta responsiva y dirigida al mismo Capitán Meares. El descifrar una sola mitad de los absurdos que Vm ha dicho llenaria un tomo tan volumino que Vm, ha dicho, llenaria un tomo tan voluminohal fiour absurditei would fill á volume aslange as yours.n rar á la comr':_a restauración de la antigua opu. lencia y poderio de la Monarquía.

La cuestión del paso del Noroeste fué desde el principio conducida por los geógrafos á una latitud tan alta, que desde luego excluía toda posibilidad de ser útil, y seguramente hubiera corrido la misma suerte que ha corrido la navegación del Estrecho de Magallanes, comparada á la de altura por el Cabo de Hornos, si la protección decidida de Mr. Dobbs 6 más bien su encaprichamiento acaudalado no hubiese (según cos. tumbre) cambiado el semblante de la proposición. La cuestión primitiva era si había en el hemisferio del Norte un pasaje útil por mar para la comunice ción de la Europa con el Asia; se les sustituyó luégo la otra de si existía una comunicación cualquiera entre el mar Pacífico y el At. lántico en el hemisferio del Norte.

Esta confusión de ideas era á la verdad re. prensible al tiempo de Mr. Lobbs, pero sin duda lo es ahora mucho más, cuando se conoce la na. vegación del globo en un grado que no es fácil sobrepujar. El objeto de la navegación es, sin duda alguna, el comercio, y así en sus especu. laciones jamás deben perderse de vista la brevedad, la seguridad, la comodidad y la economía del viaje. Cuáles son, pues, las vent : jas en estas nuevas derrotas que puedan compararse á las que disfrutan los europeos navegando á la Chi na pur el Cabo de Buena Esperanza? Será preciso contar contínuamente con la felicidad del Almirante de Fonte, el cual, no sólo navegó las 866 leguas desde el puerto Abel hasta el rín de los Reyes en veinte días ( $\mathrm{I}$ ), sino que las 260 eran por los canales que culebrean entre las islas del Archipiélago de San Lázaro, en el cual iban sus chalupas ó botes una milla por delante para sonde la profindiadi del agua y para reconocer los bajos, e ollos y rocas ciegas

$\mathrm{Ni}$ magine alguno oue la utilidad de este paso, á lo uénos para s extranjeros, no esté ceñido sólo á la navegación de China, sino que pueda comprenderse en aque as rentajas una comunicación más breve con el mar Pacítico. hacia donde en los siglos venideros la navegación europea sea tan numerosa y rica corrs es ahora mezquina, inútil y aventurada. Los escarmientos actuales de los ir eses en la bahia Botánica, y los reconocir tos bien repetidos por todas las naciones maritimas en el crecido nú-

(1) Se incluyen en estos días como completos, el de la salida y el de la llegada: la relación dice desde 26 de Mayo hasta 14 de Junio.

(2) Se omiten por demasiado chocantes, las 86 leguas andadas el día II de $\Lambda$ gosto, pasadas las cataratas fel río de Parmentieres y la facilidad con la cual el Capitán Bernarcio habia llegado has'. el grado 80 de latitud, reconociendo hasta las lagunas, hallando quicn se encargase inmediatamente de hallando quién se encargase inmediatam
correspondencia con el Almirante. 
mero de las Islas del Mar Pacífico son pruebas bien seguras que variará toda la constitución po. lítica del globo antes que los habitadores 6 los productos de aquéllas puedan llamas á sí los menores esfuerzos de los europcos.

Por lo que toca al proyecto del Sr. de la Bastide, presentado al difunto señor Conde de Fernán Núnez en París, con objeto de detallar las operaciones oportunas para el logro de esta comunicación en el Lago de Nicaragua; debiendo luégo resarcir todos los gastos con los impuestos correspondientes á la navegación extranjera, se conoce desde luego que no están calculados los límites de esta navegación, lo cual bastaría para tachar aquella Memoria de importuna áun cuando nos desentendiésemos de los muchos errores que contiene así mecánicos como hidrográficos y políticos.

Un viaje regular á la China clesde los puertos de Europa, puede considerarse de cinco meses siempre que lo haya de verificar una embarcación buena y bien gobernada, es mucho menor el plazo que necesita para las costas de Coromandel y Malabar. Todas las estaciones lo permiten, el temple no es incómodo, las escalas al mismo tiempo sanas, agradables y útiles para los intereses mercantiles, los vientos periódicos y bien conocidos; y la navegación tan económica y tranquila que apenas puede considerarse alguna des. mejora en el velamen. ¿Cómo podríamos, pues, referir estas circunstancias al único paraje en el cual quedan aún tijadas las miradas inflexibles de los geógrafos, esto es, entre los $60^{\circ}$ y $80^{\circ}$ de latitud septentrional, en donde un mar eterna. mente helado 6 un conjunto inaccesible y bien entendido de islas horribles y desiertas, no ofre. cen al navegante sino riesgos $y$ peligros?

La cuestión que en el dia vierten con tanto ardor los geógrafos, puede reducirse por consiguiente á estotra proposición desnuda ya de aquellos velos agradables con que la han coloreado hasta aquí á los ojos del público: ¿cuál será la nación cuyos navegantes, por un exceso de felicidad más bien que de habilidad, logren propasar al Norte los términos de la navega. ción fijados por los Capitanes Cook y Clerke y navegar, si hay paso, alrededor del extremo de la América hasta entrar en los mares de Europa?

A la vista de esta proposición desmayarán tal vez los clamores de los geógrafos sobre semejante hallazgo, cesarán sus insultos científicos hacia la navegación moderna, y el Monarca amante de la humanidad, y el navegante desdeña $:$ de servir para la duración de un proyecto siempre inútil, dirigirán unánimes todo su conato, ó bien al perfecto reconocimiento de los pocos puntos útiles para ia navegación, que todavia no se han examinado, 6 al próspero beneficio y fomento de los dulces la.zos de la sociedad que suministra el comercio (I).

\section{CAPITULO III}

Acaecimientos en cl Archipiélago de Nutka durante la demora de las corbctas en él.-Navegación sucesiva hasta Montercy.y cstada en aquel puerto.-Ultimos reconocimientos al andar de las costas de California y Nueva España.-Escala de la Descubierta en San Blas.-Rennión de las corbetas en Acapulco.Acaccimientos en aquel puerto y aprestos para las campañas $y$ operacioncs siguientes.

Era á la sazón Comandante de la fragata Concepción el Alférez de navío D. Manuel Saavedra, por haberse encargado del paquebot San Carlos el Teniente de navío D. Francisco Elisa con el fin de continuar con la goleta Saturnina los reconocimientos de la costa al Norte y al Sur del puerto de Nutka: estaba al cargo de aquel Oficial todo el establecimiento, compiendidas las baterías; y como se hubiese embarcado, en clase de auxiliar la compañía suelta de voluntarios de $\mathrm{Ca}$ taluña, hallábase allí al mismo tiempo su Capitán D. Pedro Alberni, retirados ya en clase de enfermos el Teniente y Alférez que le habian acompañado.

Todos los enfermos, la mayor parte escorbú. ticos y en muy mal estado, se habían restituído á San Blas en la fragata Princesa á las órdenes del Teniente de navío D. Jacinto Caamaño. El es. tablecimiento había recibido los auxilios necesarios con el paquebot San Carlos y la fragata Arınzazú, y el regreso de esta última desde el puerto de Monterey á donde se había despacha. do en busca de carnes frescas, debía con un socorro tan importante asegurar para el próximo invierno el bienestar de la marinería y tropa existentes entonces en el presidio. Veíanse en el fondo del puerto diferentes barracas construídas con tablazón; vigilaban, para su custodia y buen orden, el mismo Alberni con la tropa acuartelada en tierra; la fábrica del pan fresco, que se suministraba diariamente á todos, el cultivo de las huertas, en las cuales la Naturaleza ya prodigaba sus dones, el cuidado de los víveres y pertrechos contra un enjambre hartu destructivo de ratas, las herrerias, la misma continuación 6 incremento de las casas con el corte necesario de maderas, eran otras tantas ocupaciones en las cuale: brillaban con igual tesón la subordinación y const.uncia de los súbditos y el buen ejemplo y acierto de los Oficiales Comandantes Elisa,

(I) Sien to pública muy luégo (como debe esperarse) la Memoria escrita sobre esta cuestión por el ya citado D Martín Navarrete, el lector hallará todas las demás noticias relativas al decantado paso del Noroeste, qus aqul se han omitido. 
Saavedra y Alberni, influyendo últimamente en la conservación de la salud y en la buena har. monía que á la sazón reinaba entre todos.

No diferimos un momento en establecer el observatorio en sitio oportuno y no distante de las barracas. Examinóse el paraje de la aguada, y D. Felipe Bausá emprendió sus marcaciones desde el eastillo, ya que la tarde placentera y serena proporcionaba la vista de muchos objetos distantes, entre los cuales sobresalía muy mucho un pico interno bien notable para el reconocimiento del puertò. Continuaron luégo estas operaciones, mıdida una base para la exacta determinación del puerto, multiplicadas las marcaciones en algunas de las islas del Archipiélago interno y sujetado _.' todo á otros tantos azimutes para que no influyese en la exactitud de nuestros tra bajos la mucha variedad de las declinaciones magnéticas que había advertido el Capitán Cook. Ultimamente se emprendió el reemplazo de la aguada con las lanchas $y$ bombos, los cuales, como debiesen separarse una legua, aprovechar de las mareas y no enturbiar la buena harmonía con los naturales, se pusieron siempre al cargo de un Oficial acompañado de dos soldados armados.

Varias causas (cuyo origen es extraño para esta narración) influían cntonces á que hubiese de parte de los naturales una conducta tímida y precavida con el establecimiento nuestro. Eran pocos los pescadores que veiamos concurrir á las corbetas, y por cuanto deseásemos conocer los diferentes Caciques 6 Taquis, á los tres días de nuestra llegada aún no había parecido alguno, sin embargo que varios dones á las canoas y no pocas promesas á los que nos visitasen, debían ser incentivos harto fuertes para atraerlos.

Finalmente, en la mañana del $\mathrm{I}_{4}$, el Cacique secundario Tlupananú, venció esta barrera, con fiado á la verdad en la amistad constante que había reinado entre él y los nuestros; $y$ sin em. bargo, tímido y casi asombrádo á la vista de tantas fuerzas unidas, se le regalo por nuestra parte abundantemente, se le prometieron dones aún mucho mayores, si nos visitase de nt con su canoa grande, bien esquifada, y dispucs.a á verificar varias evoluciones así de guerra como de alegría. Y con estos incentivos, no tardaron en seguirle varios otros, 6 subalternos 6 parien. tes de Macuina, Jefe principal de toda la co marca. Nos ponderaban á veces, 6 la extensión de sus dominios, 6 la solidez de su autoridad; otras veces, sin embargo, con diferentes pretextos y disculpas daban á entender que aquel Jefe temía visitarnos, confirmándose particularmente este temor en la manana del 15 , cuando dirigidos D. Cayetano Valdés y D. Felipe Bausá á la ranchería misna de Macuina (pues que recorrían aquellas costas con objetos geodésicos), encontraron desamparadas las casas y apenas consiguieron que se les aproximase uno ú otro de los muchus que estaban escondidos en los bosques contigius.

Esto, no obstante, luégo que se concluyó la aguada pareció un deber esencial de nuestro destino el reconocer los eanales internos del $A_{-}$chipiélago en el cual nos hallábamos; pudiera aquel reconocimiento ser útil á la sazón para eliminar la cuestión de dominios sobre aquellos parajes, agitada con tanto vigor en Europa; nos dejaría lugar para estudiar las costumbres de los habitantes con algún despacio, ya que los diferentes viajeros que nos habían precedido habían discrepado tanto en describirlas; finalment te, nos sería fácil el atender á las diferentes urgencias del establecimiento para que no care. ciese de cosa alguna en el invierno próximo áun cuando no regresase la fragata de Monterey. Destináronse, pues, en la mañana del r 8 entram bas lanchas para el reconocimiento proyectado. Las mandaban los Tenientes de navío Don José Espinosa y D. Ciriaco Cevallos, y estaban provistas de los instrumentos y demás útiles que pudiesen conducir á su mayor seguridad ó aprovechamiento. Se perdieron muy luego de vista, siguiendo rumbos que les guiasen hacia la ca. leta, en donde había fondeado el Capitán Cook. Nosotros al mismo tiempo seguimos con icsón los objetos prefijados, $y$ favoreciéndonos extremadamente la estación y los tiempos claros y bonancibles, todos ellos pudieron adelantarse con un paso más bien acelerado.

En el observatorio, además del examen de la marcha de los relojes marinos $y$ de las experiencias del péndulo simple, constante para la gra. vedad, se repitieron por dos días las observaciones de las distancias lunares, ya que no era posible en la actual posición de los astros el adop. tar otro método para la dejucción de la longitud: 400 series manifestaron en aquella ocasión la longitud de $I I 9^{\circ} 5^{\prime}$ al Occidente de Cádiz, menor en 28' de la que había determina. do el Capitán Cook. Para la diferencia de meridianos con el puerto Mulgrave, se adoptó la que indicaban ei cronómetro 7I y el reloj ro5, y era de $13^{\circ} 10^{\prime}$ al Este, latitud observada por diferen. tes estrellas al Norte $y$ al Sur del zénit $49^{\circ}$ $26^{\prime} 30^{\prime \prime}$.

Las atenciones nuestras en cuanto al bien. estar del establecimiento, debieron ser al mismo tiempo bien varias $e$ importantes. Cedieronsele una parte considerabie de nuestros víveres, ves. tuario, tabaco, medícamentos y jarcias; se compusieron las armas y los utensilios de labranza y se les enseñó con mucha utilidad el método de hacer la cerveza con la hoja del pino, que llamaremos con los franceses sapineta. A la verdad, no era ésta sino una corta retribución de la genero- 
sidad, que la tropa y marinería del destacamento desplegaron hacia nuestras gentes franqueándoles cuantas verduras pudiesen sumisistrar las huertas; $y$ brindándos á cuantas fatigas les ocurrían diariamente, si podían llamarse tales : las diferentes atenciones del servicio, ó un córte metódico de leña, en el cual alternaban para su mejor conservaciór, la tropa y marinería de ambas corbetas. En 'n paraje tan abundante de buenas arboladuras, hubièramos sido por otra parte reprensibles, si nu repusiésemos las piezas rotas en el viaje anterior, $1 c$ cual suininist $\mathbf{c}$ una nueva ocupación útil á una parte de la marinería y á nuestros carpinteros. Así corrías rápidamente los días, y además de conservarse et. buen estado la robustez de torios, veíamos que ‘o eran absolutamente infruciuosos los pasos de lai: corbetas sobre aquellas costas, áun después de ha. berse frustrado el cbjeto primitivo del descubrimiento de un paso lel mar Pacífico al Atlántico.

Nuestro roce pasífico con los naturales había á la sazb́n echado raices mucho más sólides, si bien á costa de varios regalos que pedían indistintamente los Jefes y lcs súbditos, aremés de una contínua contribución de galleta. Ya no huían las canoas á la vista de nuestras embarca. ciones menores, nos rodeaban diariamente los pescadores con muchas y excelentes calidades de pescados; algunos naturales hacían noche al lado del observatorio; eran pocos los Jefes que no nos hubiesen visitado, $y$ habíamos merecido igual atención á Macuina, si bien manifestase en su rostro muclia desconfianza y no permitiese subir á bordo á tres mujeres suyas que le acompañaban; no blvidé tampoco en aquella ocasión su interés propio con la venta de una niña esclava que traía consigo. Los Oficiales de la fraga Concepción solían adquirirlas 6 con dos fusiles 6 con una ó dos planchas de cobre. Esta especie de cam. bios aemasiado ligada con las ideas de religion, de moral y de política para poderse discutir en pocos renglones, era á la sazón bastantemente introducida en nuestro establecimiento y se contaban unos 22 niños de ambos sexos, que, 6 se habían transportado á San Blas, 6 estaban próximos a transportarse, confiados para su educación y manutención venidera á uno ú otro individuo de los buques de S. M., siempre elegido entre los que agregasen á una buena conducta el hallarse casados en el Departamento.

Los regalos hechos á Macuina y á los que le acompañaban 6 le habían precedido, atrajeron aún más en los días siguientes la concurrencia á bordo de los naturales; entre ellos se distinguió siempre el jefe Tlupananuc, el cral, en la tarde del 20 nos presentó cartas y noticias de los Tenientes de navío iss. inosa y Cevallos que le habian entregado en la no he anterior al tiempo de dirigirse á los Canales a ll Tasis.
En la mañana del 23 , bien temprano, vino finalmente, á visitarnos con la canoa deseada; la conducían unos 30 remeros, cuyo canto, evoluciones y destreza nos sorprendieron en las primeras vueltas que dió alrededor de las corbetas; siguiéronse varios bailes ejecutados por los mis. mos remeros antes á bordo de la corbeta y luégo en la playa inmediata al observatorio. Tanta eficacia de parte de aquel Jefe no podía ménos de exigir de la nuestra unos regalos correspondien. tes entre los cuales se comprendió también la vela de un bote, que deseaba con las mayores ansias y destinaba para sus canoas.

El medio día del 25 regresaron ambas lanchas con 's mayor felicidad; venían de mar en fuera, pues que sio reconocimientos las habían conducido por un canal internu hasta el puerto de lf. Esperanza, paraje en cuyas inmediaciones est.uvieron las corbetas en la mañanita del i2, $v$ eran frutos de una tan útil excursión, no sblo si olano exacto de aquel puerto, si también un conincimiento prolijo de todos los canales internos, per manera que ni quedase ya duda de ser una isla el terreno disputado hasta entonces como parte del continente, ni dejasen de adquirirse cuantas nociones eran necesarias $p$ ira juzgar con rectitud de las circunstancias $y$ de la utilidad de aquel puerto.

Es verdadtramente singulir el terreno del cual se compone el Archipielago. IIasta inco canales 6 brazos no más anchos por lo común de un tercio de milla, internan por diferentes rumbos, terminando en unas ensenadas pequeñas, elegidas por los naturales para otras tantas poblacionnes 0 rancherías. Los dos canales del Es. nordeste y Este, cuyos principios había reconocido el Capitán Cook, terminan en los pueblos de Tlupananuc, y el canal que conduce al puerto de la Esperanza, se ramifica al Norte en otros tres, de los cuales el primero 6 más oriental va á parar al Tasis, residencia del soberano Ma. cuina; el segundo se dirige al pueblo del jefe subalterno Natzape, y el tercero, aunque no de menor extensión, parece, sin embargo, tener desiertas ambas orillas y la ensenada del fondo. Por lo común en todos los canales no se alcanza el fondo con 60 brazas áun en la inmediación de las orillas; los árboles y las piedras suplen aquel inconveniente para dar espías ina embarcación que quisiese internar en ellos, ó bien navegando desde el puerto de la Esperanza á Nutka, ó al contrario.

Según referían los Oficiales Comandantes, fueronal principio recibidos en las diferentes rancherías, con el semblante más desapacible y turbulento. En la de Tlupananuc (estando ausente este jefe).vieron retirarse las mujeres y los niños al paso que se les aproximabar. varios hembres armados con bastones, y sordos así á las protestas

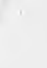

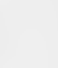

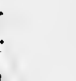

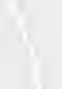
. 
prano, vino deseada; la into, evolu. en las prias corbetas; por los mis. beta y luégo o. Tanta efi. a ménos de rrespondien. también la las mayores

nbas lanchas tar en fuera, abían condupuerto de $\mathrm{l}$ aciones estulel i2, v' eran sólo i i plano 1 an coniciinternos, per ser una isla s como parte rirse cuantas gar con rectiutilidad de

terreno del Insotn inco por lo común or diferentes das pequeñas, ras tantas ponales del Es. iabía reconoan los pueblos iduce al puer. Norte en otros ás oriental va soberano $\mathrm{Ma}$ teblo del jefe aunque no de abargo, tener tda del fondo. no se alcanza amediación de $s$ suplen aquel a embarcación ien navegando a á Nutka, 6

Comandantes, diferentes ranapacible y turstando ausente res y los niños arios hembres álas protestas de paz, como á los regalos que les ofrecían. Fué aún micho mayor el número de gente armada que se les prisent ${ }^{\prime}$ en el Tasis 6 ranchería de Macuina, tomata además por los naturales la pre. caución de dispaı ẫ Úc antemano algunos fusilazos. La alarma se había diinindido por todas partes; las canoas abandonaban lat pesid, al momento que los apercibiesen. El mismo Ma. cuina, áun después que los dos Oficiales le manifestaron la mayor confianza, saltando solos en tierra y haciendo apartar las lanchas á alguna distancia de la orilla, no sólo los recibió con una mezcla de enfado, de frialdad y de temor, sino que quiso ostentar su poderío, manifestándoles un armero con quince fusiles, para cuya custo. dia estaba inmediato un natural descansando con la mayor formalidad sobre el arma.

Esta escena bastaba, sin duda, para ocupar toda la atención de nuestros Oficiales; pero debieron muy luego torcerla á otros espectáculos dignos de una mayor admiración; y eran antes la vista de algunas vidrieras puestas en la casa de Macuina, y luégo el rostro agradable de la mu. jer favorita de aquel jefe: era ésta una joven de veinte á veinticinco años, hermana de Natzape y en su agrado, color y facciones, capaz de sobresalir aun donde estén bicn determinadas las ideas de la hermosura.

En el entretanto, Macuina se había vuelto mucho más humano y afable, pues podía no du. dar de las intenciones pacíficas de nuestros Oficiales; los condujo á ver su tesoro de barras de cobre, los acompañó después en un corto paseo que dieron al frente de tas casas y en la visita que hicieron á Natzape, su suegro; finalmente, quiso tambien seguirlos hasta sus mismas lan. chas, en donde se le regaló como era debido, quedando desde aquel momento bien vindicausas nuestras intenciones pacíficas y al parecer entablada con nudos mucho más estrechos una amistad sólida y duradera.

No había incurrido Tlupananuc en esta des. confianza general. Aunque fuesen.las diez de la noche atracó á las lanchas al tiempo de volver de la pesca con una seguridad que manifestaba así la rectitud de sus intenciones como el conocimiento de las nuestras: brind6se á visitarnos en la mañanita siguiente, y se despidíb tan sólo cuando dirigiendose los nuestros hacia el Tasis, debib temer la indignación de Macuina, si le supusiese, 6 cómplice, 6 el autor de aquella navegación. Se despidí con varios pretextos, bien que prometiendo entregar muy luégo á la corbeta la carta y credenciales que le habían confiado.

Bien examinado por los Sres. Espinosa y Cevallos el número de habitantes que existían en los contornos, y formaban digámoslo así, la so. ciedad subordinaba á Macuina, le supusieron proximamente de 4.000 , constituídos por la ma- yor parte á vivir de una pesca no muy abundante, $y$ alternando su morada según aquella nece. sidad, en el verano hacia la orilla del mar, $y$ en el invierno hacia los canales internos. Agregaron ámbién á esos conocimientos el examen del suelo y de la vegetación, la colocación geodésica de varios montes internos, y finalmente, la visita de un cementerio en una isla desierta, todos da. tos que nos proporcionarán en los capítulos siguientes el dar una idea cabal de aquellos con. tornos.

Para este último intento fueron también con extremo felices para nosotros los dos días siguientes del 26 y 27 , pues concurriendo á bordo de ambas corbetas los dos herma os Natzape y Nanikiur, jóvenes de un talento, comprensión y afabilidad singulares, nos suministraron tales ideas, $\tan$ claras y $\tan$ extrañas sobre su religión, origen, leyes, costumbres, sistema gubernativo, comercio y geografía interna, que nos parecía una ilusión el comprendernos recíprocamente con tanta velocidad. E' rre los muchos Oficiales que como era natural, conociendo la importancia de esas ideas se cebaron con más ahinco á desentranarlas de la oscuridad en que estaban envueltas, merecerá siempre en nuestra memoria un lugar distinguido el Teniente de navío D. Antonio To. va, el cual, usando oportunamente de una sin. gular paciencia y agrado, de un mediano conocimiento del idioma y, sobre todo, de un método bien claro y ordenado de preguntas, nos guió con pasos rápidos á aquella serie importante de ideas fisiológicas, que procuraremos extencler con cla. ridad en los tomos siguientes.

En liv. mañana del 27 tuvimos tambien una nueva visita de Macuina, que habíamos solicitado por diferentes emisarios, insinuándole que deseábamos con ansia ratificar nuestra amistad con el, y atestiguarle con regalos de mucho valor cuánto 'os interesábamos en la solidez de una paz recíproca entre los suyos y los de nuestro establecimiento. La condu \& de las lanchas y el trato acorde de las corbetas ya no podían de. jar la menor duda sobre la rectitud de nuestras intenciones, tanto más que las afianzaban así el ningún empeño para la adquisición de las pieles, como la prontitud de la salida, luégo que nos habíamos proveído de agua y leña. Tantas razones, y mucho más la esperanza de un buen regalo), habían efectivamente obrado con mucha fuerza en el corazón de Macuina, y se leía aho. ra bien clara en su semblante esta transforma. ción deseada. Tomó algunas tazas de té á bordo de la Atrevida, costumbre que se hallaba bien introducida entre sus parientes y jefes subalternos; adorno la cabeza con una especie de tra de grana, en la cual se cosieron algunas estre. llitas de cristal; alegó las razunes de pesca y de su poca robustez, que no le habían permitido vi-
27 
") sitarnos con más frecuencia; tinalmente, encareci6 con colores bien vivos y nobles la actual situación suya, que precisándolc á vivir á alguna distancia del mar, le hacía carecer del alimento $y$ le tenía ahora tanto más débil y extenuado, cuanto mayores habian sido anteriormente sus fuerzas y su destreza, hasta el punto de atacar sólo una ballena para arponearla. Dos velas para canoa, cuatro cristales de ventana, una plancha de cobre, algunas varas de paño azul y pocas piezas de quincallería, fueron luégo los regalos que se le dieron en la Descubierta. Ratificó en aquella ocasión la cesión del terreno que habia hecho anteriormente para el actual establecimiento nacional; wos aseguro que liabria entre unos y otros una paz duradera; $y$ últimamente, se despidió manifestando liacia nosotros, con expresiones difíciles de equivocarse, tanto agradecimiento y amistad, cuantas habían sido al principio las muestras de su enojo y desconfianza.

A la sazón todos los instrumentos y efectos se habian recibido á bordo, y las tripulaciones de las lanchas habían logrado de un regular descanso y libertad; nos pareció, por consiguiente, que en la misma noche pudiéramos dar la vela con los primeros soplos del terral, y á este fin se dispusieron 6 recogieron las amarras para levarnos sobre el ancla.

Pero en esie consepto no estaban bien fundados nuestros razonamientos, los cuales, á la verdad, suponian en las cosbetas unas calidades demasiado aventajadas; pues que era preciso con tra la revesa de la marea montar de bolina las piedras inmediatas de la punta del puerto, cle las cuales no distábamos á pique del ancla sino dos cumplidos de corbeta. Dos veces la Descurier TA dí la vela, y dos veces cayó sobre las pie. dras, de las cuales, sin embargo, bastaban á pre caverle los solos botalores por el fondo con exce so acantilado; á la sazón refrescó mucho el te rral; fué inútil una espía que habíamos tendido afuera; $y$ las que dimos á la ATrevida para que nos sostuviese sobre su ancla, no sirvieron, sino para hacerla garrar hacia el mismo paraje.

Debimos, por consiguiente, desistir hacia la media noche de la idea de levarnos y disponer algunas espias para tomar una posición mejor, la cual se consiguió sin la menor avería hacia las dos de la mañana.

Nos franqueamos al otro día sobre espias, de modo que el terral ya nos fuese favorable, y así luégo que puesto el Sol se dejaron apercibir las primeras ventolinas del Nordeste, no diferimos en dar la vela y gobernar con todo aparejo á los rumbos, que con más brevedad nos franqueasen de la punta de los arrecifes.

No fue este objeto difícil mediante el viento del Norte, el cual continub fresquito en toda la noche. Al amanecer demoraban la punta San Es téban al Noite $52^{\circ}$ Este de la aguja distancia cinco á seis leguas la tierra más Este al Norte $87^{\circ}$ Este, $y$ la boca del puerto al Norte $15^{\circ}$ Este, cuya posición combinada con un tiempo suma. mente apacible y placentero, nos hacía árbitros de la navegación siguiente.

La costa que seguía al Sur del puerto de Nutka hasta unirse á la de California ya podía considerarse para la oportuna dirección de nuestras tareas bajo un semblante bien diferente al con que debíamos mirar las costas más septen. trionales. No ignorábamos, que en el año pasado los Oficiales Martínez y Quimner del Departamento de San Blas, habían costeauio hasta entrar en el Estrecho de Fuca; que actualmente se hallaba con el mismo objeto el Teniente de navío lilisa que no distaba, de alli sino muy poco el puerto de los Mártires, visitado en 1775 por el Comandante Cuadra; que D. Bruno Hezeta en el mismo año había continuado aquellos reconocimientos hasta el puerto de la Trinidad; $y$ que all podía luégo fijarse con seguridad el principio de las útiles tareas de Sebastián Vizcaino en el año de 1602 .

Con esas reflexiones ya nuestra derrota siguiente la cual debía conducirnos á la bahía de Monterey, pudo prefijarse para que fuese más segura y expedita, á una mayor distancia de la costa: sería fácil después el atracar y reconocer de cerca aquellos puntos que parceiesen los más importantes; $y$ entre ellos merecía seguramente un lugar no postrero la entrada de Hezeta, la cual si bien conforme en mucha parte con las señas del río y entrada de Martín de Aguilar, no dejaba sin embargo de suministrar nuevas combinaciones favorables á los defensores de ia comunicación de ambos mares.

Navegábamos en el entretanto á no mucha distancia de las islas que desde la Punta de San Esteban conducen hasta la entrada del Estrecho de Fuca. Vióse entre ellas antes á la vela y des pués fondeado al abrigo de las isletas más foranas una fragata mercante de los Estados Unido de la América, ocupada sin duda en el tráfico de las pieles de nutria para conducirlas á Cantón. Nosotros con un mediano andar propasamos muy luego aquellos parajes, $y$ alcanzamos en la noche inmediata las cercanías del Estrecho de Juan de Fuca. Las sondas, á una distancia de cinco leguas de la costa, indicaban el fondo de $5^{8}$ brazas piedra.

Nos hallábamos, pues, al amanecer del 3, delante de aquel Estrecho decantado, que en los tiempos pasados $y$ en los presentes había sido el objeto de muchas navegaciones apócrifas, las cuales, facilitando en esos paralelos la comunicación de los dos mares, deleitaban á lo ménos, cuando no convenciesen, las ansias del político y del comerciante. Debimos separarnos de ella, á 
ja distancia ste al Norte rte $15^{\circ}$ Este, empo suma. acía árbitros

ra derrota si. á la bahía de ue fuese más listancia de la ar y reconocer ciesen los más a seguramente de Hezeta, la parte con las n de Aguilar, nistrar nuevas efensores de la

á no mucha Punta de San a del Estrecho í la vela y des. etas más fora. Estados Unidos a en el tráfico ucirlas á Canindar propasay alcanzamos as del Estrecho na distancia de el fondo de $5^{8}$

necer del 3 , delo, que en los ates había sido apócrifas, las los la comunian á lo ménos, ias del político arnos de ella, set. 3 la verdad con algún rubor, viendo cuánto serían útiles unas pesquisas diligentes en aquel Archi. piélago inmenso; pero la estación y el plan de nuestro viaje asi nos lo dictaban, y por consiguiente los rumboc del Sur, muy luégo nos condujeron á paralelos más bajos.

En la navegación siguie"ste hasta el Cabo Mendocino ya los tiempos fueron tan apacibles y constantemente favorables, que nos recordasen más bien los climas placenteros de entre trópicos. Reconociamos frecuentemente la costa, cuando no lo hiciesen absolutamente imposible las circunstancias. Las sondas á una distancia de cua tro 6 cinco leguas alternaban desde las $40 \therefore$ las 60 brazas; veiamos en toino solazarse tranquila. mente las ballenas, los lobos marinos $y$ las nutrias; eran más frecuentes las aves; y las costas presentaban siempre un semblante frondoso $y$ alomado.

Delante de los Cabos Perpétua y Flattery del Capitán Cook, debíamos admirar de nuevo la exactitud de las descripciones de aquel navegante. No se equivocaba, por cierto, cuando contra el dictamen de los demás creía ser barrancas, las que tenian el semblante de ser pedazos de hielo. La costa efectivamente es toda abarran. cada á la orilla, ó más bien llena de manchones hlancos de arena, siendo luégo interiorm snte de regular altura, algo desigual, cubierta de arboleda y con varios cerritos que encadenándose terminan en otros montes más altos hacia el Norte.

Siguiéronse luégo reconociendo el Cabo Di. ligencia del Comandante D. Bruno Hezeta, el Cabo Blanco de Martín de Aguilar, las inmedia. ciones del Puerto de la Trinidad; y finalmente, en la mañana del 6 estuvimos á la vista del Cabo Mendocino. Este Cabo debe considerarse como el verdadero término de los reconocimientos de Sebastián Vizcaino; pues á pesar que la fragata destinada en su conserva alcanzase el Cabo Blanco y boca del río de Martín de Aguilar, fué esta navegación hecha con demasiados riesgos y precipitación, para que pudiese describirse la costa intermedia con la misma escrupulosidad, exactitud y primor que había empleado aquel Almirante hasta el dicho Cabo.

Ya nuestra navegación hasta la Punta Reyes, en las inmediaciones del puerto de San Francisco, debió por naturaleza ser bastantemente ace- lerada. Corren allí los vientos constantes del Noroeste; las aguas toman por la misma razón una dirección permanente al Sur; son las costas acantiladas, $y$ la sonda extendida hasta unas cinco leguas mar en fuera, pero rara vez se disipa la neblina $y$ esto hace que haya un peligro verda. dero para' el navegante cuando intenta fondear en el puerto de San Francisco 6 en el de Monterey. Por lo que toca á las inmediaciones del primero, fuimos bastantemente felices, logrando después de algunas horas de pairo ó bordos cortos, avistar la Punta Reyes, y áun situarla por medio de algunas observaciones en buena la. titud y longitud, pero fuimos al contrario rodeados de muchos riesgos, antes navegando desde el Sur del Puerto de San Francisco á la P'unta de Año Nuevo, y después desde ésta al fondea. dero de Monterey: equivocáronse en el segundo tránsito las situaciones respectivas, al tiempo que refrescaba mucho el viento; oianse confusos los cañonazos de correspondencia del presidio, $y$ la neblina se hacía aún más espesa; orzamos al Este ya propasada la Punta de Pinos, y el hallar. nos repentinamente sobre una costa llena de arre. cifes, cuando aún ignorábamos nuestra situa. ción verdadera, nos dictó como el partido más prudente el de dar fondo á un ancla en 28 bra. zas arena y conchuela.

Esta posición de ningún modo podia pare. cernos favorable, y desde luego hubiéramos dado nuevamente la vela, si el viento, la mar gruesa, la oscuridad y la demasiada inmediación de la costa no nos lo hubiesen manifestado como impracticable. La tarde y noche del II, debieron por la misma razón causarnos un cuidado no común. Todo nos indicaba un fondo lleno de piedras, en el cual no resistirían tal vez los cables; la mar era gruesa, y la costa á muy poca distancia tan llena de arrecifes, que nareciese imposible salvar persona alguna, si naufragá. semos en ella; por otra parte, oíamos por los tiros de conserva de la ATRevida (necesarios por la neblina constantemente espesa) que se hallaba en la misma situación que nosotros. Debio pues parecernos al día siguiente bien feliz la no esperada alteración del viento que roló al Nornoroeste y al Norte, y así no titubeamos en picar el cable dada la vela sobre codera, ciñendo luégo con regular aparejo para adquirir nuevo barlovento, y dirigirnos al fondeadero.

Todo el día fué necesario para este intento. Internamos en la bahía hacia las cuatro de la tarde: la vista accidental de la costa, el ruido de sus rompientes, y á veces los cañonazos del presidio serviannos de guía para los diferentes bordos que se iliciesen preferentes, ya que el viento se hatía declarado flojo por el Sudoeste; final. merite, calmado este de un todo hacia las ocho, dimos fondo á un anclote en 20 brazas arena, y como después nos enterásemos con el bote cuál era nuestra posición relativamente al fondea. dero, empreridimos el arrimarnos á él cōi espías, $y$ en la mañanita del $I_{3}$ pudimos ya quedar amarrados en faraje oportuno, distando una media milla escasa de la playa del presidio.

Hasta entonces, la idea que debíamos formar de aquel puerto era bien contraria al semblan. te favorable con que.la habiamos mirado desde 
Set, ", lejos. Considerábamos ya bien fundados los deseos de los navegantes de lilipinas, para que no se hiciese escala en aquella rada á pesar de las escaseces que después de una navegación tan dilatada deblais precisamente molestarnos hasta Acapulco: una entrada bien dudosa pos falta de observaciones, $y$ de la vista de tierra, un cielo constantemente triste $y$ neblinoso, las inmedia ciones harto peligrosas de la Punta de Pinos y la misma disposición del fondeadero, cuyo extremo del Norte mal podría abrigarle de los vientos reinantes, distando próximamente unas doce leguas por la Punta del Año Nuevo, cran otros tantos obstáculos para que pudićsemos formar una jdea mediana siquiera de aquellos contornos. Pero no eran fundadas nuestras con jetu ras; antes bien, variando muy luego la faz de todas las circunstancias, debíamos conocer que dificilmente pudiera proporcionarse mejor escal para los buques, que de la costa septentrional de la América vienen ya para la caída del verano aproximándose al clima ménos temible de los Trópicos.

En la recopilación de las noticias políticas y naturales de la California, se hablará con la debida extensión de cuanto sea relativo al descubrimiento y sucesiva reducción de las costas y de sus habitadores á la Monarquía española. Ahora nos ceñiremos á decir, que el presidio de Monterey, residencia del Gobernador de la provincia, se compone de un cuadrilongo cerrado y fortificado, en el cual habita una compañia de 63 hombres de á caballo con Teniente y Alférez; habiendo lugar, aunque con alguna estrechez, para que cada uno viva con su mujer é hijos. Inmediato á la Marina está un pequeño almacén, sin duda dispuesto para el uso de los buques del Departamento de San Blas, que con diferentes objetos arriban anualmente á la rada, y no dista más de dos leguas hacia el Sueste la Misión de San Cárlos, que sobre el río Carmelo reune bajo la dirección de los Padres Franciscanos, un número crecido de indios recién atraídos á la religión $\mathrm{y}$ á la vida sociable.

No bien habiase disipado la neblina, cuando ya prontos en la playa los instrumentos necesa. rios, D. Juan Vernaci pudo tomar las alturas correspondientes del Sol y deducir la longitud por los relojes marinos, fijando al mismo tiempo la primera época para el examen de su marcha. Los resultados de aquella obscrvación, fueron los siguientes:

Longitud oriental de Nutka... $\frac{\text { Cronómetro } 72 .}{4.45 .32} \frac{\text { Cronónetro } 7 x}{4.46 .38}$

De suerte que cistinuando la serie de nues. tras longitudes $y$ adoptada con preferencia la de cronbmetro 72 por conformarse mucho su actual movimiento con el que se le habia determinado en Nutka, resultaba la longitud occidental de Cá. Set. 19 diz de $124^{\circ} 23^{\prime} 14^{\prime \prime}$ para el observatorio, el cual para mayor comodidad se había trausferido á una buena habitación del cuadrilongo.

Como la escala nuestra en Monterey no tuviese en sí otro objeto sino el natural progresn de aquellas ciencias, que estuviesen á nuestro al cance, y al mismo tiempo aquel descanso y alivio á las tripulaciones, que las hiciesen aptas á resistir á las enfermedades y á los trabajos con que debían nuevamente arrostrar bajo de la Zona l'órrida, muy luégo nuestras medidas debieron dirigirse por la una parte á la combinación de una ración sabrosa y abundante, con aquella libertad y diversiones que fuesen compatibles con el servicio; por la otra, á las excursiones botánicas y demás noticias instructivas del país importante que ahora trillábamos: ciertamente es difícil ha. llar otra parte alguna más adecuada para uno y otro intento: eran los días suavemente serenos, por manera que las observaciones astronómicas no tuviesen la menor interrupción; la caza, la pesca, la actividaa de los soldados del presidio $y$ los ganados excelentes que pastaban en aquellas inmediaciones, suministraban ya una comi. da bien sabrosa, ya varjos objetos tan nuevos como instructivos para la Zoología. Proporcio. nábase luégo por las tardes una alegre corrida de novillos; á las veces las excursiones á caballo á la Misión no distante del Carmelo; en otras unos paseos entretenidos en aquellos contornos, $y$ por último, la reunión puntual de todos á bordo, cuando se retiraban las embarcaciones menores, no podian á ménos de robustecer extremadamente á la marinería. Admiraba D. Tadeo Heenke que en un clima tan favorable á la ve jetación, se hallase ahora una nueva fructificación casi tan completa como la de la primavera, y que las orillas frondosas del Carmelo reuniesen en sus in. mediaciones al mar una tal variedad de plantas (traidas sin duda sus semillas con las vertientes del invierno), que parecían pertenecer más bien al dilatado espacio de más de cien leguas, que al término bien limitado de nuestras excursiones.

Era natural, que 6 bien por una honrosa emulación ó por aquel instinto sociable que reune los intereses de los que se hallan en un mismo trance, no nos fuesen indiferentes las noticias áun más frívolas de los accidentes de la expedicıón fiancesa mandada por el Conde de la Péyrouse, Varios le habian conocido, y to. cos unánimes admiraban las propiedades que uracterizaban á los individuos de aquella expedición. El observatorio de Mr. Dagelet habia permanecido en el almacén de la playa. $\mathrm{E}$ ! se. ñor Lamanon y el Abate Mongés alojaron por algunos días en la Misión, desde donde empre:1dían sus exámenes físicos y las excursiones botánicas. El Sr. de Vancij dejó representadrí con 
ental de Cá. Set. : prio, el cual ausferido á b.

derey no tilral progreso á nuestro alcanso y ali. esen aptas á trabajos con o de la Zona debieron dirción de una ella libertad s con el ser. botánicas $\mathrm{y}$ s importante es difícil ha. para uno $y$ nte serenos, stronbmicas la caza, la del presidio ban en aquea una comi. tan nuevos - Proporciore corrida de á caballo á la n otras unos tornos, y por los á bordo, zes menores, emadamente deo Heenke ejetación, se ión casi tan $y$ que las ori$n$ en sus ind de plantas as vertientes zer más bien eguas, que al excursiones. una honrosa le que reune on un mismo las noticias is de la ex1 Conde de socido, y to. jiedades que aquella exagelet había laya. E! se. lojaron por nde empre:s. ursiones boesentadr, con
Set. :a muche arte en una lámina pequena el recibimiento hecho en la misma Misión á los señores de la Péyrouse y Langle con muchos de sus Ofi. ciales; finalmente, hallábamos como dignos ras. tros de aquella expedición y de la humanidad de sus jcfes, así una porción de semillas y árboles frutales ya propagados en aquella Misión y en las contiguas, como una pequeña máquina para moler trigo, que el Vizconde de Langle había regalado á los Padres de la Misión. Por lo que toca á los resultados de sus tareas científicas, no era menor al que habiamos hallado en Concepción de Chile el sigilo que habian guardado, haciéndose por consiguiente imposible de nuestra parte una comparación cuidadosa, que diese margen á toda la perfección que deseábamos particularmente en las cartas hidrográficas. Eran varios los conceptos sobre el paraje y las call. sas de la desgraciada pérdida de las dos lanchas de la misma expedición, sobre cuyo trance la Oficialidad guardósiempre el mayor sigilo, aven. turándose solo uno ú otro de las clases subalternas á hablar con los nuestros de aquella espe. cie lastimosa, y resultando por consiguiente muy equívocas y confusas cualesquicra interpretaciones de semejantes voces.

Entre los que con más juicio y conocimiento pudieron satisfacer en esa parte á la natural curiosidad nuestra, débese sin duda el primer lugar al Presidente de las Misiones el Padre Fray Matías de Lasuen, del Ori $\mathrm{n}$ de San Francisco, sugeto de una doctrini, un semblante y una conducta realmente apostói.cos, y de unos modales é instrucción poco comunes. Este religioso, había con mucha razón merecido el aprecio y amistad de entrambos Comandantes franceses y del mayor número de sus subalternos, logrando darles una idea de nuestro sistema re. ligioso de las misiones, que debió causarles tanta mayor admiración, cuanto era mayor èl en. cono mal cimentado de muchos escritores modernos contra ese sistema confundido hasta aquí, á las veces con la superstición, otras con los vicios particulares de uno ú otro individuo, y á veces con los defectos indispensables de la demasiada distancia y extensión.

Al medio día del 16 tuvimos también la sa. tisfacción de ver aparecer inmediata al puerto una goleta nacional, que para las dos de la tarde ya consiguib el dar fondo cerca de las corbetas. Eira la Santa Saturnina del Departamento de San Blas, que en conserva del paquebot San Carlos y á las órdenes del Teniente de navio Don Francisco Elisa, había salido de Nutka para continuar los reconocimientos de la costa al Norte y al Sur, y los vientos habían precisado á entrambos buques á emprender sus tareas desde el Estrecho de Fuca, en el cual luégo habían perma. necido todo el verano por la mucha extensión de los canales internos. Ulimamente, desemboca. Sict, th dos para regresar á Nutka, se liabían separado, y luchando en balde la goleta por muchos dias para elevarse á la latitud precisa, habín debido, por falta de agua, arribar á Monterey. Debía parecernos bien feliz la llegada de aquel buque cuando la refiriésemos á una tentativa que me. ditábamos hacer con nuestras lanchas para el recobro de las anclas perdidas al Sur le la Punta de Pinos.

Deb)ı fondear á alguna distancia del ras. treo para depósito de los víveres y pertrechos que se llevasen, recibir las anclas y cables si acaso pudiesen recohrarse, y convoyar las lanchas si alguna adversidad las obligase á correr al Sur no pudiendo reincorporarse á las corbetas. Se le proveyó por consiguiente con aguacla, viveres y amarras oportunas, $y$ en la noche del r 8 dí la vela con las mismas lanclias. Dirigla esta operación el T'eniente de navio D. Caye. tano Valdés en la lancha de la Descubierta; la de la Atrevida iba confiada á D. José Robredo, y D. Francisco Viana tuvo el cargo de la goleta, de modo que las lanchas no careciesen jamás de aquellos auxilios y abrigo que les eran tan nece. sarios. La ausencia se ciñó á dos días. Las ins. trucciones eran terminantes para que no se expusiesen ni remotamente á un naufragio; y las esquifazones de ambos buques, se formaron con aquellos marineros que reuniesen en mayor gra. do la inteligencia, la quietud y la resistencia al trabajo.

Era bien extraordinario que mientras en el puerto gozábamos (particularmente desde las nueve de la mañana) de una claridad singular en los cielos y en los horizontes, nuestras lanchas tuviesen á tan corta distancia una neblina tan espesa y constante, que á veces sujetas con la rastra, no se distinguían sin embargo una á otra: un inconveniente de esta especie hubiera sido por sí decisivo para el malogro de la em. presa, á no concurrir una actividad é inteligen. cia poco comunes en los que se habían encarga. do de llevarla á efecto. 'Trabajaban indiferente. mente de día y de noche cuando una clara aun. que momentánea les permitiese buscar las mar. caciones del fondeadero; los cañonazos de la goleta fondeada, los avalizaban entre las neblinas; el ruido de las rompientes $y$ la sonda, eran otras guías para las distancias; finalmente, el rastreo era tan seguido en las ocasiones favorables, que á veces no se interrumpiese en ocho $y \operatorname{die} z$ ho. ras, pero era un obstáculo invencible para el buen éxito, la muchedumbre de piedras que hallaron en el fondo: con este inconveniente debie. ron perder mucho tiempo, interrumpir la dirección de la rastra, rozar las guindalezas, y aban. donada toda esperanza de cobrar un ancla siquiera, regresar al puerto para el plazo prefijado. 
Set. it Concluidos asi los diferentes objetos que nos habiamos propuesto en arella escala, pareció ya llegado el plazo oportuno de la salida, para aproximarnos paulatinaniente a Acapulco. La íjamos para la mañana del 25 , ocupíndonos en los pocos dias restantes á exteidúer las sondas de la bahla por diferentes rumbos, á provecrnos de algún ganado fresco para el uso de las tripula. ciones, y á completar nuestros acopios para cl Real Gabinete. Las corbetas quedaron efectiva. mente á pique de un ancla á las nueve de la mañana del día prefijado; poco después, con los primeros soplos de la virazón, se hicieron á la 25 vela ciñendo al primer cuadrante con todo apare. jo, y en la noche siguiente después de varios bordos se hallaron bastantemente enmaradas pa. ra continuar su navegación al Sur.

Era esta ya por su naturaleza bien sencilla, frecuentíndola anualmente los buques de San Blas y lan Naos de Filipinas; al paso que los vientos co.rstantes y favorables del Noroeste la hacían sumam. nte corta y descansada, continuó con estos antecedentes nucstro método de nave. far durante la noche propasando sin reconocerlos, algunos trozos de costa. Logróse sin embargo el situar con mucha exactitud por medio de observaciones repetidas, la Punta de Pedernales i la entrada del canal de Santa Bárbara, algu. nas de las islas que forman el dicho canal, la otra de S̄an Nicolás, que está al Oeste de todas, y la de Guadalupe que suele muchas veces servir de reconocimiento ó recalada para las Naos ya indicadas.

Esta última isla puede verse desde la cubierta á distancia de $\mathrm{I}_{3} 6 \mathrm{I}_{4}$ leguas; es más eleva"ha. 1." da por la parte del Norte, sus orillas son escarpadas $y$ sin abrigo alguno. No se encuentra fondo á distancia de una milla y media. Parecen igualmente cortados á pico los islotes ó pedrus. cos del Sur; es su latitud de $28^{\circ} 49^{\prime}$ y la longitud $3^{\circ} 23^{\prime}$ al Este de Monterey.

Atracada nuevamente la costa por latitud de $28^{\circ} 22^{\prime}$, nos fué fácil reconocer de cerca las Islas de San Benito y la del Cerro. En la segunda, ya inmediatos al Cabo San Agustin admirábamos de nuevo la exactitud de las descripciones de Sebastián Vizcaino, ni las hallamos ménos prolijas sobre lá Isla Navidad, el Cabo San Bartolomé y la Punta de Abre Ojos, todos parajes que reconocimos después con una atención nimia. Finalmente, alcanzados en la tarde del 4 el Morro de San Lázaro y la bahía de Santa Marina, $y$ al dia siguiente la Misión de Todos San. tos, pudimos para la mañanita del 6 estar delante del célebre Cabo de San Lucas, extremo meridional de la Península de California. Nos era doblemente agradable aquella posicion, así porque pudiéramos referir á nuestras cartas las observaciones hechas en la Mision de San José por el
Abate Chappe y D. Vicente Doz, como porque Ot. de alli debia emprenderse con la separación de las dos corbetas una nueva multiplicación de nucstras tareas hasta Acapulco. Ein efecto, com. parados los relojes marinos entre sl por medio de señales, y observada la longitud erı meridia. nos del Cabo San Lucas, la ATreviba inmedia. tamente hizo derrota hacia el Cabo Corrientes, desde donde debia rectificar la posición de toda la costa hasta Acapulco; la Descubierra conti. nub costeando el frontón de la peninsula, para seguir después directamente á San Blas. Haciase y a necesaria una breve escala en aquel puerto, asi para reponer alfyunos pertrechos de los cua. les careciamos y en particular las anclas, como para avisar con anticipación á Méjico las medi. das oportunas para nuestros pasos venideros, los cuales como es natural tenian por objeto esen. cial reunir los Oficiales quedados en la Nueva España, y transferirnos prontamente á los mares del Asia.

La comparación de nuestra serie de longitudes, con las que se habían determinado en la Misićn de San José, correspondió á nuestros de. seos aún más allá de lo que podiamos esperar á primera vista: era casi imperceptible la diferencia de unas á otras: combinábanse con una suma escrupulosidad las determinaciones del Capitán Cook en Nutka, $y$ las de los astrónomos rusos en Ios extremos de la Siberia: todo manifestaba el estado actual de la navegación, pues apenas descubierta una extensión tamaña de costas, se hallaba ya con el auxilio de la Astronomía, riguro. samente ceñida á sus justos límites hidrográticos.

En los paralelos donde nos hallábamos y mucho más en el clima que actualmente reinaba en las costas de Nueva España, debiamos temer con justa razón relativamente $\leq$ las tripulaciones que degenerasen en calenturas intermitentes los res. friados dimanados por lo común del paso demasiado rápido del frío al calor. Por fortuna no nos habian alcanzado aún las lluvias ni las calmas, y sin embargo veíamos el termómetro en $\operatorname{los} 85 y^{\circ} 0^{\circ}$ al aire libre, y las consecuencias de un calor tan excesivo no podlan ser sino funes. tas. Bien nos habíamos precavido desde muy temprano, añadiendo á todas las medidas diarias el uso de los gazpachos por cena, el refresco á las tres de la tarde de la chicha 6 agua de maíz fermentado, Ja ventilación más repetida de los cois, un trabajo moderado si, pero frecuente; por último, la continuación del vino para racion, y fue también preciso usar al mismo tiempo de las san. grías y refrescantes; estos preservativos suaves bastaban para que en los semblantes, en el buen humor y en la disposición al trabajo, manifesta. sen á la sazón entrambas tripulaciones toda la robustez que podíamos desear. 
omo porque (hi. a eparación de plicación de efecto, com. i por medio en meridia. DA inmedia. Corrientes, ción de toda ILERTA contihinsula, para las. Haclase quel puerto, ide los cua. anclas, como co las medi. enideros, los objeto esen. la Nueva Es. á los mares

e de longituhinado en la nuestros de nos esperar á le la diferen. con una suma s del Capitán mos rusos en anifestaba el 8 apenas des. zostas, se haomía, riguro. tes hidrográ.

ábamos y muite reinaba en nos temer con ulaciones que entes los resdel paso de or fortuna no ias ni las cal. ermómetro en secuencias de or sino funes - desde muy edidas diarias refresco álas a de maiz ferda de los cois, recuente; por a ración, $y$ fue upo de las san. ativos suaves es, en el buen jo, manifestaciones toda la
Oa. La navegación de la Descunirrta hasta San Blas, no tivo acontecimiento alguno que merezca rcferirse: viéronse las Islas Marias en la tarde del $9, y$ al día siguiente costeadas de cerca la Isabela y la Piedra Ilanca, fondeamos á las cuatro de la tarde en seis brazas arena á poca distancia de la entrada del río $b$ de la dársena.

No cabe una idea del espectáculo realmente lastimoso que presentaban á la sazón las marinerias y demás habitantes de aquellos contornos: pálidos en sus rostros, desmayados en sus fuerzas, desnudos y desidiosos en sus trajes, preci. sados á buscar en el mismo estrago de los vi . cios el único alivio de sus afaner, ya que no lo fuese de su salud, hacian un contraste sin. gular con la robustez $y$ la alegría de nuestros marineros: si permaneciésemos á bordo, el calor era insufrible particularmente antes del medio dia, á cuya hora solía eutablar la virazón, y si intentábamos ir á tierra, era tal el enjambre de mosquitos y tales eran las miasmas pútridas que dimanaban de la inmensidad de aguas esparcidas en toda aquella campiña, que á más de la inco. modidad, hacíanse sumamente peligrosas las excursiones. De alli es que anduvimos con extromo diligentes para proveernos de los diferentes efec

3. tos que nos fuesen necesarios; omitióse por la misma razón el establecer un obset satorio, pues alcanzaba el uso de los sextantes á los objetos propuestos; y fuímos tan felices en todas esas medidas: coadyuvadas con una actividad extraordinaria antes por el Comisario Comandante D. Francisco Hijosa, y luégo por el Teniente de navío D. Salvador Fidalgo, que á los cuatro días de nuestra llegada ya pudimos dar nuevamente la vela. Las conferencias con este Oficial debie- ron sernos en aquella ocasión sumamente ins. (1, , tructivas. Había visitzcio en el año anterior la entrada del P'ríncipe Guillermo, Ia ria de Cook y el establecimiento ruso de Oanalaska; por manera que reunidos sus reconocimientos á los nuestros, ya no dejasen cosa alguna por desear en toda la parte de la América, comprendidu entre los paralelos indicados por Ferrer Maldo. nado: nos cedió sus diarios; adquirimos varias noticias importantes sobre las costas del seno de la California 6 Golfo de Cortés; y ciertamente hubiera sido aquella corta demora en el departa mento de una utilidad aún mayor para la expedición, si como lo intentábamos nos hubiese po. dido seguir, esquifada con marineria nuestra, un goleta recién construída en aquel astillero, oportuna para los resonocimientos de las costas de Tecoantepeque y Guatemala, que las calmas nos habían precisado á nmitir en la primaveru anterior.

A las tres de la mañana del día $\mathrm{I}+$ estuvimos efectivamente á la vela: nos sobrecogió poco des pués una turbonada bien recia con muchos rayos; pero cediendo esta muy luego al aproximarse el Sol sobre el horizonte, púdose continuar feliz mente la navegación emprendida $y$ atracar el Cabo Corrientes al anochecer del otro dia. Desde alli los vientos y las corrientes aceleraron de tal modo la navegación para Acapulco, que sin em bargo de reconocerse diariamente unos trozos considerables de costa, particularmente sobre los volcanes de Colima y los puertos de Nuvidad y Siguatanejo, en la tarde del Ig alcanzamos la Isla del Grifo y poco después fonc ramos al lado de la Atrevida, la cual se hallaba en el puerto desde la tarde del $r 6$.

\section{Separacion de la ATREvida a perfeccionar el reconocimiento de la costa entre Cabo Corrientes y Acapulco.}

Oc.. 6 Desde la mañana del 4 me había prevenido D. Alejandro Malaspina el separarme para completar las operaciones del mes de Abril, atendiendo á la escasez de anclas de este buque para fondear en la rada de San Blas, á donde la Descubierta se dirigía para recibir en aquel departamento los auxilios necesarios que no pudiésemos encontrar en Acapulco; y como dejase á mi arbitrio el momento de la separación, acordamos á la vez navegar unidos hasta el Cabo de San Lucas, en cuyo, meridiano pensaba yo observar longitudes.

Efectivamente, puestos á dos millas del refe. rido Cabo poco después de las ocho de la ma. Oct. 6 ñana del 6 , observamos longitudes en su meri. diano. Corrigióse para la marcación del Cabo con la variación de la aguja de $7^{\circ}$ Nordeste, resultando la longitud por el 105 de $11^{\circ} 5^{6^{\prime}}$ oriental de Monterey.

Según noticias adquiridas en Méjico por el Teniente de navio D. José Espinosa, supimos que la diferencia de meridianos entre el Cabo de San Lucas y la Misión de San José, era sólo de $26^{\prime}$ y no de $\mathrm{I}^{\circ}$ oo ${ }^{\prime}$ como suponían las cartas de Cuadra y la del Piloto Mendizábal; y conside. rando aquella deducción sin duda por una estima 
Ort 6 prolija 6 por marcaciones ligadas entre ambos puntos, debiamos mirarla como bastante exacta.

Longitud de San José astronómica. mente occidental de París.. . . . . .

El Cabo de San Lucas al Oeste por su posicion.. ...........

$112002^{\prime}$ o०

ongitud del Cabo de San Lucas Oes te de París. . . . . . . . . . . . .

Montercy al Oeste del Cabo de San Jucas por los horarios. u.

Luego longitud de Monterey Oeste de

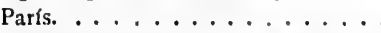
Longitud asignada por los cronómetros a Monterey.. . . . . . . . . 00.26 .00 (1) [1 2.28 .00 II. 56.00 124.24 .00 124.5314

Inmediatamente que se toriaron los horarios, se forzó de vela gobernando el Sudeste $1 / 4$ Este á buscar el paralelo de Cabo Corrientes, y la Descubierta siguió barajando la costa á la entrada del Crollo de California ú puerto de San José, y ya al medio día nos perdimos de vista.

$\mathrm{Ni}$ el tiempo hermoso, ni el viento aunque bonancible no dejó de ser constantemente favorable, alcanzando de este modo á ver las Islas Marias en la mañanita del 9 á distancia algo más de diez leguas, según lo indicaron las bases, llegando al medio día á la latitud de $20^{\circ} 43^{\prime}$ y longitud de $15^{\circ}$ I $3^{\prime}$ oriental de Monterey. y á las cuatro de la tarde avistamos confusamente al Este las ticrras inmediatas al Cabo Corrien. tes. Continuóse el ninismo rumbo del Este Sudeste, distando á la sazón unas ocho á nueve leguas de la costa. Cumplida la latitud del Cabo, se entretuvo la noche entre bordos y pairear, á fin de amanecer á distancia conveniente para dar principioá nuestras tareas acostumbradas. Desde las diez empezó á aturbonarse por el Nordeste con relámpagos frecuentes y algunos truenos, cuyos aparatos y la inmediación á que estábamos de la tierra obligó á ceñir el viento para fuera sobre las gavias.

Al rayar el día todo había despejado, y marcamos el Cabo Corrientes al Norte $60^{\circ}$ Este distantes unas cinco á seis leguas. Ceñido el viento al Norte y Nornoroeste se forzó de vela parz atra. car la costa: las corrientes habiéndonos arrastrado al Sur del Cabo, era imposible ya ganar su paralelo para la hora de observar la latitud como era mi deseo.

El Cabo Corrientes se nos presentaba formando á la vista dos puntas que creimos al principio la más distante, por el verdadero Cabo pero advirtióse luégo que rolaba ésta tanto para el Este, que le enfilábamos con la más saliente, ó el mismo Cabo al Norte $40^{\circ}$ Este; la tierra que le domina más intcrna es alta y la unen dos órdesies de montañas que aumentan su número y altura hacia lo interior de ella. Al propio tiempo se alcanzaban á ver el Monte de San
Juan y las tierras innediatas representadas por Ock. 10 la gran distancia ba jo la vista de otras tantas islas como puntos descubríamos.

A las nueve de la mañana distando tres leguas del Cabo arribamos al Sudeste $\%$ Este, rumbo paralelo á la costa. El viento igual y fresquito, la mar llana y un sumo cuidado en el gobierno para la exactitud de las bases, eran circunstancias todas que ocupaban justamente nuestro cuidado para esperar resultados favorables; pero frustróse esta confianza con una diferencia de $7^{\prime}$ al Sur por la latitud del medio día siendo esta de $20^{\circ} \mathrm{O}^{\prime}$, y la longitud de $I_{5}{ }^{\circ} 5^{\prime}$, marcándose entonces el Cabo Corrientes al Norte $8^{\circ}$ Oeste distancia de osho á nueve leguas.

Desde esta hora estrechando más la distén. cia á la costa, seguimos por la tarde favorecidos de las mismas circunstancias para trazarla, pero la demasiada inmediación á ella nos hizo conocer visiblemente por las marcaciones, que las corrientes vioientamente nos arrastraban en la misma dirección ciel rumbo. Esta observación nos ubligó á repetir los horarios á las dos y media y cinco de la tarde, para tamisién disminuir los errores si la corriente conservase la propia fuerza.

Los resultados de unos horarios á otros indicaban una diferencia uniforme con la estima, ascendiendo la total desde el medio día á los úl. timos horarios á 28' para el Este. Esta comprobada expcriencia autorizaba la necesidad de corre ${ }_{5}$ ir proporcionalmente las latitudes de las bases.

La costa desde el Cabo hasta rebasar un islite de piedra poco separado de la tierra cerca del Morro Coronado r's muy seguida y baja regularmente desde una ensenada pequeña situada al Sur de dicho Cabo, de tal modo, que nos era di. fícil elegir para las bases puntos notables en la oriıla, y sólo la inmediación á ella facilitaba el distinguir algunas manchas negras eli la dilatada playa que casi limita á toda la costa re. corrida hasta aquí. i medida que se interna en el continente, tas tierras se elevan por varios órdenes de montañas pobladas de un bosque tan frondoso como impenetrable.

A la caída de la tarde hubo muchos truenos y relámpagos que aumentaron al anochecer y una turbonada preparada, todas estas eran cir. cunstancias que exigieron por la noche separarnos algún tanto de la costa; pero con atención á marca. por la mañana el último puntc recono. cido en esta tarde. Así, después de volver á atracar la costa, reconocimos al amanecer hallarnos á la vista del puerto de Navidad según lo indi. caban unos islotes que hay á su entrada, los cuales no se advertian en otro punto de lo res. tante de la costa. Hiciéronse rumbos paralelos á ella mieracras duró el terral, al que no sustituyó 
representadas por Oct. to de otras tantas is-

istando tres leguas :e $\%$ Este, rumbo igual y fresquito, ado en el gobierno 3, eran circunstanustamente nuestro Itados favorables; con una diferencia medio día siendo de $15^{\circ} 5^{\prime}$, marCorrientes al Norte nueve leguas.

do más la disten. la tarde favorecicias para truzarla, ón á ella nos hizo : marcaciones, que nos arrastraban en o. Esta observación? os á las dos y media misién disminuir los iservase la propia

horarios á otros inrme con la estima, medio día á los úl Este. Esta comprola necesidad de co ss latitudes de las

sta rebasar un islite - la tierra cerca del uida y baja regularpequeña situada al odo, que nos era diintos notables en la á ella facilitaba el negras eis la dilaá toda la costa rea que se interna en e elevan por varios as de un bosque tan ubo muchos truenos tron al anochecer $y$ odas estas eran ciror la noche separarpero con atención á timo puntc reconopués de volver áatraamanecer hallarnos vidad según lo indiy á su entrada, los tro punto de lo resse rumbos paralelos 1 , al que no sustituy6 

la virazón hasta el medio día, hallándonos en latitud Norte de $19^{\circ} 06^{\prime}$ y longitud de $16^{\circ} \cdot 48^{\prime} 30^{\prime \prime}$ al Este del Meridiano de Monterey, notándose una diferenri al Sur de $18^{\prime}$.

Habiendo por la tarde refrescado la brisa pudimos reconocer la boca del puerto de Navidad por un fronton 6 promontorio que aparece isla $a ́$ cierta distancia con una quebrada notable en medio, y un islote inmediato en el extremo de fuera, y otro algo mayor al Este en la ensenada de Selagua cerca de tierra firme, po: cuyo color $y$ no tener nombre en las cartas, le pusimos el de Islote Blanco.

La costa desde el Islote que está sobre el puerto de Navidad, es de mediana altura, con escarpados de color rojo, y en el extremo Norte tiene varios faralloncitos. Toda la ensenada de Selngua la limita una playa igual, y hasia su mediania se advierten en la falda de un montecito dos 6 tres manchas blancas, siguiendo des. pués la costa para el Este, escarpada hasta Pun. ta de Suchiche de la cual anochecimos siete á otho leguas.

Nuestras operaciones en los dos días siguien. tes, no fueron tan felices como en los anteriores: el poco viento, á veces variable, la costa tomada, y ura marejada del Sur difícil de vencerla, fueron inconvenientes para malograr el trazarla por esta parte. Sin embargo, la esperanza de poderse, adoptar los trabajos por este paraje de nuestro anterior viaje, hacía ménos sensible aho. ra la oposiciśa de estas dificultades. También consideraba yo por otra parte, que el punto im. portante en cite tramo de costa, era el de las Tetas que engañaron al Lord Anson con las de Coyuca, y llamaremos aqui del Engaño, las cuales quedaron exactamente situadas en aquella campaña; pues no obstante, al amanecer del $x_{3}$ se reconocieron muy bien en medio de una cade. na de montañas bien elevadas que las ciñen al Este y al Oeste.

Observando al medio dia la latitud Norte de $17^{\circ} 50^{\prime}$ y la longitud de $I 8^{\circ} I 5^{\prime}$, marcamos las Tetas del Engaño al Norte $6^{\circ}$ Oeste, cuyas observaciones indicaron la diferencia al Sur de I4 y $18^{\prime}$ al Este.

Con la virazón bonancible del Oesnoroeste seguimos rumbos paralelos á la costa para determinar su arrumbamiento, no habiendo puntos notables en este trozo que mereciesen detenerse a reconocerlo. No fueron menores los obstáculos que tuvimos al día siguiente para la continuación de nuestras tareas, y nos consolaba la esperanza de que tal vez no los encontrase por aquí la corbeta Descubierta logrando evacuarlas con la perfección necesaria, restando solo un corto trozo hasizel puerto Siguatane jo en dondedebían concluirse. Nos contentarnos, pues, con aprove. char todo nionsento favorable á nuestro intento.
En la mañana del 15 con vientecito de?la tierra, se fué cósteando á buscar la entrada de Siguatanejc, marcando al medio d'ra una isla que está en la misma boca de este puerto al Norte $42^{\circ}$ Este, observando la latitud de $17^{\circ} 22^{\prime}$ Norte, y longitud de $19^{\circ} 5 \mathrm{I}^{\prime}$, á distancia de Acapulco como 42 leguas.

No fué ya mi objeto otro que el de buscar este puerto con toda diligencia, respecto á que la costa intermedia quedó bien trazada anteriurmente. Al amanecer, abandonados por el terral nos favorecib luego la virazón fresquita, con la cual contamos coger temprano el puerto, auxi liados de las corrientes. No distaríamos de é poco después del medio día más de cuatro leguas, cuando vimos un bote dirigirse hacia nosotros, cuyo patron me informó había saiido con dos canoas grandes á buscár y socorrer la fragata par. ticular el Sicramento, que :nuy maltratada de un temporal, había quedado como abandonada y casi sin recurso para poder navegar.

Con una noticia tan poco circunstanciada para poder inferir el paradero de este buque, no se presentaba partido que tomar, no habiendo podido descubrirle desde los topes, hasta que los informes en el puerto me iluminasen para el acierto de las providencias más conducentes

A las cuatro de la tarde, dentro ya de la Punta del Grifo, emprendimos sobre bordos con todo aparejo tomar el fondeadero, y después de muy poco llegamos á él, quedando sobre un ancla afuera, y rejera á uno de los árboles pro. ximos al muelle.

Tercera estada de la Irkevida en Acapulco, $y$ ocurrencias hasta la reunión á la DEscuBIERTA.

Considerando á la :ripulación algo cansada con las maniobras de bordcar y de amarrarse, no fué mi ánimo completar esta última hasta el día siguiente, fiado en las bellas apariencias del tiempo, y en mi deseo de proporcionarla,algún descanso. A esta reflexion se agregaba otra no ménus atendible, cual era la agradable ocupación en que todos se hallaban con el cúmulo de cartas de Europa que hablamos recibido, cuyas noticias así públicas como particulares, tan suspiradas por tanto tiempo, debían ser las más interesantes áun para quien fuese más indiferente á sentir la complacencia que causan. Entre éstos iv. vimos también la de haber merecido de la piedad del Rey, el ascenso á los grados inmediatos de varios Oficiales subalternos y yo, con otras gra cias para diferentes indivíduos de la misma ex. pedicion.

Apenas nos habiamos ocupado las primeras horas de la noche en gozar el gusto de estas satisfacciones, cuando las feas apariencias del timmpo vinieron á ocupar justamente nuestro 
Oct. 16 cuidado. Preparada una turbonada por el Sudeste, y precediendo muchos truenos y relámpagos, descargó con muclia fuerza como antes de la media noche. Inmediatamente se calaron vergas y masteleros, dejando caer la esperanza artes que no lo permitiese la falta del cable 6 garrásemos muy poco; con estas diligencias quedamos tranquilos, y mucho más viendo pasar por nuestro costado la falúa y canoas que habian salido á auxiliar la fragata el Sacramento, justamente en el momento en que hubieran corrido el peligro más inminente.

No bien nos habíamos desembarazado de las faenas ordinarias para asegurar el buque después de serenar el tiempo en la mañana siguien. te, cuando el Subdelegado interino D. Ramón Escalante, acompañado de D. José de la Riva Agüero, Superintendente de la Real Casa de Mo. neda de Lima y pasajero de la fragata el Sacramento, vinieron á proponerme que comisionase la lancha con los auxilios correspondientes para socorrerla, la cual había dejado el segundo pocos días antes en el estado más deplorable, desarbolada y sin timón. A la relación menuda de este suceso que me hizo Riva Agüero, me añadió haber podido persuadir al Capitán de la fragata para permitirle venir en el bote á este puerto desde la distancia de fo leguas á la mar en donde la dejó para disponer y dirigir los socorros necesarios á evitar al buque ó á su tripulación el fin más funesto, contando con la suguridad de ser su paradero al Oeste de Acapulco, en cuya dirección habían notado corrientes muy violentas, $y$ algunos días también para el Norte.

Estas últimas noticias dirigidas á probarme el paraje donde podíamos buscar la fragata, se oponían tanto á nuestras recientes observaciones que no pude ménos de suponer en las primeras todo el error tan preciso como disculpable en quien carece de los conocimientos del arte. A uno y á otro les hice ver lo infructuosa y aun arriesgada que sería la salida de la lancha hasta donde pretendían, y más no p'ıdiendo apoyarla sobre razones capaces de justificar las resultas. Xo no hubiera titubeado en conceder estos 6 ma. yores auxilios, á pesar de que la tripulación nenesitaba el descanso después de una campaña tan penosa; y aún con esperanza algo probable de lograsse el objeto, yo mismo iría con la corbeta salvar ur: buque considerado en el último trance según también les manifesté; y suponiendo el que debiese tomar algún puerto 6 playa al Sur de Acapulco, conducido por los vientos y corrientes constantes y favorables hacia aquella parte, sería entonces socorrido tan completamente como lo exigían la liumanidad y nuestra obligación.

Con la llegada de la Descubierta el ig, cesaron ya mis cuidados sobre las combinaciones ó preparativos para en caso de tenerse rastro de la fragata el Sacramento, pues enterado de todo to oct. t9 ocurrido D. Alejandro Malaspina, tampoco halló por conveniente tomar medida alguna interin ignorásemos su parađero.

Por fortuna el día siguiente confirmándose mis cunjeturas, se disiparon nuestros recelos sobre la seguridad de la tripulación con la agradable noticia de que ésta, desamparando el buque, cogió con las lanchas las orillas del río Papaga11o, is leguas al Este de este puerto, logrando así salvar sus vidas y 20.000 pesos de plata acunaada que foziñabas la parte más rica de su car. gamento. El Capitán por una buena precaución de arriar un ancla con r 30 brazas del mejor cable, logró salvar también el buque, fondeando éste después en las playas inmediatas á donde había atracado la lanclia.

\section{Nuera renenión do las corbetas en Acapulco.}

Muclias causas debían concurrir á represen. tarnos como bien agradable la escala en Acapulco, pues no sólo veíamos ahora vestidos de un verde hermoso los montes inmediatos que agostados del Sol en Abril último llevaban consigo el solo semblante de la aridez y de la quema, sino que dependían tambien de la llegada al mismo puerto, el término de una parte considerable de nuestras tareas, la reunión de los compañeros ausentes y el próximo abandono de aquellas costas; ni merecían en nuestro ánimo un menor aprecio las conveniencias locales del puerto para el alijo de $\mathrm{A}$. buques, la comodidad del observatorio, la seguridad del amarradero y dificultad de la deserción; todo, en fin, jarecía prometernos una tranquilidad y descanso poco comunes.

Debia seguramente á la sazón causarnos una no mediana complacencia el estado de nuestros buques $y$ de entrambas tripulaciones particularmente, cuando comparásemos el semblante robusto, contento y cariñoso de las últimas, con el color amarillento y la natural desidia, abyección $y$ tristeza que se advertía en los moradores del puerto.

No tardamos, pues, un momento en aprovechar una situación tan agradable; desde el día siguiente se suspendió la suministración de víveres sustituyéndole la ración en dinero: el señor de Heenke emprendib sus excursiones botánicas, se destinaron á una y otra corbeta parajes oportunos para atender al examen de sus víveres, á la recorrida de la tonelería, al reemplazo de la aguada y al depósito de sus pertrechos; finalmente, se estabieció el observatorio en una casá bien inmediata al muelle, puesto que no parecía ya prudente el usar de la casa del Castellano, que no tardaría en llegar á su destino, habiendo Su Majestad nombrado el Teniente Coronel D. Pe. dro de Tueros ron obligación de residir constan. 
de todo lo Oct. t9 mpoco halló a ínterin ig.

infirmándose s recelos son la agradalo el buque, río Papaga. to, logrando le plata acua de su cararecaución el mejor ca. , fondeando atas á dondè

1capulco.

á represena en Acapul. stidos de un os que agosaban consigo le la quema, egada al misconsiderable ; compañeros aquellas cos. menor apreuerto para el el observatodificultad re prometernos omunes.

ausarnos una de nuestros is particularemblante rotimas, con el ia, abyección zoradores del

o en aprovedesde el día ación de víve. ro: el señor de es botánicas, parajes oporius 'víveres, á mplazo de la rechos; finalo en una casa ue no parecía astellano, que habiendo St oronel D. Pesidir constan-
Oct so temente ó en la plaza, ó á lo ménos en sus con. tornos.

Las primeras alturas correspondientes se dedicaron como era natural á la deducción de la longitud con los relojes marinos: vimos con mucha complacencia, que no sólo concurrían los cronómetros $7 \mathrm{I}$ y 72 en determinar la misma diferencia de meridianos de $5^{\circ} 2 \mathrm{I}^{\prime}$ entre San Blas y Acapulco, que había determinado el núm. ro en la travesía anterior de la ATREvida, si también que se reunía n con una exactitud dificil de imaginarse los misi.'os cronómetros, con el reloj 105 , para determinar la diferencia de longitud de $9^{\circ} 45^{\prime} 18^{\prime \prime}$ entre el Cabo San Lucas y nuestro observatorio de Acapulco.

Los reconocimientos de la corbeta ATrevid. cn esta última separación, eran por otra parte bien importantes para la exactitud de nuestras tareas, las cuales ahora ligarido entre sí las determinaciones de ambos viajes de aquella cor beta y las del viaje último de la Descubierta hacían casi independiente de las bases la colocación en latitud y longitud de cada punto de la costa, y nos ponían al abrigo de los muchos ye. iros que naturalmente debía arrastrar consigo la fuerza y la constancia de las corrientes al Sudeste.

Las que había experimentado la ATREvid. eran aún mayores que las nuestras. Debieron no sólo repetir á cada paso las observaciones de longitud, si también precaverse de los errores en la latitud con diferentes alturas meridianas de estrellas medidas al principio $\mathrm{y}$ en las últimas horas de la noche, y como despiés de nuestra separación en la mañana del 6 sobre el Cabo San Lucas hubiese hecho buena derrota hacia el Ca. bo Corrientes; sin detenerse en un nuevo examen infructuoso de las Islas Marias, no le habia sido difícil atracar aquel Cabo en la mañana del II después de una fuerte turbonada, y últimamente fondear.en el puerto para la noche del 16 poco antes que rompiese una tempestad temible del Nordeste y Sudeste, que le obligó á dejar caer la esperanza.

Esta recalada de la ATREvidA, que producía ya todas las ventajas propuestas, debió parecernos aún más feliz por el casual encuentro que en la misma tarde del 16 había tenido á cuatro ó cinco leguas del puerto, de dos canoas grandes y la falúa de la plaza, las cuales con mucha gente y un mastelero de los respetos que habían dejado las corbetas, amadrinado entre las dos canoas vogaban en busca de una embarcación del comercio de Guayaquil, desarbolada pocos días antes en ayuellas inmediaciones y hecha actualmente una boya sin timón ni respeto alguno con que repararse. No avistándose buque alguno desde los topes, D. José Bustamante les había mandado volver inmediatamente y no bien ha. bian alcanzado la boca del puerto, cuando la Oct. 20 turbonada que acabamos de indicar manifestó á cuánto peligro se habían expuesto aquellas gentes inconsideradamente.

Cesaron también en mucha parte al día siguiente nuestros recelos de la seguridad de la tripulación, con la noticia de que había desam. parado el buque, y atracadas con la lancha las orillas del río Papagallo como I8 leguas al Este del puerto, logrando así salvar sus vidas y unos 20.000 pesos de plata efectiva que formaban la parte más preciosa de la carga. El Capitán tuvo la precaución de arriar un ancla con 130 brazas del mejor cable; y esa maniobra produjo, que también el buque desarbolado y hecho juguete del mar, se hallase seguro y fondeado en las playas no distantes del paraje á donde había atra. cado la lancha.

Entretanto, la casualidad de haberse atrasa. do mucho las aguas en aquel año, y de romper copiosas lluvias con vientos del Sudeste en los últimos días del mes, había empezado á descubrir la falibilidad de nuestras esperanzas harto lisonjeras, relativamente al estado de robustez, del cual á la sazón gozábarnos. La serenidad del tiempo de vuelta en la mañana del 28 , con la total despedida de las aguas, dancis lugar con la acción constante del Sol á una evajoración in. decible de miasmas, las cuales por la demasiada inmediación de los montes y una vegetación har. to lozana no podían disiparse con los vientos benéficos del mar, empezó á manifestar en ambas tripulaciones y en todos los coutornos la existen. cia de las calenturas propias de aquella estación en unos climas tan temibles.

Muy luégo ios dos desórdenes inseparables del marinero, esto es, el uso del aguardiente y la preferencia de los remedios propios y caseros á la útil mano del médico, enfurecieron la epidemia; y como era natural, aumentando el número de los enfermos en el hospital, aumentaba al mis. mo tiempo la parte correspondiente de trabajo á los que aún se mantenían sanos. Las maes. tranzas de ambos buques estaban á la sazón bien ocupadas en rehacer así la lancha de la Atrevida, construída en San Blas, cuyos defectos esenciales se habían advertido en diferentes ocasiones, como el bombo de la Descubierta que ya pasado de la broma y estropeado con dos años de un servicio contínuo necesitaba renovarse enteramente. Las fraguas, los toneleros y el armero, apenas daban abasto á sus diferentes obradores; y las embarcaciones menores, así con esas atenciones como con el preciso pronto alijo de los buques y los diferentes objetos científicos, no tenían otro momento de reposo que el concedido cotidianamente á las tripulaciones desde la mitad de la tarde hasta las ocho de la noche, horas destinadas para su recreo y libertad. 
oet. 3"

Hubiera por consiguiente sido á la sazón imposible el coadyuvar al rucobro y habilitación de] buque desarbolado, que como se ha dicho, había cogido fondo próximamente á la embocadura del Papagallo, si el aparecimiento en la tarde del 30 de la fragata Santa Gertrudis de la Marina Real, armada completamente en guerra, no hubiese con un crecido número de brazos dado nuevo vigor á nuestros esfuerzos para la habilitación de aquel buque. Ell Capitán de fragata D. Alonso de Tolres y Guerra, Comandante de la Santa Ger. trudis, nos informó que traía cincuenta y seis días de viaje desde el Puerto del Callao, en dondc permanecian las fragatas Livbrs y Santa B irbara de la Marina Real; que este plazo sin embargo había dependido del recalar á sotavento del puerto, pues que á los veintidos dias cle navegación estaba á la vista de las playas de Naguala; finalmente, que los últimos temporales del Sudeste le habian incomodado mucho, haciéndole rendir un mastelero y aconchándole sobre las costas de Sigiatanejo; había sido bastantemente feliz para conservar en todo aquel tiempo su tripulación sana, y para esplayar los impulsos de

Sov. la humanidad, auxiliando sobre Paita una embarcación inglesa destinada á la pesca de la ballena. que ya acosada extraordinariamente del escor. buto, se hallaba amenazada del último estrago.

Con este auxilio, y regresado con la lanclia de la DescubiekTA el Ćapitán de fragata D. Ca. yetano Valdés, que había reconocido prolijamente el buque abandonado, y halládole en estado de navegar luégo que se le habilitasen gente, víveres, arboladura y timón, fué fácil ocuparnos eficazmente de dicha habilitación, y así para la tarde del 3 de Noviembre ya navegó desde el puerto un pequeño convoy de dos lanchas $y$ dos botes á las órdenes del Teniente de navio Don Juan Gutiérrez de la Concha con la maestranza, víveres $y$ útiles necesarios para la habilitación de aparejo y timón. La Oficialidad y tripulación del mismo buque, reunidas de antemano y completadas con voluntarios de la fragata Santa Gertrik dis, un excelente gaviero de esta fragata, susti tuido á aquel Contramaestre enfermo, el Alférez de fragata D. Francisco Benitez entregado del mirido de la otra lancha, y las instrucciones dirigidas á que la comunicación con el puerto fuese la más segura y expedita; todo debía conspirar á que con la mayor economía y prontitud se logra se el fin propuesto.

No tardó Concha en conoce: que el único partido para el buque era el de navegar al Realejo, 6 tal ve $z$ á Guayaquil, tanto más, que se habicn declarado nuevamente las corrientes contrarias para aproximarse á Acapulco. Lo dictaban así también los cálculos mercantiles, pero exigía de nuestra parte un sacrificio harto considerable, $y$ era el de la lancha, sin la cual ni la tripulación podía considerarse segura en cualquiera evento Nov, ni procurarse de las costas de Guatemala y Tie. rra Firme, aquellos auxilios y correspondencia que pudiesen contribuir á una navegación feliz y expedita. A la verdad, el reemplazo de la lancha no era imposible en Acapulco, pero era precisn emprender hasta el corte de las maderas necesa rias y ocupar la poca gente sana, dilatando tal ve $z$ con este mismo motivo la salida.

La protección que deben los buques de la Ma. rina Real á los mercantes, prevaleció sin embar go sobre estas reflexiones. Para el medio diz del Io, cedida la lancha, concluídas las bandolas, asegurado el timón de espadilla, reemplazadas aguada $y$ víveres, cobrada el ancla, aunque se hallase en 96 brazas, $y$ hechas algunas pruebas del andar y gobierno del buque que fueron bien satisfactorias, D. Juan de Ia Concha regresó al puerto habiendo concluído su comisión con toda la actividad é inteligencia que podian desearsc.

Los comerciantes comisionados en Méjico por el dueño de la embarcación, satisfacieron puntualmente asi el valor de los efectos suministra. dos de la Real Hacienda como los jornales ven cidos por las rnaestranzas y marinerias; accedieron también á satisfacer el valor, cualquiera fuese, de la lancha nueva que se pondría inme. diatamente por obra; $y$ manifestando en repeti. das cartas cuánto se consideraban agradecidos en aquella ocasión á los esfuerzos de la Marina lieal á su favor, nos dieron la satisfacción de ver correspondidas de nuestra parte no sólo las $6 r$ denes generales de S. M. por lo que toca al at. xiliar el comercio de sus vasallos, si también las providencias del señor Virey de Méjico, que movidas de una actividad y humanidad poco comu. nes, se dirigían antes á la seguridad de los individuos y luégo del buque, si apareciese sobre la costa. Tal vez una narración tan difusa, y áun diremos nimia, parecerá á primera vista 6 inoportuna, ó artificiosamente dirigida al deseo de ensalzar los que son meramente unos deberes morales: no es así la hemos individualizado úni camente para demostrar cuánto pueden á veces $\therefore$ fuerzas unidas para un mismo fin recto, $y$ cuánto debe complacerse el marino, viendo refiuir á beneficio de la sociedad, aquellas mismas fuerzas y combinaciones que parecían únicamente dispuestas para destruirla.

No eran pocas á la sazón las circunstancias 6 favorables 6 adversas que habian variado en un todo el semblante de la expedición produ ciendo la necesidad de nuevas medidas, harto distantes de lo que á primera vista nos debíamos proponer. Si el temor de errar á pesar de lo que dicien la conciencia, el examen maduro de las circunstancias, y la aprobación de legítimos jueces, fuese en las grandes Monarquías una razón suficiente para no modificar las órdenes 
diera evento Nov. 3 mala y Tie. espondencia ación feliz de la lancha era precisr eras necesa lilatando tal

es de la Ma. os sin embar sedio díz de $s$ bandolas, :emplazadas , aunque se nas pruebas fueron bien a regres 6 al ión con toda an desearse. n Méjico por ıcieron pun. suministra. ornales ven. erías; acce. , cualquiera indría inme. o en repeti. agradecidos e la Marina ccción de ver sólo las ór toca al au también las ico, que mo. poco comu de los indiese sobre la ifusa, $y$ áun vista ó in. al deseo de nos deberes talizado úniden á veces fin recto, $y$ iendo reflui. ismas fuer únicamente

cunstancias variado en ción produ. lidas, harto os debíamos ar de lo que iduro de las e legítimos arquías una las órdenes
Nov. to primitivas según lo indiquen las circunstancias, nuestra conducta fuera á la sazón seguramente reprensible; pero adviértase cuánto sería culpable malograr en una parte siquiera por este temor el fruto que debía exigir de nosotros la irionarquía después de la inversión de tantos caudales, y se verá que si bien el bueno 6 mal éxitode aquellas medidas dependiese precisamente de inil circunstancias difíciles de precaverse, sin embargo, hubiera sido una culpa verdadera y bien reprensible el ver con una pusilánime inac. ción malograrse crecidas cosechas por el solo temor de arrimar una mano poco experta al hierro que debía disponerlas.

Unas órdenes recientes de $\mathrm{S}$. M. al señor $\mathrm{Vi}$ rey, exigían que al mismo tiempo que se termi. nasen en Nutka las últimas diferencias ocurridas scbre derechos territoriales entre la Corte nues. tra y la británica, se hiciese un prolijo reconocimiento del nombrado Estrecho de Fuca, el cual según las últimas navegaciones de los Capitanes Verklay, Meares y Quimper, parecía dar ingreso á una nueva extensión de mar, que los pocos cáutos hacían ya llegar hasta muy poca distan. cia 6 hasta una comunicación con el mar Atlán. tico: S. E. tuvo á bien participarnos aquellas órdenes y avisar al mismo tiempo, que la goleta Mejicara del Departamento de San Blas, á las ór. denes del Teniente de fragata D. Francisco Maurelle, navegaría muy luego para verificar aquel reconocimiento, mientras el Capitán de navíoDon Juan de la Bodega y Cuadra, con las fragatas Gertrudis y Princesa, y otra goleta, se dirigirían á Nutka para encontrar ó esperar allí los buques ingleses destinados á la convención indicada. Quedaba luégo la goleta Sutil para que se con. cluyese de nuestra parte la costa imperfecta desde Aguatulco hasta Tecoantepeque, Soconusco y las embocaduras del Lempa, y debían de este. modo combinarse las diferentes atenciones del Departamento, por manera que se llevasen con igual perfección hasta su término. D. Francisco Maurelle reunía á la verdad, á una suma expe. riencia marinera y á los conocimientos regulares del pilotaje, una resolución y entusiasmo capa. ces de las mayores empresas; pero ni el estado de su salud podía corresponderlos, ni la falta de los instrumentos astronómicos y geodésicos, y por consiguiente de todo medio para determinar unas latitudes y longitudes ciertas, de jaba de ser un nuevo obstáculo para la empresa, en cuyo malogro no dejaría últimamente de influir mucho el hallarse Maurelle solo, y el no tener á sus órdenes otra goleta siquiera.

Estas reflexiones no podían ya ocultarnos cuánto se aventuraban irremediablemente el Era* rio de S. M. y el honor nacional, si la expedición nuestra con la excelente Oticialidad é instru. mentos de que estaba dotada no procurase aho- ra coadyuvar á las ideas del señor Virey. Eran, Nov del mismo parecer todos los Oticiales, y diaria. mente, ya uno, ya otro, explayaban su actividad y noble pundonor, agregando por su parte nuevas tareas á las que se proponían actualmente, y brindándose á darlas pronto y exacto cumpli. miento, cualesquiera que fuesen las fatigas, ias incomodidades y los riesgos á los cuales hubie. sen de arrostrar.

Propúsose por consiguiente al señor Virey que los Capitanes de fragata D. Dionisio Galiano y D. Cayetano Ṽaldés, y á sus órdenes los Te. nientes de fragata D. Juan Vernaci y D. Secundino Salamanca, navegarían en las goletas desde Acapulco. Estos Oficiales harían luego derrota directa al Puerto de Nutka, y de alli, completa. das aguada, víveres y gente, entrarian hacia la mitad ó últimos de Abril en el Estrecho de Fuca, v le reconocerían (si fuese preciso) hasta Setiem. bre ú Octubre, retrocediendo últimamente al Puerto de San Francisco en la California para completar los reconocimientos de las corbetas y restituirse pasada la estación lluviosa, á las costas de Nueva-España; Vernaci y Salaman. ca podrían luégo recorrer con unit goleta las cos. tas no bien reconocidas de Nueva-España, y de. jándola en las inmediaciones del pequeĩo Istmo de Nicaragua, podrían examinar la calidad, éxtensión y elevación de éste, para decidir l' $\imath$ cuestión de las comunicaciones de los dos mares; $y$ últimamente, tomaríar á su cargo el fömar un mapa hillográfico bien exacto del misrno golfo de Nicaragua y de la navegación del río San Juan hasta su desembocadura en el mar Atlántico; objeto á la verdad bien importante para la prosperidad nacional, y que podía cımbinarse con el plazo de nuestra llegada á Es’jaña, para la total conclusión de la obra.

S. E. aprobó desde luego el plan propuesto; dió las órdenes oportunas para la total habilital. ción y venida de las goletas Mejicana y Sutil y nosotros, en el restante tiempo, dedicamos nuestro m.ror conato á la completa suministración de cua. necesitasen: debían servirse del cuarto de círculo y péndulo de Ellicot, del acromático grande y del reloj de longitud de faltriquera que se hallaban actualmente en poder de Don Dionisio Galiano; se les agregaron el cronómetro 6r ya compuesto en Méjico, un segundo acromático, un barómetro, algunos termómetros, un círculo de reflexión con pié, un teodolito, una aguja azimutes y una de marear; se les dieron ordenados en diferentes cartas no sólo los reco. nocimientos nuestros del último viaje, si también los de los Capitanes Meares y del Teniente de na. vío Elisa en el Estrecho de Fuca; finalmente, recibidos unos nueve marineros voluntarios de la fragata Santa Gertrudis á bordo de la DescubierTA, diez de los mejores marineros de esta tras- 
Nor to bordaron voluntarios á las goletas para servir con preferencia en todos aquellos trances peligrosos que no podian dejar de encontrarse en la campaña proyectada.

Én el entretanto eran á cada paso más agra. dables las noticias que recibíamos de Méjico: D. Antonio Pineda y D. Luis Nee, con una actividad incansable, habian enriquecido sus acopios de Historia Natural, recorriendo unas 400 leguas de terrenos varios, cuales son los que se extienden desde Acapulco á Méjico por Chilpancingo, Tistla, el Río Azul, Real de Tasco y Cnernavaca; y desde Méjico hasta Guanajuato, por Zempoala, Pachuca, Real del Monte Santa Rosa y Semiquilpan, Querétaro, las Termas de Atoto nilco el Grande, San Bartolo, Quereguaro, Acam baro, las Fuentes termales de Úcarco, Salvaticrra, y Salamanca: habían además enriquecido la importante narración de sus viajes con muchas experiencias físicas y con diferentes vistas de perspectiva sacadas por un pintor mejicano que llevaban consigo; ni se habían descuidado en hacer una útil comparación sobre el beneficio de las minas con las nociones más selectas de la Europa y con los métodos adoptados en el Perú, todos objetos de la mayor importancia para la verdadera ilustración nacional en una parte tan esencial de sus riquezas.

D. Dionisio Galiano no había sido ménos ac. tivo y feliz durante su demora en Méjico, ocupándose eficazmente en ordenar todos los elementos del viaje pasado, en continuar la serie de sus observaciones astronómicas, acopiar nuevo materiales hidrográficos y dar la última mano á su problema de deducir la latitud en cl mar por dos alturas del Sol; finalmente, D. Arcadio Pineda, con no ménos actividad y penetración, había recogido un número tan crecido y tan importante de documentos útiles para el recto conocimiento del estado actual de prosperidad de aquel Reino, que sin duda no desmayarían nuestros deseos de ser útiles á la Nación, en cuantos modos estuviesen á nuestro alcance.

D. Manuel Novales gozaba ya de su primer estado de robustez, debido á la mucha inteligencia y cuidado del Doctor O'Sullivan, de Méjico; y si bien el pintor Guío, acosado de las ter. cianas no pudiese ya pensar sino en su regreso á España, habían llegado oportunamente á Méji co para reunirse á la expedición D. Juan Rave. net y D. Fernando Brambila, hábiles Profesores de pintura nombrados por S. M. para reempla. zar á D. José del Pozo y al mismo Guío.

La reunión amistosa de tantos y tan útiles sujetos con los cuales no sería difícil en lo venidero arrostrar nuevas fatigas y peligros, debía por consiguiente coadyuvar mucho a hacernos agradable la demora en Acapulco, tanto más que nus la constituían como un verdadero descanso las tareas así astronómicas como geo- Nov. 10 désicas cencluídas en la arribada anterior y el plazo no precipitado para los aprestos: aprovecharon efectivamente de esta última circunstancia el Comandante de la Atrevida, D. Tadeo Heenke, D. Fernando Quintano y D. Francisco Viana, para emprender una excursión científica luasta Méjico, y los demás se prefijaron con un trabajo moderado, 6 bien la ordenacion y repaso de los últimos datos hidrográficos, 6 las experiencias del péndulo simple, y el acechar cuales. quiera observaciones que pudiesen corresponder con las repetidas en Méjico por D. Dionisio Galiano. Pero la mezcla natural en las cosas huma. nas, de lo dulce con lo amargo, no dejaba á la sazón de compensar tal vez con mucho exceso todas las ventajas de nuestra situación cual la acabamos de describir. Las calenturas epidéini. cas, que al principio parecían de poca monta, se declararon ahora por unas intermitentes inflamatorias, complicadas á veces con putrefacción, ó á veces acompañadas con delirio, cólicus biliosos y disenterías de sangre, cuya mejor terminación parecía ser el período tercianario para aprovechar el uso saludable de la quina exquisita, que con tanta generosidad nos había regalado en el año pasado el $\mathrm{Sr}$. D. José Villa. lengua, ex-Presidente de Quito y actual Regente de Guatemala.

Muy luego unos go hombres de la fragata Sinta Gertrudis y á lo ménos 50 de las corbetas, se vieron acosados de la misma enfermedad: una buena mitad de los Oficiales del primer buque y por nuestra parte D. Ciriaco Cevallos, D. José Robredo, D. Felipe Bausá y el Cirujano de la ATrevida acrecentaban nuestros cuidados y nuestras desazones. Si por la mayor salubridad del aire, por el mejor orden y áun por la mejor asistencia de los enfermos parecía por una parte preferente el curar los contagiados á bordo, por la otra la demasiada estrechez, el ruído casi contínuo y la mucha inmediación de los sanos parecían disuadirlo: no podían abandonarse los obradores aunque nos costasen repetidos sacrificios: la construcción de la lancha nueva procedía paulatinamente; la de la ATREviDA aún no estaba concluída: el corte de la leña ya no podía seguirse y apenas había los brazos suficientes á bordo para no desistir enteramente de las faenas indispensables de aguada, estiva, aparejo y compostura del velamen. Entretanto, el marinero nunca escarmentado y nunca sacio, agregaba nuevas causas á las influencias harto temibles de un aire maléfico y pretendía envol. ver su temor y enfado en la capa harto espesa del abandono y del estrago; tanto más, que no faltando á las horas destinadas del trabajo, parecía de nuestra parte injusto $\mathrm{y}$ áun imprudente el quererle sujetar con una disciplina tan inútil 
como geo- Nov. to nterior y el tos: aprove. circunstan, D. Tadeo . Franciseo ón científica aron con un ión y repaso ó las expe. char cuales. zorresponder Jionisio $\mathrm{Ga}$ cosas huma- dejaba á la ucho exceso ación cual la ras epidéini. ca monta, se tentes infla. outrefacción, , cólicus bia mejor terianario para a quina exd nos había - José Villa. tual Regente

e la fragata las corbetas, enfermedad: s del primer co Cevallos, á y el Ciru. nuestros cuila mayor saen y áun por s parecía por ontagiados á estrechez, el mediación de dían abandotasen repetile la lancha de la ATrerte de la leña a los brazos enteramente uada, estiva, Entretanto nunca sacio, encias harto endía envol. . harto espesa más, que no trabajo, pa$n$ imprudente na tan inútil
Nov. 2 como molesta. No teníamos tampoco tropas, pues se habian devuelto á la plaza las que ha. biamos sacado en Abril último como auxiliares;

Dic. se había dado pasaporte para regresar á Espana á un cabo de la Atrevidi, y tres soldados de la Descubierta, enfermos habituales é incurables á bordo, y los pocos restantes además de sufrir tambien mucho de las enfermedades, debían dividir con el marinero las fatigas del buque y de las embarcaciones menores.

Por ventura el método seguido desde el principio por nuestros Cirujanos é imitado en el hospital yen la fragata Gertrudis, disipó todo recelo de un fin funesto á las enfermedades indicadas por cuanto pareciesen anunciarle los síntomas lastimosos que las acompañaban; pero como los remedios dependiesen principalmente de una re. petición grande de sangrías, de muchas purgas y vomitivos y de una rigurosa dieta, el conva. leciente se hallaba en un estado tal de debilidad, que 6 el menor exceso en la comida le producía nuevos cólicos realmente terribles, ó la nisma propensión de la atmósfera les causaba nuevas recaídas de la terciana.

Agregóse después á este estado nuestro de debilidad y de sinsabores, el que el Teniente de navio D. Fernando Quintano, debió finalmente ceder á nuestras instancias y á los consejos de Doctor O'Sullivan para curarse radicalmente de sus males del estómago, harto constantes $y$ te mibles; bien que no le sería dificil el alcanzar nuevamente la expedición en Manila por medio de la Nao de Filipinas el San Andrés, que había llegado al puerto á las órdenes del Teniente de fragata $D$. Joaquín Berenguer de Marquina.

Fue muy oportuno el arribo de este navio para conce rir á nuestra habilitación bien atrasada. Reforzáronse por consiguiente nuestras obras de cortar la madera en el puerto Marqués, aserrarla y disponerla para la construcción de la lancha; y así pudimos contar, que si bien no acabada interiormente, la tendríamos a lo ménos para la mitad de Diciembre en estado de poderse conducir á bordo y embarcarla.

Continuaban, pues, los estragos de la epidemia con el mismo tesón con el cual se había manifestado al principio de Noviembre. Ni bastaban para evadir su imperio, $o$ una vida metódica y tranquila, ó las sangrías anticipadas, ó la limpieza de todos los contornos del pueblo, que según costumbre ya establecida se despojaban por aquel tiempo de las malezas que las aguas habian hecho crecer y multiplicarse.

No quedaba, por consiguiente, otro partido sino el de acelerar la salida, tanto más que conseguida ya coli el observatorio de Méjico la correspondencia de una buena observación con el primer satélite de Júpiter, repetidas con la mayor escrupulosidad las observaciones del péndulo simple, embarcada la mayor parte de los instru- Dic mentos, emprendido nuevo arreglo de la marcha de los cronómetros, y contando con la Nao para el trr isporte á Manila de aquellos efectos que no pudiesemos recibir en aquel momento, nada esencial podia detenernos luego que la lancha estuviese en estado de conducirse á bordo.

Un raro acaso debimos advertir en la manufactura del tocino para la cual habíamos preferido el metodo descrito por el Capitán Cook al que solía usar el Conde de la Péyrouse con el auxilio del vinagre. Aunque sobrecargásemos con pesos considerables las tandas del tocino y la sal fucse bien activa, no alcanzaba ésta á penetrar. le, de modo que al principio nos malogró una pequeña parte, $y$ hubiéramos probablemente malogrado el todo, si no adoptásemos la precau. ción de tajar más menudamente los pedazos y darles una buena infusión de agua hirviendo an. tes de cubrirlos con sal y sobreponerles los pesos. Se ha hecho memoria de este accidente aunque frívolo, para recordar á los que dispon. gan sus viveres para navegaciones largas, cuánto es aventurado el seguir ciegamente un método aunque bien acreditado, y cuénto es necesaria una atención constante á los diferentes trances que no hayan podido preveerse.

Es bien sabido el metodo con el cual en todas nuestras costas del mar Pacífico y en el Río de la Plata se dispone el tasajo. Muerta la res $y$ dividida en diferentes tajadas, toda la carne se deja veinticuatro horas en salmuera, y luego se expone al sol hasta que se seque enteramente quedando así esta carne con muy buen gusto y no mucha sal, de suerte que no pierda casi ninguna de sus virtudes alimenticias, pero precisamente de muy poca duración por no haberse des. pojado de todas aquellas partes, que útiles al principio para el alimento, son luégo sumamente propensas á la putrefacción.

Esta especie de precipitación nuestra para abandonar el puerto, no pudo á ménos de constituirnos en la necesidad de solicitar de la fraga. ta Gertrudis y de la Nao algunos auxilios, bien fuese en cuanto á gentes ó en cuanto á víveres, pues les sería fácil á entrambos buques, 6 el omitirlos ó el reemplazarlos en San Blas y en Aca. pulco con un mayor despacio del que nosotros teníamos á la sazón. Se nos concedió por aquellos Comandantes tuco lo que fuese absolutamente indispensable para la continuación de nuestro viaje. Llegaron al medio día del I $_{4}$ las remesas de caudales de Méjico, que en parte recibimos á bordo y en parte se repartieron en cuatro pagas á la Oficialidad, tropa y marinería, satisfaciendo además por completo hasta fines de año las pa-, gas y gratificaciones á los que se separasen de las corbetas, 6 bien con motivo de enfermedad $o$ para servir en las goletas Mejicana y Sutil. Los 
Dic. is arrieros que conducian los caudales, asegura. ban que no llegarian las harinas hasta el 24; y como en estu ocasión no sólo debiese atenderse el plazo, aunque corto, de cuatro días para el aumento de las enfermedades epidémicas, si también la demasiada inmediación de las fiestas de Navidad para el recelo de nuevos desordenes y deserciones, quedo finalmente resuelto el dar la vela en la mañana del 20 sin esperar las gole. tas las harinas ni otra cosa alguna.
Lo verificó el rg la fragata Santa Gertrudis en Dic. ig demanda del puerto de San Blas, recibidos ya todos los efectos que le estaban destinados. Nosotros el mismo día embarcamos la lancha y los enfermos, no siendo éstos en ménes número de 30 á 35 por corbeta, y emprendida al amane. cer del 20 la faena de desamarrarnos, esperamos los primeros soplos de la virazón, la cual, final. inente, nos dic lugar á levar el ancla hacia las diez para salir cuanto antes del puerto. 


\section{LIBRO TERCERO}

Continuación del viaje de las corbetas á las Islas Marianas y Filipinas.-Varias excursiones en entrambos Archipiélagos, y navegación de la ATREvida al puerto de Macao.-Ultimos reconocimientos en el Mar Pacifico sobre la tierra austral del Espir itu Santo, la Nueva Zelanda, la Nueva Holanda y las Islas de Vavao en el Archipiélago de los Amigos.-Regreso al Puerto del Callao.-Nuevas indagaciones hidrograficas, hechas sobre las Tierras del Fuego, las Maluinas, la Costa Patagonica y el Río de la Plata.-Regreso al puerto de Cádiz.

\section{CAPITULO PRIMLRO}

Naregación desde Acap:llco il las Islas Marianas, es. cala, reconocimientos y observaciones en la de Guaham. Travesia siguiente las Islas Filipinas.-Acascimientos en los puertos de Palapa y Sorsogón, primeva escala en Mani'a y tareas de ia DEScuBIERTA on la misma balía y sobre las costas de la provincia de Pangasinan.

Cuanto más la ciencia de la navegación ha hecho fácil á los europeos el atravesar los mares más dilatados y tempestuosos, en igual razón han crecido los riesgos, á los cuales han debido arrostrar visitando los países inmensos que yacen bajo de la Zona Tórrida; y bebiendo con el afán de su descubrimiento, posesión 6 conquista aquellas miasmas pútridas que tan directamente conspiran á su propia destrucción, más bien que á su mayor felicidad. Si formásemos un paralelo de los sacrificios innumerables de gente que las posesiones ultramarinas han costado á la Europa con los beneficios sociales, que el comercio y la navegación le han producido, bien sea relativamente á la suavidad de las costumbres, 6 á la multiplicación de nuestra especie, seguramente se disiparían con la mayor rapidez una porción grande de las ventajas ponderadas del descubrimiento de la América; y cesarían los proyectos abultados sobre la extensión ilimitada del dominio y la rivalidad poco reflexiva de las naciones.

Estas á lo ménos debian ser nuestras refle. xiones al tiempo de dar la vela del puerto de Acapulco, enferma una mitad de las dotaciones de entrambas corbetas, y desmayados y pálidos los demás, que dos meses antes no manifestaban sino el semblante de la robu tez y de la alegría. En la navegación siguiente hacia las Islas Ma. rianas nuestros objetos esenciales debieron por la misma razón dirigirse más bien al restablecimiento $j$ conservación de las tripulaciones que á la idea de nuevos descubrimientos. Ni á la verdad serían éstos más que imaginarios, cuando la deriota constante de las Naos por el espacio de dos siglos, había hecho aquella navegación la más fácil trillada y segura que hubiese en parte alguna del globo, cuando en el año anterior el Teniente de fragata D. Manuel Quimper con un buque del Departamento de San Blas había vi. sitado de nuevo las Islas de Sandwich, y cuando el desgraciado Conde de la Péyrouse corriendo un mismo paralelo habíase convencido de nuevo que aquel Archipielago era el que en 1555 descubrío Juan de Gaitán, navegante español, y denominó en sus diferentes Islas de Monge, Ulua, etc.

Abandonadas pues las costas, y dirigidos los bordos de tal manera, mientras continuaban los vientos variables, que con poca perdida en la latitud adquiriesemos constantemente las posibles ventajas al Oeste, pudimos finalmente álos diez y seis días de navegación, alcanzar las brisas entabladas por longitud de $20^{\circ}$ al Oeste de Acapulco; latitud $12^{\circ} 4 \mathrm{I}^{\prime}$ y variación magnética 6 a $7^{\circ}$ Nordeste. Un número inmenso de voladores, 
I. que habiamos visto poco antes, nos Ic indicaban con bastante probabilidad. Acreditaron luégo su permanencia todos Ios enfermos, que conforta. dos casi instantáneamente con un aire más puro y activo, manifestaron en la mañana siguiente una mejoria y alivjo considerables: contirmaban también los eudiómetros esa mayor snlubiclad del aire atmosférico, $y$ al paso que las distancias

I lu lunares observadas frecuentemente nos indica. ban los pequeños errores de los relojes marinos, crecian nuestras esperanzas de ver casi con emu lación acortados los térmiuos de una tan larga travesia, $y$ desterradas las cnfermedades epidé. micas que tan de cerca nos amenizalian.

[i] tiempo, el sosiego, la habilidad de cn. trambos Cirujanos, y sobre todo, el régimen de dieta á que pudieron sugetarse los cnfermos más graves encerrados en la camarita alta igualmente limpia y ventilada, triunfaron, final. mente de la perversidad del mal: así, cuando en la tarde del i I de Febrero se avistaron los altos de las Islas de Seypan y Tinian, ya casi no había enfermo alguno de cuya vida pudiésemos recelar, y por consiguiente, nuestras tareas no procederian en adelante con lentitud y desmayo.

A las cinco de la tarde terminábanse bien podian marcarse los extremos de Tinian del Sur $71^{\circ}$ Oeste al Norti $84^{\circ}$ Oeste de la aguja. Se emprendieron después las operaciones acostum bradas para las bases, horarios y marcaciones. $\mathrm{Al}$ anochecer se veían también distintamente los canales que forman con la de Tinian las Islas de Seypan y Aquiguan. Esta última es mediana. mente alta $y$ tendida, $y$ suele pasarse el canal indicado para dirigirse al fondeadero de aquélla como lo cjecutaron los Comandantes ingleses Anson, Biron y Wallis.

En la noche siguiente el viento fué fresco, los horizontes se conservaron nublados y nuestra navegación tuvo por objeto el dejar al Norte la Isla de Rota para atracar después los extremo de la de Guahan. Sólo en estas dos islas subsis ten algunos restos de la población antigua del Archipiélıgo. La residencia del Gobernador es en San Ignacio de Agaña, pueblo principal de la segunda.

Logróse el todo conforme lo deseábamos: se disiparon las sospechas de la existencia de un bajo en aquellas inmediaciones que señalaban algunas cartas españolas, equivocándole seguramente con un islotillo no distante del extremo Sudeste de Rota; atracóse después el extremo Norte de Guahan, tierra alta, bastantemente pedregosa acantilada al mar; finalmente, largas las insignias, empezamos á costear de cerca la parte occiden tal, en donde se hallan los dos fondeaderos de San Luis y de Umatac. Presentan estas costas un semblante realmenie agradable desde el uno al otro extremo, ó bien se considere la frondosi- dad y la suave elevación de sus colinas alomadas Fel. , ó la mar constantemente llana, y los muchos riachuclns que le tributan sus aguas cristalinas: Lucia las once y media ya nos fué fícil distin. guir los edificios de la capital Agaña, y al medio dia marcar su torre al Sur $6^{\circ}$ Oeste y la Punta Orote al Sur $4 t^{\circ}$ Oeste de la aguja. Fista punta es la que ciñe el pequeño puerto de San Luis, único abrigo de los vendavales y cuyo reconoci. miento debíamos por la misma razón mirar como interesante. Dirigimos pues nuestras proas lacia él, sin que pudiese servirnos del menor ausilio una embarcación pequeña de naturales, que vino a bordo, para saber en toda su extensión la verdadera dirección de las restingas; $y$ esta falta de noticias pudo arrastrarnos las cousecuencias -más funestas, porque nos hallamos repentina mente sobre la misma restinga con cuatro brazas escasas de agua.

Vencióse fácilmente con el timón el riesgo indicado, y pudicron las corbetas dar fondo poco después en paraje medianamente seguro; pero como nos manif cstase el escandallo las calidades pedregosas del mismo londo, y todos los objetos en torno, además del reconocimiento que hizo en un bote el Teniente de navio D. Francisco Viana confirmasen ya nuestras sospechas de ser aquel fondeadero poco 6 nada oportuno para nucstro intento, no bien con las primeras claras del día siguiente vimos declararse el terral, cuando dimos nuevamente la vela, no sin riesgo de perder alguna amarra, y fuimos á la rada no distante de Umatac, en donde quedaron ambas corbetas in. mediatamente amarradas una media milla al Est del castillito que le detiende.

Como en la roche anterior hubiésemo nya avisado al señor Gobernador al tiempo de femi. tirle las cartas cuáles eran los objetos principales de la escala de las corbetas en aquella rada, nos alcanzaron poco después de haber dado fondo cartas sumamente atentas de aquel Oficial, en las cuales nos avisaba que no tardaría sino pocas horas en llegar á la rada, en donde le sería más fácil ocurrir con oportınas órdenes $y$ avisos á todo cuanto pudiese contribuir á la prosperidad de la comisión. En efecto, á las nueve de la no. che estuvo en la villa acompañado de algunos Padres Recoletos de las misiones contíguas, pero nos habíamos retirado anteriormente á bordo después de un paseo tan agradable como, útil en aquellas inmediaciones.

Esta activa inmediación del Comandante de la isla no podía ménos de producirnos las mayores utilidades. Desde la mañanita siguiente, unos 14 indivíduos de la Descubrerta y seis de la ATrLvida, parte gravemente enfermos y parte convalecientes, quedaron alojados con mucha comodidad en el cuerpo de guardia de la misma casa del Gobernador: los Sres. Cevallos y Bausá 
colinas alomadas Fol. "I i, y los muchos guas cristalinas: fué fácil distin. gaña, y al medio Yeste y la Punta ruja. Esta punta to de San Luis, y cuyo reconocirazón mirar cos nuestras proas os del menor aude naturales, ctue la su extensión la ngas; $y$ esta falta las cousecuencias lamos repentina a con cuatro bra.

timón el riesgo as dar fondo poco ente seguro; pero lallo las calidades todos los objetos jiento que hizo en . Francisco Viana chas de ser aquel uno para nuestro ras claras del día erral, cuando din riesgo de perder ada no distante de mbas corbetas in. nedia milla al Este or hubiésemo nya 1 tiempo de temiobjetos principaen aquella rada, e haber dado fonle aquel Oficial, en ardaría sino pocas londe le sería más rdenes y avisos á I á la prosperidad as nueve de la nobañado de algunos es contíguas, pero mente á bordo des. able como útil en

lel Comandante de oducirnos las maañanita siguiente, CUBIERTA y seis de enfermos y parte jados con mucha rardia de la misma - Cevallos y Bausá
Fib. is que necesitaban tambien para restablecerse de alguna quietud y reposo, lograron un alojamien. to cómodo en la casa inmediata de la Mision; en la misma pudo conseguirse un paraje oportuno para armar ambos pendulos, compuesto y simple, y custodiar los demás instrumentos: el cuarto de circulo abrigado del ciscrvatorio portítil, se colocó đa muy poca distancia, y asi desde el mismo día se emprendieron las tareas astronómicas con la constancia y actividad acostumbradas.

No anduvieron tampoco omisos los encarga. dos de la Historia Natural; dirigiendose D. Tadeo Heenke hacia Agaña y los extremos septentrionales de la isla; D.' Luis Nee hacia los montes de la Vigía no distantes de la rada, y ocupándose Don Antonio Pineda con particularidad de la litolo. gía y zoología de aquellos contornos, que pa. recian bien importantes y curiosos.

La epidemia recibida en $\Lambda$ capulco, y cuyos rezagos eran por la mayor parte los enfermo que ahora intentábamos restablecer, ayudada en mucha parte de los desórdenes inevitables de navegante opuesto al régimen, á las privaciones y á la dieta, había echado en el día tales raíces, que en balde pudiera intentarsc restablecer á bordo los que ya repetidas veces habian sido perseguidos de las tercianas. La debilidad era tal en un marinero de la Dusscunierta, que á veces no prometía veinticuatro horas de vida: otro del mismo buque y uno de la ATRevida, habian de generado en disenterías mortales; de este mismo achaque la ArRevida había perdido en la travesía un marinero, y para que hasta la variedad conspirase á hacer más nociva la cpidemia, se agregaban á los anteriores otro soldado y un ma. rinero de la Drscubierta, el primero con un afecto cólico ya muy arraigado, y el segundo con un vicio temible de escorbuto que podía muy bien caracterizarse de segundo grado. Debíamos lisonjearnos que los aires, la quietud de la tierra unos alimentos sanos, y particularmente el ejercicio cuotidiano, contribuirían luégo á su tota restablecimiento. Asi no se omití cuidado por nuestra parte ni por la del Gobernador sobre el bienestar y mejor asistencia de esos infelices.

La aguada fué en aquel día la principal ocu. pación de entrambas lanchas: la poca distancia de las corbetas, la comodidad y abundancia del riachuelo que nos la suministraba, y la actividad de la marinería, hicieron que pudiesen repetirse los viajes y que para la noche tuviésemos reemplazada casi una mitad de la que nos faltaba, proponiéndonos también éste como el objeto principal de las tareas del día siguiente.

Entretanto, se aproximaba el novilunio: los vientos se habían declarado del Norte y Nornordeste frescos, con lluvias, ráfagas fuertes y mucha mar, y el ancla de la Descubier ra se hallaba casualmente sobre piedra: no parecio, pues, pru- dente el diferir más allá del siguiente día el le. reb. varla, examinar el cable, y darla fondo en are na, tanto más, que los botes enviados á sondar. indicaban que el buen fondo'apenas disiaba un tercio de cable. Por la mananita del 16 , dada por consiguiente una espía á la Arrevi1)A, hici mos que la lancha tendiese sobre ella otrit an. cla y levase por el orinque la que queriamos apartar de las piedras. Reconocimos en aquella ocasión, que ya estaba falto un cordón del cable, bien que á poca distancia de la entalingadura: enmendamos también el anclote del Oeste, y yn nus considerábamos tranquilos para los restantes dias que hubiésemos de permanecer en el fon. deadero.

l'uede por consiguiente imaginarse, cuál dc. bió ser nuestra desazón, al momento que el es. candallo nos avisó que á pesar de las faenas eje. cutadas el ancla estaba nuevamente en piedra, y que el único fruto había sido hasta entonces el de tener ambas amarras en diez 6 doce brazas de mayor fondo del que teniamos antes; fué pre. ciso emprender nuevas faenas para la mañanita siguiente, las cuales se hacian ya más complicadas por el viento fresco del Norte, la mar gruesa de la misma parte, una lluvia contínua, la nece. sidad de atender al mismo tiempo á un fondo con exceso acantilado, y el recelo de no moles. tar la ArrevisA, que parecía bien amarrada.

'odo quedó concluído á las tres de la tarde, bien que inutilizada un ancla habiéndose partido por la cruz entre las piedras. Pero nos estaba aún reservada una serie no mediana de fa. tigas. El viento bien fresco y arrafagado del Nordeste que soplaba desde el amanecer, hizo que hacia las ocho empezáramos á garrar sobre el ancla y últimamente sobrc ésta y el anclote: nos hallábamos ya en 42 brazas y demasiado atracados á la costa del Sur, de suerte que parecía por todas razones imprudente el dejar caer segunda ancla; fué por consiguiente preciso el determinarse á dar la veia soltado con buena boya el calabrote para recobrar después el cable que á la sazón teniamos enteramente fuera. Por fortuna nos había alcanzado poco antes la lancha, que alijamos luégo; siguiéronle después en la falúa del Gobernador los pocos Oficiales que á la sa$z$ ón se hallaban en tierra ocupados en el observatorio 6 para la Historia Natural. Pudimos por consiguiente emprender con aliento nuestra faena de meter el cable, ya tomada sobre el velacho arriado, los foques y la mesana, la murä estribor que á la sazón nos convenía.

El viento recio, las turbonadas, el velamen que teníamos envergado, la misma dificultad de gobernar bien sea por el ancla 6 por las embarcaciones menores que teníamos en el agua, hicieron que hasta las siete de la noche no se consiguiese echar el ancla arriba; envergáronse 
Feb. 18 después otras velas y á las ocho pudimos ceñir sobre las cuatro principales al cuarto cua.

19 drante. La mar era aun gruesa y el viento fresco; pero éste ya del Lsnordeste con carices hermosos, los cuales nos facilitaron en la ma. ñanita siguiente la vista de toda la isla aunque no distásemos ménos de siete leguas de su extremo del Sur que murcamos al Essueste.

Enterados así algún tanio de la variedad de la brisa en las diferentes horas det día y de la noche, pudimos disponer los bordos con mayor acierto, aprovechando todo el día y parte de la noche siguiente en navegar con la mura estribor, y revirando luégo desde las once de la noche al segundo cuadrante.

Logramos de este modo amanecer cl 20 á unas nueve leguas de la Punta de Orote que marć́bamos al Sueste, y como al mismo tiempo abonanzando el mar, la brisa soplase fresquita y algo más inclinada al Norte, fueron nuestros progresos hacia el puerto tan rápidos y directos, que para las diez apenas distábamos unas dos leguas de la punta; alcanzábamos á las once la vista del fondeadero y de la ATrevipa, y para el mismo día rendido ya el primer bordo sobre las rompientes de la Isla de Cocos, ceñíamos con todo aparejo, mura estribor, no distando sino tres á cuatro millas del Cástillo de $\mathrm{Hu}$ mata: latitud observada $13^{\circ} \pm 5^{\prime} 30^{\prime \prime}$. Continuaron los bordos hasta las cuatro de la tarde, entonces sondadas I4 brazas ar na, quedó la corbeta fondeada próximamente en el mismo paraje desde donde había empezado á garrar en la mañana del i 8. La lancha de la Arrevids que habia logrudo coger con rastra nuestro anclote, nos le trajo y tendió inmediatamente al Noroeste; echamos luégo las embarcaciones menores al agua y se permitió en la restante tarde y en toda la noche siguiente un completo descanso á la tropa y marinería.

No había sido poca en los pasados días la actividad de D. José Bustamante, del Gobernador D. José Aslegui y de todos los demás individuos ocupados en los diferentes objctos de la comisión: los enfermos manifestaban por la mayor parte una mejoría considerable: los Sres. Pineda y Heenke, esplayada su acostumbrada actividad en los contornos de Agaña, acababan de llegar á Umatac: D. Felipe Bausá había emprendido sus operaciones geodésicas; habia pasado al pue to de Sar Lujs el Piloto Inciarte; habian llegado los abundantes refrescos mandados acopiar por el Gobernador; y en el 'soservatorio, los Sres, Concha y Cevallos, conseguido el examen de la marcha del 105, y la observación de la inmersión de segundo satelite en la noche del 18 , habían dis puesto los péndulos pare las experiencias de la gravedad, sintiendo sí, que una nube intenipestiva, les hubiese imposibilitado observar en la si- télite.

Ya estando las cosas en una disposición tan favorab'e, $y$ estrechando mucho por otra parte el plazo de la estación buena para la continuación de nuestras tareas, pareciń $10 \mathrm{~m}$ ís prudente abandonar cuanto antes aquella rada, y con el mismo intento, en la mañana siguiente del $2 I$ se procuró completar la aguada; se dió con las alturas correspondientes nueva época para el examen de la marcha de los cronómetros; se em. prendieron las comparaciones dei péndulo simple con el tiempo medio, y el Sr. Gobernador remitió á bordo los refrescos y víveres acopiados. Destinóse al mismo tiempo al Piloto Sánchez con un teodolito á la costa opuesta para ligar con buenas marcaciones los extremos de nuestros reconocimientos á la vela; un soldado cazador inquirió para D. Antonio Pineda todas las especies de aves que pudiese alcanzar; y $D$. Juan Ravenet representó con la mayor propiedad dos naturales de la isla de uno y otro sexo y un natural de las Carolinas.

Con las alturas correspondiertes del 22 ya los relojes de anbas corbetas pudieron considerarse sujetos á un examen seguro. En la misma tarde por consiguiente se embarcaron los instrumentos y los enfermos; de éstos sólo tres de la Descublista y uno de la ATrevida de. bian quedarse para incorporársenos después con la Nao; $y$ hechos por otra parte en aquel día $y$ en el siguiente considerables acopios de leña por medio de un trabajo asíduo de la tropa y marinería, ya en la tarde del 23 pudimos considerarnos enteramente prontos para dar la rela.

Las comparaciones de los cronómetros con el tiempo medio, nos habían indicado como sospechábamos, una aceleración de $5^{\prime \prime}$ próximamente en el 7I y en el to5 y el atrasode $\mathrm{I}^{\prime \prime}$ en el 72; y atento á lo que habíamos advertido en el mar, este segundo movimiento parecía más bien el que habian llevado aquellas máquinas que no el determinado en Acapulco: así fué lo más oportuno adoptarle para la deducción de la longitud por los cronómetros y para la ecuación total de las variaciones. Era indiferente el suponer al I05 el movimiento determinado en Acapulco, pues las ecuaciones corregirian sus trastornos, $y$ corregidos éstos sería luego fácil aplicar también la corrección correspondiente al 35I, que había sido ell el viaje diariamente comparado al to5. Estos fueron los resultados que tuvimos referidos al meâio día del $x_{5}$.

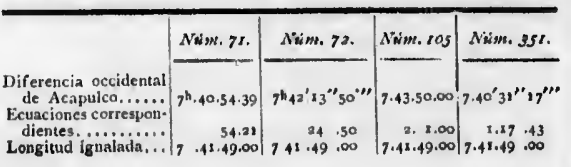


Nar. 4 ma atención se habían embarcado para servir como intérpretes, gritáan á las canoas distantes que no temiesen, antes bien que contasen con premios en ropa ó en dinero si atracaban á bordo. Todo fué infructuoso hasta las once, á cuya hora, aproximáronse dos canoas $\mathbf{y}$ condujeron los Oficiales al pueblo no distante de Palapa con los instrumentos oportunos para la observación del satélite. Se abandonó ya la latitud y emprender algunas marcaciones con el teodolito, $y$ al amanecer del día siguiente, logrados los demás objetos, pudieron los Oficiales regresar á bordo con unas noticias bastantemente exactas de aquellos contornos.

A la sazón los naturales habían depuesto toda especie de recelo, y atraídos no ménos de la facilidad nuestra de comprar, como del alto precio con que adquiríamos cualquiera objeto satisfaciéndole con plata efectiva, acudían en crecido número con sus canoas para vender todo cuanto estuviese en la esfera de su actividad. Con este motivo fué extraordinaria la abundancia de co. mestibles, y en ella merecieron siempre los gallos la primera atención, pues agregaban á su utilidad intrínseca, la de distraer las tripulaciones en las horas de su descanso con unas riñas que sirven de entretenimiento áun en nuestra Europa.

Como era natural, la amenidad de los contornos, la facilidad de usar de las embarcaciones remeras de los pueblos inmediatos, la constancia de los tiempos favorables y la misma emulación nuestra en sobresalir entre los muchos ramos que abrazaba la comisión, debieron causar una actividad extraordinaria en nuestros pasos: extendiéronse las marcaciones con el teodolito hasta las inmediaciones del Estrecho de San Bernardino, enriqueciéronse las colecciones de Historia Natural y particularmente la conchiologia: las lanchas armadas se ocuparon en la escrupulosa continuación de las sondas así en la parte interior como en los diferentes canales que conducen al río, y pues que una islita ne distante del fondeadero brindaba con sus playas un paraje excelente á los Oficiales astrónomos para las observa. ciones que ncurriesen, fué igualmente acelerado este ramo importunic, y ruestra demora en el puerto si bicn no mayor de seis dias, debió pa. recer como bastantemente útil para la verifica. ción del plan propuesto de tareas.

Las correspondientes á la Astronomía consistían en la determinación de una buena latitud con el cuarto de círculo, en observar la ocultación de las 4I4 del catálogo de Mayer por la Luna; y en una nueva inmersión del primer sa. télite de Júpiter que pudo observarse con bas. tante seguridad por los Sres. Espinosa, Conclia y Cevallos, se prefirió para el examen de la marcha de los relojes marinos el método de las alturas absolutas, pues lográbamos por la mañana de un Mar. + buen horizonte, $y$ con este motivo pudo concederse á las tripulaciones un regular descanso, no siendo preciso de noche custodia alguna en tierra para el observatorio.

Los resultados de las tareas indicadas fueron los siguientes:

Longitud del fondeadero al Oeste de CA-

diz por los cuatro relojes marinos. . . . 228.53. El satélite de la noche del $4 \ldots \ldots \ldots 228.53 .48$ El de la noche del $6 \ldots \ldots \ldots \ldots \ldots$ 228.53.13 Latitud. . . . . . . . . N. $12^{\circ} 37^{\prime} 5^{\prime \prime}$ Variación magnética. . . . . . . N. E. $0^{\circ} 20^{\prime} 0^{\prime \prime}$

Extendida la voz de nuestra llegada y digámoslo así, de las ventajas de nuestro comercio en las poblaciones no distantes de Palapa,se animaron á visitarnos á bordo otros tres ó cuatro religiosos franciscanos, y sus conversaciones fueron sumamente útiles, en cuanto pudimos formar una idea exacta de la Isla de Samar y de sus productos y habitadores: aumentaba con este motivo la cantidad inagotable de comestibles que llegaban diariamente á bordo: y como varias canoas, bien nor costumbre ó por una debida precaución, fuesen tripuladas con toda la gente armada, fué fácil enterarnos de la calidad de sus danzas militares ejecutadas repetidas veces á bordo y representadas por I). Juan Ravenet con mucha propiedad. En la noche del 9 regresaron á bordo los naturalistas, y en la mañana siguiente entrambas corbetas dieron la vela para dirigirse al Estrecho de San Bernardino.

Nuestras marcaciones desde el pueblo de Laguán, manifestaban que la distancia entre Pala. pa $y$ el Estrecho de San Bernardino, no excedía de unas I5 á 16 leguas.

Todo por consiguiente nos convidaba á aprovechar la tarde bien placentera para examinar la costa; aproximándonos luégo en la noche á la boca del estrecho, por manera que en la mañana siguiente con el viento y marea favorables, al canzásemos en pocas horas el puerto de Sorso. gón: la Naturaleza parecía vestirse en aquellos contornos con el semblante más agradabie: el resplandor de la Luna casi manifestaba querer competir con el del astro supremo: la continuación de una brisa fresquita sin que se notase en todn el cielo una nube siquiera, daba finalmente á la navegación toda aquella seguridad que mal pu. diera combinarse con la reunión de una calma, de la oscuridad y de unas corrientes bastantemente vivas.

Para el anochecer ya la Isla Jabones nos demoraba al Sur $82^{\circ}$ Este distancia de cuatro le. guas; sondáronse 5o brazas arena, y á esta dis. tancia se hacía apenas perceptible el efecto de la marea: no distábamos á la sazón sino unas siete leguas de la Punta de Viri, que nos demoraba al 
la mañana de un Mar. tivo pudo conce. ular descanso, no a alguna en tierra

indicadas fueron

de Ca.

s. . . . 228.53. 5

. . 228.53 .48

... 228.53 .13

. N. $12^{\circ} 37^{\prime} 5^{\prime \prime}$

. N. E. $0^{\circ} 20^{\prime} 0^{\prime \prime}$

a llegada y digánuestro comercio de Palapa, se anitres 6 cuatro relirersaciones fueron dimos formar una $r$ y de sus produc. zon este motivo la bles que llegaban arias canoas, bien a precaución, fue. te armada, fué fá. sus danzas militaá bordo y repre. con mucha pro. -esaron á bordo los guiente entrambas rigirse al Estrecho

e el pueblo de Latancia entre Palaardino, no excedía

convidaba á aproa para examinar la en la noche á la que en la mañana rea favorables, al. puerto de Sorsoestirse en aquellos s agradabie: el resestaba querer com10: la continuacion se notase en todo ba finalmente á la uridad que mal puin de una calma, de ates bastantemente ila Jabones nos deuncia de cuatro lerena, y á esta dis. tible el efecto de la zon sino unas siete ue nos demoraba al
Mar. so Norte $83^{\circ}$ Oeste; pareció ésta por consiguiente una buena posición plara esperar la mañanita siguiente, y así á veces ciñendo, á veces paireando con viento del Este y Essueste fresquito, procuramos eludir cualesquiera efectos de las corrientes ó mareas: á las tres de la mañana estando te la vuelta de Samar, se sondearon 40 brazá 3 arena y cascajo: el día sumamente placentero nos aceleró luégo la vista de los muchos puntos que de. seábamos marcar, y dándonos asi lugar de emprender nuestra derrota con fuerza de vela, para la hora de salir el Sol ya nos liallábamos á una legua $y$ media de la Islita de San Bernardino, que se marcaba al Sur $67^{\circ}$ Oeste. La Punta Viri al mismo tiempo demoraba al ángulo de $27^{\circ} \mathrm{en}$ el mismo cuadrante.

Luégo que hubimos rebasado á distancia de una milla dicho islote y sujetada con algunos horarios la longitud de la parte saliente del estrecho, nuestra derrota, como era natural, fué directa hacia la Punta de Galeras en la Isla de Capul. Es bien sabido que la marea entrante y favorable, se dirige con mucha fuerza á aquella isla, aconchando á veces las embarcaciones 6 por efecto de poca precaución ó por la falta del viento, de modo que hayan de pasar al Sur ó encontrarse remolinadas entre los Islotes Naranjos. Esta reflexión nos persuadió á atracarnos más á la costa de Luzón, in la cual ya veíamos á no mucha distancia el pueblo de Calantas. No nos descuidábamos al mismo tiempo en sujetar á marcaciones y elfilaciones cuantos puntos importantes nos rodeasen en aquél Archipiélago, de suerte que los muchos Islotes de Valiguatrc, la Punta de este nombre y la de Viri, ambos extremos de la Isla de Capul; la de Muertos 6 Dalupiri, los Volcanes de Albai y Bulusan y las cos tas todas de la Isla de Luzón, fuéronse poco á poco enlazando entre sí y haciendo independientes de las bases, que en aquellos parajes serían, si no peligrosas, á lo ménos inútiles.

A las ocho de la mañana no distábamos sin: unas dos leguas del bajo de Calantas, que podíamos marcar con seguridad. Nos vimos pues al. gún tiempo detenidos, y áun precisados á seguir bordos poco ventajosos con las ventolinas flojas del Noroeste y Norte; pero como no tardase el viento en rolar nuevamente al Esnordeste, para las diez nos hallamos en el canal que forma la Isla de Capul con la Punta y bajo de $\mathrm{Ca}$. lantas; $y$ al medio día navegábamos (pasados los Naranjos), entre la Isla de Ticao y la costa de Luzón. Un horizonte libre al Sur nos proporcionó la observación de la altura meridiana del Sol, y esto con las observaciones de longitud que habiamos repetido por la mañana, y renovamos poco después, daba ya tanta mayor solidez á nuestros trabajos, cuanto que debíamos ligarlos con los que verificásemos en Sorsogón con toda la prolijidad astronómica. Los volcanes de Al- Mar in bai y Bulusán eran los eslabones principales de esta cadena importante de marcaciones.

No es fácil para el que no haya surcado aquellos mares el formarse una idea cabal de tan amena perspectiva como la que allí se presenta: con la serenidad del cielo y la suave dirección de los vientos del Este, apenas el navegante admirado tiene lugar de ocuparse de la felicidad del viaje: las escenas que se le presentan á la vista son harto :arias y multiplicadas: una frondosidad uniforme, unos terrenos ó suavemente alomados 6 entrecortados con volcanes y otros montes más altos: los varios caminos que han abierto las aguas para buscar inútilmente entre esas islas un equilibrio tranquilo; las torres de uno ú otro pueblo, en Calantas, Capul y Ficao; el recuerdo inismo filosófico de las vicisitudes que han pasa. do esos moradores, $y$ de lo mucho que puede extenderse alli la especie humana, sin teñir de su propia sangre la tierra, que sólo debía alimen. tarle, hacen casi enfadoso y molesto el viento favorable, que semejante á un telón, arrebata de golpe una vista tan agradable y reflexiva.

Costeábamos, pues, la Isla de Luzón á distancia de dos millas por fondos de I $_{5}$ á i 8 brazas arena fina, con ánimo de alcanzar muy luégo el puerto de Sorsogon; y seguramente le hubiéra. mos conseguido si al principio de la roche, declarado el terral fresiso directamente opuesto á nuestro intento, no nos viésemos precisados á fondear al abrigo de la isla inmediata de Bagatao distantes unos tres cables de sus playas: fueron las lanchas armadas lu igo que amaneció, á sondar $y$ hacer diferentes marcaciones. Las corbetas dieron después la vela, y con la marea favo. rable alcanzaron sobre bordos un paraje oportu. no para fondear y amariarse.

El puerto de Sorsogón es sin cluda alguna de los más hermosos que haya formado la N..turaleza: capaz de contener escuadras innumerables con un tondo que no excede de I $_{5}$ á 16 brazas lama; con unas orillas bastantemente acantilaias, con algunos pueblos no distantes que pueden bastecerle de lo necesario, sumamente abundantc äe peces sabrosos, ofrece realmente un abrigo cómodo y agradable, particularmente en la estación de los vendarales: jues mientras relnen las brisas y no se necesiten más eue agua, leña $v$ algunos refrescos, parece preferente fondear fuera del puerto algo al Sur de la Isla de Bagatao en frente de una cascadita bien notable de agua.

Una vejetación lozana, dos volcanes á la vista y la extensión indicada del pucrto, a po. dían á ménos de atizar en suno grado la curiosidad de nuestros naturalistas: agregáronse la abundancia de peces $y^{*}$ de zonchas exquisitas, el cultivo del arroz, el beneficio del ah i y los 
Mar. xo principios de la propagación del gusano de seda, todos objetos que podían estudiarse en los puebles inmediatos. No tardaron por consiguiente en extender cuanto fuese posible sus excursiones, y pareció aún más adecuado á la utilidad del viaje, que $D$. Luis Nee se separase de las corbetas, y por el espacio de tres meses, hasta el declararse de la estación lluviosa del vendaval, recorrese á su albedrío los países que median entre el extremo meridional de Luzón y la capital de Manila, á donde debía reunírsenos. Nuestras lanchas $y$ botes en el entretanto fueron destina das á diferentes rumbos los más distantes del puerto, por manera que no quedase informe el plan emprendido, y además de esto tuviesen lugar D. Francisco Viana y. D. Felipe Bausá para trasferirse á la orilla oriental de la isla, y multiplicar all: las marcaciones del teodolito. Ni desmayaron por otra parte las tareas astronómicas, si bien se frustrasen por la mucha celajería algunas inmersiones del primer satélite: observamos por diferentes alturas meridianas de estrellas la latitud de $12^{\circ} 5^{\prime} \mathrm{IO}^{\prime \prime}$, y un promedio de los cuatro relojes marinos, adoptadas las pequeinas ecuaciones, fijó la longitud del fondeadero actual de las rurbetas $\mathrm{I}^{\circ} \mathrm{IO}^{\prime}+7^{\prime \prime}$ al (Oeste del observatorio de Palapa.

Como las ocupaciones indicadas no alcanzaban tan generalmente al total de nuestras mari. nerías, que luubiese para todos un trabajo metódico y cotidiano el cual mirábamos como uno de los estribos esenciales para la conservación de la salud, se emprendió inmediatamente y con este solo objeto, un corte diario de leña, de la cual había una suma abundancia on las orillas inmediatas. Por lo común alternando según costumbre la tropa y marinería en aquella útil ocupación, no duraba el corte sino hasta las diez de la mañana; comían luégo tranquilamente y reposaban á la sombra de un árbol. Por la tarde embarcaban la leña cortada y regresaban á bordo. Nunca faltaron un Oficial ó un sargento que dirigiesen aquellas partidas, $y$ un trozo, aunque pequeño de gente armada que custodiase las armas cargadas $y$ pudiese usarlas oportunamente contra cualquiera aparecimiento de los piratas.

En la mañanita del 22 estuvimos nuevamente prontos para dar la vela: algunas turbonadillas del Este interrumpidas con la calma nos llevaron después fuera del puerto, y reconocidas en aquella tarde las inmediaciones del puerto San Jacinto en la Isla de Ticao (abrigo acostumbrado de las Naos para csperar el momento favorable de la salida del Estrecho), antes del anochecer esturimos en el canal que forman las Islas de Burias y Masbate. Hízose la navega. ción con mucha proximidad á la primera, pairtamos después hasta el día con el objeto de continuar un reconocimiento útil y prolijo de las islas siguientes hasta Mindoro; y efectivamente, Mar. 23 al amanecer del 23 presentó á nuesta vista un espectáculo realmente agradable. La Isla de Burias no distante $y^{\prime}$ suavemente alta; la cosţa siguiente de Luzón hasta la Cabeza de Rondoc con una hermosa cordillera que la cercaba interiormente; la Isla de Masbate, las del Cobrador, Roinblón y Sibuyan más altas y más dis. tantes, no podían sino entretener la vista con una hermosa variedad, mientras no se omitía medio alguno para trazarlo todo escrupulosamente.

La calma en todo el día apenas nos dió lugar á atracarnos á los islotes inmediatos á Marinduque: fuimos más felices en la noche si. śuiente; $y$ si bien paireásemos en las últimas horas de ella, ya en la mañanita del 24 nos hallamos atracados á Mindoro y solas cinco le. guas distantes de la Isla Verde, la cual march́bamos al Oesnoroeste de la aguja.

Un nuevo encuentro concurrió á la sazón á represeñtarnos como más agradable aquella po. sición. y fué la vista de tres pancos ó embarcaciones piratas que no distaban al salir el Sol, sino una milla de nuestra proa hacia el Norte. No tardamos á ceñir con toda vela á estribor disponiéndonos al uso del cañón y del arma blanca; nos siguió la ATREvida, y las embarcaciones sospechosas emprendieron el rumbo que más le convenía, para evadirse por medio del remo que usaban con la mayor destreza. Pasaron como dos tiros de cañón de nuestra proa: nosotros viramos luégo que nos demoraron á las ocho ó nueve cuartas de barlovento; se hizo señal á la $A$ TrEvida de seguir el primer bordo, y aunque no estuviésemos á tiro, se dispararon en una y otra corbeta algunos cañonazos, con el objeto de que todo concurriese á infundirles algún temor y tal vez hacerles confundir las maniobras más oportunas. Pero muy luégo conocimos que no lograríamos el intento: con mucha pericia luégo que empr. thison la fuga habían abandonado la conserva entre sí, y sin embargo, maniobraban uniformemente virando al misno tiempo que las corbetas. Conocieron después que no les convenía la vela y volvieron á usar del remo echado abajo el palo; finalmente. despues de una hora de bordos, ya las dos mayores y mas veleras nos habian ganado una milla y media á barlovento: la tercera aunque mucho más zorrera, había ganado también considerablemente.

En esta posición sólo un viento bien fresco que ro les hiciese útil el uso del remo lubiera podido dejarnos alguna esperanza de coger si. quiera la última y más zorrera; pero sin este requisito, del cual no había la menor apariencia, nada más debíamos esperar sino el sacrificio de un tiempo precioso; abandonamos por consi- 
fectivamente, Mar. 33 estian vista un La Isla de alta; la cosţa $z$ a de Rondoc cercaba inteas del Cobra. is y más dis. or la vista con no se omitía escrupulosa.

as nos dió lu. erdiatos á Mala noche sin las últimas tel 24 nos ha. olas cinco le. a cual march́á la sazón á ble aquella poos 6 embarca. al salir el Sol, hacia el Norte. -ela á estribor bn y del arma A, y las embareron el rumbo dirse por me. la mayor des. cañón de nues. que nos demo. de barlovento; eguir el primer $s$ á tiro, se dislgunos cañona. oncurriese $a ́$ in acerles confun Pero muy luégo intento: con muron la fuga hatre sí, y sin emente virando al Conocieron des. a y volvieron á alo; finalmente. ya las dos maanado una milla aunque mucho bién considera-

nto bien fresco el remo liubieru za de coger sipero $\sin$ este reenor apariencia. el sacrificio de mos por consi.
Sar. as guiente la caza, y arribamos en derrota, atracando la costa de Luzón para pasar entre ésta y la Isla Verde.

No nos fué posible alcanzar el Estrecho sino después del medio día, y no debimos mirarlo como una desgracia, pues así se nos proporcionaba un excelente horizonte al Sur para la altura meridiana del Sol, de suerte que la latitud bien segura en aquel punto diese lugar tambien á una mayor exactitud en las observaciones de longitud que habíamos repetido por la mañr.na.

Insensiblemente el viento ya más fresco $y$ la marea, nos condujeron á la otra parte de la isla Verde propasada á muy corta distancia una goleta de guerra que había fondeado y dió poco después la vela: costeando la Isla de Maricaban examinamos prolijamente los bajos salientes que hacen algo peligrosa su costa del Oeste. Por último, no omitiendo el tomar horarios en meridianos de todos aquellos puntos cuya colocación nos pareciese importante, atracamos para las cuatro de la tarde la Purta de Santiago en la Isla de Luzón.

Ya á la sazón nos vimos obligados á navegar con trinquete y gavias: fuese luégo alargando el viento con la caída de la tarde y cediendo de su fuerza; $\sin$ embargo, para el anochecer no distábamos sino una legua del islote Fortún, y marcábamos el Corregidor al Norte $5^{\circ}$ Este y lo más alto de Mariveles al Norte $6^{\circ}$ Oeste. Por la mis. ma razón desistimos después de la iủea de navegar con poca vela: tuvimos algunas ventolinas del Sur, las cuales, aprovechadas con todo aparejo, nos hicieron creer hacia la media noche que nos sería asequible entrar en la bahía antes del día, teniendo á la vista la Isla del Corregidor, y hallándonos atracados á la costa de Limbones por fondo de 65 y 60 brazas arena. Ultimamente, después de una media hora de calma sin zobierno, entabló viento fresco del Esnordește, qृue ceñimos de una y otra vuelta sobre las tres gavias algo arriadas para no entregarnos á los efectos de la marea contraria.

Amaneció con semblante hermoso: se veían sobre bordos para entrar en la bahía diferentes embarcaciones costaneras, entre las cuales se distinguían con la bandera del Rey las dos goletas del corso. Hallábase fondeada en Mariveles una fragata mercante; algunos pontines savegaban para afuera. Todas las tierras estaban buen despejadas; $y$ marcálbamos el Frniliz al Norte $65^{\circ}$ Este; Pulo Caballo al Norte $13^{\circ}$ Este, la Monja al Norte $5^{\circ}$ Este, y la Modiania de Fortúni al Sur, $5^{\circ}$ Onste. En esta posición emprendimos con todo apare jo los bordos precisos para entrar, precaviéndonos al principio de la marea contraria con no atracar demasiado el Corregidor ni la costa de Marigundon; y al medio día liabianos adelantado considerablemente logrando en fin para las dos de la tarde montar Pulo Mer, as Caballo y costear el Corregidor por su banda del Este á distancia de media milla.

Como es costumbre en la bahía de Manila, el viento con cl adelantamiento de la tarde fue rolando más fresco al Sueste, de suerte que pudimos seguir constantemente con las muras á estribor, $y$ al ponerse el Sol marcar Manila al Norte $7 \mathrm{x}^{\circ}$ Este distancia cuatro leguas, hallándonos á la sazón en fondo ro brazas lama: se sondaron poco después ocho y media brazas á distancia de una legua de la costa, y en esta posición, viramos navegando con gavias y trinquetes hacia las costas inmediatas á Cavite: la res tante noche que fuć con exceso hermosa, se pasó desp’'lés á veces paireando, á veces ciñendo sobre las gavias para conservar un fondo de II , I2 y I 3 brazas lama, y de este modo, logramos al amanecer hallarnos una sóla legua distantes de la barra de Manila, que demoraba próximamente al Nordeste.

Permanecimos luégo hasta las ocho, ó en calma ó con ventolinas variables, que apenas permitían el gobierno áun auxiliándonos el bote con un remolque; pero llege ron tan oportunas algunas ráfagas aunque monıntáneas del Sur, qui pudimos á las nueve y needia dar fondo á una milla de la playa en seis brazas lama. Dife. rentes champancs chinos y algunas embarcaciones mercantes nacionales, sc halliban á la sa$z$ zón fondeadas en aquellas inmediaciones.

La escala actual en la bahia de Manila no debía ser á la verdad sino momentánea, y más bien dirigida á la cintrega de las cartas y pliegos recibidos en Acapulco y á la subdivisión útil de los mushos ramos de la expedición, que á cualquiera otro objeto extraño 6 bien fuese científico 6 militar. No podiamos ignorar cuánto importase ya un recto conocimiento de aquel Archupiélago feliz para el rápido incremento de la prosperidad nacional, ó bien fuesen sus navegaciones ó en sus cálculos marcantiles. No ignorábamos el periódico imperio de las monzones, que en los primeros dias de Junio con la en. trada de los vendavales harían iniructuosas cualesqu' era operaciones científicas, ó dependieren de la navegación 6 de las excursiones por tierra. Debían, por consiguiente, estos reparos aunar con extremo la mejor combunación de nuestras fuerzas y su empleo más ucelerado; lo cual dictó las medidas siguientes. La corbeta ArrevTDA tuve orden de emprender viaje para el paerto de Macao, con el objeto de repetir allí las experiencias de la "gravedad con el pénéulo simple, ya que sería impertaste en el arreglo proyectado de medidas el ebtener ana zelación directa de aquel paralslo con el primario que se admitiese: debía después regresar con la mayor brevedad á Manila, $\Sigma$ en el entretanto la 
Mar. 26 Descubierta procuraría recorrer las costas septentrionales hasta el Cabo Bojador, por manera que se franqueasen sus calas, puertos $y$ comercio útil, no tanto á una rutina local y permanente, como á los buques más distantes, con tal que fuesen provistos de buenas cartas y derroteros.

D. Antonio Pineda recorrería al mismo tiempo á su albedrío los montes y los llanos más ó ménos distantes de la capital, con dos goletas de Cavite; los Alféreces Aliponzoni y Bausá trabajarian en el plano de la bahía y extenderían las operaciones hidrográticas á las islas no distan. tes de Cabra, Lubán, Ambil y Mindoro; finalmente, si la Descubiekri pudiese verificar su viaje á las costas de la provincia de llocos, quedaría al cargo de D. Tadeo Fieenke registrar cuidadosamente las mismas provincias septentrionales, regresando por tierra á Manila. Así, con los destinos anteriormente indicados de Don Antonio Pineda y I). L uis Nee eu el centro y ell el extremo meridional de la isla, ya no quedaba parte alguna por reconocer, en cuanto lo permitía la demora de las corbetas en aquellos con. tornos: coadyuvaron con la mayor eficacia al logro de las medidas expresadas, las diferentes personas de la colonia, de las cuales dependían. El Brigadier de la Arnada D. Félix Berenguer de Marquina á la sa zón Capitán General de las islas, el Teniente de Rey D. Francisco Muñoz de San Clemente, los Directores de la Real Compañia, los Padres provinciales de las diferentes religiones que suministran los Curas Párrocos á las provincias, se esmeraban á porfía en dar aquellas órdenes é instrucciones que fuesen oportunas para nuestro intento. La ATrEviDA dió efectivamente la vela en el primer día de Abril; y el 3 lo rerificó tambén la Desce. BIERTA.

Pero en la demora indicada, si bien no excediese de ocho días, no habíamos omitido las tareas astronómicas acnstumbradas; y el método de las alturas absolutas adoptado en una y o.ra corbeta desde la misma tasde en la cual dieron tondo, nos había puesto en situación de continuar la serie de nuestras longitudes referidas por el meridiano de l'alapa al occidente de Cá. diz. El resultado de entrambos buques (descuidadas por el corto plazo las ecuaciones cliarias) fué el siguiente:

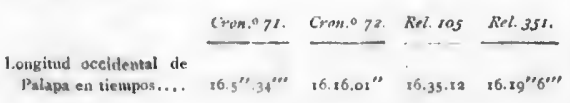

Pareció preferente en este caso el arrimarnos a los resultâdos de los dos cronómetros solos, cuyo movimiento en las comparaciones actuales era más conforme con el determinado en Sorso. gon y atendida la diferencia de meridianos entre el fondeadero y la catedral, quedo determinada la posición de ésta.

Por la serie de nuestras longitudes al

Occidente de Cádiz. . . . . . . . .

Por las observaciones de Mr. Le Gentil.

Por las determinaciones en el año an-

terior del Conde de Roself, Coman.

darite de la fragata francesa la $\mathrm{Ca}$.

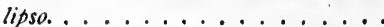

Por la inmersión del primer satélite de

Jipiter observada en la noche del 27.

Y la que acaeció en la noche del 29.

232.53 .29

50.30

Ahora, como en muchas otras ocasiones, echábamos de ménos para la debida comparación los resultados del Sr. Dagelet en la desgraciada expedición del Conde de la Péyrouse, bien que no podíamos dudar que debiesen precisamente aproximarse mucho á las determinaciones ya indicadas.

La navegación de la Descueierta hacia el Norte y al andar de las costas de Zambales y Pangasinan, no tardó en descubrir todas aque. llas dificultades que ya nos habían sugerido dife. rentes prácticas de Manila. Era la costa por lo común bastantemente fosca para que no pudiesen determinarse con claridad sus diferentes puntos: los vientos contrarios del Nordeste y Noroeste, entremezclados con algunas calmas y acompajados siempre con las corrientes bastantemente rápidas al Sur, hacían aún más difíciles nuestros progresos, cuando no quisiésemos alejarnos considerablemente de las playas; finalmente, á los sicte dias de nuestra salida apenas habíamos alcanzado la Punta Bolinao, y sin embargo la costa intermedia no podía caracterizarse por exactamente trazada.

Estos inconvenientes los cuales manifestaban el plazo del viaje emprendido seguramente más largo y ménos útil de lo que habíamos su. puesto al principio, debieron finalmente sugerirnos como más oportuno el retroceso de la corbeta á Cavite, para que se destacasen Oficiales á las costas no bjen reconocidas de Ilocos y Cagayan; á la laguna de Bay y á la contra-costa del Este y con embarcaciones del país y unas marchas aceleradas, aprovechasen en unas tareas tan importantes los últimos restos de la estación seca: púsose efectivamente la proa al Sur en la mañana del $9, y$ el $\mathrm{I}_{3}$ la corbeta ancló en Cavite, tomadas ya las medidas oportunas para la con. tinuación proyectada de tareas, conforme se verá en los capítulos siguientes. 
ones actuales do en Sorsoidianos entre eterminada la

232.53 .29 50.30

ERTA hacia el le Zambales ir todas aquesugerido difela costa por lo ue no pudiesen erentes puntos: te $y$ Noroeste, nas y acompabastantemente fíciles nuestros alejarnos conalmente, á los enas habiamos in embargo la izarse por exac-

les manifestalo seguramente habíamos suImente sugerirso de la corbeta Oficiales a las cos y Cagayan; - costa del Esto unas marchas tareas tan im estación seca: Sur en la mancló en Cavite, as para la cononforme se verí

\section{Navegación de la ATREvida desde Manila á los mares de China y entrada en el puerto de Taipa.}

Recibidas las instrucciones de D. Alejandro Malaspina, al a:ochecer nada faltaba para poder dar la vela por la mañana temprano con los primeros soplos del cerral ó ite la brisa. Este Comandante me acompañaba a! mismo tiempo con carta suya para el Gobernador de Macao, otra del Capitán General de estas islas, comunicándo le á ambos el objeto del destino de la Atrevios al establecimiento de su mando, y suplicándole que para desempeñarle me franquease los auxilios necesarios. Las experiencias del péndulo simple era un punto de mucha importancia para toda Europa, y no podríamos excusarnos de eje cutarlas en aquel territorio sin dejar de cumplir las intenciones de S. M.

Al amanecer estábamos á pique del ancla y muy luégo dimos la vela con velacho y sobremesana con viento fresquito del Esueste, dirigién. donos á pasar entre las Islas de Mariveles y el Corregidor, gobernando entonces al Oesudoeste $5^{\circ}$ Oeste. Concluídas las faenas de asegu rar las anclas y meter las embarcaciones meno. res, se forzó de vela con la brisa ya fresca, gobernando al Oeste un cuarto Sudoeste para atracar la Punta de Mariveles, precaviéndonos de bajo de San Nicolás, cuya posición, según el práctico, no era la más exacta en el plano. Seguimos después por el canal entre las dos islas al rumbo del Oesudoeste, pasando por la parte Norte de la Monja.

La derrota común que se ejecuta en esta es tación para Canton dectle las Filipinas, se hace sin perder de la mano la Isla de Luzón hasta Cabo Bojador. Por esta razón los vientos suelen ser más variables y flojos, aunque este atraso lo compensan las corrientes para el Norte, con especialidad desde Punta de Bolinao y no se experimentan tan fuertes para el Oeste no separándose de la costa.

Adelantamos no mucho en los días siguien. tes, pues hasta la tarde del 6 no llegamos á ver el fondeadero de Santa, en el cual había tres embarcaciones pequeñas que hacen el comercio de arroz con Manila; su pueblo lo marcamos al ponerse el Sol, al Nordeste $5^{\circ}$ Este, y la Punt? gorda de Santa María al Sur $72^{\circ}$ Este. Por la noche tuvimos algunas horas, viento galeno del Sudeste, con el que gobernamos al Norte $1 / 4$ Noroeste para precavernos del bajo de Saloma. que distante algo más de una legua de la tierra, del cual pasaríamos á la misma distancia. Si- guióse después barajándola á corta distancia Al. por el abra notable de Bigan, que pudimos distinguir muy bien con la claridad de la Luna lle na, advirtiendo ser bastante abierta $y$ formada por dos cerros de bastante altura.

Las marcaciones de la mañana próxima de las dos Islas de Salomaque y Sinay, que son bajas, la primera al Sur $42^{\circ}$ Este y la segunda al Norte $62^{n}$ Este, nos hicieron ver diferencias sensibles al Norte, y concebir la esperanza de ver en el día el Cabo Bojador. La latitud observada del medio día de $18^{\circ}$ o $5^{\prime}$ diferenciándose en $17^{\prime}$ al Norte de la estima, comprobó también el resultado de las maicaciones. La longitud observada por el promedio de los relojes 72 y I05, era $37^{\prime}$ $57^{\prime \prime}$ occidental de Manila.

Hacia las cuatro de la tarde se avistó el Cabo Bojador, formado por una punta baja saliente; marcóse luégo al Norte $43^{\circ}$ Este, distancia de cinco leguas. Era mi animo hacer diligencias para corregir su situación, sin embargo de que la Descunierta debía dirigirse á este objeto, pero el viento, calmando á la sazón, no hubo medio para correr una base durante la tarde, por la constancia de la calma; no obstante, empleando la distancia estimada para establecer su posición, siempı e será bastante aproximada, 6 á lo ménos, con mucha más exactitud de la que le señalan las cartas de Mr. Dalrimple.

Latitud observada al medio día á

bordo. ........................

Por estima al Norte hasta las seis de la tarde, aumentando sólo dos millas de corrientes á la distancia navegada, pues apenas hubo dife. rencia en la marcación desde las cuatro á las seis que se marcó la ultima vez.................

Latitud del buque á las seis de la

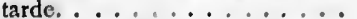

Diferencia de latitud al Norte por la marcación al Cabo, y la distancia estinada de $14^{\prime} \ldots \ldots \ldots \ldots .$.

Latitud del Cabo. . . . . . . . . N Longitud observada Oeste de Manila por los relojes marinos al medio día con el promedio de los dos.

Diferencia en longitud Este al Cabo por la maicación. . . . . . . . .

Longitud que resulta al Cabo Boja.

dor, occidental de Manila..... $0^{\circ} 24^{\prime} 57^{\prime \prime}$ $18^{\circ} 05^{\prime} 15^{\prime \prime}$

$\infty, 10.00$

$18 \cdot 15 \cdot 15$

$00 \cdot 9 \cdot 40$

$18^{\circ} 24^{\prime} 55^{\prime \prime}$

$\infty 0^{\circ} 37^{\prime} 57^{\prime \prime}$

$00 \cdot 13.00$ 
th. mente exacta áun cuando no se hubiesen repeti do los horarios á la hora de la marcación respecto de no ser necesarios por haberse seguido cons tantemente el rumbo del Norte desde los observados por la mañana, $y$ las corrientes tiran tam bién en la propia dirección.

En cuanto á la latitud puede también graduarse de suficiente confianza atendiendo á que sólo entra parte del error que incluye la distancia estimada al Cabo, y es muy corto de corrien tes habiendo mediado tan pequeño intervalo at medio dia; de modo, que no creo exceda el de la latitud en $2^{\prime}$ y siempre es muy preferente á la que expresa Dalrimple, pues se aparta en $I \eta^{\prime}$ a Norte (I).

$\mathrm{Al}$ anochecer abandonamos la vista del Cabo con brisa fresquita por el Nordeste, gobernándose al Nornoroeste $5^{\circ}$ Norte hasta el medio siguiente, en que advirtiendo una extraordinaria diferencia al Norte de $33^{\prime}$ hallándonos en longitud de $1^{\circ} 03^{\prime}$ arribamos al Noroeste $\%$ Norte. $A$ pocas horas de calma por la tarde sucedieron ventolinas de cuarto cuadrante, la atmósfera cargada suma mente de calima representaba á los astros con una grande refracción aparente, señal que rara ve $z$ se advierte cuando soplan las brisas y casi es inseparable de las bonanzas. Pasamos la noche en contínuas maniobras con las ventolinas varia bles del Nolicrdeste al Nornoroeste y Noroeste advirtiendo un ruído fuerte causado por la corriente, comprobándose esta observación por los remolinos y choques fuertes de las aguas contra el buque, sin poter atinar por entonces hacia qué dirección nos arrastraban.

Las observaciones del medio día siguiente nos sacaron de estas dudas. La latitud observa da de $19^{\circ} 53^{\prime}$ Norte no indicó diferencia alguna con la estima; pero la longitud por los relojes se apartaba de ésta en $30^{\prime}$ al Oeste, señalando el yo5 $\mathrm{I}^{\circ} 5^{\prime}$, y el $72 \mathrm{I}^{\circ} 4^{\prime}$. Por la posición de estas observaciones demoraba la extremidad Nordeste del bajo de la Plata al Norte $60^{\circ}$ Oeste distancias de r 30 millas, ateniéndonos á la situación en que le establecieron el año $r 779$ las corbetas de S. M. B. la Resolución y la Descubierta, man dadas entonces por los Capitanes Gore y King, por fallecimiento de los Sres. Cook y Clerk.

En el último tomo de sus viajes se halla la descripción que hace King de este bajo, pues le reconocieron desde su extremidad Nordeste, si. tuándola en latitud de $20^{\circ} 5^{8^{\prime}}$ Norte, y II $7^{\circ}$ de longitud oriental de Greenwich; y la del Sudoeste en $20^{\circ} 45^{\prime}$ Norte, aunque no pudieron determinar

(1) Esta determinación del Cabo Bojador ha re sultado muy conforme con la determinada despus por el Teniente de fragata D. Francisco Viana, comisionado desde Manila a situarlo. con precisión sus límites al Oeste, y en longitud de $116^{\circ} 44^{\prime}$. Mr. Dalrimple supone de extensión seis leguas en cuadro á este escollo, el cual, puesto por la Naturaleza en la derrota directa de las Filipinas á Canton se lıallará en nuestras car tas con toda la exactitud que importa á la segu. ridad de la navegación, debida al celo infatiga ble con que se interesaban en sus progresos aque. llos ilustres navegantes.

Entablóse el viento desde el principio de la noche por el Nornordeste, $y$ ciñendo mura á estri bor para pasar al Norte del bajo de la Plata, cuyo paralelo de la parte más Sur alcanzamos al medio dia siguiente, observamos la longitud de $3^{\circ} 9^{\prime}$, que volvió á repetirnos la misma diferen cia de $30^{\prime}$ al Ocste con la estima. Nuestra posi. ción no dejaba de ser un poco crítica, continuando yo en el ánimo de seguir la misma derrota si el viento nos abandonaba al estar por el través del bajo, y las corrientes conservasen las propias fuerzas para el Oeste. Como era mi intención también situar la Piedra Blanca, por ser un punto á donde recalan ó reconocen los buques que navegan á Canton en la estación presente, no era tan fácil conseguirlo si alterase la derrota pasando por el Sur del bajo.

Cobrando el viento más fuerza después del medio día, aunque sin pasar del Esnordeste y á veces más escaso, se arribó al Noroeste " Norte para disminuir el abatimiento aumentando el andar, $y$ desde aquí navegamos con vigilancis desde los topes, pues no sería extraño avistarse el bajo respecto á que gobernando á este rumbo y dando un error proporcional para el Oeste, pasaríamos á las cuatro y media como á cinco leguas de la parte septentrional.

Una cerrazón bastante oscura reunida sobre la situación del bajo, acortaba de tal modo el horizonte, que no le divisábamos por aquella parte más de dos leguas. A la caída de la tarde navegábamos sólo ya con las principales, por liaber refrescado bastantemente el viento. Las apariencias del tiemno no eran las mejores $y$ la mar había engruesado con proporción al vien. to. Sin embargo, proseguimos con los mismos esfuerzos de vela en la noche, á pesar de las fugadas repetidas, $y$ de haber faltado en una de ellas la relinga del pujamen del trinquete, y de consiguiente, haberse rifado este de alto á bajo, obligando envergar otro que quedó marcado á las nueve y media.

Con esta diligencia antes de romper el día avistamos ya varias embarcaciones pescadoras de los chinos. Aunque éstas conocidas aquí con el nombre de Lorchas, suelen salir á pescar hasta el bajo de la Plata, nos sorprendio, no obstante, verlas tan desatracadas de la costa con tiempo, al parecer, muy superior á su resistencia, creyéndonos así más inmediatos á ella
Ab. 9 
$y$ en longitud Ab., de extensión llo, el cual, ta directa de nuestras car. ta á la segucelo infatigaogresos aquerincipio de la mura á estri. de la Plata, lcanzamos al a longitud de isma diferenNuestra posica, continuanma derrota si por el través en las propias mi intención , por ser un en los buques ción presente, rase la derro-

a después del Esnordeste y á oeste $\%$ Norte umentando el con vigilancia traño avistarse o á este rumbo para el Oeste, - como á cinco

reunida sobre te tal modo el os por aquella ída de la tarde rincipales, por el viento. Las las mejores y orción al vien. on los mismos i pesar de las tado en una de trinquete, $y$ de de alto á bajo, ¿dó marcado á

romper el día es pescadoras cidas aquí con salir á pescar sorprendió, no de la costa con ir á su resis. nediatos á ella sb $"$ de lo que indicaba la estima desde el medio día antecedente, considerando sus mayores errores en parajes de corrientes, y con vientos desigua. les $y$ arrafagados.

Mis conceptos se justificaron muy pronto con la vista de la tierra á las ocho de la mañana. Por una sola altura de Sol que pude acechar á esta hora, y calculado el horario con la latitud de estima, resultaba la longitud de $5^{\circ}$ or' occidental de Manila ó $2^{\circ}$ próximamente al Este de Macao; situación que nos aseguraba el situar la Picdra Blanca si la preferencia del Sol, al parecer tan contingente, nos lo proporcionase. Nuestros rumbos sucesivos del Oesnoroeste y Noroeste $5^{\circ}$ Oeste, nos condujeron á dar vista á los islotes de Kingao demorando al Norte $5^{\circ}$ Este distancia como cuatro leguas, y esto confirmó al práctico que llevábamos, la confianza de nuestra longitud observada. Como esta marcación nos situaba casi on el meridiano de dichos islotes, observamos longitudes resultando á ellos la de $5^{\circ}$ I $9^{\prime}$ de Manila.

No bien observamos la latitud de $22^{\circ} 30^{\prime}$, cuando al poco rato vimos al Sur-Sudoeste Piedra Blanca, á tres y media leguas, cuya figura representa una embarcación á la vela. Puesto Norte-Sur con ella, á la una y cuarto se dedujo la longitud á este punto de $5^{\circ} 47^{\prime}$, y en latitud de $22^{\circ} 20^{\prime}$ Norte por la estima llevada prolija. mente hasta la hora de los horarios. Desde aquí al rumbo del Oesudoeste $5^{\circ}$ Oeste, llegamosá las cinco y media á estar al Sur de la Isla Single á una y media legua, avistando entonces la Gran Lema al Oesudoeste, continuamos el propio rumbo para pasar por el canal que forma ésta con la Isla Pootoy, y marcando al ponerse el Sol el extremo más Sur de la primera al Sudoeste \% Oeste, y la de Single al Norte, proseguimos al mis. mo rumbo del Oesudoeste $5^{\circ}$ Oeste sobre las gavias, para manejarnos más fácilmente por los canales que íbamos á atravesar.

El viento al anochecer estaba fresquito, y conservando la sonda de 18 ó ig brazas fango que tiene el canal, seguíamos para dentro. A las diez y media teníamos cerca por baborla Isla Lema y otras diferentes por estribor. Había sido mi áni. mo fondear al abrigo de algunas de estas islas durante la noche, pues la poca claridad de ella mientras no saliese la Luna, hacía algo cuidado. sa la navegación; iban prontas dos anclas para fondear en el instante de obligar á ello la calma o la corriente, y sin estas causas empezamos á navegar con las gavias arriadas braceadas unas ell contra de otras para medir la distancia al amanecer á vista de IIacao, con el fin de excusar la molesta maniobra de dar fondo y levarse en tan corto tiempo.

La Luna sobre el horizonte desde poco antes de media noche facilitaba el conocimiento su- ficiente de los canales, y áun hacer algunas enfi- Ah. \& laciones importantes: al mismo tiempo demorando la Punta Norte y Este de Lema al Sur $28^{n}$ Este, ; el lilote Waglatang al Norte, se gohernó al Oesnoroeste y poco después al Noroes. te un cuarto Oeste: después á las doce y media se hizo rumbo al Oeste para pasar á la parte del Norte de Ling, á cuyo rumbo se marcaba, y lo más saliente de Lama al Oesnoroeste $5^{\circ}$ Oeste. y lo más Oeste de Lama al Sur. $\Lambda$ la una y cuarto estábamos Norte-Sur con lo más Oeste de Lama y marcábamos lo más Norte de Lingtin al Oe. sudoeste $5^{\circ}$ Sur. Bajo de estas marcaciones se orzó al Oeste $1 \%$ Noroeste ña separarnos un poco de Lingtin y acercarnos también al extremo Sur de Chamchow. Arribamos á las dos al Oeste buscando el paso entre Chichow y los is. lotes del Norte llamados Chow. Orzamos á las tres á la isla de este nombre, gobernando al Oeste $5^{\circ}$ Sur, y á poco rato al Oesudoeste $5^{\circ}$ Oeste sondando ir brazas fango suelto cuando demoraba Lingtin al Sueste $1 \%$ Este. Estando á las cuatro y media con lo más Oeste de las Islas de Chow se orzó al Noroeste á pasar al Este de Latsame y se largó todo aparejo, amaneciendo entre la Isla de Lantao y Longsitow con viento bonancible del Esnordeste, el mismo que nos había acompañado toda la noche.

Sería difícil describir la agradable perspec. tiva de nuestra situación al aclarar el día hallándonos rodeados de una multitud de islas, que no obstante de ser áridas ó estériles, no dejaban de causar una vista tan divertida como harmoniosa, por su número, simetría y diversidad de tamaños.

A esto se agregaba una infinidad de lorchas pescadoras, que formadas en diferentes cuerpos, representaban á la distancia que las teníamos escuadras muy numerosas, para aumentar la vista lisonjera que causa la varieda? de objetos.

Nuestros rumbos se dirigieron á pasar cerca de Longsitow por la parte del Norte, $y$ cuando llegamos á estar con esta isla, ya descubríamos al Oeste $1 / 4$ Sudoeste la entrada del puerto de Taipa: como las corrientes tiraban á la sazón para el Sur, precisaron á gobernar al Noroeste. Avistábase ya la ciudad de Macao á las siete de la mañana, $y$ tremoladas nuestras insignias, nos dirigimos para el puerto con viento del Esueste, alcanzando á estar antes de dos horas entre la Punta de Cabaret y la isleta del Norte de la entrada de Taipa: de aquí seguimos al Oeste de la Punta Sur de su entrada por fondo de tres á cuatro brazas, hasta descubrir por la boca del Norte á Macao, dando fondo en cuatro brazas escasas fango: en esta situación demoraba la fortaleza más elevada de la ciudari al Norte $2^{\circ}$ Oeste, y la Punta Norte de la entrada al Este $5^{\circ}$ 
ib. is Norte, quedando luégo amarrados con dos anclas Norte-Sur.

Ocurrencius en el puerto de Tuipa y en la ciulad de Macao. - Atenciones recibilas del Gobernidor y de las Companías extranjeras; descripción de la ciudal con la forma de su Gobierno; idea de su comercio, producto de sus rentas y gastos que produce su conservación a $S$. M. F.--Reflexiones sobre el comercio de peletcria, con las ventajas de la España para des-

truir el de otras maciones que le ejecuten.

Apenas habiamos dado fondo cuando llegó el práctico portugués que reune las funciones de Capitán de puerto, y un dependiente de rentas: el primero de orden del Gobernador para enterarle de las novedades de nuestra navegación y objeto de la arribada: el segundo venía comisio. nado por la aduana para en el caso de no ser buque de guerra proceder al reconocimiento de la carga y á nombrar guardas que subsistiesen á bordo según costumbre con los mercantes. Sa. tisfechas estas preguntas se restituyeron uno y otro enviando yo al propio tiempo un Oficial á cumplimentar al Gobernador y convenir en la correspondencia del saludo, el cual ejecutaria siempre de asegurarme el ser respondido tiro por tiro.

A muy poco tiempo de haber fondeado, recibí carta de los comisionados de la Real Com. ñia de Filipinas D. Manuel de Agote y D. Julián Fuentes, ofreciéndoseme atentamente para cuanto pudiesen contribuir á nuestro obsequio: yo les contesté agradeciéndolcs el paso de atención que venian de significarme, y deseoso de corresponderla.

No tardaron los Sres. Agote y Fuentes en venir á bordo por la tarde, para manifestarme verbalmente las expresiones que les habia merecido por escrito, convidándome á comer con toda la Oticialidad para el día siguiente en la casa de la Compañía. A este tiempo enteré por menor al primero como primer factor, cuáles eran las necesidades urgentes que nos conducían á este puerto, para las cuales contaba con su diligencia eficaz para poder remediarlas en el corto tiempo que pensaba subsistir aquí; siendo entre estas muy esenciales las de proporcionarnos una casa cómoda para establecer nuestro observatorio en donde verificásemos las experiencias de la gravedad, objeto principal de nuestro destino; la adquisición de algún artífice inteligente para componer el reloj número Io, $y$ la de otru pequeño de esta misma especie, con pinturas de todas clases para proveer á nuestros profesores de las que necesitaban, sin las cuales no podian seguir en la continuación de sus trabajos.

También regresó en la misma tarde el Oficial comisionado, quien me informó que el Goberna. Ab. 13 dor y Capitán General D. Vasco Luis Carneiro de Sousa y Faro, Caballero de la Orden de Cris. to y Jefe de Escuadra en los mares de la India, le habia recibido con las señales ménos equi. vocas de urbanidad y política, haciéndole especial encargo me asegurase cuánto anhelaba con. tribuir con sus facultades personales $y$ del em. pleo, al desempeño de la comisión y obsequio de la Oficialidad de mi mando.

Aúll ne se labía visto en estos mares la ban. dera del Rey, y la concurrencia de todas las naciones europeas en Macao exigia un celo particular sobre la conducta de nuestros equipajes. $A$ este efecto se dirigieron mis primeras órdenes, intinıándoselas para qque su moderación y pru. dencia correspondiesen á mis deseos, en inteligencia de que usaría del mayor rigor para conseguirlo.

Saludamos á la plaza á la mañana siguiente con nueve cañonazos, á que respondió con el mismo número; y seguidamente pasé con la Oficialidad á visitar al Gobernador, quien nos recibib con todo el agasajo y expresiones las más atentas, agregando para justificarlas el habernos proporcionado ya una casa para el observatorio, que con gusto la cedía el $\mathrm{Sr}$. Antonio José de Acosta, cuya situación y conveniencia la hacían preferible en su concepto á cualquiera otra.

Como después supe por D. Manuel de Agote las grandes instancias que hacía el dueño de la casa pa:a que la admitiésemos, mandé conducirá ella todos los instrumentos al dia siguiente. Las alturas tomadas por los Oficiales D. Juan de Concha y D. Ciriaco Cevallos, dieron las siguientes diferencias de meridianos con Manila:

\begin{tabular}{|c|c|c|}
\hline & Nưm. $\eta_{2 .}$ & Nứm. sos. \\
\hline $\begin{array}{l}\text { Difercncia al tiempo medio } \\
\text { día } 14 . \ldots \ldots \ldots \ldots\end{array}$ & $I^{\prime} .26^{\prime \prime} .48$ & 3. $26^{\prime} \cdot 31^{\prime \prime} .14$ \\
\hline Por sus diarios á Manila. . & 27.47 .86 & 3.55 .41 .00 \\
\hline $\begin{array}{l}\text { Diferencia de meridianos. . } \\
\text { Longitud occidental de Ma- }\end{array}$ & & $0.29 .05 \cdot 76$ \\
\hline
\end{tabular}

Esta diferencia de meridiano hallada en una época de pocos días y dentro del minuto por dos relojes, dan un grado de coniianza para deter- minar la longitud de Macao, preferente á la del Capitán king, porque no habiendo ejecutado observación alguna en Macao, la que determinó fué por distancias observadas antes y después de abandonar este punto, referidas con un solo reloj. Mr. Bayly está conforme con nosotros, aunque su longitud también la deduce por dis. lancias, tomando el promedio de varias series que discrepan mucho entre sí. Igual conformidad encontramos con la que trae el conocimiento de tiempos ảel año de 88, pero ignoramos quién, 6 á qué observación absoluta se refiere. 
e el Goberna. Ab. 13 Luis Carneiro Prden de Cris. s de la India, - ménos equí. ciéndole espe anhelaba conles $y \mathrm{del}$ em. $y$ obsequio de

mares la ban. e todas las na. a un celo par. ros equipajes. meras ordenes, eración $y$ prueos, en inteli. ifor para con-

ñana siguiente spondió con el asé con la Ofi. quien nos reesiones las más las el habernos el observatorio, ntonio José de encia la hacían uiera otra. lanuel de Agote el dueño de la landé conducir á a siguiente. Las es D. Juan de , dieron las silos con Manila:

72. Núm. 105.

'.48 $3 \cdot 26^{\prime} \cdot 31^{\prime \prime} \cdot 14$

$.863 .55 .41 \quad 00$

.72 $\overline{0.29 .05 \cdot 76}$

. $45^{\circ} \quad 7^{\circ} .17^{\prime} 25^{\prime \prime}$

hallada en una minuto por dos nza para deter-ferente á la del Jo ejecutado obL que determinó ites y después de as con un solo e con nosotros, deduce por dis. varias series que ual conformidad conocimiento de ramos quién, ó á are. 1b. " Como era nuestra frecuente asistencia en la casa de los Sres. Agote y Fuentes, fueron luégo á visitarnos el Gobernador, Sindicante, los primeros Sobre -cargas de las Compañias, Francesa, Sueca, Dinamarquesa, Holandesa, algunos su. balternos de la Inglesa, y varios particulares de la ciudad. El Gobernador y estas Compañias exceptuando la Inglesa, ros convidaron á comer alternativamente, mereciéndoles á cada paso las mayores demostraciones de aprecio, que no son fáciles de describirse. Estos obsequios tan gencrales, hizo más notable al público la falta en imitarlos de Mr. Harrison, primer Sobre-carga de ln Compailía Inglesa, haciéndose aún mucho más extraño por la circunstancia de hallarse con orden de Lord Cornwallis, Comandante general de sus establecimientos de la India oriental, para que, consecuente á las que había recibido de Su Ma. jestad Británica, auxiliase con cuanto pudiesen

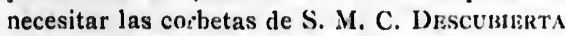
y ATrevina, en su viaje alrededordel mundo.

Esta conducta tan rara y contraria á la repre. sentación preferente que goza la nación inglesa por su opulencia en esta parte del globo, excitó tanto el sentimiento de los compatriotas de Mr. Harrison, como el empeño de lavarla con un esmero de urbanidad hacia nosotros, que jamás podrá borrarse sin injusticia, ni de nuestra memoria, ni de nuestro agradecimjento.

Entre éstos ocupará un lugar muy distinguido en nuestro aprecio, Mr. Daniel Beal, Cónsul de Prusia, á quien debimos frecuentes pruebas de atención y la adquisición apreciable de un reloj pequeño de longitud, número II, que hizo venir en diligencia, de Canton, perteneciente al difunto Mr. Cox, con quien tuvo compañia para el comercio de pieles sobre la costa Noroeste de América, en cuya navegación le había servido con mucha utilidad esta máquina. Aunque el tiempo estrechaba para examinarla, como era la única que había podido encontrarse, me decidí á comprarla, así por los informes que me dió Monsieur Beal, como por las experiencias que teníamos del crédito de su autor Arnold.

La ciudad de Macao es península de la Isla de Un-zao, y sé halla situada en la embocadura del río del mismo nombre. Tuvo su primer origen por una colonia de portugueses, hace cerca de dos siglos, con permiso del Emperador de la China á quien pagan tributos 6 coritribuyen con ciertos derechos para disfrutar la posesión de este establecimieisio. Antiguamente era una ciudad muy rica, miy poili.da y capaz de defenderse de los Golvernaćcres fe las provincias inmediatas, pero en el día ha dazaído de su opulencia y de su poder. La proitioibición del comercio con el Japón ha disminuido la actividad de los negocios $y$ aunque habitada por portugueses y mandada por un Go. bernador nombrado por S. M. F., está, sin em. bargo, á discreción de los chinos, pudiendo pri. Ab. " varla cuando quieran de los viveres para su sub. sistencia y posesionarse con facilidad de ella. Por estas razones la conducta del Gobierno aquí es siempre cuidadosa y circunspecta para no cho. car 6 más bien contemplar á los chinos.

Macao está situada desde la orilla del mar, en terreno desigual y por partes elevado; las calles participan de este defecto $y$ son también irre. gulares $y$ estrechas. Sus edificios consisten en una catedral, tres feligresias, dos colegios que fueron de los jesuitas, tres conventos de religio. sos Agustinos, liranciscos y Dominicos; otro de monjas de Santa Clara, una iglesia y casa de Misericordia, dos hospitales y tres ermitas y casa del Senado, la cual termina la única calle espaciosa y plana de la ciudad; pero así estos edifi. cios como las casas de los europeos, carecen de todo gusto y elcyancia exterior. La del Goberna. dor, situada frente del desembarcadero, goza de unas vistas las más agradables, aunque $\sin$ dis. tiución alguna notable en su arquitectura. Inmediato á ella está la factoría inglesa, de bastante extensión, y todas las restantes factorías fabricadas bajo el mismo estilo, están rodeadas de jardines. Las alturas de la ciudad dominan unas vistas muy considerables hacia el mar y á la campaña. El puerto es muy cómodo y abrigado de los vientos, pero su profundidad no admite bu. ques grandes. Macao está defendida en todas direcciones por cinco fortalezas que la dominan, llamadas Nuestra Señora del Monte Carmelo, Nuestra Señora de Guía, Nuestra Señora del Buen Parto, San Francisco y el Fortín de San Pedro; todas montan artilleria gruesa, aunque según me informaron se hallan en bien mal estado. Las guarnecen, como asímismo á la ciudad, 300 soldados portugueses con $\mathrm{cl}$ correspondiente número de Oticiales.

La jurisdicción de esta plaza está dividida entre los portugueses y chinos, sujetándose á cada una sus respectivos pueblos. El Gobierno político de la ciudad, por lo correspondiente á portugueses, perteneceal Senado de Cámara, compuesto de tres Veedores, dos Jueces ordinarios, un Escribano que sirve de Alférez Mayor, otro de la Mesa, $y$ ambos los son también de la Aduana, $y$ un Tesorero. Preside el Senado el Gobernador y Capitán general y el Oidor actual (llamado aquí el Sindicante) el Sr. Lázaro de Silva Ferreira, Caba. llero de la Orden de Cristo, desembargador de los agravos, casa da Suplicacao de Lisboa. Las sesiones de este Tribunal se tienen en la casa de que se ha tratado, fabricada el año de 1786 , y es el mejor edificio que tiene la ciudad.

La policía corresponde al Oidor y á los dos Jueces ordinarios: y el Procurador de la ciudad está encargado de conocer en los asuntos rela. tivos á los chinos. Los empleos de Veedores, 



$$
\rightarrow
$$




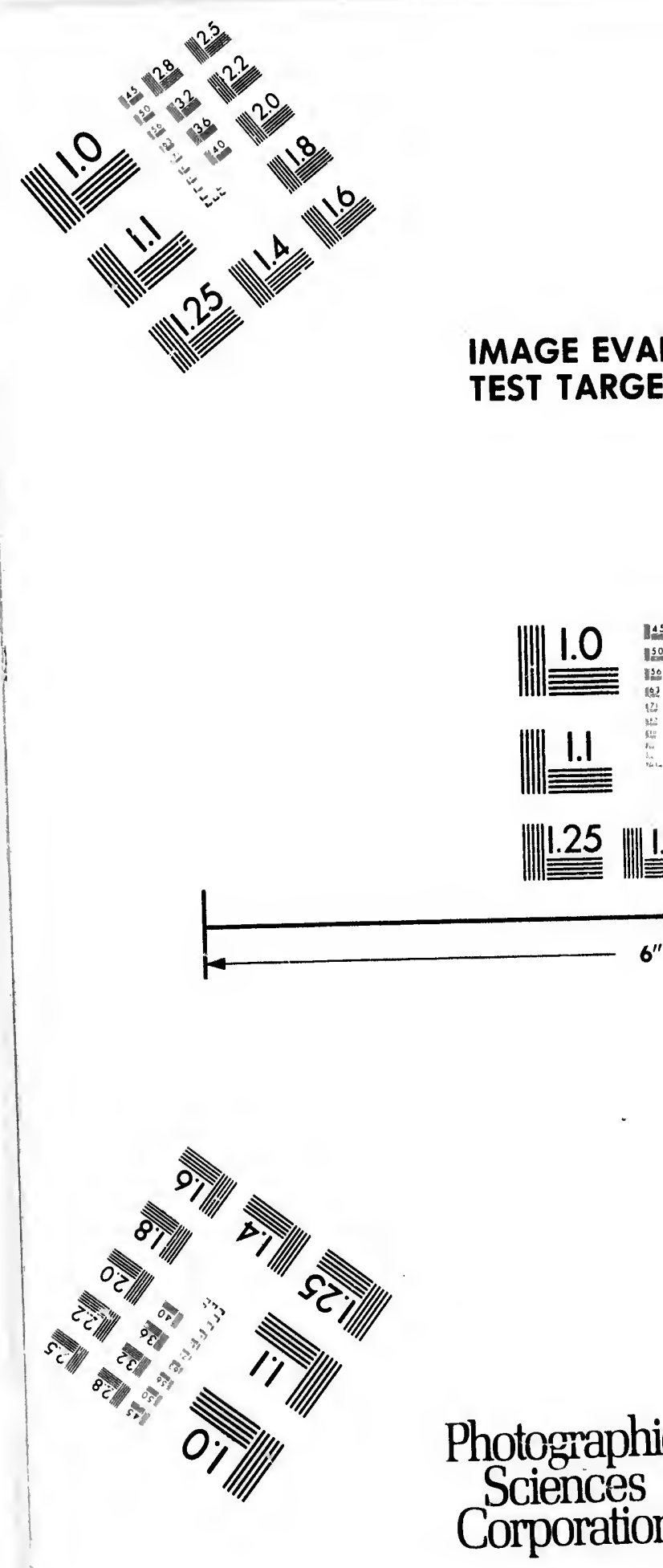




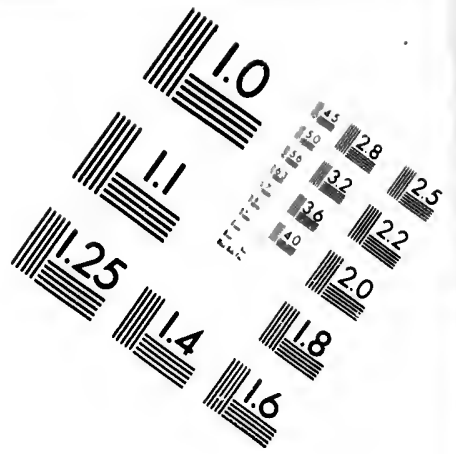

TEST TARGET (MT-3)

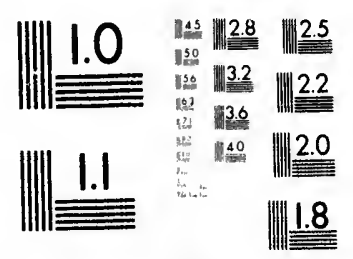

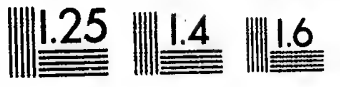

6"

Photographic Sciences Corporation

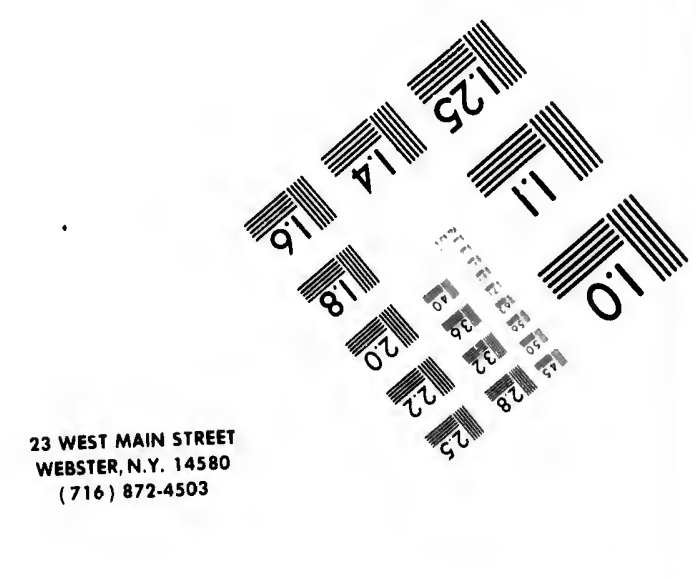




\section{CIHM/ICMH Microfiche Series.}




\section{CIHM/ICMH Collection de microfiches.}
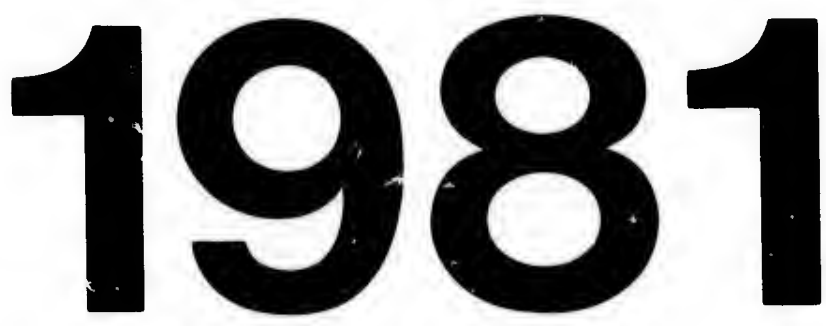
Al. " Jueces, Procurador y Tesorero sun anuales, y se nombran en la capital de Goa por elección que se hace cada tres años: siempre se confieren á los recinos de mayor respeto, ev: auienes lia de concurrir la precisa circunstancia de ser portugrueses, casados ó naturales de Nacao: el mando militar reside en el Gobernador.

A pesar del poco costo que produce al Rey de Portugal esta colonia por haber reducido el número de empleados y de sus sucldos, apenas las rentas del Erario alcanzan á cubrir estos gastos. El ingreso de éstas no puede sujetarse á un cálculo cierto, porque depende del mayor ó menor número de embarcaciones que llegan, y de lo más ó ménos faecioso de sus cargamentos. En los dos años anteriores ascendicron á 30.000 calcles (1) los que entraron en las diferentes cajas que administra el Senado.

Los derechos que pagan los géneros proce. dentes de puertos extranjeros, están reducidos á solo el 6 por roo de entrada en la Aduana sobre un avalúo moderado, y á 4 por roo sobre los que vienen de puertos nacionales: la plata y oro paga 2 por roo, rebajándose el uno por especial gracia a los buques españoles que vienen de Mlanila.

Del 6 por 100 de los géneros gruesos, cuyo avalúo no llega á diez tuleles el pico (2), se aplica el uno y medio para el Convento de Santa Clara y Casa de la Misericordia. El Senado para aumentar el producto de las cajas que adminis. tra, da de sus fondos á riesgo de mar hasta 40.000 talcles solse buques grandes, y la mitad en los de menor porte, á imitación de lo que se practica en Manila con los grandes londos de las Obras pías que se embarcan en la Nao de Acapulco. También sobre propiedades lace emprestitos el Senado por tiempo limitado al premio de tierra de 5 por 100 ai año.

Para fomentar la navegación, concede Su Majestad Fidelisima á las embarcaciones nacio. nales que cargan en este puerto, en los de Bengala, costa de Coromandel y Malavar, la rebaja de 22 por roo de sus reales derechos, como los efectos de sus cargamentos sean destinados á puertos extranjeros bajo el avalúo hecho à este fin por la casa de Indias. Sin embargo, no corres ponden los efectos de esta francuicia á los benéticos deseos de aquel Monarca, pues el año anterior llegaron á 22 las embarcaciones de todos portes que se emplearon en este tráfico, y sólo una era procedente de Lisboa.

Las Compañías extranjeras reciben on $\mathrm{Ba} \cdot \mathrm{n}$ pú de 30 á 34 buques cada año, de los cuales ninguno baja de 800 toneladas, y de este núme-

(1) Equivalen at 40.000 pesos fuertes seguin e cambio de 75 cundrines.

(2) Cada pico consiste en 37 y $1 / 2$ libras por peso que es el corriente a que le pasa el Senado. ro ordinariame e pertenecen los 20 á la nación $\mathrm{Ab} . \mathrm{s}$ inglesa. Los Factores de ella pasan á aquel sitio á despachar sus carga $s$ ientos, que por lo común lo verifican en los meses desde Octubre á Marzo, en que salen para Europa las últimas embarcaciones, que ordinariamente son de la Compañía Inglesa.

Bampú, situado como á I 8 millas de Canton es el único puerto del imperio de la China en donde es permitido el comercio á los Europeos.

Con este fin están establecidas aquí las muchas compañías europeas que comercian en esta parte oriental del globo, y estos edificios, formados bajo del estilo de la nación á quien perte. necen, se distinguen por la bandera respectiva que tremola en el paraje más notable de ellos. Listo aumenta la hermosura y población de este lugar, cuyo número de habitantes, incluyendo los que residen en los arrabales de Canton, se supo. ne no bajará su número de medio millón de al. mas, que es la mitad de las que se cuentan á Canton.

No será exagerado este cálculo, cuando se comprenda el considerable número de gentes que viven y manejan las embarcaciones de aquel tráfico; sicndo estas uno de los objetos divertidos que forman la navegación del río, tan ponderada por todos los que la practican.

La nación inglesa representa aquí, como en todos los demás puertos de la India, el primer lugar por su opulencia entre las demás europeas. Como sus miras se dirigen siempre á extender inmensamente su comercio, no perdonan medio alguno de elevarle al superior grado de riqueza en que hoy se considera.

Y aunque en la China goza la Inglaterra de la primacía á que pudiera aspirar atendienclo las circunstancias y leyes de este imperio, todavía no contenta su ambición ó su codicia, está meditando nuevos recursos para satisfacerla.

A este fin se está esperando en estos dominios al Lord Macrtney en calidad de Embajailor de Su Majestad Británica en la corte de Pekin, con todo el aparato y pompa correspondiente á inspirar la atención y el respeto de los chinos hácia la Gran Bretaña. Las ideas de su Gobierno no pueden tener otro objeto que el de conseguir alguna preferencia 6 franquicias en su comercio recípro. co para no hacerle tan desventajoso como el que sufren todas las potencias europeas que aqui le ejecutan.

Ya este pensamiento había sido confiado en calidad de Ministro al Coronel Cathcarten el año I 788 , de cuya misión, recayendo en persona de los talentos y circunstancias más sobresalientes para desempeñarla, se prometía el Gobierno las más completas y satisfactorias resultas. Pero Ia temprana muerte de este Ministro, acaecida en su viaje, malogró tan fundadas esperanzas. A 
á la nación $\mathbf{s b .} \mathbf{s}$ aquel sitio át lo común lo e á Marzo, s embarcaCompañía de Canton a China en Europeos. quí las mu. cian en esta ificios, forquien perte. respectiva le de ellos. ción de este cluyendo los on, se supo. illón de al. cuentan á

, cuando se gentes que de aquel trás divertidos n ponderada

uí, como en a, el primer ás europeas. : á extender lonan medio de riqueza

laterra de la endiendo las , todavía no stá meditan-

tos dominios nbajailor de Q Pekin, con ente á inspinos hácia la erno no pueeguir alguna rcio recíprocomo el que que aquí le

confiado en :arten el año persona de bresalientes Jobierno las tas. Pero la acaecida en peranzas. A
Ab. 13 nuestro regreso á Europa, es regular sepamos cuál ha sido el fruto de Lord Macrtney, sin embargo de que no faltan quienes no le esperen tan favorable como los ingleses se prometen ( $:$ ).

Uno de los objetos de comercio que ocupa en el día á las naciones concurrentes en esta parte del mundo, es el de la peleteria de la costa Noroeste de la América. A nuestra llegada, me informó D. Manuel Agote, la rigurosa prohi. bición del Emperador en la introducción de este artículo, extendiendo la pena de este delito hasta la capital, para que no pudiera venderse ninguna clase de picles en todos los dominios de su imperio. Esta novedad había obligado á Agote á tener en depósito como $3 \cdot 300$ pieles remitidas por el Gobierno de Manila para su venta, pertenecientes á la Real Hacienda, y conducidas de la costa de California. Al parccer, había dado lugar á esta disposición el suponer que todas las pieles procedentes de la América se consideraban de los dominios de Rusia, y como ambos imperios tenían entre sí algunas desavenencias, por esta razón se había decretado en éste la prohibición absoluta de aquel género. Las representaciones hechas por los que las tenían al tiempo de prohibirse, fueron infructuosas; y Mr. Beal, cansado de esforzar diferentes medios con el Gobierno para vender un cargamento, se vió precisado á enviarle á las Islas del Japón, prefiriendo la improbabilidad de un éxito favorable en este

(1) Publicada en Londres en I 795 la relación de esta Embajada, resulta de clla no haberse sacado las ventajas que se esperaban, pues el Emperador rehuso desde cl principio firmar $\delta$ entrar en ninguna negocia. ción o tratado por escrito con la Corona de Inglatcrra, ni con otra nación alguna, respecto á que semejante conducta por su parte, seria contraria álos antiguos usos, y a la e las Cons. A esta precisa declaración añadió el Emperador las expresiones más propias para significar la mayor atención y respeto hacia $S u$ Majestad Británica y la nación inglesa, y que, sin embargo de hallarse vivamente dispuesto á concederla mayores franquicias que a ninguna otra nación europea que comerciase en sus dominios, no dejaba de er un arreglo de los derechos que pagasen los baṇues ingleses á su arribo á Canton, ya de ser éstc uno de los puntos principales de la negociación. Al mismo tiempo, él no vodria perder de vista los verdaderos intereses de sus propios vasallos, ni sacrificar aquéllos en lo más minimo; y por esta razón, quitaria cualquicra gracia concedida á toda potencia extranjera, si acaso pudiese ser incompatible con los intereses de su imperio. A esta respuesta siguió la en. trega de una caju exquisita al Embajador para el Rey trega de una caja exquisita al Embajador para el Rey
de la Gran Bretaña, contenicndo unos retratos de tode la Gran Bretaña, contenicndo unos retratos de to-
dos los Emperadores que le habian precedido, á los cuales estaba aneja una descripción en verso por cada Emperador, describiendo a su persona y los principales hechos de su Gobierno, como también un modelo de la conducta recomendada á sus sucesores.

Al hacer el Emperador la cutrega de este presen. te al Embajador, le habló en los términos siguientes: * Entregareis esta caja al Rey vuestro amo con vuestra propia mano, $y$ le direis que aunque este presente par ezca tan pequeño, en mi estimación es el de ma yor aprecio que yo puedo dar 6 mi Imperio pudiese pensamiento, al riesgo que corrían de averiarse $\mathrm{Ab}$, conserváusolas á bcrdo ( $\mathrm{I}$ ).

Las misma dificultades habían sufrido otras varias embarcaciones de la costa Noroeste de América. Los chinos no ignoraron desde luégo que traíamos algunas pieles del mismo paraje, pero sin aireverse á hacer reconvención alguna como lo habian hecho con lus buques particula. res, intimándoles que abandonasen el puerto. Sin duda, al respeto con que miran toda embarcación de guerra atribuímos la causa de su silencio, cuyo conocimiento, y el evitar otras consecuencias, me hizo desistir de proponer á los Factores de nuestra compañia que solicitasen su venta para alivio de los propietarios, á quie. nes también les prohibí el uso de otros recursos que además de poderlos comprometer, tuviesen que sufrir las vejaciones ó tropelias frecuentes de los Mandarines, siempre prontos á cometerlas cuando interviene el vil interés que los do. mina. Todas las pieles de nutrias que se habian reunido en este bordo desde Manila pertenecientes á los equipajes de ambas corbetas, ascenderian al número de 300 con corta diferencia. Estas se hallaban ya en pocas manos desde Acapulco, en donde las noticias de la Nao sobre la baja de precios que había dado este género en Canton, hizo á unos desprenderse de ellas con poca utilidad y á otros aprovecharse de este aviso para combinar una especulación lucrativa. Esta clase de contratos entre las tripulaciones no los ignorábamos así D. Alejandro Malaspina como yo, y no parecía justo impedirlos cuando la adquisición de las pieles estaba autorizada con nuestro permiso, y este era consecuente á las órdenes de S. M. con que nos hallábamos; sin embargo, los interesados tuvieron al fin bien poca utilidad en esta negociación, pues precisados á volverlas á Manila, no pudieron sacar allí

proporcionarle; porque habiendo sido trasmitido á $\mathrm{m} 1$ por una seric dilatada de mis predecesores, es también la ültima alhaja para significar mi afecto, que yo habła reservado para dejársela á mi hijo y sucesor, fin de que le sirvicse de pauta de las virtudes de sus antecesores en la cual habla de ser la única quo estu. diase, como que asi esperaba yo inspirarle la noble resolución de imitar tan brillantes ejemplos, y según ellos lo habian practicado, fijar en la práctica de cllo cl grande objeto de su vida para exaltar el honor del Trono Imperial, y promover los proirr ns de la felicidad y prospericlad de su pueblon.

Este ha sido hasta ahora todo el fruto de esta cos. tosisima Émbajada, cuyos resultados se notan aqu para curiosidad del público, y que admire la pruden cia, política y dignidad con que procedió el Emperador: circunstaricia que tal vez muchos no esperarlan de cstc Prfucipe, ii su firmeza a la avanzada edad de ocsenta y cuatro años, después de cincuenta y seis de ocupar el Trono.

(r) Pocos meses después, supimos en Manila que el Emperador había permitido en 28 de Mayo la introducción de pieles y la extracción del ruibarbo que también estaba prolibida. 
Ab. 13 con notable diferencia, el valor que se habían propuesto conseguir en Macao.

Ha sido muy considerable to que ha disminuído el valor de este artículo de la peletería desde el último viaje del Capitán Cook, pues seyún dice king hubo entonces marinero que vendis su ancheta de pieles en 800 pesos, siendo el valor de cada una de las buenas no ménos do 120: en el día apenas of recen la mitad de esta cantidad, porque el gran número de concurren. tes ha rebajado las utilidades excesivas que ofrecía este ramo de comercio á los principios; siendo también cierto que ya con dificultad sc costean esta clase de expediciones, y no falta quien vaticine que en breve tiempo deberán por necesidad abandonarse.

Pero la Naturaleza parece haber concedido á la España el comercio exclusivo de este ramo mercantil. Nuestros establecimientos de San Francisco y Monterey, además de producir las pieles $\mathrm{c} n$ abundancia, facilitan su adquisición con producciones propias por toda la costa de América hasta la ribera de Cook con ménos costos, más seguridad y mucha mayor prontitud. Su conducción á la China goza igualmente de las propias ventajas, pues cuando la Nao de Filipinas recala sobre las costas de Nueva Iispaña en Noviembre ó Diciembre, están ya de regreso en Acapulco las embarcaciones que se destinan á este tráfico; el flete y gastos desde este puerto al de Manila debe ser sumamente moderado, porque aquel buque regresa con poca carga y es capaz de una bien considerable.

Compárense, pues, ahora estas proporciones para hacer tan ventajosamente este comercio, con las que tienen los extranjeros que le emprendan: sus expediciones deben salir de Europa por el Cabo de Hornos, ó del Asia, haciendo escalas costosas en Macao, en las Islas de Sandwich ó invernando en alguno de los puertos de las altas latitudes septentrionales de la América, á costa de mil peligros y zozobras como sufrió el año de 86 el Capitárı Meares y describe con tanta elegancia. Asímismo, los efectos que conducen para cambio van perdiendo mucho su valor en la estimación de los naturales, porque convencidos por la experiencia de que los que abordan á sus costas sólo buscan las pieles, teniéndolas en su mano pueden darles la ley en la seguridad de que han de sufrirla. No estamos nosotros en este caso con la posesion de la costa de Californiá, la cual, no sólo nos las proporciona para eximirnos de recibirla, sino produce también el renglón de las conchas peculiares de aquel suelo, muy apreciable de los indios si se les ofrece con economía: el cobre de la Nueva España y los géneros ordinarios que en ella se fabrican, tambien los desearian con codicia según nuestra propia experiencia.
Aun sin conocer muy bien los ext ailjeros estas Al. t3 ventajosas proporciones porque todavía ignoran los efectos favorables que deben resultar á la Es paña, me han concedido sin repugnancia, que nuestra concurrencia á este género de comercin arruinará siempre sus especulaciones por bien meditadas y dirigidas que sean. Las pieles entre los chinos pueden considerarse como un objeto de primera necesidad y de lujo, usándose entre todas las clases para abrigo y muchos para su adorno; y por consecuencia, aunque la abundancia haya disminuído su estimación, jamás dejará de ser un género apetecible y de mucho con. sumo. De todo lo expuesto se concluye la preferencia exclusiva de nuestra nación, para un giro sin competencia y con utilidades conocidas.

No dejó de extrañarse por 1 's chinos nuestro arribo á este puerto, como siempre lo acostumbran cuando entra algun buque de guerra. El Mandarin de Casablanca (pueblo inmediato á Ma cao) acudí luego á saber de D. Manuel Agote cuál era la causa de nuestra llegada, y sólo.pudo tranquilizarse con la seguridad de que en pocos días dejaríamos el puerto. Estas inquietudes son en el día mayores por los muchos piratas que en el mes anterior han infestado estos contornos. Los contínuos robos y vejaciones que han cometido contra cuantas embarcaciones chinas encontraban, sin perdonar las pescadoras, obligó á pedir el Gobierno á los portugueses el armamento de buques capaces de perseguirlos y exterminarlos. Este paso justifica á la verdad el atraso de la Marina de este imperio, siendo el mismo que el del siglo XVI cuando en iguales apuros apelaron á los portugueses para desalojar de Macao y de sus cercanías al famoso pirata Tchang-Silao, por cuyo particular servicio logró aquella nación europea establecerse en estos dominios.

Condescendió ahora el Gobierno portugués con esta instancia dispués de examirada en el Senado, al parecer, con las mismas ideas de lograr algún privilegio de los chinos. Compró á este efecto dos bergantines, $y$ mientras se preparaban, pasó á Canton el Sr. Botello, comisionado por el Gobierno para pedir en premio de este servicio la libertad de edificar casas en Macro sin contribución alguna á los mandarines; eximir á las embarcaciones portuguesas del derecho de anclaje, y navegar libremente entre Canton y $\mathrm{Ma}$ cao, sin otro permiso que el del Senado; pero bien hubiesen parecido excesivas estas gracias 6 porque en realidad hayan dejado estos mares los piratas, regresó Botello á fines del pasado sin conseguir otra alguna que la de manifestar el $\mathrm{Em}$. perador su gratitud al Gohernador y Senado por el apresto de dichoś buques; y que sin embargo de haber cesado el motivo, no por esto olvidaría un mérito tan especial de la nación portuguesa, para recompensarla oportunamente: por de con- 
Ab. 23 tado las embarcaciones quedan sin destino y su costo de 22.000 pesos fuertes sin satisfacerse. Los portugueses pretenden atribuir esta inconsecuencia de los chinos á la mala fé del Mandarín Giang-Chang, quien deseoso de contraer un merito con el Emperador alcanzando este auxilio, habia prometido á los portugueses aún mayores franquicias de las que fué á solicitar el co. misionado.

No pudiéramos sin injusticia omitir las particulares honras que hemos debido constante. mente al Gobernador de esta plaza, ni ocultar al público las excelentes prendas personales que distinguen su carácter, unidas á una instrucción, rectitud y firmezo, cuales son necesarias para el desempeño del mando, y un mando de tanta de. licadeza como complicado por todas sus circunstancias. A estas cualidades ejercidas con la conveniente prudencia, ha debido la tranquilidad y sosiego de que goza esta colonia, y á las compañías extranjeras una estimación particular, conciliándose así el aprecio de todas, el respeto del vecindario y la inclinación de cuantos le tratan.

Tan poderosos motivos no pudían ménos de penetrar nuestro reconocimiento y corresponder por mi parte á tantas distinciones como habíamos merecido á este jefe. Para esto y cumplir al mismo tiempo igual obligación con otras personas principales de la ciudad, convidé á todos á comer á bordo el dia 22: en la mesa se siguió la costumbre practicada en estos países, de brindarse primero á la salud del Gobernador y después por la prosperidad del comercio, acompañando á estos actos (aquí de ceremonia) el saludo al cañón. Así á este tiemgro c mo cuando saludamos al Gobernador al cañón á su salida, correspondía la plaza inmediatamerte tiro por tiro: por la tarde fuimos acompañando á tierra á este jefe varios Oficiales y yo, manifestándose en todos estos hechos tan satisfecho como agradecido, á un pequeño testimonio de nuestra parte en obsequióa su elevado carácter y satisfacer la obligación en que nos hallábamos.

Fuera asimismo culpable no hacer aquí mención de la actividad y esmero con que ha contribuído D. Manuel de Agote para cuanto hemos necesitado en este país, ni $\sin$ injusticia pudiera yo negar cuánto debo á sus auxilios para haber evacuado tan presto los objetos que me trajeron á Macao: su instrucción y conocimientos mercantiles qu igualan á un genio laborioso y activo, le harán siempre digno de ocupar los primeros destinos de la Compañia, y que goce con justicia aquí de la estimación pública y del aprecio de todos los que le conocen.

\section{Regreso á Manila.}

Desde ayer habían quedado embarcados los instrumentos y pinturas que llegaron el día an- terior de Canton, y nada faltaba ya para el it " cumplimiento de las órdenes con que me haliaba.

Empezada la faena de levarnos con la creciente para concluirla en este intervalo, se tendió al mismo tiempo una espía para franquear. nos, y ya á las cinco de la tarde marcando todo aparejo con viento al Sueste, ceñimos al rumbo del Lis:ordeste para rebasar ambas islas de la entrada antes que volviese á crecer la marea que á la sazón nos ayudaba poco. Estábamos NorteSur al ponerse el Sol con la punta Norte de la entrada, como á dos millas; siguióse el mismo rumbo del Esnordeste hasta las siete y media en que virando al Sur-Sudoeste nos condujo la esperanza de poder montar la Isla Montaña si el viento conservase igual fuerza para exceder á la de la corriente.

Ibamos prolongando la Isla de Taipa, cuando se avistó la de la Montaña, cuyos esfuerzos para rebasarla fueron infructuosos, porque habiendo escaseado y calmado después el viento, nos obligó á dar fondo á las once de la noche en cinco irazas fango. Volvió el viento á velar durante la noche, pero siendo bonancible y por el Sueste, no era suficiente á superar la marea, que llevaba en este paraje la dirección para el Este. Al amanecer marcamos lo más Oeste de la Isla Montaña al Norte $60^{\circ}$ Oeste y Punta Peack al Nordeste.

Entrada la mañana, refrescó el viento por el Sur, y al momento de perder la corriente su fuerza, dimos la vela con viento del Sur-Sudoeste, tomando la vuelta del Sueste, y atravesando por entre una multitud de embarcaciones pescadoras; y con dos bordos, favorecidos ya de la corriente, pudimos rebasar el Gran Ladrón.

A las nueve de la mañana se avistó al Sursudeste una fragata, por cuyo tamaño y no haber llegado aún la Concepción, de Manila, nos hizo suponer fuese ella. Para confirmar nuestra presunción y poder llevar esta :tgradable noticia á la Real Compañía á quien pertenece, procuramos reconocería, y nos largó la bandera inglesa. Esta fragata, según me informaron los de la Compañía de esta nación, se aguardaba por instantes procedente de la parte Norte de la Nueva Holanda, Nueva Guinea é Ista de Borneo á donde había sido destinada por la Compañía de la India para hacer reconocimientos con ideas mercantiles: nos fué sensible á la verdad, que por tan corta dife rencia de tiempo no nos hubiésemos juntado en Macao para saber las resultas de esta comisión importante á la Geografía de unos parajes poco trillados 6 reconocidos imperfectamente.

Al medio día demoraba el Ladrón, más occidental al Norte, observando la latitud de $2 \mathrm{I}^{\circ} 45^{\prime}$ Norte, y desde aquí favorecidos de uz viento fresquito, nos desembarazamos de las Islas Asses 
Ab. as é islotes al rumbo del Sudeste $\%$ Sur, perdién. dulas de vista al ponerse el Sol. Sin cesar de relampaguear y tronar por la noche, el viento no arreció hasta la madrugada, á cuya hora empeź á llover con mucha fuerza. Tardó poco el vien. to en saltar al Nornoroeste muy fresco, arreciando más con los chubascos repetidos, siendo $\tan$ frecuentes los truenos y relámpagos como en la noche. Gobernóse al Sudeste $\%$ Sur, con trinquete y gavias con la precaución co. rrespondiente á estas circunstancias. Por la tarde el viento no era ya tan constante, variando del segundo al tercer cuadrante, y cuando se acsrcaba al Sur, se prefería la vuelta del Oes. sudoeste, porque las corrientes en esta estación tiran aquí con fuerza para el Este.

Estos aparatos del tiempo que siguieron al día después, nos hizo creer fuesen para determinar la crísis de la monzón del Nordeste en estos mares y sustituirla la de los vendavales. Esta suposición fundada sobre los efectos que experimentábamos, la apoyaban también las noticias de Mr. d'Apres y el Capitán King afirmando que está última empieza 6 se anticipa en Abril. Atendiendo á esto fué preciso variar el pensamiento de hacer derrota directa, y ser preferible franquearnos de la Isla de Luzón para en el caso de anticiparse los vendavales como todas las señales lo indicalan.

Volvió el tiempo desde el medio día á cerrarse por todas partes con espantosos truenos y relámpagos acompañados de agua muy fuerte $y$ contínua: con el viento á fugadas entre el Iiste y el Sur se tomaba la vuelta más próxima ó más directa para disminuir latitud, pero sin abandonarnos durante la noche y el dia siguiente las mismas feas apariencias de los días anteriores.

No logramos la presencia del Sol hasta el medio dia del 29, cuyas observaciones nos indicaron la situación de $19^{\circ} 7^{\prime}$ en latitud, y la longitud por el número 72 de $00^{\circ} 02^{\prime}$ a! Este de Macao.

No era fácil acertar muchas veces la vuelta que sería más conveniente, por las continuas variaciones del viento, y éste siempre bonancible por lo común, giraba rápidamente del Sudoeste al cuarto cuadrante $y$ después al primero, de modo que nuestros progresos eran bien lentos,

May. a pues todavía al medio día del 2 de Mayo, estábamos en $17^{\circ} 28^{\prime}$ de latitud Norte, y en longitud $\mathrm{I}^{\circ} 29^{\prime}$ oriental de Macao: notamos en estas ob servaciones diferencias al Sur y mayores hacia el Oeste, siéndonos bien extrañas, porque en el estado avanzado de la estación, ordinariamente se experimentan en sentido opuesto. Toda esta sin gladura nos ha acompañado un tiempo hermoso, la mar muy llana y el viento ya más ya ménos fresquito del Nordeste al Este. Nuestros rumbos han sido ciñendo por babor, y la noche, con la inmediación al plenilunio, ha estado de las más May. * claras y apacibles, bajo cuyas iguales circuns. tancias se presento el Sol sobre el horizonte, pero sintiéndose mucho los efectos de sus rayos, en razón de la altura en que nos hallábamos y de sus cercanias al zénit.

Ya por las observaciones de hoy notamos en orden inverso las diferencias, especialmente en cuanto á la longitud, que discrepaba en $30^{\prime}$ al Este, con lo cual y la propia experiencia al día siguiente, aunque no tan grande, nos confirmó el concepto sobre el curso de las corrientes para el Este en estos parajes en la estación actual.

Desde el principio de la tarde empezó el viento á inclinar al Es-Sudeste y hasta el Sudeste con el que era preferible la vuelta del primer cuadrante. y ésta hubiera yo seguido, á no suponer, apoyado en el parecer del práctico, de que. subsistirían ya los vientos por el Sudeste y probablemente más al Sur, con cuya reflexión pensé seguir la singladura con las muras á babor, pasar al Sur del bajo Scarboroug, y revirar para el Este. clesde la latitud de $14^{\circ} 4^{\prime}{ }^{\prime}$ á atracar la tierra por donde lo permitiesen. Estas combinaciones nos prometía el tiempo realizarlas, según las varias llamadas que dió el viento en la noche hacia la parte que deseábamos.

Nuestras conjeturas quedaron destruídas á la mañana siguiente, declarándose el viento de nuevo al Este; y áun lo que fué peor, que cuando esperábamos con ansias las observaciones del medio día para ver lo que las coríentes nos habían conducido al Este, hallamos, contra nuestras esperanzas, que lo habían ejecutado $x g^{\prime}$ en dirección contraria, y sin poder apelar á haberse deslizado algún error en los horarios, pues repetidos por la tarde comprobaron la propia diferencia para el Oeste.

Nos hallábamos á la sazón en latitud de $15^{\circ}$ $06^{\prime}$ Norte, y en longitud de $2^{\circ} 34^{\prime}$; se siguió la vuelta del Sur-Sueste con viento del Este para pasar al Sur del bajo Scarboroug bajando al paralelo de $14^{\circ}{ }^{2} 5^{\prime}$, ó más al Sur si los vientos hiciesen preferible rumbos en el segundo cuadrante á los de en el primero.

Al medio día, observando la latitud de $14^{\circ} 29^{\prime}$ estábamos $3 \mathbf{r}^{\prime}$ al Sur de la parte meridional de Scarboroug, pero muy distante de su meridiano si suponíamos exacta la distancia de 35 á 40 leguas de la costa á que me aseguraba el práctico se hallaba. Bajo de esta suposicion será preciso excluir de la carta de Mr. Dalrimple el bajo con aquel nombre que coloca á la distancia de 57 leguas de tierra, y establecer por único y verdadero Scarbo. roug otro que sitúa en la misma latitud, pero más próximo á ella. Yo hubiera deseado el haber debido á los vientos la proporción de correr su paralelo, siendo tan importante la posicion exacta 
le las más May.

$s$ circuns-

horizonte,

suz rayos,

ábamos y

otamos en

truídas á la nto de nue. due cuando iciones del es nos hantra nues. ado $I g^{\prime}$ en $r$ á haberse pues reperopia dife-

tud de $15^{\circ}$ e siguio la Este para ando al pavientos hi, cuadrante

de $14^{\circ} 29^{\prime}$ ridional de meridiano 35 á 40 lepráctico se preciso excon aquel leguas de ro Scarbo, pero más haber derrer su paion exacta
May, 6 de este escollo como que han perecido en êl varias embarcaciones nacionales y extranjeras (I).

Continuaron las diferencias aunque ya me. nores para el Oeste, cuya disminución se notaba á medida que caminábamos á latitudes más ba jas, lo cual y la flojedad 6 bonanza de los vientos, iba produciendo mucho atıaso en nuestra lle. gada á Manila. Atendiendo á etstas razones, y á la de no hallarnos muy abundiantes de víveres, con especialidad de pan, pues sólo existe para diez y seis días completos, ha precisado á reba. jar una cuarta parte de la ración diaria de este alimento, pero aumentando tres onzas de menestras de que había mayor cantidad.

Todavía al medio día del ro no habíamos podido coger mas longitud que la de $3^{\circ} 09^{\prime}$ oriental de Macao, y ésta discrepraba mucho entre la que señalaban los tres relojes: el ro5 se apartaba en $42^{\prime}$ más al Oeste respecto á la del 72 por el que nos guiábamos con preferencia; y $3^{\prime}{ }^{\prime}$ en igual sen. tido la del ir. No habíamos tenido ocasión de rectificar algunas de estas longitudes con las de distancias, para sujetar el grado de los errores á un cálculo aproximado $\mathrm{y}$ dirigir con más acierto la recalada á la tierra; no obstante se presentó hoy la ocasión de observar una sola distancia por ocultarse los astros con las nubes, y los resultados de ella dieron una longitud muy conforme con èl número 72 , pues sólo diferenciaba en $13^{\prime}$ al Oeste, lo cual nos confirmaba en la justa preferencia dada á esta máquina sobre las otras dos.

A la mañana siguiente observamos $\mathrm{I}_{4}$ series de distar ias cuyos resultados dieron $29^{\prime}$ de diferencia al Oeste de la longitud por el 72 y $49^{\prime}$ en el propio sentido el día inmediato. Estas pruebas $\tan$ repetidas como averiguadas con cuanta exactitud nos era posible, hicieron atribuir alguna alteración también á esta máquina, por la sen-

(1) Hemos sabido posteriormente, que cl Capitán Clawson en el ridvio Sofla Magdalena, de ta Compaña sueca de la India Oriental, salió de Pulo Zapata a las seis de la tarde del 19 de Setiembre de 1793 y el 25 á la salida del Sol vió rompiente del Nornordeste al Noroeste $\%$ Oeste como a cuatro millas de distancia.

La mañana era nublada, pero á las $8 \mathrm{~h} 20^{\prime}$, pudo observar la longitud de tuda confianza por medio de su cronometro, y tuvo buena observacion de latitud al medio día: con estos datos coloca cl extremo Sudoeste del bajo, en latitud de $15^{\circ}{ }^{\circ} z^{\prime}$ Norte y en longitud $8^{\circ}$ 22' Este de Pulo Zapata y $3^{\prime}$. 8' al Este de la Gran Lama que vió el ro de Octubre.

Pulo Zapata oriental de Greenwich. . . . $109^{\circ} \mathrm{O}^{\prime}{ }^{\prime}$ Diferencia observada .......... $8^{\circ} 2^{\prime}$

Longitud del bajo. . . . . . . . .

Macao de Greenwich. . . . . . . . . $113^{\circ} 30$ La Isla del Gran Lama al Este . . . . . Longitud del bajo ........... $117^{\circ} 22^{\prime}$ Promedic ............... $117^{\circ} 23^{\prime}$ sibilidad que experimentan con las grandes va. May. " riaciones de la atmósfera, pasando de un temperamento medio á cualquiera de los dos extre mos de frío 6 calor, como en esta ocasión ha sucedido.

Volvimos nuevamente á tomar distancias lu. nares poco antes del medio día del $\mathrm{r}_{4}$, á fin de asegurarnos por tercera ve $z$ si las diferencias al Oeste del reloj, eran constantes. El resultado medio de 16 series daba ya $I^{\circ} 1_{5}{ }^{\prime}$ más al Oeste, $y$ por consiguiente, no podía dudarse de hallarnos más distantes del destino. Si á esto también sc agregaba la flojedad de los vientos y éstos escrsos, las pocas señales de que mejoren, la continuación de las diferencias al Oeste, $y$ un calor tan excesivo que el termómetro de la cámara llegó á $86^{\circ} 8^{\prime}$, es cierto que esta navegación se nos hace una de las más molestas, y en proporción á la dis tancia, una de las más dilatadas. Para compen sarnos en parte esta tediosa campaña, el viento era constantemente hermoso y apacible, y de este modo subsistio hásta el anochecer del 16, a que afirmó el viento fresquito por el Es-Sudeste, y pasando después al primer cuadrante, ceñimos para el Este, llegando al medio dia siguiente á la lati tud de $14^{\circ}$ r $7^{\prime}$ y á la longitud de $5^{\circ}+6^{\prime}$, aunque por estima creíamos estar $15^{\prime}$ más al Este.

Observados por la tarde nuevos horarios, in dicaban la longitud de $6^{\circ} \mathrm{oo}^{\prime}$ por el 72. y la de $5^{\circ} 1^{\prime}$ por el ro5: si la primera fuese exacta; la inmediación á la tierra obligaba á navegar por la noche con vigilancia, pero como nuestra confianza en las distancias debía ser correspondiente á las repetidas pruebas que teniamos de su exactitud, adquirida en la práctica continuada con que las ejecutábamos, no podíamos ménos de creer firmemente 6 atribuir á la longitud del ro5, la mayor proximidad á las distancias, y esto se confirmó con no verse la costa á la mañana siguien. te con un horizonte muy despejado.

Tal vez la oscuridad que hubo por la tarde impidió la vista de las Islas de Lubang y Cabra, pues advertíamos como al Sudeste $1 /$ Sur; una cerrazón más espesa, y áun algunos quisieron afirmar haber visto una de las citadas islas. Puesto el Sol, empeoró el semblante del tiempo, con relámpagos y truenos muy repetidos, y esperando los diferentes contrastes presentados en el horizonte: en efecto, se experimentaron éstos varias veces durante la noche, pero sin ofrecer cuidado alguno por su poca fuerza, y tain sólo la oscuridad tan grande, aumentad's por frecuentes aguaceros; no nos permitía hacer la diligencia necesaria que proporcionaba el viento del Nornordeste fresquito, á tin de amanecer en disposición oportuna para coger temprano la boca de Mariveles, sobre cuyos parajes sería arriesgado si entraba la colla (llamados así los temporales de la monzón del Sudoeste) como desde luego la 
May. 19 anunciaban las apariencias: áun el navegar para el Este era también arriesgado en el paraje donde nos hallábamos, pues si se verificaban estos recelos, era muy couveniente la posible separación de la costa, para tener más espacio en donde capear 6 resistir el temporal. Pero todas estas reflexiones, al parecer fundadas, debieron des. atenderse, porque la escasez de pan, y no hallarse el buque en buen estado de estiva, no daban lugar á la consulta de otras medidas que pide la seguridad en distintas circunstancias.

No cesaron los aguaceros á la manana sigruiente, ni el viento de variar entre el seguido y primer cuadrante, en ocasiones fresco, con los horizontes aturbonados por diferentes partes: forzóse de vela, no obstante, afirmando el viento por el Sur y Sur-Sudoeste, disminuidos ya los aguaceros fuertes.

Nuestra posición cerca del medio día por la estima traída desde la longitud observada de ayer, no avistándose aún la tierra ni las Islas de Lubang y Fortún, era á la verdad cosa bien extraña, cuando por la latitud no podían estar distantes, á ménos de suponer corrientes fuertes para el Oeste 6 para el Norte, cuya averiguación era dificultosa careciendo de la presencia del Sol, y sin esperanzas de que aclarase.

Estando en esta incertidumbre sobre nuestra verdadera posición, se aparecen á la vista las Islas de Lubang y después Fortún. Se coırió una base que determinase la distancia exacta de ellas y supliese las observaciones, en la suposición de ser bastante segura la situación de estas islas res. pecto á Manila. Concluída esta operación, arribamos al medio día al Este $1 \%$ Nordeste á cuyo rumbo nos demoraba la entrada grande; $y$ la cerrazón nos ocultó la vista de la tierra hasta la una que marcaba la Isla del Corregidor al Esnor. deste. ros dirigimos á pasar entre ella y Marive. les, con el viento más y ménos fresco entre el tercero y cuarto cuadrante.

Antes de anochecer llegamos á estar al frente de la ensenada de Mariveles, desde donde gobernamos al Nordeste $\%$ Este, advirtiendo en la carta de Mr. d'Aprés un error considerable en la posición de estos puntos de la entrada, en la cual si nos guiásemos por ella, debía gobernarse desde aquí dos cuartas más para el Este: error muy notable para un navegante de su crédito $y$ que ha estado en estos parajes.

Luégo que se marcó al Sur lo más Este del Corregidor, y navegadas doce millas al mismo rumbo para franquear el bajo de San Nicolás, se orzó al Es-Sudeste sondando I5 brazas, y con gavias $y$ trinquete seguimos para dentro en ánimo de coger el puerto de Cavite, hacia la media noche; pero abandonados á esta hora por el viento, dimos fondo en diez brazas fango suelto.

Con unas ventolinas por el Sur-Sudeste di- mos al amanecer la "ela adelantando bien poco, May, мо mientras un chubasco por el Oesudoeste afirmó el viento para conducirnos á fondear al costado de la Descurlerta, que ya veíamos, y lo verifi. camos á las nueve de la mañana en cinco brazas fango.

Poco antes llegó á bordo D. Alejandro Malaspina, y me irformó haberse visto precisado á regresar á este puerto el $\mathbf{2}$ del pasado, cono. ciendo la imposibilidad de trazar la costa hasta Cabo Bojador con mediana exactitud. Fste Co. mandante se restituyó á Manila por la tarde, lle. vándose consigo los tres relojes, cuyas longitudes deducidas por las comparaciones con el 7 I daban bastante diferencia, siendo asi por todas razo. nes preferente para nuestras cartas la diferencia de meridianos entre Manila y Macao de $7^{\circ} 18^{\prime}$ hallada unánimemente á la ida para aquel puerto por el 72 y el ro5, pues está también conforme con la que pone el conocimiento de tiempos del año de 88 , aunque ignoramos á quién se deba la observación absoluta ejecutada en Macao.

\section{CAPITULO III}

Diferentes excursiones científicas en la Isla de Luzón durante la estada de las corbetas en Cavite.-Apres. tos para las campañas siguientes. -Ocurrencias principales relativas a los armamentos y ai los buques. Plan de las siguientes campañas é individuos quedados en Manila con cste intenio.

Sería difícil, cuando no imposible, el dar una idea cabal de las diferentes excursiones que se ejecutaron en la Isla de Luzón mientras no interrumpiesen inperiosamente nuestros pasos las lluvias abundantes, que ya en una ya en otra es. tación, fecundizan y hacen intransitables las costas del Este ó las occidentales de la misma isla. Ciertamente en aquellas ocasiunes no se economizaron en modo alguno la salud y la misma vida de los Oficiales y Pilotos que se encargaron de su ejecución; y el no decir aquí lisa y llanamente que sus sacrificios fueron proporcionados á los deberes contraídos con la sociedad en ge. neral, y particularmente con la patria, sería defraudarles de aquellos justos elogios que han procurado merecer. En el corto intervalo de treinta y cinco días, el Teniente de navío Viana recorrió y dejó descritas con la mayor exactitud hidrográfica, todas las costas que van desde la Punta de Bolinao hasta los Cabos de Bojador y de Engaño.

D. Tadeo Heenke desplegó en un plazo duplicado un genio tan laborioso y una tan constante aplicación, que pudo examinar científicamente las provincias de la Pampanga, Ilocos, Cagayan y Pangasinan. Se nos incorporó el 20 de Junio D. Luis Nee, que desde la mitad de Marzo 
o bier poco, May. no

peste afirm6

$r$ al costado

$y$ lo verifi-

einco brazas

jandro Ma. precisado á sado, conocosta hasta d. Este Co. a tarde, lles longitudes el $7 \mathrm{x}$ daban todas razo. a diferencia lo de $7^{\circ} 18^{\prime}$ quel puerto en conforme tiempos del n se deba la acao.

sla de Luะón ite.-Apres. rencias prin. los buques. quos quedados

, el dar una ones que se tras no inte. os pasos las ten otra esbles las cos. misma isla. o se econoy la misma encargaron isa y llanaporcionados edad en geatria, sería ios que han ntervalo de ravío Viana r exactitud an desde la le Bojador

1 plazo dua tan cons: científicaga, Ilocos, oró el $20 \mathrm{de}$ id de Marzo
May, so corria las provincias meridionales de Albay, Camarines, Tayabas y La Laguna. Habian, por otra parte, D. Felipe Bausá y un Piloto trazado con la mayc" exactitud la bahia grande de $\mathrm{Ma}$. nila y los puertos que le son contiguos: la había. mos sondado, examinando el bajo peligroso de San Nicolás. D. Juan Maqueda recorría y descri. bia las costas orientales que desde Mauban se extienden hasta la Ensenada de Albay, término de nuestras tareas emprendidas desde Sorsngon: otro trozo, con un Oficial, un Piloto y algunos marineros, examinó en la misma contracosta las Islas de Alabat y Polillo, y el puerto de Lampon, célebre por los antiguos proyectos de la construcción y navegación de las Naos. Visitó D. Juan Ra. benet en la provincia de Bataan los negrillos ha. bitadores indígenas de la isla, y logró retratarlos con sus costumbres principales. Finalmente, al cargo del Teniente de navío D. José Espinosa siguiéronse en Manila las observaciones astronómicas por manera que no dependiesen ya la 'atitud $y$ longitud de aquel punto bien interesante de los dominios de S. M., sino de observaciones directas, las cuales referidas lucgn á Canton por medio de los relojes de la corbeta ATkEvida, reunían con los resultados dimanados del Oeste los que nosotros traíamos sin la menor interrupción por el Estẹ.

Jun. Pertenecerá á las descripciones físicas, do:una idea más individual de los diferentes aspectos 6 sumamente amenos ú hórridos con exceso, que tomaba la naturaleza á nuestra vista, según torciesen las excursiones á las fértiles llanuras cultivadas por los malayos sujetos á la Monarquía, á los montes ásperos, albergue inaccesible de mil insectos, de los reptiles y de los pocos habitadores indígenas, 6 á las playas peligrosas, por los huracanes, por los escollos que las rodean 6 por los piratas que las infestan con cuantos ardides pueden dictar el odio, el furor, la codicia y la experiencia. Si por una parte los religíosos $\mathrm{Cu}$ ras Párrocos, con un amor, un celo y una generosidad indecibles, suavizaban nuestras fatigas del día 6 dirigían con mayor conocimiento nuestros pasos siguientes y los auxilios que á cada instante necesitábamos de los naturales, tan dociles como industriosos; por la otra nos veíamos trasplantados á corto rato, donde el Sol y la humedad luchaban á porfía para hacernos igualmente peligrosos el día y la noche, 6 donde fuésemos amenazados, áun en el corto intervalo de nuestro re poso, de la fatal sorpresa de unos enemigos sangrientos y traidores.

En los reconocimientos de la costa oriental entre el Cabo de San Ildefonso y el Estrecho de San Bernardino, fueron casi diarios los encuentros con los piratas, los cuales, aproximándose ahorz en aquella parte la monzón clara y apacible, mientras los Sudoestes tempestuosos domj- naban en la otra, seguían á su placer el instinto envejecido de saquear nuestros pueblos y escla. vizar sus habitantes, cuando más descuidados atendian al cultivo de los campos 6 al transporte de sus frutos sobrantes de una provincia á la otra. Varias veces 1). Juan Maqueda, amadrinadas sus tres embarcaciones de remo para multiplicar los fuegos y reunir la defensa, debio ha. cer aguada, leña y marciciones á la vista de sie. te 6 nueve embarcaciones piratas. Ví una vez en un islote inmediato al puerto de Sisiran los tristes rastros de esos piratas, apercibiéndose aún recientes los huesos de dos cadíveres huma. r ss, devoradas sin duda sus carnes, después que rechazados del pueblo cle Pambujan, vinieron á clescansar en aquel islote con el triunfo bien mezquino de dos solos cautivos: otro día, dando caza á ocho embarcaciones, las obligó á huir con tal precipitación, que dejaron en la playa dos cautivos, los cuales fueron con estc motivo feliz. mente redimidos. Eran el uno de Mauban y el otro de Mambulao, cogidos veinte días antes en las sementeras inmediatas á sus pueblos. Tenían por único vestido un collar de bejuco y una cuerda, con la cual les sujetaban de noche cabeza, piés y manos. Declararon que á bordo de los ocho pancos había unos cincuenta hombres cautivos y varias mujeres. Unos diez de uno y otro sexo habían sido cogidos dos noches antes en la visita de Poronglooc de la Isla Catanauar.

Describían al mismo tiempo D. Luis Nee, D. Tadeo Heenke y D. Francisco Viana el singular contraste de los países que visitaban. Estudiaban las costumbres de sus habitantes, los vicios 6 las ventajas hacia el bien público de los diferentes ramos de nuestra legislación, y los indecibles progresos que pudieran adquirir en lo venidero á medida que fuesen enlazándose entre sí los intereses recíprocos de la Monarquía, y adoptasen aquellas islas felices como el centro de todas las operaciones políticas y mercantiles.

De lo dicho hasta aquí puede inferirse que los pocos Oficiales que habían triunfado de los climas harto temibles de la América, debieron ceder ahora á los efectos combinados del tem. peramento $y$ de la fatiga; pero en fin, los tres ó cuatro meses que debíamos aún permanecer en Manila, antes que la estación oportuna del Nordeste estableciese su imperio, nos aseguraban casi con evidencia que podíamos arrostrar de nuevo con la robustez necesaria, las fatigas de la campaña siguiente. Emprendiéronse por. la misma razb́n las tareas ménos violentas pero igualmente importantes, de poner en orden los muchos elementos acopiados hasta cntonces, bien fuesen hidrográficos, políticos 6 económicos, y eríre tanto, nuestras miradas y nuestros afazes externos ya tenían por solo objeto el regreso feliz de $\mathrm{D}$. Antonio Pineda, el cual des-

Jun. 
Jum de los primeros dias de Abril habla emprendido una derrota sumamente penosa hacia el Norte. A cada instante, nuestros deseos nos le repre. sentaban como presente y próximo á gozar del fruto de sus pemosas peregrinaciones... jvanos deseos.l jesperanzas infundadas! Casi en los mismos momentos en que nos poseíamos de aquellas ideas, estaba acabando en Badoc, pue. blecito de la provincia de llocos, una vida tan gloriosn como importante para el bien público. Víctima de unas tareas tan asíduas, después de un viaje combinado más bien por el celo propio que por el examen del pals y de sus fuerzas, $y$ ya acelerando demasiado tarde sus pasos hacia Manila después de haber errado por largo tiem. po entre unos montes y parajes easi inaccesibles, debió doblarse tinalmente bajo el yugo imperioso de tamañas faligas, y perder para el heneficio directo de las ciencias y del honor na. cional, una vida que mil veces se habia salvado cntre los peligros mayores de la guerra. No pare. cerá importuna al lector una narración más difusa de los últimos pasos de este hombre filó. sofo; la cual se ha deducido directamente de sus mismos apuntes.

Determinado D. Antonio Pineda á empren. der sus excursiones científicas, quiso abrazar con los objetos inás útiles la mayor extensión del pais que pudiera combinarse en el cortc tiempo que faltaba para la estación lluviosa en la región septentrional de la isla, para lo cual con. sultó á las personas más prácticas y más instruídas de ella. D. Juan de Cuellar, celoso naturalista comisionado en las islas por la Real Compañía, quiso acompañarle en sus primeros pasos, $y$ ambos convinieron en un plan: en que después de recorrer prolijamente las amenas orillas de la Laguna de Bay, examinando el plantío de la canela en Calanan y los baños termales del Maquilin, D. Antonio Pineda atravesase de Sur á Norte La Laguna y toda la Pampanga alta para continuar después por lo largo del río de $\mathrm{Ca}$ gayan, primero hasta las misiones de Ituy y $\mathrm{Pa}$ niqui, y luégo hasta Lalloc y Aparri en el extremo Norte de la isla: torcería después hacia el Oeste para retroceder á Manila por las provincias de Ilocos y Pangasinan, y siempre que se encontrasen objetos que lo manifestasen oportuno se apartaría más ó ménos del derrotero in. dicado.

Debía á la verdad oponerse á este proyecto el calor excesivo que manteniendo el termóme. tro en una altura de 24 á $25^{\circ}$ en la escala de Reaumur, constituye un clima insufrible "que "embotando las potencias y enflaqueciendo la " memoria por la contínua disipación de espíritus "animales, arrastra al viajero á una especie de "letargo interrumpido sólo por las molestas pun"zadas del sarpullido y los insectos, que le difi.
- cultan la continuación de sus tareas reflexi. Jum a vas" (t). Pero D. Antonio Pineda, poco escarment to de semejantes inconvenientes en otros paises mal sanos, arrostró á todos con vigor, y entre sus útiles observacionr brillan además de su ingenuidad genial, elegan..s descripcionea de que resumiremos algunos trozos que acrediten el curso de sus viajes.

"Provisto de un pintor joven de mediana habilidad, que diseñase los objetos más intere. santes, salió de la capital el Ix de Abril. Las frondosisimas orillas de la Laguna de Bay, cuyas fértiles campinas son interrumpidas frecuen. temente por arroyos y arboledas, le of recian escenas deliciosas. Los pueblos emboscados entre palmas y platunares, con ingeniosas calzadas rodeadas de arrozales, conservaban los indicios de la vejetación más lozena, al paso que muchas ca. sas y tiendecillas es tarcidas en desorden, constitulan una poblacióı. montinuada, y los cuadros $y$ cuadrilongos con que detienen las aguas y dividen los terrenos para el cultivo del arroz, daban el aspecto de un jardín artificiosamente desorde. nado. Se agrega la estructura de las casas bien adaptadas á las estaciones y clase de vida de los naturales; luégo al todo la contínua agitación de tareas en que se emplean los naturales para cosechar su arroz; el carabao en aquel país pantanoso presta al hombre maravillosos socorros; cualquiera otro animal metido en el lodo hasta las rodillas, se atora, se fat: ga y trabaja suma. mente; el fiemático carubao se encuentra en su elemento, la humedad le recrea y la frescura le anima; sea enfermedad, sea comezón ó disposición particular de su picl, ama los refrigerios, las fricciones le deleitan y hasta en el color lodoso, parece que fué criado para habitar los ce. nagales."

A I I leguas de Manila y cinco de La Laguna, está la hacienda de Calanan, propia de D. Fran. cisco Salgado, provista de no malas oficinas. Circunvalan su parte oriental más de dos leguas de montaña. "Los ríos de Calabang, San Nicolás, Lamot y I 7 manantiales, riegan en su jurisdicción más de 5.000 canelos que ya fructifican, y otros 500.000 de varias especies que están en el mejor estado próximos ya á la fructificación; of reciendo por todas partes terrenos aprovechados, que promeien á su dueño la crecida recompensa de sus excesivos costos bien patrib́ticos. "

Las aguas termales del Maquilin, específico para los tumores, piedra y toda clase de obstruc. ciones, analizadas según el método Bergmann por el sabio Mr. Mongé en la desgraciada expedición del Conde de la Péyrouse, lograron un nuevo examen cuyos resultados comparados con los de

(1) Las expresiones y palabras así seȟaladas, son a la letra lás de su mismo Diario. 
Jun. aquel hábil químico, afianzasen el concepto y $\mathrm{co}$. nocimiento de ellas, añadiéndoles ahora la des. cripción local del terreno, que no hizo aquel viajero.

Despedido ya de Cuellar, atraveso La Laguna haciendo noche en la Isla de Falin, y al día ai. guiente en Binangonan, pueblo situado sobre una punta en la costa Norte, en cuya inmediación como á tres cuartos de legua hacia el Nordeste, yace un peñasco tajado por todas partes y una fuente cuyas aguas merecen el título de las fres. cas de Tosclo: el peñasco es de una tierra argila. cea amarillosa con un socabón al pié, donde se re. unen las aguas que destila gota á gota. La atm6sfera, que al aire libre hace llegar el termo. metro de 25 á $27^{\circ}$, se mantiene en este delicioso. paraje de 18 á $19^{\circ}$, y examinadas las aguas con reactivos á instancias de su celoso Ministro el Padre Perdigón de la Orden de San Francisco, que le acompañó al examen, resultó que podían reputarse por las más simples que se beben.

Milla y media al Sur-Sudoeste de Moróng, lu. gar situado en el continente firme pero que se comunica, por agua, con La Laguna, hay una fábrica de balas, cuyo dueño tiene celebrada contrata con la provisión de Manila, y por medio de un subarriendo á un Sangley las cnnsigue á unos precios comodísimos. La fáb' sumamente sencilla y aún lo son mucho más sus unaniobras, que se reducen á cinco, sin emplear más que otros tantos operarios: calcinar, moler, fundir, vaciar y perfeccionar sobre un yunque las balas ya formadas, es todo cuanto hay que hacer; sin que sea ménos sencilla la estructura de los fuelles y del horno, de que hizo sus des. cripciones.

En los días siguientes hizo nuestro naturalista una excursión á los Miontes de Santa Inés, situados 12 leguas al Nordeste de Moróng, para examinar los Mineros de que se provee la fábrica. Pasb por el mezquino pueblo de Bosoboso, y dejando en él la mayor parte de sus muebles, subió á una región elevada, por caminos ásperos y casi intransitables, en donde ni era posible sin grave riesgo seguir la marcha á caballo, ni á pié se hacía sin grande incomodidad. El equipaje, aunque compuesto sólo de una manta, una almohada, barometro, pesalicores, estuches, algún pa. lay (I) y la comida más penitente, formaba sin embargo un acompañamiento sumamente embarazoso en tan fragcso paraje. Ni fueron me. nores las molestias que luégo se siguieron de trepar los cerros sosteridos de las ye:bas, pasar la noche en el campo sin otro abrigo que la manta de la cama, y sobre todo, no tener ctrn ali-

(1) Palay es el arroz con cáscara, y sirve para alimento de los animales á manera de nuestra cebada. mento que fiambres, los cuales no le sufria el Jun. estómago: estos accidentes debieron causarle un quebianto dificil de reparar.

Dos erguidas cordilleras que corren del Sur á Norte y de Suoeste á Nordeste hasta unirse 6 estrecharse en el Monte Pola hacia el centro de la isla, forman la frondosa llanura en que está Manila, comprendiendo desde el píc del Caraba. llo las provincias de Tondo, Bulacán y ambas Panipangas, con hermosísimas campinas interrumpidas por deliciosos ríos, en cuyas plácidas aguas se duplican reflejados los árboles de la orilla. "Muchos trozos de este país aplanado se "ven luégo en unas situaciones más bajas, y se "inundan tanto en las estaciones lluviosas, que use hacen navegables, y el comercio, que se in. - terrumpe por tierra, empieza á hacerse por "agua." Multitud de pueblos ocupan esta vasta extensión, en que nuestıo viajero sació su curio. sidad con útiles observaciones, entretanto que en ellos ejercitaban los naturales su industria en cultivar el arroz, maíz, añil y tabaco, si bien el estanco de este último, les atrnjo sobre sí mu. chos defraudadores armados que hostilizan $y$ Jcsolan el país, y contra cuyas invasiones han tortificado algunos pueblos con dobles filas de estacas terraplenadas. La factoría de Gapán nro. purcionś la completa vista de aquella escena, narcándose descle ella el empinado Monte Arayat 1 Sur $56^{\circ}$ Oeste.

El paso peligroso del Caraballo, única gar. ganta 6 puerto para pasar á las Misiones de los Irinayas ó de Ituy de los Padres Dominicos, sc emprendió el rode Mayo, debiendo entonces Don Antonio Pineda abandonar por algún tiempo las especulaciones de un naturalista, para sustituirles las no ménos molestas y inucho más destructivas del arte militar. La vecindad de los Igorro. tes habitadores de aquellas serranías, y sordos hasta aquí á todo atractivo de una vida ménos bárbara y salvaje, obliga á los pasajeros á varias precauciones militares, si bien por fortuna estos enemigos traidores, incapaces de atacar á un hombre armado como se encuentre despierto, profesan tanto horror á toda arma de fuego, que un solo fusilazo disparado al embocar los desfiladeros, alarma toda la montaña, sin que por eso se atrevan á acometer. Pero si los pasajeros se desnudan, se descuidan ó se duermer, tienen casi seguro amanecer degollados; y por consiguiente, supérfluas cuantas precauciones se toman para evitarlo. Candeladas, guardias y centinelas que pasasen la palabra, todo se puso en ejecución en aquel pequeño campamento, para pasar una noche en despoblado. La escolta consistía en un criado europeo, un dragón," y el pintor, todos con armas de fuego, que hacían la fuerza más respetable. El resto se componía de 20 indios recien convertidos, que sobre sus cuerpos desnudos car- 
fun. gaban con lanza, flechas, bolas y tablachines, en quienes debía confiarse poco, por más que hıbie. sen empeĩado su palabra de mantenerse leales. El paso de esta pequeña curavana, reglado por cl de su infantería, fué sumamente pausado. Cuestas penosísimas, caminos tortuosos y sombríos entrecortados de arroyos $v$ cascadas que destila el monte por todas partes, la hacían extremadamente molesta, pero en contraposición, la amenidad de la más frondosa primavera y la multitud de aves $\mathrm{y}$ árboles poco comuncs, recreaban dob:enıente los sentidos. En esta extraña región en que se compiten los peligros y los placeres, el barómetro sc fijó en el paraje más elevado en 24 pulgadas, seís líneas y $\%$ sin que el termómetro pasase de $18^{\circ}$ en la escala de Reaumur, pero no es esta altura la del verdadero $\mathrm{Ca}$ raballo; otro monte á la izquicrda de éste, que se eleva al parecer más de 500 varas sobre su mismo yugo y toma la forma de un pan de azúcar, cs el que ostenta este título.

Ya vencidos estos obstáculos que los mismos religiosos caracterizaban constantcmente como invencibles, la continuación de las tareas de D. Antonio Pineda, resultaba sí, algo ménos penosa y más sociable; pero en desquite ora mucho ménos saludable por las continuas emanaciones de un terreno al mismo tiempo cargado de minerales $y$ de humedad. Las amenas orillas del Nuevo Tajo, en cuyas fértiles márgenes los religiosos Dominicos han formado de medio siglo á esta parte poblaciones numerosas con título de misiones, of recían nuevos objetos sumamente intcresa tes. "Estas sociedades nacientes en que bajo un gobierno semipatriarcal, se presenta el hombre en los diversos aspectos de su civilización; en que se examinan sin embozo las costumbres sencillas del salvaje, su frugalidad, sus rencores y sus necesidades recíprocas, su docilidad y su inconstancia; estas pruebas sensibles pero constantes de las debilidades del hombre cuando no subordına sus pasiones á una razón ilustrada, eran la contemplación frecuente del filósofo observador; pero sobre todo merecieron su admiración los prudentes misioneros que con la dulzura de su trato civilizan aquellos montaraces: estos benéficos hombres, condenados con un corto sínodo á habitar perpétuamente en. tre infieles, removidos de toda sociedad en parajes mal sanos 6 arriesgados, expuestos siempre á las astucias é inconstancias de los bárbaros, sufren pacientes sus repetidos engaños; in sencibles á la sed, al hambre, al cansancio, trepan á pić por las más ásperas cuestas, atraviesan los ríos, colgados ó arrastrados de un bejuco, sin apartarse jamás de su memoria el horroroso martirio en que han perecido muchos otros."

La parte local la constituyen una conti. nuada serie de valles que progresivamente se suceden, estrechados por ambas cordilleras que caminan á encontrarse. Los tejidos, el algodón y el cacao, proporcionan á sus habitantes una descansada subsistencia que empieza á ser prolí. fica desde la edad de doce años y da á los Pan. gasinanes (laboriosos catalanes de esta isla) un lucrativo comercio con el cambio de aquellos frutos. No había objeto alguno que evadiese á la atenta y filosófica especulación de D. Antonio Pineda, pero su salud empezaba á no estar de acuerdo con sus deseos, molestada desde los primeros pasos; "pues la repentina alteración wdel temperamento en este nuevo terreno y los "fríos del Caraballo, le hincharon la órbita iz. "quierda, y una molesta fluxión le detuvo ence"rrado algunos días.

"La común enemistad que reina entre las "varias naciones habitadoras de Luzón, no per"mite viajar pacíficamente si no es por las pro"vincias marítimas; los caminos interiores se "encuentran siempre cubiertos de armados gine"tes provistos de lanzones, corazas 6 escudos "cuadrilongos y encorvados, flechas, arcos, chu" zos de caña y espartanas de la pesada palma "del burí. Para librarse de las sorpresas en los "desfiladeros y montañas, es forzoso pedir auxi"lio-al Alcalde ó Teniente del partido que pro"vee la escolta y las armas necesarias. En los "parajes aboscados se echa pié á tierra, se en"vían delante las guías, y las hileras de guerre"ros siguen exactamente sus huellas, que se pro"curan borrar para encubrir la derrota. Los za"catales, sembrados á veces de duras puntas por "los enemigos, no se transitar sin un buen reco"nocimiento, y nadie pone el pié sino donde otro "lo puso: de noche se forma un pequeño campa"mento, y las picas clavadas en el suelo sirven "de parapeto al cordón de centinelas."

Las cuestas de Abungul y Mamparang, siguiendo hacia el Esnordeste de Bagabag en la espaciosa cordillera que corre del Sudoeste al Nordeste, forman un puerto elevado que termina los grandes valles de Ituy, donde nuestro viajero volvió á poner en ejeçución sus prácticas militares. Este elevado paraje, aunque algo menor que el Caraballo, presenta no ménos agra. dables perspectivas; su extensión horizontal es de ro á i 2 leguas, contierıe bosques, llanadas, terrenos entrecortados, ríos y lejanas serranías, que varían y umenizan aquel cuadro.

En las faldas del Mamparang sesteaba una caravana de más de 40 personas de los pueblos de Bayoziuong y Bamgabag, que iban á proveerse de sal, aceite de coco, lati y algodón á las tierras bajas; se componía de hombres armados y de mujeres cada una con dos caballos, y estaban atrincherados con las petacas delante de su vivac, de que puede deducirse el penoso, progreso 
resivamente se Jun. cordilleras que dos, el algodón habitantes una ieza á ser prolída á los Pan. e esta isla) un bio de aquellos que evadiese á on de D. Antozaba á no estár -stada desde los htina alteración o terreno y los on la 6rbita iz. le detuvo ence.

reina entre las Luzón, no per. es por las proos interiores se e armados gine. razas 6 escudos has, arcos, chua pesada palma sorpresas en los rzoso pedir auxipartido que proesarias. En los á tierra, se enileras de guerreellas, que se prolerrota. Los $z a$ duras puntas por sin un buen recoé sino donde otro pequeño campan el suelo sirven nelas."

Mamparang, si: Bagabag en la del Sudoeste al evado que termi onde nuestro viaón sus prácticas aunque algo meno ménos agra. ión horizontal es ssques, llanadas, ejanas serranias, ladro.

ang sesteaba una is de los pueblos e iban á proveeralgodón á las tienbres armados $y$ caballos, y estaas delante de su penoso progreso
Jun. de este comercio y los cortos recursos de estas provincias internas.

Todos los terrenos que corren hacia Cagayan empiezan á declinar desde el Mamparang: las eminencias se aplanan y van progresivamente suavizándose. Una veta de cerros que se descu. bre á trechos, ocupa todo el pais desde Carig hasta Sama: estos pueblos, los de Camarag y Cagayan, formados sobre ella, carecen de frondosidad y buenos pastos. De un plantío de 3.000 piés de cacao, apenas prenden 300 , pero de ca. lidad sobresaliente. Los recodos del río fecun. dan los arrozales, yá éstos les deben la subsistencis. Describiendo esta parte del país que recorría D. Antonio Pineda, lamenta la deplorable situación de algunos pueblos ó rancherías, á quienes por solo las conveniencias del camino han arrancado de su primitivo asiento, privándoles de las ventajas del riego.

No bastaban aún todas las adversidades que hasta aquí se habían opuesto con tanto tesón á nuestro viajero incansable; en Carig estuvo á punto de que pereciesen sus trabajos por un incendio repentino que redujo á cenizas el convento; este accidente, si bien no pudiese evitarse con todas las medidas que le dictó su actividad é inteligencia, fué causa de que predan en lo sucesivo evitarse otros muchos, mediante un reglamento de policía que entregó al Padre Misio nero para semejantes casos, y que éste se ofreció á comunicar inmediatamente á las demás pobla. ciones.

Desde Ganig, primer pueblo de la jurisdicción de Cagayan, donde llegó el 30 de Mayo, se empieza ya á navegar por el anchuroso río: su cauce en los parajes medios no baja de roo á I $50^{\circ}$ varas, y sus frondosas orillas alimentan frecuentes objetos de admiración. Los pueblos de Ila gan, Tamavien, Guagua y otros varios, situados en sus márgenes ó comunicables por esteros, tienen un muelle ó rampa para el desembar. cadero, viéndose comunmente al lado algu. nos camarines flotantes y una ú otra panga. Estas extrañas embarcaciones sin quilla, presentan su fondo plano en figura de una artesa; dos giuesas curvas á popa y proa fortifican las cirras nuertas, y tienen sus carrozas bien tejidas de bambú y palma. Todos los pueblos que constituyen la provincia hacían un buen comercio con el íabaco; sus créditos de ser el mejor de la Isla atraj á los pangasinaries é ilocos que lo compraban con ansia: estancado en el día no aprovecha cosa considerable á la renta; mantiene diez empleados y ha destruídu totalmente aquel comercio. La cosecha de la cera, que exige un temperamento templado, ni muy seco ni muy lluvioso, ha disminuído también, y el cacao no pro. gresa.

Los pueblos de Tupiparao y Puig, Amuling,
Nasipin y Gattara proporcionaron á nuestro via. Jun jero la nación numerosa de los calingas, á quien poder examinar. El Vicario del primer pueblo, el Padre Lobato, le fué sumamente útil. "Su avan" zada edad, su venerable semblante y su desali. "ñada compostura, le daban un aspecto monacal - al cual añadian veneración, sus tareas apostóli. - cas realmente singulares y las diversas obras "que ya tiene publicadas: en él encontró un " verdadero hombre de mérito á quien debió un * decidido cariño, y á su experiencia y observa" ción continuada, una multitud de noticias inte. "resantes con que aumentar y confrontar sus "trabajos."

Lalloc, cabecera de la provincia y residencia de su Alcalde, goza del título de ciuclad por sólo esta circunstancia, sin que lo merezca en lo demás. Habitan en ella algunos españoles que trafican en sus barces, pero su ténue comercio, consiguiente á las tristes circunstancias en que se halla la provincia, no les permite enriquecerse. Sus vecinos, nada afectos á la agricultura, se dedican al tráfico de la sal y otros cortos efectos que transportan por el río; inay, no obstante, bastante aplicación á los tejidos, apenas se encuentra una mujer que no tenga su telar, si bien estos son tan poco ventajosos, que duplican el trabajo y alargan infinito la labor. Cuando se les encarga hacen pañuelos que podrían competir con los finos de la costa de Coromandel, pero no tienen valor porque les falta el fomento y la sa. lida.

La ciudad, situada entre un bosque de plata. nares, tiene al Este una elevada cordillera que corre en forma de barba, distante ro ó I 2 le. guas, $y$ por el Sur forma horizonte la llanada. D. Antonio Pineda daba en todas estas ocasiones una prueba nada dudosa de su excesiva atención á todas las tareas útiles, anotando las marcaciones y distancias desde todas las torres y parajes eminentes, á cuantgs objetos notables se des. cubrían.

Nuestro observador advierte que las aguas impuras del Cagayan propagan entre sus habitantes las obstrucciones del hígado; hombres jó. venes, mujeres de todas edades se veían adolecer de este mal: los vientres abultados y las durezas son comunes; sin que en toda su peregrinación advirtiese media docena de personas de hábito sanguíneo; observación tanto más verídica, cuanto que empezaba á comprobarse funestamente en toda la comitiva. El pintor, achacoso desde que bebió sus aguas, se agravaba por instantes, y ei mismo Pineda, atormentado de una fiebre ya dc algunos días, no podía, sin grave molestia, continuar sus tareas.

Los pueblos de Aparri y Banqui, apenas le permitieron algunas observaciones ligeras. Este úliimo, en donde llueve lo más del año y iay seis

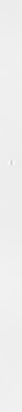


Inn. meses en que no cesa, go:a de un temple tan húmedo que el higrómetro indicaba $6^{\circ}$ más que en los pueblos anteriores: sus indolentes naturales, sin barcas ni cosa que indique navegración, pescan al anzuelo y viven en todo con gran miseria.

La salida de este pueblo puede considerarse por la Nación como la verdadera época en la cual ha perdido uno de sus mejores adornos. Todos los apuntes de D. Antonio Pineda, con algún desconcierto en sus noticias, con los rumbos equivocados y en perpétua contradicción, empezaban á dar las primeras muestras del fatal estado de su redactor. Enflaquecida la memoria, confunòidas ya las especies, y el cuerpo postrado en un talabón ó cama portátil (conducido por indios) no dejaba desembargada otra potencia que la volun. tad: envejecida ésta en el perpétuo trabajo, se esforzaba en vano á continuarlo. Debilitados los b́rganos $y$ trastornada la mente, obraba á ratos con desconcierto, anunciando en todo, los indicios de la humanidad que perecía. Perseguido de un excesivo ardor que lo iba conduciendo hacia su fin, procuraba, erradamente, templarlo con limonadas y refrescos exteriores, que sobre extremadamente ácidos le eran quizás muy nocivos; en vano le exhortaban cuantos le veían, al sosiego y á procurarse otras medicinas más análogas: seducido del pasajero deleite que éstas le pro. porcionaban, clamaba por seguir en sus tareas y regresar á Manila.

Conducido como en un letargo con frecuentes desarreglos de sentidos que advertían hasta los mismos indios, luchaba contra el destino que le llevaba de vencida; pero sin dejar jamás de describir los terrenos y formar su itinerario. Llegó ultimamente á Badoc, pueblo de la provincia de Ilocos, administrado por los Padres Agustinos, á veces nuevamente aletargado, siempre inquieto sobre la continuación de su viaje para el cual nabía tomado ya las providencias más activas, amante en los pocos intervalos tranquilos de conversar aún con el religioso sobre el fatal ob. jeto de sus tareas; nada dócil á las insinuaciones cel Padre para la caliclad de sus alimentos y la necesidad de un reposo, ni á los dictados de sus mismos conocimientos médicos para precaverse con el útil método de las sangrías, ó no creía tan próximo el término de sus días, 6 entregado desde mucho tiempo á un celo patriótico y á un amor incansable á las ciencias, le veía ya muy de cerca con una superioridad y tra:qquilidad filosóticas

Así pasó todo aquel día, y en aquella misma noche le sobrevino un accidente apoplético, del cual no volviendo ya.(tal ve $z$ por la poca pericia del curandero indio) sino para dar mues.ias al Padre de un alma tan firme en su religión como lo había sido en sus deberes sociales, terminó en la noche del 23 la gloriosa carrera de su vida á los treinta y ocho años de edad.
No es fácil encerrar cn pocos renglones el elo. Jun. sio de un vasallo tan esclarecido y los trances aún más singulares de su vida.

Don Antonio Pineda, después de una educa. ción adecuada á su nacimiento, había entrado á servir en clase de cadete en el regimiento de Reales Guardias de Infantería Española: su ca rácter sociable, su amor al estudio y su idea bien entendida de los deberes hacia la patria, muy luégo le dictaron la necesidad de ensanchar, cuanto fuese posible, sus conocimientos. Los que había adquirido con preferencia y eran los del arte militar, se hicieron bien patentes en los ataques de Gibraltar durante la guerra empezarla en I779, quedando bien cimentados, cuando sin nombre del autor se presentó y practic 6 un plan suyo para el detall de las operaciones del Ejército, dirigidas en la noche del I3 de Agosto á abrir la nueva paralela: sus servicios fueron igualmente distinguidos y su vida extraordinariamente expuesta en la batería flotante La Pastora, en la cual, y en el encuentro sucesivo de las dos Escuadras á poca distancia del Cabo Espartel, sirvió á las órdenes del Jefe de Escuadra D. Bue naventura Moreno. Finalmente, hecha la paz y desdeñando vivir en una cansada ociosidad tomar por único objeto de sus tareas la des. trucción de sus semejantes, volvió el rostro hacia la Física y la Historia Natural, en cuyas ciencias había adquirido ya muchas nociones ge nerales. Su constancia v su talento le llevaron muy luégo á un grado bien provecto en una y otra ciencia, y su celo patriótico y pundonoroso le dictó la ocasión de aprovecharlas en la expedi. ción de las corbetas Descubierta y ATrevida al mar Pacífico; cuál haya sido después la serie de sus tareas útiles para los hombres en general y para sus conciudadanos en particular, lo manifiestan la narración del viaje y la inscripución puesta en el monumento elevado á su memoria en las inmediaciones de Manila, y lo manifestará aún más la publicación de todas sus observacio. nes, las cuales redoblaron en su variedad, mul. tiplicación y utilidad, justamente. cuando las gracias del Soberano, el aplauso de la Nación, una rica herencia de los bienes de su familia, y sobre todo, los ruegos incesantes de sus compa ñeros de viaje, debían recordarle las satisfacciones honoríficas que le esperaban á su regreso á la patria.

Dividido así repentinamente y para siempre de sus compañeros, no pudo ménos de ocuparlos después incesantemente con su memoria. En un momento perdieron un ejemplo acrisolado, un hombre extraordinariamente humano, un filosofo con exceso iristruído y laborioso, un amigo siem. pre sociable y un compañero afable y ameno. A estas pérdidas por sí solas irreparables, debieron agregarse luego las que hacian de mancomún con 
pnes el elo. Jun. Jan. la Nación, sus ideas tan grandiosas cumo cabales os trances

Inia educaentrado á imiento de ola: su ca. su idea bien atria, muy ensanchar, entos. Los $y$ eran los entes en los a empezatla cuando $\sin$ icó un plan s del Ejére Agosto á cios fueron raordinaria. La Pastora, b de las dos o Espartel, dra D. Bueha la paz $y$ ociosidad $\dot{0}$ eas la des. l rostro haal, en cuyas nociones geo le llevaron tr en una $y$ pundonoroso en la expediATrevida al s la serie de an general y slar, lo maa inscrijución su memoria manifestará observacio. iejad, mulcuando las L la Nación, su familia, $y$ sus compa. satisfacciosu regreso á

sara siempre de ocuparlos noria. En un risolado, un , un filósofo amigo siem. $y$ ameno. $\mathrm{A}$ les, debieron ancomún con sobre el suelo y los habitadores de casi todo el continente americaro sujeto á la Monarquía; sobre el bereficio comparativo de los minerales; sobre el análisis de los idiomas, y sohre la policía. situación y costumbres de nuestras colonias, si bien en parte apuntadas entre sus cuadernos, perecieron casi enteramente con él. ¡Ir feliz suerte del hombre, que no derivando su felicidad sino de la felicidad agena, este mismo afán le causa mil sinsabores y lo arrastra frecuentemiente á malograr su intento por su propia debilidad!

Jul. 13 No se supieron las noticias en Manila sino en la tarde del 13 de Julio; para ei 16 se tributaron á su memoria en la iglesia de śan Agustín las pompas fúnebres y las exequias más solemnes; inmediatamente después se ocuparon, D. Juan Rabenet y D. Fernando Brambila, el primero en representar con la mayor propiedad á la nación que lo ha perdido el extremado lance de este buen vasalio y el segundo en diseñar y hacer elevar en la huerta de Malate, propia de la Real Compañía, un monumento fúnebre que recordase á la posteridad nuestra pérdida y nuestras lágrimas, las que dejó grabadas D. Tadeo Hecnke con la siguiente inscripción latina:

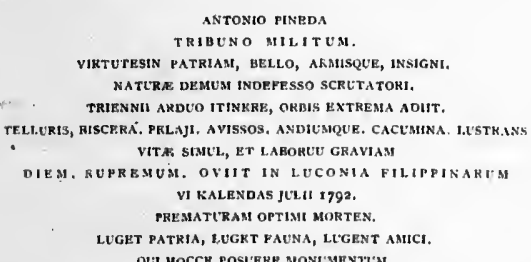

En el entretanto había establecido su impe. rio la monzón lluviosa del Sudoeste, la cual por un conjunto feliz de combinaciones debe mirarse en Manila como la más saludable; restableciéronse nuestros enfermos, se continuaron paulatinamente los aprestos de los luques, víveres y pertrechos para la continuación del viaje, y si bien las aguas fuesen tan repetidas que en sólo cinco días no bajase la lluvia de 30 pilgadas y llegase en los cuatro meses comprendidos hasta Octubre á ochenta y seis, pudieron acelerarse las medidas de tal modo, que no esperásemos para dar nuevamente la vela sino una constancia mediana en los vientos favorables del Nordeste.

Desde la mitad de Setiembre habían ya emprendido nuevamente sus excursiones D. Luis Nee y D. Tadeo Heenke, para sus acostum. bradas investigaciones de Historia Natural, dirigidas ahora en las inmediaciones de la Laşuna de lay, á un nuevo examen de los plantíos de canela, á los análisis de diferentes aguas termales, y particularmente á un reconocimiento pro. lijo del volcán recientemente extinguido de Taal.
Al mismo tiempo D. Antonio Tova hizo una Jull. 1 nueva excursión hidrográfica en la provincia do Tayabas, hacia las ensenadas de Paquilao y de Bondoc, donde no habían podido penetrar nues. tras marcaciones con las corbetas cuando veni?. mos de Jorsogon; finalmente, D. Felipe Bausá examinó con una exactitud geométrica las sondas inmediatas al tiro de cañón de la plaza, y Ios demás puntos al andar del rio Pasig y de la Laguna, para que en lo venidero no se ignorasen todas las ventajas locales de aquellos contornos felices.

Establecióse después el observatorio en Ca. vite para arreglar nuevamente la marcha de los relojes marinos, completáronse las tripulaciones con naturales voluntarios, y el Capitán inglés Dunlop del navío mercante el Yarmouth, tomó á su cargo conducir á aquella colonia nuestras remesas y cartas, para que desde alli se condujesen á Lóndres y últimamente á España, ya que no había en la colonia nuestra embarcación alguna de la Compañía, que regresase al Continente. Fuera injusto de nuestra parte no hacer aquí una honrosa y particular memoria de aquel hábil navegante, el cual alcanzado en los primeros días de Mayo el puerto de Macao, habiase propuesto ahora regresar igualmente cortra monzón por el Estrecho de Macassar, costeando antes las Filipinas. Un temporal violento le obligó á arribar desde cl extremo meridional de Mindoro, y debió ya determinarse á esperar la otra monzón para seguir después por la derrota común del Estrecho de Malaca.

Le debimos la noticia de varias determinaciones hidrográficas en los mares de la India, según las observaciones más modernas y más exactas de sus navegantes; le debimos la nueva carta de Robertson de los mares de las Molucas, Filipinas y China, que tanta claridad producia sobre las navegaciones modernas; le debimos, finalmente, una amistad $y$ un aprecio tan instructivos que no podrán jamás borrarse de nuestra memoria.

Antes de abandonar la bahía fué tambien una ocupación no mediana para entrambos armamentos, la de aparejar una goleta que á las órdenes del primer Piloto D. Juan Maqueda, agregádole como segundo D. Jerónimo Delgado, debía em. plearse en los seis meses próximos en continuar la descripción hidrográfica de las Islas Visayas o Filipinas meridionales. Reconocimiento importantísimo, así para los desembocaderos al mar anchuroso desde los Estrechos de San Juanico y Mindanao, como para la facilidad de las nave. gaciones internas que muy luégo habían de repetirse con el aumento de la prosperidad nacio. nal. Quedó luégo al cargo del Teniente de fragata D. Martín de Olavide continuar con la ordenación prolija de nuestros manuscritos, y regresar últimamente á España en la Nao de Acapul.

\section{Set.}

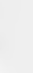


Ot. co con los papeles originales que formasen el duplicado de nuestras remesas anteriores. Así evitábamos el riesgo de cualquiera pérdida sucesiva y se iban paulatinamente reuniendo en Europa, una parte no mediana de nuestros Oficiales, que dando la última mano á las tarea ejecutadas, acelerasen en lo posible la publicación del viaje.

Niow. 6 Finalmente, en la tarde del $\mathrm{I}_{4}$ de Noviembre todo estuvo pronto para dar la vela; al amanecer del dia siguiente las corbetas se espiaron para fuera, $y$ poco después, con los primeros soplos del viento Este, navegaron hacia la boca de $\mathrm{Ma}$ riveles.

\section{CAPITULO IV}

Navegación de las corbetas hasta el presidio de Mindanao, y reconocimientos intermedios.-Escala en aquel presidio.-Dcrrotas sucesivas en el mar Pacífico.-Vista del extremo Sur de la Tierra ausiral del Espiritu Santo y de las costas immediatas á Dusky-Bay en ia Nueva Zelauda.-Escala y acaccimientos en la colonia inglesa de Sidney, en la Nueva Holanda.

Cuanto más examinásemos las navegaciones de los europeos en el mar Pacífico; cuanto más se atendiesen los objetos, la fuerza, la constitución y la utilidad de los armamentos de las cor. betas Descubierta y Atrevida, tanto más debía variar nuestro plan de los que habian seguijo los navegantes anteriores; y abandonada la esperanza de podernos llamar descubridores, debiamos dirigir las investigaciones nuestras á los progresos sólidos de la navegación y al desem. peño de los diferentes ramos científicos, con los cuales nos habíamos abrazado.

Exigía, por otra parte, este plan, que visitásemos una ve $z$ más los diferentes paralelos de la América meridional, en donde debían repetirse las experiencias de la gravedad de los cuerpos con el péndulo simple constante, que atento á la medida proyectada en Europa; inváriable y dependiente del mismo péndulo en un paralelo de. terminado, se consultase particularmente el de $45^{\circ}$ en el hemisferio austral; y finalmente, que reconocido el pequeño Archipiélago de Baban, parte de las Islas y confederación de los Amigos, donde había casualmente recalado el Teniente de fragata D. Francisco Maurelle en $\mathrm{I} 789$, se rectificasen después varias cuestiones hidrográficas. bien sea al Oeste 6 al Este del Continente de la América.

$\mathrm{Ni}$ nuestrns armamcntos podían considerarse capaces de mayores esfuerzos, aunque tuviesen á su frente una Oficialidad hábil, constante $y$ digna de los mayores elogios, pues debilitados con las enfermedades propias de los Trópicos y con las fatigas de tres años los pocos restos de "Nor. 15 las tripulaciones y tropas sacadas de Europa, y sustituídos los que faltaban con un número crecido de filipinos débiles y poco expertos; ni podiamos contar con aquella disciplina, inteligencia y humanidad que decide por lo común de la suerte de los viajes, ni su robustez era capaz de resistir unas fatigas repetidas y violentas. Se adoptaron con este mismo reparo todos los preservativos que pudiese dictar la práctica 80 . bre la conservación de la marinería nacional; sustituímos el uso del Grog ó aguardiente agua. do, al vino de Sanlúcar que habiamos embarca. do en Cádiz; la calidad de los víveres, al aseo intcrior, un trabajo periódico mas no excesivo, y una cierta tranquilidad de ánimo, inseparable de la conservación de la salud, fueron luego los estribos principales de nuestro plan para este intento. Así, veíamos, aunque distante, la época feliz que nos proporcionase el regresar al seno de la patria y el ofrecerle aquellas nociones prácticas que reunidas á las tareas de los demás navegantes europeos, pudiesen algún clía fijar su verdadera robuste $z$ y opulencia.

En el entretanto, nuestros pasos no podían ménos de dirigirse hacia el Sur, costeando las diferentes Islas de Mindoro, I'rnay, Negros y Mindanao. Ceñiríarnos de este I'ıodo al Oeste el Archipiélago Filipino mientras D. Juan Maqueda lo verificaría en sus canales internos; y un reconocimiento exacto del presidio de Zamboanga, nos daría lugar á examinar por aquella parte los verdaderos intereses nacionales, decidiendo la cuestión importante y agitada desde dos siglos: si era útil ó no su conservación harto costosa y sangrienta. La brisa fresca del Esnordeste no entabló en la bahía de Manila hasta las cuatro de la tarde. I aprovechamos inmediatamente con todo aparejo; al anochecer no distábamos sino una milla del Farallón de la Monja, islote forano á la bahía; y como en la noche inme. diata coniinuase nuestra navegación hasta propasarnos de la Isla de Cabja; en la mañana del 16 ya"nuestras tareas acostumbradas pudieron emprenderse con actividad, y costeadas $\mathrm{Lu}$ ban y Ambil, atracar á las dos de la tarde la Punta Calavite y las orillas fértiles de Mindoro. La mitad septentrional de aquella isla es más bien montuosa, encadenándose unos con otros cuatro órdenes de montes que terminan en la misma orilla poblada al principio con un bosque impenetrable y más llana después con unas 10 mas que convidan á la agricultura, cuando se hallen ménos desiertas de lo que están en el día. No se advirtieron en la noche los muchos fue. gos que habían sorprendido al Capitan inglés Meares, ni ignorábamos por otra parte que apenas en toda aquella larga extensión se anidaban pocos piratas, ocupados en la estación favorable 
restos de 'Now, 15

Europa, y hero crecios; ni po. inteligen. común de era capaz violentas. todos los ráctica so. naciona!; ente agua. embarcas, el aseo excesivo, nseparable luego los ara este inla época feal seno de nes práctidemás nalia fijar su

no podían teando las , Negros y al Oeste el an Maqueda ; y un recoamboanga, la parte los cidiendo la dos siglos: o costosa y nordeste no - las cuatro diatamente distábamos onja, islote che inmehasta prola mañana idas pưdieteadas $\mathrm{Lu}$ la tride la e Mindoro. isla es más s con otros inan en la ( un bosque on unas locuando se a en el día. uchos fueitan ingless e que ape. e anidaban a favorable
Nov. 16 á veces con la pesca del balate (I) en el bajo de $\Lambda$ po, á veces en sus correrías acostumbradas á las Calamianes y Paragua. Es luego mucho más agradable la otra mitad de la isla que recorrimos en la tarde del 17 ayudados de una brisa fresca con el tiempo más placentero que pudiésemos desear. Ya la costa mucho más llana y frondosa presentabe todos los halagos de la vida sociable para que bajo un gobierno pacífico y juicioso multiplicasen hacia aquella parte los ha. bitantes tranquilos de la orilla. Diferentes riachuelos, unas playas apacibles, la poca distancia de otras muchas islas útiles y de la misma capital, todo debía recordarnos la importancia y la utilidad de semejantes poblaciones, al paso que la vista en el horizonte, de un panco ó embarcación pirata, nos demostraba que esas mismas posesiones nos eran en extremo nocivas, por ser el abrigo de los que conspiraban con tanto tesón á nuestro daño.

Pudimos en este tránsito marcar los islotes que fijan cl extremo oriental del bajo de Apo, y algunos altos de las Calamianes; costeáronse de cerca las Islas de Illin, $y$ las otras bajas de Simiraba que median entre Mindoro y Panay; y atracadas después las frondosas y fértiles orillas de esta isla, no sin algunos amagos de huracán que se disiparon luégo, reconocimos el fondeadero de Antique, llamado con mucha propiedad el granero de Filipinas, pasamos á la Isla de Negros, y logramos en los días siguientes del 21 y 22 mantenernos á muy poca distancia de los extremos occidentales de Mindanao.

En las navegaciones indicadas nos favorecieron las brisas del Nordeste extraordinariamente. Repetíamos á nuestro placer las observaciones de longitud $y$ las marcaciones distantes. Eran las bases y los aparejos uniformes por la igualdad en la dirección y en la fuerza del viento. Las cmanaciones saludables de mil plantas aromáticas que cubrían las orillas inmediatas, embalsamaban el aire á mucha distancia. Se recreaba la vista, se enardecía la imaginación entre tantos objetos tan varios y tan agradables; $y$ en el corto espacio de solos ocho días, habíamos disminuído la latitud de unos $7^{\circ}$, siguiendo próximamente los meridianos del observatorio nuestro de Cavite: las corrientes, como debe imaginarse, conservaron siempre una direccion bastantemente rápida al Sur, que causaba un error de $15620^{\prime}$ diarios en la latitud de estima y la variación magnética fué constante de $I^{\circ}$ al Nordeste.

En la misma tarde del 22, declarada la ma. rea contraria para aproximarnos á la rada de Zamboanga, dimos fondo á poca distancia del

(1) Especie de marisco conocido por los naturalistas con el nombre de Mentula marina. puerto de la Caldera en doce brazas arena, y en Nov. la mañanita siguiente, apenas la tuvimos favo. rable, cuando levamos de nuevo el ancla, y con los remolques, ya que no habia viento alguno, emprendimos el aproximarnos al nresidio.

Eran importantes las precauciones que nos habían indicado en Manila para este caso, y es. tribaban particularmente, ell la necesidad de conservar una grande inmediación á la costa para no ser arrastrados por la marea á un fondo crecido y de mala calidad, como también en la atención de no apartarnos á más de dos cables de la playa cuando diésemos fondo, para no encontrar las muchas piedras sueltas que á mayor distancia le hacen bien molesto , peligroso. Entrambas pre. cauciones, sin embargo, pudieron costar bien caras á la Descubierta, pues antes conservándose á un cable escaso de la playa por sondas de $\mathrm{I}_{5}$ brazas arena, en donde la marea era más viva, se vió arrastrada por un remolino, sobre una puntita de piedra, en la cual no tuvo sino tres brazas de agua, y luégo ya inmediata al fondeadero, no logrando aún sonuar sino 22 brazas, debib, en busca de mejor fondo, aproximarse de tal modóa la playa del presidio, que no pudiendo refrenar la salida aumentada á la sazb́n con el viento fres. quito del Sudoeste, tocó, aunque levemente de proa: el alijo de las embarcaciones menores y una espía afuera, la pusieron inmediatamente en buen paraje; y para las cinco de la tarde, consiguio hallarse amarrada á dos cables de la playa, demorando la torre del castillo al Nordeste $1 / 4$ Norte. El ancla del Oeste qued6 en I 2 brazas arena y en 18 conchuelilla la del Este. La ATREvidA al mismo tiempo se amarró como un tercio de cable al Oeste nuestro. El Capitán D. Francisco Aznedo, Gobernador del presidio de $Z$ amboanga, ya desde el medio día había manifestado sus deseos de explayar una atención activa, no sólo hacia los objetos de la expedición, si también hacia todos los individuos que la crm. ponían: aun hallándonos á la vela le precedio el Mayor de la plaza á cumplimentarnos; no tardb el mismo Gobernador en llegar á bordo con los po$\cos$ individuos caracterizados del presidio, y la visita sucesiva que le hicimos á la caída de la tarde, no nos debió dejar ya la menor duda que todas las medidas conspirarian unánimes á nues. tro bienestar y al más breve desempeño de los objetos que traíamos entre manos.

La utilidad 6 inutilidad de la conservacion del presidio de Zamboanga con el doble objeto de refrenar las correrías de los piratas joloanos, mindanaos y macassares, y de abrigar la fuga de nuestros cautivos, ha sido y es en el dia una cuestión bien importante para los intereses na. cionales: ello es, sin embargo, que la situación del presidio no puede ser más feliz, su clima más agradable ni más sano, su campiña más fértil 
Nov. 22 y su fondeadero mís seguro, no sólo por el natural abrigo y la casi constante benignidad de las estaciones, si también por la inmediación de dos puiertos, el de la Caldera el uno, el otro al Iiste, cuyo plano hará su mayor elogio. Rigen en aqueIla latitud las mismas monzones que en Manila, anticipándose $\sin$ embargo (como es natural) la del Sudoeste, y retardándose la del Nordeste. La casualidad d’a estar tendida del Este á Oeste la Isla de Mindanao, hace que sus montes no den libre tránsito al viento Norte al tiempo de mu. dar las estaciones, $y$ con este motivo no alcanzan allí los huracanes, privilegio á la verdad tan apreciable como poco conún en el Archipiélago filipino. La demasiada inmediación de los pira. tas $y^{*}$ sus constantes osadías y ardides por lo co. muin felices para cautivar nuestras familias, son el único inconveniente para la verdadera fclici. dad de aquellos alrededores.

No tardaron en hacćrsenos patentes cas,i todas las propiedades antes indicadas. $Y$ á pesar que no se hubiese declarado la monzón del Nordeste sino unos quince días antes, y que aún casi todas las tardes soplasen vir_zones frescas del Sudoeste, uran los días por lo común claros y placenteros; las noches luégo con exceso hermosas y despejadas y con unos terrales apacibles, refrescaban de tal modo la atmósfera, que nos recordaban casi el temple delicioso de las costas de Coquim. bo y Lima. Pero al contrario, eran frecuentes así de día como de noche las alarmas por la inmediación de los piratas, lo cual no sólo nos debía precisar á una vigilancia contínua, si también debía hacer más tardos nuestros pasos para los re. conocimientos hidrográficos; siendo preciso evitar cuanto fuese posible las correrías de noche, $y$ emplear siempre las lanchas armadas con un crecido número de individuos. Hasta en los paseos y. salidas por tierra no distantes de la población, nos avisó el Gobernador que anduviésemos siem. pre cáutos y armados, pues no pocas veces es. condidos los enemigos, aunque en corto número habían causado estragos considerables.

Desde la mañana siguiente se transportaron los instrumentos á la casa del Gobernador, quien habia insistido en querernos franquear paraje oportuno para las observaciones. Era nuestro ánimo no sólo examinar con la mayor escrupulosidad la marcha de los relojes así para las determinaciones pasadas como para las venideras, si también afianzar la longitud de aquel extremo de nuestras tareas con observaciones celestes de mucha confianza, y obviamente repetir las experiencias de la gravedad en un paralelo tan próxi. mo á la equinoccial. Por casualidad, la Luna a, $\mathbf{n}$ que brillase la mayor parte de la noche sobre el horizonte, no proporcionaba ocultación alguna de estrellas fáciles á observarse. Se cimentaban por consiguiente todas las esperanzas de los Oficia. les astrónomos sobre una inmersión del primer Nov. satélite de Júpiter visible en la mañanita del $\mathbf{5}$ del próximo mes de Diciembre.

$A$ estas prevenciones se agregaron inmediatamente las de proporcionar á entrambos botánicos alojamiento, libertad y escolta para las sucesi. vas excursiones que meditaban, y la de enviar diariamente dos marineros á cortar una buena provisión de verdolagas silvestres que abundan en aquellos contornos extraordinariamente para que el caldero de la tropa y marinería no careciese jamás de tan esencial antiescorbútico. Las excursiones hidrográficas, el reemplazo complet del agua consumida, el abasto tan abuniante cuanto fuese posible de la leña, y una atención constante al asco y disciplina interiores, debían distraer y ocupar cuotidianamente $a$ todos. Los días de fiesta quedarían luégo dest nados al descanso, al recreo, al esparcimiento, y digámoslo así, á los vicios, los cuales no podian á ménos de abrigarse en mucho número en un fresidio de las Islas Filipinas, ni de hallar un agra table acogimiento entre unas marinerías recien salidas de Cavite: y ciertamente, cualquiera que haja recorrido con alguna atención los sucesos de este viaje ó reflexione filosóficamente sobre las calidades irremediables de los establecimientos europeos ultramari:1os, no extrañará la asegura. ción nuestra, que mil veces hemos deseado para la mejor conservación del marinero aquellas mismas soledades y aquellos mismos abrigos de la sola naturaleza, aunque al parecer horribles, que tanto habian ensalzado la conservación de las marinerías inglesas en los diferentes viajes dirigidos por el célebre Capitán Cook.

Hasta el medio día del 26 no se consiguieron los primeros resultados de los relojes marinos para la longitud del observatorio. Nos habia sido preciso abandonar las esperanzas de valernos del péndulo astronómico, cuya marcha resultaba con exceso irregular $y$ sujeta á diferentes paradas, pero se le sustituyó el relój ros de la ATrevida, al cual se agregó luégo el cronómetro 72 para las experiencias del péndulo simple, no omitiendo además la precaución de sujetarlos con los demás relojes por medio de señzles para que lograsen aquellas experiencias toda la exactitud que estaba á nuestro alcance.

A las determinaciones directas de los relojes marinos para la longitud fué luégo preciso adap. tar aquellas ecuaciones que dictasen como más probables las comparaciones hechas en el mar y las marchas advertidas ahora. Finalmente, la longitud del observatorio pareció muy aproxi. mada á la verdad en el modo siguiente:

\begin{tabular}{|c|c|c|c|c|}
\hline & Keligi ios. & Cransim. 72. & Reloj 17. & Cronom.71 \\
\hline $\begin{array}{l}\text { Longitud oriental de } \\
\text { Nannila en tiempo... } \\
\text { Ecuaciones............. }\end{array}$ & $\begin{array}{r}4^{\prime} 35^{\prime \prime} 37^{\prime \prime \prime} \\
2 \times 1 \\
\end{array}$ & $\begin{array}{c}21 " 1 \\
10.15 \\
10.15 \\
\end{array}$ & 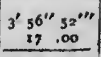 & $\begin{array}{r}3^{\prime}+5^{\prime \prime} \times 8^{\prime \prime \prime} \\
28^{\prime} .84 \\
\end{array}$ \\
\hline
\end{tabular}


del primer Nor. $4_{4}$ anita del 5

inmediata. s botánicos las sucesi. de enviar una buena de abundan mente para no carecieco. Las ex- completz abuniante ha dtención res, debían todos. Los idos al des. digámoslo á ménos de sidio de las lable acogii validas de le haja reesos de este re las calimientos eu la aseguraeseado para quellas misbrigos de la orribles, que ción de las viajes diri-

onsiguieron jes marinos s había sido valernos del isultaba con es paradas, A ATREVIDA, 72 para las o omitiendo on los demás ue lograsen ud que esta-

los relojes ceciso adapa como más an el mar $y$ almente, la uxy aproxite:
Cuyo promedio de $4{ }^{\prime} 13^{\prime \prime} 45^{\prime \prime \prime}$ daba en grado la longitud oriental de Manila de ............................. $x^{\circ} 3^{\prime} 26^{\prime \prime}$

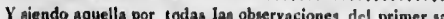
telite al Deste de Caddiz. ...................... 2.32.5

Res Ulaba finalmente Ia del observatorio de Zamboanga

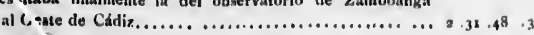

$Y_{b}$ en este mismo dia, que aparentaba muy sereno y apacible, se habían destacado con el beneficin de la marea de la noche los Sres. Bausá, Novíles y Heenke para el puerto de la Cal dera. Lrs conducía la lancha armada de la DEsCUBIER? A. Les acompañaba un práctico con una embaración pequeña, capaz de arrimarse á cua. leofuiera piedras; y como el viaje correspondies 'n su prontitud á las medidas tomadas, casi de: de el amanecer se había dado principio á 1 is base: y marcaciones por una parte, y por la otra á las excursiones botánicas. Entrambos $₫ \mathrm{~b}$ jetos pudiero: considerarse completamente lesempeñados para la mitad de la tarde, peio la desiguaidad de las mareas no permitió el regreso hasta las dos 6 tres de la ma ĩana siguie:ıte. Ningún rastro de piratas los haíá p'armado en aquella excursión.

No fué así al día siguient. Felipe Bausá con la misina lancha y canoa á la costa oriental del presidio, hasta donite el des. agle en el mar, dr.l río Balabac, forma in la más occidental de su's bocas un hermoso pueito, cuya entrada en la larra del ancho de un sable no tiene en la bajamar ménos fondo de cuatro $y$ media brazas, ilumentándose luézo est ts y ex. tendiéndose á uní y otra orilla á siet , ocho y nueve brazas. Apenss habíanse ccicluído las sondas y marcaciones y la gente de la lancha empezado su comida, cuando de las Islas inmediatas de Numpim y Anapuyan, donde se hallaban dos canoas nuestras pescadoras, se vieron aparecer $d$ $\rho$ pancos piratas, quienes navegaban para corti rles la retirada hacia la costa, siguiéndolas luęo hacia ella, aunque viesen frustrado su primer intento, fué preciso que para el abrigo de las canoas saliese nuestra lancha, la cual, apenas avistada por los perseguidores, los hizo retroceder y dirigir sus rumbos hacia la Isla de Basilan.

No quedaban ya para terminar las tareas hidrográficas sino algunas marcaciones en las islitas fronteras de Santa Cruz, que ligasen oportunamente los extremos de nuestras operaciones 9 con todos los puntos de la Isla no distante de Basilan. Fueron éstas en la mañana del 29 las tareas de nuestros Oficiales con la lancha armada de la Atrevida y no se omitió al mismo tiempo la ocasión de sondar con la canoa todos los al. redidores, y particularmente, el canal que forma con la isla más Este, el arrecife que sale de la otra en aquella misma dirección. Medida i!tima. mente una base en la playa del presidio y son. Nov. s, dadas con marcaciones de dos teodolitos las in. mediaciones del fondeadero por el Piloto Inciarte de la AtreviuA, este ramo esencial de la expedición pudo considerarse felizmente concluído, y por consiguiente, ya no distante la época de la continusición de nucstro viaje.

No se habían descitidado en el entretanto los de'nás objetos que indizamos al principio: los lombos armados y bajo 1.2 dirección de un sargento 6 condestable, iban tiariamente al corte de la leña en la embocadura dei río inmediato de Tumaga, punto que teníamos á la vista y podía. mos socorrer á cualquier instante.

Don Juan de la Concha había ya conseguido en la noche del 29 observar algunas alturas me. ridianas de estrellas, de las cuales resultaba la latitud del observalurio de $6^{\circ} 54^{\prime} 30^{\prime \prime}$; se habian hecho á bordo todos aquellos arreglos que fuesen necesarios de arboladuras, aparejo, velamen $y$ estiva; las lanchas ya desocupadas podían em. prender con mayor actividad el corte de leña; $y$ los bombos trabajar con mejor éxito en la conducción del agua, que se hacía con la mayor como. didad delante del fuerte. Finalmente, nuestros rostros y la misma agilidad y satisfacción de to. dos, indicando ya patentes los buenos efectos de una escala tan sana como agradable, nos recordaban al mismo tiempo que ya debíamos abannarla.

Hasta el día I. ${ }^{\circ}$ de Diciembre (particular. mente estando el Sol sobre el horizonte) los vien. tos se habían mantenido fresquitos del Noroeste al Oeste, moviendo á veces alguna marejada que en la actual posición nuestra de distar un solo cable del poco fondo, no dejaba de causar algún cuidado; agregábase que los habitadores del pre. sidio anunciaban para el próximo novilunio un temporal por aquella parte, no bien arraigada aún la monzón nueva del Nordeste; debían por consiguiente ser doblemente fuertes los impulsos para abandonar el fondeadero, pues esta re. volución (si acaso la hubiese) que podía sernos fatal estando al ancla, nos sería al contrario su. mamente útil á la vela, en una navegación contrariada al mismo tiempo de los vientos y de las corrientes. Además, el tiempo favorable para nuestras investigaciones en el hemisferio austral iba pasando rápidamente, y nada podia justificar una demora más dilatada en aquel puerto, con. cluídas el dia 2 las experiencias de la gravedad, cerrado el examen de la marcha de los reiojes marinos y retirados á bordo la tienda y los ins. trumentos del observatorio.

Quedó prefijada la salida para la mañanita del 6, á cuyo tiempo lográbamos también combinar la marea favorable con los pocos soplos de! terral y proporcionar á los botánicos un plazo suficiente para la completa preparación de las 
Dic. plantas que en mucho número y de un mérito singular habían acopiado en aquellos contornos: se aprovechaba así también, como lo habiamos deseado, la inmersión del primer satélite de Júpiter, visible en la mañanita del $5, y$ los demás Oficiales no estarían tampoco ociosos, abregando a las determinaciones ya hechas de la longitud del observatorio, un crecido número de distancias de la Luna al Sol, que se proporcionaban con el cuarto menguante.

En los días 3 y 4 fueron efectivamente mu. chas las observaciones de esta especie que se repitieron en una y otra corbeta con las circunstan. cias más favorables. La mañanita del 5 proporcionó igualmente á los Sres. Espinosa, Concha y Cevallos, observar con no ménos felicidad la inmersión del primer satélite de Júpiter; los resultados de uno y otro fueron los siguientes:

Por la iumersión del primer satélite de

Júpiter longitud occidental de Cidi $231^{\circ} 44^{\prime} 30^{\prime \prime}$ l'or los relojes marinos, aplicadas las

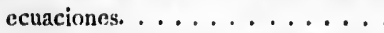

Por un promedio de distancias de la

Luna al Sol, en la corbeta ATre-

v10. ............... 231.13.15

I'or 8x fd. en la corbeta Descunirrita. . 230.56 .15

Admitíse, como era natural, la determinación del primer satélite de Júpiter, y las tablas de la marcha de los relojes marinos siguieron arre. glándose al meridiano de Manila, atento á la di. ferencia que acobamos de deducir por ellos y que confirmaba el satelite.

Nos disponíamos en la misma mañanita para ejccutar la salida al día siguiente, y la lancha de la Descubierta acababa de enviarse á tierra para, recoger los últimos restos de la aguada $y$ refrescos, cuando hacia las ocho se vicron salir de las costas intermedias entre el presidic $y$ la Caldera, tres pancos piratas, que insultando con muestras poco equívocas de audacia á las fuerzas del presidio, cuyo alcance creían imposible: acababan además de cautivar en las playas hasta seis individuos de ambos sexos que habian hallado mariscando descuidadamente. No tardaron sino pocos minutos en correr en su alcance con el mayor denuedo un panco $y$ un batalangán ó embarcación chica de remo, entram. bas con tropa del presidio; fuerzas inferiores con tanto exceso á las de los enemigos que debían causar admiración á los poco expertos en esta especie de guerra, mucho más cuando la embarcación menor, con $\mathrm{s} b l o$ siete hombres, aprovechaba toda su ventaja de andar sobre la conserva para estrecharse lo más pronto con los enemigos, los cuales iban alejándose por el canal que for. man las dos islas chicas y navegaban (ya con vela) hacia la isla de Basilán.

La inferioridad de nuestras fuerzas perseguidoras, el insulto de los piratas y nuestro mismo deber, no nos podian dejar espectadores tranqui. Dic. los de lo que pasaba, áun cuando no hubiésemos recibido al mismo tiempo una instancia del Gobernador para que nuestros buques menores cooperasen al alcance de los enemigos. Así, desde el primer instante de su aparreimiento, la ATREviDA había aparejado $y$ armado su lancha 1 las órdenes de D. Antonio Tova, de suet te que pudo con facilidad alcanzar las fuerzas del presidio, $y$ la lancha de la Descubierta (que hablamos llamado inmediatamente) con los dos botes ile las corbetas, pudo formar una segunda division capaz de operar con actividad en la caza y en los ata. ques: se había embarcado D. Juan de la Concha en el bote de la ATrevida; la lancha de la DBs. cubiekta iba a las ordenes de D. Fernando Quintano, y el Piloto Hurtado cuidaba del bote; siendo á la sazón bien difícil refrenar on una y otra corbeta el deseo general de embarcarse para el perseguimiento indicado.

Favorecía mucho á las operaciones de esta segunda división, "la doble casualidad de haberse y'a ocultado detrás de la isla más Este los pancos piratas, de suerte que no pudiesen advertir estos nuevos perseguidores, y la de haber refrescado mucho el terral para que no fuese difícil á nuestros buques el doblar al Este de las islitas y tal vez sorprender por el frente á los enemigos: á una y otra división se había de antemano prescrito que cubriesen siempre los buques del presidio, y que en cualquier caso inopinado bien fuese favorable 6 adverso, operasen de concierto, pero no se cebasen en una caza probailemente infructuosa, que pudiera alejarles de la tas por un plazo ?argo. Fueron más bien contra: rias las circunstancias á la división del Oeste: entre las islas calmb enteramente el Nordeste y aún tuvieron ventolinas de la costa de Basilán, que les precisaron á valerse del remo para mon. tar las restingas salientes y vencei la marea contraria, pudiendo así los piratas alejarse considerablemente y perderse poco después de vista al abrigo de la costa á la cual se habian atracado.

Pero todo prometía un éxito favorable á la otra división, la cual ocultada á nuestra vista con la isla grande una hora después de su sa. lida, y no abandonada del viento, con fuerza de vela y una ventaja considerable de andar, habia estrechado á los enemigos hacia una ensenada en la cual parecían determinados á varar $6 a$ eva dirse con el auxilio de diferentes ríos que en ella desembocan.

$\mathrm{Ni}$ efectivamente su ánimo podía ser otrc, atento á las circunstancias en las cuales se ha: llaban. Sin embargo, ya dueños de este partido, y advirtiendo una calma total sobre la costa, á cuya sombra bien espesa se habían ocultado para todos ménos para D. Fernando Quintano, determinaron con mucho tino y astucia no ma- 
res tranqui. Dic.s hubiésemos cia del Go. menores co. - Así, desde to, la ATre ancha á las te que pudo 1 presidio, $y$ abiamos 11 a. botes ife las ivisióncqpaz en los ata. le la Concha a de la Dss. b. Fernando aba del bote; har in una $y$ barcarse para

ones de esta ad de haberse iste los panesen advertir haber refresuese difícil á e las islitas y los enemigos: temano pres unes del presiopinado bien de concierto rob ciblemente de las corbe $s$ bien contra in del Oeste: el Nordeste y a de Basilán, mo para mon. icer la marea alejarse conspués de vista bian atracado. favorable a la nuestra vista ués de su sacon fuerza de e andar, habia una ensenada varar 6 á eva íos que en ella

jodía ser otrc, cuales se ha: le este partido, bre la costa, á abían ocultado ndo Quintano, astucia no ma- nic., lograr las dos ventajas considerables que estaban á su favor, y eran la de una marea ménos fuerte $y$ de una cómoda navegación al remo. Así, hecha inmediatamente proa al Este $y$ al andar de la costa, conocieron que sus conceptos eran fundados. En balde D. Fernando Quintano orzó al momento para aprovechar del viento un rumbo que los estrechase de nuevo; en balde, caido poco después el terral, hizo que los soldados ayudasen á la marinería en el remo y que ésta no omitiese esfuerzo para una boga acelerada; todo fué inútil; $y$ á las dos de la tarde, franqueada ya una navegación libre por los piratas, fué preciso dejar la caza y determinarse al regreso.

No fué ménos activo D. Antonio Tova, el cual guiado del patalangán ciel presidio, recorrió un trozo considerable de cosia creyendo hallar rastro de los fugitivos; pero á las tres de la tarde debió decidirse al regreso, y todos quedaron incorporados á sus buques al principio de la noche.

Este accidente y las faenas dilatadas de anclas que debian preceder al dar la vela, nos acon. sejaron como prudente el diferir la salida para el día siguiente. El descanso de las tripulaciones fué así más completo, no debieron precipitarse los aprestos, se logró un nuevo acopio cuantioso de verdolagas para la gente, y pudieron perfeccionarse los últimos frutos que la expedición debía tributar á aquella parte casi olvidada de los dominios de S. M.

Consistian éstos en los planos de unas lanchas cañoneras, adaptadas á la artillería, gente y objetos que prescribió el Gobernador y, trazó con mucho tino el carpintero de la Descubierta D. Juan del Río Miranda, y en los dibujos de la iglesia. y casa del Gobernador que debían reedificarse muy luego, y que formó D. Fernando Brambila, sujetando con mucho pulso á una arquitectura bien ordenada todas las circunstancias poco favorables para estos nuevós edificios.

Al anochecer del 6, todo qued6 pronto para dar la vela, y á la media noche, empezando á parar la marea, se emprendió el levar un ancla, cuya faena no siendo (como lo habiamos imaginado) fácil, por estar esclavizada la uña nuestra con el cable de la Arrevida, nos detuvo hasta las cuatro de la mañana. A esta hora ya la marea era favorable y se apercibían algunas ventolinas del terral, con las cuales y los remolques, no tardaınos en emprender la salida seguidos á corta distancia de la corbeta compañera.

A las ventolinas casi imperceptibles del Nordeste y Norte que reinaban al tiempo de abandonar las corbetas el fondeadero de $Z$ amboanga, siguieron al rayar el día, contra nuestras espei*nzas, vientos algo más entablados, los cuales muy luégo nos ocultaron de la vista del presidio, hicieron después inútiles los remolques, y nos condujeron para las nueve de la mañana á desem. Dic. bocar entre la isla de Cocos y la más Norte de las de Sibaj. No podía desearse un tiempo más placentero: la costa de Basilán al Sur y la de Mindanao al Norte, se presentaban á nuestra vista con el semblante más ameno. Las muchas islitas que median entre aquéllas, no descubriendo peligro alguno en sus canales, multiplicaban asi los objetos agradables para el navegante; $y$ las marcaciones repetidas con tales ventajas á los muchos puntos bien terminados, nos hacían es. perar en nuestras cartas de aquella costa, una exactitud correspondiente.

Al medio día ya nos hallábamos unas siete leguas al Este del fondeadero, por latitud de $6^{\circ}$ $48^{\prime}$. No eran sensibles los efectos de la marea, y la variación magnética, así por los azimutes como por la amplitud, parecían confirmarse de $0^{\circ} 30^{\prime}$ al Nordeste.

El plan propuesto no dejaba dudar que debíamos conservarnos atracados a la costa de Mindanao, en donde los vientos de la monzón, confun. didos con los terrales, serían probablemente más largos y constantes, $y$ en donde no sería difícil la continuación de las tareas hidrográficas, tanto más útiles ahora, cuanto que el viaje del Capitáiı Tomás Torrest, con unas equivocaciones tan multiplicadas como culpables, podia envolver al navegante en muchos erro:es sumamente peligrosos.

Abandonados, como absolutamente ageno de nuestra derrota, todo el golfo por una y otra orilla que fuese más septentrional del paralelo en el cual nos hallábamos, y hechos rumbos del Este con los vientos Hojos y variables que tuvimos desdc el anochecer; para la siguiente mañana apenas veíamos al Sur $77^{\circ}$ Oeste el pico Este de Basilan, $y$ al ponerse el Sol, ya veíamos nuevamente al Este, bien que á muy larga distancia, las costas contíguas á Mindanao, que corren luégo hasta su extremo Sur, inmediato á las Islas de Serangani. En balde á la noche anterior y en todo aquel día habíamos intentado hallar fon. do, á veces con 5o, á veces con go brazas de sondaleza. Notábamos, sí, algo aumentada la varia. ción de la agu ja y una corriente favorable al Este. El tiempo, aunque frecuentemente calmoso, se mantenía hermoso y agradable.

Desde la mañana siguiente fué fácil emprender los reconocimientos acostumbrados, habiendo navegado en la noche anterior en demanda de la costa: á las seis sus extremos demoraban al Norte $22^{\circ}$ Este distancia 6 ó 7 leguas, y la última punta al Este que parecía formar algunar slas, se marcaba al Sur $57^{\circ}$ Este: toda la costa á la vista era montuosa y cubierta de bosque, no se advertía enscnada notable entre las muchas puntas que le sobresalían, é inferíamos la existencia de algunos naturales en sus orillas, por una hu- 
Dic. s mareda bien notable, aunque navegásemos á cin. co ó seis millas de distancia. Las observaciones de latitud y longitud (repetidas por tres veces estas últimas) no nos dejaron dudar de la exac. titud de nuestras posiciones, tanto más que no interrumpiamos en modo alguno las bases, habieistose la ATREVIDA encargado de sondar aun. que fuese inútil por el mucho fondo.

No fué tampoco diferente el semblante de la costa cual li: vimos al otro dia después que disipándose algunas turbonadas pudimos continuar nuestra derroto con vientecillo galeno del Nordeste: navegamos desviados de ella de dos á tres leguas, y ya al anochecer nos era fácil distiıguir sin ricralo de equivocación el extremo Noroeste de la enssnaci grande de Sugud-Boyan indicada por los Capitais: C:arteret y Torrest y visitada por Dampierre in los últimos años del siglo pasado.

A la vercind. al paso que se nos hacian reparables los errores desmedidos asi en cuanto á la latitud como al arrumbamiento de esas costas, en los cuales había caído el Capitan Torrest, no podíamos ménos de extrañarque fuesen en mu. cha parte equivocadas las reflexiones del Capitán Carteret, atento á los diferentes parajes que había visitado y descrito el célebre Dampierre en la misma costa; pues no quedaba duda que temiendo pasar por falta de práctica (como él mismo dice) entre la tierra firme y las Islas Serangani, y no pudiendo efectivamente contar sino dos islas por la parte del Sur en cuyas in. mediaciones había experimentado diferentes temporales del Oeste, había alcanzado una grande bahia al Noroeste de las mismas islas, la cual, por el rumbo, por la distancia y por el tamaño, era precisamente la de Sugud-Boyan. Su extremo Noroeste es más bien bajo, declinando paulatinamente la costa hacia él, desde mucha distan. cia. La dirección de la boca es próximamente al Sursudoeste y Sud.

En esta posición anochecimos, conservándose el semblante del tiempo bien claro y apacible; pero no abandonándonos después hasta las dos de la mañana una completa calma, la cual no tuvo otra cosa de agradable sino darnos lugar por una demasiada inmediación á la ATRE. VIDA, de experimentar el efecto de los remos que habíamos tomado últimamente en Manila. Con mucha complacencia vimos que era aún mayor de lo que nos habiamos prometido, y un corto intervalo bast 6 para separarnos considerablemen. te unos de otros, aunque la Descubierta bogase sola y con solos tres remos por banda.

Entabladas para las dos de la mañana algu. nas ventolinas del cuarto $y$ primer cuadrante, pudimos navegar de nuevo con todo aparejo ha. cia el Sudeste, $y$ al amanecer, hallarnos mediante el auxilio de las corrientes, á la vista del extremo Sur de Mindanao y de las Islas Se. rangani. Eira noble el semblante de la costa; se Vie." veían los dos extremos de la ensenada de Sugud. Boyan; el uno suavemente alomado, convidando casi al navegante á abrigarse de sus orillas; el otro, tenazmente unido á la tierra firme, la cual se elevaba considerablemente al Norte y al Sur; la terminaban luégo por aquella parte, y muy á lo lejos en el fondo de la ensenada, diferentes mon. tes bien notables, entre los cuales no era difícil distinguir por su estructura al decantado volcán. Al Sur no eran ménos elevadas las montañas tra. seras; pero la orilla, si bien alta, parecía ya pro. meter el abrigo de una crecida población, como sablamos que la había por los diarios de los Capi. tanes Carteret y lorrest: distinguíamos ya claro el canal entre las Islas y el continente por el cual había pasado el primero, y no nos era tampoco difícil distinguir las inmediaciones del fondea. dero de la punta Butulaque, descritas por el se. gundo. liueron lentos hasta después del medio día nuestros progresos: se habian observado la latitud de $5^{\circ} 28^{\prime}$ y la longitud de $3^{\circ} 54^{\prime}$, las cua. les nos daban ya una determinación hidrográfica bjen aproximada de esos contornos, y podiamos ratificar así los errores de más de un grado en latitud del Capitán Torrest, como la suma exactitud de la que había asignado el Capitán Carteret á la Isla grande de Serangani: en la carta inglesa moderna de Robertson convenian exactamente con las nuestras las diferencias en latitud y longitud entre las islas mismas y $Z$ am. boanga. No así la dirección y posición de la cos. ta, en la cual parecía reprensible, particular. mente por lo que toca á las inmediaciones del Cabo san Agustín, que hubiese preferido las noticias á veces agenas y siempre mal combinadas del Capitán Torrest á los reconocimientos prolijos y harto costosos del Capitán Carteret.

En la mañana del r2, igualmente favorecidos del viento y de la corriente, pudimos emprender la navegación del canal de Serangani, y consi. derarnos ya próximos á desembocar en el Mar Pacítico. Veíanse un crecido número de chozas y plantios amenos desde la falda hasta las cumbres elevadas de la Isla grande de Serangani; no era ménos amena, frondosa y cultivada la costa opuesta de Mindanao; hacíanse notables los extremos de las marcaciones del Capitán Carte. ret, el canal que forma la isla más baja y orien. tal y el islotillo Illitan con los arrecifes que le son inmediatos. Los montes cercanos al Cabo San Agustín, se marcaban al Norte $30^{\circ}$ Este de la aguja, y repetidas observaciones nos daban lugar a coadyuvar con una cierta exactitud á la mayor seguridad de las navegaciones venideras en aquellos mares. $\mathrm{Ni}$ parecían, por otra parte, infundados nuestros conceptos sobre la continuación dc los terrales y virazones, los cuales muy luego nos condujesen al Este de la Nueva Guinea; 
la costa; se tic. si de Sugud. convidando orillas; el ime, la cual te $y$ al Sur: e, y muy á lo rentes monera difícil tado volcán. hontañas tra. recía ya proación, como de los Capimos ya claro te por el cual era tampoco del fondea. as por el se. és del medio observado la $54^{\prime}$, las cua. hidrográfica y podíamos un grado en mo la suma - el Capitán ngani: en la on convenían diferencias en ismas y Zam. ión de la cos. , particular diaciones del ferido las no al combinadas nientos proli. arteret.

te favorecidos os emprender rani, y consi;ar en el Mar aro de chozas asta las cum. e Seranganicultivada la e notables los apitán Cartebaja y orienecifes que le s al Cabo San ${ }^{\circ}$ Este de la $s$ daban lugar Id á la mayor leras en aquearte, infunda ntinuacjón de s muy luego 1eva Guinea;
Dic. " prometianlo asl la estacion, el noviiunio próximo y lo que habiamos advertido en los días anterio. res; pero cuanto äistasen de la realidad aquellos conceptos, lo manifestaron con harta evidencia los dias siguientes.

$Y_{\AA}$ bien internados en el estrecho, se nos de clararon contrarios al mismo tiempo la marea y el viento; aquélla para liacernos retroceder con la misma rapidez con que nos habia favorecido por la mañana: este otro, para impedirnos, me. diante una turbonada fuerte que le acompañaba, que pudiésemos intentar con bordos y aparejo proporcionado contrarestar los efectos de la primera. Nos hallábamos aún á sotavento de la bahia en donde habia fondeado el Capitán Car. teret, y fué inútil nuestro primer bordo para co gerla. La sonda tampoco dió fondo con 60 brazas. Retrocedimos hasta la Punta Batulagui, y de alli, con el terral de la noche, hicimos nueva mente proa al Este, prefiriendo en esta ocasión pasar al Sur más bien que al Norte de las Islas Serangani, para no exponernos de nuevo al albedrío de la corriente contraria.

Calmó el viento por la tarde cuando habia. mos propasado las primeras islas, la noche siguiente fué igualmente calmosa, y no bien estu vo el Sol sobre el horizonte, cuando conocimos el efecto extraordinario de las corrientes contrarias, las cuales para el medio día, esto es, en el espacio de dieciocho horas próximamente, nos habian arrastrado 50 millas al Sudoeste $1 / 4$ Oeste hacia el Estrecho de Macassar; veíase ya próxima para el anochecer la Isla de Haykopt, los altos de Siao se marcaban á larga distancia al Sudeste, y las corrientes, siempre contrarias, inutilizaban nuestros esfuerzos para aproximarnos de nuevo á las costas de Mindanao.

En la tarde del is conseguimos hallarnos casi en la misma posición del I 4; pero no fuímos más felices, siendo así que nuevas turbonadas del Este, ayudadas de la corriente contraria, nos obligaron á retroceder. Contrariados de esa manera por cuatro veces, ya nos creíamos destinados á luchar por largo tiempo con una serie de adversidades que no podíamos vencer, $\sigma$ á seguir derrota al Oeste, que por los estrechos de Banca y Sonda nos condujese antes al Océası Indico y luégo por el Sur de la Nueva Holanda al mar Pacífico, cuando repentinamente vimos mudar el semblante indicado del tiempo, con entablar virazón fresca, que al ponerse el Sol del I9, inclinándose al Norte y Nornordeste, habia adquirido una fuerza desconocida hasta entonces. Brillaba la luna casi llena sobre el horizonte, advertíanse algunas candelacias en el extremo Noroeste de la ensenada de Sugud. Boyan, y. nuestros progresos eran tales á pesar de una corriente fuerte al Sur, que en la mañana: del 20 ya marcamos los altos de Serangani al Norte $21^{\circ}$ Oeste distancia de cinco 6 seis le. Ihit an guas, y quedaban rápidamente al Ueste las islas avistadas al Sur 4 . Fiste en la tarte del 12 , de quienes no distábamos ahora inás de unas tres leguas.

Examináronse con este motivo prolijamente no ocultándose el canal y la restinga yu indica. das por el Capitán Meares; pero de ningún modo podia combinarse In que velamos, con las noticias harto confusas de los navegantes que nos habían precedido, sin exceptuar la mismi carta de Robertson. Ya no debiamos extrañar sin embargo los errores del Capitán Torrest asi en la latitud como en el número y dirección de aquel pequeño grupo; á las tres primeras que pue den considerarse reunidas, siguen luégo casi con iguales intervalos de cuatro á cinco leguas en la dirección del Esueste, otras dos islas media. namente altas cuyos alrededores parecen sin peligro alguno. Las corrientes son alli tan rápidas al Sur, que navegando las corbetas con un andar de cinco á seis millas al Este corregrido apenas lograban el rumbo directo del Sues. te $1 /$ Este según lo indicaban las marcaciones.

Sus nombres en la carta del Capitán 'Torrest no eran los naturales, los cuales hubiéramos ad. mitido con preferencia á cualquiera otros. Se les asignaron ahora por la misma razón los de Ania. ga, Anda y Armadores, que les había dado el $\mathrm{Pi}$. loto Tompson en su navegación desde Zamboan. ga á Acapulco, en el año de 1773 . Comprende su latitud desde los $4^{\circ} 4^{\prime}$ hasta los $4^{\circ} 25^{\prime}$ Norte su semblante es árido, su elevación da lugar á que se distingan desde el alcázar á cinco ó seis leguas.

Al medio día, tanto por la altura meridiana del Sol como por otras medidas tomadas poco antes, inferimos la latitud de $4^{\circ} 40^{\prime}$. No era fáci á la sazbn combinar con alguna probabilidad la verdadera longitud en la cual nos hallábamos; la isla más Este nos demoraba al Sur $23^{\circ}$ Oeste una - atro leguas.

in el entretanto continuaban nuestros adelantos al Este aunque con muchos sacrificios al Sur, y siendo como ya se ha dicho sumamente incierta la posición de las islas en todos aquellos contornos, navegábamos con tanta mayor vigilancia cuanto que los horizontes se habian cerra. do con celajería más espesa, y era difícil de comprender la verdadera posición de los bajos inopinadamente encontrados por los Capitanes Douglas y Mearcs.

No presentándose nada á la vista hasta las cinco de la tarde, aunque la distancia na. vegada al Este desde el medio día no fuese ya menor de 30 millas, empezábamos á creer que un error grande en su latitud nos hubiese ocul. tado las islitas de Kakarcoralong al Norte y las de Salibabo al Sur, hallándonos con una nave. 
Die to gución libre y bien á barlovento del Cabo Norte en la Isla Norintay. Nuestros rumbos se conser. vahan al Lste \% Sudeste con fucrza de vela; al. gunas claras del Sol, y particularmente al tiempo de ocultarse sus dos limbos en el horizonte, nos hablan dado lugar de observar por ambos medios la longitud en la cual nos hallábamos.

Pero próximamente á esta hora se apercibie. ron desde los topes y aún desde la cubierta, dos montes bastantemente elevados que marcába. mos' al Esueste $5^{\circ}$ Sur y creimos inmediatamente ser las Islas de Salibabo, aunque debiese hacérnoslo dudar en cierto modo la falta de una isla al Sur, que según la carta del Capitán Ro. bertson, habian avistado pocos años antes los navegantes ingleses. De cualquier modo, no nos era posible pasarlas á barlovento y nos era preciso navegar con mucha precaución, atento á las circunstancias que nos rodeaban. La noche, mucho más clara que el dia, favorecía nuestros pasos; y aunque navegásemos $\sin$ los juanetes $y$ á veces sin la mayor, ni fué dilícil avistar de nuevo las mismas tierias por la proa hacia las ocho de la noche, ni mucho ménos el atracarlas hacia las diez á distancia de dos leguas próximamente, calmado ya mucho el viento y allanado enteramente el mar.

Ya no quedaba la menor duda, que nuestros primeros conceptos habian sido acertados. La dirección bien diferente de las Islas Tannalabu y Salibabo, el canal comprendido entre ellas, al otro que formaba Salibabo con la Isla Kabruang, la elevación de esta última y dirección de entrambas próximamente al Sueste $1 /$ Sur, todo nos lodescubrian evidentemente, asi la Luna con su claridad, cọmo la corta distancia á que navegábamos de ellas. Procuró D. José Espinosa determinar la posicióndel extremo Nor. te de Salibabo, valiéndose para la latitud de $\alpha$ de Eridano, y para la longitud de algunos horarios de Sirio; las bases y las vistas, que no omitió D. Felipe Bausá y las favorecían ahora el viento, la mar y la cesación de las corrientes, debían dar á esas tareas nocturnas un nuevo grado de exactitud.

Hasta la una de la isañana continuamos el reconocimiento emprendido, sin que hallásemos fondo con 60 brazas de sondaleza empezamos luégo á ceñir el viento, y para el amanecer del 2 I, como hubiese refrescado mucho desde que salimos del abrigo de las islas, nos hallábamos ya distantes de ellas unas cinco leguas. El extremoSur de Kabruang demoraba al Norte $64^{\circ}$ Oeste, su extremo Norte al Norte $53^{\circ}$ Oeste; el extremo Norte de Salibabo al Norte $5 \mathrm{I}^{\circ}$ Oeste; el extremo Sur de Tannalabu al Norte $4 I^{\circ}$ Oeste, y el extremo Norte al Norte $30^{\circ}$ Oeste. Se confirmaba ahora de nuevo con mucha exactitud la descripción que de ellas había dado el Capitán Torrest, ha- ciéndose particularmente notable la elevación de Dici, la Isla Kabruang, la frondosid 'd y llanura de Sa. libabo $y$ el semblante amogotado de Tannalabu. Ningún fuego ni canoa nos indicó en la noche la muchedumbre de habitantes que encierrun todas.

No nos descuidamos luégo que estuvo el Sol elevadoalgunos gradossobre el horizonte, en deter: minar la longitud de este pequeño grupo; adopta. mos para la latitud del extremo Sur de Kabruang, - la determinación de la carta del Capitán Robert. son, que parecía bien cimentada según los apun. tes de su Memoria, y que contirmaban ahora las bases nuestras desde el principio de la noche. La longitud se dedujo del cronometro $7 \mathrm{x}, \mathrm{y}$ fueron, ésta de $6^{\circ}$ Oeste al Este de Manila, aquélla de $3^{\circ}$ $48^{\prime}$ Norte para dicho extremo: resultaba por con. siguiente en la misma carta inglesa, un error de seis á siete leguas al Oeste para la diferencia de longitud determinada entre Haycopk 6 Seranga. ni y cstas islas; error á la verdad de mucha con. sideración, en un paraje en donde se reunen á lo menos, según lo hemos experimentado, los vien. tos escasos y frescos, las corrientes extraordina. riamente contrarias, y los tiempos por lo común foscos y aturbonados.

No nos decidiremos á aventurar nuestro parecer sobre la existencia de las Islas de Kakar. coralong que pudiéramos haber visto en nues. tro tránsito, si fuesen medianamente altas $y$ en su colocación relativa á Serangani régularmente exactas. Se hace sin embargo reparable, que Dampierre no las vea en los muchos bordos que debió dar por los vientos contrarios fuera de las Islas Serangani, y que ei Capitín Torrest, el cual las comprende en su carta sin duda por informes de su práctico Juan Hadjée, omita las Meangis, de cuya existencia y posición aproximada relativamente al Cabo San Agustín, no nos queda la menor duda, leidas las noticias de Dampierre. En la restante mañana el viento continuó bastante fresco del Nornordeste y le aprovechamos con todo aparejo, de auerte que para las diez de la mañana ya habiamos perdido las islas de vista, y para el medio dia nos hallábamos en latitud de $3^{\circ} 29^{\prime} y$ longitud de $6^{\circ} 45^{\prime}$. No era menor de $30^{\prime}$ el error contraído en la latitud desde el medio día anterior, y la mayor parte lo había sido positivamente antes de atracar las Islas Salibabo, desde cuya época nos indicaron siempre las marcaciones, que caímos muy poco al Sur.

Ya, pues, con solas veinticuatro horas de tiempo favorable habíamos triunfado de una porción considerable de obstáculos. El Cabo Norte de la Isla Morintay demoraba al Sueste 1\% Este unas 34 leguas; el viento se conservaba fresco, y áun por la tarde, habiéndose inclinado más al Norte, nos daba lugar á navegar al Este corregido, si bien la mar hubiese en. 
levación de Dic." nura de SaTannalabu. la noche Ia erran todas. ituvo el Sol hte, endeter. po; adopta- Kabruang, itán Robert. in los apunin ahora las a noche. La I, y fueron, quélla de $3^{\circ}$ aba por conun error de diferencia de 6 Seranga. mucha con. e reunen álo do, los vien. extraordinapor lo común

nuestro pade Kakar. to en nues. e altas $y$ en regularmente parable, que is bordos que fuera de las a Torrest, el in duda por ee, omita las ición aproxi. Agustín, no s noticias de na el viento nordeste $y$ le e suerte que amos perdido. lía nos halláud de $6^{\circ} 45^{\prime}$. rido en la la. y la mayor intes de atraépoca nos in. que caíamos

tro horas de fado de una os. El Cabo ba al Sueste ento se cone, habiéndose gar á navegar hubiese en. nie." gruesado mucho. Las primeras horas de la no. che nos la prometian igualmente serena $y$ favo. rable, y lo que debia parecernos aún más ex. traño y feliz, la altura meridiana a de Eridano, medida á las ocho por D. José Lispinosa y otros Oficinles, manifestaba inás bien al Norte que al Sur las diferencias en latitud por efecto de las corrientes.

No tardó después en alcanzarnos en la ma. ñana del 22 una turbonada bien fresca del Sueste, con la cual navegamos inmediatamenic al Nordeste con aparejo proporcionado á su fuerza. La ATREVIDA, precisada á navegar con más vela por la inferioridad que ahora tenía de andar, tuvo notables averías en su velamen; le fue ne. cesario envergar otra mayor, otro juanete y otros foques; navegamos luégo unidos hasta el medio día, pero el viento á esta hora había calmado casi de un todo, y nos considerábamos próximainente en la misma posición en la cual habiamos amanecido. Las observaciones disiparon por fin lluestras dudas, y al medio día pudimos considerarnos como realmente introducidos en el mar Pacífico.

La latitud observada de $3^{\circ} 57^{\prime}$ y la longitud de $6^{\circ} 9^{\prime}$ por el cronómetro $7 \mathrm{I}$, nos hacían al mismo tiempo demorar el Cabo Norte al Sur $1 / 4$ Sud. oeste 25 leguas, y nos indicaban una corriente en favor, la cual nos había llevado $\mathbf{I}_{3}$ ' al Norte y $3^{2}$ a] Este de la estima.

Por la tarde volvieron á entablar vientr ' bo. nancibles del primer cuadrante, con los cualis y las muras á babor, continuamos nuestra derrota precaviéndonos de algunos chubascos: uno de éstos, por la noche hizo que variase el viento, vol. vieindo Juégo, sin embargo, para el amanecer, bien bonancible al primer cuadrante. Nuestra derrota ahora no tenia otro objeto sino adelantar cuanto fuese posible al Este, procurando no aproximarnos á las costas de ls: Nueva Guinea y Nueva Bretaña, para lograr unos aires ménos in. fectos, de una navegación más seguida y tal vez de unas lluvias más intermitentes.

Las dificultades que acabamos de experimentar en la última travesia desde Zamboanga y las que han experimentado en este mismo paraje varios navegantes que nos habían precedido, nos daba lugar á aventurar algunas conjeturas no del todo -:fundadas sobre aquella parte de la nave. gacion nacional, que, 6 bien tenía por objeto el dirigirsé luégo á las costas del Noroeste de la América y del Reino de Méjico, 6 el hacer derro. ta hacia los Reinos del Perú y Chile. En entram. bos casos, no.es temeridad asegurar que debe mirarse como aventurada, y que á lo ménos, la han de emprender embarcaciones buenas, bien aparejadas y bien manejadas, cualidades todas que se echan de ménos en los buques mercantes nacionales; y particularmente en los de Manila.
Debemos llamarla aventurada, aunque lo acreci- thie, , do á las corbetas y las derrotas de varios buques ingleses denoten que no son tan rápidas las corrientes al Sur desde los paralelos de Sanguir, Siao y Kabruang, porque Ins Capitanes Meares, Fasenbrook y l3ampoon, han experimentado bien a su costa lo contrario en estos últimos años, viéndose arrastrados, el uno entre Morintay y Gilolo, y los otros entre Gilolo y Ceiebes, de donde no pudieron salir sino con crecidos ries gos y peligros. Además, que no es fácil ni áuı para los que salen del estrecho de I'itt, elevarse bastantemente al Este para poder montar del otro borlo a lo ménos las l'alaos, y no pocas pruebas en estos años han manifestado cuánto es fuerte y contrario el efecto de las corrientes, luégo que se acercan á los paralelos de las $\mathrm{Pa}$. laos.

No dudando que eu los meses de Octubre, Noviembre y Diciembre, s^a fácil con las mareas y los vientos variables la salida del estrecho de San Bernardino, y resultando de las tureas del Piloto D. Juan Maqueda la navegación libre $y$ fácil del estrecho de San Juanico entre las Islas de Samar y Leyte, podemos asegurar que cual. quiera de estos dos desembocaderos para el mar Pacífico, nos parece más fácil; así como en el (aso de adoptarse el que nosotros hemos seguilo por la precisión de tocar en Zamboanga, de hemos aconsejar que se procuie siempre nave. zar bien atracados á la costa de Mindanao é Is las Serangani, sacrificando á veces uno 6 dos días en las inmediaciones de la bahía de Sugud-Bo. yan, para esperar vientos bien frescos del Norte, con los cuales se emprenda la travesía á montar el Cabo Norte de la Isla Morintay.

Por lo que mira á la navegación á Chile, séa. nos permitido insistir sobre la preferencia de la derrota, que desde la mitad de Diciembre condu. ce por los estrechos de Sonda al Océano Indico y de allí, por los extremos de la Nueva Holanáa y Nueva Zelanda á las costas de la América. Es fácil proveerse abundantemente de agua y leña antes en la isla del Norte inmediata á Sumatra, y luégo en los estrechos de Cook sobre la Nueva Zelanda, y seguramente el plazo del viaje no excederá de cinco á seis meses, por paralelos ahora bastante trillados y siempre tan saludables, como son infectos y peligrosos los que hay que correr bujo la Zona Tórrida, precisamente en la maynr fuerza de la estación lluviosa. Si al contrario, fuesen los meses de Junio, Julio y Agosto, el principio de una navegación al Perú desde Manila, nos parece que disfrutados los vendavales á lo ménos por unos $40650^{\circ}$ al Este de aquel meridiano, cualesquiera fuesen los sacrificios de la la titud, sería luego lo más seguro con los Nordes tes y Estes, navegar directamente al Sur y Sueste, y cumplir el viaje en latitudes altas del 
1 vic, 22 hemisferio Austral: en ninguna ocasión debía pasarse la Línea á ménos de 50 á $60^{\circ}$ al Oeste del continente de la América.

Nuestros jasos primeros en el Mar Pacífico fueron bastantemente felices si se atendiese á la celeridad del viaje 6 á la conservación de la salud en mędio de los chubascos y turbonadas que casi diariamente nos acompañaban; pero si le mirásemos con aquel afán natural de los descubridores, ansiosos de encontrar algo nuevo que alinente su pundonor, con el dominio aunque imaginario de nuevas tierras por la nación que los envía, debíamos á la verdad considerarnos bien desgraciados, pues recorriendo un espacio no menor de $40^{\circ}$ en longitud entre los $4^{\circ}$ Norte

yon la equinoccial, no habiamos encontrado el menor rastro siquiera de tierras próximas no conocidas.

Nos favorecieron al principio, corrientes bastante fuertes al Norte $y$ al Este. Interrumpiclos los vientos frescos $y$ aturbonados del Oeste con algunos días igualmente lluviosos pero con calma, nos dieron lugar á examinar, primero, la posición de Pulo Mariese, y después las inmediaciones de las Islas de Freewill y de la restinga aislada del Capitán Carteret. Navegamos comunmente de noche con poco aparejo: la una corbeta precedía alternativamente á la otra á dis tancia de una milla, dirigía la derrota y ias maniobras según fuesen más ó ménos per"eptibles los objetos en el horizonte, con el brillo casi mol reitáneo de la Luna ó con la más frecuente oscuridad de las turbonadas; finalmente, precavida con extremo, bien sea con la vigilancia de las guardias 6 con la disposıción de las señales prometía, casi con evidencia, la seguridad del segundo buque cuando algún encuentro inopinado la pusiese en los riesgos comunes á esta es. pecie de navegaciones.

Al medio día, solía el termómstro, puesto á la sombra, fijarse comunmente entre los 82 y $84^{\circ}$. Atravesa ldo después por las ininiediaciones de las Islas Matías y Ohonjava trilladas por los navegantes Dampierre, Bogainville, Carteret $y$ Maurelle, veíamos casi evidente la exactitud de su posición por el vuelo de las aves, la dirección de las turbonadas y el curso de las aguas; ni debimos extrañar últimamente la vista bien repetida de muchos troncos de árboles, á veces mons truosos, á veces con ramas, pero siempre con una costra casi contínua de conchas que los aseguraban entregados desde mucho tiempo á las olas del mar. Los viajeros que han frecuentado las costas de la Nueva Irlanda siempre los han encontrado en mucho número, y Dampierre los aprovechó para proveerse abundantemente de leña.

No habíamos tampoco omitido en la travesía indıcada, repetir cuanto fuese posible las ob- servaciones de longitud por las distancias luna. En res, valiéndonos de los astros orientales y occidentales de la Luna; tuvimos una prueba reciente en la Descubierta de la exactitud de aquel método, cuando en los días 18 y 20 de Enero vimos corresponderse con una total uniformidad los resultados de éstas y de los relojes marinos en los términos que á continuación se expresan:

\begin{tabular}{|c|c|c|c|c|}
\hline Dias. & $\begin{array}{l}\text { Numero } \\
\text { de séries. }\end{array}$ & $\begin{array}{l}\text { Longitud orien- } \\
\text { ta! de Manila por } \\
\text { las distancias. }\end{array}$ & 3d. por el $7 x$. & Id. por el us \\
\hline $\begin{array}{l}18 \\
2 ! 5\end{array}$ & $\begin{array}{l}34 \\
30\end{array}$ & & & $\begin{array}{l}37.3 .37 \\
39 \cdot 38.15\end{array}$ \\
\hline \multicolumn{2}{|c|}{$\begin{array}{l}\text { Diferencia contrai- } \\
\text { da en el intervalo. }\end{array}$} & 2.35 .33 & 2.40 .17 & $2.34 .3^{8}$ \\
\hline
\end{tabular}

Por lo que toca á la variación de la aguja, la rel. vimos aumentar hasta los $9^{\circ}$ Nordeste cuando nos hallamos próximamente en meridianos de $32^{\circ}$ de Manila. Disminuyó después hasta los $7^{\circ} a$ medida que adelantábamos al Este, y cuando torcimos al Sur para acercarnos á las tierras de Qqui. rós ó Nuevas Hébrides, aumento de nuevo con bastante rapidez, por manera que en latitud de I $6^{\circ}$ ya volviese á los $8^{3} 30^{\prime}$.

A la sazón nos habían abandonado enteramente, así las brisas flojas y variables del Nordeste, como los temporales intermedios de la monzon favorable del Oeste, y les habian suce. dido los vientos regulares del Esueste con los cuales ceñimos constantemente al Sur.

A las ocho de la mañana del día ir de Febrero, se nos presentó á la vista (disipada algún tante la calima) ia Isla de Erroman en las Nue. vas Hébrides, que conocimos luego por su corta extensión y por la elevación considerable que le había notado el Capitán Cook. No se equivocaba aquel navegante incomparable, cuando contra el dictamen del mayor número de sus Oticiales, suponía unido á la demás tierra por medio de una lengua, un Morro alto que advertía saliente al Sudoeste: puede llamarse más bien escarpada, y si juzgásemos por lo que hemos advertido en su costa del Oeste (ciertamente la más abrigada) no hay en ella población alguna.

Al medio dia, con tiempo bastante." moso, ya marcábamos los extremos de Erroman, del Norte $69^{\circ} a$ á los $85^{\circ}$ Este, y nuestra distancia era próximamente de tres leguas, causada más bien de las corrientes fuertes al Oeste, que de los rumbos que habíamos seguido, siempre di. rectos á la isla, cuanto lo permitiese el viento. En esta posicion, nuestra latitud era de $19^{\circ} 3^{2}$ Io $^{\prime \prime}$, exactamente acorde por las marcaciones á la que había determinado el Capitán Cook. Resei ióse la deducción de las longitudes hasta que comparásemos los horarios observados en neridianos de aquella isla á los que tuviesemos á la 
stancias luna- En. entales y occiprueba recientitud de aquel 20 de Enero al uniformidad elojes marinos n se expresan:

or el $7 \mathbf{y}$. Id. por el is.

1 Sur.

lia II de Febre. (disipada algún ian en las Nue. go por su corta insiderable que k. No se equiarable, cuando número de sus más tierra por lto que advertía aarse más bien lo que hemos (ciertamente la slación alguna. canterente heros de Erroman, lestra distancia , causada más Oeste, que de lo, siempre ditiese el viento. era de $19^{\circ} 3^{\prime}$ marcaciones á itán Cook. Retudes hasta que vados en meri. tuviesenos á la
Veb. " vista de Annatom. Era bien singular que una calima extraordinariamente espesa, nos imposibilitase en todo aquel tiempo el ver la isla inmediata de Tanna, á la cual hubiéramos deseado más bien el referir directamente nuestras comparasiones.

Refrescando por la tarte el viento del Essueste, no tardamos en alcanzar la vista de Anna. tom, cuyos extremos eran más extendidos al Este y Oeste de lo que á la distancia creida de diez leguas había podido advertir el Capitán Cook. Poco antes de ponerse el Sol, estuvimos á corta distancia del extremo Oeste, á cuyo abrigo quedamos por poco tiempo en calma. La Arrevida nos señaló entonces que había sondado 55 brazas, y nosotros poco después lo verificamos en 8 o.

Entrada ya la noche no nos quedó duda por los diferentes fuegos que advertimos en las alturas inmediatas, que la isla estaba habitada: también habíamos notado algunos cocales plantados $\sin$ orden en las orillas inmediatas, en las cuales se hacían al mismo tiempo visibles varias cascadas de agua y no pocos parajes de un fácil desembarco; sin duda alguna pudiera considerarse aquel fondeadero de mucha utilidad, si los vientos fuesen constantes del Nordeste al Sueste y no hubiese inmediato un puerto $\tan$ abrigado como el de Tanna.

La comparacion de nuestras longitudes era pues el único objeto al cual debíamos atender en aquellas inmediaciones, logrados ya los horarios en posiciones oportunas relativamente $a$ una $y$ otra isla. Desde luego una mayor nimiedad en esta especie de operaciones, nos convenció que era. mayor en $6^{\prime}$ de la que suponía el Capitán Cook ia diferencia de meridianos entre las dos Islas indicadas, y esta dif erencia, atento á las distancias y posiciones en las cuales se había hallado e! Capitán inglés para entrambas determi . naciones, nos inclinó á preferir la de Erroman come unás aproximada á Tanna, dándole, sin embargo, la corrección de una tercera pe .e del penueño error hallado. Los resultados fueron los siguientes:

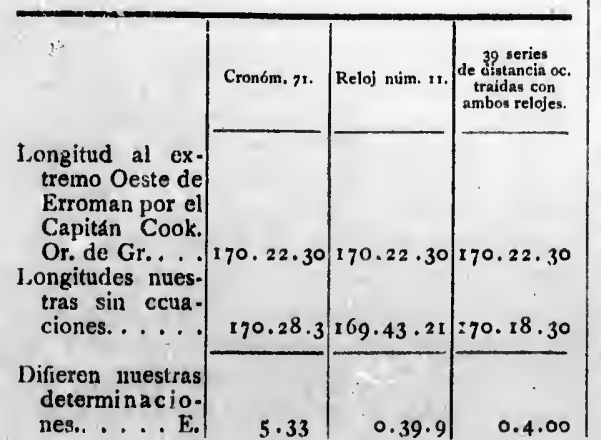

Como quiera que según nos aseguraban en Feh. .t sus narraciones el Capitán Cook y Mr. Wales, se diesen extraordinariamente la mano entre sí las observaciones de longitud hechas en Mallicolo, en Tanna, en el puerto Balade y la Isla de Pinos de la Nueva Caledonia, de suerte que conviniesen siempre las diferencias parciales del reloj marino de Mr. Rendal con las que indicaba cada promedio de las observaciones; pudimos considerar como bien auténtica esta nueva comparación, la cual, al mismo tiempo añanzaba la exactitud de nuestras últimas distancias y nos indicaba con la mayor complacencia la marcha uniforme del cro. nómetro $7 \mathrm{r}$, después de sesenta y ocho días la mayor parte excesivamente húmedos ó ardientes.

Ya, pués, conseguido uno de los obietos que nos habíamos propuesto en la navegación actual y entablada nuevamente en las primeras horas de la noche la brisa fresca del Esueste, nuestra derrota debió precisamente continuar al Sur, tanto con el objeto de dar vista si fuese posible á la Isla de Norfolk como para dirigirnos después á la Nueva Zelanda y repetir en Dusky Bay las ex. periencias de la gravedad.

El día 2 I ya nos hallamos en latitud de $40^{\circ} \mathrm{o}^{\prime}$ y longitud de $45^{\circ} 3 \mathrm{o}^{\prime}$ al Este de Manila; nos demoraban las inmediaciones de Dusky Bay al Sur distancia de roo leguas, y el Cabo Farewell en el canal de la Reina Carlota al Este ro7 leguas.

Un $r$ svo temple agradable en la atmósfera, los días más duraderos, las estrellas con un hermoso brillo, todo nos recordaba ahora cuánto para la navegación eran aventajados aquellos climas álos de trópicos. No nos abandonaron ni aún en aquella latitud los vientos fa vorables del Este, y á medida que nos aproximábamos á la costa, tuvimos á la vista un mayor número de aves acuáticas, cerrándose por otra parte los cielos y horizontes con una densa calima. Así, aunque desde el medio día del 24 por latitud de $44^{\circ} 34^{\prime}$ $y$ longitud de $4^{\circ}$ al Este de Manila nos considerábainos ya bien próximos á la costa y aun la ATREvida nos la señalase á la vista, no fué posible cerciorarnos de ella por los obstáculos de la misma calimá; y a' principio de la noche, aunque no encontrásemos fondo con toda la sondaleza, ceñimos al Oeste las ventolinas ya bien calmosas del Nornordeste.

Debieron éstas después ceder á un viento galeno del Sursudoeste, el cual empezó á entablar hacia la media noche, despejando luego la neblina que cerraba los horizontes, de suerte, que tomadas hacia las tres nuevamente las alturas á estribor, nos hallamos al amanecer de un día con excuso placentero, á distancia de cinco leguas de la costa, la cual veíamos tendida desde el Noid. este al Sursueste.

Las ser̃ales nada equívocas que con su acostumbrada exactitud había dado el Capitán Cook 
rel. 2 de aquel trozo de costa, no nos dejaron titubear ni un solo instante sobre todos los puntos que tcníamos á la vista. La punta Five-Fingers 6 Cinco Dedos, terminaba nuestros alcances al Sur, se distinguía claramente el abra del Norte de Duski Bay, y el bordo que actualmente seguíamos nos conducía muy poco á sotavento de la cntrada de Doubtfull Bay, de la cual, no distando á las nueve sino dos á tres millas, $y$ reconocidos con la mayor prolijidad sus alrededorcs, debimos separarnos para dar un repiquete y recalar del otro bordo algún tanto á barlovento.

Sería difícil una descripción más cabal de la aspereza y elevación cle aquellas costas de la que hizo ya el Capitán Cook en los reconocimientos de su primer viaje. $A$ dos millas de la orilla no crecontrábamos fondo con roo brazas, y en la entrada de Doubtfull Bay, si bien la isla intermedia presentase bastantes rastros de una vegetación no mezquina, todo el fondo del puerto, cerrado por una y otra pal ce con montañas inaccesibles y cortadas á pico, apoyaba en mucho las reflexiones del Capitán, que le habían hecho mirar aquel puerto como temible para la salida.

Sin embargo, su latitud de solos $45^{\circ} \mathrm{r} 3^{\prime}$, el tenerle á sotavento si continuasen los vientos del Sur, y la importancia del tiempo ya bien conocida sobre aquella costa, de modo que el día hermoso del cual ahora gozábamos debiese más bien amenazarnos, nos aconsejaban á no malograr aquel momento favorable para el fin pro. puesto; tanto más que cualquiera alteración del viento y el mismo examen del diario meteorológico del Capitán Cook en Duski Bay, debian hacernos creer que nos veríamos nuevamente aco. sados de los vientos del Este, directamente opuestos á ia entrada de ambos puertos.

Con estas reflexiones, conseguida al medio día una posición cómoda á barlovento para cual. yuiera paso sucesivo que las circunstancias manifestasen por más util, fué el bote armado de la 1)Escubierta á las órdenes de D. Felipe Bausá, con el objeto de examinar interiormente el puerto y particularmente la facilidad de hacer agua y leña: se le prescribió el regreso más pronto, y en el entretanto, las corbetas unas veces al pairo y otras sobre bordos cortos, cunservaron la misma posición relativamente á la entrada.

No regresó el bote sino á las nueve de la tarde; sólo á la entrada ó parte exterior de la isla había encontrado fondo de 20 y 25 brazas cascajo, pero despues en ambos canales se perdía con cincuenta ni en parte alguna alrededor de la isla podía nuevamente hallarloá un cumplido de lancha siquie ra: interceptaban á uno y otro canal algunos pedruscos aunque no arriessados para la navega. ción; abundaban interiormente el agua y leña; la extructura de la costa algo más llana y arenisca en un seno más interno al Norte, prometía allí un Feh. as paraje seguro y cómodo para fondear; el tiempo, muy limitado, no le había permitido examinarlo con el escandallo. Seguía luégo al Esueste un canal de dos á dos y medio cables, formado en los mismos montes, los cuales caían extremada. mente á pico, y últimamente el canal mucho más estrecho, torcía más al Sur á encontrar tal vez los términos de los canales internos de Duski Bay. No se advertía una grande velocidad en la marea: según las señales en la orilla parecía el principio de la vaciante próximamente al medio día: pocas aves, niugún lobo marino, solas algunas lapas chicas por lo que toca á marísco, y ningún rastro, aunque remoto, de habitantes, eran las demás circunstancias dignas de aten. ción en aquel puerto, á las cuales debía luégo añadirse la falta total del pino, componiéndose alli la vegetación de una especie de arbusto de mediana altura. En resumen, si no son las experiencias del péndulo simple ó una verdadera necesidad las que guien á algún navegante á dicho puerto, debemos creer que está destinado á ser perpécuamente desierto, y que Duski Bay será siempre la que convide en aquellas inmediaciones, á sus orillas, con un abrigo más cómodo, más seguro y más sano.

Ya entrada la noche $y$ metido el bote, permanecimos algún tanto en calma sobre la costa, objeto que nos fué luégo bien fácil vencer, habiéndose declarado poco después viento flojo del Norte, con el cual á la media nocle ya distába. mos de la costa unas tres leguas. En esa situación, deseando nr. erder momento, arribamos al Sur, y á las tres de la mañana, andadas sólo tres leguas de las siete que la latitud nos manifestaba faltar, orzamos nuevamente para atracar la costa y entrar en Duski Bay al rayar de las primeras claras del día. El viento á la sazón iba aumentando considerablemente; la costa se había cerrado con mucha neblina, y todo amenazaba una alteración contraria en el tiempo.

Las primeras claras del día nos debieron ${ }_{26}$ parecer con exceso oportunas para dirigir con mayor acierto nuestros pasos. Estas, sin embargo, ya variaban mucho de semblante, y un solo mumento parecía laber trastornado entera. mente nuestra situación ventajosa para alcanzar el puerto deseado. A las cuatro de la mañana, disipada por un breve intervalo la neblina, nos hallamos repentinamente á la entrada de Duski Bay y á la sola distancia de dos 6 tres millas de la Isla de las Rompientes, la cual de ningún modo nos era posible montar con el viento que á la sazón reinaba. Hallado así un error de tres leguas en la estima desde la media noche, viramos inmediatamente al Oeste, $y$ con viento ya recio $y$ aturbonado, reviramos nuevamente á las nueve en vuelta de tierra, aguantando para lo. 
Fet. a grar de algún barlovento, una fuerzi mi śs bien excesiva de vela.

Pero todo fué infructuoso; recalamos nuevamente en las mismas marcaciones de la mañanita, y el viento del Nordeste, á cada paso más recio y tempestuoso cuanto más nos aproximábamos á la costa, nos avisó que una mayor tenacidad en nuestro empeño pudiera acarrearnos algunas pérdidas de la mayor consecuencia. Debimos por consiguiente decidirnos á tomar de nuevo las muras á estribor y á navegar para $\mathrm{e}$ medio dít con las cuatro principales, las gavias en dos rizos. A esta hora se veían aún á ratos algunos trozos de la costa, $y$ en particular la punta de Cinco Dedos cuyas señales eran bien notables.

Lejos de ceder el vient!:, por la tarde arreció de tal modo y con mares tan gruesas, que podía llamarse un verdadero huracán; tuvimos averías considerables en el aparejo y en el velamen. Todo el aguante de las corbetas parecía inútil para resistir el trinquete y la gavia en tres rizos arriada, velas que creíamos necesarias para que los golpes de mar no nos inundasen con exceso, y para las diez ya se nos hacía temible á cada paso una avería.

Después de la media noche empezó á ceder el tiempo, pero no pudimos considerarle concluído sino á la mañanita siguiente, á cuya hora navegábamos con las cuatro principales y las gavias en dos rizos. Sicesivamente nos alcanzaron algunos leves intervalos de calma, á los cuales últimamente sucedió un viento bonancible del Sur y Sudoeste, acompañado de una calina su. mamente espesa.

Los rumbos que necesariamente habíamos seguido en el temporal pasado, nos habían des atracado considerablemente de la costa; las observaciones nos manifestaron también una corriente fuerte al Norte, $y$ así no era menor de 30 leguas la distancia nuestra de la bahía.

En esta situación, y después del escarmiento pasado, debimos precisamente dar lugar á algu. nas reflexiones, las cuales nos demostraban como aventurado el empeño de iniernar en Duski Bay con el solo objeto de las experiencias de la gravedad: se le agregaban luégo la extraña im. presión que habian hecho los fríos y el último temporal, en la ya débil y cansada marinería filipina y las lluvias abundantes que reinaban en el puerto; por manera, que á veces pudiesen pasar los quince días sin lograr de observación alguna: finalmente, debiendo nosotros trillar aún por dos veces el mismo paralelc de $45^{\circ}$ á una y otra parte del Cabo de Hornos, no sería difícil hallar oca. sión más oportuna y más expedita para aquel intento. Nos convencieron estos razonamientos que sería preferente para el reparo de los buques $y$ el descanse de las tripulaciones una es. cala en el puerto de Jakson ó en la baki ia Botá- l'cla.a nica de la Nueva Holanda; pusimos, net consiguiente la proa al Oeste sin mayor demora, y al medio día siguiente del 28 ya no distábamos ménos de 70 leguas del extremo Sur de la Nueva Zelanda.

Nuestras longitudes referidas á las del Capitán Cook, delante de la bahia dudosá dieron los siguientes resultados, bien entendido que en nuestras cartas habíamos ya corregido los errores de 30 y $20^{\prime}$ que á las dos islas de la Nueva Zelanda había hallado el mismo Capitán cn su segundo viaje.

\begin{tabular}{|c|c|c|}
\hline & Cronom. $7 \mathrm{r}$. & Num. $t$ \\
\hline $\begin{array}{l}\text { Longitud por marcación oriental } \\
\text { de Manila. . . } \ldots \ldots \ldots \\
\text { Longitud por el reloj. . . . }\end{array}$ & $\begin{array}{l}45 \cdot 35 \cdot 3^{8} \\
45 \cdot 41.1\end{array}$ & $\begin{array}{l}+5.35 .3^{8} \\
45.13 .12\end{array}$ \\
\hline Diferencia del reloj. . . . . E. E. & $n 5.23$ & 0.22 .26 \\
\hline
\end{tabular}

La diferencia hallada ahora en el cronóme. tro 7 I era pues la misma que se había notado á la vista de Erromán, y esta uniformidad, al paso que afianza.ra su buena niarcha nos manifestaba hasta qué glado habian alcanzado en su aproximación las determinaciones de los navegantes ingleses. En cuanto al número II ya no quedaba duda que las últimas alteraciones en la comparación diaria, dependian de él enteramen. te; pero no dejaba también de hacerle recomendable la compensación hallada ahora de una parte del error que liabía manifestado antes á la vista de Erromán.

La variedad de vientos, que corrían á veces en veinticuatro horas toda la aguja, pero fiján. dose más bien y refrescando al Sur y Sudoeste, hizo efectivamente, que si bien no fuese posible con este motivo el seguir una derrota, antes bien, que las mares gruesas del Noroeste y Sudoeste y los vientos frecuentemente arrafagados y osc.. ros nos causasen alguna precaución en el aparejo, fuese, sin embargo, al medio día del $\mathrm{s}$ la latitud de $37^{\circ} 30^{\prime}$ y la longitud de $3^{\circ} 30^{\prime}$ próximamente al Este de Bahia Botánica. Varios azimutes ha bian manifestado en la tarde anterior la variación de $\mathrm{II}^{\circ} 3 \mathrm{O}^{\prime}$ Nordeste. Sustituían á las aves acuáticas de las longitudes más altas, diferentes procelanias y algunas pardelas. El temple de la atmósfera era ahora mucho más agradable, en turbiándola sólo en éste y en el día siguiente, algunas turbonadillas distantes con truenos y relámpagos, las cuales nos recordaban la poca distanria de la costa. Estas mismas turbonadas nos quitaron al día siguiente deducir la latitud de la altura meridiana del Sol, algunas alturas medidas en otras horas y calculadas por el método de D. Dionisio Galiano nos hicieron suponer en latitud de $35^{\circ} 45^{\prime}$, longitud $2^{\circ}$ proximamente al Este de bahía Botánica; ambos resultados ma. 
Mar. 6 nifestaban con mucha probabilidad una corriente bastantemente fuerte al Nordeste.

Continuó el día ro nuestra navegación hacia la costa, y en la mañanita del II, con las primeras claras del día, fué por consiguiente fácil hallarnos á no mayor distancia de siete á ocho leguas. Algunas alturas meridianas de estrellas que había medido en la noche anterior D. Jose Espinosa, y las mismas pinceladas maestras del Capitán Cook, no nos dejaban dudar que era la que corre desde la Punta Roja hasta las inme. diaciones de la Bahía Quebrada. Se hacían particularmente notables el alto semej^nte á la Copa del Sombrero, y las quebradas ó mogotes de la costa algo más meridional que la entrada de la bahía: el viento bonancible del Sudoeste nos dió lugar á aproximarnos más en la restante mañana. A las diez encontramos fondo de r ro brazas are. na fina, y al medio día por latitud de $34^{\circ} 18^{\prime}$, no distábamos sino unas cuatro leguas de la costa del traves; siéndonos fácil al mismo tiempo marcar la Copa del Sombrero al Sur $62^{\circ}$ Oeste, la Punta Roja al Oeste, y la tierra más Norte al Norte $22^{\circ}$ y $\%$, Oeste, todo de la aguja.

Entro poco después virazón bonancible, con la cual y todo aparejo navegamos inmediata. mente en demanda de la Bahía Botánica, siéndonos ya fácil distinguir su entrada por ambas Puntas de Banks y Solander. A las tres, no dis. tábamos sino una legua de la costa del través dos de la boca del puerto, ei cual creíamos alcanzar antes de la noche; pero á la sazón escaseándose más el vientı hacia el Nordeste y notándose los efectos de la marea contraria que nos aconchaba extraordinariamente, fué preciso variar de idea, y tomar las muras á babor con la proa del Sudeste. Largamos al mismo tiempo las insignıas, y no tardamos en ver desplegada la bandera inglesa en un altito intermedio entre el puerto Jackson y la Bahía Botánica. Se aproximaba en el entretanto la hora en la cual, según lo había calculado D. José Espinosa, debía acae. cer un eclipse de Sol: nos dispusimos á observarle con los sextantes, y la posición en la cual nos hallábamos, nos dió lugar á esperar que no sería difícil con buenas marcaciones y el auxilio de los relojes marinos, referir sus resultados al observatorio que muy luego estableciésemos en las inmediaciones del puerto.

I as muchas nubes hicieron dudosa la determinación del principio del eclipse, cuyo apulso determinó D. Francisco Viana 4 tpe. v. $354^{\prime}$ $39^{\prime \prime}$ y $1 / 2$. D. José Espinosa, por hilación de la parte que se advirtió eclipsada en las primeras claras, " $354^{\prime} 49^{\prime \prime}$.

Despejando después la atmbsfera, emprendimos con los sextantes las medidas bien frecuentes de la parte no eclipsada y de la distancia de los cuernos, medidas las cuales podían alcanzar un grado útil de precisión por los sextantes ex- Mar. ı celentes de los cuales hacíamos uso. Se midie ron dos series de horarios y compararon los relojes de la una corbeta con la otra, y finalmente se sujetó con buenas marcaciones á los puntos más notables de la costa, el paraje en el cual se logró determinar con la mayor precisión y las mejores circunstancias el fin del eclipse.

Acaeció éste por D. Francisco Viana en tiempo vario, á $5^{\text {h }} 54^{\prime} 3^{\prime \prime} 9$; por D. Jose Espinosa á $5^{\mathrm{h}} 54^{\prime} 40^{\prime \prime}$.

Se consideró (según las marcaciones) la latitud de este punto de $34^{\circ} \mathrm{I} 7^{\prime} 45^{\prime \prime}$, y su longitud de $\mathrm{II}^{\prime} 3 \mathrm{O}^{\prime \prime}$ al Este del puerto Jackson. Bar. Mar. ${ }^{\circ} 29^{\circ} 73^{\prime}$. Termómetro al aire libre 70. 5. Con la caída del Sol, el viento se había inclinado mucho al Norte bonancible, de suerte, que ya podiamos navegar en busca del paralelo del puerto, el cual era nuestro ánimo conservar en la próxima noche, atento á las corrientes que segun el Capitán Cook y la experiencia de la tarde anterior contábamos constantes al Sur, $y$ atento á la virazón que debíamos prometernos para el medio día siguiente. Se advirtió desde el principio de la noche una grande candelada en el mismo punto en el cual por la tarde habíamos visto la bandera inglesa, y el tiempo á cada paso nos anunciaba una noche de las más templadas del verano.

A pesar de esto, á las nueve se nos declaró un viento del Sudoeste fresco, el cual antes que acortásemos de vela nos llevó rápidamente al Norte y nos precisó por consiguiente á virar hacia las diez. Reviramos luégo á las doce y con las gavias á medio mastelero mantuvimos de la vuel. ta de tierra. Cesaron las ráfagas fuertes á las tres de la mañana, se sondaron á las cuatro go brazas arena fina, y poco después emprendimos con fuerza de vela el atracar la costa y dirigirnos al fondeadero.

Nuestra posición luégo que amaneció, era tan agradable cuanto podíamos desearla. La entrada de la Bahía Botánica nos demoraba al Sur $87^{\circ}$ Oeste, y la del puerto Jackson al Norte $45^{\circ}$ Oeste de la aguja: no distábamos de la segunda sino unas tres leguas: se veían los extremos de la costa. Tremolaba la bandera inglesa en el mis. mo paraje de la tarde anterior, y el día era sumamente despejado.

Pero el viento no sólo se mantenía constan. te al Sudoeste con mar bastante gruesa, sino que no prometía la menor alteración en las ho. ras siguientes. Esta circunstancia debió decidirnos á abandonar la idea de fondear en la Bahía Botánica, y preferir el puerto Jackson que teníamos á sotavento. Así aprovechada con fuerza de vela la buena calidad de las corbetas, para las ocho pudimos recibir á bordo un práctico inglés que salió á nuestro encuentro; atracamos des. 
xtantes ex- Mar. .1 Se midie. aron los re. finalmente los puntos el cual se cisión y las pse.

ana en tiem. é Espinosa,

nes) la latiy su longito Jackson. 1 aire libre to se había e, de suerte, del paralelo o conservar rrientes que cia de la tar. Sur, y ateneternos para esde el prin. lelada en el le habíamos á cada paso s templadas

s declaró un antes que idamente al á virar hacia :e $y$ con las $s$ de la vuel. uertes á las is cuatro go mprendimos ta y dirigir-

Ianecio, era arla. La enraba al Sur d Norte $45^{\circ}$ la segunda tremos de la en el mis. día era su.

ía constan. ruesa, sino $n$ en las ho. bió decidir en la Bahía 1 que teníain fuerza de ts, para las ztico inglés camos des.
Yar. it pués la punta Sur, y las piedras salientes de ella, como á un tiro de fusil; y á las diez, dados dos ó tres bordos dentro del mismo puerto, dimos fondo á un ancla, no permitiéndonos el viento ni la marea internar á la sazón hacia el Sidney Cove distante cinco millas del fondeadero actual y punto elegido para colonia principal: la ATrevida fondeó al Sur de nosotros á distancia de dos á tres cables.

Ya de antemano un bote esquifado con el mayor orden y aseo, había pasado al costado de la Descubierta y atracado á la Atrevida. Venía en él un Oficial de la Plaza, el cual nos cumplimentó de parte del actual Gobernador interino el Mayor Grose, of reció en su nombre cuantos auxilios suministrase la colonia, y debiendoregresar inmediatamente, se ofreció á conducir en el mismo bote al Alférez de fragata D. Jacobo Murphy, el cual, como experto en el idioma inglés, debía corresponder en nuestro nombre al Gobernador con iguales atenciones y manifestarle los motivos de nuestra escala en el puerto. Reducíanse éstos esencialmente al preciso reemplazo de agua y leña $y$ al natural reparo de los buques $y$ aparejos después de un viaje de noventa y siete días; al acopio de una colección botánica y zoológica para el Real Gabinete, cual pudiesen permitivla la estación y el tiempo; á las experiencias de la gravedad con el péndulo simple, y á un pequeño descanso á entrambas tripulaciones, antes de arrostrar á las navegaciones á las cuales es. taban destinadas: Murphy debía al mismo tiem po proponer el saludo á la Plaza siempre que correspondiese tiro por tiro, $y$ asegurar al Mayor Grose, que si bien fuese nuestro ánimo aproximarnos al Sidney Cove ya que los vientos no nos habian permitido entrar en la Bahía Botánica, serían tales nuestras medidas relativamen te á la seguridad de los sentenciados y al buen orden interior de la colonia, que no se extrañaría la existencia en el puerto de dos buques de otra nación.

Despedidos con este encargo el Capitán Johnston y D. Jacobo Murplyy, y no permitiéndonos aún el viento ni la marea el emprender la navegación haciáa el Sidney Cove, nos pareció aquella una ocasión favorable para destinar un bote á la pesca, la cual debíamos prometernos bien abundante á favor de las tripulaciones, atento á los informes del práctico y al pescado excelente que ya nos habian vendido dos botes pescadores.

Entretanto eran ya las tres de la tarde, y aunque continuase viento fresco del Oesudoeste nos disponíamos á dar la vela para ganar sobre bordos y con la marea favorable el fondeadero deseado; pero empezaron á declararse ráfagas tan fuertes del mismo viento, con mal cariz y lluvia, que nos persuadieron $\hat{i}$ diferir la empre. sa para el día siguiente, tan , más, qu habien. Mar, । do garrado la ATrevida por dus veces, s había visto precisada á dejar caer la segunda ancla, y ahora necesitaba con espías buscar una posición más ventajosa para dar la vela.

A la caída de la tarde cerlió mucho el viento y despejaron cielos y horizontcs: con este motivo no tardó en regresar á bordo el Alférez de fragata Murphy, al cual acompañaban en el mis. mo bote el Teniente Rowley, Ayudante mayor de la Plaza, el Capitán David Collins, Juez togadoy Secretario de la Colonia, y el Capitán Bamb. ton, con algunos oficiales del navío Shav-Harmosia, que últimamente había llegado de Bengala con efectos vendibles, logrando de una navega. ción de siete semanas desde Calcuta hastr. Sidney. Con nuevas expresiones y ofrecimientos sumamente atentos, ratificaron las primeras ideas que habíamos podido formar por la mañana, no sólo del buen acogimiento que recibiriamos, sí también del buen orden y de la abundancia dc refrescos que ya suministraban aquellos con. tornos.

Estas noticias agradables nos hicieron esperar con ansia la mañanita siguiente; y las ráfa. gas del Sudoeste con aguaceros, que tuvimos nuevamente desde las dos de la mañana, debie. ron ahora parecernos tanto más molestas, cuanto más nos amenazaban de poder malny rar también la próxima marea favorable: sin embargo, á las cinco ya estuvimos á pique, y poco después de las seis á la vela, con viento coritrario pero más claro y sin ráfagas, el cual nos precisaba á bordos frecuentes sobre las gavias, estays y jua. netes.

No cabe una descripción adecuada de la hermosura del puerto y de la admiración que debe causar á todo navegante luégo que interna en él. La naturaleza ha ocurrido á cuanto podia hacerle igualmente cómodo y seguro. Las mareas mismas que ahora hubiéramos deseado más fuertes, no son bastante causa para estorbar la na. vegación interna á cualquiera hora del día o de la noche. Muchas ensenaditas, la mayor parte con buen fondo para buques de cualquier porte, algunas islas pequeñas $y$ las orillas por lo común escarpadas por una parte y otra, hacen la escena aún más agradable inalmente, una dis. tancia de cinco millas por diierentes direcciones siempre no distantes del Oeste, conduce al Sid. ney Cove, pequeña cala bien situada y elegida por el Comodoro Philipps para capital de todas las colonias de la Nueva Holanda.

A las diez de la mañana ya pudimos fondear en paraje oportuno para no hacer demasiado fre. cuente el roce de nuestra marinería. La ATREVIDA nos alcanzó por la tarde logrando de una virazón fresquita, inmediatamente la Oficialidad de entrambos buques encontró en el Mayor Gro. 
Mar. 3 se y en los demás individuos principales de la colonia aquel acogimiento generoso que podía inirarse como propio de la Nación que representaba.

Ya entablada de este modo uni confianza recíproca, de la cual no podian méne s de disfrutar al mismo tiempo las demás clase subaltermas por una y otra parte, nuestras medidas en la ma" ñana del I \& para ocurrir á las causas que nos habían guiado al puerto, pudieron ser bastante. mente activas. Se adoptó para observatorio una punta al Este, distante de las corbetas un cable y medio, prefiriéndola al observatorio de Mon. sieur Leoawse, por la menor comunicación con el pueblo y la mayor inmediación á las corbetas y á la orilla del mar. Las barracas de los toneleros y herreros pudieron también colocarse en las inmediaciones del obs:rvatorio: se trabajó con tesón en el velamen y aparejo, quedó todo dispuesto para empezar la aguada al dia siguiente; ambos botánicos lograron en tierra un regular sitio para el cuidado de las plantas que recogiesen, y finalmente, dieronse á bordo las instrucciones necesarias para que en los pasos sucesivos todo contribuyese á la mejor conservación de aquella amistad.

Estas medidas se reducian principalmente á que un Oficial de guerra de una ú otra corbeta presidiese diariamente la aguada, ya que era preciso hacerla en la población; que en el bote destinado á la pesca fuese un sargento ó condestable con algunas armas de fuego para evitar cualquier sorpresa por parte de los naturales, bien temibles, según nos habian informado en la colonia; que de noche se custodiase el observatorio con un cabo y dos soldados nuestros, los cuales pasa. rían la palabra con las centinelas de las dos cor. betas; que por ningún motivo se admitiesen mujeres á bordo; que se pasasen dos listas al día para castigar rigurosamente cualquiera que faltase á ellas; que no se admitiese convicto alguno en los botes ni en las corbetas; que se evitasen desde su mismo principio las borracheras y desórdenes de la marinería, y más que todo, cualquiera alienazión de su ropa; finalmente, que desde las ocho de la nuche no se permitiese atracar á bordo á bote alguno extraño, á ménos que no diese una contraseña, de la cual convendríamos después reservadamente con la plaza. Enterado de estas medidas el Mayor Grose y particularmente de la última, la cual miraba más directamente á evitar la fuga de cualquier convicto, tuvo la bondad de ofrecernos la contraseña diaria de la plaza que el Ayudante Mayor nos enviaría cerrada; pero la omitimos mientras la experiencia no la indicase necesaria, agradeciendo sí esta prueba de confianza no ménos que los honores de armas que nos hacían las guardias en tierra, iguales ente. ramente á los de sus Generales.
Con estas precauciones y contribuyendo tan- 31.4. 23 to á su exacto cumplimiento la serenidad del tiempo, la tranquilidad del puerto $y$ el buen orden de la colonia, pudimos para el 25 ver concluídas en una y otra corbeta la aguada y la leña, hechas con la mayor prolijidad las experiencias del péndulo simple, examinada la marcha de los relojes, y finalizados en el casco y aparejo todos los reparos que fuesen necesarios y que por su n'imero y por su calidad no podían parecer indiferentes.

La buena conducta de entrambas tripulacio. nes hasta este tiempo, y el deseo de proporcio. narles un justo descanso y esparcimiento, hizo luégo necesarios dos 6 tres dias de libertad para que lavasen sus ropas; sin embargo, para el 27 si se exceptúan algunas obras pequeñas de he. rrero y tonelero, las corbetas podian considerarse enteramente prontas para dar la vela.

Pero para esta época las colecciones botánicas de los Sres. Heenke y Nee estaban aún bien in formes, aunque entrambos hubiesen desplegado una actividad singular; nuestros conocimientos hidrográficos se hallaban, digámoslo así, en su niñez, y las muchas atenciones que habíamos recibido y recibiamos diariamente de los individuos principales de la colonia, exigian unas muestras nada equívocas de nuestro agradecimiento. Así, pareció que el sacrificio de pocos días á estos objetos no se miraría como absolu. tamente infructuoso; y le abrazamos con tanta mayor satisfacción, cuanto más favorables eran todas las circunstancias para reunir á las demás tareas nuestras el aprovechamiento de la observación última del eciipse de Sol.

Ignorábamos efectivamente no ménos los re. sultados de las observaciones astronómicas de Mr. Dawse, que las operaciones hidiográficas del hábil Capitán Hunter, y nos ofrecíamos por otra parte en hacer públicos antes de la salida los frutos de nuestras tareas, por manera que pudiese después hacerse la debida comparación de unos con otros y deducir la verdad con una mayor aproximación. Con este solo objeto se dirigió la lancha de la Descubierta á la bahía Butánica para levantar geométricamente su plano, y de allí traer una serie bien ordenada de trián. gulos hasta el mismo observatorio, por las ensenadas interiores del puerto.

Don Juan Rabenet combinó con esta expedi. ción otra suya por titrra hasta la bahía Botánica, á la cual le acompañaron el Capitán Johsnton y el Teniente Prentice para que tuviese mejor ocasión de concurrir con algunos naturales y retra. tarlos con sus armas y costumbres. D. Antonio Tova hizo algunas salidas para cazar; D. Ferrando Brambila emprendió algunas vistas de perspectiva; los botánicos se internaron hacia Parramata y Tungave; se continuaron las ta- 
uyendo tan- slus, as renidad del el buen or25 ver con. iguada y la d las expeada la marel casco y necesarios d no podían

tripulacio. proporcio. hiento, hizo bertad para para el 27 , eñas de he. considerarse

es botánicas aún bien indesplegado nocimientos así, en su e habíamos e los indivi. kigian unas o agradeci. io de pocos omo absolu. is con tanta orables eran á las demás de la obser-

lénos los re. nómicas de ijdıográficas ecíamos por le la salida manera que omparación lad con una bjeto se dia bahía Bue su plano, la de trián. or las ense-

esta expediia Botánica, Johsnton $y$ mejor ocales y retraD. Antonio ar; D. Fers vistas de aaron hacia aron las ta-
N..r. 23 reas del observatorio y entrambos Comandantes nos dispusimos á obsequiar á bordo, para el primero y segundo día de Pascua, al Mayor Grose y á las personas más distinguidas de la culonia.

Ya en los días anteriores les habiamos mere. cido que concurriesen con las seĩoras á almorzar (i) una pequeña barraca dispuesta para $\mathrm{cl}$ intento en las inmediaciones del observatorio, y en la cual, se nos permitía sirviésemos con preferencia el chocolate y varios comestibles de nuestra España. Además de esto, no sólo entre las clases respectivas con recíprocos convites y regalos se había estrechado cada vez más y más una amistad cariñosa, sino que se advertía entre todos una unión tan estrecha, que no dejaba duda á una verdadera simpatía nacional ligada con una buena educación; y fué para nosotros un feliz acaso que por este tiempo llegase tambien al puerto, con quince días de navegación desde la Isla de Norfolk, la embarcación inglesa la Ritty y en ella el Capitán Patterson, Mis Patterson su esposa, y el Teniente de navío Woodreef, de la Marina Real, quien navegaba como Superintendente en el mismo buque desde los puertos de Inglaterra. El primero, ya conocido del público por tres viajes hechos desde el Cabo de Buena Es. peranza hacis países interiores del Africa con objetos de Historia Natural, había ahora explayado su aplicación y amor á las ciencias por el espacio de catorce meses que había permanecido en Norfolk con su compañía.

El tiempo favorecio mucho el primer convite á bordo de la Descubierta en donde se licieron al Mayor Grose los honores de Teniente General embarcado y además se acompañaron con salvas los siguientes tres brindis: $\mathrm{r} .^{\circ} \mathrm{E} 1 \mathrm{Rey}$ de Inglaterra, el Rey de España y ambas Reales familias. 2..$^{\circ}$ El Comodoro Philipps, el Mayor Grose y la prosperidad de la colonia. $3 .^{\circ}$ Las señoras que nos favorecían con su presencia. Todos los convidados repitieron el brindis, anteponiendo el Rey de España al Rey de Inglaterrs: hicieron eco á estos sentimientos de cariño y $i$ respeto los iviva el Rey! de la marinería, y la música del regimiento tocando al mismo tiempo el aria God save the King dió á esta escena agradable y tierna todo el semblante majestuoso que merecía: el tiempo lluvioso $y$ con viento algo arrafagado, no permitió al día siguiente que las señoras concurriesen á bordo de la ATREvIDA, peró no faltó otro alguno de los convidados; se hicieron al Mayor Grose los mismos ho. nores del día anterior y se renovaron los mismos brindis.

En aquel día tuvimos también la satisfacción de ver regresar la lancha, concluídas sus operaciones por la parte exterior del puerto, no quedándole, sino les marcaciones internas, que debia emprender con un bote. Efectivamente, en

la mañana siguiente lo verificó el bote de la M.r. Descubierta, y en la tarde del 3 de Abril, que. daron concluidas todas las marcaciones.

No labíamos sido tan felices en el observatorio, á lo ménos por lo que toca á la deducción de la longitud, pues relativamente á esta, se habian frustrado por las nubes todas las inmersiones vi. sibles del primer satélite de Júpiter, y no acaecía ocultación alguna de estrellas por la Luna, de suerte que aproximándose ya mucho el plazo de nuestra salida, y siendo preciso como lo habiamos prometido el presentar en un orden ostensible los resultados de nuestras tareas astronómicas para la longitud del observatorio, debimos ceñirnos á los datos siguientes:

longitud or, de Gir.

Por el fin del eclipse de Sol acaecido en la tarde del it obscrvado á bordo de la Descubierta y calculado por D. Juan de la Concha por las fórmulas de Mr. Cagnoli. .

Por los relojes marinos, adoptada la longitud de Duski Bay del Capitán Cook.

Por la inmersión del segundo satélite de Júpiter acaecida en la noche del 24 de Marzo. . . . . . . . .

Por 42 series de distancias de la Luna

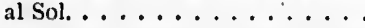
Latitud del observatorio por muchas alturas meridianas al Norte $y$ al Sur del Z. . . . . . . . . . Variación magnética. .. . Nordeste.

$15 \mathrm{I}^{\circ} 02^{\prime} 30^{\prime \prime}$

$151 \cdot 15 \cdot 25$

$151 \cdot 10 \cdot 15$

$151.18 \cdot 15$

$33 \cdot 51 \cdot 26$

8.45

Para adquirir una idea mís cabal del estado y suerte venidera de aquellas colonias, nos que daba aún el paso más interesante, y era el de una excursión á los establecimientos de Parramata y Tungave. El Comodoro Philipps, no hallando en los contornos de Sidney Cove sino un terreno sumamente ingrato $\epsilon$ infecundo para las siembras, debió decidirse en favor de Parramata para el centro de la agricultura, in tanta más razón, cuanto que además de prometer sus tierras unas cosechas ménos inciertas y escasas, la conducción de los frutos al Sidney Cove era sumamente fácil y barata con el auxilio de los canales internos. Y era esta la única perspectiva, aunque distante, para que la subsistencia de las colonias no dependiese como en el día de la navegación complicada de una mitad ó más bien diré de todo el globo, y para que aminorasen con el tiempo los gastos crecidos que causaban á la matriz; así no hubo parte alguna de actividad, de policía y de orden, que el Comodoro y sus subalternos no desplegasen en su fomento: en breve tiempo los soldados, los colonos, los sentenciados, criaron de la nada una población bien ordenada, con buenos cuarteles y almacenes: le precedieron al andar de las orillas diferentes 
Nar is haciendas, con las moradas de algunos colonos. El maiz, el trigo y la cebada, dieron aunque mezquinos, sus productos seductores. Más abundante la papa, prometíb desde luégo una subsistencia ménos dudosa en lo venidero. Los árboles Ab. frutales, la hortaliza, y sobre todo el limbn y la vid, dieron nuevos resortes á la actividad y esperanzas comunes; finalmente, las primeras crias del número aunque e: :esivamente corto de los ganados vacuno, ovejuno y caballar, hallandn en esos mismos contornos un clima saludable y unos pastos abundantes, pudieron fomentar la agradable esperanza de que no tardaría en re. unirse en ese nuevo centro de la opulencia nacional, la actividad y policía inglesas con el clima y el suelo de nuestras Andalucías.

Después de esta breve pintura, no parezca extraño que fuese á lo mẻnos igual al nuestrn el deseo de los indivíduos principales de la colonia para que visitásemos á Parramata. Esta excursión se emprendió en la mañanita del 5 por el mayor númern de la Oficialidad en los dos botes de las corbetas. Nos acompañaron los Sres. Collins, White, Johnston y Prentice. I' para no olvidar enteramente nuestros objetos hidrográficos, se añadieron á una aguja y al teodolito, el reloj de faltriquera número Ir, y el sextante de Stanchff con horizonte artificial propio de D. José Espinosa.

El tiempo, que al rayar el día nos amenazaba con frecuentes aguaceros, tomó luégo el semblante más apacible y hermoso. A las siete y media de la mañana estuvimos en casa del Gobernador, desde donde emprendimos un paseo á Tungave y á la colina inmediata para alcan. $z$ ar la vista de las montañas de Rickmond y Caermarthen: una senda diferente, vistos ya los sembrados, nos condujo luégo á ver los ganados.

Era la una de la tarde cuando alcanzamos de nuevo nuestro cuartel general y nos reunimos á los Sres. Espinosa y Brambila, los cuales ha. bían conseguido, el primero observar con la mayor satisfacción la altura meridiana del Sol, y el segundo tomar con su acostumbrado pulso algunas vistas de perspertiva, que darán mejor idea de los contornos de Parramata y de los elogios que merecen ambos Jefes de la colonia, de cuanto pudiésemos añadir aquí con una des. cripcion mezquina y mal entretejida.

Después de cuatro 6 cinco horas de paseo de bió luégo ser igualmente alegre y sabrosa la co. mida: y conseguidas á las tres de la tarde las al turas absolutas para la deducción de la longitud, regresamos al Sidney Cove, $i$ donde llegamos a las siete, trazada por D. Felipe Bausá una pare de los canales hasta donde lo permitía la aproximación de la noche. Dedujo en la mañana siguiente D. José Espinosa la posición astron6mi- ca de la casa ya indicada, la cual resulto en la titud de $33^{\circ} 48^{\prime}$ y $19^{\prime} 45^{\prime \prime}$ al Oeste del observa. torio nuestro, distante de él por consiguiente, 16,8 millas marítimas al Norte $78^{\circ}$ Oeste del mundo.

En estos ít'timos días, no había sido, á la verdad, tan arreglada como antes la conducta de nuestra gente en tierra, no porque creyésemos asequible que resistiesen á las seducciones con. tínuas de las mujeres sentenciadas, arrastra. das del vicio más bien que del interés, y tan desenfrenadas en su conducta, que pareciesen cas. tas en su cotejo las mujeres de Tenerifc cual las pinta Mr. White en su Diario, sino porque se entregaron á la bebida de algunos licores, dis. puestos seguramente para aletargarlos y robarles después el poco dinero que tuviesen. Hubo ma. rinero de la ATREvida, que con este motivo faltó a la lista hasta cuatro días seguidos. En la Descubierta faltaron igualmente á un tiempo cinco marineros, $y$ por cuanto fuesen activas las medidas del Mayor Grose para castigar estos ro. bos, aunque frívolos, y cortar de raiz semejantes desórdenes, no sólo no fué posible conseguirlo, sino que más bien iban aumentándose diariamente.

Esta era una nueva razón para qu acelerásemos la salida de las corbetas, la cual quedó fijada para la mañanita del Ir. El 8 nos despedimos unidos, del Gobernador, de cuya mesa y atenciones continuamos, sin embargo, disfru. tando hasta el último momento, y los restantes días, si bien se aprovechasen por cada uno en estrechar y hacer más duraderas la amistad, sim patía y agradecimiento que nos ligaban, debie ron amargar mucho nuestra situacion, con recordarnos una tan próxima separación y á tamaña distancia.

Merecerán siempre en nuestra memoria un lugar preferente y un ar:ecio y amistad incapa. ces de borrarse, el Capitán Nepean, el Teniente Mr. Arthur, el Párroco Johnston y los Sres. Collins y White, los cuales manifestaron desde el principio un deseo particular de complacernos y distinguirnos. Sus casas fueron constantemente las nuestras; sus dones tan finos como apreciables, y su trato tan atento como amistoso y lleno de cariño.

El Párroco Johnston extendib aún mucho más sus principios sociales, aproximándose particularmente á nuestros Padres Capelianes con una dulzura, una humildad y una sencillez realmente evangélicas, y persuadiendo con infinitas instancias al Padre Mesa, de la Descubierta, á que disfrutase de la tranquilidad y hospitalidad de su casa, para restablecer (como lo consiguio) su salud bien quebrantada; ejemplo digno de los mayores elogios y agradecimiento, y el cual no recordaremos jamás sin la mayor complacencia 
sultó en la. Ah.s del observa. onsiguiente, - Oeste del

- sido, á la conducta de creyésemos cciones con. s, arrastra. $s, y$ tan des. eciesen cas. enerifc cual no porque se licores, dis. os y robarles - Hubo mamotivo faltó dos. En la á un tiempo n activas las gar estos rosemejantes conseguirlo, dose diaria-

qui acelerácual qued6 nos despe. cuya mesa $\mathbf{y}$ rgo, disfrulos restantes la uno en esmistad, sim. aban, debie. ion, con reón y á tama.

memoria un stad incapael Teniente os Sres. Coron desde el nplacernos y istantemente mo aprecia. istoso y lleno n mucho más lose particuines con una lez realmeninfinitas insCUBIERTA, á hospitalidad o consiguí) digno de los $y$ el cual no omplacencia
16. $y$ deseo de imitarle, venerando los decretos incomprensibles de la Providencia.

Che tutti ascolta, e por ge a tutti aita.-FI. LICAJA.

Por nuestra parte, en las pocas cosas que la constitución del viaje nos permitió of recerles, debi6 más bien sobresalir la conocida imposibi. lidad de satisfacer á nuestros deseos y agradecimiento, que la esperanza de corresponderlos: el Mayor Grose recibio con agrado dos vistas del puerto y una de Parramata, trabajadas por Don Fernando Brambila con mano maestra y capa. ces de dar en Inglaterra una idea bien cabal del estado actual de aquella colonia. El mismo 13rambila ofreció al Capitán Patterson la perspectiva de una cascada en la Isla de Nor nlk, cual la había descrito él mismo; y D. Juan Ra. benet, desplegando en los últimos días un igual grado de destreza, de felicidad y de complacencia en hacer retratos en miniatura, pudo satisfacer los deseos de la mayor parte de las señoras y caballeros de la colonia, que se reducian á recordar á sus amigos y parientes en Inglaterra, la extremada distancia á que se hallaban unos de otros. Correspondieron igualmente entrambos Cirujanos á las excelentes colecciones de instru. mentos quirúrgicos que les ofrecio $\mathrm{Mr}$. White: D. Fernando Quintano y D. Felipe Bausá, repartieron la poca quina excelente que les habia quedado del precioso regalo del Regente de Guatemala; finalmente, entrambos Comandantes nos desprendimes de todas aquellas provisiones que no nos hiciesen absoluta falta y tenían algún incentivo para agradar.

En la tarde del ro quedaron á bordo los instrumentos astronónicos y los demás utensilios; fueron luégo incesantes nuestras precauciones para que no se admitiese ni escondiese á bordo individuo alguno extraño; y por último, frustradas de nuevo en la noche inmediata $y$ en las dos anteriores algunas observaciones del primer satelite de Júpiter, estuvimos desamarrados al amanecer del II, y poco después dimos la vela.

El terral del Sudoeste era á la sazón tan flojo, que apenas podíamos contrarestar la marea entrante, y una neblina sumamente densa nos ocul. taba á veces hasta los puntos más inmediatos de la costa. Esos accidentes nos proporcionaron la satisfacción de que permaneciesen algún tiempo más con nosotros los Capitanes Nepean, Bampton y Alt y el Teniente Woodreef, que había y venido á bordo á darnos un último abra. zo: fero alcanzaria á las nueve de la mañana la boca Lel puerto, disipada la neblina y entrada casi al mismo tiempo la virazón galenita, nos despedimos, y entrambas corbetas ciñeron el viento, con el cual para las diez ya esiaban fuera del puerto.

\section{CAPITULO V}

Vavegación de las corbetas desde el pwerto Fackson hasta las Islas de los Amigos.-Escala en la Bahia Maurclle del Archipićlago de Vavao y reconocimien. tos itteriores del mismo Archipićlago. - Navegaciones sucesivas al Sur hasta perder de vista las Islas de Tonzatabu y Eua.

Navegábamos con todo aparejo para alejar- Ab. $"$, nos de la costa antes que la virazón calmase 6 rolase más al Este, cuando se avistó fuera de la boca del puerto el bote del Gobernador, que vo. gaba en nuestro seguimiento con una banderoli. lla ó señal en proa, la cual no dejaba duda de su deseo de alcanzarnos. Paireamos inmediatamen. te, $\mathbf{y}$ antes del medio día le tuvimos a bordo, siendo su objeto el de conducir de parte del Ma. yor Grose un soldado de su regimiento, culpado de fraude por algunas frioleras que le había en. tregado para venta ó cambio el carpintero de la Atrevida: en pago de aquellos efectos, deseaba el Mayor que se recibiesen otros equivalentes que el soldado había presentado, y lo cual no dejamos de admitir, con la esperanza de que este mismo paso diese nuevo vigor á nuestras instancias para que se aminorase el castigo que debía seguirle. Despedido el bote y observada la latitud de $33^{\circ} 47^{\prime}$ I $7^{\prime \prime}$ marcamos de nuevo con todo apa. rejo; el viento estaba á la sazón al segundo cua. drante, calmoso. Viramos al Sur á las tres de la tarde, y para la puesta del Sol, distábamos unas siete millas de la costa de través.

Entrada la noche, las ventolinas cedieron en. teramente, dando lugar á que la marejada nos aconchase algo más sobre la costa, según el fondo de 53 y 6 r brazas arena que encontramos á las ocho y á las diez; pero para la media noche empezaron á hacerse sensibles las primeras ven. tolinas del terral, con las cuales y todo apare. jo, gobernamos al Este para separarnos. Nuestra derrota debía dirigirse por el Sur de la Nueva Zelanda á las Islas de los Amigos, en cuyas inmediaciones nos lisonjeábamos que no serían enteramente inútiles nuestras pesquisas para los progresos de la Hidrografía.

Los vientos fueron al principio variables, $y$ más bien flojos; pero las corrientes decididas hacia el Este con una velocidad extraordinaria, contribuyeron de tal modo á los progresos de nuestra derrota, que para el día 26 , por latitud de $35^{\circ}$ no distábamos sino 60 leguas de las costas de la Nueva Zelanda: variación magnetica $I I^{\circ} \mathrm{O}^{\prime}$ al Nordeste.

Ya desde el día anterior, la muchedumbre de procelarias, los horizontes sumamente cargados, las proximidades sospechosas del plenilunio y el viento más recio y arrafagado, nos anunciaban un

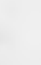

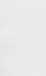

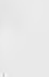

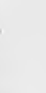

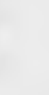


Wi. os temporal no distante, el cual, si juzgásemos por las experiencias del Capitán Cook en csos mis. mos paralelos, podia muy bien ser excesivamente recio á pesar de la latitud tan baja y de la esta. ción aún benigna del otoño. Desde el principio de la noche nos vimos precisados á navegar sin juanetes: al amanecer del 26 ya las corbetas no podian sufrir las gavias izadas; y antes de pasar el Sol por el meridiano, navegamos con dos rizos y se habian echado abajo las vergas de juanete.

Nada era inútil; á la media nuche la mar y el viento habian acrecentado cxtraordinariamente, de modo que fuese más bien demasiado aparejo cl del trinquete $y$ la gavia arriada: fué preciso aferrarla á las seis de la mañana, y en las demás horas hasta el medio día, nada puede dar una idca cabal de la fuerza que habían tomado el viento y la mar: eran contínuos los golpes que inundaban las corbetas; se hacía sumamente expuesto el capear con sólo el trinquete; había fal. tado una cadena á la mesa de guarnición mayor; no había á bordo paraje alguno enjuto y careciamos de la vista de la Arrevids por la suma ce. rrazón de los horizontes.

Al medio día, después de una oscuridad extraordinaria y algunas ráfagas excesivamente recias, venció por contraste el vicnto del Estc, el cual, sin embargo, desfogando con una lluvia Mas. abundantísima, calmó á poco rato y nos dejócntregados á las olas para su jugur.te; capeamos, aunque inútilmente solıre el cont $\operatorname{cafoquc}$ y estays mayor y de mesana; cada balance nos amenaza. ba de averías considerables; y fué el solo momento para nosotros agradable ell toda la tarde, el que sobre una clara nos proporcionó la vista de la ATREvida y le dió lugar para que con trinquete $y$ velacho arribase para reunírsenos.

No cedieron la lluvia y cl viento ha.sa el otro día, $y$ fueron precisas repetidas faenas en ambas corbetas para reparar siquiera en parte las averias sufridas; pero no bien hubo pasado el Sol del meridiano, cuando el viento roló rápidamente al Norte y Noroeste, de suerte que antes de la una ya pudiésemos navcgar con las cuatro principales $y$ las gavias rizadas.

Al medio día del 2 de Mayo, el Cabo Norte de la Nueva Zelanda nos demoraba al Sur dis. tancia de 50 leguas, y por consiguiente, nuestra navegación venidera podía mirarse como más libre y expedita.

Sólo en la mañana del día anterior habíamos tenido lugar, así en ésta como en la corbeta ATREvidi, de observar diferentes series de distancias de la Luna al Sol, habiéndolo imposibilitado hasta entonces, las mares con exceso gruesas. 6 los cielos por lo común nublados y lluviosos: nuestros resultados por un promedio de 32 series y 5 observadores, dieron la longitud de $182^{\circ} 3^{\prime} 36^{\prime \prime}$ al Oeste de Cádiź diferían de esta longitud, el número II $25^{\prime}$ al Oeste, y el May. cronómetro 72 sólo dos y medio minutos en el mismo sentido: las olsservaciones de la ATRRvinA scgún nos dijo después á la voz su Comandante, aproximaban más bien á un promedio de nues: tros dos relojes y conformaban enteramente con los 105 y $7 \mathrm{r}$ á la sazón bien próximos uno de otro.

Vencidos los meridianos de la Nueva Zelanda, tuvimos nuevos temporales recios por paralelos de 29 á $32^{\circ}$ que causaron diferentes ave. rías en cl aparejo y una debilidad extraordinaria cn las tripulaciones: la ATREvids tuvo la jesgracia de perder un marinero filipino que cayó al agua cuando eran más tempestuosos el viento $y$ la mar: $y$ alcanzada próximamente la longitud de las Islas de los Amigos, y ya sensibles los prime. ros soplos de la brisa por latitud de $29^{\circ} 28^{\prime}$ nave gamos al Nornordeste.

El Archipiélagro de Mayorga, visitado por el Comandante Maurelle en r782, y sin duda el mismo de que liabia hecho memoria el Capitán Cook en su tercer viaje, distinguiéndole, según las noticias adquiridas en Annamoka y Tongatabu, con el nombre de $\mathrm{Vavao}_{\text {i }}$ era ahora el paraje al cual se dirigian las corbetas para continuar sus investigaciones náuticas, $y$ seguramente un cxamen atento de los pocos reconocimientos útiles que aún quedaban por hacer en el mar Paclfi. $\mathrm{co}$, no de jaba duda que era este el que debía preferirse á todos, atento á los últimos reconocimientos del Conde de la Péyrouse en el Archipiélago de los Navegantes y á los anteriores del Capitán Cook en las islas inmediatas de Happai, Annamoka y Tongatabu: ni para esta preferencia eran ménos poderosas las reflexiones que nos hacian mirar el Archipiélago de Vavao como un descu. lrimiento enteramente nacional y nos prometían en él aquel abrigo y abundancia de refrescos que difícilmente hubiéramos encontrado (á lo ménos con igual seguridad) en cualquiera de las islas inmediatas. No cabían muchas dudas sobre su posición exacta en cuanto á la latitud, ni á la verdad debía haberlas tampoco en cuanto á la longitud, atento á la estima de sólo dos dias con la cual el Comandante Maurelle ligaba á las islas inmediatas de Happai los extremos meridionales de este Archipiélago. Pero para el derecho usurpado últimamente por los navegantes europeos sobre esta clase de descubrimientos, faltaban aún dos circunstancias, las cualès deseábamos revalidar ahora con la mayor autenticidad; $y$ eran un reconocimiento científico por los métodos adoptados en el día, y una posesión pública que vindicase á los ojos de la Europa la seguridad del descubrimiento y el convenio de los natura: les. Triste ambición solapada con el semblante apacible de las ciencias y de la filosofía, que dictando unos pasos al mismo tiempo injustos $y$ 
Oeste, y el May: inutos en el la ATrFvinA Comandante, dio de nues. ramente con mos uno de

ueva Zelan. cios por pa. ferentes ave. xtraordinaria vo la desgra. que cay'o al s el viento $y$ a longitud de les los prime$29^{\circ} 28^{\prime}$ nave.

sitado por el sin duda el ia el Capitán ndole, según a y Tongata. hora el paraje ra continuar guramente un cimientos átiel mar Pacifi. e debía prefe. reconocimienArchipiélago es del Capitán opai, Annamo. ferencia eran ue nos hacian mo un descu. os prometlan de refrescos intrado (á lo lquiera de las s dudas sobre atitud, niá la. cuanto á la dos dias con aba á las islas meridionales lerecho usur. ates europeos tos, faltaban s deseábamos icidad; $y$ eran los métodos a pública que la seguridad le los natura el semblante filosofía, que po injustos y
May. 9 costosos á una nación alucinada, obliga á las de. más á seguirla de cerca en sus conquistas imaginarias, no adquiridas por ventura con rlos de sangre y de dinero, sino con pocos instrumentos astronómicos, algunas bagatelas cambiadas por efectos de mucha mayor utilidad y una ú otra descripción enterrada en parajes scìalados!

Con estos antecedentes, no era dificil el tra. zar una derrota breve á las islas indicadas, ni ya permitian distraerla con otro objeto alguno, la necesidad de alguna agua y refrescos y los muchos reparos indispensables en los aparejos y cascos de entrambas corbetas.

El viento ya fresco del Sueste, iba aumen. tando mucho su fuerza é inclinando á veces al Esueste, pero con cerrazones y aguaceros particularmente de noche, los cuales nos precisaban á navegar algunas horas bien precavidos en el aparejo, sin que excediese nuestro andar de cuatro á cinco millas. El día 16 , por latitud de $24^{\circ}$ y longitud de $1^{\circ} 30^{\prime}$ al liste de Vavao, debimos aún multiplicar nuestras precauciones en la noche, prefiriendo el capear sobre la gavia en dos rizos, el contrafoque y la vela de estay de mesana: sin embargo, eran las brisas tan frescas, que áun malogradas tantas horas de cada singladura, en la noche del i8 ya pudimos considerarnos próximamente en el paralelo deseado. Diferentes series de distancias de la Luna al Sol, medidas en la tarde anterior y en la del 17 , nos indicaban por más exacta la longitud del número II, la cual, por la mañanita del I9, nos hacia suponer unas sólas 20 leguas distantes del Archipiélago indicado.

Pusimos inmediatamente la proa al Oeste, con vientos del Este ménos frescos que los díns anteriores, pero arrafagados y acompañados algunas veces con lluvia, y fuimos bastante feli. ces para que al medio dia, por latitud de $18^{\circ} 5^{2}$ $y$ longitud de $35^{\circ} \mathrm{I} 5^{\prime}$ al Este del Puerto Jackson, se nos presentasen á la vista las islas deseadas: corrian á la sazón del Noroeste al Oeste, distante de nosotros unas seis leguas, y parecían sumamente bajas hacia el extremo Sur, elevándose luégo paulatinamente hacia la parte septen. trional.

A las dos y media de la tarde, nos hallamos Norte-Sur corregido con el extremo Norte, al cual se anteponian dos islas medianas y lozanamente frondosas, ligadas luégo por nedio de arrecifes á otras muchas isletas de inferior tamaño: éstas se daban la mano con los arrecifes más meridionales, y sus rompientes eran ya visibles desde la cubierta. El rumbo del Sudoeste parecia conducirnos con seguridad al Sur de todos esos peligros, y era, por consiguiente, el que seguíamos; doblando la vigilanciạ á medida que el viento muy fresco nos empeñaba, sin permitirnos sondar al Oeste de las islas reconocidas.
No era inútil tanta vigilancia; antes de las Muy. , tres y media demorándonos ya las isletas más Sur al Oesnoroeste y distantes de sus arreci. fes unas tres ó. cuatro millas, descubrimos un bajo bastantemente extendido á distancia de dos legruas. In tarde adelantada y el viento bicn fresco y de travesia, de modo que ni fuese fácil sondar ni posible el retroceder si halláscmos nuevos peligros, dict6 nuy luego como partido más prudente tomar las muras a estribor con proa al Nordeste y la posible fuerza de vela.

Aún este partido nos debió parecer suma. mente arriesgado, porque caimos rápidamente sobre los arrecifes, arrastrados seguramente de I diucción de las aguas hacia los canales internos, y ya esta nueva contıariedad, á cada instan te más peligrosa, nos habia casi decidido á preferir antes de la noche el paso entre los arreci. fes, cuando los vigías que habiamos enviado de nuevo á los topes para examinar cl canal prolijamente, nos avisaron que se veian otras rompientes entre uno $y$ otro extremo: fuc por consifruiente preciso el continuur con el partido adop. tado, si bien la mar fuese yruesa, el viento bien fresco y nuestras pérdidas visiblemente considerables. Por ventura las buenas cualidades de las corbetas y el viento que se alargó próximamente de una cuarta, decidieron la cuestión á nuestro favor. Para las cinco, ya libes de la corriente de las aguas, no descaeciamos en modo alguno sobre los arrecifes; á las siete marcábamos el extremo Norte del Arclipipílago al Oeste distancia unas tres legruas, y pocn después, tomado un rizo á las gavias, ya nuestro único intento era el de conservarnos próximamente en esta posjción hasta la mañana siguiente. La noche fué lóbrega con repetidos chubascos, con viento fresco $y$ arrafagado. Dimos diferentes bordos sobre las principales, en los cuales no nos parecio prudente virar por avante; y á las cinen de la mañana, aunque los horizontes estuviesen bien calimosos, avistamos la costaá no mucha distancia: el extremo Norte demoraba al Oeste $5^{\circ}$ Sur unas tres y media leguas, $y$ el ezcarpe de sus orillas reurido á nuestro examen desde los topes, no dejaba duda de que estaba libre de todo peligro. Arribamos sin perder tiempo á atracarlo de cerca, y á medida que navegábamos después costeando sus orillas á distancia de una ó media milla sin encontrar fondo, cedian la mar y el viento $y$ nuestra situación tomaba el semblante más agradable.

Es esta parte de costa que no reconoció Maurelle, bastantemente alta y cortada á pico. No se advierte en ella sino una sola bahía con poca playa, en la cual se veían reposar á la sombra de las palmas diferentes naturales. Las demás puntas parecen más bien inaccesibles, son enteramente vestidas de un bosque espeso, y con. 
May. oo duce:u inclinándose poco á poco al Sur, á las canales que dieron abrigo á la fragata Princesa.

$A$ las nueve ya descubriamos en parte el primer canal y ceñlamos para atracarle los vientos del primero y segundo suadrante, extraordinariamen. te varios en su fuerza y dirección según la diferente posición de las ticrras al tas que los intercep. taban. Poco después tuvimos la satisfacción de ver atracar á bordo una canoa con tres naturales, á los cuales se iegalaron algunas bagatelits, y á las diez pudimos despachar el bote armado á las órdenes de D. Fiancisco Viana, para que re. conociese el primer fondeadero, mientras las corbetas procuraban sobre bordos, introducirse entre los muchos islotes y atracar la costa de la isla grande más septentrional. No tardó el bote en señalarnos buen fondo en el mismo pa. raje al parecer, que Maurelle habia llamado Puerto del Refugio; se nos incorporó después para el medio día cuando ya tenfamos al costado diferentes canoas de naturales y los bordos ya más ya ménos favorables nos aproximaban al fondeadero reconocido. Tuvimos también algunos chubasquillos entremezclados con calmas, los cuales nos detuvieron en una inacción casi completa; pero el logro de algunas ventolinas favorables nos condujo al fondeadero, en el cual, según las direcciones de D. Francisco Viana, dejamos caer el ancla de tierra en 20 brazas arena á no mayor distancia de la costa de dos cumplidos de corbeta, precaución necesaria para que la amarra de fuera no cayese en piedra y demasiado fondo: emprendimos in. mediatamente el amarrarnos, $y$ habiéndonos alcanzado poco después la Atrevida con el auxi. lio de los remolques y de algunas ventolinas, entrambas corbetas pudieren mirar como concluidas á la caída de la tarde estas maniobras con la sola precaución de que la ATREvida diese una codera á una piedra inmudiata para evitar el burneo, el cual por la demasiada inmediación nos exponía á frecuentes abordajes. Ya amarra. da la Descubierta con el ancla de tierra en 22 brazas arena, y la del Sueste en 34 arena y casćajo, marcaba la Punta Oeste del fondeaderó al Norte $73^{\circ}$ Oeste, la punta Este al Sur $15^{\circ}$ Este y varias islitas no más distantes de una á dos leeguas, desde este último rumbo al Sur $64^{\circ}$ Oeste de la aguja, de suerte que no habiendo abiertas sino las dos cuartas desde el Oesudoeste al Oeste, dirección enteramente opuesta á la del viento reinante, y pudiendo en este día compararse el viento frescachón que reinaba fuera, con la calma y tranquilidad que disfrutábamos interiormente, todo parecía anunciarnos un abrigo se. מiro y tranquilo cualquiera fuese el plazo de nuestra demora en él.

Entre las muchas canoas que se nos habian acercado mientras estábamos aún á la vela, se hacla digna de reparo una canoa doble, de la May, .o cual vimos subir á bordo un Eije (t) anciano y corpulento llamado el Eije Dubou. Ofrecib in. mediatamente como regalo la macana que traía, una gallina y algunas raices, y con el reciproco contacto de las narices (2), nos saludb amistosamente dándonos la bienvenida. Recompensada por nuestra parte con dos varas de bayeta esta atención primera, $y$ héchole asistir luego á nues. tra mesa en la cual se condujo con mucho decoro, admirando todo cuanto le rodeaba, nos parecib que ya no se separaria de la corbeta y que su presencia pudiera sernos útil para conte. ner los desbrdenes y robos inevitables en la mu. cha concurrencia de naturales que ya hablan ve. nido á visitarnos. No cabe una pintura de la buena fe 6 más bien del descuido con el cual estos naturales se abandonan al recien venido, no tra. yendo por lo común arma alguna consigo, 6 si la traen, siendo esta la primer cosa que cambian con cualquiera friolera sin reparar siquiera en el método precavido de nuestras centinelas armadas, de un depósito no distante de ármas, y de aquella vigilancia que no puede ménos de anun. ciar un plan concertado que estriba particular. mente sobre la desconfianza.

Ya en esta situación procuramos hacer uso para la recíproca inteligencia con los naturales, más bien de la pequeña colección de voces del Piloto Vázquez de la fragata Princesa, que de la numerosa del Capitán Cook, cuya diferencia de pronunciación nos expondría á cada paso á uras equivocaciones tan crasas como peligrosas.

En la ATREvida era aún mayor que en la Descubierta la concurrencia de los naturales. Ei Eije Tumoala había presentado á D. José Bustamante un puerco y una cantidad crecida de raíces, recibiendo en cambio un hacha: la plebe en general parecia igualmente tranquila, y ya procurada para entrambas corbetas una regular abundancia de comestibles y aproximándose la noche, exigimos que nadie quedase á bordo: pre caución no sólo necesaria para nuestro reposo, si tai ybién para asegurarnos á lo ménos en la noche,

de us robos casi contínuos, de los cuales nos véamos amenazados.

Es realmente indecible la inclinación de la plebe, y aun á veces de los Eijes, á cualquiera clase de robos: sin embargo de haberse recogido cuantas frioleras pudieran excitarles este antojo, de no permitirse á natural alguno el que se in. trodujese bajo cubierta, y que hubiese siempre muchos atentos á evitar todo desorden de esta es(r) Eije o Egur, cquivale á Jefe, do los cuales hay
después muchas clases. El Capitán Cook los distingue después muchas clases. El Capitán Co
con la voz de Chief, Chef en francés.

(2) Es una ceremonia entre aquellos pueblns la de tocarse mútuamente con los extremos de las narices que equivale al abrazo de los europeos. 
doble, de la May, wo ) anciano $y$ Ofrecio in. a que trala, el reciproco dó amistosa. compensada bayeta esta luégo á nuesmucho de. odeaba, nos la corbeta $y$ 1 para conteles en la mu. ra hablan ve. ra de la bue. el cual estos enido, no traonsigo, 6 si la que cambian - siquiera en entinelas ar. e armas, $y$ de nos de anun. a particular.

os hacer uso os naturales, de voces del esa, que de la diferencia de a paso á uras ligrosas.

or que en la los naturales. do á D. José lad crecida de icha: la plebe inquila, $y$ ya una regular ximándose la á bordo: pre. itro reposo, si . s en la noche, is cuales nos

nación de la á cualquiera erse recogido s este antojo, el que se in. iese siempre en de esta es.

los cuales hay k los distingue spuebles la de de las narices
May, pecie, se descubrio uno en la Atrevion que inabin robado un pañuelo de las faltriqueras de $D$. José Robredo, y otro en la Descuntreta abriendo con arte las diferentes ventanitas de los camarotes de estribor, habla podido sacar algunos vestidos que llevaba consigo! se castigo el de la Arknvida con algunos azotes sobre un cañon, enseñándole al mismo tiempo el fusil; $y$ la actividad de Uubou pudo conseguir en la Duscuburk'rA que se alcan. zase con otras canoas al ladrón y se readquiric. sen las cosas robadas.

Ed reemplazo del agua era á la verdad el punto más importante que debiamos tener á la vista, tanto más que era preciso emprenderlo á alguna distancia, no siendo ya nuestro ánimo el cansar las tripulaciones y aventurar las amarras, para sustituir á éste otro fondeadero tal vez mé. now abrigado. Pero al mismo tiempo no podía. mos olvidar el establecimiento de un observa. torio, la necesidad de algunos trabajos de fra* gua, un repaso grande indispensable de los cascos y aparejos bien destrozados por los últi. mos temporales, $y$ sobre todo un reconocimiento hidrográfico y físico del Archipiélago en el cual nos hallábamos, hasta donde lo permitiesen las circunstancias. La seguridad nuestra y el evi. tar todo motivo de discordia con los naturales, deblan luégo combinarse con las operaciones an. teceds: $:$ es, y entrambos objetos no podían ménos de recordarnos cuántos inconvenientes pu. diera arrastrar consigo la menor tolerancia en el uso de las mujeres.

Sea enhorabuena 6 plausible 6 digna de dis. culpa esta tolerancia entre los navegantes in. gleses y franceses, de modo que no parezca un tropiezo para la conservación de la disciplina á bordo, el que el Oticial y el marinero se vean casi acomunados en entregarse á uno de los vicios más soeces que infestan la naturaleza humana. Ello es, que en nuestra marina, el marinero pretende ( $y$ con razón) tener mayores derechos que el Oficial, para ser vicioso; que es esta pasión en él con exceso vehemente, de suerte que no sería extraño ver al hombre más quieto disputar con un puñal en la mano el uso de la misma mujer á sus mejores compañeros 6 superiores, y á veces aspirar dú con mil ardides á suplantar en sus goces al Oficial. Debian recelarse también como una consiscuencia de este permiso, los robos repetidos á bordo; los cuales confundiendo á veces al culpable con el inocente, harían incurrir á los nuestros en estos de. litos, y caer probablemente la culpa sobre los naturales. Ni eran menores los tropiezos para la conservación de una buena disciplina y la inmunidad del derecho natural de los habitadores, aunque la tolerancia desterrada enteramente de los buques se ciñese sblo á los que estuviesen en tierra, pues en breve tiempo se verían aban. donados L.ss trabajos, insultadas las brdenes y May, so. penetrados los accesos aún más distantes de la costa innzelliata, á veces para abusar del temor' á veces para alentar la osadia de los naturales que nos roleaban. Convino la Oticialidad en la precisión de estus medidas, y dispuesta á preca. ver con el ejemplo $y$ con la vizilancia tamanos desórdenes, alentó mucho cl sistema que nos hu. bíamos propuesto.

La mañana del $2 \downarrow$ fué destinada principal. mente al reconocimiento de la aguadı, á la cual coadyuvaban mucho, no sblo la amenidad del dia, sino también la concurrencia de un número cre. cido de naturales impelidos al mismo tiempo de la curiosidad, del interés y de la ociosidad en la cual viven: puntuales el Eije Dubou y otros dos amigos suyos, vinieron temprano á bordo para acompañarnos; traian consigro algunos frutos y raíces, y era el objeto del primero, ofrecer (si mal no entendíamos) una especie de monopolio en los abastos venideros, los cuales prometín abundantes, aunque acompañase estas propues. tas con un sigilo misterioso y extraño, y sus ofrendas áun para cambio fuesen sumamente mezquinas. Debió en esta ocasión contribuir mu. cho para que le creyésemos una persona de nu. cha autoridad, no sólo el convenir su nombre con cl de otros dos que el Capitán Cook y el Comandante Maurelle habian hallado en Tongatabu $y$ en Vavao, si también el ver desplegada en la tarde anterior su autoridad con buen éxito contra unn de los ladrones.

Yero esta equivocación debía disiparse muy luégo, pues ya se habia transferido desde su mo. rada á aquellos alrededores el Eije Ko-Vuna y se disponía á visitarnos. Todos los que á la sazón se hallaban : bordo ensalzaban su poderío y au. toridad, extendiéudola no sólo al Archipiélago, si también á las islas no distantes de Happai, Annamoka y Tongatabu, y precedían luego á su ve. nida á bordo algunos emisarios para hacer apartar del costado las canoas: le acompañaron después las muestras ménos equívocas de respeto de parte de los Eijes inferiores, y el regalo que ofreció de un puerco grande, muchos frutos. y raíces y algunas esteras del mayor tamaño y finura, debieron darnos una idea cierta de su generosidad y grandeza: el Eije Dubou, ya se ha. llaba á la sazón confundido en el cerco de los demás, que sentados ( $\mathrm{r}$ ) con mucho orden, parecían prestar el debido homenaje á este nuevo Jefe, cuyo porte grave y majestuoso no coad. yuvaba ménos á confirmarnos la verdad de su clase soberana.

No fueron muchas, como puede imaginarse, nuestras primeras conversaciones, las cuales se

(t) La postura re inayor respeto, es entre aquellos puoblos la de sentarse con las piernas cruzadas. 
May. « dirigieron al principio, á estrechar cuanto fuese posible nuestra amistad, después á un convenio no equívoco para que se contuviesen los robos, y finalmente, á que no tomase á mal que le dejásemos para transferirnos al sitio de la aguada: la promesa de que por la tarde Je visitaríamos en tierra y algunos regalos, parecieron afianzar luégo la amistad; cambió nombre con D. Felipe Bausá, y finalmente, poco desp'łés de las nueve regresó á la playa, dejándonos lugar á que pudiésemos emprender el reconocimiento proyec. tado.

Iban en el bote armado los Sres. Heenke y Bausá y el Eije Dubou con otros dos naturales, los cuales nos guiaron hacia los canales internos á una playa no distante una legua del fondeadero. La aguada que allí hahía, parecía al mismo tiempo, cómodz, abundante y de buen sabor.

En el entretanto, ya se habían reunido mu . chos naturales en el paraje donde estábamos, y no era Dubou ménos eficaz para que concurriésemos á beber el cava (I) en un sitio inmediato destinado seguramente para esta especie de reuniones, y apto desde luego á hacerlas más agradables y duraderas con la fresca sombra que procuraba y con la limpiéza de las esteras que le serviain de alfombra. Hombres y mujeres sentáronse en torno: tuvo lugar D. Tadco Heenke de emprender una aunque corta herborización, y miéntras Dubou se entretenía en contar lo òte había advertido de inás notable en las corbetas, no era menor la elicacia de los hombres en cicuparse da los diferentes preparativos de' sava, de lo rue fuese la de las mujeres en solicitar regalos de cualquier friolera, of reciendo por su parte la más fácil complacencia á nuestros untojos.

La vista de los aprestos dei cava seguramente no podía alentar los deseos te beberlo; sin embargo, le admitimos con la solemnidad correspondiente; posannos luégo á reconocer utra agua da no distante de que hacían muchos elogios; pero esta segunda excursión nos procuró más bien un paseo delicioso que el logro del fin propuestc, pues la poza era sumamente mezquina y distaba de la orilla del mar próximamente una milla. Debimos, pues, decidirnos al regreso á bordo, el cual se aceleró mucho con el viento fresco del Sueste que á la sazón se había enta. blado.

Inmediatamente se tomaron las precauciones para el debido orden en ambas corbetas, y á este intento quedó prohibida la admisión á bordo de toda mujer, cuye clase y oijeto no fuesen bien conocidos, c vitado el riesgo de ıoda sorpresa, quitados cel medio cuanto fuese posible los alicien.

(1) El cava es una bebida termentada servida por aquellos naturales á todas horas y en toda concurrencia. tes del robo, ceñidas nuestras excursiones á tie- May, zi rra á los solos objetos del servicio, animados bajo la inspección del Oficial de guardia los cambios de comestibles, y precavido particularmente el doble defecto bien común en estas ocasiones de omitir los repuestos por la desordenada profusión de la marinería, y de quedar ésta sin ropa alguna cediéndolo todo para la satisfacción de un antojo momentáneo. Para este últi. mo objeto pareció conforme con las intenciones generosas de $\mathrm{S}$. M. el que más bien se expendiesen por cuenta del Erario los efectos embarcados para cambios, prohibiendo así todo otro medio de adquirirlos, que ó ver en un par lis días alienada la mayor parte de 'a ropa de abrigo ó sujetado importunamente con órdenes aún difíciles de llevarse á debido efecto el apetito saludable del navegante para toda especie de refrescos. Hubiéramos deseado que pudiese llevarse á efecto al mismo tiempo otra precaución ya adoptada por el Capitán Cook, y seguramente no sólo oportuna sino necesaria en estas ocasiones, cual era no permitir cambio alguno que no fuese de coméstibles, excluyendo, por consiguicnte, la adquisición de mil bagatelas que satisfacen el antoja y la ociosidad más bien que el estudio de la Naturaleza, y que sin embargo atraen á bordo un número crecido é importuno de vendedores; pero son tan varias las interpretaciones del buen orden, tarı vario y á veces tan plausible el an. tojo; tantos los que entre una nación demaoia. do viva sienten con extremo el freno aún más suave de la disciplina, que no creimos oportuna esta especie de prohibiciones en una ni otra corbeta sin embargo de los muchos inccnvenien. tes que debía acarraar por precisión.

Eran las cuatro de la tarde, cuando nos dispusimos unidos los Oficiales de ambas corbetas á visitar al Eije Vuna: la marea y la clase del fondo inmediato á la playa no permitía verificar el desembarco en la pro:imidad de las chozas; preferimos un recodo no distante, desde el cual una sendita con exceso frondosa, nos conducía po: los altos postreros al paraje deseado: fué en esta ocasión muy advertida la conducta del que nos guiaba, el cual, sabiendo que Vuna deseaba recibirnos con agasajo, nos condujo por otra senda no distante, hacia su choza, de suerte que precedido el aviso, aunque no nos demorásemos en ella sino pocos instantes, nuestro apareciniento á la vista de la ranchería fué saludado col el inejor orden $\mathrm{y}$ con las aclamaciones generales del cerco numeroso que acompañaba á Vuna.

Cantaban bastantemente acordes y acompa. ñados de las cañas, ó hu cas ó rajadas (I) unos

(x) Estos instrumentos, ac łnás de hallarse dibujados en la colección de estan jas, so verán también naturales en ol Real Gabinete. 
ursiones á tie- May. 21

icio, arimados le guardia los ido particularn en estas ocala desordenada juedar ésta sin ra la satisfacPara este últi. as intenciones n se expendie. tos embarcados odo otro medio ar lis días alie. e abrigo 6 su. es aún difíciles etito saludable de refrescos. llevarse á efecón ya adoptada mente no sólo ocasiones, cua que no fuese consiguicnte, la atisfacen el anel estudio de la atraen á bordo de vendedores; ciones del buen lausible el an. ación demasia. freno aún más reimos oportuen una ni otra s inccnvenien. iór.

uando nos dis. umbas corbetas

y la clase del rmitía verificar de las chozas; desde el cual , nos conducía leseado: fué en nducta del que Vuna deseaba o por otra sen. de suerte que demorásemos o aparecinienaludado cos el ones generales ba á Vuna. les y acompa: jadas (I) unos
May. $:$ veinte hombres sentados en el centro del cerco, y advertidamente dividido éste en tres trozos, de los hombres, de las mujeres y de los muchachos, dividía también naturalmente el agradable soni. do de las aclamaciones, de suerte, que ya por una, ya por otra parte; las diferentes edades y sexos concurriesen con una bien ordenada harmonía á aplaudir y festejar nuestra llegada. Saludamos á Vuna y á los pocos Eijes que conocíamos y le hacían corte, y como acompañasen á este Jefe en la choza donde se hallaban, diferen. tes mujeres la mayor parte jóvenes, cuya clase distinguida no era fácil equivocar, muy luégo el mayor número de la Oficialidad no halló una ocupación violenta 71 desagradable, la de reunirse en este pequeñ cerco combinando la sencillez $y$ el decoro con tna no extraña inclinación al otro sexo; no faltaron tampoco quienes se esforzasen á rnanifestar á las del cerco exterior, que sus gracias y afabilidad podían muy bien compensar la más alta esfera de las otras; así, pasamos la tarde en la mayor unanimidad y alegría, y no fueron pocos nuestros progresos en el importante colsocimiento del jdioma.

La noche fue sumamente tranquila. Las lanchas estuviero1: prontas al amanecer del día siguiente, y D. Antonio Tova pudo dirigirse con ellas al paraje prefijado de la aguada. Uis acopio regular de armas, tres soldados y ur artillero de brigada en cada una, algunas frioleras para regalos v compras de comestibles, y la orden de que no se escasease medio alguno para que la cesión del agua de parte de los naturales fuise absolutamen.c voluntaria, fueron las demás precauciones que nos parecieron oportunas para squella comisión.

Entretanto, los nuevos amigos no se habian manifestado perezosos. Casi desde la salida del Sol empezaron á acercarse muchas canoas á una y otra corbeta, y aunque las hiciese retirar por un corto intervalo una orden circular que las llamń inmediatamente á tierra, volvieron luégo en mayor xúmero y emprendieron al mis. mo tiempo los cambios y los robos. Procurábamos á la sazón conservar en mucho valor los cfectos que más abundaban en nuestros repuestos, ocultario las hachas y los adornos mujeriles para ¿,uando aquéllos desmereciesen de valcr. jus 6 tres cuchillos medianos ó bien una vara de bayeta, eran la recompensa de un puerco regular. Las navajitas, los hilos de abalorio y de coral suplian luégo para las gallinas, las raíces, los plátanos y los cocos, de los cuales parecería cas. irucicihle la cantidad que se a:lquiría y consumía diariamente.

Entre todop los que hasta entonzes habian concurrido á bordo, se habían cautivado particularmente el amor de toda la Oficialidad, Fei. leua, jóven de unos ocho á diez años y Príncipe heredero de las Islas, y Tufoa, sobrino de Vu- May. a na, al una viveza y comprensión pocn comunes: acom. pañaba luégo constantemente al primero como en clase de ayo, otro jóven algo más aduito lla. mado Lati, cuyas ocupaciones, se reducían más bien á la conservación que á la enseñanza del Príncipe. Todos tres habían sido bien regalados en la :arde anterior, y Feileua, cambiado ya nombre con ?. José Esspinosa, habí1. sido completa y elegaritemente vestido en $\mathrm{am}^{\prime}$ as corbetas. Era pues natuml con estos antecedentes, que fuese igual en unos y otros el deseo de estrechar esta amistad. Por nuestra parte, siempre que tuviesemos á bordo á Vuna ó Feileua, no sólo lograríamos un mejor orden y una mayor quietud, si también estariamos seguros de cualquiera restitución, si las prendas robadas fuesen de algun. importancia $o ́$ para los objetos del servicio 6 para el respeto de nuestras armas. Tufoa luégo se destacaba inmediatamente adonde le enviáse. mos 6 le llamásemos, y su activa autoridad sobre la plebe, reunida á una más fácil inteligencia de nuestros deseos, disipaba un número no crecido de pequeños altercados, en los cuales hubiera sido tan pernicioso que la plebe triunfase con sus tretas, como triunfar nosotros con la superioridad de nuestras armas y disciplina.

Todos estos jóvenes y áun el crecido núme. ro de naturales que teníamos á bordo, nos anunciaban para la tarde próxima unas aiversiones bien ordenadas; y es tal su propensión á esta cla. se de ocupaciones, que desde la mañana misma no era extraño verlos á cada paso bailar y cantar á nuestro lado, como si ya la música y el concurso gereral avivasen y pusiesen en movimien. to trodas sus fibras: ni á la verdad, pudieran lıe. go ocultársenos estas disposiciones, cuand s hacia las diez, con objeto de reconocer in pedrusco aislado que parecía oportuno para el observatorioy fragua, pasamos á la playa inmediata. La marea y la calidad con exceso decigual del fondo, hubieran liccho á la sazón ar: sgado el desem. barco; pero Tufoa ocurrió á este inconveniente, mandando á una porción de naturales, los más corpulentos, que nos condujesen scbre sus hombros.

Inmediatamente fuímos á saludar á Vuna, el cual, rodeado de muchas gentes y entretenido agradablemente con el cava, veía poco á poco ordenarse y crecer las pequeñas pilas de comestibles destinadas en la tarde próxima para nues. tro regalo. Procuramos que entendiese los obje. tos que á la sazón nos cunducían á tier:a; y atento á éstos, le pediros el permiso de llevarlos á efecto $y$ el de no admitir el cava y el descanso que nos of recía con muchas instancias.

El islote 6 risco cuyo reconocimiento emprendimos ahora, parecía á primera vista in. 
May.z1 accesible; por las infinitas desigualdades que en una materia enteramente aạcárea habian labrado con igual tesón el tiempo, las intemperies y ias olas; pero su mediana elevición, su entera independencia de las orillas pol'adas, su grande inmediación á las corbetas y sobre todo la facilidad de atracar á él los botes sin la incs.rup. ción de las mareas, le hacían demasiado importunte $y$ precioso á nuestra vista para que no pro. curásemos cualquiera medio de hacerlo útil. $\mathrm{Ni}$ se frustraron nuestros deseos hallando asequible á fuerza de picos y mazos suavizar algún tanto las desigualdades más puntiagudas para abrir una senda accesible, siquiera á un marinero, $y$ formar en la parte más alta un icitaplén suficiente para la tienda $y$ el cuarto de círculo. rodas las inmediaciones brinclaban luégo un fácil acomodo para la fragua y una pequeña barraca de guardia; $y$, las solas piedras podían aparta: á cualquiera natural, para que disf rutásemos de una completa quietud y seguridad en este depó. sito importante de nuestros efectos los más preciosos, sin usar de las armas de fuego para su custodia. Conseguido con la mayor felicidad este objeto qque mirábarnos como el más importante para la tranq'ilidad recíproca de los naturales $y$ nuestra, regresamos á bordo y fueron destinados para el intento 20 hombres de la DescubierTa.

La concurrencia á bordo de los natutales era á la sazón extraordinaria; se habían agregado dos embarcaciones grandes procedentes de Apay y Annamoka, y más cargadas de personas de ambos sexos que de comsstibles. Un crceido número de mujeres, la mayor parte jóvenes, insistían lué. go desde las canoas que se les pernitiese subir, recordando á los poco cautos admiradores de la tarde anterior $\sigma$ los regalos prometidos, $o$ la no olvidada articulación de los apellidos cambiatos, ó finalmente, la esperanza de que no fuesen sorLos á las voces seductoras de la Naturaleza. Y no eran ménos eficaces los hombres, incluso Feileua y Tufoa, en persuadir á que no se retardase ya por más tiempo la preferencia á favor de una ú ot:a de las que parecían llamar á sí mismas una atenciín más general. No sería fácil sin incu. rrir en la acusación bien frecuente de las narraciones harto abuitadas de los viajeros; describir con exactitud el grado de amabilidad que en aquel clima feliz ha tocado en suerte á las mujeres, y del cual no podíamos formar sino una idea bien imperfecta; pero tal cual ella era, bastaba para probar con un crisol bien fino, no tan. to la virtud de unos navegantes, cuanto el vigor de la disciplina cuando la guín el buen ejemplo de los que deben mirarse como los depositarios del buen orden. A la verdad, del mismo modo que la marinería y la tropa atentas álos trabajos importantes que tenían entre manos, se consola. ban en parte de esta privación satisfacieıdo sus apetitos con unas comidas del mejor sabor, abun- May. dancia y variedad, no faltaba tampoco para las clases más scnsibles un consuelo eficaz en aquel amargo contraste de la razón con la naturaleza; y era el deber á estas nuevas sacerdotisas del templo de Gnido, tan contentas con recibir el regalo de un simple súorno, como debiamos imaginar, según su eficacia, que lo hubieran sido viéndose ya preferidas álas demás con la elec. :ión. Por ventura : este último arbitrio de los re ralos pudo aminorar las instancias por una parti y los impulsos de agradecimiento por otra, y á ccsta de algunos pañuelos ú otras bagatelas, nuestro concepto en aquella ocasión ganó cn lo expléidido, lo que podía laber perdido de lo sensible y i'atural.

Lran muchos á li sazón los trabajos de re. paros y aprestos que se habían emprendido en ambas corbetas. Las jarcias de trinquete de la ATREVIDA habían sufrido considerables averías en la última travesía. Las cadenas de las :mesas de guarnición mayores, estaban por la mayor parte altas en la Descubierta. Las mares, con exceso gruesas sobre la Nueva Zelanda; nos ha. bían manifestado como igualmente nece $93+\mathrm{i}$ unos guarda mesas; el velamen pendiente $r$ talia reparo; la estiva un nuevo orden y nue tra.s tripulaciones formadis en parte de hombres ya censados que seguían el viaje desde España, $\mathrm{y}^{\prime}$ cn parte de muchachos filipinos, no podíat: 6 por falta de número 6 de inteligencia, explayar toda la actividad necesaria; $\sin$ embargo, no podían llamarse lentos los progresos que íbamos haviendo, y los cuales se debían en mucho á la excelente Oficialidad de mar que dotaba ambos buques.

Era ya próximamente el medio día, cuando turimos una nueva visita de Vuna. Le acompañaban en aquella ocasión la mayor parte de las mujeres jovenes que habíamos visto en la tarde anterior, $y$ entre las más ancianas, las cuales apenas llegaban á tres 6 cuatro, se hacía pa-ticularmente notable una Dubou, hermana de Vu. na y madre de Tufoa, pues no solo á su ingreso á borcio, diferentes plebeyos le habían prestado el honenaje acostumbrado; sino que después animada de un tono igualmente lascivo y respe. tuo'so, entonaba y dirigía para el canto el coro entero de las demas jóvenes. Se díb principio á esta música seductora luégo que estuvieron sentadas todas en torno, distinguiéndose en el lado de Vuna las dos Fatafejis, ya conocidas por sus mujeres. E. canto era pausado y bastantemente vario y acorde, pero no era posible acertar con el ob. jeto de las palabras; pero si debiésemos juzgar por la facilidad con la ctral torio el coro ar. ticulalua las mismus ve podran inferir que su composición no era jueva, as a debíamos convencernus por los liferentes udemanes que la. 
May:a acompañaban, que el placer era el móvil única ó principal de esta agradable melodía.

No acertaremos á interpretar en aquella ocasión el ánimo de Vuna, relativamente á todas las demás jóvenes que traía consigo; pues lo que toca á sus dos mujeres inanifestó desde luégo decididamente que no las profanaría uria mano agena. Pero lo que no admitia duda al: guna, era que los regalos las consolarían enteramente, y así no tardamos en adoptar aquel partido; no siendonos fácil á la verdad conservar entonces una recta indiferencia, para que no fuesen absolutamente preferidas la juventud, la amabilidad y la hermosura, á las edades más an. cianas y ya despojadas de todo atractivo.

$A$ los regalos siguióse luégo una comida abundante de raíces que habíamos hecho preparar de antemano. Le agregamos el condimento de la azúcar; comió Vuna abundantemente, y no le era fácil á.la sazón disimular su alegría por ios muchos regalos que hechos á él directamente 6 á sus mujeres 6 al joven Feile ua, debian reconcentrarse en su Tesoro. Exam naba atentamente ya una, ya otra bagatela; usaba mil ardides á veces para prevenirlas, á veces para no encargar su custodia á otros; y no teniendo por otra parte ocupación alguna que le llamase á tierra á cada paso, se cebaba más y más á perma. necer á bordo, tranquilo espectador de nuestra generosidad y de los ardides de las mujeres que le acompañaban.

Un accidente no precavido le despertó sin embargo de esta tranquila ociosidad. Ya regresadas las lanchas de la aguada, nos disponiamos á comer, y para lograr un mayor sosiego había. mos solicitado que se retirasen á tierra las mujeres, alejando al mismo tiempo de á bordo el urecido número de los plebeyos que desde la mañana habian concirrido sobre el alcázar: con est: mismo intento D. Antonio Tova, quien regresaba á la ATrevida, se había encargado de recibir en el bote las mujeres que pretextaban no 'ener canoa, y el Jefe por su parte, daba las órdenes para que se retirase igualmente la plabe: pero bien hubiese entre ésta a'guno bas. tantemente osado para no obedecerle, 6 le pareciese aquella una ocasión oportuna pra hacer alarde á ruestros ojos de su autoridad liim. tada, en un solo momento, el tono más tranquilo y pausado para comunicar sus órdenes, se con. virtió en el más cruel y turbulento. Tres $\delta$ cua. tro ejccutores bien robustos, de su voluntad.se avalanzaron con sus macadras sobre la plebe, $y$ el mismo Vuna agarrada poco después una lanza que alli tenian para cambio, se mezcló entre los perseguidores con tanta crueldad, que hubienis mucrto á un plebeyo escondido en la proa, si nosotros no le hubieramos oportunamente refrenado. Faltó poco para que no zozobrase el bote de D. Antonio Tova por el mucho núnsero de los May. . que se habían salvado en él. La mayor parte se echaron á nado y cogieron sus canoas; y final. mente, Vuna, ya bien satisfecho al parecer de las muestras dadas, asíde su atención á nos. otros, como de su autoridad, volvió á tranqquili. zarse y se acercó á nuestra mesa, en la cual se hallaban también leileua, el ayo Latu y el hijo de otro Eije. Todos tres se resistieron al prin. cipio á comer por la consabida etiqueta de la presencia de Vuna; pero vencida esta dificultad. pudicron entregarse á satisfacer sus apetitos sin el menor sobresalto, y fueron diguos de reparo en aquella ocasión no solo la facilidad con la cual ambos muchachos aprendieron á comer con el mayor aseo, usando del tenedor y cuchillo, si tambićn la extremada atención de Vuna, el cual pedía permiso para tocar cualquier cosa y aun para escupir fuera de la cámara.

Se aproximaba entretanto el plazo prefijado para los bailes, $y$ Vuna hacia las tres de la tarde nos había precedido para disponer todas las cosas necesarias al intento. Así çuando próximamente á las cuatro y media nos acercamos con los botes á la playa (para evitar los rodeos de la tarde anterior) estuvieron prontas muchas canoas para conducirnos poco á poco al para je oportuno para desembareo, ya que el banco exterior de coral y la resaca bastantemente fuerte imposibi. litaban esta maniobra para los botes. Tomáronse pocas precauciones y bien sencillas para la seguridad común.

Como quiera que la falta del idioma y de un ecto conocimiento de las ideas sociales de cada uno, haga en estas ocasiones tan natural en los habitantes el deseo de frustrar la ventaja de las armas y de la disciplina á los recién llegados, como en éstos el déseo de frustrar á los otros la ventaja del número, sucede comunmente en semejantes concurrencias, que la menor equivocacion acarrea las consecuencias más serias, y que entonces sin consultar mucho las circunstancias, sólo se atiende á nrecaver los riesgos con anticipación al adversario.

Ya reunidos en la playa, nos dirigimos á saiudar á viına, el cual, como en la tarde anterior, se hallaba rodeado de muchas mujeres, siguiendo luégo á la parte interior del tingladito el cerco grande de las clases inferiores, y siendo fácil de distinguir entre ésta ${ }^{l} a$ de los Eijes subalter. uos, por su mayor inmediacion al Soherano. La música no era tampoco diferente de la que ya conociámos, si bien excediese ahora en el núr,ero de los cantores y en los vivas más alegres de la plebe, ciertamente no menor en número de I.80o á 2.000 personas.

A los of recimientos no extraños del cava, á la ratificación de nuestra amistad con Vuna y los demás Eijes y á las instancias no desaten 
Nay zr didas de las mujeres jovenes para que nuestra Oficialidad se sentase á su lado, siguiéronse inmediatamente los bailes prometidos. Los ejecutaban unos treinta hombres, la mayor parte de la clase de los Eijes, y no menos dispuestos por su agilidad que por la gallardía de sus personas, á dar mucho resalte á la escena. Cantaban al mismo tiempo acompañando la música de las cañas. La cabeza, los brazos y las piernas se movían con igual compás; una media risa, bien que varonil, las diferentes actit:ides de los ojos, la misma respiración modulada y concertada (digámoslo así) con la harmonia general, manifesta ban que no había fibra alguna en toda la máquina que no participase de! placer que á la sazón los ocupaba. A medida que el calor, la agitación y el hábito hacían más fáciles y más naturales los movimientos uniformes del baile, la música, penetrada casi de la misma sensación, aceleraba paulatinamente su compás, hasta que, llegada al mayor grado de celeridad, sin causar $\sin \mathrm{em}$ bargo el menor desorden, anim ba casi con igual grado de sensibilidad y de aleg' $\quad$ 's los demás espectadores. Variadas por du. ilas figuras del baile, y con ellas variada taiz..cin la música, debieron estos atletas entregarse por algún rato al descanso, no sin haber recibido de nuestra parte y áun de los demás espectadores los mayores elogios y palmeteos. No quedaba ya sino una media hora del día y aún no habíamos tomado pose. sión de las dos pilas ó pirámides de comestibles que veíamos inmediatas $\mathrm{y}$ sabiamos ser destinadas para nuestro regalo: pero esta atención, que debía ser de la mayor importancia, no lo era á la verdad para los den ás Oficiales, los cuales, cambiados ya sus nonbres con otras tantas jóvenes, convencidos mas y más á cada paso de su amabilidad, $y$ obviamente agotadas sus faltriqueras de cuanto tuviesen útil para el regalo, deseaban ahora ver desplegadas en un baile mujeril todas aquellas gracias y atractivos que anunciaban su trato familiar y el deseo de arradarnos. Condescendió Vuna inmediatamente á nuestras instancias, mandando que saliesen las mujeres al área; pero en esta ocasión estaba destinada á él y á nosotros una mortificación no mediana con la re. pugnancia de las mujeres en obedecer esta orden, impelidas tal vez, del reparo de no estar prevenidas de antemano ó más bien (en mi entender) de aquella ir destia común, de la cual decía el Tasso en su Aminta:

* Tu i dolci atti lascivi

Testi ritrosi, é schivi."

Nada extraña debía ser para nosotros esta negativa, y ya nos disponíamos á regresar á bordo; pero no lo fué así para Vuna, el cual en un momento, convertida de nuevo como en la mañana toda su mansedumbre en cólera y fiereza, y correspondido admirablemente por May. ฉt sus ayudantes, empezó á perseguir sin distin. cion hombres y mujeres, arwenazándolos con fuertes golpes si no corriesen con la mayor diligencia. Dos Eijes subalternos, debieron en esta ocasión esforzarse á contener la cóleı a de Vuna; desapareció el concurso, y aunque se juntaisen después hasta una docena de mujeres para bailar, fué esto ejecutado con tal frialdad y sobresalto, que ya no debíamos desear otra cosa sino ver cesado el desórden, y poder regresar á bordo con el auxilio de las canoas que nos condujesen hasta los botes. Este tránsito fué también peligroso, y D. José Robredo y D. Luis Nee, se hallaron aún más expuestos que los demás, pues el conductor les amenazó con conducirlos á otra parte ó aventurar su vida en el mar, si no le cedían un pañuelo, á lo cual puedu bien. imaginarse que no tardaron en condescender.

Ya reunidos á bordo, y bien satisfechos no tanto del fin como del principio de las diversiones anteriores, nos dispusimos á continuar para la mañana siguiente las tareas emprendidas; $y$ no pareciendo inútil una confrontación metódica, así de los progresos hechos en el idioma como de los diferentes grados de autoridad y amabilidad que habíamos advertido en los Eijes subalternos, D. Antonio Tova previno á los que debían seguirle en la dirección de las lanchas, que era mucho el concurso de los naturales, y éstos se hacían sumamente importunos en solicitar regalos; que no había Eije alguno de mucha autoridad, $y$ que se precaviesen particularmente, de una vieja, la cual solía arrimarse y entretener, ya á uno, ya á otro, con mil caricias, of recimientos y ademanes, para que otros al mismo ticmpo le vaciasen las faltriqueras.

Tuvimos la noche con exceso tranquila, y las primeras claras del día siguiente pusieron ya en movimiento las lanchas para la aguada, las cuales iban confiadas á los Tenientes de navío Don Juan de la Concha y D. Francisco Viana. Por nuestra parte nos disponíamos ya á concluir la habilitación del observatorio sin omitir los demás trabajos emprendidos á bordo, cuando antes de las siete nos sorprerdieron Vuna y Feileua en una $y$ otra corbeta, llevando cada uno la mitad de los comestibles acopiados en la tarde anteriol' para nuestro regalo.

Fueron correspondidos más bien con generosidad, y la amistad recíproca pudo ya conside. rarse de nuevo como sólidamente arraigada.

No faltaron de allí á poco diferentes causas uccidentales, que podían haberla quebrantado. Vuna, concluídas sus ofrendas en la DescubierTA pasó á bordo de la ATrevida, sin duda con el ánimo de solicitar nuevos regalos; por desgracia la centinela, la cual tenía orden de no dejar entrar natural alguno, se opuso á sus deseos, 
N1.1y. 23 sin que pudiesen luego (como era natural) en-tenderse uno ni otro en la exacción terca de su opinión. Esto bastó para que Vuna empezase á volver á sus antiguos enojos y para que manifestasen sus síbditos presentes, que hallaban en esta ocasión la majestad sumamente ultrajada. Pero el aparecimiento de un Oficial logró en fin disipar la contienda, y recibido inmediatamente á bordo, pudo Vuna poco después llamarse casi feliz por los ultrajes recibidos, ya que le acarrearon el regalo de algunas quincallerías de mucha estimación.

El trabajo de suavizar el risco destinado para el observatorio, había en el entretanto progresp do mucho; condujéronse alli al joven Tufoa y al otro Eije Dubou, los cuales evitaron el arrimo. de los demás. Pudimos así para el medio dia ver enteramente vencido aquel objeto, $y$ sistemadas

- la fragua y la barraca en que debían custodiarla.

Tanta variedad de objetos, y el número no menor de $3^{\circ}$ personas que estaban actualmente ocupadas en los diferentes destinos indicados, no podían ménos de atraer á Vuna hacia aquel paraje; ni á la verdad, aunque no le moviese estímulo alguno de curiosidad, podia presentársele ocasión más favorable para distraer algo más su ociosidad perenne, satisfechos en el día sus de. seos 6 á lo ménos sus esperanzas en cuanto á regalos, nada inquieto sobre la calidad ni sobre el plazo de sus comidas, $y$ sin otros juzgados que lcs producidos por nuestras quejas sobre algún robo, el cual, en su sentir, terminaba con igual equidad, $\leq$ Jen pasase á sus manos la prenda robada si el la rrón lograba ocultarse, ó éste perdiese la vida si lo aprehendíamos, podía dividir tranquilamente sus horas entre el sueño, el reposo y las bebidas del cava. Admirando atentamente y con aquella estúpida admiración de los pueblos no civilizados, todas nuestras obras y utensilios, nos confirmó que no había cono.. cido al Capitán Cook en ninguna de sus visitas á las islas más meridionales. Traía al mismo tiempo consigo una mujer de la plebe, que ofrecí con la mayor eficacia para nuestro uso, pero manifestado por nosotros un cierto enfado, mitigó sus súplicas, refiriéndose solamente á los trabajadores; y persuadido últimamente á de. sistir de aquella idea, no tardó en despedirla, consolándose muy luego con sentarse en las in. mediaciones de la fragua y distraerse con algu. nas tazas de cava miéntras concluíamos la obra emprendida.

Era para esto la última parte la de sistemar una guardia, la cual, no sólo contuviese la idea de cualquiera robo, si también no trastcrnase por si las medidas introducidas para las corbetas. Se puso á cargo de los sargentos y condestables de entrambas corbetas para que turnasen por cada día con cuatro soldados: en la noche debían pasar la palabra con las centinelas; debian avisar May. 23 á la Atrevida cualquiera novedad, pues no dis. taba de "i sino un cable escaso; finalmente, un depósito regular de armas y municiones y la misma situación del puerto, les daban lugar á defender la fragua é instrumentos mientras se les enviase socorro.

No parecieron indiferentes estos prepurativos á Vuna: preguntó por el objeto de aquellas armas: prometió solemnemente que ningún natural se aproximaria por esos contornos, y desde luego él mismo solicitó el permiso para que uno de la plebe le trajese algunos frutos y un poco de cava. Procuramos, por nuestra parte, disiparle cualquiera sospecha, manifestándole que nues. tras gentes no ofenderían en modo alguno mientras no se intentase robar ó aproximarse de no. che al observatorio; y para que depusiese con mayor seguridad cualesquiera recelos, le prome. timos que en una tarde de las inmediatas toda la tropa haría un ejercicio de fusil con fuegos en las playas próximas á la ranchería. Era ya la hora de regresar á bordo: admitió Vuna nuestras instancias para que nos acompañase á comer $y$ le siguieron igualmente los dos Eijes Dubou y Tufoa.

Los cambios á bordo habían sido más bien escasos aunque el concurso de la plebe fuese realmente excesivo: los cuchillos y navajas conservaban un valor regular: despreciábanse por lo común los côiales y abalorios; y al contrario las bayetas, toda especie de ropa y particularmente los granates habían adquirido un valor cuantioso; divididas al mismo tiempo las ocupaciones de los naturales y nuestras, ó en procurar el robo de cualquier friolera ó en evitar que lo consiguiesen. En este contraste de intereses resultaron sieınpre aventajados los naturales, porque era imposible precaver todos sus ardides, y porque áun desqubierto el delito, apenas podiamos contar con la estitución de la prenda robada, no pudiendo mirar con indiferencia la pérdida de la vida del agresor que Vuna y los demás Eijes nos of recían con el mayor sosiego. Ne tardó tampoco en llegar la ocasión en la Descubierta de que se explayasen con mayor evidencia aquellas verdades: uno de la plebe fué cogido con un martillo robado á la maestranza, que trabajaba á la sazón en los guardamesas de las jarcias mayores; corrió la voz inmediatamente: Vuna, que á la sazón se hallaba á bordo, pronunció sin la menor alteración la sentencia de muerte, despidiéndose inmediatamente dos emisarios para ejecutarla en el castillo de proa, en donde se hallaba el delincuente: fueron testigos nuestros Oficiales así de la fiereza con que los emisarios alzaron sus macanas para vibrar el fatal golpe, como de la humillación con que el delincuen. te se dispuso á recibirlo, puesto de rodillas y des- 
May. zs cansada su cabeza sobre las manos cruzadas que tocaban humildemente el solo: suspendieron in mediatamente, como era natural, ia triste ejecución de la orden, no sin extranar así la terquedad de los emisarios en quererił llevar á debido efecto, como la indiferencia de Vuiia sobre la suerte de sus vasallos.

La comida de este día, á la cual como ya se dijo, habiamos convidado á Vuna, debía condu. cirnos á desenvolver una nueva parte considerable de los ritos y costumbres de aquellos pueblos: Vuna, ya familiarizado con nosotros, pidió que le trajesen stu comida: se componía de una especie de pasta de raices, sobre la cual el sirviente echaba oportunamente una salsa com. puesta de algunos jugros y del agua de coco, y de un pescado no bien asado entre las hojas que le envolvían: las hojas frescas del corifa suministraban luégo modificadas en diferentes modos, ya los platos, ya la cuchara, y el mismo sirviente, dividida en partes proporcionadas la comida, tenía después á su cargo el conducirla hasta la boca del indolente Vuna, tomando todas las precauciones que pudiese dictarle el recelo de en. suciar los manteles y cuanto le rorleaba: despedido el sirviente después de haber recogido con mucho asco los resíduos de la comida, fué llama. da sin perder tiempo una ruujer de la plebe, cuyo cuidado fué antes el de satisfacer la sed del Soberano con un coco lleno, y después el de descortezar con sus dientes algunos trozos de caña dulce, que ya limpios y subdivididos, pasaba á la boca de Vuna: satisfecho á la sazón el Monarca del papel grandioso que creía explayar á n:ıestra vista, y no omitiendo una seriedad y una majestad que apenas les permitían abrir la boca cuando veía próxima la comida, debió por estas mismas causas ceder muy luégo á los impulsos del sueño, á los cuales procurábamos coadyuvar por nuestra parte, of reciéndole que se tendiese sobre los cojines inmediatos: lo hizo así sìn que fuesen necesarias muchas súplicas, $y$ entonces, como aún no se hubiese retirado la mujer que le había servido la última parte de la comida, le insinuamos que acabase de conciliar el sueño á su Soberano con el acostumbrado tuque tuque 6 percusión suave y acelerada de las manos cerradas, en los lomos y muslos del durmiente. No eran precisas tantas precauciones. Los cuidados del alma no interrumpian las series de las funciones animales; $y$ así Vuna casi en un mismo instante se acostó y quedó dormido; dejándonos en la restante comida con la sola compañía de Tufua y Dubou, quienes algo recatados al prin. cipio sobre la precisa etiqueta de no comer á la vista del Monarca, habian después insensiblemente adquirido una mayor confianza para ocu. narse solamente dei alimento.

Los vasos y botellas de cristal y los diferen. tes utensilios de loza, eran sin embargo un in- \$lay. 23 centivo demasiado fuerte para que el sueño de Vuna durase por largo tiempo: despertó efectivamente antes que nos sirviusen el café, y ya mucho ménos aletargado, manifestó fijar particularmente su atención en algunas bagatelas de las que estahan sobre la mesa, explayando en esta ocasión un respeto y una atencion igua. les al deseo que tenía de poseerlas: no omitió tampoco para este conseguimiento el arma que con justa razón debía creer la más eficaz para nosotros, y era una nueva instancia para que usásemos de las mujeres, añadiéndoles ahora con un chiste y una eficacia realmente agradables, que condescendería enhorabuena á que uno ú otro desechase agriamente sus propuestas, pero que por esto no debían dejar de admitirlas los demás Oticiales, los cuales señalaba uno á uno recorriendo en torno los comensales.

Esta chanza realmente divertida no dejaba sin embargo de refluir hacia los depositarios del buen orden un carácter realmente ignominioso, particularmente en un país donde todo convidaba al placer, $y$ en donde no se conocía otra lev' á lo ménos por lo que toca á la clase de la plebe, sinola que indicaba el Tasso para el siglo del oro.

La legge aurea, e felice,

Che Natura scolpi: S.e ci piace ei lice. am.

Lo cual dictó un ardid que no dejó de sumi nistrar nueva materia á las chanzas, y que nos fué al mismo tiempo útil en los días sigujentes. D. Juan Rabenet, en una de aquellas horas en las cuales el espíritu oprimido del navegante y la idea siempre varia del pintor, necesitan de un cierto alivio y distraccion, se habia ocupado en representar con mucha propiedad, una mujer dotada de todas las gracias personales que más comunmente solemos admirar en nuestra Europa, y vestida luégo á imitación de las Panameñas y tendiria descuidadamente sobre una hamaca, formaba un conjunto de imágenes, en el cual admirábamos á las veces la pródiga . mano de la Naturaleza, y á veces recordábamos la triste soledad del navegante: presentado este cuadro á Vuna, dijímosle que era el retrato de la mujer de uno de nosotros; que semejantes á aquélla eran las de los demás Oficiales; que no nos seguían, porque considerábamos los trabajos del mar demasiado sensibles para su delicadeza, y que ahora nos disponíamos á navegar directamente hacia el paraje donde las habíamos dejado, con el justo deseo de no separarnos otra vez de su amable compañía. La saludo inmediatamente Vuna con el acostumbrado contacto de las narices, examinó después una por una sus facciones, sus trajes y sus adornos, y á medida que las iba comprendiendo, crecía su admiración $y$ el elogio que hacía de la persona alli represen. 
argo un in- May. 23 el sueño de ertó efecti. 1 café, y ya 6 fijar par. sagatelas explayando encion igua. s: no omitió el arma que $s$ eficaz para cia para que ndoles ahora e azradables, a que uno ú puestas, pero dmitirlas los ba uno á uno.

a no dejaba positarios del ignominioso, todo conviocía otra le: e de la plebe, siglo del oro.

lice. am.

ej6 de sumias, y que nos días siguien. : aquellas ho jido del nave intor, necesi ión, se había ia propiedad cias personaadmirar en imitación de amente sobre de imágenes, es la pródiga. recordábamos esentado este el retrato de semejantes á iales; que no is los trabajos u delicadeza. 'egar directa. labíamos devararnos otra udó inmedia contacto de por una sus y á medida u admiración alli represen
Mny. as tada; pero no podian ser éstos los límites de los deseos de un hombre acostumbrado á una autoridad ilimitada y reducido á los solos goces que suministra la Naturaleza. Propuso su deseo de conocerla, se siguió muy de cerca el de poseerla, anduvo inmediatamente pródigo con of recer en su cambio cuantas mujeres quisiésemos de las Islas de Vavao; finalmente, reconvenido por nosotros de la imposibilidad de llevar á ef ecto estos contratos, propuso como una feliz ocurrencia, el que Feileua viniese con nosotros para casarse en Europa, y condujese al regreso algunas mujeres con las cuales él también pudiese casarse, pareciéndole ya despreciables y no decuadas al tálamo real, las mismas hijas del difunto Paulajo, que nosotros, á la verdad con mucha razon preferíamos infinitamente al objeto imaginario de la pintura: no fué ésta tampoco la última combinación de Vuna para el conse yectado: nos manifestó que se decidiría él mismo á acompañarnos, y fué preciso un nuevo ardid para disuadirlo, valiéndonos para esto del aviso que no era permitido entre nosotros sino una mujer sola, aunque á veces habitualmente enfermiza 6 no constante en sus primeras inclinaciones; esta noticia, pareció moderar mucho sus de seos, ni debiamos sorprendernos que le pareciese extraña, cuando no estaban á su alcance los dulces lazos del instinto sociable que busca en la union de los sexos, no tanto un tributo poco duradero á los dictados de la Naturaleza, cuanto la felicidad de los hijos y el mútuo alivio en los inuchos males que cercan por todas partes á la vida humana.

Sumamente entretenido con estas conversaciones, y no descuidando al mismo tiempo hacer las posibles investigaciones sobre los dife. rentes ritos y costumbres de aquellos pueblos, lográbamos ya hacia las cuatro de la tarde de la satisfacción de ver regresar las lanchas de la aguada: un accidente extraño les había causado la demora de unas tres horas, bien que había sido últimamente útil para evitar mayores desordenes y para cerciorarnos del respeto y de la buena fé de los naturales: un marinero de la lancha de la Descubierta, reprendido acremente por el patrón y movido de una mezcla poco proporcionada de locura y de pundonor, había tomado el partido de desertar, llevándose un hacha y una pistola: esta determinación suya no conocida sino al momento de concluir la aguada y disponer el regreso de las lanchas, había precisado á entrambos Oficiales á exigir la restitución del marinero, con un tesón proporcionado al delito; ocultaban al principio ser sabedores siquiera de la fuga; manifestaban luégo una total ignorancia del paraje á do.rde pudiera haberse dirigido, y á veces aún parecía que creían tingido 6 sin consecuencias el natural enojo de nestros Oficiales: debieron éstos por consi. Hay guiente acalorar más sus medidas, reuniendo la gente nuestra en buen orden y protestando altamente que de ningán modo abandonarían aque paraje $\sin$ la restitución del marinero prófugo: esta declaración oportuna produjo un buen efecto; se destacaron inmediatamente muchos hom bres armajos, y después de un par de horas volvieron á aparecer conduciendo al desertor, el cual había pasado á la playa opuesta, sin sabe él mismo cuáles eran los objetos y cuál el sistema de su vida venidera, ó más bien cuáles serían los medios de regresar á bordo sin castigo alguno. D. Juan de la Concha recompens 6 pró digamente este importante servicio de los naturales, que dieron en aquella ocasión una prueba inequívoca de su buen corazón, in arcediendo con mucha eficacia á favor del marinero culpable: su castigo, áun sin esta atención, debió aminornerse mucho porque su edad y conducta pasada en los puertos de la América no daban la menor sospecha de una deserción derivada de causas premeditadas que ofendiesen la disciplina ó la religión; se le puso una cadena, y se le destinó dos días después en el bote armado que á las órde. nes de D. Felipe Bausá debía reconocer la parte interior del Archipiélago.

Aproximándose en el entretanto la noche, Vuna había pedido permiso para retirarse, y al contrario se habían decidido á pasarla á bordo los tres jóvenes Feileua, Tufoa y Latu: coacyivaron estos mucho a que las restantes horas hasta las once nos fuesen igualmente entreten:das é instructivas, pues ocupándose al principio en hacer varias habilidades con el cuerpo, semejantes á las de nuestros saltimbanquis, pasaron luégo á una serie bien entretejida de conversaciones, en las cuales nos fué fácil desenvolver una porción grande de sus costumbres y de los acaecimientos pasados desde la visita del Capitán Cook. Debimos sí extrañar en squella concurrencia, que traidales la cena de tierra, el ayo Latu prestase el homenaje acostumbrado á los piés de Tufoa, y que este jóven lo exigiese tambiên del niño Feileua, el cual según creyeron advertir algunos entre nuestros Oficiales, quiso más bien privarse de la cena que prestar á nues. tra vista este homenaje humillante á Tufoa.

Hasta entonces los tiempos se nos habian manifestado poco favorables para las tareas as. tronómicas, siendo por lo común nublados cuando reinaban fuera los vientos casi constantes del Es-Sueste al Es-Nordeste. La mañana siguiente nos fué aún más contraria con una lluvia incesante, la cual, sin embargo, ni detuvo á nuestras lanchas para que continuasen la aguadáa las órdenes de los Tenientes de navío Robredo y Quintano, ni retard6 un solo instante la venida á bordo, antes de muchos plebéyos y poco después del 
Nay. a mismo Vuna, al cual acompañaba ahora otro hermano suyo llamado Xavea, menor de edad y de un aspecto y carácter extremadamente apacibles. l'ué oportuna esta venida, porque echada de ménos una lantia de la bitácora casi en el mismo instante en que habian entrado los naturales, pudimos reconvenirle con algún enfado y áun exigir que saliese inmediatamente de las corbetas, cuya amenaza, como quiera que desconcertase en un momento todo su plan de enriquecerse, no pudo ménos de moverlo á dar las brdenes más estrechas para la restitución del robo y castigo del delincuente.

Se logró inmediatamente el primer objeto y aprehendido el reo en la playa inmediata apenas alcanzaron todas nuestras súplicas para evi. tar el castigo, el cual, según nos manifestaron, debía ser precisamente el de muerte. A cada momento Vuna y los Eijes inmediatos nos instaban con la mayor eficacia á que no tuviésemos escrúpulu alguno en matar á todo ladrón: nos recordaban con este motivo los castigos del Capitán Cook en Annamoka, Happai y Tongatabu, y nos aseguraban que semejantes medidas en nada trastornarian la paz y quietud establecidas.

Adelantado ya mucho el día y recorridas según costumbre entrambas corbetas por Vuna y Feileua con nuevos tributos de nuestra parte al deseo de una concordia duradera, nos manifestó aquel Jefe que no se agotarian tan pronto sus ardides para el contínuo incremento del tesoro empezado: le vimos ahora aparecer de nuevo á bordo de la Descubierta, acompañado de unas doce jóvenes, la mayor parte reunidas á la familia real $y$ todas primorosamente adornadas con flores frescas en forma de collar, y con el acostumbrado ( $I$ ) aceite en la parte superior del cuerpo. Les seguían unas tres viejas, comprendiendo entre ellas la Dubou, hermana de Vuna; lleva. ban todas consigo algunas frioleras para regalo, y precisadas á sentarse unidas en paraje visible, entonaron suavemente sus cantos no descuidando medio alguno de hacerlos más agradables con la harmonía y con los movimientos: era la Dubou la que dirigía el coro, la que insistía con mayor eficacia sobre la continuación del canto, y la que manifestaba, aunque anciana, la mayor sensibilidad y ternura en sus movimientos: ni á la verdad era inútil semejante maestra ó directora, porque las jóvenes interrumpían á cada paso el canto, llamando á los Oficiales con quienes habian cambiado nombres con mucho cariño, con mil chanzas agradables y llenas de decoro, y con todos aquellos sobresaltos que dictan á cada paso entre los jóvenes de ambos sexos las celos, el

(1) Usamos varias veces la voz acostumbrado, por no repetir con demasiada frecuencia todo lo que est prolijamente escrito en los viajes del Capitán Cook y de Mr. Forster. enojo y el cap:icho. Las flores, los peines, la: 'tuy." flautas y una ú otra estera de poco valor se re. partían luégo prudentemente y con todas las gracias del capricho; finalmente, si hubiese alguno sordo, aún á todos aquellos atractivos, se dirigian á él particularmente las miradas, las modulacio. nes y las palabras más tiernas y expresivas del canto. Puede imaginarse que nuestros dones no fueron en aquella ocasión mezquinos, ni pocas las instancias para que despues de satisfecha su curiosidad con la vista de las cámaras, camaro. tes y entrepuentes, se retiraran á tierra y nos de. jasen comer tranquilamente con los jóventes Feileua y Tufoa, ya que Vuna había deterininado el comer con D. José Bustamante en la ATRevidA.

En aquella corbeta debian á la sazón considerarse mucho más felices que nosotros, si se atendiese al progreso más rápido y más claro de los conocimientos fisiológicos: las conversaciones con Tufoa en la noche anterior les habian dado mil nociones importantes sobre los efectos de las visitas del Capitán Cook en el Archipiélago, y sobre los acaecimientos en la Isla de Kao de la lancha del Bounty á las órdenes del Capitán Bligh. D. Ciriaco Cevallos había adquirido nociones importantísimas sobre el idioma, y estrecha. da la amistad con el Jefe 6 Arrae $z$ de una embarcación recién llegada de Tongatabu, iba desenvolviendo muchos puntos relativos á la historia, á las costumbres y á la religión de esos pueblos; finalmente, los acopios para las campañas y los aprestos del buque y del aparejo, no eran en nada inferiores a la celeridad con la cual continuaban en la Descubierta.

Nuestra aguada fué también feliz, pues no sólo hubo en ella ei mayor orden y tranquilidad, sino que se consiguió la restitución de un hacha que los naturales habian robado y ocultado ya en un paraje bastantemente distante.

No aparentaba mucho más favorable del anterior el día 25 , por lo que toca á las observaciones astronómicas: los aguaceros contínuos hacían aún molesta la continuación de la aguada á las ordenes de los Tenientes de navio Novales y Cevallos, y se agregaba ahora á estos inconvenientes un viento fresco arrafagado del Sursueste, que contra nuestras espectativas levantaba alguna mar en el fondeadero; sin embargo, eleván. dose más el Sol sobre el horizonte, no tardaron después en disiparse esos amagos, y á sucederle el día más placentero que hubiésemos conseguido hasta entonces: no tardaron en transferirse a observatorio D. Juan de la Concha y D. Fernando Brambila para atender cada uno álos objetos interesantes que debían abrazar. D. Felipe Bausá, con la escolta del joven Tufoa, emprendió el medir una base y hacer marcaciones relativas nuestro fondeadero en la misma playa de la ran. chería, y la tropa de entrambas corbetas tuvo or. 
s peines, 18: day." valor se re. odas las gra. biese alguno s, sediriglan s modulaciospresivas del ros dones no os, ni pocas satisfecha su ras, camarorra y nos de. jóvents Feiterminado el a Atrevida. sazón consi. sotros, si se más claro de onversaciones habian dado efectos de las chipiélago, y de Kao de la del Capitán quirido nocioa, $y$ estrechale una einbar. u, iba desená la historia, esos pueblos; impañas y los ) eran en nada l continuaban

eliz, pues no tranquilidad, I de un hacha ocultado ya te. rable del anas observaciotínuos hacían aguada á las Novales y Ceinconvenienel Sursueste, vantaba alguargo, elevánno tardaron y á sucederle 10 conseguiransferirse al y D. Fernan. álos objetos Felipe Bauemprendió el es relativas á ya de la ranjetas tuvo or.
May. zy den de estar pronta para hacer en tierra y á la vista de Vuna algunas evoluciones militares, con tres 6 cuatro descargas de fusilería.

Alegráronse mucho con estas noticias as! Vuna como los demás naturales, y se dispusieron por su parte á correspondernos con unas diver. siones mucho mejor ordenadas que las de los primeros días: todo anunciaba en los rostros la alegría y unión reciproca que daba lugar á estos regocijos públicos, y Vuna y Feileua no se habian descuidado antes en ofrecer dos puercos y luégo en acompañarnos al sitio de la fragua y observa. torio en donde nos hablamos transferido: manifestó entonces con menos rccato el deseo de las hachas, $y$ no fué poca su satisfacción cuando le prometimos regalarle una, pues no traíamos las bastantes para hacerlas un efecto de cambio. Comió luégo en la Arkevida recomendando particularmente al Capitán de la embarcación de Ton. gatabu, del cual parecía hacer un aprecio extre. mado: nosotros tuvimos á lieileua $y$ Tufoa, el primero tantas veces vestido, como luégo despojado por su padre cuando llegaba á tierra, el segundo siempre pronto á dar cumplimiento á nuestros deseos, con una autoridad y un despejo que parecían difíciles de conciliarse con su edad $y$ su clase subalterna.

Llegada la hora que debía dar principio á las diversiones, $y$ enviada de antemano la tropa bajo la dirección de D. Francisco Viana y D. Jacobo Murphy para que la conservasen unida y en buen orden; nos dirigimos con algunos Eijes y el mismo Vuna, al paraje destinado.

Inadvertidamente nos habíamos armado casi todos á un tiempo y á la vista de los naturales; y esto, aunque ni fuese extraordinario ni nuestras armas se redujesen sino á poca.s pistolas y sables, combinados sin embargo con las fuerzas ya respetables que teníamos en tierra, fué inmediatamente prevenido á Vuna, y le causó todo aquel sobresalto y desconfianza que eran bien naturales: procuramos disiparlos lúgo que llegaron á nuestra comprensión, pero eran vanos nuestros esfuerzos $y$ apenas este Jefe se consideraba seguro bajo nuestra escolta. A este mismo temor debimos atribuir poco después el nuevo obsequio que se nos hizo de desplegar una larga alfombra desde la orilla hasta la casa del cava, en la cual, dei mismo modo que en los dias anteriores, estaban ya unidas las mujeres acostumbradas, señoreándose entre ellas la hija de Paulajo, mujer de Vuna.

Ya dispuestos los espectadores en el cerco consabido, empezó nuestra tropa el manejo del fusil. Eran generales los aplausos en cada movimiento uniforme. Sobresalían aún más en las vueltas a derecha é izquierda, en las marchas de frente y en los diferentes modos de desplegarse en batalla. La hermosura de la tarde, el brillo del Sol sobre las armas, la mezcla agradable á l'ay. zs veces de un total silencio, á veces de unos cla. mores generales y harmoniosos, el mismo sitio ameno en el cual nos hallábamos, daban á la escena un no sé qué de grande y majestuoso. Las res descargas que se hicieron después de diferentes modos, alarmaron mucho, particularmente á las mujeres, á pesar de que las hubiésemos prevenido de antemano y que la tropa diese el frente al mar en cada descarga.

Concluido aquel espectáculo con la satisfac. ción general de los naturales, inmediatamente se retiró la tropa á los botes que estaban umarrados cerca del arrecife, $y$ esta providencia, al paso qne disipó en el ánimo de los espectadores cual. quier recelo, dio lugar á que con mayor salisfac. ción emprendiesen luégo los espectáculos prevenidos.

La música fué la primera que ocupó el cen. tro del área; Xavea, el hermano de Vuna, tocaba el palo hueco; le acompañaban, ó más bien, seguían, la caña rajada y los bombones, y sobre su compás cantaba harmónicamente un coro de 32 hombres. Cedieron éstos luégo su lugar á unos 60 hombres, que divididos en dos bandos, figuraban una batalla. Para no alarmarnos en modo alguno, habían sustituído á las macanas, remos cortos, y otros palos pequeños. No omitían el canto ni el compás; pero precipitados poco á poco uno y otro, á medida que la mayor proximidad, los ademanes más violentos y tal vez más irritados, las mismas palabras del canto, enardecian con más furorá los combatientes: finalmente, se estrechaban, $y$ sin abandonar las filas ni entre. mezclarse los dos bandos, convertían su estudio en buscar una posición que les permitiese vibrar el propio golpe y evitar el del enemigo. Fra co. mún en este trance repetir todo el banto las cortas voces que entonaba su conductor; pro. curar con movimientos rápidos de la cabeza, que se encrespasen los cabellos, embijarse la cara con la tierra amarilla que encontraban, y va. riar á cada paso de posición, ya como fugitivos, ya como perseguidores: en todos estos choques se hacia particularmente digno de atención uno de los caudillos, el cual, en un momento, con. vertía todas las muestras del furor más vivo en otros tantus ademanes, más bien propios de un arlequín 6 de un payaso, causando así frecuente. mente la risa de los circunstantes, con repetidas muecas que dirigía á unos y otros.

La violencia de los movimientos no permitía que durase por largo tiempo esta diversión. Le sustituyó inmediatamente un baile de los hom. bres, cuyo número no era menor de cuarenta, $y$ cuya clase, era en nuestro entender, toda de Eijes. Bailaron por largo tiempo, cantando ellos mismos $y$ dando diferentes vueltas alrededor: de la música instrumental. El placer, la harmo. 
May. as nia, el obsequio y la agilidad sobresalian casi con emulación. Doblaban el cuidado y la habilidad cuando desfilaban delante de nosotros, y las ideas reunidas de la robuste\%, del placer y de la tranquilidad interna, nos recordaban á cada paso una viva imagen de la edad del oro.

Pero estas ideas debian luégo ensancharse mucbo más y causarnos un grado de admiración superior á cuanto habiamos visto é imagina. do hasta entonces; cincuenta mujeres, la mayor parte de las Liguís y casi todas jóvenes, salie. ron al área y se dispusieron á emprender un nuevo baile. Al paso que la modestia y el pudor las contenian algún tanto al principio y que atentas á la mejor compostura de sus trajes no desmentian el intento de agradar, la música compuesta ahora de un coro numeroso de hombres y la alegria universal que penetraba igualmente a todos, las incitaba á no perder momento. La sola hija de Paulajo y mujer de Vuna, se abs. tuvo en esta ocasión de manifestarse al público. Sus hermanas y las demás principales que nos habian visitado á bordo, todas estaban comprendidas en el cerco. La Dubou, hermana de Vuna, parecia la maestra. No desdeñaban las mujeres más adultas mezclarse con las más jóvenes, $\mathrm{y}$ aún no había empezado á avivarse el baile, cuando cra ya preciso formar un segundo cerco exterior para que pudiesen bailar todas con alguna comodidad.

El compás, las figuras y el paso, no eran diferentes de las de los hombres, ni diferían mucho el vigor y la sensibilidad que ahora sobresa. lían. Pero cuando en lugar de estas propiedades casi innatas en aquellos pueblos, se atendiesen las gracias, la dulzura y aquella agradable son. risa, que tan propia de la mujer descubre al mismo tiempo la voluntad, la modestia y los adornos del rostro, la escena á nuestros ojos va. riaba mucho de semblante, $y$ nos representaba más bien los templos de Gnido y Amatunta que el pobre asilo de unas naciones al parecer incultas y siempre infelices. No faltaban tampoco entre unas ú otras de las más jovenes aquellas miradas preferentes, que mezcladas con el antojo y la publicidad, deciden en nuestra Europa de la suerte del corazón de los hombres. El enfado, los celos, el amor y el pudor parecían disputarse entre sí la posesión del rostro. Al aproximarse bailando en torno hacia aquellos á quienes querían dirigir más de cerca sus cuidados, se paraban algún tanto, explayaban en los pasos nuevas habilidades, las acciones parecían más expresivas y el canto más sonoro. Se les véia un momento después, despertadas casi de las ideas que las distraian, esc. ?t $^{2}$ tr $y$ seguir la música con la mayor atención y entregarse trias a la agradable elasticidad de las fibrar." Entonces acelerába el compás, los movimientos más vivos disipaban la languidez de los ojos, todo respira- May, as ba el placer; y no sólo los espectadores, sino Ia misma Naturaleza parecía tomar parte en esta escena tan agradable.

Varios objetos debian á la sazón distraer la atención nuestra para que la narración de estos liechos no careciese de la exactitud posible. Eran éstos en primer lugar, una mujer bastan. temente anciana, que fuera de las filas y con mil ademanes burlescos, imitaba al payaso ya advertido en el baile de los hombres; en segun. do lugar, las niñas de una edad áun menor tie seis 6 siete años procurar imitar y envidiar casi á las más adultas la agilidad y expresión con las cuales bailaban; finalmente, la igualdad y el compás, que dependían, al parecer, del número determinado de repeticiones del canto, y que anunciaban con bastante seguridad que eran frecuentes estos entretenimientos, aunque tal vez no tan solemnes y generales como en el día.

La continuación no interrumpida de estas diversiones, habia ya ocupado casi toda la tarde, y sin embargo, era tal la satisfacción general, que si bien cansados, no cesaban aún de saltar, ya por una, ya por otra parte los hombres, $y$ Vuna, complacido, solicitaba ahora que viésemos bailar una de sus niñas. No fué ménos divertida esta vista para nosotros: tal era la agilidad y la resistencia que se veían explayar; mas aproximándose ya la noche, nos dispusimos á regresar á bordo, prevenidos con algunas frioleras que dejasen contentos á nuestros conductores de las canoas, para no exponernos enteramente á su albedrío.

No habían sido ménos felices los Oficiales destinados á la aguada y al observatorio. Se ha. bía establecido por las alturas correspondientes una primera época que sirviese para la deducción de la longitud, el nuevo examen de la marcha de los relojes, y las experiencias de la gravedad. La longitud determinada al observatorio por este método, fué la siguiente:

Longitud oriental del puerto

Jackson.. . . . . . . .

Resulta (según nuestras su-

posiciones) la longitud oc-

cidental de Cádiz. . . . . 167.40.35 167.36.09

Para la determinacion del cronómetro $7 \mathrm{I}$, fue preciso adoptar el movimiento que habla indicado la última época en el puerto Jackson; pero si bien de este modo se aproximasen mucho sus re: sultados á las últimas observaciones de las dis. tancias lunares, parecib siempre preferente el número II, cuya marcha se conservaba exactamente la misma: se aproximaba mucho á esta determinación la del reloj ros de la ATREvida: discrepaba al contrario en una cantidad fuerte el cronbmetro 72 . 
todo respira. May. as adores, sino parte en esta

In distraer lo -ibn de estos tud posible. ujer bastan. tilas $y$ con al payaso ya s; en segun. un menor is envidiar casi esión con las ualdad y el del número anto, $y$ que que eran fre. que talvez no el dia.

de estas di-

oda la tarde, ción general, ín de saltar, hombres, $y$ que viésemos nos divertida agilidad y la is aproximán. á regresar á leras que deatores de las amente á su

los Oficiales torio. Se ha. espondientes la deduccion la marcha de la gravedad. torio por este

Cron6m. 7x.

$34^{\circ} 51^{\prime} 24^{\prime \prime}$

$167 \cdot 36.09$ metro 71 , fue aabía indicakson; pero si nucho sus rede las dis: erente el nú. exactamente ista determiDA: discrepa. rte el crono.
May. os Ni habia sido ménos activo D. Felipe Bausá, pues conciuido el plano de la bahia, ya se disponia para la mañana siguiente á navegar en el bote de la Descubierra al reconocimiento de los ca. naies y fondeaderos interiores: se ofrecío Tufoa á acompañarle. Vuna quiso presenciar el método nuestro de hacer la aguada, y efectivamente, poco después de la salida del Sol, las lanchas, á las ordenes de los Tenientes de navio Espinosa y Pineda, y el bote á las brdenes de IBausá, dieron la vela para aus destinos.

El conseguimiento de las observaciones para la latitud debió también parecernos tanto más agradable cuanto que en realidad eran pocas las ocasiones favorables para la Astronomía, siendo aquellos contornos casi contínuamente cargados de vapores. Por algunas alturas me. ridjanas á una y otra parte del $Z$. D. Juan de la Concha la dedujo de $18^{\circ} 38^{\prime} 45^{\prime \prime}$, y los tiem. pos sucesivos manifestaron evidentemente que no habian sido infructuosos sus cuidados para este tin.

Procedian al mismo tiempo, uniformes y con una actividad correspondiente, nuestros aprestos interiores: se enriquecían dialiamente las colecciones de todas especies para el Real Gabi. nete: D. Tadeo Heenke había dedicado ahora su estudio principal al conocimiento de las aves y de los peces, los cuales hallaba en mucho nú. mero $y$ variedad y aún no bien conocidos en las descripciones naturales publicadas hasta aquel tiempo: en lo que si debíamos extrañar alguna escasez, era en la adquisición de puercos, Jos cuales veíamos siempre en poco número, y puestos decididamente al alto precio de un hacha por cada uno. Esta falta, sin embargo, se reemplazaba con una cantidad crecida de gallinas, y de toda especie de raíces, plátanos y cocos, cuya utilidad en la conservación actual y venidera de los equipajes, era visible en cada dia y prometía un feliz término al viaje em. prendido. Las repetidas conversaciones con $\mathrm{Vu}$ na nos daban luégo lugar á estrechar diaria. mente nuestra amistad. Lográbamos veı̀ie bien enterado de la extensión de los dominios de $\mathrm{Su}$ Majestad, de sus fuerzas navales, de nuestro destino y de las visitas frecuentes que les ha. ríamos en lo venidero; correspondiéndonos por otra parte este mismo Jefe con las aseguracio. nes más positivas de la mayor fidclidad de parte suya y de Feileua; tidelidad en su entender tanto más ensalzada cuanto que se cuidaría mucho en Vavao de castigar los ladrones, siendo asi que en Happay, Annamoka y Tongatabu (según $n o s$ insinuaba con frecuencia) no encontraríamos ni igual legalidad, ni igual abundancia de comes. tibles. No eran menores nuestros progresos en las demás indagaciones que teníamos entre manos. El ayo Latu que solla pasar las noches en la Descubierta, satisfacía con la mayor proliji. May as dad y paciencia nuestras preguntas que á veces se dilataban hasta las once. En la Arrevida el Capitán de Tongatabu descifraba muchas contra. dicciones en lascuales velamos incurrir los natu. I'ales á cada paso. Los Eijes principales ya con más familiaridad nos entretenian hablándonos de los viajes del Capitán Cook, de sus Oficiales con quieues habian cambiado nombre; final. mente, de la lancha del Capitán Bligh y de los últimos acaecimientos de todo el Archipiélago confederado.

No variaron mucho las circunstancias en los a y y dos días siguientes, los cuales estuvieron constantemente nublados $\mathrm{y}$ con vientos bonancibles del Esueste al Este: se hicieron, sin embargo, las experiencias de la gravedad, esperando una poca favorable para determinar la marcha de los relojes: concluyeronse las obras interiores y los acopios de agua, y se destacó la lancha de la ITREVIDA á las órdencs de D. José Robredo para que al mismo tiempo sostuviese el bote de Bau. sá, y le auxiliase en las sondas y reconocimien. tos emprendidos: era muy cómoda para este último objeto la comunicación frecuente que tenia. mos unos con otros con el auxilio de los natura. les. Iil regalo mis frívolo bastaba para que con is us canoas se dirıgiesen inmediatamente á una y otras partes del Archipiélago. D. Felipe Bausá alababa constantemente las disposiciones activas $y$ carinosas de Tufoa, y su inteligencia de todo el Archipiélago, de modo que conduciéndole á un alto le hubiese manifestado la vista de un crecido número de islas y la dirección de otras mucho más distantes; encarecía luego en extre. tno la seguridad de los puertos, la amenidad de los campos y la hospitalidad de los habitantes; y aseguraba que para la tarde del 30 estaría reunido á las corbetas. Mucho insistía Vuna, á la sa$z$ zon, para que abandonásemos el fondeadero, en donde él mismo estaba incomodado por la estre. chez y distancia de la capital, y nos dirigiesemos á los interiores, en donde sus agasajos serían más proporcionados á sus buenos deseos. Mani. festaba al mismo tiempo el mayor empeño para castigar los ladrones, y efectivamente, había mandado que se diese luégo la muerte, á uno que cogi in en la ATREvida con el robo de un escoplo, le haila cchado maliciosamente al agua para que no le hallasen sobre su persona. Suspendi6 Don José Bustamante la ejecución de este castigo y le sustituyo el de cien azotes que le dieron los mis. mos Eijes, emisarios de Vuna, haciendo luégo (á imitación del Capitán Clerke) que se le rapa. se á navaja la cabeza como una señal indeleble del delito cometido.

Pero no podíamos perder de vista el estado de la expecision, de modo que evacuados los ob: jetos esenciales que nos habian conducido á 
Nay aquellas islas, no sacrificásemos un tiempo pre. cioso al solo aumento de pocas noticias, tal vez equívocas, 6 á lo ménos origen engañoso de al. gunos sistemas. Iistas reflexiones por si bastan. temente poderosas, aumentaron sil vigor mucho más en el día siguiente, en el cual, conseguida en el observatorio una serie bien satisfactoria de al. turas del Sol, se declaro viento fresco del SurSueste con mar bastantemente picada del mismo, de sucrte que no sólo se hiciese arricsgada la comunicación con la playa y el observatorio, si también debiese causarnos no poco cuidado la demasiada inmediación de las corbetas á la orilla, siendo así que el ancla de fuera estaba en 36 brazas, y su cable no podía considerarse segu. ro por las piedras 6 ratones que debiamos sospechar le fuesen inmediatos. Sin embargo, la lancha de la Descublekta á las órdenes de Don Irancisco Viana, hizo un nuevo viaje á la aguada, y el Comandante de la ATrevius, acompanaado de los Sres. Espinosa, C'evallos, Quintano, Brambila y Nee, emprendió con Vuna una ex. cursion realmente importante á visitar el sepulcro de Paulajo, último Soberano de la Isla de los Amigos, y particularmente conocido del Ca. pitán Cook, en su viaje desgraciado á aquellos mares. Los trances igualmente instructivos y curiosos que fueron las resultas de aquella excursión, han sido descritos con la mayor puntualidad por D. José Bustamante, y la copia de dicha narración inserta literalmente á continua. ción de estos párrafos, no desagradará seguramente al lector.

"Con grande empeño había deseado Vuna que las corbetas fuesen á fondear en las inmediacio. nes de Leyafú, donde habitaba. Su pretensión, en que unía á su propia utilidad nuestras ventajas, la esforzaba haciendo una pintura la más hermosa de sus contornos, y prometiéndonos una abundaneia de provisiones muy superior á la que teniamos donde nos hallábamos. Hubiera desde luego condescendido a sus instancias D. Alejandro Malaspina, si nuestras urgencias esencia. les no estuviesen ya remediadas, 6 si la escasez de refrescos nos obligase á buscarlos en aquel paraje.

"Sin embargo, Leyafú era un pueblo digno de nuestra atención, y la circunstancia de existir en él un monumento consagrado á la riemoria del Rey Paulajo, añadía un mayor motivo para nuestro examen. Vuna, á quien debiamos también esta noticia, se ofreció á acompañarnos sin que precediese de nuestra parte pretensión alguna, ya por una consecuencia en obsequiarnos, 6 porque esperaba con justicia lisonjear su vanidad en nuestra excursión á Leyafú. Las atenciones importantes del servicio y las circunstancias, habian dictado la providencia de que uno de los dos Comandantes no abandonase la inmediación de las corbetas, y consecuente á ella, dispuso May ag D. Alejandro Malaspina que yo me encargase de este viaje, acompañado de los Tenientes de na. vio, Espinosa, Quintano y Cevallos, el botánico Nee $y$ el pintor Brambila.

"Para la mañanita del 29, quedó fijada la sa. lida. lieileua, que nos había favorecido durmien. do á bordo la noche del 28 , fué á tierra tempra. no por la mañana á llamar á su padre, que llego poco después de las seis; le acompañaban cuatro de sus mujeres, inclusas la madre de este Prín. cipe y la favorita actual Fatafegi; número de personas con quienes no habiamos contado, $y$ que, atendida i: sapacidad del bote, hacian in. cómodo nuestro viaje.

* Nuestro único práctico de la derrota que ibamos á emprender, era el mismo Vuna. Desde que abandonamos las corbetas tomamos la costa de la izquierda, siguiendo por cerca de una hora al remo el mismo rumbo de las lanchas para la aguada. Doblada la punta Sur de esta costa 6 de la Isla de Vavao, nos dirigimos como al Nor. deste hacia el fondo de una ensenada, en cuyo punto veíamos la lancha de la Descubierta al Sueste muy cerca de la aguada. El poco viento que hasta aquí nos habia sido contrario del Este al Sudeste, cobrando alg una más fuerza por esta última parte, nuestros progresos empezaron á ser mucho más rápidos y á prometernos un tér. mino corto á la navegación que nos faltaba.

"Otra circunstancia debió contribuir no poco a hacer sumamente agradable nuestrr $\quad$ e. E1 encuentro de nuestra lancha y del : ls Descubierta á las órdenes de. D. Jose cuubredo y de D. Felipe Bausá, nos produjo toda aquella complacencia que necesariamente debian causarnos las agradables noticias que dieron estos Oficiales comisionados en las operaciones hidrográficas del Archipiélago. En el fruto de sus tareas habían tenido el feliz descubrimiento de dos fondeaderos excelentes, agua delicada y todas las islas vestidas con la misma 6 mayor frondosidad que la que admirábamos en la inmediata á las corbetas. Bausá nos informb de cuánta utilidad le había sido la compañía del Jefe Tufoa, no sblo para que los naturales se prestasen á cuanto deseaba, si también para dirigirle á las aguadas buenas y á las eminencias donde dominando los objetos, había conseguido el mayor grado de exactitud en sus trabajos y el nom. bre propio de cada una de las islas. Entoncies manifesté á Tufoa lo agradables que nos eran sus buenos servicios, y contase por mi parte con una buena recompensa al regreso á bordo. Pero sobre todo, las maravillas con que me pintaron entrambos Oticiales el lugar á donde nos encaminábamos, dieron ocasión para acelerar nues. tra despedida $y$ doblar nuestras diligencias para alcanzarle. Vuna á este tiempo destacó una ca- 
1la, dispuso May. encargase de entes de na. - el botánico

fijada la sa. ido durmienerra tempra. re, que llego ñaban cuatro le este Prín; número de s contado, y , hacian in.

derrota que Vuna. Desde imos la costa a de una hora lanchas para esta costa 6 como al Norhada, en cuyo scubIERTA al 1 poco viento rario del Este ierza por esta empezaron á ternos un téros fajtaba.

ribuir no poco stro e. El el 18 . Jose «uvredo toda aquella debían causarron estos Ofi. ones hidrográde sus tareas íento de dos icada $y$ todas nayor frondo-. la inmediata mó de cuánta del Jefe Tu. s se prestasen ura dirigirle á sencias donde eguido el ma. ajos y el nom. las. Entoncies nos eran sus mi parte con á bordo. Pero e me pintaron ade nos encaicelerar nues. ligencias para stacó una ca-
May, noa que seguía nuestras aguas para anunciar sin duda nuestro próximo arribo á Leyafú.

- En efecto, á las dos horas de navegación, desde el fondeadero llegamos á este sitio deli. cioso. Un crecido número de naturales de am. hos sexos salieron á recibirnos á la orilla. Como en este acto no advertimos ni la curiosidad estúpida de su carácter, ni la inquietud importuna que en tales casos acostumbrun, creimos fuese efecto de la veneración y respeto que les infun. día la presencia de su Jefe.

"Vencida una pequeña elevación que forma la ribera en donde desembarcamos, andados cien pasos salimos á un terreno llano rodeado y cubierto de árboles frondosos y encadenados, á cuya sombra defendiendo las fuertes impresiones del Sol en estas regiones, hacía una mansión la más deliciosa. A la derecha vimos luégo el sepulcro de Paulajo, y á la izquierda dos sasas, la una mucho mayor que la otra. Vuna nos condujo al interior de la más pequeña, por cuya arquitectura y decencia nos pareció digna para alojarle y por consiguiente fuese la en que habitaba.

"Catorce columnas de madera elevadas en la figura de un óvalo perfecto, sostenian todo el edificio; su techo bajaba en forma de tienda de campaña hasta una vara del suelo, acabando de cerrar este espacio por todas partes (excepto el frente reservado para la entrada) una estera de tina palma que fácil de mover en todos sentidos, se quita 6 se pone según el grado de luz 6 ventilación que se desea. La elevación de la casa por el centro pasaba de cinco varas, cuyo largo 6 mayor diámetro constaba de 30 piés y de I5 su ancho. La parte inferior del techo se formaba de maderas fuertes y primorosamente unidas entre sí; estas maderas bien curvas 6 la. bradas en la forma conveniente, daban á la casa vista por dentro, una figura cóncava, simétrica y regular. El pavimento cuidadosamente nivelado, se elevaba como pié y medio, cubierto de dos este. ras, la una que tocaba el suelo y otra más fina que la primera y sobrepuesta á ella. Entre las varias vigas que corrian de columna á columna para trabar y unir el edificio, se cruzaban cuatro per. pendiculares en el centro, formando un cuadro que sostenido por sus cuatro ángulos de igual número de pilares, servía á sostener cinco lanzas, tres mazas y otros instrumentos semejan. tes á los que usan en sus bailes, $y$ casi de la misma forma y dimensiones que sus canaletes. Estas armas, entalladas con un gusto y primor que no esperábamos del estado de las artes de estos pueblos, se hallaban carcomidas algunas de sus molduras y relieves, y el polvo que las cubría anunciaba su antiguledad y que no se usaban de mucho tiempo.

No comprendimos por la significación que nos dió Vuna de esta casa, los objetos á que estu. Mus...y visse consagruda; sin embargo, varios anteceden. tes nos condujeron á creerli comn un paraje des. tinado á la práctica de algunas de sus institu. ciones religiosas. Nuestros informes posteriores guiados por el nombre de Falcotui con que nos distinguió esta casa Vuna, no permitieron dudar que aquella voz equivalia á Casa de Dios, ni que su verdadero objeto era el mismo que hablamos sospechado. Vuna, desde el instante que entra. mos en esta casa, se sento y procuró mantenernos en la propia actitud. El pueblo, reunido y sentado eu la forma respetuosa que acostumbran, le advertiamos, como á su Jefe, penetrados de aquella profunda veneración que inspira á todos los hombres todo lugar sagrado; pero nosotros, sin conocer entonces el alto y piadoso objeto á que estaba destinado, le escudriñamos todo, y coineteríamos tal vez algunas irreverencias aunque disculpadas con nuestra propia ignorancia.

" Estaba construida esta casa en el centro de un pequeño recinto formado de cañas entreteji. das con artificio y elevadas más de doce piés. Cerraba la entrada una puerta cuadrilonga de madera, que girando sobre cuerdas en lugar de goz. nes, podía cerrarse dando vuelta á una tornaja fija al masco con un clavo de madera. Todo el espacio cerrado era llano, cubierto de verde y menuda grama; los árboles que lo rodeaban por afuera, elevados á una altura prodigiosa; sus fron. dosas ramas caían con majestad sobre este editicio rústico; finalmente, el arte y la Naturaleza parece se complacían en añadir medios de inspirar á estos lugares sagrados toda la veneración y culto que les rinden los naturales.

"Después que D. Fernando Brambila habia concluído el diseño de esta casa, pasamos á otra no distante, más capaz, pero construida bajo la misma fornia. Habitaba en ella una Dubou de quien varias veces nos habian hablado ccn vene ración los insulares. Todavía no sabíamos con certeza el origen y sucesión de la Corona de Vuna, quién fuese esta Dubou, cuál era el carácter que representaba en el día, ni por qué cau. sas gozaba de los naturales y aun del mismo Vuna una consideración que casi se confundía con la de su propia persona.

"Nuestras dudas se aclararon muy presto, unas alli mismo $y$ otras al día siguiente á bordo de la ATrevida. La Dubou era viuda de Paulajo y madre de Fatafegi y de Taufa. Feileua era hijo de la segunda, y no existiendo otro heredero que pudiese disputarle los derechos de la sucesión, recalan en él todos los de la Corona. No en vano estas dos hermanas eran el objeto de las ternuras de Vuna, á pesar de no verse tan favorecidas como otras de la hermosura, que es ordinariamente la razbn que mide el cariño entre los - pueblos bárbaros. 
May. 29 "La noble Dubou, con un semblante dulce $y$ majestuoso, nos recibió con tanto agrado como dignidad. Su aspecto, su compostura y hasta su color, todo la distinguía de los otros naturales, todo anunciaba la elevación de su carácter. Ad mití́ nuesiros presentes con una viva gratitud, la cual significaba añadiendo á las señales del semblante la expresión y ceremonia que acostum. iran. Ninguna de nuestras bagatelas la causó el asornbro que 台 los naturales, aunque más capaces de cau ivar el corazón de una mujer, ni su dignidad la permitió jamás de prostituire: : pedirnos una ú otra cosa de las muchas que le oresentábamos á sus ojos. El único antojo q:e le advertimos fué una botella y dos vasos de cristal de que nos serviamos; pero para ser consezuen. te en su conducta y tal ve $z$ no comprometerse una negativa, pidis á Vuna me interpretase sus deseos, los cuales dejé satisfechos; este sólo presente, creo la obligó tanto como todos los otros juntos. Por este modo de conducirse debía estimular más y más nuestra generosid ad hasta que agotó los bolsillos de todos. Pero, sin emivargo, como liabía yo dejado en el bote la parte más considerable de nuestros regalos, pensé volver á hacerle otro nuevo presente á la despedida.

"Cuando visitamos á Dubou, la acompanaban sus dos hijas: todos los Eijes que nos seguían quedaron fuera, á excepción de Vuna, que tomó asiento casi á la entrarla: sus mujeres ocupaban el lado opuesto, Dubou la testera, y nosotros en el centro de unos y otros. Poco después llegó un anciano llamad's Tagacala, y se colocó á la izquierda de Dubou, que tenía á su derecha á la mujer del mismo Tagacala, próxima parienta de Paulajo. Estando todos en esta disposición nuestro amign Vuna, que no había permitido comiésetinos en la casa del Otum, me insinuó que podi ımos hacerlo en ésta. Lo hicimos, en efecto, peio con el sentimiento de que los cortos principios que teníamos del idioma, nos privasen e gusto que se goza en la sociedad de una mujer amable: sin embargo, fueron suficientes para procurar lisoniearla, con la memoria de la vive. za y gracias de su nieto Feileua. Aprovechando esta ocasión, le insinuamos hiciese un viajr á las corbetas, donde nos sería fáril hacerle pïsentes que llenasen nuestre, generosidad y corre pondieran á su carácter. A todo nos resnondió ia augusta viuda de Paulajo, con cierto rubor en su semblante dulce, para anunciarnos la impresión viva de nuestras atenciones y de nuestras ofertas, temicndo el ofenderncs si no las aceptaba.

"Hasta el punto de la despedida no habíamos aún penetrado toda la autoridad de esta Dubou. Vuna er. t:ste acto se quedá el último, y vimos (no sin poca sorpresa nuestra) rendirla todos los horiores de la majestad 6 de vasallaje que pres. criben las leyes de estos puebius. Vuna, sin faltar al ritual de ellas, se dirigió á la Dubou, le tocó May. 23 con la cabeza la planta del pié, después con la mano, y beś́ esta seguidamente. Dubou recibió el homenaje con la misma dignidad que presidia todas sus accionrs, pero también con aquella indiferencia de quien recibe un tributo que de jus. ticia le pertenece. Nuestras inducciones de este ceremonial, fueron tan varias como inciertas. En lo que convinimos, fué que su ejecución la re. servó Vuna con estudio para cuando todos estuviésemos fuera de la casa, humillación que seguramente hubiera querido no presenciásemos, y á toda costa hubiera omitido de poderlo hacer impunemente. Pero esto nada influye parf. poder dudar que este Príncipe goza en el Archi piélago de Vavao de todo el poder de la soberania y de una autoridad sin límites.

"Saliendo de la casa de Dubou da principio un íano oblonge, en cuyo extremo opuesto se deja ver el sepulcro de Paulajo. Vuna parecía poco dispuesto á conducirnos hacia él, y fueron necesarias mis insinuaciones para que nos acercásemos á distancia conveniente de examinarle. Un terraplén se elevaba sobre el nivel del llano más de tres piés, formando un cuadro perfecto, cuya área tenía 4.000 piés. El borde superior de este cuadro se cerraba con grandes piedras sillares negras, puestas de canto y bien unidas encre sí. Sobre el centro de esta superficie se veía una casa de la misma arquitectura que la descrita antecedentemente, $y$ dentro del humilde edificio yacian las cenizas del Príncipe. Los dos lados colatera. les del cuadro y el de la espalda los rodeaban á 30 piés en fornia de semicírculo dos especies de árboles plantados con orden y simetría. Estos árboles, cuya aplicacion usan los naturales para símbolo de la tristeza en esta especie de lugares, son conocidos por los naturalistas con el nombre de casenrina equisetifolia el uno, $\ddot{y}$ elate el otro. El primero, semejarte al ciprés de Europa, y el segundo es una especie de palma, cuyas hojas son muy lustrosas y están siempra verdes.

"La multitud que nos acompañaba tomó r.siento á 40 pasos del teatro, sin que se les diese orden particular para hacerlo. Vuna, Tagacala y nosotros, avanzamos hasta ro piés del terraplén, donde se nos mandó sentar, indicándonos por señas, no era permitido acercarse á lugares tan devotos sin el riesgo de profanarlos. Sentados todos, creíamos esta la ocasión más propia para hacer algunas cuestiones sobre la religión de estos pueblos, de la cual eran ideas bien escasas lae que teniamos, ó muy confusas. Pero en vano lo intentamos; Vuna y Tagacala empezaron luégo á arrancar yerbas, cuya operación que no interrumpieron mientras permanecimos alli y que repitier un después á la vista de otro Fiatoga, debe tener a'guna alusión misteriosa. Estos Jefes, con sus ojos fijos en el suelo, "jayeron desde el ins. 
ubou, le tocó slay. as

espués con la

Dubou recibió

d que presidia

on aquella in.

to que de jus-

ciones de este

o inciertas. En

ecución la re-

do todos estu-

ación que se-

esenciásemos

poderlo hacer

lye pari. poder

1 Archipiélago

soberania y de

da principio un

puesto se deja

a parecía poco

y fueron nece-

e nos acercáse-

xaminarle. Un

del llano más perfecto, cuya uperior de este biedras sillares unidas encre sí. sc veía una casa descrita anteceedificio yacían lados colatera. los rodeaban á dos especies de ietría. Estos ár. naturales para ecie de lugares, s con el nombre y elate el otro.

te Europa, y el a, cuyas hojas is verdes.

mpañaba tomó que se les diese 1a, Tagacala y is del terraplén, ándonos por se. lugares tan de3. Sentados toás propia para religión de esbien escasas lae 'ero en vano lo npezaron luego n que no intenos alli y que - Fiatoga, debe Estos Jefes, con on desde el ins.
May. 29 tante en un letargo tan profundo, que si nos respondían era con violencia, y cuando lo ejecuta. ban era sin concierto: su semblante nos represer. taba la imagen misma del dolor y de la tristeza; y sus frecuentes sollozos, que parecían salir de lo más íntimo del corazbn, apenas nos excusaron de partir con ellos sus penas y sus sentimientos.

-La escena, jor otra narte, no nos of recía á la vista sino objetos lúgubrer y tiernos, capaces de inspirar dolor al corazón ménos sensible. La soledad del sitio, el silencio devoto de los naturales y el ruído suave de los tristes árboles mecidos por el viento, todo debía cor.ducirnos á sentimientos profundos $y$ á contemplaciones melancálicas. La presencia de estos lugares ne. turalmente suspende el espíritu humarı para recordarle las hazañas y virtudes del héroe á quien se consagran. El sepulcro de Paulajc nos traía á la memoria la suprema autoridad que había ejercido sobre todas las Islas de los Amigos, y los derechos tan antiguos como legítimos con que la Corona existía en su línea por cerca de dos siglos (I), nircunstancias todas que lastinaban más la suerte de este Príncipe, y añadían horror á la infeliz catástrofe en que acabó su reinado y su existencia.

"Permanecimos en este lugar bien poco tiem. po, y Vuna sin aliviarle aún la confusión que le ocupaba, nos pe-mitió dar una vuelta al mau. soleo para verlo de todas sus caras, pero sir. acompañarnos. Cuando juzgó satisfecha nuestra curiosidad, nos hizo pasar á su casa poco dis. tante de la de Dutulu, de su propia forma y algo inás pequeña. Prepsrada aquí la cava, mandó Vuna servirme la primera copa, que habiéndola yo rehusado, pasó á él mismo, y después de Vuna fueron convidados nuestros Oficiales y á continuación Tagacala $\dddot{\text { }}$ otros Eijes, según el órden de su distinción. Antes de distribuir este licor, iabbían repartido á cada natural un plắtano coci 3 , del cual comier.un una parte reservando cuidadosamente la otra.

"Servida la cava, entraron siete naturales cargados con otros tantos racimos de coces que Vuna me regaló, y se hicieron conducir a: bote, del mismo modo que un tambor de 1 a propia forsa y dimensiones del que sirvió ca el baile del 25 y se había ya com;rado en la Descu. BIERTA. No obstante, la circunstancia de ser absclutamente nuevo e! que acabábamos de adquirir y ser alhaja del mismo Vuna, le hizo muy apreciable. A estos presentes quiso Vuna añadir el c'e un cerdo, pero no habiéndolo en las inme. diariones, tan grande como lo deseaba, expidió sus ordenes para que se condujese de más lejos.

(I) Véanse los viajes del Capitán Cook y nuestras descripciones posteriores.
"La generosidad de este Príncipe estaba an. May. sq tes bien acreditada entre nosotros, pero ahora quería esforzarla á un extremo que no cono. cíamos. Añadía á sus presentes un agrado 6 un esmero que casi reprobaba la dignidad de su carácter, $y$ el anhelo que á cada paso respiraba en complacernos era buen indicio de los sinceros principios que le guiaban á practicar aquella virtud noble y plausible: virtud cuyo ejercicio pare. ce reservado á las grandes almas, porque tam. bién son las únicas capaces de sentir la dulce complacencia de ejercitarla.

"Procurábamos en esta casa girar las conver. saciones sobre aquellas muterias cuya explica. ción estuviese más al alcance de nuestros conocimientos en el idioma, y nos facilitase el persuadir los efectos que á la sazón nos penetraban.

"Don Ciriaco de Cevallos tuvo la ocurrencia, que si se juzga por las resultas, no podía otra alguna desempeñar mejor el objeto. Hizo comprender á Vuna que desde España había de vol. ver á Vavao para vivir y morir en su compañía. Vuna no supo como corresponder más dignamen. te á esta fineza sino pidiendo á Cevallos que apoyase la cabeza sobre su regazo, y cuando 10 tuvo de este modo, lo adoptó por hijo suyo en toda forma. Pronunció después una arenga á los naturales, cuya sustancia no pudimos entender; pero á consecuencia, Tagacala y otros Jefes tri. butaron á nuestro Oficial los honores debidos á su Príncipe.

"Deseábamos dar un paseo á lo interior del país para reconocurle, y Vuna nos condujo por un camino llano que dividía hermosas y dilatadas plantaciones, entre las cuales estaban esparcidas casas $t n$ un desorden agradable. La diversidad de árboles que las cubrían y lo frondoso de los contornos todos, presentaban la vista más amena y divertida. Alguna de estas casas tenían como la de Vuna, una fosa á donde acudian las aguas manantiales y se bañan los dueños; su forma era exactamente la de un cono invertido, cuya altura no pasaría de cuatro piés, ni de cinco su base.

"En la extensión de nuestro paseo encontra. mos con abundancia casi todos los árboles fruta. les que se conocen en Vavao, pero al cultivo de los plátanos se aplican los naturales con más esmero. ó á lo ménos en su conservación. Las plantaciones de este fruto estaban dispuestas en la propia forma que nuestras viñas en España, y cerradas todas para preservarlas de los cerdos, únicos animales que pueden aquí perjudicarlas. Lu rima, el coco, el árbol de que sacan sus te. las, etc., crecen mezclados entre sí sin sujeción á ningún orden. Nada podía compararse á la hermosa variedad de perspectivas que se presenta. ban à nuestrá vista en esta pequeña excursión. La regularidad de las plantaciones la graciosa har- 
May. 29 monía de sus contornos, y la cnufusión de árboles siempre matizados de flores, todo nos representaba con los colores más vivos las maravillas de la Naiuraleza. La imaginación más apagada no podria resistirse en estos amenos lugares á las sensaciones dulces y apacibles que inspiran. Aquí la nuestra se suspendía tiornamente en hacer reflexiones filosóficas sobre la vida y felicidad de estos pueblos. Admirábanos el estado de su agricultura, á la cual se apiicaban como la más útil y primera ocupación de las sociedades; ocupación á la cual no sólo debían una constitución vigorosa, sino vivir tranquilamente en el seno de la abundancia y de los placeres.

"En nuestro paseo no veíamos el término del camino, ni la fertilidad del suelo tampoco presentaba variaciones que interesasen nuestro examen, y Vuna, que suspechaba si llegaria el nuevo n-a. ser.te antes de nuestra partida, procuró et.rée. nernos hacia estos lugares, y conducirnos después á la casa de un Eije, que lindaba con el propio camino. En nada se diferenciaba la estrechura y forma de esta casa de las que habíamos visto, aunque en su capacidad igualaria á la de Dubou. Aprovechó Vuna esta ocasión para hacer tributar á D. Ciriaco de Cevallos otras ceremonias que como Príncipe debía gozar en todos los dominios del imperio. Cevallos, un poco fatigado de la caminata, manifestó á Vuna querịa entregarse por un rato al descanso, cuya prevención anticipó, por si en esta libertad se faltaba á alguna de sus costumbres.

"Tan lejos de oponerse Vuna á ella, dirigió una breve arenga al dueño de la casa, de cuyas resultas vimos ir hacia nuestro Oficial una hermosa joven con todos los encantos del agrado y de la gracia, á cumplir el mandato que se le pres. cribía. Sentada al lado de Cevallos, principió á tocarle blandamente con los puños á lo largo del cuerpo. Esta costumbre, que distinguen los naturales con la voz de Toq:itoqui, la practican con los Eijes, sus mujeres; pero Vuna la exigía indistintamente de hombres 6 de mujeres, siempre que á bordo la necesitaba en el uso que tiene de conciliar el sueño. Yo no sé si este auxilio le fa. cilite á pesar de usarie como tal, en una de nuestras colonias (I) pero por lo ménos en Don Ciriaco de Cevallos, produjo virtudes muy contrarias el remedio; remedio á la verdad más propio para promover las vigilias que para conseguir el descanso. No fué interrum. ida esta operación hasta asegurarse que en suspenderla no se desairaba la linda joven que la ejecutaba: y concluída recibió un presente del nuevo príncipe, en el cual quedaron tan satisf echos sus deseos como los derechos justos de su hermosura.

"Debiendo D. Fernando Brambila sacar la

(i) En las Islas Filipinas. vista del sepulcro de Paulajo y de la plaza don- May. zy de estaba erigido, regresamos luśgo á ella. En medio de esta plaza, y sobre uno de sus lados, hay un editicio superior á todos los restantes en capacidad y magnificencia, Esta circunstancia y algunos tambores que contenía, nos iriclinaron á creerlo como un lugar destinado á las juntas y regocijos públicos. Nuestros informes posteriores correspondieron á estas sospechas. Sentados dqui nosotros, Vuna y todo el pueblo, tuvimos cerca de dos horas de conversación. Notamos que la mayor parte del concurso despejó al presentarse en esta casa Fatafegi y la madre de Feileua, sin haber precedido orden para ejecutarlo; nosctros inferimos que en este acto de respeto se exceptuarian á las familias de los nobles ó de los Eijes, según el corto número de los que después nos acompañaron.

"Concluídas las vistas por D. Fernando Brambila y examinadas las producciones veje. tales de estos parajes por D. Luis Nee, llegó á este tiempo el cerdo que esperaba Vuna, y se hizo en el instante conducir al bote. Ya nada nos detenía en Leyafú, y sólo restaba desp':dirnos de la Dubou, lo cual insinué á Vuna para que nos acompañase. La multitud de dentro y fuera de la casa se levantó con nosotros, pero Vuna, á pretensión nía la bizo sentar otra vez, y únicamente sus mujeres se exceptuaron de esta orden, á quienes se permitió acompañarnos.

"Encontramos la viuda de Paulajo acompañada de la mujer de Tagacala, ambas empleadas en sencillas ocupaciones domésticas muypropias para gozar con más gusto de la sombra de un arbol bajo del cual reposaban. Nuestra introducción produjo la sorpresa de una visita inesperada y de ceremonia; pero la Dubou compuso su scmblante y su vestido como podía hacerlo la mujer más celosa de la decencia y del decoro debido á los que la visitan. Recibíb los segun. dos presentes con la misma gratitud que los primeros, y nos dió los últimos saludos con la afabilidad y dulzura con que sabía disponer su semblante, pero sin prescindir de representar la majestad con todos los atributos del trono. Por último, no es fácil explicar toda la sensación y complacencia a'se ncs había causado la ccnduc. ta de estr. muje: amabie, condu ita que sorprendería á'n mirada como frutn cie una educación ilustrada en el centro mismo de la Europa.

"La estatura de Dubou es más que mediana, su color bastante claro, la fisonomía agradable y el cuerpo gallardo; en cuanto á su primera hermosura, no creo hallamos estado todos muy conformes, tal vez por la dificultad de juzgarla á la edad de cuarenta y ocho años, 6 por el modo de medir las diferentes perfecciones en que cada uno constituye este precioso don de la Naturaleza.

"Antes de restituirnos á la ribera, visitamos el 
plaza don- May. 2y á ella. En sus lados, restantes en cunstancia $y$ irıclinaron á las juntas y hes posterioas. Sentados blo, tuvimos Notamos que jó al presenadre de Feia ejecutarlo; o de respeto $s$ nobles ó de los que des -

D. Fernando ciones vejeNee, llegó á Vuna, y se Ya nada nos esp':dirnos de para que nos o y fuera de pero Vuna, á vez, y únicale esta orden, s.

llajo acompaas empleadas $s$ muy propias ombra de un ucstra introvisita inespeu compuso su lía hacerlo la y del decoro ió los segund que los prios con la afadisponer su' epresentar la el trono. Por sensación y to la ccnduc. que sorprenina educación Europa. que mediana, a agradable $y$ primera herdos muy conjuzgarla á la or el modo de que cada uno Vaturaleza. , visitamos el
May. 29 cemenierio general de los Eijes. Estaba á la izquierda del camino y como 70 roesas distante de la playa. La mayor parte de los edificios que cu. brían cada cadáver, eran humildísimos ó estaban arruinados, á excepción del que contenía al pa. dre de nuestro Vuna. El amor y respeto filial que distingue á estos pueblos, no pudo aquí inspirar á Vuna tanto sentimiento como las tristes cenizas de Paulajo: tal es el imperio que ejercen sobre el corazón humano los remordimientos de la propia conciencia: las virtudes de la justicia obran como innatas sobre todos los pueblos de la tierra, y apenas habrá un hombre tan depravado que se resista á conocerlas ó se niegue á respetarlas.

"La marea, cuando llegamos á la playa, estaba baja, y sin el auxilio de las canoas, no pudimos embarcarnos. En nuestro tránsito, tuvo Vuna la pretensión de que tocásemos en Lontunague, en lo cual pareció justo complacerle. Este es otro pueblo situado sobre la costa Sur y á lo largo de una hermosa playa, que hace el desem. barco muy ::ómodo en cualquiera estado se halle la marea.

"El Eije de este pueblo Tuenuculaba, de la familia de los Dubous, á quien verosímilmente se habían anticipado noticias, nos tenía preparado un presente de cocos. Vuna, sospechando que yo no tendría ya con que poder obsequiar á Tuenuculaba, me ofreció dos cuchillos con este dt. tino: por fortuna, nuestras prevenciones no estaban todavía apuradas, ni fué necesario hacer uso de la generosidad sospechosa de nuestro Vuna.

"El jefe de Lontur gue tenía cerca de su casa, bajo de un tinglar , la mayor canoa que hemos visto en estas islas. Tenía - nicis de quilla, cuatro is manga, y tres $y$ i. de puntal.

"La tarde, estando ya muy adelantada, fuc necesario dejar este pueblo antes de lo que quisiéramos. Tuenuculaba y su familia no podían ser más amables ni más cariñosos. Sus acciones y sus palabras las dir:gían todas á que no nos fúsemos tan pronto, $y$ aún interpusieron por empeño al mismo Vuna para dilatar la partida. La impresión que causan estos hechos no es fácil describirla; son sensaciones que penetran tanto como no se aguarda. El viento nos favoreci6 constantemente, de modo que antes de las cincu de la tarde, llegamos á las corbetas. Vuna nıe manifestó que deseaba dormir en la ATrEVIDA, pero sospechando si querría le acompañasen sus mujeres, fué conducido á tierra por el bote, quedando nosotros en la Descubierta."

Poco después de haber regresado el Comandante de la Arrevida, se apareció también á la vista y se nos incorporó al anochecer la lancha mandada por D. José Robredo. Confirmó este Oficial las excelentes noticias que había escrito
D. Fcilpe Bausá, y anunció su llegada para la May. خ tarde siguiente concluída ya la mayor parte de los reconocimientos útiles. El tiempo había ce. dido mucho y prometía ser claro, pero la mar continuaba aún gruesa é incomodaba mucho particularmente la correspondencia con la playa y con el observatorio.

La situación de las corbetas en este tiempo no podía á ménos de distar como partido más conveniente, el de acelerar más bien que no re:tardar nuestra salida del actual fondeadero. Ya se habian completado así la aguada como todas las obras interiores que la última campaìa nos había dictado como precisas. Los abundantes ref. $\operatorname{scos}$ que habían disfrutado las tripulaciones, disipaban todo recelo de ia existencia más remota del escorbuto. No teníamos falta alguna de leña, sino para mejorar la estiva; pero este sólo objeto no podía justificar el que invirtiésemos una porción considerable de marineros precisamente con aquellas mismas hachas que tan. to excitaban la codicia de los naturales. Ni á la verdad, si volviesen á intablarse vientos del Sur algo más frescos del que acabábamos de experimentar, el fondeadero podia considerarse en modo alguno útil ni seguro. Además que no podía ocultarse que la quietud y sosiego de nues. tras tripulaciones de la cual había dependido la pacífica comunicación con los naturales, estribaha más bien en la sūistínua ocupación de aquéllas, que en su disposición á esta especie de privaciones.

Estas reflexiones dictaron como partido mejor el de abandonar el Archipiélago sin omitir, no obstante, todos los medios que pudiesen aumentar el acopio de nuestros refrescos. Con este ćltimo ir,tento, en la mananita siguiente, el Alftez de fragata D. J colon Murphy, fué á ver -1 Jefe luna, le presento dos haclias y algunos otros reglos que le habiamos prometido, y le avisó que debían aceierarse los cambios ya que nos disponíamos á pa tir dentro de dos días; sorprendió esta roticia i l luna y á las personas de ambos sexos que á la sazón le acompañaban en la acostuubrada ocupación del cava; pero á los primeros impulsos de un cierto cariño que empezaba á echar roíces entre unos y otros, se siguió muy lıéno 1 atención, mucho más importante, de aum cuanto fuese posible los cam. bios y no descuidarse tampoco sobre regalos.

Efectivamente, se despacharon emisarios á las poblaciones para la pronta conducción de comestibles al inercado, y declarado en una y otra corbeta unánimemente el precio de un hacha por un puerco grande y un chico, empezaron á fran. ruearse los caribios; de suerte, q* 3 en la DescuBIERTA, para las ocho 6 nueve de la mañana, ya se hubiesen adquirido unos diez puercos. Era ésta próximamente la hora de la pleamar, y por 
May. 30 consiguiente, la más oportuna para embarcar la fragua $y$ los instrumentos astronómicos. Se dis puso, pues, que lo verificase el Piloto Hurtado con dos botes oportunamente fondeados, y esta señal pública de la verdad de nuestras aseguraciones debió acelerar la venida á entrambas corbetas de Vuna, Feileua y de todo su acostumbrado acompanamiento mujeril. Manifestaba el primero con unas expresiones y muestras realmen. te cariñosas, cuánto le era sensible la resolución nuestra, y que si ésta dependía de los pocos robos que habíamos experimentado, tomaría tales medidas que seguramente no los sufririamos más. Feileua, más jóven, pero no ménos sensible, apenas podia, ya desatendidos los cariños, ocuparse de la multiplicada adquisición de trajes. Finalmente, ol tropel numeroso de las mu. jeres jóvenes, aunque reunido en la parte de al. ćzzar que siempre les estaba destinada, dividía sus cuidados entre el deseo de los regalos, el sentimiento de la ausencia, el desengaño de los amantes y los improperios no desagradables que solían echar contra el autor verdadero de los sufrimientos actuales.

El Piloto Hurtado tuvo orden de enterrar en el sitio donde estaba el cuarto de círculo, una botella, la cual encerraba el papel auténtico de la llegada nuestra y de la posesión que habiamos tomado de todo el Archipiélago en nombre de Su Majestad con el consentimiento del mismo Vuna y para que este acto solemne tuviese la mayor autenticidad así á la vista de los naturales como para noticia de los que nos siguiesen en aquellos mares, ya enterrada la botella se arbolaron en el mismo sitio las insignias, y las saludaron antes entrambas tripulaciones con siete veces de $j$ Viva el $R: y$ ! y luégo los naturales, que estaban en la Descubirrta, los cuales, á imitación de V Vuna hicieron igual número de aclamaciones.

El restante día, que fue bastantemente placentero, se emplé for nuestra parte y la de los naturales, en dejar correr á su albedrío aque instinto sociable que sin otra razón alguna nos liga á nuestros semejantes y nos convida á ali viarnos recíprocamente la vida: en esas inclinaciones, hijas de la misma Naturaleza, era luégo indispensable que sobresaliesen las que con mayor actividad atraen un sexo hacia el otro, y los regalos por una parte, las repeticiones de un mismo nombre por la otra, de suerte que pa:eciese uno śblo á la vista de estas jóvenes el $L_{e}$ y. ley, 6 cosa buena, caracterizándose todes los de más con el título de anacobic nsa mala, debían causar una sensación tanto más viva, entretenida s inocente, cuanto que giraban sobre un conocimiento recíproco del alcance honesto de sus de. seos. A las cuatro de la tarde vimos regresar á D. Felipe Rausá, concluídas felizmente con el bote de la Descubirrta las tareas emprendidas.
Tufoa recibió nuestros agradecimientos y la pro- May. 30 mesa de ricos regalos para el dia siguiente. Con las mismas esperanzas regresó Vuna á tierra, manifestándole antes de comer un surtido completo de herramientas para que agradeciese su uso y supiese de antemano que le estaba destinado al tiempo de la despedida.

Fué increible en este día el acopio que se hizo de toda especie de frutos y raíces, las cua. les, al cargo del condestable y sargento solíar. por lo común adquirirse con cuchíllos y navajas de diferentes tamaños, ó con sartas sencillas de abalorios y coral. La noche bien tranquila nos di6 lugar á un regular ćescanso, y era éste á la verdad tanto más necesario cuanto que la concu. rrencia á Łordo había sido excesiva y prometía ser aún mucho mayor en la mañana siguiente.

Era ésta nublada, pero calmosa, cunfirmándonos de este modo nuestros recelos que poco ya pudiera haber adelariado las tareas astion $6 \mathrm{mi}$ cas. Aprovecháronse, sin embargo, algunas claras por D. José Espinosa, el cual, conseguidas dos alturas absolutas con el sextante de horizon te artificial, dió una nueva época para la determinación de la marcha de los relojes; y D. Felipe Bausá, acompañándole D. Luis Nee, dos sol. dados y Tufoa, quiso subir con el teodolito á los altos inmediatos para tomar una idea más cabal de los puntos más distantes: fueron sumamente útiles estas excursiones en cuanto procuraron la medida de una buena base y una herborización importante.

No se habían descuidado (como debe imaginarse) los naturales en concurrir á bordo desde muy temprano con cuanto tuviesen digno de venta, ni en seguirles de cerca el mismo Vuna, el cual, con el nuevo regalo de un puerco aden, is de otro que habia enviado en la tarde anterior, procuraba no desmerecer la inesperada prodigalidad de entrambos buques. ía voz de $u f a$, expresión para ellos que significa un pesar grande, se oía repetir á cada momento entre los Eijes. Les acompañaba la más estudiada pronunciación de uno ú otro apellido. No era extraño el verlos á veces, 6 ya no pudiendo contener las lágrimas 6 dándonos estrechos abrazos, 6 manifestándonos finalmente, que al tiempo de nuestra salida no omitirian las muestras de mayor dolor con darse repetidos golpes en la cara y en el pecho.

Habíamos solicitado de Vuna desde la tarde anterior que condujese consigo á la hija de Paulajo, su mujer, para que D. Juan Rabenet pudiese retratarla con la mayor propiedad. Ve:ificádolo así, y no permitiendo que la acompaña. :en sino otras tres mujeres para evitar una major confusión, pudimos al principio conseguir el fin propuesto de verla retratada, y luégo enta. blar á presencia de Vuna varias conversaciones que pudieron manifestar con mayor propiedad 
tos y la pro- May. 30 guiente. Con una á tierra, surtido comrradeciese su estaba desti.

copio que se ces, las cua. rgento soliar: os y navajas sencillas de aquila nos dib éste á la ver. ue la concua y prometía a siguiente.

a, cunfirmáns que poco ya is astron6mialgunas cla. , consegu das te de horizonara la deteres; y D. FeliNee, dos soleodolito á los lea más cabal on sumamente procuraron la herborizacion

o debe imagi. á bordo desde digno de ven. smo Vuna, el uerco adensds arde anterior, rada prodigalide ufa, expresar grande, se los Eijes. Les inunciación de ño el verlos á las Iágrimas 6 ınifestándonos sstra salida no olor con darse 1 pecho.

desde la tarde a hija de Pau. I Rabenet pujiedad. Ve.ifi. la acompañaevitar una ma io conseguir el y luego entaconversaciones yor propicdad

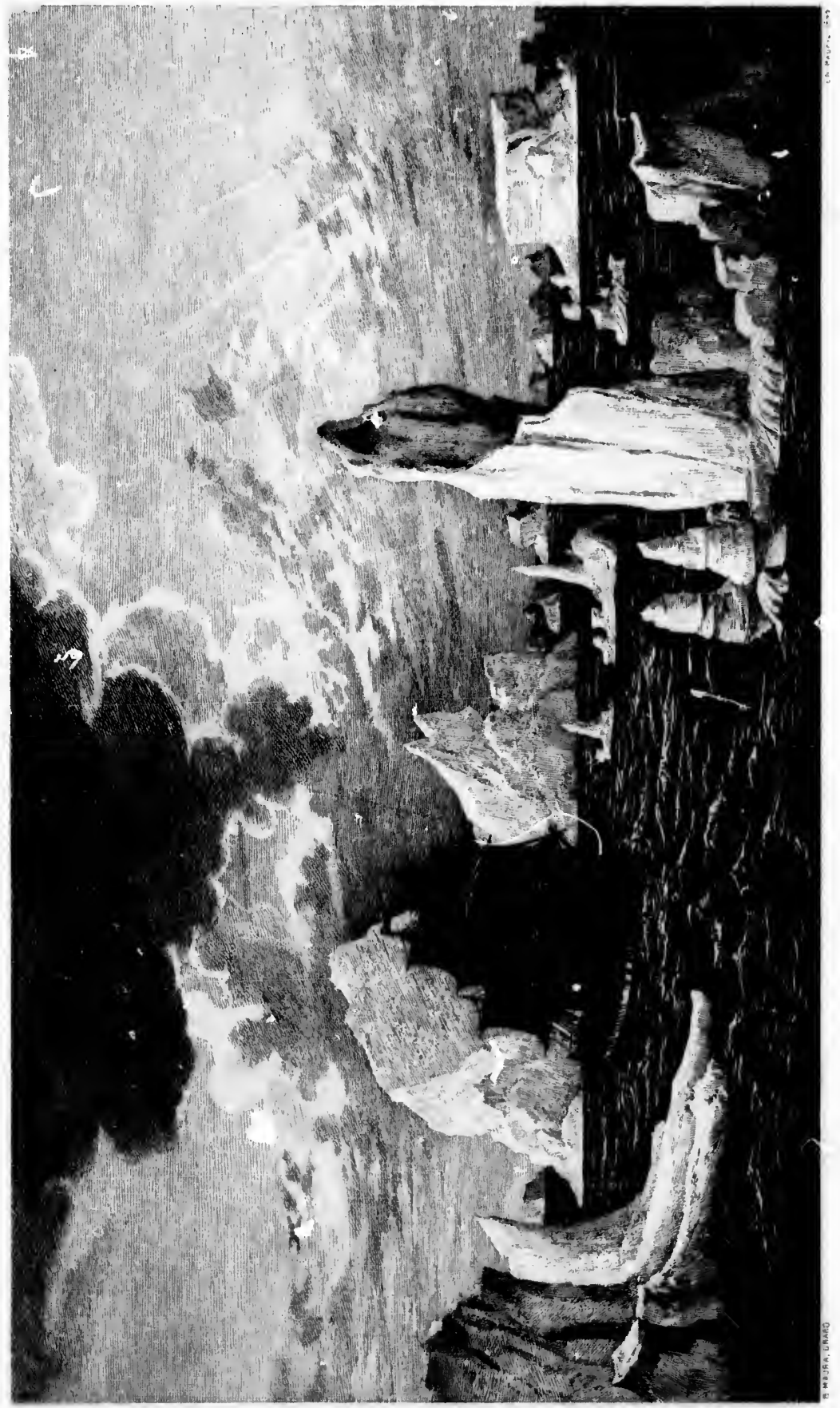


May. 3r el carácter de esta nación. No desagradaban á Vuna nuestras promesas de regresar luego á las islas _compañados de las mujeres cuyo retrato le habíamos manifestado al principio; solia en estas ocasiones solicitar nuevamente el verla, y en aquel mismo día ya las conversaciones acos. tumbradas nos habían conducido á una nueva manifestación del retrato. Le saludó con mucha ternura la Paulajo, miró atentamente sus adornos y manifestó iguales deseos á los de Vuna de que viniesen sus semejantes $\{$ las islas. En balde procuramos entonces excitarle los celos y mucho más el temor del desprecio, insinuándole que las persiguiese, si acaso venían, y recordase á Vuna la amabilidad y fidelidad de las hijas de Vavao. Con la mayor dulzura respondía siempre, que antes bien procuraria agasajarlas en cuanto estuviese á su alcance, celebrando, aunque le fuesen preferidas por Vuna, el cual se mantenía constante en asegurar, que ya á sus ojos nada merecían sus mujeres, después que habia visto el retrato de las europeas.

Estas chanzas familiares y realmente agradables, nos condujeron después á que nos prometiesen de nuevo el cuidado de las semillas que lea dejábamos. La calabaza, la papa, la sandía y el melón, formaban la parte esencial de este pequeño repuesto; y como quiera que ya habían comido las dos primeras con una grande complacencia, no nos quedó duda que procurarían con el mayor cuidado su multiplicación más breve. Eran muchas las caricias que la misma Paulajo hacía á dos gatitos, macho y hembra, que lad regalamos. Cuando la veíamos en su casa, solía. mos comunmente encontrarla con estos dos animalejos, envueltos en su misma ropa y con todo el cuidado posible para que no los tocase persona alguna.

Nos disponíamos ya á come: con esta compañía y la de las orras Fatafegis, cuando se nos aparecíb sobre el alcázar una mujer vieja y ma cilenta, á la cual todas las demás mujeres y el mișmo Feileua prestaron inmediatamente el debido homenaje. Creimos al principio que pudiese ser la viuda de Paulajo, á quien había visitado D. José Bustamante en su excursión dèl 29; pero desengañados por los Oficiales que le habían acompañado, debimos extrañar $\epsilon$ inquirir al miamo tiempo su verdadero carácter entre los demás. Nuestra juventud estaba á la sazín de. masiado ocupada en el cerco cariñoso de sus conocidas, para que no desatendiesen en cierto modo los dictados severos de la etiqueta, y así fué, que apenas después de mucho tiempo esta anciana pudo encontrar quién la condujese donde debía sentarse. tocudo en suerte, era el de una botella vacia, la cual sin embargo, parecía estimar en mucho, disponiendose finalmente á regresar á tierra, ya que no debía prometerse ni mayores atenciones, ni. May. s! mayores regalos. Avisados á la sazbn de las cualidades de esta mujer, preguntamos á Vuna quién era; y si le importunaría que nos acompañase á comer; lo cual, concedido de muy buena voluntad por este Jefe, la hicimos bajar á la cámara y disfrutar de nuestra mesa. Le siguib, aprovechando de aquella ocasión también la Dubou, hermana de Vuna, y fue la única felicldad nuestra, que entrambas por su misma moderación y por los consejos de Vuna, prefiriesen dos asientos algo distantes de la mesa, á los que con mayor satisfacción nuestra, disfrutaban ahora la hija de Paulajo y sus hermanas y compa. ñeras.

Por cuanto fuese, sin embaryo, elevada la esfera de estas últimas, vimos con mucha admira. ción que para comer se ocultaban todas de la vis. ta de la vieja, y que solo Vuna era el que dis. pensándose de aquella etiqueta, manifestaba un grado superior. Por ventura, las dos determinaron retii arse, cuyo partido le aprobamos muy de veras, y ya libres de etiquetas, pudimos aprovechar el restante tiempo en un trato más ameno y sociable.

Tufoa Feileua y Latu eran á la saz6n los que más de cerca interesaban nuestro cariño. El primero recibió en pago de sus atenciones pasadas, un hacha, un pedazo de bayeta, algunos cuchillos, y otros adornos mujeriles. Todos se esmeraban en regalar al segundo con cuanto pudiese, 6 adornar su persona 6 recordarle nuestro cariño, y en Latu se hacía tanto más recomendable un cierto desinterés y desprendimiento de los regalos, cuanto que le reemplazaba un triste silencio, que es el símbolo verdadero del sentimiento.

Fue, en fin, preciso que nos separásemos antes de la noche. Nuestros botes condujeron á tierra hombres y mujeres, concluídos los cambios dc cuanto habían traído al mercado; y vimos pnco después, $r n$ sin alguna complacencia; que en la casa de Vur. nabían las mujeres arbolado $y$ hecho tremolar un pedazo de lienzo, como señal positiva de los adioses que nos daban, cuando no alcanzaban las voces.

Al anochecer ya todo estaba pronto para dar la vela; á las diez.de la noche avisaron los centinelas que veían rondar una canoa alrededor de la Descubierta, con un siles:nio y cuidado tan grande, que no se sentía el ruído de los remos ni respondía á nuestras voces de quién vive. Fué preciso dispararle un tiro de fusil con perdigones, porque debíamos recelar que intentase cortar la boya del ancla de tierra, lo cual nos hubiera cau. sado una detención grande; esto bastó para que se retirasen.

Emprenćimos los trabajos de anclas á las dos de la mañana, contando con que al amane. cer pudiésemos eatar algo distantés del fondea

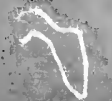


Jun. 1. dero; pero como se originasen luégo algunas detenciones leves, rayaba el dia cuando estuvieron las corbetas á la vela, y el poco viento al salir el Sol apenas las había separado una milla de la costa. Recibimos con este motivo una nueva visita á bordo de la mayor parte de nuestros co. nocidos, deteniéndose Vuna y el mayor número de las canoas á bordo de la ATkevida que naveyaba atrasada por nuestra popa con el auxilio de los remolques, y dirigiendose á la DescuriekTA, I'eileua y Latu. Se renovaron en esta oca. sión las muestras recíprocas de un cariño verda dero; aumentó considerablemente el número de los puercos cambiados, y finalmente, declarado hacia las sicte viento fresquito del lisnordeste, nos fué preciso despedirnos por la última ve\%, y entrambas corbetas navegaron unidas á conti nuar sus tareas.

A medida que el Sol se iba elevando sobre el horizonte se disipaba la calima, el viento galeno aumentaba agradablemente su fuerza, $y$ nuestra navegación hacia el Sur con todo aparejo de bolina hacía que poco á poco se confundiesen con el mar los parajes ménos elevados y más septentrionales de Vavao.

Nuestios rumbos á la sazón no podían llevar otro objeto sino completar por el Oeste el reconocimicnto emprendido del Archipiélago, atenrijencic á la verdad más bien aquella nimie dad hurográica que exigía la navegación del dia, que á la utilidid real ya bastantemente corres pondida así pur las marcaciones de D. Felipe Bausá desde los altos septentrionales, como po los bordos bien repetidos en aquella parte del mar por el Comandante D. Francisco Maurelle. Costé́ronse al principio algunas islas de media na extensión; $y$ áridas $y$ escarpadas por su part del Oeste, no tardaron luégo en descubrirse las otras más orientales que habíamos atracado a tiempo de recalar al Archipiélago, y para las once y media ya distábamos dos 6 tres millas de la islita sola, gue Maurelle llamó del Sur; pareciéndonos lo más oportuno el pairear hasta e medio día, para referir con mayor certeza aquel extremo la observación de la altura meri diana del Sol: nos hallábamosá la sazón en sondas de 59 brazas piedra $y$ conchuela; $y$ la latitud fue de $r 8^{\circ} \mathbf{I I}^{\prime} \mathrm{oo}^{\prime \prime}$.

Nada denota en la parte occidental del Archipielago el semblante lozano que le favorece interiormente. Sin rastro alguno de frondosidad ni de habitadores; , sin aquella suavidad en las orillas, que doma el ímpetu de las olas y abriga las obras lentas y misteriosas de la Naturaleza, presența al navegante una perspectiva árida y triste, en la cual no es difícil descubrir al mis mo tiempo los efectos destructores de la monzón tempestuosa del Noroeste y la falta constante de la mano próvida del hombre, destinada a dar un nuevo brillo y vida $\{$ las grandes combina- Jun. $1 . "$ ciones de la Providencia.

Ya, pues, para el medio día podíamos considerar concluidos nuestros reconocimientos en esta parte del mar; se descubria al Sur un hori. zonte despejado, el cual combinado con las na vegaciones del Capitán Cook y de D. Francisco Maurelle, disipaba toda sospecha de cualquiera objeto intermedio entre estas islas y las de Hap. pay; al Este nuestra derrota del día 18 nos dejaba bien conocidas las restingas peligrosas que interceptaban la navegación por aquella parte, y al Oeste el solo monte volcán de Late seño. reándose con una altura no indiferente, parecia llamar hacia él nuestra navegación inmediata. No titubeamos efectivamente en adoptar aquel partido como el más útil que actualmente se nos presentaba; y ya con fuerza de vela y una buena brisa del Este, pusimos la proa al Oeste, no omitiendo para la una y tres cuartos examinar con la sonda por medio de la Atrevida, si continuaba aún el banco hallado al medio día á no mucha distancia de la Isla del Sur. No ha. llamos fondo con roo brazas de sondaleza; observáronse luégo longitudes de $26^{\prime}$ al Oeste del observatorio, y como quiera que el viento se mantuviese fresquito y claro, para las cinco de la tarde ya no distábamos sino unas dos 6 tres le. guas de la costa oriental de la isla, de modo que la pudiésemos reconocer antes de la noche con bastante exactitud.

Si bien no presentase por aquella parte la menor'apariencia de un mediano abrigo, viéndose romper las olas en la misma orilla, y no advir. tiéndose en la costa sino una dirección igual y contínua, no debía, sin embargo, desalentarnos de la esperanza de encontrar un fondeadero, el reparo de ser probablemente la costa del Norte la más abrigada. La noche, ya próxima, no daba lugar á emprender luégo esta averiguacion: debimos, por consiguiente, diferirla hasta la mañana siguiente, conservando ya con algunos bordos y ya con tal cual hora de pairo, próximamente la posición en la cual habíamos anochecido.

Con estas precauciones no debio sernos difi. cil amanecer en tal posición, que las primeras claras del día nos diesen lugar á reconocer de cerca los extremos Norte y Oeste de la misma, y así, á las seis y media, favorécidos de un vien: to galeno, ya veíamos frustradas en esta parte nuestras esperanzas, pues ni á miedia milla de la playa se encontraba el fondo con 100 brazas de sondaleza, ni se veían en la orilla más que penascos enormes, prueba nada equívoca de una costa cortada á pico. Habiamos prevenido el bote y un ancla con el ánimo de reconocer siquie. ra algunos de los productos volcánicos que suponiamos se encontrarian fácilmente en todos los contornos; y en esta ocasión el roce con los ha- 
les combina. Jun. $1 . n$

díamos consicimientos en Sur un horio con las na. D. Francisco de cualquiera y las de Hapía 18 nos depeligrosas que aquella parte, de Late señorente, parecía on inmediata. adoptar aquel ctualmente se de vela y una proa al Oeste, cuartos exa. la ATreVida, o al medio día el Sur. No ha. sondaleza; ob$p^{\prime}$ al Oeste del el viento se las cinco de la dos ó tres leisla, de modo es de la noche

lla parte la mebrigo, viéndose a, $y$ no advirección igual y desalentarnos fondeadero, el osta del Norte róxima, no daaveriguacion: la hasta la maon algunos bor, proximamenos anochecido. bió sernos difí. e las primeras á reconocer de o de la misma, idos de un vien:en esta parte dia milla de la roo brazas de a más que peuivoca de una s prevenido el conocer siquienicos que supote en todos los uce con los ha-
Jum. a bitadores nos pudiera proporcionar nuevos cono. cimientos sobre los verdaderos limites de la confederación visitada: pero debimos desistir luégo de semejantes esperanzas, advirtiendoque toda la isla, desde su cima hasta las faldas, estaba igualmente poblada de arboleda silvestre, sin que se percibiese rastro alguno de lavas 6 erupciones, y que eran pocos y bien mezquinos los parajes cul. tivados, sin verse, por otra parte, canoa ni choza que indicase un número siquiera mediano de ha. bitadores.

Reconocida de este modo la mayor parte de la isla, á corta distancia, de suerte que pudiésemos determinarle la circunferencia de cuatro leguas próximamente, $y$ desvanecer toda idea de un fond adero mediano y algo útil; continuamos la navegación aprovechando las ventolinas varia. bles que al abrigo de la isla solían á veces, con. fundidas con una total calma, dejarnos entera. mente sin gobierno. Desatracados poco después algún tanto, vimos salir una canoa mediana de los pedruscos del Oeste; no pareció oportuno esperarla, porque al mismo tiempo íbase entablando la brisa fresca y no distábamos ménos de una legua de la orilla. La embarcación retroce. dió luégo y nosotros ceñimos al Sur para conti. nuar los reconocimientos emprendidos sobre las trazas del Comandante Maurelle.

Debían éstos tener ahora po1 objeto otras islas que el mismo Comandante había visto en aquellas inmediaciones: atracada la una hacia las diez á distancia de una legua, des̀cubrió inmediatamente que no era sino un pedruscs árido y amogotado de poca elevación y extensión, y probablemente formado de las mismas materias vol. cánicas que debían ser la base de la isla no distante de Late. No parecía la otra, y debíamos creer que D. Francisco Maurelle la habia equivocado con las islas cercanas de Kao y Tufoa, las cuales, en aquella dirección, parecían formar una isla sola, y ésta bastantemente elevada para apercibirse desde los parajes en los cuales nos hallábamos.

La mañana sumamente placentera, no nos había hecho descuidar la ocasión bien oportuna de fijar con nuevas observaciones de las distan. cias del Sol á la Luna la longitud del observato. rio de Vavao; fueron éstas por nuestra parte 55 series, de las cuales resultó por medio de amhor relojes la longitud del observatorio al occidente de Cádiz de $167^{\circ} 39^{\prime} 39^{\prime \prime}: 24$ series observadas en el mismo tiempo en la corbeta ATrevidA, manifestaban la longitud del mismo meridiano $167^{\circ}$ $3 \mathrm{I}^{\prime}$ bo"!.

Navegamos luégo al Sur, y ya desde las tres de la tarde, vistas las islas de Kao y Tufoa, al mismo tiempo que podíamos aún marcar los altos de Late, lográbamos no sólo ratificar con la longitud la posición recíproca de los dos Archi- piélagos, sino también hacer más segura la na. J"I" * vegación nuestra de la próxima noche sin que nos condujese sobre los alrededores peligrosos de Ofolanga, Bui y Mangone, islitıs las más sep. tentrionales del Archipiélagis de Happai.

Fucron el viento fresquito del Esnordeste, la mar sumamente llana, y la noche más bien oscu. ra y calmosa, sin que se nos ocultasen, sin embargo, desde las dos de la mañana los altos de Kao, á los cuales nos habíamos acercado considerablemente, más bien por efecto de las corrien. tes que de la navegación nuestra, la mayor parte invertida hasta aquella hora en ceñir de uno $y$ otro bordo. Arribamos sobre las gavias y los juanetes, $y$ navegando asi hasta que se disipasc totalmente la oscuridad, logranos que las prime. ras claras del día nos descubriesen un conjunto de objetos realmente aǵradables é interesantes.

Las islas de Kao y Tufoa, abierto ya el canal intermedio, elevabian sus peladas cimas hasta las nubes y nos demoraban desde el Oesudoes. te hasta el Oesnoroeste á distancia de tres le. guas: las otras, tanto más frondosas cuanto más bajas, descubrian por el Este un semblante mucho más fértil y risueño; no eran ménos de diez las que teníamos á la vista, y entre ellas, con el auxilio de la excelentc carta del Capitán Cook, no era difícil distinguir particular. mente las de l'otua y liotu, demorándonos aquella al Sur $20^{\circ}$ Este y la última al Sur $72^{\circ}$ Iiste. Distaríamos de ésta unas cuatro millas, $y$ era fácil descubrir las diferentes restingas que habian heclıo en aquella parte de mar más brevo y feliz la navegación del Comandante Maurelle que la del Capitán Cook (I). Continuando nues. tra navegación hacia el Sur, con vientos antes bonancibles y varios del primer cuadrante y luégo más entablados del Este, fué nuestro primer objeto el rectificar las longitudes; lo eual, por dos series de horarios tomados en paraje de marcaciones seguras, pudo conseguirse con la mayor escrupulosidad. La vista de Annamoka, las inmediaciones de la restinga saliente al Oeste, $\mathbf{y}$ por último, para las cuatro de la tarde el alcanzarse igualmente desde las cubiertas las dos islitas de Ungatonga y Uryakapai, nos recordaban luégo á cada paso las huellas harto memorables del Ca. pitán Cook, mientras en la otra más aspera é in. culta ce Kao veíamos un nuevo escarmiento para los europeos, con lo acaecido al Capitán Bligh en la lancha del Bo:uly, acaecimiento ya muchas veces confirmádonos con la mayor desaprobación, por los habitantes de Vavao.

Adoptadas las determinaciones del Capitán

(1) Don lirancisco Maurelle, determinándose á pasar entre la restiriga, atravesó directamente desde Happai a Annamoka, cuya derrota no se decidió á seguir el Capitán Cook ánin después de haber enviado un bote algunos días antes para que sondase. 
Jun. S Cook relativas á la longitud y referidas con nuestros relojes enteramente acordes entre si al observatorio de Vavao, podlan últimamente considerarse los datos principales para esta determinación en los términos siguientes:

\begin{tabular}{|c|c|}
\hline & $\begin{array}{l}\text { 1.ongitiud occiden } \\
\text { de Códiz, }\end{array}$ \\
\hline $\begin{array}{l}\text { Por el número il coll uisa marcha muy } \\
\text { exacta desde el puerto Jackson. }\end{array}$ & 167.40 .35 \\
\hline $\begin{array}{l}\text { P'or } 75 \text { series de distancias del Sol a la } \\
\text { Luna observadas en la Descubierta } \\
\text { al Este y al Oeste con las mejores } \\
\text { circunstancias y enteramente confor- }\end{array}$ & \\
\hline $\begin{array}{l}\text { mes entre st. } \ldots \ldots \ldots \\
\text { Por las determinaciones del Capitán }\end{array}$ & 167.40 .44 \\
\hline
\end{tabular}

La latitud nuestra por la altura meridiana del Sol de $20^{\circ} 2^{\prime} 30^{\prime \prime}$, confrontó exactamente con la de los navegantes ingleses, y diferentes observaciones bien conformes de la variación de la aguja dieron la de $10^{\circ} 3^{\prime}$ al Nordeste. No se habían descuidado los naturales de las islas inmediatas á salir desde la mañanita á nuestro encuentro. Varias canoas chicas y dos grandes aprovecharon la tranquilidad de la mar para acercarse, $y$ au. sque el viento, particularmente hacia las inmediaciones del medio día fuese bastantemente fresquito para que las canoas grandes usaran de la vela con la mayor ventaja, era tal la diligen. cia de las canoas pequeñas nunca surtidas con mas de tres bogado:es que rara vez se atrasaron considerablemente de aquéllas.

Todas, hasta el número de ocho entre gran. des y chicas, atracaron á la ATREvida, la cual, navegando por nuestra popa estaba por la mis. ma razón ménos distante de las islas, y en esta ocasión no fueron ménos importantes las investigaciones del Comandante y Oficiales de aquella corbeta y sus nuevas reflexiones sobre el estado actual de la confederación.

Unánimes convinieron en las divisiones de la autoridad suprema, cuales se nos habían indicado en Vavao; explayaron el mayor deseo de que visitásemos sus islas, $y$ cambiaron un puerco y una más que mediana cantidad de frutas; manifestaron después algunas tiras bastante nuevas y recién cortadas de bayetón azul; y las atribuyeron à la visita de dos buques europeos, que sólo dos meses antes había tenido lugar en Tongatabu. Nombraban como Jefe de esta expedición á Selecari, Fosebatia y Tocoto, entre cuyos nombres confusos no nos era fácil distinguir ni la expedición francesa de Mr. Entrecast: ‘lt (I) ni la que nos anunciaban algunos papeles públicos debía navegar á aquellos mares por cuenta de

(1) Las uitimas noticias impresas nos han convencido, sin la menor duda, haber sido la expedición francesa de los Capitanes Mr. Entrecastault y Huon, con las gabarras la Recherche y la Esperance.
Su Majestad Imperial, ni las diferentes de los Jun. 3 Capitanes Bligh, Roberts $y$ Vancoover, que el Gobierno Británico había despachado por varias partes al mar Pacíico.

1:1 cuidado con el cual estos insulares traian para venta, bien acondicionados y con la corres. pondiente tierra, dos vástagos del árbol del pan, nos haría sospechar que á esta adquisición se habia dirigido principalmente el viaje que acaba. ban de indicarnos (I).

La misma franqueza, la misma alegre con. fianza, el mismo idioma y las mismas instancias y ofrecimientos, no debian ya parecer nuevos ni extraños; pero no pudo ménos de atraer la admiración de todos, la singular destreza de un joven, el cual cambiada un hacha de piedra por un cuchillo y caído éste accidentalmente al agua, entregó inmediatạmente el hacha á un compañero, se tiró al agua, recogió el cuchillo aunque su propio peso debiese ya haberlo sumergido considerablemente y alcanzó de nuevo la canoa y la corbeta, á pesar que llevasen a la sazón un andar no ménos de tres á cuatro millas. Era difícil el comprender el estado verdadero de los ganados si se exceptuasen las cabras, cuya multiplicación particularmente en Eua parecía confirmársenos ahora. Fué preciso que nos dejaran para reti. rarse antes de la noche á sus moradas, de las cuales no distábamos ya ménos de cinco leguas, hillándonos á dos millas al Oeste del bajo que cruza delante del fondeadero de Annamoka. Fue. ron después vanas nuestras diligencias para avis. tar el otro banco igualmente de coral que más al Oeste había descubierto el Comandante Maurelle, y para el ponerse el Sol marcábamos el ex. tremo Norte de Annamoka al Norte $66^{\circ}$ Este; el extrenıo Sur de Annamokilla al Norte $82^{\circ}$ y $1 /$ Este $y$ el punto alto de Tufoa al Norte $1_{4}$ Oeste de la aguja. La Atrevida, aunque sondase en la menor distancia del banco, no había encontrado fondo con roo brazas de sondaleza.

Desde las últimas horas de la tarde, un calor excesivo, la menor fuerza del viento y su. misma dirección del Norte, nos habían anunciado próxima una revolución del titmpo; no pasó efectivamente de las diez de la noche cuando nos sobrecogió un chubasco fuerte con ráfagas recias del Sur. Fué nuestro primer partido el pairear sobre las gavias arriadas, y á la media noche, aminorándose algún tanto la fuerza del viento é inclinado éste al Sueste, pudimos cenir sobre las cuatro principales al Sursudoeste, único rumbo que nos daba lugar con bordos algo largos á hacer frente á la mar bastante gruesa del nuevo viento. Habíamos hecho las señales oportunas á la ATREvida, la cual paireaba al principio á poca distancia de nosotros; pero al

(r) Esto se ha confirmado en la misma relacion. 
Jun. 3. tiempo de forzar de vela se nos atrasó consideraulemente y la perdimos de vista hasta el ama. necer del dia siguiente.

A esta hora estaban aún los cielos y hori. zontes cargados con celajeria oscura, el viento fresco y algo arrafagado del Sueste, la Atrkv!DA como á una legua á nuestro sotavento, y se murcaban los dos islotes de Ungatongz y Unga. hapai del Norte, $20^{\circ}$ al Norte $26^{\circ}$ Oeste de la aguja distancia siete á ocho millas: arribamos inmediatamente $y$ acortamos algún tanto de vela para incorporarnos con la ATrevida, y conseguido este intento, continuamos con vela proporcionada el rumbo del Sur. A las nueve y media, disipada la mucha cerrazón de los horizontes y marcando los islotes anteriores al Norte, avistamos la isla de Tongatabu, la cual demoraba por sus extremos del Sur $39^{\circ}$ Este, al Sur $55^{\circ}$ Liste. No distábamos por consiguiente de ella ménos de cuatro leguas á sotavento y todo nos anun. ciaba la continuación constante de la brisa fresca que habla entablado en la noche antericr; nosotros la ceñimos con fuerza de vela al Sueste. La variación se mantenía de $10^{\circ}$ I $5^{\prime}$ al Nordeste; $y$ al medio día del 5 era nuestra latitud de $21^{\circ}$ $4^{\prime}$ y la longitud de $3^{\circ}$ r $2^{\prime}$ al Oeste de Vavao.

\section{CAPITULO VI}

Navegación desde el Archipiélago de los Amigos has. ta las costas del Perú.- istada en el puerto del Ca. llao y nucvas midid"; Sara la foliz conclusión del viaji sabida la declaración de la guerra contra la Francia. - Segunda escala de las corbetas en la bahía de Concepción de Chils.

Los últimos pasos de las corbetas Descu. BIERTA y ATREvida en el mar Pacífico, ya no podían ser en modo alguno importantes para la Hidrografía. Una nueva visita á las Islas de la Sociedad $\sin$ motivo alguno urgente, renovaría sólo los desórdenes de los europeos en aquellas regiones, 6 haría insufrible una disciplina rígida á bordo. Las Islas Desiertas reconocidas antiguamente por Quirós, sitas á más ó ménos distancia al Sueste de aquel Archipiélago, habían sido nuevamente avistadas en los áltimos años por los navegantes nacionales ó extranjeros; y si bién en la nueva carta de las navegaciones del Capitán Cook, se advirtiese colocado en los $32^{\circ}$ de lati. tud un pequeño archipiélago que decía haber sido descubierto por los españoles, todo parecía indicar que fuese apócrifa aquella noticia por mucho que examinásemos las navegaciones nacionales verificadas hasta nuestra época. Este último reconocimiento parecib, sin embargo, debidamente anejo á la actual navegación nuestra para las costas del Perú, á donde nos conducian diferentes objetos, casi todos inmediatamente Jun.s ligados con el feliz término del viaje.

Las brisas frescas del Lisueste al Sueste no tardaron en conducirnos al paralclo de $25^{\circ} 3^{8^{\prime}}$ longitud $5^{\circ} \leq 6^{\prime}$ al occidente de Vavao, variación observacia $11^{\circ}$ al Nordeste, Contra nuestras ex. pectativas, rolaron poco después los vientos al Noroeste con los cuales la derrota fué directa y acelerada. Así alcanzada la latitud de $29^{\circ}$ y con. servándose en aquel parulclo los vientos bien frescos del Oesnoroeste al Oesudoeste, desistiinos de la idea de navegar por latitudes más al. tas á lo ménos hasta que no nos aproximásemos á los meridianos sospechosos de las islas indicadas. Lográbamos de ese modo un andar de siete á ocho millas; los fríos se hacian llevaderos para las tripulaciones aunque poco abrigadas; $y$ uia navegración directa nos resarcía la poca diferen. cia favorable en los grados de longitud si hubié. semos corrido paralelos más altos: eran á la sa. zón nuestros aparejos de las principales y á ve. ces del juanete mayor, solíamos luégo en la noche disminuirlos hasta quedarnos frecuentemente con las dos guvias en dos rizos y arriadas, de inodio qque ni nuestro andar fuese menor aún con este aparejo de seis 6 siete millas, ni en el caso de avistar cualquier peligro dejásemos de ceñir en pocos instantes con las cuatro principales de una ú otra vuelta, según las circunstancias lo exigiesen.

Relativamente á esta clase de peligros, el na. vegante que dé una mirada filosófica á todo el globo en torno, no puede ménos de admirar y ayradecer la continua vigilancia de la Naturale. za en sus obras misteriosas. En la Zona Tórrida, donde son frecuentes las restingas y los bancos de coral que sirven luégo de incremento á la superfic:e habitable, son los vientos más periódi. cos y bonancibles, la navegación más lenta y por la misma razón ménos expuesta; finalmente, las noches tan proporcionadas con el día como el invierno con el verano, y la claridad de la Luna y del.firmamento con el brillo vivificador del Sol; pero en apartándose hacia el uno 6 el otro polo de aquella posición favorable para la multiplicacion y reposo de la especie humana, ya la escena muda de semblante; las islas se elevan extraordinariamente sobre la superficie del mar, el navegante áun en las noches frías y largas del invierno puede avistarlas sin riesgo de caer sobre ellas: el ser solas y por lo común acantiladas, favorece aún más esta fuga necesaria, á pesar de los frecuentes temporales; por último, un semblante árido y triste, unas cuevas y unos pedruscos en los cuales la Naturaleza pareció tributar á mil especies de aves, de peces y de anfibios el mismo tierno cuidado que en otras partes ha tributado á los cuadrúpedos, todo lleva consigo unas muestras nada equívocas de su in- 
Jun. s tento verdadero, de que no sean estas la morada del hombre, sino otros tantos vehlculos que le faciliten la emigronión necesaria para su navega. ción, comercio y multiplicación constante.

Continuaron uniformes en los días siguientes así el viento como la navegación: soliamos á ve. ces experimentar chuiascos y ráfagas sumamen. te recias: el termómetro do l'arenlıeit había ba. jado y se mantenía por los $6:$ y $62^{n}$ : no falta. ba otras veces, uno ú otro dia placentero en el cual li Naturaleza parecía despojarse del sem. blante horrido y tempestuoso del invierno; cn. tonces, los rabijuncos, los carneros, los tableros $y$ algunas veces las ballenas, se presentaban en inucho número á nuestra vista, asf como las procelarias y los pamperos eran, según costumbre, 'l anuncio positivo de la tempestad. En la noche del I 6 que fué con exceso tenipestuosa y oscura, preferimos capear con la gavia y el contrafoque, hasta que asomast. las primeras claras del dia, con las cuales, y hecha la señal de noche á la ATRevida, emprendimos nuevamente la derrota.

lin ei entretanto nos aproximamos á los me. ridianos de las islas que el Capitán Cook había comprendido en su carta general como descubiertas por los espanooles en 1774 . Según debiamos inferir de la narración de su viaje, había recibido esta noticia del Sr. Crozet en el Cabo de Huena Esperanza, suponiéndose que las islas descubiertas estaban en el paralelo de $32^{\circ}$ y $130^{\circ}$ de Greenwich, correspondiente ahora á $44^{\circ}$ oriental de Vavao.

Para el medio día del 2I, no contando aún sino $30^{\circ}$ de longitud, nos hallamos en el paralelo indicado de $32^{\circ}$, y empezamos á correrle con la vigilancia correspondiente. Era común en estas ocasiones no navegar de noche cuando no tuviésemos un horizonte menor de tres á cuatro leguas, $y$ aprovechar al contrario con aparejo proporcionado, las muchas horas en las cuales por una feliz combinación brillaba la Luna sobre el horizonte: los vientos, el grado de frío y el semblante del tiempo, no habían variado en nada de los dias anteriores: la rotura de una verga de gavia en la corbeta ATREvida había podido remediarse con una verga de cebadera, y por nuestra parte, atentos siempre á la mejor con. servación de la tripulación, tan débil y cansada, habíamos sustituído ahora al condimento del aceite, dos onzas de tocino, fortalecianos la ruardia entrante á las cuatro de la mañana con un ponche caliente, y cuidábamos con extremo del aseo $y$ buen orden interiores.

No faltaron para alentar las esperanzas siem pre fáciles del navegante, un rocío abundante, algunas horas de calma y la vista de dos ballenas justamente cuando nos hallábamos en los ineridianos sospechosos de $42^{\prime \prime}$ y $44^{\circ}$; pero no eran éstos sino halagos, y nuestra navegación Jum, əs actual cumbinada con las dos derrotas no dis tantes del primero y segundo viaje del Capitán Cook, y con las noticias sueltas de las nave. gaciones últimas nacionales, disipaba ya toda sospeclia de la existencia de cualquier isla en aquellos contornos. La variación magnética lia. bía a la sazon disminuido progresivamente has. ta 3 y 3 y $\%{ }^{\circ}$ al Nordeste, volviendo después de nuevo á aumentar á medida que nos aproximá bamos á las costas del continente de América.

Mluy luégo alcanzamos en el mismo paralelo los meridianos de $60^{\circ}$ mayores en $20^{\circ}$ próximamente á los que habíamos sreido sospechosos, y cicrtamente superiores á cualesquiera errores que pudiesen recelarse en una estima. Casi al mismo tiempo debimos considerarnos ya en los términos de la derrota que desde Guayaquil y Lima conducen á los puertos más meridionales de Chile y Chiloé, $y$ así pudieron igualmente cesar las pesquisas hidrográficas y las cautelas indispensables de una navegación poco trillada.

No nos habiamos descuidado en los últimos dias del mes, en repetir frecuentemente las ob. servaciones de las distancias de la Luna al Sol y á las estrellas, y sus promedios (siendo precisamente el número de roo series) se aproximaba mucho á la longitud adoptada del número I , la cual confirmaba una alteración considerable en la marcha del cronómetro 71 , como nos lo ha. bian hecho ya sospechar las comparaciones repetidas con los relojes de la ATREvidA.

Al aproximarnos al continente de la América, y ya disminuidos de $2^{n}$ los paralelos que corríamos, empezaron á suavizarse mucho la mar y el viento, sus iituyéndose ahora á los días achu. bascados y tempestuosos que nos habían acompañado constantemente, otros más placenteros y suaves, en los cuales, entremezclada alguna calma, poúíamos á vares disfrutar por largo tiempo del brillo benéfico del Sol. Conociendo ya el tem. peramento de estas costas en el rigor del invierno y las causas físicas que debian hacerle bien frío en la actual estación, no debimos extrañar que el termbmetro de Farenheit puesto al aire libre se mantuviese en los 60 y $61^{\circ}$. Aun con este leve inconveniente toda la débil marinería flipina pa. reció adquirir nuevamente algún vigor; los restantes individuos de las clases inferiores, entre los cuales había dos 6 tres gravemente enfermos, dieron muestras no ménos equívocas de un proximo restablecimiento.

No faltaron en los siguientes días algunas variaciones contrarias del tiempo, aunque conservásemos aún la latitud de $30^{\circ}$; fueron éstas, sin embargo, de muy poca duración y áun menos incomodidad. Al medio día del $\mathrm{I}_{3}$ de Julio, por la latitud de $28^{\circ} \mathrm{I} g^{\prime}$ y longitud $86^{\circ} \cdot 28^{\prime}$, ya navegábamos otra vez con vientos galenos del 
navegación Jun, 28

otas no dis-

del Capitán

e las nave.

aba ya toda

uier isla en

agnética lia.

amente has.

o despues de

ss aproximá

de América.

imo paralelo

$20^{\circ}$ próxima

sospechosos,

uiera errores

ima. Casi al

os ya en los

Guayaquil y

meridionales

igualmente

las cautelas

co trillada.

los últimos

ente las ob-

Luna al Sol

siendo preci-

aproximaba

úmero II, la

psiderable en

o nos lo ha.

raciones re.

IDA.

te la Améri-

lelos que co-

cho la mar y

s dlas achu.

abían acom.

olacenteros y

alguna cal.

largo tiempo

lo ya el tem.

- del invierno

:rle bien frío

extrañar que

aire libre se

on este leve

a filipina pa.

zor; los res-

riores, entre

lente enfer.

ivocas de un

fas algunas

unque con.

ueron estas,

y áun me.

I 3 de Ju-

tud $86^{\circ} 28^{\prime}$,

galenos del 3wy. Oeste; y confirmadas de ruevo en los dias si. guientes con 76 series de distancias del Sol á la Juna, las longitudes del número if y el error del $7 \mathbf{r}$, pudimos ya considerarnos no distantes del fondeadero deseado.

En los pocos dias que mediaron después hasta la recalada á la costa, tuvimos la desazón de perder en la Descubierta el soldado armero que habiamos recibido en Lima, de la fragata Liebri. lira este un hombre sumamente útil é ingenioso cuya aplicación y amor al trabajo le habia hecho últimamente hábil para limpiar, cuidar y compo. ner frecuentemente la mayor purte de los ins. trumentos astronómicos. Continuaba siempre, á pesar de ésto, su servicio de soldado: 'una tísis envejecida le arrebató casi repentinamente en la mañana del 19 .

Ya en la noche del 21 nos lue preciso (con. siderándonos no distante de la costa) navegar con alguna precaución en e! aparejo, tanto más que el viento era bien fresco y nuestros rumbos

a del Nordeste nos inclinaban á las costas más salientes del Oeste. Desde la mañana del 22 tuvimos luégo la vista agradable, aunque común en aquellos contornos, del agua de color de sonda, de los lobos marinos, de las ballenas y de un número crecido y vario de aves acuáticas, $y$, final. mente, observada al medio dia la latriud de $18^{\circ}$, se nos present6, aunque envuelta entrt calima, la deseada costa del Perú.

Era ésta precisamente la que corre desde la Nasca para el Morro Quemado, y en los parajes más inmediatos, no distando ya de ellos a las cuatro de la tarde, más que unas dos y media leguas, nos era fácil reconocer particularmente la Mesa de Doña María y los pedruscos los In. fiernillos. Tomamos horarios para la rectificación deseada del arrımbamiento de la costa, y corrida ina base para la mayor exactitud de esta especie de tareas, navegamos en derrota y con fuerza de vela á unos rumbos paralelós á la costa.

La exactítud de nuestras cartas y la excesiva claridad de la noche estando la Luna en su plenilunio," debieron luégo hacernos mirar como una nueva felicidad la brisa excesivamente fresca que tuvimos, siendo nuestro andar de ocho á nueve millas con el trinquete $y$ las gavias arriadas, asi con el aumento supuesto en la distancia por la dirección de las aguas; para la mañana del 23 pudimos ya considerarnos en una situación proporcionada para alcanzar el puerto en la misma tarde. Cedieron á la sazón el viento y la mar, y la neblina sumamente espesa que ofuscaba extraordinariamente la costa y hacía que nuestros vigías creyesen ver las rompientes de las inmediaciones de Chilca y Cañete, causó una variedad natural en nuestros rumbos hasta el medio dia: á esta hora, conseguida por un acaso bien feliz la altura meridiana del Sol y calcu- ladas para la longitud ulgunas otras alturas, nos Jut. 3 hallamos agradablemente en latitud de $.2^{\circ} 31^{\prime}$ y en meridiasıos de ía Isla San Iorenzo, la cual. por consiguiente, no debia distar de nosotros más que nueve leguas al Norte verdadero.

Por un breve intervalo aún después del medịo dia, equivocada casualmente la deducción de Ia longitud y disipada la sospecha de los puntos de la costa que habiamos creido ver untes, ce. nimos de nuevo con todo aparejo de la.vielta de tierra; pero á la una, dejándose ver sobre una clara la Isla San Jorenzo, cesaron nuestras du. das y pudimos gobernur en demanda del puerto. Teniamos á nuestro barlovento y distante como dos leguas, un paquebot guanero, que ceñla según costumbre diaria, de la vuclta de fuera.

La marejada y la corriente, más bien que el viento, nos condujeron en la restante tarde hasta el extremo Norte de la Isla San I,orenzo, del cual, no distáluamos para el anochecer más que dos 6 tres cables por sonda de 40 brazas: descubierta ya la bahía y puerto interiores lacia donde navegábamos paulatinamente con las ven tolinas flojas y variables del Sur. Nos alcanzaron poco después el falucho de rentas destinado á re. conocernos y los botes de las fraigatas du S. M. Liebre y Birbara, cuyos Oficiales venían con el mismo intento, y antes de las nueve de la noche logramos dar fondo á un ancla en las inmedia. ciones de los demás buques surtos en el fondeadero, cuya faena verificó al mismo.tiempola córbeta Atrevida.

En muy pocos días quedaron después las colbetas desaparejadas y desarmadas; la Oficialiclad libre para atender á su sos ego y restablecimiento, y el observatorio con todos los relojes marinos establecido en la Magdalena, igualmente que los pintores y los pilotos, cuyas ocupaciones diarias eran difíciles de combinarse con el desasosiego y vida inquieta de la ciudad. La tropa de batallones y brigadas se acuarteló con sus sargentos y con. destables en la misma Magdalena; se asignb á todos los que gozaban de la ración un real y me. dio diario; finalmente se adoptó para el buen or. den á bordo, próximamente el misno método que se había seguido en la escalamanterior en el mismo puerto.

Antes de conducir los relojes al observatorio, no habíamos omitido en la Descubiert. rectificar con algunas alturas momentáneas del Sol la longitud del fondeadero, cual nos la manifes taban los relojes marinos: debía ligar en cierto modo esta nueva cadena que venía del Oeste, así como en los años pasados la babíamos conducido con igual prolijidad en la dirección opuesta. Adoptada para el observatorio de Vavao una longitud media entre nuestras determinaciones $y$ las del Capitán Cook, esto es, considerándole $167^{\circ} 45^{\prime}$ al Oeste de Cádiz resultaba por el: 
Jul. 31

Longitud del fondeadero occidental de Cádiz.

Fran nuestras

$Y$ la diferencia actual de los re

lojes..............

Nisn, 11. Cronom. 78. $70.54 \cdot 2571 \cdot 55 \cdot 45$ 70.46 .0070 .46 .00 (n)

$8.251^{\circ} 09^{\prime} 45$

Se afirmaban de este modo nuestras determinaciones de la escala anterior con el número II, el cual no ménos por las inuchas observaciones de las distancias lunares que por el nuevo examen hecho ahora, había indicado una marcha uniforme: el error del cronómetre 7 I correspondia igualmente al nucvo examen y á las comparaciones diarias, de suerte que hubiese sido de $53^{\prime \prime}$ su atelanto diario al tiempo medio, en lugar de los 49 que liabían indicado las observaciones de Vavao.

El cuidado de los enfermos, la mayor parte ó lastimados del pecío por el cansancio y conti. nuación de las fatigas ó estenuados por los ata-

As. ques del mal venéreo, fué en aquellos días otro punto al cual debimos atender con mucha vigilancia: el hospital que les era destinado igualmente que á los demás huques de S. M., por su desaseo, ninguna disciplina y poca pericia de los facultativos, parecía dispuesto más bien á debi. litar que á fortalecer las tripulaciones, y las nuestras, ya por sí sumamente débiles y poco numerosas, hubiéranse sin duda aniquilado con este solo vicio: fué, por consiguiente, necesario buscar otro paraje en donde se evitasen aquellos inconvenientes: un hospital particular de los varios que hay en Lima, pareció lo más oportuno para el iutento por los muchos enseres de que abundaba; $y$ 'siendo la manutención en él mucho más cara que en el Hospital Real, quedó prefijado que se cargase el exceso á los individuos, exceptuada sólo una ú otra persona d. las más beneméritas de los armamentos: un Oficial de las corbetas debía por turno visitarle diariamente; frecuentarle los cirujanos para que no permaneciesen en él por demasiado tiempo los convalecientes; finalmente, alternar los mismos cirujanos en las visitas á bordo para que ni pretextasen enfermedades ni dejasen de atenderse los achaques iun más frívolos antes que tomasen un semblante serio y temible. No eran infundados nuestros conceptos solbre deberse preferir á cualquiera otro paraje el de la Magdalena para las innportantes experiencias de la graredad; en la actual estación no debían esperarse ni un día siquiera las alturas correspondientes, y las abso. lutas necesitaban no sólo de una vigilancia continua para aprovechar cualquiera clara momentánea, si también para su cálculo, del conocimiento cabal de la latitud: establecióse, pues, el cuarto de círculo exactamente en el mismo paraje en que le hablamos tenido la otra vez; y fué mucha ventura que en los primeros días de Agosto se consiguieran ya diferentes series de alturas absolutas para determinar exactamente la marcha de los relojes, de sucite que no se demorasen las experiencias del péndulo simple: concurrían á estas experiencias los 'Tenientes de navio Don Juan de la Concha y D. Ciriaco Cevallos, no era menor de dos lioras la duración de cada una, y la tranquilidad y el tiempo nos daban lugar á ensayar ahora todos aquellos medios que pudiesen producir en lo venidero una mayor exactitud en estas pesquisas tan importantes.

Procediendo así con un paso uniforme todas las medidas que á la sazón parecían las más oportunas para el decoro y la utilidad actual de la expedición, pudimos ya mirar atentamente hacia sus pasos venicieros pora que se combinasen de cerca con nuestros últimos deberes en la comisión recibida. Hiciêronse algunos trasbor. ćos en ambas corbetas. Con el dictamen de los cirujanos, quedó determinado el viaje de Don Felípe Bausá por Valparaiso y Santiago á Bice. nos Aires, para no exponerle al tránsito del Cabo de Hornos con exceso temible para el asma, dimanada de sus trabajos incesantes. Y fué un feliz acaso que mejorado algo en su salud también el Teniente de navío 1 . José Espinosa pudiese acompañarle por la misma razón; y con su sextante de horizonte artificial, con un relnjito de segundos, y un amor invencible en en. trambos á las tareas geográficas, pudiese pro. meterse la expedición nuevo lustre y nuevas utilidades.

El destino de los naturalistas era otro punto que debía ocuparnos sériamente; unn y otro igualn.ente infatigables, inteligentes $y$ útiles, hubieran al mismo tiempo sufrido inútilmente fos trabajos de nuestras navegaciones próximas y sacrificado una estacion entera, mientras las partes interiores de la América meridional esta. ban aún desconocidas para las ciencias físicas y particularmente para la botánica. Qued6, pues, decidido con aprobación del señor Virey, que D. Tadeo Heenke caminaría á Buenos Aires por Huancavelica, el Cuzco y Potosí, ateridiencio no sólo á la botánica, sino también á la zoolo. gía y litología; á cuyo fin le acompañaría en clase de disecador el artillero de mar Jerónimo Arcangel, de la Descubier'ta. D. Luis Nee"dejaría la ATREvida tan solamente en Concepción de Chile, desde donde arrimado á la cordillera y á los Pehuenches, contisuaría con mucho fruto sus investigaciones botánicas hasta Santiago y últimamente hasta Buenos Aires: este segundo viaje podía combinarse con la escala en Montevideo de una ú otra corbeta; nó pøí con el viaje de D. Tadeo Heenke, el cual por la extensión del país que habia de recorrer y por la impor. tancia de los conocimientos que podía prodicir, 
is de Agosto se ${ }_{2,5 ;}^{A r}$; de alturas abente la marcha se demorasen las e: concurrian a 5 , de navío Don Cevallos, no era de cada una, $y$ daban lugar á edios que pudiemayor exactitud

uniforine todas arecian las más tiliclad actual de rar atentamente yue se combina. os deberes en la algunos trasbor. dictamen de los el viaje de Don Santiago a Bucieal tránsito del hible para el as cesantes. Y fué go en su salud D. José Espinosa ma razón; y con ial, con un reln. nyencible en enas, pudiese pro. tre y nuevas uti-

as era otro punente; unn y otro gentes $\mathrm{y}$ útiles, rido inútilmente ıciones próximas wa, mientras las meridional estaiencias físicas y a. Qued6, pues, eñor Virey, que á Buenos Aires otosí, atendiencio bién á la zoolo. acompañaría en de mar Jerónimo D. Luis Nee deen Concepción , á la cordillera y con mucho fruto hasta Santiago y eg: este segundo escala en Montepsí con el viaje por la extensibu y por la impor. podía prodicir,
A6., tuvo permiso en sus instrucciones ara dilatar la llegada á Buenos Aires hasta Octubre ó Noviembre del año siguiente de 1794 .

Desde los primeros días de nuestra llegada al Callao, ya eran acordes todas las noticias en anunciarnos un proximo rompimiento con la nueva República francesa, cuyos caudillos, quitada ignominiosamente la vida sobre un cadalso al Rey pasado Luis XVI, amenazaban con un furor arrebatado de trastornar el orden público y el sistema político de casi todos los demás Estados de la Europa.

Efectivamente, no pasó mucho tiempo sin que estas sospechas se viesen verificadas, y hacia últimos de Agusto, un extraordinario desde Buenos Aires condujo la desag: adable noticia de la declaración de la guerra por nuestra parte, avisándose en esta ocasión á los Gobernadores de las plazas y á los Comandantes de los bu. ques de S. M., para que acogiesen y abrigasen todas las embarcaciones de la nación británica, la cual hacía la guerra de mancomún con nosotros.

Semejantes circunstancias no podian mirarse sino como extremadamente importunas para el feliz término de la comisión en que se hallaban las corbetas Descubierta y Atrevida, dotadas con poca artillería y de corto calibre, arniadas con un corto número de brazos, y más hien dis. puestas en su casco y aparejo á luchar con los temporales, que á perseguir 6 evadir los eneniigos: ni era fácil combinar una mejor habilitación militar con los destinos que ahora debíamos arrostrar, 6 bien con el puerto, en que nos hallábamos escasos de pertrechos de marina, particularmente cuando al mismo tiempo debían habilitarse las tres fragatas de S. M. Licbre, Bírbara y Gertrudis; y sobre todo, falto de gente útil para formar una tripulación mediana. Un buque anfibio de esta especie no podía ser sino un verdadero peligro para los que le navegasen y un tropiezo contínuo, para que ni sus destinos primitivos ni sus funciones militares correspondiesen al buen servicio de S. M.

La distancia á que nos hallábamos del teatro de la guerra y la reunión de una superioridad tan grande de fuerzas navales cual era la de los enemigos de la Francia, hacía á la verdad sumamente remoto el aparecimiento de fuerzas navales francesas en el mar Pacífico, y se hacía aún más remoto para nosotros un encuentro de esta especie, luégo que vencidos los paralelos de Chiloé, debiésernos inclinar nuestra navegación ha. cia la costa Patagónica occidental y á las inme. diaciones del Cabo de Hornos.

Ëstas refiexiones, dictaron como partido más conveniente el de dejar las corbetas próximamente en el mismo estado de fuerza en que habian nevegado hasta entonces, de considerarlas sin einbargo envueltas en la actual guerra (I) de Ag. ? mirar como conveniente separarlas para que multiplicasen las tareas científicas, dividiesen los riesgos de un encuentio y abreviasen la publicación del viaje en España; finalmente, de pruscribirles una guerra defensiva, más bien que una ofensiva; esto es, una clase de guerra, que tuviese por objeto la sola defes:sa propia y no la ofensa y persegrimionto de los enemigos.

Fueron los destinos de la corbeta ATrevida, reconocer la Isla de Diego Ramírez al Sur del Cábo de Hornos, visitar el extremo oriental de las Maluinas y el Establecimiento nacional de la Soledad, determinar después la posición ver. dadera de algunas islitas más orientales que los navegantes del Perú distinguían con el nombre de las Islas de la Aurora; y finalmente, atracada la costa Patagónica al Norte de los ríos Negro y Colorado, arribar al Río de la Plata y al puerto de Montevideo.

Quedó al cargo de la Descubierta un nuevo reconocimiento de la costa Patagónica occiden. tal, si los tiempos por una rara casualidad se le brindasen favorables, desde $46^{\circ}$ hasta el Cabo Pilares; recorrer después la costa exterior de! Fuego, repetir cuanto fuese posible y en los paralelos más convenientes las experiencias del péndulo simple; finalmente, rectificar la Isla de Diego Ramírez y los trozos últimos de costa in mediatos al Cabo San Antonio, que habian tocado en suerte á la corbeta Atrevida.

El arreglo de los buques y sobre todo el de sus víveres y dotaciones, al cual, como ya se ha dicho, debimos atender al mismo tiempo, no fué tan fácil de combinarse como sus destinos: nues. tros armamentos eran por todas razones sumamente débiles al tiempo de entrar las corbetas en el puerto; puede imaginarse hasta cuál grado debían serlo despues, introducidos ya entre la marinería los desórdenes del Callao, que muy luego los arr zstraban al hospital 6 á la deserción. Algunos otros adolecían de achaques habituales, ó su edad cansada les imposibilitaba de resistir la próxima campaña: debían precisamente alejarse los díscolos y poco subordinados; últimamente, el número crecido de grumetes filipinos, parecía poco apto al manejo de la maniobra así por su poca pericia y fuerza, como por la dificultad de resistir á unos climas frios tan diferentes del en que habían nacido.

Por un acaso feli $i$, la natural instabilidad del marinero y tal vez el deseo nada extraño de re-

(1) Esta expresión alude á las cartas del Conde de la lucernc, Ministro en París por la Marina y colonias en 1789 , el cual prescribió á los Comandantes generales de los establecimientos ultramarinos, que auxi. liasen nuestra expedicion en cuantos modos estuviesen á su alcance. El Gobierno británico nos habra fran. queado iguales ordenes para todas sus colonias. 
Sư. gresar á sus hogares y familias, habia hecho que la mayor parte de la marinería matriculada en la fragata Bárbara solicitase trasbordar álas corbetas; en balde les abultaron algunos los peligros de nuestra navegación 6 la parte de trabajo correspondiente á un corto número de brazos. Se mantenían constantes en su resolución, y deses. peranzado: de conseguir el permiso de su $\mathrm{C} n$ mandante, presentaron un memorial al señor Virey solicitando el trasbordo, con tanta más razón, cuanto que la Bárbara sáldría después de nosotros, y que siendo matriculados, tenian un derecho de aproximarse á sus hogares, con preferencia $A$ cualesquiera otros: por nucstra parte, podíamos ofrecer un igual número de personas entre los enfermos, los díscolos y los filipinos, la mayor parte útiles en un buque dotado en pie de guerra y en los mares tranquilos del Perú, cuando no serían sino perniciosos en las cor* betas, y alegar á favor nuestro, no sólo la necesidad de que la marinería fuese voluntaria, 0.t. inteligente y quieta, sino también las Reales órdenes que prevenían se mirase como preferente á cualquiera otros objetos, la habilitación de las corbetas en los diferentes puertos de la América.

No condescendió sin embargo S. E. á nuestras representaciones en esta parte, y seguramente (siéndonos imposible el recibir gente de leva, única que nos proponían) nos hubiéramos visto precisados á formar de los dos armamentos uno sólo en la Descubierta, para que pudiese verificarse la campaña proyectada en el próximo verano, si los Capitanes de navío D. Tomảs Geraldino y D. Alonso de Torres, Comandantes de las fragatas Licbre y Gertrudis, no se hubiesen unido en auxiliarnos con un esmero col respondiente á la situación nuestra, al buen servicio de S. M. y á los vínculos de compañeros. Estos Ofi ciales reemplazaron desde luégo con las dotaciones de sus buques, aunque extremamente cortas, I 2 de los 18 marineros matriculados de la Bárbara, que solicitaban el trasbordo, y prometieron después, completar al tiempo de la salida todos los demás que nos hiciesen una falta absoluta. Tributaremos siempre á aquellos do Oficiales los más sinceros agradecimientos, poi la eficacia con que decidieron en aquel momento de la suerte de la expedición, y evitaron que fuese molestada la corbeta ATREvidA, como has ta entonces lo habiamos creído indispensable.

Al mismo, tiempo el señor Virey previno que podíamos considerar como agregados á las cor betas, cuatro ma-ineros ingleses, pıofugos en la costa, de varios buques balleneros, y un marine. ro español que debía restituirse á su patria; con istos y los $\mathrm{r} 8$ hombres indicados, pareció ya remoia toda demenda ulterior de gente, tanto más que ya liabiamos en una y otra corbeta determi. nado conservar los filipinos, excluyendo solo los enfermos y díscolos.

No había sido tan difícil combinar el reempla. zo de víve:'es, si bien por otra parte debiese causarnos no poca desazói ver que el pan fabricado en Manila y depositado en un buque del comercio con objeto de aminorar el enjambre de cucarachas, se hallaba inútil no sólo por los destrozos anteriores, sino también por los efectos de la humedad: fué igualmente preciso excluir para condimento el aceite de nuestros repuestos de España, no siendo posible consumirlo sino para luces, y entre la crecida cantidad de menestras debió también deseciarse una porción de lente jas ó mongos, que además de empezar á picarse del gorgojo, no podian combinarse con el naturu enfado que debía causar la suministración de una misma cosa por el espacio de un año. Se reemplazaron en parte estas partidas excluidas, con otras de excclente calidad, y el repuesto de víveres de una y otra corbeta quedó reducido á las cantidades necesarias.

Tuvimos después nuevas deserciones de la mayor parte de los grumetes filipinos, los cuales fueron igualmente reemplazados con marinería voluntaria de las fragatas, $y$ por fin, en la mañana del i 6 estuvimos prontos á dar la vela. Sólo á las tres de la tarde empezaron á apercibirse las primeras ventolinas de la brisa; las aprovechamos inmediatamente con todo aparejo, $y$ aumentando luégo prulatinamente su fuerza, para las cinco y mediz ya habíamos atracado la Isla de San Lorenzo por su extremo del Norte y ce. ñíamos con buen viento al tercer cuadrante. La Atrevida, que había dado la vela al mismo ins. tante que nosotros, navegaba algo distante por nuestra proa, y se veía sobre las gavias, aún próxima al fondeadero, la fragata El Aguila, en la cual debían navegar á Valparaíso el Teniente de navío D. José Espinosa y el Alírez de navín D. Felipe Bausá: nuestra posición á las seis de la tarde nos hacía considerar á una legua de la Isla de San Lorenzo en latitud $12^{\circ} 4^{\prime}$ y $8^{\prime} 45^{\prime \prime}$ al Oeste del meridiano adoptado para los relojes. Fué luégo constante til toda la noche la brisa fresquita, con la cual ya para el amanecer distá. bamos considerablemente del fondeadero.

No nos habían engañado las apariencias de la tarde anterior sobre la ventaja de andar, $\tan$ tas veces disputada, de la corbeta ATrevida. Amaneció con los juanetes á medio mastelero y sin €mbargo adelantada en más de una lagua; y la señal convenida que se le hizo para que navegase con total independencia de la Descubierta le dio lugar á que hecha nuevamente fuerza de vela aumentase más la distancia en todo el día.

Continuaron luego las brisas del Sueste á au. mentar su fuerza, engrosando de tal modo la mar, que cansase mucho la proa y nos obligase á ve. 
ayendo sólo los Oct.

nar el reemplate debiese cauI pan fabricado que del comer. ambre de cucapor los destro- los efectos de iso excluir para is repuestos de mirlo sino para d de menestras rción de lente. pezar á picarse e con el natural ministración de e un año. Se reidas excluídas, $y$ el repuesto de ledó reducido á

serciones de la pinos, los cuales s con marinería fin, en la maĩaar la vela. Sólo on á apercibirse isa; las aproveaparejo, y ausu fuerza, para atracado la Isla del Norte y cer cuadrante. La la al mismo ins. go distante por. gavias, aún próIl Aguila, en la ol Teniente de díérez de navío ón á las seis de una legua de la $2^{\circ} 4^{\prime}$ y $8^{\prime} 45^{\prime \prime}$ al ara los relojes. noche la brisa amanecer distáideadero.

apariencias de a de andar, tan. beta AtrevidA. dio mastelero y de una lagua; y para que nave. la DEscubierta nente fuerza de t en todo el día. del Sueste á au. tal modo la mar, s obligase á ve.
Oct. 19 ces á acortar algo de vela; los días se mantenían más bien nublados, el viento era á veces arrafagado, y para el medio día del rg las observaciones nos ! arian considerar en latitud de $15^{\circ} 26^{\prime}$ y longitui de $3^{\circ} 34^{\prime}$; variacion $8^{\circ} 30^{\prime}$ al Nordeste. La Arrevida ya se había perdido de vista por la proa.

La alcanzamos de nuevo el 23 por la maña. na, ayudados sin duda más bien de haber sufrido más vela, que de alguna ventaja en el andar, á pesar de que variásemos muchr la estiva, zollásemos adentro ura parte de la artillería y sacrificásemos dos vergas de juanete.

Muy luego los rumbos dei Sur y aún á veces inclinados al primer cuadrante nos condujeron al encuentro de los variables por latitud de $24^{\circ} 45^{\prime}$ y longitud de $10^{\circ} \mathrm{r}^{\prime}$. Con ellos la otra corbeta nos dej6 nuevamente por la popa, y como los vientos le fuesen en esta ocasión más favorables que á nosutros, debimos abandonar toda espe. ranza de precederla en el puerto de Talcahuano, como nos lo hacía desear al principio una loable emulación.

Un objeto que debía á la sazón inquietarnos mucho, era el de las enfermedades bastante. mente peligrosas de tres marineros, el uno un gaviero que nos acompañaba desde Cádiz y ado. lecía ahora de un cansancio y debilidad irreparables; el otro un grumete que había pasado de la Atrevida para agresarse al pilotaje y sufría de una inflamación del hígado; el tercero, una de las muchas víctimas que diariamente causa el desorden y los males venéreos: no faltaban tampoco algunrs disenterias aunque fáciles de corregirse $y$ así casi al momento de abandonar el puerto, apenas alcanzaban nuestros cuidados y el acierto de D. Francisco Flores para evitar que no se debilitase más la tripulación.

Si como lo aparentaba el día siguient:s, hu biésemos ya alcanzado los vientos del Sudoeste y Oeste en la actual posición, nuestro viaje hubiera efectivamente porido ser breve; pero muy luego nos desengañaron los vientos del Sueste bien frescos $y$ arrafagados, los cuales debimos ceñir de nuevo al tercer cuadrante, de modo que hasta el $3 \mathrm{I}$ no alcanzamos la latitud de $3^{\mathrm{r}^{\circ}}$ y á este tiempo hubiésemos caído $14^{\circ} 40^{\prime}$ ai Oests: esta longitud la indicaban conformes ambos relojes marinos; el termómetro de Farenheit se mantenía por los $60^{\circ}$ próximamente; y ya en este último dia, alcanzados nuevamente los variables nos prometían una próxima alteración favorable, la cual nos condujese brevemente á Talca. huano.

No podía efectivamente desearse una tarde más placentera; el viento se había declarado fres. ¿9. por el Sudoeste, y con él navegábamos al Si esce en bueniz derrota; no se apercibía una nc.be sobre el horizonte, $y$ en las primeras horas de la noche el brillo de las estrellas nos presen- Uc:. . taba una escena que desconocíamos desde mucho tiempo: pero también esta vez quedaron nuestras esperanzas íustradas, pues á la media noche retrocedió el viento al Sur y al Sursueste arrafagado y lluvioso, con el cual aunque con las muras á estribor, salimos nuevamente de la derrota directa.

Así continuamos en los tres días siguientes en los cuales debimos á veces precavernos algo en el aparejo, logrando sin embargo hallarnos para el medio día del 3 en latitud de $34^{\circ} 2 r^{\prime}$, y longitud de $10^{\circ}$ oo': en esta posición despuśs de algunas horas de calma vimos declararse las primeras ventolinas $d: 1$ Noroeste, y á istas, siguiéndose poco después vientos más entablados del Oesnoroeste y Oeste, piddimos en la mañana siguiente navegar con un tiempo placentero en demanda del puerto.

Hasta el medio lía del 5 hicimos rumbos del Sursueste para entrar en los paralelos de la Concepción y óbviamente afianzar más los vientos favorables: orzamos luégo al Este corregido con vientos bien frescos del Nornordeste y Noroeste, los cuales, para el anochecer nos redujeron al trinquete y las dos gavias con un rizo tomado; fueron tempestuosas y cerradas con lluvia las primeras horas de la noche; pero antes del amanecer ya había rolado el viento al Oeste, y despejado enterainente el cielo, de suerte que pudiésemos forzar nuevamente de vela.

Ya los tres días siguientes, nuestra derrota con la continuación de vientos favorables fué bastante acelerada: corrigiéronse los rumbos oportunamente, de suerte que no nos apartasen del paralelo de la Isla Santa María, las corrientes bastante fuertes al Sur que nos indicaban las observaciones diarias de latitud: muchas series de distancias deı Sol á la Luna en los días 7 y 8 confirmaron un error de $13^{\prime}$ al Oeste en el número $\mathrm{I} x$, siendo algo mayor en el mismo sentido el del cronómetro $7 \mathrm{r}$, y en este último día, no distábamos más que 40 leguas del puerto, habiendo á la sazón calmado casi de un todo el viento Oeste que nos había acompañado hasta entonces con mares bastante gruesas: la variación magnética alcanzaba ya los $14^{\circ}$ al Nordeste, y el color del agua y la muchedumbre de aves, lobos y ballenas, nos anunciaban próxima la vista agradable de la costa.

Sólo á las tres de la tarde nos alcanzú al viento costanero del Sursudoeste: le aprovechamos con fuerza de vela; á las diez de la noche se proporcionó luégo un andar de seis y siete millas; paireamos una hora hacia las tres de la mañana, y poco después las primeras claras del alba nos dejaron ver las Tetas de Viovio y la Isla Santa María en la distanciu que suponíamos: á las siete distábamos un cable del islote Quiebra Oll $\%$ : á 
Nor. 8 las ocho estuvimos dentro de la bahia, y á la una y media de la tarde después de seis bordos en los cuales procuramos seguir otras tantas líneas de sonda, logramos alcanzar el fondeadero en Talcahuano, y quedar amarrados en seis brazas fango con el ayuste al Norte. La corbeta ATre. viDA habia fondeado después de la oración de la tarde anterior y experimentado los vientos algo más frescos y achubascados, por manera, que careciendo por tres días de las observaciones de latitud, no advirtiese los efectos de las corrientes que le hicieron recalar al Sur de la Isla Santa María. Se hallaron también surtos en la bahia dos buques del comercio de Lima la Barca y el Rosario, destinados á tomar carga de trigo.

Las primeras visitas á bordo de los antiguos amigos y conocidos, debieron desde luego entibiar mucho la natural complacencia nuestra de vernos en el puerto que considerábamos como la última escala del mar Pacífico: el señor Gobernardor Intendente, se hallaba distante, habiendo debido pasar á la frontera para contener á los indios vecinos, mientras transitase á Valdivia el nuevo Gobernador interino Coronel D. Pedro Quijada; no habia carta alguna para nosotros y las noticias públicas posteriores á las que ha. bíamos recibido en Lima, no nos nnunciaban más que una serie de desórdenes, destı : "ciones y ca lamidades que agobiaban á nuestra Lspaña de mancomún con los demás países de Europa; debía aún tranquilizarnos y más bìn producirnos una más que mediana satisfacción, ver entre to. das las demás naciones sobresalir la nuestra por el amor á su religión y á su Gobierno, ver cada clase prodigar con emulación sus hienes y su misma vida para conservar el órlen y quietud públicas; ver finalmente apurados casi los medius de manifestar un valor y una lealtad incorruptible?

Acostumbrados sin embargo á mirar de cerca el marinero por espacio de veinte años, no fiamos á los solos estímulos del ejemplo ageno la seguridad de los armamentos; en carta al señor Gobernador Intendente insistimos en que se tomasen las medidas más estrechas para arrestar á todo prófugo, y solicitamos una leva de de Io á I2 marineros hábiles entre los muchos desertores de los buques de S. M. que se halla. ban anidados en aquellos contornos harto seductores.

A la verdad, por cuanto hubiesen sido activos los auxilios en Lima dei Comandante Don Tomás Geraldino, no era fácil ocultarnos que la Descubierta se hallaba aún muy mal dotada de brazos, tanto más, que ahora por una singular fatalidad, no sólo no haíian podido repararse en el mar los extragos de la última escala del Callao, sino que se habían declarado entre muchos las enfermedades agudas propias de un tránsito demasiado repentino á los climas fríos: Nov. 8 para el alivio de estos últimos se tomaron las precauciones más eficaces, y desde luego pasaron á ser cuidados en tierra los tres que habían sido atacados de la enfermedad con ma. yor violencia: al mismo tiempo se empezó á suministrar á todos ración fresca de pan, carne $\mathrm{y}$ verduras, añadiéndoles para mejor beneficio un cuartillo diario de vino. La agaada, la leña, le conservación de una disciplina extricta a bordo y una ú otra ocupación de los botes en sondi... y planos, suministrarían después aquel ejercicio contínuo y moderado para la conser vación de la salud que mal pudiern haberse combinado con los desórdenes irremediables en los contornos de la Mocha: fueron uniformes con éstas las medidas tomadas por el Coman. dante de la ATrevida, el cual, por su parte, pensaha hacer un mayor acopio de leña, atento á la menor cantidad que había recibido en $\mathrm{Li}$ ma y á la escasez de este ramo en Montevideo.

En la mañana del Io, que fué sumamente placentera, no nos descuidamos en establecer el observatorio en el mismo paraje en que lo habiamos tenido la otra vez: se consiguio para el me dio día la primera época de la marcha da los re. lojes, los cuales eran ahora el número II y el cronómetro 7 I para las experiencias de la gravedad, siendo así que ninguna confianza podíamos aún tener del péndulo astronómico; y en la mañana del 12 tuvo ya lugar la primera de aquellas importantes experiencias: en la misma 'arde, reunida la mayor parte de la Oficialidad de entrambas corbetas, confirmó con muchas series de distancias del Śol á la. Luna la longitud del observatorio ya oue las circunstancias eran las mejores que podían desearse y carecíamos ahora de todo otro medio de determinarla.

Adoptada para el fondeadero del Callao la longitud de nuestras series anteriores, fueron nuestros resultados en esta ocasión los siguien. tes:

\begin{tabular}{r|c|c|c|c}
\hline $\begin{array}{c}\text { Longitud occiden- } \\
\text { tal de Cádiz.. }\end{array}$ & 67.07 .18 & $67 \cdot 15 \cdot 22$ & $67.5 \cdot 30$ & $67 \cdot 30.45$ \\
\hline
\end{tabular}

Las 55 series de distancias medidaz en

cl observatorio. . . . . . . . . 6 6 $7^{\circ} z^{\prime} z^{\prime \prime}$ Las 63 series observadas en los días 7 y 8

$y$ traidas con el número $\mathrm{ri} . \ldots \ldots$. 6.29

Promedio y longitud del observatorio. . Eran nuestras determinaciones del año de $1790 . \ldots \ldots \ldots . . \ldots 6 . . .66 .00$

En los dos días siguientes quedó intercepta. da casi de un todo nuestra comunicación con la tierra, por el viento Norte que reinó con mar gruesa, hasta rolar al Oeste con ráfagas y aguaceros bien violentos, los cuales últimamente ce. 
Nov. as nada absolutamente podía detenernos luégo que entablase la brisa: inmediatamente se destacó D. Francisco Viana á buscarlos en las guaridas donde podian anidarse, mientras las patrullas de tropa evitasen su fuga hacia la Mocha; y efectivamente, hacia la media noche ya se habían aprehendido dos de ellos, con los cuales regres 6

Viana á bordo al amanecer; pero los otros dos no se nos incorporaron sino bien entrada la mañana, $y$ este motivo, reunido al deseo de dar un buen descanso á la marinería ya que había tra. bajado con actividad en los días anteriores, hizo que se suspendiese la salida hasta el 27 , tanto más, que la continuación de la brisa fresca y la distancia del novilunio parecían prometernos la duración del tiempo favorable; pero en esta última suposición nos hallamos enteramente equivocados.

No bien estábamos á pique del ancla del Sur, levada la del Norte y metidas las embarcaciones menores, cuando empezaron á declararse vientos fresquitos del Nornoroeste con aguas y cerrazón; fué preciso espiarnos y dar nucvamente fondo al ancla del ayuste: continuó la lluvia en toda la tarde $y$ noche; no así el viento que habia sido reemplazado por una total calma, y ésta al amanecer del 28 , por algunas ventolinas del terral acompañadas de un semblante hermoso y apa. cible.

Siguierón luégo los tiempos variables é inde. cisos hasta el 2 de Diciembre, sin que fuese posible dar la vela; pero, en fin, en este último día lo pudo verificar la Descubierta y hallarse á las dos de la tarde fuera de la bahía. La ATREvidA defirió igual maniobra hasta el día siguiente.

\section{CAPÍTULO VII}

Navegación de la Descubierta desde la Concepción de Chile hasta el puerto de Montevideo.-Reconocimientos de las Tierras del Fuego y de la Isla de Diego Ramirez.--Escalas en el puerto Egmont de las Islas Maluinas y en la bahía Santa Elena de la Costa Patagónica. - Experiencias de la gravsdad y otras tareas y acaecimientos.

Aunque no se hubiesen aún extinguido las fiebies atabardilladas de las cuales se hizo me. moria en el capítulo anterior, y cuatro ó cinco de los últimamente afectos apenas pudiesen considerarse libres de las garras de l? inuerte, debía consolarnos ver que la convalecencia era por lo común bastante breve, y que ya la enferme. dad no se declaraba en otro alguno: en el rostro de ios demás, en su fuerza, en su agilidad y buen humor sobresallan ahora tanto las utilidades de aquella arribada, cuanto eran tristes, desmayados y macilentos los semblantes del mayor nú- mero al tiempo de la salida del Callao. Suspen. diose en el entretanto suministrar el grog por ración hasta que consumiese cada cual el vino que había recibido de regalo de los vecinos de la Mocha, y repartida abundantemente la ropa de abrigo, se procuró combinar en los trabajos diarios que tuviesen algunas horas de sosiego para coserla y prepararla á su albedrío.

Hasta el ro fueron lentos nuestros progre. sos por no haber salido aún de los límites de los variables; pero entablados en aquel mismo día los vientos tempestuosos del Oeste y Noroeste, nos condujeron con tanta presteza hacia el Sur, que para la noche del 14 ya habíamos alcanzado el paralelo de $49^{\circ}$. Aquí, los vientos, las mares y las cerrazones, lejos de ceder tomaron un semblante aún más horrible y tempestuoso, y cil la penosa alternativa 6 de luchar contrs. ellos iufructuosamente con las muras á babo: 6 de dejarnos arrollar hacia los paralelos de los $\mathrm{Ca}$ bos Pilares y Victoria, parecio el segundo partido más adaptado á las circunstancias nuestras á la sazon, y á las ideas que nos hablamos formado sobre nuestras tareas á la otra banda del Cabo de Hornos.

Diferentes veces, la derrota que ahora se. guíamos nos llevó á surcar la misma senda que habíamos corrido en el año I790, y el encontrar ahora con un mes de an:icipación tiempos aún ménos favorables de los que habíamos ex. perimentado entonces, nos convenció de nuevo cuánto era casual un momento feliz en aquellas regiones. No nos era extraña la acostumbrada compañía de un crecido número de pájarus pamperos cuando reinasen los vientos tempestuosos del Oeste, asi como en los instantes más bonancible 3 se nos aparecían las gaviotas, las pardelas y una í otra ve $z$ tal cual lobo marino.

Las últimas horas del I 6 parecieron querer transformar en un todo la escena que nos rodeaba desde ocho días; á las ráfagas sumamente recias del Oeste (símbolo ya casi seguro de su poca duración), á las cerrazones, á ląs mares ya descritas, sustitúyese ahora un tiempo sereno y apacible entremezclado 6 con una total caima ó con algunas ventolinas del segundo cuadrante. Revivieron nuestras esperanzas ya enteramente desmayadas y ceñimos in. mediatamente con todo aparejo al Esnordeste y Este, aprovechando interiormente para el aseo y conservación de la salud, la hernıosura del día y el brillo del Sol; y como las ventolinas aunque débiles continuasen en la noche siguiente, ya para las primeras claras del 18 habiamos estrechado de unas ro leguas la distancia con el Cabo Victoria.

Poco acostumbrados á la claridad y hora tem prana del crepúsculo, admirábamos á la saźon á veces el brillo lisonjero de las iestrellas, á veces 
llao. Suspen. Dic. $r$ el grog por cual el vino os vecinos de mente la ropa n los trabajos as de sosiego edrío.

estros progre límites de los el mismo día te y Noroeste, hacia el Sur, mos alcanzado tos, las mares $r$ tomaron un pestuoso, $y$ es ir contrf. ellos á babo: 6 de los de los Ca. egundo partido s nuestras á la amos formado panda del Cabo

que ahora sesma senda que $0, y$ el enconpación tiempos e habíamos exenció de nuevo liz en aquellas acostumbrada le pájarus pams tempestuosos ites más bonantas, las parde. marino.

iarecieron queescena que nos ráfagas suma ya carsi seguro rrazones, á las ahora un tiemlado ó con una tolinas del seestras esperan. y ceñimos in. a) Esnordeste ate para el aseo mosura del día rentolinas aunoche - siguiente, 8 habíamos esistancia con el 1)ic. 8 la aproximación del astro vivificado: de toda la Naturaleza, á veces las muchas aves y lobos marinos que pareclan esperarle con ansia y saludarle cada cual con sus voces broncas y poco melodiosas, cuando contra todas nuestras espectativas se aumentó esta escena con la vista de una embarcacion hacia el Sueste; y variando de un golpe el hilo de nuestras ideas, que casi nos separaban del mundo habitado, debimos sólo entregarnos á aquellos pensamientos que la inconstante ambición del hombre alimenta para su propio daño.

Reconocímosia á poco rato por una fragata ballenera americana. Enviado después el bote á su bordo, supimos con harta mortificación que había salido de los puertos de la América unos seis meses antes, de manera que sus noticias sobre el estado de la Europa fueron aún más añejas que las recibidas en Lima y en la Concepción. Dímosle algunos refrescos y las direcciones oportunas para la navegación siguiente, ya que su ánimo era buscar paralelos más bajos para la continuación de la pesca, y la despedimos, pues el tiempo se apresuraba á tomar su semblante acostumbrado.

Era ya nuestro plan reconocer la costa desde el Cabo Deseado, y no perderla de vista hasta la Isla de los Estados. Considerábamos el Diario del Capitán Cook, para suponer que lograríamos de un viento igualmente claro y manejable que nos permitiese recalar á imitación suya con alas y rastreras; pero en esta ocasión, como en otras muchas, nos estaba prevenida una nueva oposición, la cual nos recordase que si era difícil imitar á aquel célebre navegante en su pericia y tino marineros, no era ménos intempestivo y osado aspirar á un igual grado de felicidad.

Desde la media noche del Io, el tiempo empez6 á tomar tan mal semblante y el harómetro á bajar tan considerablemente, que ros parecieron precauciones indispensables ceñir ai Sur el viento ya arrafagado del Oeste y limitar el aparejo al solo trinquete $y$ las gavias en dos rizos arriadas: no eran infundadas nuestras sospechas, ni vanas nuestras precauciones, pues á las ocho de la mañana nos sobrecogio tan fuerte contraste del Sudoeste y Sursudocste, que á pesar de la re. sistencia casi indecible de nuestro casco y aparejo, se no: hacía sumamente arriesgado resistirlo: ignorábamos su duración, las mares con exceso gruesas nos amenazaban de una deriva considerable sobre la costa, si nos descuidásemos en una capa sosegada; y así nos parecíb un partido inevitable conservar largos el trinquete y la gavia en dos rizos arriada, y con esta vela más bien excesiva, continuar hasta franquearnos con las muras á estribor.

L,os islotes del Cabo Deseado, nos demoraban unas veinte leguas al Nordeste. Si el viento hubiese continuado por largo tiempo con la fuerza y dirección con que había entrado por la maña- Dic. ta na, la deriva inevitable de una mar gruesa y un aparejo limitado nos hubieran acarreado sobre los islotes del Cabo Negro ó precisádonos á na. vegar con no ménos riesgo sobre las muras á babor; ni debía parecer extraordinaria semejante duración, ciaando consultásemos las navegaciones nacionales de los últimos años, las cuales dicta ban últimamente, como preferente el partido de surcar aquellos mares con atención á los vientos, más bien en la oscura estación del invierno que en la clara pero más tempestuosa del verano: por ventura no fueron acertadas nuestras sospe. chas; el viento y la mar cedieron mucho en la no. che siguiente, y declarados después por el Sudoeste bonancible con buen semblante, nos dieron lugar á navegar con fuerza de vela en demanda de tierra.

Fueron los vientos demasiado bonancibles para que consiguiésemos avistarla antes del os. curecer del 2o, pero va á esta hora estábamos de ella á tan corta distancia, que áun con un andar muy lento y paireando desde la media noche, para las tres y media de la mañana del $2 r$, veíamos á distancia de unas ocho leguas los Cabos Glocester y Negro, el primero hacia el Nornoroeste y el segundo al liordeste \% Este de la aguja.

Luégo que la claridad del día $\mathrm{v}$ el viento aunque flojo nos permitieron coribinar cou la continuación de la derrota nuestras tareas acostumbradas, seguimos rumbo del Zsueste, el cual nos conducía aunque paulatinarnente, á pasará unas cuatro leguas del Cabo Nę̧,ro: admirábamos de nuevo la exactitud de las descripciones del Capitán Cook en este nuevo tıatro de su felicidad é inteligencia navegantes, y guiados así por mano, dejábamos aparte la idea de descubridores, para tomar el semblante no niénos útil del que para el bien público rectifica y á veces perfecciona con una cierta nimiedad científica las primeras obras, siempre algo informes cuanto más útiles y grandiosas.

F, Cabo Glocester pareció á nuestra vista un fro. 7 de tierra algo pendiente al mar y con un islote casi igualmente al to á corta distancia de él: seguía luégo la costa de mediana altura formada de muchos picachos todos entrecortados con canalizos, de modo que parecian más bien islas; y últimamente casi Noroeste-Sue te con aquel $\mathrm{Ca}$ bo, se dejaba ver con igual altura y con un color bien oscuro la isla grande del Cabo Negro; en ella se hacía particularmente notable una quebrada con dos piquitos agudos por su parte del Este y del Oeste; diferentes islotillos difíciles de percibirse sino á muy poca distancia, rodeaban luego la punta más meridional; y no era nosible (tal vez por la calima) distinguir lengua alguna de tierra que le uniese á latierra firme, antes 
1)ic. " bien, el terminar la parte oriental y baja de la isla en un mogote bastante elevado, parecía indicar que ésta fuese realmente una isla: fueron vanas nuestras diligencias para avistar los dos islotes salientes al Sur 1/, Sueste, aunque nuestra derrota nos condujese á pasar de ellos unas tres leguas apenas. El poco viento no nos permití el estar Norte-Sur con el Cabo Negro hasta después del medio día, habíamos observado la latitud Sur de $54^{\circ} 4^{8^{\prime}} 30^{\prime \prime}, y$ al mismo tiempo la longitud de $67^{\circ} 9^{\prime} 40^{\prime \prime}$ occidental de Cádiz deducida por el número II, nos daba lugar de confrontar nuestros resultados con los del Capitán Cook.

Pasado el Sol por el meridiano fué el viento aumentando considerablemente sus fuerzas $y$ agregándosele al mismo ticmpo una corriente rápida hacia el Este, de suerte que nuestros pasos fuesen en esta ocasión expeditos; antes navegamos al Esnordeste para internarnos hacia la grande ensenada en la cual el Capitán Cook había sospechado la existencia del Canal de Santa Bár. bara y luégo aproximándonos para las seis hacia el Cabo Desolación, corrimos la restante tarde al andar de la costa y á una distancia de ella de tres leguas próximamente. Era el tiempo sumamente claro y liermoso y esto nos dió lugar á que avistando el golfo intermedio entre el Cabo Negro y el de Desolación tuviésemos la casual felicidad de poderle describir tal vez con alguna mayor individualidad de la quese había proporcionado al Capitán inglés.

A la parte del Norcieste del Cabo Negro, se advierte efectivamente una grande ensenada cuyos límites al Norte no es fácil descubrir á lo ménos en una distancia de seis leguas próximamente desde los extremos del Cabo; pero pasada esta distancia, se vuelve á unir la costa, y si bien las proyecciones indiquen la existencia de una ú otra isla, no parece que sean estas las que forman la mayor porción de la costa, y no es fácil descubrir otra entrada alguna hasta llegar al Cabo Desolación. Los picachos siempre dispuestos en una figura regular volcánica empiezan aquí á multiplicarse mucho, se les vé cubiertos con manchas grandes de hielo, despoblados de arboleda y sólo en una ú otra parte de las más bajas, vestidos aunque mezquinamente de tal cual fruto de una corta vegetación.

La sonda, si consultásemos así las observaciones del Capitán Cook y nuestras, como el color del agua, no debe tampoco suponerse muy saliente al mar; y por cuanto pueda inferirse de lo acaecido á aquel Capitán en la bahía de $\mathrm{Na}$. vidad, y á los últimos navegantes nacionales en la parte interior del Estrecho de Magallanes, no debe por ella navegante alguno entregarse descuidado á la seguridad de hallar fondeadero donde vea abrigo; la mayor parte de las veces se ha- llará sin fondo á muy corta distancia de las pie- Die. sr dras.

Efectivamente, desde el Cabo Desolacion, la Tierra del Fuego toma un semblante lorrible, as! por su aride $z$ como por su elevacion y escarpe: á poca distancia del Este se advierte una entrada como de cuatro millas, y con dirección al Nordeste le forma el mismo Cabo al Noroeste $y$ otra punta no ménos alta y escarpada al Sueste; no se descubren interiormente másque tres ó cuatro islotes bastante distantes, y los arrecifes ó pedruscos que bordan luego la costa siguiente al Este, no parecen obstruir en modo alguno toda la anchura de la boca indicada; pasada ésta ya por largo trecho, no se descubre otra entrada alguna, y la costa con dirección del Esueste, corre bastante unida, hasta presentar las dos entradas grandes, de las cuales es la más óriental la de $\mathrm{Na}$ vidad que visitó el Capitán Cook.

Unas seis leguas al Este del Cabo Desola. ción, nos sobrecogió la poca luz del crepúsculo, que nos precisó á poner término á nuestras ta. reas, esperando con ansia que la claridad del nuevo día nos permitiese continuar con la misma felicidad que ahora parecia querernos acompañar. Unánime toda la Oficialidad, había con. venido en que podía aún reconocerse un trnzo re gular de costa antes de buscar el paralelo de la Isla de Diego Ramírez, cuyo reconocimiento debíamos mirar como de la mayor importan. cia; $y$ con este mismo plan esperábamos paireando sobre las gavias á unas tres leguas de la costa la hora oportuna para dar principio á nuestras tareas: en esta posición, eran nuestras sondas de 65 brazas piedra y coral, y la variacíón magnética de $25^{\circ} 30^{\prime}$ Nordeste.

Estos conceptos realmente lisonjeros, 110 fueron sino momentáneos; á la una de la mañana el tiempo inclinándose el viento al Oesnoroeste, había tomado su acostumbrado semblante tempestuoso, y nos había precisado á precavernos con dos rizos en las gavias. Semejante sorpresa alteraba nuestro plan primitivo de operaciones, porque siendo probable que el temporal durase algunos días con las cerrazones inseparables, debía recelarse que la deseada Isla de Diego Ramírez, 6 se nos ocultase, 6 la viésemos sin poder lograr de observacion alguna, 6 que finalmente nos quedase al Oeste, cuando lngrásemos de tiempos más oportu. os para reconocerla. Con estas reflexiones abandonamos inmediatamente la costa, y sin dejarnos descaecer nada del meridiano en que nos hallábamos, navegamos al Sur para entrar en el paralelo de $56^{\circ} 28^{\prime}$.

Con el temporal del Oesnoroeste, que ya ha. bía establecido su imperio, nos fue fácil alcanzar la posición proyectada: capeamos inmediatamente sobre la gavia y el contrafoque, y debió, á la verdad, tranquilizarnos mucho sobre el lo: 
cia de las pie- Dic.s!

Desolacion, la te horrible, así ion y escarpe: rte una entran dirección a al Noroeste $y$ pada al Sueste; que tres 6 cualos arrecifes o ta siguiente al to alguno toda pasada ésta ya tra entrada alEsueste, corre is dos entradas iental la de $\mathrm{Na}$ -

Cabo Desola del crepúsculo, á nuestras taa claridád del ar con la mis. uerernos acomad, había conrse un trozo reel paralelo de reconocimiento yor importanserábamos paires leguas de la ar principio á , eran nuestras ral, y la variaste.

onjeros, no fuede la mañana al Oesnoroeste, semblante temá precavernos ejante sorpresa de operaciones, emporal durase iseparables, dede Diego Ramíemos sin poder que finalmente lográsemos de conocerla. Con nmediatamente $r$ nada del menavegamos al $5^{6^{\circ}} 28^{\prime}$.

ste, que ya ha. ué fácil alcanamos inmedia foque, y debib, ho sobre el lo.
Lic. $"$ gro de nuestros deseos, considerar que aún dis. tábamos unas 35 leguas á barlovento de la posi. ción probable de la isla, y que por consiguiente no la propasariamos tan luégo. Con esta atención misma, ya que la mar y el viento eran extraordjnariamente tempestuosos, y los horizontes á veces no se extendían ni á una milla siquiera, nos pareció preferente capear, que navegar con alguna más vela sobre bordos, los cuales, 6 nos hubier:un separado mucho del paralelo en que queria. mos mantenernos, ó con las muras á babor hu. bieran en mucho menor plazo, consumido la distancia favorable á barlovento.

Nuestra curiosidad sobre la existencia de esta isla era extremada; pareciéndonos bien extraño que los solos Nodales entre nuestros navegantes la hubiesen visto, y que poco conforme en esta ocasión la Naturaleza con la harmonía general que se advierte en todas sus obras, cuasi á la vista de unas tierras elevadas, ásperas y tan pedregosas que pudiesen resistir al ímpetu de las olas, hubiese colocado como un antemuro de ellas mismas una islita baja, débil y de tan poca extensión cual nos la representaban en el dia las cartas modernas, inclusa la del Capitán Cook: resolver esta duda era además un punto harto importante para la navegación nacional, y (digámoslo así) la única pesquisa útil en esos mares que había dejado el Capitán Cook á los que le siguiesen.

Atento á este plan, no sólo en la tarde y noche actuales, sino también en todo el día siguiente, no varió nuestra capa de la gavia y el contrafoque, ni nos apartaron nuestros bordos más de siete á ocho minutos á una y otra parte del paralelo sospechoso: acechábamos con vigías cualesquiera claras, aunque momentáneas, que pudiesen extender nuestra vista á una legua en torno siquiera, y los sacrificios actuales de sufrir á costa de mil incomodidades un temporal que parecía destinado á sacarnos con.brevedad de esas mareas tempestuosas, nos hubieran parecido con exceso frívolos si no los viésemos influir extraordinariamente en la salud y en el mismo desaliento de las clases inferiores.

A las diez de la mañana del 24 , cuando más reunídos parecían los elementos para hacernos desagradable aquella demora, vimos repentinamente dividirse las nubes, rolar el viento al Sudoeste, y al mismo tiempo serenarse el cielo y tranquilizarse poco á poco el mar: no anduvi. mos omisos ni en examinar por medio de las ob. servaciones nuestra posición verdadera, ni en hacer rumbos $\mathrm{y}$ aparejo proporcionados á este intento. Nos manifestaron aquéllas que en los solos dos días últimos habíamos contraído $x^{\circ}$ de error al Este en la estima; de suerte, que un solo día más de temporal nos hubiera hecho propasar de los meridianos sospechosos, y los otros nos guiaron á avistar hacia las dos de la tarde Dic, al Nordeste la isla deseada.

Era bien diferente la idea que ahora podía. mos formar de las Islas de Diego Ramirez, de la que antes nos habian dictado las noticias antiguas; es éste más bien un pequeño Archipiélago de una más que mediana elevación, con el mismo semblante árido $\mathrm{y}$ pedregoso que presentan '१s tierras de Cabo Desolación con una extensión tal vez mayor que la de las Islas de San Ildefonso, $y$ con una dirección de Norte á Sur, que in dica al mismo tiempo su homogeneidad con las tierras inmediatas al Norte, y su estructura si. métrica según las leyes admirables de la Naturaleza.

Para las cuatro de la tarde habíamos atra. cado ei extremo Sur á distancia de dos leguas; le vimos rodeado á corto trecho de muchos pedruscos escarpados en los cuales rompía el mar con una fuerza extraordinaria; le situamos en latitud de $56^{\circ} 33^{\prime}$ y longitud occidental de Cádiz de $62^{\circ}$ $2 \mathrm{o}^{\prime} \mathrm{Oo}^{\prime \prime}$, y pareciéndonos que éste se miraría por los navegantes venideros como el verdadero término de las Tierras del Fuego, y el punto al cual debiese referirse la navegación de altura, le dis. tinguimos con el nombre de Cabo Valdés para recordar en él al mismo tiempo el protector constante de la navegación nacional y el agradeciiniento que le profesaban los que habían sido destinados á este intento en la corbeta Descu. BIERTA.

El grupo de las islas conservó el nombre de Diego Ramírez, se trazaron sus términos y arrumbamientos con repetidas bases y observaciones, y como el color del agua y disposición de la tierra nos asegurase que no había sonda en aquellas inmediaciones, continuamos, hacia las seis de la tarde nuestra derrota para aproximar. nos al Cabo de Hornos. Efectivamente, á las tres de la mañana siguiente logramos ya de la vista de aquel célebre Cabo y de sus inmediaciones, aunque los repetidos chubascos del Oeste nos la interrumpiesen á veces: la mar era llana y el tiempo no manifestaba en su semblante la menor apariencia de querernos contrariar.

Este Cabo, el que más se señorea sobre el mar en todos aquellos contornos, parece cortado á pico, le rodean varios islotillos, $y$ aunque con la mayor verosimilitud, no pertenezca el mismo sino á una isla de las muchas que componen la Tierra del Fuego, se presenta, sin embargo, como el verdadero límite de unas piedras inmensas, áridas y desiertas por la parte del Oeste; y por la del Este de unos terrenos más suaves y fecundos, y por consiguiente de un clima ménos áspero y temible: no es extra. ña esta singular variedad de todas las circuns tancias de la Naturaleza á una y otra parte del Cabo para nuestros navegantes del Perú, los 
Dic. 4 cuales, conslgujendo por lo común atravesar el Estrecho de Maire, y á veces aún costear con Noroeste las tierras siguientes al Cabo Bten Suceso, encuentran luégo en su meridiano aquellos temporaies del Sudoeste, que han hecho siempre tan duradera y arriesgada esa navegación.

Reconocidas para las scis de la mañana to. das sus inmediaciones, $y$ poco inquietos que la cerrazón y la hora intempestiva no nos permitie. sen referir á este punto ni longitud ni latitud, ya que el Capitán Cook habia verificado uno y otro objeto con las mejores circunstancias, continuamos nuestra derrota hacia el Cabo Engaño y las Bernabelas, y nos favorecicron de tal modo los vientos, que para el medio día nos lallamos en latitud de $55^{\circ} 32^{\prime}$ y longitud de $60^{\circ} 5^{\prime}$, marcando al mismo tiempo la Isla Lvout al Oeste $5^{n}$ Sur, $y$ el extremo Sur de la isla nueva al Noroeste verdadero: el tiempo había tomado un semblante apacible y despejado, y después de veinte días de temporales casi contínuos, podlamos finalmente revivir en nuestra memoria tal cual idea de la existencia de un verano.

Los rumbos del Nornordeste al Nordeste que seguimos en la tarde con el viento del Sur-Sudoeste á cada paso más bonancible, nos condujeron muy luégo á unas tres leguas de la isla nueva, viendo sucesivamente las tierras altas interiores que parecen formar varias bahías profundas y abrigadas. A las ocho y media de la tarde, el Cabo Buen Suceso demoraba al Norte $8^{\circ}$ Este, distancia de ocho á nueve leguas, y el Cabo San Antonio en la Isla de los Estados al Norte $38^{\circ}$ Este de la aguja, sin que á la sazón pudiese aperci. birse efecto alguno de corrientes. Poco después nos abandonaron de un todo las últimas ventolinas del Sur, y quedamos en una perfecta calma hasta las primeras horas de la siguiente maña. nita, en las cuales entabló vierito fiesco y contrario del Norte.

La mañanita del 26 en que se nos habían declarado vientos contrarios para entrar en el Estrecho de Maire, no nos hizo tampoco variar de idea: era el tiempo sumamente placentero $y$ despejado, la mar llana y el viento galeno, de suerte que nos parecía evidente una próxima alte. ración favorable que diese lugar á los vientos reinantes del Sudoeste; así nuestros bordos que se habian dirigido al principio al Este, variaron muy luego hacia las Tierras del Fuego; y como el viento fuese aumentando su fuerza á medida que el Sol se aproximaba al meridiano, ya para el medio día por latitud de $55^{\circ} 4^{\prime}$ no distábamos más que unas tres 6 cuatro leguas al Sur $6 \mathrm{r}^{\circ}$ Este del Cabo Buen Suceso; se veía la bahía de este nombre al Norte $32^{\circ}$ Oeste y el Cabo San Antonio en la Isla de los Estados al Norte $12^{\circ}$ Este de la aguja.

Muy luego el Norte más recio y algo más in- elinado, nos precisó á navegar sin juanetes y con Dic. on las gavias en un rizo, $y$ nos condujo á poca dis. tancia á barlovento del Cabo Buen Suceso: sa. biamos que este era el extremo Nordeste de la bahia Valentín; se mantenía constantemente nuestro ánimo de acecliar ocasiln oportuna para embocar el estreclio y la dirección de la costa. nos prometía un excelente abrigo al ancla 6 á la vela mientras permaneciesen los vientos ya muy recios del Norte.

Prevenidos con el escandallo, nos dirigimos á internar cuanto fuese posible en la bahía; no encontramos fondo ni áun á media milla del frontón del Cabo, pero á distancia de dos 6 tres cables, sondamos 50 brazas cascajo y piedra. Descubierta á este tiempo toda la parte interior de la bahía cuya mayor profundidad estaba en la dirección próximamente del Norte, prometía sí con la vista de una playucla, un fondo mejor en sus inmediaciones del que nosotros encontrábamos; pero daba también una idea nada ventajosa del fondeadero, enteramente desabrigado para los vientos del segundo y tercer cuadrante allí bastante comunes: el viento reinante á la sazón nos hubiera, sin embargo, inducido á mirar como una felicidad poder fondear, $y$ á este intento ceñíamos con las gavias y el trinquete dispuestos á repetir los bordos necesarios, mas no tardamos en conocer la imposibilidad de conseguirlo por las rachas fuertes del Norte que nos sobrecogie. ron al descubrir por la parte interior la tierra del Buen Suceso. No permitían las viradas ni la vela necesaria, y áun indicaban como precisa para el fondeadero más de una ancla, ya que las quebradas de las tierras medianamente altas que ro. dean por todas partes la bahía, causaban una fuerza extraordinaria en el viento.

El bordo que seguíamos nos condujo á disminuir el fondo á 45,37 y 30 brazas cascajo y piedra á medida que recalando al Sur de la pun. ta frontera de la del Buen Suceso, atracábamos la costa siguiente, en la cual se haría particularmente notable una lenglieta de tierra, indicio tal vez de un mejor abrigo: arribamos para costearla y reconocerla de cerca, y muy luégo desmaya. ron en esta parte nuestras esperanzas, viendo que no cubría abra alguna notable, y que á distancia de uno y medio cables conservaba aún un fondo de 28 brazas coral de la misma calidad que presentaban sus orillas: á este tiempo era fácil conocer por una grande humareda.á dos millas al Sur que aquellas inmediaciones no estaban de. siertas de habitantes, $y$ que probablemente nos habian visto.

El plano de la bahía pudiera hacer inútiles cualesquiera descripciones, tanto más que su po. co abrigo ya no la hace tan útil como deblamos sospecharlo, por las noticias de los navegantes franceses que la frecuentaron al principio del 
uanetes y con Dic, of jo á poca dis. n Suceso: sa. Nordeste de la onstantemente oportuna para n de la cost al ancla 6 á os vientos ya

nos dirigimos la bahía; no dia milla del a de dos 6 tres ajo y piedra. parte interior ad estaba en la e, prometía sí ondo me jor en s encontrába. ada ventajosa abrigado para cuadrante allí inte á la sazón ó á mirar como ste intento cete dispuestos á s no tardamos onseguirlo por os sobrecogie. or la tierra del adas ni la vela precisa para el que las quebra. altas que ro. causaban una

ondujo á dismiizas cascajo y Sur de la pun, atracábamos ría particularrra, indicio tal s para costearuego desmaya ras, viendo que que á distancia aún un fondo lidad que preo era fácil co. a dos millas al no estaban de. ablemente nos

hacer inútiles más que su po. omo debíamos os navegantes 1 principio del 1)ic. 36 siglo. La ensenada interior promete ciertamente un mejor fondo, y una abundante y cómoda pro. visión de leña y agua; pero de todos modos son preferibles en mucho la bahia del Buen Suceso y otras de la costa que corre hacia el Cabo de Hornos.

Abandonada para las cuatro de la tarde la idea de fondear en aquellas inmediaciones, fué ruestro intento mantenernos á su abrigo hasta la mañana siguiente, y después, si los vientos fuesen igualmente tenaces, pasar al Este de la Isla de los Estados para navegar al puerto Egmont de las Islas Maluinas. Efectivamente, fué preciso adoptar este partido: hiciéronse rumbos

27 y aparejo proporcionados y vencida hacia las ocho de la mañana la corriente que nos acon. claba sobre el Cabo San Bartolomé, seguimos costeando á distancia de unas tres ó cuatro le. guas: el viento era variable desde el Nordeste al Noroeste, pero casi siempre recio y acompañado con lluvia, cerrazones y mal cariz; la mar no era gruesa, pero las corrientes formaban en ella re. molinos frecuentes y elevados; finalmente, la tierra estuvo siempre cubierta de modo que no tu. viésemos marcación segura al Cabo San Juan hasta las cuatro y media de la tarde, á cuya hora le marcábamos al Norte $78^{\circ}$ Oeste de la aguja, distancia seis leguas.

Debimos pues desistir de la idea de repetir las experiencias de la gravedad en el fondeadero del Año Nuevo, pues que la debilidad y natural cansancio de las tripulaciones iba en mucho au. mento. Nos decidimos, por la misma razón, por el puerto Egmont, atento á la mayor suavidad del clima y á la facilidad de la aguada y demás objetos de las embarcaciones menores: ni á la verdad debíamos creer el plazo para alcanzar el úlitimo puerto más distante del que pudiese conducirnos á la Isla de los Estados.

Tuvimos tiempos variables $y$ inénos tempestuosos hasta la noche del 31 en la cual se deci. dí viento fresco del Sudoeste : á las diez del

En. 3." día $I .^{\circ}$ de Enero se avistaron los Salvajes, y al medio día, por latitud de $5 \mathrm{I}^{\circ} 5^{\prime}$ se les marcaba al Este $\%$ Nordeste de la aguja, distancia cuatro y media á cinco leguas. El viento bien fresco, el tiempo bastante claro, y los conocimientos prácticos que creíamos tener ya de las inmedia. ciones del puerto, nos incitaron á no esperar la mariaria siguiente para al canzarle aunque no distásemos de él ménos de 24 leguas: creíamos francos los canales intermedios los cuales nos permitirían una derrota más directa sin pasar al Norte de la isla Kasa; y las muchas jslitas que debíamos propasar, serían otras tantas valizas para fondear siquiera en la bahía exterior de la Punta Bluff, Con estas reflexiones forzamos cuanto fue posible de vela, y prefiriendo el paso entre los Salvajes y laș Llaves conseguimos para la una y media con un andar de nueve millas, En. hallarnos al Sur de la isla Rasa unas tres leguas. Ya proximos á los Salvajes fuimos sobrecogidos intempestivamente por turbonadas y rachas fuertes del Oeste hasta el Sur, las cuales, ademá de una salida demasiado precipitada sin permi. tirnos sondar, nos ocultahan á veces hasta los objetos más cercanos. 1 il marinero del tope avisó al mismo tiempo que veía por la proa una cadena de restingas que unian al Salvaje inme. diato: repetian más frecuentes las turbonadas; $y$ cualquiera partido parecía en aquel trance igual. mente aventurado. Como quiera que nuestros reconocimientos de 1789 nos debiesen hacer creer que el extremo Sur del Salvaje eran limpio de arrecifes contra lo que creian ver desde el tope, pareció el mejor partido atracar la isla á la me. nur distancia posible. Nos aproximábamos de este modo á los islotes las Llaves, cuando una clara casi momentánea nos descubrí un nuevo peligro. A distancia de una legua se apercibian dos islitas unidas con arrecife y éste se extendía luégo algún tanto al Norte formando con el Salvaje un canal de una legua escasa en el cual se notaban remolinos extraordinarios de las aguas, estrechadas sin duda por la oposición de la co. rriente con el viento. Por ventura era éste bas. tante largo para que pudiésemos orzar hasta el Noroeste, continuando así á corta distancia del Salvaje y aunque la elevación de los montes despidiese contínuamente unas rachas realmente increibles, nuestro buque y aparejo fueron ca. paces de resistirlas, por manera que sobre las cuatro principales, las gavias algo arriadas, pu. dimos poco después pasar á una milla del arre. cife dejándole al Sur, y para las tres y media encontrarnos libres del riesgo indicado. Casi á un mismo tiempo cedieron de un todo las turbonadas, la naar y el viento, se serenó el cielo y manifestándonos ya todas lás apariencias como im. prudente el aproximarnos en la restante tarde al fondeadero, emprendimos con el trinquete $y$ las gavias en dos rizos el esperar la mañanita si. guiente sobre bordos inmediatos al Salvaje.

La noche fue hermosa y apacible: no así las primeras horas del día 2 , en las cuales las turbonadas del Oeste al Sur fueron bien frecuen. tes (I).

Para la mayor exactitud de las experiencias del péndulo simple se atendió á que el observatorio se estableciese en paraje ménos expuesto á los vientos reinantes del Oeste, con cuyomotivo,

(1) Sin embargo, a las diez pudimos atracar la Punta Bluff, y antes del medio dia vernos dentro del puerto con sondas de ro brazas. El viento fresco del Sudoeste nos precisó después á dar algunos bordos para alcainzar ol fondeadero que habiamos tomado er. 789 , y asl eran las dos do la tarde cuando pudimos dejar caer el ancla a corta distancia de la aguada. 
E.n - situado en la orilla Sur de la dársena, distaba del otro del viaje anterior unos dos cables al Sur $20^{\circ}$ Este de la aguja; los cimientos para el cuar. to de círculo y para el péndulo simple se form. ron con losas sólidamente pisonadas. Depositados los dos relojes en una de las tiendas, se procuró también que estuviesen elevados del suelo, se. parados de la humedad y precavidos del frio, y si el día siguiente del 3 no hubiese sido constan. temente lluvioso á causa dil viento Norte, la pri. mera época de nuestras observaciones se hubiera sin duda establecido en aquel ı nismo dia, no pudo el tiempo contrarestarnos con iguales dificulta. des en los demás objetos de nuestra escala, los cuales, si bien secundarios, no podiamos mirar con indiferencia; y eran la caza, la pesca y un acopio abundante de apio silvestre: fué la primera abundante, pero no tanto que no se extrañase ya la mucha concurrencia de buques en aquellos contornos: tuvimos la felicidad en cuanto á la segunda de coger con corral cerrado en la ma. rea alta una cantidad no menor de 40 á 50 quin. tales, todos de la misma especie del bacalao y de un sabor y tamaño realmente agradables.

Una atención no ménos precisa en nuestras medidas actuales era sin duda el restablecimicn. to de los enfermos, los cuales en mucho número y sumamente debilitados, esperaban con el esparcimiento y recreo de la tierra aquel alivio que ya de ningún modo pudiera proporcionárseles en el mar: con este intento se había ya construído una tienda, á donde pudiesen comer, descansar y abrigarse 6 de las aguas 6 de los rayos ardien. tes del Sol, y como no tardasen en disfrutarla cuando el tiempo no era absolutamente contrario, se advirtieron inmediatamente sus efectos y vimos disiparse poco á poco en el mayor número las calentuias, obstrucciones y debilidades casi invencibles hasta entonces.

No era, sin embargo, la estación actual la más favorable para este intento ni para las ob. servaciones celestes: con mucha frecuencia nos acosaban recias granizadas y vientos del Sudoeste, los cuales hacían á veces molesta la comunición con tierra, malograban las alturas correspondientes de la tarde, é imposibilitaban la caza y la pesca; esto mismo era un nuevo inconveniente para la marcha uniforme de los relojes marinos en el observatorio, pues variaba de un momento á otro de $10^{\circ}$ y $12^{\circ} \mathrm{el}$ temperamento, $y$ la humedad repentina nos amenazaba de variaciones aún más temibles en su movimiento.

Aprovechándose á pesar de estos inconve. nientes las ocasiones oportunas para los objetos que nos habiamos propuesto, $y$ sustituyendo cuando hubiese alguna alteración notable de los relojes el método de las alturas correspondientes á las absolutas, deducida ya de antemano la excentricidad del cuarto de círculo, pudimos en un corto plazo de ocho 6 die $z$ dlas, ver repetidas con bastante pulso $y$ seguridad las experiencias de la gravedad, de modo que ya sus resultados en esta parte importantísima del hemisferio austral pu. diesen mirarse como bien satisfactorios.

lin el entretanto habian sido varios los inci dentes ocurridos, relativamente á los diverso buques americanos surtos 6 en el mismo puerto 6 en sus contornos. Casi diariamente las lanchas grandes recorrian las islas interiores; habia fondeado el día 9 en el puerto una goletilla de la misma nación perteneciente á un buque surto hacia la Punta Oeste de las Islas, e imposibili. tado por su mal estado de navegar; todos nece. sitaban galleta y este último al gunos efectos na vales que habia pedido, mas no conseguido en el establecimiento nuestro de In Soledad; finalmente, á medida que se dilataban estas demoras, cre cía el extrago de los lobos marinos de modo que su destrucción, como ellos mismos confesaban, parecía bastante próxima. Semejantes procedimientos combinados con la interpretación méno equivoca del articulo $60^{\circ}$ del último tratado de Escorial, nos decidieron, á no ser testigos indiferentes de un daño tan considerable para 108 in. tereses nacionales 6 un medio poco cauto para que con los auxilios solicitados fuesen aún más duraderas estas pescas; combinando una y otra atención, con el derecho más inviolable. de la hospitalidad, con la mayor seguridad de no enturbiar la tranquilidad pública y particularmente con cl cuidado de que no se ajase el honor del pabellón con unas intimaciones fáciles de eva dirse sin el menor escarmiento.

Jlamados los dos Capitanes de los buques surtos en el puerto y el Capitán White de 1 a goleta pequeña, se les hizo ver por cuántos títu. los debía considerarse como posesión nuestra, todo lo que se comprendía bajo el nombre de la Islas Maluinas: cuánto eran nocivas á los inte. reses nacionales las pescas en que entendian; cuánto sería reprensible que fuésemos testigos indiferentes de semejantes abusos, y cuánto les sería fácil eludir nuestras medidas transfiriéndose á otros puertos no distantes, mientras durase el plazo breve de nuestra demora en aquellos contornos; el cual seguramente no excedería de doce dias; de suerte, que esta última circunstancia nos precisaba á desalojarlos sin pérdida de tiempo cuando no alegasen razón alguna justificativa para una demora ulterior; razón á la cual suscribiríamos gustosos, ya que ni era nuestro animo molestarles su fondeadero ni dejar de auxiliarlos en cuanto fuese posible: semejantes proposiciones no podian ménos de estrecharlos; presentaron al día siguiente entram bos Capitanes de los bergantines surtos en el puerto, papeles que acreditaban su intención de salir luégo que concluyesen la aguada. En las 
repetidas con $V_{n .}$.

eriencias de la

ltados en esta

-io austral pu. corios.

arios los inci. los diversos mismo puerto te las lanchas res; habia fon. roletilia de la h buque surto é imposibili. todos nece. nos efectos na. onseguido en el dad; finalmen. ; demoras, cre. $s$ de modo que ss confesaban, antes procedi. etación menos no tratado del testigos indile para los in. co cauto para esen aún más do una y otra violable. de la idad de no en. articularmente e el honor del áciles de eva.

de los buques White de la r cuántos títuesión nuestra, nombre de las vas á los inteue entendlan; semos testigos os, y cuánto didas transfi. ates, mientras a demora en umente no exque esta últi$\{$ desalojarlos legasen razbn aora ulterior; tosos, ya qué un fondeadero fuese posible: an ménos de iiente entramsurtos eri el intencion de uada. En las t.i. . instancias para auxilios, todos comprendieron la condición precisa de abandonar inmediatamente las islas, y finalmente, convenido el modo de sa. tisfacerlos, cambiando el uno una barrica de to. cino por el equivalente en pan, $y$ el otro entre. gando pesos fuertes según precio de lima por otros 20 quintales de pan, quedó resuelto que el Capitán White, ya que no tenla plata efectiva ni cosas útiles de cambio, descontase los auxilios que se le daban, sirviendo con su goleta en una excursión de siete días á los puertos inmediatos, la cual se puso al cargo del Piloto Inciarte: era sobremanera interesante reconocer particularmente los fondeaderos de la Punta Oeste hasia el Cabo Percibal, los cuales, por su más fácil en. trada y salida $y$ por una igual 6 mayor seguridad cómoda á la que habia en el puerto Egmont, parecian desde luego los únicos útiles para esca. la en la sucesiva navegación del Perú y mar Pacífico: quedó diferida para el regreso de la goleta la entrega de la mayor parte de los efectos, y en la mañana del ro dí́ efectivamente la vela el Piloto Inciarte, con orden de no dilatar su regre6 so más allá del r6: efectivamente lo verificó así, haciendo en aquel corto plazo varios reconocimientos importantes, enterándose por menor de las pesquerias inmediatas, y logrando sobre todo, de una agradable y fina hospitalidad de parte del Capitán de otro bergantín americano fondeado en la punta Oeste, el cual, en los catorce meses que alli habia permanecido, habia logrado una cantidad más que mediana de excelentes horta. lizas y multiplicado en una isla inmediata algunos puercos y conejos.

En conserva del Capitån White y del Piloto Inciarte, vino también al puerto otra lancha esquifada con seis marineros ingleses, tres de los cuales solicitaron y obtuvieron plaza á bordo: separados voluntariamente (según aseguraban) de la embarcación inglesa á que pertenecieron siete meses antes, $y$ abastecidos con esa lancha y bastantes viveres, habian continuado por su cuenta la caza de los lobos marinos, y entregado últimamente á un buque americano que navegaba á la China esta especie de pacotilla para su venta sucesiva.

Concluídos así todos los objetos que nos habían conducido al puerto; hechos á la vela los dos buques americanos; auxiliados los demás para que lo verificasen en igual modo; restableci. da mucho la tripulación; completada la aguada y hechos en este mismo día los posibles acopios de aves $\mathrm{y}$ de apio silvestre, ya parecí́ tiempo oportuno de abandonarle, y en la misma tarde del I7 qued6 levada el ancla de tierra, y metida la lancha de suerte que pudiésemos dar la vela con las primeras claras del día siguiente, si el viento, como lo prometía, fuese favorable del Sudoeste. te, entremezclados con algunas calmas las cua. Vin. in les absorbieron los dos dias siguientes, nos fue preciso permanecer en la misma posicion hasta que hubiese ocasión oportuna de dar la vela.

Se presentó esta en las primeras lioras de la mañana del 20 , en las cuales se declararon con buen cariz vientos galenos del Nordeste y Is. nordeste. Dimos inmediatamente la vela, y al medio dia, después de algunos bordos, conse. guimos vernos fuera del puerto, y con proa al canal entre los Hermanos y las Hiedras 13lan. cas. Nacla ocurrió que merezca recordarse en la siguiente travesla hasta la bahia de Santa Elena; avistamos el Caho Blanco y observamos en sus inmediaciones para rectificar algunas du. das sobre la latitud que le hablamos asignado en 1789 . Los vientos del Oeste, bien frescos, nos condujeron después en pocas horas al otro extre. mo del Golfo San Jorge. En la tarde del 28 por sondas de 55 brazas chinos, ya no distábamos sino cuatro leguas de la Punta alta de San José, y al medio día siguiente pudimos dar fondo en ocho y media brazas arena y chinos en la caleta más Norte y Oeste.

La aparente seguridad que debian inspirarnos la estación en que nos hallábamos, la tradición de los pilotos de aquellas costas y nuestras mismas experiencias de 1789 , reunida á la inmediación de las playas y al regular abrigo de los vientos reinantes del Noroeste-Norte hasta el Sudoeste, nos hizo parecer al principio bzstante agradables, así nuestra situación como aquellos contornos, aunque la una nos dejase descubiertos próxima. mente desde el Este al Sur, $y$ los otros no presen. tasen más que unas lomas áridas en un todo semejantes á las del puerto deseado: miróse por la misma razón como accidental la excesiva fuerza con que en toda la tarde soplo el Nordeste y Nomordeste, obligándonos á dejar caer segunda ancla; y como la noche y la mañana siguientes fueron sumamente apacibles y calmosas, tuvimos lugar de aproximarnos sobre las espias tendidas en la tarde anterior cogiendo últimamente la mayor inmediación á la tierra en la caleta indicada por fondo de tres $y$ media brazas arena en bajamar: en esta posición, y ya amarrados con dos anclas Norte y Sur, distariamos medio cable de los pedruscos de la punta Este de la cala y un cable del frontón opuesto: serían otros dos cables la distancia de la playa interior en la cual ha. bíamos determinado colocar el observatorio para las importantes experiencias de la gravedad, y por cuanto hubiésemos reconocido con el escandallo las calidades del fondo, no parecian amenazarnos peligro alguno nuestras amarras: ya tranquilos por esta parte, no tardamos al mismo tiempo en tomar aquellas medidas que pudiesen conducir a la mayor seguridad del buque y á emprender las proyectadas tareas astro. 
Ein. 29 nómicas: se condujeron á tierra los relojes marinos, se plantó el cuarto de círculo con la tienda, y en la misma mañana, conseguidas las alturas correspondientes, pudo deducirse la longitud del observatorio por los relojes marinos y fijarse la primera época de su nueva marcha: el tiempo á la sazon parecía sumamente favorable á las operaciones rroyectadas, brillaban sobre el horizonte con igual claridad ó bien el Sol ó las estrellas: la playa inmediata al observatorio presentaba un abrigo fácil y constante para los botes y para la atención precisa á las mareas: era sumamente corta la distancia de la corbeta al observatorio, $y$ finalmente, el viento del Sudoeste que soplando con exceso fresco en aquella tarde nos había precisado á dejar caer la esperanza, había cedido casi de un todo al ponerse el Sol.

Este semblante placentero que había tomado á nuestra vista el paraje que ahora visitábamos, no debía ser sino momentánco, y debieran al contrario sucederle otros muchos riesgos que no podiamos imaginar. Desde las diez de la noche inmediata empezaron á entablar ráfagas sumamente fuertes del Oesudoeste y Sudoeste, las cuales, como quiera que nos aproximasen con la popa á las piedras de la punta del Este, hacían nuestra situación bastante precaria si faltara el cable ó garrara algo el ancia: era la mar gruesa, se hacía sumamente arriesgado y penoso el que la lancha, aprovechando tal cual recalmón, tendiese el anclote grande :.l Sudoeste para que nos sirviese al mismo tiempo de amarra y de espía si fuese preciso dar fondo á la esperanza.

No fueron vanas estas precauciones; el viento, poco después de salir el Sol, arreció de ta modo, que parecía imposible pudiésenle resistir los cables; fué preciso destacar al mismo tiempo un trozo de marinería que rehiciese las tiendas derribadas; toda la restante fué empleada inmediatamente con la lancha en tender el ancla de la esperanza por la espía, y el peligro de un naufragio pareció ya tan inminente, que debieron comprenderse entre las medidas del momento las de remitir á tierra los utensilios más precisos de carpintero y calafate, diferentes armas y municiones de guerra y alg'ınos aparejos para varar la lancha; al mismo tiempo para que no desmayase la empresa, ya que todo parecía amenazarnos la continuación de aquel viento, emprendiéronse las experiencias de la gravedad; el Piloto Inciarte se ocupó en medir una base y repetir las marcaciones con el teodolitn para un plano breve y exacto del puerto; - destacaron algunos cazadores, no tanto con el objeto de la caza cuanto con el de buscar agua en esos contornos; era este un punto demasiado importante para que le descuidá semos en semeja ite trance.

Pero por ventura resistieron los cables la ba. jamar (aunque estuviésemos en el novilunio); fué menor de lo que nos anunciaban las noticias ad, En. 29 quiridas anteriormente, $y$ en fin, hacia las once llamó el viento de golpe al Sursueste, el cual, á pesar que nos obligaba al mismo tiempo á ten. der una espía y sobre ella la cuarta ancla, calm6 inmediatamente $\mathbf{y}$ disipó todo recelo del naufragio.

Apenas bastó toda la tarde para desenredar. nos algo de una parte de las amarras que tenía. mos en el agua, tanto más que continuaba una ola gruesa sorda del Sueste. Las primeras horas de la noche se aprovecharon en el observatorio para determinar su latitud con varias alturas meridianas, y la mañanita siguiente, sin que se interrumpiesen las experiencias de la gravedad, la pesca, la caza y las pesquisas interiores de la aguada, se dedicó también desde las primeras claras al reconocimiento de los cables que tenía. mos averiados, debiendo sospechar la existencia de algunos ratones, aunque el escandallo no nos la hubiese indicado.

Efectivamente, los calabrotes tendidos al Sudoeste, el cable de tierra y áun el de fuera estaban considerablementr: rozados, $\mathrm{y}$ como al mismo tiempo el poco fondo en que nos hallábamos combinado con el incremento diario de las mareas nos expusiese á tocar en bajamar, fué preciso determinarnos á mejorar de amarradero y de amarras, antes que nuevos vientos tempes tuosos sustituyesen á la calma de que gozába mos: al medio día se emprendió esta faena, y antes del anochecer ya nos hallábamos en seis brazas arena distantes dos cables del amarradero antiguo y fortalecidos ó cambiados los cables.

Este día, que fué medianamente apacible, aunque con exceso caluroso, había dado muchas esperanzas á nuestros cazadores de poder en parte con la vigilancia y destreza, y en parte con la constancia, conseguir la muerte de algún guanaco: pcro eran éstos tan excesivamente finos en el olfato y ágiles en la fuga, que quedaron aquéllas enteramente ilusas, $y$ apenas pudieron resarcirlas siquiera en parte varias perdices y otras muchas aves acuáticas que aumentaron, ó nuestra comida ó nuestras colecciones de Historia Natural. Ningún rastro de agua ni de habitantes se habia hallado aún; si se exceptúan relativamente á la primera algunos pozos bien salobres inmediatos á la playa y señalados en el plano, y en cuanto á los segundos, algunas piernas de guanaco recién muertos, y los mismos huesos $\mathrm{y}$ pozos sepulcrales que ya había advertido muchos años antes el Teniente de navío D. Manuel Pando.

Entretanto, una marcha bien uniforme de los relojes, nos habia dado en el observatorio resultados seguros para las experiencias de la gravedad: el plano de la bahía estaba casi enteramente concluído: reconocidas, bien á pesar 
las noticias ad. En. 29 hacia las once este, el cual, á tiempo á ten. ta ancla, calmó ecelo del nau.

ra desenredar. ras que tenía. continuaba una primeras horas el observatorio varias alturas nte, $\sin$ que se de la gravedad, interiores de la e las primeras bles que teníaar la existencia candallo no nos tes tendidos al un el de fuera os, y como al ue nos hallábato diario de las n bajamar, fué de amarradero rientos tempes. de que gozába ó esta faena, y ábamos en seis $s$ del amarradeados los cables. mente apacible, ía dado muchas e poder en parte en parte con la de algún guana1ente finos en el edaron aquéllas dieron resarcirces y otras mu-. uron, ó nuestra Historia Natue habitantes se $n$ relativamente salobres inme. el plano, $y$ en jiernas de gua. smos huesos $\mathbf{y}$ advertido mu avío D. Manuel

n uniforme de el observatorio eriencias de la staba casi ente. , bien á pesar
En. $3 x$ nuestro las sondas, deducida la latitud, y finalmente, con nuevos resultados de los relojes marinos, comparada la longitud actual con la que habíamos determinado en el viaje anterior, re. sultaban ahora las longitudes al Oeste del puerto Egmont.

\begin{tabular}{r|r|r}
\hline & Por el núm.0 18 & Por el cronóm. 71. \\
\cline { 2 - 3 } & $5^{\circ} 32^{\prime} 52$ & $5^{\circ} 30^{\prime} 52$ \\
5.24 .15 & $5 \cdot 24 \cdot 15$ \\
\hline $\begin{array}{r}\text { Y eran las del año I 789. } \\
5.24 \text { diferencia actual por } \\
\text { consiguiente. . . . }\end{array}$ & 8.37 & al Oeste 6.24 \\
\hline
\end{tabular}

Error, á la verdad, bien despreciable, mucho más si se atendiese que una parte de esta diferencia se había advertido ya sobre el Cabo Blanco; que el movimiento de los relojes había variado según el nuevo examen, y que una breve travesía desde allí á Montevideo, pudiera disiparle todavía casi de un t.udo. La latitud del observatorio resultó de $44^{\circ} 30^{\prime}$, als $r$ menor de la que habían dado las bases de $\mathrm{r} 789$; ia variación magnética de $19^{\circ} 7^{\prime}$ al Nordeste y el establecimiento. de la pleamar en el día del novilunio á las cuatro de la tarde creciendo el agua hasta $17 \mathrm{y} / 2$ piés de Burgos, bien que por las señales advertidas en algunas partes de la costa, podía sospecharse que en algunas ocasiones llegase hasta 20622 piés.

Fel. Después de todo lo que habían desfogado los vientos del tercer cuadrante, debíamos prometernos en la apariencia una demora mucho menos incómoda, tanto más que había pasado el novi. lunio, y que la constante serenidad del cielo pa. recía apoyar tales conceptos: á pesar de esto, para las diez de la noche ya nos acosaban nuevas ráfagas recias del Sudoeste con algunos aguaceros, y para la media noche ya nos habíamos visto precisados á dejar caer por cuarta vez la esperanza: tant $v$ incomodidades y un trabajo tan asíduo de la gente, cuyo término ya no era fácil acertar, nos determinaron á abandonar lo más luego el fondeadero, con cuyo objeto se destinó tedo el día siguiente, que fué bastante apacible, á repetir por dos veces las experiencias del péndulo simple, y á reconducir luégo á bordo los relojes marinos y los muchos utensilios que en los días anteriores habíamos depositado en tierra: últimamente, para el principin de la noche quedó levada el ancla del Norte y metida la lancha y demás embarcaciones menores, prontos, por consiguiente, á dar la vela en la mañanită. siguiente.

Cuanto más nos apartábamos de las latitudes altas; eran tanto mís agradables y placen. teros los días, más suaves los vientos y más viva la memoria de aquellos paralelos felices en el hemisferio opuesto, por los cuales ansiábamos después de cuatro años y inedio. Hicimos inmediatamente derrota para atracar la costa al Feb. ı." Norte de los bajos del río Colorado, siguieronse periódicas las líneas de sonda al andar del banco y en la mañana del 9 por fondo de 24 brazas arena fina parda, se vió una larga extensión de costa presentada bajo el aspecto de diferentes islotes, según sobresalían unos á otros los mu. chos méganos de los cuales se compone.

La latitud en que nos considerábamos; la dirección siguiente de la costa hacia el Oeste y la misma disposición de las puntas apenas salientes, no nos de jaron duda que la tierra más inmediata era la que habíamos distinguido en nuestras cartas con el nombre de Punta San Jose, extendiéndose luégo los extremos más occidentales hacia la bahía de la Asunción, poco distante del río Colorado. Todo cuanto veíamos en torno desde el Oesnoroeste hasta el Nornordeste no presentaba más que un suelo arenoso y seco, en todo semejante á los méganos del Cabo San Antonio; ni era fácil descubrir ensenada al. guna que presentase un abrigo siquiera mediano, ó alguno de los muchos riachuelos, ya descritos en aquellos mismos contornos por los Padres Cardiel y Quiroga.

A medida que nos habíamos acercado á la costa había avanzado mucho el viento; y áun llamádose al Sueste de suerte que nos fué preciso con la mura estribor para continuar los reconocimientos: las sondas se mantuvieron entre 21 y 26 brazas arena fina negra, y no omitidas las bases ni las observaciones reiteradas de longitud, pudimos al medio día hallarnos á tres y media leguas de la costa por latitud de $3^{\circ} 5^{\circ}$ y longitud $6^{\circ}{ }^{\prime} 5^{\prime}$ de Santa Elena.

Fué igualmente clara y calmosa la tarde, la cual se aprovechó cuanto fuese posible, atracando las playas hasta una distancia de tres leguas escasas, sin que disminuyesen las sondas de las 26 á las 27 brazas: últimamente, á las cinco y media rolando ya al Este y Esnordeste el viento más fresquito de la virazón, tomamos las muras á babor para disponernos sobre un bordo nuevo largo á reconocer otro trozo de costa en el día siguiente.

La calidad ya indicada del terreno de las orillas, hace que no puedan extenderse á mucha distancia las marcaciones, y muy luego con el sólo apartarse de seis á siete leguas de la playa, se ocultan casi á un mismo tiempo todos los objetos, no quedando rastro alguno de las inmediaciones de la tierra, sino la sonda, pues no suelen avistarse las aves en toda ta extension del horizonte.

No tardó en las primeras horas de la noche en rolar el viento algo más al Norte, siéndonos así asequible desde las nueve no descaecer más hacia el Sur, y ceñir desde las dos de la mañana al Nordeste con un andar de cuatro á 
Fel. 1." cinco millas, y con sondas uniformes de zo á 34 brazas arena ina; aumentaron éstas luégo en la mañana siguiente hasta 40 brazas, mientras continuábamos el bordo de fuera, y disminuyeron al contrario, así que á las diez inclinándose nuevamente el viento al Nornordeste, viramos con todo aparejo al cuarto cuadrante.

Estos rumbos, y el mismo viento algo más fresco que en la mañana, nos proporcionaron ya para 'as dos la vista de la costa, cargada con muc'.ta calima y distante en solas seis leguas: en efecto, para las cuatro y media, por sondas de I7 brazas, ya nos hallamos á dos leguas y media de la orilla, en donde veíamos sobre las lomas inmiediatas pastar tranquilamente manadas numerosas de caballos: pudimos de este modo añadir it las tareas de la tarde anterior un nuevo trozo importante de costa é igualmente exacto por lo que toca á la longitud y latitud, y terninado ahora en el Cabo San Andrés, el cual quedó situado en latitud de $38^{\circ}$ I $2^{\prime}$ y longitud de $7^{\circ} 30^{\prime}$. Este punto puede considerarse como algo más notable de todos los demás que se presentan en aquellas inmediaciones, así por su mayor entra. da en el mar $y$ por ser el principio desde donde la costa inclina mucho más al Norte, como porque tiene una pequeña altura ó montecico por su parte del Oeste, compuesto de las mismas arenas, pero mucho más elevado y con figura alo. mada por todas partes.

Ya, pues, nuestras tareas de este día se daban la mano con los trabajos hechos en ${ }^{7} 789$ por el Teniente de navío D. Juan de la Concha, cu. yas marcaciones se habían extendido hasta los Feh. 10 $37^{\circ}$ y $1 / 2$ próximamente, cuando las nuestras al. canzaban ahora los $3^{\circ}$; esta reflexión debía tranquilizarnos mucho sobre los eventos venideros, aunque no fuese nuestro ánimo el alejarnos de la costa, si los vientos, variando como en los días pasados entre los terrales y las virazones, aunque siempre inclinados al Norte, hiciesen esta navegación más util y expedita.

En efecto, no tardamos en experimentar nuevas contrariedades, bien sea por la variedad ó por la fuerza y dirección del viento, las cuales al principio nos precisaron á navegar algo desatracados de la costa; y después, ya próximos al paralelo del Cabo San Antonio, nos dictaron como uecesario ceñir al Este para pasar al Sur del banco Inglés: corría á la sazón viento tempestuoso del Sursueste con mar gruesa y tiempo bien cerrado; por consiguiente, auıque la sonda nos guiase con bastante seguridad, siempre nos hubiéramos visto precisados, careciendo de la latitud, á dar fondo á mucha distancia de Montevideo y con una grande probabilidad de garrar.

Cedi6 finalmente el viento en la noche del I $_{3}$. Al dia siguiente pusimos la proa á la Isla de Lobos, y habiéndola avistado en aquella misma tarde, hicimos inmediatamente derrota para el puerto de Montevideo, y le alcanzamos en la noche del r4, con la satisfacción que de allí á po. cas horas fondease igualmente la ATrevida, "y entrambas quedasen amarradas en las inmediaciones de la fragata Comandante de Armatilla.

\section{Separación de las corbetas desde el puerto del Callao y navegación de la Atrevida al de Talcahuano.}

(2. 1793 . Atendiendo á las órdenes de S. M. para los objetos en que debían emplearse las corbetas antes de llegar al Río de la Plata, y á la decla. ración de la guerra con la Francia, se liabíd acor. dado en junta de Comandantes y Oficiales la separacion de estos buques, á fin de emplearse cada uno en los trabajos convenidos; siendo muy remoto el encuentro de los enemigos por estos mares para que los mirásemos como un obstáculo á dlesempeñarlos.

Con este fin me mandó D. Alejandro Malaspina que desde la salida de este puerto me considerase para maniobrar sin sujeción alguna á la conserva, y con toda independencia aunque fuésemos á un mismo destino, 6 hiciésemos un mismo rumbo. La salida se prefijo para el día
I5, y era difícil verificarla si el arreglo de las listas lubiese de concluirse para este tiempo. Pero estas dificultades se vencieron, trasladán. dose al Callao el Comisario de Marina D. José de Tagle, y con un trabajo constante de nuestros Contadores en los últimos días, que pudo aicanzar la ordenación de aquellos precisos documen tos, sin los cuales no podría ejecutarse el ajuste final de las tripulaciones en Montevideo, según S. M. Lo tenía mandado.

Algunos reemplazos de gente y la conclusión de otras pequeñas diligencias, no dieron lugar á la salida hasta el día siguierte. Esta demora aumentó el concurso de diferentes amigos de Lima que vinieron á despedirse para darnos las pruebas más sinceras de su estimación, liasta el 
do hasta los $\mathrm{Fel}_{\text {, to }}$ nuestras al n debía tran. s venideros, alejarnos de como en los is virazones, hiciesen esta

imentar nuea variedad 6 las cuales al algo desatra. fximos al paictaron como al Sur del ento tempes. sa y tiempo ingue la son. lad, siempre areciendo de distancia de babilidad de

noche del I3. la Isla de Louella misma rota para el mos en la no. de allí á poAtrevida, : las inmediaArmatilla.

\section{vegación}

rreglo de las este tiempc. n, trasladánarina D. José te de nuestros e pudo alcansos documeli. arse el ajuste evideo, según

la conclusión tieron lugar á Esta demora is amigos de ra darnos las sión, liasta el nct. is momento que probablcmente sería el último que nos separase durante nuestra existencia. Entre aquéllos, hemos merecido un aprecio singular á D. Matías de Larreta, á quien por las cualidades notorias que adornan su persona, se liaría tanta injusticia al referirlas, como seríar os ingratos en no publicar el celo y esmero ' on que se ha encargado de dirigir á España todas nuestras remesas ahora y anteriormente.

Desde por la mañana nos pusimos prontos á dar la vela en el punto que apareciese la brisa, la cual no entró hasta las tres y media de la tarde, á cuya hora mareamos todo aparejo en demanda de la punta Norte de la Isla de San Lo. renzo, haciendo la misma maniobra por nuestras aguas la Descubierta.

Al ponerse el Sol habiames rebasado aquella Isla, y advertímos que daba también la vela para Valparaiso la fragata mercante $E l$ Aguila que trasportaba los Oficiales D. José Espinosá y D. Felipe Bausá, que debían desde aquel puerto pasar por tierra á Buenos Aires, ntendiendo á que el estado de su salud no les permitía seguir por el Cabo de Hornos.

Durante la noche, la brisa se mantuvo fresca del Sudeste, y nuestros rumbos fueron ciñéndola al Sursudoeste, y la Descubierta constantemente por la popa: á la mañana siguiente, precedida la correspondiente señal para pedir permiso de navegar independiente, se forzó de vela aicenzando al medio día la latitud de $\mathrm{r} 2^{\circ} 48^{\prime}$ Sur y loirgitud por el ro5 de $72^{\circ}$ or occidental de Cádiz; hallándose la variación de la aguja por amplitud de $13^{\circ} 7^{\prime}$ Nordeste.

Perdimos de vista á la Descubierta en la tarde del día siguiente; y desde hoy principiamos ya á establecer el plan de combate y tomar todas aquellas disposiciones compatibles con nuestras circunstancias y el estado reducido de fuerzas en que nos hallábamos, aunque sien pre mirásemos sumamente remoto el encuentro de los ene. migos.

Se hizo saber á cada uno el sitio que debía ocupar en aquel caso, y dividida la geite en trozos se dió principio á los ejercicios de cañón y fusil, presenciados por los Oficiales encargados de su instrucción para conseguirla tan completa como era necesaria. La ejecución de estas medidas, tenían por príncipio buscar los medios łe hacerla lo ménos incómoda al marinero Nuestro objeto principal era la verificación de los ramos científicos que abraza por su natura. leza este viaje, para cuyo fin no sólo es precisa la conservación física de los individuos, sino su buena disposición del ánimo, de la mayor importancia en esta clase de comisiones. $Y$ estos principios suaves 6 contemplativos que para esta se han mirado como preferentes, no fueran adapta. bles $o$ más bien serían perjudiciales, á la disci- plina rigurosa de todo buque de la Armada con oct. Is diferente destino.

Así este plan de combate como la orden que le acompañaba incluyendo otras prevenciones oportunas para los Oficiales, se escribieron en el libro de guardias á fin de que constasen y tuviese cada uno á la mano la instrucción competente para su destino, encargando á los de guardia la doble vigilancia en reconocer con frecuencia los horizontes y registrarlos también de noche con anteojos, particularmente en esta travesía á Montevideo mientras nos hallemos en altas latitudes, para evadir el encuentro de bancas, no poco probable en la estación que debemos transitarlas.

Nos rodeaban la tarde del 20 algunas proce. larias, cuyos pájaros anuncian por lo común alteración de tiempo, aunque su presencia, siendo entre los Trópicos no podíamos recelarla, á pesar de que los carices parecían más bien los que presiden en lasitudes más crecidas en la estación de invierno, que aquellos agradables y templadas de los paralelos bajos por donde navegamos. Durante la noche, soplando el viento á fugadas y con algunos chubasquillos, obligó al amanecer tumar un rizo á las gavias.

Todavía el 2.t, en que cortamos el Trópico, no nos abandonaban una ú otra procelaria ni los mismos chubasquillos de los días anteriores: ob servamos al medio día la latitud de $24^{\circ} \mathrm{II}^{\prime}$ Sur y la longitud ie $80^{\circ} 39^{\prime}$ Oeste, teniendo ya de error la estima $2^{\circ} 42^{\prime}$ al Este de la del ro5: la variación de la aguja por cuatro azimutes resultó de $10^{\circ}$ I5 Nordeste.

I a isrde del 25 se vió distante por la popa la curbeta Descub1eĩ ra, la cual no volvió á ver se al amanecer; el viento, á la sazón, había ro. lado al Esnorcieste bonancible, y por el Norte dió la vuelta al $t$ ?rcer cuadrante. Se hicieron entonces rumbos del Sursueste $5^{\circ} \mathrm{E}^{-4} \mathrm{e}$, prefiriendo ganar más bien latitud que longitud, apoyado de ${ }_{i}$ Iformes de los que practican desde Lima ssta navegación, pues suponen no encontrarse los vientos del tercer y cuarto cuadrante en estri estación, hasta de los $30^{\circ}$ para arriba.

Sin embargo de que fundados en las referidas noticias no encontrásemos los vientos por la parte y en la altura cipresadas, al día siguiente por la noche apretó tanto el viento al Sueste, que poco después de amanecer fué preciso to mar dos rizos á las gavias para impedir un des. calabro que sin esta precaución hubiera sido inevitable. Nos hallábamos al merio día en la lati tud de $27^{\circ} 37^{\prime}$ Sur $y$ en la longitud de $80^{\circ}+4^{\prime}$. Los mismos vientos inclinados más al Este pero no tan frescos, nos acompañaron las dos singladuras siguientes; de modo que al medio día del 30 cogimos la latitud de $30^{\circ} 42^{\prime}$ y longitud de $84^{\circ} 32^{\prime}$ Oeste de Cádiz. 
Oct. $3^{3}$ Desde este punto, fueron perdiendo los vientos su fuerza, tanto, que á la media noche tuvimos ya ventolinas del Sur y Sudocste y navegamos por la mañana con viento entablado por esta parte. Nuestros rumbos fueron al Sudeste $5^{\circ}$ Sur corregido, para precavernos en caso de llaniar los vientos hacia el Polo como lo acostumbran.

Muy presto comprobamos estas conjeturas,

:ov. 1. pues no bien había pasado la media noche, que despejando la atmósfera, sc fijó por la mañana el viento al Sur bien fresco, con la mar bastante gruesa. En los dos días sucesivos se mantuvo el viento próximo al Sur no tan fresco, y aún por la noche del 3 se quedó calma para pasar al día siguiente y entablarse por el Uesudoeste; pero presumiendo yo que volviese á llamar de nuevo al Sur los rumbos que se hicieron del Sueste $5^{\circ}$ Este, era una precaución que podría acelerar nuestra llegada á Talcahuano, si se verilicasen aquellas conjeturas. Las observaciones del medio dia, indicándonos la latitud de $35^{\circ} 53^{\prime}$ Sur y la longitud de $77^{\prime \prime} 03^{\prime}$, fué ya preciso principiar la singladura del día inmediato gobernando al Este $1 /$ Sueste hasta tomar el paralelo de la isla de Santa María por los $37^{\circ}$. El viento había tomadr más fuerza por el Oesnoroeste y nada limpio como acontece aquí cuando soplan en este cuadrante; no obstante, le aprovechamos de día y noche con alas y rastrera, sin bajar la distancia por corredera, de ocho millas por hora.

Al mismo tiempo que nos lisonjeaban estas circunstancias con la llegada próxima al puerto del destino, un accidente casual ú olvido involuntario en dar cuerda á los relojes, disminuyó en parte esta complacencia. La falta del Sol para ejecutar observaciones, produjo se olvidase esta diligencia al Oficial saliente de guardia, que ordinariamente la ejecutaba. Advertido por mí á media noche en el $\mathrm{I}_{5}$ este olvido, le dí cuerda al instante, pero no anduvo. Esta misma novedad le había sucedido en otras ocasiones, y con dos $o ́$ tres sacudidas horizontales se había logra. do restituirle luego el movimiento: en vano re. petimos ahora este recurso, ni áun esforzarle como era regular, teniendo al fin que renunciar toda esperanza y persuadirme á que correría ya la misma suerte esta máquina que el núm. ro, habiendo sido las causas exactamente iguales.

Sin embargo, queriendo yo apurar los medios de repararla, me pareció podría ser la causa una contracción de los metales, originada del frío que sentíamos ya bien sensible, y que algún calor moderado aplicado al seloj podría volverle á su estado anterio1; en efecto, correspondieron las consecuencias á mis deseos, pues envolviendole en una bayeta, me acosté poniéndolo debajo del cuerpo para que recibiese suavemente el calor hasta penetrar todas sus partes interiores; y cuando al cabo de cuatro horas me parecí tiempo suficien. te de conseguirlo, logré al fin á la segunda sacu- Nor.s dida restituirle el movimiento: y salvar una má. quina, de cuyo uso hasta Euro la había perdido las esperanziss.

Una oscuridad sin intermisión de día y de noche nos había acompañado, y no nos abandono hasta la mañanita del 7 ; por consiguiente, aunque guiados por la estima á falta de observaciones de contianza, nos pusimos en el paralelo de la Isla de Santa María, cuando aquélla nos lo manifestó.

Por fortuna logramos observaciones seguras, estando al medio día en latitud de $37^{\circ} 47^{\prime}$, la cual se diferenciaba en $42^{\prime}$ al Sur de la estima en los tres dias que careciamos de observaciones de confianza. No bien advertimos esta novedad, que se gobernó desde el instante al Nordeste $1 / 4 \mathrm{Nol}^{-}$. te, porque siendo nuestra longitud de $68^{\circ} 46^{\prime}, y$ llevando un andar de siete á ocho millas, tampoco debíamos dudar de ver la tierra por la tarde.

La mar era correspondiente al viento tan fresco entre el Oeste y Oesnoroeste, como era extraño por esta parte en las inmediaciones de la tierra en la estación presente. Como las señales del tiempo aseguraban su permanencia, se dirigió la derrota á dar vista durante el día á la Isla de Santa María.

Antes de las seis de la tarde avisaron los gavieros de verse la tierra por la serviola de estribor. Por la latitud del medio día, inferimos fuesen unos altos ó cerros más al Norte de los de Tucapel, y por consiguiente, muy breve alcanzaríamos á ver la citada isla. El tiempo estaba tan calimoso hacia la tierra, que no era fácil recono. cerla sin llegar á cuatro ó cinco leguas de ella; y efectivamente, cuando cumplimos esta distancia, se nos presentó á la vista la Isla de Santa María, la cuai, siendo la tierra más saliente al Oeste, no era posible confundirla. Desde el anochecer, ceñimos el viento del Oeste con muras á babor, para cumplir durante la noche la latitud de la boca del puerto.

Al romper el día, con la costa á la vista arri, bamos al Esnordeste con fuerza de vela, cuyo rumbo indicado por las marcaciones, nos conducía á la tierra baja antepuesta á las Tetas de Viovio, las cuales, cubiertas de calima, se nos ocultaban todavía. Por las marcaciones sucesivas á los extremos de la isla, el del Norte al Sur $58^{\circ}$ Este y el del Sur al Sur $42^{\circ} 30^{\prime}$ Este, nos demoraba la boca del puerto al Nordeste 1/, Este distancia de cinco leguas.

Nos abandonó después el viento hasta el melio día, que entablado por el Sur iba refrescando por instantes, y nosotros acercándonos al puerto, gobernando al Esnordeste desde que observamos la latitud de $36^{\prime \prime} 40^{\prime}$ Sur, marcándose las Tetas de Viovio al Este $7^{n}$ Sur.

Sucesivamente se orzb á pasar muy cerca de 
Nov.8 Quiebra-Ollas, cuyo pedrusco atracamos á las tres, y rascando luégo la punta Norte de la Isla Quiriquina, ceñimos el viento, emprendiendo tomar sobre bordos el fondeadero, en el cual no se hallaba la Descubierta, y sólo dos fragatas del comercio de Lima. El estar la tarde ya adelantada y el deseo de fondear temprano, me hizo doblar las diligencias para alcanzarle á pesar de las fuertes rachas y á prolongar las bordadas cuanto era posible, cuya última circurstancia, siguiéndose el bordo sobre Morro Verde cerca de Talcahuano el Viejo, caímos en tres brazas, donde viramos al anochecer, cogienco ya de noche el fondeadero en 5 y $1 /$, brazas lama arenosa, por la popa de los buques mercantes el Rocario y la barca Bírbara.

Por la mañana temprano me avisaron de tierra hallarse á la vista la corbeta Descubierta, y á muy poco rato la vimos pasar delante de la boca chica de la Quiriquina, dando fondo á nuestro costado á la una y media de la tarde; pero al - otro día nos enmeidamos hacia el castillo de Gálvez, quedando este buque bajo las marcaciones de la punta Sueste de la Quiriquina al Norte $2^{\circ} 30^{\prime}$ Este y el Castillo Nuevo al Sur $4^{\circ} 30^{\prime}$ Oeste de la aguja.

Salida del puerto de Talcahuano y navegación en busca de la Isla de Diego Ramirez, y al reconocimiento de la parte oriental de las Maluinas por la corbeta ATrevida.

vic. 3 Ayer había dado la vela la Descubierta después de haber esperado inútilmente el correo de Santiago, en el cual aguardábamos la correspondencia de España, cuya falta daba lugar á presumir haya sido apresado por los franceses el correo marítimo.

Nosotros desde por la mañana temprane nos aprontamos á dar la vela, verificảndolo á las once y media, momento en que apuntí la brisa, navegando al Este hasta franquearse de los bajos: calmó aquélla estando sobre la Quiriquina, de clarándose el viento bonancible por el Oesnoroeste. La marea á la sazón nos era contraria, y por lo tanto, nos costó siete bordadas el rebasar á Quiebra-Ollas husta las nueve de la noche.

Pudimos separarnos de la costa durante la noche como cinco leguas, $y$ amanecimos entre una aburdancia de ballenas canal jamás habíamos visto; con el tiempo anubonado y lluvisso, no obstante, se logró abservar la latitud de $36^{\circ}$ $29^{\prime} \mathrm{Ser}$, marcando al mismo timmpo las 'Tetas de Vinvo al Sur $57^{\circ} 30^{\prime}$ Este. Entablado el viento á la tarde por el Sudoeste, se tomaron las muras 13 babor para separarse de la tierra á buscar los vientos generales y elevarse con ellos á las altas latitudes, lo cual, por la inconstancia y suavidad de los vientos, nos costó algunos dias, pues el 9 sólo nos considerábamos de la tierra 73 leguas, Dic.? sin pasar del paralelo de $37^{\circ}$. No era ya mi ánimo salir más al Oeste, porque también los vientos desde aquí se afirmaron de tal modo, que nues. tra navegación empezó á ser muy rápida diaria. mente.

El día $\mathrm{I}$, hallándonos en la latitud de $42^{\circ} \mathrm{I}^{\prime}$ $y$ en longitud de $72^{\circ} 25^{\prime}$ occidental de Cádiz, se tomaron todas aquellas precauciones para seguridad del buque 6 aumentarle la resistencia necesaria en los mares que íbamos á transitar. Se metió dentro la cebadera, se pusieron las uñas de las anclas dentro de la regala con los cepos sobre las serviolas, dando á las cañas un tortor de unas á otras; en la batería se trajeron al centro desde sus chazas los cuatro cañones de proa, pues is guerra obligaba á llevar montada la artillería, contra la práctica observada en estos mares.

Ya desde hoy empecábamos á conocer por la calidad de los horizontes las latitudes en que nos hallábamos. Á la caída de la tarde cargó el viento del Oeste, precisando á navegar con dos rizos á las gavias; nuestros rumbos desde el me. dio día al Sur nos condujeron á pasar como 60 leguas de la Isla de Ciuafo y 33 de la de Santa Catalina, siencio descie aquí indiferente el ir más ó ménos cerca de la costa, pucs lo que importaba era ganar al Sur únicamente para entrar en el paralelo de la Isla de Diego Ramírez, como 80 á roo leguas al Oeste de ella.

$\mathrm{Al}$ anochecer, entrando el viento en el cuarto cuadı:nte, aumentó con una fuerza extraordinaria, la mar muy gruesa y la garua contínua. No aclaró la cerrazón á la mañana siguiente hasta que el viento retrocedió para el Oeste y después al Oesudoeste cuando el Sol llegaba á las cercanías del meridiano. Por nuestra propia experiencia habiamos nbservado, que los vientos ordinariamente principiaban por el Noroeste ó Nornorcieste, pasaban luégo al Oeste, donde cargaban más par a fenecer en el Sudoeste; mientras estaban en el cuarto cuadrante el temperamento era regularmente templado, pero desde el instante de rolar al Oeste en que aclaraba, era bastante frío $y$ desagradable. Esta misma observación, coincifie con la que expresa Sarmiento hablando de cstos mares, y es la propia que experimentan ms en cl año de 1790 caando nos acercamos á las iostas de esta parte de la América. Así entonces como ahora hemos notado, de que sin embargo de ser travesías los vientos del Oeste al Oesudoeste, también pueee contarse con saguridad de que su duración por esta ú otrz parte rara vea excede de sein á ocho horas.

Sin dejar de tener eata alternativa de vientos entre el cuarta y tercer cuadrante, observamos al medio día ciel in la latitud de $52^{\circ} 35^{\prime}$ Sur y la 
Dic. in longitud de $74^{\circ} 3 \mathrm{I}^{\prime}$ Oeste, por cuya situación estábamos próximamente en el paralelo de los Evangelistas á distancia de Cabo Victoria 73 leguas.

17 No fueron tan felices lis dos singladuras siguien-

8 tes, pues en la primera no pudimos alcanzar la latitud de la Isla del Aterrage de Cook, ní en !a segunda la del Cabo Glocester, observando sólo la de $53^{\circ} 59^{\prime}$ Sur. En estos días se había notado una mayor abundancia de pájaros negros y de carneros, y que el viento había soplado con tanta fuerza cuando estábamos en los paralelos de la boca del Estrecho de Magallanes, que sólo nos permitía navegar con el trinquete y la gavia arriada sobre dos rizos; no obstante, tuvimos también varias horas de calma ó ventolinas del primero y segundo cuadrante. La variación de la aguja observada por azimutes era de $23^{\circ} \mathbf{2 2 ^ { \prime }}$ Nordeste.

Para entrar desde el medio día en el paralelo de la Isla de Diego Ramírez, situada por $55^{\circ} 40^{\prime}$, 1. se gobernó al Sueste, hab:endo adelantado bien poco hasta entrada bien la mañana del día si. guiente, en que entablado el viento por el Sursudoeste, conseguimos cumplir la latitud de la citada isla á las nueve y media de la tarde, á cuya hora arribamos al Esnordeste $5^{\circ}$ Norte, contando en aquel momento la longitud de $7 \mathrm{I}^{\circ} \mathrm{oz}{ }^{\prime}$, no distando ménos de roo leguas de la isla deseada. Ya en estas latitudes crecidas era el frío tan pe'setrante, con especialidad soplando los vientos del tercer cuadrante, que no alcanzaba precaución alguna de abrigo en el alcázar y castillo, haciéndose mucho más sensible á los marineros filipinos, á pesar de la ropa que se les había suministrado á la salida de puerto y de estar encendido el fogón todo el día.

Algunos chubascos presentados en el horizonte al amanecer por el primero y segundo cuadrante, se disiparon muy presto, tanto, que á las seis navegábamos con ala y rastrera de estribor.

Sin embargo de precavernos en el rumbo por algunas diferencias al Sur, toda vía la latitud observada de hoy de $56^{\circ} 5^{\prime}$, nos indicó una diferencia de $10^{\prime}$ al Sur, 6 de exceso á la que deseábamos conservar: la longitud era de $68^{\circ} \mathrm{I}_{3}{ }^{\prime}$ Oeste. En el instante se metió al Nordeste á disminuir aquella diferencia en latitud hasta las cuatro de la tarde, y desde aquí se siguió navegando de día y de noche, pues como los crepúsculos se alcanzaban unos á otros la distancia que se descubría de horizonte á las nueve, no daba recelo de navegar con riesgo de propasar la isla, de la que al medio día inmediato sólo nos considerába nos $3^{6}$ leguass en longitud observada de $65^{\circ} 26^{\circ}$, y la variación por azimutes no daba más de $2 \mathrm{I}^{\circ} 28^{\prime}$ Nordeste.

Al anochecer, descubriéndose un horizonte de siete á ocho lełguas, distábamos 18 de Diego Kamirez: tomáronse dos rizos á las gavias, y con éstas y el trinquete, navegamos hasta cumplir Dic. $28^{2}$ aquella distancia mientras no aclarase.

Hacia la media noche se largaron los rizos para estar prontos á forzar de vela desde el ins. tante de romper el dia. A la una y media avisa. ron la vista de tierra por el traves de babor coino al Norte, y á poco rato se descubría con claridad á distancia de seis á siete leguas, dirigién. donos al propio rumbo del Norte á que se marcaba. Todas las razones que nos asistían en aquel momento, debían convencernos con evidencia de ser la Isla de Diego Ramirez la que teníamos á la vista, bien que afectada de un error en la latitud casi igual á la distancia á que estábamos de ella, sujetándonos á la estima desde el medio día: pero esta novedad no era extraña si atendiésemos á los cortos auxilios de la navegación en aquellos tiempos en que la situaron sus descubridores. Nuestra latitud á las dos de la mañana era de $5^{\circ} 39^{\prime}$, y por la longitud de estima traída desde la observada del medio día antecedente, nos considerábamos en meridianos de las Islas de San Ildefonso y tan sblo diez leguas del de la isla que anhelábamos.

Apenas habíamos navegado cuatro millas en vuelta de la tierra, cuando me avisó el Piloto que puse en las crucetas, de no ser una sola isla la avistada, sino tres pequeñas, sin comprender varios islotillos separados como al Noroeste de ellas, lo cual comprobamos con nuestra vista, á poco rato, desde el alcázar. Esta novedad debió hacerme sospechar de que no fuese la isla que buscábamos, pues las noticias constantes hasta ahora, sólo aseguraban la existencia de una sola, cuyos antecedentes me inclinaron á que fuesen estas las Islas de San Ildefonso, situadas por el Capitán Cook en su segundo viaje en latitud de $55^{\circ} 53^{\prime}$ Sur. Es evidente que para apoyar esta suposición mía, era necesario atribuir á la estima un error en la latitud de $30^{\prime}$ al Norte desde el medio día anterior; diferencia, á la verdad, bastante considerable, y más habiéndose notado en sentido opuesto en los dias antecedentes; pero. como éstas no fueron crecidas para atribuirse á efecto de corrientes hacia aquella parte, tampoco era una consecuencia infalible de que ya por esta causa y por la irregularidad de su curso, guarda. sen hoy con nosotros la propia dirección que en los días pasados. Por otra parte, apoyaba tam. bién mi opinión de ser las Islas de San Ildefonso, la descripción que hace de ellas Cook, diciendo: "Que son un grupo de islas y rocas sobre el "agua, distantes cerca de seis leguas de la costa, "y en latitud de $55^{\circ} 53^{\prime}$ Sur." Esta exacta correspondencia que advertíamos en este relación con la presencia de las islas, aunque era suficiente para persuadirnos de la seguridad de esta conjetura, todavía teníamos otras razones para apoyarla. 
sta cumplir Dic. n se.

on los rizos lesde el ins. media avisa. babor coino a con clarias, dirigién. que se marlían en aquel evidencia de e teníamos á ror en la lae estábamos sde el medio a si atendié. ivegación en sus descubrimañana era stima traida antecedente, de las Islas uas del de la

tro millas en el Piloto que sola isla la mprender vaNoroeste de estra vista, á ovedad debió - la isla que stantes hasta de una sola, á que fuesen uadas por el

en latitud de apoyar esta uir á la estiTorte desde el verdad, basse notado en dentes; pero . atribuirse á irte, tampoco le ya por esta urso, guarda. cción que en poyaba tamSan IldefonCook, diciencas sobre el s de la costa, a. exacta coeste relación ue era sufi. idad de esta azones para
Die. = La posición en longitud de las islas de San Ildefonso era preciso mirarla bajo aquel grado de exactitud tan comprobado por los relojes que sirvieron á estableceria; y como nuestra longitud de aquella hora por el $72 \mathrm{y}$ to5 también estaban acordes con la que deterninó Cook á dichas islas, parecían reunirse todas estas razones para convencernos á la probabilidad de que las co. rrientes nos hubiesen arrastrado hacia el canal entre el falso Cabo de Hornos y la Isla de la Hermita, de cuy.ı punta occidental no distariamos más de 16 lę̧uas bajo de esta suposición, $y$ era justamente el rumbo ó dirección en que notábamos la diferencia.

También era cierto que esta cuestión se de. cidia, ú observando la latitud al medio día, ó con navegar en vueita de la tierra firme, para que por la distancia, siendo esta mucho menor de las islas de San Ildefonso á la costa que la de aquí á la de Diego Ramírez, nos convenciésemos así para excluir toda duda. Yo halle preferente ir á buscar el paralelo de esta isla, pues fuesen ó no ciertos mis conceptos, la latitud debía resolverlos, con la ventaja de que si no eran equivocados, resultaría entonces la doble utilidad de observar al medio día sobre ella, sin atraso alguno en la derrota: sin embargo, á precaución de toda contingencia por lo falibles que suelen ser los juicios en la mar, se gobernó desde aquí al Sueste después de corrida una buena base, hasta cumplir la distancia de 26 millas para llegar á la latitud propuesta de Diego $\mathrm{Rz}$ mírez, en la cual nos consideramos á las sjete de la mañana favorecidos del viento fresco á la sazón. Las apariencias del tiempo cerrado y garuando, nos prometían pocas esperanzas de ver el Sol en circunstancias oportunas á nuestro in. tento. No obstante, fuimos bastante felices Don Manuel Novales y yo, en acechar algunas claras desde las diez de la mañana, y se anotaban las que eran de más confianza, por si (comn así sucedi6) nos privase el Sol de la altura meridiana en uno de los días que más nos interesaba.

Pero esta falta nos la compensaron las alturas tomadas en las mejores circunstancias para esperar resultados tan exactos como por la altura meridiana. Calculadas las primeras inmediatamente por el método de Mr. Dowes, resultó la latitud de $57^{\circ} 17^{\prime}$ Sur: novedad que me sorprendio tanto, cuanto presumiendo error en el cálculo $\sigma$ en sus elementos, mandé gobernar forzando de vela al Norte $1 / 4$ Noroeste, en ánimo de avis. tar, si fuese posible, las tierras del Cabo de Hornos en lo restante del día, para que la marcación decidiera de una vez si habíamos ó no de dar por cierta la latitud averiguada.

Esta desconfianza se destruyó con los resul. tados uniformes de otras dos operaciones distin. tas, la primera con dos aituras tomadas $18^{\prime}$ antes del mediodia la una, y la otra el propio in. 13:e $z$ tervalo después; y dando todos tres cálculos, con una igualdad que admiraba, la latitud lleva. da al medio día de $57^{\circ} \quad 17^{\prime}$; no quedaba ya la menor duda de ser las Islas de Diego Ramirez las reconocidas, y no las de San IIdefonso como yo lo había imaginado.

Aunque fuese ya inútil á nuestro principal objeto continuar en demanda del Cabo de Hor. nos, seguimos sin embargo, el propio rumbo del Norte $1 / 4$ Noroeste con las principales y el viento bastante fresco por el Oeste, con el deseo de poder avistar hasta las nueve de la tarde este punto del gloino tan famoso por su nombre como temible de los navegantes. No era sólo pura curiosidad el seguir esta derrota, sino la importan. cia de rectificar la longitud de nuestros relojes, á fin de que la determinada á las Islas de Diego Ramírez, tuviesen toda la exactitud que exigiesen las facultades de nuestro alcance.

A las cuatro de la tarde se obsérvaron longitudes por los relojes y señalaron la de $61^{\circ} 15^{\prime}$ el ro5; y $61^{\circ} 20^{\prime}$ el 72 , occidental de Cádiz: con esto y ser imposible ya verificar mis deseos en avistar la tierra, hube de abandonarlos para dirigirme á dar vista al Cabo de San Juan en la Isla de los Estados con el propio intento.

Para no perder el orden en la relación de nuestras ocurrencias de este día y volver á tomar el hilo de las operaciones practicadas en la colo. cación de las referidas islas, claré primeramente una idea de ellas que sirva de gobierno á los navegantes, y una noticia individual de los medios empleados para determinar su posición verdadera: obligación precisa en que por naturaleza de la comisión estamos constituídos, para que conste la escrupulosidad con que miramos semejantes trabajos, aplicando los auxilios que facilita la navegación moderna, y expresando las circuns. tancias de su uso para no salir garantes er lo venidero si á otras más felices que las nuestras se umen invenciones más exactas de las que sirven en el dia en la fráctica y progresos de la Geografía marítima.

Las Islas de Diegro Ramírez fueron descu. biertas en el año de 1619 por Bartolomé Garcia de Nodal y Gonzalo Nodal, hermanos, marinos de reputación, que mandando las carabelas Nuestri Señora de Atochu y Nuestra Señora del Buen Succso, salieron de Lisboa para estos mares en $27 \mathrm{dc}$ Setiembre de 16r8. Según parece, tomaror el nombre del Piloto Diego Ramírez Arellano, des. pués Cosmógrafo y Piloto mayor del Rey en la casa de Contratación en Sevilla.

Es verosímil que aquellos navegantes hubiesen descubierto á larga distancia dichas Islas, y por esta razón se les hubiese representado como una sola, según acontece con los grupos de ellas, cuando un punto deterninado de vista 6 la dis. 
Dic. $z$ tancia conveniente, no facilitan distinguirlas con claridad. Nosotros hubiéramos padecido igual error habiéndolas avistado con el horizonte que tenlamos á mayor distancia de la de seis leguas, pues desde este punto, según resultaba de las bases, ya confundíamos el todo de las islas bajo la ilusión de una sola.

Así desde la cuhierta como desde los topes, no se distinguicron más que dos islotes, el uno al Este y el otro al Oeste de la isla; el primero más alto que el segundo: también se vieron algunos pedruscos inmediatos. La isla es de suficiente altura para poderla ver en días claros á diez ó doce leguas, pues careciendo nosotros hoy de esta ventaja, la perdimos de vista al cumplir 28 millas distante de ella.

Por los resultados de las operaciones y observaciones verificadas hoy, retrocedidas á la hora de haberse corrido la base sobre las islas, quedan determinados los extremos orientales $y$ occidentales de ellas entre los meridianos de $62^{\circ}$ $35^{\prime} 42^{\prime \prime}$, y de $62^{\circ} 43^{\prime} 3^{\prime \prime \prime}$ Oeste de Cádiz, siendo su extensión de Este á Oeste de ocho millas próximamente: en cuanto á la latitud, las hemos situado entre la de $5^{6^{\circ}} 33^{\prime} 30^{\prime \prime}$ y $5^{6^{\circ}} 27^{\prime}$ $24^{\prime \prime}$ Sur (I).

Habiéndose opuesto á mis deseos las circuns. tancias del tiempo á dar vista al Cabo de Hornos, nos dirigimos para la Isla de los Estados. El viento del Oeste, á la caída del Sol arreció mucho, sin abandonarnos tampoco la garua. Con trinquete y gavías arrizadas gobernamos al Nornordeste, notando que á medida de acercarnos a Estrecho de Maire soplaba el viento con más fuerza, la cual fué disminuyendo hacia la madrugada, logrando á las diez y media de la mañana avistar la Isla de los Estados á distancia de nuevé á diez leguas. Mientras estuvimos á la vista de ella, apénas nos dejó una cerrazón constante, y tan sólo aprovechamos un momento por la tarde para determinar el hallarnos á ${ }_{5} 5 \mathrm{y} \%$ millas distantes de la isla, y por consiguiente nos consideramos en latitud de $54^{\circ} 56^{\prime}$ Sur y en longitud de $57^{\circ}$ I $8^{\prime}$.

Desde este punto, hicimos rumbo directo á la Punta de Porpus en la islita más meridional de las Maluinas. Era mi ánimo recalar sobre aquel paraje para costear el cúmulo de islas pequeñas que ciñen la grande de la Soledad por la parte del Sur. E1 viento fresco del Sudoeste nos favoreció sin intermisión toda la singladura, y nuestro andar, no bajando de seis á ocho millas, nos prometíamos entrar en el puerto de la Soledad al día siguiente, pudiendo contar ésta como una travesía

(1) Estos resultados vinieron conformes con los que ejecutó separadamente la corbeta Descubier'ta áun habiendo logrado en su ejecución circunstancias más favorables a las nuestras. de las más felices, pues lográbamosá los veinti- Vic ${ } 4$ dos días atravesar desde Chile á las Maluinas.

No bien hubo lugar á entregarnos á esta re. Hexión tan lisongera, cuando un fatal accidente vino á amargarla. El marinero Jorge Ramón cayó al agua desde la uña del ancla de estribor, y aun. que nuestro andar era de seis millas llevando todo aparejo, no sólo quedamos en facha sino se echó el bote al agua antes de cumplir ocho minutos de tiempo medido por el reloj; hasta este instante me aseguraban los gavieros el verle pró. ximo á un gallinero, al cual se dirigía por estar más cerca que de la guindola, con lo cual consentimns en que nuestra presteza en las maniobras salvaban la vida de este infeliz. Pero al llegar el bote al paraje indicado ya no vieron otro vestigio de su persona que el gorro sobre el agua, ni por más diligencias que hicieron no le encontraron. Este individuo era irlandés, desertor de una em. barcación inglesa destinada á la pesca sobre las costas de la América, que vióse precisada á arribar al puerto del Callao, en donde así éste como otros tres marineros, también prófugos de la propia embarcación, fueron destinados á las corbetas por disposición del Virey á consecuencia de ordenes de S. M.

Volvimos al instante á forzar de vela en la confianza de descubrir alguna de las Maluinas antes del anochecer, tanto más preciso el conseguirlo, cuanto la falta de observaciones nos hacía desearlo con más empeño para dirigirnos en la noche próxima con otra seguridad.

El horizonte que nos rodeaba era bastante calimoso para anticiparnos la vista de las islas; no obstante, á la media tarde se descubrió una isla marcando sus extremos el del Sur al Sur $7 \mathrm{I}^{\circ}$ Oeste, y el del Norte al Sur $75^{\circ} 30^{\prime}$ Oeste, rum. bos á los cuales se marcaron al tiempo de medirse una base, pues viéndose una islita rasa al Oeste de la otra creimos, fuesen éstas las Islas de Beauchenes, mucho más no divisándose otras hasta loras después como era forzoso si fuesen las de los Leones ú otras contiguas.

Nuestras dudas tardaron poco en disiparse, pues siguiendo al principio los rumbos del Nornoroeste y Noroeste $1 / 4$ Norte con el viento muy duro por el Sudoeste, se consiguió con fuerza de vela qne apenas podía resistir el buque avistar las islas poco después de las nueve, y á poco tiempo fué preciso ceñir el viento con trinquete y gavias arrizadas la vuelta del-segundo cuadrante. El viento continuó soplando por la noche con bastante fuerza, aunque por esto no se dis. minuyó el aparejo, atendiendo áconservar el mismo punto y empezar nuestros trabajos en la ma. ñana siguiente desde la parte más meridional de las Maluinas.

Después de una noche sumamente fría, y cuando el viento desde las siete de la mañana era 
los veinti- Dic 24 Maluinas.

á esta re-

ll accidente

Ramón cayó

ibor, y aun.

as llevando

facha sino

implir ocho

j; hasta este

el verle pró-

ia por estar

cual consen.

$s$ maniobras

b al llegar el

otro vestigio

agua, ni por

encontraron.

de una em.

sca sobre las

isada á arri -

sí éste como

fugos de la

los á las cor.

secuencia de

e vela en la

las Maluinas

tiso el conse -

nes nos hacia

igirnos en la

era bastante

de las islas;

escubrió una

jur al Sur $7 \mathbf{I}^{\circ}$

Oeste, rum-

o de medirse

rasa al Oeste

slas de Beau-

otras hasta

uesen las de

en disiparse,

bos del Nor-

viento muy

on fuerza de

uque avistar

ve, y á poco

son trinquete

egundo cua-

por la noche

to no se dis-

ervar el mis-

os en la ma-

aeridional de

ente fría, $y$ mañana era
Dic. ss ya más manejable, se forzó luego de vela para llegar á las nueve á distancia suficiente para emprender nuestras operaciones. Arribamos desde aquí con viento fresco del Sursud ste prolongando las citadas islas á los rumbos del Nornoroeste-Norte, $y$ después, inclinándose para el Este, según lo exigía la dirección de las islas, de las cuales navegábamos como á tres millas. Muy presto vimos la roca de Sharg, pasando de ella todavía á menor distancia sin recelo de comprometernos, pues las sondas de la carta del Capitán Mac-Bride, de 30 á 40 brazas, nos ponía á salvo de todo encuentro peligroso. No obstante, llevábamos guardias en los topes para evitar con tiempo de toda rompiente sospechosa ó escollo que pudiera habérsele ocultado al referido Capitán ingless.

Siguiendo estas operaciones, teníamos á la vista las diferentes cartas de este Archipiélago para compararlas y elegir la que resultase más exacta.

Parecía imposible tanta discrepancia entre sí, todavía mucho más extraña al considerar la diferente latitud del puerto de la Soledad entre unas y otras, justamente á donde nos dirigíamos hoy á fondear sin otro auxilio ni práctico que estas noticias tan confusas 6 encontradas. Por un plano inserto en la relación del viaje al Es. trecho de Magallanes por la fragata Nuestra Seniora de la Cabeza, estaba colocado aquel puerto en la latitud de $5^{\mathrm{I}^{\circ}} 5^{2^{\prime}}$ Sur; por la carta del Capitán Mac-Bride en la de $5 \mathrm{I}^{\circ} 4^{\prime}$ y por Mr. de Bougainville en $5 \mathrm{I}^{\circ} 30^{\prime}$.

Tanta diversidad de situaciones nos obligaba á caminar con la debida precaución para buscar el fondeadero sin riesgo de sotaventaŕse, siendo preciso á este efecto ir costeando de cerca la tierra, á fin de que la configuración de la entrada nos iluminase para no equivocarla. Con esta precisión nos dirigimos á toda punta saliente ó ensenada, cuya derrota tan indispensable nos puso también á riesgo próximo de un naufragio.

Encaminándonos hacia una entrada, vimos repentinamente por la mura de estribor la rompiente de un bajo sin avisar ni el que estaba de guardia al tope, ni tampoco el escandallo que ibamos voleando indicaba novedad en el fondo no hallándole con $x_{5}$ brazas. En este momento distariamos medio cable del bajo, y aunque nuestro andar no era ménos de seis millas, antes que el buque obedeciese al timón, tan solo dió lugar al tiempo preciso para no estrellarnos, pasando de él al tenerlo por el través como 20 toesas.

En el mismo instante enfilamos este bajo con uno de los puntos más notables ligado antes por las bases, y result 6 hallarse en $52^{\circ} \circ 6^{\prime}$ Sur á distancia de tierra como los y media millas; situación que puede considerarse muy exacta no habiendo pasado más de hora y media de intervalo hasta la observación de al medio día. Para que Dic. as no se crinfunda este escollo nuevo con la roca de Sharg, me pareció oportuno darle el nombre de Bajo de Pascia , por la memoria del día en que le descubrimos, $y$ en celebridad de haberle evadido tan felizmente.

Nuestra navegación desde aquí debió mirarse más cuidadosa, y los arrimos á la costa nos eran mucho más sospechosos con encontrar en ellos abundancia de cachiyullo, en el cual ordinaria. mente hay poco fondo.

Antes de tomar la altura meridiana, me avis 6 el Piloto desde las irucetas, como al Oeste reco. nocía una entrada con dos islitas próximas á la costa del Sur, semejantes á las que señalaba el plano del piserto de la Soledad. Se ciño el viento al instante subre las gavias, la vuelta del Su. este, así para observar con comodidad la latitud, en el día muy importante, como para examinar aquella entrada $y$ discurrir el partido preferente que hubiésemos de seguir; pero nada consegui. mos sino aumentar el número de nuestras dudas y lamentarnos de la falta de exactitud en documentos que deciden la suerte de los navegantes.

Resultando la latitud observada de $52^{\circ} 02^{\prime}$ Sur, si nos ateníamos á preferir como cierta la situación del puerto, la más meridional de $5^{\mathrm{I}^{\circ}} 5^{2^{\prime}}$, era muy probable que la entrada á la vista, de. morando al Oesnoroeste corregido, fuese la del citado puerto.

Con este concepto viramos hacia ella, y á poco rato aumentaba tanto la abundancia del ca. chiyullo en la boca, que no podía dudarse de la falta de fondo en ella ó de encubrir algún esco. llo temible.

Ya desde aquí las tierras principiaban á ser bien elevadas, haciéndose notables por nu altura, de las que dejábamos al Sur, de modo que esta señal por sí sola, y la seguridad de hallarse el puerto 6 su entrada en la parte más oriental de la Isla de la Soledad, son dos marcas infalibles para guiar á los navegantes sin otro auxilio al fondeadero; la noticia cierta de ellas nos hubiera ahorrado los cuidados y peligros que nos produjo su falta ó el error de las que teníamos, no ha. biendo aqui todavía concluído los riesgos á que nos han comprometido antes de llegar al puerto deseado.

Se iba conservando la orilla del cachiyullo para mantener la inmediación á la tierra y dedu. cir de nuestras operaciones toda la exactitud necesaria. A las tres y media de la tarde descubrimos tres islotillos 6 pedruscos salientes a Este, que anteceden al Cabo de San Felipe y son también una excelente marca para el co nocimiento del puerto. Rebasado aquel fuímos orzando para dentro, atracando después el Is lote Pelado, y emprendiendo sobre bordos alcanzar el fondeadero anter, de anochecer, para lo 
Dic. as cual mantuvimos fuerza de vela á pesar de las rachas fuertes que soplaban del Sursudoeste. Antes de virar la primera vez sobre los bajos de Viamon vimos dirigirse hacia nosotros una lan. clia del establecimiento, maniobrando cautelosamente aunque nos viese con las insignias largas, y esto dificultó atracar, cuando ya lo intentó, quedándose en poco rato á bastante distancia por la popa, pues nuestro andar no bajaba de cinco y media á seis millas. Yo no hice diligencia de esperarla, porque hallándome con un plano que debía considerar muy exacto, me cra más importante el excusar toda detención para entrar cuanto antes en el puerto.

Pero bien pronto hube de desengañarme de la confianza que atribuía á dicho plano, y arrepentirme ya de no haber esperado la lancha para haber precavido con el auxilio del práctico los riesgos en que nos pusieron los enormes errores del plano.

A las siete y media, estando en la boca es. trecha formada por la Isla de las Cabras (que llaman también de la Paja) con la de los Chan. chos, advertimos en la medianía de ella un bajo á flor de agua, omitido absolutamente en el plano.

Una falta tan notable, ora motivo suficiente para desistir del empeño de subir al fondeadero, no pudiendo ya fiarme del único auxilio que nos guiaba, á pesar de sernos la marea á la sazón favorable. Viramos, pues, sobre la misma isla de los Chanchos, en fondo de cinco y media brazas piedra, en ánimo de ir á fondear en la cabeza del Sur de la Isla de las Cabras, cuya situación era la más oportuna para volver á dar la vela desde alli con los vientos reinantes del tercer cuadrante y coger con más facilidad el fondeadero. Iba. mos costeando el veril de la Isla de las Cabras, por fondo de seis brazas, confiados en que la exactitud de la sonda en el plano la habíamos comprobado hasta entonces, aunque no por esto dejábamos de ir voleando el escandallo.

En vano fueron todas estas precauciones, pues continuindo por la misma sonda de cinco brazas, caímos repentinaniente á tres, y por mucha presteza en las maniobras para facilitar la arribada, no obedeció el timón tan pronto, bien fuese por las pocas aguas que pescaba, como por la detención que causaría el sargazo sobre el cual navegábamos, y por consiguiente, no pudo impedirse la varada desde el portalón de estribor hasta la mura de la misma parte, infiriendo de esto $y$ del fondo en torno de la corbeta, el que apoyaba sobre alguna piedra elevada del fondo, pues sólo en aquel punto teníamos dos brazas de agua, y en todo lo restante 18 piés largos y sólo I5 á proa, calando el buque i4 escasos.

La mar ni el viento sólo fresquito viniendo por encima de la isla, nos daban el menor cuida- do. Inmediatamente se aferraron todas las velas, nic. os y el buque reposaba sin moverse para no temer que sus fondos recibiesen algún daño. $\mathrm{Al}$ mis. mo tiempo advertlamos que la marea iba crecicndo rápidamente, según veíamos cubrirse las piedras de la orilla de la cual distaríamos algo más de un cable. Para ganar tiempo, se tendió un anclote con el bote por la aleta de babor al Norte, y á poco de virar flotanos en tres brazas, de modo, que apénas estuvimos varados media hor' 1 de tiempo. I'ranqueados hasta coger seis y media brazas arena gruesa, dimos fondo al ancla de babor, sobre la cual y la espía, permanecimos en la noche.

Ya para este tiempo había llegado á bordo un Oticial comisionado por su Comandante Don Pedro Sanguineto, Capitán de fragata de la Real Armada, que á la sazón se hallaba de Gobernador de la colonia y mandando el paquebot Santa Eulalia. Por el mismo Oficial pedí el práctico para la mañana siguiente, que hasta entonces no intentaba ir para dentro.

Efectivamente, llegó este al romper el día, y advirtiéndome no debiamos perder momento de dar la vela para aprovechar toda la marea favo. rable, lo verificamos inmediatamente sobre las gavias y el trinquete con viento fresquito del Sur. Con dos bordos montamos el bajo omitido en el plano, llamado el Galon, y fondeamos Noroesueste antes de las nueve en seis brazas lama, demorando el asta de bandera al Norte $64^{\circ}$ Oeste, y la punta Sur del puerto al Norte $82^{\circ}$ Este.

Operaciones hidrogrificas ejecutadas en el puerto de la Soledad.-Reflexiones sobre el estado actual do esta colonia, y ventajas que of réce su situación.

Nuestro ingreso en este puerto reunía para nosotros la doble ventaja de combinar con un regular descanso de la tripulación, el reconoci. miento y situaciones exactas de estas inmediaciones. Aun ciñéndonos al canal de la entrada, las puntas salientes que lo forman, las isletas adyacentes, y el examen de los varios puertos contiguos á la colonia con sus sondas, eran objetos que pedían algunos días y diferentes manos para desempeñarlos.

A este fin pensaba comisionar la lancha por dos 6 tres días luégo que se concluyese la agua. da, y por otra mano se ocurrió á establecer el observatorio en el almacen del Rey, situado en la punta del puertecito donde se hallaba fondeado el paquiebot.

Era uno de nuestros principales deseos resolver la cuestión sobre la latitud de este puerto, y á este intento pasamos D. Manuel Novales, Don Jacobo Murphy y yo á observarla el día 28 en la playa al Sur del establecimiento, distante como dos millas. Al mismo tiempo D. Juan Gutiérrez 
bic. ss de la Concha qued 6 encargado de observarla por el cuarto de círculo, pues las noches no eran las más despejadas para determinarla por estrellas al zénit. El día fué uno de los más hermosos, y así no sólo conseguimos nuestros deseos, sino que Concha lograse tomar también alturas corresponclientes, por las cuales resultó la longitud del ob. servatorio de $52^{\circ} 16^{\prime} 30^{\prime \prime}$ por el núm. 72 y $52^{\circ}$ o $7^{\prime}$ I $5^{\prime \prime}$ por el ro5 occidental de Cádiz. La latitud observada en la playa fué de $5 \mathrm{I}^{\circ} 33^{\prime}$ Sur á la cual restándose las dos millas que el observatorio está al Norte de aquel sitio, resulta ésté en la latitud de $5 \mathrm{I}^{\circ} 3 \mathrm{I}^{\prime}$, próximamente la misma en que establecí $\mathrm{Mr}$. de Bougainville la colonia, situado también un poco más al Norte de nues. tro observatorio.

Pero estas longitudes, sin embargo de no haberse rectificado con toda exactitud sobre el Cabo de San Juan, con cuyo intento dirigí aquel día la derrota para avistarle, no obstante las únicas alturas tomadas en muy buenas circunstan. cias aquella propia mañana, y calculadas con la la latitud hallada por la base medida al referido Cabo; producen una longitud de $9^{\prime}$ más oriental en el núm. 72 y $16^{\prime}$ en el propio sentido por el I05 de la que resultaba por la marcación al Cabo. De aquí se concluye que adoptándose esta correccion, es preciso aumentar á la longitud determinada por los relojes el error que indicaron sobre el Cabo de San Juan, resultando así por longitud del observatorio la de $5^{\circ}{ }^{\circ} 6^{\prime} 15^{\prime \prime}$ occidental de Cádiz por el ro5, al cual damos aquí, por más confianza, la preferencia; y de consiguiente, se acorta mucho la diferencia de meridianos entre el puerto de Egmont y este de la Soledad, según los planos que me ha enseñado el Comandante Sanguineto.

Hoy nos ocupamos en la formación del plano de estos contornos, para el cual se midieron dos bases: la una sobre la altura que está á la izquierda á la entrada de la darsenita haciendo frente al puerto de Cornejo y playa contigua, y la otra en la parte opuesta, desde cuyos extremos se ligaban otros puntos distantes, como el Islote Pe. lado, los bajos de Viamon y los extremos de las islas que nos rodeaban.

El mal tiempo en los días subsiguientes, á veces con truenos y granizando, imposibilito la conclusión de la aguada y la expedición pro. puesta de la lancha. Estos mismos obstáculos se opusieron también á conseguir alturas correspon. dientes y sblo podían lograrse absolutas una ú otra ve $z$ disde á bordo entre cinco y seis de la mañiana, de modo que esta experiencia justificaba asii los informes que nos daban el Comandan. te $y$ Oficiales del paquebot, de lo ra-o que era en estos climas conseguir un día claro áun en la éstación benigna en que nos hallábamos, como las fundadas quejas de $\mathrm{Mr}$. Bougainville de 10 ingrato de este cielo para la Astronomía. Sin Bic, w embargo, este navegante determinb la longitud de este punto, por las observaciones de su astronomo Mr. Verron, en $60^{\circ} 50^{\prime}$ occidental de Paris, la cual concordando casi con la de nuestros relo. jes, se puede inferir fuese deducida á observación alsoluta, aunque no lo expresa en la relación de su viaje.

Pudo al fin la lancha desempeñar los objetos á que fué destinada al punto de naberlo permitido el tiempo: no obstante, estando fucra no le fue tan favorable para completar los objetos de su destino. En la mañana del 2 dib la vela á las órdenes del Teniente de navío D. José Robredo, prevenida de todos los auxilios necesarios y regresó á los tres días después. Este Oficial, lle. vando consigo al Piloto Hurtado, se dirigib, con . secuente á mis órdenes; al puerto de Salobreña y a Puerto Bueno, hallando en este último buen fondeadero en la extensión sola de dos á tres ca. bles con fondo lama 6 arena lamosa, siendo en lo restante de cascajo 6 piedra: observó la la. titud en la playa que le antecede de $5 \mathrm{I}^{\circ} 37^{\prime}$ y determinb la línea de sonda por Io y 12 brazas entre las orillas opuestas. Los malos tiempos no permitieron á Robredo pasar á la costa del Norte á reconocer el puerto de la Barra, y áun las operaciones antecedentes le costaron algunas averías en el casco y aparejo de la lancha. Para precaver yo esta contingencia había destinado al propio tiempo otra lancha de la colonia con un pilotín del paquebot, que sondase el citado puerto de la Barra, de cuya diligencia e informes resulta la inutilidad de. su fondeadero en ningunas circunstancias. El mismo pilotín sond6 tambien la costa hasta los bajos de Viamon y los canales del Galon.

Seguidamente comisioné á reconocer el puer. to de Cornejo al Piloto Hurtado, cuya sonda eje. cutó en bajamar y no era ménos de tres á tres y media brazas lama. Por esta razbn y ser un paraje mucho más abrigado, yo hallaria preferente que las embarcaciones invernasen en este puerto con preferencia á donde ahora lo ejecutan, y no falta ejemplar para justificarla. Lo cierto es que sería muy remoto el desamarrarse aquí los buques con los vientos duros del Sueste y Norte en invierno como frecuentemente acaece amarrados en la dársena, exponiéndolos muchas veces á bien ma. las consecuencias. No sblo ofrece este sitio ventajas tan conocidas, sino que hasta la misma co. lonia debería establecerse en las cercanías de dicho puerto si hubiese de tomar otra forma 6 sistema político, pues siendo un terreno más hajo y mucho más abrigado que el otro, propor. cionaria no sólo una mansión más cómoda, sana y agradable, sino llanuras muy oportunas para la producción de los vejetales tan útiles para la subsistencia de sus habitantes. 




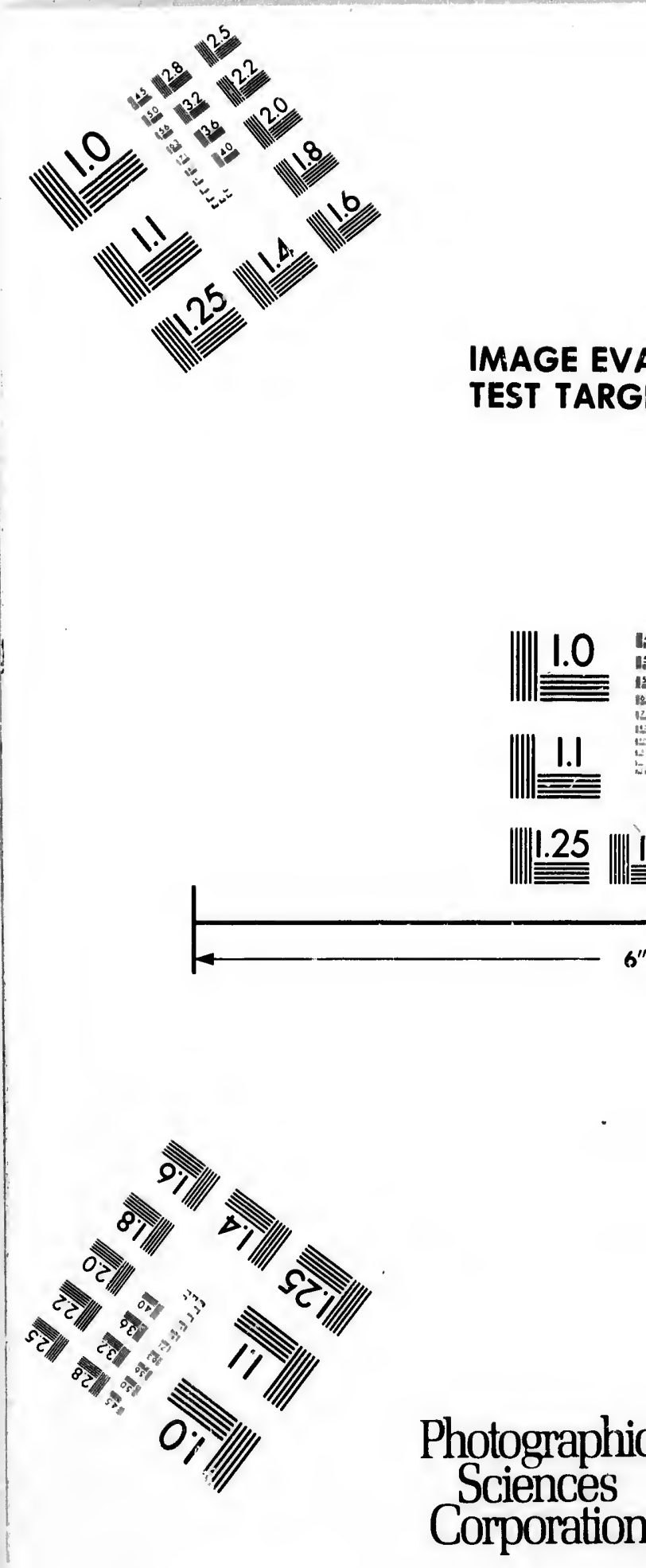




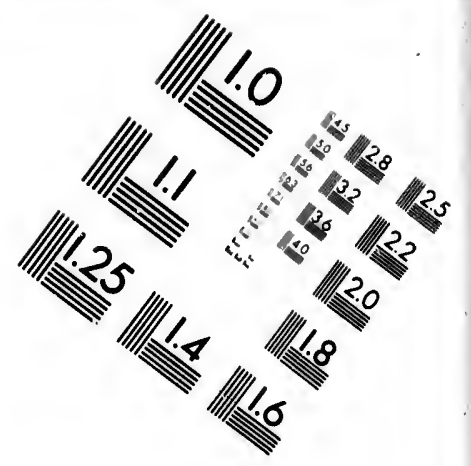

TEST TARGET (MT-3)

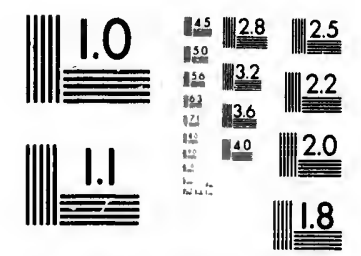

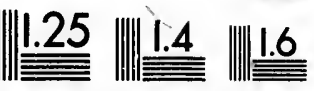

$6^{\prime \prime}$

Photographic Sciences

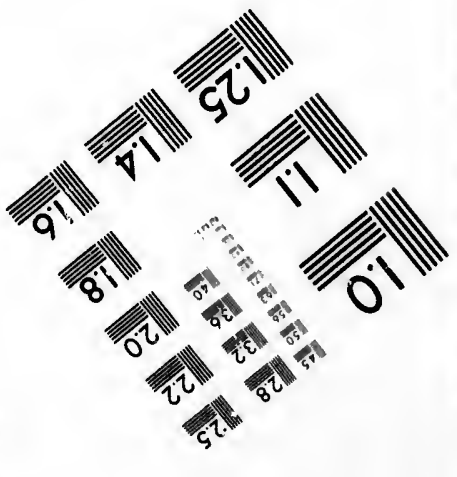
Corporation 


\section{CIHM/ICMH}

Microfiche Series.
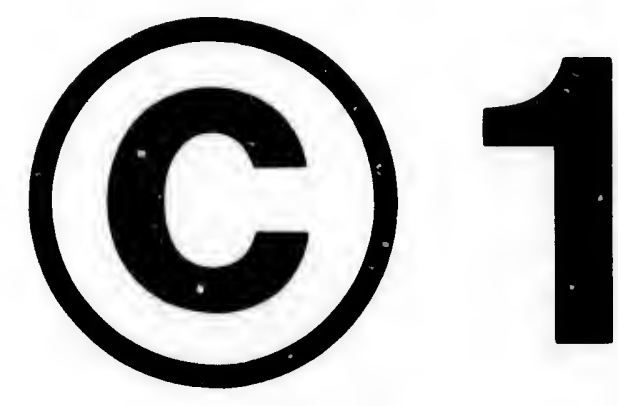
ICMH $\quad$ CIHM/ICMH fiche

\section{Collection de microfiches.}
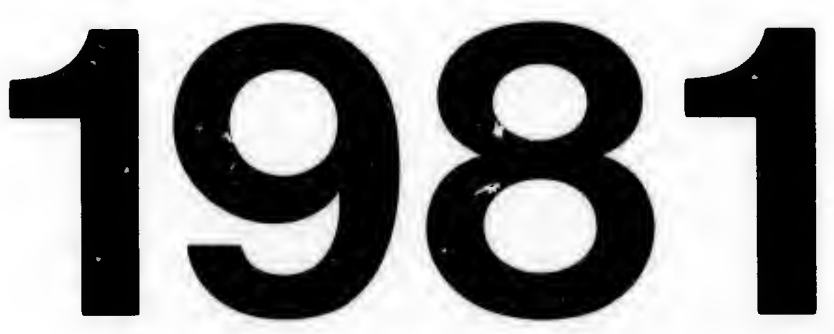
Después se siguieron las sondas desde la salida de Cornejo por la orilla de la izquierda por tres y tres y media brazas cascajo liasta el bajo visible que teníamos al Sudoeste, $y$ desde aquí vino subiendo el fondo á cuatro y cinco brazas lama dura, hasta la corbeta. Otros días se verificaron las sondas restantes, y particularmente, el veril del Este de la Isla de la Paja desde la cacabeza del Sur, cuyo fondo, á distancia de un cable de la orilla, jamás bajó de tres brazas cascajo; de donde se infiere que nuestra varada la causó alguna desigualdad del fonco en aquel paraje, y no de piedra como habíamos imaginado.

\section{Refleviones sobre el estato actual de este establecimiento.}

El número de habitantes que compone en el día esta colonia se reduce al de $3^{8}$ sentenciados, y 102 individuos que forman la dotación del paquebot. Aunque parezca reducido este número para emplearse en aquellas primeras ó más fáciles labores que fructifiquen el terreno, á lo ménos siempre sería conveniente dedicar estos hombres al cultivo de la hortaliza tan necesaria para su alimento. Este útil ejercicio, mirado hasta aquí con la indiferencia que no merece, no sólo es trascendental á la salud pública, sino también á las buenas costumbres en general. En vano se pretende disculpar este descuído con la esterilidad del terreno á toda especie de frutos, porque no faltan parajes tan estériles, ni los recursos del arte dejarían de suplir los defectos de la $\mathrm{Na}$ turaleza, produciendo las verduras suficientes para consumo de los colonos, del mismo modo que ahora las tiene el Gobernador y algún otro individuo que las busca. Esta ocupación, si es tan saludable y necesaria en todos los pueblos de la tierra, en ninguno parece más indispensable que en donde no hay otra alguna en que ejercitar álos hombres, ni que facilite más la distracción precisa de una porción de individuos á quienes la ociosidad conduce á fatales consecuencias en lo moral y en lo físico.

Otra causa contribuye también á multiplicar con exceso ambos objetos. La prohibición de mujeres aquí ha sido una cuestión muy agitada por todos los Gobernadores desde la fundación de esta colonia; pero venció al fin aquella opinión contra lo que dicta la razón y la propia experiencia. Yo me excusaré de referir los horrorosos delitos cometidos por la falta de aquel sexo que parece formo la Providencia solo para evitarlos. No pueden oirse sin espanto crímeises tan repugnantes á la Naturaleza como ofensivos á las sociedades civilizadas. Los patronos de este dictamen le han apoyado en la imposibjlidad de contener otros desórdenes cuando el número de las mujeres no fuese proporcionado al de los hombres. Yo quiero suponerlos ciertos; pero negar los medios de destruirlos no me es fácil comprenderlo, pues para estos casos tienen las layes un derecho positivo de aumentar el rigor para conseguir el escarmiento, y jamás deja éste de lograrse en una población reducida, en donde si además de no poder ocultarse el delincuente, sabe con evidencia que ha de sufrir prontamente los efectos de la justicia.

El perjuicio de la población es también aquí un daño bien notable para desatenderse. Tal vez será esta la única colonia que carezca de la parte más esencial para fomentarse. Esta pro. videncia dimanada de la pluralidad de opiniones por los Gobernadores comunicadas á los Vireyes de Buenos Aires, ha sido la causa de lia berse adoptado, pues recientemente hemos visto la contraria para los establecimientos de la costa Patagónica con motivo de la Companiía Marítima.

Es de esperar que esta Compañía piense con el tjempo establecer su pesca en estas islas para hacerla con abundancia, prestándose aquí la mayor comodidad y seguridad al intento, yentonces es consiguiente consiga la misma forma en su plantación aquí, que la que tiene en los puestos que ocupa sobre la costa. A lo ménos, según me informó D. Pedro Sanguineto, este pensamiento estaba muy próximo á realizarse, y fuera sensible que algún informe equivocado al Gobierno, lo embarazase. Según las noticias del propio Sanguineto, es cierto que es ya considerable el número de embarcaciones extranjeras que concurren todos los años á la pesca, y áun algunas hacen invernada en los excelentes puertos descubiertos por sí mismas en las islas occidentales de este Archipiélago, cuyo crecido nú mero de buques es una prueba incontestable de la utilidad que aquí sacan y la razón porque le prefieren.

Sin embargo de la excesiva economía de sus armamentos para esta clase de navegaciones, llegando ya al extremo de desertarse inuchos marineros á nuestra colonia, prefiriendo el riesgo eminente de su vida para alcanzarla, á sufrir las miserías que padecen, yo creo, no obstante, que las ventajas locales para la pesca no nos las podrán disputar los extranjeros; y á poco tiempo abandonarían estas islas, 6 disminuiría su concurrencia cuando viesen desaparecer las utilidades que antes encontraban. Este sería igual mente el único medio político para separarlos de estc Archipiélago, hacia donde tambien los llama la esperanza de poder matar furtivamente algún ganado para la subsistencia en sus inver nadas. Estos recelos han dado lugar á una disposición, que aunque justificada por la necesidad, se opone á la propagación rápida que goza aquí esta especie, obligando á reducirle el pasto 
$s$ medios En. $s$ renderlo, h derecho seguir el grarse en demás de con evios efectos

bién aquí erse. Tal ezca de la Esta proopiniones los Viresa de lia. mos visto le la costa jía Marí.

biense con islas para e aquí la hto, yenma forma ene en los lo ménos, neto, este alizarse, y ivocado al oticias del a conside. xtranjeras sca, y áun intes puer. islas occi:recido núestable de porque le

nía de sus egaciones, se inuchos lo el riesgo a sufrir las tante, que nos las po. co tiempo ría su con. las utilida. ría igual. separarlos ambien los rtivamente sus inver. á una disla necesique goza le el pasto
Fi1. \& al pequeño espacio desde la población á la bahía del Oeste; á la verdad espacio bien corto para el número de 6.000 cabezas que se cuentan en el dia. De esto se siguen dos inconvenientes graves; el primero de que se apuren en breve los pas. tos; privándosele también de los abundantes que hay en la parte del Sur, de donde ahora se le se. para para tenerlo á la vista; y el segundo debilitarse y adulterarse la excelente casta que existe actualmente.

Otra prueba convincente de las ventajas de la pesca por estos mares, es de que las invernadas han empezado á hacerse ya en el puerto de Año Nuevo, en la Isla de los Estadcs. Esta noticia, comprobada por relación de diferentes marine. ro. desertores ingleses americanos, me añadieron que el Capitán de la fragata había forruado alli una buena barraca para ejecutar las faenas necesarias y abrigarse del rigor de la intemperie en aquellas regiones. Yo no dudo que este ejemplar sea imitado por otros, ni que en adelante se excedan á pretensiones más formales, si encuen. tran medios pars. autorizarlas. La situación de la Isla de los Estados, teniendo un buen puerto, agua y leña abundante, son ventajas muy conocidas para que no las aprovechen y no quieran extenderlas con el tiempo á otras muy perjudiciales á los intereses de la España. Los tratados de paz prohiben en efecto todo establecimiento extranjero sobre nuestras costas $e$ islas adyacentes, pero eludidos aquéllos con la fuerza del primer momento favorable, no se consultan para em. plearla otras razones, sino la utilidad propia ó el daño ageno. Si algo sería capaz de malograr estas intenciones venideras, yo comprendo como único medio el que la Compañía Marítima prefiriese para establecerse el puerto de Año Nuevo al Deseado; pues llevando el primero muchas ventajas sobre el segundo, así por la excelencia del puerto como por la abundancia de leña, agua muy buena, de que carece el Deseado, y creo también sea. el terreno de aquél muy superior al de éste; son estas razones que justificarían siem. pre la preferencia, y la Compañia hallaria en las resultas de esta diusposición otras utilidades que le niega la existencia en puerto Deseado.

En este caso los auxilios y comunicación entre las Maluinas, sería fácil y utilisima á entrambos establecimientos. Si el ganado no pudiese conservarse en Año Nuevo, á lo ménos no sería difícil preservar en el invierno el que hubiese de consumir una colonia reducida, imitando lo que se practica en las partes septentrionales de la España, y cuando no procrease de este modo con la rapidez que en las Maluinas, siem. pre sería este establecimiento de la utilidad más grande para los buques de la carrera de Lima. La derrota de éstos los conduce á dar vista á la Isla de los Estados, y sin notable atraso en su viaje, entrarían á refrescar la aguada, reemplazar k.n. 8 la leña, mejorar la estiva, dar un regular des. canso á las tripulaciunics, y alguna carne fresca, á lo ménos á los enfermos.

Todas estas atenciones, de una grave consideración para montar el Cabo felizmente, saliendo de aquí también preparados para resistir los fuertes temporales que cuesta el conseguirlo.

Esta escala, áun sin proponer establecimiento alguno, se halla anteriormente recomendada en la relación del viaje á Magallanes, publicada en I 788, para evitar muclias veces la arribada costosa y dilatada al Río de la Plata. Una pe. queña colonia trasplantada aquí de la costa $\mathrm{Pa}$ tagónica, no sólo confirmaría la posesión exclusiva del puerto de Año Nuevo, sino que esta providencia disiparía las ideas ó proyecto que pue. dan formar otras naciones sobre este sitio; y tal vez algún día encontrarían los registros de Lima su propia utilidad en hacer esta corta escala, pues no pudiendo separarlos para hacerla ni los riesgos ni los gastos que tanto deben consultarse en los negocios mercantiles, le resultaría la ven. taja de disponer de más buque para la carga, con la ménos cantidad de agua y leña que en tal caso llevarían. Yo creo habría entonces una razón justa para obligárlos el Gobierno á esta arribada, sin que sea violenta ni nueva esta disposición en Europa. Los ingleses precisan á sus embarcaciones de la Compañía de la India á tocar en la Isla de Santa Elena, con solo el objeto de disminuir lo dilatado del viaje para conservación de los equipajes. Esta razón tan humana, justi fica por sí sola cualquiera providencia de esta naturaleza, tanto más necesaria en nosotros, cuanto el viaje es más penoso que el de la India, y aue nuestra marinería más sobresaliente es la que frecuenta esta carrera, en la cual ha perecido una parte muy considerable de ella.

Salida de las Maluinas.-Navegación a las Islas de la Aurora.-Descubrimiento de una nueva situación de todas y reunión en Montevideo a la Descubierta.

Dispuesta la salida para el II, previne con anticipación al Comandante Sangı.ineto, que contase con cuantos auxilios pudiese necesitar para su subsistencia y conservación de la colo. nia que pudiese yo franquearle de la corbcta je mi mando, pues estaba resuelto á quedarme cu.t solo aquellos muy precisos para llegar al puerto de Montevideo después del reconocimientu de las Islas de la Aurora á donde me dirigía; pero el próximo arribo de la corbeta Santa Escolástica, y no ser muy urgentes las recesidades del establecimiento, hizo no admitir Sanguineto sino tal cual cosa muy precisa.

Habiamos ya observado la variación de la 
En "I aguja por diferentes azimutes de $20^{\circ}$ o $0^{\prime}$ Nordeste; y la pleamar en el plenilunio la observamos también á las cuatro y media de la tarde, elevándose el agua siete piés.

Después de indecible trubajo que nos costó suspender las anclas por lo pegajoso y duro del fondo, dimos la vela á las cuatro de la mañand gobernando á rebasar la Isla de la Paja, desde cuyo punto con rumbo del Esnordeste y fuerza de vela, nos fianqueamos del Cabo San Felipe á las ocho de la mañana, perdiendo dos horas después la vista de ella enteramente. Nuestra derrota se dirigió desde aquí á entrar breve en los paralelos de las islas de la Aurora por 53 á $54^{\circ}$ para correrlos con los vientos favorables y coisstantes del Oeste.

Hallamos por la tarde la variación de la aguja por amplitud de $22^{\circ} 59^{\prime}$ Nordeste, y con viento fresquito del Oesudoeste al Sudoeste y un temperamento agradable, llegamos al medio dia siguiente á observar la latitud de $53^{\circ} \mathrm{I} 7^{\prime}, y$ la longitud por el ro5 de $50^{\circ} 39^{\prime}$ occidental de Cádiz, en doncie nos asaıltó la calma sucediéndola una ventolina que afirmó por el Este, la cual ce. nimos al Sursueste hasta cumplir los $53^{\circ} 40^{\prime} \mathrm{de}$ latitud por la misma que habíamos de buscar las referidas islas conforme á las noticias adquiri. das en Lima de su situáción.

Estos vientos del Este no dejaron de sorprendernos, cuando por lo común sólo soplan en la estación de invierro, en cuya experiencia se fundan algunos Pilotos mercantes para preferir aquella estación á la de verano, con la probable esperanza de mon'ar el Cabo de Hornos con mís brevedad, y consiguientemente acortar de mucho la navegación á Lima. Sin embargo, yo creo esta opinión falsiticada por la razón, y que para seguirla se prefirió el interés á otros motivos que reclama la humanidad y que no deben jamás posponerse. Los armadores en Cádiz necesitaban mucho tienupo para cargar sus buques, ya por su excesivo tamaño, como por la imprudencia con que los scbrecargaban en otros tiempos: seguíase de esto por una parte su poco andar, y por otra el temorde fo:zar ó de resistir la vela, hasta en los casos riás seguros para embarcaciones preparadas ba.jo de otras precauciones. Era una forzosa consecuencia de estos dos inconvenientes el llegar al Cabo después de una navegación mucho más larga de lo que debiera ser, y que las enfer. medades se propagasen rápidamente con los rigurosos efectos de aquellas latitudes, multiplicándose en razón de la debilidad de la naturaleza para resistirlas, y de las más ó ménos contra. riedades que ofreciese desde entonces la navegación.

Otra causa también ha contribuído en aque. llos tiempos á aumentar el número de los desas. tres en estos viajes. La propia razón del interés ha inducido á los propietarios de estos buques á des- En, 12 preciar la elección de las estaciones, habierdo de ser la primera que debiera consultarse.

Por lo común, cada uno ha echado al mar sus expediciones precisamente al tiempo de ir á do. blar el Cabo de Hornos er lo más riguroso del invierno, resultando de aquí todos los males que pueden inferirse de transitar unos mares de los más tempestuosos áun en la estación de verano. Sólo los navegantes se hallan en estado de juzgar de los indecibles trabajos que acarrea á la gente de mar esta disposición, tanto más sensible cuanto sólo ha querido falsamente cohonestarla el informe de algunos Capitanes, atribuyendo una bondad de tiempos al invierno, que no encuentran en el verano. Yo quisiera preguntarles si las noches casi continuas entonces en aquellas altas latitudes, facilitan al marinero maniobrar ó hacer los esfuerzos de vela quc pro. porciona lo largo de los días en la estación opues ta. Ni cómo puede resistir la gente el duro trabajo de sufrir la nieve, la garua y el frío inten sísimo de aquellas regiones sin sentir las tristes consecuencias que padece.

Por de contado aquellos informes deben mirarse como sospechosos, porque interviene en producirlos el interés propio de los Capitanes en asegurar su opinión lisonjeando el de los dueños, los cuales no tratan de la salida de sus buques sino después de no poder admitir ya mas carga. Algunos ejemplares de navegaciones felices los ha engreido en repetir estos viajes, desatendien. do la estación, sin reparo á lo que sufre y se sacrifica la gente de mar más escogida del Estado, siendo víctima de su ambición $\mathrm{y}$ de su codicia.

A las tres y media de la tarde del día siguiente entramos en el naralelo propuesto, habiendo observado al medio día la latitud de $53^{\circ} 4^{8^{\prime}} \mathrm{Sur}$, y la longitud de $49^{\circ} 5^{0^{\prime}}$, advirtién. donos una diferencia de $20^{\prime}$ al Oeste, y la propia en igual sentido tuvimos al día siguiente. El tiempo continuaba desde ayer con mal aparato, y con viento del Sursudoeste corriamos con la vigilancia correspondiente, presumiendo no esta1 distantes las islas, habiendo visto hoy sargazo y también abundancia de pájaros.

El horizonte al anochecer, difícilmente se extendería á más de tres millas, y el viento so. plaba ya con tal fuerza, que nos obligó á capear toda la noche con trinquete y gavia con dos rizos arriada.

Desde las tres y media de la manana, habiendo cedido el viento, se cazó el velacho, arribando al Esnordeste. Veíamos el sargazo más abundan. te, y también la vista de algunas gaviotas nos daban esperanza de alcanzar breve la de las is las, cuyo meridiano cruzamos antes del medio día, suponiéndole por varias noticias en $44^{\circ} \mathrm{I}^{\prime}$ occidental de Cádiz, aunque siempre esta longi- 
tes á des- Fun. to biendo de

i mar sus ir á do. uroso del hales que es de los verano. 0 de juz. arrea á la más sente coho. hes, atrierno, que a preguntonces en marinero que pro. ón opuesduro trarío intenlas tristes

leben $\mathrm{mi}$ rviene en pitanes en ss dueños, us buques as carga. felices los satendienre y se saEstado, u codicia. el día siesto, halatitud de advirtién. - la propia iente. $\mathrm{El}$ 1 aparato, us con la o no estar sargazo y

mente se viento soj á capear i dos rizos

a, habienarribando abundaniotas nos de las islel medio on $44^{\circ} \mathrm{I}^{\prime}$ sta longi-
Fo. is tud discreparía mucho de la verdadera: la nues. tra de hoy por el 105 era de $43^{n} 45^{\prime}$, apartándo. se de la de estima en $16^{\prime}$ al Este, estando en la. titud de $53^{\circ} 25^{\prime}$ Sur.

Debiamos suponer en la situación de estas islas aquel error al Este que se contrae en esta navegación desde Lima á la equinoccial, y por lo tanto, doblamos desde hoy el celo y las precau. ciones, para ni propasarnos al Este de ellas, ni navegar para evitarlo sino con latitudes muy seguras y horizontes medianamente claros. El frío á la sazón se hacía muy sensible, de modo que fué preciso relevar con frecuencia la guardia de los topes.

Antes del medio día, me avisaron éstas la vista de un bajo como al Nornordeste. Al instante nos dirigimos á reconocerle con fuerza de vela, y aunque no dejásemos de dudar de su existen. cia mientras la distancia no lo confirmase, sin embargo, todas las noticias de los que yo enviaba á las crucetas, escogidos entre los de mejor ojo, me las repetían con firmeza, por más desconfianza que yo les inspirase con ser base de alguna banca pequeña de nieve sobre la cual rompiese la mar, y fuera ésta la reventazón que notaban. Pero nada pudo disuadirlos, ni aún cuando descubrí.yo con un buen anteojo desde la toldilla el engaño, todavía sostenían su ilusión, aumentándola viendo otros dos bajos semejantes al primero, hasta tanto que la corta distancia fué sólo capaz de desengañarlos. Yo hago aquí mención de este suceso, tan solo para pievenir á otros navegantes la.desconfianza con que debe procederse en otros casos semeiantes, y que si aquí las circunstancias no nos hubiesen facilitado el desengaño, y se hubiese de ceder sin examen al informe de los marineros, era preciso situar en la carta unos bajos en donde jamás han existido.

En la mañana siguiente se vió al Nordeste una banca no distante que iba tomando las diferentes formas en que quedaba después de desprenderse las masas que de ella se desplomaban. El sargazo nos acompañaba con más frecuencia y también bastantes pájaros. Las observaciones al medio día nos indicaron un error al Norte de la estima de $15^{\prime}$, siendo la latitud observada de $53^{\circ} 25^{\prime}$ Sur, y la longitud de $42^{\circ} 42^{\prime}$, la cual también diferenciaba en $28^{\prime}$ al Este. Se gobernó desde luego al Sur $\%$ Suoeste para coger prontamente el paralelo de las islas, cuya vista podría escapársenos con un rumbo ménos directo en las cerrazones frecuentes; $y$ por esta causa 7. tampoco navegamos para el Este al día siguien. te sin aventurarnos ya á malograr nuestro objeto. La noche fué de las más tenebrosas, llovien. do sin cesar, y estas circunstancias nos imponían el cuidado correspondiente á evitar compremeternos inevitablemente sobre las islas.

Logramos al fin hoy averiguar por observa. ciones exactas nuestro verdadero lugar al cabo Fin. ss de dos días que carecíamos de ellas, gozando un día de los más hermosos que podían apetecerse en estas lacitudes: la observada de $54^{\circ} \mathrm{r2} 2^{\prime}$ nos r.anifestaba una grande diferencia al Sur, sien. do no menor otra para el Este señalancio el 105 la longitud de $42^{\circ} 24^{\prime}$. Al ponerse el Sol ya habíamos bajado para el Norte á entrar en la latitud de las islas, $y$ í este tiempo se vió al Nornoroeste á distaucia de siete á ocho leguas un mogote blanco por la mayor parte, que creímos fuese una banca respecto á que por la latitud no podíamos presumir fuese una de las islas.

Desde este punto ceñimos con las muras á estribor las gavias sobre dos rizos en ánimo de mantener este paraje; pero el viento ya al Oes. te $1 /$ Noroeste enturbió tanto los horizontes, que apenas en los dos días siguientes alcanzá- эg у bamos á ver más espacio en circunferencia que el de una milla.

Estas contrariedades tan tenaces se aumentaban á medida de lo que se acercaba el recono. cimiento de las Islas, para empeñar más nuestros deseos de conseguirle. Todas las circuns tancias se conspiraban á malograrle. Unos tiempos ó tempestuosos 6 cerrados con diferencias contínuas que nos apartaban con exceso del paralelo de las islas, en cuya latitud discrepaban tanto las noticias de los que las habían avistado, era una reunión de causas ó de esiorbos difíciles de superar sin ocurrir á unos de los acasos felices de la suerte; tal era nuestra desconfianza en conseguir ya nuestro intento, $y$ tal era mi sentimiento de verme quizás obligado á abando. nar el crucero si el conjunto de razones me es. trechasen á perder la esperanza de reconocer las islas tan deseadas.

A este tiempo nos consideráhamos ya $2^{\circ}$ al Este del meridiano de ellas, y ni esto ni la ce. rrazón, todavía continua á la mañana siguiente, desalentó mi empeño para proseguir en busca del fruto de la campaña. Apurando ya todos los recursos de la esperanza, tan solo podiamos aguardar de una suerte dichosa, la recompensa de nuestra constancia, digna á la verdad del premio que mereció.

Apenas hubo tiempo de formar otras combinaciones para en caso de hallarnos propasados de las islas, cuando la vista de una de ellas á las_cinco de la tarde vino á exinirnos del cuidado continuo en que habiamos estado. Por fortu. na, observamos ta:nbién en una clara la latitud de $53^{\circ} 40^{\prime}$ Sur y la longitud de $42^{\circ} 24^{\prime}$.

La isla, mirada á la distancia de seis leguas y cubierta de nieve, hacía dudar de su verdadera existencia. Con fuerza de vela nos dirigimos á ella al rumbo de Norte, asegurándonos á las seis y media de ser efectivamente la isla; desde entonces se arribó al Norte $\%$ Noroeste con toda 
Eis. zo vigilancia en los topes, para o an rmar un bajo reconocido el año de 1790 por la fragata Princesı, de ly ikral Compañia de Filipinas, según constaba de: Diario de su Capitán D. Martín Oyarvide, que me manifest 6 antes de nuestra salida de Lima. Esta fragata, habiendo capeado la noche anterior de avistar las islas, considerán dose cerca de su paralelo mareó poco antes de amainecer, y no bien había empezado á aclarar cuando no solo se encontró sobre las jslas sino también próxima á un bajo, demorando al Esuste de ellas distancia de unas once millas, pasando por entre ellas y el mismo bajo. Pero nosotros en vano pretendimos buscarle hasta las ocinc y cuarto que nos pusimos Este-Oeste corregido con la isla á ménos distancia de una milla

En esta situación reconocimos que la isla por muchas partes estaba cubjerta de una capa muy profunda de nieve, y por otras teniéndola superficial, descubría un color oscuro 6 negro, reflejado por el de la piedra ó color del terreno de la misma isla; y solamente cn sus orillas se descu. bría la piedra, con especialidad en las del Sur, porque siendo la parte más batida de los vientos, permitía ménos á la nieve depositarse en las in. mediaciones del agua en donde la marejada contínua la consumía.

Traídas nuestras observaciones del medio día á la hora de estar Este-Oeste corregido con la isla, resulta su posición en la latitud y longitud siguiente:

Latitıd observada Sur al medio día. . $53^{\circ} 40^{\prime} 16^{\prime \prime}$ Por estima al Norte hasta estar Este

Oeste corregido á las ocho y cuarto.

$24 \cdot 54$

Latitud que resulta á la isla. . . . . .

Longitud por el 105 tralda al medio dia.................

Por estima al Este hasta el paralelo de

la isla ..............

Luégo longitud de la isla (I). . . . .

$53 \cdot 15 \cdot 22$

$42 \cdot 24 \cdot 30$

$24 \cdot 30$

42.00 .00

Comparados estos resultados con nuestra situacion de la tarde del 18 en que avistamos el mogote tenido por banca, se concluye que esta isla debió ser la misma que aquel dia se nos presentó á la vista.

Al tiempo de llegar sobre la isla, avisaron de las crucetas descubrirse cerca un bajo al Noroeste de ella. Maniobrando prontamente á evadirlo, advertimss el engaño de la noticia, viendo ser una banquilla de nieve desprendida de la misma isla, y que estando muy á flor de agua representaba un bajo á cierta distancia, con las apariencias más engañosas. Este hecho me dió lugar á pre.

(1) A todas estas longitudes deben restarse $20^{\circ}$ que á la llegada á Montevideo tenía de error al Oes. to el reloj num. 105, y quedaran entónces corregidas. sumir que cometiese el mismo error la fragata En. Princesa, y que ocupada en desembarazarse pron- . tamente de las islas y del bajo, atendiese pocoá reconocerle con prolijida $!$, siendo difícil después en tales casos destruir la ilusion primera que se concibe. Sin embargo, fué siempre mi ánimo insistir en las diligencias para aclarar la cuestión, á cuyo fin mantuvimos toda la noche la isla á la vista, no habiendo encontrado fondo cerca de ella con toda la sondaleza.

Nuy poco favorable se nos presentó la mañana siguiente á completar nuestros deseos: el viento había llamado flojo al Norte y los horizontes tan cubiertos, que la presencia del Sol la mirábamos muy remota. Pasando después el viento al Oeste, gobernamos con todo aparejo al Esnordeste y Nordeste á fin de reconocer la parte del Este y Norte de la isla, para buscar de camino la otra y registrar también nuevamente la parte de horizonte por donde se suponia el bajo. A las cuatro y media avisaron verse tierra por la serviola de babor, la cual una hora después distinguiamos con claridad, y no dudamos fuese la otra isla, cubierta también de nieve, sólo negros los dos extremos, y un pico más elevado hacia el Noroeste: su extensión de Norte á Sur sería de unas seis millas, mucho mayor que la otra y más rasa, pues difícilmente se alcanzará á ver en días claros á cinco 6 seis leguas, cuando la primera podrá conseguirse á nueve 6 diez. Era mi intención acercarme á medirla y asimismo la distancia relativa con la isla más al Sur, para luégo volver á costear ésta por la parte del Este, para confirmar si era 6 no cierta la existencia del bajo referido. Navegando á este fin con la misma diligencia á cruzar entre las dos islas, nos asaltó repentinamente una cerrazón y garua, que apenas nos permitio hacer las últimas marcacin. nes á las islas, precisándonos á estimar las distancias deseadas por si acaso no permitía el tiem. po practicar luego estas operaciones por bases, como lo anhelábamos.

Marcábamos á las seis y media la isla más meridional al Sueste y la más Norte al Norte $1 /$ Nordeste de la aguja, cuya variación Nordeste se observó por azimutes en la tarde, de $18^{\circ} 20^{\prime}$. En estas marcaciones nos supusimos distantes de la primera isla seis millas y de la segunda de ocho á diez. Media hora después perdimos ésta de vista y la otra á muy corto rato. El viento estaba fresco por el Oesnoroeste, el cual ceñimos al Norte sobre las gavias un poco arriadas, esperando abriese el tiempo, observásemos horarios y la latitud en las inmediaciones de las islas: álas diez se sondo con 80 brazas y no se hallo fondo; á esta hora, continuando la oscuridad y garua cada cada vez con más fuerza, perdimos la esperanza de conseguir la vista del Sol ni tener observa. ción alguna en lo rest' nte del día. 
$r$ las dis-

a el tiem-

or bases,

isla más

Norte $\%$

Nordeste

$8^{\circ} 20^{\prime}$. En

ntes de la a de ocho

ta de vis-

to estaba

ñimos al

esperall.

arios y la

álas diez

fondo; á

aruá cada

speranza observa-
Bajo de este concepto $y$ de que las islas quedaban ya situadas dentro de aquel grado de precisión que exige la seguridad de los navegantes, arribamos al Este, asi para separarnos de su inmediación como porque si acaso apareciese el Sol tuviese menos error la latitud referida á las islas.

No tuvimos al fin altura meridiana, pero por fortuna, pasando el viento al medio dia del Oesnoroeste al Sucuoeste, fué disipando la cerrazón y acabándose la garua. Antes de la una y media ya teniamos la vista agradable del Sol, aunque estábamos fuera de la de las islas. Desde cl instante observamos alturas para horarios, y para deducir la latitud por dos diferentes, según el $\mathrm{r}$. stodo de Mr. Dawes, para no ornitir diligencia alguna en la exacta posición de las islas, aplicando en ella todos los medios que prescribe la navegación moderna.

Resultados de estas observaciones para la situacion de la isla.

Latitud observada por dos alturas tomadas la primera poco más de media hora después del medio dia, y la se. gunda a la una y media de la tarde, cuyo resultado corresponde a esta tiltima hora............. Latitud referida al medio dra. . . . . Por estima al Sur desde las siete de la mañana que se marcó la isla al Sur corregido distancia de seis millas.

Réstense las seis millas que estábamos al Norte de la isla . . . . . . . .

Luego resulta la isla en latitud Sur de. Longitud observada retrocedida al me.

Por estima al Este desde las sicte de la mañana que se marcó la isla al Sur Luego longitud que resulta a la isla primera. ............. 42. $42^{\circ} \circ 3^{\prime} 50^{\prime \prime}$

Situación de la isla rasa ó la mís Norte.

Latitud del buque a las seis de la ma-

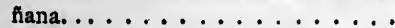
Longitud a la misma hora. . . . . . . Por la marcación de la isla rasa á las seis de la mañana al Norte $29^{\circ} 15^{\prime}$ cia de catorce millas de una isla a otra, resulta la diferencia de latitud, ála isla rasa $12^{\prime} 20^{\prime \prime}$ al Norte de.la primera isla.

Latitud adoptada a la isla primera 6 más Sur como preferente. ...... $53^{\circ} \circ 6^{\prime} 30^{\prime \prime}$ 42.05 .00 dio día desde la una tres cuartos. . corregido. ............ Este corregido, suponiendo la distan-
Diferencia on latitud al Norte en que resulta la segunda respecto a la pri-

mera. ............. 12.20

Latitud en que resulta la segunda isla á la rasa.............. 53. 2.40

Longitud del buque a las seis de la manana. ............. 42. 5.00 Diferencia en longitud Este por marca-

ción á la isla rasa. ......... 7.20 Luego longitud do la isla rasa.. . . . 41.57.40

Se deduce de las operaciones antecedentes, que hemos preferido para determinar la latitud de la primera isla la observada ayer, traída con la estima hasta la hora de llegar a su paralelo, á la de las dos alturas; pues aunque entre una y otra sólo hay de diferencia tres minutos, concurre en la primera la circunstancia para preferirse, el estar conforme con la asignada por el piloto de la fragata Aurora, poco después del medio día en el año de $\mathrm{r}_{762}$, á quien se debe el descubrimiento de estas islas. En cuanto á la longitud, se advierte la conformidad de los resultados de ayer con los de hoy, y que el error, poco despreciable al situar la segunda isla, de pende del que incluyen las distancias estimadas, jamás de consideración cuando éstas no son crecidas.

Abandonamos ya las islas, tratando s6́lo de seguir aquella vuelta que proporcionase ganar más bien longitud al Oeste que latitud al Norte. Al medio día, sin embargo de estar el viento al Sudoeste $1 / 4$ Oeste, se tomaron las muras á es tribor, fiados en el giro para el Oeste que acostumbra á tomar.

Precediendo chulascos con rachas bastante fuertes, roló en efecto al Oeste con fuerza y la mar bastante crecida. Siguióse el bordo del Sur con preferencia al del Norte, en el concepto de que tan dificultoso como es ganar aquí al Oeste, es fácil bajar al Norte, además de la ventaja en adquirir la longitud donde los grados son más pequeños.

Por las observaciones de hoy, nos hallábamos en latitud de $54^{\circ} 49^{\prime}$ Sur y en longitud de $42^{\circ}$ I $8^{\prime}$. El viento por la tarde, entrando en el cuarto cuadrante; causó la cerr ızón acostumbrada, lo cual con abundancia de pamperos y procelarias, hacían desconfiar de la seguridad del tiempo. No por esto dejó de hacerse toda fuerza de vela para aprovechar los rumbos próximos al Oeste, te niendo favorable la variación crecida de la aguja.

Se presentó la mañana siguiente con lluvia. y mal semblante, y el viento fresco por el Norors. te, desde donde pasando al Oeste arreció bas. tante. Nuestra situación hacia el medio dia próximos á los paralelos del Cabo de Hornos, y sin hallar los vientos del tercer cuadrante que $53^{\circ} 15^{\prime} 00^{\prime \prime}$ nos prometíamos, me obligh á tomar la vuelta

53.12 .00 $41^{\circ} 18^{\prime} 50^{\prime \prime}$

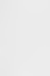

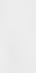


I.n. 1. del Norte para huir de los temporales de estas latitudes, y buscar en otras más bajas otra sua. vidad de tiempo para ganar en ellas la longitud al Oeste. No solo estas razones estrechaban la necesidad de seguir este partido, sino la novedad de alguna agua que hacíamos por la proa de resultas de la continuación de los malos tiempos. Pero este motivo no nos daba gran cuidado res. pecto á no ser agua baja, pues sólo aumentaba estando á la capa 6 con esfuerzos de vela: de aquí inferíamos fuese defecto en las costuras de las curvas bandas, á cuya sospecha nos indu. cía el no haberse recorrido en Manila, no lıa. biendo encontrado entonces causa para ejecu. tarlo.

No bien habíamos deducido nuestra situación al medio dia de $55^{\circ} 28^{\prime}$ de latitud Sur y $44^{\circ} 20^{\prime}$ de longitud, que la fuerza del viento por el Oesnoroeste nos obligó á capear con el trinquete $y$ la gavia hasta la madrugada siguiente, que cediendo, volvimos á marear la vela proporcionada ¿ la serenidad del tiempo, de la cual gozamos toda la singladura próxima, soplando el viento del tercer cuadrante. Con estas proporciones ejecutamos cuantas observaciones facilitase la presencia del Sol, por las cuales estábamos en latitud de $53^{\circ} 05^{\prime}$ Sur y en longitud de $42^{\circ} 53^{\prime}$ manifestándose como ayer diferencias al Norte y también al Liste pero más crecidas. La varia. ción de la aguja resultaba por diferentes azimu. tes de $18^{\circ} 10^{\prime}$ Nordeste y $17^{\circ} 20^{\prime}$ por amplitud occidua.

Hacia las cinco de la tarde que vimos pasar por el costado dos ramajes de sargazo, se avistó desde el alcázar una banca de nieve demorando al Este un 1/4 Nordeste distancia de seis á siete leguas. Mandé luégo al Piloto á reconocerla cuidadosamente desde las crucetas, y me avisó scr desde luego una isla, cuya superficie aunque $\mathrm{cu}$ bierta de nieve, \& reconocía por el color oscuro no ser banca como lo sospecliábamos. A la primera impresión de esta noticia nos inclina. mos á que fuese la propia isla del día $2 r$, pero se falsifić muy breve este concepto, comparando nuestra posición á la de ella, y también su elevación, figura y el reconocimiento prolijo que hi. cimos con anteojos nos persuadió á que era una isla enteramente nueva.

Nada podría excusarnos de rectificar estos antecedentes, ni disculparia nuestra omisión sobre un punto tan importante á la navegación y en que tanto se interesaba la satisfacción de todo descubridor.

Arribamos pues al Sueste $1 / 4$ Este, navegando hasta las diez en que cer̃imos de una vuelta y otra á barlovento de la isla logrando por este medio amanecer como tres leguas de ella marcándola al Esueste $5^{\circ}$ Este. Con rumbos convenientes fuimos á costearla enfilando con ella un islote saliente de su extremo oriental kn. v" al Norte $84^{\circ}$ Oeste. Cuandó lleg. inos á estar Norte-Sur distábamos dos millas, y reconocimos que su circunferencia era mayor que la de la primera isla reconocida, pues no bajaria de dos millas; su altura también era mayor $y$ las orillas igualmente escarpadas é inaccesibles.

Conservadas sobre las gavias la inmediación prudente, se repitieron las alturas y horarios, eligiendo las circunstancias más oportunas para conseguir resultados más exactos cuando la presencia del Sol, muchas veces interrumpida, nos la proporcionaban. También no habiamos hallado fondo con toda la sondaleza á la distancia de las dos millas, descubriendo á este tiempo un arrecife qne arrojaba la isla hacia el Sueste no de ménos extensión de las mismas dos millas, rematando el extremo en un pedrusco más ele. vado que los restantes, formando el citado arre. cife algunos ocultos por la rompiente.

Al mismo tiempo de observar la latitud en esta situación con la mayor confianza de $52^{\circ} 3^{8^{\prime}}$ Sur, se marcó la isla al Sur $89^{\circ}$ Oeste y su is. lote al Sur $87^{\circ}$ Oeste; y procediendo á determinar la situación de esta isla (que llamaremos Isla Nueva) resulta del modo siguiente:

Latitud observada al medio día.. . . . $52^{\circ} 3^{8^{\prime}} \circ 0^{\prime \prime}$ Diferencia de latitud por la marcacion

a la isla al Norte $73^{\circ}$ Ueste corregido $00 \cdot 3^{6}$ Latitud en que resulta la isla. . . . 5 52.37.24

Longitud observada trarda al medio dra................. 41.43.46 Diferencia de longitud por marcacion á la isla al Norte $73^{\circ}$ Oeste corregido distancia de 2 millas.......... Longitud de la isla al medio día occidental de Cádiz. ........ 41.46.06 Se ha preferido en esta longitud la del rosá la del cronómetro 72 , por la mayor seguridad que nos prestaba el primero con presencia del examen de entrambos en el puerto de la Soledad: $\sin$ embargo, su diferencia recíproca no es tan grande, pues sólo se aparta hoy el $72, \mathrm{II}^{\prime}$ al Oeste del ro5.

Concluídas las observaciones nos dirigimos con el viento fresco del Nornoroeste al rumbo del Sur á reconocer bien los límites del arrecife, y no habiendo notado nada más de lo que se ha manifestado, iranqueados de el, forzamos de vela para aprovechar el rumbo favorable del Oeste. A la una de la tarde me avisaron de los topes no descubrirse otra rompiente, ni la del arrecife se dilataba tampoco á más distancia de la que habíamos conceptuado.

Hoy también habian resultado de las observaciones diferencias al Norte y al Este; pero no se ha corregido este error para la longitud determinada á la isla por no poderse considerar 
oriental Yn.

á estar

nocimos

la de la

a de dos

as orillas

hediación

horarios,

nas para

lo la pre-

pida, nos

s hallado

cancia de

empo un

jueste no

s millas,

más ele-

ado arre.

atitud en

de $52^{\circ} 3^{8^{\prime}}$

e $y$ su is.

determi -

remos Isla

$5^{\circ} 3^{\prime \prime} 00^{\prime \prime}$

$00 \cdot 3^{6}$

$52 \cdot 37 \cdot 24$

$41 \cdot 43 \cdot 4^{6}$

02.20

41.46 .06

del ro5 á

uridad que

lel examen

ledad: $\sin$

tan gran-

' al Oeste

dirigimos rumbo del arrecife, y que se ha rzamos de orable del ron de los ni la del istancia de

las obserEste; pero ingitud deconsiderar
J.a. ") proporcional en cada hora respecto á haber concurrido mayores causas para producirle desde la arribada de ayer tarde, y la navegación durante la noche, que en la de la mañana, 6 por lo ménos desde la hora de los horarios hasta el medio dia. Si admitiésemos este e1sor proporcional á cada hora, es cierto que la isla resultaría $2^{\prime} 30^{\prime \prime}$ más al Este de en lo que la hemos establecido: cantidad bien despreciable aqui para tomarse en con. sideración.

Observada asimismo la variación de la aguja por azimutes de $19^{\circ} 2 I^{\prime}$ Nordeste, nada nos quedo que desear para añadir á la complacencia de este feliz descubrimiento, la de haber logrado todas las observaciones precisas para colocar esta isla nueva dentro de unos límites los más exactos.

Al paso de ir descendiendo el Sol, el viento arreciaba sin salir del Nornoroeste 6 Norte $\%$ Noroeste, con el cual resistimos cuanta vela era posible mientras hacíamos rumbos tan ventajosos y las malas apariencias del tiempo no llegasen á realizarse.

A las cuatro y media de la tarde se avistó desde las crucetas un frontón blanco como de cuatro á seis millas de extensión de Este á Oestr. El horizonte, á la sazón fosco, hacía represen. tar aquel objeto con una oscuridad por la distan. cia de seis leguas á que le mirábamos al rum. bo del Oesnoroeste, que los marineros por esta causa se engañaron creyéndole otra nueva isla. Nuestro rumbo casi hacia ella con un andar de cinco y medio millas por hora, y lo que la isla engañosa la arrastraba el viento hacia nosotros, produjo muy luego nuestro desengaño y la agradable perspectiva de ver navegar majestuosa. mente una banca de nieve de tan extraordinaria magnitud: por el costado pasaron otras pequeñas, y esto causaba para nosotros uno de aque. llos pocos espectáculos que ocupaban con agrado nuestra vista y cuya novedad entretenía gustosa mente nuestros equipajes.

El tiempo al anochecer tomo muy feo semblante, y el viento, sin permitirnos ya más que el trinquete y las gavias sobre dos rizos. La mar, creciendo excesivamente, nos ocasionb ba lances extraordinarios hacia la media noche, que ei viento era bonancible ya por el Oeste $1 / 4$ Noroeste. La oscuridad, aumentada con la garua constante, era tan densa, que difícilmente daría tiempo para eludir el encuentro repentino de al guna banca, y esto no dejaba de ocupar justamente nuestro cuidado.

Llamando el viento al Sudoeste, á las primeras horas de la mañana aclaró la cerrazbon, y principiamos á descubrir desde el alcázar diferentes bancas, y mucho mayor número desde arriba, según avisaron los guardias de los topes. El tiempo, aunque frío, estaba hermoso y apaci- ble, $y$ el viento permitiéndonos andar cuatro $6 \mathrm{En}$, 9 cinco millas por hora.

Observada la latitud de $52^{\circ} 13^{\prime}$ y la longitud de $43^{\circ} \circ 7^{\prime}$, volvimos á tener las mismas diferencias de $23^{\prime}$ al Norte y 32 para el Este, $\Lambda$ esta hora contábamos ya como roo bancas de todos tamaños, y este número se iba multiplicando á medida de avanzar para el Oeste. Seguimos, sin embargo, el propio rumbo del Noroeste 6 Noroeste $\%$ Oeste, asi porque el tiempo favorecia nuestra derrota, como yor la probabilidad de rebasarlas en el grande espacio de día que nos res. taba, tanto más de considerar yo siempre segura la salida por el Norte, en donde no se reconocían entonces los mismos embarazos.

A este ticmpo, relevadas las guardias de los topes, vinieron á decirme llenos de espanto cómo ya se descubria un archipiélago inmenso desde el Sursuoeste al Oeste y Norte, sembrado con tal espesura, que era absolutamente imposible poder atravesarle por ninguno de los rumbos comprendidos entre ambos extremos. Pareciome un poco exagerada esta noticia, y para compro. barla, mandé al Piloto á las crucetas que desde allí me.informase después de un prolijo examen en el horizonte, por los parajes indicados; pero sin neccsidad ya de este informe, no tardamos todos en justificar desde el alcázar las primeras noticias, $y$ en convencerme yo de la necesidad de variar el rumbo para separarnos del empeño á donde $n .3$ conducia el que seguiamos.

Desde luego arribamos á la una y media con toda vela al Norte \% Nordeste, rumbo en cuya dirección no veiamos obstruído el paso. Mientras seguimos á este rumbo ya atravesábamos por entre algunas bancas grandes, pasando de ellas á tiro de pistola, y dejando por consi. guiente á la izquierda toda la cordillera del cuarto cuadrante, prolongándola para el Norte en donde creíamos rematase. Navegamos bajo este concepto hasta las cuatro de la tarde presentán. dose por aquella parte á nuestra vista un campo dilatado cubierto de islas flotantes de nieve, cuya hermosa perspectiva no cabe representarla con exactitud, ni la pluma más elocuente, ni el pincel más penetrado de aquel fuego 6 entusiasmo con que una habilidad de primer orden sabe imitar todas las obras maravillosas de la Naturaleza. No nos es fácil concebir, áun oprimiendo la imaginación, el contraste raro que formaba á nuestra vista este número infinito de grandes masas, por sus figuras las más extravagantes y pintorescas. Nosotros nos contemplábamos al frente de una inmensa poblacion, que arruinada por algún terremoto, había perdido la regularidad de su planta y la magnificencia de sus edificios. Un cúmulo de objetos tan diversos y extraños sobre los cuales reflejaban los rayos del Sol para aumentar ia harmonía graciosa, debia 
V.n. as por precision atraer toda nuestra curiosidad y conducirnos á consideraciones bien distintas. La imaginación no podía ménos de recordar á nues. tra memoria, que la propia causa que ahork servía para suspenderla y divertirla, lo habla sido para producir el naufragio á otros navegantes: á la sazón nos acordábamos de la triste reciente suerte del navio inglés Bounty que se estrelló contra una banca navegando desde el Cabo de Buena Lsperanza á bahia Botánica; y del riesgo inminente y descalabros que sufrió la fragata Limeña, del comercio de Cádiz, hacc pocos anos en estos mismos mares.

Nos considerábamos bien distantes de vernos en semejantes peligros, creyendonos antes del anochecer estar fuera de todo cuidarlo. Pero las conjeturas en la mar son comunme.ite muy pre. carias, aunque muchas veces haya de fundar en ellas el navegante su seguridad. Nosotros hasta las cuatro de la tarde tuvimos viento entablado del Sudoeste, el tiempo hermoso, y los marineros de los topes nada avisaban que pudiera darnos el menor recelo para que la tripulación estuviese toda $\tan$ agradablemente entretenida con la vista de estos objetos, como distante de los grandes peligros que la esperaban.

Cumplida aquella hora me avisaron de los topes cómo se prolongaba hasta el Este la cordillera de bancas, pero tan menudamente sem. bradas, que parecía á la vista impracticable el paso. De este aviso, y del de que se distinguian sólo algunas claras entre el Norte y el Oeste, debí persuadirme á ser estas dos cordilleras en dirección de Sudoeste al Nordeste, por entre las cuales era forzoso atravesar al Oeste de ellas. Con este ánimo se gobernó al Nornoroeste $5^{\circ}$ Oeste, en cuya dirección se veían las islas ménos numerosas hasta las cinco en que volvió á ceurarse el canal que seguíamos, apareciéndose otras nuevas según íbamos avanzando, y esto nos obligaba á variar la dirección de la salida, buscíndola sucesivamente por el Nornoroeste, Noroeste, Oesnoroeste-Oeste, y últimamente por el Oesnoroeste $5^{\circ}$ Oeste. Nuestra situación, como se conoce, principiaba á ser cuidadosa, viéndonos rodeados de bancas, no tratando ya sino de entrar por donde cupiese la corbeta, el viento con un chubasco había abonanzado, y que una calma en estas circunstancias, ó la os. curidad de las noches anteriores, necesariamente nos veríamos á cada paso comprometidos.

Reconucimos franco al ponerse el Sol el horizonte del último rumbo que seguíamos como unas tres á cuatro leguas, y todo el restante estaba cubierto de grandes islas de nieve, entre las cuales medimos dos de ocho millas de largo cada una. No podíamos lisonjearnos de navegar con seguridad aquella distancia, sin recelar el encuentro de alguna banca por la frecuente alteración que tienen, originada de las varias causas que con. En. as curren en el elemento en que habitan para pro. ducirla. Con este conocimiento se tcmaron antes de anochecer aquellas justas precauciones para navegar en la noche próxima con toda la vigilan. cia indispensable en nuestra situación, · las de. más dictadas por la prudencia para tal casos.

Por de contado quedó el bote sobre los apare. jos, los botalones de desatracar á la mano, y la madera de respeto pronta á echarse al agua en el instante necesario. Mandé que la gente estuviese toda sobre cubierta, señalando su lugar á cada uno; y los Oficiales por mitad alternando duran. te la noche, debían repartirse en los parajes con. venientes para avisarme con tiempo de toda no. vedad, previniendoles era mi ánimo navegar por el canal franco descubierto la distancia indicada, y si cumplida se cerrase, buscar la salida á vien. to largo y poca vela, para entretener de este modo la noche. Esta me pareció la maniobra más adaptable á las circunstancias, pues la de pairo 6 capa privando al buque de la, locidad precisa en sus novimientos, podría esta falta acon. charnos sin recurso sobre alguna banca.

Por fortuna, la noche se mantuvo regularmente clara, el viento también galeno del Sur. sudoeste, y con el auxilio de los anteojos de no. che descubríamos las bancas á distancia suficiente para maniobrar sin temer el empeño. Estas, fuese ya por haber variado de posición unas, $y$ otras desplomadas de las más grandes, no purdiinos conservar el propio rumbo del Oesnoreste $5^{\circ}$ Oeste, para no tropezar con las que se atravesaban por la proa. No obstante, gobernando entre los rumbos del Oeste y Oesnoroeste, las íbamos sorteando, y tan sólo nos causaban algún cuidado las que por su corto tamaño no se distinguían sino á distancia muy corta. Hasta las once había sido nuestra navegacion bastante tranquila, pero á esta hora se present6 por la proa una banca muy grande, cuya extensión no bajaría de una milla, y toda era pareja. A primera vista parecía como partido preferente el de arribar para rebasarla por sotavento, pera incluyendo los dos inconvenientes, de la calma que nos daría su abrigo, y el ignorar si habría otras inmediatas que dificultasen el tránsito, resolví prontamente orzar cuanto permitía el viento con todo aparejo, teniendo lista la maniobra para tomar la otra vuelta si jo la montábamos, y por fortuna, lo conseguimos con felicidad á muy poca distancia.

Desde esta hora fuimos viendo más raras las barcas por uno $y$ otro costado, y cuando esta observación nos daba fundamento para esperar hallarnos al amanecer fuera de ellas, reconocimos á esta hora todo el horizonte cubierto enteramente desde el Noroeste por el Oeste y Sur hasta el Esté, advirtiendo en el restante tambien algu- 
as que con- En. as para pro. haron antes iones para la vigilan. h, las de. al casos. los apare. mano, $y$ la agua en el e estuviese gar á cada ndo duran. arajes con. de toda no. havegar por ia indicada,

lida á vien. her de este niobra más la de pairo tidad precifalta acon. ca. vo regularno del Sur. ojos de no. cia suficieneño. Estas, ión unas, y es, no pudiOesnoreste jue se atragobernando oroeste, las saban algún no se dis.

- Hasta las in bastante entó por la xtensión no ceja. A priferente el de pero inclu. calma que habria otras sito, resolví 1 viento con bra para toamos, y por á muy poca

Iás raras las cuando esta sara esperar reconocimos erto enteray Sur hasta mbién algu.
En. 29 nas. El viento estaba al Oeste, $y$ tomamos el bordo del Norte, por donde nos parecía más probable la salida, viéndola con ménos obstáculos que la embarazasen.

El tiempo no podía ser á la sazón más agra. dable, y nuestro andar de bolina de 4 á $4 \%$ mi . llas uos prometla el libertarnos de pasar otra noche con los cuidados de la anterior. Por nuestras observaciones estábamos al medio día en la latitud de $50^{\circ} 43^{\prime}$ Sur, y en la longitud dz $43^{\circ}$ $4{ }^{\prime}$, notando de diferencia al Norte $20^{\prime}$ y $\mathrm{Ix}^{\prime}$ al Liste. A esta hora llamando el viento al Oesnoroeste y seguidamente al Noroeste, fué necesario virar con muras á estribor para no meternos si. guiendo la vuelta del Nornordeste, entre la cordillera reconocida la tarde última, á donde necesa. riamente nos conducía aquel rumbo. Declarado el viento por esta parte, tomo un aspecto el tiem. po nada favorable, y tampoco lo eran las noticias de los topes para prometernos una noche de mé. nos zozobras que la pasada.

Al ponerse el Sol, los carices iban empeorando, la cerrazon creciendo, y el viento por el Nornorveste soplando con más fuerza. Reconocido á esta hora desde las crucetas el horizonte por el piloto, me informb como todo estaba cubierto de grandes bancas; el comprendido desde el Oeste al Nordeste por el Norte, y el del Sudoeste al Sudes. te por el Sur, advirtiéndose una única clara para poder seguirse su dirección entre el Sudoeste al Oeste cuatúo á cinco leguas. A este tiempo fue también preciso arribar al Sudoeste $\%$ Oeste por la imposibilidad de montar cuatro bancas, que rebasamos á las nueve, y desde esta liora nos preparamos con aquel aparejo más conveniente, para navegar lo ménos que fuese posible hasta cumplir la distancia reconocida; pero como el viento fué arreciando, no era verificable este pensamiento, debiendo por consiguiente meditar otro compatible con las reflexiones marineras y los apuros de la situación que nos amenazaba la noche próxima.

Esta situacion nos ponía en la dura necesided de resolver un partido con conocimiento seguro de ser cualquiera muy peligroso. La maniobra de capear no podía ni áun pensarse en este caso, porque en la rapide $z$ de un movimien. to consistiría salvarnos de un naufragio; y por otra parte havegar á viento largo sorteando los peligros, tampoco la fuerza del viento ni lo tenebroso de la noche lo aconsejaban. En esta triste alternativa de providencias, no era, pues, fácil adivinar la que incluyese resultas ménos funestas. Nuestra suerte estaba tan pendiente de su eleccion, como era dificultoso el acierto, y no es fácil sentir cuánto oprime al que manda la obligación de disponer de las vidas inocentes de los que le obedecen.

Pasando, pues, estas circunstancias críticas en que nos hallábamos, determiné niantenernos E.n. sq durante la noche sobre las gavias rizadas, y ceñir el viento en el claro reconocido, procu. rando conservarle hasta amanecer. Desde las diez ya la noche era muy oscura; el viento soplaba á ráfagas bien duras, y la garua 6 llovizna aumen. taba la cerrazón, al extremo á veces de no divisar un cumplido de la corbeta en su circunferencia. Sin embaugo de esta grande oscuridad, siempre esperábamos que el reflejo de la nieve facilitaria alcanzar la vista de las bancas á mayor distın. cia, que diese tiempo á huir de su encuentro, casi inevitable por más celo y precauciones que doblásemos para impedirle.

Antes de la media noche se vieron por la serviola de sotavento dos bancas inmediatas. Era muy dudoso montarlas áun en el caso de poderse resistir y amurar las mayores con la presteza necesaria, y así, tomando prontamente la resolu. ción de virar poniendo en facha el velacho, logramos felizmente ejecutar la maniobra.

Pero no por esto imitamos la propia maniobra en otro encuentro á las tres de la mañana, pues avistada una banca entre el portalón y la mura de sotavento, emprendimos al instante el tomar el otro bricln, cuidando mucho de aumentar la velocidad dal buque más bien que disminuirle como auteriormente, debiendo así á la rapidez del mr miento escapar de este nuevo inninente peligro, á costa de haberlo consentido, inevitables las resultas de un naufragio.

A csta hora puede inferirse cuánto ansiariamos la claridad del día, para que disminuyendo á lo ménos los peligros, pudiésemos entregarnos á gozar de algún descanso. Como subsistía aún la cerrazón, se dilataba la noche y también el número de nuestros cuidados. Por fortuna esca. pamos de uno muy grande después, que absolutamente no se hubiera evadido si la noche hubiese sido poco más larga.

Presentáronse al romper el día á sotavento tres bancas situadas en una misma línea, inmediatas entre sí, y mucho más á nosotros. No había á la sazón espacio bastante para virar, y de consiguiente, no estando el viento tan recio, á favor de la actividad con que se amuraron las mayores é izaron las gavias, conseguimos montar la primera y luégo las otras dos, tan de cercn, que recelábamos varar en alguna de sus bases sumersidas: maniobras que ejecutadas de noche se hubieran sin recurso malogrado por la imposibili. dad ni de combinarlas con acierto, ni ejecutarlas tan oportuna y prontamente como se requieren.

Este triunfo para nosotros fué tanto más plausible, cuanto la presencia del día y el viento ya manejable, nos ponía en el caso de no temer ot js peligros semejantes, $y$ aunque los horizontes neblinosos limitaban nuestra vista á un espacio bien corto, nos contemplábamos bastante fe- 
En. zo lices en no temer ahora otro enemigo que el de la calma. Seguíamos la vuelta del Sudoeste con el mismo viento del Oesnoroeste, cuya mura era la que nos alejaba más del archipiélago de las bancas, y la misma que yo pensaba continuar mientras el informe de la vista no falsificase este concepto.

Con poca confianza observamos la latitus de $50^{\circ} 5 \mathrm{I}^{\prime}$ y la longitud de $45^{\circ} \mathrm{o2^{ \prime }}$, advirtiendo al Este una grande diferencia de $5^{2}$. No aclaró el tiempo hasta pasado el medio dia, en que nos sobrevino la calma 6 ventolinas del tercer cuadrante, y esta noved ad, tan sensible como peligrosa anteriormente, nos era á la sazón indife. rente con encontrarnos distantes por todas partes de las bancas. En esta forma permaneciunos hasta ponerse el Sol, en que ciñendo el viento del Sudoeste bonancible con muras á babor, sólo se descubrían dos al Sursudoeste, bien que no era fácil reconocer el horizonte por calimoso desde el Noroeste al Sudeste, y el de la proa se limitaba á cinco 6 seis leguas.

Lo despejada de la noche no nos daba ya cuiciado, navegando hacia la parte por donde no descubríamos tropiezo alguno. El viento fresqui to por el Sudoeste permitiénidonos un andar de tres á cuatro millas con todo aparejo, nos fucilitaba prevenirle oportunamente $\sin$ riesgo de empeño, y así, aunque navegábamos con el celo correspondiente, pudo seguirse el orden de las guardias para que la gente pudiese descansar de sus fatigas tan continuadas.

Hasta el amanecer no vimos bancas, y áun entonces sólo se reconocieron tres, las dos por las muras y la otra por la pi a como á tres leguas. Pasando pocas horas después cerca de la de más á sotavento, volvimos á divisar otras dos también por la proa. Entretanto, el tiempo era bello, la mar muy apacible, y habiendo logrado las observaciones con toda confianza, observando la latitud de $49^{\circ} 52^{\prime}$ Sur y la longitud de $45^{\circ} 23^{\prime}$ Oeste, repitiéndose otra grande diferencia de ${ }_{5} 6^{\prime}$ al Este de la estima.

Desde las primeras horas de la tarde que roló el viento a! Oesnoroeste, tomamos la vuelta del Sudoeste, prefiriendo ganar aquí la longitud que no disminuir la latitud, pues además de lo que cuesta adquirir aquélla, también era mucho más importante acercarios á la costa en donde jamás recalan las bancas, y muy rara vez se han visto en los meridianos de las Maluinas. Por la tarde, no viéndose más que una ú otra, nos lisonjeábamos de salir de entre ellas, y las últimas que desnués volvimos á ver fueron dos por sotavento, á las once de la noche. Esta fué enturbiándose, y aunque no se disminuyó de vela navegábamos con todo el celo que exigía el deseo de triunfar al fin, de tantos peligros como nos habian rodeado.
La cerrazón y la garua crecieron considera- Yob. 1, blemente á la mañana siguiente, y por esto no pudimos descubrir si teníamos algunas bancas en las inmediaciones. Si hubiésemos de sacar una inducción cierta por las observaciones de nuestra experiencia, debíamos suponerlas no distantes de nosotros, atendiendo á que el color verdoso del mar como de sonda y un frío mucho más penetrante, habían sido señales seguras de hallarnos entre ellas, y las notamos aquí para que sirvan de aviso á otros y naveguen con las precauciones correspondientes, de noche 6 con tiempo oscuro.

Pcro nada habia hecho impresión en la salud de la gente con una fatiga tan contínua por es. pacio de cuatro días: su corto número les aumentaba el trabajo, por la necesidad de concurrir toda á muchas maniobras, á las cuales se han prestado con una actividad y disposición la más recomendable. Yo faltaría gravemente á mis de beres, si no hiciera aquí el justo elogio que merece la Oficialidad en esta parte y cuánta influencia ha tenido su ejemplo para inspirar en la conducta de la gente toda la vigilancia, serenidad y celo que constintemente ha observado en los diferen tes trances de la campaña. Nuestra obligación y la debida recompensa de su trabajo, nos ha conducido con gusto á procurarla todo el alivio y descanso compatible con las circunstancias. Se ha tenido el fogón encendido aún de noche, así para aumentar el abrigo en donde dormía, como para que los de la guardia bajasen alternativamente á calentarse, pues hasta en la cámara ne. cesitábamos también de igual auxilio, teniendo siempre encendida la chimenea para poder resis. tir el excesivo frío que sentíamos, á pesar de hallarnos en el rigor del verano. En los días malos se distribuyó ración doble de aguardiente, y asimismo de carne fresca en estos últimos de mayor fatiga, debiendo sin duda á estos medios y á la ropa de abrigo repartida de antemano á los que la necesitaron, el tener la gente en el estado más sano y robusto, y tan sólo se contaba un enfermo del mal venéreo desde la salida de Chile.

Libres ya de los cuidados de una navegación tan peligrosa en los días antecedentes, nos en. tregamos á formar opiniones sobre el paraje de donde viniesen estas islas flotantes de hielo, y del modo como se forman. En este último pun. to hay poco 6 nada que discurrir después de las observaciones del Capitán Cook en là Isla de la Georgia. Su opinión se resiste á admitir la recibida hasta entonces, de que la coagulación de estas grandes masas se forma helándose el agua en las bocas de los ríos caudalosos, ó porque se acumulan alli por grandes cataratas hasta que se abren ódividen por su propio peso. Si seformasen en esta forma las islas de hielo que se hallan en la mar, precisamente se habian de encontrar algu- 
ieron considera - Yeb, ,"

, y por esto no algunas bancas emos de sacar bservaciones de uponerlas no dis á que el color $\mathrm{y}$ un frío mucho ñalcs seguras de tamos aquí para aveguen cor las de noche 6 con esión en la salud continua por es mero les aumenad de concurrir s cuales se han sposición la más emente á mis delogio que merece nta influencia ha - en la conducta serenidad y celo do en los diferenstra obligación y ajo, nos ha contodo el alivio y ircunstancias. Se ún de noche, así de dormía, como asen alternativa. en la cámara neauxilio, teniendo para poder resis os, á pesar de hain los días malos uardiente, y asiúltimos de mayor os medios y á la emano á los que en el estado más intaba un enferlida de Chile. e una navegación edentes, nos enbre el paraje de intes de hielo, y este último punir Jespués de las : en lis Isla de la admitir la reci. oagulación de esndose el agua en , 6 porque se acutas hasta que se o. Si se formasen que se hallan en le encontrar algu-
Feb. t.॰ nas partes térreas entre su composicion, las cua. les buscaba Cook y jamás las encontro, ni tampoco pudo reconocer en toda la costa de la Georgia $y$ otras tierras del Sur, río ni arroyo capaz de que pudieran formarse en sus entradas. Así este insigne navegante establece su dictámen sobre lo que observó en la bahía de Posesión. "Los va"lles, dice, están cubiertos de muchas brazas de "profundidad con nieve eterna, $y$ hacia la mar se "terminan por unos promontorios de hielo de al"tura prodigiosa. Aquí es donde se forman las "islas de hielo por la nieve consolidada y la que " cae contínuamente en el invierno ó se desploma - de las montañas. Durante esta estación riguurosa, los promontorios de hielo es forzoso se va. "yan acumulando hasta llenarse todas las bahías, nsean de la extensión que fuesen. Congregados "ya por la nieve continua que cae y la que se les "aumenta de los montes, llegan hasta el punto * de no poder resistir su propio peso, y entonces use despedazan formando las que llamamos islas "de hielo."

Después extiende la probabilidad de sus conjeturas á determinar la causa de la diversidad de formas 6 figuras que toman estas islas. Supone que las que se presentan con una superficie plana sean formadas en las bahías ó al frente de los valles; $y$ otras que la tengan desigual es por haberse formado sobre rocas, picachos, precipicios 6 terrenos de una superficie irregular. Yo pienso que su primitiva forma la reciban, $s i n$ duda, de esta causa; pero después de arrojadas de las costas deben alterarla notablemente, no sólo por el choque de las aguas y el de unas con otras, sino también por la nieve que caiga sobre ellas mientras no se deshagan. Nosotros apoya remos esta opinión con haber notado á muchas de estas islas vestidas de varias capas concén tricas de nieve desde cierta altura del agua, más 6 ménos consolidadas según el orden de su antiguledad. También advertimos en otras un color verdoso ú oscuro, espccialmente en el primer cuerpo, que probaba una ancianidad intermina. ble. De aquí deducíamos que cuando estas enormes masas se conservaban á la caída del verano de magnit'd tan considerable $y$ de una materia tan compacta que no alcanzaban los rayos del Sol á derretiria, por precisión aumentarían su tama ño 6 recuperarían el anterior con la nieve que recibiesen en el invierno próximo, y por consiguiente, no es así fácil contar la edad ni el término de la peregrinaci ı de estos cuerpos flotantes, que navegan según el orden de los vientos en las diferentes estaciones del año.

En estas mismas causas y en la de la situación de la Georgia, me fundaba yo para creer que este vasto archipiélago encontrado por nosotros fuese procedente de aquella isla. La latitud de ella entre $53^{\circ} 57^{\prime}$ y $54^{\circ} 57^{\prime}$ Sur, y su lon. gitud desde $10^{\circ}$ hasta $12^{\circ} 46^{\prime}$ al Este de las Islas reb. 1." de la Aurora, es verosimil que con los vientos del Sueste y Este tempestuosos en el invieno se acerquen las bancas á estos meridianos, pues ordinariamente las han encontrado por aquí los que frecuentan la navegación al mar del Sur. Por esta razón yo aconsejaría para los que re. gresan á 'España, que atracasen las Maluinas como medio muy seguro de no verse en semejantes peligros, infinitamente mayores para todo buque mercante, privado por la naturalcza de su destino, de aquellos recursos para hacer inevitable un naufragio áun sin hallarse en situación ménos crítica que la nuestra.

El pintor D. Fernando Brambila se dedicó á formar en los dias que navegamos entre las bancas, el diseño de algunas que atrajeron nuestra curiosidad, contemplando su figura rara $y$ extraña; representando al mismo tiempo la situacion y maniobras de la corbeta, ya navegando por entre las islas 6 para evadir los peligros que nos han amenazado. En esta obra se reconoce la mano maestra del autor, y no pudiéramos prescindir, sin injusticia de hacer notoria su habilidad, poseyendo todas las reglas del arte para conseguir las bellezas de esta profesión agradable.

Habían sido bien pausados nuestros progresos hasta el día 3 , porque los vientos soplaban comunmente cerca del Oeste, y esto nos había hecho preferir la vuelta del Norte para gozar á lo ménos de un temperamento suave y un cielo mucho más despejado. Las observaciones repitieron hoy las grandes ciiferencias al Norte y al Este; esto es, $18^{\prime}$ en la primera dirección y $\mathrm{I}^{\circ} \mathrm{oo}^{\prime}$ en la segunda, hallándonos en latitud de $48^{\circ} 2 \mathrm{I}^{\prime}$ Sur y $48^{\circ} 44^{\prime}$ de longitud.

La singladura siguiente, acompañados de un viento fresco por el primer cuadrante, navegamos á rumbos próximos del Oeste hasta la me. dia noche, que se variaron al Noroeste $5^{\circ}$ Oeste, el cual nos conducía á las inmediaciones del río Colorado, por donde me proponía atracar la costa Patagonica. Carecimos al medio día de observaciones, y desde esta hora, el viento fué entrando en su estación 'acostumbrada del cuarto cusdrante, causando la oscuridad y garua consiguientes.

Con la misma alternativa de vientos, alcan zamos á estar al medio día del 7 á 7 r leguas de la tierra más próxima, que era la Península de San José, pero sin encontrar todavía fondo con toda la sondaleza.

La falta de estas noticias, la niebla muy densa y los malísimos aparatos del tiempo, me obligaron á tomar la vuelta del primer cuadrante y conservarla durante la noche con poca vela. $\mathrm{Di}$ sipó después lo. niebla para sustituirla alguna agua en las primeras horas de la noche, y cesan- 
Feb. 8 do también ésta, principió después á relampaguear sin intermisión, y á àeclararse una tempestad horrorosa que duró hasta las once y media, arrojando precisamente muchos rayos, con especialidad por el Norte y Sudeste.

Ya á las cuatro y media de la mañana, dió lugar el tiempo á marear toro aparejo en vuelta del Norte con viento Oesnoroeste. A poco rato, se advirtió visiblemente la rapidez con que las aguas nos arrastraban hacia el Nordeste, efecto que atribuimos al desagüe de los ríos Colorado y Negro, y otros diferentes que reciben estos mares de la costa. Asaltados de nuevo por otra nicbla espesa, la desvaneció un viento repentino del Sursudoeste, dejando el cielo lo más hermoso $y$ despejado. Hicimos rumbos al Nornoroeste $5^{\circ}$ Oeste para reconocer la costa desde poco más al Norte del río Colorado, en donde próximamente habíamos dado principio á nuestras tareas en el año de 89 ; y el ligar este trozo de costa hasta el Cabo de San Antonio era la única operación que me restaba por desempeñar para cumplir la instrucción hasta el puerto de Montevideo.

Llegamos al día siguiente á coger sonda en 50 brazas arena fina al medio día; observando la latitud de $4 \mathrm{I}^{\circ} 25^{\prime}$ y longitud de $52^{\circ} 5^{6^{\prime}}$ situándonos distantes de la bahía de la Asunción 52 leguas. Las diferencias habían crecido en el propic sentido que en los dius cintecedsrites, pues todavía hallamos hoy $I^{\circ} 0 z^{\prime}$ al Este y $2 I^{\prime}$ para el Norte, de suerte que á medida de acercarnos á la tierra, se multiplicaban las dificultades de atracarla.

Aún aumentaron éstas al día próximo según se dedujo de las observaciones, que nos situaron en latitud de $40^{\circ} 44^{\prime}$ Sur y $53^{\circ} 20^{\prime}$ de longitud, la primera apartándose en $12^{\prime}$ al Sur, y por consiguiente, también contraria ahora esta diferencia que no lo había sido en los días anteriores, y $I^{\circ} 24^{\prime}$ a' Este de la longitud estimada, hallándonos de la costa 35 leguas. Esta rapidez con que las corrientes nos llevaban violentamente para el Este, hacían desconfiar de poder reconocer el trozo de costa proyectado. No era mi ánimo insistir deməsiado en este empeño á costa de sacrificar mucho tiempo en vencerle, porque no siendo de una grande inportancia á la navegación nacional, sería mucho más preferente aprovechar en Montevideo los pocos restos del verano, en perfeccionar el plano del río, cuya exactitud era más interesante para la seguridad del comercio marítimo de estas provincias, $y$ no hubo tiempo de conseguirse en el año de 89 por nuestra corta mansión er aquel puerto.

Manteníamos la misma sonda de las 45 bra-

" zas arena fina negra, y paulatinamente fué disminuyendo á 40 á las tres de la madrugada. Desde esta hora empezaron los relámpagos y oscuridad por el Sudoeste á indicar una turbonada hacia Yeb. is aquella parte. Las precauciones empleadas para recibirla fueron tan inútiles, que á muy poco nos sorprendió un contraste duro por el Sursueste, de cuyos efectos 6 averías no hubieramos podido escapar sin cargar y preparar el aparejo con una presteza indecible: de aqui saltó de nuevo tem. pestuoso al Sudoeste,' volvió luégo al Sur con agua, truenos y relámpagos, y por último, detenido un corto tiempo en el Esueste, escaseó al Norte $1 / 4$ Nordeste, con el cual más claro, ya vi ramos en vuelta del Este. A esta hora no distá. bamos de la costa más que unas 16 leguas, ob. servana pocas horas después la latitud de $39^{\circ}$ $59^{\prime}$ Sur, y !ongitud de $53^{\circ} 22^{\prime}$ Oeste de Cádiz, encontrando una excesiva diferencia de $53^{\prime}$ al Sur y $x^{\circ} 2 I^{\prime}$ al Este de la estir.... Apuntamos aquí cuidadosamente los extraordinarios efectos que producen las corrierites, para instruir á los navegantes venideros y justificar mi resolución si abandonase el deseo de reconocer la costa.

Viendo, pues, por la tarde, muy distante la esperanza de mejorar el tiempo para triunfar con nuestro intento, :in dejarnos absolutamente la misma inconstanc:a de los vientos, la perma. nencia de los feos a aratos del tiempo sin cesar los truenos y relámpagos, debí ceder al deseo de abordar la costa, prefiriendo el de dirigirnie á buscar el paralelo de la isla de Lobos, persuadienaoioné á que debiendo también $D$. Alejandro Malaspina procurar recorocer este mismo trozo de costa, quizás sería más feliz en los tiempos para ejecutarlo.

Con rumbos del Nordeste $1 / 4$ Nurte y Nordes. te, nos dirigimos á buscar el paralelo propuesto, anteponiendo esta derrota á la de ir en derechura por el cabo de San Antonio á Montevideo, á causa de evitar un empeño si continuasen en aquel tránsito las mismas malas apariencias del tiempo, y que ailí sería mucho más arriesgado cualquiera partido que la necesidad dictase, cuando entrando en el río por el camino ordinario siempre hay tiempo para resolverse á la entrada combinando 6 esperando fuera de la isla de Lobos circunstancias favorables.

Declaróse muy pronto el viento al Sueste fresco acompañado de una suma oscuridad, lo cual justificó tanto el acierto de mi resolución, como nos prometía llegar al paralelo de la isla, en un corto plazo. Para esto sólo tratábamos ya de aprovechar con fuerza de vela el tiempo tan favorable, teniendo solo la mortificación de privarnos el Sol de su presencia, 6 á lo ménos á ho. ras oportunas para ejecutar nuestras observaciones ordinarias.

Eetas mismas circunstancias que nos acompañaron al día siguiente, se opusieron también á poder determinar algunas sondias con la exactitud debida, sin cuyo auxilio me parecio inútil 
la hacia Yob. II das para poco nos irsueste, $s$ podido con una vo tem. Sur con 10, dete. caseó al 0 , ya vi. lo distá. uas, ob. 1 de $39^{\circ}$ e Cádiz, e $53^{\prime}$ al untamos s efectos uir á los isolución costa.

stante la infar con nente la perinasin cesar deseo de rigirnie á persuaLlejandro mo trozo tiempos

Nordes. ropuesto, lerechura :o, á cauen aquel del tiemado cualcuando urio siemrada comde Lobos

al Sueste uridad, lo ssolución, le la isla, bamos ya empo tan in de priúnos á hooservacioios acomtambién á la exacticí inútil
Feb. 23 sacrificar el tiempo en ejecutarlas. Nuestro a:1dar no era ménos de seis á ocho millas, navéando desde el anochecer con el trinquete y lás gavias, observando poco antes la variación de la aguja por amplituit de $16^{\circ} 4^{8^{\prime}}$ Nordeste. Habíamos notado la frecuente alteración en el color del agua, tanto que á veces nos ponía en el recelo de que pasásemos sobre algunos bancos de mucho ménos fondo del que indicaban los plaros, obligándonos á sondar sin atravesarse, y con 20 brazas no encontrábamos fondo.

Pudimos hoy al medio día averiguar niestra verdadera situación por observaciones exactas; nos hallábamos en latitud de $36^{\circ}$ or' y en longitud de $48^{\circ} 12^{\prime}$ resultando de diferencias en los dos días anteriores $I^{\circ} 43^{\prime}$ al Este y I $4^{\prime}$ al Sur de la estima. Sondamos á esta misma hora en 36 brazas arena negra fina. Nos considerábamos á este tiempo 26 millas al Este del Meridiano de la isla de Lobos, y como todas las señales del tiempo no nos daban el menor recelo para mirar con indiferencia el recalar al Este $b$ al Oeste de dicha isla, nos fiamos enteramente á la seguridad de los relojes para entrar en el río, marcándola antes, como una precaución que aconsejan fundadamente los prácticos de esta navegación, en defecto de no tener de antemano latit ud observada.

Cumplida á las once de la noche la latitud de la Isla de Lobos, seguimos corriendo su paralelo con las debidas precauciones, teniendo de antemano prontas las anclas con vitadura doble la del ayuste. Desde las nueve fuimos sondando por I5, I' y 18 brazas arena fina parda. La noche, la más clara y apacible con el viento al Este fresquito; no podía ser más oportuna la entrada en el río sin el menor cuidado. Nuestro andar con trinquete, gavias y juanetes, no excediendo de cuatro millas, nos facilitaba sondar con seguridad sin precisión de atravesarse: la calidad del fondo variaba algunas veces en arena fina y conchuela, y rara ocasión la encontrábamos mezclada con "5 cascajo y' por ig 620 brazas. La lama suelta no la cogimos hasta las cuatro de la mañana por 20 y 2 I brazas, que es la dirección del canal, y con esta señal nos bastaba para estar seguros de la vista de la Isla de Lobos, luégo que amaneciese.

Efectivamente; á las cinco y media de la mañana se nos presentó por la proa esta isla con la tierra firme del Cabo de Santa María para Punta Negra, distando de ella por base medida dos y media millas, y demorando al Norte $52^{\circ} 30^{\prime}$ Oeste. El viento al Norte galeno tomando sucesivamente alguna fuerza, nos acompaño hasta cerca del medio día, que quedamos sin gobierno. Nuestros rumbos habian sido al Oeste, y el fondo, conservando la misma calidad de lama suelta, había disminuído á $I_{5}$ y I4 brazas, marcando á este tiempo la Isla de Lobos al Norte $68^{\circ}$ Este, la Pun- ta de la Ballena al Norte $8^{\circ}$ Este, y Punta Negra Feb. is al Norte $55^{\circ}$ Oeste.

Observada la latitud de $35^{\circ} 03^{\prime}$, demoraba dicha Punta Negra al Norte $25^{\circ}$ Este, estando en fondo de 12 y $1 / 2$ brazas lama suelta, sin distinguirso ya la Isla de Lobos. Declarése luégo la brisa, y aumentando sucesivamente nuestro andar hasta seis millas, seguimos con toda vela á alcanzar la marcación importante de la Isla de Flores antes de anochecer.

Por fondo de ir y Io brazas, llegamos á divisar en este tránsito, desde los topes, una embarca. ción de tres palos navegando para el Este del bordo del Norte. Sin embargo de no poderle imaginar enemiga, sin alterar nuestra derrota, se hizo prontamente zafarrancho de combate. Como nuestro rumbo nos acercaba á ella, advertimos que sus maniobras se dirigian á huir á Montevideo, y con. testadas las señales de reconocimiento que nos hizo entonces, volvió á tomar su primera derrota con muras á babor.

El Comandante de Maluinas me había prevenido haberse colocado en la parte más elevada de la Isla de Flores, un asta en que debía tremo. larse una bandera para gobierno de las embarcaciones que se dirigiesen al puerto, $y$ de noche izarse un farol en ella con el propio objeto. Esta providencia dictada por el Comandante actual de la Armadilla, justifica tanto su utilidad como la práctica que tiene de la navegación de este río, y su celo para contribuir á la seguridad de ella. Puede desde luégo asegurarse que el Río de la Plata es una de aquellas navegaciones más cuida. dosas, sobre todo en el invierno. Los vientos frecuentes del Sudeste, sucios y tempestuosos enton. ces, no dejan arbitrio desde el meridiano de la Isla de Lobos para dentro, sino á la práctica de buscar á Montevideo por la sonda ó á fondear en el placer del banco Inglés, en donde el fondo de arena impide garrar las anclas como sucede fuera de este paraje. Bien se reconoce cuán precarios son estos recursos en muchas ccasiones, pues no han sido suficientes á salvar la pérdida de muchas embarcaciones, no sólo sobre aquel escolla temi. ble, sino también sobre la costa del Norte. Yo creo sería un auxilio grande que disminuiría mu. cho los riesgos por este río, si en la Isla de Flores hubiese dos 6 tres cañones gruesos para corresponder á los cañonazos que pidan las embarcaciones que entren, pues próximas ya ála isla, la vista de los fogonazos de noche 6 el estrépito en todos casos, las iluminaría para salir felizmente del paso más arriesgado, cual es entre el banco y la citada isla. No dudo que la experiencia jus. tificaría la utilidad de esta disposicion, así como otra providencia semejante la ha comprobado al mismo objeto en el puerto de M.onterey. No dimos vista á la Isla de - Flores hasta estar bien cerca de ella al ponerse el Sol: la marcamos al 
Ftb. xs Oeste $\%$ Sudoeste, $y$ por fondo de seis á seis $y$ media brazas lama suelta y conchuela, entramos en el canal de ella y del banco, gobernando al Sudoeste hasta tanto de ponernos Norte-Sur con el asta de bandera, $y$ desde aquí al Oeste $1 / 4$ Sud neste, rumbo que continuamos hasta llegar al meridiano de Punta Brava, ó navegar la distancia de ir millas. La brisa permaneció fresca las primeras horas de la noche y como ésta fuese sumamente clara, seguimos con fuerza de vela, sin perdonar por esto la precaución de sondar á voleo por una y otra banda, y dar el correspondiente resguardo al bajo de Punta de Carretas.

Poco después de las nueve divisamos ya una luz al Oeste $5^{\circ}$ Norte del pueblo de Montevideo, y á poco rato distinguíamos también con la claridad de la Luna las embarcaciones del puerto, hacia las cuales nos dirigíamos. Las sondas fueron disminuyendo desde seis á cinco y media, cinco, cuatro y media, cuatro, y más paulatinamente hasta tres; este fondo tan corto probaba bien lo bajo que estaba el rio.

Antes de alcanzar 'as puntas de la entrada abonanzó y escaseó ei viento, imposibilitando así ir para adentro aunque fuese sobre bordos como lo habíamos emprendido; dimos luégo fondo á las once de la noche en tres brazas lama suelta demorando el cerro al Noroeste, y la punta de San José al Nordeste $3^{\circ}$ Este distantes de ella poco más de una milla.

Inmediatamente se echaron al agua lancha y bote con ánimo de ir al fondeadero aunque fuese á costa del penoso trabajo de la espía, pues aunque la sezenidad del tiempo no daba sospecha alguna, suele sin embargo alterarse aquí repentinamente formándose unas fuertes turbonadas, en cuyo caso nuestra situación no era la más segura. No bien se iba á poner el anclote en la lancha, cuando el viento á la tierra bastante fresco, obligó á arriar hasta 50 brazas de cable, $y$ desistir durante la noche de toda tentativa, como inútil para emprender la maniobra deseada.

Apenas dimos fondo, atracó á bordo la lan. cha del correo creyendo fuésemos el que se es. peraba con ansia de la Coruña hacía más de dos meses. Los correos cuando entran aqui de noche disparan un cañonazo al estar sobre Punta de Carretas, como una señal de reconocimiento para la plaza, y entonces sale la falúa de rentas á recoger los pliegos. Nosotros ignorando esta práctica disparamos un cañonazo y produjo luégo el engaño para que también viniese la falúa en busca de la correspondencia.

Desde el momento de amanecer con el viento bonancible ya se tundió la espía con cuatro calabrotes y llegando á pique de ella pudimos con ventolinas de la brisa marear las velas de estay, y coger muy luégo el fondeadero por $1 a$ proa de la fragata Santa Rufina que arbolaba el Peb. s's gallardetón del Comandante de la Armadilla.

Por la mañana temprano se había trasladado á bordo $\mathrm{D}$. Alejandro Malaspina, quien me dijo haber fondeado la tarde anterior, sin novedad particular en su navegación desde las costas de Chile, y que sin poder vencer la tenacidad de los vientos tempestuosos ó de travesía sobre las tierras del Archipiélago de Chonos había en vano empeñado sus esfuerzos para reconocerlas; pero que con ménos contrariedades en adelante, pudo atracar después la costa al Sur del Estrecho de Magallanes, y situar también las islas de Diego iRamírez: teniendo la complacencia de que sus resultados estuviesen exactamente conformes con los nuestros, y de habernos reunido felizmente en este puerto donde contemplábamos el término tan suspirado de nuestras fatigas con tanta satisfacción como la habíamos tenido en dar principio á arrostrarlas desde aquí en el año de 89 .

\section{CAPITULO IX}

Ultima cscala de las corbetas en Montevideo: varios acaccimientos cn aquel tiempo y reunión en el puerto de la fragata Gertrudis de la Marina Real, con cuatro buques mercantes de Lima: salida del convoy reunido, de Lima y Montevideo, y su navegación hasta llegar al puerto de Cádiz.

El objeto esencial de la segunda escala de las corbetas en el puerto de Montevideo, había sido al principio el de liquidar el haber de las tripulaciones, para que no sufriesen un descuento crecidoá su llegada al Continente y no trastornasen los balances de las Cajas Reales; empero ahora se le agregaban otros no ménos importantes, $y$ eran el apresto de los buques e.ı un pié regular de guerra, y la reunión nuestra al convoy de Lima, el cual, bajo la escolta de la fragata Gertrudis, debía hacer escala en Montevideo ar.tes de emprender la navegación para España. El primer pun. to nos pareció indispensable, aunque llevásemos salvo-conductos del difunto Rey de Francia Luis XVI, el cual recordaba las muchas atenciones que el conde de la Péyrouse había recibido en los establecimientos españoles: solicitaba lo segundo el Virey de Lima, y nuestras mismas circunstancias lo dictaban como prudentes, ya que debíamos recibir caudales de Buenos Aires y por la misma razón considerarnos comprendidos en los trances de la guerra.

Atento á este plan, ya la salida nuestra del puerto debió retardarse á lo ménos un par de meses, y buscar, por consiguiente, algunos objetos, en los cuales pudiera invertirse aquel plazo con ventajas del servicio. Ciertamente, no eran pocas las atenciones naturales de la expedición 
bolaba el riet...s

adilla.

rasladado

n me dijo

novedad

costas de

dad de los

ore las tie-

a en vano

erlas; pero

ante, pudo

strecho de

- de Diego

de que sus

conformes

nido feliz-

lábamos el

fatigas con

tenido en

í en el año

video: varios en el pierto ra Real, con la del convoy e navegación iiz.

escala de las había sido e las tripulacuento crecitornasen los o ahora se le tes, y eran el ular de guede Lima, el Tertrudis, de$s$ de emprenprimer pun. ique llevásey de Francia thas atencioabía recibido solicitaba lo tras mismas rudentes, ya denos Aires y omprendidos

nuestra del os un par de lgunos objee aquel plazo nte, no eran la expedicion
Feb. 16 hasta la mitad de $\Lambda$ bril, en cuya época podíamos por nuestra parte considerarnos prontos para dar la vela. La renovación de la carta del río, erra. da en algunos puntos determinados en 1789 ; la multiplicación de las sondas; el cuidado del observatorio; la redacción de las tareas hidrográticas emprendidas desde Lima; el mismo apresto de los buques y la instrucción militar de la tropa y marinería, bastaban solos para ocuparnos incesantemente. Multiplicáronse después más bien las ocupaciones, cuando empezaron á liegar los buques de Lima y particularmente la fragata Gertrudis. Sus amarraderos, sus reparos, las instrucciones y el traspaso de víveres de unos á otros, todo combinado con la escasez de los almacenes y de gente y con la estación tempes. tuosa del invierno, la cual hacía imposible en muchos días la comunicación de los botes, debieron por precisión tenernos igualmente ocu. pados.

No merecía ménos atencion en nuestras me. didas actuales el reconocimiento deseado del Golfo de San Jorge en la costa Patagónica. Hízose presente al Virey de Buenos Aires, que Su Majestad le habia mandado para aquel verano, oponiéndose seguramente después, los incidentes de la guerra, á que viniesen de Europa las personas y los instrumentos que debían realizarle. Si no se verificase debían mirarse como igual. mente desatendida la seguridad de nuestras pescas $y$ la perfección de las cartas. $Y$ era un acaso bien feliz el que se arrojase á tomarle en su cargo, aunque bien enfermo, el Capitán de fragata D. Juan de la Concha, acompañándole el piloto Inciarte, y que las corbetas pudiesen ceder los instrumentos necesarios para el intento. Fué des tinado el mismo Concha á Buenos Aires para acordar estas materias con el Virey, el cual con. descendió inmediatamente á cuanto solicitába. mos, y no tardaron tampoco en emprenderse las excursiones necesarias para la corrección ya in. dicada de la costa.

Fué preciso un nuevo viaje á Maldonado y á la Isla Gorrite; se hicieron marcaciones con el teodolito en la Isla de Lobos; por tres veces se atravesb el bajo Inglés hasta conseguir el navegarlo en torno; se reconoció igualmente el bajo de la Panela frontero á la barra de Santa Lucía otra piedra, no distante de la Isla de las Palomas, dentro del puerto de Montevideo, fué ligada con buenas marcaciones, $y$ debimos mirar como un caso bien feliz, el que naufragado en la costa inmediata al Pan de Azúcar el falucho en el cual regresaba desde Maldonado el Piloto Hurtado con los instrumentos astronómicos y el reloj número II, pudieran éstos redimirse del naufragio sin la menor avería y conducirse salvos á Montevideo. Los Capitanes y Pilotos de los correos marítimos el Colon y la Cantabria contribu- yeron también por su parte á la perfección de la Feb. $x 6$ carta con cuantas noticias útiles tuviesen parti. cularmente por lo que toca á las sondas.

Las primeras épocas de las alturas corres. pondientes en el observatorio liabian indicado las siguientes longitudes para los relojes marinos:

\begin{tabular}{|l|l|l|l|l}
\hline $\begin{array}{l}\text { Longitud del ob. } \\
\text { servatorio, occi- } \\
\text { dental de Cídiz. }\end{array}$ & 49.57 .00 & 50.48 .30 & 49.58 .00 & 50.9 .15 \\
\hline
\end{tabular}

No debió sorprendernos el error del crono. metro $7 \mathrm{I}$, cuando ya por las comparaciones diarias en la última travesía desde Santa Elena habíamos advertido sus irregularidades bien ex. trañas, y los resultados de los relojes de la ATREvidA debieron, por el contrario, mirarse por tanto más satisfactorios, cuanto que ligando admirablemente por dos medios diferentes la longitud del puerto de la Soledad, la cual no ha. bían podido sujetar á otro punto alg!rio bien si. tuado de las Maluinas, dejaban sin embargo bien situado aquel punto, y fuera de toda duda la verdadera extensión de las islas, del Oeste al Este.

No se descuidaron después tampoco las expe: riencias de la gravedad en el pendulo simple, y comparándolas el Teniente de navío D. Ciriaco Cevallos, con las demás que se habían hecho en uno y otro hemisferio, confirmaron lo que había sospechado el Abate Lacaille, esto es, que había una mayor gravedad en el hemisferio austral que en el boreal, y por consiguiente, que no debían suponerse los dos hemisferios tan simétricos como se había imaginado hasta entonces.

Para que la maestranza de á bordo no estuviese en la inacción, se agregó después á las obras interiores de las corbetas, la habilitación de la lancha de la Descubierta, á fin de que pudiese servir en la expedición de D. Juan de la Concha al golfo de San Jorge: agrandada y fortalecida esta embarcación y agregádole un falucho, sería fácil antes escoltarlas con una sumaca hasta el puerto de San Gregorio, y después verificar con ellas solas el reconocimiento inte. rior, ya que los muchos bajos le haría más ex. puesto y dilatado para cualquiera otra especie de buques.

Finalmente, el día 3 del entrante Mayo, con el aparecimiento en el puerto de la fragata mercante $I . a$ Princesa una de las del convoy de Lima, pudieron revivir de nuevo nuestras esperanzas de emprender muy luego el viaje deseado para los hogares patrios.

La llegada en la noche del ro del Paquete May. 10 correo de España, no debí tampoco variar en modo alguno nuestro plan primitivo: á possar de 
Nay, to la evacuación de Tolón por nuestra parte, las fuerzas maritimas de los enemigos habian que. dado harto debilitadas, y en muchos meses no se contaba tal ve $z$ una sola presa suya sobre los buques de las naciones aliadas. Las escuadras na. cionales é inglesas cruzaban en los varios puntos de recalada. Todo anunciaba que nuestra navegación sería feliz mucho más si la emprendiésemos con brevedad: este mismo correo traía aviso de haber sido comprendide en las últimas gracias de Su Majestad, el Brigadier D. Antonio de Córdova, Comandante de la Armadilla, para el grado de Jefe de escuadra; tributáronsele con este motivo los honores que prescribe la Ordenanza, al tiempo de arbolar la insignia en la fragata liufina, y se arrib por la misma razón el gallardete distintivo de la Descubiurta.

No fueron los siguientes días tan fuvorables á la Astronomía como debímos esperarlo: malográronse varias ocultaciones de estrellas por la Luna y no pocos eclipses del primero y' segundo satélites de Júpiter, por estar los cielos por bs común ofuscados, ó con celajería ó con calina. Las pocas observaciones que se consiguieron en

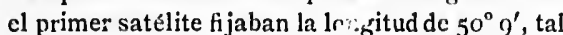
ve $z$ algún tanto crecida por hallarse generalmen te el cielo con vapores y estar además el planeta proyectado con la vía láctea, la cual reflejaba una claridad siempre contraria á la exactitud de las observaciones. El invierno, en el entretanto, parecía aproximarse á paso más bien lento; eran escasas las aguas, templado el frío, y habian ce. sado en un todo las turbonadas temibles del verano.

Muy oportuna fué la estación tan benigna para que el Neptuno y Concordia, otros dos buques del convoy de Lima, fondeasen aquél en Montevideo y el segundo en Maldonado: logra. ron amarrarse con seguridad y en buen apostadero, antes que les hiciese peligrar un pampero algo recio que tuvimos para el 17, y á favor de estas mismas bonanzas pudo librarse una fragata mercante de Europa, que había varado en el banco Inglés, lográndosele traer en vandolas al puerto, alijada en otras lanchas una parte muy considerable de su carga, casi sin avería alguna.

$\mathrm{Ni}$ á la verdad podíamos considerar estos últimos meses por ménos útiles para la continuación de las tareas de la expedición nuestra, aunque pareciese á la sazón casi entregada á la inacción y á los objetos militares. La llegada antes á Blienos Aires y últimamente á Montevideo de los Sres. Espinosa y Bausá, había enriquecido nuestro diario astronómico y nuestros apuntes sobre la geografía interior de América, con mil noticias útiles: confirmábase la determinacil $n$ hecha en el año go de la latitud y longitud de Santiago, esta última deducida ahora de un eclipse de Luna y de una inmersión del primer. satélite de Júpiter. Las observaciones tan proli- May. so jas como importantes sobre la velocidad del sonido, en la misma capital, abrían un nuevo campo á esta clase de indagaciones físicas, hasta aquí no bien sujetadas á la experiencia. La elevacion de la cordillera inmediata, su dirección, tránsito y albergues, la posición de Mendoza y Punta de San Luis, un examen diario de la variación de la aguja, y finalmente, una serie no interrumpida de observaciones de longitud y latitud que sujetasen la ruta de las Pampas hasta Buenos Aires, debían mirarse como adquisiciones de tanta mayor importancia cuanto que habian contribuído al mismo tiempo á que mejorase mucho la salud de los Oficiales indicados.

Llegó casi en los mismos días el botánico Don Luis Nee, cuyas excursiones habían sido bien útiles y laboriosas. Después de nuestra separación en Talcahuano, había internado en las tie. rras dc los Pehuenches, arrimándose siempre á las montañas; hecha luégo una breve demora en Santiago, había atravesado la cordillera, y herborizado sucesivamente así en aquella parte mon. tuosa como en las inmediaciones de Mendozay en todo el camino de las Pampas, que conduce hasta Buenos Aires. Una preciosa colección de las pie. drasque componen por aquclla parte el hueso de la montaña, debía servir ahora á perfeccionar mu. cho nuestras indagaciones 1:tológicas: diferentes excursiones sucesivas álos minerales, no distantes de la ruta, habían por lo común derribado las esperanzas siempre lisongeras de los poseedores; y al contrario, sus recunocimientos de los surgideros de agua salada en los mismos montes, habían abierto unas combinaciones mucho más útiles para el abasto de la sal en el reino de Chile.

$\mathrm{P}$ ro eran aún cortas estas utilidades, cuando las comparásemos á las que nos anunciaba en dos cartas suyas D. Tadeo Heenke, la una escrita desde el Cuzco y la otra desde Arequipa: además de sus prolijas investigaciones en la botánica y litología; además de unas excelentes y nuevas colecciones de aves en el largo trecho que había corrido, eran fruto de la mayor importancia para el público; sus análisis de muchas aguas minerales y de la célebre mina de azogue en Huancavelica; las determinaciones de la diferente elevación de la cordillera por medio del termómetro en el agua hirviendo; su reconocimiento del volcán de Arequipa y de las exquisitas aguas termales; las internaciones á los países de los Yungas y de los Chunchos; su estada en la laguna de Chucuitos y las muchas investigaciones hechas en el Cuzco. Proponíase luégo continuar su ruta hasta Potosí, visitar desde alli el país de los Mofos y de los Chiquitos, y últimamente estar en Montevideo para los primeros meses del año siguiente.

En la tarde del 21 estuvo á la vista y fon- 
tan proli- May. 20 lad del sohuevo camcas, hasta tia. La ele. dirección, Mendoza y o de la va. ha serie no gitud y lampas hasta quisiciones que habían ejorase mu. s.

otánico Don n sido bien tra separa. en las tiesiempre á demora en era, y herparte mon. Iendoza y en nduce hasta de las pie. el hueso de eccionar mu: diferentes , no distanlerribado las poseedores; le los surgimontes, hacho más úti10 de Chile. des, cuando ciaba en dos una escrita quipa: ade. in la botáni. entes y nuetrecho que r importanuchas aguas azogue en la diferente del term6. onocimiento isitas aguas aíses de los en la lagu. estigaciones ro continuar llí el país de namentc es. $s$ meses del vista $y$ fon-
May. "z dé poco después en el puerto la fragata Santa Gertrudis; la conserva con el Levante, el cual había rendido la verga mayor en el mar Pacífico y fondé ahora al mismo tiempo, le había atrasado considerablemente. Su llegada dió, pues, lugar á que pudiese ates arse seriamente á la salida de Montevideo, en la cual ya no parecía caber otra demora que la indispensable de los aprestos en una estación y en un puerto á la verdad poco oportuno para el intento.

El estado en el cual había salido de Lima la 23 Gertrudis, exigía una atención seria. Las dos terceras partes de su tripulación se componían de levas que jamás habían visto el mar; la mitad de su tropa de reclutas ó desechos del regimiento Fijo de Lima; mortalmente enfermo el Contramaestre; faltos el Contador, el Cirujano, el Maestre de víveres, el Condestable y un Oficial de guerra; sus víveres de reemplazo esparcidos en los cuatro buques; su velamen muy de. teriorado; su artillería del corto calibre de á ocho y destogonada; eran inconvenientes tanto más difíciles á remediarse, cuanto que por la una parte los almacenes de Montevideo carecían de todo, y por la otra debía también reempla. zarse por estar gravemente enfermo el Oficial de detall D. José Quevedo, T'eniente de navío: agregábase luégo á tamaños males el que mal estivada la plata, ocupaba la parte de sollado correspondiente á los cables, los cuales por la misma razón empachaban en el entrepuente; que en el costado de babor se habían quitado las hileras altas del forro del cobre; finalmente, que la fragata en la última navegación había descu. bierto un agua de cuatro pulgadas diarias, cantidad muy leve á la verdad, pero que no podía desatenderse atento al tiempo que había corrido desde su carena, á los caudales que ahora conducía y á la misma desproporción de estiva que éstos causaban irremediablemente.

Entre los cuatro navíos del comercio, los nombrados Levante y Princesa podían considerarse en cierto modo capaces de una mediana defensa, pero los Neptuno y Concordia, apenas estaban dotados cada uno con catorce cañones de corto calibre, y áun tan mal abastecidos de municiones, que parecía importuno darles el semblante siquiera de una fuerza mediana; todos, por otra parte, estaban tripulados por un corto número de marineros, y según los informes más

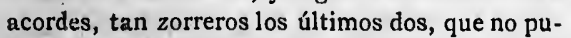
diese prometerse sino una navegación larga y penosa. Pero el pormenor de estos armamentos se comprenderá mejor en el estado último, y aquí sólo podemos añadir que las tripulaciones.eran por lo común robustas y bien disciplinadas, y que por una de las muchas contradicciones que diariamente se encuentran en el complicado sistema nuestro de la América, se hallaba autori- zado para estas marinerías el ajuste de las tra - May. .3 vesías, habiendo presidido como ayudante del Virey en el Callao el Teniente de navio D. Pe. dro Colmenares.

Al mismo tiempo de tomarse las medidas para la habilitacion de estos buques, se avis 6 también á los del comercio de Nontevideo que se les admitiría en el convoy siempre que estuviesen prontos para el I $_{5} 620$ del entrante Junio, plazo que habiamos prefijado para la salida, bien miradas las circunstancias del puerto en la actual estación y los muchos objetos á los cuales debía. mos atender para su habilitación. No parecía en modo alguno prudente una mayor demora, áun cuando no llegasen los otros tres buques de Lima, quienes con escala en Guayaquil debían últimamente reunirse con los demás, y eran los nom. brados Galga, Rosa y Sauta'uder.

Una mirada en torno á las circunstancias del viaje próximo debió manifestar en el entretantu cuáles eran las nulidades que le rodeaban, y cuáles, por consiguiente, los puntos de defensa que debían adoptarse. Los tres buques del Rey, débiles en su fuerza y en su tamaño, si por la una parte debían cuidar de la seguridad de los demás, por la otra, siendo depositarios de una crecida cantidad de caudales, debían con preferencia atender á su propia seguridad. Los del comercio al contrario: incapaces de una resistencia mediana siquiera, presentaban, sin embargo, con su mole, aparejo y baterías, unas fuerzas bas. tante considerables; pero el todo era en sí débil, lento y difícil de amalgamarse, atento particularmente á la clase de nuestros armamentos y al indispensable desaliño militar de los buques mercantes. Ya con estas consideraciones no cabía alternativa en el plan nuestro de defensa, si acaso tuviésemos un encuentro con fuerzas ene. migas. Habilitáronse los buques de Lima para la línea, y á cada una de las tres divisiones se hizo presidir un buque del Rey, de suerte que dirigiese con acierto y sujetase con tesón, cuando fuese necesario, los pocos movimientos militares que exigiesen las circunstancias. Todos á la vista de embarcaciones sospechosas debían tremolar la bandera Real, la insignia de Comandante arbolarse en el Levante, el cual era mastelote de proa de la Descubierta. La tercera división, compuesta de los navíos más zorreros y débiles, el Neptuno y Concordia, presidida de la corbeta Atrevid A, debía maniobrar por lo común sepa. rada, cuidando con este motivo del convoy de Montevideo. La Santarider, cuyo aparejo, tamaño y lizereza, podian más bien equivocarla con un buque de la Marina Réal (si acaso nos alcanzase) serviría en clase de batidora y repetidora, dotada en este caso con un Oficial de guerra y las correspondientes banderas: la repeticion de noche de ciertas ser̃ales de cañonazos y la mayor unión, 
May. "3 debian conservar en la oscuridad aquella ilusión que fiábamos de día al brden y al bulto. Las ca. zas confiadas generalmente á los buques de la Marina Real, debían siempre manifestar fqquella seguridad, que naturalmente infunde una escuadra fuerte: finalmente, paia el caso en el cua fuese inevitable un choque, se atendian igual. mente la seguridad del convoy con una pronta fuga 6 desparramarse; y la seguridad de la Gertrudis, en el modo con el cual había de huir, dis-

Jun. trayendo á los perseguidores del verdadero rum. bo que esta seguía. Quedaba después para la división del centro, compuesta de los navíos Levante, Princesa y Descubierta, el sostener la ilusión 6 el choque cuanto fuese posible, y asegurar así la fuga de los demás. Liste fué el plan propuesto, al cual se dirigieron las señales é instrucciones comunicadas, y fué á la sazón oportuna la salida del Paquete correo de España, para avisar por menor todas las medidas indicadas al señor Ministro de Marina.

Entretanto, los aprestos habían procedido con la mayor actividad. En la fragata Santa Gertrudis, aunque el tiempo y la mar gruesa interrumpiesen en muchos días un trabajo seguido y bien ordenado, y á pesar que tuviese muchos faltos, 6 bien por la natural inconstancia del marinero 6 bien por las hospitalidades $y$ otros muchos inútiles $y$ entretenidos, recibieron los víveres de los cuatro buques mercantes, completaron la aguada, se hizo la entrega complicada del contramaestre, se perfeccionaron aparejo $y$ velamen, se mejor6 la estiva de la plata, y los demás aprestos siguieron una proporción aún aventajada. En las corbetas ya nada faltaba. El navio Levante había podido reemplazar su verga mayor con una de la fragata Loreto, y así para el día ro de Junio ya todo podía considerarse pronto para la salida.

Fué éste precisamente el día en el cual llegaron los caudales y correspondencia de Buenos Aires. Nos prevenía el Virey que ya quedaba en nuestro arbitrio dar la vela, y con este motive pudieron tomarse las últimas medidas para verificarlo. En el mismo día se comunicaron á los buques pequeños instrucciones para su próxima navegación: ernn éstos en número de diez; pero algunos, aún tan atrasados en su habilitación que de ningún modo pudieron seguirnos: como quiera que esta conserva no estaba ligada por orden alguna, debimos mirarla por una y otra parte como voluntaria, y por la misma razbn no usar de la menor violencia 6 amenaza para que tuviese lugar.

Se emprendieron con igual actividad las levas, las cuales, contando con los díscolos, inútiles y algunos voluntarios que cedí el General Comandante de la Armadilla de su fragata y del paq"ebot Santa Eulalia, debian reemplazar no ménos de 50 hombres á la Gertrudis y aumentar Jun. so de unos zo la tripulación de cada corbeta. Segu. ramente, lo local de Montevideo convida mucho más á este arbitrio que cualesquiera otros países de los que hemos recorrido. El número de vagabuntos europeos es mucho mayor, las guaridas 6 escondrijos no tan comunes, y la policía cierta mente $\mathrm{m}$ śs activa y vigilante. Túvose también la precaución de aumentar hasta cuatro meses y medio los víveres de las corbetas, además de las partidas sobrantes de tocino y menestras; $y$ en la fragata Santa Gertrudis, con anuencia de su. Comandante y del Cirujano, se adoptó en lugar de las dietas vivas, el uso de las pastillas del Conde de Liniers, del mismo modo que debíamos usar. las en entrambas corbetas.

Los Capitanes de los buques de Lima hicieron á la sazón presente, que les parecía justo y áun indispensable para la mayor puntualidad de sus marinerías, hacer un pagamento, aunque corto, entre ellas, de suerte que permaneciendo dos 6 tres dias en tierra según costumbre antigua, se restituyesen luégo puntualmente á sus destinos. Concedioseles este permiso, no sin previo aviso del General Comandante; y el Teniente de navio D. Francisco Viana, recorriendo los buques, intimó de antemano las multas y los castigos á los cuales quedarían expuestos los infractores de este convenio si se les aprehendiese en tierra cumplido el plazo, como parecía sumamente probable.

Bien inoportuna fué esta ausencia de las marinerías de los buques de su destino en lá siguiente noche del $\mathrm{r} 2$, en la cual un temporal recio del Sueste los hizo garrar todos, aconchando principalmente los Princesa y Neptuno, hacia el Cerro, en donde, si no trabajasen inmediata. mente con las aguas altas que siguen siempre de cerca á estos temporales, quedarían con mucha probabilidad varados por largo tiempo. Atento á esta circunstancia, que podia sernos 6 muy favorable 6 muy adversa para la verificación de la salida, enviáronse 16 hombres de las corbetas con un Oficial de mar al Neptuno, cuyo Capitán había avisado que sólo tenía á bordo unos seis hombres; y manifestando el Capitán de la Prin. cesa que estaría por sí solo en estado de trabajar, recogida la mayor parte de su tripulación, se destacó una lancha grande al Levante para que pu. diese enmendar sus anclas y tender las espías.

La mañanita del $\mathrm{r}_{4}$ presentó con estas precauciones el espectáculo bien agradable de ver últimamente á flote, aunque no sin mucho esfuerzo, entrambos navíos Princesa y Neptuno; no pudo ser tan feliz el Levante, pero al dia siguiente lo consiguió también aprovechando un buen repunte de aguas; y finalmente, en la mañanita del I5 ya todos los cuatro buques ostaban de tal modo franqueados, que á cualquier hora pudieran 
y aumentar Juni so

beta. Segu.

vida mucho

otros países

ro de vaga-

3 guaridas 6

licia cierta -

e también la

ro meses $y$

lemás de las

tras; y en la

a de su. Co-

en lugar de

is del Conde

piamos usar-

ima hicieron justo $\mathrm{y}$ áun lidad de sus unque corto, heciendo dos antigua, se us destinos. previo aviso ente de navio buques, in fastigos á los fractores de se en tierra namente pro.

ia de las mano en là sitemporal reaconchando uno, hacia el 1 inmediataruen siempre in con mucha po. Atento á 86 muy fa. icación de la las corbetas . uyo Capitán rdo unos seis a de la Prinde trabajar, ución, se des. para que pur las espías. n estas predable de ver n mucho es. - Neptuno; no 1 día siguienado un buen la mañanita staban de tal ora pudieran
Jun. is dar la vela. Vencidn con tanta felicidad este obstáculo esencialísimo para la salida, ya los últimos aprestos de los buques de S. M. debían ace. lerarse cuanto fuese posible; y á pesar que en los dos días siguientes los vientos frescos del Noroeste al Oeste con levantar mucho las olas y causar por otra parte una excesiva bajamar en el puerto, interrumpiesen en todos los buques asi la facilidad del embarco como los viajes de las embarcaciones menores, consiguióse sin cm. bargo que al medio día del $\mathrm{r} 8$ todos hubiesen recibido la pólvora, ranchos y ganados, y que en la misma noche los buques de S. M. pudiesen emprender sus faenas de desamarrarse y ponerse en franquía: fueron en esta ocasión bien útiles, particularmente á la Gertrudis, los auxilios de la Armadilla y la activa asistencia á su bordo del segundo Comandante del resguardo D. Manuel Cipriano, el cual quiso se1virla en clase de práctico. La Atrevida continuó sirviéndose de la lancha de las corbetas, esquifada con gente del paquebot Santz Eulalia. El correo marítimo franqueó otra grande para la Descubiería.

Cortada así casi de un todo la comunicación con tierra, pudimos al día siguiente recibir en los tres buques de la Marina Real todas las levas que nos estaban destinadas. Pero como no pudieron estar con igual prontitud las listas, atento á la muchedumbre de trasbordos, ni por otra parte se hubiese franqueado un buque pequeño siquiera, fue preciso diferir la salida en un día más, plazo para nosotros tanto más feliz $y$ oportuno, cuanto que en todo el día no hubo sino ventolinas, las cuales coadyuvaron con ex. tremo á que se completasen los pocos consumos de aguada, se levase segunda ancla, todos metiesen dentro sus lanchas y botes y se franqueasen varios de los de Montevideo. Al ponerse el Sol de la misma tarde, tomó el tiempo las más bellas apariencias, y empezaron á entablar ven. tolinas galenas del Noroeste, y estas, á medida que adelantaba la noche, fueron tomando más fuerza é inclinándose al Norte.

Con las primeras claras del 21 , centinuando el viento fresco del Noroeste, pudo hacerse señal á todos los buques de dar la vela. La ex. celente disposición en la cual habían anochecido los buques de S. M., los del comercio de Lima y seis de los de Montevideo, hizo que lo ej:cutasen todos con la mayor brevedad á la viaz que la Descubierta. No así los otros cuatro 'juques del mismn comercio, los cuales, 6 por desidia 6 por no estar prontos, no se habian iranqueado en la tarde anterior, y ahora, disminuida el agua en el.puerto, no pudieron quedar á flote en modo alguno.

A las diez de la mañana estásamos Norte-Sur con la Isla Flores á distancia de dos millas. Las zouas nos habian abatizo algo al Sur, pero des. pués las marcaciones nos manifestaron que de. Jun. a caímos aún más, lo cual, sin embargo, no debía parecer extraỉo atento á los vientos que á la sa. zón corrían.

Al aproximarnos á la Isla Flores, ce nos habian presentado á la vista tres embarcaciones extrañas; la una un paquebot, el cual desde la par. te oriental del banco ceñia con todo aparejo al Oeste; la otra grande y al Esueste de la Isla como cuatro leguas, la cual seguía la misma vuelta del Oeste; y finalmente, la tercera de mediano tamaño y más distante que ceñía con todo aparejo al Nordeste. Su semblante y su misma bandera las manifestaban que cran todas nacionales, pero jamás pudimos imaginar que dos de ellas eran una parte hasta ahora desmembrada del convoy. La Princesa nos informó á la voz que la segunda era la Galga; y efectivamente, arribados sobre ella, nos enteramos era asi, por un bote quc su Capitán envió á bordo. La fragata Gertrudis, á quien hicimos señal de reconocer la otra, no tardó en señalar la numeral de la Santander, y enterada despues á la voz y por un Piloto suyo de las demás circunstancias que la rodeaban, vino á comunicarlas con la posible fuerza de vela.

Entrambas habian salido del puerto de Gua. yaquil en los primeros días de Abril y logrado una travesia sumamente feliz hasta la embocadu. ra del río; pero acosadas después de una contrariedad constante de vientos y tempestades, en balde llevaban sacrificados veinte días para la re. unión deseada en el puerto de Montevideo. La Santander había tocado con el pantoque en la cola del banco Inglés, y alijado una parte considerable de sus viveres había conseguido salir á flote sin daño alguno. La Galga, nueve días antes, había hablado á la fragata Astrea de la Marina Real, dirigida á Lima en conserva de la Rosalía; pero separada ahora y con precisión de hacer escala en Montevideo.

En ambos buques era igualmente vivo el deseo de continuar en nuestra conserva, y á este fin no se habían descuidado en presentar estados in. dividuales de cuanto necesitasen relativamente á aguada, víveres y rancho. La Galga además de esto se hallaba no sólo con una tripulación bien corta, sino que entre esta había unos ocho enfermos con afectos catarrales $y$ calenturas intermitentes, enfermedades propias, no ménos de los climas qne habían dejado, que de los que ahora habitahan.

Ya que á la sazón eran los momentos dema. siado preciosos para la continuación de nuestro viaje, tuvo orden la Galga de seguirnos, pues se le habilitaría en la primera ocasión oportuna, de cuanto le fuese necesario; dejé árbitra la Santander de hacer 6 no escala en Maldonado, con tanta más razón, cuanto que su destino álas costas de Cantabria debería separarla de nosotros, justa. 
J.w. s mente al tiempo de la recalada, cuando el convoy parecia más necesario. Entretanto no ha. bíamos descuidado la ocasión oportuna de rectificar con buenas marcaciones la marcha del cronómetro, ni nuestra derrota había sido ménos feliz de lo que pudiéramos desear. La primera por dos series de horarios (si bien por alguna casualidad no bien conformes entre sí) indicaba un resultado correspondiente á la longitud de las marcaciones; la segunda, ayudándonos casi con emulación el viento y la corriente, nos había conducido para el ponerse el Sol á la vista del puerto del Maldonado, del cual distaríamos unas seis leguas apenas. La Isle. Gorrite demoraba en esta posición al Norte $26^{\circ}$ Este; la de Lobos al Norte $45^{\circ}$ Este, y el Pan de Azúcar al Norte $21^{\circ}$ Este de la aguja, fondo 16 brazas lama, y veíamos, no sin alguna complacencia, así por éstas como por las muchas marcaciones repetidas, conio ya se ha dicho, en todo el día, que la carta últimamente construida había combinado aquella exactitud, que soliamos y debíamos desear.

Los buques de S. M. y del convoy de Lima estaban al anochecer bastante unidos, y todos proporcionaban su vela con el Concordia y Neptuno, seguramente los más zorreros. No así los seis de Montevideo, los cuales se hallaban la mayor parte considerablemente atrasados. E1 viento continuó fresco y con buen semblante en toda la noche, $y$ así no nos fué difícil estar para las nueve Norte-Sur con la isla de Lobos, ni para la mańanita siguiente haber perdido toda tierra de vista con el rumbo del Este $1 / \%$ Nordeste que seguimos constantemente.

Todo denotaba al amanecer del día siguiente ta suma disparidad de andar y áun de manejo en los diferentes buques cuya conserva nos estaba encargada. Cogían una extensión grande; se hallaban los unos muy á sotavento y otros muy atrasados: los de Montevideo ni áun cruzaban sus juanetes; el navio Concordia estaba á unas dos leguas por nuestra popa; finalmente, áun con las gavias arriadas hubiera sido difícil la incorporación del mayor número, si no nos hubiése. mos á ratos atravesado: aprovechóse, sin embargo, esta ocasión para dar á la Galga las instruccio. nes y la orden para los buques que debían auxiliarla en los diferentes artículos de los cuales carecía. Igual orden se dió después á la Santander, y desde luégo, en aquella misma tarde quedaron una y otra completas de la cuota corres. pondiente a ésta y á la corbeta ATrevida.

Hasta el 6 de Julio nuestro viaje debió mirarse como el más feliz que pudiésemos desear. Los vientos eran comunmente galenos del Oeste: los interrumpía tal cual calma, la cual no era im. portuna, pues coadyuvaba á la habilitación com-

Jul. pleta de los buques últimamente incorporados; y siendo tambien favorable el efecto de las co. rrientes (según lo indicaban los relojes mari. J nos), no habla sido dificil alcanzar la latitud de $30^{\circ} \mathrm{oo}^{\prime}$. Renováronse al mismo tiempo las observaciones de las distancias lunares, y pareció áltimamente oportuno comunicarlas por señal á los diferentes buques del convoy, referidas, como debe suponerse, al medio dia anterior.

Nuestros elementos eran los siguientes:

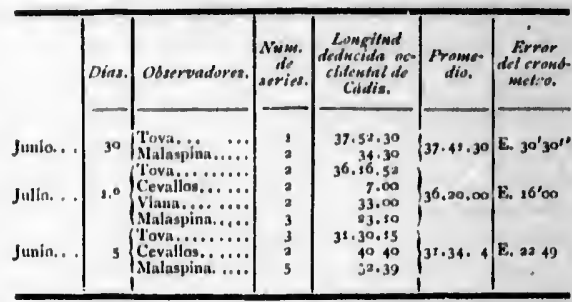

Así por ser estas últimas las observaciones de mayor confianza, como porque realmente igua. laban el error medio con las demás, fueron las que se comunicaron con la longitud de $31^{\circ} 44^{\prime}$. La ATREvidA, al mismo tiempo, había señalado para igual época la de $31^{\circ} 46^{\prime}$, y la fragata Sauta Gertrulis la de $32^{\circ} 10^{\prime}$. Quedó por la misma razón admitido en el cronómetro $7 \mathrm{I}$ este mismo error de $2^{\prime}$ al Este, el cual, sin embargo, no debió persuadirnos á variarle su marcha, porque era igual 6 menor al que en los primeros días habíamos deducido de las comparaciones con el to5.

Los vientos variables, generalmente inclinados al primero y cuarto cuadrante, no nos permitieron abandonar las bolinas para adelantar hacia el Norte. Deseábamos dar vista á lá Isla Trinidad 6 á los islotes de Martín Vaz, pero los bordos nos con ?'- :eron á pasar unas 20 leguas al Este de estos últimos, y por la latitud de $20^{\circ}$ alcanzamos la brisa del Sueste, con la cual se emprendió derrota para el corte de la equinoccial.

Ya en la mañana del 16 , manifestándose un día apacible con viento galeno del Oeste, habíamos procurado dar una leve idea del sistema militar propuesto. Importaba demasiado que no le mirasen generalmente con ojeriza 6 con desprecio, considerándole á las veces como molesto é importuno, á las veces como supérfluo é inasequible. Así, nos habíamos decidido á no exigir esta clase de movimientos cuando, ó los vientos contrarios hacían molesta la fatiga, 6 las mares y vientos hacían su ejecución demasiado complicada. Pero en aquel día, además de la mar llana y del tiempo bonancible que convidaba al uso de las bocinas, se juntaban la mucha unión en que habíamos amanecido y el rumbo que seguiamos unas nueve cuartas distante del riento. Hizose, pues, la señal al convoy de navegar á babor de la escuadra, ya que los más estaban por aquella parte, y á la escuadra la de formar la linea de combate mura babor: tomó inmediatamente su 
lojes mari. Jul. la latitud de o las obser. bareció últi. - señal á los ridas, como r.

ientes:

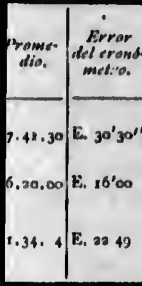

rvaciones de mente igua. fueron las de $3 I^{\circ} 44^{\prime}$. bla señalado ragata Sauta a misma raeste mismo pargo, no dercha, porque eros días ha. es con el 105 . ente inclina. no nos perura adelantar ista á lả Isla laz, pero los 20 leguas al ud de $20^{\circ}$ al. a cual se emequinoccial. estándose un Jeste, habíadel sistema siado que no ta 6 con desomo molesto rfluo e inaseá no exigir 6 los vientos , 6 las mares siado complila mar llana aba al.uso de unión en que je seguíamos nto. Hizose, á babor de la por aquella $r$ la linea de iatamente su
Jul. an puesto la fragata Certrudis; el Levunte y Princesa se colocaron oportunamente; fué r.lgo más turda la Galga; se adelantó con tino la Sautusder; y ya que se habla últimamente prescrito á la tercera división que navegase en el convoy á estribor, la ATrevida dirigió oportunamente sus señales a la una y al otro, y alucinados casi de este nuevo semblante los buques de Montevideo, arribaron á incorporarse en su lugar con una prontitud dificil á ser expresada. Ya formada medianamente la línea, era esencial manifestar el semblante militar que podía dárscla. Se hizo la scinal de que ciñese el viento á un tiempo, y la de izar la ban. dera Real el Levaute, izado también el gallarde. tón y disparado un cañonazo, hizo al todo de la línea que ya navegaba de bolina, realmente respetable. Una media hora después, parecién. donos que la ilusión perdería mucho de su mérito si fuese demasiado familiar, se mando arribar á un tiempo al rumbo de derrota, cesada la formación y arriadas las insignias.

En aquellos mismos dias tuvimos también la felicidad de ver incorporado un paquebot de los rezagados en Montevideo al tiempo de nues.

Ag. tra salida. Entretanto navegábamos con bastante celeridad hacia la Línea; y la variación magnética que sobre la isla Trinidad habia sido de $I^{\circ}$ al Noroeste aumentó después hasta 7 y $8^{\circ}$. Para el día $10^{\circ}$ de $A$ gosto, favorecidos no solo de las brisas, si también de unas diferencias diarias al Norte, pudimos ya vernos en latitud de $0^{\circ} 40^{\prime}$ Sur y por consiguiente ya tan prbximos al deseado corte de la equinoccial, que le debiésemos mirar como seguro para la noche siguiente. En efecto, fué así, y con una complacencia general quedo vencida esta nueva barrera para el feliz término del viaje; indicando á la sazón diferentes azimutes la variación de $8^{\circ} 45^{\prime}$ y el cronómetro $7 \mathrm{r}$ la longitud de $19^{\circ} 25^{\prime}$; longitud, sin embargo, que debíamos creer errada en unos $30640^{\prime}$ al Este, ya que concu. rrían unánimes en manifestarlo así, no solo nuestras observaciones de las distancias lunares, si tambien las de la corbeta ATREvida y fragata Gertrudis; las cuales señalábamos frecuente. mente al convoy para indicarle no solo la uniformidad de nuestros resultados, si también la frecuente alteración en la dirección de las co. rrientes.

Nada pudo justificar mejor que este viaje la preferencia de nuestra derrota, sobre la que suele seguirse comummente y sin atención á la diferencia de vientos en el invierno 6 en el verano. Enhorabuena que en esta última estación, contándose constantes los Nordestes sobre la costa, se hagan casi desde el mismo día de la salida del Rio de la Plata, rumbos más bien inclinados al Norte, pero en el invierno todo convida á a provechar los Oestes de los paralelos altos hasta po- nerse en meridianos de la Trinidad, para huir al mismo tiempo de los Nordestes costaneros, $y$ con las brisas del Esueste navegar algo descuartelados y en buena derrota, sin recelo de caer sohre la Isla de Fernando Noroña. Iillo es, que habiendo nosotros navegado ahora de tal modo que apenas pudiésemos evitar cinco 6 seis grados constantes de abatimiento, sin embargo, desde el paraleio de $20^{\circ}$ hasta la equinoccial, apenas pu. dimos conscrvar el mismo meridiano de $20^{\circ}$ al occidente de Cádiz.

Casi al mismo tiempo declinaron ya los vientos al Sur y Sursudoeste frescos, y con cllos nuestros progresos en los tres dias siguientes, fueron de los más lisonjeros que pudiúsemos desear.

Al medio día del 4 , ya nos hallamos en $4^{\circ}$ $45^{\prime}$ Norte $y$ en longitud de $19^{\circ} 30^{\prime}$. El crror contraído en la estima desde la entrada de las bri. sas, no era menor de $2^{\circ} 45^{\prime}$ al Oeste, $y$ por consiguiente, nos indicaba como prudente el conservar aún el rumbo adoptado del Nornordeste hasta entrar en meridianos de las Islas de Cabo Verde, hacia los cuales se inclinan comunmente los que regresan del Perú, para ir con bastante barlovento al encuentro de las brisas del Nordeste.

Esta derrota nos proporcionó para la mañana siguiente el encuentro agradable y deseado de una. embarcación nacional que con las muras á babor navegaba hacia el Sur: la señaló la AtrRvidA á las ocho de la mañana, y habiéndosele prescrito que siguiese dirigiendo el convoy y demás buques de Lima, hízose luégo señal á la Gertrudis para que siguiese la Descubierta, la cual, ya con todo aparejo y el rumbo del Norte $\%$ Nordeste, navegaba al encuentro y reconocimiento de la embarcación avistada. El vientoá este tiempo cedió mucho de su fuerza y tuvimos repetidos aguaceros: así eran bien las once, cuando pudimos atracarla, ya puesta al pairo, y enviar el bote á su bordo con un Oticial de guerra.

Era la Esmeralda de 200 toneladas y del comercio de Sar.. der, la cual desde este puerto navegaba para el de Montevideo con carga de hierro y fardería, y treinta y ocho días de navegacion; confirmó el no buen suceso de nuestras armas en el Rosellón y el encuentro bien reñido de las escuadras francesa é inglesa en la Mancha, conforme nos lo habian hecho sospechar las últimas papeletas recibidas en Montevideo: nos enteró después del grande número de buques ó nacionales ó aliados, que protegían la navegación y el comercio sobre las Azores y las costas de Cantabria y Portugal; y tinalmente, enterado por nosotros de las noticias individuales del convoy para que no se equivocasen en Montevideo $\mathrm{y}$ en Lima, se despidió poco después de las doce, ciñendo con las muras á estribor.

No nos abandonaron los Sudoestes acompa-
A 3. 
A. 9 กัados con mucha lluvia, sino en la tarde del 9 por latitud de $I^{\circ} 46^{\prime}$. Debimos despues luchar por algunos dias con muchas calmas y variedad de ventolinas, las cuales nos condujeron á poca distancia de las Islas de Cabo Verde. Finalmen.

* te, solo en la tarde del 20 por latitud de $15^{\circ} 3^{\prime}$ pudimos alcanzar la brisa verdadera del Nordeste, y ceñirla con las muras á estribor en buena union con el convoy. Se comunicaron al mismo tiempo con señales los últimos resultados de las distancias lunares, los cuales fueron los siguientes:

\begin{tabular}{|c|c|c|c|c|c|}
\hline 1)ia. & Olmervadores. & \begin{tabular}{|c} 
Nimero \\
de series.
\end{tabular} & $\begin{array}{l}\text { I.nnginud } \\
\text { deducida. }\end{array}$ & Promedio. & $\begin{array}{c}\text { Erron del } \\
\text { conomberto. }\end{array}$ \\
\hline 18 & $\begin{array}{l}\text { Cevallos. } \\
\text { All. . . . . } \\
\text { Malaspina. }\end{array}$ & $\begin{array}{l}6 \\
6 \\
6\end{array}$ & $\begin{array}{r}23.12 .3 c \\
4.5 \\
8.2\end{array}$ & 23.8 .3 & F. $1^{\circ} 8^{\prime} 3$ \\
\hline
\end{tabular}

Así referidos al medio día del 20 pudimos continuar las longitudes siguientes en los tres buques de S. M.:

\begin{tabular}{|c|c|c|}
\hline & $\begin{array}{l}\text { Longitud occidental } \\
\text { de Cuddiz. }\end{array}$ & Promedio. \\
\hline $\begin{array}{l}\text { Corbeta Descubierta. . } \\
\text { Corbeta Atrkvida. . . } \\
\text { Fragata Gertrudis. . . . }\end{array}$ & $\begin{aligned} & 23^{\circ} 19 \\
& 23 \\
& 24\end{aligned}$ & $23^{\circ} 22^{\prime}$ \\
\hline
\end{tabular}

Variación magnética por diferentes observaciones $10^{\circ} 30^{\prime}$ Noroeste, distancia á la Isla Brava 95 leguas próximamente.

Puede inferirse de los datos antecedentes, que en los últimos días las corrientes nos habían llevado vivamente al Oeste $y$ que en la noche última habíamos cortado casi sin precaución alguna el paralelo de una vigía situada al Oeste de la Isla Brava. En cuanto á estas vigías diremos lisa y llanamente que sin atrevernos á hacer frente á las ideas generalmente admitidas, esta. mos, sin embargo, bien convencidos que la $\mathrm{Na}$ turaleza, siempre consecuente en sus obras ma. ravillosas, no ha colocado en medio de un golfo inmenso unas piedrezuelas apenas perceptibles, $y$ que en la situacion nuestra, 6 de no internar ve. lozmente en el límite no bien cogido de las brisas, 6 de aventurar adelantándole uno de los buques de guerra, parecib prefererte no tomar medida alguna precavida, la cual por otra parte, hubiera sido en mucho frustrada con la crecida diferencia al Norte que tuvimos al medin día siguiente.

Cogidas las brisas, á las cuales pasando el trópico, vimor s.ceder, según costumbre, vientos largos variables del Este al Sur, nos hallamos en pocos dias con el convoy unido en latitud de $30^{\circ}$ próximamente. En diferentes intervalos de calmas 6 de vientos bonancibles, habíamos antes socorrido la fragata Gertrudis con algunos víve. res que pudiesen reemplazar los que tenía ave. riados; $y$ después los tres buques de S. M., for - As. wo mados en línea, hablamos hecho un ensayo militar de las diferentes clases de ataque y defen. sa, logrando asf soltar mucho los equipajes en el uso de las armas de fuego y del abordaje. Ni debimos tampoco descuidar una nueva repetición de las experiencias eudiométricas, la cual manifestase hasta dónde serian útiles estos datos en lo venidero para juzgar de la atmósfera interior de un buque. Para este intento se habla dispuesto que además de los aires, que soliamos comun. mente comparar entre si, se examinasen ahora el de los pañoles de comestibles, y el que despe. dia una de las vasijas de la estiva, las cuales se laabian llenado con el agua llovediza recogida sobre cubierta en las inmediaciones de la equinoccial: agui: que manifestaba, al tiempo de su. ministrarse al ganado diariamente, una cierta fe. tidez, indicio casi seguro de su corrupción: el éxito manirestó de nuevo la exactitud de nues. tras exprriencias y la posibilidad de mantener interio: mente un buque libre de toda corrupcion. Los diferentes aires hecha la absorción del ácido nitroso, dieron los siguientes grados de salu. bridad:

Aire atmosférico a las diez de la mañana. . . . 9 95 Airo del entrepuentes a las once de la noche. . 87 Aire de la sentina. . . . . . . . . . . . . 90 Aire de un panol de comestibles de rancho. . . 89 Aire de la pipa estivada de agua llovediza. . . 82

Repetidas experiencias de los físicos han ma. nifestado ya que no siempre la fetidez es una prueba indubitable de la corrupción. Estas lo manifestaron de nuevo, á lo ménos hasta el grado, el cual nos fuese útil no ignorar:

Más importantes debían parecernos aún las experiencias de los alambiques para dulcificar el agua, los cuales bien sea por la poca necesidad que habíamos tenido, 6 por la demasiada estrechez del buque aún no se habían podido sujetar á un ensayo formal el cual nos diese lugar á conocer la máxima cantidad que pudiese conseguirse con el menor consumo de leña. Desde luego el destilador aplicado al recipiente lateral, al cal. dero, y único para el uso diario mientras se co. ciese la comida, no excedio en mucho los resulta. dos que habiamos conseguido las demás veces: no fue necesario aumento alguno de leña: el agua destilada en cuatro horas no excedio de 64 cuar. tillos. Pero luégo que concluída la comida de la tripulacion pudimos aplicar al caldero el otro destilador y hacer que trabajasen los dos á la vez por el espacio de cinco horas y media, la cantidad de agua destilada en este plazo, con el s6lo consumo de dos quintales de leña no fué menor de I 89 cuartillos, siendo digno de reparo que la porción de agua suministrada por el destilador del caldero excedía á la otra en mucho; probable. 
A. m mente por las dos causas de ser mayor este reci. piente, y de usarse de la manguera para la con. ducción del agua fresca condensante en lugar del embudo y llave del refrigerio, que á imitación de la máquina del navio San Sebastion habiamos puesto en el alambique del uso diario.

Set. a Entre tanto las apariencias de un viaje feliz se iban á cada paso haciendo ménos equívocas, y por la misma razón más agradables. Ein la mañana del 2 ya navegábamos con vientos del Sur y Sursudoeste bonancibles, se sentía la mar del Noroeste y el rumbo adoptado del Nordeste de la aguja, debia conducirnos luégo á los paralelos de las Azores. Se confirmaron en la misma tarde con nuevas observaciones los primeros re. aultados de las distancias lunares, los cuales ron una suma uniformidad asignaban al cronometro el error siguiente:

\begin{tabular}{|c|c|c|c|c|c|c|}
\hline & Dhes. & $\begin{array}{l}\text { Observes. } \\
\text { dures. }\end{array}$ & $\mid \begin{array}{l}\text { Num. } \\
\text { de } \\
\text { anrife. }\end{array}$ & $\begin{array}{c}\text { Longrimed } \\
\text { dedactda. }\end{array}$ & $\begin{array}{l}\text { Promio } \\
\text { dio. }\end{array}$ & $\begin{array}{l}\text { Frrane del } \\
\text { crowdowetro. }\end{array}$ \\
\hline Agonto. . & 3 & $\begin{array}{l}\text { Tova. ... } \\
\text { Cevallono... } \\
\text { Yiana } \\
\text { Malaspina... } \\
\text { Tova ..... }\end{array}$ & 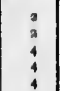 & $\begin{array}{r}30.89 .15 \\
5.40 \\
56.40 \\
36.41 \\
30.40 .00\end{array}$ & 19.34 & E. 10.46 .39 \\
\hline Setiemb. & a & Malaspina... & 4 & $\begin{array}{r}30.40,00 \\
45 \cdot 45 \\
41,00\end{array}$ & 30.45 .15 & E. .9 .44 .45 \\
\hline
\end{tabular}

Una embarcación á la vista al amanecer del día siguiente, contribuyó también no poco, á di sipar la monotonía siempre enfadosa del mar. Distaba de nosotros unas dos 6 tres leguas por la proa, navegaba proximamente al Esnordeste, y su construcción, rumbo y aparejo contribuían unánimes á hacerla creer nacional y tal vez una de las atrasadas del convoy nuestro de M utevideu. Hizose inmediatamente señal á la $\Lambda$ Trevida de que mantuviese unido $y$ dirigiese al rumbo primitivo el grueso de la escuadra y convoy; y llamada la Gertrudis para que nos si. guiese, nos dirigimos con fuerza de vela á reco. nocerla. Alcanzada á las nueve, en parte por la superioridad nuestra de andar, y en parte porque acort 6 de vela, largas ya las insignias nacionales en nuestros topes, dijo ser la fragata Esperanza, procedente de Montevideo, con es cala en el Río Janeiro y con destino á Santander. Habia dejado la costa del Brasil en ro de Julio último; había visto en aquel puerto la fra. gata Rosa, del cornercio de Lima, única que fal. taba en nuestro convoy de los registros del Sur; no necesitaba : xilio alguno; pero sí solicitaba que se le admitiese en el convov hasta que su derrota le permitiese navegar incorporada. La mar, algo gruesa, no hacía á la sazón fácil el uso de los botés para remitirle una copia de las se. ñales oportunas; pero se le dijo que siguiese á la corbeta ATrevida é imitase los movimientos de los demás, quedando luégo en la conserva. En aquella misma tarde el viento se declarb fresco y constante al Noroeste, lo cual nos decidi6 á preferir la derrota al Sur de las Azores; y nos 8et. fue este tiempo tan favorable, que al amanecer del 9 pudimos avistar al Norte la isla Santa María.

La perdimos de vista poco después del medlo dia, y como continuasen los mismos vientos, pu. dieron separarse luégo y seguir derrota al Nordeste, los buques de Santander. Lil restante con. voy, si se exceptúan algunas averias que tuvo en $10 \mathrm{y}$, los dias I I y 12 , con viento recio y aturbonado del Nornordeste, siguió con la mayor unión y felicidad; y en la tarde del 18 estuvo á la vista del Cabo San Vicente.

Algunas calmas, la necesidad de aprovechar los terrales y el ningún efecto de las corrientes favorables, nos detuvieron después hasta el medio dia del 20 á la vista del Cabo Santa Maria; pero en la mañanita del $2 x$ estuvimos delante del puerto.

Descubriéronse ya á las cinco de la mañana las costas de Rota, la población de Cádiz y su extensa bahia, en la cual, formando un espeso bosque, se velan ancladas innumurables embarcaciones. Varios buques de guerra, la mayor parte nacionales, descollaban sus topes alterosos. Distinguíanse las insignias, y los últimos soplos del terral que continuaban aún reunian al mismo tiempo $y$ aproximaban hacia el puerto todos los buques, de nuestro convoy.

Tuvirros en breve á bordo varios botes y faluchos costaneros, otros se repartieron cie igual $r$ jdo par los demás buques grauıdes: nos alcanzaron después los prácticos, y como el viento paulatinamente rolase del Norte al Este $y$ al Esueste, se hicieron preferentes para las nueve de la mañana las muras á estribor, y con ellas y todo aparejo navegamos en demanda del puerto, ordenándose por una feliz y casual combina. ción, la posición y distancia de los buques entre sí de tal modo, que se evitase todo atropella. miento y se guardase, sin embargo, un orden regular de convoy precedido por los tres buques de la Marina Real.

Fué importuna á la sazón una neblina con extremo densa, la cual precisó á los buques grandes á mantenerse cerca de una hora sobre las gavias, de la vuelta de fuera. Nosotros pudimos continuar hacia el puerto, viéndola felizmente disipada casi al mismo instante en el cual, do. bladas las Puercas, atracábamos ya los primeros buques fondeados; antes saludamos la insignis del Teniente General D. Juan de Lángara, la cual tremolaba en el navío Reina Luisa, y despues fuimos atravesando los muchos buques mercantes fondeados á la boca del puerto. Eran éstos por la mayor parte ingleses y holandeses, prontos á dar la vela al día siguiente bajo la escolta de cuatro buques de guerra ingleses.

A las diez, ya proximos á los Corrales y salu-

6 de 64 cuar. edia, la can fué menor de ro que la por. destilador del ho; probable. 
Set, " dada también á la vez la insignia del General Co. mandante, en cuyas inmediaciones nos hallábamos, dimos fondo en cuatro brazas lama. A poco tiempo ejecutaron irual maniobra y con no menor felicidad, la coibeta ATREvina y la fragata Gertrudis. Fueron después entrando uno á uno los buques de Lima, dirigidos, según costumbre, á la poza Santa Isabel y quedaron amarrados los de S. M., conservándose por este tiempo sus tripulaciones en tar buena salud, que no fuese necesario enviar al hospital un enfermo siquiera.

El estado que sigue indicará con bastante exactitud el número y el valor de los buques que navegaron unidos desde Montevideo. Aquí ya nada tendremos que añadir sino es que, en el lar- go espacio de cinco años y dos meses, fueron las Set. 28 corbetas bastante felices para no perder á bordo y en los hospitales más que diez individuos, los cuatro de la Descubierta y seis de la Arrevi. DA; pero dos de la segunda caídos accidertalmente al agua sin poderlos salvar. ¡Ojalá ios demasiados halagos de la vida tranquila é independiente de nuestras colonias no hubiesen seducido para desertar á una buena mitad de la tropa y marinería! ¡Ojalá, en fir., que el demasiado afán para los progresos de la Historia Natural y para la ilustración de su paría no hubiese conducido al último término de su vida al Coronel D. Astonio Pirıda, cuya muerte temprana llorarán siempre los que le han conocido en el grande teatro de sus tareas militares y científicas! 


\section{Descripción fisica de las costas del Noroeste de la América visitadas por las corbetas.}

El número crecido de descripciones de esta especie (I) que han salido ya á la luz pública, debiera sin duda aconsejar á todo hombre cauto y amante de la verdad, á no agregarle otra alguna; tanto más, que la poca congruencia de unas con otras, multiplicando más bien que disipando las dudas de los sabios, fomenta sólo el origen de nuevos sistemas y con ellos el velo es. peso que envuelve actualmente la verdad.

Pero la Nación exige de nosotros este nuevo tributo, yo no rendirlo por el sólo recelo de incurrir en una ú otra equivocación, fuera tanto más culpable, cuanto que ni hemos crrecido de muchos excelentes medios para alcanzar la verdad, ni nos ha de tachar 6 de omisos 6 de adictos á otro sistema que el de la realidad.

Esta Memoria abrazará sólo las costas no sujetas á la Monarquía y al alcance de nuestros reconocimientos, esto es, desde el Cabo Blanco (2) hasta la enirada del Príncipe Guillermo. En el libro siguiente, se tratará de lo correspondiente á la California 6 á los dominios de. S. M. en esta parte del mundo; pues el auxilio de las Historias de los Misioneros y del Gobierno, nos dan lugar á poderlas tratar con mayor extensión y seguridad.

La costa desde el Cabo Blanco hasta la entraád del Príncipe Guillermo, comprende tres trozos totalmente diferentes uno de otro, si se considera su direccion, el clima, las cualidades y productos del suelo. Las orillas, al principio, son por lo común abarrancadas y contínuas, sin puertos 6 ensenadas grandes, casi en dirección Norte-Sur ceñidas à la espalda por diferentes

(1) Después del viajo del Capitán Cook, cuyos méritos solo puecic comprender el que sigue sus huellas, han parecido los de los Capitanes Dixon y Mea. res; será público algún día el del infeliz Conde do la res; sera publico algurn dia el del infeliz Conde de la cado nuestros buques de San Blas, desde el año do cado nuestros buques de San

174 hasta el presente de $179 \mathrm{r}$.
(2) El Cabo Blanco es un término de nuestras posesiones, que no admite duda alguna. Lo hace auténtico la declaración del Contramaestre de la fragata Los Tres Reyes, cuyo original existe en el archivo de Simancas con los demás documentos del viaje de Sebastión Vizcaino. Aunquo los Pilotos Martinez y Haro han llegado hasta Oanalaska y el Comandante Haro han llogado has Arteaga hasta la entrada do la rha do Cook, sus Diarios no suminist tos flsicos. cordilleras de montes no muy ele rados; y de un temperamento bastante benigno, si consultásemos, 6 la poca elevación de los mismos montes, ó el temperamento de nuestra California, 6 el que se ha advertido en dos años en Nutka. E tèrmino de esta faja de costa puede considerarse en el extremo meridional de la entrada de Fuca, desde donde empieza un archipiélago inmenso, que ramificándose hacia el Noroeste-Norte $\mathrm{y}$ tal vez al Nornordeste, termina, por lo que toca á la dirección primera de que ahora hablamos, al Norte del Cabo de Engaño por las inmediaciones de la entrada de la Cruz y Monte de Buen Tiempo. Ya en este último punto, la costa con una dirección casi del Este-Oeste, sigue compacta, poblada de pinos en la orilla, y cerrada á no mucha distancia por una cordillera majestuosa y constantemente nevada, entre la cual se señorean noblemente los montes de San Elías y Buen Tiempo, elevado $: 1$ primero 2.792 toesas sobre el irivel del mar y el segundo 2.282 .

Nuestras conjeturas sobre el temperamento de estas costas pueden ya fijarse sobre datos ménos oscuros, pues á las repetidas noticias de los navegantes que han trillado estos mares en la estación favorable, pueden agregarse las noticias de los rusos ( $\mathrm{r}$ y del Capitán Mieares (2) por lo que toca al primer trozo de costa, en la helada estación de invierno; las de nuestro establecimiento de Nutka en el segundo trozo, y los viajes de Sebastián Vizcaino, relativamente á la última parte de costa entre los Cabos meridional de Fuca y Blanco.

Ya se ha dicho que una grande cordillera constantemente nevada hasta la falda, forma toda la costa desde el Monte de la Cruz hasta el extremo oriental de la ría de Cook. Le hará tal vez poco creible, que en los meses fuertes del estío, cuales son los de Junio y Julio, estos montes continuasen excesivamente cargados de hielo; pero las vistas, bien sea de perspectiva

(1) Estas solo pueden inferirse de la colección de viajes do Mr. Coxo y do las noticias sueltas del Capitán Cook, despnés de visitadas las islas Jehumagin. (2) La eloruencia (otras veces sospechosa) del Capitán Meares, no puede exagerar la situación de un buque mercante, rodeado de hielo en un parajo un buane mercanto, rodeado do hiolo en un parajo Sung-Corner de la entrada del Principe Guillermo. 
ó de marina, manifestaran que no serian encarecidas nuestras expresiones, cuando asegurásemos que estos montes, aunque no abandonados de la Naturaleza, están sin embargo destinados á ser perpetúamente la habitación de pocos osos.

El reconocimiento del puerto del Desengaño cn los primeros dias del mes de Julio nos dió aún más lugar de afianzar esta conjetura. El puerto está en la falda de la cordillera, su orilla del Oeste formada con algunas restingas ó pedruscos salientes al mar, sirve casi de base $o ́$ de cadena al hielo, que por consiguientc puede re. sistir con vigor bien sea á la internación del agua ó al efecto de una ténue marea. Mucho más aún debe resistirlos todo el banco de hielo que advertimos antepuesto á la Isla Heenke, y que ligado á la costa por todas partes ménos la del frente de la bahia, si hace firme, impenetrable y perpétun. ivi es su separación ó disolución la que forma las bancas sueltas, en las cuales nos era fácil examinar sobrepuestas á la primera, una ó dos capas de hielo más reciente y á veces no bien formado. Una explosión contínua de los montes inmediatos, semejante á la de un volcán $o$ de un trueno distante, nos indicaba á cada paso que se desplomaban crecidas masas de hielo (I) las cuales, luégo ménos adherentes entre sí, por una ú otra parte, daban lugar á que el agua del mar, labrando contínuamente en ellas, las subdividiese, las varase á veces por efecto de las mareas, $o$ bien las extrajese del puerto á dunde las veíamos flotar.

Con estos antecedentes debieron sernos tanto más agradables en aquellos contornos $y$ entre el horror que parecía rodearles, las huellas de la próvida Naturaleza.

Cles tutti ascolta, é porge ci tutti aita.-Findicaja.

En los pocos parajes inmediatos á la orilla que dejaban libre las manchas ó pedazos interrumpidos de hielo, sobresalía una vegetación abundante y florida: anidaban en sus contornos. aprovechando este corto descanso del frío, varias perdices y otra especie de aves chicas (2). Los mismos peces y en particular el salmón, aproximándose siquiera á la boca del puerto en el aduar inmediato de los naturales, parecían querer por su parte coadyuvar á esta hermosa aunque monentánea escena de la Naturaleza (3).

No le son ménos favorables las crillas del

(1) Fista descripción corresponcie enteramente con los efectos advertidos por los Pilotos del Teniente de navio D. Salvador Hidalgo en el puerto de Re. villagijedo de la entrada del Príncipe Guillermo.

(2) Don Tadeo Heenke describe esta parte de la (2) Den Tadeo Heenke describe esta parte de la
botánica y zoologia con su acostumbrada exactitud.

(3) La reunión de los Sres, Rabenet y Brambila pintores agregados á la expedición, dará lugar á que se represente esta pintura con aquellos colores a que no puede alcanzar una descripción de mane suma. mente débil.
Este que continuan hasta la Isla de Pineda, las cuales así por la dirección perpendicular del monte, como por la suma profundidad del mar(I) no dan lugar á que puedan asirse firmemente las masas del hielo, las que convertidas por consiguiente en otros tantos riachuelos 6 cascadas perennes, fecundizan en un modo admirable $y$ hacen que se vista de un verde hermoso la mis. ma roca que parecía destinada á una desnudez árida y triste.

Al Oeste y al Este de esta cordillera, considerada sólo en su falda de la bahia del Almirantazgo, se extiende al mar una porción de tierra baja, cuyo semblante es bien discints del que acabamos de describir. Diferentes canales y puertos; una vegetación extremadamente rica y com. puesta de plantas útiles 6 á la conservación del hombre ó á los progresos de la vida sociable; la concurrencia del salmón, del pejerey, de la nutria $y$ del lobo marino en sus orillas, todo convida al navegante en esos contornos, así como parece asegurarle que la Naturaleza puso por término de sus pesquisas y de los pasos á una cordillera tan dilatada é impenetrable.

Ni parecerá extraño que sean tan constantes la permanencia del hielo en la parte montuosa y la lozanía de la vegetación en la parte baja, cuando se considere que son harto raros en toda esta costa los vientos del Noroeste, únicos para franquear al Sol la directa y constante acción de sus rayos benéficos; siendo al contrario muy frecuentes los del Sueste, que impregnados de vapores pueden, sí, ser sufribles en un bosque frondoso, pero son inútiles ó insuficientes para la disolución del hielo.

Desde el puerto Mulgrave á las faldas del Monte de San Elias y del Buen Tiempo, veíamos con un sólo día de Noroeste, disolverse en mil riachuelos y áun desplomarse enteros, crecidos trozos de hielo. Las aguas del mar por la bahía de Bering, áun á distancia de dos y tres leguas de la costa, conservaban un color blanquinoso y un gusto muy poco salobre. Pero estos efectos saludables no eran sino momentáneos: se declaraba el Sueste, y la lluvia, la calima, y á veces la tempestad, sus compañeras insepa. rables, no sólo daisan al todo un semblante 16. brego y triste, si también absorían la mayor parte de los pocos meses saludables del verano.

Hé aquí, pues, por qué en el fondo de la entrada del Príncipe Guillermo (2) en el puerto del Desengaño y en la entrada de la Cruz (3), se en.

(1) La lancha de la corbeta ATrevida encargada de sondar, no encontraba a veces fondo a un cumpli. do de bote de la costa, con roo brazas de sondaleza.

(2) Véase el Diario ya citado de D. Salvador Hidalgo, hablando del puerto de Revillagijedo.

(3) Véase el viaje del buque inglés la Ifigenia, recopilado por el Capitán Meares. 
contrase tan fácilmente el hielo constante y sus montes estuviesen cargados de hielo áun en los meses de Julio y Agosto. Y si no se advierte el mismo efecto en la ría de Cook, debe sin duda atribuirse á la violencia de sus mareas y á la avenida del río Grande interno, que no permiten á las aguas la estabilidad necesaria para consoli. darse.

No nos aventuraremos á decidir cuál sea el estado de la cordillera hacia el lado opuesto del Norte; si hemos de juzgar por lo que hemos visto en la entrada del Príncipe Guillermo, en el Valle de Ruesga, al Nordeste de la Península de Kaye, y lo más interno de la bahía de Bering, los montes, bien sea en una ó en muchas hileras, pueden coger un espacio de 30 á 40 leguas de Su: á Norte y la misma extructura del Monte de San Elías parece confirmar esta sospecha.

¿Cuál sería, pues, la masa enorme de hielo que cubra la parte opuesta de la cordillera, á donde no alcanza jamás la dirección de los rayos del Sol, y adonde operan más directamente los vientos hiemales del Norte? ¿Cuáles los piés humanos que hayan de transitarla? ¿Cuáles, en fin, los objetos que al alcance de las débiles fuerzas del hombre puedan gitiar hacia csta parte su ilimitada curiosidad ó codicia?

Lo que sí pudieramos asegurar con mucha ménos desconfianza, es la época, no muy distan. te, en la cual los fuegos subterráneos causaban en esta parte del globo nuevas vicisitudes y transformaciones: áun en el día son muchos los volcanes en la ría de Cook y en las islas del dominio ruso; entre las muchas que componen el Archipiélago de Bucareli, no se cuentan ménos de siete, cuyas erupciones son también notables (I), y la misma extructura del Monte San Elías, si se compara á los volcanes de la costa de Guatemala, y se supone una cierta harmonía bien notable en las grandes obras de la Natura. leza, parece acreditar que el mismo monte, si no lo es, fué á lo ménos un volcán no indiferente: además de esto, las Islas del Puerto Mulgrave abundan en piedra pómez, y no es extraño ha. llar entre los guijarros de sus orillas y particularmente de la Punta Furner, varios ferrugino. sos negros, esponjosos, que no pueden ser sino erupciones volcánicas.

El Sr. de Heenke, quieñ examinó científicamente las diferentes piedras que de un verdadero brazo de la cordillera inmediata al l'uerto del Desengaño se condujeron á bordo, las halló

(1) En el Diario do la navegación de la goleta Sonora (an̂o de 1775) a las órdenes del actual Capitán de navio D. Juan de la Bodega y Cuadra, se lee el adjunto párrafo hablando de este Archipiélago: Las noches son sumamente claras y templadas a aLas noches son sumamente claras y templadas a
causa de siete volcanes de nieve y fuego que con sus vapores la iluminan y templan. compuestas de las calidades siguientes, las cua. les pudiéramos, por consiguiente, considerar sin temeridad, que forman casi toda la masa de estos montes.

I." Calcárea cruda, compacta, granulosa, purísima y blanca.

2." Calcárea ruuda, cenicienta y sembrada con venitas blp.ncas también calcáreas.

3." Gran osa con grano blanco, compuesta de cuarzo y feldespato.

4." Granitosa granulosa, compuesta de mica negra y feldespato.

5." Granitosa verdosa, con puntas cristalinas, compuestas de cuarzo, feldespato y basalto.

Pero no fuera fácil asegurar cuál de las dos calidades primarias componen la base de la cordillera, si bien que puede creerse lo sea la cal. cárea, á la cual estén después sobrepuestas va. rias capas granitosas que componen últimamente la cima de los montes.

Causaía mayor admiración no hallar río al. guno, ni mediano siquiera, en el largo trecho indicado de costa desde la ría de Cook hasta las faldas del Monte de la Cruz por los $7^{\circ}$, si no se considerase que los montes están demasiado inmediatos á la orilla rara que las aguas tengan lugar de reunirse antes de llegar al mar, y que así es una infinidad de riachuelos 6 cascadas la que conduce los hielos derretidos al Océzano; pero cuando se dé una mirada 6 bien á la masa in. mensa de hielo que probablemente existe á la parte opuesta, ó al paradero de las aguas llovedizas, que tal vez en el verano no tengan lugar de consolidarse y contribuyan á la disolución dé parte del hielo, no puede el físico dejar inmediatamente de fijar sus conceptos en aquellas lagunas inmensas que forman la admiración de los viajeros que han internado por el Este, y la esperanza de los que áun sostienen la posibilidad de un paso por esas latitudes.

Ya fuera tiempo de abandonar un examen tan incierto de la constitución física de esta par. te del globo, si no debiésemos hacer memoria de la existencia del cobre en sus contornos y de las reflexiones meteorológ: ias en cuanto tengan una conexión directa, 6 con el tránsito ó con la subsistencia del navegante. Que haya cobre en los contornos del Príncipe Guillermo y del Puerto del Desengaño, podía tal vez no dudarse anteriormente (I); pero ahora nos to ha confirmado el Ankan ó Jefe del Puerto Mulgrave, el cual presentándonos un morrión de guerra, ganado á sus enemigos en una batalla y ornado con dife. rentes cercos ó anillos de cobre (2) satisfizo á

(1) Véanse los viajes de los Capitanes Cook y Meares.

(2) F1 Ankau nunca quiso ceder este trofeo de sus (2) Al Ankau nunca quiso ceder este trofeo de sus con el auxilio de la pintura. 
nuestra curiosidad sobre la adquisicion de este metal, con asegurarnos que lo había en las inmediaciones de la cordillera, á donde les era fácil cogerle. Sin embargo, casi se limitaron á éste los utensilios 6 adornos de aquel metal que ad. vertimos entre ellos; $y$ así podemos tal vez asegurar, que si no es dudosa su existencia en estos montes, a lo ménos 6 su cantidad 6 su beneficio son sumamente limitados. Por nuestra parte, vistas las circunstancias que precisamente han de acompañar á este beneficio, no titubearemos en inclinarnos á que arredre por sí solo á todo emprendedor, aunque fuesen crecidas las cantidades que pudiera suminis rar, tanto más yue supliendo ahora los europeos con el útil hierro la necesidad ya conocida de los metales, mal pudieran los naturales abandonar la pesca, que les vale aquella adquisición, para ocuparse del be. neficio ménos útil y más destructivo de la mina.

A pesar de la triste perspectiva con que hasta aquí hemos representado este largr trecho de costa, no es su constitución, sin embargo, enteramente opuesta á la existencia do una sociedad civilizada, y digámoslo así, á su bienestar en el vario curso de un año. La faja de tierra llana que se antepone, como hemos dicho, aunque con muy corta extensión á la cordillera, y corre casi seguida desde la bahía de Bering hasta la parte occidental de la península de Kaye (I) presenta al hombre un asilo en el cual puede al mismo tiempo precaverse de las intemperies y proveer opiparamente á su subsistencia.

El Sr. de Heenke, examinad z científicamente la calidad del suelo y la lozanía de la vegetación en el puerto Mulgrave, y vista la singular harmonía de la Naturaleza, así en éste como en sus demás productos, no dudó en asegurar que se lograría allí la mayor parte de nuestras semillas, debiendo probablemente llegar á su completa madure $z$ hacia fines de Julio, pues que en sus principios advertimos ya inuy adelantados los gramenes, la fresa y la mora. En efecto, si se considera el mayor número de las plantas, se hallarán éstas de las misnıas especies de la Europa boreal, excepto algunas que, ó son de la Amśrica boreal, 6 Alpinas de todo el globo; si los árboles, se verá que el pino abie, el pino picea y el cupreso disticha, hermosean noblemente sus bosques, sin interceptar el paso, 6 al Sol ó al caminante, antes bien dejando de trecho en trecho como entre sembrados, diferentes prados en los cuales crecen lozanamente la fresa y la mora; si la calidad del suelo, se hallará que los prados son de una arcilla arenosia igual casi al mismo fondo del mar, $y$ en los bosques le cubre una capa alta y densa de tierra vegetal negra y friable, compuesta en el largo volver de los años de las

(I) Consulltese nuestra carta. miriades putrefactas de las plantas, árboles y musgos; si el mar intermedio, la velocidad de la marea, la tortuosidad de las orillas y la inmediata comunicación con el mar, harán creible (r) que el hielo en estos canales, no intercepte ni la na. vegación ni la pesca en la cruda estación del in. vierno; si, finalmente, el tem, seramento, se verá en nuestro Diario meteorológico que el termómetro de Farenheit llegó á los $67^{\circ} \mathrm{oo}^{\prime}$, y nosotros podremos asegurar, que ni en el abrigo de las casas, ni en la inclinación de los árboles por efecto de los vientos reinantes, ni en las noticias que pudimos adquirir de los naturales, se halla absolutamente rastro de un invierno $\delta$ cempes. tuoso, ó muy frío.

No se crea, sin embargo, que se asemeje á esta pintura la de toda la demás costa que actualmente describimos. Las faldas del Monte de San Elías y un buen trecho al Este y al Oeste, no presentan sino algunos manchones mezquinos y poco internos de arboleda, la cual luégo vuelve á tomar su primer espesor y lozanía por el Cabo Chupador y las bahías de Burgos y el Almirantazgo. En esta última ensenada, agregándose á la frondosidad de las orillas las apariencias de algunos valles internos y la menor elevación de los montes contíguos, la Naturaleza parece ofrecer al hombre otro abrigo no indiferente, antes bien, tanto más agradable, cuanto que probablemente una embarcación puede considerarse segura al Este de la Isla Dudosa, si el fondo de cuatro á cinco brazas arena fina le deja internar hasta allí.

Los naturales, que desde la Isla Iijosa salieron á nuestro encuentro, nos señalaban á la verdad otro fondeadero bueno al Oeste de la isla, en el cual, si existiese, se conseguiría en el invierno un temple mucho más suave que en las inmediaciones de la entrada del Príncipe Guillermo, por ser esta isla al mismo tiempo baja y bien separada del Continente. Pero nosotros, que la costeamos por aquella parte á distancia de dos 6 tres leguas, no pudimos advertir la menor señal de un' abrigo; sólo sí haciéndosenos creible, que esta isla esté constantemente habitada, y que la concurrencia de la nutria á sus orillas le haga un objeto no indiferente para la navegación europea.

Pero es tiempo ya de pasar á los moradores, cuyo número, costumbres y relaciones recíprocas se recorrerán poco á poco con un examen filosb́fico, para que los progresos de la especie huria. na que tanto deben interesar á sus semejantes, no parezcan haber ocupado un lugar secundario en la atención nuestra á estos objetos.

Podemos desde luego sentar como una ver-

(I) La poca inteligencia del idioma y nuestros re. celos de una equivocacion, han dejadn dudoso este
punto interesante, aunque no nos descuidásemos en punto interesante, aun
procurar descifrarle. 
dad incontestable, que es un mismo el ori en de los habitadores de la orilla desde la ría de Cook hasta la entrada 6 Archipiélago de Bucar li (r); sean enhorabuena distintos uno de otro los idiomas de la entrada del Príncipe Guillermo y del puerto Mulgrave (2), sean frecuentes las reyertas entre una y otra tríbu, antes bien, no se vean nunca juntarse entre sí sino para destruirse, no por esto podrá jamás rechazarse una verdad que estriba sobre una total uniformidad: r." del metodo de vida. $2 .^{\circ}$ De las inclinaciones y progresos sociales. $30^{\circ}$ De los trajes, armas y utensilios. $4 .^{\circ}$ Finalmente, de los ritos religiosos. Por ventura, en esta discusión importante no nos es preciso echar mano de otros conocimientos más que los nacionales; y las narraciones de D. Salvador Hidalgo por lo que toca á las rías de Cook y el Príncipe Guillermo, las de D. Ignacio de Arteaga, relativamente al Archipiélago de Bucareli, ceñidas á la verdad sencilla y $\sin$ preocupación alguna á favor 6 de la novedad 6 de un sistema, nos dan ya lugar á combinar con toda seguridad algunas propiedades generales de estos moradores, que últimamente puedan guiarnos á otras indagaciones más importantes para la historia de la sociedad. Desenvolviendo poco á poco las nociones sobre los cuatro puntos ya indicados de comparación, por lo que hemos notado en el puerto Mulgrave, seguiremos al mismo tiempo lo que dicen los señores Arteaga é Hidalgo; y la descripción y la comparación seguirán un mismo paso uniforma y ménos molesto.

Las propiedades animales de estos moradores han sido ya descritas por diferentes viajeros, entre los cuales la prolija y filosb́fica atención de los Sres. Cook y Anderson en el Príncipe Guillermo, parece que no dejaban cosa alguna que desear: son altos, membrudos, sanos y ágiles, bien sea para la pesca, 6 la caza, 6 la guerra: son igualmente sanas las mujeres, aunque cons. tituídas á una vida sedentaria, y si juzgásemos, 6 por la disposición exterior de sus miembros, 6 por el número de niños que las rodean, se puede asegurar que son igualmente dispuestas al embarazo, al parto y á la rianza, y que esta disposición les continúa hasta una edad bastantemente adulta. El semblante de los hombres, es por 10

(1) Se verá después hablando de las costas siguientes, que no serfa temeridad extender esta misma Nación hasta el paralelo de 500 6 $51^{\circ}$ por las islas de la Reina Carlota y Princesa Real.

(2) El Capitán Dixon que tocó en una y otra parto y que dio nombre al puerto Mulgrave, sospecha la total diferencia de uno á otro idioma. No asi el Capitón Meares, hablando de los que habitan en latitud de $5^{\circ} 3^{\circ}$. Es muy sensible á la verdad que estos dos autores, confundiendo frecuentemente los objetos de interes y de rivalidad, con la ilustración pública, conspiren mas bien a contradecirse que a confirmar lo que han visto. común algo fiero; siendo, por otra parte, fácil hallar un mayor grado de fiereza en $i$ is que inclinan á la caza, y que no pocas veces, sin ventaja de armas, tienen que luchar pecho á pe. cho con osos y otras fieras ( $\mathrm{I}$ ). No así por lo común con los que siguen el oficio más apacible de la pesca, ni tampoco con las mujeres y los jóve. nes, brillando á cada paso en éstos una docilidad no estúpida y en aquéllas los sentimientos de pudor y de afabilidad que puede dictar en su niñez la ruda sociedad de la especie humana.

$\mathrm{Ni}$ eran equivocadas las sospechas del Capitán Cook sobre una grande diferencia de fisono. mías entre estos naturales: nos fue fácil distinguirla entre la plebe $y$ las familias adictas al Ankau, y D. Tomás Suria las ha representado con tanta propiedad, que ya no admitirá duda esta diferencia á lo ménos por lo que toca á los hombres. Varias veces con una leve recompensa conseguimos que algunos jóvenes lavasen sus rostros, descubriendo, por consiguiente, su color natural: era éste bastante blanco y sonrosado y la tez más bien fina, sin embargo del uso ya continuado del aceite y grasas, con las cuales se abrigan comunmente para resistir al frío, y que después de algunos años deben ya penetrar la película y variarles el color.

No omitiremos tampoco de recordar los caracteres realmente singulares que sobresalen en es. tas tríbus; $y$ son el pié desproporcionadamente chico, el hueso pómulo y el ojo, ceja y borde ciliar, muy semejantes á los de los chinos, el segundo en su color y pequeñez, la tercera en la mucha escasez de pelo y la cuarta en su elevación y distancia del ojo: esta parte principal del rostro, que los físicos admiran como uno de los hechos más bien combinados en la estructura del cuerpo humano y nosotros naturalmente caracterizamos con el distintivo de sobrescrito del hombre, debe probahlemente permanecer constante en una misma rama de la especie humana, por cuanto influyan 6 el temperamento, 6 las costumbres morales, 6 la clase de vida, en variar las demás partes de su cuerpo; $\mathrm{y}$ adoptando este principio análogo á la bella harmonía de la Naturaleza, ¿cómo podremos no recordar al mismo tiempo las excelentes refle. xiones de Mr. de Saint-Pierre en sus sublimes es. tudios de la misma Naturaleza, y contemplar cuantas conjeturas sobre la emigración de la es. pecie humana se han descarnado de toda proba. bilidad, sólo porque se han desentendido los es. critores de estos rastros patentes é invariables de la Naturaleza?

Por lo que toci á la comprensión 6 amolda. miento de la cabeza desde que nace el niño, ya

(1) Para la tribu del puerto Mulgrave, se ha podido inferir, que la caza del oso es sólo cn las inmedia. ciones del puerto del Desengaño. 
nos han precedido diferentes viajeros en advertirla y describirla: sin embargo, como D. Francisco Flores tuvo ocasión de estar presente una tarde á esta operación, no parezca inoportuno el que le añadamos aqui una breve descripción: nacido el niño, no sólo no se ocupa la madre e: co. rregirle la natural prolongación de la cabe á á la sazón cartilaginosa, sino que más bien coa lyuva, comprimiendola con las dos manos en varios sentidos y por algunos días, particularmente en los huesos parietales, de suerte que la sutura sagital sobresalga con exceso y se forme una especie de cono, que desde las dos tuherosidades del hueso coronal, se incline considerablemente hacia la horizontal. La cortadura del labio inferior difiere algún tanto de la que advirtieron el Capitán Cook y D. Salvador Hidalgo en la entrada del Príncipe Guillermo. La tríbu del Puerto de Muigrave sustituye á las dentaduras falsas 6 á los otros adornos subdivididos de las mismas cisuras, una especie de roldana con figura elíptica, que sujeta á los labios por ambos bordes y colocada en una posición horizontal, sirve de adorno sólo á las mujeres; esta roldana (I) muy bien bruñida por todas partes $y$ hecha de madera de pino, tiene en su eje mayor dos pulgadas y una línea inglesas, una pulgada en el eje menor y siete líneas de grueso de uno á otro canto; suelen, sí, los hombres tener perforado el septum de la nariz, para poner algún adorno, el cual, sin embargo, nunca hemos visto compuesto sino de huesos ó clavos, en lugar de anillos, ensartas ó hileras de caracoles, que suelen usar los habitantes del Príncipe Guillermo.

Pero ¿á qué entretenernos más sobre estas cualidades materiales, $\tan$ poco varias en la especie humana, que haciendose apenas perceptible apoyan á cada paso las próvidas atenciones de la Naturaleza para nuestro bienestar?(3). Es preciso fijar nuestra atención en las cualidades morales: allí es donde el filosofo mira con una curiosa admiración los vicios y las virtudes naturales en el hombre, las inclinaciones innatas, 6 para su sustento 6 para su multiplicación; los principios informes de la Sociedad, sus progresos y sus términos; a:li es donde últimamente la reflexión, caminando siempre á pasos lentos y sobre las orillas del precipicio, conduce atenta el hilo de las ideas, para dar siquiera algunos rasgos imperfectos de la importante historia del hombre.

Nuestro viaje en esta parte ha sido más bien liz; y entre la oscuridad del idioma, la novedad

-) Se remite uno de estos adornos al Real Gavitute.

(2) Autant la nature (dice Mr. de Saint-Pierre) d affecte de varietes dans les espèces d'animaux du meme affecte de varietes dons les especes d'animaux du meme genre, quoid ils habitassent le mêtne sol, et recussent des
memes aliments, autant elle dobserve duniformite dans respèce humaine malgre la difference des climats, it des nourritures. de las ideas y la importunidad de los sistemas, hemos podido rastrear algunos conocimientos, que desde luego no desagradaran al filósofo.

La dificultad de la subsistencia, es la causa primitiva, digámoslo así, la sola causa que impide los progresos de la sociedad y la multiplicación de la especie humana en estas tríbus: constituídos á vivir de la pesca (I), á ejecutarla con canoas bien endebles que no les permiten apartarse mucho de la orilla; finalmente, á proveer en seis meses escasos (2) á la subsistencia de todo el año; habitadores por otra parte de una costa pobre de aves marítimas y de mariscos (3), han debido precisamente subdividirse en muchas tríbus; y éstas mismas, lejos de concurrir á un mismo centro que les procurase el agradable soni. do de la vida sociable, se han visto precisadas á divirirse de nuevo para poseer cada familia como propiedad un pequeño trozo de costa: en esta situación que consideraremos con el doctor Ferguson (4) como la de las Naciones rudas antes del establecimiento de la propiedad, dos causas concurrieron muy luégo á acelerar algún tanto la ci. vilización; éstas fueron la pesca y beneficio de la ballena, que necesitaba muchos brazos á un tiem. po, y la defensa del propio terreno que sin duda alguna quisieran usurpar otras tribus, á veces por necesidad, á veces por capricho; para ambos ob. jetos fue, pues, preciso reunirse, ordenarse, considerar como sus intereses recíprocos, y elegir algunos que al mismo tiempo dotados de la precisa fuerza, habilidad y concepto público, guia. sen la muchedumbre en los varios trances peligrosos, en los cuales se hallaban. La cordillera inmediata, no permitiendo, por otra parte; inter nación alguna desde la ría de Look hasta el mon. te Edgecumbre ó San Jacinto, debió hacer más frecuentes estas discordias y más escasa la pobla. ción; y seguramente pudiéramos inferir de la situación de la tríbu del puerto Mulgrave la de todas las demás costaneras hacia el Sueste, si la Naturaleza, igualmente próvida en cualquiera parte del globo, no hubiese presentado á estos emigrantes marítimos un archipiélago inmenso que los acogiese y alimentase á su albedrío. Hasta aqu'i la historia de estas naciones, derivada de los efecios poco dudosos del instinto sociable, pare-

(1) Aunque algunos se ocipen de la caza y en par ticular de la muy arriesgada del oso, no por esto deben mirarse estas naciones sino como pescajoras.

(2) Véase el viaje del Capitán Meares para el prin. cipio de la pesca, en la entrada del Príncipe Guillermo. En últimos de Agosto, los habitantes de Nutka se ocupaban incesantemente en abastecerse para el in vieruo y ́uu en mudar de morada, como se vera des. pués.

(3) El Capitán Cook no dejo de advertir esta es casez, particnlarmente comparando estas costas a las de la América meridional. Véanse también nuestros Diarios.

(4) Seccion II, parte II 
ce al abrigo de toda equivocación, tanto más, que si se examina su estado actual, poco ó nada hay que añadir al estado rudo del hombre, que acabamos de indicar (r). Pcro al momento que tratemos de indagar cuáles son los motivos que actualmente afiancen la primacía, no sólo en una familia hereditaria, si también en una familia cuyos rostros difieren mucho de los de la plebc; cuáles los límites del derecho de propiedad y del derecho público; cuáles, en fin, los cimientos de sus principios 6 legislativos ó religiosos, nos vemos en la precisión de abandonar una serie hilada de ideas $y$ hacer una narración sencilla de lo que hemos visto, dejando al tiempo ó á la perspicacia de otros el reunir estas ideas en un solo punto de vista.

Lista tríbu se llama la de los Tejunés; habita las diferentes islas del puerto Mulgrave, y no pocas familias estan establecidas en la tierra tirme ó bien frontera á las mismas islas ó in. mediata al puerto del Desengaño ó exterior del Cabo Muñoz; de suerte que pudieran considerarse sus límites actualcs desde la bahía del $\mathrm{Al}$ mirantazgo hasta la bahía de Bering: sin embargo, los que habitan hacia esta última bahía, no debieran en la realidad consiclerarse como una misma nación, porque no es fácil su comunicación con los de le las por falta de cana. les internas, ni posible su reunión para la pesca de la ballena; pero como tuviesen por caudillo un hijo del Ankau Juné (2), del mismo modo que otras rancherias internas, hemos creído que precisamente en el caso de una guerra sus intereses serían comunes.

No así con los que habitan hacia el Este, á las faldas del Monte San Elías y áun más inmediatos en las puntas de Novales y Barrientos, los cuales, si bién después de su entrada en el puerto el día $\mathrm{x}^{\circ}$ de Julio vivieron en buena unión con sus habitantes y manifestaron una es. treche $z$ y amistad antigua diferentes individuos, pudimos conocer sin embargo, que sus intcreses eran bien distintos, las guerras harto fáciles $y$ sus caudillos naturalmente opuestos entre sí (3).

El indio que vino á bordo desde aquellas faldas, manifestó á la verdad muy poca idea del nivel en que habían cstado nuestros cambios en el puerto Mulgrave; pero por su idioma $y$ por sus ofrecimientos pudimos inferir indubitablemente que ni le eran nuevas las embarcaciones

(v) Las pocas alteraciones que indicaremos muy luego, son muy recientes y áun no bien cimentadas, jues dimanan en mucha parte de la concurrencia de pues dimanan en mucha parte

(2) Es el que se ha nombrado ya nuchas veces, $y$ se ha representado con mucha exactitud en nuestras láminas.

(3) Véase el Diario sobre los acaecimientos de aquella venida. europeas, ni sus objetos ó comerciantes 6 vi. ciosos; y así parecío probable que habitasen algo más al Este $\mathfrak{c}$ inmediatos á la bahía los que nos visitaron en el puerto; bien que habiendo de tiempo en tiempo alguna comunicación entre unos y otros. Parecerá también extraño que en la ensenada del Contralor, no hallásemos rastro alguno de habitantes, cuando la calidad del terieno y las mismas orillas parecian deberlos atraer alli más hien que en otras partes más montuosas de la costa; pero si como es probable, el poco fondo interno aparta los cetáceos, lobos y nutrias y tal vez también el salmón de aque. llas inmediaciones, $s \in$ hallará evidente la razón por qué ni en ésta ni en otras muchas partes de la costa hayan podido extenderse estos habitantes.

Ya con estos antecedentes, no será difícil deducir próximamente el número dc moradores desde la entrada del Príncipe Guillermo hasta las faldas del Monte de la Cruz (I): 600 en aquella entrada, otros tantos á las faldas del Monte San Elías, 4oo de la tríbu del puerto Mulgrave y otros 600 desde la bahía de Bering hasta la entrada de la Cruz, componen un número de 2.200 vivientes, que á lo sumo pueden contarse en este largo trecho de costa (2). Y si no fuese tan sólo temeridad sino también apar. tarse de nuestro sistema adoptado el aventurar algunas conjeturas sobre to venidero, debiera. mos decir que este número menguará más bien que crecerá con la concurrencia de los europeos en estos mares. El cebo de nuestro comercio y de la adquisición de las nutrias; el deseo de tener algunos esclavos para aumentar en nuestras manos cl número de estos infelices ó franquearnos su uso si son mujeres; finalmente, la adquisición de nuevas armas, 6 ya hechas 6 sacadas del hierro, serán nuevos principios de discordia $y$ consecuentemente de una destrucción recíproca.

Es, pues, indubitable, que en estas pequeñas tríbus hay una familia en quien recae por herencia la sucesión del mando, y por consiguiente, un jefe que las gobierna en la paz y las dirige en la guerra. El Ankan Juné, era en nuestro enten. der, verdaderamente digno de esta pública confianza, reuniendo en si todas las cualidades de edad, valor, corpulencia y penetración, que de: ben precisamente acompañar la elección de un Jefe en el estado aún naciente de una pequeña sociedad. Su padre, á la cabeza de la tríbu, ha-

(1) Los rusos dijeron á D. Salvador Hidalgo que en la liz de Cook se contaban hasta 4.000 naturales sujeios al imperio, pero esta noticia parecia exagerada.

(2). Se han tenido presentes para este computo los (2). Se han tenido presentes para este cómputo los
viajes de los Capitanes Cook, Dixon, Meares y de Don Salvador Hidalgo. Nosotros hemos advertido dos humaredas entre el Cabo Buen Tiempo y la bahía do la Cruz. 
bia no mucho tiempo antes, rechazado una inva. sión enemiga y comprado con su vida' la vic. toria (I).

Su hijo contaba diferentes hazañas hechas por él en el mismo choque; $y$ un semblante, audaz, varias proezas en la caza de los osos, su actual ensayo del mando en la ranchería del puerto del Desengaño, todo manifestaba que no desmayaría en sus manos el cargo del Gobierno supremo: entre las muchas razones y datos positivos que disipaban toda duda sobre esta sucesión heredi. taria en la familia del $A n k a u$ y las distinciones que merecia, debib particularmente fijar nuestra atención el depósito de los cadáveres de la misma familia, que con toda prolijidad examinamos, $y$ cuyas particularidades se han representado con mucho primor por el dibujante Cardero: nunca pudimos comprender si el mónstruo colosal representaba un ídolo 6 era sólo un recuerdo espantoso de los estragos de la muerte; pero nos inclinaba á creer lo primero la reflexión de que existían en sus inmediaciones varias piras en las cuales se habian quemado diferentes cadáveres; $y$ en la cajita que tenía debajo de las uñas 6 manos, sc dejaban ver una esportilla vacía, una copa de sombrero europeo, una piel de lobo $y$ un pedazo de tabla: la altura del mónstruo no era menor de diez piés y medio franceses: todo de madera de pino; los adornos de la caja eran de conchitas embutidas en la misma madera, $y$ su pintura de almagra, si se exceptúan los dientes, las uñas y la parte superior de la cabeza, que estaban pintados de blanco y negro: los dos dep6sitos laterales tenían en la caja superior dos canastos uno mayor que otro, bien trincados, cuyo contenido no nos fué fácil averiguar: la caja inferior cubierta con algunas tablas sueltas y' suelta ella misma en el suelo, contenía una esportilla con algunos huesos calcinados y divididos en partes muy chicas, de suerte que apenas podia distinguirse que eran partes del cráneo y las dọ primeras vértebras del cuello (2).

La cara del mónstruo miraba al Este; su nombre (según algunos naturales de la plebe que nos acompañaban) Iukitchetch; y los monumen. tos laterales, correspondientes á dos hijos del Ankau actual, según el mismo nos informó á nuestro regreso de esta excursión. Era aún más notable otro depósito, no distante de los ya des-

(1) Ya se ha indicado en el Diario con cuánta ener. gía se expresaba ei Ankau en describirnos las circunstancias de esta reyerta, en la cual estaban comprendidos al parecer, seis fusiles y un hombre a caballo: nosotros jamás pudimos hacernos cargo de estas circunstancias tan distantes de todo lo que estaba a nuestro alcance, pues ni estos naturales tenfan fusil al guestro alcance, pues ni estos naturales tenian fusil al. guno, ni a estas costas habla llegado has aqui hom.
bre alguno a caballo. La reyerta debió ser bien sanbre alguno

(2) Una de estas cajas con la esportilla y huesos, se remite al Real Gabinete. critos sino dos tiros de fusil; y aunque el objeto fuese cl mismo de abrigar una cajita interior y elevar otra a mucha distancia del suelo, sus adornos y pinturas más bien acabadas, los cabellos que colgaban en uno y otro extremo de los palos destinados á sostener la caja y la cúspide alta posterior puesta fi:bbablemente para recc:dar la memoria al pasajero de la persona cuyas cenizas alli estaban depositadas, todo daba á este sitio un resalte admirable que adquiría luego un nuevo grado de hermosura con los amenos con. tornos que le rodeaban. Algunos Oficiales de la Descunierta que visitaron este sitio aconipañados del mismo Ankau, pudieron averiguar que era el depósito de una mujer suya: D. Antonio Tova halló, por otra parte, en la Isla Pineda igual conjunto de monumentos, en la misma djrección y con el mismo mónstruo; lo que final. mente nos induciría á creer que cada descendencia ó familia forma su monumento particular, que compuesto de madera y descuidado después, es en pocos años víctima de las intemperies $y$ del tiempo.

No es, sin embargo, proporcionada á estos distintivos ni á la autoridad militar, la que tiene el Jefe en las acciones particulares y pacíficas: pudimos advertir bien esta mengua de auturidad, comparando las dos ocasiones militares en que le vimos, con las concurrencias diarias y comerciantes: cuando aún no habíamos fondeado en el puerto y las dos canoas de guerra salieron á nuestro encuentro, con mucha parte de los hombres útiles de la tríbu, el $A u k a u$, en una canoa cerrada, dirigía todos los movimientos con un tono decidido; había puesto en cada canoa un hijo suyo, y á bordo de la ATrevida, á donde subió, sus brdenes fueron ejecutadas: del mismo modo, al tiempo de aproximarse las canoas sospechosas del Este en la mañana del $10^{\circ}$ de Julio, solicitó inmediatamente nuestro auxilio, examinó prolijamente sus intenciones, y no omitib tomar entre los suyos todas aquellas precauciones que dictaba el temido trance de un ataque. Pero en la vida doméstica no era fácil advertir una diferencia proporcionada á las ocasiones militares: su familia trabajaba como las demás para su subsistencia y bienestar; no pocas veces el mismo Ankau bogaba solo en una canoita: en los cambios no se advertía menor cesión de un monopolio, aunque seguramente la codicia le dictase cuantas tretas eran posibles para el intento; sus providencias contra los robos no eran obedecidas (I), y en los preludios de las discordias nuestras del día 3 y del 5 , ni su presencia ni sus gritos pudieron contener los más osados;

(r) Tuvimos muchas sospechas no infundadas, de que el mismo Ankau protegiese estos desórdenes; pero seguramente su conducta fué siempre muy advertida, cors secuente y capaz de alucinar a cualquiera. 
sólo, si, sus consejos en la primera ocasión y su peligro en la segunda, fueron frenos más fuertes para retraerlos de las hostilidades que intenta. ban. Finalmente, en su misma persona y trajes, no se advertía otro distintivo que el de usar la piel de zorrillo, cuando los demás las usaban, $\delta$ de nutria, ó de lobo marino, 6 de oso.

Este último distintivo fué entre nosotros por algún tiempo un objeto de disputa, pero últimamente pareció decidirle la pregunta del Ankau, si D. Juan Vernaci era hermano mío, pues le veía con un sobretodo forrado con piel de guanaco y semejante al que yo llevaba.

Debió causarnos á la verdad mucha admira. ción el uso de las mujeres que nos of recieron con snsia desde el primer día; y el orígen de esta costumbre hubiera sido un objeto no indiferente para nuestras pesquisas, si la necesidad de rechazar al principio estos of recimientos importunos y peligrosos, y las diferentes atenciones que tuvimos después por una y otra parte no lo hu. bieran imposibilitado. Hasta aquí s6lo el Capitán Dixon había visitado este puerto, $\mathrm{y}$ aunque no quedase duda de haber su tripulación usado de las mujeres, un solo ejemplo no bastaba, sin embargo, para arraigar una costumbre, y mucho más una costumbre opuesta á otras diferentes muestras que notábamos, de un grado no indiferente de amor filial y conyugal en estas familias; finalmente, varias circunstancias parecieron concurrir para aclarar siquiera en parte este punto importante de sus costumbres. Las mujeres of recidas no eran más de tres ó cuatro, estaban juntas, con todo el semblante de la violencia y de la opresión; y casi toda la tríbu estaba igualmente interesada en of recerlas y en proporcionar su uso sin el menor rebozo ó decencia. Esto hizo sospechar desde luego que serían esclavas pertenecientes á otra' tríbu, y confirmaron después esta sospecha no sólo la positiva existencia entre ellos de un hombre esclavo (I), si también el que no se renovasen estos ofrecimientos en las diferentes rancherías que visitamos después (2) y particularmente en la bastante numerosa de la entrada del puerto del Desengaño: serían sin duda también esclavas las que nos of recía el habitante de las faldas del Monte de San Elías, y probablemente será fácil encontrarlas en casi todas estas tríbus costaneras, como fruto de unas invasiones destructivas que multiplicarán con este nuevo motivo.

En el estado aún informe de esta pequeña

(I) El misı zo Ankau me nanifestó este prisionero, indicándome etí de la misma tríbu, cuyas canoas se aproximaban el dfa 1. con ideas hostiles.

(2) Apoya ahora este concepto, la venta de una mujer de otra tribu hecha en el Sung Corner al Capitán Meares por los habitantes de aquellos contornos, los cuales jamás franquearon las mujeres propias. sociedad y mucho más en el estado informe de sus costumbres y poderío, no debieron causarnos igual grado de admiración, ni la facilidad con que una madre se determinó á vender un niño suyo de pecho, ni la oposición que tenían los más adultos á separarse de los suyos; ni finalmente, el deseo que manifestaron de recobrar y apropiarse uno á otro marinero ó criado filipino, que por la desemejanza del rostro con los demás, creían robado á alguna otra tribu y reconocían con suma curiosidad y concurrencia. La cesión de una niña no es extraña en un país en donde el criarla acarrea á la madre no sólo inmensos cuidados y fatigas, si también una larga privación de los placeres conyugales (r), en donde el corto número de gentes aptas á las fatigas de la giverra y de la pesca, da al hombre un grado de utilidad y de valor infinitamente mayor que á la otra mitad de nuestra especie, en donde en fin, esta mi sma mitad desproveída de todo medio de adquirir lo necesario, no está, sin embargo, des. poseída de un cierto antojo y volubilidad á fa. vor de los adornos y de lo que ve: tampoco es extraña la oposición de los adultos á separarse de los suyos; la debilidad engendra el patriotismo y el suceso le conserva: así estos jóvenes embebidos desde sus años tiernos de la necesidad en que está la patria de su brazo y de sus auxilios, jamás proponían otra especie de cam. bios para esta emigración, sino la de un hombre nuestro agregado á la tríbu, mientras ellos estuviesen ausentes; y esta misma razón hacía final. mente que sus ansias mayores, sus diligencias en toda discordia, siempre se dirigiesen á la ad. quisición de un hombre nuestro, así como la po. sesión de uno suyo contenía inmediatamente todos los excesos de su furor bárbaro.

En verdad que considerando cuánto desmerece el valor particular de nuestra especie, cuando con la multiplicación de las fuerzas y del pode. río natural, la emulación y el lujo elevan sus aras para que se les inmolen crecidas víctimas, no podemos dejar de envidjar este rudo estado de las naciones, en el cual la misma falta de propiedad hace que el hombre trabaje para todos y sea útil á todos. ¡Cuánto más agradable pare-' cerá aún este estado, cuando revivamos á la memoria del filósofo, 6 bien la unanimidad de todos los de esta tríbu en sus cambios, á pesar que los efectos explayados casi instantáneamente á su vista reuniesen todas las conveniencias de la novedad, de la utilidad y del lujo, 6 bien la quietud y buena harmonía que se advertian en todos sus pasos y en el trabajo asíduo é interior de las familias!

Era efectivamente un contraste nada hono-

(1) Este tiltimo punto se tratará con mayor individualidad hablando do los habitantes de Nutka. 
rifico para las costumbres europeas advertir de su parte, no sólo el regocijo general de un con. trato favorable que hubiera hecho cualquiera individuo, si también la legalización y garantía que todos los demás parecian prestarle con un grito acorde y majestuoso de wó, cuando por la nuestra se velan frecuentemente dos 6 tres ansiosos por la misma prenda, y á vecess procurando adquirir. la con diferentes propuestas al mismo tiempo $y$ $\sin$ reciproco conocimiento 6 unanimidad (1).

Concurrieron muy luégo al mercado todas las clases de manufacturas que hasta aqui habia dictado á estos naturales, 6 la necesidad 6 la pers. picacia: no es dificil acertar en que todas ellas debían precisamente referirse á utensilios de pesca, á los domésticos, á las armas, y linalmente, á uno ú otro tejido (2); son aquéllos realmente in. geniosos para toda especie de pesca, inclusos los cetáccos; los segundos comprenden varios muñccos, algunas cucharas y cajitas de madera, los palillos del juego, los canastos impenetrables, para la cocina, y algunas hachas y martillos de piedra muy bien contrapesados; las armas se reducen al arco, la flecha, el punal y una especie de vestido militar de madera; finalmente, en los tejidos merece una singular atención la manta formada de la corteza del pino, hilada y tejida, á la cual está embutido por una parte con buena simetría el pelo de la piel de nutria: fuera largo, tal vez inútil y seguramente cansado, añadir aquí una extensa descripción de cada una de es. tas manufacturas: la omitiremos, por consig tiente, contentándonos con indicar, que desde el momento en que los naturales advirtieron un deseo de estas cosas de parte de la Oficialidad, y á su imitación de parte de varios de las clases subalternas, no cesaron de ocuparse hombres y mujeres en su apresto y sucesiva conducción al mercado, lo que afianza la natural actividad y penetración de esta tríbu, cuando no bastasen á acreditarla, asi el modo ya descrito en el Diario con que hacen por lo común sus negociaciones, como la excesiva preferencia que en nuestros cambios dieron siempre á la ropa de abrigo, comparada á cualesquiera otras cosas de adorno y áun al mismo hierro: las hachas, entre los utensilios nuestros de este metal, fueron la única cosa que apetecían con ansia, y si no desdeñaron conservar hasta lo último el nivel convenido de un clavo por un salmón, yo creo que debió más bien atribuirse á la abundancia de éste, que al aprecio de aquél, tanto más, que al principio respondió el

(1) Este párrafo, como lo demuestra el Diario cxtensamente, debe entenderse sólo de las clases inferiores de ambas corbetas, a las cuales se permitió la libre adquisicion de todo lo que presentasen los na. turales en el mercado.

(2) Se remite una colección completa de estas ma. nufacturas al Real Gabinete. hijo mayor del Ankau á esta propuesta, con aga. trar un punado de clavos y tirarlos al suelo.

Concluiremos ya la descripción de lo que he. mos advertido en el puerto Mulgrave, con algunas reflexiones sobre su religión y ritos, cuyas ideas, si bien limitadas, podrán, sin embargo, servir de comparación y'de cimiento á los raciocinios que se hayan hecho anteriormente ó se hagan después.

Que un pueblo que á imitación de los orientales agrega la mayor solemnidad así en sus mociones como en sus cantos harmoniosos á toda acción pública y sociable; que aproximán.lose á los parajes en donde hay cadáveres, manifiesta una repugnancia tímida y supesticiosa (I), depende, sin embargo, de la idea de una no total aniquilación del hombre; que finalmente quema sus cadáveres delante de una especie de fdolo y conserva una sola paite escogida de la injuria de los tiempos, presentando todos estos monumen. tos hacia el Oriente; que este pueblo, digo, ca. rezca de todo principio religioso, es difícil á la verdad combinarlo con la historia de la especie humana: pero al mismo tiempo no podemos determinar cuáles sean en esta religión, 6 bién el Dios, el sacerdote y la ofrenda, ó bien las leyes que dimanen de la interpretación de sus efectos benévolos ó injuriosos. Nos lison jeábamos que el uso de nuestros instrumentos astronómicos, dirigidos hacia el Sol, nos descifrasen en esta parte una ú otra verdad: les procuramos efectivamente agregar la idea de un culto religioso: todo fue en vano, $y$ enterados con anterioridad por el Capitán Dixon del uso de los anteojos, asemejaron una idea á la otra y áun los impulsos de su curiosidad fueron bien moderados. Advertiamos 'á la verdad en todas las tardes y próximamente al ponerse el Sol, que el Ankun, paseando solo en la playa inmediata á las chozas, arengaba por algún rato con mucha solemnidad; pero nunca pudimos inferir si esta arenga se dirigía á los suyos para que vigilasen sobre su conservación, ó al Supremo Hacedor para que los conservase: tampoco pudimos confirmar nuestras sospechas sobre el empleo en la tríbu de un hombre ancia. no, el cual aparecía pocas veces, tenía un semblante respetable, y en la mañana del $\mathrm{r}^{\circ}$ de Julio, al aproximarse las canoas sospechosas, dividía con el Ankau el cargo de los cuidados de las providencias oportunas. Este anciano, preguntado por mí sobre el objeto de un pequeño cerco formado con piedras, á cuyo lado pasamos, me respondió que en el entraban á jugar sólo los niños suyos y del Ankau, logrando así estar sepa. rados de los demás de la plebe.

(1) Se advirtió este temor por los STes. Tova, Bausa, Espinosa, y por $\mathrm{m}$ ! mismo en las diferentes ocasiones en que hemos visitado estos monumentos. 
a, con aga.

I suelo.

e lo que hc.

con algu.

itos, cuyas

embargo,

á los racio.

mente $\delta$ se

los orien.

en sus mo.

osos á toda

ximán!lose á

, manifiesta

osa (I), de.

una no total

ente quema

e de Idolo y

la injuria de

monumen.

, digo, ca.

difícil á la

le la especie

bodemos de-

on, ó bién el

ien las leyes

e sus efectos

bamos que el

hómicos, diri.

en esta parte

fectivamente

o: todo fué en

por el Capi-

, asemejaron

os de su cu.

dvertíamos 'á

ximamente al

ando solo en

arengaba por

; pero nunce dirigía á los conservación,

s conservase: .

as sospechas ombre ancianía un semdel $r 0^{\circ}$ de Ju echosas, divi. idados de las no, preguntaequeño cerco pasamos, me ar sólo los niii estar sepa.
Finalmente, advirtió D. leelipe Bausá al tiempo que le acompañaba un naturnl en sus excursiones hidrográficas, que este, levantando los ojos al cielo, empezo á entones un canto lamen. toso y patético, al cual acompanabn la unión fervorosa de las manos, $y$ aún instaba á que él mismo uniese su voz; pero la falta del idioma no le permitió aclarar estas ideas primitivas y sólo sí pudo inferir que no érn al Sol á quien se dirigian sus preces.

Después de todas las observaciones que acabamos de referir, no parezca en nosotros inoportuno 6 aventurado asegurar que estos naturales tienen algunos principios de religión referidos particularmente á la vida venidera; que admiten la poligamia, escuchando sin einbargo las leyes melodiosas de la Naturaleza relativamente al respeto $y$ cuidado paterno $y$ al amor conyugal y filial ( $x$ ); que son bastante industrio. sos y aumamente advertidos; que dejan traslucir en sus costumbres algunos rastros de la solem. nidad oriental; que poseen el valor ó más bien la fiereza, en el grado á que suele llevarlos en un corazón bien dispuesto, el uo temido conoci. miento de la propia debilidad; finalmente, que ligados á su propia tríbu con los vínculos estre. chos del patriotismo, raras veces enturbian la paz interna y se destruyen mútuamente, tanto más, que las ideas de la propiedad, de la distinción de clases y de la abstinencia del trabajo, no han echado aún entre ellos sus raices harto temibles y extensivas: sus cantos y su idioma corresponden bien á estas cualidades: á los himnos realmente harmoniosos de paz, guerra, regocijo y devoción, es regular que reunan los de sus pompas fúnebres que corresponderán $\sin$ duda á los monumentos con que intentan eterni. zar su memoria: y en el idioma ya adoptado por los Jefes para persuadir á sus súbditos lo que les convenga, pueden advertirse fácilmente no solu la harmonía y volubilidad oratorias acompaña. das del gesto sumamente expresivo, si también la facilidad de adaptarle á las ideas nuevas que van adquiriendo con el roce de los europeos. $\mathrm{Ni}$ su inclinacion al robo se explayb con aquella vehemencia que se ha advertido en otros puertos $y$ en otros buques: nunca comprometieron su propia seguridad, nunca parecieron reunidos en proyectos de esta especie; y el Ankalı siempre pareció dispuesto á contenerlos 6 á recobrar las prendas robadas: sin embargo, era esta la se. gunda visita de buques europeos, y seguramente no era el hierro un género escaso en ambos buques para que no meditasen alguna tentativa ó en las mesas de guarnición 6 en los candele. ros, cosas todas que tenían continuamente á la

(1) Puede verse en nuestro. Diario lo acaecido en diferentes ocasiones. vista ( 1 ), y cuyo robo podia tal vez alentar nuestra conducta sumamente paclifica.

Iin la formación del corto Diccionario que aqui se agrega, no nos hemos tampoco apartado del método lento y reflexivo que nos habiamos propuesto: muchos Oticiales han formado por si un Diccionario separado, y confrontados éstos no se ha admitido voz alguna, In cual no tu. viese la sanción general ó no descubriese de donde dimanaba una ú otra contradicción.

Vocabulario del idioma Mulgrat's.

$\mathbf{A}$

\begin{tabular}{|c|c|}
\hline KSPANO & Mter, \\
\hline Abrazar.............. & Kinashakı \\
\hline Afirmación. ................ & Aá o Aáu. \\
\hline Agua: genćricamente........ & Ku o Hiu. \\
\hline Agua de lluvia ó quizá la acción & \\
\hline 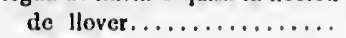 & Hin o $\mathrm{Yi}$ \\
\hline dma de leche............. & Kutlí. \\
\hline 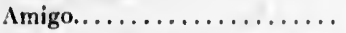 & Kokán. \\
\hline $\begin{array}{l}\text { Apio silvestre o yerba en gene- } \\
\quad \text { ral. } \ldots \ldots \ldots \ldots \ldots \ldots \ldots \ldots\end{array}$ & Kegany. \\
\hline Arrodillarse....... & Munmuk. \\
\hline Atado del pelo............. & Kechiny. \\
\hline 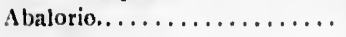 & Kukuet. \\
\hline
\end{tabular}

$\mathbf{B}$

\begin{tabular}{|c|c|}
\hline Barba.................. & Kakaki. \\
\hline 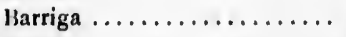 & Kayú. \\
\hline Beber............... & Huitennat/. \\
\hline 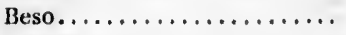 & Fklá. \\
\hline 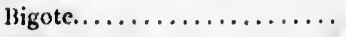 & Kagdatai. \\
\hline 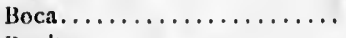 & Kategl. \\
\hline Bonito ${ }^{\prime} . \ldots \ldots \ldots \ldots \ldots \ldots$ & Kanaktuni \\
\hline
\end{tabular}

\section{C}

Cabellos.................. Schejau.

Cabeza................. Kashakuy.

Calzones................ Keguen.

Cambiar................ Kutzek.

Canalete.............. Agjá.

Canastillo................ Kashe.

Canoa grande de madera y casa

de lo mismo............... Yauk.

Canoa de cuero............. Chokuti.

Casa fïncbre 0 cementerio.... J Jitá.

Capitán 0 Jefe............ Ankau 0 Ancao.

Cara................... Kaagá.

Carrillos.............. Kaaguish.

Ceja................... Kakag.

Chaquetn. ............... Cutetz.

Choza................ Hijt.

(1) Lo que en nuestros buques que han frecuentado estas costas ha sido algunas veces efecto de una excesiva aunque prudento tolerancia, puede creerse que en los buques ingleses ha derivado del uso de las mujeres; franqueado con demasiada facilidad a la marinería. 
VIAJR ALKEDLDOK DEL MUNDO

\begin{tabular}{|c|c|}
\hline MAPANกt. & MUL.URAVY. \\
\hline $\begin{array}{l}\text { Cilindros curros de hueso y co. } \\
\text { bre que pasan por la ternilla } \\
\text { de la nariz............... }\end{array}$ & Zuot o Kakletu. \\
\hline Ciolo....................... & Kilchao Kurukthiz \\
\hline Comer.................... & Atimuthy. \\
\hline Costillas.................. & Katzukt. \\
\hline Cortar..................... & Yguashech. \\
\hline 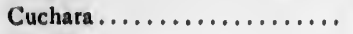 & Shetfl. \\
\hline Cuchillo................... & Cotzla. \\
\hline Cuello,.................... & Kashle. \\
\hline Cuorpo,................ & Kagkituén. \\
\hline
\end{tabular}

\section{D}

Dar la mano............. Yshán.

Dedo pulgar................ Kakutz.

Dedos: genericamente........ Katlex.

Delinear $\delta$ pintar............ Kshekit.

Dientes.................. Kauls.

Dormir................. Kantitlix.

\section{B}

Fcharse en tierra............ Tat ó Yad.

Efectos de cambio............ Kanaktunitz.

Escopeta............... Uni.a.

Especio de cuna on que ponen

los niños............... Tutu-Utú.

Estomago............... Kutexk.

Enemigo................ Kutef o Kutek.

\section{$\mathbf{F}$}

Figura humana colosal de ma dera que ponon sobro un palo en las inmediaciones de sus sepulcros, ya represente persona of idolo.............. Flechas.................. Kak

Flor................... Kentok.

Frerte................... Kakak.

Fresas.................. Shuk o Shok.

Frro...................... Shaa o Atzevet.

Fuego.................. Kaniketek.

Gorro o sombrero.......... Zauk o Zakuk.

\section{$\mathbf{H}$}

Hacha o la acción de cortar con

olla................. Taguitz.

Herir.................... Iguakhak.

Hombre............... Juazitim.

Hombro .................. Kafik.

$\boldsymbol{J}$

Juego de los palillos. Esllehká.

工

Lengua

Kakshlut.

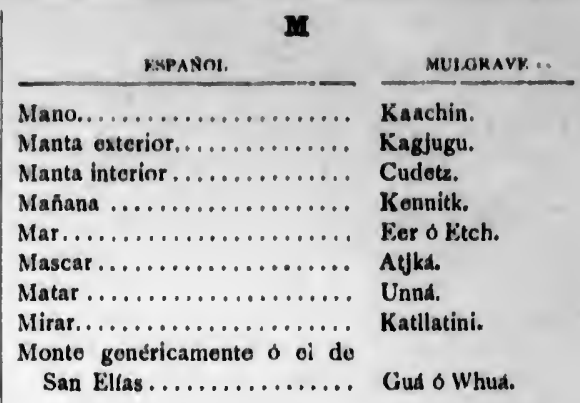

N

Nada................... Flext

Navaja.................. Zutla

Nariz................. Kaashluu.

Niño, o hijo............... Zannaguoti.

Nieve................ Shas.

No: negación.............. Gannukut.

Nombre de cacique........... Junuelo.

Idem del enterrado $y$ inuerto se-

gún parece en la refriega.... Kataukú.

Idem de la nación ó trobu..... Tejunues.

Idem $\mathbf{a}$ un indio de la plebe.... Cheutukú.

Nutria o su piel............. Yuks.

Nubes.................. Aligatchin.

0

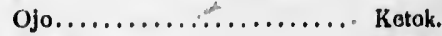

Ojos.................... Kaavak.

Orejas................... Kaakux.

Oso.................. Huteh.

$\mathbf{P}$

Palma de la mano........... Katchintak.

Pocho..................... Kasellka.

Pelo: genéricamente........ Jitil.

Palo de la barba............ Kakanatsane

Perro................... Teitil.

Pestan̂a ................ Kaguakjekt.

Pié.................... Kagkutz.

Piel: genéricamente.......... Skutl.

Piel de zorrillo.............. Kakou.

Piornas.................. Katzoyủ.

\section{$\mathbf{R}$}

Rorlivis............... Kakxi.

Roncar................ Ackitz

Ropa................... Kuteutz.

Revolución diaria del Sol...... Titz.

\section{$\mathbf{8}$}

Salmon............... Jhot.

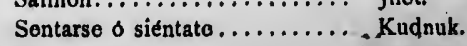

St.................... Shek Shaam o a..

Siéntate................ Kannit.

Sol.................... Akán ó Kokán.

Sombrero................. Zakuk. 
$\mathbf{T}$ KSPAROL. MURGRAVE

Tetas................... Kazld.

Tejer un sombrero............ Ayak Kakeite.

Tierra.................. Tlow.

Todo junto.............. I'otatokko.

\section{U}

Una.................... Kagkjak.

$\mathbf{V}$

Von acd............... Jakut.
Vestido............... Kudetz.
Veto................. Yutch o Yutej.

$\mathbf{z}$

Zarcillos................ Jkenot y Cunaja.

Numerales.

Uno................... Thex 6 Tlej.

Dos................... Teje.

Tres................... Nutzk.

Cuatro................. Taajún.

Cinco ................ Kuhin.

Seis.................... Kletushu.

Ocho................. Nutzkatushu.

Nueve.................. Kutshako.

Diez.................... Chinkat.

Once.................... Chinkat-tlex.

Doce................... Chinkat-tejé

Veinte................. Tlekt.

Vointiuso............... Tleka-tlex.

Veintidos............... Tleka-teje.

Treinta................. Tleka-chinkat.

Treinta y uno.............. Tleka-chinkat-tlex.

Treinta y dos.............. Tleka-chinkat-tejé.

Cuarenta................ Tejka.

Cincuenta............... Tejka-chinkat.

Sesenta.................. Nuzkeka.

Setenta............... Nuzkeka-chinkat.

Ochenta............... Tajutiat.

Noventa .............. Tajutiat-chinkat.

Ciento................ Kechin Kaa.

Ciento veinte............. Kletushú-kaa.

Aunque nuestra indagación no pasb de este último número, parece que síguiendo el mismo orden pueden contar crecidas cantidades.

Por no haber sonido equivalente en castellano, hemos adaptado el sh del inglés y se hace uso de el en las voces que exigen el sonido que se le da en este idioma.

La pronunciación de la $h$ es micho más fuerte $y$ gutural que la nuestra aspirada.

La $k$ se ha admitido en las voces que piden una pronunciación más cargada que la de nuestra $c$, apoyando fuertemente la lengua al paladar al modo de los tartamudos.

El tiempo no permite comparar ahora este á los dialectos de Nutka:y el Príncipe Guillermo.
Pero es ticmpo de volver al hilo primitivo $\mathcal{C}_{\text {. }}$ nuestros reconocimientos y emprender el examen del segundo trozo de costa: es este, como yn se dijo al principio, un Archipiélago inmenso, que corre desde los $5^{8}$ escasos, pasada la entrada de la Cruz hasta los $48^{\circ}$ en la entrada de liuca, ex. tendiéndose considerablemente al Este, particu. larmente por el Archipiélago de la Princesa Real entre los 54 y $53^{\circ}$, y presentando á la navegactón europea un nuevo campo inagotable, bien para los proyectos comerciantes 6 para los sistemas hidrográficos: dejaremos por ahora examinar hasta dónde la imaginación 6 los objetos políticos han desfigurado la realidad en ambos puntos, y nos contentaremos con una atención prolija á las cualidades del suelo y de sus moradores.

Sea cualquiera el origen de esta extraordina ria intensión de las aguas, dependa 6 no de una de aquellas grandes revoluciones del globo que apenas alcanza la sublime imaginación del hombre, no cabe duda á lo ménos que la clase del suelo es una misma $y$ bien semejantes entre si sus productos, si se atiende tan sólo á la pequeña diferencia derivada del diferente grado de la. titud: nuestras vistas ( $\mathrm{I}$ ) desde luégo manifesta. rán al examen del físico una estructura singular de costa desde la Ensenada de la Cruz hasta el Cabo San Agustin; pudieran seguirle luego las po. cas de los Capitanes Dixon y Meares para la parte que no hemos reconocido desde los 55 hasta los 50, y últimamente reunirles las que ahora hemos trazado de las tierras avistadas desde el Cabo Frondoso hasta la entrada de Fuca: todas concurren á demostrar, que bien sea al andar de la costa 6 en el Archipiélago separado de la Reina Carlota, la composicion de estas islas es de la misma naturaleza que adveitimos en Nutka; esto es, una piedra gra'itosa, granulosa, varia en el color ya más osc"ro y gris 6 ya más blanco y compuesta de cuarzo, feldespato y cristalizaciones pequeñas y reunidas. Bien sea por efecto de las lluvias, del corto tiempo de esta revolución 6 de la misma corta extensión de muchas islas, ello es generalmente que la capa de tierra vegetal es bien corta á pesar que la formen al mismo tiempo al. gunas sustancias calcáreas ó fragmentos de las conchas, y la natural descomposición anual de las plantas que la fecundiza y negrea con mil especies de miriades pútridas: el pinabete (pinus abies) parece sin duda el árbol preferente y más honogéneo á este suelo: se le encuentra con exceso lozanu en los puertos de los Remedios, Gua dalupe y Bucareli; por los Sres. Cuadra y Arteaga en el puerto Banks; en las Islas de la Reina Carlota por el Capitán Dixon, y en las inmedia. ciones de Nutka hacia el Norte y al Sur, por los

(1) Don Felipe Bausá las ha representado con su exactitud acostumbrada. 
muchos que han visitado aquellas costas; y es tanto más admirable la lozaní de este árbol, cuanto que no pudiendo penetrar sus raíces sino á una corta profundidad por efecto de la piedra inferior, ni le suministran todo el jugo nutritivo que fuera necesario, ni áun pueden conservarle firme por largo tiempo, desplomándose por consiguiente con mucha facilidad y frecuencia.

No siempre las partes mas salientes de la costa se compnnen en este dilatado Archipiélago de islotillos frondosos y destacados, como al Sur de la entrada de la Cruz, al Norte de la de Fuca y probablemente en los canales de la Princesa Real: otras veces corno al pié del monte Saı Jacinto, en la entrada de Bucareli y en los extremos de las Islas de la Reina Carlota, se elevan descle la misma orilla algunos montes, los cuales, si bien sean también parte de oiras islas y no carczcan de una frondosidad lozana, deben, $\sin$ em. bargo, causar un mayor grado de frío, así por su natural posición en paralelos más altos, cono por la duración del hielo que ha de dilatar con su misma elevación.

In los parajes en los cuales no se presentan inmediatamente á la orilla los unontes altos, no dejan de descubrirse interiormente á muy poca distancia las serianías, aunque no tan elevadas como en la costa que acabamos de describir: son estas serranías entrecortadas, puntiagudas en muclias partes, con el aspecto natural de volcanes $y$ á veces divididas en dos $y$ tres hileras, $y$ por lo comun (á lo ménos en el mes de Agosto) ya libres enteramente del hielo, si se exceptía un ú otra cañada en la cual no impidan su liquidacion, o la poca concurrencia de los rayos dei Sol, ó la misma disposición de las peñas á lás cuales esté asido el trozo de hielo: consaltando los Diarios de las navegaciones hastit aquí conocidas, algunas propiedades sirgulares de esta costa pueden desde iuego sentarse como seguras, y son: primera, ia existencia casi constante d las neblinas más espesas y más frecuentes que en el primer trozo descrito; neblinas que, ó bien sea la mengua del frío ó la multiplicación de las aguas internas, á medida que va disminuyéndose la latitud van condensándose más y $\mathrm{m}^{\prime}$ 's y haciendo al mismo tiempo más tranquilo el mar y más incierta la navegación: segunda, la alternativa, ó de los vientos del Noroeste al Oes. te 6 de los del Sueste y Sursueste; aquéllos claros, manejables y no frecuentes; éstos, nebli. nosos, incómodos y acompañados unas veces de calma, particularmente en el rerano, otras veces con temporales fuertes, lo que sucede por lo conún en el invierno.

La demasiada interr.joción de estos terrenos, ó aislados ó rápidamente montuosos, deberá también arrastrar otro inconveniente de mucha inonta, y este es ia falta de terrenos llanos y algo sçuidos para el beneficio de las semillas, que tanto importa á la multiplicaciós de nuestra es. pecie. Deberán, por consiguiente, sus moradores dedicarse precisamente á la pesca; deberá ésta suministrarles el único, ó á lo ménos, el principal sustento; $y$ así podrá asegurarse de antemano que no son estas costas, ni estns paralelos de continente de la América, los que hayan algún día de ser el dulce asilo de una crecida socieciad civilizada (I).

La Naturaleza sin embargo no ha desmentido aquí la grande harmonía que se admira en todas sus obras, y ya que el mar era un tropiezo continuo para la subsistencia del hombre, r. su seno mismo ha querido que se satisfacieren al mismo tiempo las dos necesidades esenciales del alimento $y$ del abrigo: ni el pescador pudiera á la verdad extender sus deseos á otra situación que la que présenta este Archipiélago. La corta an. cloura de los canales no expone á un naufragio sus débiles canoas y permite la pesca en todo el año: la multiplicidad de las costŕs aumenta la cría y concurrencia de los peces: es cómodo el traspaso de sus casas de una á otra parte, con el ingenioso ardid de amadrinar dos canc 3 que sufran juntas el peso y el tamaño de la tablaxón se consigue variar con facilidad de morada según las diferentes estaciones; el lobn y la nutria suministran ampliamente para sus vestidos y para un comercio activo; las orillas inmediatas proveen con abundancia, ó bien las plantas antisépticas que le 3 liberten del escorbuto 6 los ár. poles corpulentos de donde saquen canoas y utensilios para la pesca; finalmente, la misma extensión de la costa favorece admirablemente la reproducción de la especie, en cuanto puedan alcanzarla unas tribus pescadoras y por consi guiente desparramadas.

Hemos indicado al principio de este capítulo que mirábanos como una verdad casi incontes table ser del mismo origen y calidad los pueblos habitadores de este Archipiélago y los que se han descrito del Príncipe Guillermo y puerto Mulgrave: jasta“ía lecorrer la narración de los diferentes viajes emprendidos hasta aquí para admitir esta asercion; $y$ particularınente la des. cripción del Capitán Dixon de los habitantes de las Islas de la Reina Carlota (2), y los reparos del Capitán Meares al tiempo de visitar sus cos tas de $\operatorname{los} 56^{\circ} 28^{\prime}$. Pero estas reflexiones están pu. blicas y sería importuno repetirlas. Nos ceñire mos, por consiguiente, á aquellas otras que de

(I) Seguramento en una época cn la cual la sed de lo que esconde la tierra va cediendo al deseo de lo que produce su superficie, ó exp nntineainente ayudada de la mano benéfra del hoi bre, debe pare cer muy distante la realización de la conjeturas de (2) Traducción francesa de este vi le, carta 37 , pagina $55^{8}$, tomo II 
las semillas, que iósi de nuestra es ite, sus moradores pesca; deberá ésta ménos, el princiurarse de antema. estns paralelos del que hayan algún a crecida sociedad

no ha desmentido se admira en todas a un tropiezo conhombre, r. su seno faciercen al mismo esenciales del alicador pudiera á la otra situación que lago. La corta anne á un naufragio la pesca en todo el costr.s aumenta la eces: es cómodo el i otra parte, con el dos canc 3 que suiño de la tablazón; dad de morada se;; el lobn y la nupara sus vestidos $s$ orillas inmediatas en las plantas antiescorbuto 6 los ár. saquen canoas $y$ almente, la misma ce admirablemente , en cuanto puedan doras y por consi.

io de este capítuio, rdad casi incontes. y calidad los puehipiślago y los que Guillermo y puerto a narración de los is hasta aquí para cularinente la deslos habitantes de (2), y los reparos de visitar sus coseflexiones están pu. tirlas. Nos ceñireellas otras que de.

ica en la cual la sed ediendo al deseo de exp ontineamente 6 I hol bre, debe pare. de la conjeturas de mont ras brillantes. este vi. Je, carta 37, pendiendo de los viajes nacionales, aún no han visto la luz pública.

Desde luego D. Juan de la Cuadrc, en el puerto de los Remedios, advierte no sólo los adornos del septum y de las orejas muy semejantes á los del Príncipe Guillermo, si también el labio inferior cortado y la misma especie de armas: en el puerto Bucareli, D. Francisco Maurelle halla los mismos monumentos fúnebres, armas, trajes, fiereza, deseos de la adquisición de nuevos hom. bres, inclinación al robo y sobre todo el mismo ador:zo en las mujeres, del palo ó roldana elipti. ca colocada en el labio inferior ( $\mathrm{r}$ ); finalmente, los habitantes de Nutka enterándonos de las tríbus limítrofes de los Nuchimases (2) hacia el Norte, las caracterizan crnstantemente por las del labio cortado, recon scen luégo sus trajes, armas y cantos, confiese.n su genio belicoso, y áun en sus costumbres manifiestan aquella uniformidad que es inseparable del roce con otra nación. Con estos datos ya la aserción indicada no debe ponerse en duda, y podemos asegurar que á lo ménos las orillas del mar, desde la ría de Cook hasta el paralelo de $52^{\circ}$, están habitadas por una clase de hombies cuyo origen, costumbres y estado de civilización es uno mismo proximamente.

No así con las nacicınes más meridionales, inclusa la confederación de Nutka, en la cual, si bien traslucen varias características de los pueblos septentrionales, se halla sin embargo, en un grado más provecto de civilización, que ó bien sea efecto de un clima más templado, de unos vecinos más cumerciantes y apacibles, ó finalmente, de cn roce más repsilido y duradero con los europeos, no puede ocultarse al que mira con alguna prolijidad sus costumbres: evitaremos ya el hablar de las disposiciones materiales de estos moradores, que los Sres. Cook y Anderson describieron con tanta exactitud y verdad: son mé. nos corpulentos que los que habitan más al Norte; su pié es desproporcionadamente chico, su carácter belicoso y más bien fiero; finalmente, sus leyes sociales y particusarmente la subordinación más bien establecidas.

No eran sino muy limitados nuestros conocimientos en esta parte, y anenas hubieran podido pretender al sacrifici, de pocos momentos en su lectura, cuandr en los últimos días de la demora de las coricitas en el puerto, tuvimos la felicidad de coíiocer á los dos hermanos Nanikius y Nat. zapi, cuřados de Macuina, y el segundo última. mente viudo de la hija del Jefe Nuchimás, y por consiguiente admitido en're aquellos pueblos á la

(1) Los Diarios originales de uno y otro viaje, están en nuestro poder y sa han consultado.

(a) So hablará muy luego extensamente de esta nacion importante. clase de Tahi 6 Primate: entrambos son jóvenes, y Nanikius no tcndrá más edad de diez y seis á diez y ocho años: en sus ojos, en su porte, en la inclinación al roce con los europeos, y en la facilidad de entender y hacerse entender estos dos hermanos, dejan traslucir una tal perspicacia, un carácter tan humaro y una docilidad tan pronta á las ideas nuevas, que seguramente pudieran considerarse con facilidad, como los reformadol'es de estas naciones si los europeos coadyuvasen i esta útil reformi.

El acaso como en otras muchas or siones, dió lugar á que Nanikius, á bordo de la ATreviDA, desplegase los primeros rastros de su perspicacia: tenía inmediatos papel, pluma y tintero, al tiempo que le daban una taza de té (I): em pezó á señalar con algunas rayas la posición interna de algunos canales, y como ya supiésemos por los de nuestra colonia la segura existencia de las lagunas de los Nuchimases, la curiosidad de parte de los Oticiales y el natural deseo de producirse en Nanikius, muy luego dieron á la conversación un mayor grado de interés: el joven explicó distintamente esta parte importante de la Geografía; y como en esto manifestase á cada paso nuevos grados considerables de inteligencia, D. José Bustamante nte lo advirtió; y ya ni en una ni en otra corbeta nos descuidamos en aprovechar todas las ocasiones de atraerle y pregun tarle; concurriendo últimamente el mismo Nat zapi para confirmar separadamente las ideas que habíamos bebido de su hermano. Si no fuese al mismo tiempo impertinente y difuso manifes tar los medios 6 rodeos por los cuales alcanza. mos la inteligencia recíproca de las ideas siguientes, no titubeariamos en producirlas, tanto más que de ellas refluiría un debido elogio á aquellos Oficaịes que más se esmeraron en estas pesquisas: puede sin embargo, estar seguro el que recorra estas hojas, que ni nos hemos des. cuidado en tisponer las preguntas de modo que no alucinasen $a ́$ los dos hermanos, ni en recibir y confrontar las respuestas para que nos ipartasen de toda idea us sistema; y que as ienemos la agradable confianza de que no se confundan nuestros progresns científicos en estas indagacio. nes con las comunes de los viajeros, que preficren á la verdad el deseo de agradar.

I a confederación de Nutka, no excede el númєro de 4.000 individuos, según pudieron infe rir después de un examen prolijo los Tenientes de navío Espinosa y Cevallos, habiendo recorrido con las lanchas todos los canales internos; no se extiende su teritorio más allá del terreno reco. norido por los mismos Oticiales; y son sus limí

(I) El uso de toma: té está bastante introducido entre estos Jefes; los Capitanes Colnet y Kendrik, han
contribuldo mucho \& ello: no gustan tanto del vino, contribuido mucho a ello: no gustail tanto 
trofes hacia la punta rompiente, los pueblos Izcuates, dependientes probablemente a: Wicananish (I); otras tríbus hacia el Nore ste ó el Cabo Frondoso, cuyas circunstancias no nos fué fácil acertar, y finalmente, á la espalo.? los Nuchimases, cuyo número y poderío pare cen muy superiores á los de Nutka: esta voz no denota sino Archipiélago en general; es probable, sin embargo, que de ella deriven su nom. bre estas tríbus confederadas, pues jamás le oimos otro alguno hablando de sí mismos.

Reconocen todos un mismo Jefe, cuyos privilegios son grandes; le son inferiores ó subordiwados los Jefes de los otros distritos ó rinconadas (2), los cuales, sin embargo, tienen un número determinado de súbditos que les obedecen en las operaciones particulares de la sociedad, debiendo sólo reunirse para la causa común de la defensa 6 del ataque de sus enemigos: estos Jefes subalternos, bien sea casualidad, constitución ó politica derivada tal vez de unas gucrras anteriores y sangrientas, están enlazados entre si por medio de los matrimonios, $y$ es probable que bien decidida la autoridad suprema, sirva esta reunión para conservar el buen órden y no multiplicar con nuevas incorporaciones el número de los primates: la autoridad suprema reside en poder de Macuina (3), el cual, por su parte, preside á las rancherías del fondo de la Tasis y á las que están esparcidas en la isla grande, que comprende el puerto de Yucuat (4): son tres los Jefes subalternos, Natzapi, Tlupananulk y $\mathrm{Ca}$ lacan; bien que muerto éste último por el Piloto Comandante de la fragata Princesa (5) al tiempo de establecerse en Nutka, no sabemos en quièn ha recaído esta parte de dominio que Tlupa. nanulk apellidó todavía con el nombre de $\mathrm{Ca}$. lacan.

Estis familias forman la clase de los Tahis 6 Grandes, destinada á gobernar la plebe que distinguen con el nombre de Michimis: la legislación y la religión concurren á hacer más deci$\therefore$ ia esta diferencia; y así, ni la subordinación desmaya, ni el deseo del mando acarrea nuevas

(1) Consúltesc el viajo del Capitán Meares: Tlupananulk, a la verdad, dijo a los Oficiales Comandantes de las lanchas, que pertenccia a Wicananish $\mathrm{cl}$ fontes de las lanchas, que pertenccía a Wicananish cl fon-
do ó resodo más Este de nuestros reconocimientos pero es probable que entendiesc hablar de los terre10 que están á su espalda.

(2) Visto el plano de estas inmediaciones, no parecerá impropio esta voz de rinconadas.

(3) El Capitán Meares le llama Maquilla: llama Callicun al que nosotros apellidamos Calacan.

(4) Este puerto es el Triendly Cove del Capitán (4) Este puerto es el Triendly Cove del Capitán
Meares, en donde está en el día nuestro establecimiento.

(5) Estamos bien distantes de querer justificar la conducta del Piloto Martínez en esta ocasion, pero por los informes accidentales de Natzapi, d ia sazón presente vemos que el Capitan Meares ha recargado este hecho con unas adiciones no necesarias. discordias: en unas tríbus débiles, pescadoras y constituídas á guerrear con frecuencia, no debe tampoco parecer extraño que llegado el Jeje á una edad incapaz de dirigir con el brazo, el valor y el ejemplo las acciones públicas, entregue el Gobierno al hijo: no pudiéramos asegurarlo as ¿. Macuina, porque creemos no vive su padre; $\mathrm{pt}^{\prime}$, seguramente Anapi, paủe de Natzapi y el padre de Tlupananulk, que vino á bordo confundido con los Michimis, no disfrutan ya ni de la autorided ni del respeto que en el día se tributa á sus hijes: tampoco pudiéramos acertar si las hembras participan del derecho de sucesion, bien que es probable que no sea así, si debemos iuzgarlo por el pocn aprecio que merece entre ellos esta agradable mitad de nuestra especie: extinguidas las familias de los Tahis, la elección de otra nueva línea dominan:e pende del voto común de los Michimis, y combinado éste, inmediar imente recaen en ella todos los fueros de la soberanía y del sacerdocio que deben distinguir esta clase preciosa: ignoramos, sí, cuál es la especie de regencia que tomará las riendas del gobierno, cuando el heredero presuntivo, muerto su padre, no tuviese aún la edad y calidades nece. sarias para el mando.

Sea esto como fuere, estos pueblos veneran los Tahis, $y$ en el respeto y subordinación que todos profesan á Macuina, como asimismo en la propiedad $y^{\prime}$ gobierno de éste, resplandece $\sin$ duda un adelantamiento de la sociedad, que en nuestras ideas mal pudiera combinarse ó con su subsistencia 6 con su desnudez (I). El carácter de Macuina no es en el día fácil á desci. frarse: su genio parece al mismo tiempo fiero, sospechoso é intrépido; pero deben enturbjar mu. cho al curso natura! de sus inclinaciones, por una parte las ansias de los europeos para cautivar su amistad, un tesoro amontonado en pocos años, las discordias acaecidas entre los mismos europeos, y tal vez la sugestión de unos ú otros para conseguir el monopolio de las pieles; por la otra, la debilidad de sus fuerzas, los escarmientos sufridos, la utilidad del comercio y la demasiada frecuente concurrencia de buques europeos en aquellos contornos.

La person $ı$ de este Jefe no corresponde á su dignidad: es 'Jajo y macilento, bien que de una constituc:ór. nerviosa y la musculación abultada: atribuía su actual estado macilento á la escasez. de alimento descle que había debido abandonar el puerto de Yucuat, y :ecordaba, no sin dolor y valentía, al Comandante de la ATrevioa; el tiempo feliz en el cual él solo se atrevia -á arpo. near una ballena, gozando entonces de una salud

(1) No usan el taparabn come los ruizilas más

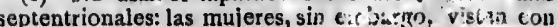
muche decencia. 
y robustez poco común (I). Es una cuestión muy vertida si sea 6 no caníbal; y puede imaginarse que no nos hemos descuidado en indagar esta verdad, tanto más que en nuestro establecimiento todos estaban firmemente convencidos que lo era, y le habían reconvenido diferentes veces: una digresión sobre este punto no desagradará tal vez a los que recorran estas hojas, mucho más, después que el Capitán Meares le ha tratado con método y prolijidad, alegando razones positivas para decidir el hecho.

El Capitán Cook, quien reconocía con ojos realmente filosóficos las costumbres de las naciones que visitó, debí extrañar desde luégo el mucho número de huesos, cráneos y manos humanas que le presentaron por diferentes ocasiones para cambios: sin embargo, combinando últimamente el carácter de estos naturales, infirió sí, que trataban á sus enemigos con un grado brut ! de crueldad no diferente del que se advir.te en todos tiempos $y$ en todas partes en el ombre no civilizado; pero no creyó que por esta razón se les pudiese acriminar con una inhı ma. nidad extraña que los guiase á alimentarse de la carne humana por solo antojo.

Este fué el concepto que conservaron despues estos pueblos, y seguramente sobre este solo concepto se aventuró á quedar entre ellos Mr. Maccay, dependiente de la expedición de Mr. Strange en el ano de 1786: la suma escasez que hubo á la sazón en Nutka pareció dar nuevo peso á esta idea: Maccay fué asistido con la posible abundancia, y no sólo jamás notó el proyecto de comerle, sino que no advirtió tampoco que en este estado ni Macuina ni los otros Jefes se va. liesen de este recurso inhumano (2).

Sin embargo, en el año siguiente, el Capitán Meares tuvo nuevos motivos para revivir la cuestion, y decidio sobre los informes de Anapi $y$ Callicun y sus mismas chservaciones, que á lo ménos Mucuina era canibal, y que le acompañaban á este hórrido convite mensual los demás Jefes de las iribus.

La voz común en nuestro establecimiento era próximamente la misma; y esta idea esparcida probablemente al tiempo de concurrir allí la $I f$ genia, ei Argonauta, el Ladi Washington y la Columbia, lograba ya mayor vigor con la decli.:ración que hacian lcs diferentes niños vendidos en varias ocasiones á bordo de la fragata Concepción: decía uno de éstos, que efectivamente Macuina gustaba de la carne humana, $y$ que la elec-

(I) Don Tomás Suria ha tenido especial acierto, asi en el retrato de este Jefe, como de todos los demás que ha formado en Nutka.

(2) Deje inferirse así, porque seguramente el Capitan Meares no omitirla un punto tan importante en su articulo Story of Mr. Maccay, tanto más que condu. cla a probar la calidad do cańbales a Macuina y sus súbditos. ción del niño para este horrible banquete dependía de la dirección de su mano, estando con los ojos vendados, pero no hacía memoria alguna ni de las ceremonias que indica el Capitán Meares, ni del uso de hombres adultos, ni de la asistencia de los demás Jefes: nuestros Oficiales ya le habían reconvenido y áun amenazado, manteniéndose él, sin embargo, tan constante en ne. gar este hecho, como los nuestros en creerlo positivo.

Con estos antecedentes ya nuestras nesquisas sobre este asunto parecian á lo ménos fáciles, $y$ el haberlas por consiguiente omitido sería en nosotros tanto más culpable cuanto que (séanos permitido el decirlo así) nos lisonjeamos aún por el honor de nuestra especie de ver de nuevo reducida la cuestión á los límites que le había prefijado el Capitán Cook.

Desde luego las primeras indagaciones nues. tras nos convencieron que no había otros datos hasta aquí para acriminar á Macrina este delito extraño, sino una relación sencilla del niño (de edad de ocho á nueve años) cuya interpretación era dudosa: diferentes visitas á su ranchería desde el Establecimienı́o de nuestro fuerte, jamás habían proporcionado el menor indicic, ó de la existencia de este terrible repuesto de víctimas, ó de los fragmentos de un sacrificio reciente de esta misma especie (I); finalmente, cuanto más iban conociendo el carácter amable de los demás Jefes de la nación, tanto más se veían dispuestos á eximirlos de esta nota inhumana, y por consiguiente, á agregar la de singular á este cruel apetito ie Macuina.

Ig' al éxito tuvieron nuestras pesquisas con los naturales; preguntado el joven Teyocot, cuñado de Macuina, cuáles eran los alimentos de este Jefe, satisfizo siempre con ceñirse á los peces, venados y yerbas ó raíces, sin que jamás ni remo. tamente nombrase la carne humana; Nanikius, que al principio había respondido afirmativamente á nuestras preguntas, muy luego nos convenció que las habia entendido mal, y repugnó con horror hasta la idea de semejante convite; finalmente, Natzapi, con quien hicimos por largo tiempo una triste memoria de la venida del Capitän '́ook á sîtc piičrto (2), nos aseguró que las 'nanos, cráneos y huesos presentados á bordo

(I) Pudiera agregarse que el señor de Ingraham, Piloto de la Columbia, describiendo en una carta al Piloto Martínez todo lo que hal'a observado entre estos naturales en el largo tiempo de un invierno, no demuestra ni la menor sospecha de esta horrible in. clinación de Macuina.

(2) Natzapi, aunque á la sazón joven de solos trece a catorce años, tenfa muy bien en su momoria varios trances de aquella expedición: la casa y ranchería vi sitadas por el Capitán Cook, fuerun las de Calacan: reconoció el retrato del Capitán, nombró por sí al Ca pitán Clerhe, y manifesto su creencia de que cl Teniente King fuese hijo del Capitán Cook. 
de la Resolución, no eran sino fragmentos de los cadáveres de sus enemigos, y que no serían extrañas las señales en las manos de una ú otra mordedura, porque los Michimis enfurecidos so lian á veces saciar de este modo los imnulsos harto vehementes de su furor: pero ni él ni Macuina serían capaces de hacer un banquete de la carne humana, idea que le chocaba extremada. mente, obligándole con frecuencia á usar de la voz Pishek, Pislık: malo, malo; y áun á decir á Macuina (quien poco después se halló por casualidad con él á bordo de la Descubier?a) cuáles eran las injustas sospechas que de él habiamos formado.

Por otra parte, no se advirtió jamás en los Michimis, la menor señal de aborrecimiento hacia. este Jefe, antes bien en la excursión de las lanchas á los canales internos, los Tenien tes de navio Espinosa y Cevallos, no pudieron dejar de admirar la complacencia con la cual respondian de algunas canoas, que eran súbditos de Macuina; estos mismos Oficiales visitando su casa, armería (I), tesoro y muicres, no advirtieron ni el menor rastro de fragme manos; finalmente, la venta contínua á la cepción de uno ú otro muchacho por cosas muy poco valor, y cl plazo de algunos días que necesitó últimamente (según voz común) para adquirir la sola niña que vendió á nuestra presencia, todo parecia convencernos que eran algo precipitadas las aserciones del Capitán Meares, sobre esta calidad de caníbal.

Nos lo convenció aún más un análisis de las razones sobre las cuales este Capitán apoyaba su concepto: la primera, de la confusión de Ma. cuina al tiempo de presentarle la mano y anillo del infeliz Mr. Millar, del sguila Imperial, ma pudiera atribuirse á él hater él mismo sido partícipe de sus carnes, cuando aquel asesinato acaeció en las costas de otro dominio: la declaración de Anapi y Callicum, es dificil de combinarse con el carácter humano giue el mismo Capitán Meares atribuye á lo ménos ai segundo y seguramente, si debiésemos juzgar por las apariencias, debía parecer más probable que se alimentase de carne humana quien descansaba su cabeza sobre un canasto de fragmentos huma nos, que no quien chupaba la sangre de una herida propia, aunque pareciese sabolearse con ella: últimamente, el vanagloriarse Macuina de la reciente celebración de uno i’ estos banque

(1) Debe imaginarse cual sería la admiración de los dos Oficiales, cuando en esta visita encontraron a la puerta de Macuina un armero coll 16 fusiles, custodiados por un Mlichini que descansaba sobre el arma: dos vidrieras, muchos útiles de hierro, una cantidad indecible de abalorios, botellas, planchas do ccbre, etc., formaban el tesoro que Macuina desplegó en esta ocasión con mucha complacencia, á la vista de nuestros Oficiales. tes, y el atribuir repentinamente esta calidad de canibal á todas las tríbus de Nutka, excepto el benéfico Callicum, no podrán jamás combinarse ni con el hambre que presencia Mr. Maccay en el invierno del 86 , ni con el manantial 6 depó. sito de tantos esclavos que debiera precisamente suponerse.

Pero, es tiempo ya de terminar esta digre. sión, la cual, desde luégo pareceria tan difusa como impertinente, si no tuviese por objeto la importante justificación de nuestra especie, y al mismo tiempo no pudiese alegar en su favor igual grado de probabilidad, á lo ménos al que hasta aquí llevaba consigo la opinión contraria: el filósofo moral que halla en los hechos harmoniosos de la Naturaleza todo lo que conspire á nuestro bienestar y á nuestra multiplicación no se complacerá tal vez en recorriendo estos renglones y el plazo á lo ménos dilatado, para admitir una verdad tan ignominiosa á nuestra especie, le recordará que hemos luchado siquiera á favor de la humanidad, y que entre las dudas hemos preferido este concepto al natural anhelo de todo viajero de distinguirse con narlizisnes maravillosas.

Existe entre los pueblos de Nutka un Código penal, depositado al parecer, en la tradición ge. neral y en la autoridad de los Tahis, del cual hemos podido rastrear con certidumbre las si. guientes leyes.

I. El que mata á otro, expía su delito con una prisión de diez días; pero la reincidencia en este delito se paga irremisiblemente con la vida.

2." Al ladrón le cortan el pelo y los dedos de las manos, le hacen cortaduras en la cara y con estas señales inextinguibles de infamia le destierran como indigno de vivir en la sociedad.

3." El a 1"Iterio se castiga en el hombre con la muerte, modificándose este castigo en las mujeres á cuatro días de reclusión: si el adúltero es algún Jefe y la adúltera mujer de otro Tahi, se juntan el ofensor y el ofendido, se injurian de palabra y se separan luégo para siempre.

Pudiéramos añadir á estas leyes, que Natzapi nos aseguraba no haber ejemplo de un adulterio entre los Tahis, que parecía igualar en la cla. se de delitos la muerte de un Tahi, con la de un Michimi, y que no alcanzamos á descifrar si Macuina solo, todos los Jefes ó todo el pueblo, eran los depositarios de la potestad legislativa, si acompañaban á estos actos de justicia, 6 los preliminares necesarios para la evidencia del delito ó las señales sucesivas del escarmiento y de la infamia; y si atento á las guerras frecuentes en que se hallan envueltos, existía también entre ellos un Código militar, referido especialmente á la poca puntualidad ó á la inobediencia en tomar las armas, y á la cobardia 6 fuga en el tiempo de la pelea, 
calidad de excepto el combinarse Maccay en ial 6 depó. recisamentc

esta digre. $\tan$ difusa $r$ objeto la especie, y al en su favol énos al que n contraria: hechos har. que conspire Itiplicación. riendo estos latado, para á nuestra eslo siquiera á re las dudas tural anhelo narl ii:innes a un Código tradición ge. his, del cual mbre las si.

su delito con incidencia en con la vida. los dedos de a cara y con nia le destieiedad.

I hombre con o en las mui el adúltero e otro Tahi, se injurian siempre. que Natzapi un adulterio $r$ en la claii, con la de á descifrar do el pueblo, legislativa, isticia, ó los encia del dermiento $y$ de $s$ frecuentes umbién entre pecialmente ediencia en fuga en el
A la verdad, en unas naciones naturalmente dispuestas á la guerra y que beben con la leche el odio de sus enemigos, la subordinación á sus Jefes $y$ aquel instinto militar que depende 6 de la propia debilidad 6 del cebo de la venganza, es bien probable que las leyes dabiesen más bien dirigirse á refrenar, que á hostigar el furor militar, cuyos excesos son luégo harto patentes en el fin trágico que está destinado á todo herido 6 prisionero.

No será tampoco muy frecuente en nuestro entender el uso de las otras leyes criminales: 10 aseguraban así Natzapi y Nanikius, y desde luego la mansedumbre de estos naturales al tiempo de concurrir al mercado, la repugnancia de las mu. jeres á cohabitar con los europeos; la reunión de los pocos Jefes entre sí, y la subordinación de los Michimis, respondiendo inmediatamente cada uno á qué jurisdicción pertenece, pueden dar no poca fuerza á esta aserción. Y á la verdad, debe pare. cer bien extraña á un filósofo desapasionado la comparación de lo que se advierte en este puerto (I) con lo que pasa por lo común en nuestros puertos de Europa. Aquí, rodeada la embarcación de canoas con los mismos efectos de venta, y.con los mismos deseos de cambio, atracando indistintamente todos con una especie da cascos sumamente endebles, cuyos choques son precisamente frecuentes, se advierte sin embargo, un silencio, una harmonia, una quietud que nadá puede interrumpir, y bien se concluya el contra. to 6 la concurrencia de muchos haga que se prefiera después un segundo contratante al primero; la misma diferencia, la misma humanidad se dejan ver en todas las o' $x$ siones: al contrario, en los puertos de Europa $a_{1}$ 'enas hay dos botes de transporte al costado de un buque, apenas se tocan recíprocamente, sin daño alguno, cuando los gritos de una rivalidad indispensable se dejan oir por todas partes, y áun le sigue no pocas veces una ofensa civil que exige la intervención de la ley criminal (2).

Deben sin duda concurrir los principios de la religión á la solidez y perseverancia de esta conducta: nuestras pesquisas en esta parte fue. ron bien felices, partiendo, según costumbre, en las preguntas de las ceremonias 6 ritos que acompaijan los funerales, y dirigiéndonos des. pués á la creencia ó supersticiones que los dirigen (3).

(r) A la conducta de los naturales en esta parte, puede muy bien apropiarse todo lo que hemos dicho anteriormente de los habitantes del puerto Mulgrave.

(2) Esta mansedumbre y harmonía general no pudo evadirse de las miradas filosóficas del Capitán Cook.

(3) Este método de penetrar en los arcanos de las diferentes religiones nos ha parecido el más expedito y oportuno: las ideas de la suerte venidera están tan ligadas con las pompas fúnebres, $y$ los deberes sociales tan naturalmente explayados en esta crisis terrible
Son solemnes las pompas fúnebres que acom. panan la muerte de Macuina (I): un llanto universal de los Tahis y Michimis, interrumpido á veces de un canto lúgubre, es el primer tributo que consagran á su memoria sus antiguos súbditos: acuden inmediatamente al Tasis convidados los pueblos vecinos de los Nuchimases; el cadáver permanece en la casa por cuatro dias; un Tahi le llama frecuentemente, y como no responda, se dispone ya al cuarto día su conducción al Conu. ma (2); los canales internos dan lugar á que haya en esta conducción la mayor solemnidad: cuatro hileras de canoas, dos á la derecha y dos á la izquierda, acompañan la canoa que sirve de féretro: el canto es contínuo y lúgubre (3): no hay in victimas ni of rendas de comestibles: lle. gada al Conuma la comitiva, se le llama nueva. mente, y á la falta de respuesta sigue luégo el cerrarle entero en una caja sin otra ceremonia alguna, y finalmente, el elevar la caja en alto dejándola próximamento en la misma posición de las de puerto Mulgrave.

Macuina entre tanto, rodeado de fatigas y de peligros, con un sumo cansancio y sin comer cosa alguna, se dirige hacia el Sol, á donde no llega sino al noveno día después de su muerte, y alli encuentra nuevamente su cuerpo qque ha permanecido otros cuatro días en Conuma, y luégo ha sido llevado casí instantáneamente al Sol: reunidas nuevamente las dos sustancias, se presenta á todos sus antepasados, que le reciben amistosamente y le saludan con la voz común Guacash, Guacash Macuina: se olvidan todas las pasadas ofensas; áun el que hubiese muerto á Macuina, al llegar es recibido por él como amigo, $y$ allí residen eternamente todos en una paz duradera y gozando una salud robusta.

No es igual la suerte de las mujeres de los Tahis: van, sí, al Conuma, pero no alcanzan el Sol, y por consiguiente, no vuelven á cohabitar. con sus muridos, oien que estando en paraje no distante tienen éstos la satisfa zión de oirlas cantar de tiempo en tiempo, y hacer con esto dulce memoria de la pasada fẻ conyugal (4): un

de la Naturaleza, que puede muy bien considerarse como el centro de las ideas de lo pasado y de lo ve. nidero.

(r) No nos atreveremos a asegurar que sean las mismas para los demás Jefes subalternos.

(2) La posición del Conuma en la rinconada de Tlupananulk puede examinarse en nuestros planos; $y$ aunque esta voz en el idioma nutkeño no signifique po. sitivamente sino monte, aquél, por antonomasia, se distingus con este solo nombre.

(3) Decfa con mucha gracia Nanikius que cantaban en esta ocasion en el mismo modo en que en los buques del Rey cantamos la Sahe Virgen pura: canto que el habra ordo sin duda a bordo de la Concepción. (4) Natzapi, quien últimamente había perdido' su segunda mujer en un viaje emprendido á los Muchimases, nos decía que en aquel momento la ostaba oyendo cantar. 
olvido dimanado de este atropellamiento de ideas nuevas y tal vez de la estr. jez del tiempo, nos hace ahora echar de ménos con mucho sentimiento el detalle de las funciones de las mujer: en los funerales de Macuina.

La diferencia advertida hasta aquí entre los Tahis y los Michimis, sobresale aún más cn lo.s materias religiosas: al Michimi muerto, después de la formalidad de llamarle repetidas veces, se le hacen alguiras cortaduras en la lengua $y$ en el vientre, se le sobrepone unz zámiseta ó estera y se entierra en paraje separado ( $\mathrm{I}$ ): el cadáver permanece siempre en la tierra alimentándose de gusanos y de piojos; la sustancia espiritual es la que vucla al Sol y disfruta alli de una perfecta igualdud con los Tahis, concurriendo siempre á recibir y abrazar los recién venidos (2).

Lo que parece extraño en esta parte tan im. portante de la religión, es la ninguna distinción que se hace en la otra vida de los buenos y de los malos, lo cual nos confirmaron entrambos hermanos en muchos modos nada equívocos, dependiendo, por consiguiente, la suerte de cada uno de la clase que tenga en ei mundo.

Hasta aqui llegaron nuestros conocimientos religiosos, no siéndonos posible rastrear cosa alguna relativamente á las ideas de la Creación, de la Providencia, de la Justicia, etc., adictas al Supremo Hacedor, ni mucho ménos del objeto, ritos y ofrendas del culto. No adoran las sombras de los Tahis, no el astro del día, ni la Luna; no la imagen de sus antepasados que representan pruiablemente los figurones de los postes y de las miscaras: no temen, al parecer, ni la voz del trueno, ni los accidentes inopinados, ni los mis. mos aguleros; y por lo que pudimos deducir, sus principios religiosos, desentendiéndose de lo pasado y de lo presente, parecen ceñirse sólu á lo venidero.

Estas averiguaciones, sin embargo, á pesar de su importancia, novedad y multiplicación, no nos distrajeron tanto que no aprovechásemos los talentos de Natzapi y Nanikius para otros objetos no ménos importantes; y eran éstos la división del tiempo, el origen de estas naciones, las obligaciones y fueros domésticos de cada uno, sus combinaciones mercantiles, y la geografía inter-

(1) Los Sres. Espinosa y Cevallos visitaron en su excursión con las lanchas la Isla de los Cemonterios, y vieron alli varios cadáveres de Michimis cubiertos con una estera y acomodados parte en el suelo y parte on unas canoas medio enterradas: la canoa para un pescador es tan honorifica como la espada para un militar.

(2) Nos quedan algnnas dudas en esta parte; porquo si bien se dedujo do Natzapi que los Michinis muertos se alimentaban de gusanos y piojos, y que sin embargo, se presentaban en el Sol al recibimiento de M rcuiua, la división de las dos sustancias es un arbitrio nuestro para reunir estas ideas combinado si con viaje de los nueve dias al Sol. na del país contíguo de los Nuchimases: describiremos las ideas adquiridas en estos ramos, con la misma sencillez que hemos procurado seguir hasta aquí.

Los nutkeños dividen el tiempo en meses lunares, diez de los cuales forman un Sol, cuya du. ración está derivada al parecer del tiempo del embarazo de la mujer; la división del día depen. de enteramente del Sol y áun más de la pesca, anticiṕndose 6 atrasándose las horas de la comida y del reposo, según lo requieran las ocurrencias y necesaria calidad de la misma pesca: como estos naturales no exceden en su numeración de diez, les es difícil expresar lcs números mayores sin algún auxilio material 6 de los dedos 6 de otros datos semejantes: así nos manifestaban sus edades, contando siempre como se ha dicho, por Soles compuestos de diez lunaciones.

Estas nociones bien escasas é incómodas en cuanto á la importante división del tiempo, no nos hicieron, sin embargo, desmayar sobre las pesquisas del origen de estos naturales: halla. mos que la ignoraban enteramente, si debiese atenderse á una tradición segura, pero sí el hábil Natzapi nos aseguró, sin recelo de duda, que su ascendencia hasta tres generaciones había permanecido en el Tasis, se perdió luégo en las épocas más distantes, á las cuales queríamos hacerle retroceder, é indicó su persuasión de que los pobladores habían venido del Norte (I).

Mucho mayores fueron nuestros progresos por lo que toca á los derechos domésticos: la poligamia está permitida á los solos Tahis, limitada sin embargo al número de cuatro mujeres, $y$ justificada por Natzapi su necesidad de la costumbre de no usar de las mujeres que crían, y de repugnarles las muy adelantadas en el embarazo: nos contaba el mismo Natzapi, que cada mujer duerme con su estera en uno de los cuatro án. gulos de la pieza, y que el marido visita á su albedrío una ú otra, usando sí en estas ocasiones no sólo del silencio, de la oscur dad y del pudor, si también de aquellos halas's que precedidos del amor conyugal nos distinguen áun en este caso de los brutos: Natzapi en el día no tenía sino una sola mujer; encarecía mucho su amor por ella y sus prendas personales; y seguramente, el detalle que nos dió de las lindas proporcio-

(I) Si quisiéramos hacer para la persuasión del que recorra estas hojas, nna fiel relación de los métodos que nos han guiado a desenvolver estas ideas, sería este un objeto harto difuso y á veces ridiculo aunque instructivo: la sagacidad de D. Antonio Tova dicto para el alcance d ticion a Natzapi de la vion del hombre bre con la mujer; del embarazo de ésta, del sucesivo nacimiento, adolescencia, etc., por cada generación: los padres y ei hijc, se representaban después con objetos materiales, y so ponían aparte en una mesa grande: en el Diccionario se han comprendido las voces de abue lo, bisabuelo y tatarabuelo, que usan los naturales. 
hases: descri-

os ramos, con

curado seguir

en meses lu-

Sol, cuya du. el tiempo del del día depen$s$ de la pesca, bras de la coeran las ocu. misma pesca: n su numera. r las números 6 de los dedos os manifestae como se ha ez lunaciones. incómodas en lel tiempo, no ayar sobre las turales: hallate, si debiese pero sí el hábil duda, que su s había permaen las épocas mos hacerle reque los pobla-

tros progresos domésticos: la los Tahis, limiatro mujeres, $y$ dad de la cosque crían, y de on el embarazo: ue cada mujer los cuatro án. o visita $\{$ su alstas ocasiones ad y del pudor, que precedidos a áun en este 1 día no tenía nucho su amor ; y seguramenadas proporcio-

persuasión de ción de los mé lver estas ideas a veces ridículo ). Antonio Tová idencias la repe hombre con la sivo nimi cion: los padre cadre con objetos ma esa grande: en el voces de abue los naturales. nes de su cuerpo, de la finura de su tez y de la blancura de su color, no desmiente las ideas de la hermosura que comunmente se han admitido en Europa.

No pudiéramos determinar si está admitido el repudio, pero debemos creer que no rija esta costumbre donde ni las mujeres faltan á los deberes conyugales, ni en la elección se oyen otras voces que las del instinto, desentendiéndose por consiguiente de la desigualdad de clases, de la cantidad del dote y de la posibilidad de combinar una excesiva diferencia de edades.

No fueron tan frecuentes nuestras visitas á sus rancherías que nos proporcionasen examinar distintamente la suerte de las mujeres ar cidnas, el grado de aprecio de las que no son favo. ritas, el grado de amor con que miran los hijos según el favor particular de que gocen á la sazón sus madres, finalmente, 6 los derechos de estas mujeres (I) en la república 6 los límites de estas elecciones de los Tahis en la clase de los Michimis: pero los Tenientes de navío Espinosa y Cevallos, quienes fueron presentados por Macuina á su favorita (2), conocieron sin embargo en aquel Jefe en esta ocasión una mezcla grande de amor y consideración hacia su mujer y al mismo tiempo un caudal no indiferente de celos, aunque según confiesan, en aquel momento no dejasen de sentir la agradable sorpresa de una hermosura tan perfecta como no esperada.

Ni era Macuina quien ocultase estos impul sos de sus celos, cuando le instábamos que volviera á establecerse en Yucuat, á poca distancia de nuestras casas, respondía con mucha prontitud que muy luego los nuestros intentarían vio. lar los derechos conyugales, aunque nuest:?s Jefes, con el ejemplo y los castigos, procurasen su. jetarlos, y que así, prefería la incomodidad y estrechez de la vida actual, á este riesgo evidente.

No advirtieron nuestros Oficiales en la visita indicada, otra persona preferida en la casa de Macuina, bien que no habiendo allí á la sazón

(1) Si como es probable era la mujer de un Tahi la que dio los golpes y un Michimi el que los recibió a la vista del Capitán Douglas de la l/figenia en las in mediaciones del Cabo de la Cruz, ya este hecho no nos suministrará la idea de una costumbre bien extra fla ea estas costas.

(2) Hé aqư la pintura que en su Diario dieron estos Oficiales del citado encuentro agradable: $« \mathrm{EI}$ Cacique nos presentó á su mujer, cuya bella figura no nos sorprendió ménos que el centinela y los fusiles: tendrá como veinte afios de edad y se distingufa entre otras muchas por su color blanquisimo, del propio modo que por la delicadeza y la proporción de sus facciones: si después de. una navegación dilatada se pudiera juzgar de la hermosura con rectitud nos atrevertamos a decir que esta graciosa muchacha excede en belleza a las heroinas de novela, tales como no las hacen concebir los prestigios de la poeśa y la imaginación de los poetas. sino algunas ancianas, la comparación era precisamente defectuosa.

Fn la segunda visita que hizo aquel Jefe á las corbetas, le acompañaron en la canoa tres 6 cuatro mujeres, entre las cuales estaba compren. dida la favorita: no permitió que subiesen á bordo por muchas que fuesen las instancias y ofre. cimientos hechos; todas asistieron en la canoa á su comida, que se compuso aquel día cie frutas silvestres, y advirtieron los Oficiales que la mujer favorita era la que le suministraba directa. mente la comida.

El amor de estos naturales hacia sus hijos ha sido visible en muchas ocasiones: Tlupananulk nos presento uno, como muchacho de muchas es. peranzas: se deleitaba en mirarle y en ver que le agasajábamos, y si como es probable, el padre .e Tlupananulk entró con los Michimis an la danza, sólo para dar con un mayor número y con su ejemplo nuevo resalte á la autoridad y dispo. siciones de su hijo, será esta seguramente una prueba del amor filial que tenga pocas seme. jantes.

Debimos, por consiguiente, extrañar mucho que Natzapi no titubease en acceder á la venta de un hijo suyo, que se le propuso para examinar en esta parte sus pensamientos: bien que como el hijo no estuviese presente, ni en nuestra propuesta se mezclase objeto alguno je cambio 6 regalo, es creible que Natzapi no entendiese bien nuestras preguntas, 6 á lo ménos nos induce $a$ creerlo así el deseo de no suponer á ese Jefe tan desprendido del amor filial.

No cabe duda que estos pueblos eran comérciantes áun antes de las primeras visitas de los europeos, que comunicaban con los pueblos in. mediatos del Sueste y del Norte, y que á veces legítimamente, á veces con la violencia, adquirían varias cosas extranjeras: el Capitán Cook hallo entre ellos no sólo una cantidad considera. ble de hierro, si también los cubiertos de plata que el Comandante Cuadra había perdido en la Ensenada de los Mártires en latitud de $47^{\circ}$; pero cuáles fuesen los productos de estas islas que daban los nutkeños en cambio, no fuera fácil acertarlo, á ménos que no les considerásemos como el canal por donde comunicaioan los $\mathrm{Nu}$ chimases con los pueblos meridionales, 6 bien no supusiésemos que el rescate de los esclavos se satisfaciese de tiempo en tiempo con estos efectos: pero si bien en aquellos tiempos sean dudosos los efectos que constituían este comercio, ya en el día nosotros le hallamos tan periódico y bien ordenado, que no fuera ituleridad atribuirie los progresos rápidos que han hecho estos naturales en las ideas de la vida sociable.

Desde mucho tiempo los nutkeños tenian una estrecha amistad con los Nuchimases; pue. blos numerosos é igualmente pescadores que ha. 
bitan en la orilla de dos grandes lagunas no distantes del Tasis al Norte, y rayanas al Este con los pueblos del labio cortado 6 de las islas fronteras á la Reina Carlota: Natzapi, consiguiendo por esposa-la hija del Jefe Nuchimas, habia logrado la distinción de Tahi entre aquellos pue. blos (r), y 6 bien él, 6 : su mujer, 6 su hermano, se ocupaban frecuentemente en acarrear á aquellos puelilos los productos útiles del comercio curopeo, cambiándolos con pieles de nutria, que los Nuchimases sacaban en mucho número de las lagunas: los objetos principales de estos cambios de parte de los nutkeños, eran el cobre y los aulunes 6 conchas de Monterey (2): sollan alguna vez introduci, algún hierro y paños, pero eran estos artículos más bien de poco valor, particularmente si se comparasen á los primeros destinados generalmente á los adornos y usos domesticos de ambos sexos (3). Con este desem. bocadero les era fácil ocurrir con un número más crecido de pieles al mercado europeo de lo que pudiesen suministrar cualesquiera otros puntos de la costa, y una cuenta bastantemente prolija nos hacía creer que la máxima cantidad de estas pieles suministradas por los Nuchimases pudiese anualmente llegar á 6.000 , si se empleasen en sú pesca todos los moradores con una felicidad correspondiente.

El viaje desde el Tasis á la residencia del Jefe de los Nuchimases (4), no deja de ser algo arriesgado, largo y penoso: es preciso llevar á lombro las canoas hasta la laguna próxima; las tempestades hacen luégo peligrosa esta navegación: en el boquete de comunicación de las dos lagunas, debe contrarestarse una vertiente rápida de las aguas, que cuelan dc la más Norte á la del Sur; finalmente, queda aún por navegar la segunda laguna, que es igualmente penosa, y que limita 'á diez días la duración de todo el viaje: Nanikius y luego Natzapi, trazaron en pa. pel la posición y distancias de estas lagunas (5), $y$ añadió el segundo que la pesca de las nutrias se imposibilitaba á veces (particularmente en el vavierno) por el demasiado oleaje, el cual les exponía á un naufragio; que el agua era profunda, no teniendo á veces pié en las inmediaciones de la orilla, y que una de estas tempestades era la que había causado la muerte de su mujer

(1) Alegaba para prueba de ser Jefe de los Nuchimases, el que llevaba unz especie de cabellerá postiza con los bucles prolongados, bien parecida en cuan to a la figura a la del Ankau de Mulgrave.

(i) Aliatis Myde, de Linneo.

(2) Aliatis Myde, de Linneo. ticularmento para la comida, y ast las de mayor tamaho aumentan extraordinariamente de valor.

(4) Para la inteligencia de la situâción de estas lagunas, véanse nuestras cartas, y la explicación do los materiales que han servido para construirlas.

(5) Se remite este papel curioso, con el depósito de los elementos de nuestras cartas. al tiempo de navegar con una porcion de cobre hacia la residencia de su padre.

No eran contratos sino regalos recíprocos los que constituian el comercio con los Nuchimases, á la pronta entrega de los nutkeños de todo lo que llevasen de algún valor, correspondía el Jefe Nuchimas con el regalo de una cantidad proporcionada de pieles; y áun le acompañaba la cere. monia de sobreponerse de antemann al hombro con mucha solemnidad cada piel que entregase como prueba de ser un legítimo regalo procedido de la hospitalidad y del buen acogimiento ( $\mathbf{z}$.

La pesca de las nutrias en esas lagunas, se lace (según Natzapi) con canoas esquifadas por dos hombres, de los cuales como es naturai, cuida el uno de la dirección y andar de la canoa, y el otro del alcance y oportuno golpe á la nu. tria: no cesa esta pesca con la entrada del invierno, á menos que no la imposibiliten los días tempestuosos; antes bien, les es ventajosa la estación fría, porque entonces la nutria pierde casi de un todo la vista y se hace mucho más fácil alcanzarla: la canoa más feliz y diestra, jamás (según Natzapi); pudiera coger en un día más de cuatro nutrias: muchas canoas, al llegar la noche, aún no han cogido ni una siquiera.

Los Nuchimases confinan y comercian al No. roeste y Oeste con los del canal de la Reina Carlota: distinguía Natzapi estos altimos pue. blos por los del labio cortado, los describía por muy belicosos, fáciles á irritarse y no pocas veces en guerra con sus vecinos: dió a entender que las canoas de guerra de unos y otros eran con mucho mayores á las de Nutka. Trazb luego una cordillera que desde el extremo de las lagunas seguía casi en la misma dirección del Nor. nordeste por otras 15 u $z u$ !eguas, haciendo diferentes tornos y presentancio el abra de dos 6 tres canales; pero siempre manifésto una total ignorancia de los paises y habitantes que raya. sen interiormente con los Nuchimases, 6 bien al Sueste 6 al Nordeste.

Como era debido, no nos descuidamos en, preguntar cuál era el paradero de las aguas que en tanta cantidad acudfan á la laguna inmediata al Tasis, á lo cual satisfizo Natzapi asegurando que no había tío alguno; pero sí que el Sol en el verano absorbia una parte no indiferente de estas aguas: con mucha perspicacia consiguib no dejarnos duda de esta explicación, mojando su propia mano con saliva y señalando despues que el. Sol quitaba aquella saliva. Pero si como es probable, son realmente estas lagunas muy caudalosas y de una grande extensión, no debiera.

(1) Este mismo metodo quiso adoptar Natzapi cambiando a bordo tres pieles de nutrias por una plancha de cobre: estas pieles que existen en la co. plancha de cobre: estas pieles que existen de la calilección del Real Gabinete, darán
dad de las nutrias do agua dulce. 


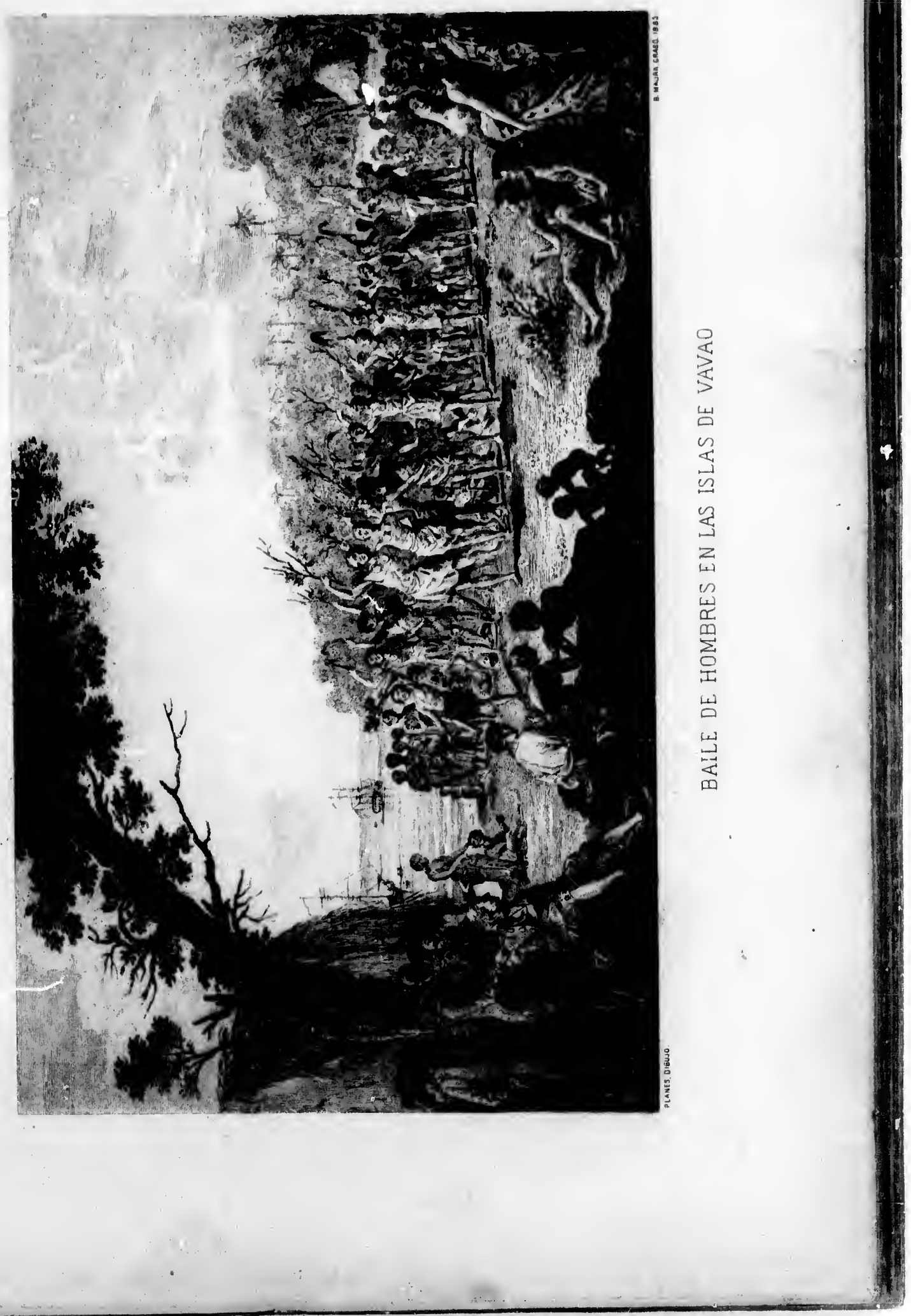



mos dudar en atribuir una parte considerable en la disminución de sus aguas á la filtración aub. terránea y constante hacia los canales inmedia. tos de Nutka, de donde derive luégo el gusto ménos salobre que en cualquiera mareas se expe. rimenta en dichos canales.

Ni el tiempo, ni tal vez una prudente reflexión á todas las circunstancias del dia, no hubiera permitido emprender un viaje á los $\mathrm{Nu}$. chimases, para el cual se brindaban Nanikius y Natzapi: pero si se examinan 6 bien el actual furor de los europeos para penetrar en los parajes más escondidos del globo 6 la unión amistosa de las dos naciones, podemos asegurar que la Europea á quien pertenezca últimamente la de. cantada manzana del puerto de Yucuat y Archipiélago de Nutka, no tardará en verificar este reconocimiento, pues ni será difícil conseguirlo con el cebo del comercio y hacerlo seguro, exi giendo en clase de rehenes en el establecimiento, á Macuina ó Natzapi mientras estén ausentes los dos 6 tres individuos que se aventuren con el caudal necesario de ciencia, á los trabajos inseparables de esta especie de comisiones.

Dos objetos de no poca importancia no se han tocado aún en esta Memoria, y que merecen, sin embargo, la prolija atención del físico: y son, la venta repetida de niños de parte de los naturales, y las observaciones agronómicas derivadas de los ensayos hechos en nuestro establecimiento.

Casi desde el momento en que los Pilotos Martinez y Haro llegaron al puerto de Yucuat, el deseo, 6 suyo 6 de los Capellanes para aumentar el número de prosélitos á la religión católica, hizo que propusiesen á los naturales la venta de algunos niños, 6 que accediesen á los ofrecimien. tos de éstos; y la facilidad y ansia por una y otra parte de continuar en esta especie de cambio, muy luego arraigó esta costumbre, extendiéndose' indistintamente á ambos sexos y últimamente á cualesquiera edades.

Al tiempo de nuestra salida de Nutka, ro era menor de 22 el número de niños de ambos sexos rescatados en los buques de San Blas y vendi. dos indistintamente por Macuina 6 los demás Jefes subalternos: solían llevar por cada nir?o una 6 dos planchas de cobre y á veces algún ca. ñón de fusil 6 pocas varas de paño, distinguien. dose particularmente en el celo desinteresado para esta especie de adquisiciones el Padre Don Nicolás de Luera, Capellán de la fragata Concepción, el cual después vigilaba sobre sus buenas costumbres é instrucción social y cristiana, y últimamente los fiaba para su vestido, alimento :y sucesiva instrucción á aquellos individuros del armamento que pudieran cuidarlos y sacar en sus familias una utilidad de la adopción indicada de estos niños.

No fuera temeridad asegurar que estos ni. ños, hasta en su situacion social, mejoraban mucho de suerte, áun cuando no fuesen verdade. ras las acriminaciones hechas a Macuina sobre su propensión á ser caníbal; pero la repugnancia natural á la esclavitud de aus semejante y el temor de que loz encargados de estos niños no pretendan al abrigo de la religión justificar una especie de dominio indeleble sobre estos infeli. ces, nos induce á desear que 6 se pusiese un 11 . mite á estas adquisiciones, 6 la legislación se ocupase de su bienestar sucesivo, atento á las inclinaciones que los muevan, á la pureza de nuestra religión y á los derechos inseparables del hombre.

Esto solo podrá justificar los inconvenientea procedidos de seme jantes contratos: inconvenientes que advirtio Mr. Carver en el Canadá examinando el celo de los jesuitas para esta especie de adquisiciónes. "Sin duda, dice aquel escritor, son sus miras dignas de elogiarse, pues han creído que sería un medio no solo para prevenir las barbaridades atroces y la efusión de sangre arraigadas entre estos pueblos, sino tambien para introducir su religión entre ellos, con cuyo motivo empeña ban los tratantes á comprar cuantos esclavos les viniesen á mano; pero los efectos no han corres . pondido á las esperanzas de estos religiosos: en lugar de prevenir las crueldades y la efusion de sangre, este partido aumenta más bien sus dis. cordias y les da mayor actividad y duración. No siendo ya la venganza ni el amor de la gloria el objeto de sus guerras, y sí la adquisición de los licores por los cuales cambian sus prisioneros, y que todos apetecen con exceso, se han hecho ahora más activos en inquietar á sus enemigos y estar siempre alerta para inquietarlos y escla. vizarlos."

Deseábamos con ansia datos positivos para averiguar de dónde y cómo traen estos prisioneros, estando divididas nuestras conjeturas en in terpretar lo que dijesen los muchachos mismos. Nos han quedado, sin embargo, muchas dudas en esta parte, de modo que no pudièramos decidir si scin robos diestramente hechos á los vecinos Nuchimases 6 Izcuates, si son fruto del dominio absoluto de los Tahis sobre sus propios Michimis; 6 finalmente, si la necesidad obliga á éstos á veces á desprenderse por cosas de poco valor de unos niños, cuya subsistencia es harto penosa y ningunas la: "ilidades en la última vejez de los padres.

$\mathrm{Si}$ juzgásemos por todas las circunstancias, nos inclinaríamos á creer que proceden casi todos de robos hechos á los Izcuates, tal vez repetidos por éstos del mismo modo (I) cuando la ocasión

(I) En esto mismo año el Teniente de navio Elisa y el Piloto Carrasco, han adquirido otros cinco o seis y el Piloto Carrasco, han adquirido otros cinco o seis
niños en Cayucat é inmeriaciones de la entrada de niños

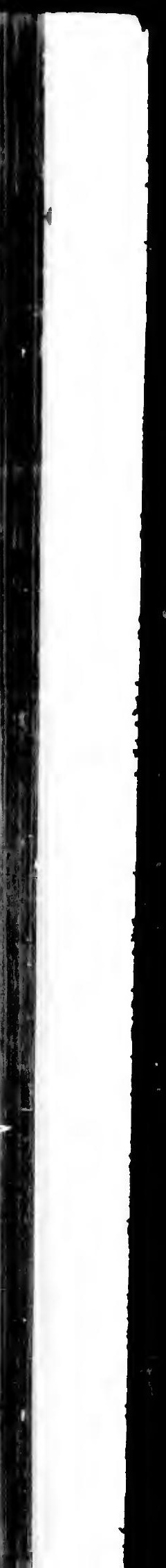


les sea favorable: á lo ménos estas dos naciones son naturalmente rivales; y los lzcuates (x) al parecer más crueles, traidores é inclinados al robo; de suerte que serian más frecuentes las hostilidades entre unos $y$ otros, si la existencia de los europeos en Yucuat y sus enlaces con Ma. cuina, nodiesen ya á estc Jefe una preponderancia de fuerzas sobre sus enemigos.

Ello es, en fin, que á pesar de esta bárbara costumbre de robar los niños 6 descuidarlos y ubandonarlos, los pucblos de Nutka pueden sin duda considurarse como bien adelantados en la civilizqción, si se comparan á todos los demás que pueblan las orillas orientales del Mar Paci. tico al Norte del 'Trópico, y que no pasará mu. cho tiempo sin que el uso de las semillas y de los ganados, les preste para el invierno açuellos auxilios que mal pudieran derivar de la pesca anticipada en el verano: á lo ménos no parece. rán intempestivas estas conjeturas cuando con. sideramos que Macuina nada aprecia ya sino los cristales para ventanas, las armas de fuego y el paño azul: que Tlupananulk nada ansiaba sino pólvora, velas y cabos de cáñamo para el uso de sus canoas; que el robo ya está casi desterrado (2) y que el talento de los hijos de Anapi es capaz por sí solo de causar esta revolución favorable y áun comunicarla muy luego á los $\mathrm{Nu}$. chimases.

Estas reflexiones nos guían ya rápidamente á los verdaderos productos útiles que pueden ofrecer estos contornos, 6 bien á sus actuales habitantes $\delta$ los que hayan de acompañaries, y por ventura la activa penetración del Capitán Don Pedro Alberni y las noticias que nos ha comunicado, nos ponen en situación de poder detallar muchas circunstancias que seguramente pueden mirarse como importantes para las medidas venideras.

El temperamento de Nutka es más bien templado, áun en el invierno (3). Los hielos no se conservan, $\mathrm{y}$ en $\mathrm{cl}$ año pasado wo ha helado sino dos 6 tres veces; las mismas lluvias jamás pue. den ordcnarse hasta una completa formación de

(1) Es probable que éstos fuesen los intrusos en el coinercio de la Resolución y de la Descubiekta, que advirtió el Capitán Cook como próximos á causar una guerra entre las dos naciones.

(2) En nuestro establecimiento y en nuestros buques, ya desde mucho tiempo no se habla de robos, auncie el roce de los naturales sea continuo y franco. D. Francisco Elisa y D. Pedro Alberni, debieron, co. D. Francisco Elisa y D. Pedro Alberni, debieron, noche. Natzapi, viendo una canoa de esta nación canoche. Natzapi, viendo una canoa de esta nación ca-
sualmente á nuestro costado, empezó á decirnos el sualmente á nuestro costado, empezó á decirnos

Pishek, Pishek; malo, malo, y ellos se retiraron.
(3) Hemos dejado al Capitán D. Pedro Alberni un termometro de Reaumur para seguir con mayor exac. titud el Diario meteorológico en el proximo invierno. Se puede ver en nuestros Diarios que el temperamento del mes de Agosto ha sido igual al de igual mes ell Europa. la nieve, $y$ la escarcha es igualmente rara en las ncches y mañanitas: las lluvias son al contrario bien coplosas $y$ frecuentes, las mueven por Io común los vientos del Sur y Sueste y las disipan los del Norte con los cuales regresa siempre el tiempo claro, si exceptuásemos los últimos meses ántes de nuestra llegada, en los cuales estos vien. tos han sido flojos, lluviosos y no muy claros. Las neblinas no fueron muchas, y los truenos sólo se ayeron por dos veces, en 5 de Noviembre $y$ en 29 de Incro. $A$ no haber temporales del Sueste y Sur, puedc contarse con los terrales y virazo. nes periódicas, en cuyas ocasiones, particularmente en el verano, el tiempo está despejado, los montes limpios y la mar llana y placentera: no se han correspondida en las variaciones me. teorologicas los mismos meses de los dos años de $179^{\circ}$ y $179 \mathrm{r}$, antes bien, ha sido tanta la di. ferencia, que merece una mayor individualider.

Afeccimes metcorológicas.

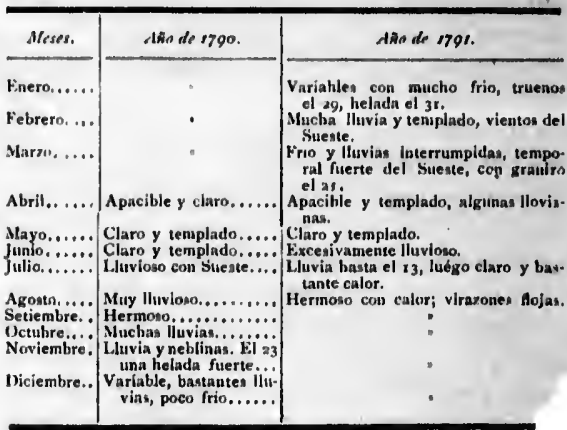

Si examinamos por otra parte el influjo u las estaciones así en la salud de los hombres como eu la producción de las plantas, 'se nos ofre cen ya á la vista otros datos no ménos útiles $y$ singulares, cuya individual descripción no des. agradará tal yez al físiço amante de la sociedad.

No serían en menor número de 250 personas las pertenecientes á las dos fragatas de San Blas que han permanecido un año entero en el puerto de Yucuat: D. Francisco Elisa y D. Pedro Al: berni, conocieron muy luégo que la conservación de estas gentes dependía más bien del contínuo ejercicio, que de los preservativos con que pudiese auxiliárseles: el desmonte hacia la marina y el establecimiento de algunas huertas fueron el primer ensayo útil de estas tareas, á las cuales siguieron muy luego la construcción de una goleta y el principio de diferentes casas destina. das 6 bien para obradores, para alojamiento 6 para repuestos: debieron acelerarse mucho los que sirviesen á este último objeto, porque una epidemia destructiva de ratas, nada dejaba seguro en las embarcaciones; $y$ asi llegó el invierno antes que pudiera alojarse gente alguna en tiesra; 
te rara en las n al contrario ueven por lo y las disipan sa siempre el ultimos meses les estos vien. uy claros. Las ruenos sólo se viembre $y$ en es del Sueste ales y virazo. es, particular. stá despejado, y placentera: riaciones me. Ios dos años lo tanta la di. ndividualider. as.

c de ingi.

mucho frio, trueno el $3 \mathrm{~s}$ :
templado, vientras del interrumpidas, cempoSilada, do.

13urioso. luego claro y bas. calor; virazones fojas.

e el influjo u le los hombres ias, se nos ofre. nénos útiles $y$ ipción no des. de la sociedad. e 250 personas as de San Blas ro en el puerto D. Pedro Al: a conservación del contínuo s con que puacia la marina uuertas fueron eas, á las cuaucción de una casas destinaa alojamiento urse mucho los 0 , porque una dejaba seguro el invierno anuna en tierra, excepto la tropa; y antes que hubiese parajes cu. biertos en donde la marineria pudiese en los dias lluviosos ocuparse en las útiles tareas de la sie. rTa y carpinteria.

La necesidad de vivir á bordo, la falta de todo alimento fresco, excepto el pescado, la mucha humedad que se encontraba en todos los contor. nos y la dificultad de no suspender el trabajo en los dias lluviosos, debieron por consiguiente dar mil zozobras sobre el bienestar del estableci. miento: y ciertamente, á no haber prendido tan luego las hortalizas, estas circunstancias hubie. ran sido desagradables $y$ tal vez funestas: pero la facilidad con la cual empezaron á prender vi. gor las coles, las lechugas, las cebollas, los ajos, las acelgas, rábanos, nabos, zanahorias, peregil y alcachofas, desde luégo no sólo inclinaron muchos más á la útil ocupación del cultivo, si también pusieron un fuerte obstáculo á los progresos irremediables del escorbuto: asl, á la calda del in vierno, apenas se hallaban unos 30 individuns atacados de este mal con diferentes sintomas: y como al mismo tiempo se remitiesen éstos á Monterey con una de las fragatas y se hubiesen he. cho progresos considerables en todos los ramos más necesarios del establecimiento, ya éste se vio libre de enfermedades y desde entonces la más perfecta salud se arraigó en todos sus individuos.

Fué mucha la tablazón aserrada que para el pronto adelantamiento de las casas prepararon y vendieron los naturales: al mismo tiempo pu. dieron hacerse nuevos ensayos en las semillas, y aunque no correspondiesen á las esperanzas 10 . garbanzos, el trigo y el maiz (I), desde luego la cebada y las papas con muy buen exito, y el frijol y el chícharo, siempre que las lluvias no fuesen excesivas, manifestaron que no seria ya precaria y dependiente 6 de la caza 6 de la pes. ca la cómoda existencia de una colonia en esta costa: en cuanto á la vegetación, no encarece. mos nada cuando aseguremos que hemos visto rábanos de tres cuartas de circunferencia y lechugas de nueve cuartas en la parte superior de las hojas. Agregarase que las vacas y las gallinas han manifestado ya poderse multiplicar admirablemente, no necesitando aquéllas sino unos tres 6 cuatro meses de pasto seco; las otras resistiendo de tal rnodo al frío, que extienden sus crias á dos cluecadas al año, y no necesitan otro cuidado más que el preservar los pollitos de las ratas y de los hurones, y finalmente, se podrá co.

(1) Para que las pruebas sobro estas semillas fue. sen más completas, Alberni tuvo la precaución de sembrarlas con intervalos de una semana; de suerte, que repetids esta operación muchas veces, hubiese que repetida osta operacion muchas veces, hubiese lugar de probar directamente el efecto de las estaciones; sin embargo, no han granado. La cebada ha dado de doce a catorce fanegas por una. nocer cuáles son las comodidades que para su bienestar brindan estos contornos al colono eu. ropeo.

Hé aqul las ideas de los contornos de Nutka. que nos lia permitido adquirir el corto espacio de quince dias (I): si satisfacen á la prolija curio. sidal del fisioblogo; si pueden algún día contri. buir á los progresos de una civilización inde. pendiente entre aquellos pueblos 6 á la prosperi. dad de una nueva colonia europea, lograrán nues. tros esfuerzos el único fin á que se dirigen, y les será uI verdadeco premio el ver que otros, con más tiempo y luces, arrostren el trabajo de proporcionarlas; asl como el ver que se derive su narración de las ideas de una verdad sencilla y no importuna, la misma que nos hace onitir una nueva repetición de las armas, utensilios, trajes, etcétera, de estos pueblos, que el Capitán Cook describió con su acostumbrada prolijidát ele. gante.

Pero es tiempo de ubandonar estas orillas y continuar el examen de las costas siguientes: si consultásemos la sola fieieza caracteristica de las naciones meridionales, no debiéramos temer de asegurar que los Izcuates se extienden á li ménos hasta el estrecho de Fuca y probable. mente hasta la ensenada de los Mártires y el puerto de Queenkytké: es este trozo de costa el teatro de la destrucción de los europeos, y por consiguiente el que deberán mirar los navegantes venideros con más cuidado, para que no se renueven ya las trágicas comparaciones del sacrificio de un hombre por la adquisición de una piel: la pérdida de siete hombres del Comandan. te Cuadra en el año de 1775 por paralelos de $47^{\circ} 26^{\prime}$ (2) la del Capitán Berkley, del Aguilu Imperial, de igual número y casi en el mismo sitio; la desventurada del Capitán Duncan con cuatro marineros en el bote del Argonauta sobre la punta de los Arrecifes; los riesgos que corrio en el mismo sitio una lancha del establecimiento nuestro de Nutka; finalmente, así la prontitud con que el Capitán Meares vio sacrificar por los súbditos de Wicananisk el hombre extraño acabado de llegar, como el tesón con que los natu. rales del Estrecho de Fuca han atacado su lan. cha y la nuestra del paquebot San Carlos, todo concurre á disipar las dudas sobre el carácter fiero y excesivamente traidor de estos natu-

(I) Ya se ha indicado cuánto nos han sido útiles las experiencias anteriores del Capitán Alberni y los rudimentos del idioma entre muchos de nuestro establecimiento. Hubiéramos deseado aproximarnos algo más do las descripciones y conjeturas del Capitán Meares.

(2) Las circunstancias de esta sorpresa irremedia. ble, y particularmente de la sucesiva salida al mar de la goleta Sonora, constituyen una época bien memora. ble en los fastos nuestros de la Marina, que en esta ocasión procurará hacerse pública y duradera con el auxilio dol buril. 
rales (r). Son además muy numerosos, más diestris en el manejo de las canoas, más unidos entre sí y más belicosos que los de Nutka; y si he. mos de juzgar por las adquisiciones y observaciones liechas hasta aquí, si bieri abunden en estas costas con exceso las ballenas, varios otros peces y las mismas nutrias, la calidad de śstas puede considerarse desde luégo como muy inferior á las más septentrionales: cn cuanto á los produistos que enriquecen las orillas, aciemás de lo que suministra el mar, creemos que no serian diferentes dicspués de un examen físico de los que se advierten entre el Cabo Frondoso y Nut. ka; bien que la naturaleza del suelo y la mayor benignidad del clima pueden tal vez llevará una wiayor robustez y tamaño los árboles que ya ha deses to y caracterizado con tanta exactitud el Sr. de Heenke.

Examinando la parte interior del Estrecho de Fuca, hasia aquí navegada por nuestros buques, y comparándola, ć bien á las ieyes naturales de la esiructura del globo y á las noticias interiores del Capitán Corver, ó bien á los últinıs detalles bien sospechosos del Capitán Meares y al ansia de las naciones europeas para ver realizados los viajes del Almirante Fonte y del Piloto Fuca, no podemos á ménos de Aiferir la publicación de nuestras conjeturas, tanto más, que si la esperanza no nos engaīa, no tardará la Europa en deber este nuevo conocimiento científico á los p"ogresos de la Marina española: una sola advertencia física terminará est: artículo ya harto difuso, $y$ es el peligro de los Suestes en las latitudes comprendidas entre los 45 y $55^{\circ}$ : la de. b:da atención á los temporales de ambos equinocsios, y la influencia de la Luna sob!e la:s alteraciones de los tiempos: el Capitáli Meares advierte una extraordinaria operacion de lns mares del Sueste en la costa al Sur del Estrecho de Fuca: los temporales que nosotros hemos ex. perimentadr, en principios de Agosto por los $54^{\circ}$, los que experimentaron el Comandante Cuadra y el Capitán Cook en los mismos paralelos finalmente, los riesgos de los buques de D. Francisco Elisa y el desarbolo del Capitán Colnett que le obligó á arribar á Cayucat, todo parece confirmar que esias costa no deben frecuentarse siro etatre los términos equinocciales de Marzo y Set:embre; á lo ménos por lo que toia al método hasia aquí introducido de seguir el comercio d. las pieles recorriendo un largo trecho de costa.

\section{Apéndice.}

Cuando-se escribió el capítulo antecedente, no se tuvieron presentes (por no haber ain lle.

(x) Puede recorrerse el viaje del Capitán Meares sobre estas costas. gado de Méjico) el viaje dol Piloto Pérez en I774 y el de D. Bruno Hezeta en 1775: como entram. bos tuviesen frecuente roce con los naturales, el primero en el extremo sepientrional de las Islas de la Keina Carlota, y éste en las costas com. prendidas entre los paralelos de 48 y $47^{\circ}$, sus descripciones pueden influir algúri tanto en la mayor ó menor exactitud de nuestras conjeturas sobre la cualidad del suelo y los moradores de los pa. ralelos que no hemos visitado; el tiempo no permite ahora confrontarlos, pero advertiremos, que atento á la natural estructura del globo, no nos fuera fácil suponer, que !a entrada de Hezeta en 'cs $46^{\circ}$ conduzca interiormente á una masa gran. le de aguas, cuando el fondo en la entrada ni es $\because$ piedra, ni es mayor de 28 brazas.

Debe advertirse igualmente, que las mantas, de las cuales se ha hecho memoria hablando del puerto Mulgrave, $y$ se remite una al Reai Gabinete, son tejidas de lana y no de cortezas del pino, bien que no nos es fácil acertar á cuál es. pecie de animales correspondan aquella, lanas.

Erenenen político de las cosiü del Noroeste de la América.

Examinadas en el capítulo antecedente las calidades físicas del suelo y de los moradores en las costas del Noroeste de la Amernca, es tiem. po ya cie referir estos conocimientos á la pros. peridad nacional. Sin un examen de esta especie, las tareas y los gastou de la actual expedición no acarrearian sino una nimiedad hidrogrática para el entiatenimiento de pocos ociosos: la Nación exige de nosotros un tributo más interesante, y

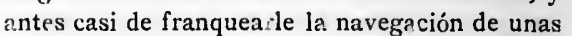
costas que poco há se miraban como abandonadas de la misma Naturaleza, es preciso indicarle cuál es la utilidad de semejante navegación; cuáles las medidas que pueden hacerla al mismo tiempo útil y segura al particular; cuáles; en fin, las consecuencias que del acierto de estas medidas pueden refluir directa ó indirectamente hacia la prosperidad y poderío nacional, comparado con las naciones más roderosas de la Europa.

Si no atendiésemos á la historia del hoinbre en tocios tiempos $y$ en todas situaciones; si su deseo innato de duminar, procedido del resorte de sus talentos ó de la fuerza adquirida de vencer sus pasiones, 6 finalmente una ú otra vez del instinto social de contribuir á la felicidad de sus semejantes, pudiese ocultarse un solo instante al filósofo no preocupado, tal vez pudieramos alucinarnos en las razones que guiaron á los europeos hacia esta parte del globo; pero no es posible que sea así, cuando á la reflexión se reune la necesidad de desengañar á una nación sobre su situación política; cuando la sola falta de este desen año hace que se malogren điariamente las 
loto Pérez en 1774 775: como entram on los naturales, el trional de las Islas en las costas com. le 48 y $47^{\circ}$, sus des. ii tanto en la mayor 3 conjeturas sobre oradores de los pa. ; el tiempo no per. advertiremos, que del globo, no nos trada de Hezeta en á una masa granen la entrada ni es brazas.

te, que las mantas, memoria hablando emite una al Reai y no de cortezas del 1 acertar á cuál esdan aquella: lanas.

del Noroeste de la

lo antecedente las $y$ de los moradores la América, es tiem. imientos á la pros. men de esta especie, actual expedición no ad hidrogrática para ociosos: la Nación más interesante, y navegación de unas 1 como abandonadas es preciso indicarle ejante navegación: en hacerla al mismo ular; cuále: : sn fin, ierto de estas mediitirectamente hacia acional, comparado ias de la Europa. historia del hombre ; situaciones; si su ocedido del resorte a adquirida de ven e una ú otra vez del i la felicidad de sus e un solo instante tal vez pudiéramos que guiaron á los globo; pero no es a reflexion se reune - una nación sobre la sola falta de este ren diariamente las más acertadas providencias de un rey únicamente ocupado del bienestar de sus vasallos.

Sean 6 no verdaderos los viajes del Almirante de Fonte (r), del Piloto Fuca, de Ferrer Maldonado, de otros holandeses, etc., puedan ó no alcanzarse el fin que guiaba á estos navegrantes, las derrotas que hicieron y el motivo de no hallarse rastro alguno fidedigno de aquellas navegaciones; las indagaciones nuestras sobre el examen político de estas costas no deben partir de otra fuente que la ligue directameo:s ron los acaecimientos del día, y esté afianzàda colre documentos ciertos y despojados de toda equivocación. Así nuestros razonamientos no empzzarán sino desde los viajes rusos, de los cuales izan dimanado muy luégo los nacionales y los ingleses.

Nada deja que desear en esta parte Mr. Coxe, historiador tan curioso como exacto (2), el cual, reuniendo en un solo punto de vista los diferentes viajes emprendidos desde las costas de la Siberia, ó bien para intentar el paso del Norueste ó para extender el comercio y conocimientos geoeráticos hacia el Sur y Este, termina su narración con los viajes del Teniente Synd y iel Piloto Otcheredin, por el año de 1770 , habiérdolos emprendido desde el de 1747 , en cuyo plazo se verificó la célebre expedición de los Comandantes Bering y Tchiricow. Los deseos de una gloriosa é ilimitada extensión del Imperio, más bien que la utilidad del comercio, movieron sin dudu los primeros pasos de los rusos en la Siberia: se conquistó un país casi desiertu, y la sola comunicación con la capital del Imperio para conservarle ó regirle cústó cuantiosas sumas: su si. tuación en el Asia y su inmediación á la América, lisonjearon sin embargo la feliz imaginación de aquella nación conquistadora: unas veces las minas (3), otras los productos felices del Asia, alentaban sus pasos escarmentados. Iué destinada una compañía de sabios y de navegantes para

(1) Eı Padre Venegas en sus apéndices á la Histo. ria de is California, trata prolijarnente y con mucho jisicio do viaje del Almirante Fonte: seguramente cualquier que lea aquellos capitulos extrafiará que

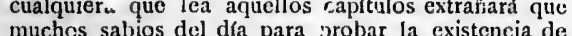
muches sabios del dra para probar la existen un paso, se ocupen en legitimar la verdad del viaje de Fonte ó Fonta: lo mismo pudiera decirse del de Fica, y en cuanto al de Ferrer Maldonado, s? examinará su legitimjdad en una Memoria aparte: entre tanto no podemos á ménos de compadecerr: de la triste constitución de las cosas humanas; vieudo que no sólo se decida en París y en i ondres, lo que habra de decidirse en he ha de decidirse en el mar, sino que los mismos naco, é incuzran co, e incuiran, como sucedo a los capitanes Dixon y Meares, en muchas contradicciones y áun insultos sobre la verdad de lo que han visto.

(2) No se puede recomendar demasiado la lectura de esta histo ia para comprender bien las ideas que siguen.

(3) Aur con los conocimientos del da no se ha destruido la mania harto envejecida en Europa, que tanto sea hablar de la América, o mas bien de las posesiones espaniolas, como hablar de las minas: nuestros reconocer prolijamente el suelo y los mares con tiguos: se describió el suelo, las cartas geográticas fundadas sobre los mejores datos astronómicos a!canzaron muy luego un grado bien alto de periección, y reconocidas las costas y archipiélagos inmediatos; muy luego diferentes buques trillaron aquellos mares, y en la corte de Petersburgo pudioron formarse combinaciones más extensas y fundadas sobre aquella parte remota de sus dominios (I).

Debemos confesar que en la serie bien larga de cincuenta años (2) los pasos rusos denotan al mismo tiempo aquella tirmeza en e! sistema $y$ aquella constancia en la ejecución, que solas pueden conducir á un feliz término las grandes empresas de las naciones: y si por una parte no se han economizado nilas medidas bien meditadas ni los caudales necesarios, ni los sabios y navegantes oportunamente escogidos, por la ctra ni las pérdidas comerciantes, ni los naufrarios repeti. dos, ni un archipiélago rodeado de bajos, de corrientes $y$ de hielos, han podido arredrar ó al negrociante ó al mariro intrépidos.

Tantos afanes, tantos gastos y tantos desvelos, no lograrán jamás en nuestro entender, del fruto á que debían aspirar; pero á lo ménos han contribuido á que la Rusia abriese los ojos á sus interesès verdaderos, $y$ ya abandonadas las conquistas, las navegaciones distantes, las minas y los proyectos mercantiles, se ciñese únicamente á una pesca y caza costaneras, hechas con la ma yor economía, y dir:gidas ó á la manutención propia ó al abasto de las pieles en el mercado de Kiackta. Es dificil acertar cuáles sean en el dia las verdaderas ventajas dc aquel comercio, que ya la concurrencia de las pieles te nutria en Canton debe haber desnivcleto considerablemente del estado en el cual le consideraba Mr. Coxe (3).

establecimientos el las islas Batanes ó Bashees, que segurainente no tuvo otro crigen que el furor de con. quista ó mís bien de la extensión de dominios, hace producir ast al Capitón Meares: About four jears be producir ast al Capitan Moares. Abont four years be fore the Spamiards had tahen poscssion of these isles in the espectation of findin.

(I) Véanse los viajes impresos de los Sres. Gme ling, Muller, Pallas, etc., y los citados de Mr. Coxe.

(2) Desde el año de i 717 en el reinado de Pedro el Grande, hasta el 1770 en el cual se sistemaron algún tanto en Rusia las ideas y proyectos sobre la $\mathrm{Si}$.

(3) Mr. Coxe prcsenta un cstado de las picles en viadas desde Inglaterra á Kiackta por Petersburgo en los años 1775,96 y $77, y$ son las siguientes:

\begin{tabular}{|c|c|c|}
\hline Años. & Castores. & Nutrias. \\
\hline 1775 & 46.460 & $7 \cdot 743$ \\
\hline $177^{6}$ & 27,700 & 72.086 \\
\hline 1777 & 27.376 & 70.703 \\
\hline
\end{tabular}

Añade después que la plus grande partie de ces pe lleteries (traldas al mercado de Kiackta), vient dc la Siberie, et des isles nonvellement decouvcrts, de suerte que puede porlas primeras inierirse la cantidad de las segundas. 
El Capitán Meares demuestra en su importınte capítulo del comercio de la China con la c) sita Noroeste de la América, que no sería difícil á la Inglaterra destruirlo por la vía de Canton; pues que yu se han visto en esta ciudad comerciante, compradores chinos de las provincias más remotas; pero si se hace una comparación de las nutrias vendidas anualmente en Kiackta, $y$ del total vendido hasta aquí en Canton (r), parece aún remota la época en la cual puedan realizarse aquellos conceptos; y de cualquier modo nuestras comparaciones políticas 10 podrán jamás referirse al comercio ruso.

Los pasos de esta nación en las costas de Siberia, no habían sin embargo llamade la atención pública hasta los años de 1771 , y ó bien fuese el no buen éxito ó el silencio de la corte, apenas las empresas vigorosas de la Rusia al. canzaban los elogios $\because$ la admiración de pocos hombres científicos, únicamente deseosos de combinar sus sistemas con las noticias más estendidas del globo. Pero en el año siguiente de I 773, el Conde de Lacy, Ministro de S. M. en la corte de Petersburgo, enterado de nuevas ideas de conquista, ó usurpación relativamente á las costas contiguas de la América, halló preciso avisarlo á Madrid con cuanta individualidad estuviese á su alcance; y por nuestra parte no se defirió un instante en tomar medidas eficaces para atajar este mal.

Estas medidas eran justas, $y$ áun diré precisas; las conducían Ministros sabios y un Virey activo é inteligente (2) y debían practicarlas Oficiales acreditados é intrépidos: sin embargo, estribaban sobre los cimientos harto engañosos de nuestro sistema de la América, y esto bastó para que desde el principio nos fueran bien nocivos, y últimamente nos arrastrasen unas discordias funestas.

Plugiese al cielo que en esta ocasión un escritor amante de la verdad pudiese continuar el hilo de sus reflexiones sobre la prosperidad nacional sin tocar de cerca esta parte de la Historia politica de nuestra América: un velo espeso no daría libre tránsito, sino al respeto y á los elogios que por tantos títulos habían merecido aquellos sabios legisladores; y la memoria de los males pasados se borraría con la esperanza del

(v) No comprendidas las pieles vendidas en Canton por cuenta de los espanoles, las del Conde de la Peyrouse, las de los Capitanes Kendrik y Grey, amePeyrouse, las de los Celice del Capitán i. "ca. ricanos, y las de la regther y 4.000 las vendidas res, que pudicran tal rez llegar a 4.000 las vendidas anteriormente, se componian(segín el Capitán Dixon), de 5.033 , cuyo valor había sido en el mercado de
Canton de 746.842 pesos fuertes, o bien a un precio

medio de 26 y $1 / 6$ pesos fuertes por piel.

(2) Los Excmos. Sres. D. Julián de Arriaga y Don José de Gálvez, fueron a la sazón Ministros de In. dias, El Excmo. Sr. D. Francisco Bucareli era Virey de Nueva Espanta. bien venidero: pero no es posible conseguirlo; un Ministerio ilustrado no advertiría en el día sino un silencio, 6 adulador 6 malicioso, y la falta ó de la verdad ó de la sencillez en esta ocasión, acarrearía tal vez un plazo más distante á aquella útil reforma de nuestro sisiema en América que hasta aquí nos ha costado tan. tos sacrificios.

En el mismo moniento en que se advirtieron por nuestra Corte las intenciones de los rusos, se trató de explorar con cautela sus movimien. tos; pero comnal mismo tiempo fuesen oscuros nuestros derechos sobre unas costas cuya extensión, antes bien, cuya existencia era aún dudosa, nuestros pasos debieron encubrirse con un misterio funesto, evadir un tratado en Europa, que muy luégo hubiera descubierto los intereses recíprocos; finalmente, derramar caudales inmensos para la averiguación de una cosá que una sria iregunta á la corte de Petersburgo hubiera $\therefore$ iediatamente aclarado.

$\mathrm{Ni}$ eran estos los peores males que debía producir la errada idea de los límites de nuestros dominios. La Marina estaba á la sazón en su infancia; y los Vireyes no habían aún depuesto la errada máxima de sus antecesores, de retrocede: cuanto fuese posible los límites del Imperio, con preferencia á las ventajas de los países ó ya conquistados ó á lo ménos conocidos (I).

Con tales antecedentes, casi en el mismo principio se torció ó más bien se abandonó el hilo cie nuestros intereses: en lugar de atravesar al liamskatka con el fin plausible que dirigía á la sazón en otras partes del globo los Bouganville, Biron, Wallis, Carteret y Cook, navegamos ceñidos al Continente; y cuando la exploración de 1774 , ó al sumo de 1775 hubiera podido informarnos no sólo de los nuevos, si también de los establecimiertos antiguos de la Siberia, apenas en 1782 logramos satisfacernos algún tanto por el viaje del Capitán Cook dei estado de los rusos en las islas de Oanalaska: pocas cruces solemnemente plantadas á veces en parajes que aún no sabíamos si eran islas ó continentes, si eran ó no habitadas, alucinaron nuestras miras políticas con el agradable semblante de nuevas conquistas; $y$ creyendo que no fuese necesario reva-

(r) Para los parrofos antecedentes se ha : tenido presentes los documentos origina! es existentes en el Archivo de Méjico, y recopilados con murtau juicio por c' Tenieute de fragata D. Francisco Maure??e: para li. justificación de éste, baste decir que la instrucción del Excmo. Bucareli al Comandante del primer buque de exploración, empieza en estos términos: al nidad del Rey, que fió a mi cuidado esto Gobierno do Nueva Fspafia, no sólo me impone en la obligación de Nueva Fspafia, no solo me impone en la obligación de
conservarie estos vastos dominios, sino también en la des procurar aumentarlos en cuanto me sea posible por medio de suevos descubrimientos en la extensión de lo no conocido, etc.» Son casi iguales las expresiones del Fxcmo. Flores en ${ }^{\prime \prime}$ Instrucción do 1788 . 
lidarlas en un tratado, malogramos aún á la vista de la Europa esta pequeña utilidad de nuestros viajes, y finalinente, nos vimos en 1788 constituí dos á emprender de nuevo las mismas exploraciones emprendidas en I774, y ya por los señores Cook y la Péyrouse, verificadas con el mayor suceso.

Tiembla la pluma al sólo echar la vista á los caudales inmensos que se han derramado en San Blas; $y$ aunque en este momento no sea nuestro ánimo extender el examen político á las costas de la California y á las previncias del Nuevo Méjico, tiembla la imaginacion al solo considerar la extensión inmensa de territorio que se pensaba agregar á la Monarquía.

Entre tanto, el'Capitán King, digno heredero de los talentos y penetración del Capitán Cook, había echado las semillas de un comercio de pieles de nutria, entre Canton y la costa del Noroeste de América: su ánimo no era, á la verdad, sino el de ocurrir á los gastos de los descubrimientos y perfecta descripción de las costas que no había visitado; pero las especulaciones mercantiles, siempre dirigidas á un desnivel yá un abuso por la excesiva abundancia de fondos y de concurrentes y por la natural rivalidad de las naciones europeas, muy luego abandonaron aquella senda, y últimamente nos han llevado á un convenio que hará una época memorable, y en mi entender feliz para la Nación (I).

Ya, pues, se han fijado límites á los dominios de la Monarquía. Ya, aunque apénas pueda alcanzarlos toda la ilustración de la Geografía moderna, están ceñidos, no por una Bula arbitraria que corra de un polo al otro, sino por tratados auténticos con las demác - otencias de Europa: y si en lo interior del Co inente de América, la política de las naciones rivales nos aún. vihar en uno ú otro rincón con los indic civilizados, ya podemos lisonjearnos que ó aniquilamiento de nuestras fuerzas, 6 un examen maduro de nuestra situación, nos desprenderán muy luego de esta senda errada: no será, por consiguiente, inoportuno el considerar toda la costa al Norte del Cabo Blanco, cciño no sujeta á la Monarquía; 6 á lo ménos, deberemos lisonjearnos que nuestros derechos para con las naciones eu. ropeas, se limitarán en cuanto á esas costas y países internos, á exigir que nadie los posea, sin pararnos ahora en que este convenio, 6 nos autorice 6 nos convide á custodiarlos: así siquiera, no vereinos renovados con otras naciones los pasados ciisturbios, y custodiando un sole palmo de terreno que nos sea útil ó necesario, miraremos

(I) Los proyectos comerciantes de D. Francisco Basadre, relativamente a la venta de pieles de nutria de la California por cuenta de la Real Hacienda, pertenecen al libro siguiente, porque no abrazan las costas de que hablamos ahora. tal ve $\check{z}$ algún día con una compasión escarmen tada, derramarse la sangre y caudales agenos, por la posesi'sl de una costa que nos hubiera tan sólo acarreado los mismos males.

Al momento que nos miremos como comerciantes en estas costas, ya caen por si solas todas las cadenas que nos agobiaban, y al ruído espantoso del cañón y de la guerra, sustituyendo los dulces lazos de un cambio lucroso, de una navegación apacible $\mathrm{y}$ del auxilio recíproco de las naciones para su prosperidad y opulencia, ya las combinaciones políticas pueden seguirse con mayor agrado, y la defensa nacional fundarse sobre la base sólida de su prosperidad.

¿Cuál es, pues, este comercio que ha merecido en el día toda la atención de la Europa, y que la sid - poco ménos que el origen de una nueva guerra, $y$ desde luego de una nueva rivalidad entre las principales naciones comerciantes? ¿Cuales son las ventajas que nos convija á abrazarlo, y cuáles los medios de no malograrlas?

La costa del Noroeste de la América no ofrece al comercio evropeo sino una muchedumbre de pieles finas, la mayor parte de nutria, que cambiadas á poca costa á unas naciones que no aprecian ni las comodidades ni el lujo, iogran luégo en el mercado de Canton un valor cuantioso, el cual es tanto más apreciable, cuanto que allí la balanza del comercio está c' scididamente contra la Europa.

El poco precio á que se adquieren, el mucho a que se venden y la utilidad de ocupar los brazos y fondos nacionales y sobre todo la navega. ción nacional, son otros tantos objetos que han hecho en el dia comprender este comercio entre las grandes combinaciones políticas, llamando particularmente la atención de la España y de la Inglaterra.

Mr. Pitt, hecha la paz de $7_{783}$, dando una mrida política hacia todas las pres del globo á dond udiese penetrar el con rercio inglés, úni co resurte de su sistema para extinguir ó mode. rar siquiera la Deuda 13. cional, comprendió que el Asia y particularmente la China, serían siem. pre los estribos en los cua, debía descansar todo el sistema de comercin: arreglados inmedia. tamente así los lí ites de la autoridad económica y gubernativa de la compañía, como los abu. sos y malversaciones de los empleados; escarmentada con un rasgn severidad contra el Gobernador Hastin quelá rinisma autoridad que tantas conquistus mercantiles había produciđo a la Nación; extendida la introducción de los paños y manufacturas inglesas por Surate en la Persia y Turquía, por el Bengala en el Mogol $y$ en el Thibet, por Canton y por Kiackta en am. bos extrenios de la China; procurada últimamente la adcuuisición de cúantos frutos precicsos pudiese suministrar el globo entero al lujo excesivo de 
la Europa y á sus colonias, no olvidó, sin embargc, que esta opulencia nacional no había llegado al grado más alto de que fuese capaz y que tal vez una actividad $y$ una industria oportunas pudieran dar á su nación toda aquella parte en el comercio de China, que aún dividían con clla las demás (r): la historia de Mr. Coxe y los cálculos del Capitán King, eran datos hartos positivos para que en estas combinaciones no tuviese un lugar postrero el comercio de las pieles de nutria: en este dehió luégo ver con mucho agrado, que si bien fuese al principio aventurado y no sujeto á unos cálculos positivos, lograba, sin embargo la nación la utilidad je franquearse la navegación del mar Pacílico por el Cabo de Hornos y la comunicación del Asia con la América, por las decantadas derrotas de la Nao de Filipi nas: propuso inmediatamente sus ideas á Benga la, í Canton y al comerciu de Londres: varios particulares recibieron como orden la propuesta del Ministro y no tardaron en fiar sus caudales a umos Capitanes bien e.xpertos, guiándolos finalmente estos mismos ensayos (2) sino á unas ganancias considerables, á lo ménos á la utilidad de lá nación de ensanchar el derecho de sus pescas á todas nuestras costas de la América.

No debe suponerse, examinando los pasos del comercio inglés, que precisamente hayan de ser éstos siempre acertados, ó bien que cualesquiera scan las circunstancias de aquella nación relativamente á una empresa, pueda siempre torcerlas á su favor y áun sobrepujar en el concurso á otras naciones á quienes la Naturaleza parece brindar el buen éxito de la misma empresa: la costa del Noroeste de la América está precisamente en este caso; y 6 bien se examinen la facilidad de la navegación, las combinaciones mercantiles 6 los géneros de cambio que constituyen este giro, todo parece convencer que la Rusia y la Espaina son indispensablemente ias naciones árbitras de este comercio.

La adquisición de las pieles de nutria no es tan fácil ni tan sencilla como hasta aquí se ha imaginado en Europa; ni su número es tanto que puedan indeterminadamente suponerle trecido los aventureros que al principio la emprendan: desde luego cualesquiera sean las suposiciones del Capitán Meares relativamente á un contra.

(1) Se verá en las reflexiones correspondientes á las Filipinas, que positivamente el sistema del Gabinete inglés se dirige el el día á conseguir el monopolio de todo comercio del Asia, le será muy útil la actual revolución de la Francia.

(2) Mr. Pitt, hablando a los Cos runes de la vio. lación de los derechos públicos por 1 Piloto Martinez en Nutka, llama con mucha propieda' el co. mercio de la costa del Noroeste de la América renfunt comcrec. Los ensayos se han hecho con todo el tino comerciante: el primer buque del Capitán Hauna que salis de Canton en 1785 , era de solas 70 toneladas con 30 humbres de dotación. bando $o$ á un comercio libre entre los establecimientos rusos, los cálculos mercantiles no pueden emprenderse sino desile la entrada del Príncipe Guillermo (I): ni por cuanto se extiendan las costas desde esta entrada hasta la de Bucareli, podrán jamás (según las experiencias de los años pasados), exceder las pieles de nutria de un número aproximado de 600 por año: esta aserción no parecerá temeraria cuando se considere que fuesen sólo 300 (2) las que pudo adquirir el Capitán Meares en el Sung Corner de la entrada del Príncipe Guillermo, desde el mes de Setjem. bre hasta el de Mayo, que rosotros apenas hemos encontrado otras tantas en el puerto Mulgrave, comprendidas algunas tríbus del Este y del Oeste; finalmente, que recorrica toda la demás costa desde el Cabo Buen Tiempo hasta el de San Bartolomé por los Capitanes Dixon, Portlock y Douglas, sus adquisiciones han sido muy cortas, á pesar que hayan sido muchas las diligencias para aumentarlas: una sola embarcación jamás pudiera recorrer todos estos puertos, ni corsecuentemente completar el número indicado en una sola expedición.

Ignoramos los progresos comerciantes que hiciese la balandra Princesa Real en el Archipiélago de su nombre; pero debemos creer que no serían muchos, cuando no se ha hecho memoria de ellos, ni la balandra cesó después sus operaciones mercantiles para navegar hacia Canton: en tal caso pudiéramos aventurarnos á creer que las islas de una y otra parte que forman el canal de Dixon y que luego siguen hasta el Cabo Boise, podrían cuando más suministrar I.000 nutrias anualmente. (3) deducidas éstas por la mayor parte del Archipielago de la Reina Carlota.

Ya en Nutka la inmediación de las célebres.

(I) Seria muy títil comprender la Rusia en nuestro próximo tratado de límites con la Inglaterra, y así como se fijen los de la Fspaña en el Cabo Blanco, fijar lns de aquel Imperio en la ría cie Cook, çueciando todas las costas intermedias, cumo las de Afrira, al arbitrio del que quiera establecerse en ellas: bien, entendido que para evitar principios de discordias, ningún estalilecimiento mercantil debe hacerse sin aviso recíproco en Europa para atender a los derechos anteriores ni alegar otras jurisdicciones en el terreno in. mediato á un establecimiento, que el que se disfrute con cortes, siembras y factorias. Nutka o el Archipielago de Macuina deben coinprenderse en este estado; pues que á el Criendly "ove ó puerto de Yucuat no corresponde sino un pequeño distrito cedido por $\mathrm{Ma}$. cuina al Capitan Mleares: en las expediciones del prócimo año de 1792 convendra sustituir este método de crures, que en los tratados de Europa no.logra luégo la rivalidación necesaria.

(2) Suponemos que las 57 restantes que cita el Capitán Dixon, se hayan adquirido en la ría de Cook.

(3) Aunque el Canitán Dixon pudo adquirir algunas máli, no sería prudente calcular por esa adquisinas mál, no sería prudente calcular por esa adquisi-
ción, prirque siendo el primer buque que comerció con aqtellos naturales, recibió las que tenían acopia das en ruchos años. 
los estableci.

tiles no pue. rada del Prínse extiendan la de Buca. eriencias de los de nutria de un ño: esta aser. lo se considere udo adquirir el er de la entrada mes de Setiem. $s$ apenas hemos erto Mulgrave, Este y del Oesla demás costa el de San Bar. Portlock y Doub muy cortas, á diligencias para ción jamás pus, ni corsecuen. indicado en una

omerciantes que en el Archipié. cs creer que no hecho memoila spués sus opera. ar hacia Canton: arnos á creer que e forman el canal sta el Cabo Boisé, ar 1.000 nutrias is por la mayor ina Carlota.

n de las célebres

Rusia en nuestro Inglaterra, y as an el Cabo Blanco 1 ie Cook, queulan umo las de Afrira se cn ellas: bien en de discordias, nin din a los los derechos an en el terreno in cl que se disfrute Jutka o el Archipiéderse en esto esta. uerto de Yucuat no rito cedido por $\mathrm{Ma}$. pediciono del pro pediciones del pro este método d 1 plantio de muchas
opa no. lngra luégo

untes que cita el $\mathrm{Ca}$ u la ría de Cook pudo adquirir alguar por esa adquisipor esa adquis uque que comerció
Lagunas de los Nuchimases, ofrece una cantidad mucho más considerable de pieles, las cua. les podrán tal vez sin imprudencia hacerse llegar hasta 3.000; pues que Natzapi, calculados todos los pescadores; los días inútiles del invierno y la dificultad de coge?' :as nutrias, las llevaba en su máximo á 4.000 .

No deben ser tan abundantes las Islas de Wicananish, el puerto de Cayuclá, antes bien, si atendemos á las noticias verbales de la goleta Saturnina, á los reco.1ocimientos hechos en el año anterior por el Alférez de navío Quimper y álos progresos bien limitados de los Capitanes Barkley y Mear's, no pueden formarse ni áun unas isperanzas lison jeras sobre la mayor facilidad de esie comercio: después de las desgraciadas pérdi. das del Crmandante Cuadra y del Capitán Barkley, la una en la ensenada de los Mártires y la otra en el Queenithee, aventurar las lanchas á tanta distancia de sus propios buques parecerá cada día más imprudente y reprensible, 'y' si se omiten estas expediciones, ya al Sur del Fstrecho de Fuca, los puertos son tan malos ó más bien carece tanto la costa de puertos, y las neblinas $y$ temporales son tan frecucntes, que fundar los cálculos mercanitiles sobre las adquisiciones que de ella dinanen fuera sumamente arriesgado: no supondremos, por consiguiente, hasta el puerto de la Trinidad, sinc vaa adquisición anual de 800 nutrias; de donde puede inferirse que la cantidad total de pieles de nutria que pueda suministrar la costa hasta aquí conocida en el espacio directo de 500 leguas, no excede anualmente de. 5.400 .

Ni nos alucinan contra estos cálculos los ejemplos de los rusos en sus pesquerías, bien sea de las islas 6 del continente: las islas abundan ciertamente de un mayor número de nutrias: las del continente son harto dudosas en cuanto á su prosperidad; todas han costadó inmensos sacrificios de gente $\mathrm{v}$ de dinero; la comunicación de un establecimiento con otro y de todos con la capital de Bolcheresk, les dió una consistencia y otro wetodo gubernativo: la vida económica, y digámoslo asi, más bárbara que la de los mismos naturales, á la cual se ven constituídos los emprendedores de esta pesca, debiendo además sacrificar a $a$ mente á su propia seguridad un número crecido de naturales ( $I$ ) no da lugar á una comparación cabal con otras naciones distantes, hechas á un temple, á una legislación y á una vida más sua. ves que las de los rusos (2); finalmente, así el no

(r) Véanse los Diarios del Capitán Cook, del Piloto Haro y del Teniente de navio Hidalgo.

(2) A la verdad, la determinacion de Mr. Maccay en quedarse y la de Mr. Strange en dejarle entre los pueblos de Nutka, que a la sazón y áun en el día tie. nen el concepto de canfbales, $\delta$ no hace mucho favor a la civilización de los ingleses, $\delta$ hacen el mayor elogio de su codicia comerciante. haber concurrentes en las islas y costas de aquel Imperio, como el tener un desembocadero más cómodo en las fronteras de las provincias septentrionales de la China, el surtirlas con el auxilio del Canadá y de la bahía de Hudson con un número proporcionado á sus necesidades, haría muy defectuosos cualesquiera cálculos que tendiesen á deducir nuestra prosperidad, del semblante con que se hallan las pesquerías rusas.

En cuanto al incremento del número indicado de pieles, que seguramente han supuesto los in gleses en sus combinaciones, es menester reffexionar que sólo podría conseguirse (áun cuando el número de nutrias lo permitiese), 6 por medio de los naturales, $́$ o por medio de los marineros nacionales de las factorías, que á imitación de los rusos, se ocupasen por sí en la pesca: lo primero no es tan fácil á suponerse, puesto que no sólo los vemos ocupados todos y casi diariamen. te en la pesca, sino que la necesidad de proveer en el verano á su subsistencia para el invierno; la de alcanzar algún abrigo para el frío; el corto número de población, y sobre todo, el no haber a umentado sus acopios (I) á pesar de las visitas repetidas de los europeos, con cuanto pudiese excitar sus antojos, no dejan muchas esperanzas de que por su parte pueda crecer ni medianamente este ramo industrial: la experiencia dictará tal vez en Nutka lo que hayan de aprovechar los ingleses con una pesca nacional protegida de una factoría: por nuestra parte nos ceñiremos sôlo á indicar que esta experiencia probablemente los desengañará muy luego (2), y que áun en el casn de no malograrla, ni el pié de nuestros sueldos y alimentos, ni nuestra pericia en el ramo de la pesca, ni la dificultad je sujetar en la conducta y subordinación nuestros menestrales en el caso que se encuentren hábiles y constantes, nos cnn-

(r) Pudiéramos citar á favor de esta aserción; los chascos repetidos de las embarcaciones que han lle. gado postreras a la costa: el Capitán Meares en la corbeta la Nootka, preccdido por el Capitán Fipping en la entrada del Principe Guillermo, no encuentra una piel: los Capitan's Portlock y J.Jixon, para auxiliarle en sus apuros, al affo siguiente le constituyen en un y pesar de esto sin cl encuentro casual de las y a pesar de esto, sin el encuentro casual de las Isla de la Reina Carlota, sus acopios hubieran sido suma. mente mezquinos: el Capitán Barkley, aprovechando el encuentro y aprestos anticipados de Mr. Maccay, apenas recibe 600 pieles en Nutka, é inmedlatamente queda el Capitán Hanna, sin encontrar más que pocos retazos: el Capitán Colnett, a su salida de San Blas, aunque llegue por Febrero a Clayucat se vé prear por diez pesos fuertes cada una las pocas que habia en uuestro establecimiento; finalmen. te, son increilbles los sacrificios que eu el presente año de r $79 \mathrm{r}$ ha hecho el Capitán Kendrik el Nutka para surtirse de un corto numero de pieles.

(2) Pudiera aventurarse la proposición de que no cel permanente el establecimiento inglés en Nutka, a pesar de ser éste el paraje más oportuno para inten. tarlo.

47 
vidan á ser los primeros á engolfarnos en esta especie de empresas.

No podremos por' consiguiente en nuestras combinaciones mercantiles suponer un mayor número de pieles de las que se manifestaron al principio; deberemos tener presente que deteriora mucho la calidad de las pieles á medida que se disminuye de latitud ( $\mathrm{I}$ ) y no perderemos de vista así la natural concurrencia de los ingleses y de los americanos, como la imposibilidad de que los tiempos, las estaciones y un feliz acaso, proporcionen entre los muchos concurrentes una distribución tal de distrites de la costa, que ninguno quede sin ser visitado, $y$ por consiguiente, $\sin$ contribuir su cuota proporcionada de pieles.

En este caso apenas nuestros cálculos los más felices podrán extenderse á la adquisición anual de r.500 á 2.000 pieles, las cuales en el mercado de Canton, al precio de 26 y $1 / 6$ pesos fuertes (2) por cada una, darán un caudal efectivo de $4^{0}$ á $5^{0.000}$ pesos fuertes: estas á lo ménos deben ser nuestras suposiciones, mientras no demuestre la experiencia una probabilidad grande de hacer exclusivo á favor nuestro este ramo de comercio, con preferencia á los ingleses y americanos.

Una comparación de ventajas con aquellas naciones, es por consiguiente, necesaria para aclarar la cuestión primitiva, reducida ya al do. ble objeto de examinar: $1 .^{\circ} \mathrm{Si}$ debemos concurrir. $2 .^{\circ} \mathrm{Si}$ podemos excluir ó á lo ménos aventajar á los demás concurrentes. La comparación de los concurrentes á una misma especulación, naturalmente se divide en los tres ramos siguientes: $1 .^{\circ}$ Cuáles son los géneros que se pueden traer al mercado. $20^{\circ}$ Cuál valor puede darse â los géneros recibidos. $3 .{ }^{\circ}$ Cuáles son los gastos que trae consigo esta doble importación (3). Por ventura la segunda de estas indagaciones puede omitirse, no liabiendo más mercado para las pieles que el de Canton, en dinde los privilegios son unos mismos para todas las naciones y una misma la necesidad de equilibrar cuanto sea posible la balanza del comercio: nuestros razonamientos no se dirigirán por consiguiente sino al primero $\mathrm{y}$ al tercer punto.

Bien examinadas las necesidades $y$ antojos de los naturales en las diferentes tríbus recono. cidas hasta aquí, y considerado con no menor atención el efecto político dimanado en toda la

(1) Puede verse esta diferencia en nuestra remesa de pieles al Real Gabinete.

(2) Sería más prudente suponerlo algo más bajo, esto es, de 20 á 25 , si el mayor número es de parale.
élo los más bajos que Nutka.

(3) Los ćllculos mercantiles son por lo común molestos si han de $F^{\prime}$, . laros: el refrán de Sir Roger de Coverly en El Especi.dor ingles, Appeny saved is " penny got, es el modo 1 iás exacto de discurrir on niateria de comercio. costa, de la concurrencia poco unánime y bien desordenada de las naciones europeas, pudiera deducirse como verdad, que las ganancias exce. sivas 6 bieii de los buques del Capitán Cook 6 de los del Capitán Portlock, deben olvidarse como ya inasequibles; y que ba desmerecido de tal modo el valor del hierro, que ya este artículo puede considerarse como de segunda necesidad entre aquellos naturales: ¿cómo podíamos imaginar jamás que en las rancherías de Macuina, al tiempo que se rehusaba una piel á un marinero por 50 conchas de Monterey (r) se le diese por dos un pote de hierro de ro á 12 libras, en muy buen estado? Sin embargo, esto acaeció á nues. tras lanchas al tiempo que recorrían los canales iñternos á las ordenes de los Tenientes de navio Espinosa y Cevallos: y por lo que toca á las partes más septentrionales, si bien tuviesen aún bastante valor las hachas en la entrada del Príncipe Guillermo y en el puerto Mulgrave, las demás cosas de hierro fueron siempie pospuestas con mucho á la ropa de abrigo y áun á los botones.

Entre los efectos de necesidad relativos á los naturales, no podremos por consiguiente com. prender sino el hierro labrado $y$ dispuesto en utensilios útiles, particularmente los que ne. cesitan el temple del acero, y la ropa de abrigo: son inciertas y sumamente inciertas sus nece. sidades relativas al lujo; los abalorios, los bo. tones dorados y plateados y los de metal con preferencia á los de hilo, fueron los efectos preferidos en el puerto Mulgrave, así como en Nutka se decidieron generalmente por los espejitos, en los cuales ya miraban con mucho empeño sus fisonomías y se justificaban á veces de no haberse lavado el rostro somo solíamos recomendarles (2), pero un efecto que correspondiendo á los de lujo, puede sin embargo consi. derarse entre los de necesidad, y áun como el más esencial en el comercio de las pieles, es seguramente la concha de Monterey, Aullun, que describe Linneo bajo la denominación de Haliotis Myde: puede agregarse el cobre para las inmediaciones de Nutka, pues que como ya se ha dicho en el capítulo antecedente, aquellos naturales lo llevan luégo á los Nuchimases (3) y ya tenemos agotados todos los efectos que púeden concurrir en el mercado de la costa.

(1) Se verá después hablando del valor do estas conchas hasta qué punto está desnivelado el comercio europeo. (2) No puede omitirse el hablar del progreso en el aseo que han hecho estos naturales, particular-
mente los Tahis: a bordo de la Descunierta Natzapi mente los Tahis: a bordo de la Descubierta Natzapi
ha pedido otro vaso de agua, porque habra un mosquito en el que le presentaban.

(3) Me aseguró Natzapi qne por una plancha de cobre de las dimensiones de las del forro, pero algo más gruesa, daría siempre tre, pieles de nutria de la mejor calidad. 
ánime $\mathrm{y}$ bien peas, pudiera nancias excetán Cook 6 de lvidarse como recido de tal - este artículo nda necesidad bodíamos imade Macuina, al á un marinero se le diese por libras. en muy acaecíb á nuesían los canales ientes de navío que toca á las en tuviesen aún ntrada del Prínlgrave, las depie pospuestas y áun á los bo.

dad relativos á nsiguiente com$y$ dispuesto en hte los que neropa de abrigo: iertas sus nece. balorios, los boos de metal con $n$ los efectos pre'e, así como en nte por los especon mucho em. ificaban á veces somo solíamos to que corresponembargo consi, áun como el más pieles, es seguraAullun, que desación de Haliotis para las inmediato ya se ha dicho quellos naturales ses (3) y ya teneque ptreden cona.

o del valor de estas inivelado el comer-

lar del progreso en aturales, particularEScUBiERTa Natzapi rque habra un mosdel forro, pero algo ieles de nutria de la
Alora, pues, examinend, nuestra situación política, se deja ver no con yoco agrado del que desee la prosperidad nacional, que seguramente las colonias e: :-ñolas parecen aventajarse á las demás en suministrar estos efectos: el hierro labrado, si es de manufactura española, es sin duda alguna mucho más caro que el de manufactura inglesa: pero como estas en sí sean cosas de poco valor, y los rendimientos no puedan ser cuantiosos, la diferencia jamás será de mucha monta ni capaz de desnivelar el comercio: en la conducción á Manila, y de allí á la costa, ó de Nueva España ó de California, ya nuestros costos pueden considerarse á lo ménos iguales á los extranjeros, ó bien vengan por Canton ó por el Cabo de Hornos: en desquite de este ramo en el cual tenemos alguna inferioridad, se nos presentan los demás muy favorablemente. El cobre y las ropas de abrigo, sacado aquél de las muchas minas de la Nueva España y éstas de Méjico y demás ciudades en donde el temple obliga al uso del paño y de las bayetas, son efectos bien baratos y de bien fácil transporte al paraje de su consumo: y por lo que toca á las conchas de Monterey, debe creerse positivamente que siendo aún allí limitadas á un corto trecho de costa, no sólo no tendrán en los buques extranjeros quien las compita, sino que será fácil darles por nuestra parte y conservarles un valor precioso.

Estas conchas poco há no tenían valor alguno en Monterey: la más leve recompensa á un neótito de la Misión que las recogiese, bastaba para juntar centenares de ellas, tanto más, que era indiferente su principio de calcinación, por estar desde largo tiempo sobre las playas: en toda la costa las han apetecido con iguales ansias (I) pero la misma facilidad de adquirirlas, ha hecho que nuestros navegantes de: San Jlas las malbaratasen, habiendo caso $\mathrm{d}$ t: dar $5^{\circ}$ conchas por una piel, cuando al prin:ipio en Nutka y últimamente en la entrada del Príncipe Guillermo (2) una 6 dos conchas alcanzaban una piel fina.

Sin embargo, es fácil poner un freno á este abuso; y desde luego sea como fuere, podemos ya asegurar que la parte de comercio en la cos. ta del Noroeste de la América, correspondiente á los efectos de importación, es bien favorable á las colonias nuestras de Nueva España, sobre las demás extranjeras, ya que éstas ni pueden conseguir las conchas (3) ni suministrar

(r) Las destinan por lo común para la comida; á veces les sirven de adorno: aumentan sin proporción de precio en razón do su tamaño, el cual puede considerarse apreciable, cuando la circunferencia llega siderarse gemes.

(z) Nos lo ha dicho verbalmente D. Salvador Hidalgo.

(3) Parecía que los nácares 0 conchas de la perla el cobre y las ropas usadas de abrigo con tanta prontitud y $\tan$ poca distancia comò nosotros.

Queda ya por examinar el ramo más importante de un comercio, y es el transporte de am. bos efectos cambiados: se combinan en esta partc todas las trabas de la legislación europea que favorecen á una más que á otra nación; la posición de las colonias ó puertos amigos de cada una, á donde hayan de aprodar las naves; peru sobre todo la economía y práctica de la navega. ción, para que los viajes sean al mismo tiempo periódicos, cortos, lucrativos y seguros.

Desmaya, á la verdad, la pluma del que mire los intereses nacionales, cuando se considere que nos cuesta hartos sacrificios la vista de una pu. sición como la nuestra para el comercio de las pieles: la posición es, sin duda alguna ventajosa, ó bien se emprendan nuestras operaciones mercantiles desde Acapulco, desde Monterey ó desde Manila; pero cuánto cuesten estas colonias á la Monarquía, cuánto le hayan costado hasta aquí, no fuera fácil describirlo en pocos rengiones; ello es, sin embargo, que nuestros viajes desde Acapulco s San Blas son igualmente breves y seguros de ida y vuelta en todo el año, que los puertos de Monterey y San Francisco á donde nuestro navegante halla todos los auxilios así para su seguricida, subsistencia y recreo, como para la continuación de sus operaciones mercantiles, pueden muy bien considerarse un distrito de la misma costa del Noroeste; finalmente; que el puerto de Manila, mediant: sus conexiones mercantiles con li Nueva Esparia y con la China, liga de tal modo sus navegaciones para la costa del Noroeste, que pueden considerar casi libres dic fletes los efectos que componen este cambic, cuando los buques extranjeros, sobre ellos sclos deben recargar todos los gastos de un viaje peligroso y dilatado.

Más felices también en este ramo por lo que toca á la economía, podemos considerar nuestra navegacival aventajada á la extranjera, no sólo en la multiplicidad de hhietos que pueden abrazarse de ida y vuelta, si uambién en el poco costo de las embarcaciones, marinería y víveres que han de verificarlos: cualquiera dé una mirada, aunque ligera, á la navegación nuestra de Fili. pinas, á la excelencia de los buques construídos en sus provincias, á la muchedumbre de buena marinería que puede suministrar (I) y á la cali-

de Panamá, Realejo, Acapulco y Filipinas debieran ser también apreciables; pero no ha sido asi, y los naturales del puerto Mulgrave han manifestado á Don Cayetano Valdés, que las tenían en aquellos contornos.

(x) Un marinero filipino de primera clase gana en la Nao iz pesos fuertes por mes, y en aquellos buques mercantes dos a tres: los marineros $i$ gieses escriturados por el Capitán Meares á bordo del Rey escriturados por el Capitán Meares á bordo del Rey
Jorge, debran ganar cuatro libras esterlinas. El pago 
dad y abundancia de los viveres, conocerá desde luego que mal pudieran competirle los armamentos ingleses del Canton, Bengala y costas de $\mathrm{Co}$ romandel y Malavar, y mucho ménos los que saliendo de Europa por el Cabo de Hornos, lleguen á la costa del Noroeste próximamente con un año de viaje y con unos riesgos que exigen seguros no indiferentes.

Luego en el comercio de las nutrias están á favor nuestro los costos del transporte ó de la navegación (I) $y$ el valor $y$ calidad de los efectos de importación, debiéndonos por otra parte parecer iguales con los demás, los precios de las pieles exportadas para el mercado de Canton: en este caso sólo unas medidas directamente opuestas á la prosperidad de este comercio pudieran des. truir esta superioridad: no será superfluo el indicarlas, no tanto con el ánimo 6 de precaverlas todas 6 de ostentar una penetración inoportuna, como con el deseo de alentar á los primeros emprendedores, de suerte que sus operaciones en unos asuntos no bien experimentados, logren en sus mismos principios de toda la felicidad necesaria.

Este comercio debiera en primer lugar depender únicamente de las medidas comerciantes de un corto número de accionistas combinados en Méjico y en Manila: las primeras expediciones deberían ser sueltas, independientes una de otra y como por vid de ensayo: los buques destinados á este ubjetı serán de poco porte, se dirigirán á Monterey para abastecir libremente aquel presidio y encontrar allí el asopio oportuno de cobre, ropas usadas y conchas, de ciunde, finalmente, se dirigirán á la costa, emprendiendo derrota directa para los puertos inmediatos al Monte San Elias: estas operaciones, movidas desde un punto distante (2) acompañadas del deseo de abarcarlo todo en un solo año y de dar un semblante

de éstos en la costa, es sin embargo, de 74 rupias 0 siete pesos fuertes proximamente. Pudieran hacers muchas comparaciones útiles de los demás precios de estopa, cables, etc, sobre aquel viaje, como de los demás comestibles en el viaje tercero del Capitán Cook.

(r) Estas ideas de comercio se desplegarán aún con más claridad en el libro siguiente, cuando se unan como es debido a la prosperidad de la California, de modo que no sea ya un gravamen constante á la Mo narquia: por ahora nos contentaremos con indicar que los paquebotes y hergantines de Filipinas empleados ea Monterey, aunque no se ocupasen sino en esto solo, siempre lograrian muchas ventajas economicas sobre los que se habiliten en Canton y Bengala. Los pilotos de San Blas, instruidos en poco tiempo de las reglas del pilotaje más exacto, puitieran guiar con mucho acierto aquellas embarcaciones.

(2) La residencia de la dirección de la Compañia de Filipinas en Madrid, serfa capaz por si sola de destruir todas las ventajas si estas ncgociaciones se apro. piasen á aquel cuerpo: las providencias son tardias, las ideas magníficas, los empleados muchos y los descarrios de la primera senda sumamente fáciles. guerrero á las miras mercantiles, inmediatamente refluirian considerables gastos contra $\operatorname{los} \mathrm{em}$. prendedores, y por último, no hallarian sino pérdidas á donde todos los cálculos les prometían crecidas ganancias.

Tampoco será útil, que en las primeras combinaciones de esta especie se mezcle ni remotamente la Real Hacienda, á lo ménos por lo que toca á unos prontos ahorros. Son harto frecuen. tcs los proyectos engañosos de economía que últimamente produciendo solo nuevos empleos vitalicios y la subvención del derecho público, acaban por extraer del Erario ó con nurvas pro. mesas, 6 por una compasión mal entendida, aquellas mismas sumas con las cuales se habian brindado á acrecentarle. Por consiguiente no debiera al principio admitirse of recimiento alguno de esta especie. Sea rico el vasallo sin vejación de sus conciudadanos, y lo será muy luego toda la Monarquía (I); manifiesten los primeros ensayos cuáles son las ventajas del comercio emprendido, y luego que se cimente será fácil extraerle la cuota correspondiente al equilibrio de la prosperidad pública. Así, si las primeras empresas nacionales tendiesen á imitar las que han hecho los ingleses desde el Asia, con sola la diferencia de tocar ida y vuelta en Monterey, el Monarca debía desentenderse de todo derecho, á lo ménos hasta la llegada de regreso á Manila, en donde podrían pagar lo mismo que todos los demás, los géneros importados desde Canton.

Pero el golpe más destructivo para la infancia de este comercio sería sin duda el pensar en un establecimiento. Ninguna nación debe estar en esta parte más escarmentada que la nuestra; y la constitución de estas costas ha demostrado ya, que apenas recorriendolas todas en la esta. ción oportuna puede completarse un mediano cargamento, pues los pocos y diferentes antojos de aquellos naturales, como su ninguna inclinación á los licores nuestros (que hacen el principal objeto de los cambios del Canadá y bahía de Hudson), no dan lugar á que se tengan almacenados crecidos efectos para ocurrir como es el ubjeto de un establecimiento, á una concurren. cia frecuente y peribdica de compradores (2).

Ultimamente, el temor del contrabando pudiera en esta ocasión, como en otras muchas, interrumpir la felicidad de las primeras empresas. Un celo aparente para el buen orden de las

(I) El sistema de derechos correspondientes se desplegará también al tiempo de combinar este co. mercio con el de las Californias y Filipinas, relativamente a la Nueva España. (2) La facilidad con la cual (segun se ha dicho
generalmente) la Compaña de Filipinas se brindaba generalmente) la Compañía de Filipinas se brindaba hace ver que no eran acertadas las ideas de este Cuerpo, sobre las ventajas de aquel comercio. 
rentas públicas no es sino el abrigo de un inte. rés verdadero en mezclarse un mayor número de empleados en un objeto nuevo, del cual se esperan crecidas ganancias: á veces con el objeto de coadyuvar servilmente al sistema adoptado, por lo común con el afán de ostentar un nuevo mérito en el mismo momento en que no se res. pira sino una ambición interesada, no bien se ha hecho público un proyecto re comercio $y$ ha merecido para sus ensayos la justa sanción del Soberano, cuando un sin fin de planes económicos se desploman de todas partes para sofocarle en su misma infancia: no son éstas unas abejas que chupando suavemente de la flor la convierten muy liego en cera y miel: son más bien unas langostas que no dejan otro rastro de su venida á un campo sino la desolación y los llantos del que pensaba cosecharle.

El contrabando de la plata no es fácil si hay un buen resguardo en Acapulco, en donde las avenidas son pocas y los buques están anclados con mucho orden é inmediación al muelle: ade. más, que si bien el traspaso directo á Canton del numerario daría unas ventajas enormes, no es creible por ahora que lo alcancen los conerciantes de Méjico, para las debidas combinaciones en el giro de letras con las ciudades comerciantes de Europa (I). Fuera de est posible suponer un contrabando: el comercio de Méjico debe considerablemente al de España, y este pago le absorbe anualmente todo el pro. ducto de las minas: debe también al de Manila; pero está tan distante de satisfacerle con prontitud, que además de haberle precisado á reformar la mitad de sus remesas (2) ni éstas se le satisfacen puntualmente: luego si no hay una deuda anterior ni puede recelarse una com. binación nueva, está patente que no debe temerse la extracción de la plata, á ménos que la introducción de géneros prohibidos no haga preceder un crédito á nuestro comercio.

En este crédito ó introducción de efectos extranjeros, debe también distinguirse un comercio periódico del accidental y despreciable de las anchetas particulares de uno ú otro Capitán ó Contramaestre: éstas no merecen un lugar en los

(I) Se verá a su tiempo cuántas ventajas producí(I) este giro oportuno á la Monarquia; esto es, haciendo pasar los comerciantes españoles á Manila y Canto pasar la plata de la deuda extranjera, tomando letras sobre Inglaterra, Amsterdan, Lisboa, etc., y nego. ciándolas luégo en Europa: este giro equilibra tanibitúl á lo ménos en mucha parte, el valor del dinero del Peru con el de Nueva Espafia, da un resorto muy activo a nuestra navegacion y debilita la extranjera bajando nuestra mavegacion y debilita la extranjera, bajando mercado de Canton: lo que más importa es que con esta precaución, la circulación en cl continente viejo no es violenta ni ahogada de su mismo peso.

(2) La Nao de Manila ya no vicne a Acapulco sino de dos en dos años y nunca lleva el dinero corres. pordiente á sus efectos. cálcilos políticos, y basta para contenerlas el escarmiento del infractor, que tarde ó tempran es por lo común victima de un delator infame: aquél, al contrario, debe precisamente tenerse ai á la vista, así por lo que' influye en el sistema general de Hacienda, como por la imposibilidacl de atajarle, cualesquiera sean los gastos, los ar. dides y las personas que se destinen al intento: pero por ventura, vemos en el día que los efec. tos del $\Lambda$ sia son más bien importunos y sobran. tes en la Nueva España que necesarios; y además, una asociación de comerciantes que ell estos ensayos tiene á la vista más bien el beneficio público que el particular, no puede abusar de la confianza del Gobierno para unas ganancias soeces y de poca monta.

Sería esta la ocasión de manifestar por extenso todas las combinaciones favorables que pro. porciona el puerto de Monterey en este giro; $s$ in embargo, le omitiremos ahora contentándonos con decir que los fondos para el comercio de las pieles pueden indistintamente enviarse á Manila ó a Monterey; esto es, en cuanto á los tres ramos preciosos de conchas, cobre y ropas usadas; pues como se ha dicho, el hierro labrado y las quincallerías, tal vez se adquirirá con mayor econo. mía en aquella colonia que en lus de la Nueva És. paña occidental: por lo que toca á los gastos necesarios para la liabilitación de un buen pa. quebot $o$ bergantín del comercio de Manila, que invernando en Monterey pudiese hacer segunda campaña á la costa antes de venir á Acapulco $y$ de alli regresar á Manila, parece que los fondos debían también derivarse del comercio de Méjico más bien que del de aquella colonia, pues que este está acostumbrado á su rutina envejecida de dar al dinero el solo giro de una ganancia exorbitante por premio, ocurriendo principalmente las Obras Pías á la duración de este vicio mercantil (I).

Hasta aquí rio se ha mirado el comercio del Noroeste de la América sino como referido á los naturales $y$ al solo objeto de las pieles; pero si no nos engañan mucho las apariencias, éste pudiera tal vez extenderse á la Siberia, y en particular al Kamskatka con los objetos siguientes.

Embarcaciones construídas, arroz, trigo, azucar, jarcias de abacá, tablazón de las Filipinas, vinos, aguardicintes, tabaco, tablazón, betunes, jarcias dr San Blas, menestras secas, carnes saladas y l:ıa ú otra ve $z$ frescas del reino de Nueva España, cuyos efectos, aunque no lograsen cambio directo por no producirse en aquellas provincias cosa alguna de extracción útil, pudieran compen. sarse sin embargo, por letras sobre Peteisísuıo, en donde la Corona, con motivo de las arbola.

(t) Se propone de oficio al consulado de Méjico un ensayo de esta especio de comercio. 
duras, no tiene en el día objeto alguno de com. pensación más que el dinero físico.

lis inútil manifestar en esta parte, que semejantes empresas no pudieran aventurarse $s i n$ un tratado anterior de comercio entre las dos cortes; y particularmente sin saber el estado actual de aquellas provincias, los valorre de cada efecto vendible, las necesidades á que no han podido remediar hasta ahora, la mayor seguridad de la navegación hasta Okosk, el permiso pảra internar hasta aquella capital, las ideas del Gobierno ruso relativamente al grado de fuerza $y$ prosperidad á que quisiera llevar la Siberia; finalmente, una idea calbal de la actual feria de Kiackta, por si nos conviniese enviar á ella por la Si. beria algunas manufacturas nacionales (I). En estas especulaciones es también evidente que debíamos mirar como un objeto de mucha monta conservar á favor nuestro el transporte y navega. ción, no permitiendo la venta sino de embarcaciones de poco porte; y favoreciendo mucho la exportación de nuestras colonias en los bajeles na. cionales, tinalmente, que debíamos dejar al prolijo cálculo mercantil, aquellos detalles, escalas y ramos secundarios que nunca puede alcanzar el que calcula sobre los intereses agenos á una distancia excesiva del mercado.

Ello es bien seguro á lo ménos, que nuestros viajes á la Siberia, particularmente desde Aca. pulco y Monterey, no nos utilizan la estación oportuna del mismo año para comerciar en las pieles, y que dependiendo este comercio de una corta cantidad de efectos nada voluminosos y la mayor parte útiles para lastre, el flete de los que se importen á la Siberia, aunque moderado, debe ser bien ventajoso á nuestros navegantes (2).

(1) Las noticias de Mr. Coxe son inperfectas; parece que no carecen del mewor grado do exactitud las de Mr. Pállas, que no están en nuestro poder: sin embargo, serán infinitamente más individuales las que so adquieran por un comerciante inteligente do Petersburgo.

(2) Los pilotos del Departamento de San Blas, enterados en puco tiempo del pilotaje fino, son ca. paces de dirigir estas navegaciones: harra muy buen servicio uno ú otro Oficial de la Marina Real, que no
Si se pregunta últimamente cuál ha de ser la conducta nuestra relativamente á una colonia in . glesa en estos mares, insistiremos en solicitar que se aparte de ella cuanto sea posible la circulación de la plata; que en las nuestras inme. diatas abunden los tabacos, vinos, aguardientes, paños, maderas, harinas, hierro, armas, etc., fa. cilitandoá los extranjeros su compra, bien que sin más intervención de parte del Rey que la que conduzca á la conservación del derecho público; que la comunicación del reino de Nueva Esspaño. con las colonizs antiguas 6 nuevamente estable. cidas, sea únicamente por Acapulco, en donde las demás costas de Chile, Perú, Quito y Guate. mala, envien aquellos efectos que puedan com. petir con Nueva España en el mercado nueva. mente establecido; finalmente, que sea Acapulco el centro del comercio de todos los dominios de S. M. que baña la vasta extensión del mar Pacífico entre si; y de éstos con la China, la Siberia oriental y las costas de la América no sujetas á la Monarquia.

Pertenece á una época posterior á ésta (I) sistemar las ideas de este comercio; en ei día su novedad, no bien aclarada, sólo influiria en preve-ir los ánimos políticos contra su admisión, cuando nuestro objeto no es otro que el de con. firnar lo que ya se indicó en los axiomas politicos; esto es, que la plata es un fruto como los demás que produce la tierra á beneficio del que la habita, que es la última necesidad de las naciones, $y$ por consiguiente, que no está en nuestra mano el darla un valor imaginario, mientras otras necesidades de mayor monta nos esclavicen á las demás; finalmente, que de cuantos frutos produ. cen las inmensas conquistas españolas, es el que menos puede contribuirá la prosperidad nacional, y el que iasta aquí ha contribuído á su total de. cadencia.

desdeñando los trámites no indecorosos de la Marina mercante, coadyuvase con sus conocimientos políticos y facultativos al verdadero progreso de la prosperidad nacional en estas navegaciones.

(I) Como muy luégo se han de examinar de cerca las Filipinas y la China, fuera imprudente ensanchar estas ideas antes de la comparación necesaria do unos intereses con otros. 

desde las últimas navegaciones del Capitan Cook. y se' continúa. la serie importante de las reflexiones del mismo naregante.

Los capítulos que anteceden con la narración individual de lo que experimentamos en el fon. deadero de las Islas de Vavao, bastarían para dar una más que mediana idea de las cualidades del suelo y de sus habitantes, áun cuando no nos hubiesen precedido en esta senda los Conk, Forster y Anderson, cuyas miradas sobre cuanto abraza la inmensa variedad de la Naturaleza, merecerán siempre los elogios y la admiración de todos los navegantes: pero el método adoptado en la serie de nuestras tareas actuales, la no difícil obligación nuestra de continuar un edificio, cuyos cimientos se hallaban ya tan sólidamente establecidos; finalmente, una nueva felicidad accidental, no diferente de la que habiamos experimentado ya en Nutka, de poder com. binar al mismo tiempo, quien : upiese preguntar y quien supiese responder, ex i in que se abrace con mayor extensión esta especie de observaciones; ni á la verdad debemos creer, atento á su variedad y á su importancia, que parezcan absolutamente inútiles 6 cansadas al hombre filósofo, el cual en toda la extensión del globo, ó se contempla á sí mismo, 6 atónito admira la próvida mano del Autor de la Naturaleza.

El Archipiélago de Vavao no desmerece en modo alguno la hermosa idea que de él liabía formado el Capitán Cook; abraza un número grande de las islas que el mismo Capitán comprendió en la lista de las que pertenecían á la confederación de los Amigos; finalmente, abre un nuevo asilo mucho más cómodo y seguro, á los navegantes que trillen en lo venidero esta parte del mar Pacífico. Se extiende desde la latitud Sur de $18^{\circ} 35^{\prime} 30^{\prime \prime}$ hasta la de $18^{\circ} 5^{2^{\prime}}$, y en la direccion de Este-Oeste es su mayor extensión de solas cinco leguas.

No son diferentes según el examen físico del Sr. Heenke, las materias de las cuales se componen estas islas, de las que ya los viajeros ingleses admitieron en las otras más meridiona. les; esto es, que la madre 6 la parte sumergida que forma la base, es una piedra calcárea, po- rosa, gris y con exceso puntiaguda; 6 bien, para decirlo en una sola palabra, es una piedra co. ralina; probablemente la misma también en los demás parajes que no hemos reconocido, la cubren luégo en algunas orillas las arenas blancas derivadas de los testáceos, $y$ en la superficie in. terio: una tierra arcillosa bastante dura, rojiza por el ocre marcial y mezclada en los parajes más cultivados, con una huena capa de tierra vegetal.

Estas islas, si bien algo elevadas, á lo menos en su parte septentrional están muy distantes de poderse considerar como altas: sería difícil avistarlas á una mayor distancia de seis 6 siete leguas, y quien las comparase con la parte más alta de Tongatabu, tal vez se aproximaría mucho á la verdad: pero las vistas de D. Felipe Bausá darán una idea más cabal de su elevación, la cual por otra parte puede considerarse también re. presentada con igual exactitud por D. Fernando Brambila en la hermosa vista de perspectiva que ha formado del fondeadero de las corbetas.

Cualquiera que examine aunque levementc lo que acaba de indicarse, deberá naturalmente inferir que una extructura semejante, no puede á ménos de producir una variedad extrema en los muchos canales que estas islas forman entre sí. Y efectivamente, no es extraño ver unas veces al. gunas islas 6 más bien pedruscos tan perpendiculares sobre el mar, que se hallen á pique las 50 6.60 brazas; encontrar otras veces unas restingas tenaces, que obstruyen toda comunicacion con los canales interiores, favorecidos de nuevo con un fonclo proporcionado para la navegación. En todas partes en donde han penetrado nuestras embarcaciones menores, son los arrecifes de una misma calidar, y ciertamente sería este un grave inconveniente para los fondeaderos, si oportunamente la Naturaleza no hubiese formado diferentes playas, en las cuales es igualmente seguro el tenedero de las amarras y el atracadero de los botes.

Es, sin embargo, una preferencia notable de 
este Archipiélago sobre los demás ya reconocidos de Happai, Annamoka y Tongatabu, el que sea más fácil y más negura la posición de sus puertos, siendo asi que con risulesquiern vientos son Ins hordos igualmente sencillos para alcanzarlos, " iuc débiéndose sospechar (como después se verá con mayor extensión), la rariedad de monzones un estos mares próximamente comn en los mares de las Molucas y Nueva Guinen, ya las cualidades de un puerto deben referirse igualmente á los vientos del Noroeste y del Sueste para que se consideren útiles en cualesquiera estaciones: tl puerto Valdés Ingra sin duda de todas estas ventajas en un grado bien favorable; pues á la inucha seguridad de sus amarraderos, particu. larmente en el sitio que hemos Ilamudo el Carc. nero, reune la inmediación cómoda de los parajes oportunos para aguada y leña; un pedrusen accesible $y$ aislado para el establecimiento de un ubservatorio, 6 de las fraguas, $y$ la poca distan. cia de diferentes rancherías, seguramente las más pohl ldas y mejor provistas de toda especie de comestil'es, no debe, por consiguiente, pare. cer temeruris. 'r aseguración nuestra, de que es, con muclio, preferente al puerto de Tongatabu, en el cual, el mismo Capitán Cook tocó los inconvenientes bien graves de la casi absoluta necesidad de un viento largo para entrar y para salir, de la mucha distancia de las poblaciones y de la no buena calidad del agua: este último objetn que los navegantes deben siempre considerar en sus escalas con la mayor predileccion, corresponde en las Islas de Vavao á la pintura que de ellas hizo el Rey Paulajo al Capitán Cook: pudiéramos asegurar que aprovechadas á un tiempo las dife. rentes aguadas, no distantes del Carcnero más de una legua, pueden conseguirse dinriamente $y$ en muy pocas horas hasta 50660 pipas de agua bien limpia y despojada de todo gusto salobre.

No es fácil emnresa acertar con las causas verdaderas, 6 más bien diré, con unos razona. mientos siquiera probables, sobre la formación primitiva de estas islas: el volcán no distante de Late, debe asemejarlas á las de Annamoka, las cuales en una casi igual distancia y dirección, ven frecuentemente los fuegos del volcán de Kan y si se comparan en unas y otras la elevación mayor, las capas ya formadas así de la arcilla como de la tierra veyetal, el estado excesivo de lns producciones y los mismos incrementos de todas las especies animales que las habitan, no debemos dudar á lo ménos que sea en entram. bàs una misma la época en la cual han salido del mar $y$ han sido posteriormente pobladas. Pero si estos efectos hayan dimanado de la acción viva de los fuegos subterráneos, 6 bien de aquel natural incremento, del cual, aunque tardo, scn capaces las plantas marinas; si elevacias ja sobre la superficie del mar en una masa desigual pero continua, hayan debido ceter luéro á la acción constante de las mareas y de los vientos, íranqueando los muchos canales que se advierten; finalmente, si puedan con el tiempo vigorizarse estas conjeturas con el exa. men sucesivo de los arrecifes que en el día se liallan aún sumergidos, son todas cuestiones qui dejaremos á otros, 6 más inteligentes, 6 más fe lices, para no alucinar ahora con razonamientos infundados á los que aspiran á un cabal conoci. miento de la formación del globo. La Hidrogralía, cual se sigue en el dia, podrá á lo ménos coactivar algún tanto á esta especie de pesquisas, $y$ los rastros ingleses y los nuestros, despues de una larga serie de años, podrán tal vez ma. nifestar á los fisicos 6 el acrecentamiento perpendicular, 6 la mayor extensión horizontal de los arrecifes actualmente reconocidos y anotados (I).

Si parece temeraria la empresa de querer indagar con alguna verosimilitud la epoca de la formación de estas islas, no lo es menenos segura. mente la de investigar el tiempo en el cual fueron pobladas, aunque toro denote que no debie. ramos retroceder á unos sighos muy remotos: hemos advertido nosotros y lo advirtí el Capi. tán Cook, que hay muchos parajes no sólo incultos, sino también sin el menor rastro de ha. ber sido otras veces cultivados; que la poblacion puede considerarse mezquina á pesar de la robustez general; que su subsistencia es suma. mente fácil; ninguna la necesidad de la pesca; legítimos todavia los derechos de la sucesión en la familia reinante; pocas las discordias y la en. vidia por la posesión del terreno, á lo ménos si se comparan á las de las Islas de la Sociedad; muy reciente según el Capitán Cook la propagación de los puercos y gallinas en Annamoka y Tongatabu; y ulltimamente ninguno el rastro de invasiones anteriores a la clase actual de los pobladores.

Tal vez la finalización del viaje, reunidas en un solo punto de vista las navegaciones antiguas; nacionales y holandesas y las más recientes del. Capitán Cook, con todo lo que hemos podido ad. vertir en la grande extensión de las costas que ahora se han recorrido, nos conducirá á aven.

(1) Una carta física de - esta especie no serfa tal vez inútil á las indagaciones venideras, distinguieıdo en punto grande y con diferentes colores, ademís de la verdadera extension de los arrecifes, los que velan los que estin ain sumer los arrocifes, Doca distancia de la supericie. Desde luego debe parecer extrah́a la sonda de la misma calidad que nosotros hallamos al Sur del Archipielago y los ingleses al Norte do Happai; la misma dirección Norte-Sur, desde lo mas Norte de Vavao hasta el extremo Sur de Elia y Tongatabu; is misma cordillera de restiugas al Este y los mismos volcanes, y sobre todo, la mayor elevacion y calidad vrecisam, $y$ sobro precisamente al Oeste, acantilada de uno y otro ex.
tremo de esta cordillera. 
an debido ce. las mareas $y$ huchos canales puedan con el as con el exa. e en el día se cuestiones que tes, 6 más fe. razonamientos cabal conoci. - La Hidrogra. rá á lo ménos cie de pesqui. iestros, después fín tal vez ma. ntamiento per. horizontal de ocidos y anota.

sa de querer inla época de la isenns seguraen el cual fue. e que no debies muy remotos: dvirtió el Capi. jes no sblo in. or rastro de ha. que la población pesar de la ro. encia es sumalad de la pesca; e la sucesión en scordias y la en. o, á lo ménos si de la Sociedad; Jook la propaga. en Annamoka y zuno el rastro de actual de los po-

aje, reunidas en cciones antigų̧s; ás recientes del emos podido ade las costas que nducirá á aven.

pecie no sería tal ras, distinguiendo olores, ademís de ifes, los que velan ca distancia de la er extraña la son$s$ hallamos al Sur Norte de Happai; - lo mas Norte de y Tongatabu; la te y los mismos vación y calidad uno y otro ex. turar algunas conjeturas sobre este caos tan os. curo como importante de la historia de nuestra especis; pero si áun esta empresa así combinada sobre unas miradas generales, debe parecer no sólo arriesgada, sino más bien impruderte, ¿cuanto inayores deben ser las acusaciones y las mo. fas contra el que se aventurase á hacerlas de. pender del solo examen de pocas leguas de te. rreno, sin amalgamar antes, digámoslo asi, las nociones de la historia del globo y las de la his. toria de la especie humana?

Abandonada, por consiguiente, esta doble cuestión de la época de la formacion de estas is. las y de su población sucesiva, sćanos permitido abrazarnos con el examen más agradable y mé. nos incierto de las cualidades fisicas y morales de los habitantes del dia. Su civilización, sus principios sociales y religiosos, su constitución robusta, sus ideas de la felicidad, probablemente alcanzarán á manifestar al filósofo juicioso, que las combinaciones morules son tan limitadas como las combinaciones físicas, $y$ que en balde nos esforzariamos á hacer dimanar de los solos razonamientos, 6 una prosperidad de la máquina, 6 unas satisfacciones del alma que no pueden combinarse con las causas extrañas que nos ro. $\operatorname{dean}(\mathrm{I})$.

I a confederación de los Amigos debe considerarse limitada por el Norte á las solas Islaq de Vavao y por el Sur á las de Eula y Tongatabu. Jamás los naturales nos han comprendido las de Hamoa como reunidas o dependientes de este Imperic, ni atento á todas las direcciones que nos han dado desde los parajes altos, pudiéra. mos convenir con el Capitán Cook (2) á que sea otro Archipiélago. La navegación de D. Francisco Maurelle en $\mathrm{r} 78 \mathrm{r}$, demuestra positivamente que no liay otras islas en la dirección indica. da, sino la que llamó de Amargura. Nunca pudieran considerarse como reunidas á un mismo Archipiélago las otras descubiertas por el Comandante Wallis, 6 lo que es lo mismo, las Islas de Consolación, de D. Francisco Maurelle, las cuales le suministraron diferentes refrescos para la continuación de su viaje. En lo que no debe caber duda, es en la frecuente correspondencia que tienen entre sí todos estos habitantes y también los de las Islas Fichis. El Eigui Tumoala, que frecuent6 mucho en la corbeta ATRE-

(r) Es imposible en este momento porler apartar de la vista la triste escena que presenta la Europa por el solnado deseo de una felicidad imaginaria, $y$ por unos derechos que tantas veces se ultrajan cuantas se nombran.

(2) Debo advertirse, que para la mayor concisión y la precisa economia del tiempo, entendemos indis. tintamente bajo el nombre del Capitán Cook, 0 sus propias noticias o las de los Sres. Forster y Ander. son. Un mayor despacio nos dara lugar a disipar estas pequeflas equivocaciones.
vidA, era de lus áltimos; entre los que dirigían el baile de los Eiguis en la tarde del 25, sobre. salia por su agilidad y por la natural alegría, un habitante de Hamoa, serguramente igual en sus facciones y costumbres á los que ahora nós ro. deaban.

La frecuencia del trato que ncabamos de in. dicar, debe, sin embargo, cousiderarse propor cionada á las conexiones particulares de estos diferentes Archipiflagos entre sl; esto es, que debe ser mayor entre los cuatro grupos que forman la confederacion $y$ cuyas distancias $y$ arrumba. mientos son mucho más proporcionados para la navegación; será luego más escasa con Hamou, cuyos enlaces no son ni comerciantes ni repú. blicos; finalmente, aún más tarda y remota con los Fichis, los cuales, á una distancia de 84 leguas y á una dirección de Este-Oeste, nada favo. rable para la navegación, reunen la misma discrepancia de intereses, $y$ probablemente, un cierta fiereza inseparable de un suelo ménos fértil y ménos extendido en razón de su número (I).

A estos conocimientos pueden considerarse ceñidas las ideas geográficas de los naturales, á lo ménos por lo que corresponde á una época anterior á la venida dt: los ingleses y nuestra. Omai les dejó ideas bien claras de la Nueva Zelanda y de las Islas de Otahiti: Vuna y algunos Eiguis (como se ha visto ya en la narración), han podi. do comprender con bastante individualidad la po. sición de nuestro continente de la America: pero inquiriendo yo repetidas veces sobre las Islas de los Navegantes, jamás he podido descubrir que tuviesen la menor idea de su existencia; ni $\in \mathfrak{n}$ la actual tradición de sus navegaciones serfa fácil hallar los rastros de descubrimientos más dis. tantes.

Sea como fuere de estas nociones, es bien positivo, que deben serles $y$ les son sumamente indiferentes: habitan un país fertil bajo de un clima templado; pucden multiplicarse mucho, sin que los alimentos les sean ó más escasos ó ménos varios y sabrosos: la división de estos pequeños Archipiélagos, subdividiendo los enlaces y las combinaciones sociables, suministra bastantes objetos para excitar con las navegaciones, con los cambios, con la misma envidia y emulación aquella variedad contínua sin la cual, aunque llena de sobresaltos, la vida del hombre se asemejaría muy luego á la de los brutos; finalmente, la na. tural codicia de los Fichis para invadir $y$ hacerse dueños de un país como éste, les recuerda siempre la necesidad de la unión propia y el bien que perderlan, si 6 abandonasen 6 dejasen indefen. sos sus hogares.

(I) Debemos suponer que las Islas Fichis sean las del Príncipe Guillermo de los holandeses y las primeramente avistadas por el Capitán Bligh en la lancha del Bonnty. 
Luego nada absolutamente debe convidarlos á nuevas einpresas, ó de conquista 6 de descubrimiento; ni en sus navegaciones pueden descarriarse frecuentemente cuando la dirección Norte-Sur las hace sencillas, sus precauciones son constantes para aminorar la travesía y asegu rar algún barlovento con las inmediaciones de Happai, $y$ su comunicación deriva más bien del antojo que de la necesidad.

Este conjunto de circunstancia. debe hacerlos naturalmente pacílicos, así como la abundancia en que viven $y$ las leyes sociales que les gobiernan, atentos $y^{y}$ amantes del decoro: tales son efectivamente sus características; sobresalen todas á cada paso; la misma diferencia de conducta entre los principales y la plabe les da un nuevo resorte; $y$ seguramente no habrá navegante alguno que no ratifique en lo venidero el nomtre Jui cioso con el cual los ha distinguido el Capitán Cook.

Ni la infracción de ias leyes de propiedad, aunque común solamente entre la plebe, puede con razón tacharse por nosotros con aquellos mismos colores negros, con los cuales solemos caracterizar el robo: es el antojo, es la costumbre la que los guía, más bien que la codicia ó el desprecio de las fuerzas y derechos agenos; $y$ el mismo plebeyo, el cual poco antes vió con indiferencia que la autoridad del Eigui le despojaba del fruto de su industria y de sus sudores, procura poco después, á costa de su propia vida, quitar indiferentemente ó un trapo inútil, ó el hacha para él tan preciosa; de allí á un instante se le ve de nuevo regalar con empeño frutos y bagatelas que trae, y con los cuales hubiera podido adquirir lo mis. mo que lia robado: se hace aún ménos feo este delito ó toma más bien el semblante de una acción inocente, cuando se advierta, que por lo común los robos de la plebe son luégo obsequio para los Eiguis; y que las ideas de la propiedad no son en esta sociedad las mismas que entre los europeos. Entre nosotros todo lo que se posee, $\partial$ es fruto de un trabajo nuestro ó de un trabajo ageno cuyo valor se nos ha cedido, $o$ representa el ahorro de un trabajo venidero quie ya sostiene auténticamente la sanción de las leyes: constituídos por una emuiación viciosa á procurar sobresalir entre los demás, nada miramos con indiferencia, y la posesión de una cosa envuelve en sí la doble complacencia de nuestra comodidad y del envilecimiento de los demás: pero entre estos pueblos, cuya clase inferior nada posee, en donde la Naturaleza no necesita de la mano del liombre para prodigar sus dones, donde visten, habitian y bogan igualmente en una canoa el Rey y el plebeyo más ínfimo, los derechos de la propiedad se reducen insensiblemente á los derechos del individuo, esto es, á la preservación de sí mismo, de sus mujeres y de sus hijos; cua- lidades todas propias del hombre animal, tal vez en mayor grado que del hombre sociable (r).

De allí es, que ni la plebe procura evadir las usurpaciones diarias de los Eiguis, ni dejan de advertirse en las concurrencias úe ünos con otros aquella familiaridad, aquel cuidado común del alimento y aquella franqueza en la cesión de lo sobrante, que mal pudieran combinarse con las ideas de la tiranía y de la opresión. Cuando en la Descubierta, 6 se repartió á Vuna y á las muchas personas de ambos sexos que le acom. pañaban una cantidad abundante de comida, 6 tuvo aquel Jefe un asiento en nuestra nesa, se notó frecuentemente su cuidado pará que participasen otros muchos de aquellas comidas; sus mujeres no cesaban de pedir, sefialando indis. tintamente para estos regalos á cualquier ple. beyo que se les aproximase: Feileua repetía sus viajes desde la cámara baja al alcázar siempre que le permitíamos llevar alguna cosa á sus in. feriores: los mismos plebeyos, llegando la hora de la comida, dividían descuidaciamente lo que tưviesen; y fué muy frecuente reparo entre nos. otros, que á esta hora, aunque fuesen muy pocos los dueños de los comestibles, todos comían con la mayor alegría y unanimiuad.

Esta reflexión del derecho casi universal sobre la plebe, de todo lo que sea relativo al alimento, no debe sin embargo considerarse extendido hasta los Eiguis, en los cuales hay un derecho de propiedad, así por lo que toca á ios paajes cercados, como al trabajo de la plebe: en general, pudieran considerarse los límites de cada uno en los términos siguientes: los productos de la tierra son comunes, fuera de los parajes cercados. á los Eiguis y á los Tuas 6 plebeyos; los cercados corresponden solo á los Eiguis, para su mayor recreo y más fácil subsis. tencia: su cultivo es fruto en mucha parte de los brazos de los Tuas, los cuales er desquite dis. frutan de una especie de cesión generosa de todo lo sobrante de los Eiguis.

Los Tuas dehen igualmente, sir premio alguno, contribuir al orden público con toda especie de trabajos personales; y estos en los pequeños pueblos se dictan únicamente por los Eiguis; en toda la sociedad dependen, $́$ del Rey mismo, ó de los intereses de su voluntad. Los vestidos, las armas y las canoas, no deben tampoco causar

(r) El filósofo imparcial debe advertir en esta ocasión, que tnman un mismo semblante el tesón de los españoles en querer introducir sus nrinsipios religiosos $y$ el de los ingleses en in introluccion do 政 principios sociales: en la violacion o repugnancia do los últimos, se hace aún más injusto el castigo de muerte, porque 110 precedo como en aquéllos el semblante de la revelación, que apoya en cierto modo la necesidad de disipar con anticipación la barbarie. Cuántas declaraciones contra los pasos espaf́oles en sus Américas se 'arían ridiculas con una sola mirada á estos datos comparativos de las naciones europeas! 
e animal, tal ve $z$ sociable (I).

rocura evadir las zuis, ni dejan de ié ünos con otros idado común del n la cesión de lo mbinarse con las esión. Cuando ell , á Vuna y á las cos que le acom. thte de comida, 6 . nuestra inesa, se - para que parti. llas comidas; sus serialando indisá cualquier pleeileua repetía sus 1 alcázar siempre una cosa á sus in. - llegando la hora daciamente lo que reparo entre nos. fuesen muy pocos todos comían con

casi universal soea relativo al aliconsiderarse extencuales hay un deque toca á ios paajo de la plebe: en rse los límites de guientes: los proes, fuera de los pa: á los Tuas 6 plenden solo á los Eiy más fácil subsismucha parte de los es en desquite disesión generosa de

nte, sin premio allico con toda espe. éstos en los peque. iente por los Eiguis; 1, ó del Rey mismo, ntad. Los vestidos, ben tampoco c2usar

e advertir en esta oca. lante el tesón de los n prin-ipios religiomrinsios religio introduccion de su ón $\delta$ repugnancia de injusto el castigo de 10 en aquéllos el sem. oya en cierto modo b. cipación la barbarie. os pasos españoles en pon una sola mirada as naciones europeas! la me or codicia: sirven de entretenimiento estas manufacturas; y basta dar una ojeada á los adornos prolijos de las macanas, á la muchedumbre de las canoas y á la sencillez de los vestidos, para estar firmemente convencidos, que todos estos objetos deben mirarse con la mayor indiferencia.

La prueba ménos equívoca de la veleidad y ninguna codicia de estos naturales, debe sin em. bargo, buscarse en el poco aprecio que manifiestan haber kecho de los ef ectos europeos. Ningún rastro se halló ahora en estas islas de las visitas del Capitán Cook, si bien debiesen recaer en Vuna todos los bienes del difunto Paulajo; y los mismos que habían cambiado nombre con los Oficiales ingleses y no habían olvidado circuns. tancia alguna de aquella época, apenas conservaban algunas cuentecitas de vidrio; ni áun contestaban con empeño cuando indagábamos el estado de los ganados en Tongatabu y Annamoka: los utensilios de labranza 6 de las artes mecánicas, (pasado el furor del deseo) deben efectivamente serles poco necesarios y áun poco agradables; los adornos no pueden en modo alguno adaptarse 6 à la sencillez de los trajes, ó á una cierta competencia con las flores que les of rece la Naturależa.

La ropa de abrigo si es útil un día, en otros muchos les es inútil, y la dificultad de guardarla debe causar su rotura inmediata. Finalmente, las armas nuestras no les parecen en modo alguno aretecibles, antes bien, en las pocas veces que nos vieron cazar, manifestaron una firme persuasión de las ventajas de las suyas, atento á los riesgos, 6 de no encenderse la pólvora, 6 'je errar el tiro.

Con estos antecedentes, no debe parecer extraño que nos fuese difícil ó más bien imposible, lescubrir cuáles eran las leyes penales relativas al robo, pues no siendo un delito entre los Eiguịs, y siendo tan remoto como inútil entre la plebe, es probable que carezcan tal vez de ejem. plos que hayan dado motivo á semejantes estatutos.

No así por lo que toca á los delitos correspondientes al adulterio y á la muerte alevosą: pudi. mos comprender, que aquél se castigaba entre los plebeyos con algunos palos; se expiaba con la muerte, si unn, ó de la plebe ó de los Eiguis subalternos, fuese el delincuente con la mujer de un Eigui, y al contrario, era una acción indiferente, ó para los Eiguis con la mujer de un plebeyo, 6 para el Rey con las de entrambas clases. El solo individuo de la plebe es igualmente sujeto á la pena capital si quitase la vida á un Eigui: cú́les sean los castigos destinados en este caso á aquella clase, no nos fué fácil ave. riguarlo.

Ya en los párratos antecedentes se ha hecho tantas veces memoria de la diferencia entre los Eiguis y los Tuas ó entre los principales y la plebe, que diferir por más largo tiempo las nociones adquiridas sobre este punto esencial de la subordinación, sería envolver al lector en una confusión de ideas dificil luégo á disiparse áun con digresiones bien largas: bien examina das todas las ocasiones diarias, en las cuales debian naturalmente aclararse nuestras dudas sobre este punto, hallamos que en nada discrepan las nociones de los habitantes de las Islas de Vavao, de las que con mayor evidencia advertimos entre los Tahis y los Michimis de Nutka; esto es, que una clase se halla privilegiada con todos los goces de la vida presente y de la venidera; mientras la otra, confundida con los brutos, sólo es destinada á una vida servil en cl mundo y á un total aniquilamiento después de la muerte.

Estos principios morai es y religiosos, si bien absurdos en sí y en radi correspondientes á la nobleza del hombre y á la justicia del Supremo Hacedor de la Naturaleza, son, sin embargo, juiciosamente reunidos para no trastornar el or. den público, particularmente en donde la educa. ción respectiva de cada individuo y la más pro. vecta organización de las leyes civiles no pueden enfrenar, como entre nosotros el libre albedrío de cada uno: la imaginación debe mirarse en la especie humana como el móvil de los razonamientos, así como éstos son el móvil de las acciones: vencida aquélla, es, por consiguiente, tanto más fácil ordenar cuaiquier sistema repúblico, cuinto ménos frecuentes son las ocasiones que puecion trastornarla con una influencia directa sobre los sentidos: así, el Tua de las Islas de los Amigos ya no considera en el Eigui su. premo un tirano árbitro de su suerte al abrigo de la violencia y de la opresión, sino le mira como el Soberano y el Sacerdote, como un sér superior, como un semidios de la antigüedad, cuya existencia, cuyas acciones y cuyo fin están mcvidas y protegidas de una mano invisible y polerosa: de allí es, que los principios sociales, in alterablemente determinados desde el nacer de cada uno elı la educación, en las ideas, en los hábitos $y$ en el temple de la imaginación, logran otras tantas raíces que los hacen sólidos é invariables; de allí es que el Tua ve con la mayor indiferencia, que si son felices sus tretas para un robo, la prenda está destinada para el Eigui, y si son malogradas, aquel mismo Eigui le quita el único bien suyo, que es su propia vida; de allí es, finalmente, que la expiación de los delitos, la invocación de la asistencia divina, los lutos públicos, la preservación de las leyes, todo estriba sobre'lcs sacrificios de esta clase infeliz, la cual, sin embargo, persuadida de que así debe ser, ama á sus jefes, vive contenta y espera con indi- 
ferencia su propia destrucción ó la privación de lo que le es preciso.

La comparación del Capitán Cook de estas leyes con las leyes feudales de nuestros antepasados, debe, por consiguiente, parecer muy poco adecuada; en cuanto el Tua entre estos pueblos, se considera aún ménos que esclavo; esto es, como un verd adero bruto, cuya vida inútil para todo pende del solo capricho del Eigui.

Las clases de los Eiguis son, sin embargo, tan multiplicadas y guardan entre sí tal orden descendente, que no podemos creer que finalmente no se confundan casi con los Tuas: pero no seria fácil para nosotros determinarlas y mucho ménos definir sus funciones y autoridad, tanto más, que echamos muy á ménos una noticia esencial, y ésta es la de saber si la elección de los Eiguis, cuando falte alguno, dimana en primer lugar de la voluntad del Rey ó de la de los Tuas; $y$ en segundo lugar, si recaiga sobre alguno de éstos (como en Nutka) ó sobre algún otro de las familias privilegiadas: hay positivamente una ley de sucesión ó de herencia, la cual entre una nación sana é inclinada á los pla. ceres conyugales, puede hacer muy raras las ocasiones de necesitarse semejantes nombramientos; pero, en fin, las dos causas, de una guerra y del establecimiento de una población nueva, no pueden á ménos de dar lugar á esta especie de nombramientos, cuya ley averiguada podrá producir en lo venidero una comparación ménos raga de estas costumbres, con las de Nutka.

Entre tanto, podemos, sin embargo, asegurar, por lo que toca al respeto y subordinación de los Tuas á diferentes clases de Eiguis, que en la primera tarde de nuestra llegada el viejo Tubou explayó mucha autoridad sobre la plebe, hasta llegar el caso de detener un robo y de despedir á tierra todos los que nos incomodaban; siendo así que en los días siguientes llegó su temor del enfado y auturidad de Vuna hasta el término de manifestarme que le mataría si se atreviese á regalarme en presencia suya: al mismo tiempo Tufoa y los demás allegados á Vuna, nos aseguraban que la clase de Tubou era de las infimas; y efectivamente, todos los Oficiales que dirigieron la aguada vieron que su autoridad era sumamente limitada: al contrario, el joven $\mathrm{Tu}$ foa $y$ un niño de solo ocho años, hijo de otro Tubou, que cambió nombre con D. Jacobo Murphy, ejercían tal autoridad sobre la plebe, que con la mayor indiferencia les arrojarían piedras para apartarla de uno ú otro paraje; y sin embargo, á la presencia de Vuna, particularmente en tierra, se sentaban con la muchedumbre y apenas podían distinguirse entre ella según el respeto y el porte de sus movimientos y acciones: Latú, ayo de Feileua é hijo de Javia se humilló á nuestra vista delante de Tufoa; y siempre la autoridad de éste fué mayor sobre los Tuas que la de aquél: Javia, ó fuese por su genio ó por su rango, jamás desplegó á nuestra vista el menor rasgo de auto. ridad ni respeto poprilar en los, bailes, en los cambios, en la corte á Vuna; en las. concurren. cias á bordo siempre parecía más i.ien un hom. bre de la plebe que un hermano del Rey; muchos prestaban el homenaje público á la 'T ubou, hermana de Vuna y madre de Tufoa; y esta mujer, sin embargo, no poría conseguir que se desatracase una canoa para dejarla atracar con alguna decencia y comodidad. La vieja que nos visitó en la Descubierta en el último día, era superior (según manifestó la etiqueta) á las mujeres de Vuna, hijas de Paulajo, y era inferior á Vuna, mientras éste se consideraba inferior á la madre de las Fatafegis. Pero los depositarios de la autoridad y de las órdenes de Vuna, los cuales probablemente sobresalían más por su ro. bustez que por su nacimiento, inanifestaron siempre, que la autoridad de este Jefe es ilimita$\mathrm{da}$, áun cuando su clase reconozca otras; y ' $\mathrm{fu}$ foa, Latu y Feileua maniftstaron siempre un desprecio tan grande por los Tuas, que siendo admitidos á un trato más frecuente y familiar con nosotros, de modo que notasen á cada paso el servicio de nuestros criados y la obediencia de las clases inferiores, ya caracterizaban unos y otros con el nombre de Tuas, pretendían ajarlos con vilipendio y poderlos echar de su presencia con el solo motivo que les incomodaban.

Para no abandonar el o:den propuesto, ya que hemos hecho derivar una parte esencial de la veneración de los Tuas hacia los Eiguis, de unos principios religiosos, es justo examinar cuáles son estos principios, debiéndonos ceñir en esta ocasión á los informes del Teniente de navío Don Ciriaco Cevallos, el cual por su perspicacia, constancia y nimiedad en las preguntas, y por su amistad bien oportuna con Mafi, Eigui de Tongatabu, puede con mucha razón apellidarse nuestro Anderson y exigir que se copien á continua. ción sus mismas palabras.

"Nadie (según Mafi) parió ni creó el Sol, la Luna ni las estrellas; estos cuerpos existían de toda eternidad tal como los vemos, pero sin sujeción á un orden regular en su movimiento; tan pronto se apartaban á distancias inmensas, como se chccaban entre sí: la tierra, cubierta por todas partes de una inasa profunda de agua, estaba desierta, cuando repentinamente salieron del seno de las sondas todas las islas conocidas: sobre la más privilegiada de todas Tonga, aparecieron un hombre y una mujer singulares, $M O$. hun Atonha y Tanha-Quina. Estos dos padres de cuanto tiene vida y movimiento, estaban sujetos á todas las necesidades y á todos los males de nuestra naturaleza: la necesidad les forzó á surcar las aguas y á cultivar la tierra; hicieron 
de aquel: ango, jamás sgo de auto. iles, en $\operatorname{los}$ concurrenien un hom. Rey; muchos I ubou, her$y$ esta muguir que se atracar con vieja que último Jía, iqueta) á las y erá inferior ba inferior á depositarios de Vuna, los nás por su ro. inanifestaron efe es ilimitaotras; y ' $\mathrm{Cu}$ h siempre un que siendo adf familiar con cada paso el obediencia de zaban unos y endían ajarlos su presencia, daban.

propuesto, ya e esericial de la iguis, de unos aminar cuáles ceñir en esta e de navío Don u perspicacia, untas, y por su Eigui de Tonellidarse nuesen á continua.

creó el Sol, la oos existían de s, pero sill suovimiento; $\tan$ nmensas, como ibierta por tode agua, estate salieron del conocidas: soTonga, apareingulares, $\mathrm{Mo}$. s dos padres de estaban sujetos s los males de ad les forzó á tierra; hicieron la primer canoa y los primeros útiles de pesca; cogieron las primeras rimas y los primeros pláta. nos: no hay instrumento cuya invención no se les deba, así como no hay planta cuyo germen no esparciesen sobre 1: tierra.

"Si Mohun Atunita y Tanha-Quina partieron con los mortales todas las miserias de su existencia, gozaron también los únicos placeres que pueden hacer esta existencia soportable: el primer fruto de su amor fué una mujer hermosa (Coloafu To. nha) que en el instante de nacer voló á los cjelos, y tomando las riendas del Univer'so, sujet'́ á leyes invariables y eternas e' moviniento de los astros: su residencia ordinaria es la Luna, desde donde preside á todas las obras de la Naturale$z a$, manda los elementos y dirige el destino de los mortales: al nacimiento de Coloaf $u$ Tonha sucedió el de otros seis dioses, todos ministros de su porler y que tienen á su cargo otios tantos ramos de la Creación. La relación entre el poder de estos dioses y el de Coloafu Tonha, no puede asignarse: pero como quiera que dejen algunas veces sus mansiones y metamorfoseados en pájaros ó bajo formas invisibles vaguen por los aires y desciendan álas islas, los Eiguis en consecuen. cia de estos principios les preparan casas que ningún mortal puede habitar y cuyo número $\mathrm{y}$ magnificencia son conformes al poder $y$ devoción de cada uno.

"El tiempo fue debilitando las virtudes productivas de Tanha-Quina: cusspués del último dios nació el primer hombre, $y$ muertos finalmente Moluun Atonha y Tauha-Quina, subieron después de morir á la Luna, donde gozan de una autoridad pasir a, siendo respetados de los dioses sus hijos, pero sin influir nada en el orden del Universo.

"La cava es el único nutriniento de Coloafu Tonha, á quien la sirven los dioses inferiores: esta diosa, la más bella criatura que ha existido ni puede existir, tiene una lengua proporcionada á sus otras facciones; pero cuando quiere la dilata y extiende desde el cielo hasita ei mar, donde por su medio bebe la cava: casi todos los naturales nos aseguraron haberla visto, y de donde pudo inferirse que confundían las trombas marinas 6 algún otro fenómeno natural, con la lengua de su diosa.

nNo han sido con mucho igualmente extensas las nociones adquiridas sobre la inmortalidad dei alma $\mathrm{y}$ su suerte venidera. Paulajo (según Mafi) se halla en la Luna, y Vuna alli ha de encontrarse con él; perc los Tuas tienen precisamente el mismo fin de los brutos; y su muerte física' es el total aniquilamiento de su existencia (I).

(I) Vésse cuánto se asemejan estos principios religiosos a les admitidos en Nutka.
- Después de estos principios, nada extraños deben parecer á nuestra vista los diferentes ras. gos que á cada paso se nos of recieron de las costumbres de estos pueblos: los templos ó $T_{a l e}$ Otuas podían distinguirse fácilmente de los sepulcros ó Tia Tukas; y éstos solo estaban destinados para los Eiguis: los Tuas, al contrario, se consideraban como las víctimas destinadas para el holocausto, siendo así que casi eran feli. ces al verse en esta parte confundidos con el puerco $y$ con las plantas, $y$ que no titubeaban en confirmarnos con bastante indiferencia la realidad de estos sacrificios humanos; $y$ si no es poca la repugnancia con la cual se aproximan todos á un sepulcro, tal vez los despojos de un alma que ya goza de mejor suerte !: puede intluir en las cosas humanas con un puder semejante a! de la Divinidad, son á lo ménos igruales, si no son superiores las muestras públicas y materiales de su dolor y de su respeto: ya advirtieron los ingleses que los árboles distin guidos por los naturalistas con los nombres de C'asuarina Équisetifolia y Elate anuncian siempre la inmediación de un Tia 'Tıka; advirtieron también con mucha propiedad hasta qué grado son aflictivas estas muestras, ó ya haciéndose algunas cortaduras sobre las carnes, $\sigma$ golpeándose con piedras en diferentes partes del cuerpo, ó acompañando con suspiros y con la voz correspondiente de of $a$ estas prue. bas nada equívocas de su dolor, ó finalmente. decidiéndose con la nuayor indiferencia al corte del dedo pequeño de la mano. Relativamente á esta última costumbre, nosotros hemos podido individualizar algo más sus límites verdaderos, $y$ se reducen (con mucha probabilidad) á que la muerte del padre exige este sacrificio de parte de todos los hijos; la de la madre lo exige solamente del hijo menor, y la del Rey, de todos los vasallos sean Eiguis ó Tuas; basta en cualquiera de estos casos cortar uisa sola coyuntura; al tiempo de enterrarse el cadáver se echa en la fosa el trozo cortado y la operación debe parecer bastante penosa cuando se considere que entre nuestros efectos de cambio dieron siempre preferencia grande á los cuchillos, sólo porque consideraban que les sería más fácil en lo venidero el corte del dedo.

No siempre, sin embargo, es esta una prueba de luto ó duelo por la pérdida de los padres ó del Rey; ó digámoslo así, no es esta una etiqueta limitada solamente á las circunstancias indicadas: la expiación de un delito 6 la invocación de la Divinidad suelen exigirlo á veces, bien que no debe ser ésta sino una acción libre á cada uno, pues que las víctimas, ó humanas ó de los animales, serán siempre las que representen las preces de toda la sociedad."

Determinados de este modo los principios religiosos, y refundida en los Eiguis y particular- 
mente en el Rey, la autoridad y el respeto que de ellos dimanan, no es ménos fácil fjjar los demás puntos de la legislación, de lo que lo hayan sido los derechos de la propiedad: si se excluye naturalmente del derecho del hombre la parte más numerosa de la sociedad, ya el gobierno público se reduce al gobierno de una sola familia en la cual los intereses son comunes y dignos de una atención particular; es igual y ménos rústica la educación; finalmente, son más frecuentes los enlaces y la comunicación recíproca de unos con otros. Este es precisamente el caso en el cual se hallan los habitantes de las Islas de los Amigos: y si son (como parece muy probable) fundadas las sospechas de D. Ciriaco Ce. vallos sobre el ser la bebida diaria del cava la representación de un dogma teórico de su creen. cia, renovada siempre con la misma solemnidad y á las mismas horas y siempre presidida por un Jefe, no hay duda que este recuerdo frecuente del influjo de una autoridad divina sobre las cosas de la tierra, debe arraigas muy mucho las ideas del orden y de la subordinación, contribuyendo últimamente á que se conserve el ánimo alegre y la salud robusta.

En la sucesión legítima de la familia reinante y en su no interrumpida descendencia desde los dioses, se advierte aún más el encadenamiento feliz del sistema que examinamos actualminte. Según los naturales, el Imperio de este Archipit. lago cuenta tanta antiguledad como el mundo: Tuguloto tuvo dos hijos que lo repartiervi entre sí; pero esta división parece que duró poco tiempo, pues Potulaje reunió en su persona todos los derechos del primer Emperador: no ha habido después otro desmembramiento del todode la Monarquía, sino el que dimanó de la revolu. ción de Tutatile en dos islas llamadas Niuas, no sin sostener una guerra obstinada y cruel contra su señor legítimo, y estas isłas se conservan aún separadas, mandándolas en el día Mahatu, descendiente de Tutafile: Vuna, cuando respondía á esta especie de preguntas, siempre se revestía de un aire noble y grandioso, y con la majestad correspondiente, nos explicaba que Mariagüy, él y Feileua dimanaban del cielo directamente, y el nombre de los Fatafegis anexo á la corona y la serie de los reyes conservada en una época bien larga, contirman este principio con el testimonio de los Sres. Cook y Anderson.

No es fácil, sin embargo, en el día combi. nar con exactitud la descendencia, después de la grande revolución que tuvo lugar entre esios pueblos hacia el año de 1784 . Paulajo, á quien había conocido el Capitán Cook en Happai y Tongatabu, fué destronado y muerto por una conspiración tramada entre Vuna, Monmuy y Tubou, mujer del mismo Paulajo. Los conspiradores salieron de Tonga con unas 20 piraguas grandes, abordaron las Islas de Annamoka y de Happai, las cuales sujetaron después de muchos comba. tes: de Happai pasaron á Vavao, donde Paulajo los recibió á la cabeza de sus gentes; hubo un choque, el cual terminó con la muerte de éste á manos de Vuna, después de haber peleado estos dos caunillos cuerpo á cuerpo: inmediatamente huyeron los del partido, quedando así todo sujeto á los conspirados: Vuna fue declarado Rey de Vavao; su hijo Tubou-Toa, de Happai; Monmuy, de Tongatabu, y si hijo Coloucala, de Ela. Fatafegi, que heredaba todos los derechos de su padre Paulajo, kijyi de Tonga, donde hizo partido y se opuso Monmuy, de quien fué segunda vez de. rrotado; llevándole, finalmente, su suerte desgraciada á ser asesinado, según algunos, y según otrns á vivir confundido con la última plebe en Tongatabu: no hubiera sido posible descifrar con individualidad el pormenor de esta grande revolución $\sin$ el auxilio del astuto Mafi, el cual la detalló con toda claridad á D. Ciriaco Cevallos, añadiendo que él había sido de los conspirados, pero sin haber podido asistir á la guerra de Vavao porque recibió antes en Happai tres heridas, cuyas cicatrices enseñaba, y de cuyas resultas perdió un ojo: todos los demás evitaban cuidadosamente estas conversaciones, inventaban mil novelas contradiciéndose á cada paso sobre los derechos de Vuna y Feileua al trono, y dieron lugar en los primeros días, á que inadvertidamente yo presentase á la hija de Paulajo el retrato de su padre, inserto en las láminas del tercer viaje del Capitán Cook; vista que no pu. ménos que chocarle y excitar en su rostro todas las muestras de un verdadero as:101 filial, recordándole el fin trágico de su vida á manos de su marido á ia sazón presente.

Contribuía sin cuda bastante á multiplicar la variedad de estos informes el aprecio que haciamos de los Eiguis y particularmente de cuantos tuviesen alguna conexión con Vuna; y fué un accidente bien natural, pero no ménos ridículo, que aumentase el número de las madres de Feileua á medida que aumentaba nuestro cariño hacia este joven; de modo que contándose ya tres, según las noticias adquiridas, todavía, sin embargo, nos quedase la duda, si l.) era realmente alguna de ellas.

El examen atento de la verdadera ascenden. cia de Feileua (en cuanto pudo deducirse de la mejor combinación de las noticias guiadas siempre por las de Mafi) parece justificar en mucha parte los pasos de Vuia en sus esfuerzos para alcanzar el trono; debiéndose, por consiguiente, inferir que más bien convenia á Paulajo el títu. lo de usurpador, de lo que convenga á los que movieron y llevaron á feliz término la conspiración indicada: Mariagui y Tubou (entrambos co. nocidos por el Capitán Cook en Tongatabu, y el 
de Happai, chos combaonde Paulajo tes; hubo un rte de éste á peleado estos mediatamente sí todo sujeto arado Rey de pai; Monmuy, de Eula. Fata. os de su padre iizo partido y gunda vez deu suerte des. funos, y según tima plebe en ible descifrar e esta grande o Mafi, el cual Ciriaco Ceva de los conspi. tir á la guerra n Happai tres a, y de cuyas - demás evitarsaciones, inéndose á cada a y Feileua al eros días, á que la hija de Pauto en las lámi. Jook; vista que excitar en sul erdadero ar.10r o de su vida á resente.

- á multiplicar aprecio que hamente de cuanon Vuna; y fué no ménos ri ) de las madres aba nuestro ca. que contándose iridas, todavía, a, si l. era real.

Idera ascenden deducirse de la 8 guiadas siem. ificar en much esfuerzos para or consiguiente, Paulajo el títu. 'enga á los que ino la conspira. (entrambos co Tongatabu, y el segundo por el Comandante Maurelle en Vavau) eran efectivamente hermanos: fueron hijos de primer Monmuy, Rey actual de Tonga, Tubou, viuda de Paulajo, actualmente visitada por Don José Bustamante en Leyafú y Tuyalafatai, ya muerto años hace en Tonga; los hijos de Tubou, fueron Vuna, Rey actual de Vavao, Xavea segundo Jefe, y la Tubou Filumanumá, viuda de Tuyalafatai y madre de Tufoa: han sido luégo los frutos del matrimonio de Vuna con las dos Fatafegis, hijas de Paulajo, primeramente Feileua, Principe heredero de Vavao, Happai y Arnamoka, y luégo otros dos niños igua!mente recomendables po sus gracias y viveza: ss probable, que TubouTua, Eigui actual de Happai y Annamoka, si bien hijo de Vuna haya perdido por la madre los derechos al trono y sea más bien un Virey, hasta que la edad más adulta de Feileua lo reduzca insensiblemente á la clase de particular: de este modo á lo ménos podemos coinlinar las aseguraciones de todos, de sei extendidos los derechos de Feileua hasta Tongatabu y de ser infructuosos para los de Annamoka los canibios que allá hiciésemos después, porque muy lué go pasarían á manos de Vuna en la visita que. ahora proyectaba á aquellas islas: á lo ménos á este intento de conducir las personas reales habia venido el Comandante Mafi con su doble canoa, y seguramente si su pericia marinera corresponde á la fidelidad y al valor de que ha dado á Vuna tamañas pruebas y á la penetración que ha explayado á nuestra vista, merece con justa razón todas las distinciones con las cuales le favorecía aquel soberano siempre que lo encontraba: á pesar de las aseguraciones de Vuna, yo no creeré, sin embargo, iue se extiendan ni su autoridad, ni mucho ménos los derechós de Feileua á las Islas de Tongatabu y Eüa: deben éstas ser el patrimonio preferente de Mariagüi; permanecer sujetas á sus descendientes Monmuy y Coloucala, y por consiguiente quedar divididas de la Monarquía hasta que algún nuevo enlace de una con otra familia las reuna en un solo soberano con las Islas de Vavao.

Pero áun mientra: permanezca esta división, y mucho más cuando algún acaso la destruya, parece probable que durará por largo tiempo una paz tranquila entre la confederación, de suerte que puedan muy luégo restaurarse, particular. mente en Annamoka, los daños de la última guerra, y estos naturales merecen al mismo tiempo el justo apellido de amigos y la felicidad que la Naturaleza les ofrece con la prodigalidad de sus dones.

Dejaremos á la excelente pluma del Car:ián Cook y á su nimiedad filosófica el describir uno por uno los utensilios domésticos, los útiles para la pesca, la caza y la guerra, la calidad y construcción de sus casas y canoas, la amenidad y orden de sus cultivos, la fertilidad de sus tierras, la excelencia de sus frutos, las ocupaciones diarias del uno y el otro sexo, las enfermedades que los acosan, las diversiones que los entretienen y las diferentes especies de animales que dividen con ellos una traı 'juila subsistencia en estas islas felices: la traducción literal de aquellos párrafos será siempre el medio más seguro de no faltar ni á la elegancia, ni á la claridad, ni á la verdad; y así limitaremos ahora la continuación de estos apuntes, á aquellas circunstancias que miradas por nosotros ó en diferente época, ó en unas ocasiones más favorables, nos liacen discrepar algún tanto de las narraciones de aquel navegante.

Eil número de los labitantes del Archipiélago de Vavao fué considerado por el Comandante Maurelle de unas 15.000 personas próximamente: nosotros, atento á las concurrencias que pudimos advertir á un mismo tiempo en el fondeadero, en la aguada, en los parajes visitados por los Sres. Robredo y Bausá y en la excursión de Don José Bustamante, y suponiendo una cortísima población en la isla de Late que reconocimos á muy corta distancia, no pudiéramos extendernos sino á un número menor de una tercera ó cuaria parte, en el cual, sin embargo, con mucha extrañeza ruestra, no puede considerarse una porción correspondiente de párvulos y de ancianos.

Esta especie de contradicción de !a Natura. leza es tanto más extraña en estas islas, cuanto que la robustez de sus habitantes y todas las demás circunstancias que concurren á hacerlos felices, deberían sobresalir especialmente en una vida larra y en una rápida multiplicación de su especie; sus alimentos son tan sanos, que compuestos por la mayor parte de sustancias farináceas, sazonados por la misma Naturaleza y modificados comunmente por ellos con la fermentación agria, manifiestan sus efectos no ménos con el razonamiento que con la experiencia; oportunamente el agua del coco y la caña dulce les sirven de un suave $y$ agradable diluente, at paso que no les hacen necesario el uso del agua común, siempre algo mezclada en estas islas con partículas térreas y salinas: no precisados ni por la ambición ni por la necesidad á un trabajo asíduo y violento, pueden evitar igualmente los ardientes rayos del Sol y los tiempos fríos y llu. viosos: la poca aistancia á la equinoccial, igualando casi la división del día en todo el año, concurre maravillosamente á que sean uniformes las horas de la vigilia y del sueño y á que las dirija según las leyes de la Naturaleza el astro que vivifica $y$ conserva todo su sér $y$ sus adornos: finalmente, la rnansedumbre y la tranquilidad de ánimo, haciendo casi un contraste harmónico con la veltidad, con la soltura y con el instinto alegre que los acomparian, dictan una 
muchedumbre de ejercicios entretenidos, en los cuales se enlazan casi con emulación el cuidado y el sosiegro, la actividad y el reposo, el an. sia de sobresalir á los demás y el deseo de no desprenderse de un verdadero amor fraternal.

Al poco abrigo y al uso inmoderado de los placeres conyugales, debe por consiguiente atribuirsc, en mi entender, esta no proporcionada duración de la especie, confirmándose desde luego csta sospecha con la mayor falta de viejos entre los hombres, de la que se note entre las inujeres; $y$ con una, aunque mediana atención á la clase de alojamientos y camas de las cuales usan generalmente: son éstos sumamente desabrigados, como to denotan nuestras vistas y como lo describió ya con la mayor individua. lidad el Capitán Cook; ni la estera ó biombo in. terno que debe abrigarlos del viento horizontal cuando duermen, puede compensar la falta de techo propio que impida ta comunicación con el aire externo, átun cuando estal especie de comodidad pudiese ser gencral y no fuese limitada ó á los solos ríiguis ó más bien á un pequeño número de ellos: en las noches muy bien templadas del invierno tampoco puede ser saludable dormir en el suelo, ni pueden suministrar bastante abrigo pocas esteras por lo común usadas, cortas y de un mal ajuste al andar del cuerpo: estas incomodi. dades á las cuales fácilmente se acostumbra el joven, no dejan por esto de influir considerablemente en el hombre anciano, hasta el caso de acelerar su destrucción unas veces con una total falta de transpiración y otras con el ingreso de las miasmas pútridas que los rodean.

Es, a la verdad, bien extraño para el que tenga á la vista las diferentes muestras de la agudeza $y$ talento de los naturales, verlos des. pués tan poco industriosos, relativamente á esta parte esencial de su conservación: el hábito puede sólo justificar senrejante descuido y el que se confundan tal vez las demandas naturales de la última edad, con las que suelen entre los jóvenes llamarse vulgarmente impertinencias del viejo.

Pero no debe mirarse esta sino como una causa secundaria del corto término de la vida, cuando se compare al uso inmoderado de las mujeres: los Eiguis, particularmente, con la libertad de poder extender hasta cuatro el número de sus mujeres y con los muchos atractivos con los cuales han sido estas favorecidas de la Naturaleza, ni dejan de aprovechar la edad áun más jóven, ni de imaginar después todos los recursos que puedan multiplicar los placeres del himeneo: en los intervalos de la noche se siguen en un or. den inalterable la vigilia, la comida y el sueño, éste último incitado siempre y luégo conservado por largo tiempo con la singulur operación del toquitoqui, de la cual están encargadas únicamente las mujeres: la duración de la noche debe precisamente dar lugar á que se renueven estos turnos, y la fidelidad conyugal no puede á ménos de desearlos y promoverlos: cuando aseguremos que el número de las mujeres nobles de Vuna no era menor de doce, además de las plebeyas que pudiesen excitar su antojo; cuando se atienda que entre aquéllas las dos Fatafegis y otras dos le acompanaban diariamente, no debe extrañarse que con la sola edad de unos cuarenta y cinco años, ya se hallase casi ciego y con muestras evidentes de una estupidez dimanada de la laxitud de las fibras: nis chanzas en este asunto cuando á bordo solia repentinamente rendirse a! sueño, no le eran de modo alguno desagraciables, y sus respucstas, sin desentenderse de un más que mediano grado de pudor, no dejaban, sin embargo, de confirmar mis sospechas.

Al mismo tiempo, si debemos en esta especie de reftexiones seguir ciegamente los pasos de la Naturaleza en la manutención y acrecentamiento de todos sus productos, podemos hallar en los mismos inconvenientes que acaban de indicarse, la principal causa del estado floreciente, al cual alcanzan hasta una cierta edad todos estos naturales; sin atrevernos á contradecir lo que advirtió en esta parte el Capitán Cook por lo que toca á los habitantes de Happai y Amamoka, no podemos á ménos de ensalzar mucho la estatura y las bellas proporciones del mayor número de los de Vavao, hasta poderlos asemejar á los que habitan las islas no distantes de los Navegantes, según la excelente idea que de ellos ha dejado el Conde de la Péyrouse entre los ingleses del puerto Jackson.

La no proporcionada cantidad de párvulos, particularmente si se atiende á la robustez y al número de las mujeres, no debe al contrario pa. reces $\tan$ extraña: hay positivamente una ley entre estos pueblos, que previene la muerte de algunos niños, sin que podamos sin embargo prefijar si esta ley se entiende á todos los que sigan al cuarto hijo (como lo manifestí Mafi en la corbeta ATREVIDA) 6 si, como repetidas vecess nos lo explicó Latu en la Descubierta, son el quinto y el noveno solos los destinados á muerte, cualquiera sea el sexo, no ś́lo de estos niños, si también de los otros que les preceden.

Esta ley por sí sola no sería tan nociva, respecto al número ya bien. crecido en el cual empieza á tener vigor, si no produjese de antemano indispensablemente una cierta cruel indiferencia de los padres hacia los hijos: indiferencia que puede muy bien hacerles anticipar ó prolongar este abuso, siempre que haya ó una incomodidad grave 6 tal cual dificultad en la sub. sistencia propia.

La edad de doce años es comunmente entre los hombres la que parece destinada á empren. der la vida conyugal: Tufoa y Latu tenían ya 
dos 6 tres mujeres cada uno: según ellos, Feileua no esperaba sino aquella edad para conseguir igual suerte; no nos fue posible comprender si había alguna persona ya déstinada para este en. lace, 6 si dependería únicamente de su gusto la eleccion de sus mujeres: aunque lo advirtiese con mucho tino el Capitán Cook, y que la narración de nuestros acaecimientos lo confirme á cada paso, no dejaremos de disipar aquí de nue. vo la errada idea de que en estas islas sea fácil $y$ general la prostitución de las mujeres: muchas veces nos ha manifestado la experiencia que los ofrecimientos de Vuna y de los demás Eiguis se reducían á las solas plebeyas, así como los hala gos y las caricias de las más jóvenes y distin. guidas, no tenían otro móvil, que una mezcla de hospitalidad, de franqueza y de interes: áun en las primeras muestras de aquel instinto reciproco (I) que atrae el uno al otro sexo, distinguieron siempre (para no prodigarlas) las que en su sentir eran ménos equívocas é indiferentes: jamás procuraron atizar nuestros deseos con movimientos lascivos; jamás insultaron nuestras repulsas, 6 con el vilipendio de una insensibilidad natural, 6 con las quejas de las voces ultrajadas de la naturaleza: conocían una ley que ponía freno al instinto; la hallaron en nosotros y no la extrañaron, $y$ últimamente, se manifes. taron ufanas de desplegar á nuestra vista con el hermoso semblante de la inocencia, aquellas mismas ideas que entre nosotros apenas pueden conservar la educación, la religión y la disciplina.

No es mi ánimo encarecer en esta ocasion los diferentes adornos que contribuían con su hermosura á causar nuevo brillo al carácter in. dicado: parecerian estas pinturas tan violentas para el navegante, como enfáticas para el via. jero; se confundirian el filósofo y el poeta, tal vez se caracterizaría por ignorancia 6 por demencia la sola idea de una virtud natural que enseña á moderar las pasiones y á sujetarlas a los dulces lazos de la sociedad; pero no podré á ménos de reunir en un solo punto de vista aquellas gracias que son comunes á todas, y que deben naturalmente hacernos envidiar á los que tengan en lo venidero ocasiones más oportunas de contemplar en este cielo feliz la Naturaleza

(I) El lector comprenderá que esto alude a aquollos versos del Car. ${ }^{\circ}$ Guarini en su Pastor Fido.

$$
\begin{aligned}
& \text { Bacj pur bocca curiosa, é Scaltra } \\
& \text { O seno, } 6 \text { fronte, } \delta \text { mano..... }
\end{aligned}
$$

$\mathrm{Ni}$ debe hallar 0 importunas 0 poco modestas estas noticias, cuando tienen por objeto el vindicar la modestia y el pudor, representándolas como una propension natural del alma y no como un antidoto violento:

$$
\text { De la logge aurea, } 6 \text { falize }
$$$$
\text { Che natura seolpi; s'if place ei tice. }
$$

vestida de sus más bellos adornos: las bodas de Feileua serán sin duda una ocasión de esta es. pecie: entonces se desplegarán á la vista del filósofo viajero la honestidad medio desnuda, la sensibilidad sin educación, la subordinación $\sin$ castigo, el respeto sin mengua de la alegría; la felicidad sin envidia y la suerte del hombre combinada con la religión, con el instinto, con los principios sociales y con todos los adornos de la Naturaleza: ;felices habitadores si no oscurecen una escena tan lisongera, con el sacrificio lúgubre de las víctimas humanas, si reconocen en la Divinidad el Padre de la Naturaleza, el centro de la paz y el Arbitro justiciero del rayo, del temblor y de los límites del mar; felices finalmente nosotros si entre los cantos energi$\cos (\mathrm{I})$ que les dictará una natural alegría en aquella ocasión, recordaran con afecto y sin el menor sobresalto el nombre español; $y$ en las semillas ya multiplicadas, en los utensilios útiles para sus usos domésticos, en los adornos inocentes con los cuales se distinguirán los novios, hallaran otros tantos rastros de una visita no enturbiada con la mengua de las costumbres ni con la destrucción de sus semejantes!

La cantidad de las provisiones que hemos hallado no ha sido correspondiente á las ideas que teníamos anteriormente formadas, á lo ménos por lo que toca á los dos ramus esenciales de gallinas y puercos: difícilmente pudieramos suponer que haya quedado siquiera una mitad de lo que nosotros hemos adquirido y cuya cantidad no debe considerarse mayor de unas 500 gallinas y 60 puercos entre las dos corbetas: de estos últimos vimos venir al mercacio los más grandes y los más chicos; vimos cruzarse las ca. noas en busca de uno ú otro á los frarajes más distantes; vendieron hasta las hem" zras preña. das, y seguramente la codicia de las, hachas les hubiera movido á cualquiera diligencia y á cual. quiera sacrificio para su adquisicion: las fritas, las raíces y los limones parecían más bien inagotables; y esta sola abundancia bastaría pura convidar al navegante á estas orillas, particular-

te cuando un corto número de buques na. vega de los mares del Asia hacia la América meridional: no desmenuzaremos con un detalle importuno los efectos más útiles de cambio: las hachas y la ropa serán siempre de una utili. dad real: lo serían aún más que aquéllas, nues. tros machetes de la Nueva España; pero por lo que toca á los adornos mujeriles, debemos avisar que podrán desde luego satisfacer un antojo momentáneo, mas nunca serían un suficiente in. centivo para la cesión de las cosas más útiles.

(1) Con mucha razón suponen los Sres. Cook, (1) Con mucha razon suponen los Sres. Cook
Foster y Anderson, que las poesias que son entre es Foster y Anderson, que las poesias que son entre es. tos pueblos el objeto del canto, sean sumamente
presivas y siempre adaptadas a las circunstancias. 
Terminaremos este capítulo con dos reparos que merecen verdaderamente la atención del filbsofo cuando quiere reflexionar con madurez sobre sus semejantes; $y$ son, el primero la atención con la cual entre estos pueblos se saluda á todo Ligui al tiempo de estornudar, usando oportunamente del mismo modo que nosotros, una voz destinada solo para el intento, $y$ es la de Seifú; $y$ el otro la familiaridad y frecuencia con la cual ejecutan el juego nuestro de la morra. No desdeñaba Vuna ell confundirse en estas ocasiones con los Eiguis; y no bien empezaba una, cuando se veían instantáneamente otras muchas parejas ocupadas con el mismo entretenimiento. Estos datos esenciales de un mayor grado de civilización, de una semejanza de costumbres á las nuestras y particu. larmente del rastro de una ceremonia que es en. tre nosotros de origen desconocido, podrán tal vez aproximar la historia del hombre con datos ménos equivocos de los que se han usado hasta ahora $(\mathrm{r})$.

(1) Un mayor despacio dara lugar a ordenar algo mejor estos apuntes y á comprender entro ollos todo lo que ha escrito el Capitán Cook y conviene con nuestras propias observaciones. Los razonamientos nuestras propias observaciones. Los razonamientos
sobro las monzones pertenecerán á la práctica do la navegación. 
Terminaremos este capítulo con dos reparos que merecen verdaderamente la atinción del filbsofo cuando quiere reflexionar con madurez sobre sus semejantes; y son, el primero la atención con la cual entre estos pueblos se saluda á todo Ligui al tiempo de estornudar, usando oportunamente del mismo modo que nosotros, una voz destinada sólo para el intento, y es la de Seifú́; y el otro la familiaridad y fre. cuencia con la cual ejecutan el juego nuestro de la morra. No desdenaba Vuna en confundirse en estas ocasiones con los Eiguis; y no bien empezaba una, cuando se veían instantáneamente otras muchas parejas ocupadas con el mismo entretenimiento. Estos datos esenciales de un mayor grado de civilizacion, de una semejanza de costumbres á las nuestras y particu. larmente del rastro de una ceremonia que es en. tre nosotros de origen desconocido, podrán tal vez aproximar la historia del hombre con datos ménos equivocos de los que se han usado hasta ahora (I).

(1) Un mayor despacio dará lugar á ordenar algo mejor estos apuntes y á comprender entro ellos todo lo que ha escrito el Capitán Cook y convione con nuestras propias observaciones. Los razonamientos sobro las monzones pertenecerán á la práctica de la navegación. 


\section{VIAJE DE DON JOSÉ DE ESPINOSA Y TELLO desde Cadiz hasta Acapulco, donde se reviro a la expedición de las corbetas DescubierTa y ATREviDA, y continuacion de este viaje. Contiene muy buenas noticias de Historia Natural, Geografia, costumbres, etc.}

Hallándome en Sevilla disfrutando de Real licencia en Abril de r790, recibi un oficio del Capitán General de la Armada con fecha 13 de aquel mes, en que me prevenía haber resuelto $\mathrm{Su} \mathrm{Ma-}$ jestad el 6 del mismo que pasase á Méjico para embarcarme en Acapulco en la expedición de las dos corbetas Descubierta y ATrevida, que habían salido de Cádiz el año anterior destinadas á dar la vuelta al mundo. Para cumplir esta soberana resolución, me trasladé inmediatamente al Departamento de Cádiz; pero como á la sazón se armasen alli varios buques sospechándose un proximo rompimiento con la Inglaterra, hice representación al Rey ofreciendome á este servicio de mayor mérito y preferencia que el de la expedición de la vuelta del mundo, y habiendo remitido la instancia al señor Capitán General, recibí por su mano el $\mathrm{r}_{4}$ de Junio la contestación siguiente:

"El Sr. D. Antonio Valdés me comunica la siguiente Real orden con fecha 8 del corriente, que traslado á V. para su gobierno y en respuesta á su representación de 28 del antecedente.Excmo. Sr.: El honroso deseo de permanecer en ese puet to para emplearse en el actual armamento, que manifiesta el Teniente de navío $D$. José de Espinosa en la representación que V. E. me dirige con carta número 734, es muy propio del celo que tiene acreditado: le es á S. M. aprecia. ble; pero considerando que no será de menor recomendación el mérito que contraiga en la expedición destinada á dar la vuelta al mundo, es su Real voluntad vaya á Acapulco á embarcarse según está mandado: lo que advierto á V. E. para su gobierno y á fin de que lo comunique á Es. pinosa."

A consecuencia de esta soberana determinación y de la de que me embarcase prontamente para Veracruz en compañ́a del Teniente de navío D. Ciriaco Cevallos, nombrado también para la propia expedición, se trat6 de nuestro embar. co en la fragata del comercio Santa Rosalía, perteneciente á D. Miguel Caraza. Detuvímonos algún tiempo á causa de varias dilaciones del dueño del buque; pero al fin dimos la vela del puer- to de Cádiz el 25 de Noviembre en la mañana, con viento flojo del Nurte.

Entre varias obras nuevas, almanaques náu. ticos y otros papeles que acababan de publicarse en Europa y podrian necesitar las corbetas durante su largo viaje, puso á nuestro cuidado el Capitán Comandante de las Compañias de Guardias Marinas D. José de Mazarredo, los relojitos de segunda suerte números 344 y $35^{\mathrm{I}}$ de Arnold, que pedimos á dicho Jefe considerando la mucha utilidad que podían rendir estas máquinas en nuestra expedición. Conducíamos asimismo un péndulo simple constante, construído de intento, que remitía el Ministerio para que se hiciesen experiencias sobre la gravedad, en todos los lugares donde se detuviesen algún tiempo las corbetas, y como estas experiencias tenían por objeto el poder comparar y ligar los resultados de la expedición con los que hallasen los Académicos franceses en el paralelo de $45^{\circ}$ Norte, pues se trataba entonces de arreglar en Francia un nuevo sistema de pesos y medidas, derivado de la longitud del péndulo que oscilase segundos en la latitud de $45^{\circ}$, nos fué sumamente doloroso el que los $\mathrm{p}$ os días que mediaron entre la llegada del pénd io á Cádiz y nuestra salida, no nos permitiese hacer en aquel puerto las experiencias que deseábamos.

El 27 nos alejamos del saco de Cádiz, haciendo rumbos del Oesuoeste y Oeste, aprovechan. do con toda fuerza de vela el vientecito flojo del Norte y rumbos próximos con anuncios bien claros de vendabal, el cual lo tuvimos con efecto el 29, aunque de corta duración, pues el 30 ya volví á entablarse al Nordeste càlmoso con carices bonancibles, rolando al Este y acrecentando más su fuerza al paso que bajábamos de latitud.

Resueltos á no ver las Canarias ni otro punto alguno, sino navegar en derechura á la Isla Española por la derrota más próxima, cortamos el 6 de Diciembre el meridiano de Tenerife por latitud $30^{\circ} 40^{\prime}$, en cuyo punto había retardado la estima $x^{\circ} 40^{\prime}$ sobre la longitud observada. Este atraso fué aumentando en razón del tiempo hasta que el 25 lleg 6 á ser de $4^{\circ} 50^{\prime}$ corriendo el para- 
lelo de $20^{\circ} 40^{\prime}$. Aquí objervamos la variación de la aguja $2^{\circ}$ al Nordeste.

Navegábamos tan asegurados de nuestra posicion con el auxilio de los relojes, que dirigimos la recalada á Cabo Cabrón por el paralelo de $19^{\circ} 30^{\prime} ; y$ en efecto, le avistamos á las siete de la mañania del 31 de Diciembre, demorahdo al Sur $31^{\circ}$ Este y Cabo Francés al Sur $61^{\circ}$ Oeste corregido distancia de cuatro leguas.

Desde el medio día del 30 hasta la hora de esta marcación, tuvimos $20^{\prime}$ al Norte de la estima, y nos acercamos, por consiguiente, demasiado al lBajo de la Plata, lo que debe servir de prevención para tomar rumbo más Sur en otra oca. sión. Costeamos la parte Norte de Santo Domin. go, favorecidos siempre del viento fresco del Este que no nos desamparaba desde el meridiano de Canarias, y el 7 de Enero marcamos Cabo de Cruz de la Isla de Cuba, que resultó en lon. gitud de $7 \mathrm{I}^{\circ} 39^{\prime}$ al Oeste de Cádiz, según la observación que hicimos con el 344 referida á di . cho Cabo.

En toda la navegación por el Sur de Cuba ex perimentamos corrientes muy vivas, y la noche del 8, á las $10^{\text {h }} 45^{\prime}$, nos hallamos de repente sobre el Caimán Chico, que felizmente montamos cerrando el timón a la banda y orzando de seis á siete cuartas. Corriamos su paralelo considerán. donos todavía lejos de dicha isla; pero como nos manifestó después el reloj, estábamos 21 millas más Oeste de lo que juzgábamos, y el Caimán se halla I2 más al Este de lo que lo sitúan las car. tas, de modo que lo vimos debajo de la proa cuando le considerábamos á 33 millas. Por nues. tras observaciones, queda ahora situado en latitud Norte $19^{\circ} 40^{\prime}$ y longitud Oeste de Cádiz $73^{\circ}$ $25^{\prime} 30^{\prime \prime}$.

El Io del mismo mes por la tarde, avistamos la tierra, y siendo muy baja y de arboleda, la tomamos por Cabo San Antonio lo más occidental de Cuba, que demoraba al Norte $1 / 4$ Nordeste corregido distancia cinco leguas.

Continuamos al Norte $70^{\circ}$. Oeste del mundo en vuelta de la sonda de Campeche, y el II al medio día observamos $2 \mathrm{r}^{\circ}{ }^{52^{\prime}}$ de latitud. El cielo se cubrió de celajería espesa, y empezó á ventar duro por el Norte con mucha mar y lluvia muy copiosa. A las diez de la noche nos considerábamos en sonda, y lo anuncí́ además el hervidero de las corrientes, que á pesar de lo fresco del viento Norte no permitían gobernar á la fragata. El 12 observamos la latitud $22^{\circ} 29^{\prime}$ y la estima era á la misma hora de $22^{\circ} 19^{\prime}$. Desde el paralelo de $22^{\circ}$ corrimos al Oeste corregido con viento duro del Norte. Al amanecer gobernamos más Sur, y á medio día nos hallábamos en $2 \mathrm{I}^{\circ} 4^{\prime}$. de latitud por estima y por observación. Ultima mente, el I $_{5}$ á las nueve de la mañana estábamos en el veril occidental de la sonda que según nues. tras observaciones reducidas á medio dia, no distará mucho por el braceaje de roo brazas de $21^{\circ} 3 I^{\prime}$ de latitud y $86^{\circ}$ y $\%$ al Oeste de Cádiz; y desde aqui navegamos en vuelta de Punta Delga. da con ventolinas del Sur y Sueste. En la noche hubo mucho relente, indicio seguro de Norte, y con efecto, lo tuvimos muy recio el dia siguiente; pero cedió alguna cosa el 17 y habiéndonos permitido reconocer Punta Delgada el I8, fondea. mos en Veracruz el i9 por la tarde.

No podemos dejar de advertir que la breve. dad de este viaje la hemos debido enteramente á la buena determinación de navegar directamente á la Isla Española, no disminuyendo de latitud sino á proporción que lo pedía la derrota, y cuando conocíamos que por ser muy arriba no estaban los vientos bien entablados al Nordeste y Este, ó que por la propia causa y lo crudo de la estación recalaban hasta el Trópico los vientos recios y variables del Océano Atlántico. En ge. neral, cuando el objeto principal con que se navega es hacer el viaje lo más pronto posible, será bien tener presente las siguientes advertencias que nos ha sugerido la experiencia de este viaje al mismo tiempo que las noticias adquiridas de varios prácticos de la carrera.

Saliendo de Cádiz se gobernará al Oesuoes. te (I), á cuyo rumbo demorará la Isla Madera, y siguiendo este rumbo se cortará su meridiano por la parte del Surá distancia de 20 ó 25 le guas, porque hay que contar con ro 612 millas de diferencia al Sur en cada día de los tres primeros de navegación, y con 20 ó 25 en cada uno de los restantes hasta llegar por latitud de $32^{\circ}$. Entre los 34 y $35^{\circ}$ se encuentra ya la brisa ó viento general del Nordeste, que empieza á ventar por el Norte y Nornordeste. Se continuará al Oésudoeste, porque se consigue andar más distancia que si se navega, sea á viento más largo, como comunmente se practica para pasar entre la Gran Canaria y Tenerife. Es preferente la derrota por el Norte de estas islas, porque se experimentan vientos más frescos y más iguales, no se corre el riesgo de dar con calmas y vientos calmosos del Norte al Nornoroeste que suele haber al Sur de Canarias, siendo probable que de dos buqques que salgan de Cádiz con igual andar, ga. nará dos singladuras el que navegue por el Norte de Canarias sobre el que dirija su derrota jor entre estas islas. Desde el meridiano de la $\mathrm{Ma}$ dera y latitud de $3^{1} y^{1} / 2^{a} 3^{2}$, se puede hacer el Oesuoeste $5^{\circ}$ Oeste, pues no hay necesidad de disminuir mucha latitud, debiendo considerar ya entablada la brisa; siempre la deriva y la mar abaten cuatro 6 cinco millas al Sur por día respecto al punto de estima, y como el viento se

(x) Todos los rumbos son corregidos de variación y las longitudes al occidente de Cádiz. 
lelo de $20^{\circ} 40^{\prime}$. Aqul ob servamos la variación de la aguja $2^{\circ}$ al Nordeste.

Navegábamos tan asegurados de nuestra posición con el auxilio de los relojes, que dirigimos la recalada á Cabo Cabrón por el paralelo de $19^{\circ} 30^{\prime} ; y$ en efecto, le avistamos á las siete de la mañara del $3^{\mathrm{I}}$ de Diciembre, demorahdo al Sur $3 x^{\circ}$ Este y Cabo Francés al Sur $6 x^{\circ}$ Oeste corregido distancia de cuatro leguas.

Desde el medio dia del 30 hasta la hora de esta marcacion, tuvimos $20^{\prime}$ al Norte de la estima, y nos acercamos, por consiguiente, demasiado al l3ajo de la Plata, lo que debe servir de prevención para tomar rumbo más Sur en otra ocasión. Costeamos la parte Norte de Santo Domin. go, favorecidos siempre del viento fresco del Este que no nos desamparaba desde el meridia. no de Canarias, y el 7 de Enero marcamos Cabo de Cruz de la Isla de Cuba, que resultó en longitud de $71^{\circ} 39^{\prime}$ al Oeste de Cádiz, según la observación que hicimos con el 344 referida á dicho Cabo.

En toda la navegación por el Sur de Cuba ex. perimentamos corrientes muy vivas, y la noche del 8, á las $10^{b} 45^{\prime}$, nos hallamos de repente sobre el Caimán Chico, que felizmente montamos cerrando el timón á la banda y orzando de seis á siete cuartas. Corríamos su paralelo considerándonos todavia lejos de dicha isla; pero como nos manifestó después el reloj, estábamos 2 I millas más Oeste de lo que juzgábamos, y el Caimán se halla 12 más al Este de lo que lo sitúan las cartas, de modo que lo vimos debajo de la proa cuando le considerábamos á 33 millas. Por nuestras observaciones, queda ahora situado en latitud Norte $19^{\circ} 40^{\prime}$ y longitud Oeste de Cádiz $73^{\circ}$ $25^{\prime} 30^{\prime \prime}$.

El lo del mismo mes por la tarde, avistamos lá tierra, y siendo muy baja y de arboleda, la to. mamos por Cabo San Antonio lo más occidental de Cuba, que demoraba al Norte $1 / 4$ Nordeste corregido distancia cinco leguas.

Continuamos al Norte $70^{\circ}$ Oeste del mundo en vuelta de la sonda de Campeche, y el II al medio día observamos $21^{\circ} 5^{2}$ de latitud. El cielo se cubrió de celajería espesa, y empezó á ventar duro por el Norte con mucha mar y lluvia muy copiosa. A las diez de la noche nos considerábamos en sonda, y lo anunció además el her'videro de las corrientes, que á pesar de lo fresco del viento Norte no permitían gobernar á la fragata. El I 2 observamos la latitud $22^{\circ} 29^{\prime}$ y la estima era á la misma hora de $22^{\circ} 19^{\prime}$. Desde el paralelo de $22^{\circ}$ corrimos al Oeste corregido con viento duro del Norte. $\mathrm{Al}$ amanecer gobernamos más Sur, y á medio día nos hallábamos en $2 \mathrm{I}^{\circ} 48^{\prime}$ de latitud por estima y por observacion. Ultima. mente, el ${ }_{5}$ á las nueve de la mañana sstábamos en el veril occidental de la sonda que según nues. tras observaciones reducidas á medio dia, no distará mucho por el braceaje de roo brazas de $21^{\circ} 3^{I^{\prime}}$ de latitud y $86^{\circ}$ y $1 /$ al Oeste de Cádiz; y desde aqui navegamos en vuelta de Punta Delga. da con ventolinas del Sur y Sueste. En la noche hubo mucho relente, indicio seguro de Norte, y con efecto, lo tuvimos muy recio el dia siguiente; pero cedió alguna cosa el 17 y habiendonos permitido reconocer Punta Delgada el 18, fondea. mos en Veracruz el ig por la tarde.

No podemos dejar de advertir que la breve. dad de este viaje la hemos debido enteramente á la buena determinación de navegar directamente á la Isla Española, no disminuyendo de latitud sino á proporción que lo pedía la derrota, y cuando conocíamos que por ser muy arriba no estaban los vientos bien entablados al Nordeste y Esste, 6 que por la propia causa y lo crudo de la estación recalaban hasta el Trópico los vientos recios y variables del Océano Atlántico. En ge. neral, cuando el objeto principal con que se navega es hacer el viaje lo más pronto posible, será bien tener presente las siguientes advertencias que nos ha sugerido la experiencia de este viaje al mismo tiempo que las noticias adquiri. das de varios prácticos de la carrera.

Saliendo de Cádiz se gobernará al Oesuoes. te (I), á cuyo rumbo demorará la Isla Madera, y siguiendo este rumbo se cortará su meridiano por la parte del Sur á distancia de 20 o 25 le guas, porque hay que contar con Io 6 I 2 millas de diferencia al Sur en cada día de los tres primeros de navegación, y con 20625 en cada uno de los restantes hasta llegar por latitud de $32^{\circ}$. Entre los 34 y $35^{\circ}$ se encuentra ya la brisa ó viento general del Nordeste, que empieza á ven. tar por el Norte y Nornordeste. Se continuará al Oésudoeste, porque se consigue andar más dis. tancia que si se navega, sea á viento más largo, como comunmente se practica para pasar entre la Gran Canaria y Tenerife. Es preferente la de. rrota por el Norte de estas islas, porque se experimentan vientos más frescos y más iguales, no se corre el riesgo de dar con calmas y vientos cal. mosos del Norte al Nornoroeste que suele haber al Sur de Canarias, siendo probable que de dos buques que salgan de Cádiz con igual andar, ganará dos singladuras el que navegue por el Norte de Canarias sobre el que dirija su derrota por entre estas islas. Desde el meridiano de la Madera y latitud de $31 \mathrm{y} \% \mathbf{a}^{2} 32^{\circ}$, se puede hacer el Oesuoeste $5^{\circ}$ Oeste, pues no hay necesidad de disminuir mucha latitud, debiendo considerar ya entablada la brisa; siempre la deriva y la mar abaten cuatro 6 cinco millas al Sur por día respecto al punto de estima, y como el viento se

(1) Todos los rumbos son corregidos de variación y las longitudes al occidente do Cádiz. 
io dia, no brazas de de Cádiz; y unta Delga. En la noche de Norte, y ía siguiente: idonos per. I8, fondea.

ue la breve. hteramente a lirectamente o de latitud derrota, y uy arriba no 1 Nordeste y crudo de la los vientos tico. En ge on que se naonto posible, tes adverten. encia de este cias adquiri-

al Oesuoes. Isla Madera, su meridiano 206025 le. 6 I2 milla los tres pri. i en cada uno titud de $32^{\circ}$. ya la brisa npieza á vencontinuará al ndar más dis to más largo a pasar entre eferente la deorque se expeás iguales, no y vientos calte suele haber le que de dos ual andar, ga1e por el Norte u derrota por ano de la Mapuede hacer el necesidad de do considerar eriva y la mar ir por día resel viento se alarga al Nordeste y Esnordeste, se consigue con no arribar de golpe, retardar el que esté á popa, en beneficio del mayor andar.

Por latitud de $23^{\circ}$ el viento es del Este y la mar gruesa y tendida como conviene á la meri. diana del Golfo. La variación de la aguja va disminuyendo al paso que se aumental de longitud, pero no guarda una ley uniforme que pueda servir de luz para rectificarla. Sin embargo, á quien carezca de mejores datos le puede ser de alguna utilidad la noticia de que por latitud de $21^{\circ}$ y longitud de $52^{\circ} 30^{\prime}$ coincidía en $\mathrm{r} 790$ el meridiano magnético con el meridiano verda. dero. Aun antes de llegar á estos parajes, suelen verse rabijuncos, pardelas y sargazo, con otros indicios que por sí solos no deben mirarse como anuncios de tierra. Se inclinará el rumbo al Sur lo preciso para recalar al Cabu Cabrón de la Isla Samaná, que está por latitud de $19^{\circ} 22^{\prime}$ y $63^{\circ}$ y $3^{\prime}$ de longitud. Esta recalada y la navegación sucesiva por el Norte de la Isla de Santo Domingo, hace tanta ventaja á la derrota antigua con que se iba á dar vista á las Islas de San Martin, la Anegada y Puerto Rico, y por el Sur de la Isla Española se buscaba á Cuba, que en la elección no cabe duda. Las observaciones diarias de latitud dirán lo que debe enmendarse el rumbo con respecto á las diferencias al Sur que suelen experimentarse al cortar los meridianos de estas Islas, y para la longitud tendrá presente quien carezca de observaciones seguras, que por lo regular se anticipa el buque $5^{\circ}$ á la estima calculada con corredera geometrica de $47 \mathrm{y} \%$ piés de París para 30" de experiencia. Reconocido el Cabo Cabrón se gobernará á pasar á regular distancia del Cabo Viejo Francés, bajo el concepto de que la corriente arrastra 20624 millas por

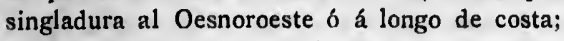
por lo cual, para aprovecharla y no acercarse demasiado á los veriles del Cayo de Plata, conviene navegar $a_{3}$ ó 3 y $\frac{1}{2}$ leguas de tierra. Las brisas son muy frescas por el Norte de Santo Domingo, y se anda muy pronto la distancia que media entre el Cabo Viejo Francés y la Isla Tortuga, desde cuyo meridiano se gobernará en demanda de la costa meridional de Cuba á recono. cer el Cabo de Cruz, situado en latitud de $19^{\circ} 47^{\prime}$ $y$ en $7 x^{\circ} 27^{\prime}$ de longitud. Es conveniente dar vista á este Cabo para hacer con conocimiento la travesía á las Islas de los Caimanes Chicos, cuyo extremo oriental está en latitud de $19^{\circ} 43^{\prime} 40^{\prime \prime}$ y $2^{\circ}$ oo ${ }^{\prime}$ al Oeste del Cabo de Cruz. Se pasará al Norte 6 al Sur de dichas islas se. gún convenga, y desde su meridiano se gobernará en demanda del extremo occidental de Cuba 6 Cabo de San Antonio, situado por combinaciones de estima en latitud de $2 \mathrm{I}^{\circ} 5^{\prime}$ y en longitud de $5^{\circ} \eta^{\prime}$ al Oeste del extremo oriental de los Caimanes Chicos. Servirá de prevención que las aguas tiran de ordinario 15616 millas al Oeste en veinticuatro horas, desde el meridiano del muelle de San Nicolás hasta los Caimanes, y desde éstos al Calso San Antonio se experimenta ménos corriente al Oeste; pero su influjo lleva también al Norte 126 I 5 millas cada día. Ke. conocido el Caho San Antonio se pueden hacer dos derrotas; ó bien entrar en sonda de Campe. che por latitud de $32^{\circ} 30^{\prime}$ y correrla del Este al Oeste para salir por entre el Bujo muevo y el Trián. gulo, 6 picar sonda más al Norte y por 23 y $23^{\circ}$ y $1 \%$ de latitud navegar siguiendo su veril septen. trional. La primera de estas derrotas es la que se practica comunmente, pero la hace ventajas la segunda, en la cual se navega más libre de cuidados, la acción de las aguas al Oeste es más rápida, y en caso de cargar un Norte recio hay mar suficiente para mantenerse 6 arribar. En la derrota ordinaria luégo que por $22^{n} y^{1} /$, de latitud se sonda 356 4o brazas, se gobernará al Sud. oeste hasta entrar en $22^{\circ}$, se corre este paralelo por 18 y 20 brazas fondo arena fina, blanca y conchuela, sin bajar de esta latitud en el primer tercio de la sonda, porque suelen abatir las aguas al Sur ocho 6 diez millas por singladura. Se irá descaeciendo insensiblemente á buscar el para. lelo de $2 \mathrm{I}^{\mathrm{n}} 45^{\prime}$, sondando de hora en hora por 18,20 y 22 brazas fondo arena, conchuela y coralillo, y rebasado el meridiano de la Desco. nocida se bajará á la latitud de $2 \mathrm{I}^{\circ} 30^{\prime}$ en demanda del canal que forma el Bajo nuevo y el Triíngulo, cuyo fondo es de arena con lama y de lama suelta. Toda la seguridad depende en estc paso del conocimiento de la latitud, y así deben ponerse en práctica cuantos métodos hay de averiguarla.

Por fortuna no se experimentan dentro de sonda diferencias crecidas, siendo lo común observar seis ú ocho millas al Sur y 10 6 12 al Oeste en veinticuatro horas. Pero con esta can. tidad que abata la corriente y otro tanto que tenga de error el rumbo, si es en propio sentido, acer: cará demasiado á uno ú otro de los puntos por entre los cuales se ha de pasar. Pero no basta la latitud; es asimismo preciso el conocimiento del fondo en confirmación de aquella, y para formar prudente juicio de la distancia Este-Oeste que se navega. Debe haber un cuidado especial do asegurarse del tiempo en que empieza á estar la arena mezclada con lama, que con corta diferencia será el mismo en que de 20 y 22 brazas au. menta de pronto el fondo á 26 y 28. Entonces dista como 20 leguas el veril occidental que por observaciones exactas se considera en $85^{\circ} 24^{\prime}$ de longitud. Ya en este punto, si es de noche se espera algunas horas de una vuelta $y$ otra $y$ se marea á la madrugada para salir de sonda al siguiente día. El fondo lama es la señal infalible de que se va por canal y por consiguiente en 
buena derrota. El braceaje va aumentando á 30, 36 y 40 brazas, y ya en esta agua, andadas seis á ocho millas, falta de golpe. Si despues de practicadas las prevenciones anteriores y con la con. fianza y seguridad consiguientes se diera alguna escandallada en 28629 brazas piedra, no debe causar sobresalto, porque este fondo es de un ro. dal que hay en la mediania del canal; pero si con. tínuase la misma calidad, se mirará como indicio de que no está lejow el Bajo muero y se inclinará el rumbo más al Sur, hasta volver a! fondo lama.

La navegación por el Norte de la sonda, que es la otra derrota que se puede hacer, obliga á ménos cuidados. Cogido el veril orientai que por buenas observaciones se cuenta por longitud de $2^{\circ} 3^{\prime}$ al Oeste del Cabo San Antonio en Cuba y $80^{\circ} 33^{\prime}$ al Oeste de Cádiz, no hay más que correr el paralelo de $23^{\circ} 3^{\prime}$ por $5^{\circ}$ y 60 brazas fondo arena. En estando á prudente distancia del pa. raje donde sitúan i is cartas el bajo del Negrillo (r), se gobernará al Sudoeste $\%$ Oeste á pasar a) Norte de la Isla Bermeja, sondando de seis en seis horas hasta asegurarse cogiendo 806 roo brazas, de que se ha rebasado el codillo y veril occidental de la sonda. La comparación de los puntos de estima y de observación en varios viajes por el Norte de ella, manifiesta que en esta derrota se debe contar con 16618 millas de corriente al Oeste en veinticuatro horas. El mayor empeño que puede ocurrir es que cargue mucho el viento si se navega con Norte, y que sea escaso para montar el bajo nombrado el Alacrán. Si tal sucediese se cambiará de bordo en vuelta del Este y con la ventaja que ofrece el mayor barlovento se emprenderá la derrota primera.

Desde el veril occidental se hará derrota á recalar á barlovento de Veracruz, según los vientos reinantes. En la estación de Nortes, se reconoce Punta Delgada, que está en latitud de $20^{\circ} 7^{\prime}$ y según se juzga que el viento si es recio del Norte, será 6 no manejable sobre Veracruz, se resuelve 6 retarda la arribada. Del veril occidental al puerto hay $4^{\circ} 30^{\prime}$ de diferencia de longitud por observación, y por estima es común encontrar $3^{\circ} 3^{\prime} \sigma^{\prime} 3^{\circ} 40^{\prime}$, de suerte que es casi seguro el curso de I6 á I8 millas de corriente diaria al Oeste ó rumbos próximos. Si estando en las inmediaciones de Veracruz calmase el viento, se puede dar fondo por 20625 brazas fango al Nornoroeste del castillo de San Juan de Ulua, y á distancia de dos leguas de él. Es el partido más prudente para de noche y siempre que falte viento entablado con que se pueda vencer la fuerza de la corriente que tira como al Noroeste.

El muelle de Veracruz está en latitud de

(1) Este baj, se halis en latitud de $23^{\circ} 24^{\prime} 54^{\prime \prime}$ y 1 ongitud $83^{\circ} 55^{\prime}$ 1 $5^{\prime \prime}$ Oeste de Cádiz. $19^{\circ} 12^{\prime}$ Norte y en longittid observada $90^{\circ} \mathrm{s}^{\prime}$ al Oeste de Cádiz; y el Pico de Orizaba (montaña muy notable y de muy fácil reconocimiento) está asimismo en latitud de $19^{\circ} t^{\prime}$ y en $9 t^{\circ} 20^{\prime}$ de longrit:it al Oeste de Cádiz: su altura sobre el nivel del mar es de 3.218 toesas, y el largo de au tangente al horizonte 152 millas, distando 105 proximamente cuando aparece un grado elevado.

La ciudad de Veracruz, conocida en todo el mundo por los grandes tesoros que en ella se han embarcado para remitirse á España, no co. rresponde en su capacidad, riqueza, ni gentlo $a$ la idea que puede haberse formado de ella por lo extendido de su nombre. Reducida á dos calles principales que corren del Nordeste al Sudeste con otras varias pequeñas paralelas á éstas, carece de edificios suntuosos y de todos los adornos y hermosura exterior que caracterizan las grandes y ricas poblaciones. Sus casas, dispuestas más bien para recibir las mercancias que por osten. tación ó grandeza, son por la mayor parte bajas, humildes y de mala vista, adornándose con rejas y barandillas de madera por no permitir el uso del hierro la cualidad salitrosa del aire, que con. sume en breve tiempo hasta los cañones de artilleria, y ennegrece las paredes de las casas de un modo muy singular.

Las iglesias son regulares sin cosa particu: lar. Hay una sola parroquia con dos capillas se paradas, que le sirven de ayudas, y los conventos de San Francisco, Santo Domingo, la Merced, San Agustin y de San Juan de Dios, con va. rios hospitales y uno particular destinado para la Marina.

El vecindario de la ciudad se compone de las cuatro clases de españoles, criollos, europeos, negros y las castas que resultan de las mezclas de las anteriores, siendo muy reducido el núme. ro de todas. Entre las familias blancas hay algunas bastante acaudaladas; pero ni en estas, ni en las demás clases del pueblo se conoce el lujo ni la opulencia. Los europeos que aquí se avecindan empiezan su fortuna por la ocupación ordinaria de pulpero. Este ejercicio, no sólo no es reparable, sino que lo hermanan también con las demás clases de comercio, que áun los hombres de más caudal tienen en las accesorias de sus casas estas tiendas pulperías, donde se ven. de todo género de comestible al lado de la tela más noble y rica. Por este medio adquieren al. gunos riquezas bastante considerables, sin que éstas se hagan visibles por la opulencia en su trato público $o$ privado.

Hállase esta ciudad, según nuestras propias observaciones, en latitud aproximada de $19^{\circ} i 2^{\prime}$ $20^{\prime \prime}$ Norte, y longitud Oeste de Cádiz de $90^{\circ} \mathbf{x}^{\prime}$

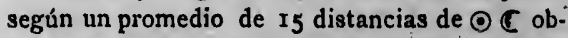
servadas en la mar y referidas á Veracruz por medio de los relojes y el movimiento uniforme 
buena derrota. El braceaje va aumentando 30 , 36 y 40 brazns, y ya en esta agua, andadas seis a ocho millas, falta de golpe. Si después de prac. ticadas las prevenciones anteriores y con la confianza y seguridad consiguientes se diera alguna escandallada en 28629 brazas piedra, no debe causar sobresalto, porque este fondo es de un ro. aal que hay en la mediania del canal; pero si continuase la misma calidad, se mirará como indicio de que no está lejos el Bajo muevo y se inclinará el rumbo más al Sur, hasta volver a! fondo lama.

La navegación por el Norte de la sonda, que es la otra derrota que se puede hacer, obliga á ménos cuidados. Cogido el veril orientai que por buenas observaciones se cuenta por longitud de $2^{\circ} 3^{\prime}$ al Oeste del Cabo San Antonio en Cuba $y$ $80^{\circ} 33^{\prime}$ al Oeste de Cádiz, no hay más que correr el paralelo de $23^{\circ} 30^{\prime}$ por go y 60 brazas fondo arena. En estando á prudente distancia del pa. raje donde sitúan i is cartas el bajo del NegriIlo (x), se gobernará al Sudoeste $1 /$ Oeste á pasar al Norte de la Isla Bermeja, sondando de seis en seis horas hasta asegurarse cogiendo 806 roo brazas, de que se ha rebasado el codillo y veril occidental de la sonda. La comparación de los puntos de estima y de ohservación en varios via. jes por el Norte de ella, manifiesta que en esta derrota se debe contar con 166 I 8 millas de corriente al Oeste en veinticuatro horas. El mayor empeño que puede ocurrir es que cargue mucho el viento si se navega con Norte, y que sea escaso para montar el bajo nombrado el Alacrán. Si tal sucediese se cambiará de bordo en vuelta del Este y con la ventaja que ofrece el mayor barlovento se emprenderá la derrota primera.

Desde el veril occidental se hará derrota á recalar á barlovento de Veracruz, según los vien. tos reinantes. En la estación de Nortes, se reconoce Punta De!gada, que está en latitud de $20^{\circ} 07^{\prime}$ y según se juzga que el viento si es recio del Norte, será 6 no mancjable sobre Veracruz, se resuelve 6 retarda la arribada. Del veril occidental al puerto hay $4^{\circ} 30^{\prime}$ de diferencia de lon. gitud por observación, y por estima es común encontrar $3^{\circ} 30^{\prime}$ ó $3^{\circ} 40^{\prime}$, de suerte que es casi seguro el curso de 16 á 18 millas de corriente diaria al Oeste ó rumbos próximos. Si estando en las inmediaciones de Veracruz calmase el viento, se puede dar fondo por 20625 brazas fango al Nornoroeste del castillo de San Juan de Ulua, y á distancia de dos leguas de él. Es el partido más prudente para de noche $y$ siempre que falte viento entablado con que se pueda vencer la fuerza de la corriente que tira como al Noroeste.

El muelle de Veracruz está en latitud de

(1) Este baj, se halis en latitud de $23^{\circ} 24^{\prime} 54^{\prime \prime}$ y 1 ongitud $83^{\circ} 55^{\prime} 15^{\prime \prime}$ Oesio do Cádiz. $19^{\circ} \times 2^{\prime}$ Norte $y$ en longitıd observada $90^{\circ} 3^{\prime}$ al Oeste de Cádiz; y el Pico de Orizaba (montaña muy notable y de muy fácil reconocimlento) eatá asimismo en latitud de $19^{\circ} \mathrm{r}^{\prime} \mathrm{y}$ en $9 \mathrm{r}^{\circ} 20^{\prime}$ de Iongrit::-1 al Oeste de Cádiz: su altura sobre el ni. vel del mar es de 3.218 toesas, y el largo de su tangente al horizonte 152 millas, distando $x 05$ proximamente cuando aparece un grado elevado.

La ciudad de Veracruz, conocida en todo el mundo por los grandes tesoros que en ella se han embarcado para remitirse á España, no co. rresponde en su capacidad, riqueza, ni gentlo á la idea que puede haberse formado de ella por lo extendido de su nombre. Reducida á dos calles principales que corren del Nordesteal Sudeste con otras varias pequeñas paralelas á éstas, carece de edificios suntuosos y de todos los adornos y hermosura exterior que caracterizan las grandes y ricas poblaciones. Sus casas, dispuestas más bien para recibir las mercancias que por osten. tación 6 grandeza, son por la mayor parte bajas, humildes y de mala vista, adornándose con rejas y barandillas de madera por no permitir el uso del hierro la cualidad salitrosa del aire, que con. sume en breve tiempo hasta los cañones de artilleria, y ennegrece las paredes de las casas de un modo muy singular.

Las iglesias son regulares sin cosa particu. lar. Hay una sola parroquia con dos capillas separadas, que le sirven de ayudas, y los conventos de San Francisco, Santo Dorningo, la Mer. ced, San Agustín y de San Juan de Dios, con varios hospitales y uno particular destinado para la Marina.

El vecindario de la ciudad se compone de las cuatro clases de españoles, criollos, europeos, negros y las castas que resultan de las mezclas de las anteriores, siendo muy reducido el núme. ro de todas. Entre las familias blancas hay algunas bastante acaudaladas; pero ni en estas, ni en las demás clases del pueblo se conoce el lujo ni la opulencia. Los europeos que aquíse avecindan empiezan su fortuna por la ocupación ordinaria de pulpero. Este ejercicio, no s6lo no es reparable, sino que lo hermanan tambien con las demás clases de comercio, que áun los hom. bres de más caudal tienen en las accesorias de sus casas estas tiendas pulperías, donde se ven. de todo género de comestible al lado de la tela más noble y rica. Por este medio adquieren al. gunos riquezas bastante considerables, sin que éstas se hagan visibles por la opulencia en su trato público 6 privado.

Hállase esta ciudad, según nuestras propias observaciones, en latitud aproximada de $19^{\circ} \mathbf{1 2}$ 20" Norte, y longitud Oeste de Cádiz de $90^{\circ} \mathrm{I}^{\prime}$ según un promedio de $x_{5}$ distancias de $\odot \underset{C}{C}$ observadas en la mar y raferidas á Veracruz por medio de los relojes y el movimiento uniforme 
ada $90^{\circ} \mathrm{s}^{\prime}$ al ba (montaña imlento) entá n $9 \mathrm{r}^{\circ} 20^{\prime}$ de ra sobre el nlI largo de su distando xo5 rado elevado. da en todo el ue en ella se sspaña, no co. ni gentlo á la de ella por lo a á dos calles al Sudeste con éstas, carece los adornos y an las grandes ispuestas más que por osten. or parte bajas, idose con rejas permitir el uso 1 aire, que con. añones de artilas casas de un

cosa particu. dos capillas se, y los conven. raingo, la Merle Dios, con vadestinado para

compone de las llos, europeos, de las mezclas lucido el númeblancas hay al. tro ni en estas, eblo se conoce peos que aquí se or la ocupación icio, no s6lo no ian también con e áun los hom. is accesorias de , donde se venlado de la tela io adquieren alrables, sin que opulencia en su unestras propias mada de $19^{\circ} i 2^{\prime}$ Cádiz de $90^{\circ} \mathrm{I}^{\prime}$ cias de $\odot$ C ob$s$ á Veracruz por niento uniforme del número 344 (1). Lis cabeza de partido, y su jurisdicción se extiende, según los cálculos más

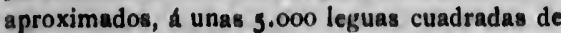
superficie, sirviéndole de limites de Norte á Sur, por la costa el río Goazacualcos y el de Tampico, distantes entre sí 120 leguas. En esta extensión se cuentan tres villas, diez pueblos grandes $y$ unos 120 pequeños, de los cuales el mayor nú. mero se halla en la marina, habitados por pesca. dores que conducen pescados salados á Méjico y otras ciudades interiores: las poblaciones mayo. rea están tierra adentro, $y$ el número total de habitadores se puede computar en 160.000 perso. nas. Su temperamento en lo general es cálido. Los frutos que produce la comarca son el maiz, cuya cosecha anual se gradúa en 300.000 fane. gas, el algodón en 240:000 arrobas, el frijol, la zarzaparrilla, pimienta, vainilla, el ixtle ó pipa Hoja, tabaco, azúcar, piloncillo y toda especie de legumbres, cera, achiote, seda, cacao silvestre y otros frutos, graduados todos en unos dos y medio 6 tres millones de pesos de producto anual; seria también un artículo de mucha considera. ción y utilidad para estos naturales el de las va. rias y exquisitas maderas que producen sus bos. ques, como caobilla, cedro, roble, ébano y otras diversas, ai la escasa población de la provincia y otras causas particulares que obran en su decadencia y apuntaremos más adelante, no hicieran inútiles estos dones preciosos con que convida por sí misma la Naturaleza, siendo tal la fertilidad del terreno, que con el único auxilio de los grandes rocío de la noche, los campos y montes se mantienen siempre verdes y se cogen al año dos cosechas de las semillas ordinarias, tanto en la una como en la otra costa de las laterales del puerto de Veracruz.

Pareciera, pues, que siendo este terreno tan feraz como acabamos de decir y sus frutos na. turales tan preciosos, que bastarían por si so. los para hacer rico á cualquier pueblo medianamente industrioso, debería ocupar la capital uno de los más amenos y fértiles parajes, 6 aprovecharse á lo ménos sus moradores acaudalados, de las riquezas peculiares de su suelo territorial, pero ni lo uno ni lo otro se verifica en Veracruz, El territorio en que está fundada no produce ni cría cosa alguna, le faltan aguas dulces y corrientes, comestibles, verduras $y$ hortalizas; no tiene fábricas ni industria, y en una palabra, carece de todo, siendo meramente un paraje de tránsito de cuanto extrae y recibe por este mar el Reino de Mejico. El sitio en que está fundada se compone de un arenal muerto y de méganos 6 montes de arena que circuyen la población y mudan conti.

(1) Las ultimas observaciones establecen esta ciudad en $10^{\circ} 11^{\prime} 53^{\prime \prime}$ de latitud Norte y $89^{\circ} 45^{\prime} 15^{\prime \prime}$ ciudad en $19^{\circ} 11^{\prime} 53^{\prime \prime}$ de latitud Norte y $89^{\circ} 45^{\prime} 15^{\prime \prime}$
de longitud Oeste de Cádiz. Ast la sittian las cartas de longitud Oeste
de la Dependencia. nuamente de lugar á esfuerzo de lop :acins vies. tos del Norte en la estación que estos reinan, y aunque á cierta distancia de Veracruz en las $\mathrm{Ha}$. nuras que median entre los méganos de arena se cultivan al presente algunas huertecillas que surten en parte a la ciudad, sin embargo, la falta de aguas corrientes y la impetuosidad de los Nortes que todo lo agostan, es causa de que no prosperen, $y$ tiene que abastecerse por agua, de comestibles y demás frutas de las poblaciones circunvecinas, especialmente de Alvarado y Talcotalpan, que son las que más remiten. Las carnes que aqui se comen no son tampoco buenas, por la falta de pastos, pero se encuentran con abundancia toda clase de aves domésticas.

Las buenas aguas que hay en estos contornos, tanto por su calidad como po: su abundancia, son las del río Medellín, y es lástima no haya lle. gado á tener efecto el pensamiento de conducirla á la ciudad, como hubieru sido acertado, á pesar de los costos de la empresa, siendo ciertamente extraño que una ciudad como Veracruz carezca enteramente de agua dulce y corriente.

En otro tiempo fué muy temible este tempe. ramento por la enfermedad harto conocida del vomito prieto, que ha sepultado aqui innumera. bles curopeos. Se atribuía principalmente, á que no teniendo declive suficiente las llanuras com. prendidas entre los méganos de arena, se estan. caban las aguas, formando pantanos cuyos nocivos vapores causaban las enfermedades. En el día se ha remediado mucho con la providencia tomada de empedrar las calles, quitando con esto la humedad continua que había en ellas, especialmente en el tiempo de las lluvias desde Marzo hasta Noviembre. Es de advertir que cuando las aguas son copiosas y casi diarias, el país se mantiene sano, pero cuando escasean empiezan á reinar las tercianas, enfermedad casi común, y que rara vez se quita hasta que entran los Nortes. Para la salud, los vientos peores son los Sur y el Sueste, pues si llegan á durar un día entero, inmediatamente sobrevienen pasmos mortales. En el verano, el termómetro de Reaumur sube hasta 25 y $\%_{2}^{\circ}$ en las piezas donde no bate el Sol; en el invierno varía desde $I 6$ has. ta 22, cuya alteración depende de los vientos Nortes, y por regla general el termómetro expuesto al aire libre durante la noche señala poco antes de salir el Sol I y $1 \% 62^{\circ}$ ménos que en lo restante del dia, con tal que no reciba la fuerza de aquél ni le alcance el reflejo de sus rayos.

A la parte Norte de la ciudad y á la distancia de algunas vaı as está el castillo de San Juan de Ulua, construído sobre un placer que en vucian. te cubre el agua un pie 6 pie y medio, $y$ en cre. ciente de cuatro á cinco.

Entre la playa de Veraciuz y los placeres mencionados que entran al mar, formando como 
cordón, queda un espacio bastante grande con muchos bajos y ningún abrigo de los vientos; por esta causa carece la ciudad de puerto 'formal, consistiendo el que hay en el que forma el Castillo, en cuya muralla del Sudoeste se aseguran las embarcaciones en argollas que tiene para este fin. El modo ordinario de amarrar los buques, es dar los dos chicotes de un cable al Nordeste á las argollas, un cable de balor por largo al Noroeste y otro por la popa al Sutste.

Cuanto han observado los mejores prácticos acerca de las mareas y de los rientos que se experimentan en Veracruz y su costa, se reduce á las noticias siguientes.

El flujo y reflujo no guarda regularidad, ni en su duración, ni en su retardo de uno ú otro, notándose á veces dos en veinticuatro horas, $\mathrm{y}$ por lo común sólo uno. Hacia los equinnccios y solsticios ascienden las mareas de tres á tres y medio piés, y de dos á dos y medio en las demás zizigies. Crezca 6 vacíc el agua, la corriente va con el viento, y así corre al Sueste si los vientos son del Nordeste al Norte y corre al Noroesie cuando los vientos son del Esnordeste al Sueste y áun con el Sur que es viento de corta duración, y en la estación de Nortes suele anunciarlos.

Sin embargo de ser el viento Este el dominante, se divide al año en dos estaciones: en el seno de Veracruz una de Nortes desde Setiembre á Abril y otra de brisas riel Esnordeste al Esueste en los meses restantes. En Noviembre, Diciembre y Enero, vienta el Norte cuarenta y ocho ó cincienta horas con gran fuerza, con carices oscuros yNoroestes más que en los meses siguientes, permitiendo orza: hasta el Nordeste. En Marzo y Abril no pasa de veinticuatro horas la mayor fuerza de este viento; viene más de tarde en tarde y los carices que lo acompañan son más claros. De nueve de la mañana á tres de la tarde sopla por lo regular muy fresco, abonanza á la puesta del Sol y suele rolar al terral á la noche; pero si no pasa del cuarto cuadrante vuelve al Norte á la salida del Sol. Si el terral llega al Oesudoeste ó pasa más al Sur, hay probabilidad de que siga su giro al segundo cuadrante y con el día se entable la brisa. Del mismo modo, aunque al amanecer haya Norte fresco, suele caer conforme va eltrando el día y rolar al primer cuadrante hasta quedar en la brisa. Varias senales hay para conocer la proximidad de este viento temible; pero las más cicrtas son el viento Sur entablado con neblina baja y espesa, despedida de la misma parte, mucho fósforo que los marineros llaman ardentía, en el agua del mar y telarañas por las jarcias. Pero el anuncio infalible le da el tiarómetro descendiendo á 29 pulgadas 80 , de 30 pulgadas 20 ( $\mathrm{r}$ ) medida de Inglaterra que es su

(1) No es una misma en todos barómetros esta al. estado regular en este clima en tiempos buenos. Al menor ascenso despues de tal bajada, rompe el viento por el Norte y será más ó ménos tenaz en su duración y en sụ fuerza, á proporción de la menor ó mayor lentitud con que suba el mercurio.

Desde el equinoccio de Marzo hasta mediado Mayo que el Sol llega al zénit de Veracruz, soplan con fuerza las brisas en los intermedios que dejan los Nortes, $y$ se alargan hasta el Sueste, velando algunas noches. Mientras el Sol se aparta de dicho punto para al Norte y hasta que á fines de julio vuelve á él, son calmosas las brisas con cerrazones y turbonadas y áun suele fijarse el viento del Noroeste al Nordeste por algunos días. Finalmente, mientras el Sol baja á la equinoccial y pasa algo al Sur, esto es, desde Agosto hasta Octubre, continúan las brisas en su poca fuerza, son mayores las turbonadas con mucha lluvia $y$ feos carices que traen viento duro si aparecen por el Este. En estos meses se experimentan huracanes en las Islas y áun en el seno mejicano. Su entrada regular es por el primer cuadran. te y dan la vuelta por el segundo ordinariamente, aunque en esto no hay regla fia. Una brisa fresca con cerrazón y llovizna suele preceder estos vientos, que por fortuna no alcanzan á Ve. racruz, y cuando más se siente en este puerto la mar sorda del huracán que ha habido en mayor latitud. Seguidamente se entablan los vientos á la cabeza y se renueva el año.

Siendo Veracruz el único puerto habilitado del Imperio Mejicano en la costa del Océano Atlántico participa, por consiguiente, de todo el comercio de géneros que alli se descargan, $y$ es el paraje donde se hacen las primeras compras de cuanto remite la Península. En tiempo de las flotas concurrían á él con este motivo en las ocasiones de ellas, recuas crecidas de mulas para la conducción de las mercancías á las ciudades in. ternas del reino, igualmente que á los minerales; y los vecinos de Veracruz, haciendo sus compras de primera mano, las conservaban para venderlas después con ventaja, en el tiempo muerto, á los traficantes de las poblaciones interiores quc alli llaman tierra-entreños, dejándoles esta especie de negociación exclusiva utilidades conocidas. En el día sólo se hace este tráfico paulatinamente y á medida que llegan las remesas de la $\mathrm{Pe}$. nínsula; pero siempre es Veracruz el centro don. de se reune todo el giro de los negociantes europeos y mejicanos.

Los efectos principales que aquellos introducen, consisten en toda clase de géneros de seda, especialmente blondas, cintas, medias y pañue.

tura, a causa de las capacidades diversas de sus cube tas; pero debe serlo la diferencia de las alturas que se comparan, y en esto estriba la observación. 
tiempos buenos.

1 bajada, rompe ís ó ménos tenaz proporción de la ue suba el mer.

$z o$ hasta mediado de Veracruz, so. $s$ intermedios que asta el Sueste, veis el Sol se aparta hasta que á fines as las brisas con in suele fijarse el por algunos días. ja á la equinoccial esde Agosto hasta en su poca fuerza, on mucha lluvia y duro si aparecen se experimentan n el seno mejica el primer cuadran. ndo ordinariamenla fia. Una brisa suele preceder esho alcanzan á Ve. e en este puerto la a habido en mayor ablan los vientos á

puerto habilitado costa del Océano guiente, de todo el se descargan, $y$ es 3 primeras compras a. En tiempo de las motivo en las ocais de mulas para la á las ciudades in. jue á los minerales; ciendo sus compras vaban para vender1 tiempo muerto, s ones interiores que ándoles esta especie lidades conocidas. áfico paulatinamenremesas de la $\mathrm{Pe}$. acruz el centro dons negociantes euro-

ie aquelloś introdu. de géneros de seda, 3 , medias y pañue - los de seda, raso, sarga, terciopelo, tafetán, etc., géneros de lana como bayetones, paños y sombreros; telas de lino y cáñamo, lienzo pintado, pañuelos y encajes y áun ropas interiores ya fabricadas; indianas y medias de algodón, espece. ría y licores, principalmente aguardiente y vino; varias clases de drogas y artefactos, armas, cera, ladrillos, loza, hierro labrado, acero, papel, hoja de lata, muebles y utensilios; toda clase de quincalla, vidrio y cristal, etc.

Los frutos de extracción son la plata amonedada y en barra, algunas alhajas, algodón de todas clases, azúcar, pimienta de tabasco, vainillas, grana, granilla, el palo tinte, algunas pieles y toda clase de drogas.

Según el estado publicado por la Secretaría del Departamento del fọmento general y comercio del Reino, era la balanza de este giro en el año de $179^{2}$, de 3.901 .000 pesos fuertes en que excedió la exportación á la importación en esta forma:

\section{P'esos. Pesns. \\ Importación (Efectos nacionales. 5.525.000i 3.812 .000 Idem extranjeron. $3.287 .000 \%$ Exportación $\left\{\begin{array}{l}\text { En plata......... 8.945.0001 } \\ \text { En frutos....... 3.768.000/12.7 } 3.000\end{array}\right.$} Difcrencia. ......... 3.901.000

A cuya cantidad, agregando 3.257 .000 pesos extraidos también de Veracruz en aquel año pertenecientes á S. M., resulta la extracción total de I5.97 I.noo pesos y la diferencia á favo de la Península de 7.I 58.000 pcsos en aquel año.

Es imposible fijar en el día á datos exactamente positivos los progresos de este giro, siendo así que ha corrido muy poco tiempo desde que empezb á tener efecto el nuevo sistema de libre comercio, y que el ansia con que han que rido aprovecharse de aquel beneficio los comerciantes de la Península, ha sido causa de que se agolpen las expediciones, acumulando las remesas en mayor cantidad de lo que permiten los fondos actuales del Reino, de modo que no pue. den servir de guía fiel para aquel cómputo los estados de importación de estoo filtimo años. Tampoco son muy seguros en esta parte los informes particulares, porque todos participan más 6 menos de la influencia de la opinión propia, no estando todavía acordes sobre la utilidad comín que ha de producir el reglamento de libre comercio; además que las epidemias y esterilidad que ha padecido el reino y dc las que aún se resiente su población e industria, son otros tantos cbstáculos que impiden caminar con seguridad en este difícil y delicado cómıuto. Sin embargo, atendiendo á los aumentos sucesivos que va tenicndo el laboreo de las minas, á la grande estimación con que se venden eu los mercados euro. peos los frutos principales de la agricultura me- jicana y á las grandes cantidades que expende el Rey en salarios y paga de empleados, que son los verdaderos artículos que constituyen la circulación del Reiro, se puede establecer que en los años sucesivos no bajará de 12.000 .000 de pescs fuertes la importación anual por la vía mencionada (I).

Es necesario advertir que muclia parte de esta cantidad pertenece al extranjero por los gé. neros con que concurre al surtido de nuestra América. Los artículos principales de su importación son los lienzos, la quincalla, alguna parte de efectos de seda, lana y las manufacturas de algodón inglesas. Ateniéndonos al estado de r792, parece que la introducción ext anjera se puede reputar en algo más de la mitad de la importación nacional; pero hay fundamentos para creer que en adelantę se disminuirá muclıo esta perjudicial introducción por los visibles acrecentamientos que diariamente adquiere nuestra inclustria en el Continente. Aun ahora se notan ya los saludables efectos de las providencias dictadas por el Gobierno desde la feliz abolición del monstruoso sistema de las flotas, y todo corazón verdaderamente patriótico halla un motivo de justa complacencia en ver desterrados de estos mercados muchos de aquellos artículos con que en días más aciagos se enriquecieron á nuestra costa los enemigos de la patria. El industrioso catalán provee casi exclusivamente al consumo que hace la América de blondas, encajes, listonería, medias de seda, algodón y pañuelos, vino, aguardiente, papel y pintados. Los paños de nuestras fábricas y los tejidos de seda de Valencia, Granada, Manresa, Málaga, Sevilla, Toledo y Talavera, han sustituido en mucha parte á iguales géneros extranjeros, y nuestra marina mercantil ha recibido un nucvo impulso, al mis mo tiempo que han logrado de ventajosa estimación los frutos preciosos de nuestra agricultura colonial.

Como nuestra demora en Veracruz no podía dilatarse y era preciso que emprendiésemos la marcha sin pérdida de momento, dispusimos nuestro viaje para el 24 , y con efecto, salimos de aquella ciudad el 25 de Enero en la madrugada, dejando nuestro equipaje al cuidado de un

(1) La importación medía en el trienio corrido de I 802 a 180.4 ha sido de 17.929 .000 pesos. En los grande varie dad procedida de la guerra martima con Inglaterra y habiendo tenido á bien permitir S. M. con este mo tivo el comercin de buques neutrales en América, han enirado en este puerto de Veracruz desde mediados de Setiemlure de 1805 liasta fin de Aloril de 1807,64 buques de dmersas nariones, cuyos cargamentos ascendieron á 4.862 .556 pesos en géneros y frutos; $y$ han extrafcio on la misma época 12.456 .454 pesos en han extralco esta forma: ro.857. 4 pesos cn plata; 9.277 arrobas de grana, cuyo valor es $927.74^{6}$ pesos y 670.794 pesos en otros frutos: total 12.456 .454 pesos. 
conductor de confianza, que salía el mismo día para llegar poco después que nosotros á la capital.

Desde luego que se abandonan las arenosas riberas de Veracruz, se sigue al Poniente por la costa, y á las cinco leguas de distancia se halla la población de la Antigua ó Vieja Veracruz, situada en la orilla occidental de un río bastante caudaloso, distante de la marina cosa de media legua: tiene este nombre por haber sido aquél el paraje en donde estuvo á los principios la ciudad de Veracruz, y que se abandonó después por no poder llegar hasta él los buques grandes, no teniendo otro puerto que el mismo río, $\epsilon$ ' cual no admite embarcaciones de mucho calado. La población se compone de una corta porción de casas bajas de madera con techo de paja, esparcidas por entre los árboles que cría el terreno naturalmente; hay entre sus vecinos algunos blan. cos, pero la mayor parte es gente de color que se mantiene con los frutos de sus sementeras, el cultivo de legumbres y la engorda de algún ganado de cerda y vacuno, con todo lo cual provee en parte á la ciudad de Veracruz; su temperamento es cálido y el terreno muy frondoso.

El río por esta parte es bastante ancho y tiene buena corriente; críase en él un delicado pez que llaman Bobo, $y$ es tan apreciable que se lleva por regalo á Méjico y se proveen de él Jalapa, Veracruz y otras ciudades en los tiem. pos de su pesca.

Desde la Antigua sigue el camino para Méjico, dirigiéndose por Jalapa, hasta donde cuen$\tan x 7$ leguas. El camino, al principio, es llano aunque algo arenoso, y sigue á poca distancia el curso del río siempre acompanaado de arbole. das de la especie que llaman guarangos. A la legua y media ya muda el piso, convirtiendose en una piedra cortada que parce se ha quebrado de intento para reducirla á pedazos pequeños, $y$ de este modo continúa hasta llegar al paraje que nombran Lencero, desde donde descubre la vista parte del territorio bajo que forma vailes y prados vestidos de árboles. Hasta aquí el camino ha ido subiendo por cuestas tendidas y pedregosas en cuanto alcanza la vista.

Lencero tiene ya una competente altura respecto al nivel del mar: las observaciones baro. métricas practicadas á las diez del día con tiempo claro $y$ viento Este determinan su altura de I.07I varas respecto de aquel nivel.

Jalapa es pueblo de mediana extensión; sus casas son bajas y con terrados 6 azoteas, según la práctica común del Reino. El temperamento de esta ciudad es templado y con muy corta diferencia el mismo que se experimenta en lo interior de aquel Reino por largas distancias. Al amanecer señala el termómetro $16^{\circ}$ y $\%$, en lo interior de las viviendas, 5 en lo exterior, I 8 á las dos de la tarde, y á las once de la noche 17. Estas cantidades son como constantes en todo el año, á excepición de aquellos días en que se mantiene el Sol nublado y vienta por la parte de los dos volcanes que tiene inmediatos. Examinado el barómetro en tres días consecutivos con tiempo claro y viento flojo de la parte del Este, se observó constantemente en 23 pulgadas nue. ve líneas, siendo su mayor variación $1 / 3$ de línea. Esta buena proporción del temperamento junto con la bondad de sus aires y lo saludable de las aguas, ha hecho elegir á este pueblo para lugar de residencia de los que enferman en Veracruz. Sin embargo, es país propenso á tercianas, y cuando las lluvias se dilatan, se experimentan otras enfermedades que molestan á los naturales igualmente que á los forasteros.

Las lluvias son aquí muy contínuas y se advierte que mientras en Veracruz reinan los Nortes, que son los que retiran las nubes, cae en Jalapa una aguilla menuda y contínua que llaman "la salud del pueblo," porque en tanto que se repite se mantiene sanoel país; así los vientos que retiran las nubes de la costa y parajes bajos, las arrastran á los altos y causan esta humedad ólluvia frecuente.

Próximo á la ciudad hay dos altos cerros que corresponden, el uno al Oesnoroeste y el otro al Oesudoeste: llámanse la silla de Perote y el volcán de Orizabal: el primero, sólo conserva la nieve algunos tiempos del año en las concavidades de las peñas que forman su cumbre; pero el se. gundo tiene tanta, que por la parte que corres. ponde á Jalapa aparece siempre cubierto de ella como liasta un cuarto de su altura.

El terreno es fertilísimo y se halla poblado de árboles frondosos y prados siempre verdes. İl más común de aquéllos es el árbol de la Chirimoya, y entre las plantas menores lo es la del jalapa, de que se conducen á Europa crecidas porciones.

Por estos campos viven esparcidos los indios, habitando en sus jacales, donde cultivan sementeras de maiz 6 las legumbres más análogas al clima. Uno de sus ejercicios más frecuentes es el de la arriería, en el cual se emplean por el tráfico contínuo que hay entre Veracruz y las ciudades y poblaciones del interior del Reino.

No podemos pasar en silencio el uso particular que hacen estos indios de los baños de estufa, para cuy fin tienen en cada jacal una estufa, que llaman "emascal; y consiste en una chocita cuarto pequeño hecho de adobes de figura circular, en el centro del cual se levanta una piedra grande que sirvé como de soleria, y en uno de los lados está un hornillo, "cuyo fogaril corres. ponde debajo de la piedra. Cuardo quieren bañarse ponen fuego en el fogaril, se calienta la piedra y el indio percibe aquel calor, con el cual 
oche I7. Es. en todo el en que se la parte de atos. Examisecutivos, con rte del Este, ulgadas nue$n 1 /$ de línea. amento jun $\div 0$ udable de las lo para lugar en Veracruz. tercianas, $y$ experimentan á los natura. nuas y se adinan los Norpes, cae en Jala que llaman nto que se reos vientos que parajes bajos, esta humedad

tos cerros que te $y$ el otro al erote y el vol. onserva la nieconcavidades e; pero el sete que corresabierto de ella halla poblado empre verdes. rbol de la Chies lo es la del uropa crecidas

idos los indios, ultivan semenás análogas al frecuentes es mplean por el 'eracruz y las $r$ del Reino.

el uso particuaños de estura, ina estufa, que una chocita ó le figura circuita una piedra $y$ en uno de fogaril corres. do quieren base calienta la or, con el cual empieza á sudar abundantemente. Al cabo de algún tiempo se retira abrigándose bien, se seca el sudor y se viste. Tienen la costumbre de bañarse todos los sábados como por vía de descanso de la fatiga que han tenido en el discurso de la semana y para curarse de sus indisposiciones, ó después de salir de una grande enfermedad, rues con ello dicen consiguen dos cosas: la u'ra, convalecer más pronto; y la otra, limpiarse de los aceites y unturas que por regla general se aplican para curar toda especie de dolencia. El modo de la estufa es bastante ingenioso y parece que la experiencia confirma la utilidad de su práctica.

Saliendo de Jalapa, á las tres leguas muda el terreno, y parece que abandonando repentinamente los países de la América se ha transportado uno á los del Norte de la Europa. Las cercanías del camino están cubiertas como en aquella parte del mundo de pinares muy derechos, altos y fornidos; ya empiezan á verse sementeras de cebada, y el temperamento cambia igualmente que las producciones del terreno; el termómetro que marcaba $\mathrm{rI}^{\circ}$ a las seis de la mañana en 4 paraje de las Vigas, cinco leguas de Jalapa, señal 6 $18^{\circ}$ en el pueblo de Perote con tiempo claro y vien to moderado del Noroeste. La línea que divide la parte cálída de la templada puede fijarse ocho le guas distante del mismo Jalapa en el paraje que llaman la Cruz Blanca, y es el principio de una llanura dilatada. En ésta se halla el cerro nombrado Pizarro, que señorea en aquel espacio como una islā en medio del Océano, distando dos leguas la serranía :nás cerca en esta llanura. En lo in terior del Reino se hallan otros en la misma disposición que lo dejan de causar admiración por no tener en sus inmediaciones serranías, lümas, ni otras desigualdades.

Antes de este paraje se pasa un pedazo de terreno como de media legua de extensión y sigue á lo largo del camino, al que llaman Mal País por estar cubierto de una costra que sale de la tierra vara y media en alto, de color negruzio al modo de las escorias del hierro: en su color y estructura parece á una materia ferruginosa derre tida y derramada por aquella tierra; es muy dura. pesada y porosa, formando ojos, por cuyas circunstancias se hace notable aquel paraje y llama la atención de cuantos pasan por él.

Perote es un pueblo de indios situado en una llanura dilatada distante ro leguas de Jalapa; lo único particular que tiene es una pequeña forta leza construída de pocos años á esta parte, que ocupa casi el centro y medianía de la llanura. Observado el barómetro en este paraje, se halló á las once del día en la altura de $2 \mathrm{x}$ pulgadas $2 \mathrm{y}^{3} /$ líneas, lo cual determina la altura de este terreno, respecto al nivel del mar, de 3.186 varas castellanas. El termómetro marcó á la ınisma hora $18^{\circ}$ segín dijimos antes.
En las diez leguas que median entre Jalapa y Perote, no se encuentra sino un solo arroyo de agua: en general, parece que este es un defectó común á todo el Reino.

Desde Perote cuentan siete leguas á la Venta de Soto, el rumbo es al Oeste inclinado al Sur; pero así estas leguas como todas las anteriores, son cortas y pueden computarse de 5.000 varas (r). El terreno es llano y en partes arenisco. Los árboles que se encuentran son de dos especies, unos tienen la hoja al modo de cipreses, pero con ramazón abjerta, y los otros son pal mas y palmillas, diferenciándose de las que se crian en los temperamentos calientes, en el tronco y la hoja. El barómetro marcó en la Venta de Soto 2 I pulgadas, 3 líneas, al tiempo mismo que señalaba el termómetro $16^{\circ}$ estando lloviendo algunas gotas de agua, aunque nn muchas.

Pasando de Soto sigue el camino II leguas hasta la Venta de San Diego: mucha parte del terreno is de la misma naturaleza que el ante. rior, pero desde el paraje que nombran Balcon. cillo en adelante hay sementeras de maíz en las llanadas, y de cebada en las faldas de los cerros.

A distancia de cuatro leguas de la Venta de San Diego, en la hacienda que nombran de Piedras Negras, se descubren ya los volcanes de Méjico, teniendo también al Este el de Orizabal; todos tres aparecen de igual volumen y altura. De los dos de Méjico, el de Poniente presenta una cumbre extendida como llanura; el otro remata en punta en figura de pan de azúcar, pero ésta se monifiesta cortada y desnuda de la mucha nieve que cubre en gran parte á aquel soberbio monte, por lo cual ca de presumir despida algunos vapores que impidan conserve la nieve en aquel espacio. No os fácil describir la impre. sión que causa en el cáminante la vista de estos tres majestuosos cerros, cuyas moles inmensas campean aisladas en estas dilatadas ilanuras aumentarido su magnificencia con los rayos reverberadores del astro del día.

Desde Acatepeque, que es una hacienda dos leguas distante de Piedras Negras, empiezan á

(I) Este camino, seguis lo anduvimos nosotros y es la práctica del pais, ge camina en litera desdo Vo. racruz hasta Perote, por wo perinitir el terreno el uso de carruajes. pero al tiempo gue esto se publica se ha contruido ya a texencas lel conselun to de Vera ha con trajo la direcion de cruz y bajo la direccion des Teniente Coronel d Dragones de Mléjico, D. Diego Garcf́a Conde, un ex celente camino real y carretero en la cxtensión de $r 7$ leguas de á 5.000 varas con 204. 110 varas cúbicas do desinonte, 424.787 de terrapléll, 42.272 de mampostería, 2 r.866 lineales de empedrado, 53.806 de contrazania y 151 alcantarillas. En el caudaloso rio do Antigua se ha coustruido tambien un puente lla Antigua se ha construido tambica un puente llamado del Rey, con 230 varas de longitud, 12 do ancho y 16 y $\%$ varas de altura desde el nivel ordinario de agua hasta el piso del camino en el arco del centro. 
verse haciendas dilatadas de magüey, de que se hace un extraordinario consumo, empleándolo en la bebida común en el reino, llamada pulque. El magüey es de la misma especie de las que nom. bramos pitas en los reinos de Andalucía y allí sirven ordinariamente para guarnecer los vallados y embarazar con sus puntas que se introduzcan los ganados y causen daño en los sem. brados. En Nueva España se plantan en tierra llana y en la misma disposición que las viñas de Europa; crecen mucho y toman un color fuerte de verde oscuro: luégo que empiezan á hincharse las pencas que rodean el cogollo, cortan éste sin tocar á aquéllas, y en la concavidad que forma el corte, recogen diariamente el jugo que mana y lo llevan á bodegas destinadas al intento, donde lo ponen en vasijas grandes: alli fermenta y queda hecho el pulque. Su bebida es des agradable para los que no están acostumbrados á ella y emtriaga usándola con algún exceso; para hacerla más grata al gusto, suelen prepararla con algunos otros ingredientes. El consumo que sa hace de ella en todo el Reino es tal, que se considera uno de los frutos de más utilidad para los dueños de las haciendas y para el Real Erario, por el derecho que satisface anual. mente: se le atiıbuye la propiedad de ser un específico contra las disenterías, enfermedad muy común en todo el Reino.

Una legua de Acatepeque está el pequeño pueblo de llangatepeque, que quiere decir "manantial de arrua entre dos cerros; " toma este nombre de un arroyo que corre inmediato al lugar y es el único que se encuentra en las $\mathrm{I}_{3}$ leguas que median desde San Diego hasta aquel paraje. 1,o habitan ell el día indios pertenecientes á la provincia Tlascala, cuya capital dista cinco leguas. 'Todavía se conservan algunas familias de las antiguas, que tanto ayudaron á los espainoles á la conquista de este Reino.

La calidad del terreno of rece la particularidad del poco grosor que de aquí en adelante tiene la capa de tierra vegetal que lo cubre: en parajes sólo es de un pié, en otros medio, y áun de mucho ménos en las alturas y pisos trajinados. Debajo de ella sigue una especie de tierra conocida en el Reino con el nomb.e de tepatatc, durísima, de extraordinaria sequedad $y$ diferente de las tierras gredosas. Camiuando por encima de ella se siente un ruído como si se pasase sobre un puente de madera; indicio cierto de que contiene bajo de su superficie algunas oquedades, pero éstas no se descubren en los cortes de los barrancos, ni aún ménos se reconoce porosidades. El agua no la penetia ni ablanda como lo hace con la greda, y se nota en los caminos más tra. ficados, que ni la sequedad, ni el contínuo trajín de las bestias y carruajes, la reduce fácilmente á polvo. En los parajes desnudos enteramente de aquella primera capa de tierra, no se cría yerba ni planta alguna.

'Tres leguas de Ilangatepeque está una gran hacienda que nombran de San Bartolomé: dos más adelante la del Molino, y una legua después el pueblo de Apa. Entre estos dos últimos pun. tos dividen su jurisdicción los Obispados de la Puebla y Méjico: á éste pertenece el pueblo de Apa; y la lacienda del Molino al de la Puebla.

A la parte de Poniente con alguna inclinación para el Norte de Apa, se halla á diez leguas de distancia el pueblo de San Juan, cuyo vecin. dario es la mayor parte de indios.

A dos leguas del pueblo de San Juan empieza á bajar el territorio para entrar en el Salado, cuyo nombre dan á la planicie de la famosa Laguna de Méjico. El camino sigue entre el Poniente y Sudoeste descubriendo á largas distancias cordilleras de poca altura, y en las llanuras, cerros aislados de distintas figuras. Ultimamente, desde la colegiata de Guadalupe situada también en la orilla de la Laguna y distante seis leguas del puebi, de San Juan, atraviesa la famosa Calzada de Méjico que tiene dos leguas de largo y es una de las obras más recomendables del Reino.

Entramos en la ciudad el 5 de Febrero $y$ cuando tratábamos de descansar de las molestias del camino anterior, llegó un extraordinario despachado desde Acapulco por el Comandante de la corbeta AtrevidA, D. José de Bustamante y Guerra, con aviso de su llegada y pidiendo al señor Virey nuestra incorporación. Aún no teníamos todos nuestros instrumentos, pero llegaron el día I 2 y en el entretanto nos ocupamos en visitar la ciudad y adquirir algunas noticias de lo más principal que hay en ella, según lo permitía la estrechez del tiempo. Por esta razón no pueder ménos de ser imperfectas nuestras nociones sobre esta grande capital, cuya descripción completa exigía otro tiempo y otros medios que los que estaban á nuestra disposición; pero tal cual la hemos podido formar la ofrece. mos al público, persuadidos 2 . yue siempre leerá con interés cuanto pueda decirse sobre esta distante y rica colonia.

La ciudad de Méjico, cabeza del Reino de Nueva España, es una de las poblaciones más ricas y hermosas del orbe. Hállase situada en la medianía de la Laguna de Tezcuco 2.929 va. ras sobre el nivel del mar (I) y en el fondo del valle que lleva el nombre de la capital. Su territorio forma une llanura casi nivelada, rodeada de cerros de mediana altura cuyos derrames interiores forman tres lagunas, de las cuales la más exiensa es la de Tezcuco ya mencionada. Sus aguas permanecen más 6 ménos abundan-

(I) Asf lo determinan las observaciones baróme tricas que se insertarán después. 
se cría yer.

tá ına gran

tolomé: dos gua después ltimos pun pados de la l pueblo de la Puebla. una inclina$i$ diez leguas cuyo vecin-

uan empieza n el Salado, e la famosa entre el $\mathrm{Po}$ argas distanlas llanuras Jltimamente, lada también te seis leguas famosa Calde largo y es es del Reino. le Febrero y las molestias ordinario despmandante de Bustamante y y pidiendo al 1. Aún no teos, pero llenos ocupamos runás noticias ella, según lo or esta razón ctas nuestras al, cuya des. do y otros me. a disposición; ar la of receque siempre rse sobre esta

del Reino de blaciones más se situada en uco 2.929 vael fondo del ital. Su terrilada, rodeada derrames inlas cuales la mencionada. os abundan. tes según las lluvias, aunque en pocas ocasiones llegan á crecer tanto que inunden la ciudad, y sólo corren por canales atravesando algunas calles según ya se refiere desde los tiempos de la conquista.

La superficie de esta ciudad deducida del plan de faroles con que se ilumina, en su totalidad contiene 3.933 .240 varas cuadradas, de modo que considerando que la extensión de sus calles coge la octava parte del terreno y despreciando los picos por lo que ocupan las plazas, se reduce la parte fabricada á 7.800 .000 varas suadradas, esto es á una área casi dupla de la de Sevilla, en cuya ciudad se pueden considerar 4.000.000 de varas de superticie labrada, po: otro cálculo semejante.

Según la numeración hecha de orden del Gòbierno en Abril de I79I, asciende el número de casas fabricadas en Méjico á 6.227, sin incluir los conventos, colegios, hospitales ni cárceles. Las casas tienen por lo común un alto con terrados ó azoteas, portadas suntuosas, hermosas balconerías y una altura proporcionada que hermosea y da á las calles cierto aire de grandeza: éstas son espaciosas, iguales, rectas y tan largas, que su termino se pierde de vista. La plaza principal es también correspondiente al casco de la ciudad: la ocupa por el Nordeste el palacio del Virey, edificio sencillo pero majestuoso, espacioso y cómodo, con hermosa balconería desde donde descubre la vista gran variedad de objetos divertidos. Al Noroeste cae la catedral, cuyo vestíbulo se adelanta hacia la plaza un espacio como de 30 varas y da la vuelta por el costado del Sudoeste conservando la misma anchura. La fachada opuesta á la catedral la ocupan las casas del Ayuntamiento construídas sobre una arquería con portal á la plaza, y la que hace frente al palacio se compone en parte de casas de particulares y de otras que las llaman del Estado, y som edificios de buena vista. Puede asegurarse que no hay en Europa plaza alguna que pueda compararse á ésta: el inmenso concurso de carruajes, recuas $y$ vendedores, $y$ la variedad infinita de trajes $y$ castas de cuantas clases hay en la América y se ven aquí reunidas, la dan cierto aire de novedad y grandeza.

La catedral, que como se ha dicho, neupa uno de los frentes de la plaza es un edificio de arçaitectura regular, aunque no de mucho ancimiento por faltarle elevación propeccionanda â su grande mole: esto procede de la. ealitted del terreno en que está fundada, çse por ser en la Laguna. Haquea y se advierte se ha hendido algo el edificio por wn lado. Las rentas del Arzobispo suben á II5.000 pesos anuales, á 22.000 la del Dean, á 8-50o las de los Canónigos, los Racioneros thenen 5.300 pesos y 2.800 las medias raciones. Es probable que estas rentas crezcan en ade- lante según el fomento que va tomando el arzo. bispado.

El palacio arzobispal es uno de los mejores edificios que tiene la ciudad; es grande y se halla distribuído convenientemente para el giro de los negocios que pertenecen á su juzgado. En gene$\mathrm{ral}$, los edificios más recomendahles son las iglesias y los pertenecientes á establecimientos públicos. De los primeros se cuentan $\mathrm{I}_{4}$ parroquias, 25 conventos de varias religiones y 15 de monjas; de los segundos, hay ocho colegios de hombres, seis de mujeres, doce hospitales, siete cárceles, dos casas de misericordia y otras dos de re. clusión, una para recogidas y otra de misericordia para nujeres casadas. Entre los conventos se distinguen particularmente por su capacidad $y$ auiorno, las casas grandes, como son la de Santo Domingo, Sas Agustín, Ja Merced y Sar. Francisco: éste tiene una hermosa iglesia y muchas capillas en el atrio, propias de ciertas proviucias de España, con ricos tarnos antiguos y uno de perlas regalado por el l'ey Felipe II. In esta misma iglesia están los huesos, el estandarte y la cota del conquistador Herman-Cortés, por donde se viene en conocimiento de que correspondia bien con su talento y valor ia altura agigantada de esie héroe memorable.

Según el padrón circunstánciado formado de orden del Gobierno el año r 790 , ascendía en aquella época el número de religiosos profesos y legos de todas órdenes á 876 y el de monjas á 907 .

Entre los colegios que se mencionan bay dos destinados úricamente para indios de uno y otro sexo: el que sirye para los varones se titula de San Gregorio y tiene por institución particular enseñarles la música á fin de que se adiestren y sirvan después á emplearse en el servicio divino; y el otro, que se llama de la Caridad, es determinadamente para niñas españolas, cuyo nimero está ceñido al de 33 , y tienen desde que entran el dote de 500 pesos para tomar estado. El colegio de San Iģnacio es también fundación particular, hecha por los vizcainos para las viudas y solteras desamporadas de sus descendientes: alli viven con separación en cuartos competentes $y$ con cuantas comodidades pueden apetecer, suministrándoseles Io pesos mensuales para avuda de la asistencia miéntras que permanezcain solteras. Estos estabiecimientos piadosos, sin otros varios de que no linsemos mención, son de mucho beneficio y utilida $f$ en una gran capital como esta, donde hallan refugio las personas menestorvas que por muerte de sus maridos, padres ó parjentes quedan em tucal orfandad.

Es por demás advertir que hay en esta cirdad academias públicas z colegios donde se enseña con perfección toda clase de artes y ciencias. Sabido es el cuidado paternal con que nuestros 
católicos Monareas á los principios de la conquista instituyeron esta Real Universidad, $y$ en el día la sustentan como un digno plantel donde se crian y pulen los agudos ingenios de estos naturales. Modernamente se han ampliado algunos establęcimientos y fundado otros varios que no tiene1 semejantes las demás ciudades del Nuevo Mundo y que aún figurarían mucho en otras grandes capitales del antiguo.

Dentro del Palacio y á la vista del Virey tie. nen su lugar y asiento los Tribunales superiores de este reino, como son la Audiencia Real, el Acuerdo, la Sala del Crimen, cl Tribunal de Cuentas, el de Cruzada, la Caja Real y el cie Comercio ó Consulado, sin otros varios consagrados á ramos particulares; de cste modo el Virey, como cabeza de todos, puede dirigirlos y recibir oportunamente la noticia diaria de cuanto en ellos pasa. Uno de los cuerpos más distinguiclos de esta ciudad es el de su ilustre Cabildo, que goza en Junta el tratamiento de Excelencia por concesión de nuest os augustos Monarcas: tiene á su cargo la recaudación de propios y arbitrios y el de los pagos y cargas anevas á estas rentas, en la misma forma que se practica en las ciudades principales de España. Los caudales que componen la entrada, sus gastos y resultados, han sido detallados últimamente en una Memoria muy extensa y curiosa presentada al Virey por D. José de lp. Peoza y Casas. De ella resulta que en el quinquenio de $178+$ á 1788 ascendieron los cárgos á 686.454 pesos y la data á 759.874 , esto es, que excedieron los gastos á las rentas en 73.420 pesos.

La Casa de la Moneda, que ocupa una cuarta parte de la cuadia que forma el edificio de $\mathrm{Pa}$ lacio, es tal vez la mejor fálbrica que se conoce aun en Europa para este fin, por la disposición de las oficinas, el repartimiento de sus máquinas, etc. A ella se conduce toda la plata y oro que se saca de las minas del Reino, para acuñarse y reducirse á moneda. Lista operación se practica con la más rigurosa prolijidad, y al intento concurren los Ministros encargados de su dirección, á fin de que las monedas salgan justas y arregladas en su peso y ley. Fsta Casa se incorporóá la Corona en el año $17 \hat{\jmath}^{2}$ y desde entonces acá corren sus labores por cuenta de la Real Hacienda. In los tiempos primitivos se solían ac11ñar anualmente desde 8 hasta 14 millones de pesosfuertes, pero desde el año de I770 se han anmentado considerablemento las labores y puede regularse un año con otro en $x 8$ á 20 millones de pesos fuertes, habiendo sido la más notable la de $x_{7} 83$ en que se acuñaron 23.700 .000 pesos. La labor de oro es corta y regularmente no pasa de 600 á 800,000 pesos.

Las suertes de moneda de plata que se labran en el día son pesos duros, medios pesos, pesetas, reales y medios reales, todos columnarios; y de oro, doblones de á ocho escudos, de 'á cuatro, de á dos y de un escudo que vale dos pesos fuertes. De la clase menuda de plata sólo se acuñan anualmente de 40 á jo.000 marcos para el surtido del comercio interior del Reino.

Tiene esta Casa, de fondos para su giro, 2.700.000 pesos, cuya cantidad no alcanza ordinariamente para su vasta negociación, y en estos casos le sirve de auxilio el ramo de Depósitos que por lo regular cuenta con un millón de pesos.

Diariamente se benefician y acuñan $\mathrm{n}$ tiempos de regular labor de ro á $\mathbf{2} .000$ marcos de plata y para esto se necesitan en sus diversas oficinas de trabajo 200.000 marcos de aquel metal de existencia diaria. En los dos días últimos del año pasado de 1790 se labraron y acuñaron 42.00o marcos de plata, cuyo valor ascendib á siete millones de reales de vellón, cantidad por cierto excesiva, pues hay Casas de Moneda que no hacen otro tanto en un año. Los operarios que se emplean diarianiente en estas faenas no bajan de $45^{\circ}$ á 500 hombres, y los Ministros principales y demás empleados llegan á go. Los gastos de la Casa, inclusos sueldos, materiales, construcción y reparo de instrumentos, etc., as. cienden anualmente á $35^{\circ}$ ó 400.000 pesos y la utilidad líquida que deja su labor pasa siempre de $\mathrm{r} .300 .000$ pesos.

Las barras de plata que contienen algún oro, van, antes de entrar en la casa de Moneda, $\alpha$ otra que llaman del Apartado, por hacerse en ella la separación del oro, practicándolo con agua fuerte. Esta manipulación se incorporó á la Corona en Octubre de 1778 , y hasta aquel tiempo la había tenido la casa de Fagoaga con oficio de vendible y renunciable. Con él se hizo poderosa esta familia, y un tal D. Francisco titulb, tomando la denominación de Marqués del Apartado. Aún vive este primer poseedor del título, Oficial retirado con grado de Coronel. Por un cómputo prudencial, se benefician anualmente en esta oficina 200.000 marcos de metal. Los metales que sblo contienen desde 16 hasta 29 granos de oro por marco, se benefician por cuenta del Rey por no resultar utilidad á sus dueños, dedu. cidos los derechos de apartado, y se les paga como plata el oro incorporado en la barra; pero los metales que contienen desde 30 granos arriba por marco, se separan de cuenta de los mineros, exigiéndoles los correspondientes derechos. Diariamente se ocupan en estos trabajos 50 jornaleros, y los sueldos y gastos de la Casa están incorporados con los de la de Moneda. Sus utilidades lí. quidas llegan un año con otro á 55.000 pesos. Hay en esta Casa hornos de vidrio para construir el sin número de vasos de distintas formas que se emplean en aquelias operaciones químicas: 
marios; $y$ de -á cuatro, de esos fuertes. - se acuñan para el sur-

ara su giro, alcanza ordibn, $y$ en estos de Depósitos millón de

uñan nn tiemoo marcos de I sus diversas de aquel me. s días últimos on $y$ acuñaron lor ascendíb á cantidad por e Moneda que - operarios que faenas no balinistros priná go. Los gas$\mathrm{s}$, materiales, ntos, etc., as oo pesos y la r pasa siempre

enen algún oro, Moneda, a otra erse en ella la con agua fuerró á la Corona Il tiempo la ha. con oficio de se hizo poderancisco titul6, qués del Apardor del título, oronel. Por un anualmente en etal. Los metaasta 29 granos por cuenta del dueños, dedue les paga como ra; pero los me unos arriba por is mineros, exirechos. Diariaso jornaleros, están incorpois utilidades li 55.000 pesos. ' para construir as formas que ones químicas
Igualmente se fabrica aquil el agua fuerte para la disolución de la plata y separación del oro, y esta elaboración no baja de $\mathbf{5} 5.000$ libras anuales, de cuyo ácido apenas tiene de costo al Rey 7 y $1 /$, reales vellón cada libra. Hay también hornos para reducir los metales á partículas pequeñas, para hacer barras de plata, para formar tejos de oro, y últimamente para fundición de tierras en la misma forma que se practica en los Rcales de Minas.

El oro que sale del apartado extraído por la vía húmeda, que es la única que aquí se usa, tiene regularmente de 23 unilates, tres y medio granos á 24 quilates.

Debe advertirse que en estos últimos años entran regularmente en la casa de Moneda de 16 á 17.000 barras ó tejos de oro, plata y metales mixtos, de cuya cantidad la cuarta parte, más bien más que ménos, procede del Real de Minas de Guanajuato, y la mitad de lo de este Real pertenece á la sola mina de la Valenciana, de modo que esta mina rinde tanto como la octava parte de todas las del Reino, y el Real de Minas de Guanajuato, vale como la cuarta parte de todos los demás minerales.

Razón de las cantidades de oro y plala acuñadas en la Real Casa de Moneda de Méjico desde $1 .^{\circ}$ de Enero hasta $3 \mathrm{I}$ de Diciembre de 1807 , con distinción de lo labrado en cada mes.

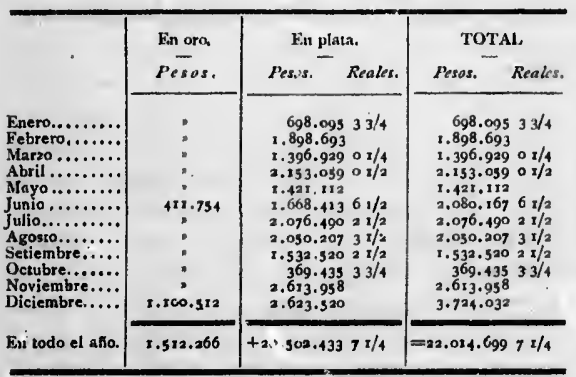

Mejico, 31 de. Diciembre de $180 \%$.

$\mathrm{Ya}$ advertimos antes, que dentro del Palacio estín las Cajas Reales, donde entran los caudales pertenecientes á la Real Hacienda según las resultas que dan los Directores principales de cada ramo. No hace mucho tiempo que todos ellos se sacaban á pública subasta, dándolos en arrendamiento al mayor postor; pero en ei dia, mejorado aquel sistema, se administran por cuenta de la Real Hacienda con conocidos adelantamientos de ésta. Los ramos principales que componen las rentas de Méjico consisten en el derecho de alcabalas, en el de la plata y oro, amonedación de éstos, tributos, tabaco, pólvora, pulques y otros varios. El estado que sigue manifiesta cuáles han sido las entradas y salidas de

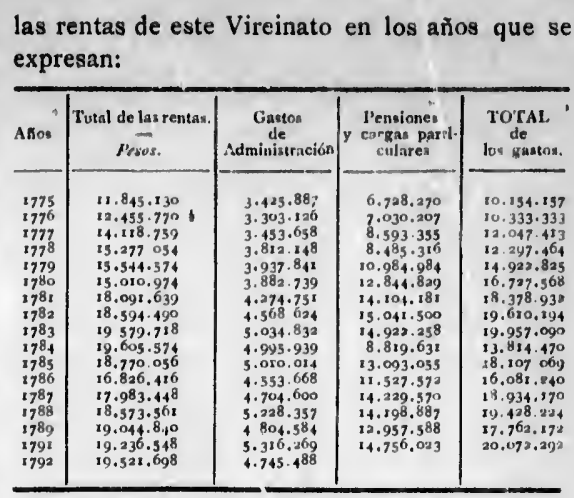

Por este estado se teduce el progresivo au. mento que han ido teniendo las rentas del Rey á beneficio del impulso que ha recibido sucesivamente el comercio en general; también se mani. fiesta que el total de los gastos iguala, si no excede, en muchos años al producto de las rentas, de modo que son muy pocos 6 ningunos los aho. rros anuales.

El renglón que se menciona de gastos de Ad. ministración, comprende los cuatro artículos de sueldos de los empleados en ella, gastos pecu. liares de este ramo, compra de especies estancadas y gastos de fábrica. Tomando por término de inadagación el decenio de $I_{78}$ á 1792 , resulta que los gastos de Administración están con los productos de ésta muy próximamente en la razón de 28 á Ioo. Las pensiones y cargas particulares que anuncia la tercera columna, comprende los artículos de sueldo, varios pensionistas, cargas peculiares del Reino y cargas ultra. marinas. Este último ramo es el más gravoso á las rentas de Méjico, pues sin él serían cierta. mente muy crecidos sus productos líquidos. Compónese en lo principal de los situados que remite á Filipinas, la Florida, la Habana, Puerto-Rico, Campeche, Caracas y otras partes y presidios del Reino, cuya suma puede computarse en unos 9.000.000 de pesos anuales, respecto á que según los estados de Aduanas, el total de las cargas ultramarinas en el quinquenio de 1785 ht I 789 ha ascendido $\{44.807 .365$ pesos.

El ramo del tabaco que es uno de los más considerables que componen las Rentas reales, fué libre hasta algunos años á esta parte, en que se estancó, y ahora se manufactura por cuenta del Rey, empleando al intento crecido número de personas de ambos sexos y de todas edades. Los edificios en que se hace esta manipulación, no tienen cosa particular, pues sólo consisten en grandes patios cubiertos para poder trabajar en ellos al resguardo de la intemperie; lo que sí admira es el rápido incremento que sucesivamente ha tomado esta renta, pues habiendo sido su producto en 1766 de 1.417 .846 pesos, ya en 
el año de 1777 era de 6.355 .303 pesos, y final. mente, en el de 1789 de $6.294 .0+8$ pesos.

Deseábamos mucho la llegada de nuestros instrumentos para determinar la posición geográfica de esta ciudad, ignorando se hubiese hecho algo hasta entonces sobre esta materia: pero á los muy pocos días de nuestra mansión en Méjico, supimos con harta satisfacción nuestra, que además de lo practicado por el Dr. Alzate, cuyas observaciones parccían aún capaces de mayor perfección, habían trabajado por varios años sobre el mismo asunto los Sres. D. Joaquín Velázquez y D. Antonio Gama, resultando tinal mente de sus tareas una determinación así en latitud como en longitud, que apenas podía apartarse una muy pequeña cantidad de la verdadera. No obstante, habiendo recibido nuestros instrumentos el 12, nos preparamos para la observación, y al día siguiente, en una casa inmediata á Palacio, observamos el paso del Sol por el meridiano con un sextante de Stanclif y horizonte artificial de azogue, resultando la latitud de Méjico referida á Palacio de $19^{\circ} 25^{\prime} 37^{\prime \prime}$ Norte, siendo de advertir que como no nos era dable repetir por entonces la observación, empleamos para mayor exactitud la aplicación ingeniosa de la fórmula de los cuadrados de los tiempos pro. porcionales á las diferencias en altura, como aconseja Mr. Bordá (r).

El temperamento de esta ciudad, según lo anuncian las observaciones del termómetro, difierc considerablemente del de los países de la marina. Por una observación diaria hecha en tiempo de verano $y$ en el espacio de tres meses por el Sr. D. Antonio Ulloa, resulta que el termómetro puesto al aire libre marca constantemente $\mathrm{I}^{\circ} \mathrm{y}^{\mathrm{H}} / 2$ á las cinco de la mañana $\mathrm{y}$ á las once de la noche, y 20 á las dos de la tarde. E barómetro observado durante el mismo tiempo se mantuvo siempre en 21 pulgadas, 6 líneas, siendo su mayor variación, media línea por exceso ó defecto, experimentándose su mayor altura con vientos del Noroeste fríos. En el verano se zoza de un temple benigno sin alteración sensible durante el día; pero en invierno cuando vientan los Nortes, se hace sentir el frío. El mercurio del barómetro no se altera en todo el año más de dos líneas, que sube 6 baja de su altura ordinaria. En los parajes altos de la ciudad, los vientos que más frecuentemente reinan son los de la parte Norte, rara vez soplan del Sur ó Sueste, y esto sólo al fin de la prima. vera y principios del estío; y cuanclo van á en-

(i) La lougitud se ha establecido en $29^{\circ} 4^{8^{\prime}}$ al Ocste de Cídiz por observaciones del Brigadier de la Armada D. Dionisio Alcala Giliano, como puede verse en la Memoria que sirvo de suplemento al viaje de las goletas Sutil y Mejivinu al Estrecho de Juan de rucis. t.tblarse se dilatan las lluvias y se experimen. tan fiebres $y$ otras enfermedades. Listos vientos son por lo regular bastante húmedos; no arrecian, $y$ en general los vientos que corren no son fuertes, ni se conoce en Méjico lo que es un verdadero hurącán.

lis esta ciudad tan poco propensa á nieves, que apenas acaece este fenómeno dos 6 tres veces en un siglo. Las lluvias son por el estío, así como en Europa en el invierno, y, ordinaria. mente empiezan de Mayo á Junio; lo particular es que en la estación de verano parece que no puede caer un pequeño rocío sin que preceda una fuerte tronada. Estas son mayores y más frecuentes cuando empiezan y acaban las lluvias; el clía, por lo común, se mantiene despejado hasta la mitad de la tarde, y á esta hora se presenta por el Norte alguna pequeña nube que corriendo con la mayor velocidad se acrecenta hasta cubrir enteramente el cielo; entonces se oyen truenos disformes que acaban en aguaceros copiosísimos y duran como una hora. Des. pués vuelve á despejarse la tarde y queda tan serena y apacible como antes.

Parece que un clima como este, tan propenso á tempestades, estaría por lo mismo exento de la terrible pensión de los terremotos, pero aun. que aquí no sean $\tan$ frecuentes como en los países orientales del Perú, sobrevienen de cuando en cuando algunos extremecimientos cuya dura. ción es grande. El más terrible de los que se han experimentado en este siglo sucedió el 4 de Abril de 1768 á las $6^{\text {h }} 47^{\prime}$ de la mañana, du. rando las oscilaciones seis minutos del Sueste al Noroeste; el último acaeció el 2 I de Abril de 1776 en que se verificaron dos temblores.

La menor densidad que el aire tiene en este territorio produce un efecto contrario al de los paises de la marina; alli se dijo corroe en breve tiempo el hierro reduciéndolo á escoria; pero en Méjico á pesar de la mucha humedad del suelo, de los canales que lo atraviesan y de las lluvias abundantes del verano, nunca se enmohecen los herrajes, y los alimentos y áun el azúcar se conserva en unos almacenes cuyo suelo mana en agua. Esta sequedad, parece no obstante poco favorable á la vida, pues ya dijimos que cuando las lluvias son escasas ó faltan por algunos días, empiezan á experimentarse las enfermedades; y no á otra causa puede fundamentalmente atribuirse las continuas fluxiones que padecen estas gentes, de donde resulta que sus dentaduras sean por lo general defectuosas, lo que se hace muy reparable en el bello sexo. También puede de. pender de la calidad del aire el mal que se pa. dece en esta capital, de diarreas, que se hacell habituales sin causa conocida; su curación es difícil y el único remedio encontrado hasta ahora es el uso continuado del chils, nombre 
el año de 1777 era de 6.355 .303 pesos, y final. mente, en el de 1789 de 6.294 .048 pesos.

Deseábanos mucho la llegada de nuestros instrumentos para determinar la posición geográfica de esta ciudad, ignorando se hubiese hecho algo hasta entonces sobre esta materia: pero á los muy pocos días de nuestra mansión en Mé. jico, supimos con harta satisfacción nuestra, que además de lo practicado por el Dr. Alzate, cuyas observaciones parecían aún capaces de mayor perfección, habían trabajado por varios anos sobre el mismo asunto los Sres. D. Joaquín Velázquez y D. Antonio Gama, resultando finalmente de sus tareas una determinación así en latitud como en longitud, que apenas podía apartarse una muy pequeña cantidad de la verdadera. No obstante, habiendo recibido nuestros instrumentos el r2, nos preparamos para la observa. ción, $y$ al dia siguiente, en una casa inmediata á Palacio, observamos el paso del Sol por el meridiano con un sextante de Stanclif y horizonte artificial de azogue, resultando la latitud de Méjico referida á Palacio de $19^{\circ} 25^{\prime} 37^{\prime \prime}$ Norte, siendo de advertir que como no nos era dable repetir por entonces la observación, empleamos para mayor exactitud la aplicación ingeniosa de la fórmula de los cuadrados de los tiempos proporcionales á las diferencias en altura, como aconseja Mr. Bordá (I).

El temperamento de esta ciudad, según lo anuncian las observaciones del termómetro, difierc considerablemente del de los países de la marina. Por una observación diaria hecha en tiempo de verano $y$ en el espacio de tres meses por el Sr. D. Antonio Ulloa, resulta que el termómetro puesto al aire libre marca constantemente $1 \mathrm{I}^{\circ} \mathrm{y}^{1 / 2}$ á las cinco de la mañana y á las once de la noche, y 20 á las dos de la tarde. El barómetro observado durante el mismo tiempo se mantuvo siempre en 21 pulgadas, 6 líneas, siendo su mayor variación, media línea por exceso 6 defecto, experimentándose su mayor altura con vientos del Noroeste fríos. En el verano se goza de un temple benigno sin alteración sensible durante el día; pero en invierno cuando vientan los Nortes, se hace sentir el frío. Nl mercurio del barómetro no se altera en todo el año más de dos líneas, que sube 6 baja de su altura ordinaria. En los parajes altos de la ciudad, los vientos que más frecuentemente reinan son los de la parte Norte, rara vez soplan del Sur ó Sueste, y esto sólo al fin de la prima. vera y principios del estío; y cuando van á en-

(1) La longitud se ha establecido en $29^{\circ} 4^{8^{\prime}}$ al Oeste de Cádiz por observaciones del Brigadier de la Armada D. Dionisio Alcala Galiano, como puede verse en la Memoria que sirvo elo suplemento al viaje Ue las goletas Sutil y Mcjiuuna al Estrecho de Juau de luca. t. blarse se dilatan las lluvias y se experimen. tan fiebres $y$ otras enfermedades. Estos vientos son por lo regular bastante húmedos; no arrecian, y en general los vientos que corren no son fuertes, ni se conoce en Méjico lo que es un verdadero huracán.

Es esta ciudad tan poco propensa á nieves, que apenas acaece este fenómeno dos 6 tres veces en un siglo. Las lluvias son por el estío, así como en Europa en el invierno, y ordinariamente empiezan de Mayo á Junio; lo particular es que en la estación de verano parece que no puede caer un pequeño rocío sin que preceda una fuerte tronada. Estas son mayores y más frecuentes cuando empiezan y acaban las llu. vias; el dia, poi lo común, se mantiene despejado hasta la mitad de la tarde, y á esta hora se presenta por el Norte alguna pequeña nube que corriendo con la mayor velocidad se acrecenta hasta cubrir enteramente el cielo; entonces se oyen truenos disformes que acaban en aguace. ros copiosísimos y duran como una hora. Des pués vuelve á despejarse la tarde y queda tan serena y apacible como antes.

Parece que un clima como este, tan propenso á tempestades, estaría por lo mismo exento de la terrible pensión de los terremotos, pero aun. que aquí no sean tan frecuentes como en los países orientales del Perú, sobrevienen de cuando en cuando algunos extremecimientos cuya duración es grande. El más terrible de los que se han experimentado en este siglo sucedió el 4 de Abril de 1768 á las $6^{\text {h }} 47^{\prime}$ de la mañana, durando las oscilaciones seis minutos del Sueste al Noroeste; el último acaeció el 21 de Abril de 1776 en que se verificaron dos temblores.

La menor densidad que el aire tiene en este territorio produce un efecto contrario al de los paises de la marina; allí se dijo corroe en breve tiempo el hierro reduciéndolo á escoria; pero en Méjico á pesar de la mucha humedad del suelo, de los canales que lo atraviesan y de las lluvias abundantes del verano, nunca se enmohecen los herrajes, y los alimentos y áun el azúcar se conserva en unos almacenes cuyo suelo mana en agua. Esta sequedad, parece no obstante poco favorable á la vida, pues ya dijimos que cuando las lluvias son escasas 6 faltan por algunos días, empiezarı á experimentarse las enfermedades; y no á otra causa puede fundamentalmente atribuirse las continuas fluxiones que padecen estas gentes, de donde resulta que sus dentaduras sean por lo general defectuosas, lo que se hace muy reparable en el bello sexo. También puede de. pender de la calidad del aire el mal que se padece en esta capital, de diarreas, que se hacen habituales sin causa conocida; su curación es difícil y el único remedio encontrado hasta ahora es el uso continuado del chils, nombre 
experimen stos vientos los; no arreorren no son que es un

sa á nieves, os 6 tres ve. - el estío, así ordinaria. lo particular arece que no que preceda ayores y más aban las 11untiene despei esta hora se eña nube que se acrecenta entonces se an en aguace. ha hora. Des. queda tan se-

, tan propenso mo exento de tos, pero aun. mo en los paíhen de cuando tos cuya duralos que se han cedió el 4 de a mañana, du. is del Sueste al 1 I de Abril temblores.

e tiene en este rario al de los :orroe en breve scoria; pero en edad del suelo, de las lluvias enmohecen los azúcar se coniuelo mana en obstante poco los que cuando or algunos días, enfermedades; ntalmente atripadecen estas lentaduras sean te se hace muy bién puede de. nal que se pa, que se liaceli su curación es ontrado hasta clits, nombre que dan aquí al pimiento, tomando además á to. do pasto el pulqu y retirándose á parajes donde no se respiren los vapores de estas tierras en. guacharnadas. Aun así la curación no es siem. pre perfecta, $y$ el enfermo por lo común viene á morir de este mal. Otra de las enfermedades que más aflijen á estos naturales es la de pleuresías, que se experimentan en la estación del inviemo, y no es extraño porque entonces se une á la se. quedad natural del aire, la frialdad de los hielos.

Según el empadronamiento formado en Me. jico el año de $I 79^{\circ}$, resulta que el vecindario de esta ciudad, sin contar con los que pasan revis. ta, compone un total de $1 \times 3.232$ almas: de ellas se enumeran 2.359 europeos, 49.587 españoles, I2.542 mestizos, 23.743 indios, 6.977 mulatos, 269 negros y 9.458 de las castas mixtas; siendo lo3 restantes hasta el total mencionado, 1.495 religiosos y religiosas y 6.802 seculares empleados en los conventos, hospitales, colegios, etc., y otros establecimientos públicos sin sujeción á profesión. Entre esta crecida población hay como en las grandes capitales, familias de muy ilustre nobleza, varias que gozan privilegio de títulos de Castilla, muchos caballeros cruzados en las Ordenes militares y mayorazgos que poseen rentas crecidas. Una parte considerable del vecindario distinguido se dedica al comercio, por cuyo medio, no sólo conservan los caudales, sino que los hacen mayores: tan general es la propensión que tienen estas gentes al comercio, que desde el grande al pequeño, desde el rico al humilde, no hay casa en donde no se vea tienda de géneros traficables. La parte de población que componen los artesanos y gente de oficio, es muy crecida y consta principalmente de individuos de todas castas, pues estimándose cada uno en la suya tanto como los de las demás, no es sonro. joso en línea de castas ser ménos blancos los de una que los de otra. Algunos han sobresalido bastante en las artes, $y$ han Horecido en varias epocas profesores diestrísimos de pintura y escul. tura, que hacen honor á su patria.

Los indios de uno $y$ otro sexo, cuyo número es crecido, como se dijo, andan por la ciudad vestidos á su modo; las mujeres usan un género de enaguas que nombran en su lengua gilotepeque,

y en el cuerpo llevan una especie de chamarra ó sobrepelliz que llaman guilpil, y además, la cobija con que se cubren á modo de rebozo. Las mestizas gastan enaguas, y en el cuerpo, de cin. tura arriba, el que llaman paño con que se rebozan. Los mestizos visten á la española; pero la mayor parte anda en cueros, cubiertos de un pedazo de manta 6 de lona, viejo $y$ estrecho, que les baja desde los hombros. Esta clase de gentes así vestida, se distinguen en el Reino con el nombre de Saragates: su número es considerable y ninguna su ocupación, pues todos vagan por las calles, llevando para vender, en la mano, algunas baratijas 6 cosas de poca monta. Las costumbres de estas gentes se asemejan bien á su traje, y no dejan de dar en qué entender á menudo á los principales encargados de la policía y buen órden.

Como entre las personas distinguidas del vecindario hay muchas acaudaladas que pueden sostener el porte y decencia que corresponde á su estado, se vé crecido número de coches que rue. dan diariamente, $y$ trenes muy lucidos destinados para los días clásicos, particularmente en los del Rey y familia Real, que se hace paseo público al cual concurre el Virey con lucida comitiva: en estos dias se presentan las damas en público con el porte correspondiente; : $: s$ demás días comu. nes visten al modo de España, cuyas modas se imitan con brevedad. Los hombres acostumbran mucho el uso de la capa y sombrero redondo, y este es el traje cuotidiano de parte de tarde.

Acostumbra mucho esta gente ir de noche á los portales de la plaza, adonde están los mer caderes, para comer pato con chile, compuesto por varias mujeres que se dedican á este ejercicio, estando esto tan en uso, que es común y bastante frecuente en toda clase de personas. El uso del chile 6 pimiento se halla tan arraigado, que entra en la preparación de cuantos manjares hay que no sean dulces, de modo que chile, pulque y cigarrillos, son tres cosas esenciales, sin las cua. les parece no puede pasarse en este país. Para el despacho del pulque hay grandes tabernas públicas, adonde concurren diariamente los indios de uno y otro sexo, y regularmente pasan allí mucha parte de la tarde: esta bebida equivale aquí á la chicha de maiz, tan usada en todo el Perú: sus derechos valen al Rey 866.796 pesos por año común, deducido de los datos de un septenio.

Puede referirse por cosa particular, uno de los man jares que se acostumbran en este país, y cuyo uso parecería fabuloso á no verse. Tal es el que nombran Aguancle, y no es otra cosa que los huevos de mosquito: su tamaño es proporcionado al del animal que los produce: á la simple vista asemejan á una tierra blanquecina, pero mirados con anteojo se descubren perfectarhente los huevecillos blancos y muy semejantes á los de ga. llina: con cllos sazonan los platos más delicados y dan cierto gusto á las tortillas de huevos $\mathrm{co}$ munes: las criollas, por lo ménos, lo encuentran exquisito, porque les comunica.un sabor algo mariscoso. Los mosquitos es mercancía que tam. bién se vende en la plaza pública, y sirven para mantener los pájaros cantores que viven de estos insectos. Esta cosecha la hacen los indios y mu. chachos en las orillas de la Laguna y de los canales: los 'mosquitos son de la figura y tamaño de los que llamamos en España záncudos. 
Esta ciudad es abundante en comestibles, pero las carnes, aunque gordas, no tienen el gusto que las de España: lo mismo sucede en las aves: las silvestres 6 de caciría de agua son abundantes, como patos de varias especies, gallinazos, etc., y su precio es correspondicnte á la abundancia. Hay un tiempo en que aparecen unas aves al modo de gallinetas, y son las más gustosas entre las especies de caza: los conejos abundan mucho, igualmente que las liebres; pero no estando en uso el comer estas últimas, andan por los campos sin huir por no haber quien las persiga. El pescado escasea algo por la distancia que hay desde esta ciudad al mar; pero en la Laguna se pescan algunos peces al modo de los al. bures de río de España: son gustosos y no tienen más espinas que la del medio: distínguenlos de los pescatos salados con el nombre de pescado blanco. Ultimamente, creemos que nada puede dar una idea más perfecta de la abundancia de esta capital que el siguiente extracto de una Memoria auténtica, que manifiesta los artículos principales que se consumieron en ella en el dis curso del año de 789 :

Toros y terneras................ Carneros..................... Puercos......................

Cabritos y concjos............... Gallinas y pollos................

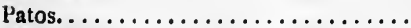
Pavos o huajolotes................ Pichones, perdices y codornices....... Varias clases de pajaros............. Cargas de pescado salado de España y

Campeche...................

Idem del Reino................ Idem de harina . . . . . . . . . . . . . . Idem de garbanzo. . . . . . . . . . . . . Idem de arroz................ Idem de frijol..................

Idem de maiz para comer........... Idem para cebar cerdos............ Idem do habas................... Idem de chile.................. Idem de sal. .................. Idem de cacao de varias partes........ Idem del de Guayaquil.............

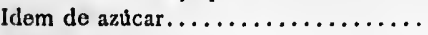
Idem de panocha................ Idem de miel................... Idem de queso................... Idem de verduras. ............... Idem de ajonjolt. . . . . . . . . . . . . . . Idem de algodón. . ................ Idem de sebo................... Idem de cebada..$\ldots \ldots \ldots \ldots \ldots \ldots$ Idem de paja. . ................. Idem de leña.................. Idem de carbón................... Idem de cera . . . . . . . . . . . . . . Idem de papas....................
18.750 298.923 50.000 24.000 $1.255 \cdot 340$ $125 \cdot 340$ 250.860 140.000

39.300 4.600 130.000

$2 \cdot 553$

I. 900

18.208

142.448

92.860

2. 911

I 2.155

5.808

$7 \cdot 486$

7.005

28.202

6.598

8.297

4.198

90.498

I. 359

6.250

$10.36 \mathrm{r}$

46.219

71.964 298.873 $3^{84} \cdot 342$
Cargas de huevos................ Idem do pulque.................. Idem de tesquezquite. ............. Idem do madera para coches.......... Idem de hierro.................. Idem de cobre.................

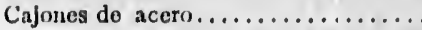
Arrobas do manteca que entraroil do

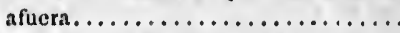
Idem do pescados de varias especies. .

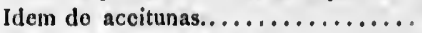
Idem de accite de Kspaña.......... Idem del Reino.................. Idem de nieve................. Cuñetes de pescado de Veracruz...... I Rarriles de aguardiente............. Idem de vino. . . . . . . . . . . . Idem de vinagre de Castilla.......... Pieles de curtiduria. . . . . . . . . . . . . Ladrillos.................... Brazados de piedra................ Canoas entre grandes y chicas cargadas

de bastimentos, flores y otras especies.

Las aguas que se beben en Méjico vienen de unos manantiales de las alturas circunverinas sobre dos arquerias de bastante altura y buena fábrica; llaman á la una la Traspana, cuyo circuito será como de dos leguas y atraviesa la Laguna; la otra sale del paraje nombrado Chapultepeque $y$ corre hasta la ciudad atravesando tam. bién la Laguna, aunque por distinto lado que la antecedente. Estas dos arquerías forman tambien dos de los paseos que tiene la ciudad, pues la prinsera pasa por el de la Alameda y la otra por el extremo del paseo que nombran de Bucareli. La Alameda es de figura cuadrada y está cercada de balaustrada con varias pucrtas: los coches andan por fuera de ella, y dentro pasea la gente de á pié por distintos cuadros de verdura y arboleda. Además de este paseo hay en Méjico otros varios dispuestos por los Vireyes en distintas épocas, siendo grande el esmero con que cada uno ha querido perpctuar su nombre y dejar á los venideros estos mudos testimonios de su celo y amor porla causa pública; pero sin pretender agraviar la buena memoria de cuantos han gobernado hasta ahora esta grande capital, parece cierto que la posteridad reconocida hará siempre una honrosa mención de lo mucho que aquella debe á su actual Virey Conde de Revillagijedo. Sus reglamentos y bandos, tanto como sus obras públicas, recordarán siempre al fundador del. buen orden y de una arreglada policía.

Fuera de esta ciudad y á diversas distancias de ella como de dos 6 tres leguas, hay parajes de diversión, con casas cómodas á donde suelen las familias en ciertas ocasiones del año salir á mu. dar de temperamento. Tales son Cacubaya, San Miguel, San Agustín y los varios pueblecillos de indios que se situan alrededor de la Laguna, en 
donde se goza en tiempo de la primavera, de la amenidad del campo y de la vista agradable de las flores. Hasta los Vireyes participan de esta clase de diversiones, y el Sr. Gálvez construyó al intento un palacio de recreo en el paraje que nombran Chapuntepec sobre las ruinas de otro que tuvo alli el emperador Moctezuma.

La Historia de la Conquista no sólo trata de la Laguna, como de un paraje que sólo contenía agua, sino que era navegable en toda su exten. sión; pero al presente únicamente puede nave. garse por los canales, estando lo restante seco en la mayor parte del año: el suelo, no obstante, es pantanoso, y por esta razon hay construídas las célebres calzadas levantadas en la misma Lagu. na, lo suficiente para que el camino sea siempre traficable. El canal 6 acequia principal corre por la ciudad y llega hasta muy cerca del palacio del Virey; por ella navegan diariamente cargadas de frutas, flores y comestibles, crecido número de canoas, cuya construcción difiere bastante de la que usan los indios en la costa del mar: son al modo de bateas planas, igualmente anchas en toda su longitud y por abajo de figura cuadrilonga, las manejan con palancas y canaletes, son grandes y cargan bastante peso.

De las tierras de esta Laguna sacan los naturales una sal mixta que llaman tesquezquite, la cual tiene mucha parte de salitre y alguna de sal común; la usan mucho, particularmente para ciertas comidas, por el gusto picante que les comunica; también la emplean para las tinturas, y es de creer sea grande su consumo según la abundancia con que la llevan las indias al mercado.

Como el país que rodea á Méjico en la distancia de algunas leguas forma una profundidad á donde se estancan las aguas que bajan de las alturas vecinas, sin que haya garganta natural ú otro desaguadero por donde corran aquéllas á buscar los ríos que descargan en el mar, ha resultado formarse tres lagunas en distintos niveles ó planicies y que las aguas de la más alta vayan á dar á la de Méjico, de modo que acrecentándose la altura de ésta en los tiempos de grandes llu. vias, ponen en peligro la ciudad y áun han causado daños considerables en distintas ocasiones. Para evitar en lo posible este riesgo, se construyó en lo antiguo un socavón que atravesando una garganta donde se juntan dos serranías, diese salida á las aguas de la laguna más alta, evitando así el que se aumentase en las ocasiones dichas, la masa de la Laguna de Méjico.

De este modo en los tiempos de abundantes llwins corre por esta profundidad, á que nombran el Cinal de Guaquetsca, un caudaloso río que evita al peligro que de lo contrario amena. zuría a lis capital, pues aunque es cierto que siempre recibe la Laguna de Méjico las af ras de su pertenencia, no son $\tan$ cuantiosas que au- menten mucho de altura, ni inspiren ins temores que antiguamente.

La extensión del valle de Méjico, tomada so. bre un mismo plano, sin atender á las desigual. dades naturales del terreno, ocupa próximamentc una superficie de 770 leguas, teniendo 35 de largo y 22 de ancho en su término medio. Las de. más particularidades que of rece su suclo, se hallan detalladas con mucha concisión y maestria en la siguiente descripción física que formó y nos comunicó nuestro amigo D. Antonio Pineda, ya difunto, Capitán que fué de Reales Guardias Españolas y encargado por $\mathrm{S}$. $\mathrm{M}$. del ramo de Historia Natural en la expedición de las corbe. tas; dice asi:

"'odas las encumbradas montañas que ro. udean el valle mejicano $y$ sus adyacentes; las "que forman y subdividen con sus ramificaciones "los de Toluca, Cuernavaca, Amecameca y Puc"bla, poco distantes entre sí, son por lo general "de una naturaleza porfírica, más 6 ménos alte"rada. Todas conservan cierta analogía en su "formación, y una figura volcánica que se anun. " cia desde la primera vista, y con efecto, en sólo "la cordillera que rodea el valle de Méjico, se re" conocen 40 cráteres decididos, de quienes los * picos más elevados están cubiertos de nieve.

"En el fondo de este gran valle casi nivela- do, se reunen las aguas de sus derrámenes formando varias lagunas, entre las cuales, la de "Tezcuco, al nivel de la capital, es la más exten"sa. Todo el terreno comprendido entre ella y San -Agustín, se ocupa de unos grandes farallones "de lavas sólidas y esponjosas, compuestos de "capas inclinadas al horizonte y quebradas. Su "totalidad podría compararse á un lago extenso "de fuego, violentamente agitado de un terremoto "que le hiciese reventar las grandes ondulacio. "nes y de repente se congelase. Las raíces de es"tas ondas son, no obstante, muy profundas y "forman un cuerpo continuado de bancas. Los "farallones salientes, recortados entre sí, presen" $\tan$ superficies escabrosas: algunos forman cue"vas; éstos tienen las capas concéntricas amelo. w nadas, $y$ en otros se forman estrías ó escarola"dos como las que toma un cuerpo lapídeo cuan"do en el estado de fluide $z$ se congela agitada la "superficie.

"Todos los valles que llevamos expresados, * deben considerarse como en un plano, y serian wen algún tiempo otros tantos lagos de fuego que "destruyeron y asolaron los terrenos y les dieron "nueva forma. La imaginación se sublima al con. - templar cuál sería el inmenso ruído, cuál el es trago y cuáles los torrentes de materias inflamaudas que vomitarian estos montes si ardieron "todos á un mismo tiempo; cuáles serían las in"mensas masas de piedra arrojadas por los aires; "qué agente tan poderoso sería el que agitaba 



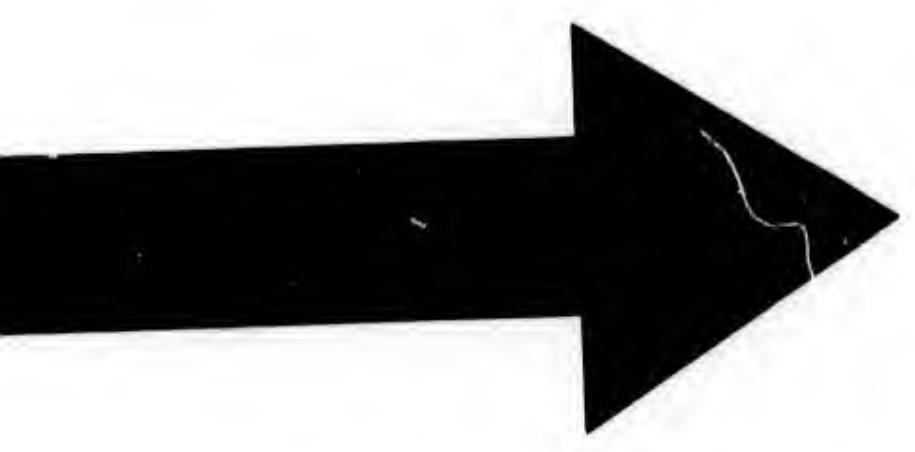




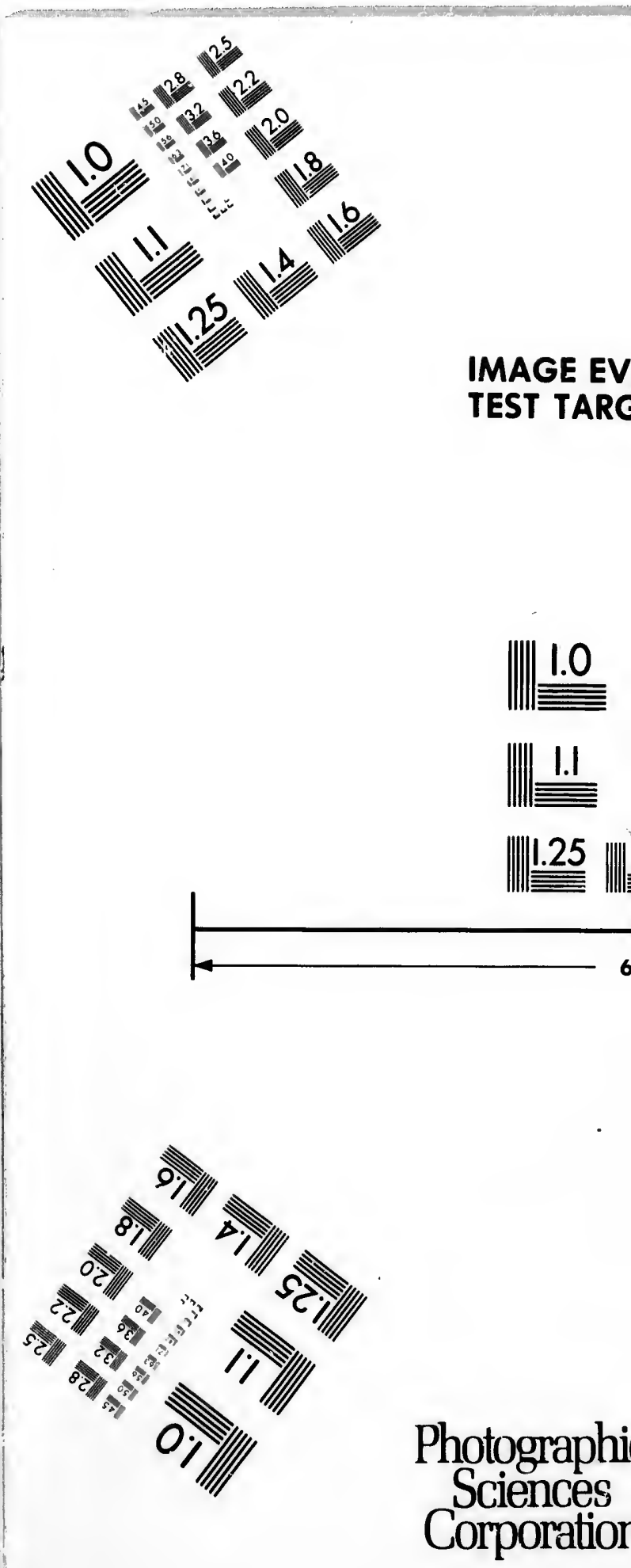




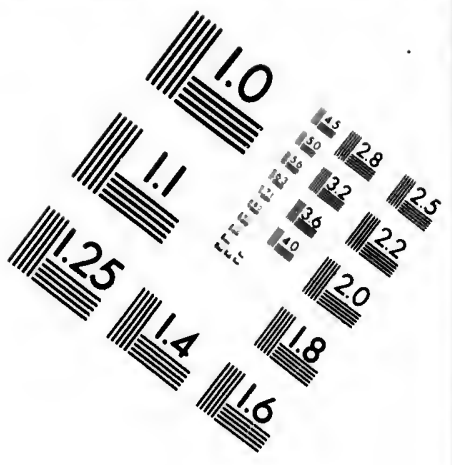

TEST TARGET (MT-3)

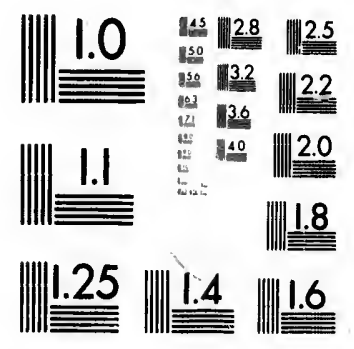

6"

Photographic Sciences

23 WEST MAIN STREET WEBSTER, N.Y. 14580

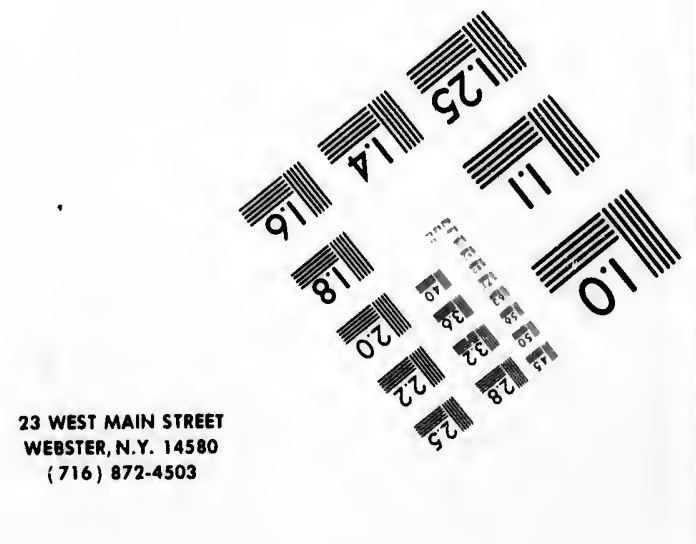
Corporation 
CIHM/ICMH Microfiche Series. 


\section{CIHM/ICMH Collection de microfiches.}
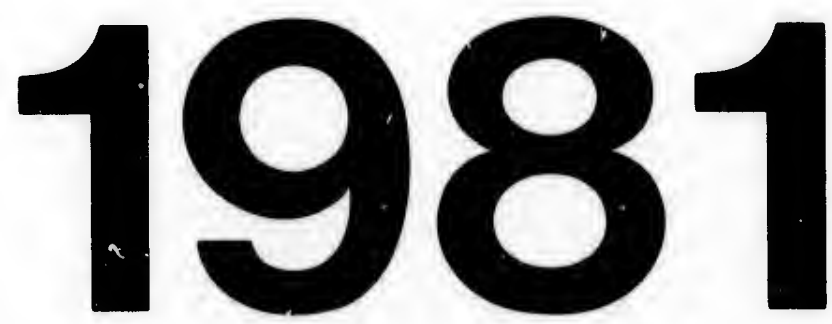
-violentamente aquel espeso licor pará que toinase forma de ondas y quedasen congeladas del u modo que ahora se encuentran después de una "serie tan dilatada de siglos.

"Además de los volcanes que forman la cor"dillera, hay otros pequeños, como los de Itza"palapa, San Isidro, la Compañia, etc., que hi" cieron sus erupciones en la parte honda del va- lle y corren, formando línea, á encontrarse con "otra serie de montes volcánicos que salen desde "las sierras nevadas entre Amecameca y Puebla. "Ellos sirven de canteras, de donde se saca el tc"sontle ó lava porosa en grandes masas, para la "construsción elegante de edificios, y reunen las " circunstancias de un gran tamaño con la solidez "y la ligereza; sus fragmentos y cenizas descom"puestas, producen la puzolana y la tierra vege"tal, que ambas contribuyen mucho á las gran-dezas de Méjico. En partes se encuentran her" mosas canteras de hidrófanos que se hacen muy "transparentes dentro del agua; pero esta rara "materia, tan preciosa en otros países, está sin nestimación y se emplea solamente en la fábrica "de vidrio. Una infinidad de pueblos y de sem. "brados se han erigido sobre las ruinas de la La"guna en la parte que ocupaban en otro tiempo usus aguas estacionarias: sea que hayan dis"minuído las lluvias ó que el terreno de la capi"tal se haya elevado, es cierto que hasta sus "aguas permanentes se han retirado de modo que "sólo ocupan una parte muy pequeña; sus orillas "despejadas, presentan por unas partes un terre "no pantanoso en que pastan los ganados, y por "otras en que se mezclan sus arenas con el te"quezquite ó álcali mineral nativo que abunda "mucho, sólo of rece unas marismas estériles de "aspecto desagradable.

"Las ciénagas y cañales que rodean la capi"tal, en donde llegan las aguas perennes de las "lagunas, están cubiertas de yerba, aunque han "desaparecido esos jardines flotantes conocidos "con el nombre de chinamp is, que en otro tiempo ucubrían la gran laguna, y de quienes aun sólo "la descripción recreaba; pero se encuentran, no obstante, algunas huertas palustres, cuyo pa"vimento adhiere tan poco al fondo, que se mue "ven de un sitio á otro con solo el impulso de "una canoa: su extructura singular es de una es"pecie de rinfer con raiz fibrosa; sus tallos son "rollizos y ligeros; su hoja, arriñonada de una " pulgada de diámetro, compuesta de una s'istan"cia porosa celular como la médula del s ’uco ó "de la enea; esta materia sobrenada y puede "sostener sin sumergirse cierta cantidad de peso "en proporción de su volumen: las hojas exten *didas en el agua forman planos; las raíces se ventrelazan y tejen un ensamblaje; sobre este " ambulante pavimento que nada como el sarga "zo, caen las semillas del cipazus, de la grama y wotras plantas; el cieno que acarrean las aguas " ordinariamente turbias, se enreda entre las rai"ces; las hojas podridas se acumulan, se van " convirtiendo en tierras y con el tiempo forman "un suelo particular poco unido al de las lagunas, que sobrenada cuando aquéllas tienen agua yy resultan esos pedazos de tierra en que forman Dlas chinampís: sólo la laguna de Xochicalco con" serva todavía algunas tan grandes, que sostie"nen arboledas y ganados, y los transportan de " un sitio á otro á discreción de los vientos.

"La estructura local del valle, la abundan. "cia de sus aguas y la benéfica tierra que resulta "de las lavas, le dan un temperamento feliz, "donde no se sufre con exceso el rigor de las es" taciones; donde no penetran con gran furia los "vientos impetuosos, por su figura aconchada; y "donde se goza, en fin, la vegretación de una " eterna primavera, bajo del temperamento mo"derado del otoño. Su atmósfera, aunque en"vuelta en ciénagas y pantanos, es no obstante, "muy reseca, como lo tiene demostrado al pú"blico el docto $\mathrm{Alzate}$, por el mucho álcali mi"neral de que está impregnada, el cual absorbe "las partículas acuosas y los vapores, dejándola "purificada. En sus montes y llanadas se ha"llan admirablemente reunidas cuantas frutas $y$ " hortalizas se cultivan en América y Europa (I). "Sus campiñas, rodeadas de arboledas y de ace"quias, of recen al pasajero una acogida risueña "que le distrae de contemplar los prodigios que "obró la Naturaleza en los terrenos que rodean "á la capital del Nuevo Mundo.

"En las faldas de las montañas es donde "prospera mejor la vegetación; su flora oficinal " está ya descrita por $D$. Vicente Cervantes en un "discurso elocuente; este digno Profesor ha de. "mostrado, como hizo en otro tiempo el gran "Hernánde $z$, los inmensos beneficios que debe á "las plantas de este suelo la especie humana, la "comparación de algunas de ellas con las que "crían las campiñas matritenses y la grande " analogía que guardan en este punto los terrenos "que rodean las dos grandes capitales de la Mo"narquía española. En los cerros del desierto es "sin dificultad mucho más copiosa; este paraje, " elegido por los religiosos carmelitas para esta"blecer la vida heremítica, es el más frondoso de "cuantos rodean el valle, casi el único en que se "conservan con feracidad los cedros que antes "adornaijan todas sus inmediaciones; sus rai"ces horizontales se extienden, se entrelazan y

(1) Debe advertirse que aunque es cierto pruebaus bien en el suelo de este valle las plantas exóticas, a las dos o tres veces que sucesivamente se siembran degeneran considerablemente y quedan por fin bran degeneran considerablemente y quedan por fin gumbres son de menor tamaño y solidez; las vituallas y plantas potajeras ménos sabrosas, y final zente, las frutas ménos dulces y agradables. 
cual absorbe es, de jándola adas se ha. ntas frutas y Europa (I). das y de acegida risueña rodigios que $s$ que rodean

ias es donde flora oficinal vantes en un fesor ha de. mpo el gran $s$ que debe a humana, la con las que y la grande ios terrenos es de la Mo1 desierto es este paraje, is para estafrondoso de co en que se s que antes s; sus rai. intrelazan y

erto prueban tas exóticas, inte se siemtedan por fin ural. Las leiz; las vituay final-iente,
- fortifican bajo las piedras, sin que la poca ana. - logía del terreno impida que imiten en la robus. ntez á los del Líbano. Todas estas arboledas dis. "minuyen á proporción que se elevan los terre"nos; de suerte que en la línea de ia nieve sólo ise cría una especie de grama. El reino animal "casi se extingue en la misma proporción, y los "pocos insectos que se conservan están muy otorpes.

"El núcleo de las sierras nevadas entre Ame- cameca y Puebla (I): es el Pórtido 6 Brecha por"fírica alterada por el fuego en diversas modifica"ciones. Las nuhes que se elevan de los valles in"mediatos, chocan 6 se rompen contra ellos. Las "montañas se cubren de espesa niebla, y estas "grandes masas colocar.as en los espacios del aire "ejercen una fuerza de atracción sobre las nubes "cuando el viento ú otra causa superior no des "truye sus efectos. El barómetro estuvo sobre uno "de sus picachos en 16 pulgadas I I líneas; y el "termómetro en $10^{\circ}$, efecto de los vapores de los "valles inmediatos.

"Todo el terreno hasta Zempoala, abunda en "tesontles y otras especies de lavas, los pórfidos "que hay en él varían mucho de colores, hay al"gunos granitos con base de esteatita shrol y "feldespato: se ven fragmentos de un pechstein, "que tiene lustre de pez, y algunas canteras de - basalto negro en masa. Los campos se adornan " con los nopales silvestres, los maguielles y los v molles que á veces parecen árboles corpulentos: "los edificios arruinados de los antiguos Tulte" cas, esparcidos por estos campos, conservan el "esqueleto de una arquitectura sólida, compuesta "de los tesontles y tierra ocrácea, la cual adquiewre una dureza extremada. Otro de los abjetos "más dignos de admiración que ofrece aquella "comarca, es la soberbia arquería por donde se " condujo el agua á Otumba, haciéndola pasar "de un cerro á otro por una altura de 45 varas, "poco después de la conquista de aquellos rei* nos; en ella hay arcos cuyo diámetro pasa de $\mathrm{I}_{4}$ "varas sobre una elevación de 45 .

"I a tierra que sigue al Oeste de Zempoala y "comp? ende el resto de la provincia, es ocrácea, "al parecer cubierta de una costra calcárèa.

"El Real de Pachuca (2), tal vez el más an-

(1) Nos ha parecido recibiría el público con agrado la continuación de la descripción anterior, que contiene la de la parte de Nueva España que reco. rrió D. Antonio Pineda. Las notas son en parte ex tractadas de varios apuntes de D. Antonio Ulloa, igualmente que algunas de las refiexiones que siguen á esta descripción.

(2) Pachuca dista unas 20 leguas al Nordeste de Méjico. La población so halla situada en una gran llanura, rodeándola muy de cerca la serrania por la parte del Norte y Poniente. Sus casas están esparcidas, ocupando un gran espacio por el cual pasa un arroyo tiene varios conventos, una iglesia parroquial y el vecindario cs bastante crecido. -tiguo del Reino, comprende reunidos ios cerios "di San Cayetano, Magdalena, San Cristóbal, la "Mesa y ia Rejnna. En ellos hay denunciadas "más de r 30 minas, de las cuales las más están "en bonanza: sus vatas corren del Este al Oeste "y atraviesan las montañas de unas á otras. Es"tas parecen á las de Chile (x): constan de pór"fidos morados con espato blanco, su fondo es de westeatita y petrosilex. El criadero está en es. "pato, calcáreo, y el metal que he reconocido de "ellos abunda en plata que contiene mucha blen. "da. El temperamento de aquel Real es templa. "do, por su situación local al abrigo de las mon"tañas. Los Sures, comunes en aquel país, son - los que reinan; pero no nieva y llueve muy "poco.

"Las montañas que van al Este hacia el "Real del monte, se componen del pórtido mora "do de que hablo en Chile, indicios seguros de "pertenecer á la gran cordillera, , cuya materia "común es esta roca compuesta. Las vetas co. - rren por lo general cruzadas: las principales "del Este al Oeste, otras de Norte á Sur y otras vinclinadas. En el se halla el famoso socavón "del Conde de Regla, adnirable más por la granudeza que por el primor de la obra, tan superior "á las fuerzas de ningún particular. Su plano en "unos parajes corre á roo varas de la superficie, "en otros, en que atraviesa farallones ó crestas "de montañas, llega á 200; su excavación sigue "siempre al Oesudoeste un espacio de 3.0no "varas, atravesando por una diagonal todas las - vetas del monte; pero éstes están todas en bo. "rrasca, sus planos se hallan más hondos, y era ^necesario profundizar más para encontrar los "criaderos. La anchura del socavón no es más "que la suficiente al laboreo, y su altura es la de wun hombre, aunque á veces es necesario doblar "el cuerpo.

"La célebre hacienda de Regla en donde se "benefician los metales con una finura é inteli"gencia de que no se da ejemplar en otra parte, "se sitúa en una barranca de un emplazamiento noval (2): su parte superior está revestida de una

(1) El autor se refiere varias veces a las observaciones que tenia hechas en Ia América meridional. Cuando tratemos de aquella parte del mundo insertaremos igualmente las noticias que nos franquea.

(2) La historia de esta trirn ofrece a un tiempo el ejemplo de la suerte del min y de uno de los más raros caprichos de la fortnna. Perteneciendo estas minas a un tal D. N. Bustamante, sujeto bien ilustrado, de particular inteligencia y conocimiento de la minería, trabajaba en ellas con el fin de desaguarlas, per. suadido por su antigua reputación y por algunas muestras de metales que se sacaban, que conseguido el tras de metales que se sacaban, que conseguido el
desaguie seria dueño de las riquezas que en otro tiompo hablan dado estos minerales. En este empeño con. sumió todo su caudal y las cantidades que le facilitaron algunos de sus amigos, los cuales, viendo el poco acicrto y lo mucho que se habla gastado on un primer socavón retiraron ios auxilios y sólo continuó 
"soberbia columna de basaltos, cuyas cabezas - se terminan en un plano y se coronan de arbus"tos; algunas de estas columnas se quiebran, "otras se desgajan de su sitio $y$ en las paredes "de la barranca se ven sus grupos en diversas "posiciones: los trozos de las columnas rotas "forman rampas que llegan hasta un arroyo y "son anuncios de las frecuentes ruinas que sufre "la ostentosa arquitectura, las cuales arrastran "tras sí no pocas veces pedazos de la hacienda, "de metal. El agua de un crecido arroyo baja "oprimida entre la columnada basáltica por un "espacio de 700 á 800 varas sobre las cabezas "pentágonas de otras columnas, y se forma un "pavimento empedrado de ellas, semejante á notro que se halla en Irlanda y ha debido á los "ingleses el título de Gianti, Causay IVay, para "indicar su grandeza. Esta cascada grandiosa, "propiamente gigantesca, se despeña últimamen"te de 12 á I 4 , varas, y forma con su caida un " estanque circular á quien rodea igual columna. "da de 30 varas de altura, que se descubre al "través de una vegetación vigorosa. La arquitec"tura natural, el ruido del agua, la frondosidad "del sitio y la singularidad de iodo el conjunto, "forman el paisaje más pintoresco que puede " crear la imaginación. La variedad de lavas po"rosas, las piedras de gallinazo y otros fracmen"tos volcánicos que hay por sus inmediaciones, "estimulan á crcer que toda esta columnada sea "una cristalización formada por la vía húmeda, " contribuyendo la acción del fuego.

"En el Real de Atotonilco el Chico, se cuen.

en ellos D. Pedro Romero Terreros, comerciante acaudalado de Querétaro, de tal inodo, que se asegura habcrle franqueado su caudal sin interés alguno ni otro fin que el de darlc esta mayor prueba de su amistad. Hallábase ya el socavón actual en la mitad de su longitud, cuando por un raro accidente murió Bustamante, dejando declarado en su testamenlo que las minas y cuanto en cllas habia, pertenecia a 'Terreros por el dincro que lo habia facilitado, sin que sus hijos pudiesen pretender más que hasta cicrta cantidad que él había gastado, suya propia.

Terreros, en fuerza de esta declaración, de ha ber invertido su caudal alli y del concepto que habia formado de las minas por lo que habra ordo á su ami go Bustamante, se vió en la precisión de abandonar a Querétaro, renunciar al comercio y dedicarse finalmente al ejercicio do minero, para el cual no tenía conocimientos suficientes ni inclinación.

Einpezó por continuar el socavón y ya se deja entender que trabajó en él mucho tiempo gastando nuevos caudales, antes de ver el fin de su empresa pero una vez concluído el socavón quedó ducño de la mayor riqueza que puede haberse conocido. La plata se ha extraldo de esta mina á millones: son in finitos los caudales que el Rey ha cobrado por razó de sus derechos, y nadie puede calcular todo lo que este hombre posera.

Terreros, sin embargo, tan modesto en su nueva fortuna como antes, ha contribuldo con mano liberal al fomento de las obras públicas del Reino, manteur ei couvento de Recoletos de Pachuca, para el fim de las misiones, y uitimamente, no ha cesado de contribuir al bien del Estado en varias ucasiones, igualmente u tan de 16 á i 8 vetas que todas corren igualmen"te del Este al Ocste si se exceptían algunas "cuya dirección es Noroeste-Sudeste que aquí "llaman diagonales. Sus metales son general. "mente azules ó colorados y sư matices son el "espato y la tierra blanca.

"En las inmediaciones de Tecozautla vuelven "á aparecer los indicios de volcanes, se observan "aguas termales, lavas, puzolanas y otras mate"rias de cuya descomposición resulta la hermosa "tierra que fecundiza las frondosas arboledas. "Este valle que en el dia asemeja á un pequeño "paraiso, conserva en su vecindad las indelebles "Señales de cuando era un doloroso teatro de las - desolaciones volcánicas. Las orillas del río que "lo ameniza, tienen enormes tesontles: hay una colina con capas horizontales de varias tierras "ya volcánicas, ya con calcáreos; su altura será - de 60 varas, y en ella se cuentan hasta 32 capas "bien discernibles, cubiertas de una tierra vege"tal, que son sin duda otras tantas erupciones cu"yo intervalo se ignora, pero que tienen un es" pesor desigual y comprueban la idea de los mu"chos siglos que duraron los volcanes. Algunas "capas tienen dos varas de grueso: en ellas se "ven las pómez vitrificadas que se van subdivi"diendo hasta que se pulverizan y forman las pu"zolanas.

"Habrá muy pocos parajes en el globo, donde " se encuentren acumuladas tantas materias vol"cánicas como en las inmediaciones de Queré"taro (I): los guijarros, los farallones y hasta los "cerros son de tesontles.

que al de los particulares necesitados que imploran su queilio. Por todas estas razones el Rey le ha concedido título de Castilla con la denominación de Conde de Regla y las minas por juro de heredad con otras gracias y privilegios quc no habia ejemplar se hubiesen concedido á otro alguno. En el dia ha decardo mucho cl producto de las minas como se anuncia arriba.

(r) Sitúase la ciudad de Querétaro al pié de una cuesta y al Sueste de una espaciosa llanura. Su capacidad es bien grande, las calles derechas $y$ anchas $y$ las casas muy cómodas, muchas de ellas con fuentes por haber abundancia de aguas corrientes que se conducen a la ciudad sobre una hermosa arqueria de 62 arcos. Tiene dos plazas grandes, una parroquia y tres ayudas de parroquia, cuatro conventos de religiosos y otros cuatio de monjas, incluso el beaterio que nombran de Santa Rosa, que es asimismo colegio para en señanza de uinos. hermosas y están ricamente doradas en los altares y adornadas con el mayor primor. En el patio externo del convento de San Francisco hay cinco capillas grandes que hacen de otras tantas iglesias separadas de la principal, cada una con su torre y campanario. El vecindario se computa dentro de las goteras en 8.000 almas de comunion sin comprender los dios. Hay bastantes personas do calidad y distinción y se cuentan más de 60 coches que ruedan. Su tempcramento es berigno, la gente afable, y especialmento las mujeres sobresalen en lo agradablo de su carácter. Hállase bien abastecida de toda clase de géne. ros europeos, y los naturales se ejercitan en hacer tejidos de lana y algodón, fabricar fresadas, paños vas tos, lienzos blancos y listados y los quo llaman pafios 
ren igualmentíaan algunas este que aquí son general. matices son el

zautla vuelven s, se observan $y$ otras mateIta la hermosa sas arboledas. á un pequeño las indelebles o teatro de las as del río que tles: hay una varias tierras, su altura será hasta 32 capas ha tierra vege erupciones cutienen un es. dea de los muanes. Algunas o: en ellas se van subdivi. forman las pu.

el globo, donde materias vol. nes de Querénes $y$ hasta los

que imploran su le ha concedido in de Conde de d con otras gralar se hubiesen decaldo mucho uncia arriba.

ro al pié de una ro al pié de una
lanura. Su capachas y anchas y llas con fuentes entes que se con a. arqueria de 62 parroquia y tres parro religiosos y aterio que nomaterio que nomos conventos sol cn los altares el patio externo y cinco capilla: lesias y separada orre y campanao de las gotera mprender los inidad y distinción ruedan. Su teme, y especialmen adable de su cada clase de gene a clase de gene tan sadas, paños vas-
ue llaman paños
- Una grande hondonada ó concha oval se pre"senta rodeada de una columnada de basaltos, cu. y yas cabezas terminan en un plano: la materia de "estas columnas es una tierra argilácea con gra"nos de shorl negro y pequeños fragmentos de la"vas vidriosas de colores. En las grandes llana"das de Quert́taro y Celaya (I) se ven lagunas y "abrevaderos en que aprovechan las lluvias y sus"tentan los ganauos. El suclo tiene una vara de " tierra negra esponjosa de las lavas mezcladas con "la caliza y dan el roo por uno de sembradura. - Están tan aprovechadas que el diezmo del partido " de Querétaro asciende á 4.00o fanegas de maiz, " sin contar las simientes ni las frutas. El tempe"ramento de la ciudad se mantuvo por una serie "bien seguida de observaciones, de 65 á $7 \mathrm{I}^{\circ}$ en la wescala de Farenheit, en el campo no varió de 63 „á $65^{\circ}$. El eudiómetro absorbía 53 partes de aire "vital de roo del común: pero cuando sopla el "viento Nordeste, que es conocidamente el más " sano, es tan superior que absorbe hasta 75 partes.

"El cerro Cimatario, distante una legua de la " ciudad, es un pequeño volcán extinguido, todo "cubierto de lavas; su núcleo, como el de los de" más de Nueva España, es el pórfido, y se notan "algunos fragmentos ferruginosos. Este volcán, á "quien no se le reconoce crater ni respiradero al"guno, eruptó probablemente por alguna boca in"ferior, como en nuestros días el Jorrullo, y el "siglo pasado el Monte Novo en Italia.

"El Real de Guanajuato(2), el más abundante uen minas y tal vez el más opulento que se cono"ce en el orbe, ocupa varias colinas que se revis"ten de flores hasta su cúspide, pero á veces des- cubren sus farallones desnudos de una especie de arenario con partículas de esteatita 6 serpentina

que usan las mujeres para rebozarse, cubriéndose $\mathrm{cl}$ cuerpo desde los hombrosá la cintura. Las salidas de la ciudad son muy amenas por las muchas huertas que la ciudad son muy am
hay en su circuito.

(r) Celaya ocupa casi la medianía de una extendida llanura: sus plazas son cuadradas; las calles anchas y derechas, $y$ por lo general las casas bajas con terrados 0 azoteas. La torre de la iglesia parroquial es particular por su mucha altura; tiene cuatro cuerpos y en los tres superiores dos arcadas acompañadas de columnas en cada uno. La iglesia de San Francisco sirve de parroquia, y su comunidad mantiene colegio de estudios y Universidad. Además se cuentan cuatro conventos de religiosos y un beaterio con la advocación del Niño Jesús. El vecindario es bastante crecido pero de gente humilde y no de muchas conveniencias; su ocnpación en parte es la fabricación de tejido: y lienzos de algodón como en Querétaro y parte la arrierfa para el tráfico interior del Reino.

(2) La población de Guanajuato ocupa un estrecho espacio que dejan entre si dos cordilleras de cerres por donde empieza á entrarse desde el paraje que nombran el Marfil; de modo quo yéndose uniendo aquéllas desde este punto viene á ocupar la ciudad las desigualdades de sus concurrencias. Por esta razón las calles son pendientes, bastante ásperas, y para fabricar las casas hay que hurtar a los cerros parte de sus faldas labrando a pico el suelo. Es bastanparte de sus faldas labrando á pico el suelo. Es bastan-
te grande y su vecindario pasa de 80.000 almas, atrai- "que, endurecida, asemeja á la pierira de afilar, "y en sus inmediaciones se ven pudins de distin. "tas piedras. En los bosques contiguos abunda el "palobobo, los combolbulus, el cactustuna, la " zinnia y otras diversas. El temperamento de "Guanajuato es bastante igual. El barómetro "marcó 22 y $1 / 2$ pulgadas cuando el termómetro "mantenía en $12^{\circ}$. Hechas las correspondientes se "reducciones, resulta que se halla este Real si"tuado $997^{22} /$ oo toesas sobre el nivel de la mar, "ó lo que es lo mismo, 2.393 "3/.00 varas caste- llanas: roo partes del arre vital que se respira "en sus calles, tuvieron ordinariamente 60 par"tes de absorción.

"La mina de Tepeyas, una de las principales, " está en un monte esquistoso con incrustaciones "ferrugíneas; su veta madre corre del Sudeste al "Noroeste con una inclinación constante de $43^{\circ}$, "sus cañones de comunicación están dispuestos "de tal manera que dan al aire una perfecta cir"culación. La profundidad perpendicular en don"de se halla el principal tiro pasa de 220 varas, "pero no es posible dar una idea del conjunto bu "llicioso y la grandeza que se observa en aque"llas cavernas subterráneas en que se emplean w cerca de 3.000 trabajadores. En ella se encuen. "tran las oficinas para el despacho, los almace. * nes de pertrechos, los depósitos de minerales, "las contadurías, y en fin, cada tiro ocupa para "sí más empleados que los que hay ordinaria. - mente en las minas más ricas de otros parajes. "Su administración sedirige con una formalidad "cual si fuera la de un reino, y el encargado par" ticular de cada boca-mina rinde sus cuentas se. " manalmente al Administrador general ( $r$ ).

das únicamente por el atractivo de las riquezas, pues no ticne territorio laborable para sementeras. Hay en la ciudad algunos buenos edificios, $y$ generalmente las casas tienen alto y balconerfa. Se encuentra con abundancia todo género de mercanclas: tiene Ayuntamiento, Alcaldes y Regidores, con un Tribunal de Hacienda, siendo cabraa de partido y asiento de los Intendentes de su provincia. La grande pensión que padece es en punto de aguas dulces: on tiempo de lluvias las que bajan precipitadas de los cerros ponen en peligro los edificios, porque acumuldndose on to en peligro los edifcios, porque acumulandose en toestrechn cáuce de las dos cordilleras y arrastrando consigo lo que encuentran al paso; cuando las secas, no corre agua ni la hay para el consumo de la población; para estos casos hay construido un estanque que se formó á tres cuartos de legua de la población en el concurso de las dos cordilleras, atravesando una gran presa de canterfa de ccrro.

(I) Esta mina se descubrió en lo antiguo y se abandonó al poco tiempo por no haberse ehcontrado metales de ley, pero para que se comprenda en algún modo lo que contribuye la casualidad y la constan. cia al descubrimiento de los metales ricos, se dirá aquil lo acaecido con esta mina.

Don Antonio Obregón liabia entablado en el discurso de su vida el trabajo de varias minas sin lograr encontrar alguna regular fortuna: su corto caudal se hallaba enteramente consumido y el crédito estaba perdido porrue la fortuna no le habia dado propor. 
"Toda la parte de Nueva España que hemrs " corrido deberá considerarse un entrelazado de " montañas, cuya dirección general es de Norte á "Sur ó del Noroeste al Sudeste; en sus faldas se "dilatan muchos valles que se formaron por los " volcanes cuando en sus respectivas erupciones " trastornaronpor esta parte la superficie del glowbo. Sus lavas, descompuestas con el transcurso - del tiempo, con las aguas y con la estación del vácido ácreo, se hacen tierras vegetales y han - cubierto las llanadas de Celaya, Salvatierra, "Querétaro, Méjico, Toluca, Puebla, Cuernava"ca y otros muchos que deben considerarse como "graneros del Reino.

"Si atendemos á la situación geográfica de "todos los Reales de minas, tanto antiguos como " modernos que se conocen en Nueva España, $y$ "estámos á los informes de los prácticos que los "laan reconocido, deben considerarse comprendi"dos en tres zonas ó cordilleras metálicas, guar" dando el orden siguiente. La primera corre del "Sueste al Noroeste con alguna ligera inflexión al "Norte: en ella se comprenden los Reales de Teteila del Río, Tepanticlan, San Juan Guetario, - Culcupaseo, Santa Clara, el Río del Oro, el del "Sombrero, Rizaclan, el Nuevo de Guadalupe y "Tecalitan, á quien sigue el de Santa María de "la Yesca y va á parar á Bolaños.

"Esta primera cordillera ocupará una extensión "de 200 leguas, porque suelen distar muclio unos "de otros. Los más de ellos están en tierra calien. "te ó cuyo nivel no se eleva mucho sobre el del u mar, y sólo se exceptúan de esta regla los de -Tetela, Teparticlan y Pisiaclan: en esta misma " cordillera se encuentran en actual indicio los "volcanes Jorrullo y Colima, cuya corresponden"cia interior está confurmada por la exacta al"ternativa que guardan en sus erupciones.

"La segunda coinserva su dirección del Esnor-

ción para corresponder á los empeños que habia contraldo. En esta disposición turo la humorada de inclinarse a la Valenciana y en 17 fo hizo la denuncia registrándola en la Caja Real contra el dictamen de los inteligentes y de sus amigos que con las mayores persuasiones intentaron apartarle de tal pensamiento considerando que serfa el término final de su ruina; considerando que serfa el término final de su ruina; y hasta 35 de tendido de veta. Durante nueve años no se hizo más labor que las que podian las fuerzas naturales del dueño ayudado de uno 0 dos indios que le acompañaban, pues hallándose en la mayor indigencia carecía enteramente de todo otro auxilio. Subia diariamente con su barreta y trabajaba cuanto podía; pero el adelantamiento era muy corto $y$ se necesitaba mucho tiempo antes qne se conociese algún progreso. Al cabo de los nueve años en que fué necesario para subsistir la mayor constancia que se deja entender, empezó á descubrir algunas muestras de metales y con estos indicios solicitó y obtuvo la compaña de algunos sujetos y principió el trabajo formal con la felicidad de que á proporción que so profundizaba, so iba haciendo patente la riqueza. Al presente es la más rica de la Nueva España, como dijimos hablando de la Casa de Moneda de Méjico. "deste al Oesudoeste: en ella están romprendidos w todos los Reales que están al Sur de Guajaca, - Tejomulco que es criadero de oro, San Jeróni"mo, el Real Viejo, todos los de In Misteca, el de "Gautla, el de Cosclatlan, el de Julián, el de Cho"malpé, el de Reguilotepec, el de Tasco, los de "Zagualtepec, Sultepec y Temascultepec, el de "Tapajagu y Guanajuato, el de los Ásientos de - Ibarra, Ojo caliente, el de Zacatecas, el del "F resnillo, $\epsilon$ l de Plateros y últimamente, el del "Sombrerete.

"La tercera cordillera, de quien hemos reco. - rrido mucha parte, sale de T'eguantepec, coge las "minas antiguas de Zempoala, el de San Miguel "de Talca, el bajo de Villalta, el Real Nuevo, "los descubiertos últimamente en Guajaca, los "de Capulalpa, Santa Catharina de Chatoa, San "Pedro Mariclie, los antiguos de Teguacan, de "las Granadas, los dos tetelas de oro y de Jono"cla, el Real de Monte, Atotonilco, Pachuca, -Santa Rosa, Capula, Zimapan, Cardenal, San "José del Oro, el Jacal, el Doctor, el Pinar, el de - la Targea del Sichu, el de los Catorce, Guadal. " cázar, San Luis, Potosí y lBoca de Leones, con - otros pequeños que no se nombran. Al lado de "esta cordillera se halla Perote y el volcán de "Orizaba."

De lo expuesto arriba, y según lo dan á entender las observaciones barométricas practicadas en la parte que hemos recorrido de la Nueva España, se deduce claramente que el territorio de este Reino no tiene una altura á corta dife. rencia igual, respecto á la superficie del mar, ni que la elevación que toma á cierta distancia de éste es por cuestas rápidas y montañas elevadas, que hacen pasar repentinamente del terreno bajo al alto. Este se va elevand. ísensiblemente por países altos y espaciosos hasta llegar á cieito término, el cual conserva después en largas distancias (I).

Según un estado comunicado por el Administrador de ella D. José Quijano, ha producido la Valenciana en los cuatro años y medio corridos desde $10^{\circ}$ de Enero de 1787 hasta Junio de $179 x, 685.22 x$ cargas de metal que valieron beneficiadas $r 3.027 .890$ pesos. de metal que valieron beneficiadas 13.027 .890 pesos ca á 2.052.073 pesos, los consumos y pérdidas de ca a 2.052 .073 pesos, los consumos y pérdidas de
azogue á 22.229 quintales y se gastaron 17.540 cajas de polvora, cuyo valor es de 213.783 pesos: se ocupan diariamente en todas las dependencias y laboreos de esta mina 3.123 personas.

(r) Desde Veracruz hasta Jalapa, que cuentan 22 leguas, las ocho primeras son enteramente llanas, y en las 14 restantes se van subiendo por cuestas tendi. das las 1.667 varas que está Jalapa sobre el nivel del mar; de modo, que á cada legua de este tránsito co. rresponden rig varas de desnivelamiento, o una vara a cada 60 de camino, suponiendo de 7.000 varas la extensión de la iegua. Lo mismo se verifica desde Ja. lupa a Perote. Entre estos dos puntos hay diez leguas de distancia y $x .5$ r 9 varas de diferencia de nivel, en qr está Perote más alto que Jalapa, por lo cual corresponden á cada legua 152 varas de desnivelamien. rresponden á cada legua 152 varas de desnivelamien-
to o a cada una de estas 46 de distancia de carniro 
comprendidos r de Guajaca, o, San Jerbni. Misteca, el de lián, el de ChoTasco, los de -ultepec, el de os Ásientos de catecas, el del amente, el del

en hemos reco. htepec, coge las de San Miguel I Real Nuevo, Guajaca, los le Chatoa, San Teguacan, de oro y de Jonoilco, Pachuca, Cardenal, San el Pinar, el de torce, Guadal. de Leones, con an. Al lado de y el volcán de

n lo dan á entricas practicaido de la Nueva ue el territorio a á corta dife. icie del mar, ni ta distancia de tañas elevadas, del terreno bajo isiblemente por llegar á cierto en largas dis.

Idministrador de la Valenciana en desde $1 .^{\circ}$ de 685.221 cargas 3.027 .890 pesos . la misma épo y pérdidas de ron 17.540 cajas 3 pesos: se ocu-

quc cuentan 22 amente llanas, or lase, or cuestas tendi cste tránsito cocste tránsito $\mathrm{co}$ iento, $\delta$ una vara de 7.000 varas 10 verifica desde $\mathrm{Ja}$. 3 hay diez leguas cia de nivel en por lo cual co por lo cual co e desnivelamien incia de cainiuo
La llnea que limita y subdivide la parte baja de la alta, puede considerarse pasa por el paraje nombrado de Perote, 32 leguas distante de Vera. cruz en la dirección del camino, y 14 y $\%$, de la marina en línea recta desde la ensenada de Cha. chalaca 6 de San Carlos. Según las observaciones barométricas que anunciamos en nuestro via. je de Veracruz á Mejico, es la elevación de Perote sobre el nivel del mar $1.365 \mathrm{y} \%$ toesas de Paris, altura igual, muy próximamente como en adelante veremos, á la que tiene la América me. ridional cuando allá se sube al país alto; y sin embargo, esta misma altura es la que conserva esta América en muchas leguas, casi hasta Guanajuato, como lo confirman las experiencias ba. rométricas, las cuales determinan las alturas de los parajes siguientes sobre el nivel del mar en esta forma:

\begin{tabular}{|c|c|}
\hline & Toesas de Paris. \\
\hline El Lencero...... & $459 \%$ \\
\hline 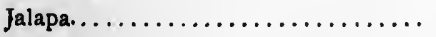 & 714 \\
\hline 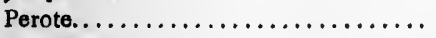 & $1.365 \%$ \\
\hline La Venta de Soto........... & 1.350 \\
\hline Méjico ...................... & 1.323 \\
\hline La Goleta: una hacienda 59 leguas de & \\
\hline Perote y 19 de Guadalupe......... & $1.336 \%$ \\
\hline En Guanajuato la Mina de la Valenciana. & 1.330 \\
\hline $\begin{array}{l}\text { Fn la casa del Administrador de la Va- } \\
\text { lenciana } \ldots \ldots \ldots \ldots \ldots \ldots \ldots \ldots \ldots \ldots\end{array}$ & I. $34{ }^{8} / 6$ \\
\hline Pachuca...$\ldots \ldots \ldots \ldots \ldots \ldots \ldots$ & $1.35^{\circ}$ \\
\hline $\begin{array}{l}\text { Real del Monte cn la posada del lugar } \\
\text { donde están las minas del Conde de }\end{array}$ & \\
\hline
\end{tabular}

\a se vé, pues, cuán pequeñas son las díe. rencias de nivel que hay entre los parajes que mencionan estas experiencias, $y$ que pueden nuy bien considerarse todos en una misma altura ris. pecto á las grandes distancias que median de unos á otros. Nótanse, sin embargo, algunas irregularidades, que proceden pirticularraente del declive que forma el terreno pa.a a je corran las aguas á buscar su centro. La población de Guanajuato, por ejemplo, I28 y $1 /$ l leguas de Perote por camino y 87 en línea recta : está más baja que 10 ordinario del país unas 8 vo varas caste. llanas, según la referida obse: vación de D. Antonio Pineda, que concuerda bitn sun otra hecha en I777 por el Sr. D. Antonio Ulloa; pero esta diferencia estriba únicamente en que esta pobla. cion se halla situada en una quebrada cuyo suelo difiere casi toda aquella cantidad ciel terreno ad. yacente, el cual empieza á descender á distancia de diez leguas en el paraje que nombran la venta de Temascatio. Por el contrario, entre el lugar de San José de Jula y la hacienda de la Goleta,

cantidad con efecto bastante insensible y que prueba la poca pendiente de las cuestas por donde se sube hasta Perote. distantes entre sí cuatro leguas, se atraviesa una cordillera no muy elevada, pero lo suficiente para dividir los paises; y el nivel de altura permanece, sin embargo, con muy corta diferencia á uno y otro lado, mediante que la Goleta está sólo $5^{6}$ varas más bajo que Perote, y todo el país tomo 3.150 más alto que el nivel del mar; termino que parece fijó la Naturaleza para que se experimentase en este país un temperamento templado e igual, favorable para los vivientes y propicio para las producciones de la tierra. Indícase bien esta igualdad de temple en las experiencias del termómetro: en parajes resguardados del aire frío 6 de las impresiones del Sol, marca constantemente desde i 7 á $20^{\circ}$ : expuesto al aire libre en los meses de Junio, Julio y Agos. to, baja á $13^{\circ}$ con la frescura de la mañana, $y$ sube á 22 desde las doce á las dos del día, no dando en él el Sol ni toldándose el cielo, como sucede muy de contínuo. La misma regularidad se nota en las observaciones del barómetro: este instrumento, que en las orillas del mar padece alteraciones muy frecuentes y sensibles, permanece constante semanas enteras desde luego que se sube á la parte alta, siendo su mayor variación de una línea. A este respecto conservan tam. bién igualdad las producciones del terreno, como lo manifiestan varias de las plantas que en él se crían, y tienen una analogía muy marcada con las del clima cálido de nuestras provincias meridionales de España.

En la estación que el Sol se retira al tropico dic Capricornio, el frío aumenta, $y$ en parajes llega á helar, aunque no en todos los años, y nunca cin exceso. Siéntese, sin embargo, el frío, $y$ se necesita de abrigo; pero siempre se hace sensible la influencia del Sol por su ménos dis. tancia al ztnit, $y$ al paso que parece frío, siente el cuerpo lá. ardentía del Sol de un modo parti. cular; las 'zentes carecen de aquella fuerza física que parece demostrar la robustez de sus cuerpos, y ácii los animales no tienen todo el vigor que en otras partes. Una carreta regular, que en $\mathrm{Eu}$ ropa la arrastran dos bueyes, aquí necesita de cinco 6 seis para tirar del mismo peso; y bien sea que por ! $a$ intensidad del calor experimentan los animales una grande disipación, 6 que ésta se verifique en las plantas y sean los pastos de poca sustancia, siempre parece que este decaimiento de fuerzas procede del calor. No á otra causa debe atribuirse tambien la falta de vigor que experimenta aquí aquella clase ite gentes, cuyas ocupaciones diarias piden un trabajo sedentario y mental de muchas horas. Les faltan las fuerzas para sobrellevarlo en las tardes y noches, $y$ el que re ve obligado á ello, siente muy luego los efectos funestos de aquellas tareas, en la mengua de su salud. Esta debilidad la experimentan los jovenes igualmente que los de edad avanzada, y 
es una prueba de que la laxitud y flojedad que se atribuye á estas gentes procede más bien de los efectos del clima que de vicio contraído por la costumbre. Esto mismo lo confirma á cada paso la experiencia, en los europeos que se establecen aquí, pues á poco tiempo participan como los naturales de los mismos hábitos que éstos, de forma que cualquier individuo hace en su ejercicio en Europa duplo ó triple trabajo que trasladado á estosi países.

Otras señales del efecto del calor que aquí se experimenta, son la debilidad de estómagos y la dificultad de perfeccionarse la digestión; la contrariedad de ciertas bebidas y particularmente el que sea nocivo el uso del vino. Parece que el cuerpo tiene necesidad de adquirir vigor con bebidas más espirituosas como el aguardiente y los licores: la experiencia ha manifestado at estas gentes, que el uso moderado de estos últimos á ciertas horas es provechoso, así como contrario el del vino, á ménos que no se use con mucha moderación y poca frecuencia. El vino, dicen, les enciende la sangre, relaja los estómagos, irrita las bilis $y$ causa diarreas que no se corri gen fácilmente. Las fluxiones que contínuamente se padecen, son también efecto del calor de la sangre, y la mayor parte de los accidentes que se contraen en estos paises, tienen origen en lo cálido del clima, á pesar de lo templado del aire $y$ de la frescura que manifiesta exteriormente.

No puede, á la verdad, ocultarse que esta parte de la América que ahora describimos, es la región peculiar del Sol, según las señales que muestran los meteoros de la atmósfera. Durante el verano, desde Mayo hasta fines de Setiembre, se sienten tormentas formidables de rayos $y$ true. nos que terminan en copiosas lluvias. Las mananas de esta estación son, por lo regular, serenas, $y$ el cielo se mantiene despejado y alegre hasta que ha pasado el Sol el meridiano; algún tiempo después empiezan á levantarse algunas nubes por el Norte, y en breve tiempo ocupan parte de la atmósfera, hasta que á las cuatro de la tarde se extienden, cubren enteramente el cielo, empieza la tormenta, y á breve rato caen aguaceros copiosísimos que templan el calor que ha percibido la tierra en el discurso del día. En estas lluvias parece consiste la sanidad del país cuando se retardan 6 dejan de ser frecuentes, son comunes las enfermerlades y estas en general las que proceden por efecto de mucho calor. Hay largas temporadas en que estos aguaceros y tormentas se repiten diariamente y con igual fuerza en unos días que en otros, sin que por esto se formen pantanos, ni la tierra se enguacharne, pues con poca pendiente que tenga el terreno se encuentra seco á la mañana siguiente. En la estacion del invierno, cuando el Sol pasa al hemisfe. rio opuesto, cesan enteramente las tormentas y las lluvias y re. an vientos fuertísinios y secos, que se hacen tan incómodos como las recias tor. mentas del verano. En cuatro meses del año no cae enteramente gota alguna de agua. Los vien. tos más frecuentes entonces, aunque no contínuos, son los del Norte: con ellos viene el irío, y en algunos años llega al término de helar. La falta de lluvias, la cualidad seca de la atmósfera y la frecuencia de los vientos recios que aumentan ordinariamente desde el medio día en ade. lante, ocasionan en esta estación enfermedades correspondientes á ella, siendo comunes las pleu. resíns y constipaciones.

Cuanto hemos dicho relativamente á las fre. cuentes turbonadas del verano en la parte alta, se verifica igualmente en la baja, siendo ordinarias las tormentas de aguaceros y truenos. La única circunstancia en que se diferencian consiste en que por lo regular cmpiezan después de puesto el Sol, 6 bien entrada la nache, y que también vienen acompañadas de vientos violen. tos, cuya duración es la misma que la tormenta. Esta abundante humedad con que se templa la tierra, del calor que adquiere durante el día, hace ménos incómodo el temperamento de la parte baja: no obstante, es bien sensible, y lo sienten los cuerpos con bastante fuerza. Hay algunos ar̃os en que se adelantan los calores, $y$ hace en Marzo y principios de Abril un bochorno y sofocación tan fuerte, como en los meses más rigurosos del verano. Esto sucede cuando reinan los vientos del Sueste ó Sur, pero pasados algunos días, vuelve á moderarse y á ser más soportable su temperamento.

Sabido es nde en los parajes cálidos de la Zona T6rrida, los efectos del aire en el barómetro son más sensibles que en los países situados fuera de ella, y que áun en aquéllos lo son más don. de reinan con fuerza los vientos Nortes. Esto mismo se verifica en Veracruz, y anteriormente hemos manifestado las grandes variaciones que experimenta el barómetro entre los vientos húmedos del Este 6 los secos del Norte, pero en la parte alta de esta América, las alteraciones del bar6metro son poco considerables, $y$ no puede de. terminarse con seguridad el efecto de los vientos secos del invierno respecto de los húmedos del verano: esto parece conduce á creer que en las alteraciones del barbmetro tiene más influencia la elasticidad del aire que su peso 6 gravedad. El calor intenso propio de este clima, juntamente con la dilatación del aire en esta región de la atmósfera, no deja de causar alguna novedad en la respiración, mucho más cuando se camina por terreno desigual, aunque no sea muy áspero: los naturales, como criados en el aire sútil de esta atmósfera, no encuentran novedad y trafican por todas partes con la mayor agilidad; pero los no acostumbrados sienten la fatiga desde los prime. 
ros pasos y una sensación desagradable por la falta de densidad en el aire que se respira.

A esta propiedad del aire debe sin duda atribuirse al de que sean desabridas las carnes que sirven de alimento. Se tiene notado que en los temperamentos verdaderamente frios y áun en los cálidos, son de gusto $y$ subor regular, pero aquí, á pesar de los abundantes pastos con que se nutren, son generalmente insípidas y de poca sustancia: los pichones, los pollos, pavos y gallinas $y$ las aves de caza, tienen el mismo defecto $y$ pa. rece confirman la idea de que la calidad del aire que se respira contribuye mucho á que los jugos nutritivos produzcan en las carnes la variedad que se nota.

Debe también atribuirse á la calidad del aire la particularidad de que no cause perjuicio á la salud la abundancia con que se usa del picante, siendo tal, que entra siempre cono ingrediente principal en el alimento común de las gentes pobres. Este consta del chile 6 pimiento mojado y molido en piedra, condimentado después con sal $y$ aceite, en cuyo compuesto que llaman cremole, mojan las tortillas de malz, $v$ es el único alimen. to que tienen $y$ con el cual se sustentan y viven como si usasen comidas más sustanciosas. Antes digimos yue el uso del aguardiente era general y que probaba bien: ahora añadiremos que sucede lo mismo con el cremole, y que á pesar te que uno y otro parecen contrarios á lo reseco del clima, viendo que los efectos no son malos, es menester convenir en que 6 estas cosas obran como estimulante, 6 que la costumbre las hace soportables, sin que por esto suceda lo mismo á los que no se hallen connaturalizados con ellas.

Todo lo expuesto hasta aquí debe entenderse en términos generales $y$ sin las excepciones á que da lugar en muchos parajes las circunstan. cias locales del terreno. Es digno que no pasemos en silencio de que hallándose el pueblo Ja. lapa en la mediania de altura que corre desde el mar hasta Perote, participe de los mismos fenó. menos que la parte alta del país: el aire no se altera con los accidentes que sobrevienen en la atmósfera; las plantas participan algo de las que son comunes en una y otra altura, $y$ finalmente, el temperamento de aquel lugar es con muy corta diferencia igual al de la parte alta, como lo de. muestran las observaciones del termómetro de que dimos razón anteriormente, de modo que todo nos lleva á pensar que sin elevarse en la $Z$ ona Tórrida más altura que la que tiene Jalapa, la atmósfera es inalterable. Sin embargo, puede muy bien suceder que el grado de calor constante de esta villa sea causado en parte por la figura particular del terreno, compuesto de varios cerros médianos que forman valles y quebradas, $y$ por la inmediación de los dos cerros de Perote y
Orizabal, que corresponden al Poniente y Sur de aquella población.

Aunque el reino de Nueva lispaña sea de una extensión tan dilatada como lo manifiestan los mapes, es menester advertir que lo poblado $y$ verdaderaniente reconocido hasta el día se extiende únicamente hacia el Norte hasta los presidios que liacen frontero á los países habitados por naciones bárbaras. Más adelante daremos algunas noticias sobre estas naciones, y ciñendo. nos á tratar por ahora de esta parte que denominamos poblada, es preciso distinguir también que nuestras ideas en Europa relativamente á lo que se entiende por país poblado no pueden aplicarse con exactitud á esta nueva región del mundo. Habitanla en el día, según los cálculos más probables, unos tres millones de almas que, como repartidas $y$ subdivididas en tan dilatada extensión, apenas permiten se conserven en algunos parajes los rastros de la especie humana. En los puntos que se aproximan al centro y que á voz común pasan por los más pobiados, se ve que esta población sólo consiste de unas hacien. das de muchas leguas de extensión, en donde hay ranchos 6 lugares de indios que se mantienen en paz y encuentra el caminante los auxilios que necesita á distinción de lo que sucede en provincias más distantes, en cuyos tránsitos se co. rre el riesgo de paciecer los insultos de los indios bárbaros. Hay no obstante aigunas grandes cju. dades como Méjico, La Puebla, Guanajuato, Guadalajara, Querétaro, Valladolid y otras de ménos nombre, cuyo vecindario, no sólo es crecido, sino,que de algunas de ellas podrían formarse otros muchos lugares sin que sintiesen aquéllos la falta de sus vecinos inútiles; pero en contraste de estas gruesas poblaciones, se presentan otras varias que sólo sirven de llevar el nombre. La mayor parte de los pueblos constan únicamente de indios, adonde están congre. gados unos cuantos españoles, muy pocos son de españoles solos, y áun en este caso su número se aumenta siempre con el de indios y otras castas mixtas; los demás, aunque toman el nombre de pueblos, usurpan en realidad este título, pues no parece deba dárseles tal á unas chozas mal concertadas y confusamente esparcidas sobre un terreno habitado no en todo de indios. Tal es en realidad la constitución de los poblados á diferencia de que en algunos parajes son los negros, mulatos, coyotes y sus semejantes los que hacen la pluralidad. Esto puede traerse como una prueba irrefragable de que las frecuentes transmigraciones de nuestros europeos á ésta América no han sido capaces de indemnizar en ella los perjuicios que su falta causó desde luego al si:eio patrio.

Como el comercio de este Reino se halla reducido en sus artículos de extracción á los que 
he nos mencionado anteriormente, la agricultura por consiguiente no ha hecho hasta ahora los progresos que parecia prometer. Hablando en general, los habitantes de Nueva España sólo siembran para comer, y no es extraño porque faltando extracción y no pudiendo guardar las semillas en muchas partes, no se encuentra des tino para lo sobrante, y los labradores miden sus siembras á aquello sólo que pueden vender prontamente. Esto tiene el grave inconveniente de que en dos años seguidos, uno de esterilidad y otro de corto acudir, entra la escasez, sigue la necesidad y á ésta las epidemias, como se verificaron en los años de $x 785$ y 86 , de cuyas resul. tas retrocedió el Reino perdiendo mucha parte de su poblacion, de la que aún no se ha restableci. do enteramente, pues trastornos de esta clase no se remedian en muchos años de bonanza.

Opinan algunos que siendo el Reino fértil y el terreno que ocupa capaz de contener al mayor número de habitantes de la Europa para culti. varlo, si se extendiese á más manos la agricultura, suponiéndola hoy abatida, acaso por la abundancia se vería entonces arruinada, mayormente correspondiendo el terreno con su natural fertilidad. Pero este argumento tiene origen en un principio equivocado, porque la decadencia de la agricultura no procede del número grande 6 pequeño de los que en ella se emplein ni se trata tampoco de extenderla hasta llegar á cultivar et Reino entero. Hay en esto como en todas las cosas un límite que parece fijar la Naturaleza, y que ésta enseña bien á los interesados por medio de la experiencia, pues ninguno ciertamente se empeña en continuar las empresas que ve le arruinan.

Lo que parece cierto es que en el modo y medios de disfrutar la tierra consiste mucha parte de la felicidad á que aspira la fatiga de conseguirla. in hay pais más abundante de oro y plata que el lieino de Nueva España, y á pesar de esta a' u.dancia son infinitos los pobres miserables, acaso sin ejemplar en otros reinos de Europa, aunque muchos lo sean voluntarios. Esto mismo puede decirse de la agricultura, su aba. timiento no depende de la feracidad del terreno ni de su mucha extensión sino de los medios y modo con que se disfruta. Aclararemos esto. En los tiempos de la conquista y poco despues, las circunstancias obligaron entonces á señalar por premios de servicios porciones crecidas de tierras en los repartimientos que se hicieror, y vinculadas éstas en los sucesores, se han formado unas haciendas tan dilatadas de 20, 30 y más leguas, que es imposible las cultiven sus poseedores sin grandes fondos $y$ una cierta probabilidad de la extracción de los frutos; tan desigual división de las tierras ha traído por consiguiente un sistema particular de agricultura. Esta honrosa y útil ocupacion sólo se fractica en lo general por los indios, y ellos solos cultivan los campos acaso bajo de un modo demasiado severo y falto de arte, mientras que unos poco 'españoles hacen su suerte á costa del ganán, pi jue los demás dueños de fincas sólo las obtienen casi precariamente y $\mathbf{s a .}$ crificando sus utiiidades al obsequio de los arrendatarios y oprimiéndolos violentamente siempre que no corresponden las cosechas, vienen los de. más al fin á abandonar sus rústicas tareas 6 si al. gunos subsisten es á costa de valerse de buenos ó malos medios.

Llamámosles malos 6 buenos porque no faltan de ambas clases. De la primera especie son ciertas tareas que sin paga alguna hacen vencer á los indios en ocasiones extraordinarias y dias de fiesta, y de la segunda, la ganancia que sue. len adquirir en los avíos de ropa y otros repartimientos que acostumbran darles á cuenta de sus salarios cua ido son á precios justos. Regla. dos estos últimos arbitrios en las haciendas que por su situacion y distancia traen comodidad al trabajo, serian indiferentes 6 cómodos, pero si las poblaciones mejorasen de condición en su situación y accidentes, no serian tan precisos estos surtimientos que con facilidad caen bajo la tira. nia y la usura, porque no hay otra parte de dondr pueda tomarlos el trabajador sino del hacen. dero.

Hay otra causa no tan conocida, pero no menos cierta, que influye de algún modo en la decadencia de la agricultura. Todos 6 los más de los indios de los pueblos, hacen sus pequeñas siembras, cuyas cosechas, multiplicadas por el número de estos trabajadores, componen un todo bastante regular. Jamás entra el indio en el cálcu. lo de costos ni cuenta con su trabajo: ve delante de sí seis 6 siete cargas de trigo, necesita dineros para el tributo, para la bebida, para la obvención ó para otras urgencias ménos justas, y se desha. ce á cualquier precio del fruto de sus sudores. Continuamente se ve que la carga de trigo que apenas podía salir de la era por 50 reales vollon, la dan por dos pesos, y áun por un peso en las provincias internas ménos distantes, y es claro que esta haratería ofende al valor que debieran tener las cosechas de aquellos que necesitan divercn modo de subsistir y costear las labores; de suerte, que no aprovechándose ellos de estas semillas, ni cediendo en beneficio público por las manos en que caen, forman un comercio vicioso de regatonería, que daña al cuerpo de labradores.

También puede decirse que los consumidores no son hoy todos los que debían ser, porque la superfluidad de gentes en el pequeño recinto de un pueblo falto de industria, es un mútuo perjuicio entre ellas mismas para tener todas ocupación. De este principio se sigue la escasez de 
medios, para subsistir la miseria, el abatimiento de esplritu y todos los males que como sombra de la indigencia la acompañan generalmente. Kista necesidad hace desconocido de millares de gentes el sabor del pan, y el maiz y los frljoles son todos los alimentos en que libran su conservación por más baratos aunque más groseros, y si algún dla alcanzaron sus fuerzas á tomar un poco de mala vaca, es sin duda porque la fortu. na no les mira entonces del peor aspecto. Todo esto aucede con aquella multitud de castas que componen la que llaman en el país gente de ra. $7.6 \mathrm{n}$, pues tratando del indio, ya se dijo anteriormente que el cremole y unas tortillas de maiz eran su alimento diario. Hé aquí, pues, por ejemplo, en el trigo, una abundancia provenida de falta de consumo, á la que llamaremos mejor sobrante, que produce la miseria.

Estas son, en nuestro entender, las causas principales que contribuyen ä la decadencia de la agricultura; la experiencia que el local su. pedita y las reflexiones de sujetos instruídos $y$ prácticos en la materia ( $r$ ), nos confirman en la idea de que el daño principal estriba en los. duenos de fincas y en los trabajadores. En aciucilos, por la razón explicada, y además, porque siendo muy rara la posesión rústica que nn soporta sobre si una cuantiosa suma de princi, ies, los snás piadosos, siempre que las cosechas no corresponden con liberalidar, $\delta$ que su abundancia hace bajar de precio los frutos, son cousecuencias precisas los concursos, sesiones, enıbargos, etcétera, quedando perdido un hombre y con él mu. chos sin ejercicio, si no hay otro, pronto á tentar fortuna donde el desgraciado acaba de desengañarse de la suya (2). Finalmente, estriba también en los trabajadores, porque siendo éstos todos indios 6 de otras castas de color quebrado, falta esta ocupación á los españoles, que se desdeñan de igualarles en tareas que ya han hecho ménos correspondientes á su calidad y jerarqula.

El comercio de la Nueva España se puede di. vidir, como el de los demás reinos, en las dos clases de externo é interno. El primero es el que hace con la Península, y en cuanto á su estado y progresos, hemos dicho lo suficiente hablando de Veracruz, y nada nos resta que añadir á lo allí expuesto, pues los consumos de este Reino dependerán siempre de la mayor 6 menor abundan-

(x) Dictamen dado por el Sr. Areche, Fiscal de Real Hacienda en Méjico, al Virey de aquel Reino.

(2) Por estas razones, y convencido el Rey do los males que causa una desigualdad tan notable en la propiedad y distribución de las tierzas ha resuelto $\mathrm{Su}$ propiedad y distribución de las tiertas ha resuelto Su Cuerpos ilustrados del Reino de Nueva España, que tos poseedores de tierra la pueblen dentro de un año con apercibimiento de perder el dominio y venderse a otros.-Real Cédula de 14 de Febrero de 1805 . cia de la pluia que produzcan las minas y de los que rinda de su agricultura.

Por lo que toca al giro interior, este se hice en parte con las cosas mismas que vienen de afuera, y los demás articulos que le componen, son muy débiles y de poca monta. El algodón y la lana únicamente pueden exceptuarse de esta regla, por el grun consumo que tienen ambas especies en varios tejidos que de ella se hacen; no obstante, tampoco forma un ramn opulento, ni hay operario alguno que viva socorrido de estos artefactos. Cada indio tiene en su casa los tela. res correspondientes para trabajar sus toscos vestidos de lana, $y$ en las castas que llaman de razón, es casi general la inteligencia en la fábri. ca de manteles de algodón, y es la tela de su uso. Las hilanderas son tantas cuantas son las muje. res de estas mismas castas y las españolns po. bres, porque siendo el arbitrio que más fácilmente se presenta, sin otro costo que el del algodón en greña y el de un huso á veces sin rueca, á él se aplica por necesidad un número considerable de familias. Llegada la tarde, que es la hora de este giro, y poniendo los compradores la ley del precio por la abundancia del efecto, sacrifican las vendedoras sus afanes por el miserable precio de un real 6 medio que emplean luégo en un corto y grosero sustento. Los demás ejercicios reatieren á estos fondos que no pueden alcanzar ndos, y algunos otros ramos hail mudado su giro por precisas alteraciones á que indujeron las cir. cunstancias del Estado.

Yuede también decirse en este ramo como se dijo en el de la agricultura, que los consumidores no son todos los que debían ser. Cerca de 420.000 indios tributarios que se consideran por las matrí culas, son otras tantas familias que nada gastan ni reciben del comercio de nuestras manufacturas. Todos ellos se visten con una piel de venado, de que forman unos imperfectos calzones, y ocho ó diez libras de lana muy basta, que seguida á lo largo y descosida en su mitad vale por camisa, y se la atan con un orillo 6 cinta de la misma materia, sin mangas ni otra figura. A esto añaden un pequeño sombrero de palma muy mal tejida, y he aquí todo lo que necesita un indio para presentarse igualmente delante del arado que del altar. Las mujeres visten de la misma lana; en unos pueblos la dan figura de enaguas cortas, y en otros se envuelven en tres 6 cuatro varas de tejido, atándolo con un cinto. El huipil de lana 6 algodón sirve en unos parajes de sobretodo, en otros de camisa, y en algunos se ponen del mismo modo que los hombres dos varas de lanilla basta, ceñida como se ha dicho. La diferencia de temperamento, ia comodidad ni la decencia les mueve á más industria; pero esta es obra de sus manos, pues poco 6 nada reciben de nosotros. Sin embargo, ha decaído mucho en estos últimos 
años el trabajo grosero de sus géneros con la mejor vista que tienen los que traen los catalanes, y ya los usan preferentemente por su mejor apariencia y más cómodo precio.

Debe agregarse igualmente al número de inviduos que no concurren como consumidores al fomento interno del Reino. el que componen las diferentes castas que llalian de razón y resultan de las tres principales, blancos, indios y negros.

Estas castas son muchas y se multiplican en grı $n$ manera, como que además de ellas mismas contribuyen contínuamente á su propaqación las tres ramas principales. Las inclinaciones de estos raros entes son correspondientes á su color y esfera. El número de ellos, que es excesivo, tiene por vestido unas bragas de mantas de algodón y tres varas de la misma materia, que al dormir sirve de cama y al levantarse de capa; otros llevan una colcha, sin más camisa, y no pocos andan sin calzones. Esta es la clase que constituye la pluralidad de habitantes, y la falta de arraigo les facilita mudar de domicilio cuando la miseria, la persecución ó el capricho les lisonjea de mejor fortuna en otro país.

El Gobierno, con las más eficaces providencias, ha disminuído considerablemente este tropel de gente desnuda $y$ holgazana que inundaba antes las grandes ciudades; se han vestido muchos, otros se han ahuyentado, y últimamente no se ven ya $\tan$ frecuentemente en las plazas y calles; pero siempre faltan estos consumidores al ramo de comercio, que unidos á los indios, componen un número prodigioso.

Ya se deja inferir que á proporción del estado de los ramos anteriores debe ser igualmente débil el de la industria de este Reino. Con efecto, bien examinadas las ocupaciones que á ella tocan, se ve que en la mayor parte no son otra cosa que unos entretenimientos transitorios. El excesivo número de artistas, en todas clases, trae por consecuencia la abundancia de artefactos; el exceso de éstos, su menor valor; éste, la poca utilidad de los artistas, y de consiguiente la pobreza.

Para persuadirse de estas pocas reflexiones, basta entrar en cualquiera de los puestos públicos de Méjico y otras grandes ciudades, y deteniéndose á oir las persuaciones de los que intentan vender sus obras industriales, se verá que desde el desatinado alio precio que solicitan, bajándoseles más allá de lo creible y manteniéndose firmes, entregan por dos 6 tres reales de América una pieza cuyo justo valor se acerca al de un par de pesos. Finalmente, como esta in: dustria no hace un artículo de comercio exterior para esperarse por ella alguna riqueza dentro del Reino, tiene su orígen y destrucción, sin que su consumo pueda ocasionar la dependencia de al- gún extraño, ya en lo relativo al lujo 6 en los artículos de segunda necesidad (I).

Todas las clases, pues, de la furtuna de Nue. va España, quedan reducidas según lo expuesto, á las que produce el giro y laboreo de las minas. Estas son muchas y muy ricas, y no hay duda que este Reino tiene un gran interés en su fomento y conservación. También lo tiene el Real Erario por los derechos que recauda, y lo tiene en gencral toda la Nación, porque cuanto mayores sean los fondos del Reino, tanto mayores serán sus consumos en artículos de lujo y otros esenciales de que le provee la Península. Pero hay que advertir que aunque los montes de la Nueva España sean unos perpétuos criaderos de los metales preciosos, no pueden, sin embargo, extraerse de sus entrañas, sino exponiendose á muchos ries. gos, aventurando grandes capitales y exigiendo últimamente la concurrencia de varios materiales, de cuya abundancia ó escase $z$ depende en gran manera la decadencia ó el aumento de la extracción. A tres pueden reducirse los ramos de auxilio que indispensablemente necesita el laboreo y beneficio de los metales, á saber: el azogue, la sal y los instrumentos y utensilios de hierro labrado y sin labrar, acero, bestias, sebo para alumbrarse, con otros varios enseres que se introducen en los Reales de Minas. El prinero del azogue, se administra por cuenta de la Real Hacienda, que lo tiene estancado con el fin de que nunca falte $y$ para fomentar también los consumos de las minas de Almadén en Esparia, cuya calidad se recomienda mucho, y con cuyo motivo nunca se han aprobado los experimentos hechos para descubrir y trabajar en este Reino las minas de azogue; pero como la calidad del estanco, las crecidas cantida. des de este ingrediente que se necesitan anual. mente (2), los acaecimientos de las guerras, y úl. timamente los varios estados que han tenido las minas de Almadén, han sido siempre causa de que escasee este preciso rnaterial, de modo que actualmente en la mina de la Valenciana, la más rica de todo el Reino, se benefician generalmente por fuego los metales que denominan polvillo $y$ jabones, aunque con más costo y menos produoto de plata por ia escasez de azogue; parece consiguiente que el beneficio de las minas de azogue del Reino debería ser libre y conservar los que la labrasen la perpétua piopiedad de ellas, semejan-

(1) El comercio interior de este Reino, igualmente que su industria, han recibido un nuevo impulso desde que S. M. tuvo a bien eu 1795 establecer dos consuladre, ino en Veracruz y otro en Guadalajara, ademas del que ya existía en Mśsico desde tiempos muy antiguos.

(2) En 1767 rayaban on 80.000 quintales de azogue los que se consumfan anualmente en las minas de Nueva España, según los datos de un quinquenio; on el día seián mucho más por el conocido adelantamiento de las minas. 
al lujo ó en los (I). fortuna de Nue. gún lo expuesto, reo de las minas. no hay duda que en su fomento y e el Real Erario lo tiene en genc. to mayores sean ayores serán sus - otros esenciales Pero hay que ad. - la Nueva Espa. ps de los metales rgo, extraerse de é muchos ries. les y exigiendo úlarios materiales, depende en gran nto de la extracramos de auxilio el laboreo y beneogue, la sal y los rro labrado y sin alumbrarse, con ducen en los Reaogue, se adminisenda, que lo tiene a falte $y$ para fode las minas de lad se recomienda za se han aprobaa descubrir y trade azogue; pero crecidas cantidanecesitan anual. las guerras, y úl. le han tenido las iempre causa de ial, de modo que alenciana, la más ian generalmente, minan polvillo y y ménos produoto ue; parece consiminas de azogue nservar los que la le ellas, semejan-

Reino, igualmente uevo impulso des -stablecer dos con, en Guadalajara, ico en ias minas de us quinquenio; en onocido adelanta. temente á lo que se practica con los dueños de las de plata y oro.

Por las mismas razones, tampoco debería estancarse la sal, tan necesaria para el beneficio de los metales, y áun sería muy conveniente corriese libre de todo derecho desde sus criaderos hasta los parajes en que se consume.

$Y$ aunque para fomentar el ramo de minería, libertó S. M. del derecho de alcabalas á los instrumentos, herramientas y otros enseres que sirven en las minas, siempre que se introdujesen por mineros, es claro que esta ventaja sólo pueden disfrutarla los acaudalados que los hacen venir desde luego por su cuenta, y no los pobres que faltos de fondos suficientes tienen que comprarlos paulatinamente á los introductores de distinta profesión y con el sobrecargo del eninciado derecho.

Estas reformas y concesiones que ya propuso el Consulado de Méjico en 1788, originarían al pronto en el Erario una disminución anual de 200.000 pesos en los derechos que ahora cobra según los cómputos del mismo Consulado; pero siendo evidente los aumentos que en adelante tendrían ías minas, lo es también el que este aumento produciría á la Real Hacienda otro muy superior al que ahora rinden !a sal y demás ren. glones que se introducen por cuenta de los dueños en los Reales de minas, conciliándose de este modo la comodidad del vasallo con las utilidades del Erario.

Habiendo recibido nuestros instrumentos en Méjico el 12 de Febrero como antes dijimos, nos preparamos para el viaje, y lo emprendimos el 15, dirigiéndonos á Acapulco, adonde ya nos aguardaban las corbetas. El camino, por consiguiente, fué precipitado y pocas las observaciones que con este motivo pudimos hacer. No obstante, indicaremos brevemente lo que advertimos, mezclando nuestras noticias con las que nos cor municó D. Antonio Pineda, y adquirió en su tránsito desde Acapulco á Méjico, advirtiendo que todo lo relativo á Historia Natural pertenece exclusivamente á éste benemérito naturalista.

Desde que se deja á Méjico se encuentran arboledas, cuya frondosidad no recrea tanto por su variedad, como las que hay en otras partes. Las componen los pinos, los madroños y algún olmo; pero lo que más abunda en esta sierra son los plantíos ordenados del magüey, de donde se saca el pulque. Hasta llegar al llano de Cuerna. vaca, el terreno se ocupa todo con las materias volcinicas; el casco del caballo resuena en hueco, la capa de tierra vegetal es muy escasa, los árboles disminuyen y se extenúan, signos todos positivos de que esta montaña es un volcán extinguido, en cuyo cráter, según las apariencias, se sitúa el pueblo de Guichilague. El azogue apenas llega en estos parajes á $\mathrm{II}^{\circ}$ en la escala del termómetro de Reaumur.

Luego que se atraviesa una gran calzada y se desciende al llano de Cuernavaca, el tem. ple varía sensiblemente y el mercurio sube hasta $20^{\circ}$.

En las inmediaciones del pueblo hay un gran pozo de mina de que se sacan piedras verdosas y unos hermosos hidrófanos. En él se cuentan al. ternadas las capas de lava y tierra hasta el número de 2o. Debajo se encubrirán otras tantas, que por lo ménos indican un número igual de erupciones, y si es aplicable en el Nuevo Mundo lo que se dice del Vesubio y Etna, será inmensa la antiguidedad de este país. El pequeño volcán de Suchiltepec exhala aún humo por algunas de sus grietas, pero esto no impide el que se alojen en ellas una multitud de arañas. Sus faldas están cubiertas de arbustos que nacen entre las piedras calcáreas vitrificales. La amenidad de aquel llano abundante de aguas vivas y canales que proporcionan los riegos, es comparable, aunque en es. cala menor, con la frondosa Granada.

Hasta muy cerca de Aguastlán en que acaba la región de los volcanes, aparecen las bancas $y^{\prime}$ pudins de lavas en abundancia; la puzolana se mezcla con la tierra vegetal, y las piedras son cenizas cndurecidas, señales todas de la inmediación al volcán de Jumiltepec.

Desde aquí hasta Atquilapan, domina principalmente el granito de diferentes colores; en adelante el terreno abunda en esquisto negro y arenario con partículas de shorl en capas que inclinan al Oriente. Las plantas herbáceas abun. dan poco, pero prosperan las arboledas. En ellas figuran los espinos blancos, amates, quiebra achas y mamanchis, cuya fruta es comestible. Los huecos se ocupan por las mimosas y los aromos plinnzrios que llaman en el país Tepeguajes; en la inmediación de los arroyos ó aguas encharcadas, los arums con sus hojas acorazonadas, suplen por los juncos y ranúnculos.

Los montes del Real de Tasco abundan mucho en el esquisto calcáreo, azul, blanco y atravesado de vetas; en partes se ve que esta misma piedra pasa al geneis 6 esquisto magnesio. Hay algunas paries ondulantes del género de la esteatita que parece en la textura al que llaman $\mathrm{Cra}$ $y e$ de Brianzón; las h.y amarillosas, pardas, con manchas plumiformes azuladas ó cenizas, grasas al tacto. La matriz ordinaria de sus vetas metálicas es el cuarzo; todas ellas corren de Sur á Norte con alguna inclinación Noroeste-Súste. Son casi paralelas entre sí, nacen del Oeste y se inclinan hacia el Este formando ángulos de $45^{\circ}$ próximamente. Todas las montailas próximas taladradas con galerías, socavones y lumbreras que profundizan á más de 300 varas, restuenan extrepitosamente con los golpes de me.tillos y barre. 
tas con que despedazan sus entrañas los codiciosos humanos.

El monte más elevado de todos los de la comarca, es decididamente el que nombran Guiteco, del cual según los prácticos, arrancan todas las retas metálicas que corren por los demás. Tiene guijarros del pórfido, fondo blanco y alguna tierra bolar muy untuosa. Hay un esquisto que se compone de arcillas, cuyos guijarros parecen maderas petrificadas; constan de capas cóncavo-convexas como de un leño podrido con estrías que pareccn las fibras longitudinales. Su vegetación es bien lozana, cría cuatro especies de encinas. La cuchaulla, cuya hoja de más de un palmo se dobla, formando como una teja ó cilindro, su periferia ondulada con espinas en los ángulos y la superficie inferior lamosa y blanca. Un madroño tortuoso con la corteza roja de quien el tronco se divide en tres ó c'ratro; sus hojas son ovales, salen en hacecillos, y el fruto en racimos rojns de un agradable sabor. La murtilla de Maluinas, una especie de echinops 6 diptacus hojas radicales como el maitajon de España aunque espinoso. Un napalium parecido al oriental. Un laurcl con la hoja angosta. Un aloes, varias especies del pino y cedro, y otro que llaman acle. Hay bromelias parasíticas y una especie de zacatón.

Los monumentos de la historia de la Naturaleza se ven esparcidos por todas partes de una manera indeleble, $y$ en estos momentos se hallan en las petrificaciones submarinas. En un guijarro calcáreo había una gran glaude intro. ducida entre la sustancia pétrea, prueba segura de que el grande Océano bramó algún día sobre estas rocas.

Todo el país que media entre Iguala y la Ca. ñada del Zopilote presenta generalmente muy buena tierra negra esponjosa como en casi todos los llanos de Nueva España, y se arriendan en cuatro cargas de maiz por una de sembradura, se ven bancas esquistosas, cuya dirección es siem. pre al No:te y otras penetradas de bancas rojas metálicas. El calor se siente extraordinaria. mente; el azogue sube á $30^{\circ}$ en la escala del termómetro de Reaunur, y á las ocho de la noche no baja de 27 , sin que se goce en ellas la frescura de los pueblos de la costa, pero en invierno es necesario vestir de paño. Los terrenos que siguen por la Cañada del Zopilote se rodean de montes calcáreos en que abundan mucho las casias, las bignonias, la hipocratca bolubilis y varias gramas que en los recodos del arroyo sustentan á los ganados extenuados y flacos. Estos paises aunque abundantes de ríos caudalos s, se resienten de una total sequedad porque la industria del hombre no ha dirigido sus cauces, ni con útiles sangrias hace regar el terreno.

Antes de llegar á Chilpansingo las tierras son esponjosas, llanas y fecundas, y en los caminos se ve una piedra arcillosa, cenicienta con clavos de piedra verde que parece serpentina. Los valles de Tixtlan, Chilapa y Chilpansingo, cuyos tres pueblos forman un triángulo isósceles, se subdividen y rudean por mon. tañas generalmente calcáreas en que se uncuen. tran esquistos, y algún granito como el maisillo del Perú y Chile. A trechos se ven bolones del mármol, conchitas con pctrificaciones bien conservadas. Todas ellas sc adornan con grandes cactus comunes á toda la Nueva España aunque de especies desconocidas la mayor parte. Entre ellos numera el que asemeja á un tenebrario ó araña de cuyo tronco común salen otros varios que se van subdividiendo has:: multiplicarse en roo ramos ó columnas perpirimulares; cada una está surcada de ocho ó diez estrías: su flor es blanca y el fruto encarnado por dentro. Otros hay como los que llaman sirius el cual es una columna solitaria de más de diez varas de alto. Estas llanadas se cubren de una tierra negra esponjosa bastante fértil que acude generalmente con el 50 por uno. Las siembras se hacen ordinariamente en Julio y se cogen por Noviembre, pero lo que abunda más son los árboles frutales. El temperamento de estos paises suele variar mucho del día á la noche; en ésti no baja sin embargo de $18^{\circ}$ el termómetro en la escala de Reaumur y en lo fuerte del calor sube á 24 . Mucha parte del año llueve con furia, acompañado de relámpagos y truenos: en el invierno suele helar y cuajarse el agua. Los insectos y reptiles de estos países tropicales, adquieren tal agilidad luégo que el Sol está sobre el horizonte que burlan las mayores diligencias para lograr su captura. Aquí se crían tres especies de abejas particulares que todas dan buena miel aunque silvestre. Entre las diversas clases de hormigas, ya domésticas, ya silvestres, $b$ ya más $o$ ménos venenosas que se encuentran, es la más particular la que llaman arriera, tan tenaz e.ı su mordedura que jamás sueltan la presa. Los in: dios reunen los labios de las heridas, y los aplican de modo que los cosan pelfectamente, y cortando después la hormiga por la cabeza queda su acicate asido y la herida bien cosida.

Las montañas que siguen están compuestas de piedras calcáreas de mármol arcilloso y algún granito. Los campos de estos parajes se visten de un verde agradable, $y$ todo anuncia un país abundante de aguas, aunque sólo se aprovechan en tal cual milpa (r) y alguna caña. En los cauces de los arroyos que rodean á Mazatlan, se ven adobes calcáreos guarnecidos de puntillos ú oquedades con surcos semicircubolares como en

(i) Este es el nombre que dan en el país á los sembrados de malz. 
das, $y$ en los bsa, cenicienta parece serhilapa y Chil. man un trián. lean po" mon. ue se uncuen. mo el maisillo en bolones del ones bien conn con grandes spaña aunque $r$ parte. Entre n tenebrario ó n otros varios multiplicarse ij-Mlares; cada estrías: su flor r dentro. Otros el cual es una varas de alto. a tierra negra zcude generalmbras se hacen en por Noviem. los árboles fru. s paises suele en éstiı no baja to en la escala alor sube á 24 . 1 furia, acomen el invierno Los insectos y , adquieren tal re el horizonte as para lograr pecies de abeuena miel aun. clases de hores, 6 ya más ó ran, es la más an tenaz $\mathrm{e}_{\boldsymbol{u}}$ su presa. Los in: das, y los aplif cctamente, y a cabeza queda :osida.

án compuestas cilloso y algún ajes se visten iuncia un país se aprovechan ia. En los cauMazatlan, se de puntillos ú olares como en las orillas del mar. La formación de sus monta. ñas contiguas acolinadas y bajas, parecía ser moderna; en ellas no se crian árboles, y las piedr.ss parecían submarinas; por lo ménos estos taladros se hicieron por los insectos cuando se hallaban cubiertas de agua y en el estado de tierras, pues la disposición local del terreno no permite que se hiciesen por :as lluvias.

Los cerros que continúan después de Mazatlan son deprinidos, si se exceptúan los del $\mathrm{Cu}$ chintlan y el Peregrino. Esta frondosa montaña tiene cascadas y arroyos que repartiendo la fragosidad por toda ella, la convierten en un bosque delicioso. Los aromos, las gleodesias y mimosas, divididas en infinitas especies, suplen en estos paises por las carrascas. Las vides, las salizas, las bignonias, las marías, los mulatos, los dragos, el palo brasil, el bálsamo, el granadillo, el roble, el pino y otros árboles corpulentos, elevan sus cervices acopadas sobre ellus, y la diversidad de verdes hermosos de que se visten, ofrecen un espectáculo variado á que contribuye mucho el aura fresquísima que se respira.

El reino animal no es el ménos abundante en estas fragosidades; en ellas se ven los tigres, leones, jabalíes, venados, tejones, ardillas negras, pardas, grises y las voladoras que emulas de. las aves, recorren las arboledas de rama en rama. Los aires están poblados de loros, cotorras, pericos, urracas, el pájaro flojo y otros varios.

El terreno inmediato al Peregrino se cubre de arcillas que después de las lluvias se endurecen y resultan varias piedras. Sus fértiles colinas remedan á las de Málaga; en ellas se encuentran con abundancia dos clases de vides de las que la una tiene sarmientos desnudos, de una pulgada de grueso, y el grano de sus racimos del tamaño de aceitunas. Entre el Peregrino y el pueblo de los Arroyos solamente se conservan arboledas en las quebradas; se ve el esquisto con partículas micáceas negras, un arenario blanco en grandes canteras y un cuarzo con partículas de mica doradas como oropel.

Desde los Arroyos en adelante, el suelo se presenta compuesto de un arenario arcilloso hlan. co, con partículas de mica. El país, entrecorta do por arroyos y torrenies, ofrece, no obstante, la imagen de la aridez en la estación de las secas; pero la superficie arenisca del terreno, $\sin$ ninguna planta herbácea, presenta, sin embargo, unos árboles pomposos y llenos de lozanía. Es. tos corpulentos vegetales profundizan en la tie. rra, donde encuentran en todos tiempos los jugos que necesitan, y los ojos investigadores de un botánico hallan siempre árboles en flor $\mathrm{y}$ una prinavera continuada. Con dificultad se encon. trará un vergel mís delicioso en la estación de las lluvias; las aguas cristalinas reunidas en las quebradas multiplican al infinito las plantas americanas. Una variedad maravillosa de aves de hermoso canto y plumaje se reunen en sus orillas, y todo, en fin, se resiente de una primavera deliciosa. A esta pintura agradable de las quebradas, se opone, como en contraste, la suerte de los montes y colinas condenadas á una soledad perpétua y á las quemas continuadas con que destruyen sus bosques las pocas familias que los habitan; se ven troncos denegridos, tierras roji. zas y cenizas pavorosas que manifiestan la desolación que las oprime.

En vano la bienhechora Naturaleza procura sacar partido hasta de sus mismas ruinas, pues aunque aumenta la capa de la tierra vegetal, estas quemas indiscretas en los parajes inaocesibles, desbaratan unos bosques que serían de infinito precio á estar. en otros parajes, $y$ hacen eriales $e$ intransitables aquellos montes.

El beneficio que dan á la tierra en estos pai. ses se limita á solas tres operaciones: desmontar ó jacotear; quemar el terreno, y luégo sembrar dos años seguidos; al tercero. se le deja sin cul. tivo, pues la experiencia acredita que da en yerba, y si se aplica el arado, es tan feraz, que da en vicio; las siembras ordinarias son de maiz y algodón en el mismo año: éste se siembra cuan. do aquél está crecido, y á su cosecha en el tiempo seco, prospera ya el algodón.

Todas las tierras comprendidas desde el Pe. regrino hasta Acapulco, pertenecen en propiedad á varios hacendados de Méjico que las alquilan ó venden al que las quiere labrar: el arrendamien. to ordinario son cinco pesos si crian ganados, y dos si sólo las siembran sin que se les limite el terreno: tan cierto es que las mayores riquezas que of rece el suelo valen muy poco si la indus. triosa mano del hombre no las dirige. Leguas cuadradas de tierras pingües, en que se cría el brasil, el palo tinte, el copal y otras diversas drogas preciosas, se ven casi sin estimación, condenadas á las llamas ó á ser abrigo de fieras. Un terreno de cuatro leguas de largo y dos y media de ancho, se vendía en la actualidad en 500 pesos.

Antes de llegar á la Sabana, las colinas y cerros presentan una aridez que se contrasta por la vegetación lozana de los Arroyos. Luégo se atraviesan varias montañas frondosas de granito, el cual se presenta bajo diversas modificaciones, y de su descomposición mezclada con alguna tierra bolar, resulta una capa vegetal que hace útiles aquellos terrenos, aunque en lo general se encuentra muy poca agua. Desde aquí se entra ya en las playas arenosas en que se sitúa Acapulco.

Las casas de esta ciudad son ordinariamente de ladrillo y teja las de la gente acomodada, y las de los pobres, chozas cubiertas de paja. Los 
muebles de éstas consisten en vasijas de calaba. za, algunas ollas de barro y tal cual taza ó plato de china, sobre un basar de una tablilla sujeta con cordeles, en lugar de palomilla de madera. Su alimento, que es el pan de maiz, lo preparan sobre una piedra, teniendo una olla á la mano con la cual remojan la pasta de cuando en cuan do. El gallo para pelear, es mueble que no falta en casa alguna, áun en las más pobres, y se halla atado á una estaca. La hamaca es otro mueble en que emplean algunos de estos naturales una buena parte desu tiempo. Suelen poner sobre sus camas unos toldos formados de la tela que llaman miliñaque, clara y barata como las de es parto que hacen en Madrid, con cuyo arbitrio se preservan de los animales ponzoñosos que abundan aquí en gran manera. "Yo maté, dice D. An"tonio Pineda, dos escorpiones que halle en la "casa donde vive ei Gobernador, y en una excur"sión encontré dos víboras del país, cuya mor"dedura es de mucho peligro, si el enfermo no "recibe pronto socorro." Celebran mucho para ello el antídoto de una pepita que viene de China y ilaman Chabalonga, mascada y tragada con la saliva: el sabor de esta pepita es amargo, y general entre cstas gentes el concepto de sus virtudes.

Hállase esta ciudad en latitud Norte de $16^{\circ}$ $50^{\prime} 4 \mathrm{I}^{\prime \prime}$ y longitud occidental de Cádiz de $93^{\circ}$ $4^{\prime} \mathrm{I}^{\prime} \mathrm{Oo}^{\prime \prime}$ (I). Su clima está caracterizado por uno cle los peores de la América y expuesto 11 terrible azote de los terremotos, con que la Naturaleza compensa en estos contornos la prodigalidad de otros bienes. Hallándose fondeada en el puerto la corbeta Descubierta el 30 de Marzo de I79I, se percibió á la una y media de la mañana un temblor muy fuerte que se sintió áun á bordo, precediéndole desde algunas horas todos los amagos de una próxima tempestad, y algunos minutos antes un ruído fuerte subterráneo, acompañado del aullido acostumbrado de los perros, y de la natural propensión de una muchedumbre de peces que se aproximaban á la superficie del agua, abandonando instantáneamente la mayor profundidad. La duración de este terremoto fué de $20^{\prime \prime} \mathrm{y}$ su movimiento de trepidación no dejó de causar extragos considerables en algunas casas.

Hace en este país un calor excesivo, y la bebida que tienen en mayor estimación para re. frescarse es el Charape. Esta la componen cogiendo en adecuada vasija cierto rocío ó agua que destilan los racimos de cocos mientras vege-

(I) Jmitimos repetir aqui los medios quo han servido para establecer esta situación, igualmente quo los de la costa Noroesto de América, pues todos se han detallado con plolijidad en la Memoria antes citada que sirve de apéndice al viaje del Estrecho do Juan de Fuca. tan en sus altas palmas, á cuyo fluído llaman Tuba; después le echan la melaza concreta que aquí llaman panocha y es la Chancaca de la América meridional, y hecho esto la dejan fermentar y resulta una bebida agridulce, análoga á la limonada y muy parecida al Guarape que en el Perú sacan de la caña. El Charape, bebido en cantidad, hace tiro á la cabeza y embriaga. También se hace aquí la chicha de piria, conocida en varias partes y de que hablar ?mos luego.

Los hombres de este país y de la clase que puede llamarse la plebe, que es el mayor número, andan en chalecu y calzones, usando muy rara vez las medias. Las mujeres van igualmente descalzas y en mangas de camisa. Esta es de miliñaque, y las enaguas de telas pintadas de listas de azul en fondo blanco. El mayor lujo lo ponen en lo que llaman $c l$ paño, y es una pieza cuadrilonga de algodón, bordado 6 con listas. Algunas lo llevan con fondo de oro y de mucho precio.

Todos los vecinos, casi sin excepción, es gente de color y negros libres, y tienen varios privilegios por estar alistados en las compañías de milicia, y en ocasiones de guerra se arman y ejercitan en la táctica militar.

Los vecinos más acomodados y que tienen los empleos de tropa, son los pulperos; el vecindario parece pobre y su comercio esencial se reduce al de la Nao de Filipinas y á lo quie se gasta en el tiempo de la feria de ésta. El surtimiento de las tiendas es la mayor parte de efectos de la Nao, como telas de algodón listadas, miliñaque, etcétera. Para formar juicio de la calidad de este giro podrá servir el estado siguiente que manifiesta el valor parcial y general de los artículos que se introdujeron en Acapulco procedentes de Filipinı, en I79I, á saber:

\begin{tabular}{|c|c|}
\hline & 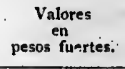 \\
\hline éneros de oro y plata.. & $11_{2}$ \\
\hline lem de seda.............. & 209.309 \\
\hline dem de algodón.......... & $3 \times 1.897$ \\
\hline e comcstibles y especerí.. & 7.108 \\
\hline e drogas..................... & 3.018 \\
\hline e varias clases............. & $5.87 \mathrm{r}$ \\
\hline Total.... & 537.315 \\
\hline
\end{tabular}

De Acapulco para Filipinas se extrajo en $\mathrm{x} 792$ lo siguiente:

Plata

\begin{tabular}{|c|c|}
\hline 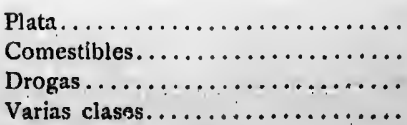 & $\begin{array}{r}1.832 .402 \\
10.88 \mathrm{I} \\
40.262 \\
7.161\end{array}$ \\
\hline Total. . & 1.890 .706 \\
\hline
\end{tabular}


fluído llaman concreta que ancaca de la la dejan ferulce, análoga uarape que en ape, bebido en abriaga. Tam. , conocida en luégo.

e la clase que mayor núme- usando muy van igualmen. sa. Esta es de $s$ pintadas de mayor lujo lo es una pieza con listas. Aly de mucho

excepción, es tienen varios las compañias ra se arman y

y que tienen eros; el vecin. esencial se relo yue se gasta El surtimiento e efectos de la as, miliñaque, calidad de este nte que manie los artículos procedentes de

\begin{tabular}{|c|}
\hline $\begin{array}{c}\text { Valores } \\
\text { en } \\
\text { pesos fuartes. }\end{array}$ \\
\hline$x_{12}$ \\
\hline $\begin{array}{l}209 \cdot 309 \\
3 \times r .897\end{array}$ \\
\hline 7.108 \\
\hline 3.018 \\
\hline $5.87 \mathrm{r}$ \\
\hline $537 \cdot 3^{1} 5$ \\
\hline rajo en 1792 \\
\hline $\begin{array}{c}\text { Valores } \\
\text { en } \\
\text { pesos fuertes. }\end{array}$ \\
\hline$x .832 .402$ \\
\hline 10.881 \\
\hline 40.262 \\
\hline $7 \cdot 16 x$ \\
\hline
\end{tabular}

Los ramos comunes de la Real Hacienda, y los particulares y agenos que componen el total de las rentas Reales que entran en la Caja de di. cha ciudad, ascendieron el año de r790 á 462.954 pesos fuertes, en esta forma:

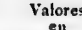
pesos fuerten.

Por los ramos comunes de derechos que pagan las embarcaciones y su cargamento a la entrada y salida del puerto. Por los ramos comunes de tierra, como alcabalas, tributos Reales, bienes mostrencos, etc................... Por los ramos particulares de tabacos, inválidos y otros.

Por Idem agenos, como depósitos, Monteplos, ingresos extraordinarios, etc. ....

$$
\text { Total......... } 462.954
$$

Con el producto líquido de estos ramos se cubren las atenciones de la Caja, que se reducen á gastos de la Nao de China, aparte del situado de Filipinas, subsistencia de la tropa y hospital Real, sueldos de empleados y otros gastos eventuales, tomando ó depositando en la Tesorería general lo que falta 6 sobra según los años, para cubrir las cargas referidas. Los sueldos de individuos empleados que se satisfacían en Acapulco por esta misma Caja, ascendian en $\mathrm{x} 79^{\circ}$, á 10.346 pesos.

El puerto de Acapulco, el mejor y más segu. ro de toda la costa meridional de Nueva España, es de figura tan circular como lo manifiesta su plano; de buen tenedero y abrigado de todos vientos. Viniendo á tomarle del Oeste y áun del Sur siempre que no haya una seguridad absoluta en el punto de longitud, será bueno dar vista á los farallones que llaman los Ciguatanejos que están como 35 leguas al Oesnoroeste de Acapulco. Son de corta extensión, muy unidos y blanquean tanto, que se distinguen á más de cinco leguas. Entre ellos y la costa hay canal limpio con 9, I2 y I5 brazas de agua, y como dos leguas al Norte está el puerto de Ciguatanejo. que es seguro y capaz, y para tomarle se dejan á estribor dichos islotes. Casi en la medianía desde ellos á Acapulco está la punta 6 morro de Satlan, y sigue la costa al Esueste, alta en lo interior pero baja hacia la marina.

Entre seis ó siete leguas al Oeste del puerto, están las playas de Coyuca, de arena muv blanca y de más de tres leguas de extensión: delante tiene placer de 20 y 25 brazas de agua que sale dos millas y es muy bueno para fondear. Desde que se llega por el Oeste á estas playas se ven dos picos altos, cuya figura mirada en el primer cuadrante ha hecho llamarlos las Tetas de Co. yuca; corren Nornoroeste, Sursueste, con la boca de Acapulco, y se enfilan uno con otro cuando dcmoran casi al Norte. Más al Este estrí un cerro aislado que llaman de la Brea, muy no. table por ser igualmente que las Tetas de Coyu ca, las tierras más altas de todas las inmediat al puerto.

Corre con la boca de éste, Norte-Sur, y es mu, buena marca para buscarle viniendo de mar en fuera, pues sin más que situarse de modo que demore el cerro de la Brea al Norte $\%$, Nordeste, 6 más Norte, y atracar la costa en esta dirección, se distinguirá la Isla Roqueta que á alguna dis . tancia se confunde con la tierra firme, y se verá el abra que dicha isla hace con las tierras orien. tales que llaman del Marqués. Entre las dos se forma la entrada del puerto, y es imposible desconocerla aunque por mucha cerrazón ú otra causa no se vean las marcas anteriores, pues basta saber que está al fin de todas las tierras altas y que desde ella pará el Este sigue por más de 20 leguas una playa de arena dilatadísima. A ve. ces lleva el agua bastante fuerza para el Esues. te, y asi, si sobreviene la noche y se resuelve pasarla fuera, es preciso ceñir con tiempo á tres ó cuatro leguas del puerto y mantenerse en bordos cortos sobre las gavias para no descaecer. Al entrar se atracará la Isla Roqueta, sin otra atención que pasar á regular distancia de la isla rasa llamada la Baja, y con vientos escasos ó contrarios se darán los bordos que convengan para ganar el fondeadero delante de la población. En estos bordos se tendrá cuidado con el bajo de Santa Ana, que es de arena y cascajo, y no tiene más de dos brazas y media de agua. Desde él se marca el farallón del Obispo al Este $6^{\circ}$ Norte, y al Sur $4^{\circ}$ Este la punta de Grifo.

Hasta el dia ha sido costumbre amarrar los buques en Acapulco Este-Oeste, dando este último cable en tierra á algún cuerpo muerto de la playa, pero en esta disposición quedan las en. barcaciones muy expuestas, especialmente desde Mayo hasta Octubre, que hay recias turbonadas y fuertes golpes de viento del Nordeste, Norte y Noroeste. Nuestro dictamen es que se tiendan las anclas á barba de gato Nordeste y Noroeste, con lo cual tambien se preserrará más de la bra. ma, el cable que siguiendo la práctica establecida, se había de dar á tierra.

Casi es insensible la fuerza de la marea en esta costa, y en el puerto asciende y baja con poca regularidad entre cuatro y cuatro y medio piés. Siempre que anochece á la vista alguná embarcación, hacen candelada en un montecito in mediato al pueblo, donde está la vigía, lo cual sirve de buen reconocimiento durante la noche. 


\section{Noticia de las principales expediciones hechas por nuestros pilotos del Departamento de San Blas al reconocimiento de la costc: Norocste de América, desde el año I774 hasta el I79I, extractada de los diarios originales de aquellos navegantes (I).}

Habianse abandonado ya mucho tiempo hacia los descubrimientos emprendidos por mar para conocer las costas scptentrionales de la Nueva España, cuando el Conde de Lacy, Ministro del Rey en la corte de Rusia, avisó en 7 de Febrero de 1773 al Marqués de Grimaldi, Secretario entonces de Estado, que habia saipido continuaban los rusos desde $176_{4}$ sus expediciones de Archangel y Kamchaka á las costas del Lste, que no podían $\mathrm{s}^{r}$ : otras que las costas de la América: que en consecuencia de las utilidades con que retornaban de dichas navegaciones por los acopios que hacían de pieles de nutrias, martas y zorras, había autorizado la Emperatriz en I 766 á una compañía de negociantes de Kamchaka, para hacer este comercio exclusivo. Que dicha compañía constaba de 24 comerciantes y 200 cosacos que habian formado establecimiento en la costa de América por los $64^{\circ}$ de latitud, y que se em. pleaban en la caza, pcrsuadiendo $y$ áun obligando al mismo tiempo á los indios á que paga. sen tributo de pieles á la İmperatriz. I últimamente, que la Rusia tenía miras de mucha importancia en estas exploraciones.

Enterado de todo el Rey, mandó comunicar estas noticias al Virey de Nueva España, Don Antonio Bucareli, ordenándole al mismo tiempo precaviese los inconvenientes que podían seguirse en el continente de América, por los descubrimientos de los rusos. Contestó el Virey que le parecía indispensable saliesen anualmente algunas embarcaciones de San Blas, para que re. corriesen la costa al Norte de Monterey; y habiéndose dispuesto así, fueron nombrados á su solicitud scis Oficiales de Marina con destino á mandar dichos buques.

Mientras llegaban á California estos Oticiales, dispuso el Virey á fines de 1773 se equipa-

(I) Incorporado ya el Teniente de uavio Espinosa a la corbeta de su destino, nos abstendremos de publicar aquellos puntos del Diario de su naveg.:ción que ya cstán expuestos al tratar dol viaje de las corbetas, y nos limitaremos a insertar unicamente los estudios y datos curiosos dignos de scr conocidos que constan en el Diario do tan ilustrado Oficial.-(Nota de P. de $N$.) se en San Blas la fragata Santiago, nombrando para que la mandase al primer Piloto de la Armada, graduado de Alférez de fragata $D$. Juan Pérez, único Oficial de Marina que había entonces en California y á cuyo cargo estaba el Departamento. En la instrucción que se dió á este Oficial, se le mandaba salir de San Blas á principios de Enero, y que después de tocar en Monterey para dejar las Memorias que anual. mente se remiten á aquel presidio, navegase hasta la latitud de $60^{\circ}$, atracase la costa reconociéndola, y que ba jase al Sur, inmediato á ella. Y aunque las órdenes de la Corte mandaban expresamente qua se desalojase de grado ó por fuerza á cualquier extranjero que se hallase establecido en estos parajes, tomando el Virey un partido más suave, dispuso que en el caso de encontrar algún establecimiento se subiese más al Norte y se tomase posesión del país en latitud más septentrional á fin de poder alegar este derecho cuando las circunstancias lo exigiesen. El primer párrafo de la instrucción decía así:

"La benignidad del Rey que fió á mi cuidado weste Gobierno de Nueva España, no sólo me "impone la obligación de conservarle estos vas"tos dominios, sino también la de procurar - aumentarlos en cuanto me sea posible por me "dio de nuevos descubrimientos en la extension "de lo no conocido, para que atraídos los nume"rosos indios sus habitantes, del dulce, suave; "apetecido vasallaje de S. M., se derrame en v ellos la luz del Evangelio con la conquista espi"ritual que les separe de las tinjeblas de la idola"tría en que viven, y les enseñe el camino de la usalvación eterna, que son las verdaderas inten"ciones que en tales empresas animan el piadoso "Real corazón de S. M. Con este objeto justo é "importante, he resuelto que $\dot{D}$. Juan Pérez, "graduado de Alfére $z$ de fragata de la Real Ar"mada, se encargue de este descubrimiento. En "todos los parajes en que tome posesión, pondrá "por señal una cruz grande de madera, forman"do su peana de piedras, en la que escondera "una redoma de vidrio, dentro de la cual intro. "ducirá una copia de escritura de posesión, fir- 
- mada por sl, por el Padre Capellán y los dos "Pilotos, 'tapándose bien la botella con pez para "que en los tiempos futuros se conserve mejor "este documento y sirva de auténtico testimounio.,

Salió Pérez, de San Blas, el 25 de Enero de I774, y aprovechando los terrales del Nornordeste y Nordeste, procuró embocar entre las Islas Marías y la costa; pero no pudo y arribó el $3^{\mathbf{I}}$ á media noche á pasar al Sur de ellas. Los vientos continuaron del cuarto cuadrante y la mar venía picada, de forma que hasta el 20 de Febrero no pudo cambiar del bordo del Norte. A este tiempo, después de algunas calmas, roló el viento al tercer cuadrante, cuando se hallaba por $26^{\circ}$ de latitud y en $20^{\circ}$ al Oeste de San Blas. Sobre 33" ${ }_{50} 0^{\prime}$ rindió los baos mayores y arribó por esta causa al establecimiento y Misión de Santa Bárbara, que está por $32^{\circ} 44^{\prime}$ de latitud. Este puerto tiene su boca al Sur, ancha de una y media milla, y la canal corre tres al Nornordeste, inclinándose más al Este, torciendo después hasta el Sueste, de modo que no es posible hallar surgidero más abrigado. El 5 de Abril se hizo á la vela para Monterey, $y$ con viento siempre del Norte ó Norte $1 /$, al Nordeste, siguió la vuelta de fuera, hasta que por $3^{1^{\circ}} 5^{0^{\prime}}$ de latitud y casi 200 leguas á la mar, rolaron al segundo cuadrante y áun al tercero, y atracó la costa fondeando el 7 de Mayo en Monterey. Dejó este puerto el 6 de Junio y con vientos del Norte y Nornoroeste y áun Noroeste, siguió alojándose al Oeste, descaeciendo al Sur hasta $33^{\circ}$. En este paralelo $y$ á distancia de $\mathrm{I} z$ o leguas de tierra, se le alargó el viento hasta el Nordeste y hasta el Sueste, y áun más cuando se hallaba por $37^{\circ}$ Norte y 170 leguas de tierra. Le acompañó el Sueste con cerrazón hasta $47^{\mathrm{n}}$ y $\%$, y entonces, llamándose al Sur y Sudoeste, aclaró el tiempo y pudo atracar la costa. Subió hasta $55^{\circ}$, y viendo que las cerrazones le impedian examinar la costa, desistió de continuar más al Norte, y con ánimo de tornar retrocedió el 2i de Julio, reconociéndola y costeándola á la distancia que permitían los vientos. A las tres de la tarde del 7 fondeó por 25 brazas de agua, fondo arena negra y lama, $\cdot a$ una legua de la tierra más cercana y en latitud de $49^{\circ} 3^{\prime}$ y $3^{\circ} 5^{I^{\prime}}$ al Oeste de Monterey. Llamó á este surgidero, de San Lorenzo, y una punta que estaba seis leguas al Nordeste, la nombró Santa Clara, y otra que quedaba dos leguas al Sueste, la denominó punta de San Estéban. Desde ésta sale una reventazón considerable, casi una legua en vuelta del Noroeste.

Habiendo entrado viento duro de travesía, no quiso Pérez empeñarse, y dió la vela continuando su navegación, sin otra ocurrencia particular hasta su llegada á Monterey que la de haber reconocido un cabo que llam6 Cabo Men. docino por $40^{\circ} 8^{\prime}$ de latitud, sin tribargo de que los primitivos navegantes cuentan á aquél $I^{\circ} 37^{\prime}$ más al Norte.

En $55^{\circ}$ de latitud trato Pére $z$ con los indios, $y$ observó que eran robustos, alegres y de hermosos ojos. Las mujeres de buen parecer, $y$ te. nían el labio inferior taladrado, en cuya aber. tura introducian un óvalo de diferentes tamaños. Hizo cambios con los naturales y advirtió tenian en sus manos una media tayoneta y un pedazo de espada, que conceptuó Pérez serían de la gente que el Capitán 'Tschirikoio mandó en su lancha en este inismo paraje y jamás volvió. Llegó Pérez á San Blas el 3 de Noviembre de 1774 .

Ė año de 1775 dispuso D. Antonio Buca. reli se armasen en San ilas la fragata Santiago, al mando rel Teniente de navío D. Bruno Hezeta que llevaba de segundo al Alférez de fragata D. Juan Pérez; la goleta Felicidal ai mando del Teniente de frarata D. Juan Manuel de Ayala, y por su segundo el Oficial de igual clase Don Francisco de la Bodega Cuadia: el paquebot San Carlos, al Teniente de navío D. Miguel Manrique, siendo su Piloto D. José Cañizares. Este buque debía pasar á examinar el puerto de San Fran. cisco, y los dos primeros tenían destino de descubrir y reconocer lo no visto hasta entonces en la costa Noroeste, desde los $65^{\circ}$ de latitud para el Sur. Con este objeto se proveyeron de víveres para un año, y dieron ia vela, de San Blas el $\mathrm{r} 6$ de Marzo de 1775 . Li i 9 del mismo mes, por enfermedad del Comandante del paquebot se le confirió su mando á Ayala y quedó Cuadra con el de la goleta, y habiéndos. echado al Oeste, reconocieron el 3 de Abril la Isia del Socorro, que no ofrece ninguno á los navegantes.

A I 20 ó I 30 leguas de la costa se alargó el viento hasta el Nordeste fresco, y con él navegaron al Norte y Oeste hasta los $32^{\circ}$ de latitud que calmó y roló al Sudeste flojo con tiempo oscuro; subieron al Norte y resolvieron atracar la costa para fondear en ella, como lo verificaron, en un puertecito que llamaron de la Trinidad, que está situado por $41^{\circ} 7^{\prime}$ de latitud y $19^{\circ} t^{\prime}$ al Oeste de San Blas.

Aqui permanecieron desde el ir de Junio hasta el 19 , hicieron agua y leña con toda comodidad, observaron las mareas que en el discurso de veinticuatro horas $\%$ crecen y menguan dos veces, $y$ habiendo sucedido la conjunción el día 13 fué la pleamar á las doce y bajó el agua nueve piés.

El Puerto de la Trinidad es un perfecto carenero, resguardado de los vientos del cuarto, primero y segundo cuadrantes, y sólo descubierto á los del tercero; es $\tan$ hondable, que pieden los buques atracarse hasta echar la plancha en tierra, pero precisa forrar los cables de tierra, porque hay mucha zahorra en las inmediaciones 
de la playa. La variación de la aguja era en esta época de $14^{\circ}$ y $\%$ al Nordeste. La tierra es muy adaptada para producir todos los frutos de Europa; los montes están cubiertos de elevados pinos envejacidos por los siglos, y de cuyos restos se mejora por instantes c- terreno. De aquí resulta una perspectiva verde y olorosa que encanta los sentidos, pues la mezcla de la rosa, orégano, lirios, llanten, apios, cardo, manzanillas y otras infinitas, producidas con aquel vario desorden con que sabe la naturaleza divertir los ojos del observador, forman el jardín más deleitoso y agradable. Los pinos son de extraordinaria altura, y de los que se hallaban derribados en las playas, se midieron algunos de sesenta varas de largo y dos de diámetro por la parte inferior. Esta madera es muy propia para arboladuras, baos y tablazón, y de hebra tan derecha, que los naturales con sólo aplicar cuñas en un extremo, dividen aquellos grandes tron. cos rajándolos directamente hasta el extremo opuesto.

El I9 de Junio dieron la vela con vientos del Nornoroeste y Norte, los cuales duraron hasta hallarse 120 leguas de la costa, y entonces mudaron al Oeste y otros rumbos que permitían ganar al Norte. El I $_{3}$ de Julio volvieron á fondear solure la costa por $47^{\circ} 24^{\prime}$ de latitud y $21^{\circ} 19^{\prime}$ longitud de estima al Oeste de San Blas. La goleta ancló como á una legua al Norte de la fragata, y estaba rodeada de arrecifes, entre los cuales impensadamente se metió. El I 4 rompían los bajos y fué preciso esperar la creciente para dar la vela, y queriendo aprovechar el tiempo de ba. jamar en hacer agua y leña, despachó una canoa con siete hombres bien armados con sables, pistolas y diez y ocho cartuchos para su defensa; pero apenas desembarcaron cuando salieron de un bosque inmediato 300 hombres, que dando sobre los nuestros los hicieron pedazos á lo que se cree, pues sólo se vió á dos que se defendían con sus sables, y se arrojaron, por huir, al mar, donde seguramente perecieron. De los otros no se supo más, y al cabo de dos loras se retiraron los naturales abandonando la play'a.

Era medio día, los arrecifes no reventaban, y perdida la esperanza de volver á ver los marineros, se dió la vela. En esto, los naturales bien persuadidos del poco número de hombres que quedaba á bordo, armaron sus canoas y llegaron por la popa de la goleta. Allí se detuvieron, y al cabo de muchas conferencias destacaron una canoa con nueve mozos de gallarda estatura, que se acercaron á cuatro ó seis varas del costado, vestidos con hermosas cueras de defensa, y tem plando los arcos para el ataque. Dispararon sus flechas, $y$ "nosotros, dice el Diario, a unque ape" nas éramos los suficientes para la maniobra, na w vegando por entre aquella cordillera de bajos,
- teníamos preparadas las armas sobre cubierta y - les hacíamos fuego con tres fusiles, pues no "éramos en más número los combatientes."

Se hicieron á la mar los dos buques que habían atracado la costa por este paraje en busca del Estrecho de Juan de Fuca, que coloca por esta

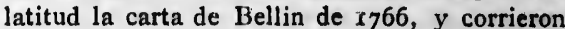
cerca de tierra desde $48^{\circ} 20^{\prime}$ de latitud para el Sur, y no hallaron puerto, ensenada ni boca que diese margen para sospechar dicha entrada. Los vientos duros del Noroeste, las enfermedades que empezaban á manifestarse en la fragata, y lo adelantado de la estación, determinaron al Coman. dante Hezeta á arribar, y recorriendo la costa para el Sur, tomar puerto en Monterey.

No fueron de este parecer los de la goleta, que llenos de entusiasmo de descu' ridores y fa. vorecidos de la oscuridad de la nothe, se sepa. raron de intento de la fragata, ciñendo para el Oeste cuando aquélla arribó el 30 de Julio, y siguiendo después su navegación llegó á Monterey el día $3^{\circ}$ de Agosto. Ya habían recibido en la go. leta el reemplazo de los siete hombres, pero áun así, era una temeridad increible tentar á subir á mayores latitudes con un buque tan pequeño, de malas propiedades, con pocos víveres, y últimamente, sin los requisitos necesarios para tamaña empresa. Sin embargo, poseídos de su idea, el día 4 de Agosto ya estaba la goleta como I70 leguas de la costa, por latitud de $46^{\circ} 16^{\prime}, y$ habiendo llamado el viento al Oeste, navegaron en vuelta del Norte. El 5 renovaron su conferencia el Comandante y Niloto, toman. do en consideración la estrechez á que debian re. ducirse por los pocos víveres, siendo así que la pequeñez de la goleta les había obligado á depositar las carnes en la fragata: el corto número de tripulación que exigía la reunión de las fuerzas de todos, la falta de recursos en aquellas costas dezconocidas, y otras dificultades que le sugería su buen juicio; pero ocupados del mismo entu. siasmo que les obligó á separarse de la fragata, se mantuvieron firmes en su primera resolución.

E1 I6 vieron la costa, y notaron perfecta: mente un monte, que colocado sobre un cabo muy saliente, se distinguía por su figura de pan de azúcar. Su cumbre estaba cubierta de nieve, y de ella bajaban varias canales hasta su falda. Por las cercanías á la nieve la tierra era muy encarnada, pero en los llanos se presentaba cubierta de altos pinos, y se descubrían campos verdes y limpios, formando el todo la perspectiva más agradable. Dieron al monte el nombie de San Jacinto, y al cabo el del Engaño, el cual está en $57^{\circ} 2^{\prime}$ de latitud, y en $34^{\circ}$ por estima al Osste de San Blas; y dando la vuelta á una en. senada situada al Norte, fondeó la goleta en el puerto que llamb de Guadalupe, por latitud de $57^{\circ} \mathrm{II}^{t}$ y abrigado de todos vientos, excepto del 
ntar á subir á n pequeño, de res, y últimarios para ta. oseídos de su taba la goleta por latitud de ento al Oeste, il 5 renovaron iloto, toman. qtie debian re. ndo así que la ligado á depo. orto número de de las fuerzas iquellas costas que le sugería 1 mismo entu. de la fragata, era resolución. aron perfecta: sobre un cabo figura de pall ierta de nieve, lasta su falda. jerra era muy presentaba cuubrían campos o la perspectie el nombie de igaño, el cual 'por estima al ielta á una enla goleta en el por latitud de s, excepto del
Sur, que le hiere de lleno en la enfilación del Cabo de Engaño.

Poco satisfechos nuestros navegantes de este fondeadero, zarparon, y costeando tirada la goleta de un remolque, navegaron al Norte y fondearon en nueve brazas arena y lama, dentro de una ensenada que los abrigaba de los vientos de primero, segundo y áun cuarto cuadrantes, á la cual nombraron el fondeadero de los Remedios. Aquí trataron con los naturales, cuyo número era corto, y viendo que los nuestros llevaban vasijas de agua, pretendieron que se les pagase, como en efecto se verifić, regalándoles muchas bujerías.

En la unión de las aguas salada y dulce había muchos salmones y róbalos; pero la falta de anzuelos y aparejos privó á los nuestros de este regalo, hasta que formando fizgas con bicheros y clavos, lograron arponar algunos peces, cuyo gusto dicen es exquisito. Los naturales sólo se diferenciaban de los del puerto de la Trinidad en las ropas, pues para defenderse de los fríos usaban pequeñas chaquetas con capuchas, al modo de los marselleses cortos de Cataluña.

Con el excesivo frío que experimentaban, enfermó la gente hasta el punto de quedar reducidas las guardias á dos solos individuos cada una. Se hicieron á la vela el $2 \mathrm{r}, \mathrm{y}$ con viento Sueste continuaron hasta el $\mathbf{2 2}$, que habiendo observado $5^{8^{\circ}}$ de latitud cambió el viento al Noroeste con mucha fuerza. En este punto resolvieron cambiar la vuelta del Sur y regresarse costeando, contentos en lo posible de haber subido á tal altura, aunque con el disgusto de que no bastase su arrojo y deseo á "roseguir la campaña, contrarestando las enfermedades y los vientos. Propusiéronse seguir las orillas de la costa para tomar conocimient $\mathrm{n}$ de las entradas y puertos, y como se hallaban en la latitud del famoso Archipielago de San L zaro del Almirante Fonte, doblaron de cuidado y desvelo á fin de descubrirlo, pero no la consiguieron. De noche se mantenían á la capa y de día corrían el fondo de las ensenadas y se atracaban, aunque sin fruto, a todas sus puntas.

El 24 de Agosto, por latitud de $55^{\circ} 14^{\prime}$, entraron en una ensenada tan abrigada, que las aguas parecían por su reposo á las de un sosegado estanque; fondearon en 20 brazas lama á dos tiros de fusil de tierra, levantaron el plano, tomaron posesión del puerto y se le dió a éste el nombre de Bucareli. Está rodeado de montes muy altos que se levantan rápidamente de sus orillas, con un bosque impenetrable de pinos, que derribándolos los vientos 6 cayéndosé de vetuste $z$, se forma de sus ruinas un terreno blando y de poca consistencia, donde se cría mucha acedera y apio silvestre. Por este paraje recalo el Capitán ruso Tschirikoio; si se supone que se ha- ilaba en $55^{\circ} 36^{\prime}$ de latitud, que es la de una de las bocas del puerto y en $\mathrm{r}_{42^{\circ}}$ al Oeste de Paris.

Concluidas las faenas precisas dieron la vela nuestros navegantes el 26 , $\sin$ haber visto habitante alguno. Se dirigieron á una isla que tenian al Sur distancia de seis leguas, que es la que llam6 Pérez, Isla de Santa Cristina, y fondearon dos leguas al Norte de ella por 22 brazas, para mantenerse contra una corriente impetuosa. Desde alli marcaban al liste y á distancia de cuatro le. guas un cabo donde terminaba la tierra, pues no se veian señales de ella más allá. Por lo recio de las corrientes coligieron, como sucedió á Pérez, que alli habia otra entrada por donde desem. bocaba algún río caudaloso, como se infería también por el color del agua; pero no pudieron averiguarlo por los vientos reinantes del Su. este, con cuyo motivo, y considerando que éstos durarian, formaron el ánimo de subir á mayores latitudes, $y$ cambiaron de la vuelta del Norte. Atracaron la costa entre 56 y $56^{\circ}$ y $\%$ de latitud, pero habiendo rolado el viento al Oeste bien fresco, les fué preciso desistir de su empresa, temerosos de que cargasen demasiado, y salieron en vuelta del Sursueste el 29 de Agosto, en cuya época se contaban siete hombres de los once de la tripulación, acometidos de escorbuto, sin movimiento en las articulaciones de los brazos y piernas, quedando por tanto solamente cuatro hábiles para el servicio de guardias, y obligados á trabajar con ellos el Comandante y Piloto. Uno y otro resolvieron navegar á Monterey sin demora, pero á la vista de la costa, para determinar en lo posible su verdadera dirección. Los vientos, á la sazón, eran del Sueste y tan recios, que el 7 de Setiembre á las dos de la mañana, rompió un golpe de mar sobre la goleta, y arrancando batayolas, candeleros y bordas, arrastró consigo cuanto había sobre cubierta, no viéndose en ella por espacio de cinco ó seis minutos sino una mar espumosa de la cual pasó mucha agua á la cámara y bodega. Al pronto creyeron que el golpe de mar se había llevado á la gente, pero no tardaron mucho en oir lamentos de los heridos, que lo habían sido unos en la cabeza, otros en las espaldas y piernas, y el contramaestre que dió un golpe contra la uña de un ancla que estaba al pié del palo mayor, quedó enteramente inútil y murió poco después á la llegada á San Blas.

Para huir á la mar arribaron en popa sobre la tierra, con la esperanza de que antes de cumplir la distancia á ella, cediese la tempestad. Por el espacio de veinticuatro horas, el Camandante, el Piloto, un guardian y un criado, dieron á la bom ba para achicar el agua que había en la bodega.

El 7 en la tarde abonanzó el tiempo y el vien. to se llamó al Noroeste; reconocieron rota una hembra del timón, y en esta disposición no fué 
posible atracar la costa por más arriba que los $47^{\circ}$ I $^{\prime}$ ' el día 20 de Setiembre. El 21 con vientos Sur y Sueste, ciñeron en vuelta de afuera, $y$ aun. que el 22 volvib el viento al Noroeste y aclarb el cielo, no pudieron acercarse á tierra porque el Piloto y el Comandante enfermaron y cayeron en cama con fuertes calenturas, cuyo accidente cons terní mucho á la tripulación. Algo mejorados el 24 se esforzaron á subir sobre cubierta, $y$ hacien. do rumbo al Este, reconocieron la costa con $44^{\circ}$ y $\%$, con el mayor empeño que les fué dable. Tenian sumo deseo de reconocer el rio de Martín de Aguilar; pero no pudieron encontrarlo desde los $44^{\circ} 27^{\prime}$ hasta los $42^{n} 50^{\prime}$ de latitud, antre cu. yos paralelos corrieron las orillas viendo en ellas las piedras de la playa. En $42^{\circ} 5^{\prime}$ notaron un cabo con manchas blancas, cortado en forma de mesa y con farallones al Sudoeste: la mar se manifestaba de color de sonda, y juzgaron por esta circunstancia era dable desaguasen en él las co. rrientes del río visto por Martín de Aguilar. Sobre este cabo, que es el que Vizcaino llama Cabo Diligencias, tuvieron vientos del segundo cua. drante, y para el día 28 que cesaron, las corrien. tes les habian arrebatado al Sur, de forma que no les fué posible tomar la costa sino por $40^{\circ} 28^{\prime}$ á la vista del puerto de la Trinidad. Lo mismo había sucedido á Pérez y á Hezeta dos meses antes.

Desde la última recalada fueron por la inmediación de la costa, solicitando el puerto de San Francisco, y el 3 de Octubre por latitud de $38^{\circ} 18^{\prime}$ $y$ longitud de $17^{\circ} 57^{\prime}$ al Oeste de San Blas, tomaron puerto en uno muy abrigado, cuyo examen convendría hacer, y entonces no fue posible. Llamaron á este puerto de la Bodega, y creyeron era el mismo que el que denominó Drake de San Francisco, desde el cual demora la Punta de Re. yes al Sur distancia seis leguas. Pero este puerto es diverso del que los navegantes antiguos llamaron de San Francisco, pues éste corresponde al Sueste y á muy poca distancia de la Punta de Reyes, demorando desde él al Sursudoeste los fa. rallones, y también lo es del Puerto de San Francisco, donde existe actualmente nuestro establecimiento, porque éste cae oclio leguas al Este de la Punta de Reyes. Como quiera, nuestros navegantes sufrieron al ancla $y$ entre puntas mucha mar $y$ vientos calmados, $y$ vieron sobre las orillas y en pequeñas balsas de tule á manera de canoas, crecido número de indios robustos, pero del mismo color que los de Nueva España. Sólo dos llegaron á bordo, y con mucha generosidad regalaron plumajes, rosarios de hueso, un tejido de plumas que traían colgado de un palo á modo de bandera, $y^{\prime}$ ruedas de plumas que ponen en la cabeza como guirnaldas, correspondiendo los nuestros á estos presentes, con varias maritatas que fueron muy estimadas de los naturales. Observa. ron el establecimiento de la marea al medio día del plenilunio y la variación de la aguja de $16^{\circ}$ Nordeste. El día 4 á las dos de la mañana entrô la creciente, $y$ encontrándose con la fuerte bajan. te, causó tal hervidero de mares, que varias veces cubrieron la cubierta de la goleta, y arrebataron la canoa haciéndola mil pedazos contra la playa. Nucho riesgo corrieron de perderse $y$ faltó una amarra.

Cuando cesó la fuerza del tiempo, dieron la vela, navegando al Sur para montar Punta de Re. yes, y el 5 en la mañana pasaron por entre unos islotes del mismo nombre, atracaron la costa reconocer el puerto antiguo de San Francisco, y después de costearlo fueron á dar vista al nuevo á las seis de la tarde, sondando desde los islotes 27 hrazas de fondo arena y lama, que disminuyeron después hasta 12. No tomaron puerto por el mal estado de la gente, y navegaron al Sur en vuelta de Monterey, que consideraban en latitud de $36^{\circ} 40^{\prime}$ y $17^{\circ}$ al Oeste de San Blas, y fondea. ron en él á ia caída de la tarde del día 7. El $10^{\circ}$ de Noviembre de 1775 dieron la vela: el 18 al ponerse el Sol vieron las Marías, y pasando al Norte fondearon en San Blas el 20 á las dos de la tarde.

No será fuera de propósito advertir aquí que el editor del tercer viaje del Capitán Cook observa en su introducción que los de la goleta se glorían de haber llegado á la latitud de $5^{\circ}, \mathrm{mu}$ cho más allá del punto adonde habían podido arribar los demás navegantes (I), y con este mo tivo, forma una comparación odiosa con los admirables descubrimientos de aquel Capitán. Pero sin que se pretenda ni competencia nj semejan$z a$, haremos la descripción de la goleta, de su tripulación y armamento, y los inteligentes juzgarán si fueron posibles mayores esfuerzos.

Tenía la goleta 18 codos de quilla, cuyo lar. go es el mismo que el de la lancha de un navio, y se construý con el intento de que sirviese para atravesar desde la costa de la Sonora á la Penín. sula de California. Toda su seguridad y aloja miento consistía en una cubierta y un pequeño camarote: no había más baules ni equipaje que la cama y lo poco que cabía en un cajón coloca. do debajo de ésta. El poco puntal del alojamien. to, no pernitía otra postura que la de estar sentado, y coino la pequeñez de la cubierta no dejaba pasear, vivieron en esta inacción por espacio de diez meses.

(i) Es de advurtir que el Diario de esta expedición, escrito por D. Francisco Maurelle, Piloto de la goleta y hoy Capitán de fragata de la Real Armada, lo ha publicado el inglés Barrington entre sus miscelaneas pagina 508 . En español no se ha la hasta ahora, sino las noticias que contiene la intro ducción al viaje para reconocer el Estrecho de Juan de Fuca. 
posible atracar la costa por más arriba que los $47^{\circ}$ I $4^{\prime}$ el día 20 de Setiembre. I: 2 r con vientos Sur y Sueste, ciñeron en vuelta de afuera, $y$ aun. que el 22 volvio el viento al Noroeste $y$ aclaró el cielo, no pudieron acercarse á tierra porque el Piloto y el Comandante enfermaron y cayeron en cama con fuertes calenturas, cuyo accidente consternó mucho á la tripulación. Algo mejorados el 24 se esforzaron á subir sobre cubierta, $y$ haciendo rumbo al Este, reconocieron la costa con $44^{\circ} \mathrm{y} \%$, con el mayor empeño que les fué dable. Tenian sumo deseo de reconocer el rio de Martín de Aguilar; pero no pudieron encontrarlo desde los $44^{\circ} 27^{\prime}$ hasta los $42^{\circ} 50^{\prime}$ de latitud, entre cuyos paralelos corrieron las orillas viendo en ellas las piedras de la playa. En $42^{\circ} 5^{\prime}$ notaron un cabo con manchas blancas, cortado en forma de mesa y con farallones al Sudoeste: la mar se manifestaba de color de sonda, y juzgaron por esta circunstancia era dable desaguasen en él las corrientes del río visto por Martín de Aguilar. Sobre este cabo, que es el que Vizcaino llama Cabo Diligencias, tuvieron vientos del segundo cuadrante, y para el día 28 que cesaron, las corrientes les habian arrebatado al Sur, de forma que no les fué posible tomar la costa sino por $40^{\circ} 28^{\prime}$ á la vista del puerto de la Trinidad. Lo mismo había sucedido á Pérez y á Hezeta dos meses antes.

Desde la última recalada fueron por la inmediación de la costa, solicitando el puerto de San Francisco, y el 3 de Octubre por latitud de $38^{\circ} 18^{\prime}$ y longitud de $17^{\circ} 57^{\prime}$ al Oeste de San Blas, tomaron puerto en uno muy abrigado, cuyo examen convendría hacer, y entonces no fué posible. Llamaron á este puerto de la Bodega, y creyeron era el mismo que el que denominó Drake de San Francisco, desde el cual demora la Punta de Reyes al Sur distancia seis leguas. Pero este puerto es diverso del que los navegantes antiguos llamaron de San Francisco, pues éste corresponde al Sueste y á muy poca distancia de la Punta de Reyes, demorando desde él al Sursudoeste los farallones, y también lo es del Puerto de San Francisco, donde existe actualmente nuestro establecimiento, porque éste cae oclio leguas al Este de la Punta de Reyes. Como quiera, nuestros navegantes sufrieron al ancla $y$ entre puntas mucha mar $\mathrm{y}$ vientos calmados, $\mathrm{y}$ vieron sobre las orillas $y$ en pequeñas balsas de tule á manera de canoas, crecido número de indios robustos, pero del mismo color que los de Nueva España. Sólo dos llegaron á bordo, $y$ con mucha generosidad regalaron plumajes, rosarios de hueso, un tejido de plumas que traían colgado de un palo á modo de bandera, y ruedas de plumas que ponen en la cabeza como guirnaldas, correspondiendo los nuestros á estos presentes, con varias maritatas que fueron muy estimadas de los naturales. Observa. ron el establecimiento de la marea al medio dí del plenilunio y la variación de la aguja de $16^{\circ}$ Nordeste. El dia 4 á las dos de la mañana entró la creciente, y encontrándose con la fuerte bajan. te, causó tal hervidero de mares, que varias veces cubrieron la cubierta de la goleta, y arrebataron la canoa haciéndola mil pedazos contra la playa. Mucho riesgo corrieron de perderse $y$ faltb una amarra.

Cuando cesó la fuerza del tiempo, dieron la vela, navegando al Sur para montar Punta de Reyes, y el 5 en la mañana pasaron por entre unos islotes del mismo nombre, atracaron la costa á reconocer el puerto antiguo de San Francisco, y después de costearlo fueron á dar vista al nuevo á las seis de la tarde, sondando desde los islotes 27 brazas de fondo arena y lama, que disminu. yeron después hasta 12. No tomaron puerto por el mal estado de la gente, y navegaron al Sur en vuelta de Monterey, que consideraban en latitud de $36^{\circ} 40^{\prime}$ y $17^{\circ}$ al Oeste de San Blas, y fondearon en él á ia caída de la tarde del día 7 . El r. ${ }^{\circ}$ de Noviembre de 1775 dieron la vela: el 18 al ponerse el Sol vieron las Marías, y pasando al Norte fondearon en San Blas el 20 á las dos de. la tarde.

No será fuera de propósito advertir aquí que el editor del tercer viaje del Capitán Conk observa en su introducción que los de la goleta se glorían de haber llegado á la latitud de $58^{\circ}$, mucho más allá del punto adonde habían podido arribur los demás navegantes ( $\mathrm{r}$ ), y con este motivo, forma una comparación odiosa con los admirables descubrimientos de aquel Capitán. Pero sin que se pretenda ni competencia ni semejan$z a$, haremos la descripción de la goleta, de su tripulación y armamento, y los inteligentes juzgarán si fueron posibles mayores esfuerzos.

Tenía la goleta 18 codos de quilla, cuyo largo es el mismo que el de la lancha de un navlo, y se construyb con el intento de que sirviese para atravesar desde la costa de la Sonora á la Península de California. Toda su seguridad y alojamiento consistía en una cubierta y un pequeño camarote: no había más baules ni equipaje que la cama y lo poco que cabia en un cajón coloca. do debajo de ésta. El poco puntal del alojamiento, no permitía otra postura que la de estar sentado, y como la pequeñez de la cubierta no dejaba pasear, vivieron en esta inacción por espacio de diez meses.

(i) Es de advurtir que el Diario de esta expedición, escrito por D. Francisco Manrelle, Piloto de goleta y hoy Capitan de fragata de la Real Armada goleta y hoy Capitán de fragata de la Real Armada,
lo ha publicado el inglés Barrington entre sus miscelo ha publicado el inglés Barrington entre sus misceláneas, página 508 . En español no se ha publicado hasta ahora, sino las noticias que contiene la introde Fuca. 
al medio dia aguja de $16^{\circ}$ mañana entró fuerte bajan. e varias veces y arrebataron ontra la playa. se falto una

hpo, dieron la r Punta de Repor entre unos ron la costa á I Francisco, $y$ vista al nuevo sde los islotes que disminuron puerto por aron al Sur en ban en latitud Blas, y fondea. 1 día 7. $\mathrm{El} \mathrm{z."}$ vela: el I8 al y pasando al o á las dos de

vertir aquI que bitán Cock ob-

de la goleta se ud de $5^{8^{\circ}}$, muhabian podido $y$ con este mo. osa con los ad1 Capitán. Pero ia ni semejan. oleta, de su triligentes juzgafuerzos.

uilla, cuyo lara de un navio, ue sirviese para 1ora á la Penín. uridad y alojay un pequeño i equipaje que n cajón coloca del alojamien. la de estar senbierta no dejaón por espacio
La tripulaci6.. se componia de $\mathrm{I}_{4}$ hombres, el Capitán y el Piloto, y entre aquella gente apenas cuatro hablan navegado, y los demás cran váqueros acabados de salir de las haciendas. F: Capitán y el l'iloto trabajaban igualmente que los marineros, y cuando estos fueron heridos por el golpe de mar que se derramo en la bodega, ellos fueron los que dieron á la bomba para achicarla; de suerte que se resolvieron á esta fatiga nada conforme á su ejercicio y que solo podian resistir dos jovenes que ardian por reputación y fama. La menor enfermedad pedía una estrecha unión de todas las fuerzas restantes, $y$ en la ocasión de quedar la mayor parte tullidos, sin movimiento, sin medicinas $y$ sin facultativos, “estando aún solıre $\operatorname{los} 57^{\circ}$ de latitud, debieron padecer, es creible, una congoja extrema.

Los viveres, era otro punto que exigía una constancia temeraria, pues la pequeñez del buque no había dado lugar á lievar las 72 arrobas de carne que le correspondian, y que por dicha causa se embarcaron en la fragata. Las propiedades de una lancha mal construida, tampoco daban lugar á medir por ella la viveza de la co. misión, y así es, que se vieron obligados á recibir un remolque hasta $\operatorname{los} 41^{\circ}$ de latitud á pesar de los contínuos abordajes que esta maniobra producia. De este modo se hallaban en ia latitud de $47^{\circ}$ después de haber perdido siete hombres á manos de los bárbaros, otro motivo para abatir su ánimo, cuando por razones que obligaban al Comandante y existian en su buque, se determino á arribar al puerto de Monterey, y cuando á pesar del referido estado formaron el temerario proyecto de separarse y morir en su lancha antes que volver sin lucimiento. Tal fué la conferencia que tuvieron en su pequeño alojamiento sobre $\operatorname{los} 48^{\circ}$ de latitud el 29 de Julio desde las siete á las diez de la noche, después de haberse esforzado por la tarde en persuadir al Comandante que el temporal no les permitía dar la popa á los mares.

En dicha sesión, bien tuvieron presente que se exponían á perecer de miseria en costas des. conocidas; que navegarian por mares no frecuen. tados; que tal vez se hallarian en archipiélagos de donde no sería fácil saliese felizmente un solo y pequeño buque; que cualquiera enfermedad los pondría en el áltimo apuro, especialmente en una estación tan avanzada; que desde el punto de la separación debían acortar la ración por lo restante del viaje; finalmente, que si volvían al puerto sin que sus progresos fuesen dignos de la consideración de los Jefes, resultarian al punto contra ellos las acusaciones de insubordinación y otras que son naturales en un dilatado viaje. Pero nada pudo preponderar al sentimiento vergonzoso con que se figuraban estos jovenes su regreso á San Blas desde aquella latitud sin haber hecho descubrimiento alguno, y asl, forzaron de vela a las diez de la noche en vuelta del Oeste, resuel. tos á seguir este rumbo hasta hallar los vientos del tercer cuadrante, quedando por tanto dueños de sus acciones desde el día siguiente por la maกิana.

Si este estado es comparable al cie dos buques bien tripulados, bien provistos $y$ con muchos y sabios Oficinles, júzguelo el público que administra justicia con imparcialidad, pero jamás se les quitará á los de la goleta la gloria de haber sido los primeros que corrieron desde aquella altura un vasto continente con mís 6 ménos averigull. ción de sus costus y puertos, según fué mayor 6 menor la proporción que tuvieron por las enfermedades y los tiempos. Viaje digno de servir de modelo de constancia á los navegantes futuros y de estímulo á los jóvenes que quieren sobresalir en la práctica marinera de su profesion.

Los nuevos conocimientos adquiridos en la expedición anterior, dieron causa á que desde principios de 1776 se ordenase este tercer viaje, el cual no pudo emprenderse entonces por falta de embarcaciones en el Departamento de San Blas; pero desde luego se dispuso construir la fragata Princesa y se trajo de Guayaquil la $F a$. vorita, y pronta una y otra, dieron la vela de San Blas el i I de Febrero á media noche. Mandaba la fragata Princssa el Teniente de navío D. Ignacio Arteaga, siendo su segundo el Teniente de fragata D. Fernando Quirós: la Favorita tenía por Comandante al Teniente de fragata D. Francisco de la Bodega Cuadra y llevaba por segun. do al Alférez de fragata D. Francisco Maurelle.

Hasta el 26 lidiaron infructuosamente con los vientos y corrientes, intentando pasar por el Norte de las Marias, pero desistieron y arribaron á pasar por el Sur con vientos del Norte y Nornordeste. Su navegación no tuvo cosa notable hasta el 4 de Mayo que fondearon en la entrada de Bucareli. Alli trabajaron en reemplazar aguada y leña, y la gente descansó de las fatigas de la campaña. El I4 dieron principio á la formación de la carta de aquella entrada, saliendo al intento armadas las lanchas á las órdenes del Alférez de fragata D. Francisco Maurelle, en cuya comision permanecieron hasta el 12 de Junio, que volvieron después de haber examinado muchos y hermosos puertos, para cuyo prolijo reconocimiento sería preciso emplear muchos meses.

Observaron tambien que los naturales de esta entrada son de color trigueño claro y algunos de un blanco regular. Su estatura es buena, tienen fuerzas considerables y espíritu arrogante, lo que los hace propensos á la guerra. Su vestido consta de una 6 más pieles unidas de nutria, lobo marino, venado y oso, que les cubre desde el cuello hasta media pantorrilla, y de unos sombreros bien tejidos y de figura semejante á la 
parte ancha de un embudo. Usan pulseras de hierro 6 cobre, $y$ en su defecto emplean la barba de ballena.

Tienen el pelo grueso, negro y largo, y lo traen por lo comán recogido en coleta. Parit cubrir las espaldas gastan unas fresadas de vara y media de ancloo y una de largo, tejidas del mismo modo que la sarga, cuyo hilo medianamente torcido es de lana bien suave.

Las mujeres son de cara muy agradable, tienen el color bastante claro, las megillas muy rosadas, el pelo negro y largo, tendido en dos trenzas. Su vestido lo traen cerrado y con man. gas, compuesto de pieles que las cubren todo e cuerpo. Algunas se presentan en las canoas vestidas de esta suerte, $y$ pueden en cierto modo compararse á las bien parecidas de nuestra Es. paña; sin ensbargo, se desfiguran mucho á la vista de los europeos por el uso singular que tie nen las casadas de introducir un óvalo de una pulgada de diímetro en un agujero hecho al intento en el labio inferior, quedando éste pendiente en aquellas que por su edad no tiencn el resorte necesario para mantenerlo derecho; $y$ átun así les sirve para que sus hijuelos reciban allí la comida que antes han masticado las madres. Las doncellas por esta razón sólo tienen un delgado alambre que mantiene abierto el conducto por donde algún día introducen el b́valo referido, ensanchando la pequeña abertura para que pueda colocarse.

Los indios, á quienes el clima y sus necesidades constituyeron de un carácter feroz y guerrero, se presentan á las batallas con un peto y espalda de la misma heclsura que las cotillas de nuestras europeas, pero formados de tablitas muy angostas tramadas con muchos hilos, de tal modo, que dejándolas flexibles para ceñirlas al cuerpo con libre movimiento de los brazos, quedan sin embargo tan estrechamente unidas, que no es posible atravesar por sus intersticios una aguja. En el cuello ponen una ancha y grucsa gola que les cubre desde cl pecho á los ojos, y en la cabeza llevan un morrión de madera que representa un animal feroz. Desde la cintura á media pierna us`.n un delantal, el cual, juntamente que con la cuera de la espalda, los deja impenetrables á las flechas, aunque sin su agilidad ordinaria, por cuyo motivo cuando se hallan en esta disposición acostumbran hacer uso de la lanza. Esta tíene cuatro varas de largo y lengüetas de hierro; las demás armas ofensivas son las flechns, cuchillos de más longitud que nuestras bayonetas, $y$ hachuelas de pedernal $y$ de otro color verde, $\tan$ duras, que partiendo cualquier madero no se percibe mella en su filo. La diff́cil pronunciación de sus voces puso un notable inconveniente al conocimiento de muchas noticias que fueran apreciables entre nosotros, pero no es extraño que la articulación gutural se hiciese incomprensibli, en tan poco tiempo.

La vivacidad y el afecto al cambio de aque. llos naturales hizo conocer los muebles y mariu. facturas suyas. Conducian diariamente esteras bien tejidas matizadas de varios colores, pieles de lobos terrestres y marinos y de nutrias, vena. dos, osos y otros animales pequeños, de las cuales unas estaban bien curtidas y otras dobladas con su propio pelo. Tralan también fresadas de lana mezcladas decolor pardo y blanco, bien tejidas e hiladas, fajas, lana limpia tan suave como la de nuestros paises, y madejas de hilo de ella, que compraron nuestras gentes, Vendlan igual. mente bateas, canoas peçueñas pintadas de va. rios colores, formundo casi siempre en sus dibujos cabezas con todas sus partes, ranas de made. ra bien imitadas, que abriéndose como cajas de polvos, les servlan para guardar sus frioleras; cajas de tabla de tres cuartas cúbicas con mu. chos dibujos representando aninales, algunos de éstos, ya terrestres, ya volátiles, con cabos inte. riores; figuras de hombres representadas con cabezas por sus pies; morrionęs que figuraban la cabeza de una fiera tal vez no conocida; $y$ por último, redes y cordeles de pescar, cobre en co. llares 6 pulseras; hierro en todo género de armas, cuyos metales nunca vendian á ménos de recibir crecido precio por ellos; y pitos que tocan como flautas, de cuyos artículos compraron los $\mathrm{Co}$ manclantes y todos los de á bordo.

Aliméntanse estas gentes de pescado fresco 6 seco, bien sea cocido 6 asado, de varias yerbas y raices del monte, en especial del peregil, de la carne del venado y de otros atimales cuyas pieles manifestaban, y para cuya caza mantienen muchos perros. No fué posible adquirir ideas ciertas sobre la religión de estos pueblos, y úni. camente pucde decirse, que ya sea por indiferen. cia hacia su generación ó por el ansia con que solicitaban el hierro, vendían por éste sus hijos, especialmente aquellos que carecían de presencia ventajosa y agradable, y de este modo se compraron en la Princesa dos niñas, la una de siete y la otra de tres ańos, y en la Favorita tres muchachos de diferentes edades, de cuatro has. ta diez años.

Los montes de toda la entrada son bien elevados y pendientes hasta las playas, á excepción de las quebradas de los puertos, donde se encuentran algunas playas, y el cuerpo de todos los cerros es de piedra viva, sobre la cual crió la Naturaleza una espesura de pinos muy gruesos y derechos, á propósito para emplearlos en la construcción de buques, y tan altos, que faltándoles con el tiempo la firmeza correspondiente en las raices, caen á esfuerzo de los vien. tos y forman al fin un terreno de poca consistencia, en donde nace el apio, anís, llanten, cele- 
parte ancha de un embudo. Usan pulseras de hierro 6 cobre, y en su defecto emplean la barba de ballena.

Tienen el pelo grueso, negro y largo, y lo traen por lo comán recogido en coleta. Paru cu. brir las espaldas gastan unas fresadas de vara y media de ancho y una de largo, tejidas del mis. mo modo que la sarga, cuyo hilo medianamente torcido es de lana bien suave.

Las mujeres son de cara muy agradable, tienen el color bastante claro, las megillas muy rosadas, el pelo negro y largo, tendido en dos trenzas. Su vestido lo traen cerrado y con man. gas, compuesto de pieles que las cubren todo e cuerpo. Algunas se presentan en las canoas ves. tidas de esta suerte, y pueden en cierto modo compararse á las bien parecidas de nuestra lis. paña; sin embargo, se desfiguran mucho á la vista de los europeos por el uso singular que ticnen las casadas de introducir un óvalo de una pulgada de diámetro en un agujero hecho al in. tento en cl labio inferior, quedando éste pen. diente en aquellas que por su edad no tienen el resorte necesario para mantenerlo derecho; y áun asi les sirve para que sus hijuelos reciban alli la comida que antes han masticado las madres. Las doncellas por esta razón sólo tienen un delgado alambre que mantiene abierto el conducto por donde algún dia introducen el b́valo referido, ensanchando la pequcĩa abertura para que pueda colocarse.

Los indios, á quienes el clima y sus necesidades constituyeron de un carácter feroz y guerrero, se presentan á las batallas con un peto espalda de la misma liechura que las cotillas de nuestras europeas, pero formados de tablitas muy angostas tramadas con muchos hilos, de tal modo, que dejándolas flexibles para ceñirla al cuerpo con libre movimiento de los brazos, quedan sin embargo tan estrechamente unidas, que no es posible atravesar por sus intersticios una aguja. En el cuello ponen una ancha y gruesa gola que les cubre desde el pecho á los ojos, y en la cabeza llevan un morrión de madera que representa un animal feroz. Desde la cintura á media pierna us:n un delantal, el cual, juntamente que con la cuera de la espalda, los deja impenetrables á las flechas, aunque sin su agilidad ordinaria, por cuyo motivo cuando se hallan en esta disposición acostumbran hacer uso de la lanza. Esta tíene cuatro varas de largo y len. guietas de hierro; las demás armas of ensivas son las flechns, cuchillos de más longitud que nues. tras bayonetas, y hachuelas de pedernal y de otro color verde, tan duras, que partiendo cualquier madero no se percibe mella en su filo. La difícil pronunciacion de sus voces puso un notable inconveniente al conocimiento de muchas noticias que fueran apreciables entre nosotros, pero no es extraño que ia articulación gutural se hiciese incomprensibl, en tan poco ticmpo.

La vivacidad y el afecto al cambio de uyjue. llos naturales hizo conocer los mueblen y mariu. facturas suyas. Conducian diariamente esteras bien tejidas matizadas de varios colores, pieles de lobos terrestres y marinos y de nutrias, vena. dos, osos y otros animales pequeños, de las cunles unas estaban bien curtidas y otras dobladas con su propio pelo. Traian también fresadas de lana mezcladas de color pardo y blanco, bien tejidas é hiladas, fajas, lana limpia tan suave como la de nuestros paises, y madejas de hilo de ella, que compraron nuestras gentes, Vendian igualmente bateas, canoas pequeñas pintadas de va. rios colores, formando casi siempre en sus dibu. jos cabezas con todas sus partes, ranas de made. ra bien imitadas, que abriéndose como cajas de polvos, les servian para guardar sus frioleras; cajas de tabla de tres cuartas cúlsicas con mu. chos dibujos representando animales, algunos dc éstos, ya terrestres, ya volátiles, con cabos interiores; figuras de hombres representadas con cabezas por sus piés; morriones que figuraban la cabeza de una fiera tal vez no conocida; y por último, redes y cordeles de pescar, cobre en co. llares ó pulseras; hierro en todo género de armas, cuyos metales nunca vendian á ménos de recibir crecido precio por ellos; y pitos que tocan como flautas, de cuyos artículos compraron los $\mathrm{Co}$. mandantes y todos los de á bordo.

Aliméntanse estas gentes de pescado fresco 6 seco, bien sea cocido $\delta$ asado, de varias yerbas y raices del monte, en especial del peregil, de la carne del venado y de otros animales cuyas pieles manifestaban, y para cuya caza mantienen muchos perros. No fué posible adquirir ideas ciertas sobre la religión de estos pueblos, y úni. camente puede decirse, que ya sea por indiferen. cia hacia su generación ó por el ansia con que solicitaban el hierro, vendían por este sus hijos, especialmente aquellos que carecían de presen. cia ventajosa y agradable, y de este modo se compraron en la Princesa dos niñas, la una de siete y la otra de tres años, $y$ en la Favorita tres muchachos de diferentes edades, de cuatro has. ta $\operatorname{diez}$ años.

Los montes de toda la entrada son bien elevados y pendientes hasta las playas, á excepción de las quebradas de los puertos, donde se encuentran algunas playas, y el cuerpo de todos los cerros es de piedra viva, sobre la cual crib la Naturaleza una espesura de pinos muy gruesos y derechos, á propósito para emplearlos en la construcción de buques, y tan altos, que faltándoles con el tiempo la firmeza correspon. diente en las raices, caen á esfuerzo de los vientos y forman al fin un terreno de poca consistencia, en donde nace el apio, anis, llanten, cele. 
ación gutural peo tiempo.

bio de aque.

bles y mariu. mente esteraa -olores, pieles nutrias, vena. s, de las cuatras dobladas n fresadas de nco, bien tejin suave como e hilo de ella, endian igual. ntadas de va. e en sus dibuinas de made. como cajas de sus frioleras; bicas con $\mathrm{mu}$ les, algunos de con cabos intentadas con cac figuraban la nocida; $y$ por , cobre en co. nero de armas, énos de recibir yue tocan como praron los $\mathrm{Co}$.

escado fresco 6 varias yerbas y I peregil, de la ales cuyas pie:aza mantienen adquirir ideas pueblos, y únipor indiferen. I ansia con que - Este sus hijos, ían de presen. este modo se ñas, la una de a Favorita tres de cuatro has-

a son bien eleayas, á excepatos, donde se :uerpo de todos re la cual crió inos muy grueemplearlos en altos, que faleza correspon. zo de los viene poca consiss, llanten, cele- donia, wauco, agenjo y muchas otras yerbas. En los paseos que dieron nuestros navegantes por las orillas encontraron ciertas piedras minemales que les dieron lugar aspechar que el cobre que tanto aprecian sea metal que extraigan ellos de aquellas vetas. Las de hierro son sin cluda muy abundantes, pues las agujas de marear llevadas á tierra, perdian luego su virtud y sus movinientos.

Observaron la pleamar el dia de la conjun. ción, á las doce y cuarto del dia, subiendo el agua 17 y $\%$ pies. El $10^{\circ}$ de Julio dieron la vela, y á les dos de la tarde se haliaban ambos buques a) Sudeste de la Punta de San Bartolome distancia de dos leguas, $y$ por consiguiente sobre $55^{\circ}$ Io' de latitud Norte, y $27^{\circ} 7^{\prime}$ al Oeste del Ca. bo San Lucas, desde cuyo paraje navegaron en el tercer cuadrante hasta el dia 3 , que con vien. to del Oesudoeste tomarnn la vuelta del Norte. El 9 de Julio á medio dia vieron tierra desde el Norte $\%$ Noroeste al Esnordeste, y tenían á la vista el elevado promontorio de San Elías, que tiene la forma de pan de azúcar. Con vientos del primer cuadrante continuaron en vuelta del Noroeste á reconocer el Caho San Islias, y el $x 6$ á las cinco de la mañana se hallaron cerca de un bajo, que consideraron en $59^{\circ} 2^{\prime}$ de latitud $35^{\circ} 40^{\prime}$ al Oeste de San Lucas. El i 7 á la's dos de la tarde estaban á una legua de Cabo San Elias y de la punta de la isla próxima, que llamaron del Carmen. Casi en la boc' comnreadida entre dicha isla y el cabo sondaron 40 brazas de agua. Dicho cabo le consideran en $59^{\prime \prime} 53^{\prime}$ de la titud Norte, y al Oeste de San Lucas $37^{\circ} 14^{\prime}$ aunque no tuvieron observación aquel dia.

Reconocido el cabo y la parte Nordeste de la isla, arribaron al Sursudoeste en demanda de su parte meridional, la cual montada, navegaron al Oeste $\%$ Noroeste, dirigiéndose á la costa occidental que tenían á la vista, y reconocieron un gran seno que se forma al Oeste. El I9 estaban en el centro de él por $59^{\circ} 57^{\prime}$ de latitud, demorándoles las tierras más distantes al Oeste $y$ la del Cabo de San Elías al Este. Aquí experimentaron fuertes corrientes que guardaban el orden de las mareas, " que los acercaban 6 alejaban de tierra según su curso. Sondaron 47 brazas lama á cinco leguas de las orillas, donde vieron bas tantes bocas que seguramente producían el impetuoso curso ile las aguas hacia una $y$ otra parte.

El 20 se les acercaron dos canoas con un in. dio en cada una, los cuales, sin detenerse, se aproximaron al costado, y mostrando las flechas con puntas de cobre, se las arrancaban y entre. gaban las varas como denotando sus intenciones pacíficas, al mismo tiempo que hacían muchas instancias para que entrasen los nuestros por una hoca que les demoraba al Deste.
En efecto, el $2 x$ fondearon las fragatas en un puerto abrigado que llamaron de Santiago, y es el mismo que denomino Principe Guillermo en $\mathbf{7 7 8}$ el Capitán Cook.

los indios que habitan estas comarcas están vestidos de pieles para abrigarse del frio; $\sin \mathrm{em}$ bargo, están endurecidos á la intemperie, son robustos, del mismo color que los de Bucareli, y naturalmente industriosos en cuanto in exigen sus necesidades: viven de la pesca y son diestrisimos en este arte, para el cual emplean unas flechas que parecen hechas al torno, y un asta larga de madera con una vejiga llena de viento, un arpon de hueso en la punta, y cordeles bien fabricados, de tripas de animales. Este instrumento lo arrojan contra el pez, lobo ó nutria, á manera de dardo, y traspasado con el el animal, atinque pretende zambullir no se lo permite la fuerza de la vejiga, y de este modo lo cogen en la canoa. Merece rarticular descripción el modo con que estos naturales fabrican sus canoas. En primer lugar forman el esqueleto de varas delgadas, afianzadas con hilos de tripa ó tendones de mediana consistencia, $y$ cubriendolo de picles por todas partes, dejan únicamente en la superior una clarabnya semejante á la boca de una tinaja, de suficiente cavidad para cuntener la cintura de un hombre; y a fin de precaver la introducción de las aguas, visten una camisa de vejiga y la ci. nen al borde de la indivada claraboya, quedando de este modo sin riesgo de sumergirse. La figura de estos débiles buques es la de un arpa, y son tan livianos, que un hombre solo los maneja fácil. mente con la mano. El idioma dc estos naturales se diferencia tanto del de los de Bucareli, que los pequeños indios adquiridos en aquella entrada no pudieron hacerse entender, ni comprendieron una sola palabra de los de este puerto.

Como los montes que atraviesan estos para. jes están perpétuamente cubiertos de nieve, despiden varios arroyos que fertilizan sus faldas y en todas partes conservan una yerba de más de vara de alto, tan verde y mezclada de flores sil. vestres, que alegran la vista del espectador. Mientras los nuestros permanecieron en este puerto, hicieron agua y leña, descansaron las tripulaciones y experimentaron alivio los enfermos con la comida de buen pescado, salmón, pargo y la yerba que llaman acedera: observaron la variación de la aguja, que á la sazón era de $26^{\circ} 30^{\prime}$ al Nordeste $y$ situaron el Puert. .. $60^{\circ} \mathrm{I} 3^{\prime}$ de latitud Norte y $39^{\circ} 46^{\prime}$ al Oeste de San Blas. La marea ascendio, según observaciones, , I8 piés.

El 28 de Julio, en la tarde, zarparon nuestros buques, costándoles sumo trabajo levantar las anclas, porque el barro del fondo se las había tragado hasta la uña superior, y el $\mathrm{I}^{\circ}$ de Agosto anclaron en las islas que están inmediatas y al 
Sur, á las cuales llamaron de Regla. Ultimamente, el 7 de Agosto se pusieron otra vez á la vela, de regreso para San Blas, en atención á que el estado de las tripulaciones no les permitía seguir más al Norte ni atracar la costa y reconocerla en vuelta del Sur, $y$ con vientos frescos del Noroeste hicieron breve su navegación, recalan. do el 4 de Setiembre á Cabo Mendocino, cuya latitud rectificaron con nuevas observaciones, resultando en ellas estar en $40^{\circ} 7^{\prime}$. Es un frontón de tierra alta, tajada al mar, colorada, con cua. tro barrancas en su frente.

El día 4 estaba la fragata Favorita media legua al Sur de la punta de Reyes, marcando los farallones de San Irancisco del Sur $7^{\circ}$ Este al Sur $\mathrm{r} 7^{\circ}$ Oeste distancia de tres leguas, $y^{\circ}$ el mismo día anclaron uno y otro buque en el puerto de San Francisco, cuya latitud observaron de $37^{\circ}$ $5^{\prime}{ }^{\prime}$ Norte y su longitud de estima $12^{\circ} 54^{\prime}$ al Oeste del Cabo San Lucas. La aguja variaba entonces $13^{\circ}$ al Nordcste. Recobrados los enfermos se hicieron al mar el 30 de Octubre y fondearon en San Blas el 2 I de Noviembre del mismo año de I 779 .

Con motivo de la guerra emprendida contra los ingleses hacia el fin del tiempo de la expedición anterior y de la atención que exigía entonces el estado de la Europa, se abandonaron en. teramente los reconocimientos emprendidos ála costa Noroeste de América, hast.u que á principios del año 787 , el Ministro de Indias, Marqués de la Sonora, á consecuencia de un aviso que le comunicó el Maestre de Campo de Concepción ae Chile, de que habiendo llegedo allí las fragatas Brijula y Astrolabio, de la marina de Francia, mandadas por el Conde de la Péyrouse, le había manif cstado la carta general que llevaba, expresiva de cuatro establecimientos que tenía la $\mathrm{Ru}$ sia al Norte de California, en Nutka 767 leguas de Acapulco, en el Principe Guillermo sobre $60^{\circ}$, an la Isla Trinidad y en Onalasca, de los cuale el primero distaba muy poco de nuestro estable. cimiento en Montẹrey; prevenía el Virey dc Méjico era la voluntad de S. M. se armasen en San Blas dos buques apropósito para reconocur la costa hacia el Norte y averiguar si existían, con efecto, tales establecimientos. Había muerto el Virey D. Bernardo de Gálvez cuando llegó á Méjico esta orden, y gobernaba la Audiencia en su lugar, la cual dió vista al Fiscal, y sucediendo en el mando el Arzobispo de Méjico en calidad de Virey interino, se tomaron en su tiempo providencias oportunas para dar entero cumplimien. to á dicha Real orden.

En 2x de Julio del mismo año la repitió el Ministerio, y el Virey ya nombrado, D. Manuel de Flores, contestó á ella que la expedición saldría á principios de 1788 á pesar de la suma dificultad que había de encontrar sujetos á quien encomendar cosa tan importante, representando con este motivo era preciso fuesen á San Blas Oficiales hábiles de la Armada, capaces de mandar las embarcaciones y de cumplir las órdenes de Su Majestad relativas á expediciones de tanta monta; y que por lo demás, añadía, era notorio desde que regresaron en 1780 los Capitanes in. gleses Gore y king del tercer viaje-del célebre Cook, que los rusos tenían dichos cuatro establecimient ss en la costa Noroeste de América, pero que áus? el más próximo estaba bien distante de los nuestros.

Equipada, pues, la expedición referida, compuesta de la fragata Princesa y el paquebot Fili. pino, se nombraron sus Comandantes, recayendo el mando de aquélla en el Alfére $z$ de navío gra. duado D. José Esteban Nartínez, y el del paquebot en el primer Piloto D. Gonzalo Lb́pez de Haro, siendo el primero el Comandante en Jefe de la expedición. Su objeto, según las instrusciones del Virey, era subir hasta los $6066 \mathrm{r}^{\circ} \mathrm{y}$ examinar con certidumbre si existían 6 no tales establecimientos de los rusos en aqueila parte.

Salieran estos buques de San Blas el 8 de Marzo de $17^{25}$ y navegaron sin ocurrencia no. table hasta el i 8 de Mayo que reconocieron unas islas pequeñas y rasas que llamaron de Hijosa y se hallan situadas de ro á $\mathrm{I} 2$ de la Isla Montagu, por $59^{\circ} 3 \mathrm{o}^{\prime}$ de latitud Norte. E1 25 fondearon en esta última isla, pero se levaron el $26 \mathrm{y}$ continuando hacia el Norte anclaron el 28 en una ensenada que llamaron de Flores, por $60^{\circ} 7^{\prime}$ de latitud y $37^{\circ} 32^{\prime}$ al Oeste del Cabo San Lúcas. Aquí trataron con los naturales y recono. cieron las inmediaciones, encontrando en ellas una sasa de madera fabricada por europeos.

$\mathrm{Al}$ atracar los indios á bordo de nuestras embarcaciones, entonaban una canción dirigida por el más respetable de ellos á cuyas voces se mo. vían guardando compás, y dando con harmonía ciertos golpes con palos en los bordos de las canoas y últimamente extendian los brazos en senal de amistad, sin cuyas ceremonias no se aproximaban á los costados. En una de estas ocasiones llegó una canoa con 18 indios, mandados por uno de figura respetable. Era blanco, tenía los ojos azules, la barba larga y medio rostro pintado de rojo. Su autoridad se advirtió particularmente en una especie de tributo que le pagaban los demás, de cuanto podian adquirir. Todos ellos son robustos, de color claro y pelo negro, $y$ tienen el labio inferior taladracio, por cuya abertura pasan un hueso liso, del cual cuelgan sartas de abalorios del propio modo que en las orejas. Las mujeres se distinguen de los hombres, únicamente en que ellas llevan la ca. beza descubierta, y éstos usan unis sombreros conicos de yerbas, bien tejidos. St s canoas son de figura de un arpa, hechas primorosamente de 


\section{e, representando}

esen á San Blas

capaces de manlir las órdenes de iciones de tanta adía, era notorio os Capitanes inviaje-del célebre thos cuatro estaste de América, aba bien distante

ón referida, comel paquebot Fili. antes, recayendo ez de navio gra$z$, y el del paquenzalo López de handante en Jefe gún las instruc. a $\operatorname{los} 6066 \mathrm{r}^{\circ} \mathrm{y}$ kistían 6 no tales aqueila parte.

San Blas el 8 de in ocurrencia no. reconocieron unas maron de Hijosa 2 de la Isla Monte. El 25 fondeae levaron el 26 y nclaron el 28 en Flores, por $60^{\circ} 7^{\prime}$ lel Cabo San Lúturales y reconoontrando en ellas por europeos. o de nuestras emnción dirigida por yas voces se mo. do con harmonía bordos de las calos brazos en se. eremonias no se En una de estas I 8 indios, manable. Era blanco, a larga y medio oridad se advirti6 ie de tributo que to podian adquide color claro y nferior taladracio, eso liso, del cual propio modo que distinguen de los llas llevan la caunis sombreros - Si s canoas son rimorosamente de delgadas varas y forradas con pieles de animales, dejando en la cubierta una, dos ó tres fogonaduras donde se meten los bogadores, quedando de este modo defendidos de las aguas que pudieran entrar por la parte superior. Estos habitantes dieron suma estimación al hierro, que no es de admirar les tentase su codicia á robar una materia que por su grande utilidad es preciosa $\ddot{y}$ de valor inestimable para ellos.

En las orillas del mar notaron nuestras gentes se cría mucho apio silvestre, cuyo uso es muy conveniente para las tripulaciones, como se advirtió en la expedición de 1779 , con la de las lanchas que reconocieron el puerto de Bucareli, sanando con el uso de aquella yerba y la ace. dera todos los efectos del escorbuto.

El 15 de Junio dieron la vela ambos buques de este fondeadero, dirigiéndose al Oesudoeste, $y$ el 26 fondeó la fragata en la 'Trinidad, por $5^{6^{\circ}} 44^{\prime}$ de latitud. El paquebot recaló el Cabo Greenwille, y habiendo fondeado en el de dos Puntas, por las noticias que le dieron los naturales de que allí había rusos, buscó y encontró efectivamente el establecimiento; su Capitán y Comandante se llamaba Haro, y esta conformidad con el nombre del Comandarte del paquebot, estrechó la amistad y produjo muy buenos efectos. Dijo que era griego, natural de Constantinopla; manifestó inteligencia en el pilotaje, $y$ habiéndole presentado una carta, señaló al punto un espaciosc canal que principia al Sur del río de Cook " sale por el Cabo Trinidad. Sobre esta misma carta dió las noticias siguientes: Que en el Cabo de dos Puntas que él mandaba, había 60 rusos y dos galeotas; á la parte occidental del Cabo Eljsabei, 4o; en Cabo Rada, 37; sobre $5^{\circ}$ de latitud, 40 en una islita; una goleta armada con 70 hombres de tripulación para proteger el comercio de pieles á la boca del río Cook; 55 rusos en $55^{\circ} 1 / 3$ de latitud en el continente, y una goleta; $y$ finalmente, 120 hombres y dos goletas en Onalasca; de suerte, que en todos había 422 hombres, repartidos en seis establecimiextos $y$ seis goletas, añaciendo çue cada tres ó cuatro años venían dos fragatas de Kamchaka con gente $y$ auxilios para mudar á los empleados en estos establecimientos. Y habiéndole preguntado si tenían alguno en Nutka, contestó pensaban formarlo el año 1790. Los nuestros repararon en el buen órden que reinaba en este pequeño pueblo de europeos, cuyas habitaciones eran cómodas y muy aseadas, tenían huertas, almacenes, capilla, casa de enseñanza 6 escuela de primeras letras; y vieron, finalmente, varios matrimonios y mujeres de porte $\mathrm{y}$ trato tan fino, como el de las mujeres educadas de Furopa. El Comandante ruso Haro y sus principales Oficiales, pasaron á ver el paquebot, y extrañaron mucho la nueva handera española, que hasta entonces no habian visto.
El 2 de Julio abandonó el paquebot aquellas orillas, y en la tarde del 3 se reunió la fragata que estaba fondeada sobre la cabeza del Nordeste de la Trinidad, cuyo fondeadero conceptúan en $56^{\circ} 44^{\prime}$ de latitud. Ambos se levaron el 5 y en vuelta del Sueste se dirigieron á Onalasca, don. de fondearon á principios de Agosto, habiendo tardado tanto por los vientos fiojos y variables que tuvieron, acompañados de contínuas neblinas. Las noticias que adquirieron en Onalasca, fueron las siguientes:

Contaba el establecimiento veintiocho años de fundación, $y$ su fuerza en aquella época constaba de 120 individuos mandados por Saycof Cosmichi. Los rusos esparcidos en el continente é islas inmediatas, ascendían al número de $\mathbf{5 0 0}$ con seis groletas de seis pedrer $\mathrm{s}$ cada una. Había en la isla 200 familias de naturales bajo la dirección de uno de ellos á quien la Emperatriz de Rusia tenía concedido el título de Juez de los habitantes de aquella parte, y todos pagaban tributo de pielcs á la Emperatriz, cuyo dominio reconocían y por cuya sola circunstancia eran tän infelices con respecto á los naturales del Príncipe. Guillermo y otros vecinos, que parecían al pronto naciones diversas. Cosmichi aseguró que desde Bering y Schiricoof no habia pasado ningún ruso al Este del Cabo San Elías y que esperaban dos fragatas de Kamchaka el año de I 789 , para pasar ron ellas á Nutka, dejar allí una colonia é impedir á los ingleses el comercio de peletería, pues según había oído Cosmichi en 1775 al Capitan Grey que retornaba á Cantón, se creían los ingleses autorizados á hacerle desde Nutka hasta las islas Shumagins. Añadió también que en 1786 se había perdido una fragata inglesa en la isla de Mandanny sobre $54^{\circ} 44^{\prime}$ de latitud, de cuyo $n_{\text {. }}$.1fragio sólo escaparon dos hombres, que se enviaron á Petersburgo.

Adquiridas estas noticias, resolvió el Comandante de la expedición el 18 de Agosto regresar para Montcrey, y así lo verificaron: el 15 de Setiembre, estando á ménos de go leguas del continente, empezaron á ver señales de tierra, sondaron en 75 brazas de agua por $39^{\circ}$ de latitud y el 17 dieron fondo en Monterey y saliero:i el $\mathbf{r} 4$ de Noviembre para San Bias adonde fondearon e! 5 de Diciembre.

Cor، estas noticias y persuadido el Virey de Méjico, D. Manuel de i'lores, no sólo del legítimo derecho que tenía la Nación Española á todo el país que corre desde Nutka hasta los $6 \mathrm{I}^{\circ}$ de que habían tomado posesión las expediciones de 1774,75 y 79 , sino de la necesidad de precaver las tentativas de Rusia y las que podian emprender los ingleses desde bahía. Botánica, dispuso al intento una ocupación provisional de Nutka, y nombró para que la realizase al mismo $D$. Esuban Martírez, el cual debía salir cie San Blas 
con la fragata Princesa llevando á su bordo alguna tropa y cuatro Religiosos Fernandinos para que insinuasen dulcemente á los naturales la voz dcl Evangelio, encargando muy particularmente el Virey al Comandante de la expedición, tratase con toda suavidad á los indios.

Salió Martínez de San Blas el i 7 de Febrero de ${ }^{7} 89$ y sin ocurrencia particular llegó á su destino el 5 de Mayo, tomó posesión de él, formó un fuerte de ro cañones $y$ levantó barracas para la tropa en el puerto amistoso á la izquierda y en la misma entrada. La primera embarcación que se vió fué el paquebot portugués $L a$ I figenia, su Capitán D. Francisco José Viana, que siguió para Macao, con pieles. Llegó después el paquebot inglés Argonauta mandado por James Coinct, Teniente de navío de la marina inglesa, y la balandra la Princesa Real al mando del Capitán Tomás Hudson. Estas embarcaciones se pu. sieron en facha á la boca del puerto y viéndole ocupado por nosotros, enviaron su bote á cumplimentar á Martínez y á saber si podían entrar, y con el sí de éste entraron $y$ fondearon. Por el mismo tiempo llegó la liragata americana la $\mathrm{Co}$. lumbia mandada por el Capitán Kendric, con quien hizo mucha amistad Martínez y fué quien le sugirió que descontiase de Colnet, diciéndole que ioa éste á formar un establecimiento en Nutka. No es de este lugar el tratar sobre lo absurdo ó verosimil de esta conjetura, pero las resultas fueron echarse Martínez sobre los dos buques de Colnct y tomarlos por sorpresa á las doce de la noche con las dos lanchas armadas de nuestras fragatas, arrestar al Capitán y á los ingleses, y poniéndolos bajo de escotilla, enviar con gente nuestra los dos buques ingleses á San Blas.

Después de un año de prisión se devolvieron á Colnet $y$ Hudson sus embarcaciones, carenándolas y equipándolas completamente. A todos los que venían en ellas se les pagó sueldo doble de San Blas, que es lo mismo que el cuádruplo del nuestro en Lima; y aunque los ingleses presentaron un avalúo de lo que liabian perdido por el malogro de la expedición, liaciendo subir aquẻl á 600.000 pesos, se les satisfizo sólo 200.000 res pecto á que habían obrado de tan mala fé que supusieron habian caryado 6.000 pieles en la costa, y que se las habíarı jagado á ioo pesos por coda unu de Macao, cuando pudieran darse por satis fechos haber adquirido $2.000 \mathrm{y}$ haberlas vendido á.13 ó I 5 pesos fuertes, que era el precio que entonces tenian en aquel mercado.

Al tiempo de comunicar al Ministerio el Virey de Nueva España los resultados de la expedición de $\mathbf{r} 788, y$ cuanto creía conveniente sobre mestro indisputable. derecho al dominio de las costas septentrionales de li América, daba también cuenta de las disposiciones que había tomado acerca de la ocupación provisional de Nutka, acompañan- do copia de la instrucción que pasó á Martínez como Jefe de la expedición, añadiendo que quedaban entonces en San Blas las fragatas Princesa, Aransazu, Concepción, Favorita y el paquebot Filipino para las providencias ulteriores que dictase el estado de este negocio.

Todas estas providencizs merecieron la aprobación de S. M. (I), quien conformándose con el parecer de su Consejo de Estado, y queriendo sostener lo dispuesto por el Virey para la ocupación de Nutka con el tesón y decoro convenientes, mandó pasasen á San Blas el Capitán de navío D. Juan de la Bo lega y seis Oficiales inteiigentes, para emplearse en las navegaciones que dispu. siese el Virey á la costa Noroeste, y que en el ínterin se haría saber por S. M. á la Corte de Rusia en términos generales, que por noticias recibidas de la América se sabía que algunos navegantes rusos se habían situado en parajes descubiertos y reconocidos con muclia anticipación por los españoles, y que se esperaba de la buena harmonia y sincera amistad que mediaba entre lasdos Cortes, que si fuesen hacia aquellos mares y costas otros descubridores rusos, no se excediesen intentando establecerse en dichos parajes que pertene. cían á los españoles.

Consiguiente á las anteriores disposiciones de la Corte, ordenó en 7 de Diciembre de 1789 el Virey de Méjico, Conde de Revillagijedo, al Comandante del Departamento de San Blas, que la fragata Concepción, el paquebot Argonauta y la balandra Princesa Real, debían salir sin falta eis todo Enero siguiente, para relevar en el Puerto de Nutka la fragata Princesa que lo ocupaba.

En estos buques, que conforme á las órdenes del Virey debían estar bien tripulados, equipados y armados, se embarcaron $5^{\circ}$ voluntarios de $\mathrm{Ca}$ taluña á las órdenes del Capitán D. Pedro Alber ni. EI todo de la expedición lo mandaba el Teniente de navío D. Francisco Elisa; el paquebot el Teniente de navío D. Salvador Hidalgo, y la balandra el Oficial de igual clase $\mathrm{D}$. Manun! Quimper. Dieron la vela estos buques el 3 de $\mathrm{Fe}$ brero, y sin ocurrencia particular cogieron el 5 de Abril el fondeadero de Nutka, en donde trataron de fortiticarse formando una nueva batería, en la que arbolaron el día ro la bandera nacional, haciendo con los cañones el saludo que exigía este acto.

Concluídas estas primeras formalidades, en tregó Elisa al Teniente de navíp D. Salvador $\mathrm{Hi}$. dalgo las órdenes $\epsilon$ instrucciones que había reci bido del Vircy de Méjico, y prevenian que se reconociese toda la costa desde los $60^{\circ}$ de latitud para el Sur, facilitándole á este efecto los auxi-

(r) Oficio del Ministro de Indias, D. Antonio Valdés, al Jirey de ivéjico con fecha de 14 de Abril de $i 789$. 
só á Martínez ndo que que. ugatas Prince. el paquebot iores que dic-

cieron la aprohándose con el , y queriendo para la ocupa. convenientes, pitán de navío es inteligentes, hes que dispu. y que en el in Corte de Rusia ticias recibidas hos navegantes es descubiertos ción por los esuena harmonía tre lasdos Cormares y costas cediesen inten. es que pertene.

disposiciones de hbre de 1789 el lagijedo, al CoSan Blas, que la Argonauta y la lir sin falta en ar en el Puerto que lo ocupaba. ne á las órdenes ados, equipados luntarios de $\mathrm{Ca}$ -

D. Pedro Albermandaba el Teisa; el paquebot or Hidalgo, y la lase D. Manun! 1ques el 3 de $\mathrm{Fe}$ - cogieron el 5 de donde trataron va batería, en la ra nacional, haque exigía este

rmalidades, enD. Salvador $\mathrm{Hi}$ que había reci. 'enian que se reis $60^{\circ}$ de latitud efecto los auxi- lios necesarios, dándole el segundo Piloto Mondofia que sabía la lengua rusa, y un marinero que hablaba inglés, con otros varios socorros :que necesitó.

Preparado de este modo dí la vela Hidalgo el 4 de Mayo, y gobernando en el tercero y cuarto cuadrante, según se lo permitían los vientos, se hallaba el I 7 en $\operatorname{los} 50^{\circ} 55^{\prime}$ de latitud, y en $3 \mathrm{r}^{\circ}{ }^{\circ} \mathrm{o}^{\prime}$ de longitud al Oeste del Cabo San Lucas, desde cuyo punto hicieron rumbos del cuarto cuadranie para recalar sobre el Príncipe Guillermo, como lo verificaron el 23, entrando por su boca y continuando bacia el Norte por la inmediación de la Isla Magdalena, reconocieron toda la parte oriental de aquel espacioso seno, y fondearon en una ensenada á que dieron el nombre de Menéndez. El 9 de Junio se pusieron á la vela para doblar una islita que les demoraba desde el fondeadero al Noroeste $1 /$. Norte, y habiéndolo ejecutado descubrieron la boca de un puerto en la costa oriental del seno principal, adonde se dirigieron y permanecieron hasta el $2 \mathrm{I}$ levantando el plano de aquel puerto, porque su mucho abrigo merecía toda atención. Llamaron á este puerto de Gravina, y lo situan en latitud de $60^{\circ} 40^{\prime}$ y lon. gitud $36^{\circ} 53^{\prime}$ al Oeste de San Lucas.

Mientras permanecieron en el puerto Gravina despachó el Comandante dos Pilotos con la lancha, acompañados de unos indios que ste of recieron á servir de prácticos para reconocer hasia su fin al seno del Príncipe Guillermo. Esta lancha llegó á la boca de un puerto muy abrigado, de buen fondo y que tiene dos bocas formadas por una isla, sobre la cual observaron la latitud de $60^{\circ} 54^{\prime} ; y$ estanio en ella oyeron muchos truenos que se aumentaban al paso que el Sol se acercaba al meridiano; $z$ conducidos por sus prácticos hasta lo interior de dicho puerto, descubrieron en su fondo septentrional una gran lla. nura de nieve que empezaba en las orillas del mar y remataba en las faldas de los montes más elevados. Apenas estuvieron á su vista cuando reconocieron que cada trueno despedía, con bastante elevación, una gran masa de nieve que, cayendo dentro del puerto, les impedía continuar la inspección de aquel fenómeno. A su regreso pasaron por un canal formado por la tierra oriental del seno y muchas islas que siempre habían tenido por costa firme, hasta que los indios los condujeron por él.

Concluído de este modo el reconocimiento de la parte más septentrional de la entrada del Príncipe Guillermo, resolvió Hidalgo ponerse á la vela y reconocer igualmente la costa del Sudoeste, á cuyo efecto salió del puerto de Gravina el 2 I de Junio, y ayudado de la vaciante y de las ventolinas del Este, se hallh el mismo día á las doce á corta distancia de la punta Noroeste del puerto de Santiago. Las tempestades, cal- mas, aguas y neblinas que continuamente sufrieron hasta rebasar la punta mericional de la Isla Montagu, les obligaron demorarse al ancla por aquellas inmediaciones hasta el 30 de Junio, que mejorados los tiempos, se vieron libres del canal que forma dicha isla con la de San Antonio.

Desde el 23 de Mayo que entraron en el Príncipe Guillermo, hasta el 30 de Junio que salieron de él, tuvieron muchas visitas de los naturales, á quienes regralaron con grenerosidad para captarse su estimación; y de la comunicación con ellos resultaron las observaciones siguientes.

Son estos indios de una estatura proporcionada, tienen el pelo negro y laxo, cortado por delante hasta media cabeza y de cuatro dedos de largo lo restante; los ojos grandes y negros, los dientes blancos é iguales, y la ternilla interior de las narices taladrada, por cuyo agujeratraviesan un cilindro de hueso de tres dedos de largo, $y$ en sus extremos cuelgan varias sartas de abalorios. Llevan el labio inferior partido y representando una pequeña boca, por la cual sacan la iengua y hacen varios gestos que les imperlecciona. De iss labios de esta boca fingida cuel zan también sartas de abalorios que los afianzan á otro hueso semejante al anterior. cosido con nerviecitos de animales. Son lampiños, pues sólo tienen bigote, con una pequeña perilla en la barba, negra y derecha. Las orejas las llevan taladradas por toda su circunferencia, $y$ de sus agujeros penden igualmente rosarios de abalorios de bastante longitud.

Se pintan el rostro de rojo y negro, formando varias figuras de aspecto horroroso; visten túnicas de pieles de animales, que les cuelgan hasta los tobillos, y una can.isa formada de vejigas de peces para defenderse de las aguas; y finalmente, tienen sombreros bien tejidos de junco, cuya copa es baja, y el ala de corta ex. tensión. Las nujeres se diferencian $\mathrm{n}$ que en el labio inferior atraviesan por pequeños agujeros varios huecesitos blancos que figuran dientes, debajo de los cuales tienen otros pequeños conductos que sirven para afianzar sartas de abalorios. También se pican la barba del mismo modo que suelen hacerlo en los brazos nuestros marineros, y por este medio la dejan de un color azul oscuro; en lo demás imitan á los hom. bres y se pintan como ellos, pero desde luego que los españoles las hicieron entender cuánto les desagradaban aquellas pinturas, tuvieron cuidado de lavarse y de presentarse limpias en lo sucesivo. Algunas de ellas eran blancas, de facciones regulares, y tenían el pelo largo y atado en castaña. Las criaturas de muy poca edad, llevaban ya hechos los taladros en las orejas, ternilla y labios, sin duda para evitarles el sumo dolor que deberían sufrir por esta operación, ejecutada en edad más avanzada. 
Las armas of cusivas de estos naturales son una lanza de dos varas y media de largo, con su lengua de hierro, mayor ó menor, según la proporción que tienen para conseguir este metal; Hechas con puntas de pedernal y algunas de cobre cliyos tiros dirigen con notable acierto. Las defensivas son unas cotillas de estrechas planchas de madera, impenetrables á las flechas, sobre la cual ajustan una túnica sin mangas, hecha de dos dobleces de piel de oso para resistir á la lanza, llevando en la cabeza un morrión de madera que representa la de un lobo marino ó de otro cualq ier anfibin. Las canoas tienen la figura de un arpa y las forman interiormente de varas delgadas y flexibles, forradas luego por la superficie exterior con pieles de ballena para que no se introduzcan las aguas, $y$ en la parte superior dejan abieı tos uno, dos ó tres agujeros por donde introducen el cuerpo, quedando de este modo sentados en el fondo del buque. Los instrumentos de pesca son flechas y unos dardos de cuatro $y$ media varas de largo, armados con un arpón bien hecho de hueso en un extremo y una vejiga de lienzo en el otro, que sirve para que sobrenade el pez herido con el arpón.

Los animales cuadrúpedos vistos en la entrada del Príncipe Guillermo, fueron osos con mucha abundancia y de gran tamaño, ciervos crecidos, covotes y zorros: los peces, ballenas, lenguados, sardinas, salmones y rodaballo cuyo peso llegaba á seis arrobas, además de los lobos marinos y nutrias, de las cuales aprovechan la carne, el aceite y la piel. Vieron igualmente muchas gaviotas, patos de varias clases, águilas de gran tamaño y cuerros.

Las mareas guardan el orden regular de $6 \%$ horas en cada tlujo ó reflujo, y olsservaron que el día del plenilunio sucedió la creciente álas $12 \%$ y subió el agua 24 piés: las corrientes son de poca fuerza en las inmediaciones de las orillas, pero llevan un impulso extraordinario en el centro y los canales que forman las islas. El extre. no septentrional del Principe Guillermo, lo cort sideran en $6 \mathrm{r}^{\circ}$ ro' de latitud, y desde este punto hasta el extremo meridional de la Isla Montagu cuentan 33 leguas de distancia. Habiendo rebasado, como dijimos, el extremo meridional del Príncipe Guillermo, continuaron con vientos variables y neblinosos hasta las inmediaciones del Cabo Elisabet y Ensenada de Regla adonde abordaron diez canoas de indios que manifestaron la proximidad de los rusos, cuyo establecimiento se hallaba algo más al Norte y sobre la mis ma costa. El 5 de Julio fondearon en el puerto que llamaron de Revillagijedo para hacer agua y leña, y cuando ya se disponían á continuar sus reconocimientos hacia el Norte por el río de Cook tuvieron noticias por el Jefe ruso, que la falta de puertos y los muchos arrecifes, les expondrían á perderse en aquella navegación, $y$ que por tanto les aconsejaba la emprondiesen con la lancha, ya que su intención era penetrar hasta el establecimiento ruso situado en $\operatorname{los} 60^{\circ} 30^{\prime}$. Persuadido Hidalgo de estas razones, envió, con efecto, la lancha $i l$ expresado reconocimiento, $y$ habiendo regresado el día 20 , se supo por ella que los rusos están en el río de Cook desde el año de 87 , que dependen dc una compañía de comercio de Petersburgo que les paga cuatro pesos y dos pesos de tributo al año á la Emperatriz, y tinalmente, que tenían 3.000 de los naturales cate. quizados $y$ amigos que pagaban asimismo tributo á su soberana. El número de rusos sería de unos 80 hombres, armados con otros tantos fusiles, pistolas $y$ sables y pedreros montados sobre cureñas de campaña.

El ejercicio de estos nuevos colonos es la pesca de nutria, lobos marinos, ballenas y otros peces, á cuyo efecto lleva cada ruso consigo to ó $\mathrm{I} 2$ indios que trabajan bajo su dirección y los pagan con tabaco de polvo, abalorios y ropa. En el invierno se dedican, cuando el tiempo lo permite, á la caza de diferentes cuadrúpedos, cuyas pieles benefician, $y$ aprovechan también sus carnes, para que con ellas y el pescado no les faite el alimento preciso, pues carecen de ctros frutos para su manutención. Estos indios son de la misma constitución y propiedades que los del Príncipe Guillermo, y así ellos como los rusos usan las mismas canoas, á excepción de que los últimos tienen algunas grandes en que bogan 14 remos; pero siempre están construidas de varas y forradas con pieles.

La costa desde las bocas del Sur del Prín. cipe Guillermo, está formada por una cadena de montes elevados, cubiertos la mayor parte de nieve. El Cabo Elisabet es el extremo meridio. nal de la Isla Maurelle; y si desde este Cabo se sigue hacia el Norte costeando sus orillas, se halla luégo una ensenada de mal surgidero, de la cual sale al Noroeste un cabo que llamaron de Gastón y poco después una islilla próxima al continente oriental con algunas restingas que se extienden milla y media. Desde este paraje se ve una pequeña ensenada donde hay casa de madera ell que habitan los rusos, $s$ in que puedan anclar en ella los buques por el fondo piedra que hay en sus centros. Dos millas al Nordeste de esta ensenada se halla la boca del puerto de Revillagijedo, y algunas más adelante la Punta de Cuadra, desde donde sigue la costa rasa $y$ limpia por espacio de tres millas, al fin de cuya distancia empiezan las rancherías de indios $y$ varias piedras que salen de la tierra $y$ siguen hasta llegar al último establecimiento que habi$\tan$ los rusos de aquel paraje en $\operatorname{los} 60^{\circ} 30^{\prime}$ de latitud, por cuya causa es preciso navegar con más aprosimación á la parte occidental del ca. 
que por tanto con la lancha, asta el estable. $30^{\prime}$. Persuadi. 6, con efecto, miento, y ha. to por ella que lesde el año de de comercio de besos y dos peatriz, y finalhaturales cate. asimismo trirusos sería de tros tantos fu. montados so-

colonos es la allenas $y$ otros ruso consigo ro dirección y los rios y ropa. En tiempo lo perdrúpedos, cuyas ambién sus carado no les falte de ctros frutos hdios son de la des que los del como los rusos ción de que los en que bogan $\mathrm{I}_{4}$ ruídas de varas

Sur del Prín. or una cadena de mayor parte de xtremo meridio. de este Cabo se sus orillas, se al surgidero, de so que llamaron slilla próxima al s restingas que esde este paraje ade hay casa de , sin que puedan el fondo piedra illas al Nordeste ca del puerto de lelante la Punta la costa rasa y s, al fin de cuya rías de indios $y$ tierra y siguen niento que habin $10860^{\circ} 30^{\prime} \mathrm{de}$ iso navegar con cidental del ca. nal. Esta costa oceidental es una cadena se. guida de montes elevaćss, entre los cuales se distingue por su mayor elevación y contínuas erupciones el volcán de Miranda. Su tempera mento parece más benigno que el del Príncipe Guillermo y la tierra más fértil, así por el color de ella como por la abundante yerba que la cubre.

Salic Hidalgo del puerto de Revillagijedo el 8 de Agosto y fondeó en el Caho de Dos Cabezas el II del mismo, habiendo experimentado en su travesía ehubascos, neblinas y oscurida. des. A poco rato de haber dejado caer el ancla, llegaron á bordo tres canoas que conducían al Jefe $\mathrm{y}$ dos individuos del establecimiento ruso que está situado al Sudoeste del Cabo mencionado. En esta visita adquirió Hidalgo las noticias siguientes.

El establecimiento de la Isla Codiac se hallaba en el mismo estado qué lo describió el $\mathrm{Pj}$. loto D. Genzalo de Taro el 1 de 80 . Habia tres galeotas, dos pilotos y 200 marineros dependientes de una compañía de comercio de $\mathrm{Pe}$. tersburgo ejercitados en la pesca de nutrias, $y$ repartidos entre dicha isla y el rio de Cook: las galeotas se tripulan con aquella marineria, y reconocen la costa comprando pieles, de modo que el año de 89 se había despachado uno de aquellos buques á la Siberia con 9.000 pielcs. Supo también que en $\mathbf{1 7 9 2}$ debia ser relevada aquella gente con otra que llegaría del $\Lambda$ sia, y que entre la Isla Codiac y el río de Cook contaban con 9.000 indios vasallos y amigos de la Emperatriz.

Adquiridas estas noticias dió la vela Hidalgo el I7 de Agosto, y el $I_{5}$ de Setiembre llegó á Monterey, en cuyo puerto halló $\therefore$ Quimper que había reconocido parte del Estrecho de Fuca, y juntos los dos salieron para San Blas el 24 de Octubre y fondearon en este puerto el $I_{4}$ de Noviembre del mismo año de r $79^{\circ}$.

\section{Descritioion fisica y costumbres de la California.}

Divídese comunmente la California en Vieja y Nueva. Aquélla comprende toda la Península que corre desde el Cabu San Lucas hasta el puer to de San Diego en latitud de $32^{\circ} 16^{\prime}$, y por Nueva California se entiende el terreno que sigue desde este último paralelo hasta el de $43^{\circ}$ en que se ha lla situado el Cabo Blanco de Martín de Aguilar.

La porción que denominamos Vieja Califor. nia y corre del Sueste al Noroeste entre los.limites mencionados, fué mirada en lo antiguo como un país rico en minerales de oro y plata y fértil de toda clase de frutos y producciones naturales; pero los reconocimientos posteriores desmintiendo la primer idea, han dado también á conocer que esta fertilidad, si tal puede llamarse, se halla únicamente encerrada en su extremidad mo:idional. Descubriéronse hace algunos años varios minerales que se trabajan aún en el día, pero la escasez de sus productos hace creer que la ponderada riqueza de este suelo está limitada á la de los placeres de perlas situados dentro del seno californico. La Sierra Madre que empieza desde el extremo austral, divide á lo largo en oriental y occidental á toda la California hasta ahora descubierta, y de esta circunstancia unida á la de la faz que presenta el terreno en ambos lados, ha tomado origen la denominación particu lar que algunos dan á sus habitadores, distin. guiendo 2 los orientales con el nombre de mora. dores ds psinas, y á los occidentales con el nombre de moradores de piedrecitas. Esta sierra, que co- rre en la dirección indicada, se acerca siempre más al seno califórnico, apartándose del mar Oceano, aunque en ciertos parajes extiende hasta él sus ramas. Su extremidad austral está poblada de arboleda, y en la eminencia hay pinos, pero al paso que sube hacia el Norte, sigue más áspera y eriaza, componiéndose sus vertientes de peña viva ó lomas enteras de piedras sueltas y amontonadas. En los parajes adonde se cubre de tierra, su profundidad no pasa de media vara, y consta, por lo general, de una especie de arcilla ó tierra blanca, como de yeso quemado, teniendo debajo peña viva y pedregales formados de cierta especie de tierra, cuya dureza no iguala á la de las otras piedras. La sierra, por lo común, se presenta desnuda, y solamente produce espinos y otras malezas. En las vertientes que caen hacia el golfo califórnico, escasean las aguas perma. nentes, y en parajes se encuentran algunos pozos abiertos en la tierra, de agua por lo común grue. sa y salobre; pero en las vertientes occidentales falta aún este recurso, y varios buenos puertos que tienen sus costas, quedan como inútiles por ayuella causa igualmente que por la carencia de leña. En la sierra vecina hay varios manantiales que forman arroyos hondos cuyo curso no extendiéndose hasta el mar, se detiene formando grandes salitrales y méganos de arena que mudan contínuamente de situación y figura á esfuerzos de los vientos recios. El agua llovediza conducida por aquellos arroyos, entra y se difunde en los 
salitrales ó méganos mencionados, y permaneciendo cncharcada, se convierte con el tiempo en sal, por cuya causa se encuentran grandes comarcas cubiertas enterames te de sal maciza ó en pedazos sueltos. Finalmes te, si hemos de atenernos á las pruebas que comı nmente pasan como signos irrefragables de que eı mar cubrió en otros tiempos paises que en el día se hallan á mucha distancia de sus aguas, no queda duda que estos parajes fueron en lo antiguo la mansión del grande Oceano. $\Lambda$ sí lo persuaden los muchos ostiones, caracoles y conchas que se encuentran pegradas á los peñascos de los arroyos, de tal modo, que hay cerros de pura concha, como lo son particularmente los que se denominan de San Juan, tres leguas distantes de Loreto, siendo de advertir que entre ellos y el mar se interpone una cordillera de lomas altas que merecerian el nombre de sierra en otro país ménos montuoso.

A pesar de la esterilidad de que vamos hablando y de la falta de aguas tan general en la Vieja California, se cría en su suelo una planta que conocen vulgarınente con el nombre de dátil, y es una especic de la palma que produce el fruto asíllamado, aunoue la de las Californias es mayor y en lugar del hueso duro del dátil legítimo tiene aquélla un agregado de pepitas negras, chatas y redondas, con cáscara algo dura. Esta planta está en flor á fines de Julio y despide un olor suave y agradable; por Setiembre, Octubre y Noviembre da el fruto, y sólo se logra la cosecha en las abundantes lluvias. La fruta, aunque dulce y laxante, debe ser muy sana y sustanciosa, según lo da á entender la constitución robusta de los naturales que la usan.

En la Sierra Madre se halla una especie de árboles altos, cuyas hojas son de un verde ameno y claro. Los llaman palo-alto ó palo-blanco, no porque su corteza sea de este color, sino porque en todas las hojas y ramas delgadas se lle. nan en Mayo de una goma blanca, transparente y dulce que agrada mucho á los naturales. La plan. ta que produce la pepita conocida vulgarmente por tohova, es un matorre útil: se halla con más abundancia en las vertientes que caen hacia el Oceano, pero siempre escasea cuando no llueve: la masa de la pepita es como de avellana muy aceitosa, con un leve sabor anargo y varias virtudes medicinales; pcro la planta que hace el primer papel, es el mezcal ó magüley de Nueva España, que sirve de pan cotidiano á íos indios, asándolo debajo de tierra. Su tamaño y calidad varía con respecto á las latitudes en que se cría. En la parte austral es grande, aunque nunca igual al de la América ulterior; por $\operatorname{los} 26^{\circ}$ queda chico, pero dulce, y en los $29^{\circ}$, especialmente entre la sierra y el Oceano, vuelve otra vez á crecer como en el Sur, pero con el defecto de ser amargo en el todo 0 en mucha parte. Para usarlo, cortan sus hojas por más arriba del tronco y envolviéndolas entre cenizas y piedras caldeadas de antemano, las dejan cubiertas por uno 6 dos días, y al cabo de este tiempo se encuentra el mezcal bien asado, jugoso y dulce.

En los años que las aguas son abundantes, nace en varios parajes cierta especie de yerba llamada teda, cuya semilla es poco mayor que el anís. Los naturales la comen tostada, echando al intento una porción en una batea formada de los palos flexibles de cierta mata pequeña (I), y scbre ella carbones encendidos con los cuales se tuesta y revienta la semilla descubriendo una ha. rina blanca. En el día, que ya tienen ollas y algunos de nuestro 1 usos, limpian y muelen la semilla después de tostada, y la comen hecha ha. rina, ó bien en poleadas. Otra cosecha muy agradable para estos naturales es la que llaman mede$s a$, fruta de unos árboles grandes, cuyo tronco y ramas son de color verde claro; la semilla se parece al fríjol, aunque es algo menor, pero difícilmente se consigue todos los años.

También hay otra especie de árboles que lla. man higucra de monte por asemejarse su fruta á los higos blancos europeos, aunque son $\sin$ comparación mucho más menudos y desabridos. Estas higueras dan también como aquéllas dos frutos al año, pero crecen generalmente sobre peñascos y en los cantiles de despeñaderos. Es ciertamente maravilloso el modo con que sus gruesas raices van introduciéndose por las angostas hendiduras de los cantiles, 6 bien cómo ellas mismas se forman estas hendiduras. Pros. peran mucho en parajes muy secos, haciendose altas y copuaas, y aunque no dejan también de crecer en terreno húmedo, siempre ha de ser piedra. El color del tronco es blanco tirando á pajizo y su madera vidriosa y quebradiza, por cuya causa no es raro el que se despeñen algunos naturales al tiempo de asirse de las ramas para coger el fruto. Finalmente, todos los árboles res. tantes que produce este país y sirven de alimento a sus naturales, se pueden reducir principalmente á cuatro clases (2). La primera es la que

(1) En el Compendio del Padre Venegas, parte primera, parrafo IV, se describen estas bateas co: el nombre de coritas, diciendo, en cuanto á su tamaño, que las hay tan grandes que caben dos fanegas de que las hay tan grandes que caben dos fanegas de maiz, y en ellas pasan de una orilla a otra sus frutos
sin tocarlos el agua, yendo los indios nadando y empujando las bateas. Desde Acapulco remitió la expedición para el Real Gabinete algunas muestras de estas primorosas manufacturas. Merece reparo el que se halle tan extendido su uso en toda la costa Noroeste para el apresto de las comidas, que casi lo hemos visto uniforme en toda la California hasta cl Puerto visto uniform

(2) Estas cuatro plantas corresponden todas a la clase de los Cactus, según los Sres. Nee y Heenke, quienes aseguran que su numero es tal en los Reinos de Nueva España, Perú y Chile que tal vez no está descrita la mitad en el sisteına natural. 
el tronco $y$ endras caldeadas por uno 6 dos encuentra el

on abundantes, pecie de yerba oco mayor que stada, echando tea formada de pequeña ( $\mathrm{I}), \mathrm{y}$ on los cuales se briendo una haenen ollas y aly muelen la semen hecha haecha muy agraue llaman mede. , cuyo tronco $\mathrm{y}$ ; la semilla se henor, pero difíños.

árboles que 1laejarse su fruta aunque son $\sin$ os y desabridos. no aquéllas dos ralmente sobre espeñaderos. Es do con que sus ose por las anes, 6 bien cómo andiduras. Proscos, haciéndose ejan también de re ha de ser pie:o tirando á paradiza, por cuya ñen algunos naramas para co. los árboles resirven de alimenducir principalimera es la que

re Venegas, parte tas bateas con el anto a su tamaño, dos fanegas de a otra sus frutos us nadando $y \mathrm{em}$ o remitió la expounas muestras de mostras de epe reparo que casi lohemos que casi lohemos onden todas a la Nee y Heenke, tal en los Reinos e tal vez no está e tal
ral. en Nueva España llaman ivizaya, y es un troncón grueso sin brazo alguno, de dos varas y media de alto, más ó ménos, y media de diámetro, rodeado de espinas sólidas y largau, que algunos emplean por mondadientes. En su parte superior echan unas hermosas flores matizadas de varios colores, y debajo de ellas hay unas bolitas que contienen la semilla, la cual es delgada y negra. Este arbol es de tal calidad que comienza á dar el fruto desde que nace. La segunda especie que los españoles llaman garambullo, es un montón de vasos que desde el suelo nacen de un tronquito; su fruta, aunque mucho menor y ménos sabrosa, es algo parecida á la pitahaya que forma la especie tercera. Esta se divide en las dos clases de pitahayas agrias y dulces. Las agrias, que sólo se dan en las costas de uno y otro mar, forman un matorral de órganos enmarañados, cubiertos de espinas gruesas que por la mayor parte arrastran por el suelo. Su fruta se asemeja á una bola casi redonda, colorada ó morada, y rara vez es blarica ó de colores mezclados.

La pitahaya dulce, propia sólo de la sierra, admite alguna variedad, siendo blancas 6 encarnadas y áun de color anteado: el arbol que las da sube del suelo en un sólo tronco, y á poca dis. tanci e divide en muchos brazos formando una copa zunsiderable. Cada brazo echa en su punta el fruto, y éste está lleno de espinas que fácilmente saltan cuando está madura la pitahaya. Las dulces son algo menores que las agrias, y éstas realmente son agridulces y tan regaladas, que regularmente son más estimadas que las dulces. Su semilla es menuda como la de los higos, pero negra. La cuarta especie es el cardón que sale de la tierra muchas varas, y á alguna distancia de ella llena de brazos que suben hacia arriba, todos igualmente gruesos y tanto como el tronco del mismo arbol. Otros hay que no crían estos brazos, y suben derechos á manera de altas vigas. La fruta de estos arboles que llaman organos, se compone de unas bolas llenas de cierta semilla negra, más gruesa đ̧àe grano de pólvora, sin masa alguna y unidas sólo entre sí por un humor grueso y viscoso; la aprecian mucho los naturales, y la comen tostada, entera ó molida. Este arbol, igualmente que las especies antes mencionadas, of recen la particularidad de que su carnaza, así interior como exterior, es siempre muy aguanosa, especialmente la del cardón como más gruesa, pues con sólo un pedazo que se corte y se exprima fuertemente, se logra una gran copia de agua 6 caldo, siendo así que estos árboles no nacen en la humedad, sino en la tierra más seca y enjuta. Sus raíces se extienden por la superficie, y jamás profundizan mucho dentro del terreno. Este es sumamente seco, los soles muy ardientes, y siendo raro el que en estas tierras caiga sereno 6 rocio, es cier- tamunte digna de investigación la causa de esta aguanosidad, tanto más cuanto que por muy es casos que sean los años de lluvia, nunca se entristecen estos árboles, y siempre perseveran con la misma frescura, color y aguanosidad.

Hemos hecho esta prolija enumeración de los medios con que provce la Naturaleza al sustento de la especie humana en un suelo tan poco fa. vorable á ella, así para manifestar cuáles sean las producciones naturales de la Vieja California, como para fijar de una vez la idea verdadera que debe tener la Nación, de un país que en otro tiempo mereció los más encarecidos elogrios por una riqueza y fertilidad que sólo existía en la acalorada imaginación de los autores que la forjaron. Nuestras noticias presentes están apoyadas en el testimonio común de los Padres Misioneros que han transitado esta región del mundo, y de los muchos viajeros nacionales que han escrito de ella, entre los cuales merece un distinguido lugar la descripción del docto Padre Fernando Consag, de quien hemos extractado mucha parte de lo antecedente. Por lo que toca á la ponderada riqueza de las minas de la California meridional, oigamos lo que añade este mismo Padre para completar la descripción física de su suelo.

"Hay cerros, dice, y lomas que pintan en la " mayor parte de metales, porque echadas algunas " de sus' piedras en la lumbre, rinden plata; mas á - vista de tanta esterilidad y falta de leña, la que - cuanto más se sube al Norte escasea más; "hasta ahora solamente en la extremidad austral "que es fértil, se trabaja en minas de plata. E:I " cobre se halla á veces en unas piedras con un "color verde muy vivo, cle que los naturales se "sirven para pintar sus flechas. Este color echa"do en la lumbre, aunque blando, no se deshace, "pero se tupe de granos chicos de cobre. Se ha"llan pedazos de hierro virgen de varios tamauños, con poca guija, pero por varias diligencias "que se han hecho no se pudo encontrar con la "veta. Azufre virgen hay en cantidad, que no nnecesita más beneficio que cargar y llevarlo. - Alcaparrosa la hubo más en el mismo paraje, "donde se cogía ya no se halla, ó porque se aca"br, 6 porque falta la inteligencia y conocimienwto. Mármoles hay de varios colores que se apre. " cian en Europa, y también del color que llaman "verde antico. El mármol blanco está algo más "al Norte de las misiones actuales, como tam- bién una piedra transparente, semejante al dia"mante de Almazón. Aunque varios cerros que "tienen boca parecen ser volcanes, sin embargo, "no se ha notado hasta aquí erupción alguna, si "bien humean algunas veces: se halla sí arena " caliente en el contorno de la boca de uno de " estos cerros, la que sumiéndose mucho con las "pisadas, sale inmediatamente humo. Se advier* ten también en estos parajes dos como respira- 
„deros de viento, el uno en una ladera pedrego. usa y el otro en un arroyo. La costa occidental wes bien fria por el contínuo viento Noroeste "que á menudo trae neblinas espesas, y porlo " común desbarata las nubes que prometían llu"vias. En la costa oriental, cuyo temperamento " puede llamarse caliente, sucede lo contrario por "estar defendida del viento Noroeste por medio "de la Sierra M.dre, de modo que por el mes "de Junio, al despuntar el Sol, en que se suda "por el mucho calor, si cruzando la sierra se - llega á paraje en donde bate este viento, aunque usea en punto del medio día, se apetece el abrigo "de la ropa y calor del fuego..

Un terreno, pues, tan poco apto para la agricultura, debía alimentar y alimenta con efecto un corto número de habitadores, haciendo al mis mo tiempo difícil su reunión y civilización. Po el empadronamiento general formado el año de r 768 en la visita de este Reino, consta que el número de habitantes de la California inclusos los párvulos recién nacidos, era en aquella época de 7.898 entre españoles, indios y demás castas. Su alimento, como ya se insinuó, son las semilias cogidas en el monte y en pocas ocasiones el ciervo ú otro animal, entre los cuales se comprenden áun los más asquerosos, como la tarántula, la araña, avispa, el murciélago, el piojo y las pieles podridas del coyote, prueba evidente de que la Naturaleza, poco propicia en este suelo para la multiplicación de! hombre, no lo es ménos para el fomento de las demás especies de animales. No deja de parecer extraño cómo estos naturales, faltos de agricultura y áun de los medios de alimentarse con la caza, no han tratado de adquirírselos por la pesca, siendo así que en una y otra costa se encuentran muchos y buenos peces, entre los cuales merece, aunque anfibio, un lugar no postrero, la nutria (r). Pero si se atiende á la total falta que hay de aguas dulces en las orillas del Oceano, á la demasiada cantidad de bajíos, y á las tempestades harto fre. cuentes en el seno califórnico, es posible suponer que en todo tiempo han distraído de la navega. ción á los naturales estas causas poderosas, tanto más que para la subsistencia de un número tan corto de familias no era preciso variar las cos. tumbres de sus antepasados. Así es, que el único producto del mar que han comprendido siempre entre sus alimentos es el marisco, y no tuvieron otro lugar en lo antiguo las conchas de las perlas (2), tan abundantes en el seno, y primer mó-

(I) En la historia del Padre Venegas se hace una larga enumeración de sstos, citando el viajo de Sebastián Vizcaino. La nucria es la que describe con el noinbre de castor.

(2) Así lo asegura el Padre Torquemada, quien dice que los indios echaban en el fuego las ostras, quemaban ó tostaban las perlas, aprovechándose de la carne sola. vil de nuestros últimos pasos nacionales hacia esta parte.

El estado de la Vieja California según se halla al presente, comprende varias misiones situadas de Norte á Sur sobre la costa, á mayor 6 menor distancia de ella, á saber: San José del Cabo, cinco leguas de la playa del Cabo San Lucas; Nuestra Señora del Pilar 6 todos Santos; Santiago de las Coras; San Francisco Javier; San José Comondú; Loreto, situada en el presidio del mismo nombre que hace cabeza de esta parte de la Península; Guadalupe; Santa Rosa. lía 6 Mulege; la Concepción 6 Cadegomo; San Ignacio; Santa Gertrudis y San lirancisco de Borja. Todas estas misiones fueron fundadas $y$ corrieron al cargo de los Jesuitas hasta el tiempo de su expulsion, y en el día se administran por los Padres Dominicos, los cuales han fundado en su tiempo las de San Fernando, Velicata, Nuestra Señora del Rosario 6 Viñadaco, Santo Domingo, San Vicente, Santo Tomas y San Miguel. Según los informes dados por el Gobernador de California, D. Pedro Tages, en Diciembre de $x 790$, resulta que estas últimas y nuevas misiones colocadas en los puntos salientes para el Norte de la Península, están rodeadas de bastante gentilidad que paulatinamente se va reduciendo. Las otras que se hallan entre el mar del Sur y el golfo, no tienen gentilidad alguna y se disminuyen poco á poco, de modo que ya las de San Javier y Santiago tocan á su último extremo. Los frutos que en estos estados se mencionan como cosecha de alguna de las misiones antiguas, se reducen á la uva, de que hacen algún vino, aguardiente y pasa, trigo candeal, considerable porción de higos de no buena calidad, carnes y la pitahaya de que antes hemos hablado, pero la cantidad de estos frutos debe sin duda ser muy limitada, si se atiende á que ha sido preciso socorrer estas mi. siones el mismo año 1790 con porciones cre: cidas de comestibles que se enviaron desde San Blas con la fragata Princesa, quedando de este modo frustradas ya las muchas providencias dic. tadas en la última visita del Reino, para el sostenimiento y fomento de esta provincia.

Uno de los medios poderosos con que juzgó el Sr. Gálvez se lograria la regeneración de la península de California, según el informe que dió al Virey, D. Francisco Bucareli, fué el de aponer en corriente algunas de las miunas descubiertas en ella, para que sirviesen de "incentivo y movimiento á los nuevos pobladores " establecidos en los pequeños Reales de Santa "Ana y otros del Departamento del Sur." Pero aunque la experiencia de cerca de dos siglos debía habernos convencido de la verdadera utilidad de estos medios en cuanto á la población siempre que faltan otros arbitrios, parece, sin embargo, estaba reservado para esta época el 
último desengaño, creciendo la necesidad cada día más de enviar comestibles al presidio de Lo. reto, habiéndose también reducido todo el laboreo de las minas á dos pequeños Reales de corto producto, situados en el Sur, en que se mantenian como 500 vecinos el año citado de 1790 .

No es fácil determinar cuánta parte tenga en la expresada esterilidad la calidad de este suelo y cuánta la frecuente sequedad de su temperamento; pero si para la subsistencia cómoda del hombre en cualquier pais es preciso exista á lo ménos una cierta abundancia de los dones de 1o Naturaleza, no será temeridad asegurar que en toda la peninsula de California al Sur del puerto de San Diego en una y otra costa, no hay cosa alguna que convide á habitarlı, aunque en la misión de San José, extremo meridional y próximo al Cabo San Lucas, no sea tal vez tan precaria la subsistencia como lo es en Loreto y en las demás misiones. Las Havias escasean casi todos los años; la arena de las orillas del Oeste no sólo absorbe el agua que le cae directamente, sino también la que derrama la Sierra Madre; y esta misma sierra, hallándose demasiado contígua á la costa del golfo, no tiene lugar para fertilizar con sus escasos dones una tierra por sí quebrada y de tan poca extensión; finalmente, siendo tan pernicioso el frío á una banda como lo es á la otra el calor, ambos extremos concu. rren á destruir toda esperanza aunque remota, de que alguna vez pueda llegar esta Península á alcanzar un grado mediano de opulencia.

Abandonémosla, pues, á su pobreza y dejemos la inútil descripción de las costumbres, tra. jes, armas y principios religiosos de los pocos moradores que aún mantiene, ya porque en el compendio de la historia del Padre Venegas se halla formada con toda la puntualidad posible, ya también porque. será más fácil reunir después estas noticias á las de otras naciones más septentrionales que habremos de examinar luégo.

En las inmediaciones meridionales del puerto de San Diego, la Naturaleza varia enteramente de semblante, $y$ ofrece á la vista una graciosa variedad de árboles, arbustos y plantas odorífe. ras, y cerca de la playa lindísimos prados. Alejándose de aquel puerto ya se encuentran caña. das muy vistosas y amenas con muchos pastos, arboleda y agua, $y$ luégo sigue un país alegre compuesto de lomas de tierra negra, cubiertas de pastos, en donde hay matas y algunos árboles de los que llaman alisos.

Finalmente; el Capitán D. Juan Bautista Ansa, que transitó en 1773 desde la Sonora á la luision de San Gabriel, vadeando los ríos Gila y Colorado y atravesando la Sierra Madre por los pasos difíciles del Cerro 6 Puerto de San Carlos, describe este país como formado de hermosísimas llanadas muy verdes y floridas, sierras nevadas con pinos, encinas y otros árboles propios de tierra fria, y el terreno apto para siembra de tem. poral y plantios de árboles frutales, igualmente que para la manutención de ganado por sus pas. tos abundaites. La grande $y$ vistosa laguna del Principe se halla circundada de floridos y amenos valles, y de varias sierras nevadas que les tributan sus derrámenes, además de otros veneros de agua muy agradable. Le sorprenden los dos valles siguientes de San Patricio y San José y la laguna no distante de San Antonio; Bucareli, parajes (dice) en el mes de Marzo tan llenos de frondosas alamedas, llores, pastos y otras yerbas útiles, que no es fácil adivinarlo á la vista de la nieve tan cercana. Ultimamente, el puerto mismo de San Diego de un excelente abrigo para buques de cualquier tamaño, las islas inmediatas de Santa Catalina, Santa Bạ́rbara, San Ambrosio y San Clemente, situadas en una latitud en que no de. jan de suavizarse con el benéfico viento del Noroeste, los ardientes calores del estio, y en donde los hielos de las montañas internas no pueden contrarestar el temple suave de la marina; todo indica que la Naturaleza, siempre varia, siempre admirable, ha derramado aquí sus dones para el bienestar del hombre.

Desde San Diego hasta el Puerto de Monte. rey y áun hasta San Francisco, puede considerarse como uno mismo el semblante halagüeño de la costa; y aunque las neblinas harto frecuentes y espesas parecen en cierto modo oponerse á la fertilidad del terreno y á la seguridad de la na. vegación, bien examinados estos inconvenientes, parecen, sin embargo, de ningún valor á la vista misma del país. Los vientos del Noroeste que casi reinan todo el año, son naturalmente claros, apacibles y fríos, y los del Sueste que traen las aguas y regularmente son tempestuosos y húmedos, apenas se sienten seis ú ocho veces en todo el invierno. Con este inotivo las neblinas, lejos de causar un daño real, producen un beneticio positivo, en cuanto á que conservando activa la hu. medad del suelo, mitigan los rayos del Sol y hacen del otoño una risueña y nueva primavera.

Puede imaginarse cuál debió ser la agradable sorpresa de todos nosotros al ver en el mes de Setiembre florecer por algunas leguas en contorno de Monterey una vegetación general tan loza. na y copiosa que no bajaban de 100 el número de plantas que devolvían á la Naturaleza esta singular fertilidad (I). Adornábanse los campos con unos bosques ya claros, ya espesos del pino. teda, del álamo, roble y encina, y á éstos seguían en las cumbres más elevadas el pino colorado, árbol mucho más alto que los demás, varias plantas medicinales, algunas venenosas, y otras úti-

(1) Don 'Tadeo Heenke halló en el laurel la semilla madura y la flor que empezaba á brotar. 
les ó agradables, laciendo subir como á 250 el número de las que reconoció D. Tadeo Heenke (I).

- Fecundizado por consiguiente el suelo con „doble vigor, presenta una tierra (dice D. Tadeo "Heenke), negra y pingue de uno 6 dos piés "de espesor, formada de las miriades pútridas y "sobrepuestas á una arcilla arenosa y cenicienta "que por lo común se halla en todos los con"tornos, excepto en las inmediaciones del mar, "las cuales se componen de bancos movibles de "arena, muy dispuestos para la filtración de la "sal, que aqui se produce en mucha cantidad ó "de una piedra granitosa cuyas hojas mayores - están formadas, primero de cuarzo blanco; se"gundo, de mica nigricante; tercero, de feldes. "pato amarillento, formando por lo común con * el horizonte un ángulo de 80 á $90^{\circ}$ : siendo su " principal dirección al Sudoeste y atravesadas de "alto á bajo con una capa, por lo común tan es" trecha, que no excede de una ó dos pulgadas, "compuesta de cuarzo puro granuloso y blan. "quizco.

"La composición de la piedra que forma el "hueso interno, digámoslo asi, de las inmediaciounes de Monterey, halló el mismo Sr. Heenke en "sus análisis, que es una piedra blanquinosa "6 amarillenta, sumamente ligera en su peso, " seca y friable al tacto, quebradiza y dispuesta "á teñir; compuesta esencialmente de marga ar"cillosa, muy propia para edítios, y que insen. " siblemente se convierte sn calcárea á medida "que se acerca á la cima de los montes. En to"das partes es oportuna para hacer cal, aunque "no de la mejor calidad, mezclándole una gran " cantidad de arcilla, con la cual hierve aunque "lentamente en el agua fuerte. De esta misma "clase son todas las piedras que eh masas muy wenormes guarnecen $y$ liacen tc ,ples todas las " costas al Norte y al Sur del río Carmelo."

Según los naturales, se hallan con facilidad áun en las colinas más elevadas que conducen desde el presidio á la misión, varias petrificacio. nes de testáceos y áun algunos dendrites, y las playas producen con albundancia la concha conocida vulgarmente por concha de Monterey, y que llaman los nat uralistas Alyotis Myde.

En cuanto á la dificultad que debe ofrecer á la navegación las frecuentes y espesas neblinas con que parece quiso la Naturaleza ocultar en estos parajts la vista de los astros y de la tierra,

(1) Entre las plantas medicinales cuenta este bo tánico, la malva, el tropcolum-majus, la arthemisia-absintium, ln arthemisia-dracumculus, la erthemisia-maritima; scorconera-dentata, solidago-cricetorum, solidaro-cimerca, gentiana-centourium, salvi frutescius st

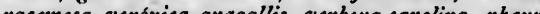
raccmos, verbmice an eallis, verbenn carolina rhannus maritimus, sichorium, virgetum, melissa prostrata, oxalis prostrata, tumarea achillea, millefolium, etc.; y entre las venenosas rhusradicans, rhustóxico, dendron, la cicuta. siides; el hippomane disrolor. está suficientemente compenseda con una sonde bastante saliente de la costa, y con la circuns. tancia particular de que jamás corren en ella vientos de travesía, y que los mismos Noroeste 6 Sueste que siguen su dirección, pocas veces 6 ninguna pueden llamarse tempestuosos. Por lo demás es claro que estas contínuas neblinas no pueden ser de una utilidad general en la agricul. tura para toda clase de semillas, pues es bien sa. bido que varias especies de granos $y$ casi todos los frutos cultivados, necesitan más 6 ménos del calor del Sol, tanto para granar como para madu rarse ó endulzar. Liste inconveniente causa, con efecto, una notable diferencia entre las produc. ciones de nuestras misiones de la orilla, comparadas con las de las situadas en el país interno; no obstante se tiene notado que en el maiz, semilla la más útil para la vida humana, parece mé nos sensible que en las demás, y particularmente en el trigo, los efectos de la escasez del Sol.

Debemos tambićn exceptuar del inconveniente mencionado las misiones fronterizas al canal de Santa Bárbara, en el cual ya sea porque las islas que lo forman reciban y contraresten las neblinas, ya porque su dirección Este-Oeste no de lugar á cue obren allí los Noroestes conla misma actividad que en otras partes, logran de cierto calor más natural y permanente, y con él de unas cosechas más seguras y abundantes como repetidamente nos lo han asegurado los Padres Misioneros.

Las semillas que principalmente se siembran $y$ cosechan en las misiones de la Nueva California (I) son el trigo, cebada, maiz, fríjol, garbanzo, lenteja, chícharos y habas. También se dan las frutas en muchas de ellas, $y$ en las de San Buenaventura y San Diego hay parras, y en la de Santa Clara se crían particularmente ricas y abundantes peras, melocotones y ciruelas, para lo cual contribuyen mucho, asi la cantidad de agua y el clima hermosamente claro y tem. plado de aquel paraje, como los huesos ó praquetas frutales que les dejaron de Monterey los Sres. Conde de la Péyrouse y Vizconde de la Langle, los cuales estuvieron en Monterey por Setiembre de $\mathbf{I} \% 86$, y explayaron su generosidad dejando igualmente diferentes granos de la mejor calidad, que en el dia han multiplicado mucho en la misión de San Carlos (2).

(1) Las misiones que hay establecidas en la Nueva California son las siguientes, situadas de Sur a Norte, a saber: San Diego, San Juan Capistrano, San Gabriel, San Buenaventura, Santa Bárbara, Concep. ción, San Luis, San Antonio, San Carlos, Santa Clara y San Francisco. Puede verse en la relación jel viajo San Francisco. Puede verse en la relacion del viajo Estrecho de Juan de Fuca el estado comparativo de las siembras y cosechas de todas estas misiones en los años de 1785,1790 y 1791 .

(2) Merecen los mayores elogios los rastros do humanidad que han dejado estos navegantes france. ses en las misiones de la Nueva California. 
con una sonda on la circuns. corren en ella mos Noroeste pocas veces $b$ tuosos. Por 10 as neblinas no 1 en la agricul. pues es bien sas y casi todos ás 6 ménos del mo para madu. inte causa, con tre las producorilla, compa1 país interno; el maiz, semi. na, parece mé. particularmente sez del Sol.

lel inconvenienterizas al canal sea porque las traresten las neste-Oeste no de tes conla misma ogran de cierto $y$ con él de unas tes como repeti. s Padres Misio-

ente se siembran ' Nueva Califorxiz, fríjol, garis. También se llas, $y$ en las de hay parras, $y$ en cularmente ricas nes y ciruelas, así la cantidad ate claro y temos huesos .6 pra. de Monterey los Vizconde de la n Monterey por 1 su generosidad ranos de la menultiplicado $\mathrm{mu}$ (2).

lecidas en la Nue ia Nue Capistrano, San Bárbara, Conceparlos, Santa Clara relación đael viaje to comparativo de tas misiones en los iavegantes france. tifornia.
No podemos continuar con igual prolijidad que hasta aquí, la descripción fisica de las tierras contiguas al mar desde la misión de San Francisco, situada en $3^{\circ}$ escasos hasta Cabo Blanco; pero si atendemos á los conocimientos que prestan de esta parte los viajes nacionales y algunos extranjeros que ciertamente han visitado este trozo de costa, se puede asegurar que la misma suavidad del clima y la fertilidad del suelo que acabamos de indicar, se extiende por toda ella hasta el paralelo de $42^{n}$, teniendo siempre pre. sente la natural diferencia de los paralelos entre si. Asi nos lo han manifestado desde el mar las frecuentes neblinas y la calidad de la costa, la cual, favorecida por una sondu bastante saliente, se compone al principio de arenales 6 barrancas, siguiendo después á corto trecho un terreno alomado y bien vestido de arboleda. Ios Sres. Hezeta y Cuadra, que en 1775 estuvieron en el puerto de la Trinidad y en el río inmediato de las Tórtolas, hacen mención particular de la frondosidad de estos parajes, igualmente que de la del puerto de Cuadra, que visitó este Coman. dante el año de I79o á su regreso del Norte. El río de Martín de Aguilar presenta en sus orillas y hasta en sus mismas aguas, árboles y troncos de un tamaño singular, y finalmente, el inglés Francisco Drake asemeja estas costas á las de Inglaterra por su frondosidad y ameno semblante. Lo que debe exceptuarse de esta general fertilidad son las sierras que forman el Cabo Mendocino, el cual, cono más saliente al Oeste y puesto casi como una barrera á los violentos esfuerzos del Oceano, se presenta acantilado, compuesto de una sola masa de piedra y escarpado casi á pico, de modo que la vegetación parece ser un objeto secundario en este oportuno antemural.

Es bien sensible que no esté á nuestro al cance poder dar una noticia de la calidad del suelo que forman las islas del canal de Santa Bárbara, ni de las que están fronteras á las costas Norte del puerto de San Diego. Ninguno de nuestros navegantes modernos las ha descrito, $y$ probablemente no las han disfrutado, y las noticias que da el redactor del viaje de Sebastián Vizcaino, además de no comprender aquellas particularidades que en el día son tan necesarias, parecen también algo exageradas, comparándo. las con el estado actual de estos paises. Nosotros sblo hemos visto á cierta distancia las más occidentales del canal y la de San Nicolás, y á juzgar de aquéllas por las muchas barrancas blanquinosas que presentaban hasta la cima y por su mezquina vegetación, compuesta de muy pocos arbustos esparcidos en una ú otra parte, se puede aventurar la idea de que son bastante estériles. La isla de San Nicolás que costeamos más de cerca, y vimos con individualidad por su mitad del Sudoeste carece aún de estos pocos arbustos, y su superficie abarrancada no presenta la menor apariencia de que haya manantiales 6 aguas corrien. tes; lo único que sospechamos es que eaté habi. tada, pues así parecia indicarlo una humareda que salia de lo más alto del monte.

De lo expuesto hasta aqui se puede deducir con bastante fundamento: $10^{\circ}$ Que la California Vieja, esto es, desde los 22 hasta los $30^{\circ}$ de la. titud, es un país árido, montuoso, estéril y seco, poco dispuesto para la subsistencia del hombre é incapaz de suplir con sus pobres minas todos aquellos inconvenientes, $\delta$ de convidar á una útil navegación en una y otra costa, á pesar del be neficio de las perlas en la oriental, y en la occidental de la pesca de lobos, nutrias y ballenas. $2 .^{\circ}$ Que de $\operatorname{los} 30^{\circ}$ en ndelante varia enteramente el semblante del pais, of reciendo una vegetación Dozana que casi continua sin interrupción hasta los $37^{\circ} 30^{\prime}$ en que se hallan las misiones de San Francisco y Santa Clara y con muy corta variedad relativa sólo á la diferencia de latitudes, hasta el Cabo Blanco en los $43^{\circ}$ de latitud. Y aunque las dos cordilleras de islas fronterizas al canal de Santa Bárbara y á la punta de la conversión, parecen naturalmente estériles como dijimos, pueden no obstante ser capaces de una crecida poblacion, ya sea por la abundancia de la pesca en el mar que la rodea, ya también por la seguridad de la navegación y finalmente por su inmediación al país mucho más fértil de la tierra firme.

Proporcionada á estas disposiciones del suelo, es la concurrencia de los animales que la Naturaleza destinó para que lo disfrutasen. Expon. dremos en un breve resumen cuanto contienen los viajes y descripciones nacionales de esta parte de la Monarquía, y las observaciones prácticas que pudo rectificar D. Tadeo Heenke durante nuestra mansión en Monterey.

Además de los cuadrúpedos $y$ aves domésticas introducidas por los misioneros, se hallan en la California meridional dos especies de montería que no se conocen en la antigua ni en la Nueva España. La primera es la que los californios en la lengua Monqui llaman Tayé. Este es un animal de la corpulencia de un ternero de año y medio, y muy parecido á él en su figura: la cabeza se asemeja á la de los venados; tiene las astas extraordinariamente gruesas, aunque parecidas á las del carnero; la pezuña grande, redonda $y$ hendida como la de los bueyes; el pelo como de venado, pero más corto y algo manchado; la cola pequeña y la carne sabrosa y regalada. La se. gunda especie se distingue poco del carnero manso, aunque es mucho más corpulento y crecido; los hay blancos y negros, pero todos son muy lanudos y de lana á propósito para hilar y tejer. Hay tambien coyotes y se encuentran algunos venados, liebres, conejos y berrendos, aunque 
no en mucho número. Son más abundautes los insectos ó reptiles propios de tierra caliente, como vivoras, culebras de varias especies, sala. manquesas, escorpiones, alacranes, arañas, cien pies, grillos, lagartijas, lagartos y hormigas, exceptuando, sin embargo, las pulgas, chinches, niguas y otras comunes de la América. También hay gran variedad de aves de rapiña, de caza, acuáticas y cantoras, pero no las nombraremos para referirlas después á la California septentrional, en donde su número es ciertamente ma. yor que en la meridional.

No sucede asl con los peces, y en particular con los anfibios, los cuales abundan en una $y$ ot -a costa de la Vieja California, haciéndose en el dia sumamente útiles para los intereses na. cionales las nutrias, los lobos marinos y las ba. llenas. En la costa oriental, además de los galá. pagos, tortugas y muchos caracoles de varios géneros, se cuenta la concha de la perla, la cual sobre ser bastantemente copiosa tiene para el buceo la comodidad de darse en solas cuatro bra. zas de agua y el ser ésta tan cristalina que ae ven las perlas como si efectivamente estuviesen sobre la superficie del agua. Advertiremos, sin einbargo, que según los Diarios del Padre Consag escasea 6 falta enteramente este rico producto y áun casi toda especie de peces en las partes septentrionales del golfo, desde que vencido el paso de Sal si puedes, las orillas y los bancos in. termedios de la desembocadura del río Colorado no ofrecen sino montes inmensos de arena, opuestos igualmente á la navegación que al ca. mino por tierra ( $\mathrm{I}$ )

Mucho más fértil la Nueva California

(1) En la descripción de la California, del Padre Consag, se hace sobre las perias las siguientes advertencias. alo que reparo es, que hasta $32^{\circ}$ pocomas o ménos desde el Sur, la perla es blanca y legitima; pero en lo restante para el Norte la perla blanca es pero en lo restante para el Norte la perla blanca es más rara: la mayor parte do las perlas remeda cl enllaman rosadas o de nácar; otras remedan cl azul del cielc. Las perlins verdes son raras pero hermos?: por su iustre; otras sc sacan en gran cantidad de culoris cian tambien las conchas, la que com, se diserun. llama madre de perla, es concha gruesa solid.. su interior de un blanco lustroso. La conshis di las otras perlas es delgada y su seno de varios colores. Cuando la perla es de cuenta por su tamaño, de ordinario al abrir la concha so sucle topar; sin embargo, algunas están tan metidas cn el callo o carnaza de la concha, que por más que se estruja y exprime el callo, quedan escondidas, por lo que los ar. madores, en unas tinas de cuero echan a podrir los callos, y deshechos éstos por la putrefaccion, bajan todas las perlas de todos tamaños."

(2) El pais que asl denominamos y corre con este nombre on nuestras cartas nacionales, es el mismo que llamó la Nueva Albión el inglés Francisco Drake, quien siguen todos sus paisanos. Pero nues. tros derechos en esta parte son incontestables, teniendo presente la navegación que hizo en 1542 Juan Rodriguez Cabrillo, siendo Virey de la Nueva Es- desde los paralelos de $32^{\circ}$ de latitud proximamente, ofrece no solo una mayor variedad en to. das las especies de animales, sino tambien una proporción aventajada en sus tamahos, propios ya de estos paralelos felices. Cuentanse particu. larmente entre los cuadrápedos, los venados (1), berrendos, liebres, conejos, ardillas, gatos monteses, ratas, osos y tigres, y entre las aves, las tórtolas torcaces, las codornices, calandrias, sensotles, tordos, cardenales, chupamirtos, gra . jos, cuervos, gavilanes, alcatraces, gaviotas, buzos y otras aves marítimas de rapiña, sin que falten patos y ánsares de diferentes especies $y$ tamaños. Los peces más abundantes son las centollas, langostas, cazones, sargos, pargos, viejas, caballas, roncadores, bacalaos, guitarras, barberos, puercos, rayas, educhos, salmo. nes (2) y una muchedumbre innumerable de sa. brosas sardinas.

No podemos abandonar la descripción de las costas amenas de Monterey, sin dar un leve bosquejo del hermoso semblante con que se mani. festaba la naturaleza á nuestra vista desde el puerto, cuando disipada la neblina entre las diez de la mañana y las dos de la tarde, se reunlan al brillo del Sol y á la frondosidad de los contornos, los céfiros suaves de la virazón del Noroeste. Mirando hacia el presidio, la variedad de objetos en que entendian los soldados, sus tallas y sus rostros extraordinariamente sanos y robustos, sus mismos hijuelos ocupados en guardar los gana. dos 6 entretenidos en enlazar una res 6 montar á caballo, renovaban á la memoria la utilidad y los placeres de la vida campestre. Corriendo la vista algo más al Oeste, unas lomas matizadas con diferentes verdes y flores, al mismo tiempo qua descubrían en el poco espesor de sus arboledas la amenidad y la sombra, dejaban ver an. siosamente ocupados en sus pastos las especies más útiles del ganado doméstico, á cuyo alrede. dor voltejeaban pacíficas mil especies de aves $y$ saltaban tímidos y ligeros el conejo, la liebre y la ardilla. Y si un bosque no muy espeso de pinos y cipreses y una costa algo árida y muy pedregosa parecían querer oponerse por un momen-

paña D. Antonio Mendoza, Condo de Tendilla, en cuyo obsequio se llamo Cabo Mendocino el extremo de la costa saliente al Oesto por los $40^{\circ}$ de latitud. El mismo navegante, en ro de Marzo de 1543, tomando altura alcanzo hasta los $44^{\circ}$ de latitud.

(r) En la vida del venerable Fr. Junipero Serra, página 207 , se habla de unos venados o especie de ellos, tan grandes como el mayor buey, con una cornamenta de la misma hechura que la del venado, pero $\tan$ larga, que se lo midieron de punta a punta 16 palmos, y habiendo muerto tres do ellos y que. riendo llevar uno entero, no pudo una mula sola cargarlo y fué preciso á trechos remudar mulas.

(2) La época on que suben a desovar estos peces

(2) La época on que suben a desovar estos peces
exquisitos en los ríos de San Francisco y del Carmolo exquisitos en los rios de San Francisco
es proximamente por Febrero y Marzo. 


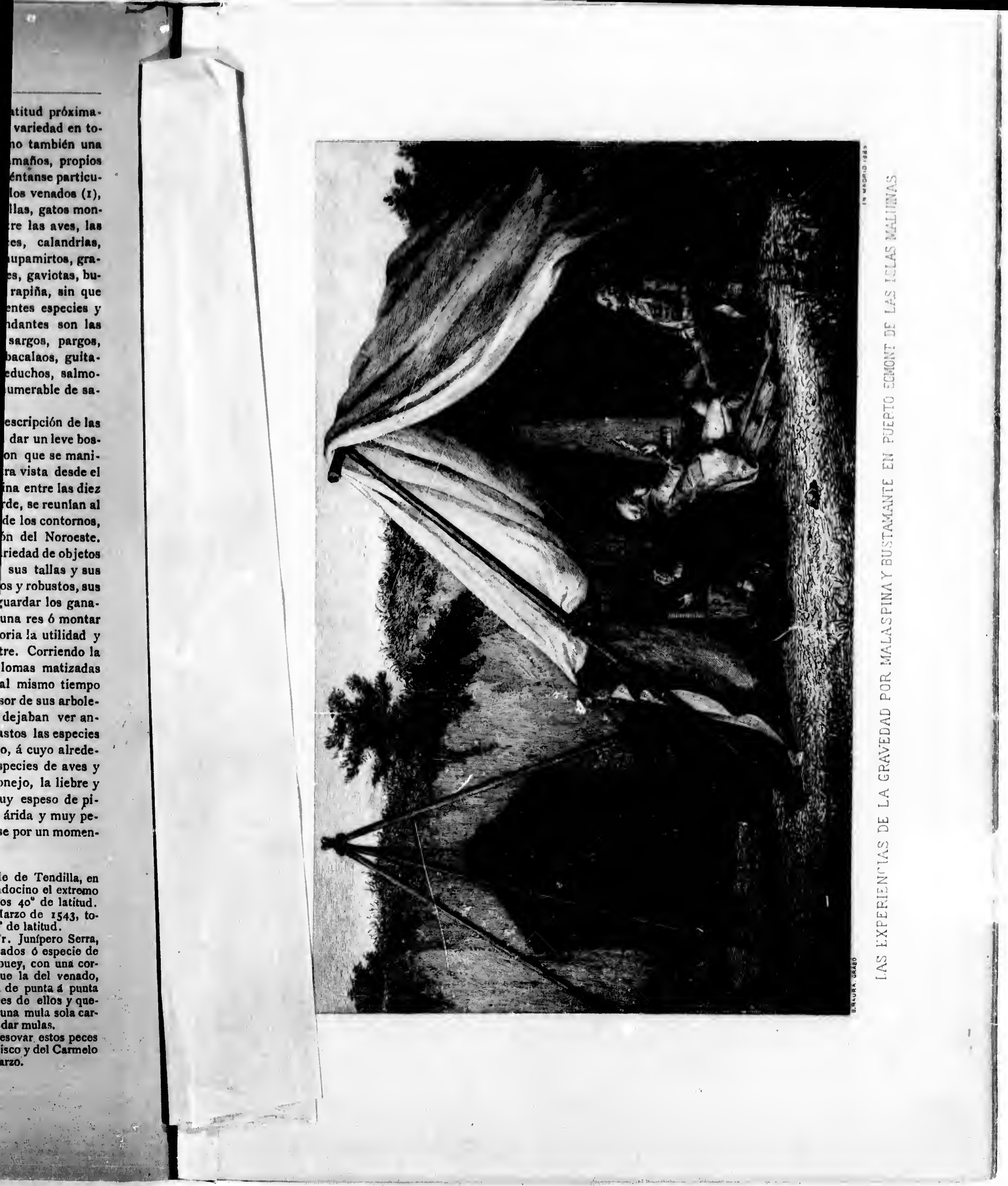




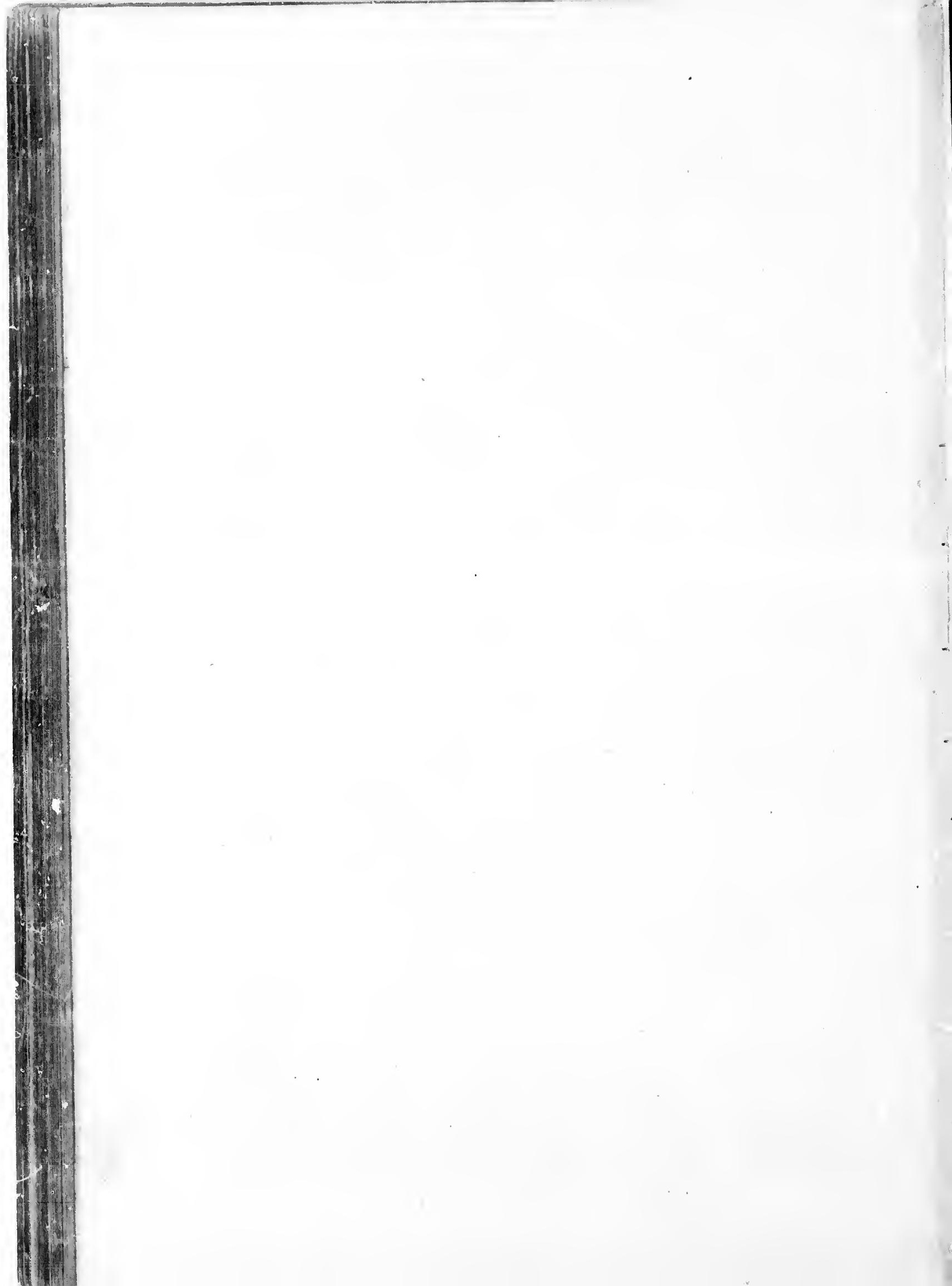




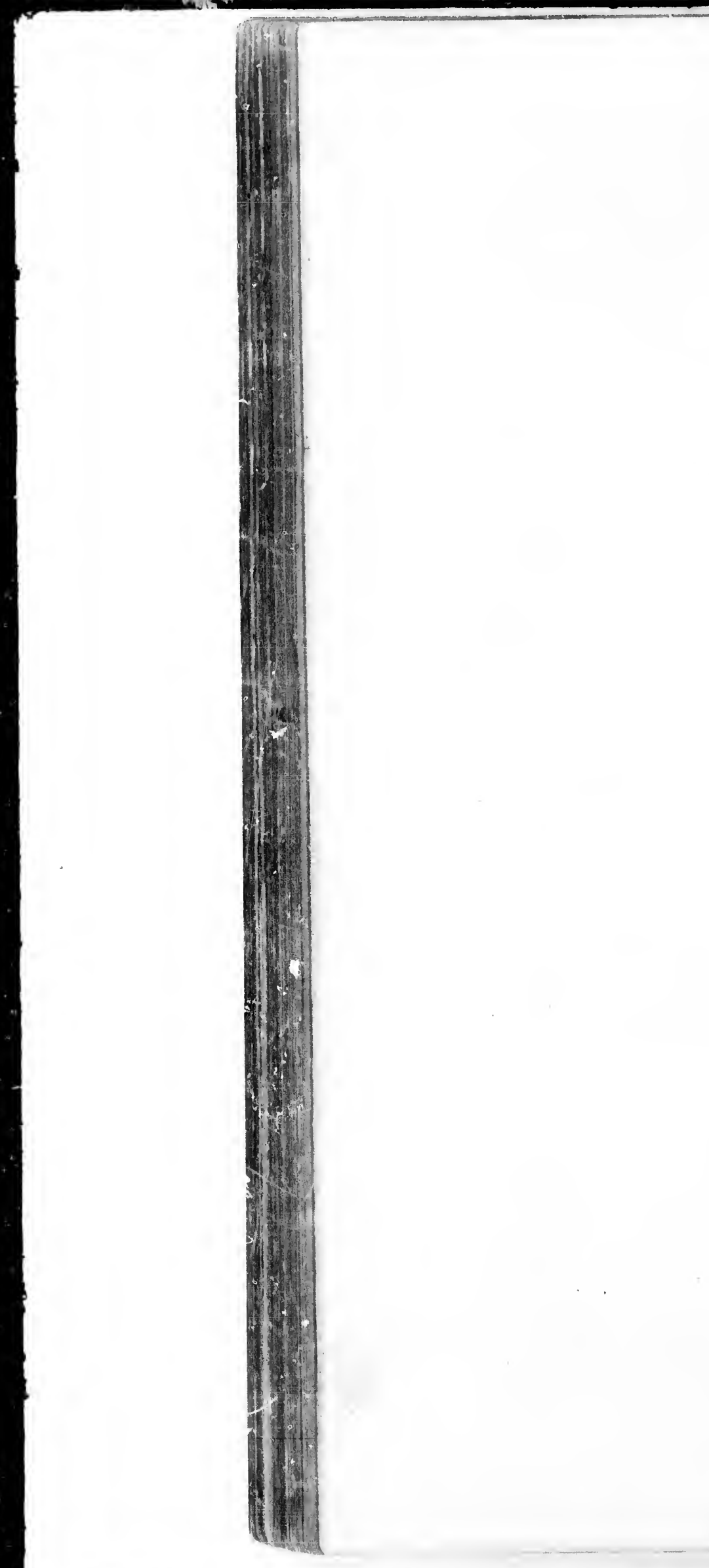


to á la continuación de esta escena maravillosa, era s6lo para que apareciese de nuevo con un semblante no tan agradable y mucho más grandioso.

Con la vista de un mar sereno é ilimitado hacia el Noroeste y Norte, se aparecían al espectador mil especies de aves acuáticas, ya ocu. padas en la adquisición del alimento, ya en el cuidado de su multiplicación 6 en las muestras nada equívocas de su tranquila felicidad en estos para.jes. La monstruosa ballena, el lobo marino y la nutria, aplaudiendo unas veces el risueño semblante de la atmósfera, otras á la suma tranquilidad de que disfrutaban, no temían solazarse casi en la mi ma playa, y en ésta, finalmente, acudía á la ed 6 al anzuelo un número casi infinito de pe zes tan varios como sabrosos y $\tan$ oportunos por consiguiente para el estudio ilimitado del naturalista, como para el sucesivo recreo del navegante.

Pero dejando aparte estas ideas risueñas, pasemos ya al examen interesante de nuestra especie, con la extensión conveniente, según las noticias adquiridas y las que prestan los Misio. neros. No cansaremos al lector sobre el número y los noml res de las muchas naciones que pueblan la California, desde su extremo meridional hasta el páalelo prefijado de $43^{\circ}$. Tampoco nos ocuparemos sobre su origen y los cimientos de sus principios religiosos, y comprendiendo todas estas confederaciones bajo el nombre general de Californıas, examinaremos primero aquellas prn. piedades en que todos convienen, y distinguiremos luégo aquellas en que se aparta cada tríbu de por sí.

Averiguaremos en primer lugar el número de sstog habitantes, y aunque no sea fácil determinarlo con exactitud, tampoco nos apartaremos mucho de la verdad, reuniendo á la población actual de nuestras misiones, la que indica para la Vieja Caiifornia el censo ya citado de $\mathbf{I} 768$, y las conjeturas probabies á que dan lugar las difereriter, exploraciones hechas hasta aqui por los viajeros nacionales. Son éstos el Ingeniero D. Miguel Costanzo, en su expedición por tierra en ${ }^{7} 769$ desde San Diego hasta San Francisco; los dif _ientes viajes del Comandante D. Juan Bo - usta de Ansa al Oeste del río Colorado; la excursión del Teniente Moriaga al Este de San Francisco; los diarios manuscritos de nuestros navegantes por las costas siguientes, desde San Francisco hasta Cabo Blanco; las noticias de los misioneros y otras adquiridas por nosotros, con cryos datos se puede computir la población total de indies como sigue:

Habituntes de la Vieja California, según el empadrcnamiento del año de $; 768$. . .

idem de los que en el día corresponden á $\mathrm{l} / \mathrm{s}$ misiones recientemente stablecidas por los Padres Dominicos, y que permanactarn errantes al tiempo de la visita. . Habitantes de las naciones situadas desde San Diego hasta San Francisco al tiempo de nuestra llegada en $1769 \ldots \ldots \ldots$. . Idem de las tribus desparramadas y contiguas a los Yumas y al Oeste del rio Colorado, incluso los danzantes y las rancherias al Este do San Francisco, según las noticias del Comandante Ansa y las ncticias del Teniente Moriaga. . . . . . . Idera de las costas siguientr, hasta Cabo Blanco. . . . . . . . . . . . . Iciem do las islas según un cómputo prudencial de los Padres Misioneros. . . . .

De este modo resulta finaimente, tod población de la California desde Cabo San Lúcas hasta Cabo Blanco, de 4 r.0oo vivientes próximamente, al tiempo de nuestra entrada en ! $\mathrm{Ca}$ lifornia Nueva por los años de 1769 y 70 , y de la sucesiva comunicación por tierra entre ésta y la provincia de la Sonora en 1774 y 75 , siendo la población actual de nuestras misiones de la Nueva California referida á fines del año de 1790, de 7.718, sin contar con los españoles y otras castas de las que nombran de razón en la América, cuyo número asciende á 997 individuos, y viven repartidos en los cuatro presidios de Monterey, San Diego, San Francisco y Santa Bárbara, y las dos colonias 6 poblaciones de San José de Guadalupe y la Reina de los Angeles.

Conviene advertir, que el cálculo anterior está fundado en la seguridad positiva de que la Caliiornia Nueva s6lo se halla regularmente poblada en las orillas del mar, y que esta población disminuye al paso que se corre al Este hacia el país interior: todos lus viajeros mencionados concueidan sobre este punto, y las internaciones del Padre Fr. Francisco Garcés, desde ia Sonora hasta San Gabriel y desde las inrrediaciones del río Colorado hacia el Norte hasta los $3^{\circ}$ de la. titud, confirman la mism's opinión, á cuyo testimotio puede agregarse el de los nebfitos reducidos de nuestras misione- .OS cuales preguntados por nosotros sobre este punto, ninguna noti. cia lian dado de naciones algo crecidas hacia el Este, $\mathbf{y}$ por el contrario, queriendo individualizar las confederaciones enemigas entre sí, siempre distinguen sut posición de Norte á Sur y nunca hacia el Oriente. También es un reparo digno de no omitirse para suponer una grande despoblación interna, en no haber halladoenestas orillas la menor idea del caballo al tiempo de nuestro establecizniento en la Nueva California, siendo así que las repetidas expediciones ejecu. tadas en el siglo pasado hacia el Nuevo Méjico, y los robos consecuentes hechos por los indios contiguos, de las caballadas nuestras, hubieran segitamente hecho traspasar hacia esta parte unos animales de tanto valor y utilidad si hubic. 
se algunas tríbus capaces de guerrear con ellos y de adquirirlos.

Finalmente, para no avesturernos en el vasto campo de las conjeturas y cer ir nuestra exposición á lo que verdaderamente se ha visto y hasta ahora está reconocido, deberá tenirse presente que todo lo expuesto anteriormente $j$ ' 0 que siga sobre la Nueva California, está comprei. tido entre el mar y una línea que, partiendo del lio Colorado, vaya á cortar la latitud de Cabo Blanco en dirección paralela á lá costa, y unas 30 ó $4^{\text {? }}$ leguas distante de ella; quedando como país incógnito el que en las latitudes altas corre al Este de esta línea á encontrar el Nuevo Méjico y las provincias internas de la Nueva España, de las cuales trataremos en otro lugar.

lodos los reconocimientos modernos nacionales verificados por gentes bastante cuerdas y sin espiritu de sistema, convienen en indicar dos naciones bien distintas, la una de cazadores y casi sin áomicilio, extendida al andar de la costa desde el puerto de San Francisco hasta el Cabo de San Lucas, y digámoslc así, los indígenas de este continente; la otra, de indios arraigados en las islas y tierra firme del canal de Santa Bárba. ra é inclinados á la pesca, industriosos, sociables y tan propensos y adelantados en la civilización, cuanto los otros parece quieren evadirla y áun la aborrecen; y ya atendar, is á las nave gaciones del General Vizcaino, á nuestros últimos viajes, 6 á los informes de nucstros Misioneros, no queda duda que esta nación ha emigrado de ocrs parte, y sería, ciertamente, una de las averiguaciones más importantes para la historia de la especie humana, la que nos pusiese en estado de decidir si ésta es una ramificación de los malayos, tan propensos á extenderse del Oeste hacia el Este (r), ó bien si procede de las provincias septentrionales del Asia, de donde podrían haber emigrado con el auxilio de la navegación, como da lugar á sospecharlo el estado de adelantamiento en que tienen aquel arte, usando para él de cartas regularmente construídas y bien manejadas. Pero no pudiendo aventurar sobre esta materia sino ideas vagas é imperfectas, abandonaremos, por tanto, su indagación á los viajeros sucesivos que tengan tiempo suficiente para desenvolver este punto con la claridad que se requiere.

Los indios cuya descripción vamos á tomar entre manos, y cuyo número según nuestro cóm puto no baja de I6.00o almas, esparcidos á una y otra banda del canal de Santa Bárbara en la dirección de la costa del mar, ofrecen una pers pectiva bastante desagradable y no muy lisonje. ra para comenzar por ellos el examen de nuestra

(1) Véanse los Diarios del Capitinn Cook hasta la Isla de Sandwich. especie cn esta parte del Continente. La vida errante de sus moradores, origen siempre de la despoblacion y de las discordias, la falta de un abriyo adecuado para las intemperies y la escase $z$ de alimentos oportunos y seguros, son unos motivos poderosos que, entregando al hombre á sus propias fasiones y al único cuidado de su conservación animal, le degradan, le entorpecen $y$ casi convierten su vida en una viva rapresentación de la de los séres irracionales.

Tal es el cuadro que por desgracia presentan hoy día en naciones que denominamos aboríjenes ce la Vieja y Nueva California. En los tiempos prinitivos accidentales, mal interpetrados y difíciles te aclarar sin el auxilio de la experiencia, fueron sin cludi causa de que alucinados al pronto los prisueros exploradores, hiciesen creer que los californios eran naturalmente pacíficos, y que podían compararse á otras naciones más civilizadas de la América. Pero la historia de sus repetidos agravios contra auestros pescadores de perlas, las contrariedades experimentadas en la costa oriental de la Península por los primeros conquistadores, la destrucción de las misiones jesuíticas en la parte meridional el año $d=\mathrm{I} z \therefore, t$ la últimas irrupciones contra la misıón ... $S_{4}$, iv go en 1775 (I) son todas pruebas d. aciou que indican evidentemente que en esta especie ruda de naciones existen cierto aborrecimiento á la vida sociable, la insubordinación, el desprecio de la vida, el conocimiento de su propia debiiidad, y por consiguiente, la desconfianza y la alevosía.

Siguiendo la historia de los rastros de estos pueblos, en cuanto pueden alcanzar las exploraciones nacionales, parece también cierto que el cuidado de alimentarse estriba principalmente en la caza, prefiriendo á ésta el uso de las semillas $y$ de los piñones en los parajes donde los hay, y sustituyéndole á veces por variedad 6 por necesidad, el uso del pescado y del marisco.

Pero antes de entrar en otros pormenores sobre el carácter y ocupación de estos naturales. alegaremos aquellas razones que fundadiaiserto convencen es una misma clase de hombres la que habita al Norte y al Sur del canal de Sarta Hárbara, luasta donde se extienden nuestros rer.onocimientos del día. Un mismo método de vida, el mismo sistema gubernativo, los mismos ritos religiosos, el mismo semblante, y sobre todo,

(1) Ucurrió este accidente el 4 de Noviembre de 1775 , minatendo a manos de los naturales el Padre Fiay Luis Jaime Mallorquin, un herrero $y$ un carpint: ro. Merecen se perpetuen para singular memoria, dos rasgos de humanidad y caridad cristiana que esta ocasión ejercitaron el carpintern y los Padies $M$. sioneros. El primero murio \& los cinco dras, primero murió a lor cinco dfas, y irallándose sin heredero forzoso, testó á favor de los mismos indios que le hsbran pitita jo la vida, la cantidad bastante crecita de tocos as susicios devengadoe. Los otros solicitaron y ilituvierun de "obierno el perdon casi total do todos os r.greece: 
paz con varios que en bieve tiempo se alojaron en las playas, en número de 300 personas de ambos sexos y de todas edades. Estos estaban divididos por cuerpos ó reuniones de familias, en una de las cuales había un niño de poco más de un año, que con arco y flecha proporcionados á su edad, daba en la palma de una mano presentada por blanco, á distancia de dos varas.

De la religión de estos pueblos ro pudo adquirirse información cierta. Sólo se vióá uno que parecía revestido del carácter de orador público, hablar algunas palabras volviéndose alternativamente á los puntos cardinales del horizonte, como para invocar la protección de algunas deidades (I) que considerarán árbitras de aquellos vientos. Habiendo fallecido uno de los naturales, se notó que cumplido el llanto, quemaron el cadáver y recogieron las cenizas.

Las armas ofensivas de esta tríbu son flechas con puntas de pedernal, cuchillos de lo mismo y algunos de hierro, mal fabricados, los cuales, scgún manifestaron, les vienen. por vía de cambio, de parajes más septentrio: ' 's. y nuede bien suceder, que del Nuevo Méj., omunicación de unas naciones con otras, ya les, ya errantes, circulen estos útiles y el hicro viejo hasta ponerlos en manos de los habitantes de las playas, que siempre son por las pescas los más ricos y capaces de comprarlos. De todo cuanto se les presenta nada les llama más su atención que el hierro, bielı sea en bruto ó en armas cortantes; siendo cierto que cometerán todos los excesos por adquirirlo, siempre que se consideren superiores en fuerzas, y no es extraño, pues les facilita la construcción de sus débiles buques, de sus casas y el logro de la pesca, y tiene para ellos un cebo mucho más racional y poderoso que el del oro para nosotros, por cuya adquisición despedaza. mos, sin embargo, hasta las entrañas de la tierra. Reciben con aprecio los abalorios y cl tabaco, que cultivari con cuidado y lo fuman en tubos parecidos á una trompa.

Cazan venados, cibolos, osos, lobos marinos y nutrias, aunque estas dos úitimas especies pueden corresponder á la pesca. Las aves que presenta el país son cuervos, gavilanes, patos, gaviotas, tórtolas y pájaros muy pequeños y en poco número. La pesca se hace de sardina, pejerey, morcillones y piés de cabra, de cuyas especies es

(1) Esta misma "perstición ó costumbre se halla arraigada en todas $s$ tribus meridionales. Con motivo de un temblor que acaeció en la rancheria as llamada en el rio de los 'Temblores, a la sazon de haliarse altr los gentiles (dice este viajero) que sin duda haría cntre ellos el oficio de sacerdote, estaba entonces en el Real, y aturdido del suceso no ménos que nosotros, empezó con voces horrorosas y grandes demostraciones de espanto, á deprecar al cielo, volviéndose a todos vientos y haciendo como que conjuraba los tiempos. muy abundante la costa, y no hacen otras quizá, porque les faltan aparejos y anzuelos, 6 porque la necesidad no les obliga á pescas más dificiles y trabajosas. Hasta el tiempo de esta expedición parece no habían visto estos naturales embarcaciones como las nuestras.

Fijando ya nuestras miradas sobre las costas del canal de Santa Bárbara y las islas que lo forman, parece que el espíritu cobra nuevos alientos al ver vindicados en esta tosca pero feliz colonia los nobles dictados del hombre, que tan vergonzosamente ultrajan las naciones circunvecinas. Compónenla en el dia, según los cómputos más probables unas $2 \mathrm{I} .000$ personas, las 15.000 establecidas en el continente $y$ las otras 6.000 en las islas, arraigadas de tal modo, que sus principios sociales, el método de vida, la fisonomía, el talle y hasta su misma capacidad, todo roncurre á caracterizar á esta nación con mucha diferencia á las demás que habitan esta parte del continente; viven reunidos en pueblos cuyas casas son de figura esférica (1), cubiertas de enea, y de unas 20 varas de diámetro. Cada casa contiene tres 6 cuatro familias: el hogar está en medio, y en la parte superior abren un respiradero para dar salida al humo. El carácter de estas gentes es afable; su talle bueno, igualmente que el aspecto: gustan mucho de pintarse, y usan por adorno grandes penachos de plumas. Andan enteramente desnudos y sólo en tiempo de frío gastan unas capas de pieles de nutria ó unos mantos formados de tiras de estas mismas pieles, las cuales las tejen torciéndolas, de modo que el pelo queda por fuera, $y$ forman una trama con el tejido de estos hilos. Las mujeres andan con mucha honestidad, ciñéndose la cintura con pieles de venado, que les cubre hasta media pierna, y un capotillo de nutria sobre el cuerpo. Son de bello aspecto y muy hacendosas: ellas tejen las bateas y vasijas de junco que les sirven para comer, beber y guardar las semillas, pues no conocen estas gentes el uso del barro, y dan á estas manufacturas mil formas diferentes y graciosas, según los usos á que las destinan.

Los hombres labran hermosas bateas de madera con embutidos firmes de coral 6 hueso, y unos vasos de mucha capacidad y cerrados de boca, que parecen hechos á torno, con un lustre tan perfecto, que cualquiera dirá es obra acabada de la mano de un artífice hábil. Nosotros debimos al Padre presidente de las misiones de Monterey, diferentes muestras de estas preciosas manufacturas, las cuales se remitieron después para el Real Gabinete. Las vasijas grandes que sirven para el agua, son de un tejido robusto de

(I) Fsta descripción se ha tomado del viaje de D. Miguel Costanzo, cuyas noticias confirman los $\mathrm{Pa}$ dres Misioneros. 
tras quizá,

6 porque hás dificiles expedición es embarca-

e las costas que lo forvos alientos eliz colonia tan vergon. cunvecinas. nputos más 5.000 esta6.000 en las s principios mía, el taroncurre á diferencia el continencasas son de , y de unas tiene tres 6 dio, y en la para dar sa. ntes es afa. el aspecto: por adorno enteramente rastan unas tos formalas cuales el pelo que. on el tejido con mucha n pieles de ierna, $y$ un ion de bello n las bateas comer, benocen estas $s$ manufacsas, según

teas de maó hueso, y serrados de $n$ un lustre bra acaba. osotros de nisiones de is preciosas on después randes que robusto de juncos embreados por dentro y de la misma figura que nuestras tinajas. Para comer las semillas que gastan en lugar de pan, las tuestan primero en grandes bateas, echando entre las semillas algunos guljarros 6 chinas caldeadas; luégo mueven la batea para no quemarla, y en estando la semilla tostada, la muelen con morteros de piedra perfectamente labrados. Son ciertamente dignas de admiración la constancia y prolijidad que emplean en acabar estas piezas, tan apreciables áun entre ellos mismos, que á los que dejan á su fallecimiento semejantes obras, se las colocan encima del sepulcro como un monunento que recuerde siempre su aplicación y habilidad.

Entierran á los muertos, tienen sus c-menterios dentro del mismo pueblo, $y$ hacen con gran pompa los funerales de los Capitanes, colocando sobre sus cuerpos unas perchas altas en que cuelgan los muebles que eran de su uso. Ponen además en el mismo paraje ga andes tablas de pino con diferentes pinturas, que servirán sin duda para explicar las hazañas de aquel personaje.

No es lícita la pluralidad de mujeres, y sólo los Capitanes tienen derecho de casarse con dos los matrimonios usan de camas separadas, compuestas de tarimas que $\mathbf{s}$ - levantan del suelo y de unos colchones ó simples petates ó esteras de enea con almohadas de lo mismo. Estas camas están colgadas con iguales esteras, que sirrsn á la decencia y para defenderse del frío, y últimamente asegura el Padre presidente de las misiones, han perfeccionado el uso de los catres cerrados, imitando con mucha perfección los de Europa.

ria: entre estos naturales una especie de hombres que viven como las mujeres, se acompañan con ellas, visten su mismo traje y se adornan con abalorios, pendientes, gargantillas otros mujeriles, logrando entre ellos de grande consideración: los llaman joyas, y el vicio abominable que deriva de esta costumbre, ha trascendido ya hasta las misiones de San Francisco y Santa Clara, según pruebas incontestables de los Misioneros que han cogido ya á varios en el acto mismo de su delito.

Sobresale la industria de estos naturales en la construcción de sus lanchas de pino, las cuales tienen de ocho á diez varas de largo y vara y media de manga. No entra en su fábrica hierro alguno, y para sujetar las tablas abren unos barrenos de trecho en trecho y á distancia de una pulgada del canto, los cuales correspondiéndose unos á otros en las tablas superiores é inferiores, pasan por estos barrenos fuertes ligaduras de nervios de venado, y luégo embrean y calafatean las costuras, pintando el todo de colores muy vistosos. Para manejarlas se sirven le remos de dos palas con los cuales las comunican una indecible velocidad y ligereza y salen mar á fuera á pescar en ellas con tres 6 cuatro hombres.
Abunda el pescado sobre su costa, conocen todas las artes de pescar y tienen comunicación con lus naturales de las islas inmediatas, de donde sacan cici tos abalorios de coral que corren por esta tierra en vez de moneda, aunque aprecian mucho más los abalorios de vidrio que les dan los españoles, of reciendo por adquirirlos sus bateas, pieles, jícaras, platos de madera y todo cuanto poseen.

El alimento principal de estos habitantes es el pescado fresco y varias semillas, como bellotas, atole, gachas $y$ otras diferentes comidas. Reina en esta grande y pacífica sociedad una paz sólida, cierto amor á la concordia, á la reunión $y$ á la vida sociable, $y$ en general mucha aten. ción para obsequiar á los extranjeros. Jamás se ve en sus manos ni en sus chozas otros instrumentos que los propios de su pesca, y no han dado hasta ahora el más leve motivo que indique desafecto hacia las débiles naciones sus vecinas, ni de que exista entre ellos el menor rastro de discordias pasadas, de rencor ó de celos, y los habitantes de las islas ya sea atraídos por la curiosidad, por el interés ó por la costumbre, viven ahora en mucho número entre los domiciliados en el continente. Dichosos ellos si cor. tentos cor la situación en que los colocó la Naturaleza, sin enemistades con los vecinos, $\sin$ disputas por la propiedad y libres de la ambición que atormenta á la culta Europa, subsisten largo tiempo en aquel apacible estado que les ofreció la madre bienhechora de los mortales.

No hemos podido rastrear por muchas diligencias que se han hecho, cuál sea el influjo 6 autoridad de que gozan los Caciques de cada po. blación ni si existe un Jefe supremo que domine en todas ellas.

Por las noticias adquiridas y las que dan los Misioneros, sólo puede deducirse con algún fundamento, que la autoridad de los primeros es limitada y que falta enteramente la del segundo, siendo así que ni remotamente la han podido traslucir los viajeros nacionales y que todos hablan de la unión que existe en esta confederación, citando como ejemplr al que en varias ocasiones se encuentran reunidos en una sola ranchería los caciques ó jefes de otras distintas. Si retiocedemos al tiempo de Sebastián Vizcaino cuando navegaba por estos mares, hallamos en la relación de su viaje no sólo la existencia de este Régulo supremo, sino otras varias particularidades dignas de fijar nuestra atención. "Sa"lió (dice) de tierra firme una canoa con cuatro "remeros, en la cual venía un indio (r) que era el "señor ó rey de aquella costa ó tierra firme.

- Esta canoa llegó á la Nao Capitana, y con "grandísima diligencia y presteza, dió tres vuel-

(1) Venegas, parte IV, apéndice II, pág. 95. 
MII tas alrededor del navio, cantando todos los que w iban en ella c.: su lengua, al modo que cantan "los indios en la Nueva is ispaña el mitote, y luego "se llegaron á ella, y sin receli alguno ni temor "entró dentro de la dicha Nao Capitara aquel in"dio reyezuelo 6 cacique a aquella tierra, y lo "primero que hizo en entrando, fué dar alrede" dor de la plaza de armas otras tres vueltas can" tando, y luégo, delante del General y de los de" más, hizo un largo razonamiento en su lengua, "que no se le tntendió cosa de las que dijo, y " habiéndole acabado, por señas claras dijo que "los de la isla Santa Catalina le habían avisado "por cuatro vías con canoas, cómo habían llega "do allí aquellos navíos, y que era gente vestida "y barbada, y de buen corazón y buen trato los -que en ellos venian, y los habían regalado y "dado muchas cosas, que saliesen á verlos, y que " por esta información y aviso había venido allí á " ofrecer su tierra y regalo si lo quisiesen recibir, "que él lo suplicaba, pedía y rogaba, que se lle- gasen con los navíos á tierra y que allí los pro"veería de lo que hubiesen menester, y como no "hubiese mujer alguna en el navío, preguntó por "ellas por señas, señalando las partes de su pu. "ridad, $y$ fué tan natural la señal, que si habla„ra en nuestro español, no pudiera decirlo más "claro.

"El General le dijo que no las llevaban ni "las habian menester; entonces el indio importu"no al General con más eficacia se fuera á su tie" rra con la gente que traía, que él le prometía de " dar á cada uno de todos los que en el navío iban "diez mu jeres, de lo cual se rió toda la gente mu"cho, $\mathrm{y}$ el indio, entendiendo que era por burlarse "de él, y que no había lo que prometía, torno á "dar sobre ello, diciendo fuese un soldado en la - barca que él había venido, á su tierra, á ver si wera verdad lo que él prometía y que él quedaría wen rehenes con un hijo suyo en el navío, en el "ínterin que el soldado fuese."

Esta difusa pero verídica narración, nos conduce á desenvolver, además de la existencia de un Jefe supremo, varios otros puntos no ménos importantes sobre el carácter y las costumbres de estos pueblos. Hallamos desde luego una misión muy antigua entre los habitantes de la isla y de los del canal: hallamos á la vista de unas gentes extrañas, cierto denuedo y franqueza propia de una civilización adelantada: hallamos también una solemnidad grande, varias ceremonias y una dilatada arenga en el primer encuentro con los extraños, $y$ hallamos finalmente, un grado tal de hospitalidad y buena $f e$, que no pudiera creerse sin el apoyo de la experiencia.

La conformidad que se nota entre las noticias anteriores, aunque de época tan remota, y las que contienen nuestros últimos viajeros, además que sirven para caracterizar á estos na. turales, muestra palpablemente el mucho tiempo que hace ha salido esta sociedad del estado rús. tico y salvaje en que subsisten sus vecinos de! Norte y Sur. Con efecto, á excepción de la existencia de un Jefe supremo, todas las demás propiedades se han confirmado sucesivamente, pues á lo que ya manifestamos antes sobre la confederación con los de las islas, su hospitalidad y buena fé, agregan también nuestros. viajeros la solemnidad de la primera arenga 6 salutación con que recibe el cacique de cada ranchería á todo recien llegado.

Estos naturales, llevando aún más adelante los impulsos de su hospitalidad, proporcionaron á $\mathrm{D}$. Miguel Costanzo alguna idea de sus bailes y de su música. "No se contentaron los gentiles (son sus propias palabras) con regalarnos de sus comidas, quisieron también festejarnos, conociéndose la porfía y contienda mútua de so. bresalir cada pueblo en los regalos y fiestas para merecer nuestra aprobación y aplauso. Vinieron en la tarde los principales y caciques de cada pueblo, unos después de otros, adornados á su manera, embijados y cargados de plumajes con unos carrizos rajados en las manos, á cuyos nnovimientos y ruído marcaban el compás de sus canciones y la cadencia del baile, tan á tiempo y $\tan$ uniformes, que no causaban disonancia. Duraron los bailes toda la tarde, y nos costó harto trabajo desprendernos de ellos; por fin les despedimos, encargándoles mucho por señas, que no viniesen de noche á incomodarnos; pero en vano, volvieron cerrada la noche, con gran comitiva de truanes ó juglares tocando unos pitos, cuyos sonidos rasgaban los oídos."

Son mucho más confusas las ideas adquiridas hasta ahora sobre la religión y los ritos de estos naturales, y sólo se halla algún rastro en la narración de Sebastián Vizcaino, pero sin que la confirmen los viajeros últimos ni los padres misioneros. Por lo mismo, fuera desacierto el fundar conjeturas sobre aquellos débiles indicios, ciñéndonos pur ahora á desear que se averigüen con toda puntualidad y sin mezcla de ideas extrañas. Advertiremos no obstante, que en nuestro concepto nunca será medio oportuno para esta clase de indagaciones, el de los Padres Misioneros, pues los naturales impulsus de su celo les hace mirar con demasiado horror todo lo que descarria al hombre de la recta senda.

A las propiedades ya indicadas, reunen estos habitantes la del agradecimiento, habiendose ofrecido al Padre presidente de las misiones dos pruebas bien evidentes de esta cualidad; la una ell un muchacho gentil, el cual habiendo recibido por la tarde unos pocos abalorios, volvíb al día siguiente con su padre para presentarle en re. compensa una cantidad crecida de piñones. Ocurrib la otra en un cacique anciano que habién- 
ucho tiempo estado rús vecinos del n de la exis. las demás esivamente, tes sobre la u hospitali. estros. viajega 6 salutada ranchería

hás adelante pporcionaron le sus bailes on los genti. egalarnos de ejarnos, coútua de so. fiestas para so. Vinieron ues de cada prnados á su lumajes con á cuyos nompás de sus n á tiempo y nancia. Ducost6 harto fin les des. r señas, que los; pero en n gran comiunos pitos,

eas adquirilos ritos de ún rastro en 0 , pero $\sin$ is ni los paa desacierto tebiles indi. que se avemezcla de stante, que lio oportuno e los Padres ulsus de su orror todo lo senda.

cunen estos habiéndose isiones dos dad; la una ido recibido olvio al día arle en reiones. Ocuue habien- dole visitado otra vez el Padre presidente y particularmente en una noche muy lluviosa, en la cual ya muy agravado de sus achaques le había enviado á llamar, restablecidocluégo, vino personalmente á la misión aunque cargado de años y de más de ocho leguas que distaba su ranchería, y manifestó cuánto le movia el recuerdo de las visitas pasadas y la esperanza de no carecer de ellas en lo venidero.

Entre los isleños fronterizos se ha notado hasta aquí una mayor dificultad para la introducción del Evangelio; se ha advertido tambien en las mujeres la costumbre de abortar con el auxilio de ciertas yerbas, pirr. no ajarse, según dicen, y ser así más gratas á los ojos de sus maridos; y en éstos, la facilidad de cortar el peloá sus mujeres por una causa aunqu frívola. Los pueblos de las misiones del canal y en particular los de San Buenaventura, tejen ya muy bien las lanas y éstas alcanzan á vestir al mayor número de los neófitos. Su inclinación á la sociedad y al decoro, crecen cada dia más y más y las manufacturas y siembras van echando entre ellos más sólidas raices.

Correspondía ahora, según el orden de nuestros razonamientos, explicar el método adoptado en estas misiones para la propagación de la fé católica, y para la reunión, instrucción y civilización de sus naturales; pero además de que una exacta descripción de esta especie nos dilataría mucho más de lo que permite nuestro plan, hemos querido omitirla de intento, conociendo no podía ménos de parecer exagerada á los ojos de un público prevenido de antemano por las riclículas inventivas de muchce autores extranjeros, que confundiendo á veces el sistema con los abusos, é ignorando siempre el objeto primario de semejantes establecimientos, han pintado como opresivas y temibles todas nuestras misiones de la América. Dias llegarán, es probable, en que algún extranjero ilustrado que visite estas costas suministre á la Europa un desengaño nada sospechoso, y á la parte sana de nuestra Nación un verdadero objeto de complacencia. Nosotros nos contentaremos por ahora con asegurarla, que la venida de los españoles ha traído á estos naturales, sin la más leve efusión de sangre, la cesación de mil guerras intestinas que los destruian, los principios sociales, una religión pura y santa, unos alimentos sanos y seguros, $y$ finalmente, un grado tal de confianza entre unos y otros, que un Misionero no teme en el día atravesar sólo y sin escolta las 40650 leguas habitadas por naciones distintas $\mathrm{y}$ enemigas, $\mathrm{ni}$ el natural, aunque no convertido, deja de asistir diariamente á las misiones y presidios en busca del alimento ó de un jornal satisfecho.

El precio de los ganadus, frutos y semillas, según regía por tarifa en todos los estableci- mientos de la Nueva California, el año de r79r, era el siguiente:

Por un toro do Resns. Realee.

Por un toro de tres años arriba........ 3 a

tres á cuatro años...... 4 ,

Por un ternero 0 ternera........... 5 un año...

Por una vaca chichigua ...............

Por una arroba de tasajo.............. n 6

Por una arroba de carne fresca....... \, 2

Por una arroba de sebo en greña...... 1

Por una arroba de dicho, frito........ , 6

Por una arroba de manteca de vaca.... 24

Por una arroba de velas do sebo....... 24

Por una arroba de manteca de cerdo... 3 n

Por un cerdo do dos años, capón...... 3 .

Por un cerdo de tres años... ....... 4 ,

Por un lechón................, ,

Por un carnero de más de dos años... 2

Por uno dicho, de dos años.......... 14

Por un carnerito primal............, ,

Por una arroba do lana sucia......... I

Por una arroba de lana limpia....... 2 .

Por un cabrito................. $\quad 21$

Por un macho cabrio..............,

Por uno dicho, de lana............ $x$

Por una cabra ń oveja............. \6

Por un eastrado de pelci, de dos años... ,

Por una gallina.................

Por una polla ronca................

Por un pollo...................

Por un gallo..................

Por un par de palomas caseras........ क 2

Por un par de pichones............ ,

Por tres.huevos................ n

Por una docena de codornices........

Por un conejo................., $1 /$

Por una liebre................

Por un cuero de res, al pelo.......... 3

Por uno dicho, en vaqueta........... 2

Por un cuero de venado, al pelo....... n 2

Por uno dicho de macho, en vaquetilla. I 4

Por uno dicho de hembra, en Idem.... 12

Por una gamuza de macho........... 1

Por una dicha de hembra.......... 12

Por una libra de queso............., $1 / 8$

\section{GRANOS}

Por una fanega de trigo........... 2

Por una idem de maiz............ I 4

Por una idem de frijol 0 lenteja...... 2

Por una ídem de garbanzo.......... 3 ,

Por una fdem de alverjon.......... I 4

Por una fdem de cebada........... $>$ n

Por una arroba de harina común...... I

Por una arroha de harina, de un cedazo. $\quad$ I 4

Por una arroba de harina de flor.......

GANADOS DE CARGA Y SULLA

Por un caballo manso, de dar y recibir. Por una yegua de tres años...........

Por un potro cerrero de tres años.....

Por una potranca de hasta dos años....

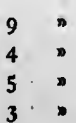




\section{Condiciones de los puertos de San Blas y Acapulco para arsena- les.-Reconocimientos en las provincias internas. Su descripción fisica, producciones y costumhres.}

Mucho se ha hablado en la Nueva España sobre cuál sea el puerto más conveniente de los de Acapulco y San Blas para que sirva de reunión y depósito de las fuerzas navales en el mar $\mathrm{Pa}$ cífico $y$ áun para construir en él, en caso necesario, los buques de cualquier porte que re. quieran las urgencias de aquel reino; y aunque la única consideración de los perjuicios inherentes al clima mal sano de San Blas, parezcan decidir desde luego la cuestión á favor del puerto de Acapulco, sin embargo, como el interés particular en unas ocasiones, en otras la falta de conocimientos facultativos, generalmente el no haber fijado la idea justa de lo que se necesita, han heclio contrarestar esta preferencia atribuyéndola á San Blas, nos ha parecido que no se considerarán como agenas de este lugar las si. guientes reflexioncs sobre el mismo asunto.

Dos son los objetos que pueden producir en América la idea de que se forme un arsenal en un puerto cualquiera: $1 .^{\circ} \mathrm{El}$ de construir buques de todas clases para aumento de la Marina Real. $2 .^{\circ} \mathrm{El}$ de atender á las composiciones y reparos de las embarcaciones que arriben ó se mantengan frecuentemente en un mismo puerto ó en las costas de su dependencia. Laabundancia de muchas y excelentes maderas que hay en varios parajes de América ha deslumbrado á muchos sobre la utilidad verdadera que resultaría de que se construyesen los buques en aquella nueva región del mundo; pero la experiencia, de acuerdo con la razón, han dado á conocer cuán difícil sería el conseguir ventaja alguna en este nuevo sistema, tanto por los costos excesivos que allí tiene la mano de obra, como por la imperfección con que éstas se ejecutan, y más que todo, por los abusos que tan fácilmente se introducen en las colonias y que es imposible se eviten por las cau. sas que son bien conocidas á todas las naciones que tienen establecimientos ultramarinos.

Admitida, pues, como una verdad constante, que ni al Erario ni á la fuerza nacional conviene el que se construyan buques grandes en la América, deben, pues, ceñirse las miras de todo astillero como el de San Blas, á los dos únicos obje. tos de construir embarcaciones pequeñas 6 costaneras, $\mathrm{y}$ al de reparar con actividad las naves que los diferentes objetos de la Monarquía dirijan sueltas ó en escuadras á los puntos más distantes de sus dominios, en cuyo caso necesita el arsenal que se forme, aún más que la mera existencia de muchas maderas, otros puntos esenciales, los cuales no será inútil recapitulemos aquí con al. guna individualidad. En primer lugar, un establecimiento de esta especie requiere un depósito anticipado $y$ abundante de cuantos efectos puedan necesitarse para la existencia dilatada de varios buques grandes en las costas inmediatas, y por consiguiente, como el valor y la utilidad de estos efectos pueden llamar por sí solos la aten. ción de un enemigo, exigen, por tanto, una defensa oportuna, cuyos costos obliga con precision á ceñir estos establecimientos al menor número posible. En segundo lugar, debe atenderse á la utilidad que resulta de que el paraje elegido sea también el mismo que frecuentan los buques de la Marina mercantil, porque estos buques unas veces prestando $y$ otras recibiendo crecidos auxilios de un depósito general, no sólo evitan el monopolio de los abastos y el flete de una embarcación que suele á veces emplearse para conducir una friolera, sino que acelera en ocasiones los movimientos de la Marina Real con el auxilio de sus pilotos y marinerías, además que como el concurso de. estos buques causa un comercio activo y de aquí el aumento de la población, las artes mecánicas se adelantan, y el Erario no tiene que mantener á sueldo fijo cada oficio por no exponerse á la casualidad de no encontra le cuando lo necesite. En tercer lugar, es preciso atender también á las ventajas locales del establecimiento, tanto con respecto á la navegación como para la utilidad común de los pobladores. Estas ventajas son, por lo que toca á la navegación, la se- 


\begin{tabular}{|c|c|c|c|c|}
\hline & Pesor. & Reales. & & Pesos. \\
\hline or una mula cerrera de tres años.... & 16 & n & Por un caballo ó mula especial, por lo & \\
\hline 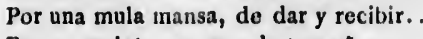 & 20 & D & que se ajusten. & \\
\hline rrero de tres años... & 14 & $n$ & Por un burro confinn............ & 6 \\
\hline or un macho manso............ & 18 & $n$ & Por una burra de vientre...$\ldots \ldots \ldots$ & 7 \\
\hline
\end{tabular}

\section{Condiciones de los puertos de San Blas y Acapulco para arsena- les.-Reconocimientos en las provincias internas. Su descripción fisica, producciones y costumbres.}

Mucho se ha hablado en la Nueva España sobre cuál sea el puerto más conveniente de los de Acapulco y San Blas para que sirva de reunion y depósito de las fuerzas navales en el mar $\mathrm{Pa}$ cífico y áun para construir en él, en caso necesario, los buques de cualquier porte que re. quieran las urgencias de aquel reino; $y$ aunque la única consideración de los perjuicios inheren. tes al clima mal sano de San Blas, parezcan decidir desde luego la cuestión á favor del puerto de Acapulco, sin embargo, como el interés particular en unas ocasiones, en otras la falta de conocimientos facultativos, generalmente el no haber fijado la idea justa de lo que se necesita, han hecho contrarestar esta preferencia atribu. yéndola á San Blas, nos ha parecido que no se considerarán como agenas de este lugar las siguientes reflexiones sobre el mismo asunto.

Dos son los objetos que pueden producir en America la idea de que se forme un arsenal en un puerto cualquiera: $10^{\circ} \mathrm{El}$ de construir buques de todas clases para aumento de la Marina Real. $2 .^{\circ} \mathrm{El}$ de atender á las composiciones y reparos de las embarcaciones que arriben 6 se mantengan frecuentemente en un mismo puerto 6 en las costas de su dependencia. La abundancia de muchas y excelentes maderas que hay en varios parajes de America ha deslumbrado á muchos so. bre la utilidad verdadera que resultaría de que se construyesen los buques en aquella nueva región del mundo; pero la experiencia, de acuerdo con la razón, han dado á conocer cuán difícil sería el conseguir ventaja alguna en este nuevo sistema, tanto por los costos excesivos que alli tiene la mano de obra, como por la imperfección con que éstas se ejecutan, y más que todo, por los abu. sos que tan fácilmente se introducen en las colonias y que es imposible se eviten por las cau. sas que son bien conocidas á todas las naciones que tienen establecimientos ultramarinos.

Admitida, pues, como una verdad constante, que ni al Erario ni á la fuerza nacional conviene el que se construyan buques grandes en la América, deben, pues, ceñirse las miras de todo astillero como el de San Blas, á los dos únicos objetos de construir embarcaciones pequeñas 6 costaneras, $y$ al de reparar con actividad las naves que los diferentes objetos de la Monarquía dirijan suel tas 6 en escuadras á los puntos más distantes de sus dominios, en cuyo caso necesita el arsenal que se forme, aún más que la mera existencia de muchas maderas, otros puntos esenciales, los cuales no será inútil recapitulemos aquí con alguna individualidad. En primer lugar, un establecimiento de esta especie requiere un depósito anticipado y abundante de cuantos efectos puedan necesitarse para la existencia dilatada de varios buques grandes en las costas inmediatas, y por consiguiente, como el valor y la utilidad de estos efectos pueden llamar por sí solos la atención de un enemigo, exigen, por tanto, una defensa oportuna, cuyos costos obliga con precision á ceñir estos establecimientos al menor número posible. En segundo lugar, debe atenderse á la utilidad que resulta de que el paraje elegido sea también el mismo que frecuentan los buques de la Marina mercantil, porque estos buques unas veces prestando y otras recibiendo crecidos auxilios de un depósito general, no sólo evitan el mo. nopolio de los abastos y el flete de una embarcación que suele á veces emplearse para conducir una friolera, sino que acelera en ocasiones los movimientos de la Marina Real con el auxilio de sus pilotos y marinerías, además que como el concurso de. estos buques causa un comercio activo y de aquí el aumento de la poblacion, las artes mecánicas se adelantan, y el Erario no tiene que mantener á sueldo fijo cada oflcio por no exponerse á la casualidad de no encontra:le cuando lo necesite. En tercer lugar, es preciso atender tambien á las ventajas locales del establecimiento, tanto con respecto á la navegación como para la utilidad común de los pobladores. Estas ventajas son, por lo que toca á la navegación, la se- 
guridad del puerto, la facilidad de seguir en sus edificios asl particulares como del Rey, aquel orden y economía que hace se emplee un nú mero menor de brazos en las conducciones, maniobras y otras faenas cotidianas; la mejor dis. posición del puerto para entrar y salir c el en todas las estaciones del año, su oportuna posición geográfica para comunicarse sin violencia ni extravio con las diferentes costas que ha de proteger, y últimamente, su distancia del centro del gobierno de los mares inmediatos $y$ sobre todo de la metrópoli. En cuanto al segundo objeto de la utilidad de los pobladores, deben ser sus principales fundamentos los de un aire sano 6 ménos malo, la mayor comodidad de los caminos internos, áun en la estación lluviosa, una cantidad suficiente de terreno para extenderse con comodidad $y$ orden, al paso que lo exijan las circunstancias ulteriores del establecimiento; final mente, la mejor proporción de los contornos y de los paises distantes, para que á medida que au. menten las necesidades del establecimiento, au. mente también la población sin violencia alguna ni sacrificios del Erario.

Sentadas estas reglas como preliminares precisos que deben servir de guía para la oportuna elección de un establecimiento como es el de San Blas, es fácil demostrar que en el paralelo de las ventajas y nulidades anejas por naturaleza á uno y otro puerto, es infinitamente aventajado el de Acapulco á la rada de San Blas, y también, yuue Acapulco es el único puerto que tiene el Rey en las costas occidentales de Nueva España, capaz de un establecimiento de esta especie.

La disposición de la costa en las inmediaciones de este puerto, es tan favorable para una re. calada, que á más de divisarse desde mucha dis. tancia las senales infalibles de el, puede cualquier buque aproximarse á muy poca distancia sin comprometer en nada su seguridad, en caso que un temporal ú otra causa inopinada le obli. gue á separarse. Desde la entrada hasta el surgidero, la distancia es tan corta y el fondo tan cómodo y seguro, que toda embarcación, cualquiera sea su porte, puede hallarse inmediatamente amarrada 6 alcanzar sin dilación los auxilios que necesite. No hay en aquel puerto peli. gro alguno que exija, como sucede en otros, los gastos de prácticos, boyas y anclas sueltas, para espiarse, ni tampoco incertidumbre en el nave. gante para entrar y salir: una escuadra entera puede maniobrar en él á un tiempo con actividad $y$ sin estrechez: los vientos reinantes, tanto en la estaci6n lluviosa, desde Mayo hasta Octubre, como en la seca, de los seis meses restantes, permiten una comunicación fácil y segura con las costas de Guatemala, Guayaquil, Perá y Chile; finalmente, la séguridad interior de los buques $\sin$ el auxilio de muchas amarras y sin el menor ries. go de un botecillo siquiera, son ventajas tar considerables, que pocos puertos hay las reunan en tanto número y con tanta utilidad. Pudieran indicarse aqul también como relativas á este lugar. otras muchas ventajas que no son indiferentes entre los objetos generales que abraza la navega. ción. No es indiferente, por ejemplo, la imposibilidad de desertar que encuentra en Acapulco la tropa y la marineria. Tampoco lo es la inmedia. cion del puerto del Marqués, en el cual puede font. dear una escuadra ó buque aliado y socorrérsele sin necesidad de tener con él roce alguno, y últi. mamente, no lo son los ejemplos de un viaje de veintidos dias, hecho por la fragata Santa Gertrudis desde Lima hasta las playas inmediatas de Naguala, poco tiempo antes de nuestra llegada á Acapulco, y el que acababa de hacer entonces en veintiocho días desde Guayaquil, un buque mercante de aquel comercio.

Cuando se considera el segundo ramo de las utilidades que proporciona para un depósito de fuerzas navales la concurrencia de diferentes buques mercantes en un puerto, no podemos desentendernos de lo mucho que habrán costado en el Departamento de San Blas todos los efectos llevados de alli por tierra descle yeracruz, cuando un corto flete desde Cádiz hasta Lima ó Manila, y otro desde estos puertos al de Acapulco, haría que nuestros almacenes estuviesen bien provistos de pertrechos navales de mejor calidad, sin todos aquellos costos y con mucha mayor abundancia. Las anclas, la artillería, las jarcias de Europa 6 de Chile, las lonas, $y$ final. mente el mucho hierro labrado $y$ en bruto que consume la navegación, todo podría transportarse á Acapulco con grande facilidad y sin los inconvenientes que ya se han tocado de tener que pasar la artillería por tierra desde el río Guazacualcos á Teguantepec, $b$ de estal:lecer una fundición en Manila, 6 de tener que suplir las anclas de hierro y las jarcias de cáñamo, con otras anclas mal equilibradas de bronce y con la jarcia poco resistente de pita.

Pero la máxima utilidad que produce la re. unión en un mismo paraje de los bajeles de la Marina Real y mercante, y cuya ventaja es peculiar de Acapulco, por ser éste el único puerto habilitado para el comercio que tiene el Rey en las costas occidentales de Nueva España, consiste ciertamente en la economía recíproca. E1 mercante compra y aprovecha todos los efectos usados que siendo útiles para sus cortas travesías, no pueden ya servir para un buque de la Marina Real que se destina indiferentemente á obrar en todos parajes y en todos tiempos: la seguridad de encontrar auxilios en caso de necesitarlos, le hace navegar con mayor economía: el jornal y asistencia de los peones, ocupados unas veces en los almacenes Reales $y$ otras en las 
cargas y descargas de los mercantes, es inferior y más uniforme por la razón misma de que lo encuentran periodica y constantemente: ultimamente, los reemplazos de marineria y maestranza, tanto por una como por otra parte, accleran consiguientemente las faenas de unos y otros, $y$ no hay precisión de precaverse de antemano, manteniendo con mucho costo un cierto número de marineria para en caso de una necesidad que tal vez no acaece en muchos años.

En cuanto al tercer objeto, que se refiere á las circunstancias locales del establecimiento, es el único en que cabe dar alguna preferencia á la rada de San Blas solsre el puerto de Acapulco, pues por lo que toca á los dos anteriores es bien palpable que están absolutamente contra el primero. Para socorrer las provincias que bordan el mar de Cortés, la situaciós de San Blas es preferente á la de Acapulco (r); pero las navegaciones á la California ó á las costas más septentrionales de la $A$ mérica, aunque pueden emprenderse indiferentemente desde uno ú otro paraje, tiene, sin embargo, el puerto de Acapulco la ventaja de que no hay ṇecesidad de volver á fondear desde el día en que se da la vela, y de que se pueden hallar con más brevedad los vientus generales. Por lo que toca á la seguridad de puerto de Acapulco, además de las circunstancias que se expresaron ya relativamente al entrar, salir, bordear y espiarse, debe agregarse que en muy pocos cuartos de hora, el hombre más sencillo puede en toda estación conducir una embarcación desde el amarradero al carenero, cuando en San Blas, en la mitad del año, infunde mucho cuidado al navegante hasta la vista de las tierras cercanas por las travesías que le abaten sobre una cosıa llena de arrccifes; $y$ en la ntra mitad, las faenas de aligerar un buque para entrarle en el río, las otras mucho más complicadas, de habilitarle para la mar, las demoras incomodidades que son consiguientes á estas faenas dilatadas y la imposibilidad de valerse para ellas de muchos botes chicos, son otros tantos inconvenientes que destruyen de un modo inconcebible la economía y celeridad en las operacio. nes, que tanto apetece el navegante. La sola faena de hacer la aguada, que en Acapulco no nos ocupó sino el bote más chico con un solo hombre para conducir á veces ro ó 12 cuarterolas de agua en cada viaje, no puede hacerse en San

(s) Aun esta ventaja quedaria nula, si como ya so ha verificado, continuase surtiéndose el presidio de Loreto con embarcaciones menores destinadas a este objeto. Del mismo modo podrian surtirse todas las costas de la Sonora o bien con fletos al comercio, y es claro que serie ib; $;$ dente equivocar la idea de un establecimiento para este solo fin, con el de ocurrir a las muchas necesidades que debe cubrir un departa a las muchas neces
Blas ain las lanchas grandes, que ocupan to y 15 hombres y en las horas de la virazón, que son las más cómodas del día.

Sobre todo, una embarcación de mucho porte que necesite cualquiera obra de carena, no puede absolutamente entrar en San l3las por el poco fondo de su canal; necesita además descargar y volverse á cargar para seguir liasta Acapulco: finalmente, el costo de una recua para bajar los pertrechos desde los almacenes hasta el embar. cadero, el natural deterioro de éstos en seme. jante faena, el riesgo de una inundacioni en el astillero, las demoras necesarias para la comu. nicación onortuna de las órdenes, y la vigilancia contínua de los Oficiales sobre los artesanos, y últimamente el limitado espacio que hay en San 13las para el astillero y embarcadero de pertre. chos, son todas circunstancias que pudiendo conciliarse ventajosamente en Acapulco, manifiestan de un modo palpable cuánto se apartan de la recta senda los que no sólo opinan de que sea San Hlas el depósito de las fuerzas nava. les en el mar Pacífico, sino también un astillero capaz de suministrar navíos para la Marina Real.

Los que apoyan este sistema se fundan en la abundancia de maderas y en la buena calidad que tienen las que hay en el Departamento de San Blas; pero convencidos como lo estamos de que es casi imposible construir en América con economía y acjerto, resulta pues, que una excesiva abundancia de madera no es una ventaja ver. dadera para el tin á que debe destinarse un establecimiento en aquellos mares.

Es cierto que las carenas, la construcción de ambarcaciones menores y el total de obras que necesariamente han de hacerse en un astillero, necesita un acopio regular de maderas, pero áun para este objeto el puerto de Acapulco no es inferior al de San Blis, pues en el puerto inme. diato del Marqués wo sólo hay abundancia de excelentes maderas para toda especie de construcción y arboladura, que en el día pueden conducirse por agua liasta atravesar una sola playa de $5^{\circ}$ pasos, sino también que en lo venidero sería muy fácil cortar esta misma playa, de modo que las balsas no necesitasen para su conduccićn sino el auxilio de un pequeño bote. Además, supuesto que los buques que anualmente auxilian los pre. sidios de la Nueva California retornan siempre vacíos, sería fácil el que ś su regreso tocasen en San Blas y cargasen allí de maderas; particularmente de tablazón aserrada.

Se dijo que una de las ventajas á que debía atenderse para fundar un establecimiento de la clase del que vamos hablando, era la propcición de poder extender la población y de darla toda la salubridad necesaria, pero ni en San.Blas hay esta facilidad, ni medios de hacerla saludable, 
cargas y descargas de los mercantes, es inferior y más uniforme por la razón misma de que lo encuentran periodica y constantemente: ultima mente, los reemplazos de marinería y maestranza, tanto por una como por otra parte, accleran consiguientemente las faenas de unos $y$ otros, $y$ no hay precisión de precaverse de antemano, manteniendo con mucho costo un cierto número de marineria para en caso de una necesidad que tal vez no acaece en muchos años.

In cuanto al tercer objeto, que se refiere á las circunstancias locales del establecimiento, es el único en que cabe dar alguna preferencia á la rada de San Blas sobre el puerto de Acapulco, pues por lo que toca á los dos anteriores es bien palpable que están absolutamente contra el primero. Para socorrer las provincias que bordan el mar de Cortés, la situación de San Blas es preferente á la de Acapulco ( 1 ); pero las na. vegaciones á la California 6 á las costas más septentrionales de la América, aunque pueden emprenderse indiferentemente desde uno ú otro paraje, tiene, sin embargo, el puerto de Acapulco la ventaja de que no hay necesidad de volver á fondear desde el dia en que se da la vela, y de que se pueden hallar con más brevedad los vien. tos generales. Por lo que toca á la seguridad del puerto de Acapuleo, además de las circunstan. cias que se expresaron ya relativamente al en. trar, salir, bordear y espiarse, debe agregarse que en muy pocos cuartos de hora, el hombre más sencillo puede en toda estación conducir una embarcación desde el amarradero al carenero, cuando en San Blas, en la mitad del año, infunde mucho cuidado al navegante hasta la vista de las tierras cercinas por las travesías que le abaten sobre una cosia llena de arrecifes; y en la otra mitad, las faenas de aligerar un buque para entrarle en el río, las otras mucho más complicadas, de habilitarle para la mar, las demoras é incomodidades que son consiguientes á estas faenas dilatadas y la imposibilidad de valerse para ellas de muchos botes chicos, son otros tantos inconvenientes que destruyen de un modo inconcebible la economía y celeridad en las operaciones, que tanto apetece el navegante. La sola faena de hacer la aguada, que en Acapulco no nos ocuṕ́ sino el bote más chico con un solo hombre para conducir á veces ro $6 \mathrm{I} 2$ cuarterolas de agua en cada viaje, no puede hacerse en San

(I) Aun esta ventaja quedaria nula, si como ya so ha verificado, continuase surtiéndose el presidio de Loreto con embarcaciones menores destinadas a este objeto. Del mismo modo podrian surtirse todas las costas de la Sonora ó bien con fletes al comercio, y claro que seric in es claro que serte h. Jdente equivocar la idea de un astablecimiento para este solo fin, cnn el de ocurrir a las muchas nece
mento formal.
Blas sin las lanchas grandes, que ocupan to y 15 hombres y en las horas de la virazón, que son las más cómodas del día.

Sobre todo, una embarcación de mucho porte que necesite cualquiera obra de carena, no puede absolutamente entrar en San Blas por el poco fondo de su canal; necesita además descargar y volverse á cargar para seguir lıasta Acapulco: tinalmente, el costo de una recua para bajar los pertrechos desde los almacenes hasta el embar. cadero, el natural deterioro de éstos en seme. jante faena, el riesgo de una inundaciln en el astillero, las demoras necesarias para ln comu. nicación onortuna de las órdenes, y la vigilancia contínua de los Oficiales sobre los artesanos, y últimamente el limitado espacio que hay en San Blas para el astillero y embarcadero de pertre. chos, son todas circunstancias que pudiendo conciliarse ventajosamente en Acapulco, manifies. tan de un modo palpable cuánto se apartan de la recta senda los que no sólo opinan de que sea San Blas el depósito de las fuerzas nava. les en el mar Pacífico, sino también un astillero eapaz de suministrar navios para la Marina Real.

Los que apoyan este sistema se fundan en la abundancia de maderas y en la buena calidad que tienen las que hay en el Departamento de San Blas; pero convencidos como lo estamos de que es casi imposible construir en América con cconomía y acjerto, resulta pues, que una excesj. va abundancia de madera no es una ventaja ver. dadera para el fin á que debe destinarse un es. tablecimiento en aquellos mares.

Es cierto que las carenas, la construccion de embarcaciones menores y el total de obras que necesariamente han de hacerse en un astillero, necesita un acopio regular de maderas, pero áun para este objeto el prerto de Acapulco no es in ferior al de San Bless, pues en el puerto inmediato del Marqués iso sólo hay abundancia de excelentes maderas para toda especie de construcción y arboladura, que en el día pueden condu. cirse por agua hasta atravesar una sola playa de 50 pasos, sino también que en lo venidero sería muy fácil cortar esta misma playa, de modo que las balsas no necesitasen para su conduccien sino el auxilio de un pequeño bote. Además, supuesto que los buques que anualmente auxilian los presidios de la Nueva California retornan siempre vacíos, sería fácil el que ś su regreso tocasen en San Blas y cargasen alli de maderas; particularmente de tablazón aserrada.

Se dijo que una de las ventajas á que debia atenderse para fundar un establecimiento de la clase del que vamos hablando,era la propcición de poder extender la población y de darla toda la salubridad necesaria, pero ni en San Blas hay esta facilidad, ni medios de hacerla saludable, 
ni es posible abreviar de modo alguno la co. municación con la capital, mucho ménos la de adquirir marineros que no sean sacados del campo, ni últimamente la de vencer una pre. ocupación tal vez fundada contra aquel clima, que ya relativamente á Acapulco lo han venci. do indistintamente los Alipinos y los de Gua.

- yaquil." ".

Quedan, pues, a favor de Acapulco todas las reflexiones que nos hablamos propuesto, $y$ de. mostrada la preferencia que decididamente merece este puerto sobre la rada de San Blas. lin nuestro concepto, disminulda á lo ménos en la mitad la dotación de las Cajas de Méjico para el departamento de California y remitiendo á Europa aquella cantidad, pudiera muy bion sin recargo alguno del Erarin, mantenerse constantemente en aquellos mares algunos buques de la Marina Real, bien construídos y dispuestos para navegar a todas partes y áun para alcanzar al enemigo, en cuyo caso estos mismos buques continuamente armados, aunque diferentemente en tiempo de paz al de guerra, conservarian oportunamente $\mathrm{y}$ con muchas ventajas económicas la comunicación del Perú y Filipinas con aquellas costas, y se lograrian finalmente cn Acapulco, para nuestras fuerzas navales, aquellas mismas ventajas que con igual método disfrutan los ingleses en Bombiay, los holandeses en Batavia y los franceses en la Isla de Francia. En tal caso era preciso dejar al cuidado de los buques comerciantes de Manila 6 á otros tomados á flete por el Rey 6 por particulares, el cuidado'de socorrer los presidios de la California, y que los del mar de Cortés, continuasen como hasta aqul surtiéndose de comestibles en San Blas, pero fun esto trae ventajas peculiares, como ya se dijo, al comercio y á los estableci. mientos.

Casi desde el trópico de Cáncer, esto es, unas 80 leguas al Norte de Méjico, empieza aquella parte de nuestros dominios que se conoce con el nombre de provincias internas $y$ se comprende entre las aguas de los dos Océanos Paclfico y Atlántico, los cuales ciñendo al principio este continente en la extensión de unas 150 leguas, se inclinan después con tal divergencia, que por el grado 43 de latitud no baja de $54^{\circ} 15^{\prime}$ de longitud la distancia de uno á otro mar, 6 bien de 880 leguas próximamente; y como las colonias americanas ocupan en esta exten. sion unas 20 leguas contando los Kentukis hasta las orillas del Mississipl, se puede por consiguiente computar en 500 6́ 600 leguaz Este. Oeste la extensión de los dominios nacionales en eata parte, que nos disputan en el día los Seris, Moquis y Apaches al Oeste del Nuevo Méjico y los Lipanes y Cumanches al Este, con igual te. son y buen éxito al que tuvieron en el conti. nente austral los pueblos contiguos del reino de Chile ( 1 ).

Renovando en este lugar nuestras anteriores conjeturas sobre una grande despoblación al Eate de los Ilmites asignados á la Nueva Cali. fornia, y siguiendo como alli los indicios de los viajeros nacionales, no cabe ya duda en que en las tierras intermedius entre el rio Colorado $y$ la Sierra Madre, pueden considerarse igualmente estériles que despobladas: tanto más cuanto que el Comandante D. Juan Bautista Ansa, que atra. vesó este terreno en dos viajes consecutivos, ase. gura positivamente que desde las márgenes occidentales del Colorado hasta la Sierra Madre, s6ln se encuentra un país árido y á veces tan escaso de aguas que el transitar por él se hace igualmente penoso que arriesgado.

El río Colorado tuvo sin duda esta denominación por el color de sus aguas, que según ad vierte el Padre Consag se manifiestan tales en unos pantanos inmediatos á su desembocadura. Recibe el río Gila 18 leguas al Norte de aquel paraje, y luégo sigue casi en la misma dirección hasta los $34^{\circ} 15^{\prime}$, en donde tuerce próximamente al Nordeste; se une después por los $37^{\circ} \mathrm{con}$ el $Z$ a. guananas, que aumenta mucho el caudal de sus aguas, y subdividiéndose igualmente que éste en una infinidad de arroyos, remontan ambos á su origen por los $39 \mathrm{y}_{4} 0^{\circ}$ de latitud.

Por cuanto hemos podido indagar hasta ahora, sólo ha sido vadeado el Colorado en tres pa. rajes diferentes. Una en el confluente con el Gila, por las dos expediciones del Capitán Ansa desde la Sonora á la California. Otra el año de 1775 en los $35^{\circ}$, por el Padre Garcés (2) al tiempo de su viaje desde la California á los Moquis; $y$ final. mente, por los $37^{\circ}$ en 1777 , por los Padres Vélez y Escalante en su viaje desde el Nuevo Méjico á las lagunas de los Yamparicas en $4^{\circ} \mathbf{r}^{\circ}$, desde donde regresaron por el pais de los Moquis al presidio de Santa Fe.

La primera idea que se ofrece al contemplar este crecido río, cuyo curso atraviesa por muchas leguas las provincias septentrionales de Nueva España, es la de que siendo navegable podia fa-

(1) Exceptuamos on la descripción que sigue, a las dos Califormias Vicja y Nueva do que hemo ratado anteriormente.

(2) El Padre Fray Francisco Garcés, franciscani, la provincia de Áragón, es un sujeto cuya memoria merece un lugar distinguido en los fastos naciona. les. Con un solo indio de compañero, anduvo muchas naciones que no se conocian antes de poblarse ol $\mathbf{C o}$. lorado; vino a la California, entró en la provincia de Moqui, y do alli pasó a la Sonora, siempro entro gentiles, sin escolta ni compañero, comia lo mismo que cllos las frutas silvestres, y lo estimaban entrafiablo mente. Era conocido con ol $V a$ Jesis, que era su samente Era conocido con ol ${ }^{\prime}$ n Jesus, quo era su salutacion ordinaria para los indios, y hacla que éstos lo saludasen del mismo modo. Más adelante hablaremo de su muerte trágica en las misiones del ró Colo. rato. 
cilitar y dar movimiento á la extracción y tráfico de aquellas provincias; pero examinados atenta. mente los diarios de nuestron viajeros, es preciso, parece, renunciar á tan lisonjera esperanza. No podemos individualizar, por falta del diario co. rrespondiente, cuál fué el cauce, ni cómo se pre. sentaban los contornos del río en el paraje por donde pasó el Padre Garcés; pero los Padres Vélez y Escalante que lo atravesaron ain gulas, encontraron mil tropiezos. "Antes (dicen), en un "rincón tudo cercado de cerros y crestones de "tierra colorada, muy elevados, que teniendo va"rias formas y siendo el plan intermedio de abajo "del misno color, tiene un aspecto agradable. "mente confuso, luégro arenales muy escarpados "y pasos dificiles con bancos peligrosís:mos de " peñas, finalmente, un vado de un ascenso tan es"cabroso, que fué preciso hacer con un pico algu"nos escalones en la piedra viva para las caballe. "rías, y bajar á mano todas las cargas y aparejos. "El vado es bucno; tendrá aquí de ancho una umilla poco más, y ya vienen incorporados los - ríos de Nabajo y de Dolores. En todo lo que por naqul vimos no se puede establecer en sus ribe. "ras población alguna, ni áun caminar por una y "otra banda hacia abajo y hacia arriba una bue. "na jornada con la esperanza de que sus aguas - sirvan para la gente ó caballada, porque á más * de ser el terreno malo va muy encajonado el río. - Todo lo más inmediato al río es de peñones y "picachos muy elevados; ocho 6 diez leguas al "Norte de él está una sierra alta, redonda y con "poca base, que los Puychis llaman Tucané 6 - Cerro Negro; se encuentran también á poca dis"tancia muchas minas de yeso transparente, al. "gunas de talco y también algunas metálicas. Fi. "nalmente, pueden servir de un mediano alimen- to las pencas de nogal chico tostadas, y el ato"le de una frutilla que da en las orillas del río, "bien que el prepararla así, molida y con agua, la "quita todo el sabor que tiene por sí sola."

En el vado que halló D. Juan Bautista de Ansa en su primer viaje, cogiéndolo corto trecho al Norte del confluente, tenía 95 brazas de ancho y cinco palmos de fondo en lo común, yendo allí de ménos el brazo que forma una isla de donde habían salido: ay no se midió, dice el Diario, al mismo tiempo el Gila, por tener ya introducido el brazo mencionado del Colorado, pero segín el informe de los indios se puede regular la mitad ménos en todo, pues sólo en la mejo:ia de agua le excede el Gila, bien que las de ambos ríos no son las mejores, pues tiran un poco á saladas. Las orillas, miradas desde un alto inmediato, eran sumamente frondosas, con una inmensa arboleda de sauces y álamos que las pueblan tanto para arriba como para abajo, $y$ hasta donde puede alcanzar la vista, útiles todos por su derechura para vigas. Se veía igualmente una sierra inme- diata, por cuya abra salo el río Colorado al Nor. noroeate; y al Esnordeste otra abra en una sierra que corta el Gila; y la conversación con un indio Soyopa proporcionó el saber que tres dius de camino río a riba se partia el Colorado, wiendo ente el más caudaloso, y el menor brazo tiraba á jun. tarse con otro río mayor que el mismo Colorado, y que aquel en la realidad tenía el agua más colorada que éste. Manifestaron los mismos naturales que el río no tenía salto alguno hasta la mar, ni tampoco sabian lo tuviese arriba en mu. chas leguas."

Al regresardel mismo viaje, pasaron nuestros viajantes los rios, en balsa, un poco más abajo del confluente, por un ancho de 6 oo varas ( 1 ; ; y volviendo á pasar el Gila por más arriba, nota. ron que, tanto alli como en todo lo andado, no bajaba su fondo en lo general de cuatro palmos, á pesar de ser aquel el tiempo de su mayor seca. Los naturales dieron á entender que en el tiem. po de las avenidas, con las aguas del verano, no bajaba su ancho de 500 varas, concurriendo á manifestarlo asl las señales particulares del te. rreno.

Estaba algo más caudaloso el río en Diciembre de 1779 , cuando el mismo Comandante Ansa conducía á Monterey y San Francisco la tropa y familias destinadas á aquellos nuevos eatableci. mientos, y prefirió, sin embargo, vadearle algo más arriba, en donde dividido el río en tres bra. zos, podia pasarse el primero en cinco palmos y medio de agua en lo general y seis en el centro, el segundo brazo en cuatro y cinco el último, que era el más ancho, tejía dond seis y medio palmos de agua, y cuatro en lán; pudiendo suponerse que, si los tres brazos estuvieran unidos, no bajaría su anchura de 240 varas, como las tendrá en donde no se divide.

La desembocadura del Colorado en la mar, según la carta y los diarios del Padre Fernando Consag, tendrá unas cinco leguas de ancho, áun tomando esta dimensión en las inmediaciones de las Islas de los Reyes, empezando los bancos por mayor anchura y mucho más al Sur. "Estos ban" $\cos$ (dice el citado Padre) obstruyen casi de un utodo la navegación: la corriente del río en las - vaciantes es tan rápida, que no pueden las ca.

(1) Aqur añade el Diario original estas palabras: « Fueron inútiles cuantas pesquisas se hicieron para naveriguar entre los naturales la existencia de la fanoveriguar entre los naturalcs a exul y laguna de azogue que noticia - Teniente D. Mateo Mangé, companero del Padro n Kino en una obra que dedico al Excmo. Sr. Virey "Kinó en una obra que dedicó al Excmo. Sr. Virey
"Duque de Alburquerque, como también el ro Ama"Duque de Alburquerque, como también el ró Ama-
nrillo del ntro lado del Colorado.n Demostración manrillo del otro lado del Colorado." Demostracion maciones de palses maravillosos, semejantes al Dorado a la grando Quivira, al Fstrocho ide Aniam, ete. Fisto la grande Quivira, al Estrecho de Aniam, etc. Esto Mangé acompaño efectivamente al Padre Kino, se. gun noticias de la historia del Padre Venegas, tomo II, pag 90. 
cilitar y dar movimiento a la extracción y tráfico de aquellas provincias; pero examinados atenta. mente los diarios de nuestros viajeros, ea preciso, parece, renunciar á tan lisonjera esperanza. No podemos individualizar, por falta del diario $\mathrm{co}$. rrespondiente, cuál fué el cauce, ni cómo se pre. sentaban los contornos del río ell el paraje por donde pasb el Padre Garcés; pero los Padres Vé. lez y Escalante que lo atravesaron sin guias, encontraron mil tropiezos. "Antes (dicen), en un - rincón todo cercado de cerros y crestones de "tierra colorada, muy elevados, que teniendo va. n rias formas y sienclo el plan intermedio de abajo - del misno color, tiene un aspecto agradable. " mente confuso, luégo arenales muy escarpados "y pasos dificiles con bancos peligrosís:mos de u peñas, finalmente, un vado de un ascenso tan es"cabroso, que fuć preciso hacer con un pico algu"nos escalones en la piedra viva para las caballe- rías, y bajar á mano todas las cargas y aparejos. "El vado es bueno; tendrá aqqui de ancho una - milla poco más, y ya vienen incorporados los - ríos de Nabajo y de Dolores. En todo lo que por - aquí vimos no se puede establecer en sus ribe. "ras población alguna, ni áun caminar por una y * otra banda hacia abajo y hacia arriba una bue"na jornada con la esperanza de que sus aguas usirvan para la gente ó caballada, porque á más "de ser el terreno malo va muy encajonado el río. - Todo lo más inmediato al río es de peñones y "picachos muy elevados; ocho 6 diez leguas al "Norte de él está una sierra alta, redonda y con "poca base, que los Puychis llaman Tucané ó "Cerro Negro; se encuentran también á poca dis. "tancia muchas minas de yeso transparente, al. "gunas de talcn y también algunas metálicas. Fi. "nalmente, pueden servir de un mediano alimen"to las pencas de nogal chico tostadas, y el ato"le de una frutilla que da en las orillas del río, "bien que el prepararla así, molida y con agua, la "quita todo el sabor que tiene por sí sola."

En el vado que halló $D$. Juan Bautista de Ansa en su primer viaje, cogiéndolo corto trecho al Norte del confluente, tenía 95 brazas de ancho $y$ cinco palmos de fondo en lo común, yendo allí de ménos el brazo que forma una isla de donde habian salido: "y no se midió, dice el Diario, al mismo tiempo el Gila, por tener ya introducido el brazo mencionado del Colorado, pero segín el informe de los indios se puede regular la mitad ménos en todo, pues sólo en la mejozía de agua le excede el Gila, bien que las de ambos ríos no son las mejores, pues tiran un poco á saladas. Las orillas, miradas desde un alto inmediato, eran sumamente frondosas, con una inmensa arboleda de sauces y álamos que las pueblan tanto para arriba como para abajo, $y$ hasta donde puede alcanzar la vista, útiles todos por su derechura para vigas. Se veía igualmente una sierra inme- diata, por cuya abra salo el rio Colorado al Nornoroeste; y al Esnordeste otra abra en una sierra que corta el Gila; y la conversación con un indio Soyopa proporcionó el saber que tres dias de camino rio a riba se partia el Colorado, siendo eate el más caudaloso, y el menor brazo tiraba a juntarse con otro rí mayor que el mismo Colorado, y que aquél en la realidad tenía el agua máa co. lorada que éste. Manifestaron los mismoo naturales que el río no tenía salto alguno hasta la mar, ni tampoco sablan lo tuviese arriba en muchas leguas."

Al regresardel mismo viaje, pasaron nuestron viajantes los ríos, en balsa, un poco más abajo del confluente, por un ancho de 600 varas (x); y volviendo á pasar el Gila por más arriba, nota. ron que, tanto alli como en todo lo andado, no bajaba su fondo en lo general de cuatro nalmos, á pesar de ser aquel el tiempo de su mayor seca. Los naturales dieron á entender que en el tiem. po de las avenidas, con las aguas del verano, no bajaba su ancho de 500 varas, concurriendo á manifestarlo asl las señales particulares del te. rreno.

Estaba algo más caudaloso el río en Diciembre de 1779 , cuando el mismo Comandante Ansa conducía á Monterey y San Francisco la tropa y familias destinadas á aquellos nuevos establecimientos, y prefirió, sin embargo, vadearle algo más arriba, en donde dividido el rio en tres brazos, podía pasarse el primero en cinco palmos y medio de agua en lo general y seis en el centro, cl segundo brazo en cuatro y cinco el último, que era el más ancho, tesía dondr seis y medio palmos de agua, y cuatro en lán; pudiendo suponerse que, si los tres brazos estuvieran unidos, no bajaría su anchura de 240 varas, como las tendrá en doncle no se divide.

La desembocadura del Colorado en la mar, segán la carta y los diarios del Padre Fernando Consag, tendrá unas cinco leguas de ancho, áun tomando esta dimensión en las inmediaciones de las Islas de los Reyes, empezando los bancos por mayor anchura y mucho más al Sur. aEstos ban- cos (dice el citado Padre) obstruyen casi de un - todo la navegación: la corriente del río en laa "vaciantes es tan jápida, que no pueden laa ca-

(r) Aqui añade el Diario original estas palabras: a Fueron inútiles cuantas pesquisas so hicieron pars naveriguar entre los naturales la existencia de la fanosa Sierra Azul y laguna de azogue que noticia sel 'Teniente D. Mateo Mange, companero del Padro "el 'Teniente D. Mateo Mangé, compañero del Padro
« Kinó en una obra que dedico al Excmo. Sr. Virey Duque de Alburquerque, como también el rfo Amamrillo del ntro lado del Colorado.» Demostración ma. nifiesta de la facilidad que ha habido en foljar rela. sciones de palses maravillosus, semejantes al Dorado, a la grando Quivira, al Estrecho de Aniam, etc. Esto A la grande Quivira, al Estrecho de Aniam, etc. Esto
Mange acompaño efectivamente al Padre Kino, se: gún noticias de la historia del Padre Venegas, tomo.II, pdg . 90 . 1. 
blorado al Norra en una sierra ón con un indio res dius de ca. do, siendo este zo tiraba á junismo Colorado, l agua más co. mismos natuJzuno hasta Ia arriba en $\mathrm{mu}$.

asaron nuestros poco más abajo joo varas (I); y is arriba, notalo andado, no cuatro palmos, su mayor seca. que en el tiem. del verano, no concurriendo a culares del te.

río en Diciem. mandante Ansa cisco la tropa y levos estableci. , vadearle algo río en tres bra. cinco palmos y is en el centro, co el ultimo, seis y me. lún; pubrazos eatuviea de 240 varas, divide.

ado en la mar, adre Fernando. de ancho, áun imediaciones de los bancos por ur. Estos banyen casi de un - del río en las pueden las ca-

estas palabras: hicieron para stencia de la faggue que noticia sañero del Padro ixcmo. Sr. Virey bién el ró Ama. emostración ma. 0 en fosjar rela. ntes al Dorado ates arado Padre Kiıo, se. enegas, tomo II, inoas centrarestarla al remo, y no entra con - menos fuerza la marea, tomando tal resaca y - embates, llue sumergio una de las canoas y - puso toda su gente en evidente riesgo de nau- fragar. Hacia la California, toda in tierra baja "se inunda con las avenidas, de suerte que whasta el pié de la serrania se ven los palos y baauras que arrollan las aguas. Se nota tam. - bién una especie de heras, aunque pequerias, - en que los naturales del pais limpian ó desyrawan una especie de semillas semejante al trigo, " pero tan menuda como el anls: finalmente, - deade la Visitación, y mucho más desde San - Felipe, la navegación parece impracticable, áun - para vasos muy medianos."

El pais comprendido entre el Gila y el Colo. rado puede considerarse como extremadamente fertil, según el testimonio de todos nuestros viajeros. Lo habitan en el día los Yumas, y apro. vechándole á veces con riego artificial y otras con las ramificaciones accidentales del agua, 10 . gran de cosechas abundantes de maiz, trigo, frí joles, garbanzos y algodón, además de un creci. disimo número de sandlas, calabazas, etc., las cuales contribuyen no ménos al bienestar y re. creo de los naturales que al alivio de los tran. seuntes. Sin embargo, es muy poca la extensión de este terreno fértil, porque aprovechándole para las cosechas y no quedando sitio oportuno para pastos, no han podido propagarse los ganados, por cuya causa carecen estas tríbus casi enteramente hasta del caballo.

A excepción de las inmediaciones del Gila todos los terrenos que rodean al Colorado parecen igualmente estériles y desiertos, siendo aún mucho peor esta perspectiva al paso que se retrocede al Sur hacia las provincias de la Sonora, costeando el seno de Cortés por su parte Este. Desde los últimos años del siglo pasado todos los Misioneros Jesuitas, y especialmente el docto Padre Kin6, habian manifestado que componiéndose generalmente la costa de la Sonora sobre el golfo califórnico de ásperas montañas y estériles arenales sin agua dulce, debía mirarse esta pro. vincia como mediterránea ( $\mathrm{I}$ ). Lo apoyó después con mayor individualidad el Comandante Ansa, quien en el Diario de su primer viaje á la Cali. fornia, hablando de algunas familias Papagas 6 Pimás, encontradas en las inmediaciones de Baipia dice: "Que en invierno bajan á nuestros es:tablecimientos dejando su país casi desierto - porque éste es de los más desdichados que pụe- den imaginarse, pues les escasea hasta el agua - precisa para su manutención, y que por falta de - ella no poseen ninguna siembra segura, siendo - los ánicos frutos que alcanzan, algunas calabazas, sandlas y melones que arriesgan al tempo.

(I) Historia del Padre Venegas, tomo II, pág. 78. "ral, y se pierden siempre que las aguas no son - extremadamente buenas; y últimamente, que - aquí parece reunida toda la infelicidad, pues no - se ven siquiera árboles frondosos para techos.. Yero aún mucho más que las reflexiones anteriores evidencian en el día la esterilidad de esta provincia los pasos sucesivos de nuestros misioneros, quienes para adelantarse al Norte se han visto precisados á establecer las misiones apartándose de las orillas, y áun así las más no han medrado $y$ casi todas se han visto inmediata. mente destruidas por los Seris no habiendo bas. tado ios esfuerzos harto costosos del Gobierno á favor de la Sonora, para desalojar de sus esté. riles inmediaciones á aquellos pueblos errantes que viven de la pesca y undan particularmente en la Isla del Tiburón y sus contiguas.

Al Norte del rio Gila y de los brazos orientales del Colorado, el pals presenta un semblante mucho más placentero. Una, sordillera bastante áspera y elevada, que corriendo un la dirección Norte-Sur atraviesa este país en la extensión de 70 leguas siendo su ancho de 30 á 40 , termina al Oeste casi por meridianos del río Colorado y hasta la latitud de $4 \mathrm{I}^{\circ}$ Io' unos campos y valles sumamente fértiles $y$ amenos, siguiendo al Sudeste las hermosas y agradables vegas que labitan los Cosminas y los Moquis, naciones contiguas por el Oeste al Nuevo Méjico, y que en el siglo pasado fueron reducidas á la Keligión y á la Monarquía, dos cosas que han abandonado después. Hállanse en estas distantes regiones (I) montes poblados de pinos y álamos de un tamaño singular, varias y grandes lagunas entre las cuales merece particular memoria una formada al Sudoeste por las aguas de la serrania indicada, de seis leguas de ancho y 15 de largo, que corriendo al Noroeste por una angostura, comunica con otras mucho mayores, todas abundantes en peces, ánsares, nutrias y otros anfibios; varias minas de yeso transparente, un hormiguero grande de piedra alumbre muy menuda, purificada y cristalina, una cordillera de mesas altas que desde la cima hasta su mitad se compone de tierra blanca y desde alli abajo se ven uniformemente matizadas de amarillo, blanco y almagra muy subida; varias aguas termales, el origen de cuatro ríos medianos, las ruinas de dos pueblos antiguos, y para el alimento en ciertos parajes algunas truchas, en otros tal cual cíbolo, licbre y carnero silvestre, y generalmente donde hay naturales, los pínolos, semillas y yerbas que suelen recoger de antema. no las mujeres para las provisiones del invierno.

En el valle de los Timpanogotzis al Norte del rio de San Buenaventura y próximo á la laguna citada, los campos se cubren de pastos loza-

(x) Relación del viajo de los PP. Vélez y Esca- 
nos, y bajo un temple de 'os más benignos y suaves se producen naturalmente y con abundancia el lino, el cáñamo, de cuyas semillas y otras mu. chas yerbas se alimentan los naturales los $s a$ buaganas ó come pescudo y hacen atole logrando también de la caza de liebres, conejos y gallinas que hay abundantemente además de la de los cí. bolos que tienen no muy distantes.

Las inmediaciones de Santa Fé, conocidas con el nombre de Nuevo Mréjico, son morícuosas, áridas 6 intransitables, $y$ sin duda muy abundantes en minerales, pues sólo los valles dan lugar á siembras y pastos, y el terreso fártil, no vuelve á encontrarse hasta los $28^{\circ}$ caninando al Este hacia los límites de la Nueva Vizcaya con la provincia de Collalluila. En ésta, y particularmente hacia el presidio actual de Santa Rosa y el abandonado de San Sabá, per los $32^{\circ}$ escasos, se presentan al viajante unas campiñas regaias por el río grande del Norte ú otros infe riores, y otras lomerías y bosques tan espesos de morales, ciruelos, perales, manzanos, con une in finidad de parras enlazadas, mexquites, cedros y palos blancos, que con dificultad perniten paso para un hombre á caballo. No es inénos fértil, llano y agradable, el terreno de 40 á 50 leguas que media catre San Sabá y Béjar, capital de la provincia de Tejas, desde cuyo vunto, ya sea en dirección del Mississipí o del mar, se encuentran bosques tan espesos y pantanosos, que si es mulesto atravesarlos en tiempo de secas, es imposible casi verif carlo en el de lluvias ó inundaciones.

Fuera este lugar oportunotle verter la cues tión sobre la facilidad y utilidad de navegar el río del Norte hasta las inmeiliaciones de Santa Fé; pero careciendo de documentes suficientes para aventurar un parecer siquiera probable, nos ceñiremos por tanto, á desear que no se dilate mucho esta importante averiguación, cuyo influjo en el sistema político de estas regiones, no sería tal vez indiferente. El Ingeniero D. Nicolás Lafora, que acompañó al Marqués de Rubí en la revista general de los presidios de esta frontera, pasó en balsa el río mencionado, cerca del $\mathrm{Ca}$ rrizal, esto es, en la división, digámoslo así, de Nuevo Méjico con la Nueva Vizcaya; v $s 6$ tam. bién á su regreso de San Sabá por los $3 \mathbf{1}^{\circ}$, hallando el río bastante rápido y caudal'rso, y finalmente, le encontró con mucha extiri.in n y fondo en las inmediaciones do Laredo, en el nuevo Santander; pero los datos que suministra la narración de estos viajes, son insuficientes por sí solos pata fijar con alguna certidumbre la posibilidad é imposibilidad de navegar en toda su extensión este río caudaloso.

No son ménos inciertas las noticias que pueden darse de nuestras provincias septentrionale al querer penetrar más allá de los paialelos con- tíguos al Norte dc los que acabamos de describir, áun fijando el límite de nuestras indagaciones en el paralelo de $13^{\circ}$, como lo hicimos para las po sesiones de la Vieja y Nueva California. Con efecto, las lagunas de los Padres Vélez y Escalante están contíguas á las llanuras que lindan con las tierras altas del puerto de San Francisco, del Cabo Mendocino ó del ouerto de la Trinidad. La cordillera ya citada de San Buenaventura va á unirse con las montañas brillantes de Carver, $b$ tienen esta preferencia las sierras montañosas de Cohahuila que por los $32^{n} y$ al Este del Nuevo Mléjico, parece se dirigen por largo trechn hacia el Norte en un país aún no trillado por nuestros exploradores. ¿El terreno que media 'ntre el rín Norte y el Mississipi, es montuoso 6 se asemeja al que entre el Ohío y el Missourí hacen en el día la felicicidad de los Kentukis y ri objeto de las investigaciones comerciales de la Inglaterra? Hé aquí una porción de dudas entre otras muchas, que no pueden resolverse según el estado actual de nuestros conocimientos, y que dejan campo abierto para las indagaciones sucesivas de los viajeros venideros que tengan tiempo y oportuniảad para hacer este servicio importante á la Gecgrafía. En el entretanto, volviendo la espalda á estas distantes regiones, continuemos hac: el Sur el examen físice del suelo que compone nuestras provincias internas. Entre lis causas principales que pueden servir de aliciente para que se pueblen alcrún día estas provincias como corresponde is su dilatada extensión, debe comprenderse el artículo inportante de las minas, las cuales son tan abundantes asi en la Sonora; como en el Nuevo Méjico, la Nueva Vizcaya y el Nuevo Reino de León, que pueden muy bien compararse con las ricas de Nueva España, y áun concederles tal vẹz cierto grado de supurioridad; prueba de esta aserción los lavaderos de oro tan abundantes en casi toda la Sonora, y particular. mente en las sierras inmediatas á Arispe, los de Bacuache, la Cananea y Peñuelas, que han dado granos hasta de siete marcos: la mina de Bana. mitzi y la de Santa Rosalía, que dió oro de 77 y $\%$ quilates, con tal abundancia, que algunas cargas llegaron á rendir r.ooo pesos, y durbesta bonanza por el dilatado espacio de veinticinco años hasta el de I748. Pero aún más abundantes que las de este precioso metal sin las de plata, de las cuales en todo el distrito de Arispe se han abierto hasta 37 minas, siendo las más acreditadas las del Espíritu-Sainto, que rendía á I 8 marcos por carga, la de Rocha á r2 y la Babicanora y otras varias desde tres hasta seis marcos, á las cuales se pueden agregar en la misma provincia de la Sonora hacia el mar de Cortés, las inmediatas al presidio ciel Altar; las de San Marcelo, de Vinotac, las de Guachuca y la Longoreña cerca de Terrenate; las suevamente descubiertas en el 
s de describir, dagaciones en para las po. lifornia. Con Vèlez y Esca. as que lindan an Francisco, e la Trinidad. enaventura va ss de Carver, 6 nontañosas de te del Nuevo 6 trechn hacia por nuestros ia intre el rín ó se asemeja - hacen en el y ri objeto de la Inglaterra? tre otras mugún el eatado y que dejan s sucesivas de tiempo y opornportante á la endo la espalinuemos haci: que compone tre lis causas aliciente para covincias como ón, debe comde las minas, en la Sonors, 'a Vizcaya y el muy bien comEspaña, y áun e sup'srioridad; ros de oro tan i, y particularArispe, los de , que han dado nina de Banaoro de $17 \mathrm{y} \%$ algunas cargas - óesta bonanza ico años hasta ites que las de ta, de las cuae han abierto ucreditadas las I 8 marcns por canora y otras s, á las cuales rovincia de la inmediatas al celo, de Vinoreña cerca de abiertas en el arroyo del Infierno y en el pot ero de las Tetas, entrambas muy inmediatas al Real del Rosario (I), y sobre todo, la célebre mina de la Ar:zona 6 las Bolas, ock.o leguas del pueblo de Surie de los Pimás altos, en la cual se hallarcí en $\mathbf{7} 73^{6}$, bolas de plata virgen hasta el peso de $\mathbf{I}_{50}$ arrobas (2).

Siguiendo por la Nueva Vizcaya y Nuevo Méjico, se encuentian las minas de Cosaguirichí con otras varias no méncs ricas de oro y plata. En el Nuevo Santanter sri, nombradas las de la Iguana inmediatas á Laredo, y en el Nuevo Reino de León, además de la famosa mina de Boca de Leones, existen aún los rastros de las labores de otras muchas, fijando especialmente la atención de todo curioso, las que se llamaron de San Diego y se beneficiaron por algún tiempo.

Adcmás de estos dos metales preciosos, un terreno tan montuoso debía producir y produce con efecto otros muchos minera'es que, aunque de ménos valor, son por lo común más útiles al país que los produce y á la sociedad en general. Tales son, especialmente $\in n$ la Sonora, el plomo, el cobre y el hierro, á los cuales se agregan también el talco, el alumibre, el almagre, el ncre y la caparrosa.

Aunque todo el país hasta aquí descrito se considere generalmente montuoso y estéril, hay, sin embargo, en casi todos los paralelos bastante terreno llano, ó á lo ménos ciertos valles en donde vuede subsistir el hombre, sana, cómora y felizmente. El valle de San Bartolomé, por ejemplo, el pueblo de Buenavista, la villa de Santiago de Salitre, las demás inmediatas de las Colcuias Tlascaltecas, las inmensas haciendas del Mrarqués de Sán Miguel de Aguaya y las inmediaciones del río Norte desde que se separan los méganos que con las arenas movidas por los vientos tempestuosos forman una cordillera de ca ri 60 leguas de extensión, son todos parajes sumanınte amenos y fértiles de los

(r) En el Real dei Rosario, segun certificación del Intendente de la provincia, publicada en la Gaceta de Mijico de 10 de Mayon de 1785 , sc habran presentado cn todo el ax̌o anterior 27.168 marcos de plata azogue, 5296 de fuego, que pagaron a S. M por los derechos de uno por ciento y décimo $3 \cdot 3 ; \%$ pesos. En el propio tiempo se presentaron tamhin $702 \mathrm{mar}$ cos de oro, que contribuyeron por el delecho de tres For ciento 2.244 pesos, y en Junio de 86 se presentaron 30.416 marcus de pl ita azogue, 6.526 de fuego y 7 r I narcos de oro.

(2) Habla de estas boles monstruosas el Compendio del Padre Venegas, tomo III, capítulo último, y el Capitán D. Juan Bautista de Ansa se cxpresa en estos términos: aEsta particularidad se ha dudado, pero es ntan cierta, que viven muchos de los que las poseyexron, de lo que puede dar igualmento documentos nque lo acreditan, como que mi padre, con dictamen - Jo sujetos peritos en leyes, las embarge por pare cerle pertenecer s $S . M$, bo por el "por el Consejo Real de Castilla.
Reinos de Nueva Vizcaya, Cohahuila y Santan. der, y no lo son ménos toda la provincia de Te. jas, las inmediaciones de Nonterey, en el Nuevo Reino de León; las de Alburquerque, en el Nuevo Méjico, y las de San Miguel de Orcasitas en la Sonora; extensión vastísima de te rreno, á la cual puede también agregarse el de los inmediaciones del Gila y Colorado, y el paí de los Moquis y Ccsminas anteriormente desc: $\mathrm{i}$ to. En todos estos parajes se dan, como es de creer, con más ń ménos abundancia todos los frutos y semillas principales y las más útiles para la vida; pero la cosecha total de ias que se cultivan es demasiado corta, porque el cebo de las minas, acarreando insensiblemente 'a población hacia las sierras y haciendo tija: la idea de las riquezas en las entrañas de la tierra, ha descuidado enteramente la agricultura, de modo que el objeto primario de las siembras es sólo ocurrir al sustento del corto número de los colo. nos, y la mayor parte de las vegas útiles de estas provincias han quedado destinadas para los ganados. Estos, sin embargo, hacen un servicio muy particular en unos parajes que, como tan distantes de las costas y de la capital, escasean de todo: la lana de las ovejas suministra el vestido; los caballos el medio preciso y único para contrarestar las invasiones de los indios enemigos; las mulas sirven para el beneficio y acarreo de los metáles, y las vacas, además de ocurri hasta cieito punto al sustento de los naturales, proporcionan un ramo muy regular de zomercio con la Nueve Galicia, en donde se venden con mucha estimac:ón el tasajo, el sebo y los cuerss. Finalmente, en uit corto espacio de terreno beneficiado, Jas uvas aan los vinos y aguardientes que pueden bastar para el alivio y recreo de estos distantes vasallos.

Limitaremos á lo expuesto el examen físico de esta parte de la Monarquía, cuya prolija descripción requiere la concurrencia de otros medios que los que hasta ahora hay, y empezaremos desde luego á examinar al hombre en estos países dilatados.

Las primeras naciones que se encuentran al Noroeste de la Sonora y en el cenfluente ó inmediaciones de los ríos Gila y Colorado son los Yumas. Estos habían sido visitados por el $\mathrm{Pa}$ dre Kinó y otros misioneros de la expulsa Corr pañía, y luégo atravesó sus rancherías con muy buen acatamiento el Padre Fr. Francisco Gar. cés, lo cual díb lugar á que con el mismo buen exito las transitase después en sus dos expediciones para la California el Comandante Don Juan Bautista de Ansa, y últimamente que á instancias de los mismos naturales se planteasen dos misiones 6 poblaciones en las orillas del Colorado, á poca distancia del confluente.

Los des Diarios de D. Juan Bautista de Ansa 
$y$ las noticias anteriores, concurren en suponer esta nación de los Yumas romo muy adelan. tada hace tiempo en la civilización. El cacique nombrado Palma, que era el jefe principal de esta tríbu cuarido pasó Ansa por ella, manifestó en todas ocasiones un grado de autoridad grande sobre toda la comunidad; explayó su opulencia, generosidad y buena $f \in$, regalando diferentes comestibles á la expedición, cambiando á los nuestros los caballos inútiles que llevaban custodian. do una parte de las cargas del convoy que no podian seguir, $y$ castigando al mismo tiempo con el mayor rigor á un súbdito suyo acusado de un robo. Ayudó y se afanó para que nuestras expediciones vadeasen el río con la mayor seguridad, disponiendo que todos sus súbditos concurriesen á este acto, y finalmente dió pruebas nada equívocas de un carácter noble $y$ confiado, en la franqueza con yuje se determinó á entregar el mando $\therefore$ uno de sus parientes y subalternos pa $a s$ sguir al Comandante Ansa como efectivameatt 10 ejecutb, acompañándole hasta las fronteras de la Sonora y luégo después hasta Méjico. Las cualidades esenciales que advirtió el mismo Coman. dante en los demás individuos de esta nación la describe en la forma que sigue:

"Esta nación, dice, es por lo general muy ro"busta, de más de ocho palmos de talla, su genio "lo mejor que se ve en indios, pues son muy "festivos, cariñosns y liberales. Su color, no n tan negro como otros, y no son de los más ra. "yados; tienen naturalmente buenas caras, pero wse hacen feroces con el embije de todo el cuerpo "y en especial la cara. Van todos los hombres " enteramente desnudos sin el más leve asomo de "rubor, y esto l,) tienen por lombría, y el ir " algo cubiertos por acción mujeril, que ellos mis"mos me lo han dicho: tienen buen pelo, que se "lo componen de muchos y diversos modos, con "lodo muy fino, sobre el que se echan un polvo "de tan buen relumbron que parece lo es de "plata, y para que este peinado no se les des* haga duermen sentados. I a cara se ha dicho "ya, se pintan extremadamente de los colores -negro y colorado, $y$ en esto se incluyen tam. -bién las mujeres; llevan los hombres horada"das las orejas, el que ménos con tres agujeros, "y lo más común con cinco, $y$ en todos ellos zar" cillos. Las narices 6 teruillas también se hora"dan y atraviesan en ellas un montón de plumas "6 más generalmente un palillo de palmo de "largo, y más grueso que el mayor c. ñón de "aves, con lo que se acaban de hacer sobre fe. "roces, espantables. A las armas y guerras pa"recen poco inclinados, raro tiene carcaj y po" cos cinco flechas malas $y$ con peor arco, de "cuyo modo va armada la tercera parte; las otras "dos sólo llevan unas astas de cuatro varas (ins"trumento para jugar) y unos garrotes. Son los
- ancianos los que usan del arco, pero á poco "frío que haga por la mañana 6 tarde, general. "mente las deponen adonde quiera, y cogen unos "tizones que regularmente se los pegan á los " estómagos 6 partes posteriores, para calen"tarse. Atribuyo á que tres horas que solo dor. " mirán de las veinticuatro del día, es por el poco "abrigo que tienen, en especial cuando están fuera "de sus rancherías, que á lo ménos en ellas tienen "sus racalillos (chozas) en terrenos bien blan. " dos en que se entierran y reunen cuantos com"ponen una familia. Su lengua es fácil para "pronunciarla y lo mismo me parece para escri. - birla. Les es muy fácil una buena pronuncia"ción del castellano. Las mujeres, en la robus. "tez y tamaño corresponden á los hombres; sus "rostros son regulares, sin apercibirse, ni extre"madamente feas, ri especialmente hermosas; " van vestidas 6 medio cubiertas de la sola cin "tura á las corbas y rodillas con unas naguillas "que hacen de las cortezas del sauce y álamo, "divididas en dos piezas, poniéndose la más " corta por delante. Hacen de las mismas corteuzas y de la del mezquite unas piozas anchas "que salen poco ménos ásperas, sunque más "tupidas que lo que en el Reino llamamos guan. "goche bruto; éstas les sirven para taparse, y la "que las lleva puede llamarse rica, y mucho "más las yue consiguen otras piezas de cueros "de nutrias, liebres ú otro animal cualquiera. "Uno y otro sexo va con el pié enteramente "descalzo. Por lo que he visto de ellos $\epsilon$ in "formado de lo que me resta, regulo habrá 3.500 "almas de esta nación Yuma, en cuyo número "conviene también próximamente el Padre Gar. "cés."

En cuanto á los ritos religiosos y á las costumbres sociales de esta nacion, nada puede in ferirse de los Diarios citados, y sólo en una oca. sion, se dice, que estando Ansa repartiendo algunos dones á un crecido número de naturales, llegó á interrumpirlos uno de ellos dando unos ayes tan lastimosos, que parecía le ocupaba la mayor aflicción y dolor. Cada uno de los circuns. tantes correspondía á estas demostraciones, dando también otros tres gritos y tentando al mismo tiempo el hombro del paciente, y preguntando Ansa la causa de semejante escena, le respondiersil que aquel recién "egado era uno de las rarcherías del riu de abajn, que traía la no. ticia de habérsele muerio su nadre, y que venía en consecuencia, á convidar á todos los presentes á que fueran á llorar al tiempo que daban fuego al cuerpo del difunto, que era la especie de fu. neral acostumbrado entre ellos. Notó también el mismo Ansr, que no parecía mujer alguna emba. razada 6 parida que no demostrase más de vein. ticinco años de edad, é indagando la causa llegó á saber le: era licita la poligamia, y que no les 
convenian las mujeres muy jóvenes, porque no sablan trabajar.

A corta distancia de lis orillas occidentales del Colorado, se encuentra otra rama de la mis. ma naciớn Yuma, distinguida con el nombre de Cofak, y que frecuentemente está en guerra con aquélla, aunque usa del mismo idioma, tiene las mismas costumbres, y se halla dotada de igual afabilidad.

Su número es algomayor que el de los Yumas, y el territorio que habita ménos extendido que el de éstos, lindando al Oeste con los méganos $y$ parajes inaccesibles de la California. En los últimos años se había cimentado la paz entre unos y otros por medio de recíprocos casamientos, y esta paz, en la cual influý el mencionado Ansa con dones, con súplicas y áun con amenazas, fué sin duda una de las causas principales de la des. trucción de nuestras misiones y poblaciones del río Colorado en $\mathrm{I} 782$ (I) con muerte de cuatro Misioneros, ocho soldados y de algunos pobladores cuyas mujeres quedaron prisioneras y se rescataron después por una crecida cantidad de ropas.

Lu's indios de la provincia de la Sonora, se pueder dividir en dos naciones diferentes por los dos idiumas enteramente diversos que hablan, reduciéndolos á Pimás y Opatas. Los primeros se dividen en altos y bajos, ó septentrionales y meridionales, incluyendo los que habitan los arenales y páramos de los Papagos al Sur del Gila, los amenos valles de Sobas, Chispurís y vegas del Gila y Colorado, comarcanos á aquéllos: á los segundos corresponden los Eudebes y Tovas.

Reduciremos también á los Seris, los Guaimas y los Hiaquis, is que habitan la medianía de la parte Oeste de la provincia, nern los Seris, igualmente que los Apaches, $r$, ns de la parte Norte, deben considerarse como u en emigos crueles que la han destruído y aniquilan, de sucte que son muy pocos los Reales poblados en qu : trabajan las minas y hacen muy difícil la des. cripción política de esta provincia, porque muda al paso que sus ventajas y desventajas.

Entre todas estas naciones, los Opatas son los más aplicados al cultivo de la tierra, y también los más animosos para la guerra, en la cual han mostrado siempre su valor $y$ fidelidad auxiliando á nuestras armas. Sus siembras consisten en trigo, maiz, fríjol, calabazas, sandías, melones y otras varias de que hacen sus buenas cosechas.

(1) Tuvo lugar este desgraciado accidente un domingo después de misa, habiéndose convenido los mingo despues de misa, habiéndose convenido los siones, que distaban tres leguas una de otra. Entre las victimas fué comprendido al Padre Garcés, de quién hemos hablado anteriormente. Puede verse el pormenor de este acaecimiento, en la vida del venerabla Fray Junipero Serra, capítulos 52 y 53 .
Tienen cierto miramiento hacia sus mujeres, en uyas circunstancias se distinguen de los Apa. ches, pues no les cargan sino el trabajo más llevadero, del cual las exceptúan también en los últimos meses del embarazo, y entonces las aplican á hilar y tejer algodón, á guisar su posole, á hacer esquite y á tostar el maiz para el pinole.

Muy adictos á sus costumbres antiguas, no quieren admitir los ielares, y siguen sus tejidos en la misma disncsición que antes del conocimiento de los europeos, sin embargo dc que se nota en ellos una imitación particular á cualquier modelo que se les presenta. Para la fábrica, dos mujeres disponen la tela entre cuatro estacas cla vadas en el suelo, determinando con ellas la extensión de la tela, después de lo cual, por medio de varios modelos mueven lá urdidura según ne. cesitan para las labores, aprietan la trama y con gran trabajo y morosidad acaban su tejido. En lo general, ningín natural de la provineia mira con cariño ni aprecio las artes de los europeos, no obstante de que algunos se aplican á cllas. Tañen instrumentos con bastante habilidad, $y$ aprenden oficios mecánicos, como los de sastre, carpintero, herrero, cantero y albañil. Hay algunos Opatas y Eudebes que saben todos éstos, y basta en ellos la voluntad para que los aprendan con la mayor facilidad.

Puede inuy bien aplicarse á los Opatas la característica de sufridos, industriosos, robustos y esforzados, particularmente á la vista de los españoles. Nada estiman tanto como aquellos honores $y$ distinciones que acreditan su fidelidad al servicio del Rey y su valor contra los enemigos. Si alguno se casa con mujer española, no quiere ya tratarse como natural, desdeña las ocupaciones y ministerios de sus parientes, y se considera como de clase superior; lo propio sucede á las mujeres cuando casan con españoles. Unos y otros afectan nu stro traje y tratamiento y se manifiestan muy deseosos de aprender el idioma; pero el po , cuidado con que se han tratado, es causa de que aún mantengan la práctica de algunos abusos y $\mathrm{co}^{\mathrm{u}}$ mhres antiguas. Sus bailes son muy hárbaros, y se acompañan del ronco ruído de un calabaza; las canciones consisten en una repetición de pocas voces, sir. expresión, cadencia ni harmonía, de tal modo, que en esta parte no se diferencia te los Apaches sino en que los Opa. tas ticne sunos bailes de religín, que conservan tociaria después de más de siglo y medio de sujeción voluntaria. Los más de sus juegos y diversiones se dirigen á ejercitar las fuerzas, la ligereza y el arco, en cuyo último ejercicio son bastante diestros, y tan aficionados á él, que áun cuando vuelve.i cansados del trabajo, se les ve en el camino tirar al blanco.

Lne. Eudebes se deben zinsiderar bajo el mismo aspecto queVlos Opatas, aunque están más

Iguna emba-

más de vein-

que no les 
atrasados que éstos en la imitación de los europeos, y :se acercan también más á sus costumbres y usos antiguos. Pero aún más zafios y agrestes que todos son los Tobas, especialmentc los que no quieren reducirse á vivir en poblaciones que son la mayor parte, excepto los cie Ponidá, Teoxarí y Mochopon. Viven en los campos y se mantienen de raices, yerbas y frutas silvestres, reduciendo sus siembras á tal cual mata de mai y á algunas calabazas y sandias. Su principal ocupación es la de hacel esteras (hipel), de las muchas y buenas palmas que se encuentran en su territorio y las llevan á los pueblos opatas jara cambiarlas por semillas ó ropas. No atentan contra las vidas ni contra las haciendas, y sólo son bravos y valientes con los Apaches, á los cuales tienen un odio mortal.

Todos estos naturales tocan las puntas de las flechas con venesio, ' para curar las heridas chupan la sangre de ellas, por cuya causa muchas veces sigue á la muerte de los heridos la de los curanderos.

Las poblaciones de los Opatas son Natora, Aritberí, Bacanora, Tonitci, Soyopa, Nacorí, Alamos, parte de Ures, Nacamerí, Opodepe, Cucuspe, Arispé, Chimaya, Bacoatzú, Curguiaratai y Babispe.

Los Pimás forman en sí una nación muy crecida: los que se denominan bajos habitan los pueblos de Taraitzí, Cumuripa, Onapa, Nuri, Moboes, Onabas, Suaquí, San José de Pimás, Santa Rosalía, Ures y Nacamerí. Hacia el Po. niente hacen frontera contra los Seris, y ellos son los primeros que recibieron la fé en esta provincia, pero no están tan adelantados en ella como los Opatas, porque les falta la docilidad que estos tienen, y tampoco los imitan en la lealtad á nuestro Soberano.

Los Pimás altos ocupan todo el terreno que hay desde Cucarpe á Santa Ana, Cabnrea, Dolores, Remedios, Cocospera, el presidio de Terrenate, las orillas del río de San Pedro, lo que media desde éste hasta su unión con el Gila. las dos orillas de éste hasta que se une con el Colorado, $y$ áun la de éste hasta su desembocadura en el golfo, pero en estos trechos hay muchos espacios despoblados y varias marismas que por la falta de agua son incapaces de poblarse. Se pueden considerar los Pimás altos, divididos en cuatro parcialidades que son los reducidos á pueblos; los Papagos, los Sobaípuris y los Gilas. También se pueden llamar Pim is altos los Opas, Comaricopas, Hudcoadnes, Yu. mas, Cuhuanas, Quiquimas - otros más allá del río Colorado, por ser todas cins naciones que usan de un idioma bastante semejante. Estos Pimás están aún más atrasados que los otros en la fé.

LCQ Pimás son en general muy infériores en el valor á los Opatas, y sólo su número suele á veces infundirles osadía.

Las armas que emplean son el arco, la flecha y una nacana ó porra de un palo muy pesado y duro con que tiran á la cabeza de sus enemigos. Los más aguerridos de los Pimás altos son los Sobaípuris fronterizos de los Apaches y encarnecidos contra ellos, pero se van retirando hacia el Sur y guareciéndose á los pueblos de Santa María Joamea, San Javier del Bacoy, Tueson y Senoytac, abandonando su ameno valle los enemigos.

La nación de ios Seris, aunque la más corta, es, sin embargo, la más cruel é indómita de todas; $y$ aunque algunos se redujeron á vivir en las poblaciones del Pópulo, Nacamerí y los Angeles, $m i$ i fué por servir de espías que con intento de continuar en la fidelidad; de lo cual se seguía que los asaltos y daños de los demás eran más ciertos y seguros. Estos indios untan sus flechas con un veneno que hace la herida mortal, por leve que sea; y tan eficaz, que acaba las más veces la vida del herido á las veinticuatro horas. Cuando se ven perseguidos acostumbran refugiarse á los ccrros, que les proporcionan en sus cortaduras y picachos una defensa natural incontrastable, y á la Isla del Tiburón y sı:s innediaciones en el golfo.

Aunque los Apaches viven al Norte y fuera de los límites qu hemos asignado á la provincia, se hace preciso tratar de ellos en este lugar, por la inmediación que tienen con ella, y porque son la causa de su decadencia y destrucción; pues con sus contínuas correrías asolan y destruyen los trabajos, hurtan los ganados y matan los habitantes. Son muchas las minas que han obligado á abandonar cuando su estado prometía el premio de los trabajos del minero; y aunque hay presidios establecidos que sirven de barrera para contenerlos, como la extensión del วaís es tanta, no es posible impedir del todo sus correrías.

Estos indios andan por la mayor parte errantes, según se les presentan las cosechas naturales de las tunas, dátiles, mescales y otras frutas y raices que les sirven de sustento. Las mujeres llevan el trabajo de las cortas siembras que hacen de maiz, y curten las gamuzas de los caballos, venados y otras que emplean para vestido. Este se reduce en lus hombres á un coleto rue les baja hasta más abajo de la cintura, á una especia de calzones y á los zapatos, pues todos desde chiquitos andan calzados. El de las mujeres consiste en unos mantelitos ajustados al cuello; pero $\tan$ cortos, que apenas llegan á cubriries ios pechos, y además unas enaguas que no les b.zjan de las rodillas. Son muy ágiles y buenas jinetes.

No se encuentra entre estos indios señaĩes de 
idolatria; s6lo sí algunos usos supersticiosos: hoy día temen particularmente al diablo, y le nombran con la misma escrupulosidad que nosotros, pero esta parece idea que han recibido despues de nuestro reconocimiento. Los que lo: gran entre ellos conceptuarse de hechiceros, consiguen el mayor respeto y ventaja, apoderándose también del lucroso oficio de curanderos. Este arte tiene por principal objeto, curar las heridas que reciben en la guerra, lo que ejecutan cis el preparativo de chuparlas, y aplicar después algunos bálsamos salutíferos con algodon, el cual penetra hasta 10 interior de las heridas, cuya cura se repite cada día. Las borra. cheras no son tan frecuentes en esta nación como entre las demás, $y$ la bebida que usan la hacen te maiz, mescal, trigo, tunas y sauco, siendo la más fuerte la de este último. Las ceremonias de las bodas entre los que no han alorazado la Religión Católica, se hat:en formando una fila de mancebos y otra de mujeres, y corriendo éstas con alguna delantera, las siguen aquéllos hasta alcanzarlas, asiéndoles del pecho izquierdo; después de aquella ceremonia se restituyen al paraje de la junta y se ponen á danzar, habiendo preparado de antemano dos esteras para cada ma. trimonio: éstos se acuestan y los demás continuan toda la noche en sus danzas, festejando á los novios.

El ejercicio que estos naturales miran como de más honor es el de las armas, y el alistarse entre el número de sus soldados les cuesta un estrecho noviciado y las pruebas más rigurosas. Tienen que tolerar con la mayor entereza que les rasguen muchas partes del cuerpo, y manifestarse tan insensibles al frio como al calor y á la lluvia, para lo cual se les hace pasar por muchas prue. bas. De este modo y no de otro consiguen el honroso título de soldados, y se destinan á de. fender la patria centra sus enemigos, precediendo en estos casos una especie de arenga 6 ser. món del Capitán, que les recuerda y encarga el cumplimiento de su obligación. Cuando salen á campaña, el mayor trofeo con que á la vuelta acreditan su gloria es traer las cabelleras de sus enemigos, y áun algunos se extienden hasta cortarles pedazos considerables; si elven vencidos entran de noche en sus pueblos, pero cuando alcanzan los trofeos de la victoria, se ejecuta esta entrada con toda ceremonia en el discurso del día, después de haber avisado anti_ipadamente para que salgan á recibirlos; entonces cada caudillo lleva una anciana que toma el trofeo, en el cual ejercitan sus iras, y á éstas siguen las ce. lebridades de las lanzas y festejos.

No consideran estos indios que las necesiciades corporales de la vida finalizan con la muerte, pues entierran á los muertos con cuanto pueden proporcionarles de sustento y ropa, echándolo todo en un hoyo, y áun las madres continúan regando por algunos días el de los párvulos, con la leche que extraen de sus pechos. Hay con todo, on esto, alguna diferencia entre las diversas cla. ses de Apaches, pues otros dejan los cuerpos en el paraje en que acabaron la vida á ménos que sea en terreno enemigo, en cuyo caso se obstinan eil retirarlos divididos en cuartos cuando no pue. den conseguirlos enteros, aunque sea á costa de todo riesgo.

Parece muy propio de este lugar agregar la descripcion de los Apaches que nos ha dejado con su acostumbrada maestría el redactor de la Historia del Padre Venegas, y cuyas circunstancias las hemos rectificado nosotros mismos, por varioz sujetos que se mencionarán luego. "El w nombre de Apache se da ya también comunmen"te á todo gentil, apóstata, belicoso y enemigo, " siendo sin embargo los Apaches de que aquí se " trata los comprendidos en aquel tramo de tie " rra casi circular que comenzando desde el rín "Chiguagua, y cruzando hacia el Presidio de Ta"nos, fronteras y Terrenate, llega al río Gila, y " subiendo al Norte hasta el Moqui y Nuevo Ménjico, revuelve al Oriente al presidio del Paso "y remata hacia el Sur en el Real de Chigua. "gua (I). En este terreno y vuelta de 300 le"guas, viven los Apaches en sus rancherías pe"queñas situadas entre valles y quebradas de

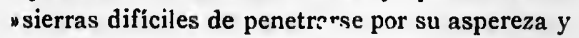
" escase $z$ de agua.

-Por algunos prisioneros rescatados, se sabe w su barbarie y rusticidad, sus cortas siembras y "frutos, el mal tratamiento que sufren de ellos "los que cien en sus manos, y que hay entre w ellos algunos a póstatas. Viven desnudos, pero whacen sus entradas en caballos robados, sin si"llas y con solas unas pieles en que corren lige" rísimamente; de las mismas pieles liacen botines "y zapatos de una pieza, que sirven de rastros en "su huída. Acometen con tal gritería y algazara "que asusta de muy lejos; su valor no es grande "pero le hacen sus buenos sucesos; son alevosos wen ei modo de guerrear; vencidos se humillan, " pero no guardan fé alguna en sus tratos; sus ar. " mas son las comunes de arco y flecha (2). El mo"tivo de sus entradas es el robo, especialmente de w caballada, no sólo para montar sino para comer; "porque esta carne es su mayor regalo; de esto wnace ser hediondos en tal grado, que sienten y se "retienen de su mal olor nuestras mulas."

A las noticias anteriores añadiremos las que

(1) La yoz de Apache se ha extendido tanto en el idioma de Nueva España, que hemos ofdo llamar así áu a los Lipanes, Navajos y Natujes que infestan co. mo antes digimos, la parte oriental del Nuevo Méjico.

(2) En el dia hacen ya uso con bastante frecuencia de las armas de fuego. 
contiene el Padre Murphi en su historia manuscrita de la provincia de Tejas, igualmente que la de diferentes misioneros; luces bien instructivas nos han comunicado sobre este punto importante los Coroneles D. José Rengel y Don Antonio Bonilla, Oficiales empleados por mucho tiempo en las provincias internas. Hé aquí lo que de ellos resulta:

"El indio goza generalmente de un temperamento sano, por la dureza en que se cría y la simplicidad de los manjares que le sirven de alimento: nace y vive en la inclemencia, $\tan$ insensible al frío como al calor; pues su cutis tostado le sirve de tanto abrigo como á nosotros los tejidos más compactos. Su alimento es invariable; pues su única y contínua subsistencia la deben á las frutas y carne asada, y de esta uniformidad de principios y el incesante ejercicio de la caza y de la guerra pende la robustez de que ordinariamente goza.

- Los $A$ paches tionen una especie de creencia que puede llamarse dogma, aunque informe $y$ sin arreglo. Titulan Capitín grande, á una primera causa que conocen, $y$ aseguran que hay destino en la otra vida para el bueno y para el malo; pero limitan sus premios y castigos al placer ó al disgusto de oír cantar en la tierra sus acciones. Suponen que estos distintivos existen en el aire, y así, los que riven, tienen la obligación de formar una especie de canciones que rezan todos los dias como oficio de difuntos; sólo son dignos de esta gloria el guerrero valiente y la esposa fiel; estas dos virtudes, que son las mayores que conocen, excluyen de toda felicidad á los que carecen de ellas, condenando á un eterno desconsuelo la cobardía y el adulterio. El solo fundamento de esta creencia guerrera bastaría para hacerlos terribles en el combate áun cuando su vida frugal y activa no fortificase sus espiritus.

"La poligamia es el uso favorito de estas gentes, sin otro límite que el antojo; pero el demasiado trabajo á que destinan las mujeres hace ventajoso el tener muchas. Las de los hermanos se heredan tengan 6 no hijos, y la afinidad no es un impedimento para el matrimonio; pero sí lo es grande la consanguinidad, que evitan escrupulosamente. Las esposas sólo se miran como unos libres instrumentos del placer para quienes no se dedican atenciones ni cuidados; las truecan ó cambalachan con grande facilidad, dando ó poniendo un ribete, según las reconocen útiles. Fi. nalmente, las prestan, las alquilan ó las venden por un caballo, un fusil ó por cualquiera bujería.

"La ligereza es una de las propiedades características, y la que les es mís ventajosa, y que sin duda han adquirido por la necesidad de perseguir la caza i $<$ :e antes de que tuviesen caballos, y que hoy día iz ejercitan en juegos y ejer- cicios cotidianos. Como sin ganados, sin siem. bras y sin cultivo no es posible que la caza baste para el sustento áun más frugal, y ménos para satisfacer los antojos, y como por esta parte estos indios carecen de caballos y de mulas, que son su delicioso alimento, desean municior:s y escopetas para la guerra y la caza, y todo esto lo hallan en los españoles: este es el orígen de sus contínuas guerras.

"Cuando emprenden la campaña, si es con la idea única de robar, juntan pequeñas partidas, y si tienen por objeto destruir los pueblos, unen entónces muchas rancherías; pero en todas ocasiones es uno mismo el modo de conducirse y gran. des sus precauciones. Unidas las tropas se nombra entre ellas un Jefe, sin distinción de clases, sin intrigas y $\sin$ cohecho: la causa pública preside en esta elección y siein pre decide por el más apto. Su autoridad en campaña se extiende hasta poder quitar la vida á sus súbditos; pero queda de soldado independiente con ellos cuando se deshace el campo. Cada soldado trae su caballo sin más arneses que un fuste muy ligero, y preservan los cascos con una funda de cuero, que quitan con prontitud cuando llega el caso de montar, lo que sólo verifican el día de la acción.

- Tienen en las marchas grandísimas precauciones. Observan cuidadosamente los caminos, y si descubren algún animal que huye, por el cual seguían, mudan al momento de dirección, 6 in. vestigan la causa de aquella fuga si se dirigia hacia ellos. Marchan desunidos, pero á la vista unos de otros para evitar la polvareda y la huella; se cubren con ramajes para no ser vistos de lejos; reparten centinelas en las copas de los árboles; destacan exploradores por muchas leguas en contorno; duermen poco y siempre desconfiados; se alarman al menor aviso; la mayor parte velan mientras descansan los restantes, $y$ contínuamente exhortan la vigilancia. Las noticias interesan. tes que ocurren en la provincia, se comunican por. humos en que saben distinguir el que los convoca, el que les manda huir ó les intima algún cuidado; de suerte, que en un momento corre la alarma por todas las rancherías. Las ideas del valor consisten en el mayor sufrimiento; saber resistir las inclemencias sin abrigo; despojarse de las pieles cuando hacen grandes fríos, y áun revolcarse en el hielo, son otras tantas pruebas que acreditan á un g"errero. Se asegura en las provincias que los costeños llevan consigo una yerba vulneraria con que detienen la sangre de las heridas; $y$ de los Apaches se dice que tienen un palito detrás de la oreja, cuya virtud los hace incansables. De estos fenómenos sólo consta la tradición entre las tropas; pero acaso son nuestras malas punterias y su habituado ejercicio, este palo y aquella yerba.

-Con el precavido silencio que dejamos indi- 
y la huella; is de lejos;

os árboles;

ias en con-

nfiados; se arte velan tínuamen. interesanunican por. los convoalgún cuiu corre la ideas del to; saber lespojarse os, y áun $s$ pruebas ura en las asigo una sangre de ue tienen d los hace consta la son nuesejercicio, cado, se dirir,en á nuestras poblaciones, duplicando las astucir s á medida que se acercan para asegurar el golpe. Acechan desde las alturas nv iros pueblos, haciendas y caballadas, y por la noche bajan á reconocerlas. Para este acto dejan los caballos á alguna distancia y marchan los más ligeros por parajess diferentes, para acercar. se cuanto puedan. En este último reconocimiento son admirables las tretas de que se valen para lograrlo: con el cuerpo cubicrto de lodo y la cabeza de ramas, de modo que no presentan más objeto que el de un pequeño matorral, van arrastrando por el sueloy llegan al destacamento hasta contar los soldados, y en tan silenciosa espía se comunican, sin embargo, lo que observan con el canto de varias aves nocturnas yanimales que imitan perfectamente. Espiado bien el paraje, quitan los cueros de los cascos de los caballos, y marchan con gran silencio hasta la precisa distancia á que consideran pueden ser sentidos, y embisten con impetu y algazara, sin dejar tiempo de que se acuda á las armas ni de ponerse en defensa. Eeta refinada astucia, incapaz de precaverse, casi siempre acierta el golpe. Con los cautivos son crueles, y las más veces les privan de la vida con mil suertes de tormentos y crueldades; gustan de disfrutar nuestras mujeres, y no perdonan medio para hacerlas más insufrible aquel tormento. Este corto rasgo de la conducta de dichos indios en campaña, basta para dar á conocer lo inevitable de sus golpes, para cuyo buen exito tienen la constancia de espiar meses enteros."

Con los Apaches occidentales rayan hacia el Norte los Cosminas y Moquis, á los cuales siguen los Yutas, visitados por los Padres Vélez y Esca. lante, $y$ últimamente en cuanto alcanzan nu:sstras noticias, los Cumanches, Yamparicas, que deben darse la mano con los pueblos más occidentales de Carver.

Los Cosminas y Moquis, romo ya se insinuó, fueron reducidos en el siglo pasado á la religión y al dominio español; pero diferentes causas accidentales contribuyeron después á que hacia el año de r68o sacudieran ambos frenos al mismo tiempo que los pueblcis aboríjenes del Nuevo Mejico. $Y$ aunque estos últimos admitieron de nuevo la predicación evangelica al principio de este siglo, aquéllos prefirieron su nuevo estado, y haciendo una especie de confederación han disfrutado desde entonces sus vegas excelentes, abandonando la vida errante para gozar pacíficamente del fruto de sus siembras y pastes á cuyos artículos tan agregado también algunas manufacturas bastas de lana para ocurrir á su propio abrigo, y para establecer un mediano comercio con los pueblos más meridionales. Son, por consiguiente, unos vecinos pacíficos, y áun útiles siempre que se abandone de nuestra parte la idea de conquistarlos. Los Padres Vélez y Escalante, y áun el Padre Fray Francisco Garcés que les habla precedido dos años antes, hallaron efectivamente entre los Moquis, mucha mayor hospitalidad y un sistema más bien entablado de lo que podía imaginarse. $\mathrm{Al}$ principio los recibieron en el pueblo de Uribi con alguna sospecha hasta examinar sus fuerzas, su conducta y sus inten. ciones; mas luego con dignidad y atención les franquearon alojamiento, les vendieron los co. mestibles necesarios, ratificaron la amistad antigua, y el cacique advirtió á los pueblos inmediatos que asistiesen con amor á los viajeros. Con efecto, así lo verificaron todos los demás caciques por cuyas jurisdicciones transitaron, pero siem. pre con cautela, por temor de que los Misioneros manifestasen sus ideas y propuestas para una nueva conversión. Sin embargo, tuvo esto lugar por medio de un anciano apóstata de las misiones de Santa Fé, el cual díb á entender la nece. sidad en que estaban aquellos naturales de un socorro de nuestros presidios contra los Apaches. nabajos, cuyas últinjas correrías ies habían causado daños considerables. No malograron, como es de suponer, nuestros Misioneros estas circunstancias $\tan$ favorables para proponerles una nueva sumisión á la Monarquía, y que se les auxiliaría con todos los medios necesarios para vengarse dt s:s enemigos. Juntáronse los magnates de éste y de los pueblos inmediatos en la mañana siguiente para deliberar sobre un punto de tanta importancia, y habiendo llamado á los Misio. neros á la estufa de la asamblea (I), les respondieron, finalmente, fue aunque deseaban algún auxilio para contener las irrupciones enemigas, y que sabrian corresponder á este beneficio con una amistad constante, lo sacrificaban todo de buena gana y sufririan gustosos nuevas invasio. nes, más bien que hacerse cristianos y entregar. se al dominio nacional. Las arengas de la asamblea tenían á la sazón el semblante más solemne, empezaban á hablar los de mayor autoridad, y á éstos seguían los demás por el orden de ésta, y aunque cadr uno hablaba, la arenga parecía más bien un diálo ${ }_{b}$, pues concluía su discurso haciendo varias preguntas á los demás, nuienes respondían asintiendo, 6 negando resr:-tivamente, conforme á la calidad de las preguntas: En estos discursos referían las tradiciones de sus antepasados, y se exhortaban recíprocamente á su observancia, de lo cual resultó, como era natural, una total repulsa dis las proposiciones hechas de nuestra parte.

El mismo viaje de los Padres Vélez y Escalante, nos suministra también algunas ideas aunque sscasas de los pueblos que habitan al Norte

(1) No individualiza el Diario lp? circunstancias de la estufa, y si era parecida a las de Monterey ó Nneva la estufa, y si era parecida a
España, que hemos descrito. 
de los paralelos de $36^{\circ}$, adonde pueden conside. rarse acaban los Moquis, Cosminas y Apaches. Son aquéllos en muy corto número, y están re ducidos á la nación 6 idioma Yuta, la cual vive aún errante, valiéndose de las semillas, de las tunas, de la caza y del pescado para su alimento. Sólo tres fueron las rancherías algo numerosas que encontraron en esta exploración. Los Yutas Lagunas se presentaron por los $38^{\circ} 30^{\prime}$ en nú mero hasta de 80 guerreros, bien montados á caballo y con otros de remuda, algunos de los cuales cambiaron con las caballerías cansadas de nuestros exploradores. Son estos indios afables, cariñosos, subordinados á sus Jefes y dispuestos á suministrar guias y á cumplir con sus contratos, cuya puntualidad arengaron á la tríbu, el Jefe principal que era joven y casado con dos mujeres, según dijo, y otro Jefe subalterno más anciano. Advirtieron en el camino en un pedrusco bien notable señaladas con pinturas toscas, tres adargas ó chimales, una hoja de lanza y dos hombres peleando. Las comidas más comunes de estos indios, son el cíbolo y el cuervo, los capulines, garambuyos, limitas y algún piñón del mismo año, advirtiéndose en cuanto al garambuyo, que si bien en la mata es sumamente agrio, después de muy asoleado, como lo usan, resulta de un agridulce muy gustoso. Estos pueblos están en contínuas discordias con los Cumanches Yamparicas, situados al Nordeste de éstos, que son mucho más ferroces y están también acostumbrados al uso del caballo.

$\Lambda$ estos indios siguen hacia el Noroeste, $y$ en los $4 \mathrm{I}^{\circ}$ largos da latitud, sobre las lagunas y río de San Buenaventura, los Timpanogotzis, otra rama de los Yutas, los cuales parecen reunir afabilidad $\mathrm{y}$ mansedumbre de los otros, un semblante más varonil y ura subordinación mayor. Vendieron á nuestros exploradores algún pescado seco, los recibieron, alojaron y despidieron con el mayor cariño y ternura, y habiéndose juntado el Capitán mayor, otros dos inferiores, varios ancianos y los súbditos de ambos sexos, determinaron unánimes afianzar con una señal auténtice. sus aseguraciones de que deseaban un establecimiento nuestro en sus tierras. Consistía esta señal en una pieza de gamuza, en la cual estaban toscamente representadas con tierra y almagre cuatro figuras de hombres, alusivas, según dijeron, la más roja ó ensangrentada, al Capitán mayor Tururianchí, porque en las batallas con los Cumanches liabía recibido más heridas; las otras dos que no estaban tan ensangrentadas, representaban á otros dos jefes subalternos, $y$ la cuarta, que no tenía sangre alguna, al hermano del Capitán mayor llamado Pi. cuchi, el cual, aunque no era Capitán de guerra, tenía, sin embargo, bastante autoridad sobre los demás.
El número de estos naturales es bastante re. ducido; tienen buena fisonomía, y los más son cerrados de barba; llevan todos por vestido uı sayo de gamuza y botas largas de lo mismo, usando además para el frío, fresadas de pieles de liebres y conejos. Alojan en unas chozas 6 racalillos hechos de mimbre, de cuya' materia forman también curiosos cuévanos y otros útiles necesarios. Finalmente, para evadir los encuentros con los Cumanches, prefieren para el alimento la pesca en la laguna á la caza del cíbolo, y con efecto, no pudieron vender en la expedición otros comestibles que pescado seco.

En las orillas de la laguna mayor y más septentrional, cuyas aguas son extremadamente nocivas y saladas, habita la nación Puacuanque ó hechicera, la cual habla el mismo idioma que los Cumanches del Este, y aunque no son enemigos, hay en el día alguna frialdad entre unos y otros á causa de una muerte acaecida algunos años antes. Esta nación se-alimenta con yerbas, es bastante numerosa y vive repartida en chozas.

Aunque sumamente reducida, no merece menos la atención de un curioso, la tercera tríbu ó nación que encont aron nuestros exploradores en este viaje, $y$ la llamaron de los Barbones. Habita por los $39^{\circ} 4^{\prime}$ de latitud, casi al Sur de los Tim. panogotzis, igualmente dócil, afable $y$ pacífica que las anteriores, cobijada con fresadas de pieles de conejo y liebre, y con la barba tan cerrada y larga, que parecen Belemitas ó Capuchinos (x). Tienen la ternilla de la nariz agujereada y en el agujero traen por canalete, atravesado un hueso pequeño y pulido de ciervo, gallina á otro animal. En la fisonomía se parecen á los españoles mís que á los demás indios hasta ahora conocidos en esta América, $y$ esto tal vez dió lugar á algunas noticias antiguas fabulosas, equivocando al río Colorado con el que llaman río del Tizón. Entre las últimas naciones que acabamos de mencionar y los Cosminas, no existen sino pocas familias dispersas, particularmente hacia los $3^{\circ} 30^{\prime}$, distinguidas con el nombre de Yubunicaris, los que no usan la siembra de maiz y se alimentan sólo de las semillas y caza; pero éstas deben ser muy abundantes si hemos de juzgar por los comestibles que vendieron á nuestros viajeros, de carnero silvestre, tuna en torta $y$ en masa y zurrones de semillas de diferentes yerbas. Estos naturales están aliados con los $\mathrm{Apa}$. ches mescaleros, y en la ocasión de visitarlos los mencionados Padres, había entre ellos uno de estos Apaches en calidad de huésped, el cual fácilmente se distinguía de los demás por su fiso. nomía poco agraciada y simpática, por el disgusto con que miraba á los españoles, y por un

(I) Esta es la expresión á la letra del Diario ori- 
cierto ánimo y descoco del cual procuraba hacer klarde á la vista de los demás. Ignoramos cuáles sean los ritos y ceremonias religiosas de estos naturales, pues aunque una extraña casualidad proporcionó el medio oportuno de investigarlos, el horror con que miran nuestros Misionerns todas estas prácticas supersticiosas, nos priva del placer de publicarlas. Acontecí aquella casuali. dad á uno de los exploradores, el cual, habiendo entrado en una choza en donde habla algunos naturales de ambos sexos, se fingí enfermo, é inmediatamente el más anciano de los concurren. tes se puso á curarle con diferentes cantos y ceremonias. Pero al llegar los Padres á esta parte de su Diario, declaman altamente contra este hecho, que reprendieron ágriamente al supuesto enfermo, y con este motivo omiten el describirnos aquellos cantos y ceremonias.

Hasta aqui, pues, se extienden nuestros conocimientos del día sobre el número y calidad de las naciones que habitan esta parte de los dominios nacionales, y se comprende entre los 30 y $43^{\circ}$ de latitud y en los $20^{\circ}$ próximamente de longitud, 6 lo que es lo mismo, desde las orillas del mar Pacífico hasta los meridianos de Santa Fé: recorramos ahora, aunque brevemente, las que desile este propio meridiano siguen al Este por los mismos paralelos.

En lo antiguo, las montañas y arenales del Nuevo Méjico dividian de los Apaches á los Keres, Tiguas, Piras, Jumos y Mansos, los cuales, aunque unidos con los Moquis y Cosminas, contribuyeron á la expulsión sangrienta de los españoles en el siglo pasado, volvieron no obstanté á escuchar de nuestros Misioneros los halagos de la religión y de la sociedad, y se redujeron á vivir reunidos bajo la dirección de los Franciscanos, parte en las amenas orillas del río Norte, á poca distancia del fuerte del Pilar, y parte en la villa de Alburquerque é inmediaciones de Santa Fé. Son estos naturales bastante humanos, y muy inclinados á la agricultura, pero se hallan contiguos al Norte los Cumanches y más al Este los Lipanes y Natajes, dos naciones sumamente feroces, y por costumbre 6 por codicia enemigas nuestras, y que anidan entre las sierras ásperas de Cohahuila 6 vagan por el pais al Este de los Yutas.

De las costumbres de estos naturales sól, sabemos, además de lo que se ha dicho ya, rue hacia el presidio de San Sabá (r), los Lipanes dieron algunas esperanzas de civilización, aun que se malograron; que el cebo de todos ellos es particularmente el robo de nuestras caballa. das; que los Mansos del Nuevo Méjico se ausen. taron al tiempo de la segunda conquista, y que

(x) Pertenéce á la provincia de Cohahuila y es de presumir esté abandonado en el dia. lo mismo han hecho después por los montes de Cerro Gordo los indios Pames que fueron redu. cidos á poblaciones por D. José Eiscandón, Marqués de Cerro Gordo, y que gobernaron é hicie. ron felices los Padres Franciscanos (I) coadyu. vando con la mayor actividad y buen éxito, á las medidas de aquel vasallo exclarecido que em. prendio á su costa esta conquista y la concluyó felizmente sin muchos sacrificics del Erario (2).

La Nación Cumanche se compone de $\mathbf{5 . 0 0 0}$ hombres de armas con corta diferencia, dividida en cinco tribus de nombres diferentes. Is muy superior á las demás por el número de sus gen. tes, la extensión del terreno que ocupa, la honestidad en el traje, sy hospitalidad con todos los que visitan, su humanidad con los cautivos que no son Apaches; $y$ finalmente, por el valor que es admirable áun en las mujeres; pero su vida errante los hace malos, $y$ es el mayor obs. táculo que hay para su reducción, pues miran con fastidio la vida sedentaria, y aborreciendo las fatigas del cultivo, la necesidad de subsistir los obliga al robo: sin embargo, son generosos con lo que poseen y tan arrogantes, que uno solo arrostrará contra un ejercito como no pueda veriticar su fuga sin testigo.

Continuando al Este de la provincia de Cohahuila, $y$ atravesando las provincias de Tejas, el Nuevo Reino de León y Nuevo Santander, hasta llegar á las tierras inundadas por el golfo de Méjico y el rín Mississipi, el número de los indios disminuye considerablemente, y sus cualida. des son tales, que si bien reducidos no nos pu-

(1) Sobre la muerte dada por los Cumanches a dos Misioneros y un soldado, sobre lo hecho en las misiones de los Pames de Cerro Gordo, pueden leerse por extenso los primeros captulos de la vida del venerable Fr. Junipero Serra. Alli se individualiza también al fdolo (achún, de los Pames, que era una cara perfecta de mujer, fabricada de tecale, que tenian en lo mis alto de una encumbrada sierra on uma ntan en lo mas alto de una encumbrada sicra cn una que se subia por una escalera de piedra labrada, por cuyos lados y en el plan de arriba había algunos scpulcros de los principales que antes de morir habian pedido que los cnterrasen en aquel sitio. La voz (achum significa Madre del Sol. Habia un sacerdote al cual acudian para que pidiese remedio en las necesidades de agua para las para las piembras, de salud en sus cnfermedades, de felicidad en sus viajes yacrras, y de una acertada eiección de mujer. Para lo último se presentaban delante del anciano sacerdote con un pliego de papel en blanzo por no saber lecr ni escribir, el cual servía como de representacion. De estos papeles se hallaron canastos llenos, juntos con muchísimos idolillos que se dieron al fuego.

(2) Era D. Josć Ess.andón Coronel del "egimiento de Querétaros, cuando empezó la necificáción de este pafs el año 748 , estableciendo á su costa 26 misiones; pais el afo 748 , estableciendo á su costa 26 misiones;
visito y reconoció el pals en cuatro entradas generavisitó y reconoció el pals en cuatro entradas genera-
les, y út timamente, protejido por la superioridad, fundo en 1755,20 poblaciones con 1.245 tamilias, por cuyos servicios y otros méritos le condecoró el Rey con la merced de hábito de Santiago y tútulo de Conde de Cerro Gordo. 
dieran acarrear la menor utilidad, estando por su lugar nos incomodan mucho. Infestan á veces las inmediaciones de Béjar, capital de Tejas, colonia española á la cual se han reunido después unos 800 indios de castas diferentes. Han hecho inútiles nuestros fuertes y misiones de los Ayseses, Nacodeches y Adaeses mediatas al Mississipí, y particularmente los P'elones hacen muy peligroso el tránsito y dificil la subsistencia en las inmediaciones de Monterey en el Nuevo Santander. Finalmente, si hemos de creer como parece bien averiguado, que los Cumanches adquirian de los franceses del Mississipí las armas de fuego con que nos hostilizahan, no cabe ya duda en que son estos misnos los que extienden sus correrías hasta las orillas occidentales de aquel rio; y por consiguiente, están fronterizos á los kentukis, y que rayan por el Sur con las naciones visitadas por el Capitán Carver hacia los desaguies del Misouri 6 del Ohío.

Hay otra nación conocida por el nombre de Norteños, muy numcrosa y que habita al Norte de la provincia de Tejas, á la cual pueden apli. carse con mucha exactitud las mismas cualidades con que los anglo-americanos han caracterizado las naciones sús vecinas.

Un odio irreconciliable y antiguo existe entre éstos y los $A$ paches: regularmente no se encuentran sino para reñir, $y$ muchas veces nos han avi. sado en las fronteras de Tejas de las traiciones que aquéllos meditaban, y que poco creídas, nos han costado en ocasiones crecidos sacrificios. Han deseado siempre comerciar con nosotros, y han mirado como pasajeras las discordias ocurridas. Finalmente, á juzgar por las diferentes muestras que han dado lugar á conocerlos, se inclinan más á la nación española que á las de. más europeas, dueñas poco hace de la Nueva Orleans $y$ de las Floridas.

Nada, dice el Padre Murphi, dará más á conocer el carácter heróico de esta nación, como el suceso de D. Antonio Treviño. Caminando este Oficial (I) con una pequeña escolta, fué asaltado de muchos Tavaoyases (una tríbu de los mismos Norteños). Desamparado de los suyos y muerto el caballo, se respaldó con un árbol, y escudado con su espada, sostuvo solo el combate por largo tiempo; pero el generoso caudillo de aquella empresa, á quien agradó su esfuerzo, hizo suspender las armas y reconvino á Treviño con su triste situación, pidiendo que se rindiese á los que le tratarían como á su mayor amigo. Vencido en fuerza de sus heridas, fue el primer cuidado de los indios el contenerle la sangre y $\operatorname{con}^{-1} u c i r l o$ en hombros con gran cuidado al pueblo de San Teodoro, donde se le destinó casa, quien le sirviese y mujer para su convalecencia. Esta fué larga y

(1) El año de 1760 temible por falta de medicinas, pero llego $\alpha$ conseguirse, y el ganb su confianza hasta admitirle en sus juntas reservadas como si fuese uno de ellos. Pero tan repetidas fnezas no hicieron olvidar á Treviño su relizión, patria y familia; se sostuvo casi dos años, y al cabo caý en una lan. guidez que publicó su disgusto. Solicitado por los Tavaoyases, venció su flaqueza con declararles la causa; ellos admiraron su constancia, ydeclarándole que jamás habia sido prisionero y que si le detenían era por creerle gustoso, le dieron su libertad proveyéndole de cahallos y compa. nía hasta Bejar, donde le dejaron con grandes muestras de sentimiento, y la precisa palabra de que había de visitarlos, ya que ellos no podían hacerlo por la guerra que mantenian declarada. Así me lo refirió Treviño en el presidio de Bejar, lo contesta el Barón de Riperdá que le comisio. nó algunas veces, y lo confirma D. Atanasio Desmesier, que fué testigo de las demostraciones de los indios y cie st roble carácter.

La población total de las provincias internas, deducidos los Aboríjenes, Opatas, Pimás bajos, Keres, Pimás, Sumos, Pames y Tejas, está reducida á un corto número de colonos, y á otro crecido de soldados que guarnecen los presidios esparcidos en esta vasta extensión de fronteras. Las poblaciones, aunque no de gran extensión ni hermosura, tienen la suficiente para log objetos á que se destinan, y á fin de no cansar al lector con una explicación prolija de cada una de por sí 6 á lo ménos de las capitales, daremos aquí una descripción del pueblo de Arispe, destinado por S. M. para capital de las provincias internas $y$ del modo con que se maneja en cuanto á los indios su Gobierno civil y militar, y esto basta. rá para deducir por ella con muy corta variedad, la disposición y gobierno de los demás pueblos de su especie.

La población de la misión de Arispe ocupa en su cabecera un terreno de $75^{\circ}$ varas castella. nas de largo, snbre 400 de ancho, en la orilla occidental del río de Gondrá y en la pendiente de un cerro de piedra arenisca, que se levanta I5o piés sobre el nivel del río. Las casas están fabricadas en dos llanos 6 mesas que corren Nordeste-Sudoeste, distando ur tiro de fusil del río, cuyas aguas entran en lo más bajo del lugar por una zanja mal dirigida y peor conservada. Está cercada de serranías más 6 ménos elevadas, que se extienden á todos rumbos por espacio de muchas leguas, y no permiten otra entrada 6 salida que las cañadas que forman los ros Bacuachí al Nordeste, el Bacanuchi al Nornordeste $y$ el Sinóquipe al Sudoeste. En la primera, y hasta sólo el paraje Chinapa, se videa el río 32 veces y algunas más en la última, in que hace el ca. mino bastante molesto y más en el invierno y en los meses de lluvias. 
La mayor y más lucida parte del vecindario de Arispe habita en el llano superior por estar en el la Plaza Mayor, la Casa de la misión y la iglesia. Esta ocupa, con la Casa de la misión, la fachada del Sur de la Plaza, y es un edificio muy elevado, sin método ni proporciones, de yo varas de largo y 20 de ancho, incluso el grueso de las paredes, que son de adobes. El techo está sostenido por gruesas vigas. Tiene dos sacristias, sunque algo estropeadas. El adorno interior de la iglesia no sólo es decente, sino rico; los va. sos sagrados, los ornamentos y otros adorros son preciosos, sobresaliendo un gran trono de plata á martillo, un cáliz de oro y un cuadro de Nuestra Señora de Loreto, cuya exquisita pintura se adorna con un marco de este precioso metal.

E1 Comandante general ocupa la Casa de la mision, que aunque no tiene comodidad alguna, es la mejor del pueblo y la única con vivienda alta. Esta se reduce á una gran sala con recámara para aquel Jefe y un cuarto para otros criados, y en la extremidad opuesta está la Secretaría, en tres pequeñas piezas y la principal con puerta al coro, donde se sufre la incomodidad del brgano y cantores. Hacen la habitación baja seis cuartos donde se aloja la demás familia, con botica, cocina, etc. El resto de la población forma un conjunto de 130 casillas sin orden ni dirección, la mayor parte de adobes, pocas de piedra y lodo, y todas mal fabricadas. En el día las habitan 305 vecinos españoles v 337 Opatas.

Los oficios qve mantiene la población para su gobierno se cur ponen actualmente de un Gobernador indio, un Alcalde y dos verdugos, que llaman Topiles, por lo que toca á lo civil; pero para lo militar hay un Capitán, un Teniente, un Alférez y dos sargentos, y para el culto y servicio de la iglesia un Mador ó Maestro de doctrina, dos Fiscales $y$ dos Tenastianes $\delta$ sacristanes.

La elección anual de estos oficios se hace regularmente con intervención del Padre Minis. tro y del Teniente de Justicia, á la puerta de la casa de éste, el cual propone los sujetos adecuados y el pueblo se conforma, poniéndolos desde luego en la posesión de sus empleos, sin otra formalidad que la de darles á conocer por tales Oficiales y entregar su bastón al Gobernador.

Los oficios dedicados al culto divino se eligen siempre al arbitrio del Padre Misionero y con anuencia del Juez. El Gobernador y el Al. calde se ocupan en el gobierno econömico y político del pueblo, cuidando de las labores de comunidad; de la distribución de los trabajos y de la conservación del buen gobierno y quietud. El alguacil prende á los delincuentes, y el Gobernador ó Alcalde los castiga por medio de los To. piles; pero cuando el delito es grave se aprisiona el reo con orden de uno de los dos, y se da cuenta a) Teniente de Justicia, el cual toma sus provi. dencias. El Capitán de g'uerra manda en todas las salidas y campañas contra los enemigos, con facultad de castigar la cobardía, la deserción, el robo y la inobediencia.

El oficio del Mador 6 Mnestro de doctrina, es el que la enseña por tarde y mañana en la Igle. sia á los niños de ambos sexos, é insta á los padres para que envien sus hijos á las horas asignadas, y en los días de fiesta instiuye á los adultos.

La ocupación de los Fiscales es celar que ningún indio falte á misa en los dias de precepto, visitar con el Mador á los enfermos, dar cuenta al Padre Ministro de su estrido para que los de cuidado no mueran sin Sacramentos, acompañarle cuando los administra, y enterrar á los difuntos. Los Tenastianes cuidan de la con. servación de los ornamentos y alhajas de la iglesia, de la limpieza del templo y de cuanto corresponde á los sacristanes. Finalmente, todos dependen del Teniente de Justicia, y éste del $\mathrm{Al}$ calde mayor de la provincia, el cual no ticne re. sidencia fija, porque puede vivir donde mejor le acomode en los terminos de su jurisdicción, y éste últimamente depende del Gobernador mili. tar y político de la misma provineia.

Los presidios que cubren á la población de Arispe y sus inmediatas, son al Nordeste el de Fronteras, distante 29 leguas; el de Santa Cruz, trasladado al paraje de las Nutrias al Norte 30 leguas; el de Tucsón á 65 Nornoroeste; el del Altar á 9o Oeste; San Miguel de Orcasitas, en el Patich, á 65 Sudoeste, y San Carlos de Buenavista roo leguas al Sur. De estos presidios hay varios en toda la extensión de nuestras fronteras, pero no pueden considerarse como estables, porque diferentes veres han sido trasladados de unos á otros parajes, variando al mismo tiempo su número y dotación, según lo exigen temporalmente las invasiones de los enemigos ó nuestros deseos de internarnos.

Su figura por lo general es parecida en un todo á los de California, y el soldado que los guarnece, estando por lo común casado y viviendo en un clima sano, con buenos alimentos, pocas distracciones y una vida extremadamente activa, logra de una robustez y corpulencia realmente singulares.

Son casi increibles los rasgos de valor que sc cuentan de esta tropa, así como no son menore: sus desgracias, ya por el arrojo intempestivo que les causa el conocimiento de sus propias fuerzas, ya también por las sorpresas de rus as. tutos enemigos, que saben aprovecharse oportunamente de los terrenos poco ventajosos. Usan estos soldados de dos géneros de armas, unas 
ofensivas y otran defensivas ( $\mathrm{x}$ ). Las defensivas son la cuera y la adarga; la primera, cuya he. chura es semejante á la de una casaca sin mangas, se compol:e de seis 6 siete haces de pieles blancas de venado, agamuzadas é impenetrablea à las flechas de los indios, como no se disparen desde muy cerca. I.a adarga es de dos haces de cuero crudo de toro, que se maneja con el brazo izquierdo, desviando con slla las Hechas, defendiéndose el jiuete á sí y á su caballo. Usan además una especie de delantal de vaqueta prendido á la cabeza de la silla, con calda á uno y otro lado, que llaman armas 6 defensas y les cubre los muslos y piernas, para no lastinarse corriendo en el monte. Sus armas ofensivas son la lanzo, que manejan diestramente á caballo, la espada ancha y una escopeta corta, que llevan metida $y$ afianzada en su funda. Visten calzon, chaleco y chupa de paño azul, y su número, inclusas cua. tro compañias de la Nueva California, es de 3.698 plazas, las cuales, a istribuidas en compañías f. jas 6 volantes, guarnecen toda la frontera.

Sin embargo, las circunstancias y la constitución ti: estos soldados, no es nada favorable para la lid á que se aventuran; su ligereza y agilidad á caballo, acaso superior á la europea, es no obs. tante inferior á la de sus enemigos, y las atenciones que exige para la muerte la vida común del soldado, no permiten en los últimos instantes aquella serenidad con que un Apache termina sus días cantando injurias al enemigo. Tampoco nuestros soldados sufren con igual constancia la intemperie ni le son indiferentes la escasez del agua ni los ataques del hambre. Finalmente, sobrecargados con tantas armas como se ha dicho, y debiendo además llevar consigo ochn 6 quince días de viveres, un calabazo con agua, una talega de pinole, la capa y manta de abrigo y una maleta con ropa, no es posible conservar de este modo la agilidad ni que resista el caballo sin cinco 6 seis remudas, cuya comitiva multiplica el tren de campaña de un modo incompatible con la celeridad y sigilo que requieren las sorpressas.

Nuestras colonias en esta parte del Globo tuvieron por primer objeto el estrechar poco á poco la barrera con poblaciones opulentas bastantemente próximas y bien armadas, para que de este modo se lograse atemorizar al enemigo 6 destruirle cuando no le atrajesen los halagos de la sociedad y el incentivo del alimento mucho ménos precario; pero como los objetos de los colonos eran bien distintos, unos quisieron establecer sus siembras, manufacturas y viñas á corta distancia de los presidios, para lograr facil despacho de lo sobrante á precios más ventajo-

(1) Se ha tomado esta descripción de las armas, del Diario de D. Migucl Costanzo.
BOS (1); otros inclinados al beneficio de las minas atrage-on hacia sus inmediaciones los obreros, los labradores, ganaderos y otras muchas artes necesarias para su manutencion, y finalmente, los misioneros, debiendo seguir las huellas de los naturales, su método de vida y la dirección de sus casuales adelantamientos, arrastraron tras si una porción no corta de los nuevos moradosea. Tantos objetos diferentes, debieron producir naturalmente, y con efecto han producido, una po. blacion desparramada, mezquina, y por consiguiente, presa fácil de los enemigos, de suerte que la mejor prueba del fatal daño de aquellas ideas, serla sin duda la historial harto difusa del establecimiento, y sucesiva ruina 6 abandono de semejantes presidios y colonias.

En el día, estas últimas están reducidas á un número muy corto, y se componen en la Sonora y Nueva Vizcaya occidental, de algunos españoles y varias gentes de casta; en los confines orientales de la misma, en el nuevo Santander $y$ en un valle del nuevo Méjico, de indios Tlascaltecas; y en Béjar, de algunas familias Canarias, conducidas por cuenta de S. M. para este intento. Los Tlascaltecas han prosperado mucho más que los otros colonos, particularmente en la Nueva Vizcaya, liacia la villa de Buenavista, donde se establecieron primero, y luégo se han extendido en varias colonias subalternas, las $\mathrm{Pa}$ rras, el Alamo, la Monclova, Boca de leones y otras hasta el número de siete. La villa de Buenavista tiene hasta 3.000 personas gobernadas por un protector español y un gobernador tlas. calteca. La población de Santiago de la villa de Salitre, cuenta hasta 8.000 habitantes, y todas estas vegas excelentes, bien regadas y poco in. festadas de enemigos, favorecen mucho la actual multiplicación de estos felices agricultores. Prosperan igualmente en el nuevo Santander, y. aunque rodeados de Apaches en el Nuevo Méjico, no dejan de sosten. se unidos y defienden con tesón sus cosechas y caballadas.

Este es, con muy corta diferencia, el estado que tienen hoy dia las provincias internas de Nueva España hasta los $43^{\circ}$ de latitud, y atendiendo á la cansada enumeración de circunstan. cias poco favorables que hemos referido hasta aquí, al frío excesivo que las pèrsigue, á la mu-

(I) La célebre hacienda del Marqués de San Miguel de Aguayo en los confines de la Nueva Vizcaya, en la provincia de Cohahuila, tenía por los años de I 766 que la visitó el Ingenicro Lafora con el Marqués de Ruiz, hasta 600 personas: además de los ganaderos fabrican en ella paños y sombreros, atienden a las siembras $y$ al beneficio de vinos $y$ aguardientest hacen siembracen el scrvicio de escoltcros para guardar la hacieuda tener limpio el camino do Lipanes a Natages, y no baja de 200.000 cabezas el numero de las que mantiene de ganado menor, y además de otro mucho más crecido de ganado mayor caballar. 
de las minas

los obreros,

huchas artes

finalmente,

huellas de

a dirección

atraron tras

moradores.

producir na-

ido, una po-

por consi.

de suerte

de aquéllas o difusa del

6 abandono

reducidas

n en la Sono-

gunos espa-

los confines

evo Santan.

oo, de indios

familias $\mathrm{Ca}$ -

AI. para este

erado mucho

larmente en

Buenavista,

luégo se han

inas, las $\mathrm{Pa}$.

de leones y

illa de Bue-

gobernadas

imador tlas -

le la villa de

ntes, y todas

$8 \mathrm{y}$ poco in

cho la actual

Itores. Pros-

inder, y aun-

- Méjico, no

en con tesón

ia, el estado internas de

tud, y aten.

circunstan-

ferido hasta

ee, á la mu.

$s$ de San Miueva Vizcaya,

- lós años de

n el Marqués

os ganaderos

ienden a las

ientes: hacen

a hacienda y

Jatages, y no

as que

mucho chedumbre de sus montañas intransitables, a la poca eaperanza de que puedan navegarse sus ros, y \& la mucha diatancia que hay de ellos al mar, no podemos ménos de presumir que á pesar de los esfuerzos harto costosos del Gobierno á favor de estas provincias (I), está aún distante la epoca de que puedan figurar y mucho ménos competir, con otras de nuestras ricas colonias del continente americano.

Lo último que nos resta ahora que examinar son los rastros que existen de las antiguas emigraciones de la especie humana hacia el Sur. El Diario de los Padres Vélez y Escalante indican el más alto de estos vestigios por los $47^{\circ} 7^{\prime}$, diciendo que era un pueblo muy antiguc, en el cual habla fragmentus de metales, jarros y ollas de barro, siendo au figura orbicular, según manifiestan las ruinas casi enteramente terraplena. das. El segundo fué hallados en Sutaquison, país de los Pimás, por D. Juan Bautista de Ansa, el cual tuvo la precaución de representarlo y des. cribirlo lo mejor que pudo: dice en su Diario, que advirtió inmediatamente la continuación de

(1) El sostonimiento de la tropa y los gastos do nuestras provincias internas cuestan anualmento al Erarto 1.200.000 pesos, como repetidamente nos lo aseguró en Méjico el Virey Conde de Revillagijedo. otro edificios, los cuales se manifiestan tien unidos en la exténsión de más de dos leguas de Jargo y cerea de un cuarto de legua de ancho, fabricados todios á una legua 6 poco ménos dis. tante del río, el cual to habian metido al centro de ellos por varias acequias del ancho por $10 \mathrm{co}$. mún de cinco varas y media, lo que ae hacia bien visible en todo lo que hablan andado aquel dia, $y$ de cuyas ruinas ablo tenian los habitantes de aquel río la remota y confusa noticia de que fueron de sus antiguos Soberanos. Finalmente, el tercero y último vestigio de esta especie, es el que se conoce generalmente en la Sonora, y -éste, según dice el mismo Ansa, es mayor que - al de Sutaquison: la fábrica es un laberinto de "que han sacado los inteligentes curiosas copias. - Se conoce tenia altos; hoy exister las paredes n tan altas, que se ven de más de una legua; esta - misma distancia es la que hay próximamente - al rio, el cual introduclan luégo por debajo del - mismo palacio y resto de la población para te- ner el agua á mano; la materia de estas obras "es de tierra puramente, pero también mixturada - con piedra menuda 6 arenas gruesas, que pare- cen por su consistencia de la más fina mezcla ó - argamasa, cuya mayor prueba es su permanen. "cia después de tantos años que debe tener." 


\section{CARTA ESFÉRICA del Río de la Plata desde su embica- dura hasta Buenos Aires, $y$ de la costa inmediata Oriental hasta el Cabo de Santa Maria, trabajada a bordo de las corbetas de S. M., Descubierta y Atrevida.-Año de 1789 .}

El Diario astronómico indica claramente cuá- les son los datos sibre que afianzan la situación en latitud y longicud de nuestro observatorio de Montevideo. Coavenimos desde luégo en la latitud con las observaciones del Brigadier D. José Varela, que determinan $34^{\circ} 34^{\prime} 30^{\prime \prime}$. Nuestro observatorio es de las casas más meridionales del pueblo, y así, los $18^{\prime \prime}$ de exceso en las observaciones nuestras, convienen con los parajes en donde se ha observado. La longitud que determinó Varela fué de $50^{\prime \prime} 7^{\prime}$, pero ignoramos si sus observaciones se han referido á las tablas celestes 6 á observaciones correspondientes hechas en Europa. Como quiera que las diferencias que pueden originarse en esta materia, miran más bien á la exactitud astronómica que á la seguridad de la navegación, nos ha parecido determinar para la construcción de esta carta la de $50^{\circ}$ $5^{\prime} 45^{\prime \prime}$, reservándonos el decidir la perfec.ión de este punto, cuando tengamos á la vista los erro. res de las tablas celestes en los cálculos que nos han servido de base, deducidos de las observaciones hechas en Europa sobre las órbitas de la Luna y de los satélites de Júpiter en los días en que hemos observado.

Toda la carta está ligada en cuanto á Jongitudes con esta determinación; pero cualquiera corrección en ésta, no influirá absolutamente en la posición respectiva de los demás puntos; pues que los relojes han determinado todas las diferencias con una exactitud en su marcha, que debíamos más bien desear que esperar: las latitu. des observadas en diferentes puntos, 6 con los sextantes, 6 cún el cuarto de círculo, y comparadas luégo con las operaciones trigonométricas, no dejan la menor duda en esta parte.

La Isia de Lobos está situada por la diferencia de meridianos observada en el número ro de ia ATREvida al tiempo de venir á Montevideo, y con. forme con el número ro5 en un via je hechodespués á Maldonado: depende en cuanto álatitud de una cerie de triángulos cuyo principio es una base de una milla escasa, medida en la punta del Este próxima á Maldenado, y de la misma serie sstá deducido el Cabo Santa María, habiéndonos sido preciso llamar así al punto que indica la carta, unánimes con algunos ingenieros y con el piloto Tafor, porque antes cada uno llamaba á su albedrío Cabo Santa María, una punta cualquieia de las muchas que salen á lo largo de la costa, hacia el Norte.

Sobre la misma base y con marcaciones re. petidas desde la Isla Gorrite y desde la punta de la Ballena, estan determinados todos los puntos del puerto de Maldonado; en la misma isla se han observado, latitud con buenos sextartes, longitud en el ro5 $y$ variación magnética en el teodolito. Los arrecifes, la boca chica 6 del Este y la parte oriental del mismo fondeadero, han sido examinadas también en cuanto á sonda por nosotros. Las demás sondas se han deducido de los planos é informes más seguros, compara. dos con lo que hallábamos en nuestras operaciones.

Siguen para ligar la costa hasta Montevideo, todas las marcaciones hechas desde la cúspide del Pan de Azúcar, las que se hicieron en la Punta Nerra á la embocadura del Arroyo de Pando, y en la costa de D. Luis Gutiérrez; finalmente, al mismo intento otras dos bases medidas, la una en el Puerto de Montevideo y la otra en la Punta de las Carretas, y las marcaciones hechas desde el cerro, y desde aqueila Punta, no sólo sitúan los demás puntos, sino que retrocediendo á la inver. sa á uñ nueva coiocación del Pan de Azúcar, unen de tal modo con los triángulos traídos desde la punta del Este, que las diferencias parciales on latitud y longitud relativamente al Pan de Azú. car, son absolutamente iguales 11 total de las diferencias observadas entre Montevideo y la Isla Gorrite.

La Isla Flores está igualmente situada por triángulos, y la latitud observada á su vista en ambas corbetas al tiempo de venir al fondeade. ro, afianzan su posición.

El Banco Ingless se ha examinado prolijamen. te, y observadas latitud y longitud en su pazalelo y meridiano, esta ú!tima por el cronómetro 72 . La extensión del banco de piedra está determinada por la reventazón á la vista en un día claro. 
Iil placer inmediato de arena, se ha deducido de los mejores planos y noticias, y se ha disminufdo de lo que suponían muchos planos anteriores, así por ser igualmente arena todo el fondo al Sur del paralelo del mismo bajo, como por ser inútil el suponer banco en donde $t l$ fondo ya se iguala con todos los inmediatos en calidad y en cantidad. Son nuestras las sondas entre el bajo y la Isla Flores y las que están en el paso del Norte de la misma isla; lo son igualmente todas las comprendidas desde Punta Brava hasta las restingas del cèrro $\mathrm{y}$ todas las interiores del Puerto de Montevideo.

Siguen los triángulos hasta el río Santa Lucía: la posición de sus puntos interiores y parte de la costa siguiente al Oeste, y sobre todo, las sondas, así del río como à la barra y áun de una parte de mar en fuera, son igualmente obra nuestra: han sido vanas las diligencias repetidas - por tres veces para reconocer un bajo, en el cual se han perdido algunas lanchas años há (según personas fidedignas); pero que aún parece algo dudoso, mediante el tránsito contínuo de las embarcaciones: lo hemos situado según las marcaciones que por estos prácticos se nos han indicado.

Una longitud observada en el I05, desde la mar y Este-Oeste con el cerro de Montevideo, sirve con las marcaciones hechas desde el mismo punto, á colocar otra parte de costa al Oeste desde el término de los triángulos: la restante hasta la colonia está deducida de los mejores planos y noticias prácticas.

El reloj ro5 y una altura meridiana del Sol, tomada con el sextante, determinan directamente la posición de un extremo de la Isla San Gabriel: las demás contiguas, los arrecifes que las rodean y los puntos de la costa inmediata, inclusa la misma colonia, están sujetas á marcaciones y enfilaciones, aunque capaces de algún leve error, por haberse tomadocon una aguja portátil y estar sujetas, no á base medida, sino á unas distancias echadas á ojo.

La diferencia de meridianos entre Montevideo y Buenos Aires, está determinada por el cronó- inetro 6r en una travesla de pocas horas, y examinada su marcha inmediatamente antcs y después: la latitud se ha observado con el cuarto de círculo grande, y entrumbos datos se han traído al Fuerte. Ignoramos dónde observaría el Brig?dier D. José Varela, cuya diferencia de meridia. no con Montevideo excede en tres minutos de la nuestra.

Desde la Plaza Mayor de Buenos Aires hasta la ersenz da de Barragán, vuelven todos los pun. tos á estar sujetos á una serie de triángulos de. terminados sobre base medida y marcaciones del teodolito. El número $6 \mathbf{r}$ y los sextantes, determinan toda la costa siguiente hasia el froritón del Cabc San Antonio, cuya posición queda así fuera de toda duda, ratificándola igualmente que á todos los puntos intermedios, la determinación al regreso de los mismos puntos, enteramente conforme con la primera, y la marcha constante del número $6 \mathrm{r}$.

Las sondas inmediatas á la ensenada de $\mathrm{Ba}$ rragán, las que rodean los arenales del Cabo San Antonio, y las que han derivado de los hordos heehos por las embarcaciones destinadas á este reconocimiento, son todas nuestras. Pero la configuración, colocación y sondas de los bancos Ortiz y Chico, y todas las que están desde el meridiano del Cabo Santa María hasta la embocadu. ra, son deducidas, ó del plano del primer Piloto D. Bernardo Tafor, ó de las noticias sumamente exactas del segundo Piloto D. José de la Peña, ó de los planos y noticias de las fragatas correos de S. M.

El Brigadier D. José Varela, cuya exactitud conoce el público así en cuanto á la Hidrografía como á la Astronomía, añade á nuestras tareas la continuación de los triángulos por la colonia del Sacramento hasta el Paraná y toda la costa desde el Cabo Santa María hasta la embocadura del río Grande, que ha trazado yendo por tierra á la demarcación de límites: así, nada se echará de ménos en cuanto á la configuración cée estas costas, y.la navegación nacional podrá euıprenderse hacia ellas con mayor seguridad y presteza.

\section{Derrotero desde las Islas de Cabo Verde hasta Montevideo.}

Ha parecido oportuno el emprender el derro tero desde las Islas de Cabo Verde para el Sur, así porque la explicación á la carta de aquellas islas, trazada por el Brigadier D. José Varela, debe abrazar cuantas noticias instructivas pue. den desearse, como también porque hasta este paraje han de considerarse desunidas las derro- tas de los que navegando desde las costas de Europa al Sur, pasan unas veces al Oeste $y$ otras entre los diferentes canales de las Islas Canarias.

Siempre que la navegación se dirija á la equinoccial, parece prudente pasar entre las islas y la costa: ni debe ser obstáculo para esta de: 
rrota el que en algunos meses del año, $y$ particularmente en los de Julio, Agosto y Setiembre, las brisas del Noroeste se pierden en nucha altura. Las calmas en aquellos paralelos son de muy corta duración, y los mismos variables dan lugar á enmendar la situación de la nave si se inclinase demasiado á la tierra firme ó á las islas.

No parece natural que se contraigan errores considerables en la estima entre las Islas Canarias y las de Cabo Verde: á pesar de esto hay ejemplos que indican lo contrario, así para el Este como para el Oeste; con cuyo motivo será prudente hallarse 30 leguas á barlovento de Buenavista, antes de dirigirse á su reconocimiento, pues haciendo una derrota más directa para la recalada, pudiera pasarse entre las islas de Sal y San Nicolás, y hallarse después al Oeste de Buenavista cuando se creyera al Este, perdiendo así el fondeadero de Praya, como ha sucedido á no pocas embarcaciones.

La recalada á estas islas suele ser difícil muchas veces, con motivo de las neblinas que son muy frecuentes en sus inmediaciones, $y$ esas mismas neblinas son á menudo las señas de su proximidad: en atención á esto debe navegarse con mucha cautela cuando se viene del Norte. Entre Buenavista y Santiago, cuya distancia es próximamente de 20 leguas y el arrumbamien. to al Sudoeste, hay un arrecife de rocas, muy peligroso: está á seis leguas de Buenavista y el derrotero portugués le da dos cables de largo y uno de ancho ( $\mathrm{r}$.

La Isla de Mayo está I 4 leguas al Sursudoeste de Buenavista: elevada principalmente hacia el centro, tiene en su extremo Norte un arrecife de piedras que sale á la mar sobre tres cuartos de legua: cuando se atraviesa de Buenavista á Santiago y es preciso pasar la noche sobre bordos, deben tomarse precauciones para no atracarla, como tampoco el arrecife de piedras de que ya se ha hablado.

Montada la punta del Norte de la Isla de Mayo, se ceñirá al Sudoeste para atracar la de Santiago y se seguirá costeando hasta la rada de la Praya, que es el fondeadero más frecuentado.

Tres leguas antes de llegar á esta rada se vo una ensenada cuyas orillas están pobladas rie $\operatorname{cocos}$, $y$ en donde hay algunas casas, pareciér:dose así á la ensenada de la Praya (2). Muchos navíos, alucinados con esta semejanza, se han hallado en inminente peligro de perderse, por los muchos bajos que tiene.

Aunque el fuerte de la Praya, situado sobre un altito, sea una buena marca para no equivo-

(1) El Capitán Cook los vió en su tercer viaje.

(2) El mismo Capitán la equivocó en su segundo car una bahía con ctra, lo más seguro es que la punta del Norte y Este de esta bahía falsa, es baja y ceñida de arrecifes, en lugar que la de Praya, que le sigue, es alta, escarpada y sin es. collos: paru ir al fondeadero es preciso atracar á ésta muy de cerca; el asta de bandera del fuerte debe demorar al Noroeste $3^{\circ} 4^{\prime}$ Norte de la aguja, y entonces demorará al Oesudoeste, la punta del Oeste de la ensenada, en cuyo extremo se ven las rompientes de un arrecife.

En lo interior de esta bahía ó cala y hacia su banda del Oeste, hay un islote llamado de las $\mathrm{Co}$. dornices, y por encima de la tierra de la isla Grande, se descubre en la noche, como al Oeste, el volcán de la Isla ael Fuego.

Siempre conviene más dar fondo en las inmediaciones de la costa del Norte y Este que en las del islote de las Codornices, en stención ála facilidad de dar luégo la vela sin riesgo de verse arrastrado por las corrientes sobre la punta de arrecifes que queda á babor, antes que el buque haya tomado el arranque necesario para no descaecer.

También se puede pasar al Sur de la Isla de Mayo para ir á la rada de la Praya: bas. tará para esto, que después de haber montado la punta del Sur de esta isla, se haga rumbo á recalar á barlovento de la punta del Este de la Praya (I).

El Capitán Cook, en su segundo viaje alre. dedor del mundo, examinó prolijamente el fondeadero de puerto Praya, y no será supérfluo el añadir aquí, traducida casi á la letra, la descripción que hace aquel célebre navegante.

Puerto Praya es una balía pequeñ氵, situada hacia la mitad de la parte Sur de la Jula de Santiago, y en latitud de $14^{\circ} 53^{\prime} 30^{\prime \prime}$ Norte, longitud $23^{\circ} 30^{\prime}$ de Gr. (2). Se conoce, en particular cuando se viene del Este, por el montecito más Sur en la Isla Grande, que es redondo, termine en pico $\mathrm{y}$ está algún tanto más adentro de la ori. lla $y$ al Oeste del puerto: esta señal es tanto más necesaria, cuanto que hay una caleta, como una legua al Este, con un arenal en su fondo, un valle, y detrás de él alpunos cocales, lo que pue. de equivocarse con el puerto Praya, como nos otros mismos lo experimentamos. Las puntas que forman la entrada del puerto Praya son más bien bajas, y corren una con otra Oeste-Sudoeste Este.

(1) Los párrafos antoriores están traducidos casi literalmente del derrotero de Mr. D'Aprés de Mannevillette. (2) Es la longitud occidental de Cádiz de $17^{\circ} 18^{\prime}$, $17^{\circ} 19^{\circ}$. En el Atlas nacional, en el cual la posición del puerto Praya se ha deducido de las observaciones del Sr. Verdun do la Crenne, resulta ser en $14^{\circ} 55^{\prime}$ de la. titud Norte $y$ en longitud occidental do Cadir de $17^{\circ} 7^{\prime}$, conforme ésta con la primera determiuación del Capitán Cook. 

orte, longin particular ntecito más do, termina ro de la ori. es tanto más a, como una u fondo, un lo que pue. como nospuntas que on más bien doeste Este.
Nordeste á distancia próximamente de media legua: inmediato á la punta del Oeste se hallan varias piedras anegadas, en las cuales se ve rom per el mar: adentro está la bahía, y demora como medi legua al Noroeste, disminuyendo progresiva $n$-nte el fondo desde 14 á cuatro brazas. Las embarcaciones de mucho porte no debieran anclar en menos de ocho brazas, en cuyo fondo, el extremo Sur de la Isla Verde (r) demora al Oeste.

La aguada se hace en un pozo que está adentro de la playa en el fondo de la bahia; el agua no es mala pero escasea, y es iıcómodo el hacerla por la mucha resaca. Los refrescos que pueden encontrarse son vacas, puercos, cabras, ovejas, gallinas y frutas; las cabras son de la especie antílope, y tan extraordinariamente flacas, que nada puede igualarlas. No lo son mucho ménos las vacas, puercos y ovejas; las vacas pueden adquirirse por dinero; suelen valer doce pesos fuertes por cabeza, y pesan de 250 á 300 libras inglesas. Las demás cosas pueden adquirirse cambiando con los naturales alguna ropa de vestir; pero la venta del ganado vacuno está estancada en una compañía de negociantes, á quienes se ha concedido este privilegio, y tienen un apoderado en el mismo sitio.

Son importantes los reparos del Comodoro Wallis, quien fondeó en el puerto Praya á fines de Setiembre; dice que muy luego supo que era esa la estación enfermiza, y que las lluvias imposibilitaban casi el traer cosa alguna de la campaña: no obstante, en tres días pudo reemplazar la aguada, lograr que le trajesen algún ganado y coger mucho pescado con la reci que hacía tender dos veces al día. Halló también con suma abundancia en el mismo valle de la aguada, una especie de verdolaga silvestre que les pareció muy agradable, 6 bien la comiesen cruda como ensalada ó la cociesen con las menestras en el caldo.

La escala en la bahía indicada de la Praya, puede ser útil muchrs veces euando 6 un viaje largo desde las costas de Europa, 6 un excesivo número de pasajeros, hacen indispensable abastecerse nuevamente de refrescos y agua; la suelen frecuentar mucho ingleses y holandeses; y en las navegaciones nuestras al Sur, además de los motivos indicados, puede también tener el de ser el mejor punto de reunión.

Sean enhorabuena muy acertados los preceptos de Mr. D'Apres sobre el corte de la Línea, cuando la navegación se dirige al Cabó de Buena Esperanza, y sean plausibles sus recelos de que el inclinarse demasiado al Oeste pueda arrastrar consigo el fatal inconveniente de no montar el

(r) Es la quo Mr. D'Aprés llama de las Codor-
Cabo San Agustín; no dejará de ser verdad, que pasando la Línea actualmente á lo ménos doble número de embarcaciones de las que iban en años pasados, ninguna deje de montar dicho Caho, aventurándose áun sobre las huellas del célebre Cook á cortar casi por el meridiano de la isla de Fernando Noroña.

En las navegaciones á la Costa Patagónica, y por consiguiente á la del Brasil y Río de la Pla. ta, fuera inútil y más bien pernicioso procurar inclinarse $a ́$ los $4^{6} 5^{\circ}$ al Este de! Meridiano de Tenerife, tanto más que repetidas experien. cias (r) demuestran que las corrientes se inclinan al Este en razón de la mayor aproximación f́ la costa de Africa.

0 las calmas son excesivas y por consiguien. te larga la demora en las inmcdiaciones de la Linea y puede asegurarse con mucha probabilidad que las diferencias por corrientes son al Este, 6 son pocas las ca! naas y rápida la derrota y en este caso no hay por qué desconfiar de la estima, ratificada pocos días antes á la vista de las Islas Canarias ó de las del Cabo Verde.

Así, las únicas reglas que pueden recomendarse para un corte expedito de Línea, son las de consultar las estaciones para saber el término de las brisas, la de seguir siempre la bordada del Oesudoeste con preferencia á la del Esudeste (2) y la de resistir siempre la vela posible, y no ceñir demasiado con un afán mal entendido de ganar latitud.

Mr. D'Aprés, sobre el examen de 250 Diarios, pone por límites ó términos de la brisa en diferentes estaciones, los paralelos siguientes: en Julio, Agosto y Setiembre se pierden las brisas del Nordeste entre los 13 y I4 $4^{\circ}$; en Junio á los ro $0^{\circ}$; en Diciembre, Enero y Mayo entre 6 y $4^{\circ}$; en Febrero entre 5 y $3^{\circ}$; en Marzo y Abril entre 5 y $2^{\circ}$ (3).

No por usto debe imaginarse que algunas veces la brisa ciel Nordeste no alcance al Sur de la Línea, y en otras no cese á los 18 y $19^{\circ}(4)$, pero el piloto, atento á aprovechar de todos los elementos, podrá aceptar con grande probabilidad estos términos áun antes de alcanzarlos.

(I) Desde que los relojes marinus han dado en la uavegación un punto diario de longitud observada, y diferentes navegantes se han valido de botecillos, co. rrederas, etc., para examinar las corrientes, la dirección y velocidad de éstas pueden mirarse como detorminadas con muclıa mayor aproximación a la verdad.

(2) Mandando la Astrea en Setiembre de I $780^{\circ}$ he debido hacer rumbos hasta del Oeste. El reloj marino me avisaba de un error en la estima de $7^{\circ}$ al Este desde la vista de las Canarias.

(3) El East India-Pilot y nuestras cartas nacionales, prudentemente lo scñalan en la rrisma carta con una figurita que indica el vientu y esta puesta en los diver. sos paralelos en que cesa la brisa.

(4) Esto uiltimn caso ha sucedido en Setiembre y

(4) Esto últimn caso ha sucedido
Agosto de los años de i 786 y 1789 . 
Cuando las brisas se inclinen del Norte para el Oeste, cese la celajería parda y movida, se vea celajería blanquinosa, y á veces algunos relámpagos hacia el Sur, puede considerarse la brisa ya próxima á sus términos, y entonces, según las estaciones, ha de precaverse el piloto con los vientos que encontrará con más probabilidad en los meses desde Junio hasta Octubre inclusive, ha de contar con Sudoestes frescos, con los cuales por consiguiente ha de prolongar la bordada del segundo cuadrante cuanto lo permita la prudencia; y en tal caso conviene inclinarse con la de. rrota más bien al Oeste que al Este. En los otros meses al contrario, como quiera que los vientos ó más bien las turbonadas han de inclinarse al Sueste, será prudente alcanzar $\operatorname{los} 5^{\circ}$ en el Meridiano de Tenerife, 6 cuando más I $62^{\circ}$ al Este, $y$ luégo, como ya se ha insinuado, preferir indistintamente los rumbos que proporcionen mayor ventaja en latitud, como no aca. rreen demasiado al Este combinados con unas calmas repetidas y largas ( $I$ ).

Así como es fácil pronosticar de un par de días la cesación de las brisas del Nordeste, es fácil tambièn conseguirlo para la entrada de las del Sueste:' si las turbonadas que se han declarado por esta parte siguen luégo despejadas 6 con celajería movida y de una regular duración; si la mar toma un color rivo azul; si los horizontes no están ni aturbonados, ni calimosos; si despiden más bien celajería parda; si á la pesadez de la atmósfera, entre la calima y los va. pores de los variables, se sigue un aire de una respiración agradable y de una sensible ligereza desde luégo la brisa no está distante; y en tal caso, los bordos del Oesudoeste y Oeste $1 /$ Sud. oeste, son los que deben afianzarla.

Fuera arrojo después de las muchas diferencias que diariamente se hallan en las variaciones de la aguja, dictar aún este método para ccnocer la posición de la nave, en longitud: además que son casi contínuos los escarinientos por otra parte inaveriguables de este método, podemos asegurar sin recelo de temerarios, que la peor observación de distancias lunares (que ya en el día consideramos al alcance del piloto ménos experto) será mejor guía para el conocimiento de la longitud, que la mejor observación de la aguja.

La misma multiplicidad de bajos, sembrados desde los paralelos de las Islas de Cabo Verde hasta la Línea, ha hecho que generalmente se dudase de su existencia; bien que naturalmente

(r) La brevedad de nuestro viaje a Montevideo ha dependido eseneialmente de seguir el bordo del segundo cuadrante con vientos del tereere, hasta las sondas de la Isla Poilon y de alli con las muras babor cortar la Linea en los $17^{\circ} 5^{\prime}$ de longitud occidental de Cádiz. cauto el piloto, sacrificase luégo muchas noches y: un viento á veces precioso, al riesgo de tropezar con alguno de estos bajos.

El haberse transferido a la carta todos los peligros que en este trozo de mar supone con mu. cho juicio el East India-Pilot, no es con otro objeto que el de excitar más y más la vigilancia del navegante. Fuera inútil indicar peligros muy dudosos, si pudiese suponerse siempre la vigilancia, mediante la cual estarían casi de un todo á cubierto las vidas y los intereses: con los vientos largos y apacibles y las noches no larơs de citre trópicos, ¿qué peligro aislado se había de presentar al navegante, que el timón y una maniobra pronta no evadiesen? Pero en ia desidia y abandono que reinan en los buques mercantes de casi todas las naciones, será tan prudente el incluir en las cartas de navegar cuantos bajos tengan aún la más remota apariencia de existir, como preciso en nosotros el encargar encarecidamente, que á lo ménos en esos paralelos sospechosos se navegue con vigilancia y con aparejo mane jable.

El dar resguardo á todos estos peligros, ó bien á unos sí y no á otros, fuera ya tanto más reprensible cuanto más influye actualmente la celeridad de los viajes, así en las especulaciones mercantiles como en el honor y lustre de la Marina Real (I).

Es común, ya alcanzada la brisa del Sueste, y haciendo derrota hacia el Río de la Plata, el re. sarcir de algunos grados los errores contraldos al Este en la estima, al tiempo de permanecer en las inmediaciones de la Línea. Así será fácil (según la estación y plazo en que'se haya permanecido

(1) No paiecerá inoportuno nombrar unn á uno estos peli cos: los que están al Fste de Buenavista se suponen vistos, el más Norte por el Capitán Levingstone en la Bonetta año de 1730 , y el más Sur por el tone en la Bonetta año de $173^{\circ}$, y el más Sur por el
Capitán Webb, año de 1734 . Pudieran tal vez ser uno Capitán Webb, año de 1734 . Pudieran tal vez ser uno va depende de una estima de dos días del Capitán Dubrewil año de $1753, y$ por consiguiente, merece al ménos su situación alguna confianza. Setenta leguas a Oeste \% Noroeste, está un bajo indicado en muchos Diarios ingleses y franceses: el bajo Das Garzas de los portugueses está situado, según Van-Keulen 107, le guas al Oesudoeste de la Isla Brava. El Capitán Hay ter, inglés, sitria este mismo bajo al Esnordeste 13 le guas; la vigfa de Cinco Palmas tiene igualmente dos posiciones: la más Oeste es; según los portugueses, la otra es según Hinman:la roca de Long champ, puede ser la Isla Solis de los antiguos navegantes: en los 4 " de latitud se halla una vigla vista al parecer por buques franceses. Los Diarios del Capitán Hayter en $3^{\circ}$ y $1 /$ y proximamente en el mismo meridiano. Hay en $z^{2}$ y próximamente en el mismo meridiano. Hay en $2^{2}$
unos bajos apropiados al César, navio francés, que los vió en 7730 . Finalmente, entre los 20 y $40^{\prime}$ Sur y $x^{\circ} 35^{\prime}$ de la misma latitud, sospecha Mr. D'Aprés que puede haber algunos parajes do poco fondo en que hayan tocado momentáneamente algunos navegantes, yos nombres $y$ Dirios yos nombres y Diarios cita : la longitud de estos bajos pudiera ser la de $14^{\circ} 3^{\circ}$ para los primeros, $y$ la de $17^{\circ} 40^{\prime}$ al Occidente del meridiano de Cádiz para el último. 
en lá Línea), graduar los errores que se hayan compensado, y dirigirse á avistar la Isla Trinidad: la vista de esta isla puede tal vez ser útil á los que se consideren muy al Este de la es. tima, pues en tal caso más bien han de desquitarse algunos grados de longitud en estos paralelos, siempre apacibles y con viento favorable, que en los del Río de la Plata, sn donde las tempestades $y$ pamperos pueden ser doblemente no. civos.

Pero de ningún nıodo es útil el ver esta isla, a los que tengan alguna confianza en su punto, y habiendi cortado la Línea algo al Oeste, no la encuentren e 2 la derrota directa que han de seguir para el Ríc de is Plata.

No podemos dar mejores noticias relativamente á su posición, que la copia del extracto original de los Diarios de l:! Santa Rosalía, que de orćen del Rey navegó en I 7\% 4 directamente á esta isla (I). Es tanto más preciosa la prolijidad en esta materia, cuarito que decide al mismo tiempo la inexistencia de la Ascensión en estos mismo paralelos, y demuestra hasta que grado habian progresado las ciencias náuticas en nuestra Marina desde aquella fecha.

Copia de lo relativo al paralelo meridional dc $20^{\circ} y^{\prime} /$ en el mar Atlántico, sacada del extracto de lis navegación a - la fragata Santa Rosalía en I774.

Travesia en el paralelo meridional de $20^{\circ} y^{1 / 2}$

Si interesa á los navegantes el conocimiento 6 noticia de las diferencias ordinarias que se experimentan de ida y vuelta por sus respectivos parajes en el crucero de la Zona Torrida en este mar, y el muy esencia! de la variación nara corregir por ella sus estimas, no se hacía ménos necesaria é importante una ilustración de este pa ralelo y sus inmediatos, en que se figuran tantos tropiezos, pues señala el derrotero portugués con las cartas holandesas cuatro 6 cinco islotes con el nombre de Martín Vaz y Santa María de Agosto, entre 20 y $2 \mathrm{I}^{\circ} \mathrm{I}_{5}{ }^{\prime}$ de latitud y desde los $10^{\circ} 22^{\prime}$ hasta los $14^{\circ} 16^{\prime}$ de longitud occidental de Cádiz; y corrigiendo los $7^{\circ} 32^{\prime}$ en que Pimentel $y$ los anti ruos erraban hacia Oriente la situación de Cabo Frío, y relativamente toda la costa del Brasil, debían recelarse los referidos islotes entre las longitudes de $17^{\circ} 54^{\prime} \mathrm{y} \approx \mathrm{I}^{\circ} 4^{\prime} 8^{\prime}$ de nuestra cuenta.

Ya Mr. D'Aprés tenía advertido, que dos balandras expresamente despachadas por la com pañía oriental francesa, el año de $3^{1}$ habían recorrido las latitudes entre I9 y $20^{\circ}$, sin encontrarlos; que en el de $39 \mathrm{Mr}$. Bouvet, Capitán de

(z) E] Excmo. Sr. D. José do Mazarredo, tuvo la bondad de remitirme el original, cuya copia es la que se incluye en este derrotero. un navio de la compañía, partiendo del Cabo de Buena Esperanza, se puso en la de $20^{\circ} 30^{\prime}$ corriéndola sin ver más que la Isla de la Trinidad; y que por último, el autor, volviendo de China en 52 , hizo 700 leguas, como hasta 80 de la costa del Brasil, por entre los paralelos de $20^{\circ} 50^{\prime} y$ $2 \mathrm{I}^{\circ}$ I $5^{\prime}$ navegando con todo cuidado, y principalmente con la precaución de no hacer camino de noche, sin descubrir alguno de tales Martín Vaz, ni tener los menores indicios de su cercanía, como había sucedido á los anteriores.

Esto es lo que hare á dichos islotes; pero no han ocurrido ménos dudas y opiniones sobre la existencia de dos islas, una nombrada la Trinidad y otra la Ascensión, sosteniendo los portugueses (y las cartas holandesas), ser dos realmente con distinta descripción de una y otra (á que ya avenían también las cartas francesas), y los demás no haber más de una, diversamente denominada, según las cstimas de los que la han encontrado. Tenía esta opinión el gran vigor de acaudillarla Edmındo Halley, que continuando sus observaciones de vientos, mareas y magnetismo, á que fué sometido, recorrió el paralelo de $20^{\circ} \mathrm{y}^{\mathrm{H}} / \mathrm{z}, \mathrm{y}$ sus inmediatos muy prolijamente, $y$ vió sólo una isla á que llamó Trinidad (porque venía del Este y era el nombre que se daba á la oriental), situándola $12^{\circ}$ largos al Este de Cabo Frío, de que los españolts la han contado siempre distante sblo poco $\mathrm{m}$ śs d: $\mathrm{\tau I}^{\circ}$ (bien que denominándola Ascensión cuando la han visto), según la estableció después Mr. D'Aprés, quien primero seguía la opinión de Halley y más común, pero cedio finalmente á la autoridad de la reciente noticia de Mr. Duponcel, Capitán de la fragata $L a$ Fama, que en 1760 , navegadas desde la Trinidad como too leguas al Oeste, vió la Ascensión, dando su latitud $r$ ' ${ }^{\prime}$ meridional á la de la primera.

Pareció, pues, al Comandante necesaria una nueva travesía por el paralelo de $20^{\circ}$ y $\%$ á fin de con nuestra observacion, agregada á las noticias referidas, poder determinar la seguridad 6 cuidados con que deba navegarse en él en lo sucesivo, y á este objeto arribó al Oeste el 23 de Marzo, hallándonos como se ha dicho en $13^{\circ} 14^{\prime}$ de longitud occidental por estima y todavía con $3^{\circ}$ de diferencia al Este, según tan contestes ob servaciones.

Al llegar al paralelo, y áun desde dos días ante :, tuvimos frescachón el viento al Este con mar del Sueste más gruesa de lo ordinario en estas latitudes y una cerrazón de semblante tal, que nos indujo á sospechar había muy mal tiempo en altura (revolución del equinoccio) confirmándolo con la casi calma que sucedi6 del 25 al 28, volviendo después á entablarse la brisa bonancible al primer cuadrante, interrumpidas al principio con algunas variedades del Norte al Noroeste. 
Navegamos como pudiera hacerse para una descubierta primera, esto es, atravesándonos por la noche de uno $y$ otro bordo, asi que se caminaba la mitad y áun ménos de lo examinado con la vista al ponerse el Sol, haciendo ruestra derrota dentro del mismo paralelo, sin otra alteración, que la de las constantes diferencias al Sur que se enmendaban diariamente.

Antes de navegar $3^{\circ}$ de longitud empezamos á ver corvas, rabi-ahorcados y bobos é inmedia. tamente algunos charranes, otro pájaro negro de su tamaño y vuelo, con tal cual rabijunco; si los charranes guardasen aquí la ley comunmente observada en Santa Elena, debiéramos haber tenido tierra no léjos; pero de nada nos apercibimos que nos indujese á sospecharla aún hasta que crecieron las especies de pájaros, entre otras los gaviotones, como mangas de beludo, multiplicándose al infinito el número de todas desde los $21^{\circ}$ de longitud; y siguiendo nuestra derrota con todas las precauciones debidas, á las seis de la mañana del 4 de Abril avistamos desde el tope, tierra que demoraba al Oeste y se reconoci6 inuy pronto, áun de abajo, ser los islotes orientales de la Isla de la 'l'rinidad, que se vió igualmente desde el alcázar, para las ocho, á más de 16 leguas de distancia.

Pusímonos para medio día precisamente en el paralelo del islote mayor, á fin de determinar exactamente su latitud, que se observó de $20^{\circ} 30^{\prime}$ por muches buenos observadores acordes: $y$ demorando al mismo tiempo lo más septentrional de la Trinidad al Oeste $I^{\circ} 30^{\prime}$ Sur como I $_{3}$ leguas, debimos notar que la menor latitud de aquel extremo ha de ser de $20^{\circ} 31^{\prime}$ y no $20^{\circ} 25^{\prime}$ en que se contaba la isla.

Afiojando entonces más el viento que era del Norte al Nordcste, se mand6 al bergantin cercar los islotes, que los contase, entilase y sondase en sus inmediaciones y canales, dirigiéndonos con la fragata al Norte de ellos: no pudo cumplir el todo de su encargo á causa de la calma; sin embargo, estuvo por la noche entre el islote grande y mediano, no halló fondo con 70 brazas é hizo varias entilaciones acordes á las practicadas por nosotros desde fuera, sin que nareciese necesario otro examen del que se ofrecú á primera vista á un mediano cuidado.

Estos islotes pueden considerarse dos, uno graude, como de tres cables de largo, casi igual en bise y altura, terninada ésta en cinco puntas semejantes, visibles éstas desde el tope á mís de diez leguas; y el otro pequeño, sumamente parecido á un torreón como el de San Sebastián de Cádiz, bien que de alguna más altura, y estará dos millas escasas al Sur del grande, el cual tiene tres hijuelos, á saber: un morro á la parte del Norte y dos pirámides del Sudoeste á Sur, destacado el que más un cable, y cl torreón tiene tam- bién su hijuelo muy cerca al Sueste, de figura de una vela latina y como de la mitad de su elevación; de suerte, que en todo componen seis jslotes, si quiere darse este nombre á todas las piedras que aparecen separadas, y pueden si llamarse de Martín Vaz por su situación oriental á la Isla de la Trinidad, respecto á haberse denominado así los que se recelaban hacia la misma parte en tan disparatadas longitudes, y que á la verdad no existen.

El 5 persevera:nos entre aquéllos y esta, algo al Norte de su paralelo, tanto porque lo flojo del viento no daba lugar á acercarse y reconocer de día la isla, como por hacer cómodamente las últimas observaciones de longitud en cotejo de las anteriores, con marcaciones seguras de ambos objetos.

Tabla de las longitudes observadas en este faralelo.

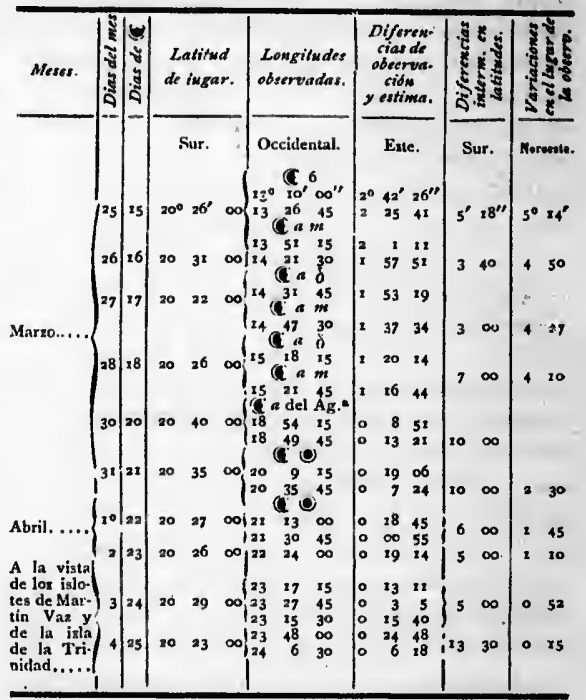

Resulta de estas observaciones, que en los I I $^{\circ}$ de paralelo que recorrimos por estinıla, se adquirió al Oeste la diferencia 6 desvio de tres que teníamos al Este, recalando en la Isla de la Trinidad con la misma estima.

Bien natural era un movimiento como este en las aguas, después de tanta parada en su direc. ción general hacia Occidente; y para persuadirse á que sucedió así, no parece necesario considerar más que el orden con que sucesivamente indica ron las observaciones la disminución de la diferencia: debe, sí, repararse en que todo este mo. vimiento se muestra hecho desde los catorce hasta los veintiun dias de Luna, y no añadir poco mérito y fé á las observaciones una reflexión se. mejante: y todavía más á favor de las de únicas en el período de la cnunciada revolución; 
empezaron después las distancias al Sol, perigea la Luna, y el instrumento en situación muy cómoda, circunstancias á que, agregado el singular esmero con que se atendió á las demás, de que penden las buenas observaciones, no dejaron escrúpulo en su exactitud, comprobando también á vista de la tierra los días 3 y 4 , no s6lo que no tiraban más las aguas al Oeste, si al contrario, por las marcaciones (bien fuese error de la estima) el que habíamos contraido en aquella singladura tres millas de diferencia al Este.

Se lograron especialmente á satisfacción las observaciones á la vista de tierra: del promedio de las tres tan acordes del tercero transferidas al islote grande de Maitín Vaz con su verdadera latitud y marcación, resultó aquél en longitud de $23^{\circ} 42^{\prime} 27^{\prime \prime}$ al Oeste de Cádiz, y del promedio de las dos del 4 en $23^{\circ} 4 r^{\prime}$, por donde puede contarse seguramente con la de $23^{\circ} 42^{\prime}, y$ deduciéndose de las enfilaciones y diferencia de latitud que dista 28 millas de la punta septen. trional de la Isla de la Trinidad, se sigue hallarse este extremo $30^{\prime}$ más occidental, esto es, en $24^{\circ}$ I 2 de Cádiz, que es la misma longitud en que la estableció Mr. D'Aprés, contando I I $14^{\circ}$ de diferencia entre este meridiano y el de Cabo Frío.

Es de observar aqui ahora, que por las longitudes astronómicas, recorrimos $14^{\circ}$ de paralelo hasta la Isla de la Trinidad, y habiendo en. trado en él con $6^{\circ} 44^{\prime}$ de variación Noroeste bien observada, así como la de ${ }_{5} 5$ Nordeste en el fondeadero de la isla, se sigue corresponder $\mathrm{r}^{\circ}$ de diferencia en la variación, á cada dos de longitud, y cuán infundada es la determinación de abrir las líneas magnéticas en unos meridianos y estrecharlas después en otros, siendo por otra parte más verosímil la uniformidad de los espacios, donde es una la dirección de los diversos magnetismos, lo cual debe dar inás confianza á todo navegante para corregir en este golfo los errores de la estima por un medio ian sencillo y prudente, cual es el de la variación, bastando saber la que corresponde en la Trinidad para un año dado; por ejemplo, en 1780 , que será de $39^{\prime}$ Noroeste por los $9^{\prime}$ anuales que crece hacia Occidente, el piloto que con una aguja igual á la de estas determinaciones ( 6 averiguada su discrepancia), observase la de $3^{\circ} 40^{\prime}$ en el paralelo, $\dot{o}$ si ántes reduciendola á el por la direccín,del Sur $1 \%$ Sueste deberá considerarse 6 contar aquel punto $6^{\circ}$ al Este de la Trinidad, y será tan prudente su juicio, que cabrán pocos de igual exactitud en la mar, pareciendo exorbitante que pueda llegar el error á $2^{\circ}$,á que segura. mente no, si se hacen repetidas observaciones en distintos dias, reduciendolas todas á un punto para tomar el promedio de sus resultados y ha. cer sobre éste la comparación.
Al amanecer del 6 demoraba la punta septen. trional de la Trinidad al Sur $55^{\circ}$ Oeste distancia de poco más de tres leguas, y entablándose dẹspués la brisa al Nordeste, arribamos á atracar aquélla; destacose el bergantín á çue la acercase bien y la sondase, y el resto de la costa del Oeste, y se envió al mismo tiempo el bote á la punta del Sueste, para que desde ella recorriese toda la costa oriental examinándola y sondán. dola, quedándonos con la lancha inmediata aun. que algo adelantada, que tambien sondaba con frecuencia. Siguiendo en esta disposición sobre la punta del Norte, no cogimos fondo hasta une miila de ella por la parte del Oesudoeste, empezando las sondas en 38 brazas piedra que continuó largo rato, hasta el tercio de la isla cerca de una pirámide y un islote inmediato tajado en tres partes, donde comenzb á indicarse la arena, disminuyendo poco. á poco el fondo hasta 27 brazas, en que á la una del día dejamos caer el ancla del ayuste, filando 60 brazas de él y á distancia como de dos tercios de milla de la costa más cercana, demorándonos la punta que aparecía septentrional al Norte $13^{\circ} 30^{\prime}$. Este; la pirámide dicha, al Norte $22^{\circ}$ Este; la punta meridional occidental con una islita muy pegada ella, al Sur $73^{\circ}$ Este; y la parte interior 6 es palda de un mo.ro grande colorado, que está hacia el extremo dis! Sueste, al Sur $82^{\circ} 3^{\prime}$ Este.

Al atracar la costa enfilamos las puntas sep. tentrional y del Sueste al Sur $4 y^{\circ}$ insts, y precisamente en el paralelo de la primera se observó á medio día la latitud de $20^{\circ} 3^{1^{\prime}} 6^{\prime \prime}$.

Se empleo la tarde en buscar con la lancha atracadero, que no se encontró á causa de la gran resaca, $y$ al anochecer se retiro el bote, que había circundado la isla desde la punta del Sueste hacia la del Norte, volviendo á la primera por la costa de occidinte, $y$ en todas partes encontró la misma fuer'ísíma resaca, que á ve. ces le precisó á echarse para fuera precipitadamente.

Al alba del 7 el Comandante y algunos Oficiales salieron en bote y lancha á eífilar las puntas de toda la costa occidental, reconocer su son . demás; hallaron la misma imposibili. dad de usracar que el día anterior, y se retiraron poco después de la una del día con conocimientos bastantes á trazar un plano de la exactitud que cabe en semejantes operaciones.

La Isla de la Trinidad, á cuya figura irregular dificultosamente se hallará nombre que convenga, es una cordillera de peñones de Noroeste á Sueste que adelgazan á los extremos, y cuyo mayor grosor en la mediania hace avanzar al Sudoeste la costa occidental y que esta quede curva-convexa y la del Nordeste algo cóncava: su extensión será de cuatro millas largas: la punta steptentrional está en $20^{\circ} 3 I^{\prime}$ de latitud Sur y en 
$24^{\circ} 12^{\prime}$ de longitud occidental de Cádiz, según resulta de las conformes observaciones citadas a su vista. Toda la isla es pura peña, cornnada en partes de leña menuda, y más gruesa y cerrada en diversas cañadas 6 ramblas, por algunas de las cuales se precipitan caudalosas vertientes de agua que deben proceder de las frecuentes lluvias, y sólo cerca de su morro meridional de Oriente se reconoce un corto trozo de terrón cubierto de verde. Por todos los puntos de su circunferencia se puede acercar á ella sin riesgo de bajo 6 poco fondo hasta las mismas peñas, pues se elevan todas tan acantiladas, que á un cumplido de lancha se encuentran seis y ocho brazas de agua en piedra y coral, formándose tal resaca, que imposibilita el atracadero hasta en dos 6 tres pequeñas playas que hay en los extremos del Noroeste y Sueste. La experiencia nos enseñó la segunda vez que anclamos aquí, como se verá después, que no siempre es igual tan grande la resaca, y sí accesible, con alguna dificultad, el atracadero en tal cual paraje, bien que nos enseñó al propio tiempo ( $y$ es rots útil el saberlo) no sólo que de un instante á otro no es posible ya el acceso, si también que nos habíamos engañado en creer de arena limpia el pla. cer que circunda la isla por esta parte de occidente (la única de abrigo) con 25 á 40 brazas desde poco más de media milla hasta cerca de dos de distancia de la costa, pues vimos á costo de ancla y cable y con prolijo examen, que aunque en la superficie sólo se manitiesta arena (que es lo que el escandallo señala, bien que perdiendo las más veces el sebo) es no más de una capa de ella sobre un piso general de piedra, lo que no pudimos advertir ahora faltos de antecedente de sospecharlo, ya porque lo constante del viento tuvo la fragata $\sin$ borneo las veinticuatro horas de nuestra mansión, y no pudo el cable rastrear el fondo, $\sigma$ ya porque accidentalmente cayó el ancla en un paraje algo más cubierto: y así, sólo puede venirse á este fondeadero teniendo un gran trozo de cadena para las entalingaduras, precaución á que si se agrega no ser tiempo de revoluciones (naturalmente el verano) podrá evitar los perjuicios indispensables de cualquier otro modo, y se remediará una extrema necesidad de agua y leña, caso único que deba inducir á la determinación de anclar en semejante para. je; y por lo demás, el fondeadero tiene la excelencia de no conocerse travesía en él á causa de la convexidad de las tierras, á más del buen abrigo de los vientos generales que deben ser bien reglados al Este en la propia benigna estación en que sin duda faltando las mares de los Sudoestes ó pamperos, no habrá la resaca, que es en la de ahora casi constante peligrosa, 6 se forma tan prontamente como lo notamos la segunda vez y acreditan varios arcos de hierro, de cuarterolas y barriles grandes, un cañon de fusil, un hacha $y$ un martillo que se encontraron entónces en tierra, indefectiblemente de alguna lancha que se vió en el caso de largarse con más aceleración aún que lo hizo la nuestra, á que costó no poco trabajo el atracadero, lográndolo solo detrás de un peñasco que deja canal á la isla, pasando ésta con el agua á media pierna en bajamaré in. transitable en la plea.

Se mat6 un jabato muy ruin que solo tenfa pellejo y huesos, color ceniciento, cerda no tan dura como la del jabalí común y ningún diente; que tal ve $z$ los perdió de viejo, indicando su $\mathrm{mal}$ estado la falta de mantenimiento para su uspecie; y parece que los hay mayores, pues se percibi6 el rastro, y subiendo algunos marineros á reconocer el origen de una vertiente de agua más arriba de una barranca de bastante grandor, donde se enlaga, precipitándose nuevamente desde ella, vieron un chivato grande que se les par6 al principio, y huy6 finalmente embestido de un perro de agua. Es de creer que estos animales fuesen traídos aquí desde el Brasil, en el designio de algún establecimsento que mejor examen hizo comprender perjudicial, pues no aparece otro indicio de haberlo habido jamás, ni es sitio en que las masas flotantes de hielos destacados de las costas los transportasen á una isla engolfada; pero lo que debe causar no pequeña admiración, es cómo se ha poblado esto de una infinidad de pájaros de garganta fina, los cuales no salen del bosque cerrado cue hay en las ramblas, $\tan$ cerrado que ninguno vieron nuestras gentes; oyéronlos sí cantar en una multitud que los aturdia, y por el gorjeo los consideraron ruiseñores, canarios y verdones; tal vez será exageración nacida de poco discernimiento; lo cierto es que en el Brasil se conocen muy raros pájaros de buen canto. La leña en las barrancas es mucho más gruesa de lo que se juzga desde fuera, pues tienen los árboles como tres varas de altura y de seis hasta doce pulgadas de diámetro. Pudo también observarse la segunda vez que anclamos, que el establecimiento es á las cuatro horas con cortísima diferencia, creciendo el agua al Norte y menguando al Sur, notándose en tierra cerca de doce piés de diferencia entre mayor y menor, que como justamente hacía el plenilunio, puede decirse sea la mayor ordinaria, idéntica á la teórica de Newton, sobre la atracción de la Luna y su efecto sobre las aguas del mar en estos parajes: lo cual se examin6 atentamente en la costa fijando un gran bichero y marcando en él la menor y mayor agua. Habitan en esta isla una infinidad de pá. jaros marisqueros de muchas especies, todas las que encontramos en el paralelo desde tan larga distancia, y es igual la abundancia de peces, muchos de.hermosas figuras, especial- 
0 discerni-

se conocen

leña en las

lo que se

boles como

loce pulga-

varse la se.

blecimiento

diferencia,

ado al Sur,

es de dife-

mo justa-

cirse sea la

de Newton,

fecto sobre

lo cual se

do un gran

$r$ y mayor dad de pá.

ies, todas. desde $\tan$ ndancia de , especial. mente los meros cuyo atigrado es singularisimo. En la Isla de Francia causan grandes es. tragos estos peces de colores, que por su hermosura punzan más á los marineros, hambrientos de refrescos; sin embargo, aqui, por la gran semejanza á los conocidos buenos meros dr la sonda de la Tortuga, se comieron sin recelo, encontrándolos de exquisito gusto, y sólo en los que se excedieron hubo algunas resultas de in. digestiones ligeras. Hay también gran número de tiburones, á que se dib buen mate, que aprovech 6 la marineria, celebrando este bocado como de los más finos.

Es cuanto ambas ocasiones nos proporcionaron observar principalmente de esta isla, cuyo feísimo pedregoso aspecto anuncia bién la uni. formidad de la materia con su base; su altura es tal, que se vé distintamente de más de 16 leguas de distancia, y su reconocimiento, viniendo de la parte del Este y Nordeste es inerrable por el encuentro de los islotes de Martín Vaz, y áun sin éstos la hace muy señalada el morro del Sueste, que desde muy lejos parece una isleta, se eleva perpendicular y tiene á su Noroeste una pirámide bastante más alta, muy gruesa en su base, algo inclinada sobre el morro, y que tam. bien parece islada desde larga distancia, como de 12 a 14 leguas. Con todo, por su figura la hace aún más conocida desde el Sursueste y Sur. sudoeste el agregarse á las mismas señales la de otra pirámide en el extremo del Noroeste, de casi tanta elevación como la del Sueste, pero de ménos grosior en su base, la cual en cualquiera otra marcación que no sea del Nornoroeste al Nornordeste, está confundida con las tierras más altas que tiene á su espalda, y Pimentel, que por su posición vertical la llama Fraile en Pié (más bien pudiera Dedo Pulgar) se equivoca describiendo que entre ella y la isla hay canal transitable á las lanchas, pues se eleva desde la misma riba de ésta: es verdad que en toła su noticia y la que da de la creida Ascension hay algo indistintamente que conviene con lo aquí visto, pero lo es igualmente que debio formarse de relaciones ignorantísimas, tanto, que indujeron al celoso cosmógrafo portugués á creer dos islas, evidenciando este jui. cio dos señales notables con que describe la As. cension: la una de una lapa 6 buraco grande (es agujero) que dice tiene al pié del pico más alto, donde entra mucho la mar, y debe ser el taladro en forma de ojo de puente que hemos observado en el extremo del morro colorado del Sueste, su direccion del Sursudoeste $1 / 2 / 4$ Sur al Nornordeste $1 / 2 / 4$ Norte: y la otra de cinco islotes, que la sitúa inmediatos por la parte del Oeste en perspectiva desde el Norte, y aparecen así, vista la isla desde el Nornoroeste á tres leguas, sin em. bargo de verse en el fondeadero, que están con. fundidos con la costa.
Los navegantes españoles, al encuentro de esta isla que llamamos Trinidad, la han nom. brado Ascensión, cometiendo s6lo un error de voz, pues la han contado en $34^{\circ}$ de longitud de Tenerife, que corresponde á $24^{\circ} 18^{\prime}$ de la occi. dental de Cádiz, considerando mucho más orien. tal la que creian Trinidad, bajo la fé de las car. tas; pero los portugueses al contrario, cuentan la Trinidad aún más cerca de la costa dei"Brasil, y entre una y otra la Ascensión.

Concluiremos este punto advirtiendo que to. madas con el octante dos alturas del picacho más alto sobre una base de 484 varas castellanas, re. sult 6 su elevación de 7 r9 y de $47 \%$ millas la tangente de su extremo al nivel del mar; de que se sigue deberse ver distintamente la isla desde cualquiera embarcación á I 7 leguas largas, y de igual operación se dedujo la altura de la pirámide septentrional de 478 varas.

\section{Salida de la Trinidal y crucero hasta volver a}

fondear en la misma, y largarnos do ella.

El mismo día 7 de Abril á las dos de la tarde nos pusimos á la vela, faena en que perdió el bergantín su ancla ya suspendida faltándole el cable, lo que entonces atribuímos á mal estado de éste, y después se pudo reflexionar ınuy bien que le tendría cortado en parte alguna piedra.

El viento estaba flojo del Noroeste, y propo. niéndose el Comandante cerciorarse de la existencia de la isla de la Ascensión, ceñimos al Oesudoeste, entreteniendo la noche y mañana siguiente en diferentes bordadas, á causa de las variedades que cesaron después de una turbon? da del cuadrante tercero, entablándose el viento desde las cuatro de la tarde al Sur-Sueste fresco, poca mar y buen semblante; y así nos pusi. mos en derrota á conservar el paralelo de $20^{\circ} 40^{\prime}$ en que debía suponerse dicha isla, según la reláción de Mr. D'Aprés, que bajo el atestado de Mr. Duponcel, la cuenta $15^{\prime}$ meridional á la Triridad, dejando antes establecida ésta en $20^{\circ} 25^{\prime}$.

Favorecidos como estábamos del tiempo, bre. ve se habían de caminar cien leguas, que se decía haber de una isla á otra: sin embargo, no se quiso ahora hacerlas tan presto como se podia para que en caso alguno pudiera tener lugar la sospecha de si la habríamos rebasado sin verla.

A medio día del 9 teníamos contraídas 155 millas de apartamiento de meridiano al Oeste de la Trinidad; hasta ponerse el Sol la misma tarde contragimos 41 más, y hecha una descubierta cuyo alcance excedería de 12 leguas, para cual. quiera tierra medianamente elevada, á favor de lo muy despejado de los horizontes, navegamos hasta las dos de la noche (ésta muy limpia) sólo 39 millas, atravesándonos entonces de una y otra vuelta á amanecer en el mismo paraje en 
que después de la descubierta sin novedad, pusimos otra vez en derrota, quedando al medio dia del 10 con $26 \mathrm{t}$ y $\%$, millas de apartamiento de la Trinidad, precisamente en $20^{\circ} 4 I^{\prime}$ de la. titud.

Empezamos á entrar en sospecha de la exis. tencia de la isla, porque aun prescindiendo de que las $3^{8}$ y $\%$ millas que faltaban á cumplir las 100 leguas, no eran bastante á tener la fuerza de la vista, $y$ supuesto un error de ochoá diez leguas en la estima, no se presentaban señales ninguna de tierra cercana, estando tan acostumbrados á ver los pájaros con tanta anticipación en la de que habiamos partido; y á la verdad, no se podía comprender natural el que de dos islas sólo dis tantes roo leguas, $y$ considerables de igual abundancia de peces, estuviese la una desierta de pájaros, sabiendo la otra habitada de infinidad de ellos, pero se doblaron los recelos al ponerse el Sol, hora en que con $26^{\prime}$ de apartamiento navegado, la suma de todas 288 , no parecía du. dable deberse ver la isla en una descubierta lo ménos de $\mathrm{I}_{4}$ leguas para la elevación en que la supone Pimentel, y no aparecía.

Determinó aquí el Comandante cruzar entre los paralelos de $20^{\circ} 45^{\prime}$ y $20^{\circ} 25^{\prime}$, haciendo los rumbos del Sursudoeste $y$ Nornoroeste á fin de granjear al Oeste sólo 27 millas entre los puntos de salida y llegada en las referidas latitudes, medio por el cual no podía faltar á la vista una piedra que fuese del tamaño de las menores de Martín Vaz, con la circunstancia de entretener la noche ceñidos para amanecer donde se anochecía, y desde la salida del Sol contragimos así hasta medio día del i I sólo I 2 millas de apartamiento, completando cabalmente el de roo leguas de la Trinidad en $20^{\circ} 26^{\prime}$ de latitud.

En el punto de medio día se vió una bandada de charranes, mezclados con ella algunos bobos (desapareció presto, excepto tal cual charrán) é indujo á bajar hasta los $20^{\prime}$, de donde volvimos al cuadrante tercero, y maniobrando en todo como antecedentemente, hicimos aquella singla dura poco más de 18 millas al Oeste, observando el I2, en latitud de $20^{\circ} 30^{\prime}$, horizontes clarísimos que facilitaban un alcance extraordinario, $y$ que no nos presentó más objeto que el de un charrán instantáneamente (iba del Este al Oeste) y una balandra pequeña que ceñía al Esueste mura á babor.

Del I 2 al I 3 navegamos del mismo modo, adquiriendo $23 \mathrm{y} \%$ millas de apartamiento, que con las anteriores hacen ya II4 leguas, á que agregado el alcance de la descubierta, aunque no sea más de diez, resulta un exceso, fuera del error que cabe en una travesía de 100 , que ordinariamente se hace con vientos favorables; se observ 6 la latitud de $20^{\circ} 34^{\prime}$, y empez6 á cubrirse el tiempo, aparentándose una revolución de las incesantes en la costa del Brasil en esta et. tación.

Del 13 al 14, tampoco hubo novedad en el método de derrota desde los 25 hasta los $45^{\prime}$ del $20^{\circ}$, si la de aclarar de nuevo el tlempo; y contragimos 29 millas de apartamiento, que con las pasadas, hacen 124 leguas, y nada se deacubrió, alcanzando la vista más de ra: quedamośá medio dia en $20^{\circ} 46^{\prime} 47^{\prime \prime}$ de latitud.

Poco antes (cuarto día de Luna) habíamos medido dos distancias de $\boldsymbol{C}$ á $\odot$, de que reaultaron longitudes acordes, y su promedio de $39^{\prime} 37^{\prime \prime}$ al Este de la estima, que valen $12 \%$ leguas de apartamiento, de modo, que siempre quedaban contar II 2 desde la Trinidad, y con la descubier. ta excedían en mucho al limite del error del es tablecimiento de la Ascensión.

A estas observaciones las ponia fuera de aquella confianza que se tiene en otras, el estar la (C en apogeo, y su poca elongación que á veces causa no percibirse bien el verdadero márgen de ella, absorbido por la excesiva iluminación del $\odot$, particularmente como entonces en las inmediaciones del medio dia, pero si cabia alli este defecto, produciría medir crecidas las distancias $y$ longitud demasiado occidental, contraria á la que aparecía; y esta consideración indujo á los observadores á tener por buena la averiguada.

Del I4 al I5, cruzando de la propia suerte entre los paralelos indicados, se granjearon 32 millas al Oeste, que agregadas á la observación, componen r 22 leguas de apartamiento, y sólo vi mos tres pájaros negros poco menores que gaviotones: observóse al medio día la latitud de $20^{\circ} 57^{\prime}$.

Tanto por hallarnos en tan crecida latitud como por la revolución que se aparentaba, cerrándose los horizontes, con algunas variedades interrumpidas de calmas, sólo granjeamos para el Norte, nada al Oeste, en las singladuras del I5 al 16 , quedando en latitud de $20^{\circ} 3^{8^{\prime}}$, sin más vista que la de algunos martimplacas, pájaros que venían huyendo del mal tiempo que se anunciaba en altura.

Entablándose el viento al Sursueste al medio día del 16 , pusimos al Nornoroeste $1 / 2 /$. Norte a fin de ganar poco al Oeste, por la corta descubierta que franqueaba la fosquedad de los horizontes. En esta fijó la atención de todos á las tres de la tarde, una ceja que parecía tierra desde el Noroeste al Oesueste interrumpida al Oeste, señales que convenían con la entrada de la bahía del Espíritu Santo, en el paralelo de 20.28 en que entonces estábamos. La vista sola no se resolvía á determinar si realmente era tie rra lo que lo parecía: sondamos orzando al $\mathbf{S u}$. doeste tomando fondo de 40 á 50 brazas cascajo gordo: cambiamos la cabeza, se repitib la sonda dos veces hallando de 80 á go brazas piedra y 
cracr jo colorado, y siguiendo para fuera á muy poco rato, ni después ya más se pudo coger fondo con x ro brazas.

La sonda confirmaba la vista de la costa del 13rasil: la situación de esta referente al Cabo Frío, cuya longitud está exactamente determinada, es susceptible de pocc error: la comparación del punto con esta vista, daba $2^{\circ}$ de diferen. cia Oeste cuando cincuenta y dos horas antes la teniamos observada contraria de $39^{\prime} 37^{\prime \prime}$ : sin embargo, doblados aquil los recelos que cabían en la exactitud de aquellas observaciones (número 72) nos supusimos á la vista del Brasil, fnterin se hacian otras más seguras; $y$ siendo indistinto $\mathrm{el}$ que fuese 6 no, esto es, el que distase diez. leguas 6 cuarenta y ocho, para determinarnos con ente. ra seguridad a creer, no hay tal isla de la As. cension entre la de la Trinidad y dicha costa: y como por otra parte sea necesario desatracarse de ella para emprender cualquiera derrota, á más de que la actual revolución de variedades, aguaceros y truenos, no hacla practicable otra mayor cercania, sin otro objeto que el de mera curiosidad, se mandó ganar al Este con el ánimo de atravesar de nuevo á la Trinidad, para examinar otra vez los meridianos intermedios.

La tarde del 7 se vieron al Oeste dos embarcaciones al parecer pequeñas, y á la misma parte se notb otra vez la apariencia de ceja de tierra como la tarde anterior, bien que estuviésemos ya 26 millas más al Este, consideración que destruía la posibilidad de que lo fuese, respecto á hallarnos indubitablemente á Oriente de los más puntos que hablamos cruzado en la singladura del $\mathrm{I}_{4}$ al $\mathrm{I}_{5}$, con un tiempo $\mathrm{y}$ horizontes propios para descubrirla á mucha mayor distancia que ahora.

Seis observaciones de longitud este día, las cuatro por oistancias de la Luna al Sol, una á Régulo y otra á $a$ de la Spiga, confirmaron la exactitud de las dos del $\mathrm{I}_{3}$, y nó permiten creer que pudiesemos haber visto la tierra, con. viniendo también en ambos casos la variación de la aguja, con la diferencia de longitud que resultaba al Cabo Frío, donde actualmente debe contarse de $6^{\circ} 15^{\prime}$ Nordeste, esto es, $2^{\circ} 8^{\prime}$ mayor que la bien observada en el momento que sondä:mos, y acorde á todas las anteriores y posteriores, de que se sigue, debernos faltar entonces $4^{\circ}$ para cumplir la longitud de Cabo Frío, y que no podiamos tener á la vista una costa que soblo étá $i^{0} 3^{\prime}$. más oriental, sin que obste el hallaz. go de la sonda, que persuadí́ á creerla, pues consta en el viaje de Jorge Anson alrededor del mundo, que la hallo de ménos braceaje áun por latitud de $23^{\circ}$ muy fuera de la vista de tierra, aun suponiendo que tuviese en su estima el error de' cerca de 40 leguas que deducia del punto de dos bergantines portugueses, procedentes de Ja. neirn, que encontró dos dias despues, y que no creyb al recalo en la Isla de Santa Catalina, te niéndole más conforme á su estima. Esta sonda debe ser Lengua de los Abrojos, como opina el Diarista de Anson.

Ya bien despejado el semblante, descle el 20 que fijó el viento al Norte y Nornoroeste (debe mirarse como no ordinario lo que persevero), seguimos ganando al Este, tomando para el medio dia del 22 la latitud de $20^{\circ} 33^{\prime}$, de donde bajamos todavia hasta $\operatorname{los} 20^{\circ} 24^{\prime}$ antes de re. calar a la Trinidad, á que dimos vista la mañana del 24 , al Este 1/2/. Sur, impidiéndonos ln ce. rrazon de la misma parte y el poquisimo viento, volverla á distinguir hasta las ocho de la no. che, perseverando el l'esto de ésta inmediatos, para anclar la mañana siguiente, 25 de Abril, como lo ejecutamos por $\mathbf{2 6}$ brazas arena, recono ciendo $30^{\prime} 48^{\prime \prime}$ de diferencia al Oeste de la esti. ma entre ida y vuelta; $y$ haciendo proporcional á los días esta diferencia, resulta, que podia ser de 15 ' al picar la sonda el r6; pero el que no se adelante á negar las evidencias de la Geo. metría, convendrá en que la corredera de que usamos (esto es, de 42 piés ingleses para $28^{\prime \prime}$ ) es tan defectuosa por corta, como que está pró ximamente en razón de II 2 á IOo con la me. dida de la tierra, determinada por tan respeta. bles sabios: y que por consiguiente, no podfamos hallarnos entonces una milla al Oeste de la estima, si algunas al Este, que se habian de destruir desandando el camino con la propia corta medida, para quedar sólo la diferencia verdadera, evidenciándose por áltimo, que fue ilusión no más la de la vista de la costa.

Excediendo en mucho los límites de una su. cinta narración, cual se quiere dar no más de nuestra navegación, se ha desmenuzado aquí esta travesia, porque no ha parecido, que bastase afir. marasí como quiera, que no hay Isla de la Aa. cension, estando tan reciente la afirmativa do Mr. Duponcel: expresas como quedan las derro. tas, no tiene el que quiere hacerse juez, más que transferirlas $a$ una carta 6 trazarlas en otro papel, y sentencie si á 60 ni á roo, r20 y hasta 135 le. guas al Oeste de la Trinidad, puede haber isla que no hubiésemos visto, no sólo en el paralelo de $20^{\circ} 40^{\prime}$ en que se indicb su existencia, mas también en todo el grado 20 hasta el 2 (que es lo que se pretendía inquirir) y áun fuera de dichos límites en distintos parajes.

No parece en razón alguna, que la aserción de la inexistencia de la Isla de la Ascensión, pueda ofender al mérito é inteligencia de Mr. Duponcel, ni ménos á la fé de que serán dignas todas sus observaciones náuticas; pues apenas se examinará un Diario de los en que puntual y sabiamente se expresa lo que se nota y acaece, en que no se encuentren estas ilusiones de tierra 
desvanecida asl que se ha puesto sobre ella á reconocerla; deduciéndose del contesto de monsieur D'Apres, que no se acercó á examinarla, pues sólo dice que aparecía una eminencia poco más 6 ménos de figura de chimenea, sin advertir s:cuito, tensión, latitudes precisas 6 variación de la aguja, como lo requerla el aviso de un punto tan controvertido. Tenemos un ejemplar reciente en el viaje de Cook, laanks y Solander alrede. dor del mundo, donde $\mathrm{s}: \mathrm{dice}$, que el 14 de Enero de 1769 , vieron una apariencia de tierra, que desde luego juzgaron la l.1a Pepys, sita en las cartas inglesas en $4^{\circ}$ de latitud Sur por $64^{\circ}$ de longitud al Oeste de Londres, desengañándose de su ilusibn á breve rato. Acerca de la Isla Pepys que buscb dos veces inútilmente el Comodoro Biron en su viaje alrededor del mundo, año de 64 á 66 , le ocurre sabiamente al autor de aquel Diario en defensa del Capitán Cowley, que la denouninb asi en honor de Samuel Pepys, Secreta. rio de Jacobo, Duque de York (después II del nombre, Rey de Inglaterra), la justa reflexión de que no puede haber sido engañar al público el designio de los avisadores de islas imaginarias, siendo muy fácil el engañarse y creer tierras los vapores y nieblas, como les sucedio muchas veces; pero aquí es inutilísimo mendigar ejemplares ulteriores que sinceren semejantes engaños, cuando está tan fresco convencido de tal por todas razones el nuestro de la vista de la costa del Brasil. Y finalmente, si no suponemos sinceridad en los demás (que debe, no habiendo evidentes pruebas de malicia), no mereceremos que se crea la nuestra y jamás quedará decidida la verdad, cuya aclaración es el objeto de todo hombre de bien, y no ménos necesaria en nuestro oficio.

Tabla de las longitudes obseriadas en este crucero.

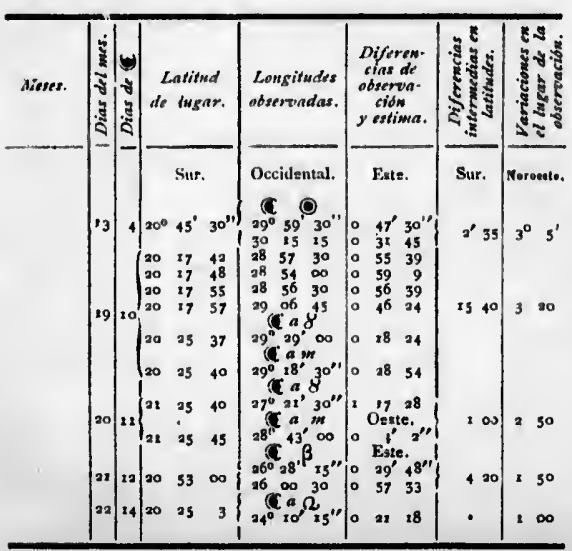

Fondeamos esta segunda vez en $1 a$ Trinidad, con objeto de tentar si podía hacerse alguna agua y. leña en reen plazo de la consumida, que ya era considerable; en efecto, la falta de marejnda del Sudoeste desde muchos dias antes, dej6 accesible el atracadero en la medianla de la iala, detrás de un peñasco y we reconocio una gran vertiente de agua, que stolo podia hacerse á barriles, por no haber inedio de disponer manguera, 6 des. embarcar piperia con seguridad, pareciendo que áun así alcanzaría á llenarse diariamente de 15 a 20 pipas; pero llenb la marea, impidio el trá. fico, y eran las diez de la mañana del 26 , sin que se observase en la lancha movimiento para regresar con solo diez vasijas, que llevó la tarde anterior.

A la misma hora, aproando la fragata al Sur, adonde querla apuntar el viento, se notb en las enfilaciones, más variedad de la correspondiente al rabeo: indujo á sospecha, se sondó sobre el ancla 28 brazas, habiendo caído en 26 , y que por marea debia haber igual agua: se virb sobre el ancla, con el ánimo de suspenderla, se advirtí fal to un cordón del cable, que se rompió á poco rato á tres brazas de la entalingadura, y dimos fondo á otra ancla; pero reconociéndose la tajadura de piedra, metido el primer cable, ain $\mathrm{em}$ bargo de que la sonda, en un gran círculo sobre el ancla, no indicaba otro fondo que el de arena blanca y negra, se penso, lo que realmente es, que sólo hay una capa de ella sobre piedras como navajas; por tanto determinó el Comandante dar la vela, mandando al bergantín no levarse hasta recoger nuestra lancha, á quien se hacía seřal para que se retirara, y acreditó lo fundado del juicio sobre el fondo, el cable segundo que salió muy rozado también, cerca de la entalingadura, sin embargo de que apenas estuvo media hora en el agua.

Asi que quedó entablado el viento al Sur, creció tanto la resaca en la costa, que fué inmensa la fatiga que costó á la lancha el largarse de ella, forzándola poco después á abandonar las pipas que traía arrizadas, tardando no poco aún así en coger el bergantín, á causa de la gruesa mar que ya estaba formada; tanto, que no pu. diendo ir éste sobre su ancla, pues balanceaba á embarcar agua por ambas bordas, picó el cable para ponerse á la vela.

Formó el Comandante el designio de reco. brar nuestra ancla y la del bergantín, esperando inmediato á la isla á que cayese la mar; y efec. tivamente, el 29 por la mañana se envib el bergantín á aquella faena, que empezb por su ancla y la perdi 6 faltando el orinque cuando la tenía ya suspendida, viéndose luégo que estaba aquel rozado de piedra: tomb el del ancla, la levant 6 con facilidad, y la tenía ya bien alta, cuando entrando á las dos de la tarde un ventazo del Oesudoeste al Sursudoeste con mucho aguaceroy gran cerrazón, se vib en lo necesidad de picar el orinque porque zozobraba sobre el ancla y se iba 
fragata al Sur, se noto en las urrespondiente and6 sobre 26, y que por virb sobre el la, se advirtio rompi6 á poco dura, y dimos endose la tajacable, sin em. círculo sobre ue el de arena realmente es, e piedras como omandante da b levarse hasta se hacia señal lo fundado del undo que sali 6 entalingadura, media hora en

viento al Sur, ta, que fue incha el largarse i abandonar las Jo no poco aún a de la gruesa 0 , que no pus balanceaba á - picó el cable

ignio de recotín, esperando a mar; y efece envió el ber. ez6 por su ancuando la tego que estaba el ancla, la levien alta, cuanun ventazo del cho aguaceroy dad de picar el tancla y se iba
1 la costa, en que estuvo en gran empeño por haberle cogido ol viento de mala vuelta y no te. ner aguas para virar; mas logrb montar el mo. rro de Sueste, y circundando la isla por su custa oriental, amanecib el 30 incorporado.

Recogimos el bote y gente que se le habla dado para aquellos trabajos, y tomándole de re. molque, pusimos al Norte $\%$ Nordeste, viento Sueste frescachón, observando al medio día la latitud de $20^{\circ} \mathrm{II}^{\prime} 20^{\prime \prime}$ Norte-Sur con la punta septentrional de la isla, $y$ asl quedo establecida para punto de salida la longitud de $24^{\circ}, 12^{\prime}$ al Oeste de Cádiz.

Esta parte de derrota, igualmente que las demás, necesita una especial atención, no sólo á las estaciones, si también á los semblantes del tiempo, conbinados con las lunaciones: en el invierro, esto es, en los meses de Marzo á Octubre, suelen experimentarse uno: vendavales tanto más frecuentes cuanto mayor es la latitud en que se halla, y en atención á esto conviene más bien el no llegar al paralelode la Isla Lobos 6 del Cabo Santa Marla hasta estar muy cerca de la costa; al contrario en verano, como quiera que la alter. nativa de terrales y virazones influye natural. mente en las calmas y bonanzas, conviene entrar en el paralelo de la isla Lobos con una ventaja en longitud de 30640 leguas; las corrientes en este tránsito desde la Isla Trinidad hasta el Rio de la Plata, suelen inclinarse más bien al Oeste.

Todo el placer puede considerarse de arena, y áun pueden sentarse sin temeridad varios principios que sirven á dirigir la recalada por la sonda. $I .^{\circ} \mathrm{La}$ arena es blanca y mezclada con conchuela y caracolillo, si en iguales meridianos se está al Norte, 6 en el mismo paralelo del Banco Ingles; es al contrario parda fina y á veces lamosa, si está al Sur de dicho paralelo. 2. ${ }^{\circ}$ En iguales meridianos crece rápidamente el fondo navegando al Sur, $y$ crece tanto más rápidamente, cuanto más se dista del meridiano de Cabo Santa María. 3. ${ }^{\circ}$ La lama es el indicio seguro de estar en buena derrota. $40^{\circ}$ Hasta las 40 brazas no puede formarse juicio de la posición verdadera, y por consiguiente puede excusarse el sondar frecuentemente. La sonda hasta las 80 brazas sale á unas 40 leguas del meridiano de Cabo Santa María; pero su declive no es proporcional, siendo bastante rápido desde las 80 hasta las 30 brazas, $y$ conservándose luégo, 6 disminuyendo paulatinamente á un número menor.

E1 Cabo Santa María está en latitud de $34^{\circ} 57^{\prime} 20^{\prime \prime}$ y longitud occidental de Cádiz de $4^{\circ} 36^{\prime} 40^{\prime \prime}$. El extremo Este de la restinga de la Isla de Lobos está en $35^{\circ} 4^{\prime} 35^{\prime \prime}$ y en longitud de $48^{\circ} 39^{\prime} 17^{\prime \prime}$. Como los vientós se inclinen regularmente al Norte y Nordeste, cuando se atraque la costa parece preferente mante. nerse en paralelos del Cabo Santa Ma:ía, y más bien algunos minutos al Norte, tanto más, que comunmente y con vientos foranos, las aguas co. rren aqui al Sudoeste.

Conservada esta latitud, y cogidas 25 á 30 brazas arena fina y caracolillo, podrá conside. rarse el navegante a 20 leguas de la costa; el fondo de 15 á 20 brazas le indicará que está ya cerca y que es tiempo de buscar la vista de tie. rra y el fondo lama.

Poco hay que decir si la recalada es con tiempo claro y vientos galenos; nada puede eatorbar of navegar con todo aparejo, aunque sea de noche; pues si la latitud al ponerse el Sol es deducida de la observación del medio día pró. ximo, y no se avista tierra por paralelos algo más Norte del Cabo de Santa Maria, teniendo aún de 20 á zo brazas arena y conchuela, nn debe quedar duda que la distancia á la costa, es aún considerable. En este caso deben hacerse rumbos del Oeste para buscar las 16 brazas arena, y descaecer con el solo efecto de las corrientes al Sur, pues de otro modo pudiera cortar el paralelo de la lama demasiado al liste, y por consiguiente no encontrando sino arena, se. guir sin valiza para el Oeste $y$ hacer contrarios los terrales del Nornoroeste y Norte. Las tierras del Norte del Cabo de Santa Marla deben verse con tiempos clarusá ro 6 I 2 leguas y por fondo de 15 brazas. Merece entre ellas particular cuidado la ensenada de Castillos, en donde han solido los correos echar oportunamente los plie. gos á tierra con un bote, cuando el pampero no les ha permitido alcanzar el puerto de Maldonado.

Cogidas las 16 brazas, si la estima manifes. tase estar aún al Norte del Cabo Santa María, po. drán hacerse rumbos del Sursudoeste hasta alcanzar el paralelo de la Isla de Lobos; pero con la atención de inclinarse al Oeste si las sondas aumentasen á más de 20 brazas, y de inclinarse al Sur si disminuyesen de las I6. El fondo entre el Cabo Santa María y la punta de Castillos, disminuye repentinamente $y$ casi sobre tierra.

El rumbo indicado llevará precisamente á una arena lamosa, en la cual, y en el paralelo de la Isla Lobos, se puede ya navegar al Oesíe conservando fondo lama y I 8 á 22 brazas. Puede estar. se en la seguridad que este fondo llevará aún de noche, con la mayor precisión, á la vista de la Isla Lobos, la cual se procurará dejar á estribor distancia de una legua, y se seguirá en derrota.

No pocas veces, á pesar de esto, se hace algo complicada, mas no peligrosa, la entrada en el Río de la Plata: suele carecerse de la latitud ob. servada: debe suponerse una corriente, y las neblinas 6 cerrazones (particularmente en invierno) imposibilitan ver la Isla de Lobos á alguna distancia: en estos casos siempre conviene asegu- 
rarse de estar al Norte de la Isla de Lobos, contando para la estima con un efecto de corrientes al Sur luego que la distancia á la costa no sea mayor de 20 á zo leguas, $b$ lo que es lo mismo, luego que la sonda no sea mayor de 40 brazas: la sola seguridad de estar al Norte bastará en. tonces para dirigir la derrota, pues que cogidas las I 8 brazas no sa titubeará en arribar al Sursudoestc hasta que, como ya se ha indicado, el fondo no haya crecido ś 20 y 22 brazas: ya en este caso, si conviniese aún afiaı zar más y más la posición que se sospecha, no deberá abandonarse el rumbo del Sursudoeste, y áun se inclinará a! go al Sur, consigiéndose de este modo. que disminuya nuevamente el fondo, y afiance así (áun sin el auxilio de la lama) rue se ha pasado el paralelo del canal: muy luégo con esta averiguación se harán rumbos del Oeste al Norte, y paulatinamente aumentando el fondo é inclinándose á la lama, disipará toda duda para buscar la Isla de Lobos.

Importa tanto más esta precaución de averiguar por la sonda el parale'o de la Isla Lobos, cuanto que si se estuviese al Sur de él con 16 brazas arena, pudiera ó irse á sotavento, navegando al Sur, ó dar en el Banco Inglés navegando al Oeste, rumbos indispensables en uno de los dos partidos, ó de buscar la canal, ó de avalizarse con la costa del Norte del Cabo Santa María. Si en otras oc ssiones y particularmente en la ocasión precisa de saberse la latitud, el navegante puede acertadamente jirigirse al Río de la Plata, pasando al Sur del Banco Inglés, de ningún modo debe intentarlo cuando se halle sin seguridad de ia latitud, $y$ sin haberse avalizado con la tierra; pues tanto como 'e son átiles las sondas para pasar al Norte del Banco Inglés, tanto le son perniciosas cuando se incline á pasar al Sur sin el auxilio de la latitud.

Ya cogidos los paralelos inmediatos meridionales de la Isla de Lobos con fondo de r9 y 20 brazas lama, sólo se ocupará el navegante de conservarlo al principio y luégo disminuirlo paulatinamente con rumbos del Oeste $\%$ Noroeste lasta 77 brazas, en cuyo fondo le demorará la Isla Lobos, del Norte al Noroeste dos 6 tres leguas. La precaución de conservarlo al principio es importante por no pasar entre la isla y la tierra firme, hacia donde pudiera acarrear también la lama, pero bajando precisamente $a$ is у 16 brazas.

La restinga del Este de la Isla Lobos sale una milla escasa, y hace que por esta parte sea imposible el atracarla: es, al contrario, muy acantilada en todos los demís rumbos.

Es preciso advertir aquí que esta derrota puede en algunos casos ser peligrosa, particularmente cuando un tiempo no decidido en el invierno y con malas apariencias, hace recelar de un Sueste, en cuyo caso es preferente á todo, el ponerse en paralelos más al Sur de la Isla Lobos de 15 ó $20^{\prime}$ antes de bajar de las 30 brazas de fondo. En este caso, y conocida la latitud, puede buscarse en derechura el placer del Banco por las siete ó seis brazas, y por él, ó navegar al Norte en busca de la canal, ó dar fondo si el viento saltase al Sudoeste.

El rumbo del Oeste $5^{\circ}$ Norte es el que comunmente lleva á la vista de la Isla Flores, pues como las corrientes con los vientos oportunos para entrar se dirijan contínuamente al Oeste, suele este rumbo, inclinándose algo más al Norte, resarcir aquellos efectos, y promediar la derrota más oportuna: el extremo Sur de la Isla Flores, situado en latitud de $34^{\circ} 5^{\prime}$ o o " y longitud de $49^{\circ} 5^{\prime} 30^{\prime \prime}$, corre con el extremo Sur de la Isla Lobos Este $6^{\circ} 45^{\prime}$ Sur y Oeste $6^{\circ} 45^{\prime}$ Norte $19 \mathrm{y} \%$, leguas. Suele proyectar en forma de dos islas, particularmente si se ve con una marcación que incline al Sur, se alcanza á ver á distancia de cuatro ó cinco leguas, y no presenta en su superficie sino arenales y algunos escarpados bajos, que son el abrigo de una infinidad de lo. bos marinos.

En esta navegación 6 travesía no debe abandonarse la sonda, cuyo braceaje y calidad son igualmente importantes: la canal tiene una lama suelta que casi no se pega al escandallo, y su fondo va disminuyendo progresivamente, desde las 7 brazas hasta las siete, por cuya sonda se está ya inmediatos á la Isla de Flores.

Son casi iguales los fondos al Norte de la canal; pero la calidad es una lama dura que avisa de inclinarse al Sur ( $\mathrm{I}$ ), al contrario, el menor fondo y la calidad de arena que pudisran encontrarse, avisan el estar al Sur la canal, y deberse, por consiguiente, torcer los rumbos al Norte pura no caer en el Banco Inglés.

Es inútil advertir, que cuando no se hubiese avistado la Isla de Lobos, se hacen precisas mayores precauciones para cerciorarse de su situación: tales son, particularmente, el saborear el agua y el avalizarse con arena, haciendo rumbos del Sur antes que el fondo lama liaya disminuí. do de $\mathrm{I}_{3}$ ó $\mathrm{I}_{4}$ brazas, pues si se esperase á estar en to ú II, y se hiciesen rumbos del Sur y Oes. te, pudiesan tal vez arrastrar á las inmediaciones del Banco Inglés.

Con mucha prudencia y muy buen éxito, las fragutas correos de S. M. que han sido sobrecogidas de los pamperos en esta travesía, han preferido dar fondo á salir de la costa; pero como la lama suelta que se encuentra en el ca-

(I) El carecer do esta noticia hizo que ambas corbetas se ensenasen de tal modo, que marcaron la Isla Flores al Sudoeite, y nccesitaron de rodos los esfucrzos y bucnas cualidades para pasarla al Sur a distancia de una milla escasa. 
nte á todo, el la Isla Lolas 30 brazas da la latitud cer del Banco él, ó navegar ar fondo si el

es el que co-

Flores, pues tos oportunos nte al Oeste, más al Normediar la deur de la Isla $\beta^{\prime} \mathrm{oo}^{\prime \prime} \mathrm{y}$ longixtremo Sur de ste $6^{\circ} 45^{\prime}$ Noren forma de con una marza á ver á disno presenta en os escarpados tinidad de 10 -

no debe abany calidad son iene una lama andallo, y su imente, desde cuya sonda se res.

Norte de la caura que avisa ario, el menor idisran encon. ial, y deberse, abos al Norte

no se hubiese a precisas mae de su situal saborear el ciendo rumbos aya disminuí. perase á estar el Sur y Oes. inmediaciones

uen éxito, las sido sobrecotravesía, han a costa; pero tra en el ca.

que ambas coriarcaron la Isla dos los esfuer. i Sur á distan. nai frustraría toda medida de esta especie dando lugar á que garrasen las anclas, se han inclinado al Sur á coger las siete brazas del placer de arena, en donde la tenezbn segura, y el mismo abrigo del Banco, no le expondrían á perder las amarras, y luégo, colı los vientos que regularmente pasan del Sudoeste al Sur, se hallarían á barlovento para navegar hacia la Isla Flores; y desde luego en mejor disposición para enmararse $\sin$ recelo de la Isla Lobos en el caso que fal. tasen las amarras.

Si al contrario, se escogiese para fondeadero en estas ocasiones el cantil del Norte, en donde la lama dura puede of recer una tenezón igualmente buena, desde luego se incurriría en los dos graves inconvenientes de exponerse á no montar Ia Isla Lobos, faltando los cables, y de estar á sotavento rolando el viento al Sur. Parece, no obstante, que los franceses que al principio del - siglo frecuentaban estas costas, se inclinaban á esta parte, tal vez por demasiado recelo del Banco Inglés ( $\mathrm{I}$ ).

Ya cogidas las siete biazas lama suelta y con la seguridad de estar en buena derrota, así por la misma calidad del fondo que se ha traído de an. temano, como por las valizas que se haya: tomado en uno ú otro cantil, se seguirá el rumbo del Oeste inclinándose al Norte, si se viesen así la Isla Flores, como la punta de las Carretas; pero no verificándolo, si las tierras estuviesen de un todo ocultas 6 confusas: el fondo en este caso irá disminuyendo hasta $5 \mathrm{y}^{1 / 2}$ brazas, y se conservará así por algún tiempo, siendo su calidad constantemente la lama suelta.

Importa mucho no inclinarse al Norte cuando no se ve la tierra, así porque pudiera no estarse aún exactamente Norte-Sur con la Isla Flores, comn porque la dirección de las aguas pudiera aconchar algo más después sobre la punta Brava, cuyas proximidades son realmente sospechosas; pero andadas tres leguas, después de encontra. das y ratificadas las siete brazas lama suelta, y encontradas cinco y media brazas á seis, puede estarse seguro que la punta Brava demora del Nornoroeste al Norte distancia de una legua, y que por consiguiente es tiempo de ceñir en demanda del puerto.

Los arrecifes más salientes de la punta Brava estín al Oeste $7^{\circ}$ Norte del extremo Sudoeste de la Isla Flores, á distancia de 14 millas. De-

(1) Se infiere asi de los viajes del Padre Feuilte y del Ingenicro Prezier: es de advertir que desde Solís Grande para el Oeste, cl fondo en las iumediaciones le la costa es més bien barro que lama. Fucra muy útil alcanzas los derroteros portugucses para la navogacion del río hasta la colonia del Sacramento. Los navegantes de esta nacion, precisamente han cimentado ia navegacion practica en razon del des el descuic con que han mirado la navegación astronomica. mora el cerro 6 monte Video al Norte $7 \mathrm{I}^{\circ} 45^{\prime}$ Oeste del extremo Sudoeste de la isla Flores, distancia 44 millas, y el paso entre la isla y el bajo de las Carretas, que de ningún modo debe emprenderse sino por necesidad, tiene de abra dos y media millas y un fondo de cinco á seis brazas lama suelta.

Ya asegurada la posición propia relativamente al puerto, si no se viese el monte Video 6 la población, sería imprudente intentar coger el fondeadero. El monte efectivamente suele cubrirse con vapores tan espesos, que á veces ni aún desde el puerto y á distancia de una legua es fácil conocerlo. En tal caso parece lo más prudente ceñir algún tanto hacia el puerto, y o buscarlo haciendo navegar el bote á estribor $y$ con la posible distancia, ó finalmente dar fondo en cinco brazas lama hasta que aclare.

En la dirección al puerto, poco hay que insinuar más de lo que dicta el mismo plano, cuyo braceaje y bajos salientes de las puntas Brava y San José, hacen ver palpablemente que es menester navegar con la proa al monte hasta franquear bien la boca, desde la cual última. mente se hará derrota á dejar caer el ancla en las inmediaciones de los demás buques y al Oeste de la medianía de la ciudad.

No deben esperarse en este paraje sino tres brazas escasas en mareas grandes y I $_{3}$ á I 4 piés en mareas bajas, de suerte, que fuera temeridad para embarcaciones grandes el intentar internarse; antes bien, como el fondo por largo trecho es casi igual, se hace sumamente molesto este puerto para embarcaciones que calen más de $\mathrm{r} 8$ piés, pues les es preciso fondear muy afuera, cogiendo sonda de cuatro á cinco brazas ( $\mathrm{I}$ )

El fondo de estos parajes es todo de lama tan suelta, que airastra consigo el grave inconveniente de no agarrar las anclas, desamarrán. dose los buques á cada paso, á pesar de la galga tendida en ayuda del cable del Sudoeste y de otro cable al Sueste, sobre las cuales y una codera al No:te, se mantiene contínuamente la proa hacia fuera ó al Sur.

No es leve tampoco el riesgo que de esta calidad de lamn resultá á las personas que echíndose 6 cayendo al agua, lleguen, como es fácil, al fondo: se empantanan de modo, que todo es. fuerzo les es inútil, y muy en breve quedan víctimas de esta especie de fondo. En desquite de estos inconvenientes, hay, no obstante, la ventaja de poder quedar varados 0 sentados en el fango, sin la menor avería, á ménos que un di. ferent: calado de popa y proa (por falta de cui. dado) no expusiese á. un quebrarito, la embar-

(1) Los navios de 74 cañones que invernaron en esto puerto cn el año 1777, pasaron una serie cons. tanto de peligros y fatigas. 
cación, que estuviese varada á popa y flotase á proa (I).

En el piserto, el agua crece de una braza y á veces de dos brazas, cuando soplan Oeste y Sudoeste. Baja mucho, al contrario, cuando los vientos son del Norte. Las mareas, trastornadas por este influjo de los vientos, no pueden, por consiguiente, considerarse periódicas; y de allí viene que todas las faenas de espiarse para ir á mayor fondo 6 con el ánimo de completar la carga ó de dar la vela, han de ejecutarse precisamente cuando con los vientos Oeste y Sudoeste, aunque lluviosos, el agua sube de su nivel. Para franquearse, es menester tomar la media canal, y más bien aproximarse al cerro; y fuera imprudente el bordear cuando no lo exijan circunstancias de mucha entidad, pues ni las distancias son excesivamente largas para no usar de espías, ni el fondo es tal que dé lugar á aprovechar los bordos favorables.

En general, el nivel del agua del puerto de Montevideo no depende del nivel del río y sólo sí de la dirección de las aguas: éstas vienen hacia el puerto con los vientos del segundo y tercer cuadrantes, y crece el nivel del agua. Salen, a] contrario, y siguen la vertiente del río con los vientos del primero y cuarto cuadrantes, $y$ entonces disminuye el fondo.

En cuanto á la corriente exterior, esto es, desde el meridiano del Cabo Santa María hasta el Banco Inglés, parece no admite duda que entra con todos vientos ménos el Noroeste; pero también que en una y otra costa hay revesas que corriendo contínuamente para fuera, equilibran cn cierto modo las aguas que entran: siempre ha de entenderse á pesar de estc, que la fuerza de las corrientes no se extiende al Sur del Banco In glés, en donde no encontrando tropiezo alguno, al contrario de lo que sucede en la costa del Norte, no adquiere velocidad alguna, ni por las revesas, ni por la resistencia.

En ninguna parte se convence mejor esta verdad, que en el puerto de Maldonado, formadis únićátiente con el abrigo de la Isla Gorrite: sean cualesquiera los cientos reinantes, siempre las aguas corren rápidamente del Oeste para e Este, saliendo por el freu que forman la Isla Gorrite y la tierra firme, y al mismo tiemoo EsteOeste con la Isla Lobos, las aguas corren con velocidad poco menor del Este para el Oeste.

Este puerto debió ser hasta aquí muy apreciable, por la facilidad que había de cogerlo y de abandonarlo sin arrostrar los muchos riesgos que se encontraban al dirigirse á Montevideo (2), pero

(2) Esta atención es precisa, particularmente para los huques de Armadilla: con la artillerfa y municiones. les es fácil igualar los calados.

(2) Muchas veces se ha insistido que fuese el Dc posito de la Mariua Real. desde que se ha hecho más fácil y segura la navegación á este último puerto, y particularmente desde que puede salirse de él, más bien con los terrales y virazones diarias, que con el Noroeste y Suoeste tempestuosos, se le ha dado preferencia.

Desde luego, si el ánimo fuese de fondear en Maldonado, importa mucho avalizarse, $\delta$ con el Cabo Santa María ó con la Isla de Lobos, para no equivocar otras tierras con la Isla Gorrite, que siendo baja y toda llena de blanquizares de arena, proyecta contra la costa opuesta, de modo que es difícil distinguirla: en este caso siempre es preferente el pasar al Norte de la Isla Lobos, y tan atracado á la tierra firme, cuanto lo dicte la prudencia: el canal es limpio y las virazones frescas, particularmente desde el medio dia hasta después de puesto el Sol; y es un anuncio casi seguro de la virazón (particularmente en verano) el verse los horizontes cerrados con reblina, desde el salir del Sol hasta las ocho ó nueve de la mañana.

Si la virazón manifestase firmeza y las inme. diaciones del puerto se descubriesen claras, fuera tanto más reprensible el no pasar entre la Isla Gorrite y la punta del Este, cuanto más difícil fuera de otro modo el coger el fondeadero más oportuno. El bajo que hace algo peligrosa esta entrada, está en las siguientes marcaciones: la punta Sur de la Isla Gorrite al Noroeste; la medianía de la población de Maldonado, Norte $3^{\circ}, 90^{\circ}$ Este; la punta más saliente de la tierra firr $\cdots$, llamada punta del Este, al Este, distancia á esta última punta dos y medio cables escasos. La canal entre el bajo y la Isla Gorrite, queda de media milla, y su fondo limpio hasta uno y medio cable de una y otra parte.

Como ya se ha dicho, hay en este freu una corriente bastantemente rápida para fuera; lo que exige tres precauciones para los que intenten pasarle: la primera de no dirigirse á él con vientos variables ó bonanzas; la segunda de no navegar con poca vela; la tercera, finalmente, de no poner la proa al medio freu, hasta salir de la enfilación del bajo, con el extremo Sur de la isla, atracándose más bien á este extremo que á la tierra firme, para no luchar con la corriente más rápida. El paraje mejor para amarrarse es Este-Oeste con las ruinas del cuartel de la Isla Gorrite, á distancia de cuatro cables de ella, y por fondo de cinco y media á seis bra. zas arena. Deben tenderse las anclas Noroeste, Sueste, y claras al Sudoeste, de modo que así se haga la mayor fuerza contra el viento por aque1la parte y la corriente del Oeste.

Al deseo de coger este puerto con virazones y tiempos claros, pueden añariirse otros dos casos, de los cuales el uno es el de ser cogidos del pampero, al Oeste de dicho puerto, y el otru 
yura la naicularmenien con los 1 Noroeste ado prefe

de fondear arse, $\delta$ con cobos, para orrite, que res de are, de modo so siempre sla Lobos, lo dicte la virazones o día hasta huncio casi en verano) blina, desueve de la

$y$ las inme. laras, fue ntre la Isla más difícil eadero más igrosa esta aciones: la ste; la meNorte $3^{\circ}=0^{\circ}$ erra firm uncia á esta sos. La caeda de meno $y$ medio

freu una fuera; 10 que intense á él con inda de no inalmente, rasta salir mo Sur de e extremo con la copara ama. del cuartel atro cables á seis braNoroeste, que así se por aque-

virazones os dos casogidos del $y$ el otro de ser sobrecogidos del Sueste en disposición de poderle alcanzar: este último caso, frecuente en invierno, pide á la verdad, que más bien se in cline el navegante á tomar la vuelta de fuera, $\delta$ á dirigirse á Montevideo, porque la costa porsí se cierra con exceso, y es fácil empeñarse sobre la Isla Gorrite, hallándose luego sin partido por el viento fresco y la travesía: pero si algún accidente hiciese precisa la determinación de entrar con Sueste tempestuoso, creo que el mejor, antes bien, el único partido es el de pasar bien cerca de la Isla Lobos, costeándola á estribor, y por ella ir á buscar la punta del Este, internando últimamente por la canal. En esta punta hay algunas chozas que pudieran verse. En la Isla Gorrite solo sobresalen una casa blanca y algunas paredes arruinadas, cuya permanencia por largo tiempo no parece probable.

La entrada con Sur y Sudoeste, que aquí son claros, no tiene el menor inconveniente haciendo proa á la punta de la Ballena hasta descubrir el extremo Norte de la isla y la entrada de puerto, en cuyo caso arribará al Este y últimamente ceñirá al Sueste y al Su: sueste cuando ya salga de la dirección de la restinga del Noroeste hasta estar en paraje oportuno para dar fondo.

Con los vientos del Sur y Sueste la mar es muy gruesa en el freu de la Isla Gorrite; chocando, por consiguiente, con la corriente que sale, forma ut marullo excesivamente grueso, del cual se originan balances muy incómodos: los cables al contrario, no trabajan en esta ocasión á causa del mismo choque, y la embarcación fondeada pudiera de este modo considerar se segura, si no debiese también tener recelo de algunos ratones que hay, segín prácticos, en las mismas inmediaciones del fondeadero, $y$ los cua les, según las disposiciones de las orillas, deben ser más frecuentes hacia la tierra firme que hacia la isla.

Hay dos pozos en la Isla Gorrite, de los cuales se pudiera sacar una regular provisión de agua, además que sería fácil ołros nuevos; y ciertamente debe ser preferible el $1_{\alpha}$ qcer agua en este paraje, así porque puede conseruirse sitio más abrigado para las lanchas, en las saletas que forman los mismos pedruscos, como porque la embarcación está más próxima y 'a marinería no tiene distracciones ni medios de separarse de su destino.

La comunicación con la tierra firme, debe hacerse para la seguridad de las embarcacione menores, más bien hacia las chozas de la punta del Este que hacia la playa de la aguada, en donde la menor marejada del Sur y Sudoeste hace ya difícil y expuesto el atracar: los arenales y la misma distancia hacen algo escabroso el camino á Maldonado, en donde no es difícil abastecerse de comestibles.
Cr:antas razones militaban á favor del puerto de Maldonado, antes de saberse con certeza la posición del Cabo San Antonio, han perdido todo su valor desde que no deja la menor desconfianza el paso al Oeste del Banco Inglés.

Muy pocas prevenciones necesita este paso, pues que la esencial se ha indicado ya, de no buscarlo viniendo de mar en fuera sino con un pleno conocimiento de la latitud ó de la tierra. Navegando al Norie han de inclinarse los rum. bos al Oeste, de tal modo, que se cojan las ocho ó diez brazas lama por latitud de $35^{\circ} 30^{\prime}$, y si no se hubiese alcanzado á ver tierra del Cabo de San Antonio ó de la punta de Piedras, cogida la lama se inclinarán luégo los rumbos al Este, de tal modo, que por los $35^{\circ} 15^{\prime}$ se cojan cinco á seis brazas arena, cascajo y conchuela; con este fondo se cstará seguro de estar Norte-Sur con el cerro de Montevideo; y se hará la navegación que exijan las circunstancias.

La valiza del Banco Inglés, por las cinco bra. zas cascajo y arena, es también útil para la salida, y no debe omitirse, mucho más cuando se aproxima la noche y calma el viento: en este caso será siempre preferente el dar fondo en unos parajes en donde no hay peor partido que el de entregarse voluntariamente al albedrío de una corriente, que por lo común lleva hacia el Banco Ortiz.

La experiencia manifiesta, y parece dictar lo mismo la reflexión, que al Sur del Banco Inglés 110 son '. 'In rápidas ni tan irregulares las corrientes, siempre que se esté 6 por meridianos del mismo Banco ó algo al Este; pero en las inmediaciones de la costa de Samborombon y del misn:o Cabo de San Antonio, han experimentado los Oficlaies gue fueron á su reconocimiento, que las corrientes tienen la misma fuerza é irregularidades que en la costa opuesta.

No creo pueda haber el menor inconveniente en reconocer las costas del Cabo San Antonio, cuando con tiempos galenos ve viene al Norte n demanda de Montevideo: á lo ménos debe buscarse en su paralelo las ro brazas arena qua condu. cen luego á la lama, y últimamente al extremo Deste del Banco Inglés.

Parece también que no es violenta la consecuencia de deser navegar al Sur toda embarca. ción que ya cogida sonda, y próxima al Cabo de Santa Maria, se viese con señales de mal tiempo y particularmerue con viento Norte; pues como quiera que ya desde el Norte el viento ha de ro. lar muy luego por el Oeste al Sur, esta derrota proporcionará la doble ventaja, en primer lugar de ser siempre árbitro el navegante del partido y rumbos que les convengan; en segundo lugar, de estar á barlovento, para con el tiempo claro del Sur, dirigirse sin el menor peligro al fondeadero. 
En cuanto á la navegación sucesiva á la colonia del Sacramento, ó bien á la ensenadu de Barragán, purede emprenderse por la costa del Sur, y pasando entre el Banco Ortiz y otro banco pequeño que está más inmediato á la costa: la sonda y las precauciones de hacer navegar los botes, ó por la proa ó pcr la banda, adonde esté el peligro más inmediato, proporcionarán mante. ner un fondo lama suelta de tres y media á cuatro brazas ( $\mathrm{r}$ ). Las embarcaciones de menor calado, pueden pasar entre el brnco pequeño y la costa, no perdiendo, por consiguiente, ésta de la vista.

(I) Mr. Bougainville explica con claridad la derota desde Montevideo á la ensenada de Barragán.

\section{Derrotero desde Montevideo a Chiloé por el Cabo de Hornos. Trata tambión del Puerto Egmont en las Islas Malvinas y de la descripción de toda la costa intermedia.}

Saliendo de Montevideo para dirigirse á pasar el Cabo de Hornos, estando como á dos leguas Norte-Sur con el cerro de Montevideo, podrá dirigirse al Sur $5^{\circ}$ Oeste, con cuyo rumbo irá encontrando por espacio de cinco leguas, fondo de cinro á seis brazas lama, hallándola sucesivamente mezclada con arena $\mathrm{y}$ conchuela, $\mathrm{y}$ finalmente, arena á 18 leguas en $\mathbf{2}$ brazas. Pasará á diez leguas del Cabo de San Antonio, distancia muy proporcionada no habiendo apariencias de vientos frescos del Norte. En su paralelo encontrará I3 á r 4 brazas arena y piedra, y á distancia de dos millas se hallarán tres brazas fondo de lama dura, por lo que en caso de necesidad se podría fondear.

Rebasado el Cabo de San Antonio, determinará su derrota al Este de la costa Patagónica, con presencia de la carta que acompaña este derrotero, según la estación, embarcación y demás circunstancias que pueden concurrir á la necesidad de variar de rumbo.

Convendrí sí advertir, que el temor de la costa separa denasiado de ella casi general. mente á los pilotos que hallándose con los Sudoestes tan frecuentes en estos parajes, experimentan las fatales consecuencias de no poder atracarla por donde les convendría para rectilicar su punto, $\dot{b}$ siendo aquellos $\tan$ fuertes que no les pe.mita ceñirlos de arribar á .Iontevideo con atraso de la comisión y gastos inseparables de las arribadas.

La experiencia demuestra, que desde Marzo á Setiembre soplan con más frecuencia los vientos Esueste, Sursueste Sudoeste y Sursudoesît y desde Setiembrc hasta Marzo del Este al Sueste.

Las corrientes tiran mucho al Nordeste desde los 40 á $50^{\circ}$ de latitud yendo como á 70 le- guas de la costa (I), y á mayor distancia ó pró ximo á la costa, se han hallado casi insensibles; aunque éstas deben considerarse también modificadas por los vientos que hayan reinador

Con estas prevenciones y la contínua aten. ción á los carices, pájaros llamados pamperos, etcétera, puede prometerse el acierto en las más de las ocasiones.

El dato de la sonda para inferir la distancia de tierra es muy erróneo, pues se tiene experimentado que suele haber más fondo á mayor distancia y uno mismo con diferencia de Io á I2 leguas. Sin embargo, respecto á que la que se ha puesto en la carta es là hecha en puntos co. locados por observación, derrota segura ó noticias las más verosímiles (2), será prudente tener atención á ella y combinarla con los demás datos.

Hasta aqui, el mayor número de los navegantes se han empenado en pasar entre las Malvinas y la tierra firme, áun cuando los vientos fuesen decididamente ccri-.;is y sólo acarreasen considerables sacrificios de tiempo y de aparejo.

No aconsejaremos pasar al Este de las Malvinas cuando los tiempos permitan pasar al Oeste, pero estamos muy distantes de prescribir en estos paralelos otros rumbos que los más favorables á ganar considerablemente en latitud.

La prudencia ha de dictar en la travesía del Cabo de Hornos, los rumbos que deben hacerse y la distancia á que convendrá pasar de tierra.

La calidad de los tiempos, la dirección de los vientos que se experimenten $y$ las propiedades de

(1) Primer viaje do D. Antonio de Córdova; viajo de la fragata Astrea año de $\mathbf{1}_{787}$

(2) Hablando de la formación de la carta, se isdica cuanto falta para que las sondas do un placer dica cuanto falta para que las sondas
tan dilatado puedan fijarse con acierto. 
ediu á cua : nenor cala. ño y la cosésta de la

ridad la de. e Barragan.

Hornos. y de la

ancia 6 pró. asi insensi. irse también yan reinador htínua atens pamperos, o en las más

la distancia tiene experido á mayor ia de ro á ra ue la que se n puntos cogura 6 notiprudente te. on los demás

los naveganlas Malvinas ientos fuesen urreasen cone aparejo. e de las Malan pasar al de prescribir e los más fae en latitud. travesía del eben hacerse ir de tierra. ección de los :opiedades de

Cordova; viaje la carta, se inido un placer la embarcación, deben decidir de los paralelos por donde convendrá pasar el Cabo y ganar al Oeste.

Parece indudable la existencia de corrientes hacia el Este (I), al Sur de la Tierra del Fuego. Se han experimentado éstas, de mucha, de poca y ninguna fuerza, ámucha yá poca distancia del Cabo, con aquella variedad que deben producir las comunes navegaciones en que faltan medios para determinarlas con exactitud.

Lo que parece más verosímil, según las no ticias de los navegantes más acr.reditados, es que las aguas vienen del Océano Pzcífico, tocan con la parte Sudoeste de la Tierra del Fuego, y siguen su dirección en la mayor pai te y variadas en pequeño según las diferentes canales que hay entre las islas y entre éstas y la tierra por donde pasan. Por lo que dice el Capitán Cook en su segundo viaje, que no teniendo precisión de tomar fondeadero, no se acercaría á tierra, porque estando separados se evitan las corrientes, que es taba persuadido perdian su fuerza á $\mathbf{2} 2$ leguas de la tierra.

Puede parecer las hay á mayor distancia, porque soplando casi generalmente los vientos desde el Noroeste al Sudoeste por el Oeste, mantienen la dirección de la marejada hacir el Este, y en muchas ocasiones la mucha fuerza te ella abatirá las embarcaciones más de lo que estén persuadidos sus pilotos.

Por tanto, es oportuno llevar en cuenta el tiempo que se haya tardado en hacer la travesía, y los vientos que haya tenido para graduar el abatimiento hacia el Este.

A la ida convendrá pasar más al Sur que á la vuelta, pues si hallándose al través de la parte Sudoeste de la Tierra del Fuego le cargasen los vientos por aquella parte, le precisarian tomar la vuelta del Sueste, á no tener el barlovento su ficiente para seguir la bordada del cuarto cuadrante; pero no debe hacerse esta prevención llevado del temor, de suerte que navegue muchas leguas y dilate su viaje inútilmente, siguiendo la común inclinación de la seguridad (2).

El Excmo. Sr. D. Antonio de Ulloa determina como lo mis conveniente pasar á la ida por en tre los paralelos de 60 á $64^{\circ}$ y á la vuelti por entre los $5^{9} a_{6} 60^{\circ}$, pero no viéndose obligados á seguir las bordadas del Sur, de suerte que no sea posible tomar la del Oeste so una disminu. ción considerable de latitud, parece excesivo el retiro hasta los $62663^{\circ}$.

(r) Veanse las referciones hrchas en la navegacion i truarla de la Astrme al tempo de navegar alrodedor dial Cabo de flormos.

(2) Los lobos mirisos en estos paralelos, no de ben causar el menor recelo tle una demasiada aproximación á la costa; así en esta navegación como en la de la Astr eu se han visto conocidameute á 50 leguas de distancia.
Parece suficiente la distancia de 30 á 40 le. guas al Oeste de Cabo Pilares en tiempo de verano para seguir en vuelta del Norte, 6 de 40 á 50 en tiempo de invierno, en medio de la poca constancia de los vientos en estos parajes.

No convendrá tampoco arrimarse mucho más á ella no precisando reconocerla, pues se experimentan tiempos más ásperos del Norte y cerrazones mucho mayores cerca de tierra que lejos de ella.

\section{Derrotu de Malvinas.}

Estando Norte-Sur con Punta Negra se navegará al Sursueste de la aguja hasta llegar al paralelo de $38^{\circ}$ de latitud, de donde se dirigirá al punto del de $47^{\circ}$ que diste de la costa 25 á 30 licguas Sur, deberá encontrar 50 á 55 brazas arena, \{ango y piedra, y si sondase 6o, será la arena gruesecita, quizá barrosa, señal que dista 30 leguas, entre $47^{\circ} 30^{\prime}$ y $48^{\prime \prime}$ se hallarín algunos chinitos.

En esta situación parece lo más conveniente navegar al Sueste $\%$. Sur para recalar á la isla Concha y difrutar los vientos reinantes. Si llegase á recalar con alguna cerrazón (que es muy frecuente) y visse tres montes altos separados que se enfilan Noroeste-Sueste, debe persuadirse son los Salvajes.

Estando Norte-Sur con ellos, puede suceder no verse otra tierra; pero si demorasen al tercer cuadrante, no siendo mucha la neblina, se verán las montañas que sobre puerto Egmont forman di'ersas figuras.

Al Norte de Puerto Egmont hay varias isli. llas: las Redondas, las de Piedra Blanca, la Culebra y las del Rosario; pero para distinguirlas es menester estar muy próximo á ellas, por ser muy bajas y rasas.

Si se avistase una sierra que hace como un pabellón en su medianía y en los extremos como picos de loro, se tendrá entendido que es la isla donde los ingleses tenían su vigía.

$\mathrm{Si}$ apareciesen siete cerros casi iguales en tamaño y figura, son los Organos ó Siete Hermanos, situados en la gran Malvina, siendo el más al Este pnco mayor y le nombran el Monte de Diamantes, por estar situado en la bahia de este nombre.

Al Norte de sistos está la Isla Borbon, que tiene tres cerritos clistantes unos de ceros, el más al Es e es el mayor.

Y así, si se viene por las cercanias de la gran Malvina, la última tierra que se vea será la bahía de los Diamantes, pero si se viaiere próximo á la Isla de Borblor estando Norte-Sur con lo sulu Este de ella we verá de cerro de Buenavicta, que estín en la beza de la brouia de San Carlos, parecido al de Montevideo, con sola la diferencia de 
ser algo más alto y cortado á pico por la parte del Oeste.

La isla Concha es muy pequeña y está situada casi Nornoroeste, Sursueste con Cabo Leal, distante dos $y$ media leguas, $y$ desde cualquiera situación que sc vea parece un navío á la vela, pues toda blanquea, por el excremento de las aves, de que está cubierta.

Si conviniere por algún accidente pasar por entre ella y dicho Cabo, se hará sin recelo por un buen canal de 30 brazas.

Cabo Leal es una punta rasa de barrenquera cortada á pico, y á su parte del Este hay una grande ensenada que sigue hasta Cabo Alto, y en todo este espacio se ven algunos montecillos tierra adentro.

Este Cabo parecido al Leal dista de la bahía del Oeste tres legruas siguiendo la costa algo más baja.

Media legua adentro de la punta del Este de la boca de dicha bahía, se verán dos montes uni. dos y uno mixyor que el otro, saliendo de aquel una cuchilla para el Sudoeste, bastante larga y de más de ia mitad de su altura.

Estando Norte-Sur con la misma boca, se distinguirá ( $n$ ) estando muy cerrado) el cerro de San Simón, alto, y su cabeza rara, situado tierra adentro.

Desde aste paraje se verá Cabo Corrientes ó punta dei Sable que tiene muy próximos unos islotillrs que sólo se distinguen yendo aterrados.

Al Sueste de esta punta y á distancia de seis á siete leguas, se hallará la restinga (que llaman Bolsa de la Barra) sale cerca de media legua, y desde la última islita de las que se quedan descubjertas se ha visto reventar una piedra á dis. tancia como de cuatro cables; se dice haber pasado por dentro de ella muchas embarcaciones.

Rebasada esta punta se aparece el referido cerro de San Simón por medio de la bahía, en los mismos términos que se dijo en la del Oeste.

Los cerros que llaman de la Vigía son tres, y se ven estando próximos á la punta del Sable, y estando el dia algo cerrado es menester alguna práctica para reconocerlos, no se debe atender á ellos para hacer el rumbo, pues cruzíndose con la tierra baja que sigue para el Este, puede uno aterrarse, de suerte que con los vientos de fuera no pueda montarse la restinga.

Si se llegase á la boca de la bahía de la Soledad con viento del tercer cuadrante duro con malos aparatos, será lo más conveniente fondear en el famoso puerto que forma la Isla Celebroña con la costa del Sur, pues hay buena tenezón de cinco, seis y siete brazas, en inteligencia, que si fuese embarcación de dieziocho piés, se atenderá á que pueda bornear por el boldroi que sale de la isla; pero si fuese embarcación menor, dará fondo sobre el mismo sargazo, sin temer á la isla que es toda acantilada y permite entrada á una y otra parte de ella.

Al Oeste de ésta, está otra que llaman Perler 6 Pelada, que puede pasarse rascando.

La Isla Celebroña está al Sur de la aguja de la restinga á la Bolsa de la Barra, y porque se proyecta en la costa y no es fácil de distinguirla, se atenderá á la barranca del Oeste que blanquea más.

Cuando se fondea hacia la mitad del puerto de la Soledad, se procura siempre estar más próximo á la costa del Sur, al parecer, para precaverse de los vientos que son más fuertes por esta parte, por la mejor tenezón y porque siempre se tiene esperanza de una mejor bordada.

Cuando se está voltejeando, no debe haber el menor recelo en rendir las bordadas cerca de tierra, pues sólo hay que resguardarse de lo que se viere y de unas piedras ahogadas que están cerca de los islotillos que salen fuera de la punta rasa de Boomon ó del Rey.

Cuando se halle entre las islas que están dentro del puerto dicho, siempre fondeará más cerca de la que llaman de la Paja que de las otras que están á la parte del Norte, por ser más acantilada.

Aunque se vean unos manchones grandes de boldro! casi Norte-Sur con lo más Este de la referida Isla de la Paja, no debe haber miedo de voltejear sobre ellos; pero si el viento fuese fiojo, conviene evitarlos, porque la embarcación pierde la salida.

Si estando de través con el Estrecho de San Carlos y el viento duro con cerrazón, quisiere tomar puerto, lo podrá hacer en bahía de los Dia. mantes ó de San Carlos, por ser las más proximas y cómodas.

Si se eligiese la de los Diamantes, seguirá en demanda de su punta del Norte que tiene una isleta alta que estando fuera parece forma la angostura del Estrecho, por lo que se hace muy conocida. Estando como á un tiro de fusil de ella, se meterá para el Oeste lo posible á fín de seguir muy cerca de la costa siguiente que es toda acantilada.

Si fuese embarcación menor puede seguir lasta estar Norte-Sur con la tercera playa grande que se verá á la parte del Norte, no temiendo pasar sobre el sargazo que sale de la punta, pues en bajamar hay dos brazas arena por todos ellos.

Siendo la embarcación mayor, conviene que. darse algo fuera de la situación dicha arriba y no pasar sobre los boldrois de las puntas, á ménos de no estar en pleamar. Navegando para dentro; se verán tres islitas, de las cuales la más Norte y Este es casi toda anegadiza sin pajonal (que tienen las más de estos parajes); es oportuno atender á ella si se llevase viento del cuarto 
cuadrante escaso y se rindiese la bordada muy cerca 6 se fondease en sus inmediaciones pu. diendo entrar el viento Norte.

Si se quisiese fondear en -la bahía de San Carlos, mediante tener esta sobre su punta Norte la gran valiza del cerro de Buenavista, seguirá en demanda suya, pasando á distancia conveniente de la costa, toda acantilada, y franqueada la boca se verán dos islas que se enfilan casi Este-Oeste, y dejándolas por estribor se dará fondo entre ellas y la ensenada que tiene di. cho monte for su parte del Este, más cerca de ésta para tencr más abrigo.

Si quisiese situarse donde con los vientos Sur y Sudoeste pueda salir cuando se le ofrezca, rebasado el cerro de Buenavista, siga la bordada por la gran boca que se ve al Sueste, y entrando por entre la punta del Oeste y el monte de Truanes (que es el primero de los de la costa del Este), dará fonclo donde quiera, pues todo es limpio, buena tenezón y 7,8,9 y 10 brazas.

En el caso sb́lo de no poder coger el fondeadero de los Diamantes, deberá pasar al de San Carlos, por hallarse este en disposición que entrando los vientos al Oesnoroeste y Oesudoeste que soplan ordinariamente duros cuando el tiempo abonanza, la embarcación que sale de él con dificultad montará Buenavista, pues el viento suele permitir el voltejear cuando la marea viene para adentro.

Adviértase que si yendo por dentro del estrecho se viere salir algún babeadero para el Este de la isleta dicha en la punta del Norte de los Diamantes que parece procedida de una restinga de piedras, no es otra cosa que un hervidero de corriente y basta pasar con cuidado del aparejo, y de no aproximarse á ménos de un tiro de fusil de la isla, que como es alta, aunque el viento sea fresco, suele perderlo la embarcacion, y quedar entregada á la corriente que la aconche.

Entrà.do en el estrecho, conviene pasar cerca de alguna de las dos costas, pues casi á medio freu y Este-Oeste con la isleta de los Diamantes, se halla una piedra que vela estando como á dos tercios la marea y rompe aún en pleamar (á ménos de haber mucha bonanza) y como estando los vientos duros se arma rompiente por todos aquellos parajes con la corriente, se hace precisa esta precaución.

Al Norte de dicha isleta, como dos tiros de cañon, hay un manchón de boldrois que parece estar en mucha agua. Si se hubiese de voltejear en el estrecho, estando entre Cabo Leal y cerro de Buenavista, no se rendirán las bordadas muy dentro de la grande ensenada que forman, pues hay mucha revesa de corriente en creciente; $y$ en menguante se pierde en lo granjeado en la vuelta, y es preciso sufrir, no sin peligro, con toda vela las grandes ráfagas que por lo común hay diariamente, y si se queda calma debe temerse lo que chupan las revesas hacia el fondo de la ensenada. Si estando de través con la bahía del Oeste quisiere 6 el tiempo le obligare á tomarla, seguirá en demanda de la punta más al Este de las dos islas que están al Norte de la bahía del Aceite, pasando de ella como dos tiros de fusil, porque en bajamar descubre una corta restinga. Desde este sitio se verá otra isla que llaman de Don Pedro Amores, y dirigiendo á su punta más proxima irá por medio de los dos bajos que se descubren en bajamar; para los cuales, cuando estín cubiertos en pleamar, sirve de valiza el boldroi es peso qive hay cerca de las piedras áun cuando corre mu ho la marea.

No es converiente pasar sin práctico con embarcación que no sea chica, por la parte Este de la Isla de Don Pedro Amores.

Si viniendo del Oeste quisiese tomar el puerto Egmont, reconocerá las Islas de los Salvajes, y después gobernará hasta ver el monte de la Vigía, que dejándola por babor, descubrirá la boca del puerto y podrá ir cerca de la costa del Sudoeste por Io y 12 brazas de agua, hasta que pasadas la punta de Natividad de dos bahías, y de la entrada del puerto, vea las reliquias del establecimiento inglés en la punta del Oeste, de hacia donde se dirigirá, y podrá dar fondo cerca de tierra y de la aguada en siete ú ocho brazas de agua. La extensión de este puerto, su abrigo y buen fondo, concurren á hacerlo uno de los mejores del mundo.

Hay muy buen agua, abundancia de aves $y$ mucho apio silvestre. Desde la isleta que se halla en la punta del Norte de la bahía de los Diamantes, corre la costa al Noroeste, y en distancia de cinco leguas se halla la de la Cruzada, demora al Sudoeste de la Isla Concha: lo barrancoso y pelado de la costa en que está situada, la da bien á conocer. Si desde las cercanias de la Isla Concha se fuese á buscar esta boca, se llevará por la serviola de babor el más Sur de los cerros que figuran un pan de azúcar, situado al Norte de los Organos, y es más bajo que éstos. Si nose viese dicho cerro 6 hubiera duda en su conocimiento, se pondrá por la serviola de estribor el monte gordo de dicha Isla Borbon, con lo que descubrirá la boca.

Al recalar, 'convendrá advertir que se tiene graduado como Este-Norte á diez leguas tierra, en sonda de 80 brazas.

Descripción de las costas Patagónicas hasta Chiloé.

La costa del Sur del Río de la Plata es de tierra negra, baja, anegadiza y muy poblada de árboles por algunos parajes. A cuatro leguas del Cabo de San Antonio se repara casi de repente, compuesta de méganos de arena de mediana altura, áridos, cuyas faldas forman muy poco de- 
clive, reventando la mar en sus orillas, sin herradura alguna, de suerte, que seria muy dificil ó impracticable el desembarcar en ellas. La variación de la aguja en el río, es de ' $14^{\circ} 15^{\prime}$ Nordeste.

Desde el Cabo de San Antonio para el Sur, va aumentando poco á poco el fondo á iguales distancias de tierra, de suerte, que por el paralelo de $36^{\circ} 4^{6}$, á milla y media, se encuentran cuatro y media y cinco brazas, y á distancia de 23 y $\%, 13$ arena y conchuela.

En $36^{\circ} 54^{\prime} 30^{\prime \prime}$ de latitud y $51^{\circ} 43^{\prime} \times 5^{\prime \prime}$ de longitud, hay un bajo de arena á una milla y media de la costa de traves, en que revienta la mar con mucha fuerza, y se ven las espumas á mucha distancia: su extensión será de cable y medio casi en la dirección de la costa, $y$ en su veril hay tres brazas de agua ( $(\mathbf{r})$.

Desde el paralelo del bajo dicho hasta los del Colorado que están en latitud de $40^{\circ} 45^{\prime}$ y longitud de $55^{\circ} 39^{\prime}$, la inayor parte de la costa no es muy alta, pero se ve regularmente de seis á ocho leguas de distancia. Sigue la dirección Nordeste Sudoeste, próximamente llena de quebradas por donde desaguan muchos ríos entre los que merece atención el de San José que está como unas 4I leguas del Colorado, pues en su embocadura forma como una especie de puertecito acomodado para embarcaciones de mediano porte, $y$ en que se halla buen agua (2).

Al Sudoeste $1 / 4$ Oeste, de éste 18 leguas, hay una herradura que proporciona desembarco de botes. Los bajos del Colorado salen como I9 leguas á la mar, no viéndose tierra desde donde se empiezan á quedar descubiertos en bajamar, la variación de la aguja $17^{\circ} 3^{\prime}$ Nordeste. Desde el río Colorado hasta el río Negro, es la tierra baja, pues con tiempo claro no se consigue verla á más de cinco leguas, $y$ toda tiene bajío afuera como dos ó tres leguas.

Para entrar en el río Negro, cuya punta Sur está en $41^{\circ}$ de latitud y $5^{\circ} 4^{6} 6^{\prime}$ de longitud, es menester atender á la marea, dando fondo fuera arrimado á la punta de la Barranca del Sur en cuatro brazas chinos, de cuyo paraje gobernará para entrar á los méganos de arena más altos que hay en la costa del Sur, pasando arrimado á otro que hay en la banda del Norte como á medio cable de distancia, rebasado el cual se puede fondear en cualquier paraje.

No pueden entrar en este fondeadero embarcaciones que calen más de nueve á diez palmos de agua (3). Desde el río Negro á la punta de

(i) Noticias de los Pilotos Tafor y Berlinguero. (2) Reconocimientos del Padre Cardiel en la carta del Brigadier Saá y Tarria.

(3) La sonda de 18 औ 20 brazas chinos, denota estar próximos al meridiano del ró Negro si se estuviese algo al Sur de su paralelo en demanda del puerto lo San José.
Belén corre la costa casi Este-Oeste; es tajada a pico, de mediana altura, con algunos cerrillos. y formando varias ensenadas; despues corre la costa algo para el Norte hasta el puerto de San Antonio, que está en latitud de $40^{\circ} 53^{\prime}$ y longitud de $59^{\circ} 9^{\prime}$. La variación en estos parajes es de $17^{\circ} 55^{\prime}$ Nordeste.

Desde el puerto de San Antonio hasta la punta Oeste del puerto de San José, forma la costa dos ensenadas que las divide una purta saliente, al Oeste de la cual hay unas sierras altas. La entrada de este puerto, situado en $42^{\circ} 8^{\prime} 40^{\prime \prime}$ de latitud y $58^{\circ}$ de longitud, se manifiesta bien, no obstante de formarla tierra baja, y áun muy próximo á ella se halla mucho fondo.

Sólo hay un bajo en la parte del Oeste, por cuya causa convendrá pasar cerca de la punta Este, no temiendo el escarceo formado por la corriente (que cuando es en favor conduce las embarcaciones dentro áun con viento contrario), y dirigirse al Sueste donde está el mejor fondea. dero, cerca de la población, en diez brazas de agua.

Desde la punta Norte de la península hasta la punta Crueles, corre la costa al Sur $22^{\circ}$ Este; desde ésta á pico de Lobos, al Sur $15^{\circ}$ Oeste, y lo restante hasta la punta de bahía Nueva, al Oeste $15^{\circ}$ Sur; debe hacerse atención al bajo situado en paralelo de $42^{\circ}$ I $7^{\prime}$ y distante de la costa de cuatro á cinco leguas: nuestra navegación nos ha dejado muy fuertes sospechas de su existencia (I).

La bahía Nueva es mala para fondear, pues cerca de tierra hay $4^{\circ}$ á 50 brazas de agua y 60 en la medianía (2). Desde la punta Sur de la bahía Nıeva, cuyo terreno es de mediana altura y llano en su cumbre, la costa va hurtando para el Oeste y descendiendo con igualdad hasta quedar muy baja, donde se forma una grande ensenada, y desde ella continúa la costa para el Sur, más alta que todo el terreno anterior.

Entre punta Atlas y Cabo Raso hay una grande ensenada llamada de Vera. Desde bahía Nueva al puerto de Santa Elena corre la costa al Sur $12^{\circ}$ Oeste, tierra igualmente alta: al Norte, y próximo á éste, está un puerto reconocido por tierra desde Santa Elena, que parece ser lim. pio y en que sólo puede perjudicar el Nordeste, que sopla poco en esto:s parajes.

El puerto de Santa Elena, situado en $44^{\circ} 36^{\prime}$ y $25^{\prime \prime}$ de latitud, y $59^{\circ} \mathrm{I} 9^{\prime}$ de longitud, es limpio y su entrada clara: para buscarla se gobernará á un monte que está en la punta de San José, que desde afuera parece isla, y dejándolo por la serviola de estribor se reconocerá la boca del puerto

(1) Véase el Diario de nuestra navegaciơn.

(2) Lo manifiesta asf el Piloto Tafor; pero no sabemos si la ha examiuado él mismo. 
es tajeda $\alpha$

so cerrillos

és corre la

to de San

$y$ longitud

rajes es de

sta la pun-

ha la costa

a saliente,

altas. La

- $8{ }^{\prime} 40^{\prime \prime}$ de

ta bien, no

n muy pró.

Oeste, por

le la punta

ado por la

conduce las

contrario),

jor fondea.

$z$ brazas de

nsula hasta

Ir $22^{\circ}$ Este;

$5^{\circ}$ Oeste, y

eva, al Oes.

pajo situado

la costa de egación nos su existen.

ndear, pues

agua y 60

Sur de 12

Jiana altura

rtando para

I hasta que-

rande ense-

para el Sur,

io hay una

Jesde bahía

re la costa

Ita: al Nor-

reconocido

ece ser lim-

Il Nordeste,

o en $44^{\circ} 3^{\prime}$

d, es limpio

gobernará á

n José, que

, por la ser.

del puerto

ación.

pero no sa- cerca de la punta acertada: tiene una isleta que esth cubierta en pleamar, pero se ve su reventa. 26n y puede pasarse sin recelo entre esta y la puntu dicha. Entrando por la banda del Sur irá á medio freu de la isla y punta de Sa' Fulgen. cio para darle resguardo al bajo Florido, y puede fondearse demorando la inleta al Sueste. El flujo máximo sucede á las cuatro y media de la tarde y sube el agua cuatro brazas.

La cala de San Sebastián, que está $2^{\circ} 3^{\prime}$ al Sur de Santa Elena, es bien desabrigada y sb́lo buena para barcos chicos. Inmediatamente se encuentra la ensenada de Camarones, cuya abertura es de cinco leguas y un tercio, con seis y un tercio de profundidad, $y$ aunque su fondo es limpio y de 25,30 y 35 brazas hasta cerca de la costa en que hay Io, su desabrigo lo hace incómodo: el flujo máximo sucede á las cuatro de la tarde. La variación de la aguja $20^{\circ} 15^{\prime}$ Nordeste.

Desde la ensenada de Camarones hasta el puerto de San Gregorio, es la costa limpia, pues entre la isla Arce y Chicas, todo su fondo es de 20 brazas. Para buscar este puerto, situado en $45^{\circ} 6^{\prime} 35^{\prime \prime}$ de latitud y $3^{\circ} 3^{\prime}$ y $30^{\prime \prime}$ de longitud viniendo de mar afuera se procurará pasar al Norte de la Isla Rasa dos leguas, procurando entrar entre la de Arce y Leones para descubrir libremente la boca del puerto, advirtiendo que el mejor fondeadero es próximo á la costa del Sur frente de dos ensenaditas con playa de arena, pues el demás es muy sucio y de piedra.

Si se of rece voltejear entre las Islas Arce y Chicas, Leones y Rasa, ó entre ésta y Arce, se podrá hacer por ser muy limpios sus canales, aunque la fuerza de la corriente forma tal escarceo entre ellas que parece reventazbn de bajo, y cuando en el puerto crece el agua corre entre las islas al Nortc y Nordeste, $y$ al contrario cuando baja. El establecimiento de la marea en el puerto es á las cinco de la tarde, subiendo el agua 28 piés.

Hay paso entre la Isla de Leones y la tierra firme, pues su fondo no baja de una y media brazas. En los pucrtos hasta aquí nombrados, se echà muy á ménos la falta casi total de leña y agua. Esta última, á la verdad, se encuentra salobre en algunos parajes algo distantes (I), pero la sola necesidad puede aconsejar su uso.

Desde puerto de Santa Elena hasta puerto Manso, son las sierras altas y peñascosas, $y$ desde éste á Punta Taforo (hasta donde está reconocido), es la tierra baja, continuando más alta para el Oeste 4'; al Oeste de ésta se halla el Cabo del Sur, que con el Cabo Blanco forma la entrada del golfo de San Jorge (2), desde aquel

(r) Son muy contradictorias eu esta parte las dife. rentes noticias de los que nos han precedido.

(a) Sregún noticias de los Patagones, interna hasta la cordillera. hasta la tierra para el Norte por espacio de cince leguas, y luego corre casi Este-Oeste. Desde el Cabo del Sur para el Oeste, sollo puede navegarse en barcos chicos por ser la costa muy sucia y ha. ber mucha corriente.

El flujo y reflujo de la marea es casi igual al de San Gregorio. La parte Sur de este golfo, no está reconocida ni la mediania.

El Cabo San Jorge está en $46^{\circ} 54^{\prime} 15^{\prime \prime}$ de latitud y $60^{\circ}$ ro de longitud, y al Sur $36^{\circ}$ Este $25^{\prime}$ de éste, está el Cabo Blanco que se le antepone un islote casi Este-Oeste.

Al Esnordeste 5 Sur á distancia de cuatro leguas del calıo, está el bajo reconocido de Tres Puntas por ei Comodoro Biron, y en cuyas inme. diaciones nuestras sondas nos han confirmado con grande probabilidad su existencia (1).

Desde Cabo Blanco á la punta Norte de puerto Deseado, corre la costa Norte.Sur próximamente, formando dos herraduras de poca profundidad. Al principio baja, y después de una regular altura escarpada en la orilla con mucha igualdad; en lo interior tiene varios mon. tecillos y picos bastantes notables. El fondo es limpio hasta llegar al paralelo de $47^{\circ} 42^{\prime}$ donde están las islas y arrecifes de San Francisco que salen á la mar I $2 / 3$ millas (2).

En $47^{\circ} 44^{\prime} 37^{\prime \prime}$ de latitud y $59^{\circ} 54^{\prime}$ 10" de longitud está la punta Norte de puerto Deseadn los arrecifes y piedras que están en su boca algo estrecha, exigen que para entrar en él atienda con cuidado al estado de la marea y viento. Se deberá tomar por marca una piedra, de lejos se mejante á una pequeña torre (3), que se haila en la parte del Sur, y gobernando á ella se descu. brirá la boca del puerto.

La reventazón de la punta del Sur se ve regularmente de cuatro á cinco millas; viniendo con viento Sur se procurará pasar á un cable de ella para franquearse de las piedras del medio, y conocerá lo ha conseguido cuando le demore la barranca de la punta de la isleta al Nordeste corregido. Y si por casualidad se vicre empeñado con dichas piedras (que por ln común revientan 6 velan) podrá pasar por la parte del Norte, pues muy próximo á ellas hay cinco brazas chinos, y si quiere fondear, podrá hacerlo pasando la punta del Arenal que está en la costa del Norte dando resguardo á la piedra que se descubre en bajamar, por lo que no será bueno rebasarse mucho de la expresada punta.

Se advierte, que si se recalase alli cuando la

(I) Adviértase que el Comodoro Biron llamaba Cabo Blanco, con Anson, el que ahora es Cabo de Tres Puntas.

(a) Primer viaje de D. Antonio de Córdova. Viaje de la fragata Astrea, año de 1787

(3) Eil examen local de las piedras que forman esta marca excelente, nos hacen tener que no permanezca mucho tierıpo. 
marea tenga mucha fuerza, convendrá fondear afuera, donde se hallará buen fondo, y esperar que el agua esté casi parada, porque de lo contrario se expone á que le abata alguna revesa de corriente sobre una ú otra restinga por su mucha rapidez.

Dentro del puerto podrá fondearse al Nordeste de punta Rasa, ó entre la Islas Paganos y $\mathrm{Ba}$ rrancas para librarse de la mayor fuerza de la marea, que en los parajes estrechos llega á seis millas.

Los auxilios de agua y leña que proporciona este puerto, son muy poco ventajoses, pues aunque hay varios manantiales, son escasos 6 distantes de las orillas y todos salobres; sólo en el que está en el paraje donde estuvo el establecimiento, se puede hacer la aguada con alguna comodidad. No hay otra leña, que espinillos, que se hallan con abundancia al Oeste de la Isla de Guanajos. La abundancia de guanacos, aves, liebres de exorbitante tamaño y buen gusto $y$ de peces, en particular de una clase que curados se asemejan mucho al bacalao, hace útil este puerto al que venga necesitado de víveres 0 necesite remediar prontamente una avería.

En este puerto merecen especial atención las embarcaciones menores, no sólo en las ocasiones en que se destaquen de á bordo, si también cuan. do regresen á él ó estén amarradas.

Para los viajes de la aguada (suponiendo sea la interior que se ha indicado cerca de la población) es menester calcular únicamente con las mareas sin atender al viento, excepto en el poco tiempo en que aquéllas ó están paradas ó llevan poca fuerza.

Además, si la dirección de la marea fuese contraria á la del viento, y éste algo fuerte, se arman en muchas puntas remolinos y revesas sumamente temibles para una embarcación sobrecargada, con cuyo motivo las lanchas deben navegar siempre muy marineras.

No es fácil acertar por primera vez con el sitio de la aguada si no se compara prolijamente con el plano la navegación que se haga con el au. xilio de la niarea. Cuando con la fuerza de la marea fuese preciso dirigirse á una ú otra costa del fondeadero, sea al remo 0 á la vela, se procurará atravesar la canal, de la fuerza de la dirección de la marea con la mayor rapidez posible, sea el que fuere el paraje adonde se lleve la proa. Será luégo fácil en la inmediación de las orillas re. sarcir al remo lo que se haya perdido al tiempo de atravesar.

Al atracar á bordo, son también precisas muchas precauciones en la embarcación menor. Por lo común solían las nuestras ponerse inuy á barlovento de la proa, y luégo dejarse caer con la marea á una distancia regular, para que le alcanzase el cabo sin tocar en el costado.
Es preciso en esta ocasión, que esté suelto en la popa, y pronto $a$ echarse un cuerpo flotante firme en dos 6 tres guindalezas, cuyo peso pueda resistir auxiliándole en caso de duda para este fin con algunos otros cuerpos intermedios.

En el caso que la embarcación menor se viese arrastrada á la popa del buque antea de alcanzarle, se echará al agua la boya indicada, la cual, corriendo con la misma velocidad que la marea, podrá desde luego ser cogida por la embarcación, la cual, 6 con los remos 6 con las ve. las, resista algún tanto á dicha fuerza.

El modo de amarrarse en este puerto, es en la misma dirección de la marea con el ayuste al Este y el cable sencillo al Oeste; no parece prudente usar de boya, porque 6 se anegarán, 6 contribuirán á levar el ancla. Se deja ver también que para tender las anclas es menester.consul. tar absolutamente la marea, que es sumamente. dañoso al cable el no tener el timón á la vía, y que, áun fondeados, se puede evitar un abordaje con el solo timón.

La importante caza de los guanacos debe buscarse en las inmediaciones de las dos agua. das que están en la costa del Sur, en cuyo caso será oportuno que el cazador esté dentro 6 en la Isla de los Guanacos, cortándoles el paso con la tierra firme al tiempo de estar alta la marea: siempre será bueno preferir el tirarles con bala.

La pesca debe emprenderse con preferencia en la Isla Pingües, pasada la de Paganos: es menester tender la red á la marea vaciante, y recogerla al instante, pudiendo así repetirse esta operación muchas veces en una misma marea, y recogerse en poco tiempo cuanto pescado se quie. ra, que es de la especie del bacalao.

Desde la punta de Guanacos hasta Cabo de los Reyes corre la costa al Sur $28^{\circ}$ Este, formando muchas ensenadillas, y una grande desde las Barrancas Blancas hasta la Isla de Megillones. $\mathrm{Y}$ tanto las que siguen próximamente á la punta dicha como las que anteceden al Cabo de los Reyes, tienen muchas piedras y arrecifes que se les anteponen.

En latitud de $47^{\circ} 35^{\prime} \times 5^{\prime \prime}$ y en longitud de $59^{\circ} 44^{\prime} 40^{\prime \prime}$ se halla la Isla de Reyes, de mediana altura. Tiene á la banda del Oeste una pequeña herradura donde puede una embarcación quedar fondeada al abrigo. El interinedio entre esta isla y la costa está sembrado de isletillas y piedras, quedando sólo un estrecho canal entre las Islas de los Leones Marinos y la costa firme con dos brazas de profundidad.

Entre Cabo de los Reyes y punta Lobeira hay una ensenada de legua y cuarto de abertura, internendo casi el mismo espacio (r).

(I) Es donde estaban los mariueros ingleses recogidos por el Capitán de navio Cordova y los cafiones gidos por el Capitán de nav
hallados por el Piloto Peña. 
Desde punta Lobeira hasta el puerto de San Julisn, aigue la costa la dirección del Sur $10^{\circ}$ Oeste proximamente; es bastante alta y montuo. sa. En la latitud de $48^{\circ} 3^{\prime}{ }^{\prime} 00^{\prime \prime}$ y longitud de $49^{\circ}$ $53^{\prime} 30^{\prime \prime}$, á cinco leguas de la costa, está un arrecifo llamado el bajo Bellaco, que tiene de exten. sion Este-Oeste un cable, y sólo revienta en bajamar (I).

Al Sur del cabo de los Reyes hay dos cerros, de los cuales el mayor y más Norte es muy semejante al de Montevideo. El otro más pequeño, redondo y avanzado á la mar. Son muy conocidos porque cuando demoran al cuarto cuadrante (que es cuando se necesitan), no hay con que equivocarlos.

Estos son una excelente marca para conocer el bajo dicho, pues demorando el primero al ángulo de $28^{\circ}$ en el cuarto cuadrante y el segundo al de $34^{\circ}$, se estaría sobre él. Distante de éste como un tiro de cañón y casi Norte-Sur, se descubren tres piedras á los dos tercios de marea, formando un pequeño triángulo isósceles, con cuyo motivo la corriente hace unos grandes remolinos que arrastran las embarcaciones hacia ellas; $y$ al Sueste, á distancia de un tiro de mosquete, hay 25 brazas fondo piedra. Noroeste-Sueste con estas y en latitud de $48^{\circ}+3^{\prime}$ distante de la costa como ocho leguas, hay otra piedra que en plea. mar está escavando aunque el tiempo se halle sereno; y como la marea tiene en estos parajes cuatro y media brazas de diferencia del flujo al reflujo, éstas son las que quedan descubiertas en la bajamar.

El flujo máximo sigue en estos bajos la misma hora que en el Cabo de los Reyes, que son las once de la mañana: en la travesía de las piedras de afuera á las otras, es todo fondo igual de 25 brazas y 30 , todo piedras y chinos. De la de afuera sale otro placer de la misma calidad para el Sur á distancia de más de una legua.

Desde punta de los Desvelos á Cabo Mirabien, corre la costa al Sur $48^{\circ}$ Oeste, y desde éste á Cabo Curioso, va formando ensenada, quedando éste en el mismo arrumbamiento: toda la tierra es bastante alta y montuosa; por el paralelo de $48^{\circ} 25^{\prime}$, á 24 leguas de la costa hay 72 brazas arena y fango (2); por $49^{\circ} 3^{\prime}$ á cinco leguas dos tercios de la costa más inmediata, 32 arena fan. go y piedras. Por $49^{\circ}$, I I á I 2 leguas 40 arena, fango y piedra.

Para buscar este puerto, situado en latitud de $49^{\circ} \mathrm{IO}^{\prime}$ y longitud de $6 \mathrm{I}^{\circ} 42^{\prime} 3 \mathrm{O}^{\prime \prime}$, se gobernará á un cerro llamado San Ildefonso, parecido il Pan de Azúcar del Río de la Plata, y deján.

(1) Sacadas de las noticias o. iginales del piloto Pcha, que acaba de reconocerle.

(a) Primer viaje de D. Antonio de Cordova: viajo de la fragara Astrea, año de r 787 . dolo algo al Norte se avistara la entrada del puerto.

Si fuese la hora de la pleamar, estando en diez brazas de agua, arena y chinitos y de una á dos millac de la punta del Desengaño, verá la reventazón de la restinga, que pasando á dis. tancia de ella como dos cables, irá en busca de la punta de Peña para ir zafo de los islotes que descubren en bajamar, y rebasada, todo el puerto es abrigado para dar fondo.

Siendo la recalada en bajamar estando en tres 6 cuatro brazas de agua chinos con greda debajo, y como dos y medio cables á la piedra más afue. ra de la punta del Desengaño, dará fondo hasta que haya agua en la barra, siendo conveniente se leve á media marea para pasar el banco que está más adentro y queda descubierto en baja. mar antes que salga el agua, pues la velocidad de la corriente que es de cinco á seis millas, no le dejaria adelantar. El flujo máximo es en el día de la conjunción á las once de la mañana, subiendo el agua veintiocho piés.

Al Noroeste de la punta de la Base á dos y media leguas, hay manantiales de muy buen agua, y al mismo rumbo, tres cables de distancia, hay una cañada, y cavando en su suelo se encuentra agua dulce.

Hacia el fondo del puerto todas son barrancas de yeso superior, y siguiendo un arroyito que está inmediato, al fondo se encuentra una salina (I), sólo se encuentran algunos espinos, pues todo el terreno es estéril y salitroso; recompen. sando la naturaleza en sal lo que rehusa de vegetales; hay mucha de espuma y de piedra en una laguna de tres leguas de largo.

Desde la punta de la boca de San Julián hasta la de San Francisco de Paula, corre la costa al Sur $3^{\circ}$ Oeste, y desde éste á la punta de Santa Cruz al Sur $24^{\circ}$ Oeste próximamente: la tierra no es al ta ni abarrancada y el fondo limpio, pues arrimado á tierra hay 30 y 40 brazas de agua.

Para conocer la entrada del rio de Santa Cruz situado en $50^{\circ} \mathrm{I} 7^{\prime} 30^{\prime \prime}$ de latitud y $62^{\circ} 21^{\prime} 30^{\prime \prime}$ de longitud, se tendrá por marca el cerro de Santa Inés, único entre este río y el puerto de San Julián, y debe darse resguardo á un bajo de pie. dra que está en la punta Norte de la boca del río: su terreno es peñascoso y su fondeadero bueno $\mathbf{6} 610$ para embarcaciones menores.

La punta Sur de Santa Cruz con la punta de Sánche $z$ corren en dirección del Sur $12^{\circ}$ Oeste formando una grande ensenada, en cuyo fondo están Cabo Redondo y una herradura á que llaman bahía de Coy: en la misma dirección á cinco leguas de distancia está el Cabo de Barre-

(1) Estas noticias son a la letra del Pilıto Tafor, excepto las de la aguada que sun del Piloto Berlinguero. 




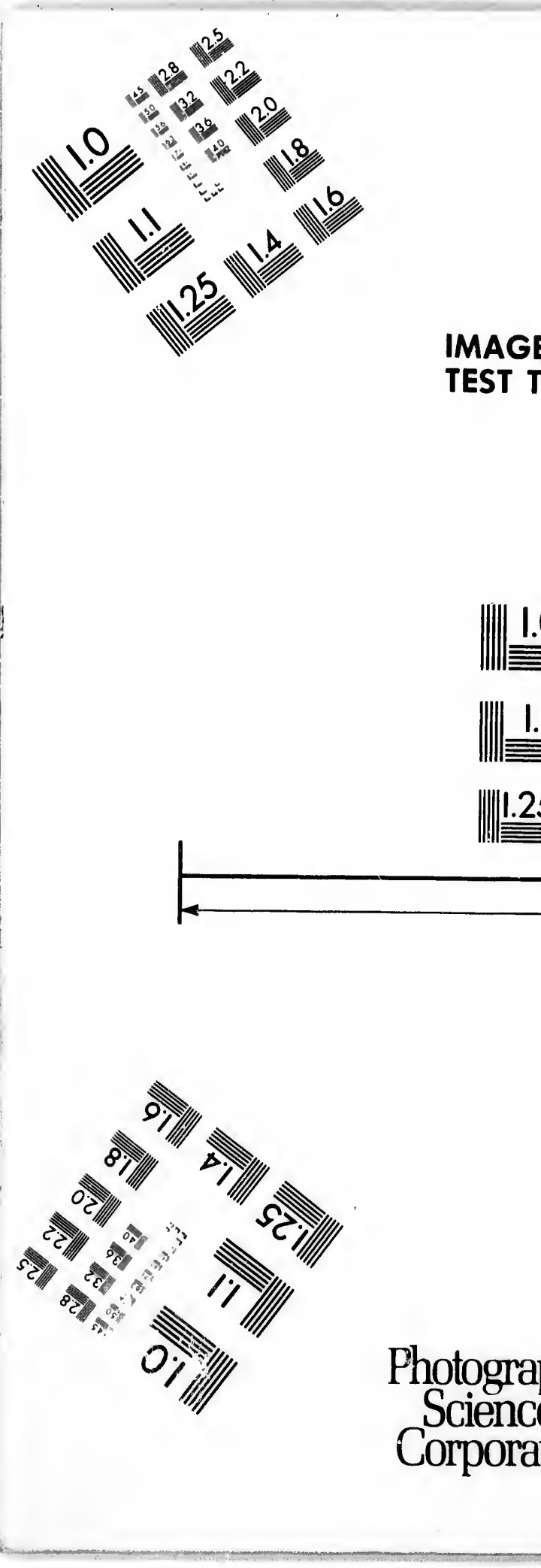


IMAGE EVALUATION

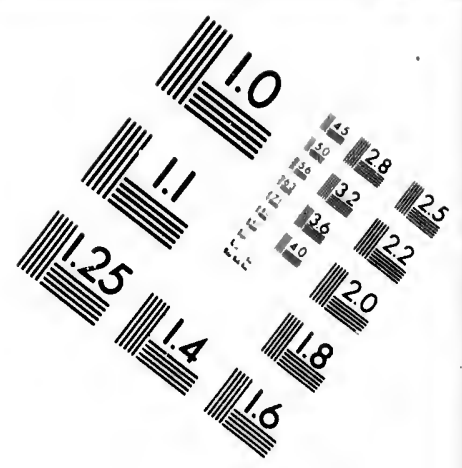

TEST TARGET (MT-3)

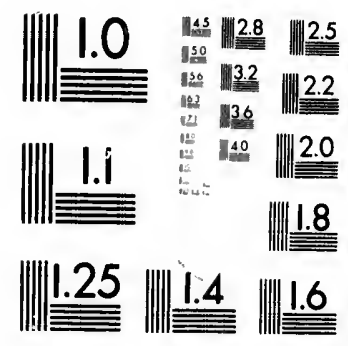

$6^{\prime \prime}$

Photographic Sciences Corporation
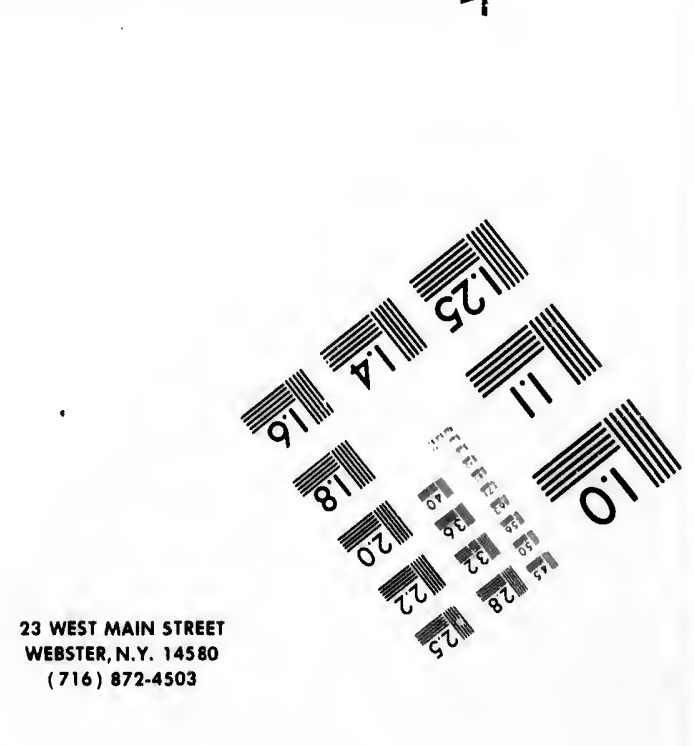


\section{CIHM/ICMH Microfiche Series.}
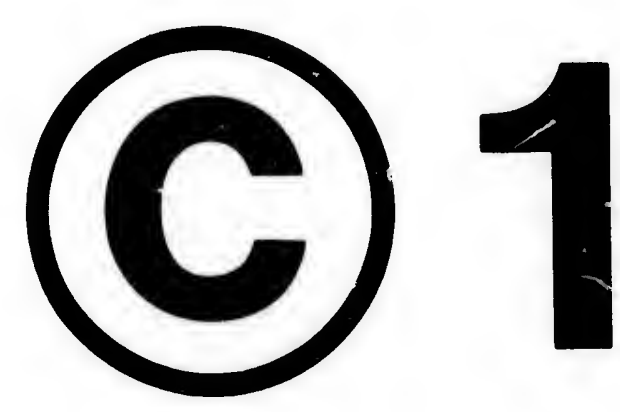

microfiches.
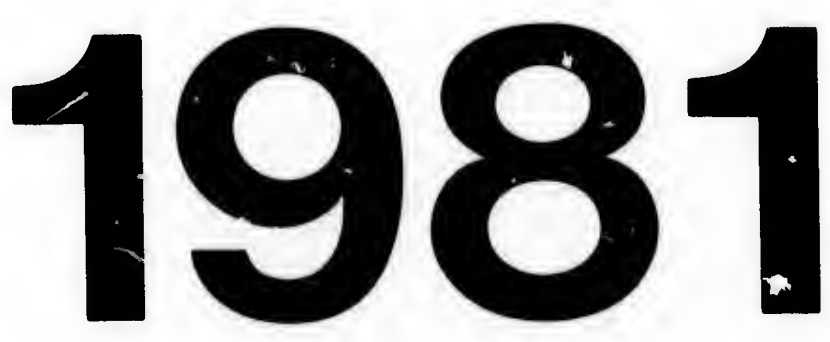
ras blancas, y entre éste y la punta Sánchez hay una pequeña ensenada toda sembrada de piedras.

El Cabo de Barreras Blancas $(6$ de Buen Tiempo) situado en $5^{1^{\circ}} 3^{\prime}$ de latitud y $62^{\circ} 5^{\prime}$ 25 " de longitud, forma un frontón de mediana altura, abarrancadoy con manchones blancos que á la caída al mar remata por la parte del Norte en una punta rasa y en la del Sur en una costa baja y pareja que sigue hasta el Cabo de las Virgenes.

Como al Sur $\%$, Sueste del Cabo de las Barreras Blancas, sale un bajo que parece es en el que dió el Capitán Walis. Como al Oesudoeste de dicho cab ise ven en la otra costa siete mo. gotes de mediana altura é igıales á que llaman los Frailes.

Desde el Cabo de Barreras Blancas va hurtando la costa para el Oeste y con el de Gracias á Dios, forman la embocadura del río Gallegos: ésta tendrá como nueve millas de ancho, después el río va estrechando hasta la punta del Carmen, donde queda en una milla y sigue de este ancho por mucha distancia: al Oeste de esta punta está la islita Deseada.

En el reconocimiento que hizo D. Andrés Peña de este río, halló que el agua estaba solo salobre á la entrada de él y habiendo crecido algo la marea, por lo que debemos creer que en lo interior $y$ al fin de la vaciante será enteramente dulce.

Vió grande abundancia de guanacos, admirándose pudiesen subsistir en un terreno estéril todo cubierto de chinos, $y$ donde solo halló un matorral de leña y algunas manchas de pasto muy malo.

Desde el río Gallegos al Cabc de las Vírgenes, corre la costa al Sur $27^{\circ}$ liste, hasta la mitad de la distancia es de tierra baja y la otra mitad algo alta y rasa, por arriba toda árida y de mal aspecto. El fondo es limpio y se puede ir costeando la tierra por $\mathrm{r}_{2}$ y $\mathrm{I}_{5}$ brazas.

El Cabo de las Vírgenes, situado en $52^{\circ} 19^{\prime} 40^{\prime \prime}$ y $62^{\circ} I 9^{\prime}$ longitud, es tajado al mar á poca é igual altura por alguna distancia que parece un trozo de muralla.

Al Sur $5^{\circ}$ Oeste del Cabo de las Vírgenes, está el del Espiritu Santo corriendo la costa casi en esta dirección luasta el Cabo Reina, desde donde va formando una grande ensenada, laboreado con otras muchas pequeñas, y sa. liendo para el Este.

En su interior, y por latitud de $53^{\circ} 28^{\prime}$ está la boca del canal de San Sebastián, como de dos leguas de ancho; este terreno es bajo hasta los $53^{\circ} 40^{\prime}$ que empieza á elevarse.

Desde la punta Adriancel hasta los Tres HerInanos, corre la cesta al Sur $58^{\circ}$ Este, entre aquella y el Cabo de Santa Inés hay una pequeña ensenada y en su fondo se ve la embocadura de un canal bastante estrecho. Este cabo es alto y la costa que sigue va elevándose algo más; en 10 interior se ven cerros de varias figu as, entre los cuales se distinguen tres mogotes casi de una altura, muy próximos y que tienen á su espalda una montaña en figura de pan de azúcar; estas sirven para el reconocimiento de la embocadura del Estrecho de Maire, del que sólo distan cinco leguas. Esta la forman, el Cabo San Diego, de tierra rnuy baja, en la del Fuego, y el Cabo del Medio en la Isla de los Estados.

Es clara la utilidad de pasar por este estre. cho, y solo debe atenderse á las circunstancias, en algunas ocasiones pueden ser muy desfavo. rables y causar una incomodidad del buque. Cuando sube el agua (que entonces viene del Sur) y los vientos soplan del Norte al Nordeste se forma un escarceo muy vivo, como si hubiese barra, y además de ser detenidas en estas ocasiones las embarcaciones por la contrariedad de las corrientes, les causa los más violentos movimientos (I)

Cerca de la Isla de los Estados (é Islas de Año Nuevo) las aguas corren mucho, y por el Cabo de San Juan aumentan su velocidad, siguiendo como un torrente la dirección del Noroeste; pero no se elevan sino cuatro pies ingleses.

Dice el Capitán Cook que en este estrecho la marea y la corriente del Sur se hace en la creciente, ó en la menguante empieza á obrar precisamente á las cuatro del día del novilunio: toda es muy hondabie, pues casi tocando á las piedras en la Tierra del Fuego hay 20 y 30 brazas de agua.

La costa Sueste de la Tierra de Fuego, alta, pedregosa y quebrada, proporciona un gran número de fondeaderos; pero la mayor parte no es. tán conocidos y exigen un gran cuidado en sus cercanías por las muchas piedras ahogadas que se les anteponen y que dichosamente están muy próximas á tierra, y puede conocerse su cercanía por la sonda cuando la oscuridad del tiempu no permita su vista.

La bahía Mauricio es muy poco útil por su desabrigo; pero la del Buen Suceso, situada en la medianía del estrecho, proporciona una buena arribada para cualquier buque: se encuentran habitantes; por consiguiente, agua dulce, mucha fertilidad en la tierra y no poco pescado. Su boca tendrá una milla $y$ tres cuartos de ancho $y$ dos millas de r rofundidad. Puede fondearse en siete ú ocho bri zas de fondo fango á distancia de media milla de la costa del Sudoeste.

(I) Con algün más despacio podrá construirse una tabla que determine las horas oportunas para en trar y salir del Estrecho de Maire según los dfas do la Luna. 
es alto y la más; en 10 is, entre los casi de una á su espalda zúcar; estas embocadura distan cinco n Diego, de el Cabo del

este estre. cunstancias, huy desfavo. del buque. es viene del al Nordeste ho si hubiese en estas oca. ntrariedad de iolentos mo-

\section{s (é Islas de}

ho, y por el elocidad, siión del Noratro piés in-

te estrecho la ce en la cre á obrar preovilunio: toda o á las piedras 30 brazas de

Fuego, alta, $\downarrow$ un gran nú. $r$ parte no es idado en sus ahogadas que te están muy :e su cercanía el tiempu no

o útil por su o, situada en na una buena ncuentran ha dulce, mucha cado. Su boca ancho $\mathrm{y}$ dos earse en siete ancia de me-
Tambien en la bahía de Valentín, al Sudoeste $\%$ Oeste de aquélla, se encuentra agua y arboleda (I). La Isla de los Estados es muy alta, su aminencia quebrada y llena de picos, cuyas sombras le dan un color arenisco. Cuatro leguas al Oeste del Cabo San Juan en la costa septentrional, está el puerto de Año Nuevo; es abrigado y muy hondable.

Puede también fondearse entre las islas, en las que se hallará agua, yerbas antiescorbúticas, muchas aves y leones marinos: de la bahía del Buen Suceso, para el Oeste la Tierra del Fuego elevándosenos, y va tomando un semblante más desagradable y la intemperie va siencio más incómoda.

Al Sur $40^{\circ}$ Oeste de la punta Norte de la bahía de Valentín, y á 63 millas próximamente, está el Cabo de Engaño. En este mismo rumbo están las Islas Bernabelas, Io millas al través las Evouts y $\mathbf{I}_{5}$ las Nuevas, todas á la parte del Oeste.

El Cabo Engaño es la punta Sur de las Islas de la Ermita, toda quebrada y rodeada de peñascos: á tres leguas de ésta está el Cabo de Hornos en latitud de $55^{\circ} 5^{8^{\prime}}$ y longitud de $6 \mathrm{r}^{\circ} \mathrm{I}^{\prime} 4 \mathrm{o}^{\prime \prime}$ : entre estos dos cabos parece haber un paso que conduce directamente á la bahía Nassau, se vèn en éste una porción de islas pequeñas, y la costa parece formar á la parte del Oeste bahías buenas y abras. El Cabo de Horncs forma el extremo meridional de un grupo de islas de varias magnitudes que están delante de la bahía de Nassau y que se conocen con el nombre de Ermita. El cabo se conoce de léjos por una colina elevada y re. donda que tiene.

Entre la punta Oeste de la Isla Ermita y el falso Cabo de Hornos, está la cntrada para la bahía Nassau. Por latitud de $55^{\circ} 55^{\prime}$ I $5^{\prime \prime}$ y como á seis leguas de la costa, está un grupo de islas, llamadas de San Ildefonso, cerca de algunos peñascos ahogados.

Como al Oeste $1 /$ Noroeste del falso Cabo de Hornos, I I leguas de distancia, hay un canal de siete leguas próximamente que corre al Esnordeste: fuera de esta dirección liay algunas islas, y en la punta Oeste de la embocadura hay dos colinas elevadas en forma de pico, $y$ al Este dos colinas redondas 6 islas situadas Nordeste-Sud . oeste.

Del falso Cabo de Hornos hasta el Cabo de la Desolación, corre la costa próximamente al Oesnoroeste. Las altas, peñascosas y estériles montañas que presenta, cubiertas en parte de nieve que no se derrite ni con el calor de los rayos del Sol en el verano, ponen horror á los más atre ,vidos marineros y movieron al intrépido Cook

(x) Fondeó en ella el chambequín Andalus. Véan. so las noticias del Piloto Berlinguero. nombrar Cabo de la Desolación, á aquél que daba principio á esta portentosa multitud de peñascos que parece desafían la bravura del Oceano, que con su violentísimo batidero ha desirozado sus orillas, y entre éstas innumerables quebradas se halla la de la Natividad en $55^{\circ} 2 \mathrm{I}^{\prime} 30^{\prime \prime}$ de latitud.

El canal de este nombre lo forman la tierra á que llamb tierra de Natividad Cook y una porción de islas: éste ofrece muchos y buenos surgideros; entre las marcas que dió el Capitán Cook para tomar el uro de ellos, son las siguientes: viniendo de la mar, déjense á babor todas las islas y peñas con que están de través, y más adentro el York Minster (cuyo nombre se da á un promontorio que hay en una de las islas que forman el canal) y a estribor el peñasco Negro que está delante de la extremidad Sur de la Isla Shagg, y estando delante de la extremidad Sur de esta isla, tírese al lado del Oeste, evitando las capas de sargazo, porque crecen siempre sobre los peñascos.

En estas abras se encuentra agua y leña, pues en los parajes en que las aguas de las lluvias y nieves derretidas han traído escombros, se han formado capas de grama; ésta en ciertos parajes sirve de alimento á los arbustos.

Como á I I leguas del canal de Maridad está la Isla de Gilbert, de igual elevación que la costa, y presenta una superficie compuesta de muchos peñascos puntiagudos de alturas desiguales: algo al Sur de esta Isla hay otras pequeñas, y fuera de éstas, rompientes.

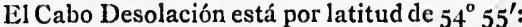
cerca de cuatro leguas de este cabo, hay un canal profundo en cuya entrada hay una isla bastante grande y otras pequeñas. Al Noroeste de] Cabo Desolación, está la grande bahía de Santa Bárbara, de la que dice Cook que al pasar como unas siete leguas, apenas se veía tierra de su fondo, y que en el espacio que corre al Esnordeste de Cabo Negro, no se descubrió tierra, creyendo podría estar allí el canal de Santa Bárbara (I).

Cabo Negro, situado en $54^{\circ} 30^{\prime}$ de latitud y $67^{\circ} 00^{\prime}$ de longitud, es una roca escarpada de una altura considerable y punta Sudoeste de una grande isla, que parece separada una legua ó legua y media de la tierra firme.

Como al Norte $10^{\circ}$ Oeste del Cabo Negro á 28 millas de distancia está el Cabo Glocester: e.j una punta avanzada, que presenta una superficie redonda de una altura considerable y parece isla.

Al Nornoroeste $5^{\circ}$ Oeste, á $\mathbf{r} 7$ leguas de éste, está la Isla de Landfall. La costa comprendida

(1) Aunque se han adoptado las frases del Capitán inglés, son compatibles con la configuración de la costa en su carta. 
entre estos dos puntos, forma dos bahías sembradas de islotes y rompientes. La costa parece muy quebrada y con varios canalizos, 6 compuesta de un gran número de islas.

Cabo Deseado está por $52^{\circ} 49^{\prime} 20^{\prime \prime}$ de latitud; es alto, y se ven sobre él montañas puntiagudas con sus cimas cubiertas de nieve.

Como al Nordeste del Cabo Deseado, y á dos leguas de distancia, está el Cabo Pilares, por latitud de $52^{\circ} 44^{\prime} 23^{\prime \prime}$ y longitud de $68^{\circ} 56^{\prime}$.

A la costa comprendida entre estos cabos, se anteponen por más de una legua muchos islotes 6 rompientes conocidos con el nombre de los Doce Apóstoles.

El Cabo Pilares es un conjunto de peñascos que se terminan en dos rocas cortadas $n$ forma de torres inclinadas hacia el Noroeste $y$ forman la punta del cabo.

De seis á siete leguas al Noroeste de este cabo se ven cuatro islotes llamados los Evangelistas, tres raros $y$ el otro de figura de un haz de heno y bastante separado (I).

Al Nornordeste, y á cuatro ó cinco leguas próximamente de los Evangelistas, está el Cabo Victoria por latitud de $52^{\circ} 22^{\prime} 3^{6^{\prime \prime}}$ y longitud de $69^{\circ} \mathrm{oo}^{\prime} 30^{\prime \prime}$.

Al Norte de éste ro y $1 / 2$ leguas, está el de Santa Isabel: no puede darse descripción de la costa intermedia por no estar reconocida.

Al Noroeste $1 /$ Norte del Cabo Santa Isabel, está una punta que dista como ro millas al Sueste \% Sur del Cabo de Santa Lucía. Dicha punta y el Cabo de Santa Isabel forman la boca de uno de los canales que forman los destrozos de la tierra firme en esta parte.

El Cabo de Santa Lucía se conoce por su tigura amogotada, y al Nordeste $1 /$ Norte de él, distancia de cinco leguas, está la Roca Partida, en que Sarmiento observó $5 \mathrm{I}^{\circ} \mathrm{ro}^{\prime}$.

Al Oesudoeste de ésta, dos leguas á la mar, hay dos faralloncs, $y$ desde ellos sale una anda. na de otros muy pequeños y bajos.

Al Nornordeste próximamente de la Roca Partida, dos leguas, está la Isla de San Francisco, y Esste-Oeste con ella el Cabo de Santiago, formando estos dos puntos la boca del brazo de la Concepción, que corre al Nordeste $5^{\circ}$ Este

Recorriendo los diferentes canales que forman el gran número de islas situadas entre Cabo de Santa Isabel y Cabo Primero, se encontrarían una infinidad de ensenadillas, caletas y puertecillos, que podrían servir de abrigo á embarcaciones menores en caso de necesidad. Pero la estrechez de estos canales, las muchas y encontradas corrientes que giran ordinariamente en las direcciones de aquella, y la multitud dé islotillos y bajos de que están sembradas, hacen casi impo-

(I) Noticias do Mr. Bougainville. sible el tránsito de embarcaciones de mucho porte.

De los mejores surgideros que proporciona este archipielago, son el puerto Bueno, situado en la ticrra firme, de mucha extensión y con siete, ochn $\mathrm{v}$ nueve brazas, limpio, arena y lama.

El puerto del Ochavario, á cinco leguas al Sueste de la Isla de los Inocentes, es una caleta abrigada $y$ tiene fondo de 20 brazas arena.

La ensenada de Guadalupe es también abrigada.

Una legua al Sudoeste de la punta del Hocicn del Caimán, hay un buen surgidero en 12 brazas arena.

E1 puerto Bermejo (llamado así por tener una playa de este color), al Nordeste $1 /$ Norte ocho y media leguas del Cabo de Santiago, es seguro de todos vientos y de buen fondo, en s:ete, ocho 6 nueve brazas; pero sólamente pueden entrar hasta embarcaciones de mediano porte, porque sale mucho un placer de la isleta que está en su boca.

También en la Isla de la Roca Partida, hay por la banda del Este un puertecito en que se halla agua dulce.

Desde Cabo de Santiago hasta una punta de poca altura situada en $50^{\circ} 57^{\prime} 30^{\prime \prime}$ y $69^{\circ} 38^{\prime}$, no está reconocido.

Desde esta punta corre la costa al Norte $7^{\circ}$ Oeste hasta Cabo de Tres Puntas, y se representa como una cordillera de cerros de piedra, medianamente altos, tajados casi á pico, con muchas quebradas y trozos de terreno bajo, notándose un abra grande por los $50^{\circ}$.

Cabo de Tres Puntas, situado en latitud de $49^{\circ} 46^{\prime}$ y longitud de $69^{\circ} 47^{\prime} 30^{\prime \prime}$, lo forma un monte con tres puntas, vulado y bajo hacia la orilla, y se reparan en él manchas blancas, par. das y negras; en la orilla hay bajos con mucha reventazón. Como al Norte $5^{\circ}$ Este seis leguas de Cabo de Tres Puntas, está Cabo Corso, ó Primero; es un morro alto y gordo, con caída hacia el Norte y parece isla, demorando al Nordeste. Tiene muchos islotes separados y muchos bajos. Estos dos cabos forman la boca del golfo de la Trinidad.

Este Cabo Corso parece formar con otra punta al Norte algunos grados al Oeste siete millas de distancia la Boca de la Campana, según la relación del Diario del Piloto Machado. Reconoció este el canal que hay entre la tierra firme y la Isla de la Campana donde esperaba hallar el puerto de Nuestra Señora, que dice Cedillo; pero no vi8 otra cosa que dicho canal Nornordes. te Sursudoeste, de seis á siete leguas, tan hondable que no es posible dar fondo sino muy cerca de las elevadas montañas que le cercan, y sobre piedra, y se divide después en otros angostos canales llenos de pedrones. 
Se infiere por su relación, que no hubieron hallado en todo el espacio desde la isla de la Campana hasta el extremo Sur de Chiloé, puerto que merezca mayor atención que la bahía de Quintín. Dice que tiene de ancho poco más de una legua y dos de fondo, que tira al Sudoeste; tiene I 4 brazas en la boca y siete en lo interior, con una playita en la parte del Norte.

La isla de San Javier tiene por la banda del Este una gian playa de 12 á I 5 brazas de fondo arena, está abrigada de los vientos desde el Nor- noroeste al Sursudoeste, aunque con Norte hay marejada.

También cerca de la bahía de Santa Bárbara hay una ensenada que tendrá de ancho como una milla y de largo dos 6 tres y corre Norte-Sur.

En el viaje del Lord Anson se celebra muchn el puerto del Pinglle Ana.

$Y$ en las Guaitecas parece haber también al. gunos medianos fondeaderos; pero este archipiélago, así como el de Clionos está muy poco conocido. ta del Hocico en 12 brazas así por tener este $/$. Norte Santiago, es fondo, en siemente pueden ediano porte, sleta que está

Partida, hay ito en que se una punta de y $69^{\circ} 3^{8}$, no

ta al Norte $7^{\circ}$ se representa dra, mediana, con muchas , notándose un en latitud de lo forma un bajo hacia la blancas, par.

os con mucha te seis leguas o Corso, 6 Prion caída hacia , al Nordeste. muchos bajos. el golfo de la nar con otra )este siete mimpana, según achado. Recotierra firme $y$ raba hallar el Cedillo; pero Nornordes. as, $\tan$ honda. 10 muy cerca ercan, y sobre tros angostos 


\section{Construccion de las cartas desde el puerto de Montevideo hasta el de Chiloé.}

Hasta los $37^{\circ} 30^{\prime}$ la costa está trazada por nu sstras tareas verificadas en la parte meridional del Río de la Plata por los Tenientes de navío y fragata Conche y Vernaci. El primer meridiano de estas cartas es el del observatorio nuestro de Montevideo, al cual se ha supuesto la longitud occidental de Cádiz de $50^{\circ} 5^{\prime} 45^{\prime \prime}$. Cualquiera diferencia que resultase en esta longitud, calculadas las ocultaciones de estrellas por la Luna, que allí se observaron, ó bien comparada á algún observatorio de Europa, nuestra observación del primer satélite de Júpiter que da margen a aquella determinación, es una cantidad absoluta que no influye en la carta siguiente.

No está reconocido en nuestra navegación el trozo de costa comprendido entre la latitud indicada de $37^{\circ}$ y $1 / 2$, y la embocadura del río Negro; pero la derrota de los Padres Cardiel, Estol y Quiroga (I) y las navegaciones y derrotas de los Pilotos D. Bernardo Tafor y D. Alejo Berlinguero, no dejan la menor desconfianza. Las embocaduras del río Colorado y del río Negro y los bajos que salen á la mar en sus paralelos, están igualmente reconocidos por los Pilotos Tafor, Villarino y Peña: éste último ha intervenido en su colocación en la carta actual.

Nuestras observaciones y bases corridas des de la embocadura del río Negro hasta la punta Belén, sujetan ya con evidencia en latitud y longitud la parte comprendida de costa: pende la determinación de latitud de la observación de la altura meridiana del Sol, conforme en las dos corbetas, dos horas antes de avistar la tierra próximamente en el mismo paralelo en que se observó.

La parte interior del golfo de San José está terminada por las sierras altas que hemos avis-

(1) Esta derrota que tuvo lugar en el año de 1746 y se emprendió desde la bahía de San Julián, por mar, á las órdenes del Capftán de navio $D$. Jonquf́n de Olivares, ha sido trazada con mucha prolijidad por el Brigadier de Ejército D. José Custodio de Saa y Tarria, residente en Buenos Aires: existe en mi poder una copia del original, que el mismo Brigadier ha revisado y me ha entregado en aquella capital. D. Alejo Berlinguero presentó a S. M. en $177^{8}$ una descrip ción de la costa Patagónica en la cual consta que reconoció por si mismo la costa desde los méganos do irena hasta el Cabo de San Andrés. tado: su configuración depende de la derrota que hizo el Piloto Villarino en estas orillas, reconocidos los puertos de San José y de San Antonio. El plano de aquel puerto, extractado de los del Piloto Tafor, puede tal vez ser capaz de una mayor perfección, y tanto más, si, como parece probable, ha de ser aquel paraje el de mayor concurrencia de nuestros balleneros. En tal caso, las embarcaciones de S. M. que protejan la pesca, pueden fácilmente ocuparse de este objeto.

De cualquier modo esto sea, desde luego toda embarcación podrá sin el menor sobresalto dirigirse al puerto de San José, pues que la reca: lada, así en cuanto á sondas como á la vista de tierra, no puede especificarse con más seguridad; y la entrada del puerto y áun el paraje más oportuno para fondear, están claramente explicadas.

En el puerto de San Antonio, faltándonos el Diario de Villarino, hemos comprendido los bajos que con presencia de aquel Diario ha puesto el Brigadier Saá y Tarria. No salimos garantes ni de su existencia, ni de su exacta posición, si existiesen.

Rechazamos, sin el menor recelo, un bajo puesto en algunas cartas al Nordeste del extrcmo Norte de la península de San José: hemos navegado algo distantes una de otra las dos corbetas en el mismo paraje, y ni la mar ni la sonda nos han dado la menor sospecha de su existencia.

Ya desde el extremo Norte de la península de San José, toda la costa siguiente está reconocida y trazada por nosotros con la posible exactitud, y á pesar que su igualład, la falta de puntas salientes á la mar y de parajes elevados hiciese difícil no equivocar unos con otros puntos, la continuación de las bases por corredera, la repetición de las de por altura de topes (I) y una estima llevada con una atención constante, nos ponía al abrigo de todo error que tenga el menor influjo en la seguridad de la navegación.

No sólo por lo que hiciesen sospechar los planos de Tafor, si también por lo que nos manifestaba la sonda, admitimos un banco situado en el

(I) Véase la introducción á las operaciones astronómicas sobre los resuliados de nuestras bases deducidas de las alturas de los ıpes. 
frontón de la península, y en el paralelo de $4^{\circ}$ I $7^{\prime}$. En esa misma tarde, una continuación de corrientes y remolinos y la alteración de rumbos dimanada del trastorno de sondas, hacen que las bases de corredera sean irregulares, y dificil á deducirse la prolija determinación de los puntos de la costa.

Siguen nuestros reconocimientos sin omitir punto alguno hasta el extremo Norte del golfo de San Jorge, y confrontadas la entrada del puerto de Santa Clara y el de San Sebastián, la bahía de Camarones y la posición de las Islas Leones, Arce y Engaño, con las posiciones determinadas en el plano de Tafor, adoptamos de la carta de está habil Piloto, también la bahía de San Gregorio $y$ el paso entre la costa firme $y$ las islas in. mediatas.

En la situación de la Isla Rasa, nuevamente avistada, y en el término de sus arrecifes, hemos puesto la mayor atención, sujetándolas á bases y observaciones particulares: pende de iguales datos la colocación del Cabo San Gregorio, del cual, parte luégo la costa reconocida por el $\mathrm{Pi}$. loto Tafor en el canal de San Jorge.

Como quiera que en todas las costas indicadas no hemos carecido diariamente ni de la altura meridiana del Sol, ni de las observaciones de longitud y variación de la aguja, conviniendo entrambas corbetas en un mismo resultado, que paireando en las pocas horas de la noche, no hemos omitido punto alguno de la costa que no estuviese sujeto á dos 6 tres marcaciones, podemos responder de la exactitud de este trozo de costa, y al mismo ti mpo, tributar al Piloto Tafor los elogios debidos, por la mucha aproximación con que le había trazado. Son suyos los planos interiores de! puerto Santa Elenia y San Gregorio: hemos tenido presentes al mismo tiempo, aunque con muy poca utilidad, los planos del Piloto Berlinguero, que navegó á las órdenes del Sr. D. Domingo Perier.

El Cabo Blanco está situado en longitud por dos series de horarios tomados en su meridiano: su latitud (r), que hubiéramos deseado determinar en su paralelo, pende, á la verdad, de bases y puntos fijados á no mucha distancia del medio dia: pero no ocultaremos, que habicndo experimentado en este día errores considerables de estima, y debiendo, por otra parte, depender dicha latitud de estimas parciales, la determinación de la Atrevida difiere en $2^{\prime}$ de la nuestra, y por consecuencia, este es el máximo error que tuviese, si no prefiriésemos próximamente la media entre las dos, $y$ es la que le hemos asignado.

Las bases corridas desde la vista del Cabo

(1) Está equivocada la posición del Cabo Blanco en la carta que se remitió desde puerto Deseado por manos del Piloto Peña, Capitán del bergantín Carmen.
Blanco hasta el puerto Deseado, alargan la costa de $\boldsymbol{7}^{\prime}$ en latitud, sobre la que determinan las la. titudes combinadas del trabajo interior y exte. rior del mismo puerto. Ess tanto más singular esta diferencia, que de ningún modo podemos combinar con el curso de las mareas, cuanto que todas las circunstancias no podían ser á la sazb́n más favorables.

En el Diario se deja ver la grande probabilidad de que el bajo hallado por el Comodoro Biron, esté en las mismas marcaciones y distancia á que lo pone aquel navegante; así lo hemos situado en nuestra carta, en la cual manifestaran la sonda y la derrota, que in Jagamos su existen. cia tan de cerca. cuanto lo permitian las circunstancias.

Están acordes en el minuto las latitudes de las dos corbetas toniadas cuatro 6 cinco leguas al Sur del Cabo Blanco y á su vista. La latitud del puerto Deseado está observacia en el cuarto de círculo, y con estrellas septentriona. les y meridionales. La de la Isla Reyes, resulta de las operaciones geodésicas con que se ha trazado todo el canal interior del puerto Deseado.

Nuestra llegada á este puerto, en el cual se emprende nuevo examen de la marcha de los relojes marinos, sierra sblo una epoca de diezisiete días desde perder de vista el cerro de Montevideo; el número ro de la ATREvidA está confrontado en el meridiano de aquel cerro el día mismo de la salida; y el número 6 I de la Descubierta, conforma con aquél, de tal modo, que la longitud del fondeadero es por éste de $9^{\circ} 5^{2}$ al occidente de Montevideo, y por el número Io de $9^{\circ} 5 \mathrm{I}^{\prime} \mathrm{oO}^{\prime \prime}$ (I).

La marcha de estos dos relojes se halla, no obstante, considerablemente acelerada en las comparaciones del puerto Deseado, y esta diferencia nos inclinaría á hacer una corrección á la longitud última y á las intermedias, si no nos detuviesen, no sólo los resultados siguientes hasta San Carlos de Chiloé que ligan exactamente con la longitud del primer satélite de Júpiter, sino la igualdad diaria de los relojes, incompatible con una variedad tan grande en la cantidad de aceleración, cual se deja ver en sus marchas respectivas. Las distancias lunares observadas en puerto Deseado determinin una longitud menor en $23^{\prime}$ á la asignada por los relojes.

Las longitudes y latitudes desde la Isla Reyes hasta el Cabo las Vírgenes, están deducidas de las tareas de los paquebotes Eulalia y Casilda, tomada la diferencia en longitud entre la punta del Guanaco y el Cabo Vírgenes, que determ:nan aquellos Oficiales, tiene solos cinco minutos menos que la diferencia que resulta por nuestros relojes: esta pequeña cantidad se ha repartido en todo el trozo de costa :on proporción á las di-

(I) Véase el Diario astronómico. 
ferencias de latitud, y una tan grande uniformi. dad como la que se encuentra en esta multipli. cidad de tareas es la prueba más evidente de su seguridad.

Las determinaciones nuestras son las siguientes:

\begin{tabular}{|c|c|c|c|c|}
\hline & cano vi & IRGKNES. & PUNTAC & GUANACO. \\
\hline & Iontitudes. & Longiludes. & Latitudes. & Longitudes. \\
\hline 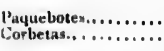 & $\begin{array}{l}52.19 .43 \\
52.39 .43\end{array}$ & $\begin{array}{l}62.19 .56 \\
62.18 .41\end{array}$ & $\begin{array}{l}47 \cdot 47.2 \\
47.46 .12\end{array}$ & $\begin{array}{l}60.3 .20 \\
59.54 .29\end{array}$ \\
\hline
\end{tabular}

El Cabo Virgenes debe también considerarse ya como uno de los puntos ultramarinos á la Europa, cuya exacta colocación en longitud pue da más bien asegurarse, y no desagradará un re. sumen de las tareas emprendidas últimamente, yue servirá al mismo tiempo de demostración en favor del método de las distancias lunares.

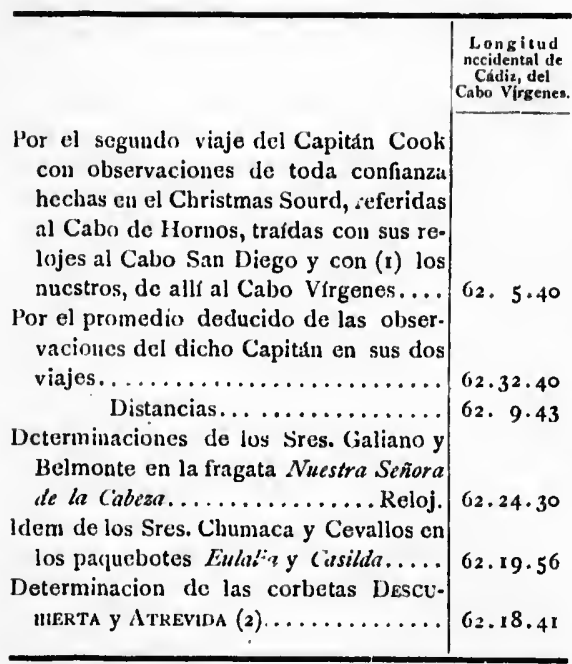

(1) La diferencia de meridianos entre Grcenwich y Cúdiz, se ha supuesto de $6^{\circ} 19^{\prime} 0^{\prime \prime}$ deducida de las diferencias parciales entre Cádiz, Parts y aquel observatorio. Se advierte la de $6^{\circ} \mathrm{r}^{\prime} 5^{\prime \prime}$ en el Requisite tables que no conviene con la anterior: siempre que comparemos nuestras longitudes á las del Capitán Cook debe entenderse que suponemos la primera diferencia.

(2) Aunque en la Atrevida y en la Descubter.ra se corricse base para deducir la verdadera distancia al Cabo Vírgenes, no la hemos adoptado por el mucho extravio que advertimos por las corrientes, comprobado en una y otra corbeta por las observaciones en longitud de aquella mañana y tarde: se ha preferido la distancia graduada á la vista, la cual no discrepa sino en tres minutos de la que detcrminan las bases bases do la ArreviDs: la longitud esta observada a la vista del cabo y la que se incluye es la del uúmero $6 r$ porque llega a Chiloé igual con la longitud del primer satélite de Júpiter: el número ro no discrepaba á la sazón sino cu dos minutos del número 61 .
En esta costa, comprendida entre el Cabo Virgenes y el puerto Deseado (en la sual como se ha dicho hemos adoptado las latitudes y longitudes de los puntos esenciales, como las determinaban los Sres. Chumaca y Cevallos), debe. mos particularmente á los Pilotos Tafor y Peña la descripción detallada de los trozos intermedios: son del primero los planos clel puerto San Julián y Santa Cruz y la descripción de la costa intermedia. El segundo ha conseguido examinar últimamente el río Gallegos, y el bajo Bellaco, de los Nodales, completando así con la mayor exactitud esta parte esencial de la costa (I).

El bajo Bellaco se ha situado por nosotros en la nisma posición, relativamente á la costa, que le determina el Piloto Peña y va inserta á la letra en el derrotero (2).

No es fácil deteruinar con exactitud el veril del banco: esta es obra de mucho tiempo y de re. sultas de un examen de muchos Diarios que en el día, ni están á mano, ni pudiéramos examinar con la madure $z$ necesaria. Hemos adoptado interinamente las sondas que determina la carta del Piloto Tafor.

Las Islas Malvinas se habian mantenido hasta aquí al abrigo de la navegación astronómica; de suerte, que no sólo su distancia á la costa y su verdadera posición quedaban dudosas, si también en su extensión y figura cabian diferen. cias notables: basta comparar la carta de monsieur de Bougainville con la del Capitán Mac. Bride (3), y ésta con la de nuestros pilotos para ver palpablemente estas diferencias.

No es nuestro ánimo el acertar exactamente las distancias y arrumbamiento del sin fin de is. las que forman este archipielago minplicado; pero podemos asegurar que toda la costa septen-

(r) Mr. de Bougainville ${ }_{5}$ no haciendo memoria que esta vigfa habla sido vista anteriormente por los hermanos Nodales, la sitúa por $48^{\circ} 34^{\prime}$ a seis 0 sicte leguas de la costa: habla sido la determinacion de los Nodales con los astrolabios, de $48^{\prime \prime} 30^{\circ}$, dicen: Fuimos muestro caminos a las cinco ó mids de la tarde encontramos nuestro canime a hes cinco onds de he tar de encontramos ro canino a has cinco o mis de ha tarde enconita mas poco mis o ménos: es muy bellaio bajo, porque esta debajo de la mar, que con ir con buen tiempo y poco mar, rompla y livaba la mar en el bajo. Sondamos junto del bajo y hallamos 20 brasas y piedra.

(2) El Excmo. Sr. Virey de Buenos Aires mo ha remitido a Santiago de Chile copia certificada de la relación del Piloto Peña. La he recibido del mismo Piloto, a Lima.

(3) Adviértase que en la carta del segundo viaje del Capitán Cook está equivocada la exteusión do las islas, según lo notaron los Sres. Galiano y Belmonte (pág. x $70 \mathrm{del}$ Viaje al Magallomesi. También merece atencion el error del Dr. Hausket Worthk en la recopilación del viaje del Comodoro Biron, determinando la distancia entre el puerto Egmont y las dos isla bajas dol Norto o Piedras Blailas: bajas dol Norta 0 Piedras Blalicas. supone 16 leguas hablando de la entrada, cuandn el planu y la misma navegación de la salida no dan sino tres á cuatro; incurro en la misma equivocación la traducción fráncesa. 
tre el Cabo

sual como

tudes y lon. ho las deter. llos), debe. afor y Peña yos interme. puerto San de la costa do examinar ajo Bellaco, on la mayor psta (I).

por nosotros á la costa, inserta á la itud el veril mpo y de re. rios que en os examinar optado intela carta del

mantenido astronómiia á la costa dudosas, si pian diferenrta de monapitán Mac. pilotos para

exactamente sin fin de is. cnnplicado; zosta septen-

do memoria iente por los a seis o siete nación de los dicen: Fuimos le encontramos eguas a la mar ine estd debajo ue esta debajo co mar, rom-
junto del bajo

Aires mo ha ificada de la o del mismo

egundo viaje teusión de las y Belmonte y Belmonte lk en la recoletermiuando las dos islas me 16 leguas , y la misma y la misma ducción frall- trional (que es la importante, pues conduce á los puertos de Egmont y de la Soledad) está ya su. mamente aproximada á la verdad.

Nuestras tareas hidrográficas conducen desde la Isla Rasa hasta la de Bc.bón, y las observaciones hechas en el puerto Egmont que les sirven de llave, determinan ya sin recelo alguno la verdadera distancia á la costa firme. Desde la Isla Borb6n hasta el puerto de la Soledad se la corrido de tal modo la costa, que sin separarse de los derroteros de nuestros pilotos que anualmente costean parte de aquellos puntos, buscásemos la latitud observada anteriormente en el puerto, que tantas veces repetida merece sin duda mucha contianza. De este modo hemos deducido rumbos y distancias, y nos lisonjeamos, que en la parte comprendida entre la Isla Rasa y el puerto de la Soledad no encuentre el navegante error alguno de entidad.

Nos ha sido preciso apartarnos de la carta del Capitán Mac-Bride, porque sus latitudes en el puerto Egmont exceden en seis minutos á las nuestras, $y$ al contrario son menores de tres mi. nutos á las nuestras, las que comparamos en el puerto de la Soledad. Convienen sí, próximamente, nuestras distancias de uno á otro extremo septentrional con las que prefija el Capitán inglés.

Desdc el Cabo Pembroke ó extremo Sur de la bahía de la Soledad, abandonamos al contrario nuestras cartas nacionales, y seguimos la del Capitán Mac-Bride, en la cual no obstante variamos la dirección del canal de San Carlos, y las inmediaciones de la bahía San José en cuanto han sido reconocidas por nuestros navegantes, y al contrario no bien atracadas á causa de los vientos contrarios por la fragata fason, del Capitán Mac-Bride.

En general, nuestros conceptos son uniformes con los que dieron margen á la carta del viaje al Magallanes de la fragata Cabsza; el trozo comprendido entre la isla Rasa y la de Jorbón procede de una serie de observaciones en latitud y longitud, acordes con las bases y con las marcaciones hechas desde la vigía del puerto Egmont; y la posición del observatorio nuestro está igualmente segura, pues su latitud se ha observado en el cuarto de círeulo de Ramsden con estrellas al Norte y al Sur; y en los relojes, de los cuales se deduce la longitud, se ha ha. llado el mismo movimiento que en el puerto Deseado: las distancias lunares se apartan en esta ocasión poco 6 nada de la longitud de los relojes.

Uno de los trozos de costa en los cuales más bien ha sobresalido nuestra felicidad, disfrutando no sólo de un tiempo hermoso y favorable, si tambiên de una grande harmonía entre las operaciones astronómicas y geodésicas, es sin duda alguna el comprendido entre el Cabo Espíritu Santo en la Tierra del Fuego, y el Cabo San Juan en la Isla de los Estados. Son repetidas nuestras longitudes observadas, particularmente desde el Cabo de Santa Inés al de San Diego, y las latitudes sobre el canal de San Sebastián y el Cabo Santa Inés, reunen cabal. mente con los extremos del Cabo San Diego y Cabo Vírgenes, á cuya vista han observado personas de la mayor confianza.

El placer de poco fondo reconocido por Sarmiento en las inmediaciones del estrecho, ha sido por nosotros confirmado, navegando en demanda del Cabo Sżn Sebastián. La posición de este cabo es craforme con lo que advirtieron Mr. Bougainville y los Oticiales de la fragata Cabcza, haciéndole formar un ángulo ménos con. siderable al Sur. Hemos llamado con Anson. Cabo de la Reina Catalina; al que le sigue inmediatc al Sur.

Se deja ver palpablemente que el Capitán Cook en su primer viaje, 6 con alguna leve diferencia en la latitud, que le hizo tomar otro por el Cabo Santa Inés de los hermanos Nodales, 6 con una marcha poco arreglada de sus relojes, determinó entre aquel cabo y el de San Diego una diferencia en longitud mucho más corta de la que nosotros hallamos (I); al contrario, esta. mos sumamente uniformes en la diferencia entre el Cabo San Diego y el Cabo San Juan, lo que parece comprobar la sospecha de que no merez. can tarito crédito las tareas del primero como las del segundo viaje de aquel ilustre navegante, sospecha tanto ménos extraña cuando se advierta que además de ser mucho más perfectas en esotra ocasión instrumentos y observadores, era también al fin de un viaje largo cuando las primeras operaciones tuvieron lugar al principio.

Fijada la longitud del Cabo San Juan, en la Isla de los Listados, y adoptada la latitud del Capitán Cook, son luégo frutos de las tareas de este insigne navegante, todos los puntos cxteriores de la Tierra del Fuego, que insertamos en esta carta; á este fin hemos colocado el Cabo de Hornos, según nuestras diferencias, desde el Cabo las Virgenes al Cabo San Diego, y las del Capitán inglés, desde el Cabo San Diegro al Cabo de Hornos, entrambas deducidas de los relojes marinos: es, pues, la longitud del cabo de $1 \mathrm{I}^{\circ} 15^{\prime}$ y $00^{\prime \prime}$ al Occidente de Montevideo, 6 bien de $6 \mathbf{r}^{\circ} \mathbf{1}^{\prime} 45^{\prime \prime}$ de Cádiz y $67^{\circ} 3 \mathbf{1}^{\prime} 45^{\prime \prime}$ de Greenwich: siguen hasta la Isla del Aterraje ó Recalada, las diferencias en longitud, determinadas por los relojes marinos del Capitán Cook en su segundo viaje: del mismo hemos deducido el planito del

(1) Es la del Cạpitán injeies de $I^{\prime \prime} 29^{\prime}$; la nuestra

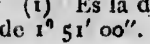


canal de Navidad, en cuanto pueda aer útil á muchos navegantes; pero no nos la sido posible hallar en las costas que ha reconocido, semejanza alguna con las inmediatas á la bahia de San lirancisco que describe en su carta el Excelentí simo Sr. Ulloa, y que nos vemos precisados á omitir.

La posición de la Isla de Diego Ramírez, al contrarino, está sacada de la carta de dicho señor excelentísimo, á lo ménos en cuanto á la diferencia de longitud deducida de aquel arrumba. miento y distancia, á cuyo fin se han supuesto los $10^{\circ}$ en latitud que faltan á la determinada anteriormente al Cabo de Hornos: asi conforma la latitud con el Capitán Cook, y no hay contra. dicción con los indicios algo oscuros de los hermanos Nodales, que la han visto.

Como quiera que el canal Santa Bárbara, según lo diseña Tretier, no tiene ni en tuno ni en otro extremo semejanza alguna con las abras avistadas exteriormente por el Capitán Cook é interiormente por los Oficiales de la fragata $\mathrm{Ca}$ bcza, es difícil acertar con seguridad el verdadero sitio de aquel canal: así, mientras algún acaso (á la verdad difícil), no proporcione reconocimientos más prolijos de los que acabamos de nombrar, la colocación y el hallazgo del canal de Santa Bárbara serán materias harto dudosas, además que ya pucde desconfiarse de la utilidad del mismo paso.

La diferencia de meridianos entre el Cabo Vírgenes y el Cabo Pilares, depende naturalmen. te de las operaciones trigonométricas; con las astronómicas han isterminado ser esta diferen. de $6^{\circ} 37^{\prime}(\mathrm{I})$ algo mayor que la supuesta por el Capitán Cook, nos obliga, por consiguiente, á extender algo más la costa de la Tierra del Fuego, desde la Isla del Aterraje hasta el Cabo De. seado; $y$ si como no debe dudarse, la diferencia determinada por los relojes entre la Isla del Aterraje y el Cabo Hornos es exacta, es claro que el Capitán inglés creyó ser el Cabo Deseado algán otro punto de la costa occidental al mismo cabo.

Como en la carta al Magallanes la dirección del Cabo Deseado relativamente al de Pilares es. tuviese combinada con atención á los viajes de los Sres. Walli, Biron y Carteret, nos ha parecido preferente á la que determina la carta del Capitán Cook.

El Cabo Victoria y los Livangelistas, dependen de las mismas operaciones de los Sres. Chumaca. Parecía á primera vista infructuosa cualquiera nueva combinación para trazar los reconocimien. tos interiores de Pedro Sarmiento, después del

(v) En cl mismo Caluo Pilares se ha observado la latitud y se ha deducido la longitud del reloj mariao: estaban a la rista los Evangelistas y el Cabo Victoria. maduro examen á que les habían sujetado los señores Galiano y Belmonte; pero como en la par. te exterior se nos proporcionasen nuevas combinaciones con el recor xcimiento de las tierras in. mediatas al Sur del canal de la Trinidad, $y$ áln con la inmediación á que estuvimos del Cabo. Santa Lucia, hemos hecho nuevo examen ae aquellos datos, con intervención del mismo $\mathrm{Ga}$. liano, $y$ han resultado algunas combinaciones más felices, pues no excluyen observación alguna de latitud y longitud, y ligan mejor los arrumbamientos $\mathrm{y}$ distancias.

Nuestro reconocimiento no nos deja duda que la costa desde el Cabo Tres Morros para el Sur, corra Sur $5^{\circ}$ Este; al contrario, Sarmiento halla ba que esta misma costa, por sus agujas, corría Sur $1 / 4$ Sudoeste; luego no sería extraño que este error fuese general en los demás arrumbamien. tos, y así parecib lo más oportuno conservar toda la posición respectiva de los lugarer de Sarmien to, girando sobre el Cabo Tres Mc ros toda la costa hasta el Cabo Santa Lucía, de suerte quie buscase el nuevo arrumbamiento, y además de. mora al Norte $15^{\circ}$ Oeste, cuando Sarmiento avisa que se demoraba la vielta del Norte, error igual al que hallamos en el Cabo Tres Morros y suponla. mos en la demás costa.

Con mucho agrado nuestro, resultó de este modo la distancia desde el Cabo Santa Lucía. al de Victoria, exactamınte la misma que indi. caba sarmiento, cuando en la combinarión primi. tiva de la carta del viaje al Magallanes aquella distancia resultaba más lata, de una cantidad cunsiderable.

$\mathrm{Si}$ á esto se agrega que nuestra navegacion sobre el Cabo Santa Lucía nos asegura que no puede salir más al Oeste, y que al contrario su. jetada aquella punta por distancia y arrumbamiento de Sarmiento queda sujeta á la longitud segura del Cabo Victoria: si se agrega tambien que nuestra latitud del Cabo Tres Morros coincide próximamente con la de Sarmiento, debe. mos lisonjearnos que ya no admite corrección sensible este trozo de costa, y que en cuanto á la utilidad de la navegación no necesita mayor perfección, tanto más que estas costas parecen destinadas por la Naturaleza á ser perpétuamente miradas con horror por el navegante.

Reuniéndose á éstos los materiales del Piloto Machado, formados ya sobre las pocas noticias que se tenían de la costa desde Cabo Tres Morros á Chiloé, y situando en su posición el extre. mo Sur y Oeste de esta grande isla, cuyo plano acaba de levantar el Piloto Moraleda, se ha po. dido asegurar á corta diferencia el arrumbamiento total de esta parte de costa, que la derrota de las corbetas asegura no puede tener un error perjudicial á nuestras navegaciones; pero de ningán modo podemos salir garantes del pormenor de 
ctado los se. ho en la par levas combi. as tierras in. hidad, $y$ ál'n del Cabo examen ae mismo $\mathrm{Ga}$ hacionea más on alguna de os arrumba.

eja duda que para el Sur, niento halla. gujas, corría raño que este rrumbamien onservar toda - de Sarmien i ros toda la le suerte que además de. rmiento avisa error igual a! os y suponia.

sultó de este Santa Lucía. ma que indi. nación primi llanes aquella una cantidad

a navegación egura que no contrario su. a y arrumba. á la longitud rega también Morros coin niento, debeite correccion en cuanto á la ta mayor perparecen des erpétuamente te.

les del Piloto ocas noticias abo Tres Moición el extre a, cuyo plano la, se ha po. arrumbamienla derrota de ; un error perero de ningún pormenor de ella, pues áun las observaciones de latitud de dicho Machado, son incombinables con las distan. cias que resultan por la carta que formó (I). Este Piloto salió de Chiloé con una goleta y dos pira. guas en 1769 , con el objeto de recoger los náu. fragos de una fragata, que por noticias de los in. dios se habla perdido sobre la costa, y con el en. cargo de que marcara y observase toda la costa hasta el Estrecho de Magallanes.

Fondeb en muchos puertos é hizo varias ob. sirvaciones de latitud con el octante, particularmente en la isla de San liernando, inmediacio. nes de la isla de Guayanecos, y en el extremo Sur de la de la Campana: algunas se afianzan reciprocamente, y manifiesta en su Diario haberlas hecho con buen Sol.

Su derrota, pasando las piraguas á hombro por el istmo de Ofgui, y luégo siguiendo por los canales de Tallos y del Castillo hasta la boca de la Campana, guiado de una india, merece una noticia particular: corresponden los tiempos que experimentó con los de Sarmiento y cor los nuestros. Todo demuestra que el navegante debe se. pararse de estas costas.

De las latitudes indicadas, ha sido preciso desechar la de la isla de San Fernando en $45^{\circ} 47^{\prime}$, pues si admitiese esta y se graduase su carta que no tiene troncos con atención á ella, quedarían los minutos desde Chiloé hasta ella, de la mitad del tamaño de los que siguen desde esta observación hasta la ınınediata nl Sur: al contrario, tomando la de la isla de San Pedro y la que hizo más al Sur, que fué en extremo meridional de la isla de la Campana, y dividiendo igualmente el tronco de latitudes de la carta, se acuerdan todas las demás observaciones á muy corta diferencia; pero la isla de San Fernando quedaría en $46^{\circ} 17^{\prime}$ en lugar de $46^{\circ} 47^{\prime}$. Si á esto se añade que el abra del puerto del Pingüe Ana, de la escuadra del Almirante Anson, está al Sur y la co. locan en la relación del viaje de este Almirante en $46^{\circ} \%$, se aumenta la precisión de desechar la tal latitud; por otra parte, reflexionando que la penínsila de los Tres Montes, quedaría en nuestra graduación dicha mucho más al Norte de lo que la ponen las cartas que tenemos de esta parte, y teniendo una marcación del Cabo de Tres

(1) Machado llego hasta el Cabo Corso, aunque dé este nombre al que ahora es Cabo Tres Morros: equivocado de unas noticias poco verfdicas, y sin consultar el viaje de Sarmicnto creyó ser el Cabo Corso una tierra alta que vela desde la tierra firme, inmedia. una tierra alta que vefa desde la tierra firme, inmedia.
ta a la Isla de Santa Barbara, asl supuso que habfa una tierra baja en un canal que veía abierto, y que es sin duda el canal de la Trinidad, cuya anchura determina de seis leguas, exactamente la misma que determinó Sarmicnto y nosotros hemos advertido. Es un acaso muy feliz que convengan las latitudes de Sarmiento y Machado con las nuestras; y esto hace tanto honor á la exactitud de aquel primer navegante como á los la exactitud de aquel primer navegante como á los
Oficiales que le han interpretado.
Morros, que hizo el dicho Machado estando una legua al Norte do las Ayaotas, se ha bajado el Cabo de Tres Montes y toda la peninsula de este nombre, 9' más al Sur para buscar asi la marcación dicha, respecto al tronco de las Jongitudes, se ha dividido en la cartu de Machado, de suer. te que resulte entre el extrcmo Sudoeste de Chiloé y el Cabo de Tres Montes, la diferencia que hemos hallado por los relojes referidos por la carta de Moraleda al dicho extremo (I).

Además de las dudas y combinaciones indicadas, hay también la esencial para una exacta colocación de la costa que Machado no costeó la parte exterior de la peninsnla de Tres Morros, la cual, por consiguiente, en sus puntos intermedios, pudiera variar considerablemente. Lo mis mo puede decirse de la Isla de Santa Bárbara: finalmente, que la existencia de la Isla de San. ta Catalina pende de sola una noticia de los in. dios dada al mismo Machado.

Ya desde la Isla de Gutujos y extremos de Chiloé, varía considerablemente la probabilidad de una exactitud constante. D. José Moraleda, primer Piloto de la Real Armada y Alférez de fragata graduado, ha costeado y trabajado prolijamente de orren del Gobierno, ambas costas del canal entre la isla y la tierra firme. Desde el extremo Sulocste de la isla, desde los altos in. mediat , al extremo Norte, y desde algunos puntos intermedios á los cuales ha transitado por tierra, ha logrado arrumbar prolijamente toda la costa occiciontal, y sus latitudes comparadas á las nuestras sobre la punta de Yaqui, no dejan la menor. desconfianza en esta parte (2), si se exceptúa un trozo de costa inmediato á las Tetas de Cucao, en cl cual hemos trabajauo nosotros mismos, y hallamos una diferencia considerable en latitud, bien que nada extraña, por no haber po. dido Moraleda transitar en aquella costa, y de. terminar, por consiguiente, diferentes distancias.

Toda la parte septentrional de Chiloé, desce el Chacao hasta la entrada del Chasco, deducida de una serie de triángulos formados con el teodolito, no hay punto en que no concurran tres 6 cuatro marcaciones, y así podemos asegurar que este trozo de costa es de los que piden de nuestra parte una mayor confianza.

Las sondas únicamente son las que hemos adoptado dęl piloto Moraleda: las ha ratificado

(1) Se han tenido presentes la navegación desde Chiloe de un Sr. Mancilla en cl año de 1767 , que pa. rece forjada maliciosamente, y existe en la Secretarfa del Vireinato del Peru; los detalles de Herrera que indica algunas distancias y arrumbamientos, y el viaje del Padre José García Alsuc, de la extinguida Com. paffía, lel que nada útil puede deducirse.

(2) : Ioraleda se ha valido del octante para las ob(2) Aoraleda se ha valido del octante para las ob-
servaciones del frente y del cuadrante para la de csservaciones del frente y del cuadrante para la de es-
palda: sicmpre se ha valido de las declinaciones calpalda: siempre se ha valido de las declina
culadas en cl conocimiento de tiempos. 
muchas veces, $y$ no podemos desconfiar de su exactitud, confrontada también en lo que hemos navegado.

La longitud de San Carlos de Chiloé es uno de aquellos puntos que merece ser desmenuzado, pues que le miramos como el verdadero concurso de las longitudes determinadas á ambas costas Patagónicas.

El número 6r de Arnold (I) la prefijó de I $7^{\circ} 34^{\prime}$ I $3^{\prime \prime}$ al Occidente de Montevideo, sobre una marcha determinada en puerto Deseado, confrontada en puerto Egmont, $y$ ratificada en los primeros días en San Carlos de Chiloé.

El número ro de la ATREvida, con iguales datos, la hacía llegar á $I 7^{\circ} 3^{8^{\prime}} 30^{\prime \prime}$, y las ecuaciones correspondientes conducen los demás relojes á ese mismo resultado: ahora, pues, la observación de la noche del 6 de Febrero en el primer satélite de Júpiter, heclıa por tres observa dores con las circunstancias más favorables, determina la de $17^{\circ} 35^{\prime} 30^{\prime \prime}$ cuando el promedio de los relojes indicados es de solos $45^{\prime \prime}$ más occidental que ésta.

Concurren agradablemente á afianzar este resultado, no ménos otra observación de la misma especie heclia en el mismo puerto, si tanbién los rcsultados de las observaciones del Padre Teville en Penco, con los cuales combina dentro del minuto la diferencia de meridianos asignada por los relojes entre San Carlos y Talcahua no (2), con cuyos antecedentes ya no es temeridad el asegurar la longitud de ambas costas intermedias en una aproximación á la verdadera uuando esté en el alcance de las operaciones ma. rítimas.

Como los resultados del número $6 \mathrm{r}$ fuesen ian aproximados á las observaciones celestes ha parecido inoportuno el variar las longitudes intermedias para el error leve de $I^{\prime}$; tanto más, que teniendo cor:espondientes en Europa así la observaciones de Montevideo como las de Chiloé, cuyos meridianos son los que terminan el trozo de que se habla, puede tal vez la pequeña diferencia que resulte en las comparaciones absorber aquel errnr por otra parte insensible.

Estas mismas diferencias no deben ya variar las combinaciones de los relojes, sí sólo repartirse en el total de la costa proporcionalmente, á cuyo fin (como ya se dijo) se ha separado la costa en distintos trozos, dependientes de un meridiano en el cuai ,e hayan hecho observaciones de mucha confianza.

Siendo la verdad la base esencial de nuestra

(I) Véase para mayer claridad e! Diario astronó nico y la narración de nuestros a.jaecimientos en aquel puerto.

(2) Esta comparaciór se hará con más individua. lidad hablando de la lrongitud de la ciudad de Concepción. tareas, no debemos omitir antes de cerrar este capítulo, que en la recalada al extremo Sur de la isla de Chiloé en la noche del $1 .^{\circ}$ de Febrero, hemos creído todos unánimes ver la costa á distancia de cuatro leguas, cuya vista combinada con nuestras longitudes de la mañana siguiente y traídas con la estima á aquella misma hora, haría creer que el arrumbamiento de la costa oc. cidental es muy diferente del que le asigna Moraleda; pero bien examinadas todas las circuns. tancias, y áun hechos cargo de la distancia á que nos vimos de la costa en la siguiente mañanita á las cinco y media, nos inclinamos á creer que realmente fué aquella una ilusion que habiamos admitido sólo por la sonda que encontramos en la tarde anterior, y que no admiten duda la posición y arrumbamientos de Moraleda (I), cuyo derrotero de la isla de Chiloé va á continuacion.

Derrotero de la Isla de Chiloé por D. Fose Moraleda, Alfúrez de fragata y Piloto de la clase de primeros de la Rcal Armada.

El modo de dirigirse de unos á otros puertos, á que el cómún de los náuticos llaman derrotero, no es otra cosa que dar noticia de la situación en latitud y longitud de los puertos, de los rumbos á que se ha de llevar el navio, expresando la configuración 6 señales de las tierras que se deben avistar, con una noticia general de la clase y circunstancias de los vientos que suelen reinar con más frecuencia, y dirección y fuerza de las mareas 6 corrientes que por lo regular se experinientan, para lograr, cuando no un perfecto conocimiento propio pues éste se consigue sólo con una dilatada serie de viajes, á lo ménos unas nociones ó luces que guien ó dirijan á ejecutar. los con el acierto y brevedad que se requiere, y de cuya importante ejecución resulta tanto bien al Estado, en paz, guerra y comercio.

Supuesto lo dicho, la Isla de Chiloé, que es la mayor del mar Pacífico, si al que la circunda se le puede dar este nombre, está situada en la costa occidental Patagónica, y según mis observaciones, entre los $4 \mathrm{I}^{\circ} 4^{8^{\prime}}$ en que está la punta de Guapacho, que es 10 más septentrional de li isla y $43^{\circ} 47^{\prime}$ en que está lo más fuera del grande arrecife de Chocheb, que es la más meridional de ella; de modo que tiene 40 leguas de Norte-Sur, cuya distancia concuerda con la que le suponen los Sres. D. Jorge Juan y D. Antonio Ulloa, Cedillo y Barreda; pero con la equivocación de colocarla los citados autores entre 42 y $4 \dot{q}^{\prime \prime} 2^{\prime}$, bien que ningunn ${ }_{\mathbf{x}}^{n}, \mathrm{r}$ inspección pro(r) El Diario que ha presentado al Excmo. señor
Virey del Perú, morece muchos clogios, no ménos Virey del Perú, morece muchos elogios, no menos
por el primor que por la exactitud con que esta trapor el prim
bajado. 
antes de cerrar este al extremo Sur de la del I. ${ }^{\circ}$ de Febrero, s ver la costa á dis. ya vista combinada a mañana siguiente aquella misma hora, iento de la costa oc el que le asigna Mo is tndas las circunsle la distancia á oue siguiente mañanita linamos á creer que lusión que habíamos que encontramos er admiten duda la poe Moraleda (I), cuyc bé va á continuacion.

por D. Fosé Moraleda, le la clase a'e primeros mada.

unos á otros puertos, cos llaman derrotero cia de la situación en dertos, de los rumbos io, expresando la contierras que se deben heral de la clase y cirfue suelen reinar con y fuerza de las malo regular se experilo no un perfecto coste se consigue sólo ajes, á lo ménos unas ó dirijan á ejecutard que se requiere, $y$ ón resulta tanto bien y comercio.

sla de Chiloé, que es si al que la circunda e, está situada en la 1, y según mis obseren que está la punta s septentrional de lat o más fuera del gran. e es la más meridioene 40 leguas de Norcuerda con la que le re Juan y D. Antonio pero con la equivoca. los autores entre 42 nor inspección pro.

ontado al Excmo. señor hos elogios, no ménos titud con que está tra- pia. Los naturales y algunos otros que le han mirado muy á bulto y observado la latitud, lo mismo la suponen 48 y hasta 60 leguas extensión de Norte á Sur; pero las observaciones di. chas de latitud deciden absolutamente y dejan fuera de duda la citada extensión de 40 leguas, 6 más bien 39, si se excluye el arrecife 6 bajo de Chocheb.

La dirección de la isla tomada en general por su costa del Oeste, es casi del Norte $1 /$ Nordeste y Sur $\%$. Sudoeste, y la longitud de la medianía de dicha costa $303^{\circ} 6^{\prime}$ con respecto á la observada astronómicamente en la Concepción de Chile. La extensión de Oriente á Occidente es muy varia por los esteros y ensenadas que tiene por la parte del Este por donde más se extiende, que es entre el morro de Quicabi (es lo más occidental de la isla) y la costa opuesta, al Oeste tiene $I_{3}$ y $1 / 2$ leguas, $y$ por donde ménos, que es entre Vilopulli y Cucao, no llega á siete.

Confina por el Norte, con la costa de tierra firme de Carelmapu, por el Este, con la isla del partido de Calbuco y costa firme de la cordillera Real de los Andes, por el Sur con el grande incógnito número de las Islas Huaytecas, á quienes comunmente llaman archipiélago de Chonos, y por el Oeste le sirve de término el Oceano Pacífico.

La costa occidental y del mediodía de esta isla, ni son accesibles para desembarcos, por sus escarpados, bajos, resaca de la contínua mar de leva, escollos visibles y ocultos, y estar por la mayor parte organizadas de rocas, ni tienen tampoco puerto alguno. La elevación mayor del terreno está en la medianía de la costa del Oes. te próximo al mar, y en mi concepto se alcanzará á ver en tiempo claro de I $_{5}$ á I 6 leguas de distancia. En esta altura se elevan algo más dos cerros contiguos, á quienes llaman las Tetas de Cucao, y son eí objeto más notable de toda la isla para reconocimiento de ella y de la situación en que se está cuando se tienen á la vista; pero es menester advertir, que ninguno debe dirigir su recalada ó aterramiento á ellas, á ménos que no carezca de latitud observada y sea muy dudosa la latitud de la estima que traiga, porque de lo contrario, se expone á que la constante mar del Oeste en bonarza, 6 un viento repentino de esta parte, lo emperie en una costa brava, cual lo es toda la de esta isla que mira al Occidente. El demás terreno de ella hacia el Norte y Sur del dicho, es casi igual de un lomaje suave, que se podrá vur de II á I 2 leguas de distancia estando el tie npo despejado.

La costa septentrional toda es accesible, $y$ lo mismo la oriental hasta el Estero de Yalad, que está por los $43^{\circ} 30^{\prime}$ de altura, y este es el terreno poblado de la isla, porque el resto todo es desierto, á excepción de un corto número de ha. bitaciones inmediatas á Cucao, aunque dispersas entre sí como todas las demás de la provincia, que no se desvian media legua de la orilla de la mar.

Las cuatro estaciones del año se distinguen bien, anteponiéndose ó posponiéndose á veces al tiempo preciso por las causas naturales que suelen concurrir á perturbar el orden regular de ellas, pero la del invierno siempre se prolonga algo más que en otros paises situados en iguales alturas de Polo, y con una atmósfera contínuamente cargada de vapores de extraordinaria densidad que ocasionan frecuentes nieblas y cerrazones, reducidas probablemente de la frondosa maleza de que está cubierta la isla, las que se difunden en muy copiosas lluvias con muy pccas tempestades de truenos ni granizo dura. dero, $y$ tal cual ve $z$ en poca nieve de media isla para el Sur; el frío áun en dichos días no es sen. sible á proporción de la latitud en que está, y al contrario, el calor que en los días de calma del verano parece excesivo respecto al clima.

Los vientos que se experimentan en esta isla y sus cercanías son varios é inconstantes, especialmente en la primavera y otoño. En esta estación dominan más los de la parte del Este, y en la otra los del Sudoeste y Oeste, pero por lo regular todos moderados con intermisión de algunas calmas, lluvia y serenidad. En el estío reinan los Sur y Sueste frescos y secos, con cielo des. pejado, aunque algunos muy fuertes turban la atmósfera, y los prácticos llaman Sures pardos: pero la tranquilidad que ofrece la estación, no se goza aquí sin algunos golpes de lluvia $y$ vientos impetuosos del Noroeste y Oeste, de modo que se pueden establecer por vientos generales los del Norte al Oeste que son propios de la estación de invierno. En ésta son tan copiosas las lluvias, $y$ aquéllos tan fuertes, que con repetidos naufragios impiden á esta provincia, desde Mayo hasta Noviembre, la conıunicación y comercio marítino con las demás de estos reinos, con notable perjuicio de ella en particular, y del Estado en general.

De dichos vientos, el que reina más y con más violencir es el Noroeste, porque aunque los Norte y Oeste le igualan en el ímpetu, no en la du. ración: éste vienta á ráfagas peligrosas, y aqué seguido por lo común, por lo que si en dicha es tacín ventando los citados vientos, el acaso 6 necesidad tuviese en estas inmediaciones algún navío, deberá preparar sus jarcias, y disponer el velamen con prontitud á recibir aumento y duración de ellos, siempre que á las horas de salir y ponerse el Sol, note horizonte voxo envuelto en la oscuridad que en semejantes ocasiones tiene la atmósfera, $y$ es la señal única que he hallado para evitar las fatales resultas de las sorpresas, ya cargando el viento 6 con repentino 
contraste del Norte á la travesia, ó de ésta á aquél, 6 al Noroeste, que son muy frecuentes, y lo mismo el retroceso de los vientos del Sur y Sudoeste al Oeste habiendo pasado de éste á aquellos, lo que en el común sentir de estos navegantes no sucede aquí sino que sigue contra el orden de la aguja al Sueste y Este hasta volver á establecerse al Norte, pero esta regla tiene muchas excepciones.

En la costa occidental de esta isla y algo fuera de ella, no se experimentan más corrientes que el contínuo choque del mar, siempre agitado de Occidente á Oriente, pero desde la entrada de los canales de Chacao y boca del Huajo para adentro, es tanta la multitud de corrientes y varias direcciones que toman las mareas, cuanto es de las inflexiones de las costas, puertos y ensenadas de la isla principal por su parte del Esste, y de los canales que ésta forma con las inmediatas, y lo mismo sucede con la rapide $z$ de su curso ó cantidad de movimiento con respecto á la mayor ó menor angostura de los citados canales, $y$ configuración y distancia al suelo del mar en ellos, lo que se manifestará en sus respectivos lugares.

\section{Notas.}

I." Que los rumbos que se expresan en estas derrotas son corregidos de abatimiento, corrientes ó mareas y variación de la aguja, que es al presente de $14^{\circ}$ en la costa del Norte de la isla $y$ de $15^{\circ}$ I $4^{\prime}$ en la del Sur de la especie del Nordeste.

2." Que en cualquiera de los puertos de estas derrotas, como en la mayor parte de las costris de la isla, se encuentra excelente agrua y leña en abundancia.

Entrada al puerto de San Carlos, situado en la latitud Sur de I $^{\mathrm{I}} 53^{\prime}$ y crola longit:al de $303^{\circ} 2 \mathrm{I}^{\prime}$ de Tonerife.

I. Todo navegante que de los mares de Europa ó de esta América venga á entrar en el puerto de San Carlos, debe proporcionar su recalada á él por los $4 \mathrm{I}^{\circ} 45^{\prime}$ á $5^{\circ}$ de latitud, á dar vista á las puntas de Pologüe, Gabun, Huechucucuy y Huapacho, que es la más Norte de la Isla de Chiloé, las que están contiguas en la península de Huapi-Lacuy (los naturales le llaman la Isla) y no hailándose muy aterrado, tendrá también á la vista, con tiempo claro los farallones de Carelnapu hacia el Nordeste y acaso la Isla de Doña Sebastiłna, lo que reconocerá, notanjo que de la citada punta de Huapachoó de la de Huechucucuy corre hacia el rumbo del Sur $1 \%$ Sudoeste la costa de la isla grande de mediana elevación, con algunos morritos y farallones pequeños cerca de ella, y de las puntas di- chas de Huechucucuy y Huapacho para el Norte no se verá costa alta ninguna, sino á larga dis. tancia, pues toda la que está al Este de los citados farallones de Carelmapu é Isla de Doña Sebastiana es la más baja de toda esta inmediación.

2. Recalando por los $4 \mathrm{I}^{\circ}$ y $5^{0^{\prime}}$, se llevará casi al Este la punta de Pologüe, la que se reconocerá, porque de ella para el Sur empieza la grande playa de Cocotue, y su ensenada, que no admite confundirse ó equivocarse con otra al. guna de sus inmediatas, que son pequeñas. Reconocida dicha punta seguirá el rumbo Norte $\%$ Nordeste ó Nornordeste á distancia como de una legua de la costa, hasta estar tanto avante con la punta de Huechucucuy que avistará casi al Este la de Huapacho, y continuará al rumbo del Esnordeste para resguardarse del bajo de Huapacho, hasta que la punta de este nombre que se reconocerá por ser como se ha dicho la más Norte, y por un islote árido que tiene cerca, demore al Esueste, que entonces se dirigirá á ella, llevándola algo descubierta por estribor, $y$ suce. sivamente al morro de Huapi-Lacuy en los mismos térmińos, el cual corre con dicha punta Sueste $1 / 4$ Sur, Noroeste $1 \%$ Norte. Montado este morro se verí al Sursueste distancia como de una legua, la punta de Agui que es la del Oeste del puerto, $y$ tiene sobre sus lajas un pequeño cerrito frondoso que aparece un islote, poco separado del grueso de la punta, el que se llevará algo descubierto por babor hasta estar de dos y medio á tres cables de ella, que se arribará á montarla, lo que verificado se hallará ya dentro del puerto de San Carlos y á la vista de su pueblo, que le demorará al Sueste $1 / 4$ Sur, y orzando seguirá para dentro al rumbo del Sursudoeste hasta rebasar los sargazos del bajo de Pechucura, que son visibles, y conseguido orzará á atracar más á la costa para fondear entre los dichos y las puntas de Barcacura y Arenas, que es el mejor surgidero de este puerto, donde dejará caer el ancla en seis á siete brazas de agua fondo de lama y arena, á distancia de tierra como de media milla, y se amarrará de Nordeste-Suloeste.

3. Advertuncias. Para entrar en este puerto, especialmente de noche, se ha de tener mucho cuidado con el estado de la marea y su curso y violencia, por lo que se hace preciso advertir, que entre las puntas de Huechucucuy y Huapacho, los dias de novilunio y plenilunio es la pleamar á las once del día, su curso casi de Este-Oeste y su movimiento de tres millas por hora con corta diferencia, bien entendido, que siempre la vaciante es algo más veloz que la creciente, y que aquella se aumenta mís en el invierno, por razón de las avenidas de los rios con lr.s lluvias, y ésta por los impetuosos vientos de fuera.

$4 .^{\circ}$ Tambien se advierte, que si entrando en 
bara el Norte á larga disste de los cisla de Doña esta inmeequeño cerrito o separado del rá algo descu. os y medio á á montarla, lo del puerto de que le demouirá para dena rebasar los que son visimís á la coslas puntas de jor surgidero $r$ el ancla en o de lama y de media miloeste.

1 este puerto, tener mucho y su curso y advertir, que y Huэpacho, es la pleamar le Este-Oeste hora con coriempre la va ciente, $y$ que no, por razón luvias, y ésta entrando en
San Carlos con vientos escasos se intenta llegar al amarradern dicho bordeando, se ha de tenecuidado de no prolongar la bordada hacia la costa del Este más que hasta la medianía de la distancia que hay de costa á costa, porque del dicho paraje para la del Este, es placer de cuatro bra. zas á ménos agua; y así, con embarcación grande, es mejor ir á remolque con marea favorable 6 á la espía, y no exponerse á varar como sucedió al navío de guerra San Pedro Alcántara en 1780 , al que una feliz casualidad de viento y mar, en las cincuerta $y$ tres horas que estuvo varado, $1 \mathrm{j}$. bertó de una pérdida, que acaso hubiera sido de mucha consideración é irreparable en la ocasión en que ocurrió aquel acontecimiento.

5. Se debe tener presente también, que la recala á la punta dicha de Pologüe, es en tiempo de verano que reinan los Sures; porque en el de invierno que vientan los Nortes, no se ha de pasar de $\operatorname{los} 4 \mathrm{r}^{\circ} 4 \mathrm{o}^{\prime}$ para el Sur por ningún caso, pero por esta altura, se presentará en aptitud de tomar el puerto con cualesquiera de los vientos propios de la estación, que como se ha dicho, son del Norte al Oeste impetuosos y con cerrazones, y la costa que desde la citada punta sigue para el Sur, toda sin guarecedero alguno, no sólo para la embercación, pero ni áun para las vidas de los infelices que tengan la desgraciada suerte de naufragar en ella, porque toda es inaccesible.

6. Entre las puntas Huechucucuy, Huapacho y Tenuy, se halla el bajo de Huapacho, que es de arena con algunas peñas, especialmente hacia su parte del Norte; tiene de largo media milla, tendido casi del Nornordeste y Sursudoeste, y de ancho como la mitad de dicha distancia; está por enfilación al Esste $19^{\circ} 45^{\prime}$ Norte de la punta de Huechucucuy lo más Norte de él distancia de tres millas, y al Oeste $2^{\circ}$ Norte de la punta de Tenuy (ésta es el islote de Huapacho, de quien se ha hablado) distancia de una milla, y lo más Sur de él distancia del fondo de la ensenada de arena de Huechucucuy cosa de media legua, cuyo espacio es de buen fondo de I 2 á 14 brazas de agua, donde por haberse guarecido el Piloto D. Juan Golindano con el paquebot Monserrate, suelen también llamar de Golindano á dicho bajo; en las peñas que tiene en su parte del Norte y Oste, se perdió la fragata $\mathrm{Bal}$ baneda del comercio de Lima la noche del 23 de Diciembre del año pasado te $\mathrm{I788}$, conduciendo el Real situado para esta provincia, del que no se salvó nada casi más que las vidas, por lo apreciable del tiempo: y en la misma noche pocas horas antes de la Bulbaneda, se perdió también en la playa de dicha ensenada de Huechucucuy el paquebot El Tránsito (alias el Papudo), de quien se salvó casi toda su carga.

$7 .^{\circ}$ Nota. Que el puerto de San Carlos es el principal de la provincia y donde se ejecuta el romercio de ella con las demás del reino: su situación es la más ventajosa para el efecto y para la seguridad de la navegación; tiene varios sitios de excelente agua para proveerse de ella; es seguro de buen tenedero sobre fondos proporcionados, y capaz de contener bastantes embarcaciones resguardadas de los vientos que doninan especialmente en el invierno; pero se surge á una legua de distancia del pueblo, la que suele ser intransitable muchos días en la expresada estación. El terreno vecino es regular para la. bor, tiene muy poca, y casi todo está cerrado de espesísimo bosque, á excepción del que se desmontó para la formación del fuerte y pueblo. Este último, aunque desordenado, es el único que merece nombre de tal en toda la provincia, porque los habitantes de ésta están dispersos por las orillas del Norte y Este de la Isla Grande, y en las contiguas á ella, con las habitaciones en distancia unas de otras de media milla, una, dos y algunas mucho más. El vecindario de este pueblo consiste en 248 familias; pero desde Diciembre hasta Narzo 6 Abril se aumenta por ser el tiempo en que viajan á él las embarcaciones de comercio: no tiene el pueblo puerto seguro para embarcaciones menores, como lanchas, piraguas, etc., por cuya razón, aunque la escasez de víveres es general en toda la provincia, se hace más sensible en este lugar por faltarle los recursos que le proporcionarian en el particular la mayor abundancia de piraguas de otros para. jes de la costa é islas pobladas, teniendo aquí un buen surgidero en que guarecerse del rigor de los tiempos de dicha estación.

$8 .^{\circ}$ El fuerte de San Carlos (no hay cosa más distante de serlo) sólo es provisional, muy reducido, y está casi desecho; pero en cual. quiera disposición que se ponga, ó bien reedifi. cando el actual, ó bien construyendo de mampostería, es inútil, y los 27 ó 28.000 pesos que costó, según dicen, al Rey, un sacrificio que la ignorancia hizo del Eraric Real. Igualmente son inútiles, ínterin no haya tropa suficiente para su guarnición. todas las baterías provisionales que se construyeron el año de i 780 (están desechas) á excepción del fuerte situado en la punta de Agui, que en mi concepto debe edificarse de obra firme, y la bateria de la punta de Barcacura. Aquí, porque debajo de su cañón han de entrar indispensablemente las embarcaciones grandes y medianas que vengan á este puerto; y la batería dicha, porquc el surgidero mejor y áun preciso del invierno, está bajo su tiro de cañón; por lo que concibo, que aunque sea provisional, debe tenerse siempre en estado de buen servicio. En lo demás, no creo absolutamente preciso otra fortificación que la movible, esto es, tropa bien disciplinada, que es de lo que enteramente se carece aquí. 
Entrada al Puertodel Chacao, situado en latitud Sur de $4 \mathrm{I}^{\circ} 54^{\prime}$ en longitud de $303^{\circ} 47^{\prime}$.

9..$^{\circ}$ Si desde el Oceano fuese el intento ir al puerto del Chacao, luego que haya montado el bajo del Huapacho, se hará el rumbo del Este hasta estar Norte-Sur distancia de una milla de la punta de su nombre, desde cuyo paraje se hará el Este $6^{\circ}$ Sur la distancia de 12 millas, por el que pasará una y media de la isla de Doña Sebastiana, por su parte del Sur 2 al Norte del bajo del Inglés, y como media legua de la punta de Chocoy, y morro de la Picuta de Carelmapu, sin riesgo alguno de las peñas de Punguñon; y al cumplir dichas 12 millas, se hallará tanto avante con la punta de Punguñon, demorándole al Sur: desde este punto se hallará el rumbo del Este $12^{\circ}$ Sur distancia de ocho millas, llevando casi por la proa algo descubierta por estribor la punta de San Gallán, que en esta situación es la tierra más Este que llevará á la vista por dicha ban. da, ála que se atracará hasta la distancia de dos á tres cables, y á esta misma seguirá costeando á rumbo del Sueste $1 \%$ Este poco más de una milla, y lo mismo al Suesie $1 / 6$ Sur, y cumplidas ambas, se hallará tanto avante con la punta de Remolinos (es de peña tajada al mar) y con el pueblo del Chacao á la vista demorán. dole al Sur, cuyo rumbo se hará hasta estar Nornoroeste Sursueste con la iglesia, distancia como de un cuarto de legua 6 media milla, donde se dejará caer el ancla en Io ó 12 brazas de agua fondo de lam?, y se amarrará de Noroeste Sueste.

Io. Advertencias. En esta derrota es también absolutamente indispensable el cuidado con la marea para navegar con la favorable, á ménos que no sea acompañado de un viento largo capaz de vencer la violencia de la contraria, que es de cinco á seis millas por hora, particularmente de Quinterquen para el Este y áun al pasar por la boca chica, que la forman lo más Este de la isla de Dona Sebastiana, y la punta del Chocoy ó centinela de Carelmapu, si el viento no es muy superior á la acción de la marea contraria, es menester fondear en 186 20 brazas de agua an. tes de abrir dicha boca, porque en ella adquierer una rapide $z$ extraordinaria las mareas, siguiendo su curso al Norte y Nornoroeste y lo chupará, como sucedió á la fragata Favorita, propia de D. José Ostolaza, en $\mathbf{7 7 4}$, la que habiendo salido del puerto de San Carlos donde la construyó, la marea creciente la introdujo en el canal del Chacao, y la contraria la arrebató, obligándola a salir al Oceano por la exf c tsada boca chica que es bastante hondable.

II. El curso de las mareas crecientes es casi al Este hasta estar tanto avante con la punta de Punguñón, y desde aquí según la dirección de la costa al Este 1/. Sueste, Esueste y Sueste; y su velocidad tanto avante con San Gallán, donde se estrecha el canal á ménos de media legua en los días de novilunio y plenilunio, llega cerca de ocho millas por hora, y casi lo mismo en la punta de Remolinos. Los vaciantes siguen curso opuesto al dicho, y su morimiento algo más acelerado que el de las crecientes.

12. La razón de atracarse á la punta de San Gallán y de ésta para adentro como se ha dicho, es la de libertarse del riesgo de la laja que está á media canal al Este $13^{\circ}$ Sur de dicha punta distancia de dos millas escasas, la que á un tercio de vaciante se descubre, y áun en la mar llena la indica la multitud de revesas y grande escarceo que forma el encuentro del agua en ella; lo que hace huir su inmediación (es bastante peligrosa) sin embargo de ser muy acantilada la peña.

13. Si se quisiere venir á este puerto del Chacao, saliendo del de San Cárlos, se pondrá á la vela en éste á media marea vaciante, y luégo que se halle zafo de la punta de Agui, se dirigirá al rumbo del Norte $1 / 4$ Noroeste guiñando para el Norte, llevando el morro de Huapilacuy bien descubierto por babor, hasta que el dicho demore al Oesnoroeste distancia como de media legua, desde cuyo punto se hará el rumbo del Norte $1 / 4$ Nordeste hasta que la punta de Huapacho $\delta$ su farallón (éste se ha dicho que es la puntilla de Tenuy) demore al Oeste I $5^{\circ}$ Sur, que estará caśi enfilado con Huechucucuy, y entonces empezará á navegar al Este $6^{\circ}$ Sur, obrando en lo demás como se ha dicho en el número $g$.

14. El puerto de San Antonio del Chacao, desde la población de esta provincia hasta el año 1768 que por Real ord ${ }^{n}$ se pobló el de San Carlos, era donde venía. las embarcaciones del Perú para hacer el comercio de tablas de Alersi y demás cortos ramos de industria de los moradores de esta isla, por cuyo motivo la población era bastante crecida respecto á la pro. vincia: residian alli el Gobernador político y militar de ella, los Oficiales y tropa veterana de su guarnición, y los Tenientes de Oficiales reales, pero ha quedado como el resto de la costa con muy pocos vecinos dispersos, porque todo se ha trasladado al de San Carlos.

15. El terreno vecino es bastante apropósito para cultivado, y lo está á proporción del número y circunstancias de las gentes que lo habitan, que como á todas las de la provincia domina la pereza, especialmente á los hombres.

I6. El puerto es bastante capáz y seguro en la benigna estación del verano, pero no así en la del invierno, porque para abrigarse de los vientos propios de ella, particularmente del Norte, apenas hay suficiente extensión para tres embar- 
a dirección te y Sueste; an Gallán, s de media lunio, llega si lo mismo ntes siguen niento algo es.

inta de San o se ha dila laja que ur de dicha ss, la que á y áun en la e revesas y ro del agua ión (es basmuy acanpuerto del se pondrá á hte, y luégo vui, se dirite guiñando Huapilacuy gue el dicho mo de media rumbo del nta de Huato que es la $15^{\circ}$ Sur, que $y, y$ entonces obrando en mero 9 .

del Chacao, cia hasta el pobló el de barcaciones te tablas de ustria de los otivo la poto á la pro$r$ político y veterana de ficiales reade la costa porque todo

e apropósito in del núme-

e lo habitan, a domina la y seguro en no así en la. de los vien. e del Norte, tres embar- caciones, y no á la gira, en la poza ó ensenada del Estero, que es donde pueden estar resguardadas; esto, los riesgos de bajos, largo del canal y violencia grande de las mareas, hace mucho más cómodo á los navegantes el comercio con el de San Carlos, donde entran y salen las embarcaciones, libres en la mayor parte de los citados riesgos.

17. Sobre un pequeño ribazo á la orilla del mar, hay un fuerte provisional, como el de San Carlos en mal estado é inútil; el Cerro de la Ermita al Este lo domina á tiro de fusil, y puede ser atacado y tomado por la espalda con mucha facilidad y prontitud, desembarcando en la ensenada de Manao que está una legua al Sur del puerto, el que para su defensa no necesita otrà fortificación que la tropa, y cuando se conciba preciso algún fuerte, parece debe construirse sobre el cerro de la Ermita, cuya natural disposición y no tener otro vecino que le domine, le hace á propósito para el efecto.

18. La pleamar en los días de Luna nueva y llena, es en este puerto á las doce del día; crece el agua 22 piés de Castilla, y en las mareas regulares I8; unas y otras son de á seis horas.

Derrota del puerto de Chacuo al de Linao, situado en la latitud Sur de $42^{\circ} 3^{\prime}, y$ en la longitud de

$$
303^{\circ} 47^{\prime} \text {. }
$$

19. Puesto á la vela en el puerto del Chacao, se gobernará al Este $1 /$. Nordeste distancia de tres ymedia millas, las que cumplidas, tendrá la punta de Tres Cruces que es la tierra más Este del Chacao al Oesudoeste como á una milla, desde donde se hará el rumbo del Sur guiñando algo para el Este la distancia de tres leguas, la que verificada, se hallará ya rebasado de la punta de Chillen, de la cual sale un pequeño bajo de arena como hasta un tercio de miila, y le demorará lo más Norte de la peninsulita Huapi-Linao al Oeste 26 ó $28^{\circ}$ Sur distancia cuatro millas, á la que llevará descubierta por babor, atracándose hasta tiro de fusil por ser muy acantilado por esta parte; seguirá para ientro al rumbo del Oesudoeste y Sudoest. Deste hasta dar fondo en la inmediación de la Capilla sobre diez ó I2 brazas de agua fondo lama distancia de tierra como dos á dos y medio cables.

20. Advertencias. En esta navegación se expresa el desvío de una milla de la punta de Tres Cruces, no obstante ser tan hondable, que en bajamar á 50 varas hay 120 brazas, porque en ella tienen las mareas casi tanta violencia como en la de Remolinos, con grande escarceo y revesas que más de una vez han hecho sumergir las embarcaciones menores, y áun á principios de este siglo, una grande del comercio del Perú tocó en la laja del canal, y con la violenta acción de la marea, detenida en la punta de Tres Cruces, las revesas y el viento Sur fresco, la sumergieron, pereciendo toda la gente á tiro de pistola de tierra.

2I. El desvío de la punta de Cliillen, es no tanto por su pequeño bajo, cuanto porque allí so encuentran las mareas contrarias, esto es, la que entra por el canal de Chacao y desde la punta de Tres Cruces sigue al Sur, y la que entra por la boca grande del Huajo, y discurriendo por los demás estrechos y canales sigue hacia el Norte hasta dicho punto, donde la línea de división que forma el encuentro es tanto más peligrosa, cuanto el viento sea más fresco, la embarcación más pequeña y la marea esté más próxima á su mediación. Desde dicho lugar toman las vaciantes un curso diametralmente opuesto, pues la que desagua por el canal de Chacao al Océano, retrocede hacia el Norte, y la que se dirige á salir por la boca del bajo, forma su retroceso hacia el Sur; esta raya del encuentro de las mareas, procuran cuidadosamente huir los naturales por las muchas desgracias que han ocurrido en ciir; fórmase otra igualmente peligrosa entre la punta de Tres Cruces, ensenada de Parua é Isla de Abtao: en todo el canal del Ciracao, hasta fuera del Huapacho al encontrarse la vaciante y creciente, con particularidad si la marea que acaba es acon1pañada de viento fresco: sobre los bajos de Chay. huau y en otras varias partes, pero las más peligrosas son las dichas.

22. En el tránsito de la punta de Tres Cruces á la de Chillen, está la grande ensenada de Manao, que es sondable y de buen surgidero, aunque desabrigada á los vientos del Este y Nordeste que suelen soplar algo frescos, pero res. guardada de los más impetuosos y frecuentes del año.

23. En el puerto de Linao pueden abrigarse bástantes embarcaciones, pero es necesario en tiempo de invierno surgir en la ensenada de Gueldan á distancia de dos á tres cables de tierra sobre 16 á 18 brazas fondo lama y arena, y en el de verano á la misma distancia de la Capilla ó en el principio del Estero sobre fondo de to á $\mathrm{s} 2$ brazas arena; que de estos parajes hacia el medio del puerto va aumentando el fondo á 30,40 y 60 brazas hasta la boca, en que hay roo. El terreno que forma el puerto es propio para el cultivo, $y$ lo tiene, en lo que pueden las $\mathrm{I}_{2}$ ó $\mathrm{r}_{4}$ familias naturales que pueblan su contorno.

24. Este puerto se reconoce por la penínsu. la Huapi-I.inao; su parte del Norte es la boca que se presenta como una isla tajada al mar por la parte del Este y Sur que es donde altea más; á corta distancia al Este se verán algunas rocas del Arrecife de Lobos, el cual sale de lo más Norte de dicha península al Este $18^{\circ}$ Sur, distancia media milla, y á tiro de piedra de el, tay 
en bajamar de seis á siete brazas de agua; también sirve para el reconocimiento, la igualdad de la tierra algo alta que está sobre el puerto, y la playa del Llihuco, que desde Huapi-Linao corre hacia el Sueste, distancia de tres leguas, y es la mayor que hay en toda la costa oriental de la Isla de Chiloé.

25. Los días de novilunio y plenilunio es la pleamar en este pterto á las doce $y$ tres cuartos del día, su aumento 22 piés, respecto á la bajamar de dichos días y en las aguas muertas 18 piés. La velocidad que llevan en la boca, es de tres millas la creciente $y$ tres y media la men. guante á media marea, que es su mayor fuerza.

Derrota dal Puerto de Linuo al de Castro, situada su boca en latitud Sur $42^{\circ} 5^{0^{\prime}}$ y en longitud $303^{\circ} 39^{\prime}$ por los canales que forman las Islas Quinchao y C'hiloé, $y$ ésta con la parte del Norte de la de Lemuy.

26. Saliendo de dicho Puerto de Linao, desde la medianía de su boca se gobernará al Este hasta que lo más Sur del Barranco de Huapi-Linao demore al Sudoeste, que hallándose ya sin riesgo del Arrecife de Lobos, s: gobernará al Sueste $1 \%$ Sur, guiñando un poco para el Este y llevando la punta de Lobos de la Isla Caucahue, que es escarpada por estribor; á las 17 y $1 / 2$ millas navegadas se hallará al Sueste $1 \%$ Este y Noroeste $1 \%$ Oeste, distancia como de una legua de la costa de la punta dicha, y demorándole el canal de entre Cuicabi y los Chauques al Sur, á cuyo rumbo se dirigirá, y habiendo navegado I I $1 / 2$ millas, estará en la embocadura del canal, y á medio freu de él sobre el rumbo del Sur $2^{\circ}$ Oeste, se seguirá hasta que lo más Sur de dicha Cuicabi, que se llevará por estribor, quede al Norte $\%$ Noroeste, que entonces se volverá á seguir el rumbo del Sur distancia seis millas, que cumplídas se estará Noroeste-Sueste con la punta de Tenaun, demorando al Oeste el canal de Quinchau, que empieza entre la punta ó Moro Calen y la islita Linlin; desde dicho punto se navegará al Ocste siete millas, con que queda rebasada dicha isla, que es escarpada por la parte del Norte y morro Calen. Desde aquí gobernará al Oeste $6^{\circ} \mathrm{Sur}$, cuatro millas hasta estar NorteSur con la Capilla de Cuetalco á estribor, y punta Buyar á babor, desde cuya situación se hará el rumbo del Oeste $29^{\circ}$ Sur cuatro $y$ media millas, que cumplidas se estará próximo á la mayor an. gostura del canal de Quinchao, que es como de 800 varas, y se pasará á medio freu en vuelta del Sursudoeste, distancia de media milla hasta montar la punta de Cuyumuy, que es lo más Oeste de la Isla Quinchao 'uego se pondrá á go. bernar ai Sueste 1/4 Su: el espacio de tres millas hasta estar Esnordeste-Oesudoeste con la Ca. pilla de Curaco en dicha isla; desde este punto na-

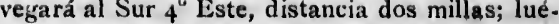
go el Este $28^{\circ}$ Sur, y á las ocho millas estará rebasada la punta y bajo Aguantao, y a la vista demorándole al Oeste $32^{\circ}$ Sur la punta Chalihue, en la Isla de Lemuy, y distante media legua al Sur la de Chelín. Desde dicho punto navegará al Oeste $25^{\circ}$ Sur, hasta que la punta de Aguantao que llevará por estribor, demore al Norte una milla 6 poco más, desde cuya situación hará el Oeste $8^{\circ} \mathrm{Sur}$, distancia ocho millas, y se hallara en la embocadura del Estero ó puerto de Cas. tro, qne la forman la punta de Tutil al Este, y la islita de Linlinao al Oeste. Del citado punto se dirigirá al Norte $8^{\circ}$ Oeste hasta estar como á un tercio de milla de la costa del Norte, que en. tőnces gobernará al Oeste $15^{\circ}$ Norte, y á poco más de media legua se pondrá al Norte $28^{\circ}$ Oes te hasta navegar una milla, que cumplida, se ha. llará tanto avante con la punta de Pebque (es la más saliente de la costa del Este de este Estern) y á media canal de la mayor angostura. Wesde este paraje se gobernará al Este $37^{\circ}$ Norte distancia dos tres cuartos millas, y de este sitio al Norte $14^{\circ}$ Este una y un tercio, que verificado, se hallará al Esnordeste-Oesudoeste con la ciudad, $y$ en el mejor fondeadero respecto de ella, donde dejará caer el ancla en I3 á I4 bra zas de agua, fondo lama, 6 lama y arena, distante de la punta de Niculao, que es el desembarca dero de la ciudad, y se amarrará de Norte a Sur.

27. Advertencias. Practicando esta derrota, si por alguna urgencia fuese necesario surgir en la playa del Lliuco, será en 20 á 25 brazas arena, á distancia como de media milla de tierra, porque más afuera aumenta el fondo repentinamente á 50, 60 y más brazas; y de dichas 20 para la costa se encueritra el placer de poca agua con muchas piedras sueltas desde Huapi-Linao hasta la Capilla de Lliuco para las puntas de Ahucho y Queñiau; el citado fondo de 20 á 25 se halla 4006 500 varas de tierra, y su aumento para fuera es pronto y considerable, desapropósito para surgidero. Toda la playa es desabrigada de los vien. tos desde el Sueste para el Este y Norte hasta el Noroeste, y muy peligrosa con los del Este y Nordeste; de los demás está cubierta, y tiene los ríos de Metenguen y Ahucho para aguala.

28. Continuando en la expresada derrota, se hallan los surgideros de Terraun y Calen, ambos son buenos, con 25 á 30 brazas de agua fondo lama, á 500 varas de tierra; son desabrigados de los vientos del Sudoeste para el Sur hasta el Este, pero están á cubierto de los restantes, que como se ha dicho son los más impetuosos, y tie. nen dos riachuelos de buen agua con particularidad el "e Terraun. De Calen para el Oeste, que ya es el canal de entre Quinchao y Chiloé, cualesquiera de las dos costas que lo forman son surgidero para toda suerte de embarcaciones mé- 
millas; lué. hillas estará

y á la vista Chalihue, edia legua al navegará al e Aguantao Norte una ción hará el y se hallalerto de Cas. al Este, citado punto estar como á orte, que en. te, y á poco orte $28^{\circ}$ Oes. pplida, se ha. e Pebque (es de este Es. $r$ angostura. ste $37^{\circ}$ Norte de este sitio que verifica doeste con la respecto de ${ }_{3}$ á I4 braarena, distan d desembarca - Norte á Sur sta derrota, si - surgir en la razas arena, á ierra, porque ntinamente á para la costa a con muchas hasta la Capi hucho y Que: halla 400 ó para fuera es to para surgide los vien- Norte hasta os del Este y ta, y tiene los aguata.

da derrota, se Calen, ambos e agua fondo sabrigados de Sur hasta el estantes, que tuosos, y tieon particula ura el Oeste, tan y Chiloe, o forman son caciones mé- nos para las que calen más de tres brazas de agua; pues no pueden pasar por entre el astillero de Dalcahue y la costa de Quinchao sino á pleamar 6 antes de media vaciante, porque es necesario fondeen antes de montar la punta i Cuyurmie, que será lo mejor, é inmediatamente que se haya montado, esperar marea para pasar sin riesgo en dicho poco fondo; teniendo siempre cuidado de surgir más inmediato á la costa del Norte que á la del Sur, porque de ésta sale un bajo de arena y concha con mucho sargazo que á bajamar casi se descubre, y se avanza hacia el Norte hasta un tercio de canal, cuyo resto hasta la costa de Quinchao tiene á bajamar escorada tres y media brazas de agua, y cste poco fondo sólo se extiende á un tercio de milla de Esueste Oesnoroeste, según la dirección del canal. La ensenada de Curaco en Quinchao, es también aplacerada, por cuya razón se debe pasar más inrıediato á la costa de Quelinquehue en Chiloé que se lleva á es. tribor, que á la dicha de Quinchao que es la de babor.

29. De la punta de $A$ guantao sale al rumbo del Este hasta la distancia de media milla, un bajo de arena que remata en purta aguda, que tiene á bajamar media braza de agua cerca del extremo del Este, peio casi repentinamente se cae á cinco brazas, profundidad suficiente para un navío de guerra.

3o. De la punta de Yenue cerca de la Capilla de Nercon, en el Estero de Castro, sale un bajo de arena lama y marisco, que con varias inflexiones sigue hasta la punta de Niculao, el cual se avanza en algunos parajes hasta 800 varas de la costa del Oeste, por lo que desde la punta de Pebque hasta el fondeadero de la ciudad, es necesario atracarse más á la costa del Este que á la dicha del Oeste. Este bajo queda casi todo descubierto á bajamar de aguas vivas, y á pique de su veril hay de cinco brazas de agua á más.

3r. En orden á mareas se debe advertir quc desde la boca de Linao hasta la cercanía del canal 6 estrecho de Quincabi y los Chauques, es el movimiento de poca consideración, pero de allí adelante son de absoluta necesidad para el viaje, y siguen con leve diferencia los rumbos que expresa la derrota y sus opuestos, y sólo resta que advertir que en dicho estrecho es la velocidad que llevan como de legua y media por hora; hacia el Sur, del de una milla ó poco más hasta la angostura entre Calen y Linlin, de aquí en adelante, su velocidad, á proporción que va angos. tando el canal (razón común á todos los demás que se expresarán) de Quinchao, y en la mayer angostura de éste es de tres á cuatro millas, la que luego se disminuye á dos y media y dos hasta estar rebasado de las puntas de Aguantao y Chaliue Isla de Chely que se disminuye más, pues apenas llega á media legua por hora hasta estar entre la punta de Tu-tin é islita de I.inlinao, que se vuelve á aumentar á dos y dos y media millas para adentro del Estero de Castro; debiendose suponer que todos estos movimientos son á media marea, y que se altera algo en las aguas vivas y tiempo de lluvias fuertes.

32. 'También se advierte, que en la derrota del rumbo al Sur para navegar desde la punta de Lobos de la Isla Caucahue hasta el Estrecho de Cuicabi, se halla al paso el bajo de Lumulmul, que es de peñas, $y$ vela hasta un tercio de marea creciente: tiene de extensión Noroeste Sueste media milla, es muy acantilado, está Noroeste. Sueste con la punta de Quinquerquen que es la más Sueste de dicha Isla Caucahue; y siguiendo la citada derrota se deja por babor al Este dis tancia como de dos millas.

33. Nota. El Estero de Castro, que sin disputa es el mejor puerto de toda la provincia, y acaso tambiën de los reinos del Perú y Chile, es excelente surgidero para grande número de embarcaciones de todos portes, con fondos muy proporcionados desde 20 hasta seis brazas que se hallan á tiro de piedra de sus costas, y en al. gunos parajes aún á ménos distancia, á excepción de la que comprende el placer ó bajo citado. Sobre suelo de lama por lo general especialmente de la punta de Pebque para el Norte, en él se está á cubicrto de todos vientos, y su mar nunca se agita con ellos en términos de ocasionar riesgo. Todo el terreno vecino, aunque algo alto el de la parte del Este, es muy á propósito para poblaciones y siembras, con particularidad el del Oeste. La población es como se ha dicho; habitaciones dispersas por la campaña; aunque por las ventajas que ofrece este terreno desde Chonchí hasta las Capillas de Tey y Quilquico, están las casas más contíguas que en el resto de la provincia, y á consecuencia, es lo más cultivado de toda ella.

34. La ciudad de Santiagode Castro, capital, está situada en la costa occidental del Estero por latitud de $42^{\prime \prime} 45^{\prime}$ y longitud de $303^{\circ} 39^{\prime}$. Sobre una bella y espaciosa meseta que se levanta des. de el nivel del mar de 55 á 60 varas, y en el mar lleno, queda lecha una especie de península formada por el río Gamboa, que la baña por los lados de Occidente y Mediodía y el Esterito de Tenten por el Norte. Se dice que en los principios fué bastante regular la ciudad, y á pocos años de su fundación la arruinó ư formidable terremoto; que reedificada de nuevo, la devastó el pirata inglés Baltasar Cordes en 1600 , y en el de I6r5 el holandés Jorge Spilguert.

35. En la cara del Occidente de la plaza hay un fuertecillo más despreciable que los de que se ha hablado. En la costa del Estero, y como media legua hacia adentro de su boca, hay una 
batería provisional sobre el terreno nombrado Tauco, capaz de ocho cañones, y está casi des. hecha.

36. Nota 2." La derrota anterior desde el puerto de Linao hasta Castro, sólo se puede ejecutar con embarcación grande, ó mediana en una absoluta urgencia, porque aunque los canales que en ella se discurren tienen suficiente profundidad pa،a los mayores navios, sus angosturas inflexiones causan por lo común varios embates de vientos diversos, ya frescos, ya bonancibles, lo que unido al defectuoso gobierno que áun á las embarcaciones más finas ocasiona la corriente ó marea en popa y sus revesas, las llevan á aquélias contínuamente expuestas á varar ya en una ya en otra costa, que casi son todas acantiladas y en muchos parajes con piedras sueltas algunas lajas, por cuya causa, la derrota más segura de uno á otro de dichos puertos, ha de ser por fuera de los citados canales, Islas de los Chauques y demás que están contíguas á la costa del Este de lade Chiloé, yendoá recalar álas puntas de Detif y á Pavón, que están en lo más Su y Este de la Isla de Lemuy, ya sea para entrar por el canal del Norte de ésta, ó ya por el del Sur de ella, que será lo mejor, á cuyo efecto se hará la siguiente.

Derrota de Linao a Castro por fuera de los canales é islas del Este de la de Chiloć.

37. Saliendo del puerto de Linao y hallándose ya Norte-Sur con lo más fuera del arrecife de Lobos, se gobernará al Sueste distancia de i 2 leguas, las que cumplidas, se hallará Tisnordeste ó Esudoeste con lo más Norte de la Isla de Cochi, que es la más Este de las de los Chauques, distancia de cuatro y media á cinco millas; desde dicho paraje gobernará al Sur la distancia de tres y media leguas, y verificada, se estará Este-Oeste con la Isla de Tac, que es baja, y está Norte-Sur con la dicha de Cochi. Desde esta situación se gobernará al Sursudoeste $22 \mathrm{mi}$ llas, y cumplida esta distancia, se pondrá al rumbo del Oeste, $y$ habiendo navegado sobre $\mathrm{Cl}$ seis leguas, se tendrá rebasada la punta de Ahoni, y se hallará Norte-Sur con la de Detif: desde este punto se hará el rumbo del Noroeste distancia dos y media millas hasta estar Este-Oeste con la Punta de Terao distancia de una escasa, que se pondráá gobernar al Nornoroeste $5^{\circ}$ Norte, y habiendo navegado dos millas y media, se hará al Oesnoroeste distancia de una, y cumplida ésta, se navegará poco más de otra al Oesudoeste, lo que verificado, se hallará á medio freu del canal del Sur de la isla de Lemuy. Desde este sitio navegará á medio canal siguiendo el rumbo del Oeste $15^{\circ}$ Norte una milla, y cumplida ésta dos al rumbo del Noroeste llevando por la proa la punta escarpada de Colulil en la Isla de Chiloé, y al cumplir dicha distancia, se hallará tanto avante con la punta de Lomemo, que es lo más Oeste de Lemuy, la que se lleva por estribor: desde este punto se hará el rumbo de! Norte distancia de una milla, y cumplida se hallará Este-Oeste con el Estero de Ychauc en Lemuy: desde esta situación navegando al Nornordeste dos y media millas se hallará entre la Punta de Tutil y la islita de Linlinao, que como se ha dicho es la boca del Estero de Castro, por lo que en lo demás de él hasta el fondeadero de la ciu. dad, se obrará como se ha dicho en el número 26.

38. Advertencias. La Isla de Cochi, que como se ha expresado es la más oriental de las de los Chauques, es algo alta, lo que se avistará en tiempo claro casi desde la boca de Linao, espe. cialmente por la parte del Este que es escarpada y $\sin$ surgidero alguno, y lo mismo la de Tac aunque baja. Siguiendo la derrota se pasará una legua al Este de la Isla de Apiao y como cuatro millas de lo más Este de la de Chaulinec; ambas son altas y carecen de surgidero por dicha parte, las que se llevan por estribor, dejando á babor distancia de cinco á seis millas las de Chulin, Chuit y Nayahe chica y grande, que son bajas y desiertas.

39. Montada Chaulinec, se verán al Oeste distancia de seis leguas, las puntas de Apabón y Detif, que como se ha dicho, están en lo más Sur de la Isla de Lemuy, y son su objeto más remarcable. La primera se puede ver de ro á I2 leguas de distancia y es el escarpe más elevado que se nota en toda la costa del Este y sus con. tiguas; al Sur del dicho se ve una pequeña abra de tierra muy baja, y luego se clcva la Punta de Detif, que es aguda y algo alta por un cerrito frondoso escarpado por todas partes, que la forman, que desde fuera hace la apariencia de una islita, desde una á otra de dichas puntas toda es baja de piedras con sargazo, que sale poco más de un cable de la costa, pero se avanza hasta tres hacia el Sursudoeste de la punta de Detif, y cerca de dos al Esueste de la de Apabón, con peñas que velan desde media vaciante del mar hasta media creciente, formando dos islotitos.

40. Desde Chaulinec, siguiendo la derrota del Oeste en demanda de la boca del canal, se doja por estribor el bajo del medio de entre Apabón y la más Oeste de Chaulinec, pasando al Sur de el distancia de una legua; es de peñas, tiene de extensión Noroeste Sueste una milla, y media de Nordeste-Sudoeste; se descubren algunos cabezos de él antes de media marea vaciante, sus sargazos siempre están manifiestos, y es muy acantilado.

4I. La punta de Ahoni que está ai Sur de las de Apabón y Detif, con quienes forma la en. 
trada del canal del Sur de Lemuy, es también alta, hace especie de morro cubierto de verde, $y$ unas y otras no admiten confundirse con al. guna de sus inmediatas ni entre sí. A dicho morro lo circuye un bajo de arena y piedras, su fondo de alfaques desigual de cinco, dos y ocho brazas á bajamar está al Este del morro como tres cables, $y$ sigue hasta la capilla de Ahoni, que está una milla escasa al Oeste del citado morro.

42. Siguiendo para adentro del canal, se verá por encima de la punta de Detif el escarpado, casi tan alto como el de Apabón, de la punta de Yal en Chiloé, que va descendiendo hacia el Norte hasta acabar cerca de la punta propia de Yal, que es baja; al Nordeste de ésta á dos tercios de milla, está el bajo de su nombre, que entre lo más Sudoeste de él y la punta dicha, deja un canalizo de $\mathrm{x}_{4}$ brazas de fondo y 200 varas de ancho, acantilado por una y otra parte; sobre el bajo, que es de arena, piedra, lastre y marisco, hay dos pequeñas islitas, la de afuera mayor, pero ambas casi las cubre la pleamar de aguas vivas, y la bajamar de las mismas descubre totalmente el bajo.

43. Las mareas son de poca consideración en esta derrota hasta estar tanto avante con la punta 6 morro de Ahoni, pero de ella en adelante es sensible, pues llega á media legua por hora hasta estar al Norte de las islitas de Yal, desde cuyo punto empieza á ser de tres y más millas, hasta estar tanto avante con las puntas de Cululin en Chiloé y Luculemuy. Desde este punto disminuye su velocidad hasta la boca del Estero de Castro, de forma, que apenas llega á una milla por hora, $y$ desde dicha boca para adentro del Estero, ya queda advertido su curso y movimiento en el número $3 \mathbf{I}$.

44. Desde la capilla de Ahoni para adentro del canal, se puede surgir en cualquier parte de la costa á dos 6 tres cables de ella, pa.ticularmente en la bahía de Terao, que es de muy buen tenedero, separándose de la costa á distancia de media milla, aumenta el fondo tanto, que es desapropósito para surgir, especialmente hasta estar al Norte de la punta Yal.

45. En fondeadero citado de Castro, es la pleamar en los días de Luna nueva y llena á las I $2^{\mathrm{h}}$ y $26^{\prime}$ del día, y aumenta respecto á la bajamar de $I_{5}$ á 16 piés, y de $\mathrm{I}_{3}$ á $\mathrm{I}_{4}$ en las aguas muertas ó mareas regulares.

46. Nota. Que aunque en los Diarios de los viajes anteriores á esta derrota y en la carta hidrográfica general de la provincia, que he formado sobre las observaciones y reconocimientos que se expresan en ellos, consta el canal que forman las Islas Chiloé y Caucahue, y así mismo haber levantado el plano del puerto de Huytin que se halla en dicho canal, no se ha hecho mención de uno ni otro, en las derrotas de Linao á Castro, porque aunque el canal es de suficiente $y$ áun excesiva profundidad, no es de extensión para emprender su paso aún con embarcación mediana. Además de su angostura, la violencia de las mareas y demás razones dichas para evitar el paso por estos canales, retardan mucho el viaje, entrando por él: no se ha hecho tampoco el del puerto citado, pues su extensión no permite un paquebot á la gira, sin embargo de ser tan decantado por los naturales del país.

Derrota de Castro a la bahia de Terao, situada en latitul Sur de $42^{\circ} 57^{\prime} y$ en longitud de $303^{\circ} 44^{\prime}$.

47. Puesto á la vela en el fondeadero de Castro, se hará derrota á los rumbos opuestos á los que se han dado en el número 26 hasta estar entre la islita de Linlinao y la punta de lutil; y desde este punto, se ejecutarán los opuestos á los que se previenen en el número 37 hasta estar Nordeste Sudoeste con lo más alto del escarpado de Yal, que se hará derrota al Sursudoeste con tal cual guiñada para el Oeste, y á poco más de dos millas navegadas al citado rumbo, descubriré por babor la capilla de Terao, y en demorándole al Sueste $1 / 4$ Este, dará fondo al ancla en 18620 brazas sobre lama y arena, distante de tierra de tres á cuatro cables.

48. Advertencias. En las derrotas de Linao á Castro quedan hechas las reflexiones necesarias á la anterior, por lo que sólo resta decir aquí, que si faltase el viento ó marea para llegar al fondeadero de la capilla, se puede surgir en cualquiera paraje de la bahía sobre 30 á 40 bra. zas de fondo lama verde, teniendo presente, que de lo más Sur de la península de Yal y alto de su escarpado, sale hacia el mismo rumbo un bajo de piedras hasta la distancia de 300 varas, y hasta 400 otro de la punta de Api que es la más Norte y Este del fondeadero dicho de la capilla.

49. La bahía de Terao está descubierta á los vientos del Este al Norte, pero agitan poco la mar y el tenedero es muy bueno; está abrigada de todos los demás, aunque no mucho del Noroeste, y siendo una 6 dos embarcaciones sueltas, pueden estar á cubierto especialmente en invierno, en el puertecito de Pacatue, que está en la misma bahía media legua al Norte $1 / 6$ Noroeste de la capilla de Terao.

50. El terreno es algo elevado por la mayor parte, pero no faltan sitios á propósito para la. bor; está poco cultivado, y su población es escasa y miás dispersa que hacia el Norte. Esta es la primera capilla de la jurisdicción ó territorio que llaman de los Payos, cuyo vecindario hacia el Sur todo es de indios.

5r. Las mareas suceden en esta bahía en los días de Luna nueva y llena á las doce y cuarto 
del día la pleamar; su aumento respecto á la baja de $\mathrm{I}_{3}$ á $\mathrm{I}_{4}$ piés de Castilla, de las mareas regu. lares de 12 á $x_{3}$, y su movimiento de milla por hora.

52. Nota. Que en el tránsito de esta derrota se halla en la costa del Oeste de !a Isla de Le. muy el Esterito de Ichuac, que es buen abrigo para embarcaciones chicas y medianas, y áun para dos 6 tres grandes, pero acoderadas, porque el pequeño ámbito del Estero no permite se mantengan á la gira.

Derrota de Terao al puerto de Caylen, situado en latitud Sur de $43^{\circ}$ I I' y en longitud de $303^{\circ} 53^{\prime}$

53. Habiendosalido del fondeadero de'Terao, desde la medianía de la boca de la bahía, se hará derrota al Este $\%$ Sueste, hasta que la punta de Detif demore al Sueste, y luégo se pondrá al Sur, cuyo rumbo seguirá hasta quc el escarpado de dicha punta demore al Esnordeste; desde aquí gobernará al Sueste $1 / 6$ Este seis y media millas, y cumplidas, se encontrará demorándole Detif al Noroeste y la Punta de Aituy al Sur distancia cuatro millas; desde este punto gobernará al Sursueste distancia de siete y tercia millas, llevando por la proa la punta de Huechupicun, que es la más Este de la Isla de Tanqui é igualmente la tierra más Sur (de las del Oeste) que tendrá á la vista; cumplida dicha distancia, se hallará Noroeste Sueste con la citada punta de Aituy, y demorándole al Sursudoeste lo más Oeste de la pequeña Isla de Acuy, á donde se pondrá la proa, y habiendo navegado á este rum. bo una legua, al cumplirla, se estará Nornoroeste Sursueste con la punta de Poquenco, en Chiloé que es rasa, y en la medianía del canal que hace con la islita dicha Acuy; desde este punto se hara rumbo al Oesudoeste media legua, llevando descubicrto por babor el escarpado de la punta de Mapu (en Tanqui), y por estribor la punta rasa de Queilen. Cumplida dicha distancia, se estará en medio del canal que forman las puntas expresadas, desde donde se hará el rumbo al Oeste $1 / 4$ Noroeste una milla, que teniendo rebasada, la de Queilen ya se pondrá al Norte $25^{\circ} \mathrm{Es}$ te, y á poco más de una milla navegada á este rumbo, dejará caer el ancla en el fondeadero de Queilen I6 á 18 brazas fondo arena, demorando la capilla ó iglesia al Este 1/ Sueste, quedando distante de la playa de tres á cuatro cables.

54. Advertincias. En toda esta derrota puede fondearse cerca de tierra, especialmente en la playa de Lebrun, dondc está el río Libon, bueno para aguada; pero de la punta de Aituy en adelante es impracticable, porque desde ella empiezan los bajos de su nombre, cuyo placer corre hasta la punta de Poquenco: algunos se descubren a bajamar y áun antes, y en la alta si hay algún viento, los indica la reventazón; lomás fuera de ellos está Sueste $\%$ Sur, Noroeste $\%$ Norte con la punta de su nombre, distancia como de una milla, y á casi igual de la costa, forman un trián. gulo equilátero como de un cable $y$ medio de lado, y en sus ángulos hay tres restingas de pie. dras de 40 á 50 varas de extensión, siendo el resto entre unas y otras, canalizos de dos á tres brazas de agua fondo arena, y entre ellos y la costa desde una y media hasta tres y media brazas á media marea, sobre arena por la mayor parte, alguna lama, tal cual manchón de lastre grueso y piedras sueltas con sargazo, y lo mismo en toda Ja ensenada desde punta Aituy hasta la de Poquenco, que es de una dilatada playa de arena muy aplacerada, y en tiempo de verano con continua resaca, tan incómoda, que áun á lanchas y botes imposibilita atracar sin riesgo.

55. La punta de Poquenco es rasa y tiene en su remate un pequeno arrecife de piedras, pero cualquiera embarcación puede atracar á ella; pues á 200 varas de distancia se está en 25 brazas arena; de lo más Norte de la islita de Aqui sale en vuelta del Nordeste $\%$ Norte hasta la distancia como de media milla, una restinga de piedras, algunas de las cuales velan á baja. mar, $y$ en la alta las indica el escarceo que se forma entre ellas y el romper del mar si hay viento del primero ó segundo cuadrante.

56. En los números 39 y $4 \mathrm{I}$ queda expresado el reconocimiento y circunstancias de las puntas de Ahoni y Detif; por lo que sólo resta que advertir, que desde la primera hacia el Sueste está la playa dicha Belelbum, que termina en la punta de Pellif, que sa de piedra tajada al mar, y lo mismo toda la costa que sigue hasta rebasar. la de Aituy, que es de la misma naturaleza, sin otra semejante en toda su mediación más que la citada de Pellif y la de Caritayhue que está en. tre las dos; el barranco es de mediana elevación, y sobre el de Aituy hay centinela de los indios payos, y lo mismo en la punta de Huechupicun. que como se ha dicho, es la más Este de la Isla de Tanqui. La islita de Aqui tiene poco más de una legua de circuito, es baja, $y$ por la parte del Norte que es donde altea más, tajada al mar. Las puntás de Poquenco y Queilen, no pueden confundirse con otras, así por ser las más rasas de toda la isla de Chiloe por su parte del Este, como porque en la derrota anterior son la tierra más Sur de dicha isla. La de Queilen de media creciente en adelante, vista desde lejos parece una pequeña islita con algunos árboles separada del resto de la costa baja por una lengua de arena que en pleamar apenas tiene 2.0 varas de ancho.

57. La dirección de mareas en esta derrota, es con corta diferencia sobre los rumbos de ella hasta montar la punta Ahony es su movimiento 
de media legua por hora; desde ésta liasta el canal de entre Aqui y Poquenco es de un s milla; pero desde la entrada de éste hasta el surgidero de Queilen lleva dos y media millas de andar: en el puerto dicho sucede la pleamar á la una del día en los de novilunio y plenilunio y su aumen. to respecto á la bajamar de los mismos, es de 20 á 2 r piés.

58. Nota. Que en el Estero de Queilen se está abrigado de todos vientos, ménos de los del Sur al Oeste, pero ni aún éstos incomodan, porque no agitan el mar con motivo de la vecin. dad de la Isla de Panqui; y aún cuando incomo. dasen, siendo unz ó dos embarcaciones grandes, pueden ponerse á cubierto de todo internándose en el Estero. El terreno en que está la capilla, exceptuando el de la ciudad de Castro, es el de mejor disposición para pueblo que haya en toda la costa de la isla; bien que su campiña ve. cina es algo áspera por su repentina elevación, pero fertil. Habitan toda esta costa muy pocas gentes y muy dispersas, y á proporción de esto y le su natural desidia es el cultivo.

Derrota del Estero de Queilen al de Compu, situada su boca en latitud Sur de $43^{\circ}$ I I' y longitud $3^{\circ} 3^{\circ} 43^{\prime}$.

59. Puesto á la vela en Queilen, luego que la iglesia demore al Este 1/, Nordeste, se pondrá á gobernar al Oeste siete millas, que cumplidas, se hallará en la boca de Compu, demorando punta de Yeculinao al Sursudeste distancia de una milla por babor, $y$ por estribor la de Tumaumon, al Noroeste \% Norte á una milla escasa; desde este punto se hará el rumbo del Noroeste $1 \%$ Oeste el espacio de una milla, y cumplida ést: el del Nornoroeste igual distancia, la que verificada, haciendo en adelante rumbo al Oeste $2 \mathrm{I}^{\circ}$ Norte que conduce por medio freu del Estero surgirá en cualquiera paraje de él, que todo es limpio hasta la islita de Achalá, que está cerca de su fondo, y puede dejar caer el ancla en ro 6 más brazas lama y arena y lama, de que es todo el suelo de este Estero de Compu.

6o. Advertencias. En el tránsito de esta derrota se lleva por babor la costa del Norte de la isla de Tanqui á distancia de poco más de una milla, y por estribor la de Chiloé á distancia de media con poca diferencia: aquella toda es limpia y acantilada hasta la islita de Conejos y en la otra se ofrecen al paso las ensenadas de Ticunetu y Estero de San Miguel de Pailar. La I." es aplacerada y tiene en medio (algo saliente) el islote Chaqualin que por el Sur es acantilado; en la 2. " se puede surgir sobre 10,126 más brazas fondo arena: una y otra tienen casi igual exten. sión de media legua, y riachuelos perennes para aguada.

6r. El Estero de Pailar se interna casi dos millas al Norte lo más, pero su excesiva angos. tura que apenas llega á 80 varas, con fondo muy desigual de alfaques, especiulmente donde estu. vo la capilla para adentro, le imposibilitan ser abrigo de otras embarcaciones que las más pequeñas. No tiene habitación alguna en sus ori. llas, y éstas por la mayor parte son de peña ta. jada al mar, particularmente la de Oeste.

62. La punta de Tumaumón que es la del Este de la boca de Compu, hace morro alto, ta jado á pico, cubierto de árboles, tan acantilado, que á 50 varas de tierra hay de 70 á 80 de fondo, y lo mismo de toda la costa de estribor entrando, que sigue para la punta de Aulen, que también es escarpada: en el barranco de ésta hay una mancha de piedra tan blanca que aún de noche se distingue.

63. En el surgidero de Compu, es la pleamar poco antes de la una del día en los de Luna nueva y llena, y aumenta el agua respecto á su bajamar, de 18 á I9 piess, su velocidad es á media marea de 1.800 varas por horas, pero entre las puntas de Aulen y Yatechue que es la mayor angostura de la boca, llega á tres mil varas 6 media legua casi; y la dirección de todas desde Cailen á Aqui es con corta diferencia la de los rumbos que se expresan en la derrota y sus opuestos.

64. En todo este Estero de Compu se puede surgir muy cerca de tierra, porque todo es fondo limpio y de muy buen tenedero. Su ámbito lo hace capaz de contener gran número de embar. caciones de todos portes, con bastante abrigo; $y$ en la costa del Norte de la Capilla tiene el Es. tero de Pereu, que es una bella dársena natural, para las menores como lanchas y botes. El te. rreno es bastante apropósito para labor; sin embargo, hay poca población respecto á las circunstancias dichas y extensión del Estero.

Derrota dcl Estcro dc Compu al de Guildad, situada su boca en latitud Sur $43^{\circ} 24^{\prime} y$ cn longitua $33^{\circ} 3^{\circ} \mathrm{I}^{\prime}$

65. Desde Cor se seguirá por medio freu del Estero á los rumbos del Este $2 \mathrm{I}^{\circ}$ Sur y Sursueste hasta tanto avante con la punta ó morro de Tumaumon.

Desde aquí se gobernará al Sueste $1 / 4$ Este, llevando por la proa el islote de los Conejos, se estará Nordeste-Sudoeste con punta Yeculinao, que es la más saliente inmediata de estribor, desde donde se harán al Sur otras dos millas y estando tanto avante con el Esterito de Charmo á estribor, se pondrá al Sueste llevando la punta de Chahua, que es la tierra más Sur y Este de la costa de estribor, algo descubierta por babor: Se harán tres y media millas á dicho rumbo, y cumplido, al del Este 1/ Sueste hasta que la dicha punta de Chahua demore al Suoeste, des. de donde se navegará al Sueste la distancia de

oles separaza lengua de movimiento 
dos y media millas, llevando la islita de Chaulin descubierta por estribor; luégo que se verifique dicha distancia estará zafo del bajito de Chahua, y se pondrá al rumbo del Sur, llevando la punta Tutil, que es la tierra más Sur y Este de estribor que tendrá á la vista por la proa, $y$ habiendo nave. kado cinco y media millas al citado rumbo estará liste-(Oeste con la boca de Guildad, y rebasado el bajo que está ul Nordeste de ella, desde dicho punto se pondrá al Oeste hasta estar Nornoroes. te-Sursueste con la expresada punta 'Tutil distancia una milla escasa, donde se fondeará en +5 á 50 brazits suelo de arena y cascajo, distante dos tercios de milla de la boca del Estero de Gildad, la que por su angostura de 195 varas, no permite sin exponerse á una desgracia, entrar á la vela, y se ejecuta con esplas tendidas á los rumbos siguientes:

66. La primeru espia será de cinco calabro. tes de 20 á 25 brazas al Oeste; la segunda, al mismo sitio de dos calabrotes, de 16 á 17 brazas, por la que se virará hasta estar en la embocadura del Estero; la tercera también de dos calabrotes sobre ocho á nueve brazas, fondo arena y lama, y en llegando á pique de ésta, estará dentro del Estero, habiendo pasado á medio freu de su boca; la cuarta espía de cinco calabrotes se tenderá al rumbo del Oeste $30^{\circ}$ Norte en fondo de 12 á I 3 brazas arena y cascajo; y estando á pique de ella tenderá la quinta espía de cuatro calabrotes sobre el rumbo del Norte $39^{\circ}$ Oeste en fondo de 20 á 2 I brazas, fonclo arena y lastre, al fin de la cual se hallará en la boca de la angostura de Queuman; desde este paraje se tenderí la sesta espía de un calabrote sobre el rumbo del Oeste $\%$ Noroeste en ocho á nueve brazas arena; y llegando á pique tenderá la sétima sobre el rumbo del Oeste $30^{\circ}$ Sur de tres calabrotes, y virando por ella antes de llegar á pique, estará zafo del bajo de Cholua, dejándolos por estribor, desde donde se dirigirá al Oeste $15620^{\circ}$ Norte con la marea, á la vela ó con espías, para dentro del estero, á surgir en las inmediaciones de la capilla sobre $\mathrm{I}_{2} \quad \mathrm{O}_{4}$ brazas fondo lama, distante de la costa del Sur ó de la capilla de dos á tres cables, o mar adentro, que todo es hondable y limpio.

67. Advcrtencias. Esta derrota ofrece al paso las ensenadas de Chazmo y su Esterc, y la de Colcao en la Isla de Chiloé que se lleva por estribor, $y$ las de Chauco y Nopue en la Isla de Tanqui que se lleva por babor; la primera está comprendida entre las puntas de Yeculinao, cuya abra es de una legua y cuarto, pero tan poco hondable, que a bajamar apenas permite entrar piragua, y en el Estero de Chazmo, que está en su medio, y á bajamar queda todo seco, el baju sale de la punta de Yeculinao en vuelta. del Sueste un tercio de milla, y como á esta distancia va siguiendo la configuración de la costa hasía rema- tar en Catalma; la segunda ensenada dicha de Colcao, la forma la expresada punta de Catalma, y la de Chagua es capaz, hondable, y buen rur. gidero con el rlo de su nombre para aguada; está cubierto de todos los vientos no comprendidos los entre el liste y Nornoroeste, pero no levantan mar, por venir por encima de la Isla Tanqui, que está á distancia de media legua.

68. Las ensenadas de Chauco y Nopue, situa. da la primera en la costa Oeste de la Isla 'Tanqui y la segunda en la del Sur de la misma isla, son muy acantiladas, tienen aguada, $y$ se puede sur. gir en ellas, especialmente en la primera que está Iiste-Oeste con el İsterito de Chazmo, ambas están descubiertas á los vientos del terces cuadrante, particularmente en la segunda, donde los vientos levantan mar, que ocusiona peligrosa resaca en la costa; entre las puntas de Chagua y Quilga en la costa de Chiloé, se puede surgir á media milla ó ménos de tierra, fondo 25 á 30 bra. zas arena y cascajo; hay aguada, pero se está descubierto á los vientos del Sursueste al Nord. este que soplan bien frescos y levantan mar.

69. Al Sueste de la punta de Chagua, distan. cia de 500, á 600 varas, está el bajo de su nombre, que á media marea tiene tres y media brazas de agua; corre Noroeste-Sueste como media mi11a. Así por éste como por el que sale de Yeculi. nao para Chazmo, se debe navegar más atracado á la costa de Tanqui que á la de Chiloé.

70. Entre la punta de Huenuguildad que es escarpada, sale en vuelta del Sueste á media milla, un bajo de arena y piedra, está lo más fue. ra al Norte $60^{\circ}$ de la boca de Huildad 1.504 va. ras, su fondo como tres brazas á media marea.

71. Las mareas en la derrota anterior, siguen casi sus rumbos; la velocidad desde la boca de Compu al Sur es de milla por hora, y en la mayor angostura del canal, que es entre las puntas de Yeculinao en la Isla de Chiloé y la de Lobos en la de Tanqui, de tres y media á cuatro, y en el resto del canal de ménos de tres: montada la Punta de Yagua, disminuye hasta ser de una milla al Sur. En la boca de Guildad es de poco más de dos millas como en la angostura de Queuman; desde aqui para adentro se disminuye de forma que desde la Capilla para el Oeste es de I.500 á I.6oo varas su andar. En el surgidero de la Capilla de Guildad sucede la pleamar en los novilunios y plenilunios á las $12^{\mathrm{h}} 3^{8^{\prime}}$ del dia, y su aumento respecto á la bajamar, es de cuatro varas en las aguas vivds, $y$ en las muertas poco más de tres $y$ media.

72. Nota I. ${ }^{\text {" }}$ Que el Estero de Guildad puede contener embarcaciones de todos portes, bien resguardadas, sobre fondos proporcionados de seis á I 2 brazas lama y arena: es el más poblado de la costa de los payos y lo último habitado de la Isla de Chiloé: sus orillas desde la angostura de Queu- 
ada dicha de de Catalma, , y buen rur. aguada; está comprendidos o no levantan T Tanqui, que

Nopue, situa. a Isla 'T'anqui sma isla, son se puede sur. primera que Chazmo, am. os del tercer gunda, donde ona peligrosa s de Chagua y uede surgir á lo 25 á 30 bra. pero se está este al Nord. tan mar.

agua, distan. o de su nom. media brazas mo media mi. le de Yeculi. más atracado hiloé.

uildad que es este á media tá lo más fue. lad 1.504 vaedia marea.

terior, siguen le la boca de , y en la mare las puntas - la de Lobos uatro, $y$ en el tada la Punta una milla al co más de dos cuman; desde ie forma que I. 500 á r.6oo la Capilla de novilunios $y$ ' su aumento varas en las , más de tres

ruildad puede rtes, bien resados de seis á poblado de la ado de la Isla tura de Queu. man para adentro, son de terreno hastante regular para cultivo, y lo está á proporción del número de sus moradores, pero todas estas ventajas 6 buena disposicion, no lo inhiben de ser puerto para una absoluta urgencia, por lo contemplativn y arries. gado de su estrecha entrada y circunstancias de la costa vecina, toda escarpada, muy acantilada, y por consecuencia desupropósito para surgir en ella, particularmente una escuadra.

73. Nota 2." Que pura entrar en el citado L̇tero, por ningún caso se ha de empezar á espiar hasta que la marea esté parada 6 muy próxima á parar para empezar á vaciar, porque el mal gobierno 6 dirección que ocasiona la corriente en popa, lo harán varar 6 tocar en cualquiera de las dos costas irremediablemente, á ménos que no se espíe acoderado y áun con todo siempre expuesto. La codera, áun espiándose para dentro con vaciante ó con la creciente para fuera, me parece precisa en las angosturas de la boca $y$ Queuman, lo que proporcionan en dichos parajes lo corto de los espías.

74. Nota 3." Que en orden al tránsito por el canal de Tanqui comprendido en la derrota anterior, se ha de tener presente lo advertido en el pasaje del de Quincha para Castro al número 36 , para escusar su paso con embarcación grande 6 mediana, dirigiendo la derrota desde Compu y Queilen á Guildad, pasando por fuera de la punta de Huechupicum, que como se ha dicho ya, es la más Este de la Isla de 'Tanqui, á cuyo efecto se hará la siguiente:

Derrota de Compu y Queilen a Guildiul por fueru de la Isla de Tamqui.

75. Desde la boca del Estero de Compu se gobernará al rumbo del Oeste-Sur, llevando por la proa la punta rasa de Queilen, y estando como media milla de ella demorándole al Este, ya sea habiendo salido del citado Estero, 6 ya del de Queilen, se pondrá al Este $42^{\circ}$ Sur, que conduce á pasar por medio freu del estrecho que forman la costa del Norte de Tanguí y la del Sur de la pequeña islita de Acuy, $y$ habiendo navegado cuatro millas sobre el citado rumbo, zafo ya de dicho estreclio, se hará derrota al Esueste, y ha. biendo navegado ocho millas, se hará Nordeste Sudoeste con la expresada punta de Huechupi. cun, desde donde se sará el rumbo del Sur distancia de cinco millaq, y cumplidas éstas, el del Oesudoeste hasta estar Este-Oeste con la punta de Tutil, á la que se dirigirá llevándola descu. bierta por babor hasta rebasarla y situarse cerca de la boca de Guildad para entrar á la espía como se previene al número 66.

76. Advertencias. La Isla de Tanqui Nordeste-Sudoeste con su punta más Este, se lleva en esta derrota por estribor á corta distancia; es despues de la de Quinchao la mayor de las con. tiguas á la grande de Chiloé; está tendida de lisueste-Oesnoroeste en distancia de cinco le. guas; es alta por su parte del Oeste, y casi con un descenso muy igual va disminuyendo su ele. vación hasta el término oriental, que es la citada punta de Huechupicun, la que en tiempo claro se alcanza á ver de nueve leguas de distancia. Las costas de ella son limpias y acantiladas, por la mayor parte escarpadas, especial. mente la del Norte descle la punta de Mapu para afuera, $y$ no tiene surgidero alguno cómodo sino para embarcaciones menores. Soblo está po. blada la isla en la punta de su nombre, que es baja con uny porción de terreno llano, conti. guo, donde está la única capilla que tiene, al Sudocste de la de Queilen distancia de una legua escasa, de modo que todas las islas contiguas á la de Cliloé pobladas, ésta es la que lo está ménos. Sin embargo, en la expresada punta de Huechupicun, puerto ventajoso par: descu. brir las embarcaciones que entren por la boca del Huajo, mantienen los naturales una centinela contínua.

77. Montada la punta de Hucchupicun, la tierra más Sur que se descubre al Oeste es la Isla de Caylin y punta de Chayguau en Chiloe, de la cual para el Norte sigue la costa escarpada de mediana astura hasta la punta de Tutil y pequeña abra de Guildad, que se reconocerá por el dicho escarpado y por dos puntitas de arena muy 'anca, que la forman la costa que sigue de dicni boca para el Norte es también alta con algunos escarpados ó barrancos, de los cuales es el mayor el de la punta de Huenu-Guildad, de donde sale el bajo citado al número 70, la que dista de la boca del Estero media milla hacia dicho rumbo; también en esta costa hay algunas playas cortas de arena, de las que carece la del Sur.

78. Siguiendo la derrota de Huechupicun para Tutil y Guildad, se de ja á estribor á distan. cia de dos millas la Islita de Chaulin que es algo baja, y de lo más Sueste de ella sale un pequeño arrecife hasta las distancia de poco más de un cable, en cuyo extremo vela siempre una peña del tamaño y figura de una embarcación media. nita sin arboladura, á la cual llaman el Navío; y efectivamente imita un casco, vista á los rumbos vecinos al Este y Oeste.

79. En el número 63 advertimos á las derrotas de Queilen para Compu, se ha dicho la dirección y movimiento de las mareas, lo que se debe tener presente para esta hasta estar fuera de la punta de Queilen. Desde este sitio hasta zafar del Estrecho de Aqui con Tanqui sigue su curso según el rumbo de la derrota con andar de dos y media á tres millas por hora, pero ya al Este del Estrecho sigue el rumbo del Sur hasta el encuentro 
con la costa de Tanqui, que lo sigue según ella corre, esto es al Sueste, con velocidad de cas cuatro millas, la que crece á cinco y algo más, con notable escarceo al mont ar la punta de Huechupicun, $y$ con mucha mar si la marea vacia $y$ hay viento de la parte del Sur ó al contrario, si creciendo aquél avienta el Nornoroeste ó Nordeste, por cuya razón se dirige la derrota á pasar una legua distante de dicha punta, para evitar el expresado encuentro ó raya, ciertamente muy temible con embarcaciones pequeñas, $y$ acaso inaccesible á ellas. Desde dicha punta en adelante, es de poca consideración la marea hasta cerca de la boca de Guildad y sus costas vecinas, pues pasa muy poco de una milla por hora, y su curso es hacia el rumbo del Sur casi directo.

Derrota del Estero de Guildad al de Yalnd, situada la boca en latitud Sur $43^{\circ} 3^{\prime}$ y en longitud $303^{\circ} 3^{\prime}$.

80. La salida del Estero de Guildad desde el surgidero de la capilla hasta hallarse fuera de la la boca, se ejecutari á los rumbos opuestos á los dados en la entrada, $y$ con el mismo método $y$ precauciones expresadids en los números 66 y 73

8I. Hallándose ya fuera de dicha boca, se hará el rumbo del Este hasta que la punta de 'Tuti' demore al Sudoeste distancia como de media legua, que luégo se hará derrota al Sursueste el espacio de siete millas, y cumplidas, se dirigirá al Sudoeste \% Sur, sobre cuyo rumbo se navegará 20 millas, las que verificadas, se halla rá ya zafo de los bajos de Chayhuau, Caylin y Laylec, y seguirá el rumbo del Oeste $1 / 4$ Norocs te el espacio de dos leguas, las que navegadas ya, se lará el rumbo dei Noroeste $1 / 4$ Norte distancia de dos millas, llevand 2 por 'a proa la pequeña Islita de Mauchil que está en la boca de Sur del Estero de Colita; cumplida dicha distancia se pondrá al Norte, sobre cuyo rumbo rave gará seis y media millas, casi à medio freu del canal que forman las Isla: Laylec, que llevará ju: estribor, y Colita por babor; verificada la citada distan:ia, tendrá la entrada de Yalad á la vista por babor, y las Islitas de Linagua que están en ella, á la que se dirigirá gobernando al rumbo de Oesnoroeste, siguiéndolo hasta estar Norte-Sur con lo más Oeste de dichas islitas, donde podrá dar fondo en I 2 ó 4 brazas lama, ó ir más adentro del Estero á los rumbos del Norte $1 / 4$ Noroeste, Nornordeste y Nordeste.

82. Advertencius. Al montar la punta de Chayhuau ó poco antes (que es la tierra más Sur de la Isla de Chiloé, que se llevará á la vista navegando de Tutil para el Sur), se verá al Sudoeste de dicha punta la Isla de Chaulin (oculta á la de Laylec que tiene al Sudoeste), y si el tiempo está algo claro, se verán por encima de ella dos cerros elevados, poco distantes uno de otro; el más Nor- te es elllamado Machaylelo, algo tendido, y está en la Isla de Chiloé, y el más Sur en la Isla de San Pedro, algo más elevado que el primero y de figura piramidal, y ambos no pueden confun. dirse 6 equivocarse con otro alguno de toda la isla grande ni vecinas. La Isla de Laylec está desviada de la de Caylin, pur un estrecho canal que casi no se discierne desde afuera, y súlo presta paso á canoas. Estas dos islas son de mediana altura por su parte del Su foeste, y por la del Nordeste bajas, con especialidad la de Cay. lin; el resto de costa de la de Chiloć es elevado, particularmente sobre Yalad.

83. Desde punta Tutil al Sur empiezan los bajos de Chayhuau, los que se continuan hasta terminarse en la de Pulileheu que es la más Sur de la Isla de Laylec: de la costa de Tutil se desvían cosa de un cable, pero este desvío se va aumentando hacia la de Chayhuau, de modo que salen al Esoeste de esta hasta cerca de una milla, y de aquí siguen al rumbo Sudoeste por las costas al Este de las expresadas Caulin y Laylec, desviándose como hasta media milia escasa de ella. Estos bajos son de arena y rocas sueltas, ninguna se descubre, piro siempre casi rompe el mar en ellas, y áun en ius días más apacibles las indica el escarceo de las mareas crecientes, cuyo choque es formanảo ángulos rectos una con otra. Dichos bajos cierran enter: mente el paso para el Estero ó puerto de Caulin por su parte del Nordeste a toda otra embarcación mayor que las goletas, pero habiendo antecedido vientos frescos del segundu y tercer cuadrante, es temible áun para piraguas, mayormente si van de viaje al Norte: aquí es donde han perecido algunas embarcaciones y acaso el principal motivo de la despoblación de Cauiin.

84. En toda esta derrota no hay surgidero en las costas inmediatas que son todas acantila. das, no obstante los bajos de las del Oriente de Caulin y Laylec, pues á poco desvío es excesiva el agua que se encuentra; sólo en la inmediación del Estero de Yalad, cerca de la punta de LileHuapí, la más Oeste de Laylec, 6 ya cerca de la. de Colita se puede fondear en 40 á 50 brazas, á dos ó tres cables de tierra.

85. Entrando en Yalad, al Sursudoeste de las Islitas de Linagua está el Estero de Colita, aun. que de corta extensión, de abrigo y seguridad para embarcaciones pequeñas su fondo de cinco á siete brazas lama, sin más riesgos que los visibles.

86. Las mareas en esta derrota siguen su curso de Norte-Sur pero apenas llegan á una milla por hora, hasta estar entre las puntas de $\mathrm{Ya}$ lec en Chiloé y Pulitehue en Laylec, que empiezan á seguir Jes rumbos de la derrota y sus opuestos, y aumentan su velocidad á algo más de dos millas: en el surgidero de las chozas es 
algo tendido, y está s Sur en la Isla de lo que el primero $y$ no pueden confun. alguno de toda la Isla de Laylec está $r$ un estrecho canal esde afuera, y sólo dos islas son de me 1 Su foeste, y por la cialidad la de Cayle Chiloć es elevado,

al Sur empiezan los se continuan hasta que es la más Sur la costa de Tutil se ero este desvío se va Chayhuau, de modo ésta hasta cerca de n al rumbo Sudoeste as expresadas Caulin o hasta media milia son de arena y rocas re, piro siempre casi áun en ius días más carceo de las mareas s formanaio ángulos os bajos cierran en. Estero ó puerto de deste á toda otra em. Jletas, pero habiendo del segundo y terce ara piraguas, mayor Norte: aquí es donde arcaciones y acaso el población de Cauiin. ota no hay surgidero e son todas acantila de las del Oriente de co desvío es excesive :́6lo en la inmediación de la punta de Lile aylec, 6 ya cerca de la - en 40 á 50 brazas, á

al Sursudoeste de las istero de Colita, auna abrigo y seguridad as su fondo de cinco ás riesgos que los vi-

ta derrota siguen su enas llegan á una mitre las puntas de Yan Laylec, que empiede la derrota y sus velocidad á algo más lero de las chozas es la pleamar los días de Luna nueva y llena á las $12^{\text {h }} 40^{\prime}$ del dia, y respecto á la bajamar en ellos crece el agua nueve pies.

87. El Estero de Yalad, es surgidero á cubierto de todos vientos, en fondos de diez á quince brazas lama, forman su entrada exterior las puntas de Yenecura en Chiloe y Colita en la isla de su nombre; en la entrada interior está la Isla de Linagua, que le hace formar dos bocas, perc la del Oriente sólo permite paso á las lanchas por sus bancos de arena y cascajo; la del Oeste no tiene más riesgos que los que están á la vista: está despoblado, y sólo en la punta de los Mamanos parece haber habido habitantes. La Isla de Colita fué habitada mientras lo fué la de Caulin, hoy hay en ella algunos caballos, el terreno es á propósito para cultivo, pero no el de Yalad, que por la mayor parte es áspero, montuoso y demasiado elevado.

Derrota del Estero de Yalud al de Caylin, situada la boca en latitud Sur $43^{\circ} 29$ y $\%$ y cn longitud $303^{\circ} 47^{\prime}$.

88. Saliet,do del Estero de Yalad desde la medianía de su boca se gobernará. al Este \% Sueste distancia tres un cuarto millas, llevan. do casi por la proa lo más Norte de la Isla Laylec hasta estar Norte-Sur con la punta Lua en la Isla de Chiloé, que lievará por babor: seguirá al rumbo del Nordeste $1 \%$ Este tres y media millas, y luego al Sueste $1 / 4$ Este dos, y se hallará en la medianía del Estero de Caylin, á donde se dirigirá haciendo el Sur, y surgirá en cualquier paraje desde to hasta 30 brazas fondo lama.

89. Advertencias. En el tránsito de esta derrota, no hay más surgidero quie la ensenada de Cuellon es la costa de Chiloé al Norte de la punta Lua; es buen fordeadero, con aguada tstá á cubierto de todos vientos menos del Este y Esueste que no son frecuentes ni impetuosos. Al Norte del abra de Caylin está en la costa de Chiloé el Esterito de Oquelan, cn cuya bosa se puede surgir, y no en st interior por el poco fordo.

30. Las mareas siguen los rumbos de la derrcta, y st mayor velccidad poco más de milla por hora; en el Estero de Caylin es la pleamar en los novilunios y plenilunios á las doce y minitos del día, y respecto á su bajamar crece el agua nueve á diez piés.

gr. El Estero de Caylin es buen puerto, abrigado á los vientos, de buen tenedero, en la parte del Sur y Este del terreno nombrado Huacao, se puede fondear á medio cable de tierra en I6 á 18 brazas arena. La costa de Sur y Oeste es ménos hondable y aplacerada, pero casi todo el placer queda descubierto á bajamar de aguas vivas, y á pique de él se hallan cinco á á seis brazas fondo arena, cascajo y piedras sueltas. La Isla de Caylin tiene 15 á 16 millas de circunferencia; estuvo habitada de los indios Huayhucles, que se trasladaron á la de Chaulinec. En la ensenada de Chohuen subsisten los fragmentos de la capilla, y hacia adentro del Estero varias casas y chozas dispersas.

92. Nota. Saliendo del Estero de Yalad debe darse la vela después de media marea vaciante á fin de encontrar la creciente, que es la que favo. rece la creciente en el caso, ya rebasada la Isla de Colita; pero con vientos á propbsito podrá desatenderse esta circurstancia.

93. Otra. Los Esteros de Caylin y Yalad son los últimos puertos de la Isla de Chiloé hacia el Sur, que carece enteramente de todo otro surgidero; pues las islas, bajos y peñascos hacen in. naccesibles á desembarcos sus ensenadas y playas, donde sólo se puede intentar surgir, en la necesidad de tirar á varar en cualquier paraje, ycon la desgracia, que el interior es todo despoblado y de una maleza impenetrable.

Derrota de los Esteros de Caylin y Yalad al Oceano.

94. Desde la medianía del estero de Caylin se harán dos millas al Noroeste $\%$ Oeste, gobernando luégo al Sudoeste \% Oeste cinco millas, y se hallará Noroeste Sueste con la Isla Linagua de la boca de Yalad, y á distancia al Este de la Isla Colica una milla scasa; desde este punto, que es común á ambas derrotas, se navegará al Sur cuatro y media millas, donde demorará la pəqueña Isla Mauchil al Noroeste, gobernando de aquí al Sursueste tres leguas, que quedará EsteOeste con la más Sur de la Isla de San Pedro, que llevará por estribor; se pondrá al Sudocste $1 / 4$ Sur, navegando cuatro y media leguas, que estará en la latitud de $43^{\circ} 55^{\prime}$, gobernará al Oeste y á las I 6 leguas rebasada yala Isla Guazo, se encontrará en el Oceano.

95. Advertencias. La Isla de San Pedro está en lo más Oeste de la de Chiloe, es la más alta de tudas las cercanas, y se podrá ver en tiempo á proposito 25 leguas de distancia: por la parte del Este y Sur tiene algunas islitas y farallones.

96. La costa del Sur de Chiloé es de mediana altura en partes, contiene el Estero de Ayentema y las ensenadas de Cheylin, Chucahua, Atizas, Nayague, Huylanlad y otras bastantes capaces, pero inaccesibles como llevo dicho: están en ellas muchas pequeñas islas y multitud de peñascos visibles y ocultos y avanzados bastante fuera de la costa.

97. La Isla de Huapiquilan está al Oeste $5^{\circ}$ Sur de la de San Pedro nueve leguas; no tiene surgidero y está guarrecida de rocas é islitas.

98. La Isla de Huajo está al Sudoeste de Huapiquilan sjete legur : $"$, es alta y no tiene ries- 
go que impida acercarse, pero tampoco puerto de abrigo para embarcación que no sea chica.

Derrota á los puertos de la Isla de Chiloé, entrando por el canal del Sur, a quien llaman boca del Huafo.

99. Debe hacerse la recalada por los $44^{\circ} 4^{\prime}$ o $5^{\prime \prime}$ más ó ménos de latitud, á dar vista á las Is. las del Huajo y Huapiquilan, cuyas circunstancias y arrumbamientos están ya expresados. Avis. tando la de Huapiquilan, gobernará al Este lle. vando la descubierta por la serviola de babor hasta estar Norte-Sur con ella distancia como de tres leguas; si la avistada fuese la de Huajo, que es más favoroble, la llevará descubierta por la serviola de estribor hasta estar al Norte de su medianía dos leguas; desde este punto navegará al Este I 3 leguas 6 í millas desde el dicho de Huapiquilan, se hallarí Nornordeste Sursurdoeste con lo más Este de la Isla de San Pedro, desde donde hará el rumbo del Yordeste cinco leguas liasta estar Este-Oeste cun lo más Sur de dicha isla. De aquí navegará al Nornoroeste tres leguas si va á Yalad, y cumplida dicha distancia estará Noroeste Sueste con la islita Mauchil, y EsteOeste con el alto de Machaylelo; desde aquí se hará el rumbo Norte costeando las Islas Colitas y Laylec, hasta descubril la de Linagua, en la boca de Yalad, desde donde, si se quiere dirigiral de Caylin, lo hará por una derrota inversa á la dada al número 94 , teniendo presente las advertencias dichas.

roo. La latitud expresada para la recalada proporciona los vientos dominantes, ya de la estación de invierno y verano, pero si por algún accidente se recala en la de verano sobre $44^{\circ} 20^{\prime}$, acompañado de los vientos propios de la estación, luégo que aviste por babor tá Isla de Huafo, gobernará al Este y Esnordeste á pasar por su parte del Sur sin algún recelo, porque entre ella y las Huaytecas, que están al Sur y Sueste, hay canal de más de tres leguas de ancho; le demorarán del Este para el Sur, el gran número de Islas Huaytecas, cuyo conjunto se presenta en apariencia de costa alta tendida Nordeste Sudoeste pero la de Huafo no puede equivocarse con alguna de aquéllas, por el considerable desvío que tiene de toda otra, y por ser de corta eytensión, alta y casi igrual, cuyas circunstancias la distinguen también de la de Huapiquilan, que tiene varias pequeñas inmediatas, algunas desigualdades en el terreno, y sólo se aparta de la costa de la de Cliiloé, poco más de una milla.

ror. Si el tiempo está despejado, podrá verse la Isla de San Pedro casi al tiempo de la del Huafo, y áun antes que otra alguna tierra de la de Chiloé por esta parte. Tal vez será lo primero que se ofrezca á la vista, la gran montaña nevada dicha el Corcobado, situada en la tierra firme, que se distingue á 40 ó más leguas de distancia, y su figura y elevación no admite equivocarse con otras de la cordillera; está enfi lada su cumbre con la más Sur de la Isla de San Pedro, Este $14^{\circ}$ Norte y Oeste $14^{\circ}$ Sur 16 le. guas.

102. Las mareas de Huapicaylan, para dentro siguen el rumbo de la derrota, y son de poca consideración hasta entre las Islas de Chiloé y Laylec, desde donde åumenta su movimiento como queda dicho.

103. Nota. Todas estas islas son frondosas, cubiertas de espesísimo bosque y algunns manzanos, señal dicen, de haber sido habitadus de los Huayhuenes antiguamente, y aún tienen algún ganado lanar.

Derrota de los Esteros de Caylin y Yalad al de Guildad.

I04. Saliendo del puerto de Caylin, desde su medianía se gobernará al Sudoeste ro $1 / 4$ Oeste pasando á media milla de la punta de Lua, y na vegadas cinco millas, se hallará Noroeste Sudes te con la Islita de Linagua, desde dicha situación hará el rumbo Sur $5^{\circ}$ Este cinco millas, y al cumplirlas se hallará Noroeste Sueste con la Is lita de Mauchil, desde donde gobernará al Sueste $\%$ Este siete millas, y verificadas éstas, al Nordeste $\%$, Norte II y $\%$, que se hallará tanto avante, y á una legua de lo más luera de los bajos de Chauchau; desde aquí hará el Nornoroeste siete millas, y estará Nordeste-Sudoeste con punta de Tutil, y Este-Oeste con : boca de Guildad, y para entrar en este Ester s obrará á la le. tra como queda prevenido.

105. Adrertencia. Las mareas crecientes, que son las que favorecen en el caso, siguen los rumbos opuestos á las vaciantes, que se explicó en el número 82 hasta $86, y$ su movimiento es algo más lento.

\section{Derrota del Estero de Guildad al de Compu.}

ro6. A la boca de Guildad, zaío ya de espías, se gobernará al Este hasta que punta Tutil de. more al Sur, desde cuyo paraje se hará al Norte cinco y media millas, llevando por la proa la punta de Nopue en la Isla de Tanqui, y por estribor la Isla Chaulin, se navegará al Noroeste dos y media millas, y zafo del bajo de Chahua se pondrá al Ocste $\%$ Noroeste, sobre cuyo rumbo seguirá media legua gobernando luégo al Noroeste tres y media millas, y rebasado el Estero de Chazmo hará dos millas al Norte y estará Nordeste Sudoeste con punta Yeculinao, desde donde gobernará al Norueste \% Oeste otras dos millas, y al cumplirlas estará ya en la boca de Compu Este-Oeste cen el morro de Tu- 
más leguas n no admite ra; está enfi. a Isla de San - Sur r6 le.

in, para denson de poca de Chiloe y movimiento on frondosas, lgunnos manhrbitados de in tienen al. roeste Sudesicha situación millas, y al ste con la Is. ernará al Suadas éstas, al hallará tanto era de los ba. 1 Nornoroeste yeste con punboca de Guil. brará á la le-

recientes, que $o$, siguen los jue se explicó lovimiento es

de Compu.

ya de espias, nta Tutil de. - se hará al do por la proa ranqui, y por á al Noroeste jo de Chahua , sobre cuyo ando luégo al rebasado el as al Norte $y$ ta Yeculinao, ste $\%$ Oeste itará ya en la morro de Tu. maumón; $y$ desde este punto hasta el surgidero hará como queda dicho en el número 59.

107. Advertencias. Se tendrá presente lo dicho en los números 67 al $7 x$ y en el número roj en orden a mareas.

Derrota de IHuylud a Compu y Queylen por fuera del caral de Tanqui.

108. Fuera de Guildad se gobernará al Este hasta estar Norte-Sur con punta Tutil, desde donde se hará el Esueste cinco millas, y luego se gobernará al Nordeste $\%$ Este ocho millas, donde tendrá la punta de Huechupicun al Nozueste $\%$ Oeste una legua, hará el Norte por es. pacio de dos y media millas, conque montará dicha punta y se pondrá á navegar al Noroeste $\%$ Norte ro millas, que estará Este-Oeste con punta Poquenco, llevándola por la proa al rumbo del Oeste, y luego que se halle á dos tercios de mi. lla, se pondrá al rumbo del Sudoeste $\%$ Oeste hasta medio freu del estrecho entre las Puntas de Queylen y Mapu; desde este punto se hará el Noroeste $1 \%$ Oeste hasta rebasar la rasa de Queylen; si se quiere surgir en este Estero, se hará el Nornordeste; si en el de Compu el Oeste $\%$ Noroeste siete y media millas, obrando en todo como queda dicho en los números 53 y 59 .

ro9. Advertencias. En los números $77,78,79$, $56,57,60$ y 63 , se han hecho todas las concernientes á esta derrota.

\section{Derrota desde Queylen y Compu á Terao.}

Iro. Desde cl Estero de Compu hasta su boca, se navegará como se expresa al número $6_{5}$, y como al 75 hasta cl Norte de punta Mapu: puesto á la vela en el surgidero de Queylen, hará el Sursudoeste media legua y seguirá al Sueste $1 /$ Este hasta que punta Mapu demore al Sur. Desde este punto es común á ambos puertos la derrota siguiente.

III. Desde esta situación se hará el Nordeste $\%$. Este tres y media millas, y zafo del arrecife de la islita de Aqui y punta Poquenco, navegará al Norte cuatro y un tercio millas hasta estar Este-Oeste con la punta de la centinela de Aytuy, y fuera ya del riesgo de los bajos de su nombre. Hará luego seis millas al Nornoroeste, que quedará tanto a vante con la punta de Ahony, se gobernará al Oeste $1 / 4$ Noroeste cinco y media millas, y hará el Norte, hasta que la Punta de Terao demore al Sudoeste dos tercios de milla, desde donde haciendo el Oeste entrará en la bahía á surgir en el paraje que quiera.

112. Advertencias. A las hechas en el número 54 hasta el 57 , resta que añadir, que siendo las mareas crecientes las que favorecen navegando al Norte, llevan su curso opuesto á las vaciantes, que se han explicado en dicho número, siguiendo unas y otras los de las derrotas.

Derrota desde la bahia de Terao al Estero de Castro.

II3. Desde la medianía de su boca hará el rumbo al Nordeste $1 / 4$ Norte media legua y luégon al Noroeste $1 / 4$ Norte una milla para rebasar las islitas y bajo de Yal, se pondrá al Oesudoeste $5^{\circ}$ Oeste media legua, y luégu cambiará al Oeste $1 /$, Noroeste una milla, $y$ dos al Noroeste: navegando luégo al Norte el espacio d: una, y al Norte $14^{\circ}$ Este 3 se hallará en el Estero de Castro, y Nordeste Sudoeste con lo más Este de la Isla de Linlinao, desde cuyo punto al fondeadero ejecutará lo prevenido en el número 26.

II4. Advertencias. En los números 30, 31, 32, I05 y II2 quedan hechas las precisas á esta derrota.

Derrota de Castro á Linao por el Canal de la Ishe Quinchao.

II5. Desde el surgidero de Castro :asta situarse Nordeste-Sudoeste con lo más Este de la Islita de Linlinao, se haritn las rumbos opuestos á losdados al fin del número 26 entrando. En esta suposición, desde el citado punto se hará el rumbo del Sudeste $\%$ Sur una milla, y luégo al Este $1 \%$ Nordeste io inilías, pasando á medio freu del ca. nal entre las Islas de Lemuy y Chiloé, y entre lá Isla de Clielin y la punta Aguantao s a hará el rumbo del Noroeste $1 / 4$ Norte, y navegada mediat legua estará rebasado el bajo de Aguantao, y hará derrota al Oesnoroeste $5^{\circ}$ Norte 6 y $\%$ millas, que estará rebasado de la punta de Queil en Quin. chao; desde aquí hará el Norte $4^{\circ}$ Oeste distancia de dos millas, luégo el Noroeste $1 /$, Norte $2 \%$ gobernará al Nornordeste media milla hasta rebasar la punta de Cuyumue á medio freu de la ma. yor angostura del Canal de Quinchao, se navegará cuatro y media millas al Este 29 Norte, $y$ quedará tanto avante con la capilla de Quetalco en Chiloé, desde donde hará el Este $6^{\circ}$ Norte 1 T millas, que cumplidas, estara fuera del canal, habiendo pasado á $2 / 3$ milla de la costa de punta Tenaun; descie esta situación hará al Norte cinco millas, y se hallará Este-Oeste con punta Chiliz. qui, que es lo más Oeste de las Islas Chauques, gobernará al Nornordeste tres millas, $y$ al cum. plirlas se hallará fuera del Estrecho de Quicabi: hará luégo el Norte $1 / 6$ Norneste 14 millas, que verificadas, quedará Este-Oeste con punta de Lobos, de Caucahue, y se pondrá al Noroeste $1 / 6$ Norte 15 millas, donde estará Este-Oeste con la medianía del abra de Linao, á donde se dirigirá con proa Oeste $1 / 4$ Sudoeste hasta la boca del puerto, obrando luégo como se ha dicho al número x9. ir6. Advertencias. Al Esnordeste de lo más 
Sur del barranco de Quicabi, como á un cable y medio, hay una peña que se descubre á bajamar, y otra al Sueste de ésta, que sale de las Islas de los Chauques, dejando entre ambas canal de poco más de una milla, por cuya causa se ha de guardar exactamente el medio freu; ambas son pequeñas y acantiladas por fuera, con mucho sargrazo la de Quicabi, la otra está oculta, y no faltan razones para dudar de su existencia; las mareas son diametralmente opuestas al número $3 \mathrm{I}$.

Derrota de Casiro a Linao por los canales del Norte y Este de Lemuy y fuera de las demís islas.

I 7. Habiendo salido del fondeadero de $\mathrm{Cas}$ tro hasta la boca del Estero, se harán los rumbos opuestos á la derrota dada al núm. 26, y luego que se halle Noroeste-Sueste con la Isla de Linlinao navegará al Este \% Nordeste nueve millas y cuatro al Sur $5^{\circ}$ Oeste, y se hallará entre la costa del Oeste de la isla Quehuy y la del Este de Lemuy, habiendo pasado á medio freu de entre ésta y la de Chelin; hará luégo el rumbo del Sursudoeste $5^{\circ}$ Oeste media legua y al Sursueste $1 /$ Sur dos millas; navegará otras dos a Este 1\% Sueste, llevando por babor la Isla de Quehuy, y zafc ya del canal de Lemuy, hará el rumbo del Sursueste por espacio de cuatro millas y I 3 al Este, de donc.e le demorará lo más Este de a Isla de Apiao al Norte $1 / 4$ Noroeste como scis millas; navegará 21 al Nornordeste y estará Liste-Oeste á cuatro millas de la Isla de Tac; hará luẻgo el Norte ir millas y se hallará Este-Oeste con lo mís Norte de las Islas Chauques, habiendo pasado á cinco millas de la de Coy, que es la más Este; desde este punto hará 37 millas al Noroeste, quedará Este-Oeste con la boca del puerto de Linao, á donde entrará como llevo dicho en los números I9 y I 5 .

II8. Advertencias. De la punta de Chalihue, que es la más Nordeste de la Isla de Lemuy, sale un bajo de piedras hasta la distancia de dos cables cn vuclta del Nordeste $1 / 4$ Norte: á pique tiene siete brazas de agua en bajamar, y su veril ‘ueda con dos y media.

Irg. Las mareas son de poca consideración liasta la entrada del canal del Este de la Isla de Lemuy, pero desde este sitio son absolutamente precisas; sus direcciones en los canales del Este y Norte son casi á los rumbos que se dirige la derrota; su velocidad en el del Norte apenas lleya á media legua por hora, pero en el del İste no baja de cuatro millas, desde que se monta la punta de Chalihue hasta que se desemboca por la de Apabón, y entre lo más Oeste de la Isla de Quehuy y la costa de Lemuy que es casi la mediania y mayor angostura de este canal, llega á seis millas por hora.

120. Nota. La derrota anterior debe preferir. se á la que le antecede, discurriendo el canal de Quinchao, así por lo dicho en el número 36 , como por la mayor prontitud del viaje, pues aunque e.1 ésta, en el canal del Este de Lemuy hay riesgo en la violencia de las mareas en favor, es incompa. rablemente menor que el canal de Quinchao, donde tambien debe fondearse, nor el bajo de Dalcahue.

121. Otra. En cualquier paraje de le. costa del Norte de la Isla de Lemuy se fondea sobre 16 á 18 brazas lama de dos á tres cables de tierra. Se puede surgir en la costa del Oeste de Quehuy y en la ensenada de la Capilla de Detif al Oeste de la punta de Apabón como á una milla, que es buen abrigo en verano $y$ áun en invierno.

Derrota de Castro al puerto de Calbuco, situado el fuerte en latitud Sur de $4^{\circ} 49^{\prime}$ Sur y en longitud $304^{\circ}$.

122. Desde el fondeadero de Castro salien. do para el puerto de Calbuco, se hará la derrota anterior hasta estar Este-Oeste, como seha dicho, con la Isla de Tac á distancia de cinco millas, y y desde este punto, el rumbo del Norte conduce directamente á pasar dos millas al Este de lo más oriental de la de Tabón, llevando lo más Sur de la de Peluqui por la proa: á las 41 millas so. bre dicho rumbo se estará Este.Oeste con la Isla Tabón distancia tres millas, desde donde se continuará el mismo rumbo hasta estar como á un̊ milla de la costa de Pulucuy; desde aquí se pondra al Noroeste $1 /$ Oeste, llevando por la proa la Isla de Quenu, y por estribor las de Pulucuy y Chizhuapi, costeando á ésta como á media milla y navegadas luégo cinco al mismo rumbo, quedará al Este de la de Quenu, y á media canal de la boca que forma ésta con la de Chizhuapi, por lo que hará el rumbo del Norte $20^{\circ}$ Oeste dos y media millas y al Nornordeste $\%$ Norte tres millas, llevando la pequeña Isla de Chaulin por la proa, por estribor la de Pulucuy y por babor la de Caycahen, donde está el fuerte, y fondeará como á una milla escasa al Oesnoroeste de él en 20625 brazas lama, amarrándose Norte-Sur.

I23 Advertencias. Este-Oeste con la isla de Tac, siguiendo al rumbo del Norte selleva por babor como de seis á nueve leguas la costa Este de la isla de Chilot́, y por estribor la de tierra firme distancia de cuatro á cinco, cuya dirección es casi Norte-Sur hasta la península de Queulin lo más Oeste de ella por esta parte, y en su interior á poca distancia sigue igual dirección la cordille. ra de los Andes, con alturas que pueden verse á más de 40 leguas.

I24. Hallándose como á seis leguas de la isla de Pulucuy se avistará la de Tabon, que está al Sudoeste de aquélla como cinco millas, se presenta dividida en tres porciones que parecen islas, pero como á dos leguas, se distinguen las gar- 
do el canal de mero 36 ,como ues aunque $e_{\text {. }}$ hay riesgo en $r$, es incompa de Quinchao, or el bajo de

je de le. costa pndea sobre 16 bles de tierra. ste de Quehuy Detif al Oeste a milla, que es vierno.

buco, situado el longitud $304^{\circ}$.

Castro salienlará la derrota mose ha dicho, inco millas, $y$ Norte conduce al Este de lo hdo lo más Sur 4r millas soeste con la Isla donde se conar como á una le aquí se ponpor la proa la de Pulucuy y á media milla, ) rumbo, quenedia canal de Jlizhuapi, por - Oeste dos y Norte tres miChaulin por la por babor la e, y fondeará loroeste de él ose Norte-Sur. con la isla de ielleva por ba. costa Este de de tierra firme dirección es de Queul:n 10 en su interior on la cordille. uneden verse á

guas de la isla $n$, que está al illas, se preparecen islas, yuen las gar. kantas ó estrechos de arena que las unen; no ticne surgidero cómodo sino para piraguas.

125. Las islas de Chizhuapi y Quenu tampoco tienen surgidero ni leña, pero sí la de Pulucuy que tiene los esteros de Chauquicel, Chipu, Machi y Pulucuy, su costa del Fiste es alta, es carpada y de mucha profundidad en su cercanía. La isla de Caycahen es alta y tendida Nordeste. Sudoeste. Las de Quenu y Chizhuapi bajas y tendidas Noroeste-Sueste, y lo más Oeste de Quenu es punta rasa de arena muy blanca, y con lo más Noroeste de Chizhuapi que también es punta de arena blanca, forman la boca del puerto, que es de una milla y acantilada por ambas partes.

126. I a Isla de Pulucuy es la mayor de las del partido de Calbuco, la de Tabon está prolon. gada Este-Oeste: á lo más Este de ella y lo más Este también de la de Quenu, está el bajo Tabon Norte-Sur con la medianía de la de Chizhuapi dos millas, por esto se hace la derrota con tanta inmediación á Chizhuapi; el bajo es de arena y marisco, su extensión una milla Noroeste-Sueste, y queda casi todo manitiesto en bajamar de aguas vivas, acantilado por todas partes.

127. Al Nornoroeste del Oeste de la isla de 'labon, como á una milla, empieza el gran bajo de Lame-huapi ó isla de Lobos, que se extiende al Nornoroeste cuatro millas $y$ tiene de ancho una $y$ media. A bajamar quedan descub ertas varias porciones que parecen islas, $y$ velan algunas hasta pleamar; lo más del bajo es de arena y lastre, $y$ es infinito el marisco de varias clase que se coge en él; el recelo de este bajo impide la entrada á Calbuco por la parte del Oeste de Tabon, como el de la Lagartija que está entre lo más Norte del anterior y la Isla de Abtao; es de arena, se extiende una milla de NoroesteSueste, y al extremo Noroeste tiene el pequeño islote de su nombre, escarpado por la parte del Este.

28. El puerto de Calbuco es capaz, está desabrigado de los vientos de la parte del Norte $y$ Sur, que son bien frescos $y$ frecuentes en sus respectivas estaciones. Su fondo es de ro á I 2 brazas lama á ménos de un cable de tierra; forman el puerto las islas cie Caycahen, la de $\mathrm{Pu}$ luqui al Este de ella dos millas, las de Quenu y Chizhuapi al Sur á distancia de una legua, y la costa de tierra firme al Norte; en la costa de $\mathrm{Pu}$ lucuy que mira al puerto, está el estero de Chau. quial y el de Chipu, ambos son capaces de algu. nas embarcaciones grandes: el primero se interna dos millas en fondo de 18 hasta seis brazas lama y tal cual manchón de lastre, ambos están des. cubiertos del Noroeste al Oeste que son los dominantes y fuertes, en la costa firme, cerca del fuerte al Norte, está el estero de Huytu, que se interna dos millas, es buen invernadero para todo genero de embarcáciones, pero para pasar á su interior es lo mejor sólo á pleamar: hay ruatro brazas de agua sobre $\mathrm{d}$ banco que atravie: a la angostura, por lo que es necesario que entren descargadas y se amarren acoderadas más de dos que cstarán á la gira. Los fondos desde el banco para adentro y fuera son desde cinco hasta 20 brazas lama, arena y lastre: para entrar se tomará el medio freu, para huir una peña que suele descubrirse algo á bajamar.

I29. E1 terreno de las islas es apropósito para cultivo, y no tanto el de la tierra firme, en las fronteras de las Islas Abtan, Caycahen, $y$ el Estero dicho de Huytu, hay algunas habita. ciones, $\sin$ embargo de haber quemado dos veces los indios el fuerte en el terreno de Calbuco y en la capilla de San Rafael.

I30. Las mareas desde la Isla de Tac son de Nortc á Sur y su curso insensible hasta cerca de la entrada de Pulucuy y Tabon, que su dirección es al Nordeste y Noroeste: al Nordeste para con. tinuar hacia el seno de la cordillera, golfo de Re. loncabi, donde llega su movimiento á cinco millas; y al Noroeste de dos y media entre Pulucuy y Tabon, y así sigue á los rumbos de la derrota. aumentando su velocidad hasta tres y media mi llas entre Chizhuapi y Quenu.

I3I. Nota. Al avistar la Isla de Pulucuy, 6 poco después viniendo en demanda de Calbuco, se verá la península de Quehulin, que por el menor tamaño de ella, no se confundirá con la Isla de Pulucuy.

132. Los días de novilunio y plenilunio, st. cederá la pleamar en el desembar'cadero del fuerte á la una del día con corta diferencia.

\section{Derrota de puerto Calbuco al de Linao.}

I33. Desde el fondeadero de Calbuzo se gobernará al Sur una milla, y dos y media al Sudoeste $\%$ Sur, llevando la medianía de la Isla de Quenu por la proa, se hallará á medio freu de la boca entre Chizhuapi y Quenu, y gobernando al Sursueste dos millas, tendrá rebasada la boca, go. bernará al Sueste $1 / 4$ Este dos y media millas y 4 al Sueste $1 /$. Sur, desde donde le demorara lo más Este de Tabon dos millas al Oeste, hará el Sursudoeste cinco millas, y $26 \%$ al Oeste, con que estará rebasado del arrecife de Lobos de $\mathrm{Li}$ nao, y se hallará á media boca del puerto, que to. mará como se ha dicho al número $\mathbf{9} 9$.

134. Advertencias. Al Sur de la Isla de Tabon, siguiendo al Oeste se llevarán por babor casi á una vista las Islas Chıuques, $y$ por la mura misma la Isla Caucahue, por la banda de estribor las Islas Quenu, Caycahen, Quihua y costa firme, y por la mura la Isla de Abtao, y luégo se empezará á distinguir demorando al Deste $1 / 4$ Sudoeste la península Huapilinao que se presenta escarpada alteando algo más par el Sur. 
135. Las mareas, desdc el fondeadero del fuerte hacen su curso casi Norte-Sur y desde la punta Sur del fuerte Sursudoeste y Oesudoeste tres millas por hora, fuera de la entrada del puerto se dirige al Sueste la que sale por el Oeste de la Isla de Tabon, y al Oesudoeste la que sale por entre lo más Este de dicha Tabon y lo más Sur de Pulucuy, en velocidad de dos millas. En el resto de la derrota se navega por la línea casi divisoria de mareas de quien ya se ha hablado al número 2I. De punta Chilen al puerto de Linao, siguen su curso casi Norte-Sur con movimiento de dos millas, que aumentar á más de tres á la boca del puerto, y de ella para adentro disminuye.

\section{Derrota del puerto Linao al ds Chacuo.}

136. Fuera del puerto Linao se gobernará tres y media millas al Esnordeste, y rebasada la punta de Cheylen se hará el rumbo al Norte nueve millas, y quedará rebasada la punta de Tres Cruces, demorando al Oeste $30^{\circ}$ Sur. Desde este punto se hará el Oeste $3^{\circ}$ Sur tres y media millas, fondeando en la poza de Chacao en nueve á die $z$ brazas arena á distancia de dos cables de tierra.

137. Advert3cia. La salida de Linao se hará antes que acabe de llenar la marea, para encontrar la vaciante rebasado ya de la punta de Chilen; al montar la purta de Tres Cruces con vientos del Sur, se orzará inmediatamente, no obstante el rumbo dado, cuanto el viento dé lugar á reparar el impulso de la corriente, no impida á tomar el fondeadero obligando á embocar el canal de Remolinos.

Derrota del puerto de Chacao al de San Carlos.

138. Norte-Sur con la iglesia del pueblo, se navegará al Norte dos millas y hallará EsteOeste $a$ media milla de la punta de Remolinos. Desde este puntc á la del Noroeste, costeando la tierra que sigue para San Gallán por babor á distanciz de tres á nuatro cables, y cumplidas tres millas, gobernará al Oeste $9^{\circ}$ Norte 16 millas, y quedará con la Isla Doña Sebastiana Norte-Sur por su parte del Oeste, zafo ya del bajo Inglés: hará el Sudoeste $\%$ Sur cinco millas, y estando como á media escasa de la costa de Agui, hará el Essi1. - te, y montada la punta de Agui, pasando á $d$ tres cables de las lajis que lo forman, har: $c_{\text {i }}$ Sursudoeste ya dentro del puerto hasta rebasa: los sargazos del bajo de Chucura, que llevará por estribor, atracando luégo á la costa de dicha banda para surgir en el paraje citado al fin del número 2 .

139. Alvert:ncias. Las mareas variantes fa. vorecen en el viaje de Chacao á San Carlos 6 para el Oceano, y siguen su curso por los rum. bos opuestos que se han dicho en los números ro y Ir. Del morro de Huapilacuy para San Carlos son de tres millas por hora en direccion Nornoroeste Sursueste.

140. Si en esta derrota se quisiese fondear, puede hacerse en cualquier paraje en 16, I 8 y 20 brazas lama, $y$ mejor en la ensenada de Huapilacuy 6 puerto del Inglés, al Sur \% Sudoeste 6 Sursudoeste del morro de su nombre en ocho ó nueve brazas fondo no de buen tenedero, pero con bastante abrigo y aguada.

I4I. Si quisiese salir al Oceano sin tocar en San Carlos, estando Norte-Sur con lo más Oeste de la Isla de Doña Sebastiana, el rumbo del Oesnoroeste le conducirá libre de tod „, riesgo.

Derrota de Calbuco al Chacao y San Carlos.

I42. Saliendo de puerto Calbuco para el del Chacao estando al Sur de la Isla de Tabon, se hará el Oesnoroeste $5^{\circ}$ Oeste if millas, y al cumplirlas se hallará Norte-Sur con lo más Oeste de la isla de Abtao, punta Chodoy: hará derrota al Noroeste ' $/ 4$ Oeste, y atracándose á la punta de Tres Cruces y costa que sigue, cuanto pueda, fondeará en la poza como se ha dicho en los números 9 y $13^{6}$.

I43. Advertencias. Por el violento impulso de las mareas se atracará á la punta de Tres Cruces cuanto sea dable para asegurar tomar el puerto de Chacao.

144. Nota. Queriendo seguir desde Calbuco á San Carlos 6 al Oceano, demorando la punta de Tres Cruces media milla al Sueste, se navegará al Noroeste $1 / 4$ Oeste dos millas, y estando. Este-Oeste como media milla de punta de Remolinos, obrará según se expresa en los números ${ }_{13} 8$ y $14 \mathrm{I}$, sin olvidar lo advertido respecto á mareas y laja del canal.

\section{Salida del puerto de San Carlos al Oceano.}

145. Se dará la vela á marea parada para aprovechar la vaciante, especialmente si el viento es poco: zafo de la punta de Agui hará el Norte $\%$ Noroeste, llevando el morro de Huapilacuy descubierto por babor, hasta que demore media legua al Oeste; goberna1á al Nornoroeste dos y media millas y estará el farallón del Oeste de punta Huapacho al Oeste $15^{\circ}$ Sur, y enfilado con la punta de Huechucucuy, la tierra más Oeste de la Isla de Chiloé; desde aquí el Oes. noroeste lo conducirá al Oceano, y zafará de entre puntas, y violenta acción de las mareas de tres y más millas por hora. El encuentro de las mareas entre si, 6 con vientos opuestos, causa en el mar notable agitación y escarceo muy incomo. do, formando varias líneas 6 hileras de reven. 
por los rum.

súmeros ro

ra San Carlos

irección Nor-

iese fondear,

en 16, I 8 y' 20

da de Huapi-

14 Sudoeste 6

bre en ocho

enedero, pero

oo $\sin$ tocar en

1 lo más Oeste

el rumbo del

tod" riesgo.

San Carlos.

ico para el del

de Tabon, se

millas, y al

- con lo más

Chodoy: hará

racándose á la

sigue, cuanto

se ha dicho en

lento impulso

punta de Tres

gurar tomar el

desde Calbuco

ado la punta de

e, se navegará

as, y estando.

inta de Remoli-

s números $\mathrm{r}_{3} 8$

pecto á mareas

al Oceano.

parada para ente si el vienAgui hará el rro de Huapia que demore Il Nornoroeste tllón del Oeste sur, y entilado la tierra más aquí el Oes. zafará de entre nareas de tres tro de las maos, causa en el muy incómo. eras de reven. tazón, tan semejante á la de un gran bajo, que es capaz de sorprender á cualquiera á primera vista.

146. Advertencius. - En la derrota anterior, desde dar la vela hasta la punta del Sur de Agui, se lleva por babor el bajo de Pechucura, de quien se ha hablado en los números 2 y $13^{8}$ cuyos sargazos están siempre manifiestos, y mucha parte de él á bajamar, tiene cuatro brazas á pique.

I47. Desde que se monta punta de Agui has. ta rebasar morro de Huapilacuy, se lleva lo más Oeste del bajo Inglés enfilado con la medianía de la Isla de Doña Sebastiana y fuerte San Carlos al Norte $5^{\circ}$ Este y Sur $5^{\circ}$ Oeste y casi Esteoeste con el morro de Huapilucuy en distancia de una legua, su dirección es Este $5^{\circ}$ Sur Oeste $5^{\circ}$ Norte tres millas, la reventazón á bajamar se manifiesta en su centro como de una milla, tiene de ancho de Norte á Sur de cuatro á cinco cables, y es todo de arena con tal cual manchón de lastre.

I48. Desde el morro de Huapilucuy hasta la distancia de un cable escaso, sale envuelta del Este el arrecife de piedras que vela en bajamar, á pique tiene seis y siete brazas fondo piedra.
Nota.-Adición al nímero 37.

No obstante mi continua indagación en solicitud de los bajos y placeres en estas derrotas, no tuve noticia del banco de Tigui, donde suelen algunos índios pescar lobos. En el viaje de visita de provincias del Gubernador Hurtado, tuvo noticia de él, y le colocó entre las islas desiertas y Chaulin y Tac, y al Este de lo más Sur de la de Cahuache ocho y un tercio millas, dándole la extensión de dos y media de Norte á Sur y una del Este-Oeste y signifić́ ser de rocas. Este bajo es obstáculo para la derrota que doy en el número 37 desde Linao á Castro, que lleva por el veril del Oeste del citado bajo. Para evitar este riesgo estando Tste-Oeste con la Isla de Tac, se gobernará al Sudoeste $\%$ Oeste ocho millas, llevando lo más Sur de la Isla de Cahuache por la proa, y así pasará más de una legua al Norte de dicho bajo, seguirá al Sur I I millas, quedará EsteOeste con lo más Este de la Isla de Caulinec á distancia de cuatro millas; desde esta situacion navegará al Sursudoeste cinco millas, y cumplidas, hará el Oeste como se dice en el mencionado número 37 y lo demás de la derrota como se previene en ella. 


\section{Construcción de las cartas hidrograficas desde Chiloe hasta Coquimbo.}

Establecidas la latitud $y$ longitud del observatorio de San Carlos de Chiloé sobre datos de la mayor confianza, pero que dependen de las observaciones correspondientes hechas en Europa, adoptamos para la continuación de nuestras ta. reas el meridiano de San Carlos por primer meridiano; así, cualesquiera innovaciones que causen en la longitud, se reparten en el total de la costa que abraza, pues ya las combinaciones de los relojes, no alcanzan, á lo ménos en nuestro entender, á desenvolverlas con probabilidad de una mayor aproximación.

Nuestras marcaciones con el teodolito llegan hacia el Norte hasta la punta Capitanes de la tierra firme; es inútil recordar con cuánta prolijidad se han heclio todas las marcaciones que conducen á la formación del plano del puerto San Carlos; estas mismas afianzan la posición de los islotes inmediatos y de la punta ya nombrada.

Ha sido preciso combinar con las tareas del Piloto Moraleda la continuación de la costa hasta el río Bueno: no conveníamos con él en el arrumbamiento de aquella punta, por consiguiente ha parecido oportuno referir á nuestras posiciones de la nisma y del río Bueno los puntos salientes intermedios, que Moraleda había marcado. Una ilusión sobre la vista de tierra después del pequeño temporal que pasamos á la salida de Chiloé, nos arrastró involuntariamente á propasarnos de este trozo de costa.

Volvemos á cogerla por paralelos del río Bueno, y las bases nos guían desde alli hasta la entrada del puerto de Valdivia, cuyas vistas, arrumbamientos exteriores y longitud, detcrminamos con grande probabilidad de que se aproximen muy mucho á toda la exactitud necesaria: los relojes tienen á la sazón una época muy corta, y concurren á afianzarlos, muchas series de distancias lunares medidas con las circunstancias más favorables.

Nuestras bases referidas al medio día anterior, en el cual observamos sí la latitud con mucha contianza; pero distábamos considerablemente de la costa, viéndonos luego precisan. $\mathrm{s}$ á buscarla con rumbos del Este, determinan al Morro Gonzalo una latitud mayor en siete minutos á la que prefijaba el Piloto Moraleda. Por ventura, se reune con la exactitud natural de este hábil Piloto la casualidad de haber observado tres veces á la vista del mismo Morro Gonzalo con buen octante y declinaciones bien calculadas, de suerte que no titubeamos un momento en abandonar los resultados de nuestras tareas, y prefijar al mismo Morro la latitud de $39^{\circ} 50^{\prime}$, en lugar de la de $39^{\circ} 57^{\prime}$ que inferíamos de las bases y navegación traídas desde el medio día: el fondeadero del Milagro, inmediato al rín Bueno, está comparado á las noticias del Capitán Orejuela.

La costa siguiente hasta la Isla Mocha se ha combinadocon los derroteros antiguos y conla carta del Piloto Moraleda, hubiéramos á la verdad deseado dar unas vistas del Morro Bonifacio que dirigiesen la recalada al puerto con los vientos del Norte harto comunes; pero en estos paralelos, como nos pareciese lo demás costa de muy poca importancia en proporción de la que se sigue al Norte de la Isla Mocha, cuya posición pudiera. mos trabajar prolijamente con el tiempo á la sa. zón claro y apacible, cosa no muy común en estos mares, navegamos una noche entera omitiendo este trozo ya reconocido muchas veces, $y$ de un arrimo nunca útil por las naciones que le habitan: los puertos de que carece, los tiempos por lo común tempestuosos y la costa coronada de ärecifes.

La Isla Mocha, en cuyas inmediaciones se han observado con la mayor satisfacción latitudes y longitudes, se ha situado también en cuanto á sus extremos por bases corridas con toda la prolijidad posible. El arrecife saliente en su extremo del Sur, no ha sido visto por nosotros; es de la extensión que le determinan los derroteros antiguos, $y$ no debe diferir muclio, por cuanto en la navegación costanera que antiguamente se hacía, no pudo equivocarse su distancia con otrn objeto alguno extraordinario.

La lancha del navío San Pablo, del comercio de Lima, ha pasado últimamente entre la misma isla y la tierra firme: las noticias verbales de su Capitán el Alférez de fragata graduado D. An. tonio Cazulo, se han tenido presentes para el derrotero $y$ el paraje más oportuno para fondear: el preferir nosotros el paso exterior, dependió del deseo de coger su vista á una regular distan- 


\section{bé hasta}

tural de este er observado rro Gonzalo bien calculaun momento stras tareas, d de $39^{\circ} 50^{\prime}$, íamos de las el medio día: diato al río ias del Capi -

Mocha se ha os y conla cars á la verdad Bonifacio que n los vientos estos parale. costa de muy a que se sigue ición pudiéra iempo á la sa. común en es : entera omichas veces, $y$ aciones que le , los tiempos osta coronada

ediaciones se acción latitu ibién en cuan. as con toda ente en su ex. $r$ nosotros; es los derroteros por cuanto en amente se ha. ncia con otro

del comercio ntre la misma erbales de su luado D. Antes para el depara fondear: ior, dependió agular distan. cia para aclarar más y más las recaladas venideras.

Siguen las posiciones deducidas de nuestras bases desde el paralelo de la Isla Mocha hasta la punta de Rumana. Habiamos corrido nueva base para la posición y dirección de la Isla Santa Maria, pero por algún accidente inaveriguable, no nos fué posible ligarla con los puntos interiores de modo qne no discrepase, ni de los reconocimientos hechos por el Excelentísimo Ulloa, ni de las latitudes anteriormente observadas por el Piloto Moraleda en el mismo paralelo: las hemos adoptado con tanta mayor seguridad, cuanto conservan luégo los misınos arrumbamientos de la isla con la tierra firme, cuya descripción hidrográfica está deducida de elementos tan segu. ros como multiplicados: toda la parte exterior clesde la Isla Santa María hasta el puerto de Coliumo pende de marcaciones del teodolito $\mathrm{y}$ de unos triángulos ligados con bases de la mayor satisfacción.

La latitud del puerto de Talcahuano se ha observadó con el cuarto de círculo: su longitud está determinada con los relojes marinos de la Descubirrra, examinado y hallado conforme su movimiento en el mismo puerto: conviene esta longitud dentro del minuto con la que determino el Padre Feuille por tres observaciones en el primer satélite de Júpiter, todas referidas á las ob. servaciones correspondientes de los Sres. Maraldi y Cassini en París ( $\mathrm{I}$.

Discrepan en esta ocasión considerablemente los relojes de la Atrevida, y la ecuación que resulta de la averiguación de su marcha en Valparalso, no alcanza con dos minutos de diferencia á igualar la que termina la Descubierta.

Un tiempo constantemente neblinoso y acompañado de calmas realmente temibles en estas costas, imposibilitó á la corbeta ATrevida el recorrer el trozo de costa comprendido entre la embocadura del rio Hitata y la punta de Lora: la hemos deducido de los mejores derroteros que merecen alguna fé en esta parte, porque con oh. jeto de acopiar algunas maderas, y áun de construir buques pequeños, ha solido frecuentarse el rio Maule, y por otra parte los ha examinado con mucha prolijidad el Piloto Moraleda.

Desde la punta de Lora por el morro de To: pocalma, bajos de Rapel y punta de Coroumilla hasta Valparaíso, toda la costa está deducida de las tareas de la corbeta ATrevida, la cual, aunque no pudiese por la muchas calmas y cerrazo. nes continuar ordenariamente sus bases, ha po-

(1) No podemos acertar cui los motivos que han dado lugar á variar en el conocimiento de tiempo la longitud del Padre Feuille, sustituyéndole otra que difiere de medio grado: es probable que proceda de una equivocrción antigua de cifras y que corrobore Mr. Dagelet los resultados del Padre Feuille. dido, no obstante, observar latitudes y longitudes en unos puntos importantes; de suerte que ninguna sospecha de error considerable puede quedarnos en cuanto á los puntos esenciales de este trozo de costa: son todas bacs bien aseguradas las que conducen desde la punta de Coroumilla hasta la de los Angeles.

No cabe mayor exactitud de la que se ha empleado para la latitud de observaciones de Val paraíso, como que dependia de ella el catálogo de estrellas meridionales que se ha intentado ra tificar 6 arreglar por los Sres. Galiano, Concha y Vernaci: en cuanto á la longitud está deducida de dos emersiones del primer satélite de Júpiter exactamente acordes entre si, y convienen en ella con la misma uniformidad los relojes de la ATREvIDA.

Los de la Descubierta, que determinan la longitud de las Islas de Juan Fernández, traídos luégo al observatorio de Valparaiso, sólo discre. pan un minuto y medio de la longritud de los satélites, y esta cantidad en el mismo sentido re. lativamente á los relojes de la Arrrvina, en que difieren los unos de los otros en Talcahuano, fija, finalmente, entre Concepción y Valparaiso, una misma diferencia por los seis relojes, y por las observaciones hechas en Chiloé y en este úl. timo puerto (I).

La posición de las Islas de Juan Fernández queda, pues, evidentemente segura: se ha observado la latitud á la vista de una y otra, fijada la distancia nuestra á la de más afuera por una base corrida y suficientemente proporcional, y ratificadas las determinaciones de un día con las del otro en cuanto á la de adentro: hemos sacado mucho partido de los reconocimientos hechos por el Excmo. Ulloa en su fondeadero, el cual también deducimos en cuanto á sonda, así de nuestros planos actuales (visitada ya repetidas veces esta isla por los buques de S. M.), como de las noticias harto individuales del Almirante Anson.

El braceaje de la de más afuera, el sitio desu aguada y la configuración de la parte occidental está copiado de las noticias exactas que costaron al célebre Capitán Carteret mil fatigas y peligros (2): muchas vistas que se sacaron de estas islas pudieran completar su descripción hidro. gráfica; pero nos obliga la escasez del tiempo á omitirlas por ahora, igualmente que una carta

(r) El Padre Fetille determina la longitud de Val. paraiso medio grado más occidental que la nuestra: no parceré extraña esta diferencia, cuando se advierno parccera ta que el Padre la deduce de una sola observación de primer satélite sin correspondiente y sin una marcha bien segura del péndulo: véase el viaje del Padre Feuille, tomo I, pág. $3^{80}$.

(2) Las contrariedades que experimentó y vencio en esta ocasión el célebre Capitán Carteret deben mirarso como una verdadera lección para un marinero. 
que las manifieste en punto mucho mayor que el general de la costa fronteriza.

La posición de la ciudad de Santiago pende en cuanto á latitud de muy buenas observaciones en el cuarto de circulo; $y$ en cuanto á la longitud, de una observación muy satisfactoria en el primer satélite de Júpiter. Difiere considerablemen. te de esta determinacion la del reloj 105 de Arnold, pero como su conducción por tierra pudo trastornar algún tanto su movimiento, y la falta del cristal de la muestra hiciese muy expuesto é incómodo el darle cuerda, no titubeamos en abandonar su resultado: el olvido involuntario de no darle cuerda á la vuelta al tiempo de llegará Valparaíso nos ha quitado el inferir nuevos re. sultados.

También se ha observado la latitud en Casa. blanca, y todo el valle de Santiago sujetado a operaciones trigonométricas; pero el tiempo no nos permite trazarlas.

Erá muy difícil sin muchos sacrificios de tiempo, salud y caudales, la operación que in. tentábamos de conducir los triángulos desde Val. paraiso á dicha capital.

- Todas las inmediaciones de la rada de Val. paraíso hasta el Concon, se han inferido, como era natural, de las operaciones trigonometricas en el teodolito; pero no ha sido tan fácil el ligar el trozo siguiente hasta Coquimbo.

En este trabajo concurrieron á interrumpir la exactitud que nos prometíamos, no ménos un tiempo muy calimoso y unos vientos calmc. sos reunidos á una corriente bastante fuerte, si también la falta casi absoluta de observacio. nes de latitud y longitud por el espacio de dos días y medio. El excelente método de hallar la latitud por dos alturas de Sol, propuesto por D. Dionisio Galiano, nos ha sido en esta ocasión muy útil, pero ha sido preciso sujetarlo á nuevas combiıaciones, en cuanto no todas alturas en un cielo cerrado con calima eran de igual confian$z a, y$ además en el primer día teníamos una sóla altura, cuya longitud mal podía deducirse ignorando la latitud: la aplicación de los relojes á la resolución de esta duda nos ha of recido por ventura datos muy aproximados, pues indicán. donos las marcaciones desde Valparaíso y nuestras bases, en qué longitud nos debíamos suponer próximamente, hemos inferido ser error de la latitud la diferencia que nos resultase, $y$ así, de la longitud verdadera se ha deducido la corrección á la latitud del medio día.

Paireando en una parte considerable de la noche, navegando muy próximos á tierra, y ayu. dados de los datos antecedentes, podemos lisonjearnos de haber triunfado en esta parte de costa de las contrariedades que querian imposibilitarnos su exacta colocación. Los tiempos hermosos de los cuales hemos disfrutado, después nos han dado lugar á trabajar con toda la exactitud; así, las inmediaciones al Sur de la Lengua de Vaca y toda la costa comprendida entre esta y la entra. da de Coquimbo, deben ser muy aproximadas á la verdad: estas últimas están también sujetas á las operaciones trigonométricas en el teodolito, y confrontadas con diferentes marcaciones y en filaciones, á la salida.

La latitud del observatorio nuestro de Coquimbo, observada en el cuarto de círculo, y la longitud, inferida de dos emersiones del primer satélite de Júpiter, de varias fases de un eclipse de Luna, $y$ de dos ocultaciones de estrellas por la misma Luna; pero mientras se logren los cálcu. los y errores de las tablas para estas observaciones de la Luna, nos atenemos al resultado de las observaciones en el primer satélite de Júpiter, que conviene exactamente con los relojes marinos (r).

Así, la diferencia en longitud entre San Carlos de Chiloé y Coquimbo, se halla, con mucha complacencia nuestra, determinada uniformemente por los seis relojes marinos (2) de entrambas corbeias, examinado su movimiento en $\mathrm{Chi}$ loé, Talcahuano, Valparaiso y Coquimbo; y concurrenáfortalecerle, varias observaciones hechas en el primer satélite, en los rismos puertos (3).

También deben sernos tanto más agradables estos resultados, cuanto que asegurando unánimes la longitud del puerto de San Carlos, quedan también aseguradas las diferencias entre aquel puerto y el de Montevideo, y por con. siguiente todos los de ambas costas Patago. nicas.

En una costa tan abundante de puertos y radas como lo es la que acabamos de describir, hubieran sido muy defectuosas nuestras tareas, si ne nos hubiésemos dedicado con el mayor fervor a reconocer y trazar siquiera las que pareciesen importantes para la navegación.

(1) El Padre Feuille determina á Coquimbo una longitud bastantemente aproximada a la nuestra; si debiéscmos atenernos á la observación del primer satélite, que no tiene correspondiente, pero que difiere en $10^{\prime}{ }^{\prime} 5^{\prime \prime}$ " de la que resulta de la observación del en ro 15" de la que resulta de la observacion del
segundo satélite correspondida por los sehores $\mathrm{Ma}-$ segundo satélite correspondida por los seńores Ma-
raldi y Cassini en Parrs; ésta diera la longitud de raldi y Cassini en Parrs; ésta diera la longitud de
nuestro observatorio de $73^{\circ} 36^{\prime} 12^{\prime \prime}$, la nuestra es de $73^{\circ} 52^{\prime} 0^{\prime \prime}$.

(2) Cuando se habla de la uniformidad de los tres relojes de una corbeta, se entiende siempre que están traldos á un mismo resultado por las ecuaciones que resultan de la comparación diaria entre sí que resultan de la comparación dia
Véanse las tablas de cstas ecuaciones.

(3) No parezca extraño que adoptemos como
(3) lanse lablas de cstas ecuacios. igual á la nuestra, la longitud del observatorio o fondeadero de Talcuhuano, determinada por el Padro Feuille, cuando las de Valpararso y Coquimbo se nos apartan considerablemente: cualquiera que recorra viaje verá que las observaciones hechas on Peorra tros tros, todas con correspondiento en Paris, todas on of primer satélite y todas uniformes entre sf. Están muy distantes las otras de hallarse en circunstancias iguales. 
exactitud; asi, gua de Vaca y sta y la entra. aproximadas á jbien sujetas á en el teodolito, raciones $y$ en-

unestro de Co. e círculo, y la nes del primer s de un eclipse estrellas por la gren los cálcutas observacioresultado de las ite de Júpiter, os relojes ma-

entre San Car. lla, con mucha rada uniforme$s$ (2) de entram. miento en Chi. oquimbo; y convaciones hechas nos puertos (3). más agradables segurando uná. de San Carlos, diferencias endeo, y por con. costas Patago-

de puertos y raos de describir, nuestras tareas, on el mayor fer. a las que pare. gación.

a Coquimbo una a a la nuestra; si ión del primer sa, pero que difiere observacióa del - los sefiores Ma'a la longitud de 2 ", la nuestra es iformidad de los onde siempre que or las ecuaciones diaria entre si es.

adóptemos como bservatorio o fonada por ol Padre Coquimbo se nos erá que recorra su chas en Penco soa Parts, todas on ol tre si. Estón muy en circunstancias
El puerto y canal interior de Valdivia está levantado con mucha prolijidad por el Ingeniero Garlan; le ha confrontado, asi en cuanto á las operaciones trigonométricas como á la sonda, el Piloto Moraleda, quien nos ha confirmado su exactitud.

La posición de los fondeaderos de la Isla Mocha y la de Santa Maria, se ha sacado de los derroteros; este último se ha combinado tam. bién con las noticias del Excmo. Ulloa, quien la hizo costear por la parte interior; la frecuentan en el dia los pescadores de la corvina.

El examen de los fondeaderos inmediatos al de Talcahuano era tanto más importante cuanto que aquella rada está enteramente descubierta. al viento reinante y tempestuoso del Nortc; así, se han levantado con el teodolito los planos de los puertos de San Vicente y Coliumo, uno y otro abrigados de aquel viento aunque no capaces de un crecido número de buques; es nuestra la sonda del puerto de San Vicente, bjen que no descubre un bajo que está en su entrada y que fué reconocido por el Piloto Moraleda, con cuya noticia le comprendemos en el plano; la sonda del puerto de Coliumo nos ha sido comunicada por un pescador que habitaba sus orillas desde mu. chos años.

A pesar de la inutilidad de la bahia de Tal. cahuano, no nos hemos descuidado en sujetarla á las operaciones trigonométricas más prolijas: el bajo grande se ha sondado por todas partes marcando al mismo tiempo al bote con dos teodolitos: lo mismo se ha hecho para las inmedia. ciones peligrosas de la costa contígua á Talca. huano, $y$ todas las piedras que hacian antes creer, que fuese muy expuesto el paso entre la misma costa y la Quiriquina. Las inmediaciones de esta isla, las del Mogote de Quiebra-ollas y las del Tomé y Penco, se han sondado sin sujeción á los teodolitos.

Se hicieron cuantas diligencias estaban en nuestro alcance para hallar dentro de la bahía otro bajo, de cuya existencia teníamos alguna noticia confusa: fueron vanos nuestros esfuerzos para el intento, áun haciéndonos dirigir por la misma persona que nos decian haber tocado en él: el Piloto Moraleda nos asegura haberlo reconocido; la posicion que le damos, por consiguien. te, en nuestro plano, está deducida de las marcaciones que nos ha comunicado.

Los triángulos empezados en la bahía de Talcahuano y prolongados al Norte hasta la Herra. dura, se extienden al Surhasta las Tetas y embocadura del Viovio, de donde después contináan hasta la ciudad actual de Penco, comprendiendo también la otra banda del río: assi, podemos responder igualmente de la latitud y longitud de la Plaza Mayor de dicha ciudad.

En la costa comprendida entre Concepcion y
Valparaiso, los derroteros indican algunos peque. nos puertos 6 calas que no son absolutamente frecuentados en la navegación actual. Son éstos, corriendo Sur a Norte, los de la Natividad de Topocalma y de San Antonio, cuyo examen nos hu. biera acarreado el sacrificio de un tiempo favorable que pensábamos aprovechar y realmente aprovechamos en Valparaiso: asl, los hemos omitido, bien que determinando sus entradas según se han podido inferir de las tareas de la corbeta ATRevion.

La rada de Valparaiso está igualmente deducida de operaciones trigonométricas, $y$ todas las sondas hasta el Concon han sido examinadas por nosotros.

E1 Ingeniero destinado en Chile, D. Pedro Rico, había levantado en el año de 1788 los planos de las calas del Papudo y Pichichangi, in. termedios entre Valparaiso y Coquimbo (I): no los creemos absolutamente útiles cn el estado actual de la navegación: no obstante, nos ha parecido oportuno el comprenderlos en esta colección.

En el trabajo del puerto de Coquimbo y de sus sondas, no hemos omitido la menor atencion: ésta se ha extendido también al pequeño puerto inmediato de la Caldera, que consideramos in. útil, particularmente si se compara al puerto, cuyo abrigo, clase de fondo, clima sano y vientos perfectamente apacibles, le harían de un valor inmenso si no careciese absolutamente de agua y leña (2).

No ocuitaremos que los errores casi innumerables en los rumbos y distancias de los derroteros más acreditados que hemos consultado á cada paso al tiempo de trazar esta carta, no nos han permitido de aprovechar la menor noticia, si se exceptúa la colocación de tal cual riachuelo ó pequeño trozo de costa, que ya las calmas y las ce. rrazones 6 las corrientes y las noches muy largas nos hiciesen propasar involuntariamente: algún más despacio del que tenemos en la actualidad, nos permitirá algún día de intentar una nueva combinación de la parte útil de aquellos derroteros.

A las longitudes inferidas po: los relojes ma rinos y por las observaciones de los satelites de Júpiter, hemos agregado á la entrada de Valdivia y' Talcahuano en Valparaíso y Coquimbo, un número considerable de observaciones de distancias á la Luna: sus resultados son por lo común muy aproximados á los demás; pero no intentamos adoptarlos para la determinación directa de las

(1) Nos asegura en oficio recibido en Lima por manos del señor Presidente de Chile, que esos pianos están hechos conla posible exactitud geométrica, que no ha sondado por falta de recursos para verificarlo.

(2) Encontramos muy aproximado a la verdad e plano de Mr. Frezier: se aparta mucho al contrario el del Padro Feuille. 
longitudes; sólo si examinaremos constantemente hasta qué grado de enactitud pueden alcanzar (1).

(t) Repetidos ejemplosnos hacen creer hasta aqui, yuo no puedin fiarse a inás de los tres cuartos ilo grado.
Los planos de las poblaciones que se comprenden en los particulares de este trozo, están todos conformes con el estado en que aquéllos se hullan en principios de 1790 . Lo mismo debe entenderse por lo que toca á fortificaciones: sólo si que damos por concluidas algunas que nolo están.

\section{Derrotero de Chilos a Coquimbo.}

Saliendo del puerto de San Carlos de Chiloé deben reconocerse, ó la ounta de Quedal en la costa firme de Chile, situada en $4 \mathrm{I}^{\circ} 4^{\prime}$ de latitud Sur, y er, $67^{\circ} 53^{\prime} 15^{\prime \prime}$ de longitud occidental del meridiano del observatorio de Cádi $z$, óla de Capitancs, sobre la unisma costa, ro millas al Sueste de aquélla. Lá primera es de mediana altura, y aunque escarpada, su descenso al mar es mucho ménos violento que el de la segrunda, cortada á pico y de doble elcración: una y otra estín cercadas de bajos como toda la costa al Norte hasta la entrada del rio Bueno, que se hace distinguir á primera vista por la profunda quebrada en que desemboca.

En esta porción de costa que corre al Norte $1 /$ Nordeste 48 millas, se hallan de Sur á Nor. te las caletas de San Pedro Caramavidamo y Ma. manavidamo, por los ríos de sus nombres, y entre las dos últimas, la grande ensenada de los Juncos, llamada así del nombre de la nación india que habita sus costas.

Desde río Bueno sigue la costa limpia, y so. bre ella empiezan los altos de San Antonio: su dirección es al Norte $16^{\circ}$ Este, formando una grande ensenada poco profunda y dominada de aquellos ccrros. Isil punta falsa de la Galera, en que termina, es tan semejante á la verdadera $c_{1} d e$ no pueden distinguirse si no se tiene una buena observación en latitud, circunstancia poco común en este sitio, especialmente en invierno: $\sin \mathrm{em}$ bargo, como las tierras próximas á aquélla al Norte y Sur, son altas, y al Norte de esta descienden sensiblemente, puede ser regla para el navegante esta diferencia, $y$ tomar por punta falsa la que vea unida á tierras elevadas por una y otra parte.

Toda la costa comprendida entre esta punta y la de Capitanes, es desabrigada, mucha parte escarpada y cubierta de bajos, y especialmente desprovista de fondeadero: así por esto como por reinar sobre ella casi todo el año los vientos del Norte al Oesudoeste huracanados, tempestuosos, y siempre acompañados de lluvia y cerrazón, conviene no acercarse á ella áun en verano, estación è que sorprendiendo á poca distancia una calina, podrian ser tan funestas las mares gruesas y perennes del Sudoeste como el mayor temporal.

La estación sóla debe decidir del paraje de recalada: de Marzo á Octubre, en que reinan los Nortes, Noroestes y Oestes, parece prudente atracar la costa á barlovento respecto de ellos, para reconocer el morro Bonifacio y las tres quebradas que presenta al Sur, llamadas de Nabos, de Val. divia y Chaininu, dirigiéndose después $\{$ la del medio, que es el pucrto, y conservando por la proa $\delta$ poco descubierto por estribor el morro Gonzalo, hasta estar tanto avante con el Oeste que demore al Sur á distancia de una milla: en esta posición, tendrá ya á la vista el pequeño fuerte de San Carlos que pondrá por la serviola de estribor hasta que demore al Oesudoeste á distancia de dos cables, que se costee ahora á la mitad de esta distancia la ticrra del Oeste, y pasando la ensenada de Amargos, se dirigirá á la siguiente del Corral, donde fondeará luégo que haya enfilado la punta del Calvario con la de lu Uña del Ancla: el modo de amarrarse es Noroes. te-Sueste con el ayuste al primer viento, el cuerpo del buque estará en seis brazas y media de agua, fondo lama.

La entrada del puerto de Valdivia no tiene otros riesgos que los visibles, si se exceptúa la piedra sala dos cables al Nordeste de morro Gonzalo, que se cubre á media marea, pero manifiestan bien, la revaninzón y escarceo de las aguas sobre ella.

Por lo que hace al interior del puerto, puede decirse que al susste de una linea tirada desde la punta de Niebla al extremo Este del Castillo del Corral, sólo hay de tres á tres y media brazas de agua: el fondo á la parte del Oeste es de ocho á seis brazas lama.

El fondeadero del Corral, única parte abrigada, es tan pequeño, que no pueden estar en el más de dos embarcaciones á la gira ni más de seis acoderadas.

De Octubre á Marzo, aunque no tienen los Nortes fuerza ni constancia, puede fondearse entre el Castillo de Amargos y Chorrocamayo, en- 
que se com. trozo, están c aquéllos se ismo debe en. ciones: solo si te no lo están.

tas las mares mo el mayor del paraje de ue reinan los prudente atra. de ellos, para res quebradas Vabos, de Val. pués á la del vando por la bor el morro con el Oeste una milla: en a el pequeño or la serviola udoeste $a$ disahora á la miOeste, y padirigirá á la urá luégo que o con la de la ise es Noroes. iento, el cuers y media de

livia no tiene e exceptúa la e morro GonJero manifiesde las aguas

uerto, puede tirada desde del Castillo y media bra1 Oeste es de a parte abrien estar en él ra ni más de no tienen los fondearse encamayo, en- frente de la ensenada que los divide: en este sitio se está desabrigado, pero el fondo es buenn, $y$ para levarse no se necesita la espia, maniobra las más veces indispensable en cl Corral.

Fn uno $y$ otro fondeadero hay abundancla de excelente agua, $y$ se hace con la mayor comodi. dad. Todo el puerto de la parte del Oeste está cercado de maleza, de modo, que en cualquiera parte se corta cuanta leña se necesita.

Los Nortes meten tanta mar, que no permi. ten el paso de las embarcaciones menores á Valdivia, por cuya razón, los castillos de la costa del Oeste tienen á prevención cierto número de raciones de repuesto.

La pleamar sucede en el fondeadero del $\mathrm{Co}$. rral. El plenilunio á las once y media de la mañana, y su elevación sobre la vaciante de seis $y$ medio á siete piés; cuando hay viento fresco del Norte, son iguales en duración y corriente, pero con Sur 6 calma, la creciente es de tres millas entre los castillos, $y$ de cuatro y media la vaciante, que suele durar siete horas por razón del desagule del río.

Es dificil en tiempos cerrados distinguir el morro Bonifacio que solo tiene de notable un pe. queño escarpado algo colorado en lo más salien. te, particularidad en que se le parecen algunos otros al Norte de morro Gonzalo: es redondo, grueso, escarpado y saliente, de modo que no puede equivocarse.

Para salir de V'aldivia es necesario contar con viento de bastante fuerza que supere las va. rias direcciones de la marea, pues de otro modo será fácil en la angostura caer sobre la costa de Niebla y punta de la Uña del Ancla, una y otrá cercadas de piedras, con vientos bonancibles y varios: conviene salir á la espía hasta ponerse fuera de los Castillos de Niebla y Amargos, de donde puede salirse con cualquier viento flojo.

La plaza de Valdivia está á seis legruas del Corral sobre la orilla del río á que da nombre; los muchos y mudables placeres de que está lleno, hacen su navegacion difícil para las lanchas cargadas, y absolutamente impracticable á embar. caciones de más de ocho piéz de calado. El río desemboca en la bahía por dos canales, dejando en medio una isla bastante grande en que pastan ganados: el brazo del Sur que Illaman Tornagalesnes es tortuoso, y mucho más largo y aplace. rado que el del Norte 6 de Valdivia, de que se ha hablado; por consiguiente, está sin uso.

Las tierras al Norte de morro. Bonifacio son de mediana altura y muy desiguales, se presentan sobre ellas los altos de Cucule, formados de muchos cerros, que prolongan la costa en su di. reccion hasta poco del río de Totten, donde bajan sensiblemente, $y$ la costa hace varias pequeñas ensenadas sin abrigo; de allí se mantiene en el mismo aspecto hasta la punta de tierra media . namente alta y aplanada en su cumbre, con gunas piedras en su pié á poca distancia; está marcada en $3^{\circ} 28^{\prime} 34^{\prime \prime}$ de latitud Sur y en $67^{\circ} 3^{\prime} 39^{\prime \prime}$ de longitud algunas millas al Norte del rlo Cauter de li Imperial; desde morro 13o. nifacio á este punto, eorre la costa iI Norte 10 " Oeste 78 millas.

La Isla de la Mocha, cuya latitud es de $3^{8^{\circ}} 23^{\prime} 10^{\prime \prime}$ y su longitud de $67^{\circ} 5^{6^{\circ}} 35^{\prime \prime} \mathrm{en}$ su extremo Sudneste cstá 15 y media millas al Norte $68^{\circ} 45^{\prime}$ Oeste de esta punta. Su direccion es casi Norte-Sur y su extensión de ocho á nueve millas. Is montuosa, escarpada por la parte del Oeste y mucha del Nordeste, y su altura bastan. te para dejarse ver a 14 leguas, en dias clarns. El freu entre ella $y$ la costa es de cinco a seis leguas, limpio por una y otra parte, y su fond" de 28 a 32 brazas lama y arena. En su medianín forma la isla una pequeña ensenada donde puede fondearse en necesidad, al abrigo del Noroeste. sobre 15 brazas, á media milla de la playa.

Todos convienen en que de su extremo Sur sale una restinga de piedras al Sudoeste, pero hay variedad en su extensión; no obstante, creen los más que es de cinco á seis millas; una terce. ra parte sucle descubrirse á mar baja, y con vien. tos del tercer cuadrante revienta el mar sobre ella furiosamente.

Hay en el interior algunas aguadas y excelentes potreros para cría de ganado: la posicion de esta isla respecto de los puertos próximos hace $\tan$ infructuoso el paso del freu, que sería imprudencia emprenderlo sin urgente necesidad: tal es en mi sentir una recalada anticipada que acerque á la costa Sur en disposición de no poder montar con el viento al Sur y Sursudoeste el bajo, o la tenacidad del viento al Noroeste y Oeste cogiendo cerca de la costa.

Desde la punta de lirua forma la costa una grande ensenada que termina en el cerro ó morro de Tucapel viejo, bien notable por su figura de un morro tajado, de más que mediana altura y de color pardo confuso.

Las tierras de esta ensenada son bajas, alo. madas, sin serranía á la espalda, escarpadas al mar y con algunas playitas: cinco millas al Sur $\%$. Oeste de Tucapel, se ve otra punta ménos alta, que parece islote, de donde salen al Norte á distancia de tres cables algunos pedruscos bastante visibles: pasado el frontón de Tucapel, cuya extensión es de una milla, escarpadoy tajadoal ma:, sigue la costa al Norte formando una ensenada regularmente honda, llamada del Carnero; su te. rritorio es desigual en la cumbre y bastante inclinado á la playa: las tierras más bajas están en el fondo de la ensenada, $y$ poco al Norte, parece el morro del Carnero, con punta $\hat{i}$ un pié poco saliente: se ven próximas á la costa sobre los pe- 
queños montecillos que la cercan, algunas manchas verdosas, blanquecinas y rojas.

La costa sigue escarpada hasta punta Rumena, donde empieza á ser desigual, aunque elevado, el territorio; entre esta punta y la de Lavapies, se vé otra baja de piedra escarpada, y el terreno á que está unida se eleva insensiblemente á formar un monte de regular aitura. La punta de Lavapiés es alta y escarpada pero delgada y bastante saliente.

Dos nillas al Norte $2 \mathrm{I}^{\circ}$ Este está el extremo Sucoeste de la Isla de Santa María, cuya dirección es en aquel rumbo, y su extensión de cerca de seis millas; tiene algunas piedras en esta punta, y una restinga de dos y media á su parte del Noroeste; no tiene fondeadero $y$ el paso entre ella y la costa es infructuoso $y$ arriesgado; es baja y se crían ganados.

Desde la punta Rumena hace la costa una grande ensenada, al principio escarpada, pero en su medianía se ven las playas de Lota al Norte de la punta de su nombre, y poco después la del desagüe del río Queule: la ensenada se prolonga hasta la umbocadura del Viovio, en cuya parte del Norte hay un islote unido por una restinga a la costa de la punta; es de arena aplacerada, por cuya razón es impracticabié la entrada en él.

$\Lambda$ la parte del Norte é inmediatas al Este, se presentan las Tetas de Viovio, altas, casi iguales Nornordeste-Sursudoeste, sobre un frontón saliente escarpado de piedra, con 'un islote tres cabies al Oeste de la punta Sur: doblada la más al Norte, se ve la boca del puerto de San Vicente, formado por ella, y otra que del extremo Sur del monte de Talcahuano sale para el Sudoeste.

Este puerto está situado en $36^{\circ} 42^{\prime} 40^{\prime \prime}$ de latitud Sur, y en $67^{\circ} 7^{\prime} 35^{\prime \prime}$ de longitud occidental al Norte, y próximo á las Tatas, cuya punta. saliente lo cierra al Sur: aunque bastante grande, como su mayor parte está descubierta á los vientos del Norte al Oeste, sólo puede llamarse tal aquella porción que cubre de ellos la punta de los islotes, y presenta un excelente fondeadero capaz de seis embarcaciones á la gira; pero su seguridad y proporciones, especialmente en invierno, son $t$ ın esenciales, que lo hacen preferente á la bahía de Concepción y puerto de Talcahuano, cionde á pesar del resguardo que baja de Marinao, del buen fondo, $y$ en las mejores amarras, están siempre expuestas las embarcaciones.

Respecto á las mercantes, á la mayor seguridad de que en él gozan pueden agregarse las ventajas de carbar y descargar sóbre una playa siempre tranquila, á un cable del wmarradero, y la facilidad de conducir á Conmpción sus cargamentos, en carros, con mayor ahorro que en Talcahuano, donde se ven precisados á ejecutarlo solıre ruuias, porque la temasiada pendiente tel cerro de su nombre y los pantanos que en él forman las contínuas aguas del invierno; lo hacen intransitable á aquéllos.

La aguada es tan abundante como en Talcahuano, de igual calidad y más próxima á las embarcaciones, sucede lo mismo con la leña.

En verano no proporciona las misrius ventajas el puerto de San Vicente, porque los vientos de la parte del Sur que reinan entonces, atraviesan todo el puerto para llegar á las em.harcaciones, levantando una mar bastante fuerte, á que se agrega; que estando aquéllas tan cercanas de la costa del Norte que sus amarras del Noroeste están en tierra, si les falta un cable, que suele ser bastante frecuente, es fácil vayan s'óbre pie. dras, que forman esta parte del puerto, antes que agarre la tercera ancla. Convendría, pues, que en esta estación, ó se amarren á mayor distancia de la costa, dando al Sur su mejor cable, 6 que tomen de Octubre á Marzo el fondeadero de Talcahuano.

Podría también amarrarse en el extremo Sur del puerto, abrigado á los Suestes de esta parte; pero á más de quedar descubierto al Norte, que tampoco es razón en este tiempo, se alarga los leguas la distancia á Concepción por un terreno pantanoso y de difícil tránsito.

El puerto de San Vicente ee limpio, y su fondo entre las puntas, de seis á nueve brazas arena y lama, fuera de ellas de 16 á 18 ; á su Oeste cana'; y se distinglien proporcionalmente al acercarse á cualquiera de las costas.

La punta interior del Sur tiene un islote ó pedrusco un cable al Nornordeste de ella, y la del Nurte á más de la restingencia 6 islotillos que si.len al Sudoeste y velan siempre, tiene un bajo de piedra, media milla al Oeste $7^{\circ}$ Sur.

De Marzo á Octubre parece prudente buscar el puerto por la punta de Talcahuano, á barlo. vento de él respecto al Norte y Noroeste, $y$ en el resto del año por la parte Rumena, rue proporciona las mismas ventajas con los vientos del Sueste al Sudoeste.

Saliendo de San Yicente sigue al Norte $1 \%$ Nordeste seis millas, el cerro $y$ punta de Talcahuano, bastante alto, en muchas partes escarpado de piedra y varios islotes; á dos cables de él, se ven algunas playitas de arena, pero así en ellas como en las piedras hay siempre mucha reventazón.

A tres cables escasos del estrecho Norte de la punta y á su Noroeste, hay una piedra 6 islote conocido por Quiebra-ollas, con una pequeña restinga en esta dirección; puede pasarse á dos cables de él, y conviene hacerlo para conservar el posible barlovento yendo entrar en la lahía de Concepción con vientos del Sur que oiligan á bordear. Montado Quiebra-ollas se debe go 'ernar á la punta Norte de Quiriquina, escarpade con 
tanos que en él for. invierno, lo hacen

ante como en Talcas proxima á las emo con la leña.

las mismus venta porque los vientos entonces, atraviear á las errharcaciotante fuerte, á que llas tan cercanas de marras del Noroeste un cable, que suele cil vayan sjore pie. del puerto, antes Convendria, pues, marren \& mayor dis. Sur su mejor cable, Marzo el fondeadero

e en el extremo Sur nestes de esta parte; bierto al Norte, que empo, se alarga los pción por un terreno ito.

nte es limpio, y su seis á nueve brazas de 16 á I 8 ; á su Oes roporcionalmente al s costas.

ur tiene un islote ó deste de ella, y la del ncia ó islotillos que empre, tiene un bajo este $7^{\circ}$ Sur.

ece prudente buscar alcahuano, á barlote y Noroeste, y en e Rumena, rue pros con los vientos de.

sigue al Norte $\%$ o y punta de Talca. uchas partes escartes; á dos cables de e arena, pero así en hay siempre mucha

- estrecho Norte de $\checkmark$ una piedra ó islote on una pequeña rese pasarse á dos ca- para conservar el ntrar en la lahía de Sur que oiligan a las se debe go 'ernar ina, escarpad con algunos pedruscos próximos, y ménos alta que las dos costas. No hay otros riesgos que los pedruscos siempre descubiertos, exc ntuando dos placeres, el primuro que rodea á distancia de dos cables la punta Gorda del Este de la isla, y se extiende todo el frente de la ensenada que le sigue al Sur entre él y la punta de Arenas; y el segundo que sale de esta punta al Sueste 1/. Este, igual distancia y se distingue fácilmente por el color amarilloso del agua sobre el fondo de arena.

Al principio del canal se encuentran 25 y 30 trazas lama que disminuyen á proporción que se entra, hasta Ir, ro y g lama y arena.

Al Sur de la punta de este nombre, en la costa, está la pequeña ensenaria del Tomé, de buen fondo, pero desabrigad a al Noroeste $y$ Oeste, que producen mucha marejada, por cuya razón, la de mayor distancia á Concepción no es frecueritada.

Doblando la punta de Arenas se halla entre ella y el cerro Sudoeste de la isla, el pequeño, pero seguro fondeadero de la Quiriquina: su fondo es desrie nueve á $\mathbf{r} 3$ brazas arena, $\mathrm{y}$ tan acantilado hacia esta punta, que se encuentran siete brazas de agua á tres toesas de la orilla: está cubierto á lcs vientos y mares del Nordeste al Oesudoeste: el repentino y viole:to descenso de la costa de punta de Arenas obliga á llevar á seco el ancla del Norte, que se entierra en la arena; la del Sur va á II brazas, pero es necesario tenderla todo lo posible al Este, huyendo la proximidad del cerro de Piedras, de que salen muchas al Sueste, que maltratan y rompen los cables. Si el concurso de muchas embarcaciones no permitiese esta precaución, podría evitarse el riesgo, dando al ancla de esta parte lás brazas de cadena que basten para que el cable no roce el fondo; á falta de otras más oportunas, pareee desempeñarían bien este destino las bozas de cadena de las -vergas mayores, especialmente en el invierno, que siendo los Sure 3 bonarcibies y raros, traba jan ménos sus amarras.

Este fondeadero es preferente á los demás, para toda embarcación que no necesite una comunicación seguida con la costa: las de guerra logran en ella de la ventaja r? cener en freno sus tripulaciones, haciendo ic este modo ménos frecuentes la desercifi, la borrachera $y$ todos los desórdenes en que se ceban en los puértos de esta costa. La isla produce abundantemente sin cultivo, manzanas, cardos, nabos y otras legumbres antiescorbúticas capaces de restablecer cualquiera tripulac' on ábbil, mezclándolas en su caldero á la comida diaria: hay excelente agia y bastante leña; es innumerable el pescado que se cría en esta pequeña ensenada, circunstancia de que carecen las del Tomé y Talcahuano, y los mariscos de varias especies que cubren las pie- dras de esta parte de la isla pasan por los miás sanos y sabrosos dt! reirs.

El puerto en Concepción ó Talcahuano, es una espaciosa bahía que se extiende más de tres leguas de Norte á Sur y dos y media Este-Oeste. La Isla Quiriquina, situada en su boca, forma dos canales ó entradas; una y otra pueden llamarse limpias, $y$ tienen sus particulares ventajas según las diferentes circunstancias del navegante: hemos hablado de la de: Este, más ancha, prefe. rente con los vientos al sur que obligan á bc:dear, y de que constantemente hacen uso las embarcaciones mercantes. La del Oeste tendrá poco más.de una milla de ancho; sus dos costas son de piedra con muchas inmediatas: conviene sólo entrar por ella con vientos del Sur al Sudoeste ó con Norte claros, posición en que se gana mucha distancia y barlovento: su fondo es de 12 á ocho brazas arena y en las orillas piedra y conchas.

Desde la punta de la Lobería, que con la del Nordeste de la Quiriquina forma el canal del Este de la bahía de Concepción, sigue la costa al Norte $2 \mathrm{r}^{\circ}$ Este dos y media millas, hasta la de la Herrería, una y otra, comola costa intermedia, son bastante altas en el interior, pero con descensc suave á la playa. De esta últiria punta, se inclina al No:te $42^{\circ}$ Este cerca de dos millas, hasta el morro de Nencoché, que hace la entrada Sur del puerto de Coliumo, y á alguna distancia aparece aislado, estandounido á la costa por una estrecha y baja lengua de arena: hay algunos pedruscos en este trozo de costa, aunque muy unidos á ella: el que esiá al Nodeste de aquel morro, dista de él cerca de dos cables.

No hay obstáculo alguno para entrar en el puerto, cuyo único $\varepsilon$ rrarradero abrigado al Norte es la pequeña enserada que forma aquel morro á su parte del Sur; el referido es de siete á nueve brazas lama y puede contener de seis á ochr buques.

El resto del puerto, aunque grande, ssíá des. cubierto y sin abrigo contra las gruesas ma: del Norte, y á pesar del cerro, deben incomodar las embarcaciones en la misma ensenada, poco profunda para librarlos de ellas; como la lengua de arena es tan baja, están expuestos tambiér á toda la fuerza del Noroeste, pero no á la mar.

La parte del Este desde la punta del Pinguerai, es limpia, y su fondo, como el del resto del puerto; hay no obstante algunos pedrusces descubiertos, próximos á la costa, que también es de. piedra, y en el fondo de $t l$ un placer de arena que sale del Estrecho Surste, donde se extiende á un tercio de milla, y tomando la figura de la costa á que está unido, termina en las piedras de la punta de los rios, cubriendo todo el fondo Sur del puerto.

La leña es abundante, y la aguada se hace en 
el río, que desemboca en la parte interior del vuerto al Sur del fondeadero. La major distancia de este puerto á Concepción, su poco abrigo, y l: escasez de víveres y carga respecto á los de Talcahuano y San Vicente, lo han hecho hasta ahora inútil, y sólo se toma en urgente necesidad; sin embargo, dos ó tres buques pueden estar en el bastante abrigados.

Al Norte de la punta del Pingueral empiezan las lomas de Malla, de más que media altura, con algunos cerritos superiores al resto: terminan aquéllas en el río de Itata: en esta porción hay unos escarpados al mar bastante notables, que forman dos puntas bajas $y$ salientes: al Norte entra la ensenada del Zorio que cierra á esta parte la punta de Cuinaya: hay un placer que sale media milla al Oeste.

La costa que entra al Norte está igrual, y la punta en que acaba tiene otro placer de igual extensión $y$ dirección que el anteceden:e; entre las dos está situada la pequeña Islita de Carran. za á dos millas de la costa. Su dirección es Norte. Sur y bastante baja.

Desde el río de Itata hasta la punta de Natividad, corre la custa al Norte $19^{\circ} 30^{\prime}$ Este 117 millas, formando varias ensenadas poco profur:das y notables; en esta porción, se vell las barran. cas de Huachapure, y 17 millas al Norte la embocadura del río Maule, aplacerada y cubierta de piedras su punta Sur: sigue á ésta la punta de Natividad con algrunos pedruscos: á medis milla de aquí sigue la costa inclinándose algunos gra. dos más al Este hasta el mor:o de Topocalma, á cuya parte del Norte $I^{\circ}$ Nordeste y á ro millas, están los bajos de Kapel: el Maipú desembioca á igual distancia de ellos al Nordeste; en ei fondo opuesto Este de la ensenada al Norte, está el puerto de San Antonio, y sobre él los altos de su nombre. Li costa corre al Norte $16^{\circ}$ Oeste tres millas hasta la punta de Auquen desde la Norte de aquel río; se ven en este espacio las playas de Cartagena, arenosas $y$ dominadas por los altos de Sutu Antonio, y pocas millas al Sur de aquella punta, la liedira Blanca, bastante grande, unida á la costa, y de aquel color hay otras dos sobre la punta de Tunquen sin aquella particularidad, y algo más distantes de ella.

De esta punta sigue la costa al Norte $12^{\circ}$ Oeste hasta la de Curauma, de donde hace un froutón de más de cuatro millas al Norte $30^{\circ}$ Este con algunas puntillas: montado en este frente se des. cubre la ensenada de Iagunillas, bastante honda $y$ de arena la mayor parte de su fondo; termina ésta en la punta de los Angeles, que forma la entrada del puérto de Valparaíso, dos millas al Norte $6^{\circ}$ Este de la qquebrada de Bueyes, honda $y$ sin playa.

El puerto de Valparaíso, que propiamente no es otra cosa que una rạda, está situado en $33^{\circ} \mathrm{I}^{\prime} 30^{\prime \prime}$ de latitud Sur y en $65^{\circ} 39^{\prime}$ I $5^{\prime \prime}$ de longitud occidental. La mayor parte está descubierto al Norte y Noroeste y expuesto á toda la violencia de sus mares:á pesar de estas desventajas, s'ı proximidad á la capital de Chile y á las más féríles campiñas de este Reino, $y$ por consiguiente, 1. facilidad de reunir en él á r.tenor costo el trigo y . Temás frutos que producen, lo han hecho el más fre-uentado de las embarcaciones mercantes. Es limp:o, y sólo hay que resguardarse de las piedras ver.ntes inmediatas á la punta de castillo Viejo de San Antonio. Sobre la costa del Oeste, y ála qus llaman Laja, próxima tambíen á esta punta y á :u parte del Nordeste á ménos de dos cables de la cista del través, puede pasarse a un cable de unas $y$ ctras sin el menor riesgo, y conviene ejecutarle así, para no perder barlovento y fondear lo más cerca que se pueda del fonto Sudoeste del puerto, suponiendo que la entrada se haga con vientos del Sueste al Su. doeste, como es probable suceda, esperialmente en verano. De otro modo, es preciso bordear perdiendo tiempo, $y$ algunas veces sin fruto, por la demasiada fuerza del viento que suele no permitir las gavias á medio mastelero.

Como estas brisas ceden en las primeras horas de la noche y terminan antes de la mañana dejando algunas horas de calma, parece lo más f "udcistc en este caso arriar el ancla donde confiere la bordacia, y esperar este momento para yanar á la espía ó remolque el buen fondeadero.

Es, no obstante, preciso atender al fondo de esta parte del puerto, $y$ por un deseo de abrigarse al Norte y Sur, no meterse demasiado en la ensenadita, que abunda en ratones y hace perder las amarras; por esta razón, el mejor paraje es á un cable de la costa del Sur, demorando la punta del castillo de San Antonio al Norte $17^{\circ}$ Este.

El ay uste debe estar á esta parte tendido por largo, $y$ el ancla del sencillo al Sur á dos ó tres brazas de la playa donde puede engalparse un anclote !ıecho firme á las estacas; así, quedará el ancla del Norte en 20 ó 24 brazas lama y el cuerpo del buque en seis ó siete arena.

Lil fondo del puerto es bastante desigual como su calidad. A, un cable de la costa del Oeste desde la punta de los Angeles, se encuentran de 12 á ocho braza', fondo, cascajos y arena; pero atravesando á ia parte del Este aumenta repen. tinamente casi hasta 20 y 25 arena y lama.

En caso de voltejear, pueden prolongarse los bordos hasta cable y medio de tierra en el del Oeste, ó tomar cinco brazas en el del Este. La leña es de mala calidad, hay poca, $y$ por consiguiente es bastante cara.

La aguada puede hacerse 6 en el arroyueln que desemboca en la playa arenosa del Alritean dral ó en la fuente de la plazueín cisl. Ca:tilis Nuevo; si per medio de manguer as se constis. 
$39^{\prime} 15^{\prime \prime}$ de lonstá descubierá toda la vio. $s$ desventajas, e $y$ á las más or consiguien:uenor costo el , lo han hecho ciones mercansguardarse de la punta del Sobre la costa , próxima tamNordeste á mé avés, puede pasin el menor para no perder que se pueda uponiendo que Sueste al Süesperialmente so bordear per. in fruto, por la suele no per.

s primeras hode la mañana parece 10 más icla donde conmomento para en fondeadero. der al fondo de seo de abrigarse iado en la ense hace perder las r paraje es á un sdo la punta del I $7^{\circ}$ Este.

irte tendido por Jur á dos ó tres engalparse un así, quedará el lama y el cuer.

stante desigual costa del Oeste encuentran de s y arena: pero aumenta repen. na y lama. prolongarse los tierra en el del -l del Este. La a, y por consicn el arroyuelo osa cicl Atriea. oi.: cisl. Cartilin os se crunst. llevar á las lanchas la âe éste, la operación será más pronta y cómoda que en la otra, donde la marejadı del Norte, Noroeste y Oeste suele maltratar aquellas embarcaciones.

Los vientos del Sur son constantes en este puerto, de Octubre á Abril, suelen empuzar á las once del día, manteniéndose bonancibles hasta las cuatro de la tarde que refrescan de fugadas, su fuerza dura de cuatro á seis horas y cesan por el mismo orden que han empezado. El resto del año reinan los del Norte al Oeste; pern según los prácticos, no tienen en este puertc la fuerza y duración que en los anteriores. Parece probable que así suceda, pues de otro modo, las embarcaciones mercantes del comercio del Perú que lo frecuentan en todas estaciones, generalmente mal provistas de anclas y cables, perecerían sin remedio.

Saliendo de Valparaísc, puede seguirse á regular distancia la costa del Norte, y se verín dos ensenadas ' equeñas que separa la punta de Reñaca; sus jlayas son di arena, perodesabrigadas; montadi, la punta de Concon, que sale al Norte pocos grados Este de ellas, se encuentra la ensenada de su nombre, tan desabrigada como aquéllas; termina ésta en la punta de la capilla, que forma al Norte una grande ensenada, donde des. emboca el río Quillota. La playa desde él lacia el Norte es de srena con montañas bastante altas á su espaiła: en él extremo están el islote y bajos de Quintero, que salen cerca de una milla al Norte $53^{\circ}$ Oeste de la costa más próxinua; casi Norte-Sur con los de fuera y á distancia de uno y un tercio millas hay una punta poco saliente y baja á que sigue la tierra haciendo una corta inflexión al Nordeste á encontrar la punta Sur que forma la entrada del pequeño y poco seguro puerto de Quintero, baja y de piedra.

A distancia de dos leguas de este puerto, demo:ando al Norte $53^{\circ}$ Este, se encuentran 92 uraras de agua, fondo arena grutzs. La enseBarla de la Sigua que sigue al Norte de la punta

ic este nombre, se interna inmediatamenie qva de arena. y se une á la del Norte mé.

hunda, formando costa pendiente. Las tie$r_{i}$ s : la ensena la y las de su punta Norte son bajas hacia el r.ar y algo ménos en el interior. La costa que continua después al Norte $30^{\circ}$ Oeste 19 millas y va á encontrar la punta del Gobernador ó Pichidanque situada en $32^{\circ} 2^{\prime}$ de latitud, y en el mismo de la punta de los Angeles de que dista $5^{8}$ millas, es de mediana altura, y poco al Sur en .: interior se eleva un monte alto y aplanado, á que llaman la Silla del Gohernador. El puerto del Gobernador á la parte Sur c.e la punta de su nombre ó de Pichidanque es bastante grarde y mucho más sryero que los del Papudo y Quintero. Un islote que tiene á su boca, cable y medio al Nordeste de aquella punta, resguarda una gran parte del viento y mares dei
Norte; puede fondcarse con entera seguriclad respecto á éste, dando un cable á las piedras de su parte Sur. Sólo tiene en sus inmediaciones el curato de Quilimay que dista de él una legua: aunque el temperamento es benigno, la falta de agua tiene sus campiñas, á muchas leguas de êl, áridas y enteramente despobladas; por esta razón, sus contornos carecen de toda especie de producciones $\mathbf{y}$-onsiguientemente está abandonado de las embarcaciones mercantes. La leña es escasa, mucho más el agua, y el puerto carccit enteramente de pescrado.

I a costa sigue al Norte de él formando tres ensenadas que terminan las puntas del Saltio del Negro, Matagorda y la de Ballena, á cuya parte del Norte entra la de su nombre cerca de su punta, y en el fondo se ve arena y ntra pe. queña eusenada donde estí el pequeño pueblo de Conchali con aguada en el río de su nombre, ane desemboca al Norte $y$ cerca del pueblo. Irente de él se ven cuatro farallones 6 islotes, 'os dos mayores y mís próximos á la costa con lgunos pedruscos á sus piés: distan de ella un tercio de milla $y$ corren entre si Noroeste Sueste con corta diferencia á los restantes; el más Oeste y Norte sale dos y un tercio millas á la costa del Este, y el cuarto más Este y Sur dista de aquel algo más de dos millas al Sueste $y$ cerca de una, de la punta de la costa más próxima.

Al Nurte del pueblo se ve un mégano de arena rrande $y$ rauy notable; cerca de él hay vtros pequeños que también se distinguen fácilmente: el terreno de la ensenada hacia el inte. rior, es montu sso, descamado, pero desigual y con muchas quebradas profundas. La punta Norte de Conchali tiene algunos pedruscos próximos, y una milla á su parte del Norte un islote de regular altura $y$ magnitud; la costa desde aquella punta, alta y cortada al mar; sigue la costa al Nornordeste formando otra ensenada que se incerna poco; la punta en que termina es escarpada, de color rojo, más baja que aquélla. Hasta el río de Chuapa sigue la costa escarpada; baja, y de piedra, desde la punta Sur á Este; de mediana altura, roja, $y$ con arena al pié hasta lá de Chuapa; es también baja la costa que fo.ma la ensersada que corre al Noroeste $\%$ Oeste cerci de dos millas. La punta Norte del río es baja de predra, escarpada, y próxima á ella hay una piedra blanca bastante notable, sobre la misma playa: el interior es montuoso, pero con muchas llanuras altas.

-De la punta de Chuapa sigue la costa al Nor. te pocos grados Oeste formando varias ensena. ditas y puntas pequeñas: se ven sobre ella las sierras llamadas Amolanas, altas, desiguales y muy próximas á la playa; á su extremo Norte y cerca de la punta que cierra la ensenada, se ve un pequeño arenal con punta saliente; doblando 
esta punta, que también es de piedra, sigue la costa al Norte pocos grados Este, de tierras bajas con serranía á la espalda y una punta saliente escarpada.

Al extremo casi de la ensenada, se ven otros escarpados más altos que el anterior, y poco después los altos de Talinay que se extienden hasta la quebrada de Limari, río considerable, que toma este nombre del valle que riega, y cuyo de. sagüe es en esta parte: la dirección de la costa es al Norte pocos grados Oeste, y su terreno después de los escarpados es bajo en la orilla, é in. clinadas hacia ella las sierras interiores.

La quebrada de Limari se forma de dos puntas regularmente altas y cortadas, al pié de una sierra elevada muy notable por dos picos que se ven en sus extremos: el terreno es escarpado hacia la parte de! Sur, con algunas ensenad.llas, y á bastante distancia de la playa se ven varias cadenas de montes elevados.

Desde la punta Norte de Limari sigue la costa igual á la anterior casi Norte-Sur 26 millas hasta la punta de Lengua de Vaca, salic n'e baja y con algunos pedruscos; termina so' ella una cordillera de montes altos y parejos que tienen su principio poco al Norte de aquella quebrada; cerca de esta punta y al Sur, hay unos peñascos bastante notables y casi pegados á la playa. Al Norte de la punta de la Lengua de Vaca, se inclina la costa al Nordeste tres millas, con una pcqueña ensenada, $y$ después al Este y Norte formando las grandes de Tongoy y Guaraquero, que divide el frontón y cerro de este nombre de mediana altura $y$ muy ancho; una y otra son de piedra con algunos trozos de arena, y están enteramente descubiertas, aunque á la primera llaman bahía y á la se'sunda puerto: del fondo de ésta se inclina la costa al Norte algu. nos grados Oeste hasta la punta de Lobos, baja, de piedra, con algunos pedruscos á su pié y á la parte del Sur cuatro manchas biancas, las tres muy notables.

De esta punta á la Sur del puerto de Coquinim. bo corre la costa al Norte $42^{\circ}$ Este cinco y media millas: en el intermedio hay varias puntillas, bajas, salientes, de piedra y muchos pedruscos á poca distancia. Casi equidistante de las dos está la Caldera, ó puerto de la Herradura, pequeño y bastante abrigado; su entrada, de un cuarto de milla de ancho, no tiene riesgo alguno cubierto; se encuentran 36 brazas de agua sob : fondo cascajo, entre las dos puntas que la for.ıan. Dentro del puerto hay $\mathrm{I}_{4}, \mathrm{I} 6 \mathrm{y}_{\mathrm{I}} 8$, á dos cables de la playa de cinco á siete; en la parte del Oeste y Suoeste es frecuente el fondo piedra, en todo el resto cascajo, la costa de arena es aplacerada, la del Norte y Nordeste está cercada de piedras desde la boca, y aunque á poca distancia, sale una restinga de la última punta interior donde empieza la arena. La leña es escasa y de mala calidad; lo mismo sucede con el agua, que se hace con trabajo en un pozo 6 laguna junto á los ranches de pes. cadores que están en la parte Sur del puerto entre ellos y los islotes conocidos con el nombre de Ballenas. La distancia de este puerto á la Serena, es igual á la que hay desde el de Coquimbo, y tan cómodo el transporte de efectos por tierra. La c ssta entre estos dos puertos, es un frontón de piedra, con puntillas de lo mismo, muy desiguales, rodeadas de pedruscos, y una pequeña ensenada al principio; casi al Norte del extremo de esta parte de ella, están los islotes 1la. mados Pájaros Niños, de piedra, bajos, escarpados y cercados de piedras pequeñas; el más Norte y mayor, tienc en el extremo Sur una restinga que sale cerca de la mitad de la distancia de uno á otro, y termina en una piedra casi anegada; su freu, por consiguiente, es sblo de dos décimos de milla, y se encuentran en él de $\mathbf{r}_{4}$ á 23 brazas de agua, fondo piedra: su excesiva angostura hace muy arriesgado el paso de este canal; no suicede lo mismo con el que forman el del Sur y la costa, ¿de el único obstáculo son las piedras que ru-

in uno $y$ otro, $y$ que siempre velan; su fondo u igual al del anterior, pero de cascajo y conchuela. Al Oeste de el de tierra hay varios islotes, pero limpios.

El Pájaro Niño, mayor, está más de una milla al Norte $55^{\circ}$ Oeste de la Piedra Pelícano, sobre la punta de Tortuga, $y$ el del Sur nueve décimos de milla al Norte $76^{\circ}$ Oeste: hay siempre mucha mar en este paraje, por tanto, sólo debe emprenderse el paso del segundo freu con viento fresco del Sur al Sudoeste.

Montados los islotes puede seguirse la costa á un calle ó cahle y medio, por ocho, nueve y ro brazas pi-dra y uascajo hasta la Piedra del Pelí. cano, cabie y medio al Nordeste de la punta de la Tortuga; la costa sigue después al Sur con piedras á la orilla, puede prolongarse á dos cables. por $\operatorname{die} z$, ocho, siete y seis brazas de agua, cascajo y conchuela, hasta ponerse Este.Oeste con dos cerritos bajos é iguales llamados los Hermanos, que están inmediatos á la playa en la parte del Sueste de la valiza.

Si en esta posición se está á dos cables de la tierra del Oeste, se dará fondo amarrándose Nordeste Sudoeste, y dando el cable de esta parte, á una piedra redonda que está á pocas brazas de la playa, y llaman por su figura la Tortuga. Así quedará casi al Oeste un pequeño almacén que hay en la playa, y se enfilará el extremo Este de un cerrito de piedras que está sobre la misma con el del Oeste de Bascuñano al Sur del fondeadero y del principio de la playa de arena.

En Coquimbo hay poca leña y muy delgada y de mala calidad: el agua es también mala y se hace con mucha dificultad. 


\section{Construccion de las cartas desde Coquimbo hasta Lima, inclusas las Islas de San Félix.}

Ya se ha manifestado con cuántas observa. ciones uniformes entre sí y de la mayor confian. za, podíamos determinar la posición de! observatorio nuestro de Coquimbo, en longitud occidental de Cádiz, de $65^{\circ} 15^{\prime} \times 5^{\prime \prime}$. En este su. puesto, nos pareció adoptarle por primer meridiano en lo venidero; $y$ hecho un prolijo examen de la marcha de los relojes marinos, siguib en la ATREVIDA como reloj magistral el número ro; en la Descubirrta se sustituý́ de nuevo al cronónetro 6r, el número 72 , que conservaba el mismo movimiento que se determinó en Valparaíso, ra. tificándole los horarios observados en meridianos del Pájaro Niño, cuya posición estaba determinada geométricamente á la iongitud del observatorio.

Nuestras marcaciones exteriores referidas el día de la salida al cerro de Guanaquero, ratifican su posición; y las bases corridas hasta la Isla de Choros, ligando con las enfilaciones y marcaciones hechas desde el puerto á la punta de Theatinos y á la isla mayor de Pájaros, no nos dejan duda que la costa hasta los Choros, no admite la menor equivocau:s:.

Las corrientes y la callın de la siguiente mañana, nos hacen perder de vista un pequeño trozo de costa comprendido entre la punta de la Barranca y la punta de Choros; le hemos dedu. cido de los derroteros, sujetándole á nuestros extremos de las puntas indicadas, en cuyas posicio. nes no teníamos la menor duda.

Unas observaciones exactas de latitud y longitud sobre nuestras bases de corredera, al mismo tiempo determiran con mucha seguridad la bahía del Huasco, y continuan la costa, hasta que la noche, las corrientes y la cerrazon de la siguiente mañana, nos obligan á valernos de los cerroteros para otro pequeño trozo, en el cual añadimos á la diferencia en latitud indicada por nuestras estimas, otros $9^{\prime}$, según lo exigen las observaciones de uno y otro dia.

Sobre el morro de Copiapó, adonde se des. unen las dos Corbetas, la longitud de los relojes de uno y otro buque sólo discrepan en un minuto $y$ medio, cuya diferencia, aunque pequeña, se atience en la reducción de las tareas anteriores, \& las que después sigue la Atravida. Los planos de los diferentes puertos de Copiapó, son obra del Ingeniero D. Pedro Rico, de cuya exactitud no podemos desconfiar, después de haber tenido la bondad de desmenuzarnos los medios de que se ha valido para este trabajo. Los confirma, por otra parte. Mr. Frezier con una grande uniformidad de resultados.

Esta corbeta sigue después con bien concertadas bases, sin corrientes que la trastornen, y sin carecer ni un día de la latitud y longitud, observadas, hasta la bahía de Arica: reconoce al mismo tiempo las radas del Chineral, Juncal, Nuestra Señora, Cobija, Algodonales é Iquique, $y$ las diferentes vistas de sus inmediaciones coadyuvan á asegurar más y más la navegación práctica. La rada de Arica está levantada geométricamente con el teodolito: la latitud ob. servada con los sextantes en muy buen horizon. te, y por tres días consecutivos: la longitud, deducida del reloj número to sobre muchas series de horarios uniformes, $y$ con una marcha ratificada sobre alturas absolutas: las distancias lunares discrepan en esta ocasión I $^{\prime}$ al Este de los relojes marinos: se aparta en 46 y $1 / 2$ en el mismo sentido, la longitud del Padre Feuille, deducida de la emersión de un primer satélite, comparada con los Sres, Maraldi y Cassini, en París.

Siguen luégo las bases uniformemente, con la misma felicidad de no tener corrientes, y de no carecer de observacicítes de la mayor confianza, por Ilo, Aranta, Chilca; Morro de Acarí, Ica, la Nasca, Morro Quemado, hasta la Iela de San Gallán.

En todas las radas y puntos notables que comprende este trozo considerable de costa, se han consultado los mejores derroteros y los via jes del Padre Feuille y Mr. Frezier, y se han oído los mejores prácticos, para no trastornar los nombres envejecidos de esta navegación costanera.

En el mismo tiempo, la Descubierta sitúa por medio de dos series de horarios y con latitudes observadas en el sextante, la Isla de San Ambrosio: las contiguas de San Félix, dependen principalmente de enfilaciones entre sí y con la Isla de San Ambrosio. Las excesivas corrientes, la desigualdad suma del viento y la misma disposición nuestra, no permiten aprovechar cuanto deseáramos las muchas bases corridas en esta scasjon. La longitud determinada por los relojes, 
referida á las observaciones 'D Coquimbo y á las de Lima, da unas diferencias parciales, cuyo total no difiere de la diferencia directa de obser. vatorios sino en $45^{\prime \prime}$ en el mismo sentido de la diferencia que se encuentra en San Gallín con los relojes de la ATrivvida: se le ha aplicado, por consiguiente, esta pequeña corrección, además de los $4^{\prime}$ I $3^{\prime \prime}$ que inferimos estar más occidental la longitud deducida de la verdadera, según la alteración de movimiento. El único fondeadero que se señala, es el que ha reconocido D. Antonio Cazulo en el navío San Pablo, y conviene esta noticia con la de otro práctico que nos la ha comunicado personalmente.

Como quiera que al llegar á Lima, examinada nuevamente la marcha y observada en nuestro observatorio de la Magdalena la emersión del primer satélite de Júpiter con la mayor confian$z a$, debemos inferir que ambos cronómetros de la DEscubizkTA han acelerado algún tanto, conservándose, por otra parte, casi uniformes entre sí, suponemos una corrección, en progresión arit. mética retrógrada, que destruya aquel error; $y$ hallando de este modo la longitud de la Isla de San Gallán por la diferencia de meridianos con el fondeadero del Callao, ya situado por nuestras observaciones, difiere la nuestra de la que determina la Atrevida en $\mathrm{r}^{\prime} 5^{\prime \prime}$ al Oeste.

Este error casi insensible, sirve á atianzar la longitud de los relojes de la ATrevida, en Arica, los cuales, por otra parte, llegan á Lima con un error de $m$ ly poca cantidad, fue no obstante se ha tenido presente en las correcciones diarias, hasta desvanecerlo.

Las bases de la Descubierta al regreso de las Islas de San Félix, empiezan por los $16^{\circ} \mathrm{y}^{\prime} / 2$; pero trastornándolas considerablemente las $c^{\prime} ;-$ rrientes, no se adoptan para detallar la costa; - jlo sí sus latitudes y longitudes sirven para ratificar las de la ATRevida con la diferencia indicada de longitud, la cual, no obstante, se resuelve al ligar desde la Magdalena, con operaciones trigonométricas, la posición astronómica del puerto con la de la Isla de San Gallán, 6 más bien con la de las Islas de Chincha, en las cuales terminan nuestras tareas marítimas, no siendo admisibles las que desde la Isla de Ascia conducen á la punta de Quilca.

Sin embargo, corno la Descubierta observe latitud y longitud sobre la Isla de Ascia y áun á la vista de la misma punta, nos valemos de estas observaciones para conducir la costa al Norte hasta que ligue con las tareas trigonomé. tricas, que de este modo no es preciso conducir en tiempos cerrados, como lo son los de esta estación hasta la misma Isla de San Gallán.

Toda la costa, desde la Nasca hasta la Isla de San Gallán, está combinada y acorde con las tareas muy repetidas del Piloto Moraleda.
La posición astronómica de la catedral de Linia pende de los triángulos emprendidos sobre una base medida en las inmediaciones de la Magdilena: estos mismos triángulos se conducen hista el castillo del Callao, desde donde una riueva base ratifica los resultr.dos anteriores, y destruye cualesquiera efectos, aunque pequeños, de la multiplicación de los triángulos, de cuya exactitud, por otra parte, nos aseguraban los teodolitos.

La latitud nuestra del observatorio de la Mag. dalena está deducida de muchas alturas meridia. nas de estrellas al Norte y al Sur; se ha atendido á elegir entre éstas las que tuviesen una declinación más bien determinada. La longitud pende, como ya se indicó, de la observación hecha el día 6 de Junio en el primer satélite de Júpiter, por los Sres. Galiano, Vernaci y Valdés: puede haberse repetido en Europa, lo que añadirá un nuevo grado de confianza á sus resultados (I), mientras nos lisonjea mucho su grande aproximación á las ilaciones de los Excmos. Juan y Ulloa, que no conformaban con la longitud asignada por el Padre Feuille sobre las observaciones del médico Durán, sư discípulo (2).

Se ha intentado por dos veces observar distancias de la Luna al Sol y á las estrellas, pero los resultados se han apartado mucho de las otras deducciones, siéndonos, por otra parte, imposible cl ratificarlas con una repetición de series que las diesen la confianza y estabilidad necesarias.

A este resumen añadiremos, que el cielo bien conocido de esta región, nos ha imposibilitado cuantas observaciones debian proporcionársenos en el dilatado tiempo que permanecimos en la Magdalena para la recopilación de todos los trabajos hechos: aún no desconfiamos poderlas renovar en el Callao, al tiempo de emprender nuevo arreglo de relojes marinos.

(1) Las observaciones de D. Jorg; Juan y D. An tonio Ulloa, son seis hechas en el ?imer satélite do Júpiter, y determinan la longitud de Lima de $79^{\circ} 24^{\circ}$ La del Sr. D. Alejandro Durán resultaba sólo do $79^{\circ} 9^{\prime} 30^{\prime \prime}$. El Doctor Peralta la dednce de dos eclipses de I das las tres a la catedral, segin los parajes en donde observaron, y nos ha referido el Sr. D. Cosme Bueno, resulta:

Por los Excmos. Juan y Ulloa......... $79^{\circ} 23^{\prime} 5^{\prime \prime}$ Don Pedro Peralta................. 79.20 .00 Nuestros resultados................. $79.25 \cdot 3^{\circ}$

(2) La legua de América se compone de 36 cua. dras, cada una de 150 varas castellanas: resulta, por consiguiente, el total de 5.400 , La legua marina es de 6.650 varas. En la Concepción nueva, como se de6.650 varas. En la Concepción nueva, como se de-
terminase dar a las calles 6 varas, en ateución a los terminase dar a las calles $\mathbf{6} 6$ varas, en atención a los
temblores, en lugar de las diez que se consideran en la división común do la América, resulta que la cuadra habitadis i manzana tir 11 e 134 varas en lugar de las 140 que se consideran $\mathfrak{a}$ las demás: se han tenido. presentes estas medidas para referir estas observacio. nes á un mismo punto. 
la catedral de uprendidos sobre fiones de la Maglos se conducen esde donde una los anteriores, $y$ unque pequeños, ngulos, de cuya eguraban los teo-

ratorio de la Mag$s$ alturas meridia. Ir; se ha atendido viesen una declia longitud pende, rción hecha el día de Júpiter, por los s: puede haberse dirá un nuevo gra(I), mientras nos cimación á las ilaflloa, que no conhada por el Padre del médico Du.

eces observar dislas eitrellas, pero mucho de las otras tra parte, imposipetición de serjes estabilidad nece-

s, que el cielo bien ha imposibilitado proporcionársenos ermanecimos en la a de todos los traamos poderlas rele emprender nue-

Jorg', Juan y D. Ano.imer satélite de de Lima de $79^{\circ} 24^{\circ}$. a resultaba solo de la deduce de dos 17 I 7 y 1725 . Referios parajes en donde ir. D. Cosme Bueno,

...... $79^{\circ} 23^{\prime} 5^{\prime \prime}$ ..... 79.20 .00 ..... 79.25 .30 ompone de 36 cua. tellanas: resulta, por a legua marina es de nueva, como se de en ancion , ención a los se consideran en , resulta que la cua. 4 varas en lugar de emás: se haul tenido rir estas observacio.

\section{DERROTEROS desde el puerto del Callao hasta el rio de Guayaquil, y' de este punto hasta el Golfo de Panamá, por D. Fabio Ali Ponzoni.}

Islas Hormigas. - En la navegación al Callao se presentan muchas veces á la vista del navegante las Hormigas, dos pequeños islotes que corren la dirección de Norte $30^{\circ}$ Oeste, separados entre sí dos tercios de milla: una distancia algo menor de ésta forma su canal de 7,8 y II brazas piedra. E1 del Sur, situado en II, 56, 20 de latitud Sur y $45^{\prime} 50^{\prime \prime}$ occidental del Callao al Oeste $9^{\circ}$ Norte del extremo Noroeste de la Isla de San Lorenzo á distancia de 40 millas es el ma yor y algo bajo, formando tres mogotes, de los cuales el del Sueste se presenta más alto, yá su pié otro chico, cuya quebrada hasta el agua, es de suerte que parece aislado. De la parte del Sur le sale un bajo á distancia de un cable igualmente que por su parte del Sudoeste y Noroeste á la misma distancia, $y$ por fuera de ellos se encuentran bien pronto 20 á 30 brazas cascajo. Una restinga que le sale del Noroeste al Oesnoroeste, se extiende dos tercios de milla.

$\mathrm{El}$ otro islote es un peñote amogotado con un farallon chico pegado á la parte del Oeste: al Sudoeste del islote, á un cable, hay dos bajos casi unidos con otro oculto á otra tanta distancia, en la misma direccion. Muy inmediato alrededor de este islote y porfuera de los bajos, se encuentra fondo de Ir y 12 brazas piedras gruesas, y siguidamente $14,1_{5}$ y 16 brazas cascajo: separán. dose luégo un poco, aumenta el agua á 25, 30 y 35 brazas cascajo.

Los Pcscadores. - $\mathrm{Al}$ Norte 3 Oeste del extre. mo Noroeste de la Isla de San Lorenzo, $y$ al Norte 75 Este de las Hormigas, distante de aquél I $7 \mathrm{y} / 2$ millas y de éstas $4 \mathrm{r}$ escasas, se encuentra la Isla del Pescador Grande, así llamada á dos islotillos muy unidos y situados en $\mathrm{II}^{\circ} 45^{\prime} 42^{\prime \prime}$ de latitud Sur y $7 \mathrm{x}^{\circ} 04^{\prime} 2^{\prime \prime}$ occidental de Cádiz. Con el nombre de Pescadores se distinguen á éstos y á una porción de farallones inmediatos, de los cuales los más distantes se apartan sólo cuatro millas de la tierra firme.

Puerto de Ancon. - Este-Oeste con el Pescador Grande á una distancia de poco más de una legua, se halla un frontón alto, que con el resto de la costa al Norte forma el puerto de Ancón 6 Antón de Rada. Diferentes playas de arena ro. dean toda la ensenada con tierras altas en lo interior, y su dirección abriga de los vientos Sures. Desde la punta Quiebrabarcos hasta la de Mulatas, extremos Norte y Oeste de la ensenada, un buen fondo de 13 brazas va insensiblemente disminuyendo, hasta hallar tres y media brazas siempre arena á tres cables del pueblo de Pescadores situado al Sur y en la playa más interna de la misma ensenada. La entrada por el Norte de los Pescadores es enteramente limpia por fondo de 30 hasta 20 brazas arena, y la que comunmente se verifica para evitar la inmediación de todos los farallones por los fuertes hilos de co. ta que forman los diferentes canales: de éstos, el paso más seguro es entre el Pescador Grande y los otros. Ancón, aunque es un fondeadero excelente para muchas embarcaciones, le falta agua dulce, por cuya razón todas sus inmediaciones son de tierras estériles, y sólo pozas suministran agua salobre: hay buena á dos leguas por el camino de Lima en un paraje que llaman Copacavana. Los indios del pueblo de Pescadores, se entretienen en la pesca sobre toda la costal é is. las inmediatas, y son casi los únicos que se avan. zan hasta las Hormigas. Las mujeres la llevan luégo en la noché á Lima, por el camino de tierra, para venderla.

Punta Mulatas hasta el río Rintac.-El fron. tón ya nombrado, y terminado por la punta Tortuga al Sur y por la de Mulatas al Norte en dirección de Norte $9^{\circ}$ y $1 / 2$ Este, es muy hondable, y casi á pique se halla fondo de 23 y 24 brazas. Al Sur el río de Carabaillo y el de Rimac hacen aplacerada una gran parte de la costa inmedia. ta, y por consiguiente no muy seguro el acercarse mucho á ella.

Las embarcaciones que vienen del Sur para el puerto del Callao y se sotaventean, dan fondo á un anciote á la vista de este pedazo de costa, para luégo sobre espías, ganar el foncleadero, en las muchas horas de calma que reina. La mala construcción de los buques mercantes que na. vegan en estos mares, su mucha carga y á veces excesiva, sus maniobras complicadas y groseras, y la poca gente que llevan, hace sin duda prefe rente el partido que toman, aunque cueste el sacrificio de muchos días, al de aprovechar sobre bordos, los vientos que soplan siempre bonancibles.

De la punta Quiebrabarcos hasta la de Pasamayo. -Desde la punta de Quiebrabarcos sigue la costa al Norte, al principio montuosa, hasta la punta de Tamasaya conocida por los cerros de arena que tienè en lo interior. Prolóngase luégo 
hacia el Noroeste, escarpada, para formar la punta Pasamayo, con cuyo nombre se distingue también un río que desemboca á una milla y tercio de esta última punta.

Hasta la punta de Huara.-Lìn la dirección de Norte $47^{\circ}$ Oeste de la punta de Pasamayo se halla la de Huara á distancia de 29 millas, coloca. da en $11,18,55$ de latitud y en $26^{\prime} 18^{\prime \prime}$ de longitud. En este trechode costa se encuentra primero la punta de Chancay, que da el nombre á un río que se halla á la parte del Sur y forma al Norte de ella un pequeño puerto de una y media millas, de fondo abrigado, de tierras altas, particularmente en la dirección de los vieistos del segundo cuadrante. Este fondeadero es cerca de un morro que demora al Sur, no muy adentro, sino en cuanto pueda abrigarse del vientn, en siete $y$ ocho brazas de agua.

Siguen al Norte las playas de Lachay y del Tambo de las Perdices, que las dividen unos pedazos de costa montuosa.

Farallones de Hiuara.-Al Sudoeste próxima. mente de la punta de Huara corren varios islotes: Tombillo es el más chico y tiene una piedra junto á él: siguen lacia fuera los Diablillos, que son tres; los Chuntales, otros tres más altos con algunas piedras alrededor; y Mazorque, el mayor y más elevado, con un islotillo inmediato bastante alto. Otro chico y alto llamado el Pelado en $\mathrm{II}^{\circ} 27^{\prime} 20^{\prime \prime}$ de latitud y $3^{\prime} 20^{\prime \prime}$ de longitud, es el más saliente á la mar y demora de la misma punta al Sur $55^{\circ}$ Oeste á I $_{4}$ y $\%$ millas. Todos ellos, llamados los farallones de Huara, forman canales muy hondables, en donde puede fondearse sobrecogido de algunas calmas, $y$ en el más ancho, que es de dos leguas entre los dos más distantes de tierra, se halla 70 brazas de agua. Se incluye también con ese nombre, un is lotillo inmediato á la punta Huara y á milla y media al Sur de ésta. Las Tortugas, otros dos is lotes muy unidos y cercanos de una punta.

Punta y puerto de Salinas. -Al Norte exactamente de la punta de Huara, siguiendo un trecho de costa de tres y media millas que forma una pequeña ensenada, se halla la punta de Salinas, baja y de piedra. Le da su nombre un cerro inmediato y un puerto pequeño que tiene al Norte.

Isla de Don Martín.-Avanzando para el Norte se encuentra la Isla de Don Martin, situada en $I x^{\circ} 03^{\prime} 07^{\prime \prime}$ de latitud y $27^{\prime} 20^{\prime \prime}$ de longitud, distante de la costa poco más de una milla. Es casi redonda, de una circunferencia de media legua próximamente, tajado el extremo Norte, bajo el del Sur, y ambos con una pequeña res. tinga: se presenta su cima llana y blanca, por el guano que la cubre enteramente.

Dos poblaciones en la costa.-En su paralelo proximo á la orilla de la costa firme, que es aba. rrancada, se ve una población, cuya iglesia es bastante visible desde la mar: la de Huara se distingue en lo interior á legua y media EsteOeste con el morro de Huacho.

Puerto de Huacho.-Forma éste un pequeño abrigo á la parte del Norte, al cual le han dado el nombre de puerto: sólo se presenta la utilidad de enviar allí una lancha, manteniéndose el bu. que á la vela, para hacer provisiones de viveres, que hay en abundancia: en sus playas se hace sentir con fuerza la resaca. El morro da el nom. bre á un islote que dista de él media milla; un fondo de 20 brazas arena fina se encuentra á dos millas mar en fuera.

De este punto se extiende la costa al Norte y Sur, en gran parte abarrancada y de muy poca elevación: siguen luégo en lo interior, lomás de arena algo notables, y últimamente, la cordille. ra muy elevada y bastante próxima.

Pico de Huara.--Entre aquellas se hace bien visible por su elevación y por su figura de pan de azúcar, el pico de Huara, situado en $\mathrm{II}^{\circ} \mathrm{o} 5^{\prime}$ y $30^{\prime \prime}$ de latitud y $18^{\prime} 5^{\prime \prime}$ de longitud á siete millas de la costa, muy parecido al de San Cristóbal de Lima; su declive por la parte del Sur se ve en gran parte libre de las colinas inmediatas, y por la opuesta, otras colinas más elevadas y que se extienden con igual altura, lo ocultan desde la mitad.

Al Norte se distingue una punta por un islotillo negro inmediato á ella llamado el Martinico, y luégo la de Supe, formada de piedra con una restinga de cerca una milla hacia la. Isla de Don Martín.

Desde la punta Supe hasta las ruinas de Panamanga.-Seguidamente forma la costa dos ensenadas poco profundas, divididas por la punta Mamasmayo, á cuyo través hay 37 brazas iama, á cuatro millas: en la más septentrional de ellas, por unas quebradas que se ven desde la mar, desemboca el río de la Barranca, que es caudaloso y con una población de su nombre y el de la Fortaleza. Entre éstos, en un valle cultivado, se deja ver la población de Patavilca. La punta Norte de esta ensenada, que la forma un cerrito puntiagudo, negro y escarpado en la orilla, se hace bien visible por las ruinas de Panamanga que tiene al Este. Dista esta punta $14 \mathrm{y} \%$, millas al Sur $15^{\circ}$ Este de la Isla de Don Martín.

Hasta la punta Hurtados.-De la misma pun. ta para el Norte 38 Este, distante 27 millas, se halla la de Hurtados con un islote inmediato hacia el Sueste: en este intermedio no ofrece la costa sino pequeñas sinuosidades, cuyas puntas principales son las de Vera, Santander y de Filita.

Hasta la p:ntta de Francos.-La punta de Hurtados, con la de Francos, corre en la dirección de Norte $3^{\circ}$ Oeste ocho leguas, y entre varias ensenadas poco profundas que hay en este trecho, es la más notable la que está al Norte de Sora. 
a de Huara se y media Este.

e un pequeño

a) le han dado

nta la utilidad

hiéndose el bu-

nes de viveres,

playas se hace

rro da el nom.

edia milla; un

se encuentra á

costa al Norte y de muy poca rior, lomas de te, la cordille. a

as se hace bien figura de pan ado en $\mathrm{Ir}^{\circ} 05^{\prime}$ ngitud á siete al de San Crisbarte del Sur se as inmediatas, nás elevadas y 10 ocultan des-

ta por un islonado el Martide piedra con acia la Isla de

as de Panamandos ensenadas punta Mamas. iama, á cuatro ellas, por unas ar, desemboca loso y con una la Fortaleza. se deja ver la Norte de esta o puntiagudo, hace bien visique tiene al las al Sur $15^{\circ}$

a misma pun-. 27 millas, se mediato hacia frece la costa. puntas priny de Filita. unta de Hurdirección de re varias eneste trecho, rte de Sora. luz. Varios islotes hay en estas inmediaciones cerca de algunas puntas, entre los cuales, un grupo de ellos llamados de Fierros. Lo interior de la costa no es muy elevado, y lo forma diferentes lomas de arena respaldadas por la cordillera.

Hasta el morro de Casura. - A 28 millas al Norte 20 Oeste de la punta de Francos se halla el murro de Casma, sitiado en $9^{\circ} 40^{\prime} 45^{\prime \prime}$ de la. titud, y.r.ro.35 de longitud occidental, el cual da el nombre á un río que tiene al Sur. En lo interior se hace visible un cerro en $9^{\circ} 30^{\prime}$ de latitud, y 1.48.40 de longitud al Norte 64 Este del morro, á ocho leguas de distancia. En el trecho de costa cumprendido entre las dos puntas ya nombradas, sólo merece la atención el pequeño puerto de Guarmey, impio y hondable, formado por una punta llana en su cima, cuyo recodo es de tierra amogotada, y en lo más interior se ven manchas de arena. El fondeadero es en ocho brazas de agua á barlovento del islote de Guarmey, del cual no deben propasarse las embarcaciones para tierra, demorando al Nordeste "/ Este. Un pequeño pueblo de indios que está inmediato al puerto y lleva su nombre, provee de maiz, leña; carne y de muy buena agua de un riachuelo que desemboca en el mismo paraje del desembarcadero.

Bocas y puerto de Ferrol.-A media legua del morro de Casma hay fondo de 45 y 50 brazas piedra. De éste corre la costa en una dirección cas seguida de Norte $28^{\circ}$. Oeste ilasta la punta Sur del puerto de Ferrol, en una distancia de $36 \%$ millas. Esta última punta se hace remarcable por cuatro islotes que tiene en su inmediación, de los cuales tres están muy juntos y corren como al Noroeste la distancia de poco más de una milla, y el otro, que es el más chico, se aparta algo más al Norte, exactamente del más inmediato. Se presentan cubieitos de guano, de una altura regular y más bajo éste último. Cubren la mitad de la boca de la ensenada inmediata, y forman con ella el puerto de Ferrol, que es abrigado, de buen fondo, $y$, en donde pueden carenarse embarcaciones. La entrada es por medio de las islas, cuyos canales hondables se llaman las bocas de Ferrol, y con este nombre se distinguen las mismas islas.

Esta ensenada es de terreno muy arenoso, más bajo queresto: el termina la costa á ambos lados de ella, de ura altura regular, de color negro, con algunos manchonès de arena.

Isla do Guambacho.-La Isla de Guambacho, situada en $9^{\circ} \mathrm{r} 2^{\prime} 3^{\prime \prime}$ y en $\mathrm{r}^{\circ} 24^{\prime} 50^{\prime \prime}$ de longitud occidental, se hace visible al Sur: es de bastante altura, y el extremo Sur termina en un monte algo menor, en figura de cono, con un declive igual á ambos lados: se extiende poco más de media milla, es casi redonda, y se halla frente y cerca de una pequeña ensenada con río. En su paralclo á cuatro leguas de distancia, se encuentran 50 brazas arena lamosa.

Hasta el morro é Isla de Santa.-La punta Norte del puerto de Ferrol, y la que forma el morro de Santa, corren al Norte $19^{\circ}$ Oeste siete millas, y casi en la misma dirección su costa. In este trec o se hace visible: primero, un abra que llaman de Silva, en cuya boca hay cuatro islotes, y seguidamente la Isla de Santa situada su medianía en $9^{\circ}$ or $r^{\prime} o^{\prime \prime}$ de latitud, y $\mathbf{r}^{\circ} 3^{r^{\prime}}$ y $10^{\prime \prime}$ de longitud. Se separa esta media legua de la costa para formar un canal muy navegable acercándose más ijien á la Isla, y su mayor extensión es al Norte $28^{\circ}$ Oeste poco más de milla y media. Presenta una altura regular, sus extremos bajos, de color rojo y blanco por el guano, y con varias quebradas, entre las cuales dos muy notables la dividen en tres alturas, y vista al Nordeste sólo parecen dos. Del extremo Noroeste de la isla se extiende un bajo cerca de un tercio de milla y a la parte nccidental: en el paralelo del extremo opuesto, á una milla de distan. cia, hay un islote negro con algunas piedras al Norte.

Puerto de Sauta.-El puerto de Santa es una pequeña enșenada con un río el más caudaloso de esta costa, formado al Sur del morro de ese nombre: éste es un montecito negro y una punta al Sur, es tierra alta en el fondo, y tienc un monte que visto Iste-Oeste presenta dos picos con una mancha de arena de alto á bajo. Al pié de la misma punta hállase un islote con el mis. mo nombre del puerto, al cual no debe acercarse por no ser limpios sus alrededores: se fondea en cuatro y media brazas, y un pueblo colocado á una legua escasa de lá costa, puede socorrer á las embarcaciones, de todas provisiones.

Eusenada de Chao.-Desde el morro de Santa hasta el de Chao, que distan cuatro leguas escasas, al Norte $28^{\circ}$ Oeste hurta la tierra cinco millas próximamente para formar la ensenada de Chao, cuya costa en la orilla es de arenales. La punta Corcobada, situada dentro de ella, es baja, y el principio para el Norte, de unos cerros puntiagudos y altos cubiertos de arena hasta la medianía, entre los cuales se hace más notable por alguna mayor elevación, el cerro de Vares.

Ll Corcobado y la Viuda.-Casi en la dirección de los dos morros ya nombrados, se encuentran dos islotes distantes entre ellos tres millas: el del Sur, que es el mayor, nombrado el Corcobado, con una pequeña restinga hacia el Noroeste, queda en el paralelo de la punta de su nombre á una legua de distancia, formando un canal navegable: llámase el otro islote la Viuda. Fuera de ambos unas cuatro millas, se coge fondo de 16 hasta 18 brazas arena lamosa y arena fina negra.

Morro de Chao y punta de Gijón.-El mo:ro de Chao y la punta de Gijón, que está al Norte é 
inmediata, forman unos montes negros, unidos á la tierra firme por un terreno bajo y arenoso, en cuyo intermedio hay una pequeña ensenada.

Isla de Chao y las Tapadas. - Una isla de poca extensión, llamada de Chao, se separa una milla $y$ un tercio de la punta Gijón en su paralelo, y al Noroeste de ella, muy cerca tiene un farallón: siguiendo esta misma dirección se encuentran dos isletillas llamadas las Tapadas, distantes entre sí dos tercios de milla, de las cuales la más Sur tiene restingas, ; forma con la Isla de Chao un canal de media legua.

Hasta el morro de Guainapc.-La punta de Gijón y la que forma el morro de Guañape, que corren en la dirección del Norte 29 y $\%$ Oes te $18 \mathrm{y} \%$ millas de distancia, comprenden una grande ensenada que la subdivide una punta saliente, en donde se avista un valle, distinguiendose la del Norte con el nombre del morro, que la termina por una parte. El terreno interior es de montes de arena de bastante altura, encadenados hasta la cordillera que se halla próxima.

Islas de Guañape. - Al Sur $18^{\circ}$ Oeste del morro de Guañape, demoran á distancia de cuatro millas las islas del mismo nombre, que son dos, cubiertas de guano y distantes entre sí dos tercios de milla: cogen ambas una extensión de poco más de dos millas en la dirección de Norte $18^{\circ}$ Este: la del Norte algo baja, tiene en sus inmediaciones varios farallones, y la del Sur sólo dos. A tres leguas del morro de Guañape en su paralelo, se encuentran 32 brazas arena fina $y$ piedra.

Fondeadiro del morro de Ginañape.-Se puede fondear á sotavento de este morro, arrimándose a un farallón blanco que se halla en una de sus puntas, por fondo de seis brazas, en ei cual se deja caer el ancla al momento que se avistan los ranchos, y se quedará en esta posición á un cuarto de legua de tierra. No hay agua, sólo sí lastre y leña.

Morro y fondeadero de Mal-abrigo.-Del morro de Guañape, siguiendo al Norte 34 Oeste una distancia de $5+\mathrm{y} \%$ millas, se halla el de Malabrigo, que forma al Norte, puerto con mucha mar y viento á rachas, en que fondean algunos navíos que van á cargar allí de harina, en cinco brazas. Desde este paraje, se ve el desembarcadero en un lincón que hacen unos peñascos situados á barlovento, y ofrece una playa para colocar las cargas, siguiendo la cual media legua de tierra adentro, se encuentran pozas de agua dulce: este morro casi cubierto de arena, se presenta en ciertas direcciones aislado por las tieras bajas que tiene inmediatas. Lo hace también visible, un islote con el mismo nombre, distante cuatro millas al Sur $10^{\circ}$ Oeste de su punta: hállase cubierto de guano, y tiene pega ${ }^{\prime} u$ otro is lote más pequeño al Norte y un farallón al Sueste.
I'soblo y puerto de Giuanchaco. - In este trecho de costa comprendido entre los dos morros ya nombrados, se hace visible el pueblo de Guan. chaco, situado en la orilla de la mar sobre una costa de arena barrancada, en $8^{\circ} 4^{\prime}$ ro $0^{\prime \prime}$ de lati. tud y $1^{\circ} 5^{\prime} \times 5^{\prime \prime}$ de longitud á dos leguas al Norte, 72 y $\%$ Oeste de la ciudad de Trujillo. Muy cerca de la parte del Este se manifiesta un cerro puntiagudo bastante notable y á su espalda la cordillera. Han dado el nombre de puerto de Gurnchaco, á una muy pequeña sinuosidad que forma la costa en estas inmediaciones, en donde la marejada sorda se hace sentir con fuer$z a$, aunque reinan siempre vientos bonancibles. Es el puerto de Trujillo, y vienen á él varias embarcaciones á cargar de harina y otras cosas para Panamá. El fondeadero se halla á tres cuartos de legua de la playa, fuera de un bajo que llaman el Buey, demorando la iglesia de Guanchaco al Este, y el cerro de la Campana al Norte $30^{\circ}$ Este, en nueve brazas lama muy suelta, cuyo fondo entierra mucho las anclas y hace preciso levarlas á menudo. Para ir á tierra, se sirven todos de prácticos, los cuales saben cuando permite la entrada al Buey, cuyo bajo dista un cuarto de legua de tierra, levanta mucha mar, y debe pasarse precisamente sobre de él. Al Oeste de las playas de Guanchaco, siete millas, hay Ig brazas lama y chinitos, y á ménos distancia para el Norte, 16 b.azas arena fina negra $y$ arena fina chinitos.

Cerro de la Campana.-Desde Guanchaco, siguiendo para el Norte, continuan varias llanuras de arena hasta el cerro de la Campana, situa do en $8^{\circ} 3^{\prime}$ I $^{\prime \prime}$ de latitud y $I^{\circ} 5^{6}{ }^{\prime} 0^{\prime \prime}$ de longitud, bien visible po: su elevación y por su figura bastante apropiada á su nombre, y cuyas faldas llegan á bañar las orillas de la mar.

Chicama.--Empieza luégo al Norte un valle muy ameno, poblado de muchas casas, y respaldado de la cordillera, que no es tan alta como la que se ve al Sur. Este valle, un río que tiene cerca, un cerro, una punta, y una ensenada hacia donde arrastran mucho las aguas, llevan todos el mismo nombre de Chicama.

Hasta la punta de Pacasmayo. - Al Norte $26^{\circ}$ y $\%$ Oeste del morro de Mal-abrigo, demora la punta de Pacasmayo, cuyo trecho de costa de $\mathrm{r} 8$ millas es baja; $y$ en lo interior lo forman tierras bastante altas y puntiagudas, casi cubiertas de arena. A dos tercios de legua de la dicha punta se hallan 20 brazas fondo, y en la costa, pocual Sur de clla, hay un pequeño recodo á que llaman puerto de Pacasmayo, sin abrigo alguno.

Desde la punta de Pacasmayo liasta la de Matienzo, que corren al Norte 16 Oeste una dis. tancia de 18 y $\%$ millas, hurta la costa para formar la ensenada de San Pedro. De esta última punta sigue la costa casi una misma direc- 
In este trecho $s$ morros ya lo de Guan. robre une ' Io" de lati. os leguas al de Trujillo. manifiesta un y á su espal. bre de puerto la sinuosidad diaciones, en entir con fuer. bonancibles. n á él varias y otras cosas halla á tres ra de un bajo la iglesia de - la Campana as lama muy ho las anclas do. Para ir á os, los cuales al Buey, cuyo fierra, levanta amente sobre anchaco, siete tos, y á ménos arena fina ne.

e Guanchaco, a varias llanu. mpana, situa $50^{\prime \prime}$ de longiy por su figura cuy'as faldas r.

Norte un ralle isas, y iespal1 alta como la río que tiene ensenada ha. aguas, llevan a.

-Al Norte $26^{\circ}$. go, demora la le costa de 18 forman tiecasi cubiertas a dicha punta costa, pocu al ó que llaman ino.

hasta la de leste una dis. la costa para De esta últi misma direc- ción, formando pequeìas sinuosidades hasta el morro de Cherepe 6 Elen, cuyos extremos demoran al Norte $\downarrow_{2}$ Oeste y distan unas 22 y $\%$ millas. Este morro, que á alguna distancia se presenta como una isla, por estar unido con tierra baja, es llano y cubierto de arena.

Tiene al Norte un fondeadero frente de la población de Cherepe, en ocho brazas, á sotavento de un bajo que sale á un tiro de pedrero de la punta del morro. Es sin abrigo alguno, con mucha mar, y sirve para las embarcaciones que vie. nen a cargar de harinas y azúcar, $y$ otros frutos para llevar á Panamá y Lima.

Del morro de Cherepe hasta la punta de la Aguja.-Al Norte de Cherepe es la tierra muy baja, de arena, y forma un valle de mucha extensión, respaldado de tierras de mediana altura. Sigue luégo la costa sumamente baja hasta las proximidades de la punta de la Aguja, y tan seguida, que no presenta objeto que marcar, si se exceptúa el Allo de Illescas, que es un monte de mediana altura, situado á la orilla de la mar á I 7 millas al Sur 68 y $\%$, Este de la punta falsa de la Aguja. Esta punta se separa de la de la Aguja cinco millas al Sur 35 Este, y en su paralelo, distante dos y media leguas, no se halla fondo con 30 brazas. La punta del morro de Chere. pe y la punta falsa ya nombrada, corren al Norte $54 \mathrm{y} \%$, Oeste en la misma dirección que la costa intermedia, y coge un trecho de 91 millas, cuyo fondo sembrado de piedras es aplacerado; de suerte, que á distancia de dos y más leguas se encuentran ${ }_{4} 4$ hasta ${ }_{7} 7$ brazas arena, mezclada unas veces con fango, otras con chinos, y otras, finalmente, con conchuela. Es arriesgado el atracar mucho este pedazo de costa, porque la marejada y la corriente abaten bastante hacia ella.

Islas de Lobos de tierra y d: fusra. - Las Islas de Lobos se presentan en estos paralelos y forman un punto notable é interesante en la navegación. La una, que se extiende cuatro y media millas al Norte $4^{\circ}$ Este, es la más septentrional, separada de la costa nueve millas, y se llama Isla de Lobos de tierra, para distinguirla de otras dos chicas y muy inmediatas que se conocen por Islas de Lobos de fuera. Se separa ésta de la otra 30 y $\%$ millas al Sur $5^{\circ}$ Este.

Isla de Lobos de tierra.-La Isla de Lobos de tierra es baja y forma su mayor altura desde el medio para el Sur. Su medianía se halla en $6^{\circ} 24^{\prime}$ $20^{\prime \prime}$ de latitud y $3^{\circ} 43^{\prime} 00^{\prime \prime}$ de longitud. Tiene varios farallones pegados á la costa del Oeste, y la cubre el guano. Sus alrededores son muy hondables, y se encuentra fondo de 30 á 40 brazas á una y dos millas por la parte Oeste. Al lado opuesto, muy inmediato á ella, una canal de legua y media de ancho permite un paso seguro por la parte de tierra. Varios fondeaderos ofrece la costa al Este y Norte: no se halla en ellos agua, y en vez, una abundancia grunde de pescado, de lobos y pájaros marinos.

El Coche.-Un bajo que llaman el Coche, situado en el meridiano de esta Isla de Lobos a 6 y $1 / 2$ millas, y que demora al Sur $70^{\circ}$ Oeste del alto de lllescas, distante de la costa inmediata cinco y un tercio millas, se hace sentir desde lejos por un ruido ronco de la mar, que rompe con fuerza en él. Esta señal precursora del peligro y del cuidado del navegante, no ha bastado para salvarse varios buques, que han perecido alli.

Isla de Lobos de fueru. - La Isla de Lobos de fuera está situada en $6^{\circ} 57^{\prime} 40^{\prime \prime}$ latitud y $3^{\circ} 4^{\prime} 30^{\prime \prime}$ de longitud, y el estrecho canal de las dos islas que la forman sirve solo para lanchas, dejando á la parte Norte entre la más oriental y unas rocas, un fondeadero en $10, I_{2}$ y $I_{4}$ brazas para embarcaciones grandes, abrigado de los vientos reinantes del Sur. Ambas islas se extienden dos millas próximamente de circunferencia, y se elevan á una altura regular, de un terreno estéril sin agua alguna ni plantas, en parte pedregoso y en parte arenoso y abundante de los mismos animales que la otra isla.

Punta de la Agrija. - Volviendo de nuevo á atracar la costa firme, se hace visible la punta de la Aguja que hemos nombrado ya, por ser el punto más occidental de todo el frontón cercano, que es saliente á la mar: es baja y la forma una loma de mediana altura llana en su cumbre, de color rojo, y cubierta de arena desde la orilla de la mar hasta su medianía. Se halla en $5^{\circ} 59^{\prime} 20^{\prime \prime}$ de latitud y $4^{\circ}$ or' $10^{\prime \prime}$ de longitud, y la rodea una restinga que se extiende cerca de una milla para fuera.

Ensenada de Scchura.-Desde esta punta va hurtando la costa para formar una grande ensenada llamada de Sechura, en que se halla el pueblo del mismo nombre, como igualmente un río cuyo caudal y rapidez aumenta con exceso en tiempo de aguas en la sierra, dejando el resto del tiempo sin indicios de su madre. Termina la ensenada al Norte en otro frontón saliente, cuyc :xtremo septentrional es la punta de Paita, que corre con la de la Aguja al Norte $2^{\circ}$ Este una distancia de $5^{6}$ millas. En el frontón del Sur forma la costa á la parte Norte de la punta de la Agu ja, las puntas de Nonura y de Pisura; aquélla, baja, escarpada, sm un manchón blanco y un farallón inmediatu al Norte, llamado de Bernal, el cual tiene á la parte exterior dos bajos, de piedra visible el uno y con escarceo el otro; la segunda punta tiene igualmente manchas blancas, con varios bajos de piedra en sus inmediaciones para el Norte. Su terreno intermedio lo forma la caida de un cerro muy tendido, llano en su cumbre, algo bajo y lleno de escavaciones por algunas partes. Empieza seguidamente á ser la 
costa al Norte más baja, y la ensenada de Sechura que forma, está rodeada de bancos de arena que salen en partes una legua. En ella y en toda la ensenada que sigue luego de Paita, se pesca en mucha abundancia, principalmente de sollo.

Frontón saliente do Paita. - El frontón saliente de la punta de Paita corre casi Norte-Sur una distancia de siete millas. Se presenta de mediana altura, escarpado, formando varias puntas $y$ en. senadillas de arena. I:n el extremo Sur se eleva un monte que domina el resto de la tierra inmediata, y una pequeña sinuosidacl que forma la cima de su mayor altura, le ha dado el nombre por su figura de silla de Paita á todo él: se halla en $5^{\circ} 10^{\prime} 00^{\prime \prime}$ de latitud $y$ longitud de $3^{\circ} 57^{\prime} 40^{\prime \prime}$.

Isla do L.obos y la Oradada.-Sigue luego al Norte una pequeña isla llamada de Lobos, y la Oradada. Aquella algo baja, escarpada, con al. gunos faralloncitos y un pequeño bajo pegado á la parte del Nordeste, se extienäe próximamente dos millas en circunferencia, y se aparta una sscasa de la costa, demorando al Norte $63^{\circ}$ Oeste de la Silla: la Oradada es un peñote muy chico, proximo a tierra, con otros menores en sus contornos, $y$ dista de la punta de Paita una y un ter. cio de milla.

Puertc y ensenada do Paita.-Desde esta punta saliente á la mar, inclina la costa al Sur y Este para formar el puerto y seguidamente la ensenada de Paita, la cual termina en los Negrillos, que distan de aquella punta 21 millas al Norte 23 Oestc. En esta ensenada se encuentra el pueblo de Colave, y al Norte de él, el de Colan á la desembocadura del río Chira, que hace curso por el pueblo de Amotape. Interna el puerto de Paita dos millas próxima. mente con igual anchura, y su pequeña pobla. cjón situada en el fondo y á la orilla de la mar, se halla en $5^{\circ} 5^{\prime} 50^{\prime \prime}$ de latitud y $3^{\circ} 54^{\prime} 55^{\prime \prime}$ de longitud. Fondean las embarcaciones cerca de ella, y las mayores quedan á un cuarto de legua.

Provisión y agua de Colan para Paita.-La entera falta de agua en Paita y el llover sino raras veces, por ser un país de valles, cau. sa una total aridez en su territorio. Le precisa tener una continua comunicación con Colan, po. blación situada en un terreno fértil dos millas al Norte del puerto del mismo nombre, el cual dis. ta de Paita Iu millas al Norte $12 \%$ Este. Le provee po: medio de balsas de agua en botijas, como igualmente de verduras y carnes, que vienen también de Amotape. Los buques que nece. sitan de aquella, hacen un ajuste con los índios de ese pueblo, para que la reemplacen.

- Derrota para la entrada en Paita.-Para en trar en Paita las embarcaciones que vienen del Sur, procuran reconocer la Isla de Lobos de Tierra $\delta$ bien la costa inmediata sobre la punta
Nonura, desde la cual prosiguen teniéndola a la vista, y dando un pequeño resguardo a la punta se la Aguja por ser muy saliente a la mar y baja, como hemos dicho. Prefieren los prácticos esta recalada á otra cualquiera inme. diata al puerto, para asegurarse de su derrots y no propasarse de su paralelo, en cuyo caso ya los vientos y el curso de las aguas contrarias, harian perder muchos dias en ganar el barlovento perdido. Como todas estas costaa inmediatas son bajas y las cubre ordinariamente la rumazón, atienden todos á dos señales que avisan la inme. diación de ellas. La una es los lobos marinos, que se hallan en las cercanias de las Islas de Lobos, y a tres 6 cuatro leguas de ellas; y la otru la infinidad de pájaros que saic: casi á la misma distancia.

Avistada luego la Silla de Paita, punto bien notable como se dijo ya, atracan sobre la Ora. dada para seguir costeando de cerca hasta el fondeadero, con sólo el cuidado de no acercarse mucho á la última punta, de la cual sale por el Norte una restinga de dos cables, que -siempre vela. Viniendo del Norte, reconocido de ante. mano el Cabo Blanco, de cuya recalada se hablará luego, y rebasados los Negritos, se procura no emperiursc en la ensenada que le sigue por el fondo, que es muy aplacerado, y por reinar siempre en ella una mar sorda.

En Paita $y$ en sus inmediaciones suelen ex. perimentarse desde Noviembre hasta Mayo, que es el verano, algunos terrales muy flojos, que al fin pasan á entablarse al Sueste y Sursueste, dirección de los vientos generales. De estos últimos abriga la rada de Paita el monte 6 ailla de Paita: las brisas que son del Norte recalan muy raras veces $\mathrm{y}$ con irregularidad.

Los Negrillos liasta la punta Parivias.--Loo Negrillos, conocidos hasta ahora por unos farallones inmediatos á la tierra, por parecerlo asf, no son sino dos pequeños morros de arena $y$ piedra en la misma costa, que es algo máa baja: sigue ésta luégo en la misma elevación hasta la punta de Pariñas, distante de los Negrillos dos millas. Desde esa punta, altea la costa con mu. chos arenales, muy igual en su cumbre $y$ aba. rrancada.

De la punta Pariñas hasta Cabo Blanco.-El Cabo Blanco, situado en $4^{\circ} 19^{\prime} 30^{\prime \prime}$ de latitud y $4^{\circ} 3^{\prime} 45^{\prime \prime}$ de longitud, forma con la punta Pariñas el frontón más saliente á la mar de la América Meridional, y coge un trecho de 24 y $\%$ millas, del cual se avanza más al Oeste la punta de Capuyana é inmediato al Sur la de Ta. lara, que dán el nombre á dos pequeños puertos, únicos puntos notables de este pedazo de costa.

Matape,-En lo interior se hacen visibles las sierras de Matape, de una altura regular, cuyos 
teniéndola a sguardo \& la saliente la Prefieren los lquiera inmesu derrota $y$ cuyo caso ya as contrarias, ar el barloven. as inmediatas ce la rumazón, visan la inme. bos marinos, e las Islas de ellas; $y$ la otru asi á la misma ta, punto blen sobre la Ora. cerca hasta el e no acercarse ual sale por $\mathrm{cl}$ , que - siempre ocido de ante. alada se habla se procura no igive por el fonreinar siempre

nes suelen ex asta Mayo, que y flojos, que al Sursueste, diDe estos últinonte 6 silla de te recalan muy

Pariñas.-Los por unos farar parecerlo así, cos de arena $y$ algo más baja: vacion hasta la 3 Negrillos dos costa con mucumbre y aba.

bo Blanco.-El $30^{\prime \prime}$ de latitud con la punta á la mar de la echo de $24 \mathrm{y} \%$ I Oeste la punSur la de Ta. pequeños puereste pedazo de

cen visibles las regular, cuyos extremos son más altos que el medio, y en la parte Oeste tiene tres picos notables, de los cua. les dos de ellos muy unidos y más salientes que el tercero. Dan el nombre á un pueblo que se

a á sus faldas y á un río que pasa á una le.

sroximamente de él, y lo hace caudaloso la abundancia de aguas en la sierra. La mayor elevacion de aquellos montes se halla en $4^{\circ} 3^{6} 55^{\prime \prime}$ de latitud y $3^{\circ} 5^{\prime} 15^{\prime \prime}$ de longitud.

Cabo Blanco.-El Cabo Blanco, ya nombrado, es el término que divide el Reino del Perú del de Santa Fc. Lo forma una lengua de tierra baja del color que le ha dado su nombre, pern á poca distancia tiene un morrito, que desde el empieza á elevarse con rapidez una loma de piedra muy socabada, pareja en su cumbre, con muchos are. nales que caen hasta la mar, y es lo más alto de este pedazo de costa al Sur. Todas estas inme. diaciones son muy hondables, hallándose 45 bra. zas lama á poco más de una legua de la costa. Las embarcaciones que van á Paita, del Norte, procuran atracar para su derrota al Cabo Blanco, in el cual, reinando siempre por un gran trecho de mar, vientos y corrientes contrarias, la experiencia les ha enseñado que los bordos han de ser muy pequeños, á no separarse una legua del ca. bo, á fin de no perder barlovento. El viento se hace sentir comunmente en el, con fuerza.

Golfo do Guayaquil.-Di Cabo Blanco y la punta de Santa Elena que demoran al Norte $8^{\circ}$ Este y distan entre sí 130 millas, son el princi pio de la costa que hurta al Este para formar el seno 6 golfo de Guayaquil.

Cabo Blanco hasta la punta Malpelo.-La punta de Malpelo, principio de los bajos de la en. senada de Tumbes, dista del Cabo Blanco 68 millas y hurta de el $49^{\prime}$ al Este: se hace solo notable en este pedazo de costa, el surgidero de Mancora á siete millas del nombrado Cabo, y seguidamente al Norte, tres cerros inmediatos á la costa, llamado el más meridional, de Aguirre, el segunde, de Castro, y el tercero de Malonda.

Desde la punta Santa Elena, hasta su extremo meridional. - En la tierra firme al Norte, inclina la costa desde punta Santa Elena al Sur y Este $4 x^{\prime} y \%$ de longitud en una distancia de 57 millas, para formar el extremo meridional de este trecho. Comprende la punta Carnero, coronada de bajos: su vista presenta un islote amogotado, y aproximándose á ella se transforma en un morrito en cuyo pié blanquea el terreno. Es baja luego la costa hasta los altos de Chandui, los cuales se hacen visibles por su mayor elevación que el terreno en contorno, $y$ forman tres picos, más agudo y notable el del Sur que los otros dos. Estas inmediaciones, como igualmente la costa que le sigue para el Sur, se han hecho temibles por los muchos bajos de piedra que le rodean $y$ por el curso de las aguas. y de la marejada; que atraen hacia ella, por cuya razón es arries. gado el acercarse á menos de dos leguas.

Nicblas que reinan en estos mares. - Concluida aquí la descripción de toda la costa compren. dida entre golfo de Guayaquil y el puerto del Callao, no será fuera de propbsito el incluir una pequeña descripción de las nieblas que cubren estos mares y costas una parte del año. "Son generalmente todas las costas del mar "desde Guayaquil para el Sur, dificiles de ser "reconocidas á ménos de lograr para ello la - coyuntura del verano, porque tanto en el in. "vierno como en su salida 6 entrada, continua. " mente están cubiertas de espesísima niebla: "tal, que á un cuarto de legua de distancia no ae - ve otra cosa que nubes, y alargándose á la mar "hasta 15620 leguas y muchas veces más, con. " servan en esta distancia la misma densidad, "pero sucede que todo la que dura la noche $y$ whasta cosa de las diez ú once del día, la niebla "está pegada contra tierra: á esta hora se retira "hacia el mar, formando como una muralla, que "sirve de estorbo á la vista del que está de la " otra parte de ella, y no puede descubrirla ni w arriesgarse á buscarla, no sabiendo si la encon. "trará ciara 6 no."

El golfo de Guayaquil es uno de los mares más frecuentados de estas costas, por su comercio de maderas, de cacao, y de las manufacturas de las provincias internas, $y$ por su astillero, en que se fabrican muchas embarcaciones. Encierra en sí dos islas principales; la una pequeña, conocida con el nombre de Santa Clara, y mejor hoy día con el de Muerto 6 Amortajado por su figura vista en la dirección del Oesnoroeste próximamente, y la otra grande llamada de la Puná, á cuya parte Norte desemboca el río Salado y el de Guayaquil.

Isla de la Puná.-Esta última isla se extiende al Norte $44^{\circ}$ y $\%$ Este una distancia de 26 y $\%$ millas, en una circunferencia de 70. Varios esteros se forman en la costa del Sueste por algunas isletas que le rodean de cerca, y por fuera de ellas se hallan placeres de arena interrumpidos con bastante fondo. Entre manglares y costa baja, de que se compone en gran parte esta isla, se hacen visibles dos $3^{\circ}$.rran: la de Mala, cerca de la costa y del extreino Nordeste de la isla, y en el extremo opuesto, perr algo inte. rior, las de las Animas, que son más extendidas y más elevadas.

A la parte oriental de un fronton que forma la isla al Nordeste, en una pequeña ensenada con el pueblo y Estero de la Puná, se halla el fondeadero del mismo nombre. Este y otro interior frente de la ciudad de Guayaquil, son los únicos puertos buenos y frecuentados que ofrecen el gol. fo y el río. Prefieren casi todas las embarcaciones el puerto de la Puná; por encontrar más fácil y 
segura ia entrida y salida, y porque les imposibilita el peco fondo de los canales que van al se. gundo, el seguir navegando cargadas. Alcanzan sólo el fondeadero de Guayaquil las embarcaciones pequeñas, $y$ con poca carga, las grandes precisadas de alguna obra de calafate 6 de carpin. tería. Consiguientemente, el puerto de la Puná es el punto de reunión de todos los buques que atienden á este comercio para recibir 6 entrezar el todo ó el completo de su carga, la cual se lleva á este paraje por medio de balsas.

El Amorticiado.-La Isla del Amortajado se hace muy interesante para la navegación del golfo, norque su vista proporciona el asegurar la posición de los buques, y determinar luégo mejor la derrnta que se hace seguidamente al Este entre sonda.

Hállase situada en $3^{\circ}$ I $3^{\prime} 20^{\prime \prime}$ de latitud y $74^{\circ}{ }^{\prime} 1^{\prime} 30^{\prime \prime}$ de longitud occidental de Cádiz, y demora al Norte $38^{\circ}$ Este del Cabo Blanco, al Norte $12^{\circ} \mathrm{V} 1 / 2$ Este de la punta de Malpelo, al Sur $62^{\circ}$ y $\%$ Oeste de la punta Arenas, extrenn Sueste de la Puná, y al Sur $28^{\circ}$ y $1 /$, Este de $I \varepsilon$. punta Santa Elena, á distancia del primero 83 millas, del segundo I9 $y 1 /$, del tercero $19 \mathrm{y}^{2} / \mathrm{s}$, y de lá última punta 72 mil!ns. Es de regular altura y sc extiende una y media mille al Norte 62 y $1 / 2$ Este, cuyos extremos están rodeados de bajos do arena y piedra: permite el paso á ambos lados: $\mathrm{s}$ del Sur lo !imitan en gran parte los bajos de Payana, y la costa firme inmt.diata, en que desaguan muchos ríos y hace desigual su fondo; por lo cual no puede acercarse á ménos de 18 brazas, y de la isla á media legua por I 4 brazas, advertencia que hace precisa principalmente sara salir del río, debiendo ganar la mar sobre bordos por los vientos contrarios.

Estos suelen alargarse en la vuelta de la tierra firme, pero no es prudente seguirla estando á medio freu.

El canal del Norte es bien pequeño, por los bajes que revientan cerca de la punta Salinas y se avanzan á la mar legua y media, y sirve pára buques pequeños, los cuales deben sólo intentar este paso, siendo muy prácticọs.

Derrota del Amortajado á la punta Arenas.Admitido ya para su seguridal el canal del Sur á toi : especie de embarcaciones, !a derrota más acert:da y practicada para internar en este golfo y $:$, es dirigirse en derechura al Amortaja. do, reconocido antes el Cabo Blanco para los btiques que vienen del Sur, y atracada la punta de Santa Elena para los que rucalan del Norte: distando de esta isla una legua próximamente al Sur, en I5 brazas, se navega al Norte $54^{\circ}$ Este unas I9 millas, un cuya dirección después de harer aumentado el fondo á 30 brazas se disminuye hasta I? trazas, en donde sc fondea para que. darse á una legua próximamente de la punta Arenas, átendiendo siempre á las mareas, que alteran no poco la derrota.

Desde este paraje, para seguir dentro del golfo $y$ seguidamente del río, la multitud ce iajos que van carabiando á menudo de posición, y aminora ó engrandece corisiguientemente los canales, como igualmente su fondo, no ménos que varía la fuerza y dirección de las mareas, precisa erviar al n'erto de la Puná por uno de los prácticos, que son de los examinados y admitidos de antemano por el Gobierno.

\section{Derrotrro desde el rio de Guayaquil hasta el Golfo de Panamá.}

Punta de Sinta Eimu.-L: la costa firme al Norte cel gelfo de Guayaquil se hace visible la punta de Senta Elena por ser muy salierte á la mar, situada en latitud de $2^{\circ} 10^{\prime} 15^{\prime \prime}$ y $1^{\circ} 6^{\prime} 45^{\prime \prime}$ de longitud occidental de Guayaquil. Forma una lengua de tierra baja, terminada de un morro alto igual en su cumbre y clgo más tajado por la parte del Esíe que por la opuesta, y se manifiesta á alguna distancia como una isla: en sus extı cmos oriental $y$ occidental sc extiende una peque. na restinga de dos cables.

Pusto do Sunta I:lsna.-A la parte Norte de la punta, se halla. el fondeadero de su nombre en una ensenada de fondo aplacerado, frente de la población, sn cuatro brazas arena á una milla de la p'aya. Ls un puerto f.ecuentado por el comer. cir de las sales y brea que se saca en este distritr. No ofrece agua dulce, y le provee el río de vaidivia, que dista i4 millas al Norte $46^{\circ} \mathrm{y} \mathrm{H} / 2$ Este.

Sigue luégo internando la eisenada, y puede llamarse su términe al Norte, las puntas de Salango, que dan el nombre á una isla inmediata, la cual demora de la punta de Santa Elena al Norte $13^{\circ}$ Este, $3^{2}$ millas. Todo este trecho es muy hondable, y en él se hacen visibles, un islote llamado el Viejo, que se separa unz y cuarto millas de la costa inmediata, en cuyo espacio se 
ir la mar sobre bordos

en la vuelta de la tiete seguirla estando á

Dien pequeño, por los e la punta Salinas y se hedia, y sirve para budeben sólo intentar ticos.

á la punta Arenas.idal el canal del. Sur ciones, la derrota más internar en este golrechura al Amortajaoo Blanco para los buatracada la punta de rccalan del Norte: dispróximamente al Sur, 1 Norte $54^{\circ}$ Este unas ción después de haher brazas se disminuye sc fondea para queramente de la punta e á las mareas, que al-

I seguir dentro del gol, la multitud cie bajos udo de posición, y amiuientemente los canaCondo, no ménos que de las mareas, precisa tá por uno de los prácninados y admitidos de

el Golfo de

s arena á una milla de suentado por el comer. se saca en este distriy le provee el río de illas al Norte $46^{\circ}$ y $1 / 2$

la eisenada, y puede rte, las puntas de Saa una isla inmediata, ta de Santa Elena al - Todo este trecho es 1acen visibles, un islose separa una y cuarto ta, en cuyo espacio se fondra, y el Pelado, otro islote en el paralclo de la punta Valdivia, que es la costa más cercana, de la cual dista poco más de cuatro millas: aquél tiene en sus inmediaciones nueve brazas, y éste 12, con un seguro fondeadero por dentro, en seis brazas. Demora el primero, de la punta Santa Elena al Norte $8 \mathrm{r}^{\circ} \mathrm{y}^{1} / 2$, Este io millas, $y$ el segundo, de la misma al Norte $4 i^{\circ}$ Este $i 8$ millas.

Los Alorcados.--Son dos pequeños farallones muy unidos, de los cuales, eí más pequizĩo y el más Norte parece formar dos; se halian in la misma ensenada, y distan sólo media milla escasa de la costa y cinco millas proximamente de la Isla Salango, que les demora al Norte $19^{\circ}$ Oeste

Ensenada y cerro de Colonche. -Punta é Isla do Salango.-Después de la ensenada que forma el puerto de Santa Elena, que es de tierra baja y pareja, con mucho ramaje, sigue al teando el te rreno, cubierto de arboleda, el cual, visto á alguna distancia, se presenta cortado y parece formar diferıntes islas, de cuyas abras se liace más notable la que se halla al Sur del río Valdivia de la pequeña ensenada de Colonche, en donḋ se fondea en seis y ocho brazas.

Un cerro de este nombre se hace visible en lo interior, á poca distancia de la costa y en $=1 \mathrm{pa}$ ralelo de aquel río: montes que se en a lenan unos con otros, corren seguidamente la costa al Norte, cubierta su orilla de arboleda, la cual termina á la mar, de piedra con algunos escarpados, hasta la punta de Salango, que is tajacia a la mar, en forma de morro.

La isia de su nombre, de regular altura, con farallones á la parte del Oeste y una pequeña restinga al Sueste, se separa un corto trecho, cuyo canal ino es transitable, ; se extiencie en circunferencia poco más de dos millas: 40 brazas arena fina $y$ arena lama se cogen á watro mi . llas de ella mar afuera, y poca ménos cantidad en sus inmediaciones.

Euscuada al Norte de la punta Salango.-Dos objetos notaìles se presentan lué, o al Norte. La Isla de la Pla , situada en $\mathrm{I}^{\circ}$ I $8^{\prime} 20^{\prime \prime}$ de latitud y $I^{\circ} 13^{\prime} 20^{\prime \prime}$ de longitud, y el Cibo de San Lorenzo: demoran éstos entre sí al Norte $37^{\circ} \mathrm{y} \%$ Este I 7 millas, y de la punta de Santa Elena al Norte $7^{\circ}$ y $\%$, Oeste 50 y $\%$ millas, y al Norte $3^{\circ} \mathrm{y} \%$ Este 66 y $\%$ millas.

Desde la Is! ı de Salango hasta cl cabo nombrado, cuyos puntos distan $34 \mathrm{y} / 2$ milla s al Nor te 5 Oeste, hurta la costa para dentro, formando diferentes ensenadas con fondeaderos. I a primera al Sur es la que termina la punta de $\mathrm{Sa}$. lango y la de Agua Blanca, y estos extremos, distantes entre si una y tres cuartos milla, son tajados al mar, algo bajos, elevándose luégo el tert eno con suevidad: se fondea en esta ensenada en I $E$ hasta $I 2$ brazas de agua, cerca de tierra, y desde un riachuelo que hay en ella hasta un is. lote inmediato á la punta de Agua Blanca, es la costa sucia.

Eusenad' de Agu: Rlanca.-Digue inmedia. tamente la ensenada de Agua Blanca, formada de las dos puntas de su nombre, las cuales se separan tres y cuarto millas, formada la del Norte por la cairiu rápida de un monte alto, bas. tante notable, en figura dc mesa. Tiene un riachuelo en su medianía y un fondeadero próximo al islote que hemos nombrado poco antes, en $\mathrm{I} 2$ hasta $I 6$ brazas.

Ensenada de Machalilla. - La ensenada de Machalilla es la que se presenta seguidamente, y da el nombre como lis otra, á las dos puntas que la terminŁn á tres millas próximamente entre ellas. Esta es el puerto del pueblo de Jipijapa, cuyo río desemboca en ella, y el fondeadero se ualla elı seis brazas cerca de tierra pegado á la costa del Norte y en ro brazas lama en la costa del Sur á la parte oriental de un islote frontero á una barranca blanca. Todo este terreno es alto y con puntos bastante notables.

Islotes die Cantagallo y del Callo.-Otros dos fondeaderos se encuentran luego, el primero al Sur del islote Cantagallo en so brazas en la en. senada inmediata; y el segundo en cinco brazas cerca de un bajo, es el puerto del Callo, que lo forma un islote de este nombre y la ensenada que sigue al Norte llamada de Picoasa, en la cual hay aguada y una población. En esta última ensenada empieza á ser már bajo el terreno, y parajes en la orilla hasta la medianía de ella, en que vuelve á altear hasta el Calıo de San Lorenzo. Toda esta costa que hemos ciescrito, está bien provista de agua y leña, y se iundea en lama, conociéndose la demasiada nroximilad de tierra en el fondo arena: á siete millas de dicho cabo, mar en fuera, no se coge fondo con oo brazas.

Isla de la Plata.-La Isla de la Plata está ten. dida de Norte á Sur una legua, con una anchura poco menor y de una altura regular, llana en su cumbre y nás alta por la parte del Norte que por la del Sur. Este extremo tiene varios fara. llones llamados de Guatimozin, que dan el nom. bre á la punta inmediata. Vista esta isla al Norte príximamente á seis $\dot{u}$ ocho leguas de ella, se pre "enta dividida en tres trozos, de los cuales los ¿as más occiclentales son iguales, y el tercero parece islotillo. Un fondeadero no muy bueno por los ratones, se halla al Este, y of recen sus costas mucho pescado, leña y agua sólo en el invierno.

Canal por entre la costa firme y la Isla de la Platx.-El canal que forma esta isla con la tierra firme, lo limita por la parte más estrecha la punta Blanca 5 de la Canoa á una distancia de cinco leguas, en cuya medianía se encuentran de 20 á 25 brazas arena lama y arena conchuela. En su navegación debe solo no acercarse á esa punta, por una restinga şue le sale dos millas al 
Sudosste, en cuyo extremo encuentranse dos brazes de agua.

Cabo de San Lorcnzo. - - El Cabo de San Loren$z 0$, situado $\mathrm{I}^{\circ} 4^{\prime} \mathrm{xo}^{\prime \prime}$ de latitud y $\mathrm{x}^{\circ} 2^{\prime}$ Io $^{\prime \prime}$ de longitud, es iajado al mar, de color negro con manchas rojas, $y$ tiene innediatos dos farallones, que llaman el Fraile y la Monja. Un morrito termina su extremo, el cual, visto desde el Sur á alguna distancia, parece un islote: altea bien pronto el terreno interior para formar un cerro de regular altura, desde el cual, en una elevación algo menor, continua hasta el puerto de Manta.

Este fondeadern y otros varios, se encierran en un seno que forma la costa entre el Cabo de San Lorenzo y el Cabo Pasado, los cuales demoran al Norte $32^{\circ}$ Este á 46 millas. Compréndese entre los dos cabos: primero, la ensenada de Pacocha, en donde se fondea n Io brazas arena y desemboca el río de su nombre: queda terminada por la punta de San Mateo y la de Pacocha, distantes entre sí poco más de dos millas, y esta última, más inmediata al Cabo San Lorenzo, se separa de él cuatro y media millas.

Ensemuda de San Matco.--Lat ensenada de San Mateo es la que sigue luego, y fórmala la punta nombrada de San Mateo y la de Barbasquillo á la parte opuesta, cuya abra es de una milla. Son ambas puntas algo abarrancadas: la primera con un islote de su nombre á media milla, y la segunda tiene una restinga de un cable que descubre la bajamar, y á su parte Norte se fondea en ro y ocho brazas. No ofrece agua esta ensenada.

Puntas de la Baja y la de Manta.-Corren segujdamente un mismo paralelo la punta de la Baja y al Este la de Manta, principio de su ensenada, ambas con un bajo inmediato de medio cable, y la orilla comprendida con un pequeño placer. La costa que viene bajando del Cabo de San I orenzo liasta la punta de Mańta, termina ésta, tajada á la mar con arenales á su pié. Al Norte $64^{\circ}$ Oeste de esta punta, hay un bajo de piedra que dista una y media milla, y forma con la costa cercana un pequeño canal de cinco brazas en marea llena y de cuatro en la marea baja.

Punta de Manta._- El fondeadero de Manta se halla al Norte de la punta de su nombre, á poco más de una milla de distancia. Lomo se al. canza este puerto siempre por la parte del Deste, pues que reconocen todas las embarcaciones el Cabo de San Lorenzo, se procura no disminuir de I I brazas, por motivo del bajo, hasta que se descubre en la punta de Manta una bodega situada á un lado de un morrito, el cual es un per̃asco grande que se aisla en la marea crecida, $y$ fren. te de él se fondea en siete brazas, demorando al Sur $24 y \%$ Este, un cerro bien visible en esta costa, llamado de Morte-Cristi. En tiempo de brisa se prefiere este fondeadero al del Callo.

Ensenada de Manta._-Termina la ensenada de
Manta la punta de su nombre y la de Camas, que distan cuatro $y$ media millas, $y$ en cuyo espacio se fondea también desde ${ }_{5} 5$ á siete brazas. En aquel fondo queda descubierto el islote de San Mateo, que sirve de marca para las embarcaciones grandes, y las demás no disminuyen de siete brazas por hallarse ol fondo sembrado de ratones. Todo lo interior del país inmediato es sumamente montuoso, y pobladas sus montañas de árboles espesos y corpulentos.

Monte Cristi.-Es un cerro de regular altura que se distingue entre los demás por su elevación y proximidad á la costa. Se extiende hacia el Sudoeste con un declive muy suave para terminar en un morrito, á que le han dado el nombre los naturales, de Rabo 6 Cola del Cerro, y al contrario, baja la parte opuesta con una inclinación muy sensible, y á su falda se avista el de su nomb.

de la punta de Camas sigue la costa para el Norte, más alta y abarrancada con manchones blancos, y su fondo proporciona diferentes fondeaderos.

Punta de Charapoto.-La ensenada de Fara. millo y dé Charapoto, se encuentran hasta la punta de este último nombre, la cual es regularmente alta, y freute de ella se fondea en siete brazas, encontrándose á ro millas fuera de la misma punta 35 brazas lama, cuyo fondo se conserva próximamente á la misma distancia de la costa que le sigue para el Norte, con sola la diferencia, que es á veces la lama vertosa.

Sicrra del B.ílsumo.-Por el paralelo de la punta de Charapoto da principio la sierra del Bálsamo, que es de una mediana altura, con algunos picachos notables, y se extiende hacia el Cabo Pasado, á poca distancia de la costa. Continúa ésta de una altura regular, cubierta de arboleda y con muchos manchones blancos.

Balía ds Caracas. - La bahía de Caracas, que se halla en este pedazo de costa, permitía antiguamente una segura entrada, pero ya hoy día queda enteramente ciega.

Cabo Pasado y su foudsadero.-Hállase situado él Cabo Pasado en $24^{\prime} 25^{\prime \prime}$ de latitud y $37^{\prime} 50^{\prime \prime}$ de longitud occidental, y forma para el Sur un frontón saliente de tres cuartos de legua, de una mediana altura, cuyo intermsdio lo cubren arboledas hasta la mar. Termina abarraniado el extremo del cabo, cuyr terreno va descentliendo con $\mathrm{m}$ ' cha suavidad un corto trecho. Le sale tina restinga hacia el Sursudoeste, de un cuarto de legua, y á la parte opuesía hállase su fondeadero muy cerca $a ́$ él en 20 hasta 12 brazas arena y conchuela, frente de una ensenadita con riachuelo en la costa, que inclina al Norte y Este, y pone á cubierto de los vientos generales.

Situación del Cabo ds San Francisco.-El Cabo de San Francisco, situado an $38^{\prime} 45^{\prime \prime}$ de latitud 
la de Camas, y en cuyo es. a siete brazas. o el islote de ra las embar. disminuyen de sembrado de inmediato es sus montañas gular altura ru elevación iende hacia el e para termiado el nombre Cerro, y al conina inclinación avista el de su

le la costa para con manchones liferentes fon.

nada de Farahasta la punta regularmente n siete brazas, de la misma lo se conserva cia de la costa ola la diferensa.

paralelo de la sierra del Bálura, con algue hacia el Cabo osta. Continúa ta de arboleda

e Caracas, que permitía antiro ya hoy día

Hállase situatitud y $37^{\prime} 50^{\prime \prime}$ ara el Sur un legua, de una 0 cubren arboani:ado el exdescendiendo o. Le sale tina n cuarto de lesu fondeadero razas arena $y$ a con riachuey Este, y pone sco. -El Cabo $45^{\prime \prime}$ de latitud
Norte y II' $2 \mathrm{O}^{\prime \prime}$ de longitud occidental, demora al Nordeste dal Cabo Pasado. Comprende desde ésta para el Norte un pedazo de costa de regular altura, en que se hallan las Sierras de Cuaques, y su Ensenada terminada por las puntas de Ballena, y de Pedcrnales 6 Palmar y seguidamente los $\mathrm{Al}$ tos del Tambor. Estos y la punta de Porteto limitan luego un terreno pantanoso y lleno de manglares, llamados los Cogimies, por varios brazos de mar que entran á él, á los cuales dan el nombre de ríos, y en su interior se ven algunas sierras de poca altura. Sigue últimamente la ensenada de Bunches, de terreno bajo, con un río y población de su nombre, la cual termina en el Cabo San Francisco.

Toda la costa entre los dos cabos es muy hondable, $y$ puede atracarse á ella si se exceptúa la que comprende los Cogimies, quienes hacen aplacerado su fondo hasta dos leguas próximamente de tierra, $y$ no es prudente el acercarse á ménos de 18 brazas: diez millas fuera de ellos se cogen 40 á 45 brazas lama verdosa.

Punta de la Ballena.-Desde el Cabo Pasado hasta la punta de la Ballena, que es baja y con pedruscos en su inmediación, hállase la costa cubierta de arboleda y con algunas barrancas blancas. Esta última punta, y la que sigue luégo poco distante de un islote blanco, forman la ensenada de Sama, en que desemboca su río, y no debe aproximarse á ella á ménos fondo de ocho brazas.

Punta de Pedernales. - Se halla distancia de la equinoccial dos tercios de milla al Sur; es baja, formándole asi un terreno alto que va descendiendo con suavidad: á la parte Nortr, no lejos, se encuentra el río de su nombre. L nalmente, la ensenada de Bunches sirve de fondeadero desde 12 ha: 120 brazas fondn lama, como igualmante frontero á la pista Porteto, que es algo baja y llena de arboleda: en aquella ensenada, aunque el viento que sopla desde el Mediodía hacia el Sudoeste sea casi travesía, no es peligroso por saltar en la noche al terral.

Cabo San Francisco hasta la pu::a de la Galera.-El Cabo de San Francisco y la punta de la Galera, limitan un pedazo de costa saliente, medianamente alta, cubierta toda de arboleda y con algunas piedras. Comprende hasta la punta del Plátano, el frontón del Cabo de San Fran. cisco, que corre dos leguas Norte-Sur, y se presenta como una isla visto al Norte y Oeste; y casi en su medianía entra un Estero con una braza de agua. Sigue luégo al Nordeste un trecho de cuatro millas terminado por la punta de la Galera, en el cual se halla un islote llamado e) Corcobado, á media milla de la costa, con un bajo de cerca á la parte exterior. Dos riachuelos desaguall en el Cabo, el uno á.su parte Norte, y el otro á la opuesta inmediato á una casa situa- da á la orilla de la mar, en una pequeña sinuosidad de la costa, entre el mismo Cabo y una punta con dirección al Sur, desde la cual fórmase un recodo para el Este, en que pueden surgir embarcaciones pequeñas para hacer agua y leña: dos islotes muy unidos se separan de esta última punta, media milla al Sueste. La punta de la Galera es baja y llana su cima: tiene en sus in. mediaciones dos farallones, y por fuera de ellos algunos pequeños bajos.

Fondeadero de la puita de la Galera.-La costa que hurta luégo para el Este, en que se halla una laguna salobre, una población de indios $y$ un riachuelo de agua dulce, sóln en invierno of rece un fondeadero á un cuarto de legua de la punta al Nordeste, lesde ro á cuitro brazas lama y arena al Noroeste de esta misma punta.

Desde la punta de la Galera inclina sensiblemente la costa para el Este, al principio de una altura regular, y seguidamente va descendiendo á formarla baja, de manglares, interrunıpida de muchos esteros y ríos, los cuales abrazan una gran parte de la costa al Norte incluyendo la de la Gorgona, y se internan entrelazándose para formar diferentes islas. Algunas casas se ven esparcidas en la orilla de la mar, y su fondo aplacerado permite fondear en muchas partes de ella.

Aquella punta y la de Manglares, que corren al Nordeste, comprenden primero un pedazo de $\cos ^{\prime} z$, en que la punta Ostiones es el término de la tierra alta, $y$ en medio de la muclia arboleda que la cubre, se ven varios mancliones rojos.

Punta de Atacanus.- Se hace visible en ella primeramente la punta de Atacames, que des. ciende de un monte regularmente alto, y termina 12. mar en un pequeño morro llamado de Azua. ordeste de esta punta se fondea desde seis a 2 bracas are a y cascajo, en cuyo fo do suele haber algun ratones, $y$ en la cost que le sigue al Este, liallase el rio y pohlación de Atacames.

Bajo fondo do Alucames. Un bajo fondo de ocho á $\mathrm{r}_{4}$ brazas piedra y cascnjo, se avanza en el meridiano de la misma punta dos y media husta cuatro leguas, cuy límitc conocido en par. tes de 17 á 20 arena gru sa, termina bien pronto á alcanzar mucho fondo, de suerte que al Noroeste de la punta de Atacames á ocho millas, hállase 4o brazas lama piedr al Nordeste de la misma á 14 millas, no wcuentra fondo con 5o brazas. Su extensión y dirección y su menor fondo, no está determinado, pero por el braceaje del puerto de Atacames, de que se ha hablado ya, por noticia de prácticos, parece poderse deducir que hay una canal hondable por dentro del bajo y cerca de tierra.

Siguien to la costa, há!lase después del río de Atacames, la bahía de Sur Nicolás, con algunos riachuelos, terminada al Este por la punta de su 
nombre: tiene ésta una de las manchas de que se ha heciso mención.

Un pequeño tajo que se extiende un cumplido de fragata, y revienta sólo en mareas vivas, se separa media legua al Norte exactamente de esta última punta, y alguna cosa ménos, de ctra que le sigue al Nordeste. Algunas embarcaciones han tocado en él, con la sola desgracia de suspenderles el timón. Forma con las nombradas última. mente un pequeño canal con cuatro brazas de agua.

Continua la costa á hacer visibles la punta de Bernal con mancha y la punta Gorda, á la cual siguen hasta la de Ostiones, tres ríos, el de Esmeraldas, río Verde y el de Santiago. Se puede fondear en la boca del primero en nueve brazas y en la del segundo en cuatro, pero adviértese que un bajo coge toda la extensión de estos dos ríos hasta media legua fuera de la costa, la cual con:prende el Valle de San Mateo.

Ancon de Sardinas. - La punta Ostiones, que es el principio de la costa baja, en parte anegadiza y de manglares, forma una ensenada algo profunda, poblada de indios, á la cual llaman Ancon de Sardinas, y la termina al Norte la punta de Manglares, de que está cubierta. Demoran las dos puntas al Nordeste, cuya ensenada comprendida, la interrumpen varios ríos pequeños, que despiden algunos ba jos cerca de la costa.

Punta Manglares. - La punta Manglares situada en $I^{\circ} 36^{\prime} 2 c^{\prime \prime}$ de latitud Norte y $5^{\prime}{ }^{\prime} 25^{\prime \prime}$ de longitud oriental, se presenta baja, pero en sus inmediaciones se ven unas pequeñaś alturas. Queda aislada, como también un pedazo de la costa cercana, por unos brazos de mar que se internan: algunos ríos la bañan igualmente, y parecen subdividirla en otras islas menores.

Se encuentra 60 brazas fondo á 23 millas ál Sudoeste de aquella punta, á la cual no puede acercarse, por unos bajos que se extienden de ella hasta una legua escasa á la mar.

En la dirección Nordeste corren seguidamente las puntas de Manglares y de Guascama, distantes entre sí 20 leguas. Su costa comprendida es aplacerada por los muchos ríos que desembucan en ella, extendiéndose más afuera el bajo fondo desde la primera punta nombrada hasta la Isla del Gallo, en cuyo trecho es preciso navegar con cuidado $y$ con repetidas sondas desde dos leguas á la mar. Entre las dos puntas, se hace primero visible una pequeña isla situada cerca de la costa á ig millas de la punta Mangla. res, en la cual se forma el morro de Tumaco, que es un monte no muy alio, con un pico de ái holes. A su parte exterior y muy cerca, hállase un iaràllon llamado el Quesillo, y entre ella y la costa firme, donde se encuentra la población de $\mathrm{Ta}$ maco formada de españoles $e$ indios, hay dos is las menores, de las cuiales la más meridional es la İla Viciosa. Ofrece un buen puerto al Norte del morro Tumaco, para cuya entrada, rodeada de bajos de piedra, es preciso avalizar la canal, que es á veces variable con fondo de seis á ro brazas: hállanse en él diferentes especies de provisiones, si se exceptúa de pan, que no se encuentra en toda la costa desde Guayaquil para el Norte.

Desde el morro Tumaco hasta la Isla del Ga. 1lo, que es otro objeto notable del pedazo de costa que vamos describiendo, forma la costa firme una ensenada algo profunda, llamada de Usmal, por unas pequeñas lonias cubiertas de arboleda, que se levantan cerca de la mar, sobre un terreno anegadizo y de manglares. En lo interior se ven las sicrras dc Barbacoas, que se dis. tinguen por su mayor el ración.

El rio Rosario, bastante caudaloso, desemboca en este trecho, del cual se avanza á la mar poco más dc una legta el Viudo, islote pequeño, rodeado de bajos que se extienden bastante para fuera.

Isia del Gallo.-La Isla del Gallo se separa de la costa por un pequeño estero: es de poca elevación, más elevada por la parte Norte que por la del Sur, en cuya dirección próximamente coge su mayor extensión, que es de dos millas. Su fondeadero es al Norte en ocho brazas arena, llamado puerto de Salaonda, por la pequeña ensenada que le está inm_diata, en que se halla una población á la orilla del río de su nom bre, con el cual se distingue también la punta que termina la ensenada al Norte, en la que se eleva un morro de mediana altura, cubierto de arboleda, y lo más alto de esta. costú inmediata.

Sigue luégo el terreno para el Norte, más bajo, no con tanta arboleda, $y$ en lo interior se ven algunos cerritos poco notables: lo interrum. pen diferentes rios, algunos de los cuales consi derables, $y$ su fondo aplacerado permite fondear en diferentes ; artes de la costa.

Punta de Guuscama. - La punta de Guascama, temible por los bajos que la rodean, se extiende más de una legua á la mar: es el pricipio de la costa de la Gorgona, la cual hurta mucho para el Este, y la forma un terreno bajo, lleno de manglares, entrelazado de los muchos ríos y esteros, cuyas aguas despiden varios bajos y placeres. Al Noroeste de aquella punta, á ocho y media millas de distancia, se cogen 35 bra. zas conct uela.

Isla d: la Gorgona.-La Isla de la Gorgona que da el tombre á su costa inmediata, queda situada á 2.4 millas al Norleste de la punta Guascama y i diez millas de la costa inmediata. Es de mediana altura, cubierta de árboles, y avistada al Nordeste \% Este, se presenta formando tres alturas igualmente distantes, de las cuales la mayor es la del medio, y le sigue luégo por su 
ierto al Norte rada, rodeada lizar la canal, de seis á ro species de pro. que no se en. uayaquil para

a Isla del $\mathrm{Ga}$. del pedazo de orma la costa a, llamada de s cubiertas de la mar, sobre res. En lo in. as, que se dis.

oso, desembo. ranza á la mar slote pequeño, $n$ bastante para Gallo se sepatero: es de pola parte Norte cción próximaque es de dos e en ocho bramda, por la pediata, en que se 1 río de su nommbién la punta $e$, en la que se ra, cubierto de ostá inmediata. el Norte, más in lo interior se s: lo interrum. s cuales consi. ermite fondear

de Guascama, an, se extiende 1 pricipio de la ta mucho para bajo, lleno de uchos ríos $y$ esos bajos y pla. punta, á ocho cogen 35 bra-

de la Gorgona nediata, queda e de la punta osta inmediata. árboles, y avisienta formando , de las cuales ue luego por su elevación la del Sur: su mayor extensión es de una legua escasa en la dirección de. Norte pocos grados para el Este. De esta isla se separa muy poco hacia el Nordeste un pequeño islote llamado el Flamenco, y al Sur de la misma, poco más distante, hállase la Ciorgonillat, que es una isleta ro. deada en gran parte de faralloncitos. Son muy hondables todos los alrededores de estas islas, y al Este de la mayor, ofrece el mejor fondeadero en 20 brazas de agua cerca de tierra, en donde unas playas de arena facilitan el atracar á ella para proveerse de agua de los varios arroyos qu: la bañan, como igualmente de leña y plátano, , pero sin otros auxilios que proporcionaría un zoblación que alli hubiese. A diez millas por la parte Oeste de la Gorgona no se halla fondo con 55 bracas.

Isía de Malpılo. - No será fuera de propósito incluir aquí, antes de seguir la descripción de la costa firme, las pocas noticias que se tienen de la pequeña Isla de Malpelo, cuya posición demora al Noroeste de la Gorgona. Urio de los prácticos de esta carrera, favorecido del tiempo y de una mar llana, saltó en tierra por la banda Norte, en una meseta que tiene, y subidos 30 escalones hechos á mano, encontró en la cima de él una gran laguna de agua llovediza, que estaba pocu limpia y con algunas plumas de pájaros: se aprovechó de esta agua para llenar algunas pipas, por la suma falta que tenía. A esto se reduce cuanto pueda hablarse con seguridad de Malpelo.

Costa de la Gorgona.-Volviendo de nuevo á la costa de Gorgona, diremos que el exacto conocimiento de ella, como de un gran trecho de la que corre al Sur, merece una descripeión más prolija de la que podamos dar, y á la verdad interesante, por los muchos ríos y esteros, varios de los cuales son considerables. Los placeres despedidos por estas aguas, que se creían enteramente avanzasen más á la mar, las diferentes corrientes encontradas que forman los mismos ríos, la tierra baja y de manglares, y las estaciones sujetas, $\dot{o}$ á muchas cerrazones, lluvias y turbcnadas, 6 bien de los vientos de afuera, han sido otros tantos estorbos para no tener unas descripciones exactas $y$ conformes de los que han emprendido estos reconocimientos por partes. Ciñámonos, pues, á lo: objetos notables para su navegación costanera, y se reconocerá primero en la costa de la Gorgona unos pequeños altos llamados Altos de la Tortig.x, a 18 leguas de la isla de aquel nombre, poco distante de la orilla de la mar, de donde se extienden los bajos más afuera que en el resto de la costa, exceptuada la punta de Guascama, y es á poco mís de una legua. Al Noroeste de estos altos se cogen $4 \mathrm{I}$ brazas lama y al Nordeste de los mismos 33 brazas igualmente lama, distante aquel fondo de la costa inmediata 21 millas $y$ éste 23.
Golfo de Choci.-De los altos de la Tortuga hasta la Isla de la Palma, compiéndese el golfo de Chocó, en cuya costa se hacen visibles los altos del Mallorquin, que forman un morrito en figura de pan de azúcar, antes de los cuales profundiza una ensenada con varios ríos, para contener la Isla de los Camachos, que se extiende cinco millas en circunferencia. Sigue al Norte la bahia de Sun Buenaventura, rodeada de bajo fondo, interna una legua, y una igual distancia que abraza su boca, queda terminada por la punta del Soldado al Sur, aplacerada, y por la de San Pedro al Norte, inmediata á dos islotes, cuyas puntas demoran al Noroeste á una legua de distancia. Sirve de fondeadero para las embarcaciones pequeñas cerca de la Isleta del Cascajal, situada en medio de la bahía en cuatro ó eineo brazas arena, y para las grandes en la costa del Sur en ocho ó nueve brazas lama frente de la playa del Soldado, la cual toma el nombre de la punta ya citada, que determina su extremo occidental. Forman esta bahía tierras bajas interrumpidas de algunos rios y esteros, pero en lo interior se ven montes de regular altura.

Desde la punta de San Pedro continúa la costa algo más alta, de piedra, un poco escarpada, con manchas blancas hasta la bahía de Málaga, en donde desaguan y se entrelazan varios rios. No es de tanto placer su fondo, y en su medianía se hallan los Negrillos, así llamados á dos pedruros bastante unidos, que siempre velan, y se separan poco más de dos millas de la tierra firme, para formar una canal de ocho brazas, y por fuera de ellos, á diez millas, se encuentran 35 brazas lama suelta.

Isla de Pulmux y bahíu de Mríluge:-L-La Isla de la Palma, baja y de manglares, y varios islotes al Norte, de igual formación, ocupan la boca de la bahía de Málaga, cuyo terreno es en partes algo más elevado. A la parte exterior de aquéllos, hay bajos, como igualmente al Sudoeste de la isla, pero en su paralelo, dos y media leguas á la mar, hállanse 30 brazas arena fina y arena, conchuela y cascajo.

Su mayor extensión es de media legua, y se separa de la costa inmediata, que es la punta Sur de la bahía, media milla, con fondo de cuatro á seis brazas.

Pienta de Chiramira. - La punta de Chiramira, visible por ser bastante saliente á la mar, demora al Noroeste de la Isla de la Palma.

Aquella punta y la costa comprendida hasta esta isla, la defiende un pequeño placer, y se presenta baja y de manglares, pero el terreno interior es algo más alto, de piedra y lleno de arboleda. Los ríos de San Juan, Chavica, Estebanico y Cacagual, desembocan poco al Sur de la punta nombrada, y al Norte de ella el tío Chiramira, todos los cuales se reunen á diferentes distancias 
y los dos primeros más en lo interior, esto es, á Io leguas próximamente de la costa.

Sigue ésta al Norte de la punta de Chiramira, igualmente baja y llena de manglares, con varios ríos y esteros hasta los Altos de Bando.

Son estos unos cerros bajos, algo interiores, llenos de picos, bien visibles por ser el principio de la tierra más alta, la cual forma algunas puntas de piedra, escarpadas y con arboleda. Seis leguas al Sur de ellos, se levanta cerca de la costa una altura notable.

Cabo Corricutes. - El terreno que lo forma es de bastante altura, y avistado á la parte del Sur, parece aislado con sólo un pico, como igualmente la costa inmediata, formando á alguna distancia varias islas, pcro mayores y más altas que la tierra del Cabo. Cerca de éste, á la parte Sur, hay fondeadero en Io y I 2 brazas, y suministra agua un manantial que despeña del mismo, $y$ se ve á corta distancia. Interna en esta costa la Eusena. da dcl Palmar, en que desaguan los ríos de Tarifa y del Platanal, y es de tierra baja su orilla, $y$ alto el terreno interior: la limita al Sur la punta de la Balsilla y al Norte el Cabo Corrientes, cuyos extremos distan cuatro leguas.

Altos de San Francisco Solano. - Una punta saliente, en que dan principio los altos de San Francisco Solano, de poca elevación, corre con el cabo nombrado, al Noroeste. Su costa com prendida, baja y de manglares, en que desembocan varios ríos, de los cuales el más meridional, llamado de Sandio es caudaloso, le dan el nombre de Anegadas por los muchos bancos anegadizos que la rodean.

Punta de Guarachins.-Desde esa punta saliente hállase la de Guarachine en la dirección próximamente del Noroeste. Termina en ésta la costa corrida para dar principio al Este al golfo de San Miguel, y lo forma su extremo á la mar, un terrann bajo, cubierto todo de arboleda; cerros algo bajos corren dos leguas la costa al Sur, desde donde siguen montes de más que mediana altura, de los cuales el más próximo á la orilla llaman C'crro del Sapo. Una legua y media al Norte de la punta de San Francisco Solano, hállase la balía de su nombre, cuya boca es de cuatro y media millas. A ésta sigue el Pucrto Quicmado que es pequeño con varios farallones á la boca, y da el nombre á un morro muy inmediato al Norte, el cual es un punto de recalada para los buques que navegan del Sur á Panamá, para no abandonar las cercanías de la costa hasta la punta de Guarachine: en este trecho se encuentran otros tres puertos igualmente pequeños, que el que nombramos últimamente.

Pucrto de Piñas. - De ellos, el de Piñas ss el más meridional y el más capar: ofrece un fondo limpio por todas partes, no méncs que alrededor de dos islotes que resguardan la bica, al Sur de los cuales se verifica la entrada. Desagua en él el río de su nombre, y es el principio para el Norte de la tierra alta. Los dos al Norte, sólo buenos para pequeños buques, son puerto Escondido y el de Caracoles.

Golfo de Panami--La punta de Guarrchine y la de Mala, que demoran al Oeste-Sur, comprenden el gran golfo de Panamá. En él se encierra el archipiélago de las Perlas, cuyas costas muy hondables dejan con la tierra firme una canal ancha y de sondas. La entrada por la parte oriental de estas islas, es la que practican las embarcaciones que vienen del Sur, y la opuesta las que bajan del Norte. Aquélla lo limitaría la Isla de la Galera, la más meridional de las Perlas con la punta Guarachine, si no la estrechase un pequeño bajo llamado de San Fosé, temible antes por el poco fondo que le suponían, y por su posición nada exacta, á que se añadía la fuerza de las aguas del golfo de San Miguel, con dirección hacia el. Reconocido últimamente con la mayor escrupulosidad, se ha vis to que su menor fondo, de ocho brazas piedra, ocupa un muy pequeño espacio, y en sus alrededores tiene 12 , I5 hasta 20 brazas, igualmente piedra. Una línea de sonda tirada ciesde la Isla de la Galera hasta el bajo, cuyo trecho es de cinco millas poco más, manifiesta que su fondo de ocho brazas piedra cerca de aquélla va aumentando poco á poco 6 . I 5 brazas de igual calidad, y luégo de arena 6 arena y conchuela á 25 brazas en la medianía de la canal, y hasta 40 en las cercanías del bajo. A la parte orrental de éste, y poco distante, hállanse 25 y 30 brazas lama.

Golfo de San Miguel.--Siguiendo la descripción de la costa, se verá que la punta Guarachine y la punta Gorda al Norte son el principio del golfo de San Miguel, considerable por los muchos ríos que desembocan en él, entre los cuales es el más principal por su caudal y por su largo curso el río Tuyra. Compréndese en este golfo, en su costa Sur la ensenada y población de Guarachine, que sigue á un pequeño frontón formado de la punta de Flores con la de Guarachine.

Bajo de Guarachine.--Para mayor seguridad del navegante, advertimos aquí que algunos planos, aunque no el mejor y levantado últimamente, colocan un pequeño bajo al Norte próximamente de esta última punta « una milla escasa de distancia.

Punta Gorda y punta de San Lorenzo.-La punta Gorda y al Este pocos grados al Sur de ella, la de San Lorenzo, forman un frontón sa. liente, de una legua, ambos notables por ser el principio de la costa que hurta cási al Norte; aquélla para seguir la dirección del golfo de $\mathrm{Pa}$. namá, y ésta para formar una de las ensenadas del golfo de San Miguel. 
sagua en él el para el Norte s6́lo buenos Escondido y el

Guaruchine te-Sur, com En él se en. , cuyas costas firme una ca. por la parte practican las y la opuesta o limitaría la al de las Pero la estrecha. San Fosé, te - le suponian, que se añadía de San $\mathrm{Mi}$. conocido últiidad, se ha vis. brazas piedra, en sus alrede. is, igualmente ciesde la Isla echo es de cine su fondo de lla va aumenigual calidad, ela á 25 brazas a 40 en las certal de éste, y azas lama.

ido la descrippunta Guarason el princiinsiderable por en él, entre los I caudal y por ompréndese en enada y poblaá un pequeño Flores con la

yor seguridad e algunos pla. ntado últimaal Norte pró-

a una milla

Lorenzo.-La idos al Sur de in frontón sables por ser el cási al Norte; golfo de $\mathrm{Pa}$ las ensenadas
En la costa baja y en gian jarte de manglares, de que formase todo el golfo de Panamá, se distinguen las sierras de Manjue, no distantes de la orilla du la mar, en que desemboca el río de su nombre. Frente de este trecho de costa se encuentra á media legua de distancia una pequeña isla llamada Majaguci y otra á una legua con el nombre de Las Sierrus y conocida también por el Tigre. Ambas corren un mismo meridiano, y en el espacio de media legua que se separan, hay un pequeño bajo fondo. Son altas, escarpadas y cortadas á pique, lo cual y los varios pedruscos que las rodean las hacen inaccesibles áun para botes.

Islote Pelado.-Este islote queda en el paralelo del Tigre en la parte occidental, y forma con un farallón que le demora al Este-Norte, una canal de cuatro y media millas; su fondo es de I 2 brazas lama arena á medio cable del Pelado, y va disminuyendo gradualmente hasta encontrar dos brazas de la misma calidad á igual distancia del farallón, y en su medianía es de nueve brazas lama.

Al Oeste del Pelado, á una legua, hay I 5 brazas lama.

Placer que corre la costa del golfo de Panamí.Un placer de arena fina y á veces de lama, corre toda la costa desde el rín Manjué hasta Panamá, y más al Oeste con alguna diferencia, en su mayor 6 menor extensión, á la mar. La canal navécuille hasta el fondeadero de Panamá, siempre de fondo lama, va disminuyendo sensi. blemente desde su medianía hacia la costa firme, pero con graduación, y aauncia desde las ocho $\mathrm{y}$ nueve brazas su mucha proximidad al placer. Este se extiende en la punta Manglares más que en el resto de la costa, y precisa muchas veces acercarse á ella cuanto sea posible á fin de aprovechar mejor de los bordos paia montar la más septentrional de las Perlas llana. da Pacheca. Demora la punta Manglares de esta isla al Nordeste; su fondo, á cuatro millas distante de ella es de dos brazas, y de nueve igual. mente lama á dos leguas.

En toda la costa que le sigue al Oeste hasta Panamá se halla fondo de tres brazas en baja mar á una legua de distancia de tierra sin temor de bajo alguno, pues los que hay de arena en las bocas de los ríos son muy poco salientes y sólo se encuentran algunas piedras en las cercanías de Panamá Viejo y en los alrededores y bajos de la Isla Chepillo. Esta isla que demora al Noroeste de la Pacheca y al Oeste-Sur de la punta Manglares, forma un canal con la costa firme, que en bajamar tiene de dos á tres brazas de agua. Es muy frondosa, llena de matorrales y despeñaderos y su terreno peñascoso: en la parte Norte formase una pequeña cala, en cuyas inınediaciones se encuentra agua en poca cantidad, pero muy buena; fué habitada por una ranchería de negros hasta el año de $8 \mathrm{r}$.

Río Chepo.-Ell río Chepo hállase en la costa firme, frente de la isla que acabamos de describir: la punta oriental de su embocadura la forma un morrito llamado el Griego, y la de Sasino que es la opuesta, tiene una casa donde se ha puesto una guardia de sargento, porque los indios se avanzaban á las canoas que se veian precisadas á fondear por allí. Entre los infinitos ríos que abrazan toda la costa del golfo, es el de Juan Díaz, al Este de Panamá Viejo, uno de los frecuentados por las canoas: éstas entran y salen por medio de las mareas, y lo frecuentan para recoger hermosos tablones de caoba, que se cortan en un cerro redondo y bajito, que se ve allí cerca en su costa oriental.

Pananná Viejo. - Las ruinas de la antigua $\mathrm{Pa}$ namá distan una y media leguas al Este de la que ocupa hoy dia: se hallan en la inmediación de un rio y á la orilla de la mar, sobre una punta, la cual forma, con la de Paitilla al Sudoeste, un trecho de costa seguida y baja, resguardada de piedras y bajos fondos, muy cerca de tierra.

A esta última punta sigue una pequeña ensenada en que desemboca á poca distancia de aquella el río de su nombre, desde el cual le rodea una playa de arena, interrumpida sólo en la medianía de dos puntas de piedra inmediatas, llamadas de Peñas Prietas y de Negros. Demora de la punta Paitilla, al Sudoeste á una y media milla, el otro extremo de la ensenada, en que se eleva la Ciudad de Panamí, defendida de un castillo á la parte meridional y mís saliente á la mar. Rodeada ésta de diferentes piedras hasta media milla poco mis, obliga á los botes separarse esta distancia elt las mareas bajas, en que se descu. bren casi enteramente. El fondo de la ensenada nombrada queda igualmente seco en gran parte, por cuya razón, colocado el desembarcadero al Norte de la cindad, hace también preciso para saltar en ticira, ganar un pequeño trecho de mar, en canoas. Tal es la fuer. .2 lias mareas en estos parajes, que cuando llenas, no sólo permite con las lanchas acercarse al desembarcadero, sino que también se atraca sin recelo la punta del Castillo. Rodeada la ciudad en gran parte, de la mar, la respalda por la parte de tierra un peque. ño valle formado de varios cerritos, entre los cuales el mas inmediato, llamado el Alarcón. se eleva Ior toesas por madida geométrica, sobre aiquel llano. Demora éste como al Noroeste, y otro, poco más distante al Oeste, es el de Gavilán: en lo interior se hace visible el Peñon, que es un monte alto al Norte exactamente de la ciudad.

Islas de Flannenco, Naos y de Perico.-Interrumpamos por un momento la descripción de ' $x$ costa que le sigue, para hablar de su fondeadero que se halla al abrigo de las Islas de Flamenco, 
de Perico y de Naos, á las cuales se añade otra menor llamada Culcbrilia, con dos farallones de cerca á la parte Sur y Oeste, todas muy frondo. sas y las dos primeras montuosas. La Isla de Perico, que es la del medio de las tres principales, redonda y de tres cuartos de milla de bojeo, dis ta de la punta del Castillo de Panamá muy poco más de dos millas, y demora su mediania de la misma punta, al Sueste.'A la parte Norte fondean las embarcaciones á dos cables de distancia, en cinco y seis brazas fondo lama, cuyo buen tenedero las asegura de los vientos á que están descubiertas, los cuales no levantan mar por su dirección que sale de la tierra inmediata. Un bajo fondo sembrado de piedras que se descubre en las mareas bajas, unz esta isla á la de Naos, situa. da al Oeste media milla escasa; y á la Culebrilla, que se halla entre una y otra, pero más cerca de ést? y con alguna inclinación al Sur. Ocupa la Isla Flamenco una extensión casi igual ála de Perico, le la cual se separa por un pequeño canal, y su dirección es de Norte-Iiste. La de Naos, algo más pequeña, es una lengua estrecha de tierra que se extiende al Nordeste. Ambas y la Culebrilla descubren su fondo por algunas partes de su orilla en las mareas bajas, como se verá bien por el plano, y son aquellas dos, las únicas de este grupo de islas habitadas por algunas familias de pescadores, que cultivan también una pequeña porción de sis terreno. Comprén. dese, finalment., en tste misms grupo, un islote llamado de San José, que demcra al Sueste en la enfilación de los dos extremos Nordeste de Pe. rico y Flamenco, y distante casi meäia milla de está última, cerca de la cual se encuentran siete $y$ media brazas cascajo, y va disminuyendo el canal que forma, hasta tres brazas, poco distante del farallón. Queda ya sólo para advertir, que hay un pedrusco con muy poca agua á la parte oriental del Flamenco, á un cable de distancia, en cuyo espacio aumenta el fondo á seis y un cuarto brazas, y otro pedrusco igualmente anegado, al Norte v muy cerca del islote.

Islas de Saroga, Savoguilla y de Uraba.-La falta de agua en estas islas obliga á las embarcaciones, concluído el objeto de su estada en ellas, transferirse á la de Savoga, frente de su población, en donde un buen fondeadero, una pequeña playa abrigada de la mar, y unas pozas inmediatas de agua manantial, no ménos excelen: te que abundante, proporciona el concluir su aguada en muy breve tiempo. Otras dos islas menores, igualmente montuosas, pero no de tanta elevación, ocupan sus cercanías; la de Savoguilla al Nordeste una y cuarto millas por la parte más inmediata; y la de Uraba, que es la más pequeña, da su nombre á un canal de poco más de un ca. ble que forma con él extremo Sueste de Savoga. Esta isla que se extiende al Noroeste una y media millas, estrecha algo al Sur de su medianía, acercando sus dos costas opuestas á un cuarto de milla de distancia: vuelve luégo á ensanchar y forma en esa angostura dos ensenadas, la del Atillo al Norte, pequeña, y mucho mayor la del Sur, llamada de Iprocá. Entre aquella ensenada y un islote cercano á tierra, que se eleva en morro, lla. mado de Savoga, hállase la población que hemos nombrado, en medio de platanales, en el pequeno llano que se extiende desde el pié de los montes y la orilla de la mar. El fondeadero es en II y 12 brazas lama $\mathbf{a}$ un cable de tierra, y á poca mayor distancia del morro. Este tiene varios pedruscos muy inmediatos en todo el frente del Este al Sur, fuera de los cuales se encuentra luego siete brazas cascajo, $y$ el pequeño trecho que se separa de la Isla Savoga, descúbrese en las mareas bajas: su demora del Islote de San José es Sudoeste, cuyo rumbo se navega para alcan. zar este fondeadero pasando á un cable de dis. tancia poco más por fuera de ambos islotes y por fondo de II y 12 brazas lama, aumentando sólo á 16 y 17 brazas no muy distante de los dos. Todo el espacio de mar comprendido por las tres islas, es de un fondo de 12 hasta 20 l razas lama. Permite una salida segura por entre las Islas de Savoguilla y de Uraba, aproximándose á ésta para evitar un pequeño bajo, muy hondable en sus al. rededores, que se separa una milla en la direc. ción Este-Norte de su extremo septentrional, y distante tres cuartos de milla al Sudoeste de un farallón llamado de Sube la Vaca, situado al Sur y no lejos de Savoguilla: el canal que forma el bajo con la Isla de Uraba, es de 20 brazas $a$ un cable de distancia de ambos, y de 22 en su medianía. Otro pequeño bajo igualmente honda. ble por sus alrededores, se halla entre el bajo y el islote nombrado últimamente.

Cosia firme. - Retrocediendo ahora para seguir la descripción de la costa firme, se verá que des. de la punta en que se halla la ciudad de Panamá, hurta sensiblemente la costa al Este para forma con la de Guinea, que le demora al Sudoeste, una ensenada cuyo fondo se descubre en las mareas bajas, y en ella desembocan varios ríos, de los cuales el principal y más interior es el Río Gran. de. A la punta de Guinea sigue un frontón, coronado en la orilla de una pequeña restinga de una y media millas, hasta la punta de playa de Tejas: de ésta se separan poco más de una milla los islotillos de Cangame, de los cuales el mayor demora al Este-Sur, $y$ una lengua de bajo fondo descubierto en las mareas bajas, la une á la punta de Guinea. En este pedazo de costra firme se eleva el Cerro de Cabra. La punta ya nombrada de playa de Tejas y la de Chame, al Sudoeste de ella, forman una ensenada en partes montuosa con varios islotes cerca de tierra, y por estos paralelos, cuatro más distantes, que 
son la Tórtola y Tortolilla, Cocabe y el islote Melo. nes, de los cuales los dos primeros, distantes entre si media legua, están situados en la medianía próxima del arrumbamiento en que corren la Isla de Naos con la Savoga, y el último se separa de esta isla dos y media millas al Oeste, po. cos grados Norte.

Punta de Ch:zme. - La punta de Chame, res. guardada de un bajo fondo que se descubre en las mareas bajas hasta media legua á la mar, y se avanza más que en las costas inmediatas, es una lengua estrecha de tierra baja, saliente al Norde ste tres millas, no muy distante de un morrito de su nombre, desde el cual se eleva un inonte bastante alto, de color rojo.

Isla de Otoque $y$ de Bona.-Al Sueste de esa punta, y al Sudoeste de la isleta Uraba, queda situada la isla de Otoque, poco distante de otra llamada de Bona, ambas montuosas, yentre ellas algunos faralloncitos. El canal que forman estas dos islas con la de Savoga, lo interrumpen dos islotes, distantes entre sí dos millas escasas, llamado el del Sur Valladolid y el otro de Chame, el cual tiene un farallón á la punta Norte.

Golfo ds Parita. - La punta de Chame y la de Mala, que demora al Sudoeste, son los dos extremos de una ensenada algo profunda que llaman golfo de Parita, interrumpida de diferentes ríos: forma su orilla un terreno bajo con varias puntillas escarpadas y playas de arena, y lo interior algunas sierras, en las cuales se hace visible un monte llano en su cumbre. Tres islotes hállanse cerca de tierra: el de Chiru en la costa del Norte, al Este de la punta de su nombre, que es baja, llana, con arboleda y escarpada: el de Guarave 6 Cuvita en la costa opuesta; al Norte de la punta Mala, el de Iguanas: ésta tiene dos millas de circuito, y se presenta baja con mucha arboleda, rodeada de arrecifes á la parts exterior, en la cual hay dos pequeñas playas, y limpia á la opuesta: entre ella y la costa firme con playa, fórmase un canal con fondo de cinco, seis y siete brazas, en que puede fondearse: al Nordeste de esta isla, poco más de una legua, encuéntrase fondo de 34 brazas arena: r 9 y 20 brazas lama á la parte exterior de Guarave, á cinco millas escasas.

Punta Mala.-Es baja pero se eleva en lo interior á formar un terreno medianamente alto, y es fácil de reconocerse, tanto porque más baja la tierra inmediata á una y otra parte, como porque se halla no lejos de la Isla Iguanas, bien visible por su arboleda. Fórmase con otra punta al Sudoeste un frontón saliente rodeado de un pequeño arrecife, y á través de este extremo meridional, se encuentra á cuatro de distancia 30 brazas piedra.

Archipiálago de las Perlas. - El Archipiélago de las Perlas, del cual se omitió hablar antes, lo forman la Isla del Key y muchas otras más pequeñas, entre infinitos falallones. Todas ellas son muy frondosas; y después de aquella isla pueden contarse entre las principales, por su extensión, á su parte oriental, la de la Galera, San Telmo, de Puercos y de Cañas, y á la opuesta la de San José, de Pedro González, Vivero, Casaya y la de Savoga.

Isla del Rey.-Dsta isla es montuosa, y se extiende cinco y media leguas al Noroeste, en una circunferencia de poco más de 15 ; termina al Sur en un frontón de media legua con un farallón inmediato, y su punta al Este, llamada de Cocos, es la mís meridional, y tiene en sus inmediaciones, fondo de 14 brazas arena y conchuela. En la costa que mira al Norte, cerca de la Isla Viveros, se halla la población, compuesta de unas 70 casas ó cliozas, con tel nombre de Nuestra Señora del Rosario, en un altito que termina á la orilla de una ensenada, cuyo fondo descúbrese en gran parte en las mareas bajas hasta fucra de las tres islas de Tutu poco distantes al Este, y no permite acercarse á la playa con lanchas ó piraguas, áun favorecido de la marea.

Isla de la Gilera. - La Isla de la Galera, de cuyo arrumbamiento y distancia con la punta de Guarachine y con el bajo de San José, se habló ya remora al Este-Sur de la punta de Cocos, nom brada poco antes. Es algo alta, y su maycr exten. sión de media legua corre próximamente EsteOeste, formando al Norte una playa que ocupa los dos tercios de su frente, y con fondo de siete y nueve brazas arena á menos de un cable de ella; pern está rodeada de reventazón, en parte por los bajos inmediatos, y en parte por la muclia marejada que siempre reina, de modo que no permite acercarse á ninguna embarcación.

Islote Elefante y bajos inmediatos. - El Islote Elefante, uno de los extremos orientales del Archipiélago, tiene á una milla de distancia dos muy pequeños bajos con seis y ocho brazas en sus alrededores. El uno al Noroeste y el otro al Sueste.

Isla Pachleca.-Esta isla es bien interesante para la navegación de este golfo por ser la más septentrional del Archipiélago: una regular ele vación la hace bien visible, y su mayor extensión es al Noroeste rerica de una milla, formando al Este una jequeña ensenada, en donde se fondea, y en el'd se hallan algunas casas de pescadores, en medio de un platanal. Un canal de medio cable separa esta Isla de otra muy pequeña al Noroeste llamado Pachequilla, y el fondo al Norte de ambas, á tres cumplidos de lancha. es de seis, siete y ocho brazas. Las embarcaciones ya en estas cercarías son visitadas de los que pue. blan varias de estas islas, y les proveen de los diferentes frutos de que ellas abundan. En. su arrumbamiento hasta la Isla de Perico se en 
cuentran 46 brazas a dos millas de la primera, 29 y $\%$ á tres y media leguas de la mis. ma, y nueve brazas á una y media milla de la segunda.

De todas las islas del Archipiélago de Perlas, se compreiden entre las bajas, de alguna extension, la de Cañas, Viveros, Bayoneta, Gibralec _t y Chapera; á excepción de la primera todas estas son habitadas, $y$ pueden contarse en el mismo número, á más de la del Rey y de Pacheca, de que hemos hablado particularmente, la de Savo. ga y la de Casaya.

Vientos y mareas. - Los vientos en la ensenada de Panamá son los mismos que se experimentan en toda la costa: las mareas ó cursos de las aguas, cerca de las islas son más sensibles que apartados de ella, y no se puede dar regla individual del rumbo que siguen, porque es según el paraje en donde se halla la embarcación, respecto de las canales que forman aquéllas entre si, $y$ varían en unos mismos conforme los vientos que reinan. Asi, bastará quede advertido, que tienen movimiento las aguas, para que cualquiera pueda aprovecharse de este aviso. Consiguiente. mente, las embarcaciones que se hallan, después de montada la punta de Guarachine, contrares. tadas de los vientos y mareas contrarias, para internar en el golfo de Panamá suelen, principal. mente en la noche, fondear en 20 hasta 30 bra. zas lama. A este aviso se añade otro no ménos interesante al navegante, $y$ es que en toda la travesía desde Panamá á Guayaquil no se experi. mentan mares alteradas, porque aunque se le vante alguna cosa cuando hay rafagas 6 turbo nadas, es muy poco lo que se agita, y cesa luégo que se echa el viento. 


\section{ESTUDIO sobre las costumbres, y descripciones interesantes de la America del Sur, por Espinosa.}

Noticias relativas a Montevideo.

El Río de la Plata puede compararse á un mar 6 golfo: hace horizonte; y si se cuenta su boca desde Cabo San Antonio ( $\mathrm{r}$ ) hasta el de Santa María (2), será su anchura de qo leguas. La Isla de Lobos es un islote compuesto de ro. cas peladas, y sólo se le advierten algunos man. chones con arbustes, estando poblado de lobos marinos y de muchas gaviotas, zaramagullones y otras aves. Más adentro se presenta la orilla Norte del río, formada de tierras bajas cubiertas de vegetales, y á cierta distancia, cadenas de montes y colinas.

La Isla de Flores (3) se compone de morros alomados y de rocas foliosas, como la que precede: tiene en su pié mucha peñolería, donde revienta la mar. Pudiera llamarse Isla de Pájaros, según la multitud de ellos que contiene.

Descubierto el cerro de Montevideo y la punta de Carretas, se presenta la población: sus casas, de un alto, y sus alrededores, llenns de casas cubiertas de paja, de corrales y gano s. Los corrales son formados de estacas y ie estidos de cueros. Hay una fortificación de cuatro baluartes 6 castillos 6 ciudadela al Este de la ciudad, en un paraje elevado, de manera que la domina. La ciudad se sitúa en una lengua de tierra que sale al Oeste cosa de una milla. Está cercada de una muralla regular con ocho baluartes: baña el mar su circunferencin, excepto por el Este, y se halla cercada de peñascos en que se estrellan las olas.

Las murallas viejas no están muy bien conservadas, y sus fosos están llenos de yerba; de manera que al autor de estas Memorias no le parecía plaza de mucha confianza, por las pocas dimensiones de sus fosos y los barrancos y desigualdades de las cercanías, que no se distinguen bien desde la plaza. Una batería á barbeta que se halla enmascarada á la orilla del río (parece que en la parte más occidental de la lengua en

(1) I a situación de este punto se ha hallado en $3^{60} 21^{\prime}$ latitud Sur y $50^{\circ} 36^{\prime} 37^{\prime \prime}$ longitud occidental de Cádiz.

(2) Latitud $34^{\circ} 57^{\prime} 20^{\prime \prime}$ : longitud occidental de Cádiz, $48^{\circ} 36^{\prime} 40^{\prime \prime}$.

(3) Su extremo Sudoeste se halla en latitud $34^{\circ} 56^{\prime}$. Longitud occidental de Cádiz, $49^{\circ} 52^{\prime} 30^{\prime \prime}$. que se sitúa la ciudad), proporcioma mås sólida defensa contra las embarcaciones que se acerquen al puerto. En tiempo de paz tienen desmontados sus cañones; las esplanadas, durmientes, batientes y demás pertrechos, se guardan en el parque de artillería, y se tienen prontos para ponerlos en batería siempre que la ocasión lo exija.

El Capitán de fragata Liniers tenla la idea de adoptar para defensa del Río de la Plata un número de lanchas cañoneras, que bajo los fuegos de la plaza hiciese la más vigorosa oposición con. tra cualquier enemigo. Cuánto se pueda esperar de estas máquinas, lo acreditan los sucesos de ellas en Gibraltar, Argel y últimamente en el Mar Negro y en el Báltico. Fstos habitantes son muy diestros ginetes $y$ prácticos en el terreno, $y$ formarian sin duda un respetable cuerpo de caba. llería contra cualquier invasión.

Se construyó esta plaza (I) en r724. liué su primer Gobernador y poblador D. Joaquín Via . na (2). Se emplcaron los brazos de los indios $\mathrm{Ta}$. pes. Por los años de 1776 , según las noticias de D. Cosme Bueno, tendría mil familias de población; pero por las más recientes que hemos adquirido, es en el día mucho más considerable, como luégo se dlrá.

Sitúase la ciudad en la parte Nurte del Río de la Plata. Tiene su jurisdicción 40 leguas de Norte á Sur, y 40 de Este á Oeste, y su población se decía ser de 20.000 almas en toda ella; pero según el padrón circunstanciado hecho en $\mathrm{I}_{7} 8 \mathrm{I}$, parece era sólo de 8.973 españoles, 586 indios, 7 I I mulatos libres, 352 negros y I. 760 esclavos, que hacen el total de 12.382 ; incluyendo la población de Montevideo, enumerada en 4.405 españoles, $35^{\circ}$ indios, 673 negros y mulatos libres y 1.088 esclavos.

Tiene la ciudad un Gobernador militaı, un destacamento de dragones, compañías de infantería, algunos artilleros, una fragata de guerra $y$ pequeñas embarcaciones de armadilla; sus Ofi-

(I) Está en latitud $34^{\circ} 54^{\prime} 4^{\prime \prime \prime} y$ en longitud $50^{\circ} 5^{\prime}$ 45

(2) El autor del Lazarillo, D. Alonso Carrio, dice que en 1731 , con poca diferencia, dió principio Don Bruno de Zabala á su fundación con I 4 familias que se trajeron de Canarias; pero parece se equivoca, al inénos, en la fecha. 
ciales keules y Administrador de Aduana, con correspondientes guardas del registro; un curato con uni iglesia de no buena arquitectura, y un hospiciode Franciscanos, cuya iglesiu es también de pobre fábrica. Las casas de la ciudad son de "a alto, de mamposteria; las calles mal empeuradas, pero rectas de Norte a Sur y de liste á Oeste, que dividen la ciudad en vas ins cuadras: muchos solares, poca limpicza y curiosidad: en tiempo de lluvias se transitan con trabajo: hacia Ia marinn hay muchns albañales y estercoleros, donde se crian muchas y grandes ratas que infestan lns cmbarcaciones: $\mathrm{cn}$ los arrabales uo se ven sino mataderos y carnicerias; toros que huyen de los ginetes que los desgarretan, toros que mueren, y hombres ensangrentados que con la mayor agilidad los desuellan, y extienden y clavan lats pieies con estaquillas en el suclo, preparándolas asi para que las embarquen los catalanes, que hacen el principal comercio.

Muchos propietarios hacen vciir su ganado á las inmedizciones de la plaza para ahorrarse el transporte de 1's c'seros, por lo cual se ven tan repetidas matanzas.

En los alrededores de Montevideo se respira el desagradable olor alcalino de las carnes: la vista se ofende con hosarios y despojos de animales, sobre los cuales caen espesas nubes de pájaros voraces, gaviotas, gallinazas, caranchos y otros, que oscurecen el aire.

T'antos despojos animales engrasan considerablemente las tierras, y se conocen por su negrura ó color más oscuro, las que fueron antiguos mataderos.

La población de Montevideo crece de día en día con la franquicia del comercio y la concu. rrencia de buques de los puertos habilitados de la Península especialmente y de las embarcaciones catalanas (I).

Un clima análogo al de muchas provincias de España, la ocasión del transporte frecuente, $y$ la facilidad de vivir donde los alimentos de prime-

(1) Cuando estuvieron alli las corbetas DescubierTA y A TREVIDA, se contaron veinte embarcaciones, inclusos dos correos martimos y los buques de armadilla; 70 tiendas de catalanes, donde se vendia todo género de lieuzos pintados, indianas, pañuelos, lien zos, cintas, zapatos y demás manufacturas de Cataluna. Los dueños de la embarcación establecen en tierra sus tiendas, y permanecen ally los meses que necesitan, hasla qua venden su cargamento. llovan en cambio cueros al pelo, cuyo consumo es considera ble, y madera del aire, á que han dado valor en estos ultimos años, y dan un real de aquella moneda por cada par de astas. El frugal catalán no pierde el tiempo durante su forzada detención: pescan en el ro, se alimentan de pescados, venden el sobrante, cuando mo hallan compradores, secan mucha parto cuando no hall para ol rancho queños viajes a Maldonado y hacen otros pequefios comercios. Resplandecen en estas colonias, principalmente los progresos del comercio y el acierto de la sabias rirovidencias que lo animan. ra necesidad eatán casi de ivalde, atrae muchos españoles. La ma or parte de la población está dispersa por los arrabales: las casas, ya apiña. das, ya en grupos, cogen' mucha extensión. Alli los guazos 6 mestizos, ó gente de campo del pais, viven en ociosa libertad que suele parar en libertinaje, sustraidos de la vigilancia de la policía. Hay en el terreno inmediato algunas huertas, que no se cultivan con el mayor esmero.

Algunos europeos son los que se dedican á la agricultura, y es su mayor trabajo destruir las muchas yerbas que produce el vicio de la tierra. - Uno de los parajes más amenos de las inme. diaciones de Montevideo, es el río Miquelete, que descarga sus aguas casi en cl centro del puerto, á más de dos millas de la ciudad, en la parte septentrional, después de huber atravesado huertas y bosques de melocotones, donde hay algunas buenas casas de campo.

El puerto de Montevideo es una ensenada en cl lío de la Plata, de forma de herradura ú otra que se acerca; de tres millas de mayor diámetro. En la punta oriental de su boca se halla la ciudad, y en la occidental un cerro elevado en forma de pan de azúcar, que le debió dar nombre. El braceaje disminuye desde la mera línea de la entrada, considerada entre la punta más Sur de dicho cerro y la de San José del pueblo, desde tres y media brazas hasta una. El fondo es un fango ó limo muy blando, en el cual encallan las embarcaciones, sin riesgo en tiempo de pampe. ros: sólo padecerán algo en sus obras vivas los bajeles poco reforzados. Por otra parte, la naturaleza del puerto las defiende de los Estes.

El cerro al Oeste de Montevideo (I) tiene la figura de pan de azúcar, pero su altura es pequeña respecto de su base. Es la única eminen. cia que la naturaleza puso en estos parajes, y la mejor marca con que se reconoce el puerto.

Las tierras de la jurisdicción de Montevideo yacen á la orilla Norte cel Río de la Plata: se componen de dilatadas llanuras, que no guardando un perfecto nivelamiento, se inclinan unas á otras y forman senos, de donde salen venas de agua que forman arroyos y continuos prados donde se crían los más pingües pastos.

Los arroyos considerables y los ríos, vienen de las montañas vecinas: todos desaguan en la orilla Norte del Río de la Plata: sus cauces son otras tantas alamedas que cruzan esta uniforme llanura, y suministran leña y agua para las po. cas poblaciones que en ella se hallan. Las ha. ciendas de los montevidenses son grandes dehesas que se contienen por el frente por el Río de la Plata, y por el Este y Oeste por dos ríos colaterales que descargan en él: por el Norte se hallan abiertas, por cuya razón sitúan por aque-

(1) Su latitud $34^{\circ} 53^{\prime} 4^{\prime \prime}$, longitud $49^{\circ} 13^{\prime} 45^{\prime \prime}$. 
es una enscnada en de herradura ú otra de mayor diámetro. oca se halla la ciu. rro elevado en fordebió dar nombre. la mera línea de la a punta más Sur de ¿ del pueblo, desde wa. El fondo es un 2 el cual encallan las n tiempo de pampe. sus obras vivas los otra parte, la natu. le de los Estes. Iontevideo (I) tiene jero su altura es peEs la única eminen. in estos parajes, y la onoce el puerto.

cción de Montevideo Río de la Plata: se nuras, que no guarniento, se inclinan $s$, de donde salen veoyos y continuos prapingiles pastos. les y los ríos, vienen odos desaguan en la lata: sus cauces son zruzan esta uniforme y agua para las pose hallan. Las hases son grandes de. el frente por el Río Y Oeste por dos rios in el: por el Norte se zón sitúan por aque.

Ila parte las casas de los capataces y guardas. listos andan cuntinuamente á caballo, rondan el ganado y hacen los rodeos correspondientes. Se sorprenden los europeos que por la primera vez ven las inmensas caballadas y vacadas que vagan por estos llanos, que hacen horizonte en muchas partes. El caballo padre con la crin ten. dida capitanea la yeguada, lil toro se encara al pasajero a distancia: estan vacas con muchos $y$ pintados colores, con becerrillos que las acom. pañan. Al acercarse el pasajero, yeguas, toros, vacas, todos corren: temen que los vayan á en. lazar: esta insidiosa arma es el terror de los animules.

Entre Montevideo y Maldonado se liallan los rios de Solis Chico, de Mosquitos y Solis Grande. Entre ellos se cuentan algunos arroyuelos de poco nombre: todos tienen arboleda, aunque de poca magnitud. Iin los parajes bajo: se encuentran muy pequeños $y$ desiguales frag. mentos de conchas, que el mar depositaría en algún tiempo. De dos en dos leguas se ven casas de paja, que son lo que en España llaman cortijos 6 ranchos de ganaderos. Otras habitaciones pertenecen á los puestos de Dragones, donde hay pequeños destacamentos para servicio de la postz, y cuidado de la caballida que la mantiene. Estos puestos, según su importancia, están á cargo de cabo, sargento ú Oficial, con correspondiente número de tropa; la que, tan dividida $y$ ésparcida, apenas tiene de tal sino el nombre: hay destacamentiss de dos y de tres hombres: rara vez ven su compañía: cuando estuvo el autor de esta descripcion se hallaban sin vestuario: solo por el bigote se reconocian por Dragones.

Si se extiende la vista entre Montevideo y la colonia del Sacramento, se registran los ríos de Santa Lucia, San José; Jufre, Coya, Los Padres y el Sauce, que son los más considerables, vadeables en verano y aun con poca agua muchos de ellos. En sus orillas tienen asiento las siguientes poblaciones: las más son modernas, hechas por el Rey y por particulares: unas son formales, y otras, casas esparcidas, á saber: se. gún un estado hecho por la ciudad de San Felipe de Montevideo en 1787.

Casas. Persomns.

Miguelete y Pantanosos.......... $420 \quad 1.430$ Piedras y Colorado.............. $240 \quad 854$ Arroyo de las Brujas . . Canelones Grande, Chico y Cerrillos. $\quad 88 \quad 484$ Santa Lucfa Grande............ $54 \quad 252$ lil Fala . . . . . . . . . . . . . 62 . 220 Santa Lucla chico, Pintado yla Cruz. $55 \quad 200$ Arroyo de la Virgen............ 54 353 San José, Cagancha de una y otra

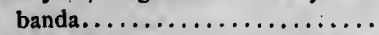

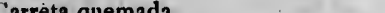

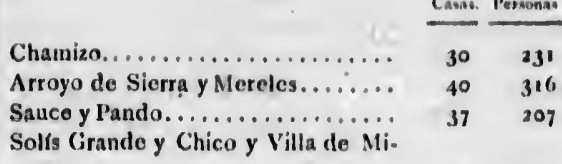

nas .................. so 37

Aumento la poblaçion desde 1781 hasta 87 , en número de 2.360 personas, y se levanta ron 529 casas más; siguiendo cada dia el au. mento por las causas que se dijeron.

En varios de los arroyos que desaguan en los de Santa Lucia y San José, se encuent: an pepitas de oro; $y$ en el paraje que llaman de las Mi. nas, según les informaron, las de plata, plomo, oro y cobre. De oro vieron en Montevideo pepi. tas cogidas en la jurisdicción. P'ero estns minas se hallan en abandono por falta de inteligentes que las trabajen.

La ocupación y conercio de los habitantes de Montevideo es la cría de ganados caballares y vacunos, en la cual tiene la mayor parte la naturaleza, pues estos útiles animales se crian en las regiones bonarienses por sí mismos, sin que el hombre ponga otra diligencia que plan. tar el hierro al ganado que paste por su hacienda. La abundancia de los pastos y la vasta extensión de las dehesas, promueven la propagación de estos animales en razón de la canti. dad de alimentos que encuentran; sin embargo de que hasta aqui matan el ganado sin distin. cion de jefes, edades, ni tiempos, lo que debe contribuir á la disminución de su número, como verdaderamente se verifica. Otro cuidado de estos provinciales es rondar las entradas y salidas de las haciendas, las matanzas, etc. Se eı uplean también en srcar el sebo. En el día se hacen ensayos para hacer extracciones de carne sulada, la que preparan muy bién, según el método de Irlanda.

Hacen del cuero de vaca cuantos utensilios y muebles necesita la vida humana. Como el cuero humedecido es una lámina flexible que recibe cualquier forma, y ésta la retiene cuando se seca, le aprovechan maravillosamente. Hacen cofres, petacas que se conocen bien en España, jaulas para cotorras, botas, cuerdas de toda es. pecie; y sobre todo, graneros en que guardan trigo y otras semillas. Esta manufactura merece particular descripción. Sacan la piel de ia vaca mediante una incisión en la región del vientre y ano, con tanta perfección, que en relle nándola de cualquier materia, parece de lejos, que vive la res. Estas singulares trojes 6 arcas las llenan de semillas y dicen que se conscrvan muy bien.

Los cueros tienen el valor de ro rs. de plata dentro de la hacienda, y concurre á su extracción gran número de embarcaciones catalanas. 
Las astas, que han tomado valor de pocos años á esta parte, valen un real de plata.

Los caballos prestan no ménos útiles servicios. Sin ellos no se manejarian unas haciendas tan dilatadas y desiertas. Los montevidenses se acostumbran tanto á su ejercicio, que ni pobres ni áun esclavos andan á pié: se ve pedir limosna á caballo y picar los bueyes que arrastran una ca. rreta. Regularmente caminan, 6 á trote vivo, 6 á gran galope. Los caballos sufren la 'atiga á un grado increible, si no se viera. Los que dieron para las excursiones á que concurría el autor, estuvieron un día en el foso sin comer, y después corrieron dos ó tres postas segridas: guardan clespués igual ayuno si no los sueltan á los pastos; aguantan igualmente la seri; los dejan con la rienda caida y permanecen como postes; tienen regularmente buena conformación, y sólo ceden á los buenos caballos de Andalucía y Chile, sin que degeneren de la excelente raza de que provienen. Se ven también caballos enteros que conservan cuantas ventajas se desean en una buena estampa. No sólo aguantan tan prolija abstinencia, sino que hacen las más extraordinarias diligencias de velocidad. Según cuentan, en aquella tierra es común andar el propio caballo $30{ }^{\circ} 40$ leguas en un día. El bajo precio en que se venden estos nobles brutos (la mejor conquista dei hombre) hace que los expongan á rudas y extraordinarias pruebas. El mejor caballo se vende, á escoger, por un peso, si está cerril; pero los enseñados á buen paso se venden res. pectivamente con estimación. Una yegua paridera vale dos reales de plata.

De las costumbres de los montevidenses, no puede ménos de alabarse su generosidad, hospitalidad y buena índole que los caracteriza. Entre la clase noble y acomodada, unos viven de sus chácaras, en que cultivan por medio de sus esclavos ei trigo y otras varias semillas de Europa. Aquel suele dar ciento por uno, y aseguran, que el dejado en los rastrojos, suple por una nueva siembra, y se coge nueva cosecha en el año venidero. Es de la mejor calidad; y si tuviera extraccion, constituiría un nuevo y extenso ramo de comercio, y remediaría muchos años las necesidades de la metrópoli. Hay tierras inmensas de pan llevar, de la mejor calidad. Pero está la navegación ahora en su infancia para que se adop. ten expeculaciones que piden unos transportes baratos. Se dedican también á la cría de sus ganados, al comercio de cueros. Gustan mucho de andar á caballo hombres y mujeres; beben mate á todas horas; hablan con cierta languidez, mayor que en otras partes; se resienten de la falta de trato, que produce cierto encogimiento. Por lo demás, son de buena disposición, tanto de potencias como de cuerpo. Los sucesivos aumentos que debe esperar en su comercio aquella po- blación, la hermosearán en su planta natural, mejorarán su policia y los habitantes adquirirán progresivos grados de ilustración. Jas pohlaciones grandes se hallan á mucha distancia.

La gente plebeya, á quien la educación no restringe las pasiones, y la civilización no enseña aquellas fórmulas de saludos y palabras que lla. man de buena crianza (mentiras permitidas), vive con cierta independencia y franqueza que les permite la favilidad de los aiimentos y la na. turaleza del país que habitan. La siguiente viva pintura, franqueada por un curopeo, excelente observador, no desagradará á nuestros lectores:

\section{Descripción dal que llaman guazo it hombre de campo.}

Un caballo, un lazo, unas bolas, una carona un lomillo, un pellón hecho de un pellejo de carnero, es todo su ajuar de campo.

Una bota de medio pié, unas espuelas de la. tón del peso de dos á tres libras, que ilaman nazarenas, un calzoncillo con flero suelto, un cal$z$ źn de tripe azul 6 colorado, abierto hasta más arriba de medio muslo, que aeje lucir el calzon. cillo, de cuya cinta está preso el cuchillo flamenco; un armador, una chaqueta, un sombrero redondo, de ala muy corta con su barbiquejo, un pañuelo de seda de color y un poncho ordinario, es la gala del más galán de los gauderios.

Su vida, siempre monótona, se reduce $\mathbf{\text { á salir }}$ al campo, siempre á caballo, y correrlo de rancho en rancho sin cuidar jamás de su manutención propia, segurn de encontrarla en la primera parte donde se apee, pues cualquiera recibe hospitalidad franca, sin el empeño de tener siquiera que agradecerla, porque siempre están surtidos los ranchos, de charque, que es una carne secada al Sol y cortada en delgadas tiras, que se asa en cuatro minutos, sin otro condimento que un poco de agí, ni otro pan que el jugo de la gordura que produce el mismio charque; $y$ este es el alimento que más usan.

No será supérfluo exponer el diálogo que acostumbran para presentarse al rancho más desconocido. Se ponen á caballo delante de la puerta de él: le dice el amo:

- Di-os lo guarde aa-mi-go, pronunciado con mucha lentitud.

$R$.- Y á Vd. lo mis-mo.

-A-pe-ese si gusta.

k.-No hay para qué.

-Va-ya, no sea son-so.

$R$-Valdreme de su fa-vor.

-Deje ahí el ca-ba-1lo, no más.

R. - Deo gra-cias (ahora va entrando)

-Ca-ba-llero sién-te-se y no más.

R. - Habrá un fuegui-to? 
en su planta natural, $s$ habitantes adquirirán racion. I as pohlacioucha distancia.

quien la educación no a civilización no enseña dos y palabras que 11 a. (mentiras permitidas), encia y franqueza que los aiimentos y la natan. La siguiente viva un curopeo, excelente dará á nuestros lec.

uth guazo í hombre bo.

nas bolas, una carona echo de un pellejo de de campo.

, unas espuelas de la. libras, que ilaman na. n fleco suelto, un caldo, abierto hasta más e deje lucir el calzonreso el cuchillo flamen. ueta, un sombrero recon su barbiquejo, un $y$ un poncho ordina. alán de los gauderios. tona, se reduce $\mathbf{a}$ salir lo, y correrlo de rancho lás de su manutención urla en la primera parte uiera recibe hospitali, de tener siquiera que pre están surtidos los es una carne secada al s tiras, que se asa en ondiments que un poco el jugo de la gordura rque; $y$ este es el ali-

oner el diálogo que urse al rancho más desIlo delante de la puer-
-Alcán-celo por su vi-da, que alí está á la vuelta.

Con estas palabras, que se pueden toma como formulario, se sientan ácomer en una banqueta de la figura de un asiento de zapatero, donde la hay, ó sobre una calavera de vaca. Se fija el asador en el suelo, que es lo más común, y puestos en rueda alrededor del asado, cada uno le tira tajos á su salvo hasta que concluyen con él, sin otra bebida que el agua. Si es verano se van detrás del rancho á la sombra $y$ se tumban: si invierno, juegan 6 cantan unas raras se. guidillas, desentonadas, que llaman de Cadena, 6 cl Perico, $6 \mathrm{Mal}$-Aubo, acompañándolo con una desacordada guitarrilla que siempre es un tiple. El talento de cantor es uno de los más seguros para ser bien recibido en cualquier parte $y$ tener comida y hospedaje. Una hora antes de ponerse el Sol se despiden de esta suerte:

-Que-de con Di os, aa-mi-go.

-Vaya con Di-os; y se va á la primera llanura: desensilla el caballo, lo monta en pelo y le da cinco ó seis carreras, que á esto llaman varearlo: vuelven á ensillarle y se van á otro ran. cho donde les hacen el mismo hospedaje. Adereza su cama con el pellón por colchón, el lomillo por cabecera $y$ el poncho por manta y sábana. Si ren aquellos dias ha carneado algunas reses $y$ ha grangeado por peonaje ó robo de cueros algunos reales, muda de estilo y rumbo, y se va á empiearlos cn aguardiente en la más inmediata pulquería, de donde no sale hasta haber acabado su caudal.

Sus pasiones favoritas son el juego de cualquiera especie que sea, carreras de caballos, corrida de patos, naipes, bochas y mujeres.

La corrida del pato merece una particular descripción: consiste, en que se junta una cuadrilla de estc.3 guazos, que todos son ginetes más allá de lo creible: uno de ellos lleva un cuero con muchas argollas, y el brazo levantado: parte como un rayo llevando I $^{\circ}$ varas de ventaja, y á una seña, él y todos corren á mata caballo, formando grita como los moros: todos persiguen al del pato y pugnan por quitarle la presa: son diestrísimas las evoluciones que éste hace para rue no lo logren, ya siguiendo una carrera recta, ya volviendo á la izquierda, á la derecha, ya rompiendo por medio de los que le siguen, hasta que alguno, ó más diestro ó más feliz, io despoja del pato, para lo que no es permitido que le cojan el brazo. En este feliz moinento todos le vitorean y le llevan entre los aplausos, alaridos y zambra, al rancho suyo, al que frecuenta, 6 bien al de la dama que pretende. Reinan todavía entre estas gentes muclios restos de la antigua gallardia es: pañola. Nuestro venturoso ginete presenta á su dama la presea: ella le convida á mate, y suele á veces premiar el valor con los maycres favores.
Lus sucesos de la corrida de patos, dan nuateria para mucha conversación: puestos en cuclillas (postura que guardan horas enteras) cueitan con $m$ is viveza que acostumbran los diversos lances de la fiesta.

La sencille $z$ de estas gentes trasciende en medio de sus pasiones $y$ vicios, $y$ es singular el modo con que enamoran. Si ven á una china, mulata, etc., ú otra mujer que les guste, pasan por junto á ella, y quitánrose $\mathfrak{\text { ll }}$ sombrero hacia atrás por cima de la cabeza (ó por costumbre, ó por no espantar el caballo: es de suponer que siempre andan á caballo) la dicen: qué linda habrá sido (lo mismo que: $q: \dot{e}$ linda cs:) y ella sólo responde: $o z$ y tira adelinte, $y$ así repiten este manejo hasta que la dama se para, y le permite más claras ex. plicaciones. No pocas veces paran estos preludios en los des6rdenes nocturnos que llaman ga teo, ya por condescendencia, y muchas reces por sorpresa $y$ timidez natural en el bello sexo.

Muchos de estos guazos ó gauderios libertinos, violan el derecho de lirspitalidad que tan francamente se les dispensa. Como todos duermen en la misma casa, pues ia estrechez de las habitaciones no permite ias separaciones que pide el buen orden y la decencia; cuando todos duermen, salen á gatas, y con el mayor silencio asal tan el lecho de las mujeres que apetecen, las que si no están de acuerdo sufren la violencia de su honestidad por evitar unos escándalos que también las violenta y exponen su crédito, $y$ usau de la defensa que permite la sorpresa y la con. fusión.

Reina no poco desórden en las costumbres do la clase pobre de nuestras Américas, por la de dormir juntas las personas de ambos sexos en la misma habitación, y lo mismo sucederá en cualquier otra parte que no se precaucionen.

Muchas veces estos ladrones de la honestidad, son sentidos por su poca destreza, y áun las mismas que están de acuerdo, son las primeras que les arañan, y todos lo burlan y denuestan.

Otras veces se ven nuestros gauderios en companía cuatro 6 cinco de ellos, y se convidan (I) á comer una pierna de vaca ó novillo: le enlazan, derriban $y$ trincan de piés y manos, y casi vivo, le sacan toda la rabadilla, le liacen algunas sajaduras hacia el lado de la carne, la medio asan, y la comen con sal, si por casualidad la llevan. Otras, mata:ı una vaca para comer el mata-hambre, que es la carne entre las costillas y pellejo. Otras, se les antojan caracues, que son las canillas $y$ huesos que tienen médula: les sa. can, descarnan bien $y$ ponen punta arriba scbre brasas, liasta que hierva dentro de la caña, y en-

(r) Noticia del libro do Carrión El Lagarillo de Ciegos, impreso en 1773. 
tonces un palito sirve para que saquen y coman aquella sabrosa sustancia.

-También estos carnívoros sibaritas hacen de las vacas un asado que merece particular descripción: la abren por el vientre, le sacan intestinos, entrañas, etc., juntan toda la gordura en el centro de la cavidad, pegan fuego á aquellas materias gras as, $y$ se forma una gran luminaria: unen las canales de la res, $y$ el fuego encerrado respira por boca y orificio: al cabo de algunas hoias, se halla la carne suficientemente asada, y estos hombres cortan de la parte que les place y áun llevan á sus casas y la sazonan con agí, que es su ordinario condimento.

En las casas de estas gentes no se ven otros muebles que charque, una cama, un fogón, asientos como banquillos de zapatero ó calaveras de vaca, un cuarto de carne colgado, algún mueble de cuero, los aderezos del caballo y apenas algún otro mueble.

\section{Noticias de varios pueblos de la provincia de} Buenos-Aires.

Maldonado es una pequeña villa situada en una llanura cubierta de pasto verde, con muchos terrenos húmedos $\mathrm{y}$ bañados. Habrá cuarenta años que se edificó con criollos de la provincia: consta de 100 casas, cubiertas de paja las más y muy pocas con teja, y las paredes de todas consisten en adobes 6 estacas. Cada casa tiene su huerto con frutales, calabazas y otras plantas trepadoras, de manera, que á distancia forman un agradable paisaje: las casas forman calles rectas, y con los huertos y corrales ocupan un área considerable.

El terreno de su jurisdicción es reducido. Se extiende por la parte del Oeste hasta Pan de Azúcar: hacia los demás rumbos apenas llega por ninguno á una legua de distancia. Le limitan por otra parte dos dehesas del Rey; una en el Rincón de José Ignacio, sobre el Cabo de Santa María, y otra que se halla desde la barra de la Laguna hasta Pan de Azúcar. Todo él se compone de dehesas que contienen pocos ganados y algunas tierras labrantías.

$\mathrm{Ha}$ sido recientemente erigida en villa con su competente número de regidores, etc. El Jefe de las armas, que actualmente es un Capitán de dragones destacado con su compañía, es su Gobernador. El vecindario elige sus alcaldes.

Tendrá 200 vecinos, la mayor parte bastante pobres. Carecen de frutos preciosos, de comercio $\mathrm{y}$ de industria.

Su poco comercio consiste en corambres, queso y manteca, que venden á las enibarcaciones y á Montevideo, y en algún trigo, que los que tienen carros propios llevan á aquella plaza, y los que no, venden á los pulqueros por los géneros que les suministran.
El mar pudiera proporcionarles ocupación y subsistencia, pues abunda de mucho y excelente pescado; y los lobos marinos les convidan en las islas desiertas de sus marts con los ricos despojos de sus pieles; pero carecen de emíarcaciones y se atienen á la pobre y ténue pesca de la caña.

Suelen ser sus regulares cosechas de ti:go, de quince por uno; pero faltan brazos y extracción áun cuando los hubiera.

Existen todavía en esta villa varios de los colonos gallegos que se trajeron para el nuevo establecimiento de la costa Patagónica, y tiene aquí su residencia un Comisario de Marina.

Otro pueblo pequeño se halla á tistancia de dos leguas al Norte de Maldunado, que de lejos presenta no ménos agradable vista. Las casas campean entre los huertos que las cercan, cubiertos siempre de verdura. Sus pocos habitantes son portugueses que desertaron de Río Grande. Su comercio, como el de Maldonado. Aquí se hallan parte de los colonos gallegos y maragatos, que como gente de país frío se creyó más propia para poblar en las altas latitudes de la costa Patagónica, y cuyas colonias se abandonaron por la esterilidad del país, que se presta poco á la vegetación del trigo y otras plantas necesarias.

La subsistencia de estas gentes parecería muy costosa, y poco correspondientes las uiilidades del establecimiento. Los colonos repartidos en varios de estos pueblos, serán 600 , á quienes el Rey pasa para su subsistencia un real plata diario.

Este pueblo, que há pocos años que se fundó, se llama Pueblo Nuevo, y tiene 200 vecinos. Su Comandante suele ser un Oficial subalterno, ó sargento, que manda un corto destacamento de tropa que aquí reside.

Se halla en los cerros de los montes más cercanos á Maldonado, en los que llaman de Verdes y el Campanero, hermosas dunas de cristales, riscos como los que los nuestros llaman de cristales de roca. También en otros, ó acaso en los mismos, hierro atraible por el imán.

La vaca es la principal riqueza de estas gen-. tes: sus quesos, leche y demás esqui .nos, proveen á sus principales necesidades, $y$ aunque pobres, distan mucho de la indigencia. Las rentas del Rey paisan de 3.000 pesos, por las alcabalas, ganado y pesca de lobos marinos.

No habiendo población alguna desde Montevideo hacia el mar, sino tales cuales chácaras de dos en dos leguas, y puestos de dragones de dos á cuatro hombres que sirven de postillones y maestros de posta; este regimiento, pues, forma un cordón de cerca de 80 á go leguas en los va. rios puestos que ocupa, desde Maldonado hasta Martín Clico; y si no pueden defender, ocupan, atalayan y exploran el vasto terreno que yace á la orilla Norte del Río de la Plata, y que se 
es ocupación y ho y excelente onvidan en las s ricos despo. embarcaciones sca de la caña. as de trigo, de y extracción

varios de los para el nuevo ónica, $y$ tiene le Marina.

á distancia de $o$, que de lejos sta. Las casas as cercan, cuocos habitantes e Río Grande. lo. Aquí se ha$s$ y maragatos, eyó más propia de la costa $\mathrm{Pa}$. ddonaron por la poco á la vegeecesarias.

$\$$ parecería muy las u'ilidades - repartidos en $o$, á quienes el un real plata

is que se fundb, oo vecinos. Su 1 subalterno, ó estacamento de

nontes más cerIman de Verdes de cristales, ó llaman de cris6 acaso en los án. a de estas gen- . squi'.nos, pro$s, y$ aunque pocia. Las rentas r las alcabalas,

desde Monteuales chácaras Je dragones de le postillones y $o$, pues, forma yuas en los va. Iddonado hasta ender, ocupan, eno que yace $a$ ata, y que se interpone con otras tierras despobladas, entre los establecimientos lejanos de los portugueses, que si hubiera abandono, intentarían, 6 la usurpación 6 el contrabando Estos vecinos, que muchas veces se han most. ado inquie:os y empren. dedores, obligan á la cautela.

Si al Este de Montevideo no se hallan pobla. ciones, no sucede así hacia el Oeste 6 Nornoroeste. En el espacio que media hasta la colonia del Sacramento, se hallan nuevas poblaciones, todas á la inmediación de algún arroyo que viene de un cordón de sierras que guarda algún paral:lismo con el Río de la Plata. Siguiendo su orilla hacia la colonia, se encuentran los pueblos llamados Canelon, Santa Lucía (que se avista en número de 40 casas reunidas, cubiertas de paja) y San José con unas 6o de la misma fábrica.

Este tiene nueve años de población, y son sus colonos castellanos viejos, maragatos y gallegos. Alrededor de estos pueblos hay sus sementeras de trigo, de que subsisten y áun se enriquecerían si hubiera mayor industria y extracción de frutos. Esta colonia está enclavada en una hacienda de Dona Gabriela Serisa, que tiene roo leguas de extensión, según dicen, $y$ parece que por cierta oposición de interés, no ies permite la propietaria que se extiendan, de cuya prohibición, en efecto, se quejaban. El arroyo inmediato, que abun. da en arboleda, les provee de la leña necesaria.

El Rosario, ténue población de olas 18 barracas, está también en la propia orilla. Aquí reside un Capitán de dragones que tiene á su cargo la principal caballada del Rey aplicada al servicio de postas y corrsos, y para los pasajeros que traen pasaporte; y está también á su mando alguna tropa y 50 peones para manejo del ganado. Esta sola caballada se componía de 6.000 caballos más que toda la caballería de España. Todos los caballos desmandados que no están en su propia dehesa, ni con el hierro correspondiente, se reputan por del Rey, y los llaman rayunos, distinguiendolos por un pico de oreja que les cortan.

Es lástima que estas colonias, situadas en un país fertilisimo, tan apto para la producción de los frutos más necesarios á la vida humana, en lugar de crecer en proporción de su antigüedad, mengüen sensiblemente. Algunos colonos las abandonan y se establecen en los rarchos de caiispo, donde se acostumbran á mantenerse de solo carne, dando de mano al cultivo de la tierra, y viviendo una vida floja y licenciosa. Domina el mal genio del país; el laborioso y trabajador gallego imita y se hace á las costumbres que ve, y su hijo suele degenerar en un gauderio.

A vista de estas poblaciones tall pequeñas, $y$ de estos ranchos, se ofrecen algunas reflexiones que nacen inmediatamente de los cbjetos, $y$ que deben instruirnos sobre los grandes medios de la felicidad y multiplicación de los hombres. Los axiomas de los mejores economistas, no pueden entenderse como suenan. Todos asientan que los hombres se multiplican en razón de los alimentos. Comparan el linaje humano al ganitdo, cuyas cabezas se multiplican en razón de la cantidad de pasto, para que mayor número de individuos se alimente; pero esto, aplicado á lo racional, no parece suceda así. Si así fuera, no habría región más poblada que la bonariense; pues ninguna abunda tanto en carnes y que apenas tiene precio la que consumirá la más numerosa familia. La caza casi se coge con la mano, y la pesca abunda, de modo que en 3uenos-Aires se tira mucha parte. Con todas estas ventajas, no se ven sino campañas desiertas, caballadas y vacadas numerosísimas á veces como ejercitos, bandadas de avestruces que de cinco ó de seis en seis corren con sus alzados cuellos por las in. mensas llanadas. Los ranchos son como una isla en un vasto mar; $y$ ya se vió de cuán poca consecuencia sean las poblaciones. Las necesidades del hombre nosólo se reducen á la del alimen. to; la del vestido igualmente le urge, y áun cuando ésta la satisfaga aquí fácilmente, pues ya se vió que un calzón de tripe dura muchos años al guazo y al hombre de campo, y se añade que las botas y otros arreos les dan las pieles de yeguas, que sacan como un guante de su pié y lo aplican para botines en los suyos; hay con todo, para que el hombre se multiplique, necesidad de unit vida moral y arreglada. No es el hombre uno de aquelios séres en quien todas sus acciones se cirigen exclusivamente á la multiplicacion: si gratifica demasiado las pasiones que conducen á ella, debilita sus órganos y no se consigue el fin de la Naturaleza. Unos placeres rapturosos, una vida :aga, no fijan al homb 4 con una compañera; no toma apego ni al terrenu ni al hogar; emplea su vida en la corrupción del débil y amable sexo, cuyos vicios crecen con los de los hombres que las seducen, $y$ que por tanto aborrecen una fecundidad que las embaraza; $y$ aunque en estos países la delicadeza y el punto del que dirán no ha introducido la horrorosa práctica dei aborto, y las mujeres, obedeciendo á las sagradas leyes de Naturaleza aunque sean solteras, crían sus hijos $\sin$ que las molesten, con todo, la falta de un padre de familia, de un hombre á quien la ley fije para que la sostenga; que cuide de !a prole, las hace considerar su estado como una desgracia, se abstienen de otro nuevo fruto, su prole desamparada queda sin un establecimiento y sólo constituirá un nuevo y estéril individun. ¡Oh Santas Leyes! ¡Oh Religión, cuán precisa es tu observancia, no ménos para la vida futura que para la presente!

Mientras la agricultura no se radique en esta 
leraz reyión, sus habitantes no se fijen en el suelo que cultiven, gusten de comer sus hortalizas, y no se cansen del monótono y uniforme alimento de la carne, tendrá grandes obstáculos la población, sus costumbres no se arreglarán á una vida civil y religiosa.

Siguiendo, pues, la serie de poblaciones al Oeste de Montevideo y Río de la Plata ariba, se encuentra la que llaman Colonia del Sacramen. to, en una punta frontera á las Islas de San Gabriel. Los portugueses ocuparon furtivamente (I) el sitio en tiempo del Regente de Portugal el lnfante D. Pedro. El Gobernador de Buenos-Aires les desalojó con algunas tropas españolas y 3.000 indios guaranis, entre infantes y caballos, que bajaron de las misiones jesuitas; y tomó la plaza, ya correspondientemente fortificada por los por. tugueses, con pérdida de 200 de los sitiados, y de los sitiadores, con la de seis españoles y 30 in. dios, además de otros varios heridos por el valor con que se expusieron. Los portugueses entablaron después negociación, y pidieron un lugar de asilo en el Río de la Plata para refugiarse en caso de temporales ó de piratas; y se les concedió esta colonia, sin atender á las consecuencias, pero con las condiciones de que la propiedad del puerto fuese sólo de la Coron 1 de Castilla; que sólo se permitiesen catorce familias portuguesas: que las casas fuesen de madera cubiertas de paja; que no se construyese fuerte alguno; que los Gobernadores de Buenos-Aires pudiesen visitar el establecimiento, como tambiên los navios que llegasen á él; y que restituyese Portugal 300.000 indios que los Paulistas habían robado de las tierras del Rey Católico. Pero los portugueses sólo verificaron el establecimiento que deseaban, $y$ en el año de r 701 , siendo el Rey de Portural garante del testamento de Carlos II, se suavizaron las anteriores condiciones.

En I704, durante la guerra de sucesión, se desalojó nuevamente á los portug jeses con lus mismos auxiliares guaranies, huyendo los lusitanos en cuatro navíos que vinieron á su socorro; pero se les volvió á ceder en 1715 łor las paces de Utrech.

En 1762 la tomó nuevamente el Gobernador D. Pedro Cevallos, y la defendió contra el socorro que les enviaban los ingleses. Volvióse otra vez á Portugal, y establecióse una especie de línea ó trinchera que llaman el Real de San Carlus, desde donde se observaba la plaza y se estorbaba

(1) Don Cosme Bueno, en su Calendario de 1 776, dió una descripción de las varias provincias del obispado do Buenos-Aires. Escribio sus noticias por do. cumentos que le remitieron los Gobernadores y Jefes de las varias provincias, etc., que entonces depeudian de las varias provincias, etc., que entonces depeudian rín en las precisas ocasiones que no se tengan otras más presentes y auténticas. el considerable contrabando que hacian. Hoy, sólo se ven las ruinas de este Real, pues el mismo Don Pedro Cevallos, primer Virey de BuenosAires, volvió á tomarla en la última guerra, y desde entonces acá, demolidas sus fortificaciones, quedó por España. Era esta plaza tan inme. diata á Buenos-Aires, que sólo distaba de aquí diez leguas un almacén de contrabandos, y se introducían géneros, no sóloá las provincias cercanas, sino á otras muy interiores. En Portugal calculaban algunos qui: hacian entrar nueve millores en dinero efectivo. Por ella salian cuantiosos caudales, tanto para emplearlos en Europa, como para pretensiones de particulares que pasaban de Lisboa á Madrid. Finalmente, padecía un grave perjuicio el Real Erario, y muy considerable el comercio de la Nación, siendo sólo al. gunos particulares los que se enriquecian.

En el sitio de la colonia forma el Río de la Plata una herradura. Una especie de gneis, compuesto de bandas $o$ vetas blancas y cenizosas, untuoso al tacto y que centcılea al eslabón, compone las rocas que bordean las orillas de este río. Se hallan en este pasaje amenos bosques de melocotones que, aunque sin cultivo, producen agradable y sazonada fruta. La población está medio arruinada: sus calles se componen en el día de pocas casas de piedra y muchos solares :'enos de yerba; de murallones desmantelados: se presentan todavía ruinas y escombros; el cam. panario y torres, como esqueleto de la que fué iglesia matriz. Pareciera que esta ciudad paga la pena de la ambición portuguesa. Hállase pobre y atrasada, ' 1 vecindario reducido, los pocos edificios que existen son los que yuedaban y libraron cuando llegó la orden de suspender su demolición. Después acá se, repolbló algo, y.el Rey, á costa de su Erario ha puesto algunos co. lonos.

Su puerto sirve en el día de escala para el correo: una sumaca mantiene la comunicación por agua con el Sacramento y Buenos-Aires, y los pasajeros que vienen por tierra de Montevideo, se embarcan en este puerto para el de Bue. nos-Aires. El Comandante de la tropa, que suele ser un Oficial de graduación del Regimiento fijo de Dragones, manda también la plaza.

A poca distancia de la colonia está la Isla de San Gabriel. Aquí tenían los portugueses sus casas de placer, y poseían huertas con varias es. pecies de frutales y de flores que recreaban la vista y el olfato; mas ya sus frutales se volvieron silvestres, y las plantas europeas que allí plantaron se confunden con las expontáneas que como propias se producen con más abundancia: los rudes cactus, muchas p'antas espinosas y matas $\mathrm{y}$ arbustos de muchas especies, confunden á los granadillos, duraznos, nogales, almendros, rosales, alelíes, manutisas y otras plantas que ador. 
acían. Hoy, sópues el mismo ey de Buenos. tima guerra, $y$ us fortificaciolaza tan inmelistaba de aquí pandos, $y$ se inovincias cerca. . En Portugal trar nueve misalian cuantiolos en Europa, -ulares que pamente, padecía b, y muy consi, siendo sólo aliquecían.

ha el Río de la de gneis, comas y cenizosas, ea al eslabón, las orillas de e amenos bossin cultivo, pro2. La población se componen en muchos solares desmantelados: ombros; el cam. o de la que fué ciudad paga la Hállase pobre :ido, los pocos quedaban y li. e suspender su bló algo, y.el sto algunos co.

escala para el comunicación uenos-Aires, y ta de Montevipara el de Bueropa, que suele Regimiento fijo laza.

está la Isla de ortugueses sus con varias es. e recreaban la les se volvieron que allí planíneas que como bundancia: los inoses y matas onfünden á los mendros, rosaintas que ador- nan los jardines. Existen las vallas de los suyos y los cimientos de sus edificios, corrales, estanques, etc. Sin embargo, el sitio es agradable, la isla parece que nace de entre las ondas, como otras que se divisan en el confluente del Paraná, y entre sus amenos bosques se esconden muchos pajarillos que recrean la vista con sus colores y el oído con su canto.

- Desde la colonia se pasa el Río de la Plata para la capital, Buenos-Aires, y aquí tiene el río ro leguas de latitud. Llegamos (dice el autor) á la ciudad al ponerse ei S.ll, y el cariz y la escena que presentaba la atmósfeı q era de las más interesantes. El astro del día aunı intaba su resplandor con la refracción terrestre, y cicondiendose grandioso detrás de la ciudad y de una gran masa de sombras y nubes, contrastaban con ellas sus brillantes rayos: diez torres descollabar sobre los demás edificios, que se confundian 'sl las sombras; presentándosenos estas vistas en le. dirección del Oeste, fondeadas ai Sur pequeñas embarcaciones, y extendida al Norte una costa baja con varias quintas y arboledas.

Aquí está la ensenada de Barragán, formada á la embocadura de un pequeño río que entra en el de la Plata á ro 6 1 2 leguas de Buenos-Aires Esueste, cuya abertura se opone directamente al curso del río, porque se vuelve al Oesnoroeste: será como de un cuarto de legua de ancho, y tiene en medio un estrecho canal que se llena cada día, y sólo permite bajeles de I2 piés de calado, fondeando los que calan más agua, en la punta de Lara, á legua y media Oeste, donde, aunque expuestos á todos los vientos, encuentran buen tenedero, pero tiene esta ensenada otras muchas incomodidades.

El que arriba á Buenos-Aires no encuentra á su desembarco ni muelle cómodo, ni barcos á propósito que le transporten á tierra. Salen muchachos con caballos ó carretas, que el poco fon. do del río permite se introduzcan mucho trecho agua adentro. A todos chor a este extraordinario desembarco, que, sin ember rgo, es el ménos inctomodo si se considera que los botecillos se enca. llan, hay que sacarlos á fuerza de brazo, y de ellos se toma tierra en hombros de marineros. Es una gran multitud la que se presenta de estos solícitos vadeadores, que arman bullas y ruido porque se les prefiera.

La ciudad de Buenos-Aires se halla situada en un llano; la baña el río por la parte Esste, y por otras direcciones se sale á hermosas campiñas cubiertas de verde, $y$ á huertas y quintas que hay en sus cercanías.

Su extensión, según el autor del Lazarillo ó Guía de caminos, es de 22 cuadras Norte-Sur y Este-Oeste: sus calles están tiradas á cordel: en las aceras se eleva el piso cerca de vara y media (lo que llaman los franceses trottoirs) para la gente de á piè, $y$ se ponen maderos perpendiculares á proporcionadas distancias, con faroles para alumbrar á los que tr'nsiten. El medio de la calle que todas son anchas, iguales y capaces, se abandona á los carros y caballerías, y á la sazón de estar allí el autor de estas Memorias no se observaba la correspondiente policía, tolerándose el echar en ellas despojos que las ensuciaban. En tiempo de lluvias hacen grandes lo. dazales, en que se atascan las grandes carretas que hay para los abastos y las caballerías, y sue. le imposibilitar el paso á la gente de á pie. La plaza es imperfecta, y sólo tiene portales la ha. cienda de Cabildo, en la que están la cárcel y otras oficinas públicas.

El palacio del Virey es una especie de fortaleza rodeada de un foso profundo, á la que se entra por sus puentes levadizos. Caen también hacia esta plaza la catedral y el palacio del Obispo con otros edificios. Se halla bien abastecida de provisiones: se contaban en la insinuada ocasion 60 grandes carretas que cada una hacía oficio de una gian carnecería, ó tabla adornada de grandes cuartos de vaca, que á lo más se vendian por dos reales. Los dias magros se ver las mismas carretas cargadas de sabrosos pescados q te da el río con abundancia y profusión, como durados, sábalos, corbinas, bagres, palometas, etc. Hicha parte de esta pesca queda sobrante, y la arrojan por los arrabales. Su putrefacción perjudicaría á la salubridad, si la bondad é ímpetu de los vientos que suelen correr, no arrastraran á otra parte los pútridus miasmas. Es de esperar que el surerior gobierno de aquel Vireinato establezca en tan principal ciudad la policía que corresponde. Se conocen, á vista áun de los ménos atentos observadores, los considerables progresos que hace en comercio y población, ya por las franquicias y libertad que se han concedido á aquel, ya por la agregacion de ricas provincias al nuevo Vireinato, la creación de nuevos Tribunales y de Real Audiencia, etc., como también por la internación de efectos y correspondencias para Chile y el Perú. Se ven muchas nuevas tiendas, y se hallan los efectos de Europa en inucha abundancia, y con bastante baratura respecto de los precios que antis tenían: en los géneros más caros se consideraba que la diferencia de la plata, dos y medio por uno, era el precio más excesivo.

Gobierna en Buenos-Aires, para lo espiritual, un Obispo con su correspondiente número de Canónigos y dignidades, cuyas rentas no son tan considerables como en otras partes de América.

Los conventos contenían en 1770 , según el estado que trae el autor de las postas por Buenos- 
Aires y el Perú, ya citado, el siguiente número de religiosos:

Santo Domingo.............. 101

San Francisco................ 104

La Merced.................. 86

Recoletos Franciscanos.......... $4_{46}^{6}$

Belemitas.................... 88

Capuchinas.................. 40

Catalinas.................. 72

Huérfanas................... 99

Clérigos regulares y monjes........ 77

Presidiarios.................. 101

Cárcel..................... 68

Tiene cinco parroquias, á saber: la Catedral, San Nicolás, la Concepción, Monserrate y lă Piedad. Los más de los españoles que se hallan en la propia ciudad y no tienen empleos públicos que lo impidan, están alistados en dife: entes cuerpos de milicias para tomar las armas en caso de invasión, en compañías de caballeria de vecinos, en compañías de forasteros y de artilleros provinciales. Hay también compañías de las diversas castas que componen la poblacion, como de indios, de mestizos, de mulatos libres y de negros libres. En 1770 era el total de la población de 22.000 almas: los dos tercios españoles, y mucha parte europea, á quien convida la analogía del clima y la baratura del país.

Hay muchos esclavos negros, $y$ varias familias no tienen otra propieciad que la de sus esclavos. A éstos obliga la ley á que contribuyan á sus dueños con cierto jornal, que la humanidad de los legisladores ha moderado, y queda á beneficio suyo el exceso que ganaren. Muchos de ellos se emplean en vender agua por las calles, subidos en sus altos caballos como timbaleros; otros, en peones de albañil y en otros varios oficios mecánicos; por lo cual, las más molestas de tales artes, no encuentran sino muy pocos pro. fesores blancos, y sale bastante cara cualquier mano de obra y sin honor: son pocos los hombres libres que las ejercen, especialmente en Montevideo: gentes de castas son las que principalmente se emplean en ellas.

Carece esta ciudad y su egido de fuentes y manantiales: la lluvia es el único riego que tienen: beben muchas veces, 6 casi siempre, turbias las aguas de su río; pero los vecinos acomodados, las posan en unos grandes tinajones: otros recogen en aseados algibes las aguas llovedizas.

El traje dc la gente ciudidana es como en España en hombres y mujeres: el de la gente de campo ya se describió. Las costumbres, como las de Montevideo; pero en una gran capital autori$z$ ada con tribunales, Virey $y$ concurrencia de comerciantes, empleados y gentes acomodadas, reinan proporciona:mente mayores grados de civilización, lujo y policía.
Los bonarienses se recrean mucho en sus quintas, en donde pasan las familias con sus amigos entre fiestas y banquetes algunos dias alegres. La juventud gusta de montar en briosos caballos, y se engalanan con ponchos bordados magníficamente. No hay la desunión de la noble. za que en otras grandes capitales de América: se juntan á sus tertulias y diversiones con más frecuencia. I,as damas se presentan, como no estén de cumplimiento, rebujadas en sus raantillas, con lo cual toman hábitos que perjudican á su natural garboso talle. Es natural que la nueva situación é importancia (decía el autor) que va á tomar la ciudad, haga crecer su lujo y corrompa las costumbres, en las cuales no se nota ni el escándalo ni la disolución que en otras partes.

El temperamento de Buenos-Aires, y lo mismo el de Montevideo, es muy saludable: sus aires parecen bastante puros. El invierno empieza en Junio, y llueve con abundancia. Algunas veces caen escarchas, que algunos guardan para helados: suelen acompañar á las lluvias truenos terribles que espantan á los no acostumbrados. Las brisas, que suelen empezar antes de las doce, templan los ardores del estío. Corren vientos violentísimos que llaman pamperos, y soplan del Poniente y del Sudoeste: vienen de la cordillera, $y$ atravesando varias llanuras de 2006300 leguas, sin bosques ni montes que moderen su ímpetu, conservan toda su violencia, degeneran en verdaderos huracanes, y si corren por el Río de la Plata, no hay á veces embarcación que los resista. Dicen que en ocasiones ha quebrado á algunas los palos, áun con los masteleros calados, y que en tierra ha hecho cejar una carreta con 200 arrobas y tirada de seis bueyes.

Las casas de Buenos-Aires tienen capaces patios, y todas son de un alto: gustan de parras y limoneros en los patios; las adornan á las modas de España: los criados son esclavos, 6 bien mulatos 6 bicn negros africanos.

Buenos-Aires recibe por su río la leña del Paraníi las maderas para edificar, que son $\mathrm{mu}$. chas y exquisitas, la yerba del mate, los géneros de $r$-stilla y todos los artículos de su comercio. Por desid:1 de sus habitantes, que se descuidaron en poner plantíos inmediatos de árboles para leña y construcción, se traen estos artículos de algunas distancias del Paraná y de los montezuelos de las Conchas.

El principal artículo de su comercio es el de cueros al pelo, sebo, carne salada, harina y trigo: el primer artículo que remiten á España, y los otros á la Habana; pero el comercio de los tres últimos artículos es nuevo, y parece que hará considerables progresos, como se podrá inferir por el siguiente estado de tres años consecutivos. 
mucho en sus milias con sus algunos días ntar en briosos chos bordados on de la noble. s de América: iones con más htan, como no en sus rhantique perjudican hatural que la decía el autor) recer su lujo y - cuales no se ón que en otras

Aires, y lo misdable: sus aires no empieza en Algunas veces dan para helaias truenos teicostumbrados. tes de las doce, ren vientos vio , y soplan del de la cordillera - 2006300 le moderen su ím. , degeneran en por el Río de ción que los re quebrado á al. teleros calados, carreta con 200

tienen capaces ustan de parras ornan á las mosclavos, 6 bien

río la leña del $x$, que son muate, los géneros le su comercio. le se descuidade árboles para tos artículos de - de los monte-

mercio es el de lada, harina y siten á España comercio de los - y parece que mo se podrá in. tres años con

\begin{tabular}{|c|c|c|c|c|}
\hline Años, & $\begin{array}{l}\text { Sebo. } \\
\text { Arrotas. }\end{array}$ & $\begin{array}{l}\text { Carue salada. } \\
\text { Ctrarterolus. }\end{array}$ & $\begin{array}{l}\text { Harina. } \\
\text { Gibras. }\end{array}$ & Trigo. \\
\hline $\begin{array}{r}787 \\
\times 788 \\
\times 789\end{array}$ & $\begin{array}{l}21.770 \\
15.228 \\
36.543\end{array}$ & $\begin{array}{l}13.925 \\
10.135 \\
33.3^{27}\end{array}$ & $\begin{array}{l}6.356 \\
6.127 \\
5.086\end{array}$ & $\begin{array}{r}0 \\
1.9^{85} \\
470\end{array}$ \\
\hline
\end{tabular}

Se ve, por estas noticias el progreso que hizo en los últimos años el comercio activo del país con la extracción de los sebos y carnes saladas. Estos preciosos esquilmos quedaban en los últimos años abandonados á las aves de rapiña, á las fieras y perros cimarrones: esquilmos que deberían constituir su principal riqueza. Sin embargo, hay todavia un considerable desperdicio, pues ni los habitantes consumen las carnes de los muchos toros que matan, ni las que se extraen equivalen á las muchas cantidades de vianda que se abandonan. Los pocos Capitanes de estos comerciantes, á veces por falta de noticias y por miedo de exponer sus riquezas en un nuevo comercio que juzgan aventurado, se retraen de este tan lucroso que la Naturaleza les proporciona. Las cálidas islas del Seno Mejicano tienen un suelo donde el trigo no vegeta, donde las vacas no multiplican, pero donde crece la caña de azúcar, los algodones, etc. La Naturaleza varia las producciones de los terrenos y parece que para convidar á los hombres á unos mútuos cambios que produciendo recíprocos intereses les haga á todos felices, consigue que cada pais disfrute de las producciones de todos.

El Vireinato de Buenos-Aires, erigido de pocos años á esta parte, se extiende en su mayor longitud Norte-Sur desde los $18^{\circ}$ Sur (I) hasta el Cabo de San Antonio á la embocadura del Río de la Plata en los $36^{\circ}$ Sur; y de Oeste 6 Este se puede considerar desde los $307^{\circ}$ hasta $\operatorname{los} 322^{\circ}$ longitud Oeste desde el meridiano de París; pues se deben considerar los límites de su vasta jurisdicción, por el Este desde las fronteras del Brasil, donde terminan los terrenos que tuvieron las misiones que fueron de los jesuitas y ocupan varios y espaciosos países á las orillas del Uruguay (río que corre Nordeste-Sudoeste para entrar en el de la Plata) y que se extienden hasta cerca de la Asunción. También se sitúan sus misiones en el país central á las orillas del gran rio Paraná, que viene del Nordeste al Sudoeste, y á los $5 \varphi^{\circ}$ de longitud se inclina al Oeste para incorporarse en el vasto río del $\mathrm{Pa}$ raguay, donde en su confluencia se sitúa la ciudad de Corrientes. Muchas bárbaras naciones, poco conocidas, habitan errantes entre nuestras misiones y las fronteras portuguesas que parecen tener una dirección Sudoeste-Nordaste desde rín Negro hasta los orígenes del Paraná por

(r) Tierras adyacentes al Marafón y término del Vireinato de Santa Fé. los $20^{\circ}$. Al Poniente confina, pues, este Virejnato con las faldas orientales de la gran cordi. llera de los Andes por la parte en que se extienden desde los 35 hasta los $20^{\circ}$ (I).

"No se pretenda (añade el autor) que dé aquí unos exactos límites, pues se trata en el día de fijar los que deben separar las posesiones de España y Portugal, negocio que hace muchos años se trata y no se concluye. Por otra parte, carecemos de las noticias de los puntos por cionde pasa la línea que divide las provincias desmembradas del Vireinato del Perú, y agregadas al de Buenos-Aires; nuevo Vireinato, á cuyos límites tal vez no se habrá dado perfecta demarcación. Contentaremonos por ahora con dar noticia de las principales provincias, reservando para cuando tengamos más tiempo, oportunidad y materiales, tratar de este punto con la extension que merece."

Comprende este Vireinato, además de los países de Montevideo ya descritos, el vasto país que compone el Obispado del Tucunian, en el cual hay vastos desiertos, que les corren los in. dios Aucaes, Ituarpes 6 Pampas, Pehuenches, Puelches, Uncos y otros. Se extiende el Tucuman desde los $22^{\circ}$ hasta los $33 \mathrm{y}^{\mathrm{y}} / \mathrm{2}$ latitud Sur, pero tiene de largo desde el arroyo Quiaca, que divide esta provincia de Chiches, has ta Melinque hacia Buenos-Aires, con 370 leguas itinerarias; y de ancho tiene por donde más Igo leguas ỉs. te-Oeste.

El pais del Tucuman puede considerarse compuesto de siete provincias, donde se hallan las respectivas ciudades que les dan nombre, $i$ saber: Córdoba, residencia del Teniente de Rey; Santiago del Estero, San Miguel de Tucuman; Salta, residencia del Gobernador, con titulo de Capitán general; Jujuy y Câtamarca, todins con Cabildos, Alcaldes y Oficios correspondie.tes, y son cabezas de otras tantas provincias cou varios ranchos y pequeños pueblos.

En el día se considera la provincia de Córdoba de'23o leguas de extensión Este-Oeste y $\mathrm{r}_{40}$ Norte-Sur, poco más 6 ménos, y su población de 80. almas, entre las cuales se contaban 26.750 españoles y $\mathbf{5 2 . 0 0 0}$ de castas de mulatos, indios, negros, etc., que pueblan las ciudades de la capital, San Luis de Loyola, Mendoza, San Juan y la Rioja.

En Córdoba tione el Obispo su residencia con su correspondiente Cabildo eclesiástico, con tres dignidades y tres canbrigos.

(1) Parece sea equivocación la existencia de la laguna de Jarelles, pues segun ins reconocimientos hechos en $175^{1}$ por el Marqués de Valdelirios y Don Jorge Meneses, Comisarios de las Clortes de España y Portugal para el arreglo do limites, se reduce a nna vasta porción de terreno anegadizo, cubierto do agua una parte del afio. 
Se regula que mantiene el terreno de esta ciudad 200.00o vacas, igual número de caballares y de 6 a 7.000 mulas y más de un millón de ovejas, de que se provee el resto de la provincia y mucha parte de Santa Fé. Tiene con el Perú un comercio activo de extracción de mulas. $\mathrm{Ha}$ cia el año 1789 sería como de 12.000 en cada uno. Parece que compran gran número de Bue. nos-Aires. Adquiere considerables ganancias en el tráfico de sus carretas, con que transportan é in. ternan los efectos de Buenos-Aires al Perú: tiene las más distinguidas familias y caballeros del Tucuman, buenos edificios, curato en una capilla de la Catedral, servido por dos curas con cuatro anexos, y en la provincia se cuentan $\mathrm{r} 2$ de $\mathrm{mu}$ cha extensión. La gente pobre se aprovecha de las lanas, de que teje mantas, bayetas, ponchos, pellones y jergas, que cambian por lienzos, cintas, tripes y paños ordinarios; y también fabrican algunos curtidos. A distancia de 22 á 24 leguas de Mendoza se halla la famosa mina de Uspalata en la cordillera, de muy rica plata, que por varias diticultades locales y rigidez del sitio frío y nevado, no se beneficia: se liallan también minas de cobre, oro y plata, plomn etc., y en uno de sus montes mana alquitrán con grande abun. dancia. El terreno es llano, de buenos pastos; pero carece de madera: otra parte de él es montuoso y continua á unirse á la cordillera. Se cultiva trigo, raiz, habichuelas $y$ otras semillas; y hay varios ríos, que se nombrall desde uno hasta cinco, los cuales nacen y mueren en la mis ma provincia, desapareciendo sus aguas en medio de las arenas.

La ciudad de Santiago del Estero, se halla, según las noticias de D. Cosme Bueno, en $28^{\circ}$ ro latitud Sur y en $312^{\circ} 20^{\prime}$ de longitud, fundada en las inmediaciones de un lago ó estero que forma el Río Dulce, en un sitio arenoso. Su población era en 1789 de 32.500 alnıas, á saber: 18.000 españoles, 8.000 mestizos, 4.500 indios, $x .000$ negros y r.00o mulatos. Tiene una parroquia $y$ tres conventos, de Santo Domingo, San Francisco y la Merced, y un colegio que fué de los Jesuitas. Comprende su jurisdicción seis curatos, cada uno con varias capillas.

San Miguel del Tucuman se halla en latitud $27^{\circ}$ Io y en $313^{\circ} 4^{8^{\prime}}$ de longitud en un campo ameno, pero escaso de agua, que nola tiene sino de pozos y en una acequia de un río que corre á una legua de distancia. Tiene una parroquia, dos conventos de Mercenarios y Franciscanos y otro de los ex-Jesuitas, $y$ tres curatos en su jurisdicción. Su población en 1789 era de 5.800 españoles, 7.20I mestizos, 6.508 indios, 600 negros, 2.700 mulatos y 22.809 de total.

La ciudad de Salta se halla en $24^{\circ}+5^{\prime}$ de latitud y en $3 \mathrm{II}^{\circ} 5^{8^{\prime}}$ de longitud, extendiéndose su provincia en áyuella época á crecido número de leguas (que no determino el autor por falta de documentos:) habitada por 22.389 almas; á sa. ber: 5.386 españoles, 4.436 mestizos, 7.620 indios, 2.640 negros y 2.3 ro mulatos.

En esta ciudad asiste el Gobernador de toda la provincia, pues el 'Teniente de Rey se halla en Córdoba. Tiene dos parroquias, conventos de San Francisco y la Merced, y otro que fué de los Jesuitas: dos curatos con varias capillas en la provincia; y al Poniente de ella, los valles nombrados de San Carlos y Chalchaqui, fértiles en vinos $y$ otros frutos. Se halla esta ciudad en te. rreno húmedo y pantanoso, en un valle de cinco leguas más ó ménos largo, y media de ancho: abunda sn trigo y pastos, con fácil riego. La residencia aquí del Gobernador es principalmente por estar á la vista de los indios del Chaco. Por Febrero se abre una gran feria de mulas y dura todo Marzo: algunos años se juntaban hasta 50.00o, se repartían por todo el Perú, y la mayor parte, 6 muchas por mano de los Corregido. res en sus respectivos repartimientos.

L.a. ciudad de Jujuy está vecina á las fron. teras del Perú, en una quebrada de más de $3^{0}$ leguas de largo, situada en latitud $23^{\circ} 18^{\prime}$ y en

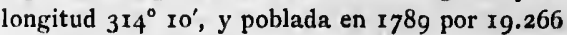
personas: españoles 923 , mestizos 3.500 , indios 13.570, negros 505 y mulatos 768 . Tiene Cajas Reales, parroquia con cinco capillas en las inme. diaciones de la ciudad, y conventos de San Francisco, Merced y ex-Jesuitas. Pertenecen á su jurisdicción tres curatos con cinco capillas: en el curato de Cochinoca y Canvirido, fabrican los indios buena pólvora $y$ se encuentran minas de oro. El principal comercio de Jujuy es la cría de ganados, con que proveen de carne y sebo las riberas del Potosí. También se aprovechan de sus potreros para criar y engordar las mulas que se atrasan para la gran feria de Salta. Rodea á esta ciudad un caudaloso río que se hace de dos arroyos grandes.

La ciudad de San Fernando del Valle de Catamarca se halla en $28^{\circ} 12^{\prime}$ latitud Sur y $3 \mathrm{II}^{\circ} \mathrm{de}$ longitud. Tiene convento de San Francisco, hospicio de la Merced y un curato á que pertenecen ocho capillas y dos pueblos de indios, y tres en la provincia con varias capillas. Contenía 20.390 almas: españoles 5.900 , mestizos 4.900 , indios 6ro, negros 834 y mulatos 8. I46. Al Oeste del. valle hay un cerro llamado. Ambato, en el que se oye gran ruído y causa grandes extremecimientos. A la parte Oeste de la ciudad, corre una serranía Norte-Sur, en cuyas faldas hay por muchas leguas haciendas de sembradíos y pastos para ganados, principalmente mulares. Hacia el Norreste, siguiendo la serranía del cerro de Am. bat j, se halla el de Aconguija, cubierto de nieve, que domina á todos. Esta provincia, como las demás del Tucuman, es pobre; y así, corriendo 
poca 6 ninguna moneda, se reciben los efectos reales en artículos de la tierra, como algodón, telas, agi, aguardiente y trigo.

Los bárbaros que bordan estas provincias, $y$ que suelen hacer frecuentes incursiones cn ellas, obligan á mantener tropas y presidios y á que se arme una parte de sus habitantes; por lo que no se puebla como corresponde á su suelo, fertilidad y bondad de temperamento. Los presidios que contienen á los barlazos que la amenazan conti. nuamente y que se situan en los pasos más expuestos á sus excursiones, son el del río Negro, el de Ledesma, Santa Bárbara, el Piquete, San Fernando en el río del Valle, otro Piquete, el Tunillar, San Luis de Ios Pitos, la Estancia del Rey, Fuerte de Valbuena y San Esteban de Miraflores; $y$ hacia Córdoba, el fuerte del Sauce y el del Tio, para contener á los Pampas; aunque hacía algunos años que con este freno y la vigilancia que había, no hacian excursiones. Los indios convertidos y los que reduzcan los celosos misioneros, servirán de ménos costosa barrera. El temperamento de este país es general. mente caliente, y se observa la anomalía que, al paso que se acerca á la Zona T'orrida, se refrige. ra, porque adquieren mayor elevación las montañas que le bordan; al paso que. se acercan á la gran cordillera: las estaciones son arregladas. La tierra, pingue y esponjosa en común hasta cierta profundidad, produce cualesquiera semillas y abunda en copiosos frutos. Crían buenos vinos en Mendoza, que tienen reputación. Pudiera man. tener cuatro millones de habitantes. Se crían buenas maderas, de que hacen comercio, conduciéndolas reducidas á tablas, en carretas, de San Miguel, que es donde más abunda, á Salta, Santa Fé y Buenos-Aires, siendo cedro, y tamblén proveen de madera lo ribera del Potosí para las má. quinas de las haciendas de beneficio. Un eje del fortísimo Quiebra-hachas, suele valer 1.800 á 2.000 pesos. Abundan también las preciosas maderas de guaya, bojes, laureles, pinos, nogales y palmas muy altas. Se coge miel de I2 especies de abejas, sin otro trabajo que cogerla: unas fabrican sus panales en los troncos de los árboles, otras debajo de la tierra: todas las mieles tienen distintos sabores, $y$ aunque ni la industria del hombre las sujeta ni las domestica, parece que ellas le convidan con sus esquilmos, pues no defienden sus casas con rigor. Se halla también grana silvestre y añil, seda de gusano y de algunas especies de araña, y otros preciosos frutos que enriquecerían cualquier país, cuyos habitantes no se contentaran con el monótono alimento de la vaca, como los naturales de Buenos-Aires. El desperdicio de aguas forma en muchas partes atolladeros, en que se atascan los ganados que transmigran a la feria de Salta. Se dividen las tierras en vastas haciendas, mal 6 no cultivadas, y los habitantes de los pequeños pueblos y cam pañas no conocen otro regalo que carne, yerba del Paraguay, tabaco, azúcar y aguardiente; pero si no el primero, los demás no los gastan tan comunmen $e$. Crianse tigres, leones pequenoos, puercos, .enados, antas, quirquinches, especies de armadillos, liebres vizcachas y usos hormigueros. Sus ríos abundan de peces, como dorados, sábalos, bagres, dentudos y bogas, y excepto dos, todos se pierden 6 quedan en el Tu. cuman, después de haber corrido, unos muchas, otros pocas leguas, en que desaparecen, 6 fil trándose por las tierras 6 formando lagunas. Los principales ríos son el Salado, que recibe varios nombres; el del Estero, que va á formar cerca de Santa Fé una laguna de 40 leguas de circunferencia, que llaman Mar chiquito, y que en otro tiempo entraba en el Paraná, hasta haber ocurrido una revolución física; el Jujuy, que pasa por la ciudad de este nombre; el río Dulce, que va por San Miguel y Santiago, y el llamado río Cuarto, que baña los términos meridionales del Tucuman, corriendo del Oeste al Este, y termina también en laguna.

Varios apéndices de la gran cordillera internan en este país y forman serranías al Oeste de èl, y cadenas de montañas que diversifican el suelo y varian las producciones, que no tuviera todo el país si Pampa fuera nivelada 6 llanos como lo son hacia el Este y hacia Buenos-Aires. Críanse, pues, en estos montes varios mineralcs de plata, que por temor á los indios del Chaco se abandonan, como en el ya nombrado cerro de Aconguija. También los hay en el de Pulares, junto al Valle de Calchaqui, $y$ en el de Acay; $y$ de oro en las fronteras de Atacama, en Incahuais y Olazos, en el cerro de la Puna, jurisdicción de Jujuy, en la jurisdicción de Córdoba, $y$ en el cerro de Famatina, jurisdicción de la Rioja pero la falta de caudales, el genio de los habitantes y su ignorancia en el beneficio, harán po. cos progresos en la minería. El comercio que principalmente prevalece en el Tucuman es el de las mulas, que conducen de Buenos Aires, Cór doba y Santa Fé, compradas á tres 6 cuatro pesos: pasan su invernada en la jurisdicción de Salta para que engorden y se fortalezcan, y se ven. den alli millares de ellas á siete ú ocho pesos, cu. yos compradores las internan al Perú, vendiéndolas por el año de $\mathrm{I}_{7} 89$ á I4 pesos; pero era de creer, según el autor, que hubieran subido ya hasta 20.

La provincia del Paraguay tiene 280 leguas de largo y 240 de ancho, formando gran parte de su población las misiones jesuiticas. Corren en ella grandísimos ríos: por la parte del Este el Uruguay, por el Centro el Paraná, y por el Oeste el Paraguay, que naciendo de la gran laguna de Jareyes, según las cartas de Mr. d'Al1- 
ville, regenera en el Río de la Plata. El Paraná entra en el Puraguay, donde está la ciudad de Corrientes, y el Uruguay, donde ya empieza á llamarse Río de la Plata. Otros varios mayores que el Tajo, corren según lo ancho de la provincia y engrosaı1 á los expresados; todos los cuales lertilizan necesariamente estas provincias (I). Se regula su población de 96.000 almas, europeos los 2.500 y el resto de indios: $y$ algunos negros se hallan en las ciudades de San Ignacio, Espíritu-Santo, Concepción, San Pedro Guarepoy, el Rosario, Nuestra Señora de Nemboy. Trece pueblos civilizados e igual número de misiones estuvieron á cargo de los Jesuitas. Eran 30 lus pueblos de indios Huaranis: ${ }_{1} 3$ del Obispado de la Asunción, y los 17 de Bucnos-Aires. En 177 I mando $S$. M., que sin variar la jurisdicción espiritual, se hiciese provincia con un Gobernador y tres Tenientes para otros tantos partidos. El del"primero comprende los seis pueblos de San Irancisco Javier, Santo Angel, San Lorenzo, San Luis, San Nicolás y San Miguel, lugar de su residencia. El segundo partido comprende los cinco puebios de Nuestra Señora de la Fé, Santa Rosa, San Cosme, Santiago y San Ignacio Gazu, con residencia en uno de los dos últimos. $\mathrm{Y}$ el tercero otros cuatro; Yapelles, La Cruz, Santo Tomé y San Borja, con residencia en el primero. lil Gobernador principal debía mandar próximamente 15 pueblos, que se deben consirle. rar como un cuarto partido, y se nombran: la Candelaria, Itapua, Trinidad, Jesús, El Corpus, San Ignacio Miní, Loreto, Santa Ana, San José, San Carlos, Santos Apóstoles, Santos Mártires, Santa Maria la Mayor, San Juan Bautista y la Concepción, con residencia en la Candelaria.

Tamibién mandó S. M. se construyese para seguridad de estas colonias un fuerte para observar y contener á los portugueses, que en algunas ocasiones entraban de mano armada á robar in. dios para sus labores. En tiempo de los Jesuitas tenía cada pueblo dos curas de aquella religión, á quienes se acudía con sínodo dẹl ramo de tributos, el que pagaban los indios desde r 666 á razón de peso por cabeza. Después de su expulsión se dieron dichos curatos á los religiosos de San Francisco, Santo Domingo y la Merced.

Son estos indios industriosos y aprenden con facilidad cuantas artes liberales y mecánicas les enseñan: música, tscul ura, estatuaria, la herrería, etc.; tejen finas telas de algodón y las tiñen

(1) Segúa el cosmógrafo D. Cosme Bueno, el terreno de las misiones de que se trata empieza desde el espacio que baña el Uruguay desde los $26^{\circ}$, ca. minando 200 leguas hasta entrar en el Paraná, cerca de Buenos Aires en los $32^{\circ}$ latitud Sur. Para mayor claridad, se entenderá que las misiones entre el Uruguay y el Paraná tieıen el nombre general de, Guara. guies. de los mís finos colores; y lienzos que exceden á la más rica holanda y áun á la seda.

Hay en la provincia considerable cantidud de ganado mayor y menor, habiendose encontrado al extranamiento de los Jesuitas 769.859 cabezas del vacuno, 81.078 caballares, 13.905 mulares, 7.493 burros, 596 cabras y 221.537 lanares; $y$ hay además muchos ganados cerriles en los pai. ses orillas del Uruguay.

La práctica que la piedad de nuestros Misio. neros sigue en denominar los pueblos, produce no poca confusión en la Gcografía, pues aunque pudiera bastar un nombre de Santo, agregado á un apelativo ó patronímico, sucede con frecuen. cia que los geógrafos omiten el segundo, y se da un mismo nombre á pueblos diversos y muy distantes: el de San 1 gnacio se repite tanto en las misiones jesuíticas, que cuesta trabajo hallarlos en las cartas sin equivocar su representación.

También comprenden muchos las misiones del Paraguay, que tenían los mismos Jesuitas entre los indios Chiquitos en un llano y vasto país del Obispado de Santa Cruz de la Sierra, de que se-liablará después.

La ciudad de la Asunción del Paraguay, situada en las orillas del río de su apellido, se puede considerar como la principal en el vasto país que se extiende desde las fronteras portu. guesas del Brasil, de la capitania de San Vicente, y hasta las faldas de Santa Cruz de la Sie. rra. Es residencia de un Obispo con su corres. pondiente cabildo, cuyas parroquias estaban al cuidado de los Padres de San Francisco.

La población de su capital (síguese tratando de hacia el año 1789 ), parece era de $5.25^{\circ}$ personas, y la de la provincia de $48 \cdot+56$ : indios criollos, 4.459; metayos, 27.977; negros, 5.310; y mulatos, 10.7 10 .

Abundan las montanas de estas regiones, de excelentes maderas, que sirven para diversos usos: los cedros son de grandísimo tamaño; y exquisito para papeleras y otros adornos curiosos el urunderay, hallándose también otras que llevan por ríos á Buenos-Aires. Entre las ricas producciones de este país, hay una planta parásita, tal vez especie de la familia de los áloes, agauses, bromelias, etc., que da unas excelentes hebras, sin otro beneficio que echarlas en agua á que se pudran, y la emplean en calafatear pequeños barcos, coser zapatos y cuanto exija hilo fuerte: una hebra de cuatro líneas de circunferencia ( 96 por 100 del pié de Castilla), y dos varas de largo, sostuvo, sin romperse, I 23 libras, y faltó á las 124 ; resistencia que se supone superior á la del mejor cáñamo.

El principal comercio de esta provincia es el de la yerba del Paraguay, que tiene muy gran consumo en todo el Vireinato y en el Reino de Chile, computándose el del primero en 68.000 
giones, de a diversos taño; y excuriosos as que lie. ricas proparásita, ;, agauses, hebras, sin lue se puios barcos, e: una he${ }^{6} 6$ por 100 go, sostuis I24; red del mencia es el muy gran Reino de en 68.000 arrobas, 86.000 el del segundo, y 22.000 la misma provincia. Sirve para infusión con el teiforme. que se usa tanto en la América meridional con el nombre de Mate. En el Reino del Perú disminuyó mucho el grande consumo de ella, al paso que se introdujo el muy considerable de café y choco. late. Este ramo producía á la Real Hacienda 24.000 pesos al año.

Uno de los principales productos de estos paises, es el tabaco, que se regula en 58.528 arrobas de cosecha anual: y también se coge azúcar.

Compréndese en este Vireinato la provincia de los indios Chiquitos, que se extiende desde las orillas occidentales del Paraguay hasta las faldas de Santa Cruz de la Sierra (r); esto es, hasta las orillas del Ginapay, que va Norte-Sur á des. cargar en el rio de las Amazonas (2). Al Sur se limita el país de los Chiquitos, y de otras nacio. nes que se comprenden bajo esta denominación. por el rio navegable el Picolmayo, que viene en dirección, cuando esta región atraviesa Noroeste-Sueste. La extensión de este vasto terreno es en su mayor longitud como 200 leguas Norte-Sur, y roo de Este-Oeste.

Habitan este terreno varias naciones indias, que se confunden, aunque con varios nombres, en la apelación general de Chiquitos, que les dieron los primeros descubridores al ver lo bajas de las puertas de sus chozas, por lo que les juzgaron de muy pequeña estatura. Al tiempo de su cunquista espiritual se les denominó piococas, punajicas, huarayos, anaporecas, bohococas, tubacicas, cibacas, quimomecas, yurucaricas, cucicas, tapacuracas, paunacacas, quitemocas, napecas, pizocas, tanipicas, juberecas, parisicas, jamanucas, tapuricas, tans, bazozocas, y hasta 22 naciones más, incluso los guayviros. Cada nación tiene su idioma particular, $y$ algunos difieren tanto como el griego del castellano. Están distribuídas en parcialidades 6 aillos, y hay pueblo de cinco, seis $y$ once de estas naciones. La lengua más general es la de los Chiquitos, sumamente dificultosa, pues además de otros tropiezos, tiene el de que el dialecto de los hombres es diverso del de las mujeres, $y$ les disuena tanto si no se usan con propiedad, que si los curas en sus pláticas refieren palabras de la Vírgen ó de Santas en el dialecto masculino, todo su auditorio se lo ríe.

Los pueblos reducidos son los de San Javier, el primero hacia el Norte en $I 6^{\circ}$ y $\%$, La Concepción, San Miguel, San Ignacio, Santa Ana, San Rafael, San José, San Juan, Santiago y el Santísimo Corazón. Hay todavía por reducir gran

(1) Don Cosme Bueno. Descripcion de la provincia de Santa Cruz. Almanaque de $177 \mathrm{x}$.

(2) Cartas de Mr. d'Anville. número de estas naciones bárbaras hacia el Maril. nón, Picolmayo y otros varios para jes. Los Pau. listas portugueses hnn hecho varias excursiones contra estos indios, bajando el Paraná en piraguas por el Anembi que viene de su distrito $y$ del Paraná, entrando por el Pardo ó Río Colorado, y de alli pasaban por tierra y sobre ruedas las embarcaciones al inmediato río de I'icuary, que descarga en el Paraguay en frente de los Chiqui. tos, en donde cautivaban con el ellgano y con lı fuerza inillares de indios, que llevaban á vender ́́ las haciendas portuguesas.

Todo este terreno es cálido y bajo renpecto de la cordillera, y se extienden por él muchos espesos bosques que impiden la ventilación y in hacen sombrio, refrigerándolo alguna cosa el viento Sur. Abunda en lagunas y ciénagas que forman las aguas desde Noviembre á Mayo, y ellas son de las que beben los naturales, cuyn número era de 24.00o en 1768 . Acabarian con ellos las epidemias si no fuera por la fecundidad de las mujeres, que paren cada año, y el celo de los neólitos que traen á los infieles de sus respectivas naciones. Abunda este país cn grillos, molestísimas culebras, vivoras $y$ arañas de extraordi naria magnitud, cuyos hilos, tendidos de un arbol á otro, son fuertes, que dificultan el paso á un hombre, y se ha visto un casquete fabricado de esta hilaza, que tenía mucha fortaleza y la propiedad de extenderse cuando le mojaban, y de disminuir tanto su volumen en secándose, que cabía en el puño. Hay también otra pequeña araña venenosa, roja, de una y media línea de diámetro, que hace una tela suave $y$ amarilla, que parece seda. Se cuentan entre sus animales, osos hormigueros; llo: is, la especie de mono barbudo, antas, tigres, leopardos, tuesruces $y$ especies de tortugas. Son estos indios por lo general vi. vos y de buena estatura, con que desmienten su nombre, ágiles $y$ hábiles para cuanto se les enseña. Las casas son de extructura regular, con ramadas al Sur y al Norte, y forman los pueblos con las calles derechas, de jando cuadradas y espaciosas plazas. Están bastante civilizados, tienen talleres de todos los oficios en las casas de sus curas, y conservan las artes $y$ disciplina que les dejaron sus antiguos misioneros. En lo temporal les mardan sus correspondientes vitalicios con Alcaldes y subalternos, etc.

Pertenece también á este Vireinato, por nueva disposición cuando se erigió en tal, el Obispado de Santa Cruz de la Sierra, que está en latitud Sur de $17^{\circ} 25^{\prime}$ en una dilatada campiña que se tiende por el Este, poblada de estancias y chá. caras de ganado hasta un río que llaman Girande 6 Huapay; por el Sur, 28 leguas hasta el nismo río; por el Oeste, 18 hasta el pié de la cordillera, y 24 por el Norte, también con varizs haciendas. La población de esta ciudad era en $177 \mathrm{I}$ 
de 6.000 almas con 1.500 de servicio, gente de castas. Es silla obispal con su correspondiente Cabildo, $y$ ticne un convento de la Merced; man. dando en lo temporal un Gobernador por el Rey y dos Alcaldes.

A 20 leguas de esta ciudad hay cuatro pueblos de Chiriguanos, que son auxiliares de los españoles; y aunque no han querido cristianarse, siri.eron con tidelidad en varias guerras contra los bárbaros, $y$ se nombran estos pueblos Piray, Cabeza, Abapo y Trinchera: se gobiernan por ius Capitanes y ponen entre todos 500 hombres cie flecha y lanza. El Huapay los divide de los demás bárbaros.

A cuatro leguas de Santa Cruz 6 San Lorenzo, se halla el pueblo de San Juan Bautista Porongo, de 1.200 almas, que sirven de barrera contra los indios Yucaraes.

Al Oesudoeste de dicha capital, se lialla el pueblo de españoles Samaypata, con 600 almas. A 12 leguas Sur de él está la ciudad de Vallegrandé, ó de Caballeros Pardos de Jesús de Montes-claros, con 3.500 almas. Se hallan también en esta provincia los pueblos de Chilon, San José de Buenavista y Santa Rosa, y contendría á la época de 177 I 16.000 almas, y se hallan en toda ella siete curatos.

Al Oeste, de Santa Cruz 6 San Lorenzo, se halla la provincia de Mizque, cuyo temperamento es por la mayor parte caliente, pero tiene tambien parajes templados y sanos. Produce trigo, maiz, legumbres, vino y algún azúcar; mas por lo general es pobre y malsana, y está por tal causa casi despoblada, de modo, que por el año de I 789 contendría 12.000 almas, habiendo sido en otro tiempo considerable su población. Tiene siete curatos, y abunda en maderas.

Al Norte de Santa Cruz está la provincia de Moxos, que se extiende en dirccción hasta el río Itenes 6 Huapore. Hacia el Sueste, interpuestos muchos bosques, cae la provincia de Chiquitos, que termina por el Sudoeste con los Andes de Apolo Vamba, y con las misiones de dicho por el Oeste, de que los divide el río Beni á I $^{\circ}$ I 7 'de latitud y $305^{\circ}$ ó $3 \mathrm{II}^{\circ}$ de longitud; 'tiene 120 leguas Norte-Sur y otras I 20 Este-Oeste. La bañan $e$ inundan tres caudalosos rios, además de otros ménos considerables, el Mamore y el Itenes, navegables en canoas y balsas, desde sus orígenes hasta el río de la Madera, que desemboca en el Marañón. Compónese de $I_{5}$ pueblos, cada uno con dos curas, y se divide en tres partidos: Moxos, Bauces y Pampas; el primero, yace á una y otra banda del Mamore, y consta de seis pueblos; el 'segundo al Este del mismo río, con otros seis; y el tercero al Oeste con los tres restantes, acercándose á $\mathbf{2 2 . 0 0 0}$ el número de indivíduos que los poblaban hacia el repetido año de 1789 .
Su temperamento es húmedo y caliente por los muchos ríos $y$ bosques que contiene, $y$ forman innumerables lagunas y pantanos, tanto, que en tiempo de lluvia se cubren las campiñas y sblo asnmain in copas de los árboles, teniendo los pueblos que comunicarse con balsas y sucediéndoles no encontrar en dos días de camino un pedazo de tierra en que asentar el pié, en cuyo tiempo enflaquecen los ganados, y consumiendo el calor una parte de las aguas, produce después calenturas y epidemias. Por naturaleza, se resiste este pais al trigo, pero abunda de los frutos de tierra caliente y húmeda, como caña de azú. car, cacao, maiz, yuca, arroz, camotes, plátanos, mani y agíes, etc. Tiene también cosecha de algodón, y en algunos parajes un mantecoso y muy apreciable cacao. Hállanse en sus bosques los preciosos guayacanes, canelos, marias, que dan el aceite de su nombre; quinaquina, cuya semilla, quemándose, exhala fragante olor; cedros, palmas, tngibos, especies de almendros, copaibas, dragos, vainillas $y$ otros. Tambien hay en ellos antas, osos hormigueros, venados, conejos y ti. gres; muchos insectos dañosos comunes á tierras calientes, culebras boas y de cascabel y murcié. lagos de tamaño extraordinario. Los ríos abun. dan de pesca, que los indios matan á flechazos: se hallan rayas, palometas, caimanes, $y$ un autor dice que toninas 6 delfines, lo que parece extrano y áun equivocación.

El gobierno de estos indios de Misiones, se: mejante á los de los Guaraníes y Chiquitos, merece la aprobación de los príncipes y de los verdaderos amigos de la religión: un gobierno pa. triarcal que acomoda y prevalece con estas gentes; $y$ que en Estados civilizados no tiene la aprobación de los políticos: dícenles misa todos los días, $y$ al anochecer rezan el rosario y se les explica la doctrina. El cura nombra los Alcaldes, Alguaciles, Capitanes para losaillos, y enfermeros. Estos Jueces vigilan sobre los desórdenes, visitan las chácaras de los vecinos para que no descaezcan y mantengan sus familias. El cura corrige â los delincuentes, les manifiesta la gravedad de su delito, y decreta el castigo. Hay grandes vacadas en potreros que pertenecen al común para el abasto de carnes. Cada indio desde que se casa, debe formar una chácara, cultivar frutos para alimento, $y$ algodón para vestidos de su familia. La chácara del cura se labra á costa del común para que de sus produc. tos se mantenga y acuda al fomento de los varios oficios mecánicos, á cuyo fin la hacen capaz para contener talleres y oficinas, en que se tejen telas finas, se fabrica azúcar $y$ chocolate $y$ se beneficia cera silvestre. El sobrante, 6 parte de estos productos, se extrae por dirección del cura para proveer á las otras poblaciones, de aquellos necesarios artículos que les faltan. 
Sobresalen estos indios en las artes, imitan cual. quier cosa, y con pluma han llegado á hacer un breviario antuerpiano que no se distinguia sino en faltarle el vestigio de la impresión.

La provincia del Potosi, según las noticias ıdquiridas, que parecen arregladas á las últiınss disposiciones, tiene 180 leguas Norte-Sur, 2 ro Este-Oeste y 600 de circunferencia; dividiéndose en cuatro partidos, cuyas capitales son lotosí, Porco, Chayanta y Lipes. La población del primero y su distrito contenia 80.000 almas; la de: segundo 31.712 ; la del tercero 13.864 y la del cuarto 10.228 , agregándose 20.000 cholos trabajadores. Por falta de documentos no pudo asegurar el autor la precisa extensión que se habia dado á sus límites cuando se agregó al nuevo Vireinato. En las descripciones de D. Cosme Bueno, se da por territorio peculiar de la villa de Potosí, so leguas Este-Oeste y siete de Norte á Sur. Reside en ella el Jefe de la provincia y Oficiales Reales; tiene Cabildo secular, Magis. trados y subalternos, Casa de moneda con Superintendente, doce parroquias, seis conventos de religiosos, dos de monjas, una casa de recogidas y siete curatos más en su jurisdicción inmediatn.

Sitúase esta villa, que nnmbran Imperial, en latitud de $19^{\circ} 4^{8}$ en una loma, dividida del cerro de su nombre, por una quebrada, por donde desciende un arroyo que provee de agua á las haciendas y oficinas de metales. La rodean ne. vados cerros, y la altura de su sitio hace muy frío su temperamento. Según las observaciones barométricas de $\mathrm{Mr}$. Godin, se halla á 600 varas sobre la superficie del mar. Fil país está lleno de cerros, riscos y quebradas; su temperamento es seco y el aire raro; los no acostumbrados experimentan fatigas en cualquier ejercicio; lo frío del temperamento hace conservar los comestibles.

El cerro del Potosí, según unos, tiene figura de un gran pabellón; otros dicen que de un pan de azúcar; le dan de altura perpendicular sobre su base 640 varas, y una y media leguas de circunferencia; otros, como D. Cosme Bueno, se la dan de r.0oo varas, $y$ todos convienen en que está horadado como un panal, todo acribado de

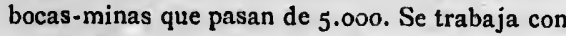
indios Metayos y con bastante economia; los metales bajaron de ley en los últimos años hacia el de $1789, y$ un cajón de 50 quintales de mina apenas daba cuatro marcos; pero los auxilios del banco del Rey sostienen este famoso mineral; y á pesar de su decadencia, producía anualmente 300.000 marcos de plata, que se vendían en el banco $a ́$ siete 6 siete y medio pesos según su calidad; quedando de cada uno al Rey cerca de un peso por los derechos de diezmos y cobros; á que se agregan los Hicates de las demás provincias que producen al Rey 100.000 pesos. La casa de la moneda dejaba 180.000 , la Adua. na 140.000, los tributos 200.000; los tantos de bulas y papel sellado, tres y medio por ciento del oro, $y$ diezmos de vajillas ascenderían á 350.000 pesos fuertes, de manera que la totalidad de las rentas montaba 1.280 .000 .

La villa y su distrito inmediato, $\delta$ sus alre. dedores, se computa tener 25.000 almas. Sus riquezas fomentan á las provincias vecinas, y áun ae extienden igualmente á las remotas. Unas dan ijichios 6 Metayos; los valles que la cercan, verduras, frutas y caza; Cochabamba y Arequipa, vinos, trigos y granos; Tucuman y Salta, grna. dos mulares, etc.; Chile y el Paraguay, la yerba de su nombre, nueces y cocos; Guamanga, ropas de la tierra, azúcar, coca y pinturas; la costa de Arica, congrio, aceitunas y otros efectos; la gran laguna de Chicuito y otros ríos inmediatos, sábalos, dorados y suches, pino, aguardiente, etc.; el Picolmayo, gran río que nace á sus inmediaciones, deberá ser navegable á no mucha distancia, y contribuir su navegación al fomento de estos paj. ses; finalmente, Lima y Buenos-Aires proveen esta población de géneros de Castilla. El montante de lo que recibe por la última vía, llega. rá á 280.000 pesos.

Sin embargo del crudo clima cle esta villa, se disfrutan en ella los mayores regalos y comodidades de la vida: los alimentos se conservan frescos mucho tiempo: son abrigadas las casas, $y$ las calles estrechas. El sexo femenino que acude de muchas partes, hermosea el pueblo, al paso que influya en la corrupción de las costumbres con sus trajes y lujo.

El partido de Porco tiene 40 leguas NorteSur, y 60 de Este á Oeste. Es de temperamento frío, á excepción de uno ú otro valle contiguo al Picolmayo: casi en su centro se sitúa la villa del Potosí. Produce los frutos que dan en esta parte del mundo las tierras elevadas y serranías, como papas, cebada, habas, y algún trigo: en las tierras bajas $\delta$ valles, varias frutas y uvas, y producen algún vino de parrales. Críanse llamas, que sirven en los minerales, vicuñas y huanacos. Hállanse términos en las inmediaciónes del Potosí (cuyo cerro, en opinión de algunos, es extinguido volcán), que su principal riqueza consiste en sus minerales, que han sido célebres y fructifican aún; y $2062+$ años antes de la época en que trata el autor, ya repetida, tuvo un particular una bonanza de tres mil millones. Tiene $\mathbf{r} \mathrm{cu}$ ratos, y reside el Corregidor en el de la Venta de Talavera de Putra.

El partido de Chayanta 6 Charcas, tiene Este á Oeste 36 leguas y 44 de Norte á Sur. Su temperamento es vario por las sierras y valles de que consta, y son también varias sus producciones. Las sierras abundan de trigo y maiz, que condu- 
cen en harina á las provincias confinantes. Hay ganado de toda especie; minas de oro, aunque de poco fruto. Sus mejores minas de plata han dado en agua. En la de Aullagas hubo mucha riqueza algunos años há, y se ignora si subsiste. Tiene esta provincia 17 curatos, los dos en la misma capital.

El partido ó provincia de Lipes, es largo y angosto. Corre 60 leguas Noroeste-Susste, $y$ tiene por donde más 20 de ancho. Su temperame:?to es seco y frío, á excepción de los terrenos de Lica y Tahua, donde se coge quinoa, papas y cebollas: hay abundancia de vicuñas, vizcachas, grandes perdices $y$ avestruces. Sus ríos son pequeños y se pierden en la arena. Se halla mucha salen los llanos, $y$ salitre en otros parajes; j no escasea el buen azufre en cuatro volcanes que hay en la provincia, de cuyas proporciones se valen los indios para fabricar pólvora de la calidad que se les pide, no en molinos, sino dentro de pellejos, en que trituran los ingredientes con piedras de mano. En el distrito de San Antonio, anexo al curato de San Pablo, se hallan vetas de pedernales redondos, como balas de 24 , que suelen reventar con estrépito, y se ven en su parte cóncava unas puntas que brillan como diamantes.

Hay minas de cobre rojo y blanco que tocan en plata y oro; de hierro, de imán y de plata en casi todos los cerros de la provincia. Es de las más poderosas, y aunque sus metales tuvieron decadencia, los vestigios manifiestan q'e sus pueblos tueron mís considerables. Tiene tres cu. ratos con muchos anexos.

El pueblo de San Antonio de Lipes, capital, fué mucho más considerable. Tiene dos anexos, cl segundo curato uno, $y$ el tercero cinco.

Habiendo de scrito las provincias del vasto $y$ nuevo Vireinato de Buenos-Aires, resta dar alguna idea del dilatado y poco conocido país que está en su centro, y que deive cunsiderarse como almáciga y criadero de los bárbaros, que escondidos en sus inmensos bosques $y$ atrincherados por sus lacrunas, no sólo se sustraen al imperio de nuestros monarcas y al infatigable celo de los Misioneros, sino que conservando sus feroces y áun abominables costumbres, infestan y moles$\tan$ nuestras posesiones por cuantas fronteras y lados bordan sus llanos y desiertos. Tiene este diiatado país el nombre del Granchaco.

Confiua por el Este con el río Paraguay, por el Nordeste con los Chrquitos, por el Norte con Santa Cruz de la Sierra, por el Oeste con muchas provincias situadas de Nort- á Sur, Tomina, Pomabamba, etc., y últimamente el Tucuman; y por el Sur, donde se estrecha, llega hasta la provincia del Río de la Plata. 'Tiene hacia el Norte, de ancho $x_{50}$ leguas por donde ná: Este-Oeste, y 250 de Norte á Sur.

El nombre Chaco significa Junta 6 Compañía, por las muchas naciones que aquí se congrega. ban, $y$ que en otro tiempo huyeron del dominio de los Incas, y después, de las conquistas de los españoles. Se internan y destacan ramos de la corclillera por el Oeste, en cuyas elevaciones se experimenta frío; pero entre estas siejras se extienden llanos que toman vasta extension hacia el Este; $y$ así resultan inmensos bosques, malezas, pantanos y lagunas, que unas duran y otras se secan, debiendo todas su origen á las crecidas iiuvias de invierno.

Riéganse estas regiones por varios considerables rús, que deben su primer origen á los nevados $A$ ndes orientales, $y$ descargan en el Paraguay después de andar grandes espacios: el Salado, el Bermejo ó Colorado y el Picolmayo, que empie. za desde cerca del Potosí. En los dos últimos se crian hasta 22 especies de pescado, y entre ellos, sábalos, dorados, pejeblanco, bogas, dentudos, bagres, cangrejos, anguilas, etc., $y$ un gran pez que llaman palometa, cuyas quijadas emplean para cuchillos.

El Bermejo, antes de entrar en el Paraguay, forma una laguna donde dicen que se crian gran. des ostras perleras. Sobre el propio río se fundaron tres ciudades en diferentes tiempos, pero todas se abandonaron.

E1 Picolmayo es seguramente navegable mucho trecho: en I zar buscaron por él los Jesuitas comunicación con el Paraguay y el Perú, nave. gando en un barco y dos botes espacio de 350 leguas por grandes tornos que hace; pero por falta de hondura hubieron al cabo de retroceder al Paraguay; mas como esta tentativa se hizo en tiempo de secas, cual Setiemlire, Octubre y Noviembre, se cree fundamentalmente que en la estación propia de lluvias se hallará agua suficiente para navegar hasta el Perú, aumque sea con barcos grandes, aptamente construídos, respecto lo mucho que crecen los ríos. Divídese el expresado Picolmayo en dos grandes brazos, 70 leguas antes de su entrada en el Paraguay.

No hay duda que importará mucho al Estado y ála Religión el reconocimiento de estas navegaciones interiores y vastos canales con que nos convida la Naturaleza, que facilitarían las importantes comunicaciones ent:e los vastos países del mundo cspañol, para el comercio, para la pollación, para la introducción de Misioneros que civilizasen tantas bárbaras naciones.

El país del Chaco, en opinión de quienes le han visto, pasa por uno de los más fértiles y hermosos de la América, ya por sus llanos, vegas y bosques frondosísimos, ya por sus lagunas y pescadosos ríos que le riegan. Entre sus arboledas hay cedros, nngales, guayacanes, quiebrahachas, algarrobos, marías, bálsamos, palmas, almendros, cacaos, cerbos, algodones, místoles, cuyos corazones emiplean para dardos y macanas, aro- 
que aquí se congrega. po huyeron del dominio de las conquistas de los v destacan ramos de la en cuyas elevaciones se ntre estas sierras se exin vasta extension hacia imensos bosques, male, que unas duran $y$ otras su origen á las crecidas

les por varios consideraprimer origen á los neva. escargan en el Paraguay s espacios: el Salado, el Picolmayo, que empiei. En los dos últimos se le pescado, y entre ellos, lanco, bogas, dentudos, las, etc., $y$ un gran pez uyas quijadas emplean

entrar en el Paraguay, dicen que se crian prane el propio río se fundarentes tiempos, pero to-

iramente navegable muzaron por él los Jesuitas aguay y el Perú, navebotes espacio de $35^{\circ}$ leque hace; pero por falta zabo de retroceder al $\mathrm{Pa}$ a tentativa se hizo en tiembre, Octubre y No. mentalmente que en la us se hallará agua sufi. ta el Perú, aunque seá imente construídos, resen los ríos. Divídese el n dos grandes brazos, trada en el Paraguay. oortará mucho al Estado cimiento de estas nave. itos canales con que nos que facilitarian las ims entie los vastos países a el comercio, para la ducción de Misioneros urbaras naciones.

opinión de quienes le le los más fértiles y herpor sus llanos, vegas y a por sus lagunas y pesn. Entre sus arboledas yacanes, quiebrahachas, samos, palmas, almenodones, mistoles, cuyos dardos y macanas, aro- mos, sasafras, quinaquina y árboles cuya interior corteza sirve de papel y parece fina holanda; el palo-borracho, que á dos varas de la raiz tiene una gran jiba, cuya corteza se deja labrar en forma de vasijas en que los indios guardan su chicha; $y$ se hallan también cañas de bastones como las de Asia.

El hombre, á cuya fuerza y maña están sujetos los demás animales, no es aquí rey de la Naturaleza, donde muchos indios viven á guisa de ellos. Andan errantes, especialmente los del Norte, con una estera, que se plantan hacia donde viene el viento ó el agua, y así forman sus aduares hasta que consumen los víveres de aquel paraje. Viven de la caza, pesca, frutos y raices. Los Chirihuanas y Churumaras tienen pueblos tijos, pero de chozas miserables, dispersas y cu. biertas de palma. Son 50 las naciones que se cuentan en el Chaco, y muchas se confunden con los Chiquitos.

Son estos indios toscos, incontinentes, var,amundos, flojos, groseros en sus conceptos, yrandes guerreros.

Hay entre ellos gran número de lenguas $y$ de costumbres. Antiguamente andaban á piẻ, pero se han hecho ya con caballos $y$ son muy diestros ginetes: suelen andar en pelo, y de un cabestro de cuero hacen rienda y freno, corriendo ligeramente y ayudando al caballo con un gran azote.

Sus habitos de flojedad, de vid $z$ holgazana y licenciosa, han hecho que tantas veces cuantas se han catequizado y reducido á pueblos, otras tan. tas, quemando sus cirácaras y robando el ganado y matando á sus Misioneros, se hayan retirado á sus bosques. Los Matahuayos, vecinos y fronterizos al Tucuman, han manifestado su perfidia diferentes veces, pidiendo Misioneros, reduciéndose en la apariencia, y repentinamente sin motivo alguno desampararon sus reducciones y huyeron á los bosques y guaridas. Aunque á vista de sus perfidias aconsejaron muchos algunas veces que se les hiciese esclavos, nunca lo permitió la piedad de ruestros Reyes; antes se les exlortu á la paz y se les admite siempre que la pidan. En más de dos siglos que se puso manoá su conversión, sôlo se tienen siete reducciones hacia la provincia del Tucuman: en las fronteras ó términos del Chaco al Sur de Santa Cruz de la Sierra hay otras cuatro de Chiriguanos: otras dos de los mismos hacia Tarija; y otra se fundó de Abipones á cinco leguas Sur de la Asunción. Nótase que todas estas reducciones est in en los confines del Chaco, que las que se fundaron dentro experimentaron su destrusción, y que entre todas no pasan de tres mil almas entre cristianos é infieles.

Pertenecen al Vireinato de Buenos-Aires las Islas Maluinas y los establecimientos que se ha- gan en la costa Patagónica: siendo una de sus principales atenciones, vigilar sobre los que hagan otras naciones, con cuyo oljeto $y$ otros importantes mantiene S. M. una armadilla que se compone de una fragata y otras embarcaciones menores.

En los últimos años (hacia el ${ }_{1789}$ ) se hicieron varios reconocinuientos de sus costas, puertos y ensenadas. No merecerá ménos cuidados al Jefe de estos dominios observar los movimientos de la nación portuguesa, que aunque no haga la principal figura en la Europa, la hace muy considerable en esta parte del globo, ya por las fuerzas que tiene en sus colonias, ya por las usurpaciones que clandestinamente hace. Si al principio se tolera una chácara ó aldea, pæsa á establecimiento considerable y lucrativo, que arrastra el empeño de una corte de sus aliados, $y$ al fin una costosa guerra.

Los muchos ríos navegables que atraviesan esta gran porción de la América mericlional, unos del Nordeste al Sudoeste como el Uruguay y el - Paraná, y otros del Noroeste al Sueste, cuál el Rojo y el Picolmayo, que entran en el rey de los ríos, el Paraguay, que atraviesa todas estas regiones, de suyo fertilísimas, producidoras de los mejores frutos, preciosidades y alimentos, proporcionan un vasto comercio interno, $y$ tal vez la mayor navegación interior, por agua dulce, que haya en el globo. Hasta ahora parece que estas importantes navegaciones se han hecho sólo por unas especies de hombres animados de fines muy opuestos. Los Jesuitas por el ardor de convertir infieles y aumentar la gloria y conquistas de su Compañía, y los poriugueses por hacer esclavos y adquirir brazos para sus haciendas.

Unos y otros han heclo estas molestas navegaciones, y enseñado á sus Soberanos, que la Providencia, sin parte alguna del arte humano, ha puesto los mejores canales de navegación que podrian descarse, para que se transporten las riquezas de tantas y tan vastas provincias, crezca el comercio, se civilicen los pueblos y aseguren al Estado y á la Religión los de neófitos que principia el Misionero, pues por nucho que se les predique é instruya, la raiseria que acompaña á sus recientes coionias, será causa đri muchas ocasiones de que desconociendo la mejora de su estado se vuelvan á las selvas.

Las rentas que saca el Soberano de estos dominios, y son al modo que en los demás Lstados y Vireinatos de la América española, se expresarán por una breve indicación; debiéndose tener presente que la moyor parte de su extensión es estéril para la Cosona, y áun gravosa, por los presidios que se mantienen y misioneros que se costean, pues la mayor parte de sus provincias confinan con naciones bárbaras, y algunas com? las del Paraguay, los tienen por todas partes. En 
cen en harina á las provincias confinantes. Hay ganado de toda especie; minas de oro, aunque de poco fruto. Sus mejores minas de plata han dado en agua. In la de Aullagas hubo mucha riqueza algunos años há, y se ignora si subsiste. Tiene esta provincia 17 curatos, los dos en la misma capital.

El partido ó provincia de Lipes. es largo y angosto. Corre 60 leguas Noroeste-Sueste, y tiene por donde mís 20 de ancho. Su temperame:to es seco y frío, á excepción de los terrenos de Lica y Tahua, donde se coge quinoa, papas $y$ cebollas: hay abundancia de vicuñas, vizcachas, grandes perdices y avestruces. Sus ríos son pequeños y se pierden en la arena. Se halla mucha sal en los llanos, y salitrc en otros parajes; $y$ no escasea el buen azufre en cuatro volcanes que hay en la provincia, de cuyas proporciones se valen los indios para fabricar pólvora de la calidad que se les pide, no en molinos, sino dentro de pellejos, en que trituran los ingredientes con piedras de mano. En el distrito de San Antonio, anexo al curato de San Pablo, se hallan vetas de pedernales redondos, como balas de 24 , que suelen re. ventar con estrépito, y se vell en su parte cónca. va unas puntas que brillan como diamantes.

Hay minas de cobre rojo y blanco que tocan en plata y oro; de hierro, de imán y de plata en casi todos los cerros de la provincia. Es de las más poderosas, y aunque sus metales tuvieron decadencia, los vestigios manifiestan q-1e sus pueblos tueron más considerables. Tiene tres curatos con muchos anexos.

El pueblo de San Antonio de Lipes, capital, fué mucho más considerable. Tiene dos anexos, cl segundo curato uno, $y$ el tercero cinco.

Habiendo de scrito las provincias del vasto y nuevo Vireinato de Buenos-Aires, resta dar alguna idea del dilatado y poco conocido país que está en su centro, y que debe considerarse como alráciga y criadero de los bárbaros, que escondi. dos en sus inmensos bosques $y^{r}$ atrincherados por sus lacrunas, no sólo se sustraen al imperio de nuestros monarcas y al infatigable celo de los Misioneros, sino que conservando sus. feroces y áun abominables costumbres, infestan y molestan nuestras posesiones por cuantas fronteras y lados bordan sus llanos y desiertos. Tiene este diiatado país el nombre del Granchaco.

Confina por el Este con el río Paraguay, por el Nordeste con los Chrquitos, por el Norte con Santa Cruz de la Sierra, por el Oeste con muchas provincias situadas de Nortr á Sur, Tomina, Pomabamba, etc., y últimamente el Tucuman; y por el Sur, donde se estrecha, llega hasta la provincia del Río de la Plata. Tiene hacia el Norte, de ancho $\mathbf{x}_{50}$ leguas por donde má: Este-Oeste, y 250 de Norte á Sur.

El nombre Chaco significa Junta 6 Compañía, por las muchas naciones que aquí se congrega. ban, $y$ que en otro tiempo huyeron del dominio de los Incas, y después, de las conquistas de los españoles. Se internan y destacan ramos de la cordillera por el Oeste, en cuyas elevaciones se experimenta frio; pero entre estas sieiras se extienden llanos que toman vasta extension hacia el Este; y así resultan inmensos bosques, malezas, pantanos y lagunas, que unas duran y otras se secan, debiendo todas su origen á las crecidas iiuvias de invierno.

Riéganse estas regiones por varios considerables rís, que deben su primer origen á los neva. dos $\Lambda$ ndes orientales, y descargan en el Paraguay después de andar grandes espacios: el Salado, el Bermejo ó Colorado y el Picolmayo, que empieza desde cerca del Potosí. En los dos últimos se crian hasta 22 especies de pescado, y entre ellos, sábalos, dorados, pejeblanco, bogas, dentudos, bagres, cangrejos, anguilas, etc., $\dddot{y}$ un gran $\mathrm{pez}$ que llaman palometa, cuyas quijadas emplean para cuchillos.

El Bermejo, antes de entrar en el Paraguay, forma una laguna donde dicen que se crian grandes ostras perleras. Sobre el propio río se fundaron tres ciudades en diferentes tiempos, pero todas se abandonaron.

El Picolmayo es seguramente navegable mucho trecho: en rzar buscaron por él los Jesuitas comunicación con el Paraguay y el Perú, nave. gando en un barco y dos botes espacio de $35^{\circ}$ leguas por grandes tornos que hace; pero por falta de hondura hubieron al cabo de retroceder al Paraguay; mas como esta tentativa se hizo en tiempo de secas, cual Setiembre, Octubre y Noviembre, se cree fundamentalmente que en la estación propia de lluvias se hallará agua suficiente para navegar hasta el Perú, aunque sea con barcos grandes, aptamente construidos, respecto lo mucho que crecen los ríos. Divídese el expresado Picolmayo en dos grandes brazos, 70 leguas antes de su entrada en el Paraguay.

No hay duda que importará mucho al Estado y ála Religión el reconocimiento de estas navegaciones interiores y vastos canales con que nos convida la Naturaleza, que facilitarían las importantes comunicaciones entie los vastos países del mundo cspañol, para el comercio, para la polblación, para la introducción de Misioneros que civilizasen tantas bárbaras naciones.

El país del Chaco, en opinión de quienes le han visto, pasa por uno de los más fértiles y hermosos de la América, ya por sus llanos, vegas y bosques frondosísimos, ya por sus lagunas y pescadosos ríos que le riegan. Entre sus arboledas hay cedros, nngales, guayacanes, quiebrahachas, algarrobos, marías, bálsamos, palmas, aimen dros, cacaos, cerbos, algodones, místoles, cuyos corazones emplean para dardos y macanas, aro. 
uí se congrega. ron del dominio conquistas de los can ramos de la as elevaciones se tas sierras se ex. extensión hacia bosques, male. as duran $\mathrm{y}$ otras en á las crecidas

varios considerarigen á los neva. nen el Paraguay os: el Salado, el ayo, que empie. s dos últimos se do, y entre ellos, pogas, dentudos, .,$y$ un gran pez uijadas emplean

en el Paraguay, ue se crian granpio río se funda. iempos, pero to-

navegable $\mathrm{mu}$ r él los Jesuitas el Perú, nave. spacio de $35^{\circ}$ lee; pero por falta retroceder al $\mathrm{Pa}$ tiva se hizo en , Octubre y Nonente que en la ullará agua sufierú, aunque sea construidos, resríos. Divídese el grandes brazos, 1 el Paraguay. mucho al Estado o de estas nave. ales con que nos ilitarían las imlos vastos países mercio, para la de Misioneros aaciones.

n de quienes le ás fértiles y her3 llanos, vegas y is lagunas y pesre sus arboledas , quiebrahachas, palmas, aimen. mistoles, cuyos y macanas, aro- mos, sasafras, quinaquina y árboles cuya interior corteza sirve de papel y parece fina holanda; el palo-borracho, que á dos varas de la raiz tiene una gran jiba, cuya corteza se deja labrar en forma de vasijas en que los indios guardan su chicha; $y$ se hallan también cañas de bastones como las de Asia.

El hombre, á cuya fuerza y maña están sujetos los demás animales, no es aquí rey de la Naturaleza, donde muchos indios viven á guisa de ellos. Andan errantes, especialmente los del Norte, con una estera, que se plantan hacia donde viene el viento ó el agua, y asi forman sus aduares hasta que consumen los víveres de aquel paraje. Viven de la caza, pesca, frutos y raíces. Los Chirihuanas y Churumaras tienen pueblos tijos, pero de chozas miserables, dispersas y cubiertas de palma. Son $5^{0}$ las naciones que se cuentan en el Chaco, y muchas se confunden con los Chiquitos.

Son estos indios toscos, incontinentes, vaca. mundos, flojos, groseros en sus conceptos, grandes guerreros.

Hay entre ellos gran número de lenguas y de costumbres. Antiguamente andaban á pié, pero se han hecho ya con caballos $y$ son muy diestros ginetes: suelen andar en pelo, y de un cabestro de cuero hacen rienda y freno, corriendo ligeramente y ayudando al caballo con un gran azote.

Sus habitos de Hojedad, de vida holgazana y licenciosa, han hecho que tantas veces cuantas se han catequizado y reducido á pueblos, otras tan tas, quemando sus chácaras y robando el ganado y matando á sus Misioneros, se hayan retirado á sus bosques. Los Matahuayos, vecinos y fronterizos al Tucuman, han manifestado su perfidia diferentes veces, pidiendo Misioneros, reducién dose en la apariencia, y repentinamente $\sin$ mo tivo alguno desampararon sus reducciones y hu yeron á los bosques y guaridas. Aunque á vista de sus perídias aconsejaron muchos algunas veces que se les hiciese esclavos, nunca lo permitió la piedad de suestros Reyes; antes se les exhorta ála paz y se les admite siempre que la pidan. Én más de dos siglos que se puso mano á su conversión, sólo se tienen siete reducciones hacia la provincia del Tucuman: en las fronteras ó términos del Chaco al Sur de Santa Cruz de la Sierra hay oiras cuatro de Chiriguanos: otras dos de los mismos hacia Tarija; y otra se fundó de Abipones á cinco leguas Sur de la Asunción. Nótase que todas estas reducciones estín en los confines del Chaco, que las que se fundaron dentro experimentaron su destrucción, y que entre todas no pasan de tres mil almas entre cristianos é infieles.

Pertenecen al Vireinato de Buenos-Aires las Islas Maluinas y los establecimientos que se ha- gan en la costa Patagónica: siendo una de sus principales atenciones, vigilar sobre los que hagan otras naciones, con cuyo objeto $y$ otros importantes mantiene $\mathrm{S}$. M. una armadilla que se compone de una fragata y otras embarcaciones menores.

En los últimos años (hacia el 1789 ) se hicieron varios reconocimientos de sus costas, puertos y ensenadas. No merecerá ménos cuidados al Jefe de estos dominios observar los movimientos de la nación portuguesa, que aunque no haga la principal figura en la Europa, la hace muy considerable en esta parte del globo, ya por las fuerzas que tiene en sus colonias, ya por las usurpaciones que clandestinamente hace. Si al principio se tolera una chácara ó aldea, pasa á establecimiento considerable y lucrativo, que arrastra el empeño de una corte de sus aliados, $y$ al fin una costosa guerra.

Los muchos rios navegables que atraviesan esta gran porción de la $\Lambda$ mérica meridional, unos del Nordeste al Sudoeste como el Uruguay y el Paraná, y otros del Noroeste al Sueste, cual el Rojo y el Picolmayo, que entran en el rey de los ríos, el Paraguay, que atraviesa todas estas regiones, de suyo fertilisimas, producidoras de los mejores frutos, preciosidades y alimentos, proporcionan un vasto comercio interno, $y$ tal vez la mayor navegación interior, por agua duice, que haya en el globo. Hasta ahora parece que estas importantes navegaciones se han hecho sólo por unas especies de hombres animados de fines muy opuestos. Los Jesuitas por el ardor de convertir infieles y aumentar la gloria y conquistas de su Compañía, y los poriugueses por hacer esclavos $y$ adquirir brazos para sus haciendas.

Unos y otros han hecho estas molestas navegaciones, y enseñado á sus Soberanos, que la Providencia, sin parte alguna del arte humano, ha puesto los mejores canales de navegación que podrían desearse, para que se transporten las riquezas de tantas y tan vastas provincias, crezca el comercio, se civilicen los pueblos y aseguren al Estado y á la Religión los de neólitos que principia el Misionero, pues por mucho que se les predique é instruya, la raiseria yุue acompaña á sus recientes coionias, será causa cli muclias ocasiones de que desconociendo la mejora de su estado se vuelvan á las selvas.

Las rentas que saca el Soberano de estos dominios, y son al modo que enl los demís Estados y Vireinatos de la América española, sc expresarán por una breve indicación; debièndose tener presente que la migor parte de su extensión es estéril para la Corona, y áun gravosa, por los presidios que se mantienen y misioneros que se costean, pues la mayor parte de sus provincias confinan con naciones bárbaras, y algunas como las del Paraguay, los tienen por todas partes. Fin 
Corrientes se mantienen tropas armadas de cuera, lanza $y$ adarga: los Pampas cortan la comunicación é impiden que se pueble aquella parte del Tucuman casi hasta Chile; de manera, que muchas partes de las poiblaciones son fronteras, se hallan los vecinos listos y con el caballo para el primer aviso; $y$ aunque sea cierto que en los últimos años (hacia el de 89) ni los Pampas han invadido las caravanas de carretas que salen de Buenos-Aires para Chile, ni los del Chaco hecho correrías en el Tucuman, ni en general se haya oído noticia de sus insultos, mediante las sabias providencias y máximas de los que gobiernan; no es, pues, todavía, un estado de seguridad absoluta, mientras estos bárbaros, al ménos los más confinantes é inquietos, no se reduzcan, ya por el celo de los misioneros, especie de hombres dignos de la humana veneración, que nn sólo extienden la santa religión que predican, sino que primero hacen civiles á los hombres para que sean cristianos. Los Príncipes, no sólo se libertan de enemigos molestos, sino que suelen adquirir vasallos fieles sin efusión de sangre, sin estipendio de sus erarios.

Aun cuando no ardiera en el corazón de nuestros católicos Monarcas tan ardiente celo por la religión santa que profesan, el interés y la razón de Estado lo piden.

Un hombre con un breviario, un crucifijo, una pequeña escolta y una asistencia de 300 pesos ánuos, que por regla general señala Su Majestađ para su manutención, penetra por los inmensos países, entre la multitud de los bárbaros, que le dan paso y áun salvaguardia, á un hom. bre desarmado é indefenso. Los donecillos, la persuasión, el ejemplo, la paciencia, recaban con el tosco salvaje, no sólo oir una nueva doctrina al principio por curiosidad, sino conocer las ventajas que le ofrece el nuevo estado de pacífico agricultor, en que asegura sus alimentos y subsistencia, $y$ despreciar el de errante y sanguinario cazador, que después de mil carreras y fatigas, apenas adquiere alimentos para cuatro dís.

La política de asegurar la subsistencia á los convencidos, de situarles sus habitaciones entre gentes fieles, hará durables $y$ seguros los frutos que adquiera el misionero. Las excursiones de gente armada contra los indios, deben compararse á una batida contra fieras: ellos, al estrépito y ruído de las armas, huyen y se esconden; pero retirados los que les espantaban, salen de nuevo, sornrenden y matan al que se descuida.

Los países productivos del Vireinato son la provincia del Río de la Plata, la del Paraguay y las del Potosí. Las rentas principales son: las que pagan los indios varones desde su juventud hasta la vejez (esto es, desde 186 6 16 hasta 50 años), que según el cálculo liecho en 1785 liasta
I 788 inclusive, importa 19.121 pesos: la del diez. mo eclesiástico, que percibe el Monarca como patrono de las iglesias de América, y asciende, deducidos varios gastos, á 754: los quintos del oro, cosa muy corta, tal vez por ser al principio y no estar bien afirmada la jurisdicción de este nuevo Vireinato, 955 ; los oficios vendibles como escribanías de cámara, fielatos, regidurías, etcétera, 9.255 ; las varias tesorerías del Vireinato en sus principales capitales, dan el mayor ren: glón de 1.472.253; el papel sellado, 3.492; el azogue que se vende de cuenta del Rey á los mineros, de que hay mucho consumo en el Potosí, etcétera, II3.002; las pulquerías, tributo de 30 pesos más ó ménos, que paga cada tienda, nombradas así en América, en que se venden comestíbles y licores, 8.or3. Los demás ramos reales que se omiten por su poca monta, son: vacantes mayores y menores, aprovechamientos, medias annatas, depósitos, penas de Cámara, donativo, Inválidos, Montes-Píos y el Municipal de guerra, que por sí sólo llega á 82.19o. Y el total producto de las rentas expresadas, junto con el no individualizado de las últimas, asciende á $x .906 .250$ pesos, un año con otro; pero siendo de creer que no se incluya la del tabaco, renta que siempre debe ser considerable, pues se administra particularmente.

El Real Erario tiene contra sí varias cargas para la buena administración y conservación de tan vastos y distantes dominios, á saber;

Sueldos de empleados de policía y judi-

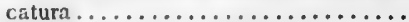
Idem de los de Real Hacienda....... Pensiones..................... Sínodos a los curas................ Gastos de lana de vicuña........... Idem de las embarcaciones del Río de la Plata.

De la Real Armada............... De la costa Patagónica............. De las Islas Maluinas.............. Gastos de la expedición de límites..... Gastos de compra y administración de

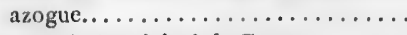
Gastos de Municipal de Guerra....... Viudedades y administración del Mınte-

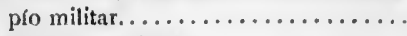

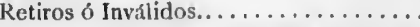
$\mathrm{Y}$ con otros varios ramos de gastos, seguin las noticias adquiridas por el autor, monta el total de cargas de este $\mathrm{V} \mathbf{i}$. reinato.................. 1.672 .635

Por mancra, que vienen á quedarse estos países con la mayor parte de las rentas que produ. cen, quedando sólo á favor de la metrópoli 233.5 14 pesos.

La erección del nuevo Vireinato hará circu-
$88.39^{1}$ 69.644 
lar en todo él mucha parte de los preciosos metales que regurjitan en los países de minas, pues las provincias que le agregaron del Perú es preciso envien mucho de su numerario á la capital. Si el comercio de España y los capitales con que se retiran á ella los particulares, no extrajeran el numerario que dan las provincias del Potosí y las otras de minas, fuera la plata una de las más viles mercaderías; pero por la extracción que hay en las más de nuestras provincias americanas, corre sin duda ménos numerario que en las más potres de España.

\section{Descripción politica de la Isla de Chiloé.}

El Jefe principal de la isla de Chiloé, era en I789 un militar con graduación de Coronel, con título de Gobernador é Intendente; y le es anejo el mando de la tropa, teniendo su Sarg nto Ma. yor, Ayudantes, un Oficial de artillería que manda la tropa de su cuerpo, y un Ingeniero que entiende en las cosas de fortificación.

Hay en toda la isla tres conventos: uno de la Merced, otro de Franciscos y una residencia de los mismos, y todos por la pobreza del país mantienen corto número de religiosos, teniendo los últimos á su cargo las misiones que estaban al de los Jesuitas, y se esperaba la reforma de los dos Observantes y un Mercenario que únicamente había extra de 15 misioneros, respecto la Real orden en que se determinó la de conventos que no tuvieran al ménos cinco religiosos.

Toda la juriscicción eclesiástica de la isla reside por la mayor parte en un cura castrense, $y$ se cuentan en toda su extensión sólo cinco pueblos, de suyo muy dispersos: la ciudad de Castro al Este, el Chacao, Calbuco, San Carlos y Carelmapu, cuya apariencia es más de campamento desordenado que de arreglada población, dispersas sus casas entre los umbrosos y desmontados bosques, formando paisajes agradables á los ojos.

Divídese la población de la isla, en curatos, y éstos en capillas. Llaman capillas, á cierto número de vecinos dispersos junto á las costas, que concurre á cada una de ellas para el sacrificio de la Misa.

El curato de Castro comprende el partido de su nornbre, Chonchi, Puquelon, Queilen, Achau Mculin y Tenaun: Castro tiene $\mathrm{x}$ capillas, Choncliv 5, Puquelon 6, Queilen 8, Achau 8, Meulin 5 y Tenaun 8 , habitados por 10.032 españoles y 8.750 indios.

El curato de Chacao comprende el partido de su nombre y el de Puderu, con 17 capillas inclusa la Real, 3.107 españoles y r.404 indios; y el curato de Calbuco contiene sólo el partido de su nombre, con $\mathrm{I}_{4}$ capillas, I.334 españoles y $\mathrm{r} .403$ indios. De manera que el total de sus labitantes sube hasta 27.000 con algunas per- sonas que no se incluyen, siendo $15 \cdot 300$ españoles $\hat{e}$ indios $I 1.700$.

La ciudad de Castro se fundó en tiempo del Licenciado Lope García de Castro, Gobernador dei Perú, por Martín Ruiz de Gamboa, en 1566 , labiendo sido al principio bastante regular, pero fué después arruinada por un temblor de tierra, y hoy está, así como el pueblo de San Carlos, compuesta de casas de madera, techadas de paja, esparcidas y desordenadamente colocadas. Tiene además de los tres conventos expresados, una iglesia parroquial, Cabildo secular, Corregidor, dos Alcaldes ordinarios y cuatro Regido. res, Escribano y demás oficios: un fuerte hacia la playa para su protección. Habrtan aún en esta ciudad muchas familias antiguas y nobles de la isla, la cual fué saqueada en r.6oo por el pirata inglés Corder, y en $16{ }_{15}$ por Jorge Spilberg, ambos saqueadores y crueles de ejercicio. Se conoce que en aquel siglo se descuidó mucho la protección de estos Seles vasallos, que sin duda mal armados y sin tropa alguna, eran víctimas de osados corsarios. En el día se 'uallan alistados sus vecinos capaces de llevar armas, en ${ }^{3} 3$ cierto número de compañías de Milicia, entre ellas, dos de la caballería que llaman de la Nobleza y otra del Corregidor, con un destaca. inento para servicio del fuerte.

Chacao (Santiago del) está en $41^{\circ} 16^{\prime}$. Sus habirantes todos toman las armas excepto cuatro, y orman una compañía con Capitán, Teniente, Subteniente, dos sargentos, cuatro cabos y 48 soldados.

Antes era aquí el surgidero de navíos que venían del Perú y Chile, entrando par un canal que por los bajos, lajas, remolinm y furiosas corrientes an tiempo de calmas, les dejalsa sin gobierno y á veces se perdían, por lo que se escogió otro puerto más seguro.

San Carlos está en el puerto cie Lacui, cerca de Puerto-Inglés, en una espaciusa y bien abrigada bahía. Tiene un fuerte escavado en la misma tierra, cuatro baluartes, foso y camino cubierto (que se hallahall, así como el fuerte de Chacao, en estado de deterioro), capaz de 24 ca- 
nones, y una batería situada en un alto collado á la entrada del puerto, que le defiende y toma el nombre á las embarcaciones que arriban á él.

Otra respetable batería ábarbeta, se situa en el mismo desembarcadero, al lado de la cañada que lo forma. San Carlos es la población más considerable de la isla, y reside en ella el Comandante General, los Oficiales Reales ó sus 'Tenientes, el Estado Mayor, Comandante de Artillería, y algunas pulquerías que son los únicos negociantes que se ven. A este puerto acuden las embarcaciones del Rey las pocas veces que arriban, y los barcos peruleros. Su muelle, que es la simple playa, se cubre de canoas y pequeños barcos del país, y hay que desembarcar en hombros de marineros, sin embargo de que la abundancia de maderas ofrece facilidad para la construcción de un mue. lle. Se tiene en él una respetable guardia, y es uno de los parajes á que concurre gente.

El cura de esta población es también Capellán Real del fuerte, y D. Cosme Bueno dice también, que tiene $r 8$ capillas de indios en su jurisdicción, dos islas pobladas y tres sin gente. Las ror familias que componen el curato se extienden á r 4 leguas de costa, distante una casa de otra cerca de una milla, entre Cauli hasta Coacague, formando un pueblo cierto número de ellas, $y$ esto es el sistema general de población en ioda la isla, excepto en San Carlos y Castro, en que se agrupan algo las casas.

La bahía puede decirse un seno rodeado de collados frondosísimos. Al Noroeste del fondeadero que tuvieron las corbetas, yace una punta, y en ella una batería que defiende el puerto. Al Sursudoeste hay un seno ó estero que forma el mar introducido entre las sierras, y al Esueste está la desparramada población de San Carlos, que parece un Real ó campamento, situada en una rambla donde se apiñan las casas, y en las faldas de los montes que la cercan; de cuya vista se sacó un buen diseño por el dibujante Cordero.

El pueblo de San Miguel de Calbuco, según las noticias del citado cosmógrafo, se sitúa hacia el Nordeste en una isla poco distante de tierra firme. Tiene un fuerte á la orilla del mar, y la población que lo circuye debe considerarse como militar.

Pertenecen á su jurisdicción $\mathrm{r} 2$ islas pobladas y I $_{3}$ despobladas. Hay dos reducciones que llaman de los indios del Rey; una la de Calbuco y otra la de la Isla de Abtao. Estos indios fue ron de Osorno, y siguieron el partido de España cuando abandonó aquella ciudad: acompañaron á los habitantes que se refugiaron á ella, y ayu(laron á hacer el fuerte en tierra firme; pero sien's atacado muchas veces por los Juncos, se construyó otro para mayor seguridad en la isla en que se halla. Sirven á S. M. cuando se les requiere, y se les da una gratificación cada año.
Al Nordeste se ve el majestuoso volcán de Huañauca, notándose en la cordillera, gruesas nubes del humo que arroja, y se dice que vorita llamas muclia parte del año.

Los habitantes de Calbuco, on concurrencia de los de Carelmapu que habitan el continente al otro lado del canal de Chacao, se emplean en el corte de alerce en la vecina cordillera.

Aquí hay un fuerte que llaman de Maullin a orillas del río lel Peñón. Carelmapu fué el pri. mer puerto que poblaron los españoles cuando vinieron á la Isla de Chiloé, cuya población en I789 se reducía á algunos ranchos, á lo que parece, desde que el pirata holandés Enrique Breaut la saqueó en 1643 y se llevó los habitantes á Valdivia, donde quiso hacer población y establecimiento.

En las islas inmediatas, hay misiones al cuidado del colegio de Franciscos de Ocopa del Arzobispado de Lima. Las misiones son la de Hachao para los Huayquenos y de los Chonos, que habitan las islas de este nombre cerca de tierra firme al Sueste de Castro: frente de ésta, la de la Isla de Quinchao, que es de las mayores: la de Conchi, en los Payos, que habitan en la costa de la isla Grande ó Chiloé, que corre de Castro para el Sur: la de las orillas de la Laguna de Cucao, en su costa occidental: y la de Raylen ó Caulen.

\section{Estado militar.}

En la descripción de Castro se dió y'a alguna noticia de la gente alistada para en caso de invasiones. Las tropas regladas que guarnecían la isla, constaban de tres compañías deá 70 hombres y debían aumentarse dos más; unas eran de dragones y otras de infantería.

El Gobernador tenia de sueldo anual. 6.600 pesos. El Ayudante Mayor............. 480 El Capitán de Artillería, al mes..... Los de Infantería, flem.......... Los de Dragones, ldem............ Los de Asamblea, al año.......... Los sargentos do Asamblea, idem,... Los cabos idem................. Y los soldados............... 50 $-1 / 2$ 780 288 $2 \mathrm{I} 6$ 120

Los ramos Reales son el tributo de cinco pesosque paga cada indio desde la edad de veintidos años hasta la de cincuenta, y por cuya pobreza se les cobra parte en tablas de alerce y parte en jamenes, y deja de cobrárseles en invierno por los perjuicios que experimentaban en la pérdida de sus canoas con los malos tiempos y de los frutos que llevabar.

La renta del tabaco asciende á 4.000 pesos anuales, sea en dinero ó en frutos.

La Aduana, en que se perciben las alcabalas, tiene Ministro é Interventor. Los soldados sirven 
volcán de a, gruesas que vornita

ncurrencia continente mplean en ra: Maullin á fué el pri. es cuando blación en lo que pa. que Breaut bitantes á y estable.

ones al cuippa del Arla de $\mathrm{Ha}$ honos, que a de tierra ista, la de hayores: la itan en la e corre de e la Lagu. la de Ray.

; ya alguna in caso de guarnecían eá 7o homras eran de de guardas, y cuando los emplean en este servicio tienen un sobresueldo de ocho pesos. Los derechos parece que se cobran principalmente de las embarcaciones.

Los habitantes criollos españoles, ó no pảgan ó pagan poco las imposiciones, pero hacen los servicios de armas sin paga ni ración $y$ otros servicios pecheros, porque los indios, ocupados en adquirir para pagar el tributo, no pueden distraerse de sus trabajos.

Según el estado de la Tesorería general, importaban los tributos en $1789,86.85^{\circ}$ pesos.

El exterior comercio de esta isla es con el Perú, por cuyos navíos recibe el situado que en: vían de Lima para pagar al Gobernador, Plana Mayor y tropa, siendo muy corto número el de otra especie de empleados. Por el mismo conducto le vienen los géneros de España y de otras partes de América; uno ó dos navíos que llegan al año forman como una especie de feria, $y$ allí reciben, necesariamente recargados, los géneros que les remiten los comerciantes le Lima (r). Estos artículos se reducen á lienzos, felpas, listones, pañuelos, medias de Barcelona, azúcar, mate, etc., comprándolo todo los Chilotes con la misma plata del situado, y con los productos de su industria $\mathrm{y}$ algunos de los frutos que da la isla.

El principal artículo es el de tablas de alerce, de las cuales cortan en el continente 200.000 al año. Para esta pequeña navegación, la interior de la isla y sus pescas, según averiguó el laborioso Intendente Hurtado, tenían los Chilotes 352 canoas y 472 piraguas. El alerce es propio para las más de las obras de carpintería, la

(r) Géneros que introdujo una embarcación en 1789, y precios á que se mandaron vender, calculándose 30 por 100 de ganancia al comercio de Lina.

\begin{tabular}{|c|c|c|}
\hline & Pesns & R. \\
\hline Docena de redecilla de torzal ........ & 24 & 7 \\
\hline Pieza de medio listón. ............. & 2 & o \\
\hline Ideın de Bella unión............... & 5 & 4 \\
\hline Docena pañuelos de Barcelona........ . & r9 & \\
\hline Vara zaraza ordinaria de fdem....... & $i$ & \\
\hline Pieza de bayeta inglesa............ & to5 & $\circ$ \\
\hline Vara de felpa de Valencia............ & 4 & 2 \\
\hline Idem de paño de Quito.............. & 3 & 5 \\
\hline Idem de paño inglés de segunda...... & 3 & 4 \\
\hline Docena de medias de mujer.......... & 87 & $\circ$ \\
\hline Sortues de bayetón con sas chupines. . & 14 & $\circ$ \\
\hline Docena de medias de lana de Burgos.. & 24 & 5 \\
\hline Docene de sombreros negros sevilianos. & 74 & 5 \\
\hline Capotones de paño de segunda, forrados & & \\
\hline
\end{tabular}

\section{Conestibles.}

Arrọia da jabón. Idem de mate.

Aguardiente de ica, la botija........ $20 \quad 201 / 4$

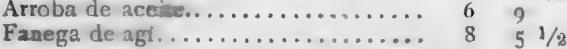
$\mathrm{Y}$ se omiten otros artículos menores por no abulsur demasiado esta relación. usan los carpinteros de L.ima más comunmente, se parece al cedro en el color y ticne muy buenas propiedades (I).

Los ponchos constituyen otro ramo de industria. El poncho es en toda la América meridional la especie de vestuario que suple por capa, y se pone encima de todo; es una pieza de un tejido como de sarga, más 6 ménos fino, bordada de labores encarnadas, amarillas, azules, etcétera, por el gusto de las mantas jerezanas, que tiene la extensión de cuatro varas en cuadro; $y$ vale por lo regular 12 pesos cada uno, llegando algunos hasta roo, y se extraen muchos para el Perú.

Labran también otras varias telas de algodón y lava, sarguilla 6 cosa que lo parece, pero en poca cas:idar:" de manera, que los Chilotes, teniendo muy imperfectas sus máquinas, no pueden multiplicar los fritos de su industria.

El cerdo es el animai doméstico que se multiplica más en la isla, contriisuyendo mucho á su abundancia la proporción y facilidad para el pasto, y las raíces, y se extraen cantidades considerables de ricos jamones para el Perú, comparables á los mejores de Galicia.

Salan el róbalo y la sardina, pero no parece que en cantidad considerable, y venden el quintal de a ${ }_{\text {inel }}$ á ro ó I2 pesos. La falta de sal, que les va de Lima precisamente cara, atrasará sus salazones y pescas, y ellos mismos aseguraban que no se costeaba con ro pesos el quintal de róbalo.

Estos son los principales artículos de comercio de los Chilotes, $\because$ no se duda tengan otros varios de que no pudo hacer mención el autor, según así lo insinua.

Las mujeres trabajan la lana, el lino $y$ el poco algodón que se coge, de que tejen los ponchos, bayetas, mantas, manteles, sabanillas ó sarga bastante buena, y sobre-camas bordadas; todo en telaues los más sencillos que pueden darse.

El telar es una especie de bastidor cuadrilongo, formado de cuatro palos às dos varas de longitud, y una y cuarta de ancho. Cuelgan del techo dos peines que suben! bajan la urdimbre. Las tejedoras, que son dos en un mismo telar, meten á mano la trama de los hilos de varios colores para que formen las diverses labores. Esta máctina, recomendable por su paco costo y facilidad de su construcción, pide twe parte del fabricante mucha paciencia $y$ tiem $\left.m_{2}\right)$ para los tejidos.

Ln ponclio de los ordinarios cuesta dos meses de trabajo los superfinos, hasta seis $y$ doce meses: y asi es, que por paco que cobren

(1) Cada tabla de alerce de 4 I/ 1 varas de largo y $1 / \mathrm{d}$ de ancho, vale dos roales de Américe.

Idem de $2 \mathrm{y}^{1 / 2}$ de largo y solve ro pul gadas de ancho, un real, disminuyendo of anneratando los pre cios según las climensiones. 
estas pobres gentes, no pueden dar una manufactura barata.

Son dignos de noticia los fáciles modos con que tiñen sus hilazas, de que resultan los más vistosos colores en las varias telas que urden, que aunque no resisten las pruebas del agua fuerte, permanecen sí hasta que se gasta el vestido. Carecen estas gentes sencillas de las artes europeas, y sin tales conocimientos, aciertan á teñir igualmente bien las materias animales, como la lana, y las vegetales, como el lino y algodón.

Generalmente ponen las hilazas en disolución de agua y alumbre, cuya sustancia salina se encuentra con abundancia en el país; es blanca y ligera y de sabor estítico y adulzorado, que descubre bien el alumbre que contiene: llámanlo los naturales porcura.

Para el amarillo emplean las raeduras del árbol espinoso que llaman mechaí, poniéndolas en infusión de agua, en que echan la hilaza preparada, hirviendo después el todo hasta que ha adquirido ésta los colores que quieren.

Para el rojo, hacen un cocimiento proporcionado de salvado lavado, en que ponen por veinticuatro horas una planta macerac'a de la fami. lia de las asperilolias $y$ verriciladas, que llaman relhbun, y tiene las hojas en rodajuela y la faz de la aparine, pareciendo una especie de valantia, en cuya infusión echan la hilaza ya preparada y la dejan hervir todo el tiem

El modo de dar el azul, dice el autor según lo que le informaron, parece singular y puerco. Ponen el añil en agua por ocho días hasta su disolución, $y$ esto y la hilaza preparada ya con la porcura, lo echan en orines antiguos y fermentados. por veinte ó treinta días á lo ménos.

Niojados los hilos en este último cocimiento, y ya que han tomado el color azul que llaman axjon, echan la hilaza en las mismas preparacio nes que para el amarillo, y resulta en ellas un hermoso verde.

Para teñir de negro echan la hilaza en agua en la disolución de una tierra negra que llaman greda, y que no tuvo ocasión de examinarla el autor.

Para calafatear las canoas y piraguas usan de una planta fibrosa, machacada, que llaman ziaca, y de una resina que les dispensa de la brea por su propiedad de impedir la penetración del agua.

Hacen cuerdas de una planta que llaman nocka, cuyos tallos delyados, largos y flexibles se dejan torcer como ćñamo, y hacen cuerdas gruesas y de bastante resisteacia.

Usan también para cordajes, de una especie de bejuco que llaman boque, y se cría entre las hendiduras y grietas de la corteza del alerce, teniendo esta planta parasítica más largo que el mismo árbol en que se cría, una y media pulgada de diá netro, raices y barbas por toda la corteza á que se pega. La machacan los naturales, y salen hebras flexibles y delgadas como las de pita, con que hacen toda especie de cordelería, de tres pulgadas hasta cables. Con ellas ensamblan sus piraguas y se excusan de clavazón: sobre el costillaje de la piragua ponen las tablas del forro con correspondientes agujeros, las cosen unas con otras, y mojadas las cuerdas, encojen de modo que aprietan las tablas sin que pueda introducirse agua alguna por entre ellas.

Son los Chilotes bastante buenos carpinteros y manejan el hacha diestramente. Hacen sus casas bastante sólidas; clavan las columnas perpendiculaxes, á tres varas de distancia, según las dimensiones que eligen; hacen un canal de dos pulgadas de profundidad, según la longitud de la columna, y asientan en él las tablas que han de formar la pared, y las montan unas á otras como las tejas, de manera que impiden la entrada al viento y agua, por cuya misma idea hacen los techos cuando no los cubren de yerba: los piés derechos son de lunna, madera incorruptible de un pié en cuadro, y no usan clavos de metal, sino de madera.

\section{Frutos de Chiloé.}

Nada satisfará tanto sobre esta materia, como la copia del estado formado por el Intendente Hurtado, cuyo extracto es como se verá:

Piés de árboles frutales.

Manzanos................
Membrillos................

\section{Cosechas de semillas.}

\begin{tabular}{|c|c|c|}
\hline Habas .............. & $3.27 \mathrm{I}$ & \\
\hline Porotos.............. & 33 & ” \\
\hline Frijoles............. & 152 & $n$ \\
\hline Quinoa.............. & 222 & » \\
\hline Bellotas............. & 200 & D \\
\hline 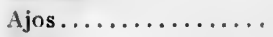 & 160 & $\bowtie$ \\
\hline Trigo............... & $\times 7.557$ & \\
\hline Cebada............. & 11.420 & $n$ \\
\hline Papas............... & 65.000 & $n$ \\
\hline Número de repollos.... & 4.800 & 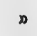 \\
\hline Zapotes.............. & 500 & 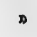 \\
\hline Lino ................ & 109 & \\
\hline
\end{tabular}

Por este estado se ven los frutos que constituyen el principal alimento de estos isleños y la cantidad de sus productos al año, con lo que se juzgará de algún modo sobre el estado de su agricultura.

Animales útiles que se hallaban en Chiloé.

Toros..................

Vacas................ 3.780 
ia pulga -

a la cor-

turales, $y$

o las de

prdelerla,

$s$ ensam-

azón: so-

as tablas

, las co-

as, enco-

sin que.

e ellas.

rpinteros

n sus ca-

inas per-

según las

al de dos

itud de la

ie han de

ras como

htrada al

hacen los

los piés

ptible de

etal, sino

materia,

el Inten-

se verá:
Caballos.................. 3.467

Yeguas.................. 3.525

Potros................. $93^{6}$

Cerdos................. 5.054

Cerdas .................. 3.38

Ovejas................ 86.683

Carneros................. 2.160

Cabras................. 17.307

Chivos................ 1.354

Gallinas................ 20.740

Pavos.................. 1,200

Gansos................ 800

El manzano, así como en el vecir.o continen. te, es el frutal que más abunda en esta isla, y las cervezas ó sidras hechas de él, podrían ser un ramo de su comercio; pero como son pocas las embarcaciones que arriban á sus puertos, serían también pocos los consumidores que tendría. El trigo, las papas y las demás semillas, como frutos que abundan en el vecino reino de Chile; no hacen ramos de extracción en esta isla. Pero sí suministran suficiente alimento á unos hombrés frugales que se alimentan comunmente de vegetales y de los productos del mar. Si se suman las partidas de semillas comestibles explicadas (dice el autor, conforme le informaron) que todas lo son ménos el lino, resultan $\mathrm{roz}_{3} \mathrm{II}_{5} \mathrm{fa}$ negas, que repartidas entre 24.000 habitantes, sin contar los 3.000 restantes, por considerarse niños de pecho, que sólo sus madres los alimentan, caben cuatro fanegas á cada uno y cerca de un tercio de otro, que viene á ser á más de $5 \mathrm{I}$ ce lemines al año, y así corresponde á celemín por semana, cantidad suficiente para mantener á un indio. De lo que se infiere cuánta población podría mantener esta isla si recibiese su agricultu ra todos los fomentos, y su suelo las mejoras que no tiene.

Las semillas y legumbres son su ordinario alimento. Consiste el princifal en harina de trigo groseramente molida y tostada, á que agregan una tercera parte te cebada preparada del mismo modo, y deslien el todo en agua caliente, cuya especie de polenta reputan por sano $y$ excelente alimento.

También usan de las papas asadas al res. coldo, en lugar de pan, y ocupan siempre una parte de sus hogares, pudiendo asegurarse que comen estas raices, más que otros alimentos que entran en gran número de sus guisados. Son muy sabrosas, y ellos las asan con inteligencia, revolviéndolas con un palito para que reciban el fuego con igualdad.

Comen tambien muchas especies de mariscos comunes á las playas de Chile, y que se encuentran con grande abundancia en las de Chiloe; varias especies de megillones, y de lapas, y varios grandes cangrejos, cuya comida es tan grata como variada. Los isleños de la parte oc. cidental son los que mariscan más; y decian que casi no comían otra cosa.

Se alimentan tainbién de una especie de fucus parecido al sargazo 6 fuc is gigantelus aunque diverso, que usan asimismo pura condimen. to, el cual tiene unas vejigas que sirvieran para sostenerlo en el agua, y sirven de pelotas á los muchachos. Sus tallos parecen correones de coche, su color negruzco y por dentro blanco y celuloso; lo usan asado al rescoldo y de otros modos, que en todos pareció insípido y glutinoso.

Aliméntanse igualmente de muchas frutillas silvestres del género del vrbustus y de la fragaria y murtillas como la que liaman luma, y la fresa chilena, é igualmente los frutos ó flores de una especie de bromeiia que se nombra quiscal, y por comerlas chupando las llaman chupones.

Sería largo de contar el todo de algunas otras plantas que usan para alimento, especialmente en tiempo de las hambres que suele padecer la isla, en cuyo número cuentan algunas criptogámicas.

Usan bastante de la pesca que les ofrece el mar con abundancia, como róbalos, lisas, sardinas, jureles $y$ otros comunes á los mares de Chile.

Es particular el modo con que la hacen: for. man, pues, unos grandes corrales con espesas estacadas, que se cubren de agua en pleamar, en los cuales queda al bajar la marea gran número de peces que entraron á cebarse, 6 de cangrejos, 6 de restáceos que se crían en las playas. Aseguraban haber pescado entre esta abundancia una especie del giotinovos 6 pez eléctrico; pero no fué posible su adquisición, con toda la diligencia con que lo procuró D. Antonio Pineda, así por éste como por otros peces raros.

No es indiferente la pesca de ballenas, que no pocas veces varan en las playas de Chiloé, y cuyas barbas, espermas y aceite aprovechan. Pescan también sobre cueros inflamados de vien. to, cuyo artificio se describirá cuando se trate de Concepción.

Carícter de los Chilotes 6 Chivenses y su modo de vida.

Esta es la parte histórica más odiosa y de inás difícil desempeño; porque á veces, si se pinta la humanidad como es, 6 se hace su sátira, 6 su panegírico. No se trasluce fácilmente el corazbi del hombre, sino por un largo trato, y transcurso de intereses que se chocan. Un viajero que reside poco tiempo en un país, aunque dotado de genio observativo, poco 6 nada alcanzará por sí; pues las operaciones comunes de la vida, apenas descubren lo que esconde el carácter interior. No obstante, pues, se darán algunas pin- 
celadas sobre el de los habitantes de Chiloé, conformes á los informes franqueados por perso. nas de larga residencia y trato en esta isla.

Viven generalmente con la mayor frugalidad entie los bosques que tocan cercanos á las orillas marítimas, excepto los que están en los pueblos ya descritos, cuyo terreno rozaron, pero que siempre brota y reverdece. Cada habitante tiene huerto en la inmediación de su casa, con plantío de habas, quinoa, papas, etc. Las casas son de madera, cubiertas de paja, que no hacen mala vista: por dentro tienen dos 6 más divisiones, una tarima que sirve de estrado y dos ó tres ponchos por alfombra; tres 6 cuatro platos $y$ algunas vasijas de cobre, y lo que puede llamarse vajilla, siempre muy descabalad.

Los más acomodados tienen braseros y materas de plata, y las casas, aunque por el mismo gusto, más espaciosas y amuebladas. Y los más pobres de la sociedad sólo tienen su fogón, tarimas de caña y pocas vasijas de barro.

Son los Chilotes, tanto indios como criollos, de buena indole, dóciles, humildes, pacíficos y obedientísimos á quien les manda: y es lástima que haya quien abuse del sagrado nombre del Soberano y de la disposición de $\tan$ buenos vasallos, exigiéndolcs bagajes, guías y otros servicios personales sin estipendio alguno. Los españoles, que parecen están exentos de algunas imposiciones 6 no pagan tributo, tienen por tanto algunas cargas pecheras; pero los indios, que pagan tributo, en toda la América cobran nada por correos, guías, etc., tanto en el Perú como en Nueva España; lo cual parece sin duda un grave abuso.

Son laboriosos; en especial las mujeres, que siempre se las veía en los telares, y ya traían agua, ya leña, ya hilaban, cardaban y hacían cuantas operaciones tocaban á sus artefactos, al menaje y á la cocina, tanto faenas delicadas como gravosas. Las casadas respetan y obedecen á sus maridos, y no se permiten la licencia que algunas solteras, cuya familiaridad con el otro sexo favorecen los bosques y las distancias en que unas habitaciones se sustraen del examen y la murmuración de las otras. Su traje parece inmodesto á los ojos del europeo, acostumbrado á ver las mujeres siempre tapadas; pero la costumbre, la pobreza y la constitución física del pais, las dispensa que cubran el pié y pierna (I). Es, pues, el traje ordinario de estas hembras (em

(I) Discúlpanlas y áun las justifican tal voz: primero, la pobreza del país, lo caro del calzado, as medias como zapatos, pues viene de Lima muy rocargado, Jespués de muchas manos, y no de Europa directamente como debiera: segundo, la lluvia y los loda zales que tienen que atravesar cada voz que salen a sus haciondas, por agua, leña, etc., haciendas que son casi exclusivamente de las mujeres, en cuyas circuns tancias es muy comodo no llevar calzado, y más sien- pezando por la cabeza, en que nollevan cosa al guna, sino pelo largo, negro y bien conservado, dividido en I 2 colgantes trenzas), camisa cerrada por el cuello como en los hombres, que cubre muy bien sus abultados pechos, un babador 6 volador, como llaman, un jubón y un faldellín con muchos pliegues alrededor de la alforza y cubo que tiene una forma campanuda y tersa, que sólo cubre hasta debajo de la rodilla, quedando descubiertos pié y pierna. "Como estas mujeres laboriosas y robustas tienen una presencia hermosa, tez generalmente bastante blanca, buenos cabellos y buena conformación en sus piernas, que siempre llevan muy limpias, y se las encontraba en quebradas y arroyos, ya la. vándose los piés, ya jabonando sus cabellos (I), ya cargadas de sus cántaros, parecía Chiloé (dice el autor), á muchos de nuestros compañeros, la misma Arcadia que pintan los poetas, donde dis currían mujeres de bella presencia, de sencillez $y$ simplicidad en el vestir, $y$ en que las princesas lavaban en los ríos."

Como desde ocho á diez años hacia el de 1780 se hallaban emancipados los indios de la esclavitud de las encomiendas en que trabajaban para los criollos sin propias utilidades, se recibió en estos la laboriosidad y la industria á que no estaban acostumbrados, sirviéndose ya todos á sí mismos, y todos trabajan ya por necesidad. La hija del capitán, la mujer del labrador, las hembras de todas clases; todas concurren igualmente á los arroyos y lavaderos: y la nobleza no tiene el privilegio de la ociosidad, pero en cambio se distinguen, no por la debilidad de su constitución y pálidos colores, sino en una modestia más interesante $y$ en mayor aseo, faltando el aparato de hombres que se mueven á la voluntad agena y la sumisa y ociosa turba que acompaña á los nobles; ni se conocen los jueces de una nobleza que insulta á lo restante del pueblo.

Acaso será la isla de Chiloé uno de los países civilizados en que las condiciones se acercan más á la igualdad, y en que sin embargo, se recono ce la nobleza y se la guardan todos los fueros legales que les concede la constitución espa.̃̃ola.

Los hombres se emplean en cortar leña, cr las labores de sus pehujales, cuidado de sus ganados y en el servicio militar. Son de robusta complexión, de mediana estatura, y de color blanco; y muchos son mestizos, cuya naturaleza se cono

do caro, que se destruiria a los primeros días; cuando los piés desnudos se lavan en el primer arroyo, la ropa alta no toma lodos, les dura más y embaraza ménos: tercero, ser costumbre del pais, que trajo la necesidad de que todas vistan de la misma manera; y como vide que todas vistan de la misma manera; y como vi-
ven en una isla que pocos de afuera los visitan, no ven en una isla que pocos de afuera los visitan, no
tienen rubor unos de otros y viven como er familia. (I) Lavan sus cabellos con la corteza de un arbol que tiene jugo saponśceo. 
ce por la poca barba. Los indios chiloenses son generalmente más blancos que en otras partes de América y de la misma suave indole $y$ subordi. nación.

Los vicios de ellos son alguna iddolencia, pues dejan al bello sexo la mayor parte del trabajo, y sin embargo de que carece la isla de mi1. chos artefactos, no se esmeran por su introduccion y viven en el mismo atraso que siempre.

El vicio del amor en las mujeres suele producir tan rabiosos celos, que los venenos no son demasiado raros, para lo que emplean las mu. chas yerbas que produce el país.

Los robos suelen ser frecuentes, pero sin efusión de sangre, y suceden pocos asesinatos.

La superstición no está desarraigada, ni áun en los criollos. No pudo el autor ver ejecutar las operaciones de la tintura, porque aquellas mujeres (así, dice, se lo dijo una de las mejores tintoreras) creen que si presencia alguno la operación, hará mal de ojo á su tintura. Los indios creen en hechizos y encantos, y se curan con huesos, cabellos y otros símbolos supersticiosos.

\section{Temperamento.}

La espesa arboleda que cubre toda la superficie de Chiloé, atrae mucha humedad de la at. mósfera, y así șuele estar ésta nebulosa y húmeda.

La costa también suele cerrarse mucho por los Nortes, Noroestes y Estes, que son lluviosos, y los que más dominan: vientos declarados de invierno, que empiezan por Mayo y duran mucho periodo.

Las granizadas son frecuentes y las nevadas en la parte oriental de la isla, suceden así como en Castro, pero en los demás parajes de ella nieva y fulmina poco. A los Noroestes de por la mañana siguen después los Sures.

La vegetación es muy viciosa, y así debe considerarse muy sombria esta isla y fangosa, como lo es en parajes.

\section{Estado politico, militar y comercial de la ciudad de Concepcion.}

Se tratará del estado de la ciudad de Concepción conforme á algunas noticias que pudieron adquirirse y á las observaciones del autor: y supóngase todo en la precitada época de 1789 .

Trasladóse, pues, esta ciudad, al sitio que hoy ocupa en el valle de la Mocha en 24 de Noviembre de 1764 , de resultas del furioso terremoto que sufrió la antigua Penco en $175 \mathrm{I}$, con inundación de sus campos y total destrucción de sus edificios; quedando situada á tres leguas Sur de Penco, entre los ríos Andarien y Biobio.

Aunque esta relación se ciña al estado que tenían las cosas al tiempo de esta excursión, y no deba abultarse con acontecimientos de la antigua historia de Penco, que se hallarán ya en varios libros impresos, no parece excusado decir que fué fundada por Pedro Valdivia, personaje que figura mucho en nuestras historias, en $\mathrm{r}_{55}$, donde se halla ahora la Vieja Penco.

En ella se erigió Audiencia Real en ${ }_{5}{ }^{6} 7$, que se extinguió á los siete aĩos, y se renovó el de 1609 en la ciudad de Santiago. Ha padecido varias ruinas, así por invasiones de los indios, como por los terremotos: fué la más principal y memorable la de 1603 , cuando aquellos destruyeron siete ciudades; y el más tremendo terremoto, el de 1730 , ocurrido el 8 de Julio, que empezó por grandes estremecimientos á la una de la mañana, y á que siguib retirarse mucho el mar, acrecentar la altura de sus aguas, volver á cobrar su nivel, traspasar sus costas y extend 1 se por las campiñas hasta que anego la infeliz ciudao. El repentino suceso obligó al consternado vecindario á guarecerse en las eminencias próximas, siendo desde allí expectador de los estremecimientos de la tierra, repetidos por tres 6 cuatro veces, hasta que á las cuatro de la mañana crecieron tanto los vaivenes, que cayeron los pocos edificios que aún se mantenían; retirándose des. pués el mar, y volviendo á inundar las tierras con mayor furia que antes.

No se logró noticia de los particulares fenomenos del último terremoto, que sucedi6 en $\mathrm{r} 75 \mathrm{I}$, elevándose el nivel del mar con movimientos cumo en el antecedente, y anegando la ciudad, en tales términos, que sólo quedaron cimientos, tapias y pilares: et seges ubi Troya fuit.

La actual ciudad de Concepción se gobernaba en 789 por un Intendente que reunía el mando de las armas y el empleo de Maestre de Cam. po. Tiene su cabildo, compuesto de dos Alcaldes ordinarios y cuatro Regidores, que se mudan anualmente, cabildo eclesiástico presidido de su Obispo, que residía en la Imperial, hasta el gran levantamiento de r6or, y compuesto de Dean, Arcediano y dos Canónigos. Se estaba construyendo la catedral, pero con lentitud por falta de fondos: tiene cinco conventos de religiosos: Santo Domingo, San Agustín, San Francisco, la Nerced y San Juan de Dios, y un monasterio de Trinitarias 
Descalzas, un Colegio conciliar y una casa de ejercicios, todos edificios pobres, $y$ que aún tenian sin concluir algunas fábricas.

En otros tiempos residia aquí seis meses del año el Presidente de la Audiencia Real, pero ya sólo está el Maestre de Campo $\in$ Intendente de la provincia, cuyos empleos recaen en un bien opinado militar, enviado por la Corte, teniendo también á sus órdenes las tropas de la jurisdicción.

\section{Descripción geogrifica del Obispado é Intendencia de Concepción.}

El terreno de esta provincia, que hace parte del Reino de Chile, corre casi de Norte-Sur, y se contiene entre el mar y la cordillera. Por el Norte le divide el río Maule del Obispado de Santiago; por el Oeste cunfina con el mar del Sur; por el Este con la cordillera, y por el Sur se extiende la jurisdicción civil algunas leguas más allá del Biobio; pero la espiritual comprende hasta vastísimos límites, y se reputa alcanzar donde la re. ligión haga prosélitos, hasta el mismo Cabo de Hornos. Desde luégo comprende la vasta Isla de Chiloe, sus islas y establecinientos adyacentes, y el Archipielago Chonos. Tendra de largo la provincia, entre los ríos Biobio y Maule, como 40 leguas, y de ancho entre el mar y la cordillera de 20 á 25, más 6 ménos, según la disposición de valles y terrenos. Varios ríos, que todos nacen de la cordillera, interceptan su suelo y forman amenisimos valles: cuéntanse por principales el Maule, Laja, Itata, Nuble y el Biobio; ninguno navegable sino en balsas, á excepción del último, que admite barcas hasta cuatro leguas de su boca. Entre varias pequeñas lagunas de que abundan los valles y cañadas que forman esta provincia, hay tres considerables, que son: la de Quinel y la de Avendaño, situadas álas inmediaciones del Itata, $y$ distantes 18 leguas de la capital, y la otra en el partido de Chillan. En la primera dicen que hay perlas de buen oriente, cuya pesca descuidan los naturales por desidia. En la de Avendaño, dice D. Cosme Bueno, que se hallan caballos marinos, pero la relación y descripción que hacen de estos anfibios, y su comparación con los caballos terrestres, es tan poco verosímil, que, 6 es un animal imaginario, 6 cuando más, alguna especie de foca, con que se les puede asemejar por tener los piés á manera de aletas, y no será ex. traño que los no acostumbrados á esta clase de objetos, no acierten con una descripción legitima.

Los partidos de la Intendencia. son: el de la capital Concepcion, cuyo corregimiento antes de la ruina se ceñia á la ensenada que forman las lo. mas altas en el contorno de la ciudad destruída, pero ya se extiende hacia el Sur hasta el Biobio, y costa que corre hasta su boca; con todo el
Hualpen y Talcalsuano. Además del curato de la Catedral tiene los de Hualqui y Talcahuano.

Cauquenes, que su corregimiento se contenia en el de Maule, pero por su mucha extension se estableció aparte al Sur de este rlo. Confina la jurisdiccion de Cauquenes por el Este con la cordillera, por el Oeste con el mar, por el Sur en la parte alta con Chillan, y bajando para la costa con el de Itata. Es su capital la villa de las Mercedes de Manso, á orillas del estero Tutuben. Tiene tres curatos; el de la Capital, el de la Isla de Maule y el de San Francisco de la Puerta, con convento de franciscanos. Abunda en gana. dos y tierras de pan llevar.

Chillan, que sigue al Sur del anterior, $y$ confina por el Este con la cordillera, por el Oeste con el de Itata, y por el Sur con el de Puchacay. Tiene por capital la ciudad de San Bartolomé de Gamboa, cabildo, iglesia parroquial y tres conventos, de Santo Domingo, San Francisco y Merced. En I 753 se erigio el de San Francisco en colegio de misioneros apost6licos destinados de España para la conversión de infieles y salen también á hacer misiones por todo el obispado. Pertenece á este corregimiento el curato de Perquilaben. Además de los frutos de la tierra y matanzas de ganados, tiene este partido la utilidad de finos vellones de lanas de que hacen algunos tejidos; $y$ sus campiñas son hermosas y despejadas, y produ. cen con abundancia ( $\mathrm{I}$ ).

Itata, que sigue al Sur del último, confinando por el Norte con el de Cauquenes, por el Este con el de Chillan y parte de Puchacay, y por el Oeste con el mar. Tiene dos villas en su jurisdiccion, la de Jesús y la de María, y se extiende hasta más allá del Itata: tiene corregimiento, tres cu: ratos, el de Quipolemu en la villa de Jesús, y los de Ninhue y Quirihue; y comercia en trigos, vinos, sebos, charques y curtidos.

Puchacay, que sigue al Sueste del anterior y confina con el por el Norte, con las orillas del Biobio por el Sur, con la jurisdicción de Concepción por el Oeste, y con los términos del Rere por el Este. Es su capital la villa de San Juan Bautista de Hualqui, y tiene dos curatos, el de Conuto y el de la Florida. Su comercio es en los mismos artículos que el partido precedente. Y el de Rere, que confina con el anterior por el Oeste y Noroeste, y por el Este y Sur con los terminos y jurisdicciones de las plazas de la frontera. Es su capital la villa de Buena Esperanza, llamada ya San Luis Gonzaga, alias la Estancia del Rey, en donde tiene un curato, y su comercio es como en los partidos antecedentes.

Algunos de los referidos curatos tienen una

(I) Fué fundada la capital por Rui do Gamboa en 1580. Molina: Historia de Chile, escrita en italiano, página 190. 
gran extensión, como de rg 620 leguas, y se in. troducen en otras provincias, por lo que deberán pertenecer á entrambas. Hay varias parroquias rurales que administran el pasto espiritual á varios colonos que se extienden por los valles y quebradas de la provincia, sin hacer poblaciones formales; aunque ya el Intendente, en $\mathbf{1 7}^{89}$ habia podido reducir á tal, algunas habitaciones dis. persas.

El autor, después de haber reconocido los alrededores de la capital y bahía hasta cierto punto, examinb también parte de las orillas del Bio. bio, Norte y Sur hasta la plaza de Santa Juana, espacio de 14 leguas; y á juzgar de toda la pro. vincia por la parte que víb de ella, opina que abunda de excelentes terrenos para pan llevar. que casi toda se cubre de bosques de hermosísimos árboles de que se visten todas sus monta nas, muy apreciables unos por sus maderas y otros por sus frutos, que la mayor parte del país es montuoso, y que sus montes suben hasta el pié de los Andes, donde vió llanos dilatados hacia el volcán de Tucapel, y que los ríos que entran en el Biobio forman algunos interesantes valles, capaces de la mayor población, si la poca vecinciad de los indios los constituyeran tranquila morada.

Constituye la parte más principal de la Intendencia, la población que se halla al abrigo de los presidios en ambas riberas del Biobio. Los presidios están situados en la parte Sur de la provincia á las orillas de este río, ya á la del Norte, ya á la del Sur, en los parajes más oportunos, bien para cerrar el paso al enemigo, bien para protejer las poblaciones; y corren, empezando desde la cordillera para el mar en este orden: en la orilla ${ }^{\circ}$ Norte 6 de la parte de acá, Santa Bárbara, Puren, Angeles, Tucapel, Yumbel, Talcamavide y Concepción; y en la parte de allá, el Nacimiento, Santa Juana, San Pe. dro, Colcura y Arauco.

\section{Estado milivar.}

Las fuerzas destinadas para la guarnición de estas plazas consisten en dos batallones de tropa reglada, el primero de siete compañías de infantería, y el otro, que vino de España en $\mathbf{7 7 0}$ con el nombre de batallón fijo de Chile, consta de seis de infanteria y una de artillería. Hay además un cuerpo de seis compañías de caba. llería, que se distribuyen en las varias plazas y otros servicios. T’ambién hay diez compañías en los distint'ss particics, crmpuestas de vecinos alistados para rervir en los alzamientos y casos necesarios con sus ermas y caballos; y varios cabos y sargentos di asamblea para que los disciplinen. Se componen estas tropas, de criollos del país, que son buenos soldados, según se acredi- taron en varias ocasiones en la guerra contra los indios sus comarcanos; gente valerosa, que aunque no disciplinada á la Europea, pelea con obstinación y con cierta táctica que le es propia.

No será fuera de propósito dar una idea de las plazas que constituyen las fronteras chilenas. Las distancias, al paso que abultan ó disminu. yen los objetos, alteran también el sentido de las palabras; $y$ asi, no se entienda que estas pla. zas sean fortalezas como las que tienen tal nombre en Europa. Las falsas ideas que se fijan á los vocablos, son el manantial de nuestros erro. res. Tanto el hombre público como el particular deben conocer el verdadero estado de las cosas.

Los fuertes que visitó el autor, se parecen á los de Chiloé, y no son en realidad más que unos fuertes de campaña, capaces de poca guar nición y de resistir solo á los indios.

El fuerte de San Pedro se halla al otro lado del Biobio, y es el primero que se encuentra frente á la ciudad de Concepción. Ll rio tiene de ancho en esta parte 2.700 varas 6 I 8 cua dras (I) que es como cuentan allí $y$ en muchis partes de nuestra América. El fuerte, y una corta población que protege, pegada contra las barrancas de la orilla del río, forman un paisaje de nacimiento: las casas son chozas de pobres vecinos y de algunos soldados de la guarnición. La fortaleza es un cuadrado con cuatro peque. nos bastiones, cercados de estacada y rodeados de foso, excepto por el frente del río, que baña su pié: toda la obra es escavada en el propio tetreno, y así no se gastan ni ladrillos ni mampos. tería, y la excavación del foso figura toda la fortaleza: se guarnecen sus baluartes con pequeña artillería de campaña, y encierra en su recinto dos 6 tres edificios militares para la guarnición; y alrededor de él hay varios pequeños huertos, que cultivan los militares y vecinos.

El fuerte de Porcura, que no se hallaba en tan buen estado como el antecedente, está sobre una loma, y tendrá unas roo varas cuadradas de área; su cortina estaba encorbada, tenía á su in. mediación algunos pequeños ranchos, y no protegía algún terreno de consecuencia.

El Santa Teresa parece de los más bién situados, entre el río y una laguna, y la parte que queda abierta se cierra con competente estacada. Guarda uno de los pasos por donde se vadea el río, cuyo mismo vado defiende también la opuesta plaza de Talcamavide; y ojalá estuviese mejor despejado y expedito el terreno que yace á la inmediación del fuerte, y no dejasen que se criara yerba, matorrales y broza. Los vecinos,

(1) La cuadra tiene 150 varas castellanas, y en ol.'s reinos de América es más ó ménos. El río tiene profundidad para barcos, pero muy desigual el fondo, como se deduce de la príctica de pasarlo en balsas. 


IMAGE EVALUATION

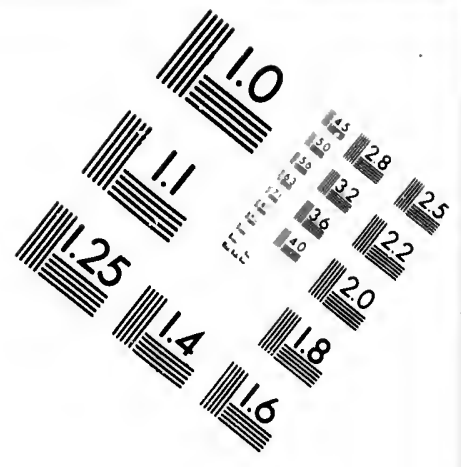

TEST TARGET (MT-3)

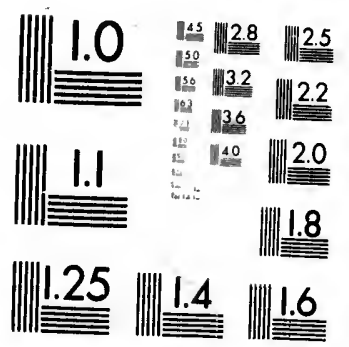

$6^{\prime \prime}$

Photographic

Sciences

23 WEST MAIN STREET Corporation

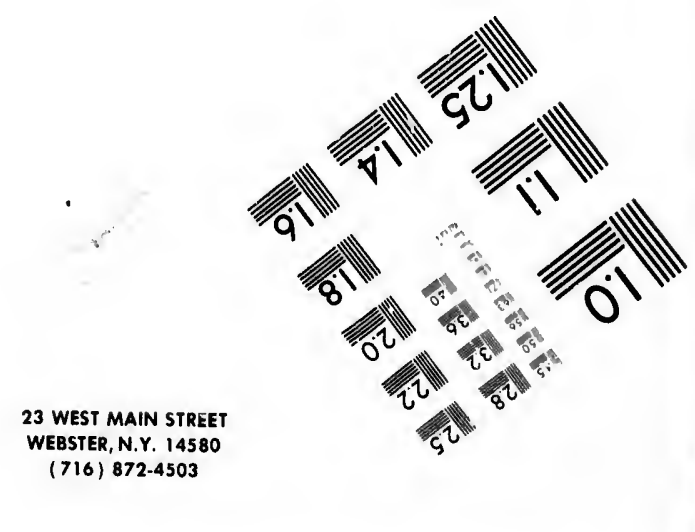




\section{CIHM/ICMH Microfiche Series.}




\section{CIHM/ICMH Collection de microfiches.}

$\begin{array}{ll}\text { hMH } & \begin{array}{l}\text { CIHM/ICMH } \\ \text { Collection de } \\ \text { microfiches. }\end{array}\end{array}$

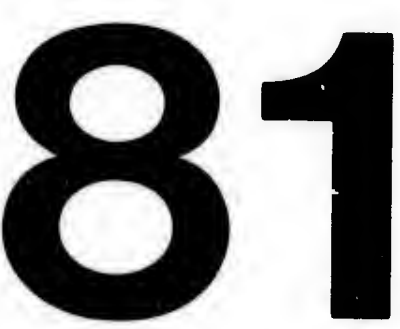


que muchos son soldados, prefieren por su comodidad la habitación inmediata al fuerte; pero las razones de guerra no debieran permitir tal abuso. Consiste la plaza en un pentágono forti ficado que consta de cinco pequeños baluartes capaces de artillería de campaña, construidos como los que preceden; y tiene ocho ó nueve cañones de á dos y de á cuatro, y cuatro ó cinco edificios militares. Al abrigo de ella hay unas roo casas, $y$ por un ameno valle muchos ranchos de colonos que pertenecen á esta población. Este valle está lleno de grupos de hermosos árboles, de pehujales, de sembrados, y tendrá dos leguas de larg.' y una de ancho, siendo su terreno de los que más producen, reg'ado por el Biobin que lo atraviesa, ó bien por alyunos arroyos ,ue entran en el, presentando una vista ciertamente hermosa, y cuya forma era cuadrilonga en dirección de Norte á Sur, cercado de varios montes.

Talcamavide está en la orilla Este opuesta, frente á Santa Juana para estorbar el paso de los indios enemigos por cualquier parte que vengan: es un cuadrado fortificado de cuatro pequeños baluartes de unas 70 varas de lado, y circundado die buen foso, á cuyo abrigo, á la parte aquende del río, hay alguna población y ranchos.

Según las noticias que adquirió el autor sobre los otros fuertes, la plaza de Yumbel contiene en su recinto cuatro ó cinco edificios militares, y se guarnecían sus baluartes con cuatro cañones de á dos y una culebrina, con sus pertrechos tolos initiles.

Tucapel, plaza de mayor consideración, al parecer, tiene foso y estacada, y se guarnecían sus baluartes con tres cañones de hierro, uno de bronce y dos de montaña, con diferentes pertrechos, encerrando su recinto cuatro 6 cinco edificios militares.

El Nacimiento tenía cuatro cañones de bronce de á cuatro y de á ocho, y de varios calibres, con sus correspondientes pertrechos y edificios militares.

Santa Bárbara tiene algunos baluartes y un rebellín, y está circundado de un profundo foso de nueve varas de hondo. Tenía nueve piezas de artillería de á dos y de á cuatro, y dos pedreros, $y$ en su recinto cinco edificios militares.

Antuco y Villacura, tienen dos fortines y artillería de campaña cada uno.

Puren ,es plaza de mayor consideración, mejor artillada, y tenían sus baluartes ir pequeños cañones y su recinto cinco edificios militares.

Finalmente, la plaza de Angeles tiene para su defensa, baluartes con siete cañones.

Aunque la paz que reinaba con todas las naciones indias desde el Biobio hasta los paralelos de Chiloé, y que la sabia cautela de mantener entre la indiada enemiga un gran número de cspias y amigos, aseguraban nuestros fuertes acordona dos en el Biobio contra cualquier sorpresa; no pudo el autor (dice) ver sin disgusto, como bu an español y vasallo, el mal estado y entretenimiento de estas fortalezas; aunque por el buen concepto que le merecía el Maestre de Campo que había entónces, $y$ que como recién entrado en este cargo no habia podido visitar todavía conve. nientemente el cordón de presidios, esperaba que providenciaría el remedio de todo; tanto más, pues era Presidente de Chile un militar que había obtenido el propio empleo, conocía las fronteras y su importancia, y mejor que otros, la guerra contra estos indins, en la que había acreditado su valor y singulares talentos.

Tuvieron'su origen estas fortificaciones $y$ barrera del Biobio, el año de $r 608$, en que cansado el Gobierno de sostener la costosa guerra de Arauca, que consumía remesas de gente de 600 en 600 hombres y correspondientes sumas de dinero y pertrechos, especialmente después de la pérdida de las siete ciudades, hubo de recurrir á providencia tan oportuna para evitar consecuencias tan desgraciadas, dotando la barrera de fuertes con 2.00o hombres pagados de presidio, y con el situado de 270.000 pesos, que desde dicha época empezó á enviarse del Perú.

Aunque el valor español había triunfado muchas veces de la desesperada oposición de estos belicosos indios, y acabado con sus Jefes en varios encuentros, no parece sino que esta nación era una hidra, que cortada ura cabeza brotaba otra. No siempre estuvo la victoria por las armas españolas: obtuvo muchas la constancia é intrepidez de los chilenos, como lo manitiestan la suerte de varios fuertes perdidos y recobrados, el hado de Valdivia, las victoriảs de Lautaro, la destrucción de Concepción, de Cañete, y finalmente, la que sufrieron en $\mathrm{I}_{603}$ las siete ciudades, Villarica, Osorno, Imperial, Valdivia, $\mathrm{Ca}$ ñete, Angel y Coya, en tiempo del General Paillamachu; bien que contra estas desgraciadas ciudades contribuyó principalmente el levantamiento de las naciones indias de los Conchos y Viliches, $y$ otras que apenas ó ninguna parte habian intervenido en las guerras anteriores.

Las victorias españolas antes y despues de este tiempo fueron de las mís brillantes. Don García de Mendoza humilló la cerviz de Arauco, no dejó Hulmen ó Jefe con vida, y conquistó á Chiloé. Cañete vió perecer en sus muros los e jér. citos araucanos: no h tbo presidio español que no les rechazase con pér jida y escarmiento, ni célebre General araucano que no cayese bajo la es. pada española. Pero la bien manejada conjuración de $\mathrm{r}_{60} 3$ hizo época en esta destructiva $y$ disputada guerra; y el sabio Gobierno, movido de los sanos consejos del jesuita Valdivia, adoptó el sistema de catequizar con la paz y el Evange- 
cordona-

presa; no

omo bl.an tenimienbuen conampo que ntrado en ria conveeraba que into más, $r$ que halas fronotros, la abía acre.

nes y ba. e cansado a de Araule 600 en de dinero le la pérrrir á proecuencias e fuertes , y con el cha época

fado mude estos fes en vasta nación a brotaba las armas ia é intreiniestan la brados, el iutaro, la y finalsiete ciudivia, $\mathrm{Ca}$ neral Paigraciadas

levantaJonchos y parte hares.

espués de

ites. Don

le Arauco, onquistó á

s los ejér ñol que no $o$, ni céle. ajo la es. a conjura. structiva $y$ movido de ia, adoptó I Evange- lio á los que la fuerza de las armas destruía y no conquistaba.

Nadie extrañe que los conquistadores de la América, que llevaron sus armas vencedoras por todas las cuatro partes del mundo, encontrasen en este rincón de él tan obstinada resistencia. Estos indios no opusieron contra los españoles una multitud indisciplinada y mal armada, cuyo número á veces por una ignorante confianza se amontona y embaraza. Las naciones araucanas, viliches, juncos, etc., y pehuenches, escogen para la guerra los más robustos; y esos opusieron á sus enemigos, conservando aún su disciplina militar, á que debieron espíritu de arrojo más que á su número, que á veces fué igual y algunas inferior. Forman el cuadro y.algunas otras formaciones; se arman de grandes lanzas, con que, al modo de la falange macedónica, oponen una muralla de picas á la caballería que les acomete; ponen caballería en las alas, al modo de otras naciones antiguas y modernas, para que sostengan la infantería; y también usan machetes y lazos, que manejan diestramente, y no hicieron ménos en las guerras con los fusiles que ganaron á los españoles. Los pehuenches defienden aún sus cabezas con morriones guarnecidos de una plancha de hierro, y cubren con corazas el tronco y parte del brazo. Los viliches también usan corazas y se quitan los calzones cuando pelean, para que noles embarace. Igualmente usan estas naciones la formidable arma del laqus, ó bolas enramadas atadas al lazo. Acostumbran no presentar batallas formales, sino atacar en pelotones, emboscadas, asaltos y correrías repentinas que llaman malocas, con cuyo método, sin tanto riesgo suyo, cansan y destruyen al enemigo. Los pehuenches son entre todas estas naciones los más atrevidos, aguerridos y bien equipados.

No sacan poca ventaja estas naciones guerreras de la frugalidad con que subsisten. El mantenimiento de las tropas es en las guerras europeas el artículo más dificultoso. Pero el guerrero chilense lleva todas sus municiones de boca, con una bolsa llena de harina de habas 6 de cebada, y con su huampar ó vaso de cusrno. Los caballos, cuya carne comen también, les constituyen otro recurso, pues cuando les aqueja el hambre, los sangran, $y$ hacen alimento para un par de dias. La harina la mezclan con agua, y tienen así el condimento necesario.

Hacen nula la ventaja de las armas de fuego avanzando intrépidamente hasta ellas, y según noticias de algunos Oficiales se meten por las bayonetas, y emprenden otras acciones de extraordinario valor, que hacen verosímil to que cant $\delta$ de ellos el poeta español Ercilla. "Me referían (dice el autor) que uno á quien no daban cuartel (que los chilenos ni lo dan ni lo reciben) como no le cortaran pronto la cabeza, dijo á su enemigo, sacando su arma: toma mi cuchillo, que el tuyo no corta."

También, dice, le informaron, que no poseen estos indios arte alguno de atacar las plazas, para lo que se valen de simples bloqueos, formando cuerpos de caballería que embisten lo fuertes, y les cortan así los socorros, mantenién. dose fuera del alcance del cañón: idea que no co rresponde á la pericia que se les supone en las otras partes de la guerra.

Pero ya se contienen en justos límites, manteniendo un recíproco comercio, y algunos, alianza con los españoles; además de que ellos mismos con las recíprocas é intestinas guerras se destruyen, de modo que dan poco cuidado á sus vecinos, á los que la experiencia de lo pasado deberá tener alerta.

Finalmente (pues no parece de omitir), en la bahía de Concepción hay una respetable batería en un emplazamiento sobre un collado, que llaman de Gálvez: con suficiente número de piezas de á 24, que se hizo para defensa del puerto en la última guerra de I $_{780}$ hasta la paz de $I_{783}$

También subsiste el antiguo castillo delante del viejo Penco, que proteje aquel fondeadero. El mar metió allí tantas arenas, que sólo se descubre el dintel de la puerta que hace frente al mar, á cuya orilla se sitúa, y donde se registra el escudo de armas de la casa de Austria. 


\section{Noticias de la manufactura de carnes saladas de Buenos-Aires.}

Malogradas por varios incidentes las tentativas hechas antes de ahora para el establecimiento de este comercio, se ha brindado á practicarle 1). Tomás Antonio Romero, vecino y comercian te tan inteligente como acreditado de BuenosAires (I). La cuenta individual de esta manufactura, hace ver que este ramo es uno de aquellos que parece /particularmente destinado á las inmediaciones del Río de la Plata: no está en oposición con otras provincias: excluye una porción no indiferente de comercio extranjero, y favorece nues trä navegación, nuestros fondos y nuestros brazos, objetos esenciales que nos hemos propuesto para la opulencia nacional. No será tal vez des. agradable al Gobierno ver el pormenor de esta fábrica, la cual, of reciendo á primera vista una ganancia considerable para los emprendedores, no solicita por otra parte más protección de Gobierno que unas providencias duraderas y una preferencia en los Derechos Reales sobre la introducción de carnes extranjeras.

PRESUPUESTO de productos y gastos de la fabrica de carnes saladas, cn tres años, supuesto un empeño de 90.000 pesos contra las existencias de la fábrica.

PRONUCTOS POR LO MENOS

Existen de rodeo, 24.000 cabezas de ganado. Su anual procreo.

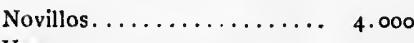

Vacas................ 4.000

Distribución de vacas.

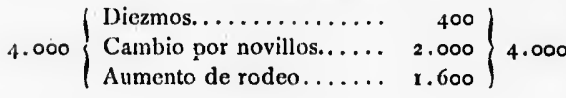

Total de novillos.

Del procreo............. 4.000

Cambio por vacas......... 1.000

Suma......... 5.000

(I) El papel de estas propuestas ha sido remitido desde Montevideo al excelentísimo señor Inspector (ieneral de Marina, el Teniente General D. Félix de Tejada. El patriotismo que realmeute mucve á Romern, merece alguna protección de parte del Gobierno.
Distribución de los 5.000 rovillos.

\begin{tabular}{|c|c|c|c|c|c|c|c|c|}
\hline Prikcips. & : & $\begin{array}{l}\text { Quin- } \\
\text { tales } \\
\text { Curme }\end{array}$ & \begin{tabular}{|} 
Quin- \\
tales \\
Charg
\end{tabular} & $\begin{array}{l}\text { Quin- } \\
\text { Pales } \\
\text { Grass }\end{array}$ & $\begin{array}{l}\text { Quin. } \\
\text { lales } \\
\text { Sebo. }\end{array}$ & Cueros. & $\begin{array}{c}\text { Qxi- } \\
\text { jadas. }\end{array}$ & $\begin{array}{l}\text { Les- } \\
\text { guas }\end{array}$ \\
\hline $\begin{array}{l}\text { Diezmo... } \\
\text { Consumo. } \\
\text { Salazozn.. } \\
\text { Tasajo.... }\end{array}$ & $\begin{array}{r}400 \\
500 \\
3.000 \\
1,100\end{array}$ & $12, \infty$ & 2.200 & $\begin{array}{r}8 \\
85 \\
510 \\
187\end{array}$ & $\begin{array}{r}8 \\
85 \\
510 \\
187\end{array}$ & $\begin{array}{r}500 \\
3.000 \\
1.100\end{array}$ & $\begin{array}{l}1.000 \\
6,000 \\
2,200\end{array}$ & $\begin{array}{r}500 \\
3.000 \\
3.100\end{array}$ \\
\hline Sumss.. & 5.000 & 12.000 & 2.200 & $7^{782}$ & 782 & 4.600 & 9.200 & 4.600 \\
\hline
\end{tabular}

Reducción de productos á pasos corrientes.

I.000 quintales de carne salada vendidos

en Montevideo á 20 rs...............

5.000 dichos de id. registrados para Espa-

ña $\mathrm{y}$ vendidos allá á 6 pesos..........

6. oro dichos de fd. remitidos de la Casa a id.

30.000

36.000

Charque.

2. 200 quintales vendidos en Montevideo

$\{2$ pesos.......................

Grasa.

782 quintales de grasa a 4 pesos........

Sebo.

782 quintales de sebo á 4 pesos........

Cueros.

4.600 cueros al pelo vendidos èn España

a 3 pesos................. 13.800

Quijadas.

9.200 quijadas á medio real..........

Lenguas.

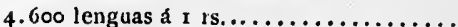

Retornos.

Fletes de retornos del Bergantín y el Ber-

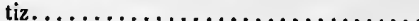

$x 8$ por roo de gauancia en el retorno del dinero de España:..............

Pesos $x 14.470$ GASTOS Á Lo SUMO

En particular carn; de Montsvidso. 500 barriles 
Carne registrada para España.

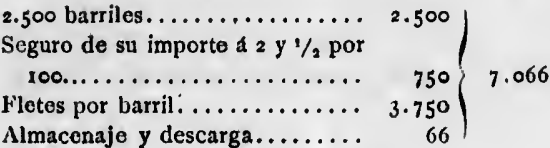

Carne remitida para la Casa.

3.000 barriles............. 3.000

Seguro de su importe a 2 y $1 /$, por

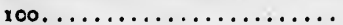

Seguro de las $3 \%$ de los barcos

a $3 \mathrm{y} 1 / 2$ por $100 \ldots \ldots \ldots \ldots$.

Gente de mar................

Recorridas............. 4.500

Ranchos................. 2.500

Almacenaje y descarga......... $99_{96}$

Grasa.

60 barriles. ....................... 160

Sebo.

160 barriles.................... $\quad$ r60

Cueros.

$\left.\begin{array}{l}\text { Seguros á } 2 \text { y } \% / 2 \text { por roo........ } \\ \text { Almacenaje y descarga........ } 345 \\ 36\end{array}\right\} \quad 38 \mathrm{r}$

Quijadas.

23 barriles...................

Lenguas.

23 barriles....................

Fletes de vuelta.

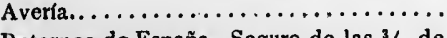

Retornos de España. Seguro de las $3 / 4$ de los barcos $a y^{1 / 2}$ por $100 . \ldots \ldots \ldots \ldots$, Salarios de la gente de la es-

$\operatorname{tancia} . \ldots \ldots \ldots \ldots \ldots \ldots$
Pan $\quad 5.699$ Pan, yerba, etc.......... 1.612 Sales................ $\quad x \times 500$ Conservación de la Chalupa.. $\quad 600$ Factorias. :............ $1 \times .447$
SUMA ANTERIOR.... $15 \cdot 33^{2}$

Para almacen y descarga............ $\quad 36$

Para salarios de la gente de la estancia... 5.699

Para atrasos de fd................ 2.849

Para íd. de la ld. do mar........... 2.040

Para sales, incluso gastos de Zumaca $y$

Balandra................... $\quad 11.500$ Para conservación de la Chalupa....... 600

Suma pesos...... 38.056

Dése que la Casa deba............ 50.000

Dése que se la supla por la anterior cuenta. 40.000

Quedará empeñada en deber........... 90.000

Tiene de productos anuales.... $\quad 1 \times 4.470$

Tiene de gasto........... 56.101

La restan cada año......... 58.369

Pague el intesés de 90.000 pesos

al 6 por roo........... 5.400

Le restan aún.......... 52.969

Dése que pierda por casos ines.

perados.............. 22.969

Tendrá cada año sobrante lf-

quido................. 30.000

Pagara en otros dos años....... $60.000,90.000$

Ha emprendido, á la verdad, un comercio de esta especie con la Habana el hacendado D. Juan Balbin: tiene una fábrica dirigida con buena economía, en las inmediaciones de aquella plaza, camino de Maldonado, y sus exportaciones no han sido indiferentes; pero como quiera que dicha fábrica carece de fondos, y que por otra parte no aspira á aquella perfección que se solicita en Europa, de ningún modo el proteger la una destruiría esotra, tanto más, que es natural que la protección del Gobierno no sea violenta, dirigiéndose á la sóla preponderancia en la balanza contra el extranjero, sin envolver igual especie del comercio nacional.

Sucede á este ramo, el de la sal, que tantas veces ha hecho creer en Europa la imposibilidad de una conducta fácil á Montevideo ó á los de. más parajes en donde fuese necesario transportarlo para el aprovechamiento de la corvina $y$ del bacalao.

Hasta aqui ha sido costumbre en Buenos. Aires el traerla por medio de carretas, desde la Laguna, que está unas I 50 leguas al Sursudoeste: se juntan en una especie de caravana, cuyo total subirá anualmente de 300 á 350: cada carreta carga I 6 fanegas. Esta sal, que suele costar de seis á ocho pesos la fanega, es tan buena, que no se ha ceshecho puesta un año en el tocino. No le es muy inferior la sal del puerto de San José, en donde unas ${ }_{2} 2$ ó I $_{5}$ carretas pudieran amontonar en poco tiempo ro 6 $\mathrm{r} 2$ cargamentos de á
Para 12.000 quintales de carne, 6.000 ba-

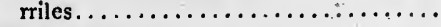
Para la grasa y sebo, 320 id............ Para seguros de la carne remitida ; or la

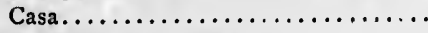
Para seguro de los barcos............ Para ranchos....................... . Para alinacenaje y descarga de la carne. 2.500 96 Suma PESOS...... 15.332 
500 fanegas cada uno (I). Abunda igua.....1te en el lío Negro, pero la navegación es allí peligrosa y sólo al alcanc : de emba:caciones de poco calado, cuando en el puerto de San José pueden entrar y cargar sin riesgo, las que á él se dirijan. Finalmente, en el puerto de San Julián, aunque

(1) En 1785 informa D. José Salazar al excelen. tísimo scñor Virey $D$. José de Bertiz, que en quince días, nueve hombres acopiaron 9r montonesde más de una estatura de un hombre cada uno. no de tan buena calidad, es tanta, que además de poder abastecer cualesquiera salados, alcanzaría sola á proveer todas las provincias.

La navegación hasta aquí poco segura for falta de pericia marinera $y$ poco repetida por falta de objetos comerciables $y$ de fondo, no ha establecido aún como único medio el conducir la sal por mar: en este caso abaratará aún mucho, $y$ desde luego, há pocos años que se ofrecíb á cuatro pesos fanega, traída del puerto de San Julián.

\section{Reflexiones politicas sobre los dominios de S. M. desde Buenos- Aires hasta Chiloe por el Cabo de Hornos.}

Una región que pareció hasta aquí abando. nada de los benéficos influjos de la vegetación, y que compuesta de costas casi inaccesibles, batida de unos vientos constantemente tempestuosos y colocada en los extremos del continente, casi como un dique contra la cólera de las olas, parecía destinada á ser el asilo únicamente de los peces y aves silvestres, ha llegado, en fin, á excitar la codicia de los europeos; y después de haber sido la causa de unas desavenencias consicierables (1), y haber fomentado una guerra (2), aún en el día amenaza nuevas discordias y exige en el Gobierno uila atención seria y constante.

El bergantín Carmen que ha navegado en conserva de las Corbetas hasta 'il Puerto Deseade, y que reconocidos luégo los ríos de Santa Cruz y Gallegos ha regresado felizmente á BuenosAires, es buen testigo de la aserción que antecede: más de 30 embarcaciones inglesas, francesas $y$ americanas 6 independientes, 6 realistas, estaban ocupadas en la pesca de la ballena en la son. da desde los 47 hasta los $39^{\circ}$. En la Isla de los Estados, al referir de la fragata francesa Ene Kar, había las barracas y demás utensilios necesarios para el beneficio de la pesca: en el río Santa Cruz y en el puerto San Gregorio se había in. tentado distraer los Patagones de nuestra amistad, se les prometía un establecimiento en el Puerto Deseado: no pocas veces habían invernado en el puerto Egmont varias embarcaciones extranjeras: finalmonte, á nuestras reconvencio-

(I) En el año de 1770 estuvo muy próxima una rotura con Inglaterra, por la expulsión de la colonia inglesa del pucrto Figmont en las Islas Malvinas.

(2) Los proyectos del ex-jesuita Falkaner sobre el internar por los Ríos Negro y Colorado hasta Valdivia, debieron dar muchas esperanzas a la Inglaterra de ofendernos sensiblemente, y desde luégo nos causaron unos gastos enormes. nes sobre el no frecuentar estos mares, respondía el Capitán inglés Botel que tenía pasaportes de su Monarca: al mismo tiempo, varios buques ingleses y americanos (entre ellos algunos bergantines) transitan el Cabo de Hornos, visitan nuestras costas, y por consiguiente, en el año de I 789 puede considerarse ya, relativamente á esta parte, franqueacla la doble barrera de los trata. dos y de la ntureyación.

la España, en sus combinaciones, está siempre ligada con tres objetos dificiles de reunirse $\sin$ que choquen y se ofendan mútuamente (I), y son: $1 .^{\circ}$ sus fuerzas y ventajas; $20^{\circ}$ sus relaciones en la balanza de Europa; $30^{\circ}$ sus relaciones con los indios moradores; y aunque en los países más fértiles, poblados y ricos de nuestras conquistas no pasen de los ya citados los puntos políticos de vista bajo los cuales ha de con. siderarse la Monarquía, ya las costas Patagbnicas, á pesar de no tener circunstancia alguna favorable, han llegado á abrazar todos estos objetos, en un grado tanto más interesante, cuanto más capaz es de un remedio temprano y oportuno.

Que la internación de cualquiera fuerza europea por la costa oriental Patagónica sea un peligro imaginario, y. un peligro que no debe ocupar ni un momento nuestro sistema defen. sivo, es punto tanto más decidido, cuanto más influyen los materiales acopiados, á hacer conocer la verdadera Geografía de esta parte del Continente.

Ya los Sres. Varela y Saá y Farria habían rebatido en Buenos-Aires estas ideas (2), cuan-

(I) Axiomas politicos.

(2) Documentos existentes en la Secretaria del Vireinato: el 1. te; y el 2. al señor Virey D. José de I rrtiz. 
do el Piloto Villarino por el Este, y los Oficiales Espinosa, Orejuela, Piñuer y Callejas por el ()este, intentaron examinar esta comunicación y descubrir los Césares y Extranjeros (I) establecidos entre los $43^{\circ}$ de latitud y el Cabo de Hornos.

Si se admite, pues, como base de nuestros razonamientos, que una invasion al Sur de Buenos-Aires y Chiloe pudiera más bien desearse que temer, en cuanto distraería con escarmiento propio algunas fuerzas enemigas, podrá reducirse ya la cuestión á unos términos más claros y sencillos, que son: $1 .^{\circ}{ }^{A} \mathrm{~A}$ que pueden sernos útiles las costas Patagónicas? 2. ¿Cuáles son los medios de conseguirlo? $30^{\circ} e^{\circ}$ Cuál ha de ser nuestra conducta con los extranjeros así en tiempo de paz como en el de guerra?

Miuy poco debe ocuparnos el primer objeto después del examen algo prolijo que se ha hecho del suelo Patagónico; una navegación escasa y violenta, unos puertos sumamente arriesgados, la falta casi absoluta de agua y leña; últinamente, unas naciones 6 más bien tríbus quietas y sin resorte alguno de los que constituyen 6 el recelo de una guerra 6 el cebo del comercio, muy luego dejanconocer que fuera reprensible el proponer la menor idea de establecimientos. Además de que, nuestro sistema de establecimientos temible ya en cualesquiera otras provincias, debe serlo aún más en !a costa Patagónica, porque unos presidios en donde no hay el menor recurso ni para un comercio mediano (2), ni para una subsistencia cómoda, han de reemplazar precisamente con sueldos crecidos y con la $\mathrm{r}$ ma malversación de la Real Hacienda, la suerte de los em. pleados, quienes desde luégo fabricaron sobre el mismo empleo la idea de una fortuna.

Examinemos un momento nuestras colonias de la costa Patagónica y Malvinas, y para no renovar á la memoria la cadena fatal de mil gastos enormes á que han dado lugar eך tiempos pasados (3) examinémoslas únicamente in statu

(r) No permiten estos discursos internarnos en la cuestión sobre la existencia de los Césares, y además fuera inútil cuando el actual señor Vircy de Lima ha tomado la medida más opcrtuna para averiguarlo, que es la de los Misioncros, pero cn cuanto á establecimientos internos extranjeros, que amenazaba el $\mathrm{Ca}$. pitán Orejuela, el solo examen de una colonia sepa. rada del mar y aislada entre bárbaros en un suelo inctil, basta para rechazar aquellas ideas. ¡Como se asemeja nuestra situación politica, a la de un viejo rico y codicioso, al cual todo rúido parece el de los ladrones que intentan robarle!

(2) Côrase un velo sobre las especulaciones socces de comercio a que ha dado lugar esta situación. Merecen una aténción seria dèl gobierno, en cuantos influyen en el modo de pensar de unas personas que pueden luégo ser depositarias del honor narional.

(3) La muchedumbre de pobladores traídos de y las expediciones malogradas de Puerto Deseado quo. Nadie ignora las causas que dieron lugar á nuestro establecimiento en el Puerto de la Soledad en las Islas Malvinas; fueron irremediables entonces, pero despuês se han conocido ya sin acción, tanto más, que si no bastase á probarlo la nisma reforma que se ha hecho en su pié de fuerza, población y asignaciones, lo evidencia. rian las repetidas veces que embarcaciones ex. tranjeras han invernado después 6 en el puerto Egmont 6 en los otros muchos que forman el label'into casi incompresible de las Malvinas.

Los establecimientos del río Negro y del puerto de San José, únicos que nos han quedado en la costa, ya no fueron dictados por combinaciones útiles $\sigma$ de comercio 6 de defensa, sino por las órdenes de hacer establecimientos adaptados á los parajes, en donde algún agua aunque salobre y un póco de tierra vegetal, prometiesen siquiera una subsistencia penosa á los pocos colonos: entre tanto que se proponían grandes ventajas de comercio, de construcción, de navegación y comunicación internas; que no dejaba de mezclarse el acostumbrado celo de la conversión de pocos indios errantes, y que se revivían las ficticias ideas de un nuevo País del Dorado en las latitudes casi inaccesibles; el Erario expen. día sumas cuantiosas y aumentaba la infelicidad de unos colonos cuya transmigración desde Es. paña era ya un paso opuesto á la prosperidad nacional. ¡Oh, cuándo llegará la época feliz de la Monarquia en la cual los proyectos para la conservación ventajosa de la América no envuelvan ni sacrificios graves del Erario, ni multiplicidad de empleados, ni un semblante de religión y riquezas que ya no admiten, ni el conocimiento del suelo, ni el del hombre (I), y en la cual no sea el Monarca el único móvil de los ensayos harto equívocos, costosos y multiplicados para la opulencia nacional!

Finalmente, estas dos colonias, después de haber sido en su origen sumamente costosas, haber interrumpido y casi cortado nuestra amistad con los Patagones (2) y habernos hecho sufrir. un choque sangriento é ignominioso con. los indios Pampas (3) y haber casi recibido en el Puerto Deseado la memoria de la infeliz Colonia de Sarmiento en el Puerto del Hambre, absorben aún en el día 84.000 pesos fuertes próximamente, si

y San Julián, ocuparían un lugar no indiferente en estas cuentas.

(1) No parezca importuna esta digresión, en quien recorriendo las Américas las ve de cerca con ojos filosóficos.

(2) Diario viltimo del Piloto Peña, año de 1789 (3) La muerte desgraciada del Piloto Villarino con otros muchos en el primer año del Vireinato del señor Marquess de Loreto, se ha cotejado verbalmente con un Oficial del regimiento Fijo de Buenos-Aires, que fué prisionero en aquella misma refriega, $y$ en cuyo tiato han manifestado aquellos indios, que ui son crueles, ni sordos a la dulzura y al agradecimiento. 
se ha de juzgar por el promedio de cuatro años en el Estado de cajas Reales de Buenos-Aires. ¿Ahora, cuáles son sus ventajas? ¿Tal vez el abasto de sal en Buenos-Aires á precios más equitativos' $\mathrm{Ni}$ se ha conseguido, ni esta atención debe ser del Rey, cuando Ins particulares pueden cargarla si quisiesen impunemente; y cuando con una caravana de carretas, anualmente extraen de aquellas inmediaciones todo lo que quisiesen. ¿Será acaso la protec ón de la pesca ó cubrir del enemigo 6 competidor un pais inmenso? Aquella no tiene otra proterción que la de los buques de la Marina Real, respecto á que pueden darle efica ces auxilios de gentes, pertrechos, escoltas, etc., y seguirla á medida que vaya siguiendo la ruta de los cetáceos 6 peces que anhela: en cuanto á la saca de aceites ó á los salados, bastaría para trastornar todas sus medidas económicas el obligarla á frecuentar uno más bien que otro paraje el obligarla á emplear los suyos, ó los brazos agenos en esas manufacturas fáciles y sercillas; además que 6 el Erario cobraría el equivalente, y es probable que la pesca quedaría recargada, $\sigma$ el Erario lo sacrificaría en benelicio de ese nuevo ramo de industria nacional; y que no hay motivo para semejantes sacrificios, tanto más que la opulencia nacional nunca ha de prosperar si son sacrificios del Monarca las ventajas del vasallo, siem pre con aquella proporción que llevan las unas con los otros (I). En cuanto á cubrir todas las costas inmediatas con aquellos puertos, es proposición harto errónea para controvertirla; pero lo será aún más, cuando se asegure que ni áun á sî mismos pueden defenderse, dotados con un corto número de malcontentos $e$ indisciplinados, $y$ con una batería tal vez de cañones inútiles, en donde hay mil parajes para fondear $y$ hacer desem. barcos.

Esta pintura rápida, puede casi en un todo aplicarse también al puerto de la Soledad en las Malvinas, el cual, en una guerra, igualmente que los dos establecimientos indicados, sería fáci presa de un corsario atrevido y bien armado, agregándose el poco tiempo que emplearía en esta conquista, para ajar más y más el honor del pabellón y del poderio nacional.

Insensiblemente hemos venido á hablar de las pescas, único punto de vista, bajo el cual podemos mirar como ventajosa á la opulencia nacional, la costa Patagónica: se insinuó ya hablando de las escalas en Montevideo, que áun fomentadas considerablemente las pescas, serían poco

(I) Es rarísimo el caso entre particulares (á no su ponerse abusos), que la ventaja sea igual al sacrificio, pues entonces los mates y bienes estarían en wa exacta balanza. El Monarca, cuando media como contrayente, no como legislador, no puede ménos de ser sacrificado, si se miran su amor al vasallo y la multiplicidad de trámites por los cuales pasa el Bienhecho. útiles á aquella colonia, en cuanto exigia una economía indispensable, que evadiese toda oc... sión de gastos supérfluos. Por ventura, los ex. tranjeros, que con tanta ansia se han inclinado á la pesca de la ballena y á la adquisición de las grasas de lobo marino, pelucón ó leon marino, y del pinguancho, nada dejan que desear en cuan. to al modo de calcular con seguridad sobre este importante ramo de industria: el huir de nuestras colonias, el navegar con poca gente, tener sus pasos libres, conservar las tripulaciones $y$ hacer la aguada donde y como convenga; invernar á veces en uno ú otro puerto para el acopio anticipado de las grasas; finalmente, el no ser molestados ni maltratados, sino únicamente auxiliados y dirigidos de la Marina Real, serán los prelu. dios positivos de la prosperidad ó decadencia de nuestra nueva compañia de pesca, emprendida con tanto amor al bien nacional, bajo la protección del Excmo. Sr. Bailío D. Antonio Valdés.

Los sucesos de la fragata Ventura, que arponeó en un mes 50 ballenas en el año de 1784 y regresó á Montevideo con I 13 pipas de aceite, parecen deben inclinar la pesca hacia los paralelos comprendidus entre el Río Negro y el Cabo Blanco; pero también debe tenerse presente, que la escala verdaderamente ventajosa para los pescadores, y sobre todo, el único paraje donde pueden invernar con facilidad y comodidad, es el puerto Egmont: una aguada cómoda, un puerto abrigado, una abundancia grande de plantas antiescorbúticas y de marisco, y sobre todo un puerto desierto, pudieran tal ve $z$ inclinar los pescadores hacia aquella parte, ó bien hacia el puerto de Año Nuevo en la Isla de los Estados, en donde, no sería prudente el invernar, particularment: en la alternativa con puerto Egmont.

Pero no es la sola pesca de la ballena la que puede hacernos útil la costa Patagónica; D. Tomás Antonio Romero, vecino y del comercio de Buenos-Aires, con un espíritu verdaderamente patriótico, y con bien meditados cálculos, apoyados sobre un caudal no indiferente ( $I$ ) ha pro. puesto la pesca y salazón del bacalao en el puerto de San Julián y sus inmediaciones, con unas condiciones harto ventajosas á la Real Hacienda, mucho más si ésta se desentiende de la cesión de aquellos enseres, después de un término señalado, y deja al libre albedrío del primer propietario la inversión ó alienación de los efectos.

A la verdad, las proposiciones de este vasallo pudieran tal vez combinarse con las de la nueva Compañía Marítima, si se advirtiese que los fondos de aquélla no alcanzan seguramente á

(r) Véase la noticia remitida desde Buenos-Aires al Sr. Inspector general de Marina. Merecen particular atención las Memorias del celoso Ministro, el In tendente pasado de Buenos-Aires, D. Francisco de Paula Sanz. 
abarcar la sola pesca de la ballena, de modo que excluya al extranjero, y que el detall de una salazón de una pesca sobre costas, con embarcaciones menores, jornaleros, etc., y de unos cargamentos dispuestos con cuidado, exigen unas atenciones bien diferentes de las que implica la pesca de la ballena, siendo probable que con tanta precisión haya ésta de evadir el Río de la Plata, como la otra depender de él enteramente.

No ocultare á la rectitud del Gobierno, que á pesar de deber las colonias en cuanto al comer. cio, ser útiles y tributarias á la matriz, no deben no obstante, perder el derecho de emplear sus fondos en los productos de su territorio, siendo este el único derecho que les queda, cuando en la importación y en los cambios ya se lęs hace tri. butarios: sin este desecho, se hallarian sentenciados á una pobreza tanto más duradera, cuanto más se le estrechase el modo de explayar su industria y de emplear 6 formar sus propios fondos.

Si como ya se ha indicado, es preciso que la prosperidad de la pesca dependa del no frecuen. tar el Río de. la Plata, por consiguiente no se han de emplear en ella resortes de su industria, $y$ tal vez 6 no se han de admitir sus fondos 6 han de servir al fomento ageno, es patente que hay violacion de derechos territoriales, y que la nueva Compañía Marítima, 6 se desentiende del be1 neficio que debe producir, 6 ella misma ha de ha. cer considerables sacrificios.

Por ventura, examinadas maduramente las circunstancias de estas dos pescas, del bacalao y de la ballena, sale en claro que la naturaleza misma de los intereses particulares, ha combinado que sea tan exclusiva la pesca de la ballena á la Compaña Europea, como debe serlo la del bacalao á la colonia. En efecto, si se advierte que la economia y despachos de aquella han de depender directamente de la Europa, y que al contrario, el detall, reparos, abastos, etc., de esotra, han de dirigirse precisamente desde BuenosAires, quedará bien demostrado que para sus mismas ventajas se ha de agregar ála primitiva compañía una subalterna para la pesca del bacalao dirigida y manejada desde Buenos-Aires, ó se ha de malograr el semblante de esa nueva y útil ocupación de industria.

En tal caso, Romero pudiera, 6 corro nuevo accionista invertir el fondo proyectado en los ensayos, en tal caso nada peligrosos, obligándole á los cuatro años á entregar toda la pesca á la Compañía, 6 desde luego se le admitiría como director en este ramo, que como se ha dicho, de ningún modo debe confundirse con el ramo de la ballena.

Concluiremos esta pequeña digresión sobre la pesca, con advertir que de ningún modo debe tratarse de establecimientos en la costa Patagónica, mucho ménos de establecimientos en los cuales el Erario 6 la Autoridad Real, tenga la menor parte, y que será muy útil ocupar al principio los Pilotos Tafor y Peña, de la Marina Real, en unas navegaciónes y proyectos mercantiles que exigen tantos conocimientos marineros, como buen aistema y harmonia en el trato con los Pata. gones.

En cuanto á las embarcaciunes de la Marina Real que protejan la pesca, alcanzarán segura. mente á todos los objetos, y no serín muy gra. vosas al Erariu si se componen de dos corbetas y dos bergantines en dos divisiones, á las cuales seguirá con intervalo de dos meses, 6 desde. Luropa 6 desde Buenos-Air.s una embarcación con víveres, que cumplid. su comisión en puerto Egmont, adonde acudirian en diferentes tiem. pos las dos divisiones á tomar lo que necesita. sen, pudiera también hacer su retorno con aceites 6 grasas.

Estas dos divisiones deberian, aunque sepa. radas, reconocer un solo jefe, quien sería res. ponsable de todos los incidentes de la pesca y cruceros: darla sus instrucciones, y en un par de encuentros de las dos divisiores, la una al tiem. po de reemplazar los viveres, combinaría sobre los reconocimientos hechos $y$ las noticias adquiridas los pasos más acertados para el plan que había de adoptar. En general, las Malvinas, los Rios de Santa Cruz y Gallegos, la entra. da del Estrechn d. Magallanes, la Tierra del Fuego y la Isla de los Estados, serían la parte correspondiente á una división; mientras la otra cruzaría el mar comprendido desde el puerto de San Julián hasta los $3763^{\circ}$, se reconocerían los puertos con una conducta fundada sobre una disciplina firme, y con regalos oportunos se atraerian más y más á nueștra amistad los pocos habitantes de estas dilatada's costas, y si no me engaño, fuera fácil y no violento habitando algún tiempo entre ellos, enterarse á fondo, asi de la geografía como de la poblacion interior.

Las fuerzas indicadas dotadas $\sin$ superfluidades, asi en cuanto á clases como al número de gentes, podían servir en la escuadra de evoluciones hasta fines de Agosto: navegar después unida cada división á la costa Patagónica, cruzar hasta Marzo y Abril del año siguiente, y luégo restituirse á España: puede asegurarse sin temeridad, que tomados oportunamente los puertos, dados á las tripulaciones unos intervalos suficientes de descanso y la precisa ropa de abrigo, aprovechados los guanacos, aves marítimas, mariscos, peces y plantas antiescorbúticas, y finalmente, explayada aquella mezcla de dulzura, aseo y disciplina, sin la cual el marinero español caerá casi en un momento de la tristeza á la enfermeda j, podrán conservarse buques y tripula. ciones, á muy poca costa, en el riejor estado y con una verdadera instrucción de la marina, lo- 
Krarse una reforma de tantos buques extraños, que seguramente no infundirán la mejor idea del respeto á que es ucredora la Nación, en sus cos. tas y dominios.

Bien se deja ver que las fuerzas indicadas bastarian para ahuyentar de las costas los pes. cadores extranjeros, 6 para cobrarles una contribución que denotase siquiera el dominio. Pero fuera temeridad grave de nuestra parte el pene. trar en los arcanos del Gabinete, ni al hombre filósofo le será jamás lícito el mover la menor idea que pueda conducir á unas hostilidades 6 á una guerra, siempre perniciosa, no ménos al Monarca que á sus vasa!los.

Finalmente, hemos de rechnzar una dificul. tad que pudiera oponérsenos sobre el abandono del Puerto de la Soledad en las Malvinas, y es la abundancia de ganado que alli existe, y que se multiplicaría mucho con ventaja de los enemigos en tiempo de una guerra: en cuanto á los edifi. cios, desde luégo creo que es corto sacrificio el abandonarlos, cuando se haga memoria que áun en el día, además de la manutención de la corbeta guarda-costas, cuesta el Puerto de la Soledad 24.000 pesos al año (I).

No hay dudas que estos ganados no deben dejarse si se abandona el Puerto de la Soledad, pero puede sacarse grande ventaja de su actual existencia y conocida multiplicación cediéndolos á particulares de Buenos-Aires, que se obliguen á costear el regreso de los empleados y colonos, así de este establecimiento como de la costa Patagónica, y á proveer en lo venidero á la sub. sistencia de los colonos, déndoles tierra para labor.

Esta sola combinación cortaría muchos cálculos intrincados de las Cajas Reales, que con el tiempo serian indisolubles, y un sacrificio aparente arrastraría tal vez unas economías sólidas, que nunca pueden ligarse con la Administración Real de América.

Con el puerto Egmont, oportunamente desierto, se of rece á las escuadras que en lo venidero hayan de pasar ai Perú, particularmente en tiempo de guerra, ua verdadero asilo para el descanso y aguadas que le son necesarias: es, sin duda, preferente á cuantos hasta aquí se han propuesto para este fin, y con la seguridad de poderlo tomar sin exponerse á los vicios y á las deserciones que tanto extrago hacen en los bajeles de la Armada, podrá una escuadra no exponerse á los riesgos á que le expone ó un embarque excesivo y empachoso, 6 una administración mezquina del agua dulce: fuera impcrtuno el precisar ni á esta ni á otra escala los buques que comunmente transitan al Sur, sean de la Ma-

(1) Véanse los Estados de las cajas Reales de linenos-Aires, afio de 1788 . rina Real 6 del comercio, aunque en los primeros merezca ya alguna atención el modo en que salen de Cádiz ( $r$ ).

Tal vez la única $b$ la prine pal razon que mo. vió al Excmo. Sr. Marqués de L,oreto á no protejer, antes bien, á oponcrse á los proyectos útiles de la pesca, fué la del comercio illcito, cont in. dose que muy luego alguno de 108 puertos de. siertos de la costa Patagónica serla el nido adonde reunidos extranjeros y nacionales cambiarian la plata, illcitamente extraida, con géneros de una introducción 6 prohibida 6 recargada de de. rechos.

Esta idea, hija á la verdad de un celo distin. guido á favor de la Real Hacienda, acarreó y puede acarrear de nuevo consecuencias funestas á la pesca, no sólo obrando directamente como hizo entónces, si también interponiendo algunos estorbos que, á pesar de influir muy poco en el bien, puede, cmpero, causar perjuicios de mu ha monta: la pesca es uno de aquellos ramos ind . triales cuyos riesgos son muchos, las ganancias moderadas y las especulaciones y combinaciones tan varias y extendídas como el Oceano que las suministra. Si los recelos del contrabando le pusiesen la menor traba; si se le obligase á ir á uno más bien que á otro puerto; si se le ciñesen por el Gobierno las estaciones, los plazos ó los parajes de su industria; si no se le dejasen combinar en sus dilatados viajes de ida y ruelta algunas otras expeculacıones, $b$ relativamente $a$ los cambios con los iridios, ó con relacion á algunos productos úfiles de las costas desiertas que frecuenten, deje temerse que el ramo de indus. tria sea violento, y que unos precios muy altos, al abrigo de la exclusiva, hagan que la Nación pague con sus sacrificios la ganancia de pocos particulares y los gastos de una administración siempre costosa en la Corte (2).

Ya el examen algo prolijo de la costa Patagónica Oriental nos ha llevado á la demostración casi evidente de las verdades siguientes: I." Que conviene abandonar todos los establecimientos, incluso el del Puerto de la Soledad, porque además de ser muy gravosos al Erario y violentos al vasallo, sólo sirven en tiernpo de guerra para comprometer más y más nuestras fuerzas marítimas; siendo fácil, por otra parte, la verificación de este abandono sin el menor recargo de gastos, con la sola cesión de los ganados de Milyinas al que haga todos los transportes y ocupe las pocas

(1) La fragata Liebre ha llegado hasta la Isla de los Estados, consumiendo el agua que llevaba sobre Bocas

(2) El existir en Madrid la dirección do la Compańa de Filipinas, hace que la Casa comisionada de Cádiz tenga un 4 por 100 de cumisión en las negocia ciones de Cádiz: si la dirección estuviese en Cádiz, ó los gastos que causa, ó la comisión, se evitarlan segu. ramente. 
familias del río Negro ( $r$ en el Rio de la Plata. 2." Que la pesca es el único producto que pode. mos sacar de aquellas costas dilatadas, pero ha de dirigirlas la economla, excluyendo todo esta. blecimiento $y$ trabas, $y$ ha de protegerla la Marina Real apartando á los extranjeros, segán lo toleren los tratados 6 antiguos ó recien heclios: podrán lograrse algunos cambios con los $\mathrm{Pa}$. tagones, muchos conocimientos del pais interior, y unos vínculos nuevos de amistad reciproca que nos afiancen su fidelidad. $3 .^{\circ}$ Las escalas en la costa Patagónica, para los buques que transiten al mar del Sur, son muchas é irremediablemente comunes á nosotros y á los extranjeros; no debe precisarse á ellas á embarcación ninguna mercantil, mucho ménos en tiempo de guerra; para la Marina Real, particularmente si navegase con transportes 6 escuadras numerosas, la del puerto Egmont parece la más segura y cómoda, suponiendo que dicho puerto se conserve desierto. 4." Finalmente, que no debe absolutamente pensarse en recelos, ni de establecimien. tos, ni de invasiones enemigas, que sólo servirian en escarmentarlos: las pocas y débiles em. presas de particulares que sin intervención pública del Gobierno intentan pequeños establecimientos ya en una, ya en otra parte del globo, pueden ahogarse en sus mismos principios, dejando á los buques de la Marina Real el ejecu. tar por si estas p gue ias providencias, bajo el semblante de una dureza natural, tal vez adoptada de lis nismas naciones sobre las cuales se explaya: asi muchas veces no se comprometerían las Cortes, y el particular intruso llevaría el es. carmiento correspondiente.

Pasaremos rápidamente las Tierras del Fuego y la costa Occidental Patagónica, cuya época de merecer la atención de los Europeos, parece ó no debe llegar jamás, ó á lo ménos ser suma. mente remota y fuera de nuestros alcances. El puerto Inchin (2) y los del Sur de Chiloé, serán siempre el asilo único de una embarcación, como el Pingue-Ana, destituída de cuantos medios contribuyen á una subsistencia aunque penosa en el mar; ni el arrimo á aquellas costas particularmente para una embarcación que esté en muy mal estado, dejará de arredrar muy luego á los que le comprendiesen en sus cálculos: un poco de agua y algún marisco nunca serán un cebo suficiente para escalas, después que bien conocidas la Tierra del Fuego, las Malvinas y la Isla de los Estados, y franqueados á la navegación otros auxilios que los que estaban al alcance de Almirante Anson, ya ninguna embarcación podrá

(I) No hubiera inconveniente on dejarlas, inclinándose á este partido si el Gobierno se desentendie se de su sustento, defensa y prosperidad.

(2) Véase el viaje de Anson: lo ha reconocido el Piloto Machado en 1769 . hallarse en las mismas circuustancias en que en. tonces estaban el l'ingue-Ana y el Wager.

Se nos presenta ya la Isla de Chiloé, la cual por su situación, clima y productos ha ocupado desde el año de 1778 la atención del Gobierno. Esta isla, como ya se ha indicado, no es escasa de pobladores, abunda de muchos productos úti. les, tiene buenos pucrtos y es el verdad cro prin. cipio de la dominación española en el mar Pacífico. Pero como hasta aquil se ha dicho, han de dividirse en su examen politico los objetos mercantiles de los militares, $y$ ligarse con unos y otros la prosperidad nacional y la economía del Erario.

Es efectivamente singular la vista de los muchos errores politicos á que expone el no dividir las materias entre sí: la defensa se fija á veces en parajes donde no pueda concurrir el comercio, y el comercio se fija luégo en paraj:s indefensos, de suerte que la Nación en éstos y el Erario en aquéllos, sufren iguales sacrificios, y se multiplican los puntos en los cuales pue. de el enemigo hostilizar y ofendernos, aumen. tando además nuestra imposibilidad de fijar un sistema de defensa. Opinaba D. José Orejuela en sus propuestas al Excmo. Sr. D. José de Gálvez, que para focientar la isla de Chiloé, debian obligarst á harer escala en el puerto de San Carlos iudos los buques que transitasen al mar del Sur, de suerte que la compra de pocas verduras arrastrase los extravios y tal vez la pérdida de muchias embarcaciones: para insistir en la reconquista de Osorno, suponía que la población de Chiloe fuese excesiva, cuando los diferentes censos nos indican so sólo que es muy corta en proporción del suelo, que puede ser capaz de labor y del comercio de ta. blas y pescas, á que puede dedicar una parte considerable de sus brazos, si también que disminuye rápidamente ( $\mathrm{I}$ ) por diferentes causas, de las cuales se han indicado ya algunas, y otras se apuntarán muy luego.

Dejemos á un lado estos y otros proyectos, y ocupemonos únicamente del recto conocimiento de la isla. Puede establecerse en primer lugar como axioma, que la administración de tributos, derechos y diezmos, es tanto más nociva al contribuyente y tanto ménos útil al Erario, cuanto mayor es la distancia del centro y buen orden de la Monarquía, y más inasequibles los esfuerzos para el remedio de cualesquiera abusos. No parezca temeridad el asegurar. que aumentadas considerablemente las contribuciones de los Chilotes en este siglo, al mismo tiempo la población ha disminuído de la mitad, y

(1) En 1713 era la poblacióa de 59.000 almas; (I) En 1713 era la poblacióa de 59.000 almas;
en 1772 de 32.000 y se ha visto que en 1787 solo llega en $1772 \mathrm{~d}$ 


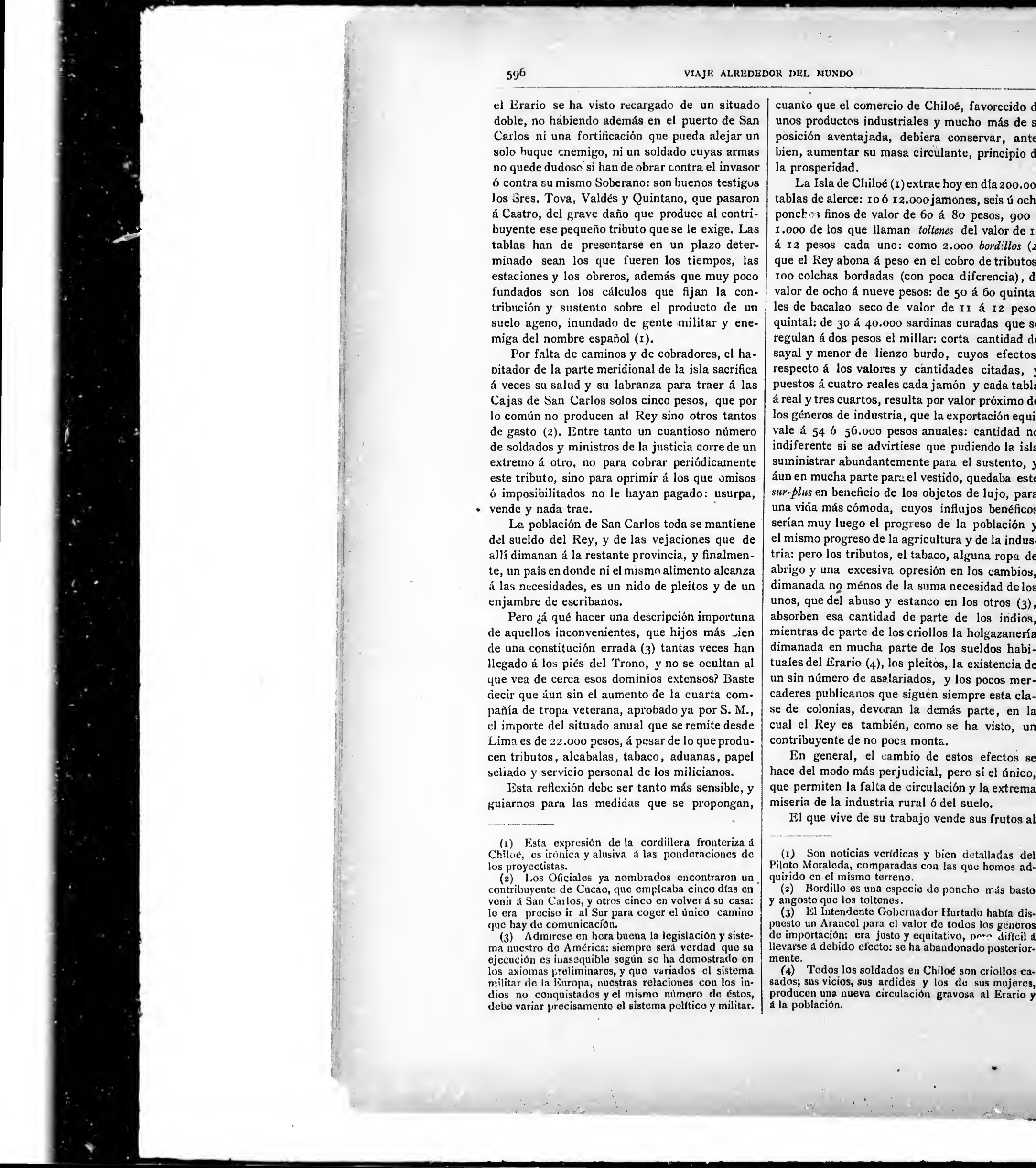


Chiloe, favorecido de y mucho más de su ra conservar, antes culante, principio de

ae hoy en día 200.000 jamones, seis ú ocho bá 80 pesos, 900 á tenes del valor de ro o 2.000 bordillos (2) el cobro de tributos: poca diferencia), de : de 50 á 60 quinta. r de II á I 2 pesos inas curadas que se r: corta cantidad de rdo, cuyos efectos, ptidades citadas, y jamón y cada tabla por valor próximo de la exportación equinuales: cantidad no que pudiendo la isla para el sustento, y estido, quedaba este bjetos de lujo, para $s$ influjos benéficos o de la población y cultura y de la indusaco, alguna ropa de sión en los cambios, ima necesidad de los co en los otros (3), arte de los indios, llos la holgazanería e los sueldos habiitos, la existencia de s, y los pocos meren siempre esta clademás parte, en la mo se ha visto, un nta.

de estos efectos se al, pero sí el único, ulación y la extrema 6 del suelo.

vende sus frutos al

- bien detalladias del on las que hemos ad-

de poncho más basto

or Hurtado habla disde todos los géueros itativo, pero diffcil a baudunado posterior-

'hiloé son criollos ca. los do sus mujeres, gravosa al Erario y precio ínfimo que alcance, y el que por la posesion del fondo necesario para proporcionar el cambio, le prefija aquel precio, al mismo tiempo sube excesivamente el valo: de aquellos efectos que le suministra en cambio. El comerciante en un país de esta especie, es un cedazo que no deja salida sino á las partículas más sutiles, y cuyos hilos puede impunemente estrechar cuanto se le antoje.

¿Quién dirá que en este comercio con Lima, que apenas absorbe cinco meses de tiempo, los géneros de Chile duplen de valor á la salida y lo duplen los de importación á la entrada? (I). Ni se crea que una navegación de esta especie envuelva crecidos riesgos, aunque la suma ignorancia de los pilotos y la mala calidad de los buques y sus armamentos hayan arrastrado pérdidas harto frecuentes. No es tampoco fundada la objeción de que la necesidad de dar fiado exponga á crecidas quiebras y demoras en el recobro del caudal anticipado: los productos de Chiloé son periódicos; luego el comercio podía ser periódico y semejante á una 6 más ferias, en la cual, para mayor comodidad de los transportes y cambios, podían pactarse anteriormente los plazos y depender los precios de una libertad recíproca de contratos fundada en el valor real de cada $\cos a(2)$.

Los efectos de importación se reducen particularmente á génerosque llaman de Castilla, y á otros que llaman de la tierra; son los primeros las bayetas, los lienzos, la listonería de Granada, paño de segunda, papel, hilo, algunos tripes $y$ buches, $y$ toda suerte de quincallería: los segundos son principalmente el tabaco, paños de Quito, pañetes, bayetas, tocuyo, aguardientes, vinos, sal, azúcar, yerba del Paraguay, añil, miel, palo de tinte, agí, jabón, sebo, poco aceite y algunas otras cosas de muy poca entidad, cuyo valor será anualmente de 60.000 pesos, precio de venta. Lo demás hasta el total del completo, compone el fondo de los empleados 6 mercaderes, que unas veces entra en circulación, otras veces sale, como perteneciente al particular que lo adquirió lícita 6 ilícitamente.

No es mi ánimo recibir aquí las llagas del monopolio, ni demostrar cuánto es opuesta á la "concurrencia libre de vendedores la intervención en el comercio de la auioridad Real, por lo común abusada: una traba de una Aduana, una acusación de un calumniador. una interpretación siniestra de una Real orden pueden trasturisar las medidas más bien combinadas de un coner-

(1) El Arancel establecíala ganancia de 30 por 100 sobre factura ce lima: se igurora si comprendia los gastos de derecho.

(2) Véanse las distinciones del valor real al nominal en el tratado dol Sr. Smith sobre el bienestar de las naciones. ciante honrado que reuniese sus ganancias lícitas con los progresos de aquella industria, $y$ hacer triunfar el monopolio que ya en los cálculos subalternos se supone como seguro en Juan Fernández, Valdivia y Chiloé.

Se han insinuado únicamente los inconvenientes anteriores para que no pareciesen luégo extrañas 6 con semblante de proyecto las proposiciones de que Chiloe es capaz de un comercio ventajoso á sí mismo y al total de la Monarquía, y que el Monarca puede conservarle si no con ventajas, á lo ménos sin recargo de su Real Erario; pero antes es preciso examinar si la conservación de Chiloé es útil á la Mionarquía; esto es, si compone tal vez uno de aquellos preciosos anillos, sean comerciantes 6 militares, de los cuales ha de resultar la cadena del poderío naciona!.

En cuanto al comercio, Chiloé en su pequeñez abraza seguramente cuatro puntos de vista bien distintos. El comercio con Europa, con nuestras colonias de Chile, Perú y Río de la Plata, con los indios comarcanos, y últimamente el interno: se ha indicado éste en último lugar porque pende de una existencia de fondos, la que jamás puede preceder a! comercio externo, principio y base de las riquezas: en cuanto á la parte militar (supuesto siempre que se dirija únicamente á la defensiva), ha de dividirse precisamente en la que mira á las potencias rivales de Europa, y en la que mira á los irdios comarcanos. Es difícil determinar hasta que punto pudiera alcanzar el comercio de Europa con la Isla de Chiloe; pues desde luego debiera absorber, no sólo todos los efectos que actualmente se extraen de Lima y que han procedido en mucha parte de Cádiz, si también varias especies de manufacturas, que del mismo modo que en BuenosAires, sólo se han conocido desde que los catalanes, con considerable ventaja propia, las han introducido: tales son los zapatos, los gorros, las camisas, las herramientas, y sucesivamente varios pequeños útiles de comodidad que en el día no se conocen en un país en donde los artefactos no han logrado aún la menor cabida. En la actual balanza económica del conercio, y áun en el sistema que nos hemos propuesto de determinar á cada país de la Monarquía aquellos ramos industriales que naturalmente les corresponden, es positivo que se deja. ver palpabiemente las infinitas ventajas que tiene el comer. cio de Éuropa sobre el de Lima para los abastos de Chiloé. La embarcación de Europa que pagando en Cádiz un derecho proporcionado á la libertad de vender en Chiló ó en Chile, cambie sus surtidos con maderas ú otros frutos vendibles, complete su carga con los frutos de Chile, descargue en Lima, é inmediatamente regrese á Europa, seguramente $\delta$ abaratará el comercio 
costanero del mar Pacífico, ó hará considerables ganancias, que recaerán toda3 sobre los fondos europeos.

No paran aquí las consideraciones relativas al comercio de Europa con Chiloé, si como más por extenso se propondrá luégo, pudiese afirmarse un comercio periódico con los Viliches, que en unas ferias bien ordenadas adquiriesen nuestros tabacos, licores, quincallas, armas, etc.: las remesas de Europa aumentarían considerablemente; y tal ve $z$ por su misma voluntad escs pueblos sacarían de la cordillera inmediata los mismos metales que ya tanta sangre costaron á la nación que intentó conquistarla.

Si no nos engaña el semblante filosófico de unas ideas sencillas, fijadas más bien sobre el conocimiento del hombre y de la navegación, que sobre sistemas, hijos ó de un soñado poderío irresistible, 6 de un celo engañoso de la religión, 6 finalmente, de un cebo envenenado por la plata, joh, cuánto pueden ensancharse para la prosperidad nacional las ideas que acabamos de indicar! Tal vez nos llevarían á una paz duradera y segura que no nos costase ni unas contínuas zozobras ni el sacrificio de muchos caudales, ni, finalmente, el ajamiento del honor nacional (r): tal vez se abrirían las puertas á nuevos comercios ventajosos, y ni el Erario costearía un ejér. cito tan gravoso como ficticio, ni concurriría el miliciano chilote á aumentar solamente su lista imaginaria á costa de mil sacrificios positivos.

Pero áun sin permitir al navegante europeo que continuase su navegación en las costas del mar Pacífico, con atención al comercio de Lima, podian tal vez un par de buques europeos, de no mucha capacidad, lograr un retorno útil para Buenos-Aires, con la tablazón y maderas gran. des, que en el día, 6 con muy poca ventaja se sacan del Paraguay, ó se traen del Brasil con ventaja de los extranjerns: la tabla de alerce serviría á mil usos doméc licos, y particularmente á la fábrica de los muchos barriles que las carnes saladas y las harinas han de ocupar precisamente (2). Tal vez lograrían de una salida ven.

(I) En Valdivia, Chiloé, y á su imitación á bordo de la Descubierta, se han hecho honores de armas, y particularmente de cañón, a los Caciquucs Viliches, que sólo vienen á cmborracharse, y que pueden dirigir, mas no enírenar los robos que se intentan por sus gubditos sobre los nuestros. FI Cacique Catiguala bizo alarde en su semblante de no temer el cañón que se disparó sobre el alcŕzar y en sus inmediaciones: pre-disparó sobre el alcŕzar y en sus inmediaciones: pre--
guntado si le causaría algún temor, dijo decididaguntado si le causaría algún temor, dijo decidida-

mente que no, y manifestó un scmblante impáido. dado como uno de los recursos para que aumente $\mathrm{cl}$ número de los buques que naveguen desde Europa al Río de la Plata pues como los géneros de exportación rean voluminosos, y al contrario, lo scan muy poco sean voluminosos, y al contrario, lo scan muy poco los de importación, no se nivelan los fletes. Esta consideración aparente hace ver cuánto es fácil chocar los
intereses de unos ú otros en una grande monarqufa, tajosa también lus jamones y los ponchos, siendo este último además un género que pudieran surtir con igual abundancia y bondad los Viliches: luego Chiloé puede abastecerse á precios mucho más cómodos de los efectos que necesita, puede influir en la prosperidad del continente y proveer á las colonias del Río de la Plata y del Perá, unos productos de fácil consumo, que desde luégo reemplacen las comodidades que necesitan, ya puestas á un precio equitativo, y puedan luego dejarle un sur-plus que sirva al fondo del comercio $\mathrm{y}$ fondos interiores.

Crece aún la probabilidad de este aumento así en las cosechas como en los cortes y áun en los tejidos, cuando se considere que en el día los indios son los únicos que se ocupan en estos ramos, y particularmente en los cortes, siendo así que más de la mitad de la población se compone de criollos, los cuales subsisten en mucha parte, de los sacrificios del Erario. A la verdad, estos mismos criollos, áun cesadas las encomiendas, y áun viéndose descalzos, conservan al mismo tiempo tanto apego á la nobleza de sus antepa. sados, y tal costunibre de ne ajarla con ocupaciones serviles y comunes con el indio, que les fuera harto sensible y lastimosu el verse abandonados del padre cariñoso que á pesar de su conducta é inutilidad, los ha alimentado con sacrificios considerables de su parte; pero les quedaba el recurso de la emigración al Perú, 6 del servicio de armas en Chile, en el caso de que no prefiriesen el trabajo saludable de la agricultura, ó los cortes periódicos del alerce en la cordillera.

Puestos así en su balanza natural la industria, la agricultura y el comercio de Chiloé, desde luego un pequeño fondo nacional ó perteneciente á sus moradores, les diera lugar: primero, á no acelerar las ventas 6 cambios, dando por consiguiente mayor valor á sus' frutos: segundo, á mejorar el suelo con los desmontes: tercero, finalmente, á ocuparse de la pesca, que excluí. dos los pastos, y adaptado mayor terreno á la agricultura, pudiera doblar el alimento de una población numerosa: los desmontes, á nuestro entender, deben emprenderse á un mismo tiempo desde los dos extremos de la mitad septentrional comprendida entre el puerto de San Carlos y la Laguna de Villunco. Serán muy asequibles si se dirigen además á derecha é izquierda del camino de Castro, desde donde la comunicación con San Carlos y la conducción de los frutos, sería más fácil y sencilla. Pudiera destinarse un pequeño derecho sobre los géneros de ingreso para propios de la isla, los cuales al principio se invertirían de

pero aquí por ventura se disipa la contradicción, por cuanto estos buques, descargando en Buenos- $A$ ires ocurririan precisamente a la'necesidad de buques va. ćos en aquella colonia. 
hos, siendo

dieran suros Viliches: cios mucho sita, puede e y proveer Perú, unos esde luégn cesitan, ya edan luégo del comer.

aumento es y áun en en el día los n estos rasiendo así se compone ucha parte, rdad, estos miendas, y al mismo us antepa. con ocupaio, que les rse abandode su concon sacriles quedai, ó del serde que no tgricultura, cordillera. industria, , desde lueeneciente á nero, á no por consisegundo, á s: tercero, ue excluírreno á la to de una á nuestro mo tiempo otentrional Jarlos y la libles si se del camino on con San sería más n pequeño ra propios ertirían de un todo en auxilios y premios del desmonte $(x)$ dados para mayor utilidad en enseres de labran. za 6 industria, según la calidad del terreno que hubiese desmontado. Es probable que el núcleo ó parte montuosa de la isla, que corre inmediata á la orilla occidental, casi á lo largo de toda ella, sería bastante para abrigar la parte baja oriental, de los vientos tempestuosos del Noroeste y Oeste; no obstante pudieran también dejarse bosques en la orilla exterior para el uso mismo de los habi. tantes; serían un nuevo freno para los extragos de las tempestades, á ménos que no precisase también á destruirlos la continuación de las aguas en tanta cantidad como hasta aquí se ha experimentado.

Se ha hablado de la posibilidad de ertablar con los Viliches unas ferias periódicas que sedirigiesen al mismo tiempo á un mayor despacho de nuestros frutos, á la adquisición de algunos otros que nos fuesen útiles, y últimamente, á una sólida unión con aquella Nación, fundada sobre la base de la tranquilidad y necesidades recíprocas: la utilidad de estas ferias 6 plazos de cambio es, sin duda alguna, evidente, y sus tiempos periódicos son naturalmente los meses de verano, en los cuales la navegación y los caminos por tierra son tan fáciles como impracticables en el invierno (2). Pero no es tan fácil determinar el paraje de estas negociaciones, ni el modo de celebrarlas, pues que fuerà imprudente tratar sin desconfianza á los Viliches, cuyo ánimo belicoso, excitado con las bebidas y con la mucha concurrencia, á veces los arrastraría á robar, á veces también á hostilizar.

Si en los parlamentos de Concepción, 6 en los que se hiciesen en Chiloé, se especificasen condiciones claras para esta especie de negociaciones, y los caciques saliesen garantes de su cumplimiento, exigiendo particularmente que no concurriesen en demasiado número, y que se evitase todo desorden, desde luego la celebración de estas ventas sería más oportuna en Carelmapu que en San Carlos, por la concurrencia de los compradores: en tal caso se resguardarían nuestros efectos con una especie de trinchera que favorece el terreno, se prohibiría á los indios el entrar armados y el permanecer allí de noche; se les prescribiría el

(1) Debe haccrse al alto de un hombre de la raíz del tronco, al cual luégo se da un fuego leve para destruirle la vegetación: las ıamas son fúciles de cortarse, y luégo pueden quemarse en pequeñas pilas ó invery luégo pueden quemarse en pequeñas pilas 6 inverfavorecio el robo del soldado destinado a la fragua de la ATrevida, tenfa hech. por sí solo un desmonte considerable, y aprovechado ci campo para semillas.

(2) No debe considerarse of extrañarse como nueva esta propucsta, cuando se advierta que el actual señor Presidente de Chile, el Mariscal de Campo Don Ambrosio Hi Ambrosio Higgins convino en su ultino Parlamento con los cuatro Mutalmapus que se colebrausan cuatro ferias al año. acampa: ó armar sus tolderías á una prudente dist uncia, y se guarnecería el paraje señalado, con algunas milicias armadas y áun con alguna artillería y tropa arreglada, si una corbeta ó bu. que menor de los de la Armadilla en el mar Pacífico combinase sus cruceros para hallarse á la sazón en el puerto de San Carlos. Este partido de celebrar las ventas en la tierra firme, nos produciría sin duda la gran ventaja de que concurriesen también las mujeres de los Viliches, las que probablemente aumentarían los cambios y harían más remotas las hostilidacies.

Perosin las precauciones indicadas, y cuantas otras dicte una verdadera desconfianza, será prudente el preferir la misma ciudad de San Carlos, franqueando sí la venida de los indios comarcanos, pero en número y plazos prefijados y siempre con algunos efectos de cambio que indiquen su ánimo de comerciar: se les determinarán los parajes de su residencia, la que costearán enterameitte por sí; se-les hará justicia en todas las cuestiones 6 disputas que presenten los contratos; pero se les vigilará de cerca y tratará casi con la misma desconfianza con que nos han tratado hasta aquí.

Dejamos á la consideración del hombre filósofo, y mucho más del nacional que recorra sus historias, el determinar hasta cué punto la rec. titud, la buena fe, el desinterés, la suposición de una verdadera igualdad de derechos, y la misma compasión hacia unos hombres entregados á sus pasiones, deben ser la guía de los que interven. gan y los que dirijan particularmente en los pri. meros años estas concurrencias 6 mercados, y dejamos al político el investigar de antemano hasta qué punto esta idea nuestra es compatible con las verdaderas utilidades de la prosperidad nacional, único objeto que jamás debe perderse de vista.

Insensiblemente las reflexiones sobre el comercio de Chiloé, nos han llevado al examen de uno de los dos puntos que constituyen la parte militar ó defensiva, y es el que mira á los indios comarcanos; pues es eviderte que mientras no salgamos de la isla en la cual está á lo ménos segura la subsistencia (si no lo está el comercio dependienie de los cortes), ni jamás nos compro. meteremos en discordias, ni habremos de temer el menor insulto, acreditando la experiencia, que la navegación será siempre el único teatro en el cual los europeos aventajarán considerablemente á la naciones conquistadas.

Luego śblo nos queda el examen de lo que pueda importar en la balanza con las naciones rivales, y este examen nos guía naturalmente á un rápido cotejo con la plaza de Valdivia. Es positivo que en el tiempo de las conquistas fúé sumamente acertada la elección de aquel sitio, que reunía al mar las ricas colonias interio- 
res ( $\mathrm{r}$ ), un río caudaloso la cubría en mucha parte de los insultos del enemigo. El puerto inmediato aseguraba al mismo tiempo un rico comercio y los auxilios necesarios para una buena defensa ó una retirada segura: fué muy luego el centro de las fuerzas militares, $y$ la Casa de Moneda, el Obispado y su misma antiguledad, la hacian mirar como una de las colonias principales.

Es, pues, probable que reconcentrados después de mil desgracias los confines de nuestros dominios hacia el Biobio, se hubiese conocido la total inutilidad de Valdivia si acaso al mismo tiempo las irrupciones de los extranjeros por el Cabo de Hornos al mar Pacífico no hubiesen llamado de nuevo la atención del Gobierno hacia el Sur: se le caracterizó muy luego de antemural del Perú, $y$ sin atender á que no estorbó jamás las hostilidades é insultos de cuantos doblaron el Cabo de Hornos, crecían considerablemente sus fortificaciones y se les honró con los nombres ilustres de Niebla, Mancera, etc. A medida que crecían las fortificaciones, fué preciso aumentar el número de defensores; $y$ finalmente, importando la sola conservación de las fortificaciones unos gastos perpétuos, llegando á zo.000 pesos el pié de paz, y habiéndose aumeintado conside. rablemente en la última guerra, siempre se creyó indefensa, $y$ la total falta de víveres y su misma situacióil apartó de su puerto una escuadra compuesta de solo tres navios.

Luego Valdivia es por su posición inútil para contener las invasiones de otros europeos, $y$ en cuanto álos Viliches, es un nuevo punto en que puedan ofendernos, sitiándonos hasta por hambre si algún acaso hiciese imposible ó difícil nuestra comunicación por mar. A lo ménos Chiloe puede considerarse al abrigo de cualesquiera insultos de lós indios, y lo que es más, cualquiera invasor enemigo no puede combinar sus fuerzas con los indios indicados: á lo ménos, allí no serán precarias ni la subsistencia ni los reparos de una escuadra; á lo ménos, los mismos habitadores podrán defeider sus propias familias $\mathrm{y}$ haciendas si ellas solas fuesen capaces de llamar algún invasor hacia aquellas costas, y finalmente, la misma posición del puerto de San Carlos asegurará que se reunan todas las fuerzas en defenderle, cuando la comunicación de los muchos fuertes de Valdivia es por sí misma inasequible, ni es fácil á una embarcación evadirse en Chiloé de los tiros de la batería de Agui y de otra que se puede poner en la Isla de los Cochinos; cuan: do en Valdivia una embarcación que cale ménos de tres piés puede desde luego evadirse del fuego del mayor número de baterías.

¡Oh! se dirá, será luego preciso abandonar un nido importante á. los buques enemigos, y

(1) Vúase la Historia ciril, por el Abate Molina. además se desvanecerán todas las ideas de economia, si en lugar de unos reparos á las fortificaciones de Valdivia, se proyectan nuevas fortificaciones para Chiloe.

Pero es fácil conocer la debilidad de estas contradicciones cuando se considere que las fortificaciones 6 han de cansar caudales inmensos 6 han de estar en muy mal estado al tiempo de una declaración de gucrra, en cuyo caso la gente y los caudales que se inviertan entonces son realmente los útiles, no los que se hayan invertido en el tiempo de una paz duradera: además, que si abandonado el puerto de Valdivia, se su. pone fácil y útil para un enemigo el posesionarse y establecerse en el, ¿por qué no do haremos an. tes nosotros con mucha ménos distancia y con auxilios mucho mayores?

En cuanto á las fortificaciones de Chiloé, fuéramos desde luego culpables si las propusiése. mos áun cuando consideremos que Valdivia de ningún modo le abriga, y que muchas más razo. nes harían creer la necesidad de defender á los enemigos la entrada del puerto de San Carlos, en cuanto proporcionándoles ya la misma reunión con los Viliches le franquearía áun sin esto la facilidad de mantenerse $y$ de emplear muchos brazos útiles 6 en las fortificaciones ó en los reparos asequibles de una escuadra: pero no olvidemos en esta parte el ejemplo harto juicioso de los ingleses en sus colonias de la India Oriental: sus fortificaciones son siempre proporcionadas á las riquezas que defienclen. Si se exceptuan Madrás, Calcuta y Bombay, este último defendido más bien de la Naturaleza, todas las demás factorías y establecimientos, ó están absolutamente indefensas, $b$ un torreón, un fuerte de madera, solo sirven para resistir un ataque de los naturales y cubrir en algún modo sus riquezas de un insulto inesperado que nunca puede ser consid .able por la atención y vigilancia con que se miran recíprocamente las naciones europeas, hasta en las más remotas regiones del globo (I).

En una palabra, 6 nuestros enlaces políticos y la opulencia nacional nos llevan á equilibrar las fuerzas marítimas de las naciones rivales, $y$ nuestros navíos serán nuestros fuertes, 6 no es asequible esa igualdad, y tanto más prudente será nuestro sistema de defensa, cuanto más se re. concentre en pocos puntos, capaces por sí de muchos resortes y desde luego dispuestos á cu.

(1) La defensa de Pendichey por Mr. de Bellicombe en la última guerra, consistió toda en el valor de los defensores; pues ni la mayor parte de las murallas estaban levantadas: ténganse presentes, por nuestra parte, las circunstancias de los fuertes ingleses de Nueva Orleans, y de las islas de la Providencia. suenan en las en las Gacetas de todas las naciones que tienen esta blecimientos ultramarinos; muchas fortificaciones que solo sirven para hacer la fortuna del que ataca $y$ del que defiende. 
as de eco-

las fortifi-

evas fortifi-

de estas que las for. inmensos 6 tiempo de aso la gente itonces son ayan inverra: además, ivia, se suposesionarse arcmos anancia y con

Chiloé, fuépropusiése. Valdivia de s más razoender á los San Carlos, sma reunión $\sin$ esto la ear muchos en los repao no olvideicioso de los riental: sus nadas á las Ian Madrás, endido más ás factorías nente indeadera, sólo naturales y o un insulto iä able por miran recíasta en las

es políticos equilibrar $s$ rivales, y s, 6 no es udente será más se repor sí de estos á cu-

Ir. de Bellia en ol valor do las do las mu. es, por nues. ingleses de ncia; suenan tienen esta:aciones que ataca y dol brir la riqueza y el comercio de nuestras colonias. Así, Chiloé sólo debe tener un pequeño fuerte de madera para abrigar de un insulto la corta propiedad de los colonos, y un par de baterías volantes: la una desde luego en la Punta de Agui, que recuerden á un enemigo el riesgo á que se expone igual á lo ménos á las ventajas que se propone, pues la destrucción de pocas casas y siembras y el acopio de pocos comestibles, nunca serán bastaute cebo para un invasor, ni pudieran evitarlo las fortificaciones de San Carlos, cuando advertidamente el enemigo se dirigiese, 6 á los puertos de la parte meridional 6 al de Cas tro. En esta situación, ya serán inútiles el gobierno y pié militar y político que en el día anidan la causa de tantos gastos y tal vez de no pocas opresiones. Un solo Corregidor militar, costeado, 6 del derecho sobre el comercio de importación, cobrado en igual cantidad sobre factura formada en el puerto de donde salga el carga. mento, para evitar guardas, administraciones $y$ trabas; 6 del tabaco que pudiera en tal caso continuar estancado para la sola introducción y comercio de los Viliches, serviría á mantener la dominación nacional en esta parte: la visita de un Oidor de la Audiencia de Chile ó de Lima, cortaria decisivamente todos los pleitos y determinaría los derechos de posesión de cada uno; y desterrados el papel sellado y el enjambre de Escribanos, debía el Corregidor decidir amigablemente todos los pleitos, á ménos que las partes litigantes no quisiesen, personalmente en la Audiencia correspondiente. Libres las milicias de muchos servicios harto penosos, formarian únicamente sus asambleas en la estación corres pondiente á las ferias, y el aparecimiento de uno ú otro buque de la Marina Real, serviría para auxiliar cualesquiera medidas activas, si fuesen necesarias para el buen orden y seguridad de la colonia.

Finalmente, sean las que fueren las propues tas de los que han creído hasta aquí ser el único modo te aumentar el Erario, 6 las imposiciones, 6 unos crecidos derechos que implican siempre un nuevo aumento de administratores ociosos, nos atrei. los á asegurar al Gobierno, que la provincia de Chiloé exige muy luégo una total franquicia de tributos y derechos para beneficiar su suelo, no ser gravosa á la Monarquía, y prometer siquiera con el tiempo un asilo útil para los progresos de nuestro comercio, navegación y opulencia.

No se crea que cualquiera medida indulgen. te que se adopte para Chiloé relativamente á lo: derechos é impuestos, sea trascendenta! á otras provincias, en donde no convienen ó no pueden practicarse iguales medidas: precisamente esa provincia aislada, sin minas, y distante á muy largo trecho de la reunión de nuestros dominios, nos demostraria, si la verdadera opulencia de la matriz y de las colonias depende 6 de un anchu. roso comercio, 6 del actual sistema de tributos impuestos que conspira á atajarle no ménos con una comunicación coartada de los pueblos veci nos, que con una circulación estancada, escasa y violenta.

En la reforma que se propone del pié militar y político de Chiloé, hay además una aterción no indiferente á favor de la necesidad de abolir todas sus contribuciones y casi todos los impuestos con que está en el día sobrecargada, y es la de proporcionar un método fácil de vida á los muchos vecinos que hasta aquí se han mantenido con los sueldos y administraciones del Rey, siendo prudente $y$ justo el no acosarlos á un mismo tiempo con la total carencia de los auxilios con que han subsistido hasta aquí, y con una di ficultad indecible de inclinarse á la nueva senda que se les propone.

Se ha omitido expresamente el liablar del sis. tema eclesiástico de Chiloé, el cual depende en muclıa parte de las misiones de los Franciscanos, costeadas por el Erario, y ya inútiles. No es nuestro ánimo ni recordar al Gobierno que existen aún en Castro (contra las últimas Reales ór denes) un convento de Observantes y otro de Mercenarios, que sólo tienen dos religiosos inútiles ni hacerle presente que en el sistema indicado de pacificaciones, será la prueba segura de la necesidad de un curato ó de una misión el que el Gobierno no la costee, dependiendo, por consiguiente, su existencia, 6 de la justa parsimonia de ministro e vangélico, ó de la voluntaria contribu ción de los feligréses. Desde luego el ejemplo de dos siglos debe convencernos, que la conversión de los Viliches ha de depender más bien de otras causas que de la predicación evangélica, á la que se han manifestado hasta aquí enteramente sordos: así, cualquiera gasto relativo únicainente á misiones, puede omitirse con facilidad; cuatro 6 seis curatos repartidos oportunamente en toda la isla, podrán ser costeados por los mismos feligreses, concurriendo últimamente las mismas cosechas y algún aumento de comercio á hacer más suave esta debida contribución para su bienestar venidero. 


\section{Descripcion fisica del terreno y habitadores de las costas com- prendidas entre Chilos y Coquimbo.}

Si se consideran con una aunque leve reflexión el rápido vuelo de prosperidad que alcanzaron en pocos años nuestras colonias meridionales de Osorno, Imperial, Villarrica, etc., las producciones que con una mala agricultura sacan anualmente los Viliches, y la semejanza del suelo nuestro de Chile en cuanto á producciones y temperamento, debemos creer que es grande la fertilidad del terreno llano, comprendido de los $43^{\circ}$ hasta la embocadura del Biobio: terreno que otras veces regamos abundantemente con nuestra sangre, y que han sabido conservarse con una cons tancia poco común los habitadores primitivos.

Tampoco debe quedar duda cuando se ...orran nuestras historias, que abunda en minerales la misma cordillera que fecundiza esas tierras con sus riegos, las abriga del Levante, próvidamente les refleja los rayos benéficos del Sol y proporciona á los vientos Nortes que oportunamente las vivifiquen con las Iluvias hiemales.

Diferentes ríos caudalosos no sólo atraviesan casi á iguales distancias este hermoso país, si también conservan hasta la misma orilla una abundancia de árboles útiles, bien sea para el uso doméstico ó para la navegación: la cordillera suministra luégo los que fuesen necesarios de una medida cxtraordinaria.

O fuese, pues, cebo militar, óbien la idea errada de que pudiesen á un mismo tiempo lograrse los dones benéficos de la agricultura y los violentos de la excavación, debemos confesar que merecen mucha disculpa los que reñían con tanto valor para la adquisición de este país. Lo habitan en el día los Viliches, los Juncos, los Araucanos y los Pehuenches, todos pueblos de un mismo origen, si hemos de creer á su idioma, su fisonomía y sus costumbres; pero luégo, desunidos entre sí y frecuentemente en guerra con los mismos motivos que en todas partes suelen originarse entre vecinos.

El Abate Molina ha caracterizado estos pueblos con muchas pinceladas maestras, que debié. ramos mirar como dimanadas de una reflexión madura y cuerda, áun cuando el tiempo y la situación nos hubiesen permitido examinarlas prolijamente: así dejeremos como importuno el comparar nuestras ideas á las suyas, refiriendo únicamente lo que ha podido alcanzar nuestro examen casi momentáneo de los Pehuenches y Viliches, aquéllos en Santiago y éstos en Chiloé.

Los Pehuenches habitan la comarca (1) comprendida deste el fuerte de San Carlos liasta el de Santa Bárbara, y, 6 sea su corto número 6 bien su posición rodeada de muchas tríbus antagonistas, son naturalmente muy belicosos, y parecen haberlo sido aún antes de la conquista, en cuya época, ya por diferentes veces habían repulsado de sus tierras los invasores comarcanos.

Preguntados, á la verdad, si son de la misma especie de los Viliches, responden que no, $y$ alegan la señal del zapato que los Viliches gastan partidos ó falto de la mitad delantera, y ellos gastan entero; pero si se comparan su idioma y acento, sus ritos religiosos, sus facciones, su arrimo á la poligamia, etc., son realmer.te de una misma especie, $y$ separados tal vez por alguna revolución dimanada de los derechos de sucesión, sostenidos por diferentes partidos: este mis mo principio puede haber influído en que cuanto más se enardeciesen nuestras guerras con los Araucanos y Viliches, tanto mayor fué su apego hacia nosotros, y la reunión de sus fuerzas con las nuestras; de sueı ie, que podemos considerarlos como verdaderos amigos, que nos han sido y serán sumamente útiles. Debe atribuirse á su corto número la absoluta oposición á la labranza, á la cual se han inclinado Jos Viliches. Esotros tienen muchos ganados, particularmente caballos y ovejas, y se alimentan de ambas especies, prefiriendo la yegua. El país que habitan es más bien montuoso, tejen la lana para sus vestidos, adquieren otros muchos efectos en los cambios con nosotros, se inclinan á la bebida; sus trajes se parecen regularmente á los nuestros.

Debe creerse que consideren unidos los Juncos á los Pehuenches, cuando los estados de Chile (2) indican la población de los Llanos y Pehuenches ce $43.089^{\circ}$.

(1) Estas noticias se han togrado verbalmente en Santiago, $y$ con el auxilio de un intérprete del Cacique D. Francisco Carilegu quien habiendo hecho juramento de fidelidad, en Mendoza, al Sr. D. Carlos IV venta á nanifestarlo asi al Presidente do Chile.

(2) Lista de reducciones que nos ha ontregado el señor Presidente de Chile, y no habla de los Juncos. 
Los Viliches ( $\mathrm{r}$ ) entre los cuales presentamos ahora muy bien imitados por D. José del Pozo, los retratos sacados del original, del cacique $\mathrm{Ca}$ tiguala y de su hijo, conservan en todo su porte i: semblante militar: y así su disciplina mo el sstado de la agricultura y de las mismas artes, indica en toda su fuerza una nación sociable y civilizada (2).

Estos pueblos son de mediana estatura, una fisonomía militar $y$ ardiente, el color aceitunado, y una grande agilidad en sus miembros: distinguen nuestros Capitanas de amigos que desde muchos años habitan entre ellos, dos especies de caciques, los unos de bastón y los otros sin bas. tón; y parece puede muy bien entenderse esta dis. tincion, interpretando que los unos gobiernen sólo la población que habitan, los otros la provincia 6 Mutalmapu, componiéndose luégo de estos últimos el cuerpo federativo para la defensa nacional (3).

Los estados de la población de los Pehuen. ches atribuyen 30.000 habitantes á las provincias meridionales, contando 10.000 desde Mendoza hasta Osorno, y 20.000 entre Pehuenches y Vi. liches. En este número consideran tres décimos en clase de Lanzas, ó gente apta para el servicio de ias armas, que ascienden, por consiguiente, á 9.000, caracterizados entre ellos con el nombre de mocetones. Esta clase, si hemos de conjeturarlo por los que se presentaron en Chiloé, admite aún las edades de diez $\mathrm{y}$ doce años probablemente; basta que puedan seguir el ejército á caballo y usar de la lanza.

Sistema gubernativo. - Bien sea entre los caciques primarios 6 los subalternos, estamos seguros que este empleo es hereditario, recayendo, no obstante, antes en los hermanos que en los hijos, á ménos que éstos no estén ya en edad dẹ aconsejar y dirigir los mocetones. Entre éstos se confunden inmediatamente los demás parien. tes del cacique, $y$ por cuanto pudimos advertir, ningún derecho absolutamente les concede aquel enlace. Es grande la subordinacion al cacique, y parece que consultando los adivinos el dictamen de aquéi, 6 más bien el de éstos, es la ley eje cutiva. Habitan unidos, y naturalmente, los campos labrados y los ríos, deben ser los términos de las jurisdicciones respectivas, las que,

(I) Asi de esta voz como de la de los Pehuenches y Puelches, véase el verdadero origen en el Abate Molina.

(2) Véase nuestro Diario de Chiloé, en cuyo puerto los tuvimos á bordo.

(3) El-sargento Negrón, de la plaza de Valdivia, quien ha trabajado en abrir amistosamente la comunicación por tierra entre Valdivia y Chiloé, es sumamento querido ea estos pueblos, ha concurrido a nuestro bordo con el cacique Catiguala y nos ha referido muchas de sus costumbres. Es original suya la lista de los caciques que pára en nuestro poder. no obstante, son causa de discordias muy frecuentes.

Adivinos y principios religiosos. - $O$ sea en los delitos de la república 6 en las hostilidades ya ofensivas 6 defensivas, procede y áun es la norma de todos los pasos la consulta del adivino, 6 á ménos que éstas no sean efecto de un arre bato, 6 aquéllas no dejen en toda su luz al de. lincuente.

Entre los Pehuenches, consultado el $\mathrm{Ma}$. gui (I) sobre las causas de una muerte inopinada, éste inmediatamente abre el costado derecho del cadáver, $y$ consulta el hepar 6 la hiel: si ésta se halla llena y limpia, caracterizan la muerte de natural, pero si se encuentra con la bilis exaltada, inmediatamente infieren que la muerte no es natural, $y$ en este caso debi 1 pro. nunciar arbitrariamente el delincuente, el cual no tarda en ser castigado de muerte (2). En la usurpación de tierras 6 agravios recíprocos, son igualmente los adivinos los que deciden del partido que convenga. No pocas veces se juntan los de una y otra parte para consultar sobre el derecho de cada uno antes de llegar á las armas: son ellos igualmente quienes después de una pérdida considerable atribuyen la causa á cual. quier individuo que caracterizan de brujo ó autor del maleticio (3).

Con estos antecedentes, ya no se debe dudar que estos Magui sean temidos: que la política de los caciques procure mantenerios siempre unidos, y que la religión de estos pueblos les dicte la idea de un principio malo, origen de todas las cosas siniestras 6 tavorables, según de ellas se rnezcle 6 se aparte.

Efectivamente, nos confirmaron unánimemente este principio religioso, y supimns que además de tener en grande concepto á estos adivinos, los mantienen del fondo público, $y$ áun los consultan para los objetos domésticos además de los nacionales.

Sistema militar.--Aunque estos pueblos real. mente guerreros hagan consistir mucha parte de la victoria en el tesón con que pelean, la misma necesidad de ser á veces sorprendidos y á veces con fuerzas naturalmente inferiores, les ha pre-

(I) Mucho se asemeja esta voz a la griega Mavoo, que significa lo mismo, y está adoptada en el lutín, español é italiano.

(2) En una nación en donde hacen mucho uso del veneno, no debe parecer absurdo este método de averiguar si una muerte es ó na violenta. Es bárbaro, s1, el método de averiguar el delincuente; peto se co. noce que depende de la excesiva credulidad.

(3) Estando á nuestro bordo con el sargento $\mathrm{Ne}$ grón, los Viliches del cacique Catiguala, entre los cua les habra un Magui, Negrón les dijo que yo me haria á la vela llevándolos distantes de sus mujeres, las cuales quedarian presas de otros: inmediatamente todos miraron al adivino, el cual los tranquilizó avisándoles que no era verdad. 
cisado á usar de las estratagemas y á introducir en sus tropas un orden militar: por lo común la infanteria forma un cuadro, y la cabalieria dividida en diferentes cuerpos, pero todos situados sobre las alas, está dispuesta á ofender al enemigo y rodearle, ó bien á cubrir la retirada de los suyos: los caciques pelean á las cabezas de sus tropas. Ignoramos si retiran sus mujeres é hijos de modo que no le.3 alcance el furor de la guerra. Desde luego usan de banderas. Son sus armas, principalmente las larzas, los sables, los machetes y los lazos: conocen el uso del fusil, pero no es común entre ellos.

Los Viliches usan de una coraza de cuero casi impenetrable, pero parece que así la cabeza como los brazos quedan desnudos, quitándose también las bragas en ocasión de combate, porque estando mal atadas pueden quitarles el andar, si se cayesen del caballo. Los Pehuenches aña. den á estas precauciones las de usar de la honda, cubrir la cabeza con un morrión guarnecido de una plancha de hierro, y alargar más la cota, haciendo también que cubra parte de los brazos.

Por lo común, concluída la refriega, hay una especie de tregua para recoger y enterrar los muertos; pero nunca se devuelven los prisioneros, de los cuales ordinariamente suelen mataise los hombres y guardarse las mujeres en clase de esclavas. Parece que hay más crueldad de parte de los Pehuenches, probablemente ó por el menor número, ó porque se crean autorizados por la amistad nuestra, á esta especie de guerra.

Vida sociable.-Ya se ha indicado, que los Viliches en esta parte exceden mucho á los Pehuenclies, á lo ménos por lo que alcanzan nuestras nociones: aquellos pueblos cultivan toda especie de semillas, incluso el lino: han adoptado nues. tro método de labranza con bueyes y arados y azadas; solo sí, que sustituyen $€ n$ el arado unas predras afiladas, al hierro. Comen indiferentemente las carnes ó crudas ó asadas; pero sohre todo, usan de las menestras ó sustancias hariná. ceas, entre las cuales el maiz y la papa parecen llevar la primacía.

La misma ley de la sucesión, que indicamos, exige la admisión de una mujer verdadera, cuyos hijos pueden mirarse como los únicos legítimos: castigan el adulterio con la muerte; quieren mucho á sus hijos; pero admiteu el uso de concubinas sean estas libres ó esclavas.

Una nación militar como ésta, naturalmente hace mucho mayor aprecio de los hombres que de las mujeres; así casi no se apercibe el do. lor en la muerte de las mujeres: es, al contra. rio, muy grande y manifestado en muchos modos, cuando mueren los parientes ó amigos. Esta mis ma inclinación á la guerra, hace que el cacique sea más respetado que el adivino, aunque este tenga en la suerte de cada uno, tanto iivilujo como ya se lia indicado.

Debe depender de la idea de que la educación sea la que influya mucho en las inclinaciones, el uso singular que hay entre estos pueblos de unir ambos sexos en edad muy corta, valiéndose ade. más, de la fou inalidad de que la niña destinada á la boda del hijo sea precisamente robada á otra familia, lo que como es costumbre, jamás origina discordias: ignoramos si ha de ser precisamente legítima, y cuál sea la suerte de los hijos ilegítimos.

Usan de la música, especialmente con trompas: nos informaron que usaban tumbién como música de guerra, de los clarines que se le habian dado en Valdivia: son frecuentes sus concurren. cias, en las cuales cantan y bailan, bien que no hemos alcanzado á comprender cuáles son estas ocasiones de regocijo.

La naturaleza y alimento de estos naturales, y el clima que habitan, los haría sin duda de una vida igualmente sana y duradera, si las guerras en muchas partes, $y$ algún tanto las enfermedades, no concurriesen á trastornarla: adolecen principalmente de tabardillos y evacuaciones de sangre: no les es desconocido el mal venéreo; pero es probable que les haya pasado de nues. tras colonias: el uso de las yerbas les es común: las infusiones son, no obstante, en agua fria, y su aplicación á las heridas es bastante feliz. No conocen el arte de escribir; pero las tradiciones son bastanțemente exactas. Es probable que las sujeten á lunaciones, conocidas sí, pero no combinadas en período alguno. Ninguna utilidad sacan para sus épocas, del año solar, según pudimos comprender, bien que esto se hace más du. doso y extraño cuando se advierte que un pueblo agricultor trae precisamente consigo la división de las estaciones, la cual depende directamente del período solar.

Sus manufacturas, que corresponden precisamente á los hombres en cuanto á la parte militar, y á las mujeres por lo que toca al vestido y demás usos domésticos, deben mirarse como realmente industriosas: tejen la lana en mu. chos modos, para ponchos, calcetas, etc.; usan de la greda para amoldar y unir el hierro; conocen los hornos; varias piedras les sirven, ya para afilar las armas, ya para amoldar los metales que usan como arorno; la suela está adoptada para zapatos, y sus caballos están regularmente enjae. zados.

Habitadores inmediatos y comercio.-Conocie. ron inmediatamente el retrato de los Patagones, los que con justa razón llaman Pehuenches 6 gente de Levante. No obstante, sólo uno de los 44 que concurrieron á bordo, los había visto: unánimes contaban que había algunos cambios entre unos $y$ otros por un boquete de los Andes, en cuyo 
-ConociePatagones, hes 6 gente los 44 que unánimes entre unos , en cuyo tránsito, el cacique Viliche dueño de las tierras inmediatas, había formado una especie de monopolio, no permitiendo á los demás el tomar parte en este comercio: aseguraban, los habla que no podían estar á caballo por excesivamente al tos, y conocieron las pieles de guanaco (I). Los Pehuenches de Santiago sólo dijeron haberlos oído nombrar. Son los verdaderos enemigos de estos pueblos, los Juncos 6 habitadores de la Marina, con los cuales, al parecer, son más comunes las refriegas que con los Pehuenches: jamAs, según se manifestaron, han chocado con los Araucanos.

Pasado el terreno de los pueblos que llamaremos confederados á la España y cuya población es muy probable que prospere, desde que el señor D. Ambrosio Higgins, en Concepción, y el Sr. D. Mariano Pusterla, en Valdivia, con una conducta recta y uniforme en nuestra frontera, los han inclinado á la agricultura, á la paz y al buen orden y á la imitación de nuestra vida sociable, sin mezclarse de una reducción violenta de poblaciones (2), ya se presenta el suelo bajo otro semblante: los volcanes se remueven de la orilla; las costas presentan un semblante ménos tempestuoso; una infinidad de cétáceos, al mismo tiempo le pueblan y hermosean, y la harmonía del mar se combina admirablemente con la de un suelo fértil y apacible.

Los veteranos españoles, que por tantos años habian peleado para conseguir unas tierras en las cuales todo convidaba al descanso y á la agri. cultura, debieron muy luego preferir la inmediación del mar de donde esperaban contínuos socorros, á la internación hacia la cordillera donde pudieran nuevamente ver el triste espectáculo de las siete ciudades arruinadas: desde Coquimbo hasta la Concepcion, muy luego toda la superficie varió de semblante: las semillas de Europa, todos sus frutos, las viñas, los olivares, una abundancia indecible de caballos y ganados, anunciaban casi con emulación, que la Naturaleza prodigaba aquí sus dones para una subsistencia fácil y tranquila. Se vieron entre los campos dirigiendo sus siembras y beneficios, los soldados envejecidos, 6 en lás guerras.de Flandes, 6 en las de Araucanos. Aún en el día resuenan en aquellos pueblos los apellidos más ilustres del Coutinente, y su desgracia, al decir de los mismos ciudadanos de Santiago, es la excesiva

(I) Esta facilidad con que hablaron de los Patagones, no se puede conbinar con el sigilo que guardan (según algunos) sobre la existencia de otros pucblos meridionales, $y$ en particular de los Césares. EI sargento Ncgrón estaba muy convencido de este sigilo: muy luego so disiparian estas dudas si con un total abandono de ideas politicas, nuestras medidas les indicasen sólo unas miras ąacibles y comerciantes.

(2) En la historia del Abate Molina pueden verse los cfectos de un ensayo de esta especie. abundancia con la cual la tierra prodiga sus frutos. E1 50 por uno en todas las semillas, es muy comun de un extremo á otro de este reino feliz, á pesar de que en la Concepción llueva muy mucho, en Santiago y Valparaíso poco (I) y en Coquimbo nada.

Como quiera, no obstante, que la misma abundancia ha hecho abaratar, antes bien, envilecer de tal modo los frutos, que ya fuera de los valles inmediatos á Santiago son más bien molestos que útiles, los habitadores han debido ceñirse á una vida campestre, y no alcanzando ni las cosas de lujo, ni áun el costo de los trans. portes, les ha sido preciso huir de la reunión, $y$ por consiguiente, las ciudades, 6 no se han formado, 6 han quedado despobladas: baste decir, que siendo la jurisdicción de Coquimbo de roo leguas de Sur á Norte y 70 de Este á Oeste, 6 de mar á cordillera, los últimos padrones sólo indican una población de $\mathbf{1 7 . 2 0 0}$ almas, esparcidas de tal modo, que cada valle en este dilatado país, es el receptáculo de pocas familias pobres.

Se hallarian casi en el mismo estado las in. medjaciones de Santiago, si no siendo éste el centro del Reino, y por consiguiente, la residen. cia de una multiplicidad de empleados que causan una circulación cuantiosa, no tuviese además la felicidad de abastecer al Perú con sus trigos y sebos y charques ó carnes secas. No obstante, es tanta la disparidad entre la masa circulante, incluso el producto ánuo de las minas, y los productos de la tierra, que una lista de precios medios de los principales, no desagradará tal vez al que recorra. estos apuntes: nos han faltado las noticias de Concepción, bien que muy luego las alcanzaríamos, y pudiśramos agregarlas para la verdadera balanza de los precios de Chile (2).

En cuanto á la población, debemos creer, según las listas originales de algunos partidos, que es mucho mayor de las 240.000 almas entre in. dios y europeos que asigna $\mathrm{D}$. Cosme Bueno á los dos obispados de Santiago y Concepción. Es aún mucho más probable esta aserción, cuando se considere que en los cuatro curatos de Santiago, se ha manifestado en los dos años anteriores la proporción siguiente á pesar de que los estados de

(a) Don José Pcrez Garcia, quien ha continuado en Santiago la historia del Padre Figucroa, incluye el articulo siguicnte: \&Siempre ha padecido la jurisdicción de Sartiago escasez de lluvias, pero nunca tanto en los tiempos anteriores como en el presente año de 8r que no llovio más que setenta y ocho horas, cuando según los anales do los doce años precedentes que de todas las lluvias lleva un curioso, el año que ménos, habia llovido ciento treinta heras, que a prorata con el que más, que habia llegado el año de la avenida á doscientas noventa y nueve horas, salen un año con otro a doscientas veinte horas. Por csto en el expresado afo hubo mucha mortandad de ganado. (2) Est ano habo manado. (2) Esta lista puede deducirse de nuestro
critos correspondicntes á una y otra ciudad. 
hospitales no denotan el mayor acierto en las curaclones, siendo así que en el hospital de mujeres de San Francisco de Borja, en donde el aseo y la asistencia casi sobresalen una á otra, ha sido la proporción de las muertas con la de las curadas, comn ro á 57 , en un promedio de siete años.

\begin{tabular}{c|c|c}
\hline \multicolumn{1}{c|}{ Anios. } & $\begin{array}{c}\text { Numero } \\
\text { de haulizados. }\end{array}$ & $\begin{array}{c}\text { Número } \\
\text { de enterrados. }\end{array}$ \\
\hline $1788 \ldots \ldots \ldots \ldots \ldots \ldots$ & 803 & $\begin{array}{c}362 \\
263\end{array}$ \\
$1789 \ldots \ldots \ldots \ldots \ldots$ & 757 & $26 \ldots$ \\
\hline
\end{tabular}

Las costumbres de los españoles chilenos (pues que el número de indios es sumamente corto) se han conservado en un estado que debe realmente complacer á la nación de donde deri. van, una presencia y robustcz realmente admira. bles en ambos sexos, una hospitalidad constante, un trato fino y amable, un idioma castizo, unos modales inocentes $y$ cariñosos, son cualidades casi generales, á las que añaden los hombres un talento $\mathrm{y}$ agilidad poco comunes, $\mathrm{y}$ las mujeres una buena educación á sus hijos, una fidelidad conyugal sin afectación, y una pasión poco común para la música.

Ya advertía D. Cosme Bueno, que la proporción de las mujeres con los hombres en el Chile, era de tres á uno: hemos corroborado particularmente en Santiago esta misma verdad, y desde luégo nos lo han confirmado varias personas sensatas, dándonos lugar á asegurar que á lo ménos de dos á uno es la proporción de las mujeres con los hombres.

Pero el tiempo no nos permite entrar en aquellos detalles que requiere el examen prolijo de estos habitantes: daremos, por consiguiente, una mirada rápida á las orillas. La descripción de los minerales y de los volcanes es obra harto prolija, ni áun pudiera emprenderse sin combinarla cientificamente con los que se han examinado después en el Perú.

La ciudad de Penco, arruinada por un temblor en 25 de Mavo de 1751 , fué transferida hacia el Biobio entre dos cerros granitosos cubiertos de tierra franca, rojiza, mezclada con arenas gordas 6 cuarzuelos y otros materiales del granito que el ácido aéreo descompone: se dejan ver algunas porciones del granito, que se cristalizan en esferas, dentro de su misma matriz de otro más tierno; $y$ debe conjeturarse que la sola utilidad de usar de la piedra para los edificios nuevos, fué la que dictó esta situación incómoda y desagra. dable.

En el terreno del fondo de la bahía hacia donde estaba construída la ciudad antigua, se conservan aún varios fragmentos, y particularmente, una portada con las armas de la casa de Austria: las costas en su inmediación son altas y escarpadas: se componen de muchos guijarros de arenisco grises, y de otros bancos de arenisco gordo, gredoso, que parece sirven de base á las rocas granitosas que componen el núcleo de eate suelo: embutidas en estos escarpados se encuen. tran unas esferas grandes de hasta cinco cuartas de diámetro del mismo arenisco que procede: en estas inmediaciones hay bancos de tierra carga . da de Ocra-ferni rojiza en capas horizontales que se rompen al aire, en fragmentos angulares, planos de tres á cuatro pulgadas de diámetro. En. tre ellas'se incrustan criaderos de hierro esites, y según informes, se encuentran también minas de hierro palustrc y de cobre, á no mucha distancia de estos parajes.

Al Cerrillo Virde sigue inmediatamente la Cuesta de Lorguen, $y$ en ella hay abundancia de guijarros, bancos de tierras ocráceas y manchas de tierras bolares color de sombra: el mar bate las playas que están al pié de estos cerros, estre. llándose contra una grande peñolería de granitos durísimos y sonoros como se dice del Saxum tintinas de algunos autores: consta de cuarzo, feldespato y prismitas oblongos de una sustancia de color argentino oscuro 6 de plomo. Es parecida á este granito la piedra campana cue se halla en algunos parajes de Buenos-Aires.

Es verdaderamente singular la abundancia de excelentes mariscos que se hallan en estas costas: sobresalen entre ellos el Pico, que es una es. pecie de bellotas de mar, que tiene hasta cinco $y$ seis pulgadas de diámetro: el Choro, el Loco, que son especies de piñas marinas y varios erizns de cuatro y cinco pulgadas de diámetro.

En la parte del collado que corre del morro de Talcahuano hacia el Occidente, hay canteras de Gneis de pizarra micicea de esquisto negro: el terreno, en la parte superior del collado, es bas. tante pingüe y útil para la labranza.

Detrás de la iglesia de Talcahuano hay una mina de conchas, de la misma especie de los Lo. cos: se hallan las mismas detrás del Penco Viejo er. altura de 30 toesas del mar: están en un estado de calcinación y tan frescas, que no parece que indiquen una grande antigüedad.

Se encuentran también en las inmediaciones de Penco $y$ en el terreno intermedio entre éste $y$ Talcahuano, bancos grandes de carbón de piedra 6 mina manteada, según la voz del país: es carbón fósil, arde muy bien en las fraguas y de calidad muy ventajosa.

Aunque en los valles que hermosean estas inmediaciones, el fondo del suelo sea de arena como la del mar, algo negruzca y por partes shorlácea y micácea, se eleva sobre ella una capa de tierra vegetable, cuya calidad es de las más fertiles, según lo anuncia la lozanía de las plantas y ár boles que en ella crecen.

El país montuoso que desde el mismo puerto continua suavemente hacia el Norte y se diri- 
nediaciones entre éste $y$ in de piedra ais: es carlas y de ca-

an estas inarena como ss shorlácea pa de tierra ás fertiles, antas y ár- ge también hacia el Liste formando valles hermosos que llevan consigo el verdadero semblante de la vegetación más prbspuera, abunda extraordinariamente en maderas, las que no obstante pare. cen demasiado escasas de resinas para que sean útiles, como debieran, á la construcción.

El lingue, el pellin, el keule, el littre, el mañi, son las especies más grandes y útiles: su conducción es sumamente fácil, particularmente ha. cia las orillas del Tomé y Coliumo.

En los pasos de algunos arroyos intermedios á esas serranias, hacia la plaza de Santa Juana, se hallo abundancia de cuarzo pingule blanco en fragmentos, y en la parte que llaman Piedra Agujereada, se vuelve á ver el gneis, que parece ser uno de los materiales de estas montañas.

Desde el alto de Guanabuch se descubrian como á 28 leguas de distancia, las sierras siem. pre nevadas de la cordillera, y á éstas se ante. ponía bien visible el volcán de Tucapel.

Abandonando ya estas orillas y pasando á las de Valparaíso, se encuentra en los cerros altos que rodean la rada, una madre de granito, bordada con vetas de pequeños fragmentos de cuarzo en varias direcciones, ya verticales, ya inclinadas al horizonte: en otros parajes se encuentran yancas de greda, ya amarilla, ya blanca; la hay en algunos, bolar encarnada, y sirve para los búcaros $y$ otras vasijas.

A medida que el suelo examinado se va apartando del mar, los valles abundan más en tierra vegetal: el mismo nivel de las tierras bajas y los muchos montes que las rodean, van elevándose considerablemente hasta terminar aquéllas en el valle delicioso del Mapocho, esotros en la cordi. llera majestuosa de los Andes, cuyas nieves exteriores $y$ ricos metales interiores, descubren al mismo tiempo unos grandes objetos de cebo y de escarmiento.

No cabe duda que estas mismas ramificacio. nes de la cordillera, compuestas por la mayor parte de tierras cuarzosas y micáceas, dimanadas de la descomposición del granito $\delta$ de algunas variedades del esquisto y del asperón ó piedra de afilar, contengan en sí algún oro, bien que no tanto que pueda decididamente corresponder á su beneficio: parece también probable que los ce. rros aislados que se dejan ver en algunos valles $y$ particularmente en el de Santiago, 6 hayan sido volcanes ellos mismos, ó hayan dimanado de al. gunos volcanes extinguidos. Entre estos cerros inmediatos á Santiago, merece particular memo: ria el de Santo Domingo, que provee toda la piedra para la ciudad. Estas piedras son aisladas y de tamaños enormes: se componen principalmente de bravalte gris, y extraidas á muy poce costa, son luégo de una resistencia grande á la intemperie.

Ya con el examen de la cordillera del volcán inmediato á Santiago y las minas de San Pedro Nolasco, se descubren nuevas tmaravillas á nues. tros naturalistas, que exigen otro examen lito. lógico del que permiten estos apuntes (t) y el tiempo actualmente muy limitado: nos ceñire mos, por consiguiente, á indicar que estas célebres montanas se componen aqul de hermoso pórido de las especies más bellas que se cono. cen y áun de algunas de que no lay noticia. De tiempo en tiempo se descomponen muchos de sus cerros, $y$ con sus tierras terraplenan las quebra. das: otros se desquebrajan y presentan montones horribles de grandes fragmentos de piedras, que forman rampas desde sus vértices hasta el cáuce de los ríos: finalmente, en no pocos parajes se ven frecuentes efectos de los terremotos y conmociones que agitan estos pináculos del globo (2).

No tiene menor elevación de las ya indicadas la mina de plata de San Pedro Nolasco. Sus productos han sido hasta aquí muy favorables á los que han emprendido su beneficio, cuyo detalle omitimos ahora, siendo enteramente igual al de Coquimbo y Lima: será oportuno, sin embargo, avisar que la misma elevación, causando una respiración difícil con la refracción del aire, se deja ver á cada paso en todos Ios que habitan violentamente este paraje. Pálidos, con una res. piración asmática, casi desnudos, sin otro goce que el de la bebida, cansados al menor esfuerzo: ni áun en el invierno abandonan la mina (3): se encierran'durante los cinco meses de esta esta. ción cruel en los subterráneos indicados y prosiguen con luces artificiales las mismas tareas que en el invierno, entre tanto que la nieve no sólo cubre la región alta, si también los valles vecinos. Cuando nieva, es precisa la contínua vigilancia de una centincla para que no se obture la única ventana por donde se les comunica el aire externo, $\sin$ cuya precaución quedarían precisamente sofocados.

Dejemos ya á un lado este triste espectáculo, y siguiendo la navegación, ‘minemos, aunque superficialmente, el suelo de Coquimbo, de cuya fertilidad interior ya se han dado algunas breves noticias.

Al Sur de la playa de Coquimbo, y á tiro de fusil de la Bodega, se ver canteras compuestas de granito de cuarzo plúmbeo y feldespato, con puntas que parecen micáceas briliantes; su superficie es llena de concavidades: 'su textura es la-

(1) D: Antonio Pineda y D. Tadeo Heenke explayan en esta ocasión una serie sumamente importante de observacinnes ffsicas.

(2) El Arquitecto Tuesca, que acompañó á D. Antonio Pineda en esta excorsión, ha sacado vistas muy oportunas de algunos de estos derrumbos.

(3) HÁ muy pocos años que se ha emprendido el (3) Há muy pocos años que 
minosa; aquellas provienen de la descomposición al aire de algunos de sus mayores compo. nentes: hay granito blanco, petro-silex blanco; el granito plúmbeo, que es sumamente pesado, se despoja también en láminas como si fuera es. quisto. Hállanse también granitones blancos.

La tierra de este terreno, que se cubre de va. rios arbustos, es una franja amarillosa arenisca, con algo de arcilla, mica suelta y friable. La roca que compone la lengua de tierra, parece por lo general un granito en masa, con hendiduras en varias direcciones. Su color amarilloso, gu grano cuarzo cubbide, ieldespato brillante blanco, echados unos cristales sobre otros. La superfi. cie escabrosa, y los fragmentos de la roca cu. bóides.

Este granito parece análogo al plúmbeo ó gris, ménos el color, que provendrá de la diversidad de materias metálicas. Hay otro granito parecido al que acabamos de describir, que se deshace en el aire y forma cóncavos esféricos y mechinales.

El suelo ya indicado por las tierras que le componen, produce varios arbustos, y se intercepta en parajes, por lagunas de aguas salinas, que cuando se evaporan dejan cristales de sales alcalinas que contienen taunbién algo de las marinas, pues hierven por una parte con el agua fuer. te, pero no afectan el gusto con sabor ácido. Esta sal cubre parte de estas marismas con una costra de algunas líneas, y presenta una super. ficie esponjosa. Lies muchas isal icornias que aqui crecen contribuirán también á esta producción; no se ha conocido que los naturales hagan el me. nor uso de estas sales.

La piedra de concha se halla más de $20 \mathrm{va}$. ras elevada sobre el nivel actual del mar, y se distingue su formacion en el puertecito de la Herradura, por la simple aglutinación de con. chas y guijarros. Las playas abundan en porce. lana de varias especies, en patelas con su espiral y su cámara abajo; en caracolitos buicínicos negros, con líneas blancas longitudinales; de ellos se cubren con una sobrecapa calcárea los peñascos donde se arriman á la playa.

Abundan las inmediaciones de Coquimbo de minerales ricos de oro $y$ cobre, $y$ algunos de plata, yel de azogue de Punitaqui: ni su examen ni su beneficio han podido aún sujetarse á datos positivos: tanto la falta de principios mecánicos y mineralogicos, y principalmente la grande escasez de fondos y la opresión consecuente en que vive el minero, han concurrido hasta ahora al malogro de este suelo, cuyos productos, as en cuanto á cultivos como en cuanto á minera les, podrán con el tiempo acrecentarse mucho.

\section{Exame'n politico del pais comprendido entre Chiloe y Coquimbo.}

Después de las nociones que se han indica. do relativamente á los Viliches y á nuestra si. tuación política de la parte meridional de Chile, fuera excusado el exaninar más de cerca esos pueblos, si ya no nos arrastrasen las reflexiones á considerarlos como vecinos.

Abandonada Valdivia y reducidas todas nuestras combinaciones políticas del Sur, á no salir de Chiloé sino como comerciantes, olvidando ya el caracter de conquistadores y el de introducto. res del Evangelio, no debíamos á la sazón considerar los naturales habitadores de la Tierra Fir. me, sino como personas á quienes arrimásemos 6 apartásemos de nuestra colonia, según nos con. viniese: pero examinando el Chile, ya se nọs presenta la cuestión bajo otro semblante, bien que por ventura puesto en toda su ley por la Historia civil del Abate Molina (I).

(r) Están en el día trabajando on refutarle una parte considerable de sus noticias, dos hombres doc. tos de Chile, pero esto no influye en nuestros razonamientos, que no dependen de los detalles, sino sólo mientos, que no dependen de
de las verdades primordiales.
El Chile es sin duda el país entre todos los que ha conquistado la España en América, que más sangre y caudales le ha costado, y ménos ventaja le ha producido: áun en el día en que una administración complicada, ya puestos en movimiento casi todos sus resortes (I) ha asegurado al Erario una renta no indiferente, todo lo absorben, 6 la misma administracion 6 el sistema militar: su posesión es gravosa al Perú por una contribución anual para Valdivia y Chiloé á la matriz por una emigración constante, bien que en los cálculos de emigración, atribuida 6 á Buenos-Aires 6 á Lima, parajes en donde desembarcan.

Empero el Chile es un país cuyos vecinos no son temibles (2), cuyos montes y orillas abundan en minas, cuyo suelo y clima son tal vez de los más fértiles y favorables á una población cre-

(i) Estancos, Aduanas, Beneficios de minas, $\mathrm{Ca}$ pitaciones, Comorcio libre y servicio personal.

pitaciones, Comorcio libre y servicio personal. (2) Se ha demostrado en pa
luégo con mayor individnalidad. 

tecito de la ión de con. in en porce. con su espi. buicínicos Idinales; de calcárea los a.

Coquimbo de algunos de ii su examen tarse á datos os mecánicos a grande esisecuente en hasta ahora oductos, asi to á minera. se mucho.

iquimbo.

tre todos los mérica, que to, y ménos I día en que puestos en $s$ (I) ha ase. erente, todo zion 6 el sisal Perú por ia y Chiloé: stante, bien Itribuida 6 á 1 donde des.

s vecinos no rillas abunon tal vez de oblación cre- cida: finalmente, cuyas costas, guarnecidas de buenos puertos, abren al mismo tiempo su seno á una defensa marítima, á un comercio fácil y directo, yá unas pescas tan lucrosas como ahun. dantes.

¡ Oh, cuánto esta pintura nada exagerada ha de incitarnos á examinar más de cerca los defectos constitucionales, cuya enmienda en una época en que ya la ilustración no pende de un arrimo ser. vil á los preceptos antiguos, f'uie la Nación á aquel prospero renacimiento, un el cual única. mente estriba au verdadera robustez!

Desde el reinado de D. Felipe II, nuestro sistema de la América se establecíb sobre unos principios tan naturales entonces como violentos ahora. La Monarquia era semejantc al minero; abandonaba un objeto de mediana riquera por un hallazgo imaginario de otras inagotables; cada palmo de un terreno que absorbia más sangre y audores de lo que produjese 6 metales á otras labores, parecía el cebo de todas las naciones europeas, y el objeto de una guerra perenne de parte de los naturales, cuando los europeos ablo codiciaban robarnos en un momento nuestros acopios de muchos años ( $r$ ), $y$ los naturales hu. bieran cedido inmensos terrenos, $y$ particularmente los montes por la sola libertad de vivir y trabajar á su albedrío: hubieran tal vez á la sombra de unos cambios pacíficos y sociables, be. neficiado aquellas mismas minas que arrastraron nuestra ruina política y la suya natural (2), se fortalecía, por consiguiente, un terreno que al día siguiente debia propasar el ansia constante de la conquista y de la riqueza. Una Nación belicosa, viva, que seguía sus propios impulsos en lo primero, y en lo segundo coadyuvaba á la complicada situación politica de la España rela. tivamente á la Europa, debíb precisamente ena. genarse en la idea harto fatal de la extensión; muy luego el español, con el auxilio 6 de unas marchas inauditas, 6 de unas navegaciones que admiràn aún en el día, víb suyas unas provincias, cuya extensión, riquezas y productos aún no al. canza á comprender; y confundido, ya con el cebo de despojarlas, ya con la precisión de s.umentarlas (3), ya con el objeto de defenderlas contra un invasor, trajo en la legislación un sis.

(x) Véase particularmente la historia de los filibusteros, en la cual están exageraciąs, si, las acciones de valor que hicieron aquellos piratas; mas no están exagorados ni áun individualizados los daños que aos hicieron.

(2) Sea permitida esta reflexión filosofica, á quien mira desdo algún tiempo con atención la constitución de la América, y ve cuánto es fácil combinar la opulencia de la Monarqufa con la felicidad de los vasa. llos que la forman.

(3) Las marchas é invasiones dimanadas de los in. tereses particulares y guerras civiles, nunca se combinaron con los intereses nacionales, que aun entonces se hubieran hallado en una contradicción constante. tema politico y militar que envolviese aquellas miras bajo un aspecto plausible.

Concurrian las descripciones de cada conquis. ta recién hecha á alucinar al Monarca y al Cuerpo legislativo ( $\mathrm{r}$ ), semejante $a$ la piedra rica que ol miriero presenta al que ha de habilitarle para la continuación de su juego aventurado, cada des. cubridor forjaba á su albedrío un semblante ha. lagueño del nuevo descubrimiento: ae prometlan las riquezas y se pedían ios socorro i; se prometía la felicidad de los pueblos y se notaba diaria. mente la disminución de su número (2).

Pero en el día, en que ha variado de un todo nuestra situación, y que ya, no temidos, o por tal cual grado de civiliza:ión, 6 por su aniquilación política los diferentes pueblos no conquistados que rodean nuestras provincias, debemos al es. tado de nuestra Marina la seguridad de nuestras costas, ya debemos subsanar aquellos males con el sistema politico que exige nuestra situacion.

Los fondos nacionales ya nos permiten una circulación peribdica, en la cual, el producto de la mina se mire con igual valor que el cacao, la cochinilla, el añil, la cascarilla, etc.; un escar miento harto dilatado nos convence que no son las minas las que constituyen nuestra riqueza, sino en cuanto la plata y el oro (3) son efectos de venta mucho más pr inta y segura que los de. más frutos; y que sólo el agua, el viento, la me. cánica y la moderacíbı deben emplearse en su beneficio, más bien que los brazos del hombre destinados á ! p.gricultura y â la industria. Finalmente, podem is muy bien escarmentar al ene. migo, no sollo con una oposicion directa, si también con cebarle en unas conquistas imaginarias.

Estas reflexiones eran precisas para el exa. men de Chile, en cuya conquista tanto sobresalieron el valor y constancia de los guerreros y de su primer caudillo Pedro Valdivia, como eran frívolos los objetos que podían moverlos á unas guerras $\tan$ reñidas $y$ sangrientas. Luego ese suelo de la Concepción distante de la cordillera, de modo que ni se conoce si hay minas, ni aunque las haya pueden labrarse, apor qué hubo de disputarse con tanta sangre? ¿Por qué las siete ciudades tan prósperas antes, y luego tan igno-

(x) Véase la descripción de Quirós de su descu: brimiento de la Tierra del Espiritu-Santo, en su Me. morial al Rey N. S., que no existe en mi poder, pero he visto en manos del Oidor actual de Méjico, D. Ciriaco Gonzalez de Carvajal.

(2) Es preciso rebatir este sistema con alguna energia, porque éun en cstos años, ol Gobernador pa. sado de Filipinas ha llamado conquista la posesion inutil de las islas Batanes; ha enviado tropa adondo pedian misioneros, y ha recargado el Erario con r 4.000 pesos de gasto, para unas islas que sólo produ. cirán la pérdida de algunas embarcaciones.

(3) No es posible explayar estas ideas con toda Ia claridad necesaria: será obra del ticmpo y do la quietud. 
miniosas para el nombre español, se estableciercn en parajes rodeados de un enemigo indómito, de modo que pocas minas costaron una emigración funesta de españoles? ¿Por qué, finalinente, aún en el día se proponen al Gobierno la rcconquista de Osorno y demás tierras al Sur, cuando la supuesta conservaciónde las tierras orientales á la Concepción nos cuesta la manutención de un ejército y de muchos fuertes, en desquite de unos frutos cuya abundancia los hace perniciosos al mismo colono?

Ya se ha indicado anteriormente cuál sea la fertilidad de Chile y cuál debemos conjeturar lo sea también la del país de los Viliches; pero esta misma abundancia es perniciosa si el disfrutaria depende de una emigración, la cual. đdemás da ser naturalmente opuesta al bien nacionai, nos envuelve en unos gastos y defeisas: harto gravosas: esta es precisamente su constitución, si la considerásemos bajo tres puntos de vista: $r .^{\circ}$ Lo que inflaya en la opulencia de la matriz como colonia. 2..$^{\circ}$ Lo que influya en la seguridad de nuestras posesiones del mar Pacítico. $30^{\circ}$ Lo que influya recíprocamente en la prosperidad de las otras colonias.

En este examen nos desentenderemos de Chiloé, quie en adelante puede considerarse como una provincia separada y marítima, sujeta al Perú en cuanto á la harmonía de las medidas militares y de la correspondencia mercantil: bien que en cuanto á esta última hemos manifestado que sería casi ninguna, luégo que ol zomercio de Europa, con una navegación libıe en el mar Pacífico, s z apropiase el tráfico costanero y abriese una nueva correspondencia 6 compensación de frutos con-Baenos-Aires.

El Chile, considerado como colonia española, se asemeja mucho á las provincias del Río de la Plata, y enieramente á las colonias americanas: es un país de una fertilidad extrema, de un suelo casi inagotable, de un clima verdaderamente análogo al europeo y 3 ie una posición ventajosa para su defensa; pues le abrigan la cordillera al Esté y el mar al Oeste. Raya al Norte con nuestras provincias del Perú y al Sur con las tierras de los Viliches, Araucanos, Puelches y Pehuenches; pueblos yá poco temibles para invasores, no sólo por su corto número, si también por los muchos piogresos que ha hecho en estos últimos años su inclinación á la labranza y al nombre español; pero por un acaso deşraciado, esa misma posición marítima, tan ventajosa para su bienestar absoluto, no le permite cambio alguro útil con la matriz, apartándole, por consiguiente, tanto de las colonias americanas y de las del Río de la Plata en sus ventajas intrínsecas, como se le asemeja en su clina y producciones. Si la España, sobrante de ge.xie, c mmo lo son la Isla de Malta, la ribera de
Génova y la misma provincia de las montañas de Santander, necesitase un pais en donde con el auxilio de la navegación se aumentase el suelo á proporción del incremento $\mathrm{y}$ opulenciade sus ha. bitantes, seguramente el Chile serî́ el país más oportuno para este objeto. Ni se nos oponga que no fué la sobrada población de la Inglaterra la que dió margen al incremento rápido de sus colonias, pues que las colonias inglesas han crecido á la verdad con una rapidez extrauriunaria, pero esto la sido al abrigo de unos privil agios y quietud constante y por los efectos de la persecución de una ú otra secta, como tambiér por la concurrencia de alemanes, irlandeses y franceses (I).

Más diremos aún. Si en el espacio prózima. mente de unos treinta años la España quisiese ver duplicar la población europea de Chile, pudiera conseguirlo di in istrativamente, sólo con la introducción de una libertad política, que influye directamente en el ciudadano la idea de su sola prosperidad y reproducción.

Pero rii la España puede suministrar un emigración ventajosa, ni la excesiva población de Chile le sería útil, cuando el fruto de sú suelo ó de sus brazos no suministre cambios oportuıos para la opulencia recíproca. Las minas, á la ver dad, pudieran aumentar mucho, y este producto (cualquiera fuese luégo su valor aumentando su cantidad en Europa), pudiera atraer una cantidad igual de frutos y géneros manufacturados del Continente; pero mientras no se gradúe en Espaiia el verdadero eiecto del oro y de la plata, y mientras el beneficio de las minas dependa sólo de los brazos, séanos permitido el no considerar entre los productos de Chile sino un millón de pesos anuales, que es lo que producen sus minas, áun inclusas las de Copiapó, que muy luego demostraremos deberá pertenecer al Perú.

Ya se dijo hablando de Buenos-Aires, rela tivamente á sus provincias interuas, que la unidad te intereses es la que debe dirigir la división de Gobier11os; y así como el sistema gubernativo de Chile haya de atender más bien al aumento de la población que al aumento de minas (2), parecía que le perteneciese el suelo fértil que media entre los paralelos de Coquimbo y Concepción, esto es, entre los 29 y $37^{\circ}$ de latitud, para que el cuida'so de las minas no fuese sino acceso-

(I) Véanso las notas del Dr. Sefherson sobro lo Estados de Virginia, y el examen historico y poli tico sobre las provincias de la América septentrional. (2) La extracción de 1789 fué la siguiente: $c n$ doblones, 680.198 pesos. Ell plata, 29I.c43. Total, 97I.241. El balance del quinquenio, hecho por $\mathrm{cl} \mathrm{Su}$ perintendento Acevedo, afo de 1786 , sólo da por perintendento Accvedo, afo de 1786 , sólo da por cantidad media 52 r.644 pesos fucrtes; pero se conoco cl remcito progresivo desdu que se establecio par ce re 
cia de las montañas de naís en donde con el e aumentase el suelo á y opulenciade sus ha. Chile serĩ el país más Ni se nos oponga que on de la Inglaterra la ento rápido de sus coias inglesas han creciapidez extrauriinaria, de unos privil agios y s efectos de la perse, como también por la , irlandeses y france.

n el espacio próximaos la Esp̣aña quisiese europea de Chile, puativamente, sblo con la ad política, que influye ano la idea de su sola jn.

puede suministrar una la excesiva población ndo el fruto de su' suelo stre cambios oportun ${ }_{4}$ os ca. Las minas, á la ver. nucho, y este producto u valor aumentando su diera atraer una cantieneros manufacturados ntras no se gradúe en to del oro y de la plata, de las minas dependa s perm:tido el no conside Chile sino un millón lo que producen sus mi'opiapó, que muy luego rtenecer al Perú. de Buenos-Aires, relais internas, que la unidebe dirigir la división el sistema gubernativo $r$ más bien al aumento mento de minas (2), pael suelo fértil que meCoquimbo y Concep9 y $37^{\circ} \mathrm{dc}$ latitud, para no fuese sino acceso.

Dr. Sefherson sobre los examen historico y poli la América septentrional 80 fué la siguiente: en fue la siguiente: en doa plata, 291.043. Total inquenio, hecho por el su de 786 , sólo da por os fucrtes; pero sc conoce du que se estableció para Moneda, y además es re lata al Perú. rio, y el principal esfuerzo de la legislación sólo aspirase al bienestar de los colonos.

Ni se imagine que disminuyendo las minas del Guasco y Copiapó, que en el día fertilizan la Casa de Moneda de Santiago, hayan de disminuir las cantidades que hemos supuesto en la circulación de Chile. Coquimbo es capaz de un aumento grande en el beneficio de las minas, y al mismo tiempo que se dirigen las providencias gubernativas al progreso de sus cultivos, puede también progresar algún tanto con el aumento de población, en el mayor beneficio de sus minas.

Ya, pues, nuestros cálculos pueden analizarse con mayor método, y examinar de cerca cuáles son los fondos de Chile, cuáles sus efectos sohrantes, y cuáles los que necesita anual. mente: para sujetarnos al mśtodo prescrito, nos referiremos de nuevo á la sola España.

El fondo de circulación de Chile, debió precisamente ser considerable, no sj́lo por la contínua suministración de las minas, precisamente útiles en un país que por sí mismo abastecía el alimento y el vestido, si también por los gasto's necesarios de una guerra casi de dos siglos, y por el aumento último de tropas y empleados por los diferentes ramos de la Administración civil y económica: proporcionándose así, que muchos poseedores de fondos pueden emplearlos en un giro prudente con Europa ó con el Perú, resulta su conservación al Reino, pues que su producto alcanza á satisfacer al lujo moderado y á la subsistencia muy barata en todo el Reino.

En el día recibe de Europa, ó directa ó indirectamente (I) (si hemos de deducirlo de los esta dos de Aduana de Santiago) r.052.412 pesos, poco más de la rnitad extranjeros y la otra parte nacionales. Los satisface casi todos con el nu. merario y el cobre ó bien con algún sobrante sobre su comercio con el Ferú: le es contraria la balanza con Buenos-Aires.

Este comercio con la matriz, debe, pues, considerarse como alcanzado á su míximo, á métıs que, ó crezca el producto de las minas, 6 se sustituyan í los actuales algunos frutos útiles á la Europa, ó finalmente, se cambicn estos mismos frutos ccn alguna otra colonia que produzca algo que restituir á la matriz. Este últims, parece precisamente el caso en que se halla el Chile: pue. de, abandonando la yerba, sustituirle el culen de cosecha propia, en cuyo caso será una deuda considerable con Buenos-Aires 6 más bien con el Paraguay, la que sube anualmente á 280.000 pe -

(x) Se ha visto en los estados do Aduanas de Valparaíso, y se ha notado en Concepción, que los pocos géneros europeos que consumen, proceden do Santiago. sos, precio de la Aduana de Santiago (I). Puede en el distrito de Coquimbo beneficiar los azícares, sustituyéndolos á lo ménos en parte, á la mucha cantidad que recibe anualmente del Perú, y que asciende á más de 400.000 pesos; al mismo tiempo, suministrando á este último, no sólo los trigos, charques, sebos, cobre, comestibles, grasas y cáñamos, si también algunos efectos ma. nufacturados que su menor abundancia de metales y la excesiva fertilidad del suelo desde luégo hacen más ventajosos, puede contraer un sur-plus relativamentc al Perú, con el cual sa. tisfacer una nueva deuda que contraiga con el Continente en efectos de lujo.

A estos objetos, debe, por consiguiente, in clinarse la legislación, favoreciendo inmediata mente la agricultura con la multiplicación de villas esparcidas en lo interior, de modo no obstante, que la conducción de los frutos sea fácil y barata, y que se incline el cultivador más hien á los que deben extraerse, que á los que sean de consumo interno, aunque sea algo más penoso el trabajo. Bien lo conoce el actual Presidente y Capitán general de este Reino, el Mariscal de Campo D. Ambrosio Higgins: bien lo apercibe ya en los pocos meses de su Gobierno é Intendencia el Brigadier Gobernador de la Concepción, D. Francisco Mata Linares: entrambos protegen, naturalmente, la agricultura; entrambos, en sus últimas visitas, reuniendo la equidad y la dulzura á otras muchas cualictides admirables que les caracterizan, han fundado nuevas vilias, han propuesto mercados públicos y pósitos, y con medidas de esta especie harán progresar considerablemente la población (2)

Con una regular multiplicación de fondos y con el aumento de gentes, sería fácil lućgo á los comerciantes de Santiago emprender por sí el transporte de sus frutos al Perú, en cuyo caso las 260.000 fanegas de trigo que se exportan anual mente á precio de ro reales y suelen en Lima valer de 18 á 20 con menor garancia, darían al mismo tiempo un nuevo rédito, y excluirían más y más el aprovechamiento de igual cosecha en Lima, que en el día, no obstante, no puede costearse con 24 reales (3). Ahora, que la mano de obra haya de ser precisamente más barata en un país en donde es mayor la población útil, mucho

(x) Se hace esta advertencia, porque la yerba, al llegar á Santiago, entre transportes, alcabalas, derechos y ganancias del comcrcio de Buenos-Aires, ba duplicado su valor.

(2) Son muy defectuosos los cálculos de D. Cos me Bueno en esta parto.

(3) Hay una ley agraria en Lima, en nuestro en(3) Hay una ley agraria en Lima, en nuestro en tender no bien meditada y por ventura infructuosa, que obliga a los panades a comprar el trigo crollo - de! pals a 24 reales fanega. l.os Sros. Mendiburu, de Lima, estableciéndose en Concepción con alguno londos, y trafirando con buques propios, han hecho una fortuna tan rápida como con...'Aerable. 
menor el lujo y más fácil la subsistencia, no debe dudarlo persona alguna. No sería extraño, por consiguiente, que muchos muebles, varias partes del vestid., y particularmente los zapatos, pues que ins cordobanes se curten en el Maule y en Concepción, se fabricasen en Chile para Lima, que de alli procediesen preparadas las tablas de alerce para duelas, como las traen del Norte á los puertos de España, que allí se fabricasen harinas, que las mismas embarcaciones de Europa invernasen una ú otra vez, ó esperasen carga en los puertos de Chile.

Bien se deja ver que cuanta deuda contrajese el comercio del Perú con el de Chile y la satisfaciese en dinero, otro tanto ménos embarcaría aquel para Europa; ipero sería ésta acaso una desvertaja? Antes bien, ¿no resultaría un verdadero prícipio de opulencia, si esie dinero, dirigiéudose siempre á lọ satriz, vivificase en su tránsito á otra colonia?

No olvidaremos en las proposiciones que acabamos de adelantar, cuánto sería difícil, bien que no imposible, el realizarlas, y que además pudieran tal vez llevar un semblante de luchar con aquella harmonía general que nos hemos propuesto para la verdadera opulencia de la matriz con sus colonias: excluyendo ó en el todo 6 en mucha partela yerba para sustit uirle el culen, se seguiría una pérdida considerable no sólo para el Paraguay que la produce, si también para el Erario, que en su traspaso cobra considerables derechos; y lo misi no sucedería relativamente al azúcar con el Perú, nero quedan fácilmente destruidas estas dificuliades, wndo se considere que el Paraguay es una provincia interna, cuya prosperidad es indiferente, pues que ni debe costear su defensa, ni puede comunicarse con la Metrópoli; que el Erario cobra indiferentemente los derechos en una ú otra circulación como la haya, siendo aún esta balanza más sencilla cuanto más directo sea el com rcio con la Metrópoli; finalmente, que Lima, con la inversión de sus fondos en el comercio interno y en la labor de las minas, podría conservar aquella misma opulencia que en el día la hace el depósito de una cuantiosa circulación.

Pueden aún ensancharse algo más las combinaciones favorables de Chile con el Continente, cuando se considere que conducidos directamente los efectos europeos de consumr, pudieran propolcionarse retornos completos á los buques, ó con el cobre, ó con los cueros, omitiendo usar de ellos para empaques del charque y otros muchos usos domésticos (I), ó con los productos de

(I) El señor Regente actual de Santiago, me ha asegurado pudieran remitirse anualmente a Europa como 30.000 cueros. Efectivamente, la matanza de novillos para el charque y de vacas para el sebo y la grasa, es considerable. la pesca, si en la recta balanza de los intercses públicos pareciese oportuno que la navegación doméstica fuese exclusiva de las colonias como lo es del comercio de Europa.

Es imposible en el día sujetar á cálculos exactos todas las operaciones así del comercio como de la administración y defensa que mueven la circulación de este Reino: pero podremos asegurar sin recelo de equivocación, que no es tan ventajoso al Perú y al Paraguay, como es dañoso á la Metrópoli; que ningún aprovechamiento resulta al Erario, y sí una emigración considera. ble al Estado; que las mismas rentas, áun administradas con la mayor puntualidad y econumi: no sufren los edificios magníficos que se han emprendido, y particularmente, la Casa de Mone. da (I); finalmente, que la recaudación de dere. chos es muy gravosa para el progreso de la agricultura y de la población, y que es extraña en un país tan despoblado, la existencia de dos Obispos, y la manutención por el Erario de tanto núme. ro de eclesiásticos y misioneros, que pudieran vivir frugalmente de los mismos dones de la tierra, que gustosos le tributarían los feligreses.

Debe advertirse que los fondos que se han indicado como propios de Chile, son relativamente propios de la sola ciudad de Santiago, y que los dos extremos del Reino, tan abundante el uno en productos de la tierra como el otro en minas, carecen absolutamente hasta del caudal ne. cesario para la circulación más escasa y ce: ñida (2).

No caben los remedios de este mal en las fuerzas actuales del Reino, pues que fueran precisos dos fondos (3); el uno de rescate de . inería para Coquimbo, y el otro de Monte-pío para las cosechas de Concepción, en cuyo beneficio, no obstante, habían de comprender sólo aquellos frutos que, 6 por su calidad 6 su poca distancia á la orilla lograsen de una venta regular y segura. Siempre fuera oportuno que los buques de la Marina Real existentes en el mar Pacífico hiciesen escala en Concepción, y allí se abasteciesen á lo ménos de vinos para una ración diaria; cuyo importe debía descontarse del sueldo crecido de que goza el marinero en la mar del Sur; y en cuanto á Coquimbo, mejorado con algunos fondos el método de sus labores, pudiera tal vez una

(1) Su arquitectura, obra sobresaliente del señor Tuesca, merece la atención de cualquier hombre culto. Estará concluída dentro de tres ó cuatro años.

(2) La escuadra, en tiempo de la última guerra, gastó en la Concepción r.300.000 pesos fucrtes, tral dos en diferentes años, 300.000 pesos fucrtes, tral vificadc; la falta de comercio activo y el ningún valor de sus vinos en Lima, los han vuelto a hacer salir.

(3) Se ha manifestado cuanto importa a los coseclieros de Santiago tener un fondo, no sólo para fabricar géneros propios, si también para no precipitar sus ventas. I.a colonia holandesa del Cabo de Buena Esperanza, se asemeja en muchas cosas al Chile. 
os intercses navegación lonias como

á cálculos el comercio que mueven dremos asele no es tan ho es dañoso amiento re. considera$\mathrm{s}$, áun admiy econumfe:, se han em. a de Mone. on de dere. de la agrixtraña en un los Obispos, anto númepudieran vide la tierra, eses.

que se han on relativa Santiago, y bundante el 1 otro en mil caudal ne. casa y cemal en las fueran prete de ineate-pío para o beneficio, ólo aquellos ca distancia lar y seguuques de la cífico hiciebasteciesen diaria; cuyo crecidn de Sur; y en lgunos fontal vez una reunión de accionistas del Perú dirigir sus fondos á esta nueva especulación, introduciendo metódicamente los efectos y azogue necesarios, y no permitiendo que pocos individuos concurriesen á la opresión del minero, con recargarle el valor de efectos casi inútiles.

La pesca en tal caso encontraría un objeto esencial de consumo: se sustituiría la esperma á la cera para el culto religioso, y una cantidad de grasas 6 aceites proporcionaría algunos retornos útiles para la Europa, pudiendo así este útil ramo competir, aunque más distante, con las costas Patagonicas, en cuanto beneliciado de antemano el producto del mar en estas orillas pobladas, fuera capaz de unas ganancias que no permiten al otro lado la necesidad de pasar al Sur casi sin carga, y al tiempo preciso para la misma pesca.

El Sr. D. Ambrosio Higgins, con medidas bien concertadas, ha empezado ya á mover esta importante máquina, y la comunidad de Coquim. bo apercibirá muy luégo este beneficio; pero si no pareciese imprudente el aventurar sin los correspondientes cálculos mercantiles algunas propuestas de esta especie, pudiéramos insinuar, que las pescas de la costa de Chile merecen la atención del Gobierno, el cual pujiera ó exigir de la nueva Compañía marítima, que dirigiese allá también sus medidas, ó permitir que la exclusiva en su favor no se extendiese al mar Pacífico, en cuyo caso pudiera emprenderse este nuevo ramo de industria por un número de accionistas 6 chilenos 6 limeños: un fondo de 50.000 pesos alcanzaría tal vezá estos objetos: dos paquebotes remitidos con carga desde Europa á Valparaíso y construídos en Vizcaya 6 comprados á americanos con la mayor economía, costearían sobre sus fletes á lo ménos un ano de manutención propia, y su primer costo $y$ habilitación no excedería de 20.000 pesos; otros $\mathbf{5}$.000 se destinarían á la construcción de las lanchas en el Coliumo, San Vicente y Tomé, puertos inmediatos á la Concepción: bastarían $\mathbf{5 . 0 0 0}$ pesos para clavazones, lon:s, herramientas y aperos de la pesca : los otros 10.000 costearían las sales, almacenes y jornales necesarios, bien que en unos paises, en los cuales los comestibles son de una abundancia excesiva, la marinería natural y mucha europea desocupadas y casi aburridas de la facilidad ociosa del alimento, que luégo no les suministra medio alguno para vestirse, y cebar sus ideas de lujo, vicios, etc., se proporcionaría sin duda la adquisición de viveres, maderas, gente y áun almacenes, sin la menor anticipación de fondos.

Los puntos de la dirección debian ser el Tomé en la bahía de Pence, y el puerto de Coquimbo. Por ventura, dos sujetos igualmente hábiles, activos y honrados, pudieran encargarse en ambos parajes, de esta dirección: D. Agustín
Ferrer (r), en el Tomé, y el Teniente Coronel D. Tomás Shée, en Coquimbo (a). Los paquebo. tes se ocuparian de la pesca de la ballena en alta mar, y harian un viaje á Juan Iernández en busca del bacalao y congrio que alli se pescase: entre tanto, las lanchas repartidas desde Copiapó á la Isla de Santa María se ocuparían, yá en las pescas de los mismos róbalos, congrios y corvinas, ya en el beneticio mismo de las ballenas, de las cuales está llena la costa, particularmente hacia Concepción.

El róbalo y la corvina se venden en Cc.zcepción á las embarcaciones de Lima, de sejs á ocho pesos quintal; pero si se atiende al informe del Cabildo de Copiapó, dado al señor Presidente Higgins al tiempo de su última visita, el congrio comprado á los pescadores sobre precios muy bajos $y$ en cambio de efectos bien recargados, como el mate, la harina, el trigo y el aguardiente, transportado luégo, suele valer en Potosí, Santiago y Lima sobre 30 pesos quintal. En Coquimbo mismo no baja de 16 á r 8 . Bien se deja ver con cuánta ventaja de precio pudiera beneficiarse en Juan Fernández y rescatarse en camb:de efectos útiles á aquel presidio.

Pero es tiempo de abandonar ias ideas económicas, en las cuales hemos procurado demos. trar, que Chile espera su incremento de la agricultura y la pesca más bien que de las minas, las cuales no deben no: consiguiente fomentarse de parte de la legislacion, siempre que erivuelvan el menor sacrificio de gente útil, que ambos ob jetos pueden proporcionarle un comercio venta. joso con la Europa; pero refluyendo los frutos de la agricultura sobre un nuevo débito del Perú que debe satisfacer en dinero sin daño propio, no obstante, ni de su comercio con la Metró-

(1) Don Agustín Ferrer, Tenientc Corregidor del Tomé, de quien hablamos ya en la Memoria del Río de la Plata, es un verdadero Patriarca que mantiene en la mejor harmonia y subsistencia, sobre 260 vecinos, extendidos desde el Coliumo al Tomé. Le obedecen como a un padre: les habla y corrige más bien como hijos que como súbditos: les dirige sus labores, emprende cortes, siembras y pescas para qu 3 semantengan sin vicios y el cenar con tengan sin vicios; y el cenar con entre marineros, labradores y peones, ha sido uno de los instantes más agradables que han tenido nuestros Oficiales. Este buen ciudadano es natural de Granada.

(2) En D. Tomás Shée, Oficial que fué del regimiento de Irlanda, destinado a un corregimiento del Perú y luégo empleado en Chiloé en tiempo de la última cuerra brilla el verdadero filósofo. En un clima tima guerra, brilla el verdadero flosofi. En un clima de los mas placcnteros, cntre una familia que no cesa de multiplicar y quererle, con una salud robusta a $p^{\text {a.- }}$ sar de una sdad bien avanzada, ve crecer sus rentas con el bien general; y ya semlrando ó plantando, ya introduciendo nuevos riegos, y ya promoviendo la pesca, coadyuva en mil modos a la Naturaleza y ésta le corresponde no ménos con sus denes muy amplios, que con el semblante risuefio que le presenta. Es inutil recordar quo ha dejado toda la de ambicion, recordar que ha dejado toda idea de ambicion, cinéndose únicamente a la de ser feliz $y$ hacer otros felices. 
poli: que la división natural de este Reino relativamente á sus miras económicas, implica que Copiapó se agregue al Perú, haciéndole, por consiguiente, un país de minas, sin mezclarse otra industria ni agricultura: que para acopiar los fondos necesarios al establecimiento de esta prosperidad, sea relativamente á la agricultura ó á la pesca, se necesita inmediatamente, 6 una concurrencia de fonclos de Eurnpa por medio de la Compañía Marítima, 6 una apertura de acciones en el Perú y Chile para Bancos correspondientes á una y otra industria: que el Gobierıo no debe tomar en estos objetos más parte que la de las franquicias, poniendo estos establecim entes tiernos al abrigo de la complicada administración subalterna de la Hacienda: finalmente, que en el permiso de conducir directamente á Chile los géneros de Europa, y áun la yerba desde BuenosAires, sin conceder franquicias al paso por esta última colonia (r), se logrará que en los cobres, en la plata, en los infinitos productos de la pesca y en la manutención económica de los armamentos, consigan sus retornos varios buques que anualmente transiten por el Cabo de Hornos al mar Pacífico, con cargas para Chiloé, Valparaíso y Conguimbo, inclusos los azogues, ferreterías y mil otros útiles para el beneficio económico de las minas.

Examinemos ya atentamente el estado militar, el cual nos lleva directamente á la Concepción de Chile, único punto que hasta aquí se ha considerado como igualmente expuesto á las invasiones de los indios comarcanos y de las naciones rivales europeas. A este fin ha sido siempre aquella ciudad la residencia del Maestre de Campo ỏ segundo Jefe militar: lo era antes por seis meses del mismo Capitán General; y toda la tropa veterana en un número mo indiferente, sostenida de un cordón de pequeños fuertes $y$ de algunas baterías á la mar, parece asegurar á la Monarquía la posesión de unos dominios que á la verdad no le son muy útiles (2), pero le han costado hartos sacrificios de sangre y de caudales.

Si debemos creer á nuestra misma experiencia, y particularmente á todo lo que pasó en el último Parlamento de $\mathrm{I} 784$, en el Valle de Lonquilmo, ni puede ya haber una confederación militar entre todos los indios comarcanos, parti. cularmente apartándose tanto los intereses de los pehuenches, de los Juncos y Viliches, y entre

(I) Ya todos los comerciantes de Chile piden la remesa de los géneros de Europa, por Valparaíso con preferencia á Buenos-Aires, por lo que se ajan y pierden de su vista y hermosura en el transporte de las carretas. El maiogro de éstas y de algunos paraguacarretas. El maiogro de estas y de algunos paraguayes, no sería

(2) Se habla del territorio ú Obispado de la Concepción. estos mismos, los de unos con otros; ni nuestras enemistades recíprocas tienen ya el cebo que tu. vieron en tiempos pasados, el de un ciego empeño por nuestra parte, de avasallarlos: el de una obstinación perpétua en ellos en resistirnos, y finalmente, poner un término á nuestras conquistas ( $\mathrm{I}$ ). Luégo que una disciplina bien ord ?nada en nuestras fronteras les ha asegurado no tanto de la conservación y existencia de nuestras fuerzas, que ya conocieron y no temieron mucho más considerables, como del pacílico sistema que en el día se ha adoptado, han dado todas las se. ñales de sumisión y de amistad, que pudiesen combinar con su libertad moral; se han estiechado con algunos de nuestros Capitanes de armas, como no abusasen de su imaginaria autoridad; han condescendido á un comercio recíproco; nos han hecho repetidas veces jueces de sus pequeñas desavenencias; finalmente, abandonando casi de un todo su vida militar, sc han inclinado más y más á la agricultura, y probablemente lo apercibe el aumento de su población.

Yero, ¿á qué engañarnos aún en nuestros cálculos políticos con una dominación imaginarı? ¿Por que intentaremos suponer que los indios comarcanos sean súbditos de la Monarquía, cuando la manutención de fuertes y tropa en la frontera, denota que los tememos: cuando los regalos casi diarios, las súplicas, los sufrimientos y los honores que les tributamos, todo convence que su amistad nos es necesaria? En tal caso pueden ya revivirse nuestras ideas sobre el comercio de Chiloé, háciendo que este enlace tan útil como poderoso, sea el único que en adelante nos reuna á esos pueblos, más bien que una mezcla de soberanía y humillación incapaz de un sistema uniforme, y tan varia como los genios, 6 pávidos ó altaneros que la dirigen y manejen; podemos, sobre todo, paulatinamente, descender al examen de los gastos enormes que causa el pié de tropa existente en Concepción. Esta provincia, cuyos frutos por falta de salida no tienen valor alguno, cuyos habitadores son pocos y ceñidos á sus haciendas por falta de aquelios recursos que deben precisamente acompañar la vida sociable, no reditúa al Erario, áun después de la administración más económica, sino de r6 á r8.000 pesos, cuando los gastos ascienden hasta I 50.000 (2). Este desnivel del Erario es tanto rnás de advertirse, cuanto menores son las ventajas que produce.

Es difícil indagar el verdadero plan que se propuso el Gobierno en el establecimiento de los diferentes fuertes que en el día forman las fronteras: parece increible que intentasen cubrir con

(1) Véase la Historia sivil, del Abato Molina.

(2) El Excmo. Ulloa cuenta por menor hasta $160.87 \mathrm{I}$ pesos luertes. Véanse sus Memorias secretas. 
; ni nuestras cebo que tu. iego empeño 1 de una obs. rnos, y finalras conquisien ord $ə$ nada ado no tande nuestras ieron mucho sistema que todas las se gue pudiesen an estiechaes de armas, utoridad; han oco; nos han bequeñas desdo casi de un o más y más o apercibe el

en nuestros n imaginaria? los indios co. quía, cuando I la frontera regalos casi os y los honovence que su so pueden ya comercio de an útil como nte nos reuna nezcla de soun sistema ios, ó pávidos en; podemos, ler al examen pié de tropa vincia, cuyos valor alguno, Jos á sus ha. ursos que dea sociable, no administra8.000 pesos, I 50.000 (2). lás de adver. ijas que pro-

plan que se miento de los man las fronon cubrir con ellos pocos campos sembrados, que no ofrecían al indio invasor otros productos que los que él tenia en sus campos; no parece tampoco probable que esperasen de los indios más que correrías, las cuales, de ningún modo pudieran con. cretarse ni con una doble línea de fuertes: estos mismos necesitaban un contínuo gasto para su manutención, y los temblores los amenazaban cada día de una ruina irremediable (I). Finalmente, sólo pudieran idearse cuando la comunicación de las siete ciudades hacía preciso el defender palmo á palmo un terreno por tantas partes disputado de unas naciones igualmente unidas y belicosas.

Pero en el día, en que debemos estar conven. cidos que la economía es el brazo principal de nuestro sistema, hemos de graduar precisamente nuestras fuerzas con lo que hayamos de conser. var, y no empeñarnos en la defensa de unos terrenos que nada valen, sólo porque fueron nuestros y pudieran quitárnoslos de nuevo: supongamos por un momento una invasión de los indios: en este caso, ó es menester reforzar cada fuerte con un aumento de gente y municiones, ó deben abandonarse unos para resistir en otros: si lo primero, no es asequible contra unos indios cuya invasión ha de ser momentánea y sin atención á derecho de gentes, ni de la Concepción. pueden enviárseles socorros sin quedar desierta la ciudad misma: si lo segundo, más vale abandonarlos ahora y no encenagarse en nuevos gastos: aunque el Erario se destruyese en el solo objeto de las fronteras de Chile, no nos queda duda que siempre nuestro número militar fuera inferior muy mucho al de los enemigos; luego si ademís de esta ventaja les concedemos la de desunirnos y la de cubrir un pás inmenso con pequeños cuerpos arraigados á uno ú otro punto, ¿cómo pretenderemos vivir en aquella tranquili:dad económica, á la cual precisamente debe dirigirse un sistema que haya de ser permanente? No desaprobaremos la existencia de un cuerpo militar en Concepción, pero sea éste reducido al solo cuerpo de Dragones, los cuales, reunidos y ejercitados á usar de la artillería entre sus formaciones, puedan marchar inmediatamente á donde convenga; y entre tanto el Biobio, tantas veces perdido y tantas ganado, sea nuevamente nuestra barrera defensiva, pues en balde nos esforzáramos á.tener un cordón al Sur de este río, cuando no hay puentes ni áun barcas que proporcionen, 6 la remesa de un nuevo socorro, 6 una prudente retirada. Al mismo tiempo procu. re combinarse una prudente defensa de la misma Concepción, asegurando los dos altos inmediatos

(1) Los temblores del 19 y 20 de Marzo de este afo de 790 , han hecho considerables extragos en algunos de los mismos fuertes de la froutera. cou des baterías cubiertas, que crucen, si es posible, los dos frentes de la anigua ciudad:'en el caso de un ataque, sea siempre la posición de nuestro cuerpo de defensa en la misma ciudad, cubriendo las familias hacia el río y haciendo frente hacia el Nordeste, resguardadas las casas y calles con palizadas, etc., que resistan un asalto: finalmente, procuren reconcentrarse en la misma ciudad los pocos bienes que posean estos colonos infelices: su mayor daño fuera que pensasen en defender sus tierras, y no viniesen inmediatamente á la capital para coadyuvar todos juntos y con un sistema bien dirigido, á la defensa verdadera de la provincia.

No obstante, no aconsejaremos que esta no. vedad 6 abandono se haga en modo alguno que llame la atención de los vecinos : creemos inútil pactarlo, á menos que algún Parlamento casualmente no lo proporcione; parece pernicioso el hacerlo de un golpe, pues en tal caso pudiera infun. dir en los vecinos, siempre atentos á nuestros pasos, ideas ó de temor ó de insidia de nuestra parte; pero sí podrá abandonarse, ya uno ya otro fuerte, á medida que se vayan arruinando; y entre tanto disminuir de tal modo el número de sus guarniciones, que sólo haya seis ú ocho hombres en los fuertes interiores, quedando siempre los últimos áevacuarse los fuertes más inmediatos al mar, y por consiguiente, á la Concepción. Este solo partido trae consigo la reforma de la mitad de los gastos actualmente inclusos en la cuenta terrible de la Concepción, pues toda la infantería debería en tal caso reformarse.

Pero ya no merecen mayor examen los pací ficos poseedores de un terreno fértil y vasto: veamos ya cuáles serían las miras de un invasor europeo.

Desde luego no serían otras que las de sa. quear el país, ó tal vez ocurrir á la escasez de víveres: nunca pudiera llevar las miras de un eśablecimiento, porque inmediatamente su situación sería tan precaria como lo es en el día la nuestra; antes bien sería peor, porque á nuestras fuerzas marítimas que viniesen á ciesalo. jarlos se agregarian inmediatamente las milicias, que con otra especie de guerra, con unos ataques casi diarios, y con un conocimiento extraordinario del terreno, harían una guerra casi irresistible.

En una invasión enemiga, que las fuerzas marítimas no puedan resistir, parece lo más prudente el no oponerse directamente al desembarco, ni jamás presentar el frente al enemigo, á lo ménos en mucho número: las escaramuzas y las retiradas oportunas, el atacar de noche más bien que de día, el convidarle más bien á que se divida encontrando un terreno vasto sir obstáculos, que á permanecer unido, viendo al frente el enemigo, son obstáculos que darán la victoria 
algo más tarde, sí, pero mucho más segura y decisiva.

Que el enemigo, aunque sea con una embarcación pequeña, no desembarque en nuestras costas entre Chiloe y Coquimbo, parece imposible conseguirlo por medio de baterías y tropa arreglada. Dando una mirada á la vasta com prensión de estas costas, á los muchos puertos que encierra, y á las islas de la Mocha, Santa María y Juan Fernández, en las cuales puede no sólo deser.'barcar si también anidarse, debemos deducir dos consecuencias útiles para nuestro sistema económico, y son; r." Que no podemos evitar que el enemigo desembarque en estas costas, y que áun estableciendose en ellas, no nos conviene sitiarlo ó combatirle á cara descubier$\mathrm{ta}$, pues son demasiadas las fuerzas de una tropa hambrienta y disciplinada para que las contrarresten unos soldados y milicias sin disciplina, acostumbrados a la opulencia, y que no olvidan sus familias, su quietud y sus campos. 2." Que la defensa esencial de nuestras colonias pende de la conservación de una ú otra ciudad, no del inmenso territorio que les corresponde: todos los corsarios que han recorrido estas costas, nos manifiestan que su ánimo y su necesidad siem. pre fueron dirigirse á una ú otra colonia para saquearla, y jamás pensaron en buscar para sus desembarcos un terreno desierto, 6 para sus in. sultos un país interior (I)

Luego ó no defendamos las costas mientras la pobreza de nuestras colonias marítimas no las haga un cebo al enemigo, ó descendiendo á éstas la opulencia de las colonias internas, varíe nuestra constitución, y por consiguiente nuestro plan de defensa: una colonia marítima opulenta, exige á la verdad unas fortificaciones que la sostengan, así porque no es fácil reunir las fuerzas con la misma celeridad con que se esparce y desembarca un invasor, ligadas, por otra parte, las fuerzas maritimas con las de tierra, como porque los mismos objetos de opulencia que la rodean, le constituyen los gastos y los recursus para una buena defensa: una colonia interna, al contrario cuyos ataques ya no son sino de la mitad de las fuerzas, pues se frustran en estos casos todos los auxilios de la escuadra que condujo al inyasor, debe fijar su defensa en una guerra abierta y defendiendo en cuerpos suel tos el terreno, de modo, no obstante, que sus retiradas vayan siempre, convergiendo á ' $\cdots$ mismo punto, el cual se elegi: rá en una pos: : militar, que no permita, mediante las ven: 3 del terreno, el adelantarse sin un ataque de las por otra parte de unas marchas penosas, de un tiempo precioso y de unos gastos enormes cuan.

(1) Palmestron y Simón Des-Cordes, en Chiloé; Sparhs, en Coquimbo; Enrique Clerk, en Valdivia. do se refieren á la utilidad que han producido ( $\mathrm{I}$ )

¿Pero qué es lo que emprendemos defender en la Concepción? ¿Cuáles medidas económicas, áun diré, mezquinas, alcanzarán á poner los gastos de ina defensa en el preciso nivel con las ventaja del territorio? Son tan cortos los caudales y ric uezas de aquel país, que pocos momen. tos bastan para examinarlos hasta Santiago. Es tan corto y mezquino el beneficio de la tierra en las labranzas, que podemos decir que ella misma brota los frutos y que un sólo año basta para reponerla. ¿Será acaso el puerto el que intentemos defender? Coronemos luégo de baterías, no sólo toda esa gran bahía, si también los puertus del Coliumo, San Vicente é isla de Santa María, desde los cuales en pocas horas, hasta la artillerir ó por tierra 6 por el Biobio puede conducirse á la Concepción.

Despoblemos la España, agotemos el Erario todo concurrirá á demostrar que la invasión momentánea no puede contrarestarse, y que la du. radera no hallará sus verdaderos obstáculos sino en la guerra abierta, la cual, por otra parte, se nos hace necesaria en cuanto no absorbe otros caudales que los del momento en que se ejercita (2).

Esto no obstante, ya que la vigilancia conque debemos vivir para con los indios comarcanos (á lo ménos mientras que esta especie de guerra no se rcpresente bajo sus colores verdaderos en nuestra España) nos obliga á mantener un pié de tropa, consideremos en adelante este terreno como un puerto de Jefensa nacional; pero ni se crea ésta precisa, ni sea tan terca y reñida que refluya luégo en la mengua de fuerzas para la capital, adonde en la realidad ha de explayarse toda la actividad de una guerra reñida.

Desde luego inferimos después del plan propu zsto, que las milicias en todo el Chile son las que han de coadyuvar á la defensa verdadera, procurándose, por consiguiente, que uno ú otro Oficial veterano, 6 como cultivador 6 como Jefe militar 6 político, resida en paraje en donde sea fácil la reunión de las milicias y la combinación de un plan antes meditado (3). Que se ha de

(r) En cl ataque y toma de Manila por Mr. Draper, sc conoció la ventaja y necesidad de la guerra abierta en el propio pás. La plaza se tomó en un momento; pero luégo el pais se defendió tan oportunamente, que ya al concluirse la paz, los mismos ingleses se velan precisados á abandonarlo.

(2) Las reflexiones de los Excmos. Ulloa y Juaa en sus Memorias secretas, apoyan las nucstras. Demuestran la poca utilidad de las baterfas de Penco y la facilidad do un desembarco en el puerto de San Vicente, o una escala cn la Isla Santa Marla.

(3) Don Tomás Shée ea Coquimbo, es el verda(3) Don Tomás Shée ea Coquimbo, es el verda-
dero modelo de esta especie de militares: la historia del Nortc-América los manifiesta en tanto número, que la multiplicación de los Cincinatus no debe parecer extrafia. 
roducido (I).

os defender económicas, oner los gasivel con las is los cauda. cos momen. Santiago. Es la tierra en e ella misma basta para e intentemos ías, no sblo puertus del María, desla artillería conducirse á

os el Erario, nvasión moque la du: táculos sino tra parte, se bsorbe otros que se ejer-

ilancia conos comarca- especie de dores verdaá mantener delante este tcional; pero rca y reñida fuerzas para explayarse ta.

el plan prohile son las verdadera, uno ú otro 6 como Jefe $n$ donde sea ombinación re se ha de

Mr. Draper, zuerra abier i urs momen. irtunamente, ingleses se

Jllea y Juan uestras, De. de Penco de Penco y arto de San tría. is el verda: la historia numero, que ebe parecer fomentar la multiplicación de caballos, $y$ no ha de haber miliciano que sirva á pié; que con el motivo de algunas ferias, fiestas 6 diversiones han de reunirse anualmente estos pequeños cuerpos, procurando sus jefes en estas ocasiones cautivarse su amor; pero no siendo posible ordenarlos como regimientos, cuyo número, disciplina y manutención, piden ya otras medidas que las que alcanza la simple milicia; que de ningún mocio se excluyan el poncho, el uso del lazo y del al fanje; podrán agregárseles las pistolas, pero jamás la carabina ó fusil; que en uno ú otro paraje interior y desde luego en la Concepción, se deposite alguna artillería de campaña con sus cureñas y carros municioneros, dispuestos de modo que puedan seguir la milicia á caballo; agregán. dose á estas prevenciones las de la madera, pernería y jarcia oportuna para formar planchas de artillería en los muchos ríos que haya que atra. vesar para buscar 6 para evadir el enemigo; que no se influya una especie de aborrecimiento al servicio de la milicia, con distraerla en otros mil objetos extraordinarios, 6 contratarla en sus penosas tareas como una tropa asalariada, debiendo comprender evidentemente que el Rey no exige del cultivador más de lo que le exige su bienestar; esto es, la defeısa de su país, en mancomún con los del distrito embestid- inalmente, que no sea el Erario, sino las comunidades, que ocurran á estos acopios, dando el Rey tan sola. mente la artillería en la orilla del mar ( $(\mathrm{)}$ ). Si ali. viado el Rey de unos gastos harto enormes de defensa, cediese luego á esos pueblos alguno de aquellos impuestos, que nunca útiles, á veces perniciosos á su Erario en los países pobres y dilatados, siempre son el instrumento de la opresión del vasallo y de los vicios del opresor subal. terno, tal vez vería esta parte de sus dominios persuadida de poder por sí sola contrarestar las invasiones comunes, segura del auxilio del Monarca con sus fuerzas marítimas en los casos extraordinarios, y cebada en su agricultura, en sus pescas y er el beneficio de sus minas al abrigo de un comercio próspero $y$ arreglado contribuir considerablemente á la prosperidad de la matriz, sin faltar al debido alimento del Erario (2).

Omitiremos ya el hablar de Coquimbo, el zual, en cuanto á defensas, no ha ocupado hasta aquí el menor sacrificio del Erario, ni debe ocuparle en lo venidero, según el plan propuesto:

(1) Los pedreros y trabucos son también armas muy útile- para la defensa del país propio, en una casa, iglesia, molino, ctc.

(2) Puede asegurarse que ni en Cóncepción ni en Coquimbo producen las administraciones la menor ventaja, cuando en Valparáso, pueblo de alguna opuventaja, cuando en Valparaf́so, pueblo de alguna opulencia y de una concurrencia considerable de buques, resultan en cinco años a beneficio de las cajas, 7.094 pesos fuertes. sólo sí que en el caso de ser ó el paraje de con. currencia de muchos buques mercantes, particu. larmente en el invierno, como lo es en el día V'alparaíso, se asegure en tiempo de guerra el fondeadero con una ó dos baterias artificiales, ó con una embarcación de guerra que les dé al mismo tiempo convoy, pero de ningún modo debe em. plearse en la menor cantidad en tiempo de paz, antes bien, verlas arruinar con aquella indife. rencia que trae consigo un sistema fundado sobre principios inalterables.

No es nuestro ánimo, hablando de las reformas oportunas y casi necesarias, hacer penetrar la pluma al examen del sistema legislativo, el cual nos guiaría tal vez á demostrar, que en la extensión y multiplicación de Audiencias tuvo la legislación más bien por objeto el contrarestar la autoridad militar, que el administrar una jus ticia fundada. La historia interna de nuestras Américas, la sola parte de las últimas revolúciones de la América meridional, que ha podido a] canzar el público, tal vez lo evidenciaran más bien que cualesquiera razonamientos; nos contentaremos ahora de manifestar que caben muchas reformas en la administración de Chile, sin que mengile la autoridad Real, $y$ al contrario aumentando considerablemente la prosperidad y nervio de los vasallos y su amor al Soberano y á la constitución que los gobierna.

En cuanto á la existencia de una escuadra para cubrir los puertos de Chile en tiempo de una guerra, la creyéramos útil si pudiese combinarse al mismo tiempo la defensa del Perú, como se proyectó en la última guerra: pero cuando se considere que puestas en un regular estado de defensa nuestras colonias, sólo debemos abrigarlas del apercibimiento de un corsario, siempre temible, reserváṇdonos á enviar igual número cle bajeles cuando una prudente cautela nos indique que el enemigo piensa pasar á aquellos mares (I), ceñiremos el pié de guerra en el-mar Pacífico á un soln navío de $74 \mathrm{y}$ cuatro fragatas, todos buques sumamente veleros, y confiados á Oficiaies de la mayor actividad, unión y economía. Estos deben estar en un contínuo crucero, carenar si fuese posible y necesario en el puerto de San Vicente, proveerse de víveres, incluso el vino, precisa. mente ó en Concepción ó en Coquimbo, y permanecer en este último puerto como de invernada. En dos divisiones mientras no haya enemigos, recorrerán periódicamente la costa desde Chiloe hasta Lima, protegiendo la pesca, el co. mercio costanero y la tranquilidad pública, con aquel vigor que tanto trasciende al bien general, pudiendo cada división dejarse ver descansadamente, á lo ménos dos veces al año en cada paraje:

(1) Este era precisamente cl caso de las escuadras infelices de los Almirantes Anson y Pizarro. 
apartarán así todo corsario 6 contrabandista; y en el caso de una invasión no prevista, concurrirán inmediatamente á la defensa de Lima, con sus gentes, buques y artilleria.

Pero quien se interese en el bien nacional, no puede ménos de recordar al Gobierno que la escuadra fondeada en Talcahuano en la última guerra, seguramente no abrigaba las costas de un solo corsario, á quien no hubiera podido al canzar, $\dot{y}$ al mismo tiempo perdía mil ocasione oportunas, no sólo de destruir en Macao todo el comercio inglés de la China, quemando y varando sus buques, si también de decidir luégo en la India la balanza en favor nuestro, reuniéndose al 13ailío Suf-Crein, con una fuerza considerable de gente y de pertrechos ( $x$ ), y obligar á los enemigos á que en los años siguientes, 6 abandonasen el comercio de la China con un daño indecible, $\delta$ empleasen crecido número de buques de guerra en su defensa sucesiva: supuesto, pues, que cualquiera otra guerra nacional haya de ser precisamente con la Inglaterra, será éste un golpe de mano que deberá seguir inmediatamente á las noticias de la rotura, que no es preciso consultar con nación alguna aliada, y que el mismo Virey del Perú puede poner en práctica con una parte de los buques del comercio, armados en guerra, si el temor de que lo penetrasen con tiempo hacía difícil el desfilar algunos buques de la Marina Real al mar Pacífico: ni se aleguen las dificuitades del derecho de gentes con los portugueses chinos, las fortalezas de Macao ó el número de los buques mercantes: todo es frívolo para un Oficial que sepa dirigir esta operación, graduar con realidad los peligros, y sobre todo, evitar la confusión de las lanchas incendiarias, en las cuales, no obstante, sería preciso disponer Oficiales de inteligencia y reflexión para apartar el daño cuanto fuese posible, de los demás buques.

Ultimamente, ya que hemos hablado de las carenas en el puerto de San Vicente, inmediato á Túlcahuano, añadiremos que á la verdad pue de ser probable que las maderas de los bosques contíguos á la Concepción (2) no tengan aquella duración que se cree necesaria: pero que la tendrán seguramente las maderas de la cordillera, que con consentimiento de los Araucanos y Pehuenches, $y$ tal vez con los mismos enlaces benéficos del comercio, pudiéramos conseguir por el Biobio hasta el mismo puerto (3).

(1) Este pensamiento, que sólo se apunta superficialmente, debe hacer comprender, que bien dirigida nuestra Hacienda y fijado a pocos puntos nuestro sistema de defensa de la América, las fuerzas de una Monarquia como la cspañola son muchas é irresistibles.

(2) Estc es el parecer de D. Antonio Cazulo, Ingenicro carpintero en Lima.

(3) Particularmente los pinos y cipreses para tablazones y baos: las ligazones son muy buenas a lo
Ya se han construído en él buques de mucho porte, entre otros el San Miguel, de 60 cañones, L.os Angeles y otros chicos, todos del comercio de Lima: no faltan peones, cuyo jornal es sumamente corto, mucho más si se envuelven en la ración mensual, tabaco, yerba y aguardiente: los obreros, sean carpinteros ó calafaics, pueden conducirse: pueden llevarse también todos los utensiljos, sean clavazones, fraguas 6 herramientas: pueden aprovecharse las tropas de Concep. ción en clase de peones, y conservarlos así en una vida activa: finalmente, puede establecerse un sistema de construcción que resista tal ve $z$ al sin fin de abusos fáciles de deslizarse en la América en cualquiera proyecto, áun el más bien combinado.

Sin embargo, no es nuestro ánimo proponer directamente una construcción en el puerto de San Vicente, por cuenta del Erario: sólo sí pu. diera por el señor Gobernador Intendente, tantearse un contrato con los Araucanos, para que reunidos con algunos hacheros españoles, proveyesen unas ú otras cantidades de madera: se les darían, en cambio, utensilios de labranza, algunas armas, varios adornos, algunos ganados.si los quisiesen, y cualesquiera otras bagatelas, incluso el aguardiente, que más pudiesen ocurrir á sus antojos, y al mismo tiempo se anularía el derecho de posesión, á los que han creído, sobre una sola demanda, considerarse dueños de un país inmenso, que ni fué conquistado ni lo será jamás, sino devolviéndolo á sus antiguos dueños, y haciéndolo útil'á los cambios (I). Conseguido este punto esencial, pudiera tal vez con mucha probabilidad de buen exito, emprenderse por el Real Erario un ensayo de construcción, próximamente sobre el siguiente plan: una de las embarcaciones de S. M. que naveguen el mar Pacífico, habia de fondear 6 en Talcahuano ó en San Vicente con las clavazones y demás utensilios correspondientes para construir un bergantín 6 una corbeta: llevaría á su bordo, en lugar de 24 marineros, 18 carpinteros, seis calafates y cuatro herreros, éstos con sus correspondientes fraguas: el mismo Capitán del buque, con sus Oficiales y Contador, serían los Directo-

largo de la costa del Tomé, Coliumo, Pingueral, etc. El Capitán de tragata D. Isidoro Garcfa del Postigo, ha hecho un viaje á la cordillera para cortes de madera para la escuadra: serfa bueno consultarie; pero advirtiendo, que la actividad y la maquinaria no han penetrado aú on la América y que los dos inicos penctracos medios que el Rcy hasta aqui ha puesto en acción para adquirir las cosas, ha sido, ó la fucrza o $\mathrm{cl}$ derramar sus caudales.

(r) Como en la concesión de tierras al tiempo o des $_{\text {r }}$ es de la conquista se considerase nucstro todo el pais conocido, se han repartido las tierras de los Araucanos, y estas escrituras so reviviran luego que con los cortes pacficos se diese alguin valor a esas ticrras. 
les de mucho 60 cañones, comercio de al es suma. uelven en la ardiente: los ices, pueden én todos los 6 herramien. de Concep. arlos así en establecerse sta tal vez al e en la Amréel más bien

mo proponer el puerto de : sólo sí pundente, tan. os, para que ñoles, proveadera: se les ranza, alguanados si los telas, incluso ccurrir á sus tia el derecho bre una sola país inmen. á jamás, sino s, y haciénseguido este mucha proderse por el cción, próxila de las emel mar Pacithuano 6 en demás utenruir un bera bordo, en os, seis calais corresponI del buque, los Directo.

Pingueral, etc. del Postigo del Postigo, cortes de ma. nsultarlc; pero jisaria no han os dos únicos sto en acción crza ó el de-

is al tiempo ó nuestro todo tierras de los rán luégo que I valor a esas res de la construcción: se evitaría todo establecimiento duradero, de suerte que concluida la construcción, nada absolutamente quedase alli del Rey, y cimentado el método, podía la embarcación de la Real Armada hacer sus cruceios peribdicos y regresar siempre al mismo puerto, de. jando el Capitán, cuando se ausentase, el cargo de la construccion, á dos Oficiales de su confianza y al Contador, quien asistiría constantemente á las listas y consumos.

Debian evadirse todas las subdivisiones de autoridad marítima, aunque niveladas sobre nuestro método actual de arsenales, cuando no reconcentrasen toda la responsabilidad en uno solo; debían darse al Comandante, de las cajas de Santiago ó Lima, las cantidades de dinero necesarias para los sueldos y raciones, interviniendo él solo en todos los gastos é inversiones; pero al mismo tiempo debia encargarse así al señor Gobernador Intendente (I) como al mismo Comandante, que la menor desavenencia sería no sólo muy desagradable á S. M., sino un motivo suficiente para que abandonase la construcción meditada, de la cual tantas ventajas podían resultar no ménos al país que al Erario y poderío nacionales (2).

(r) Fuera inutil esta cláusula si pudiese haber seguridad de que todos los Gobernadores Intendentes fuesen como el Sr. D. Ambrosio Higgins y el señor

D. Francisco Mata Linares, á quienes todo Uficial de Marina tributará siempre todos los respetos y clogios que merecen.

(2) Debe entender todo Oficial de Marina, director de estas construcciones, que la misma economia serfa perjudicial si tendiese a atropellar el buen orden civil o militar con fueros mal apropiados ó mal inter civio militar con fueros mal apropiados $0 \mathrm{mal}$ presentes a S. M. las mejoras que hallase admisibles.
Iguales pruebas y tal vez al mismo tiempo podian renovarse en Coliumo; se omitirian en uno y otro buque varios adornos que en los países distantes sólo sirven para desfigurarlos á costa de mucho dinero, una popa y león er:allados, una cámara interior adornada, debian ser obras que se reservasen para Europa, pero al mismo tiempo no dejarian de hacerse comparaciones de sus verdaderos costos y mermas, comparadas con la brea de Paita, alquitrán de Sonsonate y estopas 6 cáñamos de Chile.

La brea, el alquitrán y la estopa debían también traerse de Europa. En cuanto á las fábricas de jarcias en este último puerto, convendri siempre que se conserven, así porque son de muy bucna calidad y sumamente útiles al pais, como porque aliviados del derecho del alquitrán de Europa y economizados varios rodeos, pudieran sin duda surtir el comercio del mar Pacífico, y sobre todo el departamento de San Blas, hacia donde toda conducción, sea por las Filipinas ó por tierra, ha de hacerla precisamente más cara.

La falta de sosiego y de tiempo, no nos han permitido ensanchar como debiéramos las reflexiones antecedentes, las que llevando en sí el semblante de la verdad, pueden tal vez convencer al Gobierno, que Chile es capaz de muchos progresos así en cuanto al comercio nacional como á la prosperidad interior; que puede resistir una invasión sin aumento de gastos; finalmente, que auxiliado de los oportunos extipendios del Erario puede refluir luégo hacia él, cantidades considerables que fortalezcan el poderío de la $\mathrm{Mo}$ narquía. 


\section{INTRODUCCIÓN al vocabulario de Vavao, por el Teniente de navio D. Ciriaco Ceviallos.}

Son tantas las causas que promueven la emigración de los pucblos, que verosímilmente no se liallaría sobre toda la extensión del globo una sola tríbu is nación, cuyo idioma sea rigorosamente nuevo $a b$ origine 6 no tenga conexión con alguna otra. Ciertamente no lo es tampoco la de los pueblos del Archipiélago de los Amigros, como lo demuestra su afinidad con el Malayo, el Visaya, el de Sandwich, y con otros muchos dialectos conocidos al Sur y al Occidente. Los idiomas, lo mismo que las demás instituciones sociales, siguen en su formación el mismo orden de las necesidades que las dictaron. Hay, "pues, voces que corresponden al origen de.los idiomas, otras á sus progresos, á su perfección; y el que conozca bien la naturaleza humana y sea capaz de pesar y calcular las circunstancias de lugar y tiempo, se equivocará pocas veces determinando la antigledad de las voces, el orden en que fueron compuestas, y la mayor parte de las variaciones que han debido sufrir. Sigue de esta teoría, que si la identidad 6 semejanza de varios dialectos prueba un origen común á todos los pueblos que los hablan, el examen particular de las voces idénticas ú homólogas puede también conducir á conjeturas bastante seguras sobre la antigüedad de las colonias, y el orden en que se difundieron. Si se considera por otıd parte que las voces no son otra cosa sino el signo de las ideas, se percibirá que las costumbres de los hombres deben leerse en sus propios idiomas: y si se añade á todo, la utilidad que puede resultar á los navegantes fu. turos, de conocer (aunque groseramente) el lenguaje de un pueblo con quien la necesidad le obligue á comerciar, se convendrá en que la aplicación á esta clase de conocimientos, ni es el ménos importante ni debe mirarse como el último objeto de un viajero ilustrado y filósofo. De es tas consideraciones ha nacido la diligencia con que en todos tiempos, y particularmente en los modernos, han procurado los navegantes adquirir la significación de algunas voces entre los pueblos que visitaron. Pero sería de desear que estos hombres tan justamente acreedores á nuestra gratitud, hubieran sacrificado á la precisión de las voces una parte de su número. Es preciso confesarlo: en el sistema indispensable de nues- tros viajes, la copia y abundancia de un vocabulario debe mirarse como la primera prueba de su inexactitud. Para percibir la seguridad de esta regla, considérese por un momento el acceso de nuestros buques á estos pueblos desconocidos y remotos, con nociones aunque confusas de la mayor parte de nuestras artes. ¿Qué asombro no debe causarles las veıtajas de nuestras obras á las suyas? Nuestras embarcaciones, armas, trajes y nuestras mismas bagatelas, jcuántos motivos para excitar su admiración! Sus primeros sentimientos ceden al deseo de poseer las cosas admiradas; uno pide, aquál cambia, el uno roba, $y$ todos procuran adquirir lo que desean, sin pararse en la legitimidad ni decencia de los medios. Hasta el respetable cacique (sicm jre blasonando las prerogativas de su dignidad) se prostituye y confunde con nuestras últimas clases por la adquisición de una cuenta de vidrio. Si en mf.iio de estos accesos tumultuosos de la codicia se llama á un natural para saber el sig. nificado de una voz, 6 no entiende lo que se le pregunta, ó no está con humor de responder. Pero supongamos que á expensas del tiempo y la paciencia, que á fuerza de gestos extravagantes $y$ de contorsiones energúmenas lo pusimos en el camino de unestras ideas: el brillo de un botón, el ruido de. una campanilla, cualquier cosa, es suficiente para distraerlo del asunto, y áun para hacerle fastidiosa nuestra curiosidad, si insistimos en volver á recoger el hilo de la cuestión. No se puede ponderar la displicencia con que satisfacían á nuestras preguntas, por lo ménos cuando pasaban de cierto número. Latu me dijo un día cun mucha gracia, que se había de coser los labios para evitar la molestia de mis preguntas ó para no responder.

La necesaria oscuridad de nuestras preguntas, lo ambiguo de sus respuestas, y la propia sed de saber, son otros nuevos estorbos para conseguirlo. No pudiendo alejar la idea del poco tiempo que podemos permanecer en el lugar de nuestras observaciones, las hacemos al mismo tiempo sobre cien objetos distintos, y como es natural concluiremos con saber poco de cada uno.

De la combinación de todos estos obstáculos y de la insuficiencia de los idiomas para copiar los sonidos de los otros, han nacido las 
enormes diferencias que se notan entre los vocabularins de un propio lenguaje, formados por distintos viajeros: diferencias de que no están exentos los observac ores más hábiles y diligen. tes. El Sr. Cook dice que á la Isla Koa, la lla. man los naturales de $\Lambda$ ghan, y á la de Taman Hay-Bay. Mr. Forster da el nombre de Nipoara al mismo jefe que llama Anderson, Siboula, etc. Pudiéramos escribir mil ejemplos de estas dife. rencias que han servido para despertar nuestra atención $y$ para limitar nuestro diccionario de Vavao, á pocas más de trescientas voces. El mayor número está á la verdad bien comprobado; pero ¿quién podrá asegurar, sin embargo, que no hemos tomado algunas veces la voz figurada por la propia, la equivalente por la directa, etcétera?

Si es difícil formar en pocos días un diccio. nario copioso, no lo es ménos hacerse cargo de la propiedad, extension y modo de las voces asi como de la sintaxis del idioma. Cuando vemo que con una sola palabra, Majale, por ejemplo, dicen, ir fui, fuiste, irse, etc., creemos que no distinguen los tiempos ni las personas; ipero por qué no se pueden dar á las vocales de aquelia palabra tantos sentidos como son precisos para hacer estas distinciones? $\mathrm{Si}$ nosotros distinguimos los tiempos variando las terminaciones, jpor qué otros no harán la misma distinción variando de acentos, particularmente cuando se sabe que los acentos hacen casi todo el juego gramatical en los idiomas no escritos?

Supongamos la existencia de una lengua que tuviera los cinco tonos enteros de nuestro diapasón (por ejemplo); pregúntese á un calculador: ¿de cuántos modos realmente distintos podría pronunciarse en este idioma la palabra Majale? $Y$ responderá que de 123.860 maneras diversas, sin pronunciar nunca más de cuatro sílabas $y$ cuatro tonos, $y$ sin tardar más tiempo en la pronunciación de la voz entera del que tarc̉amos nosotros en decir Majale, según nuestio modo de pronunciar: quiere decir, quc este idioma (tal vez poco más entonado que el de Vavao), no sólo podría distinguir los modos de los verbos et. cétera, por medio de los acentos, sino dar á una misma voz más de cien mil significaciones que nosotros no podriamos distinguir en la escritura. Tal vez parecería extravagante hacer una apli. cación del binomio de Newton, hablando del mecanismo del idioma, y convendremos en e!lo como se convenga en la exactitud del cálculo. Por lo demás, no queremos decir que el dialecto de Vavao distingue precisamente cinco acentos, ni que pronuncie cuatro sílabas de diez mil modos: nuestro objeto es* solo indicar que cons tando su prosodia de más acentos que la nuestra, y acentos verdaderamente musicales, no sólo puede distinguir por ellos lo que nosotros con las terminaciones, sino también multiplicar inme. diatamente las acepciones de las voces. Después de lo dicho, no entendemos al Sr. Anderson, cuando dice que siendo el idionat de estos naturales bustante chico para enunciar tolas sus ideas, sus ta. lcutes son poco mumerosos (r). Supongo que este sabio observador no habla de los elementos de la palabra, porque los insulares no sólo pronun. cian nuestras cinco vocales y la mayor parte de las consonantes, pero usan de otras articulaciones que no pueden expresar las letras de nuestro alfabeto, de cualquier modo que se com. binen.

lil uso de sincopar la mayor parte de las vo: ces, y el de anteponer á todas las partes de la oración la palabra coe, pueden mirarse como dos propiedades caracteristicas del lenyuaje de es. tas islas. No sólo abrevian las dicciones supri. miendo las sílabas del medio, que es lo que cons. tituye la verdadera síncopa, sino suprimiendo también el fin, á lo cual llaman nuestros gramá. ticos apócope: hé aquí una voz sincopada longa. julu, diez, en lugar de toucojongo julu: hé aqui un apócope sı (grande en número 6 cantidad), en lugar de suave. La mayor parte de las voces que incluye nuestro diccionario están sinco. padas.

El intento del artículo en nuestras gramáticas es distinguir el género de los nombres; pero como los naturales anteponen el coe no sólo á los nombres sino también á los verbos, etc., no se puede decir que $\cdot c o e$, es un artículo, á lo ménos un articulo como nosotros lo entendemos.

La misma naturaleza indica el orden en que deben colocarse las palabras para formar las oraciones. Fatafegi, concibio a Feileua, esta es una oración de régimen natural; pero los insulares dicen así: Funau, Feilcua e Fatafegi. Estas transposiciones son frecuentísimas entre ellos, y no pueden tener otro objeto que el de hacer más harmoniosa la conversación. Volvemos á repetirlo; la observación ha hecho conocer que en los idiomas no escritos, la cadencia ha dictado casi todas las reglas. El coe que por sí solo no tiene significación alguna; la $a$, que tampoco la tiene, y suelen anteponer á muchas voces, pueden tal vez compararse á las partículas, cuyo único y primer destino fué aumentar la sonoridad de loś períodos.

En medio del poco tiempo que hemos permanecido en Vavao, nos atrevemos á decir que el idioma de los naturales es rico, prosódico y sonoro. Hacen tanto uso de las vocales, que en-

(1) Tercer viaje de Cook, tomo II, pág. 118 , de la traducción francesa. El juicio de Anderson es tanto mas inconcebible, en cuanto su propio diccionario de estas islas consta do muchos sinonimos; esto es, de muchos signos de abuadancia, etc. 
tre todas las voces de nuestro diccionario, ape. nas se encuentran dos solas que terminen en consonante, distinguiendo más acentos que nos. otros, $y$ supliendo tal vez con ellos la variedad de nuestras terminaciones: cuando hablan, pa. rece cantan 6 recitan. Un idioma de esta natura leza, nacido $y$ conservado en climas tan felices $y$ donde apenas es necesario el trabajo para go. zar fas comodidades de la vida, debe ser todo el hijo de las pasiones, al contrario de nuestras lenguas de Europa, exactas, pero frías; copiosas, pero sin expresion: casi todas ellas son triste como el ciclo bajo que han nacido: casi todas ellas tan duras como las necesidades que las han formado.

El dialecto del Archipiélago de los Amigos, compuesto, figurado, músico y lictado por el sentimiento, debe por consecuencia prestarse mucho á la verdadera poesia; pero nosotros sólo podemos hablar de su parte mecánica, y áun de esto imperfectamente.

Todas sus canciones están sujetas á una medida rigorosa y la mayor parte rimadas. En los bailes del 23 y 25 pudimos percibir dos clases de metros: los unos cuya cadencia casi corres ponden a las de nuestros versos conocidos con el nombre de arte mayor, desterrados de la poesía moderna, y cuyo uso fué muy frecuente entre los antiguos romanceros. Tuisua, Tacaola y Feileua, que comieron á bordo el 24 , cantaron otros dos géneros de versos, cuya correspondencia á los nuestros no me atrevo á determinar.

En todas estas composicione rimas, pareando las consonantes, verosímilmente sabrán combinarlas de otros modos diversos, y verosimilmente tienen más variedad en las composiciones, de la que nosotros hemos notado. La poesía, este arte celestial tan antiguo como las sociedades y consagrada en todos tiempos y lugares á conservar las primeras tradiciones de los pueblos, es tal vez el más perfeccionado en el Archipiélago de Ios Amigos: y ¿quién sabe si la poesía de estos hombres podrá sostener una comparación con la nuestra? Suplico á los que califiquen de ridícula esta duda, que tengan pra. sente lo que eran los griegos cuando Homero empezb́ á recitar los cantos de la Iliada; digo, cuando empezó á recitar, porque según una opinión bastante probable aunque poco común, el principio de la epopeya no alcanzó el tiempo de la escritura.

Por lo que hace á las diferencias que se encuentran entre este pequeño Diccionario y otros que tengan las mismas voces, nada podemos alegar en nuestro abono. Nous croyons (dice Mr. de Bougainville) avoir bien entendu, et bien rendu les sons qus plusieurs fois ont frappé nos oreilles; les anglois sont aussi daus la mémí poysuation: se serait ant natupel á nous suget.
Notus.

Para suplir los efectos de nuestra escritura, $y$ con el fin de aproximar en cuanto sea posible nuestra pronunciación á la de los naturales, se han puesto algunas notas al lado de las voces á quienes corresponden.

Cuando se vea una $g$ sucedida de algunas sí. labas, quicre decir que estas silabas deben pro. nunciarse guturales.

Asp. $h$, quiere decir que la $h$ se debe aspirar, por $a s p . h$, quiere decir que la $h$ se aspira poco.

Una línea (-) cubriendo una parte de la voz, quiere decir que la parte cubierta se pronuncie con mucha celeridad.

Una linea (-) dividiendo unadicción, quiere decir que la dicción se pronuncia en dos tiempos.

A

A. Preposicion............ Que (ce).

Abalorios............... Cula.

Abrazar................ Tonga-Túa.

Aceite de coco............ To-ote.

Acostarse............... Togo-too (g-to-go).

Adelgazar. ............... Oloy.

Actitud............... Unima $(\mathbf{r})$.

Afoitarse............... Fafay.

Agua................. Bay.

Agua dulce.............. Bay-litey.

Agua salada.............. Bay-touha (asp. $h$ ).

Aguja ............... Usi.

Almohada (do palo)......... Cali (g. li).

Amanecer (primera claridad del

dia hasta la salida del Sol)... Ajo.

Amigo................. Apilufan.

Amistad ................ Teti-Comi.

Amistad (término mas cxpresivo). Ufa.

Arco $y$ flecha.............. Tana.

Anillo.................. Mama.

Anoche.................. Anapó.

Anular (dedo)............. Tegia (g. gi.)

Anzuclu................ Paa.

Arbol................... Acau

Arbol (de los que tenfamos a la

vista)............... Manga

Asentadera................ Semi.

Asf es, bueno(como aprobación). Coya.

Atravesar una cosa........... Joca tonga.

Ayer.................. Aneafi.

Arriba................. Tavo.

Afeitar .............. Amuch-abusa.

B

Bailar................ Guiliguili.

Baile...................

(r) La actitud que toman en ciertas solemnidades los plebeyos delante do los Jefes, y que equivale a la última expresion de respeto. Esta actitud consiste en sentarse con las piernas cruzadas del mismo modo que las manos, inclinando la cabcza casi hasta cl suclo y hacia el objeto de respeto $y$ veneracion. 
ra escritura, o sea posible naturales, se le las voces á

le algunas si$s$ deben pro.

debe aspirar, aspira poco. rte de la voz, se pronuncie ccibn, quiere dos tiempos.

\section{VAVAO}

(ee).

za.Túa.

to.

-too (g-to-go).

(I).

litoy.

ouha (asp. h).

(g. li).

ifan.

Comi.

\section{a.}

\section{ya.}

tonga.

ch-abusa.

guil

ne.

solemnidades equivale a la ad consiste en mo modo que ista cl suelo y

\begin{tabular}{l}
\hline kspaso \\
\hline Barba $\ldots \ldots \ldots \ldots \ldots \ldots \ldots \ldots$
\end{tabular}

\section{C}

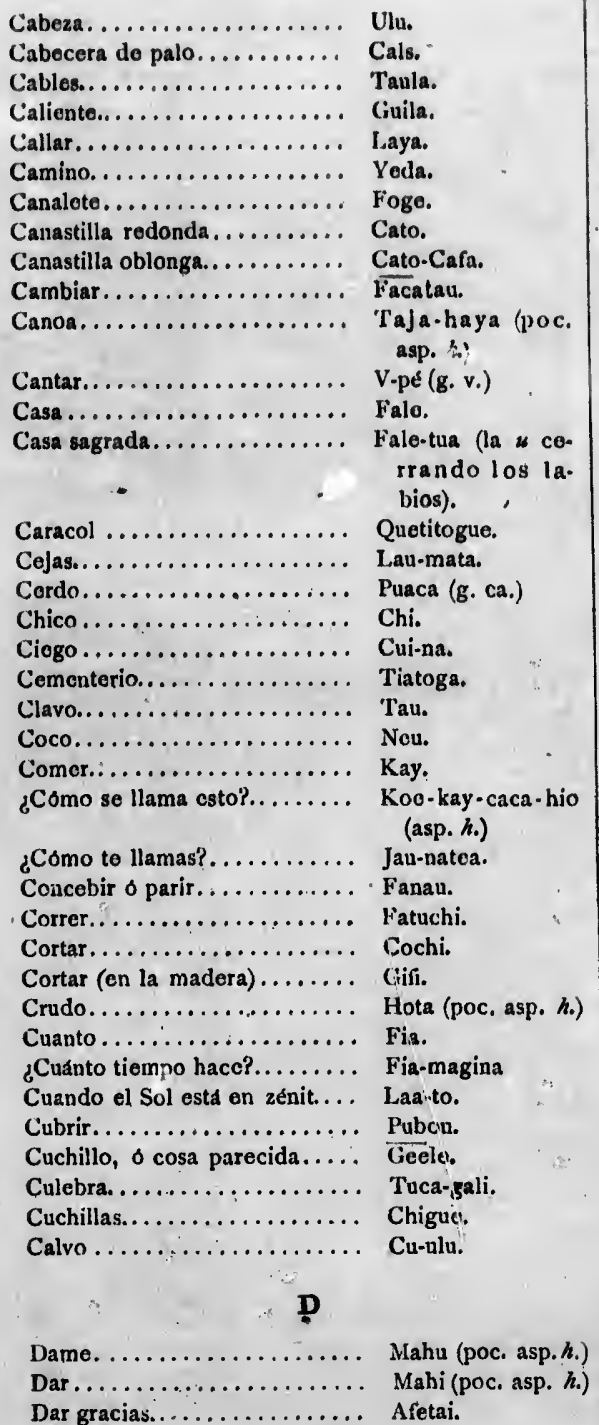

\begin{tabular}{|c|c|}
\hline ISPANOH. & VAVAO \\
\hline Dar un puntapic.............. & Aca. \\
\hline 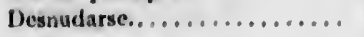 & Veveti. \\
\hline 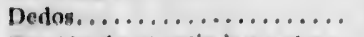 & Pechipechi. \\
\hline $\begin{array}{l}\text { Dfa (desde el galir hasta ol po. } \\
\text { nerso el Sol)............... }\end{array}$ & Po. \\
\hline 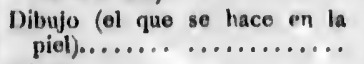 & Ta. \\
\hline Dientes, ................ & Niso. \\
\hline Dios $\ldots . \ldots \ldots \ldots \ldots \ldots$ & $\begin{array}{l}\text { Otua (la u apre. } \\
\text { tando mucho Ins } \\
\text { labios). }\end{array}$ \\
\hline 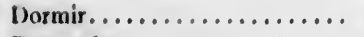 & Mloge (g. ge.) \\
\hline Dame algo.......................... & May-jamea. \\
\hline Dame do comer. ............ & May-jamea kay. \\
\hline Descubrir d uno que esta tapado. & Tatalautu. \\
\hline Despertarse............... & Ha (asp. h.) \\
\hline 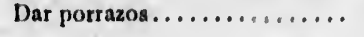 & Chilonaga. \\
\hline
\end{tabular}

F

Enterrar ................ Tanı

El ompoine. .............. Paali.

Envolver, doblar.......... Fatu.fatu.

Embarazada............... Fey-tama.

Embarcación............. Baca.

Escopeta................ Mea fana (voz compucsta.)

Espaldas............... Tha.

Espojo................. Uniota (poc. la o).

Espinillas ................ Chipu.bay.

Entender o desenvolver........ Folage (g. ge.)

Estera................. Faale.

Estofa (lo que visten)......... Bala o Natu.

Estrellas................. Ofetu.

Esconderse.............. Iola.

Embarcación chica.......... Baca.chi.

P

Falto ............... Cv.

Feo.................... Quino.

Flauta ............... Fangu-fangu.

Flecha $y$ arco............. Fana.

Imucho ............. Loto.

Fondo $\left\{\begin{array}{l}\text { mucho } \ldots \ldots \ldots \ldots \ldots \ldots \\ \text { poco } \ldots \ldots \ldots \ldots\end{array}\right.$

Fornicar................ Foichi, copi (1).

Frente.................. Lac.

Frío.................. Moco-chro.

Euego................. Hafi.

G

Gallina $\delta$ Gallo.......... Moa

Garganta............... Monga. (Se pronuncia poco la $\&^{r} y$

Golpes (castigar) gutural).

(1) A la palabra Michi michi dan la nisma significa A la pala vo introducida aqui por los equipacacion; pero com propia jes del Capitán Cook, no debe mirarse com propia
del idioma de estas islas, no obstante de esta: adoptada generalmente entre ellos. 


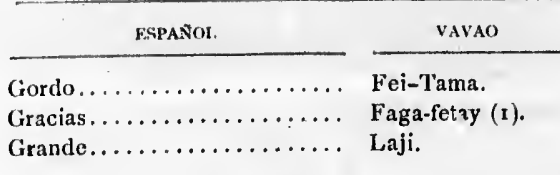

\section{$\mathbf{H}$}

\begin{tabular}{|c|c|}
\hline 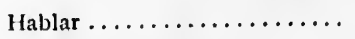 & Lea. \\
\hline Hace poco tiempo........... & Fuo. \\
\hline arto, repleto, satisfecho...... & Magunna. \\
\hline lermano................... & $\begin{array}{l}\text { Jona-cainha (as } \\
\text { la h.) }\end{array}$ \\
\hline Ierida ó enfurmedad .... & Mate. \\
\hline Iermoso................. & Liley. \\
\hline Iijo................... & Toja. \\
\hline Hombre................ & $\begin{array}{l}\text { Tan-hata (poc. as } \\
\text { la h.) }\end{array}$ \\
\hline Hombro & Huma (îtem). \\
\hline Hoy, luégo, esta tarde........ & Anay. \\
\hline Huirse, escaparse.......... & Gipuna. \\
\hline 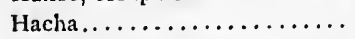 & Toqui. \\
\hline Hacer aire .............. & Alo-Alo. \\
\hline gallina............ & Jo-moa. \\
\hline ownes & Caigha (asp. h.) \\
\hline
\end{tabular}

\section{I}

Incision (la que hacen en el prepuciol................... Indice $(\mathrm{el}$ dedo $) \ldots \ldots \ldots \ldots \ldots \ldots$. F Injr rioso ................ Tua Ir, iré, vóime............. Majale. Iris (el arco)............. Humata (poc. asp. la $h$.

Isla $\ldots \ldots \ldots \ldots \ldots \ldots \ldots \ldots \ldots \ldots \ldots$, Motu-Chi Iza. . . . . . . Inmediato ............. Quene.

\section{$\mathbf{J}$}

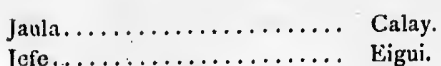

\section{$\mathbf{L}$}

\begin{tabular}{|c|c|}
\hline Labios...... & (g. nu.) \\
\hline 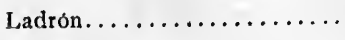 & Chito (2). \\
\hline lanza ................. & Tau. \\
\hline 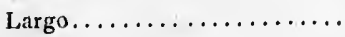 & Cafu. \\
\hline 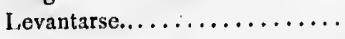 & Tuque-aluna. \\
\hline ejos................... & Coe-tu. \\
\hline 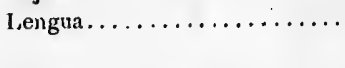 & $\begin{array}{l}\text { Elelo (respirando } \\
\text { fuerte). }\end{array}$ \\
\hline enar.... & Cuo.pito. \\
\hline lolover.................. & V-ha (asp. h.) \\
\hline 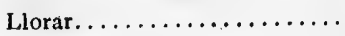 & Tangi. \\
\hline oro $\ldots \ldots \ldots \ldots \ldots \ldots$ & Cula. \\
\hline 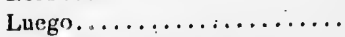 & Anahi. \\
\hline go luego............... & Yni. \\
\hline
\end{tabular}

(I) Cuando se hace un presentc to ponen sobre la

cabeza y dicen esta palabra.
(2) Término de uso común entre ellos, pero introducido por el Caritín Cook.

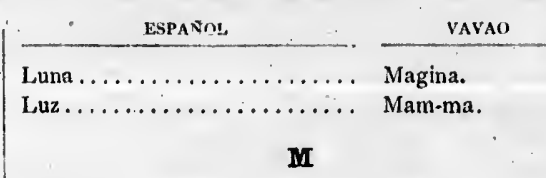

Madro................. Ona.

Mamar................ Jufu.

Mranos................. Afinimaa.

Airñana. . . . . . . . . . . Pongui-pongui (or dinariamentuan teponen la $a$.)

Mar.

Peas

Marejada................. Psau.

Mas.................. May.

Masa (composición de rima y

plátanos que comen)....... Moheya.

Matar............... Fana.

Matrimonio.............. Ojoana.

Medio (el dedo del)........ Tujulito.

Medio dí................ Tonumario

Mejillas.................. Mata-tugui.

Mellado.................. Nijo-cu.

Mentira................ Loge.

Meñique (el dedo)........... Lougi.

Miembro viril.............. V.le

Mio ................... Guhu (poc. asp. $h$.

Morir................. Mate

Muchacho................ Tamochi (poc. asp.

la o.)

Muchos.............. Lau-aie.

Muclas.................. Ahu (poc. asp. $h$.)

Mujer.................. Fefine.

Muchącha.............. Fefine tamoachi-i.

Musles................. Ten-h.

Mucho fortho. ............ Loto.

\section{$\mathbf{N}$}

Nadar................ Anu-anu.

Nadie, $n \_d a . . \ldots \ldots \ldots \ldots$ Cot.gi.

Naran as................ Moli.

Narice: $\ldots . . \ldots \ldots \ldots . \ldots$ Yfu.

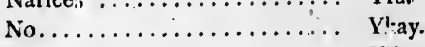

Negro ................. Vli.

Noche................. Pouli.

Nubes................... Hao.

Nueces.................. Ameguta.

Número (un gran)......... Fua.

Nuevo, $\sin$ romperse......... Amu.

No vale n:tda............ Chin

No corta.................. Pegu.

\section{$\mathbf{0}$}

Oscuridad............... Pouli.

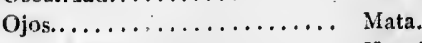

Olor Bueno............. Kasula.

Olor Malo............... Namuga.

Orinar ................. Minis

Obsar................... Chico.

\section{$\mathbf{P}$}

Poce fundo.............. Mamara.

Pillo, insolente............ Angha-covi-tua

(asp. la h.) 


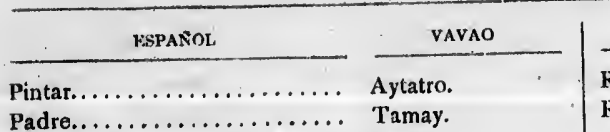

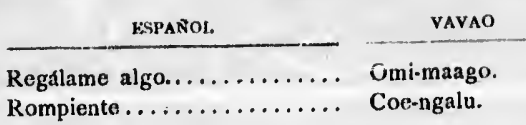

Pala del remo............. Thivi.

Palmear. ................ Pachi.

Paloma ................. Gutum gutum.

Pantorrillas.............. Fay-bay.

Parir $\delta$ concebir............ Fanan.

Párpados............... Futu-futu.

Partes de la mujer........... Toli.

Partir, dividir .............. Toji.

Pasado mañana............ Onoy-jabs (x).

Pasear, andar............. Fog-gui.

Pocho................ Fata-fala

Peine.................. Gelu.

Pelo..................... V Vlu (g. v.)

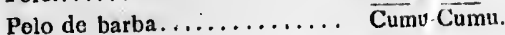

Pellojo.................. Fogi.

Perro.................. Culi.

Pertenece, me pertenece..... Golu.

Pescado ............... Yca.

Pescuezo................. V-aa (v. g.)

Pestañas................ Quemo.

Pié.

Planta del pié............. Afi-bay.

Piedra................. Maca.

Platano ................ Fuchi.

Plebeyo................. Tua.

Posillo (todo útil de barro).... Y Yoc.

Prohibir................. Tabu.

Puerco of cerdo ............. Puaca (g. ca.

Pulgar (dedo).............. Motua-Nima.

Puñada................ Tigui.

Ponerse el Sol............ Tonomarie.

\section{$Q$}

Querer ver alguna cosa....... Mamata. Qué es esto?............. Coe jae. Quitate................. Quitu.

$\mathbf{R}$

Raices comestibles......... Uji.

Regalc................ Atupemo-itu.

Relámpagos............. dian.

Remio................. Toge.

Responder (cuando uno llama a otro responda ordinariamente as $). \ldots \ldots \ldots \ldots \ldots \ldots$ Oa. Reir................. Tiata (asp. h.)

Rodillas................ Tuy.

Rojo (color) ............. Hula (poc. asp. h.)

Roncar................ Taau-ulu.

Romper................ Matu.

Roto.................. Mau-mau.

Rima................... Mey.

Rancherra................ Fonua.

Risa................. Cata.

(r) La expresión onoy, se antepone siempre al día que se quiere señalar; por ejemplo, se quiere decir: para el dia 5 ; se dirá onoy nima.

Sentado con las piernas cruzadas. Fagatane.

Sentarso ............... Nofo

Saludo .................... (r).

Sazonado (fruto).......... Pay.

Sangre.................. Toto.

St $\ldots \ldots \ldots \ldots \ldots \ldots \ldots$ inic.

Silbar. $\ldots \ldots \ldots \ldots \ldots \ldots$ Mapú.

Salida del Sol.............. Alujague.

Soñar.................. Talanoa.

Sentimiento of dolor.......... Ofa.

Sanar, de enfermedad........ Muy.

Sordo.................. Tafanga.

Sol. ................ La.a (2)

Sueño................. (3)

\section{$\mathbf{T}$}

Toma.................. Coe-na.

Timonel. . . . . . . . . . . . . .

Tirar algo............... Lafu.

Tela do árbol............. Natu.

Toronja................ Mori.

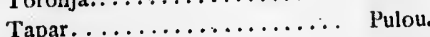

Tartamudo............. Chiguilea

Techo................ Faca-malu.

Testiculos. ............... Lajo.

Tetas. ................ Julu.

Tierra................ Yuta.

Tierra rica, buena.......... Ynta-bu.

Timon................. Lasifoque.

Tobillos................ Tonga-ibay.

Jocar, pa!par.............. Tetau.

Tocar la fiauta. ............. Yofi.

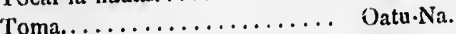

Tortuga................ Fonu.

Trueno................. Fatulichi.

Tuerto................ Cui.

U

Uñas. ................ Echiminin.

Usado................. Modua.

\section{$\mathbf{V}$}

Ven acá, ven conmigo......... Jau.

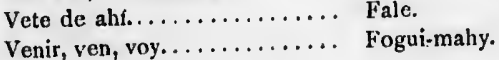

Venir, ven, voy..........................

(i) Li saludo ordinario entre los naturales consiste en tocar nariz con nariz. Cuando esto se hace ce hombre a hombre le llaman Huma, y cuando de hem. bre A mujer Feguita. Cuando alguna persona de dis tinción ostornuda, los circunstantes dicen Sey-sua.

(2) iltima a se pronincia gutural y como toziendo al inismo ticmpo. Esca voz es de muy diffeil pronunciación.

(3) Para conciliar el sueño a los Eiguis, sus muje(3) Para conciliar con las manos a lo largo del res les tocan suavem llaman toqui-toquit voz cuyo sonido coerpo; que á bict a la acción que significa. 


\begin{tabular}{|c|c|c|c|}
\hline ESPANOL & VAVAo & FSPAÑOL & VAVAO \\
\hline 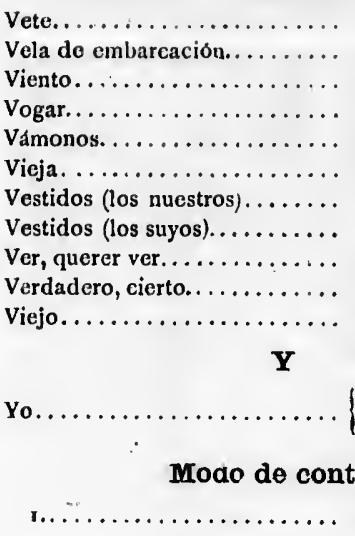 & $\begin{array}{l}\text { Falu. } \\
\text { Coe-la. } \\
\text { Yfi. } \\
\text { Alo. } \\
\text { Tau-vo. } \\
\text { Feu-feu. } \\
\text { Papaa-langui. } \\
\text { Cofu. } \\
\text { Maumeta. } \\
\text { Moni. } \\
\text { Papanga. }\end{array}$ & 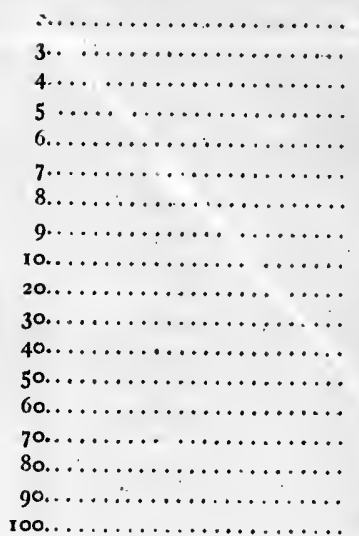 & $\begin{array}{l}\text { Hua. } \\
\text { Tolu. } \\
\text { Faa. } \\
\text { Nima. } \\
\text { Ono. } \\
\text { Fito. } \\
\text { Faula. } \\
\text { Guiba. } \\
\text { T'ao congo fulo. } \\
\text { Wfulo. } \\
\text { Tacungo-Fulo. } \\
\text { Fangu-fulu. } \\
\text { Nuna-no fulo. } \\
\text { Onongo fulu. } \\
\text { Fliongo fulu. } \\
\text { Baluro fulo. } \\
\text { Giba gufulu. } \\
\text { Teau. }\end{array}$ \\
\hline
\end{tabular}




\section{DISCUSION sobre las loingitudes de las costas de Chile $y$ Perú, por D. Felipe Bauzá.}

Es sabido que las observaciones más propias para situar los puntos del globo astronómicamen. te, son las ocultaciones de las estrellas por la Luna, los eclipses del Sol, los de los satélites de Júpiter y eclipses de Luna, y en su defecto, por medio de los cronómetros marinos cuando se puede averiguar su movimiento en cortos períodos de tiempo; pues de lo contrario, la experiencia ha manifestado de cuántas anomalías son susceptibles estas máquinas, y mucho más cuando no se atiende á la temperatura de la atmósfera para su uso y en sus conducciones de á bordo á tierra y á la inversa. y como dice el célebre astrónomo Barón de Zach, hasta en su posición horizontal o vertical. Por ln tanto, en esta pequeña discusión manifestaré no s6́lo los datos que hay por observaciones hechas por indivíduos na ionales, sino también aquellas que hayan hecho los extranjeros, para poder proceder con acierto in asunto de tanta importancia.

\section{San Càrlos de Chiloé.--Castillo.}

Por las Corbetas Descubierta y ATREvida en r79o, y por estrellas al

Norte y al Sur del zénit, se dedujo la latitud del Castillo, Sur.... " $4 \mathrm{r}^{\circ} 5^{\mathrm{r}^{\prime}} 23^{\prime \prime}$

E! 6 de Febrero de 1790, por la inmersión del primer satélite de Jú-

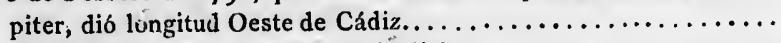

El 15 del mismo, puz la emersión de dicho.................

Por los cronómetros de la Descubierta, al Oeste de Montevideo.... 17.34. 5

idem por los de la Atrevida, unos y otros en noventa días........ I7.37.15

$467^{\circ} 30^{\prime} 15^{\prime \prime}$

$\$ 67 \cdot 30,15$

Medio......................... $17 \cdot 35 \cdot 4^{\circ}$ Montevideo, Oeste de Cádiz................ 49.54.24

El promeảio es longitud del observatorio de Chiloé....................

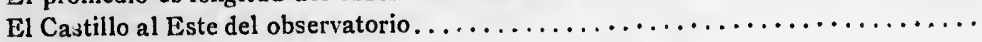

Longitud del Castillo de San Carlos de Chiloé, O. de Cádiz... .......... 67.30. 3

Con ceferencia á Valparaíso................................ 67.22.19

Ain whargo de la admirable conformidad que se advierte en estas tres longitudes, más adelante s. e retrocediend's de punto bien situado, y en muy corto intervalo de días, no resultan tan tes somo apare'sen, y á mi entender, las muchas diferencias que se observan en estas com. binac : leben depender de no contar en el uso de los cronbmetros con la temperatura, particu larmente cuando se pasa de pronto de los climas fríos a los ardientes re trópicos, como lo manifiesta D. José Luyando en el extracto de su Diario desde Cádiz á Ver‘cruz eñ è año àe $\mathbf{7} 8$.

\section{Talcahuano.}

Las corbetas DEScrjBIERTa y ATREvida establecieron el observatorio en una casa próxima á la a: illa del mar, la misrna en que el Conde de la Péyrouse colocb el suyo cuatro años antes.

a. 'atitud se observó por estrellas al Norte y Sur del zénit, de.. Sur.

s cro: ómetros de la DescubirRta dieron diferencia al Este de

Chiloé................................... $00^{n} 3^{8} 24^{\prime \prime}, 7$

Los de la Atrrevida..... ........................... $00.4^{1} \cdot 54,0$

Promedio........................ oo.40. 9,3 
San Carlos de Chiloé como se ha dicho, O. de Cádiz..........67-30. 3,0

Longitud de Talcahuano al 0 . de Cádiz............. 66.49.53,7

Eil Capitán Hall, de la Marina inglesa, en 1820,21 y 2a, coloca á Tal-

cahuano, reducida al observatorio en.............. $66.42 .39,0$

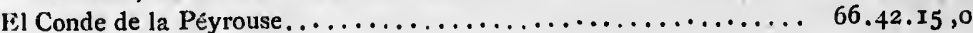

las corbetas hallaron por cronómetros, Talcahnano 0 . de Valpa-

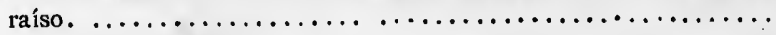

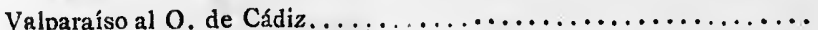

Longitud de Talcahuano............... 66.42 .9

$\frac{66.4^{2} \cdot 9}{66.4^{2.21}}$

Valparaiso.

El observatorio de las corbetas se estableció en el castillo del Rosario, que está 1o" ,7 al O. y $14^{\prime \prime}$ al Sur del fuerte de San Antonio.

La latitud por estrellas al Norte y al Sur del zénit, se dedujo de........ Sur... $33^{\circ}$ or $^{\prime} 55^{\prime \prime}$

El día I9 de Marzo de I790, inmersión del primer satélite de Júpiter,

(a) dió longitud $O$. de Cádiz..................... dudosa. 65.23 .45

(a) El día 25 de Marzo íd. íd. íd.............. ....... buena.. $65 \cdot 25 \cdot 30$

El dia r 1 de Abril id. íd. íd............... ......... dudosa. 65.20 .00

vi) Capitán Hall el 28 de Octubre de 182 r observó la inmersustu de Antares por la đa,

y dió la longitud para el fuerte de San Antonio, que reducida al del Rosario..... 65. 63.46

El mismo en dicho día por la ocultación de la 644 de Escorpión reducida......... 65. r r.21,7

Pero el Capitán Hall en su viaje la determina de $7 \mathrm{r}^{\circ} 3 \mathrm{I}^{\prime} 00^{\prime \prime} \mathrm{O}$. de Greenwich,

reducida ................................... $65.13 \cdot 55,7$

En los planos de la expedición hidrográfica en las costas del Perú y Chile por D. Mariano Isas. viribil, y en el plano de este puerto, sitúa el castillo del Rosario en latitud de $33^{\circ}$ or $^{\prime} 45^{\prime \prime}$ y la longitud.

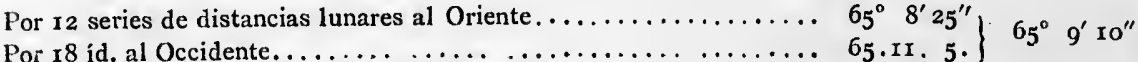

En un papel de apuntes que tengo á la vista, hay la nota siguiente: "For el eclipse de Sol de Agosto de $\mathrm{I} 804$ observado en Coquimbo por el Teniente de navío D. Mariano Isasviribil, Co"mandante de la expedición hidrográfica, resulta estar la costa de Chile de 12 á I4' más al Este "de lo que está situada en las cartas del Depósito." Nunca he tenido noticia de semejante observación, y sin duda por la muerte trágica de este sabio y laborioso Oficial, se extraviaron sus papeles.

Si se atiende á esta nota y se toma el promedio de los 12 á $14^{\prime}$ que se

dice estar la costa al Este, tendremos longitud en la carta....... $65^{\circ} 2 \mathrm{x}^{\prime} \mathrm{oo}^{\prime \prime}$

$$
-I_{3}
$$

Además de estos datos tenemos para Valparaíso otros que me comunicó el difunto Mr. MeLiain en su carta del 25 de Mayo de r8or.

Jara Valparaíso, dice Mechain, tenemos por tres emersiones é inmersiones del primer satélite de Júpiter en I9 y 26 de Mayo y I I le Abril de r79o (a) comparadas á las

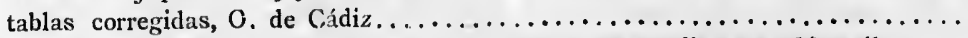
Por el eclipse de Sol de I I de Marzo de I709, con correspondiente en Marsella.. . . Loscronómetros de la Descubrerta dieron para Valparaíso, Este de Chiloé $2^{\circ} 9^{\prime} 8^{\prime \prime}$ fos de la Atrevida........................... 2. $7 \cdot 39$.

Promedio...................... 2. 8.23 .

C.hiloe $O$. de Cádiz, como se ha dicho...............667.30.9. 65.21 .46 
Resumiendo estas observaciones, tendremos:

Por la ocultación de Antares..................... 65.13.55,7

Por el eclipse de Sol de r I de Marzo de r $709 . \ldots \ldots \ldots \ldots \ldots \ldots \ldots \ldots$. 65.20 .30

Por los satélites de Júpiter, según Mechain..............

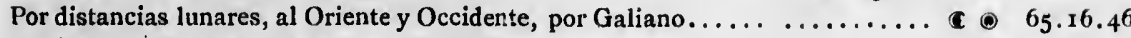

Por los cronómetros, diferencia con Chilns...................... 65.21.46

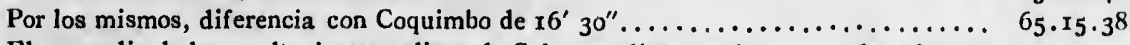

El promdio de las ocultaciones, eclipse de Sol y satélites, será..... 65. $66.29,5$

El de todas reunidas.......................... 65.15 .22 .

Que sblo difiere de $I^{\prime} 3^{\prime \prime}, 4$ de la ocultación de Antares, pero la calidad de esta observación la hace preferible á todas las demás; por lo tanto es longitud del Fuerte del

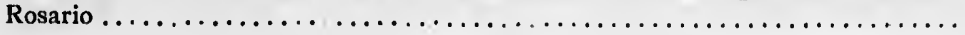

Coquir.bo.

10",7 al 0

$33^{\circ}$ or $^{\prime} 55^{\prime \prime}$

$65 \cdot 23 \cdot 45$

$65 \cdot 25 \cdot 30$

65.20 .00

65.13 .46

$65.11 .21,7$

$65 \cdot 13 \cdot 55,7$

Mariano Isas. $45^{\prime \prime}$ y la lon.

$65^{\circ} 9^{\prime}$ ×

ise de Sol de usviribil, Comás al Este :mejante obraviaron sus

Las corbetas Descubierta y Atrevida establecieron su observatorio en la Chacara de la Buena Muerte, en el pueblo de la Magdalena, el día 2 I de Mayo de I79o, desde donde por operaciones geo-

En I8 de Abril de 1890 se estableció el observatorio de las Corbetas en una casa situada en la playa occidental del puerto, cuya latitud por el paso de estrellas al Norte y al Sur del $z$ énit, resultb de........................ Sur.

En 28 de Abril se observ6 la ocultación de $2 a$ de Aries inmersión y emersión y

dió, calculada por D. Juan Tiscar, longitud al O. de Cádiz............ 65.00.40,5

La misma, calculada por Mr. Mechain.......................64.56.51, o

El mismo día, ocultación de la I. $^{*} a$ de Aries, calculada por Tiscar...........65.05.4I, o

E1 I 8 de Abril emersión del primer satélite de Júpiter................. $65 \cdot 02.30$

E1 20 " " $"$ "

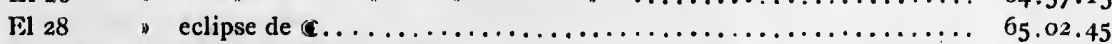

Por los cronómetros de la Descubierta al Este de Valparaíso..... I I $5^{\prime} 54^{\prime \prime}$

Por los de la Atrgvid ........................ $17.22,5$

Por el Capitán Hall, reducida al observatorio.............. I $5.3^{2}$

Promedio....................... I6. 16,2

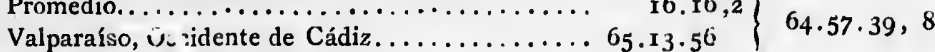

E: Capitán Hall sitúa la bahía en $64^{\circ} 5^{8^{\prime}} 2 \mathrm{I}^{\prime \prime}+\mathbf{2 8}^{\prime \prime}$ será para el ubservatorio.... . $\overline{6} 4 \cdot 59$. 9, 0

Resumiendo las observuciones celestes, tendremos:

Por la ocultación de $2 a$ de Aries, calculada por Tiscar............... 65.00.40,5

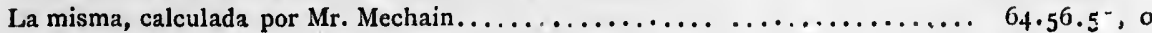
Por la ocultación de la $\mathrm{I} .^{\mathrm{A}} a$ de Aries, calculada por Tiscar.............. $65.5 .4 \mathrm{I}, 0$

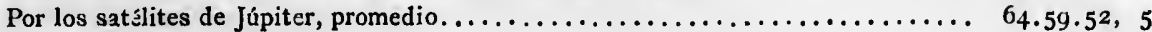

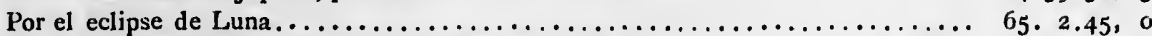
Por los cronómetros de las corbetas y del Capitán Hall. . . . . . . . . . . . . 64.57.39, 6

Promedio será longitud del observatorio de Coquimbo......6 65.00.34, 9 $6 . \ldots \ldots 6.65 .00 .35$

La conformidad que se advierte en estas observaciones, tanto las celestes como las cronomé. tricas indican la buena posición de Coquimbo, así como también la de Valparaíso; por lo tanto, estos dos puntos deben tomarse como de partida para los demás, tanto al Norte y al Sur de ellos.

\section{Castillo del Callao.} Murte, en el pueblo de la Magdalena, el dia 21 de Mayo de 179o, desde donde por operaciones geo- 
désicas se estableció la Torre del Castillo del Callao $5^{\prime} 5^{\prime \prime}, 2$ al 0 y $\mathbf{r}^{\prime} 7^{\prime \prime}$ al Norte del observa. torio.

Por pasos de estrellas al Norte y al Sur del zénit so dedujo iq latitud del observa. torio de $12^{\circ} 4^{\prime} 3^{8^{\prime \prime}}$, que deducida al Castillo del Callao es de $\ldots \ldots \ldots \ldots$. Sur. $\mathbf{r}^{\circ} 3^{\prime} 3^{\prime \prime}$

Por la emersión del primer satélite de Júpiter el 5 à lunio de 1790 , resultó la

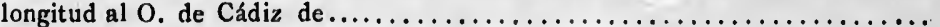

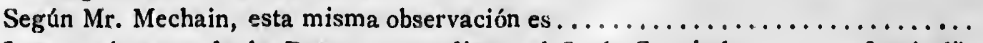

Los cronómetros de la Descubirrta dieron al 0 . de Coquimbo..... $5^{\circ} 5^{\prime} 2^{\prime \prime}$ $70.47 \cdot 35$

Los de la Atrevida......................... 5.43 .30 $70.42 \cdot 50$

$$
\begin{aligned}
& \text { Promedio..................... } 5.47 .28
\end{aligned}
$$

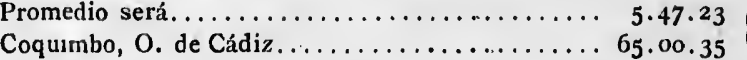

Estas son las únicas observaciones que se pudieron hacer, por la estación de nieblas en aquellos climas, en la época que la expedición de Malaspina estuvo en Lima: á continuación voy á manifes. tar otras hechas antes y después de esta época, para que se pueda venir en conocimiento de la verdadera longitud del Callao de Lima.

Hay una observación interesante que pudiera fijar la longitud de Lima con la mayor exactitud, si el Barón de Humboldt, que la hizo, hubiera tenido toda la seguridad con la observación del contacto exterior de Mercurio, como la tuvo en el interior. Véase su observación (Observacioncs astronónticas, etcétera, tomo II, redactadas por Jacobo Oltmanns, pág. 42I).

Día 9 de Noviembre de 1802 . Paso de Mercurio por el disco del Sol, página 42 I y siguientes, en la pág. 426 da el resultado medio por esta

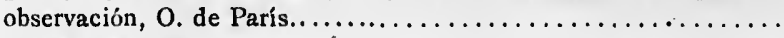

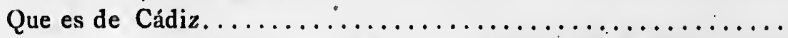

En la pág. 403, por seis emersiones del primer satélite de Júpiter observadas por D. Jorge Juan y D. Antonio Ulloa, eligiendg sólo dos de mejores circun.s. $\ldots \ldots \ldots \ldots \ldots \ldots \ldots \ldots \ldots \ldots \ldots \ldots \ldots \ldots .24 \cdot 46,5=70.47 .1,5$

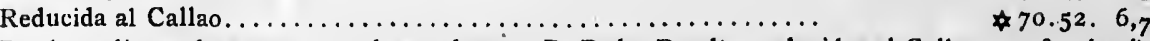

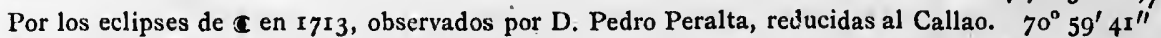
Por los cronómetros del Barbn de Humboldt. . . . . . . . . . . . . . . 70.52.33

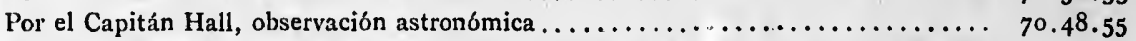

El Alférez de navio D. Antonio Martínez, observó en Novienıbre y Diciembre de

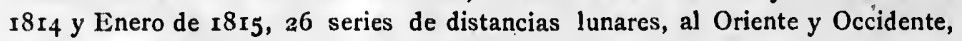

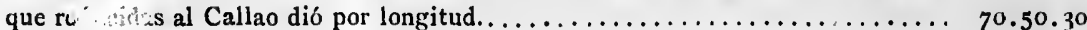

Resumiendo todas las observaciones, tendremos:

Por el paso de Mercurio de 9 de Noviembre de 1802,0 . de Cádiz.......... (I) $\nleftarrow 70.56 .22,5$ Por dos emersiones del primer satélite, por D. Jorge Juan y D. Antonio Ulloa. (2) $\$ 70,5^{2} .6,7$ Por los eclipses de $c$ en r713...........................

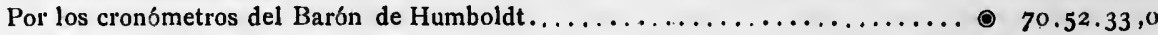
Por el Capitán Hall. Observación astronómica................... (3) $\$ 70.48 .55,0$ Por el promedio de los cronómetros de ambas corbetas y del Capitán Hall, confor-

mes, diferencia con Coquimbo........................ $70.47 .58,0$

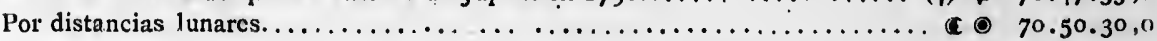

El promedio de todas será .

$70 \cdot 51 \cdot 57,6$

Por el promedio de las observaciones astronómicas (I), (2), (3) y (4), desechando la

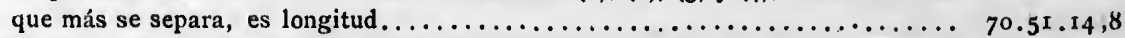
Por lo tanto parece debe adoptarse para la longitud del castillo del Callao pos estas observaciones ................................ $70.5157,6$ 


\section{Guayaquil.}

En el año de $179^{\circ}$ se coloc6 el observatorio de las corbetas Descubierta y Atrevida, en una casa próxima á la orilla del río en la ciudad de Guayaquil nueva, situada 6 ", 5 al Norte y I $3^{\prime \prime}, 5$ al Este de la Iglesia matriz.

La latitud se dedujo por pasos de estrellas al Norte y Sur del zénit de....... Sur. $2^{\circ} \mathbf{I 2}^{\prime} \quad 3^{\prime \prime}$

El I4 de Octubre de 179ó se observ6 la inmersión de la 798 de Mayer 6 de Sagitario por la parte escura de la c y hecho el cálculo por el Capitán de navío D. Juan Tiscar, díb longitud al 0 . de Cádiz reducida á la matriz. . . . . . . .

El 23 del mismo por el eclipse de con correspondiente en Cádiz y Greenwich, cuya

diferencia de meridianos es $6^{\circ} \geq 7^{\prime} \geq 5^{\prime \prime} \ldots \ldots \ldots \ldots \ldots \ldots \ldots \ldots \ldots \ldots \ldots$

Los tres cronómetros de la Descubierta conformes en o", I dieron Gua-

yaquil al 0. del Callao......................... $2^{\circ} 39^{\prime} 35^{\prime \prime}$

Los tres de la Arrevida bastante conformes ................. 2.39.I4

Promedio, diferencia ric Guayaquil 0 . del Callao............ 2.39.240

$2.36,34073.28 .34,0$

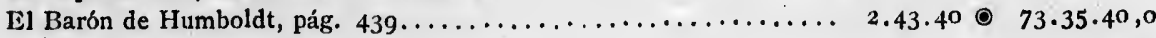

El promedio de todas será. . . . . . . . . . . . . .

Sin embargo de la conformidad que se advierte en estas longitudes, me parece debe adoptarse la que resulta por la ocultación de $\underline{e}$ de Sagitario, de . . . . . . . 70.31 .53,5

\section{Panamá.}

El observatorio se estableció en esta ciudad en la sala de armas del Castillo de Chiriqui, que está $6^{\prime \prime}, 5$ al Sur y $13^{\prime \prime}$ al Este de la torre de la Catedral. La latitud se dedujo por paso de estrellas al Norte y al Sur del zénit de........... Norte.

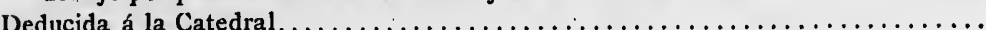

El I9 de Noviembre de 1790 se observó la inmersión de 0 . de Aries por el limbo oscuro de la $\propto$ y hecho el cálculo por $\mathrm{D}$. Juan Tiscar, dib longitud al $\mathrm{O}$. de Cádiz, reducida á la Catedral...............................

El 2 de Diciembre ocultación de $\lambda$ Virgo por la parte clara de la emersión é inmersión calculada por 'Tiscar dib longitud reducida................. 73.00.16,4

El promedio de estas dos longitudes tan conformes es ................. 73.00 .42

El 26 de Noviembre, por la inmersión del primer satélite de Júpiter.......... 73.11.30

El 3 de Diciembre por ídem.............................. $73.7 .3^{\circ}$

Los cronómetros de ambas corbetas dieron con corta diferencia el promedio de $19^{\prime} 2^{\prime \prime}$ la Catedral al Este de Guayaquil.......... $70^{\circ} 3 \mathbf{I}^{\prime} 53^{\prime \prime}, 5$

La Catedral de Panamá al Este............................

19.25

$73.12 .28,5$

Aquí se observa una de aquellas anomalías de que hemos hablado, pues entre dos puntos situados por observaciones astronómicas, y las diferencias cronometricas tan iguales como se pudieran desear, sin embargo la longitud varía una de la otra en $I^{\prime} 46^{\prime \prime}, 5$. Sin embargo, no se puede prescindir de adoptar para la Catedral de Panamá al $O$. de Cádiz el promedio de las dos ocultaciones tan conformes............................................

Arica :

El $x 6$ y 17 de Mayo de $179^{\circ}$, la corbeta A Trevida estuvo en este fondeadero, y en el se observaron varias latitudes, cuyo promedio dieron. . La Iglesia al Sur..................... $+\begin{gathered}13^{\circ} 27^{\prime} 55^{\prime \prime} \\ +\quad 25\end{gathered} 8^{\circ} 28^{\prime} 20^{\prime \prime}$ 
Los cronbmetros dieron la longitud al Este de Coquimbo........ I. 3.30

Coquimbo está al 0 , de Cádiz..........................

Será longitud de Arica, el fondeadero.

Será para la Iglesia

El Capitán Hall, halla la diferencia de longitud entre Coquimbo y Arica :

La Iglesia..................................... 1. 3.08

Coquimbo, como hemos dicho...................... 65. 0.35

Arica al o. de Cádiz...

Promedio será longitud de Arica la Iglesia.

Veamos el resultado de la longitud de Arica con referencia á Lima:

Callao de Lima, como se ha dicho..................... 70.51 .57

Arica al Este, por los cronómetros..................... $6.46 .3^{8}$

Longitud de Arica con referencia á Lima. $64.05 \cdot 19-22^{\prime \prime} 64^{\circ} 4^{\prime} 57$

Promedin será Iglesia de Arica.

El Capitán Hall, halla la diferencia de longitud cronométrica entre Valparaíso y Arica de.................................. Valparaíso, como hemos dicho

Longitud de la Iglesia de Arica. (b) 63.56 .12 $63^{\circ} 56^{\prime} 12^{\prime \prime}$

Por lo dicho, parece preferible para la longitud de Arica el promedio de las dos longitudes $(a)$ y $(b)=0$. de Cádiz..............................

Estos a puntes manifestarán al inteligente hidrógrafo, que no se puede errar mucho en la situación de los lugares que se establezcan por ellos; en la eléćción de las longitudes será algo difícil para aquellos que busquen una exactitud demasiado nímia, porque como se ve en esta corta discusión, áun en aquellas observaciones que no debían dejarnos duda alguna en cuanto á sus resul. tados, sin embargo, se hallan algunas diferencias bien notables que dependen de muchas causas que no se ocultan al inteligente en estas materias y no deja de ser una el modo de calcularlas, como lo hemos visto en la célebre ocultación de Antares por la c, observada en Puerto-Rico por el difunto $\mathrm{D}$. Cosme de Churruca, cuya memoria debe ser eterna en la Marina española.

Se notarán también algunas pequeñas diferencias en las latitudes, y á mi entender, dimanan de que no se hizo uso del barómetro y termometro para corregir las declinaciones de refracción.

Posiciones de los lugares de que trata esta Memoria.

\begin{tabular}{|c|c|c|}
\hline & Latitudes. & $\begin{array}{l}\text { Longitudes n. } \\
\text { de Cádis. }\end{array}$ \\
\hline $\begin{array}{l}\text { n Carlos de Chiloé (Castillo } \ldots \ldots \ldots \ldots \ldots \ldots \ldots \ldots \ldots \ldots \ldots \ldots \ldots \ldots \ldots \ldots \\
\text { lcahuano (Pueblo) } \ldots \ldots \ldots \ldots \ldots \ldots \ldots \ldots\end{array}$ & & \\
\hline aíso: Castillo del Rosario..... & & \\
\hline nbo: Observatorio en el puerto........ & $\begin{array}{l}33.01 \cdot 55 \\
29.56 .22\end{array}$ & $\begin{array}{r}65.13 .56 \\
65.00 .35\end{array}$ \\
\hline Castillo del Callao....... & $12.03 \cdot 31$ & $70 \cdot 51 \cdot 57,6$ \\
\hline & 2.12 .03 & \\
\hline namá: Catedral.... & 8.57 .10 & $73.00 .42,0$ \\
\hline
\end{tabular}

Con estos datos, y teniendo á la vista las bases corridas por las corbetas en los intermedios de estos puntos principales, las diferencias por el Capitán Hall y los trabajos de la expedición hi. drográfica del Perú y Chile, podrán corregirse los demás puntos de las costas, así como las Islas de Juan Fernández y San Félix, que dependen de Valparaíso y de Coquimbo. 


\section{$63 \cdot 5^{6} \cdot 43$ \\ Discusión sobre las situaciones astronómicas de las costas de Chile, Perú é islas adyacentes.}

63.57 .27

$63.57 \cdot 5$

$64^{\circ} 4^{\prime} 57$

64. I. I

$63^{\circ} 5^{\prime} 12^{\prime \prime}$

$63 \cdot 5^{6} \cdot 3^{8}, 5$

o en la situa. rá algo difícil sta corta disó sus resul. uchas causas e calcularlas, erto-Rico por ola. der, dimanan e refraccion. pedición hino las Islas
Para poder fijar con más acierto la posición geográfica de muchos puntos de estas costas, se hace preciso manifestar antes las de aquéllos que por tener observaciones absolutas, sirven de base á las demás con quienes hay diferencias cronométricas á operaciones geodésicas, practicadas desde la mar $y$ en tierra.

\section{Callao de Lima.}

La observación astronómica de mayor importancia que se ha hecho para tijar la verdadera situación geografica de este punto, es la que hizo el Barón de Humboldt, del paso de Mercurio por el disco del Sol el día 9 de Noviembre de 180z: esta interesante observación, calculada por el Se. noor Oltmans (Observaciones astronónicas por Mr. Humboldt, tomo II, páginas $418,419,421$ y 426) resultó para la longitud del Callao, Occidente de París, $79^{\circ} 34^{\prime} 30^{\prime \prime}=70^{\circ} 56^{\prime} 45^{\prime \prime} \mathrm{O}$. C.

Además hay otras observaciones hechas anteriormente, que pueden servir de rectificación de esta, y son las siguientes:

El tiempo no permitió que el Sr. Malaspina pudiese hacer otra observación que la emersión del primer Satélite de Júpiter el día 5 de Junio de 1790 en el pueblo de la Magdalena, en donde fijó el observatorio. Esta observación, según el Sr. Oltmans, comparándola con las tablas corregidas de Mr. Delambre di6:

Longitud 0 . de París........................... $79^{\circ} 35^{\prime} 54^{\prime \prime} \quad 70^{\circ} 5^{8^{\prime}} 9^{\prime \prime}$ Seis emersiones del primer satélite de Júpiter observadas por los señores

D. Jorge Juan y D. Antonio Ulloa, reducidas al Callao........... $79 \cdot 31.41,6 \quad 70.53 \cdot 5^{6,6}$ Por un eclipse de $C$ observado por D. Pedro Peralta........... $79 \cdot 37 \cdot 26,6 \quad 70.59 \cdot 4 \mathrm{r}, 6$

El promedio de estas observaciones será.................. $\overline{79 \cdot 35.00,7} \frac{70.57 .15,7}{79.34 .53}$ El de las cuatro, contando con el paso de Mercurio............ 79.34.53,0 70.57.09,o

que sólo difiere en $23^{\prime \prime}$ de arco, de la observación del paso de Mercurio, de consiguiente es la longitud del Torreón dẹl Castillo del Callao, $70^{\circ} 57^{\prime}$ o9" Occidente de Cádiz.

\section{Guayaquil.}

Las observaciones hechas en esta ciudad durante el tiempo que permaneció en ella la expedición de Malaspina, al paso que fijan la verdadera situación geográfica de este punto sirven de confrontación á la longitud del Callao. El día I 4 de Octubre de 1790 , se observó la inmersión de ę de Sagitario por el limbo oscuro de la c, cuyo fenómeno, calculado por el Sr. Oltmans, dió longitud al

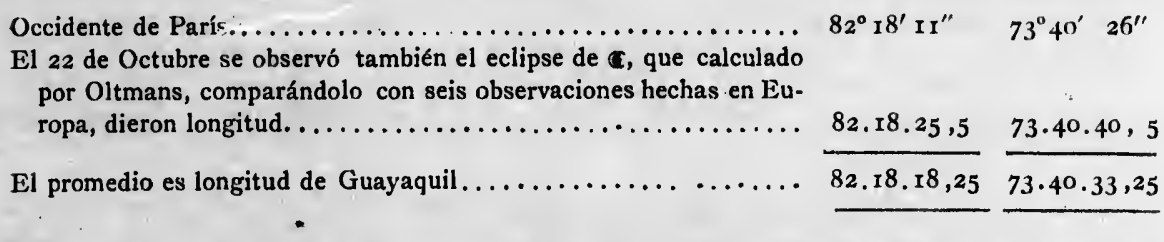

Suponiendo la longitud del Callao como se ha dicho $70^{\circ} 57^{\prime} 9^{\prime \prime}$ Occidente de Cádiz, véase como resulta la de Guayaquil por diferencias cronométricas. 
Malaspina hallo la diferencia de longitud entre el Callao y Guayaquil, por varios cro-

nómetros, de $\ldots \ldots \ldots \ldots \ldots \ldots \ldots \ldots \ldots \ldots \ldots \ldots \ldots \ldots \ldots \ldots \ldots \ldots \ldots \ldots$

Lil Barón de Humboldt. . . . . . . . . . . . . . . . . . . . . . . . . .

lil Capitán Hall de la Real Marina británica.......................

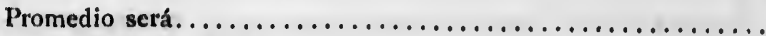

Longitud del Callao, Occidente de Cádiz...........................

Longitud de Guayaquil, Occidente de Cádiz.....................

Por observaciones astronómicas.

70.57 .9

Diferencia

Si se adopta la diferencia cronométrica $2^{\circ} 43^{\prime} 40^{\prime \prime}, 5$ que halla el Barón de Humboldt, re:ultará para Guayaquil $73^{\circ} 40^{\prime} 49^{\prime \prime}, 5$, que síln difiere de las observaciones astronómicas, la despreciable cantidad de $16^{\prime \prime}, 5$ de arco; de consiguiente, parece que la longitud de Guayaquil debe fijarse en $73^{\circ}$ $40^{\prime} 33^{\prime \prime}$ al Occidente de Cádiz y que la del Callao es igualmente tal como se ha fijado.

\section{Valparaiso.}

Malaspina estableció el observatorio en el ángulo Norte del Castillo del Rosario, cuya latitud observada fué de ............................ Sur.

I." Por una inmersión y dos emersiones del primer satélite de Júpiter observadas en los días r9 y 25 de Marzo de 1790 y Ir de Abril con correspondientes en Green.

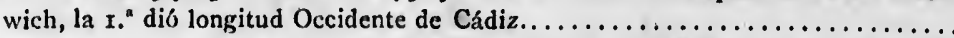

2." Pero siendo la de más confianza la emersión del 25 de Marzo, según los apuntes del Diario astronómiro de aquella expedición, resulta Occidente de Cádiz.......

3." Según una carta del difunto Mr. Mechain, data del 25 de Mayo de 180 r, dice este astrónomo, que habiendo comparado las inmersiones y emersiones del 19 y 25 de Marzo y II de Abril con las tablas corregidas, resultó para Valparaíso

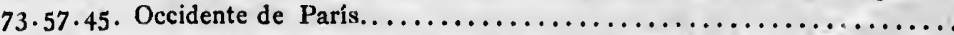
4." El mismo Mr. Mechain, por el eclipse de Sol de rx te Marzo de r 7og (Efe mérides d:Viena, pág. 385) comparando la correspondiente en Marsella y disminuyendo $3^{\prime \prime}$ de tiempo que Mr. Triesnecker supone Marsella más al Oriente de Pa-

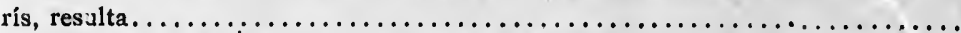

Posteriormente se han hecho en Valparaíso dos observaciones de importancia. El Capitán Hall, de la Marina británica, y el Teniente Foster, del buque Conveay, observaron la inmersión de Antares por la el 29 de Octubre de 182 y el mismo día la $6+4$ de Escorpión: por la primera, según los cálculos originales que he visto, resulta el fuerte de San Antonio al Occidente de Greenwich.............

Por la segunda.

Promedio.........................., $\overline{71.29 .48,2}$

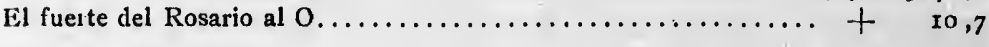

Longitud de Valparaíso, fuerte del Rosario................ 7 x.29.59

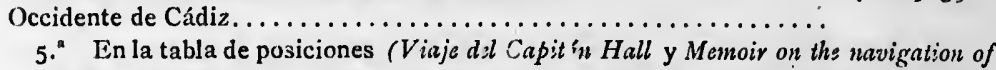
So:th Amsrica, píg. 48), se halla 7r.3r.oo para el Castillo de San Antonio

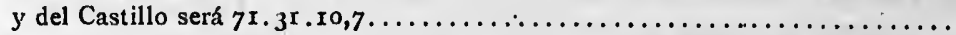
6. Hecho el cálculo el Sr. Oltmans de la ocultacín de Antares, resulta Valparaíso al Occidente de París 74. Ir.4o 6 de Cádiz reducida al Castillo del Rosario.

Resumiendo las observaciones astron6micas, tendremos:

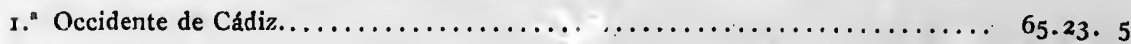

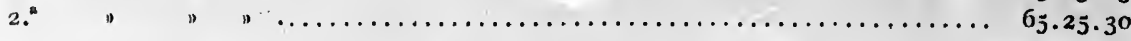


Diferencias cronométricas entre Coquimbo y el Cállao:

Por los cronómetros de la corbeta Descubirkta..................... $5^{\circ} \mathbf{5}^{\prime} \mathbf{2 6}^{\prime \prime}$

Por Ídem de los de la Arkgvibs......................................

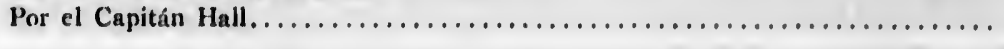

$5 \cdot 47.19$

Promedio.

(a)

$5 \cdot 47 \cdot 19$

Longitud en que se ha supuesto el Callao.

$$
70^{\circ} 57^{\prime} 9^{\prime \prime}
$$

$70^{\circ} 57^{\prime} 9^{\prime \prime}$

$70 \cdot 37 \cdot 9$

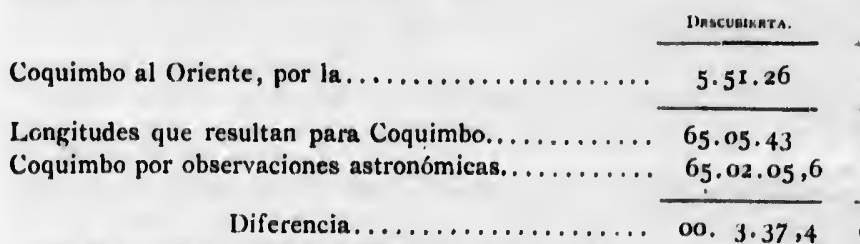

Si se adopta la diferencia promedio de las tres.

$\frac{5.43 .12}{65.13 .57} \frac{5^{\circ}+7^{\prime} 19^{\prime \prime}}{65.09 .50}$

$65.02 .5,6 \quad 65,12.5,6$ endremos: Longitud del Callao.

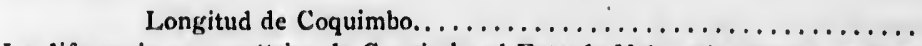

....................

$00.11 .51,4$

(a)

0o, $7 \cdot 44,4$

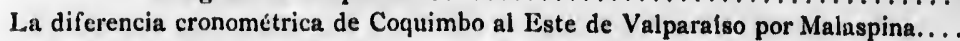

57. 9

Idem por la corbeta ATREvidA................................ 17.22

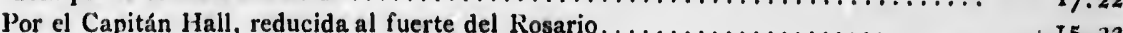

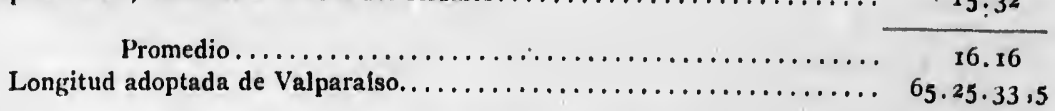

Lo: gitud de Coquimbo por diferencias cronometricas con Valparaíso.

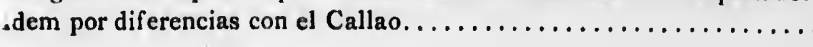

$65.09 .17,5$

Promedio ............................
Por las observaciones astronómicas, esta longitud es igual á.

- 65.9 .33 .7

Por las observaciones astronomicas, esta longitud es igual a...

Medio....................................

Cuando se recalculen las observaciones practicadas en la expedición de Malaspina, quizás desaparecerá esta diferencia; miéntras será longitud de Coquimbo $65^{\circ} 2^{\prime} 5^{\prime \prime}, 6$ más bien $65^{\circ} 5^{\prime} 49^{\prime \prime}, 6$ promedio de las observaciones astronomicas y diferencias cronométricas.

\section{Arica.}

Malaspina halló por dos cronómetros la diferencia de longitud entre Arica y el Ca.

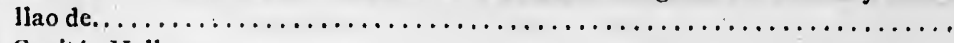

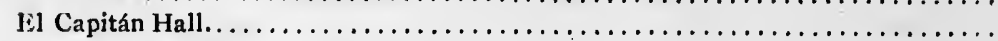

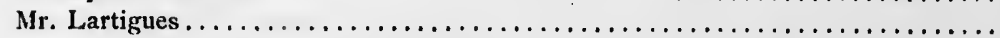

Prumedio.............................. Callao al Occidente de Cádiz, según hemos dicho................ 70.57. 9

Longitud de Arica. (I.") $64.08 \cdot 54$

'T'enemos tambien Arica al Este de Valparaíso por Lartigues. Por el Capitán Hall.

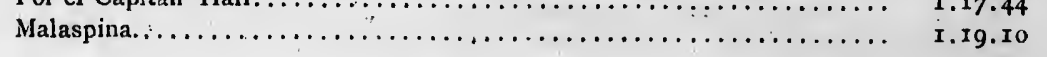


$70 \cdot 57 \cdot 9$

Capiudn 1fall.'

$5^{\circ}+7^{\prime} 19^{\prime \prime}$

65.09 .50

$65 .+2.5,6$

oo. $7 \cdot 44,4$ 5.47. 19

70.57. 9

65.09 .5

I5. 54

I7. 22

I5 $: 32$

I6. 16

$65 \cdot 25 \cdot 33,5$

$65.09 .17,5$

65. $9.50,0$

$65 \cdot 9 \cdot 33,7$

65. 2. 5,6

$65 \cdot 5 \cdot 49,6$

$7.28, I$

, quizás des n $65^{\circ} 5^{\prime} 49^{\prime \prime}, 6$

$6^{\circ} 46^{\prime} 3^{8^{\prime \prime}}$

$6.48 .5^{6}$

6.49 .11

6.48 .15

$70.57 \cdot 9$

64.08 .54

I. 18.28

I. 17.44

I. I9.10

Aunque parece no ser de este lugar las longitudes de Cartagena de Indias, Panamá, Acapulco, San Blas de Californias, San Jose y Cabo San Lucas, que van á continuación, lo son atendiendo á que todas están ligadas entre si y cada una de ellas con los puntos de las costas de que habla esta Memoria.

\section{Carlagena de Indias.}

Ln el tomo II de las Obscrvuciones astronómicas del Harón de Humboldt, calculadas por Oltmans, desde la página ${ }_{4} 6$ en adelante se hallan los cálculos y discusiones sobre la longitud de esta plaza, concluyendo en la página 181 con los resultados siguientes:

1. Por las observaciones antiguas del Padre Feuille, D. Juan Herrera, D. Jorge

Juan, D. Antonio Ulloa y Mr. de Puysegur: Cartagena Occidente de París. .(1.") $77^{\circ} 52^{\prime} 00^{\prime \prime}$

2. Por el eclipse de c observado en la Iglesia Baru en 30 de Marzo de 1801 por el

Barón de Humboldt, y referido á Cartagena por el cronómetro.......... (2. $) \quad 77.46 .57$

3. Por la ocultación de a de Escorpión, en 23 de Marzo de 1802 , observada por No-

guera, de la Marina Real de España........................... 7 77.48. I5

4. Por las observaciones del primer satélite, por el mismo, comparadas á las tablas

$$
\begin{aligned}
& \text { y con correspondientes. ............................ (4." } 77.51 .15 \\
& \text { Promedio ............................ }
\end{aligned}
$$

Pero Oltmans, se fija en......................... 77.50 .00

Después de estos datos, el Capitán de navio D. Juan Tiscar nos ha facilitado las siguientes obervaciones que el mismo ha calculado:

I803 2 de Abril. Ocultación de Regulus por la $\ldots \ldots \ldots \ldots \ldots \ldots \ldots \ldots\left(5 .^{\prime \prime}\right) \quad 77^{\circ} 47^{\prime} 26^{\prime \prime}, 2$

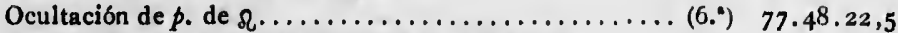

al de Febrero. Eclipse de Sol con correspondiente en la Habana........ (7. $\left.{ }^{\circ}\right) \quad 77 \cdot 49 \cdot 55^{\circ}, 5$ 1802 Desprendimiento de Mercurio del disco del Sol, con correspondiente en Vivieres, circunstancias dudosas...........(8.3) $77.46 .00,0$ Por la ocultación de $a$ de Escorpión calculada por Ferrer.. (9. $\left.{ }^{\circ}\right) \quad 77 \cdot 51.45,0$ Idem id. por Tiscar....................... (10) $77 \cdot 51.11,2$

Resumiendo estas longitudes, tendremos:

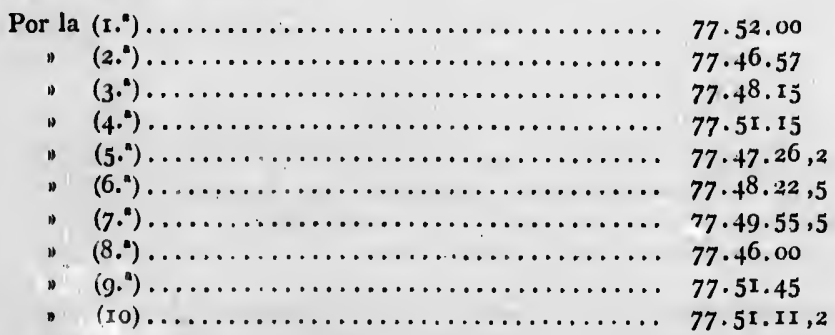

Occidente de Daris Occidente de Cadis.

Promedio. Longitud de Cartagena de Indias............... $77^{\circ} 50^{\prime} 18^{\prime \prime}, 7 \quad 69^{\circ} 12^{\prime} 33^{\prime \prime}, 7$ Oltmans la fija........................... 77.50.00,0 69.12.15,0

Diferencia despreciable. ............ $\frac{77 . \ldots, \ldots, 7}{18,7}$ Por tanto, es la longitud de Cartagena, Occidente de Cádiz..... $\star 69.12 .33,7669.12 .34$. 


\section{Panamá.}

Malaspina estableció el observatorio en la sala de armas del Castillo de Chiriqui, que está 6",5 al Sur y $\mathrm{r}^{\prime \prime}$ al Este de la torre de la Catedral.

Por estrellas à! Norte y al Sur del zénit, se dedujo la latitud Norte del observatorio. $8^{\circ} 57^{\prime}$ 10"

De la Catedral.................................. 8.57.16,5

El día 19 de Noviembre de 1790 se observó la inmersión de 0 . de Aries por el limbo oscuro de la $\mathbb{C}, y$ hecho el cálculo por D. Juan Tiscar.

Dió longi ad al Occidente de París.................. $8 \mathrm{I}^{\circ} 3^{8^{\prime}} 45^{\prime \prime}, 4$ Día 2 de Diciembre. Ocultación 7. de Virgo. Cálculo del mismo...... 81.37.48,4

Promedio longitud de Tanamá. Observatorio

(d) $8 \mathrm{r} .38 .17$

O. de Cádiz

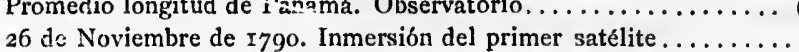

$73^{\circ} \mathrm{oo}^{\prime} \mathbf{3}^{\prime \prime}$ 3 de Diciembre

id.

id.

$73.11 .3^{\circ}$

Promedio

$\frac{73 \cdot 7 \cdot 30}{73.6 \cdot 30.7}$

Como se ve, el resultado de las ocultaciones de estrell::3 varía bastante de las observaciones del primer satélite de Júpiter; de consiguiente, nos valdremos de otros m.edios (como á continuación se expresan) para hallar la longitud de Panamá, y que ai mismo tiempo nos manifiesten cuál de estas ingitudes es la preferente.

Malaspina halia la diferencia cronométrica entre Panamá y Guayaquil por dos cronó-

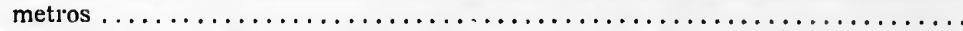

"n cronómetro de la corbeta Atrevida, de la mis,ma expedición................

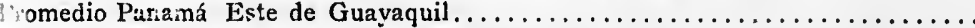

iuayaquil, Occidente de Cádiz según hemos dicho..................... $73^{\prime} 40^{\prime} 33^{\prime \prime}, 0$

Panamá, Oćcidente de Cádiz.................... $73.21 .18,3$

Longitud de Panamá con referencia á Cartagena.

Hemos vistu que la longitud de Cartagena es al Occidente de Cádiz.

69.12 .34 Porto Belo (fuerte re San Jerónimo) U. de Car-

tagena.......................... Por Puysegur $4^{\circ} 7^{\prime} 35^{\prime \prime}$ Por Fidalgo. $4^{\circ} 6^{\prime} 23^{\prime \prime}$

Cartagena. O. de Cádiz .............. 69.12.34 69.12.34

Long ${ }^{\text {tudes de Porto Eelo............. } 73.20 .09}$

El promedio de ambas será..................... $73^{\circ} 19^{\prime} 33^{\prime \prime}$

Según Fidalgo, el Castillo de Chagres al O. de Porto Belo................

$20^{\prime} 30^{\prime \prime}$

Longitud del Castillo d. Chagres................. (b) 73.40 .03

En el tomo I de las Memorias del Depósito, Memorir segunàa, pı. 53 , se ve que:

El Castillo de Chagress sstá al O. de Panamá, por ei cronómetro...

$28^{\prime} 4^{\prime \prime}$

Por la observación det primer satélite en ambos puntos................ 33.30

Esta diferencia parece preferible á la que resultó por el cronómetro, cuya máquina pudo tener alteraciones, ya por el clima como por las sacudidas que sufria en el vlaje, por lo que tendremos:

Longitud del Castillo de Chagres........................... (b) $73^{\circ} 40^{\circ} 03^{\prime \prime}$

Panamá al Este.............................. $33.3^{\circ}$

Longitud de Panamá con respecto á Cartạgena..................... 73.06.33

Idem por el promedio de las observaciones astronómicas ................ (c) $73.06 .30,7$ 


\section{Longitud de Panamá con referencia á Acapulco.}

'hiriqui, que está $6^{\prime \prime}, 5$

vatorio. $8^{\circ} 57^{\prime} 10^{\prime \prime}$

…. $8 \cdot 57 \cdot 16,5$

or el limbo oscuro de

$3^{\prime} 45^{\prime \prime}, 4$

$37.48,4$

O. de Cádiz

38. I7 $73^{\circ} \mathrm{oo}^{\prime} 3^{\prime \prime}$

$73.11 \cdot 30$

73. $7 \cdot 30$

73. $6 \cdot 3^{\circ}, 7$

e las observaciones del omo á continuación se anifiesten cuál de estas

s cronó-

$\ldots \ldots \ldots \quad 19^{\prime} 25^{\prime \prime}, 5$

$\ldots \ldots$ Ig. 3,9

I9. 14,7

…... $73^{\prime} 40^{\prime} 33^{\prime \prime}, 0$

$\ldots \ldots \overline{73.21 .18,3}$

$59.12 \cdot 34$

7idalgo. $4^{\circ} 6^{\prime} 23^{\prime \prime}$

69.12 .34

73.18 .57

...... $73^{\prime \prime} 19^{\prime} 33^{\prime \prime}$

(......

$20^{\prime} 30^{\prime \prime}$

.... (b) 73.40 .03

ve que:

$28^{\prime} 4 I^{\prime \prime}$

33. 30

iquina pudo tener alteo que tendremos:

$\ldots(b) \cdot 73^{\circ} 40^{\prime} \mathrm{o}^{\prime \prime}$

….. $\quad 33.30$

73.06 .33

.... (c) $73.06 .30,7$
Según las Memorias del Depósito, la longitud entre Panamá y Acapulco es de...... 20.33. 5 La longitud de Acapulco se ha fijado al Occidente de Cádiz............. $93 \cdot 34 \cdot 5^{6}$

Será longitud de Panamá...................... 73.01.51 Muy conforme con el resultado de las ocultaciones $(d)$ calculadas por Tícar de.. $73.00 \cdot 3^{2}$

Resumiendo estas longitudes, ter.iremos:

Por el promedio de las ocultaciones de estrellas.................. (a) 73.00 .32

Por el primer satélite en 26 de Noviembre....................

Por idem en 3 de Diciembre.............................. (c) $73 \cdot 7 \cdot 30$

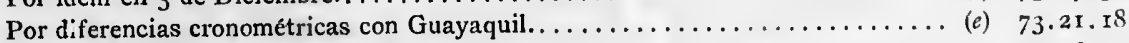

Por ídem con Cartagena.................................. 73. 6.33

Por ídem con Acapulco con escala en Realejo.................... 73 . I.5I

Desechando la $(e)$, será el promedio de las cinco restantes............... $73 \cdot 5 \cdot 35,3$

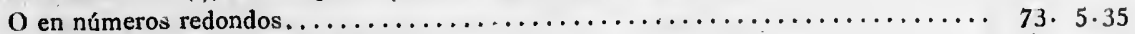

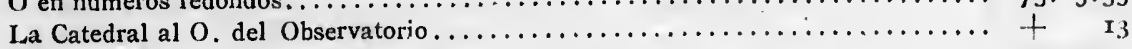

Longitud de Panamá, Occidente de Cádiz...................... $73 \cdot 5 \cdot 4^{8}$ Por el promedio de las tres observaciones astronómicas $(a),(b),(c)$ reducidas á la

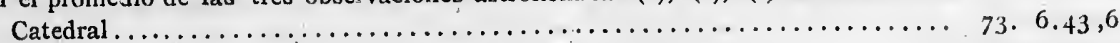

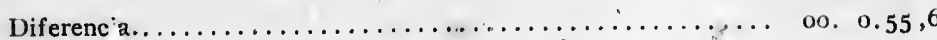

\section{San Fosé de Californin.}

El paso de Venus observado en esta Misión el día 3 de Junio de 1769 por ei Abate Chape, D. Vicente Doz y D. Salvador Medina, ha sido calculado por el Sr. Oltmans, (Observaciones astronómicas, píg. 6r6), concluyendo la lungitud Occidente de París $112^{\circ} 01^{\prime} \circ 7^{\prime \prime}, 5$ y'103 $23^{\prime} 22^{\prime \prime}, 50$. de Cádiz.

Este mismo cálculo con los datos originales de Doz y Medina, ha sido támbién 'calcéndo por D. José Joaquín Ferrer, en está feima:

Contacto interior del ingreso en el centro de la Tierra...... En Paris, por el conjunto de observaciones de Europa y Asia.

ijiferencias de meridianos, ingreso

$0^{\text {h }} 15^{\prime} 28^{\prime \prime}, 7$ egreso $5^{\text {h }} 57^{\prime} 23^{\prime \prime}, 3$ $7 \cdot+3 \cdot 32,6 \quad 13 \cdot 25 \cdot 27,6$

ingreso................

7.28. $3,9 \quad 7.28 .04,3$

Idem por el egreso........................, 7.28.4,3

$$
\text { Pro. edio.................. } 7.28 .4,1
$$

Suponiendo la Paralaje Solar 8",590 y excluída la obser-

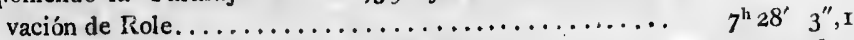

Será longitud de San José, Occiderte de París.......... 11 $2^{\circ} 00.4^{6,5}$ O. C. ${ }^{2} 103^{\circ} 23.1,5$ Segín Oltmans............... 112 . $1.7,5$ " $103.23 .22,5$

Promedio, verdadera lo gitud de San José.........

\section{Cubo de San Lucas.}

Por una base medida con todo cuidado desde la mar á bordo de lós buques de la expedición de Malaspina, resultó el Cabo de San Lucas al Occidente de San José... Misión de San José al Cecidente de Cádiz....................... ${ }^{10} 3^{\circ} 23.12$. Longitud dei Cabo de San Lucas ......................... I $103 \cdot 3^{2} \cdot 4^{2}$. 


\section{San Blas de Californias.}

Malaspina estableció su observatorio en una casa de la Plaza Mayor, y le dedujo la latitud de la Contaduria.

Por el cuarto de círculo. ................................. Norte. (a) $21^{\circ} 32^{\prime} 46^{\prime \prime}$

Desde el fondeadero......................................... 2 I. 5 I.

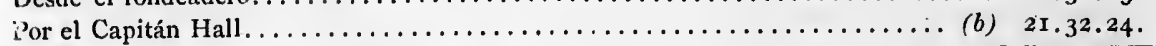

El prorıedio de las dos más próximas $(a)$ (b) será................ Norte. 2 I.32.35.

Para la longitud tendremos:

El día 7 de Abril de I791 se observó la emersión del primer satélite de Júpiter en buenas circunstancias, que según los cálculos de Oltmans (Obseriaciones astronómicas, pág. 6I6), dió longitud al Occidente de París.................................. Promedio.

El día I I de Octubre, tin del eclipse de calculado por el mism: , I07

El día 26 de Mayo de 1822 , el Capitán Hall ob-

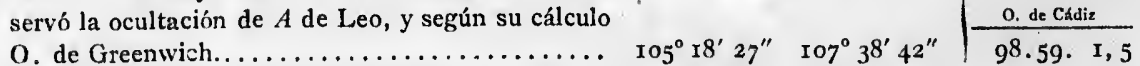

Por las distancias lunares, Capitan Hall......... 105.17. 9. 107.37.24.

Longitud de San Blas por diferentes cronómetros con Cabo San Lucas:

Malaspira halló esta diferencia por los cronómetros números 7 I y 72 de Arnold... $4^{\circ} 33^{\prime} 25^{\prime \prime}$ El Cabo San Lucas se ha establecido al Occidente de Cádiz................ 103.32.42

Longitud de San Blas al 0 . de Cádiz......................... 98.59 .17

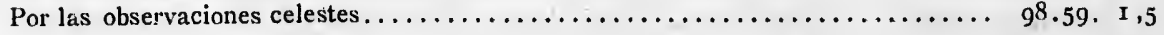

Diferencia despreciable..................... $0.0 .15 ; 5$

Se ve desde luego que la conformidad de estas longitudes nada dejan que desear; por lo tanto, reuniéndolas, tendremos :

Por el promedio de las observaciones celestes, Occidente de Cádiz........... $9^{8^{\circ}} 59^{\prime} \mathrm{I}^{\prime \prime}, 5$ Por diferencias cronometricas con el Cabo San Lucas................... 98.59.17, Por las distancias lunares, Capitán Hall. . . . . . . . . . . . . . . . . . . 98.59 .39

Promedio longitud de San Blas al Occidente de Cádiz................. $98.59 \cdot 19,2$

\section{Acapulco.}

Malaspina estableció el observatorio en $179 \mathrm{r}$ en el castillo de San Diego, y en cuyo paraje por estrellas al Norte y al Sur del zér. Ł, se dedujo la latitud de.... Norte.

Para la longitud el día Ig de Febrero de I7gr se observó la ocultación de v de Leo por el limbo oscuro de la cu, cuyo cálculo hecho por el Sr. Oltmans, dió longitud 0 . de París............................................... 6

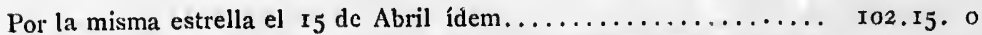
Por tres inmersiones y cinco emersiones del primer Satslite comparadas 102.14.30

Por

Promedio longitud de Acapulco.............. ro2.13.12 $\quad 93.35 .22$ Pero Oltmans, dando la preferencia á las ocultaciones, fija la longitud en $102.12 .33 * 93 \cdot 34 \cdot 48$ Don Juan Tiscar, habiendo calculado las ocultaciones, hace esta longitud de..... 93.30.19,5 


\section{Longitud de Acapulco por diforencias cronométricus.}

Malaspina halla la diferencia entre estos dos puntos:

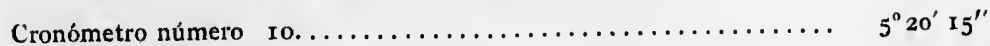

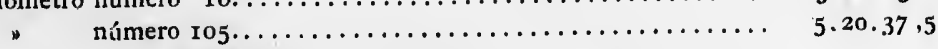

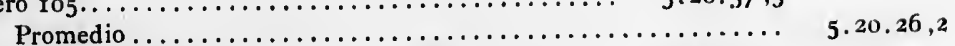

El Capitán Hall, halla esta diferencia de............... 5.24 .40

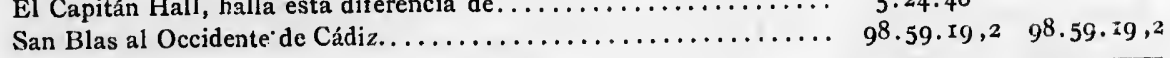

Longitud de Acapulco por diferencias crononétricas........... $93 \cdot 34 \cdot 39,2 \quad 93 \cdot 3^{8 \cdot 53,0}$ Por las observaciones celestes $O$. de Cádiz.............

Diferencia

o. $0.08,8$

o. $4.05,0$

Se ve desde luego que la diferencia cronométrica que el Capitán halla entre Acapulco y San Blas, es muy conforme con las observaciones astronómicas y desde luego preferible á la que halla Malaspina; por tanto, se puede fijar la longitud de Acapulco, sin error de consideración, en esta forma:

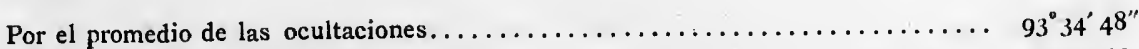

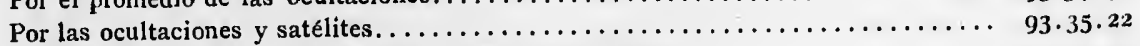

Por diferencia cronométrica con San Blas: Capitán Hall. . . . . . . . . . . . 93.34.39

Promedio de longitud de Acapulco.

$4093 \cdot 34 \cdot 5^{6}$

\section{Realejo.}

Malaspina colocó el observatorio en la parte meridional del puerto, y á la voz del paraje en donde estaban fondeados los buques de su mando.

La latitud se observó por pasos de estrellas al Sur y al Norte del zénit, de $12^{\circ} 29^{\prime} 50^{\prime \prime}$ Norte. El 24 de Enero de $\mathbf{7 9}$ I se observó la inmersión del primer satélite de Júpiter (Memo-

rias, tomo I, pág. 55) y dió longitud al Occidente de Cádiz............. $80^{\circ} 47^{\prime} 00^{\prime \prime}$

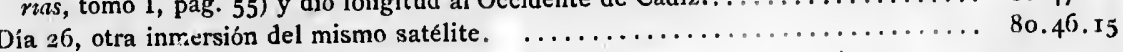

$$
\text { Promedio longitud de Realejo.... } \ldots \ldots \ldots \ldots \ldots \ldots \downarrow \overline{80.46 .37,5}
$$

La difer cia cronométrica entre este puerto y Acapulco, hallada por

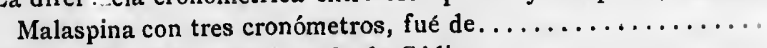

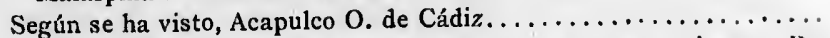
El mismo Malaspina hallo también la diferencia cronométrica con $\mathrm{Pa}$ -

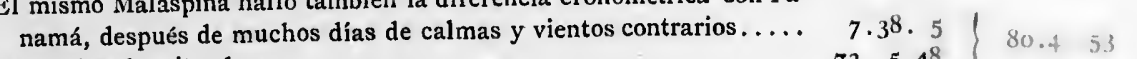

Panamá se ha situado en ....................... $\left.73.5 .4^{8}\right\}$

Promedio será longitud de Realejo.............. 80.43 .29

\section{San Carlos de Chiloé.}

Malaspina colocó su observatorio en una casa inmediata á la orilla del mar $27^{\prime \prime}$ a ı wur y $6^{\prime \prime}$ al (). del centro del fuerte de San Carlos.

La latitud se observó por estrellas al Sur y al Norte del zénit, reducida al fuerte... $4 \mathrm{I}^{\circ} 5^{0^{\prime}} \mathbf{2 3}^{\prime \prime}$ Fl 6 de Febrero de 1790 se observó la inmersión del primer satélite de

Júpiter: dió longitud Occidente de París......... $7^{\circ} 08^{\prime} 00^{\prime \prime}$

Fil I 5 de dicho, emersión del mismo satélite....... 76.08 .00 .

Promedio longitud de Chiloé, $O$, de París... $76.08 .00 .=: 67 \cdot 30.150$. de Cádiz. 
Los cronómctros de Malaspina en la corbeta Drscubierta dieron Chiloé al O. de

Montevideo.................................. $17^{\circ} 34^{\prime}{ }^{\prime \prime} o^{\prime \prime}, 4$

Los de la corbeta Atrevida........................ $17.37 .13,6$

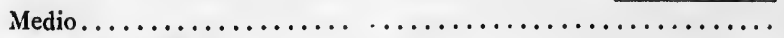

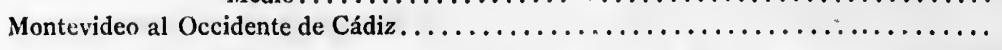

Longitud del observatorio de San Carlos de Chiloé................. 67.31.44,6

La díerencia de meridianos fué hallada también por Malaspina, entre Chiloé y Val-

paraíso, de 2.7 .39 y 2.9 .8 cuyo promedio es igual.................. 8.23

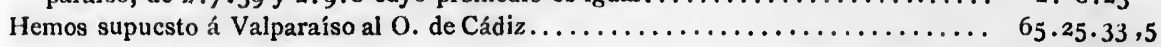

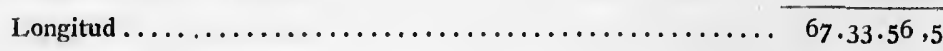

Resumiendo las longitudes, tendremos:

Por los satelites.................................. $67.30 .1_{5}$

Por diferencias cronométricas con Montevideo......................... $67 \cdot 31 \cdot 44,6$

Por ídem con Valparaíso..................................... $67.33 .56,5$

Promedio longitud del observatorio de Chiló..................... $\overline{67 \cdot 31 \cdot 57,5}$

El Castillo de San Carlos al Este................................

Longitud del Castillo de San Carlos al Occidente de Cádiz... $\longdiv { 6 7 . 3 1 . 5 I , 5 }$

Determinadas las situaciones geográficas de los puntos que deben servir de base para correçir los intermedios, debe tenerse presente que Malaspina situó los puntos de las costas, por bases desde la mar, á más y ménos distancia de ellas, según las circunstancias, anotando los nombres que el Piloto práctico indicaba, por cuyo motivo no debe parecer extraño que en las cartas publicadas por el Depósito Hidrográfico de Madrid, se hallen algunas equivocaciones.

\section{Costa de Chile y Archipiélago de los Chonos.}

Cabo de Tres Puntas.--Noroeste de la Isla de Madre de Dios.

Malaspina, á distancia de 34 millas, sitúa esta punta en latitųd Sur de.

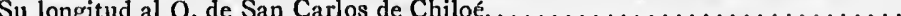

$\mathrm{Y}$ al $\mathrm{O}$. de Cádiz.....

$49^{\circ} 46^{\prime} 00^{\prime \prime}$

$\mathrm{I} \cdot 5^{2} \cdot 5^{\circ}$

Isla del Huafo.-Punta Sur. Su latitud, deducida de la observada al día siguiente, resultó de...................................... Sur.

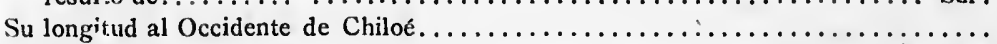

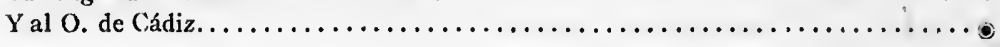

Pun!a de IIuentemo.--Isla de Chiloé. La latitud de esta punta se halló de...... Sur.

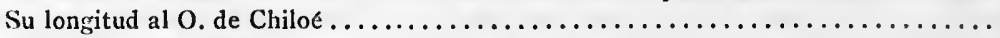

Y al Oecidente de Cádiz...................................

Volc'n de Purarrague.-Continente. La situación de este monte depende de las operaciones geodésicas ejecutadas en Chiloé y sus inmediaciones. Su latitud resultó ser de............................................. Sur 1

Su longitud al Este de San Carlos de Chiloé...........................

De consiguiente, 0 . de Cádiz.............................

Punta Parga ó Estaquillas. - Esta punta se coloco igualmente como la ar terior. Su latitud resultó de....................................... Longitud al Occidente de Cádiz............................

Pınta Qusdal.-El Piloto Vila, quc observó en su pualelo, la coloca el latitud

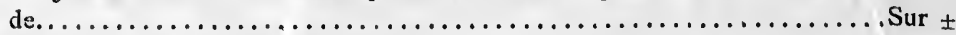

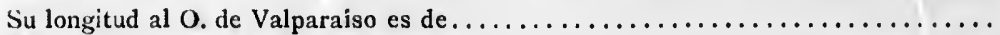

De consiguiente, al 0. de Cáliz..........................

$44 \cdot 4 \cdot 30$

49.20

$68.2 I .11$

42.46 .40 I6. 50 $67 \cdot 48 \cdot 4 \mathrm{I}$

$4 \mathrm{r} .16 \cdot 30$

I. 3.20

66.28 .51 
Punta de la Galera.-Malaspina, desde la mar y á distancia de seis á siete millas, coloca esta punta en latitud.......................... Sur. $39.53 \cdot 30$

Su longitud al Este de Chiloé, resultó ser de.................... $8.4^{0}$

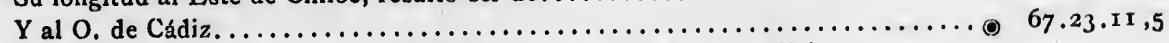

La punta de la Galera está al $O$. del Castillo del Corral de Valdivia,

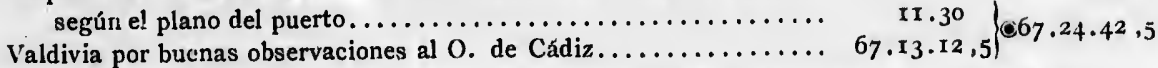

Longitud que parece debe preferirse á la anterior, arnque se diferencia en muy corta cantidad.

Castillo del Corral._En Valdivi:. Mr. Lartigue halla la latitud (Eclaircissements sur les jositions geographiques determinées en $182 \mathrm{I}, 22$ et 23 par Mr. Lartigue, etc. Connais-

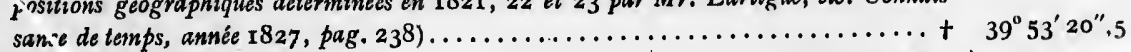

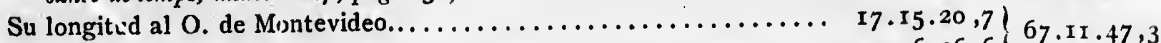

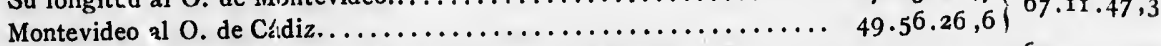
Suponiendo V.alparaíso, como se ha dicho, al 0 . de Cádiz.............. $65 \cdot 25 \cdot 33,5$ Mr. Lartigue halla que el Castillo del Corral está al $0 \ldots \ldots \ldots \ldots \ldots \ldots \ldots \ldots \ldots \ldots$. 1.+9.4

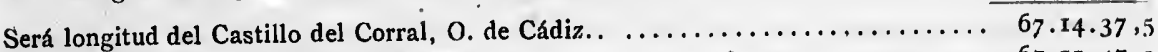

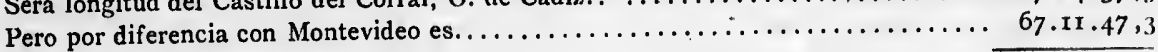

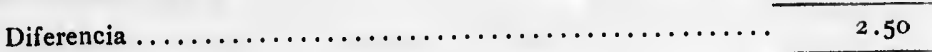

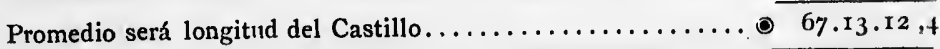

Rectificada la longitud de Valparaíso, probablemente desaparecerán estas pequeñas diferencias, que ellas mismas manifiestan, que la longitud de Valparaíso, tal como se fija, no está muy lejos de la verdadera.

Punta Maquin.-Dice el Piloto Vila, que la latitud observada de esta punta, es de $39^{\circ} 26^{\prime} 00^{\prime \prime}$ Sur, Y su longitud al $O$. de Valparaíso $=\mathrm{I}^{\circ} 5^{\circ} 8^{\prime} 45^{\prime \prime}$. - Será longitud $O$. de Cádiz...... $67^{\circ} 24^{\prime} 18^{\prime \prime}$

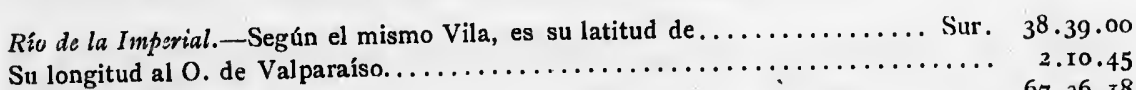
Y al O. de Cádiz............................................... 67.36

Isla Mocha.-Don Mariano Isasviribil. levant6 el plano de esta isla, y da las situaciones siguientes:

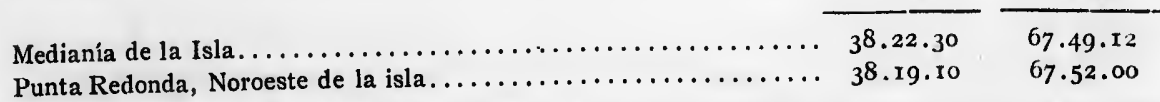

Estas longitudes parece que fueron determinadas con cronómetro; pero se duda á qut punto ó puerto de la costa las refiere; por tanto, es preciso valerros de la situación que da Malaspina á esta puerto de la costa las refiere; por tanto, es preciso
isla, que es como sigue. Este Oficial, desáe la mar á distancia de cincóá seis millas, y en el meridiano y paralelo de la Isla de la Mocha, deducc:

Punta Noroeste de ella, latitud Sur......................... 38.19.00

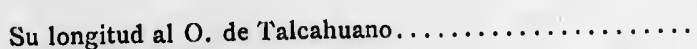

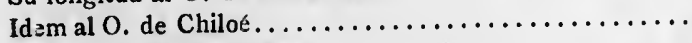

Idem al 0 . de Valparaíso.......................

Promedio longitud de la Punta Redonda, Noroeste de la

Isla Mocha............................. (h) La longitud al Occidente de Valparaíso..... 2.15.17
Anteriormente................

Diferencia ................... $40^{\circ} 00^{\prime \prime}+66.5^{2} \cdot 45,5=67 \cdot 32 \cdot 45 \cdot 5$ $00.20+67.31 .5 \mathrm{I}, 5=67.32$. I, 5 2. $8.00+65.25 \cdot 33,5=67 \cdot 33 \cdot 33,5$
$67 \cdot 32 \cdot 50$ 38.19 .13
$67 \cdot 4^{0} \cdot 5^{0}$

$67 \cdot 3^{2} \cdot 5^{0}$ 
No pudiendo ser despreciables las autoridades de Malaspina y del Capitán Hall, veremos por otro medio cuál de las dos longitudes debe ser preferida.

Más adelante se ve que la longitud de la punta Norte de la Isla Santa María, es, Occidente de Cádiz...................................... 67.20.10

Malaspina halla la diferencia de longitud entre ambas puntas, de.............

\begin{tabular}{|c|c|}
\hline 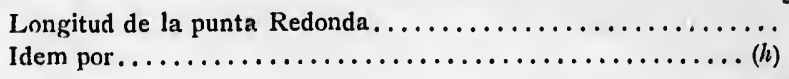 & $\begin{array}{l}67 \cdot 31 \cdot 50 \\
67 \cdot 3^{2} \cdot 50\end{array}$ \\
\hline ferencia ........... & I.00 \\
\hline
\end{tabular}

Promedio. Longitud de Punta Redonda. Noroeste de la Isla Mocha........... $67^{\circ} 3^{\prime 2} \mathbf{2 0}^{\prime \prime}$
Latitud según Isasviribil, observada en tierra......................... $+3^{8.19 .10}$

Isla de Santa María.-Según el exacto plano levantado por D. Mariano Isasviribil,

resulta la punta Sur de la isla 6 punta de Lobos. Latitud .............. 37. 3.5 I

Su longitud al Oriente de Chiloe $=12^{\prime} 4^{\prime \prime}+67^{\circ} 3 \mathrm{I}^{\prime} 5 \mathrm{r}^{\prime \prime}, 5=$ será longitud..... 67.19.47,5
La punta Norte ó del Cansancio, íd. Ir.49+ íd.
$=\ldots \ldots \ldots \ldots . .$.
(I) $67.20 \cdot 2,5$

íd.

Punta de Lavapié, en el Continente, íd. 8. I - íd. $\quad=\ldots \ldots \ldots \ldots \ldots 66.26 .23 .50,5$

Malaspina desde la mar, á distancia de ocho millas y fuera del paralelo, sitúa la punta Norte de la

isla en latitud de $37^{\circ} \mathrm{oo}^{\prime}$ oo" y $28^{\prime}$ al Occidente de Talcahuano, suponiendo Talcahuano al Oeste

de Cádiz $66^{\circ} 5^{\prime}{ }^{\prime} 45^{\prime \prime}, 5$, será para la punta Norte................... 67.20.45,5

El mismo Malaspina, al Este de Chiloé $I \mathrm{I}^{\prime} 20^{\prime \prime}-67^{\circ} 3 \mathrm{r}^{\prime}{ }_{5} \mathrm{r}^{\prime \prime} 5,=\ldots \ldots \ldots \ldots 667.20 .3 \mathrm{I}, 5$

Promedio. Longitud de la punta Norte de la isla, por Malaspina.

(2) $67 \cdot 20 \cdot 3^{8,5}$

El Capitán Hall sitúa dicha punta Norte en latitud de $36^{\circ} 58^{\prime} 35^{\prime \prime}$, sin determinar su longitud; pero situando el pueblo de Arauco en latitud de $37^{\circ} 14^{\prime} 30^{\prime \prime}$ y $\mathrm{I}^{\prime} 42^{\prime \prime}$ al $\mathrm{O}$. de Valparaíso la referiremos á la punta Norte de la isla.

En el plano que ha publicado el Capitán Hall en r821, la punta Norte de la Isla de Santa Ma. ría se halla al 0 . de Arauco.................. I2' I5"

Arauco al 0. de Valparaíso.................. $+\mathrm{r}^{\circ} 42$ oo

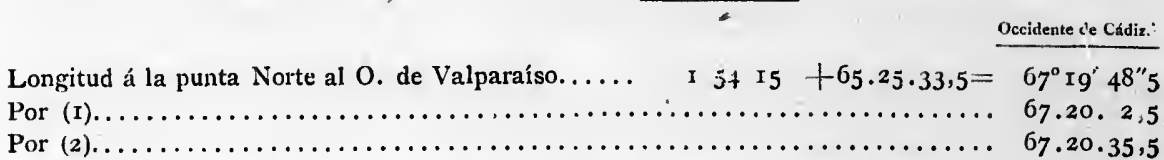

Promedio. Longitud de la punta Norte de la Isla de Santa María, números redondos. 67.20.10

Punta Norte de la Isla de Sarta María..... $067^{\circ} 20^{\prime} 10^{\prime \prime} \quad$ Latitud $+36^{\circ} 56^{\prime} 42^{\prime \prime}$

Plano de Isasviribil, pünta de Lavapié.... O. + 3.40 .

Longitud de la punta de Lavapié...........
La punta Sur de la Isla ó de Lobos estáal Este

de la punta Norte o' $15^{\prime \prime}$. Será de Cádiz...

Pueblo de Arauco por el Capitán Hall $\mathrm{I}^{\circ} 4^{2}$ de

Valparaíso...................... $67 \cdot 7 \cdot 33$.

$67.23 \cdot 50$. O. de Cádiz. Latitud $\$ 37 \cdot 6.39$.

$67 \cdot 19 \cdot 55$

Latitud $\Delta 37 \cdot 3 \cdot 5 \mathrm{I}$.

Talcahuano.-Malaspina sitú el observatorio en una casa inmediata á la orilla del mar y en el fondo Sudoeste del puerto, la misma en que Mr. Pagelet estableció el suyo cuatro años antes, en la expedición del desgraciado Conde de la Péyrouse.

La latitud fué observada por estrellas al Norte y al Sur del zérit de Sur. Por tres cronómetros de la corbeta Descubierta resultó Talcahuano,

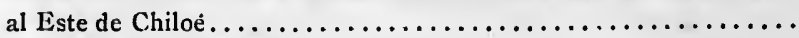

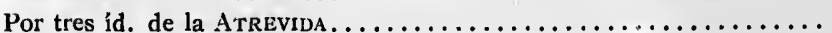

Chiloé al Occidente de Cádiz........................ 67.31.51. 67.31.51.

Longitudes de Talcahuano ........................ 
E] Capitán Hall, halla que Talcahuøio está al Oeste de Valparaíso, re-

ducida al observatorio de Malaspina.................... $1^{n} 29^{\prime} 15^{\prime \prime}$

Según Malaspina.......................................

Promedio........................ $1.28 .37,51$

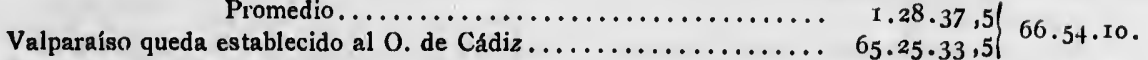

Por los cronometros de la Descubierta.............................. 66.53 .30 .

Longitud de Talcahuano................................ 66.53 .50$.

Tetas de Biobio.-_La más Norte. Por las operaciones geodésicas hechas en Talcahua-

no por la expedición de Malaspina, rcsultó latitud................... $36^{\circ} 45^{\prime} 42^{\prime \prime}$

Su longitud al 0 . de Talcahuano.................. $3^{\prime} 40^{\prime \prime}+66.53 \cdot 50=\Delta 66.57 \cdot 3^{\circ}$

Río Itata.-Punta Sur. Malaspina, desde la mar y á distancia de I2 á 13 millas, sitúa este rio en latitud de.. ................................... 35.58 .30

Su longitud al Este de Talcahuano...................... 8 8 $-66^{\circ} 53^{\prime} 50^{\prime \prime}=66.35 .50$ al O. de Valparaíso.................... ${ }^{0} 10-65 \cdot 25 \cdot 33,5=66.35 \cdot 33,5$

Promedio longitud del río Itata, O. de Cádiz............ 66.35 .42

Río Maule.-El Piloto D. Claudio Vila sitúa la boca de este río latitud $35^{\circ} 4^{\prime}$ oo" con el signo $\Delta$ de situación geodésica; pero dudamos qué género de operaciones practicó. La longitud dice ser de $65^{\circ} 42^{\prime}$ oo" al $\mathrm{O}$. de Cádiz; mas, como vamos á ver, hay un error de consideración, dimanado sin duda de la posición del punto á que este Piloto refiere sus longitudes.

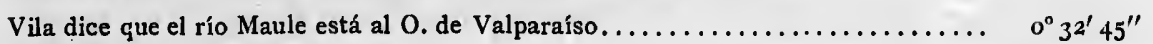

Valparaíso al 0. de Cádiz...................................... $65.25 \cdot 33,5$

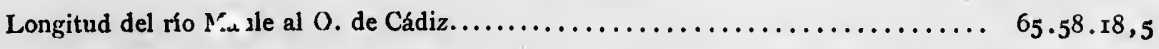

El mismo da la diferencia de longitud entre los Bajos de Rapel ó Topocalma y el

río de Maule de......................................... 0.23 .00

Los Bajos están al O. de Cádiz................................... 65.40. 2

Longitud del río Maule.................................. 66.3 .2

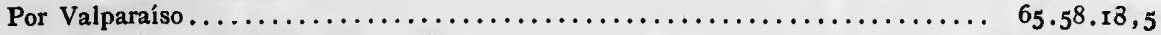

Promədio, longitud del río Maule, 0. dr: Cádiz............... 66.00.40 Latitud....................................... 35.4 .00

Bajos de Topocalma ó de Rapel.-Según las observaciones de Malaspina están en la.

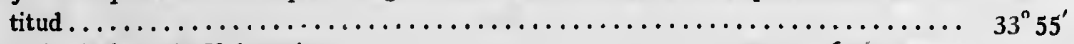

Longitud al 0 , de Valparaíso................. $\mathrm{r}_{4.20}=65.39 \cdot 53,5$

" al Este de Talcahuano................ $1.13 .40=65.40 .10$

Medio....

65.40 .2

El Capitán y Piloto D. Claudio Vila llama á éstos Bajos de Rapel, y según sus observaciones, la latitud es la misma que la que les asigna Malaspina, y la longitud al Occidente de Cádiz $65^{\circ}{ }^{\prime} 9^{\prime}$; pero contando Vila la longitud de Valparaíso $65^{\circ} 9^{\prime} 15^{\prime \prime}$, será la diferencia entre estos dos puntos igual á $9^{\prime} 45^{\prime \prime}$, y de consiguiente, la longitud de los Bajos (suponiendo á Valparaiso $65^{\circ} 35^{\circ} 33^{\prime \prime}, 5$ ) de $65^{\circ} 35^{\prime} 18^{\prime \prime}$, menor de $4^{\prime} 44^{\prime \prime}$ de la que hemos hallado por diferencias con Valparaíso y Talcahuanu.

Punta de Piedra Blanca.-Malaspina coloca esta punta, á muy corta distancia de ella, en latitud de....................................... $33^{\circ} 24^{\prime} 30^{\prime \prime}$ 
Su longitud al 0 . de Valparaíso.......... $6^{\prime} 30^{\prime \prime}+65^{\circ} 25^{\prime} 33^{\prime \prime}, 5=0$. de Cádiz $65 \cdot 32.3$ Al O. de Coquimbo................. 25.30 +65. 5.49

Promedio longitud de Punta de Piedra Blanca.

Punta de Coruma Alta. - La colocación geográfica de esta punta depende de operaciones desde la mar y de tierra.

Su latitud resultón................................... $33^{\circ} 10^{\prime} 00^{\prime \prime}$ La longitud al 0 . de Valparaíso............ $9^{\prime} 20^{\prime \prime}+65.25 \cdot 33=0$. de Cádiz

Punta del Concon.-Malaspina colocó esta punta por operaciones geodésicas desde

Valparaiso, resultando su latitud de ....................... S La longitud al Este de Valparaíso.......... $6^{\prime} 35^{\prime \prime}-65.25 \cdot 33=0$. de Cádiz d

Campana de Quillota.--Montaña en el interior: se colocó por el mismo Malaspina y por operacioites geodésicas desde Valparaíso en latitud Sur................. Longitud al Occidente de Cádiz.................................

Herradura de Quintero.--Por las operaciones geográficas de la expedición de D. Mariano Isasviribil, se coloc6 la punta de Molles, que está en el fondo meridional del puerto por latitud de $. . \ldots \ldots \ldots \ldots \ldots \ldots \ldots \ldots \ldots \ldots \ldots \ldots \ldots+$ Su longitud al Este de Valparaíso $6^{\prime} 2^{\prime \prime}$. Será 0 . de Cádiz..............

Puerto del Papudo._Lo más Sur por el mismo Isasviribil:

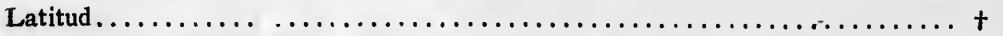

Longitud al Este de Valparaíso r2' $52^{\prime \prime}$. Al 0 . de Cádiz..............

Puerto ds Pichidangui.-Punto en la parte Sur de la isla de este nombre: por dicho, latitud......................................... 32.27 Longitud al Este de Valparaíso $8^{\prime}$ 17". Será de Cádiz.................. 65.17.16

Punta de las Amolanas.-Malaspina, á corta distancia de la costa sitúa esta punta en latitud de.......................................... 31.00

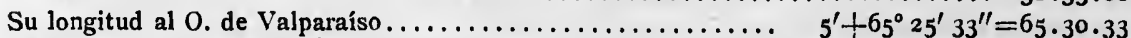
Idem al 0 . de Coquimbo......................... $24 \cdot+65 \cdot 5 \cdot 49=65 \cdot 33.49$

Promedio longitud de la punta, O. de Cádiz. $65 \cdot 32.11$

Punta de Lengua de Vaca.-A muy corta distancia de la costa se situó esta punta por

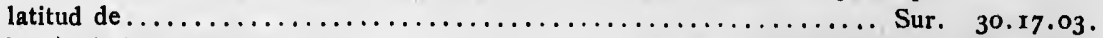
Su longitud al 0 . de Coquimbo................ $25^{\prime}+65^{\circ} 5^{\prime} 49^{\prime \prime}=65 \cdot 30.49$. Idem al 0. de Valparaíso. . . . . . . . . . . . . . . . . . $6 .+65 \cdot 25 \cdot 33 \cdot=65 \cdot 31 \cdot 33$.

Promedio es longitud de la punta, al 0 . de Cádiz......... $65 \cdot 31$. rr.

Ciudad de la Serena ó Coquinbo.-Por operaciones geodésicas desde el puerto de Co-

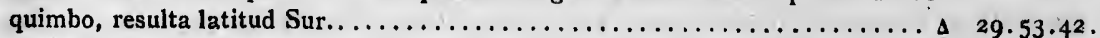

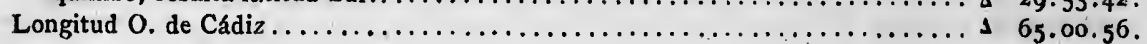


Monte de Fum Soldado ó del Cobre.-Desde Coquimbo se colocb este cerro por operaciones geodésicas como el anterior, resultando en latitud de.......... Sur. $\Delta 29.42 .30$.

Su longitud al Este del observatorio de Coquimbo $2^{\prime} 30^{\prime \prime}$. Longitud O. de Cádiz... A 65 3.19,6

Isla de Choros. - La más Norte. A distancia de dos millas sitúa Malaspina esta isla en latitud.......................................... 29.27.45.

Su longitud al $O$. de Coquimbo $16^{\prime}{ }^{\prime} 5^{\prime \prime}$. Será al 0 . de Cádiz.............. $65 \cdot 22 \cdot 34,6$

Islus de Pájaros.--La más Sur. A distancia de ménos de tres millas sitúa Malaspina lo más Sur de la isla meridional en latitud de...................... Sur. $29 \cdot 35.00$.

Su longitud al 0 . de Coquimbo oo' r $^{\prime \prime}$. Será longitud de Cádiz.............. 65.6. 4,6

Isla Chanaral ó Cañaveral.-Los Oficiales de la Marina Real, Isasviribil y Colmenares, situan esta isla en latitud de $29^{\circ} 2^{\prime}$ oo" Sur, y dicen que dista de la costa de dos á dos y media millas. Su extensión de Norte á Súr es de media legua y puede verse en días claros, á cinco leguas de dietancia.

Punta del Huasco.-Malaspina, á distancia de dos millas sitúa esta punta en latitud

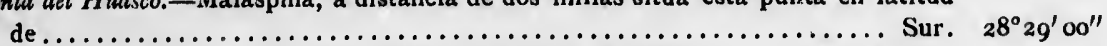
Su longitud al Este de Coquimbo $3^{\prime}$ será longitud $O$. de Cádiz ...... $\left.65 \cdot 2.49,6\right) 65 \cdot 5 \cdot 49,8$

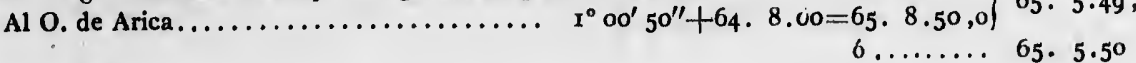

El Capitán Hall coloca la roca exterior de la punta, en latitud............. 28.27.00. Su longitud al Este de Valparaiso $2 \mathrm{r}^{\prime} 55^{\prime \prime}$, pero el punto que coloca

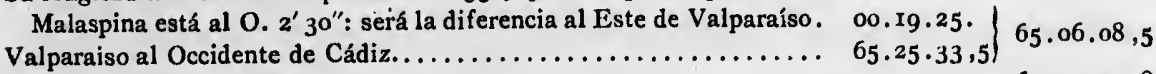

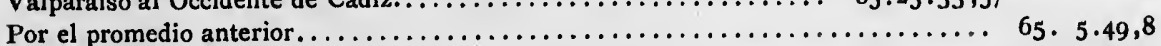

Longitud de la punta del Huasco, promedio.................... $65 \cdot 5 \cdot 59,0$

Morro de Copiapó.-Punta Oeste. Malaspina, como á distancia de cuatro millas, casi

en su paralelo, sitúa este Morro en latitud de................. Sur. 27. 9.00

La longitud al Este de Coquimbo, de............... I $2^{\prime}$ I $5^{\prime \prime}-65^{\circ} 5^{\prime} 49^{\prime \prime}, 6=64 \cdot 53 \cdot 34,6$ Al 0 . de Arica............................. $51.45+64.8 .00,0=64 \cdot 59 \cdot 45,0$

Promedio.................... (a)............. 64.56.39,8

El Capitán Hall, que fondeó en este puerto, coloca la punta que lo forma por la parte occidental llamado Puerto Inglés, en latitud.................. 27. rg.oo

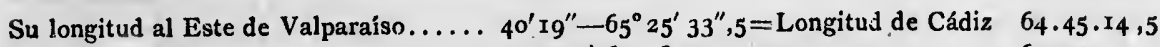
$Y$ al 0 . de Arica .................. $37.25+64.8 .00=64.45 .25$

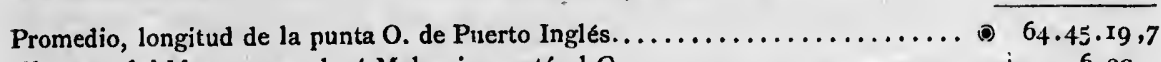
El punto del Morro que colocb Malaspina, está al $0 \ldots \ldots \ldots \ldots \ldots \ldots \ldots \ldots \ldots \ldots \ldots+6 . \ldots \ldots$

Longitud del Morro......................

No conforme con el resultado (a) de $64^{\circ} 5^{\prime} 39^{\prime \prime}, 8$, y mucho ménos con la latitud, cuya diferencia es de $1 \sigma^{\prime}$; de consiguiente, es muy probable que Malaspina desde la mar colocó un punto distinto del que se conoce por Morro de Copiapo, nada extraño respecto á que el práctico de la costa, que llevaba y embarcó en Valparaíso, se equivocaba á cada momento: por tanto, será la situación geográfica de Copiapó:

Punta O. del Puerto Ingless: latitud $27^{\circ} 19^{\prime}$. Longitud $O$. de Cádiz 64.45 . 20, pudiéndose deducir por el piano la situación del Morro. 
Morro de Megillones.-Malaspina, á distancia de cinco á seis millas, lo sitúa en la.

titud Sur....................................... 23. 5.00

Su longitud Este de Coquimbo.................. 56 $6.65 .5 .49,6=64 \cdot 9 \cdot 49,6$

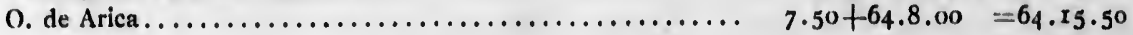

Promedio longitud del Morro 0 . de Cádiz............ 64.12.49,8

$$
6 \ldots \ldots .64 .12 \cdot 50
$$

Cobija.-Malaspina, á la distancia de 20 millas, sitúa este puerto en latitud.,.... 22.29.00 El Sr. Roberto Hunter................................. 22.30.00

Medio................................22.29.30

Malaspina, al Este de Arica.................. $12^{\prime} 30^{\prime \prime}-64^{\circ} 8^{\prime}=$ long. $63 \cdot 55 \cdot 30$

Idem al Este del Callao.................. 7.00.12-70.57,9= 63.56 .57

El Sr. Hunter idem. .................. $6.59 .20-70.57,9=$ " 63.57 .49

Promedio longitud de Cobija al 0 . de Cádiz........... 63.56 .45

Pabellón de Pica.-Monte en forma de tienda de campaña, situado sobre la costa y punto muy notable de ella: la larga distancia de 27 millas á que Malaspina pasó de este punto, hace algo dudosa su situación.

La latitud que le asigna este Oficial es de..................... Sur. $20^{\circ} 5^{8^{\prime}} 30^{\prime \prime}$

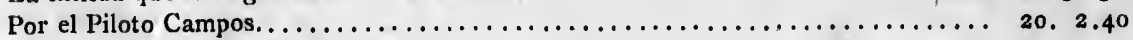

Por \{dem Bandini.$\ldots \ldots \ldots \ldots \ldots \ldots \ldots \ldots \ldots \ldots \ldots \ldots \ldots \ldots \ldots \ldots \ldots \ldots \ldots \ldots$ 21. 1.00

Promedio de las dos últimas: es latitud del Pabellón. . . . . . . 2I . I.50

La longitud, según Malaspina, es al Este de Arica ......... 12 $30^{\prime \prime}-64^{\circ} 8^{\prime} 00=063 \cdot 56.30$

Según una carta construida por el Teniente de fragata en

Lima, D. Andrés Baleato................... 5.20-64. 8.00 =64. 2.40

Mientras no se sepa bajo que datos form6 Baleato su carta, se adopta la longitud

para el pabellón de Pica, la hallada por Malaspina de............... 63.56 .30

Isla de Iquique.-Malaspina sitúa esta isla á larga distancia, pues pasó de ella I9 mi-

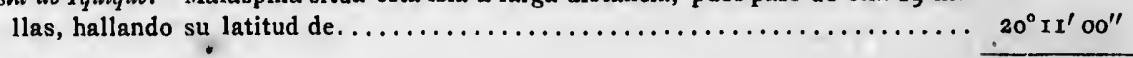

El Piloto Vila la sitúa en ................................. 20.13. 5

La longitud, según la carta de Malaspina, Este de Arica $2^{\prime} 00^{\prime \prime}$

Según el Piloto Vila, ídem............... 0.50 .

Promedio..............

Quebrada de Camarones.-Como el punto anterior, adolece éste de haterse colocado á larga dis. tancia, y según se verá en adelante debe haber alguna equivocación del práctico en la indicación de este punto.

Malaspina, á distancia de I $_{5}$ millas, sitúa la quebrada de Camarones en latitud Sur

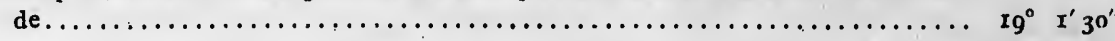

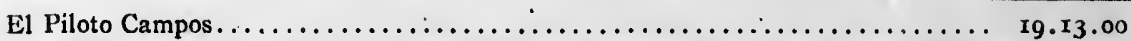

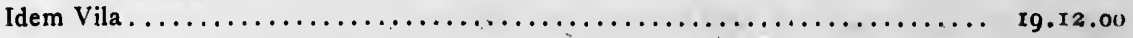

Promedio latitud de la Quebrada.................. Sur. I9.12.30

La longitud por Malaspina al Este de Arica............. I' $45^{\prime \prime}-64^{\circ} 8^{\prime} 00^{\prime \prime}=64.6$. I5 $_{5}$

Según Vila al O. de Arica.......................30

Por Campos ídem ...........................

Promedio................... (I) $2.27,5+64 \cdot 8.00=6410.27,5$ 
23. 5.00

$=64 \cdot 9 \cdot 49,6$

$=64 \cdot 15 \cdot 50$

$64.12 .49,8$

64.12 .50

22.29 .00

22.30 .00

$22.29 \cdot 30$

. $63.55 \cdot 30$

$63 \cdot 56 \cdot 57$

$63 \cdot 57 \cdot 49$

$63 \cdot 56.45$

y punto muy

hace algo du.

$20^{\circ} 5^{8^{\prime}} 30^{\prime \prime}$

20. 2.40

21. I.00

$21 \cdot 1 \cdot 50$

$063 \cdot 56 \cdot 30$

$=64 \cdot 2 \cdot 40$

$63 \cdot 56 \cdot 30$

$20^{\circ} I^{\prime} 00^{\prime \prime}$

$20 . x_{3} \cdot 5$

$64 \cdot 6 \cdot 35$

á larga dis indicación de

$\mathrm{Ig}^{\circ} \mathrm{I}^{\prime} 3 \mathrm{O}^{\prime \prime}$

19.13 .00

rg.12.00

$19.12 \cdot 30$

64.6 .15

$64 r 0.27,5$

Malaspina al liste del Callao.

(2) $6^{\circ} 48^{\prime} 35^{\prime \prime}-70^{\circ} 57^{\prime} 9^{\prime \prime}=64 \cdot 8 \cdot 34$

Promedio total es.......................... 64. 8.25.5

El promedio de las dos últimas................. (1) (2) $9=64,9 \cdot 30,7$

Es, pues, la situación de la quebrada de Camarones, latitud.............. 19.12.30

Longitud al 0 . de Cádiz..................... 64.9.31

Quebrada de Víctor.-Casi en su paralelo, y á distancia de siete millas, sitúa Malas-

pina esta quebrada, que el práctico llamb de Victor, en latitud de.......... I $8^{n} 43^{\prime} 30^{\prime \prime}$

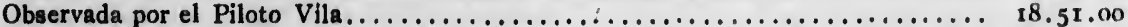

La longitud por Malaspina al liste del Callao...........6.6. $44.5 \rightarrow 70.57 .9=64.13 .4$ Al O. de Arica....................... $45+64.8 .0=6.4 .10 .45$

Promedio longitud de la Quebrada de Víctor........... $64.11 .54,5$

Morro de Fual Diaz. - Su latitud y longiţud resulta de marcaciones hechas desde el Morro de Arica y observaciones desde la mar: latitud ...................... $18^{\circ} 9^{\prime} 00^{\prime \prime}$ Longitud al O. de Arlca.. ................... r. $6^{\prime} \quad+64^{\circ} .8^{\prime} .00^{\prime \prime}=64^{\circ} 24^{\prime} 00$ Carta de Baleato........................... $3.45+64.8 .00=64.21 .45$

Promedio longitud del Morro.................. 64.22.52

Mcrro de Sama. -Latitud según las observaciones de Malaspina............ T7.57.20 Según la carta de Baleato.................. 17.58.00

Promedio será latitud. ..................... Sur 17.57.40 Longitud al 0 . de Arica.................... 35 $00^{\prime \prime}+64^{\circ} 8^{\prime} 00^{\prime \prime}=64.43 .00$ Al Este del Callao.........................6. 1r.50 $-70.57 .9=64.45 .19$

Promedio longitud del Morro de Sama............... 64.44. 9,5

Punta de Coles.-Por las operaciones yr icticadas á distancia muy corta desde la mar, y proximos al paralelo de esta punta, Malaspina la sitúa latitud $17^{\circ} 42^{\prime} 00^{\prime \prime}$, igual á la que le asignan el Capitán Hall y Baleato.

Según Malaspina, su longitud al 0 . de Arica................. $0^{\circ} 56^{\prime} 0^{\prime \prime}=65^{\circ} \cdot 4^{\prime} 00^{\prime \prime}$ Al Este del Callao................................ 5.50.50 $=65.6 .19$

Por el Capitán Hall, Este de Valparaiso................... Ir.25 =65.14.8

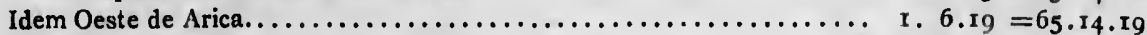

Idem Este del Callao. ............................ $5.46 .35=65.10 .58$

$5 \cdot 42 \cdot 37=65 \cdot 14 \cdot 3^{2}$

El promedio de todas estas seis longitudes será igual á $65^{\circ} 10^{\prime} 42^{\prime \prime}, 7$, muy conforme con la que resulta de $65^{\circ} 10^{\prime} 5^{\prime \prime}$, adoptando la longitud del Callao astronómica del Capitán Hall, $77^{\circ} 6^{\prime}$ I $0^{\prime \prime}$ 0 . de Greenwich, y la diferencia cronometrica con punta de Coles $5^{\circ} 46^{\prime} 35^{\prime \prime}$ : por lo tanto, fijamos á Punta de Coles en longitud 0 . de Cádiz, $65^{\circ} 10^{\prime} 43^{\prime \prime}$ y latitud $17^{\circ} 42^{\prime}$ Sur.

Punta de Islay ó Ilay. - Sin duda hay tambien una equivocación del práctico que tenía Malaspina, pues las diferencias de los resultados con el Capitán Hall son muy notables, como se vé á con. tinuacion:

Según la carta de Malaspina, se halla esta punta en latitud............... $16^{\circ} 43^{\prime} 00^{\prime \prime}$

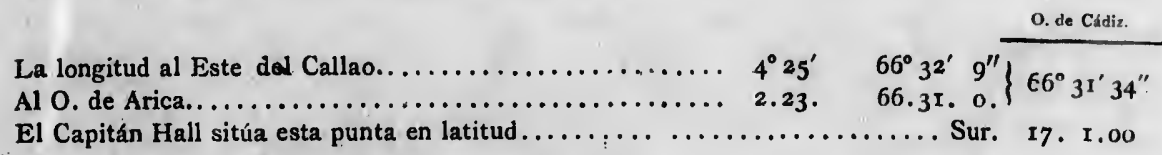

El Capitán Hall sitúa esta punta en latitud.................... Sur. 17. 1.00 
La longitud al 0 , de Valparalso.

$29.15+65.25 \cdot 3 .=65 \cdot 54 \cdot 4^{\prime \prime}$

Idem al de Arica............................ 1.46.59+64. 8.00. $=65.54 .59$

Idem al Este del Callan..................... 5. $1.57+70.57 \cdot 9 \cdot=65.55 .12$

Idem fidem.......................... 5. 5.55 idem. $=65.51 .14$

Baleato en su carta 10 , de Arica.................. $x .44 .30+64.8 .=65.52 .30$

Promedio será longitud de la Punta de Islay.

$65 \cdot 53 \cdot 44,6$

Es evidente que lo que colocó Malaspina por Putia de Islay, es.cuo punto de la costa, y que debe colocarse por aquella latitud y longitud.

Quilca-Caleta.-Los buques de Malaspina pasaron á nueve millas de la costa, que señalb el práctico estar la caleta de Quilca, la que se situó por operaciones practicadas desde á bor do, re. sultando:

Latitud.................................. $16^{\circ} 24^{\prime} 00^{\prime \prime}$

Su longitud al Este del Callao....................... $3^{\circ} 49^{\prime} 20^{\prime \prime}=67^{\circ} 7^{\prime} 49^{\prime \prime}$ Al O. de Arica.............................. 2.57.30. $=67 \cdot 5 \cdot 30$.

Promedio

El Capitan Maclean sitúa lo que ilama Seal

Pinck. Latitud.................... $16^{\circ} 44^{\prime} 50^{\prime \prime}$ y $72^{\circ} 21^{\prime} \times 5^{\prime \prime}$ O. G. ${ }^{h} \ldots \ldots .=66^{\circ}$ o $40^{\prime \prime}$ El Capitán Hunter id............... r6.43.00. 72.20 id. $010 \ldots \ldots=66.2 .45$ Apuntes del Piloto del bergantín peruano.. $16.40 .00 \ldots \ldots \ldots \ldots \ldots \ldots \ldots \ldots=66.7 .00$ Los Pilotos y Capitanes Vila, Bandini.... r6.4r.00. Carta de Baleato........ $=66.8 .00$ Colmenares, Isasviribil............ 16.41.20. O. de Arica $2^{\circ} 9^{\prime} \ldots \ldots \ldots=66.17 .00$ Mr. Lartigues sitúa esta caleta en....... 16.4r.ro.

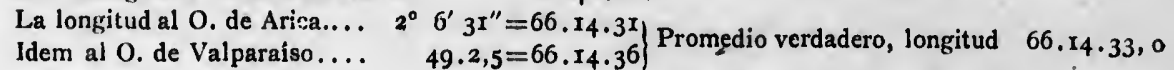

Latitud.

16.41.10.

Es también claro que Malaspina situó otro punto que creyó (p̣or mal informado) era la caleta de Quilca.

Morro de Acari.-A distancia de siete millas de este Morro y tres y media de la costa lo situ6 Malaspina en latitud Sur.................................... $15^{\circ} 2 v 00^{\prime \prime}$

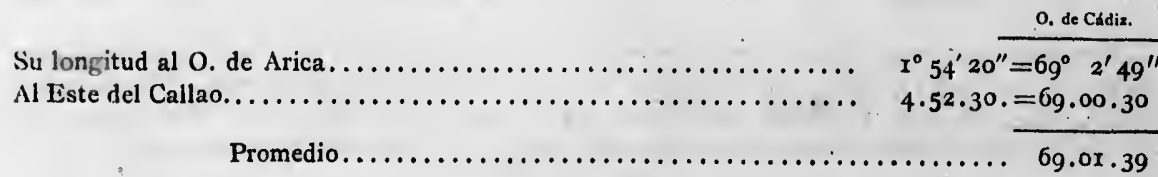

Así como en otros puntos de la costa, puede haber muchas dudas, por poco conocimiento del $\mathrm{Pi}$. loto práctico, el cual díb este nombre á muchos morros 6 montes, que se presentaban á la vista, por cuyo motivo hubo en Lima, una junta de Pilotos prácticos de la costa, y habiendoles presentado las vistas de la costa y de otros morros, decidieron ser el Morio de Acari el que se determina aquí.

Morro de la Nasca.-A distancia de seis millas se situo este morro 6 punto más sa-

liente al Sudoeste en latitud de. .

Su longitud al $O$. de Arica........ $5^{\circ} 9^{\prime} \cdot 30^{\prime \prime}=69 \cdot 19 \cdot 49$.

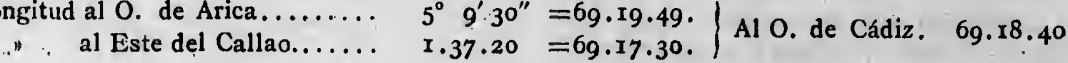


Fi: Capitán Hall sitúa también este punto ó proximo a el, con el nombre de Nasca 6

Punta de Cabarads, en latitud Sur de......................... $14^{\circ} 5^{8} 53^{\prime}$ $\begin{aligned} \text { La longitud al O. de Arica......... } & 5.10 .41=69.88 .41 . \\ \text { Este del Callao...... } & 1.40 .14=60.16 .55 .\end{aligned}$

Se ve, pues, lo conforme que se hallan las longitudes ca Malaspina y Capitán Hall; pero lo mu. cho que discrepan en la latitud. La situación del primero fué hecha por bases desde la mar y en el intermedio de un dia al otro; de consiguiente, cuando se observaron las latitudes, se estaba muy distantes del Morro, y no es extraño, á pesar que se corregian las bases por las latitudes y longi. tudes observadas, que resultase esta diferencia, aunque la considero demasiado crecida; por tanto, y considerando que el Capitán Hall haria su observación en circunstancias más favorables.

Situamos al Morro de la Nasca 6 Punta Caballas, en latitud de.............. 1 $4^{\circ} 5^{8^{\prime}} 53^{\prime \prime}$ Su longitud el promedio de ambas al 0 . de Cádiz................... 69.18.14

Mesa de Doila Maria.-A distancia de 15 milla se situb este cerro notable, que sirve de punto de recalada para la navegación á Lima, en latitud. . . . . . . . . . . 14.42.45 Su longitud al Este del Callao....................... $\mathbf{r}^{\circ} \mathbf{2 3}^{\prime} \mathbf{5 0}^{\prime \prime}$ O. de Arica ........................ 5.23.00.

Resulta longitud 0. de Cádiz............................. 69.32. 9

Islotes Infiernillos. - La situación de Malaspina, según la Carta (en lo que puede haber

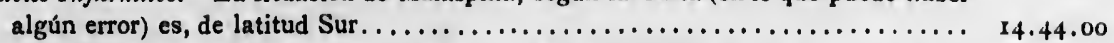 Su langitud al 0 . de Arice $5^{\circ} 30^{\circ}=60.38 .00^{\prime \prime}$
Este del Callao..
5.30
I. 17 $\left.\begin{array}{l}=6.38 .00 \\ =69.40 .9\end{array}\right\}$
Promedio O. de Cádiz. $69.39 \quad 4$

El Capitán Hall determina la latitud de cstos islotes en................. I4.42. 5 Su longitud al O. de Arica.... $5^{\circ} 3^{\prime}$ I $^{\prime \prime}=69.39 .17 . \mid$ Medio O. de Cádiz ... 69.38.24

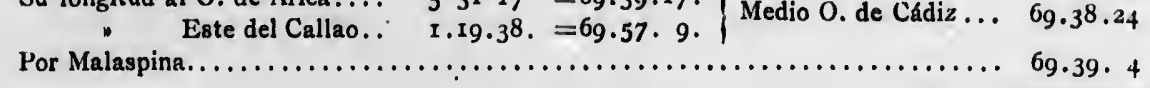

Promedio longitud de los Infiernillos, 0 . de Cádiz......... 69.38.44 Latitud: el promedio de ambas ...................

Monte de las Mercedes. - A este monte dió nombre Malaspina, situándolo á la distancia de diez nillus por latitud de $14^{\circ} 3 \mathrm{r}^{\prime} 00^{\prime \prime}$ fuera de su paralelo.

Su longitud al O. de Arica.... $5^{\circ} 36^{\prime} 30^{\prime \prime}=69 \cdot 44 \cdot 30$.

$$
\text { Este del Callao... r.11.00. }=69.46 .9 .
$$
$\begin{aligned} \text { Su longitud al } 0 . \text { de Arica.... } & 5^{\circ} 50^{\prime} 32^{\prime \prime}=69.58 \cdot 32 . \\ \text { Este del Callao... } & \text { I.00.23. }=69.56 .3^{6} .\end{aligned}$ Medio...........

El mismo Capitáı Hall, en su tabla de posiciones dice, que este monte está al Occidente Greenwich $7^{\circ} 3^{\prime} 4^{\prime \prime}-6^{\circ} 17^{\prime} 15^{\prime \prime}=(b) 69^{\circ} 46^{\prime} 33^{\prime \prime}$. Longitud que está muy conforrne con la que halla Malaspina; quizás el Capitán Hall sitú algunos de los cerros inmediatos, por lo que resulta esta diferencia: mientras que otros datos nos sacan de esta duda, determinamos la posición geográfica del Monte de las Mercedes, promedio de ambas, latitud. ............. Sur. I $4^{\circ} 33^{\prime} 14^{\prime \prime}$ Longitud igualmente promedio de $(a)$ y $(b) \ldots \ldots \ldots \ldots \ldots \ldots \ldots \ldots \ldots \ldots \ldots \ldots .4 \ldots \ldots .56 \ldots$

Los Amigos.-Montes situados al Norte de una punta con islotes, distancia de cuatro millas.

Malaspina sitúa uno de estos montes en latitud. . Su longitud al 0 , de Arica. $55^{\circ} 4 I^{\prime} 00^{\prime \prime}-69.49 .00$. Este del Callao ........... I, 5.00. $=69.52 .9$.

El Capitán Hall da el nombre de los Amigos á las rocas que hemos dicho estar al Sur de los montes que Malaspina llama Amigos: 
La latitud de Hall es de................................ I $4^{\circ} 20^{\prime} \mathrm{Oo}^{\prime \prime}$ Estando los montes al Norte 4 millas, resultaría para estos. 14.16.00. Diferencia
Malaspina los sitúa en........... 14.23.00. demasiado considerable.

La longitud del Capitán Hall es al 0 . de Greenwich $76^{\circ} 7^{\prime} \mathrm{I} 6^{\prime \prime} .=0$. de Cádiz $69^{\circ} 50^{\prime} \mathrm{I}^{\prime \prime}$ muy 'onforme con la longitud que establece Malaspina: no sucede así determinando esta longitud por las diferencias con Arica y Callao, que en los puntos anteriores ha habido tanta conformidad.

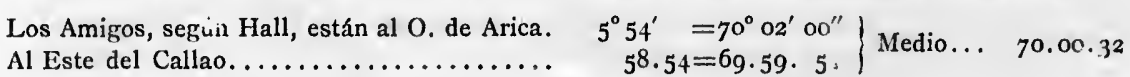

En vista de estas anomalías, parece que los Amigos (montes) deben situarse según los establece Malaspina.

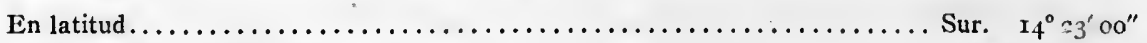
Longitud al $\mathrm{O}$. de Cádiz.......................... $66_{3.50 .34}$

Isla de Sangallan.-Punta Sur, estando pióximo á si paralelo, sitúa Malaspina este

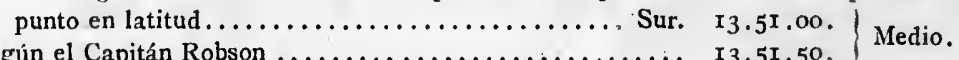

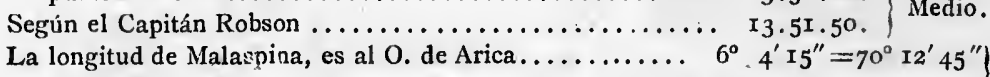

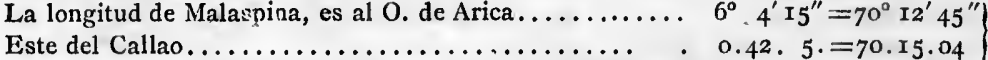
Según la carta del Capitán Robson al Este del Callao............ $42.20 \quad 70.14 .49$ Promedio longitud de la Punta Sur de Sangallan: O. de Cádiz......

Islas de Chincha.-La más Norte á distancia de ra millas: se situb́ este islote por Ma-

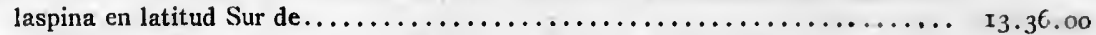

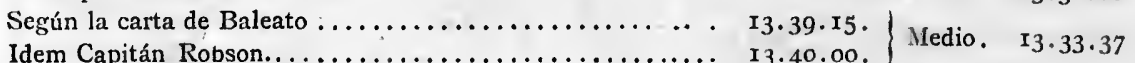
Longitud al O. de Arica......... $6^{\circ} I^{\prime} 45^{\prime \prime}=70.9 \cdot 45$.
Este del Callao...............

Morro Lechuza.-A muy corta distancia situó Malaspina la cúspide de este morro en

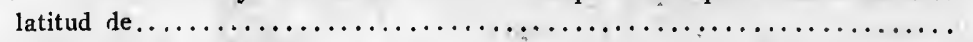
. o. de Arica................... $6^{\circ} 4.00=70.12 .00 .9$ Promedio. 70.12.54 Este Morro además se halla ai Este de lo más Sur de la Isla de Sanga.

llan, por operaciones geodésicas desde el mar...... I. . 5 . $\{$ Longitud. 70.13.06 El extremo Sur de la isla se situó en ............ $70 . x_{4} .2 x$.

Promedio será longitud del Morro Lechuza, O. de Cádiz...... 70.13.00

Valle de Tambo.-El Capitán Hall sitúa este valle en latitud de............ Sur. I7. I3.00

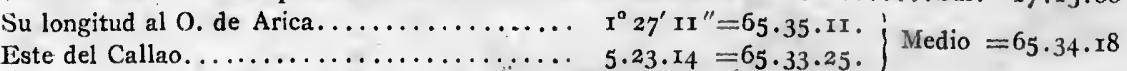

Mollendo: p:teblo.-_Por el Capitán Hall está este pueblo en latitud........... Sur I7. 2.15

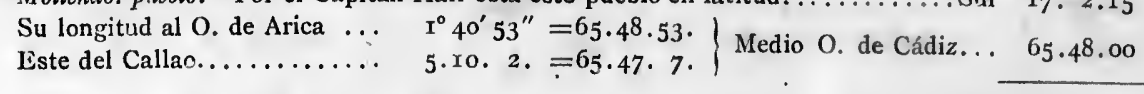

Valle de Camana.-Según Colmenares é Isasviribil, es su latitud.......... Sur $16 \cdot 37 \cdot 30$

Punta do Chilca.-Malaspina, á muy corta distancia de la costa, sitúa esta punta en

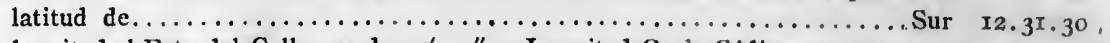
La longitud al Este del Callao es de $45^{\prime} 5^{\prime \prime}=$ Longitud O. de Cádiz.......... 70. 12.04 
$\ldots \ldots 14^{\circ} 20^{\prime} 00^{\prime \prime}$

Esta longitud puede rectificarse por las marcacione hechas desde tierra, en las operaciones practicadas en Lima y Pachacamac, que no se pueden verificar por no tener presentes estos docu. mentos.

Isla de Fuan Fernindez, de tierra.-Malaspina se dirigib desde Talcahuano á situar estas islas, y desde ellas volvíb sobre la costa al puerto de Valparaíso; por tanto, tenemos estos dos puntos y el de Chiloé, con cuyas diferencias cronométricas pueden situarse con toda precisión.

Estando á muy corta distancia del estremo occidental, se situó este puerto en latitud. $33^{\circ} 45^{\prime}$ La longitud al $\mathrm{O}$. de Talcahuano.......... $5^{\circ} 5 \mathrm{I}^{\prime} 00^{\prime \prime}+66^{\circ} 53^{\prime} 5^{\prime \prime}=\mathrm{O}$. de Cadiz $72^{\circ} 44^{\prime} 50^{\prime \prime}$ " al de Valparaíso............ $7.19 .00 .+65.25 \cdot 33 .=$ " $72.44 \cdot 33$

$" \quad$ al de Chiloé.............. 5.11.14. $+67.31 .51=" 72.43 .5$

Promedio longitud del extremo 0. de la isla $=0$. de Cádiz....... O72.44.9

La conformidad de estas longitudes no deja duda sobre la buena situación de esta isla, y al mismo tiempo, de estarlo entre sí, Chiloe, Talcahueno y Valparaíso. Sin embargo, manifestaremos á continuación las situaciones que han dado varios navegantes á esta isla, para que en adelante pueda rectificarse, no obstante que por lo dicho parece no debe quedarnos ningún género de duda.

El Capitán Pipón sitúa el fondeadero en latitud Sur de ................. $33^{\circ} 3^{8^{\prime}} \mathrm{r}^{\prime \prime}$ Su longitud al O. de Greenwich.......... $78^{\circ} 49^{\prime} 00^{\prime \prime}-6.17 \cdot 15=0$. de Cádiz. $7^{2} \cdot 3^{1} \cdot 45$

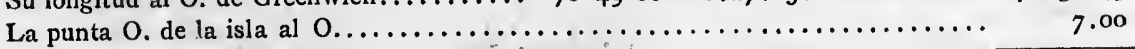

Longitud del extremo 0. de la isla ................ $7^{2.3^{8.45}}$ y estando el extreino O. de la isla al Sur dẹl fondeadero, próximamente $4^{\prime}$, será la-

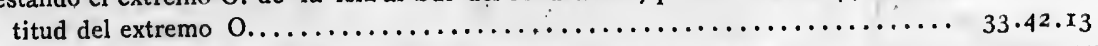

El Oficial de la Marina Real de España, D. Antonio Martínez, halla la latitud de lo

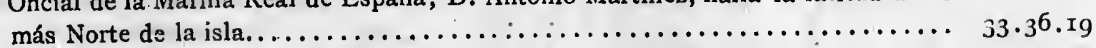
Idem D. Eugenio Cortés la misma punta...................... 33.37.00

Promedio latitud de lo más Norte de la isla ............. $33 \cdot 3^{6.40}$ La punta O. al Sur próximamente............................ 7 .

Latitud de la punta 0. de la isla................. 33.43 .40

Martínez, por cronómetro y distancias lunares, la punta Sueste, 0 . de Cádiz....... 72.47 .27 Cortés, por cronómetro, sin referirse á punto de la costa.............. $72.49 \cdot 30$

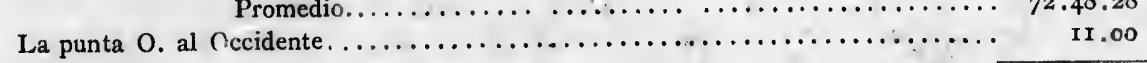

Longitud de la punta $\mathrm{O}$ por Martínez y Cortés................... 72.59 .28 Resumiendo estas longitudes, tendremos:

Por Malaspina. . . . . . . . . . . . . . . . . . . . . . . . . . . . . $72.44 \cdot 9,0$

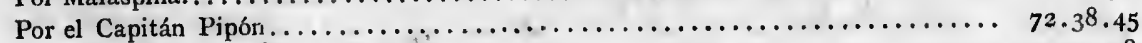
Por Martínez y Cortés.................................. 72.59 .28

El promedio será longitud de la punta de $0 \ldots \ldots \ldots \ldots \ldots \ldots, 72.47 .27$ Pero en vista de lo expuesto, fijamos la latitud del extremo $O$. de la isla, en lati.

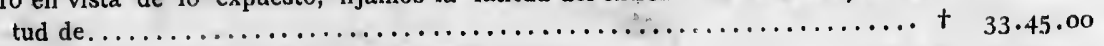
Longitud al Occidente de Cádiz................. $72.44 \cdot 9$

Isla de $m$ is afuera. - A la distancia de 28 millas de la isla y á su parte oriental, se siinó el centrc por Málaspina en latitud Sur........................ $33^{\circ} 45^{\prime} \mathrm{oo}^{\prime \prime}$ Por el Capíán y Piloto Mestre, en su paralelo á distancia de cuatro leguas..... 33.45. 7 Por el Capitán Carteret, fondeado en ella........................ 33.45. o

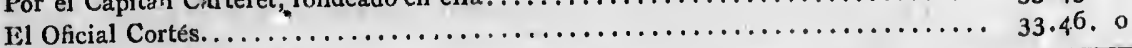
Promedio latitud del centro de la isla $\ldots \ldots \ldots \ldots \ldots \ldots \ldots \ldots \ldots \ldots \ldots, 45 \cdot 16,7$ 
Malaspina determinó la longitud por una base desde la mar, en malas circunstancias, y dedujo longitud al 0 . del extremo occidental de la Isla de tierra....... In $34=74.18$. 9

Según el Capitán y Piloto Vila por crónómetro.................. . ${ }^{\circ} 5^{6: \cdots 74.40 .9} 9$

El Oficial de la Armada D. Antonio Martínez la sitúa en................ 74.36.35

Idem D. Eugenio Cortés.............................. 74.44.00

Desechando la primera por lo dicho, será el promedio de las tres, Longitud de la Isla 74.40 .14

Latitud Sur............................. 33.45.16,7

Isla te San Ambrosio. - La más oriental de las de San Félix.

Maluspina, partiendo de las inmediaciones del Morro de Copiapó para la situación de estas islas, verificó la del extremo O. de la de San Ambrosio por latitud..... Sur 26.20.00

Su longitud al 0 . del Morro de Copiaṕ............... $8^{\circ} 40^{\prime}+5^{\prime \prime}+64^{\circ} 5^{\prime} 40^{\prime \prime}=73^{\circ} 36^{\prime} 55^{\prime \prime}$, al O. del Callao..................... 2.44.40 $+70.57 .9=73.4^{\mathrm{I} .49}$ al O. de Coquimbo................. 8.28.00 +ó5. $5.49=73.33 .49$

Promedio longitud del extremo O. de la Isla de San Ambrosio ... 73.37.3x Pero se ha dicho qui el Capitán. Hall coloca la puntaO. del Puerto In.

glés en Copiapó, en longitud de.................... 64.45. 19,7

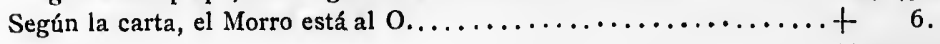

Longitud del Morro.......................... $\overline{64.51 .19,7}$

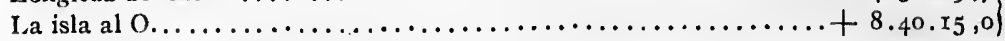

$73 \cdot 3^{\mathrm{I}} \cdot 35$

D:ferencia................................

Por tanto el promedio de ambas longitudes $73^{\circ} 37^{\prime} 3 \mathrm{r}^{\prime \prime}$ y $73^{\circ} 3 \mathrm{x}^{\prime} 35^{\prime \prime}$ será igual á longitud del extremo O. de la isla de San Ambrosio.

Islotes Hormigas.-Malaspina dispuso la salida de un falucho con un Oficial de su expedición, para que desde el Callao situase estas islas: los movimientos violentos del falucho hacen aigo du dosa la situación de ellas.

El resultado fué: Latitud de la Hormiga chica.

Idem de lá Hormiga mayor..............

Diario de Malaspina.--Hormiga mayor......

El Piloto Vila dice que el farallón Sur, 6 el

may'or, está en....................

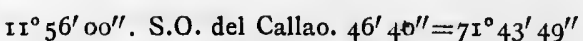
II.56.20. idem $\quad 4^{6}$. Io. $=71.43 .19$

Ir.54.40. ídem $34.00 .=71.3 \mathrm{I} .9$

Ir.55.48. ídem : $36.50 .=71.33 \cdot 59$

Posición que adoptamos, mayormente, cuando en el Diario de Malaspina se leen estas expresio. nes: "Salieron en el falucho el Teniente Don Manuel Novales con el Guardia Marina Alí-Ponzoni para reconocer y situar los Islotes Hormigas, lo que no pudo verificarse á satisfacción, y sí con duda, á causa de viento extraordinariamente fresco del Sur, el cual, engruesando mucho la mar, ni les permití permanecer fondeado entre aquellos pedruscos, ni đejó de exponerles á mucho riesgo el pode: alcanzar nuevamente el puerto del Callao." Sin embargo, cuando los buques de la expedición salieron del Callao, se dirigieron á rectificar esta posición, y según el Diario de Malaspina, la posición geográfica del islote mayor de las Hormigas; es de:

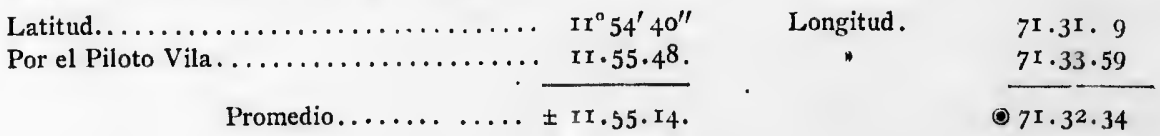


RESULTADOS de las situaciones geográficas de que trata esta Memoria.

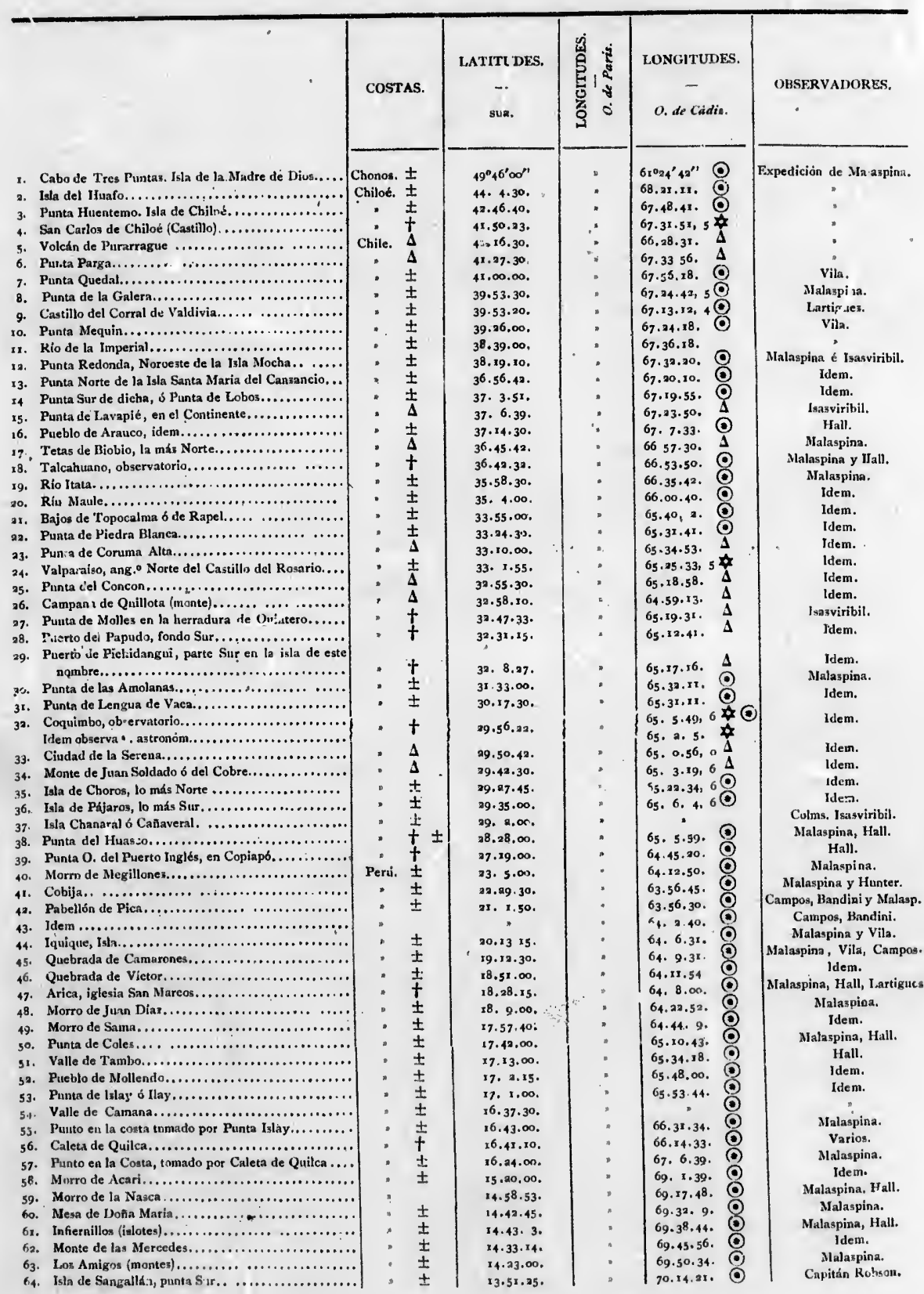

$=71^{\circ} 43^{\prime} 49^{\prime \prime}$

$=71 \cdot 43 \cdot 19$

$=71.31 .9$

$=7 \mathrm{r} \cdot 33 \cdot 59$

stas expresio. aa Alí-Ponzoni y sí con duda, nar, ni les perriesgo el pode: spedición salie-

1a, la posición

$71 \cdot 31 \cdot 9$

$7^{1} \cdot 33 \cdot 59$

$71 \cdot 32 \cdot 34$ $\because 74.40 .9$

74.44 .00

$33 \cdot 45,16,7$

$73 \cdot 31 \cdot 35$

su expedicion, acen aigo du-

\section{$=73.4 \mathrm{I} .49$}

$73 \cdot 37 \cdot 3 x$

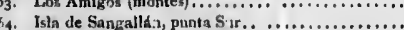


65. Islas de Chincha, la más Norte....

66. Morro de Lechuza (cüspide)

67. Punta del Chilca...

68. Callan, Castill

69. Izla de Juan Fernández de Tierra, parte occidental.

7o. Isla de más afuera, centro....................

72. Islas de San Félix, lo más Oriental de la de San Am-

brosis.................................

73. Islotes Hormigas, el mayor

74. Panamá, Catedral.

75. Cartagena, baluarte Santa Catalina

76. Puerto Belo, Castillo San Jerónimo

77. Chagres, Castillo...........

78. San José de Californias.......

79. Cabo de San Lucas, en 1539 se llamó Santiago.....

80. San Blas de Californias, contad.......

81. Acapulco, Castillo San Diego........

.

\begin{tabular}{|c|c|c|c|c|}
\hline COSTAS. & $\begin{array}{c}\text { LATIDUDES. } \\
- \\
\text { sUr. }\end{array}$ & 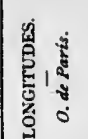 & $\begin{array}{c}\text { LONGTYUDES. } \\
\text { - } \\
\text { o, de Cádis. }\end{array}$ & OBSERVADORES. \\
\hline 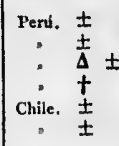 & $\begin{array}{l}\times 3^{0} 39^{\prime} 37^{\prime \prime} \\
23 \cdot 53 \cdot 30 . \\
22.31 \cdot 30 . \\
12,3 \cdot 3 r . \\
33 \cdot 45 \cdot 00 . \\
33 \cdot 45 \cdot 17 .\end{array}$ & : & 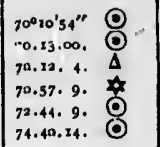 & \begin{tabular}{|} 
Baleato y Capitán Robson. \\
Malaspina. \\
Idem. \\
Humboldt y otros. \\
Malaspina. \\
Vila, Martinez, Cortés.
\end{tabular} \\
\hline 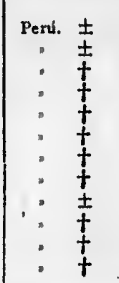 & $\begin{array}{l}26.20 .00 . \\
1 \times .55 .14 . \\
2.1 \times .56 . \\
8.57 .16,5 \text { Norte. } \\
x 0.26 .9,5 \\
9.34 .29,5 \\
23.323 . \text { Norte. } \\
22.52 .30 . \\
21.32 .35 . \\
16.50 .40 . \\
12.29 .50 .\end{array}$ & $\begin{array}{c}\vdots \\
\vdots \\
\vdots \\
\vdots 122^{\circ} 00^{\prime} 37^{\prime \prime} \\
\vdots \\
\vdots\end{array}$ & 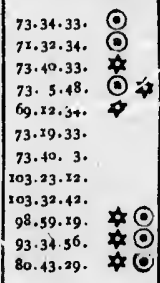 & $\begin{array}{c}\text { Malaspina. } \\
\text { Malaspina y Vila. } \\
\text { Malaspina y Humboldt. } \\
\text { Malaspina. } \\
\text { Humboldt, Fidalgo y otrox } \\
\text { Fidalgo. } \\
\text { Idea.. } \\
\text { Chape, Doz y otros. } \\
\text { Malaspina. } \\
\text { Malaspina, Hall. } \\
\text { Idem. } \\
\text { Malaspina. }\end{array}$ \\
\hline
\end{tabular}




\section{OBSERVACIONES de la velocidad del sonido, de latitud, longitud y variaciones hechas en Santiago de Chile, por el Teniente de navio D. Fosé Espinosa y el Alférez de navio graduado D. Felipe Bauzh.}

De la velocidal del sonido.

Ha manifistado la experiencia, que el sonido nace del movimiento de vibración. que ocasiona en el aire el temblor de las partes insensibles de un cuerpo sonoro, las cuales, puestas en accí́n por el choque de otro cuetpo, hacen viturar en todas direcciones las partículas del fluído que lo rodea. Ya sea fuerte el sonido, ya sea débil, corre espacios iguales en tiempos iguales, de modo que el sonido que se extiende, por ejemplo, á una legua, tarda en andarla lo que tardaría en hacer la primera legua ú otra cualquiera de ellas, el sonido que anduviese mayor número, $y$ así es que el estrépito del cañón, aunque 11 'ga más lejos que el del fusil, por ser mayor la masa de aire á que comunica, no va más veloz, si no tarda más tiempo á proporción de la mayor distancia que alcanza. Como las pequeñas variaciones que en esto se advierten proceden de la imperfección de las experiencias mismas y de varias circunstancias de tiempo y de lugar, fundándose en los ho. chos anteriores, puede decirse que la propagación del sonido nace de la acción de un resorte isócrono, asímismo en todas sus vibraciones, que las hace de la misma duración, mientras conserva la misma elasticidad, aunque esté impelido con diversos grados te fuerza. Aplicando estos principios al aire, considerado como el medio que nos transmite los sonidos, y reflexionardo las vicisitudes que sufre de contínuo su der sidad y su resorte, se echa de ver que la propagación del sonido debe variar por aquellas causas, como va. ría la co.sstitución de la atmósfera en que se produce; pero cuáles scan los límites de esta variación, ś́lo pueden decirlo las experiencias. Por eso las han practicado en todos tiempos, sujetos celosos de los progresos de la Física general, y nosotros, animados del propio espíritu, hemos hecho las siguientes en el llano de Maiṕ en el Reino de Chile, donde no se habían practicado hasta ahora. Consultándolas, se verá que la ley con que se propaga el sonido no es una misma en todos los climas; que varía bastante de unos á otros para que pueda servir de fundamento en ningún caso á las operaciones geográficas exactas, y que áun para emplearla con utilidad en los usos ordinarios de la navegación, convendrá repetir todavía algunas experiencias en varios ? gares, y hacer un análisis reflexivo de las que lay, para todo lo que tenemos muchos materia. 1:s preparados que ordenaremos con gusto si la stperioridad aprobase este trabajo.

\section{Experiencia de la velocidad del sonido.}

Toda la observación se funda en el principio siguiente. Cuando se ve la explosión de un arma de fuego á alguna distancia, percibe la vista la luz de la pólvora inflamada mucho tiempo antes que se oiga el sonido, y como la luz se propaga con tanta rapide $z$ que no tarda dos segundos en ve. nir de la Luna á la Tierra, puede decirse que la vista la percibe en el mismo momento que sale del cuerpo sonoro, en vez de que el estrépito producido al propio tiempo por éste, emplea en llegar al órgano del oído un tiempo sensible y deter. minado. L uego midiendo con precisión este tiempo y la distancia del observador al sitio donde se produce el sonido, se sabrá la velocidad actual de éste: para la medida de éste nos valimos de dos buenos relojes de segundos, ajustados al movimicnto medio por observaciones del Sol, y comparados frecuentemente á dos péndulos de medios segundos que construímos, y usamos ya uno ya otro de estos instrumentos en las experiencias, para que fuesen más independientes los resultados. Con esta mira, las repetimos en va. rias direcciones y á diversas distancias desde dos hasta ocho millas, trasladándonos á los puntos $C, D, E, F$, cuy as posiciones hallamos respecto al punto $B$ del modo siguiente: En el paraje que llaman el Conventillo se midió la base $A B$, de 2.900 piés de París. Sobre un terreno perfectamente horizontal que ofrece el llano de Majpó por est? parte, se había alineado de antemano la distancia por medio de jalones verticales colocados de ro en ro toesas, enfilándolos unos por otros y con dos perchas perpendiculares que servlan de señales en los extremos $A$ y $B$ de la base 
en dichos puntos, de ro en ro toesas se clavaron estaquillas de un pié, y puestas sus cabezas á cuatro pulgadas de altura, se hizo firme á la primera un cordel, pasándole bien tirante de unas en otras, y así quedó determinada una línea pa. ralela á la del terreno; para medirla nos servivos de tres perchas de á tres pulgadas de grueso y nueve piés de largo cada una: la operación era facilisima, pues bastaha poner las perchas sobre el terreno cuidando de ajustar sus aristas al cordel con el auxilin de pequeñas cuñas, $y$ adelantar siempre la percha más inmediata al principio de la cuenta, poniéndola con precaución para evitar todo retroceso en las fijas. Con estas atenciones se midió por dos vecesla base en sentidos opuestos, y sólo hubo seis pulgadas de diferencia. Para tomar los ángulos, empleamos un buen teodolito y aunque nos aseguramos de su exactitud, midiendo el contorno del horizonte subdividido en varios ángulos, cuya suma fué siempre igual á cuatro rectos, no se excusó la observación del tercer ángulo en todos los triángulos en que lo permitió el terreno. La figura manifiesta la situación ventajosa de la base medida y de las distancias que por ella se concluyeron, y han dado á coriocer con todo el rigor de la Geometria las de

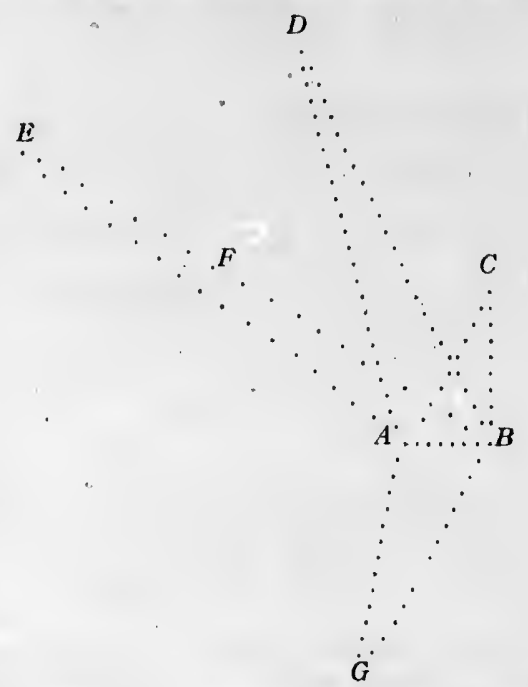

los puntos $C, D, E, F$ del llano al extremo $B$ de la base.

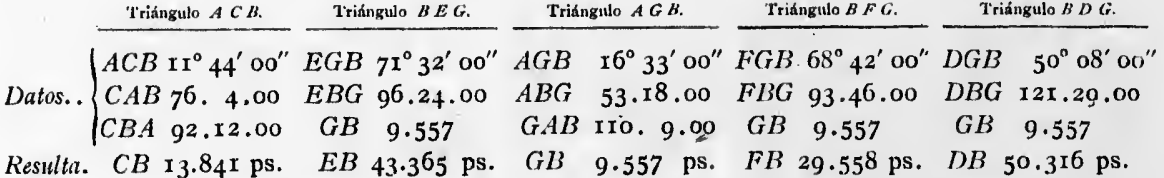

Concluídas las operaciones geométricas, se colocó en el punto $B$ un cañón de á ocho, y se dió principio á las operaciones en la forma sigujente:

Día 13 de Enero al anochecer: experiencia primera observada desde la Chácara de Cañas $E$, á $7^{\text {h }} 5^{0^{\prime}}$ de la tarde, cohete en el Conventillo, señal de preparación, contestado desde Cañas á $7^{\text {h }} 5^{2^{\prime}}$.

\begin{tabular}{ccc} 
Tiros en el Conventillo. & Se víb la luz desde Cañas. & Se oyó el estallido. \\
\hline á $8^{\text {h }} 00^{\prime} 00^{\prime \prime}$ & $8^{\text {h }} 00^{\prime} 00^{\prime \prime}$ & $8^{\text {h }} 00^{\prime} 3^{\prime \prime}$ \\
810.00 & 8 ro.00 & 8 ro. $3^{8}$ \\
820.00 & 820.00 & $820.3^{8}$
\end{tabular}

Viento Sudoeste, muy flojo, casi calma, atmósfera cargada. Barómetro, 25 pulgadas, glíneas. (Termómetro $\mathrm{r} 8^{\circ}, \mathrm{o}$.

Dia $1_{4}$ de madrugada; en el propio paraje $a^{\text {h }} 5^{0^{\prime}}$ de la madrugada, cohete de preparación en el Conventillo, contestado desde Cañas á $3^{\text {h }} 5^{2^{\prime}}$.

\begin{tabular}{|c|c|c|c|}
\hline Tiros en ol Conventillo. & Se víb la luz deade Cañas. & Se oyó el estallido. & \\
\hline á $4^{h} O O^{\prime} O 0^{\prime \prime}$ & $4^{h} 00^{\prime} 00^{\prime \prime}$ & $4^{\text {h }} 00^{\prime} 3^{8^{\prime \prime}}$ & ( En calma: alguna calima. \\
\hline 410.00 & 410.00 & $4 \mathrm{ro.} 3^{8}$ & Barómetro, 25 pulgadas.-Ter- \\
\hline 420.00 & 420.00 & $420 \cdot 3^{8}$ & mómetro, $16^{\circ}, 0$ \\
\hline
\end{tabular}

Desde Cañas demora el cañón situado en el Conventillo, Norte $69^{n} \mathrm{O}$. del muudo. 
Dia 14 de Enero al anochecer, experiencia segunda observada desde la Chácara del Peral $D$.

\begin{tabular}{|c|c|c|}
\hline \multicolumn{2}{|c|}{ Tiros en al Conventillo. } & Se viś la lux en el Peral. \\
\hline$a$ & $7^{h} 30^{\prime} 00^{\prime \prime}$ & $7^{h} 30^{\prime} 00^{\prime \prime}$ \\
\hline & 40.00 & 40.00 \\
\hline & $50.00=$ & 50.00 \\
\hline & 8.00 .00 & 8.00 .00 \\
\hline & 10.00 & 10.00 \\
\hline & 20.00 & 20.00 \\
\hline
\end{tabular}

\begin{tabular}{c} 
Se oyó el estallido. \\
\hline $7^{h} 30^{\prime} 43^{\prime \prime}$ \\
40.43 \\
50.43 \\
$8.00 .43^{\prime} /$ \\
No se oyb. \\
8.20 .43
\end{tabular}

8.20 .43
Viento Sudoeste fr'esquito en el Conventillo; en el Peral algunas bocanadas de Norte.-Barómetro 25 pulgadas, 9 lineas. - Termóme. tro $23^{\circ}, 0$.

Día ${ }_{5}$ de madrugada en el propio sitio.

\begin{tabular}{c} 
Tiros en el Conventillo. \\
\hline a $\quad 4^{\text {h }} 00^{\prime} 00^{\prime \prime}$ \\
$4 \cdot 10.00$ \\
$4 \cdot 20.00$ \\
$4 \cdot 30.00$ \\
$4 \cdot 50.00$
\end{tabular}

\begin{tabular}{l} 
Se viú la luz en el Peral. \\
\hline $4^{\text {h }} 00^{\prime} 00^{\prime \prime}$ \\
4.10 .00 \\
4.20 .00 \\
$4 \cdot 30.00$ \\
$4 \cdot 50.00$
\end{tabular}

\begin{tabular}{l} 
Se oyo el estallido. \\
\hline $4^{\text {h } 00^{\prime} 43^{\prime} \%}$ \\
4.10 .43 \\
$4.20 .43 \%$ \\
$4.30 .43 \%$ \\
$4.50 .43 \%$
\end{tabular}

En calma, alguna calima.-Barómetro 25 pulgadas, 9 líneas. - Termómetro $20^{\circ}, 0$.

Tiesde el Peral demora el cañón del Conventillo, Norte $44^{\circ} \mathrm{O}$.

Día 16 del mismo, al anochecer; experiencia tercera, observada desde la Chácara de Macul $F$ á las $7^{\text {h }} 5^{\circ}$ de la tarde. Cohete señal de preparación en el Conventillo, contestado desde Macul á $7^{\text {h }} 5^{2}$.

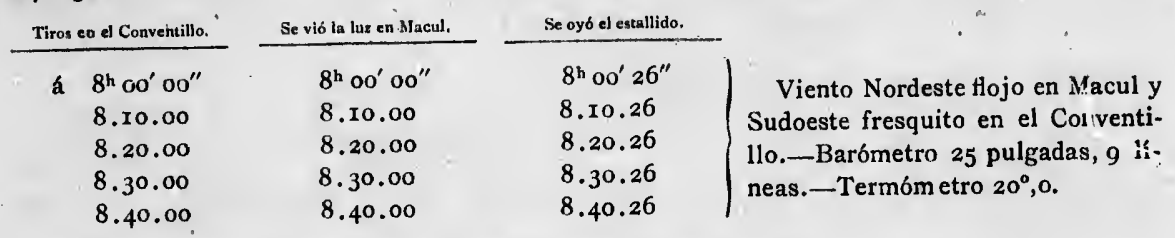

Desde Macul demora el Conventillo, al Norte $72^{\circ} \mathrm{O}$. del mundo.

Día I 7 del mismo al anochecer; experiencia cuarta; observada desde el punto $C$ del llano: á las $7^{\mathrm{h}} 20^{\prime}$ de la tarde. Cohete de preparación contestado á $7^{\mathrm{h}} 22^{\prime}$.

\begin{tabular}{|c|c|c|c|c|}
\hline \multicolumn{2}{|c|}{ Tiros en el Conventillo. } & Se vio la luz en $C$. & Se oyó el estallido, & \multirow{5}{*}{$\begin{array}{l}\text { Viento Sudoeste fresquito: tiemfo } \\
\text { claro:-Barómetro, } 25 \text { pulgadas, } \\
9 \text { líneas.-Termómetro, I } 8^{\circ}, 0 .\end{array}$} \\
\hline á & $7^{h} 3^{\prime} 00^{\prime \prime}$ & $7^{\mathrm{h}} 30^{\prime} 00^{\prime \prime}$ & $7^{\mathrm{h}} 3^{0^{\prime}}+2^{\prime \prime}$ & \\
\hline & $7 \cdot 35.00$ & $7 \cdot 35.00$ & $7 \cdot 35 \cdot \times 2$ & \\
\hline & $7.4^{0.00}$ & $7 \cdot 40.00$ & $7 \cdot 40.12$ & \\
\hline & 7.45 .00 & $7 \cdot 45 \cdot 00$ & $7 \cdot 45 \cdot 12$ & \\
\hline & $7 \cdot 50.00$ & $7 \cdot 50.00$ & $7 \cdot 50.12$ & \\
\hline
\end{tabular}

Desde el punto $C$ demora el Conventillo, al Norte $20^{\circ}$ ก. del mundo.

Todas las experiencias que anteceden son de entera confianza, y examinándolas con cuiclado, se vé que en la determinación del tiempo cabe cuando más medio segundo de error, que repartido en el número de las hechas en cada lugar, es un error despreciable.

El viento sólo pudo tener algún influjo en la cuarta experiencia, retardando el sonido media toesa por segundo: en las experiencias restantes, 6 no hubo viento, 6 fué exactamente transversal y siempre flojo: de suerte, que repartiendo el número de toesas que distan cada uno de los puntos $C, D, E, F$, del punto $B$ por el número de segundos que tardó el sonido desde el cañón al observador, se hallan las velocidades siguientes: 


\section{Algunas observaciones astronómicas hechas en Santıago de Chile desde Enero a Marzo de I794, por Bauzá.}

Observación de latitud, dia II de Marzo.

\begin{tabular}{|c|c|c|}
\hline \multirow[b]{2}{*}{$a^{\prime} \mathrm{II}^{\mathrm{h}} 53^{\prime} 35^{\prime \prime} \ldots \ldots \ldots \ldots \ldots \ldots \ldots \ldots$} & & Altura meridiana. \\
\hline & $59^{\circ} 4 \mathrm{I}^{\prime} 45^{\prime \prime}+2^{\prime} 7^{\prime \prime}$ & $59^{\circ} 43^{\prime} 52^{\prime \prime}$ \\
\hline 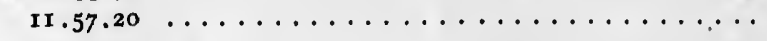 & $43.20+22$ & $43 \cdot 42$ \\
\hline$\ldots \ldots \ldots \ldots \ldots \ldots \ldots \ldots$ & $43.30+00$ & $43 \cdot 30$ \\
\hline $\begin{array}{l}\text { Altura meridiana muy exacta. } \ldots \ldots \ldots \ldots \ldots \ldots \ldots \ldots \ldots \ldots \ldots \ldots \ldots \ldots \ldots \ldots \ldots \ldots \ldots \ldots \ldots \ldots \ldots \ldots \\
\text { Sem. }{ }^{0}+p^{e}-r^{n} \ldots \ldots \ldots \ldots\end{array}$ & $\ldots \ldots \ldots$ & $\begin{array}{r}59 \cdot 43 \cdot 4 \mathrm{I} \\
+\mathrm{I} 5 \cdot 3^{8}\end{array}$ \\
\hline Las observaciones del año r $79^{\circ}$ determinan la latitud de. & & 33.26 .00 \\
\hline Altura meridiana $0 . \ldots \ldots \ldots$ & & $59 \cdot 59 \cdot 19$ \\
\hline 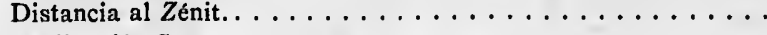 & . & $30.00 .4 \mathrm{I}$ \\
\hline Declinacion Sur. $\ldots \ldots \ldots \ldots \ldots \ldots \ldots \ldots \ldots \ldots$ & & 3.25 .24 \\
\hline atitud Sur & & 33.26 .05 \\
\hline
\end{tabular}

\section{Observaciones de longitud.}

A $14^{\text {h }} 53^{\prime}$ del 29 de Enero cuenta astronómica en Santiago de Chile inmersibn total del primer satélite de Júpiter: la atmósfera estaba clara; se distinguían las bandas del planeta, buena obser. vación, comparándola con el cálculo, da longitud de Santiago 0 . de Greenwich $7 \mathrm{I}^{\circ} \mathbf{r}^{\prime}$. Se observó con un anteojo de nueve ps. de largo, propio de D. Manuel Cotapos.

A $7^{\mathrm{h}} 20^{\prime} 53^{\prime \prime}$ de la tarde del 20 de Febrero, hora verdadera en Santiago, fin del eclipse de Luna, observado con el anteojo dicho: la atm6sfera estaba clara, observación de confianza, resul ta longitud de Santiago O. de Greenwich $70^{\circ} 55^{\prime} 00^{\prime \prime}$.

Las observaciones del año r $79^{\circ}$ determinaron la longitud de $70^{\circ} 56^{\prime} \mathrm{oo}^{\prime \prime} .:$

\section{Observaciones del termómetro.}

No se puefe llamar riguroso el calor del verano en Santiago, pues raras veces se ve á $24^{\circ}$ el ter. mómetro de Reaumur, y esto al medio día, en aquellos en que no hay virazón, y nunca permanece más de tres minutos cortos en este estado. Los ascensos y descensos del termómetro han sido diariamente este verano como sigue: al salir el Sol, en 16 ó $18^{\circ}$; en $20^{\circ}$, á las $10^{h}$; á medio día, en $22^{\circ}$ y $24^{\circ}$ á la siesta, faltando la virazón, que sucede pocas veces; por la tarde y noche, 20, r 8 y I $6^{\circ}$ y aún ${ }^{\circ} 4^{\circ}$ á la media noche: á la madrugada vuelve á subir, continuando la misma marcha.

\section{Obscrvaciones del barómetro.}

Es tan constante el estado de la atmósfera de este país, que casi no se hacen sensibles en el barometro, sus variaciones, de suerte que dentro de un tercio de línea ha estado en 25 pulgadas desde Diciembre hasta Marzo. Es cierto que en estos meses no han pasado de cuatro los días nublados, ni ha caído una gota de agua, ni soplado un viento recio. La excesiva sequedad sirve de algún contra- 
peso á estas ventajas del temperamento: comparando dicha altura del barómetro con la que tiene el nivel del mar, $y$ valiéndonos de las formulas de Mr. Bouguer, hemos hallado la elevación del suelo de Santiago de $954 \%$ varas castellanas sobre el nivel del mar.

Observación de la variación de la aguja.

Repetidas veces hemos observado azimutes magnéticos con el teodolito, y ha resultado de $14^{\circ} 28^{\prime}$ la variación Nordeste, promedio de muchas observaciones que no se apartan medio grado entre si.

Observaciones del barometro, de latitud, longitud y varacion de la aguja, hechas desde Santiago de Chile a Mendoza y BuenosAires, en Marzo y Abril de 1794.

Observaciones del barómetro y determinación de la allura de varios puntos del camino principal de la cordillera de los Andes.

\begin{tabular}{|c|c|c|c|c|c|c|c|c|}
\hline \multirow[b]{2}{*}{$\begin{array}{c}\text { Nombres } \\
\text { de lon lugares de las observaciones. }\end{array}$} & \multicolumn{2}{|c|}{$\begin{array}{l}\text { Altura del mercurio en } \\
\text { el barométso. }\end{array}$} & \multirow{2}{*}{$\begin{array}{l}\text { Termómetro. } \\
\text { Fnrh. Rmer. }\end{array}$} & \multirow{2}{*}{\multicolumn{2}{|c|}{$\begin{array}{l}\text { Elevación ó depresión } \\
\text { de los lugares entre si, en piés } \\
\text { ingleses. }\end{array}$}} & \multicolumn{3}{|c|}{ Eleviciones subre el mar. } \\
\hline & Pulg. ing. & Pulg. franc & & & & $\begin{array}{c}\text { Pits de } \\
\text { Inglnterra. }\end{array}$ & $\begin{array}{l}\text { Pits de } \\
\text { Costilla. }\end{array}$ & $\begin{array}{l}\text { Torsus } \\
\text { de Francia }\end{array}$ \\
\hline \multicolumn{9}{|l|}{ Valparaíso al nivel del } \\
\hline $\operatorname{mar} \ldots \ldots \ldots$ & 30,00 & $28, x_{4}$ & $62, x_{4}$ & Elevacion & 0000 & 00000 & 00000 & 0000,0 \\
\hline Santiago de Chile... & 273 & 2575 & $72 \mathrm{I} 8$ & Id. & 2620 & 02620 & 02864 & 0409,7 \\
\hline Casa de las Calab." . . . & 2064 & I9 40 & 6I I3 & Id. & 7984 & 10604 & II $59^{\circ}$ & $1658, I$ \\
\hline Casa de la Cumbre.. & I9 3 & I7 83 & 456 & Id. & $2 I 35$ & 12739 & I3892 & I987,4 \\
\hline Casa de las Cuevas .. & $20 \times 6$ & 1892 & 54 गо & Depresion & $\mathrm{I}_{5} \mathrm{I}_{4} \%$ & 11225 & $1224 \mathrm{I}$ & 1747,2 \\
\hline Casa de los Puquios. . . & $2 \times 45$ & 20 I0 & $57 \mathrm{II}$ & Id. & 17 to $\%$ & 09514 & ro399 & $x_{4} 87,7$ \\
\hline Mendoza . . . . . . . & $269 \mathrm{I}$ & 2525 & $68 \times 6$ & Id. & $5039 \%$ & 04475 & 04891 & 0699,7 \\
\hline
\end{tabular}

Nota. Aunque estas observaciones no sean de una exactitud incontestable, merecen confianza por el cuidado y esmero con que las hicimos con un buen barómetro de tubo capilar, en cuyo uso, así como en el cálculo de las observaciones, nos hemos guiado por las reglas y advertencias de los observadores más exactos.

Observaciones de latitudes, longitudes y variación.

á $24^{\circ}$ el tera permanece an sido dia. edio día, en 1e, $20,18 y$ marcha.

Jles en el bagadas desde nublados, ni lgún contra-

$\begin{array}{r}\text { Altura meridiana. } \\ \hline \begin{array}{r}59^{\circ} 43^{\prime} 5^{\prime \prime} \\ 43.4^{2} \\ 43.3^{\prime}\end{array} \\ \hline \begin{array}{r}59.43 .4 \mathrm{I} \\ +\quad 15.3^{8}\end{array} \\ \hline \begin{array}{r}33.26 .00 \\ 59.59 .19 \\ 30.00 .4 \mathrm{I} \\ 3.25 .24\end{array} \\ \hline 33.26 .05 \\ \hline\end{array}$

pse de Luna, ulta longitud

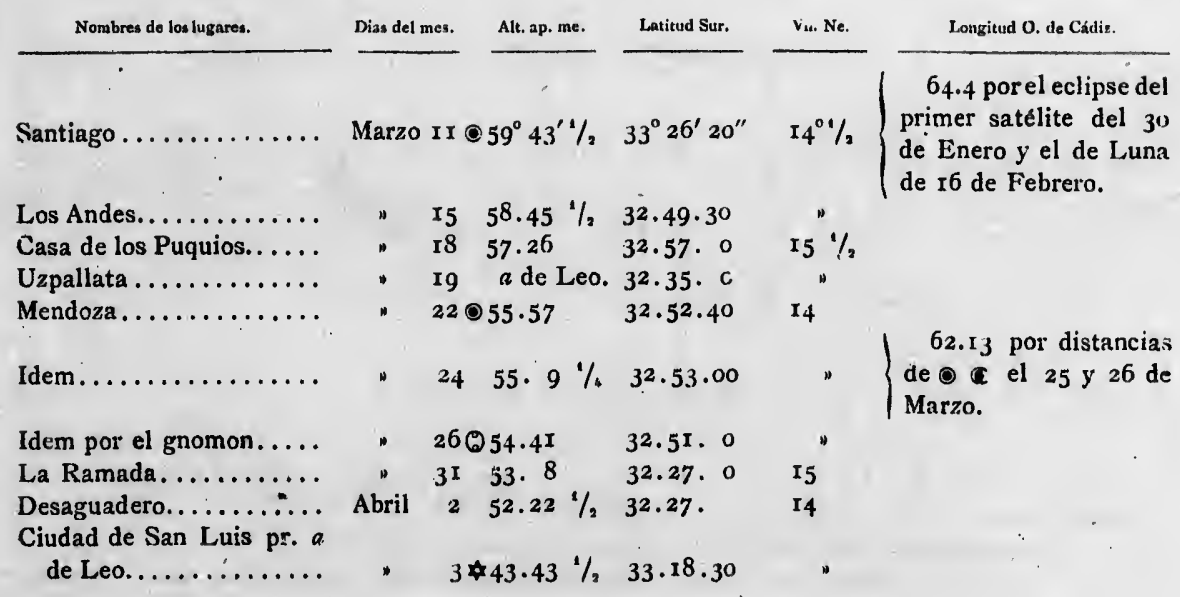




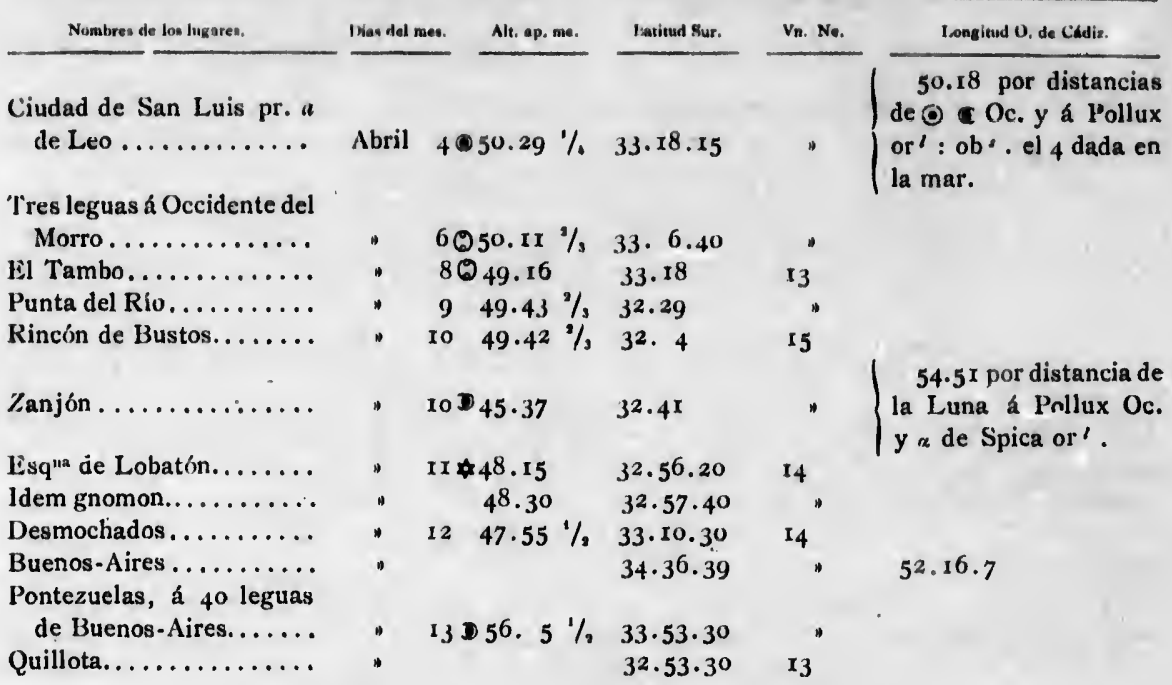

Nota. Las alturas meridianas referidas al centro con esta señal $Q$, se observaron con un gno. mon de seis pulgadas de alto que construimos en Mendoza, porque necesitábamos, corriendo en posta, de un instrumento de uso más expedito que el sextante y suficientemente exacto, como manifiestan las observaciones hechas en muchos parajes con los dos instrumentos.

El tiempo hermoso, la precisión de ver amanecer y correr todavía algunas horas después de puesto el Sol, en que nos ponía la diligencia del viaje, las llanuras interminables de las Pampas y el deseo de sacar algún partido del tiempo, nos moví á observar muchas veces la duración del crepúsculo y á calcular la depresión del Sol cuando apuntaba 6 se confundía en el horizonte la luz crepuscular; daremos una de estas observaciones hecha el 7 de Abril en latitud de $33^{\circ}$ entre el Tambo y la Punta del Río.

A $5^{\text {h }} 36^{\prime} 30^{\prime \prime}$ de la tarde, hora verdadera, se ocultaron las luces últimas del o en el horizonte. A $7^{\text {h }} 4^{\prime}$ oo" de la noche, tiempo verdadero, se confundío con el horizonte la luz crepuscular, formada en arco.

$I^{\text {h }} 27^{\prime} 3^{\prime \prime}$ duración del crepúsculo, y calculando con este ángulo horario la latitud del lugar y la declinación del Sol, que era á la sazón $7^{\circ} 11^{\prime}$ Norte, la depresión del astro resulta de $17^{\circ} 18^{\prime}$. Otras observaciones han dado $17^{\circ} 30^{\prime}$ y $18^{\circ}$, de suerte, que confirman de nuevo estas observaciones, que el Sol dista del horizonte entre 17 y $18^{\circ}$ cuando empieza 6 finaliza el dia.

Alturas de varios montes de la tierra.

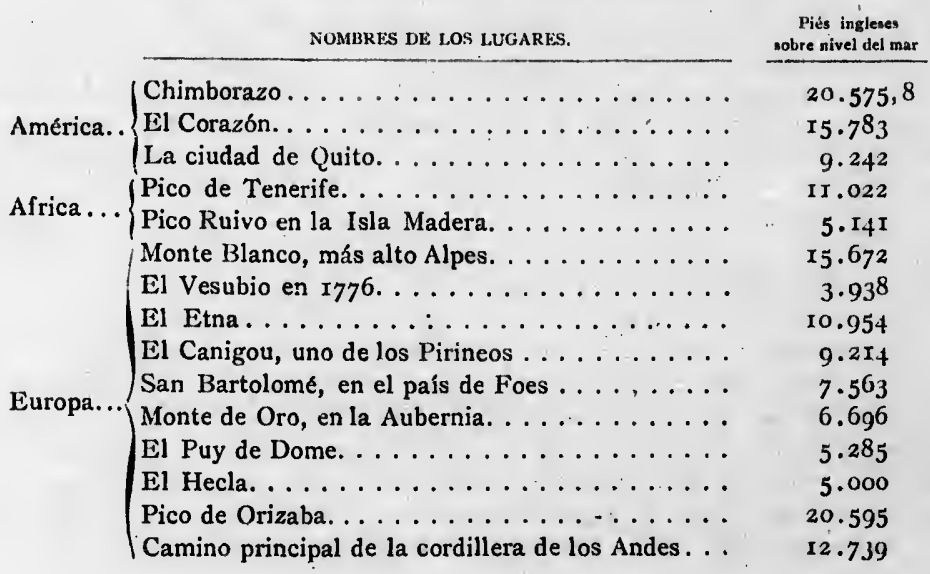


ESTADO donde se manifiesla la relacion de gravedades entre diversos lugares dil mundo, segün las experiencias hechas por las corbclas del Rey, Descunterta y ATREVIIA, formadi por el Tenicule de navio D. Ciriaso de Cevallos.

distancia de Pollux Oc. ica or'.

con un gnocorriendo en , como manis después de as Pampas y ción del crezonte la luz $33^{\circ}$ entre el el horizonte. crepuscular,

del lugar y de $17^{\circ} 18^{\prime}$. sservaciones,

HEMISTERIO ÁRTICO

\begin{tabular}{|c|c|c|c|c|}
\hline " Lugarea de observación. & Latioudes. & Longitudes de $\mathrm{Cad}$ & & Kaspresiones de gravedad. \\
\hline Mulgrave.............. & $59^{\circ} 33^{\prime} 10^{\prime \prime}$ & $133^{\circ} 44^{\prime} 42^{\prime \prime}$ & Oc. & 1004629,2 \\
\hline Nutka ............... & $49 \cdot 35 \cdot 13$ & I $20 \cdot 33 \cdot 42$ & & 1003014,2 \\
\hline Monte-Rey............ & $36.3^{6} .10$ & $1 \times 5 \cdot 50.20$ & & 1001505,9 \\
\hline Acapulco............. & $16.50 \cdot 32$ & $93 \cdot 50.15$ & & 1000532,9 \\
\hline Manila.............. & 14.36 .00 & 120.55 .00 & Or. & Paran los originales en España \\
\hline Ialas Ladrones. . . . . . . . . . & 13.18 .00 & 150.42 .27 & Or. & 1000027,7 \\
\hline Macao............. & 22.12 .00 & $113 \cdot 36.00$ & & Paran los originales en lispaña \\
\hline (Mindanao) Zamboanga.... & 06.55 .00 & $231 \cdot 44 \cdot 55$ & Oc. & I 1000000,0 \\
\hline
\end{tabular}

HEMISFERIO ANTARTICO

\begin{tabular}{|c|c|c|c|}
\hline Lugares de observeción. & Latirude w. & Longitudea de Cadix. & Viaprenimies de gravedad. \\
\hline Puerto Egmont. . . . . . . . . . & $51^{\circ} 2 I^{\prime} \circ 8^{\prime \prime}$ & $53^{\circ} 54^{\prime} 30^{\prime \prime}$ Oc. & $10032 \times 9,7$ \\
\hline Santa Elena. . . . . . . . . & $44 \cdot 29 \cdot 55$ & $59 \cdot 25 \cdot 3^{0}$ & 1002882,6 \\
\hline Talcahuano........... & 36.42 .18 & 67.02 .53 & 1001 895,2 \\
\hline Montevideo. . . . . . . . . . . & $34 \cdot 55.08$ & $5^{0} .00 .45$ & $\operatorname{coor} 889,4$ \\
\hline Puerto Jackson. . . . . . . . . . & $33 \cdot 51.28$ & $202.27 \cdot 30$ & Ioor 789,3 \\
\hline Vavao (Islas Amigos) ..... & $18 \cdot 3^{8} \cdot 45$ & $167 \cdot 49.18$ & 1000623,3 \\
\hline Magumena (en Lima)..... . & $12.04 \cdot 3^{8}$ & $70 \cdot 5^{2} \cdot 30$ & I 000119,2 \\
\hline
\end{tabular}

La incertidumbre en que estamos relativamente á la longitud del péndulo de observación, embaraza la deducción de los resultados absolutos, así como la comparación de nuestras experiencias con las hechas por otros filósofos en diversos lugares del mundo. Pe:o cualquiera que sea aquella longitud, como estas corbetas han repetido sus observaciones en ambos hemisferios, pueden deter. minarse las relaciones de la gravedad entre todos los puntos de observación. Tal es el objeto de la tabla anterior, cuya forma hemos tomado de $\mathrm{Mr}$. Maupertui en el estado general que hizo de toda: las experiencias del péndulo hechas hasta su tiempo. Este geómetra omite las fórmulas que le con dujeron á sus resultados, y que nosotros hemos suplido.

Se sabe que un cuerpo sumergido en un fluído pierde de su peso el peso del fluído que desplaza. Según este principio, la lenteja del péndulo, en virtud de cuyo peso se hacen las oscilaciones, debe perder una parte de este peso igual al peso del aire que ocupa. Si cl aire fuese un fluído igualmente denso en todas las regiones de la Tierta, no habria necesidad de ninguna corrección, porque produ. ciendo entonces disminuciones iguales, no había causa que alterase la relación entre las gravedades; pero como los pesos del aire son distintos en diversos lugares, y para un mismo lugar en distintas circunstancias, de aquí nace una corrección sin la cual confundiríamos muchas veces las disminuciones reales de la gravedad, con las causas que sólo son un estorbo de ejercerse. Nuestras expe rienciàs están todas reducidas á las $29 \%$ pulgadas del barómetro.

Según Neivton la gravedad se ejerce en razón inversa de los cuadrados de las distancias al centro. Nos hubiéramos salido de este principio para reducir las experiencias de una propia altura; pero no ha sido necesario, porque todas se han hecho al nivel del mar, con diferencia de cuatro á seis toesas, cantidad absolutamente despreciable. También se ha hecho atención á la correc ción que deben tener las oscilaciones, por la circunstancia de no ser cicloidares, etc.

Después de lo dicho, y mientras no se da la historia individual de estas experiencias, basta aña dir, que para hacerlas se han tenido presentes todos los principios fundamentales de tenria, y la conducta de los que nos han precedido en esta clase de observaciones. 


\section{ESTADOS DE DERROTA}

LSTADO de derrola correspondiente á los meses de Julio y Agoslv: manifiesta la posición de la corbeta Desccunerta en cada medio dia, los errores de la estima, vientos, fuerza, estado del mar y variaciones de la aguja.

Sallida de Cádiz para el Rio de la Plata.-1788.

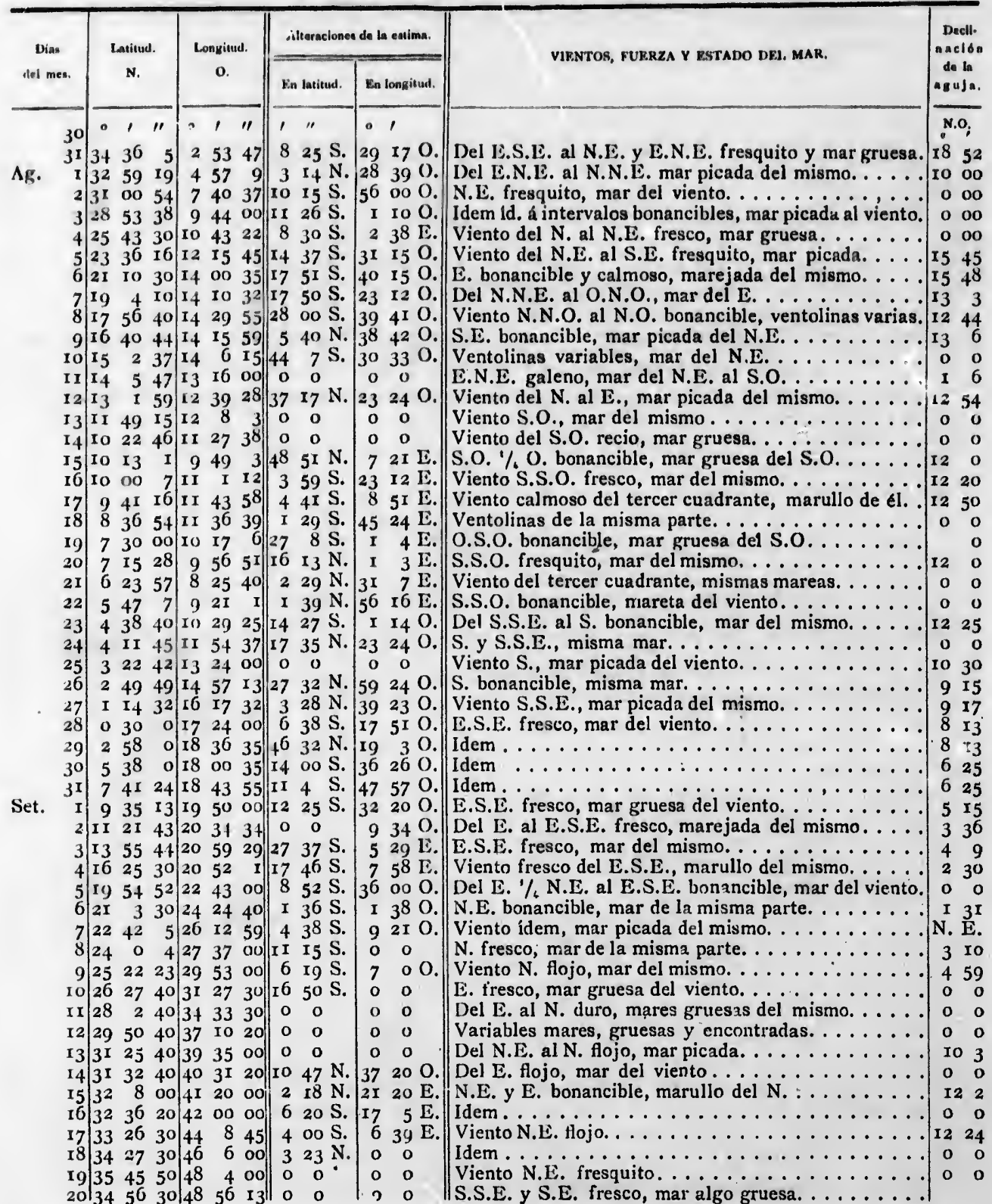


cibn de la corbeta ar $y$ variaciones

8allda del Rio de la Plata para ol Puerto Deseado. - Mee de Movlembro.-1789.

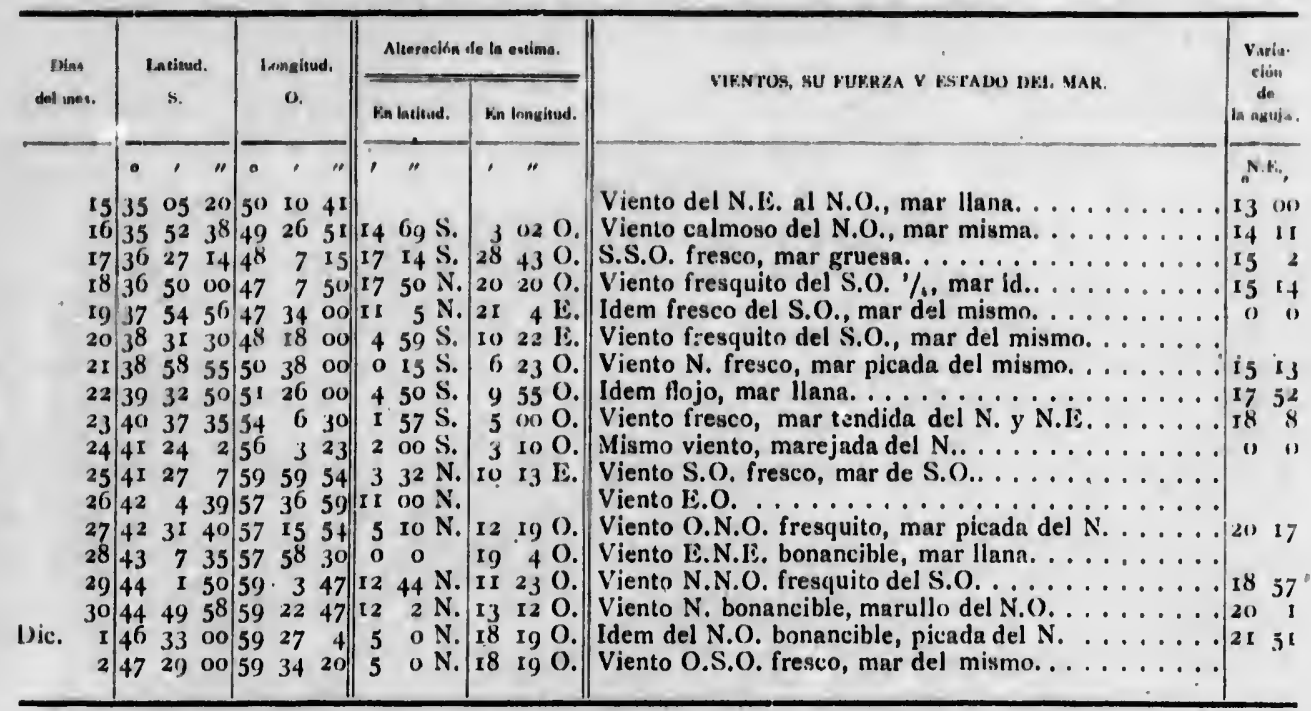

Salida del Puerto Deseado para ol de Egmont.-Mes de Diciembre.-- 1789.

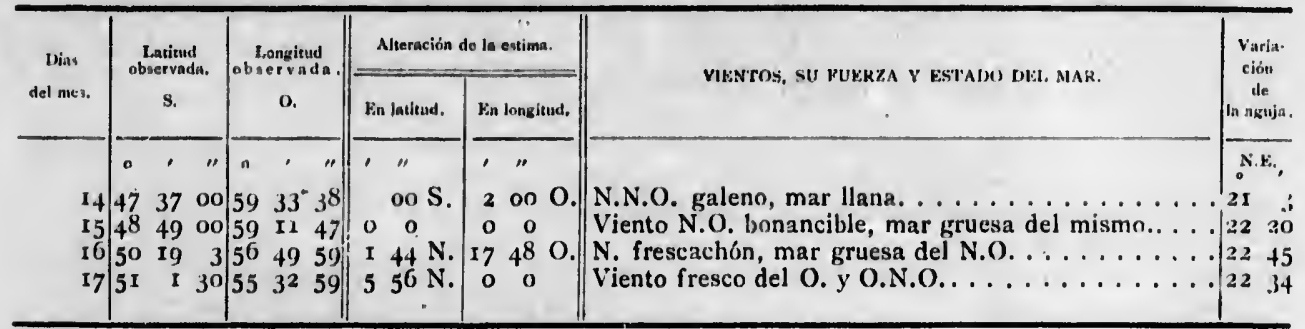

Sallda del Puerto de Egmont.-Diclembre.

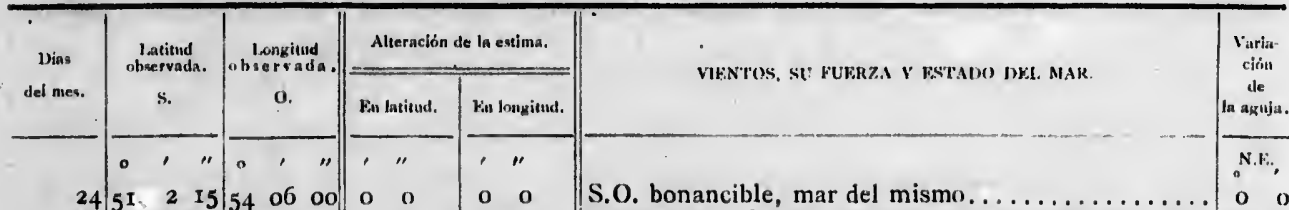

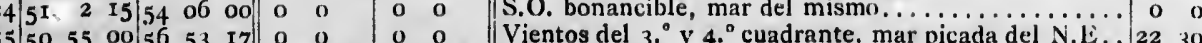

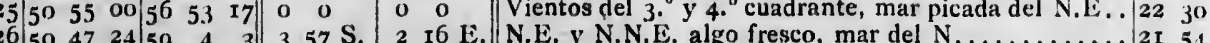

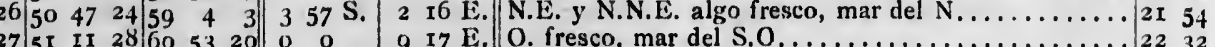

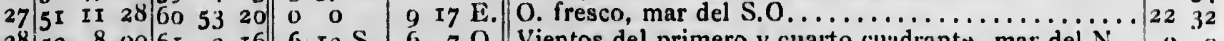

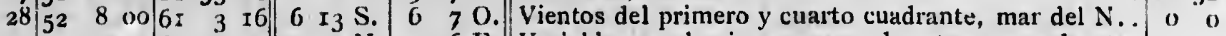

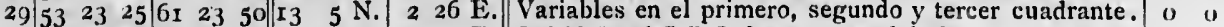

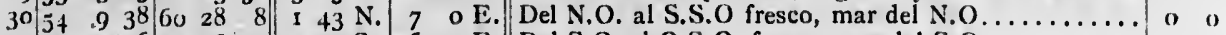

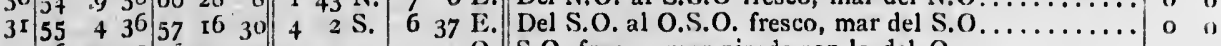

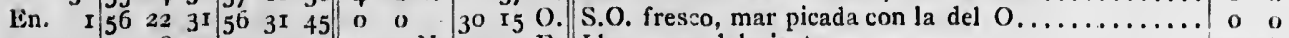

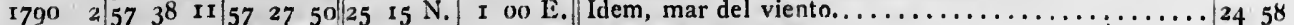

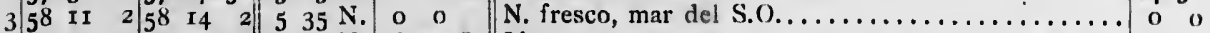

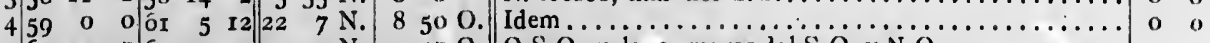

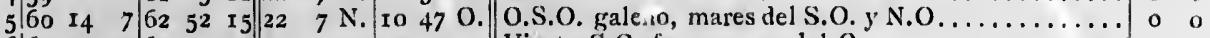

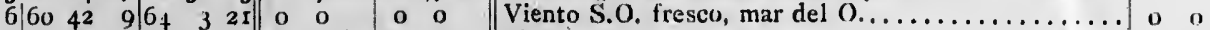

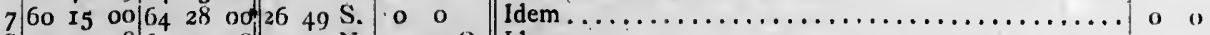

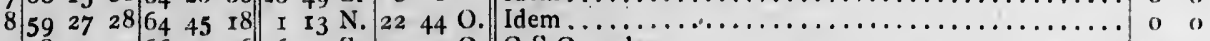

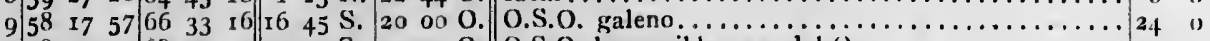

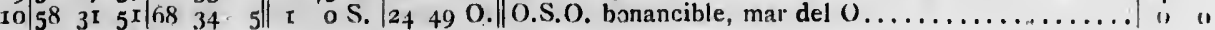


Continuación de la misma campaña on los meses de Enero y Febrero. - 1790.

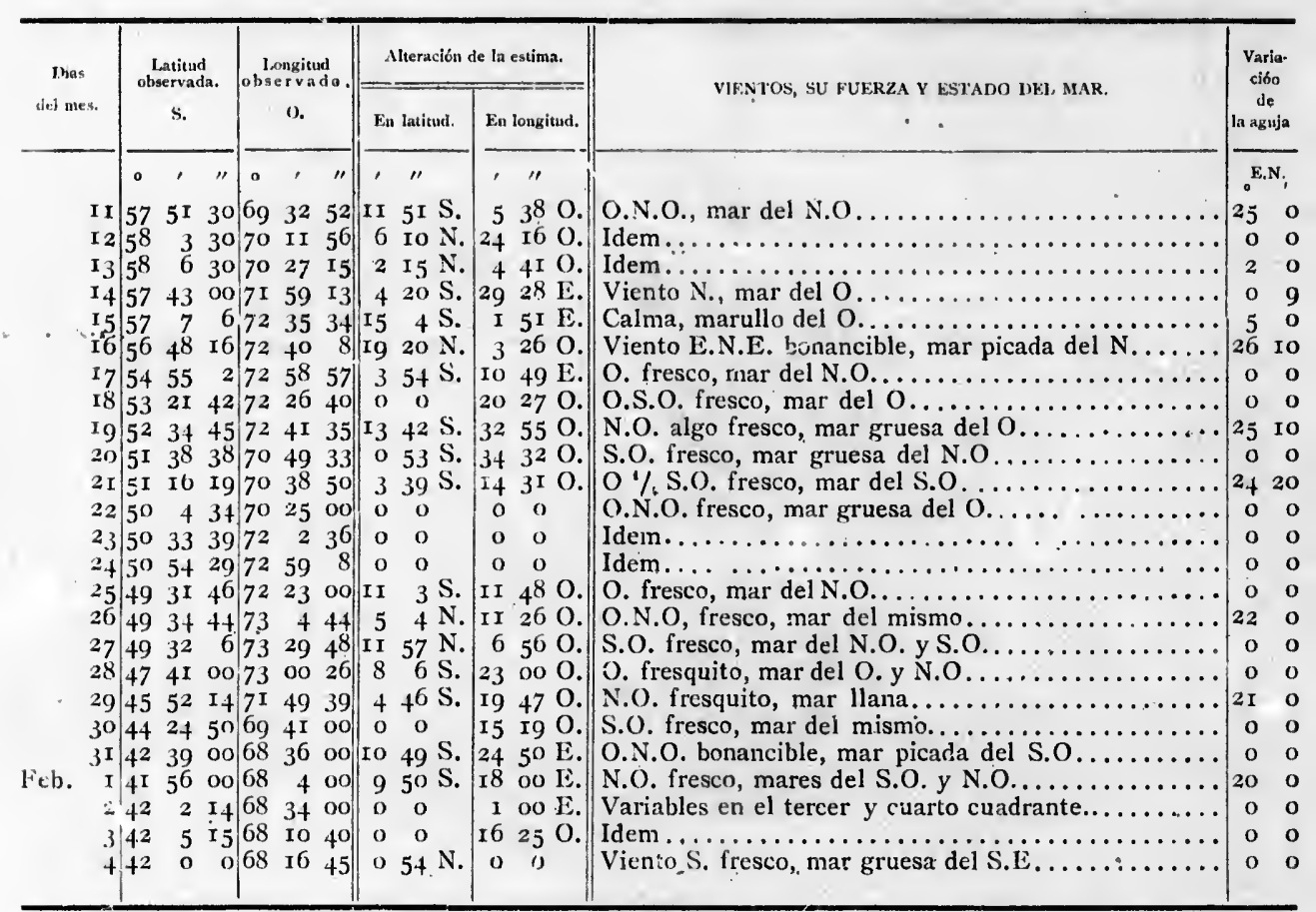

Salida del Puerto de San Carlos, en la Isla de Chiloé, al de la Concepción.-Mes de Cebrero.-1790.

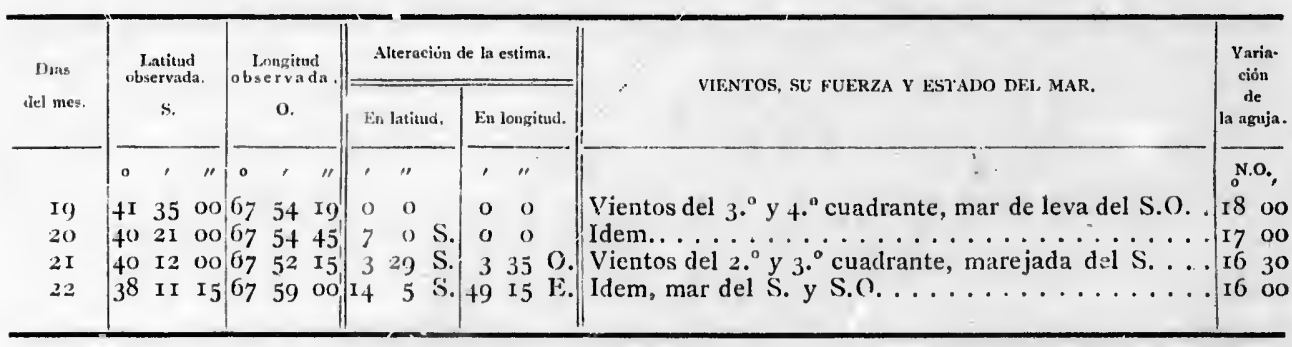

Salida de Concepción à las Islas de Juan Fernández y regreso á Valparaiso.- Mes de Marzo de 1790.

\begin{tabular}{|c|c|c|c|c|c|c|c|c|}
\hline \multirow{2}{*}{$\begin{array}{l}\text { 1)ias } \\
\text { del mes. }\end{array}$} & \multirow{2}{*}{\multicolumn{2}{|c|}{$\begin{array}{c}\begin{array}{c}\text { laatitud } \\
\text { olservada. }\end{array} \\
\mathrm{s}\end{array}$}} & \multirow{2}{*}{\multicolumn{2}{|c|}{$\begin{array}{c}\text { Longitud. } \\
\text { obsery ada } \\
0 .\end{array}$}} & \multicolumn{2}{|c|}{ Alteracion de la estinat. } & \multirow{2}{*}{ VIFNTOS, SUU FUYRZA Y ESTADO DEL MAR. } & \multirow{2}{*}{$\begin{array}{c}\text { Varin. } \\
\text { ción } \\
\text { de } \\
\text { la aguja. }\end{array}$} \\
\hline & & & & & En latitud. & En longitud. & & \\
\hline & 0, & & - & $"$ & , " & , " & & N.E. \\
\hline $1 \mathrm{I}$ & 35 I 5 & & 69. & 3416 & I oo $\mathrm{S}$. & $0 \quad 0$ & Vientos del tercer cuadrante, mar griesa. & \\
\hline 12 & 33434 & & 72 & $4^{2} 49$ & $545 \mathrm{~S}$. & $243^{6} \mathrm{E}$. & Viento del segundo cuadrante, mar idem. . . . . & o $\quad \mathrm{c}$ \\
\hline 1.3 & $333^{2} 1$ & $\mathbf{I} 7$ & 73 & 4854 & 5 I I S. & $635 \mathrm{I}$. & Vientos del tercer cuadrante, mai del viento. . . . & 1530 \\
\hline 14 & 33240 & $00 \%$ & 71 & $3.35 \mathrm{I}$ & $95+\mathrm{S}$. & 2. 30. & Idem del segundo y tercer cuadrante, mar gruesa. . & 00 \\
\hline 15 & $\begin{array}{lllll}33 & 37 & 3\end{array}$ & 386 & 68 & $\begin{array}{lll}58 & 32\end{array}$ & $1332 \mathrm{~S}$. & $2056 \mathrm{E}$. & Vientos del segundo cuadrante, mar del viento. . . . & 0 \\
\hline $3 \ddot{6}$ & 3300 & 60 & 67 & I9 9 & $232 \mathrm{~S}$. & $\begin{array}{lll}32 & 7 & 0\end{array}$ & Bonancibles en el $20^{\circ}$ y $3{ }^{\text {er }}$ cuadrante, mar del Sur. & 15 \\
\hline 17 & 337 & 70 & 66 & 2220 & 00 & 0 & Idem, mares del S. y S.O. . . . . . . . . . . . & \\
\hline
\end{tabular}


Salida de Valparaiso para Coquimbo. - Mes de Abril. -1790.

\begin{tabular}{|c|c|c|c|c|c|c|}
\hline \multirow{2}{*}{$\begin{array}{c}\text { Dins } \\
\text { del mes. }\end{array}$} & \multirow{2}{*}{$\begin{array}{c}\begin{array}{c}\text { Latitud } \\
\text { observada. } \\
\text { S. }\end{array} \\
\end{array}$} & \multirow{2}{*}{$\begin{array}{c}\text { Longitud } \\
\text { observada } \\
\text { o. }\end{array}$} & \multicolumn{2}{|c|}{ Alteraclón de la estima. } & \multirow{2}{*}{ VIFNTOS, SU FLERZA Y ESTADO DEI, MAR. } & \multirow{2}{*}{$\mid \begin{array}{c}\text { Vari,.. } \\
\text { ción } \\
\text { de } \\
\text { Ia agija }\end{array}$} \\
\hline & & & En latitud. & En longitud. & & \\
\hline I 4 & $\mid \begin{array}{ccc}0 & 1 & 1 \\
3^{2} & 56 & 30\end{array}$ & $\mid \begin{array}{ccc}0 & 1 & 1 \\
65 & 3 I & 30\end{array}$ & $\begin{array}{ll}1 & \prime \prime \\
0 & 0\end{array}$ & $\begin{array}{ll}1 & \prime \prime \\
0 & 0\end{array}$ & Vientos del $2 .^{\circ}$ y $3 .^{\text {er }}$ cuadrante, mar sorda del S. . & N.K., \\
\hline I5 & $\begin{array}{lll}32 & 35 & 48\end{array}$ & $\begin{array}{lll}65 & 30 & 30\end{array}$ & $642 \mathrm{~N}$. & 0 & Idem.. $\ldots \ldots \ldots \ldots \ldots \ldots \ldots$ & 0 \\
\hline I6 & $31 \quad 4620$ & $65 \quad 34 \quad 15$ & $\begin{array}{ll}0 & 0 \\
\end{array}$ & 0 & Vientos del tercer cuadrante, mare jada del S.O. . . & \\
\hline I7 & $3^{0} \quad 3900$ & $65 \quad 4 I \quad 57$ & I5 455 S. & 0 & 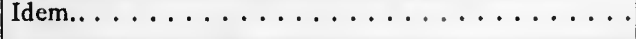 & \\
\hline
\end{tabular}

Salida de Coquimbo para Arica.-Mes de Mayo.-1790.

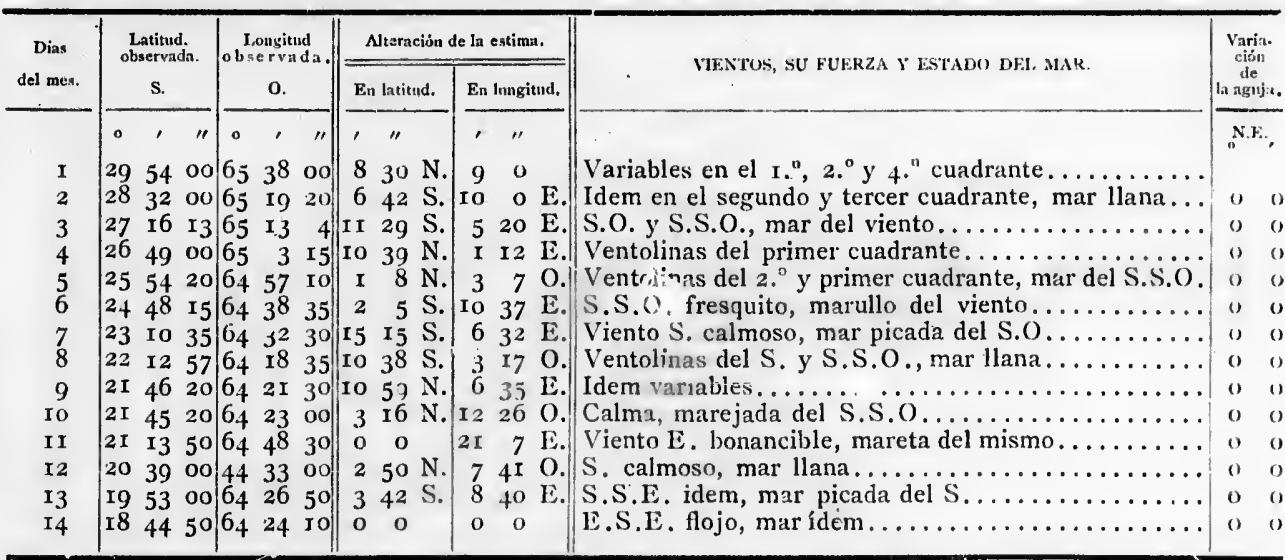

Sa lida de Arica para el Puerto del Callao de Lima.-Mes de Mayo. - 1790.

\begin{tabular}{|c|c|c|c|c|c|c|c|c|}
\hline \multirow{2}{*}{$\begin{array}{c}\text { Dias } \\
\text { del mes. }\end{array}$} & \multirow{2}{*}{\multicolumn{2}{|c|}{$\begin{array}{c}\begin{array}{c}\text { Latitud } \\
\text { observada. }\end{array} \\
\text { S. }\end{array}$}} & \multirow{2}{*}{\multicolumn{2}{|c|}{ 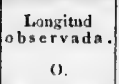 }} & \multicolumn{2}{|c|}{ Alteración de la estima. } & \multirow{2}{*}{ VIENTOS, SU FUERZA Y ESTADO DEL. MAR. } & \multirow{2}{*}{$\begin{array}{c}\text { Vari.t. } \\
\text { ción } \\
\text { de } \\
\text { la agujit. }\end{array}$} \\
\hline & & & & & En latitudl. & En longitud. & & \\
\hline & & , " & 0 & , & & & & N.k. \\
\hline 19 & I8 & $303^{x}$ & 64 & 265 & $0 \quad o^{\prime}$ & $\begin{array}{lll}3 & 0\end{array}$ & Viento S.O., mare jada del S.O. . . . . . & \\
\hline 20 & 18 & 32050 & 64 & $47 \quad 25$ & $425 \mathrm{~N}$. & I 3520. & S.E. galeno, mar ídem. . . . . . . . & o \\
\hline $2 \mathrm{I}$ & 17 & 74030 & 65 & 1215 & $62 \mathrm{~S}$. & Io 100. & N.N.E. fresco, mar llana. . . . . . . . . & () \\
\hline 22 & 17 & $\begin{array}{lll}9 & \mathrm{I}_{5}\end{array}$ & 65 & $5^{8}$ 10 & $57 \mathrm{~S}$. & $555 \mathrm{E}$. & E. calmoso, marejada del S.O. sorda. . . . . . . . . & 0 \\
\hline 23 & 16 & 53920 & 66 & $5^{8} 30$ & 00 & I5 144 E. & S.S.E. fresquito, mar del S.S.E. . . . . . . . & 0 \\
\hline 24 & $I_{5}$ & 53724 & 68 & $49 \begin{array}{ll}45 \\
4\end{array}$ & -2 โ6 N. & $24 \quad 45$ E. & S.l. frescachón, mar del S.S.E. . . . . . . & 0 \\
\hline 25 & I.3 & 5120 & 70 & 2255 & $922 \mathrm{~S}$. & $540 \mathrm{E}$. & S.S.E. fresco mar del mismo. . . . . . . . . & 0 \\
\hline 26 & 12 & $433^{0}$ & 70 & 5045 & $622 \mathrm{~N}$. & $826 \mathrm{E}$. & Idem. . . . . . . . . . . . . . . . . . . & 0 \\
\hline 27 & 12 & 3830 & 70 & $5^{2} \quad 55$ & $248 \mathrm{~N}$. & 654 E. & Ventolines del S.S.O., mar del mismo. . . . . . . & () \\
\hline
\end{tabular}

Sallda del Callao de Lima para el Rio de Guayaquil. - Mes de Setiembre.-1790.

\begin{tabular}{|c|c|c|c|c|c|c|c|c|c|}
\hline \multirow{2}{*}{$\begin{array}{c}\text { Dias } \\
\text { det mea. }\end{array}$} & \multirow{2}{*}{\multicolumn{2}{|c|}{$\begin{array}{l}\text { 1.aritud } \\
\text { observada. } \\
\text { s }\end{array}$}} & \multirow{2}{*}{\multicolumn{3}{|c|}{$\begin{array}{c}\begin{array}{c}\text { Longind } \\
\text { abservad } x\end{array} \\
0 .\end{array}$}} & \multicolumn{2}{|c|}{ Alteración de la estima. } & \multirow{2}{*}{ YIENTOS, SU FUERZA Y ESTADO DFL MAR. } & \multirow{2}{*}{$\begin{array}{c}\text { Varin. } \\
\text { ción } \\
\text { ter } \\
\text { ta aguj..t. }\end{array}$} \\
\hline & & & & & & En latitud. & Fin longitud. & & \\
\hline & & , " & 0 & , & & $"$ & $"$ & & N.i: , \\
\hline 2 I & II & 2300 & 71 & $3+5$ & 50 & $55^{6} \mathrm{~S}$. & I5 3 I E. & Viente S. bonancible, mareta del mismo. . & \\
\hline 22 & Io 1 & IO IO & 72 & 2 & 4 & $832 \mathrm{~S}$. & I9 34 E. & S.S.LE. fresquito, & \\
\hline 23 & 83 & 3700 & o 72 & 340 & oo & $939 \mathrm{~S}$. & $2055 \mathrm{E}$. & Viento S.S.E. fres & \\
\hline 24 & 75 & 5320 & o 73 & I0 4 & 46. $\mathrm{I}_{4}$ & $44 \mathrm{IO} \mathrm{S}$. & $332 \mathrm{E}$. & S.E. fresco, marejada del mismo. . . . . . & 0 \\
\hline 25 & 64 & 4445 & 573 & 404 & 46.17 & I $7 \mathrm{I}$. & o IE. & S.S.E. fresce & 0 \\
\hline 26 & 6 & $6 \mathrm{xc}$ & $7 \cdot 7$ & $32 \mathrm{r}$ & & I $35 \mathrm{~S}$. & 55 I9 E. & Viento S. fresco, marejada del mismo. . . . . & \\
\hline 27 & 45 & 5220 & 975 & oo 5 & 501 & $329 \mathrm{~S}$. & $663^{\circ} \mathrm{E}$ & S.S.E. fresco, mar de ídem. . . . . . . . . & 0 \\
\hline 28 & 33 & 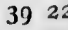 & 274 & I $\mathrm{x}$ & 5 5 8 & $82 \mathrm{IS}$. & . $5955 \mathrm{E}$. & Idem... . . . . . . . . . . . . & 7 \\
\hline 29 & 3 & 20 & & 305 & & I $47 \mathrm{~N}$. & $.6800 \mathrm{k}$. & 0. fresco, $\operatorname{mar}$ gruesa. . . . . . . . . . . . . & \\
\hline
\end{tabular}


Salida del Rio de Guayzquil para el Puerto de Panamá.-Mes de Noviembre.-1790.

\begin{tabular}{|c|c|c|c|c|c|c|c|c|c|c|c|}
\hline \multirow{2}{*}{$\begin{array}{l}\text { lous. } \\
\text { icl mes. }\end{array}$} & \multirow{2}{*}{\multicolumn{3}{|c|}{$\begin{array}{c}\begin{array}{c}\text { Latitud } \\
\text { observada. }\end{array} \\
\text { S. }\end{array}$}} & \multirow{2}{*}{\multicolumn{3}{|c|}{$\begin{array}{c}\text { Longitud } \\
\text { observada } \\
0 .\end{array}$}} & \multicolumn{3}{|c|}{ Alteración de la estima. } & \multirow{2}{*}{ VIENTOS, SU FUEKZA Y ESTADO DEL, MAR. } & \multirow{2}{*}{$\begin{array}{c}\text { Varia. } \\
\text { cióa } \\
\text { de } \\
\text { la aguja }\end{array}$} \\
\hline & & & & & & & & En latitud. & Ful Inngitud. & & \\
\hline & & , & & & , & $"$ & & , " & , " & & N.E., \\
\hline $\mathbf{I}$ & & 20 & & & It & 27 & & a 0 & & Viento fresco, fresquito y bonancible del $3{ }^{\text {er }}$ cuadrante & \\
\hline 2 & & 29 & & & 36 & 29 & & 5 oo $\mathrm{N}$. & 00 & Bonancible en el cuarto, mar del S.O. . . . . . . & o \\
\hline 3 & & 37 & & 74 & 57 & 26 & & $731 \mathrm{~N}$. & I I3 0. & Bonancible del O.N.O., marejada del mismo. . . . . . & o \\
\hline 4 & & 57 & & 74 & 34 & 36 & & $45^{2} \mathrm{~N}$. & 21240. & Viento del O.S.O. y S.O. fresco, mar de él. . . . . & 0 \\
\hline 5 & & $\begin{array}{l}4^{6} \\
\text { N. }\end{array}$ & & 74 & 27 & 10 & & $946 \mathrm{~N}$. & $44 \mathrm{E}$. & Del O.S.O. al S. fresco y bonancible, mar idem. . . . & 910 \\
\hline 6 & & 50 & & 74 & 25 & & & $420 \mathrm{~N}$. & $232 \mathrm{E}$. & Fresco en el tercer cuadrante, mar agitada.. . . . & $o$ \\
\hline 7 & & 57 & & 73 & I 3 & 10 & & $948 \mathrm{~N}$. & $12 I_{4} \mathrm{E}$. & Idem, misma mar.. . . . . . . . . . . & \\
\hline 8 & & 32 & $5^{\circ}$ & 71 & 43 & & & $9 \cdot 22 \mathrm{~N}$. & 2390. & 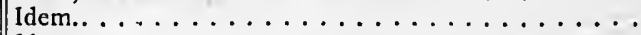 & o \\
\hline 9 & & 42 & 30 & & 44 & & & $020 \mathrm{~N}$. & 300. & Idem.. . . . . . . . . . . . . . . . . & \\
\hline Io & 6 & I 8 & & & 39 & 20 & & $249 \mathrm{~N}$. & 28 oo 0. & 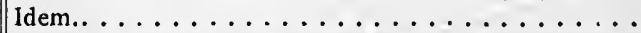 & \\
\hline II & & 46 & & & & 38 & & 00 & 00 & Variables y bonancibles en el $20^{\circ}, 30^{\circ}$ y $40^{\circ}$ cuadrante. & o \\
\hline 12 & & 52. & & 73 & 33 & 13 & & $344 \mathrm{~N}$. & $6940 \mathrm{E}$. & Idem en el tercero y cuarto cuadrante. . . . . . . . & 0 \\
\hline 13 & & $2 \mathrm{I}$ & 50 & 73 & 3 & 15 & & 3 Io $N$. & 2 Io E. & Bonancible y calmoso en el $x^{\circ}$ y $40^{\circ}$ cuadrante. . . . & \\
\hline
\end{tabular}

Salida de Fanamá para el Puerto de Acapulco.-Mes de Diciembre.-1790.

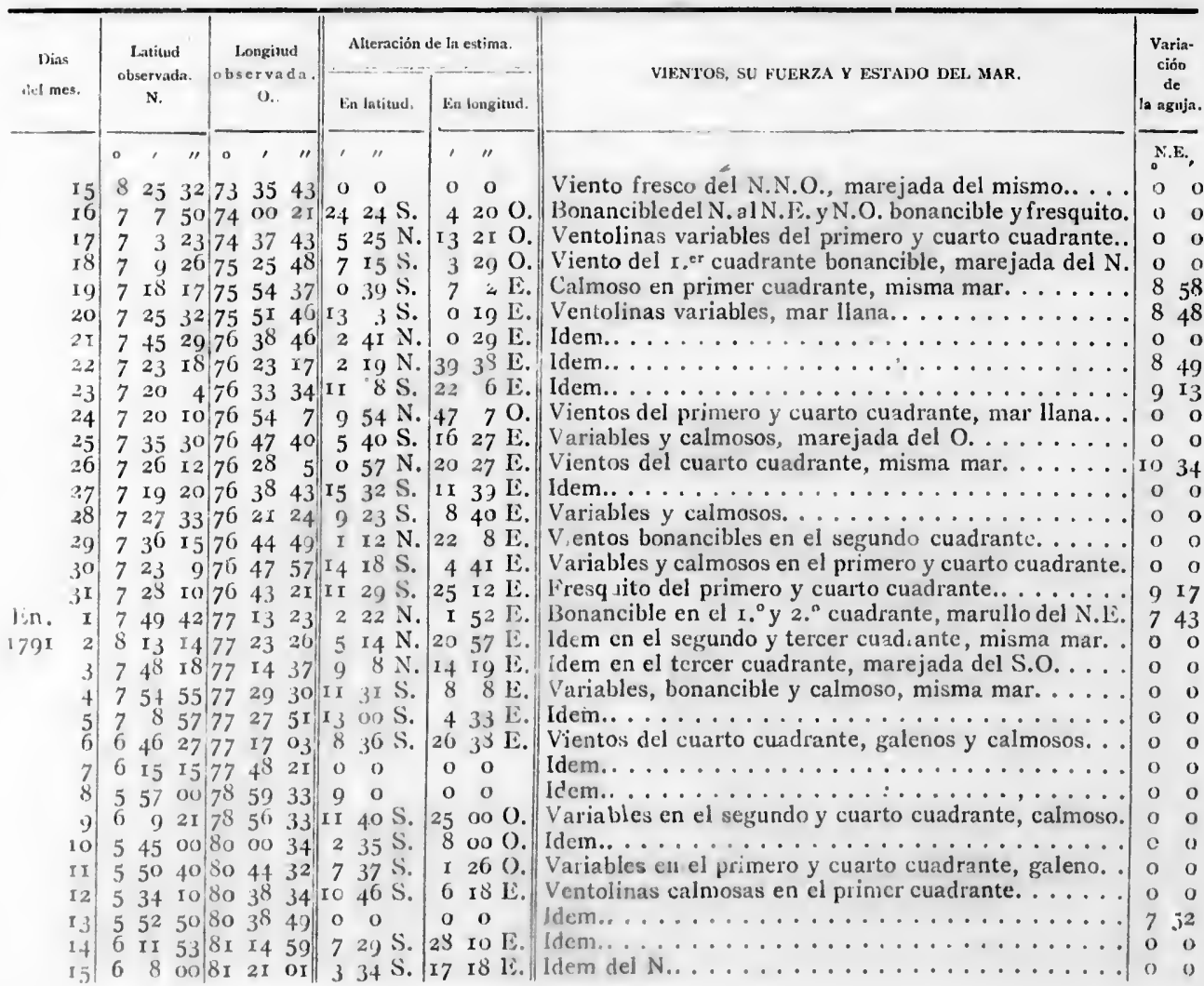


Continuación de la salida de Panamá.-Mes de Enero.-1791.

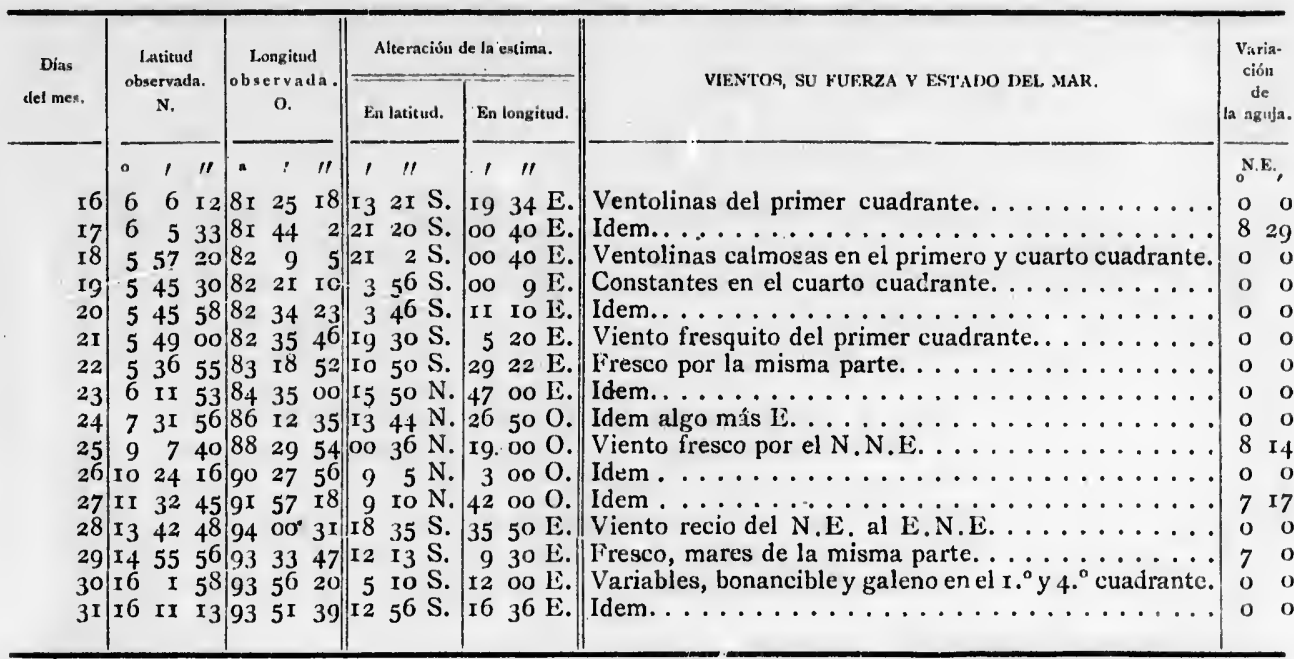

Salida del Puerto de Acapulco al de San Blas._-Meses de Febrero y Marzo._179I.

\begin{tabular}{|c|c|c|c|c|c|c|}
\hline \multirow{2}{*}{$\begin{array}{c}\text { Días } \\
\text { del mes. }\end{array}$} & \multirow{2}{*}{$\begin{array}{c}\text { Latitud } \\
\text { observada. } \\
\text { N. }\end{array}$} & \multirow{2}{*}{$\begin{array}{c}\text { Longitud } \\
\text { observada. } \\
\text { o. }\end{array}$} & \multicolumn{2}{|c|}{ Alteración de la estima. } & \multirow{2}{*}{ VIENTOS, SU FUERZA Y ESTADO DEL MAR. } & \multirow{2}{*}{$\begin{array}{c}\text { Varia- } \\
\text { ción } \\
\text { de } \\
\text { la aguja }\end{array}$} \\
\hline & & & Ein latitud. & En loogitud. & & \\
\hline
\end{tabular}

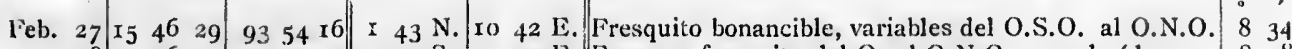

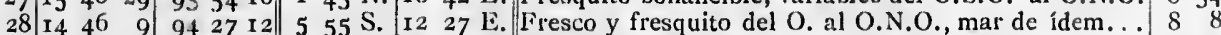

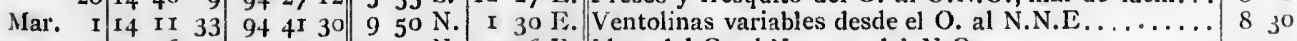

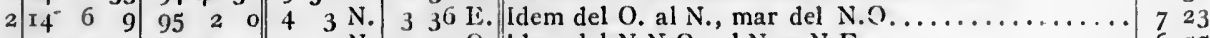

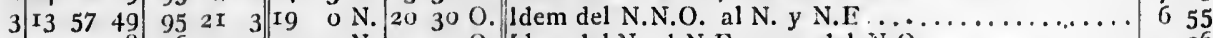

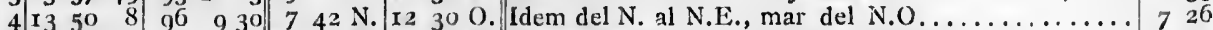

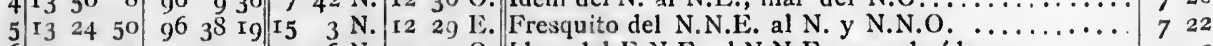

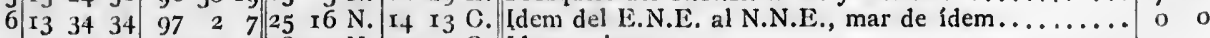

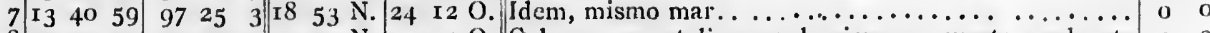

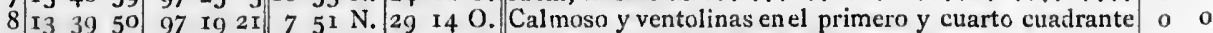

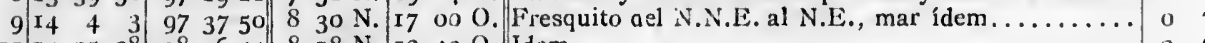

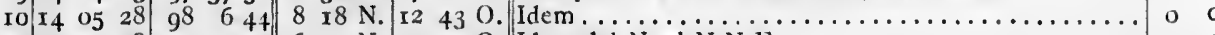

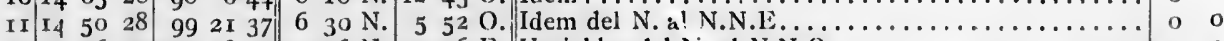

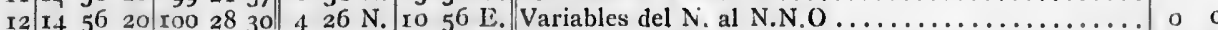

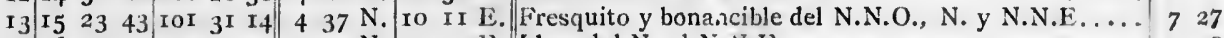

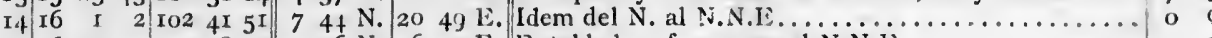

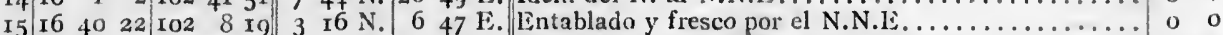
16 I 72724 I03 43 30 I 2 S. 240 O. Idem del N. al N.N.E., mar del viento... ...... 7 I5 17 I 7 34 I3 105 t5 Io I 2 II N. 46 oo E. Variables y bonancibles del N. al N.N.E. y N.E.... 0 4?

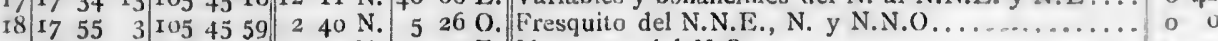

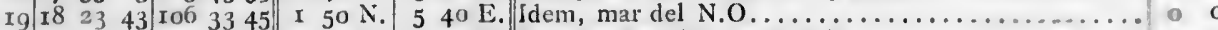

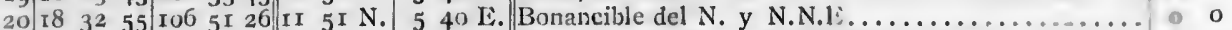

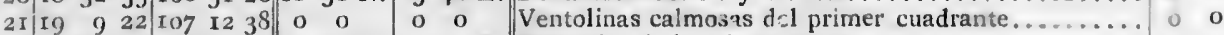

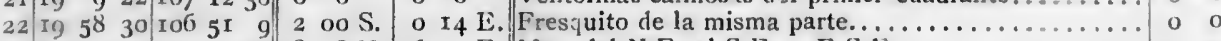

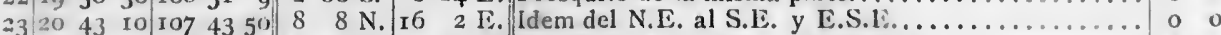
$2421 \quad 27 \quad 9 \quad 108 \quad 5230 \quad 6 \quad 7$ N. $12 \quad 52$ E. Entablado en el primer cuadrante............... 625

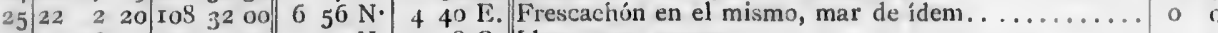

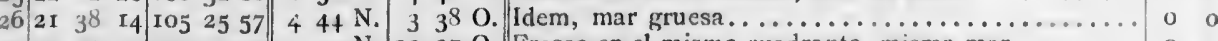
272130 oo 103 I 4 40 3 30 N. I 227 O. Fresco en el mismo cuadrante, misma mar............. 282 I 24 oo Ior 5 o 220 N. 725 E. Frescachón del N. y N.N.O., mar de ídem......... 0 o

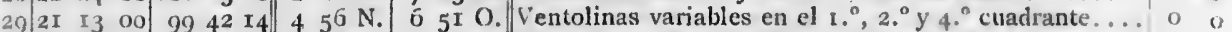

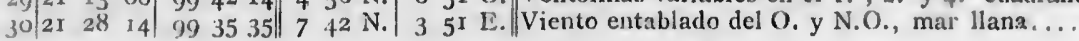


Sallda del Puerto de San Blas para el de Acapulco.- Mes de Abrll.

\begin{tabular}{|c|c|c|c|c|c|c|c|c|}
\hline \multirow{2}{*}{$\begin{array}{c}\text { Dias } \\
\text { del mes. }\end{array}$} & \multirow{2}{*}{\multicolumn{2}{|c|}{$\begin{array}{c}\begin{array}{c}\text { Latitud } \\
\text { ohyervatla. }\end{array} \\
\text { N. }\end{array}$}} & \multirow{2}{*}{\multicolumn{2}{|c|}{$\begin{array}{c}\text { longitud } \\
\text { o bserváda } \\
0 .\end{array}$}} & \multicolumn{2}{|c|}{ Alteración de la estima. } & \multirow{2}{*}{ VIENTOS, SU FUERZA Y FSTADO DELL MAR. } & \multirow{2}{*}{$\begin{array}{c}\text { Varia- } \\
\text { ción } \\
\text { de } \\
\text { la }\end{array}$} \\
\hline & & & & & En latitud. & En tongitud, & & \\
\hline & & , " & & , $"$ & $"$ & $"$ & & N.O, \\
\hline I 3 & 3 I & I 300 & 99 & 2535 & $730 \mathrm{~S}$ & $13 \quad 160$. & Yiento $\mathrm{N}$. galeno y bonancible. ..... & o 0 \\
\hline 14 & 18 & 57 10 & 99 & $4 \mathbf{1} \quad 19$ & $1230 \mathrm{~N}$ & 5400 & Del N. al E. fresquito y bonaiscible........... & \\
\hline 15 & 18 & 3440 & 98 & $5^{I} \quad 35$ & $1320 \mathrm{~N}$. & 4 io 0 & Variables $y$ bonancibles del N.O. al N.E........... & 628 \\
\hline I 6 & I8 & 285 & 98 & 2340 & 3 I5 S. & I3 $8 \mathrm{E}$. & 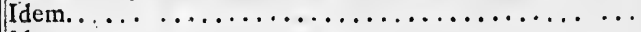 & o \\
\hline I7 & 18 & 640 & 96 & 2330 & $630 \mathrm{~N}$. & I6 Io E. & 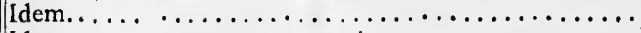 & o \\
\hline I 8 & 17 & 2950 & 95 & 58 I 5 & $32 \mathrm{~N}$. & I6 $6 I_{5} 0$. & 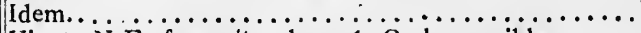 & $\mathbf{o}$ \\
\hline I9 & 17 & 630 & 94 & 57 I 5 & $22 \mathrm{~N}$. & 00 & Viento N.E. fresquito, después 0 . bonancible....... & o \\
\hline
\end{tabular}

Salida del Puerto de Acapulco para el de Mulgrave.-Mes de Mayo.

\begin{tabular}{|c|c|c|c|c|c|c|c|c|c|}
\hline \multirow{2}{*}{\multicolumn{2}{|c|}{$\begin{array}{l}\text { Dias } \\
\text { del ines. }\end{array}$}} & \multirow{2}{*}{\multicolumn{3}{|c|}{ 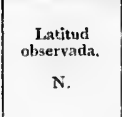 }} & \multirow{2}{*}{ 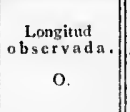 } & \multicolumn{2}{|c|}{ Alteración de la estima. } & \multirow{2}{*}{ VIENTOS, SU FUERZA Y ESTADE DEL, MAR. } & \multirow{2}{*}{$\begin{array}{l}\text { Varia- } \\
\text { ción } \\
\text { de } \\
\text { la aguja }\end{array}$} \\
\hline & & & & & & En laritud. & En Iongitud. & & \\
\hline & & & ' & & 0.111 & & ' ' & & N.E. \\
\hline & 2 & & I3 & 30 & 941040 & $\begin{array}{ll}0 & 0 \\
\end{array}$ & 00 & 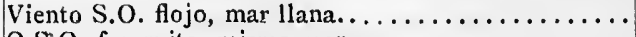 & \\
\hline & 3 & I5 & 35 & 20 & 94 II 50 & 7 oo N. & 3 I 500. & 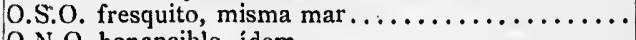 & \\
\hline & 4 & I 5 & Io & 50 & $94^{29} \mathrm{I}_{3}$ & $2 \mathrm{I}+9 \mathrm{~N}$. & I2 500. & 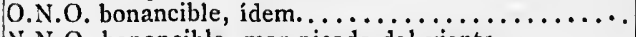 & \\
\hline & 5 & It & $5^{I}$ & 30 & $944^{8}$ г & $85 \mathrm{~N}$. & I8 50 E. & N.N.O. bonancible, mar picada del viento $\ldots \ldots \ldots$ & \\
\hline & 6 & I4 & 30 & 50 & 9549 Io & $730 \mathrm{~N}$ & $\begin{array}{rrr}2 & 20 & 0\end{array}$ & 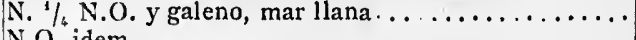 & \\
\hline & 7 & I4 & 23 & 30 & $9^{6} 3^{6} \mathrm{Io}$ & $834 \mathrm{~N}$ & $\begin{array}{lll}13 & 0 & 0\end{array}$ & O. idem $\ldots \ldots \ldots \ldots \ldots \ldots \ldots \ldots \ldots \ldots \ldots$ & \\
\hline & & I4 & I3 & ool & 972520 & ro $\quad 8$ N. & 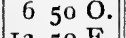 & N.O........... & \\
\hline & 9 & 14 & 20 & 50 & $9^{8} \quad 4230$ & $9 \mathrm{~N}$. & I3 $50 \mathrm{E}$. & N.E. galeno, marejada del N.N.O. . . . . . . & \\
\hline & ro & I 4 & 27 & 20 & 1002320 & I $50 \mathrm{~N}$. & Io $40 \mathrm{E}$. & $\operatorname{lem}_{1} \ldots \ldots \ldots \ldots \ldots \ldots \ldots \ldots \ldots \ldots \ldots \ldots$ & \\
\hline & I $\mathbf{1}$ & $\mathbf{I}_{4}$ & 53 & $5^{\circ}$ & 10240 Io & $822 \mathrm{~N}$. & 25 or $\mathrm{E}$. & picada del viento. $\ldots \ldots \ldots \ldots$ & \\
\hline & I2 & 15 & 39 & 20 & 1052350 & $420 \mathrm{~S}$. & I7 $30 \mathrm{E}$. & $\ldots \ldots \ldots \ldots \ldots \ldots \ldots \ldots$ & \\
\hline & I3 & I6 & 25 & Io & 108 19 20 & I $50 \mathrm{~S}$. & I $730 \mathrm{E}$. & $\ldots \ldots \ldots \ldots \ldots \ldots$ & \\
\hline & 14. & I7 & 4 & 50 & IIIO 50 & $430 \mathrm{~S}$. & I5 $00 \mathrm{E}$. & $\ldots \ldots \ldots \ldots \ldots \ldots$ & 9 \\
\hline & I5 & I 8 & 36 & 30 & 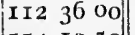 & $43^{\circ} \mathrm{N}$. & I 6 Io 2 . & N.E. fresco, mar del viento. & \\
\hline & I6 & 20 & 3 & $5^{0}$ & I I 4 Io 50 & 6 20 S. & I $450 \mathrm{E}$. & Idem . . & 900 \\
\hline & I 7 & $2 \mathrm{I}$ & I8 & Io & II 52 I 30 & $2320 \mathrm{~N}$ & $\begin{array}{lll}1 & 23 & 0\end{array}$ & $\ldots \ldots \ldots \ldots \ldots \ldots$ & 920 \\
\hline & I8 & 22 & I2 & Io & I I 62930 & $2320 \mathrm{~N}$ & I 230. & $r \ldots \ldots \ldots$ & \\
\hline & I9 & 23 & I & 50 & $\begin{array}{llll}1 & 17 & 30 & 30\end{array}$ & $33 \mathrm{~S}$. & $255^{\circ} \mathrm{E}$. & $\ldots \ldots \ldots \ldots \ldots \ldots \ldots$ & 9 \\
\hline & 20 & 24 & 25 & 20 & $1 \begin{array}{llll}1 & 8 & 21 & 30\end{array}$ & Io $40 \mathrm{~S}$. & $\begin{array}{ll}0 & 0 \\
\end{array}$ & $\cdots \cdots \cdots$ & 9 \\
\hline & $2 \mathrm{I}$ & 25 & 42 & oo & II9 I2 & $440 \mathrm{~S}$ & $1230 \mathrm{E}$. & $\ldots \ldots \ldots$ & 9 \\
\hline & 22 & 26 & $3 \mathrm{I}$ & oo & 1203920 & 00 & $\begin{array}{ll}0 & 0 \\
0 & 0\end{array}$ & N.N.E. fresco, misma mar. . . . . . . & 930 \\
\hline & 23 & 27 & $2 \mathrm{I}$ & 40 & 122 Io I & 8 o S. & I6 o E. & N.E. fresquito, mar del N........... & Io 0 \\
\hline & 24 & 28 & 35 & 20 & $123 \quad 650$ & I4 $20 \mathrm{~S}$. & $750 \mathrm{E}$. & Idem galeno....... & Io \\
\hline & 25 & 29 & 5 & Io & 124 I0 30 & $530 \mathrm{~S}$ & $530 \mathrm{E}$. & .. & In \\
\hline & 26 & 29 & 9 & 20 & $125 \quad 850$ & I $\quad$ o $N$. & $430 \mathrm{E}:$ & V & ro 30 \\
\hline & 27 & 29 & 30 & 40 & 1252750 & I4 I8 N. & $64^{\circ} \mathrm{E}$. & is del $N$. y del S... & 1030 \\
\hline & 28 & 28 & 8 & 30 & I25 30 Io & 8 I 0 N. & $200 \mathrm{O}$ & O bonancible, & Io \\
\hline & 29 & 29 & I6 & 00 & I $255^{8} 39$ & Io $30 \mathrm{~N}$. & 3 I7 0. & ar......... & Io \\
\hline & $3^{0}$ & $3^{0}$ & It & Io & $\left|\begin{array}{lll}127 & 2 & 40\end{array}\right|$ & t I Io S. & I5 $2 \mathrm{E}$. & $\cdots$ & I0 30 \\
\hline & $3 \mathrm{I}$ & 30 & 48 & 00 & 1275 & 0 & 0 & $r$ del $N \ldots \ldots$....... & 1030 \\
\hline Jun. & $\mathbf{I}$ & 32 & 6 & 40 & 1283650 & ro 50 S. & I 7 I6 $\mathrm{E}$. & Viento N.E. fresquito, niar del O.N.O. & 1030 \\
\hline & 2 & 33 & 7 & Io & $128 \quad 43$ Io & $820 \mathrm{~S}$. & Io $20 \mathrm{E}$. & N. bonancible, mar del N.E...... & 0 \\
\hline & 3 & 33 & Io & 20 & 1294050 & $54^{\circ} \mathrm{N}$. & $840 \mathrm{E}$ & Viento N.O., misma mar. . & 0 \\
\hline & 4 & 34 & 2 & 00 & 129 工 550 & I $50 \mathrm{~N}$. & I6 oo E. & & I I \\
\hline & 5 & 34 & 20 & & {$\left[\begin{array}{llll}128 & 20 & 50\end{array} \mid\right.$} & $742 \mathrm{~N}$. & $1620 \mathrm{E}$. & Ider & 12 \\
\hline & 6 & 34 & I8 & & 1284340 & $230 \mathrm{~S}$. & I7 $20 \mathrm{E}$. & Calm & 0 \\
\hline & 7 & 35 & II & & $\left|\begin{array}{lll}128 & 53 & \text { Io }\end{array}\right|$ & $\begin{array}{ll}0 & 0\end{array}$ & I 50. & har del N... & 0 \\
\hline & 8 & 38 & Io & 23 & 1205350 & II Io S. & 6500.1 & & 0 \\
\hline & 9 & 37 & I3 & Io & 129250 & $630 \mathrm{s.}$ & 17500. & , mar del & o \\
\hline & 10 & 37 & I4 & 50 & I 3 I & $600 \mathrm{~N}$. & $2320 \mathrm{E}$. & del N.E.......... & $r_{3}$ \\
\hline & I I & 37 & 46 & 10 & I 31 & $040 \mathrm{~S}$. & $5730 \mathrm{E}$. & & 0 \\
\hline & I2 & 40 & $I$ & oo & 13002330 & $823 \mathrm{~S}$. & on $\mathrm{O}$. & r resquito, mar der s.u............... & 0 \\
\hline & I3 & $4 I$ & & 50 & I $28 \quad 5320$ & I $6 \mathrm{~N}$. & I6 6000. & & 0 \\
\hline & & & & & & & & & \\
\hline
\end{tabular}


Continuación de la misma ca mpafia. - Mes de Junio.

\begin{tabular}{|c|c|c|c|c|c|c|c|c|c|}
\hline \multirow{2}{*}{$\begin{array}{c}\text { Días } \\
\text { ciel nes. }\end{array}$} & \multirow{2}{*}{\multicolumn{3}{|c|}{$\begin{array}{c}\text { Latitul. } \\
\text { obse rvadn. } \\
\text { N. }\end{array}$}} & \multirow{2}{*}{\multicolumn{2}{|c|}{ 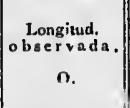 }} & \multicolumn{2}{|c|}{ Alteraciones de la estima. } & \multirow{2}{*}{ VIENTYOS, SU FUERZA Y ESTADO DEI. MIAR. } & \multirow{2}{*}{$\begin{array}{c}\text { Varia- } \\
\text { ción } \\
\text { de } \\
\text { la aguja. }\end{array}$} \\
\hline & & & & & & En Jatitud. & En longitud. & & \\
\hline & & ' & & $\circ$ & , " & , " & , " & & N.F., \\
\hline $\begin{array}{l}\text { I5 } \\
\text { I6 }\end{array}$ & & $\begin{array}{r}2 \\
52\end{array}$ & & $\begin{array}{l}129 \\
128\end{array}$ & $\begin{array}{ll}17 & 40 \\
58 & 30\end{array}$ & $\begin{array}{ccc}14 & 20 & \mathrm{~S} . \\
0 & 0\end{array}$ & $\begin{array}{rrr}16 & 10 & 0 . \\
8 & 30 & \mathrm{E} .\end{array}$ & $\begin{array}{l}\text { O.N.O. fresco, mar del viento } \ldots \ldots \ldots \ldots \ldots \ldots \ldots \ldots \\
\text { S.E. fresquito, mar del S.O. . . . . . . . } \ldots \ldots \ldots \ldots\end{array}$ & $\begin{array}{ll}0 & 0 \\
0 & 0\end{array}$ \\
\hline I7 & 47 & $5 \mathrm{I}$ & Io & $r_{3} \mathbf{I}$ & II 15 & I6 Io $\mathrm{S}$. & 8200 & 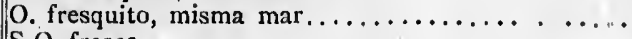 & 15 \\
\hline I8 & 48 & 36 & & 132 & 700 & $640 \mathrm{~S}$. & $950 \mathrm{E}$. & S.O. fresco $\ldots \ldots \ldots \ldots \ldots \ldots \ldots$ & 15 \\
\hline I9 & $4^{8}$ & $44:$ & $5 \mathrm{I}$ & 132 & $44 I 5$ & $750 \mathrm{~N}$. & $53 \quad 56 \mathrm{E}$. & O. calmoso, mar llana. . . $\ldots \ldots \ldots \ldots \ldots$ & 0 \\
\hline 20 & $5^{2}$ & 8 & ro & 132 & 25 & I2 oo S. & 14400 & O.N.O. fresquito, mar del viento, . . . . & 0 \\
\hline $2 \mathrm{I}$ & 53 & $I_{5}$ & 00 & 133 & 950 & 8 oo S. & $520 \mathrm{E}$. & $\operatorname{Idem}_{2} \ldots \ldots \ldots \ldots \ldots \ldots \ldots \ldots \ldots \ldots$ & I6 \\
\hline 22 & 54 & $3^{\mathbf{I}}$ & $3^{1}$ & I3 $3^{1}$ & 3450 & $4 \mathrm{I} 7 \mathrm{~S}$ & 14500. & O.S.O. Hojo, hiar llana . . . . . . . . & 17 \\
\hline 23 & $5^{6}$ & I7. & 30 & 130 & 2650 & $3840 \mathrm{~S}$. & I $30 \mathrm{E}$. & 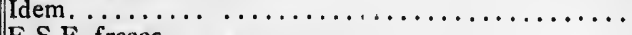 & 17 \\
\hline $2+$ & 57 & Io & 10 & $r_{3} \mathbf{r}$ & 36 工o & $1250 \mathrm{~S}$. & $\begin{array}{lll}0 & 0 \\
& -1 & 0\end{array}$ & E.S.E. fresco $\ldots \ldots \ldots \ldots \ldots \ldots \ldots \ldots \ldots \ldots \ldots \ldots \ldots$ & 24 \\
\hline 25 & 57 & 59 & 40 & 132 & $5^{8} 50$ & 4 Io S. & $3.20 \mathrm{E}$. & O. fresco, mar del S........... $\ldots \ldots$ & 24 \\
\hline 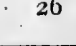 & 59 & oo & & $13^{2}$ & 4440 & $240 \mathrm{~N}$. & 6400. & S.S.O. tresquito, marejada del S.O............ & 24 \\
\hline
\end{tabular}

Salida del Puerto de Mulgrave para el de Nutka. - Mes de Julio. - I79I.

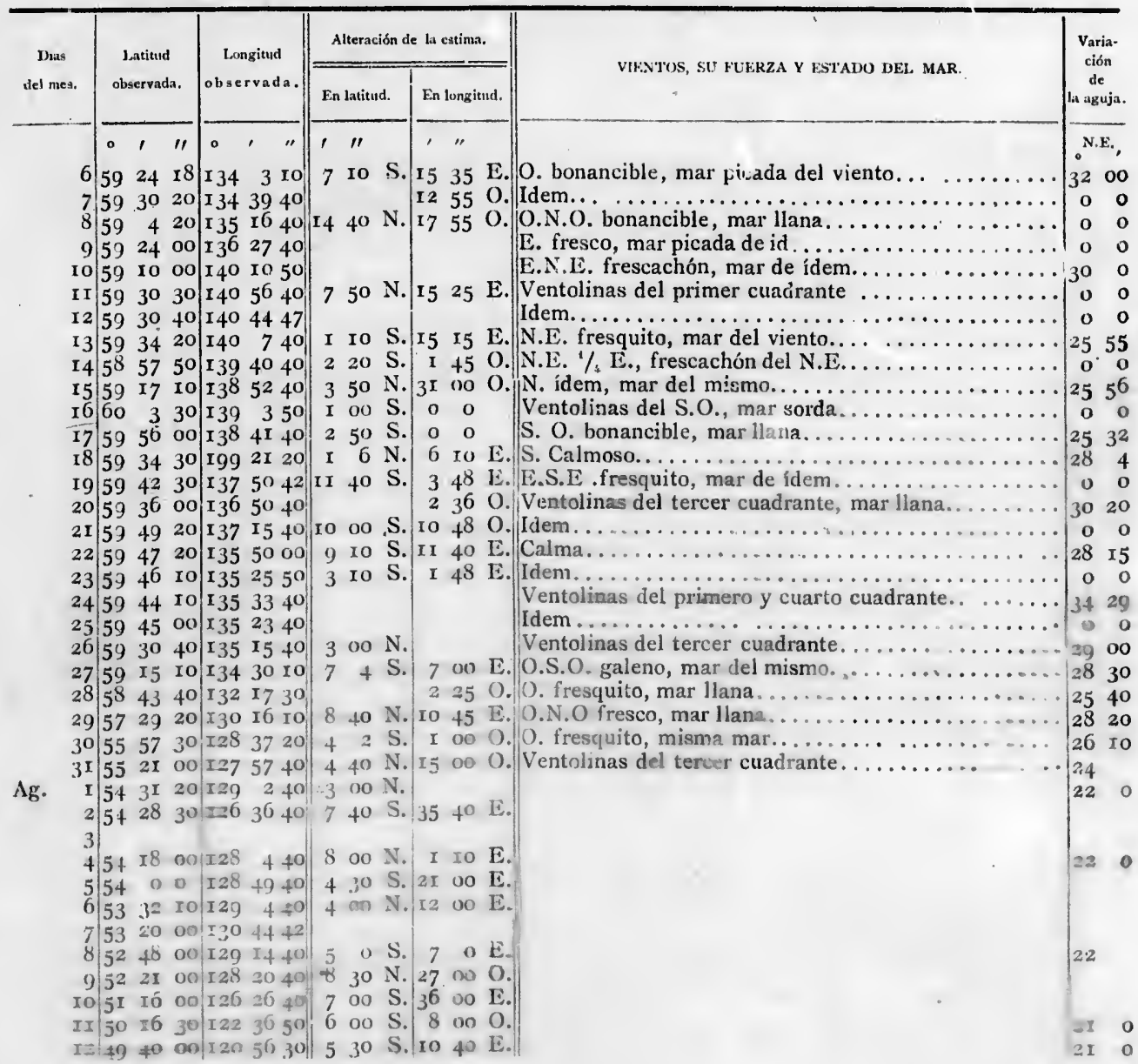


Salida de Nutka parci el Puerto de Monterey. - Mes de Agosto.

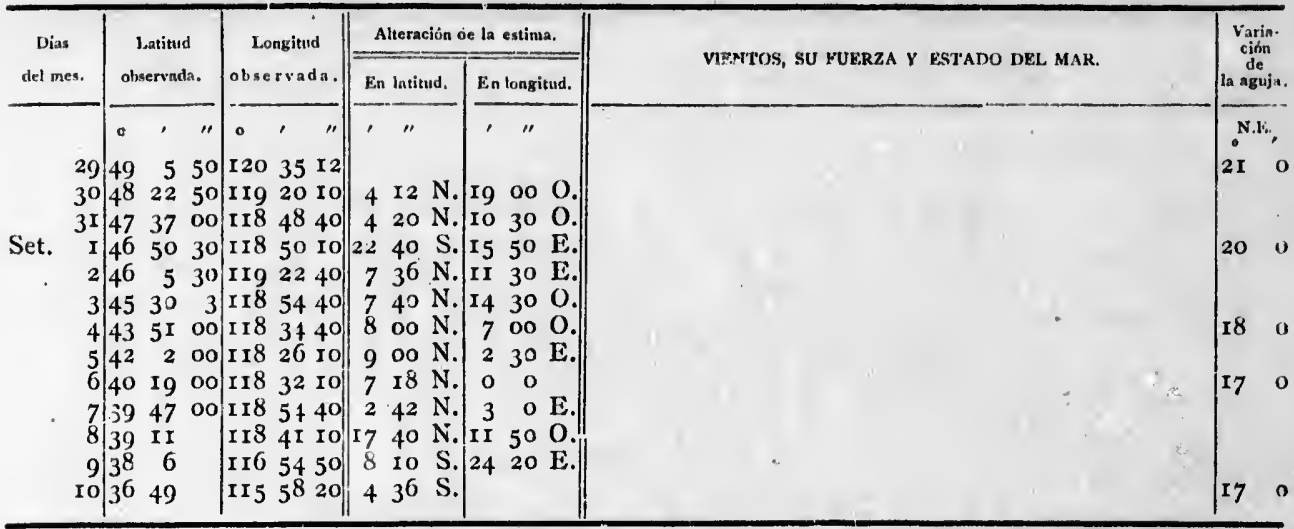

Salida de Monterey para el puerto de Acapulco. - Mes de Setiolinbre.

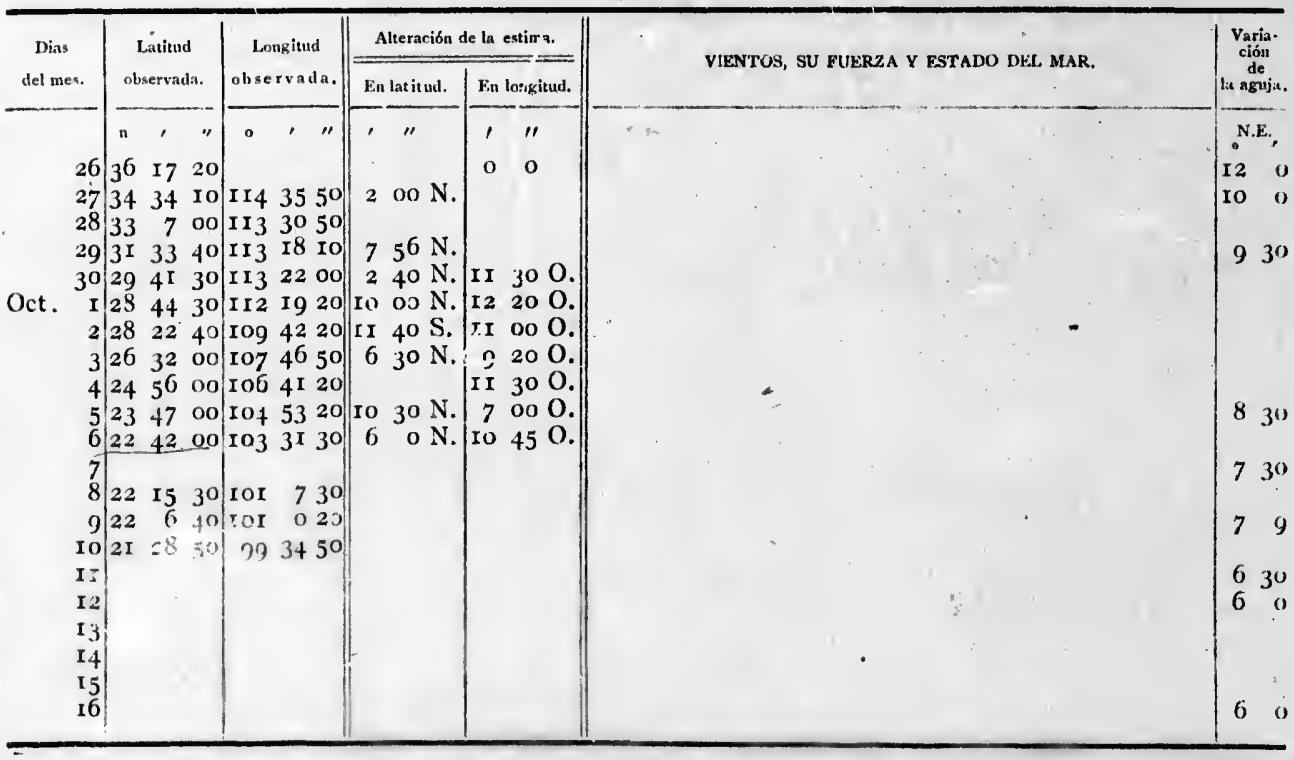

Salida del Puerto de Acapulco para el de Hu mata - Mes de Diciembre.

\begin{tabular}{|c|c|c|c|c|c|c|}
\hline \multirow{2}{*}{$\begin{array}{c}\text { Dias } \\
\text { del mes. }\end{array}$} & \multirow{2}{*}{$\begin{array}{l}\text { Latitud } \\
\text { observada. }\end{array}$} & \multirow{2}{*}{$\begin{array}{c}\text { Longitud } \\
\text { observada. }\end{array}$} & \multicolumn{2}{|c|}{ Alteración de la estima. } & \multirow{3}{*}{ VIENTOS, SU FUKRZA Y ESTADO DM, MAR. } & \multirow{2}{*}{$\begin{array}{c}\text { Varia- } \\
\text { ción } \\
\text { de. } \\
\text { la aguja. }\end{array}$} \\
\hline & & & En latitud. & Ea longitud. & & \\
\hline & , " & , " & , & , " & & N.E., \\
\hline ic. $2 \mathrm{I}$ & I6 1920 & $93574 \pi$ & $48 \mathrm{~S}$. & 40 & Viento $\mathrm{O}$. bonancible, marejada del S.E. & 730 \\
\hline 22 & I5 3 I 00 & $9 \mp 5255$ & $\mathrm{II} \mathrm{I}_{4} \mathrm{~N}$. & 400. & S.O. iden, m & \\
\hline 23 & $155^{5} 324$ & 9427 I 5 & $22+\mathrm{S}$ & $650 \mathrm{l}$ & E. flojo, mis & $0 \quad 0$ \\
\hline 24 & $155^{\circ} 30$ & $9+52 \mathrm{IO}$ & $28 \quad 32 \mathrm{~S}$. & $240 \mathrm{E}$. & Ventolinas d I primer cuadrante, & 730 \\
\hline 25 & 155020 & 955550 & I0 $40 \mathrm{~S}$. & 25 IO E. & Del S.E. al E.S.E. bonancible, mat del viento. & 620 \\
\hline 26 & I5 2 I 30 & 974640 & $1000 \mathrm{~N}$. & $3+50 \mathrm{E}$. & fresquit & \\
\hline 27 & $1+3^{3} 5^{0}$ & 9) 32 I0 & $730 \%$ & $540 \mathrm{E}$ & $\ldots \ldots \ldots \ldots$ & \\
\hline 28 & $14+53^{n}$ & 1005200 & ro ro S. & 2 In $\mathrm{O}$. & S. E. iden.. & \\
\hline 29 & I 42943 & IOI 5 I 20 & $050 \mathrm{~S}$. & 580. & It & \\
\hline 30 & I4 3 I 33 & 103 I I 20 & 4 IO S. & $3257 \mathrm{E}$. & & \\
\hline $3^{1}$ & 154340 & $\mid \mathrm{IO}_{4}+4 \mathrm{In}$ & 2 ro S. & $750 \mathrm{I}$. & 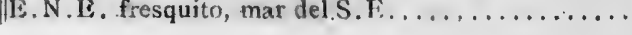 & \\
\hline
\end{tabular}


Continuación de la salida de Acapulco.-Mee de Enero.-1792.

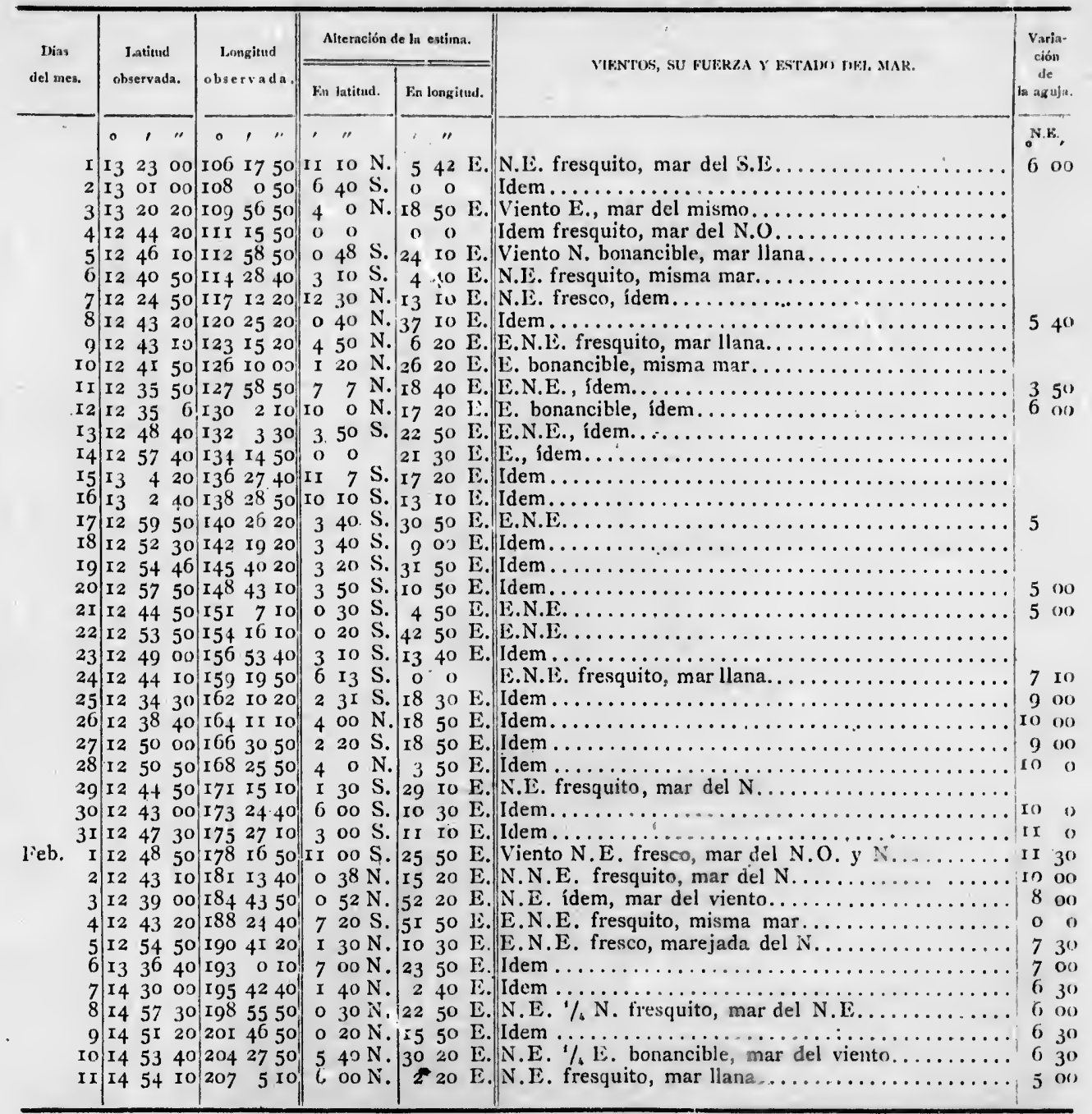

Sallda del Puerto de Humata hasta la boca del Estrecho de San Bernardino. - Mes de Febrero.-1792.

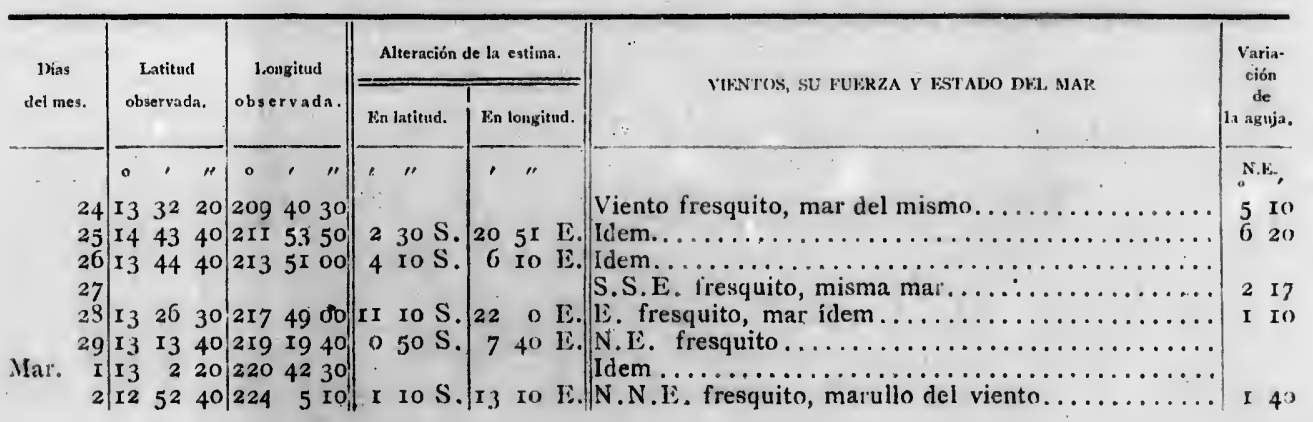


Salida de la bahia de Manila para el Puerto de Zamboanga, en la Isla de Mindanao. Mea de Noviembre. - 1792.

\begin{tabular}{|c|c|c|c|c|c|c|}
\hline \multirow{2}{*}{$\begin{array}{l}\text { Dias } \\
\text { tel mes. }\end{array}$} & \multirow{2}{*}{$\begin{array}{c}\text { Latitud } \\
\text { observada. }\end{array}$} & \multirow{2}{*}{$\begin{array}{c}\text { Longitud } \\
\text { observadz. }\end{array}$} & \multicolumn{2}{|c|}{ Alteración de la estima. } & \multirow{2}{*}{ VIENTOS, SU FUERZA Y ESTADO DEL, MLAR. } & \multirow{2}{*}{$\begin{array}{c}\text { Varia- } \\
\text { ción } \\
\text { de } \\
\text { la aguja. }\end{array}$} \\
\hline & & & En latitud. & En longitud. & & \\
\hline & o, , & -, 11 & , " & & F $\mathbf{N}$ li frescunito mar del viento & N.E; \\
\hline $\begin{array}{l}16 \\
17\end{array}$ & $\mid \begin{array}{rrr}13 & 3 & 4^{0} \\
12 & 35 & 50\end{array}$ & $\begin{array}{llll}233 & 27 & 00 \\
232 & 59 & 30\end{array}$ & 18 I6 N. & I $22 \mathrm{E}$. & 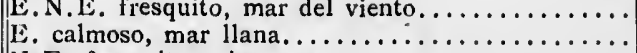 & 2230 \\
\hline I 8 & 112140 & 2312140 & ro $18 \mathrm{~N}$. & I3 $50 \mathrm{O}$. & 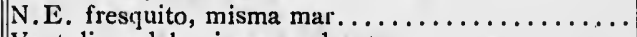 & \\
\hline x & I0 $5^{8} \quad 20$ & $23 \mathrm{I} 5 \mathrm{I} 4 \mathrm{O}$ & $48 \mathrm{~S}$. & $550 \mathrm{E}$. & 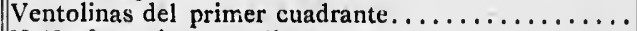 & 3000 \\
\hline 20 & $94 \mathrm{I} 5 \mathrm{O}$ & 2312700 & $.327 \mathrm{~S}$. & 3 oo 0. & 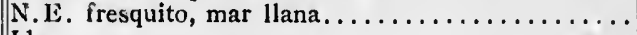 & I 00 \\
\hline $2 \mathrm{I}$ & 75220 & 2314230 & $339 \mathrm{~N}$ & I7 $50 \mathrm{E}$. & 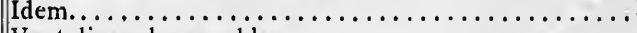 & \\
\hline 22 & 7420 & $23 \mathrm{r} 4 \mathrm{r} 30$ & $744 \mathrm{~N}$. & $24 \mathrm{E}$. & 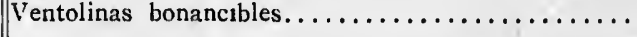 & I I2 \\
\hline
\end{tabular}

Salida del Puerto de Zamboanga para el de Jackson, en la Nueva Gales Meridional. Mes de Diclembre.-1792.

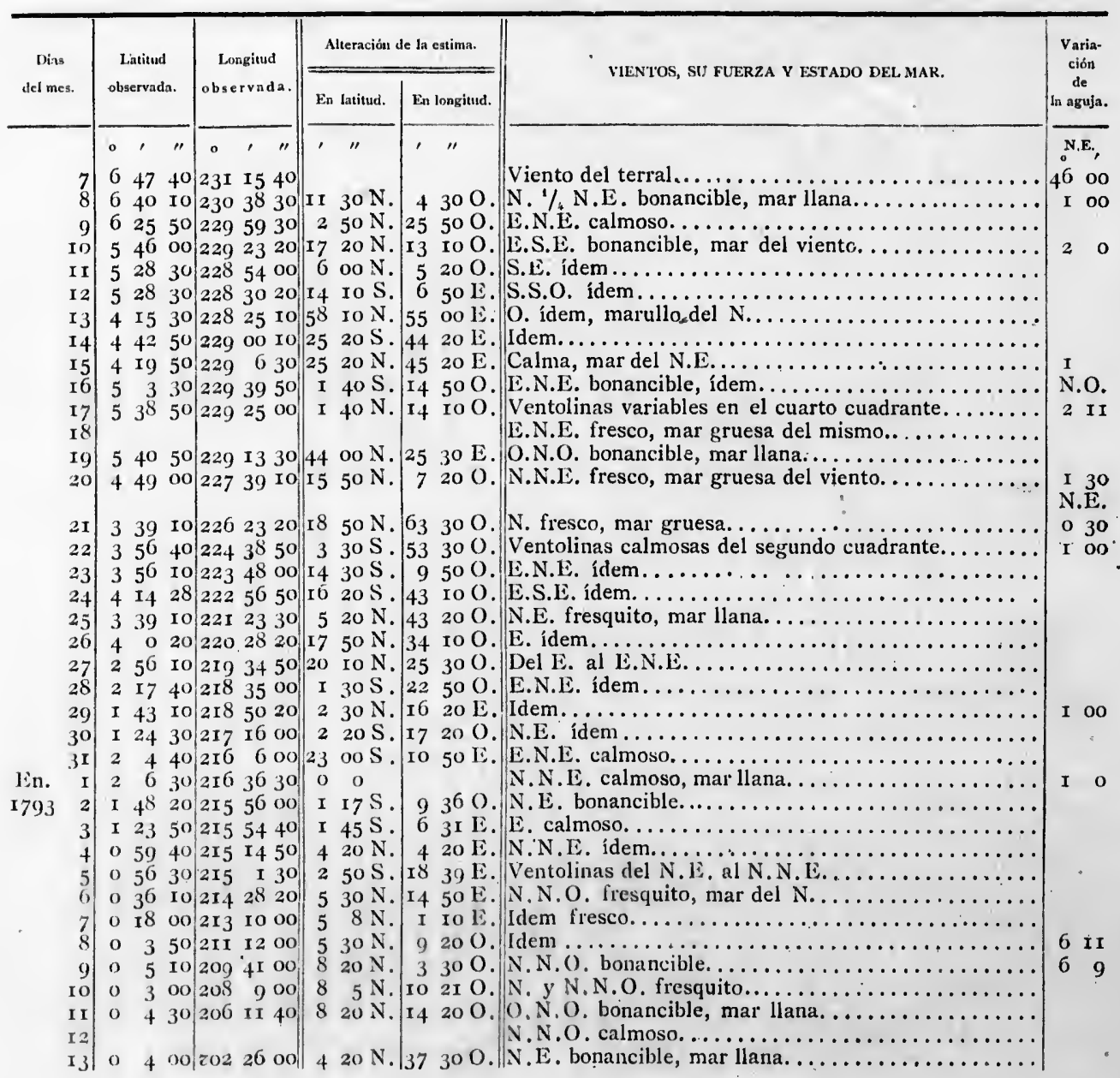


Continuación de la misma campana., - Mes de Enero.-1793.

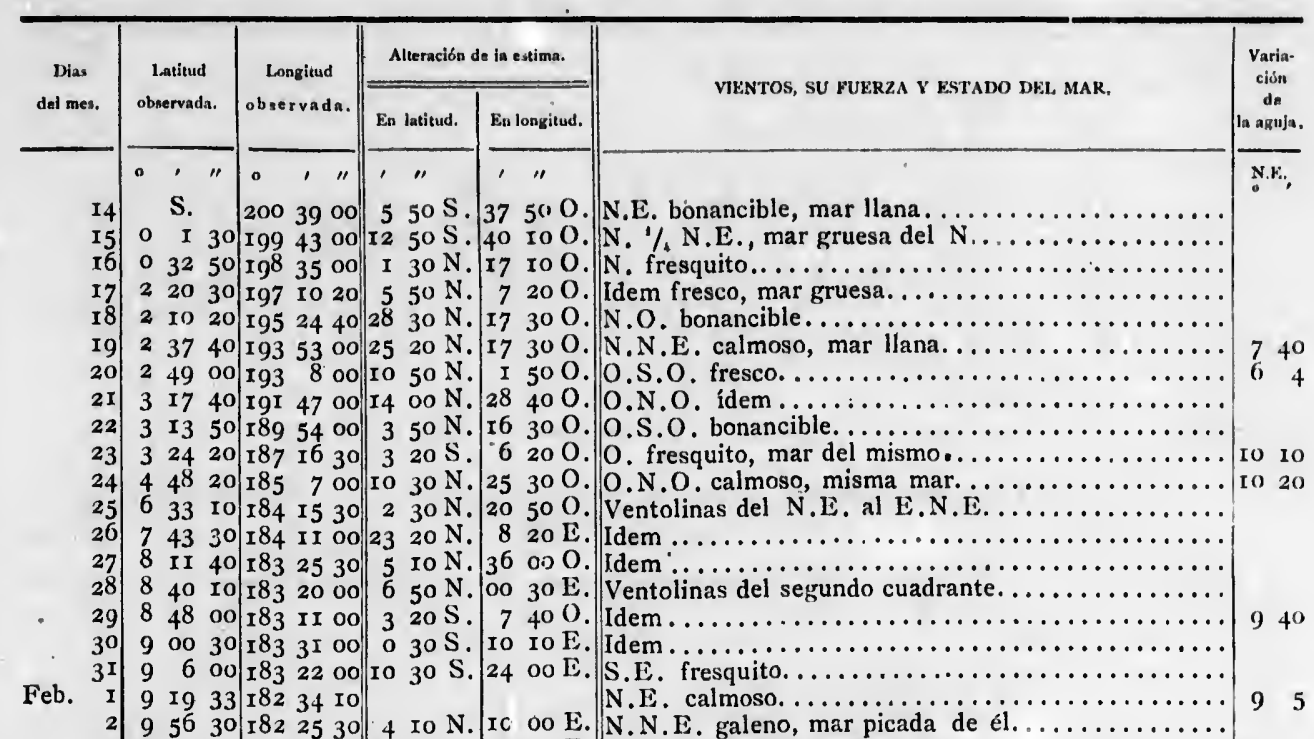

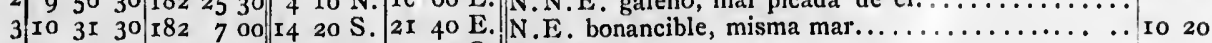

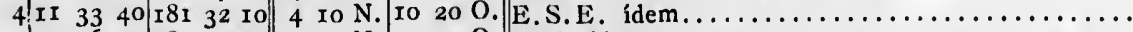

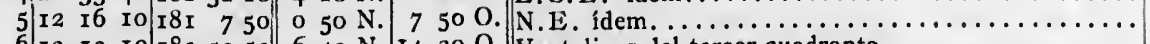

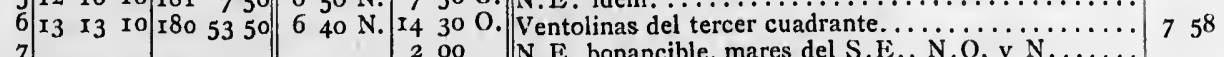

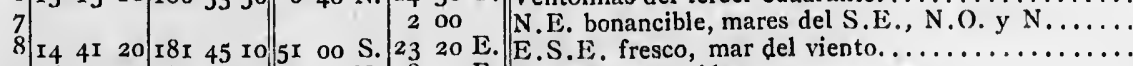

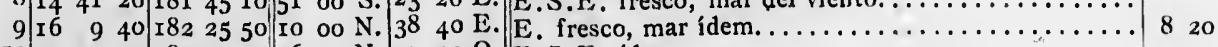

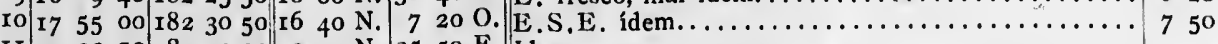

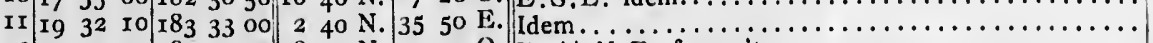

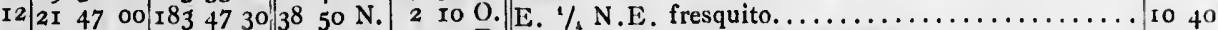

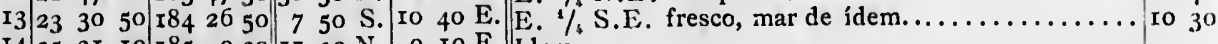

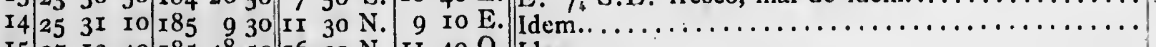

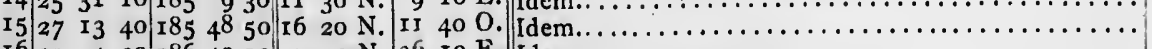

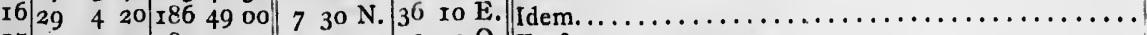

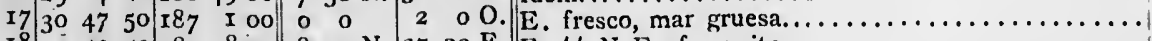

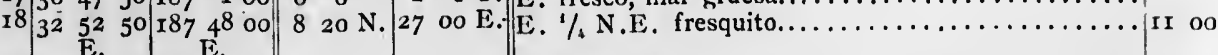

I. 30

o 30

I9 $34 \quad 4920 \mid 18757 \quad 40$

$20 \mid \begin{array}{lllllll}37 & 9 & 30 & 187 & 23 & 00\end{array}$

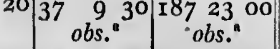

2 I $40 \quad 2$ no 187 I 2 "0o. 52 10 N. 5 40 E.

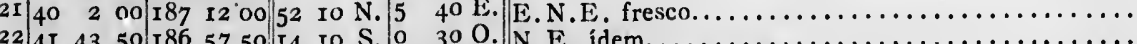

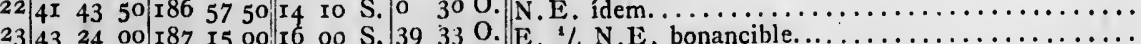

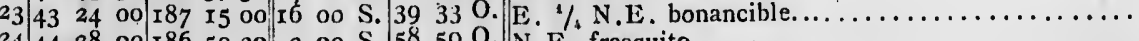

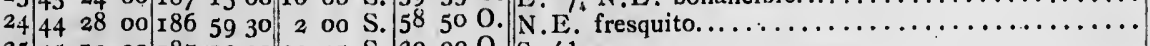

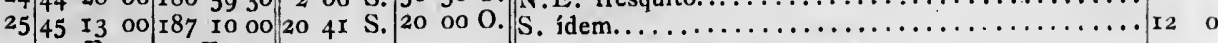

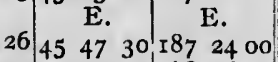

$27 \quad 44 \quad 43 \quad 40$ I 88 26

$28 \begin{array}{llllll}42 & 57 & 00 & 189 & 4 I & 00\end{array}$

N. E $1 / 4$ N. frescachón. .......................

Ventolinas variables................................. $\mathrm{r}_{3}$ ou

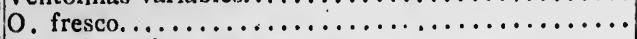

Mar. I I I $324^{8}$ IgI 2 I 50 I oo S. 645 E. S. O. fresquito, mar gruesa.............. I2 40

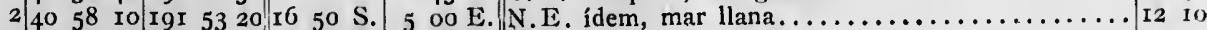

$340 \begin{aligned} & 58 \\ & 40\end{aligned}$

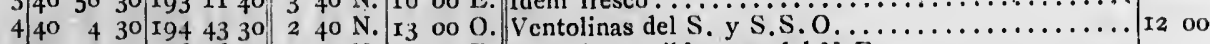

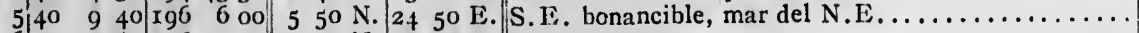

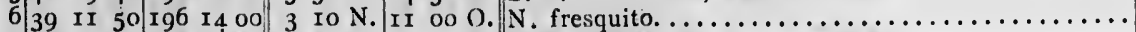

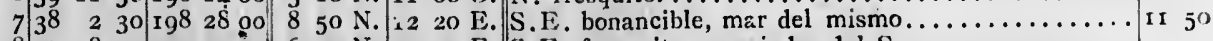

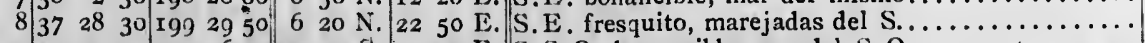

9354740 20I 620 20 50 S. 20 E. S.S.O. bonancible, mar del S.O............ I I Io

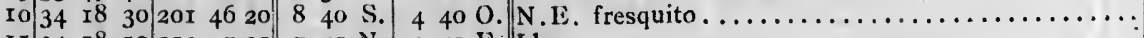

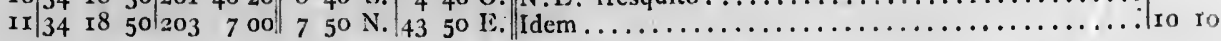


Sallda del Puerto de Jackson hasta las Islae de Vavao.- - Mes de Abril. - 1793.

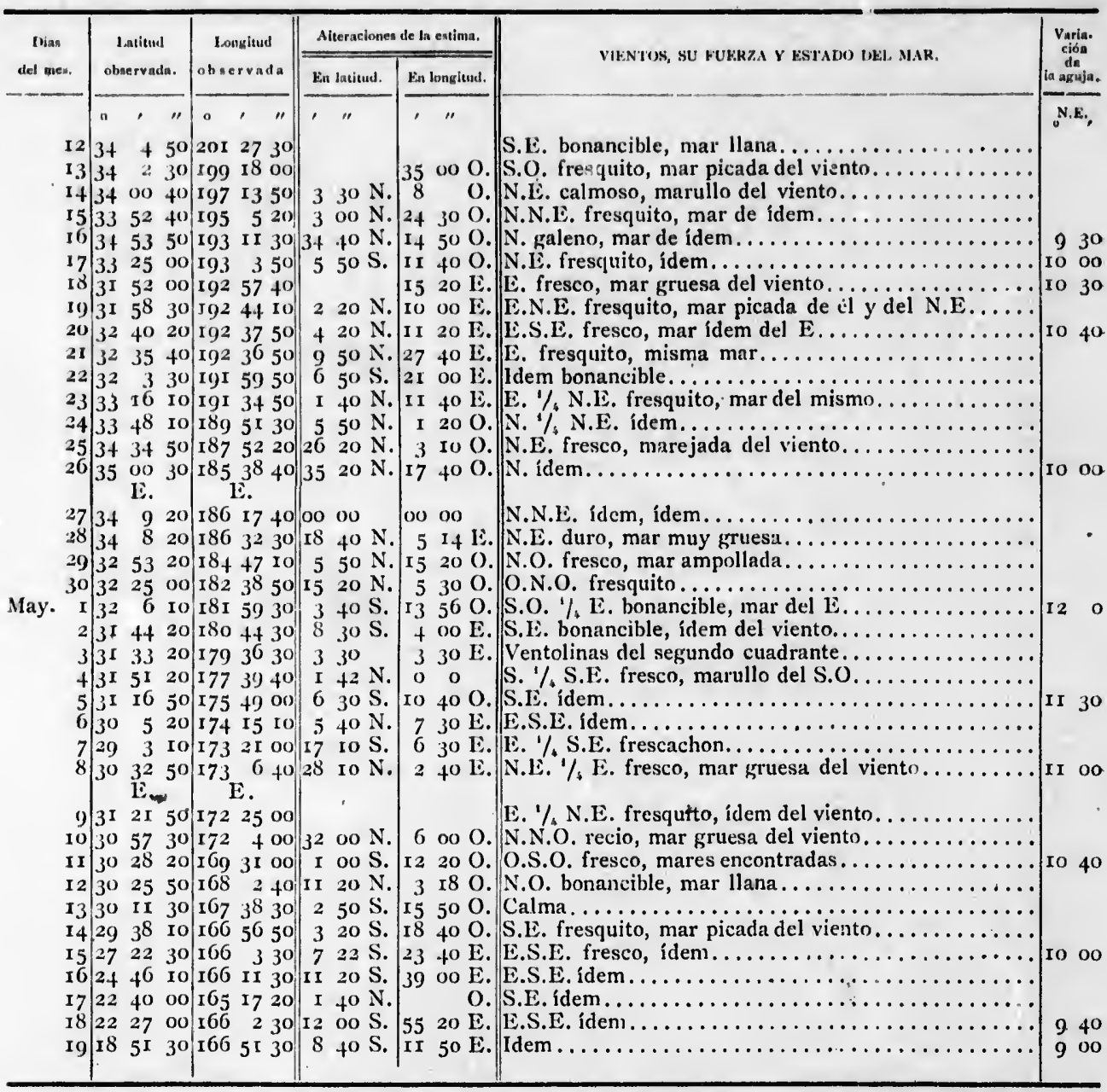

Salida de las Islas de Vavao para el Puerto del Callao de Lima.--Mes de Junio.-1793.

\begin{tabular}{|c|c|c|c|c|c|c|}
\hline \multirow{2}{*}{$\begin{array}{l}\text { Dins } \\
\text { del mes. }\end{array}$} & \multirow{2}{*}{$\begin{array}{c}\text { Latiluad } \\
\text { observada. }\end{array}$} & \multirow{2}{*}{$\begin{array}{c}\text { Longitud } \\
\text { obscrvada }\end{array}$} & \multicolumn{2}{|c|}{ Alteración de ta estima. } & \multirow{2}{*}{ VIENTOS, SU FUERZA V ESTADO DEL MAR. } & \multirow{2}{*}{$\begin{array}{c}\text { Varia. } \\
\text { ción } \\
\text { de } \\
\text { la nguja. }\end{array}$} \\
\hline & & & En latitud. & En longitud. & & \\
\hline & $\circ \quad, \quad$, & , " & $"$ & , " & $\cdot$ & N.E. \\
\hline $\mathbf{I}$ & I8 5 I 00 & $1675^{8} 5^{0}$ & & & E. bonancible, ma llana............ & 950 \\
\hline 2 & I9 300 & 1682550 & 2 Io N. & $335 \mathrm{E}$. & 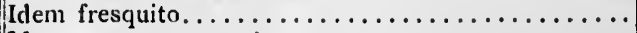 & \\
\hline 3 & $20 \quad 220$ & $168+50$ & $832 \mathrm{~N}$. & $950 \mathrm{I}$. & 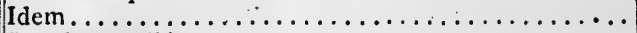 & \\
\hline 4 & $2055 \quad 10$ & 1692740 & $4.20 \mathrm{~S}$ & It IO E. & 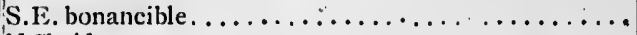 & Io ro \\
\hline 5 & $2 I \quad 4 I \quad 50$ & 1710040 & $3+0^{\circ} \mathrm{S}$. & 30 oo E. & 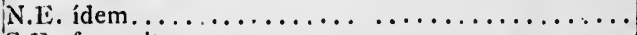 & 1030 \\
\hline 6 & 222900 & $17140 \mathrm{IO}$ & 00 & 0 & 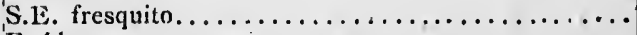 & 900 \\
\hline 7 & 225940 & I7I 22 I0 & Io.12 S. & 45 Iо 0 . & 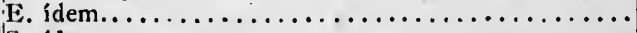 & Io 00 \\
\hline 8 & 24 I 720 & I 72 I8 10 & $240 \mathrm{~N}$. & I5 to $1 \mathrm{E}$. & 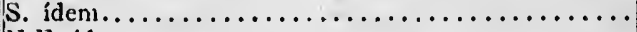 & Io 30 \\
\hline 9 & $253^{8} 3^{0}$ & I73 5 ro & $55^{I} \mathrm{~S}$. & 5 oo 0. & 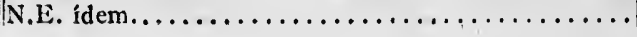 & \\
\hline
\end{tabular}


Continuación de la miema campafia. - Mes de Junio. - 1793.

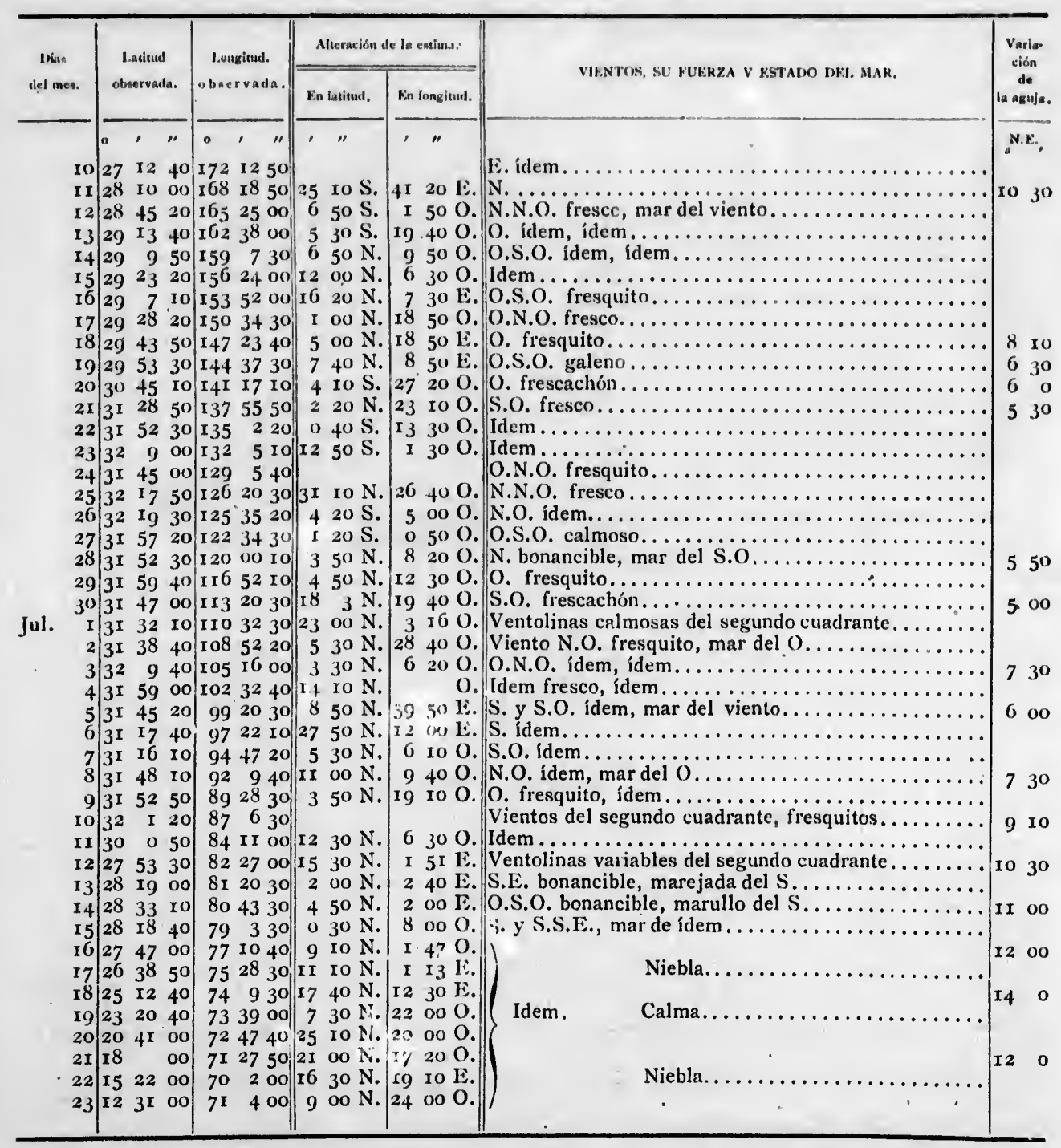

Salida del Callao de Lima para el Puerto de Talcahuano.-Mes de Octubre.-1793.

\begin{tabular}{|c|c|c|c|c|c|c|}
\hline \multirow{2}{*}{$\begin{array}{l}\text { Shies } \\
\text { Jlel mes. }\end{array}$} & \multirow{2}{*}{$\begin{array}{c}\text { Latitud } \\
\text { observada. }\end{array}$} & \multirow{2}{*}{$\begin{array}{c}\text { Longitud. } \\
\text { observada. }\end{array}$} & \multicolumn{2}{|c|}{ Alteración de la estima. } & \multirow{2}{*}{ VIENTOS, SU FUERZA V ESTADO DEL MAR. } & \multirow{2}{*}{$\begin{array}{l}\text { Varia. } \\
\text { ción } \\
\text { de } \\
\text { Ia aguja. }\end{array}$} \\
\hline & & & En latitud. & En longitud. & & \\
\hline $\begin{array}{l}\text { I7 } \\
\text { I } 8\end{array}$ & $\begin{array}{ccc}0 & , & \prime \prime \\
\text { I2 } & 44 & 40 \\
\text { I4 } & \text { I } & 20\end{array}$ & $\left|\begin{array}{ccc}0 & 1 & 11 \\
71 & 54 & 5 \\
73 & 3.5 & 10\end{array}\right|$ & $\begin{array}{ccc}1 & 1 \\
& & \\
8 & 0 \\
0 & 0\end{array}$ & $\begin{array}{ll}\prime & \\
\text {. I } & 500 . \\
13 & 100 .\end{array}$ & 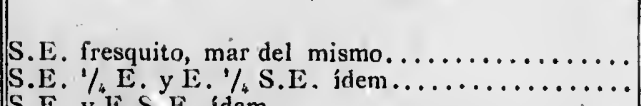 & $\begin{array}{l}\text { N.E. } \\
8 \text { 30 }\end{array}$ \\
\hline $\begin{array}{l}\text { I9 } \\
20 \\
2 I\end{array}$ & 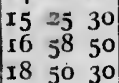 & $\left|\begin{array}{rrr}74 & 32 & 00 \\
75 & 52 & 00 \\
77 & 7 & 20\end{array}\right|$ & $\begin{array}{lll}6 & \text { Io } & \mathrm{S} \\
4 & 50 & \mathrm{~S} \\
2 & 30 & \mathrm{~S} .\end{array}$ & $\begin{array}{lll}2.3 & 20 & 0 \\
I_{3} & 0 & 0 \\
17 & 40 & 0\end{array}$ & 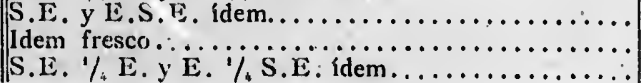 & 840 \\
\hline
\end{tabular}






\section{IMAGE EVALUATION}

TEST TARGET (MT-3)
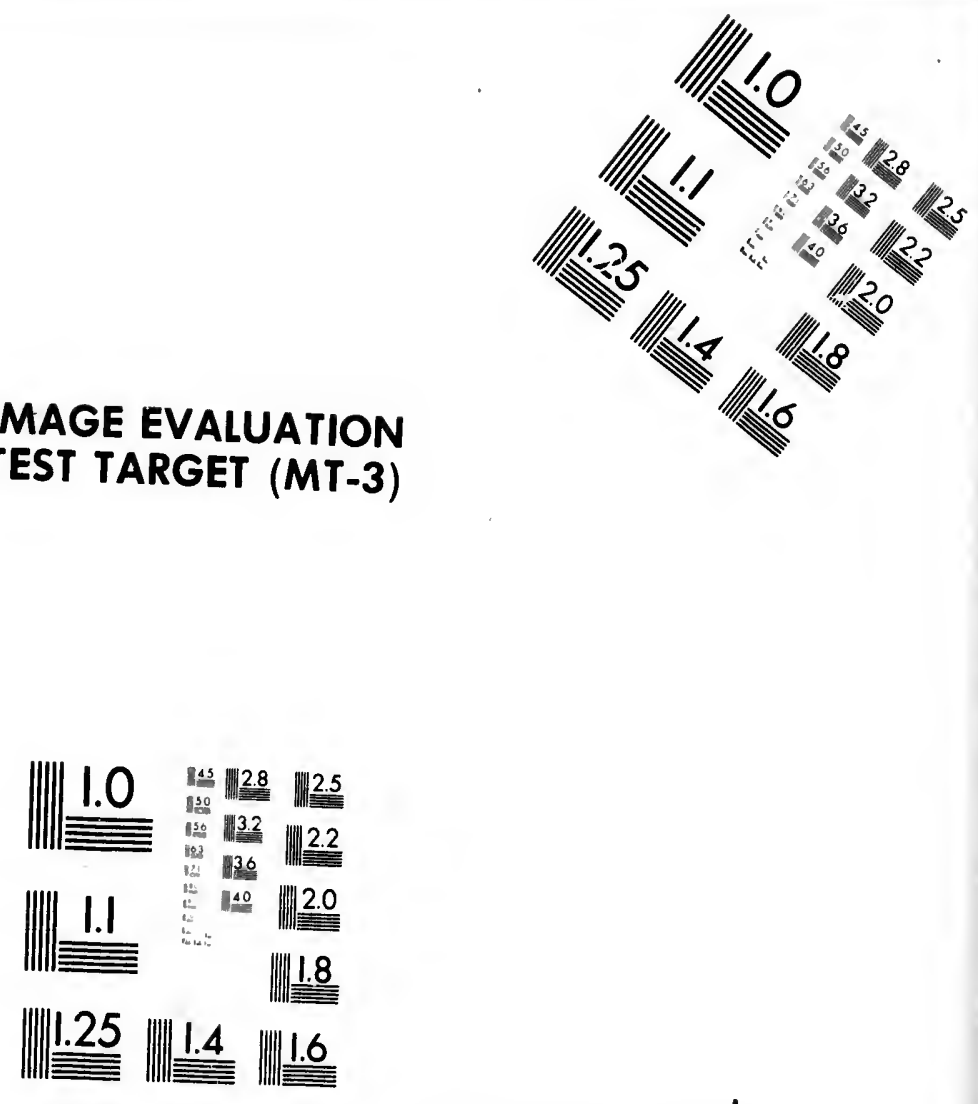

$6^{\prime \prime}$

hotographic Sciences uorporation

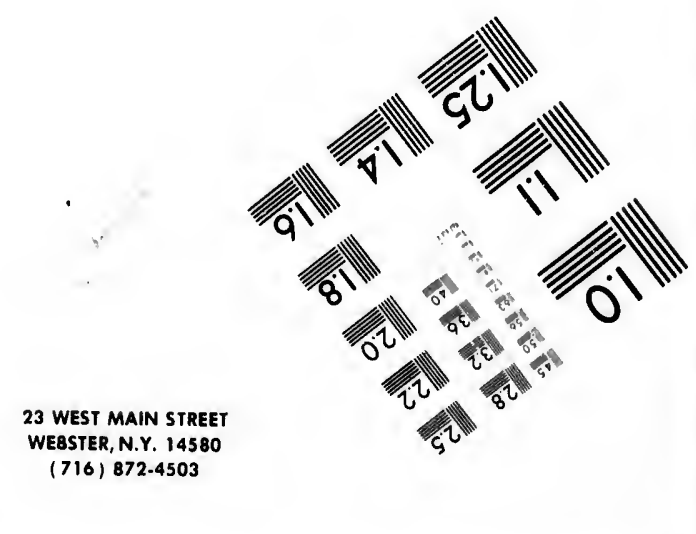


CIHM/ICMH Microfiche Series.
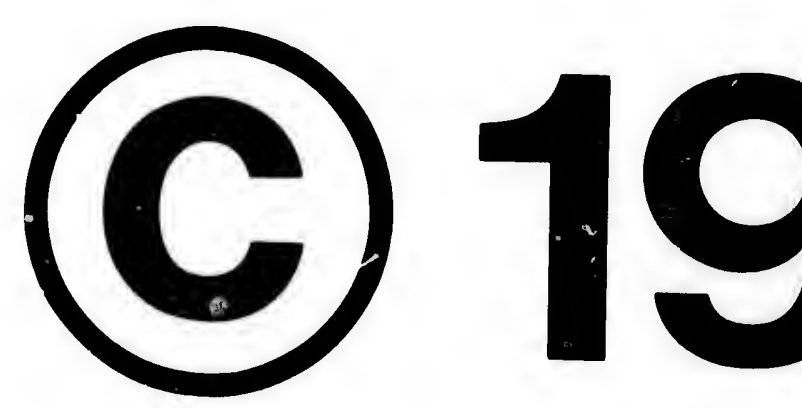

microfiches.

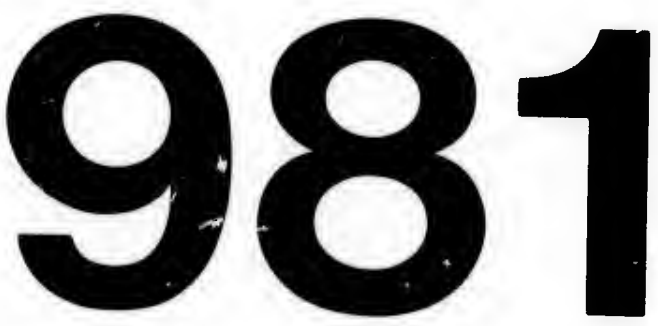


Continuación de la misma campafia. - Mes de Octubre.-1793.

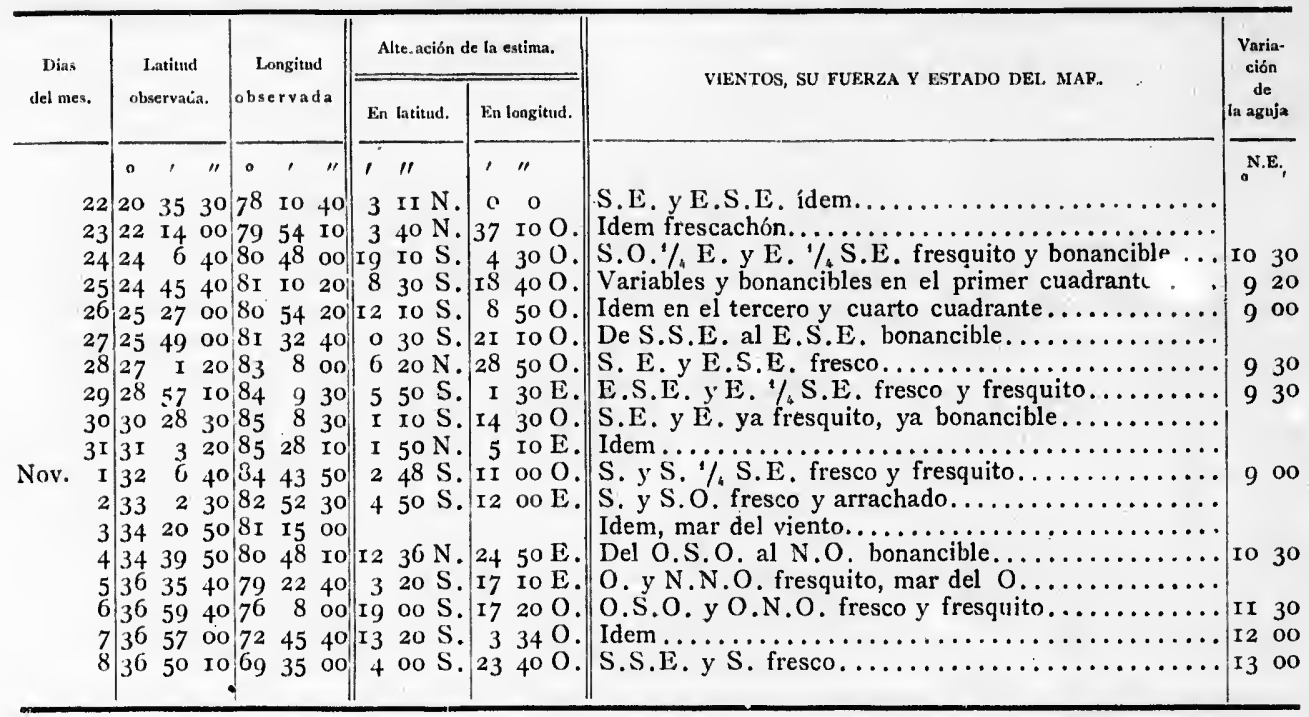

Salida del Puerto de Taicahuano para el de Egmont.-Mes de Diciembre.-1793.

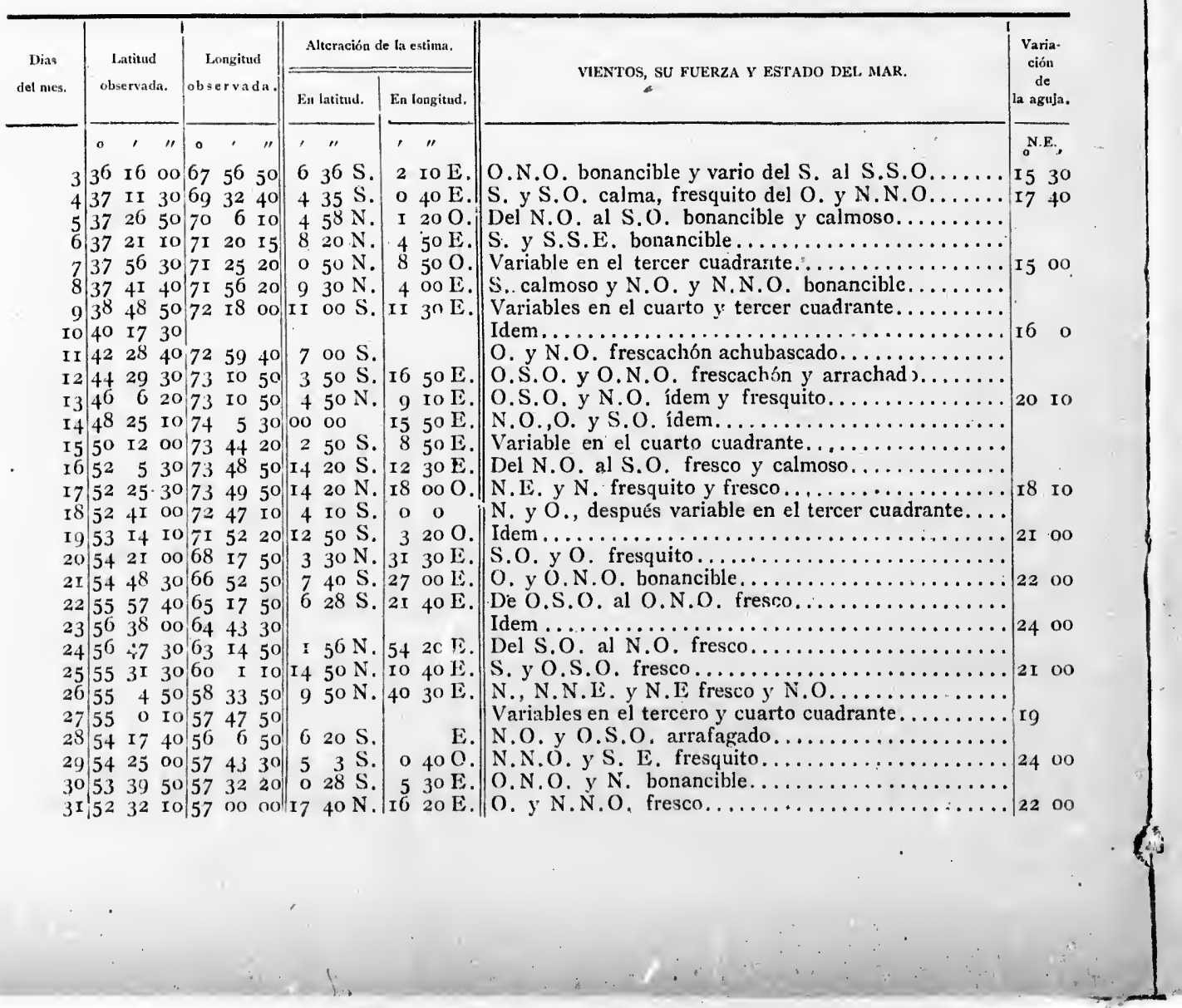


Sallda del Puerto de Egmont para el de Santa Elana en la Costa Patagónica. - Mes de Ēnero.-1794.

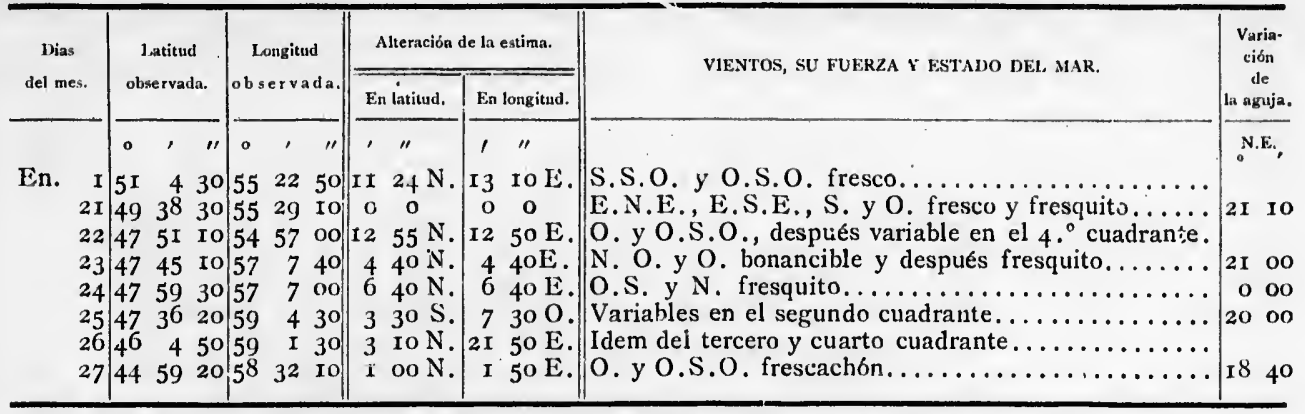

Salida dal Puerto de Santa Elena para el de Montevideo.-Mes de Febrero.-1794.

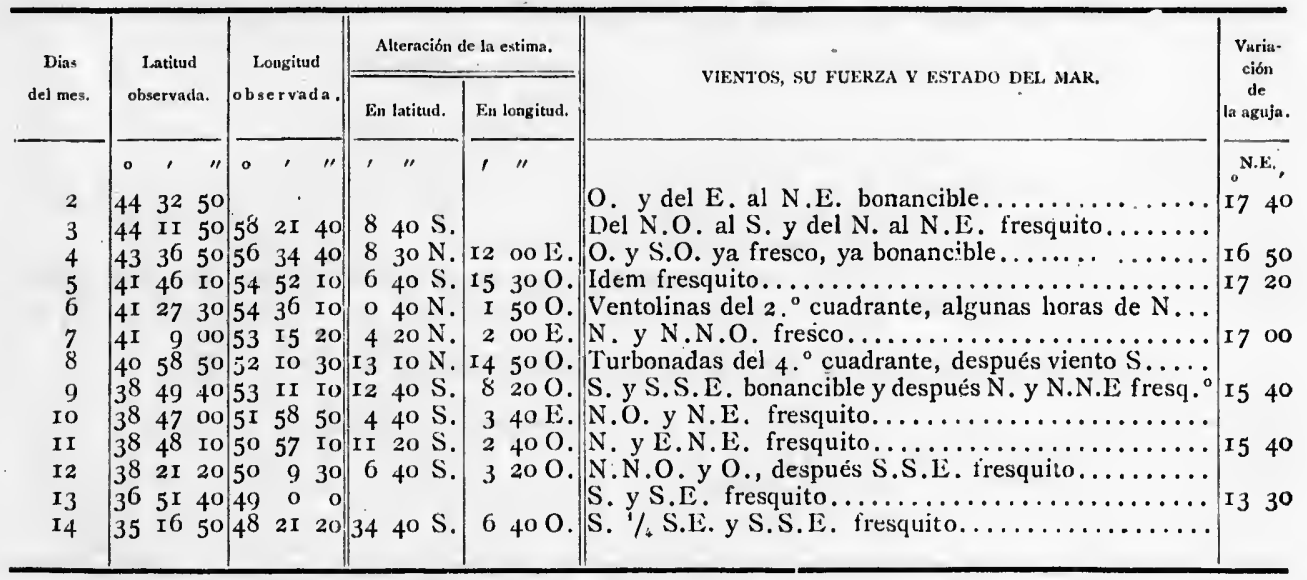

Salida dei Puerto de Montevideo. - Mes de Junio. - 1794.

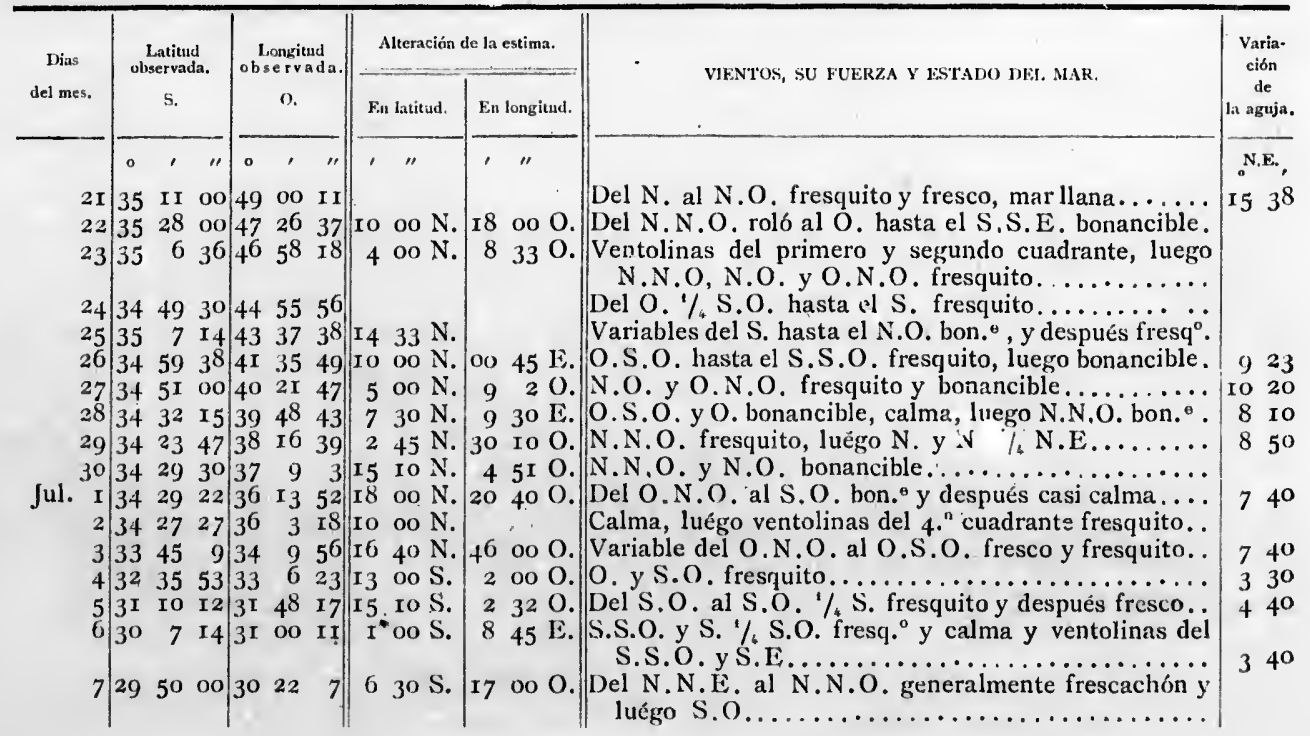


Continuación de la misma campana.--Mes de Julio.--i794.

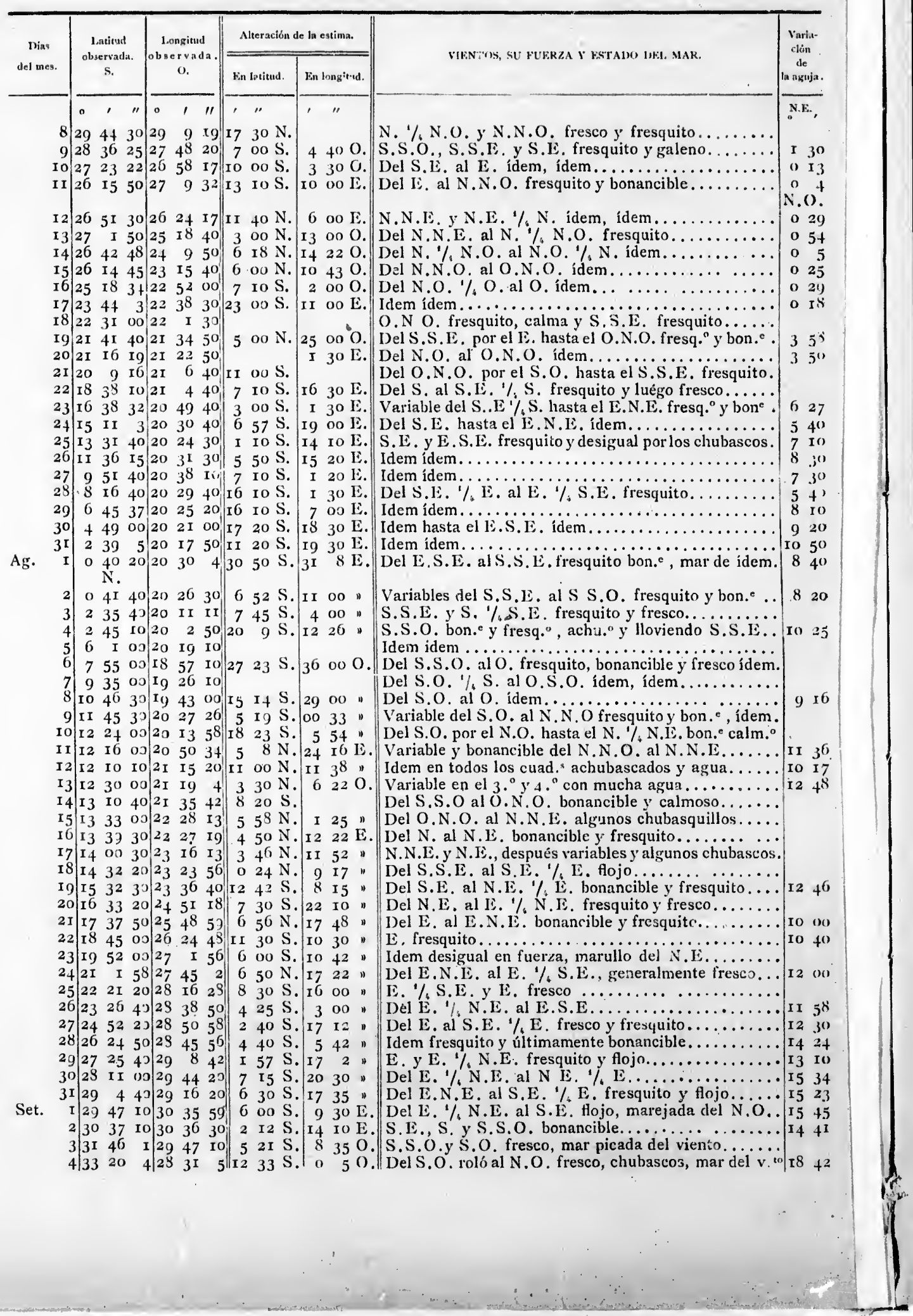


Continuación de la misma campafia.- Mes de Setiembre.-1794.

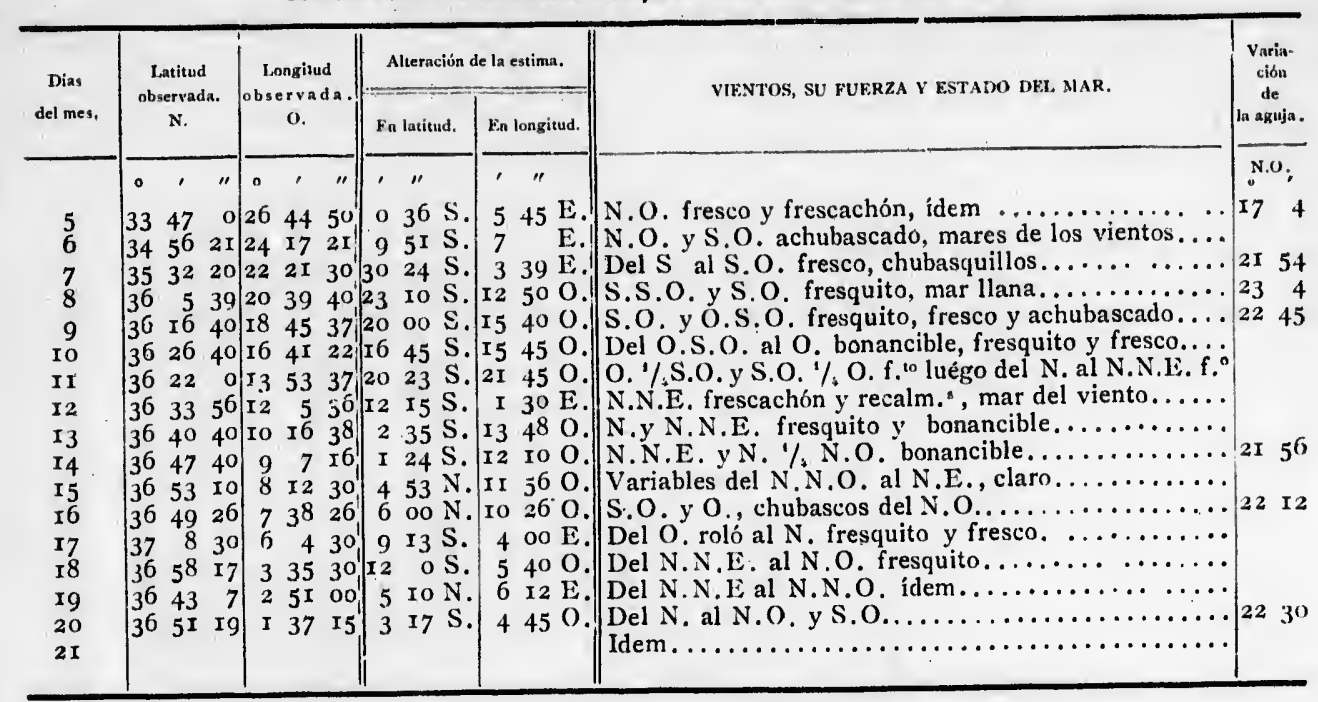




\section{NOTA CURIOSA}

Al dar por terminada la publicación del viaje de Malaspina y sus compañeros, debo hacer presente que esce libro puede considerarse, no obstante sus dimensiones, como un extracto 6 compendio, siendo así que los originales manuscritos ocuparían siete volúmenes iguales al presente. Como dato curiosísimo de las dimensiones de la obra y del costo calculado á su publicación, léase la siguiente carta dirigida por el sabio D. Felipe Bauzá al ilustre D. José de Espinosa, ambos Oficiales de las corbetas.

\section{Madrid y Enero o de 170.5.}

Amadisimo Espinosa: Cuánto celebro la mejor salud de Vm., y cuánto más celebraría poder contribuir a ella con la robustisima que disfruio, sin embargo de un duro constipado que acaloo de pasar.

Yo apruebo la resolución do $\mathrm{Vm}$, y mucho más con este desbarajuste; cada momento se picnsa una cosa y en nada hay orden. Fabio está encargado de los Derroteros; por mi partc hay que fundir las cartas y querlar en las longitudes que incluyn a Vm.: por fortuna dejan a mi arbitrio y sin responsabilidad el manejo de ellas: haré todo lo posible para que no les falte nada, y si Vm. mo insinúa o advierte algunas cosas, no vendrán fuera del caso. El cómputo de toda la obra, con 70 cartas y 70 láminas y figuras y sicte tomos, asciende á pos MILLONES DE REALES; hágame Vm. el favor de decirme de dónde saldra esto y si no estamos borrachos.

Hace dos días que el Rey y Reina vieron las monas y presentaron á los dos Pintores; éstos, por fin de fiesta, fueron a comer en casa del Embajador de Alemania. D. Juan, con osto, está inaguantable; pero gracias á Dios que lo veo do veinte á veinte ó treinta a treinta días un minuto, y esto por precisión la mayor parte de las veces.

Hace pocas noches que el Sr. D. José Mazarredo me volvió la carta y estuvimos hablando más de hora y media: me hizo muchas preguntas de la América, y preguntándome por Vm., me dijo que Vm. debía venir á $N^{\prime}$ drid; saldrá para Cádiz el 20 lo más tardar.

Galiano, en el Sitio, escribiendo la Introducción para el libro de observaciones: éste va a tener una riña matematica con Mendoza sobre el cálculo de latitudes por dos alturas. Vernaci continúa sí obra, y creo se unirá a ella todá nuestra campaña á la costa Noroeste.

No hay más que E. Adan no habla porque no le acaben de conocer.

Estos señores saludan a Vm. y le dan muchas expresiones; igualmente Sesma y su familia: Vm. me ofrecera á los piés de su madre y hermana, dando muchas expresiones a sus nermanos, sin olvidar á Vargas.

Quedo en noticiar cuanto ocurra, y entretanto sabe Vm. que lo ama con todo su corazón.=Bauzd.

No ménos de siete tomos en folio y no ménos de dos millones de reales hubiera inportado en aquella época la impresión completa y digna del viaje. Cierto que eran entonces de suma utilidad las setenta cartas levantadas por ellos, asf como los dibujos que hoy ya carecen de iniportancia en su mayoría.

Pero sin embargo de llamar compendio al presente volumen, hemos procurado encerrar en él todo lo más interesante y práctico, todo lo que puede aún servir de enseñanza á la Marina y de provecho á los navegantes. 


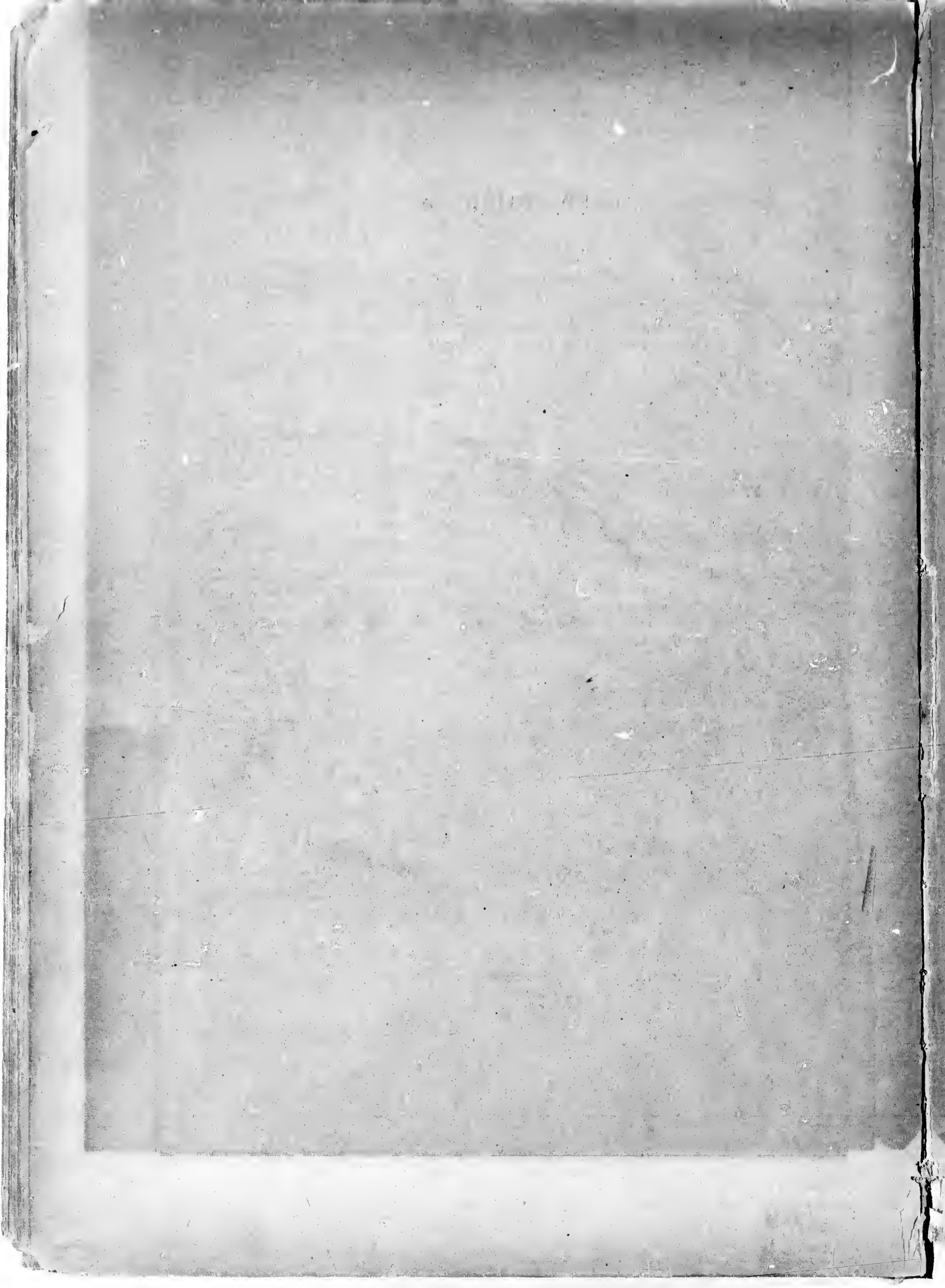




\section{N D I C E}

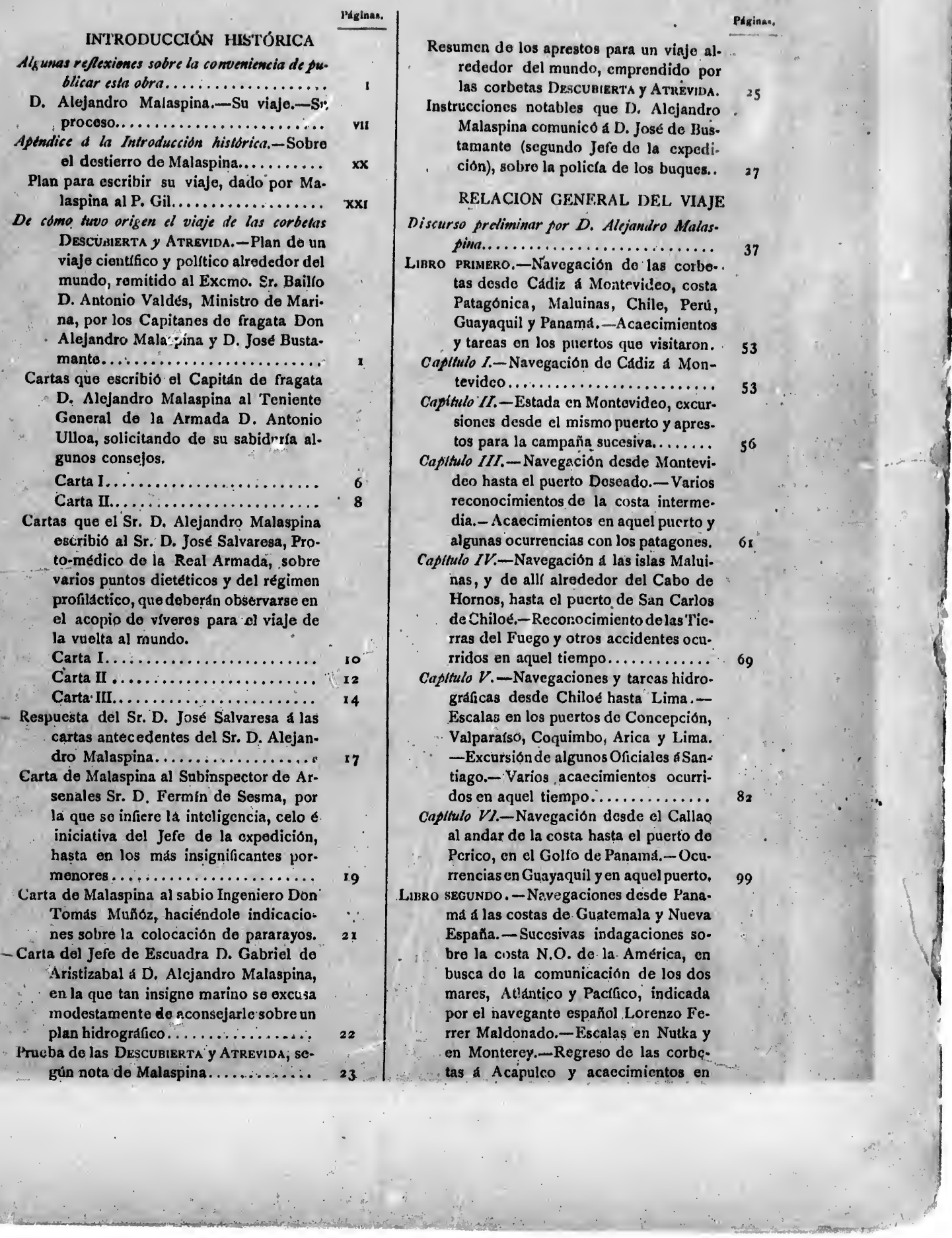


aquel puerto hasta el momento do dar vela hacia las Islas Marianas y Filipinas. Capirvlo I.-Navegaciones y reconocimien. tos de las corbetas al andar de las cos. tas de Tierra Virme y Costa Kica, - Se. paración do entrambos buques. - Ta. reas de la Descunientra sobre las cos. tas de Guatemala y Nueva España.Viaje directo de la AT'REviDa a los puertos de Acapulco y San Blas.-Ul. tima reunión do las corbetas en Acapulco.......................

Viajo ofectuado por la Atkevida duranto su separación de la otra corbeta, según relación do Bustamante...........

Navegación de la Atrevida al reconocí. miento do la Isla de Cocos, y sucesiva A los puertos de Acapulco y San Blas.

Salida de Acapulco y navegación hasta San

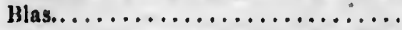

Descripción del Departamento de San Blas, origen do su establecimiento y ventajas que ofrecerra trasladado a Acapulco ......................

Salida de San I3las; navegación en busca de unos bajos al N.O. del Cabo Corriontes, $y$ rcunión a la Descubierta en A capulco..................... Reunión de las corbetus. - Continian viajando en conserva...............

(apilulo II.-Objetos de la siguiente cam. paña sobre la costa N.O. de la famerica. - Navegaciones, escalas y recr. nocimiento en el paralelo de $60^{\circ},-$ Rc greso al Archipićlago de Nu+sa.-Reflexiones sobre las dos Memorias que dieron lugar á estos reconocimicntos.

Relación del descubrimiento del Estrecho de Anian, que so atribuyó el Capitán Lorenzo Ferrer Maldonado.........

Memoria sobre uste descubrimionto, leida en la Real Academia de Ciencias de Paris por Mr. Bauche, geografo mayor de S. M. Cristianisima.........

Disertación sobre la legitimidad de la navegación hecha en 1588 por Ferrer Maldonado, desde las inmediaciones do Terranova al mar Pacfíco $y$ al contrario. Se examinan las reflexione del Sr. Bauche presentadas a la Real Academia de Ciencias de París en 13 de Noviembro de 1790 ; los rastros engañosos de otras navegaciones seme jantes y la utilidad verdadera para la. navegación al Asia, de una comunicación cualquiera entre los dos mares..

Capthulo III.-Acaccimientos en el Archipiélago de Nutka durante la demora de las corbetas en él. - Navegación sucesiva hasta Monterey y estada en aquel puerto. - Ultinos reconocimientos al andar de las costas de California Nueva España. - Escala de la Descu-

\begin{tabular}{|l}
113 \\
\hline 113
\end{tabular}

Herin en San Blas. - Reunión de las corbetas en Acapulco. - Acaecimien. tos en aquel puerto $y$ aprestos para las campañas y operacioı is siguientes... 190

Separación do ?a ATkEvid, 'perfeccionar el reconorimiento de la costa entro Cabo Corrientes y Acapulco.........

Tercera estada de la Atreviba en Acapul. co $y$ ocurrencias hasta la rounión a la Descunikkta.................

LIBro tercero. - Continuación del viaje do las corbetas a las Islas Marianas y Filipinas. - Varias excursiones en entrambos Archipiélagos, y navegación do la Atrkvida al puerto de Macao.Ultimos reconocimientos en ol mar Pacffico sobre la tierra austral del Es. plritu Santo, la Nueva Zelanda, la Nuo. va Holanda y las Islas de Vavao en el. Archipiéle zo de los Amigos. - Regre. so al puor 1 del Callao. - Nuevas in. dagaciones s.'drograficas hechas sobre las Tierras del Fuego, las Maluinas, la Costa Patagónica y el Rio de la Plata.-Rogreso al puerto de Cádiz. .

Capitulo I.-Navegación desde Acapulco á las Islas Marianas; escala, reconocimiontos y observaciones en la de Guaham.- Travesfa siguiente a las Is. las Filipinas.-Acaecimientos en los puertos de Palapa y Sorsogon; primora escala en Manila y tareas de la DesCUBIERTA en la misma bahía y subre las costas de la provincia de Panga$\operatorname{sinan} . . \ldots \ldots \ldots \ldots \ldots \ldots \ldots . . . \ldots \ldots$

Navegación de la Atrevida desde Manila á los mares de China y entrada en el puerto de Taipa................

Ocurrencias en el puerto de Taipa y en la ciudad de Macao,-Atenciones recibi. das del Gobernador y de las Compañias extranjeras. - Descripción de la ciudad con la forma de su gobierno: idea de su comercio, productos de sus rentas, $y$ gastos que produce su conservación a $S$. $M$. $\mathbf{F}$. - Reflexiones sobre el comercio do puleterla, con las ventajas de la kspaña para destruir el de otras naciones que lo cjecuten......

Regreso a Manila.................

Capllulo III.-Difercntes excursiones cien. trficas en la Isla de Luzón durante la estacia de las corbetas en Cavite.Aprestos para las campañas siguion. tes.-Ocurrencias principales relativas a los armamentos $y$ á los. buques. Plan de las siguientes campañas é individuos quedados en Manila con este intento.................... 23

Capitulo $I V_{1}-$ Navegación de las corbetas hasta el presidio de Mindanao, y roconocimientos intermedios. - Escala en aquel presidio.-Derrotas sucesivas 
on el Mar Pacifico, - Vista del axtre mo Sur de la tierra austral del ispiritu Santo $y$ do las costas inmediatas Dusky-Bay on la Nueva Zolanda.-Escala y acaecimientos on la colonia inglesa do Sidnoy, en la Nueva Holanda.......................

Capitulo $V_{0}$-Navogación do las corbotas deste el puerto Jackson hasta las Islas do los Amigos.-Escala en la bahía Maurolle dol Archipiélago de Vavao y reconocimiontos interiores del mismo Archipićlago. - Navegacione sucesivas al Sur hasta perdor do vista las Islas do Tongatabu y Eua........

Capitulo VI.-Navogación dosde el Archipiélago de los Amigos hasta las costas del Perú.-Estada on el puerto dol Callao, y nuevas medidas para la foliz conclusión dol viaje, sabida la decla. ración do la guerra contra la Francia.-Segunda escala do las corbetas en la bahla de Concepción de Chile.

Capitulo VII, -Navegación de la DescuBierta, desde la Concepción d ti Clilo hasta ol pucrto do Montevideo.- lit conocimiento de las Tierras del Fuego y de la Isla de Diego Ramícez.Escalas en ol puerto Egmor t io las $I_{j}$. las Maluinas y on la bahla santa Ele na de la costa Patagonica. - Experion. cias de lit gravedad $y$ otras tureas y acaecimientos.................

Separación do las corbetas desde el puerto del Callao, y navegación de la Atrevido al de Talcahuano.........

Salida del puerto de Talcahuano y navegación en busca de la Isla de Diego Ramirez, y al reconocimiento de la parte oriental de las Maluinas, por la corbeta Atrenida..............

Operaciones hidrograficas ejecutadas on el puerto de la Soledad.-Refiexiones sobro el estado actual de esta colonia y ventajas que ofrece su situación... 312

Salida de las Maluinas. - Navegación á las Islas de la Aurora.-Descubrimiento de una nueva situación de todas, $y$ reunión en Montevideo á la DescuBIERTA......................

Capitulo IX.-Ultima escala do las corbetas en Montevideo. - Varios acaecimientos en aquel tiempo, y reunión en el puerto de la fragata Gertrudis, de la Marina Real, con cuatro buques mercantes de Lima.-Salida del convoy reunido de Lima y Montevideo, su navegación hasta llegar al puerto de Cádiz...................

Descripcion fisica do las costas cul Noroes. te de la América, visitadas por las corbetas.......................

Vocabulario del idioma Mulgrave.......
Examen politico de las costas del Noroento de la América..................

lixamen ftsico del Archipiclago do Vavao y do sus producciones y habitantes. So individualizan diferentes puntos hist $\delta$. ricos relativos a toda la confederacion do las Islas do los Amigos, desdo las últimas navegaciones del Capitán Cook, y so continua la scrie importan. te de las reflexiones del mismo nave. gante.......................

Viajo de D. José de Espinosa y 'Tello, desde Cadiz hasta Acapulco, dondo se re. unió a la expodición de las corlsetas, y continuación de esto viaje. Contieno muy buenas noticias de Historia Natural, Geograffa, costumbres, etc......

Noticia de las principales expediciones he. chas por nuestros Pilotos del Departa. mento de San Blas, al roconocimionto do la costa Noroeste de América, desde $r$ anfo 1774 hasta el 1791 , oxtractada de lis Diarios originalez do aquellos naverantes.................

Descripción fisica y costumbres do la Cali-

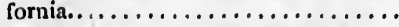

Condiciones de los puertos de San Blas y Acapulco para arsenales.-Rcconocimientos en las provincias internas. Su descripción física, produccionos y costumbres..................

Carta esférica del Río de la Plata, descle su embocadura hasta Buenos Aires, y de la costa inmediata oriental hasta el Cabo de Sunta Maria, trabajada á bordo do las corbotas, año de $\tau_{7} 89 . \ldots$

Derrotero desdo las Islas de Cabo Verde hasta Montevideo. ............

Derrotero desde Montevideo á Chiloé por el Cabo de Hornos. Trata también del puerti) Egmont en las Islas Maluinas y de la descripción de toda la costa intermedia....................

Construcción de las cartas desde el puerto de Montevideo hasta el de Chiloé...

Derrotero de la Isla de Chiloe, por D. Jose Moraleda, Alférez de fragata y Pilcto de la clase de primeros de la Real Armada................... 504

Construcción de las cartas hidrogránicas desdo Chiloé hasta Coquimbo.......

Derrotero de Chiloes a Coquimbo........ 530

Cosstrucción de las cartas desde Coquim. bo hasta Lima, inclusas las Islas de San Félix.........................

Derroteros desde el pucrto del Caliao has ta el Rlo de Guayaquil, y de este punto hasta el Golfo do Panamá, por D. Fabio Ali-Ponzoni............. Istudio sobre las costumbres y descripciones intercsantes de la América del Sur, por Espinosa............ 557 Noticias relativas a Montevideo....... 557 


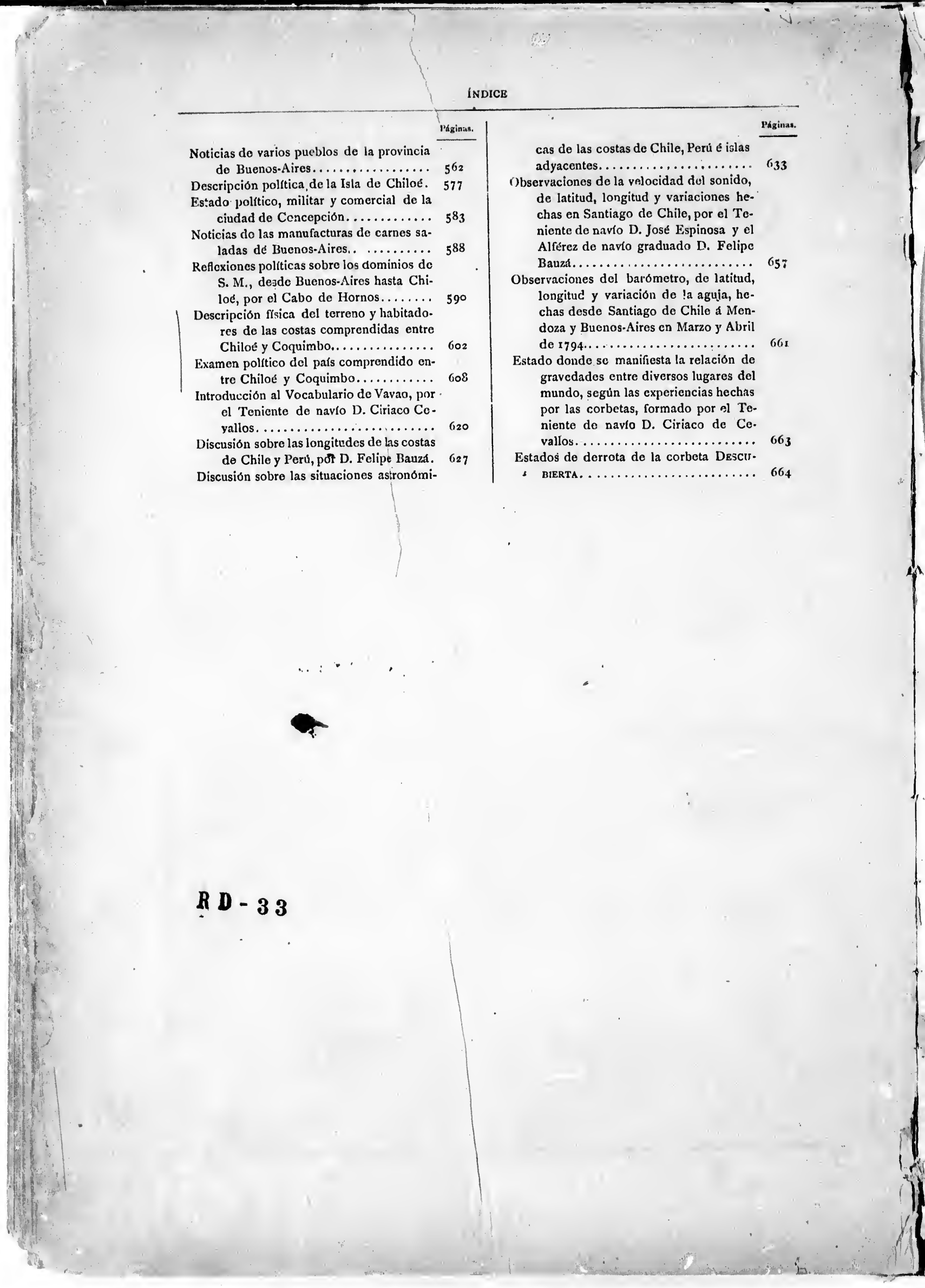




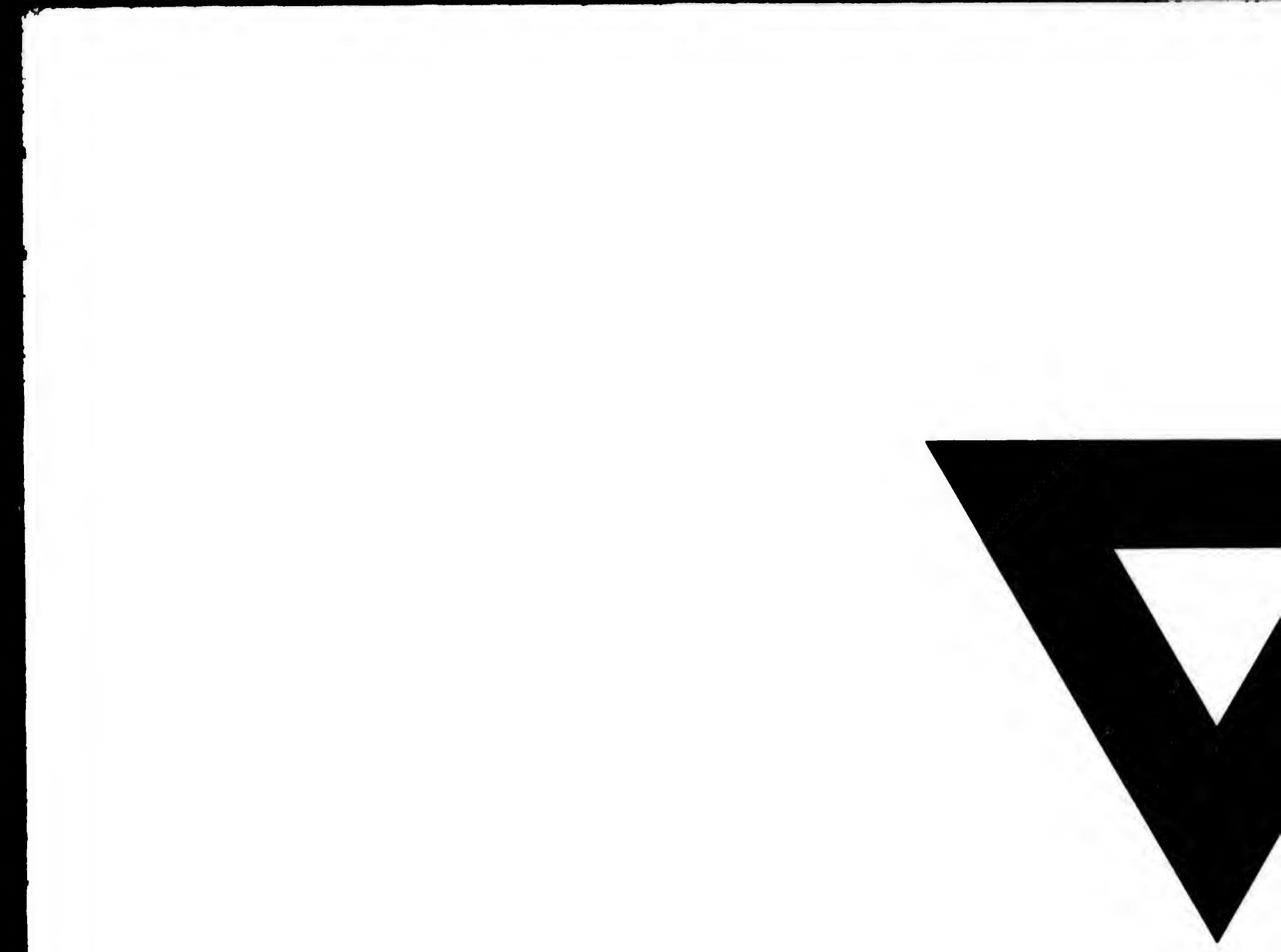




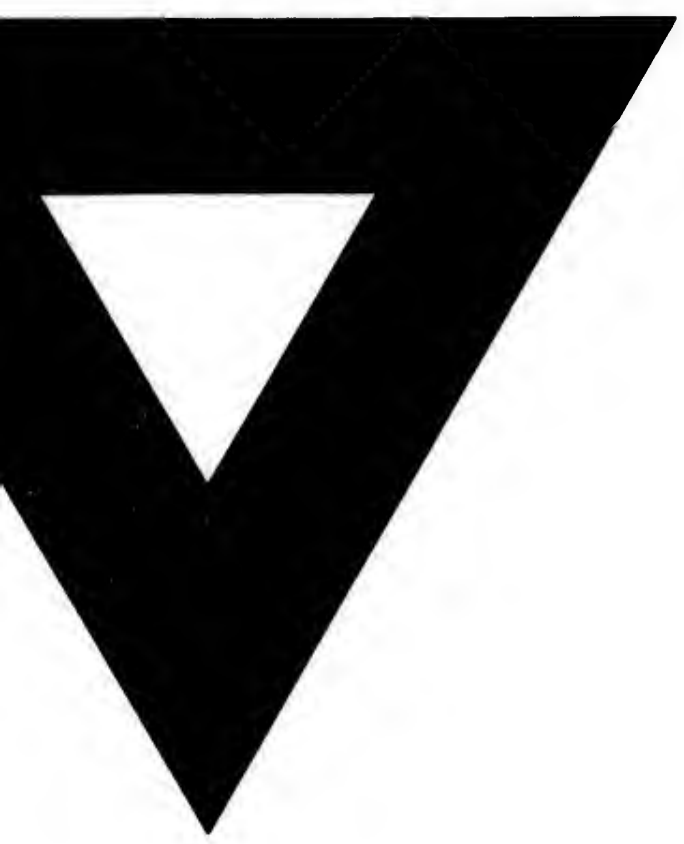

